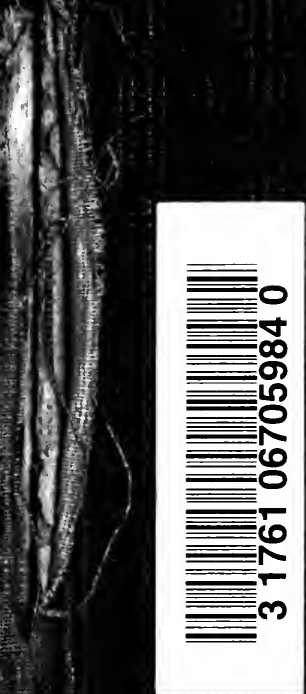

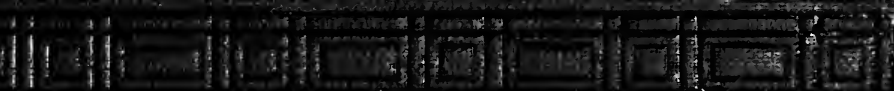

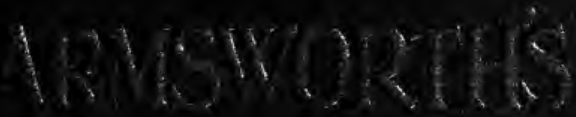

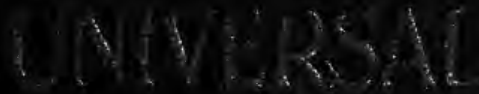

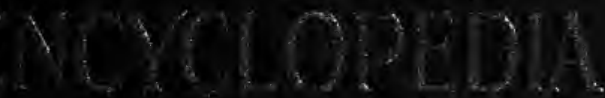

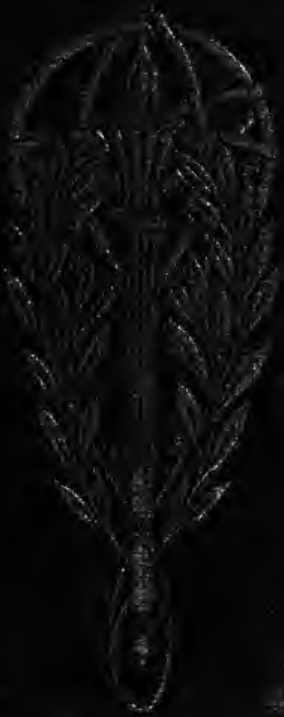




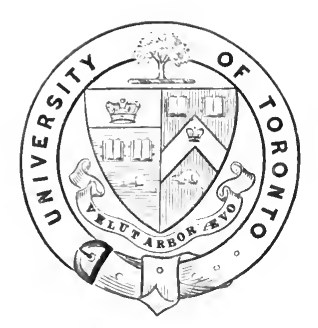

Dresented to

Tbe Library

of the

University of Toronto

G.H. Arunstrong. Aoy. 


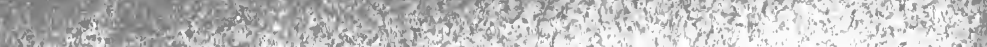

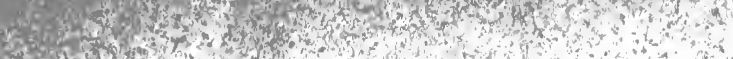

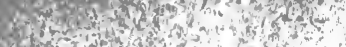

23)

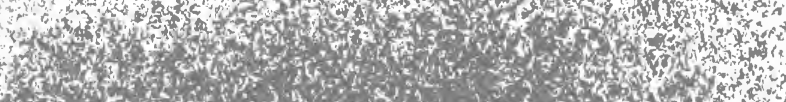

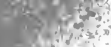

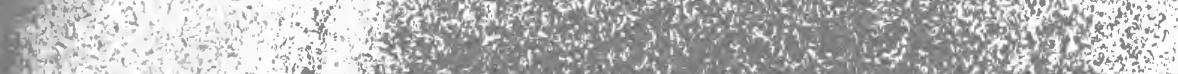

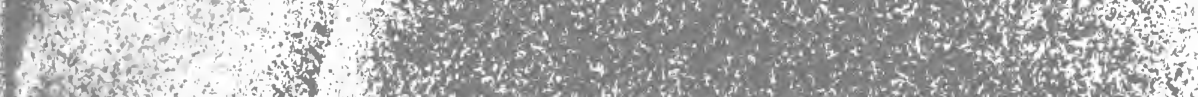
(1) 3)

titis (19)

(19)

पite vintint 10

ing

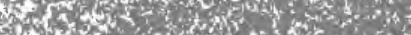

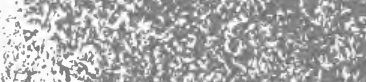

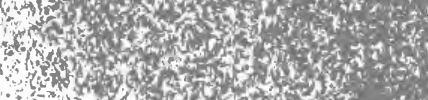

ativisicis

of

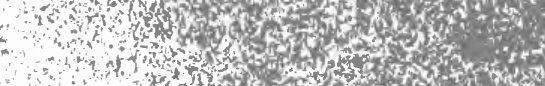

$i_{i, 2}$

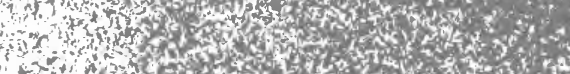

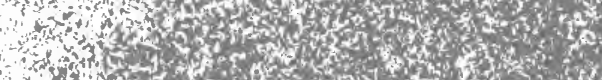

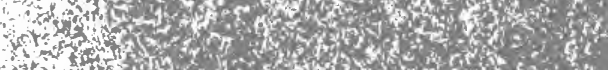

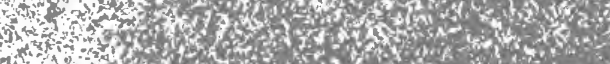

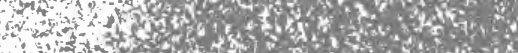

ily:-

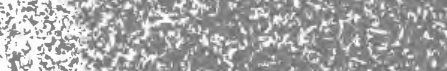

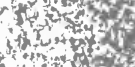

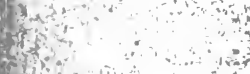

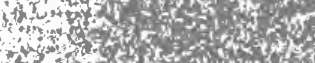

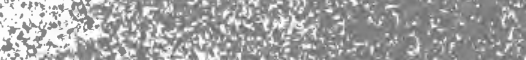

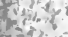

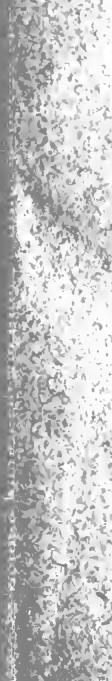
intonds (1)

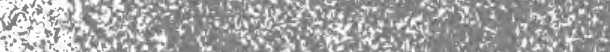

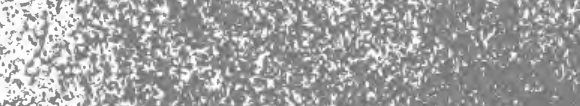

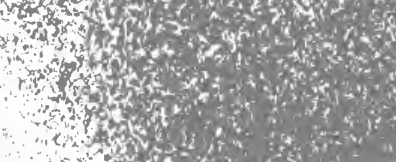

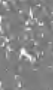
TH:

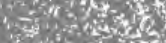

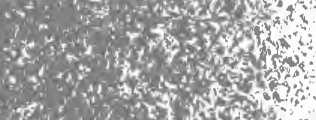
r. (N) 4$)^{2}$ 


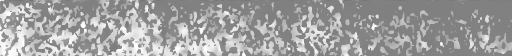

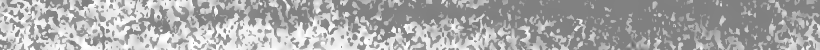

ans.

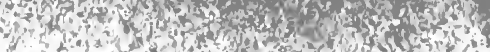

tis.

(n)

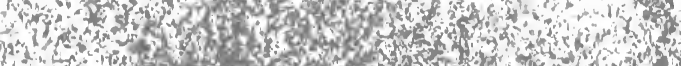

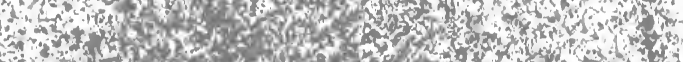

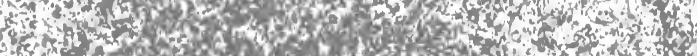
w.

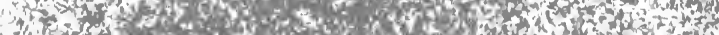

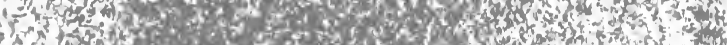

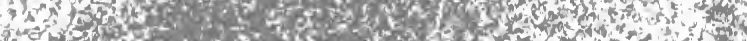

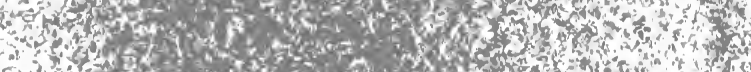

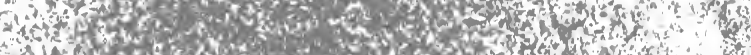

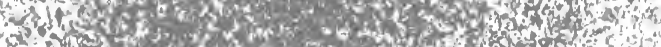

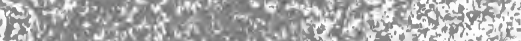

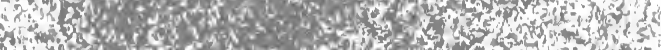

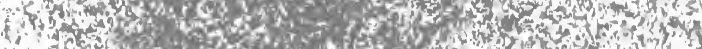

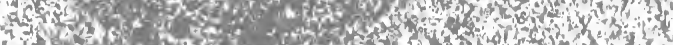

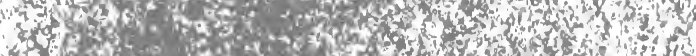

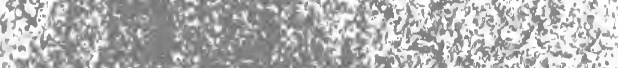

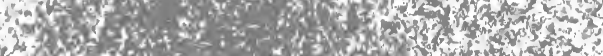

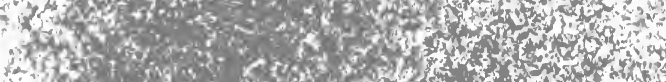

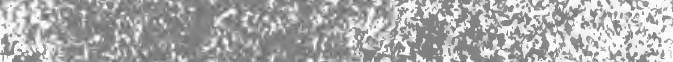

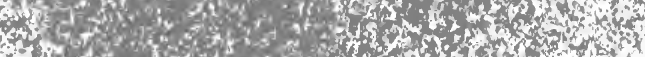

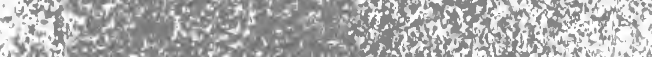

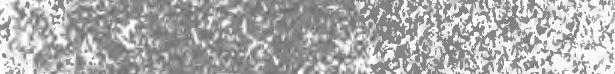

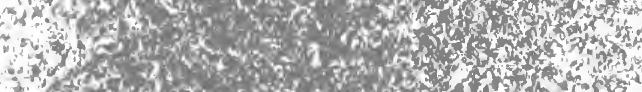

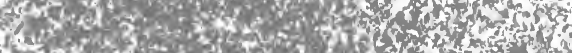

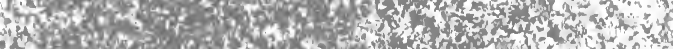

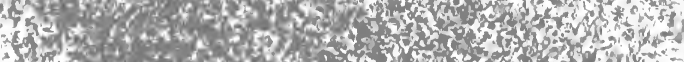

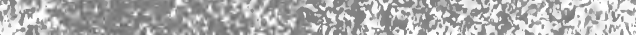

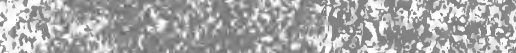

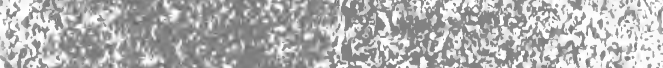

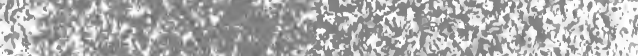

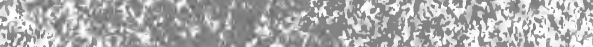

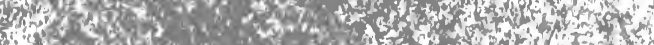

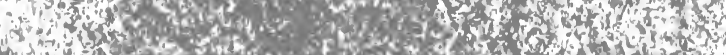

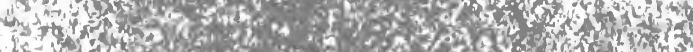

$r^{4}$.

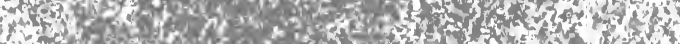

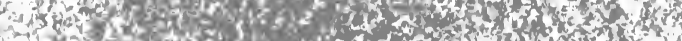

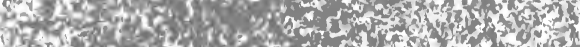

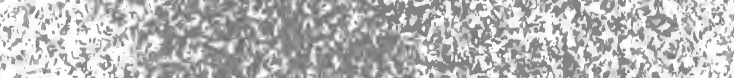

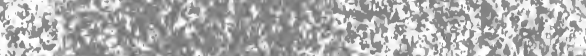

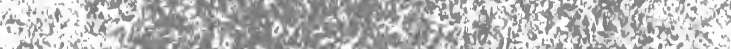

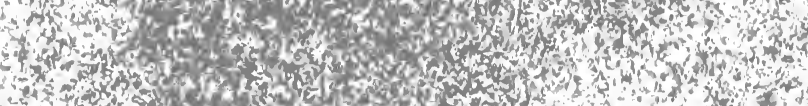
(t)

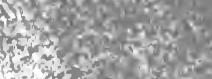

$2 i_{3}$

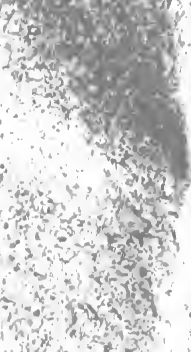

hin

wa

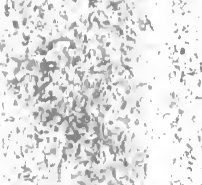

100

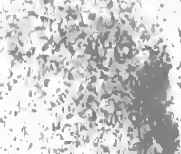

romets

in

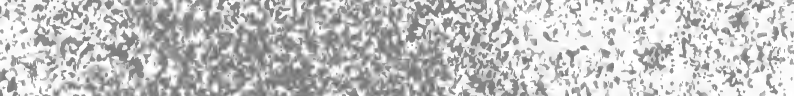

1.

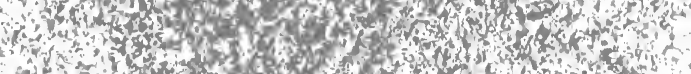

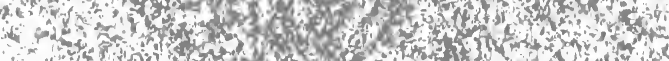

on 


\section{Harmsworth's UNIVERSAL ENCYCLOPEDIA}





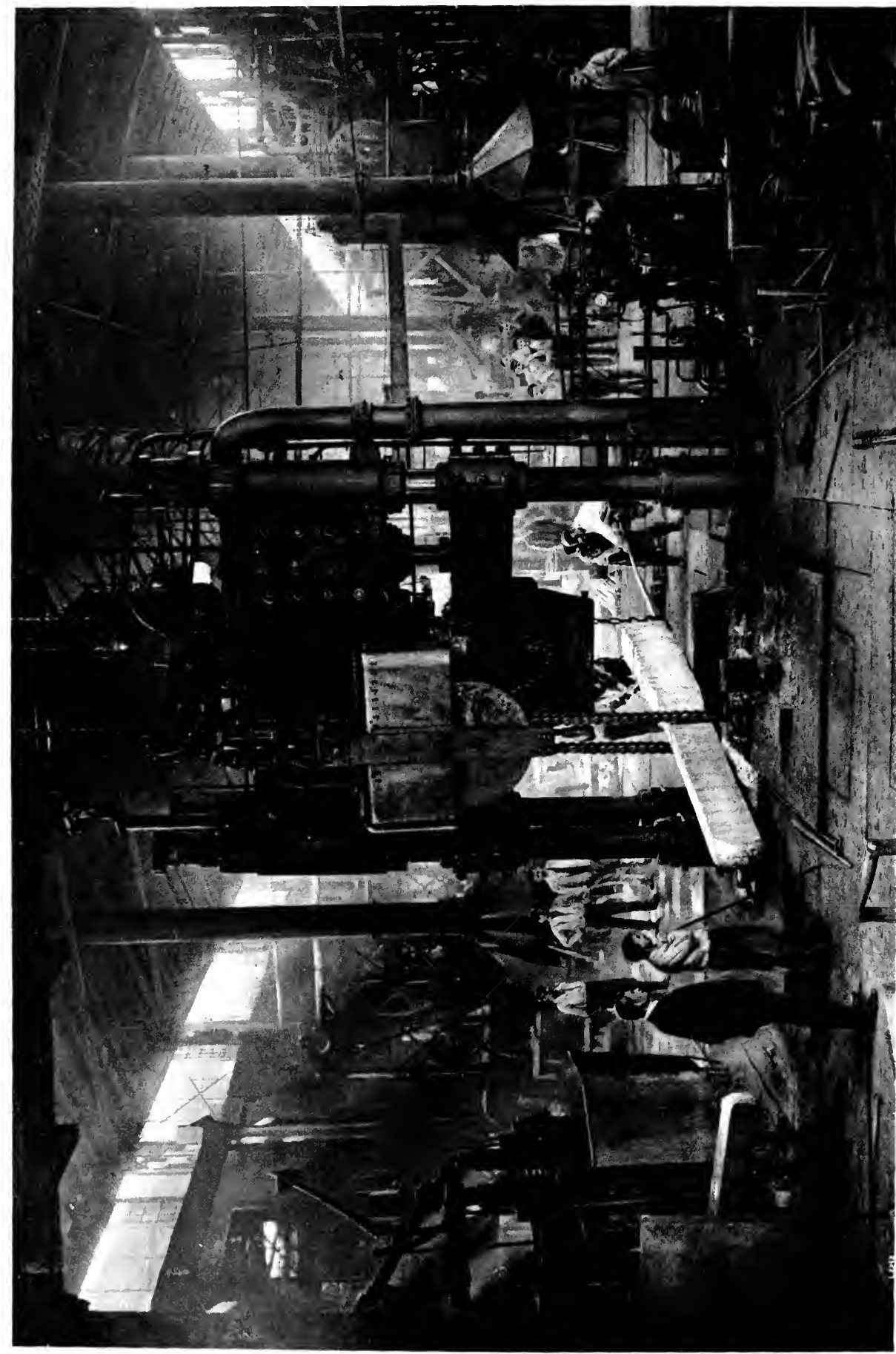

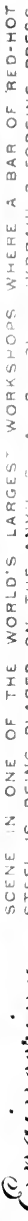


42886

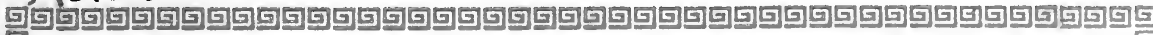

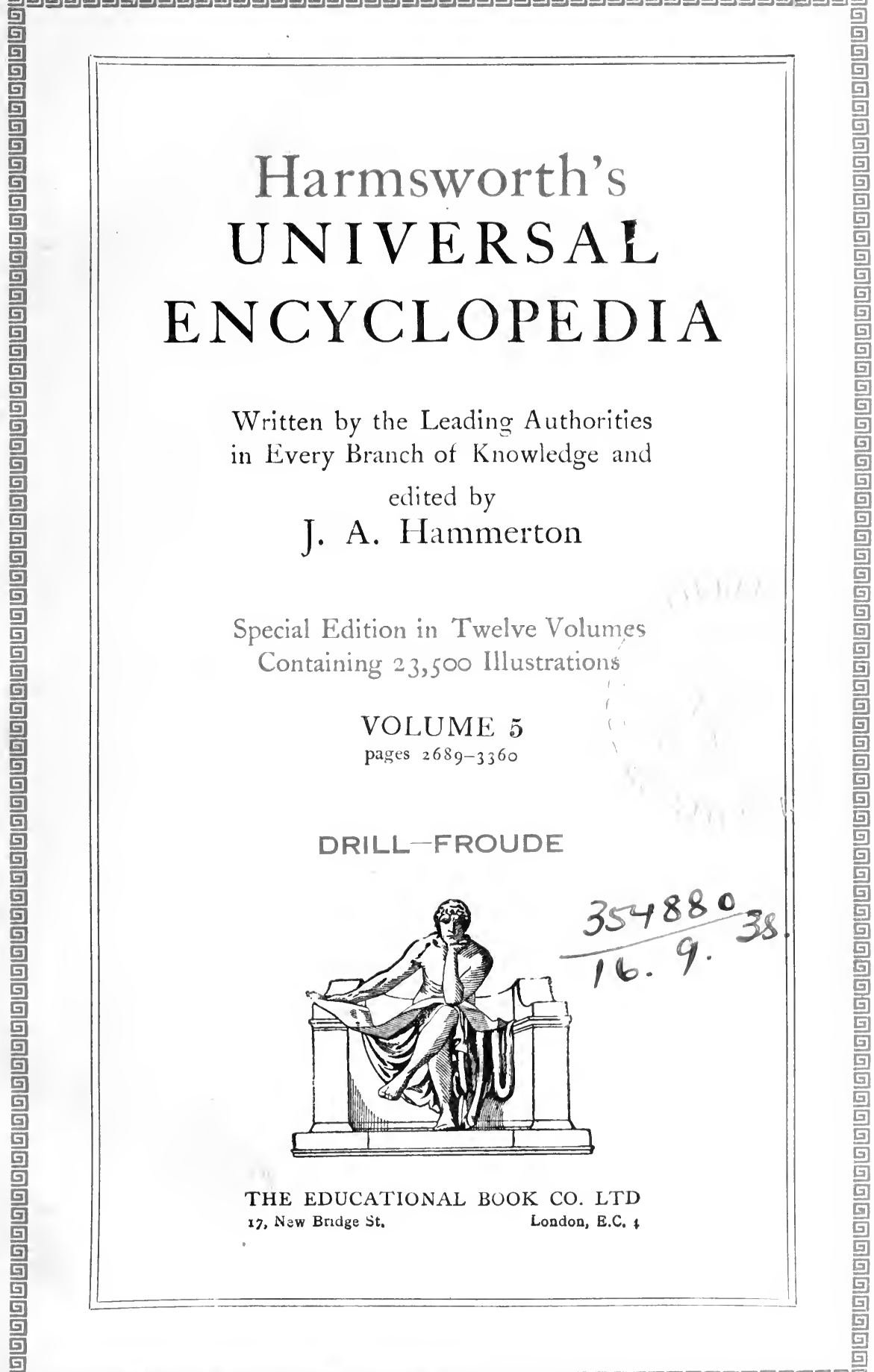


Drill on DrmLINa (Ger. Drillich, Lat. trilix, triple-threaded). Strong linen or cotton fabric used to make suits for wear in the tropics. Khaki cotton drill is worn by troops on service in hot climates. The pattern is a twill, often of a round, screw-like diagonal, and the tightly twisted warp yarn is predominant upon the surface. Cotton drills are employed for pocketing and frequently for corset making, and other purposes for which strong stuff is required.

Drin. River of the Balkans. It is formed by the union, at Kula Liamu, of the White Drin, rising in the Albanian Mts., and the Black Drin, issuing from Lake Ochrida, and flows into the Adriatic below Alessio, after a course of $110 \mathrm{~m}$. Anciently it was known as the Drilo or Drilon. During the Great War the gorges of the two streams and of the main river were traversed by the Serbians in their retreat to the sea in 1915.

Drina. River of S.E. Europe, forming part of the boundary between Serbia and Bosnia. It rises among the mountains of E. Montenegro in several headstreams, the chief of which is the Tara, and flows N., N.W., and then N.E. to effect a junction with the Save, 58 $\mathrm{m}$. W. of Belgrade. The principal of its many affluents is the Lim. Its length is $160 \mathrm{~m}$.

Drina, Batrle of the. Fought in Sept., 1914, between the Austrians and the Serbians. It began Sept. 8 and 9,1914 , with the Austrian crossing of the river in their second invasion of Serbia. The attack developed more strongly in the $\mathrm{S}$. of the region bordering the Drina than in the N., where the Serbians were in force and threw back the invaders.

The critical fighting took place among the mountains $S$. of the Jadar. At the outset the Serbians, under pressure of much superior forces, were pushed from some of their positions on the Guchevo, Boranja, and Jagodnia ranges. By Sept. 11 the Austrians held Shabatz, while the Sokolska Planina as far as Petska was in their hands. On Sept. 14 the Serbians, who had been reinforced from the N., attacked the Guchevo heights and carried Kulishte, but, fearing envelopment, retired from it. Three days later they renewed the engagement, and drove the Austrians from it to the Drina. Southward, on Sept. 16, the Serbians stormed the summits of the Sokolska, and drove the enemy in disorder to the river. Thereafter the struggle centred on the commanding position of Matchko Kamen or the Cat's Leg, which was taken and retaken eight times. Finally both sides, being exhausted, settled down to trench warfare, and, the battle of the Drina died away, the advantage resting with the Serbians. See Serbia, Conquest of.

Drink. Drama adapted by Charles Reade from Zola's L'Assommoir, and produced June 2 , 1879, at The Princess's, where it had a run of 222 performances. Charles Warner (q.v.) achieved his greatest success in the part of the drunken workman, Coupeau.

Drink Traffic. Name given to the trade of making and selling intoxicating liquors. Owing to the evils caused by excessive drinking this trade is subject throughout the civilized world to special control by the state. See Liquor Control; Local Option ; Prohibition ; Tem. perance Movement.

Drinkwater, JoHN (b. 1882). British poet and critic. $\mathrm{He}$ was born June 1, 1882, the son of an

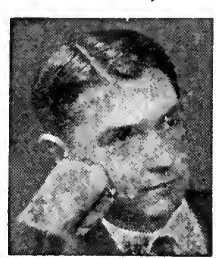

John Drinkwater, British poet Hoppe actor, and educated at $\mathrm{Ox}$ f ord $\mathrm{High}$ School. He was for a time a clerk in an insurance office, and published his first volume of verse. in 1908. One of the founders of the Pilgrim Players, he became manager of the Repertory Theatre, Birmingham. His published work includes an essay on the Lyric, 1916 ; studies of William Morris, 1912, and of Swinburne, 1913; two plays in verse, Cophetua, 1911, and Rebellion, 1914, and several volumes of poetry. His play, Abraham Lincoln, produced at Birmingham in 1918, had a long run at The Lyric, Hammersmith, in 1919. Later plays were Oliver Cromwell and Mary Stuart.

Dripstone. In architecture, the projecting tablet or moulding placed on the crown of an arch, window, or dsorway. See Moulding.
Driscoll, JIM (1880-1925). Professional boxer. Born at Cardiff, Dec. 15,1880 , he has more than 50 victories to his credit. $\mathrm{He}$ secured the feather-weight championship in 1910 , and became the winner outright of the Lonsdale belt for that weight. His two defeats were by Harry Mansfield in 1904 and by Freddy Welsh (q.v.), to whom he lost on a foul in the tenth round, at Cardiff, Dec. 20, 1910. Driscoll announced his retirement from boxing after his drawn battle with Owen Moran, Jan. 27, 1913. He died Jan. 30, 1925.

Driver. Longest club in a golfer's outfit, with a wooden head and almost straight face, used for tee shots. The beginner should learn to drive with a brassie, and when he can use this club successfully, should procure a driver with a similar lie and of equal length to the brassie. Only when the ball "sits up" well is it possible to use the driver through the green. See Golf.

Driver, SAMuel Rolles (18461914). British Biblical scholar. Born at Southampton, Oct. 2, 1846, he was edu. cated at Winchester and N e w College, Oxford, where he took high honours. He was a fellow of N ew College, 1870-73; tutor member of the $S$.R. Sume O.T. Revision

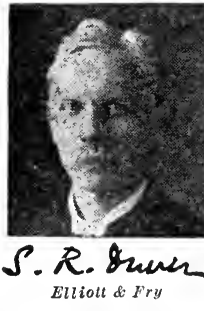

company, 1876-84; and Regius professor of Hebrew and canon of Christ Church, Oxford, from 1883 until his death, Feb. 26, 1914.

One of the greatest Hebraic scholars of his time, Driver collaborated with F. Brown and C. A. Briggs in editing A Hebrew and English Lexicon of the Old Testament, 1906 (based on E.Robinson's translation of the work of F. H. W. Gesenius). His Introduction to the Literature of the Old Testament, 1891, aroused much controversy, but with his other writings is now generally held to reconcile what is known as the higher criticism of the $0 . T$. with a sincere belief in its inspiration and religious authority. His other works include A Treatise on the 
Use of the Tenses in Hebrew, 1874; a revised translation of Jeremiah, 1906; commentaries on various books of the O.T.; The Parallel Psalter, 1898; and Modern Research as Illustrating the Bible, 1909.

Driving. Controlling and guiding a horsc or horses harnessed to any vehicle. The British have always excelled as whips, as is shown by the records of the Brighton road in the times of the Regency and of the coaching period of the 1Sth and early 19th centuries. But in modern times mechanically propelled are rapidly displacing horse-drawn vehicles, and skilful driving has become rather a pastime than a necessity.

In driving a single horse the reins should be taken in the left hand, the left or near side rein being held between the forefinger and thumb, and the off-side or right-hand one between the second and third fingers. The arm should be held at almost a right angle across the body, with the hand about 6 ins. in front of the bottom
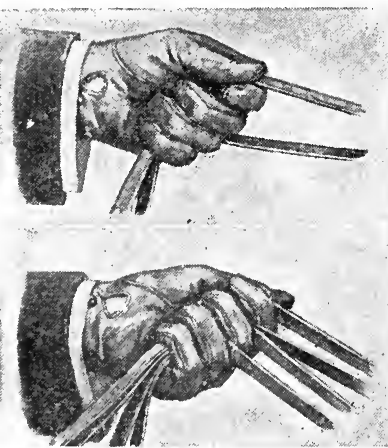

Driving. How reins should be held when driving a four-in-hand ; above, band grip for single reins

buttons of the waistcoat; this will enable the right hand to be easily used when it becomes necessary to employ both hands. In driving a pair the reins are held in the same manner, but since there are two horses to control instead of one the task is more difficult as they may not pull equally. It is impossible to give in words an adequate description of the manipulation of the reins in driving tandem or four-in-hand; instruction and practical illustra. tion should be sought from an expert. Tandem, the driving of two horses, one in front of the other, attached to a dogcart, was once greatly favoured, but is now seldom seen except at horse shows.

The term "hands," of which the novice will hear much discussion, implies the exact weight or pres- sure put upon a horse's mouth in guiding him and the give and take of the driver's hand or hands to the pull of the horse. 'This is more often a gift than an acquirement.

In Great Britain there are hard and fast rules of the road to be $\mathrm{ub}$. served when driving. The ieft hand side of the road is always adhered to and retained when passing another vehicle coming in the opposite direction. When overtaking anything going in the sarne direction, it is necessary to draw to wards the middle of this road and pass on the right side. See Horse; Riding.

Bibliography. Hints on Driving, C. S. Ward, 1870 : Driving, 8th Duke of Beaufort, 4th ed. 1894 (in Bad minton Lib.) ; Driving, F. M. Ware 1904 ; The Law of the Road, J. W. Thatcher and D. H. J. Hartley, 1909.

Driving Band. Metal strips placed round shells. Made of soft metal, usually copper or cupro nickel, they are secured round the bodies of shells to fill up the grooves of the rifling in the barrel, thus giving the shell a rotary motion and preventing the gases from the propellant charge escap ing past the projectile. In the early types of shell, of cylindrical shape, for use in breech-loading rifled guns, it was usual to provide a complete lead jacket to serve this purpose, this being superseded by a wide lead band at the centre of the shell. At the present time copper is the metal most used, and generally one narrow band near the base of the shell is suffi. cient, except for very powerful guns. The bands are fitted in grooves turned in the body of the shell, the base of the groove being either roughened or provided with wavy prominences and the band secured being shrunk on.

In general the driving band is fitted as close to the base of the shell as is consistent with the ability of the steel to resist tre base of the shell being pulled off. See Shell ; Windage.

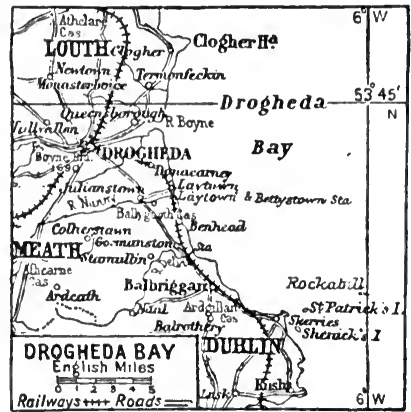

Drogheda Bay, on the $E$. coast of Ireland
Drocourt. Village of France, in the dept. of Pas-de-Calais. It is $6 \mathrm{~m}$. S.E. of Lens, and was the N. end of the German Wotan, or switch, line which $\operatorname{ran} S$. to Quéant, forming part of the Hindenburg Line. The DrocourtQuéant line was stormed by the Canadians on Sept. 2, 1918, in the fifth battle of Arras (q.v.). The village was captured Sept. 27. A memorial is to be erected by the Canadian Government at Dury, midway between Drocourt and Quéant, to commemorate this feat. Dury was captured from the Germans on Sept. 2.

Droeshout, Martin (fl. 162051). English engraver. Probably of Dutch extraction, he came to reside in England some time previous to 1623 , in which year was published his frontispiece portrait of Shakespeare in the first folio edition of the Comedies, Histories, and Tragedies. Among other portraits engraved by him were those of John Foxe, the martyrologist, and John Donne, dean of S. Paul's.

Drogheda. Mun. bor., seaport, and market town of co. Louth, Ireland. It stands on the Boyne, $4 \mathrm{~m}$.

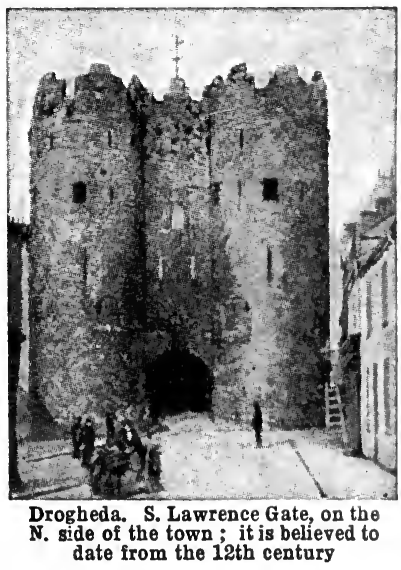

from Drogheda Bay, and $32 \mathrm{~m}$. N. of Dublin by the G.N.I.R. It has a good harbour and a brisk trade in cattle, sheep, and agricultural produce; linens, cottons, beer, soap, etc., are manufactured. Market day, Sat. Pop. 12,501. In 1649 Cromwell entered the town and massacred its defenders, and it was surrendered by James II in 1690 . Pron. Droh-he-da.

Drogheda Bay. Bay on the E. coast of Ireland adjacent to the counties of Louth, Meath, and Dublin. From Clogher Head in the $\mathrm{N}$. to the Skerries in the S. the distance is $25 \mathrm{~m}$. The estuary of the river Boyne forms a deep indentation useful for coastwise shipping. 
Drogheda, EARL of. Irish title borne since 1661 by the family of Moore. The family traces its descent to two brothers, Edward and Thomas, who settled in Ireland in the time of Elizabeth. Edward obtained some former monastic lands in co. Louth, and his descendant, Garrett, was made a baron and a viscount by James I. President of Munster and an Irish M.P., he had previously served Elizabeth against the rebels. His son Henry, 2nd Viscount Moore, married a daughter of Viscount Loftus, whose son Henry inherited from the Moores estates in Kildare.

In 1661 Henry Moore was created earl of Drogheda, perhaps as a reward for his father's loyalty to Charles I, and from him the present earl is descended. Charles, the 6th earl (1730-1821), entered the army and rose to be a ficld-marshal and master-general of the ordnance. In 1791 he was made marquess of Drogheda, and in 1801 a baron of the United Kingdom. When his grandson, the 3rd marquess, died in 1892, the marquessate became extinct, but the earldom passed to a cousin, a descendant of the 5th earl. In 1908 Henry Charles Ponsonby Moore (b. 1884) became the 10th earl. His seat is Moore Abbey, co. Kildare, wherein his estates mainly lie; his eldest son is known as Viscount Moore. Pron. Dro-heda.

Drohobycz. Town in the Galician portion of Poland, $17 \mathrm{~m}$. W. of Stryj. It has a fine Gothic church and is a rly. junction for lines to the neighbouring oil wells at Bory. slaw. Pop. 20,$000 ; 36$ p.e. are Poles, 33 p.c. Germans, and the rest Ruthenes. Nearly half the inhabitants are Jews.

Droitwich. Mun. bor. and mar. ket town of Worcestershire, England. It stands on the Solwarpe, $5 \frac{1}{2} \mathrm{~m}$. N.E. of Worcester and $126 \mathrm{~m}$. N.W. of London, and is served by the G.W. and Mid. Rlys., while a canal connects it with the Severn. It is a market for agricultural produce, but the chief industry is the production of rock salt. It is chiefly known, however, as a water. ing-place. Its brine springs have radio-active properties and are efficacious for rheumatism, neuritis, gout, etc. There are fine baths, hotels, etc., for visitors, and a public park. Droitwich has two old churches, S. Andrew's and S. Peter's. In the older part of the town the ground has subsided a good deal owing to the pumping out of the brine. It became a corporate town in 1554, and is now governed by a mayor and corporation. Market day, Fri. Pop. 4,146.

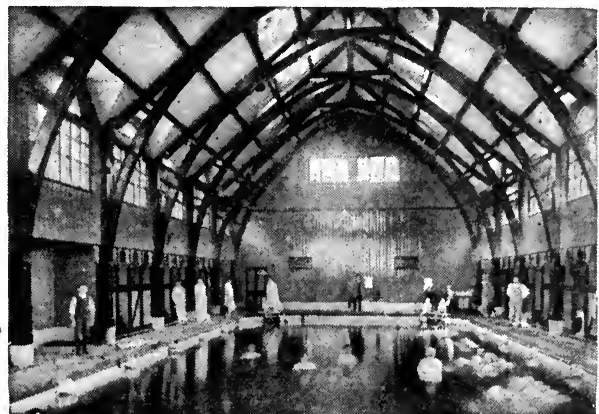

Droitwich, Worcestershire. Interior of large brine swimming bath

Drôme. Department of France. It lies in the S.E. of the country and has an area of $2,532 \mathrm{sq}$. m. It is a mountainous region, especially in the Alpine E. The Rhône forms its western boundary, while the Isère, the Drôme, and other tributaries also drain it. Agriculture is the ehief industry. Wheat is grown in the valleys, especially in the fertile district of Valloire. Vines are widely cultivated, and olives, figs, and mulberries are important crops. Silkworms are largely produced. Many cattle are reared on the extensive uplands. Valence is the capital and other towns are Die, Nyons, Crest, Romans, and Montélimar. It is divided into four arrondissements, and before 1790 was part of the provinces of Dauphiné and Provence. Pop. 290,894.

Dromedary. In zoology, the one-humped camel (Camelus dromedarius) of Arabia and N. Africa. In common speech the term is used for riding camels as distinguished from the heavier baggage animals. The late Latin name dromedarius (classical form dromas) comes from Gi. dromas, running. See Camel.

Dromio. Name of two comic characters, twin brothers, in Shakespeare's The Comedy of Errors (q.v.).

Dromore. Urban dist. and mkt. town of co. Down, Ireland. It stands on the Lagan, $17 \frac{1}{2} \mathrm{~m}$. S.W. of Belfast, by the G.N.I.R. An ancient town, Dromore was formerly the seat of a bishopric, which was united to Down and Connor in 1842. Both town and cathedral were destroyed during the insurrection of 1641 ; the present church contains the tomb of Bishop Jeremy Taylor, its builder. There are castle ruins and a large Danish encamp̀ment. Linen is manufactured in the town. Market day, Monday. Pop. 2,364.

Drone. Name given to the male of the honey bee. It is intermediate insize between the queen bee and the workers, and is stingless. It does not work, and its only function is to fertilise the queen. At the be
Drontheim. Alternative speliling of the name of the Norwegian city of Trondhjem (q.v.).

Drood, EDwIN. Character from whom Charles Dickens's last and unfinished novel, The Mystery of Edwin Drood, 1870, takes its name. $\mathrm{He}$ is betrothed in infancy to Rosa Bud, quarrels with Neville Landless, and after a reconciliation mysteriously disappears.

In 1907 an attempt was made to prove that Dickens founded the story on personal recollections of T. C. Druce, owner of the Baker Street Bazaar. Several attempts have been made to trace the probable course of the novel, notably by J. C. Waters, 1905, and W. Robertson Nicoll, 1912. Of dramatised versions one by $J$. Comyns Carr was produced at Cardiff, Nov. 21, 1907, and at His Majesty's Theatre, London, Jan. 4, 1908.

Dropmore. Hamlet of Buck. inghamshire, England, It is $4 \mathrm{~m}$. N.E. of Maidenhead, and $2 \frac{1}{2} \mathrm{~m}$. from the station at Bourne End on the G.W.P. It is famous for the mansion and grounds here. The gardens, arnong the most extensive and remarkable in England, include an Italian garden and a Pinetum. They were laid out by the prime minister, Lord Grenville, 1801-5. In 1920 the estate belonged to J. B. Fortescue. Pop. 350. The Dropmore Papers, published by the Hist. MSS. Comm. contair political correspondence of the time of Grenville.

Dropped Wrist. Ccadition in which the extensors of the hand, i.e. the muscles which bend the hand backwards, are paralysed, and when the arm is raised the hand hangs loosely and helplessly downwards. It may be due to in jury or disease of the nerves supply ing these muscles, and is not in frequently a symptom of chronic lead poisoning. The course of treatment depends upon the cause the outlook for recovery or in provement being better when it is due to injury than when resulting from disease. 
Dropsy (Gr. hydrops, from hydor, water). Accumulation of Hluid-the watery part of the blood -in the tissues and cavities of the body. Dropsy arises in conditions which impede the normal cireulation of the blood and increase the pressure in the vessels, causing fluid to transude through their walls. The commonest conditions giving rise to general dropsy are disease of the heart, kidneys, and liver. Localised dropsy, or oedema, may result from local weakness of the vessels, as in varicose veins, and from inflammation.

Dropsy is generally first notiee able in puffiness of the evelids, and in swelling of the ankles. If the swollen tissues be pressed with the tip of the finger, a small depression is produeed which persists for a brief interval. In more advaneed eases fluid collects in the abdominal cavity, producing the condition known as ascites (q.v.), which sometimes leads to great distension of the abdomen. Aecumulation of fluid in the lungs eauses a " waterlngging" of the organs whieh may bring about difficulty in breathing, and eough.

Treatment must be direeted towards the cause of the condition, but frequently great relief is afforded by measures which drain the body of fluids, such as the administration of diuretics to stimulate the flow of urine, and purgatives, which cause eopious watery evacuations. In severe cases of accumulation of fluid in the abdomen or pleural cavities, tapping may be adopted.

Dropwort (Spiraca filipendula). Perennial herb of the natural order Rosaceac. A native of Europe, $\mathrm{N}$. Africa, and $\mathrm{N}$. Asia, it is a plant of downs and dry pastures. It has an erect, grooved stem, $2 \mathrm{ft}$. or $3 \mathrm{ft}$. high. The leaves are ehiefly from the rootstock, broken into many pairs of deeply-toothed leaflets. The small, but numerous, white flowers are rosy on the outside, and borne in panicles.

Droseraceae (Gr. droseros, dewy). Natural order of perennial herbs, of wide distribution in marshy places. It consists of six genera and over 100 species. The flowers consist of four to eight sepals, a similar number of petals, 4-20 stamens and 1-5 styles. They are all insectivorous, eatehing their prey by various means and digest. ing the bodies, upon which they mainly subsist. All have poor roots-in one species none at all. See Sundew ; also illus. p. 1219.

Droshky. Russian w ord mean. ing a little wagon. A droshky is a light earriage on four wheels and without a eovering. The first droshkies were formed of a board placed aeross two pairs of wheels, enabling the passengers to sit side. ways, as in an Irish jaunting car.

Drossing Oven. Furnace used in the manufacture of red lead. In that proeess pig lead is melted in a low: arched furnace,

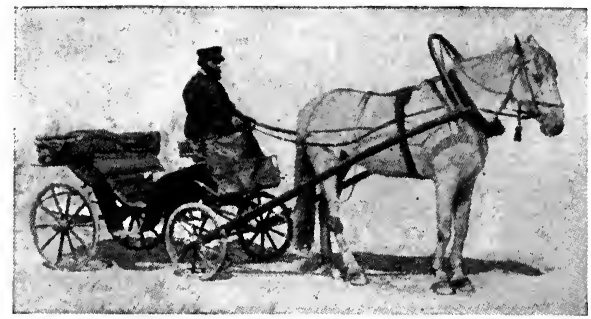

Droshky. Light vehicle which plies for hire on the streets in Russia

that has a bed formed of firebrieks supported on a cast-iron base and provided with openings for int:odueing the fuel and the metal. The molten metal is rabbled about in this furnace and thus exposed to air until it is converted into oxide or litharge. The temperature is not allowed to rise suffieiently high to melt the litharge. What in effeet is done is, to use the works' term, to convert the lead into a dross. See Lead.

Droste-Hülshoff, AnNetTe ElisabeTh, Baroness von (17971849). German poet. Born at Hülshoff, near Münster, Jan. 10, 1797, she eame under the influence of her cousin, afterwards arehbishop of Cologne. Her principal works are Poems, 1838: and the

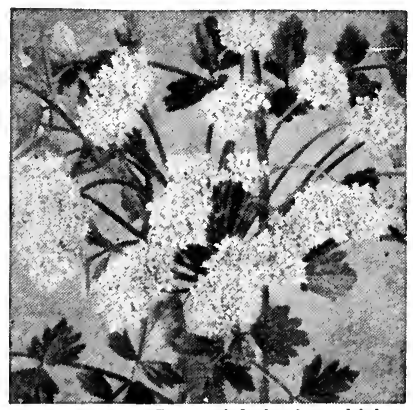
Dropwort. Perennial herb, which
grows on downs and dry pasture land

Spiritual Year, 185l. She died at Meersburg, on Lake Constance, May 24, 1848.

Drouais, FrançoIs HuberT (1727-75). Freneh portrait painter. Born at Paris, Dee. 14, 1727, he studied under his father, Hubert Drouais, a miniature painter, Van Loo, Boucher, and Natoire. He became an academician in 1758 ; and a little later painter to the court. Notable portraits by him are those of the Pompadour (at Orleans) and the Comte d'Artois (in the Louvre). He died in Paris, Oct. 21,1775 .

His son, Jean Germain (1 1763 88 ), also a painter, born at Paris, Nov. 25, 1763, studied with his father and with J. L. David (q.v.). In 1784 he won the prix de Pome with his Woman of Canaan at the Fcet of Jesus Christ, and in 1785 accompanied David to Italy. He died at Rome, Feb. 13, 1788.

Drouet, Jean Baptiste, Comte D'ERLoN (1765-1844). Freneh soldier. Born at Reims, July 29, 1765 , he en. tered the army as a private in 1782 , and had risen to the rank of briga die r - general by 1799 . $\mathrm{He}$ played a prominent part at Jena and in

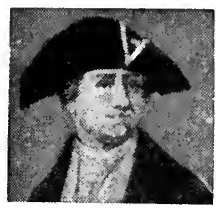
J. B. Drouet, French soldier

the elosing stages of the Peninsular War. Imprisoned in the citadel of Lille for alleged complieity in an anti-Bourbon conspiraey, when Napoleon returned from Elba in 1815 he escaped and seized and held the citadel for his old master. After the Waterloo campaign, in whieh he took part, Drouet went into exile, but returned to Paris in 1825. In 1834-35 he was governor of Algeria, and in 1843 was made a marshal. ' $\mathrm{He}$ died at Paris, Jan. 25, 1844.

Drought. Spell of dry weather sufficiently long to cause serious deficiency in the supply of water. Countries which normally receive the greater part of their rainfall at one season often suffer from droughts during the dry season. Thus the countries bordering the Mediterranean Sea, and those in similar latitudes on the W. of continents, whether $\mathrm{N}$. or $\mathrm{S}$. of the equator, e.g. California in N. Ameriea and Central Chile in S. Amcrica, have most rain in winter, while the summers are droughty. Conversely, countries having a monsoon type of climate, e.g. India, have wet summers and droughty winters.

Vast areas where prolonged droughts are experieneed at all seasons, i.e. arid desert lands, are chiefly found on the W. of continents in the latitudes of the Trade Winds. The type of pressure distribution largely determines rainfall 
or drought. Low pressure cyclones generally mean rain, but the high pressure of anti-cyclones usually gives dry weather, so that pro. longed periods of anti-cyclonic weather cause drought. See Climate; Flood; Weather.

Drouyn de Ihuys, Edodard (1905-81). French . statesman. Born in Paris, Nov. 19, 1805, he

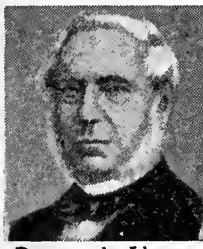

Drouyn de Lhuys, French statesman entered the diplomatic service and was employed in the embassies at Madrid and The Hague. In 1840 he became chief of the commerc i al department in the ministry of toreign affairs, but, going into opposition, he lost his place. By Louis Napoleon he was appointed minister of foreign affairs in 1848 , and from 1849-51 he was ambassador in London, returning to Paris in 1851 to be foreign minister. $\mathrm{He}$ resigned office in 1855 , but held the portfolio again from 1863 66. On the downfall of Napoleon III in 1871 he took refuge in Jersey. He died in Paris, March 1, 1881.

Drover. Variant form of driver, restricted to drivers of sheep or cattle. Before the invention of railways a large class of men engaged in this occupation, making long journeys on foot with the cattle in their charge. See Cattle.

Drowning. Death from as. phyxia owing to submersion of the mouth and nostrils beneath water or other fluid. Sometimes, however, shock or syncope, caused by the sudden immersion in cold water and the state of terror experienced by the individual, com. bines with asphyxia in causing death. The number and causes of death from drowning in England and Wales in 1918 are shown as follows :

\begin{tabular}{r|c|c|c}
\hline & $\begin{array}{c}\text { Accident } \\
\text { and } \\
\text { Negligence }\end{array}$ & Suicide & Murder \\
\hline Males . . & 1,704 & 339 & 7 \\
Females. & 402 & 349 & 13 \\
\hline Total .. & 2,106 & 688 & 20
\end{tabular}

Post-Mortem Appearances. The face is usually ashy pale, but in some cases is slightly livid, with rosy patches about the cheeks. A characteristic sign is the presence of fine froth, sometimes tinged with blood, about the mouth and nostrils. Rigor mortis comes on early. The condition known as cadaveric spasm, a form of rigidity occurring at the moment of death, is sometimes observed, and articles grasped during the death-struggle, such as reeds or plants, may be found firmly clenched in the hands. This is a valuable indication in distin. guishing cases of drowning from cases in which the body was thrown into water after death. Internally the air-passages are found to contain a clear or blood-stained froth, and perhaps mud or portions of water-plants. The lungs are voluminous and distended, and when cut into exude a frothy, bloodstained fluid. Minute haemorrhages mav be observed beneath the pleura, and the right side of the heart mav be engorged with venous blood, the left being comparatively empty. The presence of water in the stomach, particularly if it contains pond-weed, etc., is virtually a conclusive sign of death from drowning, since experiments have shown that water very rarely enters the stomach of a body im. mersed after death.

Directions for Rescuers. Great care and presence of mind are required when endeavouring to rescue a person who cannot swim, since the rescuer may be clutched and his movements impeded, while he runs the risk of being drowned himself. When the drowning person is struggling, the rescuer should leave him for a few seconds until he becomes quiet; then seize him by the hair, turn him on his back, and swim on the back towards the shore, or support him face up. wards in this way until a boat arrives. Should the rescuer be clutched the best plan is for him to take a full breath and allow himself to be drawn under, when the drowning person will almost always release his grip. If he does not let go, the rescuer must try to break away by forcing his knees against the chest of the drowning person.

Treatment afterRescue. When a person is recovered from water in an apparently lifeless condition, artificial respiration should be resorted to as soon as the sufferer is in the boat or has been brought to the shore. The most convenient method of performing artificial respiration is that recommended by Schäfer (see Figs. 3, 4, p. 656). The finger is introduced into the mouth in order to clear out any mud or froth, and the patient is then placed face downwards, the head being turned toward the side. The attendant kneels either by the side of or astride the patient, and, spreading his hands over the lower part of the back and sides of the chest, gradu. ally throws his weight forward so as to exert a firm, steady pressure upon the thorax. He then swings backwards, so as to relax the pres. sure and allow the lungs to expand This backward and forward move ment should take about fivo seconds, and should be repeated at the rate of about twelve times a minute.

While artificial respiration is being performed further restora. tive measures should be applied. The wet clothing should be drawn off, the body wiped dry and covered with hot blankets, and hot bottles may be placed to the feet care being taken that these are not so hot as to burn the skin. Friction of the limbs from below up wards is useful. Ammonia may be cautiously held to the nostrils, and a hypodermic injection of strych. nine may be given. When breathing is established a hot bath is a useful means of restoring the bodily heat. See First Aid; consult also Forensic Medicine and Toxicology, J. D. Mann, 5th ed. revised, 1914. W. A. Brend, M.D

Droylsden. Urb. dist. and small town of Lancashire, England. It stands on the Rochdale Canal, $5 \mathrm{~m}$. E. of Manchester by the L. \& N. IV.R. There are cotton and print factories, and dye and chemical works. Pop. 13,259.

Droysen, Johann Gustav (1808 84). German historian. Born at 'Treptow, Pomerania, July 6, 1808 ,

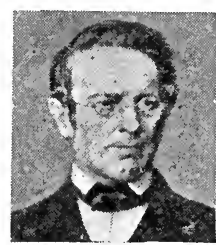

J. G. Droysen, German historian and educated at Stettin and Berlin, from 1840-51 Droy sen was professor of his. tory at Kiel, from 185̃ -59 at Jena, and from 1859-84 at Berlin. Droysen's róle as an historian was to glorify Prussia and her rulers, which he did especially in his monumental History of Prussian Policy, 14 vols., 1855-86. The central idea of this work is that Germany's destiny was to place herself under the rule of the Hohenzollerns. It takes the story down to 1756 , and bears marks of infinite labour.

Droysen wrote, as an historian, in favour of Prussia's elaim to the duchies of Slesvig and Holstein and as a politician he took part in the Frankfort parliament of 1848 . He wrote in early life a valuable History of Alexander the Great, 1833; a History of Hellenism 1836-43; and a life of the Prussian soldier Yorck von Wartenburg. 1851-52. He died in Berlin, June 19,1884 . His son Gustav was the editor of the well-known Historical Atlas, 1885, and wrote several his. torical works. 
Dru, Aiguille DU. Rocky needle or peak in the Mont Blane chain, near the Aiguille Verte. The Grand Dru or Pointe Este (alt. $12,320 \mathrm{ft}$.) was first ascended by Dent and Hartley in 1878; the Petit Dru or Pointe Charlet (alt. 12,244 ft.) by Charlet-Straton in 1879. See Alps.

Drug. Medicinal substance obtained from the vegetable and mineral kingdoms. The term also includes the substances as prepared for use in the treatment of disease, but these are better dis. tinguished as pharmaceutical preparations. Sometimes the word is employed to indicate narcotic sub. stances, such as opium and cocaine.

London is the world's chief port for drugs, hundreds of which arrive in the crude state from all parts of the world. They are stored in special warehouses at the docks, and the importers hold drug auction sales about twice a month at the Commercial Sales Rooms, Mincing Lane, the purchasers generally being wholesale drug. gists or exporters. Cinchona bark is brought to Amsterdam, because the Dutch colonies are now its chief producers. Liverpool is the port for American drugs. In the case of wholesale druggists the drug, as imported, generally has to be sorted over- " garbled," as it is known in the trade-to separate the various grades. For cxample, pieces of rhubarb root of fine appearance are reserved for selling retail to the public, but broken pieces are equally well suited for reducing to powder, or for pharmaceutical preparations. Some drugs, such as aconite, belladonna, digitalis, henbane, lavender, peppermint, etc., are grown in Great Britain. Others require warm or moist climates for their successful cultivation.

Drug Habits. Continuous taking of certain drugs produces in some persons an irresistible craving for them, despite their injurious effect upon both mind and bodv. The commonest instances are ad. diction to alcohol and smoking. The less frequent drug-hahitssuch as the taking of opium or cocaine-may originate in taking the drug in the first instance under medical orders, its use being continued because of pleasurable sen. sations produced.

Many victims display a progres. sive deterioration of their moral faculties, and when fully in the grip of the habit will lie frecly and resort. to any tricks to satisfy their crav. ing. Another characteristic feature is the marked degree of tolerance acquired after taking a drug for a considerable time, the victim of a

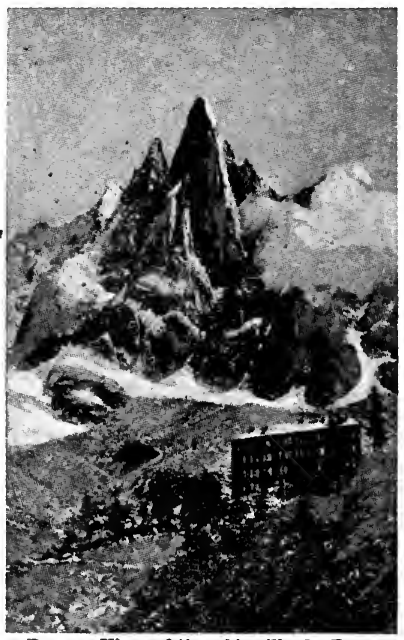

Dru. View of the Aiguille du Dru, near Chamonis

drug habit sometimes taking daily an amount of poison which would be fatal in an ordinary person.

In most cases the habit of taking opium is initiated by taking the drug to relieve pain, and is more frequent in women than in men. Morphia may be injected hypoder. mically, laudanum drunk, or solid opium eaten; opium smoking is more common in the East than in Europe. Those who are addicted to this habit become pale or sallow, and suffer from nausea, vomiting, loss of appetite, sleeplessness, and emaciation. P'eriods of severe mental depression follow the tem. porary exaltation at first produced by a dose. The temper becomes irritable, and the moral faculties degenerate, the sufferer becoming untruthful and utterly unreliable.

Delusions and hallucinations may occur. Remarkable tolerance for opium may be established. De Quincey (q.v.) states that at one period he was taking 320 grains of opium a day, the full Pharmaco. poeial dose being two grains. When the habit is definitely estab. lished, it needs strong will-power to overcome it. The patient should enter a home or institution where he will be unable to obtain the drug. When the habit has not been of long duration, it may be possible to stop the drug at once, or reduce it very rapidly, but in long-standing cases the symptoms induced by abrupt withdrawal may be severe, and it is generally advis. able to reduce the drug gradually.

The habitual taking of chloral hydrate is nearly always started by its use to prevent sleeplessness. The symptoms of chronic poisoning which gradually develop are dys. pepsia, eruptions on the skin, weakness of the heart and respiration, and impairment of mental power. The acquirement of tolerance is not so marked as with opium, and a slightly greater dose than usual may be fatal.

Cocaine is sometimes taken as a constituent of a snuff by persons suffering from nasal catarrh, and in this way the habit is initiated. Both the mental and bodily faculties become affected in course of time.

The taking of Cannabis Indica frequently becomes a habit in Egypt, India, and other Eastern countries, where it is taken in the form of hashish, bhang, or ganga. It produces symptoms resembling those of mild intoxication, followed by sleep which is often accompanied by pleasant dreams.

To check the serious growth of the drug habit an act of parliament was passed in 1923 which particu larly aimed at the suppression of illicit traffic in cocaine and other dangerous drugs.

Drug. District, subdivision, and town of Central Provinces, India, in the Chhatisgarh division. Area, 3,807 sq. m. ; pop. 775,688 , fivesixths Hindus. Of the total area about one-quarter is under cultivation, rice and wheat being among the chief crops. The town has small metal and weaving industries. Pop. 7,048, four-fifths Hindus.

Drugget (Fr. droguet, dim. of drogue, poor material). Coarse woollen stuff, woven or felted, sometimes printed with a pattern. It is chiefly used as a protection or substitute for carpets. The name is also applied to a stout fabric of linen warp and worsted weft for rough aprons, etc. In early times drugget was much used for clothing, being sometimes partly of silk.

Druggist. One of the titles reserved by the Pharmacy Act, 1868 , for persons who keep open shop for the sale of poisons and are registered under the Act. The list of poisons which can only be sold retail by registered persons is given in the schedule of the Poisons and Pharmacy Act, 1908, this list replacing the schedule given in the Act of 1868. The sale of poisons wholesale, i.e. to retailers only, requires the article to be labelled "poison." The title wholesale druggist is not a protected one. In Ireland the title druggist as regards retail vendors of poisons is regulated by the Pharmacy Act (Ireland), 1875, Amendment Act, 1890. Druggists deal generally in imedicinal substances and chemicals required in the arts; in Great Britain they dispense prescriptions, but are not qualified to do so in Ireland. 
Druid. Priest among the Celtic peoples, especially those of Britain and Gaul. The Druids were among the bitterest opponents of the Roman invaders, and in Britain were virtually exterminated during the Roman domination. The earliest detailed account of them is given by Caesar in his Gallie War, and his account is probably equally applicable to the Druids of Britain, which was the headquarters of Druidism. They are described as priests and law-givers, among whom all nobles and men of dignity were found.

The chief of them was elected, and no hereditary positions were recognized. They were learned in the natural sciences and astrology, while some of the classic writers describe them as sorcerers and masters of medical knowledge (Pliny): and as soothsayers and bards (Strabo). Their worship was carried on in groves, the oak being their sacred tree, and the oakgrown mistletoe played a particular part in their rites. It was cut with a golden weapon by a Druid elothed in white, was received from the tree on a spotless cloth by another Druid, and borne away by white oxen. Druidic worship entailed human sacrifices at special festivals; the victims being impaled, shot with arrows, or burned in wicker cages; the Druids exercising their peculiar art of divination from the movements of their dying victims, as well as from the flight of birds, etc.

The last stand of the Druids in Britain was made at Mona, or Anglesey, when the Romans are said to have exterminated them and destroyed their sacred groves (Tacitus). After being exterminated in Britain, Druids are mainly heard of in Ireland, where tradition associates them with witcheraft and sorcery.

Biblingraphy. Irish Druids and Old Irish Religions, J. Bonwick, 1894 : Origin and Growth of Religion as mlustrated by Celtic Heathendom, J. Rhys, 3rd ed. 1898; Social History of Ancient Ireland, P. W. Joyce, 1903; Les Druids et les Dieux Celtiques, M.H. d'Arbois de Jubain. ville, 1906 .

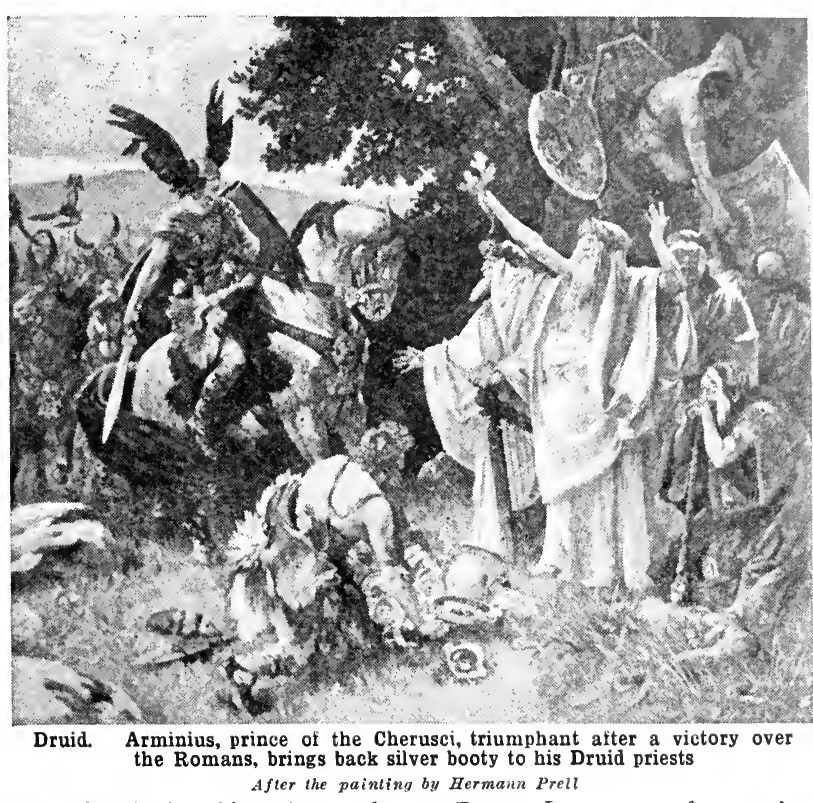

Druid Circle. Name in popular usage for a prehistoric stone eircle. One, vested in the National Trust, is near Keswick, Cumberland. Regarded by 18th eentury antiquarians as sites for Druidic worship, the exposed sepulchral dolmens often found with them were ealled Druid altars. Now recognized to be pre-Druidic, their subsequent adaptation for religious rites by the British priesthood of Caesar's day lacks definite proof. See Stonehenge ; Stone Circles.

Druids, ANCIENT ORDER OF. Friendly society established on masonic principles and with masonic rites, and so called from an imagined imitation of the ancient Druids. The order was founded in London in 1781, and spread throughout England in independent but allied lodges. These lodges were later organized into groves and presided over by a Great Arch Druid. The order was introduced into the U.S.A. in 1883, where it spread rapidly.
Drum. Instrument of percussion, consisting of a hollow body over which a membrane is stretched. In primitive form the body was a gourd, shell, or earthenware vessel, struck often by the finger tips.

To-day the drums in use are of two main kinds: (1) Drums of cauldron shape, made of metal, with single head of vellum, used in the orchestra, and known as kettledrums (or 'Timpani). These are struck vertically by pairs of padded sticks, and produce notes of definite musical pitch. They were formerly used in pairs tuned to the tonic and dominant of the key of the music, but often three or more kettledrums are used in modern music, and they are given melodic as well as rhythmic passages. A pair of small kettledrums is used in cavalry bands.

(2) Drums of cylindrical shape, made usually of wood with two vellum heads. The pitch of these drums is indefinite. The smallest size, the shallow side drum with

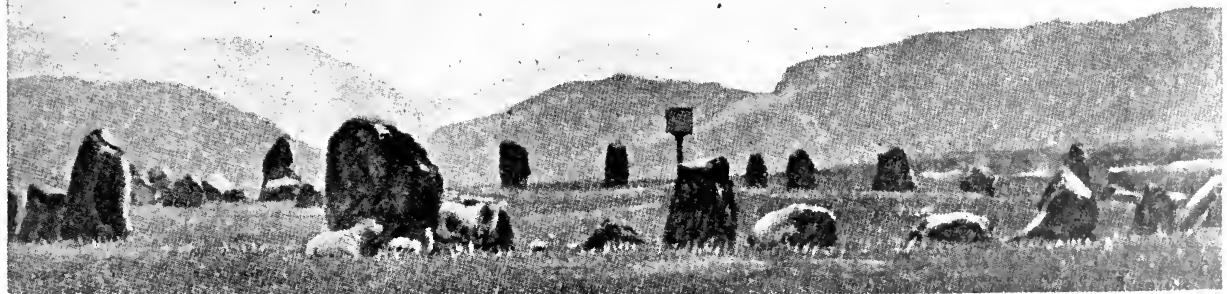

Druid Circle. The circle near Keswick, Cumberland, about $100 \mathrm{ft}$. in diameter. It was vested in the National Trust in 1913 


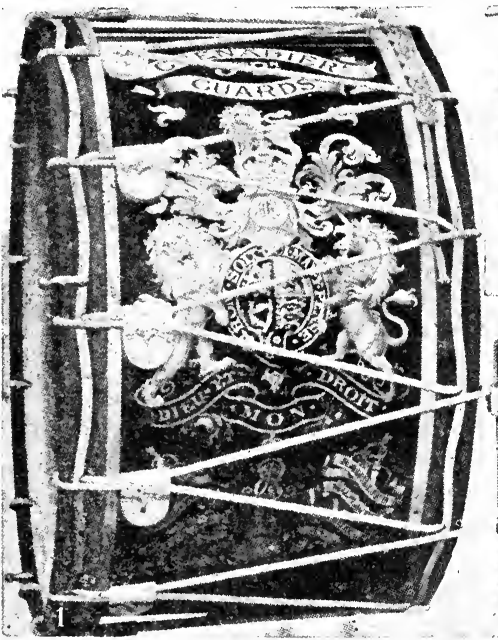

Drum. Fixamples of military and orchestral instruments. 1. Guards' bass drum. 2. Orchestral side-drum 3. Military side-drum 4. Guards' pattern side-drum 5. Cavalry kettledrums. 6 . Sticks for side-drum. $\%$. Sticks for bass drum By courtesy of Hawkes \& Son

metal sides, is played with hard wooden sticks, as is also the deeper military side-drum of wood. 'The largest is the bass drum, struck horizontally by heavy padded sticks. Of intermediate size is the tenor drum, used in bands of pipers. See Bagpipe; Cymbal.

Drum. In engineering, a cy. linder, usually of cast iron or cast steel, mounted on a shaft and geared up to an engine, motor, or haind lever. A hoisting or hauling rope or chain is secured to the drum or mav be given several turns round it. When the machinery is set in motion the drum, revolving, winds the rope arourd itself, paying out an equal length when the rope mercly passes round it with. out being secured to it.

Drumclog. Hamlet of Lanark. shire, Scotland. It is $6 \mathrm{~m}$. S.W. of Strathaven, near the border of Ayrshire, and was the scene of a victory of the Covenanters over the king's troops under Claverhouse (Viscount Dundee), on Sunday, June 1, 1679. A granite obelisk marks the site of the battle. Drumclog figures in Scott's Old Mortality. See Covenanters.

Drum-Fire. Expression for a rapid bombardment said by the German Staff account of the battles of Champagne to have been first used on the Champagne front in Feb., 1915. It is, however, much older, and occurs in Tolstoi's description of the Allies' bombardment of Sevastopol in Aug., 1855.

Drum Language. Method of communication by drum-signals, employed by primitive peoples. It has a possible range of $10 \mathrm{~m}$. Across
Central Africa, from the Nile to Cameroons, it is in daily use for the exchange of news.

Drumlanrig Castle. Seat of the duke of Buccleuch in Dum. friesshire, Scotland. It stands on the Nith, 17 m. N.W. of Dumfries. It was built (1679-89) by the lst duke of Queensberry, and suffered damage at the hands of Prince Charles Edward in $\mathbf{1 7 4 5}$. In the grounds are the remains of Tibber's Castle destroyed by Robert Bruce in 1311 .

Drumlin. Arched, oval-shaped hills composed of till or boulderclay usually containing rock frag. ments. They often attain a length exceeding a mile and a height of

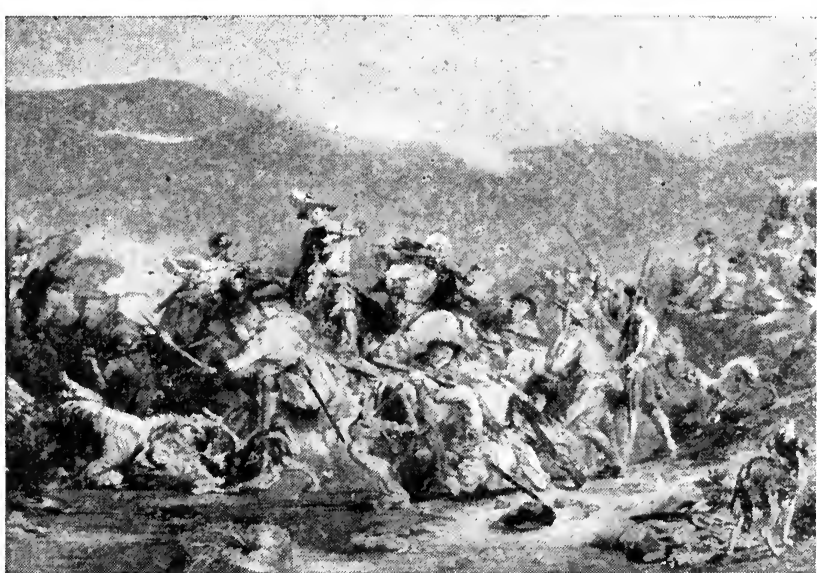

Drumclog. The battle on Drumclog Moor, Lanarkshire, in which the Covenanters defeated Graham of Claverhouse, June 1, 1679 Painting by Sir George Harvey, R.S.A. 
Drum Major. Originally the principal drummer in a corps of infantry who " beat the best drum, had command over the other drums and taught them their duty." $\mathrm{He}$ is called the serjeant drummer. The ranks of drum major, trumpet major, and pipe major were abolished in 1881. See illus., p. 968.

Drummond, Henry (17861860). British banker and politician, one of the founders of the Irvingite or Catholic Apostolic Church. He was educated at Harrow and Christ Church, Oxford, became a partner in his father's bank, in 1810 was elected M.P. for Plympton Earls, and from 1847 till his death sat for W. Surrev. $\mathrm{He}$ founded the chair of political economy at Oxford, 1825. He died at Albury, Surrey, Feb. 20, 1860.

Drummond, HeNrY (18511897). Scottish theological writer and scientist. Born at Glenelen,

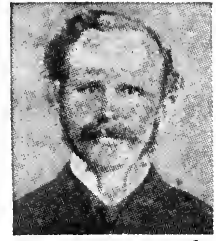

Henry Drummond Lafayette Scottish theologian Stirling, Aug. 17,1851 , of an e vangelical family, he was educated at Crieff; at Edin. burgh, where he studied geology under Geikie, and at Tübingen. $\mathrm{He}$ was trained for the ministry at

New College, Edinburgh, but did not adopt the title of minister. From 1873-75 he worked with D. L. Moody and I. D. Sankey, was appointed in 1877 lecturer on, and in 1884 professor of, natural science at the Free Church College, Glasgow. He held this appointment until his death, at Tunbridge Wells, March 11, 1897.

In the intervals of extensive travel he devoted himself to mission work, particularly among young men, and to the organization of the Boys' Brigade. His attempts to reconcile science and theology, as expressed in his Natural Law in the Spiritual World, 1883, and The Lowell Lectures on the Ascent of Man, 1894, are now regarded as heterodox, but with his Tropical Africa, 18.58, and other works, these books enjoyed a large circu. lation in Europe and the U.S.A. See Life, George A. Smith, 1899.

Drummond, James (18351918). British theologian. He was born at Dublin and was educated at Trinity College. In 1860 he became colleague to the Rev. W. Gaskell, husband of the authoress of Cranford, at Cross Street Chapel, Manchester, and in 1869 he was ap. pointed professor of Biblical and Historical Theology at Manchester New College, London. He became principal in 1885 in succession to Dr. James Martineau, and held this position until 1906. In 1889 the college was removed to Oxford. He was the author of many theological and expository works. $\mathrm{He}$ also wrote the Life and Letters of James Martineau, 1902, to which his colleague, C. B. Upton, contributed the section on Martineau's Philosophy. Drummond died at Oxford, June 13, 1918.

Drummond, SIR JAMES FrIC (b. 1876). British diplomatist. He was born Aug. 17, 1876, a younger

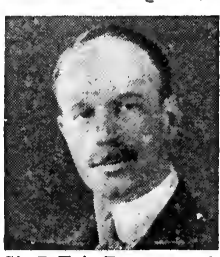

Sir J. Eric Drummond, British diplomatist son of the 14th earl of P.erth, educated atEton, and entered the Foreign Office in 1900 , in 1906 being appointed private secretar $y$ to the under - secre. tary. In 1912 he became private secretary to H. H. Asquith, then prime minister; but in 1915 he returned to the Foreign Office. Knighted in 1916, he became in 1919 the first secretary-general to the League of Nations.

Drummond, Thomas (17971840). British engineer and administrator. Born in Edinburgh, Oct. 10, 1797, he was educated at the Edinburgh High School and at the Royal Military Academy, Woolwich, and in 1815 entered the Royal Engineers. Having obtained a post on the trigonometrical survey of Great Britain in 1820, he invented the "Drummond Light," a limelight contrivance for long-distance surveying, and also an improved form of heliostat. From 1835-40 he was under-secretary for Ireland. $\mathrm{He}$ died at Dublin, April 15, 1840. See Life and Letters, R. B. O'Brien, 1889.

Drummond, Williali (15851649). Scottish poet. He was born at Hawthornden, near Edinburgh, Dec. 13, 1585, the son of Sir John Drummond, and descenclant of the mother of James I of Scotland. Educated in Edinburgh and France, he studied for the law, but on his father's death in 1610 settled down at Hawthornden to the companionship of his books, the pursuit of his hobby of mechanical invention, and his writings. His best work is in his sonnets, in which he followed closely Italian models. He invented the metre adopted by Milton for his Hymn to the Nativity. He was one of the first Scottish poets to write in pure English. The bcst example of his prose is A Cypress Grove, 1623, a meditation on death.
Scholar and Platonist, he was a sincere royalist. The outstanding incident of his life is the visit Ben Jonson paid to him in the winter of 1618-19, his Notes on which, pub-

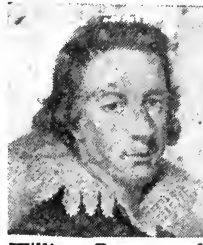

William Drummond of Hawthornden

After Jansen lished in 1842 have been the cause of much controversy. He died Dec. 4 , 1649. In 1893 a memorial to him was erected at Lasswade, where he was buried. See Life, David Masson, 1873 ;

Poetical Works and A Cypress Grove,ed.L.E.Kastner, 2vols.,1913.

Drummond Castle. Scottish seat of the earl of Ancaster. The ancient home of the family of Drummond, it is in Strathearn, Perth. shire, $2 \mathrm{~m}$. S. of Crieff. Parts of it date from the 15th century.

Drummond's Bank. London bank. It was established in 1717 by a Scotsman, Andrew Drum. mond, who had settled in London as a goldsmith. It remained in the hands of the family until 1924, and from 1804 was known as Drummond \& Co. It was absorbed in the Royal Bank of Scotland in Jan., 1924.

Drummoyne. Picturesque and rising suburb of Sydney, New South Wales. It is on the Parramatta river, $3 \frac{1}{2} \mathrm{~m}$. from Sydney (q.v.). Pop. 8,678.

Drunkard's Cloak, THE. Instrument used in some parts of England during the 16th century for the punishment of drunkards. It consisted of a tub with holes in the sides for the arms to pass through, and was fitted on to the offender, who then had to walk through the streets as an object of public scorn.

Drunkenness. State of intoxication which in certain cases is an offence against the law. In English law, it is no excuse for crime. At the same time, when it is a question of quo animo, or with what intention a man did an act, he may escape because he may have been so drunk as to be incapable of forming any intention at all. 'Thus, a case of homicide may be manslaughter if committed by a man so drunk as not to know what he is doing, though the blow may be struck or the shot fired with apparent deliberation. If a man takes drink to nerve himself to commit a crime, he cannot escape the consequences by showing that he was so drunk as to have lost all inten. tion. It is an offence to be drunk in a public place or a licensed house, or to be drunk and disorderly. An habitual drunkard 
may be ordered to be confined in an inebriates' home by sentence of the magistrate. A person may voluntarily offer to go into such a home: and may then be com. pulsorily detained there. A contract made by a drunken man is voidable by him when he becomes sober: but only if the other party knew he was drunk when he made it. See Liquor Control: Prohibition ; Temperance Movement.

Drury, AlFred. British artist and seulptor. Born in London, he studied at the Oxford School of Art,

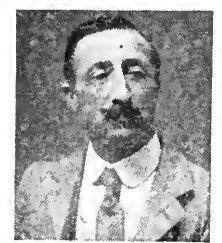

Alfred Drury, British artist at S. Kensington, and under Dalou. He was first attracted to sculpture by the clay models of Chantrey's works in the Oxford University galleries. His first contribution to the Academy was the Triumph of Silenus, 1885; and in 1896 his bronze S. Agnes was bought for the Chantrey collection. He was elected A.R.A. in 1900, and R.A. in 1913. His other works include The Age of Innocence, 1897 ; The Prophetess of Fate, 1900 ; King Edward VII, 1903; and statues and decorative work at Leeds. His technique is best shown in ideal portraits of children.

Drury Lane. Thoroughfare and district in London, W.C., largely rebuilt in recent years. Extending from the moderi erescent of Ald. wyeh (q.v.) to Broad Street, S. Giles's, and High Holborn, the lane was originally known as the Via de Aldwyeh, after a Danish settlement in S. Clement's, which it linked with the hospital of S. Giles's monastery. Its present name derives from Drury Place, a mansion built in the loth century by a member of the IJury family In this mansion Essex and his fol. lowers planned the abortive rising of 1600 . Rebuilt by William, ear of Craven, supposed husband of Elizabeth, the widowed queen of Bohemia and daughter of James I, the mansion was renamed Craven House, and on its site in 1805 Philip Astley built the Olympia Pavilion. later the Olympic 'Theatre.

On the W. side of Drury Lane in Russell Street, is Drury Lane Theatre, with entrances in Russell Street and Catherine Street, and near by is the disused burial ground of S. Martin's, associated with Tom-All-Alone's of Dickens's novel Bleak House. Near Holborn, on the E., is the Winter Garden Theatre, formerly The Mogul, and sterwards the Middlesex music hall. A serv. ing man of the ancient inn near here, The White Hart, gave first warning of the outbreak of the plague which started in the vicinity in 1665. In the adjacent coal. yard was born Nell Gywnn, who later lived at a house in Drury Court, pulled down in 1891. Drury Lane was also the birthplace of Anne Clarges, afterwards duchess of Albemarle. On the E. side, S. of Great Queen Street, was Cockpit Alley, later Pit Place. A cockpit was here, as were the Cockpit and Phoenix theatres.

Once lined with hedgerows and houses of the nobility, Drury Lane became in the 18th century a place of ill repute, its mazy courts and dark abodes the theme of satiric reference by Gay, Steele, Pope, and others, while it was the scene of Hogarth's Harlot's Progress, Lewknor's Lane, renamed Charles Street, N. of Parker Street, being especially notorious. Of notable residents were the poet Donne, who found hospitality in Drury House; William Alexander, earl of Stirling ; Elliston, when lessee of the Olympic ; Thomas Campbell, in Vinegar Yard ; Charles and Mary Lamb, in Russell Court; and the actresses Anne Bracegirdle, whom Lord

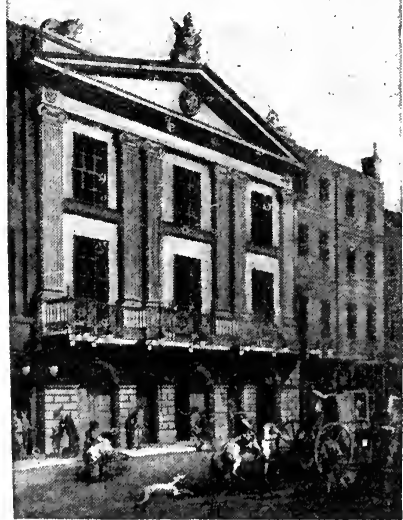

don playhouse. The first theatre on the site of the present building was erected in 1661, and opened April 8, 1663, by the King's Servants-one of Charles Il's two companies of players-under Thomas Killigrew, with Beaumont and Fletcher's play, The Humorous Lieutenant. 'This theatre was burnt down in 1672. Sir Christopher Wren designed its successor, which was replaced in 1794 by a much larger edifice, also destroyed by fire in 1809.

Benjamin Wyatt was the archi. tect of the 4th and present theatre, opened Oct. 12, 1812. It was on its boards that Edmund Kean achieved his first great triumph on Jan. 26, 1814, and there he appeared for the last time, March 12 . 1833. Drury Lane won new prestige from Macready's brief manage. ment during 1842-43. It was here that he produced Browning's The Blot on the 'Scuteheon. Under the management of Augustus Harris, and afterwards of Arthur Collins, the huge building was associated with immensely popular pantomimes and spectacular melodramas, and here in 1917 Sir Thomas Beecham began a series of seasons of grand opera. The theatre was reconstructed and re. organized in 1921-22 and was opened on April 22, 1922, with Decameron Nights, a spectacular musical play.

Druse (Ger., decayed ore). Cav. ity in an igneous rock or ore-vein which is lined or studded with minute erystals. The Cornish miners call it a vug. This drusy condition may also appear on the surface of natural crystals. Beautiful crystals of quartz, beryl, topaz, tourmaline, garnet, and other minerals are fre. quently derived from granite druses. When globular nodules are hollow and drusy-lined they are called geodes (earth-like)

Druses. Syrian people in habiting the W slope of Lebanon, anti-Lebanon and Hermon, and Hauran (Druz). Occupying some

Mohun attempt. ed to abduct from her dwell. ing here, and Hannah Pritchard. See Lon. don ; consult also Old Time Ald. wych and Kingsway, C. Gordon, 1903 ; illus. of Craven House, in Londiniana, vol. iv, E. W. Bray ley, 1829.

Drury Lane Theatre. Lon.

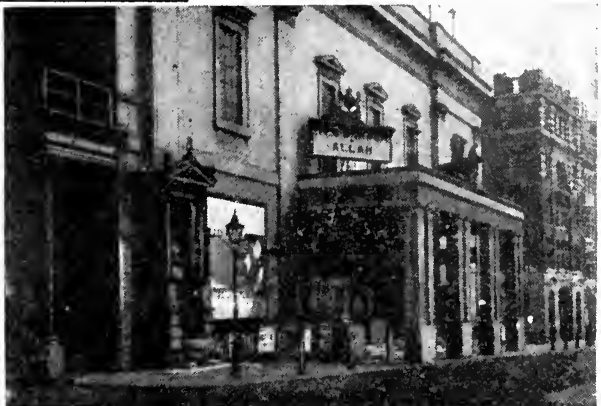

Drury Lane Theatre. Main entrance in Catherin Street. Above, frontage of the old theatre in 1776 


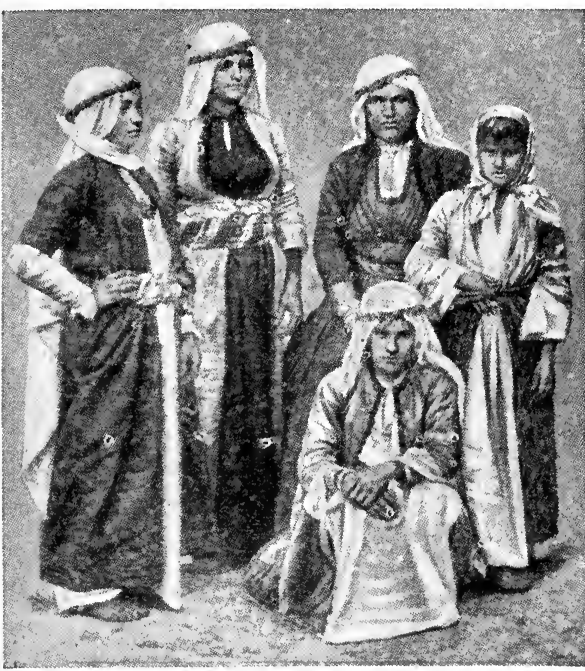

Druses. Women of the Syrian peop.e from the Lebanon district, wearing their characteristic costume in 1840. The adoption of $\mathrm{Ma}$ ronite $\mathrm{Christi}$. anity by another Beshir led to civil war. Druses and Maronites were put under a separate kaimakan or governor, but after the Damascus massacre of Christians in 1860 , the Lebanon district was placed under a Christian governor. Turkish misrule led to fresh disturbances in 189596 , which, as the Turks made some concessions, were followed by a period of com parative quiet. See La Nation 100 towns and villages and scattered elsewhere amongst other races, their total number is estimated to be from $100,000-200,000$. They are probably an admixture of different stocks, with a preponderating Arab element, the language spoken by them being Arabic. Others regard them as Iranians. They are under sheikhs or village headmen, themselves subordinate to ameers, both, together with the landed proprietors, forming a kind of supreme council. The vine, olive, and tobacco plant arecultivated, and silkworms reared.

Their religion is a curious mixture of Mahomedanism, Judaism, and Christianity, but they pride themselves on being Muwahiddin, believers in one god. This one god is said to have manifested himself ten times in the flesh, the last time in the person of Hakim, the Fatimite caliph of Egypt (996-1021), who is expected to reappear as the Messiah. From his disciple and supporter Darazi, the name Druses is supposed to be derived. The people are divided into Akils (learned), who alone possess knowledge of the sacred books and mysteries; and Jahils (ignorant). They believe in the transmigration of souls, the soul passing from one body to another until it finally becomes perfect.

Forced to submit to Murad III in 1588, under their chief Fakred-din in the early 17 th century the Druses enjoyed their greatest prosperity. Beshir (c. 1786) kept himself in power by offering his services to various rebels, being finally obliged to quit the country when the Porte reconquered Syria
Druse, H. Guys, 1863; Arab and Druze at Home, W. Ewing, 1907 ; The Druses, E. Sell, 1910. Pron. Droozez.

Drusilla, Livia (d.A.D. 29). Wife of the Roman emperor Augustus. She was previously the wife of Tiberius Claudius Nero, whom Augustus compelled to divorce her. Her elder son by the first marriage became the Roman emperor Tiberius, while her second son, with whom she was pregnant at the time of the divorce, was Drusus. She is not to be confounded with Drusilla, wife of Felix, procurator of Judaea before whom S. Paul preached; nor with the daughter of Germanicus. league of Gaius Gracchus in the tribuneship, 122 B.c. Won over by the senate, he vetoed the bills brought forward by Gracchus and brought forward others making far greater concessions, in order to secure popular favour. His son, of the same name, tribune in 91 , made various proposals dealing with the distribution of public lands and rearrangement of the jury-courts. Having aroused suspicion by sug. gesting that the franchise should be extended to the Italians, he was assassinated.

Drusus, Nero Claudius (38-9 B.C.). Roman soldier. Son of Livia Drusilla by her first husband, Tiberius Claudius Nero. Her second husband, the emperor Augustus, conceived a great liking for Drusus, who became one of his most distinguished generals, and conducted a campaign in Germany which extended the Roman dominion to the Elke. He was the father of
Drusus, Marcus Livius. Col- the emperor Claudius. This Drusus was called Senior, to distinguish him from his nephew, the son of 'Tiberius, who was poisoned at the instance of Sejanus (q.v.).

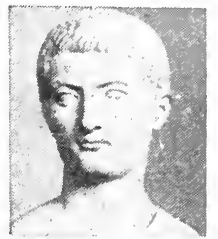

Nero Claudius Drusus, Roman soldier

From a bust in Brilish
Museum

Dryads (Gr. drys, oak). In Greek mythology, nymphs associated with trees. A dryad was supposed to live only as long as the particular tree with which she was associated. See Nymph.

Dryas (Dryas octoptlula). Perennial dwarf shrub of the natural order Rosaceae. It is a native of Europe, Asia, and N. America. The short stem is embedded in the soil, and the numerous spreading and closcly packed branches lie along the surface, bearing many tufts of oblong, toothed, evergreen leaves. The white flowers are $1 \frac{1}{2}$ in. across, and the fruits are provided with long. feathery awns.

Dryburgh Abbey. Monastic ruin in Berwickshire, Scotland, on the Tweed, $4 \frac{1}{2}$ m. S.E. of Melrose. Generally stated to have been founded in 1150 , it suffered at the hands of Edward II in 1322 , was partially destroyed by Richard II in 1385, and almost totally demolished by the earl of Hertford in 1544. After the Reformation the property, no longer put to religious uses, passed to the earl of Mar. The existing remains include the chapter house, parts of the large and beautiful church, and traces of the monastic buildings. Sir Walter Scott and several of his relatives are buried in S. Mary's aisle. In 1918 it was presented to the nation by Lord Glenconner.

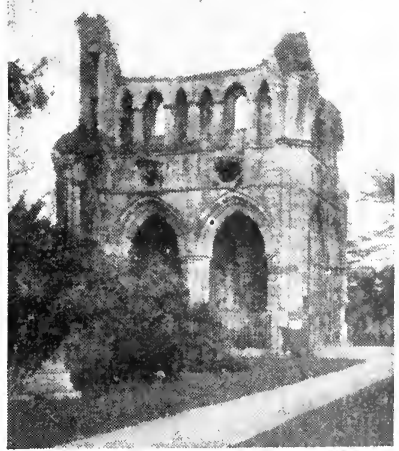

Dryburgh Abbey. S. Mary's aisle, containing the tomb of Sir Walter Scott 
Dry Cell. In electricity, a type of cell in which the solution is converted practically into a solid by the addition of chemicals of gelatinous materials which vary according to the type of cell. The advan. tages of dry batteries are portability and cleanliness. See Cell. Voltaic.

Dryden, JoHN (1631-1700). English poet. Born at Aldwinkle, Northamptonshire, Aug. 9, 1631, he was educated at Westminster and Trinity College, Cambridge. Being possessed of a competence from his father's estate, he decided upon a literary career, and, to satisfy popular taste, he began to write plays, continuing to do so, chiefly for financial reasons, all the rest of his life. He wrote twentytwo in all, but he had no real sift for dramatic composition, and apart from certain isolated passages, Dryden's plays add nothing to his reputation. The best known are perhaps The Indian Emperor, 1665 ; The Conquest of Granada, 1670 ; and Marriage à la Mode, 1672. The plays are tainted with the licentiousness which characterises the Restoration drama.

Dryden's career in poetry proper began in 1659 , when he published some verses on the death of Cromwell. A subsequent effort in 1660, Astraea Redux, a poem on the restoration of the monarchy, has laid Dryden open to the charge of trimming, but panegyric prompted by the passing of a great man is not necessarily inconsistent with an expression of welcome towards a new order of things after the gloomy years of Puritan rule. A much finer effort is the Annus Mirabilis, 1667, a poem on the wonderful year of 1666 which saw the end of the Great Plague of London, the Great Fire, and the Dutch War. A long period of writing for the stage ensued, and it was not until 1681 and 1682 that Dryden published his three great satires Absalom and Achitophel, The Medal, and MacFlecknoe. The first is an attack upon Lord Shaftesbury. $\mathrm{He}$ is Achitophel counselling the young duke of Monmouth, who is Absa. lom, to rebellion against his father. When Shaftesbury was tried for ligh treason and acquitted, his friends had a medal struck to celebrate the occasion. This provoked from Dryden the second satirical poem, considerably inferior to the first. "The rival partisans engaged the minor poet Shadwell to reply in kind. Shadwell's effort was so vulgar and scurrilous that it provoked yet a third poem from Dryden entitled MacFlecknoe-from the name of an obscure Irish bard-a masterpicee of subtle satire, which rom pletely overwhelmed the unfortunate Shadwell.

Dryden's next poems, Religio Laici, 1682, and The Hind and the Panther, 1687, show him in quite a new light. The first appears to have been written in defence of the Church of England, while the second is in defence of the Church of Rome, to which he had in the meantime become a convert. The "milk-white hind immortal and unchanged " is the latter, while the spotted panther is the former. During the closing period of Dryden's life appeared his two noble odes, the Ode for S. Cecilia's Day, 1687, and Alexander's Feast, 1697 ; several verse translations of classical poets, and a number of miscellaneous writings, including a paraphrase of some of Chaucer's Canterbury Tales.

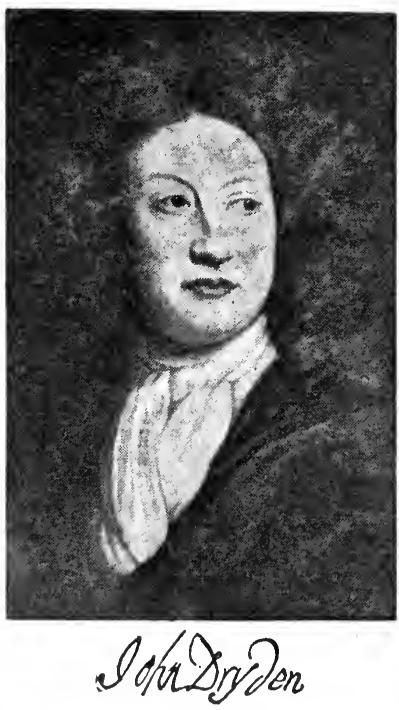

Afler Bneller

Up to the revolution of 1688 Dryden had enjoyed some degree of prosperity, having been made Poet Laureate in succession to Davenant, and receiving several other government appointments. Quite early in life he had marricd Lady Elizabeth Howard, daughter of the duke of Berkshire. The advent of William III deprived him of his laureateship and other offices. He died May 1, 1700, and was buried in Westminster Abbey.

There are echoes of the Elizabethans in the poetry of Dryden, but he belongs essentially to the classical school of poetry, which in the matter of form, at any rate, was brought to its highest point of perfection by Pope in the next century. Less polished than Pope, Dryden has much more vigour in his poetry. The same quality of vigour is shown in the admirable prose of the prefaces to his plays. See English Literature.

John McBain

Bibliography. Works, ed. with Life, Walter Scott, 1808, revised by G. Saintsbury, 1882 93; Poetical Works, ed. with Memoir, W. D. Christie, 1870 (Globe ed.); Johnson's Lives of the Most Eminent English Poets, ed. P. Cunningham, 1854 ; Johnson's Life of Dryden, ed. A. J. F. Collins, 1914; Among My Books, J. R. Lowell, repr. 1912.

Dry Farming. Special method of growing crops. In regions where the annual rainfall is under $20 \mathrm{ins}$. such as large tracts of Africa, Australia, and North America, they cannot be successfully grown on ordinary lines. To deal with such cases dry farming has been introduced. The essential feature is summer-tillage every other year, or once in three years, so as to store up moisture in the soil for the use of the crops that follow. Disk-harrowing, followed by deep ploughing and again by pressing with fluted rollers, removes all moisture-stealing weeds and produces a finely divided surface layer of "mulch," which checks evaporation and conserves the water in the soil. Most cereals do well, but barley, being shallow-rooted, is not to be recommended. See Agriculture ; Crops.

Drygalski. Islet in Davis Sea, Antarctica. Off the coast of Queen Mary Land, it is about $9 \mathrm{~m}$. in diameter. It was discovered and named by Sir Douglas Mawson, of the Australasian Antarctic Expedition, Jan. 21, 1914.

Drygill Shales. Group of sedimentary rocks on Caldbeck Fell, Cumberland. Like the Dufton shales on the W. Pennine slope in Westmorland, they represent isolated residual outcrops of strata deposited in late Ordovician time, when the Sleddale group of Coniston limestones was being laid down farther S. over the Lake district.

Drying Machine. Apparatus for removing moisture from textile materials. Excess moisture is removed from loose textile materials by centrifugal dryers, and also by squeezing rollers and afterwards passing the material through hotair chambers upon conveyers. Cloth may be semi-dried by suction in passing over a cylinder, and further dried by transit over steamheated cylinders. Drying cylinders for textile fabrics are arranged horizontally or vertically at will, and the speed of driving is adjusted to suit requirements. See Woollen. 
Dry Point. Process of etching. It is closely akin to line engraving, in the preliminary stages of which it was often used, especially in outlining the general disposition of a subject. The tool is a steel rod tapering at one or both ends to a strong, fine, sharp point. With this the etcher draws with a firm hand, the point scratching a line of exquisite sensitiveness on the copper plate, and raising, as it goes along, a very distinct burr on the sides of the furrow, which lends particular value to early prints from the plate.

Dryptosaur (Gr. dryptein, to tear; sauros, lizard). Extinct $\mathrm{N}$. American reptile of the genus Dryptosaurus, alternatively called Laelaps. It was a carnivorous, beast-footed dinosaur, living in Montana in Upper Cretaceous times, and allied to the English megalosaur. It was $20 \mathrm{ft}$. long, rapacious and sharp-toothed; it used the hind limbs and tail in kangaroo fashion. See Dinosaur.

Dry Rot. Diseased condition of timber due to the ravages of certain species of fungi, especially Merulius lachrymans. This fungus rapidly consumes the woody cells and fibres, the affected parts crumbling to a brownish powder upon exposure to a dry atmosphere. A certain degree of moisture is essential to the growth of the fungus, and is visible where it spreads its lacelike film over wood confined within a damp and stagnant atmosphere. The popular term serves to distinguish this condition from wet rot, a kind of putrefaction occurring in wood exposed to the weather.

A single plant of Merulius lachrymans puts forth millions of reproductive spores, which, being of microscopic size, may be borne about by the air, or conveyed im. perceptibly from infected to sound timber by a saw; or the disease may be propagated by the dispersion of infected sawdust, or by the creeping of the fungus from one piece of timber to another, even when the pieces are separated by some material from which the fungus can derive no sustenance, but which it will use as a bridge, such as brick or stone. The com. mon idea that the fungus eats away the interior of beams which outwardly appear sound is probably erroneous. Thus, in the old roof of Westminster Hall some of the beams and rafters were hollowed to mere shells, but it was found that the damage was due to a boring beetle. Dry rot, it is believed, cannot develop (though it may long remain latent) in wood to which air-currents have free access, and from which moisture is excluded.
Conformably to this assumption, architects and builders are legally required to provide effective ventilation and otherwise prevent dampness by incerting damp-proof courses, concreting foundations, and forming dry areas (see Brickwork; Building). Steeping the wood in corrosive sublimate has been recommended as an additional precaution against dry rot. The dry rot of oak-built ships is usually due to another species of fungus, Poria hybrida.

Drysaltery. Term applied to the business of a drysalter or the articles sold by him. These consist of heavy chemicals (borax, salt, soda, sulphur, etc.), dye-stuffs (alkanet, indigo, etc.), gums (arabic, shellac, kaưri, resin), oils (paraffin, linseed oil, boiled oil, turpentine), and crude drugs (linsced, senna, Epsom salt, Glauber's salt, etc.). Drysalters also sell pickles, preserved meat, and sauces.

D.S.C. Abbrev. for Distinguished Service Cross (q.v.) (formerly Conspicuous Service Cross).

D.Sc. Abbreviation for Doctor of Science.

D.S.M. Abbrev. for Distinguished Service Medal (q.v).

D.S.O. Abbreviation for companion of the Distinguished Service Order (q.v.).

Dual. Grammatical form originally used in some languages to express the idea of things naturally thought of in pairs, as the eyes and feet. It was then extended to other objects associated in twos (two men, two books). It is found in Sanskrit, ancient Greek, Arabic, and Hebrew, and traces of it occur in Anglo-Saxon.

Duala. Town and district of Cameroons, W. Africa. The town is situated on the Cameroons river about $18 \mathrm{~m}$. from the sea, and is the chief seaport of Cameroons. Duala proper, i.e. the port and European quarters, occupies the site of the former Bell Town. Akwa is a large native centre and Dido the residential quarter for the native clerks and workmen employed at the port. These three towns, known collectively as Duala, represented the headquarters of the three native chiefs at the time of the German occupation in 1884.

Duala occupies a position of great importance with respect to maritime trade in W. Africa. The Northern Rly. runs from Bonaberi, opposite Duala, northward, and will eventually be prolonged to a point on the Shari river, probably Fort Lamy. The Midland Rly. leaves Duala in a southerly direction and runs to the Njong river, whence it will be continued to Wesso, on the navigable Sanga tributary of the Congo, in the one direction, and to Bangui, on the Ubangi river, in the other. Duala will thus become the main outlet for French Equatorial Africa and the Lake Chad region. There is an extensive trade in palm oil and palm kernels, cocoa, and rubber. Duala is now in the French sphere. It was captured by a combined British and French force on Sept. 27, 1914. Pop. of district, 77,000, and of town 22,000. See Cameroons, Conquest of; also illus. p. 1612.

Dual Control. Any system of controls for engine and aeroplane, whereby either the pilot or passenger can operate them. It is principally employed in the instruction of pupils. Two sets of rudder and control levers are installed, and these are interconnected so that the instructor can correct the faults of the pupil. See Airmanship.

Dual Ignition. Arrangement by which two forms of ignition apparatus are fitted to an engine. One system is by accumulator and coil for starting purposes, and by magneto for the subsequent operation. The term is sometimes applied to the system of fitting two sparking plugs to the engine cylinder in order to produce two sparks simultancously and thus facilitate the ignition of the explosive mixture.

Dualism (Lat. dualis, containing two). The assumption of two principles, as opposed to monism, the assumption of one. It may be applied to man (anthropological), to God (theological), to the world and existence (cosmological, metaphysical). Anthropologica! dualism regards man's body and soul as two distinct existences; theological dualism assumes two first principles, a good and a bad, eternally in conflict; cosmological dualism lays down two original substances or entities, mind and matter, thinking substance and extended substance, of which everything is composed.

In the ancient philosophies dualism appeared as the opposition of matter and form, later as a contest between objectivity and subjectivity, the last attempt to reconcile them being that of neo-Platonism. Descartes was the first of modern philosophers to substitute for this the dualism of mind and matter, and from his time the question how their relation to each other as manifested in experience is to be inter preted has engaged the attention of thinkers without any satisfactory or generally accepted explanation being reached. The reaction against idealism, which amounted to an abolition of dualism, has led to the reassertion of the latter by some philosophical writers. 
Dual Monarchy. Name given to the empire of Austria-Hungary. Formed in 1867 by the union of Austria and Hungary, for half a century the two countries were joined under the same ruler, em peror of Austria and king of Hungary. As a result of the Great War they bccame separate republics. See Austria-Hungary: Czecho-Slovakia.

Duars. Submontane tract of N. India. The land at the foot of the Himalayas is known as the tarai or terai; it is largely jungle forest, inhabited by wild beasts, and has heavy monsoon rains. Portions of the luxurious vegetation have been clcared for tea plantations, paddy fields, and jute and tobacco crops. The width of the duars is about $25 \mathrm{~m}$., and the total area 3,500 sq. m. Pop 120,000 .

Dubail, Augustin Yvon Ed MOND (b. 1851). Freach soldier. Born at Belfort, April 15, 1851, he

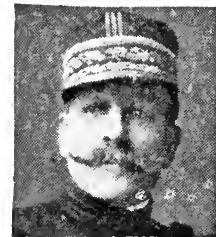

Augustin Dubail
French soldier became a lieu. tenant of infantry in the French army in 1870, and served in the Franco-Prus. sian War. For ten years he was chief of staff of the Al. gerian Division and colonel of the lst Zouave Regiment in Algeria. On his return to France, after holding various ap. pointments, he became chief of staff of the French army, com. mander of the 9th Army Corps, and a member of the superior council of war. On the outbreak of the Great War Dubail was given the command of the French First Army operating in Alsace and Lorraine. successfully defended Nancy, and afterwards held up the Germans on the Heights of the Meuse. In April, 1916, he was appointed military governor of Paris, and held that position till June, 1918.

Dubawnt. River and lake of the N.W. Territories, Canada The river rises from Wholdaia Lake, almost on the border of Saskatchewan, and flows almost due N.N.E. to Dubawnt Lake. Issuing from this, it bends round to the $\mathbf{N}$. again and then turns $\mathrm{E}$. until It falls into Chesterfield Inlet, in Hudson Bay. Its length is about $580 \mathrm{~m}$. The lake is really an ex. tension of the river and is about $1,650 \mathrm{sq} . \mathrm{m}$. in extent. Other lakes on the course are Aberdeen and Baker. 'The river's main tributary is the Thelon, which joins it as it trurns E. It was discovered in 1770 . The Dubawnt Basin forms part of

the Barren Grounds, almost treeless and frequently frostbound, even during certain summers.

Dubbin. Dressing applied to leather to soften it and render it waterproof. It is composed of Russian tallow softened with cod. liver oil and is especially employed for waterproofing heavy boots.

Dubbo. Town of New South Wales. It stands on the Macquarie river, $278 \mathrm{~m}$. by rly. N.W. of Sydney, and is the trade centre of a vast pastoral and coal and copper mining area. Pop. 5,389.

Dubica. Town of Yugo-Slavia. It is situated on both banks of the Una, one portion being in Croatia and the other in Bosnia. The

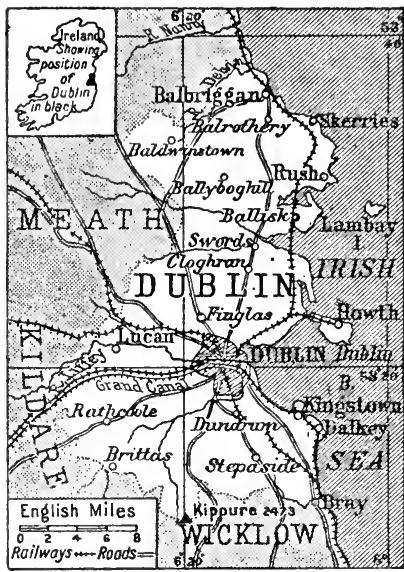

Dublin Map of this maritime county of Ireland, in the province of Leinster

Croatian town is served by the main line of rly. from Zagreb to Belgrade. Pop. Croatian portion,

\section{DUBLIN : CAPITAL OF IRISH FREE STATE}

In addition to the following article there are articles on all the Irish cities and towns; also on the Liffey; Phoenix Park, etc. See also, for the events of I9I6-20, Ireland: History ; Sinn Fein

The city of Dublin is a seaport, county, and parl. borough in the prov. of Leinster. It is situated

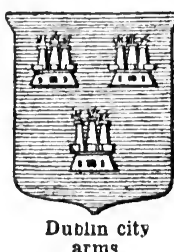

arms on Dublin Bay, at the mouth of the Liffey, 61 m. W. of Holyhead. En. closed by the Circular Road, $9 \mathrm{~m}$. in circuit, the city is divided into two nearly equal parts $-\mathrm{N}$. and S. - by the Liffey, which Is spanned by 12 bridges.

Dublin may be the Eblana of Ptolemy. The name means Plack Pool (Dubh-Linn), suggested by the pool at the confluence of the tribu.
Arthur W. Garbutt, of The Irish Times

7,330 , almost equally divided between Roman Catholic Croats and Greek Orthodox Serbs; Bos.

Dubissa. River oi Russia. It joins the Niemen W. of Kovno in the govt. of that name. It came into prominence in 1915 during the fighting between the Russians and Germans when the latter at provinces. (May-July) along the river line, on July 20 the Germans broke through the Russian positions. See Courland.

Dublin. Eastern maritime county of Ireland, in the prov.. of Leinster, with about $72 \mathrm{~m}$. of including indentations. Dublin Bay is the largest inlet, the iffey, which debouches into it, the chief river, and Howth Head the most prominent cape. Lambay and several smaller islands near the coast are included in the county. $2,473 \mathrm{ft}$.), but the surface is genera gently undulating plain, almost entirely under cultivation, at, oats, barley, and potatoe being the chief crops raised ; the $\mathrm{N}$ and $W$. parts contain much pasture land. Mineral products include ead and copper ores, and granite fishing is a thriving industry, and the leading manufactures are whisky, beer, and hosiery. The G.S. and W., M.G.W., G.N.I., L. \& N.W., and the D. \& S.E. Rlys. afford communication. Dublin (county town) and Kingstown are the most important towns. Formerly it returned 4 members to Parliament. Its area is 342 sq. m. Pop. exclusive of Dublin city, 172,394.

tary Poddle with the Liffey, which otherwise spread over marshy land. A track made of hurdles across the marshes gave the place its older name of Ath Cliath. The Poddle is now a sewer under Dublin's oldest streets, but the place of its outflow to the Liffey was the site of the oldest elements of the city, and the Custom House stood there till the close of the 18th century. In this area are Christchurch Cathedral, founded in 1038 and estab. lished as a cathedral in 1541 , and S. Patrick's Cathedral, fuunded in 1190 and restored in 1865 at the expense of Sir B. L. Guinness. Both are in the hands of the Protestants; the Roman Catholics, though 

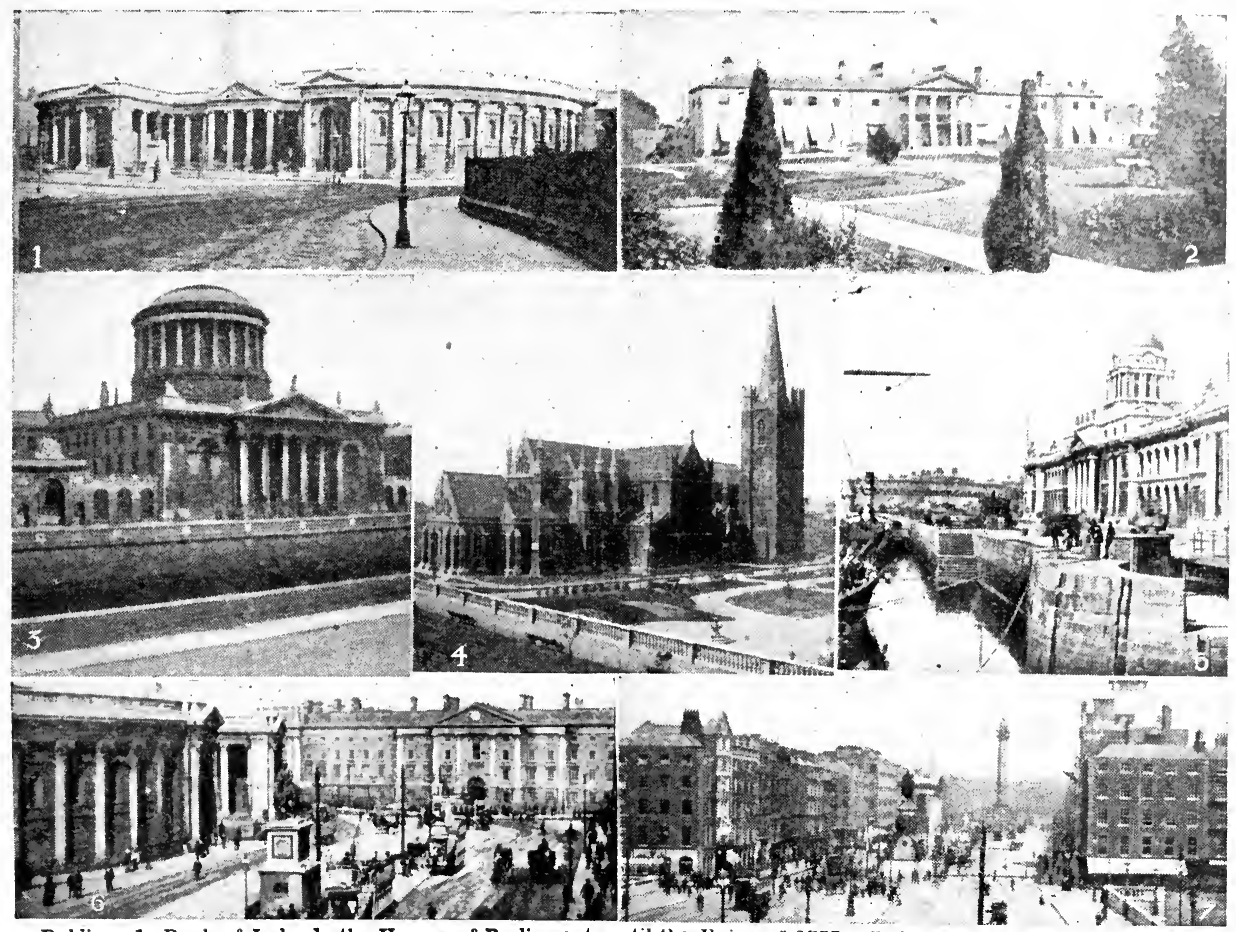

Dublin. 1. Bank of Ireland, the Houses of Parliament, until the Union of 1800 . \%. Viceregal Lodge, Phoenix Park,

formerly the residence of the Viceroy. 3. Four Courts, King's Inn Quay, before the bombardment of 1922

4. S. Patrick's Cathedral from the N.E. 5. Custom House, before destruction by fire, 1921. 6. College Green : left, the Bank of Ire!and ; facing, Trinity College. 7. Sackville Street, looking towards the Nelson Pillar

numerically the larger element, provements have been effected in have so far only a pro-cathedral.

Near S. Patrick's cathedral, which includes memorials of Stella and of Dean Swift, who was born in Hoey's Court, is a district formerly inhabited by a colony of weavers and their descendants, who carried on a once important industry. Of present industrial importance are the breweries and distilleriesnotably Guinness's-in this S.W. quarter of the city. From the centre at College Green, going S. by Grafton Street-the Bond Street of Dublin-Stephen's Green, a well laid-out public park, is reached, and beyond it are the suburbs of Rath. mines, Rathgar, Ranelagh, and Donnybrook. Northwards from College Green, another radial cuts the Liffey at O'Connell Bridge, and is continued along a broad thoroughfare well known as Sackville or O'Connell Street, which is being handsomely restored after the destruction caused in the insurrection of 1916. Eastwards, on both sides of the Liffey, run the lines of quays; there are also docks and ship building yards of rapidly increasing importance.

The harbour is protectea by two large breakwaters, and great im. recent years. The Dublin Port and Docks Board, created in 1898, exercises control over the port. The Grand Canal Docks lie on the S. side of the river. The handsome Custom House, de. stroyed by fire by Sinn Feiners in 1921 , was on one of the northern quays. Westwards from O'Connell Bridge are the Four Courts Buildings, much damaged in 1922; and further up the Liffey, on its $N$. bank, is the main gate of Phoenix Park, in which are situated the viceregal lodge, the lodge formerly occupied by the chief secretary, former headquarters of the R.I.C., an infirmary, the zoological gardens, and a fine polo-ground. The park, 1,750 acres in extent, was the scene in 1882 of the assassination of Cavendish and Burke.

The shipment of live stock is one of the chief activities of Dublin port. Other industries not already mentioned are biscuit-making and the preparation of artificial manures and fertilisers. With government departments, the judicature, the two chief universities, and national organizations of all kinds centred in Dublin, the civil service and professional element is at least as important as the commercial In May 1924 the Dublin corpor ation was dissolved by the Irish Free State ministry for local gov ernment, and its powers transferred to three commissioners: its duties were not being effectually dis. charged. The municipal council consisted of 80 members, one aiderman and three councillors to each of 20 wards. The corporation had, however, to deal with the old, over crowded city arca, expensive to administer witlout assistance from the newer and more easily admin istered suburbs, which have pre ferred to remain independent, though their inhabitants, for the most part, make their living in the eity. The valuation on March 1 1919, was $£ 1,136,519$. The elec tricity supply is municipal, but not the gas: the corporation controlled an excellent water supply for Dublin and its dependent areas, but the tramway service is an in. dependent enterprise

Dublin has many educational and artistic institutions. The chief of these are Dublin University or Trinity College, Dublin, and the National University, virtually a Roman Catholic university. The former has a well-known medical 
school, and there are also the Royal College of Physicians and the Royal College of Surgeons of Ireland, both examining and to some extent teaching bodies. The National Gal. lery of Art and National Portrait Gallery has acquired a fairly good collection, considering the lateness of its start. To the energy and brilliant ventures of the late Sir Hugh Lane was due the assembly of a unique modern art collection as a municipal gallery, which contains a number of represcntative works by modern and contemporary artists, British, Irish, and foreign.

Dublin has long taken a lively interest in music and the drama, as befitted the birthplace of Balfe and Sheridan and the scene of the first production of The Messiah under Handel's personal direction. Its Abbey Theatre (q.v.) was the home of a significant modern movement in drama, and is still conduc. ted on repertory lines. The Royal Irish Academy of Music maintains a high standard of musical teaching.

\section{Dublin Horse Show}

The Royal Dublin Society, which has a noble home in the former town house of the dukes of Leinster, includes music among its varicd subjects; other subjects are scientific research, the improvement of Irish horse-and stockbreeding and agriculture in Ireland generally. It holds the annual Dublin Horse Show, famous for the display of hunters and for the brilliant social season associated with it in August. The Royal Irish Academy, which has a commodious Academy House next to the Mansion House, while generally promoting the humanities, specially favours archaeological and antiquarian studies. There are four morning and three evening daily papers, and numerous periodicals. An Irish Republican parliament, consisting of Sinn Fein members who were elected by Irish constituencies at the general election of Nov., 1918, but did not attend the Imperial parliament at Westminster, held several sessions at the Mansion House in 1919-20.

Rly. facilities are adequate, the city being served by several lines, and communication with the Shannon is effected by the Royal and Grand canals. A regular steam boat service is maintained with the principal ports of Great Britain. The annual value of exports amounts to $£ 3,000,000$, and the im ports to $£ 150,000$. The celebrated Dublin horse and cattle shows are held at Ball's Bridge. Market days, Tues., Wed., and Fri. Pop. 304,802.

Hrstory. Publin begins its history as a Scandinavian settlo. ment, a base, often hardly main.

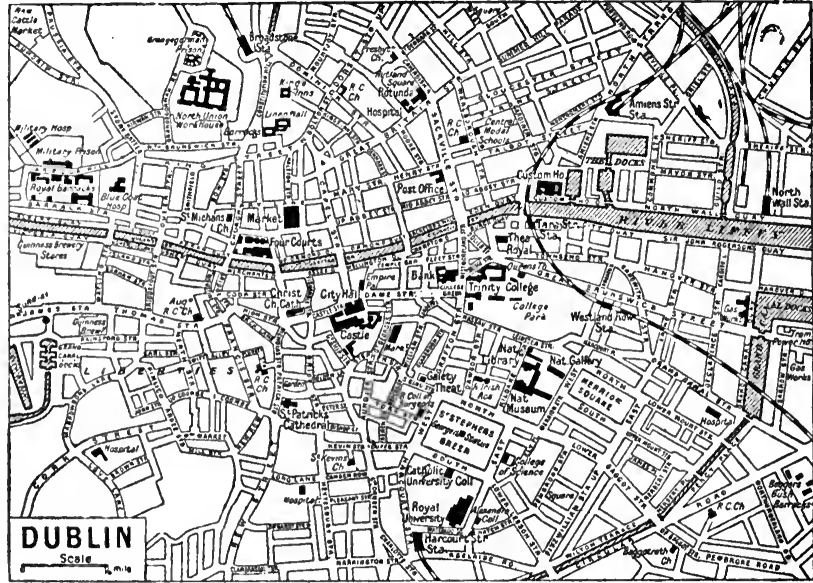

Dublin. Plan of the capital of the Irish Free State, showing the situation of the Castle and other principal buildings

tained against the assaults of the native Irish and their allies, for the Norse rovers. A dist. of old Dublin is still called Oxmantown, from Ostmen-town, the invaders being called Ostmen. Between the Norse settlers and foragers and various Irish chieftains and tribes a bitter and alternating conflict was waged for centuries, and the battle of Clontarf, fought on the $\mathrm{N}$. side of the city in 1014, was the bloodiest of a long series of encounters. In 1170 the Anglo-Norman adventurers under Strongbow came, and for long thereafter Dublin was the capital of the English Pale. Henry II granted the city to his " subjects of Bristol" in 1173, 500 of whom were massacred at Cullens Wood on Easter (Black) Monday, 1209. Dublin suffered greatly during the Civil War, and in 1647 was sur. rendered by the duke of Ormonde, who two years later was defeated at the battle of Rathmines. James II held a parliament here in $\mathbf{1 6 8 9}$. The chief events of more recent times were the rebellions of 1798 and 1803, the Sinn Fein revolt of 1916 , and the battle of July, 1922.

\section{The Irish Parliament}

The title of lord mayor was given to the city's chief magistrate by Charles II in 1665. In 1729 the building of the houses of parliament for the Irish parliament was commenced, and the priod of the Irish parliament was a brilliant one for Dublin. It ended in 1800 with the Act of Union. There was a seriou rising in Dublin at Easter, 1916, and further trouble there during the disorders of 1919-22.

Bibliography. The Book of Trinity College, Dublin (Belfast), 1892; Thom's Business Directory of Dublin and Suburbs, 1906, otc.; The
Story of Dublin, D. A. Chart, 1907 ; Dublin, S. A. O. Fitzpatrick, 1907 ; Disturbed Dublin: story of the general strike, 1913-14, A. Wright, 1914.

Dublin BAY. Inlet of the Irish Sea. It penetrates the E. coast of Ireland as far as Dublin, a depth of about 10 m., and from its entrance at Howth peninsula on the $\mathrm{N}$. to Kingstown on the $\mathrm{S}$. is $6 \mathrm{~m}$. Owing to its difficult navigation numerous lighthouses have been erected along its shores. The Liffey is the principal river discharging into the bay. TheHill of Howth at its N. end (562 ft.) and Killiney Hill at its S. (480 ft.) form conspicuous landmarks at the entrance. Its depth varies from $2 \frac{1}{2}$ to 10 fathoms.

Dublin AND SoUTH-EASTERN RaIfWAy. Irish rly. from Dublin to Waterford. It has a total mileage of 218 , and its headquarters and works are in Dublin, where it owns Westland Row station. The line was opened in 1856, and took over an older one, the Dublin and Kingstown. Until 1907 it was known as the Dublin, Wicklow, and Wexford Rly. It has a capital of $£ 2,500,000$ and owns two hotels.

Dublin Fusminers, Royad. Former regiment of the British army. It originated in the early days of the

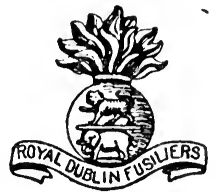

Royal Dublin Fusiliers badge British rule in India. In 1662 a regiment was raised in Eng. land for the de. fence of Bombay, and was soon taken into the service of the East India Company. In 1748 another was formed to serve at Madras, and the two were known as the 
Bombay and Madras Fusiliers. They fought at Plassey, Wandewash, Seringapatam, Nundydroog, and elsewhere, went to Aden and Burma, and took part in Mahratta and Sikh campaigns. In the Indian Mutiny they marched under Havelock to the relief of Lucknow, and when the East India Company ceased to exist became regiments of the British army, the 102nd and 103rd. In 1881 the two were united as the Royal Dublin Fusiliers.

The regiment rendered conspicuous service in the $\mathrm{S}$. African War. In the Great War the 2nd batt. was in the Mons retreat, and the lst shared in the landing in Gallipoli, April 25, 1915. The 6th and 7 th Dublin Fusiliers, part of the 29th brigade of a new Irish division raised by Kitchener, took partin thelater Gallipoli operations. The 8 th and 9 th fought in the battle of the Somme, and the 10th helped the naval men in the attack along the Ancre, Nov., 1916. It was disbanded in 1922 .

Dublin Society, RoYal. Irish learned society. It was founded in 1684 as the Dublin Philosophical Society, on the model of the Royal Society of London, Sir William Petty being the first president. It obtained a botanic garden, a museum, and a laboratory, but came to an end in 1687. In 1693 it was refounded, and Trinity College became its home. I'his society, too, failed to last, and in 1731 was succeeded by the Dublin Society for improving husbandry, manufactures, and other useful arts. In 1750 this was incorporated as the Royal Dublin Society, and, aided by grants of public money, did much for Irish industries and art. It has published its Transactions and Proceedings, and issues a journal. The headquarters are at Leinster House, Kildare Street, Dublin.

Dublin Untversity. Irish university, consisting of Trinity College, Dublin. Founded in 1591, it has always been the educational headquarters of Protestant Ireland, and its religious tests were only abolished in 1873 . It is governed by a chancellor, senate, and council; the executive head is the provost. There are senior fellows, junior fellows, and scholars, and its courses resemble those at Oxford and Cambridge, with which Trinity is closely connected. 'Undergraduates, as a general rule, must reside for a certain period in college, or in the vicinity. The normal course is four years; those therein being known os junior freshmen, senior freshmen, junior sophisters, and senior sophisters. The buildings, which are entered from College Green, are very extensive. Parliament Square contains the chapel, dining-hall, and examination hall, while in Library Square is the library with a priceless collection of manuscripts.

Among the modern buildings are the museum, and those for the medical school. Around is the college park, while at Dunsink is the university observatory. The college has also various museums and laboratories, as well as botanic gardens. Women have been eligible for the degrees since 1903, and for them there is residential accommodation in Trinity Hall. Goldsmith, Burke, and Berkeley, as well as the great Irish orators and statesmen, were here. In the 19th century may be mentioned Lecky, Dowden, Mahaffy, and Bury. There is also in Dublin another university, the National University of Ireland, a Roman Catholic institution.

Dubno. Town of Ukrainia, in the govt. of Volhynia. It stands on the Ikva, $32 \mathrm{~m}$. W. of Ostrog. The inhabitants, chiefly Jews, are engaged in tanning, brick-making, and tobacco manufacture. At the two yearly fairs much trade is done in grain, cattle, wool, and tobacco. In the Middle Ages, Dubno assemblies of the Polish nobility were held there. Pop. 14,000.

Dubno, Battles or. Fought between the Russians and AustroGermans, 1915-16. The first phase was the campaign of Aug.-Sept., 1915 , leading up to the capture of Dubno by the Austrians. After the fall of Kovno and Brest-Litovsk in 1915, Gen. Evert's line formed a large salient on the Russian front, and Hindenburg designed to concentrate an immense force to envelop the Russian armies.

The great blow for Dubno was launched tcwards the end of Aug. along the front from the Dniester to the S. fringe of the Pripet, with the result that Dubno, Brody, and Lustk, and the line of the Strypa river, fell to the Austrians. The Russians' counter-attacks in Sept. and Oct. proved unsuccessful, and Dubno remained in Austrian hands.

The second battle, June-July, 1916, culminated in the recapture of Dubno by the Russians. The Russians, under Brusiloff, began their great offensive against the Austro-Germans on the S. part of the E. front on June 4, 1916, attacking on the whole front from the Pripet to the Pruth, but making progress mainly in Volhynia and in the Bukowina.

The Austrians, with considerable German supports, made a determined effort to prevent the Russians from crossing the Ikva, but after a swaying battle lasting four days the Russians captured Dubno on June 9.

Dubois. Borough of Pennsylvania, U.S.A., in Clearfield co. It is $78 \mathrm{~m}$. direct and $129 \mathrm{~m}$. by rly. N.E. of Pittsburg, and is served by the Pennsylvania and other rlys. A busy trading centre for coal worked in the locality, it has ironworks, blast furnaces, railway repair shops, and glass factories Settled in 1873, it was incorporated in 1881. Pop. 14,010.

Dubois, Clément Francois Théodore (1837-1924). French composer. Born at Rosnay, Marne, Aug. 24, 1837, he studied music at the Paris Conservatoire, where he became a professor in 1871, and was its director from 1896-1905. He was organist of the Madeleine, 1875-96. Dubois's compositions in clude operas and oratorios. $\mathrm{He}$ died June 11, 1924.

Dubois， Guillaume (16561723). French statesman and cardinal. Born at Brive, Limousin, Sept. 6, 1656, he was educated by the monks in his native town, and entered their order. He completed his education at Paris, where a friend, Antoine Faure, secured for

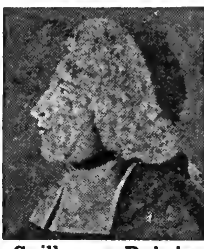
French statesman him the post of tutor to the prince, who became the regent Philip of Orleans. Dubois showed a taste for political intrigue, and after 1715, when Philip became regent, was his chief counsellor.

The great work of the priest was to reverse the traditional policy of Louis XIV. He was strongly hostile to Spain, and brought about an alliance between France and Great Britain and Holland. Dubois secured the archbishopric of Cambrai, and was made a cardinal in 1721 . $\mathrm{He}$ remained chief minister when Louis XV came of age, but almost at once died at Versailles, Aug. 10 , 1723. See Memoirs of Cardinal Dubois, P. Lacroix, Eng. trans. E. Dowson, 1899.

Dubois, Paul (1829-1905). French sculptor and painter. Born at Nogent-sur-Seine, July 18, 1829, he studied under Toussaint and at the Beaux Arts. From 1880 he exhibited regularly in both the sculpture and the painting sections of the Salon, excelling in portraiture, and became keeper of the Luxembourg and director of the Beaux Arts. He died in Paris, May 23, 1905 . 
Dubois, Pierre Joseph Louis ALFRED (b. 1852). French soldier. Born at Sedan. Nov. 21, 1852, he

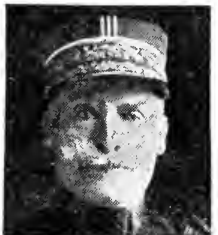

French soldier Manuel
Herre J. Dubois, joined thc French army as a lieutenant of the 24th Dragoon regiment in Oet., 1874. He saw active service in Algeria and Tunisia(1882), and again in Algeria, 188586. Promoted brigadier-general in March, 1905, he was made director of cavalry under the minister of war in the following Aug. In April, 1913, he was appointed commander of the 9 th Army Corps, and when the Great War broke out this corps, forming part of the Second Army, under Castelnau, was heavily engaged in the region of Nancy, Aug.-Sept., 1914. Later the corps formed part of the army of Belgium, incessantly fighting from Oct. 21 to Nov. 13, 1914. Dubois was made G.C.M.G. in Dec., 1914. He was put at the head of the French Sixth Army in 1915, and in $1916 \mathrm{was}$ in com. mand at Verdun. He was placed in the reserve in 1917, after holding various commands.

Dubovka. Town of Rusia in the govt. of Sarator It stands on the right bank of the Volga, $32 \mathrm{~m}$. N.N.E. of Tsaritsyn. There are tanneries and mustard factories, and considerable trade is done in salt. Dubovka, formerly the residence of the hetman of the Volga Cossacks, has lost its importance since the construction of the VolgaDon Rly. Pop. 17,000.

Dubuque. City of Iowa, U.S.A., the co. seat of Dubuque co. It stands on the Mississippi river, $168 \mathrm{~m}$. W.N.W. of Chicago, and is served by the Chicago Great Western and other rlys. An important river port and rly. centre, it com. inunicates with the $\mathrm{E}$. bank of the river by three bridges. Its buildings include the Government office, the free library, several hospitals, and a number of colleges and schools, the chicf being S. Joseph's College, Wartburg Seminary, and the state institute of science and arts. Situated in an important coal, zinc, and iron mining district, it bas rly. workshops, flour and lumber mills, foundries, pork. packing establishments, and booi and shoe factories. First settled in 1788 by J. Dubuque, in whose memory a monument has been erected, Dubuque was founded in 1833 and incorporated in 1837 , its city charter being granted three years later. Pop. 40,100
Ducange, Charles do Fresne, SIEUR (1610-88). French scholar. Born at Amiens, Dec. 18, 1610, and educated by the Jesuits, Ducange became a lawyer. He passed most of his life in study in Amiens and Paris, where he died Oct. 23, 1688. Hc edited the works of several French and Byzantine historians, Joinville among them, but his great work is his Latin glossary, 1678 , which is really a compendious dictionary of medieval Latin. It has been frequently revised and enlarged, notably by the Benedictines, 1733-36, and the last edition was published at Niort, 1883-87. Ducange compiled a Greek Glossary on similar lines published in 1688 .

Ducat. Name of a coin, generally of gold, which circulated widely on the Continent in medieval times; value, 9s. 4d. It was first coined in silver, by Roger II of Sicily, 1140. The gold ducat of Florence, coined in 1252 , was followed by that of Venice, 1283. The name is derived from the word ducatus on Roger's money, referring to his duchy of Apulia. From Italy the coin and the name went to Hungary, Bohemia, Austria, and Germany. Its use ultimately spread to Russia, Spain, Denmark, and Holland; to Hanover, as late as George III's reign, and in 1887 to England, as the name of a trial decimal gold coin, worth 100 pence. See Sequin.

Duccio di Buoninsegna (c. 1260-1340). Sicnese painter. The only extant work indisputably by this painter is the altar-piece for the high altar at Siena cathedral, now in the cathedral museum, representing the Virgin and Child surrounded by angels and saints. Duccio was the first Sienese painter to abandon the Byzantine tradition.

Ducie, Earl of. British title borne since 1837 by the family of Moreton. The family is descended from Henry Ducie of London. His son, Sir Robert Ducie, lord mayor of London, left a large fortune which came eventually to his grand-daughter Elizabeth, the wife of Edward Moreton. Their son Matthew was, in 1720, made Lord Ducie, baron of Moreton. This title died out in 1770 , but in 1763 another barony of Ducie had been created, which passed to Thomas Reynolds, a nephew of Lord Ducie. He took the name of Moreton, and his grandson 'l'homas was made an earl in 1837. Henry John, the 3rd earl (1827-1921), succeeded to the title in 1853. His brother Berkeley Basil (1834-1924) was the 4th earl. The family estates are mainly in Gloucestershire. The earl's eldest son is known as Lord Moreton
Duck (Mid. E. dukan; Ger. tauchen, to dive). Name of the largest group of birds of the order Anseres (of the family Anatidae), which includes swans, geese, and ducks. There are over 40 genera of ducks and nearly 200 species. They are distinguished by short legs, webbed feet, and a depressed and expanded beak. All the species are more or less aquatic, and most are powerful flyers. They are mainly herbivorous, with the exception of the merganser, which lives on fish, but frogs and worms are also readily eaten. The plumage is dense and compact, so that the water readily runs off it, a property augmented by the free use of the oil gland. As a rule, the malc, or drake, has more showy plumage than the female, for which the term duck is commonly reserved. All the species lay uniformly coloured eggs, and the young are able to swim shortly after being hatched.

Ducks are found all over the world, but are most numerous in the northern regions. They associate in flocks, and the majority migrate further $\mathbf{N}$. for the nesting season. On the wing the flock always assumes a wedge-shaped lormation, which probably helps to overcome the resistance of the air.

The numerous breeds of domesticated ducks are believed to have descended from the mallard, or wild duck, which breeds quite freely in captivity. All domesticated ducks interbreed with the wild duck, and their offspring is fertile, which goes to prove that the species is identical. The polygamous habits of the domesticated duck, the wild duck being monogamous, are probably merely the result of living under non-natural conditions. Domesticated ducks may be classed as ornamental, and those intended for the table. The ornamental varieties are mainly different species of British and foreign wild ducks maintained in a half-tame state on lakes and in parks.

Less than a dozen Europuan breeds can be regarded as of practical utility for the table or for supplying eggs. Of these the Aylesbury is by far the most esteemed and most commonly bred variety in Great Britain. Its plumage is pure white, and it carries its boat-shaped body almost level with the ground. As it matures rapidly and attains a weight of from $8 \mathrm{lb}$. to $10 \mathrm{lb}$., it is much in demand for table pur. poses. The Rouen, for which France is famous, is simply a cul. tivated mallard. In plumage almost identical with the wild bird, it often attains a weight of $11 \mathrm{lb}$, and its flesh is much superior to 
that of any other native breed. But it is not altogether in favour outside France, for it matures so slowly that it often costs more in food than it fetches in the market. The Pekin duck, which came originally from China, may be re-

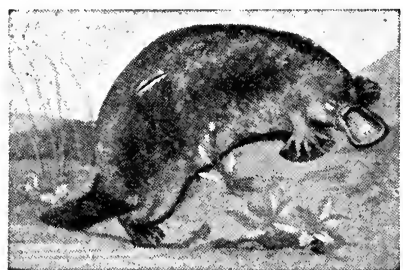

Duck Bill. Oviparous mammal of Australasia

cognized by its yellowish-white plumage and its very upright carriage when walking, the legs being set very far back. A large specimen will weigh as much as $9 \mathrm{lb}$, but it is as an egg-layer that the breed is valued. The Indian runner is also a prolific layer of small eggs, which are often proffered for sale as those of the hen, but otherwise it is not a useful breed, as it seldom weighs more
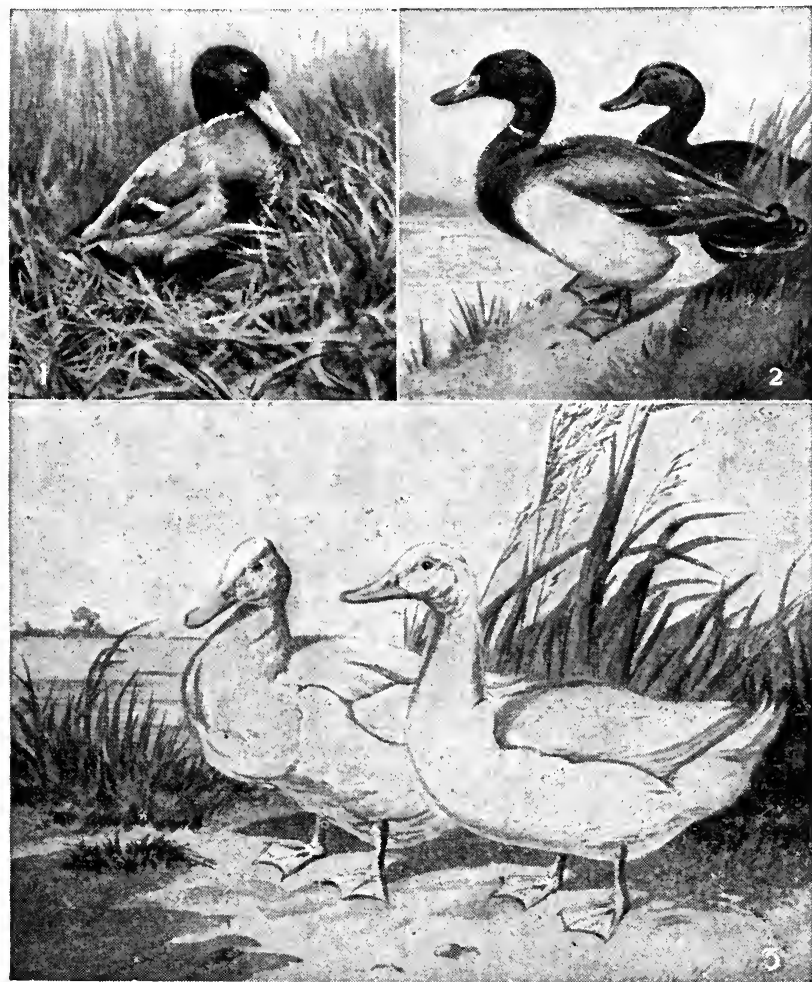

Duck. 1. Mallard or wild duck, which breeds freely in captivity. 2. Rouen duck, much favoured in France. Its plumage is similar to that of the wild variety. 3. White Aylesbury ducks, the most esteemed and most commonly bred variety in Great Britain (from a drawing by Harrison Weir) Britain, and possess good table qualities.

The demand for ducklings far exceeds that for older birds, which are apt to be oily and strong in flavour, and the breeder should, therefore, aim at mating the birds early, Oct. being the best time. As ducks are not good sitters, the eggs are usually or in the incubator. See Poultry Farming.

Duck (Dutch doek, linen cloth). Untwilled fabric, lighter and finer than canvas, used for clothing, sails, wagon covers, bags, etc. It is usually made of linen, sometimes of cotton. The word also denote the creamy tint of linen yarn during bleaching. than $4 \mathrm{lb}$. Swedish and Flemish ducks are also

by lowering the beam. The last record of its infliction was at Leominster, 1809.

Duck-Shooting. Sport mostly practised on the E. shores, inlets, estuaries, and broads of Great Britain. It may roughly be divided into (1) shooting with stanchion guns fixed in single or double handled punts; (2) from a punt with an ordinary gun while the birds are in flight; (3) and following on foot by open streams or drains.

The British wild ducks p̈rincipally met with are the mallard, shoveller, gadwall, pochard, teal, and widgeon. These generally feed on fresh waters, and are therefore more valuable for eating purposes; scaup, eider, and the long-tailed ducks seldom leave the sea, and are useless as food. Wild ducks are very difficult to approach, and when using a punt it is necessary to lie flat along the bottom directly birds are sighted, and to remam in that position until after the shot. 
It is the practice in some countries to mask the bows of the boat with green leaves and branches; and in some instances decoy birds (q.v.) are used to induce the wild ducks to come near. See First Les. sons in the Art of Wildfowling, 1896 ; Bird. Life of the Borders, 2nd ed. 1907, A. Chapman.

\section{Duckweed} (Lemna). Genus of minute, scale-like flowering plants of the natural order Lemna. ceae. They are

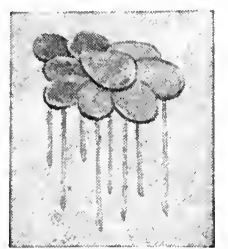

Duckweed. A thickleaved variety, Lemna gibba annual aquatic plants, floating on the surface of ponds and ditches, and consisting of a green disk, with or without a simple root or roots. They sometimes produce elementary flowers in the clefts of the margin, but rarely seeds, and are propagated by budding and by bulbils which hibernate in the mud.

Duckworth, Sir Dyce (b. 1840). British physician. Born Nov. 24, 1840, and educated at Liverpool,

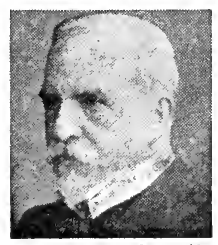

Sir Dyce Duckworth, British physician Ellote \& Fry he afterwards studied medi. cine at Edin. burgh University and $\mathrm{S}$ Bartholomew's Hospital. After a short time (1864-65) as assistant surgeon in the navy, he settled down to a consulting practice in London. $\mathrm{He}$ was made consulting physician to Edward VII, when prince of Wales, treasurer and then senior censor of the Royal College of Physicians, and consulting physician to $\mathrm{S}$. Bartholomew's and the Seamen's Hospitals. From 1904-10 he was medical referee to the Treasury. In 1886 Duckworth was knighted, and in 1909 was made a baronet.

Duckworth, Sir John Thomas (1748-1817). British sailor. Born at Leatherhead, Feb. 28, 1748, he entered the navy when 11 years old, and was present at Quiberon Bay. He then served in N. America and the W. Indies, and was promoted commander in 1780. Returning to England in 1793, he was appointed to the Orion, in which he greatly distinguished himself at Ushant, June I, 1794.

Knighted in 1801, in 1803 he was commander-in-chief of Jamaica, was promoted vice-admiral 1804 , and defeated the French off San Domingo in 1806, for which he received a 1 ension of $£ 1,000$ a year.
The following year he was sent to Constantinople to dictate certain conditions to the Porte. With the assistance of the French, the Turks had strengthe ned the fortifications of the Da rdanelles, b u t D u ck worth forced the straits, destroyed a squadron of

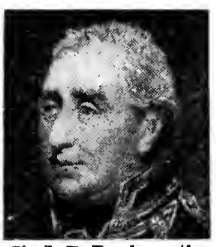

Sir J. T. Duckworth, British sailor
From an engraving

Turkish fri-

gates, and finally anchored $8 \mathrm{~m}$. from Constantinople, where he was held up by wind and current, and, his force being insufficient, he was obliged to retreat. He was governor of Newfoundland from 1810-13, and was made a baronet in 1813 . $\mathrm{He}$ was appointed commander-inchief of Plymouth in Jan., 1817, and died Aug. 31 of the same year.

Duckworth, WYNFrID LaURENCE HenRY (b. 1870). British anthropologist and anatomist. Born at Liverpool, June 5, 1870, and educated at Birkenhead School, Dinan, and Cambridge, he studied medicine in Paris and London, and anthropology in Paris. In 1898 he became university lecturer in physical anthropology at Cam. bridge. He published Morphology and Anthropology, 1904; Prehistoric Man, 1912, etc.

Duclaux, Madame (b. 1857). British poet and essayist. Born at Leamington, Feb. 27, 1857, daughter of G. T. Robinson, she is also known under her maiden name of Agnes Mary Frances Robinson, as Madame Darmesteter-her first husband was James Darmesteter (q.v.) - and as Madame Duclaux. She married Émile Duclaux, director of the Pasteur Institute, Paris, in 1901. Her first volume, A Handful of Honeysuckle, appeared in 1878. Her Collected Poems, displaying much lyrical charm, appeared in 1901 ; in addition may be noted studies of Emily Brontë, Margaret of Angoulême, Mme. de Sevigné, Renan, Twentieth Century French Writers, 1914, and A Short History of France, 1918.

Du Cros, William Harvey (1846-1918). British business man. Born June 19, 1846, he belonged to a Huguenot family that had migrated to Dublin from Montpellier in 1702 . He was educated for the medical profession in Dublin, but soon turned his attention to the pneumatic tire industry, and later became largely interested in the motor industry. From 1906-8 he was Unionist M.P. for Hastings. He died Dec. 21, 1918. Of his sons, Artbur Philip was M.P. for Hast- ings, 1908-18, and then for the Clapham division of Wandsworth. In 1916 he was made a baronet. A younger son, Alfred, was M.P. for Bow and Bromley in 1910.

Ducrow, ANDREw (1793-1842). Equestrian performer and mimic. Born in Southwark, Oct. 10, 1793 , the son of a celebrated strong man, he was early trained to equestrian and other circus feats. In 1808 he was chief equestrian and ropedancer at Astley's ; and in 1813 gained fame as a pantomimist in the part of Florio the dumb boy, in The Forest of Bondy. After touring the Continent, he returned to Astley's, which he eventually took over. On June 8, 1841, the building was totally destroyed by fire. His mind gave way under the shock, and he died Jan. 27, 1842.

Ductility. In metallurgy, the general property of metals which permits them to be drawn into rods or wire. It is closely related to the property of malleability, but it is not quite the same; though, as it happens, gold and silver are at once the two most malleable and most ductile of all the metals. The relative measure of the ductility of a metal is determined by the fineness of the wire down to which it can be drawn; thus gold will draw finer than platinum. The metals rank as follows in order of ductility: 1 , gold ; 2 , silver ; 3 , platinum ; 4 , iron ; 5 , nickel ; 6 , copper ; 7, zinc ; 8, tin ; 9, lead. The ductility of iron is greatly increased when the iron is converted into steel; and similarly many of the copper alloys-bronze, phosphor bronze, Delta metal, and others, have greater ductility than copper. See Metallurgy.

Dudeney, Mrs. Henry (b. 1866). British novelist. Eldest daughter of Frederick Whiffin, she was born Oct. 21,1866 , and educated at Hurstpierpoint, Sussex. In 1884 she was married to Henry Ernest Dudeney, author of The Canterbury Mrs. Henry Dudeney, $\mathrm{Puz} \mathrm{zl}$ e $\mathrm{s}$ British novelist Amusements

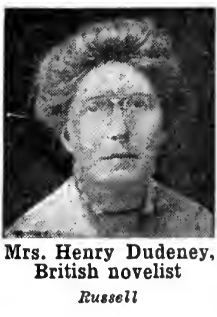
in Mathematics, etc. Her novels include A Man with a Maid, 1897 ; The Maternity of Harriott Wicken, 1899; Folly Corner, 1899 ; Spindle and Plough, 1901; The Story of Susan, 1903; The Wise Woods, 1905 ; The Orchard Thief, 1907 ; Married when Suited, 1911; Set to Partners, 1913; The Sccret Son, 1915 ; Travellers' Samples, 1916 ; The Head of the Family, 1917. 
Dudley. County and mun. bor. of Worcestershire. In a detached portion of the county, it is $8 \mathrm{~m}$.

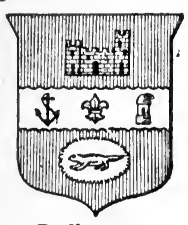

Dudley arms
N.W. of Birmingham and 121 from Lon$\mathrm{d}$ on, and is served by the L. \& N.W. and G.W. Rlys. ; also by a c an a l. Electric tramw a y s r u n through the town and to adjoining places. Dudley is in the heart of the Black Country; there are coal and iron mines all around, with which the chief industries are connected-ironworks, brass foundries, engineering works, and the like. Cycles and beer are also made and stone is quarried.

The buildings of the town include the parish church, a town hall, school of art, and grammar

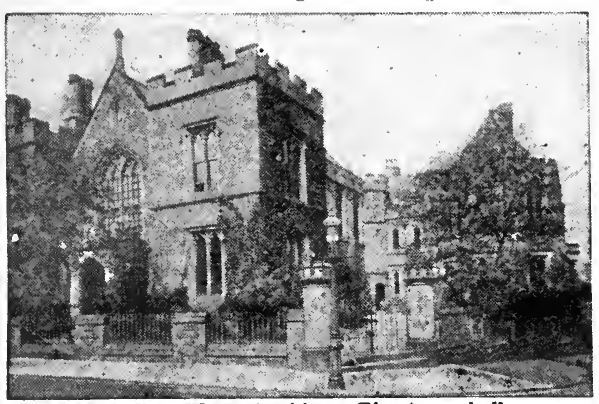

Dudley, Worcestershire. The town hall Valentine

school. There is a hospital, founded by Joseph Guest, a technical school, and a geological museum. There are the ruins of the castle around which the town grew, the grounds being now a pub. lic park. Adjacent to Dudley, but in Staffordshire, are Brierley Hill and Kingswinford, while Netherton is another industrial suburb. Dudley existed before the Norman conquest, and was a borough in medieval times, being represented in Parliament in 1295. Its present incorporation, however, only dates from 1865. It is governed by a mayor and council, and sends one member to Parliament. Market day, Sat. Pop. 51,079.

Dudley, Earr of. English title held by the family of Ward since 1860. In much earlier times there was a baron of Dudley, who lived in Dudley Castle. The first baron, who lived in the 14th century, was named Sutton, but his descendants took the name of Dudley from their residence. Among them were Elizabeth's favourite, Robert Dudley, earl of Leicester, and other noted men of Tudor times. The barony remained in the family until its ninth holder died without sons in 1643 . It passed then to his granddaughter, the wife of a wealthy goldsmith, Hum. ble Ward, and in this way the two families became connected. Ward's son Edward succeeded, but in $\mathbf{1 7 5 7}$ the barony fell into abeyance.

Meanwhile, another branch of the Wards was becoming prominent, and John Ward, another descendant of Humble, who had inherited the barony of Ward, was made Viscount Dudley in 1763. His grandson, John William Ward, 4th viscount (1771-1833), was foreign secretary in 1827-28, and a prominent figure in his day. In 1827 he was made earl of Dudley, but the title became extinct on his death in 1833. Another descendant of Humble Ward, William Ward (1817-85), inherited much of his great wealth, and in 1860 was made earl of Dudley. His son, William Humble, 2nd earl (b. May 25, 1867), was lord-lieutenant of Ireland $\mathrm{from}$ 1902 to 1906 , and governor-general of Australia from 1908 to 1911 . The countess of Dudley was drowned while bathing in Ireland, June 26, 1920. The wealth of the Wards is due to the possession of rich coalfields round Dudley. 'The earl's eldest son is known as Viscount Ednam, and his chief seat, until its sale in 1920 , was Witley Court, Worcestershire.

Dudley, DUd (1599-1684). English ironmaster. Natural son of the fifth Baron Dudley, he was educated at Balliol College, Oxford. In 1619 he was placed in charge of his father's ironworks at Pensnet, Worcestershire, where he experimented with coal as furnace fuel. In spite of successful demonstrations, in 1651 he was forced to abandon his attempts. During the Civil War he was colonel in the king's army, and general of ordnance to Prince Maurice. In 1665 he published his work Metallum Martis or Iron Made with Pit-Coale, etc., but was careful not to describe his process. He died at Worcester, Oct. 25, 1684.

Dudley, Edmond (d. 1510). English lawyer. $\mathrm{He}$ studied at Oxford and Gray's Inn, and early gained the favour of Henry VII. While still very young he was made a privy councillor, and in 1504 became Speaker of the House of Commons. Working with another lawyer, Richard Empson, he enriched himself and the king by a system of extortion based mainly on antiquated penal statutes. 'The day after Henry VIII's accession, Dudley and his colleague were arrested. They were found guilty of constructive treason, and were executed on Tower Hill, Aug. 18, 1510.

Dudley, Sir Henry Bate (17451824). British journalist. Born at Fenny Compton, Warwickshire, Aug. 25, 1745, he was the son of a clergyman, Rev. Henry Bate. Educated at Queen's College, Oxford, he entered the Church of England and became, in succession to his father, rector of North Fambridge, Essex. However, he took his duties very lightly, and it is as a journalist and society figure that he is known. He was editor of The Morning Post from 1772 to 1780 and afterwards founded The Morning Chronicle. His writings were often violent, while his behaviour was eccentric: always ready for a duel, he was called the fighting parson, and he spent at least one term in prison. In 1784 he took the name of Dud. ley on succeeding to some money, and in 1813 he was made a baronet. At one time he lived in Ireland, where he had livings and was chancellor of the diocese of Ferns. He died at Cheltenham, Feb. 1, 1824. The friend of Garrick and of other notables of the time, Dudley wrote several comic operas. See Noble Dames and Notable Men of the Georgian Era, J. Fyvie, 1910.

Dudleyport. Village of Staffordshire, England. It forms a ward of the urban district of Tipton and has a station on the L. \& N.W.R. See Tipton.

Dudweiler. Town of Germany, in the Prussian Rhine province. It stands on the Sulzbach, $40 \mathrm{~m}$. from Metz, near a coalfield, and it manufactures include machinery and other kinds of iron goods, bricks, and pottery. Pop. 21,932.

Duel (Lat. duellum, old form of bellum, battle, from duo, two). Single combat engaged in by arrangement after challenge, and carried through on a recognized method of procedure, to settle a private quarrel or vindicate personal honour.

Historically the ducl derives directly from the old legal method of settling disputes by ordeal by battle. The legal sanction given to decisions so arrived at com mended the method to the popular mind, and the issue of a duel came to be accepted as a definitive settlement of a dispute between individuals over matters with regard to which they deemed it either undesirable or useless to appeal to law. 


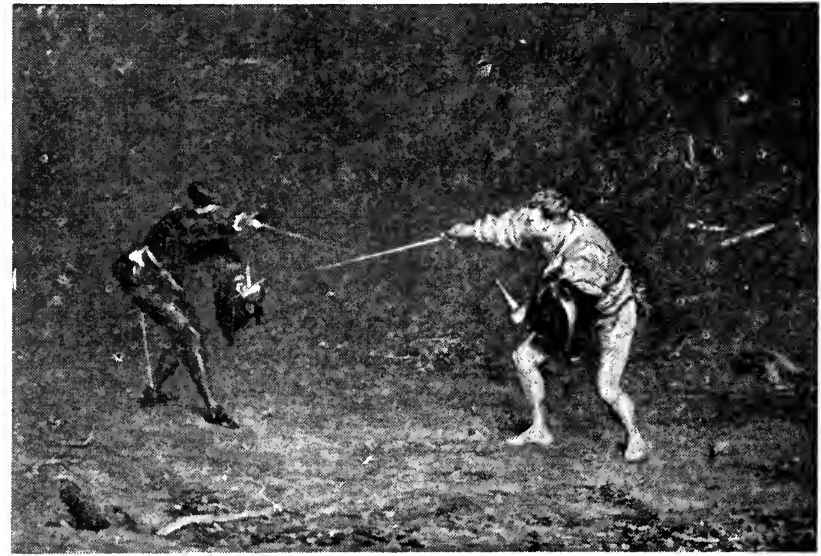

Duel. Sword and Dagger Fight, a masterly representation of a sixteenth century duel, from the painting by John Pettie, R.A.

France is the country of origin of the modern duel. It was forbidden in civil matters as early as 1305 , but without effect, and in the next two centuries duelling was generally prevalent. Francis I sent a challenge to Charles V of Germany, and although it was not accepted, this royal example was enough to sanction a fashion peculiarly congenial to the national temperament. It grew under Charles IX and became almost a mania under his successors, the third and fourth Henrys and Louis XIII, despite more than one ordinance and edict threatening penalty of death to principals and seconds alike. Rostand's picture of Cyrano de Bergerac and his brother cadets is no caricature of the young gallants of that day who mistook swashbuckling for chivalry, and who doffed cloak and drew rapier on any pretext or none. These hot-heads found a quarrel everywhere, and soon were not content with one second apiece, while the second for his part ceased to be content with looking on to see fair play. In the reign of Louis XIV the dukes of Nemours and Beaufort fought a duel in which four friends joined in on each side. Three of the ten were killed, including Nemours, and all the other seven were wounded. The duel had almost grown into a battle. As in Italy, as pictured by Shakespeare in Romeo and Juliet, again no exaggerated caricature, so in France duelling became an intolerable evil

Despite the spectacular encounter mentioned, Louis XIV has the credit of doing much to suppress the prac. tice, by establishing a supreme court of honour, and still more by insisting on the punishment of all who disregardcd the edict agsinst it. As a practice, chiefly indulged in by the aristocracy, the Revolutionists ignored it in their legislation, and during the first Republic and the first Empire it almost died out. It was revived, however, with the Restoration, and remains a custom in France, resorted to for the most part by ebullient editors and poli. ticians, and not often a bloody business, although as late as $1900 \mathrm{M}$. Marlier, a municipal councillor, was killed by M. Ferrette, a deputy, in Paris. A bill to stop duelling was submitted to the French Chamber in 1920 .

In England duelling dates back as a custom to the beginning of the 17 th century, in the latter part of which, after the Restoration, it experienced a great revival. Beau Fielding went out with Sir Henry Colt, the member for Westminster, in Feb., 1696, and wounded the baronet, who, however, succeeded in disarming his opponent. Lord Byron killed Mr. Chaworth in 1765 , and the duke of York met Colonel Lennox in 1789. Mr. Christie killed Scott, editor of The London Magazine, Feb. 16, 1821, and on March 21,1829 , the duke of Wellington had a bloodless encounter with the earl of Winchelsea. On July 3, 1843. Colonel Fawcett died of wounds re. ceived two days before in a duel with his brother-in-law, Lieut. Nunro. The case led to action by the Prince Consort with regard to the military etiquette of duelling, in obedience to which alone Munro had gone out. In the event it was ordained in the articles of war that any officer who participated in a duel, whether as principal or as accessory, or who did not do his best to prevent a duel, should be cashiered. and the regulation is still in force.

In the German army, up to the revolution of 1918 at least, officers

were required to submit dispntes to a council of honour which arranged the matter if possible, and, if not. supervised the conditions of the encounter. The German students' duels are a more or less harm. less form of university amusement. By English law duelling is an offence amounting to murder or manslaughter in the event of a death, and Major Campbell was hanged, in 1808, for having killed Captain Boyd in the previous June. In 1813, again, when Lieut. Blundell was killed in a duel, his opponent, Mr. Maguire, and both the seconds engaged, were convicted of murder and sentenced to death. In the event they were pardoned, but cashiered. On Oct. 19, 1852, when E. Barthélemy shot M. Cournet, an ex-officer of the French navy, at Crown Farm, between Windsor and Egham, both principals and seconds were refugees. Barthélemy, notwithstanding ferocious professions of Republicanism, was always suspected by other French refugees of being in the pay of the French police, and the cause of the duel was political.

Duet (Ital. duetto). Composition for two single voices or instruments, occasionally a double theme for a single instrument. In instrumental music the expression is used generally for a work for two similar instruments, e.g. two flutes. When written for different instruments, e.g. violin and flute. the more correct term is duo.

Dufaure, Jules Armand Stan. ISLAS (1798-1881). French advocate and politician. Born at Saujon, he was minister of the interior for a short period in 1848 , and again in 1849. After a long period of office he was minister of justice, 1871-73, and again from 1875-76. From March 9 to Dec. 2, 1876 , he was premier at a period of particular difficulty, when feeling ran high between the parties of Church and State. Both the president, Marshal MacMahon, and the senate were opposed to the premier's policy, and he resigned, only to return to office once more as premier on Sept. 14, 1877, until Feb. 1, 1879. He died at Paris. June 28, 1881.

Duff, Alexander (1806-78). Scottish missionary. Born in Perth.

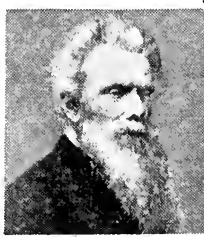

Alexander Duff, Scottish missionary shire, A pril 26 1806, he was educated at S t. Andrews. In $1829 \mathrm{he}$ went as a $\mathrm{missionary}$ to India, the first sent by the Church of Scotland, and 
at once began the task of associating educational with evangelistic work. $\mathrm{He}$ was instrumental in setting up many schools and colleges. He had much to do with founding Calcutta University, and for a time heedited The Calcutta Review. At the disruption of 1843 Duff followed the leaders of the Free Church, and in 1851 he was its moderator, as he was again in 1873. In his later years he was professor of missions at New College, Edinburgh, and travelled all over the world in the interests of his work. He wrote The Indian Mutiny, 1858. Duff, who is commemorated by Duff Hall, Calcutta, died Feb. 12, 1878. See Life, G. Smith, 1879.

Duff, Sir Alexander Ludovic (b. 1862). British sailor. Born Feb. 20, 1862, he entered the navy. Promoted lieutenant of the royal yacht in 1884, he was naval assistant to the 3rd sea lord from 1905-8, and was appointed A.D.C. to the king on Aug. 21, 1911. The same year he became director of naval mobilisation, Admiralty War Staff, which office he was holding on the outbreak of the Great War. Promoted rear-admiral in 1913, he commanded the 4 th battle squadron, 1914-17, being mentioned in dispatches and given the C.B. for his action in the battle of Jutland. From 1917-19 he was assistant chief of the naval staff, was promoted vice-admiral in 1918, and made commander-in-chief of the China squadron in 1919.

Duff, Sir Beauchamp (18551918). British soldier. Born Feb. 17. 1855, the son of Garden W. Duff, of Hatton Castle, Aberdeenshire, and educated at Glenalmond, he passed through Woolwich, and in 1874 entered the artillery. Having served in 1878-80 against

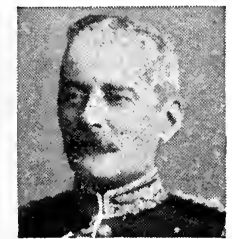
the Afghans, he transferred to the Indian army. In 1895 Duff was made military secretary to the com manderin-chief in India, and in Sir Beauchamp Duff, British soldier Elliotl \& Fry 1899 was in S. Africa, first with Sir G.

White in Ladysmith and then on the staff of Lord Roberts.

Having returned to India, he commanded a brigade, and was made a major-general. From 1903-6 he was adjutant-general in India, from 1906-9 chief of the staff there, being knighted in 1906, and in 1913 became commander-in-chief. He was in India when the Great War broke out, and his share in or-

ganizing the expedition to Mesopotamia was severely censured by the commission of inquiry. This undoubtedly hastened his death, which took place Jan. 20, 1918.

Duff, Sir Mountstuart ElphinSTONe Grant (1829-1906). British author and politician. Borm Feb. 21, 1829, at Eden,A ber. deenshire, he was educated at Edinburgh and Balliol College, Oxford, and was called to the bar at the Inner Temple, 1854. M.P. for the Elgin

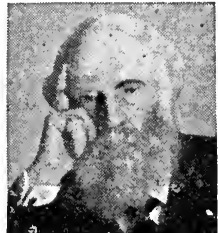
Sir M. Grant Duff, British author Elliout \& Fry

Burghs, 1857-81, he was undersecretary of state for India, 186874, and for the colonies, 1880. From 1881-86 he was governor of Madras. He wrote many books, chiefly biographical and political, but will be best remembered for his series of Notes from a Diary. Other works include: Studies in European Politics, 1866; A Political Survey, 1868 ; Notes of an Indian Journey, 1876 Sir Henry Maine, a brief memoir, 1892; Ernest Renan, 1893; and a biographical notice of Baron de Tabley in that writer's Flora of Cheshire, 1899. He died at Chelsea, Jan. 12, 1906.

Dufferin and Ava, Frederick Temple Hamilton-'Temple BlackWOOD, IST MARQUESS OF (18261902). British diplomatist and ad. ministrator. Born at Florence, June 21, 1826, son of the 4th Baron Dufferin and Helen Selina, granddaughter of Richard Brinsley Sheridan, he was educated at Eton and Christ Church, Oxford. He succeeded in 1841 to his father's title, an Irish one, and in 1850 was made a British peer as Baron Clandeboye. He went as special commissioner to Syria in 1860 to inquire into the religious massacres, was appointed under-secretary for India in 1864 for war in 1866 , and was created

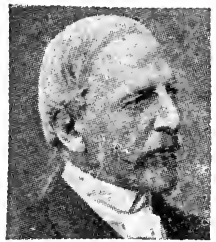
an earl in 1871 Governor. general of Canada, 1872 78 , and viceroy of India, 188488 , he became ambassador at Rone in 1888. and in Paris in

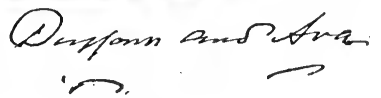

1891. In 1888 he was created marquess of Dufferin and Ava.

After an exceptionally brilliant career, Lord Dufferin's later years were clouded by his unfortunate action in 1897 in accepting the chairmanship of the London and Gloke Finance Corporation, of which Whitaker Wright (q.v.) was managing director, without adequate inquiry into its affairs, over which he had no control, but for the disastrous collapse of which he had to share the blame. 'This and the death of his eldest son, the earl of Ava, who was killed in South Africa in 1900, led to a breakdown in health, and he died at Clande. boye, Feb. 12, 1902. See his Specches in India, 1890 ; Life, Sir A. C. Lyall, 1905. He was succeeded by his second son, Lord Terence Temple-Blackwood (1866-1918), on whose death the title passed to his third son, Lord Frederick Blackwood (b. 1875).

Dufferin, LADY (1807-67). Irish song writer. Eldest daughter of Tom Sheridan, and grand-daughter of $\mathrm{Rich}$ a rd Brinsley Sheridan, she mar. ried in 1825 Commander Price Blackwood, who succeeded $h$ is father in 1839 as Baron Dufferin (d. 1841). She then devoted herself to the education

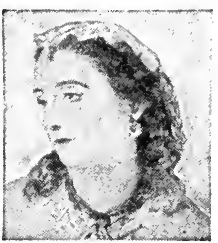

Lady Dufferin, Irish song writer By courtesy of John Bf urray of her son, the future marquess of Dufferin $(q . v$. ). In 1862 she married the earl of Gifford, then on his death. bed. She died at Highgate, June 13, 1867. Her best known poem is The Irish Emigrant, 1845. See Songs, Poems, Verses, with Memoir of the Sheridan Family, ed. by her son. 1894.

Duffy, Sir Charles Gavan (1816-1903). Irish nationalist and colonial statesman. Born at Mona-

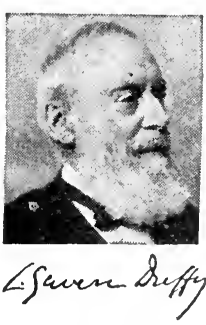

Elliott \& Fry ghan, April 12, 1816, in 1842 , with John Dillon and Thomas Davis, he founded The Nation, the organ of the Young Ireland party. M.P. for New Ross from 1852-55, h afterwards cmi

grated to Australia. He became a member of the Victoria House of Assembly, 1856, was twice minister of land and works, and in 1871 prime minister of Victoria. Knighted in 1873 , he died at Nice, Feb. 9 , 1903. Besides political writings he published the popular anthology, Ballad Poetry of Ireland, 1845. 
Dugdale, SrR William (160586). English antiquary. Born at Shustoke, Warwickshire, Sept. 12,

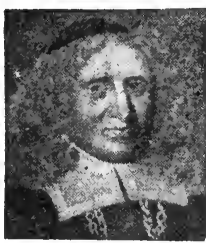
1605 , he came to London in 1635 to collect materials for his Antiquities of Warwi ckshire (1 656). $\mathrm{H}$ is royalist lean. ings led to his receiving sevGulielmus Dugdate appointments, From a portrait in the which he util. Bodleian Library ised for various county "visitations." He was made Garter king-of-arms and knighted in 1677. He published a History of S. Paul's Cathedral, 1658 ; collaborated in a history of religious foundations, Monasticon Anglicanum, 1655-73; compiled a History of Embanking and Draining of Fens and Marshes, 1662; and The Baronage of England, 1675-76. He died Feb. 10, 1686. See Life, Diary, and Correspondence, ed. W. Hamper, 1827 ; Athenaeum, Nov. 3,1888 , in which portions of his diary were first printed.

Dugong (Halicore). Genus of herbivorous aquatic mammals, known as sea-cows. They are found in the Red Sea and around the $\mathbf{E}$. Indies and Australasia. From 8 to $12 \mathrm{ft}$. long, they resemble a miniature whale.

Dug-out. Primitive form of boat or canoe. In forest regions riverain tribes familiar with floating logs, probably soon developed a method of hollowing out a tree trunk by means of fire or an adze. See illus. pp. 1211, 1653 and 2207.

Dug-out. Term used in the Great War for an underground shelter for troops. Dug-outs were constructed in or near the fire
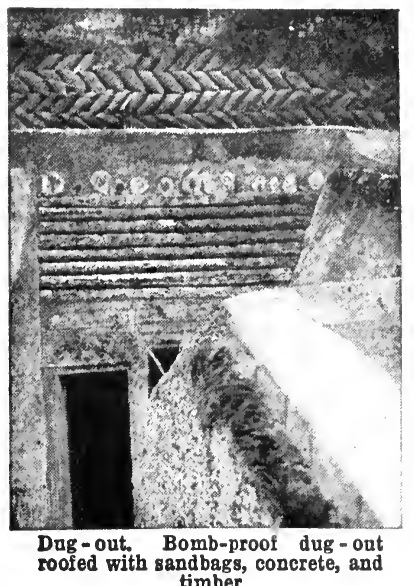

trenches to provide rest accommo. dation for the officers and men by day and night, and as comparatively safe cover from bombardments. See Trench.

Duguay-Trouin, RENE (16731736). French sailor. Born at St. Malo, June 10,1673, in early youth he gave up clerical studies and took to the sea, where he distinguished himself in the war against England and Holland. $\mathrm{He}$ obtained a commission in the Frerch navy in 1697 and fought witl / distinction in the War of the Spanish Succession, capturing Rio de Janeiro in 1711. He died at Paris, Sept. 27, 1736.

Duhamel, Jean Pinare FranÇOIS GUILLOT (1730-1816). French metallurgist. Born near Coutances, he was officially appointed to visit

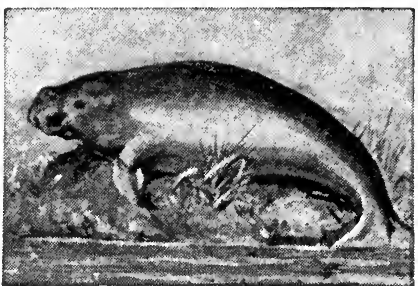

Dugong, or sea-cow, a large squatic mammal

the mines of Forez and two years later the Harz. By his discoveries and inventions he greatly improved steel manufacture in France. From 1781-1811 he held the professorship of mining and metallurgy at the French school of mining. In 1795 he was appointed inspector-general of mines. He died Feb. 19, 1816.

Dui or DuE. Fortified post and penal settlement on the W. coast of the island of Sakhalin. It was founded in 1857 on the site of some coal mines worked by convict labour. The vicinity produces fireproof clay for brick-making.

Duiker Bok. Small S. African antelope of the genus Cephalophus. There are nearly 40 species, varying in size from the dimensions of a hare to those of a small donkey. They have short straight horns, usually with a crest of hair between them, and are of light and graceful form. Pron. Diker.

Duisburg. Town of Germany, in the Rhine prov. It stands between the Rhine and the Ruhr rivers, $15 \mathrm{~m}$. N. of Düsseldorf, and owes its great growth in the 19th century to the collieries. Its industries include founding, engin. eering, shipbuilding, and the manufacture of cotton goods, soap, etc.

Duisburg, once a Roman station, was included for some centuries in the auchy of Cleves, and with it be- came part of Brandenburg in 1614. During the troubles of $1919-20$ there were several risings in the town. Pop. 229,483.

Dujailah. Fortified Turkish position on the $S$. bank of the Tigris. It was the key to the EsSinn position, which barred the way of the British Kut relief force, 1916. Unsuccessfully attacked on March 8, it was carried by the British, May 19. See Es-Sinn; Kut ; Mesopotamia, Conquest of.

Dujana. Native state of India, in the Punjab. Its founder was Abdul Samand Khan, a Pathan soldier of fortune, who was employed under Lord Lake. Opium and grain are the chief products. Chief town, Dujana, $37 \mathrm{~m}$. W. of Delhi. Area, 100 sq. m. Pop. 25,485, four-fifths Hindus.

Du Jardin, Karel (c. 1625-78). Dutch landscape painter. Born probably at Amsterdam, he studied under Nicolaas Berchem and at Rome. On his return to Holland he met with great success, but he preferred to make Italy his home, and died in Venice. His landscapes are Italian rather than Dutch in feeling. The National Gallery, London, possesses a representative example of his work. $\mathrm{He}$ died Nov. 20, 1678.

Duke (Lat. $d u x$, leader). Title of nobility. The word was first applied to military commanders in the early Ro. man empire. Later, as in the Frankish om pire, a duke was a civil and military offi.

cial. There pole were also ter-

ritorial dukes, who ruled over large districts, e.g. Saxony. Gradu. ally all the dukes became territorial. In Great Britain duke is the highest title of nobility. The first English duke was Edward the Black Prince, created duke of Cornwall in 1337. The first Scottish duke was David, son of King Robert III, who was made duke of Rothesay in 1398. See Peerage.

Duke, Henry Edward, Baron Merrivale (b. 1855). British lawyer. A 8 a journalist he was for a time in the press gallery of the House of Com mons. Called to the bar in 1885 he soon ac quired a large practice on the western circuit. In 1900

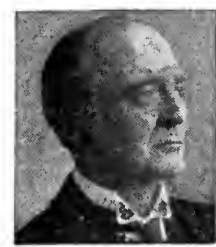

Sir Henry E. Duke, British lawyer 
he entered Parliament as Unionist M.P. for Plymouth, lost his seat in 1906, but in 1910 was returned for Exeter. In 1915 he was made attorney-general to the prince of Wales, and early in the Great War he acted as chairman of two royal commissions appointed in connexion therewith. In May, 1916, Duke occupied the chief-secretaryship of Ireland, vacated by Birrell after the outbreak of rebellion in Dublin, and retained the post until 1918, when he was appointed a judge of the court of appeal, and knighted. In Oct., 1919, he succeeded Lord Sterndale as president of the Probate, Divorce, and Admiralty Division, and in 1925 was created a peer, taking the title of Lord Merrivale.

Duke of Albany. British armed boarding steamer. She belonged to the L. \& Y. and L. \& N.W. rly. companies, and had a tonnage of 1,997. She was torpedoed by a Ger. man submarine, Aug. 24, 1916.

Duke of Cornwall's Light Infantry. English regiment. Originally of two battalions, the old32nd,

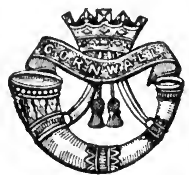

Duke of Cornwall's L.I. badge and the old 46 th Foot, it was raised in 1702 and served as $\mathrm{Ma}$ rines in the defence of Gibraltar, 1704-5. It took part in the battles of Dettingen and Fontenoy, the conquest of Canada (1760), the capture of Copenhagen (1807), the Peninsular War, the Waterloo Campaign, the second Sikh War, and the Crimean War. A great episode in the regiment's record was its defence of Lucknow during the Indian Mutiny. Later it took part in the Egyptian Campaign (1882), the Nile Expedition (1884), and the Burma and Tirah expeditions. In the S. African War the regiment was commanded by Sir Horace Smith-Dorrien. The nicknames, Red Feathers and Murray's Bucks, are popularly associated with the regiment. The former dates from the American War, when the old 46th, after surprising the Americans at Brandywine, stained the feathers of their headgear red in order that they might be more easily identified by the enemy. The latter commemorate: a colonel of the regiment.

In the Great War the first batta. lion went to France in 1914, and was brigaded with Sir Charles Fergusson's Fifth Division, especially distinguishing itself on the Aisne and at Ypres. The second battalion was in China at the outbreak of war, but was sent to France and rendered fine service at St. Eloi and
Neuve Chapelle (1915). The regi. ment was commended by Sir Douglas Haig for gallant fighting at Guillemont and Ginchy in the battle of the Somme (1916). To commemorate its part in the war it was decided to erect a statue of Cornish tin at Bodmin, represent. ing a soldier in fighting kit going "over the top," with at the base shields, one for each battalion, briefly recording their respective war services. 'The regimental depot is at Bodmin.

Duke of Edinburgh. Ship of a class of British cruisers built in 1906. They are two in number, the

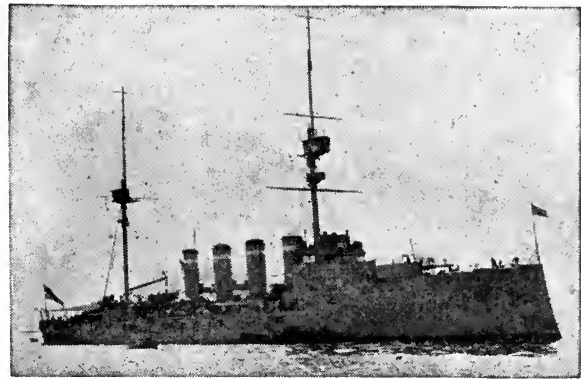

Duke of Edinburgh. British cruiser, sister ship of the Black Prince, built in 1906 Cribb, Southsea

Duke of York's School. For. merly known as the Royal Military Asylum, this school, for the sons of British soldiers, founded at Chelsea, London, by Frederick, duke of York, in 1801-3, was transferred to Dover in 1909. A similar establishment in Dublin is called the Royal Hibernian School. At Dover and Dublin about 920 boys are maintained and educated between the ages of 9 and 14. The Queen Victoria School for the sons of Scottish soldiers and sailors at Dunblane maintains 275 boys. To commemorate the old boys of the Duke of York's Royal Military School who fell in the Great War a library and reading room are to be built at Guston (Dover).

Duke of York's Theatre. London theatre, in St. Martin's Lane, W.C., designed by Walter Emden and originally known as the Trafalgar Square 'Theatre. In it Ibsen's The Master Builder was produced in 1893. It was reopened

Duke of Edinburgh and the Black Prince. The Duke of Edinburgh is $480 \mathrm{ft}$. long, $73 \frac{1}{2} \mathrm{ft}$. in beam, has a normal displacement of 13,550 tons, and has engines of $23,000 \mathrm{~h}$.p. giving a speed of 23 knots. Her main armament is six $9 \cdot 2$-in. guns, four 6-in. guns, with strong batteries of lighter weapons, and three torpedo tubes. She has an armoured belt tapering from 6 ins. to 3 ins. in thickness, with 7-in. plating on barbettes and a protective deck. The Duke of Edinburgh assisted Indian troops in capturing Turkish forts at the $\mathrm{S}$. end of the Red Sea, Nov. 15, 1914. Of this class the Black Prince was lost in the battle of Jutland, 1916 , as the result of an explosion while attacking in Arbuthnot's squadron. She displaced 13,550 tons and carried six $9 \cdot 2$-in. guns. See Cruiser.

\section{Duke of York} Islands. Group of islands formerly part of the Bismarck Archi pelago(q.v.). They were eaptured by a $n$ Australian force from the Germans, Sept., 1914.

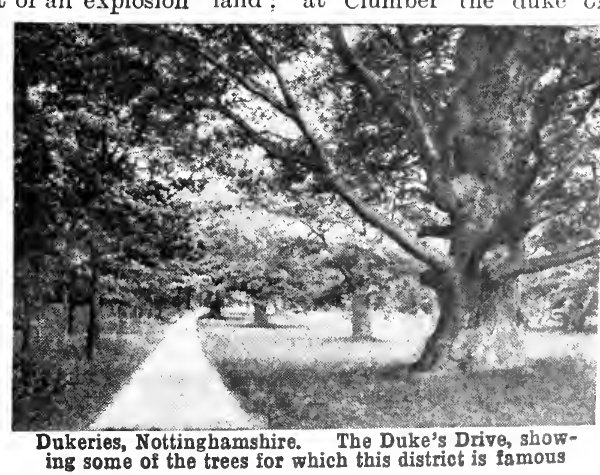


Newcastle ; at Thoresby, now the seat of Earl Manvers, the duke of Kingston; and at Worksop Manor the duke of Norfolk.

Duke Town. Former name of old Calabar, situated on the Cala. bar river, Nigeria. See Calabar.

Dukhonin, General. Russian soldier. During the early part of the Great War he held important staff appointments. His ability was recognized by his appointment as chief of staff of the Northern Army carly in 1917. He was made commander-in-chief by Kerensky early in Uct. of that year, in succession to Korniloff, and tried to stem the increasing disorganization of the armies. After the Lenin coup d'itat, Nov. 7, he was superseded because he refused to negotiate an anmistice with the Germans. Remaining loyal to Russia, he continued to act as commander-in. chief at the front after the flight of Kerensky. On Dec. 3, 1917, he was eaptured at Mohilev by a naval guard, and after being insulted was stabbed and killed. See Kerensky ; Korniloft.

Dukinfield. Mun. bor. of Cheshire, England. It stands on the Tame, and is mostly within the parl. bor. of Stalybridge, $6 \mathrm{~m}$. E. of Nanchester by the G.C. and L. \& N.W. Rlys. The principal buildings are the town hall, free library, technical school. There are churches, schools, a pub. lic park and re. creation grounds. The borourh unites with Stalybridge, Hyde, and Moseley in a joint system of electric tramways and lighting. 'The chief industries are cotton manufacture, calico-printing, iron-working, engineering, and coal-mining. A bridge across the Tame connects Cheshire with Lan. cashire. Market day, Mon. Pop. 19,422 .

Dukla Pass. Pass over the Carpathian Mts. between Galicia and Hungary. It is named after Dukla, it town of Galicia, 17 m. S. E. of Jaslo. See Carpathians, Fighting in the.

Dulac, EDmund (b. 1882). Franco-British artist. Born at Toulouse, he settled in Great Britain in 1905. In 1907 an exhibition of his Irawings at the Leicester Galleries caused a sensation; and his illus trations to fairy tales and other classics enjoy a wide popularity. His Book for the French Red Cross (1915) is specially merzorable An cxhibition of his caricatures was given in London in 1920.
Dulce. Gulf or inlet of the Pacific Ocean, between Costa Rica and Panama. At its entrance are the points of Matapalo on the $\mathrm{N}$. and Burica on the S.

Dulciana (Lat. dulcis, sweet). Organ stop. The pipes in it are open and of small scale, possessing a delicate tone. Its invention is ascribed to Snetzler (18th century). They are usually of $8 \mathrm{ft}$. pitch, but are sometimes $16 \mathrm{ft}$. or even $4 \mathrm{ft}$. See Organ.

Dulcigno (anc. Olcinium; Turk. Olgun). Harbour of Montenegro, on the Adriatic. Though deep and commodious, it is difficult of access. The town is built on Cape Kadilie, a rocky promontory, and trades with Italy in olives and oil. Formerly Byzantine, it was in turn Serbian and Venetian, and became Turkish in 1571. During the Great War it was captured by the Austrians in Jan., 1916, and occupied by the Italians in Nov., 1918. Pop. 5,000.

Dulcimer (Lat. dulcis, sweet: Gr. melos, song). Musical instrument, from which the pianoforte has been evolved. It consists of a trapezeshaped sounding-board, over which metal strings are stretched. These are struck by two hammers with flexible stems, and heads of which

\section{one side is hard and the other}

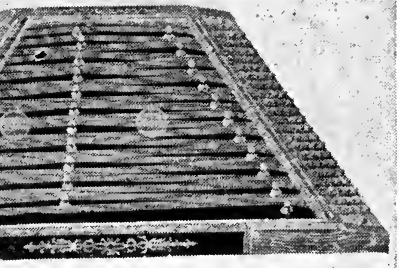
Duluth. City of Minnesota, At the W. end of Lake Superior, $152 \mathrm{~m}$. N.E. of St. Paul, it is served by the Chicago and Milwaukee and other rlys., and is the terminus of three of the lines. It has one of the best natural harbours in the world, formed by Minnesota Point, a narrow tongue of land which parts it from the lake. The waterway of the Great Lakes and the ample rly. facilities make Duluth one of the leading commercial ports in the country. Its industrial establishments include steel and iron works, blast furnaces, flour and saw mills, and match factories. Settled in 1853 , it was incorporated as a city in 1870 and has grown rapidly since. Pop. 97,077.

Dulverton. Market town and parish of Somerset, England. It stands on the Barle and near the S. edge of Exmoor, $20 \mathrm{~m}$. W. of Taunton. It has a station on the G.W. Rly. In the midst of lovely scenery, it is a fishing and hunting centre. Near is Pixton Park. Dulverton is referred to in B!ackmore's Lorna Doone. Pop. 1,526.

Dulwich. London residential suburb. It lies S.E. of the city, between Denmark Hill, Herne Hill, and West Norwood on the W., and Peckham Rye, Nunhead, Forest Hill, and Upper Sydenham on the E. The oldest part, which retains 
much of its rural charm, is known as the Village, and contains the buildings, much restored, of the college founded by Edward Alleyn, the chapel of which has served as the parish church and as a chapel of ease, the rest of the quadrangle being offices and almshouses. Dulwich Park, 72 acres, was presented to the public by the college trustees in 1890. Dulwich Picture Gallery is notable for its perfect quiet, as well as for its artistic treasures.

On a site occupied by the Grove Hotel stood the Green Man, a noted hostelry in the 18th century, in the grounds of which was a well producing the once famous spa-water :

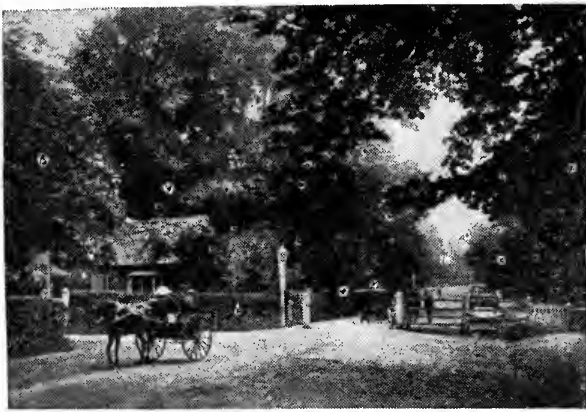

Dulwich. Toll gate in the rural part of this residential London suburb

and here, later, was Dr. Glennie's Academy, which had Byron for a pupil. Anciently known as Dilwyshe, Dulwich was a manor be. longing to the abbey of Bermondsey, presented after the dissolution to Thomas Calton, from whom it was purchased by Edward Alleyn. S. Stephen's Church, College Road, designed by Sir Charles Barry, was built in 1869, in the Early English style; S. John's, a Gothic structure, in E. Dulwich, dates from 1865. Dulwich is served by the S.E. \& C. and L.B. \& S.C. Rlys., and by electric trams from Blackfriars. See Alleyn, Edward: consult also Norwood and Dulwich, Past and Present, A.M. Galer, 1890.

Dulwich College or THE COLLEGE OF GOD's GIFT. English public school at Dulwich, founded and endowed by Edward Alleyn, the actor, in 1619. The property, which is land in S. London about $3 \frac{1}{2} \mathrm{~m}$. in length by $1 \frac{1}{2} \mathrm{~m}$. in breadth, increased enormously in value, and in 1857 a new scheme was approved by Parliament and carried out. This provided for two schools, an upper school, Dulwich College proper, and a lower school, known as Alleyn's School.

The college contains four sides, classical, modern, science, and engineering. It has ample buildings, laboratories, workshops, etc., and 175 M.C.'s.

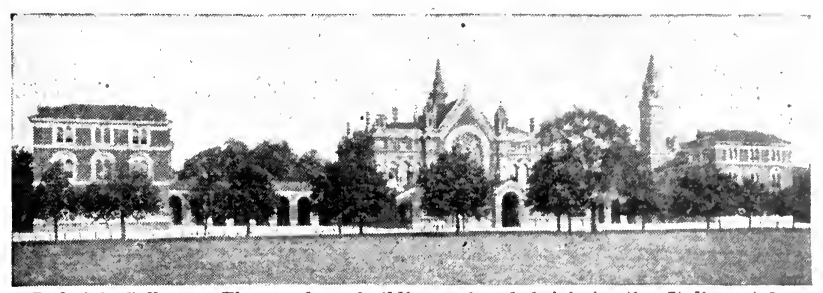

Dulwich College. The modern buildings of red brick in the Italian style. situated in College Road, Dulwich, and opened in 1870

extensive playing fields. The new buildings of red brick in the Italian style were from the designs of Sir Charles Barry. They are in College Road, and were opened in 1870 . The boys number about 700 , most of them day boys from the residential suburbs of S. London, but there are four boarding houses. There are a num. ber of scholar. ships to the school, and from it to the universities. Over 3,000 Old Alleyn ians served in the Great War, of whom 441 were killed. The decora tions won include five V.C.'s, 76 D.S.O.'s, and

Dulwich Gallery. Collection of pictures housed in a building near old Dulwich College. Noel

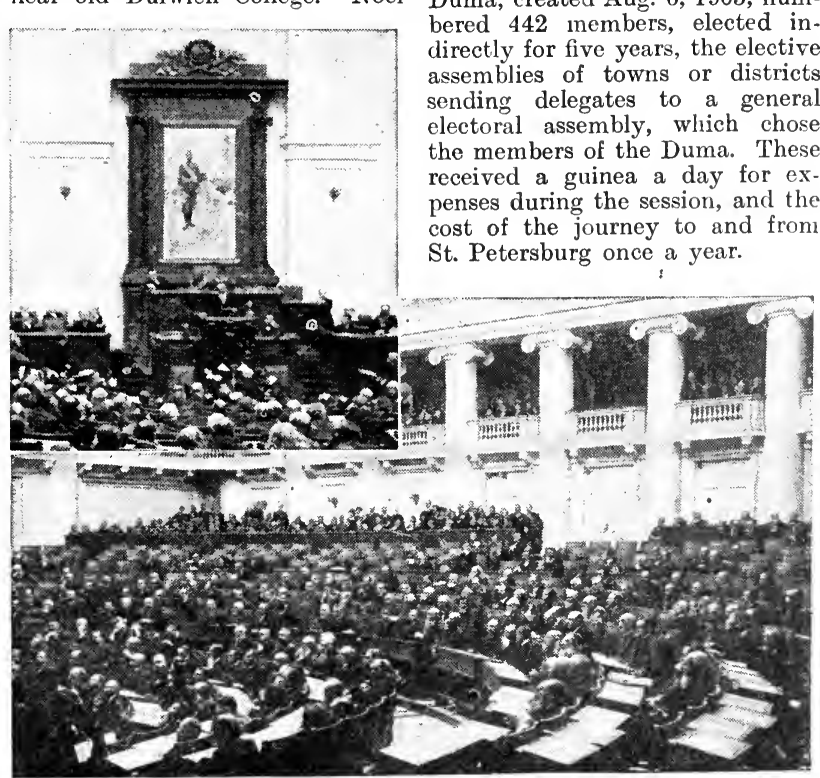

Duma. A sitting shortly before the final dissolution in 191\%. Above, President Rodzianko in the chair beneath a portrait of Tsar Nicholas II
Joseph Desenfans (d. 1807), a London dealer, left his pictures, originally collected for King Stanislaus of Poland, to his friend, Sir Peter F. Bourgeois, R.A. (17561811), who in turn bequeathed them to Dulwich College. Madame Desenfans commissioned Sir John Soare to design a building, which was opened in 1814. The collection of about 450 pictures is exceptionally rich in examples of the Dutch school; but it is noted for Watteau's Bal Champêtre, Reynolds's Mrs. Siddons as the Tragic Muse (whether original or replica is a moot point), and Gainsborough's Mrs. Sheridan and Mrs. Tickell. There are also characteristic works by Rembrandt, Adrian van Ostade, Albert Cuyp, Gustave Doré, Murillo, Velasquez, and other masters.

Duma. Representative state council of the former Russian Empire. It formed, with the halfelected and half-nominated council of the empire, or second chamber, the Russian legislature. The Duma, created Aug. 6, 1905, numsistricts sending delegates to a general assembly, which chose from

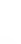


The Duma could not touch " the fundamental laws of the Imperial Administration," but within its sphere were the making of new laws, the modification of existing laws, the national budgets, the construction of state rlys., and any matters submitted to it by Imperial Decree. The chamber could be summoned or dissolved by the ukase of the emperor. - No measire was submitted to the tsar for his sanction until it had been passed by both the Duma and the Council of the Empire. The course of its brief history was stormy. The military revolution of Nov. 7, 1917, transferred the government of Russia to Commissioners set up by Lenin, and the Duma ceased to exist. See Russia, D. Mackenzie Wallace, rev. ed. 1912.

Dumaguete. Town of the Philippine Islands, capital of the prov. of Negros Oriental. It stands on Negros Island at the entrance to Tañon Strait, $90 \mathrm{~m}$. (direct) S.E. of Bacolod. Its chief trade is connected with turtles and cotton. Pop. 15,000.

Dumangas. Town of the Philippine Islands, in the prov. of Iloilo. It stands on Dumangas river, near the S.E. coast of Panay Island, and has tobacco and linen industries. Pop. 12,400.

Dumanjug. Town of the Philip. pine Islands, on Cebú Island. It stands at the mouth of the Duman. jug river, $38 \mathrm{~m}$. S.W. of Cebú town, and carries on a brisk trade in maize and other produce of the district. Pop. 22,000.

Dumas, Alexandre (1802-70). French novelist and dramatist, whose full name was Alexandre Dumas-Davy de la Pailleterie. He was born at Villers-Cotterets, July 24, 1802, his father being the illegitimate son of a French noble, the Marquis Alexandre Davy de la Pailleterie, who had settled in San Domingo, and of a negress named Marie-Cessette Dumas. The father became a general in the French republican army.

About 1822 Dumas went to Paris. His first success was with a play, Henri III et sa cour, 1829; and competent French critics citing this piece, together with Christine, Charles VII, La Tour de Nesle, and Mademoiselle de BelleIsle, claim for him an even higher place as a dramatist than as a teller of tales.

But to the majority of readers throughout the world Dumas is the author of that fantastic and unwearying romance, The Count of Monte Cristo, 1844-45, which translations Lave almost made a classic in numerous lan. guages. To many English-speaking readers the most familiar of his other works are The Three Musketeers, Twenty Years After, Memoirs of a Physician, The Queen's Necklace, Taking the Bastille, Chicot the Jester, The Black Tulip, and other romances. Many are unfamiliar with what is beyond question Dumas' masterpiece, Le Vicomte de Bragelonne (26 vols., 1848-50), prodigious in extent, and scarcely rivalled in literature as a piece of pure, sparkling, and unflagging narrative.

He has set his name to a thou. sand or twelve hundred volumes; dramas, romances, books of travel, historical scraps, compilations on art, crime, and cookery. Clearly there was a good deal of hocus. pocus, of literary legerdemain, and worse, in the career of this amazing man. The air was charged with stories of Dumas' " ghosts," assistants, and collaborators-Maquet

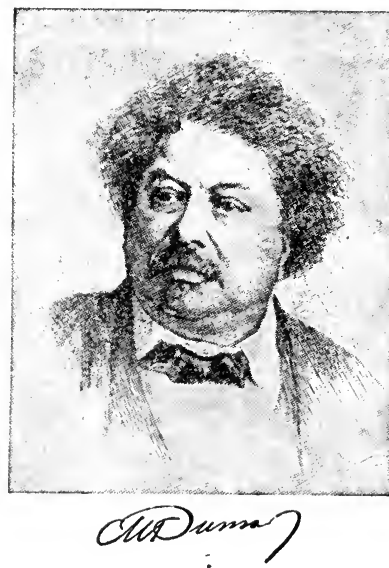

and others. It may be said (I) that Dumas, who could keep half. a-dozen plots going at once, and was burdened with few scruples as to their origin and evolution, seems to have taken help from all quar. ters ; (2) that, whatever tasks he may have assigned to his jackals, his own brain during many years was probably equal to the creation of what is best in the wonderful romances; and (3) that not one of these associates or auxiliaries, unassisted by the master, proved his rival in any field.

The day came when the power of the great man waned. This was the day of the shifts, schemes, devices to which none but a Dumas would or could have risen or de. scended. He put his name to any MS. that was brought to him, started impossible newspapers, lent himself to the wiles of advertising

Paris tradesmen. $\mathrm{He}$ died at Dieppe, Dec. 5, 1870.

Bibliography. Dumas' Memoirs, Eng. trans. E. M. Waller, 1907; Life and Adventures of Alexandre Dumas, P. H. Fitzgerald, 1873 ; Memories and Portraits, R. L. Stevenson,1887; Alexandre Dumas Père, H. Parigot (in French), 1902 ; Parisian Portraits, F. Grierson, 1911.

Dumas,Alexandre, Fils(182495). French novelist, dramatist, and academician. Born July 27,

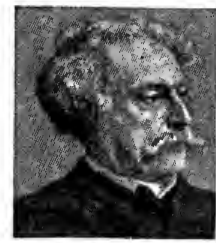

A. Bumas. 1824, he was the natural son of the famous $r \circ \mathrm{m}$ a $\mathrm{n}$ c e r, whose dramatic genius he inherited, but with whom otherwise he $\mathrm{h}$ ad little in common. When only twenty-four he made a sensation with a novel of passion, La Dame aux Camélias. After this be wrote other novels (e.g. Diane de Lys, 1851, L'Affaire Clémenceau, 1866); but the success of the dramatised versions of $\mathrm{La}$ Dame and Diane turned his energies to the stage, and it is as a playwright rather than as a novelist that he keeps his distinctive place.

Dumas was firmly convinced of the utility of the stage for the discussion of ethical questions and as an agent of social reform, and his plays, notably La Question d'Argent, Le Fils Naturel, Le Père Prodigue, L'Ami des Femmes, Les Idées de Mme. Aubray, Une Visite de Noces, are problem plays. While as plays they suffer at times from overstress of didactic purpose, Dumas' keen sense of the stage generally saved him from sinking into the mere preacher, while his incisive wit and brilliant style further contributed to his popular success. He died at Paris, Nov. 27, 1895. See Monograph, J. Claretie, 1882, and Nouveaux Essais de Psychologie Contem. poraine, P. C. J. Bourget, 1886.

Dumas, Jean Baptiste Andre (1800-84). French chemist. Hewas born at Alais, in the dept. of Gard, July 14, 1800 , where he was apprenticed to a pharmacist. In 1823 he was appointed assistant to Thénard at the Ecole Poly. technique, Paris, and shortly after.

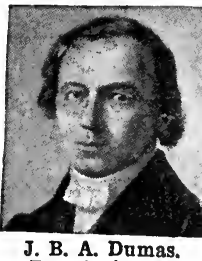
J. B. A. Dumas. wards succeeded Robiquet as professor of chemistry at the Athenaeum. 
Here he investigated experimentally the atomic theory enunciated a few years previously by Dalton. Then he began a study of the compound ethers, which was followed by investigations concerning other organic compounds. He established the fact that the organic acids form homologous series, i.e. series which differ from each other in chemical composition by multiples of carbon and hydrogen. He subsequently devoted more attention to physiological subjects, such as the phenomena of nutrition, the formation of sugar in the organism, and the composition of blood. In 1869 he lectured on Faraday at the Royal Institution, London. He died at Cannes, April 11, 1884.

Du Maurier, Georae LouIs Palmella Busson (1834-96). British artist and author. Born at Paris, March 6, 1834, he studied chemistry at University College, Lo ndon, su b s e. quently setting up as an analytical chemist. In 1856 he be. an art $\mathrm{m}$ tur student,

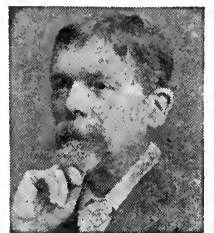

first in Paris and then in Antwerp. In 1865 he joined the staff of Punch, then under Mark Lemon's editorship, and began his famous series of social satires. In 1881 the Royal Society of Painters in Water Colours elected him a member. His sight failing rapidly towards the close of his life, he took to novel-writing, and produced Peter Ibbetson, 1892 ; Trilby, 1894 (serially in Harper's Magazine); and The Martian, published post. humously. Trilby, largely a reminiscence of Du Maurier's student days in Paris, enjoyed an extraordinary success. These and other volumes, illustrated by him, included Thackeray's Esmond (Lib. ed.), 1869; and F. C. Philips' As in a Looking-glass, 1889. He died at Hampstead, Oct. 8, 1896. See Memoir of Thomas Armstrong, L. M. Lamont, 1912 ; George Du Maurier : a review of his art and personality, T. M. Wood, 1913.

His elder son, Guy Louis Busson Du Maurier (1865-1915), entered the army from Sandhurst in 1885 . He served through the $\mathrm{S}$. African War, when he gained the D.S.O., and was killed in France, March 11,1915 . He was the author of a successful play, An Englishman's Home, produced in London, 1909.

Du Maurier, SIr GERALD (b. 1873). British actor. Son of George Du Maurier, he was born in

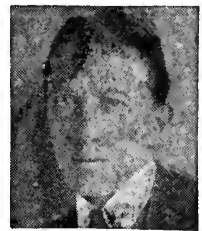

Sir G. Du Maurier, British actor Hugh Cecil
London, March 26,1873 , and Harrow. He first went on the stage at the Garrick Theatre, London, 1894, and in 1910 became the manager at Wy $\mathrm{ndh}$ a m's Theatre. Theoriginal Captain Hook in Peter Pan, he was knighted, 1922.

Dumba, Konstantis. AustroHungarian diplomatist. In 1913 he went as ambassador in Wash. ington, U.S.A., where he came into prominence in the early part of the Great War. $\mathrm{He}$ was con. to defeat the and in 1915, to gether with

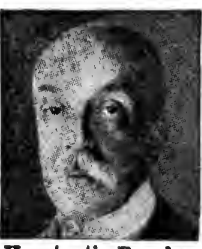

Konstantin Dumba, Austrian diplomatist Papen, Boy-Ed, and others, engineered a vast conspiracy with the object of disorganising the output of munitions for the Allies in American factories. He planned strikes and explosions, and in other ways abused his position. [He threatened Anstro-Hungarians working in the production of war material that they would be punished if they continued to work. Documents, including a letter from Dumba to Baron Burian, the Austrian foreign minister, suggesting certain measures for handicapping the output of munitions, were found on J. E.J. Archibald. President Wilson de. manded Dumba's recall, which was agreed to by Austria-Hungary, and the latter, granted a safe conduct by the British government, sailed from the U.S.A., Oct. 5, 1915.

Dumbarton. Royal, mun. and parl. burgh, also a seaport and the county town of Dumbartonshire, Scotland. It stands where the river Leven falls into the Clyde, $15 \frac{1}{2} \mathrm{~m}$. from Glasgow. It is on the N.B. \& educated at cerned in plots Allied cause,

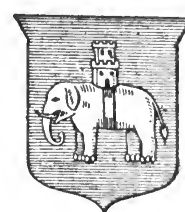

Cal. Rlys. The town proper is on the left side of the Leven, but across it is the suburb of Bridg end. The chief industry is ship. building, but Dumbarton arms there are also engineering works, brass foundries, and establishments for making ropes and sails.

The chief buildings include the castle, standing on a bold rock $240 \mathrm{ft}$. high; the burgh hall, the county hall, the Denny memorial, the public library, the academy, hospital, etc. Both a Celtic and a Roman settlement, Dumbarton was known as Alcluith, hill of the Clyde, and was the capital of Strathclyde. Market day, Tues. Pop. (1921) 17,428.

Dumbartonshire. Western county of Scotland. It is almost entirely surrounded by water-F.

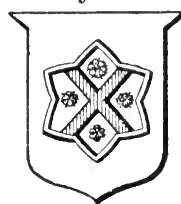

Dumbartonshire arms by Loch Lomond, W. by Loch Long, and $\mathrm{S}$. by the Clyde estuary, a small detached part of it lying between Stirling and Lanark. The surface is moun tainous in the W.

(highest point Ben Vorlich, 3,092 ft.), and generally hilly elsewhere, except in the $\mathrm{S}$. where the soil is well cultivated. The mountain, glen and loch scenery is magnifi. cent. The chief rivers, after the Clyde, are the Leven and Kelvin. Roseneath Castle, on Roseneath peninsula, is a seat of the duke of Argyll. Cattle and sheep rearing, engineering and shipbuilding are thriving industries, cotton goods, glass, and sewing machines are manufactured, and along the Vale of Leven are many bleachfields and dye works. Coal, iron and slate are the principal mineral products. The N.B. and Cal. rlys. and the Forth and Clyde Canal serve the county.

D u m barton

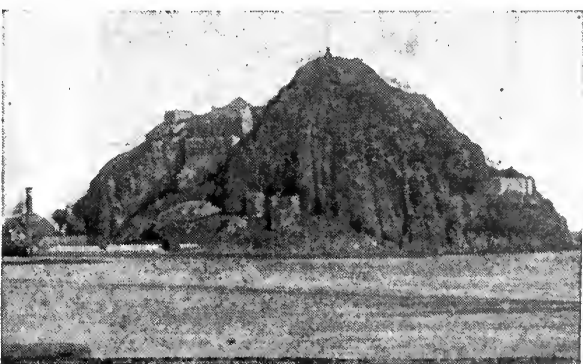

Dumbarton. The Rock of Dumbarton. showing the castle where Wallace was imprisoned (county town). Clydebank, and Kirkintilloch are the largest towns ; Helensburgh and $\mathrm{Kiloreggan}$ are health resorts. One member is returned to Parliament. Formerly Dumbartons hire was part of the old Scottish territor of Lennox. Arci 267 sq. m. Pop (1921) 150,868 


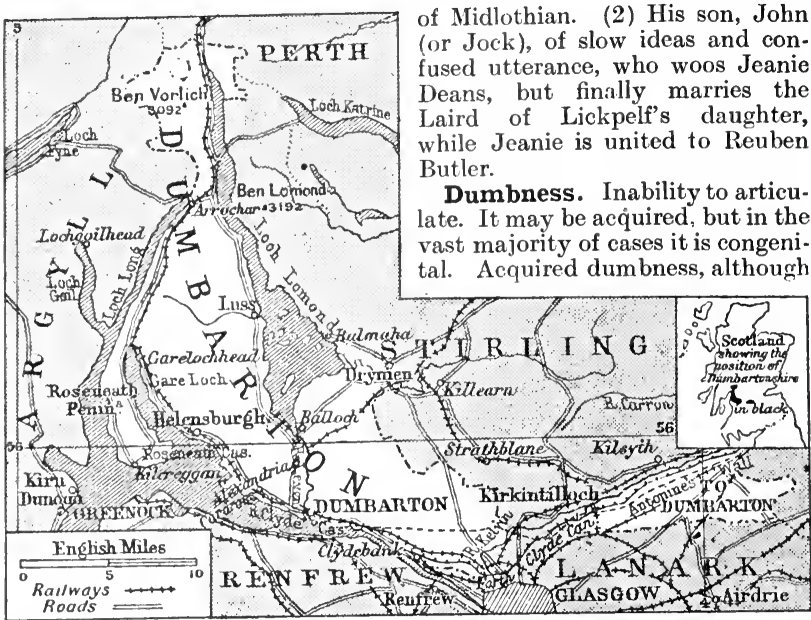

Dumbartonshire. Map of this western county of Scotland; a small detached part lies between Stirling and Lanark

Literary Associations. Tobias Smollett was born near Renton, where a $60 \mathrm{ft}$. column was erected to his memory. David Gray, the poet, was born at Merkland, Kirkintilloch, and died there at the early age of 23 . He is buried in Kirkintilloch churchyard. Many associations linger about Loch Lomond, which is partly in this co., notably with Scott's Rob Roy.

Dumb-Bell. Short iron or wooden bar with a knob at each end. used as an aid to health and by athletes as part of their training. They are grasped, one in each hand. and a series of exercises are then gone through. It is claimed that their use brings every muscle of the kody into play. Iron dumb-bells. which are most in use, weigh from $4 \mathrm{lb}$. to $6 \mathrm{lb}$. each, but heavier ones are occasionally employed. Ther are sometimes covered with loather. The first dumb-bells consisted of sticks loaded with lead at the ends. and werc so called because these ends were shaped like bells. Dumbbells are said to have been first used in the time of Elizabeth.

\section{Dumb Cane (Dieffenbachia seguina). Evergreen perennial} plant of the natural order Araccae, native of the West Indies. It has a fleshy, cane-like stem, about $6 \mathrm{ft}$. high, and ublong, deep green leaves spotted with white. The juice is acrid and poisonous. Old. time planters are said to have punished refractory slaves by com. pelling them to bite the stem, which rendered them speechless for several days, owing to swelling of the mouth parts.

Dumbiedikes, The LAIRD OF. (1) The grasping landlord of David Deans, in Scott's novel, The Heart

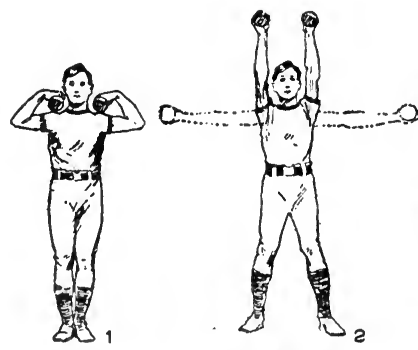

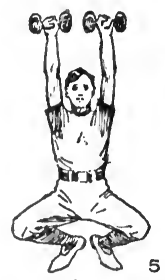

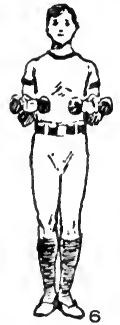

loudly; in the other varieties coughing is impossible or very feeble. General treatment will relieve the hysterical variety. At times a sudden fright or the application to the neck of a strong current of electricity is immediately successful. Recovery is usual from dumbness following diphtheria, but tumours require removal by operation. If the whole larynx has to be removed, speech can be regained by wearing an artificial larynx.

Congenital dumbness may be due to mental weakness, but much more frequently to deafness, congenital or acquired in infancy. The child cannot speak because it has not the use of its ears to guide its speech. Even partial deafness occurring in childhood may cause dumbness. It is important to ascertain whether the deafness is very marked or comparatively slight. Any middle ear disease or adenoids should be dealt with to improve the hearing up to its maximum. See Deaf and Dumb.

Dum-Dum or Damdama (Hind. raised mound). Town of India. It is in the Barrackpore sub-division of the district of the twenty-four Parganas, Bengal, 7 m. N.E. of Calcutta. The town comprises two municipalities, N. and S. DumDum, the former containing the cantonment, once the headquarters of the Bengal Artillery. There is a government ammunition factory at Dum-Dum.
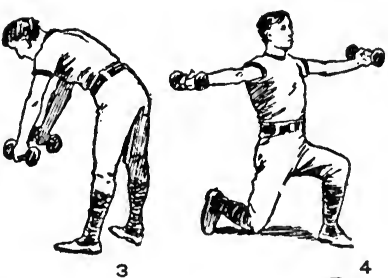

3

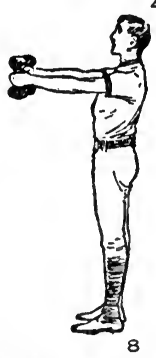

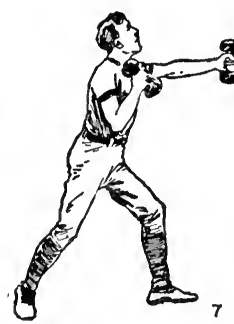

The start with the bell on the shoulders. 2. Position with feet apart and bells above the head before swing between the latter. The arms are raised above the head again and then swing between the latter. The arms are raised above the head again and then
lowered right and left until level with the shoulders (see fig. 2). 4. This position shows drop on the right knee, with left knee bent. 5. Movement to exercise the thigh and calf muscles. 6. Exercise for muscles of arms and chest. 7. The lunge movement. 8. Employment of arm and chest muscles 
Dum-Dum Bullet. Popular term for all projectiles of small calibre which expand or flatten
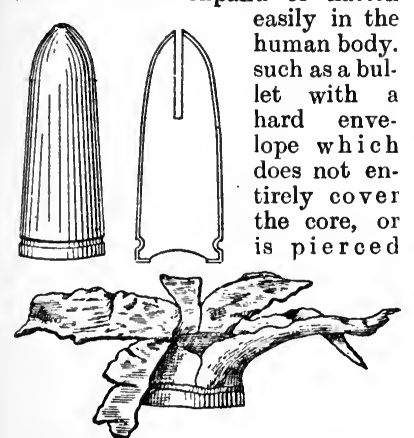

Dum-Dum Bullet. Above: the projectile, and sectional view showing cavity in the nose. Below: the bullet after impact

with incisions. This class of bullet was invented to meet a demand for a projective that would stoptherush of savages on whom the small-bore ine-bullet of the ordinary type makes little impression. Controversy centred upon an invention of Captain Bertie Clay, of the ammu. nition factory at Dum-Dum, near Calcutta, and so the name has stuck to bullets, such as the official mark IV, which mushroomed on impact. This bullet actually shot better for having a cavity in the nose, but at Bisley, in 1899, it was pronounced to be dangerous to the firer, as the lcad core separated from the envelope, and in the Boer War a return was made to mark II. the original cordite cartridge. See Bullet; Explosives.

Dumfries. Royal, parl., and mun. burgh, river port, and co. town of Dumfriesshire, Scotland.

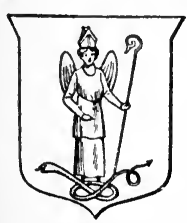

Dumfries arms It stands on the Nith, 82 m. S.E of Glasgow, on the G. \& S.W.R. and is connected with Maxwelltown, its suburb. by three bridges. A flourishing industrial town, Dumfries manufactures tweeds, hosiery, hats, and clogs, and has ironworks and tanneries. Among prominent buildings are the new town hall, Crichton institute for the insane, and the county build. ings. Robert Burns was buried in S. Michael's churchyard, and his remains were transferred to a mausoleum erected in the churchyard to his memory in 1815 ; there is a marble statue of the poet (1882) in front of Greyfriars Church, the scene of the murder of Comyn, by Robert the Bruce, in 1307. Market day, Wed.- Pop. (1921) 15,778.

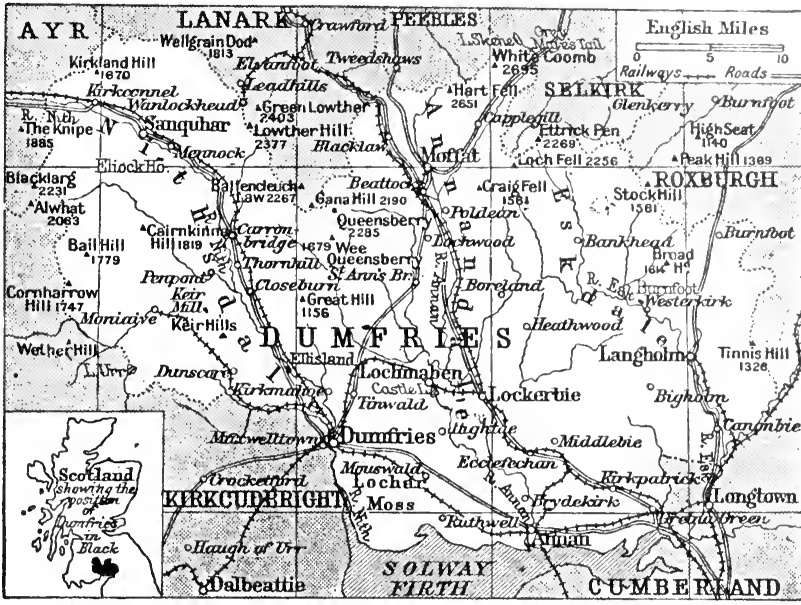

Dumfriesshre. Map of the south-western border county of Scotland, which has a coast-line of 21 miles along the Solway Firth

Dumfriesshire. Border county of Scotland, with coast-line of about $21 \mathrm{~m}$. along Solway Firth. Hills

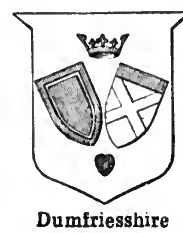

arms (highest summit, White Coomb, $2,695 \mathrm{ft}$.) line the N., W., and E. boundaries, whence the sur. face declines to Lochar Moss, a marshy expanse in the S., now largely reclaimed. The county includes three sections-Nithsdale, Annandale,

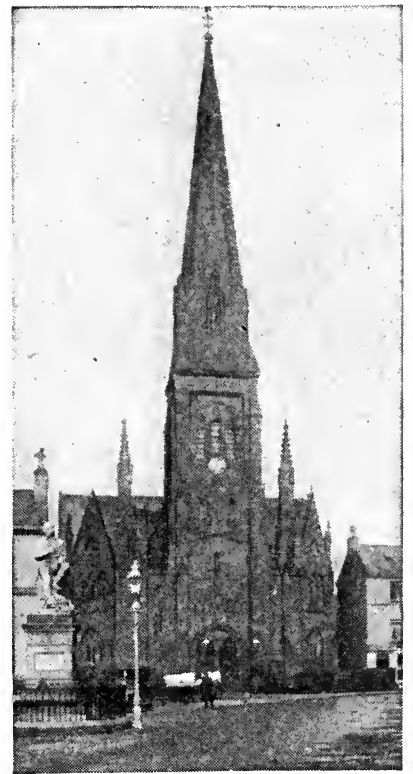

Dumfries. Greyfriars Chnrch, built in 1867 , with Burns statue in front and Eskdale; these dales contain fine holms for pasture besides arable land. The rivers are well stocked with salmon and trout. Lochs Skene and Urr and the cluster round Lochmaben are the chief lakes; the first gives rise to the Grey Mare's Tail waterfall. Lead ore underlies the Lowther Hills in the N., and sandstone, limestone, and coal are worked. Agriculture is not extensively followed, but cattle and sheep are reared in good numbers on the abundant pastures. Moffat is visited for its mineral springs. The Cal., G.S. \& W., and N.B. rlys. supply communication. Dumfries (co. town), Annan, Langholm, Lockerbie, and Moffat are the largest towns. Gretna Green $(q . v)$ is on the S. border. One member is returned to Parliament. Area, 1,100 sq. m. Pop. 75,365.

Literary Associations. Dum. friesshire claims many associations with Scottish and English literature from the time of Hector Boece or Boethius, the 16th century historian, who, like Ben Jonson, belonged to an Annandale family. James Crichton, the Admirable Crichton, was born at Eliock House, Sanquhar, while Robert Flint (18381910) belonged also to Annandale. W. J. Mickle, poet and translator of Camoens, was born at Langholm, and Allan Cunningham was born at Keir. The richest poetic memories of the county are associated with Burns, who passed the last eight years ô his life at Ellisland, Dunscore, and Dumfries, where he died and is buried. The soldier author: Sir J. Malcolm, was born at Burnfoot, Westerkirk. Edward Irving was born at Annan. The greatest man of letters who was a native of the county was Thomas Carlyle. 
Dumont,FrançoIs(1751-1831). French miniature painter. Born at Lunéville, he studied under Girardet, and became an academician in 1788. Mlost of his miniatures are portraits, and include those of the dauphin (Louis XVIII) and Ma. dame Vigée Le Brun, both in the Wallace Collection. Healso painted historical pieces in miniature.

Dumont, Pierre Etienne Iouis (1759-1829). French writer. Born at Geneva, July 18, 1759, he went to St. Petersburg in 1783, to take charge of the French Protestant church. In 1785 he came to Eng. land, where he became tutor in the family of Lord Shelburne (later marquess of Lansdowne). He was in Paris during the early part of the French Revolution, and became very friendly with Mirabeau. In 1791 he returned to England, and became intimate with Jeremy Bentham, much of whose work he translated into French. In 1814 he returned to Geneva. He died at Milan, Sept. 30, 1829, leaving in MS. his Souvenirs sur Mirabeau, 1832 (Eng. trans. by Lady Sey. mour, as The Great Frenchman and the Little Generese, 1904).

Dumouriez, Charles FrançoIs (1739-1823). French soldier. He was born at Cambrai, Jan. 25, 1739.

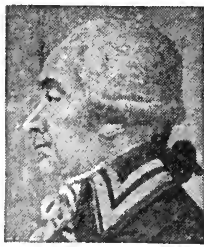

Chas. F. Dumouriez, French soldier At the age of 18 he entered the French army, and fought in the Seven Years' War. Having been sent on a mission to Poland and Sweden, he fell into disgrace; was recalled, and imprisoned for some months in the Bastille. When the Revolution broke out, he took the popular side, and became minister of foreign affairs. $\mathrm{He}$ resigned office to take command of the army of the north against the duke of Brunswick, whom he defeated at Valmy, Sept. 20, 1792, and in the same year he won another victory at Jemappes. In 1793 he was badly beaten by the Austrians at Neerwinden. Accused of conspiring for the restoration of the monarchy, he took refuge with the Austrians, and for some years wandered about Europe with a price on his head. He finally settled in England, where he died near Henley-on-Thames, March 14, 1823. See Dumouriez and the Defence of England against Napoleon, J. H. Rose and A. M. Broadley, 1909.

Dumping. Originally, the act of throwing down a large quantity of material in a heap, as in shooting rubbish. In economirs the term is applied to a practice adopted by some countries, e.g. Germany, of producing goods in vast quantities with the assistance of bounties or tariffs, and then exporting them to other countries; thus flooding the market and underselling the manufacturers there with the object of killing their industry and securing control of the market. Tariff reformers urge the imposition of tariff on imports on the ground that it would prevent dumping. On the other hand some manufacturers uphold the practice of dumping on the ground that it enables them to maintain that volume of output which is most economical to produce and thus most profitable in the long run. An act to prevent dumping in the United Kingdom, known as the Safeguarding of Industries Act, was passed by Parliament in 1921. See Political Economy; Tariff Reform.

Dumraon. Town of India. It is in Shahabad district, in the Patha division of Bihar and Orissa, and contains the palace of the maharaja, whose estate, Dumraon Raj, covers an area of $758 \mathrm{sq}$. miles. Pop. 15,042; five-sixths Hindus.

Dun. Celtic word meaning hill or fort. The dun was either a circular row of large stones on the top of a hill, or a regular building, known as a "Danish" fort, with a double wall. It is a common prefix in towns of the British islands, sometimes altered to dum-, don-: e.g. Dundalk, Dumbarton, Doncaster.

Dïna. Alternative spelling of the Russian river better known as the Dvina (q.v.).

Diinaburg. Alternative spelling of the Russian town, better known as Dvinsk (q.v.).

Dunaföldvár. Town of Hun. gary. It stands on the right bank of the Danube (Duna) about $50 \mathrm{~m}$. $\mathrm{S}$. of Budapest. It is on a branch rly. which keeps fairly close to the river and terminates at Pács, some $16 \mathrm{~m}$. farther S. It is one of the small towns which have grown up on the relatively high right bank of the river where they are secure from the floods. Pop. 12,100, mainly Magyar Roman Catholics.

Dunajetz, Battles of THE. Fought between the Austro-Germans and the Russians, April and May, 1915. During the Russian offensive of April, 1915, in the Carpathians, Hindenburg assembled large forces in and around Cracow. His purpose was to make a fresh movement $\mathrm{E}$. in Galicia, in combination with the Austro-German armies already in and about the passes, the total strength being at least 2,000,000 men, with some 4,000 guns of all calibres. The nominal commander was the Arch. duke Frederick, but the real head was Mackensen.

The Russian armies in Galicia, with Ivanoff in chief command, were much inferior in numbers, especially in guns and material. From the Vistula S. to near Bart. feld, and thence E. to the Dukla Pass, stood the 3rd Russian Army, under Radko Dmitrieff. From the Dukla to the Pruth the Carpathian front was held by Brusiloff with the 8th and 9th Russian Armies, while $N$. of the Pruth were two corps of Russian cavalry. The total of the Russian forces was 14 corps as against the Austro-German total of 24. On the line of the Dunajetz-Biala, Dmitrieff had five corps, and when the enemy attack began in force there Mackensen disposed of 12 corps in this sector, with superior strength in artillery and munitions.

The first assault took place in the Gorlice district, however, with which coordinated assaults were delivered by Hindenburg in Cour. land and on the Rava, the Pilitza, and the Nida between the Lower and the Upper Vistula, in order to pin down the Russian forces $\mathrm{N}$. of Galicia. On April 28 Mackensen's right wing, moving from Novo Sandec (Sacz) through Gry. bov on Ropa, was in position on Dmitrieff's left, on the Biala, while higher up, on the Dunajetz, the Austro-Germans were beginning to bombard his right.

As the attack from Ropa on Gorlice developed the Russians withdrew slightly N.E., and on May 1-2 their whole line from Ciezkovice to Malastov, $8 \mathrm{~m}$. S. of Gorlice, was subjected to an unprecedented artillery fire, which virtually wiped out the first lines of Russian trenches. Prussian troops broke through Dmitrieff's front at Ciezkovice and Staszkovka, the Russians falling back towards $\mathrm{Ol}$ piny and Biecz. The result of the struggle in the Gorlice district was that the Russian defence was broken on a front of $10 \mathrm{~m}$.

In the N., on the Dunajetz the Austrians, under the Archduke Joseph Ferdinand, tried to break through in the direction of Tarnov under heavy artillery cover, but failed on May 2-3 to get across until the Russians there withdrew in consonance with Dmitrieff's general retreat $\mathrm{E}$.

Desperate fighting took place on May 3-4 between the Biala and the Wisloka, the Russians being driven back by superior numbers. To the S. a Hungarian assault rendered Jaslo untenable on May 4. S. of Jaslo Bavarians and Austrians were on the same day close to the 
Dukla at Zmigrod and Krempna, and the Russians retreated with difficulty thence and from the Bartfeld district. On May 7 Mackensen forced a crossing of the Wisloka at Jaslo with his own individual oommand, which had most of his heavy artillery, and which came to be known as his "phalanx."

The Russians then fell back to the Wistok, but on May 8 were forced from it at Frystak and Rymanov. They made a stand at Dembitsa, and to cover the retreat of the Russian left from the Dukla and the Lupkov passes Ivanoff sent out strong forces from Sanok, which temporarily checked the AustroGerman advance in the S. But by May 11 the retreat of the Russians was general to the San, after hardfought delaying actions on the three preceding days on a line across Mid-Galicia from the Vistula to the Uzsok Pass. During Mackensen's advance he captured upwards of 100,000 Russians, but he did not succeed in destroying the Russian armies. See San, Battles of the.

Robert Machray

Dunaverty. Promontory and bay of Argyllshire, Scotland. It is $5 \mathrm{~m}$. N. of the Mull of Kintyre. On the promontory there formerly stood a castle, belonging to the Lord of the Isles, which was several times besieged.

Dunbar. Royal and mun. burgh and seaport of Haddington. shire, Scotland. It stands at the

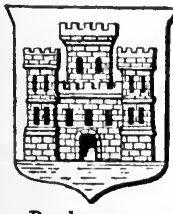

Dunbar arms mouth of the Firth of Forth, 29 m. E.N.E. of Edinburgh on the N.B.R. A popular health resort, Dunbar has a good golf course and a racecourse near. Of its two harbours the Victoria Harbour (W.) is a refuge for ships in distress. The herring fisheries are important, and other industries include rope and agricultural imple-

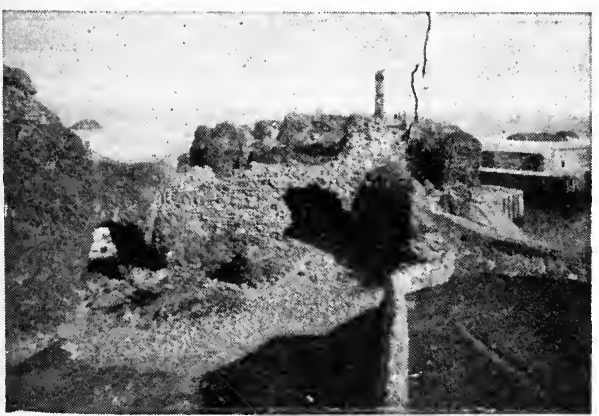

Dunbar. Ruins of the Scottish castle founded in $\mathbf{8 5 6}$, and long held as a defence against the English ment making. There are ruins of the old castle, captured by Edward I in 1296 and successfully defended against the English in 1338 by Black Agnes, the countess of Dunbar. The battle of Dunbar, in which Cromwell defeated the Covenanters, took place close to the town in 1650. These historic events indicate the strategic position of the town on the east coast route now followed by the rly. to Edinburgh Market day, Tues. Pop. 4,830.

Dunbar, BatTle of. Fought Sept. 3, 1650, between the English and the Scots. Cromwell, seeking to crush finally the cause of Charles II, had invaded Scotland. With 16,000 men he approached Edinburgh only to find the Scots under David Leslie in a strong defensive position. Anxious to keep in touch with his supplies on board ship, Cromwell fell back to Dunbar. Then a second time he advanced to Edinburgh, but again the Scots were in a strong position, and again he retired to Dunbar.

This time Cromwell was followed by the Scots. He encamped on Sept. 1. on the low ground near the town and the coast, while Leslie on the hills sent a force to bar the road to England. Sickness was rife among the English troops, who numbered barely 11,000 effectives as against 20,000 Scots, and their position was perilous when the Scots, urged on by the ministers who were with the army, left their position of vantage in order to attack.

The Scots at first stood with their backs to England, and between them and the English was a stream called the Broxburn. Cromwell opened the engagement before daybreak on Sept 3. by sending some of his horse and foot across the stream. The Scots were not yet ready, so the English had time to take up a position with the sea behind them and the hills in front. The infantry under Monk advanced, as did the horsemen on either side of them; but the Scots, now fully ready, met their assault firmly. For a time there was no advan. t a g e, but a t length Cromwell led up his reserves. This was decisive. The Scottish right broke, and the infantry in the centre was also routed, and the
English horsemen came round their flank. The sun was only just rising when Cromwell called out "Let God arise, let His enemies be scattered." The Scots were followed as they fled, and altogether 3,000 of them were killed. About 10,000 more, with their arms, artillery, and baggage, were taken. The English losses were slight.

Dunbar, EARL OF. Scottish title now extinct. Its origin is obscure, but it was certainly in existence in the 12th century when Waltheof de Dunbar, who married a daughter of William the Lion, called himself earl of Dunbar. He was descended from a family that had lands in the Lothians and a connexion with Northumbria.

Succeeding earls, mostly named Patrick, were persons of import. ance in Scotland. One was made regent in 1255, another was one of the claimants for the crown in 1291. This latter was called also earl of March, presumably because he had lands on the marches, and henceforward the earldom was known as that of March or Dunbar. A 14th century earl was in all the fighting between England and Scotland, being sometimes on one side and sometimes on the other. His wife was the renowned Black Agnes, who in 1338 defended Dunbar castle against the English. A great nephew, George, succeeded to the honours, and his son George was deprived of his lands and titles in 1435. In 1605 James I made Sir George Home earl of Dunbar and March. He was the lord who, by first hanging a gang of outlaws and then trying them, gave rise to the phrase Jeddart justice. He died in 1611, and the title soon became extinct. See March, Earl of.

Dunbar, William (c. 1460 1513). Scottish poet. He is believed to have been born in East Lothian and educated at $\mathrm{St}$. Andrews. Becoming a member of the Franciscan order, he travelled as an itinerant friar through Scotland, England, and part of $\mathrm{N}$. France. About 1490 he entered the diplomatio service, which took him to Germany, Italy, and Spain In 1505 he received a pension from King James IV as Court Laureate, but was unsuccessful in his efforts to obtain a benefice. The king's marriage with Margaret, daughter of Henry VII, occasioned Dunbar's most famous poem, The Thistle and the Rose (1503). Dunbar is not heard of after the battle of Flodden, and it is most probable that he fell on the field.

His poems also disappeared about this time, to be discovered some 200 years afterwards by 
Allan Ramsay in a eountry house. His poetical genius, influenced by Chaucer, was manv-sided: the rich allegorical poem The Thistle and the Rose is far removed from the grim humour of The Dance of the Seven Deadly Sins, or the serious pieces, such as 'The Passion of Christ. See Poems, ed. J. Small (for the Seottish Text Society). $188 t-93$.

Dunblane. Town and police burgh of Perthshire, Seotland. It stands on Allan Water, 5 m. N.N.W.

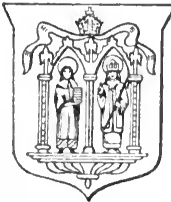

Dunblane arm of Stirling on the C.R. It has a hydropathic es. tablishment and a mineral spa. Once the seat of a bishopric, its cathedral is one of the few which es. caped destruction at the Reformation; restored in 1893 , it is now the parish chureh. Robert Leighton, bishop 1661-70, is eommemorated by the Leightonian library, Bishop's Walk and Bishop's Well. The Queen Victoria Military School (opened 1908 ) is $1 \mathrm{~m}$. N. of the town, and the battlefield of Sheriffmuir (1715) is $2 \mathrm{~m}$. to the $\mathrm{E}$. Many of the people work in the woollen mills. Market day, Thurs. Pop. 4,591.

Duncan (d. 1040). King of the Seots. He suceeeded his grandfather MaleoIm II as king in 1034. Little is known of him except that he was slain by Maebcth, thane of Cawdor, Cawdor Castle being the traditional scene of the crime. Shakespeare's version of the tragedy is based on legend.

Duncan, Adam Duncan, Viscount (1731-1804). British sailor. Born at Lundie, Forfar, July 1, 1731,

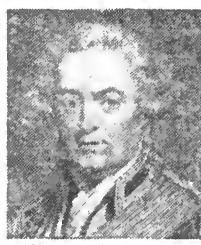

Viscount Duncan. British sailor

Aster Hoppner he entered the navy in 1746 . He was present at the actions of the Basque Roads (1757). Goree (1758). and the blockade of Brest (1759). After his return to Great Britain (1761) hesary no further service until 1778, when he was appointed to the Suffolk. In 1782 he became first lord of the Admiralty, and in the Blenheim took part in the relief of Gibraltar.

In 1795 , promoted admiral, he hoisted his flag on the Venerable as commander-in-chief in the North Sea. On Oct. 11, 1797, he obtained a decisive vietory over the Duteh fleet off the village of Camperdown. For this he was created Viscount Duncan of Camperdown. He died

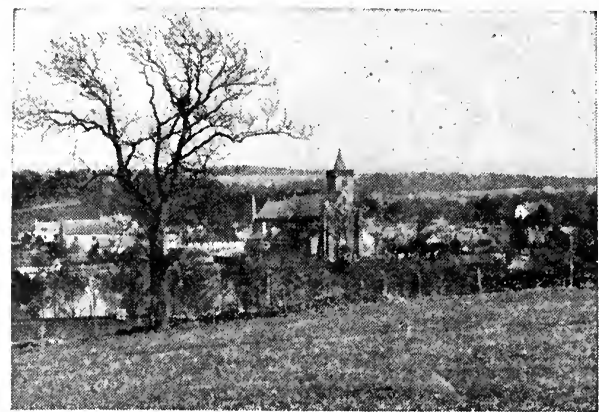

Dunblane. The town seen from the north-west, with a view of the 13 th century cathedral

suddenly Aug. 4, 1804. See Camper. down, Battle of Camperdown, Earl of ; consult also Life, 3rd Earl of Ca m perdown. 1898.

D u n c a $\mathbf{n}$ George (b. 1883). $\mathrm{British}$ golfer. 1) unean was seventh in the Open Championship in 1907, and played for Scotland against Eng. land in 1906, 1907, 1909 , and 1910 .

He won the Belgian Open Cham. pionship in 1912. and the following year was French champion.

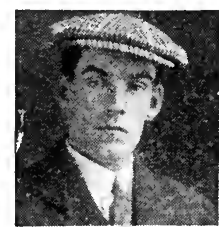

George Duncan, British golfer

Arthur Haves D u n c a n, American dancer. One of the most interesting figures in the history of dancing, she was born at San Francisco, and made her first appearance in Chicago in 1899 without much suecess. In Europe, however, she attained great popularity, appearing in Paris, Berlin, Vienna, St. Petersburg, and London. Her ideal of daneing derived from nature through Greek art created a great impression. Isadora Duncan lived for some years in Paris, and founded there, and at Grünewald, near Berlin, a dancing sehool where children received free board and education.

Duncan, Thomas (1807-45). Seottish painter. Born at Kinclaven, Perthshire, May 24, 1807, he began to study art under Sir William

Open Cham. pionship at 1920. Duncan, professional at ganger $\mathrm{Hil}$ Golf for Women, 1914.
Allan at the Trustees' Academy, Edinburgh. $\mathrm{He}$ was made a member of the Royal Scottish Academy in 1830, and succeeded Allan as master of the 'Trustees' Acad. emy. In 1843 he was elected A.P.A. His large and spirited painting of Prince Charles Edward and his Highlanders en. tering Edinburgh

\section{Duncia d} THe. Satiric poem by Alexander Pope, first published a n o n ymously, May 28, 1728.

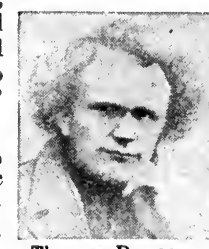

Thomas Duncan, Scottish painter Self-portrait
The poet, who had been vulgarly abused by hack-writers of the time, unmercifully retaliated on them in this poem.

Duncker, Maximilian WolfGANG (1811-86). German historical writer. He was born in Berlin, Oct. 15,1811 , and became professor of history at Halle in 1842, and sat as a Liberal in the Prussian legis. lature from 1849-52. Appointed professor at 'Tübingen, 1857, he resigned the post to enter the ministry of state in Berlin in 1859. He was direetor of the Prussian state archives from 1867-74. $\mathrm{He}$ died July 21, 1886. His chief works 
are Origines Germanicae, 1840 ; Geschichte des Alterthums, 185257, Eng. trans. in two portions as History of Antiquity, by E. Abbott, 1877-82, and History of Greece, by S. F. Alleyne and E. Abbott, 1883-86.

Duncombe, Thomas Slingsby (1796-1861). British politician. Educated at Harrow, he served

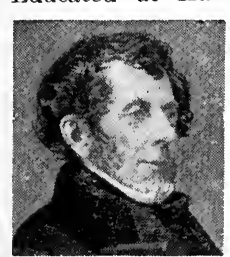
for a short period in the army. He entered Parlia. ment in 1826 as member for Hertford, and afterwards sat for Finsbury. $\mathrm{He}$ presented

Thomas S. Duncombe, the Chartist British politician petition toPar liament in 1842 , and, actively interested in European revolutionary movements, is said to have assisted Louis Napoleon's escape from Ham in 1846. He died Nov. 13, 1861.

Dundalk. Urban dist. and co. town of Louth, Ireland. It stands on Castletown river, near Dundalk bay, $54 \mathrm{~m}$. N. of Dublin on the G.N.I. and L. \& N.W. Rlys. An important rly. centre, the G.N.I.R. has its locomotive works here, and distilling, shipbuilding, tanning, and iron-founding are active industries; agricultural and dairy produce are exported. Market day, Mon Pop. 15,330. Here in 1315 Edward Bruce proclaimed himself king, and was killed in battle in the neighbourhood in 1318. The town surrendered to Cromwell in 1649 and to Schomberg in 1689.

Dundalk Bay. Inlet of the Irish Sea. It penetrates the $\mathrm{E}$. coast of Ireland, co. Louth, about $6 \mathrm{~m}$., and at its entrance between Cooley Point on the N. and Dunany Point on the $S$. its width is $7 \mathrm{~m}$. It receives the waters of the rivers Dee, Glyde, Fane, and Castletown, and other smaller streams. The bay affords excellent anchorage

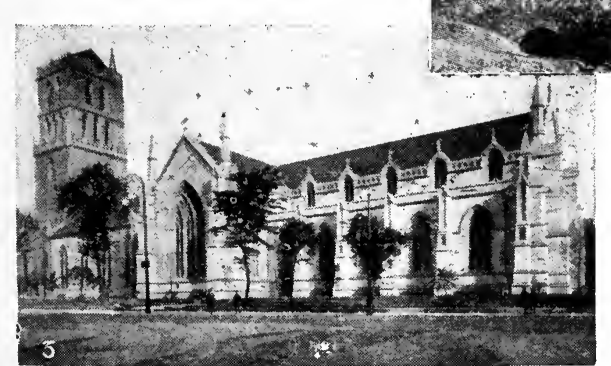

Dundee. 1. General vicw of the city from the docks. 2. Ruins of Mains Castle, once the residence of Claver. house. 3. Town Churches: the churches of S. Mary,

S. Paul, and $S$. Clement under one roof, and the 12 th century steeple Valentine in a depth of from 4 to 6 fathoms. Several fishing villages stand on its shores.

Dundee. City, parl., royal, and co. burgh, and seaport of Forfarshire, Scotland. It stands on the N. shore of the Firth of Tay, $59 \frac{1}{2}$ m. by rly. N.N.E. of Edinburgh, on the Cal. and N.B. Rlys., and is the third largest town in Scotland. The Tay Bridge, opened in 1887 in place of an earlier structure de(see plate facing p. 1374). Prominent buildings include the town hall

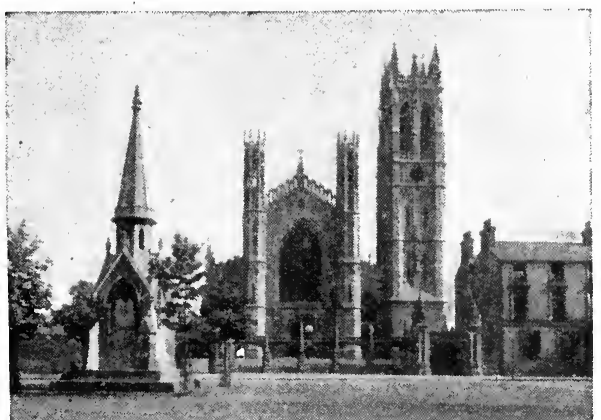

Dundalk. Front of the Roman Catholic Cathedral ; its design is based on that of King's Col!ege Chapel, Cambridgs stroyed in 1879 , is $3,593 \mathrm{yds}$. long

central reading room and sculpture gallery and five branch libraries situated in the various districts

The Town Churches-three beneath one roof -are the most notable of many churches. Educational institu. tions are represented by the University ColDundee arms lege, founded in 1880 by Miss Bax ter and Dr. J. B. Baxter, opened in 1893 , and incorporated with the university of St. Andrews in 1897 ; the tech$n$ ical institute founded and en. dowed by Sir D. Baxter and opened in 1888 the high school with $\mathrm{museum}$ and the Morgan Academy.

Dundee has a commodious har bour extending for $2 \mathrm{~m}$. along the river, with a dock

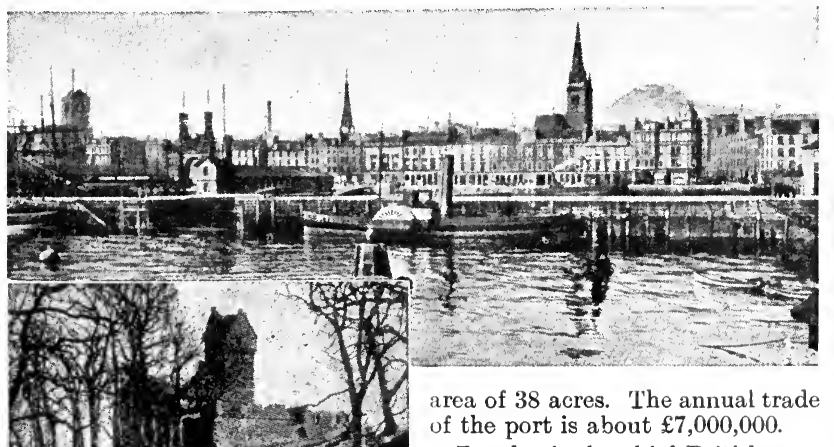

Dundee is the chief British port for the seal and whale fishery. The city, moreover, is the centre of the Scottish linen industry, while its jute, hemp, and flax manufactories are among the most extensive in the world. Other industries include engineering, shipbuilding, dyeing, and fruit preserving, Dundee being noted for its marmalade. The largest public parks are Baxter Park, 37 acres; Balgay Hill, 36 acres; Lochee Park, 25 acres and Cairo Park, 178 acres. Dundee Law, the hill at the back of the town, is a well-remembered landmark. Two members are returned to Parliament. Market days, Tues, and Fri. Estir zated pop. of mun. bor. (including Broughty Ferry). 189,000 


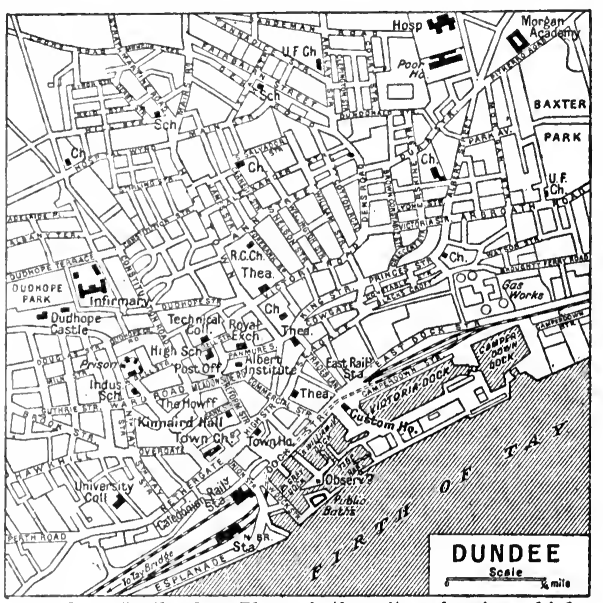

Dundee, Scotland. Plan of the city, showing chief public buildings and docks

Dundee (Lat. Taodunum, hill or fort on the Tay) was besieged by Wallace in 1297 and sacked by the marquess of Montrose in 1645. In $1651 \mathrm{Gen}$. Monk burned the town and massacred a large number of the inhabitants. It was among the first Scottish towns to adopt the doctrines of the Reformation, and here Wishart preached during the plague of 15it. See illus. facing p. 1374.

Dundee, JoHN GRAHAM OF Claverhouse, Viscount (c. 164989). Scottish soldier. The eldest

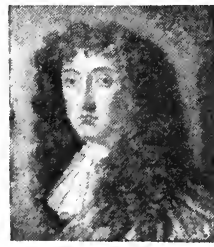

Graham of Claver Dundee After Lely house, Viscount son of Sir Wil liam Graham, he belonged to the family that had ac. quired the estate of Claverhouse, near Dundee. $\mathrm{He}$ was educated atSt. Andrews University and served in France and Holland, distinguishing himself in 1674 at the battle of Seneff, where he is said to have saved the life of the prince of Orange. He was sent as a cavalry leader to Scotland, 1678 , with orders to enforce conformity to the cstablished church, and by his relentless repression of the Covenanters carned the name of

"Bluidy Clavers." In 1688 he was created Viscount Dundee by James II. He was an ardent supporter of the Stuart cause, and was mortally wounded at the battle of Killi. crankie, July 17, $1689 . \quad$ The title became extinct when his son died in the same year. The use of

"Bonnie Dundee" as an epithet for Graham dates from Sir Walter Scott's song, the original old ballad of that name being concerned solely with the town of Dundee. See Covenanters; consultalso Lives, C. S a n f ord Terry, 1905; M. Barrington, 1911.

Dundonald, EarL OF. Scottish title borne since 1669 by the family of Cochrane. In 1647 Sir W. Cochrane, a supporter of Charles I, was made a baron, and in 1669 earl of Dundonald. His grandson $\mathrm{Joh} \mathrm{n}$ became the 2nd earl, which title passed to other descendants. William, the 7th earl, was killed at the siege of Louisburg in 1758. Thomas, the 8th earl, followed. Archibald, the 9th earl, was a noted scientist, while his son Thomas, the loth earl, was the famous admiral.

In 1885 his grandson Douglas (b. 1852) became the 12th earl. A soldier, he saw service in various cam. paigns in Egypt and the Sudan, and in 1899-1902 went through the $S$. African War. In 1902-4 he commanded the Canadian militia, returning home after a speech which the authorities regarded as indiscreet. His seat is Gwyrch Castle, Abergele, N. Wales, and his eldest son is known as Lord Cochrane. Dundonald is the name of a large parish in Ayrshire, which contains the ruins of a castle, long the residence of the Cochranes.

Dundonald, Thomas Cochrane, 10Th EarL of (1775-1860). British admiral. He was born at Annsfield, Lanark, Dec. 14, 1775, the eldest son of the 9th earl. In 1793 he entered the navy, and in 1801 he captured a Spanish frigate. In 1806 he became M.P. for Honiton and in 1807 for Westminster, and as a Radical became known by his denunciation of abuses in the navy.

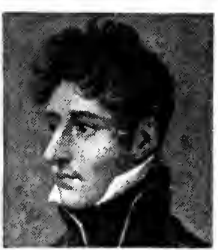

In 1809 Dundonald took part in the attack on the French squadron in the Basque Roads. He contended that he had Drmannaed not been proFromanengraving ported by Gambier, the admiral in command. A court-martial was held, by which Gambier was acquitted and Coch. rane consequently discredited.
In 1814 he was unjustifiably arrested with others in connexion with a false rumour affecting the funds, and was sentenced to a year's imprisonment and a fine of $£ 1,000$. He was struck off the navy list, expelled from the House of Commons, and ignominiously removed from the Order of the Bath. The amount of his fine was raised by popular subscriptions.

In 1817 Cochrane accepted the command of the Chilean navy and, 1819-23, carried out a series of daring and brilliant exploits. In 1823-25 he commanded the Brazilian, and, 1827-28, the Greek navy. In 1831 he became 10th earl of Dundonald and in 1832 was granted a "free pardon" for a crime which he had not committed, and restored to his rank in the navy. In 1847 he was reinstated in the Order of the Bath. He was an early advocate of the use of steam in the navy, and was the author of the famous secret war plan, by which he claimed that he could destroy any fleet or fortress in the world. He died at Kensington, Oct. 31, 1860, and was buried in Westminster Abbey. The eldest son, Thomas Barnes (1814-85) then became the 11th earl.

Bibliography. Dundonald's Narrative of Services in the Liberation of Chili, Peru, Brazil, 1859, and Autobiography of a Seaman, 1860 ; Life, by his son and H. R. Fox Bourne, 1869 ; Dundonald, J. W. Fortescue, 1895 ; The Trial of Cochrane before Ellenborough, J. B. Atlay, 1897.

Dundreary, LORD. Character in Tom Taylor's comedy of Our A m e r i c a $n$ Cousin, first produced in New York, 1858. Originally designed as a subsidiary part, it was so developed by its creator, E. A. Sothern that it became the chief char. acter. Dundreary is a good - natured but foolis h man of fashion, conspicuous for his sidewhiskers

\section{Dundrum} Bay. Inlet of co. Down, Ireland. It ex-

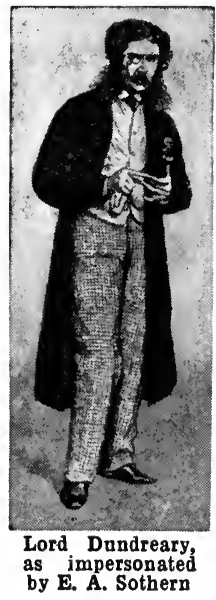

tends from St. John's Point to Dullish Cove, a distance of $9 \mathrm{~m}$. Dundrum Harbour is on the $\mathrm{N}$. of the bay. On St. John's Point is a lighthouse. 
Dune (Ir. dun, hill). Hill formed of sand. Where the prevailing winds are relatively steady, dunes may gradually advance, owing to the particles of sand being driven by the wind up the dune and over the crest to the leeside. Sand dunes occur in deserts, where they often present a monotonous succession of crests and troughs, and along sandy coasts, e.g. Belgium, Holland, Germany, and Denmark. In deserts, any obstacle, such as a cactus or a large stone, is sufficient to start the building of a dune, although desert dunes may be formed without such aid. The typical isolated desert dune is crescent-shaped, its horns pointing in the direction of the prevailing wind, while the windward is steeper than the leeward slope.

Dunedin. Chief city in South Island, New Zealand. It stands on Otago Harbour, $8 \mathrm{~m}$. S.W. of Port Chalmers. It has good sea communication with other N.Z. ports, Sydney and Melbourne, and is the chief rly. junction on the main E. Coast line. The town is surrounded by a forest preserve called the Town Belt. The most important manufacturing centre of the Dominion, its chief industries are woollen manufactures (Mosgiel and Roslyn), refrigerating works, bootmaking, foundries, and rolling mills. A great educational centre, most of the churches have their residential colleges at its university (opened 1871), which possesses medical and dental schools and a school of mines. It is the seat of Anglican and Roman Catholic bishops. Its museum, containing remains of the moa and other rare N.Z. birds, and art gallery are important buildings. Pop. 55.256 : with suburbs, 68.7I6.

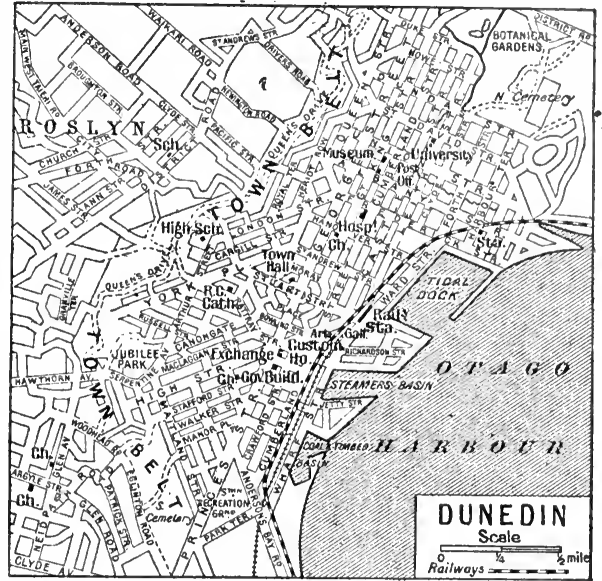

Dunedin. Plan of the city and docks of the principa port of South Island, New Zealand

In 1905 Murray left Parliament to become president of the court of session, and was made a peer as Baron Dunedin. In 1913 he was appointed a lord of appeal.

Dunes, Battis OF THE. Fought on the dunes outside Dunkirk between the French and the Spaniards, both supported by English contingents, June 4, 1658. To relieve Dunkirk, th e $\mathrm{n}$ besieged by the French, the Spaniards sent an army under Don John

Fourded in 1848 by members of the Free Church of Scotland, its com. mercial prosperity dates from the discovery of gold in Otago in 1861.

Dunedin, Andrew Graham Murray, Ist BaroN (b. 1849). British lawyer and politician. Born Nov. 21, 1849, he was the only son of T. G. Murray of Stenton, Perthshire, crown-agent for Scotland. Educated at Harrow and Trinity College, Cambridge, he became an advocate in 1874 and a Q.C. in 1891. In the same year chosen M.P. for Buteshire, he entered the Unionist ministry as solicitor-general for Scotland. In 1895 he was again appointed to that position, and in 1896 was promoted to be lord advocate. From 1903-5 he was secretary for Scotland and a cabinet minister.

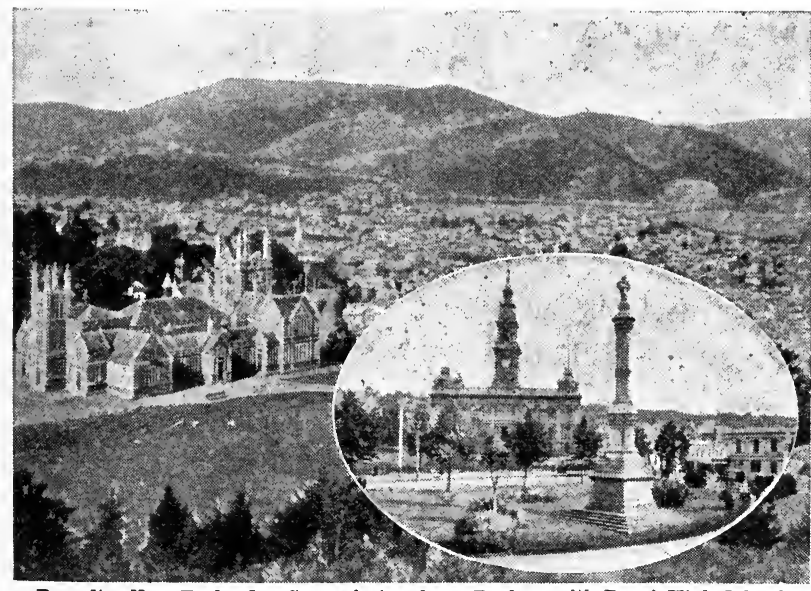

Dunedin, New Zealand. General view from Roslyn, with Boys' High School in foreground. Inset: The Octagon, showing town hall and memorial to the Rev. Thomas Burns of Austria, one of its leaders being the great Condé. With it were five English, Scottish, and Irish regiments under James, duke of York. 'To aid France Cromwell had sent six regiments of his Ironsides.

The French were arranged in the conventional order of battle, cavalry on the wings and infantry in the centre, the English being on the left centre. The Spaniards had a line of infantry in front with the horsemen in column behind. On their left was the canal to Bruges, and the French stood with their backs to Dunkirk. The battle began with the advance of the English foot against the Spaniards' strongest position, a sand hill held by veterans. In spite of heavy losses they reached the hill and drove back the Spaniards. A few of the royalist English horsemen tried to save the day, but supports arrived for the Ironsides, and soon this wing of the Spanish army was completely broken. On the other wing, the Spaniards and their allies offered a poor resistance. The victory led to the fall of Dunkirk.

Dunfermline. Royal and municipal burgh of Fifeshire, Scotland. It stands on the Firth of Forth,

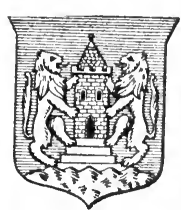
$17 \mathrm{~m}$. N.W. of Edinburgh, and is on the N.B.R. Since 1911 the burgh has been extended to include the new naval base at Rosyth. It was Dunfermline arms a favourite resi dence of the Scottish kings, and the Benedictine abbey, founded by Malcolm Canmore in 1072, was their burial place from the 11 th to the 14 th century. The abbey was 


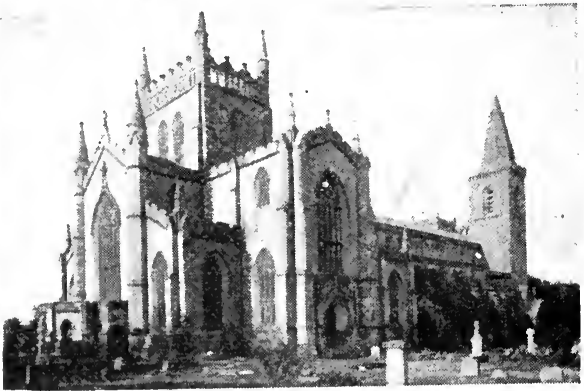

Dunfermline. The New Abbey Church, built in 1821 on the site of the old abbey, of which a tower and some remains are seen on the right
It exports agricultural produce and has woollen mills. Its fisheries are important. There a re two R.C. churches, a Protestant church, two convents and a monastery, and remains of a 7 th century Augustinian abbey, of a castle built by King John, and, at Abbeyside, of the castle of the McGraths. Marpartly demolished by Edward I, and except for the nave, which did duty as the parish church till 1821 , was destroyed by the Re. formers in 1560. In Pittencrieff Glen, which, with the estate and an endowment yielding $£ 25,000$ per annum, were presented to the burgh in 1903 by Andrew Carnegie, a native, are the ruins of Malcolm Canmore's castle and palace. The garden city between Dunfermline and Rosyth is a famous example of town planning. The town is celcbrated for its table-linen, and is also engaged in ironfounding, distilling, bleaching, and dyeing. Market day, 'Tues. Pop. '39,886.

Dungannon. Urban dist. and market town of co. Tyrone, Ireland. It is $40 \mathrm{~m}$. W. of Belfast on the G.N.I.R. It was the ancient residence of the O'Neills, titular kings of Ulster, who founded castles and an abbey of which no traces remain. There is a grain trade and linen and muslin manufactures. It returned two members to the Irish Parliament, and from 1601 to $188 \tilde{j}$ was represented by one in the Parliament in London. Market day, Thurs. Pop. 3,830.

Dungaree. Name given to a coarse Indian calico. From it comes the word dungarees, applied to trousers of this material.

Dungarpur. Native state of Central India, in Rajputana. It is bounded on the N. by Udaipur. 'The surface is wild and rugged in the N. and E., the remaining portions being made up of jungle forest, stony tracts, and a little arable land. The chief rivers are the Mahi and Som. Products are stone and timber. The ruler is a maharawal, entitled to a salute of 15 guns. The chief towns are Dungarpur (the capital), Sagwara, and Gailiakot. Area, 952 sq. m. Pop. 159,192, Hindus and Animists.

Dungarvan. Urban dist. and market town of Waterford, Ireland. It stands at the mouth of the Colligan on Dungarvan Bay, $28 \frac{1}{2}$ m. S.W. of Waterford by the G.S. \& W.R. ket days, 'l'ues. and Sat. Pop. 4,977.

Dung Beetle or Dor BeEtle (Geotrupes stercorarius). Common British beetle belonging to the family Scarabeidae. It feeds upon dung, in which it deposits its eggs as a feeding site for the future larvae, thus

doing useful work as a scavenger. Metallic black in colour, and an inch long, it is often seen flying about at dusk in sum mer, when it makes a rather loud droning sound.

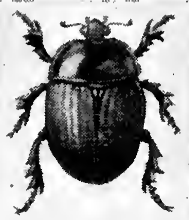

Dungeness. Low promontory on the S. coast of Kent, England. It has a lighthouse, coastguard station, Iloyds' signalling station, and small fort. The scene of many wrecks, it was off here that Tromp lefeated Blake in 1652 during the entry of Queensland, Australia. It stands on Hinchinbrook Channel, $935 \mathrm{~m}$. N. of Brisbane, and is the port for the traffic, chiefly sugar exporting, on the Herbert river. Pop. (district), 7,000 .

Dungeon. Name for a prison, especially a prison in a castle. It is derived from the Norman word donjon, meaning a keep, in which part of the castle the prisons usually were. See Castle; Prison.

Dungog. Town in Durham co., New South Wales, Australia. It is situated on the Williams river, which flows between Durham and Gloucester counties, in a dairying and maize district. There is a coach service to Sydney, $156 \mathrm{~m}$. distant. Pop. 1,712.

Dunite. Massive granular crys. talline rock, a species of peridotite. It consists ahmost wholly of opaque olivine, with some chromic iron, and is named from Dun MI., near Nelson, New Zealand, which is surmounted by this rock. It occurs first Dutch war.

Dungeness. Town and port of also in Andalusia, Scotland, and Kentucky.

Dunkeld. Market town of Perthshire, Scotland. It stands on the Tay, here spanned by a 7 -arched bridge, $151 \mathrm{~m}$. N.W. of Perth by the Highland Rly. The chief object of interest is the ruined cathedral, presented to the nation in 1918 by the duke of Atholl. This was built in the 11th or 12 th century, but was partially destroyed at the Reformation. The ruins include a bcautiful nave, a chapter house, and a tower, as well as thechoir, which has beenrestored to serve as the parish church. Near is Dunkeld House, a residence of the duke of Atholl. The town has a modern town hall, and in the market square is a fountain commemorating a duke of Atholl. A mile away, across the Tay, is Birnam. Pop. 600.

Dunkers or Tunkers (Ger., dippers). Sect of Baptists founded in Germany by Andrew Mack, in 1708. About 1720 they fled under persecution to America, where their leader, Conrad Peysel, founded a settlement at Ephrata, about 50 $\mathrm{m}$. from Philadelphia. Men and women dwelt apart, marriage was forbidden, and strict vegetarianism practised. Divided into three sects, the Dunkers have numerous independent congregations in the U.S.A.

Dunkery Beacon. Hill on Exmoor, Somersetshire, England. About $5 \mathrm{~m}$. S. of Porlock, it is 1,707 $\mathrm{ft}$. high, the highest point on the moor. It is $12 \mathrm{~m}$. in circumference, its slopes are covered with trees, and on the summit is a large cairn. The lighting of the beacon on Dunkery is described in Lorna Doone.

Dunkirk or Dunkerque. Seaport of France. It stands on the Strait of Dover, near the Belgian

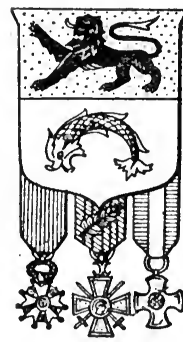

Dunkirk arms boundary, in the dept. of Nord, $40 \mathrm{~m}$. N.W. of Lille. The flat district around it is called the Wat. teringues. It is still rather a Flemish than a French town. One of the chief ports of the coun. try, it has an outer and an in. ner harbour, large floating basins, dry docks, quays, and ample accommodation of all kinds for shipping. Normally the port exports the coal of Belgiumand north-eastern France, the manufactures of the industrial region therein, and the agricultural produce of other adjacent areas. Wool is a main import. Shipbuilding is carried on, while other industries 


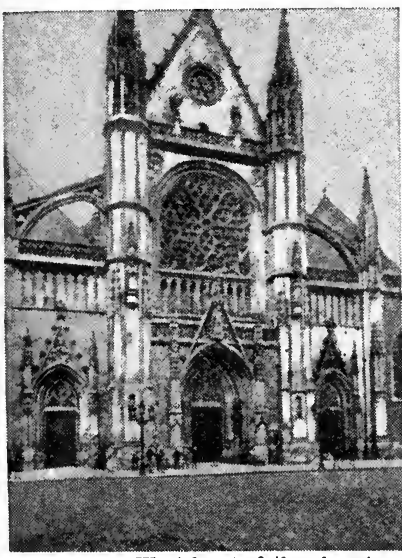

Dunkirk. West front of the church of S. Eloi

include the manufacture of machinery, soap, and the shipping accessories. There are oil refineries, saw mills, and flour mills. Steamers regularly ply between here and London, Hull. and other ports

The old buildings include the church of S. Eloi, with a modern façade and a detached belfry, and the pilgrim chapel of Notre Dame des Dunes. The church of $\mathrm{S}$. Jean-Baptiste dates from the 15th century. On the Place Jean Bart is a statue of the seaman of that name. Outside the old town are S. Pol-sur-Mer and Rosendael. Malo-les-Bains is a watering-place.

Dunkirk, meaning the church in the Dunes, was at first two small settlements around chapels named after S. Eloi and S. Gilles. It was taken and retaken by France and Spain, it having passed to the latter country with the other lands of the duke of Burgundy. From 1658-62 it was in English hands. In 1713 , by the treaty of Utrecht, its fortifications were pulled down, but later in the 18th century it again took its place as 2 . seaport and a fortress. It was besieged by the English in 1793. During the Great War Dunkirk was heavily bombed by air, and bombarded from sea and land. Pop. 38,925.

Dunkirk. City of New York, U.S.A., in Chautauqua co. A port of entry on Lake Erie, it is $40 \mathrm{~m}$. S.W. of Buffalo, on the Lake Shore and Michigan Southern and other rlys. Industrial establishments include locomotive and gas-engine works, and agricultural implement and shirt factories. Settled in 1809 , it was chartered as a city in 1880. Pop. 21,310.

Dunlin or Ox BIRD (Tringa alpina). Species of shore bird belonging to the Sandpiper group. It brceds rather rarely in Great

Britain, and is usually seen about estuaries. It is about 8 ins. long. and greyish coloured in winter, but in the breeding season the male is clad in chestnut and black.

Dunlop, JoHN BOYD (18391921). Irish inventor. After training, he began to practise as a veterinary surgeon at Belfast. About 1888 the idea of an intlated tire occurred to him. This Dunlop tire was placed on the market by the Pneumatic Tyre and Booth's Cycle Agency. A patent was taken ont for the wire edge attachment by the Dunlop Rubber Co. This expired in 1904 . He died Oct. 23, 1921. See Cycling; Tire.

Dun more. Borough of Pe n n s ylvania, U. S. A., i $n$ Lackawanna co. A d jo in i n g Scranton on the N.E., it is served by the Erie and other rlys. In an anthracite coal district, it has rly. workshops, and manufactures silk and bricks. Settled in 1835, it was incorporated as a borough in 1862 . Pop. 19,750.

Dunmore, EarL of. Scottish title borne by the family of Murray since 1686 . 'The first earl was Lord Charles M urray, a younger son of the marquess of Atholl, made baron, viscount, and earl in 1686 . William, the 3rd earl, shared

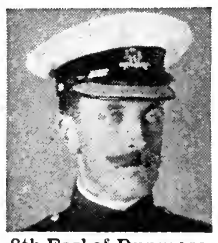

8th Earl of Dunmore, British soldier

Elliott \& Fry

in the rebellion of 1745 , but was pardoned, and his grandson, the 5 th earl, was in 1831 made a peer of the U.K. Alexander. the 8th earl.

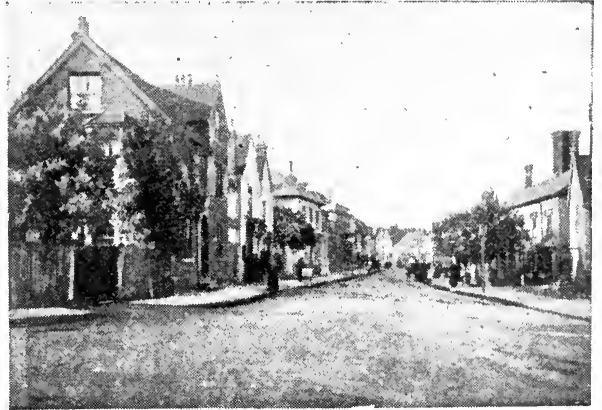

Great Dunmow. Main street of the Essex market town who succeeded in 1907 , gaincd distinction as a soldier. He won the V.C. in 1897, and in the S. African War commanded a battalion of ycomanry. He served also in the Great War. 'The earl's eldest son is known as Viscount Fincastle. 'The family seat is in the Isle of Harris, and the extensive estates are mainly in the Highlands and islands.

Dunmore, JoHN Murray, 4TH EARL of (1732-1809). British ad. ministrator. Son of William, the $3 \mathrm{rd}$ carl, he succeeded to the title in 
Dunn, James NrCoL (18561919). British journalist. Born in Kincardineshire, Oct. 12, 1856, he was educated at Aberdeen. He was intended for the law, but joined the staff of The Dundee Advertiser, and later that of The Scotsman. He was in turn managing editor of The Scots Observer and The National Observer, under W. E. Henley, 1888-93; news editor of The Pall Mall Gazette, 1894: and editor of Black and White and The Ludgate Monthly, 1895-97. In 1897 he became editor of The Morning Post, and in 1905 of The Manchester Courier. In 1911 he was made editor of The Star, Johannesburg, and in 1914 London editor of The Glasgow Evening News. He was president of the Institute of Journalists in 1904 . He died at Denmark Hill, June 30, 1919. Of his three sons, two fought throughout the Great War, and the other became Reuter's chief of staff in S. Africa.

Dunnage. Pieces of wood laid at the bottom of a ship's hold to keep the cargo from touching the deck beneath. The object is to protect the cargo from damage by any water that may find its way into the hold.

Dunne. Automatically stable aeroplane, designed by J. W. Dunne. The wings are $\mathrm{V}$-shaped, and each wing has a variable camber and angle from shoulder to tip. See Aeroplane.

Dunne, Finley Peter (b. 1867). American humorist. Born at Chicago, from 1891 to 1900 he attracted notice by contributing to the Times-Herald, of Chicago, a series of sketches in which, speaking as Martin Dooley, an Irish. American publican, he commented on social and political topics in genially, sometimes pungently, humorous fashion. His works include Mr. Dooley's Philosophy, 1900 ; Opinions, 1901 ; Observations, 1902; Dissertations, 1906 ; Mr. Dooley Says, 1910; and On Making a Will, 1920.

Dunnite. Filling for high explosive shell. Its essential ingre. dient was picric acid, adopted by the ordnance authorities of the U.S.A. before the Great War. It has been superseded by trinitrotoluene and amatol.

Dunnottar. Town and parish of Kincardineshire, Srotland. It stands on Carron Water, 1 m. S.W. of Stonehaven. At Dunnottar in 1793 Walter Scott met Robert Paterson, the stonemason original of Old Mortality. Pop. 2,255.

Dunnottar Castle. Ruined stronghold about $2 \mathrm{~m}$. S.E. of Stonehaven, Kincardineshire, Scotland. It is situated $150 \mathrm{ft}$. above the sea, and dates from the 7 th cen. tury. In one of its dungeons, know as Scot. land's Black Hole or Whigs' Vault, in 1685, during the Covenanters' rebellion, 167 men, women, and chil. dren were incarcerated. Cromwell laid siege to the castle when he invaded Scotland, but did not take it until theScottish crown jewels, placed in it for safe keeping, had been secretly/ removed to Kinneff Church. The castle was dismantled in 1720 .

Dunois, JeAN, CoMTE DE (1402$68)$. French soldier and popular hero. Born at Paris, Nov. 23, 1402, a natural son of Louis, duke of Orleans, and brother of Charles VI, he was known as the Bastard of Orleans. Originally intended for the

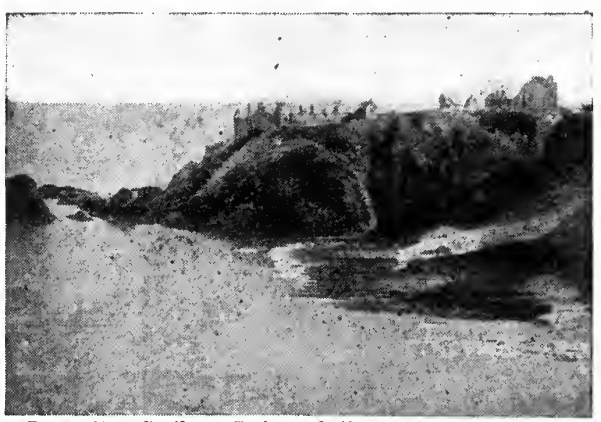

Dunnottar Castle. Ruins of the ancient stronghold seen from the north

Church, he became a soldier, and first came into prominence by defeating the English and raising the siege of Montargis in 1427. His next exploit was the defence of Orleans, which he held until succoured by Joan of Arc, with whom Dunois now set himself to the task of clearing the country of the English. The task was not interrupted by the capture and death of the Maid of Orleans. The taking of Chartres in 1432 enabled Dunois to ixpel the English from Paris; by 1450 he had driven them from Normandy; and by 1455 Guienne was once more French. He died at St. Germain-en-Laye, Nov. 24, 1468.

Dunoon. Town and police burgh of Argyllshire, Scotland. It stands on the W. shore of the Firth of Clyde, $8 \mathrm{~m}$. W. of Greenock. Formerly a small fishing village, it is now one of the most popular watering-places on the W. coast. It includes Kirn and Hunter's Quay, and with these the town has a frontage of three miles on the firth. There is a statue to Mary Campbell, the Highland Mary loved by Burns, who was born here. Pop. 9,859 .

Dunraven, EARL OF. Irish title borne since 1822 by the family of Wyndham-Quin. ValentineR.Quin, an Irish land. owner and a supporter of the Union of 1800 , was made a baronet in 1781 , a baron in 1800 , a viscount in 1816 , and in 1822 earl of Dun. raven and Mount. earl. $\mathrm{His}$ son Windham Henry had already taken the additional name of Wyndham on inheriting valuable property in Clamorganshire through his wife, a daughter of Thomas Wyndham of Dunraven Castle in that county. On this account the elder Quin took the title of Dunraven on being made an earl.

Edwin, the 3rd earl (1812-71), who was M.P. for Glamorganshire 1837-51, was made Baron Kenry, a British title, in 1866. A remark. able man, he was archaeologist,

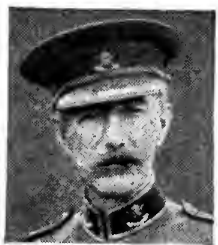

4th Earl of Dunraven Russell astronomer, and author, and was interested in s pirit ualism. He became a Roman Catholic, and Montalemibert was one of his friends. In 1871 his son

Windham 'Thomas (b. 1841) became the 4th earl. In 1885-86 and $1886-87$ he was under-secretary 
for the colonies. He was in early life a war correspondent in Abyssinia, in Paris 1870, and in 1900 he went to S. Africa. He was at one time chairman of the Irish Reform Association and chairman of the Irish land conference, 1902-3. The earl's seats are Adare Manor, Limerick, and Dunraven Castle, Glamorganshire.

Dunrobin Castle. Seat of the duke of Sutherland, Sutherlandshire, Scotland. Beautifully situated on Dornoch Firth, it is one of the oldest inhabited mansions in Great Britain, the earliest portion dating from the 13 th century. The main building, however, is modern. In the well-wooded grounds are two "brochs" or circular towers, and a museum of antiquities. Dunrobin Glen has a picturesque waterfall.

Duns. Police burgh, county and market town of Berwickshire, Scotland, $55 \mathrm{~m}$. S.E. of Edinburgh by the N.B.R. The original town of Duns or Dunse was situated on Duns Law (713 ft.), which has traces of the encampment set up by the Covenanters in 1639. Linen is manufactured. Market day, Tues. Pop. 3,042.

Dunsany, Baron. Irish title borne since 1439 by the family of Plunkett. The first baron was Sir Christopher Plunkett, a landowner in co. Meath, from whom the title passed to his son and other successors. Randal, the 11 th baron, was outlawed for adhering to James II, but this disability was removed, and his successors in herited his title and estates. Dunsany is in Meath, $7 \mathrm{~m}$. from Trim. Its old castle, which became the property of Sir Christopher Plunkett, has been replaced by a modern building in the Gothic style.

Dunsany, EDward JoHn MOREton Drax PlunKeTt, 18Th BaroN (b. 1878). British author. Born July 24, 1878, he was educated at Eton and Sand. hurst, and held a com mission in the Coldstream Guards. He served during the S. African War, and also in the Great

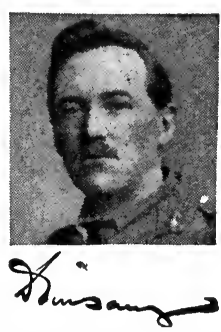

War. His travels in the Far East helped to give colour to some of his imaginative writings. His works include Time and the Gods, 1906 ; The Sword of Welleran, 1908 ; The Book of Wonder, 1912 ; Fifty-one Tales, 1915; Unhappy Far-off Things, 1919; Tales of Three Hemispheres, 1920 , and several plays, including The Glittering

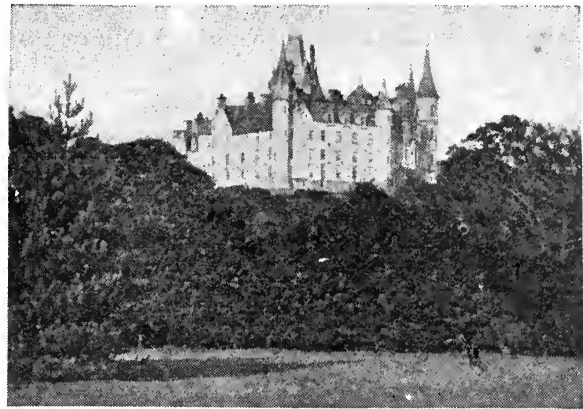

Dunrobin Castle, Sutherlandshire. View of the castle from the south-west, showing the 13th century walls and turrets

Gate, 1909 ; The Gods of the Mountain, 1911; A Night at an Inn, 1916.

Dunsinane. Peak of the Sidlaw Hills, Scotland, $8 \frac{1}{2}$ m. N.E. of Perth. On it are traces of an ancient fort known as Macbeth's Castle. Shakespeare has immortalised the defeat here of Macbeth by Siward, earl of Northumbria, in 1054. See Macbeth.

Dunsink. Hill and village of co. Dublin, Ireland. It is $4 \mathrm{~m}$. N.W. of the city of Dublin. On the hill (alt. $210 \mathrm{ft}$.) is Trinity College observatory, founded in 1785.

Duns Scotus (c. 1265-1308). Medieval schoolman. Little but legend exists as to his personal his. tory. Often referred to as a native of Duns, in Berwickshire, as in the case of Johannes Scotus Erigena (q.v.), his birthplace is variously assigned to England, Scotland, and Ireland. He appears to have been professor of theology at Merton College, Oxford, to have joined the Franciscans, and about 1304 to have gone to Paris, where, in contention with the Dominican up. holders of the teaching of Thomas Aquinas, his dialectical skill won for him the name of Doctor Subtilis (the Subtle Doctor), and where he popularised the theory of the Immaculate Conception of the Virgin Mary, since 1854 a dogma of the Roman Catholic Church. Sent to contend against the Beghards and Dominicans at Cologne, he died there, Nov. 8,1308 . His tomb, in the Minorite Church of S. Pantaleone, is inscribed : Scotia me genuit, Anglia me suscepit, Gal. lia me docuit, Colonia me tenet (Scotland bore me, England adopted me, Gaul taught me, Cologne holds me).

The writings of Duns Scotus tes. tify to his familiarity with the works of Porphyry, Boethius, Aristotle, Plato, and the Arabian and J e w is h schoolmen. They concern philosophic grammar, logic, metaphysics, and theology. His commen. taries on the Sententiae of Peter Lombard are the more often referred to. The edition of his works publ. at Lyons in 12 vols., 1639 , by Luke Wadding, an Irish Franciscan, is incomplete; another ed. appeared in Paris, 1891-95.

While his teaching appears to be no longer binding on Franciscans, his views have influenced modern theology and philosophy. To him theology was a practical science, faith an act of will, and will the controller of the intellect. Though intentionally orthodox, his philosophy has its effects in modern materialism. An exponent of the inductive principle, he anticipated Bacon and Newton. In logic a quodlibetarian, one who, stating the pros and cons of an argument, leaves his hearers to draw their own conclusions, he influenced the modern doctrine of conceptualism.

From Duns Scotus and Thomas Aquinas arose respectively the schools of Scotists and Thomists, opposed especially in regard to the Immaculate Conception, and generally as to free will, grace, and kindred topics. The Scotist views were later adopted by the Jesuits. The term dunce, originally a Duns man, was applied as a term of contempt by Thomists to Scotists. See Aquinas; Concept; Nominalism; Realism; Scholasticism. 
Dunstable. Mun. bor. and market town of Bedfordshire, England. It stands at the entrance of one of

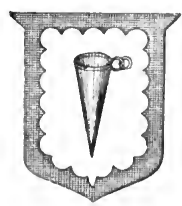

Dunstable arms he gaps of the Chiltern Hills, 37 m. N.W. of London by the L. \& N.W. and G. N. Rlys. The parish church of S. Peter is a part of the Augustinian priory founded by Henry I in 1131. Here Cranmer held in 1533 the court which dissolved the marriage of Catherine of Aragon. Dunstable is situated at the crossing point of Watling and Icknield Streets and is thought to have been a Roman station. The gram. mar school, founded in 1715, was rebuilt in 1888 . Straw-plaiting and printing are among the industries. Market day, Wed. Pop. 8,057.

Dunstaffnage. Ruined castle of Argyllshire, Scotland. It stands at the entrance to Loch Etive, $3 \frac{1}{2}$ m. N.E. of Oban, and dates from the 13 th century. The traditional seat of the kings of Dalriada, it was wrested from the MacDougalls by Robert Bruce in 1308, and was garrisoned for the crown during the risings of 1715 and 1745 . It figures in Scott's Lord of the Isles, and was for a time the prison of Flora Hacdonald. The Stone of Destiny, which now forms part of the coronation chair at Westminster Abbey, reposed here before its transference to Scone.

Dunstall. Ward within the borough of Wolverhampton, Staffordshire. It has a station on the G.W.R. See Wolverhampton.

Dunstan (d. 988). English saint. 'I'he son of a West Saxon noble, he was born at Glastonbury, where he was educated, and became abbot about 945 . The chief adviser of King Eadred, he was banished by his successor, Edwy, but recalled by Edgar, who appointed him bishop of Worcester in 957, bishop of London in 959, and archbishop of Canterbury in 961. From then until 979 he was the most powerful man in the country. He died May 19, 988. Dunstan is eredited with skill as a metal-worker.

Dunster Market town of Somerset shire, Eugland. Situated

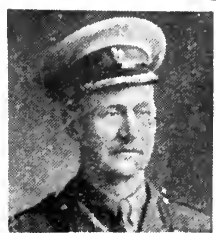

I. C. Dunsterville, British soldier

Eltoft \& Pry $23 \mathrm{~m} . \mathrm{N} . \mathrm{IV}$. of 'Tauton by the G.W.R., it is a quaint old town, containing many interesting b u i lding $\mathrm{s}$. DunsterCastle dates from the 12 th century, and the Yarn
Market, a wooden structure, from the beginning of the 17th century. Market day, Friday. Pop. 1,380 .

Dunsterville, Lronel Charles (b. 1865). British soldier. Born Nov. 9, 1865, he was educated at Westward Ho College, where he had as a schoolfellow Rudyard

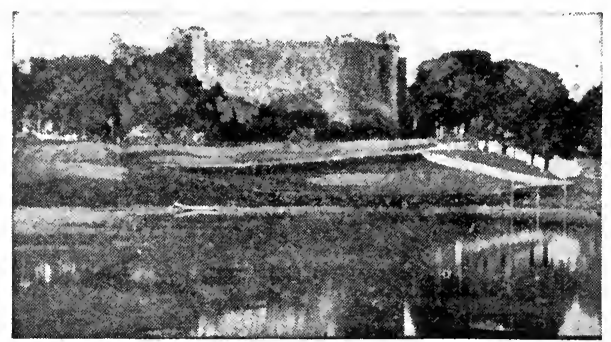

Dunstaffnage, Argyllshire. Ruins of the 13th century castle on the shore of Loch Etive are the ivy-clad ruins of a 13 th century Franciscan priory. Pop. 156.

Duo (Ital.). Music for two voices or instruments. See Duet.

Duodecimal (Lat. duodecim, twelve). System of notation in which twelve is the base. The base of the ordinary scale of notation is ten. D uodecimal arithmetic is sometimes used for computations involving feet and inches.. See Notation.

Duodecimo (Lat.duodecimus, twelfth).Designation originally applied to a book each sheet of which was folded so as to make

Kipling, who made him the hero of 12 leaves. Commonly it will meaStalky \& Co. Dunsterville entered sure 7 ins. by $4 \frac{3}{4}$ ins. The word is the R. Sussex Regt. in 1884, after which he joined the Indian army. $\mathrm{He}$ served in the Waziristan expedition, 1894-95, on the N.W. frontier, 1897-98; and in China, 1900. In the early part of the Great War he held various appointments in India, then went to Mesopotamia, where in 1918 he com manded the expedition to Baku (q.v.). He became a major-general in June, 1918. See his The Adventures of Dunsterforce, 1920; With the Persian Ex. pedition, M. H. Donohoe, 1919.

\section{D u n s t o n.} Eccles. district and village of Durham, England. It stands on the Tyne, 2 m. S.W. of Gateshead by the N.E.R. Pop. 9,209.

Dunvegan. Sea-loch on the N.W. coast of the Isle of Skye, Scotland, penetrating inland for $7 \frac{1}{2} \mathrm{~m}$., with a breadth of $2 \frac{1}{4} \mathrm{~m}$. On the E. shore is Dunvegan Castle, long the seat of the Macleods.

Dunwich. Coast parish and villacre of Suffolk, England. It stands on the North Sea, $4 \frac{1}{2}$ m. S.IV. of Southwold. The chief town and harbour and at one time the only see of East Anglia, Dunwich has suffered severcly from sea encroachments, which at various periods swept away the palaces and houses and blocked up the harbour. The last remains of the ruined church of All Saints fell in 1920 . Near by, on the edge of the cliff, abbreviated $12 \mathrm{mo}$ or $12^{\circ}$. See Paper, Sizes of.

Dupanloup, Félix Antoine PhiLIBERT (1802-78). French bishop. Born near Chambéry, Jan. 3, 1802, he was ordained priest in 1825 . He was placed in charge of the 
his self-denying labours during the siege of Paris. He died Oct. 11, 1878. He was the author of several works on ecclesiastical and educa. tional subjects, including La Pacification Réligieuse, 1845 ; De l'Éducation, 1850-62 ; La Souveraineté pontificale, 1860 ; Histoire de Jésus-Christ, 1869. See Life, F. Lagrange, Eng. trans. Lady Herbert, 1885 .

Dupin, André Marie Jean JACQUES (1783-1865). French jurist and statesman. Born at Varzy (Nièvre), Feb. 1, 1783, he is usually called the elder, to dis. tinguish him from his two brothers, also eminent lawyers. In 1815, as member of the Chamber of Representatives, he opposed the proclamation of the young king of Rome as emperor. Elected to the Chamber of Deputies in 1826, he assisted in the revolution of 1830 , and was made procureur-général. In 1832 he was elected president of the Chamber of Deputies, and in 1848 Dupin led the young count of Paris into the Chamber and proposed him for king. He eventually took office under the second empire, declaring that he "belonged to France, not to parties." He wrote several legal works, his Libertés de l'Eglise gallicane, 1824, being condemned by the Congregation of the Index at Rome. He died in Paris, Nov. 10, 1865.

Dupleix, Joseph Françors(1697 -1763). French administrator. Born at Landrecies, Jan. 1, 1697, he was the son of a merchant. As a youth he went on voyages to India, where, about 1720 , he settled. He was associated with the French East India Co., trading also successfully on his own account. In 1730 he was made governor of Chandernagore, and in 1741 became governor of Pondicherry, and the chief official in French India.

The career of Dupleix in India is that of a great plan thwarted.

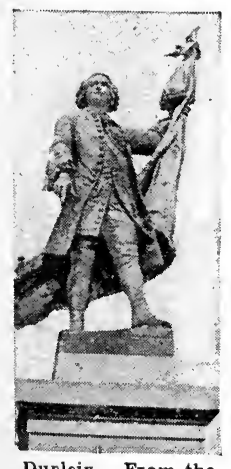

Dupleix. From the statue in Landrecies to In 1744 war broke out be- tween Britain and France, and he took vigorous action. Repudiating terms arranged by his col. league, La Bourdonnais, he kept Madras, but failed in an attempt on Fort St. David. Then came the

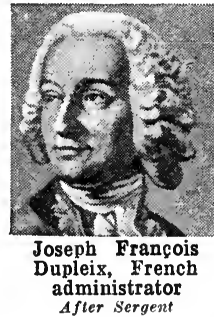
peace of 1748 . Turninghisat. tention to the Carnatic, Du. pleix managed to depose one ruler, and set up another and within a year his candid a tes a p peared $\mathrm{mas}$ ters, not only of the $\mathrm{Car}$

natic, but also of the Deccan.

The appearance of Clive changed the position entirely, the defence of Arcot being the turn of the tide. Unsupported by the officials in France, Dupleix struggled on galwas recalled to France. He lived in obscurity and poverty until his death, Nov. 10, 1763. See Clive: India ; consult also Dupleix, G. B. Malleson, 1890 ; Life, J. Biddulph, 1910 ; Dupleix and Clive, H. Dodwell, 1920.

Dupont, Pirrre (1821-70) French poet. Born at Lyons, April 23,1821 , he settled in Paris. and became a contributor of verse to periodicals. His Deux Anges, 1842 , was the Academy. But his popularity, wid e though tran-

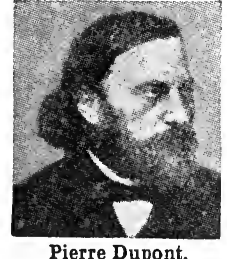
Pierre Dupont gained by his songs, many of them political, of which he wrote both words and music. $\mathrm{He}$ died at St. Etienne, July 25, 1870 . See Causeries du Lundi, April 21, 1851. C. A. Sainte Beuve, Eng. trans. E. J. 'Trechmann, vol. vi, 1909.

Duppel. Village of Slesvig-Holstein. It stands on the mainland, opposite Sonderburg, on the island of Alsen. In 1848 and 1861 the Danes held it against the Germans. In the war of 1848-49 the Danes succeeded in keeping back their foes. In March, 1864, however, the Prussians laid regular siege, April 18. It was successful, and many Danes were taken prisoners.

Dupplin Moor. Spot on the Earn, the site of a battle fought Aug. 12, 1332. A party of Scottish nobles, among whom was Edward Baliol, deprived of their estates, took refuge in England. To relantly for a time, but in 1754 he crowned by the final assault being delivered on

cover their possessions they sailed from Ravenspur to Kinghorn. The Scots, under the earl of Mar, met. them on Dupplin Moor, but their archers did such deadly work that the Scots fell back in disorder. The battle resulted in Baliol's temporary restoration,

Dupré,Jules(1812-89). French painter. Born at Nantes, April 5, 1812, he was the son of a potter, who taught him to decorate his wares, but he was otherwise selftaught. His first landscape, a forest scene, was shown at the Salon of 1831 , and he then began a lifelong connexion with the Romantic group. His technique is imperfect, but he ranks high among the Barbizon school. He died at L'Isle-Adam, Oct. 6, 1889.

Dupuy, Charles Alexandre (1851-1923). French politician. B. at Puy, Nov. 5, 1851, he began his career as a teacher, and in 1885 turned lis attention $t o$ politics. In April, 1893, he became pre mier in succes sion to Ribot. The general election in

Aug. gave him

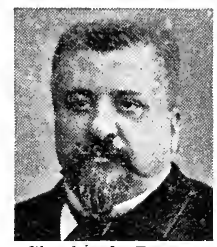

Charles A. Dupuy. French politician a large majority, but in Nov. he resigned owing to a difference with President Carnot, and became president of the Chamber of Deputies. In May, 1894, Dupuy returned to power with a cabinet including Poinearé, Delcassé, and Hanotaux. In June Carnot was assassinated, and Casimir-Périer became president. The Dupuy government remained in office, but before the year was ended came the arrest of Dreyfus, and in Jan., 1895, the president's resignation was soon followed by that of Dupuy, after an adverse vote in the Chamber. He was premier a third time, 1898 99 , and became a senator in 1900 . He was minister of agriculture, of commerce, 1899-1902, and of labour, 1912-14. Hedied July 23, 1923.

Dupuy, Jean (1844-1919). French journalist and politician. Born at Saint-Palais, Gironde, Oet.

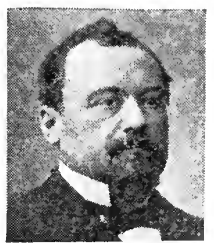

Jean Dupuy

French journalist Dec., 1919 tered journalism, and from 1888 was direc. tor of Le Petit Parisien. $\mathrm{He}$ was minister of agriculture, 1899-1902, of co $m$ erce
1912-13. He died at the close of 1844, he en 
Dupuytren's Contraction. Condition resulting from chronic inflammation of the palmar fascia, or dense fibrous tissues in the palm of the hand, leading to permanent flexion or bending of the fingers into the palm. It is most often seen in elderly individuals, and is sometimes associated with gout or rheumatism. Continuous pressure on the palm as in using an awl has been suggested as a cause. Surgical measures are the only form of effective treatment. The condition is named after Baron Guillaume Dupuytren (1777-1835), a French surgeon.

Duquesne. Borough of Pennsylvania, U.S.A., in Allegheny co. On the Monongahela river, it is $12 \mathrm{~m}$. S.E. of Pittsburg by the Pennsylvania Rly. It manufactures sieel. Settled in 1885 , it was incorporated in 1891. Pop. 18,575.

Duquesne, Abraham, Marquis (1610-88). French sailor. Born at Dieppe, the son of a naval officer,

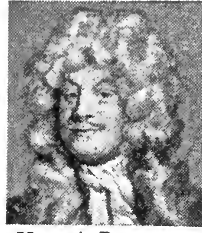

Marquis Duquesne, French sailor he entcred the merchant ser vice, in which he saw much fight. ing in the war with Spain and won a high repu. tation. Peace having been signed with Spain, he obtained a high position in the Swedish navy, which he led to victory against the Danes near Gothenburg. Again in France, he won glory in 1680 by compelling the surrender of Bordeaux. His greatest successes were his two defeats of the Dutoh fleet in 1676-off Stromboli and in the Gulf of Catania, where de Ruyter lost his life. Duquesne died on Feb. 2, 1688.

Dura Mater (Lat., liard mother). Dense: fibrous membrane which surrounds the brain and spinal cord. It is the outermost of the meninges or three coverings of the brain. See Brain.

Durance. River of Firance. It is formed by the union of three streams that rise in the Alps and unite near Briançon. It then flows in a $\mathrm{S} . \mathrm{W}$. direction through the de partments of Hautes Alpes and Basses Alpes, afterwards forming the boundary between Vaucluse and Bouches-du-Rhône. It joins the Rhône near Avignon, its length being $220 \mathrm{~m}$. The Durance is used to supply Marseilles with water. A canal extends from the river at Pertius to the city, $97 \mathrm{~m}$. away.

Durand, Asher Brown (1796 1886). American painter and en graver. "He was born of French parentage at S. Orange, New Jer. sey, Aug. 21, 1796. Having studied art, he worked in painting portraits, history, genre, and landscape with fair success, and engraved Trumbull's picture The Declaration of Independence. He is known as the founder of the American National Academy. He died Sept. 17, 1886.

Durand, Sir Henry Marion (1812-71). British soldier. Born on Nov. 6, 1812, he was commissioned in the Bengal engineers, and went to India in 1830 . He distinguished himself at the capture of Ghazni in the Cabul expedition, 1839, becoming secretary to the governor-general, Lord Ellenborough, 1841-44. Later he held several minor political posts, and, on the outbreak of the Mutiny in 1857 was agent to the court of Holkar at Indore. With only a few troops Durand maintained a foot. hold in Central India. Member of the council of India, 1859-61, he was on the governor-general's council, 1865-70, becoming major-general in 1867. He died Jan. 1, 1871, shortly after liis appointment as lieutenant. governor of the Punjab.

Durand, Sir Henry Mortimer (18500-1924). British administrator The second son of Sir Henry Marion Durand, he was born Feb. 14, 1850 . Educated at Blackheath and Tonbridge, he was called to the bar at Lincoln's Inn, 1872, and in the following year joined the SirMortimer Durand, Bengal Civil Britishadministrato Service. In $1879 \quad$ Elliott \& Fry

he served as secretary to Lord Roberts during the Kabul campaign. From 1880-85 he was under-secretary in the foreign department of the government of India ; from 1885-94 foreign secretary in India. From 1894-1900 he was British minister at Teheran 1900-3 ambassador and consulgeneral at Madrid ; and 1903-6 ambassador at Washington. His numerous publications include Lives of Sir Henry Durand, 1883, and Sir George White, V.C., 1915. He died June 8. 1924

Durango. State of N.W. Mex. ico. It lies $\mathrm{S}$. of the state of Chihuahua, and is mainly mountainous, paralleling the Sierra Madre, which penetrates the $W$. portion. Agriculture is carried on where possible, and wheat, vegetables, cotton, and sugar are produced. The staple industry is mining, and silver, gold, copper, iron, and other minerals are worked, especially silver. Durango is the capital. Area, 38,000 sq. m. Pop. 509,585.

Durango. City of Mexico, the capital of Durango state. Originally called Guadiana, and sometimes known as Ciudad de Victoria, it stands in the Guadiana valley, $570 \mathrm{~m}$. N.W. of Mexico city. The seat of a bishopric, it has a fine cathedral, a government palace, a public library, a college, and other buildings. A flourishing mining and commercial centre, its industrial establishments include cotton, woollen, sugar and flour mills, and foundries. Pop. 34,085.

Durani. Name bestowed by Ahmad Shah upon his native $\mathrm{Ab}$ dali clan when establishing an empire in E. Afghanistan in 1747. It has since become the tribal name of the dominant Afghans. His attempted national fusion by associating Afridi, Mohmand, Orakzai, Yusafzai, and others under the appellation of Bar Durani failed. See Afghan.

Durazno. Dept. in Central Uruguay, S. America. It lies between the rivers $\mathrm{Yi}$ and Negro. The surface is diversified and the soil fertile; many cattle, sheep, and horses are reared. The capital is San Pedro del Durazno, which is connected by rlv. with Montevideo, Paysandu, and Brazil. Area, 5,525 sq. m. Pop. 54,930.

Durazzo. Town of Albania, the ancient Dyrrhachium. It stands on the Adriatic, $60 \mathrm{~m}$. S. of Scutari, and is now an ineonsiderable place,

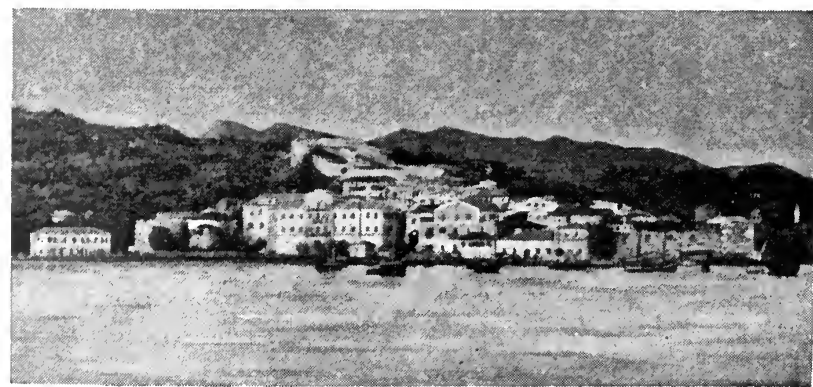

Durazzo, Albania. View from the sea showing the landing place and, in the centre, the palace 
but extensive ruins attest its former greatness. Founded 621. B.c. by Corinthian and Corcyrean colonists under the name of Epidamnos, it was renamed Dyrrhachium by the Romans, who made it the port opposite Brundisium on the W. side of the Adriatic, and later constructed from it the highway across the Balkans to Byzantium. In 1501 it passed to the Turks, who held it until 1913. It is a port whose trade in oil, tim. ber, and fruit is capable of much development. Pop. 5,000.

Durban. Commercial capital of Natal, S. Africa. It is situated on the S. shore of a land-locked bay. Laid out by the

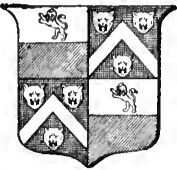

Durban arms

Dutch in 1834 , it was occupied by the British under Sir Benjamin D'Urban in 1842. There are a fine town hall (opened in 1910), public gardens and parks, racecourse, public library, and museum. It is connected by rly. with Pietermaritzburg and the Transvaal. It is the headquarters of a whaling industry established in 1908. Distance from Southampton, $6,790 \mathrm{~m}$. via Cape 'Town; 8,501 m. via Suez. Pop. (whites), 48,475.

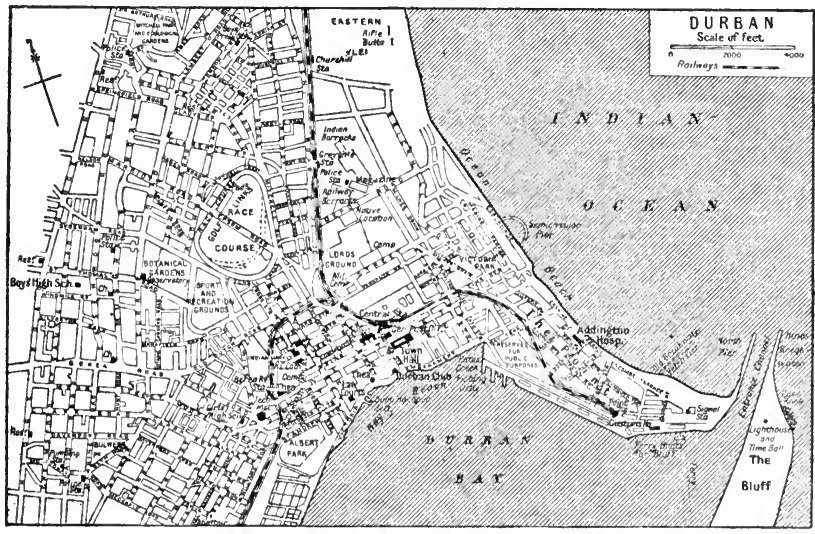

Durban. Plan of the commercial capital of Natal, South Africa

Durbar (Pers. dar, door ; bar, admittance, court). Term used in India for the court, council, or council chamber of a native ruler, for an official reception or audience, or for a great state ceremony. Specially magnificent durbars were held at Delhi on the proclamation of Queen Victoria as empress of India in 1877 and of Edward VII and George $V$ as emperor in 1903 and 1911 respectively.

Durchmusterung (Ger., examination). Name for the modern telescopic star catalogues. Among

the more famous are the Bonn Du rchmusterung, which enumerates 324,189 stars (Argelander), and the Cape Durchmusterung (Schön. feld and Gill), c o m p r i s i n g 454,875 stars. See Stars.

Düren. 'Town of Germany, in

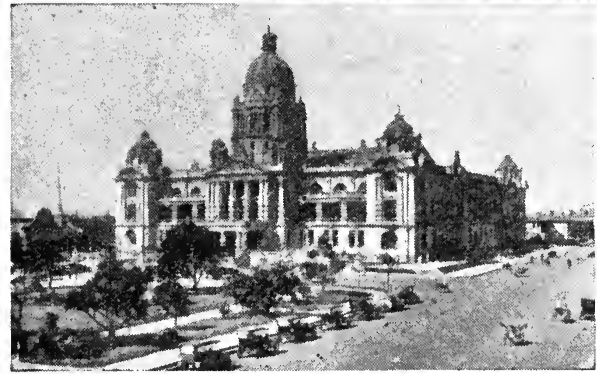

Durban. Town Hall of the capital of Natal. Above, view of the bay from the promenade

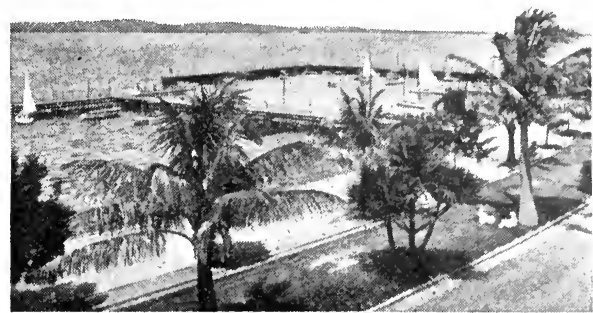

school of Michael Wohlgemuth. In 1490 he set out on a tour abroad. He was at Colmar in 1492, where he made the acquaintance of Martin Schongaucr's three brothers, at Basel in 1492-94, and at Strasbourg in 1494 In May, 1494, he returned to $\mathrm{Nu}$ remberg, to find that $a$ marriage had been arranged the Rhine prov. It stands on the river Roer, $20 \mathrm{~m}$. E. of Aix-laChapelle. Its industries are chiefly textile manufactures, including

cloth, carpets, etc., but paper and iron goods are also made. It has been a chartered town since about 1300 and was of importance much earlier. It was part of the duchy of Jülich, and became Prussian in 1815. Pop. 32,511.

Dürer, ALBERT OR ALBRECHT (1471-1528). German painter and engraver. He was born at Nuremberg, May 20, 1471, the third of eighteen children of a goldsmith, Albert the Elder. He was brought up to the goldsmith's business, but in 1486 was allowed to enter the for him with the daughter of Hans Frey. The marriage was celebrated on July 7,1494 . The story told by Pirkheimer,Dürer's intimate friend, as to the greedy, idle, and passionately jealous disposition of his wife Agnes is neither borne out nor contradicted by Dürer's silence in regard to his married life.

In the winter of 149.1-95 Dürer made his first journey to Venice, which appears to have been unfruitful. His second visit was undertaken late in 1505 , at the invitation of the Nuremberg merchants established in the city, who

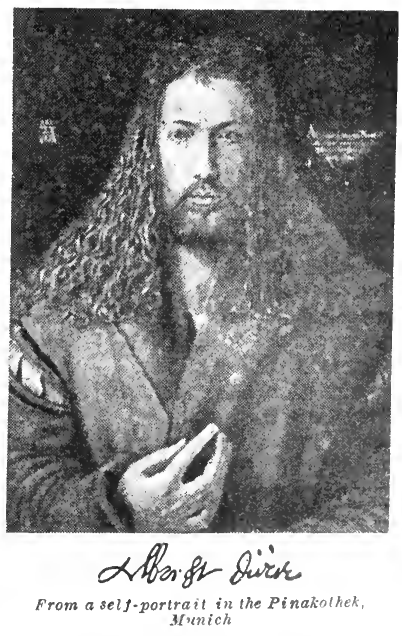




\section{q}

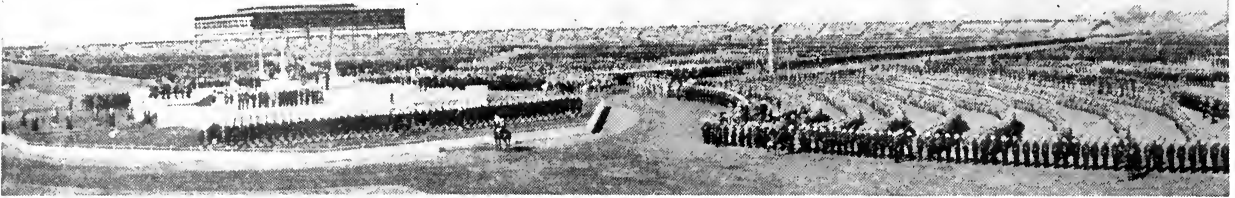

Durbar. Central pavilion and throne dais where George V was proclaimed Emperor of India at the Delhi Durbar, Dec. 12, 1911. Within the amphitheatre troops were marshalled in geometrical formation

desired him to take part in the Great Passion and The Little decoration of their bourse, the Passion. His famous woodcuts Fondaco de' Tedeschi. During his sojourn, which lasted till the beginning of 1507 , he was cordially received by the nohles, philosophers, and poets; less cordially by the painters, of whom one only, Giovanni Bellini, gave him the hand of friendship. He began in Venice The Feast of the Rosary. On his return to Nuremberg in 1507 , he produced the following paintings at short intervals : single figures of Adam and Eve, 1507; 'The Massacre of Ten Thousand Christians. 1508: The Virgin of the Iris and The Adoration of the Trinity, 15l4. Between 1512-19 he was in the service of the emperor Maximilian. In 1520-21 Dürer made a journey to the Netherlands, probably to obtain the continu. ance by Charles $V$ of the pension granted lim by Maximilian. On his return to his home, he devoted himself to unceasing labour until his death on April 6, 1528. He was buried in the graveyard of S. John, Nuremberg, and his house there is now a Dürer museum.

His friend Melanchthon said of the artist that his least merit was his artistic genius: and the friends he attracted to himself, Luther, Melanehthon, and the rest, suggest the attractiveness of his personality and the extent of his culture. On the whole, Dürer was less a painter than a clesigner : his colour is more truthful to the model than original or beautiful. But in power of design, in nolleness of imagination, in his application of scientific theory to practice, in the introspective quality of his portraits, he has few, if any, equals. As a copper-plate engraver he is supreme; one can only cite the Arms of Death, 1503; the Adam and Eve, 1504; The Great Horse and 'The Little Horse, 1505 ; the Knight, Death and the Devil, 1513; St. Jerome in his Chamber, 1514 ; and the series of The Passion, not to be confused with the wrodeuts of The include the series of The Apocalypse, 1497; the 20 scenes of the Life of the Virgin, 1511; and a number illustrating the writings of Maximilian I. Dürer also published Four Books on Human Proportion, 1528. See illus. pp. 1261, 1872, 1993.

Biblioyraphy. Life, W. B. Scott 1869 ; Albrecht Dürer, his Life and Works, M. Thausing, Eng. trans. ed. F. A. Eaton, 188: Literary Re mains of A. D., W. M. Conway, 1889 ; Versuch einer Dürer Bibliographie, H. W. Singer, 1903 ; Die Kunst Albrecht Dürers, H. Wölfflin, 1905: Albrecht Dürer, Life and a selection of his works, F. Nüchter. Eng. trans. L. D. Williams, 1911.

Duress (Lat. duritia, hardness). Term used in English law. It means compulsion by means of threats or imprisonment. The court will not allow anyone to retain the advantage of any gift or contract obtained by duress.

D'Urfey, Thomas (1653-1723). English dramatist and song writer. Born at Exeter of Huguenot ancestry, he soon began to write. His works include both tragedies and comedies, but the latter, which in -

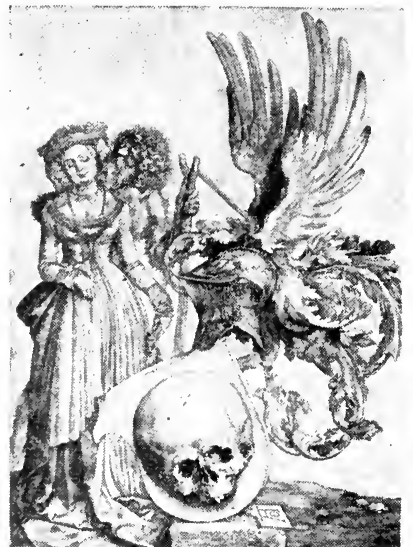

Albert Dire

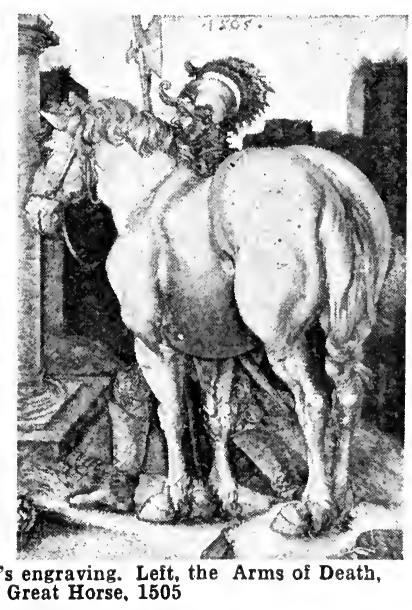

clude The Fond Husband, 1676; Squire Oldsapp, 1679 ; and Sir Burnaby Whig, 1681 , were the most popular. Like other dramatists of his time he was attacked by Jeremy Collier in his Short View of the Im. morality of the English Stage. He was also a prolific writer of songs, of which two series were published, entitled New Collection of Songs and Poems, 1683; and Wit and Mirth, or Pills to Purge Melancholy, 1719-20. A man of amicable character, he won the favour successively of Charles I, James II, William and Mary, and Anne, but latterly his vogue as a dramatist declined, and he died in poverty, Feb. 26, 1723. See A Study of the Plays of Thomas D'Urfey, R. S. Forsythe, 1916-17.

Durham. County palatine and N.E. county of England. With about $33 \mathrm{~m}$. of coast line, its area is $1,013 \mathrm{sq} . \mathrm{m}$. Branches of the Pen. nine Chain, the highest summit of which is Burnhope Seat, 2,452 ft., enclose a series of fertile valleys in the W., whence the surface slopes away to the E. Immense coalmeasures occupy the centre, the annual production of coal being 


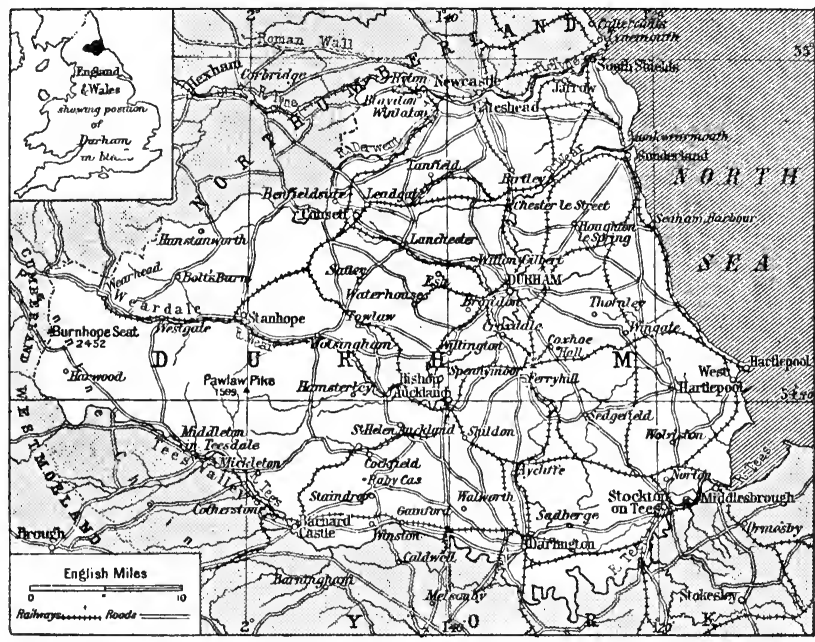

Durham. Map of the coal-mining county of north-eastern England, notable also for its shipbuilding, ironworks, and manufacturing industries mouth : Richard de Bury, author of Philobiblon, and bishop of Durham, died at Auckland and was buried in Durham Cathedral. At Stanhope, in Weardale, Joseph Butler, its rector, wrote The Analogy of Religion. Joseph Ritson, the antiquarian writer, was born at Stockton, and Elizabeth Barrett Browning at Coxhoe Hall, near Durham. Scott's Rokeby has much about Barnard Castle and the upper Tees valley.

Bibliography. 'The County Palatine of Durham : a Study in Constitutional History, G. 'T. Lapsley, 1900 ; Victoria Hist. of the County of Durham, ed. W. Pase, 1905-7; Hist. and Antiquities of the County Palatine of Durham, R. Surtees (1816-40), repr. 1908, etc. ; Memorials of Old Durham, ed. H. R. Leighton, 1910 ; Durham, J. E. Hodgkin, 1913.

Durham. City, mun. borough, and county town of Durham, England. It stands on the Wear, $287 \mathrm{~m}$. from London, and has a nearly $38,000,000$ tons. The Wear, Tyne, and Tees, all navigable in part, are the chief rivers, and in their vicinity and the valley districts the soil is arable and well cultivated. In addition to coal, large quantities of lead, iron, limestone, millstone, granite, salt, etc. are obtained.

Durham is noted for horses and shorthorn cattle, and sheep-rearing is carried on. Its manufactures are important, and shipbuilding, sail-making, and the production of chemicals, glass, woollens and earthenware are leading branches; there are also numerous blast furnaces, iron works, and machine shops. The N.E. is the only rly. serving the county.

Durham is the couney town, and besides the large shipping ports of

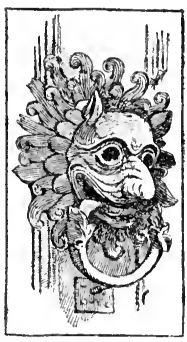

Durham. Sanctuary knocker at

the cathedral Sunderland, Stockton-on. Tees,Jarrow, the Hartlepools, and South Shields, the largest towns a re Gateshead and Darlington. Ten members are returned to Parliament. Pop. $1,478,506$. Durham formed part of the kingdom of Nor thumbria. The regal authority of the bishops of Durham was finally withdrawn in 1836.

Literary Associarions. These start with the Benedictine monastery at Jarrow, founded by Benedict Biscop, but its greatest name is that of the Venerable Bede (q.v.), who was born near Wear-

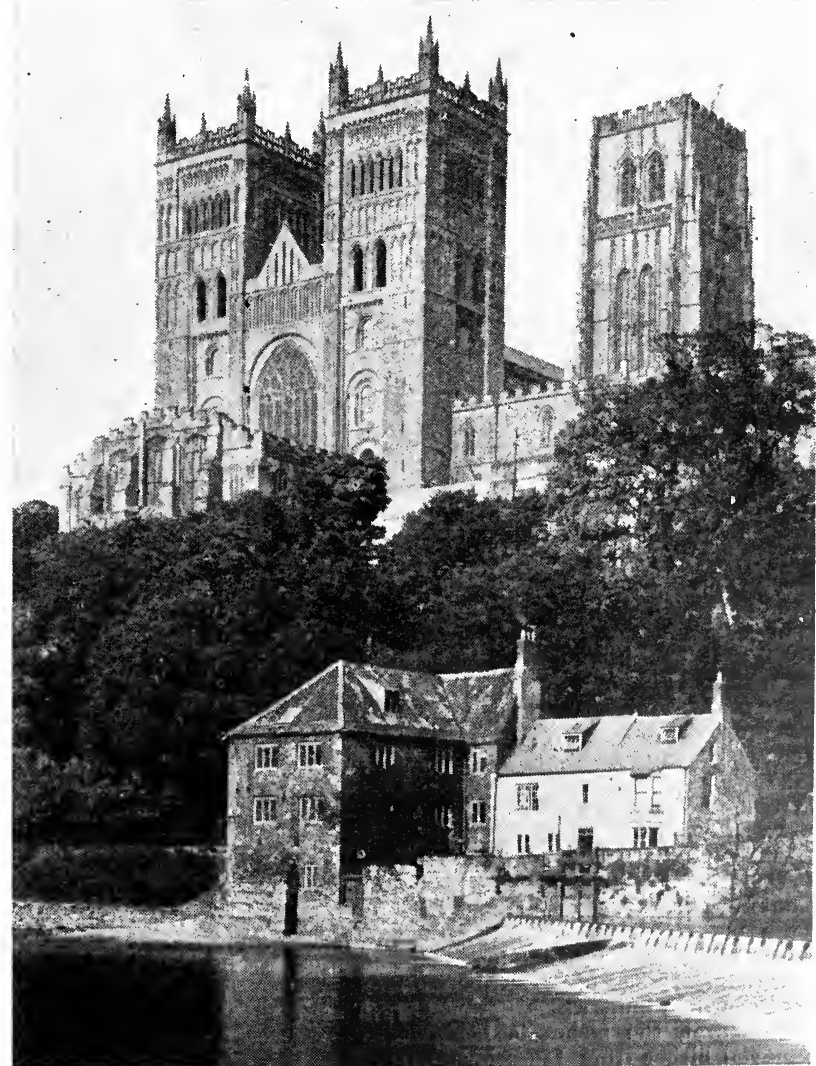

Durham. The cathedral, seen from across the River Wear. The lancet and perpendicular work of the two western towers, and that of the central tower, is imposed upon the original Norman architecture, among the finest of its period in England 
station on the N.E. Rly. The older part of the city is on and about a hill round which the river bends; the newer parts are on the other side of this.

The glory of Durham is the cathedral, and near it, on the river peninsula, is the castle. The present cathedral, which replaced an older one, was begun in the 11 th century, and much of it is Norman; this includes the nave and the restored chapter house. The Galilee chapel (q.v.) is a notable feature, as are the central tower and the chapel of the nine altars. There are a valuable

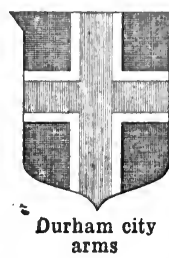

library and some relics of S. Cuthbert. The cloisters and other parts of the monastic buildings still exist. The first castle was built by William the Conqueror, but little of this remains. Much of the present building, which is the headquarters of the university, is old, and some portions are highly interesting.

Other objects of interest in the city are some of the churches and the bridges across the Wear, especially Framwellgate, of the 14th century. Elvet Bridge, leading to the suburb of Elvet, is also old, and on it are still a few houses. The churches include S. Margaret's, S. Oswald's, S. Mary le Bow, S. Mary the Less, and S. Giles. The town hall dates from the 16th century. The grammar school is an old foundation; its present house dates from 1844. At Ushaw is the Roman Catholic college of S. Cuthbert.

The city lives largely on the business brought by the presence of a cathedral, a university, and the county headquarters. It has some other industries, including the manufacture of iron, and there are many coal mines in the neighbour. hood. It has been a chartered town since 1179 , and is governed by a mayor and corporation. It was represented in Parliament by two members from 1673 to 1885. The number was reduced to one in 1885, and in 1918 the representation was merged in that of the county.

The city owes its origin to the monks of Lindisfarne, who, looking for a place of safety, considered this to be such, and settled here in 995 with the bones of S. Cuthbert. A church was built which became a cathedral, the bishopric being removed hither from Lindisfarne. Market day, Sat. Pop. 17,329.

Durham, UNIVERSITY OF. Founded in 1832, its constitution was modified in 1908, when it was

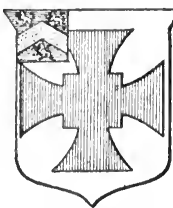

Durham

University arms

mains so, its colleges being mainly occupied with preparing candidates for the Anglican ministry. These are University College, and three halls-Bishop Hatfield's, S. John's, and S. Chad's -and the dean and chapter of Durham are the governors. There is also a hostel for women students, and women are admitted to all the courses and degrees except the theological. The Newcastle division consists of Armstrong College and the College of Medicine. The former, until 1904 called Durham University College, was founded in 1874 ; the latter dates from 1832 , and was united with the university in 1852 .

The university has seven faculties-arts, letters, theology, law, medicine, science, and commerce. Science and commerce are taught exclusively at Armstrong College, which also grants diplomas in engineering, naval architecture, agriculture, and mining. It has land at Chopwell for instruction in forestry, and two stations, Cocle Park and Offerton Hall, for agricultural research, as well as a marine biological station at Cullercoats. At Durham residence is necessary in order to qualify for a degree, but not at Newcastle. Before the Great War the university had about 200 students at Durham and about 1,700, day and evening, at New. castle. Codrington College, Barbados, is affiliated with Durham.

Durham. City of North Carolina, U.S.A., the co. seat of Durham co. It is $26 \mathrm{~m}$. N.W. of Raleigh on the Southern and other rlys. The seat of Trinity College, founded 1851, it has schools of art and music, a public library, and hospitals. A busy centre of the tobacco industry, it contains also foundries, cotton mills, and a fertiliser factory. Incorporated in 1869 , it became a city 30 years later. Pop. 26,160.

Durham, EARL OF. British title borne since 1833 by the family of Lambton. The Lambtons had lands in Durham as early as the 12 th century, but they remained commoners until the time of John George Lambton, who, having made a reputation as a statesman and administrator, was made Baron Durham in 1828, and Viscourt Lambton and earl of Dur- ham in 1833. His grandson, John George (b. 1855), who became the 3rd earl in 1879, is a K.G. and a patron of the turf. : His twin brother, F. W. Lambton, was a Liberal M.P. from $1880-85$, and a Unionist M.P. from 1900 to 1910 ; another brother, Hedworth, who distinguished himself at the siege of Ladysmith, took under a will the name of Meux (q.v.). The earl's seat is Lambton Castle, Durham.

Durham, John George LambTON, lsT EARL OF (1792-1840). British statesman. Born April 12,

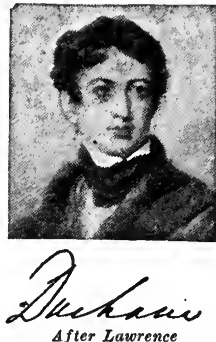
1792 , he was the son of William $\mathrm{H}$. Lambton of $\mathrm{L} a \mathrm{~m} \mathrm{~b}$ t o $\mathrm{n}$ Castle, D u r. $h$ a $m$, $t o$ whose estate he succeeded when only a child. From Eton he entered the army, but forsook that service for politics, becoming an M.P. for the county of Durham in 1813. Prominent among the Whigs, to which party his family had been long attached, he advocated parliamentary reform and other changes. His en thusiasm as a reformer earned for him the name of Radical Jack.

In 1828 Lambton was made a peer, and in 1830 he entered Grey's Cabinet as lord privy seal. He had a large share in drafting the Reform Bill of 1832 and in tho negotiations that preceded its passage into law. In 1833, differing from several of his colleagnes, especially Brougham, he left office, but still held a very strong position in the country. For two years he was ambassador at St. Petersburg (1835-37), and then went as governor-general to Canada. after the rebellion of 1837 . It is with his work there that his name is chiefly associated. $\mathrm{He}$ was armed with unusual powers, which he exercised freely, but the result was hardly satisfactory. Brougham attacked him for send. ing eight rebels to Bermuda, and Parliament decided that the step was illegal. Unsupported by the cabinet, Durham had no course but to resign. He defended himself in a public proclamation, and returned to England.

Durham then prepared his famous Report on the Affairs of British North America (1839), described as "one of the greatest statc papers in the English language," and certainly one of the most influential. Therein he advised the union of the two Canadas, re. sponsible government, the building 
of an intercolonial rly. and other liberal measures afterwards approved and carried out. $\mathrm{He}$ died at Cowes, July 28, 1840. In 1833 he had been made an earl, and his successor was his son, George. See Life and Letters, S. J. Reid, 1906.

Durham Light Infantry. British regiment, of which the two battalions were formerly the 68th

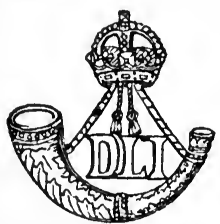
and 106 th regiments of light infantry. The former was raised in 1756 as a 2nd battalion of the 23rd regiment, becomDurham Light Infan- ing in 1758 try Regiment badge a se parate corps numbered the 68th. Organized as a light infantry regiment in 1808 , it was called the 1 st battalion Durham Light Infantry in 1881. The battalion fought in the West Indies in 1761, and was granted the motto "Faithful" for its services against the natives in St. Vincent. It took part in the illfated Walcheren expedition (1809), in the Spanish canıpaign of 1811 , in which it earned distinction at Salamanca and Vittoria, and in the Crimean War it fought, at Alma and Inkerman.

The 2nd battalion, raised in 1826, served in the Mahratta War, 1844, and the Persian War (1856). Other important services include the Maori campaign, the Egyptian War, 1885, and the South African War (Colenso, Spion Kop, Pieter's Hill). During the Great War the lst battalion remained in India in 1914, and the 2nd arrived in France while the battle of the Aisne was in progress, Sept., 1914. The 8th Durhams formed part of a division of northern Territorials, and were present at the second battle of Y pres, April, 1915. Some Durhams waged another desperate fight around the Butte of Warlencourt in Oct., 1916 , where a memorial has been erected to their honour; and Durhams formed part of the force which made a gallant stand to save Mer. ville in April, 1918. The depot is at Newcastle-on-Tyne.

Durian (Durio zibethinus) Large evergreen tree of the natura! order Malvaceae. It is a native of Malaya and the Indian A rchipelago. The prickly fruit, as large as a man's head, is greatly esteemed by the Malays and Chinese, but for Europeans it is an acquired taste. At the right point of ripeness it is a sort of vegetable custard, and equal to the finest of nectarines and pears. But it has an indescrib. able odour which fills many with

disgust, though its flavour is most tempting to the palate.

Durra. Name for the seeds of Indian millet (q.v.) or Guinea corn.

Dursley. Parish and market town of Gloucestershire, England. It is $15 \mathrm{~m}$. S.S.W. of Gloucester by the Mid. Rly., at the foot of the scarp of the Cotswolds. Cyeles are manufactured and bath-stone is quarried. Pop. 2,60l.

Duruy, Jean VicToR (1811-94). French historian and academician. Born in Paris, Sept. 11, 1811, he became successively master at the Ecole Normale and professor at the École Polytechnique. In 1863-69 be was minister of public instruction. His works include histories of France and Greece and a monumental Histoire des Romains, 7 vols., 1879-85. He died Nov. 25, 1894. See Life (in French), E. Lavisse, 1895.

D'Urville Sea. Portion of the Antarctic Ocean. It lics off Adélie Land, on the Antarctic Circle of Mertz Glacier, and contains Commonwealth Bay. It was named after the French explorer, Dumont d'Urville (1790-1842), by the Mawson Antarctic Expedition,

1911-14.

Dury. Village of France. It is on the Arras-Cambrai road in dept. of Pas-de-Calais, about midway between Drocourt and Quéant. The village and hill commanding the Arras-Cambrai road were captured by Canadians, Sept. 2, 1918. There is another village of this name about $1 \frac{3}{4} \mathrm{~m}$. S. of Amiens, in the dept. of Somme. See Arras, Fifth Battle of.

Duse, Eleonora (1859-1924). Italian actress, born near Venice. Oct. 3. 1859. Her parents belonged

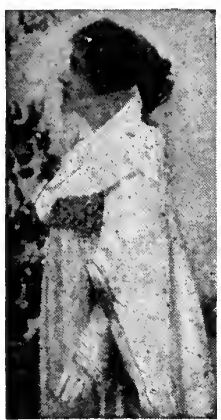

Eleonora Duse Italian actress

further success As As Marguerite Gautier in La Dame aux Camélias at Rome, 1883 , she was recognized as one of the greatest living actresses, a reputation confirmed by her subsequent performances at Vienna and Berlin, London, and New York. Her finest impersonations included Magda, La Tosca, San tuzza in Cavalleria Rusticana, Mirandolina in La Locandiera, Paula in The Second Mrs. Tan queray, Nora in A Doll's House, and heroines in D'Annunzio's dramas. She died April 21. 1924

Dusius. Demon among the an cient Gauls mentioned by S. Augus. tine. It was suggested by John Brand (1744-1806), in his Observations on Popular Antiquities, that the exclamation, Deuce, commonly accepted as signifying the devil, is really derived from the name of this Dusius. See Demonology.

Dussek, Johann Ladislates (1761-1812). Bohemian pianist and composer. Born at Czaslau, Feb. 9, 1761, the son of a musician, he studied music at Iglau and Prague and gained a great reputation as pianist, composer, and teacher. He was successively organist at Mechlin,Bergen-op-Zoom, and Amsterdam. After 1786 he was a fashionable pianist and teacher in Paris, and from 1790 to 1800 in London, which he left to avoid his creditors. He was afterwards in the suite of a Prussian prince and later in that of Talleyrand. He died March 20,1812. The playing of Dussek was distinguished by its beauty of tone, and he was a prolific composer of piano music. Pron. Dooshek.

Düsseldorf. City and district of Germany, in the Rhine prov. It stands in the centre of a plain, at the confluence of the

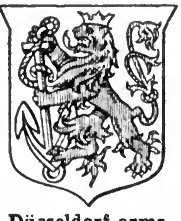
Rhine and Düsselbach, at the junction of several rlys., $24 \mathrm{~m}$. by rly. N.W. of Cologne. A prom. enade between the fine Rhine bridge (1896-98) was completed in 1902. The narrow, irregular streets of the old town, which is separated from the new by the broad Alleestrasse, with statues of Wilhelm I, Bismarck, and Moltke, contrast with the open and picturesque aspect of the new, with its broad and treelined avenues and squares. The old electoral palace, once the home of the Academy of Art, was almost destroyed by fire in 1872. The Gothic-Renaissance Rathaus, 1570 -73 , was extended in 1885 . In front of it is Grupello's bronze equestrian statue of the elector Johann Wilhelm, erected 1711. Notable among the 37 churches, two-thirds of which are Roman Catholic, are S. Lambert, 14th century Gothic ; S. Andrew, 1629, once the church of the court and of the Jesuits ; and S. Roche. The Hofgarten, 1769, 


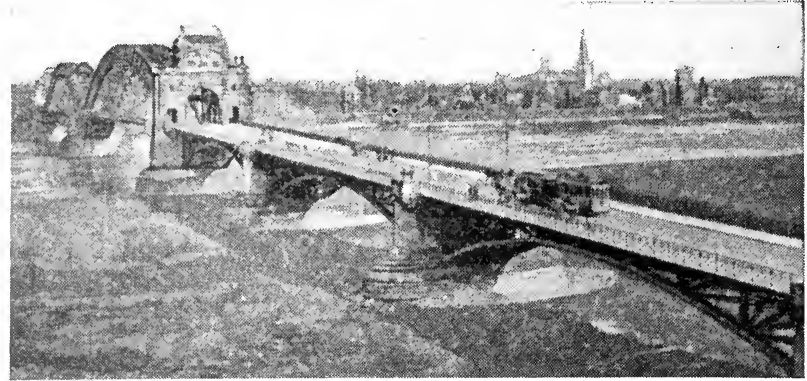

Dusseldorf. The town seen from the left bank of the Rhine, where it is spanned by the bridge built in 1896-98

extended 1804-13, whose Castle Court was immortalised by Hcine, is one of several delightful pleasure grounds; another is the Kaiser Wilhelm Park.

There are many educational institutions, industrial and historical museums, a public library, a municipal theatre, palace of justice, post office, banks, hospitals, and a cemetery. The Academy of Art, a famous school of genre painters, founded by the elector Charles Theodore, 1767, is housed in a Renaissance building, 1879 , with lecture hall. The greater part of the collection of old masters in the origina ${ }^{1}$ picture gallery, founded by the elector Johann Wilhelm, was removed to Munich in 1805 . The Düsseldorf art school flourished 1820-40 under Pete- Cornelius and W. Schadow. The Kunsthalle or municipal art gallery, 1881, enlarged 1902, with frescoed stairease, is devoted to modern work. Of recent years Düsseldorf has developed large iron, textile, brewing, distilling, printing, dycing, and other industries, and has become an important banking centre. Gas, waterworks, tramways, and electric plant belong to the municipality.

"First mentioned in 1159, Düssel. vorf received municipal rights in 1288. Early in the 16th century it was the residence of the dukes of Berg, and from 1609-1716 that of the princes palatine. In 1795 it became French and in 1815 was annexed to Prussia. It was in the neutral zone after the Great War. In the town were born the painters Cornelius and Suhadow, the philosopher Friedrich H. Jacobi, and the poet Hcine. Pop. 360,000 .

Dust. Fine dry particles of matter. Dust is of great importance, a fact which, however, has only been fully recognized within recent years. Without the presence of dust in the atmosphere, for ex. ample, there would be no cloud formations. John Aitken showed (1880) that the particles of dust in the atmosphere act as centres of condensation for the formation of rain drops. Without dust the atmosphere would reach a higher state of saturation than now holds, resulting in the condensation of wateron buildings, trees, etc., and on the clothing, as in mists.

Atmospheric dust particles are so small that the microscope has failed to distinguish many of them, and Aitken invented an instrument, known as the dust counter, for estimating the amount of dust in a given volume of air. Large cities show a heavy amount compared with country districts, while the air of mountain districts is freest from dust, particularly the High. lands of Scotland. But on Ben Nevis over 14,000 particles of dust per cubic centimetre have been recorded, and over a quarter of a million in big cities.

Volcanic dust is composed of minute mineral fragments ejected during volcanic eruptions. Sometimes called ash, it comprises the pulverised forms both of lava and of sedimentary rock dislodged from vent-walls. The distance from the originating centre at which any particle settles on land or sea is determined by the relation of its mass and maximum elevation to the force and duration of the wind.

Dust from the great Iceland eruption of 1783 destroyed the crops in Caithness, Scotland. After the eruption of Soufrière, St. Vincent, in $1812,3,000,000$ tons of "May dust" fell $100 \mathrm{~m}$. away on Barbados. The Tomboro eruption in Sumbawa, 1815 , distributed 50 cubic $\mathrm{m}$. of material-185 times the mass of Vesuvius-orer $1,000,000 \mathrm{sq}$. m. The most impalpable particles may float in the upper air for long periods, being incieed a predominant source of atmospheric dust everywhere. At Krakatoa, Malay a rchipelago, Aug. 26-27,1883, the dust-column, rising to $30 \mathrm{~m}$., caused darkness for 150 m. around. Some of it completed the circuit of the earth in 15 days, and remained floating at high ele- vations for three years in a belt between $60^{\circ} \mathrm{N}$. and $10^{\circ} \mathrm{S}$., producing remarkable sunsets seen in all parts of the world.

Vast areas in Nebraska and Kansas, U.S.A., are covered with ancient volcanic dust up to $30 \mathrm{ft}$. thick. When such deposits, formed in geological time, are subsequently consolidated, they are called tuffs. Submarine eruptions are attended by similar phenomena, producing volcanic muds.

The inhaling of dust is responsible for chronic disease of the lungs and air passages, increasing suscep. tibility to tuberculosis. Those most frequently affected are miners, quarrymen, earthenware and pottery manufacturers, cutlers, file makers, etc. The evil is reduced to a minimum by efficient ventilation, the use of hoods which prevent the lust from rising to the worker, or outlet shafts which draw it away as formed. In some processes it is possible to keep the dust down by sprinkling with water.

Dust-Storm. Wind-current of great velocity, laden with minute solid particles. The distance to which dust derived from the desiccated surface of exposed soil is transported is determined by the force and duration of the wind The local air-eddies which raise "March dust" are dust-storms in miniature. They especially characterise the dry desert-winds of wide, arid regions. The result of dust-laden wind-drift long continued is seen in such deposits as the clayey loess, sometimes 2,000 ft. thick, of N. China.

In central Asia the noonday sun is often obscured by fine, yellow loess-dust. On April 2, 1892, a dust-cloud, mostly of loess felspar, covered 2,000 m., and was driven $400 \mathrm{~m}$. out into the China Sea. The Sahara is another potent breeding ground of dust-storms, called in Egypt the khamsin, in the Mediterranean the sirocco, in Madeira the leste, in Guinea the harmattan, in W. Asia the simoom. It causes dry, red fogs off the W. African coast; when rain falls through them, so-called blood-rain results. A storm of March 9-12, 1901, trans ported 1,800,000 tons of fine Sabaran dust across Europe towards Russia.

Dusun. Primitive people of Indonesian stock living in $\mathrm{N}$. Borneo. Estimated (1911) at 88,000 , they form an important part of the Murut group. They have absorbed an immigrant Chinese strain, and adopted buffalo drawn ploughs and systematic irrigation. Tall, slender, long-headed, they are darker than the land Dyak of the Klemantan group. 
DUTCH ART: SURVEY AND APPRECIATION

\author{
C. Lewis Hind, Author of Iives of Rembrandt, Velasquez, etc.
}

The art of most of the countries of the world is described under the country, e.g. France; Germany; Italy; but this is an exception. Further information is given in the biographies of the great masters, Hals and others. See also Art; Greece: Art; Rome: Art, etc.

In the 15th and 16th centuries a few great painters arose in the Netherlands, who are ranked to-day with some of the best Italian masters. The pre-eminence of such early Netherlandish artists as Dirk Bouts, Gerard of Haarlem, and "Peasant" Brueghel is unquestioned; but it is not easy to say which of these masters are Hollanders and which are Flemings. The modern kingdom of Holland, as a monarchical state, dates from 1814, and by then the flowering time of Dutch art was over.

The great period began with the 17 th century, and extended through it, masters following one another in bewildering profusion. Not all were great painters, but the majority were extremely competent craftsmen, and were quite content to practise their art modestly, and for small remuneration. No Dutch painter fraternised with princes, as Titian, Raphael, and Leonardo did. Hobbema, whose Avenueat Middleharnis is in the National Gallery, London, was the last of the Dutch 17 th century masters, and, like many of the others, he died a pauper.

The 18th century did not produce one Dutch painter of eminence; but in the 19th the genius of Holland again flowered forth. In Jacob Maris (1837-99) land. scape pairti ig reached a height of sensitiveness and beauty that has never been excelled. Holland has rightly been called Landscape Land, and no one has interpreted the pearly light and moist atmosphere better than Jacob Maris.

\section{The Star of Frans Hals}

In the history of art certain nations have taken the lead in turn. Italy was the pioneer, and her great masters are still unapproachable; but when the star of Frans Hals, the first great light of that wonder. ful $17^{\text {th }}$ century in Holland, rose, Italian art had quite spent itself. Raphael had been dead 60 years when Frans Hals was born in 1580 .

Dutch art derived nothing from Italy. The materials of painting were similar, but the outlook was ontirely different. In Italy art was the handmaid of the church and of the wealthy noble. In Holland art served the people, and ministered to the pride of the bourgeois in his country, his houses and possessions. Art was a family affair. The homely Dutchman painted his home, was quite in. different to ideal subjects; he never attempted mythological, heroic, or religious themes. Dirk Bouts, Gerard of Haarlem, and Gerard David in the 15th century had painted religious pictures ; but in the 17 th hardly a Dutch painter ever thought of choosing a religious subject. Rembrandt was the exception, but his pictures dealing with sacred themes were spiritual rather than religious. Such masterpieces as S. Matthew Inspired by an Angel, and The Pilgrims at Emmaus, were painted from his heart. They taught no dogma. They were the personal expression of his spiritual emotion, not, as in Italy, a statement commissioned by the Church. The same may be said of his etchings and drawings of religious subjects.

\section{Dutch National Spirit}

Holland produced an everyday homely art, which attained, at its best, such exquisite craftsmanship that, in their particular métier these Dutch pictures are unrivalled. There was good reason for this love of country, and the Dutchman's desire to laud it in pictures. This unpretentious patriotism began when the disastrous war with Spain ended with the truce of 1609 , and the dogged strenuous citizens had time and opportunity to realize their aspirations after a national life. As their churches were plain and unadorned, they lavished their pas. sion for beautiful things upon their homes, which was followed by a desire to have pictures of those prosperous interiors; so arose the genre or home picture. With the demand came the supply from such masters as Vermeer of Delft, Terburg, de Hoogh, Metsu, Jan Steen, and numerous lesser masters. These home pictures ranged from such exquisite performances, wherein light is the principal subject of the picture, as Vermeer's Young Lady at a Spinet, and de Hoogh's Courtyard of a Dutch House, to the village inn scenes of Jan Steen and Brouwer, coarse according to our standards. But Jan Steen (1626-79) could also paint beau. tiful and restrained interiors, as in his Grace before Meat in the National Gallery, London, and his Sick Girl at Amsterdam.

The burghers in their fine clothes also desired portraits of themselves, and of their wives und children. The Civic Guards and
Companies of Archers were equally eager to be commemorated: so arose the doelen pictures, groups of men banqueting, or in conclave, which may be seen in profusion in the Ryks Museum at Amsterdam. Rembrandt was among those who were commissioned to paint doelen pictures, and they were the initial cause of his financial disaster. His patrons wanted likenesses of themselves. He gave them a work of art. So disputes arose, then the cold shoulder, and Rembrandt, withdrawing moreand more in to himself, became Rembrandt the great artist.

There was the beautiful. placid country which the Dutchman had wrested with such labour from the sea, and from the heel of the conqueror. That also had to be portrayed; hence arose the school of Dutch landscape painters of which the chief masters were Jacob Ruis. dael, Cuyp, and Hobbema.

Among this galaxy of 17th century painters four stand out pre-eminent-Rembrandt (1607$69)$, the greatest artist in paint the world has known; Frans Hals (1580-1666), whose portraits and doelen pictures have a vivacity and mastery of technique which places him in a class by himself ; Jacob Ruisdael (1625-82), the most profound of Dutch landscape painters ; and Vermeer of Delft (163275), who, as a painter of the subtleties of light in portraiture, genre, and landscape, ranks among the greatest craftsmen of the world.

Frans Hals, the first purely Dutch painter of eminence, is not adequately represented in the $\mathrm{Na}$ tional Gallery of London; a journey to Haarlem is necessary to sce him in his full power. His last works, painted when he was an old man, have a depth of vision and a fluency of technique that are more astonishing each time they are seen. Atmosphere and Landscape

The name of Hercules Segers has lately come into prominence, due mainly to the researches of Dr. Bode, of Berlin. He was a leader in landscape painting; he originated the "bird's-eye view," and Rembrandt, who missed nothing, learnt from Segers, and acquired his pictures. Van Goyen was an early tone painter. Timidly but tenaciously he introduced atmosphere into landscape. Terburg (1617-81) is represented in the National Gallery, London, by his beautifu Guitar Lesson, and by his wonder. ful little representation of The Peace of Münster. Cuyp (1620-9l) has won the heart of the world by the golden glow of his landscapes. The skies of J. Van de Capelle ( $c$. 1624-79) (see the pair of Capelles in the National Gallery, London) 


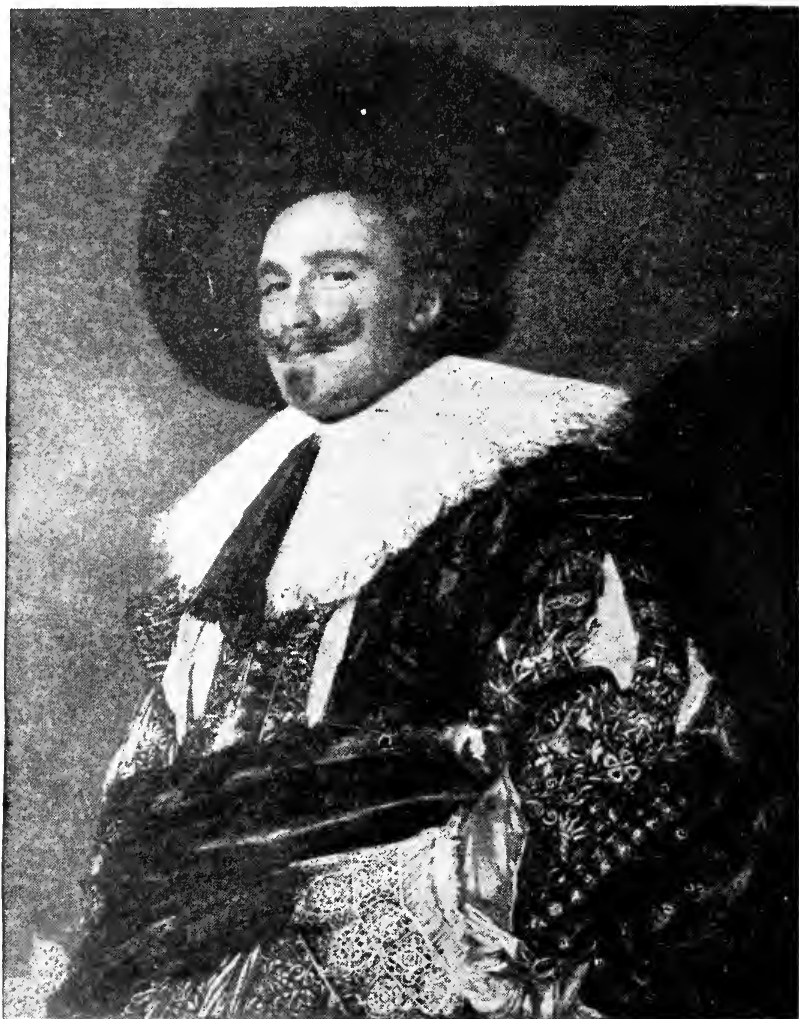

Dutch Art. The Laughing Cavalier, one cf the best known works of Frans Hals (1580-1666)

Wallace Collection are the despair of many modern artists. Paul Potter (1625-54) is famous for one of his lesser important pictures, The Bull. Jacob Ruisdael shows such a magisterial feeling in his work that one can look at almost any one of his land. scapes and say "a masterpieee." The same can be sajd of Vermeer of Delft. Two of his pictures may be mentioned-the portrait of an Artist at Work, supposed to be himself, in the Czernin collection at Vienna, and his View of Delft in the Hague Museum. With Hobbema (1638-1709) we reach the end of the 17 th century galaxy of stars in the Dutch firmament.

In the 18th century Dutch art merely glimmers. We are grateful for the flowers and fruits of Van Huysman and Van Os. The epitaph of Paul La Fargue, and of 18th century Holland, is written in a sentence: "Paul La Fargue eopied the older Dutchmen."

In the 19th century a new life sprang from the soil with Bosboom (1817-91), and with Jongkind, who has been aptly described as sad and weary art of Israels (18241911 ) is sometimes significant ; but he fumbled overmuch. Mesdag (1831-1915) was greater as a connoisseur and influence than as a painter. Mauve had a frank, fresh, and delicate talent; but the three chief figures in modern Dutch art are the brothers Maris-Jacob (1837-99), Matthew (1839-1917), and William (1843-1910). For pearly light, and fresh colour, the landscapes of Jacob Maris have never been excelled, and Matthew Maris is one of the very few modern artists who deserve the title of mystical painter. Bloomers, Breitner, and Bauer have all won European reputation; but their reputation pales beside that of Vincent van Gogh, who died in 1906. During the last decade Van Gogh has been more discussed, with approbation and disapprobation, than any other painter. $\mathrm{He}$ and the Frenchmen, Cézanne and Gauguin, have been docketed as leaders of the Post-Impressionist movement, and eertainly the work of Van Gogh has been a great influence among the young painters of the 20th century. Lastly, mention must be made of Louis Raemaekers (b. 1869), whose war car. toons, in fertility of invention and in range of satire, have been the chief pictorial commentary on the Great War. There must be great vitality and an astonishing power to meet new conditions in a country which, in the 17 th century, can produce a Vermeer of Delft and a Pieter de Hoogh, and in the 20th a Vincent van Gogh and a Louis Raemaekers.

Bibliography. Frans Hals, G. S. Impressionism. J. H. Weisenbruch, true to the traditions of Landscape Land, painted the moist air and the veiled sunlight with the lightest of hands. The
Davies, 1904 ; The National Gallery, G. Geffroy, 1904; The Complete Work of Rembrandt, W. von Bode and C. H. de Groot, Eng. trans. F.

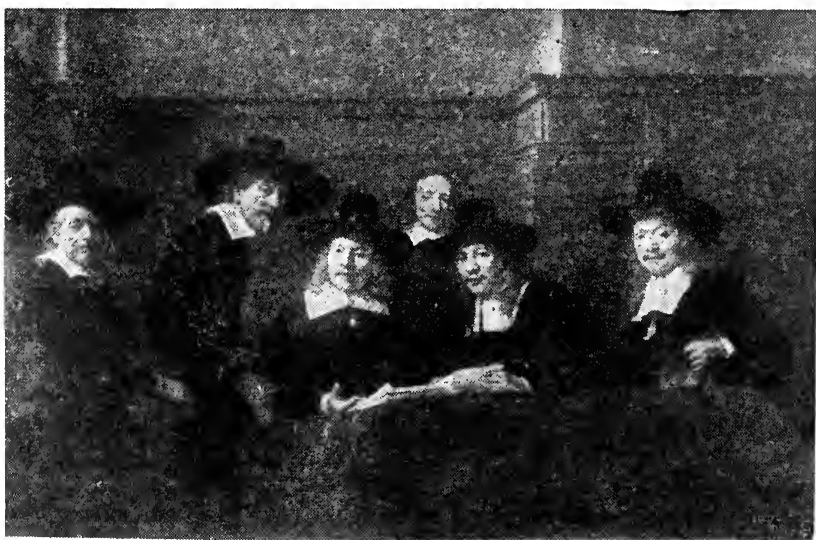

Dutch Art. One of Rembrandt's masterpieces, The Syndics of the Guild of Clothmakers, painted 1662

Ryks Museum, Amsterdam 
Simmonds, 1897-1906; Vermeer de Delft, G. Vanzype, 1808 (in French); Great Masters of Dutch and Flemish Painting, W. von Bode, Eng. trans. M. L. Clarke, 1909 ; Hist. of Painting, Haldane Macfall, vol. v, 1911.

Dutch Auction. Auction at which the property is offered at a price higher than the seller will accept. The price is lowered until a purchaser bids, when the lot is at once knocked down, or sold, to him at the sum last mentioned by the salesman. See Auctioneering.

Dutch Church, The. Name given to the predominant Protestant Church in Holland. Holland was the first country in Europe to accept the principle of toleration for all forms of religion, and to subsidise out of the state funds all religious denominations willing to accept its bounty. At the time of the Reformation, Protestantism assumed the form of what is known to-day as The Reformed Church. From 1648 to 1795 it was recognized

After the Revolution all churches received equal recognition, but the Reformed Church never lost its prestige and is still recognized as as the state church of Holland.

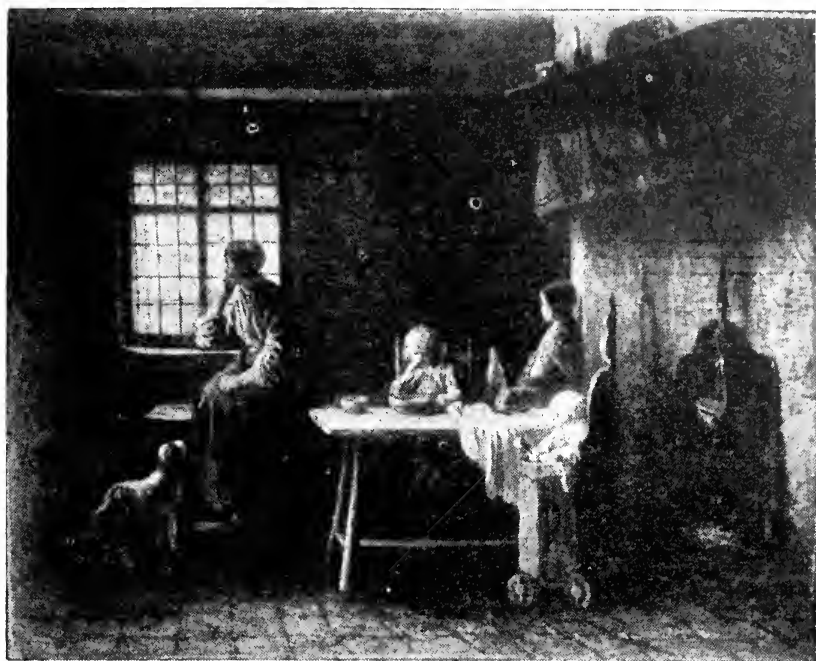

Dutch Art. The Anxious Family, by Josef Israels (1824-1911), a good example of the domestic spirit in the modern Dutch school of painting

From a private collection

the Confession of Faith of the Synod of Dort, 1619 .

The Dutch Church has about

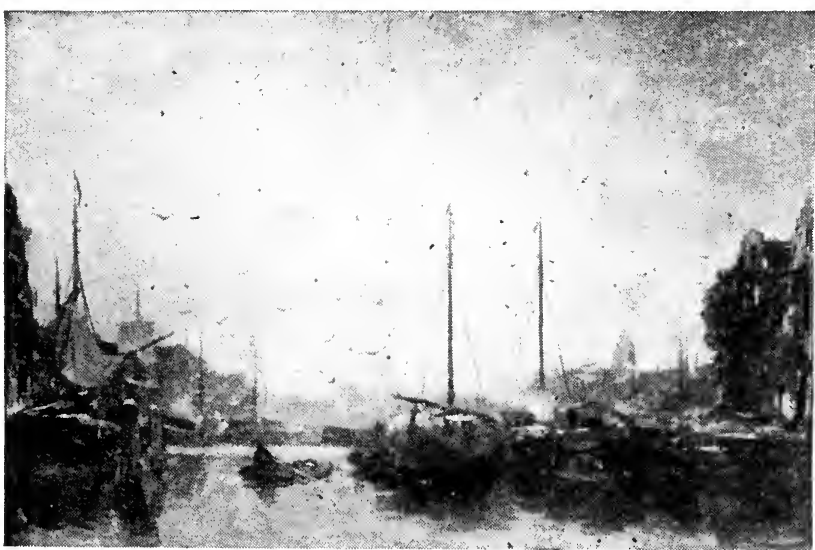

Dutch Art. The Port of Amsterdam, by Jacob Maris (1837-99). The picture's soft, warm colouring is characteristic of his work

vational Collection, The Hague

the predominant Protestant church of Holland. The constitution of the Dutch Church is based on the Presbyterian model. Each local congregation is governed by a consistory composed of deacons and elders. The local churches are grouped into 148 circuits and 44 classes or presbyteries. From these 10 provincial synods are formed, and in addition there is a general synod representing the whole country composed of 19 members, which acts as a final court of appeal. The theology of the Dutch Church has always been Calvinistic, and its credal basis is two million members in Holland itself, and its influence in the Dutch colonies and in South Africa is very extensive. At different periods in its history there have been schismatic movements formed to emphasise some principle of theology or Church government which had seemed to fall into neglect. Thus the Christian Reformed Church was started in the third decade of the 19 th century to protest against the growing laxity in the treatment of the creed.

DUTCH REFORMED CHUROH. Name given to the particular form of the Dutch Church which has taken root in America. The earliest Dutch settlers in America carried with them the religious principles of the Reformed Church which had been founded in Holland after the Reformation, and a church was organized in 1628, gradually strengthened by the stream of immigrants.

The church was at first supplied with ministers from Holland, and was regarded as forming part of the Presbytery of Amsterdam. In the following century, however, the American Church sought and with some difficulty obtained its independence and its right to educate and ordain its own ministry. Some secessions took place as the result of the new policy, but the breach was subsequently healed, and in 1812 a constitution was adopted which still remains in force. In its polity the American Church adopted the Presbyterian mode of Church government used in the mother church in Holland (with some minor modifications), with its consistory for the local church, its presbytery or class is for the district, and its synod for the province. The doctrinal basis of the church is strongly conservative and Calvinistic, being based on noless than five creeds: the Apostles', the Nicene, the Quicunque Vult, the Belgic Confession (1561), and the canons of Dort (1618-19). The Heidelberg Catechism (1560) is used as a manual of doctrine, and acceptance of its statement is required of all seeking for Church membership. The Dutch Reformed Church has about 800 churches, chiefly in the states of New Yorkand New Jersey, and about 125,000 members. 
Dutch Liquid or EThylene DICFLORIDE $\left(\mathrm{C}_{2} \mathrm{H}_{4} \mathrm{Cl}_{2}\right)$. Thin oily liquid with a sweetish taste and pleasant smell. Discovered in $\mathbf{1 7 9 5}$ by four Dutch ehemists, it is prepared by passing ethylene into a warm mixture of manganese dioxide, salt, water, and sulphurie acid until the black colour of the manganese has disappeared, and then distilling off the ethylene dichloride. It ean be made from coalgas, is obtained as a by-product in the manufacture of chloral, and is used as an anaesthetic.

Dutch Metal. Alloy of copper and zinc, and therefore technieally a brass. The proportion of the copper may range from 77.75 to 84.5 p.c. The colour varies from a pleasing pale yellow to a dark yellow, according to the proportions used. It is a very duetile metal and much used in the preparation of Dutch gold leaf, which is made by rolling down small east bars to ribbon, beating under a steam hammer to a certain thinness, annealing, pickling in dilute sulphuric acid, boiling in solution of argol, washing and drying, and then beating with hand hammers, as in the manufacture of gold leaf proper. Dutch leaf is largely used for gilding purposes, being much cheaper than gold; while its colour may be preserved for a long time by painting with transparent lacquer. The colour is sometimes changed to red, violet, or green, or other shade by adding to the laequer a small quantity of pure aniline dye. See Alloy: Brass.

Dutch New Guinea. Posses. sion of Holland, included in the Dutch East Indies. SeeNew Guinea.

Dutt, Michael (182!-73). Bengali poet and dramatist, properly Madhu Sudan Datta. Born at Sagandari village, Jessore district, Bengal, he was sent to the Hindu College, Caleutta, at the age of 13. Six years later, objecting to a marriage that was being arranged for him, he ran awav, forsook his caste, and became a Christian. He then completed his education with four years at the Bishop's College. $\mathrm{H}$ is first book, 'The Captive Ladic (1849), in English verse, though containing much that was remarkable in one writing in a foreign tongue, was less notable than his subsequent poetry written in Bengali. His Sermista (1858) and Ratnavali (1859) are the first ex amples of classical and regular drama in Bengali. Of both of these he made English translations.

Ilis other poems include two great epics in blank verse, Tillottama (1860) and Meghanad hadh Kavya (1861), the latter being deseribed by a compatriot critic (R. C. Dutt) as the greatest literary production of its centurv. His name has become a household word among the people of Bengal, and he is by common consent regarded as the chief master in modern Bengali literature. $\mathrm{He}$ travelled in Europe, 1862-67, and died June 29, 1873. See The Iiterature of Bengal, R. C. Dutt, 2nd ed. 1895.

Dutt, Romesh Chunder (18481909). Indian statesman and author. Born in Caleutta, Aug. 13, 1848, and educated at the Presidency College, Calcutta, and University College, London, he was called to the bar at the Middle Temple, 1871. A member of the Indian Civil Service, 1871-97, he held office as a divisional commissioner, 1894 and 1895 ; and was a fellow of Calcutta university. $\mathrm{He}$ became revenue minister, 1904-7, and prime minister, 1909, of Baroda. Made a C.I.E. in 1892 for his administrative and literary work, he was author of a History of Civilization in Ancient India, 1889-90; condensations in English verse of the Mahabharata (1899) and Ramayana (1900); books on the economic history of India ; and a number of historical and social novels in Bengali. He died Nor. 30, 1909. See Life and Work, J. N. Gupta, 1911.

Duval, Craude (1643-70). High wayman, born at Domfront, in Normandy. He came to England at the Restoration in the train of the duke of Richmond, took to the road, and became notorious for his daring robberies and for bis gallantry. He was eaptured while drunk in a London tavern and executed at Tyburn. $\mathrm{He}$ was buried in Covent Garden Church. Duval is the subject of a wellknown picture by W. P. Frith.

Duveen, SIR Joseph JorL (18431908). Anglo-Dutch art dealer. Born in Holland of Duteh parentage, he started as an antique dealer in Hull in 1865. In 1877, with his brother Henry, he founded in New York the art-dealing firm bearing their name. Opening in London in 1879, the firm quickly became noted for its discrimination and ability, among its famous purchases being the Kahn collection of old masters for nearly $£ 2,000,000$. Duveen presented the Turner wing to the Tate Gallery (opened 1910), and many works of art to the national collections, and was knighted in 1908. He died at Hyères, Nov. 9, 1908.

Duveyrier, HeNRI (1840-92). French explorer and geographer. Born in Paris, Feb. 28, 1840, he travelled in the desert hinterland of Algeria and Tunis, reaching as far S. as El-Golea and Ghadames
(1859-61). This exploration work secured his appointment, in 1867, as secretary of the Société de Géographie. In 1874 he resumed his exploration of French N. Africa. His published works include Exploration du Sahara: les Touareg du Nord, 1864 ; La Tunisie, 1881 ; Le Transsaharien, 1889-90; Sa. hara algérien et tunisien, 1905 . He died April 25, 1892.

Dux (Lat., leader). Word sometimes used, especially in Scotland, for the head boy of a school.

Dux. Town of Czecho-Slovakia, in Bohemia. It stands at the $\mathrm{S}$. base of the Erzgebirge, $18 \mathrm{~m}$. N.W. of Leitmeritz. Sugar, earthenware, glass, and poreelain are manufac. tured, and there are large coalmines in the neighbourhood. Its castle has a fine collection of armour, pictures, and boolss. Pop. 12,100.

Duxite. Safety explosive. It is typical of a class in which gelignite has been modified by the addition of salts which contain a considerable quantity of water of crystallisation and produce water on disintegration, thus lowering the temperature of the explosion flame. Duxite consists of nitroglycerine 32 p.c., gelatinised with nitrocellulose, 1 p.c., sodium nitrate, 28 p.c., wood meal, 10 p.c., and ammonium oxalate, 29 p.c. The latter compound is the salt employed to reduce the flame temperature, and the explosive passes the severe Rotherham test for safety explosives for use in coal mines with a charge of 12 ozs. See Gelignite.

D.V. Abbrev. for Deo volente, God willing.

Dvina, Northern. River of N.E. Russia, in the govt. of Vologda. It is formed by the union of the Suk. hona and Yug. Flowing N.W. by Archangel, chiefly through level, marshy districts, it discharges itself into the White Sea by five mouths. It is navigable in summer throughout its entire length of $360 \mathrm{~m}$., but the shoals at the mouth are a nuisance to traffic. Fish abound, especially a peculiar kind of cod (navaga).

Dvina, Western, or Duna. River of W. Russia. It rises in the lakes and marshes of the Valdai plateau in the govt. of Tver. Running S.W. and then N.W., it falls into the Gulf of Riga, $9 \mathrm{~m}$. below Riga. As it forms a connexion with the Baltic and Black Seas through the Beresina canal, it is used for timber transport, partly floated and partly by boat.

Dvina, Batries of the. Fought between Russians and Germans, 1915-16. The first battle took place Aug.-Sept., 1915. The German armies arrayed against the Dvina, one beyond the Vindava $W$. of Riga, under Lauenstein, and a 
second, under Below, S. of Friedrichstadt, belonged to the army group commanded in person by Hindenburg. Mitau had been taken on Aug. 1, and a day or two later forces advancing from Shavle were at Posvol, $30 \mathrm{~m}$. almost due S. of Friedrichstadt, and other troops marching from Ponievicz were at Subotch, about $50 \mathrm{~m}$. W. of Dvinsk. On Aug. 5 the Germans were only $10 \mathrm{~m}$. from Riga, and preparations for evacuating the city were being made. A naval attack on the port was definitely repulsed by Aug. 21, and all attempts on the land side failed, but the Germans, after heavy fighting, moved forward towards Jacobstadt and Dvinsk. They were driven back in the second week of August, but were advancing again on the 24th and the following day.

\section{Struggle for Friedrichstadt}

About Aug. 28 Below began a great assault on the line of the Dvina, with Friedrichstadt as his chief objective. This town, on the S. side of the river, offers the only practicable crossing between Jacobstadt and Riga; on the other side of the Dvina ran the railway from Riga through Kreutzberg to Dvinsk and Vilna; from Kreutzberg passed a railway through Friedrichstadt to Mitau, and of this the Germans gained possession. On Aug. 29 the Russians repulsed a determined assault on the Fried. richstadt bridgehead, which had carried some of the enemv across the Dvina. During the night of Aug. 30 Below's troops renewed their desperate attempt to capture the bridgelead, but their repeated attacks broke down.

On Sept. 2 German eavalry stormed the bridgehead near Lennewaden, N.W. of Friedrichstadt, and next day the Russians were found to have withdrawn from the Friedrichstadt bridgehead. All through Sept. 1 and 2 Below, strongly rein forced, had pounded the Russian defences with his heavy guns, and under this pressure the Russians retired across the river. S. of Fricdrichstadt the Germans advanced towards Jacobstadt, stubborn actions taking place between that town and the Lautse. On Sept. 11 a Russian offensive from Jacob. stadt drove the Germans back in this district. On the same day their main attack shifted S.E. in a move across the Sventa which reached Utsiany on Sept. 12 and Svientsiany, on the Dvinsk-Vilna railway, on Sept. 13, the Russians with. drawing to Podbrodzie, the purpose of the Germans being to participate in the operations against Vilna. Meanwhile the first battle of the Dvina had died down.
The second battle was fought during Jan.-Aug., 1916. At the beginning of the year the Russian line was practically that estab. lished at the end of Sept., 1915, after the Russian retreat from Warsaw. Beginning at the coast near Riga, it ran along the left bank of the Dvina, which it crossed in one place and passed close to Dvinsk, still held by the Russians. Then, leaving the river course, it ran S. to the neighbourhood of Molodetchno, also held by the Russians, then S. to Pinsk. On this northern sector, from the Baltic to Friedrichstadt, Hindenburg was in command on the German side, and, from Feb., Kuropatkin, on the Russian. In March and April there was some intermittent fighting.

\section{Hindenburg's Attack}

On May 11 Hindenburg launched an ambitious but abortive offensive against the Russian positions at Selburg on the Mitau-Jacobstadt railway. He resumed his efforts on the next day, and fighting took place on the outskirts of the village of Yepukn. Another attack was launched at the beginning of June against the sector to the S. of the station of Neu Zelburg, N.W. of Jacobstadt. Henceforth Galicia became the critical area of the Eastern front, and with the repulse of a Russian attack in the Dvina sector at the end of August the second battle died down.

Dvinsk (Daugavils). Town and fortress in Latvia, in the govt. of Vitebsk. It stands on the right bank of the Dvina, at the junction of the Petrograd-Warsaw and Riga. Snolensk rlys. There is a considerable trade in grain, flax, and timber. Founded in 1278 by Liv. onian knights, the town was destroyed by the Russians in 1577, and rebuilt by Stephen Bathory, king of Poland, in 1582. In 1772 it was added to Russia, remaining part thereof until the collapse of the Russian empire in 1918. During the Great War, after much fighting for its possession, it wasoccupied by the Germans Feb.18,1917. Pop.110,000.

Dvinsk, BatTles FOR. Fought between the Russians and Germans 1915-16. During Sept., 1915, Hindenburg's attack on the line of the Dvina had given him Friedrich. stadt, on the S. side of the river, but had failed to carry him across to the opposite bank. Fighting in the immediate neighbourhood of Dvinsk had resolved itself into trench warfare; behind their line the Germans, however, were mass. ing heavy guns, and Sept. 24 saw the beginning of a determined effort to capture the town, which, as the centre of railways and roads, was strategically important. Dvinsk was protected by fortified lines 10 $\mathrm{m}$. to $12 \mathrm{~m}$. S., in a region of lakes and marshes, whieh were formidable obstacles to an assaulting army. The chief of these lakes were Lake Sventen and Lake Medum on the S.W., and Lake Drisviaty and Lake Rytchy on the S. and S.E. Between Sventen and the Dvina ran the railway from Shavle by Ponievicz to Dvinsk, and N. of the railway passed the highway from Illukst; between Medum and Drisviaty were the highway, passing $\mathrm{N}$. through $h_{2}$ Novo Alexandrovsk, and the railway from Vilna to the town.

Along these railways and roads the attack was unimpeded by natural obstacles, but while Hindenburg in his offensive of Sept. 24-25 made use of these approaches he assaulted on the whole front from the Dvina to Drisviaty. He had some success near Illukst and along the Novo-Alexandrovsk road, where his infantry pushed on to within $8 \mathrm{~m}$. of Dvinsk. Elsewhere he was checked and even thrown back, as at the village of Drisviaty, which was recaptured from him on Sept. 25. As a whole the attack failed, and resulted in very heavy losses.

The Autumn Campaigns

Then followed a lull till about Oct. 3, when Hindenburg made his second great effort, his strength having been vastly increased in men and guns. By this time the cavalry thrust to Sventsiany and E. of Vilna had been completely held up, and thus the possibility of a drive on Dvinsk from the $\mathrm{E}$. which otherwise might have materialised, had vanished. Hindenburg now mainly confined his attention to attacking in masses on the W. and S.W., while his big guns bombarded the Russian trenches in the S.E. Making a strong push near Illukst, he took the Schlossberg ridge and Illukst itself, but was held up in front of the Illukst river near the Dvina. $\mathrm{S}$. of the Ponievicz railway there was a sanguinary struggle about Garbounovka and Pashalina, the former finally remaining with the Russians, on Oct. 10. Along the Novo-Alexandrovsk road the enemy progressed to the village of Medum, but was unable to advance nearer Dvinsk. This second attack was also a failure as a whole.

Russian Counter-Offensive

The third attack, which began on Oct. 25, made some progress from Illukst after furious encounters, and broke through at Garbounovka, but was countered and led to no further result. On Oct. 31 the Russians assumed tho offensive between Lakes Sventen and tho neighbouring Lake Ilsen, and in 
ten days of very heavy fighting completely defeated the Germans. Towards the close of Nov. the Russians recaptured part of Illukst, and Drinsk was perfectly safe.

The second battle for Dvinsk lasted throughout the first half of 1916. The result of the Germans' campaign against the Russians in 1915 was an important gain of territory in Poland, but their ultimate object-the destruction of the Russian armies-was as far off as ever. To capture Dvinsk became a pressing need if headway was to be made in that direction. The 1915 campaign left the line on the Russian front practically one, running due $\mathbf{N}$. and $\mathrm{S}$. from Dvinsk to the point where the frontiers of Rumania, Galicia, and Bessarabia meet, on the rivers Dniester and Pruth. N. of Dvinsk the line followed the river Dvina N.W. to the Baltic near Riga. N. of the Pripet marshes, the northern Russian army was commanded by Kuropatkin, the centre group of armies by Evert, and the southern by Brusiloff. The German northern armies were commanded by Hindenburg.

\section{Von Below's Army Order}

The Germans opened the second battle for Dvinsk on Jan. 19. They selected the district of Tennenfeld for their opening artillery attack, which was later followed by two infantry attacks easily repulsed by the Russians. On Feb. 13, the Dvinsk sector was again the scene of great activity, the enemy artillery fire being most intense near Illukst. They also attempted to surround Garbounovka, 9 m. N.W.of Dvinsk, which the Russians had just taken from them, but this attack was defeated by the Russians' crossfire. Soon after this Von Below issued his notorious Army Order, summarising the situation and forecasting his operations.

On Feb. 28, the Russians, near Garbounovka and N. of the Ponievicz rly., succeeded in driving back the Germans and making a small advance. The Germans also assumed the offensive, and between Lakes Ilsen and Medumskoi, W. of Dvinsk, and S. of the latter, made massed attacks. A notable tactical phase of the battle was the rupture by the Russians of the German line at Jacobstadt, on the Dvina, between Riga and Dvinsk, on March 23. As a reply to this threat the Germans made aggressive attempts in the Dvinsk theatre, but without effecting any result. Two days later the Russians again attacked. Both sides were now making desperate efforts, as the course of events was largely determined by the weather con.

ditions and the approach of the spring floods. This factor determined the Russian attack of March 25 , when a slight advance was made on the left bank of the Dvina at Dvinsk. April was taken up with fierce but indecisive fighting.

On June 26 Hindenburg made another costly and fruitless attack on the Dvinsk positions. Brusil off's Galician offensive had by this time proved highly successful, and the energies of both sides were con. fined to merely defensive opera. tions. The Dvinsk battle flared up at the beginning of Oct., when a heavy German attack by artillery was repulsed. A Russian gas attack on the German trenches towards the end of Nov. rounded off the second battle for Dvinsk. The fierce fighting of 1915-16 left the town in Russian possession, though there were signs that the break-up of the Russian armies was rapidly approaching. What the German armies could not accomplish, German propaganda readily effected.

Dvorak, Antonin (1841-1904). Bohemian composer. Born at Mühlhausen, Sept. 8, 1841, the son of an in nkeeper, he obt a ined his musical training at Prague. In $1862 \mathrm{he}$ joined the orchestra of the National Theatre, and began to devote him.

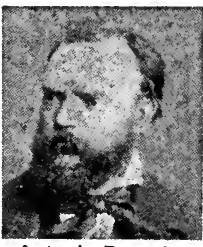

Antonin Dvorak, Bohemian composer self to com- Bohemian composer of Brahms, he was invited to write a set of Slavonic dances, which made him famous. From 1892-95 he was principal of the National Conservatoire of Music at New York, but returned to Bohemia, where he died, May 1, 1904. His works include a Stabat Mater, a cantata, The Spectre's Bride, several brilliant symphonies and overtures, and fine examples of chamber music. He was essentially a national composer, as his strongly marked rhymes and striking har. monies attest. Pron. Dvorzhāk. See Studies in Modern Music, W. H. Hadow, series ii, 1895.

Dvior Králové (KöNIGINHOF). Town and district of Czecho-Slovakia, in Bohemia. The town is an important textile centre, and is 105 m. by rly. E. of Prague. The Aus. trians defeated the Prussians here June 29, 1866. In the neighbour. hood the Elbe valley is very fertile. Most of the inhabitants are Roman Catholics, four-fifths are Czechs, the rest Germans. Pop., town, II, 000 ; district, 30,000 .

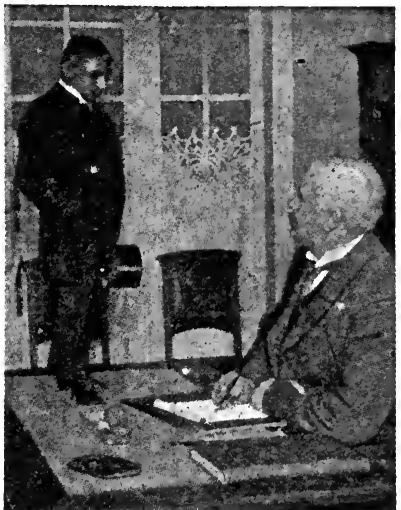

Dwarf. Samson, a South American dwarf, standing on the table while his manager explains a contract

Dwarf. Abnormally short human being. The Asiatic negrito and African negrillo races, with a maximum stature of $4 \mathrm{ft}$. 11 in., are usually called pygmies. The conventional maximum of spectacular dwarfism in the white and vellow races is $4 \mathrm{ft}$. Notable court dwarfs were Queen Mary I's John Jervis, 24 ins., and Queen Henrietta Maria's Jeffery Hudson, 18 ins. at 30 , and 45 ins. at death. Examples exhibited in London during the I9th century included the Polish count Boruwlaski, 39 ins.; the American, Charles Stratton (General Tom Thumb), 31 ins., who married Lavinia Warren, 32 ins.; the Fairy Queen, 16 ins. ; the Mexican Midget, Lucia Zarate, and the French princesse Topaze, each 20 ins. in height.

Dwarf races are primitive peoples whose average adult male stature is below $4 \mathrm{ft}$. 11 ins. There are two main groups: Asiatic negritos, comprising Aeta, Andamanese, Semang, Tapiro, and others ; African negrillos, including Akka, Batwa, Bambute, and allied tribes.

Some writers hold that this stock, with dwarf stature as jts normal characteristic in all ages, was the parent stock of all mankind. This view is unsupported by early skeletal remains, which show diminutive size in only a few scattered examples in palaeolithic Europe, besides some neolithic sta tions near Schaffhausen and else. where. Others consider these infantile peoples as dwarfed by their adverse environment. This in its turn fails to account for the constancy of the pygmy type, which has not varied since early dynastic Egypt. Even when settled husbandry introduces improved conditions, stature increases only after racial admixture. 
The most satisfactory theory of pygmy origins regards these peoples as representing the early divergence from the main human stock of a tropical hunting type which has conserved its physical characters and primitive culture in racial isolation. This explains the absence of dwarf races from tropical America as well as from cold latitudes. The arctic Eskimo, the E. Siberians, and the European Lapps, together with the austral Yahgans of Tierra del Fuego, the Cape Bushmen, and the Ceylon Veddas, are short rather than dwarfish, being well above the pygmy stature, and alien to the pygmy culture. See Giant; Man; Negrito ; Pygmy.

Dwarka. Municipality of India. It stands on the N.W. promontory of Kathiawar peninsula, belonging to Baroda state. It contains the temple of Dwarkanath (Krishna), and is one of the holy places of India, the resort of Hindu pilgrims. Pop. 6,548, nearly all Hindus.

Dwelling. Habitation of mankind for repose, shelter, and domestic life Dwallings may be natural or artificial, temporary or habitual, portable or fixed. That primeval man dwelt in tropical forest trees is a conjecture sup. ported by anthropoid usage. Arborcal structures still characterise some primitive peoples, as among the Khas, Mois, and in the Solomon islands. When he migrated to the limestone lands of temperate Eurasia palaeolithic man utilised the rock-shelter and the cavedwelling. This type of habitation also survives.

The rudest effort of art upon the ground level is the wind-screen, sometimes primarily to protect the fire. Hence emerged the hut, formed by binding the tips of saplings, and often skin-covered in cold weather. Devised in the palaeolithic age, it still exists in primitive forms among the African pygmies, Bhils, Botocudos, Fuegians, and Veddas. The natural hollow, and its simulation by an artificial pit, gave rise to the beehive roof and the lean-to or pentroof, resting on the ground. Their conical or gabled surfaces were covered with thatch, turf, carth, or skins; rudimentary forms are still known-Ainu, Chukchis, and the Eskimo snow-house (igloo).

Thus arose the two simplest of structural types, the round and the oblong. "The former prevailed in neolithic andearly-metallic Europe. The Swiss lake-dwellers plastered their timbered huts with clay ; this wattle-and-daub construction sometimes as a secondary deriva. tive from the plain thatch-still endures. The dome-shaped or conical hut, developed in local forms in aboriginal America, prevails over wide regions in negro Atrica. It may have a bamboo palisade, a loose-stone wall, or a defensive stockade. When used by nomad peoples it became the round Kirghiz yurt or the American tipi.

The introduction of metal tools and carpentry replaced pit-digging by the erection of posts, walled with unhewn or hewn timber, matting, stone, or clay. Sun-dried bricks, developed early along the Nile and the Euphrates, still survive in Mexico and the Sudan. The pent became the elevated roof, whose construction displays much diverse ingenuity, from the Bantu thatch, which may be double, as in Uyanda, to the interlaced palmleaves of Polynesia and the elegant timber carving of Japan. The neolithic lake-dwellors introduced pilefoundations in shallow waters, a practice still extant in Borneo and New Guinea. This cultural advance found its full development in the hewn masonry of Egypt, whose influence, passing into the Aegean, affected the architectural achievements of the Graeco-Roman and the Indo-Aryan world, spreading thence across the Pacific to the ancient American civilizations.

The early-Aryan rectangular house led to the formation of streets, and in the eastern branch to the quadrangular enclosure, at first a cattle-pen, afterwards the courtyard characteristis of the civilized Orient. The roof-angle is determined by the problem of rain and snow, as in the steep Scandinavian gable. The flat roof characterises Semitic life in surny lands. Many-storeyed dwellings are developed in every continent. House partition for sex-segregation is traceable to a remote antiquity. With many primitive peoples the social organization involves separate dwellings for unmarried girls and unmarried men. Communal houses for family or tribal groups are exemplified by the long-houses of the Iroquois and the Melanesian peoples. See Bce Hive Structure; Cave, Cliff, and Lake Dwellings Igloo; Kraal ; Wigwam.

Bibliography. History of Man. kind, F. Ratzel, Eng. trans. A. J. Butler, 1896-8; The Races of Man, J. Deniker, 1900 ; Handbook to the Ethnographical Collections in the British Museum, T. A. Joyce and O. M. Dalton, 1910 .

Dwight, JoHN (fl. 1671-98). English potter. $\mathrm{He}$ is believed to have been born in Oxfordshire, and to have been a member of Christ Church, Oxford. In 1671 and 1684 patents were granted him by
Charles II for the manufacture of porcelain, the secret of which he claimed to have ro-discovered; but he can only be credited with the invention of an improved process of stoneware. He employed Italian workmen at the Fulham pottery works which he founded; and, in addition to utilitarian stoneware, he produced many fine statuettes and busts, including those of James II and Prince Rupert.

Dwight, Тгмотну (1752-1817). American Congregationalist and poet. Born at Northampton, Mas-

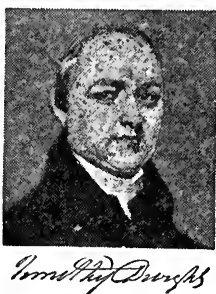
achuse May 14, 1752, and a grand. son of Jona. than Edwards, he was educated at Yale College. An army chaplain during the Civil War after being a minister at Greenfield, Connecticut,17821795, he was president of Yale from 1795 until his death at New Haven, Jan. 11, 1817. His Theology Explained and Defended, 1818, a course of 173 sermons, has passed through more than 100 editions. He wrote the patriotic song, Columbia, and an epic, The Conquest of Canaan, and was author of an Essay on Light,

First of the great American college presidents, the number of students at Yale almost trebling during his presidency, Timothy Dwight was an advocate of co-education and of the higher education of women. (See ThreeMen of Letters, M.C. Tyler, 1895.) His grandson, Timothy (1828-1916), was professor of New Testament Greek and Exegesis, Yale divinity school, 1858-86; president of Yale, which during his term of office assumed the status of a university, 1886-99; and a member of the American committee for the revision of the English Bible, 1872-85. He contributed to the New Englander a series of articles on The True Ideal of an American University, 187071 ; and was the author of Memories of Yale Life and Men, 1903.

Dwyka Series. Shales and conglomerates beneath the Ecca formation in the S. African Karroo system. They extend for $800 \mathrm{~m}$. from the Transvaal through the Orange Free State prov. and Natal into the Cape prov., with a naximum thickness of $2,300 \mathrm{ft}$. The lower Dwyka shales, of Permo-carboniferous date, were overlaid by deposits in and around the vast Karroo lake, into which icebergs broken from the faces of glaciers 
dropped huge striated boulders of granite, jasper, and other rocks. The resultant conglomerate resembles English boulder-clay, but so greatly hardened as to be quar. ried at Umgeni for road-metal This eonglomerate was overlaid by the fine-grained upper Dwyka shales, whose fossil reptiles and plants correlate them with the Indian Gondwana system. 'This series is named after the J)wyka river.

Dyak or DAYAK. Popular name for the Indonesian non-Malay peoples in Borneo. The land Dyal embrace some settled agricultural tribes in the Klemantan group. 'They use $8 \mathrm{ft}$.blowguns, sumpitan, with en$\mathrm{v}$ e $\mathrm{nom}$ ed d arts, and
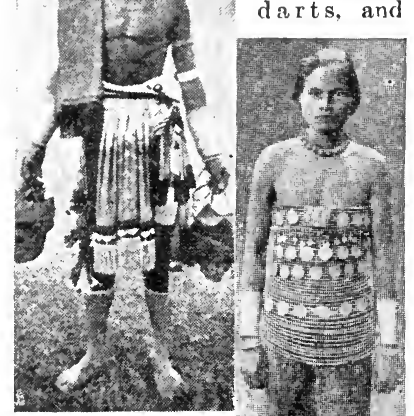

practise crema tion. 'The rounderheaded proto. Malayan sea Dyak, preferably called Iban, are the most tattooed Bornean tribe and were the most inveterate head-hunters. See Borneo.

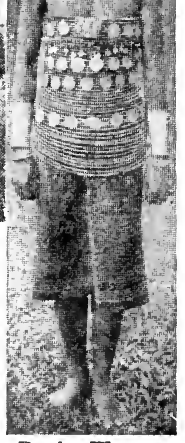

Dyak. Woman in native costume. Above man in gala dres

Dyas (Gr., the number two). Alternative name for the uppermost system of palaeozoic rocks, called by R. Murchison the Permian. It was introdueed by J. Hareou, on the analogy of the 'Trias which lies above it, beeause it is represented in Germany by two well-marked stages, the red sandstone (Rothliegende) and the minestone (Zechstein). See Permian.

Dyce, Alexander (1798-1869). Shakespearean editor and literary and dramatic eritie. Born at Edin. burgh, June 30,1798 , he was educated at the High School and Exeter College, Oxford, subsequently taking orders. In 1825 he gave up clerical work and devoted himself to editing the old dramat. ists. He brought out George Peele, 1828; Joln Webster, 1830; and Robert Greene, 1831. In 1833 he

completed Gifford's edition of Shirley, and edited Thomas Middleton in 1840, and John Skelton in 1843. He brought out the Works of Beaumont and Fletcher in 11

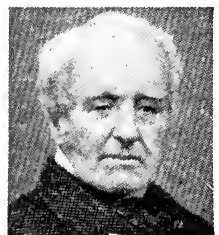

Alexander Dyce. Shakespearean edito vising when he London, May 15, 1869.

Dyce, William (1806-64). Scottish painter. He was born at Aberdeen, Sept. 19, 1806, and educated at the Maris.

chal College.

In 1830 he settled at Edinburgh as a portrait-paint. er. In 1835 he was elected Assoriate of the Scottish Academy. Suecessful in the

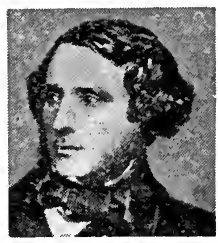

William Dyce, Scottish painter

\section{West minster}

Hall competition, he produeed a fresco, The Baptism of S. Ethelbert, the first to be completed in the existing Houses of Parliament, 18.5; and in 1848 became R.A. He died at Streatham, Feb. 14, 1864. See illus. p 753.

Dyer, Sir Edward (c. 15401607). English courtier and pret. Born at Sharpham Park, Somersetshire, son of Sir Thomas Dyer, he was educated at Oxford, and after Continental travel was introduced at court in 1566. A close friend of the Sidneys, and a member of the literary coterie known as the Areopagus, he enjoyed a high reputation as a man of character and a poet. He was sent by Elizabeth on a diplomatie mission to the Low Countries in 1584 , acted as one of the pall bearers at Sir Philip Sidney's funeral in 1586, went on a diplomatie mission to Denmark in 1589 , and acted as commissioner for the attachment of forfeited lands. Knighted and made chancellor of the order of the Garter in 1596 , he retired after the accession of James I. He died in 1607, and was buried in S. Saviour's, Southwark. As a poet, he is best renuembered as author of the ballad, My Mind to Me a Kingdom is, published (without author's name) in William Byrd's Medius: Psalms, Sonnets, and Songs of Sadness and Piety, 1588. See Works, ed. with memorial introduction A. B. Grosart, 1872 (Fuller Worthies' Lib.).
Dyer, Jонм (1700-57). British poet. A Welshman by birth, after studying art for a short time he became a clergyman. His chief merit is in the appreciation $10 r$ nature shown in his poems Grongar Hill and 'T'he Country Walk, both published in Savage's Miscellany, 1726. The Ruins of Rome appeared in 1740 . He died Hee. 15 , 1757. See Poems, ed. with biographical introd. E. Thomas, 1903.

Dyer, REginald EDward HaRRY (b. 1864). British soldier. Born Oet. 9,1864 , he was educated at Middleton College, co. Cork, and entered the R.W. Surrey Regt. in Ang., 1885. Proceeding to India, where be passed through the staff college, he joined the Indian army, reaching the rank of colonel in June, 1910. Dyer became a brigadier-general in 1916, and was created C.B. in 1917. In 1919 he commanded the 45 th infantry (Jullunder) brigade, and to cope with disorders at Amritsar, he arrived there on April 11.

(n April 13 he ordered his troops to fire on the mob of 5,000assembled at the Jallianwallah Bagh, when about 379 natives were killed and 1,200 wounded. A committce appointed in Oct., 1919, to investigate the disturbances, issued its report in May, 1920, in which Gen. Dyer was severely censured. Having been superseded in India, his case was considered by the Arm y Council in

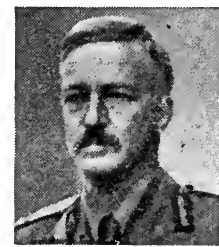

R. E. H. Dyer, British soldier
June, 1920, by whom the report of the committee was approved, and he retired in July. There was a good deal of sympathy expressed for Dyer by those who thought his prompt action had averted a serious rising, and through The Morning Post over $£ 21,000$ was raised for him. See Amritsar, N.V.; India.

Dyers' Company, THe. London city livery company. Incorporated 1471 , it was originally one of the

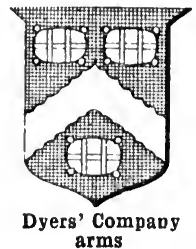
12 chief com panies. With the Vintners it has the right of keeping swans on the 'Thames, and it administers a number of charities. The hall in Dowgate Hill, E.C., e rected

1857, is one of four, the first of whieh, on the site of Dyer's Ha! Wharf, was burnt in $\mathbf{1 6 6 6 .}$ 
Dyers' Greenweed or Woad- extends into.N. and W. Asia. The WAXEN (Genista tinctoria). Dwarf bright yellow flowers are small, shrub of the natural order Legu- and are succeeded by smooth, flat minosae. A native of Europe, it

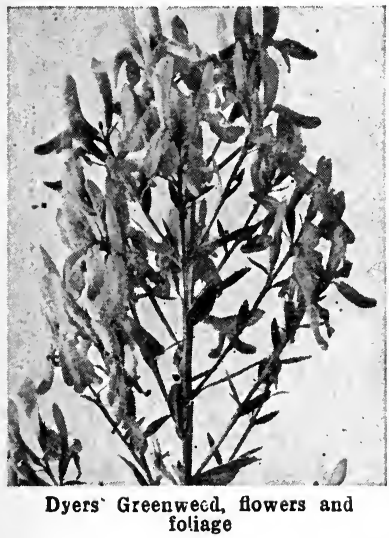

ods, an incli long, containing about five seeds. It yields a yellow dye, which was largely used by dyers in connexion with natural indigo.

Dyers' Oak (Quercus velutina). Large tree of the natural order Amentaceae. A native of $\mathrm{N}$. America, it is known asquer. citron and yellow-bar ked oale, the rough, brown bark being orangecoloured internally. It has variously dirided large leaves and small hemi. s p h e r i cal

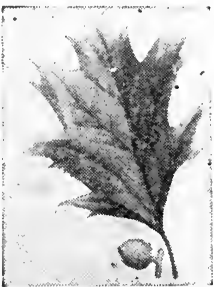

Dyers' Oak, leaf and acorn

acorns. The bark is extensively used in tanning and dyeing.

\section{DYES AND DYEING : A KEY INDUSTRY}

Mark Meredith, Edito of The Indian Textile Journal

This article classifies the various kinds of dyes and describes the materials of which they are made. See the articles on matcrials which are dyed, e.g. Cotton. See also Perkin and other chemists

Dyes or dyestuffs are substances used for dyeing the various textile fibres, as wool, silk, cotton, artificial silk; also for dyeing leather, paper, etc., and for colouring oils, varnishes, foodstuffs.

Chemically, dyestuffs are of very diverse character, and with a few exceptions (mineral dyestuffs) are composed of carbon and hydrogen, associated with one or more of other elements, as oxygen, nitrogen, sulphur, chlorine, bromine, iodine, and sometimes with the metals sodium, potassium, or calcium.

Mineral dyestuffs comprise Prussian blue, iron buff, chrome yellow, chrome orange, manganese bronze, and metallic oxide khaki. They are chiefly used for cotton, but have lost their former importance. They are produced by depositing coloured salts of metals within the fibre, i.e. cotton cloth is impregnated with a soluble salt of a metal, squeezed, and then treated with another solution so that an insoluble metallic compound is formed and firmly fixed on the fibre. The mineral dyestuffs are very fast to light and washing, except that Prussian blue is turned brown by alkalis. Metallic oxide khaki, produced from salts of iron and chromium, was largely used. during the Great War.

Natural Dyestuffs. Dyestuffs may be divided into (1) natural and (2) artificial. The first class comprises the vegetable dyestuffs, logwood, etc., also cochineal and lac dye, the two latter being produced from an insect. The famous Tyrian purple of history came from certain molluses.

The most important natural dyestuffs are natural indigo, logwood, fustic, cochineal, Persian berries, orchil, cudbear, and cutch. of lesser importance are barwood, Brazilwood, camwood, Sanderswood, and weld. In 1914 only the members of the first group were used to any great extent, and the consumption of these (especially natural indigo) was gradually declining.

During the Great War all natural dyestuffs again became more prominent, owing to the great shortage of artificial colours, and in 1920 the demand for logwood and orchil was greater than the supply. Mention should be made here of " madder," formerly much used for madder reds, but the colouring principle of this vegetable dyestuff, alizarin, is now produced artificially, and the natural product is only used in very small quantities for use in indigo vats. The chief sources of the natural dyestuffs are the W. Indian Islands, India, S. America, and S. Europe.

\section{Natural Dyestuffs}

With the exception of indigo and orchil, the natural dyestuffs are those which, applied alone to the textile fibres, possess little affinity for them, and are only of use when combined with metals, previously applied to the fibres in the form of salts. They are, moreover, polygenetic in character, i.e. they produce different shades according to the metallic salt (chrome, aluminium, tin, or iron) previously applied to the fibre, this latter operation being technically called "mordanting." Hence the natural dyestuffs are called mordant colours, in distinction to the classes in the artificial dyestuffs, such as acid, basic salt, etc.

\section{Indigo and Logwood}

Natural indigo is marketed in lumps, varying in strength, and must be ground before use in the indigo vat. It belongs to the series of vat colours, and is one of the oldest dyestuffs. Logwood is used in the form of rasped wood, logwood extract, and haematein crystals. Haematein crystals contain the actual colouring principle haematein, and are the most concentrated form of dyestuff. Log. wood is used in conjunction with fustic, chiefly for blacks on wool and silk, and is noted for its fine bloomy shade, which is difficult to reproduce with artificial colours. Cochineal dyed on a tin and aluminium mordant was formerly used for scarlet. Cutch is mostly employed on cotton, giving very fast browns.

Artificial Dyestuffs. These are commonly called coal tar dyes. The first artificial dyestuff was discovered by Perkin in 1856 and called mauve. Since that date some thousands of dyestuffs have been put on the market by different makers, but these do not all repre. sent individual colours, as the same dyestuff occurs under many different names, and many also are mixtures.

\section{Dyestuffs from Coal Tar}

The artificial dyestuffs comprise a very large number of organic compounds, varying in composition from a simple derivative, such as picric acid, to a very complicated one, as indanthrene dark blue. Chemically, they are divided into about 15 classes, the dye. stuffs in each conforming to a definite structure; but dyestuffs from different classes may behave alike from a dyeing point of view, and taking the latter as a basis for differentiation, the following classes of dyestuffs are obtained : (1) acid, (2) basic, (3) direct cotton or salt colours, (4) mordant, (5) sulphide, (6) vat, (7) insoluble colours or colours formed on the fibre.

As the name indicates, the dyestuffs of this group are derived from coal tar. From this are obtained by various processes of distillation and purification such important substances as benzene, toluene, 
phenol, naphthalene, and anthracene. These are all (except phenol) hydrocarbons, i.e. compounds of carbon and hydrogen. Phenol contains oxygen as well. and is commonly called carbolic acid. These substances are the primary raw materials for the production of all artificial dyestuffs.

Before the actual formation of a dyestuff can take place, the substances mentioned must be converted into what are called in. termediate products, and sometimes more than one intermediate takes part in the formation of a dyestuff. The formation of an intermediate or its practical manufacture is often more difficult than the actual production of the final dye product, it being frequently essential that the intermediate should be pure, otherwise the resulting shade of the actual dyestuff is impaired. Sometimes these intermediates are coloured and give coloured solutions, but do not possess the property of dyeing. It will thus be seen that for the actual manufacture of dyestuffs, the production of large quantities of pure intermediates is of primary importance. The formation of intermediates from the primary raw materials is carried out by the action of various agents, such as sulphuric acid (oleum), nitric acid, chlorine, bromine, etc., and these processes are called sulphonation, nitration, chlorination, reduction, etc.

DyestuFfS FROM BENZENE Starting from benzene $\left(\mathrm{C}_{6} \mathrm{H}_{6}\right)$ by nitration we obtain nitrobenzene ; by reduction, under various conditions, this passes into aniline and benzidine. From aniline are obtained, among others, most important basic dyestuffs; from benzidine by certain other processes, cotton colours of the direct type are produced. The first cotton colour dyeing cotton directly was obtained from benzidine. By introducing chlorine as well as nitric acid into bcnzene, a compound is obtained which forms the raw material for the preparation of the important sulphide blacks. Diagrammatically, the processes may be represented thus:

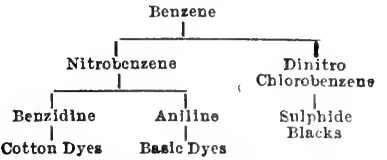

Dyestufes From Toluene. From toluene by nitration is obtained nitro-toluene (further nitration produces T.N.T. trinitrctoluene, the well-known explosive). Nitrotoluene on further reduction gives the toluidines and tolidine, both important intermediates for direct cotton colours. From toluene also by further reactions benzaldehyde is obtained, and this is one of the intermediates for both acid and basic colours.

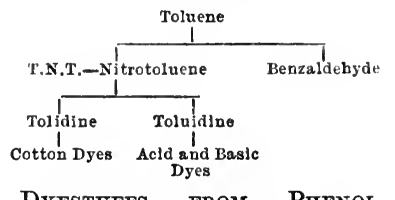

Dyestuffs from Phenol. Phenol on nitration gives nitrophenols which, further nitrated, give picric acid, and also by complicated reactions yield dianisidine, the intermediate also valuable for cotton dyes. Phenol, however, by other suitable treatments, furnishes salicylic acid, which is an important constituent of certain mordant colours, as diamond black and also certain cotton dyestuffs.

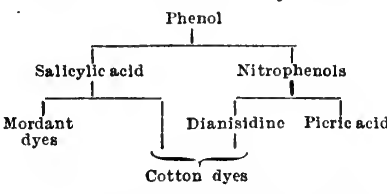

Dyestuffs from Naphthalene. Naphthalene is a most important primary product, and from it, by processes of nitration, reductions, sulphonation, fusion with alkalis, are obtained nitronaphthalene, naphthylamines, naphthols and sulphonic acids of these derivatives. The latter possess besides the groups at first introduced, sulphonic acid groups, which are important constituents, and not only make the resulting dyestuffs more soluble but give them an acid character. These intermediates yield acid dyes, cotton dyes and mordant dyes.

Nitro Naphthalene
Naphthajemine and
its Sulphonic acids
$\begin{gathered}\text { Naphonthidene direct cotton, and } \\ \text { Nordant dye stufis }\end{gathered}$

Besides the above dyestuffs, naphthalene forms a source of manufacture of synthetic indigo. By a series of chemical changes, naphthalene is converted into the intermediate phthalic acid, from which are obtained dyestuffs of most brilliant shades such as rhodamine.

Dyestuffs from Antriracene. Anthracene furnishes the starting point for a large number of most important wool and cotton colours, these being especially important on account of their very good fastness to light, wear, etc. The most striking is alizarin, produced artificially at the same time by Perkin and the German chemists Gräbe and Liebermann. Anthracene by oxidation gives anthraquinone which on sulphonation and then a subsequent fusion of the product with caustic alkalis yields the most important dyestuff, alizarin. Besides alizarin, other mordant colours are obtained from anthraquinone, also very important acid colours such as alizarin saphirol. Again, from anthraquinone the latest series of vat colours are evolved. These vat colours are solely used for catton dyeing, the vat colours dyeing wool being derived from indigo.

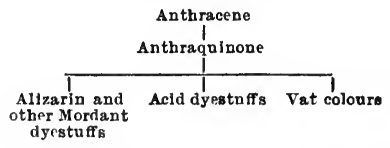

Acid Dyestuffs. These are largely used for wool and silk dyeing. Among them are colours which are fugitive to light, also others which are extremely fast to light. Their fastness to other agents, washing, etc., also varies considerably. They are employed for woollen and worsted piece goods, especially for ladies' wear.

Basic Dyestuffs. To this class of colours belong the most brilliant of artificial dyestuffs, which, however, as a class are very fuyitive to light. They also possess the objectionable property of rubbing off on to adjacent white material. They find their chief employment in calico printing, also for cotton dyeing for which the cotton has to be previously mordanted with tannic acid and tartar emetic. They can also be dyed on wool.

Salt dyestuffs are so named because they are used for dyeing cotton from a bath containing common salt. Used in enormous quantities (especially blacks) for this purpose, this group contains colours of every shade, which possess properties of very varying degrees of fastnoss. Some are very important for union dyeing, as they dye wool equally well from a salt bath.

Mordant dyestuffs form a class of extreme importance, especially for wool dyeing. Used where great fastness is required, especially to the operation of milling, they probably find their greatest application in loose wool dyeing, but are also employed on pieces, especially for men's wear. On cotton, alizarin is used for the Turliey red process.

Sulphide Dyesturfs. These colours are only of importance for cotton dyeing, although they can 
be applied to wool. They are used in large quantities, especially sulphide blacks. At present a good range of sulphide dyestuffs is not available, a bright red being absent. These colours are not soluble in water, and have to be dissolved with the aid of sodium sulphide. On cot. ton they produce shades of extreme fastness to washing,vary in fastness to light, but are poor to bleaching.

Vat Dyestuffs. This is now an important class of colours, although indigo was the only one known up to comparatively recent times. They are all insoluble in water, and are made soluble by a process of reduction, whereby they become soluble in an alkaline bath. Only indigo and its derivatives are used for wool dyeing on account of the strongly alkaline bath required for the other classes (Indanthrenes, Algoles, etc.). All are used for cotton dyeing, and the class contains some of the fastest colours existing. They are used for curtains, etc., where great fastness to light is required.

Insoluble Colours. To this group belong aniline black, Para red, etc. Aniline black is formed on the cotton fibre by the oxida. tion of aniline, previously applied to the fibre in the form of a soluble salt. It is a very fast black, and recognized as a standard for cotton goods, but it has been replaced to a considerable extent by sulphide blacks, which are easier of applica. tion. Para red is obtained by actually forming an insoluble colour on the fibre by the successive com. bination of its components.

Before 1914, 90 p.c. of the total quantity of artificial dyestuffs was produced in Germany. After 1918, however, large factories were erected in Great Britain, America, and France.

Bibliography. Dictionary of Dyes, Mordants and other Compounds, C. Rawson and others, 1901: A Treatise on Colour Manufacture, G. Zerr and R. Rübencamp, Eng. trans. C. Mayer, 1908; A Manual of Dyeing, E. Knecht and others, 2nd ed. 1910 .

Dyke or Drke. Defensive earth. work or its adjacent ditch, especially in early Britain. Dykes may ke promontory forts, or protective works as used in Holland, and in Great Britain as fenland causeways. Some were made or re-used for national or tribal boundaries. Red Earl's Ditch, along the Malvern Hills, was feudal. The greatest, Wansdyke, $80 \mathrm{~m}$. long, from the Severn to Inkpen Beacon, Berks, was pre-Roman. Black Dyke, from Richmond, Yorks, across the Roman Wall to Peel Fell, Northum. berland, continues as the Catrail for $48 \mathrm{~m}$. to Galashiels, Selkirk. shire. Roman Dyke, Rushmore, Wilts, was Romano-British. There are 25 in Dorset, and, perhaps, 50 elsewhere, some being of Commonwealth date. (See Devil's Dyke; Grim's Dyke.)

In geology, dykes are wall-like masses of rock formed in vertical or highly inclined fissures in older for. mations The name arose from their resemblance, when the softer enveloping rocks have been weathered away, to the structures made by man; in W. Scotland they are actually utilised as enclosures.

The most typical dykes com. prise basalts and similar rocks in truded by igneous action. They often form ribs spreading radially from voloanic craters. When the molten lava has receded from the inner part before cooling, hollow dykes result. A vast system, covering $40,000 \mathrm{sq} . \mathrm{m}$. from Orkney to Yorkshire, comprises dykes varying from a few inches to $70 \mathrm{ft}$. in breadth, and up to $100 \mathrm{~m}$. long, notable examples being the Cleveland and Acklington dykes. The long line of fissure-eruptions occurring in Jceland in 1783 formed a new subterranean dyke $20 \mathrm{~m}$. long.

Sedimentary dykes have been formed in all geological ages, such as the pre-Cambrian sandstone dykes at Ben Slioch, Ross-shire, and those of limestone near San Fran cisco. These are sometimes due to the filling-up of fissures caused by submarine earthquakes.

Dykes, JaMes Oswald (18351912). British theologian. Born at Port Glasgow, Aug. 14, 1835 , and educated at

Dumfries Acade m y, Edin. burgh University, and New College, Heidelberg, and Erlangen, he was ordained at East Kilbride, 1859 .

Colleague of Dr. James Oswald Dykes, Candlish (q.v.), British theologian at Free S. Moff at

George's, Edinburgh, 1861-64, he resigned through ill-health. After spending three years in Melbourne, Australia, he was minister of Regent Square Presbyterian Church, London, 1869-88 : and principal, 1888 -1907, of the English Presbyterian College, Queen Square, London, afterwards removed to Cambridge, and known as Westminster College. His works include The Beatitudes of the Kingdom, 1872; The Gospel According to $\mathrm{S}$. Paul; studies in the first 8 chapters of his Epistle to the Romans, 1888; and The Divine Worker in Creation and Providence, 1909. He died Jan. 1,1912.

Dykes, Јонм Bacchus (182376). British musician and church- man. Born at Hull, Mar. 10, 1823, he studied music at Cambridge and became a clergyman. In 1849 he was appointed precentor of Durham Cathedral and vicar of $S$. Oswald's, Durham. He was one of the editors of Hymns Ancient and Modern, and composed a large amount of church music, including many hymn tunes; some of these - Nearer my God to Thee, and Jesu, Lover of my Soul-have attained immense popularity. He died Jan. 22, 1876. See Life and Letters, ed. J. T. Fowler, 1897.

Dykh-Tau. One of the heights of the Caucasus $(17,000 \mathrm{ft}$.) in the highest part of the range.

Dymoke. English family in which the ancient office of king's champion is hereditary. The origin of the Dymokes is variously traced to the village of Dymoke, in Gloucestershire, and to a place of that name on the Welsh border. Sir John Dymoke (d. 1381) was champion at the coronation of Richard II, the earliest recorded perform. ance of the ceremony, and based his right on his ownership by grand serjeanty of the manor of Scrivelsby, in Lincolnshire. Henry Dymoke (d. 1865) was champion at George IV's coronation, after which the ceremony was discontinued, though the office re. mained. In the reign of George $V$ the champion was Frank Seaman Dymoke. See Champion.

Dynamical Equivalent of Heat. Whenever work is converted into heat, or vice versa, there is an unchanging relation between the work done and the heat produced or lost. The quan. tity of work exerted to producc the unit quantity of heat energy is called the dynamical equivalent of heat. The first to determine this equivalent was Joule, whose first method consisted in measuring the heat developed when a known amount of work was done in stirring water. It has been found that the energy converted into sufficient heat to raise the temperature of one gramme of water one degree (from $14.5^{\circ}$ to $15.5^{\circ}$ ) is 4.182 centigrade times 10,000,000 ergs, where the erg is the unit of work. See Heat; Thermodynamics.

Dynamics (Gr. dynamis,power). Branch of the science of mechanics which investigates the action of force. It therefore includes the investigation of the conditions of bodies which are in a state of equilibrium owing to the forces acting upon them, although this special branch of the science is often referred to as "statics." The investigations depend ultimately on the Newtonian Laws of Motion. The various depart. 
ments embrace the dynamics and statics of a particle which is acted upon by forces in one plane or in more than one plane; the plane dynamies of a rigid body; the three dimensiona! statics or dynamics of a rigid body, with which is associated the theory of screws; and by an extension within modern limits of the meaning of the term dynamics, those problems of analytical dynamics which investigate the action of forces on systems of particles, or the "problem of three bodies," which refers to the mutual at tractions of three bodies in space, e.g. the Earth, Sun, and Jupiter, a problem which can only be solved in special cases. See Motion.

Dynamite. Name applied to a variety of high explosives of which the essential feature is a high content of nitroglycerine, absorbed in an active or inert porous base. Dynamite was invented by Nobel in 1866 , when, owing to many disastrous explosions nitroglycerine was prohibited in various countries. $\mathrm{He}$ found that it could be rendered comparatively safe by absorption in kieselguhr $(q . v$.$) , which is cap-$ able of retaining up to three times its weight of nitroglycerine. This mixture is still known as No. 1 dynamite, whilst No. 2 and No. 3, which are more rarely used, contain 35 p.c. and 25 p.c. of nitroglycerine respectively. About 1 p.c. of magnesium carbonate or chalk is usually added to neutralise the acid evolved by nitroglycerine on storage.

The calcined kieselguhr is weighed out into a rubber bag, after it has been thoroughly mixed with the carbonate and sieved, the nitroglycerine being added in small portions, while the mass is kneaded by hand to form a paste, the operation lasting about 30 minutes. The dynamite is formed into cartridges by pressing it into parchment paper tubes by a wooden plunger working through a funnel. All these operations are dangerous and only small quantities of explosive are dealt with in light buildings protected by mounds.

In America kieselguhr has been largely displaced as the absorbent by " active" bases, generally consisting of a mixture of wood meal, flour, or similar carbohydrate and sodium or potassium nitrate. A whole serics of dynamites is made with nitroglycerine contents rising by 5 p.c. from 15 p.c. to 69 p.c., but this range of dynamites has never been popular in Europe, although a variety of explosives of the same type are employed for various purposes.

Dynamite is a powerful high explosive of considerable brisance, while its plasticity is a great advantage in filling boreholes and applying it to solid objects for demolition purposes. It is safe to handle and transport, but is too sensitive to shock for employment in shell, and since it is detonated by the impact of a rifle bullet it is not a safe military store. If ignited in small quantities it burns fiercely but does not explode. Black powder will cause it to explode, but complete detonation can only be effected by initiation with a de. tonator.

Dynamite has two marked disadvantages, one being that exposure to moisture displaces the nitroglycerine, causing exudation and dangerous sensitivity, and secondly, it freezes about $10^{\circ} \mathrm{C}$. when, whilst it is more insensitive to detonation, causing misfires, it is more sensitive to shock and friction. Frozen dynamite must be carefully

\section{DYNAMO: A GENERATOR OF ELECTRIC POWER J. L. Pritchard, Editor of The Aeronautical Journal}

In this article is given in brief outline the principle of the dynamo from Faraday's initial discovery. Further information on the subject will be found under the articles Alternating Current; Alternator; Armature: Commutator: Electricity; Magnetism

Oersted in 1819 discovered that a wire conveying an electric current is surrounded by a magnetic field, a magnetic needle tending to set itself at right angles to the wire carrying the current. Following this Michael Faraday experimented to find out if the converse were true, i.e. if a magnetic field could induce an electric current, and eventually in 1831 he succeeded in making this all-important discovery the forerunner of the modern dynamo.

Faraday discovered that if a magnet were passed through a coil of wire a current of electricity was induced in the wire while the magnet was moving. The same effect was produced if the magnet were kept still and the wire moved. If the magnet be horseshoe in shape the magnetic field is concentrated, and if a ring of copper wire be passed between the poles, cutting the lines of force of the magnetic field at an angle, an electric current passes along the wire.

This is the essential principle of the dynamo or electric generator, and from this simple fact has been built up the complicated modern dynamo. Fig. 1 shows Faraday's famous experiment.

Since the strength of the magnetic field is not constant at all points of the magnet, it follows that as the coil of wire moves across it the strength of the in-

duced electric current varies. Moreover it is found that decreas. ing the number of lines of force passing through the conductor produces an induced current in one direction, while increasing the

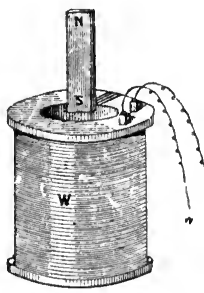

Dynamo. Fig. 1. Faraday's experiment. $N \mathrm{~S}$ is a mag net which is moved into the bollow coil of wire, W, causing

a current along the wires $w, w^{\prime}$ force, is proportional to the strength of the field, or rather to the number or lines of force cut by the ring in a given time, and the direction of the current is at right angles to the lines of force and to the direction in which the ring is moved. If the plane of the moving ling is parallel to the lines of force, equal and opposite currents would be induced and would neutralise one another. By a device known as the commutator the alternating 
current induced in the coil can be changed into a direct or continuous current travelling always in one direction. Fig. 2 shows the essential principle of a commutator. The ends of the coil are joined to two halves of a split tube, which is fastened to a spindle on which tbe

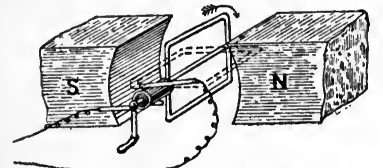

Dynamo. Fig. 2. Diagram showing essential principle of a commutator. $\mathrm{N}$ and $\mathrm{S}$ are the opposite poles of a magnet between which

the wire coil is made to revolve

coil revolves, in such a way that the two halves are insulated from one another. Two metallic plates, or brushes, are arranged so that the induced currents pass through them to the external circuit from the segments of the coil. The segments change brushes as the coil takes up the position where the induced current is zero.

The intensity of the current is increased if a flat coil of many turns of wire be substituted for the simple coil, but even then a cycle occurs only once per revolution 'To increase the number of cycles and so make the current more constant, a large number of coils are used, arranged at angles to one another in external grooves cut upon the surface of a drum of soft iron plates, which has the effect of concentrating the lines of magnetic forces into the path of the coils. An intense magnetic field is obtained by using electric magnets, excited by a current through the coils encircling them, in place of the permanent magnets employed in the early machines. These two chief parts of a dynamo are the Armature and Field Magnet System or Field.

In direct current maclines the armature is the revolving part, but in alternating current machines it is usually found expedient to employ stationary armatures and revolving field-magnets.

Direct Current Dynamos. The armature of a direct current dynamo consists of a number of very thin circular sheets or lan. inations of charcoal iron pressed together on a shaft or spindle so as to form a cylinder or drum. Each disk is insulated from its neighbour, in order to reduce the so-called Foucault currents which would cause a solid mass of iron to heat excessively. The soft iron core of an armature, whether revolving or fixed, concentrates the magnetic field. The surface of the drum has

longitudinal slots (Fig. 3) in which the conductors or windings are embedded. The three openings surrounding the central hole communicate with air ducts for the purpose of ventilating and cooling the armature. Very large armatures have a hollow or ring core. The ring is carried on radial spokes from a hub keyed on to the shaft, the arrangement being termed a spider. At one end of the armature is the commutator, composed of a number of segmental copper bars insulated from each other, and from the shaft. A complete drum armature is shown in Fig. 4, the commutator being the smaller of the two cylinders.

There are a number of ways of winding the wires on the armatures, and the most easily grasped principle is that of the ring winding of the Gramme and other early

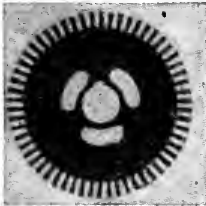

Dynamo. Fig. 3 Diagram showing longitudinal slots in which the conductors of an armature are embedded

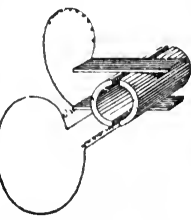

Dynamo. Fig. 2a. Diagram of a splitriagram of a splitcuit when the E.M.F. in the coil is reversed, causes the current to flow in one direction. If, instead of being connected to the commutator bars the beginning and the end of the complete spiral were joined to a separate collecting ring, the current would not be rectified, but delivered as alternating current.

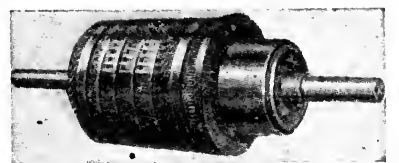
Dynamo. Fig. 4. Complete drum
armature

Nearly all modern drum armatures are wound upon what are known as the lap and the wave principles, the first being adapted to large currents of low voltage and the second to small currents of high voltage.

In lap winding each winding forms a loop, lapping over other loops, and each end is joined to a commutator segment. Wave winding follows a zigzag line round the core, the successive coils being connected in serics.

The term brush used here is derived from the bundle of copper wires, thin sheets or gauze formerly employed; but carbon is now used except for the collection of currents of very low tension. Contact with the com $\mathrm{mu}$. tator is main. tained by the pressure of a light spring

The field magnet system

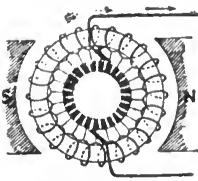

Dynamo. Fig. 5. Ring winding on an armature, matically. N and $S$, north and south net shown diagrampoles of the mag-

of a dynamo, originally in the form of a hardened steel permanent horseshoe magnet, or assemblage of magnets, as in Fig. 6, usually consists of two, four or more cores, contained within a circular yoke. For many years the horseshoe form was retained, but in this the loss of strayed magnetism is greater. It was early discovered that the residual magnetism present in soft iron was sufficient to provide for the generation of an initial current by which the magnetism could be "built up;" the final result being a field far more powerful than could be obtained from permanent magnets. Soft wrought iron and special kinds of soft steel have a higher "permeability " or magnetic conductivity than cast-iron, and the magnet cores are therefore of this material, except in the case of very small machines. In quite small machines the low residual magnetism of wrought iron leads to excitation difficulties, besides which the cast-iron construction is cheaper.

Magneto machines are still used for special purposes where instant generation of small currents is required.

The direction of the winding of the magnet coils is such that the cores become $\mathrm{N}$. and $\mathrm{S}$. poles alternately, and the winding may be in "series," "shunt," or a combination of both ("compound") with the external circuit.

In series winding (see Fig. 7) the whole of the current passes

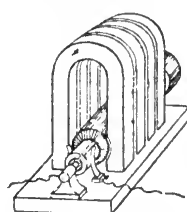

Dynamo, Fig. 6. Field magnet system, original form of magneto through the magnet coils, which in this case consist of a small number of turns of thick wire. In other words, the armature, field coils, and the external circuit are in series. A series 
machine generates, within limits, a current of constant quantity: increase of output being represented by a rise in voltage. Series machines were formerly much used for series arc lighting. With "shunt" (Fig. 8) winding only a fraction of the current delivered to the circuit passes through the field

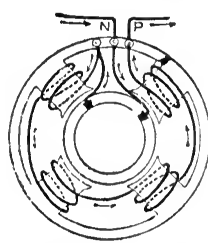

Dynamo. Fig. 7. Series winding

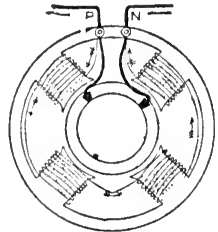

Dynamo. Fig. 8 Shunt winding coils, which contain many turns of fine wire.

In the compound-wound dynamo (Fig. 9) the series winding compensates for the loss of voltage in the armature due to increased output, and a compound machine may be made self-regulating for varying loads. By "over-compounding," that is, increasing the proportion of the series winding, it is possible to provide for an increase of voltage with increase of load. In this way a loss of pressure in distributing mains, owing to the extra work put upon them, may be made good. Compound dynamos or generators are employed for direct electric lighting and for power and traction services.

Figure 10 represents a modern direct-current dynamo. Small pole-pieces between the main pole. pieces will be noticed; these are known as "interpoles," or " commutating " poles. They are excited by a few turns of series winding, and their function is to reduce the effect of armature reaction, and so prevent sparking between the brushes and the commutator when a change of load takes place. A change of load causes a change of flux, and this formerly necessitated an adjustment of the position or "lead" of the brushes which required constant watchfulnese.

Alternating Current Dyna. MOS. In the early days of elentrical engineering, motors, arc lamps and other appliances had not been developed for alternating-current, therefore all dynamos were provided with commutators, which changed the alternating into direct. currents. One special kind of machine - the "uni-polar" or "homopolar" -actually generates a direot current, but although it has occupied the attention of inventors for many years past, it is still in the experimental stage. Improve. ments in static transformers (whieh can only be emplnyed with alternating currents) and a recognition of the value of high voltage for long-distance transmission of clectrical energy, directed attention to the "alternator."

Direct current dynamos are not adapted to the production of high

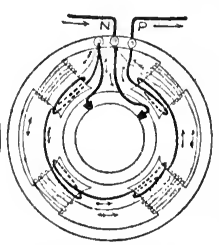

Dynamo. Fig. 9 Compound winding voltage cur. rents. owing, mainly, to the practical diffieulty in col. lecting $\mathrm{such}$ currents from the commutators, and partly to thedifficulty in insulating the coils on the revolving arm ature. With alternators these difficulties can be overcome and ma. chines have been constructed to supply current at 15,000 volts. A lower pressure-from 12,000 to 13,000 volts-is, however, generally regarded as the advisable limit.

If a higher voltage is required, the usual practice is to raise it by means of a transformer. The high voltage generally associated with the alternators has led to a funda. mental change in their design, viz. the moving of the magnetic field in

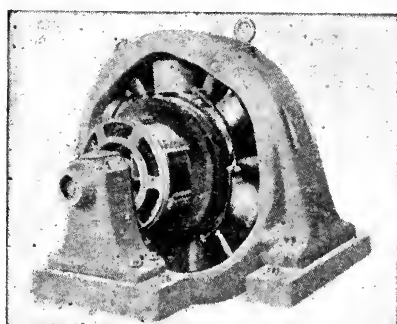

Dynamo. Fig. 10. Modern directcurrent dynamo

relation to the armature wires, in stead of the armature in relation to the field. The field-magnets are, except in the case of small machincs of low voltage, includod in the revolving parts (see Fig. 11) whilst the armature (Fig. 12) fornis the stationary part. Fig. 13 shows the machine assembled with the field-magnets inside the armature.

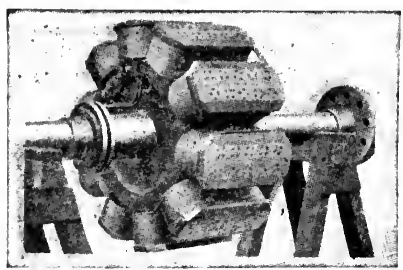

Dynamo. Fig. 11. Field magnet of alternator

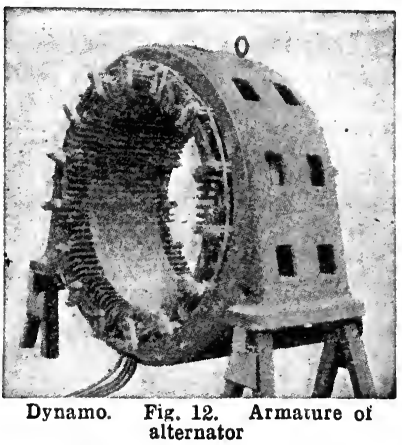

In this way the current from the armature can be led off without the interposition of any moving collector, while the insulation is not cramped or subjected to miechanical stress. The current necessary to excite the field magnets is of low voltage, and is led to them by carbon brushes bearing upon two "slip" rings revolving with the field-magnet system. In another kind of machine (the "Inductor" Alternator) both field magnets and armature are stationary, but have an annular space between them. The annular space is traversed by bare poles ("inductors"), attached to a revolving spider. The poles complete the magnetic circuit between the field-magnets and the armature coils as they pass between them, and, in doing so, cause the necessary variation in magnetic flux. 'To avoid confusion, the revolving portion of an alter. nator is called the " rotor" and the stationary part the "stator"names which do not necessarily distinguish between armature and field-magnets. It has been pointed out that to increase the number of alternations per revolution, a large number of coils are employed. One complete impulse outwards and then back is produced by the revolution of two pole-pieces past a conductor (or vice versa), so that the number of alternations per second " periodicity" or "frequency ") is governed by the speed of revolution and the number of pairs of poles.

Formerly machines giving as many as 100 or more cycles per second were employed; to-day the frequency varies from $2 \hbar$ to 60 cycles, but, except for special purposes, the present tendeney is in favour of 50 cycles. If the exciting current be direct (non-alternating), the generator is said to he of the "syruchronous" type, since at $x$ given speed the frequency will always be the same, depending, as before mentioned, upon the number of poles and angular 
velocity. This does not hold good of the "induction" alternator in which the frcquency depends upon the characteristics of an external (polyphasc) atternating current producing the ficld. So far, alternators have only been considered in respect of what is known as a "single-phase" circuit. If a second set of arniature coils be interposed in the spaces between the original set (doubling the armature, in fact) two distinct alternating currents will be generated, tlie

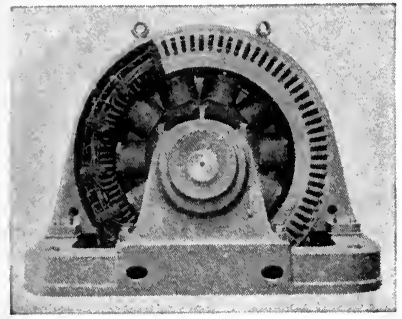

Dynamo. Fig. 13 1,000 k.w. Westinghouse 3-phase alternator, showing field magnets inside armature

one following the other at a quarter of a period. For this reason this is sometimes called the "quarterphase" system. If the principle be extended to three similar, but separate sets of coils, three equal alternating currents, one-third of a phase apart, will be obtained (see Fig. 14). 'The use of "polyphase" currents secures a greater output for given weight of generator and also requires less copper in trans. mission lines and is far mure suit. able tor motor circuits. See Distributor.

Dynamo-Metamorphism (Gr. meta. implying change; morphe, form). Alteration of rock-structure by the lateral pressures in. duced by movements in the earth:s crust. The term was introduced by $A$. Harker to denote the effects of high pressure and low temperature, thermo-metamorphism being used to denote the effects of low pressure and high temperature. The alternative terms, revional and contact metamorphism, are roughly svnonymous with dynamic and thermal metamorphism respectively.

The changes produced are phy. sical and mineralogical, and usually render rooks more highly crystal. line. Homogeneous rocks under pressure develop cleavage-planes, foliation and schistose structure. T.hus clays, shales, or fine-grained volcanic dust may become roofing. slates, coarsc-grained rocks may become gneisses. Heterogeneous rocks, if brittle and yielding strata are intermingled, develop folding and faulting. Mineralogical

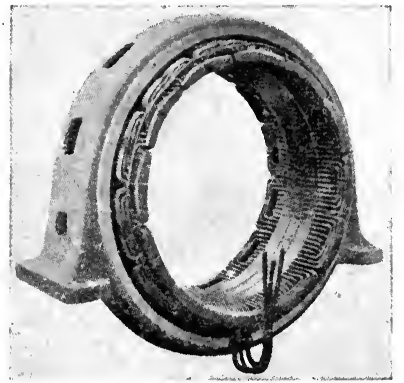

Uynamu. Fiz. 14. Armature of 3-phase aiternator, 6,600 voits

changes include re-crystallisation into a mosaic of smaller crystals and the formation of mica. See Crystallography.

Dynamometer (Gr. dynamis, power ; metron, a measure). Device for measuring force or power.

Though the term dynamometer has becn extensively used for many different kinds of measuring instruments, it is more commonly applied to instruments used for measuring the h.p. of engines. They may be divided into three classes: (I) those for measuring the pull of anything; (2) those for measuring the push or thrust ; and (3) those for measuring twisting power or torsion.

The first type measures such forces as those exerted by railway locomotives, traction engines, etc., and consist essentially of a powerful spring balance through which the power is applied. The second type measures such forces as the thrust of an aeroplane pro. peller or $\mathrm{s}$ te a $\mathrm{ms}$ hip screw, and the third the force exerted by a revolving shaft, and both the latter may consist of recording springs or brake attach. ments.

$\mathrm{W} h$ e $\mathrm{n} \quad \mathrm{a}$ brake is used it absorbs power and the dynamometer is called an absorption dy namometer. Transmis. sion dyna. $\mathrm{mometers}$ measure the

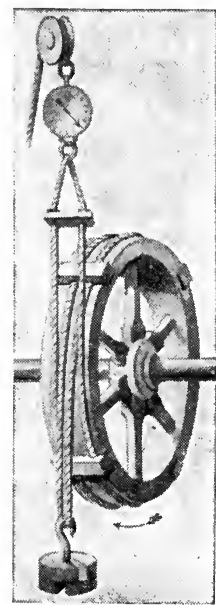

Dy namometer. Com. mon type of brake dynamometer

horse-power of machines without any absorption of power, save that due to friction, and the majority consist of recording spring devices.
The illustration shows a co1...non type of brake dynamometer. To one end of a rope, encircling the fly. wheel of the engine, is attaehed a weight, and the other end is fastened to a spring. The motion of the wheel tends to lift the weight, and this tendency is measured on the spring and from it, and the known revolutions per minute of the flywheel, the horse-power being cxerted may readily be ealculated.

Dynamotor. Combined form of motor and dynamo. It consists of one field magnet and two armatures, ur one armature with two windings, one receiving current as a motor and the other generating current as a dynamo.

Dyne (Gr. dynamis, power). Unit of force which, applied to a mass of one gramme, produces an acceleration of one centimetre per sccond every second. This foree is very nearly equal to the force with which the earth attracts a weight of one milligramme. The erg, the unit of work, is done when a body aeted on by a force of one dyne moves through a centimetre in the direction of the force. Approximately an erg of work is done when a milligranme is raised through one centimetre. $10,000,000$ ergs equal one joule.

Dynobel. British safety explosive of the perchlorate type. It consists of nitroglycerine, $32 \cdot 5$ p.c., partially gelatinised with nitrocellulose, 0.7 p.c., potassium perchlorate, 27 p.c., wood meal, 10.3 p.c., and ammonium oxalate. 29.5 p.c. The dry salts and part of the wood meal are placed together in a pan and mixed by hand; the partially gelatinised nitroglycerine is then added, the container being wiped out with the rest of the wood meal, and the whole roughly mixed by hand and then incorporated in a machine of the type employed for blasting gelatine or cordite at a temperature of about $30^{\circ} \mathrm{C}$. for an hour.

Dysart (Lat. desertum, solitude). Royal and mun. burerh and seaport of Fifeshire, Scotland. It stands on the Firth of Forth, $28 \mathrm{~m}$. N.F. of Edintourgh by the N.B. Rly. It derives its name from a cave near Dysart House reputed to have been the cell of $\mathrm{S}$. Serf. It has a good liarbour, and engages in linen manufacture, shipbuilding, and the export of coal. Pop. of mun. bor. 4.197 .

Dysart, EARL of. Seotrish title borne since 164.3 by the families of Murray and Tollemache. Sir Liunel Tollemache, a member of a family long settled in Cheshire, was made a baronet in 1611. His grandson, Lionel, married Elizabeth, daughter of William Murray, who, in 
1643, had been made Lord Huntingtower and earl of Dysart. Murray had no sons, and his daughter succeeded to the earldom, obtaining from Charles $\mathrm{Il}$, in 1670 the right to name her own hcir. She became later the wife of the duke of Lauderdale, but harl no children by her second marriage.

Her son Iionel became the 3rd earl, and the title continued with his descendants until the 6th earl died in 1821, when it passed again to a female, his sister Louisa Manners. She became countess of Dysart, and her grandson hccame the 8th earl in 1840. In 1878, William John Manners Tollemache became the 9th earl. The earl's seats are Buckminster Park, Grantham, and Ham House, Petersham, and his eldest son is known as Viscount Hunting. tower.

Dysentery (Gr. dys, implying badness; cntera, intestines). Medical term applied somewhat loosely to several distinct affections. These resemble each other in having irritation of the bowel as a prominent symptom, often associated with diarrhoea and blood in the motions.

Amoebic dysentery is caused by a minute organism (amoeba) which enters the body with food or drinking water. The disease is widespread througkout the tropics, and is also met with in the U.S.A., Germany, Russia, and Italy. In the acute form the onset is abrupt, with pain, diarrhoea, and passage of blood. 'The patient rapidly loses flesh, and death may occur in a week or ten days from exhaustion and enfeeblement of the heart. The chronic form may follow an acute autack, or may develop in. sidiously. The condition may persist for years, with alternating periods of constipation and diarrhoea. Ultimately emaciation may be very marked. Abscess of the liver is a frequent and serious complication; gangrene of the bowel and peritonitis sometimes occur. The treatment consists in keeping the patient in bed, with skilled nursing and very careful dieting. Ipecacuanha, or its active principle emetine, has proved of great value. Intestinal irrigation may be useful, and in some cases sur. gical methods afford the only hope of saving life.

Bacillary dysentery is caused by infertion with a bacillus of which there appear to be several forms. 'This variety of dysentery occurs all over the world, though it is more frequent in hot than in temperate climates. The disease is very infectious, the bacilli being conveyed into the system by food and drinking water. Flies take an

active part in its spread. In the acute form the symptoms are pain, rapid rise of temperature, and diarrhoea with passage of blood. Death may occur within a few days. In cases which improve, the patient is convalescent in two or three weeks. After an acute attack, chronic dysentery may persist for years, with intermissions of varying length.

Dysidrosis (Gr. dys; hidrös, sweat), Ромрноцух (Gr., bubble, vesicle) OR CHELRO-POMPHOLYX. Acute eruption of vesicles on the slin of the hands and feet with excessive sweating. It sometimes follows local irritation, as in mertical men after the use of antiseptic solutions. Burning and extreme itching are the most marked symptoms. The condition is worse in spring and summer and often tends to recur at the same period of the year. Scratching may lead to secondary infection and severe eruptions. Treatment consists in building up the general health, while local applications of zinc ointment, salicylic acid, and other drugs are useful. Exposure to $\mathbf{X}$ rays has proved beneficial in intractable cases.

Dyson, Sir Frank Watson (b. 1868). British astronomer. The son of a Baptist minister, he was

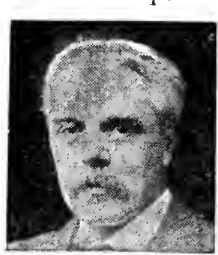

Sir Frank Dyson.

British astronomer Russell born at Ashby, Jan. 8, 1868 , and went from B r a d f o r d G r a m m a r School to Trinity College, Cambridge, of which society he became a fellow. In 1894 he entered the Royal Observatory, Greenwich, as chief assistant. Five years later he became secretary of the Royal Astronomical Society, and in 1901 F.R.S. In 1905 Dyson was made astronomerroyal for Scotland, and in 1910 was transferred to the corresponding position in England. In 1915 he was knighted.

Dyson, WruL (b. 1883). British cartoonist. Born at Ballarat, Australia, and educated at Melbourrie, he first attracted atterition with his car toons for The J)aily Herald. As a pictorial satirist of unusual imagina. tive and dra. matis power, he championed not only the rights of La. bour, but also the larger cause of political freedom. His cartoons of the Great War were specially incisive.

Dyspepsia or Indiastion (Gr. dys; pessein, peptein, to cook, digest). Acute dyspepsia or acute gastric catarrh is most frequently due to errors in diet. It may be caused by eating too large an amount of food or unsuitablo food, such as unripe fruit, or food which has begun to decompose. Alcoholic excess is another cause, and acute dyspepsia is sometimes an early symptom of many of the infectious fevers. The symptoms are pain in the stomach, nausca, romiting, bringing up of wind, headache, and depression. Sometines, particularly with children, there may be a rise of temperature. Jjiarrhoea or constipation may follow. The tongue is furred. Treatment consists in withholding foud for the first 24 hours, and subsequently giving a light and easily digested diet. In children, a duse of castor oil is often helpful, and for adults a dose of calomel. followed next morning by a saline purge.

Chronic dyspepsia results from chronic gastritis, which may follow the long-continued habit of taking unsuitable food, or excess of alcohol, or may te a symptom of manv diseases, such as gout, diabetes, Bright's disease, tuberculosis, anaemia, and cancer of the stomach. 'I he symptonis are a sense of fullness or distress after eating, with pain apparently in the regicn of the heart, known as heartburn, nausea, sometimes romiting, flatulence, headache, depression, and usually constipation, though sometimes diarrhoea. In simple chronic dyspepsia the treatnucnt consists in taking a light and easily digested diet. Meals should be eaten slowly and well masticated. Pepsin, pancreatin, and other digestive forments may be administered. Bitter tonics, such as quassia and gentian, are often useful.

Where the dyspepsia is a symptom of a general disease, that condition also must receive the appropriate treatment. Some persons suffer from chronic dyspepsia for which there is no apparent cause, and in whom all the urgans appear to be healthy. See Diet; Food.

Dytiscus (Gr. dytès, diver). Generic name for the larger carnivorous water heetles coinmon in ponds throughout Great Britain. They swim with considerable speed, but have to come to the surface to obtain a fresh supply of air, which is stored under the wingcases for breathing when under water. These beetles prey on tad. poles and the fry of fish. See Beetle. 


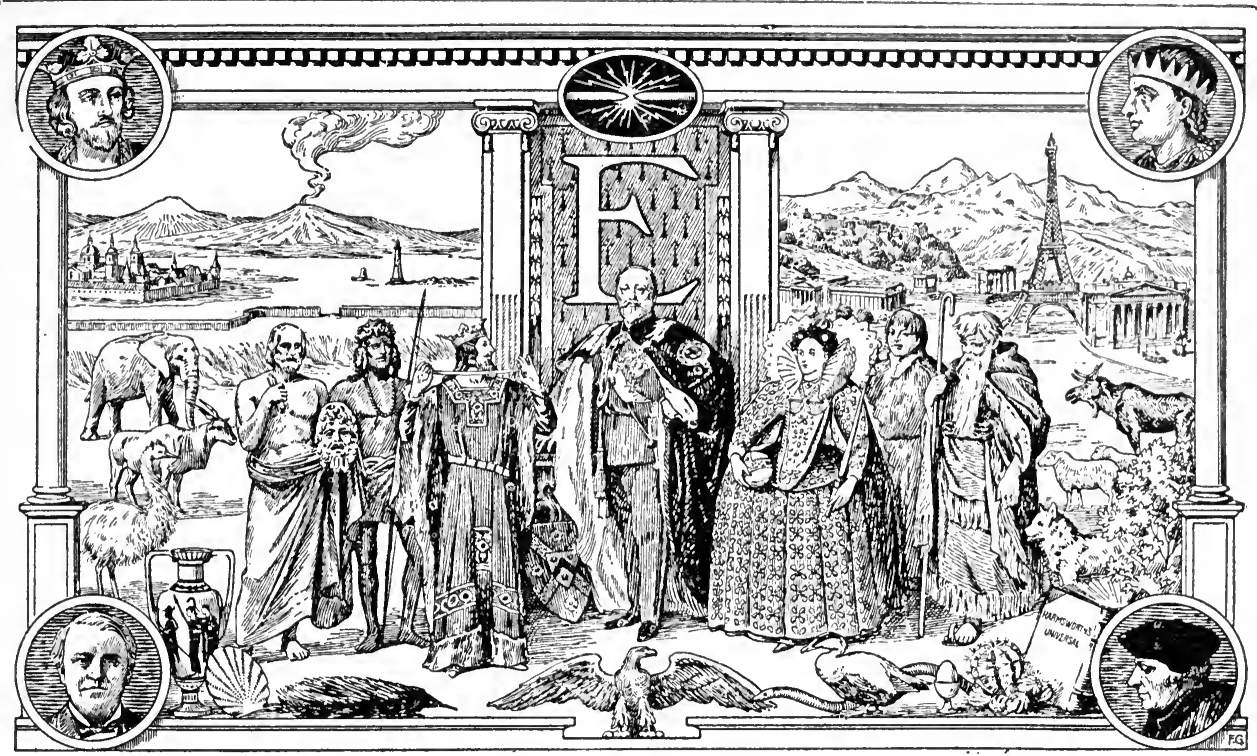

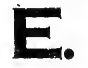

Fifth and most trequently used letter, and the second vowel of the English and Latin alphabets. Its chief sounds are those heard in $m e$, the Italian $i$, and in men, really the short sound corresponding to $a$ in mane. In words like there, here, her, the pronunciation is influenced by $r$. In clerk, serjeant, $e$ has the sound of $a$. As a rule, $e$ final is itself mute, but its usual effect is to lengthen the preceding vowel; e.g. mat, mate, but give, live. When $c$ and $g$ precede, their pronunciation is generally modified, e.g. fence, certain, gender.

The combinations of $e$ with other vowels represent various sounds : ea usually ee, as in meat, but at times as in bread, head, great, pear, heart; eau in French words is a long $o$, as in portmanteau, but in beauty as iu ( $\left.y^{\prime \prime}\right) . \quad E i$ is a long $a$ or $e e$, as in weight, deceit, but has a short $i$-sound in foreign, sovereign, sometimes long as in height, neither (also neether). Eo is a long ee, as in people, but yeoman is an exception; in words like gudgeon, surgeon, the sound is almost that of short $u$ or $o$. E $u$, ew have the sound of iu $(y u)$, as in deuce, new, but of $o$ in sew. In $e y$ when accented, the sound is that of a long $a$, as in purvey, but when unaccented, as in valley, the sound approaches that of short $i$. Key, like its homonym quay, is pronounced kee. See Alphabet; Phonetics.

E. In music, the third note of the natural scale of $\mathrm{C}$. $\mathrm{E}$ is two whole tones higher than C. See Key Signature ; Pitch.

E. Class of British submarine. Begun in 1911, the E subniarines were the latest in commission when the Great War broke out, and were numbered 1 to 23 . Their dimensions varied, but the usual armament wis 4 to 5 torpedo tubes, two 3-in. guns: their surface speed was calculated as 16 knots, and submerged speed as 10 knots. See Submarine.

E 3. British submarine. She was commanded by Lieut.-Com. mander G. F. Cholmondeley, and was sunk in the North Sea Oct. 18 1914. She was the first British sub. marine destroyed by enemy action during the Great War.

E 11. British submarine. Com. manded by Lieut.-Commander Martin E. Nasmith, she took part in operations in the Heligoland Bight in 1914. On May 26, 1915, she forced her way into the Sea of Marmora, torpedoed a store-ship off Constantinople, and sunk other enemy craft, including a transport. For his share in these exploits Nasmith was awarded the V.C.

E 14. British submarine. She was sunk by gunfire off Kum Kale, Dardanelles, on Jan. 28, 1918; seven of her crew were made prisoners, and her commander, Lt.-Comdr. G. S. White, was posthumously awarded the V.C. E 14 was one of the submarines that in April-May, 1915 , dived under minefields into the Sea of Marmora, and destroyed Turkish armed ships. Her commander, E. C. Boyle, received the V.C.

E 15. British submarine. On April 17, 1915, she grounded on Kephez Point while trying to get through the Dardanelles. Ten of her crew were lost, and three officers and 21 men taken prisoner by the Turks. Two picket boats from British warships on the night of April 18 blew up the submarine to prevent her falling into enemy hands.

E 22. British submarine. She was sunk by German warships in the North Sea, April 25, 1916. 'Two of the submarine's crew were rescued and made prisoner.

E. \& O.E. Abbrev. for the commercial term errors and omissions excepted. It is commonly used when sending an account to a customer or client.

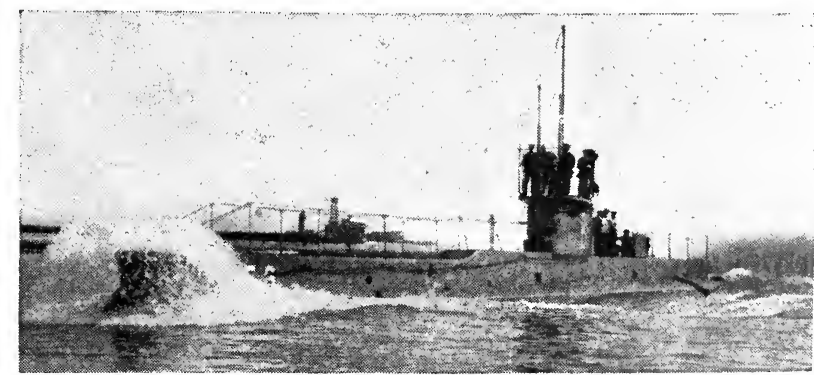

E Class submarine. One of the type in the British Navy built 1911-14 Cribb, Southsea 
Ea. God of Babylonian myth. ology. He is said to have arisen out of the Persian Gulf, bringing with hin the elements of culture $\mathrm{He}$ was the god of wisdom and of life, the trees of which grew under his protection in the Babylonian Paradise, which was watered by the rivers Euphrates and Tigris, created by him at the beginning of time. He was also known as the potter who moulded gods and men.

Eade, SiR 1'ETER (1825-1915). British physician. He was born at Acle. Norfolk, Jan. 19, 1825, and

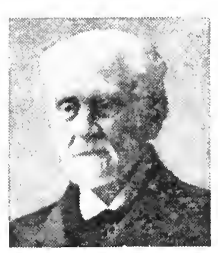

Sir Peter Eade, British physician educated at Y a r mout h G r a $\mathrm{m} \mathrm{m}$ a r School and London. $\mathrm{H} \mathrm{e}$ g $\mathrm{r}$ a d u a t e d M.D. at LondonUniversity, tised in Norwich for fifty years. He was president of the British Medical Association, 1874; sheriff of Norfolk, 1880-81; and twice mayor of Norwich. He was the author of Notes on Diphtheria, 1883; and Influenza, 1891; and part author of a report on the cattle plague in Norfolk, 1865. He also wrote on the topography of Norwich. He was knighted 1885 , and died Ang. 12, 1915. See Autobiography, ed. S. H. Long, 1916.

Eadie, Dennis (b. 1875). British actor. Born at Glasgow, Jan. 14. 1875 , in 1899 he toured with the

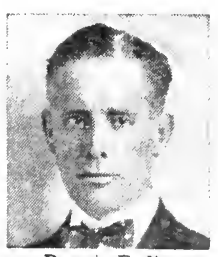

Dennis Eadie,

British actor

Hugh Cecil
St. James's Repertoire Co m p a n y, making his first appear. ance in London under George Alexander at the St. James's Iheatre, Feb. 7,1900 , in The Prisoner of Zenda. $\mathrm{He}$ entered into managoment of the Royalty with J. E. Vedrenne in 1911, in the same year talingr the part of Patent in the command performance of Money at Drury Lane, May 17. As John Rhead he made a success in Mile. stones, which was produced in 1912. On June 27, 1913, he appeared as Martin in the all-star performance of London Assurance, at the St. James's. In 1915 he played in The Man Who Stayed at Home. In 1920 he played in The Romantic Young Lady at the Royalty.

Eadmer or EdMer 'd. c. II24). English historian. Brought up a monk at Canterbury, he became King's College, 1850 , and prac- the intimate companion of Arch. bishop Anselm. Elected to the arch bishopric of St. Andrews, Scotland, 1120, he refused to be consecrated except by the archbishop of Canterbury, and on the Scottish king denying the jurisdiction of Canterbury, Eadmer remained in England, and eventually renounced his claims to the see. He wrote a life of S. Anselm and Historia Novorum-the latter an English history from 1066-1122. Both works were edited by M. Rule, for the Rolls Series, in 1884.

Eads, James BuchanAN (182087). American inventor. Born May 23, 1820, at Lawrenceburg, Indiana, he began life as a clerk at St. Louis, when quite a boy. Employment on a steamer on the Mississippi led him to the study of navigation, and in a few years he became a recognized authority on river engineering. In 1861, just after the outbreak of the Civil War, he was entrusted by the Federal government with the work of building a fleet of warships for river service, a task quickly carried through. He was responsible for building the bridge across the Mississippi at St. Louis, and later for the entrance to that river; this was his greatest work. He died in the Bahamas, March 8, 1887, being then engaged on planning a canal across the isthmus of 'Tehuantepec. See Life, L. How, 1900.

Eagle (Fr. aigle, Lat. aquila). Group of large birds of prey, in. eluding some fourteen genera and a large number of species. The true eagles belong to the hawk family, of which they are the largest members. All have strong, curved beaks with sharp eutting edges, and the head has usually a flattened and rather snakelike look. The plumage is generally dark, and the wings are long and powerful. deepening and otherwise improving
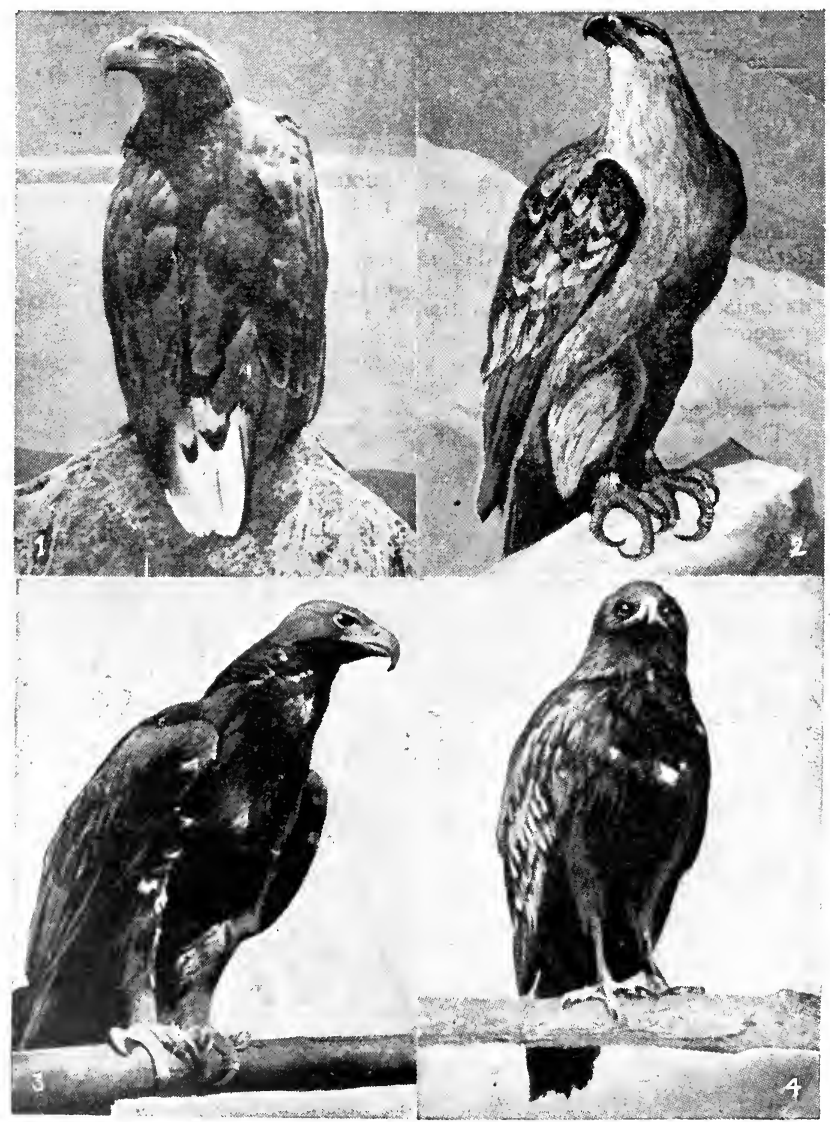

Eagle. Typical examples of this large bird of prey. 1. White-tailed sea eagle, found in the Hebrides. 2. Imperial eagle, a native of Asia and S. Europe. 3. Golden eagle, found in certain districts of the British Isles. 4. Spotted eagle, occasionally found in the British Isles in winter 
All are exclusively carnivorous, and most of them eat carrion. They are found throughout Europe, Africa, Asia, and North America.

The most familiar member of the genus Aquila is the golden eagle (A. chrysaëtus), which is not uncommon in Scotland and in the wilder parts of Ireland. The golden eagles seen in England have always turned out to be white-tailed species. The bird is about a yard in length, with dark brown plumage showing a tawny tinge at the neck. It lives mainly on hares, rabbits, and game birds, and will occasionally attack a lamb or young fawn. Its nest, made of sticks and often of a huge size, is usually built on a ledge of an inaccessible cliff. The whitetailed sea eagle (Halietus albicilla)

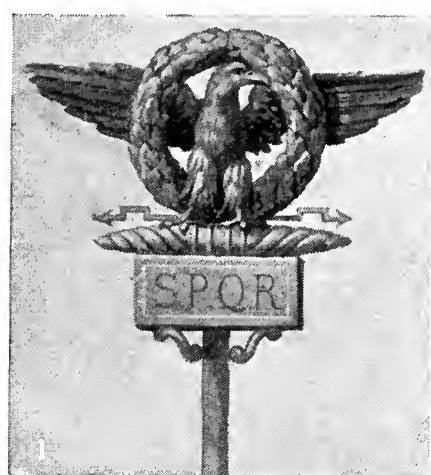

Eagle. The bird as displayed on military standards. 1. Of the armies of Ancient Rome. 2. Of those of Napoleon I and Napoleon III is found in the Hebrides. The spotted eagle ( $A$. maculata) is a rare winter visitant. See illus. p. 990.

Eagle. Symbol in heraldry. It was employed by several nations before the beginning of heraldic science, notably by the Hittites, Persians, and Egyptians. In heraldry it is almost universally displayed full front, with expanded wings, but is shown in a great variety of positions, as close (wing closed), rising (wings elevated or displayed), volant or flying, truss. ing or preying (devouring quarry), and double-headed, in which form it was adopted by the Russian and Austrian empires.

From a Roman standard-symbol it became the emblem of the rulers of the Eastern Empire, from whom Charlemagne adopted it after his coronation at Rome in A.D. 800, thus making it the badge of the medieval empire. From this early form was" evolved the later German imperial eagle, which, origin. ally one-headed, is represented on the coins of the emperor Louis the Bavarian as double-headed, to typify the union of the royal and imperial dignities. This continued

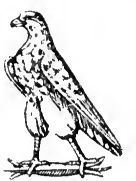

1

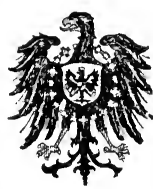

5

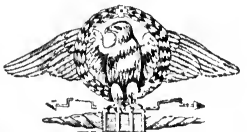

2

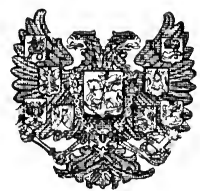

6 to be the basis of the arms of the Holy Roman Empire till its close in 1806. The Austrian Empire preserved the double-headed eagle. The Russian tsars assumed the double-headed form in 1472 under Ivan III, to signify their succession from the Greek emperors. The modern German Empire adopted the single-headed eagle on its formation in 1871

The origin of the assumption of the eagle as a national emblem by the United States of America is obscure, but there is good reason to believe that it was adopted from Indian usage. Its images, carved in wood, or its stuffed skin, surmounted the council lodges of the Creek Indians, its feathers composed their war flag; and it was worshipped by the Natchez, Alanzas, and other tribes. The American eagle carries in its talons a bundle of arrows and an olive branch, bears on the breast a shield cressed by six red vertical bars, and from its beak issues a band with the motto $E$ pluribus unum. The eagle was adopted by the Mexican Republic because of an Aztec legend that when the site of Mexico City

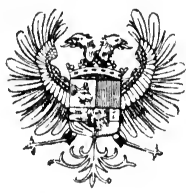

3

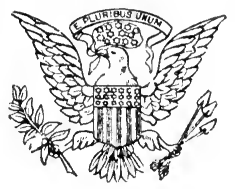

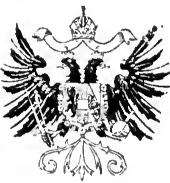

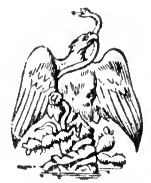

Eagle. Representations of this bird on the flags and standards of various nations. 1. Taken from an Egyptian coin of the time of the Ptoremies. 2. Ancient Rome 3. Holy Roman Empire 4. Austria 5 German Empire 6. Russian Empire. \%. U.S.A. 8. Mexico. was discovered an eagle with a serpent in its talons was seen perching on a cactus plant. The alerion is an heraldic form of the eagle, without beak or legs.

Eagle. Name given to military standards employed in ancient Rome and in France under Napoleon I and Napoleon III. In Rome the eagle was traditionally believed to have brought the symbols of earthly power to King Tarquinius Priscus, and was first adopted as a military emblem in the second consulship of Marius (104 B.c.), when the older tribal standards were laid aside and the eagle, as the bird of Jupiter, was alone retained. It was at first made of wood, but later was cast in silver and bronze, with $e_{x}$. panded wings, the model being of no very great size. Under the iater emperors it was carried by the various legions. which were sometimes spoken of as eagles. Under the eagle the head of the reigning emperor was frequently shown.

The Napoleonic eagle, which was served out to regiments and vessels of war, was represented as gilded and crowned and perched on a thunderbolt. It was first issued on Dec. 3,1804 , the day after Napoleon's coronation, and the officers who received it took oath to "sacri. fice their lives in defence " of the standard. Twelve Napoleonic eagles are preserved at the Chelsea Hospital, London, but the only naval eagle known is in the museum at Madrid. On the restoration of the Bourbons, the eagles in use were destroyed, but when $\mathrm{Na}$ poleon returned from Elba new eagles were issued. After Waterloo another destruction of eagles was ordered, and only one of those which had not been captured by the British-that of the old Guard -was saved, remaining in possession of the officer who secreted it. The older Napoleonic eagles bore only the number of the regiment, 
but those made in 1815 bore the legend L'Empereur des Français, and the names of the four principal engagements in which the regiment had taken part. The practice of carrying eagles in French regiments was restored by Napoleon III in 1852 , but was once more abolished by the Republic in 1870 .

Eagle. Gold coin of the U.S.A. value ten dollars, about $£ 21$ s. 6 d. Double-, half-, and quarter-eagles are coined. It bears a representation of the U.S.A. crest, an eagle, whence the name.

Eagle. Floating aerodrome of the British navy. She was built in England for Chile under the name of Almirante Cochrane, but the Admiralty acquired her and turned her into a floating aerodrome. Launched in 1918, she is $625 \mathrm{ft}$. long, displaces 30,000 tons, and her hull above water resernbles a huge hangar with a flat roof upon which aircraft can take off and alight.

The first British naval ship of this name dates back to 1650 . In 1776, when the third Eagle was lying off Governor's Island, near New York, a member of the American navy undertook to blow her up by means of a submarine-boat. $\mathrm{He}$ approached the Eagle, but his torpedo exploded before it could reach the vessel.

Eagle. American warship, the first of a class of 60 submarine chasers built by Henry Ford at Detroit. They are $200 \mathrm{ft}$. long, $25 \mathrm{ft}$. in beam, have a draught of $18 \mathrm{ft}$., and displace 500 tons. They have oil engines of 2,260 h.p., giving a speed of 18 knots. They carry two 4-inch guns and a depth charge projector. These craft were not completed early enough for use in the Great War, but the American authorities had previously built a large number of wooden submarine chasers of 17 knots speed and $110 \mathrm{ft}$. long, armed with 3 -inch guns and depth charge throwers, over 30 of which operated in the Mediterranean. Their base was at Corfu.

Eaglehawk. Mun. bor. of Victoria, Australia, in Bendigo co. It is $5 \mathrm{~m}$. by rly. N.W. of Bendigo, and lies in a rich gold-mining district. Pop. 6,998.

Eagle Hut, THe. American Y.M.C.A. centre, in Aldwych, London. Opened on Sept. 3, 1917, it continued as a "home from home" for American troops in the metropolis until Aug. 25, 1919, when it was taken over by the Metropolitan Police Force as a training centre for police recruits. It was later demolished when this site was built on. During the two years it was open, two million meals were served in the but, the daily average being 3,000. Entertainments of varied character were provided, and sight-seeing trips organized. The Eagle Hut had a staff of about 800 voluntary workers, chiefly women. The hut was open day and night, and was equipped with 410 beds. See Y.M.C.A.

Eagle Owl $(B u b o)$. One of the largest members of the owl family. Occasionally found in Great Bri-

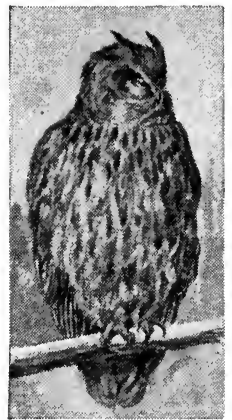

Eagle Owl, a nocturnal bird of prey tain, it is over $2 \mathrm{ft}$. long, with $h$ an d s omely mottled brown plumage and very conspicuons ear-tufts. It is nocturnal in habit, is bold and sav. age, and preys upon game birds, rabbits, and young f awns. See Owl.

Eagle Pass. in Maverick co., it is about $165 \mathrm{~m}$. S.W. of San Antonio, and is an important stock-breeding centre with considerable trade in coal. Pop. 3,200.

Eagles' Nest. Hill in co. Kerry, Ireland. Overlooking the Upper Lake, about $6 \mathrm{~m}$. S.W. of Killarney, it rises conically to a beight of $1,100 \mathrm{ft}$. Its bare, precipitous summit formerly sheltered eagles. From the lake beneath a remark. able echo can be heard.

Eakins, Thomas (1844-1916). American painter. Born July 25, 1844, Eakins studied at Pennsylvania and Paris, painted many studies of American life and sports, and was professor of painting at Pennsylvania Academy. He died on June 25, 1916.

Ealing. Parl. and mun. bor., Middlesex, England. It is $5 \frac{3}{4} \mathrm{~m}$. W. of Paddington by the G.W. and Met. Dist. Rlys., there being stations at Ealing Common, Ealing Broadway, and West Ealing. Until the middle of the 19 th century it was a village on the road from London to

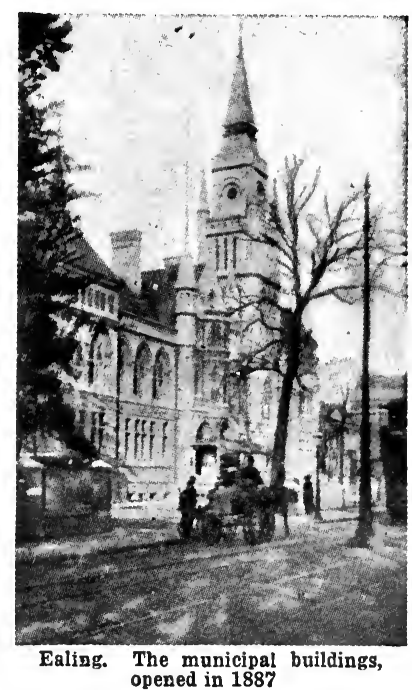

Slough and Windsor, and was fre. quented by highwaymen.

With the advent of the rly., about 1810, Ealing's modern progress began, and in 70 years it was covered with shops and houses, and extended into $\mathrm{W}$. and S. Ealing. Corporate exist. ence began in 1863, and since

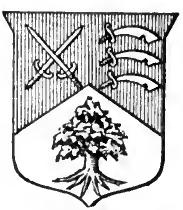

Ealing arms
1901 it has been a borough. Its chief buildings are the Victoria Hall and the adjacent town hall. Its open spaces include Ealing Common and Walpole Park. Perivale, a pretty rural part of Ealing, has a tiny church, probably 800 years old. The corporation owns the electric lighting works. The chief churches are S. Mary's, the parish church, and Christ Church. In 1920 a movement was started to unite Ealing with Chiswick, Brentford, Hanwell, and Greenford into one county borough. One member is returned to Parliament. Pop. (1921) 67,753.

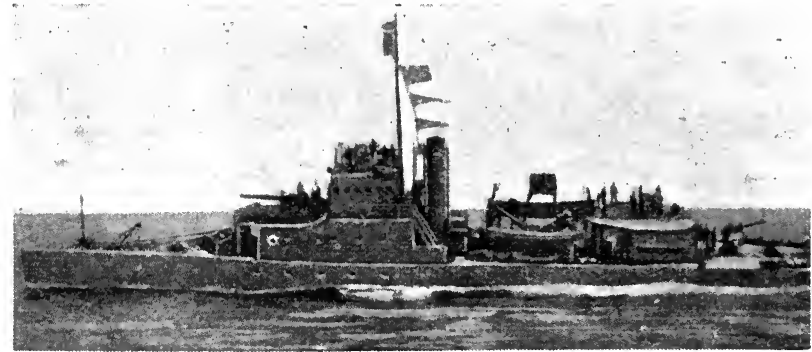

Eagie. Type of swift oil-dnven submarine chaser designed for the U.S. navy 


\section{THE EAR: ITS ORGANISM \& FUNCTIONS}

T. S. A. Orr, M.D., Aural Surgeon, Westminster Dispensary

The Ear, Deufness, and Deaf and Dumb, with shorter entries, e.g. Cochlea, form a group of related articles, another such group being those on the Eye, Blindness, etc. See also Anatomy; Man; Surgery

The ear is the organ of hearing, more strictly the end organ of the eighth cranial nerve. It has two functions: it collects and concentrates the vibrations of air known as sound waves and transmits them to the nerve in order that they may be perceived and interpreted in the brain; and it harbours the chief organ of balance or equilibration.

The ear is divided into three parts : (I) The outer ear composed of $(a)$ the auricle, or pinna, applied to the side of the head, concave on its outer aspect, and leading into (b) the external auditory meatus, a llarrow tube passing inwards to the drum of the ear. The outer ear is composed chiefly of a framework of cartilage covered by skin. The skin contains hair only in the male, but in both sexes it has sweat glands. Wax in the ear, due to dried sweat accumulating in the meatus, often causes sudden and severe deafness and can be seen as a dark plug well down the meatus. In man the pinna is small and of little importance.

(2) The middle ear is a small cavity in the side of the skull separated from the outer ear by the ear drum. It has a chain of minute bones, the hammer, anvil, and stirrup bones, which run across it and carry sound waves from the drum to the oval window, a small hole, closed by a membrane and leading into the inner ear

\section{Relation of Throat and Ear}

The cavity in addition transmits the nerve of expression, the facial, and an important norve of taste, the chorda tympani. It has in front a tube that connects it with the throat, the Eustachian tuke, and behind and above it communi. cates with the air cells in the mas. toid process, the projection of bone seen behind the auricle. Inflammatory processes starting in the throat may, therefore, pass up through the middle ear to the mastoid process. As this is in very close relationship to the brain, the danger of all middle ear inflammation is apparent. In health the Eustachian tube allows air to pass into the middle ear in order that the pressure of air inside the drum may equalise the atmosphere pressure.

(3) The inner ear is a cavity em. bedded in the skull deeper than the middle ear, and communicates with it through the oval window, a membrane like the drum of the ear in. tervening. It is filled with fluid, called perilymph, submerged in which are two hollow structures composed of membrane-the coch. lea and the semicircular canals. These again are filled with fluid, called endolymph. The cochlea is a spiral tube, and has been compared to a snail-shell. The nerve of hearing terminates in it, in a multitude of minute hairs, which float in the endolymph. Sound waves are carried through the outer and middle ear and put the membrane closing the oval window in motion, which is communicated to the fluid filling the inner ear. The movement in this fluid is communicated through the membrane composing the cochlea to the fluid contained therein, in which the termination of the nerve of hearing floats, the stimulus thus given to the nerve being perceived in the brain as sound.
The semicircular canals are thrce tubes, at right angles to one another, semicircular in shape, and joined together. Like the cochlea they are filled with fluid, having finc hair-like nerve terminals floating in it. Any movement of this fluid stimulates the nerve. The fluid is set in motion by any change in the position of the body. The stimulus so produced is carried to the brain and enables it to judge of our position in space and automatically to adjust our muscles accordingly.

Functions of the EAR. The cochlea is the only part of the inner ear concerned in hearing. It is absent in fishes ; first appears in amphibia and reptiles, increases in birds and attains its maximum perfection in mammals. The semicircular canals, on the other hand, are entirely concerned in the balance of the body. They can be extirpated in birds and mammals without causing any perceptible depreciation of hearing; destruction of
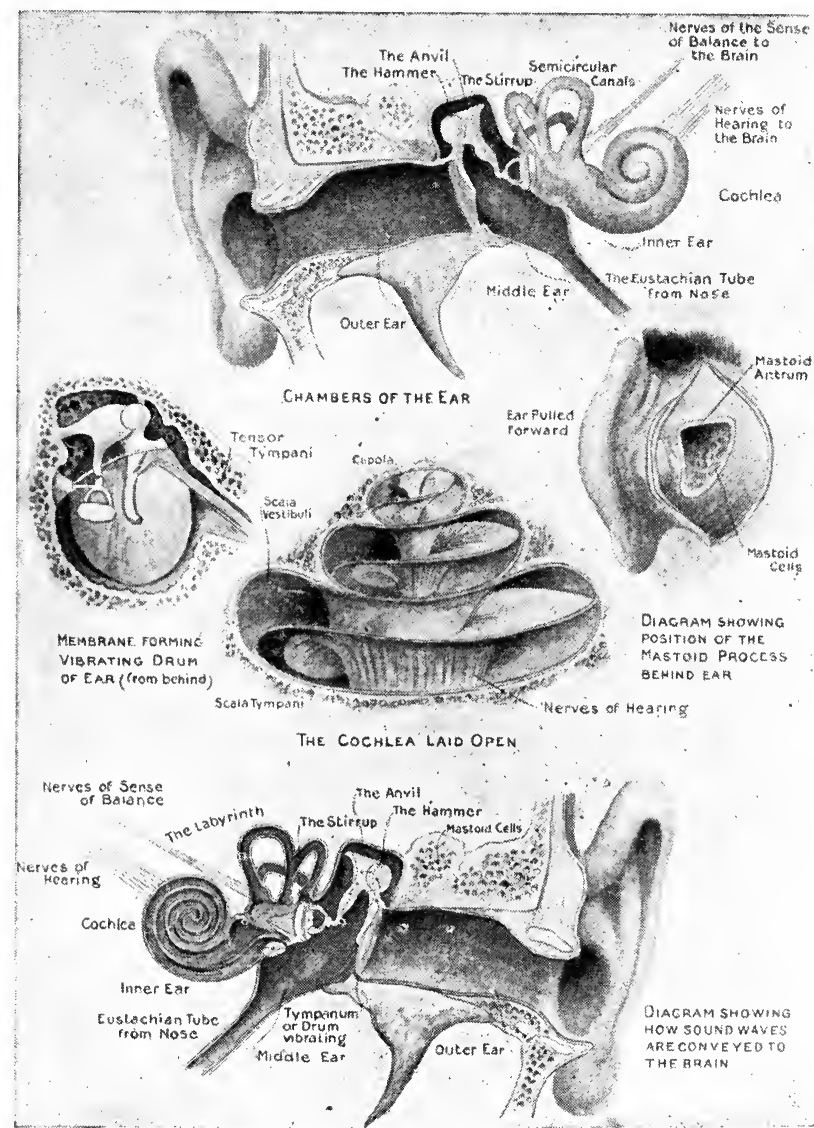

Ear. Sectional diagram showing the construction and delicate mechanism of the ear 
the cochlea, on the contrary, produces deafness.

Sensations of sound are dis. tinguished by three charactersloudness, pitch, and quality. Loudness depends on the extent of movement of the sound waves. The dog is able readily to detect sounds inaudible to man, his master. The ear in this animal and in many other mammals is large, its pinna has a considerable degree of mobility, its meatus can be narrowed or widened at will, and the area in the brain set a part for hearing is extensive. The pitch of a sound depends on the number of vibrations occur. ring per second. It is possible to detect a sound whose pitch is so low as to be produced by 16 vibrations per second; or so high as to be produced by 30,000 . There is reason to believe that some animals can hear sounds of a higher pitch, but the sensory cells along each side of the fish, which correspond with the mammalian ear, are only capable of perceiving vibrations of very low frequency -6 per second. The quality of a sound depends on the manner in which the vibrations succeed one another. If these are irregular a noise is produced, if regular and orderly, a musical note.

Equilibration is the second function of the ear. An individual normally halances himself by the sense of sight, his muscles, and the semicircular canals in the inner ear. When flying through the air the aviator's eyes may be useless, as when in a cloud or in darkness. With then he may not know whether he is upside down or downside up. In an unstable and rapidlymoving machine his muscle sense is of little avail. It is pre-eminently on his ear mechanism that he relies to maintain his equilibrium, the semicircular canals alone giving him the accuracy necessary to guide so delicate a mechanism as the flying machine. The bird is continually in the position of the aviator, and in this animal the canals are remarkably well developed. The movement of the endolymph inside them stimulates the delicate hair-like endings of the nerves which float therein. As the canals are arranged like three adjacent sides of a cube, the fluid in them moves in a different way with each position in space. The unusual agitation in this fluid-produced in one who is unaccustomed to flying or sailing-gives rise to disagreeable sensations, well-known as air-sickness or sea-sickness.

There is a close connexion be. tween the semicircular canals and the eyes. Stimulation of the former produces quick jerking movements in the latter, known as nystagmus.
This peculiar movement of the eyes may be seen in a railway passenger looking at the passing scenery. It also occurs in some nervous diseases and is frequent in coalminers, when the individual affected is stationary, but is asked to look far over to one or other side. When the physician wishes to investigate the condition of the semicircular canals in disease, or in men who wish to become airmen. he brings on nystagmus by rapidly rotating theindividual to be tested, for about twenty seconds in a revolving chair. The fluid in the canals is set in motion and it continues to move after the body has stopped. The nerves in the canal are strongly stimulated, and owing to their connexions with the eye nystagmus is produced. It should last nearly half-a-minute. If it is absent, if it does not last so long, or if it is un duly prolonged, the canals are at fault, and the capability of the body to balance itself is not satisfactory.

Earby. Urban dist. of West Riding, Yorkshire, England. It is $6 \mathrm{~m}$. S.W. of Skipton, on the Midland Railway. Pop. 6,032.

Earl. Title in the British peerage, ranking third. The French equivalent is comte, and

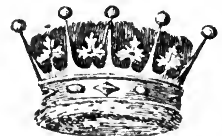
the German is Graf. The wife of an earl is called a count. ess, a reminder of the days when earl and count were synEarl's coronet onymous. His eldest son bears
his father's second title; the other sons are known as the Hon., the daughters as Lady So-and-So. Including Scottish and Irish there are over 200 of them in the peerage.

Earl is the oldest title of nobility. Under the form eorl it first appeared in England in Anglo-Saxon times, being used for those of noble blood as distinguished from the ceorls. In the 11 th century, Canute set rulers over parts of the country. He named them jarls, a Danish word, but this became earl in England. This idea remained, and after the Conquest most of the counties had an earl as the head of their administration, hebeing entitled to the third part of its revenues. These earls were sometimes called after their residence, but gradually it became general to call them after their county. The office was not at first an hereditary one, but some earls managed to make it so. They corresponded to the counts in France and other parts of Europe.

Gradually the title became a mark of rank rather than a mark of office. Earls who had no connexion with the rule of a county began to be created in the time of Edward III, and fo!lowing the first creations of the higher ranks of duke and marquis, they took their present place in the peerage, the title carrying with it the right to a seat in Parliament. The premier earl of England is the earl of Arundel, a title held by the duke of Norfolk. Of those who have no higher title, the earls of Shrews. bury (1442), Derby (1485), and Huntingdon (1529) are the senior. The Prince of Wales holds the earldoin of Chester and the Scottish one of Carrick. In Scotland the earl of Crawford is the senior earl, dating from 1089 . See Peerage.

Earle, JoHN (c. 1601-65). English divine. Born at York, he was educated at Merton College, Oxford. He was made rector of Bishopston, Wilts, tutor to Charles, prince of Wales, and chancellor of Salisbury. In 1643 he became dean of West. minster, in 1662 bishop of Worcester, and in 1663 bishop of Salisbury. He was the author of Microcosmo. graphy, or, A Piece of the World discovered in Essays and Characters, 1628, a work valuable for its reflection of contemporary life, and for its pointed humorous style and insight into human nature. Earle died at Oxford, Nov. 17, 1665, and was buried in the chapel of Merton College.

Earle, Jонn (1824-1903). Bri tish philologist. He was born Jan. 29, 1824, near Kingsbridge, Devon, and was educated at Mag dalen Hall. Oxford. F r o m 1849-54 he was professor of Anglo-Saxon in the university of Oxford, and again from 1876 until his death, Jan. 31, 1903.

Ordained in

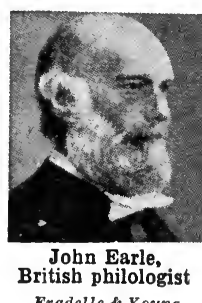

1857, he was for many years a clergyman at Bath and prebendary in Wells Cathedral. His best-known work is his Philology of the English Tongue, 1871, his most important an edition of Two of the Saxon Chronicles, 1865.

Earl Marshal. In England the eighth great office of state. $\mathrm{He}$ is head of the Heralds' College and has various ceremonial duties. Since 1672 the office has been hereditary in the family of Howard, duke of Norfolk. On the death of the 15th duke, 1917, his brother, Lord Edmund Talbot, was appointed deputy earl marshal, the 16th duke being a minor. Until 1386 the title was marshal. With the lord high constable he was judge of the court of chivalry. The office 


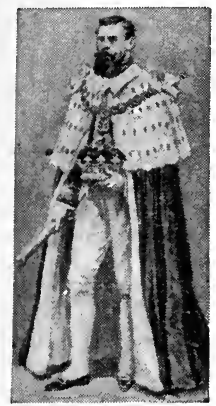
England. The 15 th duke of Norfolk in the robes of office
Larl Marshal of

of earl marischal (formerly great marischal) of Scotland was hereditary in the Keith family until the at tainder of George, the loth earl marischal, in 1716 , when it was abolished

Earl's Court. District of Lon. don in the met. bor.of Kensing. ton. To modern Lond on ers Earl's Court is synonymous with exhibitions, which, from that of the Fisheries Exhibition, in 1884, down to 1914, delighted millions of patrons. The Great Wheel was removed in 1906 . The exhibition grounds were taken over on Oct. 15 , 1914, as a clearing station for war refugees, and a permanent residence for a certain number. Schools and workshops were estab. lished, and nearly 100,000 refugees, including Belgians, coloured men born under the British flag, Serbs, and Italians, were given shelter until 1919. Later it was used as a centre of the Disposal Board.

Earlsfield. Eccles. and residential dist. of London. Within the met. bor. of Wandsworth, it is $2 \mathrm{~m}$. S.W. of Clapham Junction by the L. \& S.W.R. Pop. 18,286. See Wandsworth.

Earlston. Parish and small market town of Berwickshire, Scotland, formerly Ercildoune. It stands on Leader Water $72 \mathrm{~m}$. S.E. of Edinburgh by the N.B.R. and is a noted angling resort. There are traces of the old tower of Thomas the Rhymer (d. 1299), whose remains lie in the church. yard. The industries include dyeing and the manufacture of tweeds and ginghams. Cattle and horse fairs are held. Market day, Mon. Pop. 1,749.

Early, Jubal Anderson (181694). American soldier. Born at Franklin, Virginia, Nov. 3, 1816, and educated at West Point, he practised as a lawyer, 1838-52. Though a supporter of the maintenance of the union he threw in his lot with the Confederates on the outbreak of the Civil War. At the first battle of Bull Run he commanded a brigade, and at Fredericksburg and Gettysburg a division. A succession of defeats by Sheridan and Custer, in 1864, led to his being relieved of his command in 1865 , yet competent authorities regard him as the best
Confederate general after Lee and Jackson. He was the author of A Memoir of the Last Year of the War for Independence, 1867. and other military and historical writings. He died at Lvnchburg, Virginia. March 2. 1894

\section{Early Closing.}

Movement among shopkeepers and others to secure shorter working hours on week days. In 1886 the Shop Hours Regulation Act limited the working hours for young persons under 18 employed in shops to 74 hours a wcek, while the Shop Hours (Amendment) Act of 1893 contained provision for the appointment of inspectors.

In 1904 another Shop Hours Act introduced the principle of closing by local option by a twothirds majority. The shop-assistants' charter, however, is the Shops Act of 1912, which consolidated previous legislation and gave a compulsory half-holiday on one day of the week.

During the Great War the need for economy of coal and the lighting restrictions led, in 1916 , to the issue of a compulsory closing order for shops at 8 p.m. on four nights of the week, and 9 p.m. on Saturday; these hours were very generally shortened still further in some localities. This order remained in force until Aug., 1920. In 1920 a private bill to bring about compulsory closing (with few exceptions) at 7 p.m. and 8 p.m. on Saturday reached the report stage, but the third reading was prevented by lack of time. Considerable opposition to this and earlier bills was due to the fears of small traders in competition with large firms.

The organization mainly responsible for the movement is the Early Closing Association, founded in 1842. Its offices are at 34-40, Ludgate Hill, London, E.C.

Early English. Style of architecture originating in the reign of Henry II, and prevalent throughout the 13th century. The term is also used for a period of literature covering about the same years as the architectural one (see English Literature).

Architecturally it has been called the "lancet " style or period, from the resemblance of the slender pointed arch, its leading characteristic, to a surgeon's lancet. Nor man work had retained the round arch of Romanesque pattern; and Early English inaugurated the new era of Gothic architecture by substituting the pointed for the round. In essence, Early English indicates a revolt against the slightly uncouth forms of the Romanesque style in England, and a striving after more elegant forms of construction and ornament. Vaulted roofs in stone take the place of the old flat timber roofs. Windows are lengthened and crowned by the lancet arch; piers are formed of clustered columns, each having its own cap, but united under one ?apital from which spring the tre. foiled pointed arches of the vault mouldings are deeply undercut, often with dog-tooth ornament; the entire design becomes more elegant and flexible.

The choir of Lincoln Cathedral (12th-13th century) is one of the earliest and most beautiful extant examples of Early English architecture. The choir and Lady Chapel of Southwark Cathedral, still preserved. were built in 1207 ; the stone-webbed vault of this fine Early English church is an example of the style at its best. In other English cathedrals portions of Early English work are still preserved, notably at York Minster, Westminster Abbey, Salisbury, Durham, and Ely. The plan of churches built in this period shows the absence of the semicircular apse which was characteristic of Norman and Romanesque structures, and the substitution of a square east end; and the transepts generally divide the length into two almost equal parts. It is noticeable that the Early English style was coincident with a movement within the Church towards simplicity and reticence. The Reformed Orders, especially the Cistercians, were largely responsible for an architectural development which, beginning with a lightness and beauty unknown to the Norman period, was to attain, in the Decorated and Perpendicular styles which followed it, an ever-increasing magnificence. See Architecture; Gothic Architecture: also illus. p. 531.

Earmark. Term used in Eng lish law to signify a sum set apart for a particular purpose. For example, when executors have to pay a legacy to a person, say at 21 , and they set aside and invest for that purpose some particular fund apart from the general investment of the estate, it is said to be earmarked for the legacy, and cannot be applied to anything else. The term originated in the practice of marking beasts by cuts in the ear, for identification purposes.

Earn. Loch of Perthshire, Scotland, about $11 \mathrm{~m}$. W. of Cricff. Lying $317 \mathrm{ft}$. above sea level, it is $6 \frac{1}{2} \mathrm{~m}$. long and $\frac{3}{4} \mathrm{~m}$. wide, with a maximum depth of $287 \mathrm{ft}$. Trout are plentiful. The lake occupies a rock basin scooped out by the ice sheet which crossed Perthshire 


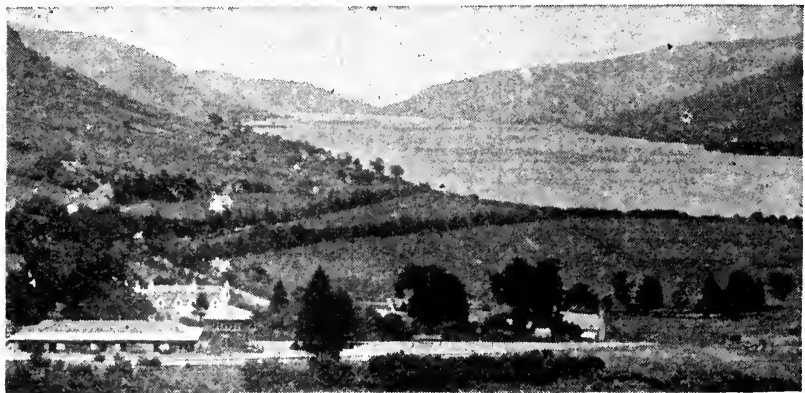

Earn. View of the loch looking eastward from Lochearnhead

during the Ice Age. Scott's Legend of Montrose introduces Ardvorlich House, on its shore, as Darnlinvarach.

Earn. River of Perthshire, Scotland. It issues from Loch Earn and flows E. for $46 \mathrm{~m}$. across Strathmore to the Tay, which it enters $2 \mathrm{~m}$. N.E. of Abernethy. Salmon, trout, and other fish abound. It is subject to floods, but small vessels, not excceding 50 tons, can approach Bridge of Earn.

Earnest. Name given to a sum of money paid on account in order to show the good faith of the buver. Such payments are recognized in English law, and also in other codes, the fact that such has been made being taken as proof that a contract has been entered into. Strictly speaking, earnest is not part
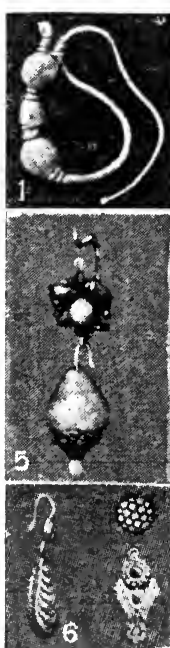

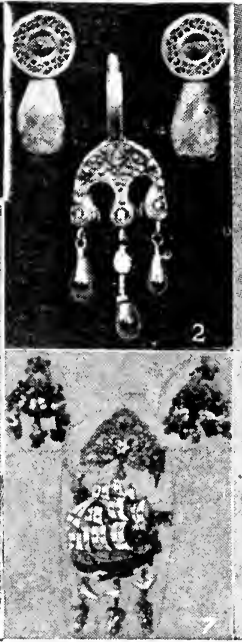

payment, although it has some similarity with the arrha of Roman law which was such. See Contract.

Earring. Object attached to the ear, usually by passing it or a subsidiary ring or hook through the lobe. Its purpose may be amuletic ceremonial, or ornamental. Un traceable in the prehistoric stone age, earrings appear early in the metal age in the form of plain bronze and gold bands or wires, sometimes twisted, sometimes with one end clubbed. In the Swiss lakedwellings, which have yielded hun dreds of specimens, occurs a doublecoil design which survives among the Sumatra Battas. In ancient Egypt the simple hoop developed complex forms, with animal head terminals and gems, partly under foreign influence.

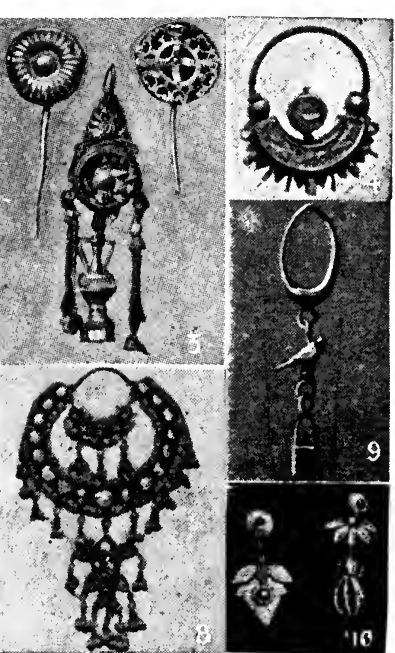

Earring. 1. Ancient Egyptian, mounted with beads. 2. Gold with jacinth drops, on cillier side pierced earrings with emerild matrix drops, all three Roman. 3. Aucient Greek gold earring set with jewels and enamels, c. 400 B.C. (centre) : sminll Koman earrings of gold. 4. Enamelled Byzantine, set with nenrls. 5. 16ih century Italian, pearl set in gold. 6. Left, turquoise, c. 1840: righit, moileru llatian set with seed pearls; above, turquoise, $c$ 1840. $\%$. 16th cell. Italıan, sliaped like a ship in full sail: on either side, 16th cent. Venetian peari peudunts for earrings. 8. Modern Indian, set with diamonds and emeralds. 9. I'Loenteran earring from Tharros. 10. Modern Italian, gold set with seed pearls From Chals on Old Jeuellery, by Maclver Percival; and Jewellery, by Cyril Delonport
Except in Babylonia and Assyria these ornaments were usually confined to women. Many O.T. references to such rings properly concern nose-ornaments; that mentioned in Isaiah 3 was an amulet. The development of design is observable in Mycenae, 'Troy, Etruria, and $\mathrm{S}$. Russia, through the winged sirens of Greece and the pearls and other jingling jewels of imperial Rome to the massive pendants of the Byzantine age.

Dormant during the Middle Ages, the use of earrings revived after the Renaissance. Mediterranean mariners introduced the single plain gold hoop to the seafaring world, where it is still in favour. In modern India rings may have a

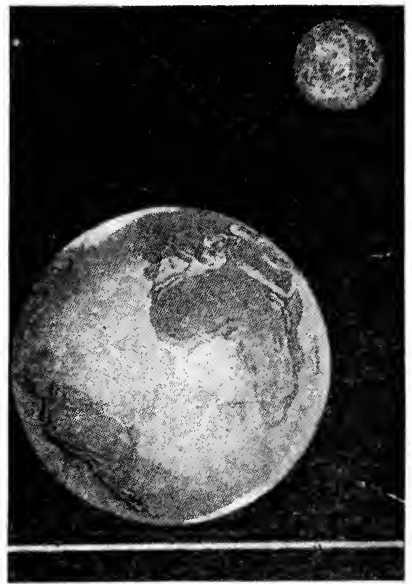

Earth. Diagram to show the relative sizes of the earth and its satellite, the moon. The whitc band below indicates the distance between them on a scale where the width of the band equals the earth's radius

hundred pendant pearls, with supporting chains over the top of the ear, or the ear may have 12-13 borings, each with a separate ornament. Garo women sometimes wear 50 brass rings in each ear. Silver is preferred by Syrian women : other materials are the iron wire of the Dinka, shell of the Hot tentots, cuttlefish bone of Formosa, and tortoiseshell of the Solomon Islands. See Mutilation Customs.

Earsdon. Parish and urban dist. of Northumberland, England. It is $4 \mathrm{~m}$. N.W. of North Shields, and the inhabitants are employed in the local collieries. Pop. 10,568.

Earth. Name given to the planet on which we live. It is also used for the soil and other constituents of the earth's crust. The solar system comprises the sun, planets, satellites, comets, asteroids, meteorites, and the rings of Saturn. The earth is a planet with the moon 

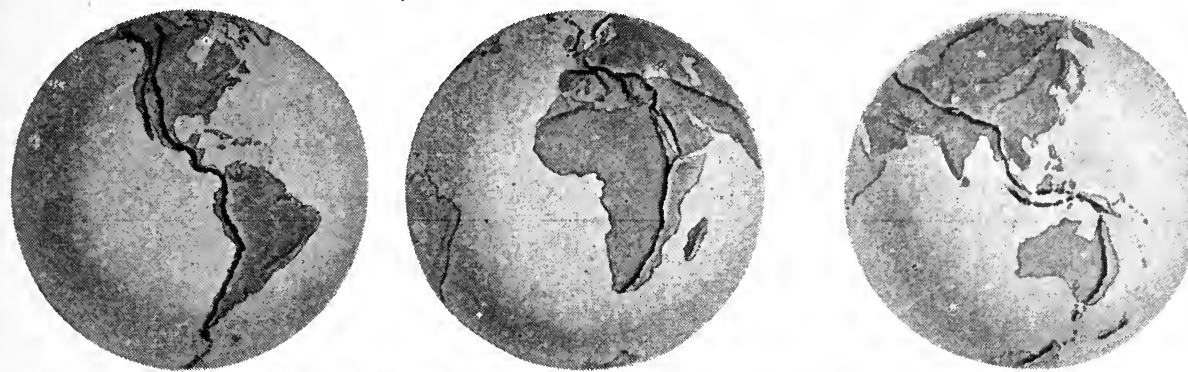

Earth. Three views of the earth showing the three mountain ridges which meet in the plateau of Antarctica. These ridges indicate the shape which is being assumed by the earth's crust as the earth itself cools and contracts

as its satellite. Many solar systems form the universe.

The earth's rotation, or spin, upon its axis through the poles is the cause of the rhythmic succession of day and night and the steady

the path of the pendulum and was not underneath it again until a day had passed. The floor turned round the pendulum in a day because the earth rotated.

The axis of rotation through the

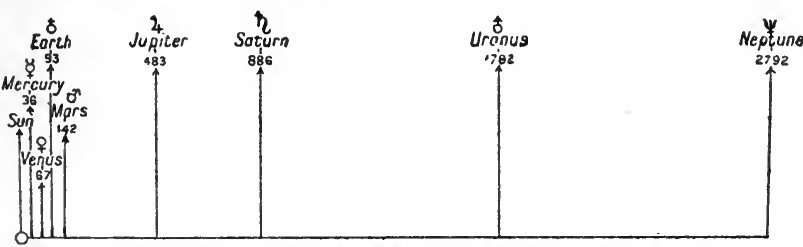

Earth. In this diagram the distances, in millions of miles, of the earth and the other planets from the sun are indicated along the bottom line regions are tilted now away and later towards the light. The angle of tilt $23 \frac{1}{2}^{\circ}$ determines the arctic and antarctic circles $\left(90-23 \frac{1}{2}=\right.$ $66 \frac{1}{2}$ ), which are the edges of the areas which have no sunrise at their mirtwinter and no sunset at their midsummer.

At midsummer, in England and similar latitudes, the sun is $47^{\circ}$ (twice 231 ) higher in the sky than at midwinter. At the equinoxes the sun rises due east and sets due west, and day lasts for 12 hours; in England in the summer the sun rises north of east and sets north of west, and day varies from 12 to 18 hours; in winter the sun rises south pulsation of the oceanic tides. The direction of rotation from west to east causes the sun to rise in the east, and the cyclonic planetary winds to swirl in different directions, anti-clockwise in the northern and clockwise in the southern hemisphere.

The fact that the earth rotates is demonstrated by Foucault's pendulum. Foucault in 1851 sus. pended a pendulum from the dome of the Pantheon in Paris and started it swinging above a mark on the floor. A pendulum always swings in the same path. The mark along the floor moved away from
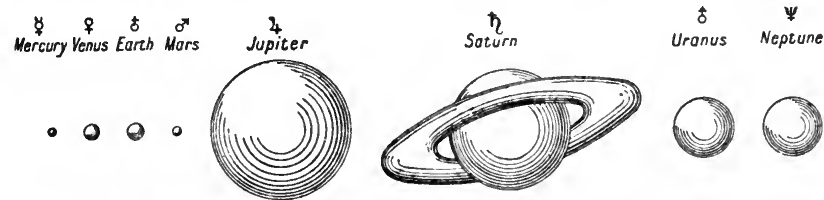

Earth. Diagram showing the relative sizes of the earth and the other seven planets. The earth is one of the four smaller planets. Note the relatively immense sizes and distances of the four major planets

poles tilts through an angle of $231^{\circ}$ from the vertical towards the line joining the centres of the earth and the sun. Sunlight reaches the earth in rays parallel to the line of centres; consequently the polar

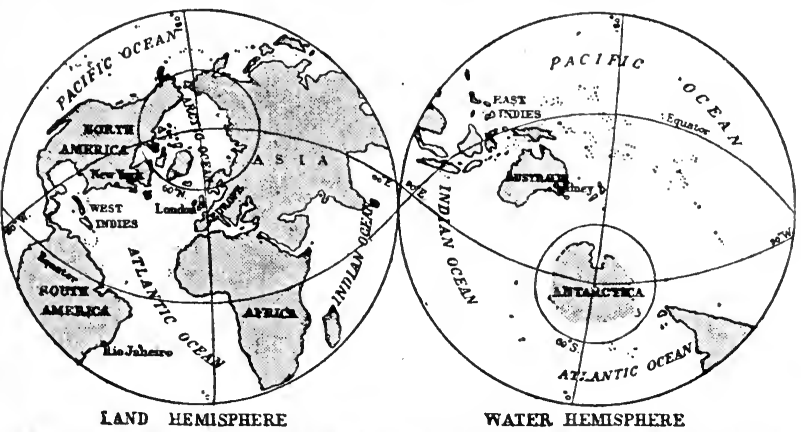

Earth. The world in hemispheres. The land bemisphere has its centre approximately at continent : Africa is antipodal to the grst basin of the Pacific. The water hemisphere includes Argentina, Australasia, the East Indies, and the southeast corner of Asia

of east, sets south of west, and day varies from 6 to 12 hours. The tilt of the earth's axis is theretore responsible for the seasons, and for the fact that variation in mean monthly temperature through the year follows the same rhythmic curve for all places on the earth, differing only in amplitude from place to place. Like the other planets the carth has a spherical shape, rotates upon an axis inclined to the plane through which it revolves round the sun in an elliptical orbit, and receives Jight and heat from the sun.

Owing to its rotation the earth is not a perfect sphere, but has a bulging belt round the equator and a flattening at the poles, so that it is an oblate spheroid. This bulge is a reminder of the way in which at an early stage in its career the earth, then much larger in diame. ter, had a greater bulge which even. tually broke away from the earth in fragments, which later coalesced to 
form the moon. This process repeated on a small scalc the method by which the earth itself was formed from the sun. The earth's diameter is $7,900 \mathrm{~m}$., less than a hundredth part of that of the sun. The eartb is the third planet in order from the sun, Mercury, the nearest and smallest planet, heing 36 million miles while the earth is 923 million miles from the sun, and Neptune, the most distant, is 2,775 million miles from it. The earth rotates once in $23 \mathrm{hrs} .56 \mathrm{mins}$, the sun in 25 days, and Jupiter in 9 hrs. 55 mins. While the revolution of the earth round the sun occupies a year, Mercury only takes 88 days and Neptune takes 165 years.

\section{The Moon and the Earth}

The whole solar system is held together by the influence of gravity. While the sun is very hot and the moon quite cold, the earth still retains within it a certain amount of heat which tends to be dissipated through space. The moon is without an atmosphere, but the earth and Mars have a gaseous envelope surrounding them, the troposphere. The moon causes eclipses of the sun, the wave movements of terrestrial waters called the tides, and reflects a small quantity of solar light and heat to the earth, but the main external source of supply of energy to the earth is the sun. The earth, how. ever, only receives a very small portion of the total radiant energy, light, heat, electricity, etc., which streams continuously into space from the sun.

The earth is a rigid body, approximately twice as rigid as steel, in that it resists compression, yet although the interior is not fluid, it is fluidible and will flow when opportunity offers, as in lava streams.

\section{Hydrosphere and Lithosphere}

The earth is a cooling body, and therefore is very slowly becoming smaller. The geometrical solid which combines a maximum of surface area with a minimum of volume is a tetrahedron, which has four corners, four faces, and six edges. Because the earth's crust is attached to a shrinking interior the crust crinkles into folded mountains which have adopted the tetrahedral outline. One corner is Antarctica, the opposite face is the Arctic Ocean. 'Three edges, the Andes, the African ints., and the ridges of Malaysia and Australasia, point towards the Antarctic Corner. The remaining three edges are formed by the mountain ridges which run east and west in the northern hemisphere.

The hydrosphere, or water covering of the earth, consequently tends to form four basins : the best marked of these is the Arctic Ocean. Of the total surface of $196 \frac{1}{2} \mathrm{mil}$ lion sq. m., $14 ! 1 \frac{1}{2}$ million sq. m. are water, most of which is found in the Water Hemisphere, which has its pole close to Antipodes Island and includes Australasia, Antarctica, and small portions of South America and S.E. Asia. The maximum depth of the hydrosphere does not reach $6 \mathrm{~m}$. The hydrosphere is the source of the water which in the form of rain, ice, and flowing streams tends to wear down the surface of the lithosphere or solid earth to a uniform slope which would leave only the tetrahedral edges as mountain ridges; this process is most marked all round the Arctic Ocean in the great plains of Canada and Russia. Although it is probable that the bulk of the lithosphere is of the same composition, the known diversity in the composition of the outside crust is responsible for the minor variations of ridge and valley which are infinitesimal in relation to the earth's bulk ( $1,000 \mathrm{ft}$. compared with 8,000 miles, i.e. roughly 1: 40,000).

Flux of Atmospheric Conditions

The earth is the home of man. In common with the forms of life which provide his sustenance man exists on the earth because of the atmosphere. His yearly and daily round is regulated by the motion of the earth. The annual revolution, with the consequent variation in the earth's tilt relative to the sun, causes the seasons and the wellmarked differences between the tropical and polar belts. In relation to these differences the tetrahedral conformation produces variations in atmospheric circulation which govern the several climatic differences which cause the weather to vary from place to place.

The net result of these differential conditions is the production in the neighbourhood of the tetrahedral ridges of the northern hemisphere of areas where the atmospheric conditions are in a state of continuous flux. It has been demonstrated that man reaches and retains his highest development in response to such a kaleidoscopic environment. It is not an accident that modern civilization in its highest expression is found on the edge of the Alpine ridge, where the northern slope abuts on the junction of the Arctic and Atlantic basins. See Planet. B. c. wallis

Earth. Term used in several senses besides that of the name of a member of the solar system. Two only need be noted here, one in connexion with electricai and magnetic phenomena, and the other with the so-called rare earths.
The chief rare earths are cerium, terbium, and ytterbium, occurring in small quantities in Scandinavia, the Urals, America, and Australia, and yielding radium, the discovery of which has revolutionised the theories of the constitution of matter.

In 1600 Gilbert showed that the earth was a magnet; the magnetic poles corresponding approximately to the geographical poles. The cause of this magnetisation of the earth is unknown, but it has been observed to vary in strength with the appearance of spots on the sun. That there is an intimate connexion betwcen solar phenomena and magnetic storms on the earth has long been known. These magnetic storms are of such strength as to interfere with and often prevent the transmission of telegraphic messages. They are notably severe at times of brilliant displays of the aurora borealis. See Magnetism ; Telegraph and Telegraphy.

Earth Colours. Pigments universally employed before the introduction of oils. The cave men used red, yellow, black, and white for their crude but spirited drawings of animals, and the ancient Egyptians and Greeks resorted to similar though somewhat more numerous pigments. Honey or one of the gums was probably the binding medium. The earth colours include the ochres, umbers, sienna brown, and terre verte.

Earth Density. This has been determined experimentally by several physicists, beginning with Cavendish. The mean density as calculated most recently by C. V. Boys is 5.5268; or rather more than five and a half times that of water. See Cavendish Experiment.

Earthenware. Name given to all pottery that is not translucent. It includes Faience, Delft, Stoneware, and such modern makes as Granite ware, Silicon, Semi-porcelain, and so forth. It may be glazed or unglazed, the terracotta of the Greeks, flooring tiles and building blocks, or the Majolica and Enamelled wares all coming under the general term. Its origin is lost in antiquity, dating back before the age of metal working to a primitive culture when plaited baskets were encased in clay for cooking food. See Pottery; also illus. pp. 139 and 2083.

Earth-House. Primitive underground structure of the early metal. lic age, especially in Scotland. Normally it is a round or rectangular chamber of unhewn masonry, with a beehive roof, beneath an artificial mound. Frequently one or more chambers are approached by stone. 
lined, stone-paved corridors, often planned with a sharp bend, as at Tealing, Forfarshire, where it is $80 \mathrm{ft}$. long, $5 \mathrm{ft} .8 \mathrm{ins}$. high, with cup-markings. On the moor of Clova, Aberdeenshire, about 50 of these so-called Picts' Houses lie within two sq. m. At Skerrebrae, Orkney, several groups of chambers-one $21 \mathrm{ft}$. by $11 \mathrm{ft}$.-were reached from a common corridor. At Cairn Conan, Arbroath, the underground chamber lay near surface foundations, pointing to its probable use for refuge and storage in connexion with surface dwellings. The cultural range of the associated remains-querns, spindlewhorls, horn and bronze implements, rough pottery, Samian ware - resembles that of the Broch. Similar structures occur in Ireland and Cornwall. See Underground Dwellings.

Earthly Paradise, The. Poem or cycle of narrative poems by William Morris, published in four parts from 1868-70. The stories, chosen from classical and medieval sources, are supposed to be told by a miscellaneous group of 14th century story-tellers, banded together in search of that earthly paradise which gives its name to the whole. The first poem in the series, The Life and Death of Jason, was published as a separate volume, 1867.

Earth Movement. Ever since the outer rocky layer, or crust, was formed on the surface of the earth, it has been crumpled, folded, and otherwise disturbed. Areas have been elevated or depressed within historic times, as mav be seen along the sea coasts. Thus, at the Temple of Serapis at Pozzuoli, near Naples, a pavement now below present beach-level, with several neighbouring pillars, still upright, which bear marks of boring by shell-fish that neverlive above highwater mark, indicates both movements. At more remote periods, sea-beaches have been raised many feet above present beach-level ; on the other hand, depression of land has caused areas of thick vegetation to be turned into submerged forests.

Simple movements of elevation have raised great land-masses to form plateaux. When the strain on the strata becomes too great, fractures take place, the lines where they break being known as faults. In this way large areas are sometimes let down to a level lower than the surrounding country, and rift valleys have been formed. The valley of the Jordan is an example. 'The Dead Sea, the Red Sea, Nyasa and Tanganyika, and other lakes in E. Africa, lie in such areas. Earth stresses producing horizontal movements result in crumpling and folding of strata, and, on a large scale, in the formation of mountain chains. The Alps are folding $\mathrm{mts}$. Rock-beds may be arched, forming anticlines, or depressed into troughs, forming synclines; complications in bending may result in compound flexure or fan-structure. See Earthquake; Fault.

Earth-Nut Cake. Artificial feeding stuff. It is prepared from the underground fruit of the leguminous plant variously known as earth-nut, ground-nut, monkeynut, or pea-nut (Arachis hypogaea), after the oil has been extracted. In the decorticated form, which is better known than the undecorticated, the husk has been removed, and it is then a good substitute for decorticated cotton-cake. Fercentage composition : Water, 10.43 ; oil, 8.17 ; albuminoids, 48.32 ; digestible carbohydrates, $22 \cdot 99$; fibre, $4 \cdot 67$ : ash, $5 \cdot 42$.

Earth Pillar. Pillars of clay capped by stones. In an area consisting of clay or soft rock contain-

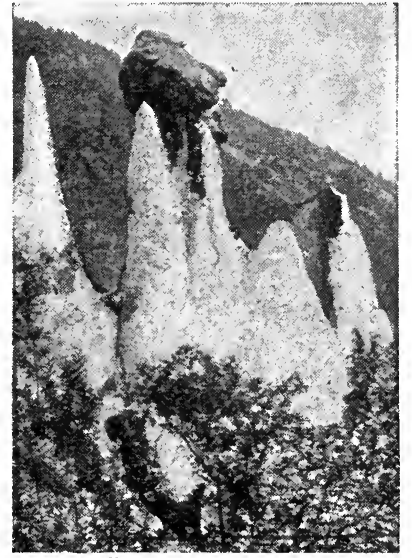

Earth Pillar. Example of this curious nature formation at Euseigne, Switzerland. It is caused by large stores, acting like umbrellas, protecting the rock beneath, after the softer material nas been washed away by rain

ing large stones the softer materials will be readily washed away by the rains, but the stones, acting like umbrellas, will protect the clay or soft rock immediately beneath them. In this way pedestals capped by stones are formed. See Geology : Rock.

Earth Plate. Metal plate, frequently of copper. Buried in the ground, to it the end of an electric conductor is secured. In telegraphy an earth plate is employed at each end of a conductor. See Circuit.

Earthquake. The crust of the earth, the outside layer of solid rock, is not always still ; it is sub. ject to strain and stress due to the cooling of the earth, to its revol!1tion, and to the attractive force of the other heavenly bodies. The crust not being homogeneous, these strains produce varied results in different areas. Large sections of the crust have sunk below the general level of the neighbouring portions; thus, for example, the basin of the western Mediterranean is a depression caused by sinking of this nature during remote geological eras. The edges of such depressions are lines of wcakness in the crust, and are usually marked by the existence of extinct or active volcanoes. In the western Mediterranean area are the volcanoes Stromboli, Etna, and Vesuvius, as well as the extinct volcanoes of Central France.

These lines of structural weak. ness in the outer crust of the earth sometimes give opportunity for earthquakes, which occur when a hidden segment of the crust breaks away from its original location. The shock produced by the sudden fracture sets up vibrations in the solid matter of the earth's crust, and these vibrations, waves or tremblings, travel long distances and produce movements in buildings, bridges, rly. lines, etc. Near the volcanoes in Italy there have been two great recent earthquakes : the Neapolitan earthquake of 1857, in which more than 12,000 lives were lost. and that of Messina in 1908, which cost 77,000 lives. In Sept., 1920, earthquake sbocks occurred in N. and Central Italy, causing hundreds of deaths and much damage. The modern study of earthquakes, the science of seismology, dates from 1857.

Earthquakes usually arise at no great depth below the land surface, and the stability of the " outer skin" of the earth depends partly upon its angle of slope. Earthquakes are not to be expected where there are extensive plains, but wherever the slope of the land is very steep the rocks tend to slip and give rise to earthquake shocks. The coast lands of the Pacific are usually tilted very sharply; deep water is close to the sea shore and high mts. rise close to the coast; consequently, Japan is a land of earthquakes, which also occur in New Zealand near Wellington, while San Francisco was devastated by the earthquake and subsequent fire of 1906. For a similar reason there have been severe shocks near the base of the Himalayas, e.g. at Shillong, Assam, in 1897. Tho highest mts. of the world are located roughly along two lines-in America from N. to S. close to the Pacific shores, in the Old World in a west-east direction 


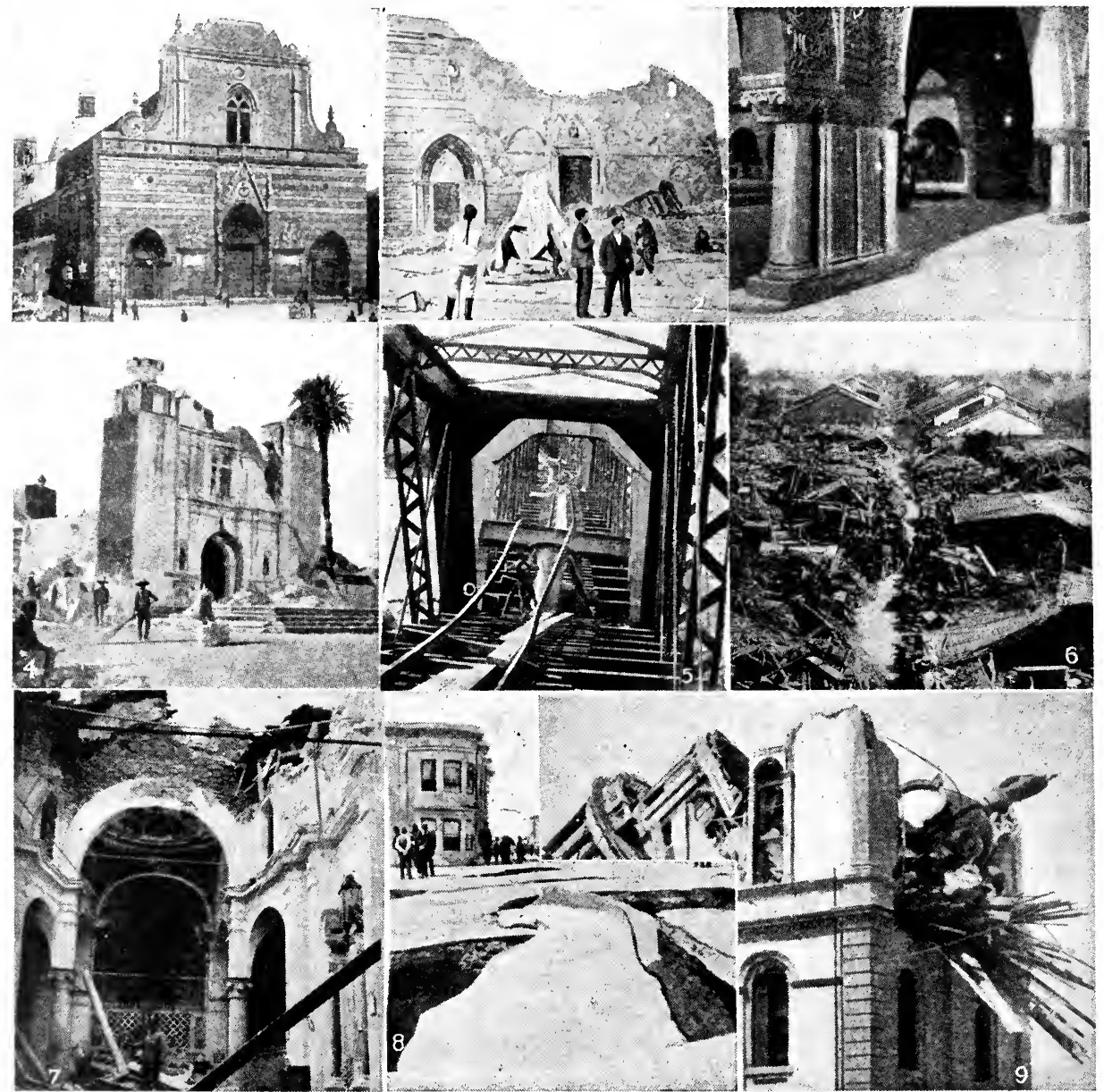

Earthquake. Examples ot aamage wrought by modern eartoquakes. 1. $r a_{\text {q }}$.ut of Messina Latredral betore the earthquake of 1908. 2. As it appeared afterwards. 3. Capitals of colnmns displaced at Leland Stanford Jr. University, Cal fornia, 1906. Cathedral destroyed in Guatema'a City, 1918. 5. Wrecked rail way bridge 4 ear Gifu, Hondo, Japan. 6. Ruined street in Gitu. 7. Interior of the church of Calcinaja, near Pisa, destroyed in Sept., 192C. 8. Street rent asunder in San Franc:sco, 1906. 8. Collapsed tower at Santa Rosa, Cali_ornıa, 1906

from Italy to Burma Count de The seismograph, or earthquake Montessus de Ballore tabulated the recorder, is a solid pillar set up records of over 170,000 earth- solidly in the ground at a distance quakes, and found that all but from all chance causes of surface 5 p.c. occurred near these two vibrations in the earth, and so mountainous axes.

Seismology owes much to Japanese interest; during seven years, $1885-92$, over 8,000 shocks were recorded in Japan, most of them happily of small dimensions; yet in 1891 a severe shuck left exposed a new escarpment which extended $50 \mathrm{~m}$. and attained a height of $20 \mathrm{ft}$. The San Francisco earthquake was marked by a vertical displace. ment which in places amounted to $10 \mathrm{ft}$. and which extended for over $\Xi 50 \mathrm{~m}$. Usually the shock lasts for a little longer than a minute; the am. plitude of the vibrcition diminishes with distance from the origin. ways, buildings may become heaps of rubble. Great waves may be generated in the ocean.

In earthquake areas great attention must be paid to the stability of buildings; they should be low upon a broad foundation, so that the swaying roof does not move far beyond the outside limits of the foundations. It used to be thought that the typically light bamboo house of the Japanese was developed in consequence of the frequency of earthquakes, but the thick, heavy. solid roofs of these houses show that the lightness of the walls is not due to fear of earthquakes. If Japanese domestic architecture owes any of its characteristic features to th. tre. quent earth-waves, it is in the shape and lowness of the buildings 
Earth-shine. Illumination of the moon by reflected light from the earth. It can be observed with greater or less distinctness, according to locality and atmospheric conditions, when the portion of the moon illuminated by the sun appears only as a slender crescent. The earth-shine on the new moon was successfully photographed in Feb., 1895, at the Lick Observatory by Prof. Barnard, who thus described it: "The earthlit globe stands out beautifully round, encircled by the slender crescent. All the seas are conspicuously visible, as are also the other prominent features, especially the region about Tycho. Aristarchus and Copernicus appear as bright specks." Humboldt endorses an observation that the light reflected thus on the moon changes in colour according to the region of the oarth which reflects it. See Moon.

Earth-star (Geaster). Genus of fungi, of the natural order Gastromycetes. They are distin.

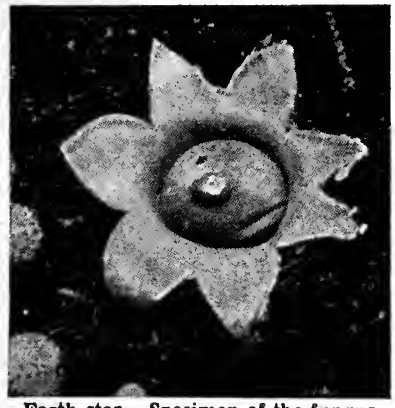

Earth-star. Specimen of the fungus showing its pounted segments

guished from the puff-balls (Lycoperdon) by the two outermost layers splitting from the apex into several pointed segments which expand and give the plant its stellate form. The numerous species grow upon the ground.

Earthwork. Ancient strong. hold defended by earthen mounds. There are several thousands in England and Wales. Promontory forts, utilising natural defences, are either coastal or inland. They developed into cliff castles. Hill. forts are characteristic of neolithic Britain. Plateau forts are on flatter ground. When round or oval they are pre-Roman, but often were used successively by neolithic, Celtic, Roman, Saxon, and Norman occupants. There is a good earthen hill-fort on Midhill Head, Midlothian, but Scottish strongholds are mostly of stone. See Caesar's Camp; Dyke; Rath.

Earthwork. In engineering, the excavation and disposal of materials which can be loosened with- out blasting. Railway engineers, when running their surveys, en deavour to fix formation levels which will balance excavation and embankment, preventing useless

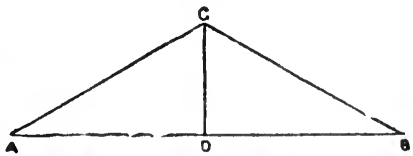

Earthwork. Diagram illustrating angle of repose

dumping and too much borrowing from outside areas.

The cubic contents of a cutting or embankment relatively to its average depth is governed by the angle of repose of the material under the conditions to which it will be exposed when the work is completed. If dry sand is poured on to a horizontal surface A B (see diagram), it forms a conical pile, the slopes of which make an angle of about $35^{\circ}$ with A B. As long as the heap remains dry, the angle is unchanged, and the heap is stable. Therefore angle C A B (= angle $\mathrm{C} \mathrm{B} \mathrm{A}$ ) is the natural angle of repose. Addition of water reduces the friction between the particles, and the heap spreads out until a condition of equilibrium is reestablished, the angle of repose being reduced to $22^{\circ}-26^{\circ}$.

The angles of repose of other substances are approximately: damp clay, $45^{\circ}$; wet clay, $16^{\circ}$; earth deposited in layers and rammed, $60^{\circ}-70^{\circ}$; damp earth piled in bulk, $45^{\circ}$; dry earth, $30^{\circ}$; wet earth, $16^{\circ}-18^{\circ}$; gravel, $45^{\circ}-$ $50^{\circ}$. Assuming that proper provision is made for drainage, a slope in which A D : C D : : $1 \frac{1}{2}: 1$ is safe for average earthwork in both cutting and embankment. To allow for the effect of heavy rain, it may be prudent to make the slope more gentle than this, as extra work done in the first instance is less expensive. The shoulders and toes of embankments should be rounded off, and the slopes covered with grass, which protects the earth against the loosening influence of rain.

\section{Ditches and Drainage}

If there be any likelihood of water flowing down into a cut from higher ground, a ditch is dug near the edge to intercept the water and carry it to a point where it can pass away without doing damage. In clay it is often necessary to cut $Y$-shaped ditches in the direction of the slope and fill them in with lump chalk, clinkers, etc. The arms of a $Y$ catch the water, which flows down the leg into permanent drains along the foot.
A cutting is usually excavated in successive 'lifts or layers, each opened out by deep trenches traversing the whole length of the cutting. The faces of the trenches are attacked by men working about $5 \mathrm{ft}$. apart, and extended laterally till they meet the slopes or one another. For very large cuttings a system of terracing is sometimes adopted, and work proceeds on a number of longitudinal benches on both sides at different levels, each provided with its own tem. porary way. A cut is made near the centre line, and widened out to three or four times its original width, after which a second cut is sunk under the first. While this is being extended, the limits of the cut above also are receding. The process is repeated till formation level is reached. The same system of benches is useful on side. long ground, i.e. where a notch has to be cut along the face of a hill.

Economic Removal of Spoil

Mechanical excavators are em. ployed wherever the scale of work justifies their use. With handwork. 14-60 cubic yds. per man per day can be loosened by picks; and 10-30 cubic yds. shovelled, according to the nature of the ground. Removal of the spoil is effected most economically by barrows over distances up to $500 \mathrm{ft}$., by two-wheeled carts, $500 \mathrm{ft} .-1,700 \mathrm{ft}$. ; by four-wheeled carts, $1,700 \mathrm{ft} .-3,500 \mathrm{ft}$. ; and by wagons on rails for longer hauls.

Railway embankments are generally formed by tipping over the end, and allowing the débris to find its own angle. Settlement of the materiai by consolidation must be allowed for to the extent of $\frac{1}{12}$ to $\frac{1}{7}$ of the height of the pile. If the earth be spread in layers, subsequent shrinkage is small. To open the road quickly it may prove economical to run a temporary trestle across a fill and dump earth from it to both sides. The stringers are removed as the earth reaches them; the uprights and crossbracings are left in position and help to give solidity.

If the maximum density be required, as for the embankments of reservoirs and behind retaining walls, earth is spread in layers a few inches thick, and well rammed. See Embankment; Engineering.

Earthworm. Segmented worm living in the soil. Their rounded shape and the short bristles with which the segments are provided enable the worms to push their way through the soil and to form burrows. They eat their way also, and derive their food largely from the vegetable matter contained in the soil swallowed. When this has 


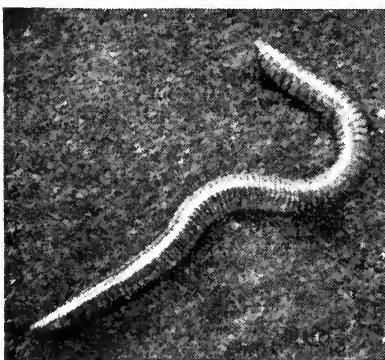

Earthworm. The common species, a valuable agent in lertilisation

been extracted, the soil, after being reduced to fine powder in the intestine, is discharged at the mouth of the burrow in the familiar worm. castings.

In his Formation of Vegetable Mould through the Action of Worms, 1881, Darwin estimates that in an acre of average garden land there are about 53,000 earthworms, and that every year about ten tons of soil pass through their bodies, with the result that they spread fresh soil on the surface at an average rate of an inch in five years. In this way they are continually turning over the soil, and their burrows give access to light and moisture. The destruction of earthworms is therefore an economic mistake.

Although without eyes, earthworms dislike light and only emerge from their burrows after dark, unless flooded out by storms. Even when they have emerged, they usually keep their tail in the hole ready for instant withdrawal if alarmed. They are in the habit of plugging the mouth of the burrow with leaves or small stones; and vegetable matter is drawn in for future consumption. They can certainly smell and taste, and it is probable that they can appreciate the vibrations caused by sound.

Earthworms are hermaphrodite, and impregnation is mutual in the union of the sexes. The egus are deposited in a kind of horny cocoon, which is formed by a secretion round the swollen ring which may be noticed on the body of an adult and is often mistaken for the scar of an old injury. When a worm is cut in two by a spade, the two halves often survive and reproduce the missing parts.

Earwig. Family (Forficulidae) of orthopterous (straight-winged) insects, which vary considerably from other members of the order. The fore wings are modified into elytra, and the hind wings-which are rarely used-are folded like a fan. They are readily recognized by the pincer-like appendages on the abdomen. The female sits on her eggs and watches over her young for some time. It is generally supposed that these insects are garden pests and feed on plants and fruit : but this is very doubtful. Recent observers maintain that they are largely carnivorous. See Insects.

Easel. Upright wooden trame of varying size and strength with a rest for the artist's canvas or board. The rest may be adjusted to any convenient height by means of a stop-slide at the back. The word easel (Dutch ezel, Ger. Esel) comes ultimately from Lat. asellus, little ass (dim. of asinus), meaning that which carries or supports. See Painting.

Easel Picture. Term applied in art criticism to works small enough to be painted on the easel. The name might be given to all cabinet and panel pictures, and most examples of genre and landscape, but not to distinctly large canvases, even though painted at the easel.

Easement. Term used in Eng lish law for what is called servitude in Scots law and in other legal systems. There must be two pieces of land (tenements), and the owner of the one, called the dominant tenement, has a right over the other, servient tenement. Thus, the owners of Whiteacre (dominant) have a right to use a footpath which runs across Blackacre (servi ent); this is called a right of way. Other common easements are right of light, or the right to prevent obstruction to windows; drainage support for buildings-e.g. where one house leans on another.

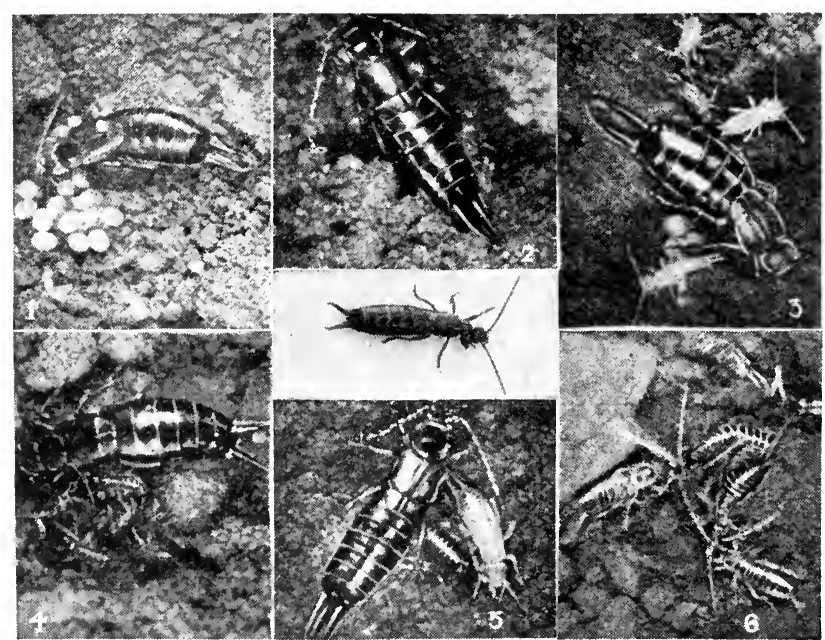

Earwig. Stages of life history. 1. Female earwig rearranging her eggs in the soil. 2. Assisting the hatching-out process. 3. The young earwigs, silvery at first, emerge after 15 days. 4. The family now increased to 48 . 5 . As they grow, the young earwigs moult to silvery white again. 6. Starting life at a month old. \%. Earwig, natural size. Figs. 1 to 6 are enlarged two diameter
If the dominant and servient tenements come into the same ownership, the easement vanishes, and if the ownership is again divi-

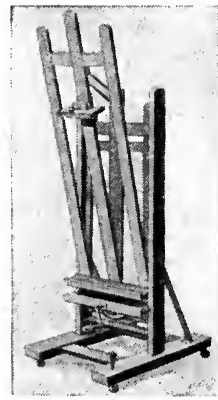

Easel. Example of a siudio easel ded a fresh ment is re quired. Ease. nents are acuired by grant from the vient owne ant ow ner: but a grant will be implied in some cases, where a grant would be useess without an easemente.g. if A grants to B a field in the middle of A's land, and there is no wrant of a right of way over quired bylong user. See Prescription.

East. One of the cardinal points. When the observer faces north the east is on the right hand. At an equinox the sun rises due $\mathrm{E}$. and

As a noun East is used for Asia and the eastern part of the world generally. That part which lies, roughly, east of Germany is known in Britain as the Near East, the Middle East, and the Far EastChina and Japan. Churches are usually built so that the worship. pers face the east, and at the east end the altar is always placed. made which ets due W. 
East, Sir Alfred (1849-1913). British painter and etcher. Born at Kettering, Dec. 15, 1849, he studied

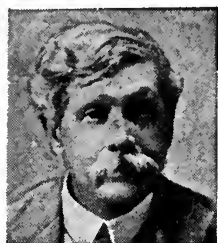

Sir Alfred East. British painter

Ellioll \& Fry at the Glasgow School of Art and at Paris under Tony Fleury and Bougue reau. $\mathrm{He}$ became a l a nd s c a pe painter of pronounced in. dividuality, though with a strong symHe was elected A.R.A. in 1899 and R.A. in 1913 ; was chosen president of the Royal Society of British Artists in 1906, and was knighted in 1910. Few landscape painters are so well represented in municipal art galleries. Evening in the Cotswolds is at Hull, Autumn in the Ouse Valley at Oldham, The Silent Somme and Autumn at Manchester, Gibraltar from Algeciras at Liverpool, Hayle from Lelant at Birmingham, The Golden Valley at Leeds, An Idyll of Spring at Preston, Autumn in the Valley of the Seine at Leicester, and Autumn in England at Brisbane, while to Kettering he left a collection of his works which was opened in 1913. He is also represented at Pittsburg and Chicago, Budapest, Venice, Milan, and the Luxembourg. He wrote The Art of Landscape Painting in Oil Colour, 1906; and the posthum. ously published Brush and Pencil Notes in Landscape, 1914. He died in London, Sept. 28, 1913.

East Africa. General term applied to that part of the African continent which includes British East Africa, i.e. Kenya Colony, Uganda Protectorate, and the Zan. zibar Protectorate, Tanganyika Territory, and Portuguese East Africa. See Kenya Colony; Uganda Protectorate; Zanzibar Protectorate; Tanganyika Territory; East Africa, Portuguese.

East Africa, Conquest of. British operation during the Great War. The campaign falls into two parts, desultory and indecisive operations throughout 1914 and 1915, and the conquest of the German colony by the British and their allies in 1916 and 1917 . In the former period the British were in the main on the defensive.

On Ang. 13, 1914, a British cruiser bombarded Dar-es-Salaam, destroyed the wireless station, and by sinking the floating dock and a ship made the port temporarily useless. On land there were attacks by both sides on the frontier posts, especially on the Uganda side of the colony; there was also some fighting on the lakes and on the Rhodesian border. On Nov. 4 the British, reinforced by a white battalion, the lst Loyal Lancashires, attacked Tanga. They took it, but their losses were very heavy and they were compelled to retreat to their ships, which carried them back to British soil. Longido was another failure.

On Jan. 2, 1915, the British occupied Jassin, a German port. On Jan. 19 the Germans returned to it with 2,000 men, and the garrison surrendered. Following this the British retired from German soil, but soon they cleared the Germans from the Victoria Nyanza, took the island of Mafia, and on Feb. 28 declared the coast of the colony to be in a state of blockade. On June 23 they captured Bukoba on the Victoria Nyanza, and on July 11 destroyed the Königsberg, which had run up the Rufiji river. The main task, however, was still almost unattempted, and although the Germans were cut off from the outside world, their position was by no means hopeless. Their colony, which was intact, was defended by a strong force, well. trained and well led, and this was continually raiding British posts, especially those on the Uganda rly. Throughout it was under von Lettow-Vorbeck.

In the autumn of 1915 , the serious nature of the task being by then realized, Sir H. Smith. Dorrien was sent out to take the chief command, till then in the hands of Brig.-Gen. J. M. Tighe. His health, however, was unequal to the task, and General Smuts took his place. On Feb. 19, 1916, he arrived at $\mathrm{M}$ om bas a, and from that event the conquest really dates. Troops for the campaign had been raised in $S$. Africa, and he had soon some thing over 30,000 men under him. In addition, the Belgians were preparing to march on to the German soil.

Froin Mom. basa, the Bri. tish base, the best way into the German colony was through the gap of KilimaNjaro, the alter- native being an attack, as at Tanga, from the coast. Smuts decided on the former, and in March his force succeeded in forcing the defences of the gap. One division attacked in front, while the other made a detour. There were several encounters, but the plan worked well and soon the Germans were retreating rapidly; their main body got clear, but only by the narrowest margin of time. Smuts moved his headquarters to Moschi and prepared for another sweep.

The new operations began in April, three divisions being employed, while other forces, Belgian and British, began to enter the colony from the $W$. One division marched into the interior, took Kondoa Irangi, where it was at. tacked by 3,000 Germans on May 10 , and made the Germans anxious for the safety of their main line of rly. The main force operated nearer the coast. In the valley of the Pangani river the German askaris, aided by the thick bush, fought well, but they could not prevent the occupation of Wil. helmstal, Handeni, and other posts. The rly. to Tanga was also seized, and minor actions, one or two naval, made the hold of the British on the N.W. part of the colony secure. Across it and around the Victoria Nyanza small but useful successes were also recorded.

By this time the main enemy force was concentrated in the Ngura Hills; consequently this was the next objective. The 2nd division meanwhile had reached one of the main objects of the campaign, the line of rly. running from Dar-es-Salaam right across the land, and in July about $100 \mathrm{~m}$.

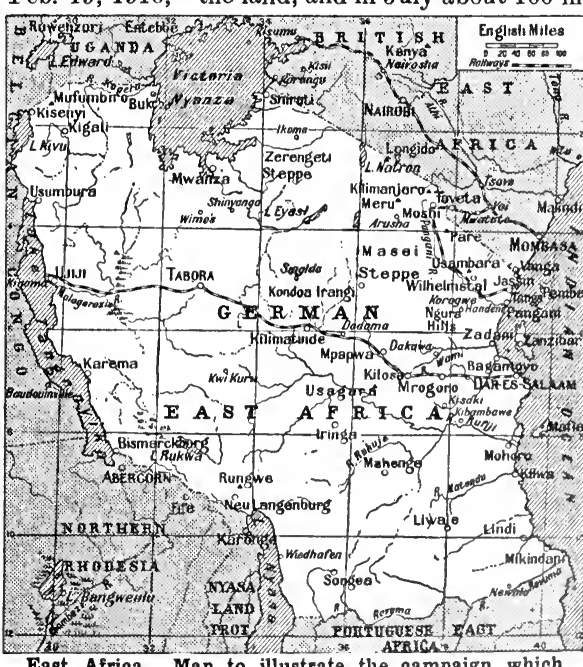

East Africa Map to illustrate the campaign which ended in the congnest of the German colons 
of this was British. Important operations were the British occu. pations of Tanga (July 7), Mwanza ('July 12), and Dodoma (July 30). All around forces were closing in on the Germans, whose one line of retreat was to the S. Early in Aug. Smuts set his main force moving again. It attacked in several places, and one after another the defended positions were taken. By the 18th the British force was at Dakawa, where the Wami is crossed. The 2nd division came along the rly. from the $W$. and the result was the German retreat on Mrogoro. An attempt was made to surround and destroy the foe there, but it failed, and again pursuer and pursued pressed $\mathbf{S}$.

The Germans, who were by no means routed, put up a succession of fights, and once, at Kirsaki, they had the better of the exchanges. However, they could not stop the advance, which won an additional advantage by the surrender on Sept. 4 of Dar-es-Salaam. The other ports were quickly occupied, and the enemy was by the end of Sept. confined to the district between the Rufiji and Portuguese territory, where another foe was preparing to receive him.

The 1917 campaign opened well. The British reached Kilambawe on Jan. 5 and surrounded a German force on Jan. 24. One of the great tasks of this campaign was the crossing of the Rufiji river. This was accomplished on June 5, 1917, and the area at the disposal of the enemy was again steadily con. tracted. The Germans were in two main bodies, while smaller detach. ments were occasionally troublesome. They fought hard, especially in the Kilwa district, but on Nov. 28 one of the main bodies surrendered. The other, under von I Lettow-Vorbeck, crossed about the same time into Portuguese territory and the colony was cleared.

The concluding operations, which were conducted by General van der Venter, included a British success near Manunga, May 5, 1918, the occupation of Malema, June 13, and the surrender of von Lettow's forces, Nov, 14. The British casualties approached 20,000 , and the loss in animals was enormous. See Tanganyika; consu't Three Years of War in East Africa, A. Buchanan, 1919; My Remir. iscences of East Africa, von Lettow-Vorbeck, 1920.

East Africa, Portugứese; or Mozambique. Portuguese colony, bounded on the $\mathrm{N}$. by Tanganyika Territory, on the W. by Lake Nyasa, the Nyasaland Protectorate, Rhodesia and the Transvaal, on the S. by the Zululand portion of Natal, and on the E. by the Indian Ocean. 'The colony stretches along the coast from Cape Delgada to the Rovuma. From the coastal swamps the land rises gradually to for. ested hills and the African plateau. A rea, 428,132 s q. m. P o p. $3,120,000$.

The colony comprises t e r r $\mathrm{i}$ tories directly administered by the State, and others under the control of the Mozam. bique and Nyasa Companies. The first are divided into six districts -Lourenço Marques, Gaza, Inhambane, Quilimane, Tete, and Moz a m bique. The Mozambique Company is responsible for an immense block of territory in the centre of the colony, including the Manica and Sofala districts, whilst the Nyasa Company administers the northern territory between the river Rovuma, Lake Nyasa, and the river Lurio.

The whole country is extremely rich in tropical products and min. eral wealth, and is capable of great economic development. The chief products are sugar, nuts, copra, rubber, vegetable oils, wax, and ivory. There are two important rlys. from Lourenço Marques to the Transvaal, and from Beira to Buluwayo in Rhodesia. Railways are under construction from Beira, Quilimane, and Mozambique to the Nyasa districts, and from Porto Amelia to Lake Nyasa. The principal commercial centres are Ibo, an ancient trading port $\mathrm{N}$. of the fine natural harbour of Pemba Bay; Porto Amelia, on Pemba Bay; Mozambique, the original capital of the colony ; Quilimane, an undeveloped but well-situated port; Chinde, situated on the only navigable outlet of the Zambezi river and the principal port for the Nyasaland Protectorate; Beira, the chief port and capital of the Mozambique Company's territory Sofala, an ancient and decayed harbour; Inhambane, a small port of local importance ; and Lourenço Marques, the chief port and capi-
Delagoa Bay.

Mozambique was visited in 1498 and 1502 by Vasco da Gama, and in 1505 by Albuquerque, who established it as a Portuguese province. During the height of the Portuguese power considerable progress was made in the exploration of the territory. In the 18th and early part of the 19th centuries it became a stronghold of the slave trade. In 1875 and in 1885-91 disputes arose with Great Britain regarding the precise boundaries of the Portuguese territories around Delagoa Bay and in Mashonaland, Matabeleland, and Manicaland, which were settled by arbitration on July 24, 1875, and by the AngloPortuguese Convention of 1891.

Bibliography. The Portuguese in S. Africa, G. M. Theal, 1896; Records of South-Eastern Africa, ed. G. M. Theal, 1898-1903; Portu. guese Nyassaland, W. B. Worsfold, 1899 ; Mozambique : its agricultural development, R. N. Lyne, 1913 ; Three Years' Sport in Mozambique, G. Vasse, Eng. trans. R. and H. M. Lydekker, 1909 ; Zambezia, R. C. F. Maugham, 1910 .

East Anglia. One of the kingdoms into which England was divided from the 6 th to the 9 th century. It embraced the present counties of Norfolk and Suffolk, and the name suggests that its 
founders were Angles. The first East Anglian king about whom anything definite is known is Raedwald, who died about 620 . His successors were in turn the vassals of Northumbria, Mercia, and Wessex, until the Danes invaded their land and killed their King Edmund in 870 . In the loth century also there were East Anglian kings, but they were only underlings of the English kings, as were the earls who ruled the land subsequently. To-day East Anglia is used loosely to describe the district between the Wash and the Nore.

Eastbourne. County borough and watering-place of Sussex, England. It stands on the English

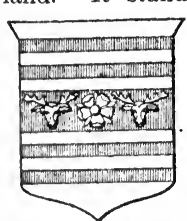
Channel, wit Beachy Head on the W. and is $66 \mathrm{~m}$. S.S.E. of London by the L.B. \& S.C. Rly. 'The many at tractions include a fine parade Eastbourne arms nearly three $m$. long, running right along the sea front, with its gardens, known as the Meads. There are a pier and pavilion, golf links, and provision for tennis, croquet, and other sports, as well as baths, while the South Downs, with their old-world villages, provide pleasant opportunities for walking. The open spaces include Devonshire, Gildridge and Hampden Parks, while there are some fine hotels and ample accommodation for visitors. Much of the ground belongs to the duke of Devonshire, who has a residence, Compton Place, here. The chief buildings are the fine block built for municipal purposes, and the Princess Alice Memorial Hospital.

The chief church is S. Mary's, the old parish church of the village of East Bourne, which is about a mile inland. 'The other churches are modern, but some of them are fine buildings. The Lamb Inn is interesting, and there is a redoubt and a martello tower. There are many schools, the chief being Eastbourne College. Eastbourne, which only became a borough in 1883 , is governed by a mayor and corporation, and gives its name to a division sending one member to Parliament. Early in the 19th century it consisted only of three hamlets, but the discovery of its advantages as a seaside resort quickly brought fame and size to it. Pop. (1921) 62,030.

Eastcheap. London street extending from Gracechurch Street and Fish Street Hill to Great Tower Street; E.C. Owing its name to a butchers' market held here as early as the time of King John, and later removed to Leadenhall, the thoroughfare has varied in both length and name, but was known as Eastcheap from about the time of Henry III to the 16th century. About 1831 the W. end disappeared, as did the church of S. Michael's, Crooked Lane, in the new London Bridge improvements, and the E. end became known as Eastcheap and Little Tower Street. When the street was widened in 1884 the old name was restored for the whole of it. The site of the Boar's Head Tavern, Eastcheap, mentioned by Shakespeare, is marked approximately by the statue of William IV at the junction of King William Street and Gracechurch Street.

Easter. English name for the eccles. festival commemorative of the Resurrection of Jesus Christ.

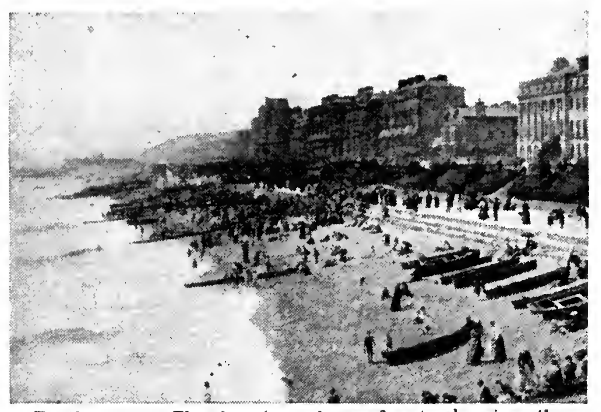

Eastbourne. The beach and sea front, showing the Meads, and looking towards Beachy Head

The feast, the most important in the Christian year, known as Ostern in Germany, in other countries is called by modifications of the Greek and Latin Pascha. which derives from the Aramaic Pischa and Hebrew Pesach $=$ Passover, the name of the Jewish festival which coincided with the Crucifixion. Thus we have in Welsh Pasg, Italian Pasqua, Spanish Pascus, and French Pâques. While applied especially to Easter as being the feast of feasts, the word Pasch is extended to other occasions. The sacrifice of Christ, typified by the paschal lamb slain at the Passover, was celebrated as well as $\mathrm{His}$ Resurrection; there was a Pasch of the Cross as well as a Pasch of the Resurrection.

Celebrated generally in Christendom since the 2 nd century, though for varying periods, Easter is a movable feast, and its occurrence governs the dates of the preceding Lent and the festivals following it. It was long observed as a special time for baptism, for the recon. ciliation of penitents and the release of prisoners, for the distribution of alms and for offerings to the clergy.,. Both the Roman
Catholic and Anglican churches expect their members to receive holy cornmunion at Faster, and have special services for Sunday, Monday, and Tuesday. Many special ceremonies also pertain to the celebration of Easter in the Roman Catholic Church. British Nonconformists, who in the 17 th century formally repudiated the keeping of this festival, now commonly observe it. A number of pagan customs associated with the vernal equinox survived at Easter until the Middle Ages, and others were adapted by the Christian Church. In regard to the giving of Easter or pasch eggs, the idea that the egg symbolises resurrection is of a comparatively modern origin. Eggs, having been forbidden as food during Lent, were restored at Easter.

The secular im. portance of Easter is that it governs law, university, and school terms and business arrangements generally. Since the sth century in Western Christendom, Easter Day has been celebrated on the first Sunday after the first full moon, or after the 14th day of the moon, following March 21. 'Thus it cannot fall before March 22 nor after April 25. 'The 14th of the calendar moon, or eccles. full moon, which regulates the date of Easter, falls, however, usually on the 15th or 16th of the real moon. Reviving an ancient and oft-repeated proposal, Lord Desborough, at a conference of the associated chambers of commerce in 1920, moved, on behalf of the London chamber, a resolution in favour of a fixed date for Easter.

Both the origin of the word Easter and the time of its observance have been subjects of controversy. Following the Venerable Bede, the derivation of Easter from Eastre or Eostre, the name of a Teutonic goddess of spring, has been commonly accepted. The dispute in the early Church as to the date of Easter was between the Christians of Asia Minor, who were called Quartodecimans because they kept the Resurrection on the third day after the 14th of the Jewish month Nisan, on whatever day of the week it fell; and the Western Church, which maintained that Easter should always be held on the Lord's Day following the 14th. The latter prevailed, and the 
Council of Nicaea, 325, fixed the Sunday for universal observance. But for many centuries the difficulty of adjusting the Julian calendar to the Jewish system, and of finding the true date of Easter, was acute. As the reform of the calendar in 1582 was not accepted in the East, the Eastern Churches still keep Easter on a different date from that in the West. See Calendar; Metonic Cycle; Passover.

Bibliography. Companion to the Almanac, A. De Morgan, 1845 ; Church of Our Fathers, D. Rock, new ed. 1903-4; The Ecclesiastical Calendar, S. Butcher, 1877 ; Church Year and Kalendar, J. Dowden, 1910 ; The Golden Bough, J. G. Frazer, 3rd ed. 1907-15.

Easter Island OR RAPANUI. Lonely volcanic islet of the $\mathrm{S}$. Pacific. It is $2,300 \mathrm{~m}$. W. of Chile, to whom it belongs. Area about $50 \mathrm{sq}$. m.; alt. $1,970 \mathrm{ft}$.; lat. $27^{\circ} 7^{\prime} \mathrm{S}$.; long. $109^{\circ} 20^{\prime} \mathrm{W}$. It was discovered on Easter Day, 1722, by the Dutch admiral, Roggeveen, although its discovery is claimed for Davis, the buccaneer, in 1686. The few inhabitants are of Polynesian descent; Cook, visiting it in 1774 , reported them as having the lobes of their ears extended almost to their shoulders. But its chief interest lies in some 500 ancient statues or torsos, stone huts and sculptural rocks, with pictographs (undeciphered) and Megalithic remains. Most of the carved faces are very high, one measuring $37 \mathrm{ft}$. Examples of these sculptures are to be seen at the British Museum. Attempts at deciphering some incised wooden tablets, called hyloglyphs, have not been altogether successful. The island is now a Chilean convict station. Pop. about 100. During the Great War it came into notice in connexion with the commerce-destroying raids of the .German auxiliary cruiser, Prinz Eitel Friedrich, w hich towed some of her captures to the island and there sunk them. The crews of certain ships taken by the cruiser were left on the island, Dec., 1914-Jan., 1915. See Te Pito Te Henua or Easter Island, W. J. Thomson, 1891 (for Smithsonian Inst.); The Mystery of Easter Island, Katherine Routledge, 1919.

Eastern Bengal and Assam. Province of India from 1905 to 1912. On Oct. 16, 1905, Eastern Bengal and Assam was constituted from the territories formerly administered by the Chief Commis sioner of Assam, together with the Bengal divisions of Dacca and Chittagong, and the districts of Jalpaiguri, Dinajpur, Rangpur, Malda, Bogra, Rajshahi, and Pabna. It had a total area of 111,569 sq. m., including the native states of Hill Tippera and Manipur, and a pop. of $30,961,459$ (census of 1901). The capital was Dacca. This partition was revoked in 1911, when George $V$ announced at the Delhi durbar the reconstruction of Bengal with the presidency of Bengal, the lieutenant. governorship of Bihar and Orissa, and the chief commissionership of Assam. The new division of territory came into force April 1, 1912.

Eastern Cadet. Name given to certain British officials. They are sent out to the British possessions in the East, Ceylon, Straits Settle ments, Federated Malay States, and Hong-Kong, to manage the civil affairs of those countries, much as the Indian civil service manages those of India. The service is entered by competitive examination, the same as that for first-class clerkship in the home civil service and the Indian civil service. The examination is usually held every August. Candidates must be British subjects, between 22 and 24 years of age. See Civil Service.
Eastern Church. 'Term for the Greek, as distinguished from the Latin or Western Church. It is applied specifically to the Greek Catholic or Eastern Orthodox (Russian) Church, and generally to the churches of E. Europe, Asia, and Africa, including the Nestorian or East Syrian, Armenian, Jacobite or West Syrian, Coptic (Egypt), Abyssinian, Malabar (India), and Maronite (Lebanon) Churches. The Eastern Church flourished in the East Roman Empire, claims a greater antiquity than the Western Church, and was divided into the patriarchates of Constantinople, Alexandria, Antioch, Jerusalem, and, after the separation of East and West, Moscow. See Greek Church.

Eastern Province. Name given to several provinces, owing to their geographical position:. (1) Province of the Belgian Congo, comprising the districts of Upper Nele, Lower Nele, Ituri, Stanleyville, Aruwimi, Lowa, Kivu, and Maniema. Each district is under a commissioner and the prov. is governed by a vice-governor. The capital is Stanleyville. (2) Province of the Uganda Protectorate, comprising the districts of Busoga, Bukedi, Teso, Lango, Karamoja, and Lobor. The prov. is under direct administration, with the cxception of the districts of Karamoja and Lobor. Included in the area of this prov. are the lakes of Kioga, Kirkpatrick, and Mpologoma. The highest point is Mt. Elgon, which lies on the S.E. boundary; it has an alt. of $14,152 \mathrm{ft}$. There is a forest on Mt. Elgon containing valuable timber, the area of this being estimated at 50 sq. m. (3) Province of Ceylon. It has an area of $3,848 \mathrm{sq}$. m. and a pop. of 183,317. A large lagoon runs parallel to part of its coast-line.

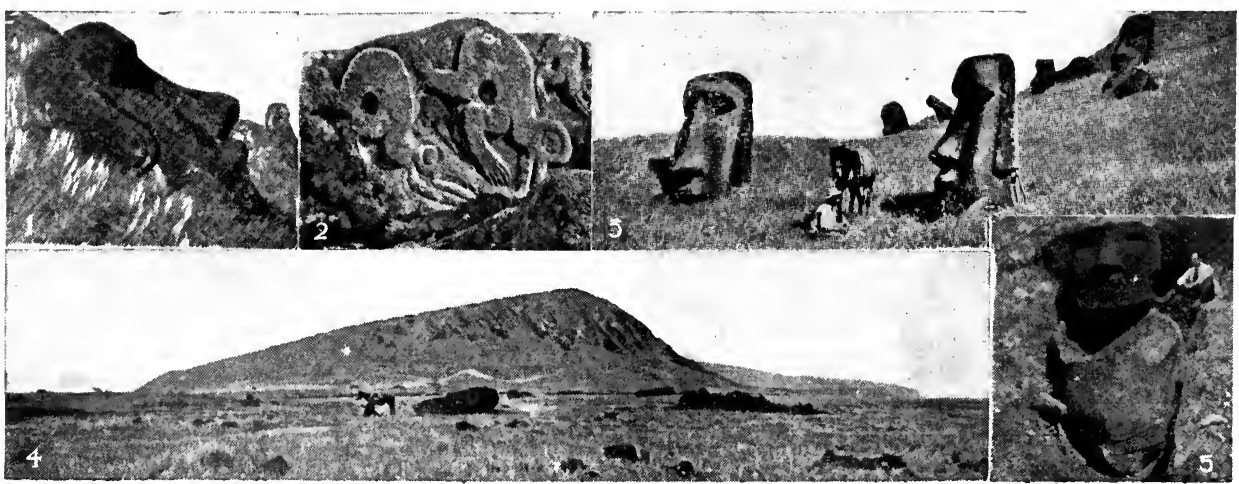

Easter Island. Views of some of the prehistoric remsins. 1. Typical head showing long ear and pouting lips. 2. Bird-men carvings on rocks of Orongo. 3. Statues on the slope of Rano Raraku. 4. Hill of Rano Raraku, with prostrate images in the foreground: above are the quarries. 5. Image on Rano Raraku excavated to show the hands 


\section{THE EASTERN QUESTION}

Arthur Jones,. M.A., Lecturer in History, Birkbeck College, London

The origin and nature of this perplexing problem is here described.

Related information will be found in such articles as Beaconsfield;

Bulgaria; Constantinople; Turkey. See also Europe: History

'The Eastern Question deals with the disintegration of the Ottoman or 'Turkish Empire in the Balkans and Mediterranean basin. That empire was acquired during the period extending from the fall of Constantinople in 1453 to the death of Solomon the Magnificent in 1566. Despite the follies of degenerate sultans, Turkey survived the 17 th century intact, excepting that Austria gained Transylvania, Slavonia, and Croatia, 1698, and Turkish Hungary, 1718.

The treaty of Kutschuk Kainardji, 1774, whereby the Russians forced the Turks to tolerate Christianity in Moldavia and Wallachia (modern Rumania), inaugurates a new phase in the Eastern Question in which the tsars project the subjugation of entire European Turkey. They coveted the Mediterranean ports and the Levantine commerce. As heads of the Orthodox Church they would emancipate an Ortho. dox majority in the Balkans from the domination of a Moslem minority. As monarchs of a Slavonic empire, their nascent PanSlavonic sentiment fostered a desire to embrace the Slavs of the Balkans within their political influence. Catherine II clinched the maiter by inscribing in 1774, over the entrance to the Crimea, "The way to Constantinople."

The period 1821-78, from the war of Greek Independence to the congress of Berlin, sufficed for the establishment of autonomous Balkan states. The former ended in the establishment of an attenuated Greek kingdom in 1832, while by the Russo-Turkish treaty of Adrianople, 1829, the Danube and Dardanelles were opened freely to navigation; Moslems were banished from Moldavia and Wallachia, whose hospodars ruled for life with sovereign powers independent of the Porte; Serbia became autonomous but tributary, and in 1830 elected its own prince. Mehemet Ali revolted, and in 1840 received the pashalik of Egypt, practically as an hereditary dominion. The quarrel over the Holy Places in 1850 led Czar Nicholas I boldly to propose a partition of the "sick man's" possessions, the Balkan states to have autonomy under Russia, England to compensate herself in Egypt, Cyprus, and Crete. Instead, came the Crimean War.

The peace of Paris, 1856, placed

the Danube under an international commission, and freed Moldavia and Wallachia (now increased by a strip of Bessarabia) from Russian influence. Despite European diplomacy, these two principalities united quietly, 1866 , to form the kingdom of Rumania. Christian Turkey was in a condition of latent insurrection, which became active in the revolt of Bosnia and Herzegovina in 1875 and Bulgaria, in which Serbia and Montenegro participated. Turkey's ferocious retaliation produced "the Bulgarian atrocities" and the victorious intervention of Russia. The congress of Berlin, 1878, transferred the Dobruja to Rumania in exchange for Bessarabia, and founded the independent principality of Bulgaria, shorn, however, of Rumelia and without Nish and Mitrovitza, claimed by

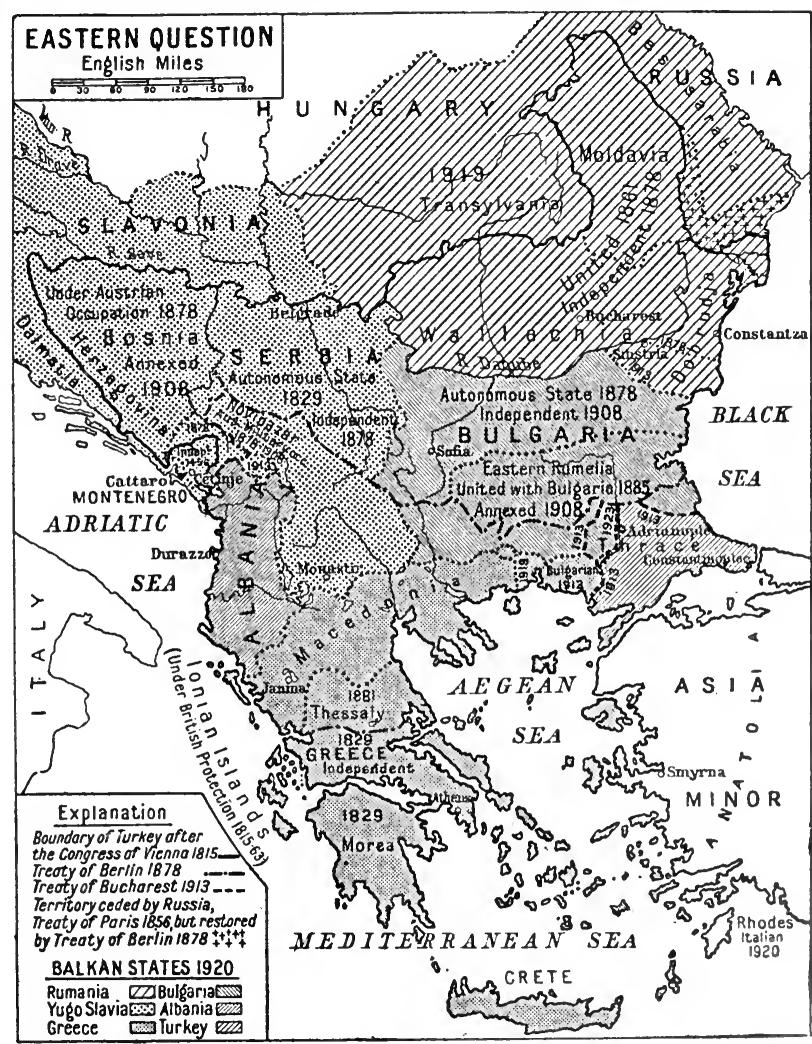

Eastern Question. Map of the Balkan States, showing the territorial changes

Eastern Question. Map of the Balkan States, showing the territorial cha
between 1815 and 1920, and, in addition. Turkey's 1923 boundary

Bulgaria but allotted to Serbia Montenegro obtained the ports of Antivari and Dulcigno. Austria was entrusted by the Powers with the guardianship of Bosnia and Herzegovina and the sanjak of Novi Bazar.

Russia was the driving force that emancipated the Balkans, but from the beginning she found that it was not, as she conceived, a Russian domestic question, but one involving the interests and activities of all Europe. Britain dreaded that a powerfully aggres sive Russia predominant in Turkey would destroy her Levantine trade and menace Indian communications, a dread intensified by the opening of the Suez Canal in 1869. Liberal opinion championed the national aspirations of the Balkans; Conservatives regarded Turkey as a buffer against Russia to be preserved at all costs

Austria after 1866, expelled from Germany, and by the Zollverein cut off from the ports of the Baltic and North Sea, wanted to assimilate the Balkans. Russian influence 
there she abhorred as incompatible with her own ambitions.

Ever since the time of Francis I (d. 1547) France had maintained an entente with Turkey, thus checking Austria and helping French power in the Mediterranean. The 19th century saw her aspiring to possess Algeria, Morocco, and Tunis, and especially Egypt, and investing huge sums in Turkish enterprises. Both cash and policy depended upon the preservation of Turkish integrity.

Between 1859 and 1870 Italy expelled the Austrians. Fearing Austrian vengeance, she wished to strengthen her frontier by acquir. ing the Trentino and the Isonzo. To check Austria in the Balkans, to protect her exposed eastern seaboard, and to enhance her maritime supremacy, she dreamed of regaining the ancient Venetian dominion in Istria and the Dalmatic coast, and establisbing herself in the Albanian ports of Durazzo and Valona, her policy challenging Albanian sentiment and Greek ambition.

On every occasion the annihilation of European Turkey was prevented at the last moment by the mutually destructive aims of the Christian powers. They delayed the evolution of the Balkan states, tried to make them helots of European diplomacy, deprived them of legitimate territory, and left them with burning grievances. So the end of the 19th century witnessed a new phase-the Balkan states repudiating European patronage and adopting an aggressive policy. In 1881 Greece received Thessaly and part of Epirus, and Rumania became a kingdom. Milan of Serbia became king in 1882 . Rumelia joined Bulgaria, 1885, under Alexander of Battenberg, and subsequently under Ferdinand of Coburg, 1887, although recognition was withheld by the Powers until 1896 The Greco-Turkish war of $1897 \mathrm{ob}$ tained autonomy for Crete in 1898 .

Ferdinand Proclaimed Tsar

Then followed a general at tack upon Mediterranean Turkey. France allowed Britain sole sway in Egypt, 1904. Serbia signalised her independent attitude by murdering the Austrophil Alexander Obrenovitch, and enthroning Peter Karageorgevich, 1903. The Balkan states began to draw together, the first sign being the Serbo-Bulgarian customs union (1905-6). Austria stimulated the movement by taking advantage of Russian preoccupation in Manchuria to annex Bosnia and Herzegovina, 1908, although by abandoning the sanjak of Novi Bazar, 1909, she offered the apple of discord to
Serbia, Grcece, and Bulgaria. Bulgaria repudiated Turkish suzerainty, and Ferdinand proclaimed himself tsar, 1909.

The moment was favourable. A military convention between Serbia and Montenegro (1908) expanded into the Balkan League, 1912, of Serbia, Bulgaria, Greece, and Montenegro, which drove Turkey behind the Chatalja lines. But woe to the conquerors! The treaty of London, May 30, 1913, proved nothing, except that the historical, ethnological, and geographical claims of the Balkan states were so mutually confounding that it was humanly impossible to satisfy those claims and delimit permanent frontiers. Bulgaria, prompted by Austria, treacherously attacked Greece and Serbia.

Her defeat, the Turkish reoccu. pation of Adrianople, and the intervention of Rumania forced her into the treaty of Bukarest (Aug. 10,1913 ) and a treaty with Turkey (Sept. 29, 1913). At Bulgaria's expense Rumania took a further strip of the Dobruja; Bulgaria expanded westwards by absorbing territory as far as Strumitsa, and southwards the seaboard from Kavalla to Enos, with the port of Dedeagatch and the Thracian hinterland; Greece took Epirus, Southern Macedonia almost to Monastir, and within a great curve thence to Kavalla, including Sal. onica, and lastly all the islands of the Aegean save Imbros, Tenedos, and the Sporades; Serbia had Central Macedonia with such disputed towns as Monastir, Uskub, and Nish, and also the sanjak of Novi Bazar.

\section{The Great War and After}

The new situation was pregnant with trouble; with the Balkan entente dissipated; Bulgaria disgraced, resentful, coveting Central Macedonia and the Thracian har. bours, and driven into intrigue with Austria and Turkey; Greece coveting Bulgaria and Turkish Thrace, Albania, and Crete ; Serbia without a harbour and severed from the Slavs of Bosnia, Herzegovina, Croatia, and Carniola ; Montenegro lamenting Scutari; Italy intent upon Istria ; Russia determined to revenge Austrian treachery and regain her Balkan footing; while Germany, with her dream of a German Middle East, a corridor to Constantinople, a Berlin to Bagdad rly., and her economic exploitation of the Near East, encouraged mischief. The Eastern question, together with the Serajevo murders of June 28, 1914, produced the Great War.

The peace of Versailles, 1919, brought no peace to the Near East, nor is the Turk banished from Con- stantinople and Europe. A French mandate for Syria was opposed by the Arab Emir Feisul, who was depused from his kingdom of Damascus. Greece, firmly established in Crete, and mandatory for the western coast of Asia Minor, including Smyrna, 1919, was in 1920 fighting irreconcilable Turks under Mustapha Kemel. Granted Bulgarian Thrace from Kavalla to Enos, 1919, the Greeks claimed Turkish Thrace, 1920, and occupied Adrianople (July 25, 1920). Serbia, with Bosnia, Herzegovina, Croatia, and Carniola, formed a "Serb-CroatSlovene state," 1919 , and with Montenegro, a Yugo-Slav Confederation, 1920. Bulgaria, excluded from the Mediterranean, has a valueless coast-line on the Black Sea, and has lost large populations to Greece and Serbia. Austria and Russia are defunct as Balkan powers, Constantinople is the centre of an international zone including the Bosporus, the Sea of Marmora, and the Dardanelles. Rumania, besides the Bukowina and a huge slice of Hungarian Transyl. vania, occupies Russian Bessarabia.

Bibliography. The Balkans, W. Miller, repr. 1899: Modern Europe, W. A. Phillips, 1901 , etc.; Turkey and its People, E. Pears, 1911; History of Serbia, H. W. V. Temperley, 1917; Rise of Nationality in the Balkans, R. W. Seton Watson, 1917.

East Ham. Mun. bor. of Essex, England. It is a populous district, with stations on the London, Tilbury, and Southend and G.E. Rlys., $6 \mathrm{~m}$. E. of London. The residents are mainly of the industrial class, and work at the docks or in the many factories and workshops of the borough ; the industries include engineering works and the making of chemicals, soap, etc. There is an old church, the parish church of S. Mary Magdalene. The borough, which is outside the county of London, is governed by a mayor and corporation, having been made a municipality in 1904. It sends two members to Parliament. Pop. 156,500.

East India Company. Name of a trading corporation, authorised by government to trade in the $\mathrm{E}$. Indies. The Dutch company, 16021798, the French company, 16641794, and the Danish company, 1729-1801, followed the setting up of the English company, which survived them all. On Dec. 31, 1600, a charter was granted by Queen Elizabeth to "The company of Merchants of London trading to the East Indies." The establishment of three factories or trading-stations was sanctioned: at Surat, on the W. Coast, by the Mo. gul Jehan Gir in 1612; at Fort St. Goorge, afterwards Madras, on the 
S.E. coast, by another native prince in 1639 ; at Honghii, on the Ganges delta, 50 years later moved a little lower down the river to Calcutta, by Shah Jehan in 1640 .

In 1661 the Portuguese gave Bombay to Charles II as part of the dower of his bride; he conveyed it to the company, and it took the place of Surat as the western emporium. The three factories at Bomthe nuclei of the three presidencies.

The company was exclusively a trading concern. It had much difficulty in suppressing the embarrassing rivalry of independent traders called "Interlopers," who ignored its exclusive charter. In the reign of William III a rival company was actually sanctioned and started, but in 1701 the two were amalgamated as the Honourable East India Company. In 1746 Dupleix, the governor of the rival French company, attempted to oust the British and establish a French political ascendancy with the native princes. He was frustrated by Clive, with the general result that in come the official administrators of the great province of Bengal, while sundry of the great princes were virtually their dependents.

The home government now became alive to a responsibility for the dominions acquired by the company ; the unsuccessful experiment of Lord North's Regulating Act was followed by Pitt's India Act in 1784, which instituted the dual control shared between the com pany itself and a board of control appointed by a committee re. sponsible to Parliament. After the Mutiny of 1857 the government of India was transferred to the crown, and the East India Company was abolished by the India Act of 1858. See India.

Bibliography. Annals of the East bay, Madras, and Calcutta became 1765 the trading company had be-

India Company, 1600-1708, John Bruce, 1810 ; The Dawn of British Trade in the East Indies as re. corded in the Court Minutes of the East India Company, 1599-1603, ed. H. Stevens and G. Birdwood, 1886 ; Letters received by the East India Company from its Servants in the East, ed. F. C. Danvers and W. Foster, 1896, etc. ; A History of British India, W. W. Hunter, 1899-1900 ; The Trade of the East India Company from 1709-1813, F. P. Robinson, 1912 ; The Trade Re. lations Between England and India, 1600-1896, C. J. Hamilton, 1919.

East Indiaman. Name applied to the large sailing vessels employed in the East Indies trade. They were often armed for self-defence.

\section{East India United Service}

Club. London club founded in 1849 for those connected with the services, military and civil, in India. Its premises are at 16 , St. James's Square, London, S.W.

East Indies. Popular name loosely applied to India, IndoChina, the Malay Peninsula, the islands of the Malay Archipelago, Sumatra, Java, Borneo, New Guinea, the Philippines, etc. All are described under their respective headings.

The Dutch East Indies are possessions belonging to Holland. They lie between $6^{\circ} \mathrm{N}$. and $11^{\circ} \mathrm{S}$. latitude, and between $95^{\circ}$ and $141^{\circ} \mathrm{E}$. longitude. They include the islands of Sumatra, Java, Madura, Celebes, Billiton, Banca, Bali, Lombok, the Sunda Islands, the Molucca Islands, part of Timor archipelago, RiauLingga archipelago, and large portions of Borneo and New Guinea. The land area is approximately 735,000 sq. m., and the pop. $48,000,000$, with 81,000 Europeans. From 1602-1798 these possessions were governed by the Dutch East India Company, but are now administered by a governor-general, assisted by a council of five.

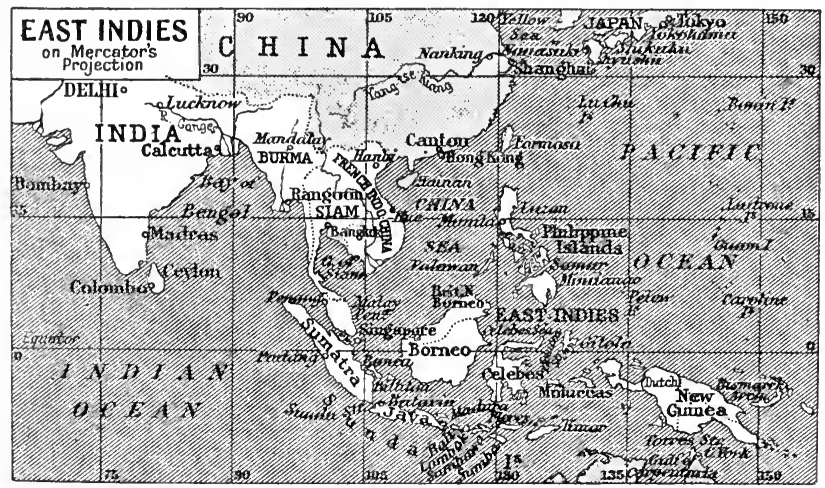

East Indies. Map of the East Indian islands, the land bridges between Asia and Australia
East Kent Regiment, THE. Regiment of the British army. Formerly the 3rd Foot, this regiment

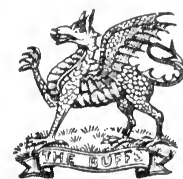

East Kent

Regiment badg had its origin in the train-bands of the city of London. Elizabeth sent a force of them to help the Duteh, which was known as the Holland regi ment. It was after its return to England that the regiment first received the designation of the Buffs, from the colour of its facings. It became a regiment of the British army in 1665. The East Kents fought in Flanders in 1692, and took part in Marl borough's campaigns, and in some of the battles of the Peninsular War Later the regiment was engaged in the Crimea, and in China, $\mathbf{1} 860$.

The regiment had a splendid record in the Great War. Of its two regular battalions, the ]st reached France in Sept., 1914, joining Pulteney's third corps. The 2nd, from India, joined the army in the field the following winter. A reserve (militia) battalion reached France in 1914. There were in all ten battalions, eight of which saw continuous active service. 'The regimental depot is at Canterbury.

Eastlake, Sir Charles Lock (1793-1865). British painter and writer on art. Born in Plymouth, Nov. 17,1793 ,

he was taught d rawing by SamProut and history painting by Benjamin Haydon, later attend. ing the schools of the Royal Academy. In 1827 he was electedA.R.A. and in 1829

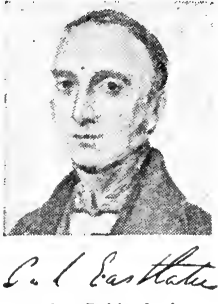

R.A., and in 1842 librarian to the Academy.

He was keeper of the Nasional Gallery from 1843-47, and in 1850 was chosen president of the Academy, and knighted. $\mathrm{He}$ was appointed the first director of the National Gallery in 1855. The Es. cape of Francesco Carrara, 1834; Christ Weeping over Jerusalem (his masterpiece), 1841; and Sisters, 1842, are in the 'Tate Gallery, London. His Materials for the History of Oil Painting, 1847, once enjoyed considerable vogue. $\mathrm{He}$ died at Pisa, Dec. 24, $1865 . \quad$ See Memoir by Lady Eastlake, 1870; Pictures by Sir C. Eastlake, with biographical and critical sketch, W. C. Monkhouse, 1875. 
East Lancashire Regiment. Formerly the 30 th and 59th Foot and one of several regiments raised

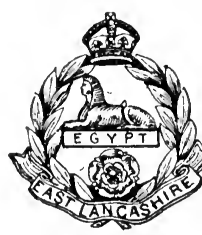

East Lancashire

Regiment badge in 1702 for ser. vice as marines on board ship. They took part in the capture of Gibraltar in 1704 and in the subsequent naval action off Malaga. In 1727 -28 they helped to defend Gibraltar, and in 1806 were in Sir David Baird's force which seized the Cape of Good Hope. In the Peninsular War the East Lancashires fought at Corunna, Badajoz, Salamanca, and Vittoria; they were at Waterloo and took part in the Mahratta War (1817-19). In 1825 the regiment distinguished itself at the capture of Bhurtpore, as it did later at Inkerman; it shared in the storming of Canton (1857), the second Afghan War, and the Chitral expedition. It did excellent service in the South African War.

During the Great War the lst battalion beat back a strong German attack in the first battle of Ypres, 1914, and the 2nd participated in the British attack on the Aubers Ridge, 1915. The 11th distinguished itself at the battle of the Somme, 1916, and men of the East Lancashires took part in the third battle of Ypres, 1917. Two battalions formed part of the East Lancashire Territorials mobilised in Aug., 1914, as the 42nd division. The latter fought in Gallipoli and in the early stages of the Sinai desert campaign, and proceeded to France in March, 1917. The regimental depot is at Preston.

Eastleigh. Urb. dist. (Eastleigh and Bishopstoke) of Hampshire, England. It is $5 \frac{1}{2} \mathrm{~m}$. N.E. of Southampton on the L. \& S.W.R., which has works here for the manufacture of rolling stock. A great aerodrome situated between Eastleigh and Swaythling on the main L. \& S.W.R. was begun some time before the armistice, Nov., 1918 , but was never used by the R.A.F. It was taken over by the American naval air service, but it was never put to any real use as a flying station. The civil aviation department controlled it for a time, but it was later allowed to remain derelict. Pop. 15,247.

East Liverpool. City of Ohio, U.S.A., in Columbiana co. It stands on the Ohio river, $44 \mathrm{~m}$. W.N.W. of Pittsburg by the Pennsylvania Rly. The staple industry is porcelain manufacture, the city being the chief pottery centre of the country. Yellow ware was first made here in 1839, white ware being introduced in 1872 . Bricks, steel, and machinery are also manufactured. Settled in 1796, East Liverpool was incorporated in 1834. Pop. 22,940.

East London. City and seaport of Cape Province, S. Africa. It stands at the mouth of the Buffalo river, mainly on the $\mathrm{E}$. side, 887 m. by rly. from Cape Town. It has a spacious harbour, and by dredging

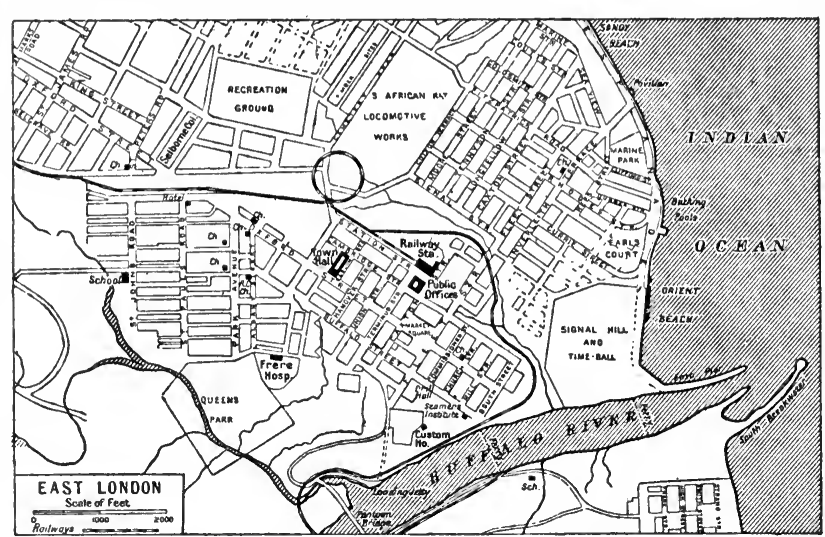

East London. Plan of the $\mathbf{S}$. African seaport and watering-place, at the mouth i of the Buffalo river

operations the great obstacle to its development, the bar at the river mouth, has been in large part overcome. There are ample wharves and other shipping accommodation. The city is a rly. terminus.

Apart from the shipping the chief industries are connected with the trade of a large district. It has also some fishing. The chief buildings are the city hall and the public offices. The city is lit by electricity and has a service of electric tramways. It is also a watering-place, with good facilities for sea-bathing, and there is ample accommodation for visitors, including a space prepared for tents. Pop. 20,867.
East Lynne.- Novel by Mrs. Henry Wood (q.v.), published in 1861. It achieved an enormous contemporary success, was trans. lated into all European and some Oriental languages, and is still very widely read, while several dramatic versions have enjoyed almost equal popularity. The chief interest of the book-an interest which is intensified in the plays founded upon it-lies in the situation which Isabel returns to her home and children disguised as a nurse. East Lynne has little literary merit, but the plot is well constructed and the reader's interest continuously sustained.

Eastman, George (b. 1854). American inventor. He was born at Waterville, N.Y., July 12, 1854 , and educated at Rochester, N.Y. He experimented in the making of dry plates, and in 1880 began to manufacture them; four years later he produced the first efficient roll-film, and in 1888 perfected his first Kodak camera. Two years later he patented the first machine

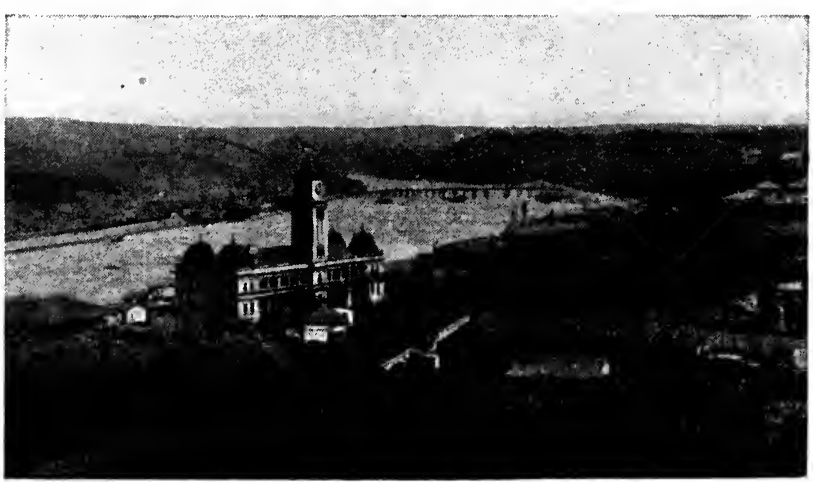

East London, South Africa. View of the town and the Buffalo river 
for making rolls of transparent film. As head of the various Kodak companies he amassed great wealth. He endowed the Rochester Mechanics' Institute and the laboratories of the university of Rochester, and in 1912 gave $£ 100,000$ towards the endowment of that university.

Easton. City of Pennsylvania, U.S.A., the co. seat of Northampton co. It stands at the union of the Lehigh and Delaware rivers, $76 \mathrm{~m}$. W.S.W. of New York on the Pennsylvania and other rlys. Near the coalfield, it is a busy rly. and industrial centre, with manufactures of silk, textiles, woollens, pumps, drills, stoves, and organs. The seat of Lafayette College, founded 1832, it has a number of schools and a public library. Several treaties with the Indians were concluded here between 1756 and 1761. Founded 1750, it was incorporated in 1789 , and became a city in 1887. Pop. 32,000 .

Easton's Syrup. Syrup of iron phosphate with quinine and strychnine. Each fluid dram contains $\frac{1}{3 \frac{1}{2}}$ of a grain of strychnine. It is used as a tonic in cases of anaemia and general debility in doses of $\frac{1}{2}$ to 1 fluid dram. It is also prepared in the form of sugar-coated tablets.

East River. Channel com. municating between Long and Manhattan Islands, U.S.A. On the $\mathrm{N}$. it is connected by the Harlem river with the Hudson river. Its length is $15 \mathrm{~m}$. and its breadth varies from $\frac{1}{2} \mathrm{~m}$. to between $3 \mathrm{~m}$. and $4 \mathrm{~m}$. Four great suspension bridges and numerous ferries connect New York proper with its Long Island suburbs. See illus. facing p. 1374.

East Surrey Regiment. Raised in 1702 , this regiment served until 1713 as marines at Gibraltar and

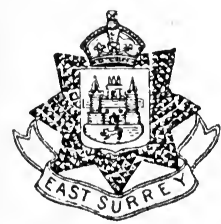
elsewhere. It then became the 31st Foot, and fought at Dettingen, where George II gave the men their nickname of East Surrey Regi- the "Young ment badge

Buffs." In 1756 a second battalion was raised; this was numbered the 70 th, and the two were united as the East Surreys in 1881. The regiment fought in America in 177677 and in the W. Indies in 179396. It rendered excellent service in the Peninsular War, especially at Talavera and Albuera. In 1842 it marched to Kabul and spent nearly two years fighting in Afghanistan; in 1845-46 it served against the Sikhs, and later in the Crimean War, the China War
(1860), the New Zealand War (1863), and the Egyptian War (1884-85). Under Buller in the S. African War the regiment fought hard to relieve Ladysmith.

In the Great War the lst bat. talion fought with the 5th division in 1914, and distinguished itself at Mons, Le Cateau, at the battle of the Marne, and at La Bassée. It also did fine service at Hill 60 . The East Surreys were notable for the charge they made on the opening day of the battle of the Somme, July 1,1916 . The 9 th battalion lost heavily in the preliminary assault on Guillemont, Aug. 16, 1916, and parties of the 13th distinguished themselves at the first battle of Cambrai, Nov., 1917. Men of the East Surreys were heavily engaged in the third battle of Ypres, 1917, and participated in most of the battles of 1918. The regimental depot is at Kingston-on-Thames.

Eastward Position. Term applied to several observances of the Christian Church, especially to the position taken up by the officiating priest at the celebration of the Holy Eucharist and the practice of turning to the E. at the recitation of the creeds. The position of the priest has been the subject of much controversy in the Anglican Church, consequent on the conflict between the rubric of 1552 and the replacing of the altar in 1660 .

In the primitive Church converts at baptism turned to the W. when renouncing the devil and to the E. when confessing their faith in Christ. Thus Augustine says, "When we rise for prayer we turn towards the East." Chancels of churches are usually in the E., so that worshippers, when turning towards the altar, face the E. Similarly arose the custom of burying Christians with the feet towards the E. and the face upward, so that at the Resurrection they might be ready to meet Christ and be in a posture of prayer as soon as raised. Pagans commonly worshipped with their faces towards the rising sun, and the Christian adoption of the custom gave rise to the charge that they were sunworshippers (Tertullian). The Jews in exile turned towards Jerusalem when they prayed (Dan. 6 ) and Mahomedans face Mecca. See Oxford Movement.

Eastwood. Urban dist. of Nottinghamshire, England. It is $9 \mathrm{~m}$. N.W. of Nottingham by the G.N.R. Collieries provide the chief employment. Here took place the meeting of colliery owners which marked the first step in rly. construction from which the M.R. was developed. Market days, Fri. and Sat. Pop. 4,692.
Eastwood. Parish of Renfrewshire, Scotland. It contains the towns of Pollokshaws and Thorn liebank, and part of Shawlands, forming an outlying suburb of Glasgow. Pop. 24,515.

East Yorkshire Regiment. Formerly the 15th Foot, this regiment was raised in 1685 at the time

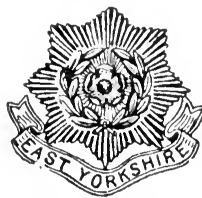

East Yorkshire Regiment badge of Monmouth's rebellion. After serving in Flan. ders (1694-97), it was engaged in Marlbor ough ${ }^{2} \mathrm{~s}$ campaigns, and was one of the regiments that led the attack at Blenheim. In 1758-59 it served under Wolfe in the captures of Louisburg and Quebec. The East Yorkshires did good work in seizing the West Indian Islands from the French both before and after they served against the American Colonists. They fought in the Afghan War of 1879-80, and one battalion was in the 8th Division during the South African War.

In the Great War the first battalion won distinction in the battle of the Aisne, 1914. The East Yorkshires were very hard hit by the German gas attack at Frezenberg, May, 1915; the 12th and 13th battalions showed remarkable skill and courage on the Ancre, Nov., 1916. Men of this regiment fought at the third battle of Ypres, 1917, and in the subsequent campaigns on the western front. The regimental depot is at Beverley.

Eating House. Obsolete term for what is now generally known as a restaurant. It has passed, with cook-house, coffee-house, and dining-house, out of ordinary usage, and is now only used colloquially, or applied to the humbler places of refreshment. See Coffee House.

Eaton, Sir John Craig (18761922). Canadian merchant. $\mathrm{He}$ was born at Toronto, April 28 , 1876 , and was educated at Toronto public schools and Upper Canada College. He became president of the great trading firm of Timothy Eaton Co., of Toronto and Winnipeg, founded by his father. Knighted in 1915, he died March 30, 1922 .

Eaton Hall. Seat of the duke of Westminster, Cheshire, England. It stands on the river Dee, $4 \frac{1}{2} \mathrm{~m}$. S. of Chester. A magnificent Gothic structure, built 1867-80, the fourth on the same site, it stands in a well-timbered demesne of 400 acres. The interior is richly decorated, and besides examples of Rubens, West, and Millais, the pictures include a fine collection of portraits of famous 


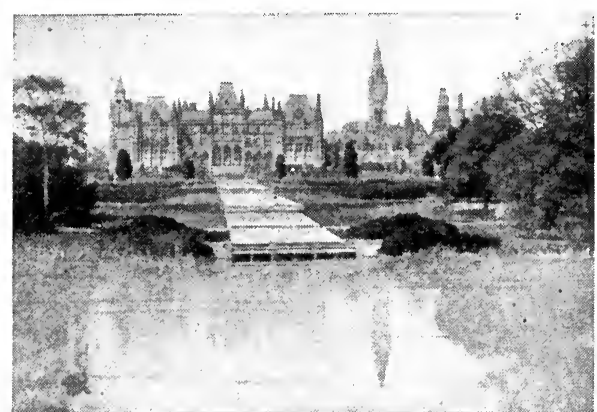

Eaton Hail. View from the gardens of the Cheshire seat of the Duke of Westminster

racehorses owned at various times by members of the family. The western portion of the Eaton estate was sold for $£ 330,000$ in 1919 .

Eaton Square. Largest square in Belgravia (q.v.), London, S.W. Covering about 5 acres, it has six gardens, is named from the duke of Westminster's Cheshire seat, Eaton Hall (q.v.), and was built 1827-53. At the $\mathrm{E}$. end is the church of S. Peter, 1824-26, restored 1872, where many fashionable marriages have taken place. No. $71 \mathrm{was}$, for a time, the official residence of the Speaker of the House of Commons.

Eau Claire. City of Wisconsin, U.S.A., the co. seat of Eau Claire co. At the confluence of the Eau Claire and Chippewa rivers, $88 \mathrm{~m}$. E. of St. Paul, it is served by the Chicago, Milwaukee and St. Paul, and other rlys. Its buildings include a Carnegie library, the county court, schools, and a sanatorium, and it has several parks. A busy lumber centre, it contains foundries, iron and steel works, paper mills, and canneries. Settled in 1846, it was granted a city charter in 1872. Pop. 18,875.

Eaucourt L'Abbaye. Village of France, in the dept. of Somme. It lies slightly $\mathrm{S}$. of the AlbertBapaume road, about $1 \mathrm{~m}$. S. of Le Sars. Captured by the British Oct. 1,1916 , it was retaken by the Germans in March, 1918, and recovered by the Allies in Aug., 1918. See Somme, Battles of the.

Eau-de-Cologne. Perfume said to have been invented by an Italian chemist, Johann Maria Farina, who settled in Cologne in 1709 . It is believed that the original recipe has never been discovered, though many chemists in Cologne, using the name of Farina, claim to be the sole owners of it. The perfume is prepared from alcoholic vegetable extracts, essential oils, and rectified spirits. The usual recipe prescribes twelve drops of each of the essential oils, bergamot, citron, neroli, orange, and rosemary, with one dram of Malabar cardamoms and a gallon of rectified spirits, which a re distilled to. gether. Ea u-deCologne is largely made in Great Britain, where the oils are mixed with a highly purified spirit, and distillation is unnecessary.

Eau-de - Javel. Bleaching liquid first made in 1789 at the Javel Chemical Works, Paris. It was the first practical means of utilising the bleaching properties of chlorine. Eau-deJavel, prepared by passing chlorine gas into a solution of potash, was also employed as a disinfectant. Shortly afterwards CharlesTennant, of Glasgow, prepared bleaching powder by passing chlorine gas over quicklime, and Labarraque, a French chemist, made a better bleaching liquid, eau - de - Labarraque, which is a solution of sodium hypochlorite made from sodium carbonate and calcium hypochlorite.

Eau-de-vie (water of life). Old French name for brandy. The product of a distilled winc was so called in the 13th and 14th centuries, and the name is still used. The eaux-de-vie de marc are distilled from wine lees or from the residue in the stills after the best brandy has been made. See Brandy; Fire-Water.

Eaux-Bonnes. Watering-place of France. In the dept. of BassesPyrénées, it is $28 \mathrm{~m}$. S. of Pau. It stands 2,460 ft. high, just where two streams, coming down from the Pyrenees-the Sourde and the Valentin-meet, and is named on account of its waters. These have been known since the 14th century, and are good for lung and other bodily troubles. Winter sports are held and the place has several hotels. Pop. 622.

Eaux-Chaudes. Watering-place of France. In the dept. of BassesPyrénées, it is $5 \mathrm{~m}$. from EauxBonnes, standing where a stream, the Gave d'Ossau, comes down from the Pyrenees, its valley being one of the most beautiful in the neighbourhood. The town has hot springs-hence its name-which, being sulphurous, are good for rheumatism, affections of the respiratory organs, etc.

Ebbsfleet. Coast hamlet of Kent, England. It stands on Pegwell Bay, $3 \frac{1}{2}$ m. S.W. of Ramsgate, and is the traditional landing point of Hengist and Horsa in 449-450, and also the place at which $\mathrm{S}$. Augustine and his forty monks disembarked in 597 .

Ebbw Vale. Urban dist. of Mon. mouthshire, England. It stands on the Ebbwfawr, a headstream of the Ebbw river, $21 \mathrm{~m}$. N.W. of Newport, on the G.W., L. \& N.W., and Rhymney Rlys. In a busy colliery district, it has large ironworks, iron and steel being here manufactured on a large scale and the coal exported. Christ Church, a modern building in the Early English style, is the chief building. Market day, Sat. Pop. 30,541. Pron. Ebboo.

Eben, Max von. German soldier. $\mathrm{He}$ commanded the 2nd Baden dragoon regiment previous to the Great War. In Sept., 1914, he was appointed to command the 10 th reserve army corps, and in 1916 had command of the Bavarian regiment on the Russian front. He had charge of an army in the German thrust for Paris, July, 15, 1918. See Marne, Second Battle of the.

Ebenaceae. Natural order of trees and shrubs: the ebony family. They have alternate, undivided leaves, and regular flowers, succeeded by berries. They are chiefly natives of tropical countries. The timber is hard and darkcoloured. See Ebony.

Ebenezer (Hebr., stone of help). Name of an unidentified spot where the Hebrews were defeated by the Philistines (1 Sam. 7); also that of a stone set up by Samuel near Mizpah in memory of an Israelitish victory over the Philistines (1 Sam. 4). It is used as a Christian name.

Eberhard (1445-96). Duke of Württemberg. Born Dec. 11, 1445, a member of the ruling family of Württemberg, he became count of one part of it in 1457 . In 1482 he secured the rest of the country, and in 1495 was raised to the rank of a duke. By uniting Württemberg and by obtaining support for certain changes, both from the emperor without and from his own nobles within, he is re. garded as the founder of the country. One who shared in the intel. lectual awakening of his time, he founded the university of Tübingen and encouraged scholars. His wife, Barbara, one of the Gonzaga family, shared his tastes. Eberhard, who was known as the Bearded (im Bart), died Feb. 25, 1496, at Tübingen, where he is buried.

Ebers, Georg Moritz (183798). German Egyptologist and novelist. Born March 1, 1837, at Berlin, he studied at Göttingen and Berlin, and early specialised in Egyptology. To popularise his 
favouritestudy through themedium of fiction, he wrote An Egyptian Princess, 1864, Eng. trans. 1870-71. In 1865 he became lecturer and later prof e s s or i n Egyptology at Jena.

After his first travels in Egypt, Ebers wrote Egypt and the Book of Moses, 1868.

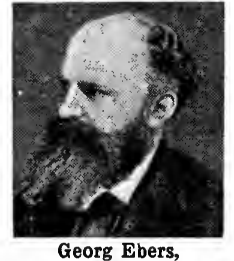
German Egyptologist

$\mathrm{He}$ was appointed professor of Egyptology at Leipzig, 1870, a post which he resigned in 1889 He revisited Egypt in 1872-73, and discovered at Thebes one of the finest examples of ancient papyri-Papyrus Ebers, now in the Leipzig Museum. This is a medical treatise from Sais of the 16th century B.C., and includes a long chapter on the eye, an extraordinary coincidence, since nearly ten years before Ebers had written in An Egyptian Princess of such a MS. and its fortunes. In addition to many novels based on Egyptian history, he wrote historical novels descriptive of South Germany and the Netherlands in the 16th century. He died at Tutzing, Aug. 7, 1898. See Autobiography, Eng. trans. M. J. Safford, 1893.

Eberswalde. Town of Prussia. It is $28 \mathrm{~m}$. N.E. of Berlin, with which it is connected by rly. and also by canal. The chief buildings are churches and schools, one of the forner being a 14th century building, while the latter include a school of forestry. It has several industries, including the making of paper, bricks, nails, and brass founding. Pop. 26,100.

Ebert, Friedrich (1870-1925). German statesman Born at Heidelberg, and educated at an

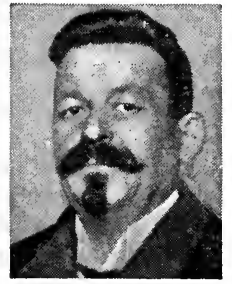

Friedrich Ebert, German statesman elementary school, he was apprenticed to a saddler of that town. In 1892 he became editor of the socialist organ, Bremer $\mathrm{B} \ddot{\mathrm{u}} \mathrm{rg}$ er z e i. tung, and in 1894 married Louise Kamp, who, he said, proved his best counsellor through. out his career. In the Revolution of 1918 he succeeded Prince Max of Baden as chancellor on Nov. 9, and then became provisional president of Germany. He maintained his position through the stormy days of Jan., 1919, and at the opening of the new National Assembly at
Weimar, Feb. 6, 1919, he made a long protest against the armistice terms, and urged the union of German-Austria with Germany. On Feb. 11 Ebert was elected first socialist pressdent of the German republic. He died Feb. 28, 1925 See Germany.

Ebionites (Hebr. ebyōn, poor) Name given to certain Judaising sects in the Christian Church in the second century. Denying the divinity of Christ, they regarded Christianity as merely a reformed type of the Jewish religion, and Christ as only a natural man of exceptional spiritual attainments acquired by a strict observance of the law of Moses. References in the writings of Irenaeus and other Fathers state that the Ebionites observed all the details of the Mosaic Law, recognized only the Gospel of S. Matthew, and rejected S. Paul as an apostate. At a later period the Ebionites largely held the Gnostic heresy of the dualistic origin of the universe.

Eblis or IBLIS. A Mahomedan name for Satan or the prince of darkness. In the Koran it is stated that God, having made Adam, called upon the angels to bow down and worship him; all did so except Eblis, who refused, and became the declared enemy of the newly created race of men. Eblis is also described as chief of the genii.

Ebner-Eschenbach, Baronkss MARIE von (1830-1916). Austrian dramatist, novelist, and poet. She was born Sept. 13, 1830, in Moravia, the daughter of Count Dubsky, and married an Austrian officer, Moritz von Ebner-Eschenbach, who afterwards became fieldmarshal. She published several plays, including Maria Stuart in Schottland (1860), and then turned to fiction. Her first tale, Die Prinzessin von Banalien, appeared in 1872 ; and Zwei Komtessen (1885) became widely popular. Parabeln Märchen und Gedichte appeared in 1892. The author takes a leading place among modern German women writers.

Eboli (anc. Eburum). Town of Italy, in the prov. of Salerno. It occupies an elevated position, alt. $470 \mathrm{ft}$., overlooking the Sele river, $16 \mathrm{~m}$. by rly. S.E. of Salerno. It contains an old château of the prince of Angri, a church with 14th century paintings, and a few remains of Eburum, the old Lucanian city. Pop. 12,741.

kabonite or Vulcanite. Hard vulcanised rubber made by mixing pure rubber with about onethird of its weight of sulphur, and heating for a number of hours in temperature rising to $300^{\circ} \mathrm{F}$. Ebonite is largely used as a sub. stitute for bone, ivory, and horn, for making small ornamenta articles, as combs, knife handles, buttons, etc. It can be moulded, cut, carved, and polished to a high degree of perfection. See Rubber.

Ebony (Diospyros). Trees of the natural oider Ebenaceae, whose heart-wood is the ebony of commerce. Several species furnish the timber, the differencc being denoted by the place of origin. Mauritius ebony is the produce of D. ebenum; Coromandel ebony

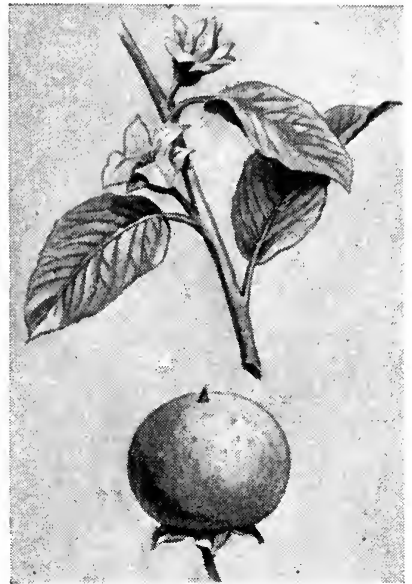

Ebony. Fruit and leaf of Persimmon (Diospyros Virginiana), one of the Ebonies

of $D$. melanoxyion; and the bastard ebony of Ceylon is obtained from $D$. ebenaster. Calamander-wood, a variegated ebony, is the timber of $D$. hirsuta from India and Ceylon. Some of the species have edible fruits. See Date-plum : Persimmon.

Ebor. Abbreviation of Eboracum, the Latin name for York. It is still used as a signature by the archbishop of York, e.g. Cosmo Ebor. See York.

Ebro (anc. Ibèrus). River of N.E. Spain. Rising in the Cantabrian Mts., in the prov. of Santander, it flows S.E. to the Medi. terranean. Its length is about 460 m., and it drains some $35,000 \mathrm{sq} . \mathrm{m}$. Its chief affluents are the Jalon, Huerva, Guadalope, Aragon, Gallego, and Segre. Running through narrow valleys, its channel is obstructed by shoals and rapids. Ships can proceed only as far as Tortosa (16 m.).

Eburacum or EBoracuM. Ro. man town on the site of which the city of York, England, now stands. Erected by the Ninth legion on an earlier Caer Evrauc about A.D. 75, the fort of 52 acres-still traceable in the lower courses of the multangular tower-was garrisoned by 
the Sixth legion. A municipal colonia flourished on the opposite bank of the Ouse. Here in 120 Hadrian held court, here also died Severus in 211, and Constantius Chlorus in 306. Pron. Eburācum. See York.

E.C. Abbrev. for East Central postal district, London.

Eça de Queiroz, Josf́ Marla (1845-1900). Portuguese author. Born at Povoa do Varzim, N. of Oporto, and educated at Coimbra

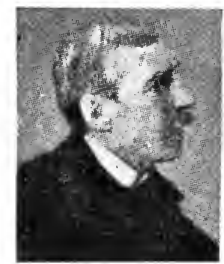
university, he began life as a journalist, and in 1871 was on the staff of the critical journal As Farpas. Three years later he pub. lished a novel wh ich at. tracted a good deal of atten.

J. M. Eça de Queiroz Portuguese author tion, O Crime do Padre Amaro. he was Portuguese consul successively at Havana, Newcastle, Bristol, and Paris. His later storics included O Primo Bazilio, 1877 (Eng. trans. Dragon's Teeth, 1889) and A Reliquia, 1886. The posthumous collection of Contos, 1902 , contained the famous stories, $O$ Defunto and $O$ suave milagre, respectively translated into English as Our Lady of the Pillar and The Sweet Miracle.

Écarté (Fr., discarded). A card game for two players which had a great vogue in France at the beginning of the 19th century. The six down to the two inclusive of each suit having been removed from the pack, the players cut for deal, and the pack is shuffled by the dealer, and cut by his opponent. The dealer then gives five cards to the other player and to himself : either three and two or two and three alternately. The eleventh card is turned up for trumps, the remainder of the pack forming the stock. Should the eleventh card be a king the dealer scores one point; otherwise the turn-up has no scoring value.

The players then look at their hands, and should the non-dealer (the leader) be satisfied with his cards, he may at once proceed to play them. But if he considers it would be advantageous to change any or all of them, he says, "I propose" or "Cards." The dealer then has the option of changing his cards also, and on deciding to do so says, "I accept" or "How many ?" Should he be satisfied with his cards, he may rofuse, and exclaim "I refuse" or "Play." If either player refuse to change cards, then both must play their original hands Otherwise the discarding of cards for others in the stock may proceed so long as both are agreeable. The players being satisfied with their hands; the play begins. If either holds the king of trumps he must declare it before playing his first card, and is entitled to mark one point.

The object of the game is to make tricks; the highest card of a suit wins, though a trump naturally scores over that of another suit. A player must always take a trick if able to do so. The cards rank in this order : King, queen, knave ace, ten down to seven. The winner of a trick always leads to the next. The score is made as follows: Turning up or holding the king of trumps counts 1 ; winning three tricks out of five is called the point and also counts 1 ; winning all five tricks is termed the vole and counts 2. If either player fail to make three tricks after having de. clined cards, his adversary scores 2 . A game consists of 5 points. See The Standard Hoyle, 1887 ; Foster's Complete Hoyle, 1897.

Ecbatana. Capital of Media. The Hebrew form Achmetha (Ezra 6 ) survives in the modern Hamadan. Situate $5,930 \mathrm{ft}$. above sealevel, near M.t. Elwend, it was the suinmer residence of the old Persian and Parthian kings. Its identification with the seven-storeyed fortress described by Herodotus as built by Deioces ( 700 B.C.) is in doubt. The so-called Syrian Ecbatana was at Hamath.

Ecca Shales. Strata found in the S. of Cape Colony. They often show sun-cracks and ripple-marks, formed soon after they were laid down, in Permian times. Minor beds of sandstone occur, and fossil plants belonging to the Glossopteris Flora are found in the series.

Ecce Homo (Lat., Behold the Man). Short title of a survey of the life and work of Jesus Christ by Sir J. R. Seeley. It was published anonymously in 1866, and caused a storm of criticism. It attempted to present Christ as an exclusively human personality, the founder of a new system of society.

Eccentric (Gr. ekkentros, out of the centre). In engineering a metal disk mounted eccentrically on a shaft, to give reciprocating movenent to a valve or pump or lever. The edge of the eccentric is grooved and encircled by an eccentric strap, one half of which is secured rigidly to the front end of a connecting rod. In effect an eccentric is a cam: or it may be regarded as a crank having a pin larger than the shaft. See Steam Engine.
Ecchymosis (Gr. ek, out of ; chymos, juice). Outpouring of the blood into the tissues beneath the skin. Sce Bruise.

Ecclefechan. Village of Dum. triesshire, Scotland. It is $6 \mathrm{~m} . \mathrm{S}$. E. of Lockerbie by the C.R., and has been identified as the original of Entepfühl in Sartor Resartus It was the birthplace and burial place of Carlyle (q.v.). Near by are the Roman camps of Birrens and Birrenswark. Pop. 670. See illus. p. 1709.

Eccles. Mun. bor. of Lancashire, England. It stands on the Irwell, $4 \mathrm{~m}$. W. of Manchester, of which it is an industrial suburb. and is served by the L. \& N.W.R. Locally famous for its Eccles cakes, the town is actively engaged in the cotton and other textile industries.

\section{Pop. 41,944 See Manchester.}

Ecclesfield. Parish of W.R Yorkshire, England. It is $5 \mathrm{~m}$. N. of Sheffield, on the Mid. and G.C Rys. The church of S. Mary, a Perpendicular edifice formerly desig. nated the Minster of the Moors, contains some fine oak carving. There are large cutlery and tool works, paper mills, iron works, and collieries. Pop. 22,404.

Ecclesia (Gr. ekkalein, to call torth). In ancient Athens, the as sembly of the whole body of free citizens. The meetings were held in the Pnyx and latterly in the theatre; on special occasions they were held in the agora. In theory the ecclesia was the supreme power in the state, and any citizen had the right to speak; but in practice its power was virtually confined to the business which had been prepared for it by the boule, or council of 500 . Voting was by show of hands, and on special occasions by ballot. In addition to some 40 regular meetings a year, the ecclesia could also be convoked for special business by a chief magistrate. The Greek name ecclesia (Fr. église) came to be applied in Christian times both to the assembly of Christians and to the place of assembly. See Cathedral ; Church.

Ecclesiastes. Title adopted, through the Vulgate, from the Septuagint, for the O.T. book which in Hebrew bears the title Kōheleth. The meaning of the Hebrew term is disputed, but may be "one who

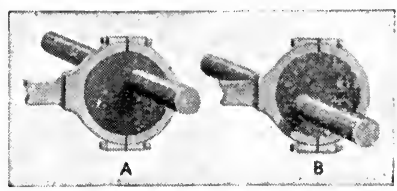

Eccentric. Metal disk on a shaft fixed out of centre. A and $B$ show two positions of this moving shaft 
speaks in an assembly" (hence Jerome's rendering concionator and the English translation "the Preacher"). In $\mathrm{i}, 1,12$ the writer seems to be identified with King Solomon, to whom tradition ascribed the authorship. But the language of the book, which contains Persian and possibly Greek words, and represents a transitional stage in the development of Mishnic Hebrew, is that of an age much later than Solomon's. The book cannot, however, be later than Ecclesiasticus (c. 200 B.c.), which presupposes its existence. It presents a strange mingling of despair and pessimism ("Vanity of vanities, all is vanity") with an irresistible sense of the goodness of God. Thus the writer's utterances often seem contradictory.

The true explanation seems to be that the book is a series of reflections representing two or more moods, or in other words is the record of the negative and positive phases in a soul's struggle for light. Hence, probably under Greek influence, a philosophic materialism and epicureanism; under the in. fluence of national subjection, a general despondency; and yet, under the influence of an innate religious trend, an unquenchable faith in a divine dispensation. The materialistic element will account for the hesitation with which the book was admitted into the $\mathrm{He}$. brew Canon. The writer in one mood sees little profit or progress in life; the same happenings recur perpetually ( $c f$. Nietzsche's philosophy). The best course in life seems to be to eat and drink and enjoy things as much as possible. But in another and wiser mood it is realized that true happiness is dependent upon fear of God and obedience to $\mathrm{His}$ commandments (xii, 13). See Proverbs, Ecclesiastes and Song of Songs, ed. G. Currie Martin, 1908 (in the Century Bible).

\section{Ecclesiastical Commission.} Body constituted in 1836 to man. age the extensive estates of the Church of England. Under its direction the large incomes of certain bishops and other dignitaries were gradually reduced to a more uniform scale, and the surplus was devoted to the endowment of poor parishes.

The commissioners are the two archbishops, the English diocesan bishops, 5 cabinet ministers, 4 judges, and 12 others, but in reality the work is directed by the three principal commissioners, one of whom is usually a member of the House of Commons. In certain cases, in 1836, the dean and chapter refused to hand over the cathedral estates to the commis.

sioners, and several such incomes were reduced owing to agricultural depression. Those which took the other course receive a fixed income whatever the rent-roll of the surrendered estates may be. The Commission deals with an annual income of nearly $£ 2,000,000$, and after paying the various stipends it usually sets aside some $£ 400,000$ a year for increasing the endow. ment of poor livings and providing something for new ones. The offices are in Millbank, Westminster, S.W. See The Ecclesiastical Commission: sketch of its history and work, I. T. Dibdin and S. E. Downing, 1919.

Ecclesiastical Courts. Courts of law that deal with offences against ecclesiastical law, i.e. cases affecting benefices and the like. Such are in their nature confined to an established church, or to one that, although no longer a state church, was so formerly, and retains part of its old organization. The courts held by the pope and by the various prelates of the Roman Catholic Church are ecclesiastical courts. (See Curia.)

In England clerics are now for practical purposes on the same footing before the law as laymen. Formerly this was not so, and the church courts dealt with all kinds of offences committed by clergymen as well as with all cases affecting marriage (divorce, etc.), and wills-two subjects which the church regarded as peculiarly its own. The process of reducing the powers of the ecclesiastical courts

\section{ECCLESIASTICAL LAW IN ENGLAND}

Farold Hardy, Barrister-at-Law, Author of The Benefices Act, etc.

This article deals with Ecclesiastical Law, the main branch of which is that under which the Church of England lives and works. Another aspect of the same subject is dealt with under Canon Law. See also Church of England

Ecclesiastical law may include all laws affecting any church or religious society ; or, it may be restricted to the law which regulates a particular church controlled by the state, as, for instance, the established church of Scotland. In this article, however, ecclesiastical law means the law relating to the Church of England as administered in the courts of the country, including the common law based upon custom, the canon law, and statute law.

Ecclesiastical law relates to the officers, who are the archbishops, bishops and clergy, and the laity, who are persons not in Holy Orders; the government and discipline; the faith, form of worship, rites and ceremonics; thefabric of the church vicarage house and buildings, and other forms of church property.
Ecclesiastical law is administered in the civil courts, and in the ecclesiastical courts which have both civil and criminal jurisdiction. It includes part of what is called the common law of England, based on custom; it also comprises a considerable body of statute law; while the canon law is binding upon the officers of the church and to some extent upon the laity. The chief officers of the church are the two archbishops, who exercise jurisdiction in their respective provinces of Canterbury and York. Each province is divided into dioceses, presided over by a bishop, who has an ecclesiastical court where cases, generally relating to church property, are tried before his law officer, the chancellor.

Archbishops and bishops are appointed by the crown, and are 
consecrated. An archbishop is en. throned, whereas a bishop is in. stalled. A bishop is in legal docu. ments often styled the ordinary, because he is the judge in ecclesiastical cases, having ordinary jurisdiction in his own right, and not by way of delegation or as deputy. In England the bishops of London, Durham, and Winchester have seats in the House of Lords, together with twenty-one other bishops, who are summoned in order of seniority.

The other orders of the clergy are priests and deacons, who are ordained by a bishop and receive a certificate called letters of orders. Only a priest can have a cure of souls, which is committed to the incumbent of the parish. The appointment of the incumbent, who is called the vicar or rector as the case may be, is by the presentation of the patron of the living; followed by institution, by which the bishop entrusts him with the spiritual care of the parish ; and induction, which invests him with the emoluments of the benefice. After institution, the incumbent can officiate in any consecrated building in the parish, and no other elergyman may do so without his consent, except under certain statutory provisions. An incumbent is like a tenant for life in respect of the property belonging to the benefice.

\section{Rights of Incumbents}

He may cut timber for repairs, grant leases of, or sell, the glebe under certain conditions. He is liable for dilapidations of the vicarage house and buildings. $\mathrm{He}$ has possession and a limited ownership of the church and churchyard, but in many parishes a lay rector has certain proprietary rights in the chancel. He is entitled to the custody of the keys of the church, the registers of baptisms, marriages and burials, and has a general control over the organist and choir, the sexton and the bellringers. He appoints the curate, and by custom chooses one of the churchwardens, the other being elected by the par. ishioners at the Easter vestry. As a rule no one can be ordained priest until he has served as a deacon for the period of a year. The functions of a deacon are, generally speaking, the same as those of a priest, but he cannot have a cure of souls, nor may he consecrate or administer the Holy Communion. He may conduct morning and evening prayer, the services of baptism and of burial, and assist at the service of Holy Communion. He may also preach. And, if required, he may solemnise a marriage, though it is more regular for a priest to do so. No one can be ordained deacon under the age of twenty-three, unless he has special permission from the archbishop of Canterbury.

The vestry is the council of the parish that deals with ecclesiastical matters. The right to attend and vote at a vestry meeting belongs to every parishioner of either sex whose name is registered in the rate book. The incumbent, or the clergyman acting for the incumbent, is the chairman of a vestry meeting, and he has a casting vote, if the votes are equal. The church. wardens are appointed annually at a meeting of the vestry, generally in Easter week.

\section{Duties of Churchwardens}

In an ancient parish, churchwardens must be resident in the parish. In the statutory parishes, the churchwardens are required to be "fit and proper persons," and must be members of the Church of England. The general duties of the churchwardens are the custody and care of the church property in the parish. Collections made in church "for church purposes" are under their control, but the offertories at Holy Communion are to be disposed of "to such pious and charitable uses as the minister and churchwardens shall think fit " ; in case of disagreement, the bishop decides. They must provide the necessaries for divine service, maintain order during its performance, and see that the church and churchyard are kept in a proper condition. The churchwardens have a right to arrange in what seats the congregation shall sit. They have no right of access to the church, chancel, or belfry without the consent of the incumbent, but if permission is refused on fitting occasions their remedy is by way of application or complaint to the bishop. It is the duty of the churchwardens to use all reasonable means for providing the necessary funds for church expenses with the assistance of the incumbent. After churchwardens are appointed at the Easter vestry, they appear at the next visitation of the bishop or arch deacon and are formally acimitted to the office.

Parish clerks and sextons in ancient parishes are appointed according to custom for life, but may be removed from office for serious misconduct.

In some parishes the parish clerk also performs the duties of sexton, digging the graves and ringing the bell. In statutory parishes, created under the Church Building Acts, the clerk is appointed annually; but in parishes under the New Parishes Acts he is appointed for an indefinite period by the incumbent, who can dismiss him, with the consent of the bishop, for misconduct. A clergyman may be appointed parish clerk, but he must be licensed by the bishop in the same way as a stipendiary curate, and the licence may be revoked subject to the right of appeal. Parish clerks and sextons are usually paid a small salary, and they are entitled to fees on marriages and burials.

The endowments for the mainten. ance of the clergy are derived principally from voluntary gifts made for the purpose in ancient as well as in statutory parishes. They consist chiefly of tithes, glebe lands, and funded property. A large portion of these are administered by the Ecclesiastical Commissioners (q.v.), who pay the income of the clergy out of the funds at their disposal. In many parishes the collections on Easter Day are given to the incum. bent. There are also fees payable to the clergy on marriages and burials. The fees on baptism have been abolished. In every parish a register must be provided in which all baptisms are to be recorded by the incumbent or officiating minister, and a copy of the entries must be sent each year to the registrar of the diocese by the churchwardens. The entry is evidence in law as to the names and condition of the parents, but not as to age.

\section{Ecclesiastical Courts}

There are ecclesiastical courts in the various dioceses in England and Wales in which the judge is called the chancellor. These courts have both civil and criminal jurisdiction over ecclesiastical matters within the diocese. In civil suits petitions are presented for a facuit y or licence to make alterations in the church or churchyard, and a citation is posted at the door of the church which gives notice of the proposed alterations to the parishioners so that they may have an opportunity of bringing any objection they may have before the court. The criminal jurisdiction is exercised when an offence against the ecclesiastical law has been committed.

Bibliography. Ecclesiastical Law, Richard Burn, 9th ed. R. Phillimore, 1842; The Ecclesiastical Law of the Church of England, R. J. Phillimore, 2nd ed. W. G. F. Phillimore and C. F. Jemmett, 1895 ; Practical Guide to the Duties of Churchwardens, C. G. Prideaux, 16 th ed. F. C. Mackarness, 1895; The Book of Church Law, J. H. Blunt, 9th ed. W. G. F. Phillimore and G. Edwardes Jones, 1901 ; The Legal Position of the Clergy, P. V. Smith, 1905 : Church Law, B. White. head 3rd ed. 1911; A Summary of the Law and Practice in Ecclesiastical Courts, T. Eustace Smith, 6th ed. 1911 . 
Ecclesiastical Titles Act. Act passed by the British Parliament in 1851. It was a reply to the brief of Pope Pius IX which restored the Roman Catholic hierarchy in England, making Westminster an archbishopric and selecting various towns, not occupied by Anglican bishops, as new seats for the episcopate. In response to Protestant politica? agitation Lord John Russell introduced the bill, which was passed into law. The Act was from the first a dead letter, and was repealed in 1871 .

Ecclesiasticus. Name in the Vulgate of one of the most important of the O.T. Apocrypha, which in the Greek version is called the "Wisdom of Jesus, son of Sirach." The book was called Ecclesiasticus ("belonging to the Church") because, though not canonical, it was. considered suitable for use in the public worship of the Western Church. By the decree of the Council of Trent it was declared a canonical book of the O.T. in the Roman Catholic Church.

It was originally written in $\mathrm{He}$ brew, between about 190 and 170 B.C., by Jesus the son of Sirach, and was translated into Greek soon after 130 B.c. by a grandson of the same name. The Hebrew text was lost until 1896, when Mrs. Agnes Lewis discovered a fragment in Palestine. Subsequently other fragments came to light, and now the greater part of the work may be read in Hebrew. The book belungs to a class of Hebrew literature known as Wisdom Literature. The author gathers up ethical proverbs, precepts, and wise sayings concerning a great variety of matters in the conduct of life. See Apocrypha.

Ecclesiazusae. Comedy of Aristophanes, produced 392 B.c. It represents the women of Athens as controllers of public affairs and founders of a socialistic state in which property and husbands were held in common, as in Plato's re. public. The title means Women in the ecclesia (general assembly).

Ecclesiology '(Gr. ekklesia, church, assembly; logos, discourse). Science treating of the organization and development of Christianity and of ecclesiastical architecture and decoration, especially in regard to their liturgical sig. nificance. See Christianity; Church.

Echegaray y Eizaguirre, Jost (1832-1916). Spanish dramatist, poet, and politician. He was born at Madrid, and educated at its university. Before entering politics, 1868 , he was a teacher of mathematics. He held office in the Radical-Monarchist government of $1872-73$, as minister of education,

and in 1874 and 1905-6 was minister of finance. His versatility was extraordinary, and he was a director of commercial companies, as well as a philosopher and poet. In 1904 he won the Nobel Prize for literature. His dramas, numbering over eighty, have been translated into most European languages. $\mathrm{He}$

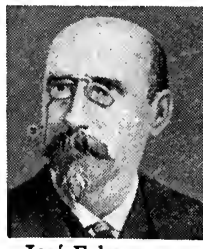

José Echegaray y Eizaguirre. Spanish dramatist is regarded as the founder of the new school of Spanish dramåtists. $\mathrm{His}$ plays include Mariana, 1893, adapted in English, 1897. at the Court, and revived, with Mrs. Patrick Campbell in the title-rôle, at the Royalty, 1901 ; El Gran Galeoto, 1881, produced in London, 1889, under the title of Calumny. He died Sept. $16,1916$.

Echelon (Fr., round of a ladder). Military term. Troops are said to be in echelon formation when the units are all facing in the same direction, are in parallel rows with intervals between their flanks, and units to the rear are on the flank of those in front of them. Battle-ships are in echelon when advancing in $\mathrm{V}$ formation, the apex leading.

Echidna (Gr.-Lat., viper). Spiny ant-eater of Australia and New Guinea, of which there are two species, the five-toed and the three-

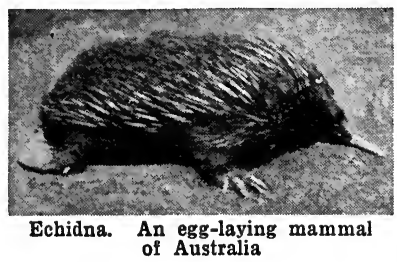

toed. They are egg-laying (Monotremata). The back of the head and body is covered with short spines, like porcupine quills, and the head is provided with a slender beak. In the breeding season the female lays a single egg, which is incubated in a pouch on the underside of the body. The echidna and the ornithorhynchus are the only mammals that have a cloaca (q.v.).

Echinoderma (Gr. echinos, hedgehog; derma, skin). Phyla or sub-kingdom of invertebrate marine animals. They comprise the feather-stars (Crinoidea), starfishes (Asteroidea), brittle-stars (Ophiuroidea), sea-urchins (Echinoidea), and sea-cucumbers (Holothurioidea); certain other orders are represented only by fossils. They are organized on a five- parted symmetrical plan, though this is not at once evident in some of the sea-cucumbers. The skeleton consists of a soft integument in which is deposited carbonate of lime in the form of plates, bars, or spicules. Although there is no distinct head, there is a mouth on the underside, except in the sea-cucumbers, where it is placed at one of the two extremities. The alimentary canal is separated from the general body cavity.

The nervous system, which is not of a high grade, has its principal seat in a five-angled ring around the gullet, from which branches radiate in all directions. What was formerly considered to be a heart is now known to be the centre of the generative system. There is no heart; but there is a system by which the products of digestion are circulated. The most remarkable feature of echinoderm organization is the series of water-vessels known as the ambulacral system, from its function of supplying hydraulic power for locomotion.

The outer surface of the echinoderms varies in the several orders. In the sand-stars and brittle-stars it consists of overlapping plates which allow the rays to be thrown into horizontal curves. In the common star-fish and its near allies it is studded with hard bosses and short spines; and in the seaurchins it is armed with long or short spines which move on balland-socket joints. There are also sense organs of varying character in the different groups. The starfishes have rudimentary eyes at the tips of the rays.

The echinoderma are of the widest distribution, being found in all the seas, at all depths. They are a very ancient group, for their fossil remains are found in the rocks as far back as the Ordovician period.

Echinoidea (Gr. echīnos, bedgehog; eidos, form). Order of echino. derma containing the sea-urchins. They include regular urchins, of which the somewhat spherical common sea-urchin (Echinus esculentus) of Britain's rocky coasts is a familiar example; the oval heart-urchins (Spatangus) of the sandy shores; and the depressed cake-urchins (Clypeaster) which are not represented in British waters.

The common sea-urchin has beneath its coat of about 4,000 bristling spines a thin stony box composed of nearly 600 five-sided plates, placed edge to edge. Through the minute perforations issue the delicate sucker tubes. Certain plates bear polished bosses upon which the spines turn in any dircetion. Each tapering spine has 
a polished cup at its base to receive the boss, and the two are held together by muscular tissue. Among the spines will be found stalked and sessile organs resembling the bills of birds, which have the power of snapping. Around the Mediterranean tho sea-urchin is esteemed as food; hence its name esculentus.

The heart-urchins, which burrow in muddy sand, are clothed with silky bristles, all pointing backwards. The scoop-like mouth is at the broad end and without teeth.

Echo. Reflection of the air waves by which sound is propagated. See Sound; Wave Theory.

Echo. In Greek mythology, a mountain nymph. At one time the companion of Hera, having displeased the goddess, she was punished by being rendered incapable of speaking except when spoken to. Subsequently Echo fell in love with the beautiful Nar. cissus, but, her love not being returned, she pined away and was changed into a stone which retained the echo or answering voice.

Éno, THE. London independent Radical evening halfpenny newspaper, started by Cassell \& Co., Dec. 8, 1868, with Arthur Arnold as editor. Sold in 1874 to Baron Grant, who made it a Conservative organ. it passed into the hands of John Passmore Edwards, who restored its former political character and made it a first-class property. In 1884 Andrew Carnegie became part proprietor, but Mr. Edwards soon reacquired the paper, and it remained under his control until 1897. It ceased publication in 1905 . Another evening Echo appeared from The Daily Chronicle office in the spring of 1915 , and after running for six weeks was amalgamated with The Star (q.v.).

Echo Iountain Observatory. Observatory, $3,500 \mathrm{ft}$. high, on Echo Mountain in the Sierra Madre Mts., California. It has a 16-in. equatorial telescope. The observatory was founded at the end of the 19th century by Thaddeus S. C. Lowe, an American scientist and inventor, who did much pioneer work in aeronautics and the investigation of the upper atmosphere, and invented the first apparatus in the U.S.A. for making artificial ice. A cable rly. runs up Echo Mountain to the observatory and on the adjacent Mt. Wilson is the famous observatory of the Carnegie institution. See Observatory; also illus. p. 715 .

Echo Organ. Small organ of delicate tone, either placed at a distance from the main organ or enclosed in a box, or both, in order to produce distant effects.
The idea dates back at least to the Restoration, but the introduction of electric mechanism has greatly extended its possibilities. Good examples are the celestial organ at Westminster Abbey and the altar organ at S. Paul's Cathedral, London. See Organ.

Echternach. Town of Luxemburg. It stands on the Sure, near the frontier of Prussia, and is fam. ous for its annual festival and its association with $\mathrm{S}$. Willibrord. In the church, a Romanesque building of the 11 th century, restored in the 19 th, are the remains of the saint. There was a rich Benedictine abbey here until 1801. The festival, which dates from 1300 or earlier, is held every Whit Tuesday. It is attended by pilgrims and invalids, as well as high ecclesiastics, who are accompanied by a singing and dancing crowd as they go in procession to the church. Echternach has a town hall and some small in. dustries. Pop. 4,300.

Echuca (formerly Hopwood's Ferry). Town of Victoria, Australia. It stands on the Murray river, $156^{\circ} \mathrm{m}$. by rly. N. of Mel. bourne. It is the chief river port on the Murray at its junction with the Campaspe. A bridge (railway and roadway) $1,905 \mathrm{ft}$. in length spans the river here, connecting with Moama in New South Wales. Echuca is the outlet for the wine, wool, and timber of this district. A private line $45 \mathrm{~m}$.

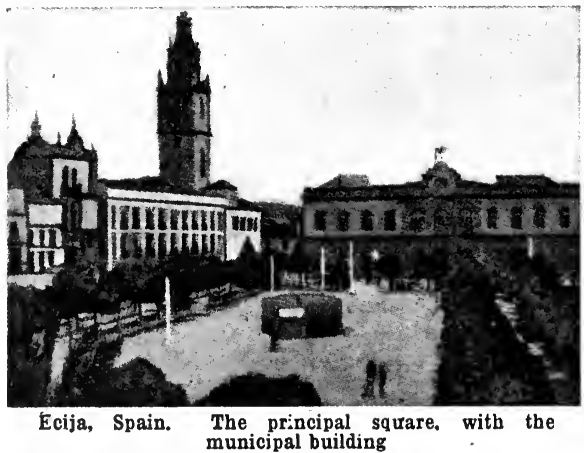
Feb. 13,1543 .

Eckermann, JoHANN PeTER (1792-1854). German writer. $\mathrm{He}$ was born a t Winsen, Hanover, Sept. 21, 1792. After early hardships he served in the war of 1813-14, and later studied at Göttingen. In 1822 he sent Goethe the MS. of $\mathrm{h}$ is Beiträge zur Poesie, and this long to Deniliquin, on the Edward resulted in his going to Weimar, river, taps part of the N.S.W. Riverina trade. Pop. 4,137.

Écija (anc. Astigi). Town of Spain, in the prov. of Seville. It stands on the Genil, here crossed by an old bridge, $34 \mathrm{~m}$. by rly. S.W. of Córdoba. Ecija, once a Roman colony (Julia Augusta Firma) and a Moorish town, retains many traces of ancient civilization. It is now occupied in the manufacture of boots and shoes, and cotton, wool, silk, and linen fabrics. The surrounding fertile plain produces corn, cotton, and where he acted as secretary to Goethe, and assisted in the preparation of the final edition of his writings. $\mathrm{He}$ is best remem. bered by his Gespräche mit Goethe (183648), Eng. trans. Conversations with Goethe, John Oxenford, 1850. He died at We i m a r, Dec. 3, 1854 .

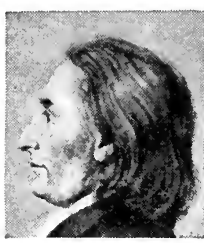

J. P. Eckermann, German author 
Eckhardt, JuLIUS voN (18361908). Russo-German diplomatist and author:, Born at Wolmar in Livonia, he was educated at St. Petersburg and Berlin universities. He founded with Bärens the Rigasche Zeitung, a periodical advocating German expansion in the Russian Baltic provinces. $\mathrm{He}$ resided in Germany from 1867, and was connected with the journal Grenzboten, 1867-70. A noted Pan-Germanist, he was appointed privy councillor of Prussia in 1884, and became German consul at Tunis, Marseilles, Stockholm, Basel, and Zürich. His works included The Baltic Provinces of Russia (2nd ed. 1871), and Berlin-Vienna-Rome, in which he advocated German expansion by means of a customs union of Central European powers.

Eckhart, JoHanNes (c. 1260 1327). German mystic and theologian. Born at Hochheim, near Gotha, he became a Dominican friar, and in 1298 was prior of Erfurt and provincial of Thuringia. In 1300 he was lecturer in Paris, and in 1307 he was vicargeneral of Bohemia and provincial of Saxony. He was subsequently lecturer at Paris, Strasbourg, and Frankfort, and from 1320 until his death was professor at Cologne. Certain expressions used by Eckhart were condemned as heretical, and he was suspected of pantheism. But he made com plete repudiation of error and submission to Rome.

Eckhart, who is known as the Master, was the founder of German mysticism. His writings do not present a definite system of philosophy, and his teaching is mainly concerned with the Divine essence in all things, the relation of the human soul to God, and the attainment of God by casting off all that hinders knowledge of God. No complete Eng. trans. of his works exists. For the German see Deutsche Mystiker des 14 Jahrhun. derts, ed. F. Pfeiffer, 2nd. ed. 1907.

Eckington. Parish and town of Derbyshire, England. It stands on the Rother, $6 \frac{1}{2} \mathrm{~m}$. S.E. of Sheffield by the G.C.R. Agricultural implements are manufactured, and there are coal mines in the neighbourhood. Market day, Friday. Pop. 12,164.

Eckmühl, Battle of. Victory of Napoleon over the Austrians, April 22, 1809. In an attempt to reopen his communications, which had been broken by the French, the archduke Charles emerged from Ratisbon to give battle. His troops were routed by Davout and Oudiro', and the whole Austrian army was demoralised and forced across the Danube. For his part in the day's success Davout was created prince of Eckmühl.

Eclecticism (Gr. eklektikos, picking out). In philosophy, a method which, while not excluding independent thought, selects and works up into a whole what is acceptable in other philosophical systems.

The most important Greek representative of this practice, which first made its appearance in the Stuic school, was Antiochus of Ascalon (lst century B.c.), the head of the so-called Fifth Academy, whose teaching led to the adoption of eclecticism by the Academy in place of scepticism as its ruling principle. Among the Romans, Cicero, who attended his lectures at Athens, although by no means an original thinker, skilfully selected and combined Sceptic, Stoic, and Peripatetic doctrines. Among modern eclectics Leibniz and Victor Cousin may be specially mentioned.

Eclipse (Gr. ekleipsis, failing). In astronomy, the passing of one celestial body between another and the observer. The term is usually restricted to the eclipses of the sun and moon and those of the satellites of planets by their primary.

It is clear that if the earth, the sun, and the moon moved in the same plane, there would be an eclipse each time the three were in a straight line. Since, however, the moon moves in an orbit inclined at an angle of $5^{\circ} 8^{\prime}$ to the plane of the sun's path, the ecliptic (q.v.), there can only be an eclipse when the three bodies are in an approximate straight line at the moment the moon is crossing the plane of the ecliptic. The points where the moon crosses the ecliptic are called the nodes, and when new moon happens at one of these nodes there will be an eclipse of the sun. When full moon occurs at one of the nodes the earth is between the moon and the sun, and there will be an eclipse of the moon by the earth's shadow.

The eclipse of the moon by the $s$ adow of the earth will be more or less visible to the whole side of the earth turned away from the sun. The moon casts only a restricted shadow on the earth, and therefore the sun will appear in eclipse only in the path of this moving shadow.

Owing to the refraction of the sun's rays the moon is hardly ever quite swallowed up in blackness. The eclipses, however, of 1642 , 1761,1816 , and Oct. 4,1864 , were notable for the complete disappearance of the moon.

A total lunar eclipse may last about 1 hour 45 minutes. If the moon is not exactly at the node at its cclipse, a partial eclipse may result, the lower or the upper limb of the moon being obscured by the umbra, or darker portion of the earth's shadow.

In a total eclipse of the sun by the moon the diameter of the moon's shadow cast on the earth averages only about 150 miles and sweeps across the earth from $W$. to $\mathrm{E}$. with great rapidity. The eclipse can only be visible in places swept by the shadow, and the longest time the total eclipse of the sun by the moon can be visible at any place is a little more than seven minutes.

Partial eclipses occur when the new moon is not quite at the node ; annular or disk-like eclipses are due to the fact that the moon is sometimes too far from the earth to hide the sun entirely from the view of an observer on the earth. The length of the cone of the moon's shadow varies with the moon's distance from the sun between 230,000 and 238,000 miles. The moon is sometimes as near as 221,614 miles to the earth, and sometimes 252,972 miles away, so causing the variation both in the appearance and the length of time of solar eclipses.

The maximum possible number of eclipses of the sun and the moon in any one year is seven, while the usual number is four. In 1920 there were four, two of the sun and two of the moon. Although there is no connexion between one eclipse of the sun or moon and the one immediately following, there is a
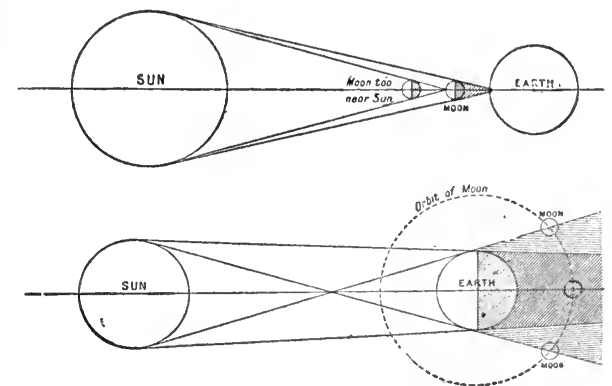

Eclipse. Diagram showing the phases of an eclipse of the moon by the shadow of the earth. Above, eclipse o the sun by the moon. When the moon is too near the sun there is an annular eclipse 
cycle, known as the saros, of a little over 18 years of eclipses, and it was due to a knowledge of this fact that the ancients were able to predict eclipses of the moon, though since eclipses of the sun are very rare at any given place on the earth's surface, the similar sun cycle was overlooked.

Eclipses of the sun have been fruitful in discovery. The eclipse of 1868 resulted in the discovery of helium in the sun, 27 years before it was found to be a constituent of one of the rare earths, cleveite, while the eclipse of May 29, 1919, provided an opportunity to prove Einstein's generalised theory of relativity by showing that light was attracted by the sun and deflected from a straight path.

In addition to the eclipses of the sun and moon, the eclipses of the satellites of Jupiter by their primary are of importance in astronomy. It was due to the studying of these eclipses, exactly analogous to the eclipses of the moon by the earth, that it was found light did not travel instantaneously. Closer ap. proximations to the velocity of light and refinements in modern telescopes have enabled astronomers to use the eclipses of Jupiter's satellites to olstain the distance of the earth from the sun, the astronomical unit. See Ecliptic; Jupiter; Moon; Occultation; Sun.

Eclipse. English racehorse, regarded as the greatest that has ever lived. Foaled April 1, 1764 , he was named because on that day there was an eclipse of the sun. He ran in his first race May 3, 1769, and from then until Oct., 1770, ran in 18 races, never being beaten. $\mathrm{He}$ was bred by the duke of Cumberland, but at the time of his successes was the property of $\mathrm{D}$. O'Kelly. After 1770 he was used for stud purposes, and from him a large number of racehorses are descended. The horse's skeleton is in the Royal Veterinary College, Camden Town.

Eclipse Stakes. Race for horses of 3 years and upwards run at Sandown Park over a distance of $1 \frac{1}{4} \mathrm{~m}$. It was inaugurated in 1884 and formed the first of the $£ 10,000$ races. Danny Maher rode the winner of this event on five occasions. One of the most popular wins was that of Orme, after recovering from his supposed poisoning, in 1892. The race was abandoned during 1915-18. See Horse Racing.

Ecliptic (Gr. elleiptikos, relating to an eclipse). Track in the heavens along which the sun appears to perform its annual march. The sun's motion in this connexion is only apparent; it is the motion of the earth about the sun which pro- duces the appearance of the sun's itinerary. The plane of the ecliptic is the plane of the sun's apparent, and of the earth's real, motion. The obliquity of the ecliptic is the angle $(\Omega)$ the ecliptic makes with the celestial equator. This can be determined by marking the apparent heights of the sun in the sky at the moments of its passing the meridian on June 21 and Dec. 21, and halving the difference in angular altitude. In London this is about $23 \frac{1}{2}$ degrees. The plane of the ecliptic is subject to variation, termed the secular variation of the obliquity of the ecliptic. See Sun.

Eclogite (Gr. eklogos, picked out). Crystalline, foliated rock, composed chiefly of omphacite and red garnet, with quartz, hornblende, etc., as minor constituents. When fractured, it presents a beautiful appearance, the red garnets sparkling in a light green matrix. Most frequently occurring as irregular masses in schist, it is found in Bavaria, Saxony, Silesia, Pennine Alps, and Scotland.

Eclogue (Gr. eklogē, selection). Pastoral poem relating the lives and loves of shepherds. Properly, almost identical with the idyll, the term is generally restricted to pastoral poems in dialogue form, such as the Bucolics of Virgil. Spenser set the fashion anew with his Shepheards Calender, and the form was much employed in the artificial poetry of the 17th and 18 th centuries. The name has sometimes been used for dialogue poems other than pastoral, as in Phineas Fletcher's Piscatory Eclogues (1633) and John Davidson's Fleet Street Eclogues (1893-96).

Ecnomus. Headland on the S. coast of Sicily, between Girgenti and Licata. Off here in 256 в.c. the Romans under Regulus utterly defeated the Carthaginian fleet.

Ecole des Femmes, L' (The School for Wives). Five-act comedy by Molière, first produced at the Palais-Royal, Paris, Dec. 26, 1662. The scene is in Paris. A selfish middle-aged bachelor, Arnolphe, brings up a young girl, Agnes, to make her his wife, keeping her ignorant of the world; but fails to prevent her from falling in love with Horace, a son of his old friend Oronte. Unaware of Arnolphe's relation to Agnes, Horace reveals to Arnolphe his love story. The lovers do not meet before the audience until the last act. Molière acted the part of Arnolphe.

École des Maris, L' (The School for Husbands). Three-act comedy by Molière, first produced at the Palais-Royal, Paris, June 24, 1661. The theme of two brothers, Ariste and Sganarelle, in charge of two wards, sisters, whom they desire to marry, was suggested by The Adelphi of Terence. Ariste is generous as Sganarelle is mean and masterful. Molière acted the part of the latter. The scene of the play is laid in the French capital.

Ecology (Gr. oikos, house; logos, discourse). Science dealing with the relations of individual plants to their habitats. In this connexion are recognized vegetation-units or plant-communities, such as wood, moor, heath, implying particular kinds of soil as well as the plants associated with it, and plant associations, dealing with the characteristic vegetation of each unit.

In each of these associations one species usually dominates the others, and according to the situation and soil of the unit, many subordinate species will be associated with it which will interact upon each other by competition, cooperation, etc. The ecological botanist maps his district into areas, showing in each the dominant species and the subordinate species associated with it, the adaptations of the plants to their habitat, the influence of man in cultivating or draining land, the effects of the presence of herbivorous mammals in pasturing, of birds in dispersion of fruits and seeds, of insects in pollination and defoliation, etc. Thus ecology tries to explain why certain plants are successful in the struggle for existence, which plants are social in their habits, and which are solitary, and so forth. See Botany ; Cytology.

Economic Man. Term used to describe man as discussed in the works of Ricardo, John Stuart Mill, and other political economists. $\mathrm{He}$ is a person who is actuated solely by material interests, who judges every transaction by the loss or gain afforded to him. Later writers have emphasised the fact that man is not actuated solely by material considerations, and have disputed his existence.

In the mass and in the long run men tend to act along certain well-defined lines, e.g. they tend to cease production which does not pay. Hence it is useful to conceive an average man whose family is of average size, whose needs are satis fied in an average way, whose work yields an average return, and so on. Such an imaginary economic man provides a ready standard of com. parison. Just as the mathematician needs the perfect circle which does not really exist, so the political economist postulates an economic man for the study of his science. See Political Economy. 
Economics (Gr. oikos, house; nomos, law). Originally the art of managing a household. This use survives in the phrase domestic economy, but there are also economics of other kinds. The most useful definition of the word is as a synonym for what is known as political economy, i.e. the study of the production and distribution of wealth. Economics is sometimes regarded, however, as having a somewhat wider meaning than political economy, including certain matters which were outside the scope of the older science; the physical welfare of the worker, for instance. Political economy is used for the main article in this work. See Political Economy.

Economics and Political Science, LONDON ScHOOL OF. School for the study of economics founded in London in 1895 . It is a school of the university of London, and its courses are specially adapted for those who devote their time to research work, and also for those studving for degrees in economics. The subjects upon which professors and lecturers are provided include accounting, commerce, geography, sociology, statistics, and transport, as well as political economy, history, and law. The school occupies the Passmore Edwards Hall in Clare Market, London, W.C., but the foundation stone of new build. ings was laid in 1920 by King George. Its principals have been Sir H. J. Nackinder, Hon. W. P. Reeves, and Sir W. H. Beveridge.

Economiser. Apparatus for heating the feed-water of steam boilers, and so reducing the consumption of fuel. The heating agent is either waste furnace gas or steam. The Green economiser, the type most commonly employed with Lancashire and other large cylindrical land boilers, consists of a number of vertical pipes, about $4 \frac{1}{2}$ ins. in diameter, arranged in a brick chamber interposed between the boiler and its chimney. Annular scrapers are moved mechanically up and down the outside of the pipes to keep them free from soot. Other forms of tubular feedheaters are fitted in the uptakes of water-tube boilers, and in the fore part of large locomotive boilers. On ships exhaust steam or highpressure steam is utilised to warm separate heaters, or the heater is combined with the condenser. The saving of fuel effected by an economiser may be from about 10 p.c. to about 15 p.c. See Boiler; Condenser.

Econom ist, THE. London weekiy paper devoted to political economy. It was founded in 1843 by James Wilson, who edited it until 1859, Herbert Spencer being sub-editor, 1848-53. From 185977 the paper was edited by Walter Bagehot, and 1907-16 by Francis W. Hirst. It has always discussed financial questions from a social and economic standpoint, and in its early days was a staunch advo. cate of free trade and the repeal of the Corn Laws.

Écorché (Fr.). Animal stripped of its skin in order that the dispo. sition and character of the muscles may be studied. In figure work the life class or study from nature supplies the bulk of the draughts. man's needs, but a species of écorché is supplied by the coloured plates of the muscular system used in some text-books of anatomy.

E.C. Powder. One of the oldest British smokeless powders for use in sporting guns. Invented in 1882 at the works of the Ex. plosives Company, hence E.C., at Stowmarket, it consisted essentially of nitrated cotton mixed with nitrates, the mass being granu lated. A separate company was formed to manufacture it at new works erected at Dartford, Kent, where it is still made. At present E.C. powder is a 33-grain powder, i.e. 33 grains of the smokeless powder is equivalent to the old standard charge of 82 grains of gunpowder. E.C. powder is com. posed of nitrocellulose, 79.0 p.c. wood meal, $3 \cdot 8$; camphor, 4.1 ; barium nitrate, $\mathbf{7 \cdot 5}$; potassium nitrate, $4 \cdot 5$; volatile matter, $1 \cdot 1$.

Ecrasite (Fr. écraser, to crush). High explosive employed in Aus. tria for charging shell and other projectiles. It actually consists of ammonium cressylate, prepared by boiling trinitrocresol with a solu. tion of ammonium carbonate, or by neutralising a solution of trini trocresol with ammonia, the result. ing product occurring as pale reddish yellow needles easily soluble in water. It melts at about $100^{\circ} \mathrm{C}$., and is comparatively insensitive to friction and shock. Projectiles may be filled either by ramming and pressing the powdered explosive into them, by forming it into cart. ridges which are inserted complete through a removable base plate, or by pouring in the melted compound. It is detonated by means of a fulminate detonator and gaine containing powdered ecrasite.

Écrins, BarRe DES. Mt. of S.E. France. It is the highest summit of the Pelvoux group of the Cottian Alps, which lie between the depts. of Hautes-Alpes and Isère. Alt. $13,460 \mathrm{ft}$.

Ecstasy (Gr. ecstasis, displacement, trance). Name given to various states of consciousness, in which, the mind being concentrated on a definite object, the senses are temporarily inactive, and external sensations inoperative. It has been experienced at various times by many Christian mystics, notably by S. Teresa. and valued as a supernatural pheno. menon. According to their own testimony the mystics have received, in ecstatic condition, special manifestation of the will of God. The term is also sometimes applied to the abnormal mental conditions of catalepsy, the hypnotic trance, somnambulism, and to the trances of spirit mediums. The chief points distinguishing these states from ecstasy are the absence of con. sciousness and of all memory of what has taken place during the trance. See Dreams.

Ectoderm (Gr. ectos, outside ; derma, skin). Term applied to the outer layer of the embryo, from which the skin and nervous system of a vertebrate animal originate. It is also used for the outer layer of cells in the Coelentera. See Embryology.

Ectopic Gestation or Extra. uterine Pregnancy (Gr. ectopos, out of place). Condition in which the fertilised ovum, or egg cell, instead of developing within the uterus, becomes implanted in the Fallopian tube which leads to the uterus, or escapes into the body cavity and there begins to develop. The cause is unknown. It is rare in young women, and is most often seen in women who have been married for a number of years without having had a child, and in cases where a long time has elapsed since the last pregnancy.

The symptoms are not very definite, but some of the signs of pregnancy may be present. Often, however, the first indication is a sudden attack of acute pain with collapse, and signs of internal haemorrhage, due to rupture of the sac of the developing embryo. In most cases operative treatment provides the best hope of saving life. See Pregnancy.

Ectozoa(Gr. ectos, outside; zōon, animal). Term applied to parasites which live on the exterior of their hosts, in contrast with the entozoa, which live in the internal organs. Lice and ticks are examples of the ectozoa, tape worms and flukes of the entozoa.

Écu (Fr., shield; Lat. scutum). Obsolete French silver coin. First struck by Louis IX, its value was three livres. Charles VI issued, in 1384 , a piece known as écu. de la couronne, the écu being called in England a crown. There was also minted a double silver écu of six livres, worth about 5s. See Crown. 
ECUADOR: ITS RISE AND PROGRESS

\section{F. A. Kirkpatrick, Author of South America and the War}

As in the case of other countries, this article describes the physical nature of the land before passing to its history, constitution, literature, etc. See South Amcrica, and the articles on the Chimborazo; Cordilleras, and other features

Republic of S. America, lying between Colombia on the $N$. and Peru on the S. It is so named be-

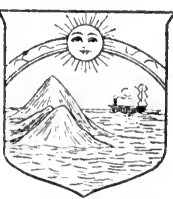

Ecuador arms cause the equatorial line runs through the country. Its western shores, $500 \mathrm{~m}$. in extent are washed by the Pacific Ocean. The Colombian boundary was settled by treaty in 1917 , but the Peruvian frontier has not yet been fixed. The republic embraces the provinees of Azuay, Bolivar, Cañar, Carchi, Chimborazo, Esmeraldas, Guayas, Imbabura, Leon, Loja, Ianabi, Oro, Pichincha, Los Rios, Tungurahua, the territory of Oriente, and the Galápagos archipelago. Its area is approximately $116,000 \mathrm{sq}$. m., and its pop. about $2,000,000$.

The dominant geographical fea. ture is the gigantic mountain system which traverses the land from $N$. to S. Two towering mountain ramparts, the Eastern and Western Cordilleras, run parallel to one another, enclosing between them a broad elevated valley, from $20 \mathrm{~m}$. to $50 \mathrm{~m}$. wide, and $8,000 \mathrm{ft}$. to $10,000 \mathrm{ft}$. above sea level. This trough is walled on cither side by the famous "avenue of volcanoes," above a score of peaks in a double line, nost of them rising far above the snow line, sometimes facing one another in pairs at heights of from 16,000 to $19,000 \mathrm{tt}$. No fewer than 20 of these summits can be counted from Quito, the capital, which stands on the central plateau at a height of $8,400 \mathrm{ft}$. The volcano of Pichincha (about $15,910 \mathrm{ft}$.) is notable for its perilous proximity to the capital; but most conspicuous among these mountains is the perfectly sym. metrical and dazzling cone of Cotopaxi $(19,600 \mathrm{ft}$.). Higher yet soars the imposing snow-clad mass of Chimborazo $(20,500 \mathrm{ft}$.). And above the snows, volcanic craters emit their clouds and ashes. Several of them are dormant, but eruptions have been frequent since the coming of the Spaniards, and the whole region is subject to earth. quake shocks and tremors. 'This vast mountainous region presents an cndless variety of altitude and climate: the torrid, forest-clarl plains bordering the lower spurs : the warm, temperate, pleasant, and productive valleys of the moderate heights; the cool regions of the lofty plateau; and, higher yet, the páramos, or icy, wind-swept plains and slopes approaching the limit of perpetual snow.

Although the mountains predominate, the greater part of Ecuador lics in the forest-clad plains which stretch to $\mathrm{E}$. and W. from the foot of the two Cordilleras. In fact, Ecuador has three distinct zones : first, the coastal plain; then the Andine mountain system; and then the montaña, the densely wooded region stretching into the interior from the base of the Eastern Cordillera, and intersected by the multitudinous upper waters of Amazonian affluents.

The most valuable and produc. tive part of the country is the broad coastal plain, richly tropical and humid in character. This plain, watered by innumerable streams and originally covered by dense forests, supports the extensive plantations of cacao, which supply
Through the towering wall of the Western Cordillera, lofty passes lead to the Andine plateau. From this plateau steep and difficult mountain passes lead eastwards, up between the peaks of the Eastern Cordillera, and then down along twisted and precipitous river valleys to the montana, where scanty tribes of savage Indians support life by hunting with the blow-pipe and with poisoned arrows. This is the most inaccessible and least developed part of the republic.

This region resembles in its character the forests of Brazil ; its woods and waters are haunted bv a multitudinous variety of reptiles, saurians, fishes, birds, and insects. Trees, lianas, flowering shrubs, and rich orchids grow in countless varieties. Tha mammals include jaguars, pumas, tapirs, sloths, bears, deer, and armadilloes.

The volcanic group of the Galápagos Islands lies on the Equator, $600 \mathrm{~m}$. from the W. coast of S. America. Named from the gigantic tortoise (galápago) found on the islands, they are remarkable for the fact that about half the in digenous plants, all the reptiles, and nearly all the birds are peculiar to this archipelago. In the 17th

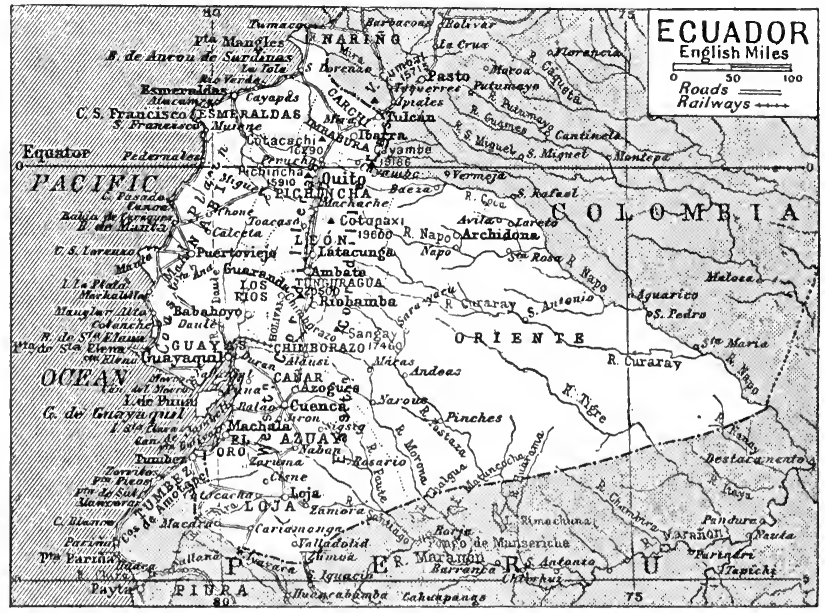

Ecuador. Map of the South American republic which lies between Colombia on the north and Peru on the south. Its western shores are washed by the Pacific Ocean

the chief part of Ecuador's exports, besides plantations of bananas and other tropical products. Numerous streams, particularly those con nected with the port of Guayaquil, provide access to the cacao plantations. 'The forest is valuable for its thickets of bamboo, and for the various products yielded by many kinds of palms, besides the palm like plant whose fibre is woven into Panama hats. and 18th centuries the islands, at that time uninhabited, were the resort of buccaneers and pirates. The government now maintains a penal settlement on the largest island, about $60 \mathrm{~m}$. in length, and there are a fow other inhabitants.

People, Laxguage, etc. The population is of mixed origin, descended partly from Spanish settlers, partly from indigenous 
Indians, and partly-though in a less degree-from negro slaves inıported in former days. Most of the people are pure Indians, simple and ignorant, who perform all the manual labour, and bear with a kind of customary apathetic submission the domination of the ruling class. These Indian peasants and labourers are virtually devoid of any sense of nationality or citizenship, and are indifferent to forms or methods of government, although they have been swept into contending armies, in numerous civil wars, by caudilos on either side. Some scanty tribes still subsist in primitive and savage independence in the eastern montaña; and others in the northern part of the coastal plain enjoy virtual independence under their cacique, who is recognized by the Ecuadorian government. Thedominant class, which forms a society of typically S. American culture, is largelyof mixed blood. The official language, and the tongue in general use, is Spanish.

Constitution, Religion, etc. The president is chosen by direct popular election for four years. The 32 senators and 48 deputies are elected upon a limited franchise which is withheld from illiterates, an arrangement which secures ascendancy to the oligarchy of white, or quasi-white, blood. The Roman Catholic faith is generally professed, but is not officially established; all religions are tolerated. Primary education is frec, and, in theory, compulsory. There is a small standing army, but no compulsory military service. The coinage is now upon a gold basis; the unit is the sucre, and the 10-sucre gold piece is equal to the sovereign

Economic Conditions, IndusTRY, ETC. A large part of the world's supply of cacao comes from Ecuador, where cacao far outweighs all other products put together. The weaving of Panama hats is a considerable industry. Apart from this there is little in the way of manufacturing industry. The chief exports are cacao, trgua or vegetable ivory, Panama hats, coffee, hides, and rubber. Some gold is produced in the Andes, but mining is not, as yet, a developed industry. The considerable deposits of petroleum are for the most part still undeveloped. Guayaquil, the chief port and the largest town in the republic, is linked with Quito, the capital, by a mountain rly., $300 \mathrm{~m}$. long, which traverses one of the passes of the Western Cordillera. There are also a few short lines connecting important points. The various streams which unite to form the river Guayas provide access from Guayaquil to - a large part of the cacao-bearing region of the southern coastal strip. The lower reaches are navigated by river steamers, the upper waters by canoes and rafts. But over the greater part of the country the only roads are bridle-paths, and mules are the only means of transport.

History. Before the European discovery of America, the mountain plateau was the seat of a monarchical native civilization, inferior to that of the Incas, but notable for its organization and marked by considerable skill in the arts of building, stone-carving, weaving, pottery, and the working of gold and silver. Towards the end of the 15 th century the Inca monarch, Huayna Capac, defeated the king of Quito, and added his dominions to the Inca empire. By the daughter of the conquered chief, the Inca conqueror had a son Atahualpa, who, upon his father's death, became the Inca ruler of Quito. He then claimed the throne of the Inca empire, and dethroned his brother, the legitimate heir. He himself lost his kingdom and his life at the hands of Pizarro, the Spanish inva. der, in 1533. The conquest of Peru by the Spaniard was naturally followed by the occupation of Quito. The kingdom of Quito, which included a considerable territory now belonging to the republic of Colombia, constituted thenceforth a presidency or government, subordinate to the Spanish viceroy of Peru. But in the 18th century the presidency of Quito was made subordinate to the newly established viceroyalty of Santa Fé de Bogotá.

In 1808 a revolutionary or republican movement broke out in Quito; but, after four years of confused tumult, Spanish authority was re-established, and subsisted until the decisive victory of the republican commander Sucre in the battle of Pichincha in 1822. Quito was now incorporated into the extensive republic or federation of Colombia under the authority of Bolivar. But in 1830 that rather artificial political system was broken up into the three separate republics of Venezuela, New Granada (now Colombia), and Ecuador.

There followed a stormy period of personal rivalries, despotisms, factions, civil wars, and frontier wars with Colombia. From 1859 to 1875 the country was ruled by Garcia Moreno, an ultra-clerical conservative, who attempted to set up a kind of Catholic theocracy, to be guided by the authority of the pope. His dictatorship, although more stable than previous governments, was by no means peaceful ; and his assassination in 1875 openerl a fresh era of disorder and conflict; nor can it be said that the promulgation of a new constitution in 1906 brought peace to the republic. However, Eeuador has had some share in that movement of economic progress which has transformed S. America generally during the past generation. In the Great War, Ecuador severed political relations with Germany, and was a signatory of the Peace Treaty.

Bibliography. Travels in the Wilds of Ecuador, A. Simson, 1886 ; South America, A. H. Keane, 2nd ed. 1909 (in Stanford's Compendium); Travels amongst the Great Andes of the Equator, E. Whymper repr. 1911; A History of South America, C. E. Akers, 2nd ed. 1912 ; Latin-America : its rise and progress, F. Garcia-Calderon, Eng. trans. B. Miall, 1913 ; Ecuador, C. R. Enock, 1914.

Ecurie. Town of France, in the dept. of Pas-de-Calais. It is $3 \mathrm{~m}$. N.E. of Arras and was the scene of fierce fighting between the French and Germans, Jan.-June, 1915. See Arras, Second Battle of; Artois, Battle of.

Eczema (Gr. ek, out; zein, to boil). Inflammatory disease of the skin. Certain persons exhibit a marked predisposition to eczema, the exact cause of which is unknown. The immediate exciting cause may be debilitating illness, gout, Bright's disease, diabetes, constipation, dyspepsia, overwork, anxiety, and exposure to damp and cold winds. Infants and aged persons show especial susceptibility to it. A similar condition is produced by the action of certain irritants on the skin, e.g. turpentine, but this affection is better termed dermatitis.

The essential characteristics of eczema are : redness of the skin, formation of small blisters or vesicles, watery discharge, formation of erusts and scales, and usually extreme itching. Various types are recognized: erythematous eczema, in which bright red patches appear on the skin papular eczema, characterised by the formation of small red papules or pimples about the size of a pin's head; vesicular eczema, marked by the appearance of crops of vesicles and watery discharge; and pustular eczema, in which pustules containing matter are formed, and on rupturing give rise to yellowish-brown scabs.

In all cases attention should be paid to the general health. The diet should be simple, alcohol should be avoided, rest of the affected part, if a limb, is important, and severe cases should be confined to bed. The irritated areas should be washed as little as possible and soap should not be used. Lncal treatment with ointments, powders, 
lotions, etc., varies with the type of the condition and the stage it has rearhed. I'ron. ék-zem-a.

Edalji Case. Beginning in Feb., 1903 , and continued at intervals until the end of June, a succession of cattle-maiming outrages took place in the parish of Great Wyrley, Staffordshire. At the same time anonymous letters. purporting to come from the perpetrators, were sent broadcast throughout the district. It was mainly on the evidence of these that George Edalji, a young Birmingham solicitor, was arrested on Aug. 18, 1903. In Oct., 1903 , he was tried at Stafford, found guilty, and sentenced to seven years' penal servitude.

A number of persons, including Sir Arthur Conan Doyle, R. D. Yelverton, and Edalji's father, the vicar of Great Wyrley, were tireless in their efforts to draw public attention to what they were convinced was a grave miscarriage of justice. In 1907 a commission of inquiry was appointed, and on May 17 the Home Secretary advised his Majesty to grant Edalji a free pardon, but without monetary compensation.

Edam. Town of the Netherlands, in the prov. of $\mathbf{N}$. Holland It stands on the Zuider Zee, $12 \mathrm{~m}$. N.E. of Amsterdam. The name is derived from a dam built on the little stream Ye. Edam possesscs some old brick houses, and a fine church, S. Nicholas, dating from the 14th century and restored. 1602-26. It is noted for its dairy produce, and in particuls $r$ for the round red-rinded cheese which bears its name. Pop. 6,623.

Edar or IDAR. Native state of Gujerat, India, in Bombay presidency. It is bounded $N$. by Udaipur, E. by Dungarpur, and S. and $\mathrm{W}$. by Bombay and Baroda. Area 4,966 sq. m. Pop. 250,000. The soil is generally fertile, but there are barren and stony tracts near the hills. The principal products are mangoes, sugar cane, oil seeds, and various kinds of grain. Its ruler is a maharaja entitled to a salute of 15 guns. Edar, the chief town, is $64 \mathrm{~m}$. $\mathrm{N}$ E. of Ahmedabad. Pop. 6,000 .

Edda. Two collections of Icelandic literature, known respectively as the Elder, or poetical, of Saemund, and the Younger, or prose, of Snorri. The former were discovered by Brynjulf Sveinsson, an Icelandic bishop, in 1643 . He attributed them to Seamund Sigfusson (1055-1132), but an earlier date is generally assigned by critics. The Prose Edda was com. piled by Snorri Sturiason (11781241 ), and is generally ascribed to the 12 th century.
Eddington, Arthur Stanley (b. 1882). British astronomer. Born at Kendal, Dec. 28, 1882, he was educated at Owens College, Manchester, and Trinity College, Cambridge. In 1904 he was senior wrangler, and became fellow of Trinity, 1907. Eddington then devoted himself wholly to astronomy and was made chief assistant at the Royal Observatory, Greenwich. There he remained until 1913, when hewas appointed Plumian professor of astronomy at Cambridge, next year becoming director of the university observatory. He wrote Stellar Movements and the Structure of the Universe, 1914 ; Space, Time and Gravitation, 1920. $\mathrm{He}$ contributes the article on Stars to this Encyclopedia. See photo, p. xxi.

Eddoes. Tuberous stems of several species of colocasia, caladium, etc., of the natural order Araceae. Though acrid in a raw state, they are used as food when cooked. Colocasia antiquorum, an E. Indian species, is largely cultivated for food, even in S. Europe, under the name of taro $(q . v$.$) .$

Eddy. Swirl in water caused by the meeting of two currents or by some submerged obstacle. A whirl. pool (q.v. ) is simply a large eddy.

Eddy, Mary Baker (1821-1910). Founder of the religion named Christian Science and the Church of Christ Scien-

tist. Born at

B ow, N ew

$\mathrm{Hampsh}$ ire,

July 16, 1821, she received a liberal educa. tion, her father being a large land owner. She was mar-

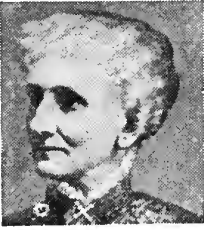

Mary Baker Eddy. Chnstian Scientist ried threetimes,

first to Major George W. Glover, a contractor and builder, in Charles ton, S.C., who died less than a year after his marriage. Her second husband was D. S. Patterson, a dentist of Franklin, N.H., who she divorced for desertion and infidelity in 1873. Her third husband was Asa Gilbert Eddy, who died 1875. She published Science and Health with Key to the Scriptures, the only textbook of Christian Science. Her other writings include Miscellaneous Writings; Unity of Good; No and Yes; Rudimental Divine Science; Church Manual Prilpit and Press; Messages to The Mother Church: The First Church of Christ; Scientist and Miscellany ; Christ and Christmas ; Christian Science versus Pantheism ; and Poems. Mrs. Eddy died at Newton, Mass., Dec. 3, 1910. See Christian Science ; consult also Life, Sybil Wilbur, 1908.
Eddystone. Lighthouse on the Eddystone Rocks, a dangerous reef, $14 \mathrm{~m}$. S.W. of Plymouth.

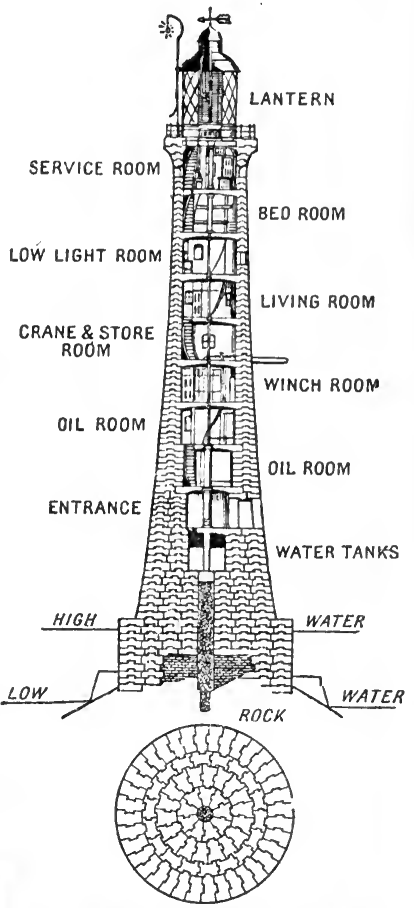

Eddystone Lighthouse. Diagram
showing sectional elevation and showing sectional elevation and
plan of base

There have been four of them The first, a wooden structure, $120 \mathrm{ft}$. high, by Winstanley, was destroyed by a hurricane in Nov. 1703 , three years after its completion. The second lighthouse, $92 \mathrm{ft}$. high, was erected by John Rudyerd in 1709 , and was burned down in 1755. The third, a granite building by Smeaton, $95 \mathrm{ft}$. high, was completed in 1759 . It was the first in which the stones were dovetail jointed, and remained a model for other designs till 1877, when it was found necessary to dismantle it, as the rock foundation had become insecure; the upper sections were transferred to Plymouth Hoe. 'The present tower, completed in 1882 , is located 40 yards from the previous one.: Built of granite, with dovetailed 'stones, it is $168 \mathrm{ft}$. above low water, and is built in circular sections. The lantern shows a group flashing light of two flashes every thirty seconds, and has a range of nearly $18 \mathrm{~m}$

Ede. Town of S. Nigeria, W. Africa, in Yoruba country. It is $173 \mathrm{~m}$. by rly. N.E. of Lagos, and lies at an alt. of $850 \mathrm{ft}$. Pop. 26,577. 


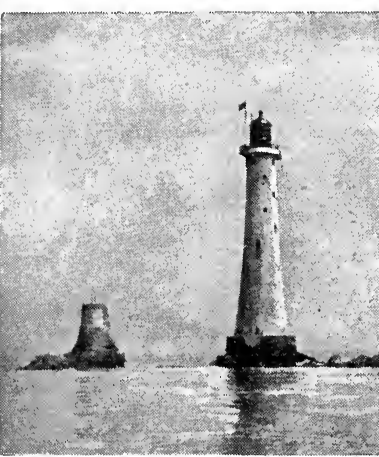

Eddystone Lighthouse. The lighthouse built by Sir James Douglass in 1882. To the left are the rein 1882. To the left are the re-
mains of Smeaton's tower of 1759

Edea. Town of Cameroons, W. Africa. It stands on the Sanaga river and is a station on the line running inland from Duala, being about $50 \mathrm{~m}$. from that port. The capital of the district of the same name, it is a centre for collecting palm oil and palm kernels. During the campaign in Cameroons a British and French force took the town, Oct. 26, 1914, the Germans making a futile effort to retake it in Dec., 1914, and in Jan., 1915. Pop. of district, 97,000. See Came roons, Conquest of.

Edelfelt, Albert Gustaf ARIsTIDE (1854-1905). Finnish painter Born at Helsingfors, July 21, 1854 he was trained at Antwerp Academy and at the Ecole des Beaux Arts under J. L. Gérome. He painted landscapes, portraits, and compositions with equal skill. In vited by'Tsar Alexander III to paint the portraits of his children, he produced, while in Russia, several works in landscape and genre. $\mathrm{He}$ died at Borga, Aug. 18, 1905. His finest and most characteristic works are Divine Service in the Skaergaad, at the Luxembourg; Pasteur in his Laboratory, at the Sorbonne: Laundry; Jesus appearing to Mary Magdalen, and Women in the Churchyard, both at Helsingfors.

Edelinck, GÉRARD (1640-1707). Flemish engraver. Born at Antwerp Oct. 20. 1640, he was the pupil of

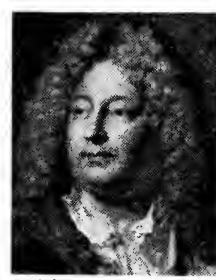

Gérard Edelinck, Flemish engrave After Rigaud obtained ample patronage from Louis XIV, was received in the Academy in 1677, and died in Paris April 2, 1707. He became one of the most brilliant line engravers of the 17 th century. In portraiture Edelinck was no less accomplished, his portraits of John Dryden and Philippe de Champaigne being of particular excellence.

Edelweiss (Leontopodium al. pinum). Perennial herb of the nat. ural order Compositae. A native of the mountains of S. Europe, and Himalaya, it is thickly coated with long woolly hairs, which give it a white appearance, accentuated in the bracts which surround the cluster of terminal yellowish flowerheads. The leaves are lanceshaped, and the plant is about 6

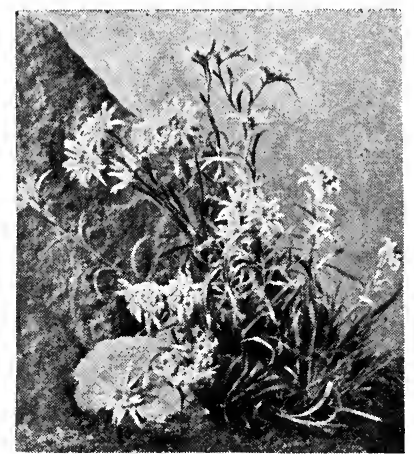

Edelweiss. Specimen of the plant, photographed on a mountain side

ins. high. It occurs locally in the Alps, but the idea that it is exceedingly rare and can only be gathered in circumstances of great danger is erroneous. The name is German, meaning " noble white."

Eden. English river rising on the borders of Westmorland and Yorkshire, and flowing N.W. past Kirkby Stephen and Appleby into Cumberland, and then past Carlisle to the Solway Firth, which it enters at Rockcliff. Its length is $65 \mathrm{~m}$., and it contains salmon.

Eden. River of Fifeshire, Scot land. It is formed by the confluence of two small burns, the Beattie and the Carmore, at the Kinrossshire border, and flows E.N.E. through the Howe of Fife and past Cupar to the North Sea, which it enters by a muddy estuary $6 \mathrm{~m}$. in length; total length $30 \mathrm{~m}$. There is good salmon fishing.

Eden. British destroyer. She displaced 550 tons, and had four 12-pdr. guns, two 18-in. torpedo tubes, and a speed of 25 knots. She was sunk in the English Channel as the result of a collision on the night of June 16, 1916. About 40 officers and men were lost.
Eden, GaRDEN OF. In the earliest Biblical account (the Jahwistic) of Creation (Gen. ii, 8-25) Yahweh Elohim plants a garden eastward (from the Palestinian standpoint) in Eden (Gen. ii. 8) for man to dwell in. In the Septuagint the word for garden, Heb. gan, is represented by paradeisos, a loanword (Hebraised pardess) from the Zend pairi-daêza, "enclosure"; hence arises the term Paradise as a description of Eden and of the Christian Heaven. The garden of Eden seems to have been thought of as a park or pleasure-ground, in Gen. iii, 8, Yahweh Elohim is described as walking in the garden in the cool of the evening ( $c f$. Isa. li, 3 ; Ezek. xxviii,13, xxxi, 8). The name Eden has been derived from the Babylonian êdinu, plain or steppe, but a more likely derivation is from the Hebrew eden, delight.

The location of Eden is difficult to determine. Sayce identifies the garden with the sacred garden of the Babylonian deity Ea at Eridu, the river which watered it (Gen. ii, 10) being the Persian Gulf, and the four branches $(v v .11-14)$ being the Palla. kopas, the Choaspes, the Tigris, and the Euphrates. E. Naville (Archaeology of the O.T., 1913), comparing Gen. xiii, 10, ".like the garden of the Lord, like the land of Egypt as thou goest unto Zoar," and identifying Zoar with the Egyptian Zar (mod. Kantarah), thinks that the narrator located the garden in Egypt in the western part of the Delta between the Tanitic and Pelusiac branches; Fall of the Nile. See Creation Legends; Fall.

Edenbridge. Market town of Kent, England. It stands on the Eden, $251 \mathrm{~m}$. S.S.E. of London by the S.E. \& C. and L.B. \& S.C. Rlys. It is an agricultural centre. Market day, Wed. Pop. 2,993.

Edenhall. Parish and village of Cumberland, England. It stands on the Eden, $3 \mathrm{~m}$. N.E. of Penrith.

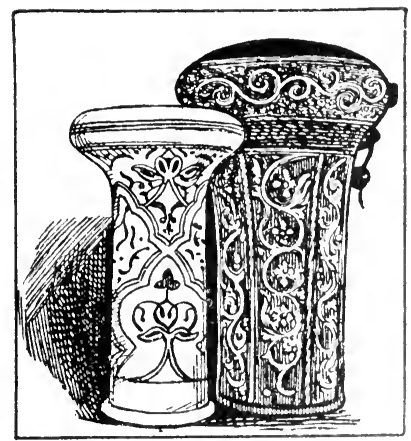

Edenhall. Drinking gob!et and case known as the Luck of Eden the Frencl school. He case known as th

From a drawing by C. A. Haryer 
At Eden Hall, the seat of the Musgraves, there is an ancient enamelled drinking goblet, known as the Luck of Eden Hall, which, according to tradition, was taken from the king of a fairy band feast. ing near S. Cuthbert's Well in the grounds, who, when departing, exclaimed :

$$
\begin{aligned}
& \text { If e'er this cup shall break or fall, } \\
& \text { Forewell the luck of Eden Hall. }
\end{aligned}
$$

In Longfellow's translation of Uhland's ballad, the glass is represented as having been destroyed. The mansion and estates were announced for sale in 1920 . P'op. 256.

Edenkoben. Town of Bavaria, Germany. In the Bavarian Palatinate, it is $6 \mathrm{~m}$. N. of Landau. The chief buildings are churches and schools. 'There are several manufacturing industries, while the town trades in wine. There is a sulphur spring. Near by is the villa of Ludwigshöhe. Pop. 5,400.

Edentata (Lat. edentatus, toothless). Order of mammals without front teeth, and in some cases without cheek teeth also. They comprise the sloths, ant-eaters, and armadilloes, all of which are S. American. The pangolins and the aard-vark are sometimes also included in the order. Where cheek teeth are present in the edentates, they are of very simple structure, have no enamel, are without roots, and continue to grow throughout life. All the genera are land animals, and while the sloths and some ant-eaters live in the trees, the armadilloes are burrowing animals. They are insectivorous, except the sloths, which are vegetable feeders.

The living representatives of this order are insignificant in number and degenerate in structure compared with those found in a fossil state. Fossil skeletons are found in the Pampa formation of S. America. See Mammals.

Edessa. An ancient city of Osroēnē in the north-west of Mesopotamia, on the river Scirtos (Daisan). Founded by Seleucus I and called Antiocheia Kallirhoë by Antiochus IV, after the downfall of the Seleucid empire it became the capital of an independent kingdom from 137 B.C. to A.D. 216 , under rulers called by the title Abgar (q.v.). It then became a Roman military colony, under the name of Colonia Marcia Edessenorum. After the division of the Roman Empire into East and West, Edessa became an important centre of Christianity. During the reign of Justin I it was destroyed by an earthquake and rebuilt as Justinopolis in 525. It is the modern Urfa (q.v.).
Edfû or ATBo. Town in Egypt on the left bank of the Nile, $485 \mathrm{~m}$. S.S.E. of Cairo. It is celebrated for its beautiful and almost perfect temple dedicated to Horus, one of the finest Ptolemaic buildings in Egypt; now that the temple of Philae is submerged this is the best example still to be seen. Edfa is the Greek Apollinopolis Magna. Pop. 12,594. 사

Edgar or EADGAR (944-75). King of the English. The younger son of King Edmund, he became king as the result of a rising against his brother Edwy. The brothers were not apparently hostile to each other, but one party wanted Edgar for king and the witan decided that he should rule the land north of the Thames. In 959 Edwy died and Edgar became king of the whole country. His coronation, which did not take place until May, 973, is important in the history of that ceremony.

It was after this that the king sailed to Chester, and on the Dee was rowed by six or eight vassal kings. At this time he assumed a certain vague overlordship, his authority extending to Ireland, and called himself imperator. $\mathrm{He}$ fought against the Welsh, but his reign rightly earned for him the title of the peaceful. He formed a fleet for service against the pirates, and showed zeal in putting down crime. Edgar died July 8, 975, and was buried at Glastonbury. Two of his sons, Edward, called the Martyr, and Ethelred the Unready, succeeded in turn to the throne.

Edgar Atheling (d. c. 1130). English prince. The son of Edward the Exile and grandson of Edmund Ironside, he was born in Hungary, but was brought to England in infancy. After Harold's death in 1066 he was proclaimed king by the northern earls, and in 1068 and 1069 was involved in unsuccessful rebellions in the N. of England. Re conciled to William the Conqueror in 1074, he lived at his court in Normandy for twelve years. In 1097 he deposed the Scottish usurper Donald Bane and seated his own nephew Edgar on the throne. $\mathrm{He}$ went on crusade in 1099 and in 1106 was taken prisone at the battle of Tinchebrai while fighting for Robert of Normandy against Henry I. He was released, but the rest of his life was spent in obscurity. He died about 1130 .
Edge, Selwy Francis (b. 1868). British motorist. Born in Sydney, N.S.W., he was brought to England in infancy. Having taken up cycling, he became the best 100 -mile cyclist of his time, riding at Herne Hill track in 5 hrs. 6 mins., and covering the distance from London to York in $12 \mathrm{~h} .50 \mathrm{~m}$. One of the pioneers of the motor industry in Britain, he founded the Motor Power Company in 1899, and later joined other leading firms,

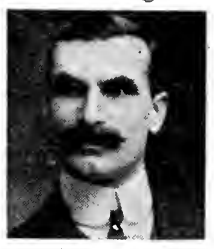

S. F. Edge, Elliott \& Fry British motorist

including that of Napier, by which name the cars of S. F. Edge, Ltd., were known. He won the GordonBennett International Paris-Vienna race in 1902 See Cycling; Motoring.

Edgehill, BatTl: of. First battle of the Civil War, fought between Charles I and the parliamentarians, Oct. 23,1642 . The hill is a ridge in Warwickshire, on the borders of Oxfordshire. The king was marching from Shrewsbury to London, and the parliamentarians, under Essex, moved across to intercept him. On the morning of the 23rd Essex marched out of Kineton to find the royalists drawn up on Edgehill, about $3 \mathrm{~m}$. away. His artillery had not yet arrived, so he left the initiative to his enemies, who opened the fight.

Each army was drawn up with the infantry in the centre and cavalry on the wings. On both wings the royalist horse, under Prince Rupert and Wilmot respectively, drove the parliamentarians before them and followed them for miles. In the centre, however, the parliamentarians stood firm and the horsemen charged the royalist centre. Only the return of Rupert's following and the oncoming night saved Charles from utter defeat. Charles had about 14,000 men; Essex about 10,000.

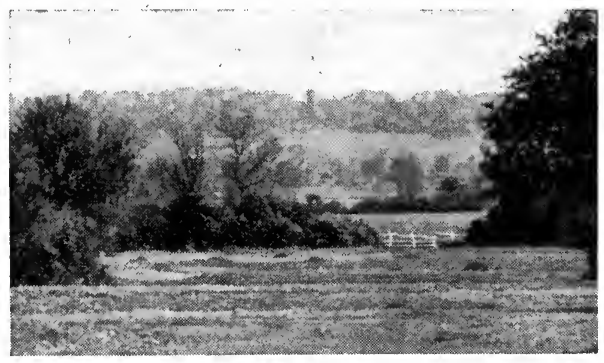

Edgehill. The Warwickshire ridge on which the battle was fought, Oct. 23,1642 
Edgeworth, MARIA(1767-1849). British novelist. Born at Black Bourton, Oxfordshire, Jan. 1, 1767, she was one of the many children of Richard Lovell Edgeworth, whom she accompanied to Ireland in 1775. She spent most of her life on her father's estate at Edgeworthstown, obtaining her knowledge of the Irish peasantry from dealing with his tenants and her familiarity with fashionable life

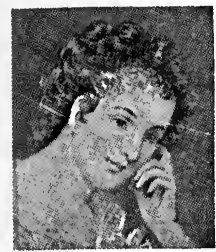
from associa. tion with his neigh bou rs, Lady Moira and Lord Long ford. Practical Education, 2 vols. (1798), was written in collabor a tion with her father,

\section{Turwe Requerity.}

and it was largely on his account that she rejected a proposal of marriage made to her by Count Edelcrantz, a Swede, at Paris, in 1802.

Visits to London and the Continent between 1803 and 1844 brought her into touch with the best literary and fashionable society of her time, and in 1823 she visited Scott at Abbotsford, a visit returned by him at Edgeworthstown two years later. Scott's admiration of her literary ability is recorded in Waverley, where he declared that her presentation of Irish life and character had induced him to attempt a like service to his people in The Waverley Novels. In addition to the three novels of Irish life on which her fame is based-Castle Rackrent, 1800 ; The Absentee, 1812 (in Tales of Fashionable Life, vols. $v$ and vi); and Ormond, 1817-she wrote the Parent's Assistant, 1796, enlarged ed. 1800; Moral Tales for Young People, 1801, and completed her father's Memoirs, 1820. The amiable and practical qualities displayed in her life distinguish Maria Edgeworth's books, which despite their didacticism still make a strong human appeal. She died May 22, 1849.

Bibliography. Life, H. Zimmern, 1883 ; Life and Letters, ed. A. J. C. Hare, 1894; The Edgeworths: a Study of Later 18th Century Edu. cation, A. Paterson, 1896 ; Life, E. Lawless, 1904 (in Eng. Men of Letters); Maria Edgeworth and Her Circle in the Days of Buonaparte and Bourbon, C. Hill, 1909.

Edgeworth, RICHARD LOVELL (1744-1817). British author. Born at Bath, May 31, 1744, he belonged to the English family that made their home at Edgeworthstown, Ireland. Educated at schools in
Drogheda and Longford, he went to Trinity College, Dublin, and then to Oxford. Of independent means, Edgeworth was able to devote his time to study, friendship, travel, and experiment. He was respon. sible for several inventions, was one of the early believers in the possibility of electricity, and had theories on education. He helped to found the Royal Irish Academy. From 1772 until his death, June 13,1817 . most of his time was spent in Ireland, looking after his estates and writing, while for a short time he sat in the Irish Parliament. His works include Practical Education, 1798, and Memoirs, parts of both being written by his daughter Maria.

Edgeworth de Firmont, HENRY Essex (1745-1807). Last con. fessor to Louis XVI of France. The son of an Irish clergyman, he was educated in France for the priesthood, and at ordination took the name of de Firmont from the Edgeworth family estate of Firmount, in Ireland. He settled in Paris, and in 1791 became confessor to Princess Elizabeth, and in 1793 to her brother, Louis XVI, whom he courageously attended to the scaffold. After several narrow escapes the Abbé Edgeworth, as he was commonly known, arrived in England, 1796, and subsequently became chaplain to Louis XVIII. He died at Mitau, May 22, 1807. See The Abbé Edgeworth and his friends, V. M. Montagu, 1913.

Edging Plants. Edging garden beds and borders with tiles, shells, wood, or bricks is now out of date. The only dead edging permissible is one of rough sandstone, carefully sunk into the ground almost to the level of the path, in order that creeping plants may hide it. The best permanent living edging is box, but this is of slow growth, though when once established, and annually clipped, it will flourish for generations. The most satisfactory quick - result edging is Virginian stock or dwarf nasturtiums, while more pretentious subjects,

and those which possess longer lasting properties, are some of the saxifrages, stonecrops, pansies, dwarf veronicas, and white pinks.

It is a good plan while permanent edgings are establishing themselves to plant such quick-growing annuals as Virginian stock or dwarf nasturtiums as temporary stop gaps. Culture and treatment are the same as for the rest of the inhabitants of the bed or border. Dwarf edible peas were occasionally planted as war-time economical edging plants, with good results both from an ornamental and profitable point of view.

Edgren, ANN CHARL,TTF LEFFLer, Dúhess of Cajanello (1849-92). Swedish novelist and dramatist. The daughter of Prof. Leffler, a mathematician, she was born near Stockholm, Oct. 1. 1849, and married G. Elgren in 1872 . Her earlier tales were issued under the pen-name of Carlot, but in 1882 she began a series of novels and plays under her own name, and many of these, with their modern note, enjoyed considerable success. One of the plays, Sanna Kvinnor, 1883, was translated into English by H. L. Braekstad as True Women, 1890. In 1890 she married the Italian mathematician, the duke of Cajanello, and died at Naples, Oct. 21, 1892.

Edgware. Small town of Middlesex, England. It is $8 \frac{1}{2} \mathrm{~m}$. from the Marble Arch, on the high road to St. Albans. Formerly called Eggesware and Edgworth, and once the first village of note on the Watling Street, its manor has been since 1443 the property of All Souls College, Oxford. The W. side is in the parish of Little Stanmore. The parish church of S. Margaret, rebuilt 1765 and 1845 , has a square stone tower, and is said to have been part of a monastery ; near it was a house of refreshment for the monks of St. Albans as they travelled to and

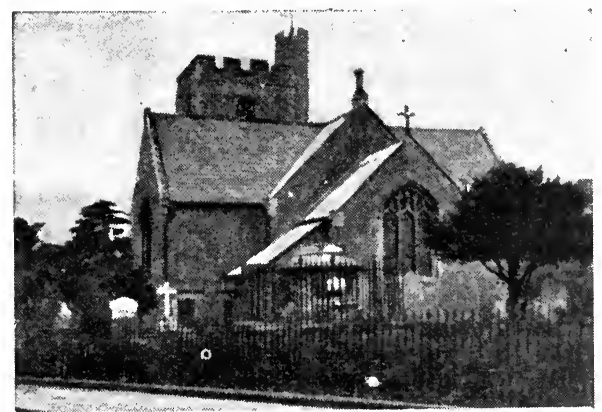

Edgware. Parish Church of S. Margaret, viewed from the east

from London. Of the old inns, The Chandos Arms has a fireplace from the mansion of Canons (q.v.). At Edgware was the forge of William Powell, whose work on the anvil is said to have suggested to Handel the melody of 'The Harmonious Blacksmith. Piper's 
Green preserve the tradition that a former lord of the manor pro. vided a minstrel for the amusement of the tenants in his service. Brockley Hill, $1 \mathrm{~m}$. farther N., is supposed to be the site of the Roman station Sulloniacae. Edg ware has stations on the G.N.R. and on the extension of the Hampstead tube rly. Pop. 1,233.

Edible Birds' Nests. Nests of certain species of swift (Collocalia), found in Australia and the East Indies. They are composed chiefly of the saliva of the birds and are attached to the walls of caverns. The Chinese value them as a delicacy

\section{EDINBURGH : THE CITY AND ITS HISTORY}

\begin{abstract}
To Sir H. Maxwell's account of the history of Edinburgh there has been prefixed a description of the city as it is to-day. Special features, e.g. Arthur's Seat; Canongate; Greyfriars; Holyrood, are dealt with separately. See also Scotland
\end{abstract}

The capital of Scotland and of the county of Midlothian stands on the S. side of the Firth of Forth, 390 m. N.N.W. of

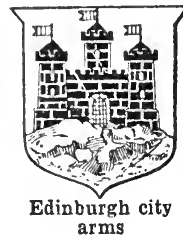

London. The pop. is 420,281 , and the rateable value is estimat ed $a \mathrm{t} \quad \mathrm{a} b$ ou $\mathrm{t}$ $£ 3,000,000$. The hills on which it is situated and those around it, of which Arthur's

Seat is the most notable, give it a most picturesque appearance, and this, increased by the nature and grouping of its buildings, have won for it the title of the Modern Athens. Its historic and literary assoeiations added to this entitle it to be numbered among the famous cities of the world.

Edinburgh is a station on theN.B. and Cal. Rlys., both of which lines have here fine stations, hotels, etc. As the capital of the country it has many public offices, and here reside a large number of civil servants, lawyers, etc. It is a great centre for insurance and banking business, while it has many warehouses for its distributing trade. Its chief industries are printing and brewing, but there are many others, including distilling as well as papermaking, and others auxiliary to printing. By means of Leith, its port, it is connected by sea with the great ports of England and the world. Several important publishing firms have their headquarters here.

The oldest part of Edinburgh, affectionately known as Auld Reekie, lies between the castle and Holyrood. The former, originally a fortress on a rock and still retaining its military character, has been associated with many stirring and convert them into a kind of glutinous, but almost tasteless, soup. Edict (Lat. edictum). Promulgation, on his entry upon office, by a Roman magistrate, especially a praetor, of the principles upon which he intended to administer the law during his term. The result of this practice was that side by side with the civil law there grew up a great body of magisterial aw which ultimately became the most valuable part of Roman jurisprudence. The word was also used later, especially in France, for certain laws, e.g. the edict of Nantes. See Praetor; Roman Law.

scenes; in it are S. Margaret's chapel, the banqueting hall, the arsenal, the armoury, and the old prison called the Argyll Tower. Holyrood House consists of a palace and remains of an abbey; the picture gallery is the chief apartment. Between the castle and Holyrood are Lawnmarket High Street and Canongate High Street, the lofty tenements of which, called "lands." give an idea of what old Edinburgh was like. The Parliament House, with its magnificent hall, now contains the Iaw Courts, and around it are modern additions erected for legal business. These include the Advocates' and Signet Libraries, whereof the former shares with the British Museum and the Bodleian Library of $\mathrm{Ox}$ ford the privilege of receiving a copy of every book published in the United Kingdom. There still remain the Water Gate and some other vestiges of the city's walls and boundaries.

\section{The City Churches}

Of the many churches, the chief is that of S. Giles, rich in memorials of various kinds, with its most recent addition, the magnificent chapel of the Knights of the Thistle. Others are S. Mary's and S. John's, two episcopalian ones, the former being the cathedral; and S. George's, S. Cuthbert's, and S.Andrew's, belonging to the established church. Free S. George's is the most famous of those belonging to the United Free Church. The Canongate and Tron churches are somewhat older. Greyfriars churchyard is an historic spot, as are the Grassmarket, the Cow. gate, and the Tolbooth in the Canongate.

In the modern city the most interesting thoroughfare is Princes Street, overlooked from the E. by
Calton Hill, with its public build. ings and monuments, which include the unfinished national memorial, the prison, a cemetery, and the city observatory. There is a new prison at Saughton. There are many other notable buildings, including some careful restorations. Among these are the Mercat Cross in the High Street,restored by Gladstone; John Knox's house near it; Moray House ; the White Horse Close in the Canongate; Riddle's Close, and the 17th century house restored by Lord Rosebery, in the Lawnmarket. More modern are the county buildings, the public library, and the sheriff court buildings. There are a number of statues and memorials.

Edinburgh is famed for its educational advantages. The university, specially equipped for training in medicine and surgery, occupies the site of Kirk o' Field. The Heriot-Watt College, George Watson's College, Fettes College, and the Royal High School are widely known. There are also several theological colleges, while here are the headquarters of the Scottish colleges of surgeons and physicians. The chief paper is The Scotsman.

Edinburgh and Leith

Edinburgh is governed by a council, presided over by the lord provost. It sends five members to Parliament. There is a good supply of water, gas, and electricity, while the city has an excellent system of tramways, which also connect it with Leith and other adjacent places. The city boundaries have been enlarged several times, and they now include Granton, Liberton, Portobello, and Duddingston, and the various hills around them. In 1920 an Act was passed for the inclusion of the port of Leith in the municipality of Edinburgh.

In primitive times, when what is now Scotland was peopled by tribes chronically at war with each other, but combining on occasions against some powerful invader, isolated crags or mounts were highly esteemed for defensive purposes. Among numerous sites of that character in northern Britain, none stands out more conspicuous than the Castle Rock of Edinburgh, which would no doubt be seized by the early colonists of Lothian and fortified by the usual rampart of stone and palisade. Within the enclosure they planted their wattled huts, and subsisted by the chase ; for according to Strabo (25 B.c.), and Dion Cassius (c. A.D. 150-235), the natives of Northern Britain were ignorant or independent of agriculture when the Roman le. gions arrived there.

Of Edinburgh as a town, nothing 

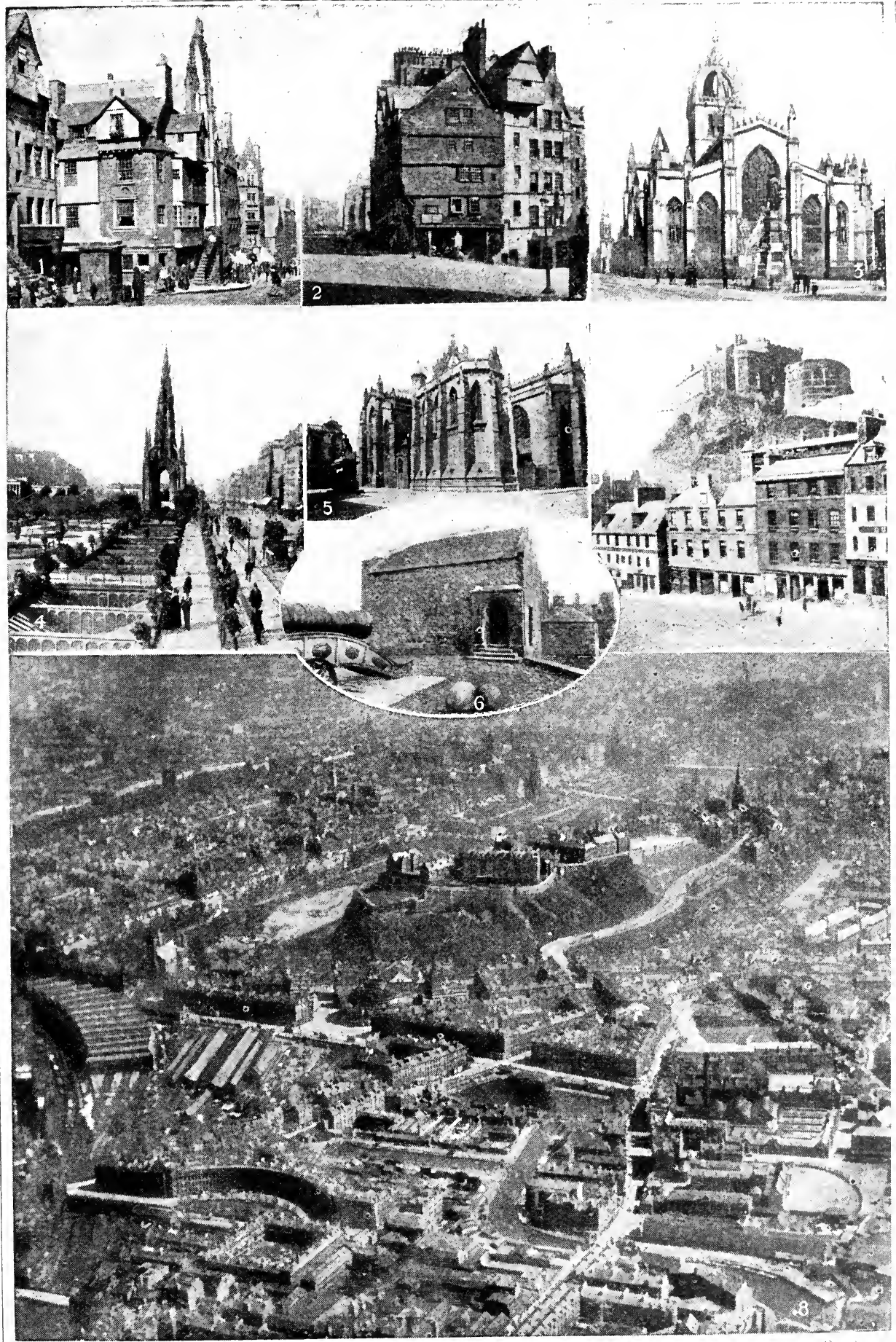


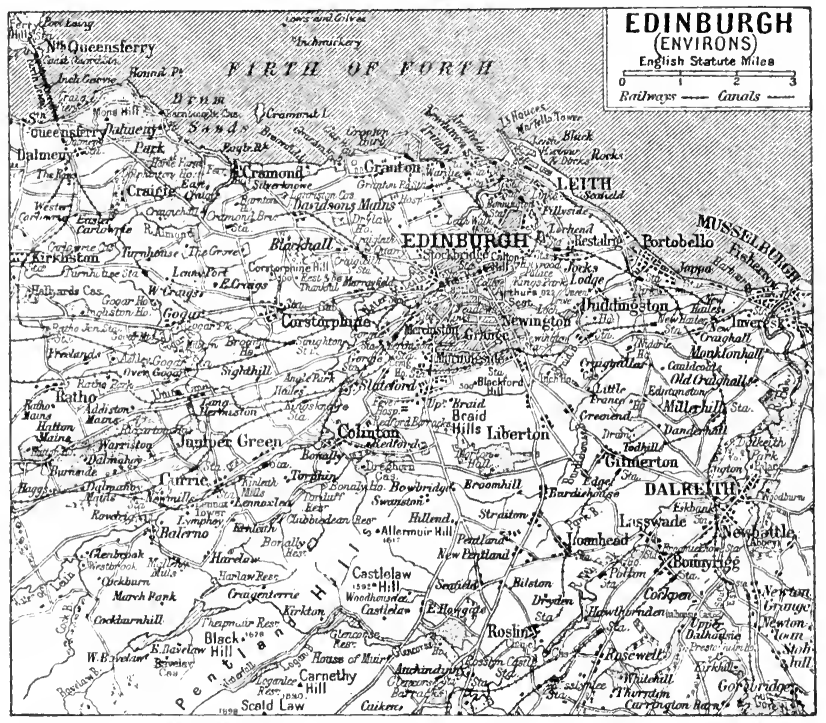

Edinburgh. Map of the environs of the Scottish capital, including part of the, Pentland Hill

appears, even in tradition, until after the conquest of Lothian by Eadwine, Saxon king of Deira (Yorkshire) and Northumbria, in the 7 th century. It appears from King David's foundation charter of Holyrood in 1128, and Simeon of Durham's chronicle written in the same century, that King Eadwine was thus early regarded as the eponymus, for in both of these writ. ings the place is called Edwinesburch. The Gaelic branch of the Celts called it Dunedin; among the Welsh population of Strathclyde it was known as Dineiddyn or Mynydagneid, the latter name appearing to signify the mount of the Painted People or Picts. According to the Pictish Chronicle the Saxons held Oppidum Eden till they surrendered it to Indulf, son of Constantin king of Scots (954-962) ; but all is misty and vague until Malcolm III was persuaded by Queen Margaret to remove his seat of government from Dunfermline to Edinburgh. about 1060 .

In 1128 David I founded the abbey of Holyrood, and empowered the convent to form the burgh of Canongate, which re tained its separate jurisdiction until 1856 , when it was united to the corporation of Edinburgh. The date of the erection of Edinburgh into a royal burgh is unknown. Doubtless it had already received a charter before David I (1124-53) made it his principal residence, but many years had to run before it was recognized as the capital of Scotland. The strategic import ance of Edinburgh having been and burnt by Richard II in 1385 and besieged by Henry IV in 1400 , but the castle held out until Henry had to raise the siege in order to deal with Glendower's rebellion.

From this period onward Edinburgh, in common with the whole of Scotland, suffered from the arbitrary power of the great barons, who made full use for selfish ends of the opportunities afforded by the imprisonment in England of David II and James I, and by the frequency with which the succession to the throne devolved on an infant, the average age of seven successive sovereigns from 1406 1567 on their accession being but six years. Thus the 4 th earl of Douglas, keeper of Edinburgh Castle, and a number of other nobles and officials, not only refused to pidy the duties leviable upon wool and hides which they exported, but did not scruple to appropriate money which the customs officer had collected. In consequence, the gross customs of the city, which amounted to $£ 2,047$ in 1416 , had fallen to $£ 1,0985 \mathrm{~s} .4 \mathrm{~d}$. in 1418, though the volume of trade was considerably greater. Bitter complaints of oppression were continually made to the government; Livingstone, guardian of the boy king James II, and Chancellor Crichton made these serve as excuse for ridding themselves of a dangerous rival, the 6th earl of Douglas, a lad of 17, whom, with his brother David, they lured to a banquet in Edinburgh Castle and had them both butchered in the king's presence.

In 1448 the Town Council, taking advantage of the respite of English invasion during the wars of the

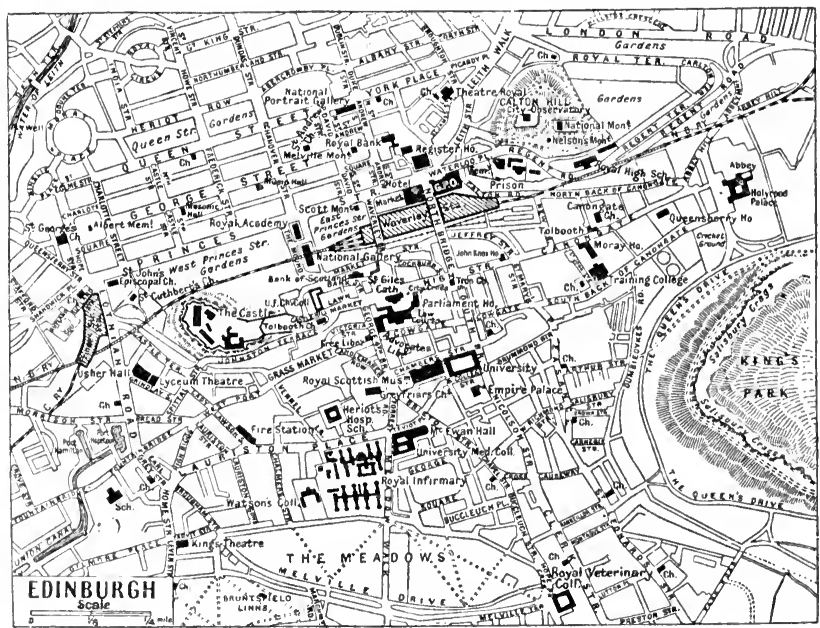

Edinburgn. Plan of the central part of the city. The valley spanned by the North Bridge separates the Old Town on the S. from the New Town on the N. 
Roses, set to work to strengthen the defences of their city. The king's garden on the $\mathrm{N}$. side, now occupied by the Waverley rly. station and lines, was inundated by a dam thrown across the E. end, thereby forming the North Loch, whence a wall was built round the E. and S. sides of the city to the Castle Rock near the West Bow.

During the reign of James IV (1488-1513) the revival of learning first made itself felt in Edinburgh. The guild of chirurgeon barbers received a royal charter in 1505 , to develop under a fresh charter in 1684 into the Royal College of Surgeons of Edinburgh, In 1507 the first printing press in scotland was established in Edinburgh. But a new era of bloodshed was inaugurated on Flodden Field in 1513, where James IV was killed with the flower of Scottish nobility and gentry. In 1544 the earl of Hertford sacked and burnt Edin. burgh, wrecked Holyrood Abbey, drove away the monks, and gutted the palace, but was repulsed in attacking the castle. He returned in 1547 under his new name of Protector Somerset, and completed the destruction of Holyrood.

\section{The Scottish Reformation}

In the 16th century Edinburgh became the vortex of the Scottish Reformation. Parliament enacted the establishment of the Protestant religion in 1560 , proscribing the Mass under penalty of death. Queen Mary, returning as a young widow to the capital which she had left as a child of six years, found the churches stripped of all adornment, the altars wrecked, the clergy, secular and regular, of her own faith banished, while from the pulpits Knox, Bruce, and other zealots hurled vehement denuncia tion against the Scarlet Woman. Knox laid the foundation of that system of national education to which Edinburgh owes so much of her distinction as a seat of learning and letters; but, dying in 1572 , he did not live to see the foundation of the university in 1583 .

Queen Mary's personal reign covered no more than six stormy years, perhaps the darkest and bloodiest in the whole history of Edinburgh. Conspicuous among the crimes perpetrated were the slaughter in Mary's presence of her favourite, David Rizzio, in 1566 , and the murder of Darnley in 1567 .

The city, which is believed to have contained at the time some 30,000 inhabitants, suffered considerably in trade when James VI succeeded to the throne of England and removed his court to London. $\mathrm{He}$ promised to revisit Edinburgh every third year, but fourteen years went by before he returned for the first and last time. Charles I was crowned in Holyrood in 1633 . eight years after his accessionthe only coronation ever performed in the Scottish capital, except that of James II in 1437. In 1637 the city was thrown into ferment when Charles sent Laud's liturgy to Edinburgh, with a command that it was to be used in all the churches. Edinburgh had been staunchly loyal hitherto; but this gave immediate birth to the National Covenant which was signed in Greyfriars Churchyard, Feb. 28, 1638. The obnoxious liturgy was withdrawn, Sept. 17, but things had gone too far; the Covenanters were under arms, and in $1639 \mathrm{Sir}$ Alexander Leslie, one of Gustavus Adolphus's veterans, stormed and captured Edinburgh Castle. After the pacification of Berwick, it was handed back in 1640 to Sir Patrick Ruthven, who also had served long under Gustavus Adolphus, for the king; but when war broke out afresh in June, it was eaptured once more by the Covenanters under Leslie.

In 1612, when King Charles took the field against his Parliament, the people of Edinburgh were fervid Covenanters; but the Scottish privy couneil declared for the king by eleven votes to nine. On Aug. 2,1643 , the general assembly pro. mulgated the Solemn League and Covenant, which sought to impose Presbyterianism by compulsion on both England and Scotland. Charles I having been executed Jan. 30, 1649, the Scottish Estates caused his son to be proclaimed king at the Mcrcat Cross of Edinburgh on Feb. 5, but the Covenan. ters would have none of him.

\section{Covenanters and Anti-Jacobites}

The duke of Hamilton, the earl of Huntly, and the marquess of Montrose were executed in succes. sion in Edinburgh. Cromwell invaded Scotland, July 22,1650 , utterly defeated Leslie's Covenan. ters at Dunbar on Sept. 3, took possession of Edinburgh and proclaimed the Commonwealth. Ten years later, at the Restoration, "the Maiden," an instrument similar to the guillotine, was set to work at the Mercat Cross.

In 1688 the Edinburgh populace was vehemently anti-Jacobite. King James VII and II had es. caped to France, but the mob overpowered the guard in Holyrood Palace; wrecked the abbey church, which had been redecorated as the Chapel Royal, and, bursting open the royal burial place, scattered the bones of Scottish kings and queens. The duke of Gordon still held the castle for the king, and his historic parting with Dundee, when that intrepid soldicr rode from the Nether Bow to his death at Killiecrankie, forms the subject of Scott's lyric Bonnie Dundec.

The city was riotously convulsed during the proceedings in the Scottish Parliament over the legislative union with England in 1707. It was little affected by the Jacobite rising of 1715 , but in 1745 Prince Charles Edward, after defeating Sir John Cope at Prestonpans, took possession of Edinburgh, proclaimed his father king James VIII at the Mercat Cross, and held a brilliant court at Holyrood for more than two months.

\section{Intellectual Edinburgh}

Notwithstanding the loss of custom and prestige caused by the departure of James I and his court in 1603 , the misery and bloodshed entailed by the civil wars and religious persecution of the $17 \mathrm{th}$ century, and the further loss consequent on the union of Parliaments in 1707, Edinburgh continued to advance both materially and intellectually. Allan Ramsay the Elder, 1686-1758, who began life as a wig-maker, must be honoured as chief pioneer in the revival of literature, for he founded the literary coterie called the Select Society, reconstructed in 1755 as the Society for Encouraging Art, Science, and Industry. The torch which he kindled was passed from hand to hand by such writers as James Hamilton of Bangour, Thomson of The Seasons, David Hume the historian, John Home the tragedian, Dalrymple Lord Hailes, Home Lord Kames, Burnett Lord Monboddo, "Jupiter" Carlyle, Adam Smith, political economist, and Henry Mackenzie, the "Man of Feeling," who introduced Burns to Edinburgh society in 1787 . These created a literary atmosphere which lingers in the Scottish capital to this day, having received fresh vigour from Jeffrey, Brougham, Lockhart, "Christopher North," and, most illustrious of all, Walter Scott.

Of social gaiety in Edinburgh there was no lack in the 18th century. Scotland had entered at the Union of 1707 on a period of prosperous industry which had been impossible during the war with England and the civil wars of the $17 \mathrm{th}$ century. The revival of agriculture set country gentlemen at work reclaiming waste lands; their increasing revenues enabled them to bring their families to town for the season to lodge in "lands" (flats, as they wculd be called now), erected high over the malodorous, crowded "wynds" and courts opening out of the High 
Street. The Old Town, indeed, had become congested in a degree incompatible with common decency and sanitation. The narrow limits of the ridge whereon the city was built made lateral expansion impossible, unless the North Loch were drained away and a New Town laid out on the far side thercof. Plans wcre prepared by the architect James Craig, and the foundations of the first house in the New Town were laid on Oct. 26,1767 . The result has been the creation of one of the most striking urban landscapes that can be found in any country. The picturesque features of the Old Town liave, indeed, been greatly impaired by the removal of at least two-thirds of the ancient "lands," as the lofty houses piled high on the ridge were called; but enough remains to offer striking contrast to the spacious streets and commodious architecture of the New Town. The scene would have been even more impressive had the North Loch been purified and retained as an ornamental sheet of water, instead of being drained away and its led occupied by the North British Railway But enough is left to justify the pride with which her citizens speak and think of Edinburgh as the Modern Athens, the Castle Rock being no mean counterpart to the Acropolis, while the Calton Hill reflects the contour and relative position of Lycabettus.

Bibliography. Cassell's Old and New Edinburgh, James Grant, 1880-83 ; Edinburgh Past and Present, J. B. Gillies, 1886 ; Royal Edinburgh : Her saints, kings, prophets, and poets, M. O. Oliphant, 1890 ; Memorials of Edinburgh in the Olden T'ime, D. Wilson, 2nd ed. 1891; The Story of Edinburgh, WV. H. O. Smeaton, 1905; Traditions of Fdinburgh, Robert Cham. bers, repr. 1912 : In Praise of Edin. burgh, R. Masson, 1912; The Heart of Edinhurgh. J. Geddie, 1913; Edinburgh: a Historical Study, H. E. Maxwell, 1916.

Edinburgh, Alfred ERNEST Albert, DUKE OF (1844-1900). The sceond son of Queen Victoria.

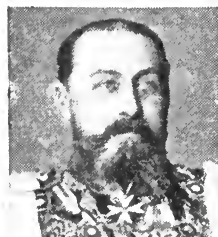

Alired Ernest.

Duke ot Edinburgh Russelt he was born at Wind sor Castle, Aug. 6, 1844. He was educated for the navy, and in $1893^{\circ}$ was made admiral of the fleet. In 1862 he was elected king of Greece, but for political reasons he refused the crown. He was created duke of Edinburgh in 1865, and in 1893 became reigning duke of Sixe-Coburg and Gotha, surrendering his privileges as an English peer, but retaining his rank of admiral. In 1874 he married Marie Alexandrovna, only daughter of Alexander Il of Russia, who died Oct. 25, 1920. He died July 30,1900 , and was succeeded as duke of Saxe-Coburg by his nephew, Leopold Charles, duke of Albany (q.v.), as his only son had died, Feb. 6, 1899. The duke was a skilled musician, especially on the violin.

Edinburgh, UNIVERSITY oF. Founded in 1583, this obtained in 1621 the same privileges as the three other Scottish universities, which were confirmed at the time of the Union (1707). Alterations in its constitution were made in 1858 and 1889. Edinburgh has six faculties, arts, science, divinity, law, medicine, and music, and its professorships usually attract distinguished scholars. Except in divinity women are admitted to its courses and degrees equally with men. Its medical school is specially efficient Edinburoh also pays much attention to agrieultural education, and has courses for the training of teachers and army officers. In 1919-20 Edinburgh had 4,300 students.

The university is ruled by a university court, a university council, and the senate, while the city council has some share in its government. Its head is the chancellor, but the actual direction is in the hands of the principal. The lord rector, another honorary official, is elected by the students every three years. It unites with the other Scottish universities to send three members to Parliament.

The present buildings, begun in 1789, occupy the site of Kirk o' Field. Prominent among them are the hall and the library. which contains a most valuable collection of books and MSS. In Teviot Row are the extensive buildings of the medical school. The university has numerous and well-equipped labor. atories and museums, and offers many scholarships to intending students. In 1919 a site of 115 acres for scienre laboratories was acquired on the southern outskirts of the city, between Mavfield and the Blackford Hill. On July 6 , 1920, King George laid the foun. dation stone of the new buildings.

Edinburgh ACADEMY. Scot. ish public school. It was founded by royal rharter in 1824, and the buildings near Stockbridge stand in grounds eovering three acres. They include a school hall, gymnasiun, rifle range, library, and fives courts, as well as class-rooms, laboratories, etc. There is a pre- paratory school. The total number of boys is about 650. Most of them are day boys, but there are three houses for boarders. The headmaster is known as the rector, and the school is governed by a board of directors. : The Edinburgh Academicals, composed of old boys of this school, is one of the most famous of Scottish football clubs.

Edinburgh Review, The. First of the great critical quarterlies, but the second of the same name. Its predecessor was brought out in 1755, under Adam Smith, Alexander Wedderburn, and others, and only ran to two numbers. The famous blue-and-buff Whig organ was projected by Sydney Smith, who edited the initial number published at Edinburgh in Oct., 1802. Francis Jeffrey was editor, 1803-29, Macvey Napier, 1829-47, William Empson, 184752, Sir George Cornewall Lewis, 1852-55, Henry Reeve, 1855-95, Arthur Elliot, 1895-1912, and since 1912 Harold Cox. Francis Jeffrey's literarycriticisms provoked Byron's English Bards and Scotch Reviewers. Lord Macaulay's Essays first appeared in the Edinburgh; other contributors were Lord Brougham, Lord Houghton, Lord John Russell, Robert Lowe, and Jchn Stuart Mill.

Edinburghshire. Name of the county more correctly known as Midlothian (q.v.).

Edison, Thomas Alva (b. 1847). American physicist and inventor. He was born at Milan, Erie co., Ohio, Feb. 11, 1847, of mixed Dutch and Scottish descent. At the age of twelve he began life as a newsboy on the railway, and before long distinguished himself by set.

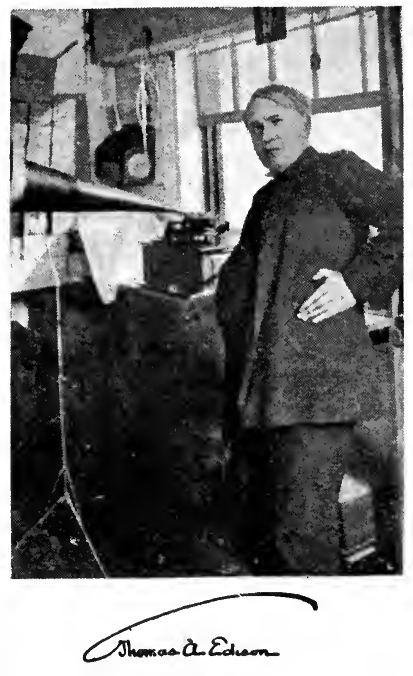


ting up and printing on the train a little news sheet, The Grand Trunk Herald. He learnt the elements of telegraph operating, and shortly after began to invent a remarkable series of improvements on the then crude methods of electrical transmission which revolutionised telegraphy throughout the world. The automatic repeater, the quadruplex and printing telegraph, and the sextuplex method of transmission followed in rapid succession.

While still a young man he set up an establishment largely devoted to experimental work in all branches of science. Here he brought to perfection the phonograph, the forerunner of the modern gramophone, the kinetoscope, out of which developed the cinematograph, and many other inventions which were practically fundamental. More than 900 patents have been granted to him for his inventions, and he has been honoured by innumerable scientific bodies and universities. During the Great War he designed benzol and carbonic-acid-producing plants on a large scale.

The range of Edison's inventions is such that he has left his mark on nearly every branch of science. Many of them, as the kinetoscope and phonograph, have resulted in the creation of entirely new industries and methods of thought and news distribution, while his improvements in telegraphic methods of communication may be compared with those of wireless due to Marconi. See Cinematography; Phonograph ; Telegraph; consult also Lives, E. C. Kenyon, 1896 ; F. A. Jones, 1907 ; F. L. Dyer and T. C. Martin, 1910.

Edith Cavell. Mt. of Canada. A peak of the Rocky Mts., it is situated in Alberta, close to the border of British Columbia; 14 m. S. of Jasper on the G.T.P. Rly It is about $11,000 \mathrm{ft}$. high, and was named after Nurse Edith Cavell (q.v.).

Editor (Lat. edere, to produce). One who controls the production and contents of a newspaper, book, or magazine. On daily newspapers his personality and political and business acumen and knowledge of men and affairs are more vital than literary facility, the necessity of his close attention to detail being obviated by subdivision of labour." In book and magazine production he needs special qualifications according to the nature of the work on which he is engaged. In all cases practical knowledge of the various processes connected with printing, illustration, etc., is essential. See Journalism; Newspaper.
Edmonton. Urban district of Middlesex, England. It stands near the New and Lea rivers, $2 \mathrm{~m}$. N. of Tottenham by the G.E.R. and $2 \mathrm{~m}$. $\mathrm{s}$. of Enfield. It has some timber trade on the Lea, and the place is associated with Cowper and Keats. Charles and Mary Lamb lie buried in the parish churchyard. The National Aircraft Engine Factory built here during the Great War on a site of 14 acres, at a cost of $£ 133,000$, was purchased by a motor firm in 1919 . One member is returned to Parliament. Pop. 64,797.

Edmonton. Capital of Alberta, Canada. It stands on a high tableland overlooking the $\mathrm{N}$. bank of the North Saskatchewan river. 793

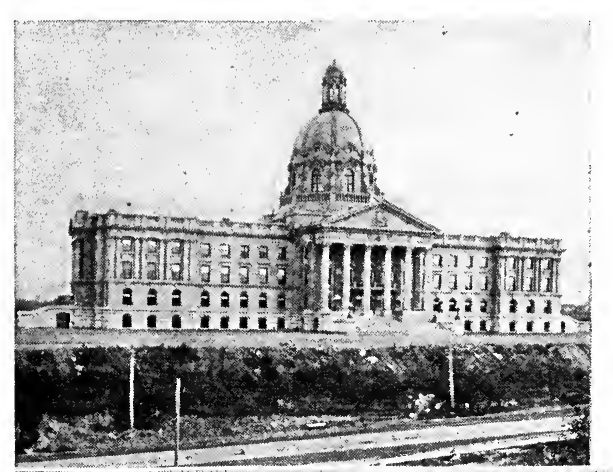

Edmund or EADMUND (811-70). Saint and king of East Anglia. Late legends describe him as the son of Alkmund, king of the Saxons, and state that he was born at Nuremberg and adopted by Offa, whom he succeeded as king of East Anglia in 855. Captured by the Danes on their invasion in 870 and refusing to give up Christianity. he was beheaded at Hoxne, Suffolk. His body was removed in the 9th century to Bury (now known as Bury St. Edmunds), where thefamous shrine was erected. He was held in great veneration as a saint, many English churches are dedicated to him, and his festival is kept on Nov. 20. See Life, J. B. Mackinlay, 1893.

Ed mund $(c$. $922-46)$. King of the English. 'The son of Edward the Elder and grandson of Alfred the Great, he succeeded his halfbrother Athelstan in 940 . He fought against the Danes in the north, the result being a division of the kingdom. This did not last long, as Edmund crushed the Danes in Mercia.

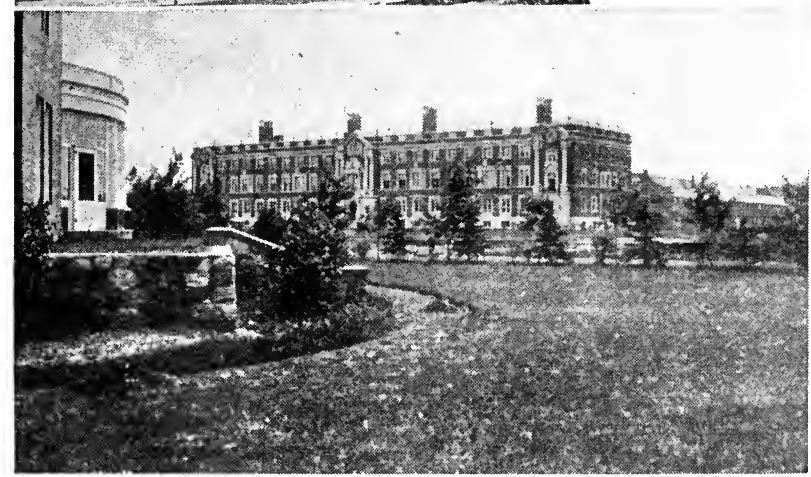

Edmonton, Canada. View of Alberta University, founded in 1906 ; above, the Parliament buildings of the province of Alberta

m. W. of Winnipeg. Served by the and was again ruler of the whole Canadian Pacific, Grand Trunk land. He subdued Cumbria in Pacific, and Canadian Northern 945 and bestowed it on Malcolm, Rlys., the city has grown rapidly king of Scotland, on condition in recent years. Edmonton's that he should be his "fellow. public buildings are substantially worker by sea and land." He built and the churches have some was mortally stabbed by an outarchitectural merit; the suburbs law at Pucklechurch, Gloucesterare extensive. There are large shire. May 26,946, and was buried meat-packing plants, saw-mills, etc. at Glastonbury. Edmund's miliThe Hudson's Bay Co. established tary victories and reforms in church a post early in the 19 th century, and state gained him the name of and it is largely to the fur trade the Deed-doer and the Magnificent. that the city owes its prosperity. His two sons, Edwy and Edgar, Pop. 61,045. See Alberta. became kings after him. 
Edmund (c. 1175-1240). Saint and archbishop of Canterbury, known as Edmund Rich. Born at Abingdon, after studying and lecturing at Oxford and Paris he became in 1222 treasurer of Salisbury. He preached the Crusade in Eng. land, 1227 , and on the nomination of Gregory IX was elected archbishop of Canterbury, 1233. Edmund vainly endeavoured to persuade Henry III to get rid of his foreign favourites, and was equally unsuccessful in establishing discipline amongst the monks at Canterbury, and in his protest against the provision of English benefices for Italian clergy. Finally in $1240 \mathrm{Ed}$ mund withdrew to France, where he died at Soissy. He is buried at Pontigny, and was canonised 1247. His festival is kept in the Roman Catholic Church on Nov. 16, the day of his death, and a college is dedicated to him at Ware. See Lives, F. de Para vicini, 1898, and B. Ward, 1903.

Edmund Ironside (c.981-1016). King of the English. A younger son of King Ethelred the Unready, he appeared in public life about 1015. He was ruling Mercia, evidently as an under-king, when Canute invaded the land, and raised an army for its defence. Beaten, he was forced into Northumbria, and the war was raging when Ethel. red died. Edmund was chosen king in London and Canute at Southampton, and the war between them was continued more fiercely than before. In Somerset the English king was victorious, and after a protracted battle at Sherston, in Wiltshire, he was left master of Wessex. He then fought battles to relieve London from the attentions of Canute, but then followed the terrible defeat at Assandun. After this the two kings met and decided upon a division of the kingdon, but Edmund had not reaped the benefit of this when he died in London, Nov. 30, 1016. He was buried at Glastonbury, and left two sons, Edmund and Edward. Edmund won his name by the personal bravery which he consistently displayed, and his fighting record of a single yean.

Edmunds, George FrankLIN (1828-1919). American politician. Born at Richmond, Vermont, Feb. 1,1828 , he became a barrister in 1849. From 1854-59 he was member of the Vermont house of representatives and Speaker of the lower housc, 1856-59. Member of the state senate, 1861-62, he acted as president, and from 1866-91 he was member for Vermont in the U.S. Senate, and leader on the Republican side. In $\mathbf{1 8 8 2}$ he was author of the Anti-Polygamy Act, known as the Edmunds Act, and

in 1890 of the Anti-Trust Law. After retiring from the U.S. Senatc, 1891, he resumed practice and gained a leading position as a constitutional lawyer. $\mathrm{He}$ died Feb. 27, 1919.

Edom. District situated to the S. of Palestine. It stretched from the Dead Sea to the Gulf of Akabah, covering an area of about $100 \mathrm{~m}$. by $20 \mathrm{~m}$. The name Edom (red) is probably derived from the prevalent red sandstone of the district. Its first recorded inhabitants were a cave-dwelling race known as the Horites, who were conquered by Esau and his sons. During the Exodus, the inhabitants of Edom refused to allow the Israelites passage, and hence arose a feud which lasted till the end of the second century B.c. Both David and Solomon defeated them,but in the reign of Jehoram they threw off the yoke. Amaziah and Uzziah again sub. dued them, but after the fall of Judah they again became free till the days of the Haccabees, when they were finally crushed and forcibly proselytised by John Hyrcanus. The Edomites were polytheistic in religion, and marriages between their women and the Hebrews were a frequent source of trouble. The Herods were of Edomite origin. See Palestine.

Edremid. Variant spelling of the port of Asia Minor better known as Adramyti (q.v.).

\section{EDUCATION: ITS MEANING AND AIMS}

John Adams, M.A., LI.D., Professor of Education, London University

In addition to this introductory article, the subject is considered under School; University; Co-education; Froebel System; Kinder. garten, etc. See also the articles on the universities of the British Empire and on the leading colleges and public schools

The uncertainty about the precise meaning of the term education is strikingly illustrated by the titles of four books: The Meaning of Education, N. M. Butler, 1898; What is Education? Stanley Leathes, 1913 ; What do we Mean by Education? J. Welton, 1915 ; What is Education ? E. C. Moore, 1915. For practical purposes, how. ever, it may be taken as generally agreed that education means whatever is done deliberately by one generation to pass on to its successors all that it has gained in the way of knowledge about how to make the most of life. The element of deliberate purpose is usually included in attempts to define education more or less scientifically.

In a general sense, men and women are being educated all thcir life, from the cradle to the gravc. In Latin educare means really the bringing up of children. The French élever, the German erziehen, and the
American colloquial term " raise," have this underlying meaning.

Education as such has to do with the proper upbringing of children, the training of their mental and physical powers, the formation, moulding, and direction of their character. But since the instrument used in our schools to accomplish this purpose is knowledge, there has arisen a not unnatural impression that education consists in the imparting of knowledge. Schools have come to be regarded as information-shops, and teachers have taken rank as knowledge-mongers.

In the public schools of England this prominent position hås not been assigned to knowledge ; indeed, the tendency has been rather in the opposite direction; too little attention has been paid to actual instruction. Critics maintain that in the public schools in the past the pupils have been actually discouraged from taking or 
showing any interest in things intellectual. On the other hand, it is generally admitted that nowhere has the training of character been more successfully carried on than in these schools. This was well recognized even before the Great War. The avowed aim of the English public schoolmaster is to turn out gentlemen, and the instrument hitherto used in the process has not been so much knowledge as games. An excessive use was perhaps made of this instrument, but the schoolmaster succeeded in accomplishing his aim. It is thought, however, that the schoolmaster could combine the excellences of his method of character training with a much greater amount of actual instruction in more or less useful subjects. The introduc. tion of this term useful raises a problem.

\section{Education and Utility}

Universities and secondary schools have been long dominated by the concept of what is called a liberal education, by which is meant an education suitable for a free man : an education that will make him as nearly as possible a perfect human being as suri , apart from any consideration of work or vocation. Thus one of the essential qualities of a liberal education is freedom from any taint of the useful in the ordinary meaning of that term. The pupil shall develop fully and freely all his qualities as a human being, irrespective of any use to which these qualities may be put. Some have gone the length of advocating the cult of the useless as something in itself desirable, but the more usual attitude is that the truly educated man is one who has been trained in subjects that are not required in earning a living, and that are not to be put to any use leading to material advantage.

Along with this more or less avowed cult of the useless, there grew up a theory that did some. thing to salve the conscience of practical English people. It was admitted that, as artisans and other humble folk had to be specifically prepared for the particular line of work that was to be their portion, so it was desirable that even those who would be called upon to sit in the seats of the mighty should get some sort of training that would have the direct result of fitting them to discharge their duties efficiently. Princes have quite a specific train. ing, and certain other high dignitaries have an equally satisfactory preparation for their life work. The lure of the liberal arts was, how. ever, very strong, and the fortunate free men of the world were willing that the education of their children should be marked off from that of the unfree and artisan class.

A justification of this purely general and unspecific training was found in the theory that the subject studied did not in itself matter; that the training acquired in the process of mastering it did. The mind could be trained apart altogether from the nature of the material upon which it was exercised. The student of classics and mathematics learned not only to be a mathematician and a classical scholar, but to be a well-trained man in general. His mind was trained as mind, and was ready to be applied to any subject.

This is the much debated doctrine of formal training, accord ing to which a man who has been trained in any subject can carry over the results of that training to any other subject; so that, for example, a man who has been trained in physics and mathematics may at once turn his training to account in governing a district in India.

\section{Culture and Vocation}

The cultural ideal stands at the one extreme, the vocational at the other. Those who believe in specific education hold that pupils should be prepared definitely for the particular line of life they are to follow. Naturally certain difficulties arise at once. To begin with, it is im. possible to tell at an early age what the vocation of a particular pupil is to be. In olden times, when a man was practically born into a particular vocation, all went well. But in these days of wide opportunity the pupil must be left un fettered as long as possible so that his bent and capacities may be discovered. Indeed, one of the main problems of education in the future will be this determination of the possibilities of each individual pupil. The educator will be called upon, not merely to train for a particular kind of work, but to discover what the kind of work ought to be in each case. This will imply division of labour, and there will be cooperation between those who test capacity and those who develop it. Everything is therefore in favour of a gradual narrowing of the curriculum as the pupils advance in schoo, determined by the develop. ment of capacity and bent.

Vocational education must not be understood to apply only to the preparation of artisans. On account of confusion under this head the Workers' Educational Association is suspicious of vocational education, for it fears that the employing classes are anxious to get workmen broken in to their life's occupation as soon as possible, and thus to turn them into specially efficient cogs in the industrial machine. There are, however, other than economic reasons for postponing as long as possible the decision of a pupil's ultimate vocation. A large part of the preliminary stage of education must be the same for all. Reading, writing, elementary arithmetic, and rudimentary drawing are of this kind, and have to be learned by all, irrespective of the use to which they have afterwards to be put. Certain other subjects are of value to all, no matter what their social position afterwards may be. Geography, history, literature, music, art, and general science belong to this group. By the time these subjects have been studied for some years the teachers will be able to deter. mine the ability and the bent of the different pupils, and to advise them with regard to their further studies.

Every child is assumed to have a right to claim from the state an education suitable to his capacity, and without reference to his social rank. Has the state a corresponding right to educate its citizens: is the right to claim an education paralleled by a right to impose one? The remark comes down to us from classical times that states. manship is "architectonic to education," in simpler language, that the educator has to take his orders from the statesman, because the statesman uses the human material prepared by the educator. In actual practice this principle is now generally recognized. No doubt in the past the influence of the state in education was largely negative; certain sections of the community were denied the privileges of education, and the segrega. tion of ranks was so secured.

\section{Education and Politics}

But in modern times the state exercises the right of modifying the education of its citizens to suit its own ends. Germany is the conspicuous example of this attitude. In 1806, after Jena, Prussia was deprived by Napoleon of every chance of self-government -except in education. But the Prussians under the leadership of Fichte, von Humboldt, and others, deliberately set about regenerating their nation by means of education. As a result, Bismarck was able to say that it was the schoolmaster who conquered at Sadowa and afterwards at Gravelotte. Though used for a bad purpose, German education was no less powerful in moulding national character and opinion from 1871 to 1914 . Japan offers an equally striking, but more pleasing, example of the power of national education when deliber. 
ately applied to political ends. The rulers there determined to western. ise the country, and by intelligent and purposeful manipulation of the educational system accomplished their end in a single generation.

As was to be expected from the English spirit, education has not developed in this way in Great Britain. Many attempts have been made to dominate education for sectional ends, mainly religious, but the spirit of compromise won at last, and the existence of the conscience clause which provides that no pupil shall be taught religious doctrines to which his parents object, or suffer because he is withdrawn from such instruction, is a clear proof that even ecclesiastical zeal has not been able to obtain complete control of the schools.

\section{Schools and Propaganda}

It would be impossible to use the English schools after the German fashion for purposes of propaganda in the interests of a ruling class. Hitherto the main demand for propagandist opportunities has come from honest enthusiasts who have some social panacea, and know that an entry into the schools is the best way possible of bringing influence to bear in favour of their nostrums. Prohibitionists, esperantists, advocates of the metric system, antivaccinators, anti - vivisectionists, and other particular theorists have sought to gain admission to the schools. No doubt with increasing intercommunication between the home and the school there will in the future be a wider use of educational organization for purposes of social and ethical propaganda, but no propaganda will be toler. ated that does not command very wide popular support.

Many people, however, regard with uneasiness the growing centralisation of the educational administration of England. The intense individualism of the Englishman makes him inclined to resent any interference with what he regards as peculiarly his own, and under this head his children hold a prominent place. The nation, however, has got beyond the stage at which one is inclined to claim that, with regard to the education of one's children, one ought to be allowed "to do what one will with one's own." It has learnt that for the best working of national education there must be a certain amount of central control. But English people seem to want this control kept within narrow limits. They have watched with uneasiness the history of state interference in education.
Since the first government grant in 1833 the state has been gradu. ally gathering under its control th 3 educational system. At first it eonfined its authority to the elementary schools, but by the power of the purse it has been able to bring the secondary schools more and more under its control, and now by an extension of the grant system the universities themselves are coming within the range of state authority. There has not, however, been any attempt to influence unduly the schools, the colleges, or the universities of the country. Indeed, the Board of Edu. cation is showing itself particularly anxious that the local authorities should share the burden of ad. ministration, and recent changes in the distribution of financial burdens between central and local authorities make it much easier for central and local authorities to work harmoniously together.

In England the educational expert and the educational administrator have in the past been brought far too little together. The Edueation Act of 1918 marks an important advance in this matter. For the first time there was a minister of education who was really in intelligent sympathy with educational principles and methods, and the Act benefits accordingly. It has the great merit of making provision for the adolescent period, the period of most importance in the development of the individual, but a period that had not been specially considered in previous educational legislation. In this and in other points the Act recognizes fully the need to take account of the results of those who are engaged in educational research.

\section{Progress of Scientific Method}

Hitherto education has been car. ried on on a basis of generalised opinion rather than of established principles. Not merely administrators but profëssional teachers them. selves have been content to accept traditional opinions and methods. There has been no satisfactory means of comparing the advantages of the different educational schemes suggested from time to time. In short, there has been no science of education. Whether such a science can ever be developed is a point in dispute.

Although it can never become an exact science, education is be. coming more scientific in its methods. It is perhaps impossible ever to establish a real objective standard in education that might do something like what the thermometer or the barometer does for other sciences; but we are on the way towards it. Statistical and experimental methods are being widely developed in education, and educational results now published are no longer mere subjects of logical debate, but are at once tested by repeating the experiments or observations on which they are based.

In this sifting process much help may be looked for from the scien. tific methods used by Prof. Karl Pearson, Prof. Spearman, and others. Although the results of these mathematical investigations may be over-valued, there can be no doubt that they provide an in. strument that will be of the first importance in making real educational progress possible.

\section{Development of Child-Study}

A contrast to this over-exactness of mathematical formulae is pro. vided by what is called child-study ; with the result that we have a very happy combination of the abstract and the concrete. Such investigations as Prof. Binet carried on to determine scales of intelligence are examples of child-study scientifically conducted. The correlation of bodily with mental age is a helpful concept, and promises to be of great value. It provides what is practically an objective standard in determining the normal, the sub. normal, and the supernormal child. The nature of the defective child is becoming much clearer, thanks to the tests developed from the Binet scheme. The treatment of supernormal children is only now receiving serious attention from educational authorities, and a profound modification of class organization is likely to follow. At this point the social changes coming into educational organization call for mention. The correlation of scientific testing of individual pupils with the social school organization implicit in such a scheme as is worked out at Gary, in Indiana, cannot but lead to fundamental changes. We are indeed on the brink of a real, but not a sudden, revolution in education.

Biblography. Essays on Educational Reformers, R. H. Quick, 1868 ; Teaching and Organisation, ed. P. A. Barnett, 1897 ; Common Sense in Education, P. A. Barnett, 1899; Education: intellectual, moral, and physical, Herbert Spencer, repr. 1903 ; 'The Educative Process, W. C. Bagley, 1905 ; A Text. book in the History of Education, P. Monroe, 1905 ; Sonnenschein's Cyclonaedia of Education, ed. A. E. Fletcher, revised M. E. John, 1906 ; The School and Society, J. Dewey, 1911 ; Cyclopedia of Education, ed. P. Monroe, 1911-13 ; 'The Evolution of Educational 'i'heory, John Adams, 1912 ; A Text Book in the Principles of Education, E. N. Henderson, 1911; Principles of Education, F. E. 
Bolton, 1911; Educational Problems, G. S. Hall, 1911; What is Education ? S. M. Leathes, 1913 ; From Locke to Montessori, William Boyd, 1914 ; Principles of Secondary Education, ed. P. Monroe, 1914; What do we Mean by Education? J. Welton, 1915; Schools of To. morrow, J. Dewey, 1915 ; What is Education? E. C. Moore, 1915; The New Terching, ed. John Adams, 1918 ; Experimental Education, R. R. Rusk, 1919; The Measurement of Intelligence, L. M. Terman, 1919 ; Short History of Education, J. W. Adamson, 19 19; Education : its Data and First Principles, T. P.Nunn, 1920.

Education, BOARD of. Body established ih 1899 to supervise public education in England and Wales. Its head, the president, is a party politician, usually a member of the Cabinet, and receives a salary of

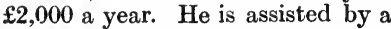
parliamentary secretary and a permanent secretary, under whom are a large staff of inspectors and other officials, and also by a consultative committee. The chief departments of the Board are concerned with elementary education, secondary education, technical education, and training colleges. The Board looks after the Science Museum at South Kensington and the Geological Survey and Museum.

Before the establishment of this Board education in England and Wales was controlled by a com. mittee of the privy council, first appointed for this purpose in 1839 . The lord president of the council was the head of this, but the real minister of education was the vicepresident, also a politician. In Scotland education is looked after by an education department under the general control of the secretary for Scotland; in Ireland the work is done by the national education board as regards elementary, and the intermediate education board as regards secondary education. In Canada, Australia, and also in the various states and provinces therein, there is a department of education presided over by a minister, as there is in manv foreign countries.

Education Acts. Series of Acts dealmg with education in England and IVales from 1870 onwards. The principal of these were the Elementary Education Act of 1870, which instituted a state system of compul. sory education, side by side with the voluntary schools, and initiated the long controversy on the subject of relicious instruction: the Act of I891, which reduced or abolished schoolffees: the Act of 1902 , by which an education rate was levied in respret of all schools, both state and voluntary: and the Act of 1918, which dealt comprehensively with the whole question of educa- tion, raising the school age, and providing free and compulsory instruction for young persons up to the age of 18 by means of continuation schools. See Continuation Schools Education ; Evening Schools.

Edward, LAKE, formerly Alber't Edward Nyanza. Lake of East Central Africa, $150 \mathrm{~m}$. W. of the Victoria Nyanza. Lying at an alt. of $3,000 \mathrm{ft}$. above sea level, it is con nected on the N.E. by a tortuous channel with Lake George. The latter was discovered by $H$. M. Stanley in 1875 , who believed it to form part of the Albert Nyanza; but, while tracing the source of the Semliki river in 1889, he dis covered the lake he named Albert Edward Nyanza, and also the channel connecting it with Lake George. The length of Edward Lake is $44 \mathrm{~m}$. and the breadth $33 \mathrm{~m}$.

Edward. Masculine Christian name. Of Teutonic origin, it means able to guard. It was very popular among the Anglo-Saxons, being borne by Edward the Elder, Edward the Confessor, and other kings, and has since been one of the most used of English names. The Anglo-Saxon Edward is sometimes spelled Eadward, a form which gives the best idea of the diphthong with which it began in that tongue. Eduard, Edouard, and Edoardo are the German, French, and Italian forms. Edward is the form used throughout this Encyclopedia.

Edward, CALLED THE Elder (d. 924). King of the English. The son of Alfred the Great, he fought against the Danes and was called king before his father's death. In Nov., 901, the witan chose him as Alfred's successor. His succession was disputed by his consin Ethel. wald, who rebelled and was slain in battle in 905 . By 918 Edward brought the Danes into subjection ; in 919 , on the death of his sister Ethelfleda, he absorbed Nercia; and in 921 he subdued the Welsh. $\mathrm{He}$ ruled as far nurth as the Humber, and his overlordship was acknowledged by all the other kings. The "unconquered king," as Florence of Worcester calls him, died at Farndon, Northamptonshire, and was buried at Winchester. He left a large family, including his successor Athelstan, and daughters who married Hugh, count of Paris, and the emperor Otto the Great.

Edward, called THE MARTYR (c. 963-978). King of the English. The son of Edgar, his right to the succession was disputed on Edgar's death in 975 by his stepmother Elfrida, who put forward her son Ethelred (the Unready). Edward was supported by Archbishop Dunstan, and was crowned. On Mar. 18, 978, he was assassinated by
Elfrida's orders, while being offered a drinking-cup, and was hastily buried at Wareham. In 980 his body was transferred to Shaftes. bury, and his tomb became a place of pilgrimage. He was long rever. enced as saint and martyr, his festival being kept on March 18.

Edward, CALIED THE CON FESSOR (c. 1005-66). King of the English. The son of Ethelred the Unready

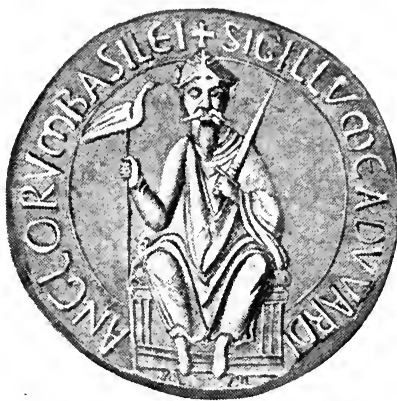

Great Seal of Edward the Confessor

and Emma, daughter of Richard, duke of the Normans, he was born at Islip, Oxfordshire. He was taken to Normandy by his parents when Sweyn became king in 1013. Invited to England in 1041 by his half-brother, Hardicanute, when the latter died in the following year Edward was chosen ling, and placed on the throne largely by the help of Earl Godwin, whose daughter Edith he married in 1045 .

His reign was peaceful, though marked by struggles for power between the English and the Normans, the latt $\rightarrow r$ being befriended by the king. Edward's chief interest was religion, and he devoted a large part of his revenues to the erection of Westminster Abbey. It was consecrated at the end of 1065 , and Edward died Jan. 5, 1066. He was canonised in 1161, and his festival is kept on Oct. 13 . See Lives of Edward the Confessor, ed. H. R. Luard, Rolls Series, 1858.

Edward I (1239-1307). King of England. 'The eldest son of Henry III, he was born at Westminster,

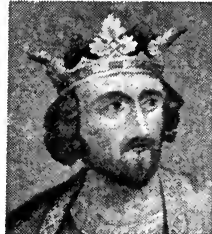

Edward I.

King of En 7 land, 1272-1307 June 17, 1239. In the differences between the crown and the baronage, Edward sided with his father, and was taken prisoner after the battle of Lewes, 1264 . He es a p ed. however, and directed the royalist victory orer Simon de Montfort at Evesham in 1265. He succeeded to the throne 
in 1272. During his reign, Edward conquered Wales, and endeavoured to form a united kingdom embracing the whole island by asserting his sovereignty over Scotland, which regularly rebelled whenever the king was sériously engaged elsewhere. Edward was at the head of an invading army when he died, July 7, 1307, at Burgh-on-Sands.

Edward ranks as one of the greatest kings of England. He systematised the English laws, and gave the English parliamentary system its definite form by summoning to the Model parliament of 1295 not only the higher elergy and baronage, but knights and burghers. $\mathrm{His}$ tomb in Westminster Abbey bears the inscription, Malleus Scotorum, "the Hainmer of the Scots." and his motto, Pactum serva, Keep troth. Edward's first wife was Eleanor, daughter of the king of Castile, and his second wife was Mlargaret, daughter of Philip of France. See Edward I, T. F. Tout, 1893; also illus. p. 2240.

Edward II (1284-1327). King of England. Son of Edward I, he was born at Carnarvon, April 25, 1284. In 1301 he was created prince of Wales at Lincoln and he acted as regent when his father

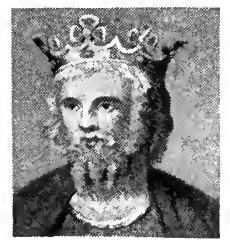

Edward II,

King of England, $1307-27$ was a w a : however, he early revealed the indolence and $1 \mathrm{ev}$ it $\mathrm{y}$ that fin a $11 \mathrm{y}$ destroyed him. In 1306 he was given the province of $\mathrm{G}$ a scon $\mathrm{y}$, and in 1307 he became

king. He abandoned the war against Scotland, and was married to Isabella of France.

Edward was already under the influence of Piers Gaveston. The barons took up arms with Edward's cousin, earl Thomas of Lancaster, at their head, and they forced upon the king the banishment of Gaveston. A reconciliation, brief and insincere, followed. In 1314 the Scotch war was renewed and Edward suffered defeat at Bannockburn. 'This was Lancaster's opportunity, and for a time the king was a cipher, but he found fresh favourites in the Despencers, and a combination of circumstances brought about the defeat and death of earl 'Thomas in 1322 . Edward and the Despencers were then supreme until 1326. Isabella, alienated from her husband, crossed from France with some followers. Caught in Wales, he was formally deposed, and on Sept. 21, 1327, he was murdered at Berkeley Castle.
See Place and Reign of Edward II in English History, T. F. Tout, 1914 ; also illus. pp. 1077 and 1713.

Edward III (1312-77). King of England. Born Nov. 13, 1312, he was raised to the throne by the deposition of his father, Ed. ward II (Jan., 1327 ). The government was in the hands of the queen - mother Isabella and Roger Morti-

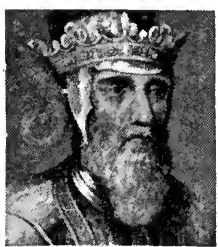

Edward III, King of England, $1327-7 \%$ mer till the young king, who married Philippa of Hainault, 1328, overthrew them by a coup d'état in 1330 .

At first Edward warred against the Scots, but his ambitions were soon turned to France, and in 1338 began the Hundred Years' War. In the course of it he secured the English supremacy of the narrow seas by the naval victory of Sluys, June 24, 1340, established the prestige of the English soldiery and the military supremacy of the English archers by the startling victory of Crécy, Aug. 26, 1346; and in 1347 captured Calais. A victory was won by his son Edward the Black Prince at Poitiers, Sept. 19,1356 , and Edward was confirmed in the independent sovereignty of Aquitaine by the treaty of Brétigny in 1360. He died, prematurely senile, June 21, 1377. His family included the dukes of Clarence, York and Lancaster, whose descendants fought for the crown during the Wars of the Roses. He was the first king who conspicuously directed poliey to commercial expansion, the security of the trade with Flanders being one of the objects of his French wars. See Lives, W. Longman, 1869; W. Warburton, 2nd ed. 1876; J. Mackinnon, 1900.

Edward IV (1442-83). King of England. The eldest son of Richard duke of York, and Cicely Neville. he was born at Rouen, A pril 28,1442 . In Dec., 1460, he became the leader of the Yorkists and their candidate for the crown. Acting with great energy, he erushed the L a n c a strians at Mortimer's Cross, and in

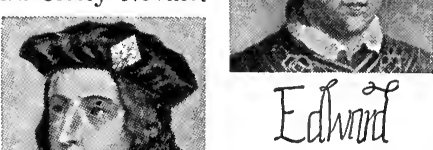

After a victory at Towton Edward was able to hold his own, although not absolutely secure. In 1469 , however, came a change. He had made many enemies by the favour he showed to his wife's kinsfolk, the Woodvilles, and when Warwick and Clarence, the king's brother, joined his foes, his position was precarious. He prepared to meet them in the field, but the desertion of 6,000 men was fatal to his cause, and in great haste he left Lynn for the Netherlands. Returning with an army, he won battles at Barnet and Tewkesbury. In 1475 he con ducted a short war with France and he had some trouble with Scotland, but in general he kept the land at peace. He died April 9, 1483. See Life, L. Stratford, 1910; also illus. p. 1802.

Edward V (1470-83). King of England. He was born in the Sanctuary, Westminster, Nov. 3, 1470 , a son of Edward IV and E l i z a b e th Woodvi]le. When he succeeded to the throne, April 9, 1483 , his uncle, the duke of G lou cester, was his a refor d i a $n$.

Gloucester, however, imprisoned the boy king and his brother in the Tower, and had himself crowned as Richard III, July 6, 1483. According to Sir Thomas More, endorsing contemporary belief, Edward and his brother were murdered very shortly after. See Richard III.

Edward VI (1537-53). King of England. He was born at Hampton Court, Oct. ]2, 1537, the son

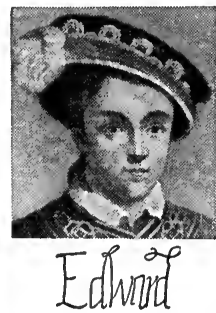

of Henry VIII and his third wife, Jane Seymour, and succeeded to the throne, Jan. 28, 1547. His uncle, the duke of Som erset, was pro tector and the real ruler for the first half of the reign, and on Somerset's fall and execution, to which the young king calmly assented, his rival, the earl of Warwick, later duke of Northumberland, held the chief power. The young king favoured Northumberland's plan for securing the succession of his daughter, Lady Jane Grey. Edward died at Green. London was hailed as king. He wich, July 6, 1553. See King then seated himself on the throne Edward VI: an appreciation, C. R at Westminster on March 4, 1461. Markham, 1907. 
EDWARD VII: KING AND PEACEMAKER

J.G.J. Pencerel-Brodhurst, Author, The Life and Times of Edward VII

As in the case of other kings of England, an article is devoted to the life and work of this monarch. For the history of his time see Europe: France; Uniled Kungdom, elc. See also Victoria

Albert Edward, the second child and eldest son of Queen Victoria and Prince Albert of Saxe-Coburg, was born at Buckingham Palace, Nov. 9, 1841. He was educated upon pedantic and rigid lines, which made his boyhood a weariness and his adolescence a struggle for emancipation. His day was carefully mapped out; every hour had its allotted subject, and light reading was frowned upon; he was kept in on every side by governors and tutors, and allowed to associate intimately only with youths of his own age. carefully chosen for their high qualities. 'This method excluded much of the human side of life, and left little room for the escape of the high animal spirits which Edward VII possessed almost to the last. He studied science at Edinburgh, and went up succes. sively to Christ Church, Oxford, and Trinity, Cambridge, but took no degrees. The wisest part of his education consisted of travel, and the Prince Consort exhibited ad mirable foresight when, in 1860 , he arranged a long tour for his son in Canada and the U.S.A. At the end of 1861 Prince Albert died. and immediately afterwards his son paid a visit to the Holy Land.

In 1863 he married Princess Alexandra, daughter of Prince Christian of Glücksburg, who shortly afterwards became king of Denmark. Good-looking, goodhumoured, frank and open, with an untiring zest for life, of cosmo politan tastes, yet an Englishman to the core, his marriage greatly increased the popularity which he had always enjoyed. For very many years he performed with tact and assiduity the representa. tive functions which Queen Vic. toria felt herself unable to face. The more tedious duties of royal personages in a democratic mon. archy are hardly a training for statesmanship, but they bring a prince into contact with the people, and provide him with the means of becoming acquainted with every corner of his country and with manv social grades.

King Edward made the best of such opportunities. He had an inexhaustible interest in men. They were the books from which he learned. and as time went on his knowledge of social and political movements became extensive. $\mathrm{He}$ knew all the distinguished men in Europe, and gradually developed a keen and sane interest in affairs, and especially in foreign politics. Yet his political knowledge was acquired externally and by inter. he was turned fifty was Queen Victoria's assent obtained to his receiving copies of important dispatches. Foreign politics fascinated him, and from middle life to the close of his short but brilliant reign he was profoundly in. terested in the external relations of the Empire.

Side by side with this absorbing interest he developed keen sympathy with social reform. He was a member of a royal commission on the housing of the poor ; to him the London hospitals owe in large measure the present living interest in their work. His solicitude for the alleviation of pain course with politicians. Not until

From the portrait by Harold S pecd. By permission of the Fine Arts Publishing Co. and sickness was to some extent the outcome of his own grave illness from typhoid in 1871, when he was saved from death only by the most skilful nursing and a robust constitution. It was the social and charitable side of freemasonry which made him an enthusiast for "the Craft," and brought him to the English grand mastership.

As heir to the throne the prince necessarily sat upon the crossbenches of the House of Lords. Both as prince of Wales and as king he was a great traveller, and in 1875 he paid a memorable visit to India which laid the foundations of the more modern relations of that empire with the mother-country. Yet, despite the popularity won by his unfailing tact, inherent dignity, and careful attention to the duties which fell upon him, or which he made for himself, he was not exempt from criticism. There were those to whom his love of the turf-he
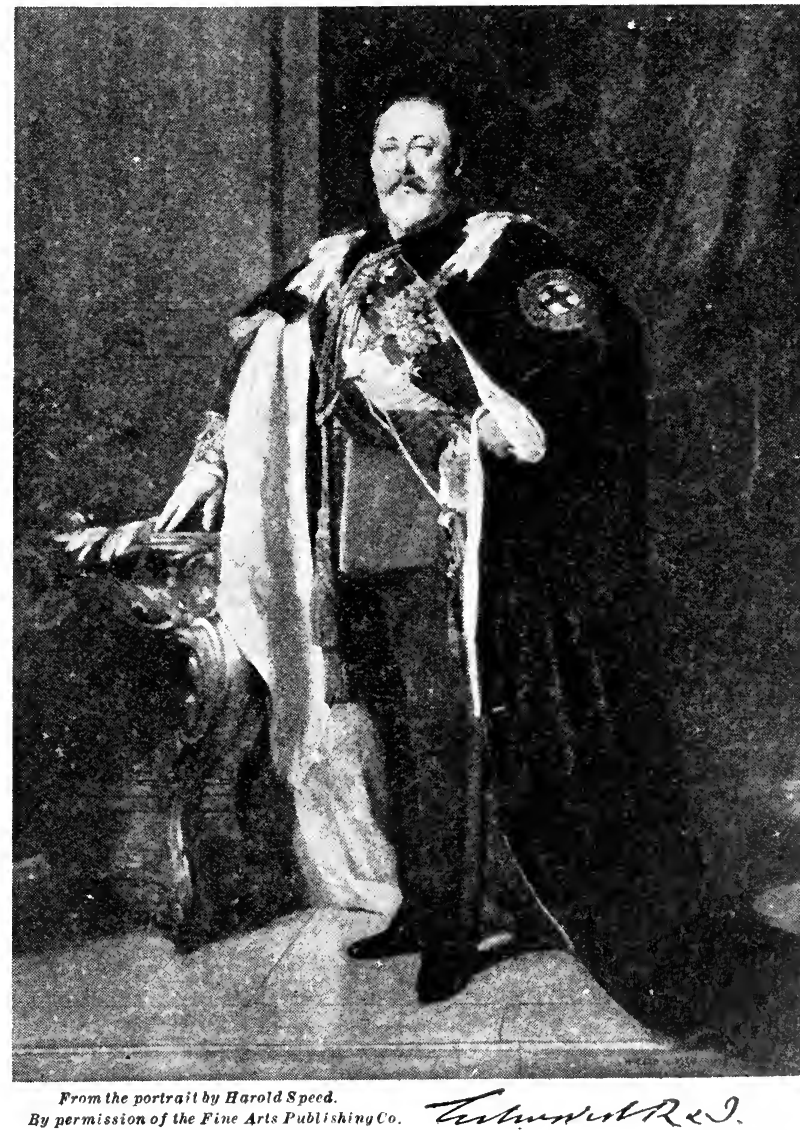


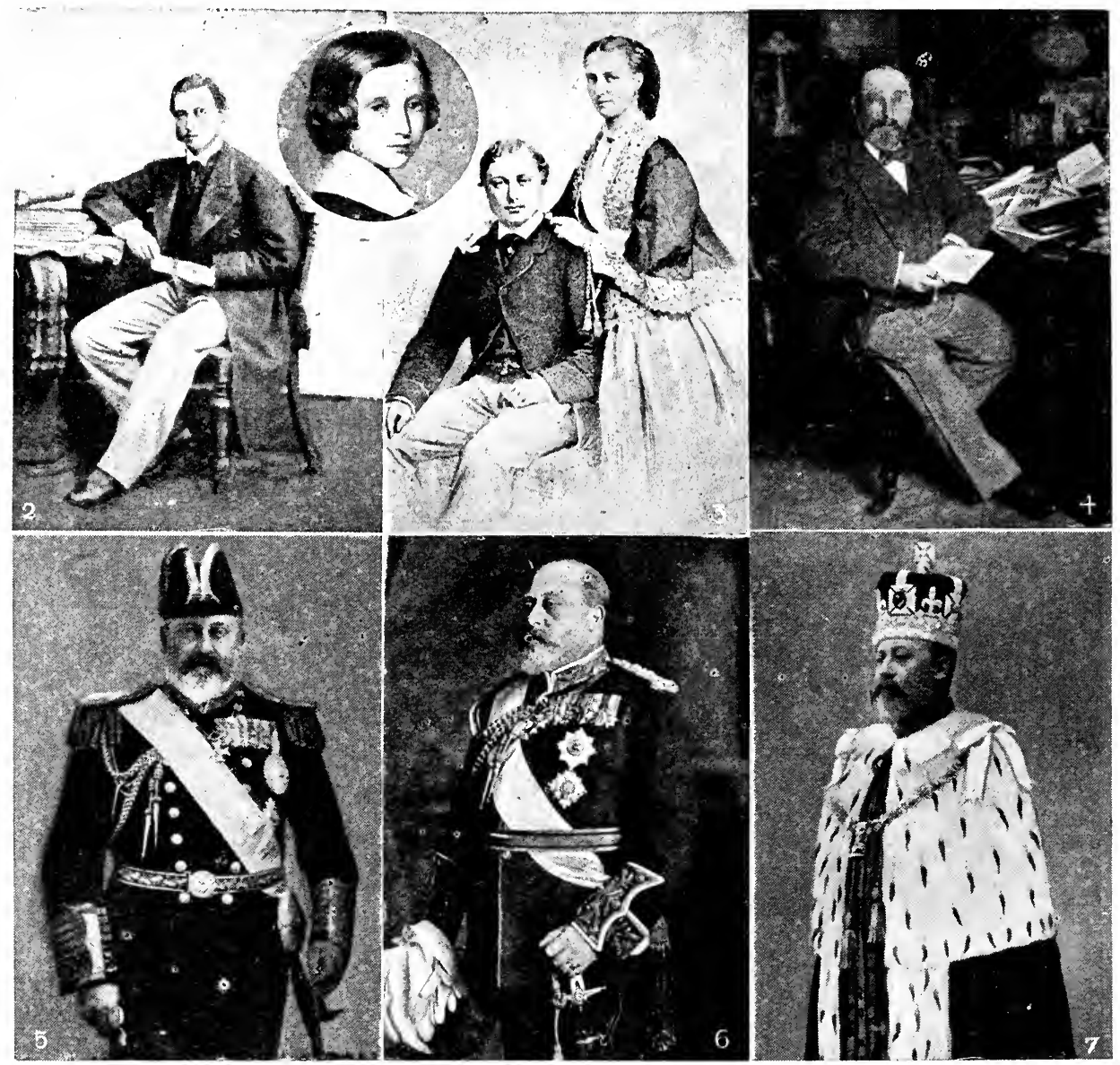

Edward VII. 1. Aged eleven, from a painting by Winterbalter. 2. A photograph at the age of 21. 3. Edward and Alexandra on the eve of their wedding, from a drawing. 4. King Edward in his study. 5. As Admiral of the Fleet. 6. As Field-marshal. 7\%. In his coronation robes

won the Derby thrice-was an offence, and others who blamed him for what appeared to be an undue tendency to select his friends from among those who shunned the sterner walks of life. These feelings were expressed by the country generally when, in 1891, a fanous lawsuit followed a scandal at cards on an occasion when the prince of Wales was banker. Little more than six months later-in January, 1892 the prince's eldest son, the duke of Clarence, who had just been betrothed to his cousin, Princess Victoria Mary of Teck, died, and all was forgotten in sympathy with so tragic a grief. This sorrow did much to draw prince and people more closely together, and when, on January 22, 1901, he ascended the throne, affectionate regard was merged in ready and loyal homage.
Edward beeame king in his sixtieth year. With much intuition, a quick and flexible mind readily open to new im pressions, and a clear appreciation of the functions of a limited monarch, he associated much of the tenacity of his family with an extraordinary knowledge of men and affairs and unfailing industry.

King Edward's aptitude for kingcraft now began to enjoy the scope it had hitherto lacked, and in the spring of 1903 he paid a series of visits devoted to strengthening the bonds of friendship between Great Britain, France, Italy, and Portugal. Three visits with a similar object were paid to Ireland, and later he went twice to Germany, where the ex-Kaiser bore public testimony to his uncle's "unremitting endeavours" in the cause of peace. It is an open secret that his diplomacy averted war between Sweden and Norway in 1905 when the two countries dissolved partnership, and the consolidation of a good understanding with Russia owed much to his personal efforts. It has been hotly denied that he had any influence whatever in bringing about the entente with France. It is nevertheless idle to suppose that his friendship with French presidents and politicians, and his own frank delight in France and appreciation of the French character, can have counted for nothing.

King Edward's death came in the midst of the heavy political anxieties attendant upon the sharp conflict between the two houses which issued $\boldsymbol{n}$ the Parliament Act. He fell quickly before an attack of bronchitis, and died May 6, 1910; he had reigned for a 
little more than nine years. He had five children who survived infancy: the duke of Clarence, who predeceased him, King George $\mathrm{V}$, the princess royal, princess Victoria, and the queen of Norway.

Bibliography. Life, 5 vols., J. P. Brorhurst, 1905-11; Edward the Peacemaker, W. H. Wilkins, 1910-11; King Edward VII as a Sportsman, A. E. T. Watson, 1911 ; King Edward in his True Colours, E. Legge, 1912 ; More About King Fdward, E. Legge, 1913; The Influence of King Edward, Viscount Esher, 1915.

Edward (b. 1894). Prince of Wales. The eldest son of King George V and Queen Mary, he was born at White Lodge, Richmond, June 23, 1894. and christened, on July 16, Edward Albert Christian George Andrew Patrick David.

In 1907 the prince entered the Royal Naval College, Osborne, for two years' training, going next to Dartmouth. He was created prince

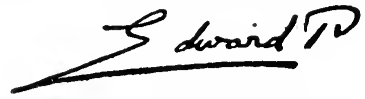

of Wales, June 23, 1910. His in. vestiture as prince of Wales, at Carnarvon, was notable because he was the first of nineteen princes of Wales to be invested in Wales itself. As midshipman he sailed on H.M.S. Hindustan, where he proved himself a thoroughly hard worker. The prince's first public ceremony was at the presentation of a silver oar to Dartmouth, in March, 1911 ; he was invested Knight of the Order of the Garter, June 10, 1911, and a few days afterwards took a leading part in the coro. nation of his parents. In 1912, being eighteen, he celebrated his majority. In 1913 he entered Mag. dalen College, Oxford, after a visit to Paris, where he received the Legion of Honour.

When the Great War broke out in August, 1914, he made an appeal for the national fund to allay dis. tress, and millions of pounds were subscribed. He was gazetted, Nov. 17,1914 , as aide-de-camp to the commander-in-chief of the Expeditionary Forces, and went to France. He was attached in turn to army corps, divisional and brigade headquarters, and was frequently under fire. He carried the dispatch concerning the battle of Neuve Chapelle on his brief leave in April. 1915.

His 21 st birthday passed without public celebration, by his wish, but a separate establishment was provided for him in St. James's Palace. He served in Egypt in 1916 , as captain on the general staff, and visited the Italian front at a time of crisis. During short

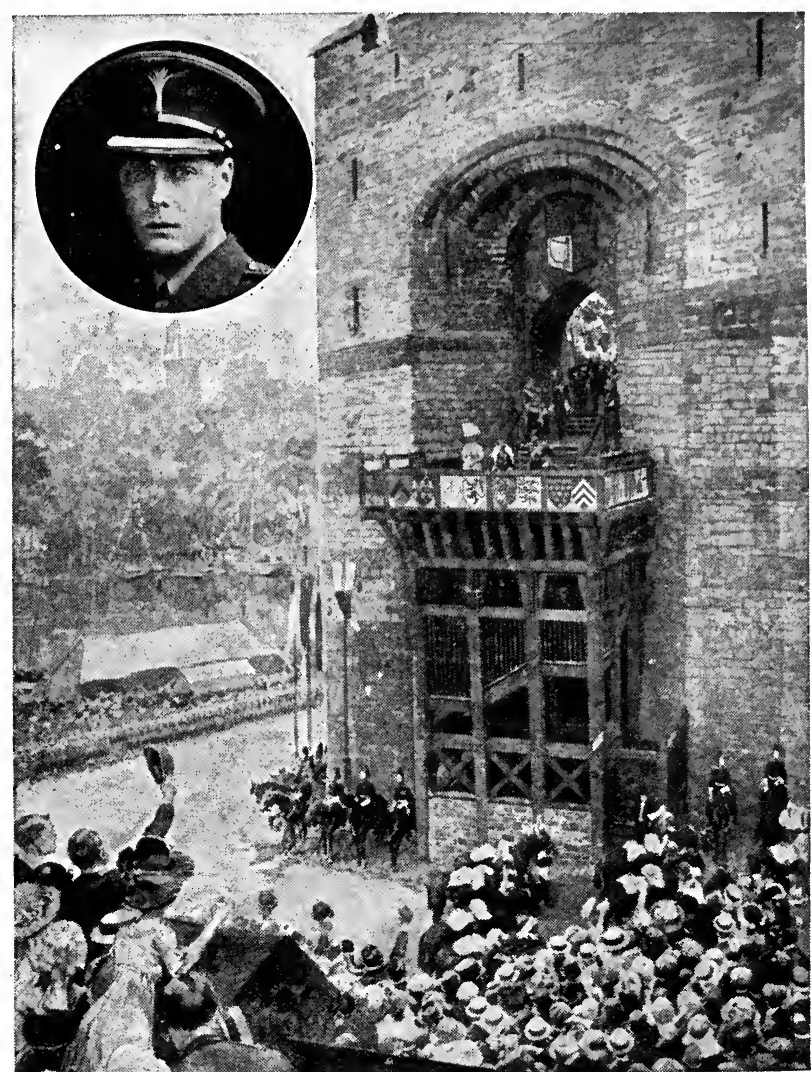

Edward. Prince of Wales. Scene after the investiture at Carnarvon Castle, July 13, 1911. The Prince is standing between King George and Queen Mary on a platform at the top of specially constructed steps at the gate where, according to tradition, the first infant prince of Wales was presented by Edward I to the Welsh chiefs. Inset : His Royal Highness as Colonel of the Welsh Guards (photo Vandyk)

leave, the prince took his seat in the House of Lords, Feb., 1918, being promoted major in the same month. After the armistice he undertook many public duties; and took up the freedom of the City of London, May, 1919. He toured through Canada and the U.S.A., August-December, 1919 , visited Fiji, New Zealand, and Australia in 1920, and made a tour of the Indian Empire in 1921-22. Possessed of a simple directness of speech, combined with geniality and tact, the prince discharged his varied duties with success. David Williamson

Edward (1330-76), known as the Black Prince. Eldest son of Edward III of England, he was born at IVoodstock. June 15, 1330 ; in 1333 was made earl of Ches. ter, four years later duke of Corn. wall, and in 1343 prince of Wales. In 1345 he accompanied his father on the French campaign and dis- tinguished himself at the battle of Crécy. Two years later he was at the capture of Calais, and in 1350 he was in the sea fight off Winchelsea against the Spaniards. In 1355 Edward was sent to Gascony, when he led the English armies in a series of raids over the French territory. In the following year a similar expedition culminated in the battle of Poitiers (q.v.).

In 1357 he returned to England and in 1361 married his cousin Joan, known as the Fair Maid of Kent. In 1362 his father granted him Gascony and Aquitaine. He took part in a disastrous expedi tion for replacing Peter of Castile on the throne. but soon many disattected lords of his territories rose against hım, and many of his towns surrendered to them When, after a month's siege, he re-tuok Limoges, he ordered a general massacre of its inhabitants. In 1371 Edward returned, in broken 
health, to England. He supported the bishops against the evil administration of Lancaster. He died at Westminster on July 8, 1376, and was buried in Canterbury Cathedral. He was not called the Black Prince until long after his death, the name being probably given him because he wore black armour. His son was Richard II. See Lives, G. P. R. James, 2nd ed. 1839 ; R. P. Dunn-Pattison, 1910.

Edward, Thomas (1814-86). Scottish naturalist. He was born Dec. 25, 1814, at Gosport, where his father, a private soldier, was on service. He was taken by his parents to Banff at an early age, and remained there for the rest of his life. From childhood he displayed a great love for natural history. A poor shoemaker, he for many years spent the whole of his nights out of doors. He discovered between twenty and thirty species new to science, in addition to add. ing to the British fauna a vast number of species hitherto unknown in these islands. In 1866 he was elected an associate of the Linnean Society, and a civil list pension was awarded to him. He died April 27, 1886. See Life of a Scotch Naturalist, S. Smiles, 1876.

Edwardes, GEORGE (1852-1915). British theatrical manager. He was born Oct. 8, 1852, of Irish parents, and started his career as business manager at the Gaiety Theatre, Dublin. - In 1875 he became business manager for D'Oyly Carte at the Opéra Comique, London, and went with him to the Savoy. $\mathrm{He}$ joined John Hollingshead as joint manager at The Gaiety, London, Dec., 1885 , and in 1886 became the manager of that theatre, which he directed for nearly thirty years, pro. ducing a long series of successful musical plays. He died Oct. 4, 1915.

Edwardes, Sir Herbert BeNJAMIN (1819-68). British soldier and Indian administrator. $\mathrm{He}$ was born at Frodesley, Shropshire, Nov. 12, 1819, and became a cadet in the East India Company in 1840. In $1845-46$ he was aide-de-camp to Sir Hugh Gough in the Punjab campaign. As first assistant to Sir Henry Lawrence, the resident at Lahore, he administered Bannu, and his courage and resourcefulness were conspicucusly seen in his defeat of the diwan of Multan, 1848. Edwardes rendered signal service during the Mutiny by securing the neutrality of Afghanistan. Knighted in 1860 , he re turned to England in 1865, and died Dec. 23,1868 . See Memorials of Life and Letters, E. Edwardes, 1886.

Edwardesabad. Alternative name given to the town of Bannu (q.v.), N.W. Frontier Prov., India.

Edward Medal. Medal instituted in 1907 by Edward VII to reward heroic acts in civil life, es.

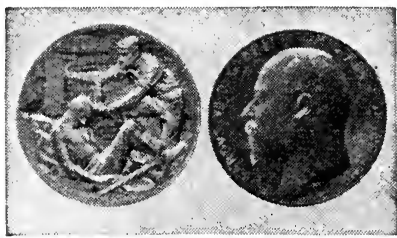

Edward Medal, instituted as a reward for heroic deeds in civil life (reduced)

pecially in mines and quarries. It consists of two classes, the Edward medal, and the Edward medal in silver. Bars are awarded for further conspicuous acts of bravery. The medal bears a portrait of King Edward. The ribbon, which is worn in a bow by women, is dark blue with narrow yellow edge.

Edwards, Alfred George (b. 1848). British prelate, the first Anglican archbishop of Wales.

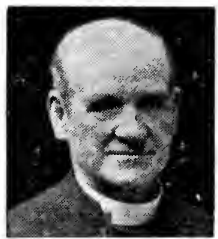

Alfred G. Edwards, Archbishop of Wales Russell

rural dean of Carmarearand was consecrated bishop of St. Asaph. In April, 1920, Dr. Edwards was elected the first archbishop of the new province of Wales. See Wales, Church of.

Edwards, AMelia Blandford (1831-92). British novelist and Egyptologist. She was born in London, June 7 , 1831 , and for many years wrote stories for Household Words and All the $\mathrm{Year}$ Round, besides contributing articles to The Saturday Review and The

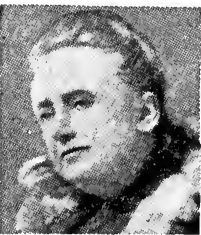

Amelia B. Edwards, British novelist

Morning Post. Barbara's History, 1864, was translated into German, Italian, and French; and Lord Brackenbury, 1880, ran into 15 editions. In 1882 she founded the Egypt Exploration Fund, and the rest of her life was devoted to that object. She endowed the first Chair of Egyptology at London University. She died April 15, 1892.

Edwards, JoHs PAssmore (1823-191]). British journalist ard philauthropist. Born at Black. water, Cornwall, on March 24, 1823 , the son of a carpenter, he trained himself to be a journalist, com ing to London in 1846. He was proprietor and director of the London even. ing journal The Echo, 1876-96, and sat as Liberal M.P. for Salisbury, 1880-85. Active in political and

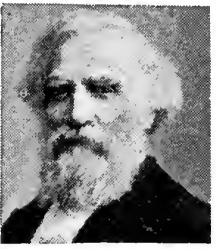

J. Passmore Edwards, British philanthropist Elliott \& Fry social reform, he is chiefly remembered for his benefactions to hospitals, libraries, art galleries, and other public institutions, of which he founded more than 70 of various kinds. He died April 22, 1911. See Echo; Passmore Edwards Settlement; consult also the autobiographical A Few Foot. prints, 2nd ed. 1906.

Edwards, JoNATHAN (1703-58). American divine and metaphy. sician. He was born Oct. 5, 1703 at East Windsor, Connecti. eut, and in 1727 became minister at Northampton, Massachusetts. $\mathrm{H}$ is extreme and logical Calvinism was e $x$ p ounded with unusual

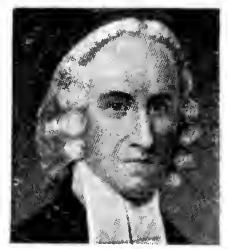

Jonathan Edwards, American divine power, but his insistence on church discipline brought dismissal from the pulpit. From $1750-58$ he resided at Stockbridge as a missionary to the River Indians, and a few weeks before his death, March 22, 1758 , he was appointed president of Princeton College, New Jersey. Edwards was the author of many books, of which the most important was A careful and strict Enquiry into .... Freedom of Will, 1754 . Works, ed. with Memoir, S. E. Dwight, 10 vols., 1830. See Calvinism; consult also Life, A. V. G. Allen, 1889.

Edwin OR EADWINE (c. 585633). King of Northumbria. The son of Ella, king of Deira, he was driven from Deira after his father's death by the king of Bernicia, and took refuge with Raedwald, king of E. Anglia, who defeated and slew the Bernician king in 617 . Edwin then annexed Bernicia and became king of Northumbria. In 625 he married Ethelberg, sister of the king of Kent, and in 627 was baptized by Paulinus and his king. dom became Christian. Edwin: overlordship extended over all Anglo-Saxon Britain except Kent, 
and his rule was notable for its justice and peace. On Oct. 12,633 , Edwin was defeated and slain at Hatfield. Yorkshire, in a battle against a coalition of heathens under Penda of Mercia and Cadwallon of North Wales. Edinburgh, which he fortified, is named after him, and he was long venerated as a saint.

Edwin and Angelina. Simple ballad, sometimes called The Hermit, by Oliver Goldsmith. It was privately printed for the coun. tess of Northumberland in 1765 and first published in The Vicar of Wakefield (1766), where it is introduced by way of contrast with the false taste and meretricious exuberance of language in the poetry of the time. It tells of the coming together of separated lovers; Angelina, disguised as a youth, seeks guidance from a hermit, only to find that he is her lost Edwin. From this sentimental ballad the names have come to be applied, rather derisively, to any loving young couple.

Eeckhout, Gerbrand van DEN (1621-74). Dutch painter. Born at Amsterdam, Aug. 19, 1621, he was the favourite pupil and later the friend of Rembrandt. He painted genre, portraits, and scriptural sub. jects, but his cabinet pictures are superior to those executed on a larger scale. Among his best works are The Raising of Jairus's Daughter (Berlin), Tobit and the Angel (Brunswick), The Presentation of Jesus in the Temple (Dresden), Soldiers Gambling, Jesus Among the Doctors (Munich), Merrymaking in the Guard-house, and the portraits of Oliver Dapper, the geographer, and Rembrandt. He also executed a number of etchings. Eeckhout died at Amsterdam, Sept. 29, 1674.

Eecloo. Town of Belgium, in the prov. of E. Flanders. It stands on the Liève, $11 \frac{1}{2} \mathrm{~m}$. N.W. of Ghent. A rly. junction, it is connected also with neighbouring towns by tramways. It carries on a large trade in grain, and its manufactures include lace, woollen, and linen goods. Pop. 13,536.

Eel (Anguillae). Group of fishes with elongated snake-like bodies and no visible scales. They are found in both sea and fresh waters in most parts of the tropical and temperate regions of the world. The common European eel ( $A$. vulgaris) is a familiar example of the class.

The life history of the eel, long a complete mystery, was worked out by the Italian zoologist, Battista Grassi (b. 1855). It is now known that the broad-nosed and sharp nosed eels are not two varieties, but that the former is the male and the latter the female. The male is rarely found except at the mouths of rivers and in brackish water, but the female is common in most riversand ponds. In an. tumn the mature eels migratedown the rivers to the sea, and those in ponds will often go overland for considerable distances at night to reach the rivers.

Eels spawn in the sea during winter, apparent. ly in deep water some hundreds of miles from land. The eggs hatch out as little fish known as Lepto. cephali or glass fishes, so entirely unlike their parents that they were formerly thought to be a distinct species. They are flat, rib. bon-likecreatures about 3 ins. long, curiously deep in body, scaleless and transparent, with small heads.

These Leptocephali do not appear to feed in the sea, and they gradually shrink both in length and depth, and become round in body, when they are known as glass eels. In this state they make their way up the rivers in such countless millions that the water is often black with them. In ponds eels often live for several years before descending to the sea to spawn, where it is supposed they die after depositing their eggs.

Eels are largely used as food by most European nations, and the British supply comes largely from Holland and Denmark. In Feb.. 1919, the Fresh Water Fish Com. mittee urged that steps should be taken for the cultivation of eels in

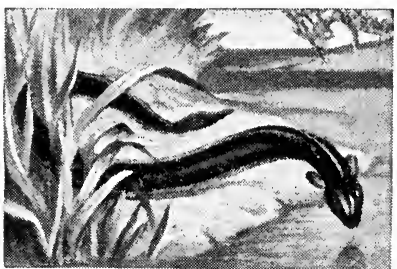

Eel. The electric eel, a large

South American fish which can impart a powerful electric shock Before the Great War the Germans had established a large elvercatching depot on the Severn, whence many millions were ex ported to Germany for cultivation there between 1908 and 1911. The committee recommended that an experimental eel-cultivating establishment should be inaugurated under government auspices, and that use be made of the German depot, which the ministry of agriculture and fisheries was endeavouring to acquire in 1920 . See illus. p 2205

Eel, Electric (Gymnotus electricus). Large eel-like fish found in the rivers of Brazil and Guiana Though resembling an eel in general appearance, it is widely removed from it in internal structure. It attains a length of $6 \mathrm{ft}$., and is notable for the powerful electric shock that it can give. The electricity is generated by four organs lying in pairs under the skin, but their precise mode of action is not fully understood. The animal uses this power for killing or stunning the fish on which it feeds, as well as in self-defence. The force of the shock varies greatly, but is sometimes sufficiently strong to overpower a horse. Sep Flectrin Fish 
Eel-grass (Valisneria spiralis). Perennial aquatic herb of the natural order $\mathrm{Hydrocharidaceae}$ It is a native of warm and temperate re. gions, includ. ing S. Europe. The short stem is immersed in the mud of rivers and lakes, and from it arises a tuft of thin grass-like

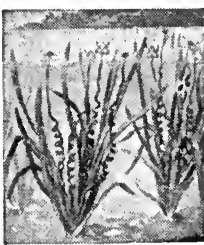
Eel-grass. Plants of the aquatic herb leaves a yaid long, but only $\frac{1}{t}$ in. wide. 'The female flower has a very long spiral stalk which enables it to lie upon the surface of the water. The male flowers (produced by separate plants) have very short stalks which break away from their attachment. so that they float to the surface, where they pollinate the females. This accomplished, the female, by the spiral contrac. tion of its stalk, is withdrawn to the bottom, where it develops into a cylindrical berry.

Eel Pie Island. Islet in the 'Thames opposite York House Twickenham. Also called 'Twickenham Eyot, it has long been noted as a favourite resort of anglers and boating parties. The inn on the islet occupies the place of Eel Pie House, pulled down in 1830 .

Eel Pout (Lota vuigaris). Popular name for the burbot. It is a fresh-water fish, common in Euro. pean and American rivers, but found in Great Britain chiefly in the Cam and the Ouse. It is about a yard long, and somewhat eel-like in shape.

Effendi. Turkish title of respect. It is applied in the East to government officials, men of learn. ing, and others. It is a corruption of the Greek authentès (mod. pron. afthendēs), a iord.

Effervescence (Lat. efferves. cere, to boil up). Name applied to the phenomenon of the rapid escape of gas from a liquid. It is usually the result of chemical action. A familiar example is seen in the mixing of a seidlitz powder with water. When soda water is withdrawn from a syphon the evolution of carbon dioxide is du to physical causes.

Efficiency (Lat. efficientia, a carrying out). Term meaning in general the quality of producing some desired result. Apart from its use in engineering, it is in creasingly used in industrialism and economics, considerable attention being paid by doctors and others to the efficiency of the worker.

In engineering, efficiency is the ratio of the amount of energy given out from a condusting, con verting, or transmitting device to the energy received by it. In all cases the efficiency is less than unity, as some of the energy is dissipated or used up unprofitably. The efficiency of a joint is the ratio of the strength of the joint to a similar section of unjointed material. In aeronautics, where the main spars are spliced, the efficiency of the splice is its strength relative to that of the unspliced wood of similar section.

The heat-absorbing efficiency of a boiler is represented by the per. centage of the heat units of the burnt fuel which is found in the water and steam. The efficiency in very good boilers may be as high as 80 p.c. The heat-converting efficiency of a steam engine is its capacity for converting units of heat energy into units of mechanical work on the basis of one thermal unit being equivalent to 778 foot-pounds of work. So much heat is wasted by conduction, condensation, etc., that the efficiency, even in the best engines, does not cxceed 15 p.c. to 18 p.c. The brake or effective h.p. of an engine is less than the indicated h.p., owing to loss in overcuming friction. Similarly, the converting efficiency of a dynamo or electric motor respectively is its capacity for trans. forming mechanical into clectrical, or electrical into mechanical energy. 'The difference between energy units received and delivered de. cides the transmitting efficiency of lines of shafting, belt drives. etc.
A good example of the cumula. tive effect of losses due to effi. ciencies being less than unity is afforded by the propelling apparatus of a ship. Assuming a boiler efficiency of 75 p.c., an engine heat-efficiency of 15 p.c., a transmitting efficiency of 90 p.c., and a propeller efficiency of 60 p.c. -all well above the average-out of 100 units of heat-energy developed by the burning of boiler fuel only $\left(100 \times \frac{75}{100} \times \frac{13}{100} \times \frac{90}{100} \times \frac{60}{100}\right)$ $=6.075$ p.c. are converted into use ful work. See Boiler; Steam Engine.

Effigy (Lat. effigies, image, likeness). Monumental effigies on toinb. lids in Christian churches from the 13th century onwards abound in England and W. Europe. Originally carvings in low relief, which gave rise to monumental brasses, they developed into figures in the round, usually recumbent. Ancestral effigies, kept in great houses in ancient Egypt and Rome, suggested to medieval Europe the funeral effigies placed upon the biers of royal and other personages.

In primitive culture effigies are important adjuncts of sympathetic magic. There are palaeolithic cave-portraits of food-animals, speared symbolically to ensure success in hunting. The piercing or melting of waxen images to induce sickness or death, practised in early Egypt, Babylonia, Vedic India, Greece, and Rome, prevailed throughout 13 th -17 th century Christendom. See Numismatics.

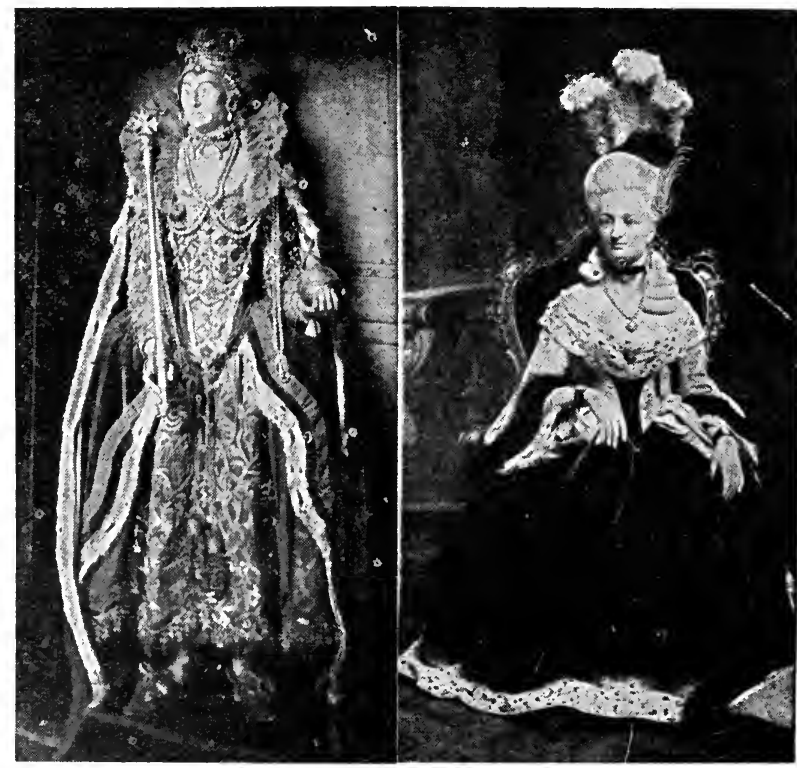

Effigy. Two examples in wax. Left: Effigy of Queen Elizabeth in Westminster Abbey. Right (by courtesy of Messrs. Tussaud): Effigy of Queen Marie Antoinette, originally shown at Versailles 
Effingham, EARL of. British title borne by the family of Howard from 1731 to 1816 , and again since 1837. The family is descended from Lord William Howard, a son of the 2nd duke of Norfolk. He served Henry VIII and his three children in various confidential capacities, and was in 1553 made Baron Howard of Effingham, in Surrey. His son Charles commanded the English fleet against the Spanish armada and was made earl of Nottingham in 1596. The earls of Nottingham held the barony of Howard of Effingham until their extinction in 1681 , when it passed to Francis, whose son Francis, the 7 th baron, was created earl of Effingham in 1731. In 1816 the earldom became extinct, and the barony devolved upon a kinsman, Kenneth A. Howard, created earl of Effing. ham in 1837. The titles are held by his descendants. The estates are in Yorkshire and Oxfordshire.

Efflorescence (Lat. efflorescere, to bloom). Term applied in chemis try to the changes which some crystals undergo when exposed to air. The surface of the crystals becomes covered with a fine powder, fancifully known as flowers. The change is due to the giving up of water owing to the higher vapour pressure of the crystal compared with that of the surrounding atmo. sphere. A familiar example is seen in washing soda, which, at first transparent, after exposure becomes opaque on the surface. The change is due to a reduction in the quantity of water of crystallisation normally present in the crystals. The word is also used in botany for the process of flowering. See Chemistry ; Crystallisation.

Effusion (Lat. effundere, to pour out). Escape of a gas under pres. sure from the vessel in which it is enclosed, through a small opening. This escape will follow precise laws expressed by Graham as follows : "The velocity with which a gas effuses varies directly as the square root of the difference of pressure on the two sides of the opening (in the vessel and outside it) and inversely as the square root of the density of the gas."

Efik. Negro tribe in the Calabar coastland, S. Nigeria. They predominate between the Cross and Ikpan rivers, and having long acted as middlemen between the white traders and the interior peoples, they are largely Christianised and Europeanised, many being in Government service. Their speech is semi-Bantu.

Egan, Pierce (1772-1849). British sporting author. He spent his life reporting races, prize-fights, cock-fights, cricket matches, trials,

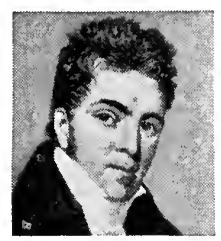

Pierce Egan, British author

After Sharples

Day and Night Scenes of Jerry Hawthorn, Esq., and his elegant friend, Corinthian Tom, accom. panied by Bob Logic, the Oxonian, in their Rambles and Sprees through the Metropolis, issued in monthly parts from 1821 and illustrated by I. R. and G. Cruikshank. Of his numerous other writings Pierce Egan's Book of Sports and Mirror of Life, 1832, was the best. Egan died in London, Aug. 3, 1849

Egba or Egbaland. Province of Southern Nigeria. It is situated $\mathrm{N}$. of Lagos, and is surrounded by Ibadan, Ikorodu, Badagri, and Meko. Its area is a bout $1,869 \mathrm{sq} . \mathrm{m}$. Pop. 264,814 natives and 80 Europeans. The native population consists of four local tribes known as the Egba-Alake, Egba-Oke-Ona, Egba-Agura, and the Owus. The country is undulating. The S. is largely forest, especially from Oba to Igaun, but is well watered, very productive, and has large portions under cultivation. The N.W. portion is hilly and not well watered. Cotton is grown. The principal means of communication, in addi tion to the roads, are the Ogun river, about $150 \mathrm{~m}$. long and navigable for canoes, and the main Iddo-Kano railway, which runs through the country. The capital is Abeokuta.

In 1857 the British Government established friendly relations with the Egbas, and in 1892 a treaty of protection was arranged and a council of the Egba nation formed with the Alake of Abeokuta as pre sident. The Alake is the senior of the four kings and visited England in 1904. The country remained an independent native kingdom within Nigeria, with a British resident, until 1914, when it was placed under the direct government of the protectorate of Nigeria.

Egbert (d. 839). King of Wessex. The son of Ealhmund, a king of Kent, he was driven into exile to the court of Charlemagne and returned to England as king of the West Saxons in 802. He then subdued West Wales or Cornwall, de feated the king of Mercia at Ellandune, annexed Kent, and in 829 became overlord of all the English kings. He was defeated by Scandi- navian pirates in 836 , but in 838 routed a formidable army of North. men and West W e I s h $\mathrm{H}$ i n g s to $\mathrm{n}$ Down, i n Cornwall. $\mathrm{H}$ died in 839 and was succeeded

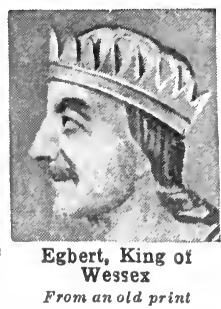
by his son Ethelwulf. See The Mak. ing of England, J. R. Green, 188I.

Egede, Haxs (1686-1 758). Scandinavian missionary in Greenland. Born in Norway, and educated at Copenhagen University, he was a Lutheran minister at Vaagen from 1706-17. Four years later he went with his wife and family to Greenland, where he worked among the Eskimos for fifteen years and converted many to Christianity. In 1736 he returned to Copenhagen, but continued to superintend the missions in Greenland until his death, Nov. 5, 1758. He wrote accounts of his work, and A Description of Greenland (1729-41), Eng. trans. 1745. See The Story of Hans Egede, Jans Olaf, Eng. ed. 1864.

Egedes Land. That portion of E. Greenland lying N.W. of Den. mark Strait and N.E. of King Christian IX Land. It is named after Hans Egede.

Eger. River of Bohemia. It rises in the Erzgebirge in Saxony, but most of its course is in Bo. hemia. It flows almost due E. until it fallsinto the Elbe near Leitmeritz. It drains the S. side of the Erzgebirge, Eger and Karlsbad stand on it, and its length is about $140 \mathrm{~m}$.

Eq er. Town of Bohemia, CzechoSlovikia. It stands on the ght bank of the Eger, $92 \mathrm{~m}$. W. of Prage, beneath un $\mathbf{H}$ ich telgevirge. Its chief object of interest is the ruined castle on a rock above the town built by the emperor Frederick $I$ in the 12 th century. The main buildings are the old Gothic church of S. Nicholas, restored in the 1 ith century, and a museum; the latter was formerly the burgomaster's house, in which Wallenstein was murdered in 1634 . 'There is an old town hall, while other objects of interest are the Schillerhaus, where the poet lived for a tine, the merchants' hall, and the market place. The town has manufactures of textiles, ma chinery, etc. The inhabitants are mainly Germans, although the town has been part of Bohemia sirce 1350 . Before then it was in Germany or in Austria, and was the capital of a district called Egerland. Its Czech name is Cheb. Pop. 26,619. 
Eger or ERlad. City of Hungary. It stands in a beautiful and mountainous region, $70 \mathrm{~m}$. N.E. of Budapest. Its ehief industry is the making of red wine, the vines being largely grown on the hills around; but it is more famous for its churches. The eathedral, a handsome building in the Italian style, was ereeted in the 19th century; the ehurch of the Brothers of Mercy and the minaret of an old mosque are also noteworthy. Other buildings include the palace of the archbishop, the town hall, and the observatory. The town grew up around the bishoprie founded about 1010 . It was taken by the Turks in 1596, and they kept it until 1687. The city was made the seat of an archbishop in 1814. Pop. 28,052.

Egerdir. Lake of Asia Minor. Lying between the Sultan Dagh and the Taurus Mts., it is $27 \mathrm{~m}$. long and from $3 \mathrm{~m}$. to $10 \mathrm{~m}$. wide. On it stands the town of the same name. Pop. 6,000 .

Egeria. In elassical legend, a nymph beloved of Numa Pom. pilius, king of Rome, who set great store by her advice and propheeies. On the death of Numa her grief was so great that she dissolved in tears, and was turned into a fountain by Diana. The name is given in modern times to a lady who stimulates and inspires a man's intellectual activity. Pron. Ee-jeri-a.

Egerton, Srr Raleigh Gilbert (b. 1860). British soldier. Son of Sir Robert E. Egerton, he was born Sept. 25, 1860, and joined the Leicestershire Regt. in 1879. Later he entered the Indian army, reach. ing the rank of colonel in 1907 . He was A.A.G. of the Indian army, 1900-3. His war services include the Hazara and Waristan expeditions, the Chitral campaign and that in Dongola. During the Great War he served in Mesopotamia, especially distinguishing himself as a corps commander under Marshall, 1917-18. He was knighted in 1916 and made lieut.-general in 1917. See Mesopotamia, Conquest of.

Egerton Prize. Award given annually by the Admiralty to the naval officer who, when qualifying for gunnery lieutenant, passes the best examination in practical gunnery. The prize was founded in 1901 in memory of Commander F. G. Egerton, R.N., killed in Lady smith, Nov, 2, 1899.

Egg. Reproductive cell formed in the body of the female animal, which, when fertilised by union with the spermatozoon of the male. produces a new individual. Except in the lowest forms of life, when propagation takes place by fission or budding, every animal begins its life history as an egg. In the viviparous animals, as in nearly all mammals, the development of the egg takes place in the body of the mother; in the oviparous it is extruded and development proceeds apart from union with the mother. (See Embryology.)

Only such eggs as are "laid" by the female and hatehed externally to her body are here considered. This phenomenon oceurs in all the phyla or sub-kingdoms of the animal world exeept certain of the lowest and most primitive. In the mollusea, which inelude the snails and the shell-fish, eggs vary considerably in form and size. In the largest of the British snails (Helix pomatia) the egg is enelosed in a chalky shell, and is as large as a moderate-sized pea ; while one of the snails of Barbados (Strophocheilus oblongus) lays a white egg as large as that of a pigeon.

Some inseets, as the moths and butterflies, lay an enormous num. ber of eggs; but the most prolific animals of all are the fishes. The ling produces more than 500,000 eggs to each pound of her weight ; sturgeon is credited with about $7,000,000$ eggs.

Nearly all reptiles lay eggs. Those of the crocodiles and tortoises have hard, limy shells, but most are enclosed in membranous eapsules. Those of the amphibians, like the frogs and newts, are deposited in gelatinous masses. Speaking generally, eggs laid in the water or in wet plaees are without hard external eoverings.

All birds deposit eggs, varying immensely in size and colour. In size they range from that of the ostrich, which equals about twelve hen's eggs, to the tiny produetions of the humming-birds. 'The colouring of birds' eggs is of a protective nature, and is usually adapted to the surroundings. The eggs of razor bills and guillemots, which lay on exposed edges of rocks, are of tapering shape, so that when disturbed by wind or by a passing bird they simply turn round. Among the mammals, eggs are laid only by the ornithorhynchus and the eehidna. See Biology; Cell.

Egg, Augustes Leopold (181663). British artist. Born in London, May 2, 1816, he studied under Henry Sass and at the R.A. school, exhibited for the first time in 1838 , beeame an A.R.A. in 1848, and R.A. in 1860. A subject painter, his best work ineludes Queen Elizabeth Diseovers She is No Longer Young, 1848; Peter the Great Sees Cath. erine for the First Time, 1850 ; and The Night Before Naseby, 1859 $\mathrm{He}$ died at Algiers, Mareh 26, 1863. See illus. 8, p. 2569.
Egga. Town of N. Nigeria. It stands on the right bank of the Niger, a few miles above Baro, the terminus of the Baro-Kano rly. It is the commereial outlet of the Gando country. Pop. about 10,000.

Eggar Moth. Group of fairly large moths. There are four British eggar moths, belonging to three

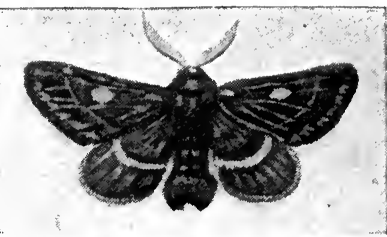

Eggar Moth. Example of small eggar moth, Eriogaster lanestris

distinct genera. Three of them are reddish-brown in colour and the other is grey; the expanse of the wings varies from 1 in. to 3 ins.

Egg Grenade. Simple type of time fuse hand grenade largely used by British forces during the

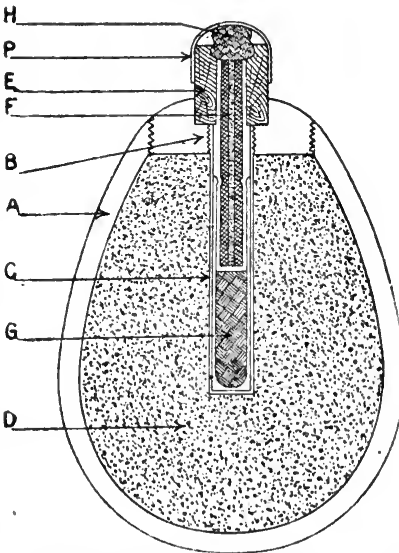

Egg Grenade. Se stional diagram showing principle of the grenade. For explanation see text

early part of the Great War. It consists of an egg-shaped cast-iron body, A, closed by a screw plug, B, which carries the detonator holder, $\mathrm{C}$, and the grenade is filled with explosive, D. The fuse eonsists of a wooden plug, E, earrying a short length of safety fuse, $F$, to the lower end of whieh is crimped the detonator, G. In the upper end of the wooden plug is a large bead of friction composition, $\mathrm{H}$, the other end of the fuse touching this eom. position. A piece of waterproof parer, $P$, is secured over the end of the plug to protect the eom position. The explosive used is ammional or a similar ammonium nitrate explosive. See Ammunition; Explosives; Grenade; Mills Bomb. 


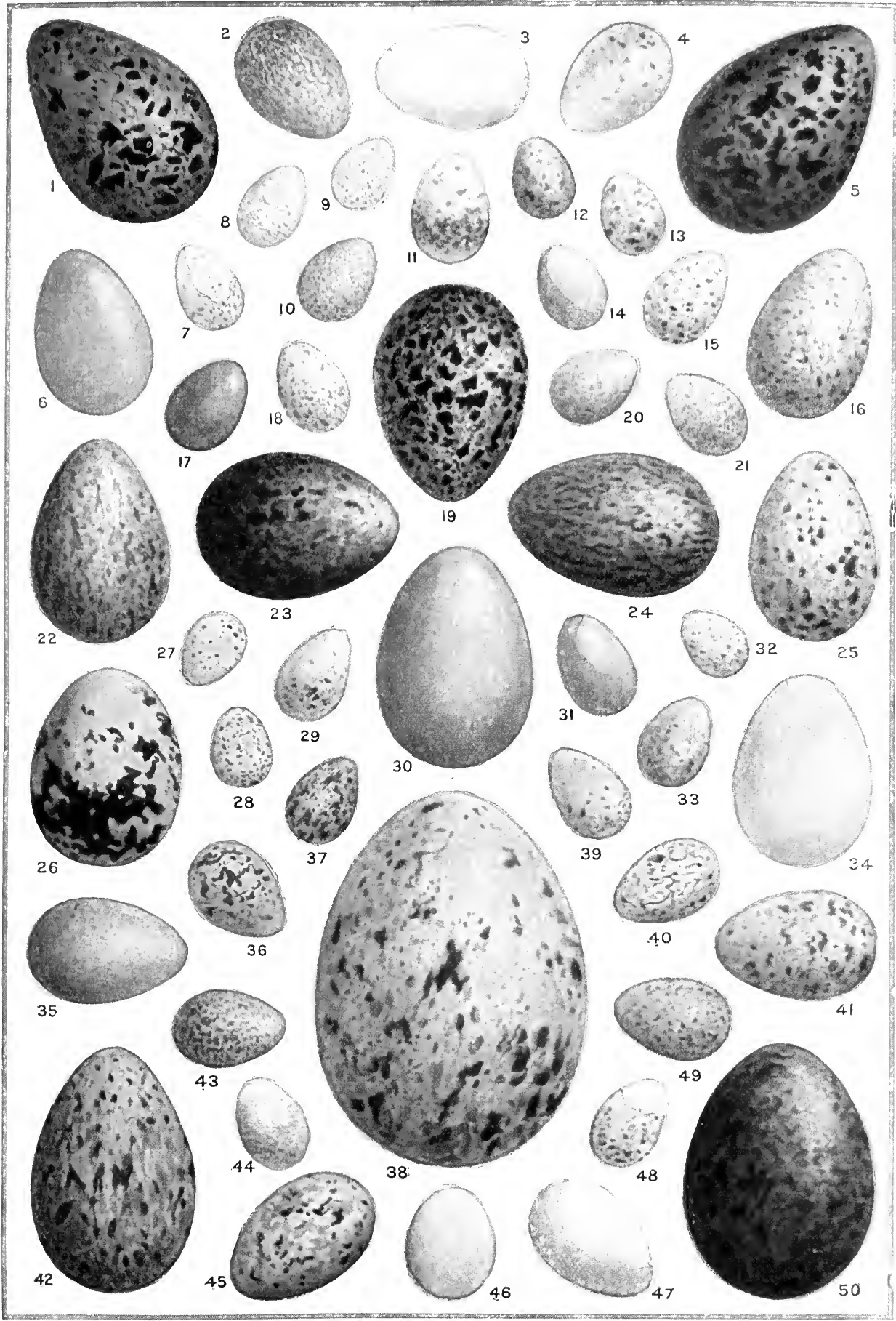

i. Lapwing. 2. Blackbird. 3. Green woodpecker.
4. Song-thrush. 5. Golden plover. 6. Partridge. 7. Gold4. Song-thrush. 5. Golden plover. 6. Partridge. 7. Gold finch. 8. Lesser redpole. 9. Common wren, ro. Pied 13. Marsh warbler. I4. Whinchat. I5. Swallow. I6. Magpie. I7. Nightingale I8. Spotted flycatcher. 49. Cuckoo hawk. 27. Chiff-chaff. 28. Great tit. 29. Bullfinch. 3o. Pheasant. 3I. Hedge-sparrow. 32. Blue tit. 33. Blackcap. 34. Barn owl. 35. Jay. 36. Common bunting. 37. Ree warbler. 38. Golden eagle. 39. Chaffinch. 40. Fellowhammer. 4I. Missel thrush. 42, Raven. 43. Skylark.
44. Stonechat. 45. Nightiar. 46. Kingfisher. 47. Starling. 

Eggishorn. Mountain of the Bernese Oberland, Switzerland, in the canton of Valais. It is the loftiest peak of the ridge separating the Aletsch Glacier from the Rhône Valley. Alt. 9,625 ft. On its S.E. slope is the Jungfrau-Eggishorn Hotel, at an alt. of 7,195 $\mathrm{ft}$.

Egg-plant (Solanum melon. gena). Herb of the natural order Solanaceae. The leaves are oval, lobed, and woolly beneath; the flowers are similar to those of the tomato, white, yellow, or purple. The fruit, a berry as large as a goose-

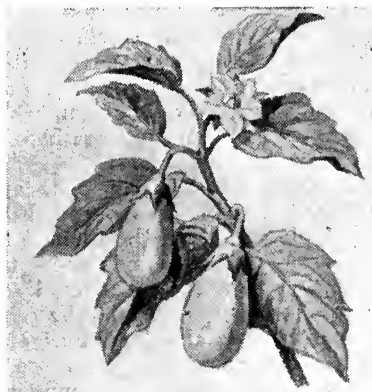

Egg-plant. Specimen of the edible herb. showing leaves, fower, and berries

egg, is white or purple. The herb is edible, and largely grown for food. It is also called brinjal, Jews' apple, and rind apple.

Egg Society. Cooperative syndicate for collecting the eggs of small producers, grading and marketing them. Some counties have as many as nine or ten egg societies. and one society will collect and dis. pose of 10,000 eggs in a singleseason.

Egg Testing. Eggs are tested by holding them to a light, special lamps being sold for this purpose. A perfectly fresh egg is quite clear and uniform. An egg that has been. kept some time has a space at one end owing to evaporation through the shell, and sometimes air bubbles are scattered about the interior. When the egg is bad the interior shows dark spots and the yolk is often seen clinging to the side of the shell. In large egg stores eggs pass on an endless chain over a brilliant light and the examiner removes those that are not fresh.

Egham. Urban dist. and parish of Surrey, England. It stands on the Thames, $21 \mathrm{~m}$. W.S.W. of London by the L. \& S.W.R. Here are the Royal Holloway College, which provides advanced education for 250 women, and Holloway Sanatorium, a large private asylum for the mentally deficient, opened in 1885 . Pop. 12,551.

Egin or Exim. Town of Armenia, in the vilavet of Mamuret. ul-Aziz. It stands on the right bank of the Kara Su or Western Euphrates, 140 m. S.W. of Trebizond, and was the scene of mas sacres of Armenians in 1895. During the Great War it was occupied by the Russians in 1915, and abandoned by order of the Bolshevist government during the winter of 1917-18. Pop. 8,000.

Eglantine. Name applied by the earlier poets, notably Chaucer. Spenser, and Shakespeare, to the sweet briar (Rosa eglanteria). In Milton it probably refers to the honeysuckle (Lonicēra pericly. menum), still called eglantine in parts of Yorkshire. See Sweet Briar.

Eglinton. Village of Ayrshire, Scotland, in the parish of Kilwinning. It is chiefly notable for its castle, a seat of the earl of $\mathrm{Eg}$. linton. This is a modern building dating from 1798 , but modelled on the baronial cas. tles with towers and a keep. The village is on a coalfield, and near are large ironworks and coal mines.

Eglinton, EARL oF. Scottish title held by the family of Montgomerie since 1508. Sir Alexander Montgomerie was made a lord of the Scottish parliament about 1445 , and his grandson Hugh, the 3rd lord, was made earl of Eglinton in 1508. Hugh, the 3rd earl, was a supporter of Mary Queen of Scots.

and when the 5th earl died the family in the male line became ex. tinct. The titles and estate then passed by special settlement to Alexander Seton, a grandson of the 3rd earl, who became the 6 th earl, taking the name of Montgomerie.

Archibald, the 11th earl (172696), served in America against the French. His successor, Hugh, became earl in 1796 , and was made a peer of the United Kingdom in 1806. He was responsible for building Eglinton Castle. His grandson and successor, Archibald, the 13th earl (1812-61), a Tory politician, was the organizer of the famous Eglinton Tournament. In 1859 he was made earl of Winton, a title held by his ancestors. the Sctons.
Eglinton Tournament, 'THE. Revival of the medieval tourna ment by the 13th earl of Eglinton. It was held at Eglinton Castle, Aug.

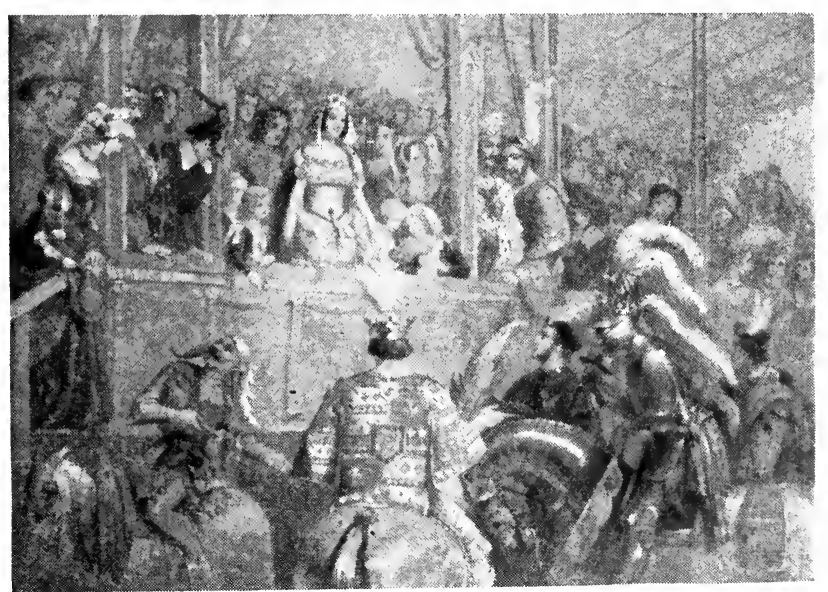

Eglinton Tournament. The Lord of the Tournament, the Earl of Eglinton, being presented to the Queen of Beauty, Lady Seymour

Froin a contemporary print 
2S, 1839. The week's pageant was entirely spoiled by rain. Arrayed in complete suits of armour and representing characters in chivalry. some 15 knights tilted in ancient fashion, breaking their spears in the jousts and finally paying their devoirs to the queen of beauty. Lady Seymour, afterwards duches: of Somerset.

Egmont. Cone of an extinct volcano, North Island, New Zealand. It rises from the Taranali plain to a height of $8,260 \mathrm{ft}$. It is perpetually covered with snow, and is a well-known landmark forsailors.

Egmont, EarL of. Irish title borne since 1733 by the family of Perceval. In 1661 Sir John Perceval was made a baronet, and the baronetcy passed in turn to several descendants, being inherited in 1691 by another Sir John (16831748). He was an M.P.. and the first president of Georgia, which colony he helped to found. He was made baron, viscount, and earl.

John, the 2nd earl (1711-70), was a prominent politician in the time of George II. From 1761 to 1766 he was first lord of the Admiralty. In 1762 he was made a British peer as Baron Lovel and Holland, and with that title the present earl sits in the House of Lords. Spencer Perceval, the prime minister, was his son. For long the earls lived at Cowdray Park, Midhurst, but early in the 20th century it was sold to Sir Weetman Pearson, later Viscount Cowdray, and the earl's seat is now Avon Castle, Ringwood, Hants. The title is taken from a little place in co. Cork, near where, at Burton House, the earlier Percevals lived.

Egmont, Lamoral, Count of (1522-68). Flemish statesman. He was born at La Hamaide Castle, Hainault, Nov. 18, 1522, and in 1541 was with Charles $V$ on his expedition to Algiers, and in subsequent canıpaigns against France. In 1545 he married a sister of the elector palatine and later was an-

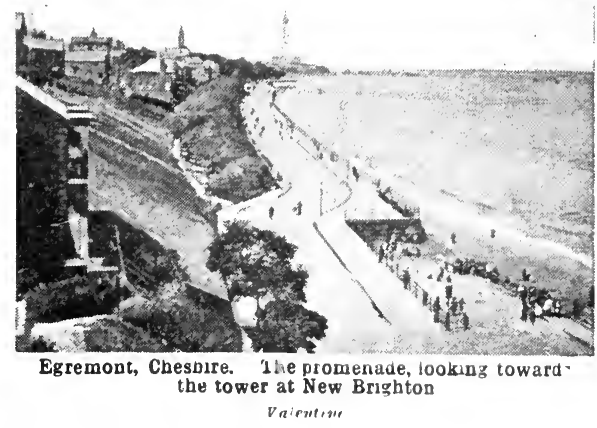
sics), 1906.

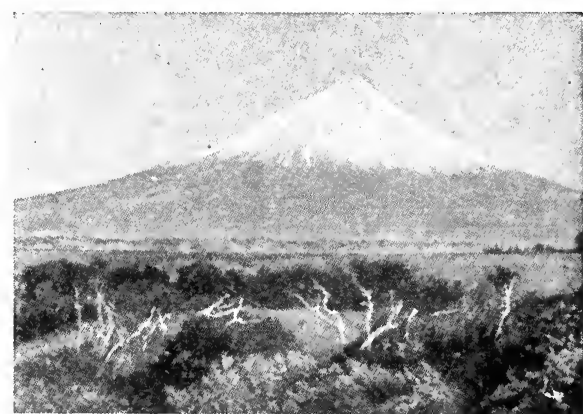

Egmont. The snow-capped cone of the extinct volcano of North Island, New Zealand is presented a remorseless delineation of egoism fostered by circum. stance.

Egremont. A town and ecclesias. tical district of Cheshire, a residential suburb of Liverpool and Birkenhead. It stands on the $\mathrm{S}$. side of the Mersey, 2 m. N.W. of Birkenhead, and, with Seacombe, has a station on the - Wirral Rly. pointed governor of Flanders. In spite of his proved loyalty to the Spanish government he fell under suspicion, and was beheaded at Brussels, June 5, 1568. His life forms the subject of Goethe's well. known tragedy (1788). In 1865 a monument to his memory was erected in Brussels. See Rise of the Dutch Republic, J. L. Motley, vols. i-ii, new ed. (World's Clas.

Ego (Lat., I). In philosophical terminology, the thinking subject as distinguished from that which does not belong to it-from the object, the non-ego (not-I). It is the constant factor of the data of experience, identical and permanent in all living, conscious beings. In spite of the constant change in the physical individual, the ego continues the same. Thus, if I am writing at one moment and reading at another, the $I$ is the same in both cases.

Egoism (Lat. ego, I). In phil. osophy, the theory that only "I" exist, and that everything else is only an idea of this "I." 'This is now more commonly called solipsism (solus, alone; ipse, self). Egoism is more generally understood as the theory of self-interest, which leads a person to act with a view to securing pleasure or advantage for himself without any con. sideration for others. Egotism. as distinct from egoism, is thinking or telling too much about oneself.

Egoist, Т н E. Novel by George II e red ith (q.v.), published in 1879 . If not great as a itory it is yet one of Meredith's great. est prose works. In the central character, Sir Willough by Patterne.
'Tramways and a promenade connect it with New Brighton, while steamers go regularly from here to Liverpool. Pop. 15,961.

Egremont. Urban dist. and market town of Cumberland, England. It stands on the Ehen, $5 \mathrm{~m}$. S.E of Whitehaven and close to the Irish Sea. An ancient town, Egremont was a parl. bor. in the reign of Edward I, and has ruins of a 12th century castle. Iron ore is mined and limestone quarried. Market day, Sat. Pop: 6,305.

Egremont, Earl of. British title borne by the family of Wynd. ham from 1750 to 1845 . It was

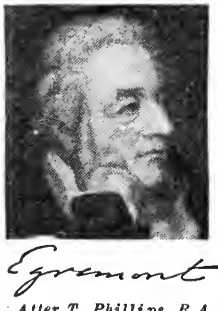
first a subsidiary title of the $7 \mathrm{th}$ duke of Somerset, Al. gernon Seywhom it was created in 1749. From him it passed, in 1750 , by special arAfter T. Phillips, R.A. rangement to his nephew, Sir Charles Wyndham,Bart. (1710-63), who was secretary of state from 1761 Wyndham (1751-1837), made Petworth, his Sussex residence, noted for hospitality. When he died he left his estates to his natural son. George Wyndham. who was made Baron Lecontield in 1859. The title, howcver, passed to a nephew, and became extinct on his death in 1845 .

Egret. Name applied to several species of small white herons, of which the little erret is one of the best known examples. It occurs very rarely in Gireat Britain, but is common in S. Europe and in See Aigrette

Egri Palanka. 'Town of YugoSlavia. It is situated on the bigh road from Uskub to the Bulgarian frontier. It is a trade centre of strategic importance Pop. $\mathbf{5 . 0 0 0}$ $\mathrm{mour}$, for -63 . 'The 3rd earl, George O' Brien many parts of Asia and Africa. 


\section{EGYPT: IN ANCIENT AND MODERN TIMES}

Prof. W. M. FIINDERS PETrIB, F.R.S., and S. A. MosexEX, A uthor of With Kitchener in Cairo

This article is divided into two main parts, one dealing with the Egypt of old, and the other with the modern country. The former describes its wonderful civilization; the latter includes its history until its grant of independence in 1920. There are also articles on the Pyramids, on Dendera, Karnak, and other famous places, and on the various rulers. For modern Egypt see the biographies of Cromer, Kitchener, Mehemet Ali, and others. See also Suez Canal; Turkey; Alexandria; Cairo

Egypt, owing to its unique climate, the amount of sunshine being more than tropical, is one of

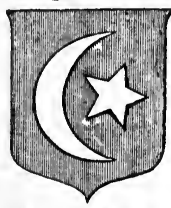
the most impor. tant lands in the history of man. Its productive power is un. rivalled, while the usual $\mathrm{N}$. wind makes it cooler Egrpt. Arms in than any country Turkish period of that latitude, except ocean coasts. These conditions, with a very healthy climate, made it particularly fitting for the growth of an early civilization. The advantage of having excellent building stones along the whole valley, with easy water transport, and the necessary lack of agricultural work during the inundation for a third of the year, were the most favourable conditions for a great architecture. The extreme dryness of the country has further led to the wonderful preservation of even the frailest materials. It is thus possible to take a longer continuous view of human changes than in any other land. The only hindrance is that, the Nile bed and water level of the country having risen about 5 ins. in every century, the early dwellings of man in the plain are now $20 \mathrm{ft}$. under water.

Earliest Human Work in Egypt

The Nile Valley began its history as a fault in the Eocene limestone which covers the surface for $400 \mathrm{~m}$. from the sea. This was much raised on the E. side, up towards the Red Sea mts., while on the W. side the surface dips down in the Fayum to more than $100 \mathrm{ft}$. below sea level, and also in the oases. The fault in the strata, due to this strain, naturally received the drainage of the plateau, and so gouged out the Nile Valley. The continuous changes in the history of the country that can be observed begin with the first interglacial period, when there is evidence of a fall of sea level about $300 \mathrm{ft}$. below the present, compared with $200 \mathrm{ft}$. in Europe. Next came, in the second glacial period, a rise of the sea to $650 \mathrm{ft}$. above the present level, compared with $900 \mathrm{ft}$. in Europe. Of these two ages no human remains have been found in Egypt.

The earliest human work in Egypt is of the second interglacial age, that of the grand Chellean flint work of Europe, fully equalled in Egypt. This would be placed by some authorities at 250,000 years ago. The sea had retreated in Europe to $600 \mathrm{ft}$. below the present level, making land continuous from Africa to far W. of Ireland. The climate was warm and dry, and mankind took a step forward in the artistic perception, shown by the imperishable flint remains.

\section{A Rainless Land}

To this succeeded the third glacial period, long ages of cold and high sea level, cutting Europe into scattered islands. The misery of this age is seen by the decay of the only art we can trace-flint working. In Egypt the sea level rose to $800 \mathrm{ft}$. over the present, like the rise of $700 \mathrm{ft}$. in Europe. The Nile Valley and its tributaries were silted up with rolled gravel and sand, which still remain in some places cut through by later clearances; and rolled beds of gravel are found at the top of high cliffs. After this, when the sea retreated and the Sahara dricd up, there was no more moist wind to form rain, and Egypt became the rainless land we now know. Of the later stages of the stone age in Europe, known by the artistic products of cave man, there are the equivalents in Egypt on the surface. Flints of Muusterian, Aurignacian, and Solutrian types are found in sites on the desert and the Magdelenian types are those of the prehistoric civilization which can be traced generation by generation into historic times.

Ist Prehistoric Crvilization. The earliest step of the unbroken line of civilization is found in burials in shallow circular pits in the ground. The body is doubled up, with the knees near the chest, and the hands before the face, lying on the left side, head south. This is the regular attitude down to the historic period. The earliest burials have no woven cloth, the bodics being wrapped in goat skins; usually a single cup of pottery lies near the face, rarely some steatite beads are found, while a copper pin shows that metal was already known, though very likely only native copper hammered. Such is the beginning of the great civilization of Egypt, which we can follow through seven ages of decay and revival, without a break, down to our own days.
The next change was the introduction of more pottery in the graves, and the decoration of it with patterns of white lines on the red polished surface. The colouring materials and the patterns are exactly like those of the highland Algerian pottery of the present day; and, as the skulls of the prehistoric Egyptians are almost exactly of the same size as those of the prehistoric Algerians, it seems that these earliest civilized Egyptians were all one with the $\mathrm{N}$. African people. Stone vases, usually of basalt, were also made, entirely formed by handwork, without turning. Šlate palettes became usual for grinding the malachite which was painted round the eyes as a preservative. The palettes were made in the forms of the elephant, stag, turtle, bird, fish, etc. Ivory combs to fasten the hair were usual, with figures of animals standing upon them. Flint working was highly developed, equal to the best European, and only exceeded by some in the next age. The whole civilization seems to have been much on the level of the Maori, or the best Pacific island stage.

\section{Beginning of Written History}

The method by which the prehistoric age is reduced to its order of growth may be briefly stated. If we have a full record of all the varieties of pottery and other objects, found in a thousand, or more, groups in graves, then it will be seen that some forms are obviously derived by degradation from others. A rough classing by such means can be extended by statistics of the percentage of forms like those already classed; this is similar to the percentage of recent shells in various Tertiary strata. By many other modes of sorting and comparison, the various groups can at last be put in their most probable order, which will be that of keeping all resemblances as close together as possible in the scrics. Such a series, extending over all the prehistoric civilization, is divided into numbered stages, from 30 to 78 , at which point the first dynasty begins the written history. The order of the prehistoric time is therefore stated, not by years but by sequence dates from S.D. 30 to S.D. 78 ; roughly these stages seem to have been at least a generation each. 
2Nd Prehistoric Civilization. The lst period, as we have said, begins with S.D. 30 , a number assigned to leave room for any earlier discoveries. By S.D. 36 considerable changes begin; new types of pottery rapidly appear, and others die out between 38 and 43. The older stone forms cease at S.D. 40 , the newer forms begin at 39. New materials come in, silver at 38 , lazuli at 39 , haematite at 40 . In every direction a new style begins. In the pottery the characteristic is a class of light brown hard ware, decorated with painting in red lines, and evidently copied from stone forms, in place of the basket patterns of the older pottery. The links of various kinds are with the $\mathrm{E}$. rather than the W., and it seems likely that the capital was Heliopolis, which was a prehistoric centre of worship.

The climax of this civilization was about S.D. 55. Much more metal was used; the flint flaking reached a perfection of skill not known anywhere before or since; the hardest stones were perfectly cut for vases; gold, amethyst, turquoise, obsidian, and porphyry, all came into use; the invention of glazing - applied to stone-started then. The spread of commerce is shown by the figures of large ships upon the pottery.

The 1st Historic Civilization

In later prehistoric bodies there is seen, in some forms, a considerable change toward the historic types. Probably for some centuries before tbi lst dynasty a fresh race had been permeating the country. At last a body of about a tenth of the siumber of the male population entered Egypt as conquerors. They seem to have started in Upper Egypt, and it is probable that they came across the desert road from the Red Sea to Koptos. They were of a higher civilization than the natives, bringing with them the elements of writing, and a great artistic skill, as well as more organization. They held Upper Egypt at first, centreing at Hierakonpolis $(40 \mathrm{~m}$. $\mathrm{S}$. of Thebes), and later at Abydos (40 m. N. of Thebes). Thence they conquered down to near the Fayum, where they centred about S.D. 77-78. Memphis became the capital in S.D. 79 under Menes and his successors of the Ist dynasty.

At this point we touch the continuous written history of the country. About the close of the IVth dynasty the Egyptians set up an engraved chronicle, known as the Palermo stone, stating the main event of every year, and the height of the Nile, from the begin. ning of the Ist dynasty. Later there were papyri containing com. plete lists of the kings, with the reign of each stated in years, months and days, and summaries. Parts of such a papyrus of the XVIth dynasty remain, known as the Turin papyrus. There are monumental lists of kings at Abydos, set up in the XIXth dynasty, but only of the best known periods. Lastly, there are the transcripts of a Greek version of the history compiled by Manetho, which, with many minor corruptions, gives a consecutive record of the whole of the dynasties. All these records agree in their general account, they agree with the total reckoning quoted by Herodotus, they agree with the various ex ternal checks-astronomical and others-that can be discovered. This account is therefore accepted here; but many writers prefer to abandon the authorities, and construct fanciful systems of shorter length, bringing down the Ist dynasty from 5500 B.c. of the Egyptian record to about 3000 B.c. ; all dates before 1587 B.c. are also reduced.

The Ist dynasty (about 5600 5300 B.c.) was the highest point of the Third civilization. Much of the old arts continued; the hard stone vases, the rich burials, the style of pottery, all show continuity. Yet there was an immense change: writing became usual; a large official class had arisen to administer the country, each office, with its seal, down to the gatherer of lotus seed; jewelry shows skilful work; building both in wood and in brick was much increased; ivory carving was excellent for its natural character and freedom of expression; the use of copper was much extended; and glazing became a decorative art for building. The IInd dynasty was only a gradual decay, but the IIIrd shows a fresh influence which led up to the greatest age of all.

\section{Glories of the IVth Dynasty}

The IVth dynasty (about 4800 to 4500 B.c.) established the Fourth civilization. The Egyptians here reached the highest mastery of art, of grandeur, and of conception. Never lias the immensity or the accuracy of the great pyramid of Khufu (Cheops) been equalled in later ages; never has there been a greater expression of character and dignity than in the portrait sculp tuie; never has any people created a greater mass of artistic detail for their tombs, and presumably also for their dwellings now lost to sight. The personal character shown in the portraiture is most attractive ; the firmness with kindliness, the dignity unspoiled by mere pride, the vigour, insight, determination: all this agrees with the ideal character set out in the maxims of that age : "If thou art found good in the time of prosperity, when adversity comes thou wilt be able to endure" ; "Let thy heart be overflowing, but let thy mouth be restrained"; "The cautious man succeeds, the accurate man is praised "; "I am one that smooths difficulties; I am one prudent in preventing and easing grief, quieting the mourner with pleasant speech"; "Make not terror among men." During the Vth and VIth dynasties Egypt retained its great civilization, diminished in some respects, with wider diffusion but less care and splendour. By the VIIth dynasty, about 4000 B.c., foreigners were pressing into the country. The old art lingered on in an absurdly degraded form during four centuries.

The Coming of the Syrians

The XIIth dynasty (about 36003400 B.c.), established the Fifth civilization. By the middle of the XIth dynasty the princes of Thebes began to sprear isir power, large tomios were again excavated, and monaments carved. The XIIth dynasty reunited all the country, and pushed upinto Nubia, civilizing and consolidating that region at least as far as the third cataract (lat. $20^{\circ}$ ). The most magnificent king of this age was Amenemhat III, whose sepulchre was a tank, cut and polished in a block of glasshard sandstone, $22 \mathrm{ft}$. long inside, and weighing 100 tons. $\mathrm{He}$ reclaimed a large part of the Fayum which had been till then a swamp. The whole character of the age has less originality and freshness than before, more regularity and exact detail, and a more formal treatment of every subject. The Syrians were beginning to press into the country, and in the decadent dynasties, the XIIIth and XIVth, some even rose to be kings. These were the forerunners of the great Hyksos conquest about 2600 B.c.

The XVIIIth-XXth dynasties (1587-1102 B.c.) established the Sixth civilization. The XVIIth dynasty was a Nubian family which headed the southern Egyptians against the Hyksos, who were finally expelled from Egypt by Aahmes, the founder of the XVIIIth dynasty. This revival centred specially at Thebes, which became the largest city of the time, and has left a great mass of temples and painted tombs. The most import. ant aspect of this age was the foreign intercourse, by conquest in Syria and by trade with Babylonia, Crete, and Greece. 
By about 1530 B.c. Tehutmes I had conquered all Syria out to the Euphrates near Aleppo. All this was retained until the wars of Tehutmes III, about 1460 , and almost as much until the crumbling of the foreign hold under Akhenaten about 1370 B.C. In the XIXth dynasty Sety I recovered Syria entirely, about 1320 B.C.; and Rameses II, though pressed by the Hittites, kept the greater part of that land till about 1250. After that, Egypt barely held a little of the S. of Palestine. On the W. Egypt did not extend any political influence, and the connexion was only by trade, which is mainly seen by objects of Amenhotep III, about 1400 B.C., at Mycenae and other centres, and by great quantities of Greek vases imported into Egypt, especially about 1370 B.c. When Egypt became weakened, there were great coalitions of the Algerian and western peoples against it in 1229 B.C. in the reign of Merneptah, and again in 1197 in that of Rameses III. This was followed by a coalition of Syrians and western peoples in 1194 , who were overthrown in a great naval battle.

\section{Semitising of Languages and Art}

The frequent wars in Syria led to the bringing of great numbers of Syrian men and women into Egypt, and so to the semitising of Egyptian language and art. A greater change took place in 100 years than had arisen in 1,000 years before. The fashion of the time was for a light and piquant style, as seen in Crete; and the sober matter-of-fact Egyptian responded to it, with fatal results to his own character. Graceful and pleasing as many of the tomb scenes are, they have none of the solidity of the old tomb sculptures or paintings on hard rock; a mere coat of plaster or mud over a very rough chamber, all askew and irregular, was sufficient grounding for the perishable colour washes, which would be ruined by a touch of water ; the older work was so firm that it could be scrubbed without removing the colour.

The XXIst dynasty (1102-952 B.c.) was an age of poverty and weakness. The land was amicably divided between a succession of priest-kings at Thebes, and the kings at Tanis in the Delta. The main interest lies in the desperate attempts to save the mummies of the kings of the XVIIth-XXth dynasties from destruction by robbers. After many had been attacked, and most had been examined and shifted about for safety, the priest-kings at last made one great cache at Deir el Bahri, whieh was left unopened because it was known that no gold remained with the bodies. Thus it was left until our times, and we can now see most of the celebrated kings of this age face to face in the Cairo Museum.

The XXIInd and XXIIIrd $\mathrm{dy}$. nasties (952-721 B.c.) revived the power of Egypt somewhat. They were due to the energy of a Mesopotamian adventurer, Shesheng or Shishak, and his family, who settled at Bubastis. But there was no revival in the life of the country, the products were only a continued degradation of the style of the XIXth dynasty.

The Ethiopian invasion about 727 B.c. found Egypt split up among eighteen or more little states, but it seems to have put fresh life into the country, and a real revival of work can be seen. The Ethiopian kings who ruled till 664 B.c. were vigorous and able men, and they had a good system of appointing the crown-prince as viceroy of Egypt, so that there was energetic management under experienced control.

The XXVIth-XXXth dynasties (664-342 B.c.), founded the Seventh civilization. They were under Ethiopian influence and then largely controlled by Greek action, and under Persian rule. There was some revival of energy abroad. Necho in 609 raided all Syria to the Euphrates and held it more or less for four years, when the new power of Babylon defeated him, and he retired to Egypt. The Persians held the country from 525 to 401 B.C., and then the native Egyptians in the Delta revived for a couple of generations, forming the XXIXth and XXXth dynasties, 399-342 в.с. Ten years of miserable destruction under the degenerate Persian ushered in the golden age of Alexander's conquest.

\section{The Rule of the Ptolemies}

The transition from Alexanderand his heir to the rule of the old general PtolemySoter(theSaviour) was very gradual. Ptolemy, it may be said, ruled from the death of Alexander in 323 . The earlier of the family were very able men, wary, strong and enlightened, backed by powerful queens of their own family. Egypt had not been so peaceful and prosperous for some centuries as it was from 300 to 200 B.C. Even under the effete rule of the later Ptolemies, the country was one of the most learned and richest in the world. This dynasty possessed Cyprus and Cyrene for a long time, and parts of Syria and the S. of Asia Minor in the intervals of the perennial squabbles with the Antiochi.

The Roman Age (30 B.c. to A.D. 640). The end of Egyptian inde- pendenee was the death-stroke to the country. From being one of the richest lands, it became the milchcow of the emperor of Rome, the private property of the Crown. It was steadily drainerl of all wealth, taxed in corn to feed Rome, taxed in money, and after three or four centuries even the shabbiest eopper coin ceased to be struek, and the people were reduced to barter. ()eea. sional massaeres were a bout the only events that marked the Roman rule.

The Arab Rule (A.D. 640-1517)

This was the Eighth Civilization. The Roman government collapsed before a few thousand wild Arab horsemen. Yet such was the vitality of the country, that under the alien but just rule of the Arab, within two centuries the land tax alone produced six or seven million sterling - far the largest revenue of any country of that agc. There ean be no comparison between the advantages of Roman and of Arab rule. Yet that, like all other power, decayed, and the Mamluk dynasties, for some centuries before the Turkish conquest, were a ceaseless turmoil of fighting and plundering. This unrest was renewed when Turkish power waned, and only the strong hand of Mehemet Ali recovered the advantages of a united government.

The People. Egypt, in spite of its isolated position, has been subject to continued mixtures of race. Starting with an Algerian stock, there have been four or five inflows from the E., two more from the W., a large Greek population in the Delta, and continual mixtures of Southerners from slave labour. Yet the national type of character has remained much the same, and the skull measurements after each mixture return in a few centuries to the older size. Agriculture has always been the main industry of the country, the regular inundation and strong sunshine making it very profitable. Cattle are not kept in large numbers, as all the fertile land is inundated for a third of the year, and there is no permanent pasture. The usual feeding of cattle is by tethering in green crops, or by hand in the summer.

The ancient organization, which may still be seen in the remote country, is for each district to be the property of a great man-anciently an hereditary noble. The police and guards of his district were his personal servants. On his estate he kept workmen for all current purposes; in his great house lived all the artificers that were needed for manufactures; weavers, earpenters, smiths, jewellers, boat builders all belonged to the establishment, and worked as direeted. Trade was 


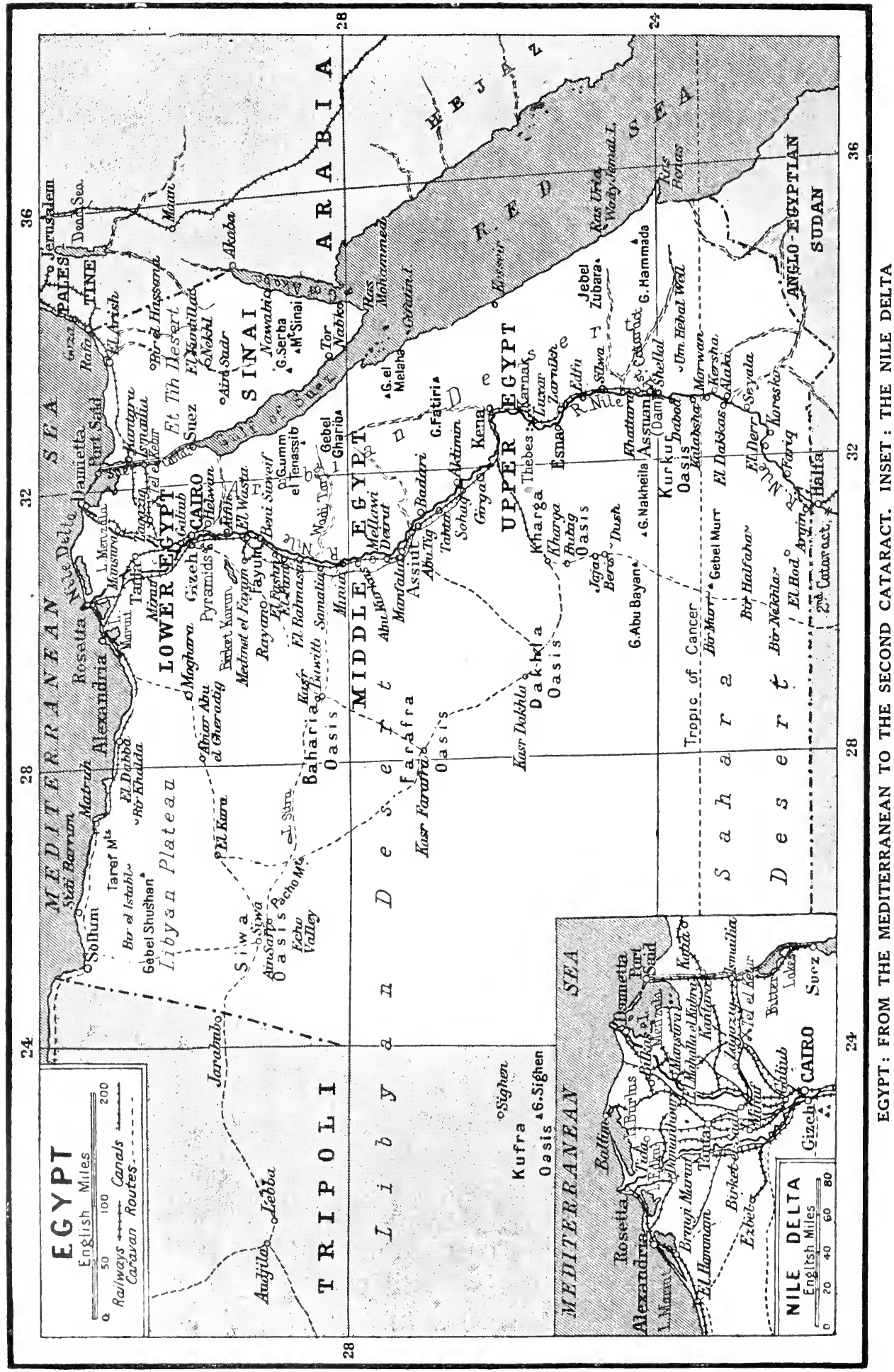


mostly in petty market wares, and in raw material not produced on the estate. The government was on the same model. The royal court was only the greatest of the nobles? estates, and the ordinary government was carried on by the officers of the king's household, who only interfered when needful with the local administration of the nobles. It was something like the British control over the native states of India. When a noble wanted great blocks of stone, or anything only produced on the royal estates, he applied, and was granted the present of the material. The tribute sent from different nobles to the court was trifling, merely pinmoney for personal use, showing that all cost of government was borne locally by the nobles. The system gave great social stability to the country, everything went on as usual, whether the king was strong or weak. The only purpose of the kingdom was to prevent local fighting and to unify the land for defence.

The official class was probably always corrupt; the management of cases and witnesses under Rameses X reads like modern police work. Where a capable noble can be found, the purely local ad. ministration is more likely to be just than where a centralized professional police are in authority.

The army was originally on a small scale, probably the king's people from his estates. By the XIIth dynasty the scribe of recruits is found, and in the great military age of the XIIIthXXth dynasties the recruiting was severe in Egypt.

\section{Native Troogs and Auxiliaries}

The army was divided into four brigades, named after the great gods of different regions ; the army of Amen from the Thebaid, that of Ptah from middle Egypt, that of Ra from the upper Delta, and that of Sutekh from the E. and lower Delta. Besides the native troops, there were many auxiliaries -Libyan and negro archers in early times, Sardinian and other Mediterranean folk later. The Greek accounts of the army forming a regular caste with hereditary lands, was probably a continuation of the Rameside system. The Ptolemies further settled Greek troops, largely in the basin of the Fayum, which they reclaimed by reducing the inflow of the Nile.

The position of women was always high until the Arab conquest. Property was essentially held by women. A man might even have to declare at marriage that all his earnings passed to his wife. Down to Coptic times a wife's consent was necessary for a valid sale in an open market; even though a mere formula, it proves original intention. The wife always appears side by side with her husband on monuments, and parentage was almost always reckoned one or two generations farther back on the female than on the male side. Apparently the inheritance to the kingdom de. pended entirely on the female line, and whoever was king in fact had in law to marry the heiress. Polygamy was unusual but not prohibited; in one case of a childless wife the husband took six others. There is no ceremony of marriage preserved, and as in Christian Egypt it was a legal contract, rather than religious, it was doubtless so before then. In the Christian contract there was a divorce clause, stating that either party could cause divorce by proclaiming it in the congregation. The husband's gift was only 12s. and the divorce penalty seven times that sum. In the XXVIth dynasty the penalty was only the returning of half the marriage portion.

\section{Simplicity of Native Costumes}

Dress was simple, befitting the climate. In prehistoric ages the men wore a girdle, the women a short linen petticoat like the Dyaks, or later the Malay sarong. The dynastic men wore a waist. cloth or kilt, like that enjoined by Mahomet, from the navel to the knees; the women wore a long, white wrapper, from below the breast to the ankles, held up by shoulder-straps. These remained the dress represented in art till the XIXth dynasty ; but in reality, as early as the Vth dynasty women wore tight, high dresses with very tight sleeves, like the modern galabiyeh. At the same period, pleated linen drawn into folds was also used. In the late XVIIIth dynasty and onward, very full pleated linen dresses were used for men and women. For the winter, a thick, quilted robe was worn, as shown on an aged king of the Ist dynasty; thick, stiff, long wrappers were usual for viziers and high officers in the XIIth dynasty. In Greek times, thick outer wraps, often with fringes, were usual. Stuff with very long, loose threads all over it, like a shaggy fur, was woven in the XXIst dynasty. The weaving of coloured patterns began in the XVIIIth dynasty, but was extremely rare. The common use of colour patterns on elothing is cntirely of the Roman period, and most used in the Christian age, as satirised by Jerome.
Education. The Egyptian was always business-like, and kept tallies of all goods, from the Ist dynasty onward. A tally of the XVIIIth dynasty gives the ensign of the Nile boats and the number of blocks of stone which each carried. From these tallies elaborate accounts were drawn up, listing every goat or pigeon on an estate, or putting down as gifts to the gorls every item of 106,792 loaves of one kind or $1,975,800$ nosegays. Every noble had a staff of scribes on his estates to keep all the bailiff's accounts, and they are very often shown in the tomb seulptures. By far the greater part of the documents that are preserved of all periods are the accounts. This proves that there was a large class of men all through the country who could write, though probably the peasant or petty trader was not as well educated as in Babylonia.

Education was probably in general from father to son, but in the XVIIIth dynasty schools were attended in the towns. A rough and practical geometry was used by the scribes, for the areas of fields and the contents of conical granaries. There was certainly also a much more skilled geometry and astronomy by the pyramid builders, who were capable of setting out a building true to 1 in 10,000 and positions by the stars to 1 in 1,000 . In the XVIIIth dynasty the clepsydra or water clock was made as a wide conical vessel, to compensate for the quicker flow of water at greater pressure, and was graduated for each month to compensate for the changes of temperature. In the same age botany was studied, and Tehutmes III sculptured a chamber with the foreign plants of his Syrian wars, having separate figures of fruit and seed like a botanical work. The Egyptian always had a keen eye for differences of race, and showed on monuments the types of all the peoples that he visited.

\section{Egyptian Literature}

The literature begins in the pyramid period with maxims and wonder-tales of magicians, parallel to medieval tales of miracles. In the XIIth dynasty tales of foreign adventure were in fashion, succeeded in the XVIIIth dynasty by tales of character. The growth was therefore much the same as in the last few centuries in Europe. There were also serious works which showed the deeper thoughts of the time. In the XIth dynasty they wrote:

Since the time of the ancestors-

The gods who were aforotime-

Who rest in their pyramids

Their place is no more 
None cometh from thence

That he may tell how they fare

Until we depart

To the place wlither they have gone. Encourage thy heart to forget it

Making it pleasant for thee to follow thy desire

Until that day of Jamentation cometh unto thee

There is also the song of the man who is weary of the world :

Death is before me to-day,

Like the recovery of a sick man,

Like going forth into a garden after sickness.

Death is before me to-day,

Like the odour of myrrh,

Like sitting under the sail on a windy day.

Death is before me to-day,

As a man longs to see his house

When he has spent years in captivity.

The Gods of the Egyptians

The earliest belief about gods so far as is known, is tribal monotheism, of which traces remain in the early historical writings. Each tribe in the Nile valley seems to have had a separate divinity. As the tribes amalgamated in prehistoric ages, they joined in worshipping two gods, as husband and wife, or father and son, or three gods as a triad. Later, in historic times, when the relationships were already settled, fresh gods were brought in by compounding names, as Ptah-SokarOsiris, belonging to three different sources of population. This process was not complete till the XVIIIth dynasty.

Four great classes of gods can be distinguished, the animal gods of the earliest population, the Osiride gods in human form of western origin, the Solar gods of eastern introduction, and the abstract gods, as the Father god, Mother goddess, Creator god, goddess of Truth, etc. All these classes had been mixed in Egypt before the historic times. The belief in passing over a water of death was as old as before the first prebistoric civilization, as the king is said to do so on a float of reeds, whereas boats were usual in the second age. The myths of hunting and killing the gods and feasting on their cooked limbs is older than the Osiris worship, as he is expressly said to have led the Egyptians from cannibalism and violence. From various such in dications it is possible to restore several stages in the growth of beliefs long before the date of records that we have. Certainly there was a firmly accepted belief in a ritual for the dead, as from the earliest graves known until historic times the position is al. ways the same, and the funcral offerings do not alter but only incrcase as time goes on. There must have been a generally accepted ritual for the position of most of the offerings, which proves settled and continuous beliefs.

In historic times the principal gods were the baboon and the ibis of Hermopolis, lions in some Delta towns, cats at Bubastis, bulls at Memphis, Heliopolis, Kanobos (Canopus), Hermonthis, rams at Mendes and Thebes, crocodiles in the Fayum, hawks at Hierakonpolis and Koptos, serpents at Buto, and several kinds of fish. The principal animal-headed gods were Khnumu the creator and Hershefi, both ram-headed, Bast of Bubastis, Anubis jackal-headed, Thoth ibis-headed, and Horus hawk-headed. The purely human gods were Osiris, Isis, Nebhat, Horus; Amen, Mut and Khonsu open along the front. The next stage is to have a store chamber at the back, then a way to the roof ; after that more chambers and then a roof chamber forming an upper storey. This was no doubt the growth of the superior house also, and as the temple was the house of the god, it is the plan of the temple. In the latest of the temples the old verandah remains as the vestibule hall open in front, the courtyard is the temple court, the store chambers come behind the hall. The peristyle court is an expansion of the verandah around the front court. The hypostyle hall, farther in, is the usual inner hall of the dwelling house. It has also been proved that the course

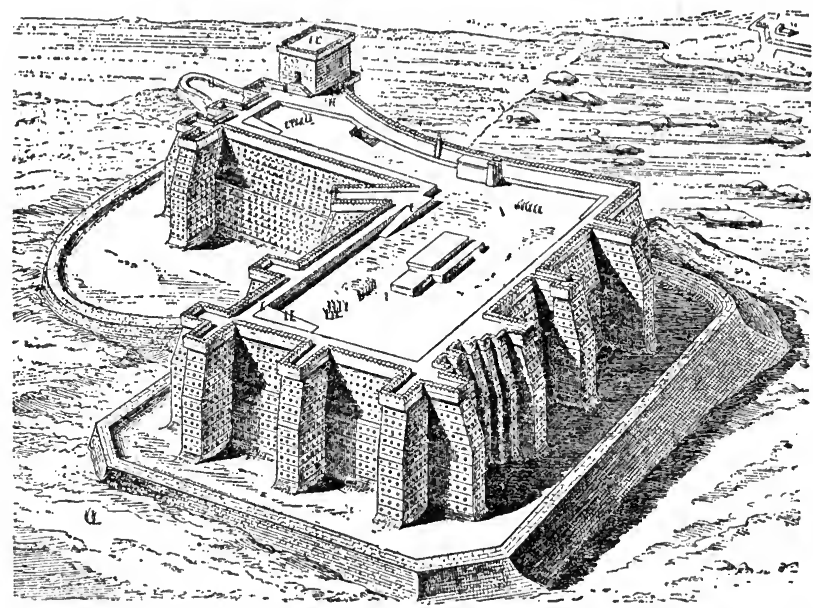

Egypt. Bird's-eye view of the ancient fortress of Semneh, as restored by Charles Chipiez From A Bistory.of Art in Ancient Egypt, $G$. Perrott and C. Chepiez, by courtesy of

the triad of Thebes, and Neit of the Delta. The cosmic gods are $\mathrm{Ra}$ the sun, also called Aten, Anher the sky, Sopdu the zodiacal light, Nut heaven, Geb earth, Shu space, Hapi the Nile. The abstract gods were Ptah the Creator, Min the Father, Hathor the Mother, Maat Truth, Safekht of writing, Nefertum of vegetation.

One great break in the religion must be mentioned, the entire dominance of a scientific worship of the radiant energy of the sun, called the Aten or "lord," to the exclusion of all other gods. This hardly survived the life of its founder, Al.henaten (1383-1365 B.c.).

Art and Architecture

The simplest beginnings of archi. tecture are seen in the models of the peasants' huts that were placed on the graves for the spirits. The essential is a verandah with an enclosed court before it, perhaps developed from the Bedawi tent, of daily worship of the priest was directly copied from the domestic service to a noble.

The great growth of the temples was generally due to successive additions by different kings, as in London the building of Westminster Abbey extended over four or five centuries, although on a single plan. Beside tho house templc, just noticed, there were shrine temples, copied from the hut shelters put over the sacred ark of a god; these were open front and back, so that a procession could pass through them to ake up the ark or deposit it.

The earlier temples are very simple and plain, but of massive structure. The earliest columns of the pyramid age and the XIIth dynasty are monoliths of red granite from $16-20 \mathrm{ft}$. high. The hardness of the granite enabled the spacing to be made wide and airy. When soft sandstone was 

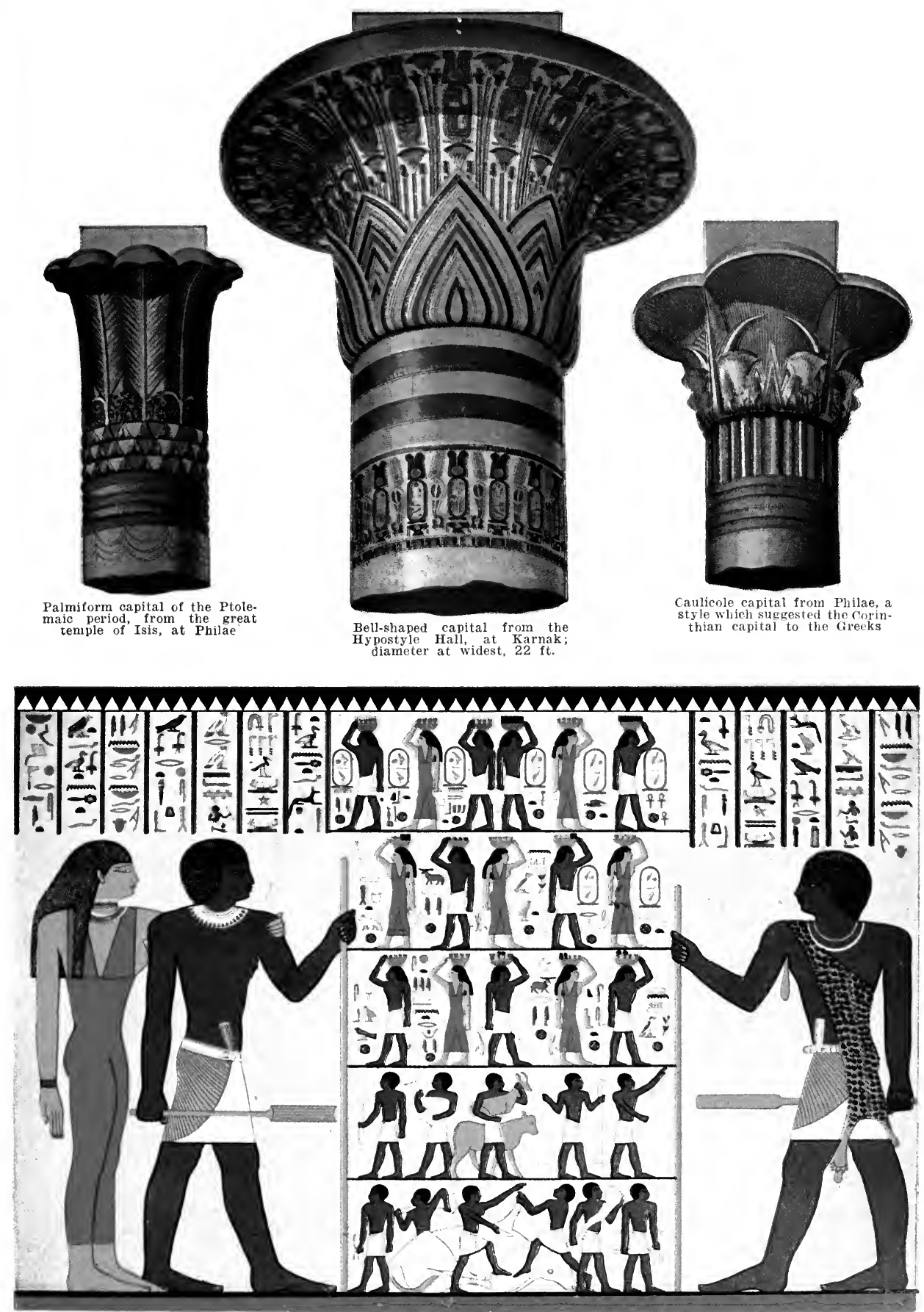

Inscription from the tomb of Merab at Gizeh. Between the two figures of Merab, who, on the left, is accompanied by his mother, are seen subjects carrying baskets of wine, food, etc. The two bottom rows show the chief butcher followed by his assistants bearing a goose and a calf and cutting up an ox

EGYPTIAN ART: RICH ORNAMENT AND COLOURED INSCRIPTIONS OF AN ANCIENT CIVILIZATION To face page 2820 

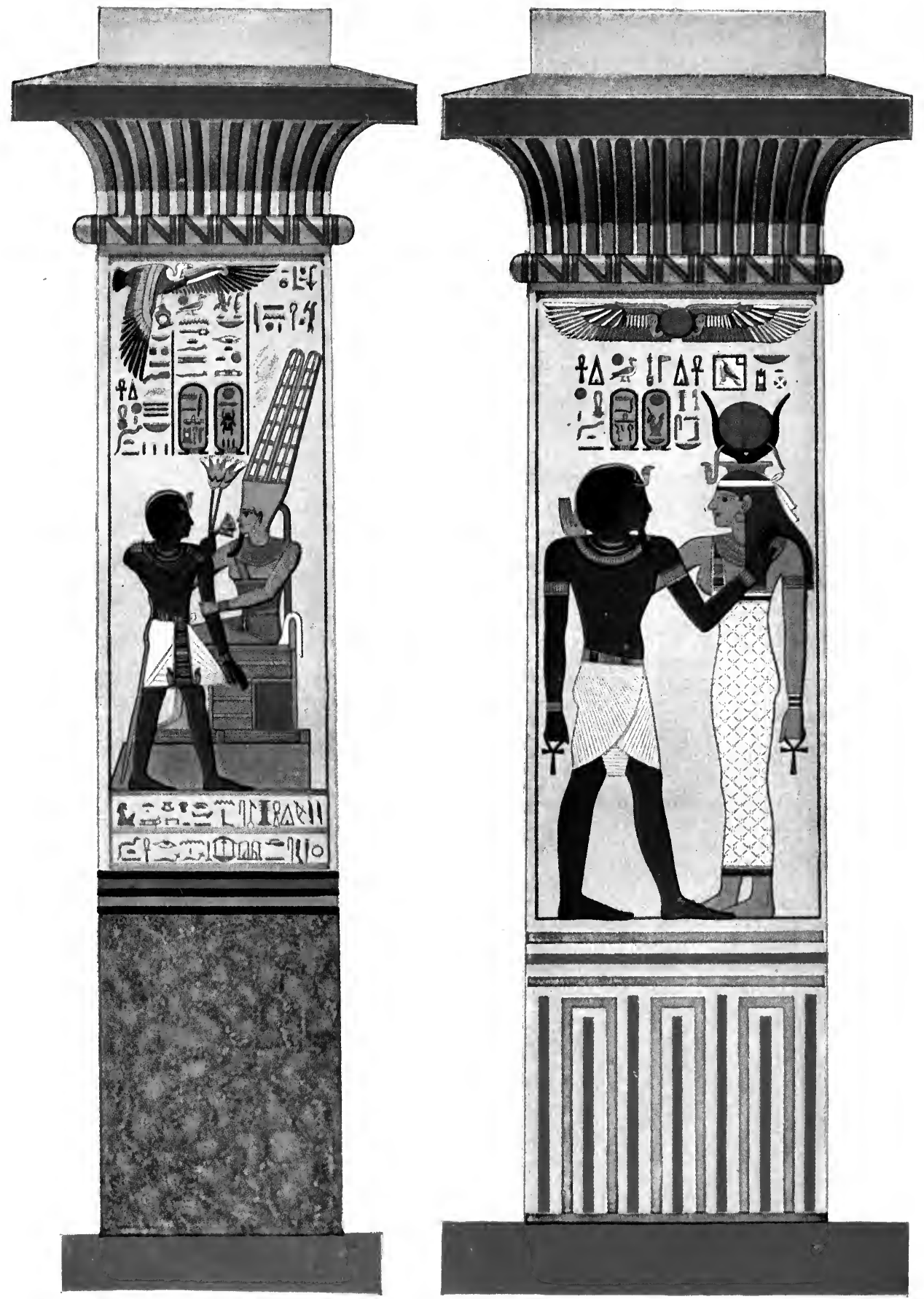

Piers, with capitals, belonging to the X VIIIth dynasty, I 700-1600 B.c. The left pier, I $7 \mathrm{ft}, 6$ ins. high, shows Amen on a throre receiving an offering of lotus flowers from Amenhotep II, whose names and titles are inscribed above. On the right pier, $13 \mathrm{ft}, 1 \frac{1}{2} \mathrm{ins}$. high,

is seen Amenhotep III and the goddess Hathor (Isis), who bears on her head the solar disk resting between two horms and the Uraens, or serpent emblem. Both noures carry the ankh or key of life. Above are the names and titles of the goddess and the king 
used in the XVIIIth dynasty, and later, the larger temples became choked by the bulky columns required, as at the Great Hall of Karnak. The decoration of the temple with scenes of offering was not for ornament, but in order that the representation should magically be equivalent to the perpetual performance of the successive acts of divine worship. The sculpture in the temples followed the general course of the art.

'The complete temples remaining are, of the IVth dynastr, the granite temple at Gizeh; of the XVIIIth, of Hatshepsut at Deir el Bahri, Tehutmes III at Medinet Habu, Tehutmes I to Ptolemies at Karnak, Amenhotep III at Luxor and El Kab; of the XIXth, of Sety I at Abydos, Qurneh, ana Redesieh, of Rameses II at Ramesseum, various Nubian and Abu Simbel, of Rameses III at Medinet Habu, Ptolemaic at Edfu and Dendereh, Roman at Esneh. Three series of royal tombs are known-the underground brick and timber chambers of the Ist and IInd dynasty at Abydos, the pyramids of the IIIrd-XIIth dynasty at Gizeh and scattered for $40 \mathrm{~m}$. S., the rock-cut chambers of the XVIIIth-XXth dynasty in the tombs of the kings at Thebes; no later king's tomb is known.

More recent excavations, con fined chiefly to the Valley of the Kings in the Thebes district, were conducted by the 5th Lord Carnarvon and Howard Carter (q.v.). The latter on Nov. 5th, 192\%, in almost the last unexplored pieces of ground, made the sensationa. discovery of the tomb of King

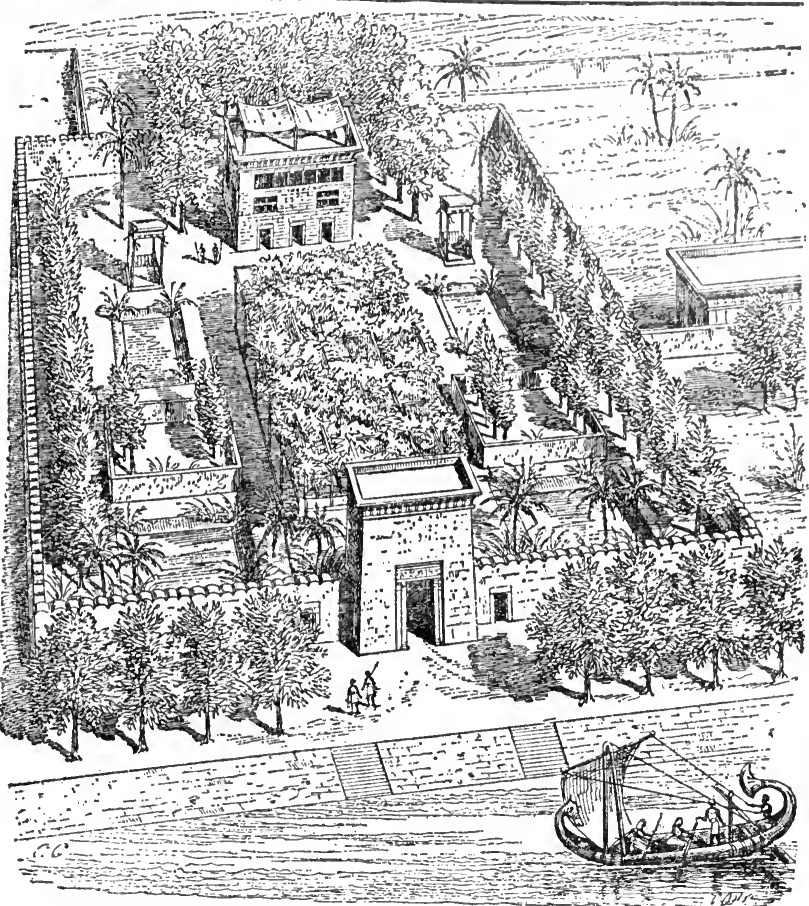

Egypt. Ancient riverside villa, as restored by Charles Chipiez By courtesy of Chapman \& Hall, Ltd.

Tutank hamen $(q \cdot x)$, and he super intended the removal of the trea sures found therein.

The mummies of the kings are preserved from these Theban tombs, but no others. Great cemeteries of private tombs with seulpture and painting are at Gizeh and Sakkarah for the pyramid age, at

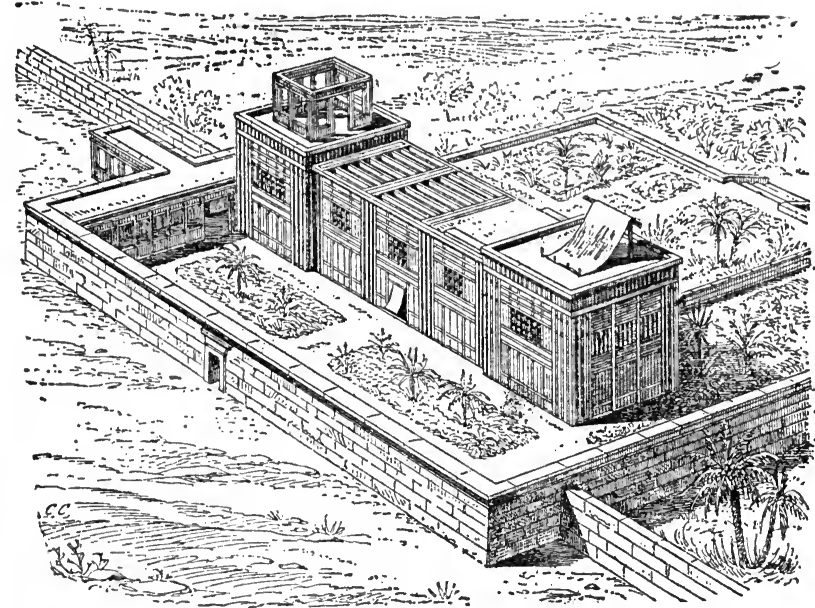

Egypt. Reconstruction of a wooden building, made from imitations of assembled wooden construction found in tombs

By courtcsy of Chapman \& Ball, Ltd.
Bent-Hasan tor the XIIth dynasty and at Thebes for the XVIIithXXth dynasties. Forts of massive brick enclosures, with panelled pattern outside, are of the IInd dynasty at Abydos, and of the XIIth dynasty in Nubia. Temples were of ten fortified with immense walls, as that $80 \mathrm{ft}$. thick at Tanis. The only complete plan of a town is of the XIIth dynasty; it has many large mansions of 60 rooms and rows of streets of workmen's houses, all laid out in a regular plan. The houses and the earlier temples were built of mud brick, which was covered with lime. wash or stucco, on which fresco painting was placed in the better houses; the early brick temples were sometimes lined with glazed tiling of large size.

Statuary is known from the Ist dynasty onward. It begins in limestone and ivory, with an entirely naturalistio style, full of character and life, and superior to later work in its truth and absence of convention. A copper statue is recorded in the IInd dynasty, and a large eopper statue has been found of the Vlth dynasty. Diorite and other hard rocks were also sculptured. In the XIIth dynasty tho style was more finished and delicate, but less living. The XVIIIth dynasty had more vivacity, but 

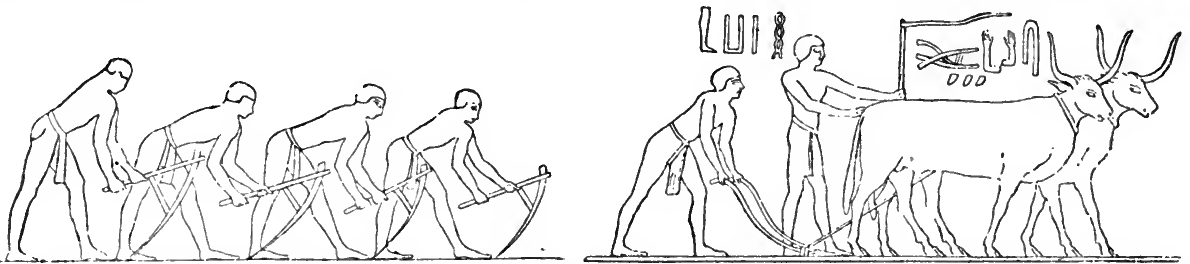

Ezypt. Agriculture as depicted on ancient monuments. Left, four men hoging, from Beni-Hasan ; right, a ploughing scene, from the necropolis at Memphis

By courtesy of Chapman \& Hall, Ltd,

generally less able work; hard rocks were mostly used, and many colossal statues were carved, ranging to 900 and even 1,200 tons weight. Though work declined in the XIXth dynasty and onward, there was a revival in the XXVth and a modification by Greek in. fluence after that; but there is no sculpture of merit after Alexander.

Metal work-mostly in copperwas skilfully wrought. Large vessels were made by hammer work, often figured in the tomb sculptures; a narrow-necked flask of copper is only 1-40th in. thick. The casting, a thin form of copper in place of a wax model, was carried on from the IInd dynasty ; for figures a core was made of ash and clay, a thin coat of wax was put over it and finely tooled, an outer mould was placed around that, the wax melted out, and copper or bronze run in. The metal is often not more than 1-50th in. thick. A ring handle playing loose in its ring attachment were cast all in one. Spinning thin metal bowls in a lathe was perfectly done in the XIXth dynasty.

Jewelry was delicately made as early as the prehistoric, when minute beads of gold, and thin gold worked over a core of limestone, are found. In the Ist dynasty gold was perfectly sol. dered, and in the XIIth dynasty there was the most delicate work of soldering cloisons of gold on an open-work basis, and inlaying with hundreds of minutely cut pieces of coloured stones-turquoise, lazuli, and cornelian. No later jewelry exceeded this in beauty and delicacy, though the same style was maintained till Greek times. Granulated work was finely made in the XIIth dynasty; minute globules of gold in close rows were soldered on curved surfaces in regular patterns with perfect precision. In the XVIIIth dynasty there was less delicacy, and the favourite process was the inlaying of one metal in another to form figures and scenes.

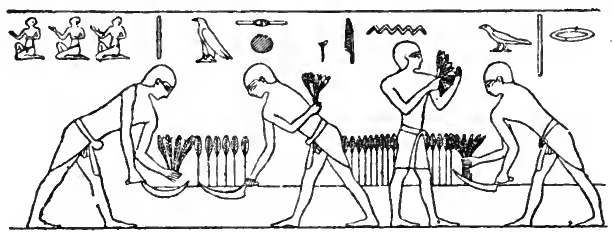

Egypt. Harvest scene, as shown on a tomb at Gizeh

In the XXVth-XXXth dynasties this inlaying of gold thread in bronze was carried out so as to clothe statues completely with designs copied from embroidery.

Glazing was known from the beginning of the prehistoric civilization, and used to cover both faience and stone. Vases with twocolour glazing were made in the Ist dynasty, and tiles of many colours in the IIIrd dynasty. The great development of glazing in many colours was in the XVIIIth, for tiles, inlay of walls, vases, dress ornaments, and cheap jewelry. Innumerable statuettes were made of glazed ware, often with minute detail of features, especially in the XXVIth dynasty. Glass was brought in rarely in the second pre. historic age, Ist and XIIth dynasties, from some unknown source. The great output of it in Egypt was after the Syrian craftsmen were brought in during the XVIIIth dynasty. Then there was an immense output of coloured glass vases, beads, and other work. This was revived in the Ptolemaic and Roman times as minute in. lay or mosaic work of the greatest delicacy. Blown glass vessels were not known till late in the Greek o $\mathrm{r}$ o $\mathrm{m}$ a $\mathrm{n}$ period. Alex. andria was the main home of fine glass work in classical times, until superseded by Venice after the Arab invasion. Painted glass lamps were the form of this craft which was maintained by the Arabs. The fine work of furniture, gilding, stucco, weaving, and other kinds cannot be well de. scribed here; but the Egyptian was for thousands of years the most skilful craftsman of the world.

\section{W. M. Flinders Petrie}

Liblingraphy. The Manners and Customs of the Ancient Egyptians, J. G. Wilkinson, rev. ed. S. Birch, 1878 ; History of Egypt, vols. i-iii, W. M. Flinders Petrie, 1894, etc. ; Primitive Art in Egypt, Jean Capart, Eng. trans. A. S. Griffith, 1905 . Ancient Records of Egypt : historical documents from the earliest times to the Persian Conquest, collected and edited with Eng. trans. by J. H.
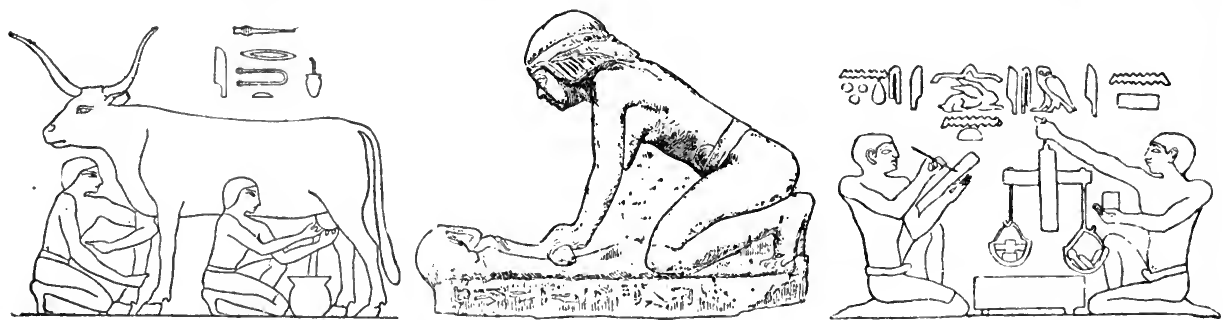

Egypt. Everyday scenes depicted in inscriptions. 1. Milking, from a tomb at Sakkarah. 2. Corn-grinding, figure from Boulak. 3. Scribe registering the weighing of merchandise from Sakkarah 
Breasted, 5 vols. 1906-7 ; The Arts and Crafts of Ancient Egypt, W. M. F. Petrie, 1909 ; A History of Egypt from the Earliest Times to the Persian Conquest, J. H. Breasted, 2nd ed., 1909; Guide to the Antiquities of Upper Egypt from Abydos to the Sudan Frontier, A. E. P. B. Weigall, 1910 ; The Dawn of Civilisation: Egypt and Chaldaea, G. Maspero, Eng. trans. 5th ed. repr. 1910; The Struggle of the Nations: Egypt, Syria and Assyria, G. Maspero, Eng. trans., M. I. McClure, 2nd ed. 1910 The Passing of the Empires, 850 B.C. -330 B.c., G. Maspero, Eng.trans. 1900 ; Egypt and Israel, W. M. F. Petrie, 1911; The Revolutions of Civilisation, W. M. F. Petrie, 1911 Development of Religion and Thought in Ancient Egypt, J. H. Breasted, 1912 ; Manual of Egyptian Archaeology, G. Maspero, 6th Eng. ed. A. S. Johns, 1914; Elementary Eoyptian Grammar, M. A. Murray, 3rd ed. 1914.

MODERN EGYPT. The main physical features of Egypt are the Nile and the desert. Egypt is bounded N. by the Mediterranean, S. by the Anglo-Egyptian Sudan, E. by the Red Sea, and W. by Tripoli and the Libyan desert. The area of the country is roughly $350,000 \mathrm{sq}$. m., of which all but a fifteenth is desert. A division is made between Lower, Middle, and

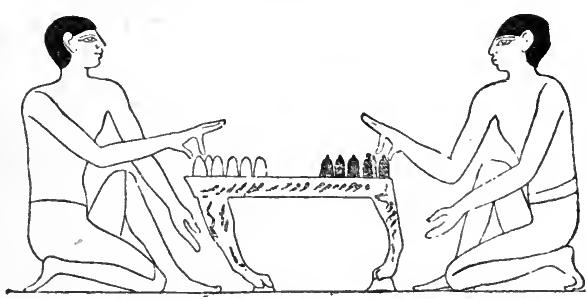

Egypt. Ancient representation of a table game, from an inscription at Beni-Hasan

hills. The valley lands in this region are well cultivated.

The chief towns are Cairo, the capital ; Alexandria, the chief seaport; and Port Said. The coastline is over $600 \mathrm{~m}$. on the Mediterranean, and about $1,200 \mathrm{~m}$. on the Red Sea. Part of it is rocky, but nowhere do the cliffs exceed a height of $1,000 \mathrm{ft}$.

The Nile enters Egypt proper at Halfa, just N. of the second cataract, flowing through a narrow valley as far as $25^{\circ}$ north.

The delta extends some $100 \mathrm{~m}$. $\mathrm{S}$. to N., and $155 \mathrm{~m}$. on the shore of the Mediterranean between

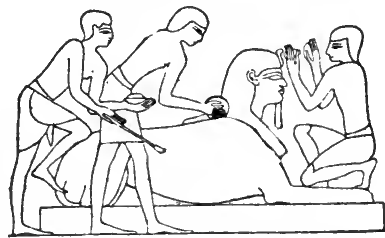

Egypt. Artists at work on a statue, from an inscription at Thebes

Alexandria on the W. and Port Said on the E. The surrounding land, southwards, is watered by a network of canals and the two branches of the Nile, Damietta and Rosetta. The lakes of the delta, Mariut, Edku, Burlus and Menzala are all shallow, the water being salt or brackish. Lake Menzala (780 sq. m.) is the largest.

The desert plateaux extend on either side of the Nile valley from the $\mathrm{S}$. borders of

Upper Egypt. Lower Egypt is the northern part-the delta of the Nile; Middle Egypt is the land between Cairo and Assuan, and Upper Egypt is the southern partthe middle Nile valley. The fertile portions of the country are mostly around the delta, the Nile valley and the oases. With the continual improvement in drainage and irrigation the cultivable area is yearly increasing.

The majority of the population of $12,750,918$ are fellaheen (agriculturists), and depend upon the resources of the Nile. Egypt's river has conquered the desert and by its annual overflowing has deposited much sediment, which it carries from the Abyssinian mountains through the Atbara and Blue Nile, converting sandy land into cultivable areas. In Upper Egypt the Nile valley is narrower and the desert on either side is bounded by
Egypt to the delta in the N. The E. area, the Arabian desert, between the Nile and the Red sea, varies between $90 \mathrm{~m}$. and $350 \mathrm{~m}$. in width. To the W. the Sahara extends unbroken for many hundreds of miles. The great oases, Siwa, Baharia, Farafra, Dakhla and Kharga, in the western desert, receive water from a sandstone bed about $400 \mathrm{ft}$. below the surface.

The flora of Egypt is scanty, the country being barren of woods or forests. The growth of most importance is the date palm, of which there are some 30 varieties all over the country. Other trees are the orange, clove, lemon, mulberry and pomegranate. Sycamore, tamarisk and milk trees are in evidence. Grapes are largely found in the Farafra. Egypt also grows limes, bananas, melons, prickly pears or Indian figs, and olives.

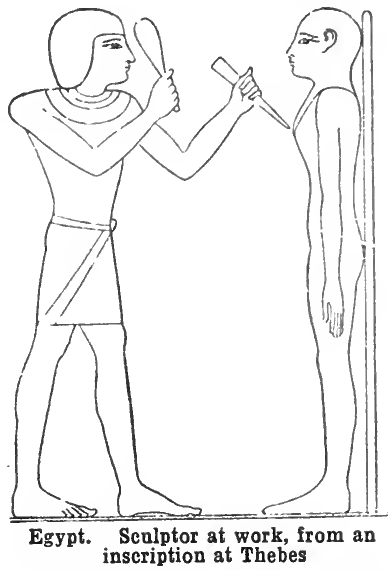

Of animals, the camel, ass, sheep and buffalo are most used. The horse is not so much in evidence. Among the wild animals of Egypt are the hyena and gazelle, while the hare, fox, and jackal are often found in the desert, and the lynx, ibex, and bats in the desert in the Nile vallev. Reptiles include the horned viper, the echis, and the hooded snake. Lizards are numerous ; so are spiders, beetles, fleas, mosquitoes, and scorpions ; locusts are not so common. Fish are plentiful. Over 300 species of birds are found.

Egypt is virtually a rainless country. The annual rainfall in Alexandria, and on the Mediterranean coast of Egypt, does not exceed 8 ins. Southwards rain is very irregular. The mean tem. perature at Port Said and Alexandria varies between $57^{\circ} \mathrm{F}$. in January and $81^{\circ} \mathrm{F}$. in July. At Cairo it is $53^{\circ} \mathrm{F}$. in January, and $84^{\circ} \mathrm{F}$. in July. The temperature is high by day and falls quickly at night.

People and Language. The population of the country is $12,750,918$, showing a remarkable increase since the beginning of the Turkish occupation, when an estimate gave it as less than $2,500,000$. Of the present population 11,658,148 are Mahomedans.

The most interesting type is the fellah or peasant; the most picturesque, the Beduin. The fellah has been often described as the backbone of the country. Tall, thin, and wiry, he reveals by his sad and weary aspect the tale of the last centuries. To the nomad Arab the term fellah signifies humility and even contempt. The fellah leads a life of extreme simplicity ; a galabieh, or blue cotton frock, and a turban complis 3 his wardrobe; his fare consists of millet bread and raw vegetables. 

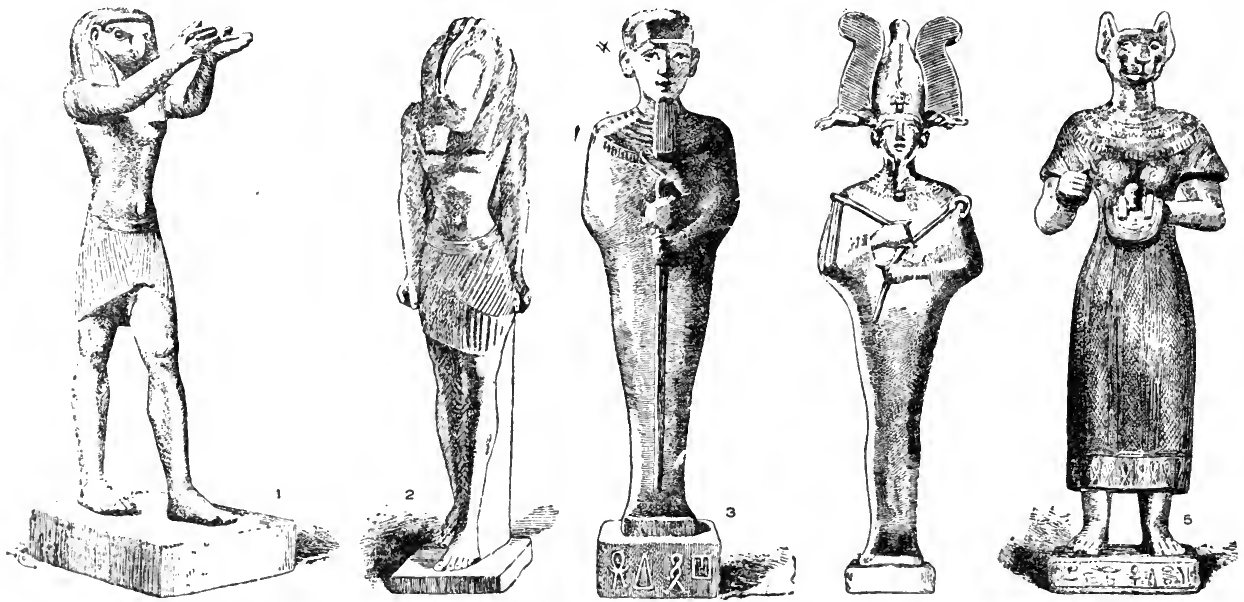

Egypt. Ancient divinities represented in Egyptian sculnture. 1. Horus, hawk-headed god of day. 2. Thoth, god of wisdom. 3. Ptah, the creator, chief god of Memphis. 4. Osiris, god of the underworld. 5. Bast, goddess of Buhastis

The Beduin presents a brighter picture. These " people of the tent" are shepherds and herds. men of sturdy but somewhat un. dersized stature, with coarse, thick, black hair, and wellchiselled features. The Nubians, or Berberins, dwell in Upper Egypt, and are of mixed negro and Arab blood. The majority are peasants. The Copt is the native Christian of Egypt, and is usually of a studious or commercial type. According to the latest census the Coptic Orthodox Chureh numbers 854,778 followers.

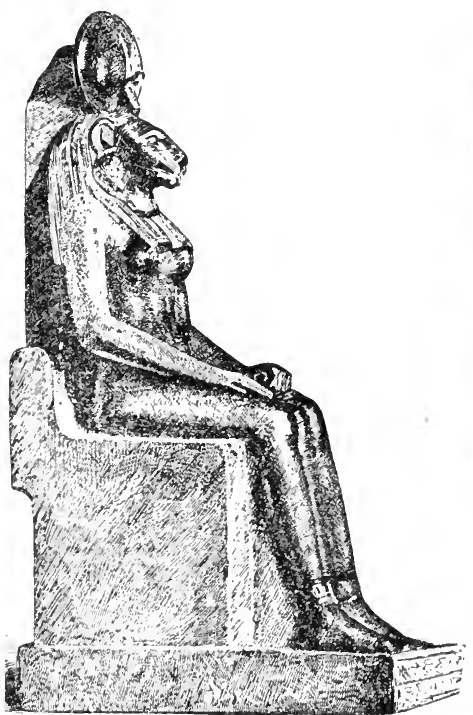
of Chap

The women of Egypt have been described as models of beauty in body and limbs between the ages of fourteen and twenty, but few retain either good looks or fine physique beyond the age of forty. Many women of the upper classes are rapidly becoming Europeanised in both dress and habits. The maidens of Egypt marry at an early age, generally between ten and sixteen. Divorce is of a facile order. If the husband repeats the words " Thou art divorced" three times the divorce is a fait accompli.

Arabic is the universal language of Egypt. Turkish is rarely spoken, and until recently French was used by the better educated Egyptians. The English language, however, is coming into greater use. The literary record is scattered, since Arabic is also the language employed by other Eastern countries. After the fall of Bagdad, Cairo sprang into prominence as the chief literary centre of the Islamic world, and to the present day it retains this distinction through its university of Al Azhar.

History. The Turkish conquest of Egypt in 1517 effected
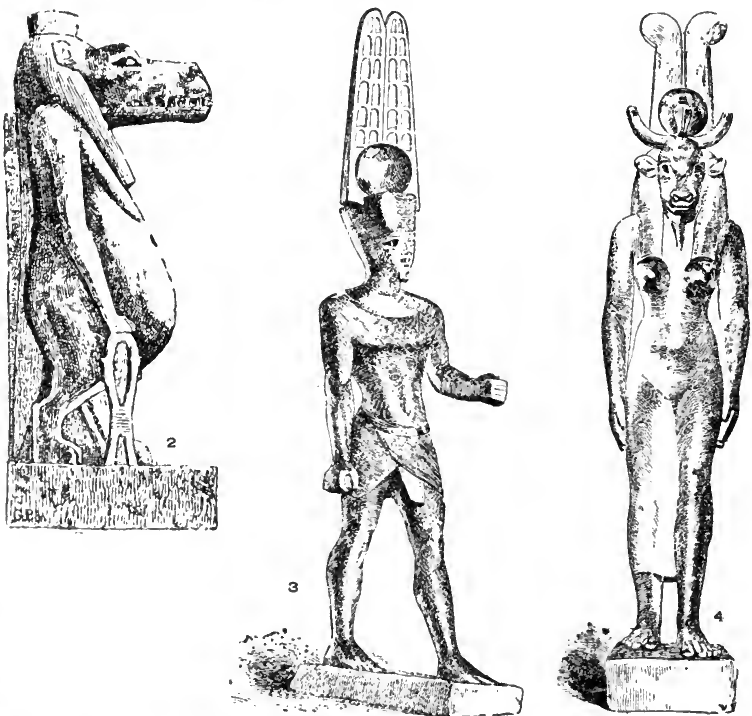

Egypt. Ancient deities. 1. Sekhet, goddess of war. 2. Touaris, or Opet, goddess of childbirth. 3. Amen, or Ammon, the sun god worshipped at Thebes. 4. Hathor, goddess of love, mirth, and social joy By courtesy of 'hapman \& Mall, Ltd. 
little change in the administration of the country. The apathy of its Turkish rulers led to a long period of unrest, which culninated in 1609 in a mutiny among the Tur. kish army of occupation. The rebellion, however, was curbed in Feb., 1610, by the governor, Mahomed Pasha. Risings among the Egyptians and the Turkish soldiers, plagues, pestilence, and famine mark subsequent years. Disease in the spring of $1619 \mathrm{car}$ ried off 635,000 persons, and simi lar ravages in 1643 completely wiped out 230 villages.

This rather doleful and somewhat obseure period of Egyptian history offered little opportunity for a great man, although in the next century Ali Bey appears to have succeeded in introducing a measure of order and reform. By stern methods he suppressed the notorious outlawry of the Beduin in Lower Egypt. In 1768 Ali declared the independence of Egypt, and was afterwards given the title of sultan. Turkey, however, defeated Ali in 1773, and much the same dismal state of things that existed during the previous Tur. kish occupation was re-established. A new epoch, however, opened with the short-lived conquest of Egypt by Napoleon. Insurrection broke out and after war with Turkey, in which the British intervened by landing a force in 1801 , Napoleon evacuated the country. Turkey now concentrated her at. tention against the Mamelukes, and by treachery and massacre overcame this troublesome but brave band. The chief personage of this, the darkest period of Egyptian history, was Mehemet Ali, who in so far as massacres were concerned showed no disposi. tion to depart from the rule of his predecessors, but nevertheless promoted several sound projects.

\section{European Intervention}

The financial chaos whieh characterised Egypt during this period reached a climax in 1876 , when the khedive suspended payment of his treasury bills. The debt of Egypt was now $£ 91,000,000$. Corruption and maladministration generally were rife, and ultimately France, Italy, and Austria each nominated representatives on the commission of public debt which had been promulgated by khedival decree. Great Britain was unwilling to interfere, although she was invited by the khedive to nominate a British Commissioner, and even tually this position was offered to Lord Cromer, then Sir Evelyn Baring. Financial affairs after this European intervention improved. But a political storm was brewing.

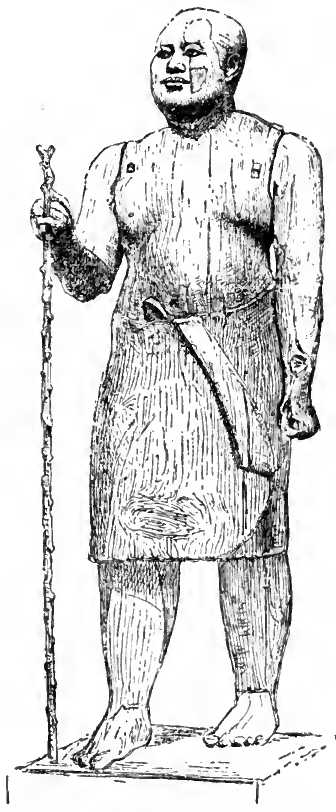

Egypt. The Sheikh-el-Beled. Wooden figure from Boulak

By courlesy of Chapman \& Hall, Ltd.

In 1879 Nubar Pasha, minister of public works, and Sir C. Rivers Wilson, the minister of finance, were assaulted by a crowd of Egyptian officers. Ahmed Arabi, an Egyptian of humble origin who had risen to be colonel of the 4 th regiment, led a successful revolt of the army, and compelled the khedive to change his ministers. The country at this time had come virtually under the direction of

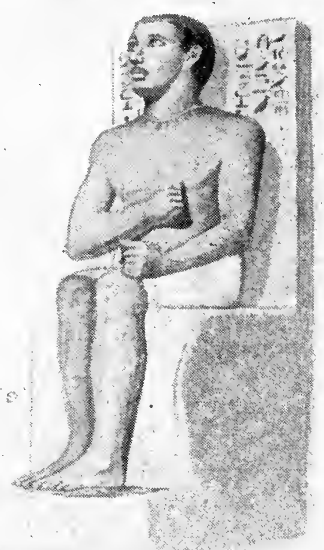

Egypt. Ancient sculptured figures of pyramid times from the Boulak Museum. Left, Ra-Hotep, an Egyptian prince ; right, the princess Nofri, or Nefert, limestone figure

By courtesy of Chapman \& Hall, Lld.
Arabi's party, and disturbances rendered foreign intervention necessary. Arabi's challenge by raising batteries at Alexandria with the intention of using them against the British fleet was followed by the bombardment of these batteries by the British. At Tel-elKebir Arabi's army was defeated and eventually surrendered. Even now the British government declined to remain in Egypt; its declared object was to establish order and stability.

\section{Trouble in the Sudan}

One of the difficulties of the British reformers was the trouble in the Sudan. In 1883 the Egyp. tian army, under the command of General Hicks, which had been sent by the British Government to restore order in the more distant regions of the Sudan, was annihi. lated in Kordofan. The British government, reluctant to associate itself with any military en. terprise in that direction, decided to abandon the Sudan and with. draw all the garrisons. In the meantime, however, Mahomed Ahmed, a religious fanatic known as the Mahdi, had risen to power. General Gordon, who was sent to report on the military situation and on the means necessary in order to accomplish the evacuation, arrived at Khartum and was killed by the Mahdi's troops in 1885. A relief expedition was sent but arrived too late. Sir Herbert Kitchener, sirdar of the Egyptian army, recaptured Khartum on Sept. 2, 1898.

The more settled state in the Sudan helped directly in the pro. gress of Egypt, and a variety of reforms were instituted; harsh 


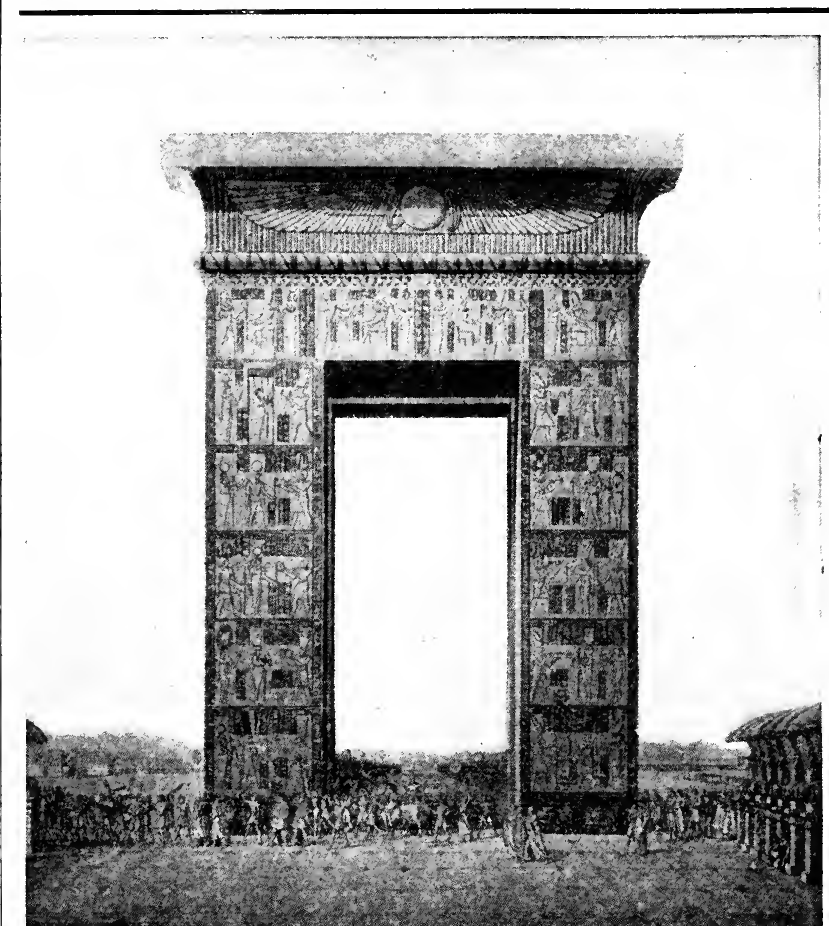

Egypt. Restoration of the gate of the temple of Khonsu at Karnak. part of Thebes, on the right bank of the Nile

taxes were abolished, and the problems of drainage and irrigation were being solved. The contract for the construction of the Nile reservoirs was signed in 1898 ; post-office savings' banks were introduced in 1900; navigation dues on the Nile were abolished, and the Anglo - French Convention was signed in 1904.

In 1907 Lord Cromer's work in Egypt came to a close, the country then experiencing an era of peace and prosperity unprecedented in its history. He was succeeded by Sir Eldon Gorst, but after a short régime, during which time a group of political agitators took advantage of the friendly attitude of the new British agent, Sir Eldon broke down in health, and in 1911 Viscount Kitchener of Khartum was appointed. Lord Kitchener's efforts weredirected towards increasing the water supply of Egypt by means of barrages and reservoirs; he also built roads, and succeeded in pacifying various religious and political factions. $\mathrm{He}$ devoted much attention to the interest of the fellah, and established cotton markets throughout the country which provided means of insuring the ignorant peasant against dishonest traders; another measure of interest to the small. holder was the Five Feddans Law, which prohibited the agricultural holdings of farmers who did not own more than five acres of land from being seized for debt.

The relationship between Lord Kitchener and the khedive was always strained, for it was known the khedive Abbas was not amic. ably inclined towards the British. In Dec., 1914, Abbas II was deposed and Prince Hussein, his uncle, succeeded him with the title of sultan of Egypt; at the samo time Great Britain declared the Turkish suzerainty at an end, and a British protectorate was declared. Hussein died Oct. 9, 1917, and was succeeded by his youngest brother, Prince Ahmed Fuad.

\section{Egypt during the Great War}

During 1914-16 Egypt was on the whole prosperous and quiet, although when Turkey entered the war the country was overrun by spies and secret agents in the pay of Germany.

Martial law was proclaimed, as a measure of precaution, but the British were able to use the Egyp. tian army freely for policing the frontiers of the Sudan, and in the reconquest of Darfur. Egypt rendered great assistance by its labour corps, camel transport, and other services. The entry of the
Egyptian Expeditionary Force into Palestine in 1916 removed all danger of hostile invasion.

In 1919 a group of national. ists advocated a degree of complete autonomy which would leave Great Britain only the right of supervision with regard to public debt and facilities for shipping on the Suez Canal. They elected a committee which carricd on an unceas. irg agitation throughout the country. They asked to be allowed to send a deputation to London, but the British government replied that, while sympathising with the idea of giving Egypt an ever-increasing share in the government of the country, they could not abandon their responsibility for good order and good government, and refused to allow the nationalist leaders to proceed to London to put forward their demands. Early in March four prominent nationalists were deported to Malta for conducting an anti-British agitation, among whom was Said Zaghlul Pasha, leader of the nationalists in the legislative assembly.

Disturbances in 1919

About this time Hussein Rushdi Pasha, who had been prime minister since April, 1914, resigned, and serious events followed quickly. The Egyptian nationalists demanded the immediate release of their leaders. Grave riots and disturbances broke out, and Lord Allenby was appointed special high commissioner for Egypt and the Sudan.

The unrest was general from Assiut in Upper Egypt down to Alexandria, and students were prominent among the rioters.

On March 14, 1919, the mob rushed the station at Galiub $(\mathrm{N}$. of Cairo), attacked trains and British officers, and murdered soldiers, while disturbances also broke out at Zagazig. In Cairo and Alexandria collisions took place between the rioters and patrols. At Cairo a patrol fired on the mob, killing and wounding several, and on March 15 a British officer was murdered at Minia in Middle Egypt.

On March 17 serious disturbanoes took place at Damanhour. while at Alexandria a procession of workmen and students came into collision with the troops. Between Birket el Saab and Cairo several stations were destroyed. A leading event in this month was Gen. Bulfin's warning to the notables, whom he summoned to a meeting, of the serious consequences of the prevailing grave outrages, and his warning to the inhabitants of the Fayum and Upper Egypt that if further shootings of British soldiers by Beduins occurred repressive measures would immediately follow 
All through April the unrest continued. On the 9 th a new ministry under Hussein Rushdi Pasha was formed, while about the same time the four arrested nationalists were released on Allenby's order, and an inquiry into the causes of the disturbances instituted. Up to July 21 the casualties in the various riots were 800 killed and 1,500 wounded.

The autumn of 1919 saw a recrudescence of rioting. On Oct. 25 a serious outbreak occurred in the native maritime quarters of Alexandria, when troops had to fire on the rioters. In both Cairo and Alexandria outbreaks occurred on Nov. 15. In Dec. excitement was caused by the El Azhar incident. British soldiers, irritated by being stoned by students from within the El Azhar University, Cairo, followed their assailants inside. The authorities of the university regarded this as a grave insult and protested strongly to Allenby, who replied there had been no intention to pollute the sanctity of the mosque, and expressed regret for the incident. During this time it had been found impossible to form a stable ministry, one after another having resigned in despair.

Realizing that reforms were imperative, the British Government at the end of 1919 sent out a mission under the colonial secretary, Viscount Milner, to inquire into the matter. This reached Alexandria in Dec. and was in the country about six months. On its return certain proposals were laid before the Cabinet, while the nationalist leader, Said Zaghlul, arrived in London in June, 1920, to discuss the question of the future of Egypt with Lord Milner and his colleagues.

In Oct., 1920, although the result of the negotiations between the Egyptian nationalist delegation in London and Lord Milner's com. mission had not been officially announced, an outline of the agreement was published in the press. It was stated that the new constitutional reforms would go a long way towards meeting the grievances of the people of Egypt. These negotiations were continued early in 1922 and the British government on Feb. 28th, 1922, declared Egypt an independent state. The Sultan Ahmed Fuad Pasha was proclaimed king as Fuad I on Mar. 16th, and his first cabinet took office with Sarwat Pasha as premier.

\section{Egyptian Independence}

The fundamental points in the agreement were: Great Britain was to recognize the independence of Egypt, and guarantee its integrity against outside aggression, in return for which Egypt was to recognize Great Britain's privileged position in the valley of the Nile; Great Britain was to maintain a garrison only in the canal zone; Egypt was to have control of her foreign affairs, provided she did not make treaties at variance with British policy; the capitulations were to be done away with and the veto on legislation affecting foreign. ers to be vested in the high commissioner: two British officers were to look after the public debt com mission and legislation affecting foreigners. The final agreement was to be submitted for confirmation to the British parliament and the Egyptian national assembly It amounted to a grant of independence to Egypt, subject to British control over its foreign policy, with provisions for safeguarding British and other interests in the country's debt and in the Suez Canal.

Constitution and Government. Before 1913 the affairs of Egypt were controlled by two public bodies known as the legislative council and the general assembly. These bodies dated from 1882 and were in the main consultative only, legislation being in the hands of the khedive and his ministers. In 1913 important constitutional changes were introduced. The council and assembly were replaced by a new body called the legislative assembly. This con. sisted of 66 members elected by the people, but by an indirect vote, the ministers and 17 nominated members. Early in 1923 a new constitution providing for a reformed electoral system, including cabinet responsibility to Parliament, was drawn up. It was signed by King Fuad on April 19th, 1923. It substituted a democratic for an autocratic government and abolished the legislative assembly in favour of two chambers of parliament.

Justice and Education. Gne of the main foundations of justice in Egypt is the capitulations. They

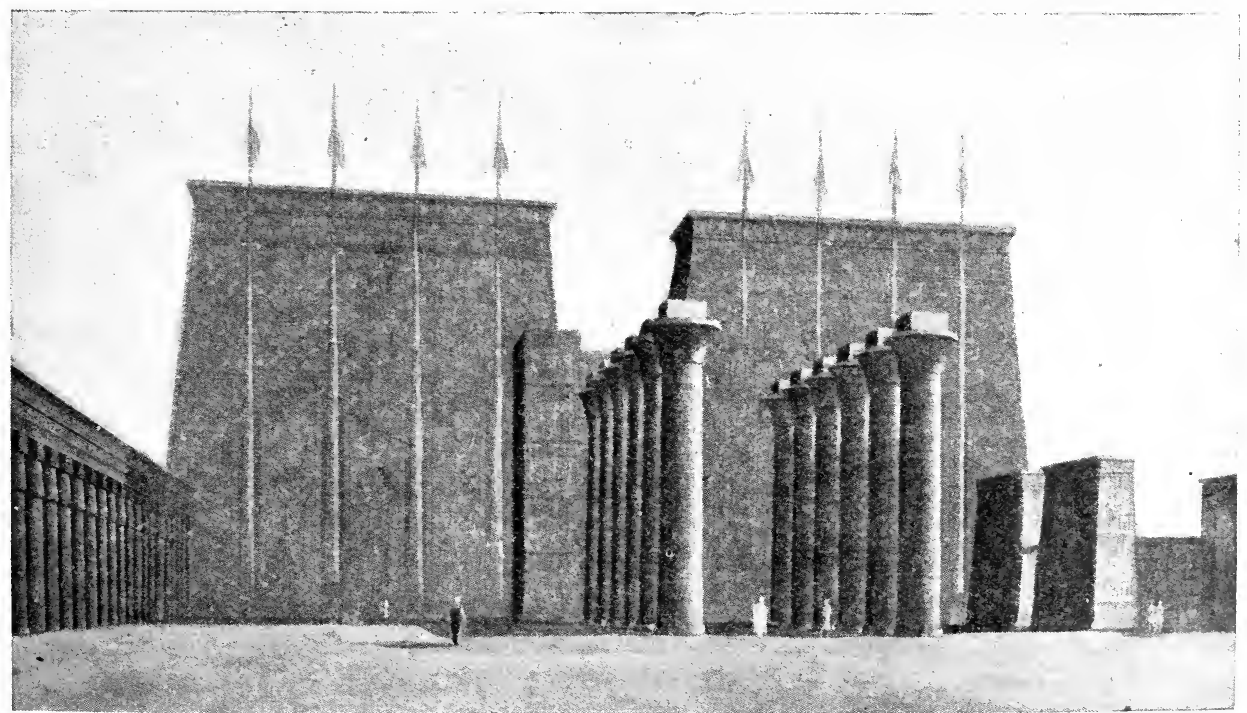

Egypt. Restoration of the great temple of Amen-Ra or Ammon at Karnak, Thebes, viewed from within and showing the vast pyramidal towers which served defensive purposes 
were introduced in order to protect foreign merchants and encourage commerce, but involved a multiplieity of judicial systems. Two referred to Egyptians, one to foreigners only, and another to foreigners and natives. Moreover, the capitulations offered relief to criminals of all shades, since foreigners were free from the jurisdiction of the native courts. The judicial system has been universally denounced, and has undergone constant and considerable modifications. The native courts have both native and foreign judges. The courts of summary jurisdiction are presided over by one judge, and there are central tribunals with three judges. There is a court of appeal at Cairo. Criminal prosecutions are entrusted to a procureur-général, whose representatives are attached to each tribu. nal. There are special children's courts. The police service is under the administration of the ministry of the interior.

\section{Native Education}

Under the ministry of public instruction, education in Egypt has made strides within recent years. The natives are educated in kuttabs, schools attached to mosques. Some of these native schools are under the ministry. Here, in addition to instruction in the Koran, the pupils are given an elementary secular education. There are over 1,000 of these kuttabs attended by more than 25,000 pupils. There is also a grant-in-aid system. Such grant is made to other schools where no other language but Arabic is taught, and where a good standard of education is maintained. The number of scholars in these schools rose from 7,536 in 1898 , at which date the grant-in-aid system began, to 218,184 in 1919. There are also secondary schools and colleges where training for the various professions is given, these including law, medicine, engineering, accountancy, agriculture, etc.

Industry. The Egyptian is an agriculturist. Ancient Egypt was the granary of the Roman world, and exported great quantities of corn. With the coming of the Turks a different order of things was created, and a long period of depression and misery followed. The revival of Egyptian industry began with the elimination of the Turk by the British. Vast schemes of irrigation and drainage were being developed when the Great War broke out. With the improvement of the Assuan dam in 1913 a further considerable area of the Nile valley came under cultiva. tion, with the result that the total cultivable area of Egypt proper was reckoned in 1918 at $7,820,801$ feddans, or a little over $8,000,000$ acres. This makes an interesting comparison with the figures given at the time of the French occupation in 1798, when it was found that the cultivable area totalled $3,520,000$ acres.

Egypt, as the first sultan of Egypt said, has three assets - the Nile, the Egyptian sun, and the fellah. Very full use is made of both the sun and the Nile by the fellah. The sun shines all through the year, and the Nile is stored up so as to be available in any season. In addition, the fellah is extremely hard-working, and it is towards helping him in making the fullest use of the Nile that British brains and science have been directed. In the past the fellah had to wait upon the flood-tides. Nowadays, instead of obtaining water for his land for only a portion of the year, he obtains a regular and sufficient supply all the year round. In other words, the whole system of irrigation is being gradually directed towards perennial irrigation-thus assuring two and often three crops every year.

Where perennial irrigation is impossible, the basin system has been adopted, whereby water is stored in August and is kept in reserve till October, when it begins to be used. The basin system is the oldest system of irrigation known to Egypt. Only one crop a year can be grown from it.

Another system is used on the high lands near the Nile. These lands cannot be reached through canals, so a system of pumping the water is utilised. The British use of steam-pumps has been largely developed, several thousands being in use. The water-wheel, worked by buffaloes, or the water-lift (shaduf), worked by hand, is still in favour with the conservative fellahs. Over 100,000 of these water-wheels and water-lifts are in use. There are three agricultural seasons. Cotton, sugar, rice, and, in a lesser degree, millet and vegetables, are grown in summer; wheat, barley, flax, and vegetables in winter. Maize, millet, and flood rice are grown between August and November - the Nili period.

\section{Cotton Production}

Egypt has also a future in other directions. Such industries as oil and tobacco are being developed. There are gold-mines in the eastern desert.

The present prosperity of the country, however, is due mainly to cotton, which represents over three-quarters of the total value of Egyptian exports. It is estimated that the present total output of this commodity is $7,500,000$ kantars. Considerable trade is done with Manchester, and altogether Great Britain purchases more than half of Egypt's total production. The progress of Egyptian trade can be seen by the increase in her exports from $£ 19,000,000$ in 1882 to $£ 59,495,417$ in 1919 . Her raw cotton export in 1918 alone was $£ 38,034,467$. Egypt exports chiefly raw cotton, cotton seed, sugar, beans, cigarettes, onions, rice, and gum-arabic-which come from the Sudan. Other exports are eggs, hides and skins, wool, quails, lentils, wheat, and dates. Sugar is another highly important commodity. Egypt's imports are confined to such manufactured articles as cotton goods and other textiles, coal, iron and steel, timber, tobacco from Turkey and Greece, machinery, flour, alcoholic liquors, petroleum, fruit, coffee, and live animals.

\section{Trade Routes}

The lines of commercial com. munication to Egypt are, by virtue of the country's geographical position, the most important in the world. Besides being a distributing centre for the Levant, it holds a commanding position on the trade routes from Europe to the East. By the completion of the Suez Canal in 1869, a direct sea route was opened up between the Mediterranean and the Red Sea. Considerable use is made of the ports of Alexandria and Port Said by foreign steamship companies among which the Germans were pre-eminent. Passenger traffic is at its height in the winter when there is an influx of tourists seek ing pleasure or health. The rly. system forms the northern section of the Cape to Cairo scheme; the main line follows the Nile to Shellal, S. of Assuan. See N V

Bibliography. England and Egypt, E. Dicey, 1881; The Nilo Quest, H. H. Johnston, 1903 ; Eng. land in Egypt, Lord Milner, 11th ed. 1904; The Egyptian Sûdân : its History and Monuments, E. A. T. W. Budge, 1907; Modern Egypt, Lord Cromer, 1908 ; The Making of Modern Egypt, Auckland Colvin, repr. 1909; Baedeker's Egypt and the Sûdân, 7th ed. 1914; Egypt in Transition, Sidney Low, 1914 ; Egypt of the Egyptians, W. L. Balls, 1915; History of Events in Egypt from 1798-1914, A. F. P. B. Weigall, 1915; Macmillan's Guide to Egypt and the Sûdân, 7th ed. 1916; With Kitchener in Cairo, S. A. Moseley, 1917; Through Egypt in War Time, M. S. Briggs, 1918: Modern Sons of Pharaoh: study of the Manners and Customs of the Copts of Egypt, S. H. Leeder, 1918; The Egyptian Problem, Valentine Chirol, 1920. 
Egypt, National Bank of Egyptian bank established in 1898. Its head offices are at Cairo, and there are branches at Alexandria and elsewhere in Egypt; also at Khartum and other places in the Sudan. It has the exclusive right of issuing notes in Egypt. The capital is $£ 3,000,000$, and the London offices are at 6 and 7, King William Street, E.C.

Egypt Exploration Society. Society founded in London, 1882, for exploring ancient sites in Egypt. The society has excavated Pithom, Tanis, Naucratis, Tahpanhes, Bubastis, Dendera, and other sites, besides its exhaustive operations at Deir-el-Bahri and Abydos. The archaeological survey branch, founded 1890, has reproduced wall. paintings and reliefs in rock-cut tombs at Beni Hasan, el-Bersheh and el-Amarna, in mastabas at Sakkara, and elsewhere. The Graeco. Roman branch, founded 1897, publishes texts and translations of papyri. From Oxyrhynehus 1,600 were so dealt with by 1916 , besides the Tebtunis and Hibeh finds. The offices are 37, Great Russell St., London, W.C. See Archaeology; Egypt; Egyptology.

\section{Egyptian Blue.}

Colouring matter used by the Romans in the early centuries of the Christian era. It is seen in several early frescoes in the Vatican and at Pompeii. Fouqué, a French chemist, showed that it consists of a double silicate of calcium and copper, and on account of its permanence urged that its manufaeture should be resumed.

Egyptian Hall. London place of amusement, 1812-1904. Situated at 171, Piccadilly, W., between St. James's Street and Duke Street, it was built in 1812 by G. F. Robinson, for the natural history collections of William Bullock, F.S.A., dispersed in 1819. Here were exhibited the Living Skeleton (Claude Amboise Seurat), in 1825, and the Siamese Twins, in 1829. B. R. Haydon, in 1846 , complained that while in one week "Tom Thumb" (C. S. Stratton) attracted 12,000 people, his own picture exhibition drew $133 \frac{1}{2}$ - the $\frac{1}{2}$ being a little girl. Later the hall was a centre for such entertainments as those of Albert Smith, Artemus Ward, and "Mrs. Brown." From May, 1873, until Christmas, 1904, when he removed to St. George's Hall, in Langham Place, J. N. Maskelyne made it "England's Home of Mystery." For many years the exhibitions of the Dudley Gallery Art Society were held here. The figures of Isis and Osiris at the entrance were by Gahagan. The name is preserved in the block of business pre mises known as Egyptian House.
Egyptology. Study of the an. tiquities of Egypt. It is concerned not only with the material remains, but also with religion, his. tory, language, art and social life. although the re. mains are the main sources of knowledge.

Excavation of the buried treasures of Egypt was begun in the 18 th century, but

was carried on in a very desultory fashion and mainly for the purposes of curiosity and gain. However, as gradually their richness and extent were revealed, a highly specialised branch of study came in to existence. Archaeologists accompanied Napoleon on his expedition to Egypt in 1798 , and soon after this the first experts in Egyptology appeared, of whom Champollion was, perhaps, the greatest. Another was Lepsius, who had charge of an important expedition sent by the Prussian government to excavate in Egypt in $1842-45$, about which period the word Egyptology came into use. In 1858 , to protect their treasures from acquisitive foreigners, and from Arab spoliation, the authorities in Egypt set up, under Mariette, a special department to which a museum was attached, the work of which has grown greatly in recent years.

The modern scientific treatment of Egyptian antiquities dates from about 1880, and is associated specially with Gaston Maspero and Flinders Petrie. To provide funds for this work, an Egypt Exploration Fund was started in Great Britain; 15 years later an independent Egyptian Research Account was established, and out of the latter a British School of Archaeology arose in 1896. France has a similar society, and work has also been done by various universities and other learned societies. Egyptology is now a recognized subject of study, in which several universities, among them Oxford, Liverpool and London, provide instruc. tion. See Archaeology; Egypt.

Ehrenbreitstein. Town of Germany. It stands on the right bank of the Rhine, opposite Coblenz, with which it is connected by bridges. Its industries include a trade in wine. Until 1918 it was one of Germany's strongest fortresses, a rock overlooking the Rhine and the Moselle being the centre of the system of fortifica- tions. Once a Roman station, the town was part of the electorate of Treves, to whose electors its earlier fortifications were due. Owing to its strategic situation it was often attacked and sometimes taken by the French. It became part of Prussia at the settlement of 1815 and was made into a modern fortress after 1870 . Pop. 5,500.

Ehrlich, Paul (b. 1854). German physiologist. Born at Strehlen, Silesia, March 14, 1854, his

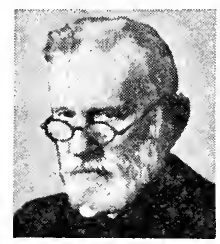

Paul Ehrlich, prolonged experimental re$\mathrm{s}$ e a $\mathrm{r} \mathrm{ch}$ e brought him world-wide renown, and in 1908 he shared with Metchnikoff the Nobel prize for physiology and mediGerman physiologist cine. In 1899 he became director of the Speyer Institute of experimental therapeutics at Frankfort, which he made famous by his laboratory work in connexion with cancer. The founder of chimotherapy, Ehrlich also laboured to discover a safe and effective cure for syphilis, being latterly assisted by a Japanese doctor named Hata. When Hata joined him Ehrlich had already tried 418 combinations of arsenic, and it was not until 606 experiments had been made that any real success was in sight. Even this formula was admittedly imperfect and dangerous in practice, and further experiments were necessary. But it was Ehrlich who did most of the spade work.

Eibar. Manufacturing town of Spain, in the prov. of Guipúzcoa. It is $39 \mathrm{~m}$. by rly. W. of San Sebas. tian, makes guns, swords, etc.. and is noted for its damascened arms and other metal ware. Pop. 9,659.

Eichendorff, Joseph, FreiHeRI vow (1788-1857). German poet and novelist. He was born at Lubo witz, March 10, 1788, near Ratibe 
Silesia, a member of a noble Catholic family. He published his first romanticnovel, Ahnung und Gegenwart, in 1815 , but is better remembered as a poet, his simple nature lyries having taken their place in German popular song. $\mathrm{He}$ served against France, 1813-15, and from 1820-44 oceupied various public appointments, and in his later years was distinguished as a Catholic publicist. $\mathrm{He}$ died at Neisse. Nov. 26, 1857.

Eichhorn, HERMANN voN (18481918). German soldier. Born at Breslan, Feb. 13, 1848, he entered

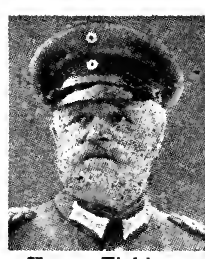

H. von Eichhorn, German soldier $\mathrm{man} W \mathrm{ar}$, 1870-71, and reached the rank of general in 1912. On the outbreak of the Great War he was one of the commanders under Hindenburg on the E. front, and operated in E. Prussia and towards the Niemen. In command of the German 10th army, he took Kovno in Aug., 1915, and Vilna a month later, being made a field-marshal for these successes. In 1918 he led the German forces in the Ukraine, and for some time was military dietator of that country. His arbitrary rule made him unpopular, and he was murdered at Kiev, July 31, 1918.

Eichhorn, JohanN GotTFRIED (1752-1827). German seholar. He was born at Dörenzimmern, Oct. 16, 1752 , and in 1775 was appointed professor of Oriental languages at Jena, and in 1788 at Göttingen, where he lectured for the rest of his life. He was the first scholar to suggest that the synoptic gospels have one common source, and was a pioneer of the rationalist criticism of the Bible. He died at Göttingen, June 27, 1827.

Eichhorn, KARL FrIEDRICH (1781-1854). German jurist. Born at Jena, Nov. 20, 1781, son of Johann Gottfried Eichhorn, he studied at Göttingen and lectured on law at Frankfurt-on-the-Oder, and obtained a professorship at Berlin. He fought against France in 1813 , and after 1815 was professor at Göttingen and at Berlin. In his later years he held high positions in the public service. He died at Cologne, July 4, 1854 Eichhorn is perhaps the greatest authority on the laws and institu. tions of the Germans. Besides his great Deutsche Staats- und Rechts. geschichte $(1808-23)$ he wrote on private and ecelesiastical law.
Eichstätt. City of Bavaria, Germany. It stands on the Altmühl, $15 \mathrm{~m}$. N.W. of Ingolstadt. Its industries include the making of boots and beer, but it is chiefly famous for its old buildings and its episcopal associations, for its bishops were princes of the empire until their lands were secularised in 1802. The cathedral, which is dedicated to $\mathrm{S}$. Wilibald and con-

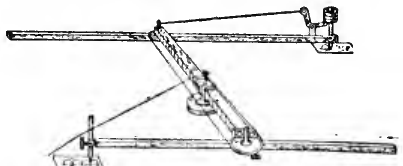

Eidograph. Diagram of the instrument. The arms bearing tracer and pencil respectively move parallel in all directions, the connecting beam resting on a fulcrum

have mottled brown plumage. The common eider (S. mollissima) is resident in Great Britain throughout the year, but breeds only on the Farne Islands. The king eider (S. spectabilis) and Steller's eider (Polysticta stelleri) are rare visitants to Britain.

All the eiders are divers, and feed upon shell-fish and small crustaceans. They keep to the rocky shores and nest on the ground. It needs about six nests to yield a pound of the famous down.

Eidograph (Gr. eidos, form ; graphein, to write). Instrument for copying drawings, designs, ete., redueed or enlarged, within limits, to any desired proportion. Somewhat on the lines of a pantograph, it comprises a slotted beam adapted to slide in a socket, having its axis in the centre line of the slot.

tains the tomb of that saint, is Underneath each end of the beam largely Gothic, but the towers are is a wheel; the wheels are of the Romanesque. Of the other churches same diameter and geared together the most notable is S. Walpurgis, by a chain. Sliding in a guide in dating from the 17th eentury and each wheel is an arm, one of which visited by pilgrims on $\mathrm{S}$. Walpurgis' earries a tracer and the other a Day(May 1). 'There is a palace where the bishops and later the dukes of Leuchtenberg lived; this is now used as a law court, while another palace is used as a library and museum. Above the town is the Wilibaldsburg, once also a residence of the bishops, but now a museum. From 1817 to 1855 Eichstätt was part of the duchy of Leuchtenberg, but it was Bavarian from 1802-17, and again from 1855. Pop. 7,900.

Eider. River of Slesvig-Holstein. It rises near Kiel, and flows N.W. and W. across the peninsula to Tönning, where it forms a bay. Its length is about $115 \mathrm{~m}$. Before the opening of the Kiel Canal it was important for navigation. Vessels could go along it as far as Rendsburg, whence a canal took them to Kiel, thus uniting the Baltic and North Seas. This eanal developed into the Kiel Canal.

Eider Duck (Somateria). Genus of wild duck. Including several species, it is famed for the soft down which it uses for lining its nest. Eiders have eomparatively short beaks; the males have black and white plumage with green markings on the head, while the females

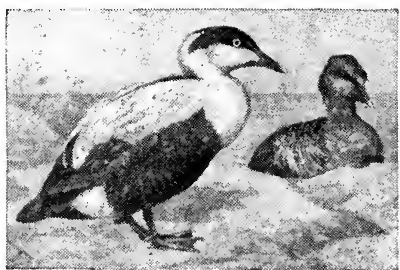

Eider Duck. Male, black and white ; female, mottled brown pencil, or the equivalent, for eopying. The gearing together of the two wheels ensures that the arms will remain parallel for all positions of the instrument. The size of the copy is determined by the position of the beam in the socket.

Eifel. Mt. range of the Rhine province, Germany, forming an extension of the E. Ardennes. Of

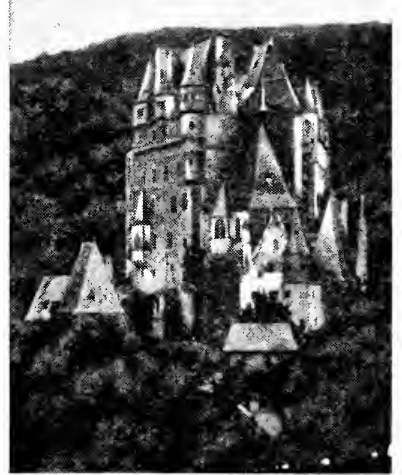

Eifel. Castle of Eltz, in the Eifel

low altitude (highest peak 2,500 ft.), they trend E. by $\mathrm{S}$. between the Nette and the Ahr rivers towards the Rhine and the Mo. selle. The E. section is known as the Hohe Eifel, the W. section as Schnee Eifel, while the S. part is called Vorder Eifel. NearCochem, on the steep wooded banks of the river Eltz, stood the castle of Eltz, a beautiful medieval building of wood and plaster, burnt down in Sept., 1920. range, burnt down Sept., 1920 ( 
Eifelian. Name given to a stage of stratified rocks of Middle Devonian age. It consists of flagstones, shales, and beds of limestone attaining a thickness of 500 $\mathrm{ft}$. in the Dinant district (Belgium), and contains numerous fossil remains of corals and brachiopods. One series of shales (the Calceola shales) is named after a peculiar form of coral. It is well developed in the Eifel district, whence the name, in the Rhine valley, the Hunsrück, the Taunus, and in Bohemia.

Eiffel Alfxandre Gustave (1832-1923!. French engineer. Born at Dijon, Dec. 15, 1832, he

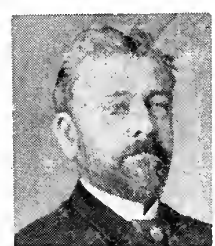

Gustave Eiffel, French engineer stuctied at the Ecole Centrale, and executed his first notable work, the bridge over the Gar. onne at Bor. deaux, in 1858 . In 1865 hefoundea ironworks at LevalloisPerret, Seine

His outstanding engineering achievements include the bridge over the Douro at Oporto, 1876; the Garabit viaduct, Cantal, 1882; the great Eiffel Tower, Paris, 1887-89; the movable dome of the Nice $\mathrm{Ob}$ servatory; and the framework for Bartholdi's colossal statue of Libcrty in New York harbour. $\mathrm{He}$ was one of the first engineers to employ compressed-air caissons in bridge building, and invented movable section bridges. $H$ is in vestigations of air resistance were of service in the development of

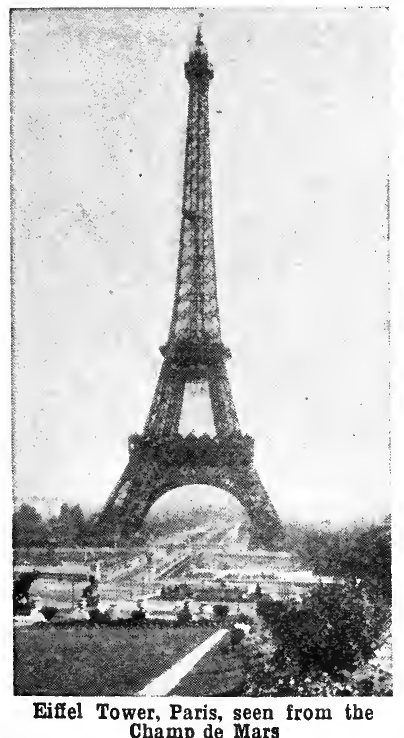

aeronautical cngineering. He diel at Paris. Dec. 28, 1923.

Eiffel Tower. Building in I'aris. It was designed and erected by Gus. tave Eiffel, for the Paris Exhibition of 1889. It is $984 \mathrm{ft}$. high, and is built of iron throughout, 7,300 tons of that metal being used in its con. struction. The shape is that of a curved pyramid. Electric lifts run to the top. The tower is an important wireless telegraphy station and metcorological centre.

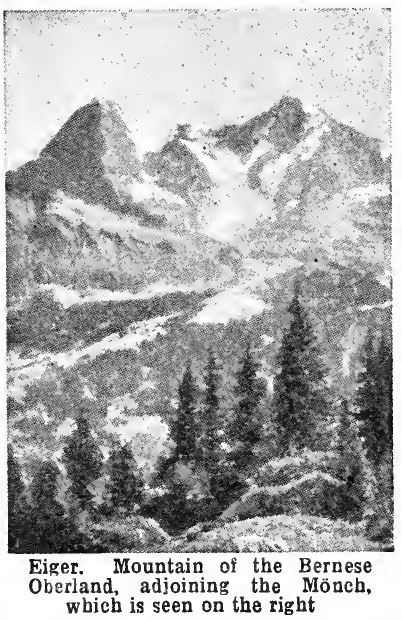

Eiger. Mountain of Switzer. land, in the Bernese Oberland (q.v.), adjoining the Mönch; alt. 13,042 ft. It was first ascended by Charles Barrington, 1858.

Eigg on EGG. Island of the Hebrides, Inverness-shire, Scotland. Facing the entrance to the Sound of Sleat, it is $6 \frac{1}{2} \mathrm{~m}$. long and $4 \mathrm{~m}$. broad. In the S.W. is the Scuir of Eigg, a porphyritic peak 1,289 ft. high. 'The rocks have been described by Hugh Miller in his Cruise of the Betsy. Pop. 181.

Eight. In rowing, a name ap. plied collectively to the members of a racing crew, when such consists of eight men, in addition to the cox. For the Oxford and Cambridge and other important boat races it became usual to have crews of eight, and so the word came to be used in this sense. See Rowing; also illus. p. 1211.

Eight, Prece of. Name given to the old Spanish silver coin, the piastre. It was so called because it was divided into eight silver reals, circulated in Spain and Spanish America during the 17th and 18th centuries, and was commonly met with through W. Europe. Its value was about four shillings.

Eight-Hour Day. Term used popularly for a working day of this length. Since about 1832 this has been the irleal of many reformers and numerous workers have secured it, either by legislation or by negotiation. In Australia it is very general, while it has been in. troduced in the U.S.A. and else. where. In 1908 the miners in the United Kingdom secured it, and in 1919 it was granted to the railway. men. See Labour.

Eighty Club. British political club. It was founded in 1880 to celebrate the victory gained by the Liberals at the general election of that year, its main object being to unite the younger members of the Liberal party and to encourage them in active political work. A president, usually a leader of the Liberal party, is elected annually. Lady members were admitted in 1920. The club's headquarters are at 3 , Hare Court, Temple, London ; it has no club house.

Eikon (Gr., image). Holy image or sacred picture used in the worship of the Greik Church, more usually spelled Ikon or Icon (q.v.).

Eikon Basilike (Gr., royal like. ness). Book purporting to be written by Charles I, and published inmediately after his execution, although most of the early editions bear the date 1648 Its sub-title is The Pourtraicture of His Sacred Majestie in His Solitudes and Sufferings. It professes to give the king's views of the events of his reign, and a number of his prayers. Milton, in Eikonoklastēs, replied in detail to the work and first hinted at doubts as to its authorship. Historians take sides respectively for Charles and for John Gauden, later Bishop of Worcester, who claimed to have written it. See editions by C. M. Phillimore, 1879; and E. Almack, 1904; consult also Bibliography of the King's Book, E. Almack, 1896

Eil. Sea-loch between Argyllshire and Inverness-shire, Scotland. Forming a W. extension of Loch Linnhe ; it is $8 \mathrm{~m}$. long and has a mean breadth of $\frac{1}{2} \mathrm{~m}$. See illus. p. 1065.

Eildon Hills. Range of hills in Roxburghshire, Scotland. Situated S. of Melrose, they rise into three peaks, the highest of which is 1,385 ft. On the slopes are a supposed Druidical tumulus and remnants of a Roman encampment. According to popular tradition, the single hill was split into three by the "wondrous wizard," Michael Scott of Balwearie.

Eileithyaspolis or Eileithyia. City of ancient Egypt. It has been identified with the present El Kab, on the E. bank of Nile, $44 \mathrm{~m}$. above Luxor. The goddess of the town, Nekhbet, was regarded by the Greeks as identical with Eileithyia, 
the goddess of childbirth, hence the Greek version of the Egyptian name (Nekhab) of the city. The ruins are extensive.

Eilenburg. Town of Prussian Saxony, Germany. It stands on an island in the Mulde, $15 \mathrm{~m}$. N.E. of Leipzig, and is a rly. junction. It is a centre of the textile industry, and has also a trade in cattle, while other manufactures include chemicalsand agricultural machinery. The castle, after which it is named, dates from the 10th century, but the town, known earlier as Millenamstoll, is older. It was part of Meissen and then of Saxony, in which it remained until given to Prussia in 1815. Pop. 17,400.

Eimeo. One of the Society Islands, in the Pacific Ocean. It lies to the N.W. of Tahiti, in lat. $17^{\circ} 32^{\prime} \mathrm{S}$. and long. $150^{\circ} 2^{\prime} \mathrm{W}$., and is a French possession. It is $9 \mathrm{~m}$. long and $5 \mathrm{~m}$. broad; area, $51 \mathrm{sq}$. $m$. The London Missionary Society have a station and a college on the island. In 1903 a tidal wave devastated the island and many people perished.

Einem, Rothmaler KarL voN (b. 1853). German soldier. Born at Harzberg in the Harz, Jan. 1,

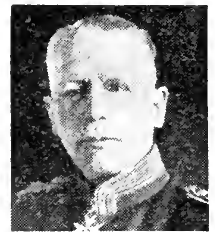

Karl von Einem, German soldier

and in the latter year Prussian minister of war. In 1907 he was general of cavalry and two years later commanded the 7th army corps. In the second battle of the Marne, July, 1918, he commanded the third German army which unsuccessfully attacked the French, under Gouraud, E. of Reims.

Einhard or EgINHARD (c. 770840). Frankish historian. Born in East Franconia, he was educated at the monastery of Fulda and at the court of Charlemagne, where he was a pupil of Alcuin. He was made secretary and superintendent of public buildings by Charlemagne and was responsible for the royal palaces at Ingelheim and Aix-lachapelle. He continued to enjoy favour under Louis, Charlemagne's successor, who entrusted him with the education of his son Lothair, and in 815 bestowed on him the domains of Michelstadt and Mühlheim. In 827 , unable to compose the quarrels between the emperor Louis and his sons, Einhard retired from court to
Mühlheim, where he founded a monastery. His wife was Emma, the sister of the bishop of Worms, and not a daughter of Charlemagne, as the later legends represent. His chief works are his Epistolae, and his Life of Charlemagne, one of the best biographies of the Middle Ages, and the source of most of our information about the great emperor. His authorship of the Annales Regum Francorum is disputed.

Einsiedeln. Town of Switzerland, in the canton of Schwyz. It stands on the Alpbach, 2,908 ft. above the sea, $25 \mathrm{~m}$. by rly. S.E. of Zürich. One of the most famous pilgrim resorts of the world, it owes its importance to the great Benedictine monastery, containing a miraculous black wooden image of the Virgin. The abbey was founded in 934, but rebuilt in the 18th century; the French sacked the place in 1798 , but the treasury and library, with 50,000 vols. and valuable MSS., still contain many precious objects, portraits, etc. Thronged in the Middle Ages, it still attracts many thousands of pilgrims annually. Pop. 9,000.

Einstein, Albert (b. 1879). German physicist. He was born at Ulm, in Germany, in March, 1879, of Jewish par. entage. His school days were passed at Munich, which he left at the age of 16 in order to pursue his studies at the $\mathrm{Z}$ ü r i c h higher technical s chool

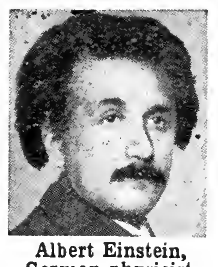

Albert Einstein,
German physicist (1896-1900). In 1901 Einstein was naturalised as a Swiss, and accepted a post in the patent office at Berne. While holding this position he published many scientific papers dealing with such subjects as the Brownian movement, the "quantum" theory of energy, and, what attracted the greatest atten. tion, the theory of relativity. It was in 1905 that Einstein formulated his own theory of relativity in its narrower or "spe. cial" form, and this formulation at once raised him to a high place among European scientists. In 1909 he was appointed professor at the university of Zürich, and in 1911 he left Zürich for Prague, where he was professor of physics in the German section of the university.

In 1912 Einstein was recalled to Zürich as professor of the poly. technic, and in 1914 he went to Berlin as a member of the Academy of Science. In 1915 he caused a veritable sensation in the scientific world by his explanation of gravitational attraction, based on the wider or "general" form of his theory of relativity, and accompanied by an explanation of the anomalous motion of the planet Mercury. $\mathrm{He}$ then made a remarkable prediction as to the bending of light rays from the stars which passed close to the sun; the verifying of this prediction by the British solar eclipse expeditions in 1919 made Einstein world-famous. Some scientists place Einstein on Newton's level. See Relativity; consult also The Special and the General Theory: a Popular Account, A. Einstein, 1920.

Eisenach. Town of Germany, in the federal state of Thuringia. It stands at the union of the Nesse and the Hörsel, $32 \mathrm{~m}$. by rly. W. of Erfurt. The chief secular buildings are the town hall, the palace on the market place, until 1918 the residence of the duke of SaxeWeimar-Eisenach, and a small castle called the Klemda. The chief churches are the Gothic Market Church and the Romanesque S. Nicholas. The house where Luther stayed still stands, and there are the Thuringian museum of antiquities, also Bach and Wagner museums.

The town has a school of forestry and other schools, as well as a theatre. Before the Great War it had an English church. The chief industries are spinning, the building of wagons, and the making of pottery, cigars, beer, etc. Near the Thuringian Forest, the town is visit. ed by tourists. One attraction is the

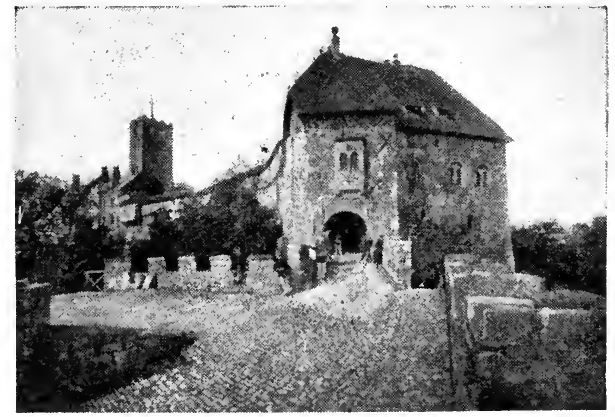

Sisenach. Entrance to the Wartburg, founded in 1067 and until 1440 the residence of the landgrave of Thuringia 
Wartburg (q.v.), just outside, and a ruined castle stands on an adjacent rock. The town was founded by a landgrave of Thuringia, and after being part of Thuringia passed to Saxony. It was the capital of one of the little principalities into which Saxony was divided for a number of years, until in 1741 it was finally united with SaxeWeimar, of which it became the second capital. Pop. 38,362.

Eisenberg. Town of Germany, in Saxe-Altenburg. It is $24 \mathrm{~m}$. S.W. of Altenburg, and is on the rly. to Leipzig. The buildings include a castle, churches, schools, etc., and there are several manufactures. Pop. 10,750.

Eisenstadt. Town of Hungary, in the prov. of Odenburg, known also as Kismarton. It is $25 \mathrm{~m}$. S.E. of Vienna, at the base of the Leitha Mts. It is famous for its magnificent palace, long the residence of the Esterhazy family. Built in 1683, and enlarged in 1805, this has a fine library and beautiful gardens. The town has also a Franciscan monastery, with a church in which the Esterhazys are buried. Haydn was conductor of the palace orchestra from 1760 to 1790 , and he is buried in a church near that of Maria-Einsiedel, a popular pilgrim resort.

Eisfeld. Town of Saxe-Meiningen, Germany. It stands on the Werra, $23 \mathrm{~m}$. from Meiningen, and is known for its association with Luther. The town church, a 16th century building, contains a statue of the reformer, and near is the grave of his friend, Justus Jonas, who was its minister. Pop. 4,100.

Eisleben. Town of Germany in the Prussian prov. of Saxony. It is $20 \mathrm{~m}$. W.N.W. of Halle, and is famous for its association with Luther, who was born and died there. The chief churches are those of S. Andrew and SS. Peter and Paul. The memorials of Luther include the house in which he died, now a museum, a school which he founded, and a bronze statue. Eisleben has a school of mining, and is the trading centre for the silver and copper mines of the neighbourhood. Eisleben is divided into an old and a new town. It was long on the lands of the counts of Mansfeld. In 1710 it passed to Saxony, and in 1815 became part of Prussia. Pop. 24,629 .

Eisner, KURT (1867-1919). Name adopted by Salomon Kosnowsky, a German socialist writer and politician. He was born in Berlin, May 14, 1867, of Galician-Jewish origin. Joining the socialists he became associate editor of their organ, Vorwärts. When the

Great War broke out he joined his party in supporting it, but before

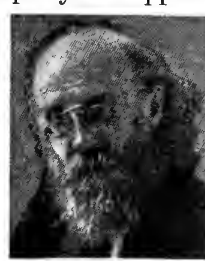

Knrt Eisner

German socialist the end he was one of the South German leaders who opposed the Kaiser. On the outbreak of the revolution he himself took the position of prime minister and minister of and later that of first president of the Bavarian republic. He sought to separate Bavaria from the other German states, and to make separate peace arrangements with the Allies, but unavailingly, and was assassinated in Munich, Feb. 21 , 1919. His collected writings, 2 vols. appeared in 1920.

Eistaler Spitze. Peak in Czecho Slovakia, $8,630 \mathrm{ft}$. It is one of the most difficult climbs in the High 'Tatra, but theview from the summit over the wide plain of Galicia to the N., and the Hungarian lowlands to the S., well repays the climber.

Eisteddfod (Welsh, session). Welsh national bardic festival. According to tradition, under the name of the Gorsedd or Druidic congress, it was celebrated before the Roman invasion of Britain, and was the repository of the laws, science and poetry of the country. Authentic records go no farther back than the 12th century. The Eisteddfod flourished under the Tudors; on one occasion, in the time of Elizabeth, the assembly being summoned by royal com mission. In the Cromwellian period it fell into abeyance, but a notable revival was witnessed in the 19 th century. For some time it has been held annually, in the north or south of the principality alternately. Noteworthy features of the occasion are the crowning of the chief bard and the award of prizes for choral, vocal, and lyrical compositions and their rendering, and for excellence i n handicrafts, etc. In A ug., 1920, the Eisteddfod was held at Barry, when expression $w$ a $s$ given to the desire that the festival should concern itself less with ancient bardism and local matters, and be made more representative of national progress.

Eject $\mathbf{m}$ en t (Lat. ejectare, to cast out). Name of an old English action to recover possession of land. Originally it could only be brought by a leaseholder and not by a frceholder; but by the fiction of John Doe judges allowed it to be made use of by freeholders, who preferred it to the cumbersome remedies of a writ of right, or a writ of Novel Disseisin. By the Common Land Procedure Act, 1852, John Doe was abolished, and now an action for the possession of land may be brought by anyone entitled to such possession. See Land Laws.

Ejector. Appliance for operating a vacuum brake by exhausting or ejecting air from the brake cylinders. It consists of a pipe within an outer casing with an annular space between the two. When steam is admitted to the pipe, in the act of escaping at the outer end it draws the air from the annular space which is connected by piping to the brake cylinders. Valves are provided for controlling the amount of steam and air ad mitted. The ejector is fitted in the driver's cab, and is controlled by the engine-driver, but valves are provided in guards' vans so that a guard may apply the brakes independently. The ejector of a gun is a mechanical device which throws out the used cartridges after each round.

An ejector pump is one used principally for the drainage of flat districts and works by means of compressed air supplied from a central station. The pressure of the air forces the drainage through a system of valves, until it reaches its discharging point. These ejcctors save the necessity for large central power pumping stations, and for complicated deep-laid drainage systems. As a rule each is suited to control a small district. See Injector ; Pump; Steam Engine.

Ejiboo or EJigbo. Town of Nigeria in Yoruba. It is $150 \mathrm{~m}$. N. of Lagos.

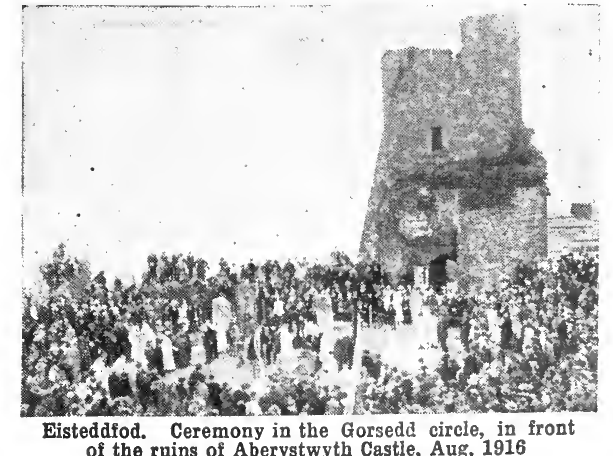

Eisteddfod. Ceremony in the Gorsedd circle, in
of the ruins of Aberystwyth Castle, Aug. 1916 
Eka-iodoform. Name applied to a sterile iodoform produced by mixing with iodoform a small proportion of paraform.

Eka," the Sanskrit word for one, was used by Mendeléeff as a prefix for the hypothetical elements which filled the blanks in his arrangement of the elements according to the periodic system.

Ekaterina (Port Catherine). Harbour of Russia, in the govt. of Archangel. It stands on the Murman coast of Kola Bay, $85 \mathrm{~m}$. E. of Lake Enara. The harbour is ice-free all the year round. The naval port of Alexandrovsk close by was founded in 1899 .

Ekaterinburg. Town in Russia, in the govt. of Perm. It stands on the Isset, $175 \mathrm{~m}$. E. of Perm, and is an important station on the Trans-Siberian Rly. It is the centre of the Ural metallurgical works, the assaying laboratory for all the gold of the district. There are iron, marble, porphyry, tallow and soap works, and factories for polishing ornamental stones. Ekaterinburg was founded in 1723 by Peter the Great, and named after his wife. There are two cathedrals, both built in the 18th century. Here, on July 16, 1918, Tsar Nicholas II and his family were murdered by Bolshevists. Pop. 70,000.

Ekaterinodar. Capital of the Kuban republic in the Caucasus. It stands on the river Kuban and a branch of the Rostov-Vladikavkaz rly. It was founded by Catherine II in 1792, and carries on an important cattle trade. It became prominent in the Bolshevist advance against Gen. Denikin's forces in the spring of 1920. Pop. 107,360 .

Ekaterinoslav. Government of Ukrainia. It is bounded on the S. by Taurida, on the N. by Poltava and Kharkov, on the W. by Kherson, on the E. by the Don Cossack territory, and on the S.E. by the Sea of Azov. Three-quarters of the population are Little Russians, the remainder being very mixed. The area is $24,477 \mathrm{sq}$. m. The soil is the "black earth" and generally fertile. The chief occupations are agriculture, cattle-breeding, bee-keeping, and fishing. The minerals are salt, bog-iron, coal, and sandstone. and the industries includethe manu. facture of rails, machines, tobacco, and bricks. There are iron-foundries, breweries, tallow boileries, and spirit distilleries. The chief ex ports are grain, cattle, horses, wool, tallow, leather, and hides. Pop. 3,537.300. Pron. Yekaterinosláf

Ekaterinoslav (Russ., Catherine's glory). Town of Ukrainia, chief town of the govt. of Ekater. inoslav. It stands on the Dnieper near the beginning of the rapids, $250 \mathrm{~m}$. N.E. of Odessa. There are cast-iron, railway line, and tobacco factories. Ekaterinoslav, which is the chief emporium for the trade with Odessa, was built in 1786 by Potemkin as a summer residence for Catherine II on the site of an old

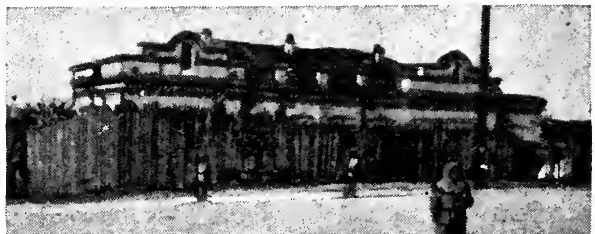

Ekaterinburg, Russia. Barricaded building in which Tsar Nicholas II and his family were imprisoned and murdered by Bolshevists
Chinese species, E. vernicia, is obtained an oil useful for mixing paints.

Elaenlite (Gr. elaia, olive ; lithos, stone). Dark-coloured variety of the mineral nepheline, chemically a silicate of alumina, soda, and potash. It shows no definite crystal form, has greasy lustre and rough le avages, and occurs in many volcanic rocks, e.g. the lavas of Monte Somma and Vesuvius, and in zircon-syenite of Brevig (Norway). See Nepheline.

Elagabalus or HEL I O G A BALUS. Roman emperor A.D. 218-222. The

Polish fortress. The town was captured by the Germans in April, 1918. Pop. 220,100 .

Ekhmim, Акнмгм, Акнмум, oR Eкнму м. Town of Egypt. It stands on the Nile $70 \mathrm{~m}$. S. of Assiut. For more than 2,000 years it has been the chief centre for the manufacture of the cotton shawls used by the natives. Here are the remains of the temple of Pan (the Egyptian Amsu or Min) and other ruins, and an extensive Egyptian and Roman cemetery. In Early Christian times Ekhmim was an important Christian centre. In the neighbourhood, near the village of Hawawish, have been found valuable papyri, in cluding the "Gospel of Saint Peter." Pop. 23,800.

Ekron. Ancient town of the Philistines. It is the modern Akir, a small village situated $23 \mathrm{~m}$. N.W. of Jerusalem.

Elaeagnaceae (Gr. elaia, olive ; hagnos, pure). Small natural order of shrubs and trees, natives of the $\mathrm{N}$. temperate and tropical zones. They are more or less covered with silvery or brown scales. They have entire leaves, and small white or yellow flowers. The fruit is mem. branous, and enclosed in the tube of the calyx. The two best known species are the Oleaster (Elaeagnus) and Sea Buckthorn (Hippophaë).

Elaeocarpus (Gr. elaia, olive ; karpos, fruit). Genus of evergreen shrubs and trees of the natural order Tiliaceae. Natives of the East Indies and Australia, they have alternate, lance-shaped or oblong leaves, and small, white, fragrant flowers in sprays. The cherry-like fruit has a rough-shelled seed.

Elaeococca (Gr. elaia, olive ; kokkos, seed). Genus of plants of the natural order Euphorbiaceae. They are natives of China and Japan. The seeds by pressure yield valuable oil, and those from $E$. ver. rucosa, a Japanese plant, are used for burning in lamps; from a son of Sextus Varius Marcellus and Julia Soaemias he was originally called Varius Avitus Bassianus. He was born and brought up at Emesa was made priest of Elagabalus, the Syrian sun-god, and assumed his name. By pretending that he was the natural son of Caracalla, his grandmother, Julia Maesa, persuaded the legions in Syria to pro-

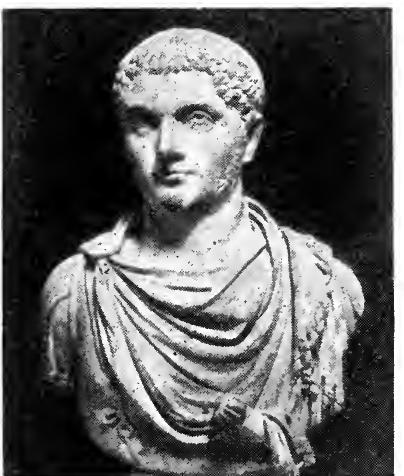

Elagabalus, one of the worst of the Roman Emperors

From a bust in the Capitol, Rome

claim him emperor, under the name of Marcus Aurelius Antoninus.

Abandoning the reins of government to his mother and grand. mother, he devoted the first year of his reign at Rome to the introduction of the worship of the sun-god, represented by a large conical black stone which he had brought with him from the East. A sexual pervert, his short reign was a continuous orgy of vice. An attempt to murder his cousin Alexander, whom the senate had induced him to adopt as his successor, was frustrated by the praetorian guards, who took Alexander under their protection and afterwards murdered Elagabalus. Pron. Ela-gabb-alus. in Syria, where at the age of 13 he 
Elaine. (1) Character in La Morte d'Arthur. She was the daughter of King Pelles and married Sir Lancelot. Their son was the blameless knight Sir Galahad, who achieved the Holy Grail. (2) Daughter of Sir Bernard of Astolat and known as the Maid of Astolat. Her story appears in Tennyson's Idylls of the King (q.v.).

Elam. Biblical name for a lowland and mountain region in S.W. Persia, N. of the Persian Gulf. Partly known also as Elymais, it comprised the lowlands $\mathbf{E}$. of the Tigris, with the highlands lying $\mathrm{N}$. and E. Wars were frequent between the Assyrians and the Elamites, and Ashurbanipal conquered the latter in 644 B.c. Susa, the Biblical Shushan, in Persia, became the capital of the country, which was watered by the Kerkha (Choaspes). Its neolithic population, perhaps anterior to but allied with the Sumerian, developed their agglutinative speech, picture-writing and industrial art under local impulses. At one time dominating Babylonia, it afterwards became subject, allied or independent, and experienced both Semitic and Iranian infiltration. Its vigorous native art excelled especially in metal-casting and jewelry. See Babylonia; Mesopotamia; Susa.

Elamites. People of ancient Elam. The ethnic relationships of the Elamites await further research. Although the early human remains are scanty, a shortish, long-headed, black-haired, glabrous stock, allied to the Mediterranean brown race, apparently occupied this region. Semitic intermixture gave them a ruling class, afterwards affected by Aryan elements, resulting in the racial strains discernible in the early Persian domination. The Elamites of Acts ii descended from Jewish settlers in Shushan after the exile, having no ethnic affinity with the native people, whose characters are now submerged under the Beni Lam Arabs of the modern Persian province of Arabistan.

Elan. River of S. Wales. It rises on the E. boundary of Cardiganshire, and flows S.E. through the W. portion of Radnorshire to Brecknockshire, where it turns N.E. to form the boundary of these coun. ties and enters the Wye after a course of $15 \mathrm{~m}$. The watersheds of the Elan and Claerwen, its tributary, have been acquired by $\mathrm{Bir}$ -

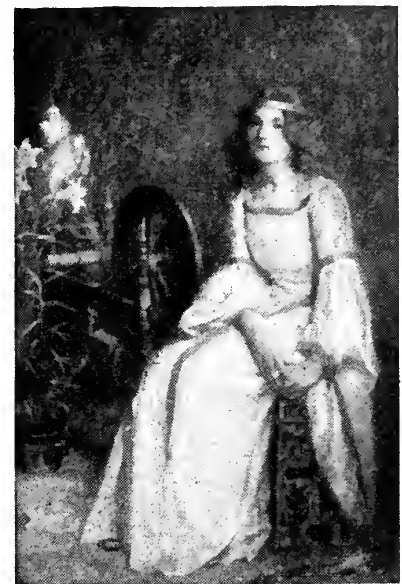

Elaine, the beautiful daughter of King Pelles, in the Arthurian tales, as depicted by Mouat Loudon By permission of the artist

mingham, and three reservoirs have been constructed on the Elan, whence the water is carried to the city by an aqueduct $74 \mathrm{~m}$. long.

Eland. Genus of large antelopes, found only in Africa. They are the largest of all the antelopes, a fine bull standing nearly $6 \mathrm{ft}$. high at the withers. In colour, they vary from light fawn to grey, and the bulls usually have a thick tuft of dark hair on the forehead. Both sexes bear horns, about $2 \mathrm{ft}$. in length, and more or less twisted. They are found in most parts of $\mathrm{E}$. Africa, but appear to be extinct in the South. They frequent wooded districts, and go in herds of fifty or more. Attempts have been made to acclimatise them in Great Britain, where they do well in parks, but they mature so slowly that they cost more in food than they are worth.

Elandslaagte. Village in Natal, known for an engagement in the early part of the S. African War. It is on the hills, $16 \mathrm{~m}$. N.E. of Ladysmith, 3,614 ft. above sea

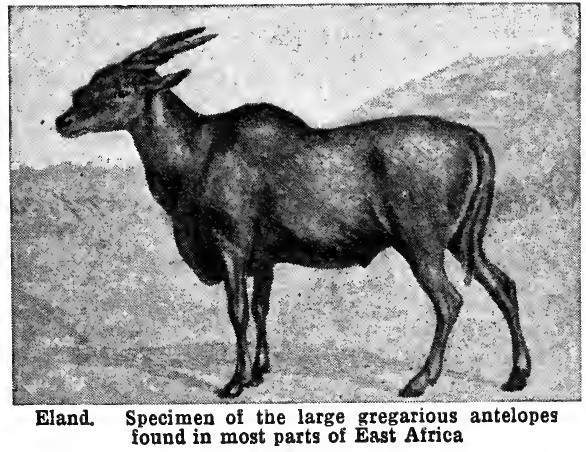

level. On Oct. 21, 1899, General French, with a small force moved out of Ladysmith to attack the Boer positions in the hills. He had with him only a few hundred men, but as the artillery duel was opening he realized that he was outnumbered and telephoned back for reinforcements. British battalions, Gordon Highlanders and Devons, were soon on the scene, also some Lancers and other cavalry, and the attack was pressed, the British advancing in open order up the hills. The Boer artillery was weaker than the British, and with a few casualties their position was taken. Some Boers resisted, but the majority rode away, while about 200 were made prisoners. The British lost 41 killed and 220 wounded; the Boers about 250 .

Elasmobranchs (Gr. elasmos, metal plate; branchia, gills). Subclass of fishes, which includes sharks and rays. They are characterised by the possession of cartilaginous or gristly skeletons, though sometimes the bones are partly calcified. The scales are few and distant, often of a bony character, and somewhat resemble the teeth in structure. The external gill openings are not protected by plates; the mouth is usually placed on the under side; there is no swim-bladder; and the two tail fins are of unequal length. Of their four orders, three are now extinct; only the sharks and rays survive. They are marine in habit, though some occasionally ascend rivers.

Elastic. Term more particularly used for a special fabric containing strands of rubber, usually made in the form of tapes, cords, and bands. The word is derived from an assumed $\mathrm{Gr}$. form, elastikos, from elaunein, to drive, set in motion. See Elasticity; Rubber.

Elasticity. Property of matter in virtue of which it resists change in shape or bulk, and tends, after distortion, to recover its original shape or bulk when allowed to do so. Fluids have no fixed shape, and therefore no power to resist change of shape; they have no " elasticity of form" : but they resist compression and have "elasticity of bulk." Solids possess both kinds of elasticity.

An external force producing distortion in a body is known as a "stress" and the distortion itself is called a "strain." The mathematical theory of elasticity deals with the various kinds of strain which a body may suffer, and the stresses corresponding thereto. If the strains are small, the general principle of the relation between stress and strain is "Hooke's Law" - the stress is proportional 
to the strain it produces. It is generally assumed that the strain is small, as the elasticity of a solid has a definite limit (the "elastic limit"), and when the strain exceeds this limit it produces a permanent deformation or actual fracture.

A simple example of Hooke's Law is afforded by a steel wire stretched under the tension of a weight suspended from it. Hence the weight is the stress, the longitudinal extension of the wire the strain, and it is found that for comparatively small strains the extension is proportional to the weight. Moreover, if wires of the same material, but of different lengths and thicknesses, are com. pared, the ratio of stress to strain is still constant, if each is measured on a suitable scale. It is found that for any given material, such as steel, the ratio of stress to strain is constant, and this constant number is called "Young's modulus" for the material. For steel wire it is about 13,000 tons to the square inch, and from this value it is easy to calculate by simple proportion the longitudinal extension of a steel wire of any given length and cross-section, when stretched by a known weight.

In this case the wire suffers a change in volume as well as in form ; the longitudinal expansion is accompanied by a slight lateral contraction, but the volume of the wire is on the whole increased A strain in which there is pure change of form with no change of volume is known as a "simple shear" ; it may be illustrated by twisting a wire. Here, again, for small twists the ratio of the "shearing stress" to the "shearing strain " is constant, this constant being known as the "rigidity." When a solid or a liquid is compressed, the ratio of the compress. ing force per unit of surface area (stress) to the proportionate diminution in volume (strain) gives another constant, the "volume elasticity," or " bulk modulus."

The theory of elasticity is of great importance to the engineer who has to deal in every kind of structure and machine with material in a state of stress, and

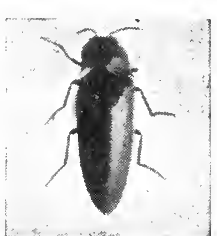
consequently to some extent in a state of strain. See M a terials, Strength of.

Elater Beer tle (Gr. elatèr, driver). Group

siater Beetle. Skipjack beetl of the genus wire-worm is the larva of one of these beetles; and the fire-fly of the $W$. Indies belongs to the same group. See Beetle; Click Beetle.

Elatinaceae. Natural order of herbs and small shrubs, distributed generally over the globe. They are

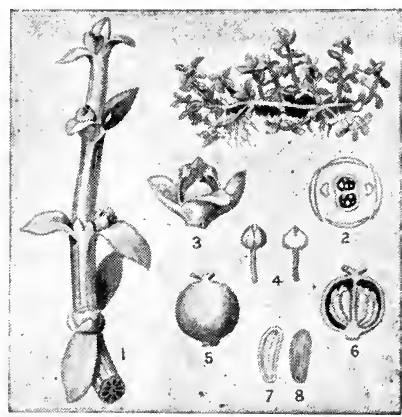

Elatinaceae. 1. Flowering branch, magnified. 2. Diagram of a dimerous flower. 3. A flower. more magnified. 4. A magnified stamen ontside and inside view. 5. Pistil, magnufled. 6. Pistil, vertical section showıng placentae. 7. Magnifled seed. 8. Transverse section of seed

mostly small annuals, growing in marshes, with opposite or whorled leaves. The minute flowers have two to five sepals and a like num. ber of petals, and the fruit is a membranous capsule, containing many seeds. Some of the plants are acriư, being known as waterpeppers.

Elba (Gr. Aithalia; Lat. Ilva). Island of the Mediterranean, belonging to Italy and included in the prov. of Leghorn. It lies $6 \mathrm{~m}$. S.W. of Piombino, the nearest
Marina are among the chief villages In 453 в.c. Elba was laid waste by the Syracusans. Pop. 30,450.

Elbasan, Town of Albania. On the Skumbi, about $65 \mathrm{~m}$. W. of Monastir, it is one of the few important towns of the country, and is the seat of a Greek bishop. It has hot sulphur springs. During the Great War it was the head. quarters for a short time of a government formed by Essad Pasha, the Albanian notable who sided with the Allies. After their conquest of Montenegro and $\mathrm{N}$. Albania, the Austrians occupied it in 1916, but it was recovered by the Allies in Oct, 1918. Pop.13,000.

Elbe (anc. Albis). River of North-Central Europe. It rises in a number of streams which unite at the foot of the Schneekoppe, a lofty summit of the Giant Mts. (Riesengebirge), which extend along the N.E. boundary of Bohemia. From this mountain, at an alt. of 4,500 ft., it flows S. and W. to Melnik, the head of navigation, $21 \mathrm{~m}$. N. of Prague. It penetrates the Mittel. gebirge and the Erzgebirge, waters Saxony, and pursues a N.W. trend to fall into the North Sea, near Cux. haven, through an estuary of $70 \mathrm{~m}$. between Holstein and Hanover.

At its mouth it is nearly $14 \mathrm{~m}$. in width, its length is $725 \mathrm{~m}$., and its drainage area about $57,000 \mathrm{sq} . \mathrm{m}$. It is navigable by small steamers for more than $500 \mathrm{~m}$., as far as its junction with the Moldau at Melnik. The tide is perceptible as far as Geesthacht, about $110 \mathrm{~m}$. from its mouth. Besides the Moldau, the chief of its many tributaries are

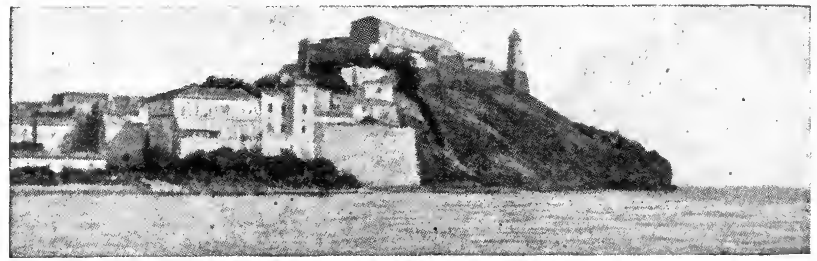

Elba. Fortress and lighthonse of Porto Ferrajo, the capital

point on the mainland, and is $19 \mathrm{~m}$. long by $6 \mathrm{~m}$. broad, with an area of about $90 \mathrm{sq}$. m. It is wholly mountainous, rising to $3,350 \mathrm{ft}$. in Monte Capanne, with fertile valleys. The produce of the island includes iron, which has been worked from antiquity, salt, granite, marble, chalk, and wine. Many of its fisherfolk are engaged in the tunny and sardine fisheries.

The capital is Porto Ferrajo (q.v.) on the $\mathrm{N}$. coast, the residence of Napoleon while in exile, May 5 , 1814, to Feb. 26, 1815. He had also a villa a few miles S.W. of the town and a country house on Monte Capanne. Porto Longone and Rio the Havel, Saale, Eger, and Mulde. The Elbe is linked up by a series of canals with the Oder, the Spree, and the Trave, the latter, opened in 1900, connecting Lübeck with Lauenburg. Hamburg, Magdeburg, Meissen, Aussig, Dresden, Torgau, and Wittenberg are important cities on its banks.

There is an enormous traffic along the Elbe, principally by barges, which are assisted by an ingeniously contrived towing chain. Immense quantities of timber are floated downstream trom the forests of Bohemia. Plenty of fish are to be obtained, including sturgeon, salmon, pike, and shad. 
Elberfeld. Town of Germany, in the Rhine Province. It stands on the Wupper, $16 \mathrm{~m}$. N.E. of Düsseldorf, and with Barmen, which it adjoins on the E., may be described as the Manchester of Germany. Municipalised in 1610, its industrial prosperity began about 1750 . Textiles of all kinds, chemicals, hardware, paper, and beer are made; there are leather, rubber, bleaching and dyeing industries. Railways connect the town with all parts of the Continent, and intercommunication is facilitated by numerous bridges across the Wupper, an overhead electric rly. (Schwebebahn) suspended above the Wupper, and an efficient tramway system. Of the churches the Reformed, Lutheran and adjacent Bergischer Dom of Altenberg are notable; the public buildings include the new Rathaus, law courts, state hall, almshouse, museum, hospital, and head offices of the Bergisch-Märkisch Rly.

There are two large theatres, many educational establishments, botanical gardens, zoological gardens, and hotels ; the more modern part contains many fine private residences, and the picturesquely wooded surrounding hills and val. leys are dotted with garden-restaurants. Müngsten, which has the highest steel rly. bridge in Germany, built 1893-97 at a cost of $£ 125,000$, central arch $560 \mathrm{ft}$. in span, height $350 \mathrm{ft}$., total length $1,657 \mathrm{ft}$. : and Burg, with its schloss, founded about 1140 and restored 1890-94, are favourite holiday resorts. Elberfeld, which is notable for the poor relief system to which it gives its name, passed with the grand duchy of Berg to Prussia in 1815, and has a history dating from the 12 th cen. tury. Pop. 170,195.

Elberfeld System. System of poor relief which originated in the town of Elberfeld, Germany, early in the 19th century, and was reorganized by Daniel von Heydt in 1852. It is carried out by unpaid officials who carefully investigate each case calling for relief. The town is divided into precincts, each with an almoner, who is empowered to administer immediate relief in cases of emergency, and a visitor. Almoners and visitors meet under a district overseer at regular intervals to consider cases and vote relief; and their proceedings are reported to a central body, also unpaid, which includes the mayor, four councillors, and four citizens. Monetary relief is granted according to a schedule; sometimes relief is given in kind, as in the provision of tools, etc. . and the system aims especially at avoiding pauperisation by enabling those who receive relief to achieve a position in which

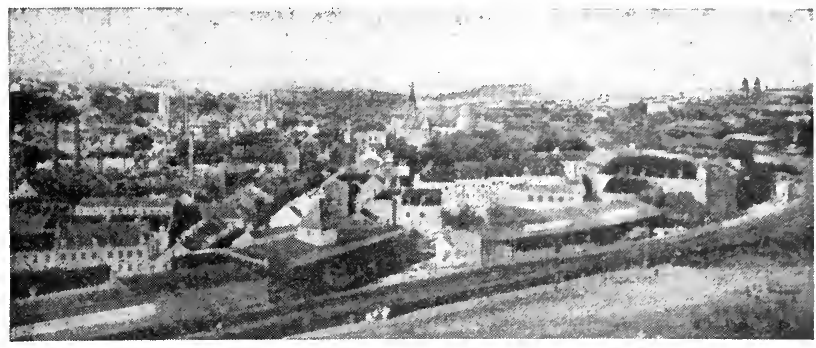

Eiberfeld, Germany. General view of the industrial quarter of the town, looking E. from the Kiesberg

they can repay in money or kind the help given to them. The system has spread to other parts of Germany. See Pauperism.

Elbert. Granite mt. of Colorado, U.S.A. It is in the Sawatch group of the Rockies, the highest peak of the group, and has an alt. of $14,421 \mathrm{ft}$.

Elbertian. Devonian rocks occurring in Colorado. They consist of thin limestone, sandstone, and calcareous shale, and contain fragmentary remains of fossil fish. Their thickness is from $25 \mathrm{ft}$ to $100 \mathrm{ft}$.

Elbeuf. Town of France. It stands on the left bank of the Seine, in the dept. of Seine-Inférieure, $12 \mathrm{~m}$. S.S.W of Rouen. Across the river is the suburb of S. Aubin. The chief buildings are the churches of S. Jean and S. Etienne, two Renaissance buildings, and the town hall. There is a museum, and several technical and other schools. The main industry is the making of woollen goods. Elbeuf gives its name to a forest around the town, and at one time there was a duke of Elbeuf. Pop. 18,290.

Elbing. Town and seaport of Prussia, in the prov. of West Prussia. It stands on the Elbing, about $5 \mathrm{~m}$. from its mouth in the Frisches Haff. It is $50 \mathrm{~m}$. by rly. E.S.E. of Danzig, and is also connected with the Vistula by a canal. Although an old place, Elbing is in most respects a modern industrial town. S. Mary's Church dates trom the 13th century; another, Corpus Christi, is nearly as old. It has an old school, the town hall, library, and most of the other buildings are modern. The chief industries are shipbuilding, iron-working, and the manufacture of machinery, while there are some textile manu. factures and a trade in grain. The town has a service of electric tramways, and steamers ply to various ports. Until 1918 much work for the German navy was done here. The town originated round a castle built by the Teutonic Knights; it became a member of the Hanseatic League, and was included in Poland in 1772; at the partition of that country a little later it became part of Prussia. Pop. 58,500.

Elbow. Joint formed by articulation of the lower end of the humerus, or upper arm bone, with the radius and ulna, the two bones of the forearm. The articulation between the ulna and the humerus forms what is termed a hinge-joint, a deep notch in the ulna, the greater sigmoid cavity, gliding backwards and forwards over the trochlear surface of the humerus. The disk-shaped head of the radius contains a depression which articulates with a prominence on the humerus termed the capitellum; the edge of the disk articulates with the small sigmoid cavity of the ulna. These articulations permit the rotation of the forearm. The tip of the elbow is formed by a process of bone called the olecranon; the bony prominences. which can

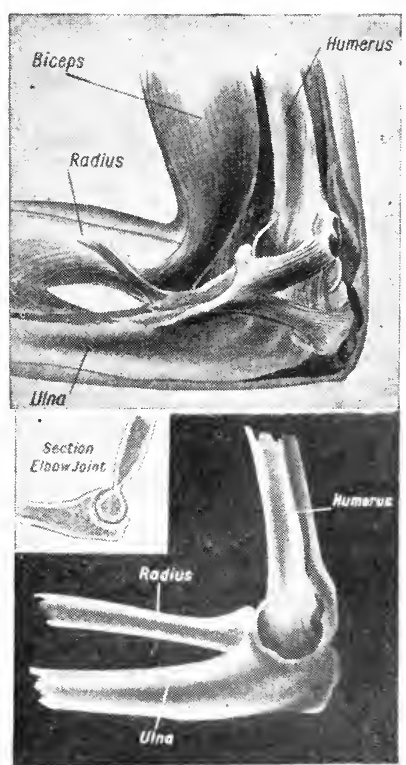

Elbow. Dragram showing the three bones forming the joint ; above, relations of the bones and muscles 
be felt on the inside and outside of the elbow when the arm is held with the palm of the hand facing forwards (supination), are the internal and external condyles of the humerus.

IndURIEs to the Elbow. These may involve both radius and ulna together, or only one bone. The most frequent dislocation of the two bones together is backwards, and may be associated with fracture of the olecranon, or the coronoid process, a prominence which forms the lower part of the greater sigmoid notch. This condition is accompanied by pain, swelling, and changes in the relative positions of the bony joints to each other, the forearm being kept partially bent and the hand held midway between supination and pronation, i.e. between complete external and internal rotation. The dislocation can usually be reduced without much difficulty.

Dislocations of both bones for wards or sideways are much less frequent. When a single bone is dislocated, it is most frequently the radius, since the articulation between it and the humerus is less firm and close than that between the ulna and the humerus. In forward dislocation of the radius the head of the bone rests against the front of the lower end of the humerus, which prevents the patient from completely bending his elbow. Reduction can be effected by pulling the forearm forwards while it is bent at a right angle, and at the same time pressing the head of the bone back into its place.

Sprain of the elbow, or " pulled elbow," is an accident not infrequent in young children, in which the head of the radius slips down, and one of the ligaments becomes nipped between the radius and humerus. It is easily replaced by bending the limb and then extending it. Fractures of the bones form. ing the elbow-joint frequently com. plicate dislocation. The humerus may be broken across just above the condyles, or either condyle may be fractured.

Diseases of the Elbow. Tuberculosis of the elbow is more frequent in children than in adults. The joint becomes swollen and painful, and chronic abscesses form which may extend to the surface and break through the skin, thus giving rise to a sinus. Treatment consists in keeping the limb at rest and building up the general constitution. Sometimes surgical measures are a ppropriate. Arthritis of the elbow joint may be the result of septic or gonorrhoeal infection, chronic rheumatism, or gout. Synovitis, which may be acute or chronic, is inflammation of the synovial membrane which lines the joint. Inflammation and enlargement of the bursa, which lies over the olecranon process, gives rise to the condition known as "miner's elbow." See Anatomy ; Arm ; also illus. p. 2600.

Elburz OR Elbruz. Highest mountain of the Caucasus. It is a little to the $\mathrm{N}$. of the main chain, near the border of the Kuban and Terek provinces. It consists of two extinct volcanic peaks, 18,526 $\mathrm{ft}$. and 18,460 ft. respectively. Elburz was first ascended in 1829 . According to tradition, it was the first resting-place of the Ark. See Caucasia.

Elburz. Mountain range skirting the $\mathrm{S}$. shore of the Caspian. It extends for a length of $600 \mathrm{~m}$., and to a width in places of $200 \mathrm{~m}$., through N.W. Persia. On its N. slopes are fertile valleys, and at various points naphtha and petrol are found in considerable quantities. The highest peak is the volcano, Mt. Demavend (q.v.).

Elche. Town of Spain, in the prov. of Alicante. It stands on the Vinalapo, $13 \mathrm{~m}$. by rly. S.W. of Alicante. Of Moorish appearance, with flat-topped houses, open squares, and narrow streets, the town is nearly surrounded by a plantation of date palms, the fruit beiny exported as "Barbary" dates. It has an ancient castle of the duke of Arcos, a bishop's palace, and a handsome church (Santa Maria), with a beautiful blue-tiled dome. An important rly. junction, it carries on a trade in fruit, and exports grass mats, wine, hemp, leather, flour, oil, and soap. Santa Pola, its port, lies $2 \mathrm{~m}$. S.E. At the feast of the Assumption, a 14th century musical play is performed. Pop. 30,713. Pron. El-chay.

Elchingen. Village of Germany, in Bavaria. It stands on the Danube, $8 \mathrm{~m}$. N.E. of Ulm, and is famous for the battle fought here between the French and the Austrians, Oct. 14, 1805. This was part of the campaign that ended in the capitulation of the Austrians at Ulm and their defeat at Austerlitz. The two armies met at the bridge which here crosses the Danube, and which was then in ruins. The French, however, quickly remade it, and the army got across. The Austrians under Mack were already demoralised, and only one part of the army stood to fight, and this was hampered by difficulties of every kind. The chief feature was the surrender of a large number of Austrians. Ney was made duke of Elchingen as a reward for his distinguished services here. See Ulm, Campaign of.
Elder (Sambucus). Hardy shrubby trees, natives of Britain, of the natural order Caprifoliaceae.

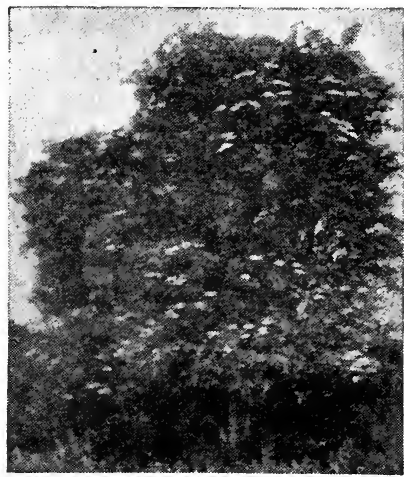

Elder. A large specimen of the tree in bloom

Their height is about ten ft. ; the flowers are white and variegated. They may be grown in any ordinary soil in open shrubberies. There are a few varieties of S. European origin, but they are rarely seen to advantage in British shrubberies. They are propagated by cuttings in autumn or spring. $S$. nigra is the familiar native elder, the berries of which are used for the manufacture of home-made wine. A liquid distilled from the flowers, elder-flower water, is largely used for flavouring confectionery. Owing to its lightness, balls made from the pith are largely used in electrical experiments.

Elder. Word used in a civil and an eccles. sense for an overseer. Of frequent occurrence in the Bible, in the O.T. it is applied to the heads or representatives of tribes and families, especially of the Israelites, as the word sheikh is among the Arabs. In the N.T. it is used to define officers of the Church who originally may have been identical with the bishops. Certain office-bearers in the Presbyterian and other churches are called elders. The word alderman (q.v.) is a familiar English equiva. lent of the word. See Bishop; Kirk Session; Presbyter.

Elder Brethren of the Trinity House. Members of the corporation of Trinity House, Tower Hill, London, E.C., sometimes known as Trinity Masters. They consist of members of the royal family, prominent statesmen, retired naval officers of high rank, and commanders in the mercantile marine. Ten of these are acting members, who, when required, assist the judges of the admiralty division as nautical assessors in shipping cases. See Trinity House. 
Elder Dempster Co. British ment as M.P. for Weobley. He steamship line. It was founded in forced himself into notice by fre1868 by Alexander Elder and John quent speeches, and in 1788 Pitt

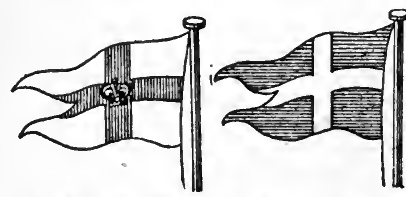

Elder Dempster Co. flags. Left. African Steamship Co. Right, British and African Steam Navigation Co.

Dempster, and greatly developed after 1879 by Sir Alfred Jones. The Beaver Line, one of its undertakings, was sold in 1903 to the Canadian Pacific Railway, but the services to $\mathrm{S}$ Africa, W. Africa, and the $W$. Indies were retained. The firm was reorganized as a registered company in 1910 , the control being acquired by Lord Pirrie and Sir Owen Philipps. At present it manages the British and African Steam Navigation Co., the African Steam. ship Co., the Elder Line, and the Imperial Direct Line. Liverpool, London, and Rotterdam are the chief ports from which the ships go to Africa. The head offices are at Colonial House, Water Street, Liverpool, and the London office at 4, St. Mary Axe, E.C.

An offshoot, the Elders and Fyffes line, was started in 1902 by Sir Alfred Jones to bring bananas and other fruit from the W. Indies.

Elder Statesmen. In Japan an informal body of statesmen who, having retired from the public service, are called upon by the emperor for a.dvice and council on occasions of national emergency or difficulty. The word is sometimes used in a general sense for men of similar character in Great Britain.

Eldon, JoHn Scotr, Ist EARL of (1751-1838). British lawyer. Born at Newcastle-on-Tyne, June 4,

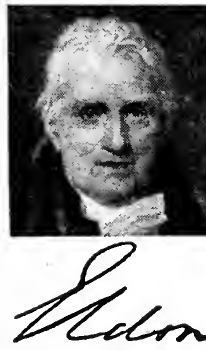

Afler Lawene $1751, \mathrm{~h}$ is father was a coal merchant in that town. $\mathrm{He}$ was edu. cated at the $\mathrm{Gr}$ a $\mathrm{m} \mathrm{m}$ a $r$ School, New. castle, and at University College, Ox. lord, where he gained a $f \circ l$ low ship and was for a time a tutor. He did not, as at first intended, enter the Church, but in 1776 was called to the bar and soon began to practise in London. Success was not immediate, but it came, and in 1782 he became a K.C.

In 1782 Scott entered parliamade him solicitor-general. In 1793 he was promoted attorney. general, and in 1799, having in the meantime conducted the prosecu. tion of Horne Tooke, and others holding republican ideas, he was made chief justice of the court of common pleas, and a peer, as Baron chancellor, leaving office on Pitt's death in 1806.

In 1807 Eldon returned to the post of chancellor, which he was destined to fill for 20 years, holding the office for a longer period than any other chancellor. During that time he was the most powerful man in Lord Liverpool's reaction. ary cabinet. He left office in $\mathbf{1 8 2 7}$ and died Jan. 13, 1838.

Eldon married Miss Surtees, the daughter of a banker, having run away with her in 1772. His two sons died before him, and his titles - he had been made an earl in 1821-passed to his grandson John (1805-54). The title is still held by his descendants, the earl's eldest son being known as Viscount Encombe. Eldon's elder brother, William Scott, was also a distinguished lawyer; in 1821 he was made Baron Stowell. See Life, H. Twiss, 1844 ; Lives of the Lord Chancellors, Lord Campbell, 3rd ed., 1848.

El Dorado (Span., The Gilded One). Name successively applied to a gilded man, a golden city known as Manoa or Omoa, and a region abounding in gold and precious stones, reputed to exist in S. America. The El Dorado legend apparently originated in a cuistom said to have been observed by an Indian tribe dwelling on the table-land of Bogotá at the installation of a new chief. His naked body, after being smeared with balsam, was covered with gold. dust, and be plunged into the sacred lake of Guatavita, whilst the assembly cast gold and precious stones into the water.

The Spaniards in America put such faith in the El Dorado legend that the governors of Guiana were styled also governors of El Dorado. They organized many fruitless ex. peditions in search of this legendary city, Manoa, the earliest being led by a German governor of Guiana, Ambrose Dalfinger, in 1529. In 1595 Sir Walter Raleigh claimed to have located Manoa on an island in Lake Parima, but this lake was proved by the 19th century German traveller, von Humboldt, to be non-existent. The name El Dorado came to be applied to any place reputed to abound in easily acquired wealth. Eldon. In 1801 he became lord
Eleanor (c. 1122-1204). Queen of Henry II of England. The daughter of William, duke of Aqui-

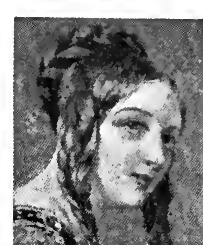

Eleanor of Aquiaine, Queen
Henry II taine, her first h usband was L, $O \mathrm{u}$ is VII of France, to whom she was married in $1137 . \quad \mathrm{H}$ e r dowry was the great duchy of Aquitaine. In a short time Eleanor and Louis were on bad terms, and in 1152 the marriage was dissolved. In the same year she married Henry of Anjou, who became king of England in 1154. She was the mother by Henry of the turbulent princes who disturbed his reign. Indulgent to them, the queen was concerned in the revolt of $1173 . \mathrm{Al}$. though of a great age, she moved about in France trying to help John in his fight against Richard. She died April 1, 1204. See Queens of England, A. Strickland, vol. i, 1840.

Eleanor (d. 1291). Queen of Henry III of England. The daughter of the count of Provence, she was brought up amid the poets and troubadours there, and was more a c c o mplished than most ladies of her time. In 1236 she was married to Henry at Canterbury. Throughouther

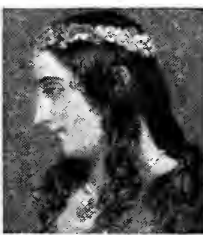

Eleanor of Provence, Queen of Henry III residence in England she was most unpopular. The charges against her resolve themselves into a love of foreign relatives and avarice. In 1276 she entered a religious house at Amesbury, Wiltshire, where she died, June 25, 1291. Her two sons were Edward I and Edmund, earl of Lancaster. See Queens of Eng. land, Agnes Strickland, vol. i, 1840.

Eleanor (d. 1290). Queen of Edward I of England. The daughter of Ferdinand III, king of Castile, she was married to Edward in Oct., 1254. She fled to France in 1264 when her husband was worsted by the barons, and was in Palestine with him in 1270 . She died at Harby in Nottingham. shire, Nov. 28, 1290, and was buried at Westminster. The king erected crosses at the places at which her body rested on the journeyLincoln, Grantham, Stamford, Geddington, Northampton, Stony Stratford. Woburn, Dunstable, S. Albans, Waltham, Westcheap, and Charing. See Qucens of England, Agnes Strickland, vol. i, 1840. 
Eleatic School. One of the chief pre-Socratic Greek philosophical schools. It was founded by Xenophanes of Colophon at Elea in Lucania in lower Italy; its other chief representatives were Parmenides and Zeno (both of Elea), and Melissus of Samos. The kernel of their doctrine was the unity and unalterableness of Being (that which really had a right to the name of existence), the unreality of Becoming (material changes), of Plurality, and of sensual perceptions. The real nature of things cannot be perceived by means of the senses, but is only attainable by thought. All that is given us by the senses is mere appearance. Since the senses show us only plurality and the manifold, and since the separate parts of the world, such as it presents itself to our senses, both differ in them. selves and are subject to constant change and movement, they asserted that Being was only one, unchangeable, and immovable. Only Being is ; non-Being is not; there is no Becoming. Starting from the assumption that the idea of real Being excludes anything contradictory, the Eleatics argued that Plurality, and above all Movement, could neither be Being itself nor found in connexion with Being.

Election (Lat. electio, choice). Term used in several senses, legal, theological, and political. In English law a man has sometimes to choose which of two courses he will take. Thus, if A. B. sells me first quality oats and delivers second quality, I can either reject them altogether or keep them and pay for them, counter-claiming for breach of warranty of quality. But I cannot keep the oats and decline to pay. If I do not forth with reject them I have elected to keep them. Again, circumstances sometimes arise where one has to choose, or elect, whether one will retain the benefit of a gift inter vivos (among the living), as, for instance, under a marriage settlement or a deed of appointment; or give it up and take a proffered benefit under a will. Election implies knowledge ; that is, a man can only elect where he knows his rights.

Election. Term used in theology for the doctrine that God from eternity has chosen certain persons for eternal life. In the O.T. the term clect is appliod to the Israelites, as the chosen people of God. In the N.T. the members of the Christian Church are called the elect in 1 Peter 2, and in S. Paul's epistles to Thessalonians, Colos. sians, and Timothy. The Calvin. istic view that God has elected certain persons to be saved and others lost, and this solely by His own Will and irrespective of any merit or demerit in the individuals, was never held previous to the Reformation. The usual view was to identify the elect with the baptized, in the sense that they had been chosen and called to a Chris tian profession; but to recognize the possibility of falling away from such a profession. Only those who persevered in Christian living to the end could be regarded as the people whom God had foreknown and chosen from the beginning as His faithful followers. The Church catholic has never maintained that the election of the faithful implied the condemnation of those denied the opportunity of election.

Election. In politics, and to some extent in business, the choosing of representatives. The methods of election vary, but, generally speaking, a bare majority of votes is sufficient to secure election, although this may be either a majority of the votes cast, or a majority of those entitled to vote.

The first elections were decided by the casting of lots, a method in force among the Greeks and Romans, but modern ideas are averse to this. Election by the votes of the electors began with the growth of the idea of representation. In the 12th century, and perhaps earlier, the reeve and four men represented the village communities of England on various occasions, and in some rough manner these four men were elected by those for whom they spoke. The system grew with the growth of parliamentaryinstitutions; knights of the shire, and burgesses for the boroughs, were elected, as well as other officials. Until quite modern times the method was rough; those present just held up their hands, or shouted, much as they do at a public meeting to-day, and the sheriff declared certain men elected.

There is proof that the sheriffs abused their power, declaring the election of persons not rightly chosen, and checks upon them were intro. duced. For parliamentary elections there came in the method of open voting on the hustings, and then the present system, which is almost entirely the creation of the 19 th cen. tury. It includes voting by ballot, a careful enumeration of the votes cast, and, if necessary, a scrutiny and recount; indeed, every pos. sible device to secure that the wishes of the voters prevail.

Elections are divided into general and bye. A general election is when at a stated time all the members retire, as on the dissolution of parliament; and a bye-election is when an election is necessary through a death or resignation. In elections for many local bodies, e.g. town councils in England, it is customary for one-third of the mem. bers to retire every year, so there is never a general election. County councils, however, have a general election every third year.

A fundamental division is between direct and indirect elections. In the former the voters themselves choose their representatives, each voter having as many votes as there are members to be elected. Elections to the House of Commons are the best known of this kind. Indirect elections are when the electors choose certain men who, in their turn, elect the actual representative. The most notable existing instance of this kind is the election of the American president, who is actually elected by a college of electors. The Venetian republic had an elaborate system of indirect election when choosing a doge. The election of aldermen in English boroughs and county councils is a somewhat different kind of indirect election. They are chosen by the directly elected councillors, but the latter are not returned solely, or even mainly, for this purpose. In some countries members of the Senate or second chamber are chosen by indirect election.

Elections at the best are but a crude test of the people's will, so vast are the numbers engaged, and so great the possibilities of manipulation. It has actually happened more than once that a minority of electors have returned a majority of the members to the British House of Commons. To make this impossible, and also to secure the representation of minorities, various proposals, proportional representation and the alternative vote, for instance, have been put forward.

At elections of company directors a show of hands is usually sufficient, but, under certain conditions, those dissatisfied with the decision can demand a poll. In elections of this kind, unlike political ones, the shareholders have votes in proportion to their interest in the company. A further device prevails at elections of members to clubs and societies. There a small number of mombers can keep out a candidate by voting against him ; this is called blackballing, from the practice of using black balls for this purpose. Election is the term used for the choice of fellows or scholars at the colleges of Oxford and Cambridge. Professors are also elected in most cases; those appointed to choose them being called electors. See Alternative Vote; Company Law; Politics; Proportional Representation; Voto. 
Electoral Commission. Name given to the body of men created by an act of Congress in the U.S.A., Jan. 29, 1877, to settle certain disputed questions in connexion with the electoral votes of four states in the presidential election of 1876 . It was the only disputed election in American history. It was decided to create a commission to determine which of two or more conflicting certificates received from any state of the votes cast by the electoral college of such state for president and vice-president in the 1876 election was the certificate provided for in the constitution. Thejudgement in each case was that the certificate of the votes cast for Rutherford B. Hayes and William A. Wheeler, the republican candidates for president and vice-president respectively, was the certificate containing the lawful electoral vote of the said state. The other certificates were declared void. The electoral votes were then counted, and Hayes and Wheeler were declared duly elected.

Electorate (Lat. eligere, to select). Name given to the whole body of electors or voters in a constituency or country. See Election.

Electors. In general, persons who have the right of voting at elections. In a special sense, however, the name was applied to the German princes who in the Holy Roman Empire voted at the elec. tion of the king.

Like many other early peoples, the Germans elected their kings; but, unlike them, they retained this practice-at least, in theoryuntil modern times. These elections may be said to have begun with the choice of Conrad I as king in 911 , but it was often merely a form, the eldest son of the late king being confirmed as ruler, as was Otto the Great. The electors were powerfal when there was no obvious successor to the throne, two or more candidates claiming it, as in 1198 , and more so after the death of Frederick II in 1250. At first all the princes took part, or were entitled to take part, in the elections, but soon many of them ceased to attend. In 1257 the number taking part was seven. This number became fixed, was recognized by the pope, and at Aix-la-Chapelle statues of the seven were erected.

Trouble then arose as to who were the favoured seven. Certain princes, e.g. the archbishop of Mainz and the elector palatine of the Rhine, were acknowledged to be electors, but in other cases there were difficulties, especially when two men divided a duchy between them. The matter was settled in the Golden Bull issued by Charles IV in 1356, which fixed the number at seven, who were named. Three were archbishops-Mainz, Cologne, and Treves-and the other four were the elector palatine, the duke of Saxony, the margrave of Brandenburg, and the king of Bohemia. Each held an office at the em. peror's court. The clerics were archchancellors for his three kingdoms, Germany, Italy, and Burgundy; the elector palatine was his steward, Saxony his marshal, Brandenburg his chamberlain, and Bohemia his cupbearer. The archbishop of Mainz was president of the electoral college, and on the death of a king summoned the electors to Frankfort.

The power of the seven electors was greatly increased by the Golden Bull. They were made almost sovereign rulers, with privileges not enjoyed by the other princes of Germany. They formed a college, one of the three sections of the imperial diet. The composition of the college remained unchanged until 1623, when the elector palatine lost his vote, which was given to the duke of Bavaria. In 1648 he was restored as an eighth elector. A ninth electorate was created in 1708 for the ruler of Hanover, and this was held by George I and other English kings. To keep up old theory these new electors also held offices, the elector palatine being treasurer and Han. over standard-bearer. In 1778 the ruling family of Bavaria became extinct, and the elector palatine secured their lands, thus uniting two votes. In 1806, with the dissolution of the empire, the electors ceased to exist. See Empire; Germany; Golden Bull.

Electra. In Greek mythology, daughter of Agamemnon and Clytaemnestra. She incited her brother Orestes, when he grew up to manhood, to murder his mother, Clytaemnestra, in revenge for the latter's murder of his father on his return from Troy. The tragic life of Electra forms the subject of tragedies by Sophocles and by Euripides. See Agamemnon; Clytaemnestra; Orestes.

Electric (Gr. èlektron, amber). Term referring to anything with which electricity is associated. In addition to the articles in this Encyclopedia which appear under compounds and variants of the word, e.g. Electricity; Electrostatics ; Electro-metallurgy, etc., there are numerous other articles on electrical matters, but for greater convenience these are placed under the main word. The advantage of this system is that it enables the electrical aspect of a given subject to be placed with the non-electrical branch of the same subject. Thus Electric Clock is a section of the article Clock and Electric Bclls of the article Bells. The chief of these articles are:

$\begin{array}{lll}\text { Arc } & \text { Fuse } & \text { Radiator } \\ \text { Battery } & \text { Generator } & \text { Railways } \\ \text { Bells } & \text { Heater } & \text { Resistance } \\ \text { Cable } & \text { Lamp } & \text { Sign } \\ \text { Clock } & \text { Lift } & \text { Symbol } \\ \text { Coil } & \text { Lighting } & \text { Telegraphy } \\ \text { Condenser } & \text { Locomotive } & \text { Testing } \\ \text { Conductor } & \text { Machines } & \text { Traction } \\ \text { Current } & \text { Meter } & \text { Unit } \\ \text { Fire Alarm } & \text { Motor } & \text { Welding } \\ \text { Furnace } & \text { Potential } & \text { Wiring }\end{array}$

Electrical Engineers, INSTITUTION OF. British organization founded as The Society of Telegraph Engineers in 1871. Its name was afterwards changed to The Society of Telegraph Engineers and Electricians, and finally, in 1889, to its present designation. It was incorporated under the Board of Trade in 1883. The institution has local centres in Great Britain and at Calcutta, Cape Town, and Hong Kong. Its London address is 1, Albemarle Street, W.

Electric Charge. Term used for certain states of electrification of a body. When two substances are pressed hard or rubbed together and then drawn apart they are found to have developed properties which they did not apparently possess before, the most striking being the power of attracting each other and light particles of other substances. They have developed or acquired an electric charge and are said to be electrified.

All bodies seem able to develop or acquire such a charge more or less, but if different substances so charged be examined the remarkable fact emerges that, while the charges have certain properties in common and act in accordance with the same laws, there are two different kinds, one kind being developed by certain classes of substances and the other by other classes, with this qualification, that either kind may be developed on some substances according to the material with which they are rubbed. The two kinds of charge are represented by that developed on a glass rod when rubbed with silk, and by that produced on a stick of resin when rubbed with fur or wool; the former has received the name of positive electricity and the latter that of negative elec. tricity. Another remarkable characteristic of these charges is that one is never developed by itself but both are always produced at the same time, one kind being found on one of the bodies rubbed and the other kind on the other body.

No adequate explanation has yet been found for these phenomena. 
Neither the development nor the dissipation of an electric charge makes any measurable diffcrence to the weight of the body. The phenomena are doubtless bound up with the elemental constitution of matter, and as our knowledge of that constitution increases the explanation of the electric charge and its double character will duly appear. See Electron.

Electric Discharge. Act of neutralisation of an electrieal charge. Electricity which resides chiefly on the surface of bodies may disappear in any one of several ways. It may be carried away continuously through a wire or metal rod, and is then said to disappear by conductive discharge; it may disappear suddenly as in a spark or a flash of lightning, which is said to be a disruptive discharge; or it may go gradually by being communicated to particles of air in its neighbourhood, which then fly off by repulsion, when it is said to disappear by convective discharge. Convective discharge may take place in a liquid as well as in air.

The electricity which disappears in any of these ways reappears in some other form of energy. Thus the energy which goes out in a conduetive discharge may present itself in the light of an electric lamp or in some chemical action; that of a disruptive discharge presents itself in the form of sound or light or heat, or all three, or in some mechanical effects, as when a sheet of glass is shattered or pierced by the discharge; that of a convective discharge may be found in the movements of the particles of air which may be set flying in all directions with increased temperature.

The discharge in a resisting medium, as in air, is always accompanied by the development of heat; an electric spark will light a gas jet; the discharge in certain forms of electric furnaces will melt the most refractory metals. The discharge is now applied in industry in the manufacture of nitrates and nitric acid from the air, and in detonating high explosives as in shells and mining cartridges. Very beautiful luminous effects are produced by the discharge through vacuum tubes, that is in rarefied air or gas ; while the physical effects produced in the gas or air are very remarkable, the molecules of the gas being broken up and the atoms interchanged, thus producing what is called ionisation. The Röntgen or X-rays $(q . v$.$) are indirectly pro-$ duced by such elcctric discharges.

Electric Fish. Genus of fishes possessing the power of administering an electric shock. There are three known fishes which possess

such a power, these being, in the order of their electrical strength, the electric eel (q.v.), the African catfish, and the torpedo, a species of ray fish.

The electrical catfish (Malap. terurus electricus) is found in all the larger rivers of Africa, the finest and most powerful occurring in the Nile. It frequents the darker and more sluggish portions of the streams, where it kills or stuns other fish which it eats. It is found up to four feet in length. In some catfish the electrical power seems present all over the body, in others just under the skin at each side.

The torpedo or electrical ray is the most numerous of these fish. A considerable number of species occur in the warmer seas of the world, and at least two are found near the southern shores of the United States. The best known is the Torpedo marmorata of the southern shores of Europe and of the Mediterranean; large specimens may weigh as much as $80 \mathrm{lb}$. The eleetricforce resides in the powerful tail.

The muscles and the nerves which are concerned in the exercise of the electrical power of these fish

\section{ELECTRICITY : GENERAL INTRODUCTION}

James Rice, M.A., Lecturer in Physics, Liverpool University

This article forms an introduction to the group of articles on electrical subjects which follows it, and also to others scattered throughout the work. It is followed by articles dealing with special forms of electricity, e.g. Atmospheric, Medicinal, etc.

The scientific study of electricity began in the 16th century. The ancient Greeks were acquainted with some isolated facts concerning the electrification of a few substances by friction, the epithet "electric" being, in fact, coined from the Greek word elektron, the name for amber, which was one of these substances. This term, among others, was introduced by William Gilbert, of Colchester, who made the first detailed study of the property of attracting light materials, which bodies acquire after being rubbed with textiles such as silk or flannel.

Gilbert, who might be called the father of electricity, published in 1600 his great work On the Magnet, Magnetic Bodies and the Great Magnet the Earth, paving the way for the systematic and scientific experiments on electrical phenomena which culminated with those cf Faraday. Until Gilbert published his results nothing was known about electricity, save that certain substances as amber, jet, etc., attracterl light objects such as leaves, feathers, etc.

The researehes of Boyle, Newton, and Gray in England, of Von Guericke in Germany, and Du Fay in France, had, by the first half of the 18th century, established the fact that all materials could acquire this property, i.e. be electrified, by friction. In the case of some substances such as very dry glass, sulphur, wax, ebonite, and mica, the property is confined to the portion of the surface which has been rubbed; but in general it tends to be diffused over the surface, no matter where friction has been applied. This power of "conduction" is manifested most notably in the case of the metals, but is also possessed by most of the materials which constitute the earth's crust, also by animal tissue and any damp surface. It is for this reason that such materials cannot retain the electrification unless suspended or supported by insulating strings or rods of silk, sulphur, glass, etc., and thus the earliest experimenters, notably Gilbert, were misled into the belief that these wcre "non-electric."

Du Fay (and also Kinnersley and Franklin in America) discovered the dual quality of electri. fication, and ultimately Franklin's terminology was adopted, which referred to bodies as "positively" or "negatively" electrified, according 


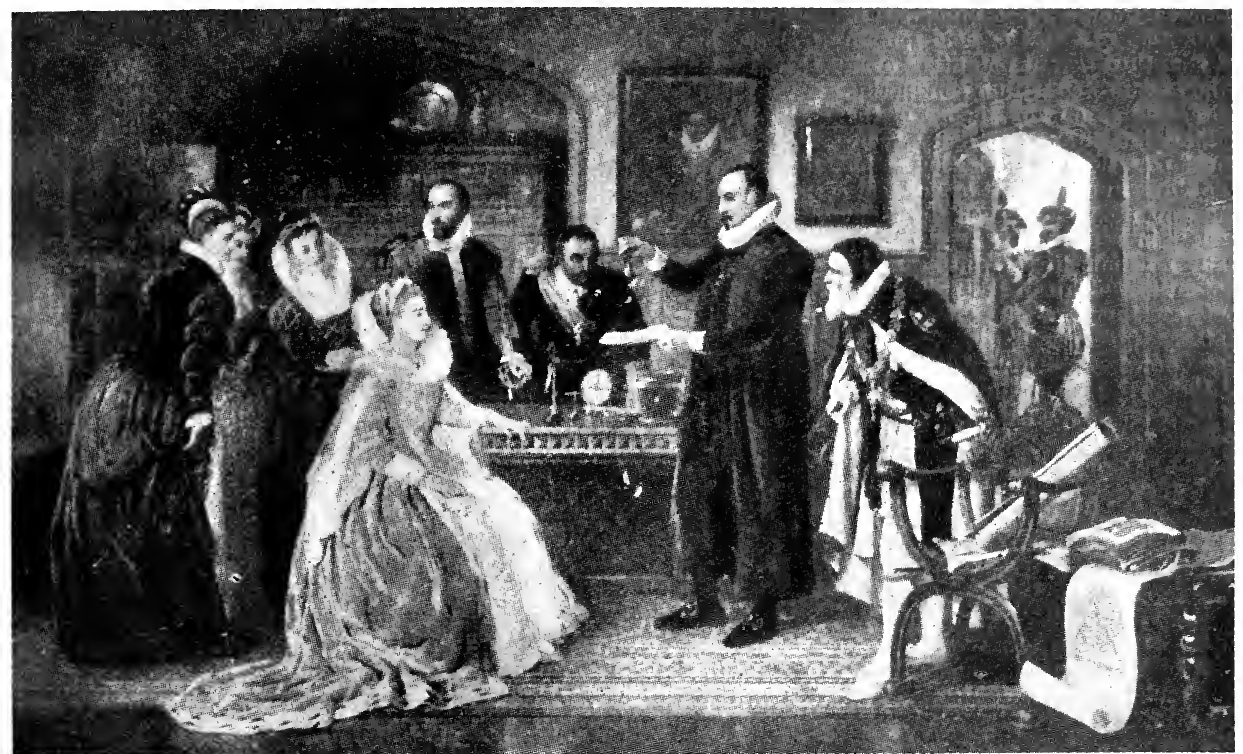

Electricity. A demonstration of electrical experiments made before Queen Elizabeth by William Gilbert of Colchester (1540-1603), an English pioneer in electrical discovery

After the painting by A. Acland Bunt

as they exerted a force of repulsion on a glass rod which had been rubbed with silk or on a stick of resin which had been rubbed with flannel. Quite early in the eighteenth century electric machines capable of producing fairly intense effects, such as spark and physiological shock, were designed. They took the form of balls, cylinders, or disks of sulphur or glass rotated by hand and rubbed by the dry palm of the operator or by a pad of silk, flannel, or rubber, coated with a metal ama'gam.

\section{Electricity's Dual Nature}

It was Du Fay who apparently was the first to make the postulate that electrification is the result of an inequality in the amounts of two "electric fluids" or "electricities" which a body possesses, an excess of positive fluid producing positive electrification (similarly for negative), equality of amount resulting in neutrality or absence of " charge." Franklin, in America, maintained a one-fluid theory, neutrality corresponding to the possession of a normal amount of the fluid on the part of the body, while positive and negative effects are the result of excess over or defect under this amount. As a mat. ter of fact, while the main results of the science can be expressed readily in terms of either theory, recent research on the structure of the atom rather emphasises the dual nature of electricity.

Much more important than either of these speculations was the discovery of induction and the development of condensers. Modern text-books make a point of presenting the concept of potential to the student's mind at an early stage. There is no doubt in any teacher's mind of the difficulty experienced in acquiring correct ideas concerning this concept, probably due to the fact that, as human beings, we possess no sense corresponding to that by which we appreciate temperature (the analogous concept in the science of Heat); and so great use is made of analogies in such presentation. For example, the notion of pressure is appealed to, and the flow of electricity from one conductor to another at a different "potential" is likened to the flow of gas along a tube from one flask to another at different pressures.

The Leyden Jar

All these analogies, however, break down in one important particular. The mere juxtaposition of a flask of gas at great pressure does not affect the pressure of gas in a neighbouring receptacle. But the presence of an electrified body has a very marked influence on the potentials of all neighbouring insulated conductors. The first discovery of this fact is due to Von Guericke in the 17th century; but its application to the manufacture of condensers, i.e. conductors which can retain a relatively enormous charge at a moderate potential, did not begin until the middle of the eighteenth, when the socalled Leyden jar was accidentally discovered by Musschenbroek and Cunaeus while endeavouring, by means of a chain depending from a machine, to electrify water contained in a bottle which rested on the observer's hand.

Development of Electrokinetics

This discovery was the starting point for the development of the condensers, which play such an important part in the induction coils, telegraphic, telephonic, and wireless apparatus of to-day, and also of the influence or induction machines of the Voss type, which have completely displaced the old frictional machines. The middle of the 18th century also witnessed Franklin's famous investigations on atmospheric electricity, his identification of lighting with the electric spark, and the subsequent discovery that even in fine weather there is a progressive difference of potential between the air and the earth's surface with increase of altitude. In the 18 th century were laid the foundations of the mathematical theory, due to the discovery of the inverse square law of force between electrified bodies by Coulomb, in France, and indepen. dently by Cavendish in England.

At the very beginning of the 19th century came the extremely important researches of Volta at Pavia, leading to the development of electrokinetics. His prime discovery was that two plates of 
different metals when immersed in a solution of a salt or acid remain at slightly different potentials even when connected with a conducting wire, and so on any theory of the material nature of electricity, there must be a flow of electricity along the wire. Further, that by connecting any number of such "voltaic cells" in series there is theoretically no limit to the difference of potential which can be established between the terminal plates of the battery (excepting, of course, a breakdown in the insulating power of the air). During the early years of the century various batteries of a more constant strength were devised by Daniell, Grove, Smee, and others, and employed in the study of electro-chemical decomposition of solutions, the earliest attempts in this direction being made by Carlisle, Nicholson, and Davy in England, and Ritter in Germany. These researches were continued later by Faraday with signal suc. cess, and in 1835 modern physical and electro-chemistry may be said to have come into being with the enunciation of Faraday's wellknown laws of electrolysis.

\section{Science of Electro-Magnetism}

In another direction Volta's work was to lead to still greater results. In 1819 Oersted of Copenhagen discovered the existence of a "circuital" magnetic field round a wire joining the terminal plates of a battery. The science of electromagnetism originated in that experiment. Within a few years Ampère had extended Oersted's experimental work and had published a mathematical theory of it, afterwards amplified by Weber. Gal. vanometers of various types were invented by Nobili, Pouillet, Thom son, and D'Arsonval. But no inves. tigations rank higher than those of G. S. Ohm, who between 1825 and 1830 published the results of his work on the connexion between current strength in a conducting wire and electromotive force.

It is a rather deplorable fact that the very thorough and com. plete experimental work which $\mathrm{Ohm}$ carried out in support of his famous law is absent from nearly all current text-books. In fact, even in his own day, many physicists were entirely ignorant of his experiments and believed that he hadonly given a theoretic deduction of the law. The introduction of the concept of "resistance" into electrical science produced considerable reactions both in theory and experiment, and by 1843 Wheat. stone, then holding the chair of physics at King's College, London, had perfected his well-known method for determining resistance.
Michael Faraday's work on electrolysis has already been mentioned. But his work on electromagnetism was destined to play a more revolutionary part in science. By 1831 he had discovered the exis. tence of electromagnetic induction, i.e. the creation of electric currents in a conductor by the variation of a surrounding magnetic field. Later, continuing some investigations of Jenkin, he discovered the phenomenon of self-induction. It should be stated that similar results were obtained independently and almost simultaneously by Joseph Henry at Albany, New York. Modern dynamo-electric machinery originated in these famous experiments.

Faraday and Clark Maxwell

In another direction Faraday revolutionised electric theory. He destroyed the old "action at a distance" view of electric force by his discovery of the effect of the surrounding medium on the force between two charged bodies-the "specific inductive capacity" of the medium, as it is called. This discovery led Faraday to postulate transmission of electric force through the "polarised" particles of the medium, a view which was eagerly accepted by J. Clark Maxwell and developed by him with great mathematical power in his famous work on the subject. In Maxwell's hands the theory predicted the transmission of electric waves through space, a result beautifully confirmed in 1888 by Hertz, which has had such marvellous fruition in wireless telegraphy and telephony.

Space only permits us to mention that the work of the twentieth century has had its own distinctive impress. Beginning with the experiments of J. J. Thomson on electric discharge in vacuum tubes and of Curie, Rutherford, and Soddy on radioactive materials, it is unlocking the secret of the atom and finding confirmation of Du Fay's old notion of the two "fluids," in the "electron" and the "positive nucleus," the planet and sun of the "solar system" which is accepted by all physicists nowadays as a working model of atomic structure.

James Rice

Electricity in Medicine. It is not surprising, having regard to some of its remarkable manifestations, that the idea should have presented itself to many minds that electricity is a "vital " force. It has been long recognized that it is a force that kills; and the conception that it should be able to cure, more or less, the physical ailments of man is not unnatural. Un. fortunately a good deal of oharlat. anism has been associated with the idea of the curative powers of electricity, not only in Great Britain, but perhaps still more on the continent of Europe and in America. The so-called electric or magnetic "belts" in connexion with which the public is frequently informed that " electricity is life," may be dismissed quite briefly. As a matter of fact magnetism alone has no physiological action whatever. Any curative effects which such appliances may appear to produce are

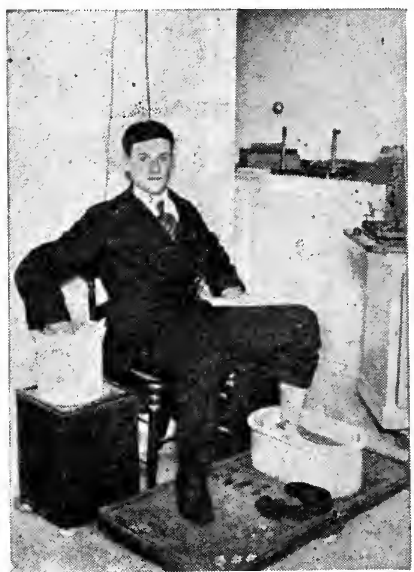

Electricity in medicine. Patient with hand and foot in electrical bath undergoing treatment for heart disease

due to the warmth which they com. municate to the body of a patient by their substance only, and to the faith which they inspire in his mind, and not at all to any electrical power which they possess.

For the first demonstration of the physiological effects of electricity we have to go back to 1678 , when Swammerdam showed to the Grand Duke of Tuscany that a piece of the muscle of a frog's leg hanging by a thread of nerve bound with silver wire would instantly contract if both nerve and wire were simultaneously touched by a piece of copper. Galvani and Volta, not knowing of Swammerdam's demonstration, made their classical experiments on dead frogs and their legs more than a century later, and first excited general scientific interest in the physiological effects of electricity. Since then many experiments have been made on newly killed animals, always with the result that muscular move. ments were produced.

In practice electricity is used in the three forms, static, galvanic, or continuous, and alternating, or what is sometimes termed faradic. For the production of the first the Wimshurst influence machine may be used. This form is employed to 


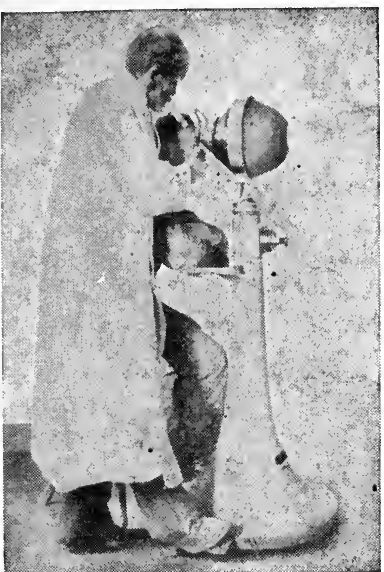

Electricity. A powerful electro-magnet used by an oculist to extract a steel splinter from a workman's eye

regulate and modify functional processes such as nutrition, secretion, circulation, and sleep; and in some inflammatory conditions, paralysis, skin affections, consumption, and cancer. For the production of the "faradic" form an induction coil is used, the current from the secondary coil being applied to the body by means of electrodes, as when the galvanic form is employed. Faradic electricity is used in spinal and some other forms of paralysis, in gout, rheumatism, muscular rheumatism, and cramp, eczema, constipation due to indigestion, hypochondria, neurasthenia, and hysteria. When applied to the abdomen or spine a flat, oval electrode is used; when it is desired to pick out a particular muscle a small needle-shaped electrode is em. ployed; while the current is also applied directly in the stomach by means of a small bean-shaped electrode at the end of a wire covered with india-rubber, which is introduced into the stomach and withdrawn when the necessary dose has been given.

\section{Use of Electrodes}

Drugs are introduced into the system through the skin by the aid of special electrodes carrying at their extremities a little roll of blotting or absorbent paper which is saturated with the drug to be introduced; the paper is attached to the cathode or negative end of the circuit and is applied to the skin where it is desired to introduce the drug, the other end of the circuit being applied to some other portion of the skin. In this way the drug is grad. ually introduced into the tissues just where it is required, and may have more active effect than if taken through the mouth or ad. ministered in the ordinary hypodermic fashion. In general debility and in convalescence after illness electricity may greatly aid recovery by improving nutrition, and by its general tonic effect. Used in health under proper control its tendency is to increase muscular power.

Electricity is used also in medicine to illuminate the interior of certain parts of the body by the direct introduction of minute electric lamps and particularly for the examination of the throat and the eye ; and as a cauteriser for the destruction of superfluous hairs, warts, and other abnormal growths ; while powerful electro-magnets are employed to pull particles of iron out of the eye. The X-rays, while not strictly electrical, are indirectly so, being a secondary product of electric action, and constitute probably the most valuable of all the contributions made by electricity to medical science.

Atmospherio Electricity. The atmosphere, for a certain distance above the earth, has been proved to be almost continuously charged with electricity. Normally the electricity of the air is positive and that of the surface of the earth negative, and if we take the average of fine weather as determined by a series of careful examinations carried out at Kew many years ago, as repre. sented by +4 as the potential, it would appear that in this country the potential rarely falls to 1 , though now and again it may drop for a moment to as low as 0.1 . It is strong during E. and N.E. winds ; in wet weather with sudden heavy showers it may be as much as 30 either positive or negative ; during snow the strength is about the same as in wet weather, but it is nearly always positive. With high wind and snow or severe frost it may go to +100 or even higher. In thunder-storms it will often be over 100 either positive or negative, though at such times it may reach -200 , there being usually a preponderance of negative electricity in thunder-storms. It may change instantly from positive to negative or negative to positive with a flash of lightning, and with only less rapidity with a sudden shower of rain. Even in fair weather the changes may be rapid, while in storms the oscillations may be so frequent and violent as to keep the indicating instruments in continual agitation. In all regions there appear to be at least one period of high intensity and one of low every twenty-four hours, and in some two such maxima and minima periods.

Apart from the normal electric condition of the atmosphere and the obvious manifestation afforded by thunder-storms, the Aurora offers another evidence of profound electrical disturbance in the earth's atmosphere. It cannot, however, be said that our knowledge of the cause or causes of atmospheric electricity is as yet either exact or complete.

Theories of Atmospheric Electricity

Many plausible theories have been put forward to account for the phenomena : evaporation of water from the surface of the earth, the friction of the particles of air in the wind, or of particles of water in the air, the heat currents in the atmosphere, the volumes of steam emitted by volcanoes and geysers, have all been suggested as causes and rejected as inadequate explanations. The fact that the ultraviolet rays of the solar spectrum will discharge a negatively electrified body as if they were them. selves positive, has suggested that radiation from the sun may give a positive charge of electricity to the atmosphere which in turn would induce negative at the sur. face of the earth.

A theory propounded by Sir J. J. Thomson appears to offer a satisfactory explanation of some of the immediate phenomena of atmospheric electricity. This assumes that when the vapour of water in the atmosphere first condenses it does so by preference on particles of dust that are negatively electrified, and that in consequence the first formed parts of fog or cloud are heavier than those formed later, and, falling first to the ground, carry with them the negative electricity. The theory, however, does not go very far. It is possible that all the suggested causes to which reference has been made contribute more or less to the electricity of the earth's atmosphere, but there is little doubt that we must look to radiation from the sun as the chief source.

\section{Electron Theory}

Arrhenius, the Swedish scientist, has suggested that the sun is continuously bombarding space with electrons (q.v.), that the great mass of those approaching the earth are gathered up by the magnetic forces which are concen. trated about the earth's poles, where, owing to the rarefied atmosphere in those regions, they become manifest in aurora, precisely as in a vacuum tube when a discharge of electricity takes place therein. Accepting this highly probable theory, it is easy to suppose that not all the electrons are carried to the poles, that some penetrate other portions of the earth's atmosphere. And, in any 
case, air currents may well suffice to distribute electricity from the polar regions through the rest of the atmosphere. A. J. Liversedse

Electric Lighting Acts. Acts of Parliament regulating the supply of electric lighting. When it became evident that electricity might become a rival of gas as a source of private and public light, it became desirable to put its generation and supply for such purposes under more or less legislative control, on similar lines to that governing gas and water. The first Act was passed in 1882, and was extremely severe in its conditions,

\section{ELECTRIC POWER AND ITS USES}

A. J. Liversedge, Associate Member, Institute of Civil Engineers The extent to which Electric Power is used may be deduced from this article; also the various uses to which it is put. See Dynamo; Energy; Fuel; Railways; and the various articles on electrical subjects

The dynamo may be classed with the printing press, the steam-engine, and the papermaking machine, as among the great epoch-making inventions of mankind. It has already revolutionised industry, and it would not be easy to set a limit to the ultimate developments in the economic and social life of the world to which it may give rise. The steam-engine concentrated industry in regions where coal abounds ; electricity is diffusing it over regions where, but for its remarkable power, manufactures would be impossible.

At one time the power-mechanical energy required for industry had to be generated where it was needed. To-day, however, it may be generated at one centre and utilised over an area of thousands of square miles. Formerly anyone who wanted power on any considerable scale had to generate it himself, and a large portion of his capital would be sunk in the powergenerating plant. To-day power has become a common commodity to be bought and sold, in all es. sentials precisely like any other commodity. And this development has been brought about, like many other industrial and social changes, by improved means of transport which electricity has provided. The profound significance of this revolution is perhaps not yet fully appreciated. It may mean the displacement of many of the great industrial centres of the world.

Electricity does not create power; it is itself a product of mechanical or chemical cnergy, and not an original source. The dynamo takes in power from some other agent, and gives it out again in the form of mechanical energy, chemical action, heat or light; the conversion always means some one clause providing that a local authority could take over an undertaking supplying its people after 21 years upon paying the owners of the undertaking the net value of the works, land, etc., at the time. This clause undoubtedly delayed the development of electrical services in Great Britain to a serious extent. Another Act passed in 1888 modified the former, while a third passed in 1909 still further encouraged enterprise, and has led to considerable development in works for the supply of electricity "in bulk." See Lighting, Electric.

loss of energy. The advantage of electricity lies in the extraordinary facility with which it may be transmitted over long distances and then reconverted into any form of industrial energy required. It is this property which has led to the utilisation all over the world of elevated bodies of water as sources of mechanical energy. Water from these elevated sources is led in pipes down to some convenient point, at anything from 100 to $3,000 \mathrm{ft}$. below, and there drives hydraulic motors which, in turn, drive electricity-generating machines. Such hydro-electric power stations are now in operation in Great Britain (on a very small scale), in Scandinavia, France, Switzerland, Spain, Italy, Germany (small), Czecho-Slovakia, India, Tasmania, New Zealand, S. Africa, most of the countries of S. America, and on an immense scale in the United States and Canada. The greatest power stations are those, American and Canadian, which utilise the Falls of Niagara; the total power now available at those stations being about 500,000 kilowatt $(666,000$ h.p.).

\section{British Electric Power Station}

Coal, however, is probably still the chief immediate source of electric power, and in Britain with one or two trifling exceptions. the sole source. In the United Kingdom there are now 276 electric power stations, of which 190 are municipal undertakings, the remainder being companies. The largest of these is that of Manchester, which in 1919 delivered $181,075,000$ units at an average price of $1 \cdot 15 \mathrm{~d}$. per unit. Sheffield supplied $161,839,000$ units at an average of $99 \mathrm{~d}$. per unit; Glasgow, $144,930,000$ units at $1 \cdot 41$ d. ; and Birmingham, $140,908,000$ at $1 \cdot 6$ d. per unit. The total units supplied by all these undertakings in that year amounted to $2,840,000,000$, of which about $600,000,000$ were used on tramways. The lowest average price at which the electricity was supplied by these undertakings, according to public returns, was -85d. per unit, at which rate Stockport supplied $23,000,000$ units in the year ended Dec. 31, 1919. The supply of electric power by these undertakings is under the control of the Board of Trade, and the highest rate permitted to be charged is $8 \mathrm{~d}$. per unit; average prices of from $6 \mathrm{~d}$. to $7 \mathrm{~d}$. pcr unit were, in 1919, charged in a considerable number of instances.

Problem of Economic Transmission

Just before 1920, two Government committees investigated the whole question of the provision and supply of electric power in Great Britain, one having been specially concerned with the possibilities in connexion with waterpower as the immediate source of the energy, the other with the possibilities in connexion with coal, upon which it is recognized that the country must still chiefly depend. The direction in which improvement is to be sought lies in concentrating the development of the electric energy in large stations situated in the great coal-producing centres, and transmitting the energy so developed to the power consuming districts. In this way it is believed great economies could be effected in the cost of developing electric power as compared with the present costs in the many power stations scattered over the country. Such a concentration would permit the use of large individual generating units with a considerable economy in the first cost of plant. Until recently the largest units used in Great Britain were the 6,000 kilowatt turbogenerators $(8,000$ h.p.) at the Lots Road Power Station. London, which supply current to most of the London electric underground railways. Units of 10,000 kilowatt and 7,500 kilowatt are, however, now running. A Parsons turbogenerator of 25,000 kilowatt capacity was recently installed in the central power station of Chicago, U.S.A.

Electric power is now being rapidly extended to rlys., for which service it has many advantages over steam, more particularly for suburban lines with their numerous stations; to the smelting and refining of metrals, and to many chemical manufacturing processes. Among these latter may be mentioned particularly the production of aluminium which is 


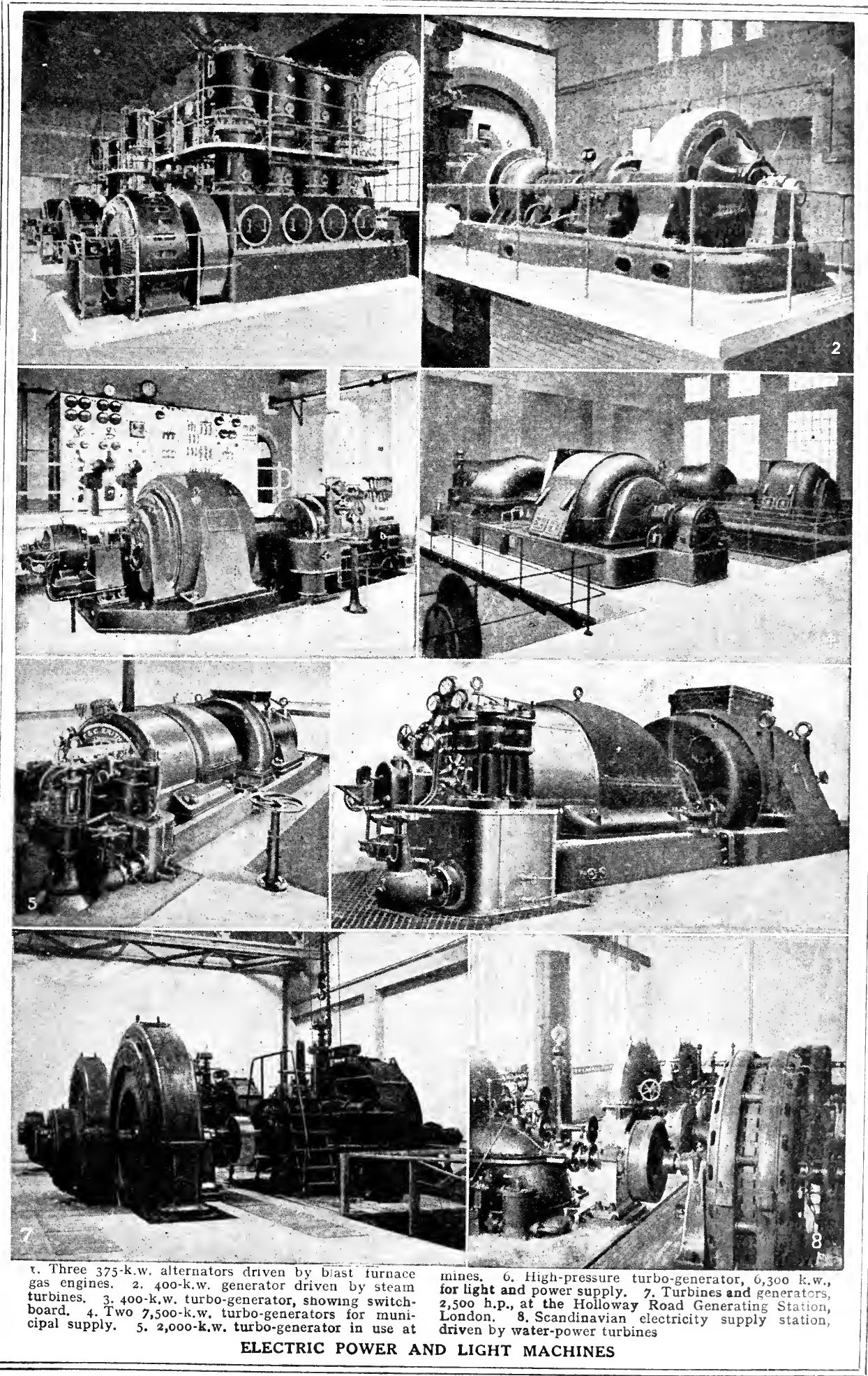


now obtained solely by the aid of hydro-electric power; and the manufacture of artificial fertilisers by the fixation of the nitrogen of the atmosphere, which is now being carried out on a considerable scale in Scandinavia, the product as prepared for agricultural use being known as nitrolime.

The useful properties of elec. tricity together with the increasing cost of coal are now compelling attention to the possibility of using other and new sources from which to obtain the energy. Natural oil offers no appreeiable advantages over coal in this connexion, though low classes of oil are now being used in Diesel engines (q.v.) for the development of electricity. It has been predicted that we shall one day cultivate oil-yielding plants specially for the purpose of providing fuel to be used in such classes of engines for the development of electric power. It is possible that the tides, especially where they run to considerable heights, may one day be utilised; and in tropical and subtropical regions, the direct rays of the sun. Edison has studied the possibility of constructing a voltaic cell in which the latent energy of coal, much the larger part of which is now wasted in the most economical systems of power development, would be directly converted into electric power. Sir Oliver Lodge looks ultimately to the liberation of atomic energy; while Sir Charles Parsons, reviving an old project, would obtain energy from the internal heat of the earth.

\section{Utilisation of Natural Steam}

Meanwhile the most remarkable electric power development system in the world is to be found in Italy, where the internal fires are actually being utilised. The soffioni of Tuscany are well known and have long been a principal source of borax. They are openings in the crust of the earth through which, from time immemorial, volumes of steam have poured day and night. Prince Gironti-Conti, on whose estate soffioni occur, has now tapped some of this natural steam before it comes to the surface by driving pipes into the ground, and is using it as the heating agent in special steam boilers for the develop. ment of electric power by turbogenerators.

Transmission and DistribuTION. Since the earliest days of the present industrial era, even before the inventions of James Watt gave so great a stimulus to industrial development, the transmission of power, mechanical energy particularly, has always been a branch of applied engineering of the highest importance. Until the modern de- velopments in electricity, transmis sion was effected chiefly by shafting and gearing, belts and ropes, and in some cases by wire cables running over pulleys. All these systems, even the latter, were extremely limited in their scope. Here and there the attempt has been made to transmit power over considerable distances by means of steam, water, or air carried in pipes underground. None of these agents, however, can compare with electricity in regard to the facility with which convertible energy can be transmitted over long distances.

Telegraphic Power Transmission

Electric transmission may be considered under three heads, factory, local, and long distance. The principles involved are the same in all; the differences lie chiefly in the scale on which those principles are applied. The medium mostly employed to-day for transmission, and for distribution, is copper wire, though aluminium is now being used to some extent, and may ultimately displace copper ; weight for weight it is a much better conductor, and therefore at equal cost and equal durability would be the more economical medium. For telegraphic power transmission, galvanised iron wire is mostly used, being permis. sible because of the relatively small amounts of current which need to be transinitted. In all cases of electric transmission a medium for the return of the current to the source of generation is requiredthe circuit must be complete. This medium may be provided by a separate wire, by the rails of a tramway or railway, or by a system of separate rails or $\mathrm{T}$ bars, or by the earth, which is a universal conductor and equaliser.

Transmission and distribution, in the case of factories where the electricity is generated on the premises, present no difficulties. The current is usually continuous or direct and the voltage comparatively low, 200 to 250 volts, and rarely over 500 . In large establishments with many buildings and much machinery a separate system for lighting, and heating, may be installed; otherwise the lighting distribution will be taken off the same mains which supply the electric motors for driving the machinery. The mains or conductors will be encased so as to avoid risk of personal contact or short circuiting, exposure to moisture, accidental injury, as by the driving in of a nail, or any conditions likely to cause personal injury or fire.

A question that may call for careful consideration will be as to whether the machines shall be arranged to be operated in series or in parallel, that is to say whether the current shall pass through one machine to the next, or each take its own supply independently from the main. Arc lamps are largely operated in series; and some economy in cost of installation may be secured by adopting that system, but as the system involves the addition to each machine or lamp of a shunt device which will automatically cut out a lamp or machine from the circuit if it goes wrong, and pass the current round it on to the next, and as, further, it is practically inapplicable to incandescent or glow lamps, the balance of advantage lies with the system of working in parallel, under which the failure of one lamp or machine does not necessitate any disturbance of the remainder.

Local transmission and distribution represents a much larger, more complex, and difficult problem. The work is in the hands either of a municipal authority or of a public company; in either case it may assume a four-fold aspect-the provision of light and heat to domestic and business users, public lighting, the provision of power to workshops, and lastly power for electric traction. The supply of private light and heat will usually be the first consideration, and two antagonistic factors will present themselves. The ordinary domestic incandescent or glow lamp cannot take current at more than 200 volts ; large numbers still in use must be supplied with current at a much lower pressure.

\section{Cost of Installation}

On the other hand, the conductors for transmission and the distribut. ing lines, whether of copper or of aluminium, are costly, and the only way by which the cost of instal. lation can be kept within reasonable limits is to generate the current, and put it into the main at as high a pressure as may be permissible. As in the case of steam the higher the pressure the larger the amount that may be passed through a given size of pipe ; so with electricity the higher the pressure-voltage-the smaller may be the size of the mains for the transmission of a given quantity. Thus the conditions at one end require a low voltage; at the other end a high voltage; and a compromise will have to be adopted having regard to all the conditions of the district to be served.

Voltages as low as 100 are in use in the stations of Great Britain, but the newer installations will usually be arranged for voltages between 250 and 550. Hence the current put 


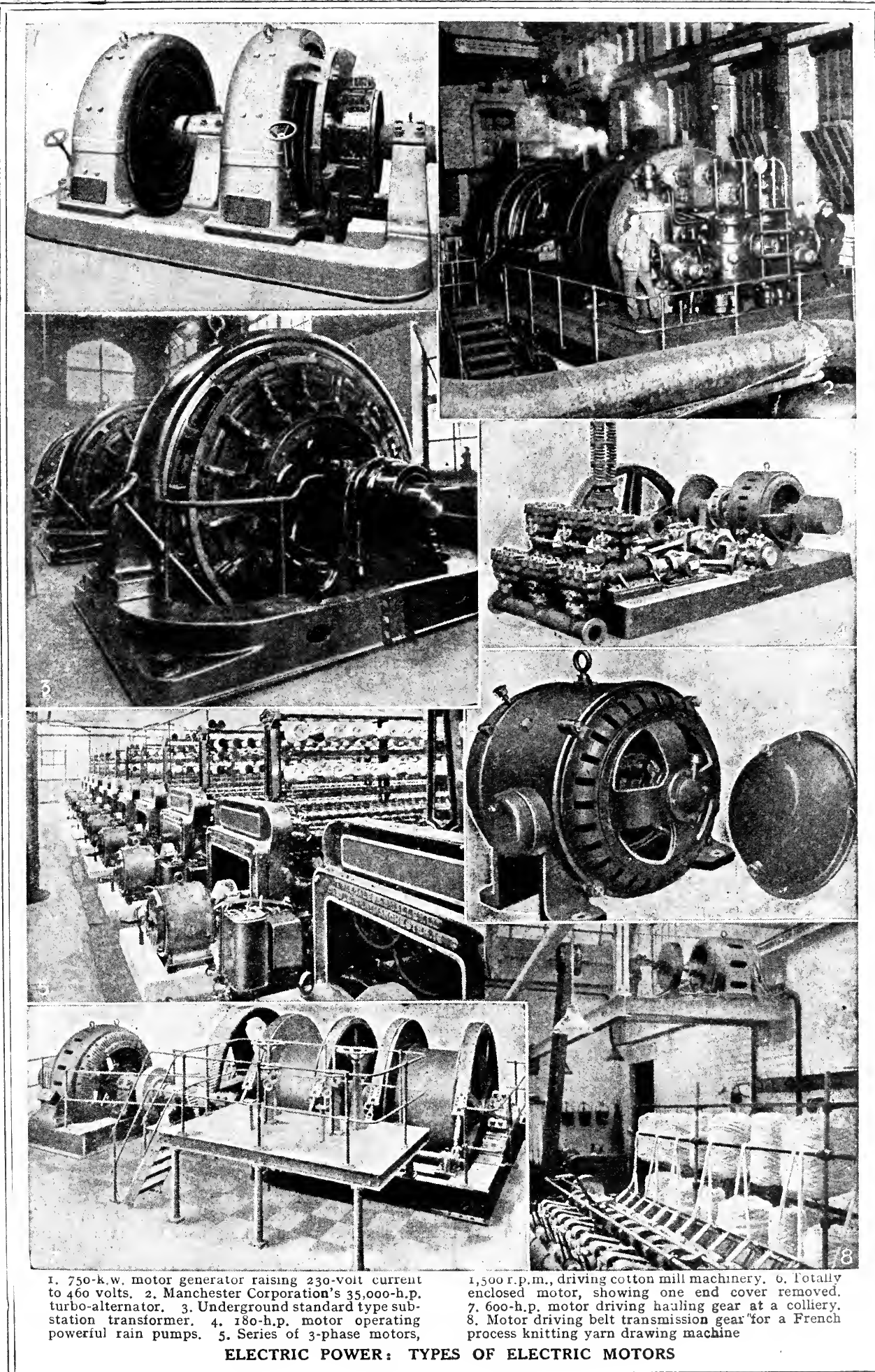


into the conductors for transmission may have to be "stepped down " at convenient points, and here the character of the current, as well as the strength, will have to be determined, that is whether continuous or direct, or alternating. Direct or continuous current, which has the advantage of simplicity, cannot be stepped down directly without the use of rotating machinery. In large systems this may be accomplished by the aid of substations to which high-tension current is transmitted from the central station, to be there let down by mechanical transformers to suit the local needs. Alternating current, on the other hand, may be stepped. down by the use of static transformers, which are automatic and require nothing more than a street box for their installation.

\section{The Hopkinson System}

An ingenious method of meeting the requirements where direct current is employed was devised by Dr. John Hopkinson, and is known as the three-wire system of distribution. This is illustrated in the appended diagram. A and B are two dynamos coupled in series, that is, the current from $A$ passes through B. C D are two mains or conductors constituting a primary

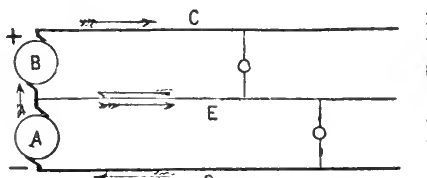

Electric Power. System of transmission devised by Dr. John Hopkinson. See text

circuit. If the voltage of each dynamo is 100 , the current put in to the main $\mathrm{C}$ will be at 200 volts : that is, the potential difference between $\mathrm{C}$ and D. But the current from A dynamo is going into the third wire $E$ at 100 volts, and the potential difference between $\mathrm{E}$ and $\mathrm{D}$ will therefore only be 100 , which will also be the difference between $\mathrm{E}$ and $\mathrm{C}$; and consequently any lamps between $\mathrm{E}$ and $\mathrm{D}$ or $\mathrm{E}$ and $\mathrm{C}$ will be receiving current only at that voltage. A further subdivision by means of additional wires is sometimes arranged.

Except for tramlincs, where the current is mostly carried by the familiar overhead lines, local transmission and distribution is carried almost universally in Great Britain by conductors placed underground. The conductors may be simply wire or cables thoroughly insulated and protected against damp or mechanical injury, and laid in the ground under the footpath. In more elaborate schemes, groups of conduits composed of earthenware pipes are prepared.

The pipes are carefully cemented together to exclude water, and a number are left empty for future use. At suitable points the conduits are interrupted and provision is made by which access can be got down to them. The cables are pulled through these conduits from point to point, and in order that they may stand the severe usage to which they are subjected in being drawn through the conduits, they are encased in lead.

Apart from the main transmission conductors, there will usually be laid supplementary conductors known as feeders. These convey current to some more or less distant point of a main conductor, and compensate for whatever may have been taken from the main up to that point by distributors. In large systems where extended areas are to be served, and a great variety of demands have to be satisfied, the transmission and distributing network may become very complex. To meet such cases, alternating current at high tension, ranging from 1,000 to 6,000 volts, is being employed at several stations in this country. At one London station the current, alternating, is generated and transmitted to sub-stations at 10,000 volts; at the sub-stations it is stepped down by motor generators (see Motor, Electric) to 400 volts continuous current, which is supplied to users for power at that tension, and, by means of the threewire system, to users of light at 200 volts.

\section{Long Distance Transmission}

For long distance transmission alternating current is almost invariably employed, because of the facility with which it can be lowered by the aid of stationary transformers ; while the current is usually three-phase on account of the economy of copper required for transmission. The most remarkable transmission system in the world to-day is in the state of California, U.S.A., where current generated by water power at Big Creek is transmitted to Los Angeles, a distance of $240 \mathrm{~m}$. From the great stations of Niagara, current is transmitted locally at 2,250 volts, but is sent into Buffalo 16 miles away at 11,000 volts. A remarkable system is in operation in the south of France, where continuous current is used at 58,000 volts. See Current, Electric; Dynamo; Volt.

Electric Wave. In an insulated conductor carrying a charge of electricity, the charge will be distributed in a regular manner over its surface, and if another conductor be brought near it the dis. tribution of the charge will be al tered, say negative at the one end, positive at the other. If now the second conductor be suddenly removed the original charge will return to its former distribution, but not at once. Before the original condition is reached the charge will oscillate along the conductor, positive and negative each rushing from one end to the other and then back again.

These oscillations are extremely rapid and quickly die away. This movement suggests that of a wave, but it is not strictly of that character. But if two conductors be discharged by a spark there will again be oscillations set up between the terminals of the conductors, with this differencethe charge thus liberated sets up disturbances in the surrounding medium which are in the nature of true wares and go on travelling through space. These waves have been found to possess all the optical properties of the waves of light, and can be reflected, refracted, and polarised. These facts were demonstrated in 1888 by Heinrich R. Hertz, who succeeded in producing electro-magnetic waves by means of " oscillators" in such a way as to permit him to trace their propagation through space, which he found went on at the same velocity as that of light. See Light; Wireless.

Electro - Ballistics.

Determination of the velocity of projectiles fired from guns by electrical methods, the success of which depends upon the fact that the time taken for an electric current to travel along a wire over any such distances as those covered by the range of even the most powerful guns, is inappreciable.

The appliances used consist of frames of light "wire mesh electrically connected with a chronograph. One such frame is placed near the muzzle of the gun that is to be tested, as close up as may be so long as it is far enough away to be unaffected by the blast of the discharge. The frame is placed in the line of flight of the projectile; the resistance offered by the wire mesh to the projectile is negligible. A similar frame is placed at a measured distance from the gun also in the line of flight ; or a series may be placed at measured intervals. When the gun is fired the projectile crashes through the wire mesh, the electrical arrangements come instantly into action and the exact moment is indicated by the chronograph. It is only necessary to compare the times recorded by 


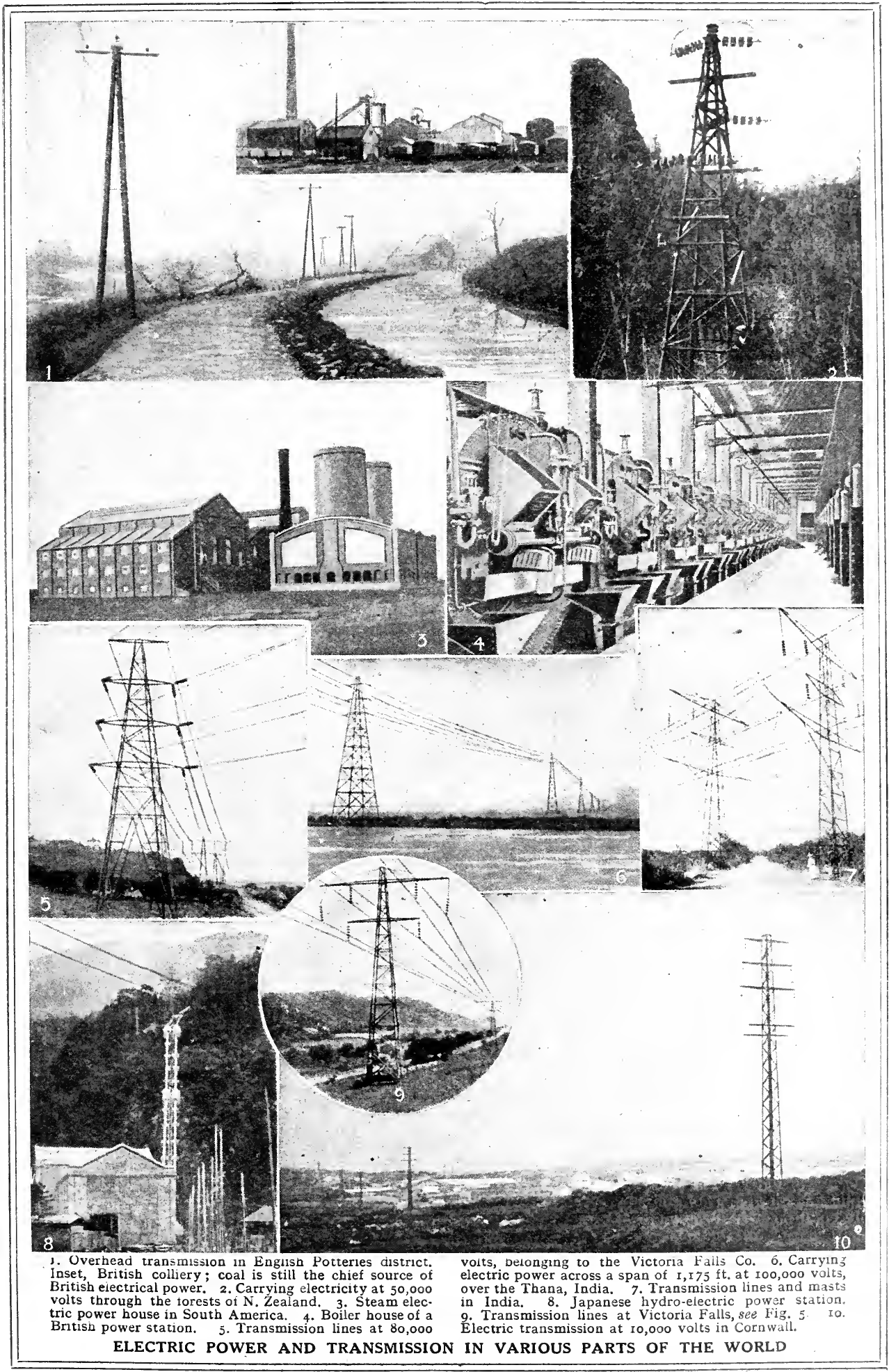


the two or more instruments in order to determine the time of flight and the velocity. By analogous arrangements fitted in the barrel of the gun itself the velocity of the projectile from the instant when it begins to move in the barrel till it leaves the muzzle are determined. See Artillery; Gunnery.

Electro-Chemistry. The determination of chemical reactions, that is to say, the splitting up of bodies into their elements or into other compounds and the forma. tion of new bodies, by the aid of electricity. Like most other branches of science, it has two sides, the purely scientific or theoretical, and the applied. That an intimate relation existed between the two branches of physics, chemistry and electricity, was suspected by the early electricians; its existence was demonstrated when the two Dutch scientists, Deimann and Paets van't Troostwyk, at Haarlem in 1789, first decomposed water into its elements by the aid of electric sparks between the ends of two wires in a glass tube, though

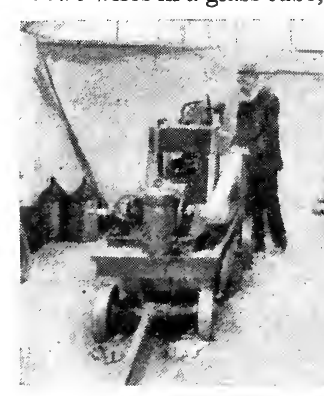

they did not succeed at the time in collecting the separated gases, i.e. oxygen and hydrogen.

The discoveries of Volta and the classical experiments of Sir Humphry Davy placed the new science on a firm basis, though it was not till 1834 that the true laws of electro-chemical action were explained by Faraday. Helmholtz, in 1847 , suggested that the heat of chemical reaction in a voltaic or galvanic cell could be entirely transformed into electrical energy, a proposition that was further developed by Thomson (Lord Kelvin) in 1851 Since then further researches by many eminent scientists, particularly Van't Hoff, Arrhenius and Sir J. J. Thomson, have only confirmed the profoundly intimate nature of the relationship between chemistry and electricity.

The chemist has long had his conceptions of the molecule and the atom and of the constitution of matter; but the electrician has now suggested that what has hitherto been described as matter may after all only be a particular form of electricity. It has been shown that when copper deposits itself out of a solution of copper sulphate on a piece of iron wire introduced into the solution, the action is really electrical; and the question is suggested whether what has hitherto been called "chemical affinity" is not a form of electrical action. By either of these two forms of energy we are able to develop heat and light ; and each is able to accomplish ends which, to our present knowledge, the other is not able to achieve; and it is certain that if we ever obtain any definite conception of the constitution of matter and the real nature of the atom, it will be reached by the aid of electro. chemistry.

On the practical or industrial side electro-chemistry has given us the art of electro-plating and of electro-deposition generally, embracing the electrical refining and smelting of metals; many metals, such as sodium, potassium, aluminium, magnesium, which could not otherwise be produced on an industrial scale; the electrolytic production of caustic soda and potash, chlorine and bleaching powder; of cyanamide and other ammonia compounds, nitric acid, and artificial fertilisers such as "nitrolime." N or

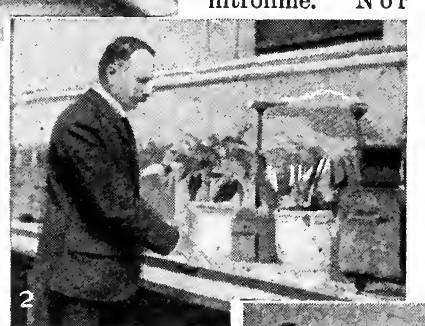

is its scope confined to the production of inorganic co mpounds; chloro. form, chloral, and jodoform are now being manufactured by its aid, as well as certain dyes. It is being utilised to facilitate the processes of tanning, a current of electricity being passed through the tanning pits and causing the process to be com. pleted in a much shorter time. For purifying sewage, ageing wines, and preparing ozone, electricity is coming more and more into daily commercial use.

Electro-Culture. Study of effects of electricity on plants. Currents of certain low strengths appear to be beneficial to plants; strong currents soon cause their collapse ; while currents of inter. mediate strengths apparently set up no particular reaction. The idea of utilising an electric current, either through the ground or in the atmosphere, to stimulate the growth of plants or increase their yield, was preceded by the idea of stimulating the growth by electrifying the seeds themselves before planting. The Abbé Nollet, the French philosopher, about 1760, Berthollet, and Specnew experimented in this direction, apparently demonstrating that electrified seeds generally germinated earlier and gave higher yields, and that a larger proportion of the seeds germinated.

There are three directions in which electricity has been applied to growing plants; by the setting up of electric currents in the soil, by electrically exciting the atmosphere, and by providing artificial light. The question as to which is the better of the two first systems is not yet determined. Careful experiments carried out under the direction of the Agricultural Department of the U.S.A. have shown that currents set up by zinc and copper plates placed in the soil near the plants and connected by wires have much in creased the yields of tomatoes, peas, beets, turnips, carrots, parsnips, and lettuce; but upon the whole the American experiments suggest that an electrification of the atmosphere produces still better results. Electric light, if shielded properly so as to cut out the ultra-violet rays, gives much

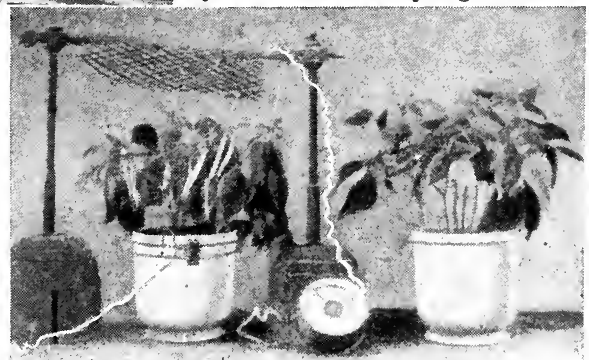

Electro-Cultnre. Scenes at Prof. D. Berthelot's experimental station at Meudon, near Paris. 1. Plant for supplying the electric current. 2. Inspecting progress. 3. French beans grown, left, by electro-culture; right, nnder natural conditions 
quicker and increased yields ; lettuce benefiting in so remarkable a way that the system has been adopted commercially in the States for the production of forced lettuce for supplies when the ordinary product is not available. Alternating current would appear to be better than direct or continuous when used to electrify the atmosphere.

In Great Britain important experiments have been carried on for some years, particularly in the $\mathrm{S}$. of Scotland, and have given very remarkable results. The method chiefly employed has been to electrify the atmosphere immediately above the plants by means of a network, or rows, of wire stretched from poles at a height of about $7 \mathrm{ft}$., through which a current of electricity was passed at a tension of not less than 50 volts. The current is not continuously applied, but is given for an hour or two at a time at regular intervals. In 1916 one acre in a field of nine acres under oats was so treated, with the result that the electrified acre gave a yield of 20 bushels of grain, say $840 \mathrm{lb}$,, over the average yield of the rest of the field; while the yield of straw was increased by over 80 p.c.

Hence it would appear that the possibilities in connexion with electro-culture are very great; but so far it has not been shown that the process is likely to be commercially successful when carried out on a large scale. The cost of the current is considerable, and the cost of installing and maintaining the plant is high. In countries, however, where, owing to abundant water power, electricity can be produced very cheaply, as in Scandinavia, Switzerland, the S. of France, Italy, Tasmania, the nor. thern and western states of America and Canada, and probably India, it is possible that electro-culture could be successfully practised over considerable areas. See Agriculture; Crops.

Electrocution. American term for death from electrical shock. It is an attempt to combine the old term execution with the word electricity, but it is expressive and has now taken its place in the English language. Electrocution of criminals was proposed with a view to avoiding the more revolting and objectionable features which are necessarily associated with any me. thod of hanging, and still more with decapitation, and was first adopted by the state of New York in 1890 , the first criminal to be electrocuted being William Kemmler, who suffered this penalty, Aug. 6 of that year. The method has since been adopted by other states of America.
In carrying out the sentence the condemned criminal is seated in a special insulated chair, to which he is firmly strapped. A cap is placed on his head covering his eyes, and containing a metal plate which forms an electrode of the electric circuit. The criminal's head is shaved sufficiently to permit a firm and close contact to be made ; the other electrode, another metal plate, is strapped to the leg; the current thus passes through the whole body, and while three shocks are usually given, there appears to be no doubt that on the passing of the first shock, which is only of two or three seconds dura. tion, death is instantaneous and quite painless. The strength of the current used varies from 1,800 volts down to 200 volts. See Capital Punishment.

Electrode. Term applied to the terminals of an electric cell. Faraday distinguished the one by which the current enters the cell as the anode, and the one by which it leaves the cathode. In an electro-plating bath, the articles being plated constitute one of the electrodes of the bath. The term is also applied to the two carbons of an electric are lamp and the terminals of an electric furnace, where one may be a rod of carbon, and the other the metal container of the furnace cell.

Electro-deposition. This subject is considered under three heads : electro-plating or electrogilding, in which one metal is permanently deposited on another, either for protection against wear or corrosive action, to give a cheaper metal the appearance and some of the properties of a more valuable one, or for ornamentation ; secondly, electro-typing, in which a metal is deposited on a surface from which it is afterwards removed; and thirdly, electrometallurgy, where metals are refined by causing a pure element to be deposited on a metallic surface while foreign elements are rejected in an electrolytic bath. The physical action on which all these processes depend is described under electrolysis, while the processes themselves are dealt with under their respective headings.

Electrodynamics. Term used for the study of the laws of electricity in motion. It first came into prominence through $\mathrm{A}$. $M$. Ampère's treatise and investiga. tions in 1820, when he laid down the fundamental laws which govern the science. He announced that parallel conductors containing electric currents flowing in the same direction attract one another, and repel when the current is flowing in opposite directions. See Current, Electric.

Electrokinetics. Term applied to that branch of the science of electricity which treats of electricity in motion or current electricity, as distinguished from electrical charges merely, which are the sphere of electrostatics. It is a modern form of the older term electrodynamics.

Electrolier. Name for a pendant or type of hanging fitting for use with electric lamps. See Lighting, Electric.

Electrolysis. Decomposition of liquids by electric current. The liquid which undergoes such action is described as an electrolyte. In the case of water it may be entirely decomposed into its two elements, oxygen and hydrogen, the gases being liberated at opposite sides or ends of the apparatus-a cell-in which the operation is carried out. In the case of solutions-such, e.g., as sulphate of copper in acidulated water-the decomposition may be only partial, while under suitable conditions, though decomposition goes on, the state of saturation

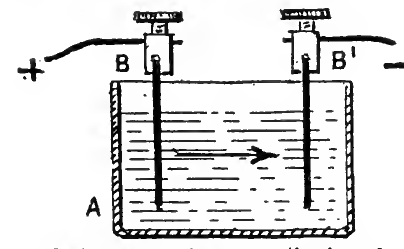

Electrolysis. Diagrammatic view of cell for decomposition of liquids by electric current. See text

of the solution will be maintained constant.

The elements necessary for the exhibition of this phenomenon are shown in the accompanying diagram, in which A is the container, which must either be of a material which is non-conducting electrically or be insulated so that the current of electricity will not pass through it, while $\mathrm{B}, \mathrm{B}^{1}$ are two conductors immersed in the liquid, each being provided with an arrangement by which it may be connected to a source of electricity. The combination constitutes a cell. The current enters the cell at B, which thus becomes the positive pole or anode of the element, and, after traversing the bath, escapes at $\mathrm{B}^{1}$, which is thus the negative pole or cathode, these poles being distinguished by + and - symbols.

If the conductors be two strips of platinum and the liquid water, then, when the current passes, oxygen is liberated at the surface of the anode and hydrogen at the surface of the cathode. The two gases may be easily collected by an 
arrangement indicated in the diagram, which represents the original voltameter. A and B are inverted glass test tubes, each having introduced into it at the bottom one of the electrodes. The tubes are first filled with the electrolyte-the water, which is usually slightly acidulated to facilitate the action - and when the current passes, the gases which are released at the surfaces of the electrodes rise to the top of the tubes and displace the liquid. Two notable points are to be observed here: the gases collect separately, and no action whatever is apparent in the body of the bath between the two tubes. But, obviously, when oxygen in the one tube is set free, hydrogen must be liberated at the same instant; the latter does not, however, collect side by side with the oxygen in the tube where it is separated, but by some invisible action passes out of that tube across the bath and appears in the other tube. Similarly, there must be a migration of the oxygen from the hydrogen collecting tube back to the oxygen tube. Thus one of the elements separated travels with the electric current and the other against it; to the former Faraday gave the name cation, meaning that which goes down, and to the latter the term anion, or that which goes up. No theory yet propounded fully explains the phenomenon indicated.

The phenomenon of electrolysis is not only profoundly interesting from the purely scientific point of view, but it has received industrial applications of the first importance. Electro-metallurgy depends largely upon it, and electro-chemistry wholly. The phenomenon may not, however, be always beneficial. In industrial practice the electric current is generated and caused to flow through the cells by means of a dynamo; but a current may be induced in the cell itself, as in the ordinary voltaic or galvanic batteries, by the employment of two dissimilar metals immersed in a suitable electrolyte. A current may even be set up between two metals of the same kind, provided there be a slight difference in their molecular or chemical structure. Such a current may be very slight, but still sufficient to set up electrolysis if other conditions are favourable. Hence, in the case of machinery or metal structures immersed in water, or in solutions, we may have all the conditions necessary to set up electrolytic action and decomposition. See Cell; Electro-Chemistry ; ElectroMetallurgy: Voltameter.

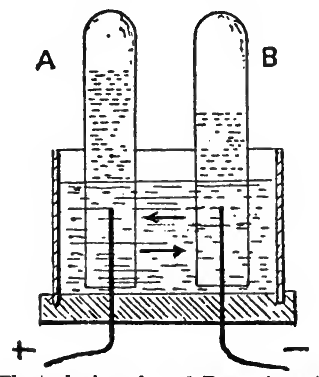

Electrolysis. $\mathbf{A}$ and $\mathbf{B}$ arc inverted test-tubes collecting the oxygen and hydrogen set free from water by electrolytic action

Electrolyte. Term given by Faraday to a substance capable of being electrolysed. It is thus the term by which the bath of an electrolytic cell is known; it may be either a solution such as a dilute acid, or of a metallic salt such as sulphate of copper, or it may be a mass of molten metallic compound. See Electrolysis.

Electro-Magnetism. Term used for the branch of science which deals with the connexion between electrical and magnetic phenomena. In 1819 Hans Christian Oersted (q.v.) discovered that a wire conveying an electric current is surrounded by a magnetic field, and that a freely moving magnetic needle sets itself at right angles to the wire carrying the current. Oersted's discovery was followed by the researches of D. F. J. Arago and A. M. Ampère and others, but it remained to Michael Faraday (q.v.) to show how to obtain electricity from magnetism, and thereby lay the foundations of the modern dynamo and the extensive electrical industry of the present day. See Dynamo; Electricity; Magnetism.

Electro-Metallurgy. The most important advance in metallurgy since the development of the Bessemer and Thomas-Gilchrist processes is represented by the application of electricity to the extraction of metals from their ores, and to metal refining. In its broad sense the term electro-metallurgy covers the entire field of the electrical treatment of metalliferous ores and the working of metals by electricity, and thus includes electro-plating, the use of the electric furnace, and electric welding, all of which subjects are treated under their respective headings.

Electro-metallurgy is an entirely modern art which sprang into life after the discovery by Volta of the galvanic cell in the first year of the 19 th century. Three different types of processes occur in this branch of metallurgy; first, those in which the action is purely electrolytic, i.e. does not depend on any heating effect of the electric current; secondly, those in which electrolytic action and heating are combined; and thirdly, those in which the effect desired is brought about solely by the heat developed by the electric current.

The first class of these processes is well represented by the electrolytic refining of copper, by which the larger portion of the metallic copper of the world is now produced, nearly the whole of the production of the U.S.A. being so treated. The principle of the process has been explained in the article electrolysis; in practice the material operated upon is either "blister" copper or converter

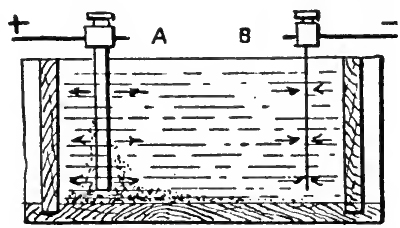

Electro-Metallurgy. Diagrammatic view of copper-refining vat. Spe text

copper (see Copper). Both contain considerable impurities, including gold or silver, and usually some of each, and the treatment may be either chiefly a pure refining operation or a process for the recovery of the precious metals, which are frequently present in sufficient quantities to pay for the cost of the entire treatment.

The operation is carried out in large wooden vats as indicated in the accompanying illustration, where $A$ represents a plate of the crude copper to be refined (the anode), and B, a very thin plate of the purest copper available, usually electrotype copper (the cathode). The bath in which the plates are suspended (the electrolyte) is a solution of copper sulphate in water acidulated with sulphuric acid, the whole forming an electrolytic cell. The electric current from a dynamo enters the cell at + , passes through the plate $A$, across the bath, up the plate $B$, and out at - . The current decomposes the solution, throwing out the copper which is deposited in a practically pure condition on the cathode, the thin copper plate. At the same time the plate of crude copper begins to be broken down; the copper goes into solution taking the place of that removed from the solution and deposited on the cathode; any iron and zinc present in the crude metal will also be dissolved; but the gold, silver, and frequently other metals present, while 
set free by the action, will not be dis. solved, but will settle to the bottom of the vat in the form of slime.

The action goes on so long as there is any copper left at the anode and the current is continued, or until the bath becomes "sick" with the dissolved impurities, when the current is cut off, the bath allowed to settle so that all the gold and silver may go down the liquid carefully decanted, and the slimes removed for separate treatment for the recovery of the precious metals. The cathode will have grown in thickness by the deposition of pure copper, and is removed for further treatment because, while it contains only minute traces of foreign substances-perhaps 4 or 5 parts in 10,000 parts of the metal-its physical condition is too spongy to allow it to be sent directly into the market It is, therefore, melted and cast into ingots, and appears in commerce in that form as electrolytic copper. The solution, loaded as it is with impurities, is usually thrown away.

The refining process is slow; it cannot be hastened beyond a certain limit without detriment to the quality of the finished metal the crude copper plates may weigh anything from $200 \mathrm{lbs}$. to $600 \mathrm{lbs}$. each, and the entire operation may require several weeks' time. A large refinery (there are now establishments turning out 50,000 tons of refined copper a year) contains a considerable number of cells which are formed into batteries, the cells in each being connected in series. In addition to the simple type of cell shown in the diagram, a more complex form is also used, in which a number of plates are suspended side by side. the crude and the pure plates alternating. The process is of great importance not only because it is a highly convenient method of obtaining copper, and economical especially where cheap water power is available for the development of electricity, but because of the remarkable purity which may be given to the finished metal, which makes it peculiarly suitable for electrical work.

"Base bullion," i.e. gold or silver collected in a mass of lead, is also refined by this process. The bullion is cast into thin plates, which are enclosed in muslin bags and made the anodes of a cell ; the cathode is a thin sheet of pure lead, and the bath is a solution of lead sulphate in sodium acetate. The lead of the bullion passes into solution, and then deposits on the lead cathode, leaving the gold and silver, and perhaps other metals, in the muslin bag in a form ready for subsequent treatment. The process in this instance may be regarded as a lead refining operation. Zinc is also refined on similar lines.

The Elmore process $\left(q . v_{t}\right)$ is a particular application of this principle of electro-metallurgy. The recovery of gold from a cyanide solution in the Siemens' modification of the McArthur-Forrest process is another example of this type of electro-metallurgical operations, only in this instance it is a case of the extraction of a metal from its ores, and not of refining. It has been proposed to apply this system to the extraction of other metals, particularly copper, from its ores, and while this has not been done on any considerable scale, the trend of metallurgical science is strongly in that direction, and there can be little doubt that this development will come in due course, particularly in regions where cheap water power, as in Tasmania, is available contiguous to the source of the ores. Mount Lyell mine already uses the electrolytic process in the treatment of its crude copper from the Bessemer convertor.

For the two other types of electro-metallurgical processes, i.e. those in which heat is an active agent either by itself or in combination with electrolytic action, what is essentially a furnace, and not merely a cell or battery of cells, is required. See Aluminium; Furnace.

Electrometer. Iustrument for measuring electricity. It is to be distinguished from indicators, such as ampère meter $\mathrm{s}$ (ammeters) and the volt meter, and also from electric meters, although all these instruments are used to measure electricity. These latter instruments, however, are the more permanent, practical instruments of industrial electricity power development and commercial supply. The electrometer, while it is continually being used for practical purposes and for certain determina. tions is indispensable, is more an instrument of research and of special and delicate tests and indications. Its purpose is to measure difference of potential, that is to say, electric pressure; it may be said to be a highly developed electroscope.
Various forms of electrometers have been proposed. Interesting designs are associated with the names of Dellmann and Peltier, but the first really effective instruments were introduced by Lord Kelvin, when Sir William Thomson. The instruments almost universally in use to-day are in all essentials of Kelvin's design. These are mostly two, the first being what Kelvin called the attracted-disk or trap-door electrometer, and the other the well-known quadrant electrometer.

The former consists essentially of a Leyden jar (q.v.) containing special provision for keeping its interior dry, in which are placed two parallel disks of metal, one fixed at the bottom of the jar and the other adjustable and suspended over the former in such a way that it can be moved closer to or farther away from the fixed disk as required. The fixed disk has near its centre a hole covered with a thin piece of aluminium constituting the trap-door and the indicator of the instrument. The trapdoor is attached to a fine platinum wire, and prolonged so as to have the form of a lever, the arrangement being such that it may be

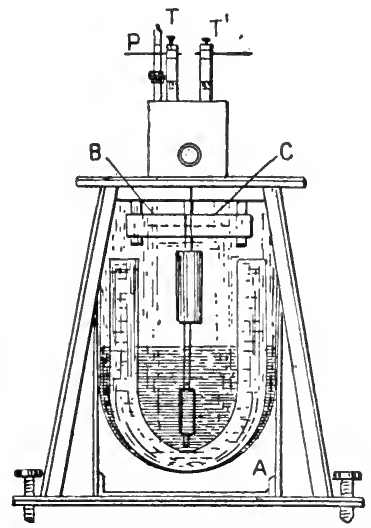

G

Electrometer. Kelvin's quadrant electrometer, showing ent as a whole and explanation see text

attracted by the adjustable disk above it when the electrical connexion is made. The potential difference is determined by the distance apart of the two disks when the trap-door is in a determined position and the current passing. This distance is read on minutely divided scales forming parts of the instrument.

Kelvin's quadrant electrometer is shown in its essential features in the views appended, showing one form of the instrument as a whole, and enlarged views of the quadrants and the enclosed needle. The body 
of the instrument is again, in effect, a Leyden jar A, the lower portion of which is filled with sulphuric acid, which serves four purposes-it acts as the inner coating of the jar, keeps the interior dry, and provides means by which the movement of the needle may be steadied, and by which the magnetism of the needle is permanently maintained. The outside of the jar is coated with foil in the usual way and the foil connected with the earth.

The jar is a powerful condenser of electricity, and exists to provide what may be called an electric atmosphere so powerful and steady that it will be unaffected by any electricity that may enter the instrument during any test. B, C, are two of the quadrants, the other two being removed in the upper lefthand Fig. so that the needle may be seen. They are secured to the frame of the instrument. The quadrants and the needle are shown on an enlarged scale in the Fig. They are small brass boxes with two open sides and are four in number. Opposite quadrants are joined by a wire, thus making them one electrically. The "needle" is a thin vane of aluminium-the lightest suitable material-with rounded ends as shown, anything in the way of a point which might tend to discharge the electricity of the vane being avoided. The needle is attached to a stiff platinum wire which is suspended by a silk fibre secured at the top of the instrument so that it hangs vertically with the needle floating horizontally as shown. The wire continues below the needle and ends in a vertical vane dipping in the sulphuric acid which serves to steady or " damp" the movement of the needle. $M$ is a small concave mirror attached to the wire, so that it revolves with the needle.

One pair of quadrants is connected with the terminal, $T$, and the other pair with $\mathrm{T}^{\mathrm{l}}$; these are the chief electrodes, and are connected to the two bodies, the potential difference of which is to be determined, one of the bodies being usually the earth. $\mathrm{P}$ is the charging electrode by which the jar is charged. When the circuit is completed the needle will turn horizontally in one direc. tion or another, according as to which pair of quadrants carries the higher potential. A ray of light falling on the mirror will be reflected through a narrow slit on to a scale some few feet away as the mirror turns in sympathy with the needle, the intensity of the potential being shown by the degrees over which the reflected ray travels on the scale. Various modified forms of this beautiful instrument are now in use. The torsion balance is also a form of electrometer. See Electroscope ; Meter, Electric.

Electron. Name given by Johnstone Stoney in 1891 to the "atom" of electricity, that is to say the smallest quantity that can exist by itself or can be transferred from one atom of matter to another. Electricity is supposed to consist of enormous quantities of such atomic particles all of equal dimensions. The electron is negative; and a charge of negative electricity on a body means that there is no accumulation there of electrons. An electron may exist by itself or in association with atoms or molecules of matter; but if there are such things as atoms of positive electricity they are always combined with atoms of matter.

The origin of the conception of the electron may be traced to a lecture delivered by Von Helmholtz in London in 1881 on the electrical theories of Faraday; but it was more immediately developed upon the discovery of the cathode rays of the late Sir William Crookes. The phenomena of these rays, as shown in a vacuum tube (q.v.) in which a discharge of electricity is taking place, can be best explained by supposing that, from the cathode of the tube, flights of electric particles or corpuscles proceed at tremendous velucities, all being negatively electrified with equal charges. These particles are electrons. The single charge of a negative ion in electrolysis is believed to be identical with the electron of the cathode rays. The electron has infinitely little weight and dimensions.

The diameter of a molecule of hydrogen is perhaps $1 / 42,000,000$ th part of an inch, but it is 140,000 times as big as an electron; while the weight of an atom of hydrogen, the lightest substance of which we have any actual knowledge, is from 1,800 to 2,800 times that of an electron. It will be seen that the electron is a philosophic conception; its value and interest lie in its usefulness in explaining the phenomena of electricity and matter. See Electricity ; Ion ; Radio-activity.

Electrophone. Term first applied by a French scientist, M. C. Ader, to a high tension electric sound-transmitting instrument of his design, intended to be used for the purpose of enabling conversation to be carried on through a submarine electric cable. It is now applied to the apparatus used in connexion with an ordinary telephone service for the purpose of enabling one to listen to a concert or theatrical performance or to a public speech which is being carried on or delivered at a considerable distance away. "By its aid a telephone subscriber, in London, for example, who is connected also with the Electrophone Exchange, may sit in his drawing-room in the evening and listen to any one of a number of theatrical performances going on at the theatres, and be switched off from one and put on to another as he may desire. The transmitters are usually fitted in sets of four near the footlights of the stage or platform, or in front of the speaker at a public meeting.

Electrophorus. The simplest device which has been introduced for the development of electricity. It was invented by the Italian scientist Alessandro Volta in $\mathbf{1 7 7 5}$, the general arrangement being shown in the accompanying illus. tration. It consists of a metal dish about a foot in diameter, called the sole-plate; a layer of some good non-conducting substance, glass, indiarubber, ebonite, or pitch may be used, but the usual material is resin; a metal disk, called the cover, rather smaller than the soleplate; and a glass rod attached to the disk and serving the purpose of a handle by which it may be lifted.

In using the apparatus the parts are usually first warmed to ensure that they are dry, and the resin base is then struck or rubbed with a piece of cat's-skin or other fur, or a piece of dry woollen cloth, and is thus electrically " excited," the charge of electricity developed upon it being negative. The metal upper plate is then placed on the resin base; it does not, however, receive from the resin any direct charge of electricity, but by induc. tion develops a charge of positive electricity on the surface of the disk where it is in contact with the resin and a charge of negative elec. tricity on the upper surface of the

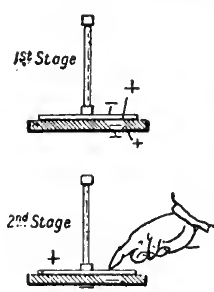
disk, as shown in the sectional illustration. If now the upper surface of the disk betouched by the finger and thus put into electrical contact with the earth, or " earthed," to use the technical expression, the negative charge of the disk will pass to earth leaving the disk positively electrified through. out, and if now Electrophorus, the simplest electricity maker. For explanation see text lifted away 
from the resin it will give a spark if the knuckle or any conductor be brought near it.

The sole-plate performs an important function by the mutual induction which takes place between it and the upper plate or cover. When the latter develops its positive charge on being put in contact with the earth, the sole-plate receives a corresponding negative charge from the earth, and in this way the original positive charge of the cover due to the negative charge of the resin base may become an appreciable amount. The electrophorus may be worked almost indefinitely, i.e. every time the cover is put back on the base and its surface touched with the finger the action takes place and a spark may be obtained when the cover is lifted.

An arrangement has been devised by which the connecting of the cover with the earth is performed automatically. In this form of the instrument the cover is fitted with a strip of tinfoil which makes contact with the sole-plate when the cover is laid on the resin, so amounting to the same thing as connecting the cover with the earth through the finger. Nothing is created by the action of the electrophorus, although something appears to be. The initial charge of electricity is due to the mechanical energy expended in rubbing the resin, supplemented by the mechanical energy expended in lifting the cover. The influence electrical machine may be regarded as a mechanical electrophorus acting on the same principle.

Electro-plating. The deposition of a metal on another sub. stance, usually another metal, by electro-chemical action, either for the purpose of protecting the latter metal from corrosion, as when iron is electro-plated with copper, or for the purpose of giving to a comparatively cheap metal the appearance and some of the properties of one more costly, as when a teapot of Britannia metal is plated with silver. The art is based upon the discoveries or inventions of Volta and Galvani in connexion with electro-chemical action at the end of the 18th century. The first application of those discoveries to plating appears to have been made by Jacobi, at St. Petersburg, who, in 1838, published a description of his process of reproducing line engravings on copper by galvanic action. A similar application was made about the same time in Great Britain by .Thomas Spencer, of Liverpool, by whom shortly afterwards the first electro-plating business was started.
The scientific principle upon which the art is immediately based is described in the article on electrolysis. The operation can be carried out on a domestic scale with small and simple apparatus; but when carried out on a commercial scale a large vat or bath is used, constructed usually of stout wood lined with lead or slate, though sometimes asphalt or cement is used, or the vat may be built of enamelled iron. It is usually rectangular in shape, and is fitted with a flange round the top, to which are attached two rectangles made of brass tubing, one being a little larger all round and fixed a little higher than the other, as shown in the illustration. The rectangles, and the vat itself, are insulated both from one another and from the earth.

The outer ring is used to take the current into the vat, and is therefore known as the anode ring; the current passes out through the other rectangle, the cathode ring. The bath is filled with a solution which varies according to the nature of the work to be done. The electric current is furnished either by a dynamo or by an electric battery. The articles to be plated, when of convenient size, are suspended in the solution by means of wires from crossbars resting on the cathode ring; while plates of the metal which is to be deposited on the articles are suspended from similar bars resting on the outer or anode ring. The arrangement enables a considerable number of articles to be placed in one vat together with an appropriate number of anode plates, which may be disposed along the brass rectangle as most convenient.

A simple example will serve to illustrate the entire process, whatever the metal that is to be deposited. Let it be supposed that a teapot of pewter or other alloy is to be plated with silver. The teapot is first made as nearly as possible chemically clean, which is done

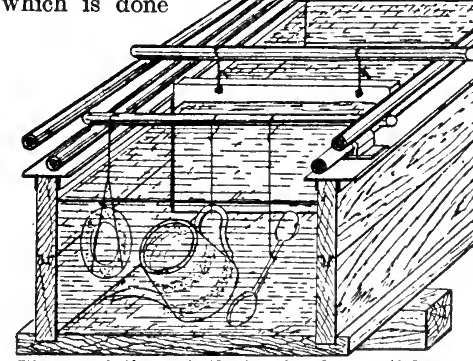

Electro-plating. Bath showing how articles are electro-plated with silver by first boiling it in an alkaline solution to remove grease, washing freely in water, dipping in a nitric acid solution, washing again, after which it is "quickered " by dipping in a solution of nitrate of mercury in order to deposit a film of mercury on the metal, which assists the deposition of the silver. The wire to suspend the teapot in the bath is attached immediately after the dipping in the mercury solu. tion in order that the teapot need not be again touched with the hands. The teapot is suspended in the vat from one of the crossbars of the cathode ring, as shown in the figure. The solution is prepared from cyanide of potassium and cyanide of silver precipitated from nitrate of silver, in water. It contains $1 \mathrm{oz}$. of silver to the gallon.

The anode plate is of commercially pure silver ; it is, of course, connected with the positive terminal of the dynamo or battery. When the current passes, the silver in the bath is thrown out of solution and deposited on the teapot, while at the same time an equal amount of silver is dissolved off the anode plate, and, entering into solution in the bath, takes the place of that deposited on the teapot. The process goes on so long as the current is maintained, until the anode is entirely dissolved or until as much silver has been deposited on the teapot as is desired, when it is stopped. The time occupied ranges from two hours to twelve or even longer, according to the work to be done and the thickness of the deposition or plating required. The amount actually deposited on such an article as a teapot is about $1 \frac{1}{2} \mathrm{oz}$. per square foot of surface covered, the thickness of ordinary writingpaper. The teapot, as it leaves the bath, has a fine granular-looking surface of chalky whiteness. The smooth, bright finish of the shops is given by polishing with wire brushes kept moist by stale be er, after a thorough washing in plain water, dipping in boiling water, and drying in not sawdust.

While silver is the chief metal used in electroplating, ot hers commonly em. ployed are copper, nickel, and gold. Gold-plate is usually silver electro-plated with gold. During recent years the practice of plating iron with copper has greatly developed; 
while the use of nickel. plated articles both of ornament and utility is rapidly extending. The process is precisely the same as that which has just been described in the case of the teapot; the only differences being in the solutions and in the anode plates employed, which must be prepared according to the metal to be deposited. In some cases a preliminary plating is given to promote the deposition and adhesion of the final plating metal. 'Thus, when iron or steel articles are to be nickel-plated they are first given a coating of copper. Such nickel-plated articles are now largely used for military weapons, household utensils, and parts of bicycles, motor-cycles, and motorcars. Other metals occasionally deposited include tin, on iron cast. ings; and iron, on engraved copper plates or on electrotypes to give harder surface so as to permit a greater number of impressions to be taken. See Electrolysis.

Electroscope. Term given to an instrument universally employed in the study of electricity for the purpose of determining whether a body is electrified or not, and if so, the character of the electrification, whether positive or negative. In its simplest form it consists of two small balls of pith suspended by silk threads from the arm of a metal stand, as shown below. An almost equally simple form is represented by the balanced needle, similar to the needle of a mariner's compass, devised by Dr. Gilbert of Colchester in 1600 .

The usual

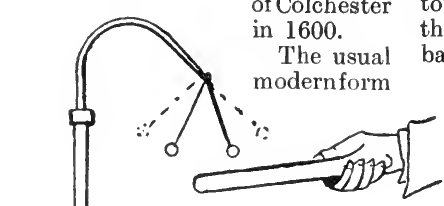
touch the strips of foil they lose jar commonly fitted with a brass ring round the bottom or fitted to a wooden base so as to be easily removable. The jar has a stopper of ebonite in which is fitted a stout brass wire with a removable plate or ball at the top, and from the bottom of which two strips of gold or aluminium leaf depend. Opposite each strip and within reach of its end is a strip of tin foil attached to the interior surface of the jar. To ensure the dryness of the interior of the jar when very delicate determinations are to be made, a shallow dish containing sulphuric

acid may be placed within. A glass been rubbed, if brought cause the leaves to repel one another; in their charge to the earth, and fall back into their normal positions.

In Volta's condensing electroscope the normal plate of an electroscope is enlarged and a second is prepared to rest upon it as shown; the under surface of the latter is well varnished to insulate it from the lower; the upper surface of the latter may also be varnished. The two plates make a condenser. In using the instrument one or other of the plates is charged by means of the body to be tested while the

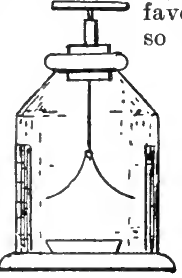

Electroscope

Modern form of deaf elec- into the plate or pels the same which fly apart in accordance with ricities repel and unlike attract. kind of electricity on an object, the oscope is first charged by glass rod that has been rubbed with diverge under the influence of posibe brought near the plate and the leaves diverge still further, the body
is electrified positively; if the leaves close, it has a negative sides of the jar are used to prevent the lcaves from being damaged by the violence with which they are repelled or from adhering to the

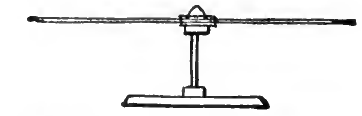

Electroscope. Balanced needle type invented by Dr. Gilbert of Colchester other is connected to earth; they thus receive charges of opposite kind. If now the upper plate be raised the charges become intensified in accordance with the principle of the electric condenser, the one becoming more strongly the well-known law that like elecsilk, which causes the leaves to whose character is to be determined negative and the other more strongly positive, with the result that an extremely weak charge will be detected by the divergence of the leaves.

By means of this instrument Volta demonstrated that the contact of dissimilar metals in air gave rise to opposite kinds of electrifica. tion. The electroscope has rendered valuable service in the study of radio-activity and of the character. istics and properties of atoms.

Electrostatics. Term applied to that branch of the science of electricity which is concerned with electricity at rest or with electric charges, and is particularly occu. pied with the measurement of such charges. The science deals alike with the most elementary facts of electricity, such as the phenomena exhibited by a rubbed glass rod, and with the profound problems associated with the electrical rela. tions of atomic particles.

Electrostatic machines are machines for the conversion of mechanical work into electric energy and are of two kinds, frictional and influence machines. Ramsden's plate electrical machine belongs to the former class, and Wimshurst's well-known appa. ratus to the latter.

Electrotyping. Particular form of electro-deposition. It differs from electro-plating in that the metal deposited does not become an intrinsic portion of the article on which it is laid, but is removed

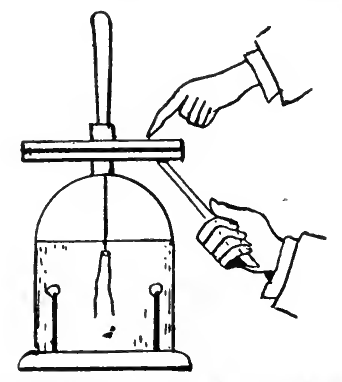

Electroscope. Volta's condensing electroscope

from the latter after it has been deposited ; its object is not to encase or permanently cover one metal with another, but to make a copy of a surface. It is largely used for making reproductions of coins and medals and other works of art, and for preparing "electrotypes" for printing, both from typed matter set up in the usual way and from engraved surfaces in wood or metal. Electrotype is the term given to the product of the process.

If a reproduction of a medal is required, and the original is not too 
valuable to be risked in the deposit. ing solution, it may be used as the cathode of the operation. It is prepared by having a wire twisted round its edge leaving sufficient length for attaching to the terminal of the electric battery or machine. The face which is not to be copied is embedded in guttapercha; the face to be reproduced is slightly greased with olive oil by means of a fine hair brush, to prevent a too powerful adhesion of the deposited metal, after which the medal is ready for the bath.

The solution is prepared according to the metal to be deposited, usually copper; after from twelve to twenty-four hours the deposit will have acquired the necessary thickness, probably about 0.015 in., and the medal will be removed from the bath, when the electrotype may be detached. If now a mould be taken of this electrotype, and then another electrotype taken off that mould, the second electrotype will be a duplicate of the face of the original medal. In a similar way a duplicate of the other face of the medal may be obtained, when the two halves may be trimmed and soldered together, making a complete reproduction of the original, which may then be electro-plated, if required, with any appropriate metal. In this way the copies of rare or historic coins and medals in museums have been made.

If the original coin or medal is too precious to be risked in the electrotype bath a plaster cast will be prepared, or, better, a mould in gutta-percha by the aid of pressure, which is indeed precisely the process followed in the preparation of an electrotype from a forme of type. The type is first thoroughly cleaned, dried, and blackleaded, one object of the latter being to prevent too firm adhesion of the deposited metal. A shallow tray is filled with a molten mixture of beeswax, turpentine, and plumbago, and the surface, when set, blackleaded. The forme of type is then forced into this mixture by pressure and a mould thus produced. This mould is coated all over with plumbago, and has a copper wire embedded in it all round the impression which is to be reproduced in order to increase the conductivity of the mould when in the bath, the wire being connected with the terminal of the vat, in which the mould becomes the cathode.

The anode is a plate of copper and the solution is copper sulphate. A powerful current is used to give a rapid deposition and secure the necessary thickness in the shortest possible time. When the electro- type is finished in the bath it is removed and separated from the wax bed by melting the latter in hot water, after which it is laid face down on an iron plate, heated, surrounded by a frame of iron bars, and "backing" metal poured over it to a depth of from $\frac{1}{4}$ to $\frac{3}{8} \mathrm{in}$. It is then trued up on a steel plate by hammering till perfectly flat, trimmed, and mounted on a wooden block to make it "type high"; or if it is to be used on a rotary printing machine it is bent by rollers to the required curva. ture. If many impressions are to be taken the electrotype so prepared may be "steel faced" by having a deposit of iron given to it by a separate operation in the electrolytic bath. While still important, improvements in the art of stereo. typing have deprived the electro. type of some of the value which at one time it possessed. See Electrolysis ; Printing.

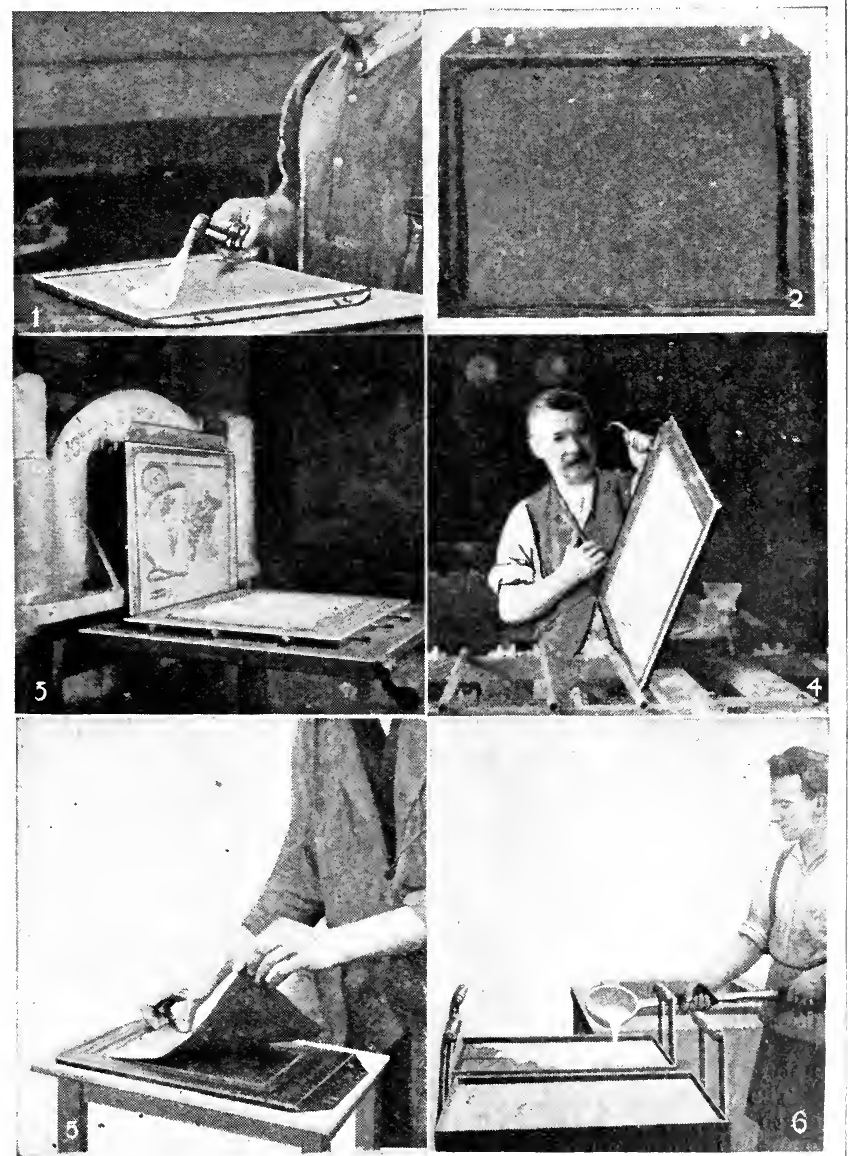

Esectrotyping. 1. Smoothing out the wax. 2. Wax mould in position. 3. Wax impression from block. 4. Copper shell on mould when taken from the battery.

5. Peeling copper shell from mould. 6. Pouring in backing of molten lead

Electrum. Term at various times applied to different materials. In ancient days it was given to amber, in the Middle Ages to common brass, in modern times to an alloy of copper 8 parts, nickel 4 , and ziue 3.5 (sometimes the nickel is 6 parts), a beautiful artificial silver with a bluish tint much used for the manufacture of drawing and other instruments; also to an alloy of copper, zinc, and tin, and to native minerals containing gold and silver, the latter running from 20 p.c. to 50 p.c. An alloy of gold and silver ( 15 p.c. to 35 p.c. silver) known by this term, of a pale yellow colour, hence the association of the term with amber, was much used by the early Greeks and Romans for ornaments and coins; the earliest coins known were made of it; while rods having 651 parts gold and 334 silver in 1,000 were used as money in Asia Minor. See Metallurgy. 
Elegy (Gr. elegos). .. Originally a threnody or lament written in elegiac metre, each couplet in which consisted of a hexameter and a pentameter. The theme of such songs varied, the term being employed for the form rather than the spirit. In modern literature the elegy has mostly been associated with the spirit rather than the form, and has come to be understood as a short mourning, or memorial song, usually a tribute to an individual, but sometimes of a more generally mournful character, as in the case of Gray's Elegy Written in a Country Churchyard, 1751.

Earlier poets used the term with wider significance, as when Donne described a series of his amatory poems as Elegies and labelled his memorial poems specifically Funeral Elegies. Although there were earlier memorial poems of distinction, such as the beautiful anonymous The Pearl (14th century) and Chaucer's Book of the Duchess (c. 1369), these can hardly be strictly described as elegies owing to their length and treatment. Some of the more notable elegies in English are Spenser's Daphnaida, 1591 (on Lady Douglas), and Astrophel,1595 (on Sir Philip Sidney); Milton's Lycidas, 1638 (on Edward King); Shelley's Adonais, 1821 (on John Keats); Tennyson's Ode on the Death of the Duke of Wellington, 1852 (his In Memoriam is rather a series of elegiac poems than an elegy); Matthew Arnold's Thyrsis, 1867 (on Arthur Hugh Clough); Swinburne's Ave Atque Vale, 1867; and William Watson's Lachrymae Musarum, 1892 (on Tennyson). See Poetry; consult also English Elegies, ed. J. C. Bailey, 1900 .

Element (Lat. elementum, first principle). In chemistry, a simple substance which as yet has not been decomposed further by any method of ultimate analysis. The earliest elements, as stated by Aristotle, were not actual substances, but rather properties or conditions of matter. Aristotle called earth, water, air, and fire elements, and the alchemists added others, such as salt, sulphur, and mercury. Boyle first defined an element in its present sense, and Lavoisier compiled the first list of 23 substances which could not be resolved into simpler forms. The number is now 83 , and there are possibly others, not included, as the evidence of their elementary nature is not conclusive.

The whole mass of the globeearth, water, and air-and the planets is made up of these elements and compounds formed of them. The earth's crust, for examplc, consists to the extent of about 50 p.c. of combined oxygen, and of silicon, the next most plentiful element, to the extent of about 30 p.c. Some elements, on the contrary, such as radium, are very rare, but the evidence of their elementary character has been satisfactorily established. New elements are discovered chiefly by examining newly found minerals, the spectroscope being employed for the purpose.

The composition of the sun and stars is also determined by the spectroscope. In recent years groups of elements were discovered by Sir William Crookes in the rare earths, by Sir William Ramsay in the atmosphere, and by other workers as the result of the discovery of radium by Pierre Curie. The alchemists strove to transmute baser metals into gold, but, so far as is known, never succeeded in doing so. Sir William Ramsay, however, advanced evidence in regard to the radio-active group of elements to show that transmutation or disintegration actually takes place. It is not unreasonable to suppose that these examples of transmutation in comparatively short periods may by analogy be supposed to be taking place in other elements now regarded as stable. See Chemical Signs; Earth.

Elemental Spirits or ANGELS of the Elements. Spirits supposed to rule over the four elements of fire, water, air, and earth. The Jewish Kabbalists and the Gnostics of early Christian days largely developed this idea and introduced a host of minor angels or spirits who had charge of departments of the four great elements, such as wind, rain, etc. Hence arose an elaborate system of angelology not unlike demonology, but generally beneficial or at least harmless in its influence. In the Middle Ages, the spirits of fire were known as Salamanders; those of water as Nixies or Undines; those of air as Sylphs; those of earth as Gnomes. The name Salamander survives as that of a batrachian reptile supposed to be capable of living in fire.

Elemi. Resinous exudation from a plant the botanical source of which is still undetermined. Probably the plant is Canarium commune. The resin is imported from Manila and is of a pale yellow colour resembling stiff honey in consistence. It has an odour which reminds one of fennel. Elemi was formerly used in medicine as a stimulating application to wounds.

Elephant (Gr.-Lat. elephas). Family of large, hoofed mammals, surpassing in size all existing animals except the whales. Only two species now survive, the African and the Asiatic, though several others are known in the fossil state. The feature which distinguishes the elephant from all other mammals is the development of the nose into a long flexible trunk, used by the animal in conveying food to the mouth, and also for drawing up water which is afterwards squirted down the throat.

In respect of dentition the elephant is unique among animals. The incisors, which are only found in the upper jaw and are two in number, are developed in the male, sometimes in the female also, into a pair of long curved tusks. These tusks are quite different from those of the boar and other animals, which are simply large canine teeth. The elephant has no canines. Only two cheek teeth or molars, on each side of both jaws, are ever in use at any one time; but four others exist beneath the gums. These teeth are of great size, and the sur. face consists of a large number of transverse ridges of enamel. As these molars become worn out they are replaced by the reserve teeth, which grow through the gum.

The ponderous body of the elephant is encased in thick wrinkled skin, covered sparsely with coarse hair in the young animal but almost bare in the adult. The legs are massive, and the knee joints are much lower down than in most hoofed animals. This causes the elephant, when lying down, to rest with the hind legs bent much in the fashion of a kneeling man, while the fore legs are thrust out in front.

The head is enormous, and suggests the presence of a large brain. But this appearance is deceptive. The brain is curiously small for the size of the animal and is placed at the back of the head, the huge skull consisting of a mass of bone completely honeycombed by cells, an arrangement which provides for the attachment of the great jaw and trunk muscles without making the skull so heavy as to be a burden.

Elephants are entirely vegetar. ian in diet, feeding on the leaves and twigs of trees and on grass which they gather by the aid of their trunks. Trees are often uprooted by pressure with the head for the purpose of feeding on the branches. Where force is required, the elephant relies upon leverage with the tusks or pressure with the skull. The trunk is a delicate sense organ for smell and touch, and the animal is always careful to keep it out of the way of rough usage. When an elephant holds a heavy weight it rests it on the tusks or holds it with the teeth, using the trunk only to steady it. 
The Indian elephant is easily distinguished by its massive bulbous head, comparatively small ears, and the presence of four nails on the hind feet. It is dark grey in colour, but is occasionally more or less blotched with white. This elephant is rarely much more than $\mathbf{9} \mathrm{ft}$. high at the shoulder. It has been known to live in captivity for over a century, and in the wild state probably attains a much greater age.

The African elephant has a smaller and narrower head, very large fanlike ears, and only three nails on the hind feet. The molar teeth present differences in structure from those of the Indian species, and the trunk has two finger-like processes instead of one. It also attains a greater height, has longer legs, and a generally less heavy and clumsy appearance. Owing to continuous destruction

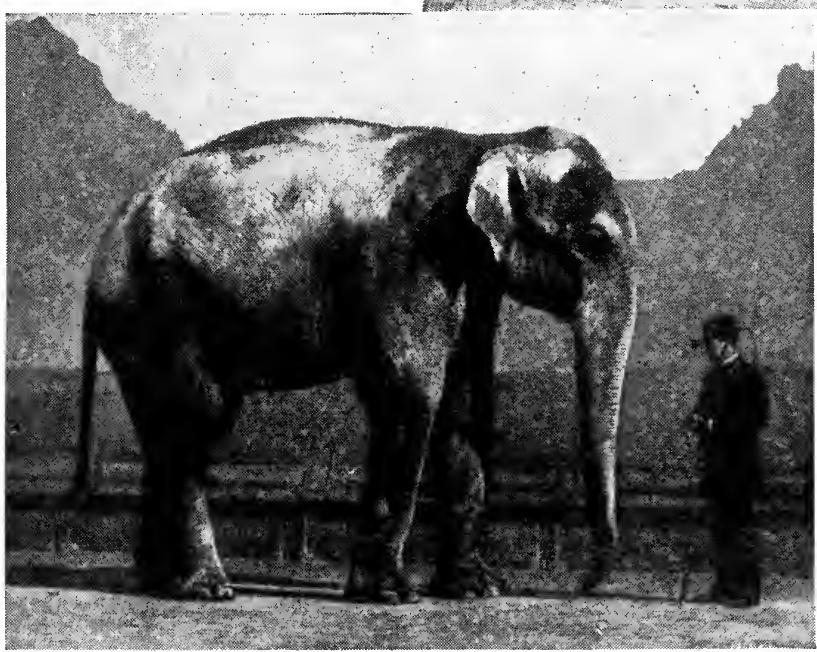

Elephant. Specimen of the Asiatic elephant in the Zoological Gardens, London, showing the whitish markings characteristic of this species. Above, African elephant

Photo of Asiatic elephant by Gambier Bolton, F.Z.S.

for the sake of its tusks, the African elephant has been greatly reduced in numbers. This elephant is of more savage disposition than the Indian species. Economically the African elephant is valued for its ivory, the Indian for its qualities as a draught animal.

In 1917 two mature specimens, male and female, of dwarf African elephants were brought to England. They measured about $5 \mathrm{ft} .6$ ins. to $6 \mathrm{ft}$. in height. See illus. facing p. 428.

Elephant. Island of the South Shetlands, Antarctica. The most northerly of the group, it lies S.E. of Cape Horn and Drake Strait.

Elephant, ORDER OF THE. Danish order of knighthood refounded in $\mathbf{1 4 5 8}$ from an earlier institution, light blue watered silk.

Elephant and Castle. Design found in early MSS. and in mediearmed men into battle were used in the East from immemorial days. They were first encountered by the

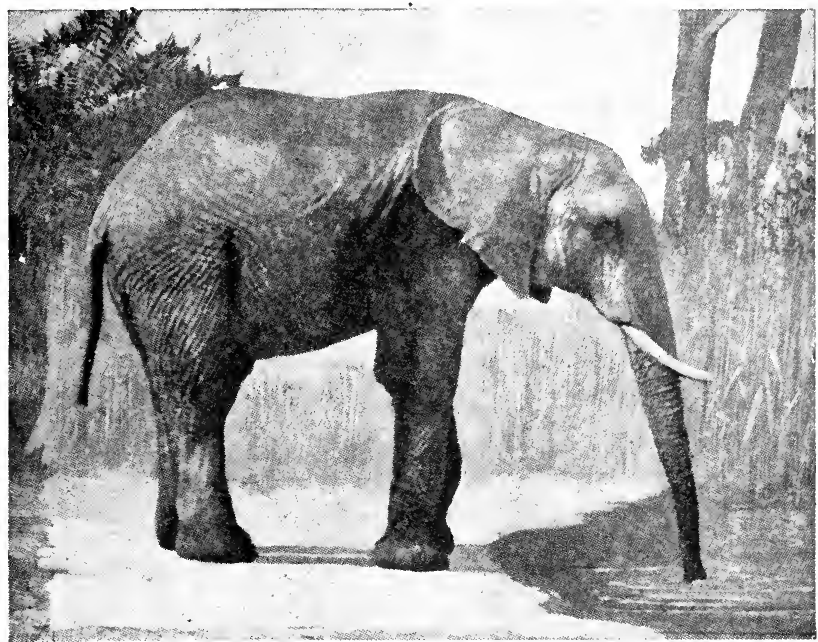

Romans during the war with Pyrrhus in the 3rd century B.c. Polyaenus records that an elephant carrying archers in a houdah led the advance when Julius Caesar forced the passage of the Thames nea r Chertsey in 54 B.C.

Caesar Fred. erick, a Venetian merchant of the 16th

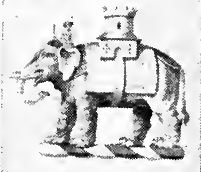
that the king of Pegu had 4,000 war elephants with castles on their backs, and the Cutlers' Company, who had a large trade in ivory, adopted the animal so castled as their crest.

Elephant and Castle. London tavern in the met. bor. of South wark, $1 \frac{1}{4} \mathrm{~m}$. from Ludgate Hill. The name is now applied also to the district of which it is the centre. The tavern stands at a point from which six thoroughfares radiate: New Kent Road, Walworth Road, Newington Butts, St. George's Road, London Road, and Newington Causeway. See London.

Elephanta or GHARAPURI. Island in Bombay Harbour, India. From $4 \mathrm{~m}$. to $4 \frac{1}{2} \mathrm{~m}$. in circumference, it consists of two long hills. It was so called by the Portuguese from a large stone elephant. The island is famous for its caves or rock temples, supposed to date from the 9th century. See illus. p. 1799.

Elephant Apple (Feronia eleval times. Elephants carrying phantum). Large evergreen tree of the natural order Rutaceae. A native of Coromandel, it has glossy leaflets and white flowers. The fruit is as large as an apple, with a hard, woody rind containing 
seeds embedded in pulpy flesh. The pulp is eatable, and is made into a jelly; it is also useful in dysentery and diarrhoea. The wood is hard and beavy but not durable. The tree exudes a gum from wounds.

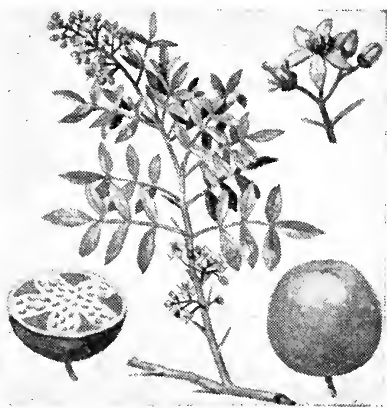

Elephant Apple. Leaves, flower, and fruit, showing arrangement of seeds within the fruit

which forms a constituent of what is known as Indian gum-arabic.

Elephantiasis OR BARBADOES LEG. Disease characterised by chronic inflammation of the fibrous connective tissue, resulting eventually in excessive swelling of the leg, scrotum, arm or breast, and less frequently other parts. The condition is due to obstruction of the lymph circulation, most often caused by infection by a parasite worm, the filaria.

The disease, which was recog. nized in ancient times, probably originated in Asia, and has spread thence to Africa and America. It is now most often seen in India, Ceylon, China, Japan, the Philippine Islands, Fiji, Samoa, many parts of Africa, the S. United States, Central America, the West Indies, Brazil, and Peru. Its distribution is influenced by that of mosquitoes, but the exact conditions governing its transmission have not yet been determined.

Elephantiasis frequently begins with high fever, pain in various parts of the body, and swelling of the extremities. The swelling may abate after the first attack, but in subsequent attacks the limb becomes more and more swollen until eventually it may attain an enormous size. Treatment is not very satisfactory. Castellani and Chalmers state that the best results are obtained by keeping the patient in bed and injecting fibrolysin daily for three to six months.

Elephantinē. Island in the Nile at Assuan, Upper Egypt. Marking the $S$. limit of ancient Nile navigation, it contained the Old King. dom frontier station, $\mathrm{Abu}$, or elephant town, an entrepôt of the Su. danese ivory trade. On the W. Nile bank opposite are rock-hewn tombs of Old and Middle Kingdom governors. Under Thothmes III, Rameses II. and other kings, its governor controlled the Assuan granite quarries. During the Persian supremacy there was a Jewish garrison, with a temple of Jehovah here. Aramaic papyri, recovered 1901 and 1906-8, elucidate 5th century life. An interesting object is the nilometer, recently renovated, which dates from the Ptolemaic period.

Elephant Seal (Macrorhinus). Large species of seal. It is called sea elephant because the nose is prolonged into a short proboscis in the adult male. Large specimens attain a length of $20 \mathrm{ft}$., and the girth is about equal to the length.

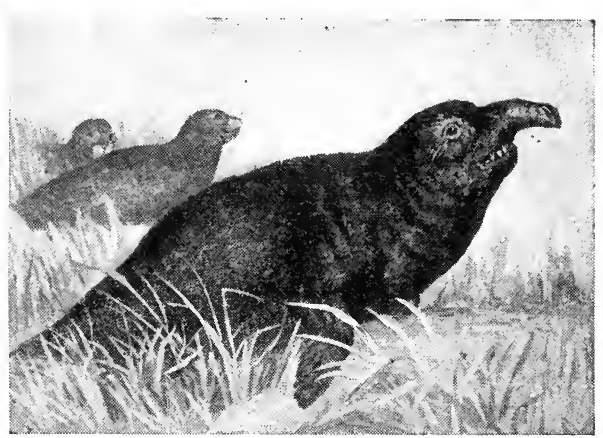

Elephant Seal, or Sea Elephant, a large marine animal found in the Indian and Soutbern Oceans

These animals are found only in the Indian and Southern oceans.

Elephant's-foot, HotTentot Bread, or Tortoise Plant (Testudinaria elephantipes). Perennial climbing herb of the natural order Dioscoreaceae. It is a native of S. Africa. The huge rootstock (as much as $4 \mathrm{ft}$. across) is covered with a corky bark, ultimately

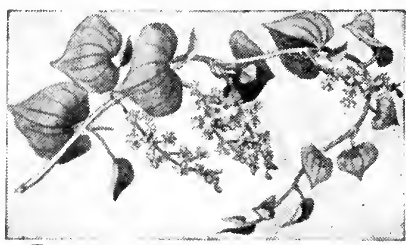

Elephant s-root. Leaves and tlowers ot the S. Atrican climber

cracked into angular protuberances. It contains a store of starch, eaten by the Bushmen. The slender stems climb to a height of $30 \mathrm{ft}$. or $40 \mathrm{it}$., and bear small heart-shaped leaves and sprays of tiny greenishyellow flowers.

Elephant Shrew (Macroscelides, long-legged). Name sometimes given to the jumping shrew, owing to its long and trunk-like nose. They are small African in. ger-fashion at sectivores, and have the hind legs so long in proportion to the body that they look rather like miniature kangaroos. They are nocturnal in habit, feed mainly on insects, and proceed by a series of leaps.

Elephas Primigenius or MAMмотн. One of the extinct elephants, almost identical with modern elephants, but differing in greater de. velopment of curly tusks, and in the woolly hair. It was far more widely distributed than the modern elephant, remains being found in America, the bed of the North Sea, the Thames Valley, within the Arctic Circle, and in the frozen earth of N. Russia. See Mammoth.

Eletz. Town in S. Russia, in the govt. of Orel. It stands on the Sosna, $105 \mathrm{~m}$. E. of Orel, at the junction of several rlys. There are leather, flour, soap, stearine, and candle factories, tanneries, and iron foundries. Con siderable trade is done in grain, cattle, leather, and iron. The chief in. dustry is linen weaving; the women are expert lace makers. Eletz, mentioned in 12th century chronicles, was long the chief town of a principality conquered by Tamerlane. Pop. 58,000.

Eleusine. Genus of grasses of the natural order Gramineae. Natives of warm regions, they are distinguished by the flower spikes being arranged fin. the top of the stem. As a genus they are of little im. portance, but E. coracana is grown in $\mathrm{Ja}$.

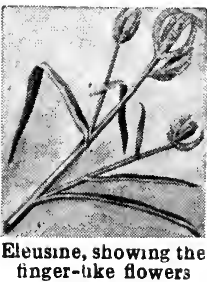
par and on the Coromandel coast, its large seeds being used as corn.

Eleusinia or Eleusinian MYs. TERIES. Festival held in honour of the nature goddess, Demeter, more especially that held at Eleusis in Attica in Sept. each year. Only those who were properly initiated were allowed to take part in the rites. The precise nature of the rites is not known, as they were never divulged in ancient times, though the festival continued till nearly A.D. 400 . They were doubtless symbolical of the death of $\mathrm{Na}$. ture in autumn and its rebirth in spring. See Demeter: Mystery 
Eleusis. Ancient city of Attica Said to have been founded by Triptolemus (q.v.), it stands on the Bay of Levsina, $12 \mathrm{~m}$. N.W. of Athens, with which it is still connected by the old causeway called the Sacred road. It was the chief seat of the worship of Demeter, in whose temple the Eleusinia were performed. During the Persian Wars this great temple was destroyed, but soon rebuilt, additions being made by Pericles, and later by Demetrius Phalereus. Still further enlarged by the Romans, the city continued intact until it was destroyed by the Goths under Alaric in A.D. 396. Eleusis was the birthplace of the great tragic poet Aeschylus, and after the Peloponnesian War its citadel was seized by the remnants of the Thirty Tyrants (q.v.). Though the site is strewn with ruins, little of the temples but two porches remain, with a sacred well, a council hall, and lesser temple. Eleusis, later Eleusin, is now represented by the village Levsina, lying $15 \mathrm{~m}$. by rly. N.W. of Athens, chiefly inhabited by Albanians.

Eleuthera. Island of the Bahamas. It is $50 \mathrm{~m}$. N.E. of New Providence, and is separated from Great Abaco by the Providence Channel. Long and very narrow, it is fertile and produces cascarilla, oranges, pineapples, onions, and tomatoes. The capital is Governor's Harbour, with a good, fortified harbour. Area, $235 \mathrm{sq}$. m. Pop. 6,533.

Elevation. In architecture and engineering, the vertical view of a building, machine, or other object drawn to scale, but ignoring per.

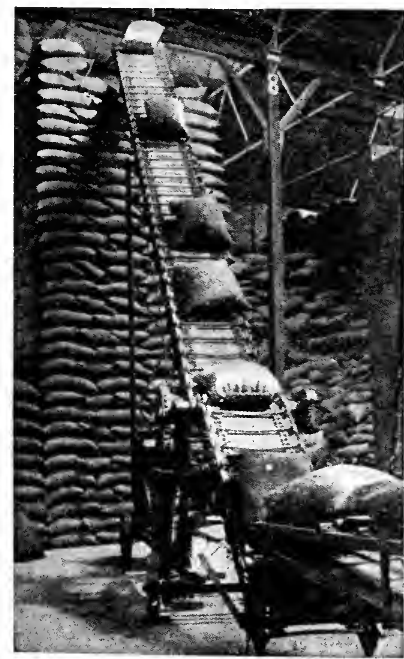

Elevator. Interior of a grain elevator ; belt conveyer stacking sacks of grain

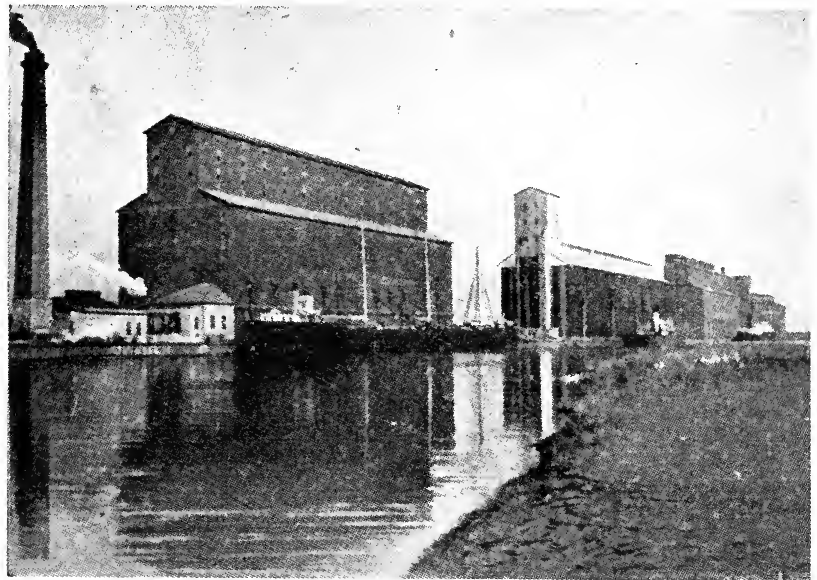

Elevator. Grain elevator on the Canadian Pacific Railway at Fort William, Lake Superior, Ontano

spective. In astronomy it is the a bucket elevator, which carries it angular height above the horizon to the distributing floor at the top of a star or other celestial object; of the building. Here it is received and in gunnery the angle between the axis of the gun and the horizontal. See Gunnery.

Elevator (Lat. elevare, to lift up). In aeronautics, the flap, or hinged controlling surface, which governs the speed of the aeroplane to which it is fitted by raising or depressing the nose of the machine. It is usually mounted at the rear of the machine, and is operated by the fore and aft movement of the control lever. The elevator is also employed in steep banks or sharp turns to bring the machine round. When the elevator is moved downwards by pushing the control lever forward it presents its surface to the air stream at an angle which sets up increased resistance. A lifting effect is thus produced at the tail of the machine where the elevator is fitted; the machine rises at the tail and tilts down. wards at the nose. To make the aeroplane rise, the elevator is tilted upwards. The air resistance is now felt at the upper surface of the elevator. It is consequently pressed downwards, and with it the tail of the machine, while the nose rises. See Aeroplane.

Elevator. American name for a grain silo or store. It contains a number of deep vertical bins, circular, hexagonal, or square in plan, and constructed of steel plates or reinforced concrete; and is equipped with elevating, cleaning, distributing, and discharging apparatus. On arrival the grain is emptied by means of a bucket or pneumatic elevator into a receiving chamber, whence it passes downwards, through an automatic weigher and a cleaning machine, to on a system of belt conveyers and is rapidly delivered into one of the bins. These have conical bottoms and are self-emptying. Trucks are run under them and loaded directly or the grain is transferred to ships by belt conveyers, or through spouts. The largest silos have a capacity of several millions of bushels; will take in $40,000-$ 50,000 bushels an hour, and discharge 100,000 bushels and upwards in the same time. A lift for goods or passengers is sometimes called an elevator.

Elf. Small being common to the folklore of most countries of northern Europe. Grimm says that an elf comes as much short of human size as a giant towers above it. The white elves are well formed and symmetrical, the black ugly and misshapen. The latter mostly work underground at their forges, and, like their white brethren on the earth's surface, take pleasure in teasing mankind. If left undisturbed they maintain peace with service; but if interfered with re-

Elves are generally gifted with wisdom and sometimes with divination. A common characteristic of the elf was his power of becoming invisible, frequently by means of a cloak or cap: thus, Siegfried in the Nibelungs Song has an invisible cap which he obtains from Alberich, the elf-king. In most stories elves are peculiar to the earth and underguishable from the forge-working dwarfs and gnomes of the moun. tains; while in others they are associated with light and flowers, men and delight in doing them taliate with mischief. ground, and are scarcely distin- 
and blend in the more general term of fays and fairies. There have been attempts to link the elf tradition with a primitive northern people of small stature.

Flint arrow-heads were called elf-arrows or elf-bolts from an idea that they were weapons of these little people. They are worn as amulets (Ancient Etruria, Italy), and reproduced for sale (Mecca). In Ireland water poured over them is given to cattle. Other things associated with them were elflocks, hair matted together by them in mischief, or as they wore it; elf-child, a changeling; elfknot, the hole in a piece of wood from which a knot has fallen, being the hole through which an elf can pass; night-elf, the nightmare; elf-light, will-o'-the-wisp ; elf-lay, an enchanting fairy song. See Folklore.

Bibliography. The Fairy Mythology, T. Keightly, rev. ed. 1847; Teutonic Mythology, J. L. C. Grimm, Eng. trans. from 4th German ed. J. S. Stallybrass, vol. iv, 1888; Testimony of Tradition, D. MacRitchie, 1890.

El Fasher. Capital of Darfur, in the Anglo-Egyptian Sudan. It is about $200 \mathrm{~m}$. N.N.W. of $\mathrm{El}$ Obeid, the W. terminus of the Sudan Government rlys., and is a caravan centre with considerable trade.

Elgar, SIR EDward (b. 1857). British composer. Born at Broadheath, Worcestershire, June 2,

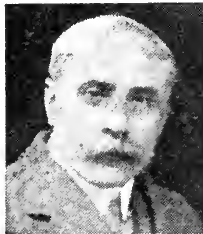

Sir Edward Elgar. British composer Hoppe

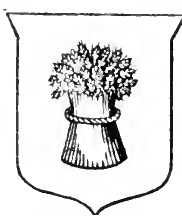

Elgin arms
1224, burnt down in 1270 , rebuilt, and again destroyed by fire in 1390 by the Wolf of Bade. noch. Restored to greater magnificence, it was wrecked by the

fall of the central tower, 1711 .

Remains exist of the bishop's palace, a royal castle, and monas-

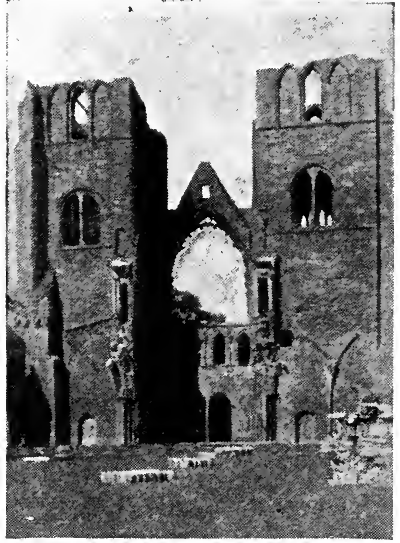

Elgin, Scotland. The western towers of the ruined cathedral. viewed from the chancel end

teries of Blackfriars and Greyfriars; the Greyfriars chapel was restored by the third marquess of Bute. Woollen manufacture, ironfounding, and tanning are indus. tries. A park of over 40 acres was presented by G. A. Cooper in 1903. Market day, Fri. The shire is more usually known as Morayshire (q.v.). Pop. of mun. burgh, 8,656 .

Elgin. City of Illinois, U.S.A., in Kane co. On the Fox river, which supplies power for the industrial establishments, it is $36 \mathrm{~m}$. W.N.W. of Chicago by the Chicago, Milwaukee, and St. Paul Rly. Dairy farming is an important local in dustry, and the city has large watch factories and manufactures condensed milk, flour, boots, shoes, and shirts. There are several hospitals and a public library. Settled in 1835 , it was granted a city charter in 1854. Pop. 28,560.

Elgin, Earl of. Scottish title held by the family of Bruce since 1633. Sir Edward Bruce, master of the rolls under James I, was made a baron in 1601, and his son Thomas was made earl of Elgin and later an English baron. The 2nd earl was made earl of Aylesbury in 1663. In 1746 the direct line failed, and there was a division of the titles, the earldom of Elgin passing to Charles Bruce, 9 th earl of Kincar. dine, whose successors have borne the double title. Thomas Bruce, 7 th earl of Elgin and 11th earl of Kincardine, a general in the army and ambassador at Brussels, Berlin, and Constantinople, is remem. bered as the collector of the Elgin Marbles (q.v. ). His son and grandson served the state in various high capacities. The family seat is Broomhall, Fife, the earl's son is known as Lord Bruce, and the earl sits in the House of Lords by virtue of a barony created in 1849 . Pron. Elg-in.

Elgin, James Broce, 8TH EarL of (1811-63). British diplomatist. Born in London, July 20, 1811, son of the 7th earl, whom he suc. ceeded in 1841, he was governor of Jamaica from 1842-46, and governor. general of Canada from 1846 - 54. He was raised to 8th Earl of Elgin, peerage in 1849. In 1857 he was sent as envoy to China to demand reparation for the seizure of the British lorcha Arrow, and on the way out diverted his troops to assist Lord Canning in the Indian mutiny. He negotiated the treatise of Tientsin and Yeddo in 1858, and in China again in 1860 secured the ratification of the treaty of Tientsin. In 1862 and 1863 he was viceroy of India, where he died Nov. 20, 1863. See his Letters and Journals, 1872; Lives, J. G. Bourinot, 1905; G. M. Wrong, 1905.

Elgin, Victor Alexander BrUce, 9TH EARL OF (1849-1917). British statesman. Born at Montreal,

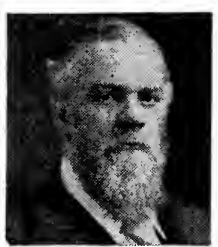

9th Earl of Elgin, British statesman Elliott \& Fry May 16, 1849 , when his father was governor. general of Canada, he was educated at Glenal m o n d, Eton, and Balliol College, Oxford. In 1863 he succeeded to his father's es. tates and titles, these including the earldom of Kincardine. With Gladstone he became a Home Ruler, and in the government of 1886 was treasurer of the household and first commissioner of works From 1894-99 he was viceroy of Iñdia. In 1902 he was chairman of the royal commission appointed to inquire into the preparations for the Soutb African War, and later of the one that reported on the ecclesiastical crisis in Scotland, caused by the 
judgement of the House of Lords on the property of the Free Church. In 1905 Campbell-Bannerman made Elgin colonial secretary, but he did not retain this office when Asquith became premier in 1908, refusing then the marquessate offered him; his cautious policy and freedom from partisanship had not been altogether acceptable to the extremists in his party. $\mathrm{He}$ died at Broomhall, Fife, Jan. 18, 1917, when his eldest son (b. 1881) became 10th earl of Elgin and 14th earl of Kincardine.

Elgin Marbles. Collection of sculptures brought from Greece by the 7 th earl of Elgin, while ambassador to the Porte. Keenly interested in the remains of ancient art in Athens and other Greek towns, his first intention was to have accurate drawings of them made, but seeing that they were fast going to ruin, he obtained the Porte's sanction to remove various relics. These consisted largely of sculptures by Pheidias and other great artists from the Parthenon and the temple of Nike A pteros (Wing. less Victory) in Athens. Despite enormous difficulties, including the wreck of the ship conveying the precious cargo to England, the Elgin Marbles (as they were afterwards collectively called) were brought to London in 1806. Added to in later years up to 1812 , they were finally acquired for the British nation in 1816 for $£ 35,000$, less than half of the sum $(£ 74,000)$ Lord Elgin had paid to preserve them from total destruction, and are now in the galleries of the British Museum. Lord Elgin was accused of van. dalism, and even dishonesty, but

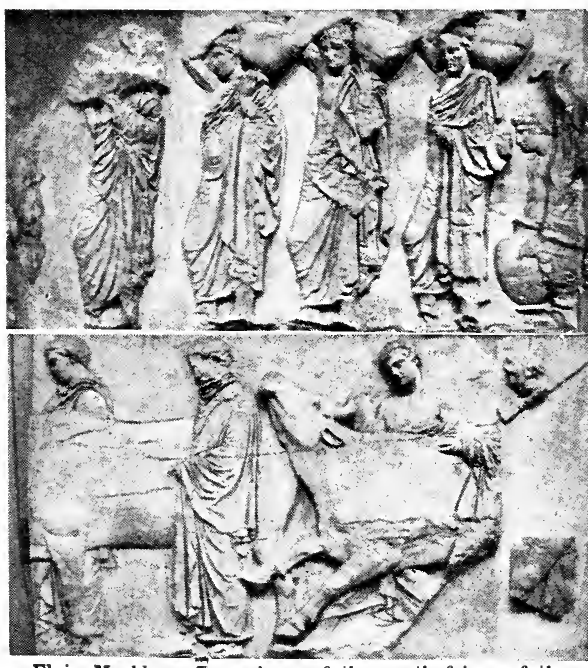

Elgin Marbles. Two views of the north frieze of the Parthenon, now in the British Museum the select committee of the House of Commons appointed to investigate the whole subject entirely exonerated him. See illus. p. 643 .

Elgon. Extinct volcano, 14,097 ft. high. It stands on the frontiers of Uganda and Kenya Colony, 60 m. N.E. of the Victoria Nyanza. The rivers on the $W$. side drain into Lake Kioga, those on the E. into the Victoria Nyanza. The forest (about 50 sq. m.) on Mount Elgon is little known.

Eli. Judge and priest of Israel in the later period of the Judges. Through Samuel, who was in his service as a boy attendant, God indicated his anger at the misdeeds of Eli's sons. When the news came that the Ark of the Covenant had been taken by the Philistines, and both his sons killed, Eli fell back and broke his neck.

Elia. Name taken by Charles Lamb. It was that of a clerk in the South Sea House, and was first assumed by Lamb when in 1820 he began to contribute essays to The London Magazine. See Essays of Elia ; Lamb, Charles.

Elibank, BARoN. Scottish title borne since 1643 by the family of Murray, and now merged in that of Viscount Elibank. Patrick Murray, a person of importance in Selkirkshire, where Elibank is situated, and on the Scottish borders generally, was made a baronet in 1628, and a baron by Charles I in 1643. His title passed to his son Patrick in 1650, and then down a line of descendants, of whom George, the 6th baron, became an admiral. In 1871 Montolieu Fox Oliphant (b. 1840) became the 10th baron, and in 1911 he was made a viscount of the United Kingdom, His eldest son, Alexander, was made Lord Mur. ray of Elibank in 1912, after serving as chief whip of the Liberal government ( $s e e$ Murray). Of Vis. count Elibank's younger sons, Gideon had a long record of service under the colonial office, and Arthur was chosen M.P. for Kincardineshire in 1908 , and was reelected in 1910 and 1918. The latter won the D.S.O. in the Great War.

Elie. Police burgh, parish, and watering-place of

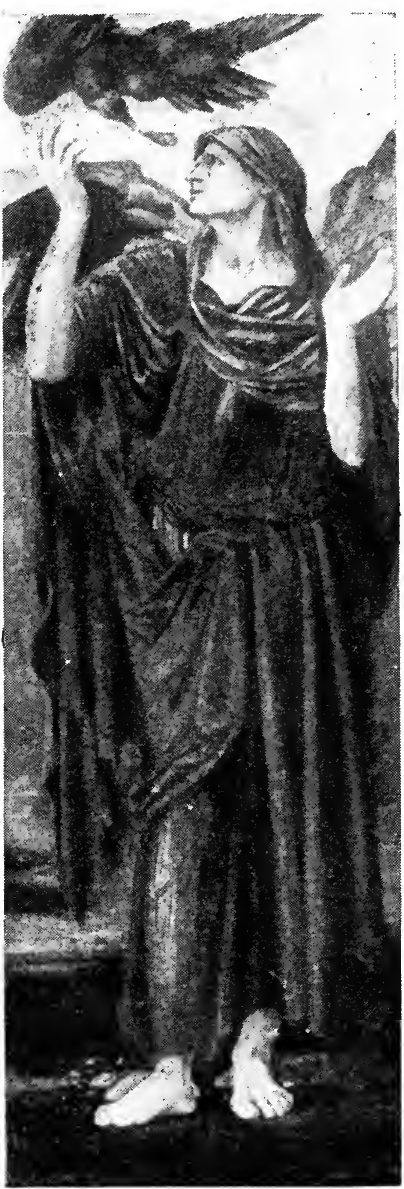

Elijah. The prophet fed by ravens in the wilderness

After the painting by Burne-Jones

Scotland, in Fifeshire. It is on the $\mathrm{N}$. side of the Firth of Forth, $10 \mathrm{~m}$. $\mathrm{S}$. of St. Andrews and $45 \mathrm{~m}$. by rly. N.E. of Edinburgh. It includes Earlsferry, a royal burgh. It has a harbour and pier, and is a coastguard station with a flashing light on Elieness. The chief buildings are a church of the 17th century, and the town hall. There are fine golf links. Pop. of parish, 1,147.

Elijah. Hebrew prophet. A sative of Gilead (1 Kings xvii, 1), he lived in the days of Ahab. He appears to have led a kind of hermit life in the mountains, only emerging at intervals to denounce Ahab and attack the priests of Baal. On Mount Carmel he challenged the priests of Baal to a test of the rival religions by calling down fire from heaven, after which he had to flee from the wrath of Quean Jezebel to Beersheba, where 
he seems to have wandered about the desert for six weeks.

When Ahaziah succeeded Ahab, Elijah warned him that he would die as a result of an accident that he had suffered. Towards the close of Jehosapliat's reign Elijah was still living, for he sent a letter to Jehoram, the king's son. When the end came, we are told that Elijah passed in a chariot of fire into the heavens. Jewish tradition long held that he would reappear before the coming of the Messiah, and the chair of Elijah is still set ready at the Passover meal.

Legend points out Elijah as the founder of the Carmelite Order, and in the Greek Church he is regarded as the patron saint of the mountains. He appears to have had some connexion with the mysterious religious communities known as the "Sons of the Prophets," of which there were a large number in Palestine in his period. In the N.T. he is referred to as Elias.

Eliot, Str Charles NortonEdgeCUMBE (b. 1864). British diplomatist. He was educated at Chelten-

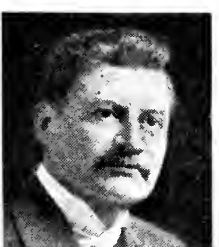

Sir Charles Eliot, British diplomatist Lafayelle ham and Ox-
ford, where he graduated in 1885. Entering the diplomatic service, he served in the embassy at St. Peters b urg, 1888-92 and Constanti. nople, 189398. C li argé d'affaires at Morocco 1892-93, Bulgaria 1895, Serbia 1897, he became secretary at Washington in 1898, and was appointed British High Commissioner at Samoa in 1899. Knighted in 1900 , he was agent at Zanzibar 1900-4, in which year he retired. He became vicechancellor of Sheffield University in 1905 , and was made the first principal of Hong Kong University in 1912. In 1918 he became commis. sioner for Siberia, and the following year was appointed ambassador to Japan.

Eliot, Charles William (b. 1834). American educationist. Born at Boston, March 20, 1834, he was educated

there and at Harvard.

1854 he became a mathematical tutor at $\mathrm{Har}$ vard, and later assistant professor of mathematics and chemistry in the Lawrence Scientific
School. After studying in Europe he was appointed in 1865 professor of chemistry in the Massachusetts Institute of Technology. In 1869 he was chosen president of Harvard, being made president emeritus on his retirement in 1909.

At Harvard Eliot did great work. He improved its teaching by adopting reforms from Europe, and in other ways widened the aims of the university. He became known as a writer on education and as an advocate of international peace. In 1913 he was offered the post of U.S. ambassador in London. His books include Educational Reform, 1898 ; Four American Leaders, 1906; and The Road Towards Peace, 1915.

\section{GEORGE ELIOT AND HER WORK}

R. Brimley Johnson, Author of Some Contemporary Novelists (Women)

For further information about this writer see the articles on her books and characters, e.g. Adam Bede, Mrs. Poyser, Middlemarch, etc. See also English Literature; Lewes, G. H.

Mary Ann, or Marian Evans, known as George Eliot, was born at Arbury Farm, near Nuneaton, Nov. 22, 1819. The daughter of a carpenter, turned estate agent, living for us in Adam Bede and in Caleb Garth (of Middlemarch), she early became wise in all that pertains to country life in Warwickshire, of which she has given us so intimate a picture. Her mother's

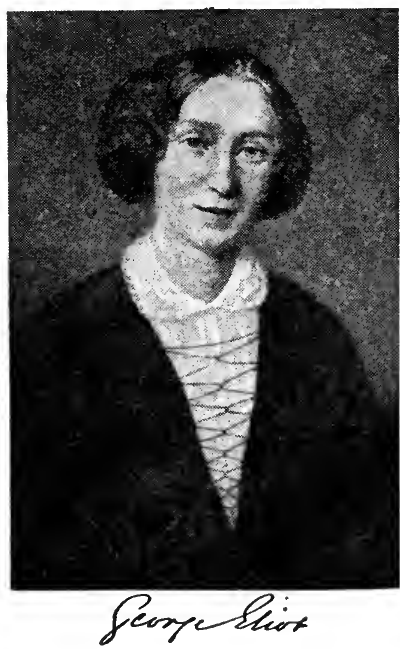

After F. D'Albert Durade

death, and the marriage of her elder sister, Christiana (also drawn in Middlemarch) threw on her shoulders, at 16 years old, the responsibility of her father's household. Here she was surrounded by the narrowest influences of evangelical revivalism, deeply confirmed by her aunt Elizabeth, the original of Dinah Morris (in Adam Bede).

A move to Coventry, in 1841, first brought her into a wider and more literary atmosphere. A student of German and Italian, Latin and Greek, and music, she now mingled with those for whom books were their most treasured companions and philosophy the chief staple of daily talk. Though too sensible and too affectionate to risk perma. nently estranging her father by any formal and visible break with the religious observances of her child. hood, she turned her mind to such tasks as a translation of Strauss's Life of Jesus, and, in her own heart, gave up orthodox faith for ever.

When, however, in 1849 , the old man died, it was only natural that she should seek further freedom of intellect in London among the men and women then chiefly inspired by the materialistic agnosticism of Herbert Spencer. She was soon afterwards appointed assistanteditor of The Westminster Review, where she published some weighty articles on ethics, and through which she met George Henry Lewes. The life-long union between them was not lightly entered upon. George Eliot's preoccupation with the problems of married life, her continual insistence upon the bind ing nature of promises between husband and wife, are pathetic testimony to her uneasiness, which never left her, in a position that could so easily be criticised from her own standard of duty. But as she had entered into it with deliberation, she never admitted dis. loyalty to her own conscience; and from a literary point of view, the consequences were almost an unmixed gain.

It was Lewes who first discovered, well-nigh by accident, her genius for fiction. Instantly recog. nizing a new force in literature, he encouraged her somewhat diffident aspirations, and himself carried out all the negotiations with editors and publishers, which resulted in the anonymous appearance of three stories in Blackwood's Magazine, published in 1858 as the wellknown Scenes of Clerical Life. Being immediately popular, they were followed by Adam Bede, 1859 ; the Mill on the Floss, 1860 ; and Silas Marner, 1861. Henceforth she lived happily and stren. uously among the thinkers of the 


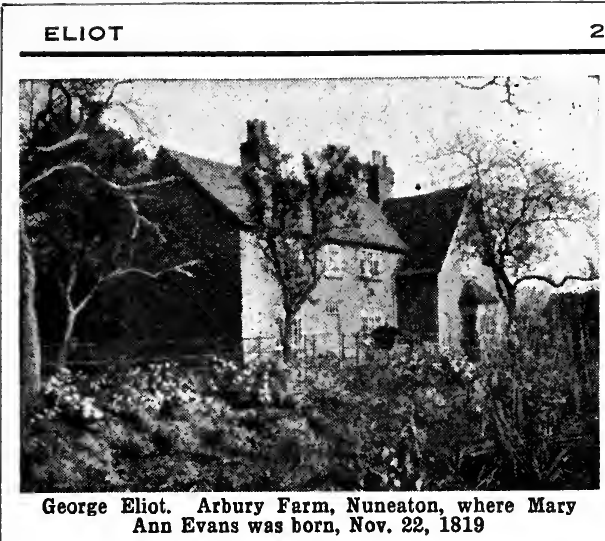

day; a professional woman of letters, whose work enjoyed not only critical appreciation but an exceptional measure of popularity and influence among thoughtful middle-class readers. Her later output embraced Romola, 1863, a painstaking reconstruction of the past ; Felix Holt, the Radical, 1866, a political treatise, Middlemarch, 1871-72, a problem novel with three loosely-knit plots; Daniel Deronda, 1876, a study of an alien race besides The Spanish Gypsy and The Legend of Jubal in verse, and the somewhat ponderous collection of short essays entitled Impressions of Theophrastus Such. After Lewes' death in 1878 , she married in $1880 \mathrm{John} \mathrm{W}$. Cross, afterwards her biographer, but died on December 22 of the same year.

It was the grafting of a somewhat arid philosophy upon the Calvinism of early years that gave distinction and popularity to George Eliot's work. Always profoundly religious, and mastered at all times by an uncomfortably strict sense of duty, she met the questionings of the mid-Victorians with a rare and illuminating sincerity, and awoke echoes in many a young, ardent spirit newly alive to the serious mysteries of life.

She was, in fact, more receptive than original or independent ; her poems, and Theophrastus, and in lesser degree her later novels, reveal the dangers of undigested analysisin imaginative writing ; she was overmuch weighted with anxiety about the soul of mankind. But, because she was, before all things, a great artist and a warm-hearted and sympathetic woman, she was able to create an immortal gallery of human beings, whose joys and sorrows can never lose their hold on the affections. Her excellent professional training, moreover, secured fine fruit for her varied powers of ordered memory, acute observation, and dramatic instinct. The earlier novels reach right into the heart of things because they are built on the most intimate experi. ences of youth, with spontaneous hum. o u $r$ and deep emotion. If the style, the plot, and the psychology of what followed yield s o m e what to affected pedantry, we have, at least in Middlem a $\mathbf{r} \mathrm{h}$, many a revelation in emotional prob. lems of profound interest.

Like her great feminine prede cessors she was realistic and parochial ; but what Charlotte Brontë first bitterly proclaimed on a few passionate topics became with her a definite philosophy universally applied. She insisted that women should dare to think for them. selves, establish their own moral standards, follow their own conscience, and even demand man's acquiescence) (No writer of fiction has illustrated with greater power the ultimate ethical truths of life, the tragic pathos of continual backsliding, and the eternal sig. nificance of the choice between good and evil. Her passionate faith, indeed, called for more than reason could give to doubt. Her message was not final.

But she left an unrivalled revelation of all that our forefathers were feeling, thinking, and striving for: a living picture, admirably studied, of Victorian domesticity, the farmer, the tradesman, and their womenkind-that great army of hitherto inarticulate, middle. class Englishmen who were to prove themselves eventually the backbone of the Empire.

Bibliography. George Eliot in Derbyshire, Guy Roslyn (pseud.), 1876 ; George Eliot's Life as related in her letters and journals, ed. J. IV. Cross, 3 vols., 1885; Monographs, Mathilde Blind, new ed. 1888; $O$. Browning, 1890; and L. Stephen, 1902.

Eliot, SIR JoHN (1592-1632). English statesman. Born at Port Eliot, Cornwall, and educated at

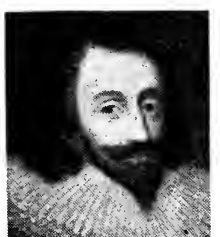

Sir John Eliot, English statesman

From a painting in the possession of the Ear Exeter College, Oxford, he was $\mathrm{knighted} \mathrm{in}$ 1618 , and in 1619 was appointed vice. admiral of Devon as a sup. porter of the duke of Buck. ingham. First elected M.P. in $1614, h$ e a t t a c k e d
Buckingham in 1626, and was a principal promoter of the Petition of Right, 1627. On March 2, 1629, Eliot read a protest against unauthorised taxation, whilst he had the Speaker forcibly held down in his chair, and two days later he was sent to the 'lower. Refusing to yield to Charles I, he remainedin the Tower until his death, Nov.27,1632. See Life, John Forster, 1864

Eliot, JонN (1604-90). English missionary to the Red Indians. He was born at Widford, in Hert-

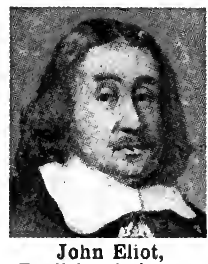

English missionar fordshire, and ed u cated at .Jesus College, Cambridge. In 1631 he went as a Protestant missionary to the Indians in Massachusetts. His headquarters were at 690. Eliot translated the Bible into the native dialects, in addition to preparing a grammar and catechism. He assisted in the preparation of the famous Bay Psalm Book (q.v.). See Life, C. Francis, new ed. 1848 (in Jared Sparks' Lib. of American Biog.).

Elis. Country on the W. coast of Peloponnesus, Greece. Its chief city was Elis, on the Peneus, while another city, Pylos, was the seat of the kingdom of the Homeric hero Nestor. In Elis was the district of Pisa, where the great Olympic games were held every four years. It forms the modern dept. of Achaia and Elis, the capital of which is Pyrgos. See Greece.

Elisha. Son of Shaphat, and companion of the prophet Elijah, whose successor he became. At the translation of Elijah, he received his mantle as a sign of office. He flourished in the reigns of Jehoram, Jehu, Jehoahaz, and Joash, and had considerable influence in public affairs. His many miracles were mainly of a beneficent character.

Elixir (Arab. el iksir, the philosopher's stone). In pharmacy the term is used for preparations containing alcohol, flavouring agents, sometimes active ingredients as senna. It is a tincture of various substances held together by alcohol.

In alchemy, the elixir of life (elixir vitae) was believed to be a substance which would prolong indefinitely the life of anyone who consumed it.

Elizabetgrad. A town of Ukrainia, in the govt. of Kherson. It stands on the Ingul river, 135 m. N. of Kherson on the Kharkov. Odessa rly. The district is fertile, 
tobacco and fruit, especially melons, being much cultivated. Pop. 75,800. Pron. Yelizavetgrad.

Elizabeta. City of New Jersey, U.S.A., the co. seat of Union co. Near the mouth of the Elizabeth river on Staten Island Sound, it is $4 \mathrm{~m}$. S.S.W. of Newark, and is served by the Pennsylvania and other rlys. There are large sewingmachine factories, shipbuilding yards, chemical works, foundries, oil refineries, and tanneries. Its port, $2 \mathrm{~m}$. to the S.E., is on Staten Island, and ships anthracite coal and iron. Settled in 1664 , it was incorporated as a town in 1796 and became a city in 1855. Pop. 88,830 .

Elizabeth. Feminine Christian name. It originated in a Hebrew word, Elisbeba, meaning God hath sworn, and became very popular throughout the Christian world.

\section{ELIZABETH : HER REIGN AND ITS GLORIES}

A. D. Innes, Author of England Under the Tudor

This biography is one of the most important of the series on the sovereigns of England and Scotland. Further information is under England: History; Mary Queen of Scots; Armada. See also biographies of Burghley; Drake; Leicester; Philip II, etc.

Elizabeth was the daughter of Henry VIII and Anne Boleyn, whom he married before the Eng. lish law courts had pronounced his earlier marriage with Catherine of Aragon invalid. Elizabeth was born on Sept. 7, 1533 ; Catherine did not die till 1536. According to Roman Catholics, therefore, Elizabeth was not born in wedlock. In 1536 Anne was executed, after a pronouncement of the courts that her marriage had not been valid. The title under which Elizabeth succeeded her half-sister Mary in 1558 was conveyed by the will of Henry VIII. The actual legitimate heir to the throne was her cousin Mary Queen of Scots, the granddaughter of Henry's elder sister, Margaret.

Elizabeth's girlhood was hard and loveless; she lived in an atmosphere of suspicion, in which she learnt that duplicity was the condition of self-preservation. During Mary's reign she was charged with complicity in Wyatt's rebellion, though it was found impossible to bring the accusation home to her. Throughout the reign she was kept under suspicious surveillance, but successfully evaded definite profession of her sister's religion. It was imposed upon her by her position that she should take her stand as a Protestant. Her own wisdom taught her that her strength must depend upon the solid support of her Protestant subjects.

From her accession in 1558 Eliza. beth was herself the ruler of her
It has various forms, one of which is Isabella, and is common in Russia and eastern Europe as well as in the west. Eliza, Elsie, and the Scotch Elspeth are among its bbreviations.

Elizabeth (1207-31). Hungarian princess and saint. Daughte ungary, she rn at Presburg, and early Married in 1221 to Thuringia, she was driven from the court on his death in 1227. Reouncing the world, she lived at 1arburg under the influence of Conrad of Marburg, and subjected and self-denial. She died there Nov. 19,1231 , and was canonised in 1235 , after many miracles reported from her tomb at Marburg. See Life, C. F. R. de Montalembert, Eng. trans. F. D. Hoyt, 1904.

country, though she chose and trusted her counsellors with profound insight. Public opinion demanded that she should marry, and secure an undisputed succession. She herself never had the slightest intention of marrying, but understood to the full the diplomatic use that might be made of the fact that it was open for her to choose a hus band. For five-and-twenty years

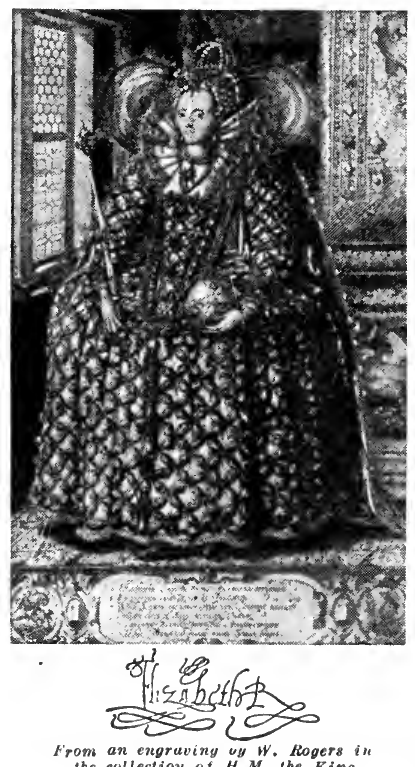

she played with marriage proposals, the most notable of her suitors being Philip of Spain,whose offer she declined in the first months of her reign; the Austrian Archduke Charles; Henry of Anjou, afterwards Henry III of France, her junior by eleven years ; and finally his younger brother, Francis. Fears were at one time entertained that she might marry her undesirable favourite, Robert Dudley, whom she made earl of Leicester. It was not till she reached the age of fifty that the theory of her probable marriage was finally abandoned.

The antagonism between Elizabeth and Philip of Spain was the controlling factor in her policy. Elizabeth saw that Philip's hands were tied; if he struck at her successfully the succession of Mary Stuart to the English throne would be the inevitable result, and Mary's association with France was so intimate that her accession would almost inevitably mean the close alliance of England and France, to the great inconvenience of Philip. Hence for five-and-twenty years a positive rupture between England and Spain seemed always imminent, but was always postponed, which was precisely what Elizabeth wanted.

Elizabeth and Mary Stuart

England had been weakened by years of misrule, and Elizabeth did not mean to fight until Eng. land was strong enough to make sure of winning. Year after year, though she carried on and encouraged what was, in fact, a covert war against Spain, she abstained always from the last provocation which would have compelled Philip to open war. Primarily because the life of Mary Stuart was an obstacle to Philip. she kept Mary Stuart alive and a prisoner, in spite of the personal danger to herself. But Elizabeth's hand was at last forced; in 1586 she was obliged to give open official support to the United Provinces of the Netherlands and sanctioned the execution of Mary Stuart.

The result was the coming of the Spanish Armada, and its annihilation in 1588. After its destruction maritime war between England and Spain continued through the remaining ten years of Philip's life and the five years by which Elizabeth outlived him. For the old queen those years were embittered by the tragedy of the young earl of Essex, Robert Devereux, to whom she became devotedly attached, but whose arrogant folly led him into treasonable acts, from the consequences of which the queen could not save him. 


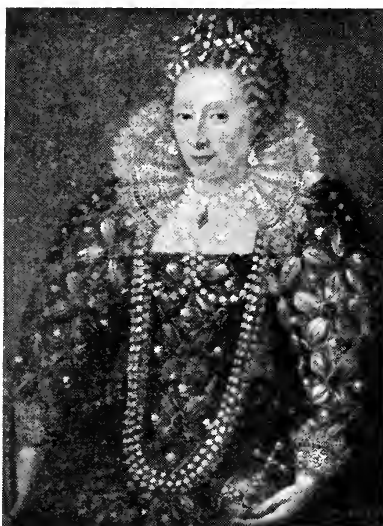

Queen Elizabeth

From the painting oy $F$. Zuccaro

To the last Elizabeth persisted in her refusal to make any pronouncement as to her successor on the throne. Besides King James of Scotland, the son of Mary Stuart, there were various living descendants of the two sisters of Henry VIII, all of them Protestants, on whose behalf more or less plausible claims might be put forward. There was also a possible claimant in the person of a daughter of Philip of Spain, who claimed de. scent from John of Gaunt. But for Elizabeth to have nominated an heir at any time would have been an inducement to her own assas. sination. Only at the point of death, at Richmond, Mar. 24, 1603, was she said to have approved by a sign the name of the Scottish king.

No reign in our annals is more glorious than that of Elizabeth. Its extraordinary political success was due in great part to her own extraordinary political intelligence and to the peculiarities of her character. Between good fortune and her own ingenuity she was in. variably provided with some way of escape from every complication which she herself wove, or which was woven about her. In the last resort she deliberately utilised as sumed feminine weaknesses as justifying the unjustifiable in her conduct. She made full use of the shrewdest brains, the strongest hands, and the stoutest hearts that could be called into her service; and she never misjudged her servants. But ever she went her own way-devious always, not seldom false, not often generous, but never without knowing exactly what she was doing. And exactly what she was doing was what no other living man or woman, including her most intimate advisers, ever knew. She outwitted every states- man in Europe ; none outwitted her. And she raised England from the degradation into which it had fallen under her immediate predecessors to the highest rank among nations.

But it is not only Elizabeth's political success that gives to the Elizabethan era a unique place in history. It was the era in which England sprang suddenly into the position of maritime supremacy, and an era also of such poetic achievement as could be paralleled only by Athens in the past, and once again by England herself early in the 19th century.

In Elizabeth's reign the English seamen came to their own. They acquired the skill in ocean navigation which gave them a complete ascendancy over the earlier ocean sailors, Spanish and Portuguese. Frobisher and Davis explored the far northern shores of the recently discovered American continent and penetrated deep into the Arctic seas. John Hawkins and many another sea-dog of Devon made the voyage to the Spanish main,

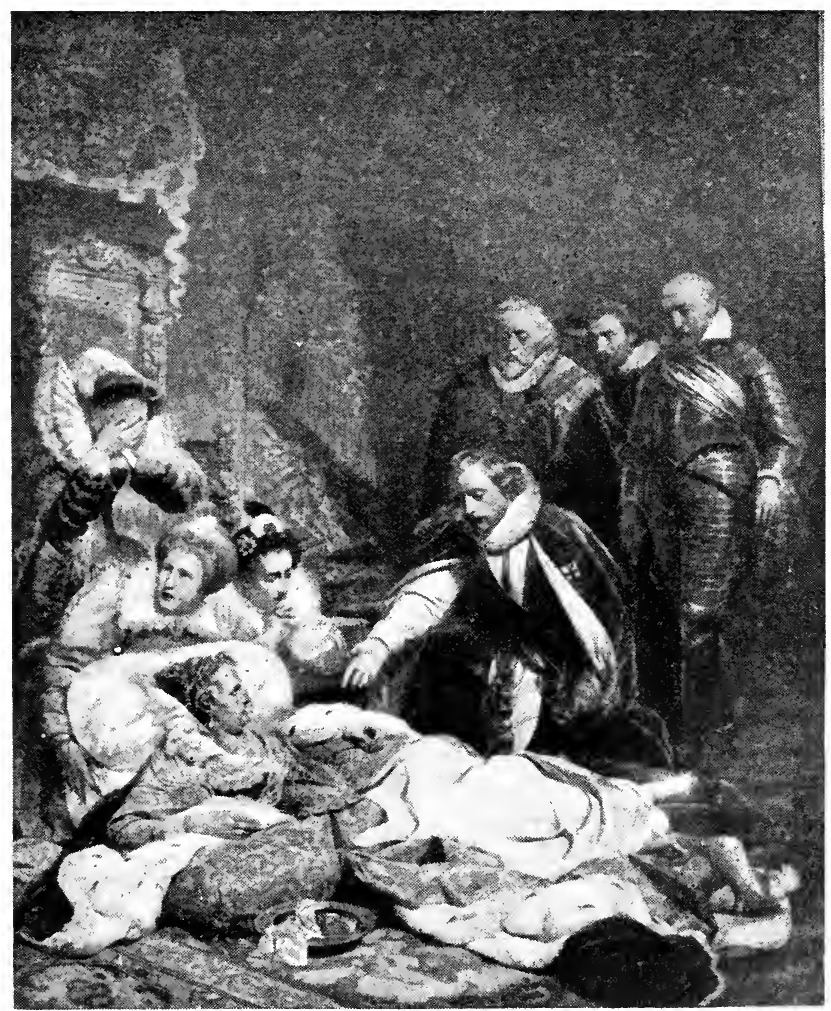

Queen Elizabeth. The last scene in the royal palace of Sheen, Richmond, where the queen passed away, March 24, 1603, in the presence of some of ber advisers After a painting by $P$. Delacroix, in the Lowvre, Paris and learnt to make little account of fighting with Spanish ships of thrice their tonnage. Save the Spaniards and Portuguese, the Englishman, John Oxenham, was the first European to lay keel in the Pacific. Francis Drake was the first captain who sailed the whole way round the world, since the Portuguese Magellan died before his voyage was completed. Before Elizabeth was dead, Cavendish, too, had sailed round the world. The Englishmen who destroyed the Armada first made it manifest that the ship of war should be herself a weapon of war, with sailors, not soldiers, to fight her; that seamanship is the grand factor in naval warfare, and is the inheritance of Englishmen more than of any other people. The Elizabethan seamen laid the foundations both of the commercial and of the naval supremacy of England, though neither was quite decisively established until nearly another century had passed.

No less astonishing was the literary development of the latter 
half of Elizabeth's reign, extending almost to the close of the reign of her successor. Before this time it would be hard to name any English writers with a real title to the epithet great, except Chaucer and perhaps Thomas More. But at last the creative literary spirit was fermenting. 'The drama was born. After the Armada the great poetic flood burst forth-Spenser's Faerie Queene, Marlowe's tragedies, and then Shakespeare; and, following upon Shakespeare, Ben Jonson and others. The foundations were laid also of an English prose literature by the Essays of Francis Bacon, Hooker's Ecclesiastical Polity, the vigorous narrative of Raleigh, and also by the eccentricities of Lyly and imitators, and the efforts of Sir Philip Sidney, in the search for a prose style.

Both the maritime and the literary energy were the expression of what was the fundamental characteristic of the Elizabethan period, its intense vitality, with free play for its activities. The "spacious days" are rightly named. Intellectually, as well as geographically, the horizon had been infinitely enlarged, the cramping conditions of the Middle Ages had been broken down; the new oceans and new lands were only the material type of the new intellectual and spiritual field which lay open to exploration and cultivation. Seeillus. p. 1113.

Bibliography. Lives of the Queens of England, A. Strickland, 1857 ; Lives of Elizabeth, E. S. Beesly, 1892; Mandell Creighton, new ed. 1899; The Courtships of Queen Elizabeth, M. A. S. Hume, rev. ed. 1904 ; Political History of England, A. F. Pollard, vol. vi, 1910.

Elizabeth (c. 1437-92). Queen of Edward IV of England. She was the daughter of Sir Richard

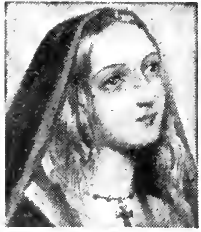

Elizabeth Woodville, Queen of Edward IV
Elizabeth (1465-1503). Queen of Henry VII. The daughter of Edward IV and Elizabeth Wood-

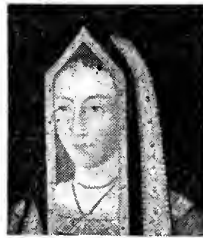

Elizabeth of York Queen of Henry VI
France, afterwards Charles VIII, being arranged. She was, however, unmarried when Edward died, in 1483 , and after the murder of her two young brothers in the Tower, she, the eldest of five daughters, was his heiress. She was then in the power of Richard III, who contemplated marrying her. Before this time, the names of Elizabeth and Henry Tudor had been coupled, and the princess, then in Yorkshire, was probably in the plot that culminated in the battle of Bosworth. She and Henry were married, after Parliament had ap. proved of the match, Jan. 18, 1486, the rival houses of York and Lancaster being thus united. She was crowned queen Nov. 25, 1487.

Elizabeth had four children; Arthur ; Henry, afterwards Henry VIII ; Margaret, who became the wife of James IV of Scotland ; and Mary, afterwards the wife of Louis XII of France; as well as three who died in infancy. She died Feb. 11, 1503, shortly after the birth of the youngest.

Elizabeth (1837-98). Empress of Austria. Born Dec. 24, 1837, the daughter of Maximilian I, king of Bavaria, she married Fran. cis Joseph of Austria, April 24, 1854. Her attempts to modify the strict etiquette of the imperial court aroused opposition amongst the

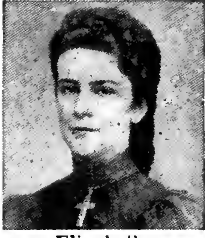

Elizabeth

Empress of Austria wid o while hunting, and married her secretly in 1464 , and in 1465 she was acknowledged queen and crowned. Of her children by the king her eldest son became king as Edward V, and her eldest daughter, Elizabeth, became the queen of Henry VII. She refounded Queens' College, Cambridge, originally founded by Henry VI's consort, Margaret of Anjou. She was buried in $\mathrm{S}$. George's Chapel, Windsor. of Bohemia. The eldest daughter of James I, she was born at Falkland, Fife, Aug. 19, 1596. In 1612 palatine Frederick V, whom she married early in 1613, beginning wedded life at Heidelberg, the elector's capital. In 1618 Frederick was chosen king of Bohemia, and the 'Thirty Years' War began. He and his wife were crowned at Prague in 1619 and lived there for a time, but soon were fugitives, the queen ultimately reaching Holland, where Maurice of Orange befriended her.

By this time Frederick had lost the pala. tinate as well as Bohemia, and the exiled pair remained in Holland. where in 1632 the elector died.

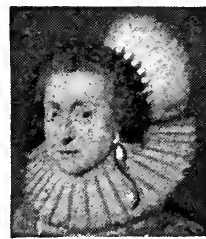

Elizabeth,

Elizabeth Queen of Bohemia After Mierewald
Elizabeth (1596-1662). Queen she was betrothed to the elector

strove to obtain the lost palatinate for her eldest surviving son, Charles Louis, and in 1648 had the satisfaction of seeing him settled at Heidelberg. He did nothing, however, to relieve the considerable poverty to which she was reduced by her husband's misfortunes and the loss of her own annuity as an English princess after the civil war broke out. She remained in Holland, befriended by the earl of Craven, to whom report, probably incorrectly, said she was married, until 1661 , when she crossed over to England and was given a pension by Charles II. She was living in Leicester Square, London, when she died, Feb. 13, 16u2. Elizabeth had thirteen chil. dren; two, Rupert and Maurice, fought in the Civil War for their uncle, Charles I, and the twelfth was Sophia, the mother of George I. See Life, M. A. E. Green, rev. ed. S. C. Lomas, 1909.

Elizabeth (1843-1916). Queen of Rumania. Born at Neuwied, Dec. 29, 1843, the daughter of nobility, but she soon gained the love of the people and retained it to the last. In 1877 she was crowned queen of Hungary. In 1889 her only son, Rudolph, died in very tragic circumstances; her cousin, Leopold of Bavaria, com. mitted suicide, and her sister, Sophie, duchess of Alençon, was killed in a fire at a Paris charity bazaar, 1897. The empress herself was mortally stabbed by an Italian anarchist at Geneva, Sept. 10, 1898. See Life, A. de Burgh, pseud., 1899.

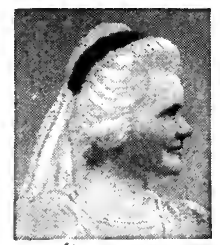
Prince Her. mann of Wied, in 1869 she married King (then Prince) Carol of Ru. mania. She endeared herself to her adopted country by her minis. trations to the wounded in

the war with Turkey (1877-78), and founded the order of Elizabeth 
to reward distinguished Red Cross work. She became a widow Oct. 10, 1914, and died March 2, 1916.

A woman of cultivated tastes, a fine musician, and no mean painter, the queen wrote under the pen-name of Carmen Sylva and published poems and stories in Rumanian, German, French, and English. Her chief works are Stürme, 1881 ; Leidens Erdengang, 1882 (Eng. trans. by M. A. Nash as Suffering's Journey on the Earth, 1905); Les Pensées d'une Reine, 1882: Pelesch Märchen.1883, a book steeped in Rumanian folk-lore.

Elizabeth (1709-62). Empress of Russia. Daughter of Peter the Great, and therefore called Eliza-

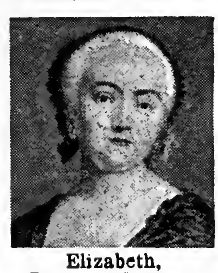

Empress of Russi

From an old engravin beth Petrovna, she was born Dec. 18, 1709 . Under her cousin Anne's reign, $1730-40$. she took no part in court aff a irs, but, living her own life, gave rein to her some. what abandoned tastes. On Dec. 6, 1741, aided by her intimates and partisans, she dethroned the child emperor, Ivan VI, by a coup d'état at the Winter Palace, and mounted his throne. Through. out the Seven Years' War she worked steadfastly for Russian interests, implacable in her opposition to Frederick II of Prussia. Joining with France and Austria against Prussia in 1757, she was a tower of strength in that combina. tion which brought Prussia almost to destruction by the end of 1761, her army having entered Berlin in 1760. To Frederick's great relief, Elizabeth died on Jan. 5, 1762. Before her accession an indolent woman, as empress she ruled with unselfish energy, strengthening Russian prestige all over Europe, and carried out various internal reforms. She founded the university of Moscow, 1755, and the Academ $v$ of Arts at St. Petersburg.

Elizabeth (b. 1876). Queen of the Belgians. Born July 25, 1876, at Possenhofen, she belonged to a younger branch of the family that until 1918 ruled over Bavaria. Her father was Charles Theodore, duke of Bavaria, a n d she was the younger of his two daughters. On 0 c t. 2 , 1900 , she was

married at Munich to Albert, who, in 1909, became king of the Bel. gians. During the Great War the queen with her husband worked constantly for the good of her country, its soldiers and inhabitants. See Albert; Belgium.

Elizabeth (1635-50). English princess. The second daughter of Charles I, she was born Dec. 28, 1635. She was placed in the charge of Par. liament, a n d appealed in a touching letter to the House of Lords for permission to retain her at. tendants. I n 1648 she helped

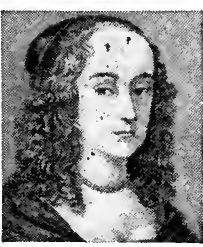

Elizabeth, English princess From an old prixt her brother From an old print She said good-bye to her father the day before his execution, and, after a visit to Penshurst, was sent in 1650 to Carisbrooke Castle, where she died, Sept. 8, 1650, from fever She was buried in S. Thomas's Church, Newport, where is a monument to her by Baron Carlo Marochetti erected by Queen Victoria in 1856 .

Elizabeth, Philippine Marie HELÈNE (1764-94). French prin cess, usually known as Madame

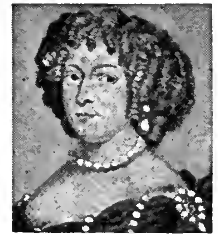

Elizabeth, French princes Varennes, and captivity in the Temple. Accused of aiding Louis and the royalist troops in 1792, she was guillotined, May 10, 1794.

Elizabethville. Town of the Belgian Congo and headquarters of the Katanga prov. It is $2,305 \mathrm{~m}$. from Cape Town and $292 \mathrm{~m}$. from Bu. kama, on the Lualaba portion of the Congo river. The Etoile du Congo mine is $8 \mathrm{~m}$. distant, and there are other rich copper deposits in the neighbourhood. The surrounding country is well wooded and there are numerous agricultural settlements. Pop. (European), 929.

Elizabetpol. Govt. of Transcau. casia. It is bounded N. by the govts. of Daghestan and Tiflis, $\mathrm{E}$. by Baku, W. by Erivan, and S. by the Persian prov. of Azerbeijan. A mountainous steppe region, with extensive forests, it is traversed by the river Kur. The inhabitants are chiefly occupied in cattle rearing, agriculture, cultivation of vines, and silkworm breeding. Other industries are copper mining, silk spinning and weaving. The area is $16,991 \mathrm{sq}$. m. Pop. $1,117,200$, mostly Armenians and Tartars.

Elizabetpol. Town of Transcaucasia. Chief town of the govt. of Elizabetpol, it is $90 \mathrm{~m}$. S.E. of Tiflis, on the Gauja and the 'TiflisBaku Rly. There are many Armenian churches in the town. The inhabitants are chiefly engaged in the cultivation of fruit, vegetables, and tobacco, and in silkworm rearing. Elizabetpol, formerly the residence of a Moslem khan, was taken by the Russians in 1804 . Some ruins in the neighbourhood have yielded coins of many nations. Pop. 63,400.

Elk (Alces machlis; Gr. alkē, Lat. alcës). Largest member of the deer family, known in America as the moose. The European elk is found in Scandinavia. E. Prussia, Poland, and parts of Russia; but is now much diminished in numbers. and

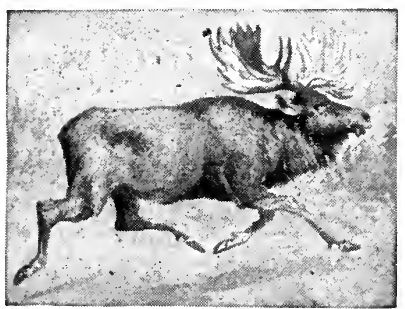

Elk. Specimen of the common elk, or moose, Alces machlis

only occurs very locally. The adult elk is usually about $6 \frac{1}{2} \mathrm{ft}$. high at the withers, and may weigh as much as $1,000 \mathrm{lb}$. It is very long in the leg, of heavy build, short in the neck, with long ears, and has a very long head with overhanging muzzle. The antlers of the male are very broad and palmated. It inhabits dense forests, where it feeds mainly on the leaves and young branches of the willow and birch as well as on lichens and moss. The flesh is apt to be coarse, and has a musky flavour. See Moose.

Elk. Group of mountains of Colorado, U.S.A., in Pitkin co. They form a section of the Rockies near Aspen, and the highest summit is Castle Peak, with an eleva. tion of $14,259 \mathrm{ft}$.

El-Kab. Site of the ancient city Nekheb, near the right Nile bank, $44 \mathrm{~m}$. above Luxor, Upper Egypt. The predynastic capital of the S., it was sacred to the vulturegoddess Nekhbet. Within the girdle-wall, $37 \mathrm{ft}$. thick and enclosing 75 acres, Quibell conducted excavations in 1897. In the vicinity 
are many rock-cut tombs with agricultural and domestic scenes. The royal residence lay across the stream at Hieraconpolis,

El Kantara. Town of Egypr, situated on the Suez Canal. Here on Jan. 26, 1915, in their first invasion of Egypt, an advance guard of Turks came into touch with a British patrol. On Feb. 3 they launched subsidiary attacks against the canal at El Kantara and other points to cover their main attack at Serapeum, $32 \mathrm{~m}$. further S. This battle for the canal ended in the complete defeat of the Turks. A British war memorial is to be erected here. See Egypt ; Palestine, Conquest of.

El Kefr. Village of Palestine. It lies in the foothills of Mt. Ephraim, $18 \mathrm{~m}$. E. by N. of Joppa, and $16 \mathrm{~m}$. S.W. of Shechem. It was captured together with Refat by the British on April 9, 1918. See Palestine, Conquest of.

Elkesaites oR Elchasaites. Heretical 3rd century sect which followed alleged revelations contained in the Book of Elchasai. This taught that the Son of God had been manifested in the persons of many good men, and that Christ was merely one of these manifestations.

Elkhart. City of Indiana,U.S.A., in Elkhart co. At the junction of the Elkhart and St. Joseph rivers, $100 \mathrm{~m}$. E.S.E. of Chicago, it is served by the Lake Shore and Michigan S. and other rlys. Settled about 1833, it received its city charter in 1875. Pop. 21,735.

Elkhorn. River of Nebraska, U.S.A. Rising in the N. part of the state, it flows $200 \mathrm{~m}$. S.E. to $\mathrm{La}$ Platte river, an affluent of the Missouri.

Elkington, GEORGE RICHARDS (1801-65). British manufacturer. Born Oct. 17, 1801, at Birming. ham, the son of a spectacle-maker, he became partner and afterwards sole proprietor of his uncle's silverplating business in that city. By energy and experiment he made electro-plating a commercial proposition, and superseded the oldfashioned method of plating by soldering thin sheets of silver upon copper. He died Sept. 22, 1865.

El Kosseir. Seaport of Upper Egypt. It stands on the Red Sea, $96 \mathrm{~m}$. E. of Keneh, and has a good harbour. Pop. 2,000.

Elk's-horn Fern (Platycerium). A small genus of large epiphytal ferns. They are natives of Australia, Malaya, and Africa. The lower fronds, which are barren, are thick and undivided, and spread close to the tree-trunk on which they grow. The much longer fertile fronds present the appearance of a

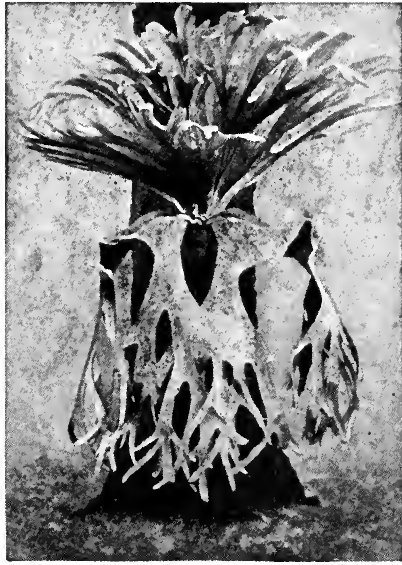

Elk's-horn Fern. Specimen of Platycerium grande, growing on a tree trunk

stag's antlers. In an Indian species $(P$. biforme) they are from $6 \mathrm{ft}$. to $15 \mathrm{ft}$. in length.

El Kutrani. Village of Hejaz. It is on the Hejaz Rly., $80 \mathrm{~m}$. N. of Maan on the borders of Moab, and was finally captured in the great Allied offensive in the autumn of 1918. See Hejaz; Palestine, Conquest of.

Ell (Lat. ulna, Ger. ellenbogen, Eng. elbow). Medieval European measure of length. It varies from the English ell, probably borrowed from France, which equals 45 ins., to the Scottish of 37 ins. and the Flemish of 27 ins.

Ellagic Acid or BezoARdic AcID $\left(\mathrm{C}_{14} \mathrm{H}_{6} \mathrm{O}_{8}\right)$. Constituent of the animal concretions which are met with in Oriental countries under the name of bezoars. It can also be made artificially by treating gallic acid in acetic acid solution with potassium persulphate and sulphuric acid. The name is Fr. galle (gall) reversed, with suffix-ic.

Elland. Town and urban dis. trict of Yorkshire (W.R.). It stands on the Cald er, $3 \mathrm{~m}$. S.E. of Halifax, and has a station on the L. \& Y. Rly. The industries include the manufacture of textiles, while there are stone quarries in the neighbourhood. The chief of several public buildings is $\mathrm{S}$. Mary's Church. Pop. 10,676 .
Ellenborough, EDWARD LAw, BARON (1750-1818). British lawyer. Born at GreatSalkeld, Cumberland, Nov. 16, 1750, he was educated at Charterhouse and Peterhouse, Cambridge. He was peer He AfterSir Thos, Lawrence called to the barinl780and eight years later was leading counsel for W arren $\mathrm{H}$ a s t in g s (q.v.). In 1802 he was ap. pointed lord $\mathrm{ch}$ ief justice and created a signed office in Nov., 1818, and died Dec. 13, 1818.

Ellenborough, EDWARd LaW, EARL of (1790-1871). British administrator. Born Sept. 8, 1790,

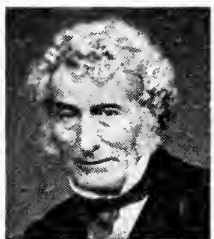

1st Earl of Ellenborough,

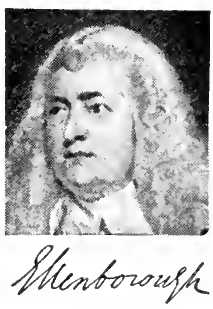
the eldest son of the first Baron Ellen. borough, he was educated at Eton and $\mathrm{S}$. John's College, $\mathrm{Cam}$ bridge, and in 1813 entered Parliament. Made lord privy seal transferred the same year to the presidency of the board of control, and in 1841 became governorgeneral of India. He annexed Sind in 1842 and subdued Gwalior in 1844. He was made first lord of the Admiralty in 1846, and president of the board of control in 1858. He died Dec. 22, 1871.

Ellen's Isle or ErLean Molach. Islet in Loch Katrine, Perthshire, Scotland. It is largely the scene of Scott's Lady of the Lake.

Ellerman Lines. British steamship company. An offshoot of the Bibby line founded in 1840 , it was

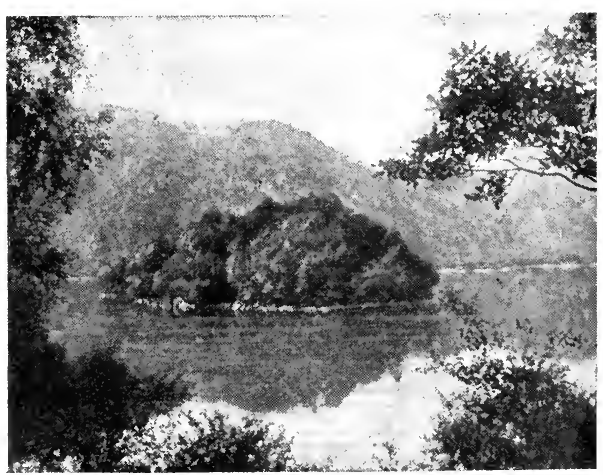

Ellen's Isle, the woody islet on Loch Katrine immortalised in Scott's poem. The Lady of the Lake 
purchased in 1870 by Frederick Leyland \& Co., and flourished as the Leyland line until 1902, when it was sold, the Atlantic services being acquired by the International Mercantile Marine, an American combine, and the Mediterranean services by sir J. R. Ellerman. The latter, born 1862 , was created C.H. in 1921, and was interested in news. paper enterprises, including The Times.

The Ellerman lines control the City, Ellerman, Hall, Bucknall, Papayanni, Westcott and Laurance, and Wilson lines. The City and Hall lines run fast passenger steamers from Liverpool to India and Egypt; the Ellerman and Bucknall lines have a big fleet going to almost all parts of the world-Africa, Australia, New Zealand, India, Mesopotamia, the Far East, and New York; the Westcott and Laurance line serves the Mediterranean, the Black Sea, and the Danube. The headquarters of the combination are 12 , Moorgate Street, London, E.C.

Elles, Hugh JAMLESON (b. 1880). British soldier. Born April 27, 1880 , he was gazetted to the R.E.

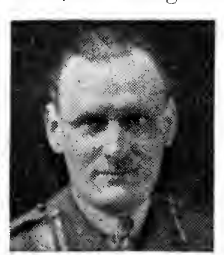
in .1899 and served in the South African War 1901-2. He passed the Staff College course, 1913-14. Cross. ing with the Ex. peditionary Force in the lat-

Hugh J. Elles, British soldier ter year, he served in France throughout the Great War, becoming major, 1915, brevet-lieut.-colonel, 1918, and colonel, 1919. He was promoted temporary major-general com. manding the Tank Corps in 1918.

Ellesmere. Urban dist. and market town of Shropshire, England. It is $11 \mathrm{~m}$. S.W. of Whitchurch, on the Cambrian Rly., and on the mere and canal of the same name. No traces remain of its castle, whose site is now occupied by a recreation ground; S. Mary's Church is a fine Gothic structure. Malting and tanning are industries. Market day, Tues. Pop. 1,946.

Ellesmere. Large island of British N. America. In the Arctic region, N. of Devon Island, it is separated from Greenland by Smith Sound, Kennedy Channel, and Robeson Channel. It is deeply indented, especially on the W. coast, and has the Prince of Wales mountains on the E. It is a desolate tract covered with ice and snow.

Ellesmere, EARL or. British title borne since 1846 by the family of Egerton. Francis Leveson.
Gower, a younger son of the 1st duke of Sutherland, assumed the name of Egerton in 1833, when he inherited the estates of the Egertons, dukes of Bridgewater. $\mathrm{He}$ was a politician with remarkably enlightened views, and won some distinction as a writer and a patron of the arts. He was created earl of Ellesmere in 1846, and died Feb. 18,1857 , and from him the present earl is descended. The earl's chief seat is Worsley Hall, Manchester, but he has property in Shropshire, where is Ellesmere. His eldest son is called Viscount Brackley.

Ellesmere and Chester Canal. WaterwayofEngland andWalesconnecting the Dee and Mersey. It connects Chester with Ellesmere port, on the Manchester Ship Canal line.

Ellesmere Port and Whitby. Urb. dist. of Cheshire, England. It is $7 \mathrm{~m}$. N. of Chester, at the junction of the Manchester Ship and Ellesmere Canals. An embankment about $1 \mathrm{~m}$. long separates the Mersey from the Manchester Ship Canal. There are large docks, warehouses, and dyeworks, and synthetic indigo is manufactured in large quantities. Pop. 10,366.

Ellice Islands. Group of cora islands in the Pacific Ocean. Called the Lagoon islands, they lie N. of Fiji, between lat. $5^{\circ} 30^{\prime}$ and $11^{\circ} \mathrm{S}$. and long. $176^{\circ}$ and $179^{\circ} 50^{\prime} \mathrm{E}$. The chief industries are connected with phosphates and copra. They were formally annexed by Great Britain in 1916 as the Gilbert and Ellice Islands Colony, and are under the jurisdiction of the high commissioner for the W. Pacific.

Ellichpur. 'Town of India, chief town of Berar prov. It is $100 \mathrm{~m}$. W. of Nagpur. Once an important city, its prosperity has declined. By local tradition it is supposed to date from the 11th century; it is known to have been prominent in the 13th century, and then passed under Mahomedan rulers. Besides an old palace, the town contains a number of early remains, including a burial shrine associated with a mythical hero, Shah AbdurRahman. Cotton is the chief industry. Pop. 13,909, three-fifths Hindus, one-third Mahomedans.

Elliot, JANE OR JEAN (17271805). Scottish song writer. The daughter of Sir Gilbert Elliot, 2nd bart., of Minto, she is famous as the author of The Flowers of the Forest, which Sir Walter Scott included in his Minstrelsy of the Scottish Border, 1802. She died in Edinburgh, March 29, 1805.

Elliot, John (d. 1808). British sailor. Son of Sir Gilbert Elliot, a Scottish judge, he entered the navy and in 1758 served under Hawke and Anson. He distinguished him- self in 1760 off the coast of Ireland in the capture of three French vessels. After serving in the Mediterranean and at Plymouth he commanded the Trident to America. In 1779 he sailed under Rodney to the relief of Gibraltar, distinguished himself at St. Vincent, and fought under Kempenfelt.' From 1786-89 he was commander-in-chief at New. foundland, and was promoted admiral, 1795, when he retired. $\mathrm{He}$ died Sept. 20, 1808.

Elliott, Charlotte (1789-1871). English hymn-writer. She was born at Clapham, March 18, 1789, and after an uneventful life, passed for the most part as an invalid, she died at Brighton, Sept. 22, 1871. Her hymns, amounting to about a hundred and fifty, made her among the foremost of British women hymn-writers. Many of them became very popular, notably "Just as I am, without one plea."

Elliott, EBenEZER (1781-1849). British poet, known as the Corn Law Rhymer. Born at Mas. borough, Yorkshire, March 17, 1781, he was engaged, like his father, in the iron trade. $\mathrm{He}$ attributed his father's ruin and his own early losses to the bread tax, and in his Corn Law Rhymes (1831) $\mathrm{h} \mathrm{e}$

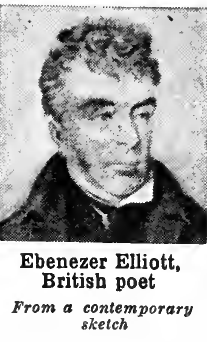
depicted in vigorous language and with intense feeling the sufferings of the poor under the Corn Laws. His hymn beginning "When wilt Thou save the People?" is still sung. He died at Great Houghton, Dec. 1, 1849. See Life, John Watkins, 1850; Poetical Works, ed. Edwin Elliott, 1876.

Elliott, Grace Dalrymple (c. 1758-1823). Reputed mistress of George IV. She was a daughter of

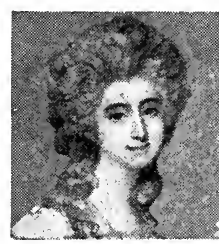

Grace Dalrymple Elliott,

British adventuress After Cosway Hew Dalrym. ple, an Edin. burgh lawyer was educated in France, in 1771 married John Elliott, and was divorced in 1774 . About 1782 she gave birth to a daughter, of whom the prince of Wales

acknowledged himself the father. She subsequently settled in France, and died near Sèvres, May 16, 1823. Her account of her life during the French Revolution was published in 1859. 
Elliott, Maxine (b. 1873). American actress. Born in Rockland, Maine, Feb. 5, 1873, she

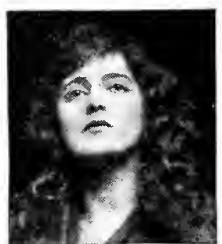

Maxine Elliott, American actress -L, Casvall Smith

School, he made his first appearance at Bath, as Tressel in Richard III. On Aug. 29, 1796, he played Sir Edward Mortimer in a revival of George Colman's The Iron Chest at The Haymarket, where he acted during the summerseasons of 1803-5 and 1811. He made his début at Drury Lane, Sept. 20, 1804, succeeding Kemble as Rolla in Pizarro, continued a member of the company till 1809 , rejoined it from $1812-15$, and was lessee of the theatre from 1819-26, when he retired, bankrupt. He afterwards became lessee of the Surrey Theatre, where he played until within a fortnight of his death in 1831. Both as a tragedian and a comedian Elliston stands high in the annals of the British stage. See Life and Enterprises of R. W. Elliston, George Raymond, 1857.

Ellora. Ruined town of India, in Hyderabad state. Situated $13 \mathrm{~m}$. Majesty's, 1913). Her sister, Gertrude, also an actress, is the wife of Sir J. Forbes-Robertson (q.v.).

Ellipse (Gr. elleipsis). A curve such that the sum of the distances of any point on it, from two fixed points within it, is constant. When the fixed points coincide the curve becomes a circle. SeeConic Sections.

Ellipsis. Figure of speech, whereby part of a sentence, strictly necessary for complete fullness of expression, but which can easily be supplied from the grammatical connexion, is omitted. It is often deliberately employed in writing, in order to lay stress upon what is more important and essential, unessentials being omitted.

Ellipsoid. Solid of which all sections are either ellipses or circles. See Geometry.

Ellis, Robinson (1834-1913). British classical scholar. $\mathrm{He}$ was born at Barming, in Kent, Sept. 5, 1834, and educated at Rugby and Balliol College, Oxford, where his career was most distinguished. In 1883 he became reader in Latin at the university, and in 1893 pro. fessor of Latin. He is chiefly known for his work on Catullus, whose poems he edited and also translated in the original metres; while his Commentary on Catullus (1876, 2nd ed. 1889) ranks as the highest authority on its subject. He died at Oxford. Oct. 9, 1913.

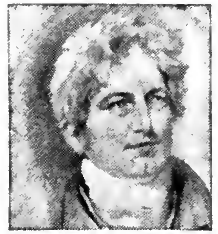

Elliston, ROBERT WILI. IA M (1 7741831). British actor and theatrical manager. Born in London, April 7, 1774, the son of

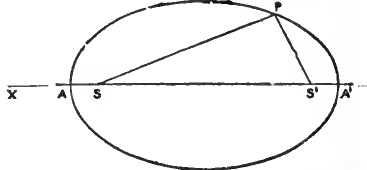

Ellipse. S S' are foci on the axis $\mathbf{X} \mathbf{X}^{\prime}$. $\mathbf{A} \mathbf{A}^{\prime}$ is called the principal diameter. $\mathbf{P}$ is any point on the ellipse, and has the property that $\mathbf{S} \mathbf{P}+\mathbf{S}^{\prime} \mathbf{P}$ is constant

N.W. of Aurangabad, it is famous for the Kailas temple built in the 8 th century, and for its rock tem. ples and caves dating from the 5th to the 9 th or 10th century. These caves cover the face of a hill for $1 \frac{1}{4}$ $m$. and belong to three groupsBuddhist, 12 caves, Brahminical, 17, and Jain, 5. See illus. p. 1799.

Ellore. Town of Madras, India, in the Kistna dist. It stands near Colair Lake, $38 \mathrm{~m}$. N. of Masulipatam. Ellore is noted for its carpets, and has a large trade in grain. Pop. 37,819, nearly all Hindus.

Ellsworth. City of Maine, U.S.A., the co. seat of Hancock co. A port of entry on Union river, at the head of navigation, it is $30 \mathrm{~m}$. S.E. of Bangor on the Maine Central Rly. It has several prominent buildings. There are foundries and an important fish hatchery. Settled in 1763 , it was incorporated in 1800 and granted a city charter in 1869 . Pop. 3,549.

Ellwood, Thomas (1639-1714). English author and Quaker. He was born at Crowell, Oxfordshire, and became a Quaker in 1659 , a conversion which cost him several terms of imprisonment. He became after the latter lost his sight, and suggested to him the idea of Paradise Regained. He assisted George companion and reader to Milton
Fox in the dissemination of his principles, and wrote various polemical treatises, but his most important work is his autobiography, which was finished by Joseph Wyeth and published in 1714: new ed. by Crump, 1900 . He died March 1, 1714.

Elm (Ulmus). Familiar native tree of Britain, of the natural order Urticaceae. More frequently found in aven. ues, parks, and hedges than in woods and forests, elms flourish in any soil, but to attain to their full height of $80 \mathrm{ft}$. or thereabouts, and to make the best wood, re.
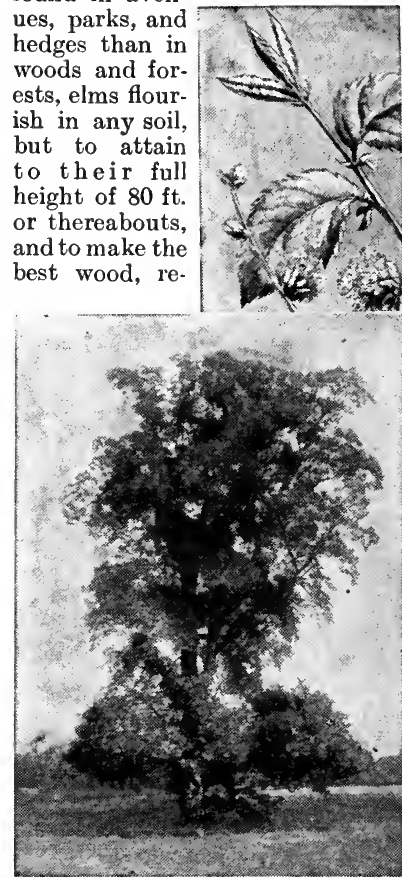

Elm tree in full foliage. Above, leaves and flowers of the common elm Photo, F. R. Hinkins

quire a rich alluvial loam. The most familiar species are wych elm (U. montana) and the bell elm (U. campestris). Both may be planted in open weather at any time between autumn and spring. The usual way of increasing in private gardens is by layering, or in the case of the bell elm by removal of suckers, as this tree seeds scantily.

Elms should not be planted near dwelling-houses, as the timber has a tendency to decay inwardly, involving danger of the limbs dropping off suddenly, without any warning, especially in high winds.

Elmalu, Elmali, or Aimali. Town of Asia Minor, in the vilayet of Konia. Situated on the river Myra, $25 \mathrm{~m}$. from its entrance into the Mediterranean, it is about $60 \mathrm{~m}$. S.W. of Analia. Pop. 4,000. The word means apple town. 
Elman, Mischa (b. 1891). Russian violinist. Born at Talnoi, Russia, Jan. 20, 1891, he received

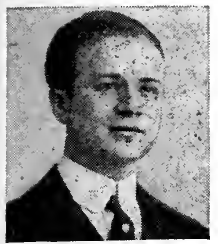

Mischa Elman,

Russian violinist his musical education at Odessa and St. Petersburg. He made his début there in 1904, a f t e r w a r d s appearing in Berlin, Dresden, and elsewhere. His first appearance in London took place March 21, 1905; in New York in 1908. From the first he was recognized as one of the world's greatest violinists.

Elmet. Name of a little British kingdom in Yorkshire. It existed in the 6th century and earlier, but was ended when conquered by Edwin, king of Northumbria, about 617. Its extent, roughly, corresponded to the West Riding. The name was long preserved by the forest of Elmet.

Elmina or ST. GEORGE DEL Mina. Small port of the Gold Coast colony, 8 m. S.W. of Cape Coast Castle. Here is a castle, built by the Portuguese in 1482 and succeeding years, taken by the Dutch in 1637, and transferred to the British in 1872, with the other Dutch settlements in West Africa. Pop. 5,091.

Elmira. City of New York, U.S.A., the co. seat of Chemung co. On the Chemung river, $145 \mathrm{~m}$. S.E. of Buffalo, it is served by the Erie and other rlys. It contains the state reformatory, a federal building, a state armoury, and other public buildings, and among several educational institutions are Elmira College for women, a free academy, and a school of commerce. A busy rly. and industrial centre, it has rly. workshops, iron works, foundries, and glass, tobacco, and boot and shoe factories. Settled in 1788, it was incorporated in 1828 and received a city charter in 1864 . Pop. 38,275.

Elmore Process. Method of making seamless copper (or other metal) tubes by depositing the metal by electrolytic action on a bar or mandrel kept rotating in the electric bath. It was devised by J. O. S. Elmore, an engineer in India, in 1896. A tube so formed would be wanting in mechanical strength if the deposition only were depended upon. Elmore therefore compacted the tube as the deposition of metal proceeded by rotating the mandrel against an agate burnisher, and thus greatly increased its strength. The advantage of the process lies in the purity of the product and the elimination of smelting processes. See Copper ; Electrolysis.

Elmshorn. Town of SlesvigHolstein, Germany. It stands on the Krüchau, about $10 \mathrm{~m}$. from its junction with the Elbe and $23 \mathrm{~m}$. from Hamburg. It is a river port, and has a shipping trade. Other industries including the manufacture of textiles, beer, and boots; also shipbuilding. Pop. 14,790.

Elmsley, Peter (1773-1825). British scholar. Educated at Westminster School and Christ Church, Oxford, he showed a remarkable aptitude for study. He was ordained, but devoted most of his time to the study of the classics and won a reputation throughout Europe by his critical work on the Greek tragedians. He wrote for The Edinburgh Review and The Quarterly Review. In 1823 he became principal of St. Alban Hall and Camden professor of ancient history at Oxford. He died March 8, 1825. See History of Classical Scholarship, vol. iii, J. E. Sandys, 1908.

Elmslie, Wrlulam Gray (184889). British divine. Born at Insch, Aberdeenshire, Oct. 5, 1848, he was educated at Aberdeen University and New College, Edinburgh, and later studied in Germany. In 1873 he became assistant to Dr. J. Oswald Dykes, at Regent's Square Presbyterian Church, London, and was chosen minister of Willesden Presbyterian Church in 1875. In 1880 he was appointed tutor of Hebrew in the Presbyterian College, London, being elected to the professorship of Hebrew and O.T. literature in 1883. He died in London, Nov. 16 , 1889. His son, William Alexander Leslie (b. 1885), a distinguished Oriental scholar, wrote Aboda Zara or The Mishna on Idolatry, 1911 , and Studies in Life from Jewish Proverbs, 1917. See W. G. Elmslie, Memoir and Sermons, ed. W. R. Nicoll and A. N. Macnicoll, 3rd ed. 1890.

El Mughar, Battle of. Fought between the British and the Turks, Nov. 13-14, 1917, and also called the battle of Katrah. After capturing Gaza, Gen. Allenby pushed N. without delay, and on Nov. 8, 1917, struck hard at the Turks from both Gaza and Sheria, Scots and Indian troops advancing along the coast to Deir Sineid, from which the Turks had a rly. to Huj, and Londoners, assisted by yeomanry, taking $\mathrm{Huj}$ and Jemmameh.

Allenby's objective was the junction station where, from the Central Palestine rly., a branch line ran E. to Jerusalem, possession of which meant depriving the Turkish forces in the Holy City of supplies by rail from the N. and the separation of these forces from those on the coast. With the 52nd (Scots) division, Indian, and other troops on his left, next the sea, Londoners and yeomanry in the centre, and Anzacs and other cavalry on his right, Allenby swept forward, occupying Ascalon, Ashdod (Esdud), and Tel es Safi (Gath), and on Nov. 13 began a general assault of the position that the retreating Turks had taken up from El Kubeibeh on the N.W., through El Mughar, to Beit Jibrin on the S.E.

Most of the country was open and rolling, dotted with small villages, two of which, Katrah and El Mughar, stood on a ridge which the Turks had fortified, and was the centre of the fighting. The Scots and yeomen got on the ridge, but twice were repulsed. Charging a third time, and assisted by $W$. of England infantry and other yeomanry, they took both villages, capturing 1,100 prisoners. After losing El Mughar the Turks abandoned the junction station, and the British occupied it on Nov. 14. See Palestine, Conquest of.

El Mugheir. Village of Palestine. It lies slightly W. of the Jordan, $17 \mathrm{~m}$. N. of Jericho. British and Indian troops occupied it Sept. 19, 1918. See Palestine, Conquest of.

El Obeid. Town of the AngloEgyptian Sudan, capital of the prov. of Kordofan. It is the terminus of the Kordofan extension of the Sudan government rlys. (completed 1911), and is situated about $160 \mathrm{~m}$. by road $\mathrm{W}$. of the Nile and $430 \mathrm{~m}$. by rly. S.W. of Khartum. A primary school where English is taught has been opened here. The pop. fluctuates, but the normal figure is about 12,000 .

Elobey. Two small islands, called Great and Little, off the mouth of the Gabun river, W. coast of Africa, belonging to Spain. Great Elobey is covered with bush, and has an area of $\frac{3}{4} \mathrm{sq}$. $\mathrm{m}$. The area of Little Elobey is 36 acres. The islands are under the control of a sub-governor, who is responsible to the governor-general resident at Santa Isabel on the island of Fernando Po. Pop., Gt. Elobey, 123 ; Little Elobey, 222, mostly of the Benga tribe.

Elocution (Lat. eloqui, to speak out). The art of effective public speaking. In classical times it included oratory, but now refers solely to the method and manner of delivery, the right study of which includes breath control, voice production, articulation, pronunciation, and expression.

Breath is the motive power of 
the voice. Authorities agree that the intercostal diaphragmatic method of breathing, i.e. the free expansion laterally of the lungs at their base with the descent of the diaphragm in inspiration and the reverse action with an even abdominal pressure in expiration-inhaling quickly and silently and exhaling slowly and evenly-gives a maximum of breath with a minimum of exertion. There should always be a supply of breath in the lungs, and inspiration should be renewed well before expiration is accomplished. A speaker's words should be poised on the breath, for any escape through or between the words will cause loss of tone and powes, and, under continuous strain of public work, may lead to permanent injury of the voice. An open throat, a mobile jaw, muscular control of the tongue and soft palate, together with right control of the breath, are the keynotes of correct voice production.

A knowledge of present-day accepted pronunciation is essential; provincialisms must be overcome. A sense of rhythm and beauty of diction, with a distinctive delivery, is as essential in the speaking of modern, as in that of classical, selections. Enunciation is the medium for expressive pronunciation, clearness of articulation being of the greatest importance. The tongue, hard and soft palate, gums, teeth, and lips all constitute part of the articulating organs, and by their partial or complete contact the consonants are formed. Vowels, being purely vocal, are produced by the changing shape of the mouth cavity and varying positions of the tongue. Pace must be varied according to the different emotions expressed. Emphasis is used principally to mark the salient word or words of a sentence, so as clearly to define the meaning. Its too frequent use negatives its own value, and over-emphasis is an offence to the intelligence. Pauses facilitate proper phrasing, and at the same time permit the reciter to take breath; the rhetorical pause, in which the breath is suspended, is used to emphasise some special effect. Tone should illumine and colour the words so that the full beauty of the theme is appreciated by the hearers. Lack of variety in tone renders many a speaker dull and spiritless.

Gesture should directly help the meaning of a passage. It should never be redundant, and, when used, should be spontaneous and easy, the arms moving from the shoulders, not from the elbow, the hands conveying the expression and completing the signific- ance of the gesture. The body should be well poised and the position firm, the weight being shifted easily from one foot to the other so that there is a free and full command of all movements. Facial expression, the complement of voice and gesture, indicates the changing thoughts or feelings as they pass through the speaker's mind, the eyes visualising the intensity of the emotion and marking more than all else the persomality of the speaker.

The prevalent method of speaking is careless and slovenly. This inefficiency is due largely to the indifference with which this im. portant subject is treated in our present educational scheme. Elocution should be compulsory in all schools, and it should apply to all classes alike. It should be taught from childhood, when the imitative faculty is more active.

Acton Bond

Bibliography. A Grammar of Elocution, J. Millard, 2nd ed. 1882 ; The Art of Speaking, Ernest Pert. wee, 3rd ed. 1904 ; Voice Production in Singing and Speaking, Wes. ley Mills, 5th ed. 1920.

Elohist. Term used in Biblical Criticism to denote the writer of one of the documents used in the compilation of the Pentateuch, or rather the Hexateuch. This is called the Elohistic document because the writer uses consistently the name Elohim for the God of the Hebrews, whereas the writer of another document (the Jehovistic) employs with equal consistency the divine name Jehovah. See Criticism; Hexateuch.

Elopement. Name given to the secret flight of a pair of lovers, generally with the object of marriage. Unless abduction can be proved it is not an offence against the law. See Abduction.

El Paso. City of Texas, U.S.A., the county seat of El Paso co. A favourite health resort and a port of entry, it stands 3,760 ft. above sea level on the Rio Grande, which separates the state from Mexico. Situated opposite Ciudad Juarez, it is the terminus of the National of Mexico and several other rlys. Among its buildings are the federal building, the city hall, a Carnegie library, and a sanatorium. It contains also military and civil educational institutions and a large number of parks. It trades largely in lead, copper, and silver, and has foundries, rly. repair shops, flour mills, and cigar and wood box factories. El Paso received its city charter in 1873 . Pop. 69,150.

Elphinstone, MountSTUART (1779-1859). British administra tor. Born Oct. 6, 1779, the fourth son of the 11th Baron Elphinstone, he entered the Bengal civil service in 1796. Appointed resident at $\mathbb{N a g}$ -

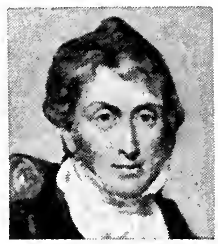

Mounstuart Elphinstone, British administrator From a portrait in the British Museum pur in 1804, he was sent as envoy to Kabul in 1808 , and was resident at Poona from 1811-17, and commis. sioner after its annexation. From 1819-27 he was governor of Bom. vay. $\mathrm{He}$ returned to England in 1829 and lived in retirement, twice refusing the governor-generalship of India. He compiled the famous legal code known by his name, and virtually founded the system of state education in India. Elphinstone College, in Bombay City, was endowed by the natives as a memorial of his administration. He wrote a valuable Account of the Kingdom of Cabul and its Dependencies, 1815; and a History of India (Hindu and Mahomedan periods), 1841. He died Nov. 20, 1859 . See Life, J. S. Cotton, 1892.

Elphinstone, William (14311514). Scottish prelate, founder of Aberdeen University. He was educated at Glasgow University, of which he became rector in 1474, was made bishop of Ross in 1481, and nominated to the see of Aberdeen in 1483 . In 1488 he was appointed lord chancellor, and lord privy seal in 1492. In 1494 he established King's College, the original foundation of Aberdeen University, appointing Boece (q.v.) its first rector, and securing grants from James IV for its maintenance. He introduced the printing press into Scotland, 1507. He died at Edinburgh, Oct. 25, 1514, it is said through grief at the battle of Flodden. See illus. p. 17.

Elsass-Lothringen. German name for the district better known as Alsace-Lorraine (q.v.).

Elsie Venner. Novel by Oliver Wendell Holmes. After serial appearance in The Atlantic Monthly under the title of The Professor's Story, the novel was published in volume form in 1861 as Elsie Venner : a Romance of Destiny. Its theme is the possible effect of antenatal influence upon individual conduct. In this case a mother is bitten by a rattlesnake shortly before giving birth to her child. The romance shows Elsie Venner's whole life and character affected by that pre-natal poisoning, since her nature turns out to be half that of a snake. 


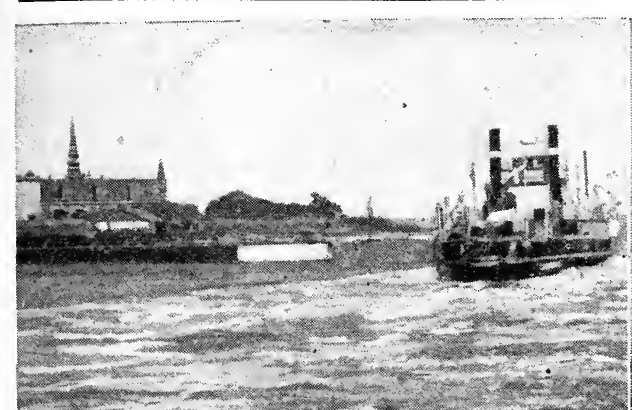

Elsinore, Denmark. View of the Narrows at the entrance to The Sound, with the ferry which crosses to Helsingborg on the Swedish coast

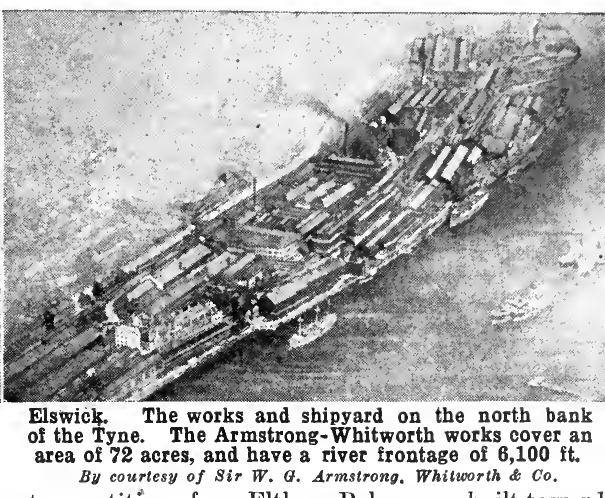

Elsinore (Dan. Helsingör). Seaport in Denmark. In the dist. of Frederiksborg and on the island of Zealand, it stands on The Sound, and has ferry communication with Helsingborg on the Swedish coast, and connexion by rly. with Copenhagen. Shipbuilding is the principal occupation, and iron-founding, engineering, and agriculture are carried on. The place is referred to in Shakespeare's Hamlet. Pop. 13,783.

Elster. Name of two rivers of Germany, the Schwarze (black) and Weisse (white). The former rises in the mountains between Saxony and Bohemia and flows mainly $N$. until it falls into the Elbe $10 \mathrm{~m}$. from Wittenberg. Its length is $110 \mathrm{~m}$. The white Elster rises near Eger in the Elstergebirge in Bohemia, but most of its course is in Saxony. It falls into the Saale in two branches, one near Halle and the other near Merseburg. It flows past Plauen and Leitz, and past Leipzig, where the Pleisse joins it. Its length is $120 \mathrm{~m}$. The town and watering-place of Elster stands on the white Elster near the Bohemian border. The Elstergebirge is a range of mountains in Bohemia. It runs from the Erzgebirge to the Fichtelgebirge, and reaches a height of $2,630 \mathrm{ft}$.

Elstow (formerly Helenstow). Parish and village of Bedfordshire, England. It is $1 \mathrm{~m}$. S. of Bedford and is noted as the birthplace of John Bunyan (q.v.). Pop. 499.

Elstree. Parish and village of Hertfordshire, England. It is a station on the M.R., $7 \mathrm{~m}$. S. of St. Albans. The church of S. Nicolas was rebuilt in the 19th century. Here are paper mills and a large reservoir used for fishing and boating. Pop. 1,939.

Elswick. Parish of Northumberland, England, forming a ward in the W. of the co. bor. of Newcastle, with station on the N.E.R. Here are situated the extensive Elswick Works of Sir W. G. Armstrong, Whitworth \& Co., Ltd. During the Great War vast quantities of munitions of war were manufactured here. Elswick. Park was opened as a public recreation ground in 1878. Pop. 58,352. See Armstrong, Whitworth \& Co.

El Teb, Battle of. Fought by the British, Feb. 29, 1884, against the Arabs. El Teb is a post in the Anglo-Egyptian Sudan, on the road from Trinkitat on the Red Sea to Tokar. In 1883 Osman Digna was besieging Tokar, and Valentine Baker, with a force of 4,000 men, was sent to relieve it. On Feb. 4, 1884, he was met by the tribesmen and was routed, two-thirds of his men being killed. Tokar then surrendered.

A British force of 4,400 men was then collected from Egypt and India, and under Sir G. Graham was landed at Suakin. On Feb. 29 this force faced the Arabs in their camp at El Teb. The latter threw themselves in wild fury against the British square, but after a fierce combat they were decisively beaten. The British casualties were 34 killed and 155 wounded, largely incurred in a charge made by the 10th and 19th Hussars.

Eltham. Parish of Kent, in the met. bor. of Woolwich, $7 \mathrm{~m}$. S.E. of London Bridge. Once a marketing town, it contained a palace, the fine banqueting $\mathrm{h}_{\mathrm{a}}$ ll of which still rem ains. Well Hall, an Elizabethan mansion, is supposed to have been occupied by Sir Thomas More's daughter. Eltham has many open spaces, including Eltham Common, Eltham Green, Eltham Park, and Avery Hill. During the Great War Eltham was bomb. ed by enemy air. craft. Pop. 13,450.
- Eltham Palace was built towards the end of the 13th century. It probably owes its origin to Anthony Bec, bishop of Durham, who appears to have lived here from 1297 to 1311. At first a fortified manor house, it was subsequently converted into a royal residence. Its extant portions, viz. the great hall and part of the old kitchens adjoining, are fine examples of domestic architecture of the reign of Edward IV. The 15th century bridge across the moat, which still remains, led by way of a gatehouse to a large court, to the right of which stood the chapel and the royal apartments. The architecture of the palace is notable for the fine oriel windows, the open timber roof of the hall, and the gables, with beautifully carved barge boards, of the kitchens.

Eltham. Township of North Island, New Zealand. It is on the main line from Wellington to New Plymouth, from which it is distant $36 \mathrm{~m}$. The chief centre of the Taranaki district, it has an extensive dairying industry. Pop. 1,711.

Eltham, EARL of. Title borne by the eldest son of the marquess of Cambridge (q.v.).

El Tineh. Village of Palestine. It lies about $15 \mathrm{~m}$. N. of Beersheba, on the branch rly. of the Lydda-

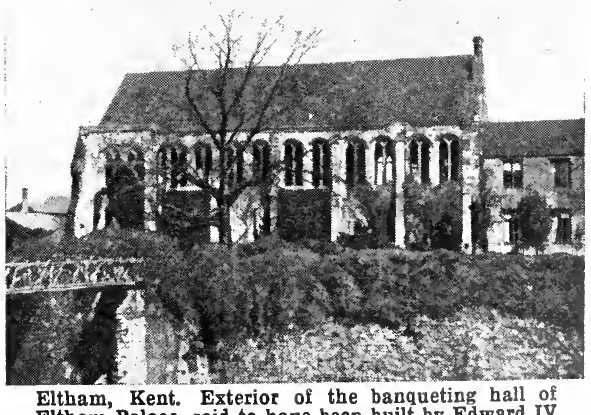

Eltham, Kent. Exterior of the banqueting ball of 
Jerusalem line, and is the junction for Gaza and Beersheba. It was captured by Australian troops Nov. 13, 1917. There is another El Tineh on an inlet of the sea, S.E. of Port Said, Egypt, near the ruins of Pelusium. See Palestine. Conquest of.

Elton OR YeLTON. Salt lake of Russia, in the govt. of Astrakhan. It lies on the border of the Kirghiz Steppes, $60 \mathrm{~m}$. E. of the Volga. Area, $60 \mathrm{sq} . \mathrm{m}$. Although it receives the waters of several streams, and has no outlet, it is very shallow, and strongly impregnated with salt, thousands of tons being extracted from it yearly. The Kalmucks call it the lake of gold.

Elul. Sixth month of the sacred and twelfth month of the civil year of the Jews, corresponding approximately to September. It is mentioned in the book of Nehemiah. See Calendar.

Elutriation (Lat. elutriare, to wash out). Process of obtaining mineral substances in a finely powdered condition by diffusing them in water after they have been ground or crushed. The coarser particles rapidly subside, and the water which still holds the finer particles in suspension is decanted into another vessel and the powder allowed to settle. The process is used for obtaining emery of different grades of fineness, and also for preparing jewellers' rouge free from gritty matter.

Elvan. Term applied by miners to the dykes frequently met in Cornish tin and copper mines. These dykes have been intruded into vacant spaces in the formations originally over them. In chemical and mineralogical composition they are identical with the granites of Cornwall, but their mechanical structure is different. They vary in width from a few feet to many yards, and have been often worked for tin. The word elvan is said to be derived from the Cornish term for a spark, elven, from the fact that the rock being hard emits sparks when the pick strikes against it. Other terms by which the rock is known are whinstone, granitic or quartz porphyry, and elvanite. Mineralogically it is a granular mixture of quartz and orthoclase. See Mineralogy; Tin.

EIvas. Frontier city of Portugal, in Portalegre dist. It stands on an affluent of the Guadiana, $170 \mathrm{~m}$. E. of Iisbon and $10 \mathrm{~m}$. W. of Badajoz, on the Lisbon-Madrid Rly. It has a Gothic cathedral, a 15 th century aqueduct, and an arsenal. The manufactures include pottery and brandy, and the exports olives and plums. The Roman Alpesa or Helvas and the

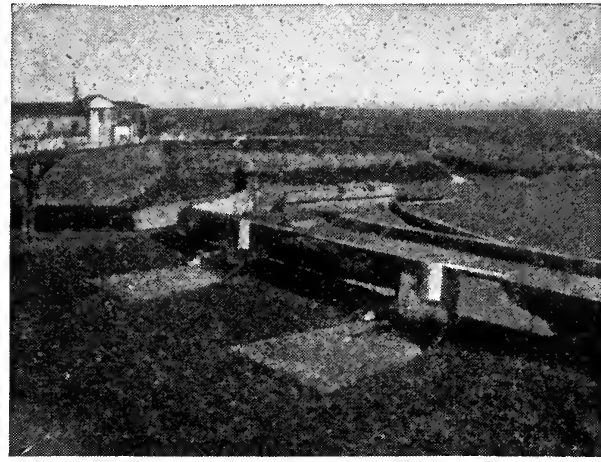

the estate of his uncle, Sir Hervey Elwes of Stoke College, Suffolk, he assumed his name. The estate having been originally much e $\mathbf{n}$ c u m be red, habits of frugality had turned Sir Hervey into a miser, and John Elwes proved an apt pupil. Goodhearted by nature, and of unim peach a ble

Elvas. Fortifications of the city defending the Spanish frontier of Portugal

Moorish Balesh, Elvas is an historic place; it held out against the Spanish in 1658 and 1711 , but fell to the French in March, 1808. Pop. 14,018.

Elvey, Sir George Job (181693). British organist and composer. Born at Canterbury, March 27,

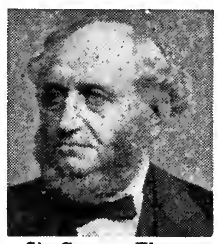

Sir George Elvey, British organist

until 1882. He was knighted in 1871, and died Dec. 9, 1893. Elvey's compositions are chiefly church music. See Life, M. Elvey, 1894.

Elvira, Council of. Ecclesiastical assembly held at Elvira in Granada, early in the 4th century. It was attended by nineteen bishops, and put forth about eighty canons dealing with church discipline. It forbade the veneration of pictures in churches, ordered attendance at mass on Sundays, and enjoined celibacy on the clergy.

Elwell, Frank Edwin (b. 1858). American sculptor and art critic. Born at Concord, June 15, 1858, he studied art under D. C. French at New York, and later at Paris under Falguière and at the Beaux Arts. He was the first American sculptor to have a statue erected in Europe. His work reproduces to some extent the characteristics of ancient Egyptian sculpture, of which he has made a profound study. $\mathrm{He}$ was curator of the sculpture section at the Metropolitan Museum, New York, 1902-5.

Elwes, Јонv (1714-89). British miser. Born April 7, 1714, son of Robert Meggott, on succeeding to himself. After a life of the utmost penury and nigg a rdliness, during which he let the estate go to ruin for want of re. pairs, he died Nov. 26, 1789. He left a for. tune of over $£ 500,000$.

\section{Elwood. City} of Indiana,

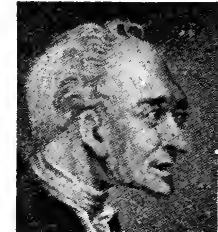
John Elwes, British miser U.S.A., in Madison co. It stands on a small stream, $39 \mathrm{~m}$. N.E. of Indianapolis, and is served by the Lake Erie and Western and other rlys. Situated in the natural gas district, it has large tinplate works, and manufactures flour, glass, and furniture. Formerly known as Quincy, it became a city in 1891 . Pop. 11,028.

Ely. Episcopal city, urban dist. and market town of Cam. bridgeshire, England. Situated on

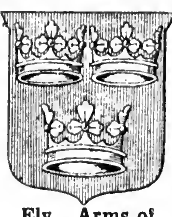

Ely. Arms of the bishop an eminence on the left bank of the Ouse, in the Isle of Ely, $16 \mathrm{~m}$. N.N.E. of Cainbridge on the G.E.R., it is fam ous for its magni. ficent cathedral. In $673 \mathrm{Ethel}$. dreda founded a monastery here for monks and nuns, and became first abbess. It was destroyed by the Danes in 870 , and in 970 was refounded as a Benedictine monastery by Ethel wold, bishop of Winchester.

The present cathedral was begun by Abbot Simeon in 1083 . It embraces every style of architecture from Early Norman to Late Perpendicular. It is $537 \mathrm{ft}$. long and $189 \mathrm{ft}$. across the great transepts. The W. portion of the nave and $W$. tower were added in 1180 ; the fine Galilee or W. porch was completed about the beginning of the 13th century; the choir was 


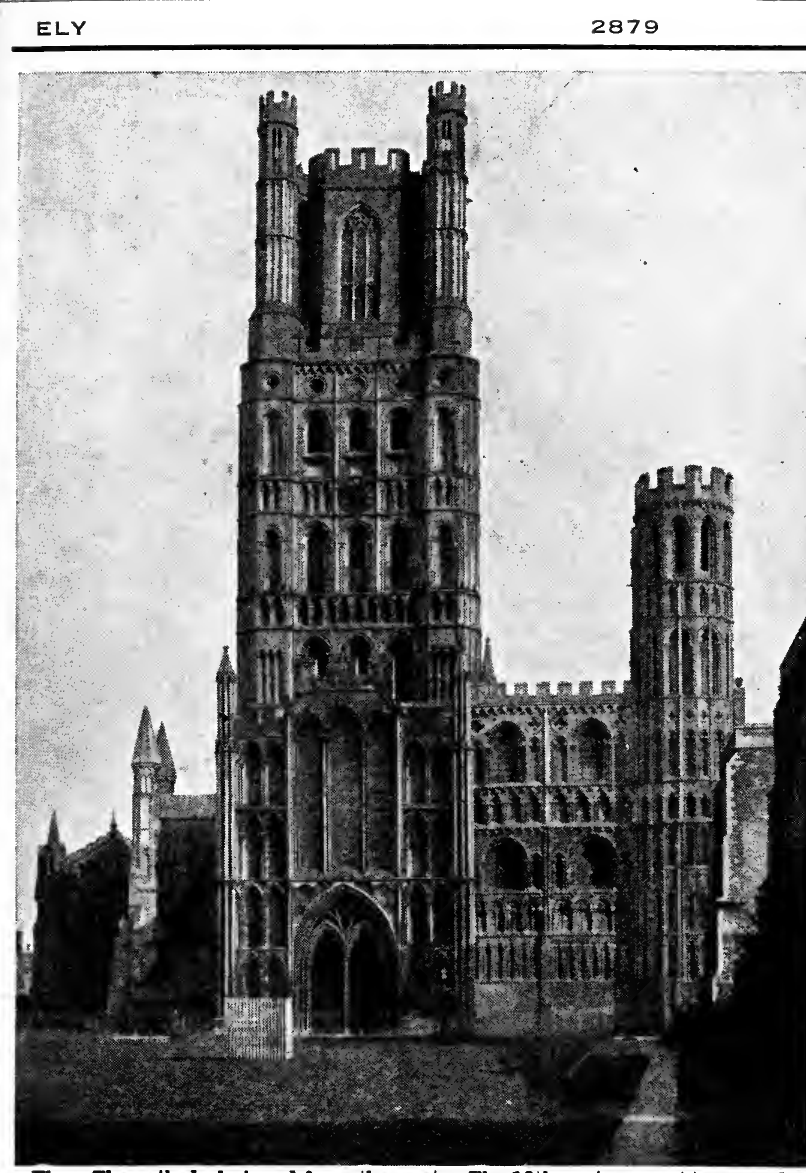

Ely. The cathedral viewed from the west. The 12 th century west tower and Galilee porch; to the right, the sonth-west transept and tower, of Transitional Norman architecture Photochrom

erected between $1235-52$; the minating in a marquessate in 1800 , beautiful Decorated octagon tower the reward for his support of the and lantern (170 ft. high), finished union of 1801 , when he was made in 1328, took the place of the central tower, which collapsed six years earlier; the lady chapel (now the parish church) dates from $1321-49$. Since 1845 the edifice has undergone general restoration. Within the cathedral's precincts are the Tudor bishop's palace, the King's School (1541), and a theological college. Ely became a bishopric in 1109 . Market day, Thurs. Pop. 7,917.

Ely, Marquess of. Irish title borne since 1800 by the family of Loftus. In 1771 Henry Loftus, an Irish landowner, was made earl of Ely, taking his title from Ely in Fermanagh. The title died with him in 1783, but his nephew, Sir Charles Tottenham, Bart., inherited his estates and took the name of Loftus. He was postmaster-general and was made a baron in 1785 . Other Irish honours followed, cul- the inn or hostel of the bishops of Ely, of which the church of $\mathrm{S}$. Etheldreda, restored to Roman Catholic worship in the 19 th century, was the chapel. John of Gaunt died in Ely House in 1399 , and Henry VIII is said to have first met Cranmer here. The church, one of the most perfect examples of Decorated architecture in England, has windows $\mathbf{E}$. and $\mathrm{W}$. with exquisite tracery, and an unrestored crypt. Ely House was demised to the crown under Elizabeth, and transferred to Sir Christopher Hatton.

Elyria. City of Ohio, U.S.A., the co. seat of Lorain co. On the Black river, $25 \mathrm{~m}$. W. by $\mathrm{S}$. of Cleveland, it is served by the Baltimore and Ohio, and the Lake Shore and Michigan rlys. It trades in building stone obtained from local quarries, and has chemical, motor-car, paint, and lace manufactures, iron and steel works, and tanneries. It became a city in 1892. Pop. 19,503.

Elysée. Palace in Paris, the official residence of the president of the French Republic. In the Faubourg St. Honoré, a garden separates it from the Champs Elysées. It was built in 1718 for the comte d'Evreux, but passed later into royal hands, and was the residence of Madame de Pompadour. Others who lived here included Napoleon I and Napoleon III. After 1870 it became the official residence of the president.

Elysium or the Elysian Fields. In classical mythology, the abode of the souls of the good after death. Some legends make Elysium a part of the underworld, others make it an island or islands in the Atlantic Ocean-the Fortunate Islands or Isles of the Blessed. Elysium is represented as a place of perpetual sunshine with flowery meadows and pleasant streams.

Elytra (Gr. elytron, covering, sheath). Horny sheaths or cases into which the fore wings have been modified in the beetles and certain other insects. They usually cover the back of the insect, and the hind wings are folded under them. See Insects.

Elze, Friedrich KarL (182189). German student and critic. Born at Dessau, Anhalt, May 22, 1821, he studied at Leipzig and Berlin. Having published a life of Byron (1870), Eng. trans. 1872, and various worke on the Elizabethan drama, he was appointed to the chair of English literature at Halle in 1875 . His best known work is a biography of William Shakespearc (1876), Eng. trans. 1888. He died at Halle, Jan. 21,1889. 
Elzevir. Name of a family of printers which is given also to some famous books printed by them, e.g. pocket editions of the Greek Testament, Latin and Italian classics, and French memoirs. The firm, founded in Leiden in 1583 by Louis Elzevir, was carried on after 1655 at Amsterdam by members of the family until 1681, and ended in 1712. The first edition of the Caesar of 1635 is the acknowledged masterpiece in type, ornaments, paper, printing, and purity of text. More than 150 spurious Elzevirs are known to experts. The publications of the firm dated from 1626 to 1680 are generally the most valuable. See Bibliotheca Curiosa: Catalogue of all Publications of the Elzevier Presses, E. Goldsmid, 1888.

Emanation (Lat. emanare, to flow out). In philosophy, the theory that all things proceed from a higher original principle (as light from the sun), into which they are again received and absorbed. This form of pantheism, of eastern origin, was adopted by the neoPlatonists and developed by the Gnostics and Cabbalists.

Emanuel I (1469-1521). King of Portugal. Born May 3, 1469, he ascended the throne in 1495 . $\mathrm{He}$

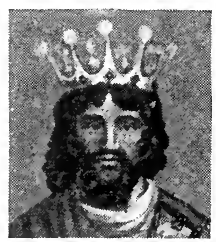

Emanuel I, King of Portugal

From an old engraving inspired the expeditions of VascodaGama, Albuquerque and Cabral to Brazil, Goa, Malacca, a n d $\mathrm{S} \mathrm{u} \mathrm{m} \mathrm{a} \mathrm{t} \mathrm{r}$ a. Under his guidance Portugal be c a me the principal maritime power in the world. He died Dec. 13, 1521.

Emanuel, WALTER LAWIS (1869-1915). British humorous writer. Born April 2, 1869, in London, and educated at University College School and at Heidelberg, in 1896 he became a solicitor, but had already begun contributing to humorous periodicals. In 1902 his amusing comment on current mat. ters, Charivaria, became a regular feature in Punch. $\mathrm{He}$ died in London, Aug. 4, 1915. His books included $\mathrm{Me}$ and Some Others, 1901; A Dog Day, 1902; The Dogs of War, 1906; Never, 1907 ; Puck Among the Pictures, 1908 ; One Hundred Years Hence, 1911.

Emba or Yemba. Non-navigable river of Central Asia, in Uralsk and the Kirghiz Steppes. It rises in the Mugojar hills on the $\mathrm{E}$. border of Uralsk to the N. of the sea of Aral, flows from $\mathrm{E}$. to W., and falls into theN.E. of the Caspian Sea after a course of about $300 \mathrm{~m}$.
Embalming (Fr. em, in, baume ; Gr. balsamon, balm). Art of preserving dead bodies. Among the ancient Egyptians, and possibly

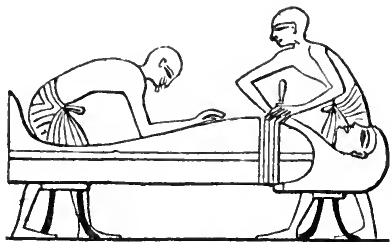

Embalming. Egyptian embalmers at work, from a relief

the Peruvians, embalming originated in the idea of the resurrection of the body. Herodotus describes three Egyptian methods. In the most expensive process, after removing the brains and intestines the abdomen was rinsed with palmwine and filled with myrrh, cassia, and other perfumes, and the incision in the left flank sewn up. The body was then steeped in natron (native sodium carbonate) for 70 days, washed, and wrapped in gummed linen cloths.

A less expensive method was to inject the body with Kedria (cedar pitch) in order to remove the intestines, and then steep it in natron. In embalming the poor the abdomen was rinsed in the substance known as syrmaea and the body steeped 70 days in natron. Usually the internal organs were embalmed and placed in jars. The Egyptians also embalmed cats, crocodiles, hawks, and other sacred animals and birds. See illus. p. 1503.

The ancient Persians apparently embalmed with wax, the Assyrians with honey, and the Guanches, the aborigines of the Canary Islands, in the Egyptian manner. Embalming has long been practised in Europe and is fairly common in the U.S.A. See Burial Customs.

Embankment. Mound of loose material artificially formed, or a bank supported by artificial means. Embankments may be classed as (a) embankments formed simply by tipping material and allowing the sides to assume the natural angle of repose of the material of which they consist, as in railway embankments ; $(b)$ reservoir embankments for containing and resisting the pressure of water; (c) embankments of earth or similar materialre tained, supported, and protected by walls, sheet piling, or other means

Railway embankments, which consist for the most part of materials excavated in cuttings, serve the purpose of carrying a railway across a valley or depression, in order to avoid steep gradients; they are also constructed to raise the level of railways across wide plains, especially where the soil becomes waterlogged, the necessary materials being obtained by excavating trenches known as borrow pits on either side of the line. When formed along the side of a hill a side excavation is usually made, the excavated material being utilised to form the bank portion, the sloping ground under the bank being first cut into steps to prevent side-slipping of the deposited material. Broken stone, gravel, and good sand are the best materials ; wet clay and surface soil are liable to cause trouble and expense, as the initial angle of repose may become much flatter. An embankment should be made higher than its permanent level to allow for subsidence; the allow.

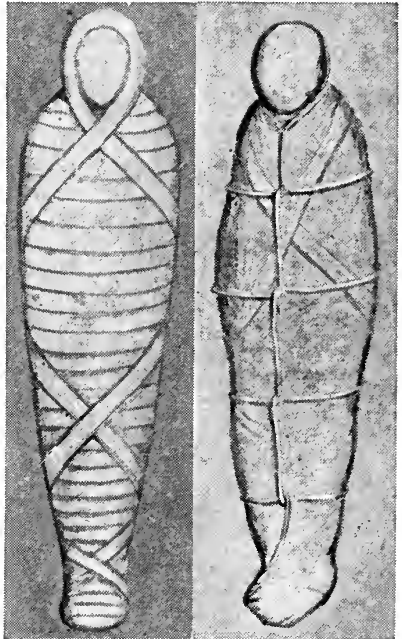

Embalming. Left, inner and, right. outer bandages wrapped by the ancient Egyptians round an embalmed body or mummy

ance varies from $\frac{1}{12}$ to $\frac{x}{5}$ of the height. Tipping should always proceed in a forward direction, as materials tipped sideways are liable to slip.

In first-class work the slopes are finally covered with surface soil for a depth of a few inches and either turfed or sown with grass seed, as grass binds the surface and tends to prevent washing away by rain. Embankments in still water should have their slopes pitched with stone; if subject to the action of waves or currents they should consist of rubble or be contained by walls. When a stream of water is encountered, a drain, culvert, or bridge is inserted Along each side of an embankment a ditch is cut into which surface water drains, and by which it is carried and discharged into the nearest stream. 


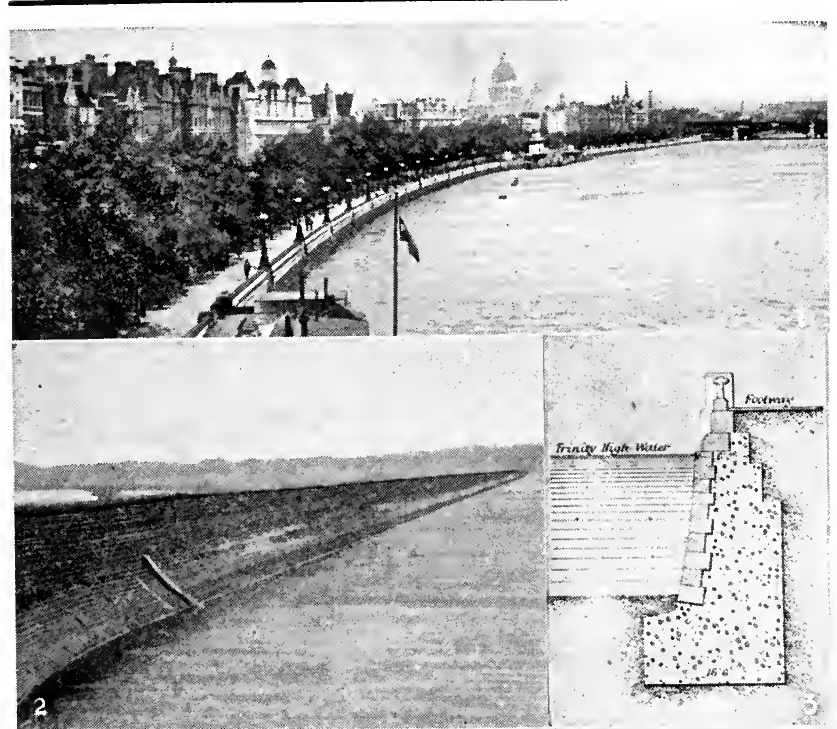

Embassy. Term used for an ambassador and his staff collec. tively. It is also used for the build. ing which serves as their headquarters, e.g. the British Embassy in Paris. By international courtesy the building is regarded as standing on the soil of the country to which the ambassador belongs. This means, for instance, that in the French embassy in London English law is not operative. Writs cannot be served there or orders of the court executed. See Diplomacy.

Embattled, ImbatTled, OR BATTLED. In heraldry, a line of division, or outline, showing square projections like the crenellations or embrasures of a castle wall. The term crenel. lated is some. times used.

Ember Days. In the Angli. can and $\mathrm{Ro}$. man Catholic

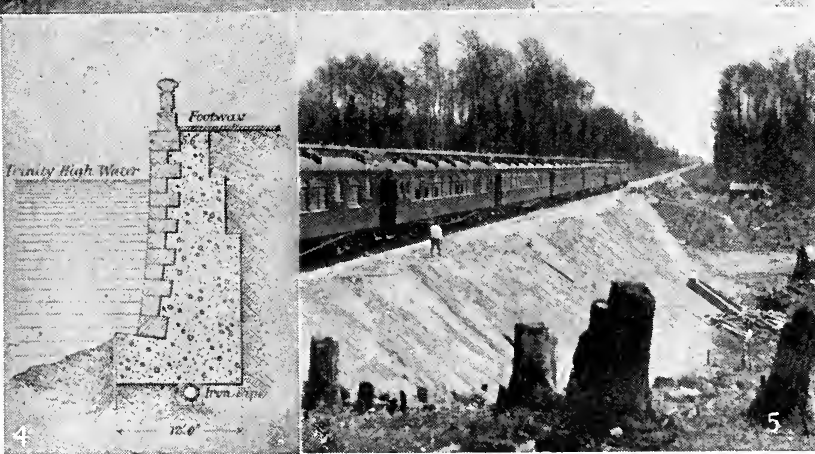
Churches, fasts

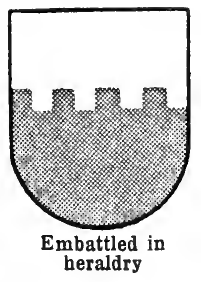
of the four seasons. They are the Wednesday, Friday, and Saturday after the lst Sunday in Lent, Whitsunday, Sept. 14 (Holy Cross Day), and Dec. 13 (feast of S. Lucy). T'he weeks in which these days occur are called Ember Weeks. They were introduced into England by $\mathrm{S}$. Gregory (590-604). Ordinations in the Anglican Church take place on the Sundays following the Ember Days, and in the R.C. Church on the Saturdays of the Ember Weeks.

Embezzlement. In English law, the wrongful appropriation to his own use, by a clerk or servant, of money received by him from his master. It must be distinguished from larceny by a servant. In the latter case the servant steals property which has been in his master's possession; in embezzlement he intercepts it. For example, if a shop assistant receives a shilling for goods sold and simply puts it in his pocket, and does not account for it to his master, it is embezzlement. If he puts it in the till, and then takes it out again and steals it, it is larceny by a servant.

Emblem (Gr. emblèma, an insertion). Originally meaning an ornament inserted on a mosaic or vase, the term is now generally used for an object or representation symbolic by reason of its connexion with another object, person, or event. It is also used for the marks used by printers to distinguish the work of their press.

In art the emblem has played an important part, especially in the re. presentation of Christian saints, etc. The work of the old masters, and

A wharf contained by sheet piling with earth filling, or the protection or reclamation of a foreshore or
The term is used by analogy for embargo on places of amusement, on imports, and so on. See Blockade 
the pages of old missals, Bibles, etc., are full of sueh representations. It has been estimated that the emblems of the saints number over 800 , or including variant forms, over 3,000 .

Among the commonest are the keys of S. Peter, the sword of S. Paul, the spiked wheel of $\mathrm{S}$. Catherine, the lamb of S. John Baptist, the lion of $\mathrm{S}$. Jerome, the dragon of S. George, the X-shaped cross of S. Andrew, the serpent of S. Patrick, the arrows of S. Sebastian. For the most part these objects are emblematic of the death suffered by the saint, or of miracles attributed to him.

Emblems are also given to various virtues and religious conceptions, e.g. the hand, marked with a cross or sacred heart, is found to stand for labour; a globe, surmounted by a cross and rest. ing on a heart, for the reign of love and concord on earth; a lily for purity and the Virgin Mary. The patriarchs, prophets, and sibyls have their emblems, as Adam with a spade, Moses with the tables of the law, David with harp or sling, or Sibylla Agrippina with a scourge. An early emblem of Christ was a fish, the letters of the Gr. ichthus, fish, standing for Jesus Christ Son of God the Saviour. During the 15th century, when heraldry was at its height, armorial bearings incorporating many emblems were devised for almost 100 saints. See Haginlngy.

Bibliography. Emblems of Saints, F. C. Husenbleth, 3rd ed. 1882 ; Symbols and Emblems of Early and Mediaeval Christian Art, L. Twining, new ed. 1885 ; Saints and their Emblems, M. Drake, 1916.

Emblements (old Fr. emblaement, harvest; late Lat. imbladare, to sow). Term used in Eng. lish law for certain rights of the tenants of a manor, e.g. the right to cut timber for the repair of the housc and fences.

Embolism (Gr. embolos, stop. per, plug). Obstruction of a bloodvessel by material which has been carricd along in the blood-stream. The commonest cause of embolism is detachment of a blood-elot or portion of a blood-clot which has formed in a vein. Other substances which may form emboli are portions of growths on the heartvalves resulting from endocarditis, calcareous material from degenerated vessels, pieces of tumours, fat, masses of bacteria, and air bubbles.

Enbolism of a coronary artery may cause sudden death; embol ism of the brain may lead to paralysis: embolism affecting the main blood supply to a limb leads to sudden pain, swelling, and pulse- lessness, followed by gangrene in some cases and by reeovery in others where other vessels enlarge and replace the blocked circulation. If the embolus contains infective micro-organisms, as, for instance, when it has been broken off from a septic clot, the result is often to set up an abscess where it lodges. Air may accidentally find entrance into the blood-stream during operations involving the large veins of the neck, and when the bubbles reach the heart they become churned up with the blood, leading to dilatation of the heart and sudden death.

Embossing (Fr. em, in; bosse, hump). In architecture, ornamenting a surface with decorative work in relief, obtained by hammering, stamping, or other mechanical force on metal or stone. Reliefs obtained by carving or casting cannot be termed embossed work. See Architecture.

Embouchure (Fr. em, in ; bouche, mouth). In music, the part of a wind instrument through which it is blown. It is also used for the adjustment of the player's lips, teeth, and tongue to the mouthpiece of his instrument. Upon this adjustment depend the pitch, quality, and power of the tone produced. See Mouthpiece.

Embowed. In heraldry any charge which is bent, as an arm or a curved dolphin, is said to be em.

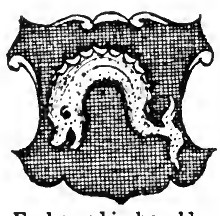

b o w e d. A human limb is sometimes said to be "flexed."

$\mathbf{E} \mathbf{m} \mathbf{b} \mathbf{r}$ acery. In English law, an a $t \mathrm{t}$ e $\mathrm{m} \mathrm{pt}$, whether suc. Embowed in heraldry cessful or not, to influence a jury in favour of one party to a trial, whether by promise, persuasion, monetary bribery, treating, or the like. The person who attempts to so influence a jury is called an embraceor; and the same term is applied to one who comes into court to overawe a jury, or for reward, and speaks in favour of one party. It is a mis demeanour punishable by fine and imprisonment. The word is derived from old Fr. embracer (mod. embraser), to set on fire, excite ; to embrace, meaning to clasp in the arms, is from Fr. em, in ; bras, arm (Lat. bracchium).

Embrasure (Fr., aperture with sloping sides). Military term for the opening made or left in the parapet of a defensive work for a gun to be trained and fired through.

Embrocation (Gr. embrochè, fomentation). Medicinal preparation intended to be rubbed into the skin. It is also known as liniment.
Embroidery. Art of decoration by means of needle and thread. Its practice is of the highest antiquity. There are references to it in the description of the Tabernacle, and Ezekiel (xxvii, 7) mentions "fine linen with broidered work from Egypt." Phrygia and ancient Babylon were renowned for their embroideries. The art was well known in ancient Greece, and to Greek workmanship of the 4 th century is attributed one of the oldest specimens extant, in the Hermitage, Petrograd. The ground is purple cloth, upon which is sewn a palmette ornament in green and yellow.

In Christian times embroidery became the handmaid of the Church, and so the most ancient examples are ecclesiastical vestments. These were most ornate in very early times, for we learn of a Christian senator of Rome in the 4th century whose robe was decorated with no fewer than 600 figures representing incidents in the life of Christ. The oldest existing vestments are those at Arles, which date from the 6 th century. In Durham Cathedral are a stole and maniple, found on the body of $\mathrm{S}$. Cuthbert. Of ancient vestments, perhaps the most beautiful is the dalmatic in the Vatican reputed to be that of Charlemagne, but now attributed to the 11 th century. One example of medieval embroidery that stands alone is the Bayeux Tapestry (q.v.).

In the 13th century English embroideries were without equal and the "Opus Anglicanum" was eagerly sought after. Matthew Paris states that in 1246 the pope, astonished at the number and magnificence of the vestments worn by the English bishops, sent letters to the English abbots urging them to procure a quantity for him. Apparently one of the characteristics of early English embroidery was the amount of gold, pearls, and precious stones. Examples of magnificent early English copes are exhibited in Ascoli-Piceno, Pienza, Anagni, Madrid, Toledo, South Kensington, and elsewhere. French and German embroidery reached a high pitch of excellence during the 13 th and 14th centuries, as did also the Italian ateliers in Milan and Florence. These developed a realistic style which in the 16 th century was characteristic of Italian work. In the 15th century Finglish embroidery deteriorated.

In W. Europe, embroiderỹ was both a professional and amateur handicraft. In the Middle Ages the lady of the castle during the absenec of her lord on warlike or hunting expeditions passed her 
time in embroidering scenes from Scripture, history and legend, or decorating banners with the family devices. The reputation of Queen Matilda was equalled by Catherine of Aragon, Bess of Hardwick, countess of Shrewsbury, and Mary Queen of Scots, who used to work at her embroidery all day long until very pain caused her to give it up. At that time the elaborate embroidery on ecclesiastical vest. ments was extended to secula dresses and furniture, and cross stitch or petit point came into use for panels and cushions. Magnifi cent bed-curtains ornamented with trees and large leaves full of elabor. ate detail were made in the Jaco. bean period, while that of Charles ] is characterised by the highly raised style known as "stump work." A return to simplicity in the early 18 th century is seen in the powderings of natural flowers worked in chain-stitch on a light ground, and many beautiful sam. plers of the period yet remain Under the Hanoverian kings, the highly ornate court dresses afforded excellent opportunity for the art of the needle, and the upholstered chairs were covered with cross-and tent-stitch work. Later the art sank to a low ebb in copying prints in black and white and slavish imitations of paintings, but the pre Raphaelite movement, the revela. tion of Japanese art, and the study of Eastern examples have restored embroidery to a very high level.

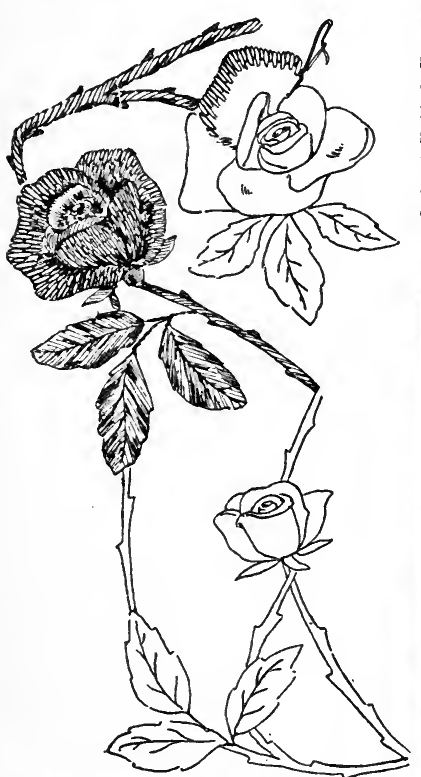

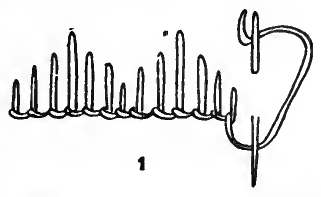
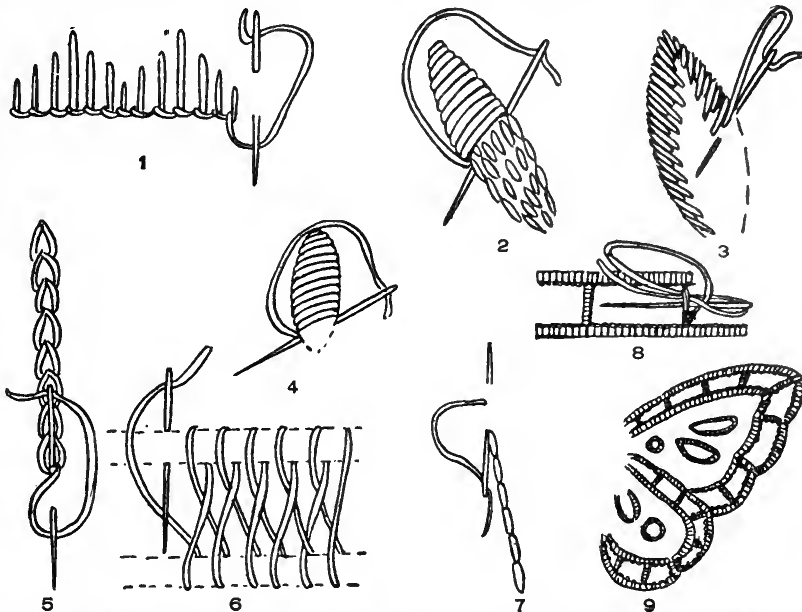

Smbroidery. Stitches in common nse 1. Buttonhole 2. Long and short stitches. 3 and 4 . Satin. 5. Chain. 6. Eastern or Oriental. 7. Back stitch. 8. Working diagram of cat work shown complete in 9

There are many kinds of embroi. dery, such as cut-work, appliqué, couching, quilting, etc., while the principal stitches are chain, feather, satin, cushion, comb, cross, tent, lace, long-and-short, back, herringbone, buttonhole, and many Eastern stitches. w. G. Thomson

Bibliography. Needlework as Art, M. M. Alford, 1886 ; La Broderie du XIe Siècle jusqu' à nos Jours, L. de Farcy, 1890-1900; English Embroi. dery, A. F. Kendrick, 1905 ; La Bro. derie (Les Arts du Tissu), G. Migeon, 1909 ; Art in Needlework, F. Day and M. Buckle, 4th ed. rev. 1914.

Embrun. Town of France. It stands above the Durance in the department of Hautes Alpes, being nearly $3,000 \mathrm{ft}$. high. Although a small place it has much historic interest. It was once the seat of an archbishop, and its magnificent cathedred, built in the 12 th cen. tury, remains. Dedicated to Notre Dame, it has a fine tower and other features. The palace of the arch. bishops is now used for public purposes, and there is an old tower, a relic of the fortifications which were pulled down in 1884. Pilgrims visited Embrun in the Middle Ages to venerate a picture of the Ma. donna painted on the cathedral door. A large Roman station, the place became a bishopric soon after 300. The bishops (later arch. bishops) were princes of the Empire and rulers of an extensive territory. The see was transferred to Gap in 1791. Pop of commune, 3,556.

Embryo (Gr. en, in; bryein, to swell, teem with). Word used in various meanings. In a general sense it expresses an undeveloped idea or conception, the initial stage of anything. In biology it is the living creature which develops it. self in the egg or womb; in botany, that part of the seed from which the plant is formed.

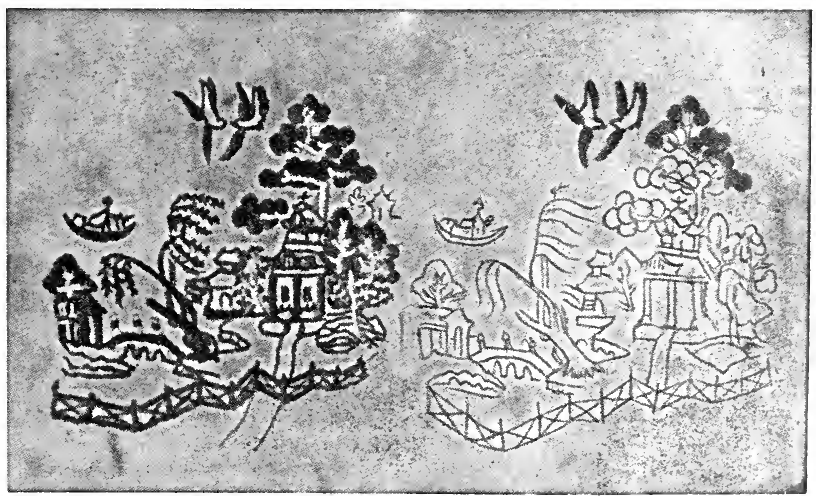

Embroidery. Examples of artistic designs. Left, rose and leaves, illustrating how the pattern traced on the clote is followed. Centre and right, willow pattern design showing finished work and original tracing 
EMBRYOLOGY: THE SCIENCE OF LIFE

J. Arthur Thomson, Regius Professor of Natural History, Aberdeen With the article on this department of the science of biology should be read those on Biology; Evolution; Life. See also Bacteriology; Cell; Eugenics; Heredity, etc., and the biographies of Dartein and other bislogists

Embryology (Gr. embryon, em. bryo ; logos, science) is the science of the individual life-cycle, especially of the early stages during which a germ grows into a body. In other words, embryology is the science of individual development. From what looks like a minute drop of living matter, though it is doubtless a little world with intricate organization, of which the microscope gives us a hint, there is gradually built up a young bird or mammal, or some other creature, whether animal or plant. Out of apparent simplicity there arises obvious complexity, and this development is one of the most mysterious processes in the world.

In the great majority of cases the individual life of plant or animal begins in the intimate union of two germ-cells or gametes, a more passive egg-cell or ovum and a more active sperm-cell or spermatozōon. What follows refers chiefly to animal development.

EGG-CELL OR OVUM. In most animals the egg-cells or ova are formed by the multiplication of primitive germ-cells within the ovary. These primitive germ-cells are the unspecialised descendants of the fertilised egg-cell which developed into the body, and they retain its essential qualities. They increase in number by repeated division, and some of them increase in size and become unripe ova. It frequently happens that an ovum absorbs its less successful sistercells, or that they form a protec. tive and often nutritive covering (follicle cells) for it. In the ovary of the frcsh-water Hydra and the marine Tubularia there is usually only one ovum left out of many.

Formation of the Yolk

The egg-cell usually accumulates yolk-material, which may come to be enormous in amount. The yolk is furnished by the blood or other nutritive fluid of the parent, the follicle cells often acting as inter. mediary units; or it may be furnished by special yolk-glands. It accumulates in the ovum as glob. ules or platelets mainly consisting of a substance called lecithin.

Around the egg are eventu. ally formed sheaths or envelopes of various kinds: $(a)$ a delicate vitelline membrane made by the egg itself immediately after fertilisation; (b) a follicular envelope secreted by the follicle cells; and, it may be, (c) a hard shell formed by special glands in the walls of the oviduct. The follicular envelope is often formed before fertilisation, and is perforated by a minute aper. ture (the micropyle) or by several of them. Otherwise the spermatozōon could not effect entrance.

The calcareous shells of birds' eggs and the horny mermaid's purse round the eggs of skates and dog. fish are formed after fertilisation. What is called a bird's egg consists of a hugely dilated egg-cell heavily laden with yolk, of a follicular envelope of some complexity around this, of a large amount of albumen or white of egg, of a tissue-paperlike shell membrane, and of the porous shell. Most ova are minute spheres, and the majority are microscopically minute. The nucleus of the unripe ovum is usually a vesicle full of clear nuclear sap (the germinal vesicle of the older embryologists), with grains of readily stainable chromatin material borne on fibres crossing the sap, and a dense corpusclecalled the nucleolus.

\section{Plant Egg-cells}

The egg-cell or oosphere of a flowering plant lies within an "embryo-sac," within the ovule, within the ovary. When it is fertilised, by a nucleus from the pollen-tube, it divides and re-divides to form an embryo. Thus the possible seed or ovule becomes a real seed able to germinate.

The Sperm-cell or Sperma Tozōon. Primitive germ-cells, usually localised in a special reproductive organ or testis, increase in number enormously and decrease in size, becoming spermatocytes. These divide further into unripe spermatozōa or spermatids, which become mature spermatozōa. A typical spermatozōon is an extremely minute cell, hundreds of which might be suspended in a drop on a pin's head ; it is sometimes only about $\frac{1}{100}$ th of the size of the egg-cell which is often the size of a pin's head. In typical cases it shows three parts: the essential " head" consisting chiefly of nucleus, the mobile "tail" which is often fibrillated, and a small middle piece between them which bears a little corpuscle called the centrosome. The spermatozōa of threadworms and most crustaceans are of a different type, slug. gish and inclined to be amoeboid. The spermatozōa of different ani. mals differ considerably in detail. In flowering plants the male element is represented by a generative nucleus within the pollen-tube which grows out of the pollen-grain. In flowerless plants the male element is usually a motile antherozōoid, as in ferns and mosses.

Maturation. In the history of the germ-cells, both ova and spermatozōa, a remarkable process occurs which is known as maturation or reducing division. In the nucleus of the immature stages of the germ-cells there are a number of readily stainable bodies or chromosomes which separate from one another, and can be counted when division is going to occur. The number is quite definite for each species, e.g. 2 or 4 in the two races of the threadworm of the horse, 12 in the grasshopper, 24 in the mouse, and 24 in man. This definite " normal number," whatever it may be, is often (but not always) demonstrable in all the cells of the body as well as in the germ-cells.

In the mature ovum and the mature spermatozōon the number of these chromosomes is half the normal, therefore in one way or another, at one stage or another-for it seems to occur variously in different types-there is a process of reduction, by which, in the division, half of the whole chromosomes go to each daughter-cell, whereas in an ordinary cell-division each chromosome is halved longitudinally, and one set of halves passes to each daughter-cell. The peculiar kind of cell-division which occurs during the maturation of the germ-cells is called a reducing or meiotic division; the ordinary method is called an equation division.

\section{Reduction of Chromosnmes}

If we compare the chromosomes with the wooden matches in a box, a reducing division would be comparable to putting half of the matches into another box, while the equation division would be comparable to splitting each match longitudinally and then putting one set of halves into another box. When the egg-cell is ripening the nucleus moves to the periphery and gives off an abortive sister-cell, the first polar body, which often divides into two, but never comes to anything. The nucleus of the ovum then divides again and gives rise to a second polar body, which also comes to nothing. The reduction of the number of chromo. somes is often effected in the formation of the first polar body, and there is a corresponding reduction in the penultimate division of the spermatocytes.

In the sperm-cell lineage 
spermatogonium divides into "spermatocytes of the first order"; each of these divides into two sper

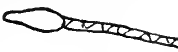

matocytes of the second order; each of which divides a gain into two spermatids, which become sperma. tozéa. In this case all the four cells which are descended from a spermatocyte of the first order become sperma-

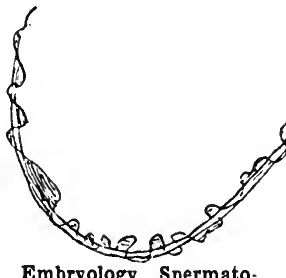

Embryology. Spermato. that of a horse zoon of man. Abore, maternal hereditary contributions, (2) the restoring of the number of chromosomes to the normal, tozōa; in the egg-cell lineage the first polar body and the second polar body are useless. The whole subject is very difficult, but it is very important, for maturation probably affords opportunity for new arrangements among the hereditary qualities which are borne, in part at least, by the chromosomes. It is held by many that it is in the maturation-division that the germ-cells are segregated into two contingents differing in the hereditary factors they carry, as is suggested by the facts of Mendelian inheritance (see Heredity). According to others, the segregation of qualities is not confined to the reduction-division.

Fertilisation. The intimate union of the mature ovum and the mature spermatozōon is called fertilisation. The head of the spermatozōon, penetrating the ovum, swells up and becomes the " male pronucleus"; it moves tothe "female pronucleus"; the two coalesce to form one nucleus- the "zygote nucleus"-which will presently divide.

Fertilisation implies (1) the mingling of the paternal and the

Embryology Sectional view of the embryo of a frog, illustrating how the

braun, spinal cord, vertebrae, and alimentary canal are among the earliest parts to form

(3) the introduction of a centrosome (along with the middle piece of the spermatozōon) which plays an important part in the subsequent division of the ovum, (4) a stimulus to the ovum to divide or the removal of some fetter that was keeping the ovum from dividing, and (5) a rapid physical and chemical change in the periphery of the egg-cell which nips off the tail of the spermatozonon and makes the egg-cell non-receptive to other spermatozōa, the entrance of which would cause abnormal division.

By the brilliant work of Loeb, De l a ge, and others it has been $\mathrm{shown}$ that "artificial par. thenogenesis" can be readily induced in a large number of ova (of starfish, sea-urchin, of some worms, molluscs, fishes, and of the frog) by a variety of mechanical, physi. cal, and chemical stimuli. If the

eggs of the sea-urchin be placed for alittle while in sea-water whose com position has been slightly altered by the addition of a small quantity of magnesium chloride, they will develop without fertilisation and become larvae or even small sea urchins when restored to sea-watcr. wards the reduced ovum-nucleus-
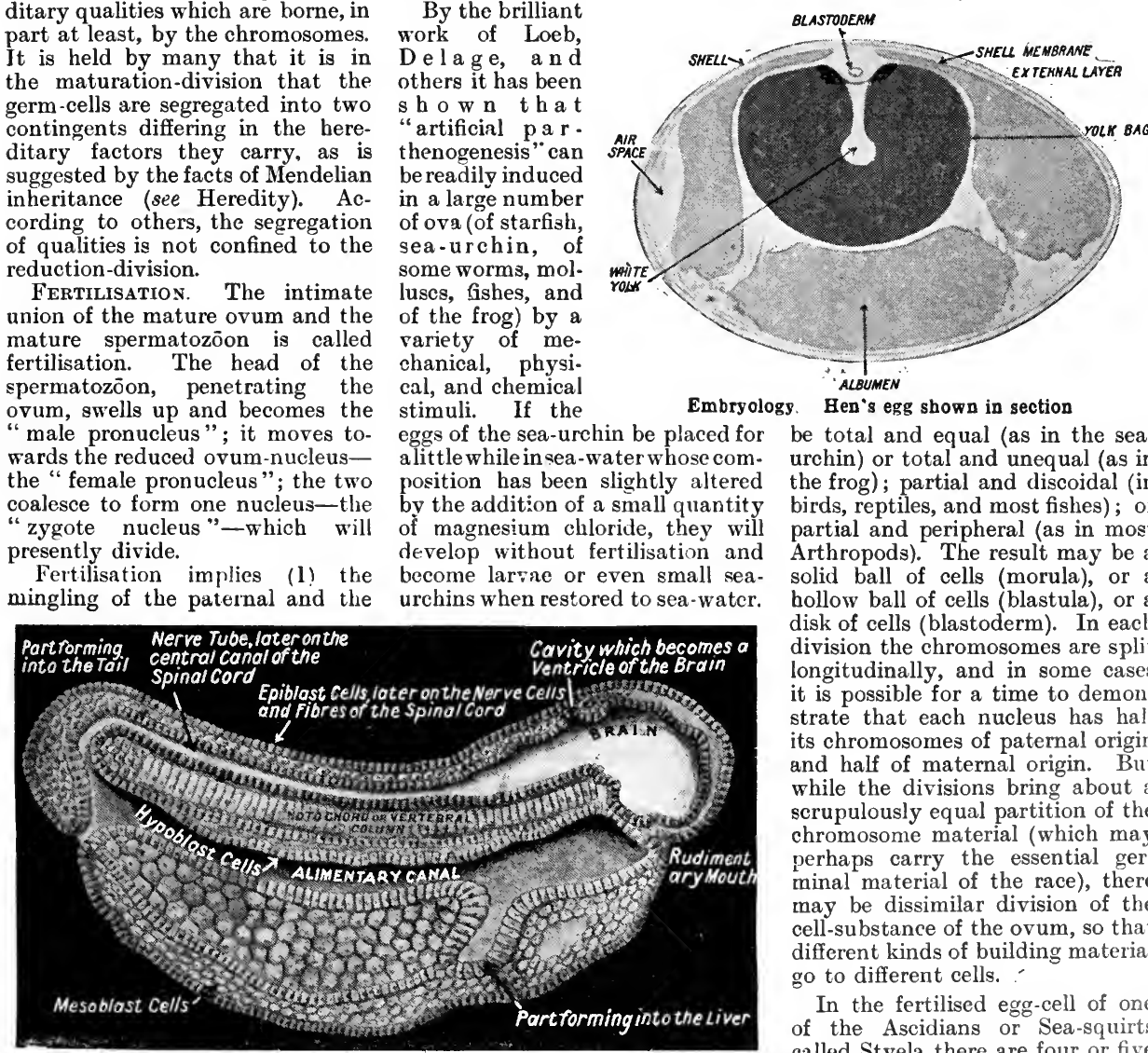

Embryology. Hen's egg shown in section
If the eggs of the frog be pricked with a fine needle, washed in blood, and restored to fresh water, they will develop without fertilisation and become tadpoles or civen frogs.

It should also be noted that in some cases the occurrence or nonoccurrence of fertilisation determines whether the ovum is to develop into a female or into a male. Thus the unfertilised eggs of a hivebee develop into drones. In other cases, where there are two kinds of spermatozōa, the nature of the fertilisation settles the sex of the offspring. Though the external features of fertilisation in plants are very different from those typical of animals, the essentials are the same. (See Sex.)

Segmentation. On the heels of fertilisation comes segmentation or cleavage, the egg-cell dividing into many daughter-cells or blastomeres. The segmentation differs according to the amount and distribution of the yolk. Thus it may BLASTODERM urchin) or total and unequal (as in the frog); partial and discoidal (in birds, reptiles, and most fishes) ; or partial and peripheral (as in most Arthropods). The result may be a solid ball of cells (morula), or a hollow ball of cells (blastula), or a disk of cells (blastoderm). In each division the chromosomes are split longitudinally, and in some cases it is possible for a time to demonstrate that each nucleus has half its chromosomes of paternal origin and half of maternal origin. But while the divisions bring about a scrupulously equal partition of the chromosome material (which may perhaps carry the essential germinal material of the race), there may be dissimilar division of the cell-substance of the ovum, so that different kinds of building material go to different cells.

In the fertilised egg-cell of one of the Ascidians or Sea-squirts called Styela there are four or five different kinds of substance which occupy different positions, and 
are distributed in the course of development in different ways. They happen to have different colours, so that they can be followed. There is a yellow peripheral layer which gathers at the lower pole of the egg (where the spermatozonon enters) and there forms a yellow cap. It afterwards moves to form a crescent around the posterior side of the egg just below the equator.

On the anterior side of the egg there is a grey crescent, at the lower pole between the two crescents there is a slate-blue substance, and at the upper pole there is a zone of colourless living matter. Now, when the egg divides and redivides the yellow crescent goes into those cells which will become muscle and mesoderm, the grey crescent into cells which become nervous system and the supporting rod ealled the notochord, the slate-blue substance into the endoderm cells lining the future food. canal, and the colourless substance into more ectoderm cells.

Germinal Layers. In many developing eggs which are not encumbered with much yolk material, a hollow ball of cells (a blastula) becomes in-dimpled or invaginated to form a two-layered sac of cells (the gastrula). The outer layer of cells is called the ectoderm or epiblast, the inner layer, the endoderm or hypoblast. The cavity which corresponds to the future digestive cavity is called the archenteron, and the mouth of the sac the blastopore. In sponges and stinging animals there are only two fundamental layers; in higher forms an intermediate layer, the mesoderm or mesoblast, is established. It is important to notice that these three layers give rise to the same sort of structures throughout the animal kingdom.

Thus the ectoderm forms the epidermis, the nervous system, and the foundations of the senseorgans. The endoderm forms the lining of the digestive tract and of outgrowths from it. The mesoderm forms muscle and connective tissue, and in many cases (e.g. all vertebrates) the skeleton. It is possible in many cases to go farther back, and point to certain particular cells in the segmented ovum which will form certain structures in the adult, and no others. An early localisation of organ-forming substance is often demonstrable, and it is a remark. able fact that an artificial disarrangement of the cells may be put right again by regulation processes which are very characteristic of development

Differentiation. As development proceeds new kinds of ma- terial become evident; all sorts of different cells-nervous, muscular, glandular, connective, and so on-appear; tissues and organs arise. In a word, there is a mysterious process of differentiation. There is interaction between nuclear substance and cellsubstance, there are movements and localisations of different kinds of building material, there are differential (i.e. dissimilar) divisions of the cell-substance into heterogeneous daugnter-cells which are in some measure partitioned from one another. Thus, to use a metaphor, the developing embryo becomes like a garden in which different plots have come to have different kinds of soil, as well as different relations to one another and to the outer world. A similar handful of seeds, including a score of different kinds (corresponding to the nuclear material), is sown in each plot, but while each plot gets the same kind of seeds, those able to develop in each are different.

But while differentiation is in pro. gress the developing body is also in.

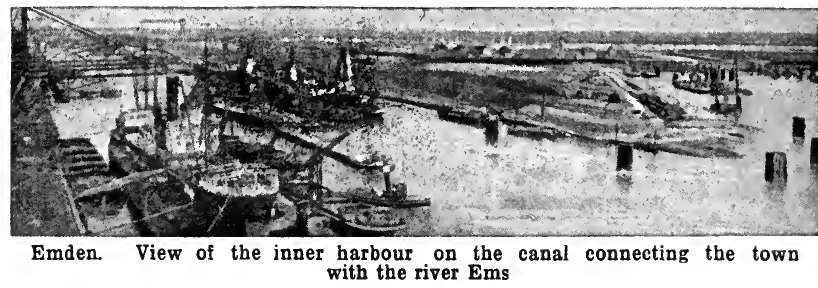

tegrated. That is to say, it becomes more and more of a unity, and nothing is more remarkable than the way in which different parts work into one another's hands, and conspire, as it were, towards a cooperative result. The germ is what it is because it has somehow had enregistered within it the many developments manifested in the past by the race to which it belongs. Development is the actualisation of this inheritance, and it comes about in such a way that there is in the individual, especially in the making of organs, a condensed recapitulation of the evolution which has been the work of ages.

In a general way the develop. ing organism climbs up its own genealogical tree. It must further be noted that the development of the inherited nature always requires at least a minimum of ap. propriate nurture if it is to develop aright, and that the fullness of the development depends in some measure on the fullness of the nurture supplied. In this fact, as well as in the slow improvement of the breed, there is hope for mankind.
Bibliography. Human Embryology, C. S. Minot, repr. 1897 ; The Cell in Development and Inherit. ance, E. B. Wilson, 2nd ed. 1900 ; The Science and Philosophy of the Organism, H. Driesch, 1908; Experimental Embryology, J. W. Jenkinson, 1909; Textbook of Em. bryology, ed. W. Heape, 1914, etc. ; Heredity and Environment in the Development of Man, E. G. Conklin, 2nd ed. 1916.

Emden. Seaport and town of Germany. In the Prussian province of Hanover, it stands near the mouth of the Ems, 50 m. W.N.W. of Oldenburg, and is the terminus of the Dortmund-Ems canal. The port and its harbours are on a ship canal, which connects with the Ems, $2 \frac{1}{2} \mathrm{~m}$. away, and other canals passing through the town. The chief ecclesiastical buildings are the Great Church, the Gasthaus Church, and the New Church. The Renaissance town hall, built in the 16 th century, contains a valuable collection of firearms, and there are museums, colleges, schools, etc. Emden has a large shipping trade, and is an important fishing centre.

Shipbuilding is carried on. Originally a town in East Friesland, in 1595 it became a free city under the sovereignty of the Dutch Republic, and in 1744 it was handed over to Prussia. In 1815 it was transferred to Hanover, passing with that kingdom to Prussia in 1866 . Pon. 24,000 .

Emden. German light cruiser. A sister ship to the Dresden, she displaced 3,600 tons and had ten $4 \cdot 1$-in. guns. She was launched in 1908. During the Great War the Emden did much damage to British and Allied commerce Von Müller, her commander, showed humanity by providing for the safety of the crews of the vessels he sank. While convoying Australian troops to England, the Australian cruiser Sydney learned that the Emden was at Cocos Island and drove her ashore at North Keeling Island and destroyed her, Nov. 9, 1914, with the loss of 230 of her crew. Müller, who was allowed to retain his sword. was among those saved. This was the first actual fighting done by any ship of the Australian 


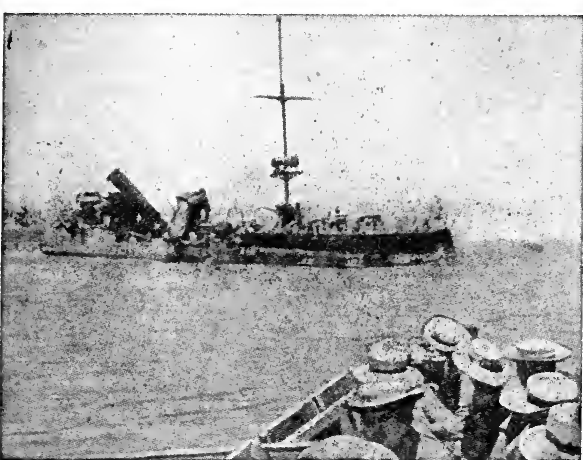

Emden. The German light cruiser when she had been driven ashore on North Keeling, one of the Cocos Islands, after her battle with the Australian cruiser Sydney "scientific emer. alds," contains from 7 p.c. to 8 p.c. of beryllin, but although almost identical with, are of lower specific gravity and refractivity than, the true stones, and are almost always "cloudy" or "mossy." "Emer. aldines" are arti. ficially coloured chalcedony.

E m e r a 1 d Green. Name ap. plied to certain green colouring matters. The two

navy, and relics from the Emden were distributed to various Australian cities.

Another German light cruiser, built in 1915, was christened Emden in fulfilment of a promise made by the Kaiser when the first was destroyed that a new one should sail the seas. This vessel was among the warships surrendered to the Allies after the armistice, and was allotted to France in 1920.

Emerald (Gr. smaragdos, Fr. émeraude, Span. esmeralda). Green variety of mineral beryl, a metasilicate of beryllium and aluminium found in granitic or schistose rocks, and in veins traversing them. It crystallises in hexagonal system, and forms long six-sided prisms; it is valued as a gemstone on account of its colour. Perfect crystals are rare, many stones show " mossiness," due to tiny fissures and air bubbles, while the colour is often very irregularly distributed. Emeralds of antiquity came from Egypt; its mines, reopened in the 19th century, yield handsome stones, though generally small in size and rather pale in hue. The finest crystals come from South America, chiefly Colombia, and from the Urals; a few are found in Austria, Australia, and the U.S.A.

Certain other stones are known as emeralds. The "oriental" emeralds are Australian sage-green corundums ; "Brazilian" are tourmalines; "Uralian "are green garnets ; "lithia" are spodumenes ; "evening emeralds" are bottle-green peridots; "false" are fluor-spar ; while " mother of emerald " is green quartz; and " emerald copper" a dioptase (a green silicate of copper).

Artificial emeralds are made by fusing together 4,608 parts of strass, 42 parts of copper oxide, and 2 parts of chromic oxide. A finer quality, known as "synthetic" or mineral emerald greens are aceto. arsenite of copper and hydrated chromium sesqui-oxide. The aniline dye known under this name is prepared by the action of benzaldehyde upon dimethylaniline and subsequent oxidation.

Emergency Ration. Ration carried by troops on active service or at manoeuvres to serve in the event of their being beyond reach of the ordinary daily issue. Also known as an Iron Ration, most stringent regulations are in force to prevent its consumption except in the last emergency. In the British army it consists of four biscuits, one tin of bully beef, and a small quantity of tea and sugar, all contained in a ration bag which may only be opened by order of an officer.

Emerson, Ralph WaLdo (180382). American poet, essayist, and philosopher. He was born at Boston, Mass., May 25, 1803, the son of a Unitarian minister, and was educated at the Boston Latin school and Harvard. After graduating in 1821, he spent three years in teaching, and then, having entered the Unitarian ministry, was appointed joint minister of the Second Church in Boston, 1829. In the same year he married Ellen Louisa Tucker, who died in 1832 , and in that year he resigned his ministry in consequence of his widened views, to which he had given expression in a sermon on the Lord's Supper (Works, vol. xi, 7), not meeting with the approval of his congregation.

In 1833 Emerson travelled in Europe, visited Carlyle, and began that lifelong friendship with him which bore literary fruit in a notable collection of letters. On returning to America he settled at Concord, Mass., and entered upon his career as writer and lecturer, which, in a few years, was to place him in the front rank of American men of letters. The year after settling in Concord, he married again, his second wife being Lydia Jackson (1802-92). In 1836 he published a slim volume, Nature, in which he briefly stated the case for a new outlook on things in place of the continued acceptance of mere tradition. In subsequent addresses, lectures, and essays, the thoughts enunciated in Nature were enlarged upon and developed. In 1840 he commenced writing for The Dial, and edited it for two years; this magazine came to be regarded as the special organ of the New England 'Transcendental movement in religion, literature, and philosophy.

The first volume of those essays by which he was to become most widely famous was published in 1841 , and a second series followed three years later. In 1847 the first collection of his poems was published, and in the autumn of the same year he revisited England on a lecturing tour, delivering a series of addresses on Representative Men - Plato, Swedenborg, Montaigne, Shakespeare, Napoleon,

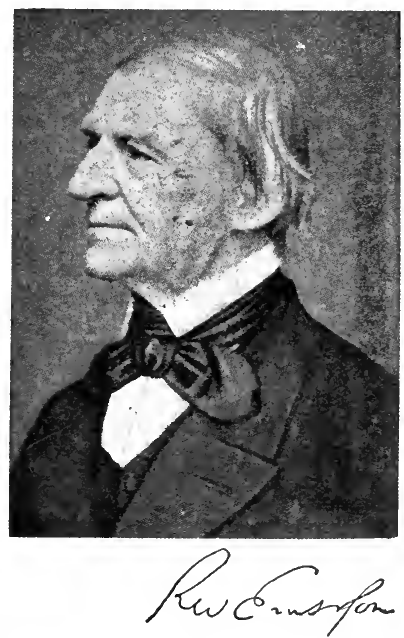

and Goethe. The volume containing these addresses was publisher in 1850 . He had returned to Concord in 1849, and in 1856 the fruits of his observation during his extended stay in England werc em. bodied in that admirable, and, on the whole, rarely discriminating volume, English Traits.

Writing and lecturing, he came to take a high position as the chief leader of American thought of his generation, and, despite some unfavourable comment on his somewhat staccato literary style, to be recognized in England as a great suggestive and stimulating writer. 
Thus his successive works met with a cordial welcome on both sides of the Atlantic. In June, 1872, his house at Concord was partly destroyed by fire, a disaster which caused him a severe shock; it was, however, rebuilt by his friends and admirers, and he sought health by revisiting Europe, $1872-73$. $\mathrm{He}$ died at Concord,

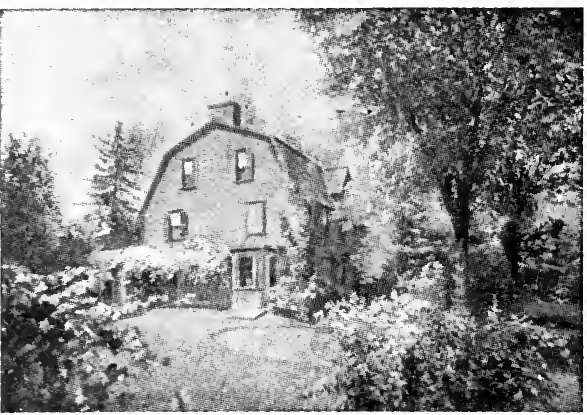

Emerson. The old manse at Concord, Massachusetts, where Emerson settled in 1833, and where Nathaniel Hawthorne lived from 1842-46 where his house still stands, Apr. 27, 1882 , and is buried in the famous cemetery of Sleepy Hollow, at that town.

The work which Emerson left, alike in prose and in poetry, is peculiarly individual. $\mathrm{He}$ was, perhaps, essentially a poet, but only in a small degree a singer; his verse, often marked with penetrating thought and lofty conception, is, for the most part, lacking in any beauty of form or music. Though a philosopher, his philosophy is that of the moment's consideration rather than that of any fully deve. loped scheme ; is, indeed, the philosophy of the poet rather than that of the scientist. It is, therefore, less as master of any definite course of philosophy than as a stimulator of thought along idealistic and optimistic lines that he exercised as great an influence as he did on his time. His position in this respect is perhaps best summed up in the words of Richard Garnett: "More than any of the other great writers of the age he is a Voice. He is almost impersonal. $\mathrm{He}$ is pure from the taint of sect, clique, or party. He does not argue, but announces; he speaks when the spirit moves him, but not longer. Better than any contemporary, he exhibits the enigma how Confucius, and Buddha and Socrates and greater teachers still should have produced such marvellous effects by mere oral utterance." The effect of his work, it has been said, is that of good and stimulating conversation, but it should also be said that it is conversation on a high and impersonal plane. His utterance has something of a fincly. balanced sanity, and though at times it may suggest the mystic, it is the mysticism of a glorified common sense, not that of mere nebulosity.

walter Jerrold

Bibliography. Works, Centenary ed., 12 vols. 1903-15; Lives, O. W. Holmes, 1885 ; J. E. Cabot, 1887 and R. Garnett, 1887; R. W. Emer

son, F. B. Sanborn, 1901; Remembrances of Emerson, J. Albee, 1903 , Emerson and his Philosophy, J. A. Hill, 1919.

Emery (Gr. smyris, old Fr. émeril, Span. esmeril). Dark, granular variety of mineral corundum, chemically an oxide of aluminium. In association with schistose rocks it occurs in Saxony, and in Naxos and other Greek islands. In the U.S.A. it is largely worked at Peekskill, New York, where deposits are probably segregations of the basic oxides in a norite rock. Owing to its extreme hardness, it is used for abrasive purposes, the commercial emery being a mechanical mixture of corundum, magnetite or hematite, and sometimes spinel.

Emery, Winifred (1862-1924). Stage name of Isobel Winifred Maud Emery Maude, British act-

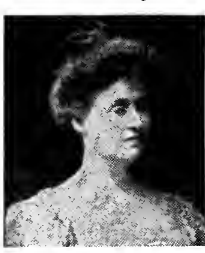

Winifred Emery,

British actress Vandyk

e stage was 1870, Amphitheatre, Liverpool, Bushes. Her first London appearance was in pantomime at The Princess's, Dec. 1874. Her début as an adult was at The Imperial, Westminster, April 14, 1879, in Man is Not Perfect. A versatile actress, she appeared with Wilson Barrett. Comyns Carr, ForbesRobertson and Beerbohm Tree. She accompanied Henry Irving to the U.S.A. in 1884 and 1887-88. She died July 15. 1924

Emetic (Gr. emetikos). Drug which causes vomiting. Emetics are occasionally used as therapeutic agents in cases of simple illness. Dyspepsia and sick headache caused by excessive eating may sometimes be relieved by evacuating the stomach of its contents. Another use is in conditions of difficulty of breathing caused by bronchitis, especially in children, the act of vomiting stimulating the respiratory mechanism and relieving the symptoms.

The great use of emetics is to remove poison from the stomach. This form of treatment may be adopted with safety in almost all cases where poison has been swallowed, except poisoning from strong mineral acids and carbolic acid, which are apt to corrode the stomach wall and render violent movement of the organ undesirable. Some knowledge of emetics should be possessed by every household, for the prompt administration of an emetic may avert serious symptoms, and even save life, which would be lost if treatment were delayed. The simplest emetics are a tablespoonful of mustard, or one or two tablespoonfuls of salt, in a tumbler of warm water. The following emetics should be taken only under medical advice.

Zinc sulphate. 10 to 30 grs. dissolved in half a tumbler of warm water, repeated if necessary. Am. monium carbonate. 15 to 30 grs. dissolved in warm water. Ipeca. cuanha. Four to six drams of the wine, or 20 to 30 grs. of the powdered root.

Apomorphine is best administered hypodermically in doses of $\frac{1}{10} \mathrm{gr}$. This emetic stimulates the nerve centre in the brain which controls the process of vomiting, and is therefore particularly useful in poisoning by narcotics such as opium, or drugs, such as carbolic acid, which tend to produce loss of sensation in the stomach.

Emetine. Chief alkaloid found in the roots of ipecacuanha (Cephaelis Ipecacuanha). It is extracted by mixing the finely powdered root with an equal weight of lime, making into a paste with water, and after drying the mass, extracting it with chloroform. The emetine is dissolved by the chloroform, and after the evaporation of the solvent, remains behind. Eme. tine is a violent emetic, but in medicinal doses is a valuable remedy for certain forms of dysentery.

E.M.F. Abbrev. for electromotive force, a measure of the strength of an electric current.

Emigrants' Information Office, THE. Name formerly given to a department of the Colonial Office. Its function was to give information to intending emigrants, especially those going to other parts of the Empire. It is now merged into the Oversea Settlement Office (q.v.) 
Emigration (Latin e, from; migrare, to change one's residence). Systematic migration of the surplus population of one land to another for the purpose of settlement. This movement has been one of the great factors in shaping the modern world, more potent even than military conquest. The military victor holds his possessions at the point of the sword, often over a rebellious people; settlers absorb the land and sooner or later obtain control of it.

The modern emigration movement began after the discovery of America, developing contemporaneously with the era of the merchant adventurers. Spain led the way, absorbing enormous areas in S. America and in the southern half of N. America. S. America is still overwhelmingly Spanish, in language, customs, and life. Portugal and Holland played no inconsiderable part, but Spain's main rivals were France and Britain. The enterprise of the merchants of Bristol gave Great Britain a foothold in Newfoundland from which the British people spread to the Pacific in the W. and Mexico in the S. Everywhere, but especially in N. America, French and British found themselves as rivals in the race for new empire.

Religion played a large part in the first emigration movements. Zeal for the Catholic Church led Spain to attempt to establish on a large scale model Catholic nations in S. America. The effort to create new peoples to overcome the growing heresies of Europe influenced the French kings in their pious endeavours to build up New France along the banks of the St. Lawrence. The departure of the Pilgrim Fathers from Plymouth in 1620 for New England laid the foundations of the U.S.A. of to-day. A second great impelling force has been poverty. The most marked example of this was the steady exodus of the Irish people to America during the Irish famines in the 19th century. The third cause is love of adventure and ambition, of which the most striking instance is to be found in a large part of the emigration from England and still more from Scotland.

\section{The Outflow from Europe}

As Spain and Portugal declined, the outflow of their people ceased. The Dutch settlers in many parts -notably in the state of New York-were gradually absorbed in the English-speaking race. S. Africa remains the outstanding example of successful Dutch settlement, and is still mainly Dutch in language and institutions, al- though British in government. France, đefeated in her struggle for political supremacy in $\mathrm{N}$. America after the Napoleonic wars, became one of the least $\mathrm{mi}$ gratory nations in Europe, but the province of Quebec still re mains distinctively French under the British flag. Britain maintained the outpouring of her people. While she lost political control of a large part of N. America, the U.S.A. still remained British in speech, and the British stock predominated. The convict settlements of New South Wales and Tasmania gave way to the free British commonwealths of Australia and New Zealand. The growth of Australia and the opening up of the Pacific coast of $\mathrm{N}$. America were enormously stimulated by the discovery of gold in California and Victoria in the middle of the 19th century.

The defeat of the liberal movement and the triumph of imperialism in Germany stimulated a German migration westwards, which militarism and poverty did much to encourage. The German people prefer not to settle in Ger man-ruled colonies, and betore the Great War went mostly to the U.S.A. and to S. America. After the war their migration to the U.S.A. was checked, and they tended to go in larger numbers to S. America, Poland, and W. Russia. Italy, Russia, and the states of South-Eastern Europe in the years immcdiately before the Great War wcre the main sources of European emigration.

\section{Migration to the U.S.A.}

The abundant industrial openings and the high wages of the U.S.A. have made it for many years the Mecca of the European emigrant. The flow of population early in the 20 th century averaged $1,000,000$ a year, and in 1914 was over 1,200,000. Three-quarters came from Russia, Italy, and Austria-Hungary. Most of this migration was closed down for a time by the Great War. The large German and Eastern European settlements, and the considerable negro population $(9,827,763$ in 1910 , and rapidly increasing) present some of America's gravest social problems. Despite the large Eastern European immigration in recent years, the most considerable section of the foreign white stock in the U.S.A. is to-day English speaking.

Canada failed to draw any considerable number of new settlers until near the close of the 19th century. Then, partly on account of the closer settlement and growing scarcity of land in the U.S.A., a big movement, largely of farmers, started from there into the prairie provinces. This ran parallel with a movement from Europe. Between 1901 and 1911, the population rose from $5,371,135$ to $7.206,643$. In the next decade, owing to the war and economic difficulties, the growtl was slower, but by 1920 the population exceeded 8,000,000. The Dominion Government showed a certain timidity in dealing with immigrants immediately after the war, partly owing to fear of the Labour vote. Australia had gone through a similar experience earlier, but, learning better, launched out on fresh schemes for attracting im. migrants.

\section{Japanese on the Pacific Coast}

One of the most significant movements of recent years has been the large Japanese emigration all over the Pacific coast and islands due to the rapid growth of Japanese population. This has given rise to serious difficulties with the white nations of the Pacific, more particularly with the people of California, who have caused deep offence in Japan by carrying exclusive legislation. The Japanese claim the right to be treated like white men. The Californians say that for them to do so would involve the Japanese absorption of their land. Despite all repressive legislation there are close on 90,000 Japanese in California alone. The Japanese are a majority of the population in Hawaii, they are spreading through Eastern Siberia, and they have settlements in almost every port or trading centre in Eastern Asia. See Alien; Immigration; Population.

F. A. McKenzie

Emigrés. Term applied to Frenchmen who sought refuge in foreign countries during, and immediately after, the French Revolution. Most of these supporters of the old régime went to the Rhenish states of Germany, but everywhere actively advocated the restoration of the Bourbon dynasty. Their hopes of a speedy accomplishment of this object were shattered when the French Revolutionary armies defeated the Prussians and their allies at Valmy in 1793. After the final overthrow of Napoleon in 1815 the emigrés who were still alive or had not permanently settled abroad returned to France. See French Revolution.

Emilia. Administrative division of N. Italy. It slopes from the Apennines to the river Po, and facing the Adriatic. The name is derived from the Roman Via Aemilia, the great $\mathrm{N}$. road which passed through the territory. The 
compartimento includes the provs. of Bologna, Ferrara, Forli, Modena. Parma, Piacenza, Ravenna, and Reggio Emilia. Low-lying along the coast, it is elsewhere hilly, and is drained by tributaries of the Po. Area, 8,042 sq. m. Pop. 2,809,187.

Eminescu, Mrrail (1849-89). Rumanian poet and editor. Born at 1 pateshti in Moldavia, Dec. 26, 1849, he was edncated at the universities of Vienna, Jena, and Berlin. In 1870 he contributed two memorable poems, Venere si Madona, and Epigonii, to the Conrolbizi Literare, and in 1874 he was appointed school inspector and librarian in the university of Jassy. He died at Bukarest, J une 15, 1889 , and is regarded as a great lyric and satiric poet.

Emin Pasha (I840-92). German administrator. Born at Oppeln. Silesia, March 28, 1840, of

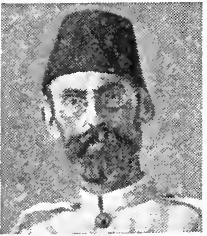

Emin Pasha, German administrator Jewish parents, his real name was Ed ward Schnitzer.After studying medicine at Breslau and Berlin, he took up an ap pointment on the staff of Hakki Pasha, in Turkey, and adopted a Turkish name. In 1876 he went to Egypt, and in 1878 was appointed by Gordon governor-general of the Equatorial province. When the Sudan was abandoned in 1883, Emin was left in the heart of the country, whence he was rescued by Stanley in 1889. Returning to Equatoria in the German service, he met his death at the hands of Manyama Arabs in Oct., 1892. His suecess in abolishing the slave trade in the district under his control, his eareful survey of over 4,000 miles of road, and his observations of the flora, fauna, and meteorology of the country gained him an enduring reputation. See his Ietters and Journals, Eng. trans. Mrs. R. W. Felkin, 1888; New Light on Dark Africa, C. Peters, Eng. trans. H. W. Dulcken, 1891 .

Emir. Arabic word meaning commander, also spelt ameer or amir. It is used for chiefs and other rulers of certain Mahomedan peoples, the form emir being mainly confined to those in Africa.

Em'ly, Litrte. Character in Dickens's David Copperfield. A pretty and attractive girl, the niece and adopted daughter of the old boatman, Daniel Peggotty, and en. gaged to her cousin Ham, she runs off with David Copperfield's old schoolfellow, Steerforth, by whom she is ultimately abandoned.
Emma. Novel by Jane Austen, written in 1815 and published the following year. It is one of the best of its author's works, full of character and humour in the presentation of the society of Highbury, a "large and populous village almost amounting to a town."

Emmanuel College. One of the colleges of Cambridge University. It was founded by Sir Walter

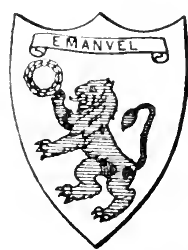

Emmanuel College arms Mildmay in 1584, but is now governed by statutes made in 1882 . The head is the master, and there are both senior and junior fellows. The build. ings in St. An. drew's Street date mainly from the latter part of the 16 th century, although Wren designed the chapel. Those which they replaced belonged before the Reformation to a house of the Dominicans. The college names include Archbishop Sancroft, John $\mathrm{H}$ a r vard, and Bishop Percy. It wa long a stronghold of Puritanism.

E $\mathbf{m} \mathbf{m}$ a $\mathbf{u} \mathbf{s}$ Ancient town of Palestine. It is now represented by the village of Amwas, on the road between Jaffa and Jerusa. lem, noted for a medicinal spring. It is not to be confused with the Emmaus of the N.'T., near which Christ appeared to $\mathrm{His}$ disciples after the Resurrection, the site of which is unknown.

Emmen. Town of Holland, in the prov. of Dreulbe. It is $29 \mathrm{~m}$. S.S.E. of Groningen, just N.W. of the Berger Meer, and on the road from Groningen to Koevorden. The inhabitants are principally engaged in agriculture and sheep and cattle rearing. Pop. 37,156.

Emmerich. Town of Germany in the Prussian Rhine province. It stands on the right bank of the Rhine, $5 \mathrm{~m}$. from Cleves, and not far from the frontiers of the Netherlands. The chief building is the minster church, built in the 11th and 12th centuries, while another is the church of S. Aldegunde. A steam ferry crosses the Rhine here. Emmerich is an old place, having been a Roman settlement. In 1217 it was made a town; later it joined the Hanseatic League, and as part of the duchy of Cleves it passed into the possession of Brandenburg in 1609. Having been for a few years part of Berg, it was returned to Prussia in 1815. Pop. 13,400 .

Emmet, ROBERT (1778-1803). Irish nationalist. Youngest son of the physician to the viceroy, and

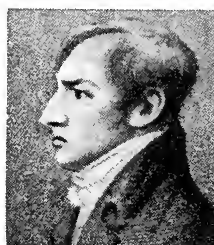

Robert Emmet Irish nationalist After Petrie brother of the United Irish. man, Thomas Addis Emmet, he was born in Dublin and educated at Trinity College. $\mathrm{Be}$ tween 1800-2, Emmet travelled on the Continent, and was fired with the idea of seeuring French aid from Bonaparte in a rising against England. $\mathrm{He}$ succeeded in collecting arms at various depots in Dublin and drew up a full plan of campaign for a rising on July $23,1803$. 
of the Great War, he was in command of the army of the Meuse that invaded Belgium and attacked Liége, which he captured on Aug. 7, 1914. In April-May, 1915 , he took part in Mackensen's drive in Galicia. He died Dec., 1915.

Emmott, Alfred Eмmotт, 1st BARON (b. 1859). British politician. The son of Thomas Emmott, a Quaker cotton spinner of Brookfield, Oldham, he was born May 8, 1859 . After graduating at London U n i . versity, he spent some years in business at Old. $\mathrm{h} \mathrm{am}$, and in 1899 was returned at a byeelection as Liberal M.P. for the borough. In

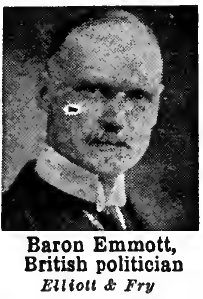
1906 he was chairman of ways and means in the House of Commons, a post he retained until 1911, when he was made Baron Emmott of Old. ham. In the same year he was appointed under-secretary for the colonies, and in 1914 he became first commissioner of works, leaving office on the fall of the Asquith ministry in 1915. In 1918-19 Emmott was director of the War Trade Department. His Nationalization of Industries was published in 1920 .

Emotion (Lat. emovere, to agitate). Mental state or feeling brought about by sensations, as contrasted with cognition or volition. Emotions are subjective and isolated. Thus, when I hate some one, I am conscious that I am the person who hates and that $I$ hate a particular person who arouses the emotion of hate. I am concerned only with my particular hate and with the particular object of it. Love, hate, fear, anger, joy, sorrow are emotions. Emotions may be roughly divided into pleasant or unpleasant, to which others add those emotions that produce excitement or depression, tension or relief. The psychical disturbance caused by emotion as a rule produces a corresponding external disturbance.

Empedocles (c. $495-435$ B.c.). Greek philosopher of Agrigentum in Sicily. He was the first to teach that all material substances are compounded from the four socalled elements, fire, air, earth, and water. These four elements are continually being separated and mingled by two moving forces, one Love or Friendship, the other Strife. He thus combined the Being of the Eleatics (q.v.) with the Becoming of Heraclitus (q.v.).
According to legend, Em pedocles threw himself into the burn ing crater of Etna in order that the com pleteness of his disappearance $\mathrm{might}$ engender the

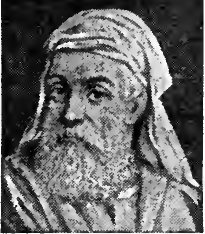

Empedocles, Greek philosopher

belief that he had been translated alive to heaven. This legend is the subject of Matthew Arnold's Em. pedocles on Etna (1852). Pron. Emped-o-kleez.

Empennage (Lat. penna, feather). French word used generally for the feathering or complete equipment of minor plares, fins, etc., at the tail of an aeroplane. It thus comprises the fixed tail or stabiliser, the vertical fin, the rudder, and the elevator. Empennage would be more accurately restricted to the tail plane and the fixed vertical fin. See Aeroplane.

Emperor (Lat. imperare, to command). Title applied to sovereigns of the highest class. It was first used in this sense by Julius Caesar, who, among other titles, called himself imperator, a title hitherto borne by certain officials while in command of troops abroad. His nephew Augustus es. tablished the empire, and the title was borne by his successors both in Rome and in Constantinople ; it was taken by Charlemagne when, in 800 , he founded the medieval empire. The rulers of the Holy Roman Empire bore it until the dissolution of that body in 1806, and in the 19th century it was assumed by several rulers who regarded themselves as more powerful than ordinary kings. Chief among these was Napoleon, who in 1804 assumed the title of Emperor of the French, an example followed in 1853 by Napoleon III.

While the English translated the word imperator as emperor and the French as empereur, the Ger. mans had rendered it as Kaiser, a tribute to Caesar, and this was the title taken by Francis II when he became emperor of Austria in 1804. In 1871 William I took the title of Deutscher Kaiser, but in both these cases the idea was well represented by the English word emperor. Less correctly, perhaps, the Russian word tsar was freely translated emperor.

In the New World there were emperors of Brazil from 1821 to 1889 , and in 1864 Maximilian of Austria took the title when he set up his empire in Mexico. The word is also used to translate the titles of rulers of $\mathbf{E}$. countries: for in. stance, we speak sometimes of the emperor of Japan. The British sovereign is called emperor of India, a translation of Kaiser-i-Hind, the title taken by Queen Victoria in 1876. The Greek word basileus is usually translated emperor. This was applied to certain rulers be fore the Christian era, and was afterwards taken by the emperors at Constantinople.

The original idea was that there could be only one emperor, whose authority extended throughout Christendom, and who was the overlord of kings. The modern tendency is to use it for the ruler of a collection of countries, but, al. though we speak of the British empire, it has, strictly speaking, no emperor. See Sovereignty

Emperor Butterfly or PURPLE EMPEROR (A patura iris). Large British butterfly, found locally in woods in the S.E. counties of England. It usually haunts the tops of oak trees and rarely visits the ground. In colour the male is dark brown, with a rich purple lustre; with a white curved band crossing the wings that bear white spots at the tips. The female, which is larger than the male, lacks the purple lustre. See Butterfly; also Fig. 23, on colour plate 2 , following p. 1528 .

Emperor Moth (Saturnia pa. vonia). Large night-flying moth, fairly common in many parts of

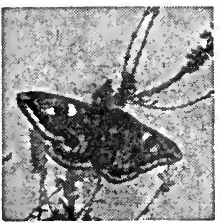

Emperor Moth, Saturnla paronia Great Britain. The wings are mottled brown and tawny, with a conspicuous eye in the $m$ id d le of e a ch, which readily dis. tinguishes it from any other British species. The caterpillar feeds on the sallow, bramble, heather, and other plants, See Moth; also illus. p. 454.

Emperor Nicholas II Island. Partially explored land N. of North East Cape, or Cheliuskin, Siberia. See Nicholas II Land.

Empetraceae (Gr. empetros, growing on rocks). Natural order of evergreen heath-like shrubs. They are natives of the $\mathrm{N}$. tem. perate and arctic zones, and also of

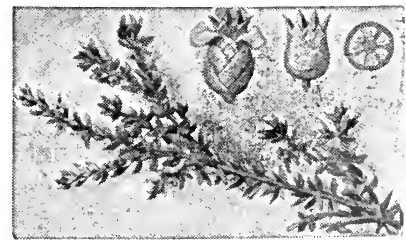

Empetraceae. Leaves and fruit, also shown in section, of red crowberry 
Chile and Fuegia. They have small, narrow, alternate leaves, and small, regular flowers, succeeded by fleshy berries. See Crowberry.

Emphysema (Gr., inflation). Condition in which the alveoli or air-cells of the lungs are over-distended with air and their walls atrophied. It is due mainly to longcontinued increase of pressure of the air within the lungs and is most often seen in players on windinstruments, glass-blowers, and sufferers from chronic bronchitis.

Emphysema produces enlargement of the chest, which becomes barrel-shaped owing to arching of the ribs and sternum; the costal cartilages frequently become calcified, and movement of the ribs during respiration is much diminished, breathing being effected chiefly by means of the diaphragm muscle. The symptoms come on gradually, the earliest being some difficulty in breathing and feeling of "tightness" in the chest. The incomplete oxygenation of the blood may lead to cyanosis or blueness of the face. The disease may persist for many years, but gradually becomes worse. Death may occur from pneumonia, or the long-continued pressure in the lungs may lead to dilatation of the heart and dropsy. Medical treat. ment is not of much avail. Sufferers are always worse in winter than in summer, and if possible the winter should be spent in a warm climate.

Subcutaneous or surgical emphysema is a condition in which air finds its way into the tissues of the body, most often due to an injury which has resulted in an abnormal communication between an air-containing cavity and the subcutaneous tissue. In rupture of a lung, for instance, air may pass under the pleura or lining membrane, and spread up into the root of the neck and over the chest, producing swelling and a characteristic crepitation on pressure. Fracture of the frontal sinuses or aircells may lead to subcutaneous emphysema in the forehead.

Emphyteusis (Gr.-Lat., implanting). 'Term of lioman law. It meant the right to enjoy the fruits of property belonging to another, on payment of a pensio or rent to the owner. It applied not only to land and houses, but to other property, e.g. slaves. The lessee might not allow the thing to deteriorate in value; and was bound to pay the rent whether the thing was beneficial to him or not.

Empire. Word derived from the Roman word imperium and meaning rule. It was used to describe the lands ruled by an cmperor, the most powerful of temporal rulers, who claimed to be superior to kings. The Roman empire founded by Augustus was succeeded by the medieval empire, known as the Holy Roman Empire, and by the Byzantium empire at Constantinople. In the 19 th century there arose the Austrian, French, and German empires, and in the New World those of Brazil and Mexico.

The word is used also for large states of the E., and we speak of the Chinese and Japanese empires. Moreover, the great states that existed before the Christian era are, for convenience, called empires, and we are familiar with a cycle of empires-those of Assyria, Persia, Macedonia preceding that of Rome. At present the tendency is to describe a federation of states as an empire, the great use of the word in this sense being for the British Empire (q.v.). See Rome.

Empire, Holy Romax. Medieval institution that lasted from 800 to 1806. The Holy Roman Empire was born on Christmas Day A.D. 800, when Charlemagne was crowned emperor by the pope. It expired in 1806 , when Francis II dropped the ancient title and called himself emperor of Austria.

From A.D. 475 to A.D. 800 Constantinople had been the seat of the lineal successor of the Roman emperors, whose supremacy in the W. had been a mere figment, while the bishops of Rome had asserted a claim to be the spiritual head of Christendom in defiance of the E. authority whether temporal or ecclesiastical. Charlemagne made himself effective master of $\mathrm{W}$. Europe, and the defender of the papacy against its enemies; and, as at Constantinople the empress Irene usurped the imperial throne, the pope crowned the Frankish king as the heir of the Caesars and Roman emperor. The actual title, the Holy Roman Empire, was adopted by Otto I in 962 .

\section{The Dominions of Charlemagne}

The new Roman Empire, then, was at first co-extensive with the dominions of Charlemagne. The British Isles were outside it; so was Scandinavia; and so was the greater part of Spain. Roughly speaking, the line of the Elbe and the Adriatic Sea marked its E. boundary. Under Charlemagne's successors it was parted into three portions: the Latiniscd West, which retained the Frankish name, and was ultimately shaped into the kingdom of France; the eastern or definitely German section, which was gradually extended till it em- braced all the German and some of the Slavonic peoples; and the cen. tral portion, lying about the rivers Rhine and Rhône, and including the greater part of Italy, of which, however, a S. remnant continued to be attached to the E. empire.

In spite of the division between the princes of the Carolingian house, one was recognized as enjoying a sort of primacy, and he bore the imperial title. But the Carolingian dynasty wore itself out by the beginning of the 10 th century in the eastern and middle kingdoms; with the result that France became independent, while the supremacy in the empire passed to an elected German king, who himself only bore the imperial title when he had been crowned in Rome. Fragments of the middle kingdom were attached to France, but the greater part of it was included in the empire.

The first German king was Henry the Fowler; under his son Otto the Great, the Holy Roman Empire was reconstituted. There was no hereditary right of succession to the German kingdom; but the descendants of a powerful emperor usually retained the succession for generations. The ruler was therefore German king by a mixture of election and descent, for the elected king was more frequently than not a son or near relative of the late ruler.

\section{Great Congeries of Principalities}

A custom grew up by which, in order to avoid an electoral struggle on the death of an emperor, the future emperor was designated during the lifetime of the reigning one, and he bore the title of king of the Romans. The Empire in fact was a great congeries of principalities large and small, lay and ecclesiastical, of which one of the princes was the official head, by right of election and by sanction of the exercise of physical force superior to that of rivals or recalcitrants. From the middle of the loth century to the middle of the 13th the emperor is in the first place a German prince having a limited authority over the rest of the German princes. In the second place he is the legal overlord also of Italy; the tradition and title of the Empire fosters in the emperors a desire to be Roman Caesars rather than German Kaisers. Thirdly, the emperors incarnate the idea, but not the fact, of Christendom as a unity.

But beside the Empire as unifying Christendom stood the papacy, actually dominating the entire ecclesiastical organization of Western Christendom, claiming for the 
pope a spiritual supremacy overriding that of the emperor as the temporal head of Christendom; and overriding that of all temporal authorities whatever within their own dominions. Theoretically, the papacy did not claim to exercise control over things temporal. But practically the lay and ecclesiastical interpretations of the spiritual and temporal spheres of control differed and overlapped, so that there was an endless contest of authority. Thus we have the emperors in their fourth aspect, as the supreme representatives of secular authority in antagonism to ecclesiastical authority, in the contest between Church and State.

\section{Guelfs and Ghibellines}

The Saxon emperors, Henry and the three Ottos, finally rolled back or stemmed the advance of more barbarian races on the E., and penned the Magyars into Hungary. They dominated the papacy, nominating several of the popes. They were followed in the 11th century by the Franconian or Salian series, Conrad II and Henry III, IV, and $V$. The reign of Henry IV was marked by the struggle between the emperor and Pope Gregory VII, with whom begins the great period of papal domination. With Henry's death the rivalry opened in Germany between the Saxon house of the Welfs, or Guelfs, and the Swabian house of the Hohenstaufen.

The Swabians secured the imperial crown for some generations ; hence the anti-imperialists in Italy adopted the name of Guelf as a party title, while the imperialists were called Ghibellines. The emperor Frederick Barbarossa (1152$90)$ was worsted in his struggle with the popes, while the cities of Lombardy succeeded, after a hard struggle, in securing their liberties ; but in Germany he broke the power of the Guelfs and established his own supremacy, which was maintained by his successor, Henry VI. Henry, by his marriage, acquired the kingdom of Sicily; his son, Frederick II, the last Hohenstaufen emperor, succeeded to the empire after an interval of contest between other rivals. But he was in effect a Sicilian, not a German. His reign and the strife which preceded it destroyed what Frederick I had done towards the unification of Germany itself. Frederick II's death in 1250 was followed by the great interregnum during which no imperial authority was recognized. It was brought to an end by the election of a minor prince, Rudolph of Hapsburg, 1273, who laid the foundations of the greatness of that famous house.
The medieval European system was now breaking up. The papacy lost prestige by its transference from Rome to Avignon. The im. perial crown passed from one house to another; from Hapsburg to Luxembourg, from Luxembourg to Bavaria, from Bavaria back to Luxembourg. It was at this time that a group of German princes were definitely established as the electors with whom alone lay the right of fixing the imperial succession. Sigismund, son of the em. peror Charles IV, acquired the kingdom of Hungary by marriage, though it was not brought within the imperial bounds as was Bohe. mia. With Charles IV the efforts of German rulers to maintain their position in Italy came to an end.

The reign of Sigismund, during the early part of the 15th century, is chiefly notable for the reinstate. ment of the papacy after the great schism at the council of Constance (1414-18), and also for the establishment of the first Hohenzollern margrave of Brandenburg, the progenitor of the kings of Prussia.

On Sigismund's death, in 1437, Albert of Hapsburg became king and emperor; and from his day until 1806 a Hapsburg was, with one exception, at the head of the Holy Roman Empire.

\section{Effect of the Thirty Years' War}

In 1519 Charles $V$ succeeded his grandfather, Maximilian I, as emperor. His reign is contemporaneous with the development of the Reformation. The hereditary Austrian and other German estates of the house of Hapsburg were transferred to Ferdinand, the brother of Charles, and he suc. ceeded his brother as emperor in 1556. The pacification of Passau, procured mainly by his agency just before his accession, gave Germany peace for some 60 years by establishing a compromise between the Roman Catholic and Protestant princes. The attempt of Charles $V$ to establish the personal supremacy of the emperor throughout Germany, failed ; German princes, big and little, were nearly independent sovereigns.

In the 17th century Ferdinand II, in the Thirty Years' War, sought to bring the Protestant princes into subjection, while Wallenstein, careless of the religious question, sought by means of the war to make the emperor absolute monarch of Germany. Both attempts failed. After the Thirty Years' War (1648) the independence of the greater German princes was an established fact, while the still nominal imperial authority was little more than a fiction. The struggle of the next 100 years between Bourbon and Hapsburg was not a struggle between the Empire and France, but between the Hapsburgs and France. Although the war of the Austrian succession included a contest for the succession to the imperial crown between the Bavarian claimant, Charles Albert, and Maria Theresa, the representative of the Hapsburgs, that was altogether a minor aspect of the struggle.

\section{End of the Holy Roman Empire}

Charles Albert was made emperor, but on his death the crown reverted to the Hapsburgs in the person of Francis of Lorraine, whose son Joseph II again aimed at establishing an imperial ascendancy by the consolidation of Hapsburg dominions within Germeny. The attempt, however, collapsed when Frederick II of Prussia formed the Fürstenbund (League of Princes) to maintain the constitutional rights of the German princes-which meant in effect their freedom from any recognizable imperial control.

In 1792 the French Republic went to war, not with the Empire, but with Austria. It was Austria, not the Empire, which was brought to submission by Bonaparte in 1797, again by Moreau at the battle of Hohenlinden in 1800, and by Napoleon at Austerlitz in 1805 , when Napoleon had already proclaimed himself emperor. There was no longer any plausibility in maintaining the pretence that there was one imperial head of Christendom, so in 1806 the em. peror Francis dropped the title and the Holy Roman Empire ended.

The history of the Holy Roman Empire down to the 16th century is, in respect of one part of it, identical with the history of Germany, and, in respect of another part, is intimately bound up with the histories of Italy and of the papacy. In the 16th century it is practically the history of Germany ; the emperor is the German emperor with no pretensions to being the Roman emperor or the head of Christendom. From the middle of the 17th century the emperor is the Austrian emperor ; the German or Holy Roman Empire exists only in name, with the survival of constitutional forms, until even the name disappears in 1806 . See Charlemagne ; Electors ; Golden Bull; Papacy; consult also The Holy Roman Empire, J. Bryce, 1864 and later; The Empire and the Papacy, T. F. Tout, 1898; The Medieval Empire, H. A. L. Fisher, 1898; The Close of the Middle Ages, R. Lodge, 1901.
A. D. Innes 
Empire Day. British im. perial cclebration held annually on May 2t, the anniversary of Queen Victoria's birthday. The first official celebration was held in 1904. The movement was started in 1902 and unremittingly carried on by the earl of Meath, whose aim was to introduce into schcols a training that would produce patri otic citizens of the empire, special prcminence being given to saluting the flag. The idea was quickly taken up and soon gained wide official recognition. At the earl's request the movement was taken over by the Royal Colonial Institute, 1921 .

Empire Powder. Sinokeless sporting propellant manufactured by Nobel's Explosives Company. It is of the type designated 33-grain powder, the nomenclature signifying that this weight of propellant is the normal charge for a 12-bore gun, and comparable to the standard charge of 82 grains of black gunpowder. It consists essentially of nitrocellulose, containing about 12.5 p.c. of nitrogen, with small quantities of barium and potassium nitrate. Powders of this type, which are also known as condensed powders, are greatly valued on account of the low recoil imparted to the gun, owing to the fact that the products of explosion are ejected from the muzzle with a higher velocity than the shot. See Ammunition; Explosives; Nitrocellulose; Smokeless Powder.

Empire Style. In decoration and furniture, a development of the Directoire style, an outcome of the admiration felt by the leaders of the French Revolution for Greek and Roman culture. The style was, therefore, severely classical in outline and decoration. As regards outline, the rectilinear was adopted, legs of tables and chairs were straight or tapered, round and fluted or reeded. Classic mouldings, capitals and pediments, with a few republican symbols and animal masks, were the principal decorative commonplaces.

With the Empire some of the solidity and simplicity of the Directoire disappeared. The furniture was rather light in con. struction, and while the straight line was the rule in contour, curved lines were introduced in the decorative designs, such as wreaths of laurels, olive and palm, dainty ribbon bows and lyres. Imperial symbols, such as the eagle, bee, and crowned $N$, replaced the republican designs, while the sphinx was also used. Medallion portraits and figures (painted, enamelled, or porcelain plaques) were used, together with heavy gilded mountings of classic design. Much of the furniture was painted white, or gilded. White, gold, crimson, and dark blue were adopted for upholstery and hangings. The tripod and $\mathrm{X}$ legs are often seen. See Furniture.

Empiricism (Gr. empeiria, experience). In philosophy, the theory that regards experience as the only source of knowledge. It is closely akin to sensualism, the theory that all knowledge is only transformed sensation. The Stoies occupied a position midway between empiricism and idealism (q.v.), in that they considered the impressions made upon the soul through the sensations to be alone certain, but held that the truth or falsehood of these impressions depended upon their being cbaracterised by an arresting power of conviction.

The founders of empiricism in modern philosophy are Hobbes, who maintained that all knowledge comes from the senses and that the activity of the mind merely consists in combinations of words, and Locke, according to whom the mind is a blank slate indebted for all its knowledge to the senses, which give it sensation and the perception of external objects, and to reflection which is exercised upon the operations of the mind. In more recent times its chief upholder is John Stuart Mill. See Philosophy.

Employers' Liability. Legal term for the liability of an employer for injuries to his employees. By the common law of England, when a servant was injured in the course of his employment through the fault of a fellow-servant acting in the scope of the same employ. ment, the employer was not liable. This was held in Priestly $v$. Fowler, 1837, where a butcher's man was hurt through a fellow-servant overloading the van, and in Hutchin. son $v$. York Railway, 1850, where a railway servant was killed in an accident caused by a fellow-servant's negligence.

Neither the Employers' Liability Act of 1880 nor the Workmen's Compensation Acts abolishes this doctrine. The former Act gives right of action for damages to persons engaged in manual labour other than domestic servants on account of (I) defect in machinery through master's or fellow-servant's negligence; (2) negligence of responsible official ; (3) wrongful act done in obedience to byelaws of firm or its authority; (4) negligence on the railway. master's negligence rendering him liable may consist in employing a person knowing him to be incom. petent or retaining in his service an habitually negligent person, or allowing premises to be in a dan. gerous condition.

The doctrine of common employment is a good defence, except in the above category. It has been held that miners and surfacemen, and a chorus girl and a sceneshifter are fellow-servants for this purpose. But the rule does not apply where $A$, the injured man, is employed by a contractor, and $B$, who caused the accident, is the servant or contractor's employer. It has been held that the Em. ployers' Liability Act does not apply to a tram-driver, a 'bus conductor, or a grocer's assistant, nor in the case of accidents not coming within the above categories.

Except in the case of death notice of claim must be given within six weeks of the accident; action at law must be begun within six months in case of injury, and within a year in case of death. Process must be taken in the county court, damages being limited to three years' earnings. Good defences include $(a)$ the workman has contracted himself out of the Act ; (b) contributory negligence; (c) Volenti non fit injuria (consent does away with injury).

The Workmen's Compensation Acts give nearly every class of servant the right of compensation for all accidents arising out of their employment. Where a sufferer can proceed either for damages at common law or under the Employers' Liability Act, or for com. pensation under the Workmen's Compensation Acts, he must make his choice.

In addition to the Acts above cited, Lord Campbell's (Fatal Accidents) Act, 1846, also concerns the liability of employers. It enables the wife, or husband, or parent, or child of a workman, or any other person whose death is caused by the wrongful act or neglect of another, to claim damages, provided that the claimant has suffered some loss, e.g. of education or support, which can be appraised in money. Process must be begun within a year of the death. The jury apportions the damages among those entitled where there are more than one. The Act does not apply to Scotland. See Workmen's Compensation.

Employment Exchange. British organization for bringing employer and employee into touch. Previously known as labour exchange $(q . v$.$) , the name was altered$ in 1916 to employment exchange. Labour exchanges are found in the principal countries of Europe, but their existence in the United 
Kingdom is of comparatively re. cent date. They were established under the Unemployed Workmen's Act, 1905, and managed by local authorities. The royal com. mission on the Poor Laws and Relief of Distress, 1909, recommended the setting up of a national system of labour exchanges to deal with unemployment. The Labour Exchanges Act of that year provided the necessary machinery, and the first exchanges under the Act were opened Feb., 1910. Their control was placed in the hands of the board of trade, with general advisory committees in principal centres. Exchanges exist in all the larger, and also in many smaller, towns and country districts.

As first established in 1910, their functions were to act as a clearing house for labour, and to bring master and man into touch. They formed the basis of the unemployment section (Part II) of the National Insurance Act of 1912. No fees were charged, and the system was purely voluntary. The organization was solely industrial.

Originally the exchanges were of much use in coping with prevailing unemployment and the disorganized casual labour conditions. Men of the labouring class used them in particular. They entered their names at the local exchange, and called daily until suited. Registration of application for work held good for seven days from date of registration, but could be renewed within that period for a like term. Employers registered their requirements at the exchange, and in this way master and worker were put into touch with each other. The exchanges took no responsi. bility with regard to wages or other conditions, but were merely the agents whereby a man found work.

During the earlier part of the Great War the exchanges did much to maintain industries and muni. tion establishments, and later on placed a large number of dis. charged sailors and soldiers in civil employment. With the end of the war, Nov., 1918, they were confronted by serious difficulties, as not only the demobilised service men, but demobilised war workers at home were thrown upon their organization. In addition to providing work, and administering the unemployment insurance scheme, they had to administer the out-ofwork donation which was paid both to ex-soldiers and munition workers, male and female. The work done by the exchanges in the period of resettlement, 1918-20, was, therefore, very onerous and responsible. Later the exchanges came under the control of the ministry of labour, under whose auspices domestic servants were dealt with, and a scheme for the co-operation of private registry offices with the exchanges was inaugurated in Oct., 1919.

At the end of 1919 there were 414 exchanges, and 1,203 branch exchanges in operation. The total cost of the employment exchange service during the six months ended June 30,1919 , including the cost of special war services chargeable to the vote of credit, and all expenses incurred at divisional offices, was $£ 1,500,000$. The numbers of individuals who applied to the exchanges since their institu. tion in 1910, and the numbers placed in employment, down to 1919, were as follows:

\begin{tabular}{c|c|c}
\hline Year & $\begin{array}{c}\text { Individuals } \\
\text { applying }\end{array}$ & $\begin{array}{c}\text { Individuals } \\
\text { placed }\end{array}$ \\
\cline { 1 - 1 } 1910 & $\mathbf{1 , 1 2 7 , 4 4 7}$ & (Not known) \\
1911 & $1,513,369$ & 469,210 \\
1912 & $1,643,587$ & 573,709 \\
1913 & $1,871,671$ & 552,306 \\
1914 & $2,164,023$ & 814,071 \\
1915 & $2,326,803$ & $1,058,336$ \\
1916 & $2,843,784$ & $1,351,406$ \\
1917 & $2,837,650$ & $1,375,198$ \\
1918 & $3.045,263$ & $1,324,743$ \\
1919 & $5,003,786$ & $1,137,875$ \\
\hline
\end{tabular}

The out-of-work donation paid through the exchanges between November 11, 1918, and June 18, 1920 , was $£ 53,209,000$, of which

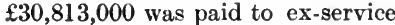
men and women, and $£ 22,396,000$ to civilians. The number of separate payments was $42,350,000$, of which $21,973,000$ were to exservice men and women, and $20,377,000$ to eivilians. Criticism having been directed against the exchanges on the grounds of their cost to the nation and practical use, a committee was appointed by the ministry of labour in June, 1920 , to examine their working and administration. See Labour; Un. employment; Wages

Empoli. Old town A. A. Leask the prov. of Florence. It stands on the Arno, $20 \mathrm{~m}$. by rly. W. of Florence, in a fertile district. The collegiate church, founded 1093, retains part of its curious original façade; its pictures are mostly housed in a neighbouring gallery. Jacopo Chimenti, the painter, was a native. It has manufactures of cott on, leather, glass, and art pot. tery. Pop. 21,566

E m p r es s Feminine of em peror. It is a corruption of the Latin imperatrix. and is applied by courtesy to the wives of emperors and also to the few women who have ruled over an empire. Maria Theresa was an empress or kaiserin as the Germans call it, and Queen Victoria was empress of India. The women rulers of the Byzantine empire, Irene, for instance, and Catherine and Elizabeth of Russia, are also known in English as empresses. See Emperor ; Sovereignty.

Empress of Ireland. Passenger steamer belonging to the C.P.R. On May 29, 1914, outward bound from Quebec to Liverpool with 1,367 people on board, the Empress of Ireland was rammed by the Nor. wegian collier, Storstad, in the St. Lawrence river during a fog. The Empress of Ireland sank in ten minutes, and 934 persons went down in her.

Empson or EMson, Sir RichARD (d. 1510). English lawyer. Born at Towcester, Northants, he became member of parliament for that county, and speaker of the house in 1491, and, knighted in 1504 , was made chancellor of the duchy of Lancaster. A favourite of Henry VII, he collaborated with Edmund Dudley (q.v.) in that king's obnoxious fiscal policy, and became universally unpopular for his harshness. After Henry VIII.'s accession he was tried on a charge of constructive treason, attainted by parliament, Jan. 21, 1510, and beheaded with Dudley on Tower Hill, Aug. 17, 1510.

Empyema (Gr., suppuration). Collection of pus in the pleural cavity - that is, between the layers of membrane lining the chest-wall and the lung. The condition may be due to infection from within, following simple pleurisy or septic pneumonia, or sometimes tuberculous broncho-pneumonia; less frequently to infections from without, as a result of fracture of a rib or a penetrating wound of the chest. The symptoms may begin suddenly with pain in the chest, sweating and rise of temperature, but when, as usuaily, the condition develops in the course of simple pleurisy or a morbid condition of the lung, there is no marked line of separation in the symptoms.

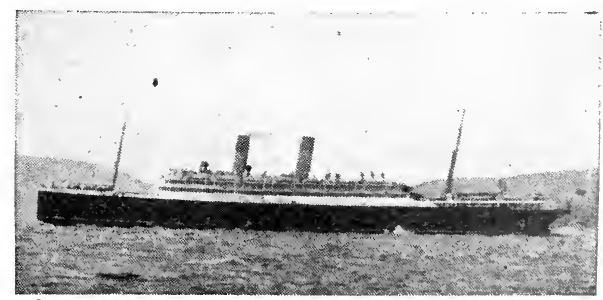

Empress of lreland. C.P.R. passenger steamer rammed and sunk in the St. Lawrence river, May 29, 1914 
Empyema is a serious condition, and if left untreated is likely to prove fatal. In mild cases it may be sufficient to draw off the pus by aspiration, but generally it is necessary to secure thorough drainage of the pleural cavity by making an opening between the ribs or removing a portion of a rib so that a large drainage tube can be inserted. This causes collapse of the lung on the affected side, but if the operation has been performed early there is a good prospect of the lung re-expanding after the discharge has ceased and the wound has healed.

Ems. River of Germany. It rises in Westphalia, in the Teutoburger Wald, and flows mainly in a $N$. direction through Westphalia and Hanover to the Dollart, an opening of the North Sea. Its length is about $210 \mathrm{~m}$., and its chief tributaries are the Aa, Haase, Hessel, and Leda. It has been canalised as part of the system of German waterways. (See Dortmund-Ems canal.) Emden is at its mouth. On Oct. 6, 1914 , the British submarine E 9 torpedoed and sank the German destroyer S 126 off the Ems river.

Ems. Town and watering. place of Prussia, Germany. It stands on the Lahn, in the prov. of Hesse-Nassau, $11 \mathrm{~m}$. from Coblenz. It lies on both sides of theriver, and is in three parts-Bad Ems, where the waters are; Spiess Ems, and Dorf Ems, the original village. There are some mines near by, but the town is chiefly known for its waters, these and the beautiful scenery attracting many visitors. For them there are many hotels and places of amusement of all kinds, including the Kursaal in extensive gardens and a theatre. The royal Kurhaus, where many of the springs and baths are, and the new bathhouse, have every comfort for those taking the waters. There is a wire rope rly. to the summit of the Malberg, one of the picturesque hills in the neighbour. hood, and steamers on the Lahn. Before the Great War there was an English church here. The congres: of Ems in 1766 drew up the Punctation of Ems, a protest against the interference of the pope in the affairs of the church in Germany. Pop. 6,800.

Ems Telegram. Message pub. lished by Bismarck in 1870 which was the immediate cause of the Franco-Prussian War. France had just succeeded in obtaining the withdrawal of Leopold of Hohenzollern as a candidate for the throne of Spain, but put for. ward a further demand. On
July 13, 1870, Benedetti, the French ambassador, interviewed King William I, who was staying at Ems, and requested a promise that he would not allow the candidature to be renewed. The king refused, and later in the day declined to reopen the discussion. To Bismarck at Berlin he sent an account of the proceedings, and this was the Ems telegram.

Bismarck thereupon published the telegram with certain alterations, especially in that part of the message in which the king informed Benedetti that he could not discuss the matter further. These made it appear that instead of this being merely a courteous refusal to reopen the matter, it was a dismissal of the ambassador from his presence. Thus it was treated by France as a casus belli. The vital sentence was "His majesty refused to receive the French ambassador, sending word that he had nothing more to communicate."

Emsworth. Seaport of Hampshire, England. It stands at the mouth of the Ems, a small stream. With a station on the L. B. \& S.C. Rly., it is $76 \mathrm{~m}$. from London and 9 from Portsmouth. The port has a coasting trade and oyster beds. Pop. 2,200.

Emu (Port. ema, ostrich) (Dromaeus novae-hollandiae). Large bird belonging to the division Ratitae. It is found only in Australia and certain neighbouring islands. The second largest bird now living, it is only exceeded in size by the ostrich, which it somewhat resembles in general build. But the wings of the emu are more rudimentary, and the bird depends entirely on its swiftness as a runner to escape its foes. The slender feathers are brown, mottled with grey, but the younger birds bear longitudinalstripes of lightercolour. Emus are rare except in the wilder parts of the country, where they live in small flocks and feed chiefly

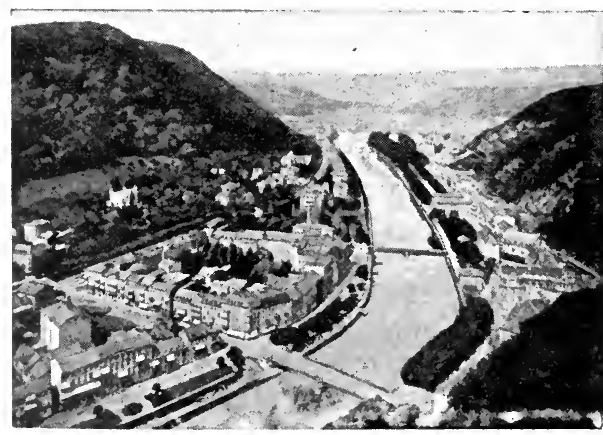

Euns, Germany. Town and bathing-place stanang in the valley of the river Lahn upon small fruits. Although not web-footed, they swim well, and take to the water readily. They are hunted with dogs, and when brought to bay can deliver seriou. kicks. These birds are easily domesticated, and breed readily in captivity. The male, which is smaller in size than the female, in cubates the eggs, which are green.

Emulsin (Lat. emulsus, milked out) OR Synaptase. Unorganized ferment (enzyme) present in al. monds and mustard seeds. The action of emulsin on the amyg. dalin also present in almonds produces essential oil of almonds in the process of manufacturing the expressed oil. Emulsin may be

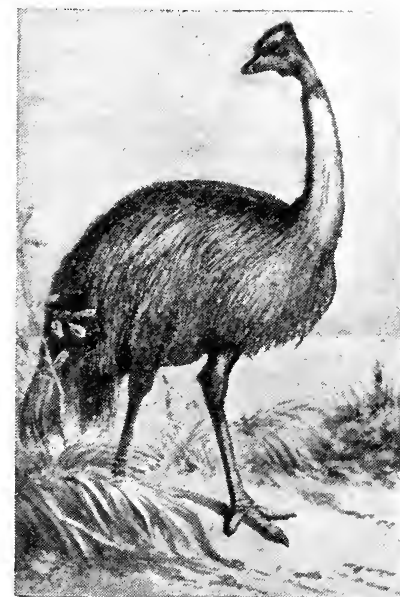

Emu. Specimen of the large

made from an aqueous extract of almond press cake by adding to it an equal volume of alcohol. The granular precipitate which falls is emulsin.

Emulsion. In photography, a mixture containing the silver com. pounds, sensitive to light, used in the manufacture of photographic plates and printing papers. Gelatin emulsions, by far the most commonly used, are made by forming the silver compounds in a hot solution of gelatin, which is al. lowed to set to a jelly, shredded and washed, and re-melted for coating on plates or paper, on which it rapidly sets. In collodion emulsions, the 
sensitive compounds are dissolved or formed in collodion (q.v.), and are left distributed in the pyroxyline on the solvents evaporating from the coated materials. See Photo. graphy.

Enabling Act. Popular name for the National Assembly of the Church of England (Powers) Act, which became law in Dec., 1919. It was introduced by the archbishop of Canterbury in May, 1919 , the object being to set up for the Church of England a national assembly with considerable powers for the government of the Church.

The national assembly consists of three houses, the two houses of convocation and a house of laity. It can discuss any proposal concerning the Church, and pass measures thereon, provided that such do not attempt to define the doctrine of the Church. Its decisions are then submitted to a legislative committee of Parliament, 15 members from each house, which reports upon them. They are then laid before Parliament, which simply by resolution can approve or disap. prove. If a measure is approved it receives the royal assent and becomes law.

For electing members of the house of laity and for other purposes the Act sets up a roll of electors in each parish. These form a parochial Church council for the affairs of their particular church. The various diocesan conferences elect the members of the house of laity. See Church of England; Convocation; National Assembly; consult also Church Self-Government, P. V. Smith, 1920.

Enamel. Transparent or opaque glassy substance applied to metal or other surfaces in the form of a paste and then fired to fix it. The material-ground very fine, mixed with gum, water, or oil of spike to render it adhesive, and reduced to a pasty consistence-is brushed on to the object, which, when duly decorated, is placed in a furnace. In pots, pans, and culinary utensils an internal lining of enamel protects the iron body from oxidisation when exposed to heat and wet or from corrosion by acids. The metal, after having been annealed to bear the heat, is dipped into the glaze and fired in a furnace at $1,500^{\circ} \mathrm{F}$.

In the fine arts enamel is principally used in connexion with pottery and porcelain wares, jewelry, watches, snuff-boxes, plaques, and articles for the toilet table. The enamel may be applied by the enclosed method or cloisonnée (q.v.), the engraved or incised method or champlevé, and the surface method, in which the whole
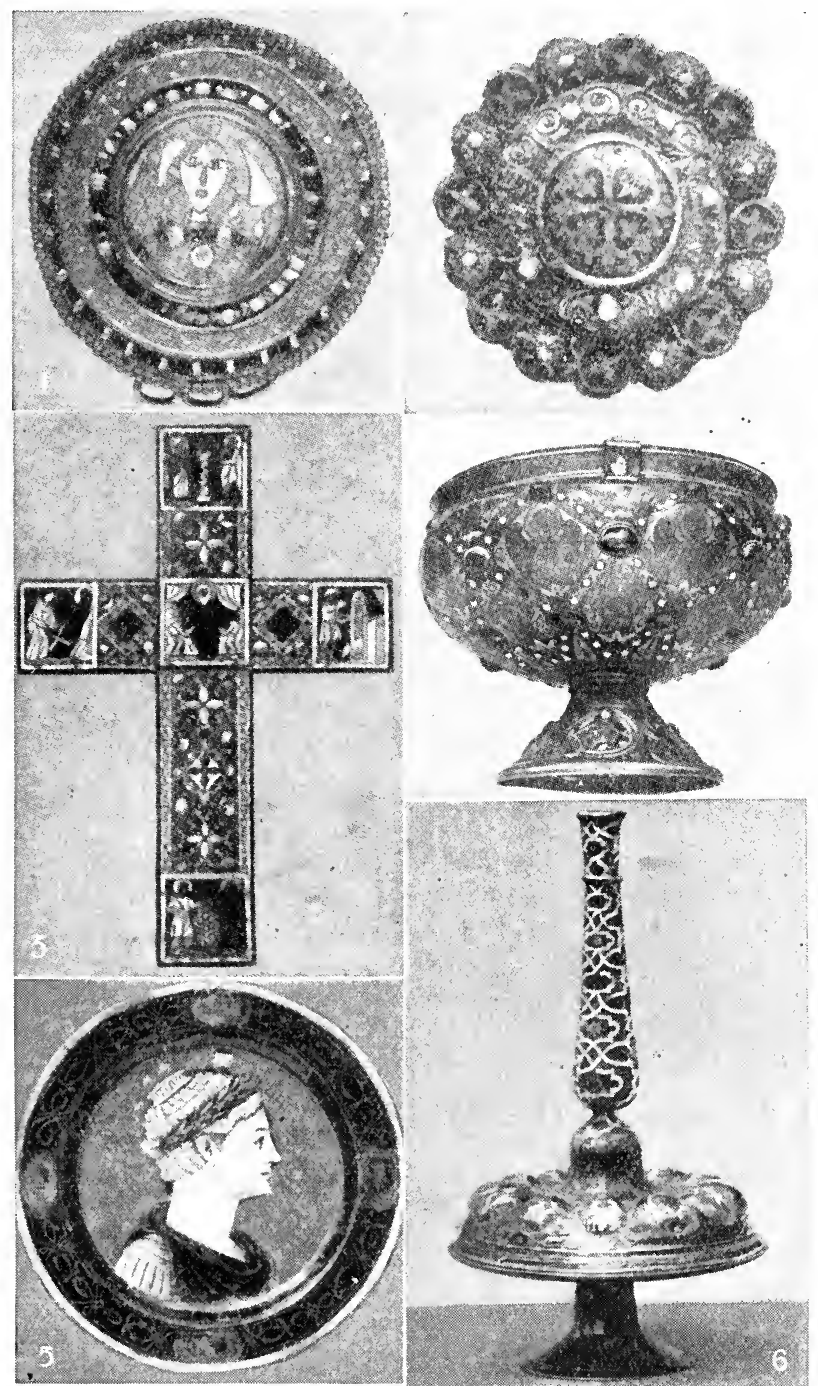

Enamel. 1. Gold brooch with bust in cloisonné enamel, Italian, $c$. 7 th century. 2. Gold brooch of German make with Byzantine cloisonné enamels, 11th cent. 3. Enamelled cross, attributed to Godefroid de Clare of Huy, late 12th cent.

4. Ciborium of Limoges work, 13th cent. 5. Plate in brilliant colours of Limoges work, c. 1530. 6. Pillar candlestick, Limoges, $c .1560$

surface is covered with enamel on which the design is delicately painted and fired. Coloured enamels were used by the Egyptians, the Greeks, and Romans, but the art was brought to a high state of perfection under the Byzantine emperors. A special style was developed among the Orientals, while a kindred art of polycoloured enamelling was carried out extensively in N. Europe. Of the surface style the enamels for which Battersea was noted in the 18th century are an example, while in
Limoges enamel, which was a variety of surface work, painting was carried to rare perfection by the practitioners of the 16 th century. Copper was the metal customarily employed for this pur. pose, but gold and silver were sometimes used.

Enare. Lake in Finland, in the N. of the govt. of Uleăborg. It is fed by a number of rivers, and dis. charges its waters through the Pasvik into the Varanger Fiord in the Arctic Ocean. Its area is $550 \mathrm{sq} . \mathrm{m}$. Pron. Enah-re. 
Enarea. Plateau region of Abyssinia, S. W. of Shoa. It has hills attaining an elevation of $8,000 \mathrm{ft}$. above sea level, upon the slopes of which coffee grows in abundance. The people are an off-shoot of the Gallas. The chief town is Saka, near the Gibbe river.

Encaenia (Gr. en, in ; kainos, new). Feast of dedication or renewing. It is used especially for an anniversary of the dedication of a church or temple. Among the Jews it is applied particularly to the anniversary festival of the dedication of the temple at Jerusalem. At Oxford University, Commemoration, the festival at the end of the academic year, when founders and benefactors are commemorated, is also known as Encaenia.

Encalada, Manuel Blanco (1790-1876). Chilean soldier and diplomatist. He was born at Buenos Aires, and having been educated at Madrid and the naval academy at Leon, returned to S. America, where he joined the revolutionary party. He was with Cochrane (earl of Dundonald) in his Pacific campaign as commander of the Chilean navy. In 1853 he was appointed Chilean minister to France. He died Sept. 5, 1876, at Santiago de Chile.

Encarnacion. Department of S.E. Paraguay. Watered by the Paraná and tributaries, it is one of the most important, fertile, and best cultivated districts of Paraguay, the chief products being fruit. Villa Encarnacion, the capital, stands on the river Paraná, $175 \mathrm{~m}$. by rly. S.E. of Asuncion. Its harbour is the port of five lines navigating the Paraná. Pop. 12,500.

Enca us tic (Gr. enkaustikos, burnt in). Species of painting with colours and wax, said to have been invented by Polygnotus (5th century B.c.) and much practised by the ancient Egyptians and Greeks. Their technique is not definitely known, but it is surmised that coloured powder was mixed with white wax and kneaded into small cakes. When required metal disks with cuplike indentations were heated and a cake was laid on the palette, a different colour in each depression, and gradually melted. The process was rapid, for the wax, laid on with a brush, cooled quickly and the work had then to be touched again with moderately hot irons, which fused the tints. En. caustic painting has been revived by $\mathrm{H}$. Cros and C. Henry, who adapted Caylus' formula for the blending of the wax and pigments.

Enceinte (Fr., circuit, enclo sure). Innermost line of continuous earthworks or other fortifications enclosing a fortress, strong point or locality. The general modern arrangement is an outer ring of detached fortresses, then a series of prepared defences on favourable positions which permit of a step by step retirement if the outer ring falls, leading up to the enceinte, the last line of resistance. This defence is provided at Metz, Strasbourg, Verdun, and fortifications of similar dates, but conditions of modern warfare render the enceinte of little if any value as a line of resistance. See Castle; Fortification.

Encephalartos (Gr. enkephalos, in the head ; artos, bread). Botanical name for the plant producing kaffir bread (q.v.). Seeillus. p. 2416.

Enchantment (Lat. incantare, to chant a magic formula). Magical spell or incantation by means of which the subject, animate or inanimate, is thought to be brought under the influence of sorcery or witchcraft. See Magic.

Enchondroma (Gr. en, in ; chon$d r o s$, gristle,cartilage).Tumourcomposed mainly of cartilaginous tissue.

Encina or ENzINA, JUAN DE LA (c. 1468-1534). Spanish poet and dramatist. He was born, it is surmised, at the village the name of which he bore, and was educated at Salamanca University. His first plays were acted in 1492, and two years later, when his Representaciones were performed before Ferdinand and Isabella and the court, he was secretary to the duke of Alva. In 1496 his plays, partly autos (q.v.) and partly secular, were published, and shortly after he went to Rome, where he became a priest and received an appointment in the pope's chapel. In 1519 he made a pilgrimage to Jerusalem, and published an account of it in 1521. He was made prior of Leon, and died at Salamanca, 1534. As founder of the secular drama he occupies an important position in Spanish literature, and his contemporary popularity was such that six editions of his plays were produced between 1496 and 1516 .

Encke, Johann Franz (17911865). German astronomer. Born in Hamburg, Sept. 23, 1791, he studied in Göttingen, and in 1817 became director of the Seeberg Observatory near Gotha. In 1825 he succeeded to the post of as. tronomer of the Academy of Science, and director of the Berlin Observatory, then in course of e:ection. In 1863 he retired into private life at Spandau, where he died, Aug. 26, 1865. Encke worked out, from the observations of the transits of Venus of 1761 and 1769, the first authentic value of the sun's parallax; determined the path of Pons' Comet; and undertook the observation of another comet, since known as Encke's Comet.
Encke's Comet. On Nov. 26, 1818, Pons of Marseilles discovered an inconspicuous comet whose elements Encke calculated with the unexpected result of finding that it revolved about the sun in a period of $3 \frac{1}{4}$ years $(1,208$ days $)$. The period is considerably shorter than that of any other known comet. Its outward journey takes it round the planet Jupiter, to whose family it belongs. Its great point of interest is the irregularity of its movements. For some six or seven successive appearances it will appear according to its time table, then it will suddenly appear before it is expected ; and yet again will resume its normal periodicity. The ir. regularity of its movements has given rise to the speculation that there may be in the solar system some very attenuated resisting medium which retards its movements, and so shortens its orbit. See Comet.

Enclave (Lat. in, in ; clavis, key). Detached part of a country or state entirely surrounded by the territories of another. The name is used by the country owning the surrounding land, the separated tract being an exclave from the point of view of the country possessing it.

Enclosures. Word which is used specially for common land which is enclosed, i.e. converted by private persons to their own use. This began in England with the decay of the manorial system, when the lords of the manor frequently enclosed common land. From time to time there was an outcry against it, this being specially so in Tudor times. Latimer referred scathingly to enclosures, while Somerset, acting for Edward VI, appointed a commission to inquire into the matter. The law about it during the Middle Ages was contained in the statute of Merton of 1235, which allowed the lords to enclose land, provided that they left sufficient common unenclosed to meet the rights of the commoners.

About 1700 there was a change. Enclosures continued, but they were done by special Acts of Parliament, each dealing with a special enclosure, and these distributed the land between the lord of the manor and the various persons who had rights in it. Between 1700 and 1845 there were about 4,000 of these Acts, under which about 5,000,000 acres of land were enclosed. In 1801 an Act said that the consent of threefourths of the freeholders and copyholders of the manor was necessary before land could be enclosed. In 1845 the matter was put in the hands of enclosure com. missioners whose business was to 
examine suggested enclosures, and see that some part of the land was set aside for public purposes. About then the movement for the preservation of common land began. Suggested enclosures, the case of Epping Forest being the standing example, were prevented, and in 1876 an Act virtually put an end to the practice. In Scotland and Ireland the matter never attained the importance it did in England. See Commons ; Manor.

Encore. Exclamation by listeners to music or play, signifying desire for a repetition. The word is a French adverb, meaning again, but is also used as a substantive, an encore; and as a verb, to encore. It was employed in Great Britain as early as the beginning of the 18th century.

Encounter Bay. Inlet of the coast of S. Australia, between Port Elliot on the N. and Jaffa Cape on the $\mathrm{S}$. It is $90 \mathrm{~m}$. across its entrance and is the last important indentation of the coast before the state of Victoria. Off the N.W. corner of the bay lies Kangaroo Island.

Encratites (Gr. enkratēs, selfcontrolling). Ascetic sect of the 2nd century. They taught the essential evil of matter and abstained from flesh, wine, property, and marriage. Encratite doctrines seem to have been first taught systematically by Saturninus early in the 2 nd century, although the principle was combated already in I Timothy iv and the sect became organised under the leadership of Tatian. Encratism spread widely in Asia Minor, and the apocryphal Gospel according to the Egyptians furnished some of its arguments. In the 4 th century they became merged with Gnosticism and Montanism.

Encrinites. Popular name for the crinoidea (q.v.).

Encyclical (Gr. enkyklios, circular). Eccles. term for a letter from a Church authority, not addressed to any particular individual or community. Thus the General Epistles of S. Peter and the pronouncements of councils which were sent forth to the Church at large were thus named. The term is now used for a communication of the Pope to the bishops generally on some ecclesiastical topic. It differs from a bull, since it does not deal with any special case, but indicates general principles to guide the bishops in dealing with important questions.

Encyclopedia. Woŕd derived from the Greek (enkyklios, circular, complete ; paideia, education), which may be translated as the whole circle of knowledge. For many centuries it expressed this idea to scholars trained in the tra. ditions of Rome, but it was not used as the title of a book until the 16th century, some years after the in. vention of printing. Before then, however, many works had been written which may be fairly described as encyclopedias, for their authors claimed to give information in them about all the interests of the human mind.

The first of these known encyclopedias is the Historia Naturalis of the elder Pliny; and the Middle Ages saw the production of Etymologies by Isidore, bishop of Seville (d. 636) ; and of The Origin of Sciences by the Arab scholar, Alfarabi (d. 950); as well as of a number of less notable ones. The most outstanding encyclopedia, however, written in Latin, was by Vincent of Beauvais (d. c. 1264). It was called Speculum Majus (Greater Mirror), and is divided into four main parts, dealing with science, theology, history, and morality (the last section being possibly wrongly ascribed to Vincent).

The material in these encyclopedias was arranged according to subjects, not in alphabetical order, but some time after the invention of printing the advantages of the latter arrangement became manifest. About the same time, too, it was realized that if encyclopedias were to be read they must be written, not in Latin, but in a popular language. However, before these important changes came about J. H. Alsted, in 1620 , had produced a Latin work of the old kind, notable because it was the first of any size to be called an encyclopedia. The two in. novations just mentioned were both introduced to the world by a Frenchman, Louis Moréri. His Grand Dictionnaire, 1674, was an encyclopedia in the modern sense, although, like his immediate successors, he preferred to call it a dictionary. It was very popular, and so was that of Pierre Bayle, which in 1697 appeared as an im. provement on Moréri.

The first encyclopedia written in English was the Lexicon Technicum, 1704, of the Rev. John Harris, though as early as 1398 John Trevisa had translated a Latin work of this kind into English. Harris was followed by a much greater name in the history of encyclopedias,Ephraim Chambers, the real originator of the modern work. In 1728 Chambers produced his Cyclopædia: or Universal Dictionary of Arts and Sciences. A little earlier an Italian, M. V. Coronelli, had begun a more ambitious work, but it was never completed. In 1732-54 was published
Zedler's Great Universal Lexicon, a German work ed. by J. A. Frankenstein and others, but usually known by its publisher's namc.

The effects of Chambers's work were felt in France. It was translated into French, and on it was founded the most celebrated of all encyclopedias, the Encyclopédie, which, edited by Diderot and D'Alembert, counted Voltaire and Rousseau among its contributors. Neither Chambers's nor the Encyclopédie included biographies, although Moréri and other earlier writers had done so.

The British counterpart of the Encyclopédie was the Encyclopædia Britannica. The first edition of this, ed. W. Smellie, appeared in three volumes in 1771. From it biography and history were excluded, but both appeared in the second and subsequent editions. Throughout the 19th century further editions of the Britannica appeared, to which the leading scholars of the age contributed. The eleventh edition, issued by the Cambridge University Press, was published in 1910-11.

Meanwhile, a host of "other encyclopedias had appeared both in Britain and abroad. In France there was La Grande Encyclopédie, also that of Larousse ; in Germany the Konversations - Lexicon of Brockhaus and that of Meyer; in the U.S.A., the New International; and many others. Among the Eng. lish works of the kind were The Penny Cyclopædia of Charles Knight, 1833-43, and the one issued by the Edinburgh firm of Chambers in 1859-68, and several times revised.

At the end of the century a gigantic and novel advertising campaign carried on by The Times in order to sell the ninth and tenth editions of the Britannica had an enormous effect in popularising the work and in stimulating a demand for books of this kind. This was seen in 1905-6, when The Amalgamated Press put upon the market The Harmsworth Encyclopædia. Sold in sevenpenny fortnightly parts this was an unprecedented success. Recent years have witnessed the output of a host of encyclopedias devoted to a single branch of human knowledge-theology, sport, agriculture and education, for example; but the day of the general encyclopedia is by no means over, as was proved when, in Feb. 1920, The Amalgamated Press brought out the UNIVERSAL. A. W. Holland

Encyclopédistes. Name given to the contributors to the Encyclo. pédie edited by D'Alembert and Diderot. They were writers of high repute in literature and philosophy, 
inclnding Ruusseau, Grimm, Voltaire, Baron d'Holbach, and the two editors. Several of the ency elopédistes held advanced views on political and social matters, besides being sceptics with regard to Christianity, and this was reflected in much that they wrote. The influence thus exerted by the Encyclopédie upon the minds of the educated classes helped to ripen French public opinion in favour of the Revolution.

End. In place names, e.g. Audley End, Crouch End, a small suburb, or hamlet. Its older form is endship, and this is used in this sense by Bunyan and Defoe.

Endecott, JoHn (1589-1665). English colonial governor. Born at Dorchester, Dorset, he sailed

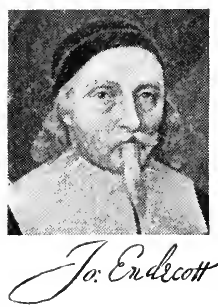
to $\mathrm{N}$. America in 1628 and became manager of the Naum. keag (now Sa. le m) planta. tion. Being superseded by J o h n Wi n. throp, he em. ployed himself in fighting the Indians. In

I 641 he was made deputy-governor of Massachusetts and three years later became governor, a post he held with intervals until his death at Boston, March 15, 1665.

Endemic (Gr. endèmos, native). Term applied to infeetious diseases which are always more or less present in certain localities, as distinguished from epidemic diseases which may be widely prevalent at one time and completely absent at another. SeeDisease; Publie Health.

Enderby Land. Desolate tract of Antarctica. It extends S. from the Antarctic Circle. It was discovered by John Biscoe in 1831, who named it after his employers, Enderby Brothers.

Endive (Lat. intibus). Plant of the same genus as chicory (q.v.).

Endocardium (Gr. endon, within; kardia, heart). Smooth membrane which lines the interior of the chambers of the heart. Inflammation of this membrane is termed endocarditis. See Heart; Rheumatic Fever.

Endogamy (Gr. endon, within ; gamos, marriage). Primitive institution binding a man to marry within his own social group only. The best developed example is the Hindu caste, with exogamous elans or gotras. See Family; Marriage.

Endogens (Gr. endon, within; gen, to produee). Name formerly applied to the division of flowering plants now known as monocotyledons (q.v.).
Endolymph (Gr. endon, within ; Lat. lympha, water). Anatomical term denoting the fluid which oceupies the interior of the membranous labyrinth of the ear of higher animals. See Ear.

Endometritis (Gr. endon, within ; mètra, womb). Inflammation of the membrane lining the interior of the uterus or womb. See Womb.

Endor. Village of Palestine, now known as Endur, about $6 \mathrm{~m}$. from Nazareth and close to Mt. Tabor. It was the home of the witch whom Saul consulted.

Endorsement oR INDORSEMENT (Lat. dorsum, back). Something written on the back of a document. It is used mainly for the signature which must be put upon the back of a eheque, bill of exchange, etc., when it is passed from one person to another. The endorsement must correspond with the name on the front or it will be irregular. $\mathrm{By}$ endorsing the owner of the cheque or bill transfers his rights to another.

Endosperm (Gr. endon, within ; sperma, seed). Tissue found in the spores of ferns and their allies and in the seeds of many flowering plants. In the pines (Gymnosperms) the endosperm is formed before the embryo comes into existence ; in the flowering plants proper (Angiosperms) embryo and endosperm are formed simultaneously. If a longitudinal section is made of a ripe pine-seed, for example, the embryo will be found to oceupy a central ca vity, surrounded by a mass of cellular tissue. This is the endosperm, which is gradually absorbed as food by the developing embryo or seedling to tide over the eritical period in whieh it is establishing its roots and expanding its first leaves.

Endothermic AND ExoTHERMIC Reaction. Terms used in physics for the liberation or absorption of heat during chemical ehanges. It is important to know in any partieular ehemical reaction what kind of heat phenomena arise and what amount of heat is transferred, as the possibility of a suggested indus trial proeess or its economy may be determined by these considerations.

When heat is absorbed or dis. appears during the produetion of a chemical eompound, the reaction is said to be endothermic, for heat enters into the new body, and if the new body be subsequently deeomposed, heat will be liberated. The formation of nitro-glycerine is an example of an operation in which heat disappears, to be liberated again should the nitro-glyeerine be decomposed, often with great violence. On the other hand, where, in forming a new eompound, heat is liberated, the reaction is said to be exothermic, i.e. heat is given out. The reduction of iron in the blast furnace furnishes an example of such reaction.

Endowment (Lat. dos, a dowry or gift). Gift of money or land to whieh the idea of permanence is attached. Such indicate the vast amounts that have been given or bequeathed for the support of churches, eolleges, schools, hospitals, and charitable institutions of all kinds. In the United Kingdom ancient endowments are under the general eontrol of the state, aeting through bodies appointed to supervise them. Sueh are the Ecclesiastical, or Chureh Estates Commission that controls the endowments of the Church of England, and the Charity Commission that eontrols funds left for almshouses, hospitals, and the like. Endowed schools are under the supervision of the board of edueation. The process of time frequently makes trusts governing old endowments quite out of keeping with the age, and from time to time Parliament has dealt with the matter. Thus the Endowed Schools Acts of 1869 74 removed many abuses and enabled these trusts to be worked in a more modern spirit. See University.

Endurance. Sir Frnest Shackleton's shipin hissecond Antarctie expedition. She left England in 1914 just after the Great War had begun, and was crushed in the ice, Oet., 1915. See Antarctic Exploration.

Endymion. In Greek mytho$\log y$, a youthful shepherd of great beauty. Of him the moon-goddess Selēné became enamoured, as he lay asleep on Mt. Latmos in Caria. Selēnē caused him to sleep for ever, so that she might be able to visit him and kiss him every night with. out his knowing it.

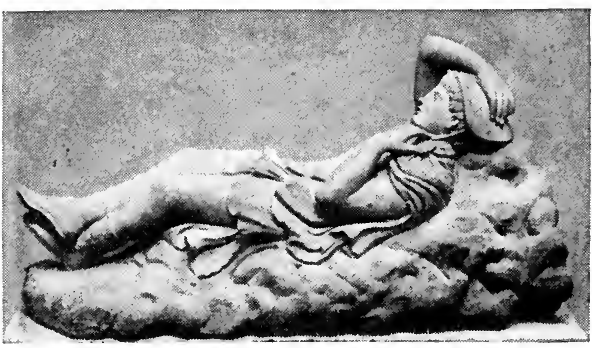

Endymion. Greek statue of the sleeping shepherd. in the British Museum 
Endymion. Poetic romance in four books of rhymed couplets by John Keats, first published in 1818. A rhapsodical rendering of the classic story of the beautiful youth who inspired love in Cynthia, it is full of poetic riches, both of language and thought. Its opening line, "A thing of beauty is a joy for ever," has become one of the most familiar of quotations.

Endymion. Novel by Benjamin Disraeli, earl of Beaconsfield, first, published in 1880. It is a presentation of political and social life in England during the middle of the 19 th century, opening with the death of Canning and passing lightly through the Reform period. Though the story is slight, the characterisation is brilliant; and the narrative has much of the sparkle and less of the ornateness of Disraeli's earlier novels. Many of the characters were but thinly disguised delineations of actual people of the period, Lord Palmerston, Lady Jersey, and others.

Enema (Gr., injection). Fluid preparation for injecting into the rectum. Enemata are used for washing out the rectum in cases of severe or chronic constipation, when they usually consist of soap and water and may amount to one or two pints ; for introducing into the bowel substances such as quassia for the purposes of destroying threadworms; and for provid. ing nourishment when acute disease of the stomach prevents feeding in the ordinary way, enemata for this purpose being small in volume and consisting usually of peptonised milk, raw eggs, and meat extracts.

Enemy (Lat. inimicus). Generally one who is antagonistic or hostile. In time of war, however, it has a special and narrower meaning referring to the state and its subjects with which another state is at war. By the laws of war these are on a very different footing from friends or neutrals. Their persons and property can be seized, and freedom of movement denied to such of them as are on the soil of the country with which they are at war. They become enemy aliens, sharply distinguished from friendly or neutral aliens. See International Law; War.

Enemy Trading. Term used generally during the Great War to denote all commercial and economic relations with Germany, Aus. tria, Turkey, and Bulgaria. On Aug. 5, 1914, a royal proclamation was issued relating to trading with the German Empire, and extended to Austria-Hungary, Aug. 12. British firms were not restricted from trading with German or Aus- trian firms established in neutral or British territory, but only with those in hostile territory. A proclamation of Sept. 9 defined enemy country as the territories of the German Empire and of the dual monarchy of Austria-Hungary, with their colonies and dependencies, and prohibited the payment of money to or for the benefit of an enemy. In the same month certain licences were granted permitting payments, exchange transactions, and payment of fees to obtain the grant or renewal of patents. Later proclamations placed an embargo on the import of enemy-produced sugar (Sept. $30)$, and the entering into new marine, life, fire, or other policy or contract of insurance (Oct. 8).

In 1915 many additional licences and prohibitions were issued-as the treasury licence (Jan. 8) permitting transactions by certain Turkish banks with their establishments in France, Cyprus, or Egypt, certain regulations as to property, and so on. The Trading with the Enemy (Extension of Powers) Act of this year applied to certain firms in the U.S.A., and the blacklisting of enemy firms in that country led to an American Note of protest. Statutory black lists were also in existence for Holland, Denmark, Spain, Sweden, and other countries.

Late in 1916 the business com. munity of London agitated for the closing of alien enemy banks in Great Britain, and a drastic review of certificates of naturalisation granted since 1904. The board of trade appointed a controller in July, 1918, to wind up the businesses carried on in the United Kingdom by the various German banks, of which the Deutsche was the chief, and these were restricted from carrying on business for five years after the end of the war. With the end of the war many prohibitions were withdrawn, and the black lists ceased to operate.

Energumen (Gr. energoumenos). Greek word meaning one wrought upon by a spirit, usually evil. It was applied to demoniacs in the early days of Christianity. Persons suffering from mental disease were supposed to be inhabited or controlled by a demon, who could only be expelled by exorcism. See Demonology.

Energy (Gr. energeia). Capacity to do work. A weight raised above the earth has the power of doing work as it returns to the earth's surface. A body in motion possesses the power of doing work while losing its motion. The energy of a body is measured by the work it can do while changing to some standard state; or, conversely, the work which has to be done on the body to bring it from some standard state to the state in which it is. In the two examples chosen, the work the weight can do before it reaches the ground, or the work the body can do before it comes to rest, can be measured. The energy is evidently of a different kind. The weight raised above the ground owes its energy to its position. It has potential energy. The energy of the body is due to its motion. It has kinetic energy.

The weights of a grandfather clock are given potential energy when they are raised, and as they gradually sink they expend it in keeping the wheels of the clock going, in overcoming friction, and in other ways. The mainspring of a watch has potential energy, which was imparted to it when the spring was coiled or wound up, and which it expends as the spring uncoils. In the example of the spring the material of the spring or cord is in a state of strain, and it is owing to this strain that the body possesses potential encrgy. The potential energy conferred by weight, or the attraction due to gravity, is regarded as due to a strain set up in the ether. If a body of mass $m$ is moving with a speed $v$, its kinetic energy is $\frac{1}{2} m v^{2}$.

Energy, Conservation of. Potential energy and kinetic energy can be changed one into the other, but the total quantity of energy is constant despite the change. When a watch spring runs down, or when a dropped stone comes to rest on the ground, both the kinetic and the potential energy seem to have vanished. But that is not so, because the energy has been converted into heat, which is another form of energy. Joule showed early in the 19th century that a given amount of work (or energy) entirely spent in producing heat always produced the same quantity of heat. From his experiments it is concluded that in every case without exception the sum total of all the energy within any given boundary through which energy is not allowed to pass remains constant, although the energy within the boundary may be transformed into any of the many forms in which it is capable of existing. This is the doctrine or principle of the conservation of energy. Energy is indestructible and uncreatable by man. It exists independently of human senses and human reason, though it is known to man solely by their aid. The discovery of the radio-active elements has thrown a new light on this doctrine. See Radium. 


\section{ENERGY: THE DISSIPATION OF POWER}

Sir Oliver J. Lodge, F.R.S., Author of Man and the Universe This article, following those on Energy and Conservation of Energy, dcals with the waste of power, i.e. the loss due to its dissipation throughout the universe, in machinery, and in other ways. Consult also Heat; Physics; Thermodynamics

Lord Kelvin first noticed and formulated in 1852 " a universal tendency in nature to the dissipa. tion of mechanical energy." The idea is associated with that of different forms or grades of energy, some higher in the scale than others, from the point of view of utility or availability.

Energy is protean in form, and in the physical universe activity is always accompanied by transformation of energy; as soon as all transformation ceases, activity ceases, and torpor sets in. Now some forms of energy are readily controllable, and are transformable into others at will. A rotating flywheel and a raised weight are types of easily transformable energy; either can be made to drive machinery, and so do any thing required. In such cases very little energy need be wasted by taking the form of heat, though friction cannot altogether be avoided. An electric current is another useful and tractable form of energy. But some forms are comparatively in. tractable, such as sound and light and random eddies; the only result that can be shown for such forms, when they have ceased to be, is a modicum of heat.

\section{Energy and Heat}

In every activity contrived by man some portion of energy is always liable to run down into the form of heat. The analogy of water running down hill may be adduced. When taken from a high. level source, water can be em. ployed to drive water-wheels or turbines, but as it descends its working power becomes less, and ultimately, when it reaches the level of the sca, though the quan. tity of water remains the same, its availability for power is lost.

So when energy has reached the form of heat, not much can be done with it mechanically, unless indeed the body possessing it is at a high temperature. Heat at high temperature can be utilised by engincers, through steam engines, internal-combustion engines, and other devices. To work any form of heat-engine there must be a difference of temperature; one body, acting as source, must be hotter than another, acting as sink; just as in the utilisation of water one reservoir must be at a higher level than another. If all were at dead level, or all at the same tem. perature, nothing could be done.
But everyone knows that reservoirs tend to leak, and hot bodies tend to cool, without doing any work at all ; in other words, speaking thermally, useful inequalities of temperature tend to become obliterated by the ordinary processes of radiation and conduction. Hence heat is considered the lowest form of energy. The proportion of heat that can be utilised by a perfect engine, working between given limits of temperature, depends directly on the difference of tem. perature and inversely on how far the higher of the two temperatures is above absolute zero.

\section{Laws of Thermodynamics}

This, in mathematical language, is called the second law of thermo. dynamics, a law which we owe originally to the genius of Sadi Carnot (1796-1832). This law involves in a precise and mathematical manner much that has been the dissipation of energy. The conservation of energy, similarly expressed, is called the first law of thermodynamics; a law which, though simple to state, was by no means obvious, and had to be proved, notably by Joule's experiments between 1840 and 1860 The second law, on the other hand, was established by reasoning, and historically preceded the first law.

It may be perceived that in a popular statement of the second law of thermodynamics, or the law of metrical dissipation of energy, such terms as " utility " or " availability" are naturally employed; this tends to show that the law is associated with our present means of utilising the energy of heat. And even when expressed precisely, the terms heat and temperature when we consider what heat and temperature really are, and think of them in terms of the motion of molecules, we perceive that if only the molecules themselves could be harnessed we could extract their energy from them and utilise it, just as we utilise the energy of a driven flywheel. If we possessed such power, the idea of different grades of energy would be superfluous or misleading. But since no means of dealing individually with molecules has as yet been discovered, heat is, to us, a low form of energy; and the tendency of all other forms of energy sooner or later to degenerate into heat, and popularly expressed above about are essentially employed. Now for heat to become of uniform tem. perature, is what is meant by the universal tendency in nature to dissipation of mechanical energy.

It is unwise, however, to base on this law any confident eschato. logical prediction about the universe, because it is always conceivable that a mode of utilising molecular energy may be dis. covered, less indirect and statisti. cal than any so far known. People have, in fact, speculated whether some low forms of life may not be already selectively extracting the energy of quick-moving molecules. But for practical purposes, at present, the law of dissipation of energy, as well as the law of con. servation, holds sway.

If there is any appearance of contradiction between these two laws it is only superficial, and can be avoided by precision of state. ment and careful definition of terms, especially by careful definition of the term energy. The irregular motion of a set of molecules, called heat, is as much energy as their regular motion, called wind ; but one is easy to utilise, while the other is not. Hence, when wind or water currents run down into generally diffused heat, their energy is not destroyednor diminished in quantity, but for all useful purposes is dissipated; the case is similar when milk is spilt upon the ground.

\section{The Problem before Humanity}

We live in a stream of continu. ously dissipating energy, emitted by an exceptionally hot body, the sun. Plants are able to utilise and store some of this, and thus temporarily rescue it from dissipation. Dissipation of the energy so stored in wood or coal ultimately occurs in our homes, furnaces, and factories. Without solar energy everything on earth would be stagnant. The chief problem which faces humanity is to see that the uses to which we put all this beneficent energy are good.

Enfantin, Barthélemy Prosper (1796-1864). French Socialist. Born in Paris, Feb. 8, 1796, he was educated at the Ecole Polytechnique. In 1825 he met SaintSimon and adopted his teaching, which he and Bazard disseminated during the next five years. In 1832 he was sentenced to a year's im. prisonment for his public advocacy of free love. After a journey to Egypt he was appointed postmaster of Lyons, and in 1845 became a director of the Paris-Lyons Rly. He died at Paris, Aug. 31, 1864. Enfantin's principal works are Doctrine Saint-Simonienre, with Amand Bazard, 1830 ; Écono. mie Politique, 1831. 
Enfield. Urban dist. and market town of Middlesex, England. It is $10 \frac{1}{2} \mathrm{~m}$. N. of London by the G.N. and G.E. Rlys. The New River intersects the town. The chief buildings are a 16 th century palace opposite the church, used by the Constitutional Club, a grammar school founded in 1557, and the parish church of S. Andrew, which contains a beautiful 15th century brass. The Ridgeway is a residen. tial district, and in the neighbourhood are Forty Hall, White Webbs House, and Middelton House. The famous chase of Enfield was disforested in the 18th century. At Enfield Lock is the Royal Small Arms Factory, erected in 1856, where the once celebrated Enfield rifles were made. Pop. 56,338.

Enfield is mentioned in Domesday Book as Enefelde. Edward VI and Queen Elizabeth lived here, and the chase was a favourite hunting ground of James I. It has associa-

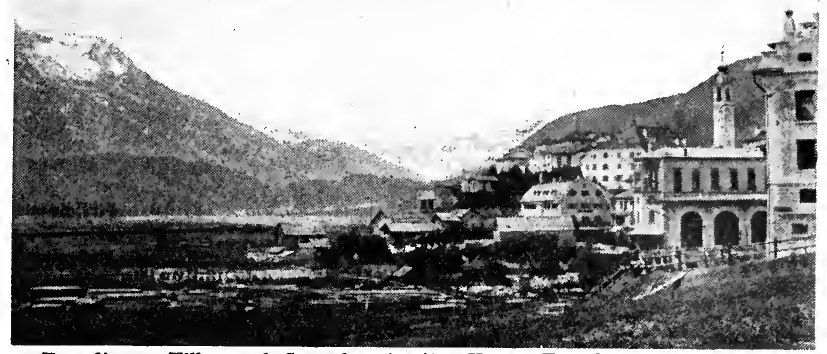

Engadine. Village of Samaden in the Upper Engadine, with the Piz Rosatsch on the left

into a freehold. This can be done by mutual consent, or at the in. stance of the lord of the manor or the tenants thereof. If they cannot agree on the terms, these are settled by the Board of Agriculture.

Engadine. Upper portion of the Inn valley, Switzerland, in the canton of Grisons. Divided
Engagement. Word meaning originally to bind by a gage or pledge, and used in several senses. It means an undertaking to marry and also a more general kind of pledge-e.g. an engagement tò pay a debt or to meet a friend. It is also used as a synonym for a battle ; this comes from an old meaning of

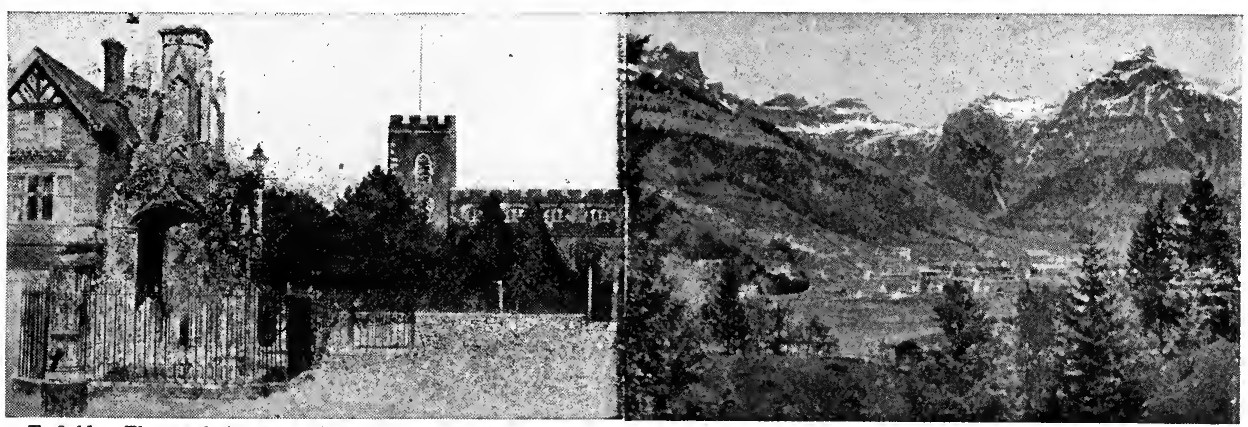

Enfield. The market cross and parish church of S. Andrew

Engelberg. The Swiss village at the foot of the Titlis Alp

tions with Keats, Captain Marryat, and Charles Lamb, who lived at Chase Side. During the Great War it was a busy munition centre.

Enfield Lock. Lock on the river Lea, Enfield, Middlesex. The name is also applied to the district around it.

Enfilade (Fr. enfiler, to thread). Military expression which indicates fire along the direction of the enemy's line or trenches-i.e. from a flank. It robs the defenders of an entrenched position of their cover unless the line is very well traversed and few weapons in the line can be brought to bear to counter it. If a unit in action has to change its front it runs grave risks of coming under enfilade fire at once. The advantage of gaining a position on the enemy's flank when attacking is enhanced by the opportunity it gives of subjecting him to enfilade fire. See Artillery; Tactics.

Enfranchisement (old Fr. en. franchir; en and franc, free). In English law, a term meaning the turning of an estate of copyhold into the Upper and Lower Engadine, it stretches $60 \mathrm{~m}$. between two chains of the Rhaetian Alps, and is $1 \mathrm{~m}$. to $1 \frac{1}{2} \mathrm{~m}$. broad. From Martinsbruck, on the border of Tirol, it runs S.W. up to the Maloja Pass, traversed by a good carriage road, and there are rlys. to S. Moritz and Pontresina. The Upper Engadine has a series of small lakes and is more frequented than the Lower Engadine, which, however, has the attraction of its mineral springs at Schuls. The sides of the surrounding mts. are covered with pine forests to the height of $7,200 \mathrm{ft}$. The strong, bracing air of the valley renders it an extremely popular health resort. The inhabitants, mostly Protestants, still speak Latin or Romansch, a speech akin to Italian and French.

Engadine. British seaplane carrier. She was present with the fleet at Jutland, May 31, 1916, and sent out the seaplanes that scout/d for Admiral Jellicoe. Later, she towed the Warrior out of the firing line. engage, that of joining or fastening, as when, in architecture, two beams are said to engage or interlock.

Historically, the engagement is the agreement signed, Dec. 26, 1647, by Charles $I$ and the Scots represented by the marquess of Hamilton. Charles was a prisoner at Carisbrooke, and he agreed, in return for Scottish assistance in restoring him to the throne, to establish Presbyterianism in. England. See Charles I; Civil War.

Engelberg. Village of Switzerland, in the canton of Unterwalden. It stands at the $\mathrm{N}$. foot of the Titlis, $14 \mathrm{~m}$. by electric rly. S. of Lucerne. It is a favourite summer and winter tourist resort, with numerous hotels and boarding-houses and an English church. The abbey church is interesting ; and the library has 20,000 vols. and 210 MSS. The large Benedictine abbey, founded 1120 , was rebuilt in 1729 ; it has a school and its farm is noted for its cheeses. Engelberg owns common lands, which help to maintain its poor. Pop. 2,434. 
Engels, Friedrich (1820-95). German socialist writer. Born in Barmen, Prussia, Nov. 28, 1820,

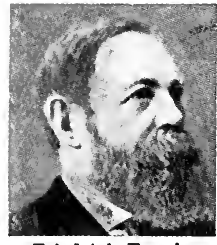

Friedrich Engels, German Socialist known as the International, for Italy, Spain, and Belgium, this organization was formed in 1864 with the object of ending war and subordinating capital to labour. Engels was the friend of its moving spirit, Karl Marx, with whom he collaborated in the communist manifesto of 1847. Engels' works include The Condition of the Working Classes in England, 1845; Eng. trans. repr. 1920; and The Origin of the Family, Private Property and The State, 1884 . He died in London, Aug. 5, 1895.

Enghien, Lotis AntoIne HenrI DE Bourbon Conde, Duc D'(17721804). French noble. Born at Chantilly, Aug. 2, 1772, he entered the army in 1788 . In 1792 he held a command in the royalist army raised by his grandfather, the Prince de Condé, fighting against the republicans until the peace of Lunéville, 1801. In 1804 he was falsely accused of having taken part in the Cadoudal-Pichegru conspiracy against Napoleon, was seized in the neutral territory of Baden, hurried to Paris, and, after a mock court-martial, was shot at Vincennes, March 21, 1804. The murder of the duc d'Enghien, a crime from which Napoleon vainly tried to exculpate himself in St. Helena, occasioned the famous saying of Fouché : "It was worse than a crime ; it was a blunder." See Napoleon; consult also Corres. pondance du duc d'Enghien, etc. ed. Boulay de la Meurthe, 1904-13.

Engine (Lat. ingenium, skill). Generic name now given to a class of machines for the conversion of one form of energy to another. Formerly a term used for a large variety of mechanical appliances, as beer-engine, water-engine, etc., its present-day usage is confined chiefly to the names of steamengine, gas-engines, and oil or in. ternal combustion engines.

In the sense of a mechanical con. trivance the term engine was used for a warlike appliance, and it was in this connexion that the first engine was ever suggested, by Nye, the mathematician, who in The Art of Gunnery, 1647, suggested

the use of water suitably heated as a propelling force for shot instead of powder, followed in 1655 by the marquess of Worcester's description of a steam-engine for raising a column of water a height of $40 \mathrm{ft}$. The conversion of heat energy into mechanical energy by means of the steam-engine turned inventors' thoughts to the use of other substances besides water, and there appeared the hot-air engine, and in later years the gas-engine, oilengine, etc. The invention of the internal combustion engine has had an enormous effect upon the progress of the world. See Air engine; Internal combustion engine; Oil engine; Steam engine; also illus. p. 1332 .

\section{ENGINEERING : A GENERAL SURVEY}

\section{A. H. Gibson, D.Sc., Prof, of Fngineering, University College, Dundee}

This article serves as an introduction to those on engineering sub. jects, e.g. Breakwater; Bridge; Docks; Harbour, etc. See also Hydraulics; Railways, etc.

Historically considered, engineering is the earliest of the arts, emerging in the first dawn of civilization when the first tool was made by man.

Little is known as to the earliest development of engineering knowledge. It must have been of a com. paratively high order to render possible the construction of the monumental works of Egypt and the East, and the priests of many of the ancient religions probably had an expert knowledge of some branches of mechanics. The aqueducts and bridges built by the Romans, and the remains of metal pumps of the Roman period, show that the principles of civil, mechanical, and hydraulic engineering were well understood before the Christian era.

\section{The Medieval Engineer}

In England the term engineer as defining an occupation appears to have dated from the 13th century. In the wardrobe account of Edward I (1300) occurs a statement of sums paid to engineers for military artificer's work, while in 1344 the army records have a note of the number of engineers borne on the strength of the ordnance. The duty of such engineers was, not only to direct warlike engines and weapons, a duty afterwards delegated to the artillery, but also to undertake the design and construction of fortifications, roads, bridges, machinery, and other works of military service.

About the 12th century public attention in France became directed to the internal communications of the country, and an association was formed under the name of the Frères Pontiers with the main olject of building bridges.
The association was extended throughout Europe, and built a large number of important works, including the first stone London Bridge. This is perhaps the earliest example of a definite body devoting itself to civil engineering works.

\section{Early Civil Engineering}

The real birth of civil engineering in its modern sense, however, dates from the beginning of the 17th century. At that time the rivers of $\mathrm{N}$. Italy, which had been in use for navigation and regu. lated for irrigation from early times, appear to have relapsed into a bad state of order, with the result that many disastrous inundations took place. To prevent this, the most learned scientific men of the day were called into consultation, which led to a series of valuable studies and experi. ments. A class of practitioners was called into existence capable of dealing with hydraulic works and with their necessary mechanical arrangements, and the scope of their work was gradually extended to cover also the design and construction of roads, bridges, docks, workshops, and machinery in general. In view of the fact that the class of work undertaken was analogous to that allotted to the engineers of the military service, the new profession adopted the title of engineer, prefixing the word civil to distinguish its members from their military brethren.

Probably the best definiticn is that used by the Institution of Civil Engineers which defines engineering as "the art whereby the great sources of power in nature are converted, adapted, and applied to the use and convenience of 
man," a definition which covers all the activities of the engineer, whether he call himself civil, mechanical, or electrical.

The development of the steam engine led to an enormous and rapid expansion in the branch of civil engineering devoted to the design and construction of motivepower machinery and mechanical appliances, and to the development of manufacturing processes, and from this period dates the professional term mechanical engineer. Still later, the devclopment of the electric dynamo and of all the electrical appliances and accessories to electric power and lighting, rendered this sub-branch of mechanical engineering sufficiently important to justify the use of the professional title of electrical engineer.

\section{Specialised Branches}

The more recent rapid developments in all branches of engineering have necessitated further intensive specialisation, and aero engineering, agricultural enginecring, chemical engineering, and metallurgical engineering are now to all intents and purposes separate professions. In general the term civil engineering is now confined to the design and construction of such works as roads, bridges, railways, docks, harbours, canals, dams, and coast defences, all of which are essentially of a foundational and stationary character.

The scientific study of engineering principles is of comparatively recent growth. The first engineering school attached to any uni. versity in the United Kingdom was founded at Glasgow. This was quickly followed by similar schools at other universities, and a training in the profession can now be obtained at any university or technical institute in the kingdom.

In the domain of mechanical engineering the steam engine has been developed and improved until in its modern form its output of energy per pound of fuel is immensely greater than that of its predecessors. Other forms of prime mover, steam turbines, gas, oil, or petrol engines, have also been developed, until from the point of view of efficiency little further scope for improvement seems possible. Thanks to the reduction in weight found possible by scientific attention to design and by the use of high tensile steels and aluminium alloys developed by the metallurgical engineer, the weight per h.p. of the petrol engine has been cut down to a figure which, only a few years ago, would have been thought fantastic, and the performance of the modern aeroplane has been rendered possible.
In electrical engineering, the development of high-tension overhead transmission lines, by which electrical energy may be transmitted for very long distances comparatively cheaply and efficiently under a pressure of several thousand volts, has rendered it possible to harness many large waterfalls and other sources of water-power remote from any industrial centre, and to transmit this energy, developed by the use of hydraulic turbines coupled to electric generators, to be used at the most convenient site. In the U.S.A. and Canada such transmission lines, some of them exceeding $200 \mathrm{~m}$. in length, have long been in use.

In view of the success of these systems, of the comparative cheapness with which water-power can be developed, and of the rising cost of coal, great interest is being taken in the harnessing of waterpower in most countries of the civilized world, and such hydroelectric development promises to provide a most interesting chapter of engineering history. The possibility of utilising very large powers in this way has reacted on the mechanical side of hydraulic engineering. The size of the turbine units has increased by leaps and bounds, culminating, for the present, in the units of 100,000 h.p. each, now under consideration for the Queenston-Chippewa project on the Niagara river.

Electro-chemical and other Processes

The possibility of obtaining large blocks of power at the low prices obtaining in many hydroelectric developments has given a great stimulus to electro-chemical and electro-metallurgical processes. Many processes, partly chemical and partly engineering, e.g. the manufacture of aluminium and the production of electrolytic copper, are only commercially possible where electrical energy at a very cheap rate is available. On the European continent much electrical energy derived from water-power is also being used for the production of artificial fertilisers from the nitrogen of the air.

In view of the rapid depletion of ine world's natural nitrate deposits, and of the diminution in fertility of most of the great wheat and cotton growing areas, the production of such artificial fertilisers must become a question of worldwide importance. Among other important developments in electrical engineering may be mentioned electric lighting by the arc and incandescent lamp, electric traction as applied to tramways and, more recently, to suburban and main railway lines, and wireless telegraphy and telephony.

The developments in civil engineering have been probably less marked than in any other branch. Methods of construction have been in general improved and rendered more efficient by the extended use of labour-saving machinery; the design of masonry structures and of stcel bridges has been put on to a more satisfactory footing, and the necessity for road surfaces capable of withstanding the wear and tear of highspeed motor traffic has led to advances in the art of road construction. The introduction of ferro-concrete, with its combination of steel bars embedded in concrete to increase its tensile strength, has given rise to a distinctive type of construction which for such structures as bridges, retaining walls, and large buildings often offers many advantages in the way of cheapness of construction and maintenance over theolder type of masonry or steel structure.

\section{Training of the Engineer}

This brief review indicates to what an extent the material prosperity of mankind depends on the work of the engineer. Its means of communication, transport, and locomotion, whether byland, water, or air; its energy supplies; its water supplies and drainage, are dependent on his activities. In. deed, civilization in the modern sense of the word and engineering may be said to be synonymous. While the enormous range of the subject renders it imperative for the engineer to specialise in some one branch of his profession, the training of the young engineer should be on as broad lines as possible, and the wider his grasp of the outlines of all its branches, the better are his prospects of ultimate success. The professional training should include a three years course in the engineering school of some university or technical insti. tute. The first two years of this course are common to all branches of engineering, and usually include the study of chemistry, physics, and mathematics, and the elementary study of civil and mechanical engineering construction, strength of materials, heat engines, hydraulics, mechanics, along with design work in the drawing-office.

The third year is usually devoted to a more advanced treatment of the subjects relating to some special branch of engineering, and this theoretical training should be followed by a course of practical work in the appropriate workshops or engineering office. It is in some respects an advantage for the 
practical training to be taken, whether wholly or in part, before the university course, while in some universities provision is made for a "sandwich" course, in which the engineer takes his workshop training during the summer months of each year, and his theoretical training during the six winter months.

Bibliography. Hydraulics and its Applications, A. H. Gibson, 1908 A Practical Treatise on Bridge Con struction,T. C. Fidler, 4th. ed. 1909 The Steam Engine and Other Heat Engines, J. A. Ewing, 3rd. ed. 1910 ; Civil Engineering as applied in Construction, L. F. V. Harcourt, 2nd. ed. revised by Henry Fidler, 1910 ; Surveying and Surveying Instruments, G. A. T. Middleton, 3rd. ed. 1912; Natural Sources of Energy, A. H. Gibson, 1913; The Gas, Petrol and Oil Engine, D. Clerk, rev. ed. 1909-13 ; Strength of Materials, A. Morley, 4th ed. 1916; The Principles of Electrical Engineering and Their Application, G. Kapp, 1916, etc.

Engineering. London illus trated weekly journal devoted to all branches of the engineer's work, and giving full attention to the theoretical, practical, and economic sides. It was founded in 1866 by Zerah Colburn, the editorship passing early in 1870 to William H. Maw, M.Inst.C.E., and James Dredge. On the death of $\mathrm{Mr}$. Dredge in 1906, B. A. Raworth, who had for many years acted as assistant editor, was appointed joint editor with IV. H. Maw, a position he occupied until his death in 1919. He was succeeded as joint editor by Alex. Richardson, M.P. The volumes of Engineering contain a valuable record of developments in the construction of steam and other prime movers, as well as in the manufacture and treatment of steel and other products employed by the engineer.

Engineer Officer.

Commissioned officer of the British navy. $\mathrm{He}$ is a technical specialist, responsible for the running of all main and subsidiary machinery in a warship and the control of the engineering workshops and repairs aboard. In the smaller vessels he frequently also performs the duties of acoountant officer. Since 1903 engineer officers have been trained as executive officers and are com. petent to take executive duties and rise to the highest ranks in the navy. They enter training like other naval cadets, pass through Osborne and Dartmouth, where the general course includes engineering, spend eight months on a training cruiser and qualify as midshipmen. Having been commissioned and spent one to three years in the ranks of sub-lieutenant and lieutenant, those who volunteer for specialist branches take a course at the Royal Naval College, Greenwich, and the engineers then take a further course at the engineering school at Keyham, near Devonport. An engineer officer is distinguished

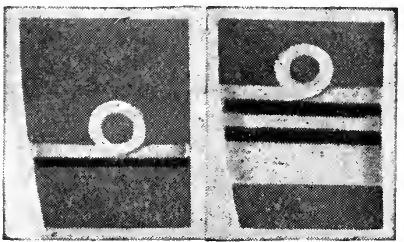

Engineer Officer. Cuff badges of officers in British navy. Left, sublieutenant; right, vice-admiral

by wearing strips of purple cloth between the bands of gold lace denoting his rank.

Engineers, Royal. Technical corps of the British army, popularly termed the Sappers. The origin of the corps is of considerable antiquity. There was until 1716 a Chief Engineer who was responsible for the care of all engines of war and had headquarters at the Tower of London before 1350. The ordnance department was constituted a separate unit in 1450 , but the Engineers were responsible for the guns until 1716, when the Royal Artillery was established.

The corps may be said to have originated in its modern form in the company of military artificers raised by Sir William Green at Gibraltar in 1772, which, during the long siege, distinguished itself in the construction of galleries on the north face of the Rock and by the repair of breaches made by the enemy's fire.

In peace time the corps is organized as field, signal, bridging, survey, fortress, railway, printing, and postal companies and troops-descriptions which indicate the wide activities of the units and which have been con$\mathrm{t}$ in ually a u. mented as science has played a more and more impor-

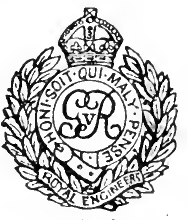

Royal Engineers badge tant part in warfare. During the Great War, special companies were added, whose duty it was to investigate and direct the use of poison gas and the measures adopted to countract it. Meteorological companies were responsible for informa. tion regarding the weather which was essential for aviation and valuable in ordinary strategy.

The corps does not take the field as a unit, but sends detached companies to organize the signal and communication services, etc., of divisions and other units, advise on the construction of trenches, superintend and organize large defence works, entrenchments, mining of enemy positions, and the destruction of communications in a retreat.

During the long periods of trench warfare the Engineers were chiefly employed in tunnelling and mining, At one stage of the war they used the geophone, an instrument for magnifying the sounds of enemy mining. Later they were provided with the seismomicrophone, which transmitted sounds from as many as fifty gallery faces to a central station, which was situated in a place of safety. This saved the many casualties formerly entailed by listening at each face. Also their work included the improvement of the communications, organizing and manning searchlight stations, and the duties previously outlined. In the advance of August to Novem. ber, 1918, they erected in the battle area 326 steel bridges (the longest having a $180-\mathrm{ft}$. span), 213 heavy timber bridges capable of carrying loads of 17 to 30 tons, and necessary for tanks, as well as hundreds of lighter bridges suitable for fighting units and first line transport. In addition to serving in France and Flanders, the Engineers were conspicuous by their intrepidity and persistence in the campaigns in Italy, Salonica, Egypt, Gallipoli, Palestine, and Mesopotamia. On the outbreak of the Great War the Corps of Royal Engineers totalled 1,808 officers and 23,521 other ranks. In November, 1918, its strength was 17,711 officers and 322,739 other ranks, its casualties in killed, died, and missing during the war exceeding 1,100 officers and 17,500 other ranks.

A memorial to the services of the Engineers in the Great War and to the fallen is to take the form of $(a)$ an educational scheme for the benefit of all ranks and all branches of the corps as at present constituted; and (b) a monumental memorial in Lon. don. The cost of the entire scheme was estimated to be $£ 150,000$. Its motto is Ubique (Everywhere) See illus. facing p. 614 .

Engineers, Societr of. British learned society. Established in 1854 , it was incorporated in 1910 , when it was amalgamated with the Civil and Mechanical Engineers' Society, dating from 1859 . It exists to further the interests of the engineering profession. The society consists of fellows, members, and associates, and its head offices are at 17, Victoria Street, Westminster, S.W. One of the largest of the trade unions was known until 1921 as the Amalgamated Society of Engineers. See Trade Unions. 


\section{ENGLAND: ITS TOPOGRAPHY, HISTORY, ETC.}

A. D. INNES, Author of A History of England, B. C. WALIIS, and A. W. HOLIAND

$A$ description of England from the topographical, the geological, and the climatic point of view, is followed by some account of its industries and communications. Then come sections dealing with its government and its history, the latter being taken down to I707, from which date it is continued under the heading of United Kingdom. In addition, some thousands of articles describe the counties and torens, rivers and mountains of England, dcal with the lives of kings and statesmen, with wars, battles, and political and social movements. The government is described in detail in a series of articles from Parish to Parliament

England, originally Angleland or the land of the Angles, covers the larger and southern part of the island of Great Britain, excepting only that western part of it known as Wales. It is bounded by Scot. land on the $\mathrm{N}$. and Wales on part of the W.; elsewhere its borders are the North Sea on the E., the English Channel on the S., and the Atlantic Ocean and the Irish Sea on the W.

The area of England is 50,874 sq. m., being nearly two-thirds of Great Britain. It measures $430 \mathrm{~m}$. in extreme length, from the Lizard to Berwic'-on-Tweed, and $370 \mathrm{~m}$. in extreme width, from Land's End to Lowestoft. In shape it is an irregular triangle. The coast, especially on the W., is broken with numerous openings, making a total length of $1,800 \mathrm{~m}$. The W. coast is high and rocky, bold cliffs and buttresses of hard rock standing out to sea. On it are three large openings-Solway Firth, Morecambe Bay, and the Bristol Chan. nel, as well as the mouths of the Ribble, the Mersey, and the Dee, which, however, is Welsh on one side. Between England and Wales there is only a county boundary.

Coast-line and Harbours

The chief headlands are St. Bees Head, Hartland Point, and Land's End. The S. coast combines the peculiarities of both the $\mathbf{E}$. and W. coasts, the two sections being divided by the Isle of Wight. East of it is a coast-line with a low, clay shore, broken here and there by chalk cliffs; W. of it the coast is high and bold. Its chief openings are harbours, several of which are unusually good. They include Portsmouth Harbour,Southampton Water, Weymouth Bay, Tor Bay, Plymouth Sound, Falmouth Harbour, and Mount's Bay. The chief headlands are the Lizard, Start Point, Portland Bill, St. Alban's Head, Selsey Bill, Beachy Head, Dungeness, and the S. Foreland.

The E. coast is regular in outline, broken only by the estuaries of rivers. In places it is high and rocky, lut much of it is low and sandy, and along parts of it the sea is encroaching. The principal river mouths are those of the Tyne, the Tees, and the Humber, the Wash, and the Thames. The chief headlands are Flamborough Head, Spurn Head, Lowestoft Ness, the Naze, and the North Foreland.

The $\mathrm{N}$. boundary is formed by the course of the Tweed, the line of the Cheviots, and three streams-Kershope Burn, Liddel Water, and the Sark-falling into the Solway. Its length is just under $100 \mathrm{~m}$.

There are but few islands off the coast of England. The Isle of Man and the Isle of Wight are the largest, but the former is not, strictly speaking, part of England, having its own laws and government. Off Northumberland are the Farne Islands, Lindisfarne or Holy Island, and Coquet Island, but off the $\mathrm{E}$. coast there is nothing else until Foulness Island,off Essex, is reached. Thanet and Sheppey cannot properly be called islands. Off the W. coast are Walney Island, opposite Barrow, and Lundy Island in the Bristol Channel. Off Cornwall is a group, the Scilly Islands.

\section{The County Divisions}

England is divided into forty counties, varying greatly in size. Some of them are further divided for local government and other purposes, while in the three ridings Yorkshire has a more historic division. The counties and their acreage, which includes the sheets of water therein, are as follows. The number after each indicates its relative position as regards size.

\section{County}

Bedford (37)

Berkshire (32)

Buckingham (30)

Cambridge (25) .

Cornwall (14)

Cornuarland

Derby $(20) \quad \ldots \quad$..

Devon (3)

Dorset (23)

Durham (21)..

Essex (9)

Gloucester (17)

Hampshire (7)

Hereford (27)

Hertford (35)

Huntingdon (38)

Kent (10)

Lancashire (6)

Lincoln (2)

Middlesex (39)

Monmouth (36)

Norfolk (4)

Northampton (22)

Northumberland (5)

Nottingham (26) ..

Oxford (31)

Rutland (40).

Shropshire (16)

Somerset (8)...

Stafford (18) ...

Suffolk (12) ..

Surrey (33) ..

Warwick (24)
Westmorland (29)

Wiltshire (15)

Worcester (34)

Yorkshire (1) F.R.

N.R.

505,330

864,101

458,352

750,214

:,773,529

This table does not include the county of London, formed in 1888 out of the counties of Middlesex, Surrey, and Kent. Its area is 74,816 acres.

Population. The population of England, according to the census of 1921 , was $35,678,530$.

Of these, $16,984,087$ were males and $18,694,443$ were females. The increase since the 1871 census, according to the decennial census figures. was as follows:

$\begin{array}{ccccc}\text { Year } & & & & \begin{array}{c}\text { Population } \\ 1871\end{array} \\ 180 & \ldots & \ldots & 21,495,131 \\ 1881 & \ldots & \ldots & \ldots & 24,613,926 \\ 1891 & \ldots & \ldots & \ldots & 27,489,228 \\ 1901 & \ldots & \ldots & \ldots & 30,813,043 \\ 1911 & \ldots & . & \ldots & 34,045,290\end{array}$

Taking England and Wales together, the average pop. per sq. $\mathrm{m}$. had grown from 389 in 1871 to 618 in 1911. The population of England and Wales, when the first census was taken in 1801, was $8,892,536$, or 152 to the sq. m.

In the years between 1911 and 1921 there were great movements of population, this being due to the general upheaval caused by the Great War. A full revelation of the extent and nature of these changes can only be seen when the census figures for 1921 are complete.

Each year the registrar-general, with the various vital statistics before him, makes an estimate of the population of the country. $\mathrm{He}$ includes Wales with England. For the years 1914-19 they include the civilian population only. They are as follows, the date being June 30 each year :

$\begin{array}{ccccr}\text { Year } & & & & \begin{array}{r}\text { Population } \\ 1914\end{array} \\ 1915 & \ldots & \ldots & \ldots & 36,960,684 \\ 1916 & \ldots & \ldots & \ldots & 35,358,896 \\ 1917 & \ldots & \ldots & \ldots & 34,500,000 \\ 1918 & \ldots & \ldots & \ldots & 33,711,000 \\ 1919 & \ldots & \ldots & \ldots & 35,994,700 \\ & & & & \end{array}$

In 1915, and still more in 1916 , 1917 , and 1918, the military population was large, something like $4,000,000$ at one time, although these did not all come from England. It was considerable in 1919 , when the population was returned at just about a million below the 1914 figure. It seems, therefore, fair to assume, on the basis of the registrar-general's figures, that the 
population of England in 1920 was about the same as it was in 1914. The losses of the war had been made good, but that was all.

The following table gives, according to the census of 1921 , the population of the various counties. It includes that of the county boroughs which are within their areas, although not under the control of the county councils :

Bedford (34)

\begin{tabular}{llll} 
Buckingham $(22)$ & $\ldots$ & $\ldots$ & 236,209 \\
\hline
\end{tabular}

$\begin{array}{lllll}\text { Cheshire }(9) & \ldots & \ldots & . & 1,025,423\end{array}$

Cornwall (27) $\quad \cdots \quad$.

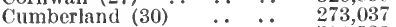

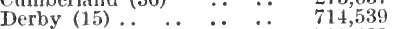

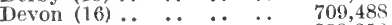

Dorset (33) $\quad$..

Durham (3) $\quad$.

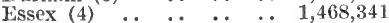

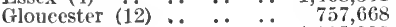

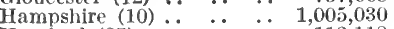

Hereford (37) $\quad \ldots \quad \ldots \quad \ldots{ }^{113,118}$

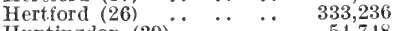

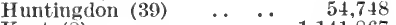

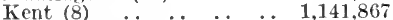

Lancashire (1) $\quad \ldots \quad$..

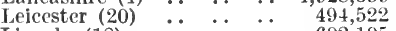

Lincoln (18) $\quad$.

Middlesex (7) $\quad$..

$\begin{array}{lllll}\text { Monmouth (22) } & \text {. } & \text {. } & \text {. } & 450,700\end{array}$

$\begin{array}{lllll}\text { Norfolk (19) } & \ldots & \ldots & \ldots & 504,277 \\ \text { Northampton } & \ldots & \ldots & 349,384\end{array}$

$\begin{array}{llll}\text { Northampton }(25) & \ldots & \ldots & 349,384 \\ \text { Northumberland }(13) & \ldots & \ldots & 746,138\end{array}$

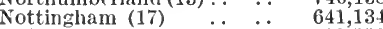

$\begin{array}{lllll}\text { Oxford }(36) & \ldots & \ldots & \ldots & 189,558\end{array}$

$\begin{array}{lllll}\text { Rutland (40) } & \text {. } & \text {. } & \text {. } & 18,368\end{array}$

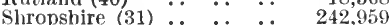

$\begin{array}{lllll}\text { Somerset }(21) & \ldots & \ldots & \ldots & 465,68\end{array}$

$\begin{array}{lllll}\text { Stafford }(6) & \ldots & \ldots & \ldots & 1,349,225\end{array}$

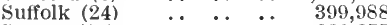

Surrey (11) $\quad$.

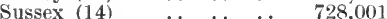

$\begin{array}{lllll}\text { Warwiek }(5) & \ldots & \ldots & \ldots & 1,390,092\end{array}$

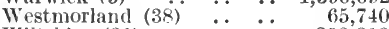

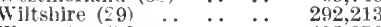

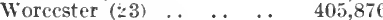

Yorkshire (2) E.R. $\quad . . \quad \ldots \quad 544,769$

$$
\begin{array}{rrrr}
\text { N.R. . . } & . . & 456,312 \\
\text { W.I. } & . & . . & 3.181,654
\end{array}
$$

From this talie, too, London is excluded. Its population was $4,483,249$.

In 1921 there were in England 42 towns and urban districts with populations estimated as in excess of 100,000. This excludes London. There were in addition a further 52 places with populations in excess of 50,000 . The population figures for the largest towns were :

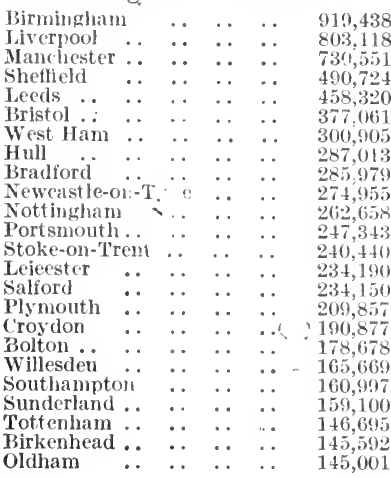

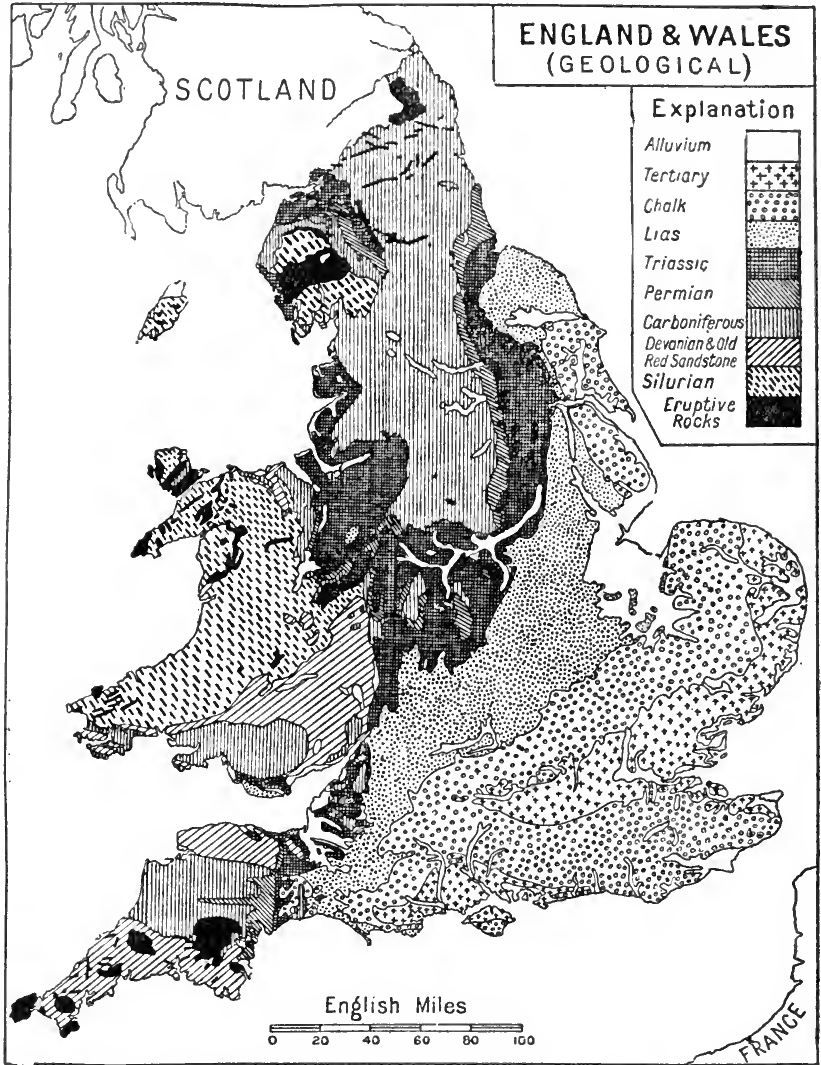

England. Map showing the genera! geoiogical tormation of Engiand and Wales

$\begin{array}{llllll}\text { East Ham . . } & \text {. } & \text {.. } & \text {. } & 143,304\end{array}$

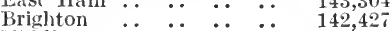
Middlesbrough $\quad \ldots \quad \ldots \quad \ldots \quad 131,103$ $\begin{array}{llllll}\text { Derby . . } & . & \ldots & \ldots & \ldots & 129,836\end{array}$ $\begin{array}{llllll}\text { Leyton } & \text {. } & \ldots & \ldots & \ldots & 128,432\end{array}$

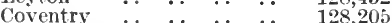

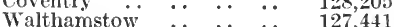

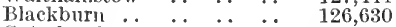
Gateshead .. $\begin{array}{llllll}\text { Stockport } & \text {. } & \ldots & \ldots & \ldots & 123,315\end{array}$ $\begin{array}{llllll}\text { Norwich } & \text {. } & \ldots & \text {. . } & \text {. } & 120,653\end{array}$

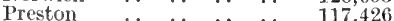

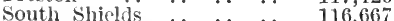
$\begin{array}{lllll}\text { Huddersficld } & \ldots & \ldots & \ldots & 110,120\end{array}$ Southend-on-sca $\quad \ldots \quad \ldots \quad 106,021$ $\begin{array}{llllll}\text { Burnley } & . & \ldots & \ldots & \ldots & 103,175\end{array}$ St. Helens $\quad . \quad \ldots \quad \ldots \quad$.

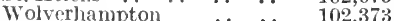
Blackpool $\begin{array}{llllll}\text { Halifax } & \cdots & \cdots & \cdots & \cdots & 99,129\end{array}$ $\begin{array}{llllll}\text { Walsall } & \ldots & \ldots & \ldots & . & \\ \text { W } & . & & 96,964\end{array}$ Reading

92.274

These populous centres fall into three groups: the manufacturing towns on the coalfields of Durham, Lancashire, Yorkshire, and the Midlands; the seaports such as Portsmouth, Plymouth, and South ampton: and the outer suburbs of London, urban districts such as Leyton, Tottenham, Walthamstow, and Willesden, with Brighton put in this category. Norwich is the only large centre outside this classification.
Description. England is the largest of the four countries which compose the United Kingdom, comprising two-fifths of the total area.

The situation of England with reference to France and the continent of Europe is of supreme importance. The E. and S. coasts make an angle with its vertex just where the British seas are narrowest. Through this S.E. corner continental civilization reached Britain, and through it Britain maintains its closest ties with modern Europe. The English people, as distinct from the Scots, Welsh, and Irish, com. prise diverse elements, and similarly the English land consists of rocks representative of many more geological ages than are encountered elsewhere in the British Isles.

The Geological Formation. From the modern alluvium of the Wash to the oldest rocks present in Cumberland and Cornwall the geological series is almost complete. England has been gradually built up by successive additions to the older Cumbrian and Cornish lands 
as the marine deposits of the several geological ages have permanently emerged from below the sea.

The old western lands occur in three portions. The Lake District is the oldest, with Ordovician and Silurian rocks and large massive or eruptive basalt. The Cornish peninsula and Herefordshire are mainly Old Red Sandstone and Devonian rocks with eruptive granites in Cornwall. Here the rivers have bitten into the rocks and carved the upland into stcep-sided, narrow, winding valleys. Between rounded smooth-topped ridges and domes lie marshy alluvial flats, where the streams meander across valley bottoms made by more powerful torrents. In the Lake District the ice sheet gave a slightly different character to the land surface, and in the valleys carved by glaciers long narrow lakes walled by steep slopes radiate from a central knot of mountains.

Between the rivers Tweed and Trent the carboniferous rocks form a chain of uplands which make a definite water-parting between the rivers of the North and the Irish Seas. Flanking the Pennines are the coal measures, which lie in pairs. In the N. the Cumberland and Durham and Northumberland coalfields reach the coast; $\mathrm{S}$. of the range the Lancashire and $N$. Staffordshire coalfields on the W., and the York, Derby and Nottingham coalfield on the E., lie on the slopes between the watershed and the almost flat plains of Cheshire and the vales of York and Trent.

Farther S. the carboniferous rocks only appear in detached fragments in the midland coalfields between the Trent and the Stratford Avon; in the mountain limestone and the Forest of Dean coalfield on the edge of the Old Red Sandstone of the Wye and Usk.

\section{The New Red Sandstone}

On the E. margin of the carboniferous rocks, along a line from the mouth of the Tyne to that of the Exe, are detached portions of the Permian system. From Tynemouth to Nottingham both Permian sandstone and magnesian limestone appear in long narrow bands.

Triassic rocks cover a V-shaped area reaching from Middlesbrough to Gloucester, and from Gloucester to the shore of MorecambeBay. Detached portions fringe the coast of the Lake District, form the valley of the Lower Eden, and extend across the isthmus of the Cornish peninsula. Their best known representative is the New Red Sandstone. Triassic rocks are asso. ciated with lowlands, the vale of York, the valley of the Trent, the Cheshire plain, the Fylde of
Lancashire, and the lowlands W. of the Severn.

The remaining portion of England comprises rocks which have no representatives on the $\mathrm{W}$. The Lias stretches in an almost unbroken band from Lyme Regis, E. of the Severn and the Stratford Avon, E. of the Trent, and from Goole to the coast near the mouth of the Tees. Fringing the lias along its eastern margin lies the oolitic limestone, which gives rise to a line of residual hills, from the Cotswolds to the N. York moors.

Between the Wash and Dorset a narrow band of Greensand separates the oolite from the chalk which gives rise to a series of hills-the $\mathrm{E}$ Anglian Heights, the Chilterns, the Marlborough, and N. and S. Downs. Within the V-shape of these hills lies the London basin with its young rocks.

'I'he N. and S. Downs are relics of a ridge of chalk which was raised as the Wealden uplift to form a continuous ridge from Wiltshire to France. The middle of the ridge has been worn away to form the Wealden plain and expose the Greensand along the inner scarped edge of the chalk. the Wealden clay within the Greensand, and the Hastings Sand within the clay.

\section{Scenic Differences}

Each of these geological horizons has been weathered into characteristic land forms. The steep cliff faces of the Millstone Grit in Derbyshire are in striking contrast to the chalk landscape of the downs, marked by rounded contours. The Triassic landscape of the vale of Trent or the Cheshire Plain differs widely from either the oolitic Oxford Clay or the younger London Clay of Herefordshire or Middlesex.

These scenic differences are em. phasised by the vegetation typical of each type of rock. The beeches and silver birches of the sandstone of Sherwood Forest differ widely from the woodland which clothes the sides of the narrow Cornish valleys and leaves the uplands bare.

Similarly, the coastal edges of the formations give an infinite variety to the shores of England. The chalk cliffs of Dover and Beachy Head, with their vertical white faces, differ from the sandy cliffs exposed near Bournemouth in the eocene of the Hampshire basin ; the miles of iron-bound coast along $\mathrm{N}$ Cornwall from Tintagel southwards are totally different from the sandy lowland shores of the Triassic formation in the Wirral peninsula.

Rivers and Valleys. Although the highest ground of England is largely due to those foldings of the earth's crust which produced the Pennine and Wealden uplifts, the residual features are largely the work of rivers. In the N.E., in Northumberland and Durham, the North Sea drainage reaches to a water-parting on the western side of the Pennines; near Cross Fell $(2,930 \mathrm{ft}$. $)$ the Tyne, Wear, and Tees rise close to each other. From Haltwhistle the S. Tyne and the Tyne itself flow due E. ; the valley of the S. Tyne leads W. through the Tyne Gap in the Pennines at a lower elevation than $500 \mathrm{ft}$. to Carlisle. The Coquet, Wansbeck, and Blyth cross the coastal plain of Northumberland, and the Wear and Tees for more than half their length are on the Durham lowland.

\section{River Drainage}

Between Teesmouth and the Wash almost the whole of the drainage is concentrated on the Humber. The large rivers, except the Yorkshire Derwent, rise to wards the W. side of the Pennines, the Trent even on the western slopes, and drop through the dales to the level of the Triassic sandstones and marls in the plains of York and Trent. Rich. mond, Leyburn, Ripley, Sheffield, Stoke-on-Trent, the first large places on the rivers, mark the termination of Pennine valleys. Lower down stream the rivers flow over the sandstones to the main streams of Trent and Ouse which flow parallel and close to the E. edge of the Trias.

The drainage has hollowed the sandstone into a trough with Lias clays on the E. The Yorkshire Derwent is the one exception to the rule that no long rivers cross the Lias to the Triassic plain. This stream rises close to the coast, flows across the oolitic vale of Pickering between the Cleveland Hills and the Yorkshire wolds in an abnormal course which was determined originally by the presence of sea ice during the ice age in the North Sea. This ice barrier forced the drainage towards the S.W., so that a permanent valley was carved across the Lias clay.

The Wash, Witham, Welland, Nen, and Great Ouse rivers rise on or close to the Lias, and carv. ing out the low residual oolitic hills, drain the trough of clayey land bounded on the $\mathrm{E}$. by the chalk ridge N.E. of the Chilterns. The water gap at the great bend of the Witham is dominated by the city of Lincoln on the oolite ridge above the river.

Probably the Thames ence flowed over dry land to join the Rhine and make a great river which flowed N. across the North Sea floor. The Yare, Waveney, Orwell, Stour, Colne, Blaokwater, 
and Crouch are thus the relics of longer streams which drained from the chalk ridge eastwards to this parent stream. The Kennet rises in the angle where the Chiltern and Downs chalk ridges meet in the Marlborough downs, and flows in a straight course to the Thames at Reading in the general line towards Southend. This is the real lower Thames, with all the left bank tributaries, Colne, Lea, etc., coming down from the chalk across the London clay.

The upper Thames makes a great break through the chalk at the Goring Gap to reach Reading, and the shape of its basin in the Oxford clay plain between the Cotswold oolitic ridge and the Chilterns is due to the general drainage to the S.E. and the sideways drainage in the clay hollow.

River System and Market Towns

The Churn, Coln, Leach, Windrush, Evenlode and Cherwell and the Thames itself between Oxford and Reading flow to the S.E. ; the Ray and the Thame (vale of Aylesbury), the Ock (White Horse vale), and the Thames above Oxford flow at right angles to this main direction across the clay.

The Wealden rivers rise along a water-parting which roughly follows the line from Hythe to Hind. head. From the northern clay vale the Wey, Mole, Medway and Stour cut through the $\mathrm{N}$. downs. The Arun, Adur, Ouse and Cuckmere sut through the $\mathrm{S}$. downs to the English Channel. The Rother alone is entirely on the Weald, and crosses the Hastings sand.

The Itchen, Test, Avon, Stour and Frome flow from the chalk to the Hampshire basin. The Avon drains Salisbury Plain. All around the coast from the Wash to Poole harbour the rivers reach the sea along a low coast, where the rise and fall of the tides makes a great difference to each estuary.

The river systcm in general has determined the situation of the market towns. Guildford, Arundel, and Lewes are gap towns on the downs. Oxford, Reading Chelmsford and Norwich have each been influenced by the confluence of two streams.

The peninsular rivers of the S.W. are developed from the Exmoor, Dartmoor, and Bodmin moorlands. The Tamar and Torridge, rising in the Ditchen Hills inland from Hartland Point, are exceptions; the valley of the Tamar makes a lowland way across the peninsula. Falmouth Bay is a typical Cornish estuary. The rivers of the oldest rocks in Eng. land are tiny streams which flow into large rock-walled estuaries which are the drowned valleys of the middle or lower courses of the streams; they indicate a period when the streams were larger, longer, and more powerful, and which preceded the inflow of the sea or the sinking of the coast. The Camel estuary is the only large break in the iron-bound coast of N. Cornwall between St. Ives and Hartland Point; here miles of sand at low water attest the fact that the estuary is too large for the tiny stream which drains into it ; the river and estuary are not conformable.

The Parret, Brue, Axe, and Bristol Avon belong to an area where many geological formations are crowded together. The Parret is bounded S. by greensand hills, like Leith Hill in the Weald ; the Brue and the Axe belong to Sedgemoor, a fen district in miniature with the limestone Mendip Hills to the N. The scenery of the Mendips repeats that of the Peak district, with lead mines, swallow holes, and caverns. The Cheddar Gorge is, however, without parallel in Derbyshire; the cliffs are probably the sides of a great cave of which the roof has fallen. The Bristol Avon rises in the oolitic Cotswolds, crosses the S. portion of the Oxford clay plain, cuts a gorge through the oolite, crosses a lias clay plain, and cuts a second gorge at Clifton through the carboniferous limestone of the Bristol coalfields to the Bristol Channel.

\section{The Severn and Thames}

The Severn is a Welsh river of which the middle and lower courses are English. It originated probably as one of a series of streams which flowed in a general S.E. direction from the Cambrian mts. The young stream, in all prob. ability the parent stream of the Thames, flowed across a slope where the surface features were of small magnitude. In time the softer clay rocks of the lias and the oolite were worn away, leav. ing outstanding sandstone and limestone hills and ridges. Strug. gles were initiated betwcen the streams and the harder rocks; there was a chance that the Cotswold and Chiltern ridges would cut the young stream into three sections. The Goring Gap was cut through the chalk, but no gorge was malle in the oolite, and the young stream grew into two rivers - the Thames and the Severn. On the one hand the Severn is parallel to the Cotswolds and the general lines of the Thame, Thames, and Upper Bristol Avon; on the other, it lies on the lias clay, close to the edge of the Trias, and is related in this respect to the lower Trent.
The vales of Evesham and Berkeley resemble the vales of Newark and York. Above the confluence with the Stratford Avon between Tewkesbury and the Coalbrookdale Gorge at Ironbridge, the Severn valley belongs to the Trias; the Worcester plain is like the plain of Burton on the middle Trent. The Teme, Wye, and Usk may be considered as Severn tributaries. In their English sections they cut valleys in the Old Red Sandstone.

\section{Lancashire and Cheshire Estuaries}

The Triassic plain of S.E. Lancashire and Cheshire is drained by the Mersey and its affluent the Irwell, the Weaver, and the lower Dee. Their outlets to Lancashire Bay, the Mersey and Dee estuaries, are not conformable with the streams themselves. In both cases the estuaries are being silted up, sandbanks a few feet below the sea continue the Wirral peninsula far to the N., the main channel winding at low water as a narrow stream across the sand-choked Dee estuary. The bottle-neck formation of the Mersey estuary assists the daily scour of the tides, but large dred. gers have to be maintained to provide a regular channel for liners. Ribblesdale belongs to the mountain limestone of the Pennines, and connects with Airedale at the Aire Gap.

Lonsdale is a reminder that the Lune is a Pennine stream with a silt-filled estuary. The tiny streams of the Lake District which reach Morecambe Bay are really longer than the map indicates, since they form definite valleys across Morecambe sands and have lower courses which are only obscured at high tide. The Eden rises close to the sources of the Swale and Ure, flows across Permian sandstone to the Triassic Solway Plain ; its affluent, the Irthing, completes the Tyne Gap in the Pennines. Like all the Triassic bays, Solway Firth has vast stretches of sand exposed at low tide. The Lake District culminates in Scawfell, but the lake valleys radiate from Helvellyn. Windermere, Coniston Water, Wastwater, Ennerdale Water, Buttermere, Derwent Water, Bassenthwaite, Thirlmere, Ullswater, and Hawes Water are typical lakes of a glaciated area, and fill part of the narrow dales which lead downwards between tree-clad ridges from the central dome where ancient sedimentary rocks are exposed in Skiddaw, and intrusive volcanic rocks raise weathered peaks, as at Scawfell. Walney Island and the coast from Foulney Island to S. Bees Head is Triassic low land. Windermere, Ambleside and 


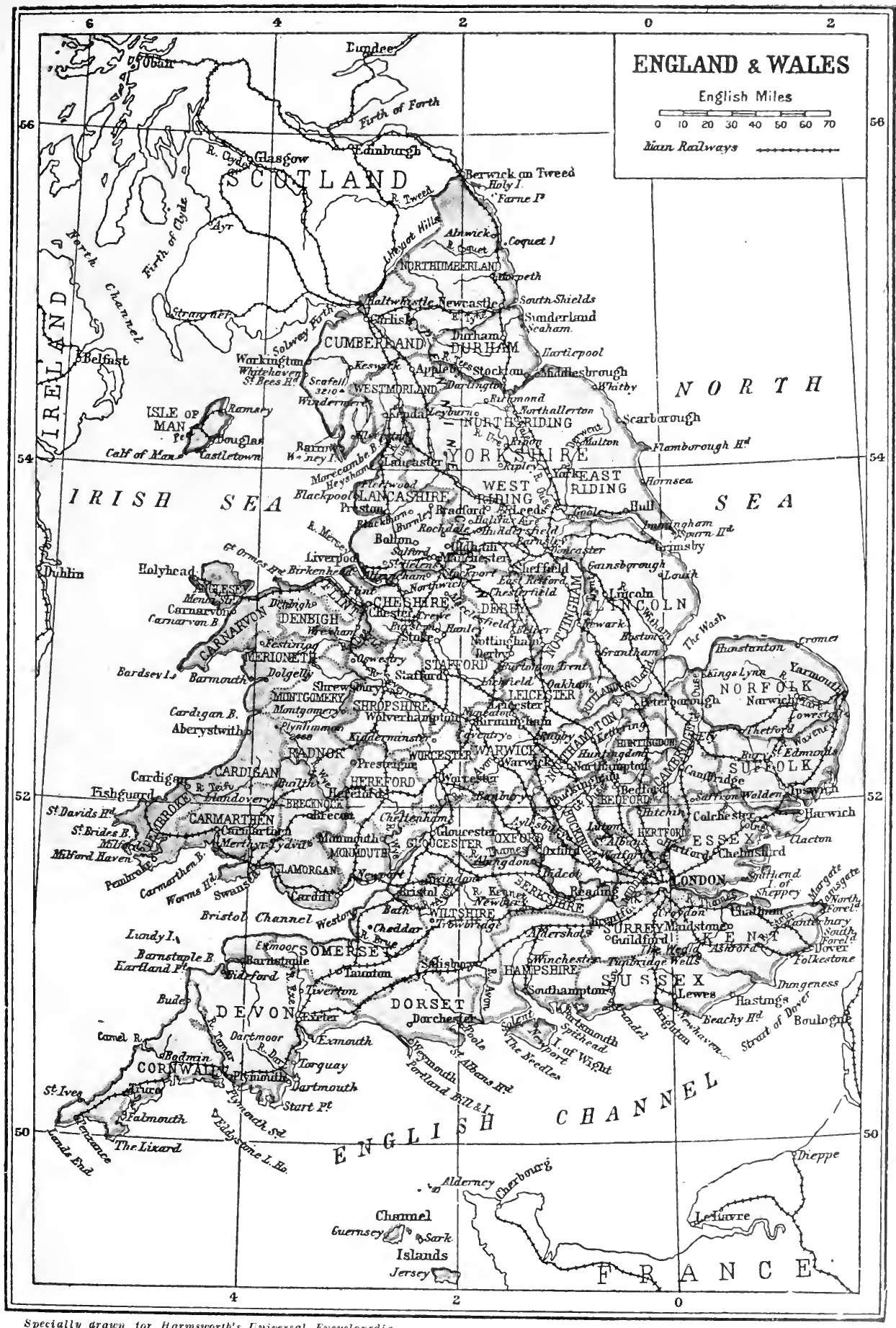

Harmsworth's Cniversal Encyclopedia

Fuller topographical details of England and Wales will be found in the larger scale maps given undar the headings of the To face page 29 ro respective coun ties 


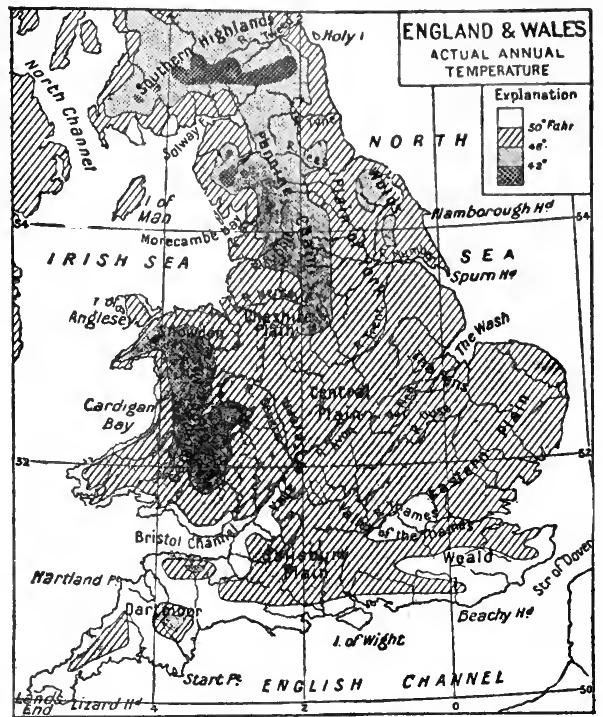

England. Map indicating the mean actual annual temperature of England and Wales lies the Azores area of high pressures, to the E. over the mainland the pressure is usually high, to the N.W. over the Atlantic the pressure near Iceland is usually low.

The prevalent surface $w$ in ds are, therefore, those with a westerly direction which bring oceanic influences to bear, for these winds are usually moisture-laden,warm in winter and cool in summer. The net result is that English seas, rivers, and lakes are never frozen, that England has the mildest winters of any part

Keswick are examples of settlements where a route leads from one dale to another.

The shallowness of British seas and the gradual shelving of the English shore are important in reference to the rhythmic pulsations of the tides. In few countries is the tidal effect felt so far up the rivers. In the characteristically English unconformable estuaries the scour of the tides keeps open the regular channels, with the result that there are scores of tidal harbours round the English coasts. No part of England is more than $70 \mathrm{~m}$. from a section of this tide-swept coast.

Climate and Weather. Ultimately, the climate depends upon solar insolation and upon the currents in the atmosphere between the lower surface in habited by man and the isothermal layer about $5 \mathrm{~m}$. or $6 \mathrm{~m}$. up. The lower faces of these currents are disturbed into eddies and whirls by the varied configuration of the land surface, but the general movements are steady and continuous. The climate of England is determined within very wide limits by the intensity of the sun's rays which it receives; because of its situation England is not tropical like Ceylon, nor arid like Egypt, nor a frozen waste like Spitsbergen.

The limits set to its clima te by its latitude are very far apart. The precise range of the climate within these extremes is determined by the atmospheric currents, which move in relation to three areas of definite types of atmospheric pressure. To the S.W. over the Atlantic of the world in corresponding latitudes. These results are chiefly due to the clouds and the consequent rain. The masses of moisture-laden air carried to England from the Atlantic are necessarily cloudy; England has usually a high percentage of cloud-covered sky. The clouds are a blanket in winter and a screen in summer.

In winter when the earth should cool rapidly and dissipate the warmth stored in summer the clouds restrict the radiation of hea t, condense in to relatively warm rain, and in so doing release heat and bring ' $\mathrm{muggy}$, foggy days. In summer the clouds screen England from the fierce rays of a sun high in the sky, and supply frequent $\mathrm{rains}$. As more water is in summer than in winter frequent rainfall means a lowering of the temperature by the absorption of the heat necessary to cliange the water in to gaseous moisture. An eva porated
English July may therefore be cool and rainy.

The isotherms, which indicate corrected temperatures at sea level, show that in July London in the S.E. is hottest, over $64^{\circ} \mathrm{F}$, and that the strip of land along the Scottish border is coolest, below $59^{\circ} \mathrm{F}$. But in Jan. Land's End is warmest, over $44^{\circ} \mathrm{F}$., and the E. coast from Flamborough Head to the Nore is coldest, below $38^{\circ} \mathrm{F}$.; London is no warmer than Carlisle or Berwick, Liverpool is as warm as Southampton.

\section{Effect of Winds}

The actual weather which is probable at any English town is determined by local conditions of elevation and slope and by general variations from the normal. The prevalent winds usually reach England as cyclonic storms which follow more or less definite tracks from the Atlantic; sometimes the storms are fended away from Eng. land because the continental high pressure extends over the S.E. counties and brings clear skies, cool or cold nights with a frosty period in winter; at other times the Azores high pressure approaches the S.W., and Cornwall has bright, sunny days while the $\mathrm{N}$. is cloudy, cool, and wet.

These general variations affect the entire country while the surface configuration introduces purely local variations. The annual temperature of England, were it entirely a plain, would lie between $48^{\circ} \mathrm{F}$. and $54^{\circ} \mathrm{F}$. ; the map shows that it actually lies between $38^{\circ} \mathrm{F}$.

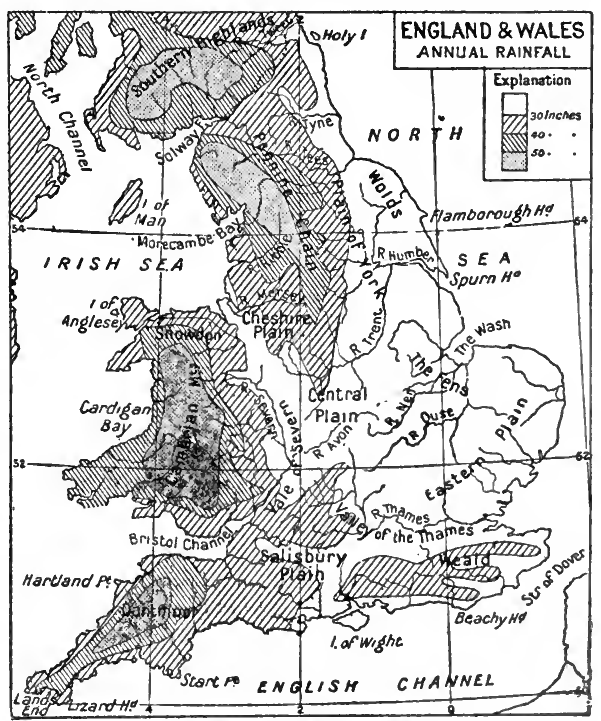

England. Map showing the annual distribution of rain fall in England and Wales 
and $52^{\circ} \mathrm{F}$., and that the hills are cooler than the lowlands. Really the S. coast, the London area, and the lowlands of the S.W. are warmest, the Lake District is coldest, and the Vale of York is as cool as the tops of the N. Downs or the Chilterns. The rainfall map shows primarily the effect of elevation; the wettest place in England is in the Lake District, and even minor ridges are wetter than the plains beneath; the tops of the Downs receive more rain than the Weald plain. But rain clouds come from the ocean, so that the W. of England is wetter than the E. Dartmoor and Bod. min Moor are wetter than the Peak, and the $500 \mathrm{ft}$. level on the Lan. cashire slope of the Pennines receives 10 ins. more rain a year than the corresponding level on the Yorkshire slope; Holderness is drier than the Wirral.

The actual number of hours of sunshine experienced in England varies considerably. Cornwall, Norfolk, and the S. coast receive more than 1,500 hours, the $\mathrm{E}$. slopes of the Pennines less than 1,200 hours. But the difference is bargely neutralised by the slope of the ground. Although the sun shines almost equally upon both sides of the S. Downs the southern slopes are so tilted that the sun's rays have an increased heating effect, while the northern slopes are, as it were, tilted away from the sun's activity.

The climate and weather of England have, therefore, a definite character. There are no extremes, there is constant change, and, within a small space or a short period, considerable variety.

Movements of Porulation. Celt, Saxon, Dane, and Norman left their impress upon the English people, and the prosperity of England later attracted Welsh, Scots, and Irish from within the British Isles and strangers from the Continent. British freedom drew many immigrant aliens from Central Europe, particularly the Jews. Consequently, the English people is almost as kaleidoscopic as the English rocks or English weather. The total of some 36 millions is unevenly distributed over the area of 51,000 sq. m. England contained twothirds of the population of the British Isles in 1871 and three-quarters in 1911 ; the rate of increase per decade has gradually diminished from 134 per thousand, 1861-71, to $105,1901-1911$. In 1801 the population was $8,900,000$, and in $1851,17,900,000$.

The Pennine, N. Yorkshire and Cornish moors, and the Cumbrian Mts. are uninhabited; in the in- habited areas there is a continuous gradation towards definite areas of concentration. Roughly, in a belt of country stretehing from Weymouth across Salisbury $\mathrm{Pl}$ a in and the Clay Vale to near Peterborough, past Lineoln and Gains. borough to York and the N. half of the plain of the Tees, the population is least dense. E. of this belt there is approximately a $\mathrm{s}$ te ady increase towards the London area. W. of it there are several foci of population. Bristol, the Black Country, the Pot. teries, the inverted sickle of S.E.

Lancashire, and the W. Riding with the continuation to Derby and Nottingham, the Durham district from Darlington to Newcastle-all these are crowded, and the population gradually thins out away from these centres.

\section{Varying Areas of Population}

A closer examination of details indicates that the areas of dense population such as the London dis. trict include nuclei of very dense population grading off to areas of relatively few inhabitants. Consider the area composed of the counties of Chcshire, Derbyshire, Nottingham, and the N. half of Staffordshire. In 1801 more than half the area had fewer people than 128 per sq. $\mathrm{m}$. In the W. half Chester, Nantwich, Northwich, Macclesfield, Stoke, Stockport, and Altrincham were small urban areas with at least 1,920 people per sq.m. In the E., Derby, Nottingham, Newark, Retford, and Chesterfield were similar urban areas. By 1851 the areas of sparse population had grown smaller and the urban areas excceding 1,920 per sq. m. were more numerous along certain definite lines, from Birkenhead to Stockport along the Mersey, from Stcke N. to Macclesfield, from Derby N. to Chesterfield ; the Nottingham nucleus was larger, but those of Chester, Retford, and Newark were unchanged.

By 1901 the areas of sparse population were nearly as large as in 1801: the rural areas were being depopulated. The urban nuclei, already developed in 1851 , had be- larger except at Newark. New nuclei had grown along the lines already noted, but the greatest change occurred near Nottingham, where a small urban area had expanded to make almost a complete ring something like $5 \mathrm{~m}$. wide. Throughout two-thirds of the area the population was less numerous in 1901 than a century earlier ; in parts there had been an almost continuous decline, elsewhere there had been growth until 1841 and subsequent decline. The urban areas already specified had multiplied their numbers by from 4 to 10 times. Near Birkenhead, round Stoke, in a belt of country from Nottingham to Chesterfield, there occurred exceptional growth.

\section{General Conclusions}

An inquiry into the circumstances attendant upon these changes yielded the following conclusions. The purely farming areas either absolutely declined in numbers or increased by little more than 50 p.c. In the lead-mining districts the population was almost stationary until the mines failed, when it declined absolutely. In the colliery districts the population increased approximately eightfold. In the salt-mining areas of Cheshire the people increased steadily.. In the districts where cotton factories were established growth in population was rapid, but the failure of factories established in unsuitable localities during the boom caused a decline. Results may be summarised thus : the industrial development of the area 
attracted the people from the farms and also drew to the urban nuclei large numbers from other parts of England. Similar conclusions may be drawn from an investigation concerning the population of the W. Riding ; the farming areas tend to decline in population, the purely mining areas increase steadily, the iron-working and textile areas increase rapidly, the latter especially from the advent of female immigrants.

English towns may be divided into 7 groups: 1. The ring of dormitory towns round London : East Ham, West Ham, Wimbledon, Richmond, etc. 2. Factory towns for textiles, pottery, iron goods, etc. : Manchester, Leeds, Bradford, Birmingham, etc. 3. Mining towns : Barnsley, Nuneaton, etc. 4. Trans port centres: Crewe, Swindon, Liverpool, Bristol, Hull, etc. 5 . Historic market towns: Oxford, Chester, Bath, Canterbury, etc. 6 . Playgrounds: Brighton, Scarborough, Blackpool, etc. 7. Towns of specialised industry: Reading, Luton, Bedford, etc.

Industries, Trade, CommunicaTios. England grows 2 p.c. of the world's wheat and oats, 4 p.c. of the barlev, and contains 2 p.c. of the world's cattle and horses, and 3 p.c. of the sheep. These products only supply a fraction of the cereals and meat required by the inhabitants, with the result that England is proportionally the greatest food importing country in the world. The wheat is grown chiefly N. of the Thames, and E. of a line drawn from London to Goole. In the U.K., with a small increase in production and a decrease in imports of wheat during the Great War, the proportion of home-grown to the total consumption of wheat increased from 22 to 27 p.c. Oats are spread over the lowlands. The largest county vields are in the $\mathrm{E}$. Riding and Cambridgeshire, but do not equal those of F. Ulster. In Cheshire three-quarters of the arable land is devoted to oats to supply the local needs. Only a small proportion of the oats consumed in England is grown outside the U.K. Barley is grown in the driest E. counties, Norfolk, Suffolk, and Lincoln; the dryness of the harvest improves malting quality, and the warm spring vields specially valuable crops. During the Great War the quantity of barley grown was considerably diminished.

\section{Cattle and Dairy Farming}

Cattle are most numerous in the W. lowlands, extending from the plains round Morecambe Bay in a wide sweep along the Severn valley into the Cornish peninsula, where the rainfall exceeds 40 ins. an- nually, and the clays and alluvial flats yield rich meadow grass. A third of the cattle belongs to dairy farmers. The great centres of population have brought into existence many small farmers with small lierds of milkers on poor grass-land. The demand of London has produced special rly. facilities for bringing the milk from as far as the Vale of Persey, in Wiltshire. In Cheshire the dairymen supply the cotton towns with milk, and make cheese; Derbyshire and Leicestershire produce Stilton cheese. Cornwall is almost purely a cattle county, the milk being made into butter and clotted cream. In Devon the cattle are reared for their inilk as in Cornwall, but also for the butcher, being sold to graziers as two-year olds and sent to the Midlands or Hampshire. During the Great War the number of cattle increased by at least 5 p.c.

\section{Sheep Runs and Farm Lands}

Great Britain contains probably the largest number of sheep in proportion to area of any country. Kent has the most sheep per sq. m., the short pasture and dryness of the chalk hills being specially suitable. Wiltshire, Dorset, Iincolnshire, and the E. Riding are great sheep counties for the same reason. The hill slopes of Shropshire, Hereford, Monmouth, Northumberland, and Cumberland are also important. The number of sheep declined by 16 p.c. during the Great War, in Wiltshire and Hampshire the decline amounting to 30 p.c.

In thousandths of the total area of England the proportions of the various kinds of farm lands are as follow : Mountain and heath used for grazing, 84 ; permanent grass, 392 ; oats, 70 ; wheat, 66 ; barley, 44 ; mixed corn and rye, 7 ; beans and peas, 14 ; potatoes, 14 ; turnips, swedes, and mangolds, 40 ; clover and other rotation grass, 62 : bare fallow, 20. The average number of animals per 1,000 acres are respecPROPORTIONS OF CROPS AND

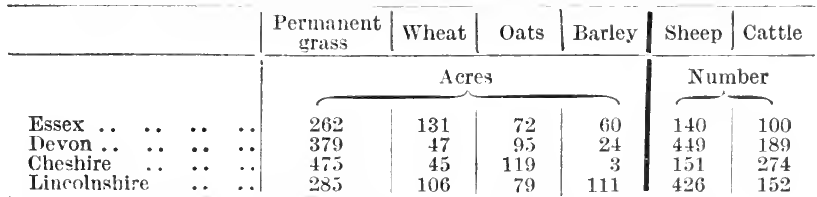

tively: horses, 38 ; cattle, 166; chief English mineral is coal. A sheep, 420; pigs, 50 .

A comparison between these average values for England as a whole, and the return for four selected counties, indicates roughly the effect of climate and soil upon the farmer's work.

F.ssex is dry and near London; Lincolnshire is equally dry, but distant from dense areas of popu- lation. Devon and Cheshire are wet, and Cheshire is near populous S.F. Lancashire. The minor crops of Essex are beans, peas, potatoes, and other roots; glasshouses supply grapes, tomatoes, etc., to Covent Garden ; there are numerous seed and fruit farms : rose culture is important. The cattle supply much milk to London.

Devon has few towns; the wheat yield per acre is one of the lowest in England; apples, pears, plums, etc., are largely grown; Devon cattle fetch high prices and Devonshire cream is celebrated. Cheshire grows considerable quantities of potatoes, and roots for winter feed; damsons are the chief stone fruit; the cattle consist chiefly of dairy cows.

Lincolnshire is definitely a farming county; the acreage under barley roughly equals that under wheat, and exceeds that of any other county ; peas, beans, pota. toes, and other roots are important crops; Lincoln shorthorns are good milkers and Lincoln sheep are exported for breeding to the $\mathrm{S}$. hemisphere. A large proportion of the cattle are bred for the butcher.

Comparing the tabulated results, it appears that the wetter W. has a relative excess of permanent grass and cattle, the cattle of Cheshire being 60 p.c. above the average. Devon has above the average number of sheep. All four counties exceed the average in oats, but the greater excess is in the wet west. In the drier counties Essex has an exceptional area under wheat and Lincolnshire under barley; the $W$. has little of either crop. Essex has below the average in both sheep and cattle.

\section{Distribution of Coalfields}

In estimating the value of $\mathrm{min}$. ing in the U.K. and in England in relation to the rest of the world, it is necessary to consider the statistics for the period immediately preceding the Great War. The quarter of the world's coal was mined in the U.K., one-fifth in England alone. To get this coal occupied about a million workers, so that about 10 p.c. of the U.K. population was dependent upon the collieries. The distribution of the coalfields depends upon the presence of the carboniferous rocks, but the E. coalfields, in particular 
those of York, Derby, and Nottingham, have an indefinite boundary under the newer rocks to the $\mathrm{E}$. of the earboniferous series ; thus coal may be found at greater depths on the E. margins.

Britain produeed about one. righth of the world's iron, chiefly on the coalfields, where the ore was found between beds of coal. and, in addition, in Cleveland and Furness. where there are large deposits of haematite ore. The demand for iron ore for war purposes led to the inereased mining of low-grade ores in the newer strata E. and S.E. of the Trent, and modern methods of iron-mining, eombined with high prices, may mean the continued exploitation of these ores.

\section{Decline of Lead-mining}

Less than one p.c. of the world's lead was mined, chiefly in Derbyshire, but lead-mining has been deelining for many years. Cornwall produced less than 4 p.e. of the world's tin, chiefly at the E. Pool and Tresavean mines. Zine in Cumberiand, manganese in Cornwall and Devon, and tungsten in Cornwall are minerals of minor importance. The most important non-metallie mineral is salt, which is chiefly found in the Nantwich district in Cheshire, but also in Laneashire, Woreestershire, and Durham.

The chief English fishing towns are on the E. ccast. Grimsby, Yarmouth, and Lowestoft account for most of the cateh on this coast. which amounts to more than three-quarters of the English total. Newlyn, near Penzance, is the chief fishing centre on the S. coast, and sit. Ives and Fleetwood on the W. coast. The main eateh in the N. Sea is herring, in the Cliannel, mackerel and pilchard.

The most important English manufactures are textiles. Cottons oceupy 500,000 workers and are focussed on Manchester ; the chief districts are Blackburn, Oldham, Bolton, Stockport, Preston, and Roohdale. Woollens are chiefly made in the W. Riding, with Bradford as a technical and Leeds as a marketing centre, the other ehief districts being Huddersficld and Halifax. The manufacture of woollens extends W. to Rochdale, that of cottons E. to Halifax and Bradford. Silk goods are made over a wider area and on a smaller scale, the main centres being Bradford, Stockport, Halifax, Stoke, Birmingham, and London. Jeicester, Nottingham, and Derby manufacture lace and both cotton and woollen hosiery. The distribution of the textile industry is largely controlled by the S. Pennine coal. fields.

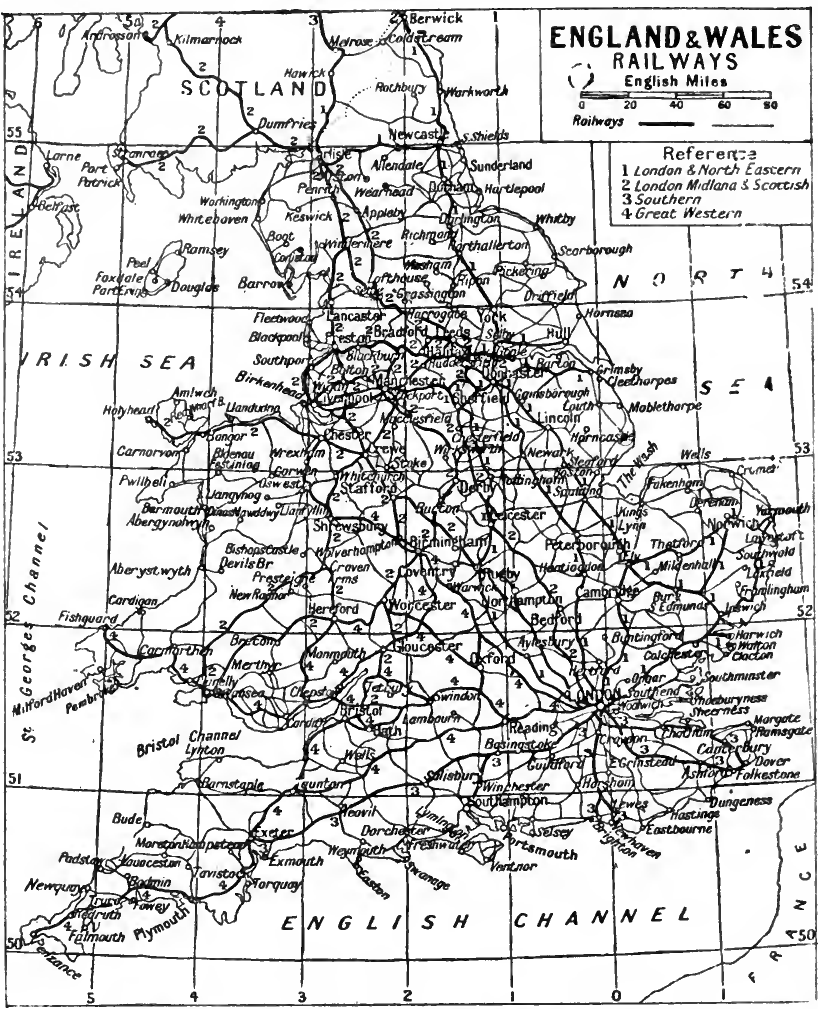

England. Map showing the principal railway systems of England and Wales

Because England took the lead in manufacturing on a large seale, the English manufactures of iron and steel were for a long time more important in rly. construction, and in iron and steel shipbuilding, than those of any other country.

Smelting operations are usually carried out near the mines, especially in Cleveland and the Black Country. Pig iron is made to the extent of nearly $3,000,000$ tons annually of each type : forge and foundry, Bessemer, haematite, and basic; for these purposes iron ore is imported ehiefly to Middlesbrough to supplement loeal supplies. Steel is made chiefly by the open hearth process; the Bessemer process yielding only a fifth of the total; during the decade 1910-20 many electrie furnaces were established for special steels. Sheffield steel and Birmingham hardware are famous all over the world.

The ehief shipbuilding district extends from the Tees to the Tyne. The Great War led to a rapid expansion of the iron industry; numerous factories were extended or newly built, and it remains to be seen whether they will survive.
The great centres, Sheffield, the Black Country, the N.E., and Barrow-in-Furness lie on coal or iron fields, although the newer factories are more widespread. Metal faetories and workshops for zine, copper, aluminium, and tin goods are associated with the iron works, but are also developed, e.g. the metal parts of motor-ears, in the large urban eentres such as London and Manchester. Wolverhampton is an important metal centre.

\section{Localised Mannfactures}

Certain manufaetures are specifically loealised. The Potteries on the N. Staffordshire eoalfield use local clay and coal for making crockery and earthenware, coal purchase being the main factory expenditure. Northampton and Leicester are the main eentres for boot and shoe manufaeture. Walsall special. ises in harness and saddlery. Chem ieals, alkali, and soaps are made chiefly near the Mersey in close relation to the Cheshire salt for 'aw material and the textile works for consumption of part of the finished products. Steam-driven flour nills have superseded water mills : nd are located at the wheat-1mk:rt. ing ports, London, Hull, ets. 
The main English rlys. radiate from London. The L. \& Y. and the N. Staffordshire Rlys. are the two principal lines not based upon London. The L.N.L. Kiy. forms an integral part of the $\mathbf{E}$. coast ruste from London to Scot. land. The lure of London traffic saused the Manchester, Sheffield, and Lincolnshire Rly. to become the Great Central Rly., with a I.ondon terminus at Marylebone. Although London has profoundly influenced the railway system, it has not overwhelmed provincial traffic even outside the textile area of Lancashire and Yorkshire, for the ports of Bristol and Southampton are well served, especially trun the Midlands. A new group ing system came into force in 1923 (See Railways.)

\section{Canals and Roads}

During the later 19th century the several rly. companies competed vigorously for traffic, but later the stringent economy in rolling-stock and personnel added to the ever-mounting cost per passenger- or per ton-mile. The gradual electrification of the rly. service is of great importance.

English barge canals have been subordinated, by rly. competition, mainly to the slow carriage at low cost of heavy, bulky, and nonperishable commodities. The canal map shows roughly four main canal routes radiating from the Midlands to the Mersey, Humber, Thames, and Severn estuaries. These routes, at present, suffer from differences of section, i.e. width and depth of water, which limit the carrying capacity of "through" boats.

The only ship canal of importance has made Manchester a port and has brought ocean steamers some $30 \mathrm{~m}$. inland, almost to the doors of the cotton factories.

The main roads, roughly a dozen, radiate from London to all points of the compass ; but Leeds, Manchester, Chester, Birmingham, and Gloucester are also road centres. There are two great routes which do not touch London; from Sheffield through Birmingham, Gloucester, Bristol, and Exeter to Land's End, and from Chester through Shrewsbury and Hereford to Gloucester. The minor hills do not affect the roads, but the Pennines are only crossed by four main roads, through the Tyne and Aire Gaps, over Blackstone Fdge to Manchester, and by Buxton from Manchester to Derby. Road development will, however, follow the demand for improved surfaces, wider and straighter roads, and better cross connexions between one and another.
The exchange of commodities within England and hetween England and other portions of the U.K. constitutes the home trade. The geological division of the country into an area of new rocks in the S.E. separated by the oolite ridges from the older rocks of the $\mathrm{W}$. and $\mathrm{N}$. corresponds roughly to a division into an agricultural S.E. and an industrial Midlands and $\mathrm{N}$., and has definitely localised many occupations. The specialised local products are interchanged; London coal is brought by rly. to the area $\mathrm{N}$. of the Thames, and by sea for that $S$. of the river; the textiles warehoused and retailed in the metropolis are brought by train from Lancashire and Yorkshire; jams, metal products, luxury commodities of all kinds are distributed from London.

Burton beer, Stoke crockery, Northampton boots, Leeds readymade clothing, Yarmouth fish, Scilly Isles flowers, Reading biscuits, Bristol tobacco, Nottingham curtains, are a fow articles of home trade. Welsh mutton, lrish butter, Scottish oatmeal, Belfast and Dundee linens, Swansea tinplate, Isle of Man fish, Channel lslands potatoes and tomatoes increase its total volume. In addition to long. distance trade each urban centre is a market attracting a considerable traffic in foodstuffs.

\section{The Market of the World}

England is probably the greatest market in the world. The worldprice of wheat, for example, is affected by the price which im. ported wheat fetches in England. The desire to supply England has brought about cold storage for mutton and beef, perishable fruits, etc., and has caused great developments in canning, drying, or preserving foodstuffs. Wheat is harvested, and fruits are picked somewhere in the world every week, and consequently the world can send to England a continuous stream of foodstuffs ; the products of the S. hemisphere, wheat, mutton, beef, butter, fruits, etc., are at their best when the supplies of the $\mathrm{N}$. begin to fail. In addition to these supplements to home supplies, tea, coffee, rice, etc., are imported.

But England is a market for raw materials as well as foodstuffs. The prices of raw cotton and raw wool are affected by the English demand. Iron ore in distant parts of the world could be mined cheaply if it could be utilised locally, but it is undisturbed because the price in the English market will not yield a profit after freights and mining expenses are met. Copper, tin, lead, zinc, manganese, either smelted or as ores, are all largely imported. England also obtains large quantities of semi-manufactured articles, chiefly for textile and metal trades.

Finally, England buys the specialities of other lands : Parisian finery, American motor-cars, and, before the war, German pianos, chemicals, etc. England pays for these imports by the services of the merchant shipping, of the teehnical experts lent to other lands, and by the export of coal and English manufactures. English textiles are sent over the whole world, English machinery and metal goods cover almost as wide an area. Except for the coal most of the exports represent English labour much more than English material. On a broad view, therefore, England's overseas trade consists in the receipt of food supplies which are paid for almost entirely by the sale to the rest of the world of English technical skill, i.e. human labour exerted through machinery.

\section{Seaports of England}

London and Liverpool rank among the greatest seaports of the world. They are approximately equal in total value of trade in normal times, but London has an excess of imports, in the ratio of 2 to I, over exports, while at Liverpool exports and imports balance. They are each responsible for a third of the overseas trade of England. Hull, Manchester, and Southampton are the chief of the smaller ports; their imports exceed their exports. Grimsby, Newcastle, and Goole have exports and imports to balance. Bristol, Harwich, Newhaven, Dover, and Folkestone are characterised by an overwhelming excess, about four times as valuable, of imports.

The above facts refer to pre-war conditions. During that critical period Harwich, Dover, Newhaven, and, to some extent, Southampton, were closed, and Falmouth rose to considerable importance by being used to a large extent instead of London. Similarly Newcastle was used in preference to Hull.

Constitution And GovernMENT. The system of government which for centuries served to regulate the affairs of England has been extended to deal with those of the other three parts of the United Kingdom, and to some extent with those of the British possessions throughout the world. The result is a system unsound theoretically. bewildering and confused historically, but from the practical point of view workable, and on the whole satisfactory. Fortunately there is one fixed point amid the confusion - the British monarchy. 
The official who by a series of events added to his duties and powers as king of England those of ruler of Ireland, Wales, and Scotland, and then of vast territories in America, Asia, Africa, and Australia, had before these events his ministers, his parliament, and his court. As his duties expanded so too did theirs, although in an unequal and illogical manner. His chancellor became the lord chancellor for Wales and Scotland, but not for Ireland; his secretaries took over certain duties in the other countries, but by no means all, nor on any consistent plan. The result is a ministry in origin that of England alone, but com posed of ministers exercising varying degrees of power over the rest of the United Kingdom.

Parliament, too, has extended the area of its duties. It has been transformed, with very little structural alteration, into one representing the four countries of the United Kingdom, and controlling, in addition, the affairs of the British Empire. Here, however, there are neither limitations nor exceptions. Parliament has exactly the same power over Ireland and Scotland as it has over England ; theoretically, at least, it has equal authority over Canada, Australia, and the rest of the Empire.

\section{How the Democracy Works}

England, classed from the point of view of government, is a demoeracy, perhaps the most complete the world has ever known, and the demoeracy exercises its power through the representative system. Since 1918 the vote has been possessed by practically all adult males and females, and by them the members of the House of Commons are elected. Every possible device. trickery, and even deception may be used to influence their choice, but the fact remains that they are free to send to Parliament man or woman, whomsoever they will.

The democracy, however, works through certain traditional and historical forms. It has secured the supreme power in the state without making any violent changes in the constitution. The state has a figure-head in the person of an hereditary monareh, while, part of the high court of Parliament, there is a House of Lords, in which again the hereditary element prevails. The House of Commons, too, employs very much the same methods as it did a century or two ago. Democracy in England has found less violent ways of securing its omnipotence than by beheadings and bloodshed. It has made the House of Commons its instru ment of action, by transforming it into the dominant factor in the constitution.

The Legislature. The constitution of England may be considered under three heads: the legislature, the executive, and the judicature, three departments with entirely different functions. Of these, the legislature is supreme. It consists of king, lords, and commons, or the king in Parliament, and the laws are made, theoretically at least, by the three together. This untrammelled law-making power is the reason why the legislature is supreme. Everything else flows from it. All that is necessary to abolish the House of Lords, to sell off the navy, to make

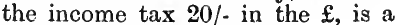
law passed by Parliament.

\section{Legislature and the Commons}

It is hardly true, however, when we come to actual facts, to speak in the 20th century of legislation by king, lords, and commons, while it is little more than a pleasing ceremonial that requires the assent of the king to Acts of Parliament. In practice the legislature is the House of Commons. It has two partners in the matter, it is true, but they have no power whatever to stop any measure which the Commons are determined shall become law.

To the House of Commons Eng. land returns a clear majority of members. Of a total of 707 . no less than 492 are returned by English constituencies: 230 by the counties, 255 by the boroughs, and 7 by the universities. There is also a majority of Englishmen in the House of Lords.

The House of Commons is the supreme organized body in the state. By degrees, curbing the powers of the king and of the House of Lords, it has attained that position, the final touch being given to this process by the Parliament Act of 1911. 'The king's veto has passed into disuse, while that of the House of Lords is only a suspensory one for a short period of time. It is true to say that the House of Commons alone possesses the law-making power, and there is no possible way of questioning the laws it makes, save by violence; judges cannot, as they ean in the U.S.A., be called upon to pronounce upon their validity; they can only interpret their meaning. However absurd a ineasure is, however unpractical, if the House of Commons wishes it and is prepared to push it through the necessary stages, it becomes the law of the land quite as much as Magna Carta. The house can even, as it did in 1715 and in 1915 , prolong its own existence.
The Executive. The House of Commons cannot, by its very size and constitution, do more than legislate and exercise a general supervision over affairs of state, and it is that fact which is the real check on its own omnipotence. It is frequently faced with the dilemma of suffering a violation of its wishes or parting with a minister who may in many ways suit it well, while its zeal is tempered by the reflection that its master, the electorate, might possibly, if asked, endorse the action of the offender.

At the head of the executive is the prime minister, the most powerful man in the state, and one whose powers have increased vastly since about 1900 . Originally a minister of the king of England, he is now the prime minister of the whole country, and in a sense of the whole empire. Acting with, or rather under him, are other ministers, the most important of whom form the Cabinet. These Cabinet ministers are bound together by a common set of prineiples, this being especially so when they belong to a singlo political party, but it is also true of a coalition, even if it is only the common principle of forgetting them. The modern tendency, however, is rather for the decisive bond to be the common enjoyment of the prime minister's confidence.

\section{Powers of the Cabinet}

The powers of the cabinet can hardly be defined, so much depends upon the personality of its members, but they are considerable. It has a marked influence on legisla tion beeause, without its support, a proposal for a new law has little chance of success. In practice the Cabinet initiates legislation. It is the ereature of the House of Commons, and is never unmindful of its creator's will if such is emphatically expressed, but in the dealings of the one with the other the Cabinet has the inestimable advantage of being a small body animated by a common purpose against a large one in which the common purpose is rarely present.

The ministers are in charge of the various departments of state, being responsible for their working in Parliament. The outward sign of this responsibility is their presence in one or other of the Houses of Parliament in order to answer questions, or to defend, if need be, the actions of the departments over which they preside. The depart. ments are manned by civil servants, permanent officials who stay in office and carry on its everyday work, while ministers come and go.

Apart from the executive, but equally under the control of Parlia- 
ment, is the judiciary. At its head is the lord chancellor, who presides over the House of Lords, which is the supreme court of law, save for certain classes of cases in which the judicial committee of the privy council serves that purpose. For England and Wales there is a supreme court of judicature, from which apnaals lie to the House of Lords. This consists of two branches, a court of appeal and a high court of justice. The latter is further divided into chancery, king's bench, and probate, divorce and admiralty divisions, while special branches, e.g. bankruptcy, have been established. The judges of the king's bench go round the country on circuit, there being for England and Wales eight circuits, and in each a number of assize towns. London is outside the circuit system, and for it there is a central criminal court.

Justice is administered locally by recorders and magistrates, who sit in quarter and petty sessions. They deal with minor cases, sending those of a more serious character to the judges at the assizes. County courts all over the country deal with civil cases involving less than a certain amount of money.

Local Government. Under the supreme control of Parliament, the people of England enjoy a large measure of local government. Here again each unit is a democracy working through the representative system. The men and women of county, borough, district, and parish elect certain men and women to form a council which manages such matters as Parliament has entrusted to it. In many, but not all, of these councils there is an element not directly elected, the aldermen.

\section{The County and the Borough}

The main division, as far as local government areas are concerned, is the venerable one between county and borough, although the demarcation is by no means complete. The forty counties of England have had some sort of local government for a thousand years, but the existing system only dates from the Local Government Act of 1888. The officials who until that time governed the counties, lord-lieutenant, high sheriff, and magistrates in quarter sessions, retain their positions, but not their powers, which passed in 1888 almost entirely to elected bodies called county councils.

The county councils set up in 1888 do not correspond altogether to the counties as they existed before that date. For the forty old or geographical counties, as they are called, fifty county councils were set up and there arc, consequently, fifty new or administrative counties. Most of the old counties were simply given county councils without serious change of boundary, but a number were divided to make fresh counties. The additional ten were found by making the three historic divisions of Yorkshire and the three of Lincolnshire into counties, each with a council, by dividing the five counties of Cambridgeshire, Hampshire, Northamptonshire, Suffolk, and Sussex into two each, and by creating a new county of London from parts of Surrey, Middlesex, and Kent.

\section{The County Boroughs}

The county councils hold elections every third year, and their powers over education, police, public health, and other matters are laid down in the Acts of 1888 and following years. Towards their expenses they receive large sums from the government, but the balance they raise by a rate on all property within the county. There is no limit to the amount they can thus raise, but their accounts are supervised by the ministry of health. They can, under certain conditions, borrow money.

The Act of 1888 affected also the boroughs. It created a class of boroughs called county boroughs, placing them entirely outside the authority of the county councils, and thus established a system by which every place is in a county, either county proper or county borough, and consequently every voter is represented in one or the other of the councils. A county borough must have a population of at least 50,000, and it is a recognized practice that as soon as a borough attains that size it is made a county borough by order of the ministry of health. There are about 70 of these county boroughs, but the number is bcing steadily increased. They have exactly the same powers as the county councils received under the Act of 1888, together with any others they may possess under Acts regulating the affairs of the boroughs.

We come now to areas and councils which are subordinate to the county councils. Excluding the county boroughs, every part of England is either a borough, an urban, or a rural district, and every one of these is part of an adminis. trative county and is represented in its county council.

The borough is a place which has received a charter of incorporation, and, excluding the county boroughs, there are over 200 of them in England. Their local government is regulated by the
Municipal Corporation Act of 1835 and an amending Act of 1882 . These made their constitutions uniform. Each borough, and each county borough also, is governed by a mayor and council consisting of aldermen and culincillors. The councillors are elected for three years, one-third of them retiring every year, and they choose the aldermen, who form one-third of their number.

Since 1888 the affairs of these non-county boroughs have been supervised to some extent by the county councils, to which they send representatives. There is thus a division of authority. In some the borough has its own police force, in others the county council provides this. Education again is sometimes controlled by the one and sometimes by the other. These boroughs levy their own rates and also raise something towards the expense of the county council. A special class of boroughs are the 28 into which the county of London is divided. They are subordinate to the London County Couneil and their powers are somewhat different from those of the ordinary boroughs. Although of considerable size, they are not county boroughs.

\section{Urban and Rural Districts}

The country outside London and outside the provincial bornughs is divided into urban and rural districts, called into existence by an Act of 1894. Urban districts are the thickly populated areas which have not yet become boroughs; rural districts are the country areas. The division is not absolutely rigid, and occasionally a rural district is found to be quite populous. Each is governed by a council, elected for three years. The head is called chairman, not mayor, and there are no aldermen.

These councils .work in general under the supervision of the county council. If their population exceeds 10,000 they manage their own education, but the chief duties of the bulk of them are connected with the public health.

A. W. Holland

Bibliography. Parliamentary Government of England, 2 vols., A. Todd, 2nd ed. 1887 ; Europe, vol. 2, G. G. Chisholm, 1902 (in Stanford's Compendium of Geography and Travel); Local Government in England, J. Redlich (trans. F. W. Hirst), 1903 ; Stanford's Geological Atlas of Gt. Britain, H. B. Woodward, 1907 ; Britain and the British Seas, H. J. Mackinder, 2nd ed. 1907 ; A Geography of the British Isles, A. M. Davies, 1909 ; The Governance of England, S. Low, rev. ed. 1914 ; The Victoria History of the Counties of England, ed. W. Page, 2nd ed. 1900 , etc. ; The Statesman's Year Book, publ. annually. 


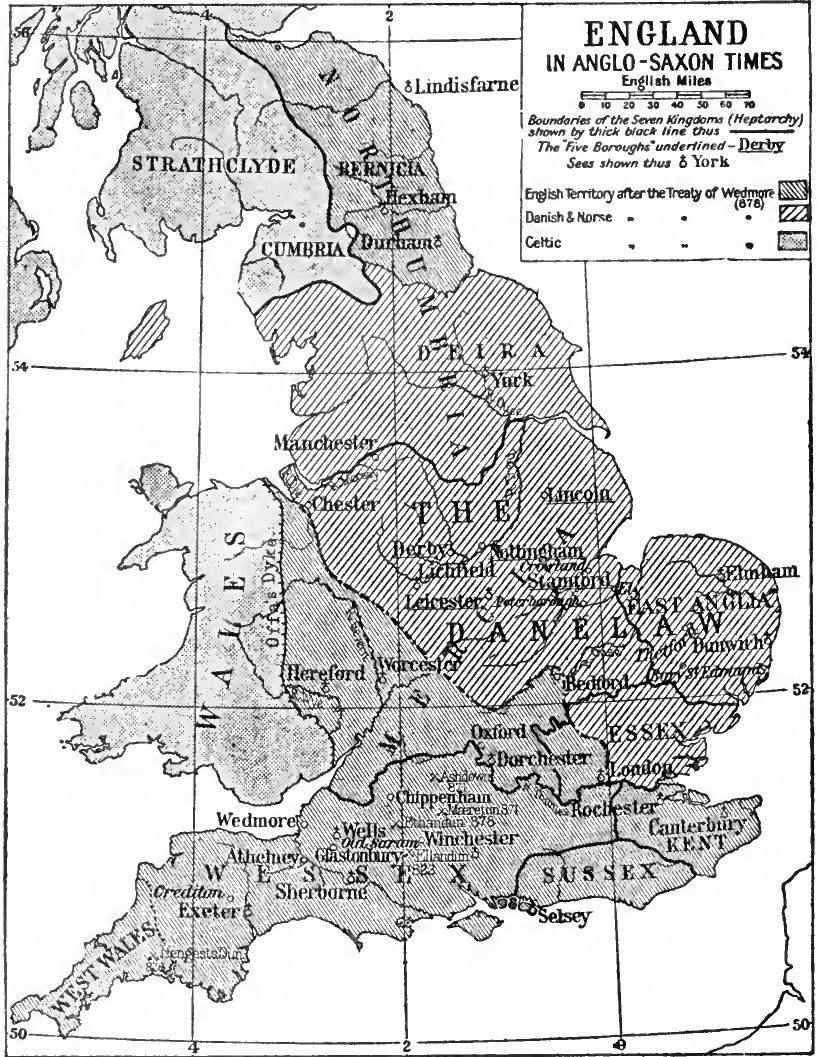

England. Map of the country noder the Anglo-Saxons, showing the divisions of the heptarchy and the territories occupied by the varions peoples

History. The departure of the Roman legions in A.D. 407 left Britain without any controlling government, but the old system of local principalitics soon revived. The N. however, was open to attack by the Picts and Scots, the W. coast to invasions from Ircland, and the E. to raiders from the European coast. About the middle of the 5th century, Jutes from Denmark made a settlement in Kent which became permanent. During the next hundred years, Angles and Saxons sent fresh hordes which established themselves on the $\mathrm{E}$. and $\mathrm{S}$. coasts, pushing inland till they had mastered the country F. of a line running roughly from Dunbar to Portsmouth.

Between 560 and 613 the ncwcomers overran the midlands, pushing the Britons further to the W., and thrust wedges up to the sea both on the N. and on the S. of Wales. In 596 Christianity was introduced into Kent. Thence it spread N., where through the greater part of the 7 th century Northumbria was the most power- ful of the English states. In the Sth century the supremacy passed to Mercia, and in the 9 th to Wessex.

The second half of the century saw a desperate struggle between the English and a new host of invaders, the Danes, who established their mastery over half the island, but were forced back by Alfred the Great. In the 10th century Edward the Elder and his sons subjugated the Danes, and the kings of Wessex became kings of England.

\section{The Battle of Hastings}

But the subjugation of the Celts on the Cumbrian hills and the Devon moors was slow and incom. plete; while in Wales they success. fully preserved their independence. In the 1 l th century Sweyn, king of Denmark, and his son Canute es. tablished a bricf Danish dynasty; but on the death of the last of Canute's sons, Edward the Confessor was recalled to the throne of England. When he died in Jan., 1066, the English elected Harold, Godwin's son, as king, but the crown was claimed by William, duke of Normandy, who shattered Harold's army at Hastings, and was crowned in London on Christmas Day, 1066.

During the next six years risings in the N. and W. compelled William to subdue the whole country by merciless force, and provided him with an excuse for confiscating much of the land and distributing itamong his Norman followers, though a substantial number of small estates remained in English hands. Theoretically, the Norman king reigned as the legitimate succcssor of the Wessex kings, by the same laws, legislating with assent of the Witan, the assembly of magnates, occasionally expanded into the common assembly of such freeholders as might choose to attend. Actually the conquest effected a revolution, because all the magnates and half the barons or lesser land. holders werc now Norman instead of English ; the law was interpreted by them in their own interests and they reduced many of their own tenants to serfdom or villeinagc.

\section{Rule of the Normans}

Wiiliain and his two sons, William Rufus and Henry I, were powerful monarchs who utterly crushed the attempts of the new baronage to ignore or defy the authority of the crown. They called to their support the English population, who were infinitely more hostile to the local Norman tyrants than to the crown, though William II was himself a tyrant. After a reign of 35 years, Henry was succeeded by his nephew Stephen, whose claim to the crown was disputed by Henry's daughter, Matilda or Maud. The reign was a long horror of anarchy; the strife for the crown wrought less havoc than the private wars waged against each other by the barons, who pillaged, robbed, and murdered on all sides. The evil days were brought to an end on the death of Stephen in 1154 by the accession of Henry II, grandson of Henry I, the first Plantagenet.

Henry, already by inheritance or by marriage in possession of half France, did great work in the reorganization of the government of England. The baronage on the whole cooperated loyally with the king in the work. Revenues were collected, and the higher courts of justice were conducted by the king's officers, removable at his pleasure; the practical freedom of appeal to the royal courts against local injustice'was greatly extended. The old system by which the king's officers could call up the freemen of the shire in arms was revived, counterbalancing the feudal right of every baron to call upon his own tenants for military service, while incidentally, through the practice of 
obtaining the formal approval of the Great Council for the measures upon which the king had decided, the idea developed that the Council had a right to be consulted. In the course of the reign a Norman baronage was planted in Ireland, and, through the formal homage of the Irish chiefs, the island was annexed to the English crown.

Henry's elder son, Richard I, left the governance of the kingdom to justiciars, while he himself was engaged on crusade or in his French dominions. Public spirit and respect for law developed, so that in the reign of Richard's brother, John, who repeatedly overrode the law for his own ends, the barons combined to wring from him Magna Carta. Incidentally, also, John's reign brought about the severance of Normandy and most of the Plantagenet possessions in France from the English crown, making the baronage of England an English baronage with exclu. sively English interests.

In spite of Magna Carta, John's son, Henry III, in the course of a reign of 56 years, persistently attempted arbitrary and illegal methods of government, choosing for his ministers his own or his wife's foreign kinsmen in place of the English nobles, who regarded such offices as due to themselves of right. At length the baronial party combined under the leadership of Simon de Montfort, in effect to transfer the supreme control from the hands of the king to baronial committees. Faction among the barons led to the fall of Montfort in 1265 .

\section{Henry III and Parliament}

But he had championed two great principles - first, that the sanctity of the law was to be main. tained as sternly on behalf of the commons as on behalf of the barons and, secondly, that the government should rest upon the assent of the realm expressed through the common council of the realm, which was now acquiring the name of Parliament. The practice of sum. moning thereto elected representatives of the freeholders had been developing all through the century; Montfort in 1265 established the principle of calling also representatives elected by the boroughs. Montfort himself failed, but his cause had triumphed. Acting as champion of the law, he, like Cromwell four centuries after him, found himself compelled to ride roughshod over the law, to adopt unconstitutional methods of asserting constitutional principles. His mantle fell upon the man who had overthrown him, who, as Edward I, made the law supreme.
The reign of Edward $I$ is a crucial epoch in the history of England. In it the English nation, finally consolidated and unified, realized that the common interests of all classes were of more importance to each than the antagonistic interests of individual classes and groups; that the law which should be directed to the goorl of all should be uniform and fixed. It was the great era of definition, regulation, systematisation. It declared, though not finally, the powers of the crown for raising revenue, the jurisdictions of the baronage, the rights of the national assembly to consultation. It established the law of inheritance, and the subjection of the clergy to the civil law. Above all, it defined for 500 years the constitution of the national assembly itself; this being in the Model Parliament of 1295.

\section{Yeomen and Serfs}

But while Edward succeeded in unifying England and shaping the structure of the constitution upon foundations which had already been laid, he was not equally successful in accomplishing his desire of extending the unification to the whole island. Hard fought campaigns in Wales brought her into the English system; the attempt to absorb Scotland upon pretexts of feudal law forced her into temporary and incomplete subjection tempered by persistent insurrection, and finally issued in complete failure during the reign of his son and successor, Edward II.

During the 13th century England had become definitely the Merrie England of the ballads. The old hostility of Norman and Englishman had disappeared. The rural population had fallen into the two divisions of those who had succeeded in preserving their legal freedom, the yeomanry, and those who had been thrust into serfdom or villeinage which bound them to the soil on which they were born.

But already the practice of com. muting services for payment, and correspondingly of hiring service for wages was becoming widespread; the lot even of the villein was not generally a very hard one. The larger towns were flourishing commercial centres, although being still to a great extent agricultural communities which had purchased rights of self-government and immunity from the jurisdiction of overlords from the king. These rights were conveyed to them by charter. There was already an extensive foreign trade; cloths, wines, and many other European products being imported, while the leading English exports were wool and hides, and rural products of all kinds.

An incompetent king, Edward II, succeeded Edward I. There was a recrudescence of the struggle between the crown and nobles, who looked upon themselves as the champions of constitutionalism, but were in fact endeavouring to concentrate politival power in the hands of a narrow oligarchy. The civil strife, whether latent or active, caused that complete neglcet of the Scottish question which enabled Robert Bruce gradually to clear Scotland of the English garrison, and to recover an unqualified independence by inflicting upon the English the decisive defeat of Bannockburn in 1314 .

In 1327 Edward II was deposed and murdered by his French wife, Isabella, and her paramour, Roger Mortimer, while the crown was set on the head of Edward III. Three years later the king, then eighteen years of age, effected a coup d'état which ended the intolerable government of the regency, and executed Mortinier. All this time Plantagenets had retained posscssion in France of their hereditary fiefs of Guienne and Gascony, which successive French kings on various pretexts had sought to filch from them. This process was continued by Philip VI. On his accession, a fairly tenable claim to France had been put forward on behalf of Edward of England through his mother, the sister of the last ling of France; but France had decided in favour of the Valois succession, and of the principle that there was no right of inheritance to the French crown by or through a female.

\section{The Hundred Years' War}

The strife over Guienne and Gascony was a standing cause of quarrel; the claim to the French throne provided another pretext; while a serious subject of contention was the attempt to restrict the valuable trade between England and Flanders which was a fief of the French crown. On account of this the Flemings were ready to take part with Edward if he assumed the char. acter of their lawful suzerain by asserting his claim to the French crown, and on this combination of pretexts the Hundred Year's' War between France and England was embarked upon in 1337.

The English longbow and the clothyard shaft had first been brought into effective play by Edward $I$ in his Scottish wars. The Scots and Flemings had recently proved the power of 
spearmen to defy the shock of the charge of mailed cavalry. The two principles were combined by Edward IIl and his son, the Black Prince. The English archery and dismounted men-at-arms shattered superior forces at the battles of Crécy (1346) and Poitiers (1356). King Edward captured Calais in 1347 , to remain as a gateway to France for 200 years. In 1360 he forced on the French the treaty of Brétigny, which conceded to him a quarter of France in full sovereignty.

Twelve years later all that had been won was practically lost; England retained only a precarious hold upon a part of Guicnne and Gascony, as well as Calais. The war was enormously costly, and its costliness developed the power of the Parliament, which was now strong enough to forbid the imposition of taxes, other than those formally sanctioned in the reign of Edward $I$, except by its own vote. The power of the purse passed definitely into the hands of Parliament, and with it a certain limited control of poliey; the royal revenues were insufficient, at least for war programmes, unless supplemented by the land and property taxes, known as tenths and fifteenths, and afterwards as subsidies, which the lords and commons voted.

\section{The Black Death}

The general prosperity was checked by the tremendous visitation of the Black Death in 1348 . A third of the rural population is said to have perished; for lack of labour the harvest was left to rot and the fields were left untilled, while famine followed upon the plague. The landholders sought to revive all their old powers of enforcing service; the peasantry refused to work except at very high wages, and the government stepped in with the Statute of Labourers, vainly attempting to fix a standard wage. A class animosity was born, quite different from the bygone hostility between the English oceupants of the soil and their Norman conquerors. This bore fruit in the peasant revolt of 1381. The revolt was crushed, but was not followed by any enactments for the removal of grievances; the system of villeinage, forced agricultural services, and restrictions upon rural wages remained.

Edward III in the pursuit of revenue had grasped the advantages of encouraging and organiz. ing trade under state supervision. The export of staple goods, wool, hides, etc., was restricted to the Company of the Merchants of the
Staple, trading only in authorised localities, known as the staple towns; the import of manufactured goods was mainly in the hands of foreign trading societies, notably the German Hanse ; both groups paid for their privileges and enjoyed powers of regulating the traffic. But at the same time the process of manufacture in England itself advanced greatly, and English cloth goods began to compete in foreign markets as well as in England. Although a gloomy picture of rural life is presented in Langland's Vision of Piers Plowman, the pages of Geoffrey Chaucer convey an altogether convincing impression of an England materially prosperous, genial, and light-hearted, and full of a robust kindliness.

\section{Rule of the Lancastrians}

Richard II (1377-99) found him . self much in the hands of a faction of the nobility, who, however, could no longer usurp the functions now acknowledged to lie in Parliament. Soon after coming of age, he succeeded in recovering the roval authority, but though he ruled well for several years, he was unhappily nursing vindictive schemes and plans of arbitrary rule. He turned suddenly upon the nobles who had once held him in restraint, put some of them to death, banished others, and imagined himself undisputed master of the kingdom. But in 1399 his banished cousin, Henry of Lancaster, returned to England. The discontented nobles rallied to Henry's standard, Richard was deserted and brought a prisoner to Iondon, a parliament was called, Richard was compelled to abdicate, and the parliament declared Henry king of England by lawful descent.

With Henry IV began the rule of the Lancastrian branch of the house of Plantagenet. Raised to the throne of the cousin who was done to death soon afterwards, while yet another cousin, the child Edmund Mortimer, had a better claim than his own to the succession as descending from an elder son of Edward III, Henry knew that he ruled by a parliamentary title. Parliament knew it, too, and the result was that the Lancastrian kings were very much at the mercy of their parliaments. Also, as clerical influences had been vigorously applied on Henry's behalf, the house of Lancaster was com. pelled to conciliate the clergy. Hence Henry was led to a rigorous suppression of the Lollards. The teaching of Wycliffe, about the end of the reign of Edward III, had attained considerable popularity during the reign of Richard II in a country where the anti-clerical sentiment was always strong, until it began to be applied as a sort of communistic propaganda; but burning at the stake as the punishment for the unrepentant heretics first became the law of the land in the reign of Henry IV.

That monarch's uneasy rule of fourteen years was followed by the brilliant reign of his son Henry $V$. In the anarchy which had overtaken the French kingdom, Henry found occasion for a preposterous revival of the claim of Edward III to the French crown. In 1415 he invaded France, captured Harfleur, and at the head of no more than 8,000 men won the victory of Agincourt. Three years later he returned to France and set about a systematic and organized conquest. The factions of French politics brought over to his side the powerful duke of Burgundy and the French queen, when all Normandy was already in his possession. The king of France was compelled to acknowledge Henry as his heir, while the dauphin Charles and the greater part of France remained defiant. Inch by inch Henry made himself master of N. France, but in 1422 he died, leaving the English crown and the French succession to his infant son, Henry VI, and the government of the country to a council of regency.

\section{Loss of Burgundy and Guienne}

The resources of England were not equal to a conquest of France. In spite of the abilities of Henry's brother, John, duke of Bedford, the subjugation proceeded slowly, and was stopped altogether by the extraordinary interposition of Joan of Arc. T'he death of Redford himself in 1435 was fatal to English ambitions; the defection of Burgundy was still more decisive, and from that time the record of the French war was one of almost continuous defeat; until in 1453 even Guienne was lost, and Calais was the only foothold left to the English in France.

The usurpation of Henry IV and the aggression of Henry $V$ brought their Nemesis. Popular disgust was kindled against the faction who exercised control over the imbecile Henry VI as being responsible for the disastrous mismanagement of the war and the feeble government at home. The opposition was led by Riohard of York, representative of a branch of the descendants of Edward III senior to the house of Lancaster. Richard claimed to be the effective head of the government. The rebellion of Jaek Cade in 1450 was not, as is commonly supposed, an 
agrarian rising like that of Wat Tyler, but was, primarily at least, a popular protest against the unpopular government. The strife of the factions in high places issued in the War of the Roses.

From 1455 to 1460 war and truce between the parties alternated. It was not until 1460 that Richard startled his own supporters by asserting his own claim to the crown, a claim modified into demand for recognition as the heir, although King Henry had a young son. Richard was killed at the battle of Wakefield, but his son Edward, supported by Warwick, proclaimed himself king, shattered the Lancastrian army at Towton in 1461, and maintained himself on the throne till his death in 1483 .

During the first ten years of his reign there were repeated Lancastrian insurrections; the defection of Warwick actually drove Edward IV in flight from the country in 1470 ; but, returning in the next year, he crushed Warwick and the Lancastrians at the battles of Barnet and Tewkesbury, and for the rest of his reign ruled without fcar of any rivals.

On Edward's death his brother, Richard of Gloucester, after an interval of a few weeks usurped the throne of his young neplew Edward V, who was shortly afterwards murdered in the Tower with his brother. The usurper instituted a reign of terror so intolerable that after two years Henry Tudor, earl of Richmond, a descendant of John of Gaunt, though by an illegitimate line, and the acknowledged head of the Lancastrian party, was able to return to England from the exile into which he had retired, to slay Richard III at the battle of Bosworth, and to claim the crown, a title acknowledged by the parliament which he summoned.

\section{The Reign of Henry VII}

During 25 years the power of the sword had decided who was to be king in England; parliaments had been summoned, but were attended only by partisans of the dominant faction. Each side had attainted of treason all the leaders on the other side, put them to death when it could lay hands on them, and redistributed their estates. The old families were almost blotted out, and the new generation of nobles bore names which had hardly been heard of fifty years before. It was the business of Henry VII (1485-1509) to restore peaceful and orderly government, commercial prosperity, and reforms, at least of law. The claws of rebellion were clipped and the royal treasury was simultaneously filled by the systematic process of fines and confiscations, drastically applied wherever an excuse could be found. Parliament was habitually summoned and treated as the king', responsible partner in all his acts.

Foreign policy was directed to the development of commerce and the acquisition of indemnities for campaigns on which nothing had been spent ; commerce itself, on the other hand, was applied as a weapon for making the rulers of France and Burgundy compliant. The king ruled always by forms of law ; taxation and legislation were the province of parliament, though a skilful king rarely failcd to procure from parliament the powers or the money which he required. Rebellions raised on behalf of pretended members of the house of York, Lambert Simnel and Perkin Warbeck, were suppressed. Henry's marriage to Elizabeth of York put the title of his son to the succession beyond question ; the marriage of his daughter Margaret to James IV, king of Scotland, in 1503 , placed a stuart on the English throne as the legitimate monarch a hundred years later. When Henry died in 1509 the house of Tudor was firmly established on the English throne, and the crown with a full treasury enjoyed an almost unprecedented power.

\section{The Discovery of America}

The reign of Henry VII fell upon that period of transition when the medieval world was passing into the modern. In 1477 the first printing press had been set up in England. The intellectual movement long active in Italy reached England and awakened a new spirit of criticism. Columbus discovered the West Indics, the Cabots from Bristol reached Labrador, the Portuguese sailed across the Indian Ocean to India. Europe was emerging into a new state system. With Henry VII dawns the conception of international relations as being concerned with the preservation of a balance of power among the great states. In the reign of Henry VIII (1509-47) Cardinal Wolsey stands out as the diplomatist who made it his aim to hold the balance between the king of France and the king of Spain, who was at the same time lord of the Netherlands and German emperor-Charles V.

But Henry's international activities were merely an episode. The great feature of the reign was the ecclesiastical revolution which fixed the grip of the state irresistibly upon the church, annexing the greater part of its wealth, and repudiated the authority of the papacy. The instrument of the revolution, the artificer who designed its methods, was Thomas Cromwell, who, after Wolsey's fall in 1529, won Henry's confidence and retained it till 1540 , when he had completed the work, not only of subordinating the church to the crown, but of obtaining for the crown by strictly legal parliamentary process such a latitude of power as it had never before possessed.

\section{When Henry initiated the} ecclesiastical revolution with the primary object of getting rid of his wife in order to marry another, he took the nation into partnership and secured parliamentary sanc. tion for everything he did. $\mathrm{He}$, however, procured from it first a weapon for silencing all external opposition in the Treasons Act of 1534 , and then a virtually absolute authority for himself, though not for his successors, by the Royal Proclamations Act of 1539. Henry left one young son, whose legitimacy was indisputable, and two older daughters by mothers whose marriages with him had both been pronounced invalid, though before his death it had been formally laid down that the right of succession remained to both children.

While Edward VI was king $(1547-53)$ the government was in the hands of a council controlled first by Edward's uncle, the protector Somerset, and then by John Dudley, carl of Warwick, best known as duke of Northumberland.

Henry's extravagance had depleted the treasury; he had sup. pressed the monasteries, the only institutions in the country which were officially concerned with the relief of poverty. For more than half a century the peasantry had been ousted from the land, and distress and suffering were widespread.

Both Somerset and Northumberland, from conviction or from policy, actively fostered the religious reformation, and carricd out the protestantising of the Church with gross and unseemly violence, though without extreme persceution. The accession, however, of Mary in 1553 was followed by an extreme reaction with the sanction of parliament-under which some 300 persons, including five bishops, were burnt at the stake. The effect of the persecution was not the suppression of heresy, but the development in the popular mind of an intense hostility to Romanism. The general impoverishment and the miserable misgovernment during the two reigns of Edward VI and Mary brought England to such low estate that she was unable to 
retain her hold upon Calais, which was retaken by the French in 1558 , leaving her without a footing on the Continent for the first time since 1066 .

Elizabeth in 1558 found the country in evil case indeed, but with all the elements for a glorious recuperation. An unfailing judgement in the selection of counsellors and instruments, a supreme confidence in the spirit of the nation with which she identified herself, a complete frcedom from conscientious scruples, an intuitive perception of the weaknesses of her enemies, a perfeet mastery of stage effects, united with an indomitable determination to raise England to the position of the first power in the world, made her the most brilliantly suecessful of all English monarchs. The national finanees were reorganized with a rigid economy which ensured full value for every penny spent.

The question of religion was taken in hand, on the principle of permitting the widest possible latitude of opinion compatible with uniformity in practice, while explicitly requiring the subordination of all authority to that of the state, and rejecting any eompromise which implicitly attributed autho. rity to the pope. The enterprise of the seamen who set at naught the Spanish claims to a monopoly of the New World was unofficially encouraged. Nearly thirty years passed before that open rupture with Spain came, but by that time England was ready, and there eame the annililation of the Spanish Armada, in the fight of July 20-August 2, 1588.

\section{Period of General Prosperity}

A regular government, pursuing a popular policy with conspicuous success and with inereasing stabil ity, free from every kind of unsettling caprieiousness, eneouraged energy and enterprise in every direction. The regulation of trading and apprenticeship, the multiplication of chartered mercantile companies, the gradual readjust. ment of the rural population to the agrarian upheaval of the first half of the century, and the judicious experiments which culminated in the poor law of 1601 , established a general prosperity. The queen ruled, but always with the express assent of her people.

Elizabeth was the last of the offspring of Henry VIII. She was sueceeded therefore by the legitimate heir, James VI of Scotland, the great-grandson of Henry's elder sister Margaret. James I (1603-25) came to the thronc of England with a title less disputable than that of any monarch since Richard II, except Henry VIII and Edward VI. By the peculiar cunning which he called kingcraft, he had already acquired for the crown in Scotland a control over the government enjoyed by none of his ancestors sinee Robert Bruce. James claimed and sometimes tried to exercise the power of overriding the law by divine right; but a wholesome fear of arbitrament by battle always kept him from overstepping the limits of English endurance. He wronght the country up to a high pitch of irritation, destroying utterly the basis of mutual goodwill between the crown and the people, whieh had in fact been the basis of the apparently despotic authority of the 'Tudors.

\section{Charles's Struggle with Parliament}

Charles I (1625-49) reaped the bitter fruits of his father's theories. Elizabeth's parliaments loved her and bore with her caprices. The parliaments of the Stuarts did not love them at all, and were only too ready to discover grounds for quarrelling with the monareh. Charles gave them ground enough by entrusting the direction of policy to his favourite, George Villiers, duke of Buekingham, by standing on what he regarded as his legal rights of raising revenue without sanetion of parliament, by overriding the law in the punishment of recalcitrants, and by repressing all latitude of religious doctrine and observance; enforcing his will through the arbitrary powers of the courts of Star Chamber and High Commission.

Charles's parliament, on the other hand, refused supplies until grievanees should be removed, asserted the novel claim to a right to the control of religious affairs, and in 1628 compelled the king to accept the Petition of Right, which unfortunately failed of its precise purpose-the accurate definition of the limits of the royal prerogative. Eleven years of arbitrary rule without parliament were ended in 1640 by the arming of Scotland - an independent king. dom to whose king accident had also given the crown of the neighbouring kingdom of England. Scotland found the king's rule too arbitrary ; the king eould not suppress his Scot 1 ish subjects without the aid of English arms; all his expedients had not provided him with the money for an army, and he was obliged to summon the English parliament, and then to dissolve it, and summon it anew.

The Long Parliament, instead of aiding him against the Scots, attainted and beheaded Strafford, impeached Laud, and proceeded to force the king to accept a series of enactments abolishing the arbitrary courts, and explicitly depriving him of the disputed prerogatives. A coup d'état, the attempted arrest of five members on Jan. 4, 1642, failed completely; the king left London, and after several months of futile negotiation, the great Civil War opened in August, 1642 .

The struggle was conducted with a decency and humanity which offer a pleasing contrast to the horrors of the Thirty Years' War, then rasing on the Continent. After various vicissitudes, the army of the parliament was reorganized by Oliver Cromwell and won the decisive victory of Naseby on June 14, 1645. Charles surrendered to the Scots, who had associated themselves with the cause of parliament, in May, 1646 , was by them handed over to the parliament in Feb., 1647. and was carried off into the custody of the army on June 3. From his confinement he intrigued with his own supporters and negotiated with three scparate groups-the chiefs of the parliament, the chiefs of the army, and the Scots-each of whom now had different objects in view. The king's attempt to recover his ascendancy by playing them off against each other failed disastrously. His own attempt to escape to France in November, cavalier insurrections, and a Scots invasion in 1648, threw the control into the hands of the victorious army, and determined its chiefs that the king's death was the necessary condition for the restoration of a stable government. An arbitrary court condemned him to death and he was executed on Jan. 30, 1649 .

\section{The Commonwealth}

England was now proclaimed a commonwealth or republic. The Scots recalled the prince who was de jure Charles II, but the English Conmonwealth could not afford to have the claimant to the throne of England seated on the throne of Seotland. A war with the Scots followed and culminated in Crom. well's crowning victory at Worcester (Sept. 3, 1651), but Charles II made his escape from the country. The remnant or rump of the parliament, which had constituted itself the sovercign body by its own authority, sought to transform itself into a permanent oligarchy, with the result that it was forcibly ejected by Cromwell in April, 1653 ; and from that time Cromwell, who was made lord protector by the army in December, was virtually the absolute ruler of England. The former champion of parliamentary government found all attempts to work in harmony with the 
parliament vain. His government was necessarily arbitrary, butstrove at least to be as just as the circumstances permitted, while his vigorous Imperial policy, though it helped to raise France to a dangerous height of power, made England feared on the Continent as she had never been feared before. With Cromwell's death (1658) came chaos. The country was sick of the rule of soldiers and saints, and it was with a practically unanimous satisfaction that Charles II was recalled to the throne (1660).

The Restoration meant nothing ar all like the triumph of the Stuart conception of monarchy. Half the royalists in the Civil war had been men who had been on the side of the parliament against the king until the parliament of 1641 was dominated by the advanced Puritan element. The country intended parliament to be predominant, and, as far as concerned legislation and taxation, the king found that it was neither to be cajoled nor overridden. But parliament, rendered by the arbitrary Puritan rule of the Commonwealth intensely hostile to Puritanism, which it smote in a series of enactments much more repressive than was at all pleasing to the king, proved no less hostile to Romanism; to the surprise and disappointment of Charles, who had promised himself and his cousin, Louis XIV of France, the restoration of a Romanist ascendancy.

\section{Charles II and Parliament}

Under the mask of frivolity and dissipation, however, Charles concealed an invincible determination to avoid fighting with parliament in deed, but to make himself entirely independent of it by secretly selling himself and the country to the king of France. For 25 years he successfully deceived statesmen, courtiers, politicians, English and foreign, and the king of France himself. On March 28, 1681, with Louis XIV's purchase money in his pocket, he dissolved his last parliament at the moment when its leaders imagined that he was fast in their grip. In those 21 years he had built up a standing army sufficient for his purposes. In the next three years he cancelled and renewed the charters of the boroughs in such a manner that the crown had a practically absolute control over their parliamentary elections.

Having no legitimate children, he had secured the succession to his Roman Catholic brother James. His death left James II with all the master cards in his hands, had he but known how to play them skilfully. Fortunately he did not. The loyalty of the country was turned first into uneasiness and then into grim hostility. When he alienated ardent royalists and fervent churchmen by arbitrarily suspending or overriding the law for the advancement of Romanism, men of every party joined in calling to their aid his son-in-law, William of Orange. William landed in Tor Bay on Nov. 5,1688 . James took flight, and on Feb. 13, 1689, William and Mary were proclaimed king and queen of England, having accepted the declaration of right which laid down what were to be in future the fundamental limitations of the power of the crown--limitations which were put forward as the historic right of the people. Scotland followed suit and the crowns remained united.

Development of the Party System

The accession of the stadtholder of Holland, the lifelong enemy of Louis XIV, carried England ful into the vortex of international politics. The ascendancy of the English navy, long disputed by Holland, and now for a moment challenged by France, was decisively established and was never again lost save for a moment between 1779 and 1782. The right of parliament to fix the course of the succession to the throne was established ; the state system of finance was reconstructed by the creation of the national debt and the Bank of England. The party system inaugurated by Shaftesbury under Charles II developed steadily. William died on March 8, 1702, at the moment when he had organized the Grand Alliance which was plunging England into the War of the Spanish Succession. He was succeeded by Anne, the second daugh ter of James II, under whom that war was fought out to its issue. But another issue had arisen. Scotland demanded a permanent union with England upon terms agreeable to herself, threatening in the alternative to name for Scotland another successor to the thronethan that of England. On May 1, 1707, the Act of Union came into effect. From that hour the history of England as a sovereign state is merged in the history of Great Britain.

A. D. Innes

Bibliouraphy. Constitutional His. tory of England from Henry VII to Death of George II, H. Hallam, 1827 , frequently reprinted, History of England from the Accession of James II, T. B. Macaulay, 1849-61 ; Constitutional Hist. of England, W. Stubbs, Lib. ed., 3 vols., 1880 . Oxford Manuals of English History, cd. C. W. C. Oman, vols. i-v, 1894-95 ; Political Hist. of Fngland, ed. W. H.unt and R. 1. Poole, rols. i-ix, 1905-10 ; Hist. of the British Nation, A. D. Innes, 1912; Constitutional Hist. of England since Accession of George III, T. Erskine May, ed. F. Holland, I912; Short
Hist. of the English People, J. R. Green, brought down to 1914 by A. Stopford Green, 1917 ; Outline of English History, S. R. Gardiner, new ed. 1919.

Englefield. Parish and village of Berkshire, England, $5 \frac{1}{2}$ m. W.S.W. of Reading. Here Alfred defeated the Danes in 870. Pop. 399.

Englefield Green is a residential district in Surrey, $1 \frac{1}{2} \mathrm{~m}$. N.W. of Egham at the S. of Cooper's Hill. The cottage on the green was for some years the home of George IV's Perdita (Mrs. Robinson).

English Bázár or ANGrazaBAD). Town of Bengal, India, in the Malda district. It stands on the right bank of the Mahananda river, $56 \mathrm{~m}$. N. of Murshidabad. The East India Company established a silk factory here, and there were also Dutch and French settlements. The chief trade now is in grain. An embankment prevents the overflow of the Mahananda. Pop. 15,000.

English Channel (Fr. La Manche, the sleeve). Stretch of water separating the $\mathrm{S}$. shore of England from the N. coast of France. It communicates with the North Sea on the E. and the Atlantic Ocean on the W. Its extreme length from the Strait of Dover to a line drawn between Ushant, in France, and Land's End, in Cornwall, is $280 \mathrm{~m}$. Its width from Dover to Cape Griz $\mathrm{Nez}$ is $21 \mathrm{~m}$., from Land's End to Ushant $110 \mathrm{~m}$. Its widest part is between St. Malo and Lyme Regis, a distance of $145 \mathrm{~m}$. Its maximum depth is 70 , its average depth 30 fathoms. In the Strait of Dover there is a chalk ridge at a depth of 12 fathoms. The bed of the channel is composed of coarse gravel. England has a coast line of $392 \mathrm{~m}$. while the French seaboard is 574 $m$. Many rivers discharge their waters into the Channel, the principal being the Seine, on the French coast. The chief islands are the Isle of Wight, and the Channel Islands. Fishing is carried on, the principal catches being mackerel and pilchard.

English Church Union. Association of clergy and laity of the Church of England. It was founded in 1859 for the defence of the doctrine and discipline of the Church. It is the leading organization of the High Church party, and has frequently defended clergymen charged with illegal doctrine or ritual. Lord Halifax was president until 1920, when he was succeeded by Sir Robert Newman. It organ is the Church Union Gazette.

English Horn. Double - reed wind instrument of the hautboy family, and of tenor pitch. See Cor Anglais. 


\section{ENGLISH LANGUAGE AND LITERATURE}

This article is divided into two sections. The language may be studied further under Alphabet; Phonetics: while for the literature there are articles on the great figures of English literature: Milton; Shakespeare; Dickens; Fielding, and others. See also the general article Literature, and those on various verse and prose forms, e.g. Ballad; Essay; Novel; Ode

The earliest form of Fnglishfrom the beginning to about one hundred years after the Norman Conquest - is sometimes called Anglo-Saxon, but nowadays more generally simply Old English. The people who lived in the oldest period called themselves Angel cynn, and their language Englisc in the vernacular, or, in Latin, generally Argli, sometimes Angli sive Saxones, and Sermo Anglicus or Lingua Saxonica. These terms are applied to all the tribes and to all the dialects.

Old English is shown by its vocabulary and its system of inflexions to be a W. Germanic language, closely akin to Old Frisian and Old Saxon, and still closely, though more remotely, to the High German dialects. The resemblances between Old English and Old Frisian are indeed so great and numerous that some regard these two groups of dialects as forming a special branch of W. Germanic speech subsequently differentiated into English and Frisian which they call the Anglo-Frisian branch. From the earliest records four main dialect types in Old English, corresponding to tribal divisions, may be distinguished : the Anglican dialects, i.e. Northumbrian and Mercian; the Saxon dialect; and the Kentish, spoken by the Jutes. The differences between these are comparatively slight, so far as they can be traced in the rccords, but the subsequent history of the several types is very different. The Angles settled in the N. and Midlands, the Saxons in the S. and S.W., and the Jutes in Kent, the Isle of Wight, and parts of Hampshire.

\section{The Old English Alphabet}

The English, in common with other Germanic tribes, possessed an angular-shaped alphabet suitable for cutting or scratching upon metal, bone, and other hard substances. This is known as the Runic Alphabet, and the !etters are called runes. A fow inscriptions in this form survive on stones and whalebone, but probably none are much older than the oldest written documents of the ordinary kind. After the introduction of Christianity, the English learnt the art of writing from Irish monks, and the ordinary Old English alphabet is almost identical with that in which Old Irish was written. It was soon found convenient, however, to borrow from the Runic alphabet two symbols to express characteristically English sounds-b called "thorn" for $t h$, and $p$ called "wen" for $w$. In modern editions of Old English works it is now unusual to reproduce the shapes of the MIS. letters, which are printed in ordinary type except $p$ and $\sigma$ which also stands for $t h$; the vowel symbol $x$, for the vowel sound in Modern hat; and occasionally $\delta$ the Old English form of $g$. The spelling of Old English, allowing for certain inconsistencies, is on the whole phonetic.

Sound Changes and Dialect

Perhaps the most important aspect of the evolution of language is the change in pronunciation which continuously proceeds. Sound changes have a far-reaching effect upon the history of every language and bring much else in their train. Not only does sound change alter the whole external aspect and character of a language, so that by this means chiefly, or alone, dialect is often differentiated from dialect, and language from language, but sound change involves the alteration, or it may be the destruction, of inflexional suffixes, whereby the main features of accidence are modified or swept away, and these losses of significant endings may, and often do, bring about a revolution in the syntax of the language.

It is now recognized that sound changes are regular in their effects, and that they take place, within a given period and in a given language, according to definite principles and conditions. Within the above-mentioned limitations of time and language and phonetic conditions the same sound will always change in the same way or dircetion. By the side of regular sound change, the principle of linguistic analogy, or the close association of form with form, whereby one is modified by the other, with. out normal phonetic development, is recognized as of hardly inferior importance to the action of phonetic laws. It must be remembered that language cannot exist apart from living human beings who speak it, and that change in lan. guage implies a change in the phy. sical and mental habits of the speakers.

The History of English. The history of English may be said to have begun from the moment when the group of dialects known as Old English had become differentiated from the parent W. Germanic stock. At the moment of its earliest appearance in a written record, Old English had already undergone a number of characteristic changes which separate it from the nearest cognate languages. Under the conditions of complete geographical separation from the speakers of the other W. Germanic languages of the Continent, English underwent still further independent changes.

While alterations in the consonant changes were comparatively slight, those involving the vowels were considerable. There are two main classes of sound changes: Isolative, which arise in the sound of a language in the course of its history, without any discoverable reason, and without any influence exerted by the neighbouring sound in the word or sentence ; and Combinative, which result from the influence of one or more sounds in the word, or sentence, upon another sound, or from the effect of the position of the accent or stress in native words, upon the root syllable, not upon the prefix or suffix. In English, unstressed svllables have always been very liable to weakening, and are often eliminated altogether.

The Old English vocabularv is of a characteristic W. Germanic nature, and the great bulk of words are of this origin. There is, however, a considerable element of Latin loan-words: (a) those borrowed during the Continental period, e.g. straet " street," Lat. stràta via, paved way; (b) those borrowed from Latin-speaking Britons in this country, such as ceaster, town, Lat. castra, camp ; (c) those borrowed from Roman ecclesiastical sources, e.g. pāpa, pope.

\section{Effect of Spoken Latin}

Latin must have been freely spoken among the upper classes of the Britons, and in the larger towns of Britain. Several Latin words which expressed ideas for which no equivalent existed in Old English were literally translated, such as welwillend for benevolens. It has been suggested that, if the English invasion had not taken place, the chief language of the country would not be a form of Welsh, but more probably a neo-Latin, or Romance language. Celtic exerted 
only a small influence upon the vocabulary in the Old English period, except in the names of hills, rivers, and other geographical features, which retained their old designations-pen, avon, cumb, dūn, etc. The Scandinavian influence, which began in the 8th century, shows very slight traces in the written documents before the 11 th, by which time the English and the Danes in certain districts had amalgamated, and having passed through a bi lingual stage, had settled down together, with English as the surviving language in a form which retained many elements of the language of the once hostile settlers.

With the rise of Wessex to the ruling political position among the Old English states, the literary labours of King Alfred made the diale't of this nrovince the chief vehicle of literature. All the works of literary importance, both poetry and prose, which have survived, are written in a form of West Saxon, occasionally with traces of other dialects. 'This form of English may be regarded as a common literary standard for the whole country from the beginning of the 10 th centurv.

\section{From old to Middle English}

The Conquest had at tirst little effect upon the spoken language. Few Englishmen learnt French for several centuries, and they could not borrow words from a language which they did not know; nor was there any reason why the presence of foreigners ignorant of the native tongue of the country should in any way affect its pronunciation and inflexions. The changes made apparent by the spelling in the middle of the 12 th century are not the result of the Norman Conquest, but the normal development of tendencies which were active before the Normans came. The rather abrupt contrast observable in the language of documents from about 1150 onwards dues not represent any sudden new development, but implies that the old literary tradition, which largely concealed the facts of speech by means of an antiquated convention, has almost passed away, and that a new literary convention, and to some extent a new scribal mode of spelling, have begun which are nearer to the language of everyday life than was the older tradition.

The language of the last part of the Laud, or Peterborough Chronicle, writtell soon after 1157, is still in a sense Old English, but many changes are observable. The highly inflected Old English definite article has to a great extent given way to an uninflected form, $p$, "the," which never varies, but takes prepositions before it to express case-relations which Old English expressed by inflexion. Such constructions as pe wreece men of pe land "the wretched men of the country," betwyx pe linges freond and pe earles freond "between the king's friends and the earl's friends," sound strangely modern. Already in the latter part of this Chronicle the unstressed vowels are fairly regularly written $e$, as in the later Middle English neriod, to represent Old English $o, a, u$ and $e$. The Norman scribes have taught the Englishman the useful graphic distinction between $f$ and $v$. whereas the latter formerly wrote $f$ for both sounds. The Old English accusative singular of the third personal pronoun masculine, hine, has already teen lost in favour of the dative him, as at present, the feminine pronoun scoe, the ancestor of she, first appears instead of the old $h \bar{e} o$.

The present-day use of a preposition at the end of a sentence occurs-me lihtede candles to aten by "men lighted candles to eat by." The case-endings of adjectives are largely lost. Although most of the typical Middle English changes in the vowcls are not yet consistently expressed in the spelling, there appears an uncertainty and a tentative groping after the best way of expressing a pronunciation which is evidently changing. As regards vocabulary, a few French words are used, all more or less technical, expressing new and foreign conceptions or institutions, offices or titles-canceler, prisun, cuntesse, emperice. The only word which might be considered non-technical and belonging to everyday lite is pais, "peace." A few new Scandinavian words are used: $1 \bar{o} c$ "took," and oc "and." The usual English words niman "take" and and are also used.

\section{The Middle English Period}

This may be held to begin about 1200. The process of change is more rapid in the dialects of the $\mathrm{N}$. and those of the E. Midland than in those of the S. and of the S.W. Midland. In the N. especially the loss and confusion of flexional endings has gone very far by the beginning of the $14 \mathrm{th}$ century. A characteristic of the Middle English period is the great dialectal variety which finds expression in the written documents. The main types are the N., which includes the dialect of S. Scotland; the E. Midland; the W. Midland; the S.W. Midland,including the dialects of Herefordshire, Worcestershire, Oxfordshire, and Shropshire; the S. dialect, including all types as far
E. as Surrey : the S.E., including the speech of Kent and Essex. The London dialect, which in its earliest forms shows a mixture of purely S. with Kentish or S. Eastern forms, becomes increasingly important from the first quarter of the 14th century onwards.

\section{The London Dialect}

Early in the 14th century the London dialect is still largely pure S. in type, that of Surrey and Middlesex, but shows certain Kentish or S.E. features, and a slight tinge of E. Midland. By the end of the century, Chancer and those of his contem. poraries who write in this dialect show an increasing number of purely E. Midland features, rather strong S.E. influence, and a certain survival of $\mathrm{S}$. characters. Chaucer is fairly representative of the best London and court English of his day. Owing to the political and commercial importance of the capital, the type of English there spoken was naturally bound to become the leading variety in the country, and the prestige of Chaucer and the popularity of his writings led to many initations, not only of his style but of his dialect, even among writers who did not speak London English.

Nevertheless, for the most part, throughout the 14th century, people continurd to write in the dialect which they spoke. The beginnings of a change may be seen when Chaucer's contemporary, Gower, writes, not in the Kentish dialect which was naturally his own, but in a close approximation to that of London, with but few provincialisms to betray his native dialect. The Middle English period may be said to close with the death of Chaucer, or in the first quarter of the 15th century, and soon after that date there are no more literary works written in pure provincial dialect, except in Scotland, which had a standard of its own, so that the history of English centres more and more round that one form which has become the universal standard. But while the London type predominates increasingly in written documents of all kinds, from whatever area, there are plenty of traces, far into the 15th century, of the provincialisms of the writer's native speech.

The vocabulary of Chaucer is very largely our own. He uses Norman French words, not here and there, like early Middle English writers, but as indispensable elements of his style. Norman French words are no longer foreign, but hundreds have penetrated into the very fibre of English speech, and it is not very easy to write many consecutive sentences not containing words of 
this origin. Norman French having been the language of the upper classes for nearly 300 years, and the official vehicle of law and govern ment, was abolished in courts of law in favour of English in 1362 ; in 1385 it was no longer used in schools ; by the end of the century it was probably dead as a spoken language. The Scandinavian element is very large in Middle English in the N. and E. Midland dialects.

\section{Modern English}

The chief event in the general history of English since the beginning of the 15th century has been the gradual aeceptance of a virtually uniform dialect by all writers. This agreement was greatly helped by the introduction of printing in 1476. Caxton, himself a Kentishman, adopted the London dialeet for his translations and prefaces, and a knowledge of this type was rapidly diffused throughout the country through his labours. Even by the middle of the 15th century, provincial or regional dialect was falling into disuse in writing.

The adoption of a standard of spoken English was a much slower process. George Puttenham, in his Art of English Poesie (1589), says that in the $N$. noblemen and gentlemen spoke their own dialect; Aubrey has it from one who knew Sir Walter Raleigh that he spoke broad Devonshire all his life. In the 17 th century comedies country gentlemen who eome to London for the first time are made to speak a broad rus tic form of English, and as late as the 18th century Fielding makes Squire Western speak pure Somersetshire. It was the language of the court which in Elizabeth's day was reeognized as the best form of spoken English, and upon this the !iterary English of the day, the ancestor of our own, was based. The English of Caxton is virtually the descendant of that of Chaucer. The differences between the two are due chiefly to the growing encroachment of the E. Midland element in London English since Chancer's time.

Since the Mirldle English period English pronunciation has changed consideratuly, although the conventional spelling handed on, with few modifications of importance, from the early printers who derived it from the professional Middle English scribes, reveals next to nothing of this. All the long vowels and all the Mirddle English diphthongs have altered completely in charaeter. Many changes in the pronunciation of consonants have also taken place, though some of these have since been "restored" through the influence of the received spelling. The same factor has influenced to some extent the pronunciation of unstressed vowels which in the Early Modern period had undergone considerable weakening.

It is a necessary result of the recognition of a standard dia. lect, which in origin was that of the upper elasses, that other forms fall into disrepute, and are considered either vulgar or merelv provincial and rustic. The latter cpithets are now applied to the modern regional dialects, while the former justly applies to certain forms of English, cognate with the best form of spoken English in origin, but differentiatcd from it in the mouth of the humbler and less refined elasses of society. The principal sound changes were probably complete, or at least well under way, hy the end of the 16th century, though the final distribution of the various dialect types which com. pose standard English was not yet finally settled. The subsequent listory of standard spoken English is very largely the result of the influence exerted upon this by other elass dialeets, and to some small extent by regional or provincial dialects.

\section{Modern English Sound Changes}

The changes made in the English vowel system from the "Continental values" to approximately our present pronunciation are traceable from occasional spellings of the scribes, in some cases as early as the early 14 th century, very clearly and frequently in the 15 th century, when private letter writing began to be practised by all sorts of persons, and in the $16 \mathrm{th}$ and later periods, not only from this source, but also from deliberate descriptions of English pronunciation. Most of the typical modern vowel changes began very early, but acceptance of many of these in court English was eonsiderably later than the 15th century, and some appear to have been accepted only in a few words. Many of them were considered vulgarisins at first, and penetrated into the standard language through the influence of lower class London English. Many pronunciations used by the best speakers duting the 17 th and 18 th centuries would now appear vulgar, rustic, or, at least, antiquated. Among these may be mentioned sarvis, sarvant, sarmon, vartue, Booshop. goold.

There is ample evidence from the 15 th century on wards that the present day natural pronunciation of the vowels in unstressed syllable either with the "murmur vowel" (ə) as in second syliable of falher, or with $i$ was already in vogue. In the 18th eentury words with on were often pronounced as with in, e.g. flaggin, dunjin, sturjin for flaggon, dungeon, sturgeon, ete. The ending ure was pronounced like -er far into the 18th centuryjointer, picter, nater, ete. Such a word as fellow was pronouneed feller (without $r$ ), and Pope rhymes it with prunella. The present-day pronunciation of the suffix -es, -est, -eth, etc., as -iz, -ist, is already established as the polite one in the court English of the 15th and 16th centuries by such spellings as horsis, princis, eldist, givith, etc.

\section{Spelling Pronnnciation}

In the 18th century nus, pus, Usly, thusty are the spellings of a writer on pronunciation to express the proper forms of nurse, purse, Ursula, thirsty. The ending -ing was pronouneed as -in as early as the 15th century, and this was probably universal in standard English until the end of the first quarter of the 19th century, when the spelling. pronunciation won the day to some extent. Usage now varies. The loss of the sound of $g h$ in the middle of words before $t$ is shown to have been caused in the 15 th century by the omission of the symbol in words where it belongs historically, and by such spellings as dought " doubt," ought "out," uright " write." In the 16th century even Spenser often writes whight, quight, ete. The sound of $w$ develops initially before $o$ and ho; won for one is fairly common in the 15th century, and in the 16th occurs in the letters both of Henry VIII and Elizabeth. The spelling whole has been retained. Consonants are often lost, finally and in combinations, as is proved by spellings from the 15th century onwards.

Similar pronunciations are recorded in the 18th century. The following 15 th and 16th century spellings show losses in combinations in the midrle of words : Whysson weke "Whitsun" ; Wensday, morgage, sepukyr, Woetreet "Wood Street." Queen Elizabeth herself writes "often" offen. Lunnon was a polite 18 th century pro. nunciation. Many of these forms survive at the present time, but the consonants are now often restored from the speiling. At the beginning of unstressed syllables $w$ was normally dropped already in Middle English. It bas been largely restored, however, through the influence of the spelling. While $w$ is still omitted in Norwich, Southwark, etc., it has been re. stored in forward, earlier forrard, Edward, ete. Eddard was the polite 18 th century pronunciation, and 
survived as such among oldfashioned speakers far into the 19th century.

Weak plurals are more frequent among good writers in Early Modern English than now, e.g. housen, shone, eyen, All Soulen, peason, etc. The old feminine possessive without $-s$ is found commonly as late as the 16 th centuryOur Lady Mary Grace, the Queen Grace, etc. These survive now in Lady Chapel, Lady Day. The personal pronouns her (possessive) and hem (dative plural) are frequently used in the 15th century by the side of their, them. The former is apparently not found after the early l6th century; the latter is rare in the 16th and early 17th, but reappears in the 18 th century as 'em. "Group inflexion" in the possessive of nouns is found as early as the 15th century-the erle of Wiltones wyf-by the side of the older construction, the dukys daughter of Northfolke. Such constructions as for Jesus Christ His sake are vely common in the 15th and 16 th centuries, the pronoun being often detached and written $i s$, and sometimes joined to the preceding noun as a possessive suffix, which indeed it originally was in this case.

\section{Continuity amid Constant Change}

The old Southern present plurals of verbs in -eth linger on in occasional literary and colloquial use far into the 16th century, though the form without ending is far commoncr. In the 15th century the forms in $-e n,-i n$ are still often used. The third person present singular ends in -eth, -ith or -th during the whole of the 15th and 16th centuries in the best English. The forms in $-s$ come in very gradually, and are at first chiefly used either in poetry for the sake of rhyme or metre, or in fairly colloquial style. They are by no means universal by the end of the 16th century. Hath and doth survive far into the 18th century both in colloquial and literary use. In the 18th century Pope and other good writers use was instead of were after you, when onc person only is addressed. This practice survived in good colloquial use well into the 19 th century.

A careful study of the history of English from the earliest times to the present day, based on an intelligent interpretation of the written records of the successive ages, leaves an impression of continuity amid perpetual change. The history of standard English during the last 500 years has been largely one of the varying distribution of elements drawn first from regional, and later from social dialects. The standards of what is polite and correct shift from age to age. What is vulgar in one generation becomes the pattern of propriety in the next; that which was elegant and habitual to the most refined speakers is felt to be slipshod or worse. There is no doubt that since the early 19 th century there has been a great striving after "correctness" in English speech. Our speech to-day is far less untrammelled in its colloquial forms than that of the 17th and 18th centuries. Good speakers then seem to have been content to follow the natural tendencies of unstudied utterance, and were less anxious for "correctness" as this was later understood.

\section{The Future of English}

This process is still going on, and, with the increased diffusion of education among those who have no traditional knowledge of the best speech, bids fair to alter our language out of all recognition. But other tendencies may arise. It is impossible to foretell the future of English, though we may well believe that it will be no meaner or less splendid than its past. New standards of speech will arise in all probability, with the growth of new centres of culture in this country, and still more in our distant colonies, whose populations are still "mewing their mighty youth," and future historians of spoken English will have to take into account the many varieties of our mother tongue, spoken by peoples of very different experiences and modes of life, throughout the Empire.

H. C. I. Wyld

Bibliography. History of English, General : A New English Grammar, H. Sweet, 1892-98: The History of the English Language, O. F. Emerson, 1894; Historical Outlines of English Accidence, R. Morris, rev. ed. 1895; The Making of English, H. Bradley, 1904; Growth and Structure of the English Language, O. Jespersen, 2nd ed. 1912; A Short History of English, H. C. Wyld, 1914 (contains Bibliography with lists of Authorities and Editions of O. and M.E. Texts); A History of Modern Colloquial English, H. C. Wyld, 1920.

English Vocabulary: New English Dictionary, ed. J. A. H. Murray and others, 1884, etc.; Principles of English Etymology, IW. W. Skeat, 1887-91; A Shakespeare Glossary, C. 'i'. Onions, 2nd ed. 1919.

old and Middle English: An Anglo-Saxon Reader, H. Sweet, 8th ed. rov. 1908; An Old English Grammar, Joseph and E. M. Wright, 2nd ed. 1914; A Middle English Reading, O. F. Emerson, rev. ed. 1915.

Texts and Editions. The chief O. and M.F. works are published by the Early English Text Society ; some are in the Camden Society, and the Rolls Series and Percy Society. The English Reprints, ed. Edward Arber, include a number of important Early Modern works, exactly reproduced from the original editions.

Literature. Anglo-Saxon literature is interesting rather as a document illustrating the spirit of the English stock, Angles and Jutes, than as a direct ancestor of English literature as traced from Chaucer. For modern English literature does not derive directly from Old English literature. From the 11th century, even before the Conquest, to the 14th century, England was a pupil in the school of France. For the greater part of this time Latin was the language of learned, French of polite, literature. For three centuries English and French were jostled together, with the result that when at last in the 14th century English came to its own, it had become the rich composite speech, in vocabulary and syntax, which was to be the medium of English poets from Chaucer to the present time; and in the same centuries, English poets gradually assimilated, adapting it to the genius of the English language, the syllabic, accentual metre which had been first heard in the Latin hymns of the Church and Provençal and French Song.

French literature itself was only beginning when the Normans conquered England, but in the course of the 12th and 13th centuries the French poets of Provence and Gascony, of France proper and of England, created the romantic and lyric literature which is the fountain-head of all modern Europcan literature. The new love-poetry of Provence, with its courtly and ideal, but also conventional, cult of love, the romances of Charlemagne, of Arthur and his Knights, of 'Troy, Thebes and Alexander, beast-epic and allegory and fabliau - these were made by the French familiar to every country of W. Europe and reproduced in other tongues. In the creation of this courtly literature as such England took no part; but when English literature began to awaken again it was in the reproduction of French themes and forms.

The first English poem written after the Conquest which is really a work of literature, Layamon's Brut, is a long and interesting elaboration of that legendary history of Britain, from Brutus to Arthur, which had first taken the shape of history in the Historia Regum Britanniae of Geoffrey of MIonmouth, and had been already thrown into verse by the Norman 
poet Waee. But Layamon makes interesting additions from Welsh oral tradition. The verse is apparently intended to follow the Old English model, but is rapidly approximating to an English reproduction of the French octo. syllabic or four foot verse, the long line falling into two parts. Even in religious and didaetic works of no great literary merit, the Ormulum, the Bestiary, ete., we can note the interaetion of old English form and feeling with the new influences; but the full effect of French in. spiration in the begetting of a new literature, fresh in spirit and in form, is seen in the lyrics and the romances of the 13 th and early 14th eenturies.

\section{Early Lyrics and Romances}

The earliest English lyries, songs like Sumer is i-eumen in, Lenten is come with love to town, are the work of pocts familiar with the French lyric, its rhythms and its tone,gayer than tbat of Old English poetry. They blend in humorous fashion lines English, French, and Latin. The same is true of the first English romances, all probably translations, even when, as in King Horn, Havelok the Dane, Richard Coeur de Lion, Bevis of Hampton, and Guy of Warwiek, they deal with native legendary themes. And all the varieties of French romanee, Carlovingian, e.g. The Sowdone of Babylon; Arthurian, e.g. Lybaeus Desconus; Oriental, e.g. King Alisaunder; classieal, e.g. The Destruction of Troy; and miscellaneous romances of adventure, e. $g$. Ipomydon, are represented.

All lack the eourtly tone of French romance, being composed for popular audiences who love a genially told story of adventure rather than refinement of sentiment. In their dietion we see the shaling together of the elements, English, French, and Scandinavian, which make up the rieh tongue of Shakespeare and Milton; while in the metrical, not alliterative, poems, we can trace the proeess by which the syllabic rhythm of French verse was adjusted to the idiosyneracies of stress and cadence in English pronunciation. Outside romance and lyrie, poctry of the 13th and early 14 th centuries is didactic-the Cur. sor Mundi, a long paraphrase of Scripture history and Church legend; the Pricke of Conseience, a summary of theology, erroneously attributed to Riehard Rolle of Hampole, a writer of mystieal works in Latin and English prose; Robert of Gloucester's verse his. tories, and other works.

The 14th century witnessed the victory of English over French, in the schools, the law eourts, parliament, and even the court where French still to some extent held its own and Freneh poets found admirers and patrons. In the same eentury appears an English poetry artistically on a level with the best of France and Italy. The movement to raise the artistie level of poetry took two directions. One was an artificial and abortive at tempt to revive and elaborate, with or without the addition of rhyme, the old alliterative versea movement which produced the finest of the English romances, Gawain and the Green Knight ; the beautiful elegiae and symbolic poem, The Pearl; and the interesting, if inchoate, satirical, didactic, and mystical poem known as The Vision of Piers Plowman, attributed to William Langland, of whom the poem supplies a shadowy outline.

But the future of English poetry lay with those who completed the naturalisation of French poetry, its regular metre, its refined and courtly spirit, its graee and elegance of style. John Gower, after experimenting in a satirical Latin poem, and a tedious didaetie poem in French, composed at the elose of his life a long poem in English, Confessio Amantis, in whieh he sets in the framework of the eonfession of a lover to Genius, the priest of Love, a series of stories drawn from many medieval and classieal sourees and narrated in smooth, equable, well-turned octosyllabic couplets.

\section{Spirit of Chaucer's Poetry}

Geoffrey Chaucer, however, did more than this. Brought up at court, and sent in later years on mission o various lands, ineluding Italy, Chaucer was educated in the tradition of contemporary French poetry. His earliest poem, The Book of the Duehess, is an elegant but jejune dream allegory, a love poem whose incidents are represented as happening in a dream the eharacters being personified abstractions. But the majority of Chaucer's extant poems were written after he had made aequaint. ance with the Italian poetry of Dante, Petrarch, and Boccaecio.

The House of Fame, an in complete, ironical allegory, shows the influenee of Dante in style and incident. The Parliament of Fowls enriched its decorative fahric with borrowings from Boceaccio. Chaucer's first and greatest dramatie story, Troilus and Criseyde, is based on the same poet's Filostrato with an in. cident from the Teseide. The Teseide itself is the source of the chivalrous story of Palamon and Arcite which became the Knight's Tale in The Canterbury Tales. The stories colleeted in the Legend of Good Women are drawn from Ovid and from a eouple of Latin works by Boeeaccio. The charming Prologue to the poem is Chaucer's own.

But much as Chaucer learned from Italy, the more serious and idealistic spirit of Dante and Pet. rarch did not pass into his poetry. That transmission was reserved for the 16th century. To the end the spirit of Chaucer's poetry is that of the French love-poetry, allegoric and romantie, qualified by his own bent towards a more realistic and humorous handling of conventional themes. The latter bent achieved its complete emancipation in the Prologue to The Canterbury Tales, with its vivid and ironical pietures of all the social types of the England of the 14th century.

\section{Chaucer's Successors}

Some of the tales themselves are probably earlier compositions, but the best are in the vein of the Prologue, fabliaux, short satiric tales, told with consummate dramatic and poetic art. Only in the fragment of 'The Squire's Tale does the poet reopen the well of pure and enehanting romance. Chaucer gave England a courtly poetry superior in dramatic and poetic interest to the poetry of France. He embellished it with beauties de. rived from the great Italian poets. He breathed into the whole a spirit entirely English, and in his hands the English language attained to all but the highest perfection of poetical diction and metrical beauty.

Chaucer had no adequate suceessors for nearly two eenturies. John Lydgate and Thomas Oeeleve kept faintly burning the tradition of didactic allegory and story, and handed on the lamp to its last representative, Stephen Hawes, author, in Henry VIl's reign, of The Pastime of Pleasure. In Seotland this courtly poetry enjoyed a brighter S. Martin's summer.

The popular literature of the 15 th eentury is of greater interest than the eourtly. The religious drama, the mysteries and miracle plays, reached their highest level in the 14th eentury, and gave place in the 15 th to the moralities. To the 15th century probably belong also the oldest of the ballads which, taking the place of the longer lays, preserved the quintessenee of the old romances in a way that was to quicken the romantic spirit with surprising and delightful results in. later English poetry. Of artistic prose in Middle English, the tentative beginnings may be best. studier in Chaueer's translation of. Boethius. The 15th century witnessed a fairly steady advance of 
prose as an artistic medium whose finest result is the Morte d'Arthur of Sir Thomas Malory.

The revival of learning in the 15th century made Italy the centre of influence in literary fashions as definitely as France liad been so in the 12th and 13th centuries. That influence came to England in two successive waves - from Italy direct in the reign of Henry VIII. from Italy by way of France in the reign of Elizabeth. Stephen Hawes was still writing dull allegory, and John Skelton was burlesquing the same in individual fashion; the older tradition of amorous and gay songs and carols after the French manner was still in vogue with Henry VIII and his musicians; when Sir Thomas Wyatt and Henry, earl of Surrey, having "tasted the sweet and stately "measures and style of Italian poesie," began to cultivate this more dignified and passionate note in sonnets, in irregular imitations of the canzone and other Italian forms, and in songs, all published after their death in Tottel's Mis cellany (1557).

French and Italian Influences

The twenty years which followed was a period of arrested development and of experiment, especially in verse translation from Latin, e.g. Arthur Golding's Ovid. The one bright ornament is Thomas Sackville's Induction and Legend of the Duke of Buckingham, contributed in 1563 to The Mirror for Magistrates, which, apart from these poems, was but a dull continuation of Lydgate's moralising "tragedies," and sententiously narrated stories of the overthrow of great men through the fickleness of fortune.

When the Shepheards' Calender of Edmund Spenser appeared in 1579 , the artistic influence of Italy and France was reacted upon by the temperament of a people whose national self-consciousness had grown eager and intense, and whose spiritual life was being profoundly modified by that religious Reformation which tended to separate them from the Latin peoples who were their artistic tutors. The result was naturally complex, a literature at once national and exotic, at times Italian in its dissolute moral tone, again already growing Puritan in its moral ardour, rich in felicities and beauties of style and verse, yet abounding in fantastic extravagances.

Spenser's pastoral, The Shepheards' Calender, his allegorical romance, The Faerie Queen (1590-96), and all his shorter poems, satirical, elegiac, and lyrical, reveal the influence of French and Italian poetry, of Italian Platonism, of Chaucer and of Sir Thomas Malory; but the spirit which strives to harmonise the whole is that of an Elizabethan Englishman passionately patriotic and Protestant. And if much remains unharmonised, the discords are held in solution by a style diffuse in picture and melody, a verse in which the grave iambic movement of Sackville's Induction is heightened by every resource of varied cadence which English metre permits, and adorned with all the accessories of alliteration and vowel-music which English verse welcomes.

Of all the exotic forms natural. ised by Wyatt and Surrey, the sonnet enjoyed the greatest popularity in the closing decades of the century. One sequence of love sonnets, after the fashion of Petrarch's Laura, followed on another in rapid succession, including Sir Philip Sidney's Astrophel and Stella, Samuel Daniel's Delia, Michael Drayton's Idea, Spenser's Amoretti, and the later published Sonnets of Shakespeare. The Elizabethan sonnets are largely translations and imitations, and abound in the conventional and extravagant conceits which are common to the kind, while few or none have the exquisite perfection of form which makes Petrarch a classic. But on the best of the English sonnets, as on Michae Angelo's, is set the impression of personality, the insolent gallantry and passion of Sidney, the brooding thought, the self-abnegation in friendship, of Shakespeare.

\section{Elizabethan Poetry}

The same poets experimented in many kinds, e.g. in the decorative Ovidian idyll, as Marlowe's Hero and Leander, Shakespeare's Venus and Adonis and Rape of Lucrece and the same overwrought rhetoric characterises Daniel's Rosamund a continuation of the Mirror for Magistrates type of story, and Drayton's antithetic imitations of Ovid's Heroides, imaginary loveletters in verse, England's Heroical Epistles. But Daniel and Drayton cultivated a severer style in their historical poems, suggested by Lucan's Pharsalia, Daniel's Civi Wars between York and Lancaster, and Drayton's Barons' Wars.

Daniel, George Chapman, Dray. ton, Sir John Davies, author of Orchestra and Nosce Teipsum, John Donne, Sir Henry Wotton, and others cultivated a grave philosophical poetry, frequently epistolary in form, in which Stoicism and Christianity are blended. Distinctively religious poetry, whether Roman Catholic, like Robert Southwell's St. Peter's Complaint and Henry Constable's Spiritual Sonnets, or Protestant, like Joshua Sylvester's translation of Du Bartas' Divine Weeks and Works, shows the same elaboration of style and sentiment. The crown of Elizabethan verse translations are George Chapman's Iliad and Odyssey.

The greatest and happiest work was achieved in drama and song. In the closing decades of the century a new impetus was given to song writing by the study of lute music and the coloured, cadenced lyric of the French renaissance poets, Ronsard and his fellows, with the result that a lyric of many moods, and a new wealth of imagery and harmony, adorned romance and drama, or was garnered in song-books and anthologies such as England's Helicon and Davison's Poetical Rhapsody. Songs were composed by all the poets of the day, and many of the most charming are anonymous.

\section{Growth of the Drama}

The drama is a larger subject, and its history in the 16th century is one of shifting and confusing development, of overlapping kinds, of natural evolution crossed and disturbed and directed by extraneous influence. The Morality, which had produced in the later 15 th century such a fine flower of serious drama as Everyman, was responsible in the 16th for the impressive Cradle of Security. Farce of a realistic kind-thumb-nail sketches of low life in Londonmingles with the serious element, especially in Moralities dealing with the follies of youth.

The gencral tendency of the Morality is to be dull, and this was intensified by the Renaissance schoolmaster's love for the didactic, as in John Rastell's Interlude of the Four Elements, by such political allegory as Lord Governance, and by the Reformation passion for polemic, as in John Bale's The Three Laws, etc., Lusty Juventus Respublica, and others. Queen Elizabeth checked this intrusion into controversy. The same Bale's Kyng Johan and a play like Thomas Preston's King Cambyses, or the weird version of Aeschylus's great story, Horestes, show how Morality blended with story and developed into the characteristically Elizabethan product, the story play, serious or farcical, or more commonly a blend of both.

Classical influence made itself felt, here as in other countries, in attempts to reproduce the exact 
form and features of Seneca's Latin tragedies, e.g. in Sackville's Gorboduc, and of Latin comedy, e.g. Nicholas Udell's Ralph Roister Doister. The at tempt miscarried, and the dominant type of play of the '60's and ' 70 's was the story-play, the play which brought on the stage all the crowded incidents, dramatic and undramatic, of a story drawn from any and every source, with little interest of character and no beauty of style. The artistic, refining effect of classical and Italian influence made itself felt when into these story-plays was breathed something of the spirit of ancient comedy and tragedy, and they were clothed in a new beauty of form, prose and verse.

\section{Marlowe and Shakespeare}

John Lyly led the way in the reform of the drama as literature with his light and graceful, if flimsy, mythological and courtly comedies. George Peele sweetened the versification and brightened the fancy of comedy and romance, and Robert Greene is mainly responsible for the woodland settings and the fair maidens of Shakespeare's As You Like it and Twelfth Night. Thomas Kyd achieved a success by his Spanish Tragedy, which popularised the melodramatic revengemotive and the stilted rhetoric of Seneca, while eliminating the choruses and loosening the structure. But the great forerunner of Shakespeare was Christopher Marlowe (Tamburlaine, Dr. Faustus, Edward II), who gave to serious English drama stateliness and splendour of form, while quickening within it the soul of dramatic interest. His blank verse is the overture to the fuller, more varied harmonies of Shakespeare and Milton.

In William Shakespeare a great tradition found its fullest expression. The statue had been blocked out, the tools were ready to his hand. It was no restraint to him, it seems rather to have been a help, to revise older work, to collaborate with lesser men. But the miracle of genius remains. The tradition broke into a new life in his hands. The old play, the lesser dramatist, found through him their fulfilment. Ho neither led nor followed, he moved instinctively with the changing currents of taste. His early tragic histories, Henry VI and Richard III, are Marlowesque in spirit and style; his early comedies and romances, Love's Labour's Lost, and A Midsummer Night's Dream, absorbed and enriched all the currents that flowed more faintly in Lyly and
Peele and Greene. As the century draws to an end he satirises the bombast of Marlowe and Kyd through Ancient Pistol, and Lyly's Euphuism in the wit of Falstaff, and blends heroic history, full of the same spirit as Daniel's and Drayton's Chronicle poems, with genial and boisterous comedy.

And when Jonson turned drama from romance to realism, Shakespeare passed to tragedy, tragedies of character and adverse stars in Hamlet and Julius Caesar, tragedies of great souls driven from their orbit by passion to clash and destroy and perish in Othello and Lear, and the style and imagery and verse change with the change of theme. Lastly, when Beaumont and Fletcher revive the flutings and falsetto of romance, Shakespeare, too, turns back to the charm of romantic setting and pathetic lovers and children and flowers and poetry and reconciliation. $\mathrm{He}$ works with all his fellows, but gives to each kind of play an infinitely richer dramatic and poetic worth.

English prose in the 16th century felt the influence of Latin in vocabulary and structure. The prose of the 16th century-of John Fisher, Thomas Elyot, Roger Ascham, Thomas North, and others - is a happy blend of simple, direct, colloquia: English, with \& free importation of Latin words and a sentence shaping towards the Latin period. The finest product of this are the translations of the Bible, from Tyndale to the Authorised Version, a book which has shaped and coloured, as perhaps no other, the diction and rhythm of the best English prose and verse.

\section{Hooker and English Prose}

For the last two decades of the century prose, like verse, came under the influence of the taste for elaborate rhetoric. Lyly's Euphues set the fashion of antithesis, alliteration, and artificial simile for a succession of imitators in novels and pamphlets, Robert Greene, Thomas Lodge, Thomas Nash, and Thomas Dekker; though in Nash and Dekker a racy colloquialism blended with and superseded the tricks of Euphuism. Sidney cultivated a more poetical rhetoric in his Arcadia, and, with much less of artifice, in the De. fence of Poesie. Richard Hooker, in the Ecclesiastical Polity, raised the Latinised, periodic prose to a higher level of rhythm, and dignified eloquence, and made English a fitting medium for philosophical disquisition.

The literature of the earlier 17th century is as varied in character as that of the $16 \mathrm{th}$. The first fifteen years witnessed the culminating achievement of the drama in Shakespeare's great tragedies and the sombre, extravagant, but im. pressive work of Marston, Chapman, Middleton, and Webster, and in the sardonic, unromantic " humours " comedy of Ben Jonson and his classical tragedies. In the work of Beaumont and Fletcher, Massinger and Ford, Shirley, and smaller men, we study the setting of a brilliant day in a sky rich in the colours of sentiment and phrasing.

John Donne and Ben Jonson

In poetry Spenser found no follower in the endeavour to revive, and give a new significance to, the chivalry of medieval romance, though Ariosto and Tasso were translated by Sir John Harrington and Edward Fairfax. But Spenser's pastoralism was variously tuned by many poets, as William Browne, Britannia's Pastorals; and Drayton, The Muses Elizium ; and the Scottish Drummond of Hawthornden, a late Elizabethan, in his Italianism and his love for sonnets and pas. torals. The didactic, allegorical, religious aspect of Spenser's work appealed more strongly than the romantic and chivalrous to ardent Protestants like the poet brothers Giles Fletcher (Christ's Victory and Triumph) and Phineas (The Purple Island).

None, however, of these overflows from Elizabethan poetry, modified by the changing spirit of the time, represents quite clearly the two main directions in which literature moved during the century, on the one hand towards an increasing weight and fullness of thought and conceit, to which is sacrificed grace and beauty of form and verse, on the other towards more definiteness, uniformity, and correctness of style and verse. The dominant influences in this twofold movement are the late Elizabethan poets, John Donne and Ben Jonson. The poems, erotic, satirical, complimentary, and religious, of the former fascinated all the younger, bolder spirits by their intellectual subtleties and passionate perversities of feeling, their rugged strength and frequent felicities of phrase, their contemptuous violations of smoothness and sweetness in versification with the deep and plangent harmonies which none the less they repeatedly achieve.

Ben Jonson, in his songs and epigrams and odes and verses, complimentary and satirical, combines the same compacted pregnancy of thought with a constant, though not always successful, striving after 
classical definiteness of form, classical finish, and felicity of phrasing. The influence of both is obvious in English poetry to the time of Cowley and Dryden. Jonson's and Donne's best disciples are the courtly lyrists, Thomas Carew, Richard Lovelace, John Suckling, Thomas Stanley, and a host of others down to the earl of Dorset, the earl of Rochester, Charles Sedley, Aphra Behn, and John Dryden himself in the years after the Restoration. The greatest of them, as artist and poet, is Robert Herrick, the greatest Epicurean and fanciful song. writer in our literature. The in. fluence of Donne, his metaphysical wit and his passionate egotism, is most directly traceable in the religious poets, Anglican and Catholic -George Herbert, The Temple; Henry Vaughan, Silex Scintillans; Richard Crashaw, Steps to the Temple, and Carmen Deo Nostro; in Thomas Traherne, and others. But, together with Donne's influence, that of Italian religious poetry, with its sugared conceits and the mysticism of Spanish writers, as S. Theresa and John of the Cross, can be recognized.

The Poetry of Milton

The greatest of seventeenth century poets, John Milton, shares the taste of his age for compacted thought and multifarious learning while despising its fantastic and metaphysical conceits. In his poetry, Ben Jonson's ideal of classical form and finish is ministered to by a finer ear and by a poetic temperament and imagination as spontaneously creative as those of the greatest Elizabethans. The early Cambridge and Horton poems, the Nativity Ode, At a Solemn Music, On Time, L'Allegro and Il Penseroso, Arcades, On the Marchioness of Winchester, Comus, Lycidas, combine the spontaneity, fancy, and ravishing music of Spenser and Shakespeare with a consciously elaborated art, architectonical, stylistic, and metrical, which, on this scale, was a new thing, and has never been surpassed in the history of English poetry.

Paradise Lost is built from the stern experiences and the rigid political theology of the years of rebellion and pamphleteering. The freshness and charm of the earlier poems are gone, but their loss is compensated for by grandeur of epic creation in incident, character, and setting, and by the most majestic and harmoniously modulated blank verse which English ears have ever heard. Paradise Regained is a paler reflex of these qualities, but into Samson Agonistes, Milton's experiment in classical tragedy, he poured the passion of his own sufferings and the defeat of his cause, the pride of his defiant will, clothing them in words and measures as sublime as they are severe.

But the movement towards classification, definiteness, and perfection which fulfilled itself so strikingly in Milton followed a line of less resistance in the work of Edmund Waller, John Beaumont, John Denham, William Davenant, and Abraham Cowley. In Cowley's Mistress and Pindarique Odes and Davideis the extravagances of the earlier period are made the more obvious by the subsidence of the imaginative passion which in Donne inspired and condoned for these ; but the common aim of the others, conscious or unconscious, was the rejection of this extravagance, the limitation of the pattern which verse might follow, and the exaction of a highcr degree of correct. ness within that pattern.

The movement was carried to a triumphant success by John Dry. den, a far inferior poet to Milton, but the first and among the most accomplished of English men of letters-dramatist ; poet, eulogistic, lyrical, satiric, and didactic ; translator; literary critic; and essayist. In Dryden's verse and prose the English language is written as we still use it; he is our first modern. His satires, as Absalom and Achitophel, and didactics, as Religio Laici, The Hind and the Panther, are an idealised reflection in verse of easy, masculine conversation or eloquence. His odes are our supreme examples of lyrics in which there is not a note of song but all is artfully managed noise and declamation. Working within a still more limited pattern, Alexander Pope achieved, in the next generation, a yet higher degree of pointed and polished perfection.

\section{Dryden and Pope}

Nothing can surpass in its own way the eloquence of Eloisa to Abelard, the satirical miniature-painting of The Rape of the Lock, the aphorisms and declamations of the Essays on Criticism and Essay on Man, the condensed, polished, poisonous satire of the Dunciad, Moral Essays, and Imitations of Horace. Dryden and Pope are the high priests of a school of poets including Prior and Gay among their contemporaries and a succession of elegant, conventional poets, continued to the end of the century and beyond, whose work may be studied in a collection like Dodsley's.

The Restoration drama of Eng'land is represented by the highflown and absurd, but eloquent, heroic plays of Dryden, the path. etic, rhetorical tragedies of Nathaniel Lee and Thomas Otway, the brilliant, polite, licentious comedy of George Etherege, George Farquhar, William Wycherley, John Vanbrugh, and especially William Congreve. Thereafter, except for brief intervals, as in the plays of Goldsmith and Sheridan and the drama of our own day, the acted drama has not formed an import. ant section of English literature, although almost every poet, Addison, Thomson, Gray, Wordsworth, Coleridge, Byron, Shelley, etc., has tried his hand at poetic drama, Elizabethan or classical.

\section{Development of English Prose}

The same idea of uniformity, of a definite but not too rigid pattern, " correctness," shaped the prose of Dryden, Temple, and their followers. The earlier prose of the $17 \mathrm{th}$ century had shared in the irregular greatness of the poetry. The prose of Francis Bacon's Essays, and History of Henry VII ; of the great Anglican preachers, Lancelot Andrewes, John Donne, poet in prose as well as verse, Jeremy Taylor; of philosophical humorists as Robert Burton, The Anatomy of Melancholy, Thomas Browne, Religio Medici, and Urn Burial; the controversial pamphlets of Milton, as Areopagitica; the historical memoir-writing of Clarendon, History of the Rebellion-all illustrate the erudite, imaginative phraseology, the splendid but not perfectly controlled harmony, the too long and complex sentencestructure of a prose which en. riched our language, but was not a fully developed and controlled medium.

A simpler style is tracéable in the antithetic sentences of the character-writers, as Earle's Microcosmographie; the prose of moderate divines like Chillingwortb, The Religion of Protestants, and Hales, Golden Remains ; and the viriie, well-girt style of the philosopher Hobbes, Leviathan. The strain of racy colloquialism in 17 th century prose, coloured by a sensitive and imaginative temperament, and enriched by the sublimer phraseology of the English Bible, gives individuality to the Grace Âbounding to the Chief of Sinners and Pilgrim's Progress of John Bunyan. A gentler temper sweetens the talkative prose of Izaak Walton's Compleat Angler, and Lives, and the multifarious, witty writings of Thomas Fuller. The new prose, colloquial but urbane and weighty, begins in the Sermons of Tillotson and South, the Essays of Sir William Temple, and, above all, in the prefaces and essays of John Dryden, whose 
critical prefaces manifest. for the first time, the qualities of urbanity, of ease and elegance combined with force, which mark the prose of a people who have come of age socially and culturally.

The new instrument lent itself to all the purposes of an age in which political and social life entered into the elosest union with literature. The first of these is satire: and the pamphlets and oceasional pieces of Jonathan Swift, from The Tale of a Tub to the Travels by Lemuel Gulliver, made him a power in English political life, and revealed the greatest mastery of irony in the English or perhaps any other tongue. Richard Steele and Joseph Addison. paniphleteers on the other side from Swift, showed in The Tatler and The Spectator how the same stvle, used with less masculine vigour than in Dryden's, and less incisive virulence than in Swift's prose, but with a delightful blend of irony and "sweet reasonableness," might be made to incul. cate good sense and purer manners on a society which still felt the evil effects of Puritan and Restoration excesses. The Tatler and The Spectator had many successors down to the end of the eentury, including The Guardian and Johnson's Rambler and Idler.

\section{Birth of the Modern Novel}

The first of modern novels in Western Europe was Cervantes' Don Quixote, whose fame was quiekly diffused. The most interesting precursors of the novel in English were such varied produets as the picaresque and sentimental extravagances of Aphra Behn's Oroonoko and The Forced Marriage; Bunyan's realistic alle. gories; Daniel Defoe's stories, which are almost the complete thing, e.g. Robinson Crusoe, Captain Singleton, Moll Flanders, Captain Jack; and the fantastic real. ism of Jonathan Swift's Gulliver's Travels. But a potent sluaping influence was that of the press, which, beginning in the reign of James $\mathbf{I}$, had developed in the News Books, Mercuries, etc., of the Civil Wars, the last phase of which was the Newsletters of Henry Muddiman and the fuller journalistic work of John Dunton and Daniel Defoe.

The man in whose work these various elements-realistic narrative, the minute portrayal of contemporary life and manners, the didactic interest in conduet-crystallised, finding their centre in the sympathetic analysis of a human soul passing through a moral crisis, was Samuel Richardson, whose Pamela, Clarissa, and Sir Charles Grandison created a type of novel which has been more assiduously cultivated in France than in England. A different kind of plot, deriving from Don Quixote, full of adventures at inns, bringing together all sorts and conditions of men, a more masculine philosophy of life and conduct, made Henry Fielding, dramatist, essayist, and novelist, the father of a novel more characteristically English than that of Richardson. Jeseph Andrews, Jonathan Wild, Tom Jones, and Amelia are the most genial and vivid pictures of English life which the 18th century has bequeathed.

\section{Smollett and Goidsmith}

$\mathrm{He}$ was followed bv an illconditioned Seot of genius, Tobias Smollett, a sardonic and angry painter of sordid and violent life, the creator of some immortal types, as of the English sailor, in Roderick Random, Peregrine Pickle. and Humphrey Clinker. The tendeney of the novel in Smollett's hands to revert to picaresque story was checked by Laurence Sterne, whose self-conscious sentiment and whimsical humour, which owed much to Rabelais, Montaigne, Cervantes, Burton, and Swift, found expression in The Life and Opinions of Tristram Shandy, Gent., and the Sentimental Journey, a tour through France and Italy, tales which, following no plan, vindicated the right of the novel to take what form it please, so it mirror the idiosyncrasies of character and feeling. Among the followers of these great painters of manners is Frances Burney, with Evelina, Cecilia, and Camilla, while Johnson's Rasselas is but an expanded epilogue of the type of Addison's Vision of Mirza. Goldsmith's The Vicar of Wakefield, with its fanciful, humorous, pathetie picture of life seen through the idealising atmosphere of reminiscence, had an influence on Goethe and Continental writers hardly inferior to that of Richardson. In Horace Walpole's Castle of Otranto the first wave of the Gothic revival reaehed the novel.

The novel was only one channel of prose literature in the century. If the didactic spirit invaded and chilled poetry, the regard for form, for correetness, elegance and dig. nity of composition, gave artistic interest to work of kinds which a later age has too scrupulously di. vorced from literature. John Locke, Essay concerning Human Understanding, was a diffuse and cum. brous writer; but there are few finer practitioners in the prose of Dryden and Addison than George Berkeley, Three Dialogues, Alciphron, and David Hume, Essays. Johnson, poet, lexicographer, es. sayist, and eritic, saerificed the lightness of Addisonian style for more force and dignity, not untouched with pomposity, qualities not more evident in his own work than in the record of his conversation preserved in James Boswell's immurtal Life.

English prose acquires grace and charm in the work of Olicer (Yoldsmith, whose Citizen of the World, Vicar of Wakefield, and somedies have an unfading freshness. Edward Gibbon made the same dignified prose the purple vestment of his not more learned than splendidly ordered Decline and Fall of the Roman Empire. Edmund Burke, the most diffuse and gorgeous of English orators, eom. bined with eloquence a unique intellectual and imaginative insight into the principles of politics, the mainsprings of man's social nature.

A didactic purpose, a regard for " correctness" within a narrow but widening pattern of diction and verse, are the accepted principles of English poetry to the time of Blake and Wordsworth, and even later. The beginnings of a change showed themselves first rather in an enlarged choice of subjectsNature, the Middle Ages, Liberty, and the Natural as opposed to Civilized Man, and in some experiments in earlier verse forms, than in any radical change of spirit and style.

\section{Augustan Conventions}

James Thomson's blank-verse Seasons; John Dyer's octosyllabic Granger Hill; the essays in Spenserians, as Thomson's Castle of Indolence ; Thomas Gray's pensive Ode on a Distant Prospeet of Eton College, or Elegy in a Country Churchyard; and the equally pensive, less finished and sustained, but more spontaneous and sensitive odes of William Collins: the minor poetry of the Wartons, Thomas and Joseph, and of Mark Akenside; the poems, more Pope-like in form, of Dr. Johnson, as The Vanity of Human Wishes; Oliver Goldsmith's The Deserted Village, and George Crabbe's The Village, all show in different ways the change that is being effected, but are still quite Augustan in their conventional "poetic diction," their studied "correctness" in spirit and form ; and so, despite their romantie themes, are Gray's more ambitious odes. The Progress of Poesy and The Bard.

But the new spirit was to find its proper style, to substitute for a poetic heightening of eloquence a style whose ideal is the free and natural outpouring of the heart. The frost is loosening in the poetic prose of Maepherson's Ossian, and 
Chatterton's Rowley Poems, in Goldsmith, and in Cowper's The Task. It is broken up in the songs of William Blake, mystical poet and painter, Songs of Innocence, Songs of Experience, and in the Lyrical Ballads of Wordsworth and Coleridge.

The long poetical career of William Wordsw orth was run in the fervour of imaginative and mystical insight into the life of naturc and its significance for the soul of man, to which he had attained through the meditative country life of his youth and the spiritual auitations of the French Revolution. The Prelude, The Excursion, The Recluse, fragments of a nevercompleted autobiography and spiritual creed in blank verse; lyrical and narrative poems inspired by nature, ehildlood, the peasant, the affections, patriotic sonnets, have one common theme, and are composed in a style which Wurdsworth was disposed to make something of a religion too-bald and prosaic and even awkwardly pompous when inspiration fails, at its best unique in passionate, im. aginative simplicity. Coleridge's best poetry shows the influence of Wordsworth in thought and feeling and style, but what is most individual in The Ancient Mariner, Christabel, Kubla Khan, is not these Wordsworthian qualities, but the magic with which the reawakened sense of beauty and mystery is expressed in phrase and in subtle music of vowel and consonant and cadence.

\section{Poetry of Scott and Byron}

The spirit and art of Words. worth's and Coleridge's poetry were too novel and elusive for immediate appreciation. Public taste had to be stimulated and purged by the more crudely romantic poetry of Walter Scott, Byron, and Thomas Moore. Scott's stirring but somewhat rococo lays are of less pure poetic worth than the delightful snatches of song in which he revived the impersonal, chivalrous note of medieval lyric. The fiery, brilliant, crude improvisations of Byron in lyric and lay, and the blend of description and rhapsody in Childe Harold are the unreflective, potent expression of the spirit of pure revolt in romanticism, but Byron's best work was satire in conversational style and ottava rima, Beppo, Don Juan, and The Vision of Judgment.

Scott and Byron enjoyed a European reputation. They are the most human and worldly of the poets of the period; there is more passionate flesh and blood in Byron's technically inferior work than in the work of any of our poets save Shakespearc and Burns. The "desire of the moth for the star" is the burden of the lyrical dramas, Prometheus Unbound and Hellas, rhapsodies as Alastor, and elegiac poems as Adonais, and the songs in winged and ethereal rhythms of Percy Bysshe Shelley. Beautv, the beauties of nature, of Spenser's poems, of medieval chivalry, of Greek mytholngy and art, of Miltonic cadences and Shakespearean phrases, are the theme and inspira. tion of the Endymion and later poems and odes of John Keats. The curiously carved Gebir, Hellenics and Lyrics of Walter Savage Iandor are inspired by a like sense of the statussque beauties of Greek poems and epiurams and by a finer scholarship. if a less spontaneous creative genius.

\section{The Revolutionary Novel}

The last great novelist in the 18th century school of manners and character was Jane Austen, whose Northanger Abbey was an early skit on the new romantic novel. Her exquisite pictures of genteel English life in the country and at Bath include Pride and Prejudice, Emma, and Persuasion. But the novel, too, came under the influence of the taste for romantic scenery, a medieval atmosphere, the marvellous and mysterious, dreams of the perfectibility of human nature and political regeneration. The result is seen in revolutionary novels as William Godwin's Caleb Williams ; didactic stories like Thomas Day's Sandford and Merton and Miss Edgeworth's tales; Mrs. Radcliffe's tales of mysterious adventures, The Mysteries of Udolpho; crude experiments in historical fiction as Longsword, Earl of Salisbury, Clare Reeve's The Old English Baron, Jane Porter's The Scottish Chiefs. Maria Edgeworth's Castle Rackrent and other tales extended the study of manners to the Irish gentry and peasants.

These and the historical stories are interesting now only or mainly as marshalling the way to the great achievement in the Waverlcy Novels, from Waverley to Count Robert of Paris, of Sir Walter Scott, who combined and harmonised the interest in character and manners of the great 18th century novelists, the romantic passion for other times and other manners and for a picturesque setting in scenery rich in historical associations, and that respect and affection for the peasantry which had grown steadily throughout the 18 th century from Thomson and Gray to Rousseau and Burns and Wordsworth.

The influence of the romantic movement on prose work other than the novel can be studied in the picturesque, archaically coloured prose essays and Elizabethan critical studies of Charles Lamb, Essays of Elia, Specimens from the Dramatic Poets; in the vivid, passionate, impressionistic essays and criticism of William Hazlitt, Lectures on the English Poets, Lectures on the English Comic Writers; in the cadenced prose, musical and fanciful, of Thomas De Quincey, The Confessions of an Opium Eater : and in the pleasant chat about letters and art and scenery of Leigh Hunt, The Examiner, etc. William Cobbett's racy, idiomatic prose, Rural Rides, continues the tradition of South and Swift.

The poetry of the reign of Queen Victoria is a continuation and elaboration of the romantic revival. The chief themes are the same-Nature, the romantic past, medieval and classical, the problems of life and death. There is less of the suggestion of a prophetic burden (that is taken over by prose writers like Carlyle and Ruskin) than in Wordsworth and Shelley, more of consciously artistic handling, of antiquarian accuracy of reproduction, of analysis and inquiry, of dramatic interest which, except in Scott, had been somewhat overshadowed by the large topics-Nature and Liberty and Romance. The purification of style, the rejection of a stereotyped convention in poetic diction, had led to an enrichment of phraseology, a more imaginative style that owes much to older poets, and in the elaboration of which Keats is a principal agent, and Keats's influence is obvious in all the Victorians.

\section{Tennyson and Browning}

The most representative poet is Alfred Tennyson, whose careful experiments in the artistic expression of moods culminated in the two volumes of 1842 , lyrics and idylls of nature and English rural life, of character, Simon Stylites and Ulysses, of medieval and classical legend, and of the problems of sin and death and immortality, The Vision of Sin. In the years which followed the style thus studied and mastered became the medium of longer, more ambitious, not always entirely successful poems, The Princess, In Memoriam, Idylls of the King, jewelled settings of tales from Malory and the Mabinogion, touched with modern feeling. Tennyson's later ballads and idylls reflect with great but unequal power his passionate patriotism and the trouble of soul with which he contemplated the changing spirit of his age. 
A wider dramatic range, a more curiously analytic mind, a more colloquial style, and a less melodious but more varied verse distinguish the not essentially different dramatic monologues and lyries of Robert Browning. The long and somewhat chaotic and obscure poems, of which the happiest is Paracelsus, were followed by experiments in dramas intended to be acted (as some were), and then Browning found himself in a series of shorter dramatic lyrics and monologues, beginning with Pippa Passes and closing with Dramatis Personae. The longest of his dramatic, analytic studies of the human soul, The Ring and the Book, was followed by many similar stud. ies, subtly intellectual but more fitfully inspired.

As a revival of the life and art and spirit of past times the movement which began in the 18th century culminated in the exotic, cultured poetry of the middle of the 19 th century. But this poetry also reflects that change of spiritual temper which troubled Tennyson and Browning, on the one hand the revival, actual or artistic, of medieval Catholicism, on the other the Lucretian philosophy of life to which modern science tended.

\section{Learning and Lyrical Inspiration}

In this philosophy, in the poctry of Greece, in Goethe and Wordsworth, Matthew Arnold found the inspiration of poems, lyrical, narrative, and in Greek dramatic form, with a piercing elegiac note of their own. Medieval art, early Italian poetry, Keats and Browning were the influences which shaped and coloured the ballads, monologues, sonnets, and lyrics, sensuous, mystical, and elaborate, of Dante Gabriel Rossetti. Early French poetry, Froissart and Chaucer, Rossetti and Browning, the architecture and decorative arts of the 12th and 13th centuries, the passionate, stoical heroism of lcelandic myth and saga, a socialism which is in part an artist's hatred of modern machinery and commerce, are the blended strains in the lyrical and narrative poetry and prose of Willian Morris, reteller of stories classical and northern after the manner of Chaucer, but without his humour.

A deeper sympathetic conıprehension of the spirit, but even more of the form, the metrical complexities and beauties, of Greek poetry, superior to that of Gray, perhaps even of Milton, for Milton was limited by the scholarship, more Latin than Greek, of his day; an equally intimate know- ledge and understanding of French psetry from Villon to Victor Hugo; a love amounting to idolatry for Shakespeare and the Elizabethan dramatists-are the sources of the poetry, decorative and intoxicatingly harmonious, of Algernon Charles Swinburne. Never have learning and lyrical inspiration been more strangely blended; never has poetry so spontaneously lyrical been so purely literary in its sources and motives.

\section{Old Forms and Modern Feeling}

To this school belongs the intimate, ascetic, religious poetry of Christina Rossetti; and one of the most remarkable products of the tendency to find inspiration in the past and adapt old forms to modern fceling is Fdward Fitzgerald's Rubaiyat of Omar Khay. yam. There is no room here to speak of lesser work, as Keble's The Christian Year, the Lays of Lord Macaulay, the Festus of Bailey, the poetry of Taylor, Alexander Smith, Sidney Dobell, and Arthur O'Shaughnessy, or the lighter verse of William Edmonstoune Aytoun, C. S. Calverley, and Lewis Carroll.

Among the many prose writers other than novelists of the early and middle century, historians like George Grote, History of Greece; Lord Macaulay, Essays, History of England; James Anthony Froude, History of England; philosophers as John Stuart Mill, Logic, On Liberty, Utilitarianism; and Herbert Spencer, Principles of Psychology, First Principles theologians and religious writers as John Henry Newman, A pologia pro Vita Sua, Grammar of Assent critics of literature and art as Matthew Arnold, Essays on Criticism; and Walter Pater, Studies in the History of the Renaissance, Marius the Epicurean, Appreciations, two stand out most vividly. The first is Thomas Carlyle, the tormented, passionate, eloquent prophet of duty and work, whose Sartor Resartus is at once a spiritual autobiography and a philosophy, following Swift and Purke, of the clothes, political and religious, in which the liuman spirit is ever concealing its "shivering nakedness," only to find them grow old and drop away, if not burnt up in Protestant Reformations and French Revolutions, and to begin again to weare them in time's tireless loom.

In the French Revolution Car. lyle portrayed, with an amazing vividness of dramatic and cinematographic presentation, an era of dissolution and rebirth, the flaming apparition of modern democracy.
In Heroes and Hero-worship, Cromwell's Letters and Speeches, and History of Frederick II, he dilated upon and dramatically reconstructed some of those great spirits who, penetrating to the reality which underlies the illusions of life, are the true leaders of men.

The reference to current events which runs through all his work found clearest expression in Chartism Past and Present, and Latter Day Pamphlets. The other Victorian prophet is John Ruskin, the more musically eloquent expounder of art, painting and architecture, in its relation to the moral na. ture of man and the ordering of society. Modern Painters, Seven Lamps of Architecture, Stones of Venice, Unto this Last, Sesame and Lilies, Fors Clavigera, Preterita are among the principal works which brought art into a closer relation with literature than had ever been done before in England, and trace the troubled progress of a great and sensitive soul. A less prophetic but equally prejudiced and individual writer of the period was George Borrow, the first interpreter of the Gipsy character, and a writer of natural, racy prose, Lavengro, and The Romany Rye.

\section{Dickens and Thackeray}

The Victorian novel resumed with certain definite limitations imposed upon it by the moral taste of the time, the work of the great I8th century novel, the serious and humorous portrayal and the active criticism of contemporary life and manners, with occasional digressions into the historical. Charles Dickens, humorist, sentimentalist, pictorial describer and dramatic, not to say melodramatic, narrator, social critic and reformer, began with The Pickwick Papers a series of novels and tales that enthralled the readers of the world. The greatest are probably Pickwick, Nicholas Nickleby, Martin Chuzzlewit, David Copperfield, and Great Expectations. Barnaby Rudge and A Tale of Two Cities are historical novels, the latter coloured by the reading of Carlyle's French Revolution. Dickens's favourite subject was the character and manners of the lower middle classes.

But the most penetrating critic of the devastating snobbishness of English upper class society, never worse than at this time, when wealthy merchants were pressing for aristocratic recognition, was William Makepeace Thackeray, the most unerring portrayer since Fielding of human nature as it is, 
the novelist who gives us no heroes. Vanity Fair, Pendennis, and The Newcomes are, with his shorter sketches, the greatest of his novels of contemporary life. In Esmond, and in a lesser degree in its sequel The Virginians, the same delicacy of satirical and svmpathetic portraiture is given an historical setting of wonderful com prohensiveness and atmosphere. The early sketches of provincial life by George Eliot(Marian Evans), Scenes from Clerical Life, Adam Bede, The Mill on the Floss, Silas Marner, and Felix Holt, have a freshness and power that somewhat failed her in the later more learned and philosophical works, Romola, Daniel Deronda.

The tendency to make of the novel a political, social or ethical and religious pamphlet, which is obvious in Dickens's works, though eonstantly transcended by his buoyant humour and creative power, is dominant in the brilliant political novels of Benjamin Disraeli, Coningsby, Sybil, Tancred, Lothair, and Endymion; in the ardent and vivid pictures of contemporary and past problems and agitations of Charles Kingsley, Alton Lncke, Hypatia, Westward Ho, and Hereward; and in the stories of Mrs. Gaskell. The Brontë sisters, Charlotte and Emily, poured into the sume form, Jane Eyre, Villette, Wuthering Heights, the lyrical record of their own lives and passionate thoughts. Anthony Trollope, with his delightful sketches of clerical society, Barchester Towers, Framley Parsonage; Charles Reade, ardent social reformer, It Is Never Too Late to Mend, The Cloister and the Hearth; and Lord Lytton, cxperimenter in all kinds of novels, The Caxtons, My Novel, The Last Days of Pompeii, A Strange Story, are typical Victorian novelists.

\section{George Meredith and Thomas Hards}

Of the later Victorian writers and their followers four have been most influential ; of the older men George Meredith and Thomas Hardy, novelists and poets, whose influence to-day is greater than in the heyday of their productivity; Robert Louis Sterenson, essayist, novelist, and poet; Iudyard Kipling, story-teller and poet-younger men, whose influence was more immediate, and probably more ephemeral; for the older men were more prophetic of the main movement of thought and literature. They turned their back on the romantic reconstruction of earlier ages, the self-conscious revival of artistic fashions and forms.

Their primary concern is with nature and life seen through eyes that are cleared of the beliefs and prejudices, religious and ethical, which formed the background of English literature from Chaucer to Tennyson and Browning, but in the course of the 19 th century had been in process of disintegration or reconstruction. They re-interpret life for themselves in the light of Darwinian science. Meredith's poems, Modern Love, A Reading of Earth, and novels, The Egoist, Richard Feverel, etc., preach a stern, high lesson-of nature's harsh, inevitable discipline, whose finest flower is the intelligence of man. In his style subtle analysis, grotesque wit, and poetical metaphor combine and obscure by their brilliance; his verse is a blend of wonderful felicities of phrase and rhythm with painful obscurities, incongruities, and harshness.

Great Analysts of the Human Soul

Thomas Hardy depicts in langu. age of quiet clarity and beauty the rural and urban life of "Wessex," Dorsetshire and surrounding country, which had already found an interpreter in the dialect poems of William Barnes. His theme is, like Meredith's, man and nature, their mutual interaction, their significance as factors of one problem, but Hardy dwells on failure rather than on conflict, on the strange, ironic, tragic circumstances of which men and women are the helpless victims, the sport of the Immortals with Tess and Jude; and the chorus to his tragedy is the homely, resigned, quaintly humorous peasan. try of his chosen district.

Hardy's poems, and the Dynasts, are instinct with the same spirit, the same sensitive appreciation of the tears in human things, be it an individual life or the destinies of nations. Far from the Madding Crowd, The Woodlanders, The Return of the Native, Tess of the D'Urbervilles, and Jude the Obscure, are representative of his spirit and style as a novelist.

The influence of one or other of these great analysts of man's soul is traceable in all that is most " modern" in recent literature, ali that has endeavoured strenuously to fulfil the high task of literature and reveal man to himself, A. E. Housman's Shropshire Lad, the more realistic and dramatic part of H. G. Wells's work, the novels of Arnold Bennett, Joseph Conrad, the poetry of Masefield, Gibson, Lascelles, Abercrom bie, and others.

But a more widely diffused influence was that of Stevenson and Kipling. Robert Louis Stevenson poured the keen, hectic joy of a short, consumptive life, full of travel, adventure, experiment, and achievement, into essays, Virginibus Puerisque. poems, English and
Scottish short stories, New Arabian Nights, Dr. Jekyll and Mr. Hyde, and novels, Treasure Island, Kidnapped, The Master of Ballantrae, Weir of Hermiston, all with a buoyant, courageous philosophy of their own and a studiously elabor. ated beauty of style.

His essays continued the tradition of Montaigne,Cowley, Addison, Lamb, and Hazlitt; to Hazlitt and to Sir Thomas Browne his style owes a debt of influence. His novels blend the historic, adventurous romance of Seott with a dramatic euriosity as to psychological and moral subtleties which is partly French in origin, and with a strain of the fantastic humour of Poe and De Quincey. He taught the English novelists a regard for form; and even the popular novel of later 19 th century writers, the work of writers like Anthony Hope, Stanley Weyman, and others, is superior to its diffuse Victorian predecessor, not in character and humour, but in technique, style, and the $w^{\cdot}$ rking out of the story.

In Rudyard Kipling's work the spirit of modern journalism passed into fiction and poetry. Descriptive journalism-as distinct from the periodical essay-had attained to the rank of literature in the reports of the Crimean War written for the press by William Russell, and of the Franco-Prussian War by Russell and Archibald Forbes. Trained to journalism in India, at the same time a lover of the rich colours and varied rhythms of tho school of Rossetti and Swinburne, Rudyard Kipling, after some experiments in verse and story concerned with Anglo-Indian life, came to his own in short tales of Indian life proper, of the soldier of the old regular army serving in India, and in verses, Barrack Room Ballads, on the latter theme.

Rudyard Kipling's Popularity

Clever journalism and imaginative interpretation are inextricably interwoven in his work, which touches its highest level in stories of Indian life like Kim and The Conversion of Purun Dass, animal stories as The Jungle Book, sketches of Sussex life and character, poems as Recessional, Kabul Town, A Ballad of East and West. For good and for ill no writer has enjoyed so wide a popularity since Dickens. The twang of his banjo is audible in much English and Colonial verse; his peculiar blend of realism and romance has been reproduced in the work of almost every writer who has touched on the life of Englishmen and others on the outskirts of civilization.

In the 'nineties of the 19 th century the influence of contemporary 
French literature was felt in the spirit and the form alike of English novel and poetry and critical prose. The doctrine of " art for art's sake" found ardent disciples in Oscar Wilde, whose early imitative poems were followed by prose essays of original and subtle beauty, Intentions, comedies in which something of the art of Congreve was revived, and one or two poems, The Ballad of Reading Gaol, which owed their tragic beauty to the bitter experience of which they were born; Arthur Svmions; Ernest Dowson, author of at least one immortal lyric; Lionel Johnson, the rare quality of whose scholarly and thoughtful verse time will make more manifest; Rachel Annand Taylor, whose lyrics have the jewelled richness and hardness of the Italian art of the Renaissance. The older tradition of the Humanities in English poetry, classical in spirit and form, was preserved in the verse of William Watson, and of Robert Bridges, the poet laureate.

\section{The "Art for Art" Movement}

But poetry has never been for Englishmen so purely an art, a ques. tion of exquisite form cultivated for its own sake, as for the French. For the English inspiration has ever been its source and raison d'être, and inspiration is born of a quick. ening theme, of life realized with a heightened intensity on this side or that-religion, country, nature, the vicissitudes of human experience. The "art for art" movement yielded place rapidly to poetry of two kinds - that whose inspiration comes from within, spiritual, symbolistic, religious, and that which seeks its subjects in the changing face of nature and men's lives, realistic, prophetic, combative. William Butler Yeats learned from Blake the significance of the imagination as the revealer of transcen. dental truths, and found in Irish mythology the symbols in which these truths may be shadowed forth. His lyrics hold a place of their own among the finest in the language.

Francis Thompson, morbid and devout, sensuous and metaphysical, found in all his themes, nature, child and woman, symbols of Catholic truth and Divine mys. teries, the ultimate object of his ecstatic ardours expressed in a style full of rich tangled imagery reminiscent of Crashaw and Keats and Shelley, and in luxuriant, trailing rhythms. In The Hound of Heaven he has made one certain contribution to all future anthologies of English verse, a poem abounding in "images which find a mirror in every mind, and with sentiments to which every bosom returns an echo."

But if Yeats and Thompson represent one direction in which poetry moved away from the eult of imagery and rhythm for their own sake, the stronger current was that which flowed towards actuality, the absorption into poetry of all the stuff of everyday experience, the employment, in preference to the jewelled, precious diction of romantic poetry from Keats to Thompson, of " language really used by men," including the slang and oaths of the low street. William E. Henley, as well as Kipling, led the way in Hospital Verses and London Voluntaries; he was followed by John Davidson, and the bulk of Georgian poets, John Masefield, William H. Davies, Wilfred Wilson Gibson, Ralph Hodgson, Rupert Brooke, Lascelles Abercrombie, though there are individual divergents, as Walter de la Mare, Sturge Moore, and the Irish poets A. E. (George Russell) and James Stephens.

This movement, too, has its metaphysical aspect, and it is here that one feels the influence of Meredith and Hardy. For these poets, also, have endeavoured to see the world round them through unprejudiced eyes, have broken with the tradition, religious, ethical, and artistic, of English poetry from Cliaucer to Tennyson, have put forth on a North-West Passage of their own, with what result time only can tell. The effect of the Great War was, if anything, to intensify the movement, the desire for actuality, the groping after a metaphysic that corresponds to that actuality. Of all the abundant poetry which flowed home from the trenches but little dealt with the traditional topics of war, glory, and conquest.

\section{The Great Sacrifice}

It was charged with memories of England, of the beauty and sweetness of the homeland for which the writers were making the great sacrifice; a strenuous endeavour to see the terrible things around them as they really were, a seeking after some view of life that wuuld with. out illusion reconcile these things in an harmonious whole. The haunting verses of Charles Sorley are typical poems of this generation, strangely unconcerned with the topics of young men's songs, wine and women and the luxury of passing sorrow, piereingly natural and direct in style, thoughtful and original, full of a high spirit of effort and resolve :

If I have suffered pain,

the poetry of one who has awak- ened to a sense of the inner meaning and mystery of things before he has realized all their appeal to the senses and the imagination and the heart.

The English drama, which since Congreve has only at rare intervals, in the comedy of Goldsmith and Sheridan, been a channel of any importance to the stream of English literature, was given a fresh interest and significance by the witty social comedy of Oscar Wilde; and by the clever, vivid, paradoxical comedies of Bernard Shaw, who adapted Ibsen to the British taste for practical teaching and hearty humour; by Galsworthy's sensitive and sombre pictures of social injustice and cruelty; by others like Granville Barl:er, and by the very different Irish plays, poetic and symbolic, or, in the work of J. M. Synge, ironical and reflective, and the light and fanciful plays of J. M. Barrie.

Aspects of the Later Fiction

But no form of literature has diminished the popularity of the novel. The English writers who bulked most largely in the first two decades of the 20th century were the novelists : H. G. Wells, author of scientific romances and satirical social studies, reflecting as in a clear, many-sided crystal the tastes and tendencies of various strata of English society ; Arnold Bennett, fantastic humorist and realistic portrayer of life in the "five towns" ; John Galsworthy, whose novels are the counterpart of his plays ; Joseph Conrad and Compton Mackenzie, realists with a fine sense for the beauty of setting and style. Gilbert Chesterton and Hilaire Belloc, poets, humorists, and essayists, are also authors of novels fantastic and satirical.

H. J. C. Grierson

Bibliography. A Literary History of the English People from the Origins to the Renaissance, J. A. A. J. Jusserand, Eng. ed. 1895, etc. ; Chambers's Cyclopxedia of English Literature, ed. D. Patrick, 190i-3; A Short History of English Literature, G. E. B. Saintsbury, 3rd ed. 1903 ; English Literature, R. Garnett and Edmund Gosse, 1903-4 The Cambridge Hist. of English Literature, ed. A. W. Ward and A. R. Waller, 14 vols., 1907-16 ; English Literature : Medieval, W. P. Ker, 1912 ; Modern English Litera. ture from Chaucer to the Present Day, G. H. Mair, 1914.

Englishman, 'Тн. Leading daily newspaper in Caleutta. First appearing July 2, 1821, as John Bull in the East, in 1833 it was bought by $H$. Stocqueler, who changed its name to John Bull. A year later it became known as The Englishman. Under Major Fenwick's editorship it became a 
recognized authority on military affairs. Macaulay is said to have written for it, and some of his Essays were printed and corrected in its office before being sent to The Edinburgh Review.

English Review, The. English literary monthly, started in 1908 . Austin Harrison was editor in 1910-23 The review has made a feature of poetry by Thomas Hardy, John Masefield, and others. In its pages in 1913 Frederic Harrison and Lord Roberts uttered striking warnings of the coming national peril. Other contributors have included Arnold Bennett, Joseph Conrad, John Galsworthy, R. B. Cunninghame Graham, Maurice Hewlett, Ford Madox Hueffer, Eden Phillpotts, G. Bernard Shaw. and Sidney Webb.

English River. Estuary on the W. side of Delagoa Bay, in Portuguese E. Africa. It is formed by the union of the rivers Umbelosi and 'Tembi.

Englishry. Term used in early English law. Presentment of Englishry was the offering of proof, in cases of violent death, that the person killed was an Englishman, not a Norman, as, if a Norman was killed, the community had to pay a fine. This collective punish. ment was abolished in the time of Edward III. The term was also used by Macaulay and others for the English settlers in Ireland.

Engrailed. In heraldry, a line of division, or an outline of a charge, of irregular form, showing

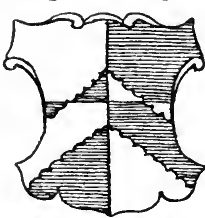

Engrailed in herald a series of semicircles, with points outwards. The word. from $\mathrm{Fr}$. grêle, hail. literally means cut into points like hailstones. tidae). Genus of small cylindrical beetles, of which there are numerous species. Most of them burrow under the bark of trees, where the fenale lays her eggs in a straight

t tunnel, from which the grubs I burrow out at right angles. Most of the species are extremely destructive, causing much damage ton the forests of the U.S.A. and Europe. See Beetle.

Lny raving. (1) Art of drawing on metal or wood by means of an incised line; and (2) impression in ink obtained from such drawing on paper or similar substance. In wood engraving the lines to be printed appear in relief, the wood between them being cut away. In the metal process, known as in. taglio, the lines are sunk or incised
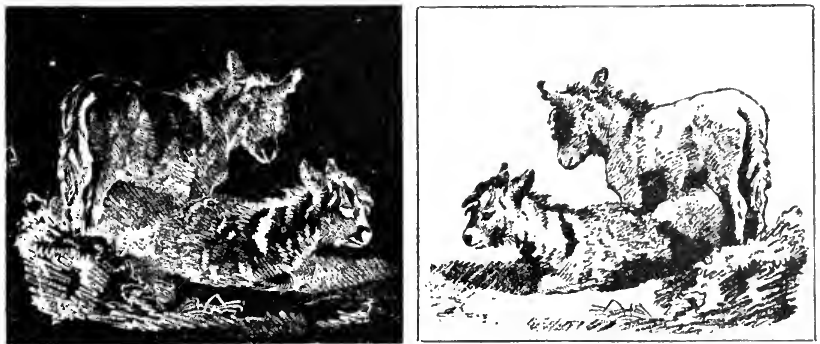

Engraving. Example ot stippled engraving on copper of a sketch by $\mathrm{G}$. Morland. Leit, the copper piate on which the design was engraved. Right, the impression

by means of a graver or burin. The latter implement is a steel rod, four or five inches long, of square or lozenge section, with a cutting point and edges obtained by sharpening the head in an oblique section. There are various forms of wooden handle, the commonest one resembling an elongated half pear.

Plates of several different metals have been used for intaglio engraving: copper, steel, zinc, iron, silver, and even brass and pewter. Copper and steel, however, and especially copper coated with a thin layer of galvanised steel, are by far the most common. Pure copper is softer and easier to work than pure steel, but for the same reason does not wear so well under the press as the harder metal, and so does not throw off as many good impressions. The use of stcel plates, though less ductile, was developed during the 19 th century on account of their greater powers of resistance, until the copper plate covered with galvanised steel was substituted for them.

Wood engraving is real'y wood cutting, and so cioes not come with. in the scope of engraving proper. Lithography. which is a form of engraving on stone. is dealt with
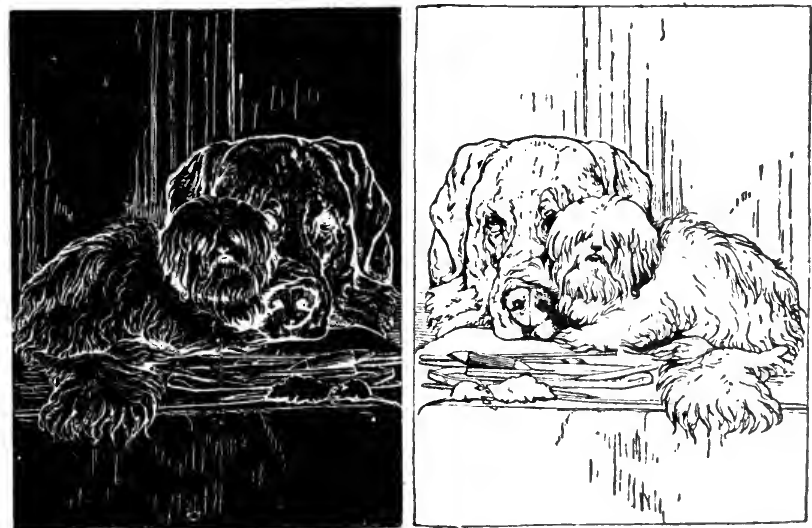

Fngraving Wood block of a drawing by Harrison Weir, after Sir E Landseer. Lett the wood block on which the outlines showing white are raised to catch the ink and make the black lines in the finished resulc shown at the right 
first the taking of impressions from the gold and silver plates engraved according to the niello method by the goldsmith or silversmith was, doubtless, for the sake merely of checking his work; later, as the artistic value of the impression itself beeame evident, the scope of engraving was extended.

Among famous Italian painters of the 15th eentury who practised engraving were Antonio Pollaiuolo and Andrea Mantegna (q.v.); while Marco Antonio Raimondi, the engraver of Raphael's pietures, may be claimed as the first of the "reproductive" engravers. In Germany an illustrious school of engravers flourished in the late 15th century, including in its ranks Martin Schongauer, Albrecht Dürer, Albrecht Altdorfer, the Behams, and Heinrich Aldegrever. Line engraving was somewhat later in beginning in France, but Jean Duvet (1485-1561) and Jean Cousin (1501-89) were famous 16 th century engravers, and the lirench portrait engravers of the 17 th century touched heights that have hardly been equalled since. In Great Britain the great artists of the 18th and early 19th centuries owe mueh to British "reproductive" engravers, and William Blake's original work in this medium was unique.

Engrossing (1 r. en gros, in large). Term used by English lawyers for the copying out, in a "fair hand," of any legal document. A lawyer always makes out a dratt of any important document, and has it engrossed, and the engrossment is executed by the parties concerned.

Engrossing. Word used in former days in England for what amounts to buying and selling wholesale. In other words the engrosser was a middleman. This was early regarded as an offence against law and custom, for it tended to put up the price, and various statutes declared it illegal, the chief bcing one of 1552 . These were directed mainly against the buying and selling of corn and other foodstuffs wholesale, and the operation of the laws tended to keep these in and around the places where they were grown. As society became more specialised this was very irksome, and even when the laws were in full force licences were issued allowing certain persons to buy and sell wholesale. In 1663 an Act permitted engrossing as long as the price of corn did not exceed 48s. a quarter; and in 1773 the earlier statutes against it were repealed, but as an offence against the common law engrossing disappeared finally with further Acts in 1844.
Enham or KNIGHTS ENhaM. Parish of Hampshire, $2 \mathrm{~m}$. N. of Andover. In 1919 a scheme was started for taking over the Enham estate of 1,027 aeres to erect buildings for the treatment and training of disabled soldiers. The treatment covers electric, whirlpool, and paraffin baths for men with stiff limbs, and psychotherapeutic methods for neur asthenic and shell-shock cases. The training embraces agriculture, horticulture, the care of stock, poultry farming, carpentry, furniture and boot-making, tailoring, building, and painting. The British Red Cross Society made a grant of $£ 10,000$ for the purpose of building and equipping a medical block, the first of its kind to be established in England. Pop. 169.

\section{Enhanced}

(A n glo-Fr. enhauncer, to raise). In heraidry, any ordinary borne higher up than its usual position is said to be enhanced. Enhanced in heraldry See Ordinary.

Enharmonic (Gr. enarmonikos, fitting in). In nusie, the interval between, for example, $E$ natura and $F$ flat, or C sharp and D flat. Through the influence of the keyboard instruments, with their fixed twelve notes to the octave the term often loses this meaning and is delined as " a change of name without a change of pitch." Key $\mathrm{F} b \quad$ Key E $\begin{gathered}\text { Schubert, } \\ \text { Op.94, No. } 1\end{gathered}$

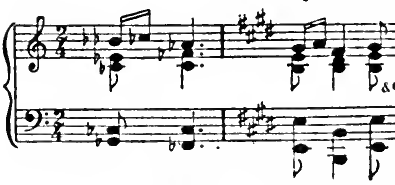

Enharmonic. Example of enharmonic change in music

Enid. Feminine Christian name. Of Celtic origin, it means spotless purity. Enid is a character in the Arthurian legend, being the pure and faithful wife of Geraint.

Enid. City of Oklahoma, U.S.A., the co. seat of Garfield co. It is 54 in. N.W. of Guthrie, and is served by the Atchison, Topeka, and Santa Fé and other rlys. The seat of Phillips University, it contains a colleg 2 of fine arte and a free public library. It has foundries, machine shops, flour mills, lumber mills, and boiler works, and trades extensively in poultry and the agrieultural produce of the locality. It dates from 1893, when it was granted its city charter. Pop.21,355.

Enlarging. Photographic process of making prints of larger size from negatives. The usual process is to project an image of an illuminated negative by means of a lens upon a sheet of bromide paper $(q . v$.$) . When the negative is illu-$ minated by artificial light it is usually necessary to place a condenser behind the negative to equalise the illumination. The condenser consists of two plano-cenvex lenses of diameter a little greater than the diagonal of the negative. The negative image is thus projected and focussed upon an easel as in the use of an optical lantern. The operation with such apparatıs is carried out in a dark rooin, but enlarging boxes and eameras are made for use in full daylight, the bromide paper being then carried in n loose dark slide. See Camera; Photography.

Enlistment. Act of the individual in voluntarily contracting to render military service as a private soldier to the state. The form of contract is the attestation paper, which the recruit, after being accepted and passed medically fit, is required to sign when taking the oath of allegiance, in the presence of an offieer, magistrate, or other public dignitary, who witnesses or attests the signature. The period of serviee in the British army is laid down in the Army Act and recruiting regulations, and is normallv 12 years, of which from three to eight is spent with the colours and the remainder in the reserve. Recruits may choose the branch of the service they prefer, and skilled men usually select one of the specialist corps which offer better pay. In the line the recruit may choose any regiment for which he has a preference and which is open to recruiting. He cannot then be transferred to another regiment without his consent. A special branch of the army is detailed for recruiting duties, with an officer in charge of each district. Enlisiment is only applicable to voluntary recruiting. It enables a professional army of high qualifications to be obtained even in competition with other employers of labour.

The disadvantage is obvious when, as in the case of the Great War, a greatly increased army is essential, and it is necessary, even after the introluction of compulsory service, to pay the soldiers at the normal high rate as compared with other countries, who, by a normal system of conscription, obtain practically gratuitous military service from the male popu. lation. Aliens and negroes may be enlisted in the British army, but cannot be promoted beyond the rank of warrant officer. See Army, British ; Compulsory service. 
Ennel. Lough or lake in the S. of co. Westmeath, Ireland. It is about $5 \mathrm{~m}$. long and $2 \mathrm{~m}$. hroad, is drained by the Brosna river, and has several wooded islets.

Ennerdale. Lake in the W. of Cumberland, England. From it Whitehaven draws its water supply; it is $3 \mathrm{~m}$. long and $\frac{1}{2} \mathrm{~m}$. broad.

Ennis. Urban dist. and county town of co. Clare, Ireland. It stands on the Fergus river, $25 \mathrm{~m}$. N.W. of Limerick, on the G.S. \& W. and West Clare Rlys. Here are the Roman Catholic pro-cathedral and college of the diocese of Killaloe, and the ruins of a Franciscan abbey. It has a statute of O'Connell and in the neighbourhood are the ruins of Clare Abbey. There are large flour mills and breweries, and timber and grain are exported through Clare Castle, its port. Market day, Sat. Pop. 5,472.

Enniscorthy. Market town and urb. dist. of Wexford, Ireland. It stands on the Slaney, $77 \mathrm{~m}$. S. of Dutase by the Dublin and S.E. Rly. The chief building is the castle, built by the Norman conquesors in the 12th century. The town is an important agricultural centre, hav. ing fairs and markets, while there is some shipping on the river. There are other industries, including brewing, distilling, and tanning. Near by is Vinegar Hill (q.v.). Made a municipality about 1610 , Ennis corthy was represented in the Irish Parliament until 1800. Market days, Sat. and Thurs. Pop. 5,500.

Enniskillen or INNISKILLING. Market town and co. town of

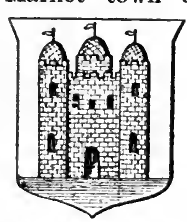
Fermanagh, Ireland. It stands on an island in the river between the upper and lower lough s Erne, and has suburbs on either side, with which Enniskillen arms $t$ is connected G.N. of Ireland Rly., 116 m. N.W. of Dublin. There are some small manufactures and a fair trade in agricultural produce, while steamers go along the river. Enniskillen became a municipality about 1600 . and was represented in the Irish Parliament. From 1800 to 1885 it sent a member to the parliament of the United Kingdom. It is chiefly famous, however, as a Prote tant stronghold in the time of William III, and as giving its name to two regiments of the British army, fusiliers and dragoons. Market days, Tues. and Thurs. Pop. 4,850.

Enniskillen, EarL of. Irish title borne since 1789 by the family of Cole. In 1760 John Cole, an Irish M.P., was made a baron, and his son William, the 2nd baron, was made a viscount and an earl, both in the peerage of Ireland. The 2 nd earl was made a British peer as Baron Grinstead in 1815, and from him the present earl is descended. William Willoughby Cole, the 3rd earl (1807-86), made a fine collection of fossil fishes, now in the British Museum. Florence Court, Enniskillen, is the earl's chief seat, and his eldest son is known as Viscount Cole.

Ennius, QUINTUS (239-169 B.C.). Earliest of the great Roman poets. Born at Rudiae, in Calabria, he was not a full Roman citizen, acquiring that privilege at a later date. While serving in the Roman army in Sardinia, he attracted the notice of the elder Cato, who took him to Rome, where his knowledge of Greek and literary acquirements procured him admission to the Seipionic circle. His works embraced a wide variety of subjects, but it was as the author of some twenty tragedies and of the Annales, an epic of Roman historyin which, for the first time, the Latin language was moulded to the Greek hexameter-that he achieved immortality. Only fragments of his works survive, chiefly in the form of quotations in later writers, especially Cicero. His reputation as a poet stood very high, some ancient critics regarding him as the equal even of Virgil. His versification, though possessing a certain rugged dignity, is harsl compared with the finish which Latin poetry attained in the hands of Horace and Virgil.
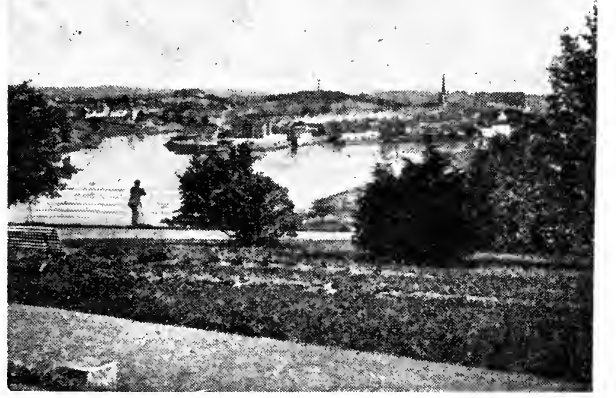

Enniskillen, Fermanagh, Ireland. View of the town and quays on the river connecting the upper and lower loughs Erne
Enns. Town and river of Austria. The town, which is $11 \mathrm{~m}$. from Linz, stands just where the river falls into the Danube. An old place, it grew up around a castle built about 900 . It became a free city, and was at one time a prosperous commercial place. Its chief buildings are the town hall, the castle, built in the 18th century, and a Gothic church. It was at one time fortified, and it is said that the money for the fortifications came from the ransom of Richard I. Near it is the monastery of S. Florian (q.v.). The river rises in the mountains near Radstatt and flows through Styria, passing through lovely mountainous scenery. Its course is east and then north. Its chief tributaries are the Salza and Steyer; its length is about $150 \mathrm{~m}$.

Enoch. Name of four men in the O.T. They are a son of Cain, a grandson of Abraham, a son of Reuben, and a son of Jared. The last, the father of Methusaleh, is recorded to have lived 365 years, and to have been translated without dying. He is described as being the seventh from Adam, and the Epistle of Jude (verse 14) quotes a prophecy ascribed to him. See Enoch, The Book of.

Enoch, The Book of. One of the non-canonical O.T. Apocrypha or Pseudepigrapha (i.e. works written under an assumed name), written originally partly in Aramaic and partly in Hebrew. It incorporates fragments of the Book of Noah. The work is not a unity in any sense, and ranges from about 200 B.C. to A.D. 64. It has therefore been described as a library rather than a single book. In the words of Dr. Charles (Religious Development Between the Old and the New Testaments), "it touches upon every subject that could have arisen in the ancient schools of the prophets." These subjects include the origin of evil, the millennium, the Messiah, the future life, and even the Hebrew calendar. The book seems to have had a consid. erable influence on N.T. theology. See Apocrypha.

Enoch, Book of the SHCrets of. A book belonging to the same category as the Book of Enoch. Dr. Charles describes this book as 2 Enoch and the Book of Enoch as 1 Enoch. The work, preserved only in Slavonic, seems to have been written by a Hellenistic Jew in Egypt at about the beginning of the Christian era. It is related in some way to a Hebrew book referred to in Jewish literature (in the Zoliar) as "the book of Enoch" and the "Book of the Secrets of Enoch." The author is orthodox, but at the same time so broad- 
minded as to adopt into his philo. sophical system Platonic, Egyp. tian, and Zend elcments. The book describes Enoch's ascension and voyage through the seven heavens.

Enos. Town of Thrace, the ancient Aenos. It lies at the mouth of the Maritza, on the Aegean Sea, about $40 \mathrm{~m}$. N.IV. of Gallipoli, and carries on some tradc. In April, 1915, an Allied landing took place in Enos Bay. l'op. 7,000.

Enschede. Town of Hollan', in the prov. of Overyssel. It is $29 \mathrm{~m}$. N.E. of Zutphen, and is a seat of the cotton-spinning and weaving industries. Enschede is a rlv. junction and has communication with the coal rlistricts of Westphalia. It was severely damaged by a conflagration in 1862. Pop. 41,602.

Ensemble (l'r.. together). Concerted vocal or instrumental piece. In opera it is a performance by all the principals who are on the stage.

Ensiform Cartilage (Lat.ensis, sword ; forma, form). Thin process of cartilage forming the lower end of the sternum or breastbone, and projecting downwards between the cartilages of tne seventh ribs. See Cartilage.

Ensign. Flag which a ship carries astern to indicate her nationality Each country has separate

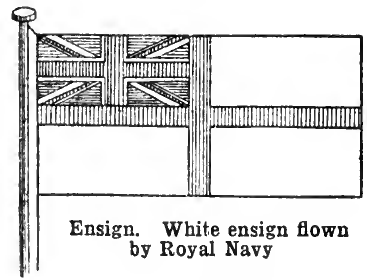

ensigns for its navy and its mercantile marine. Great Britain has three: the white ensign, flown only by slips of the Royal Navy and vessels of the Royal Yacht Squadron; the blue ensign, which is the flag of the Roval Naval Reserve; and the red ensign, the flag of the merchant service. War Department craft fly a blue ensign with crossed swords on it. The earliest date on which the S. Ceorge's Cross was flown by English admirals was in the Cadiz Expedition of 1596. When a ship flies her ensign upsicle down it denotes that she is in distress. See Flag.

Ensign. Rank in the British army, now obsolete. The rank was that given to an officer of the infantry on first being commissioned, and it was his duty to earry and guard the regimental colours, both on parade and in the field. The eorresponding rank in the cavalry was cornet, and both were discarded in 1871 when the purchase of commissions was abolished, the rank of second-lieutenant being substituted.

Ensilage (Span. en, in ; silo, underground granary ; Lat. sirus). Method of kceping grass, clover, maize, and any green fodder crops in a succulent condition throughout the winter. It can be usefully adopted in a year of drought, when root-crops fail, or in a very wet season as an alternative to haymaking. The herbage to be converted into "silage," as the finished product is termed, is placed in a specially constructed receptacle (silo), or simply heaped up in a stack or clamp and covered with earth. When a silo is employed the material is usually chaffed up, to allow of better packing. The resulting silage differs in texture and chemical composition from the raw material, and also from hay, owing to changes brought about by processes of fermentation, due to bacteria, and to ferments (enzymes) in the herbage. It is necessary that air be excluded, and this is effected by the application of pressure and by enclosing the raw material in an airtight space.

A distinction is drawn between sweet and sour silage, that made in a stack being as a rule sweet, and that made in silos and clamps, sour. Sour silacge is made at a tempera. ture bclow $120^{\circ} \mathrm{F}$., and owes its acidity to the action of various acid-forming bacteria. Its unpleasant odour is readily absorbed by milk, and consequently it should not be used for milch cows. To make sweet silage, which is sweetish to the taste and possesses an aromatic sniell, a temperature of $130^{\circ} \mathrm{F}$. to $160^{\circ} \mathrm{F}$. is necessary, as the formation of acid is thereby prevented. The desired temperature cannot be secured if air is at first excluded, and therefore the herbage must be filled slowly into the receptacle and pressure applied by degrees.

Properly made silage is a valuable feeding-stuff in both its forms, but is not of precisely the same nutritive value as the herbage from which it is made. The chief results of the chemical changes that take place during fermentation are loss of sugar, alteration of part of the albuminoids into nitrogenous substances (amides) of less food value, and conversion of part of the fibre (cellulose) into a digestible form.

The system of ensilage was intro. duced into Great Britain from France about 1880-85, but the results were less satisfactory than in France and the U.S.A., and it has not bcen generally adopted. See Agriculture; Crops; Pasture.

Enstatite. Common rock-forming mineral. One of the pyroxene group, it crystallises in the rhombic system, in stout prismatic crystals. Chemically a metasilicate of magnesium, it occurs in serpentines and peridotites, in the Whinsill dolorite, the Cheviot andesite, and generally as a primary constituent of intermediate and basic igneous rocks. The word enstatite, from Gr. enstates, adversary, refers to the re. fractory nature of the mineral. See Crystallography.

Entablature. Term in architecture signifying the combination of architrave, frieze, and cornice at the summit of a building. In early Greek architecture the entablature, like the supporting column, was frequently of wood; and there is evidence to show that it was constructed of this material for some time after wooden columns had been replaced by stone or marble. In the Greek towns of S. Italy wooden entablatures upon stone columns are known to have been in use for several centuries. The entablature is necessarily a prominent feature of the classic or horizontal styles of architecture, rather than of the Gothic or vertical styles; but its principle is universal. The original meaning of the word was a board work or flooring (Lat. tabula, plank). See Architecture; Building; also illus. p. 2275.

Entail. Legally, the settling of an estate on a man and his heirs. In feudal times land was granted to a man and his heirs in tail male or tail general, the idea being that if an heir failed it would revert to the king or lord who granted it. In time, however, the practice grew up of regarding it as a free estate as soon as an heir was born, thus depriving the grantor of his rights. The statute De Donis Conditionalibus of Edward I put an end to this practice, but only for a time, as legal fictions for evading it were invented. The entailed estates of today are simply settled estates, but they can only be settled on living persons and a period of 21 years beyond. The entail can be broken with the consent of the heir and after the performance of certain legal formalities. The word comes from the French tailler, to cut, the idea being that from an entailed estate, something, i.e. freedom of bequest, had been cut. See Land Laws: Real Property; Settlement.

Entebbe. Administrative capital of the Uganda Protectorate, E. Africa. It is situated on a promontory to the W. of Murchison Bay in Lake Victoria, and is connected with Kisumu and other lake harbours by steamer. Mengo, the capital of Buganda, is $25 \mathrm{~m}$. to the N.E. Pop. dist. (European) about 150 . 
Entente Cordiale (Fr., cordial understanding). Phrase that became current early in the 20 th cen. tury to signify the friendly rela. tions then beginning to exist between Britain and France. The entente began soon after the South African War and was greatly helped by the influence of Edward VII and the steady realization of the German menace. It culminated in the alliance of 1914.

Enteric Fever (Gr. enterikos, intestinal). Infective disease caused by the bacillus typhossus. It is most frequently conveyed by drinking water. $\mathrm{Se}$ Typhoid Fever.

Entering Edge. Front edge of an aeroplane wing. It is this which first encounters or enters the mass of air through which the machine is to progress. See Aeroplane.

Enteritis (Gr. enteron, intestine). Intlammation of the mucous membrane of the intestine. The condition may be due to eating un. suitable or unsound food, such as unripe fruit or decomposing meat, or to irritant poisoning by arsenic, mercury, and other substances. Secondary enteritis is a symptom of many diseases, particularly cholera, dysentery, and tvphoid fever.

The prominent symptoms are abdominal pain, severe diarrhoea, and sometimes blood in the evacuations. In severe cases ulceration of the intestine may be followed by perforation and fatal peritonitis. Epidemic enteritis, or "summer diarrhoea," is a very fatal disease among infants under one year of age, in large towns sometimes accounting for one-fifth of the total infant mortality. The causation is not fully known, but the disease is most prevalent in hot, dry weather, the dust blown up from dirty streets and refuse heaps being an important factor.

Enteroptosis (Gr. enteron, in testine; ptōsis, falling). General dropping or downward displacement of the abdominal organs, chiefly the stomach and intestines. It usually develops gradually. The condition is more frequent in women than in men, and is often associated with neurasthenia. Massaso, electricity, and physical exercises may be employed to improve the tone of the abdominal vessels, and the symptoms are often relicved by wearing a belt so as to support the sagging organs.

Enterprise. British steamship, the first to make the passage between Great Britain and India. She left London Aug. 16, and reached Calcutta Dec. 7, 1825. The Enterprise, which displaced 480 tons and had engines of $120 \mathrm{~h} . p$., was also the first steamship to double the Cape. A light cruiser of this name, the first of a new type, was launched in 1919. She had 89,000 engine-power, giving a speed of 33 knots, was $535 \mathrm{ft}$. in length, and carried seven 6 -in. and other guns

Entertainments Duty. Tax levied in the United Kingdom on persons attending theatres, music halls, and other places of amusement; also football and cricket matches, and other open-air sports. Introduced in the Budget of 1916 , it was charged on all tickets of admission as follows :

$$
\begin{aligned}
& \text { Below 22d. … .. 1d. } \\
& \text { Between 22 d. and } 4 \frac{1}{2} \text { ll. . } 1 \frac{1}{2} d \\
& \text { 4. . . } 7 \text { d. .. } 2 \mathrm{~d} \text {. } \\
& \text { i.l. } \quad " \quad 1 /-\ldots 3 i 1 . \\
& \text { " } 1 /-\quad ", 2 /-\ldots 4 d . \\
& \text { " } \quad \frac{2}{3} /-\quad, \quad 3 /-\ldots 64 \text {. }
\end{aligned}
$$

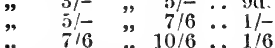

$$
\begin{aligned}
& \text { " } \begin{array}{rllll}
7 / 6 & , 10 / 6 & \cdots & 1 / 6
\end{array}
\end{aligned}
$$

Beyond this it was $2 /-$ on the first $15 /-$ and id. for every $5 /-$ or part of $5 /-$ in excess of that amount. It was paid to the inland revenue authorities by the proprietors, who charged it on the tickets of admission. Entertainments promoted by schools and for charitable purposes were excmpt By thic budget of 1924 , when the payment, excluding the amount of the duty, does not exceed sid no duty is levied. Also other reductions were made.

Enthymeme (Gr. en, in ; thymos, mind). Term in logic. According to Aristotle, it is merely a rhetorical syllogism, founded on probability, and therefore not demonstrative. A later meaning is a syllogism in which one premise has to be "men. tally" supplied: e.g. All men are mortal ; therefore Socrates is mortal; where the minor premise, Socrates is a man, is omitted. See Logic.

untombment. Literally a burial. In a special sense, however, it is applied to the burial of Jesus Christ, and as such is the subject of several notable paint ings. The most famous of these are one by Raphael, in the Borghese Palace at Rome, one by Titian in the Louvre, and one by Caravaggio, in the Vatican.

Entomology (Gr. entomon, insect; logos, science). Branch of zoology which deals with insects. The offices of the Entomological Society of London are at 11, Chandos Street, Cavendish Square, W. See Insects.

Entomostraca (Gr. entomon, insect; ostrakon, shell). One of the great divisions into which crustacea are divided. It includes the lower forms of crustaceans, characterised by a variable number of body segments, the absence of the gastric mill (grinding apparatus), and life usually beginning in the nauplius stage. See Crustacea.
Entophytes (Gr. entos, within ; phyton, a plant). Name given to plants which live on other plants. See Fungus; Parasite.

Entozoa (Gr. entos within; zoon, animal). Name given to parasitical worms which live in the interior of the body of their host, as the tape worm and flukes. They are opposed, therefore, to the ectozoa, which live on the exterior. See Parasite.

Entr'acte (Fr. entre, between ; acte, act). Short piece of music played by the orchestra between the acts or scenes of a play. It is generally of a suave and melodious character. Sometimes, in a musical play, it consists of the development of a melody or leitmotiv embodied in the work; sometimes of an independent piece.

Entrcasteaux, JosepH ANTOINE BRUNI D' (1739-93). French sailor. A native of Provence, he entered the navy. He commanded a ship in the war against Britain, but his great work was as a discoverer. As commander of the French fleet in the E. Indies, he visited China; he was also governor of Mauritius and the Ile de Bourbon. He sailed into the south seas and made several discoveries therein, a strait, a point, and a group of islands commemorating his name. He was in the East when he died, July 20, 1793.

Entrée (Fr.). Term in cookery. It is usually applied to a "made" dish served between courses, e.g. before the roast or principal dish of a dinner. In France, on the other hand, entrées may consist of fish or roast or braised meat, and are not merely fancy dishes.

Entremets (Fr. entre, between ; mets, dish). Term in cookery. It is used for a side dish, such as a sweet or savoury, served after the roast at dinner.

Entre Minho e Douro. Prov. of N.W. Portugal. It lies between the Minho and Douro rivers, facing the Atlantic. Mountainous and well watered, it has a mild climate, and produces maize, wine, oil, fruit, and nuts, while palms and fuchsias thrive. Cattle and pigs are reared, timber is cut on the mts., and fish abound in the rivers. Though implements are primitive, agriculture flourishes. The roads are bad; ox-traction is the chief means of transport. Oporto is the chief port. The prov. is divided into the three districts of Vianna do Castello, Braga, and Porto Area, 2,790 sq. m. Pop. 1,289,859.

Entrenching Tool. Implement carried by each soldier in the firing line and used to excavate temporary cover for protection against the enemy's fire until complete 
trenches can be dug. In open warfare, when the advance is held up by hostile fire, the troops lie down and dig a narrow, shallow pit in which to lie, throwing the earth to the front to form a parapet. If $r$.
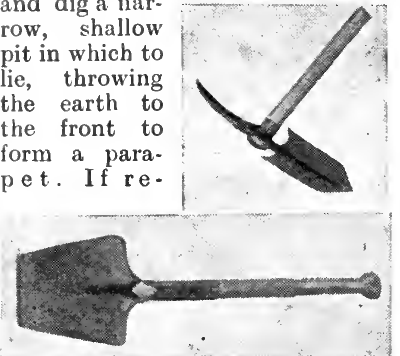

Entrenching tool used in German army. Above, type issued to British troops

quired, the pit may be deepened to provide cover in a kneeling and then standing position, and if it is finally necessary to hold the position the pits may be linked up to form a trench. The British entrenching tool is double-ended, and provides both a pick and small spade. the handle being easily detachable and carried apart from the head The German tool is merely a small spade to which the handle is a fixture.

Entrenchment. Military term meaning the employment of excavated positions for the protection of troops in attack or defence. This method of warfare appears to have been introduced by the Turks. but was not adopted by the soldiers of Christendom until about the 16th century During the Great War most elaborate trench systems were used, including shelters many feet below the surface which were unaffected during bombardments ex cept by a direct hit from large calibre explosive shell. Concealment of trenches from enemy observation is most important, but aerial reconnaissance has rendered this extremely difficult. For a parapet which will resist modern rifle fire at medium range the following depths of various materials are required : shingle, 6 ins. . brickwork, 12 ins. ; sand in bags or boxes, 18 ins. : loose sand, 30 ins. ; earth, 40 ins. See Tactics; Trench Warfare.

Entrepôt (Lat. interpositus, placed between). French word meaning a bonded warehouse, i.e. a place where imported goods are stored pending the payment of duty thereon. In English usage, however, it has come to mean a seaport or an inland town through which much produce merely passes; e.g. Singapore, a great port on a smail island, is one of the most im. portant of the world's entrepóts.

Entrepreneur (Fr. entre, between; prendre, to take). 'Word used for one who brings capital and labour together. Employing them as he thinks best, he pays interest to the one and wages to the other, keeping any balance of profit for himself. The old theory of economics that the partners in industry were the landowner, the capitalist, and the labourer left out of account the fact that in large undertakings the directing brain often belonged to none of these classes. He was simply one who hired the others, and the word entrepreneur was invented to describe him. The term has never taken any deep hold in England, however, although sometimes used by economists for convenience. See Labour : Political Economy : Prices.

Entre Rios (Span., between rivers). Prov. of N.E. Argentina, occupying the angle between the Paraná and Uruguay rivers. The surface is low, alternating between swamps and prairies, while in the N. it is heavily forested and furnishes wood for building and cabinet-making. Cattle, sheep, and horses are raised by the million, and, together with hides, horns, and other animal products, are exported. Cereals, wine, and alfalfa are grown. It has a healthy climate, and, traversed by several rlys. and waterways, it is one of the most prosperous provs. in the republic. The capital is Paraná. Area. 29,241 sq. m. Pop. 425.373.

Entre Rios. Town of Brazil, in the state of Rio de Janeiro. It is about $50 \mathrm{~m}$. by rly $\mathrm{N}$. of Rio de Janeiro, in a coffee-producing district. Pop. 8,000 . There is another Brazilian town of this name in the state of Goyaz, 45 m. N.W. of San José.

Entresol ( $\mathrm{Fr}$ entre, between, sol, ground). Term used in French architecture for an intermediate storey in a building. Its use is generally confined to a low storey placed between the ground floor and the first floor proper. In this sense it is really a sub-division of a lofty ground storey.

Entropy (Gr. entropē, turning 1n). An important concept in the theory of heat engines and the science of therinodynamics. The entropy of a substance is a quantity which increases with any increase in the total heat of the substance and likewise decreases with any decrease in the total heat. The change of entropy is measured by the change in the quantity of heat divided by the absolute temperature at which this change takes place. Thus the entropy of a system under what are known as adiabatic conditions. where heat neither enters nor leaves the system. is constant.

Where heat simply flows from o hot body to a cold one, the loss of entropy by the hot body is more than made up by the gain of entropy by the cold body. so that there is a net gain of entropy on the whole. In a heat engine, heat flows from a hot body to a cold one, but in the process some of the heat disappears, being converted into work. In the case of a theoretical engine of maximum efficiency, there is no change of entropy due to this process, but no actual engine succeeds in converting as much of the heat into work as the theoretically perfect engine, and the effect of an actual heat engine is a net gain of entropy.

As heat is everyw t:ere flowing from hot budies to culd ones, the entropy of the universe as a whole is continually increasing, and is often said to be tending towards a maximum. In such an imaginary condition of maximum entropy, there would be no motion, all the existent energy of the universe would be converted into heat, and the whole would stagnate at a unitorm tem. perature. See Carnot's Cycle ; Energy ; Thermodynamics.

Enurësis (Gr. en, in : ourein, to urinate). Involuntary discharge of the urine. It is most frequently seen in young children who have not acquired normal control over the bladder. It is sometimes due to irritation of the bladder by urine containing uric acid crystals, or may result from irritation set up by a polypus or worms in the rectum. Care should be taken not to frighten a nervous child by threats of punishment.

Envelope. Cover tor a letter. The making of envelopes, one in which female labour is mainlv em. ployed, is connected with the stationery trade. The processes, usually carried out by machinery, are those ot cutting, gummin-, and folding the paper. See Paper, Stationery.

Envelope. In geometry, a curve generated by the successive positions of a line The envelope is a curve to which the line, or family of lines as it is more usually expressed, is always a tangent. A caustic curve (q.v.) in optics is a familiar example of an envelope.

Envelope. Gas bag of an airship, or, in a rigid airship, the whole body of the vessel within which the gas bags are boused. Gas bags are made of skin or fabric. and the outer envelope of the rigid airship is of a stouter tabric, rubberised or otherwise treated so as to resist the absorption of moisture and the effects of weather. See Airship.

Enver Pasha (18S2-1922). Tur. kish soldier and politician. Born at Constantinople of humble parentage, he entered the Turkish army in 1896 . He hirst came into notice 
in connexion with the Young Turk movement in 1905 at Salonica, and three years later joined the revo-

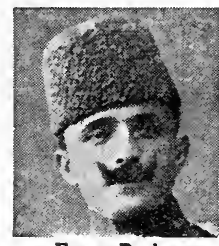

Enver Pasha, Turkish soldier lutionaries, who in July, 1908 , captured Mon a s tir. where a constitution, accepted by the sult a n A b d u l Hamid, wa proclaimed. Enver soon afterwards

was appointed military attaché at Berlin, but on the outbreak of the Turkish counter-revolution in March, 1909, he returned to Salonica, and assisted in the deposition of Abdul Hamid.

Enver then went back to Berlin, and in 1910 paid a visit to London. In 1911 he organized the Arabs of Tripoli against the Italians in the Tripoli War. In the second Balkan War he recaptured Adrianople from the Bulgarians in July, 1913. Shortly before he had become minister of war with the rank of a pasha, and married one of the imperial princesses. One of the leading spirits of the Committee of Union and Progress, the central organization of the Young Turks, he was personally pro-German, his influence being one of the factors that brought Turkey into the Great War against the Entente. After the submission of Turkey in 1918 Enver fled to the Caucasus. He encouraged the Turks in their resistance to the terms of the Peace Treaty in 1920. He was killed in Bokhara, Aug. 4, 1922.

Environment (Fr. environ, around). Biological term for the sum total of all the conditions, agencies, and influences which affect the development, growth, life and death of an organism, species, or race. Various theories of evolution have maintained; on the one hand, that variations in animals and plants arise so that they may be adapted to environment; on the other hand, that environment itself produces modifieation in the living organism. In the absence of adaptation to en. vironment, no organism could live or reproduce itself, and the main object of a living creature must be to become more and more perfectly adapted to its surroundings. The term is usually understood to refer to physieal, chemical, or material agencies. With reference to man it includes, in its widest sense, mental and spiritual agencies, so that it may be said that each individual lives in a physieal, mental, and spiritual environment. See Evolution.
Envoy (Fr. envoyer, to send). Term used for one sent on a dip. lomatic errand. It is more general than ambassador, being used for persons who go on temporary missions to foreign courts as well as for more permanent officials. The former are merely described as envoys ; the latter are envoys extraordinary, and inelude ambassadors. See Diplomacy.

Enzeli. Town of Persia, in the prov. of Gilan. It stands on the $\mathrm{S}$. shore of the Caspian Sea, $16 \mathrm{~m}$. N.W. of Resht. A shipping centre, it came into prominence in Aug., 1918, in connexion with a British move on Baku (q.v.). In May, 1920 , a small British force stationed here was withdrawn on the arrival of a Bolshevist force from Baku.

Enzyme (Gr. en, in; zymēe, leaven). Substance formed by micro-organisms and living animal and vegetable cells, which trans forms organic compounds into simpler bodies. The most familiar example of enzyme action is the fermentation of sugar by means of yeast, a minute unicellular organism. The yeast cells contain an enzyme called zymase, which converts sugar into alcohol and earbonic acid gas. The enzyme itself is unchanged in the process, and a very small quantity is therefore capable of causing a large amount of transformation. The process probably resembles the familiar catalytic action of inorganic chemistry. Enzymes play a large part in the digestion of food. Ptyalin, which is secreted by the salivary cells, converts cooked starch into dextrin and maltose pepsin, secreted by cells in the stomach, changes protein to proteoses and peptones ; and enzymes in the pancreatic juice convert fat into simpler bodies. The souring of milk and the decomposition of meat by bacteria are other in. stances of enzymic changes.

Eoanthropus (Gr. eōs, dawn; anthropos, man). Systematic name of the oldest known European race with distinct head traits. It was given by $\mathrm{A}$. S. Woodward to some fossil bones now in the British Museum, unearthed in 1912 at Piltdown, Sussex. After their discoverer, Charles Dawson, the species is called E. Dawsoni. Other remains were subsequently found. See Man ; Piltdown Skull.

Eocene (Gr. eōs, dawn ; kainos, reeent). Name given to the earliest part of the Tertiary period, when stratified rocks, the eocene system, were being formed. It followed the Cretaceous period, the strata of both ages merging gradually in $S$. Europe,America, and New Zealand. In W. Europe, at the end of the
Cretaceous period, great geographieal changes were in progress ; eonsequently there is a sharp line of demarcation between the two sets of strata. Eocene beds usually rest on eroded surface of ehalk. Eocene rocks of W. Europe are usually soft sands and clays, with some limestone and marl; all were laid down in loeal basins under marine, braekish, or fresh-water conditions. In $\mathrm{S}$. Europe, Caueasus, Asia Minor, N. Africa, through Persia towards China and Japan, great thickness (several thousand feet) of lime stone developed, made up in places largely of the fossilised shells of large disk-shaped foraminifera (nummulites). Volcanoes were aetive in eocene times, old lavas and other forms of rock being found in Antrim, the inner Hebrides, Apennines, and western U.S.A., Tasmania, etc.

The forerunners of nearly all kinds of animals now living appeared in eocene times. The early ancestors of the horse had then five toes; small, pig-like, marshdwelling animals in Africa represented the original stock from which elephants came. Placental mammals appeared in great num. bers. Crocodiles and toothed birds lived in a sub-tropical estuary where London now stands. Iniportant areas of eocene deposits are known as London, Hampshire, and Paris basins. Various beds in the London basin, in order of succession, are Thanet Sands (at base), Woolwich and Reading Beds, Blackheath Pebble Bed, London Clay, Bagshot Sands ; total thickness about $970 \mathrm{ft}$. Those of the Hampshire basin are much thicker, and slightly different: no Thanet Sands at base, great development of Barton Beds at top, and Bracklesham and Bournemouth Beds in the middle.

Eolith (Gr. eoss, dawn ; lithos, stone). Stone implement of ruder workmanship than those of the Palaeolithic Age, socalled in 1892 by J. Allen Brown. Theoretically the Chellian hand-axe had a long an. tecedent history, baek to the time when primeval man, or even his anthropoid precursors, first employed unwrought stones as tools. Many such flints have been found, notably at Ightham, Kent, and in the Ipswich Red Crag, for which human use is claimed. A characteristic hawk-beak form (rostrocarinate) is regarded by Ray Lankester as ancestral to true palaeoliths. The eolithic stage of industry was traceable in modern savagery among the Tasmanians. See Stone Age; consult also PrePalaeolithic Man, J. P. Moir, 1920 ; also illus. facing p. 458. 
Éon de Beaumont, Charles (1727-1810). French diplomatist. Born Oct. 17, 1727, he entered the

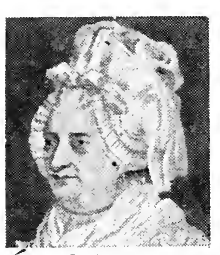
army in 1755 , and in 1757, having attracted the atten tion of Louis $\mathrm{XV}$, was sent, disguised as a woman, on a diplomatic mission to Russia. Én de Beaumont, In 1762 hecame French diplomatist to England, where in a fit of pique he pub. lished certain libels, for which he was convicted in 1764 and outlawed. The question of his sex had aroused such controversy that heavy bets were made and gambling policies of assurance effected. General opinion declared him a woman, and Éon took no steps to decide the matter. He returned in $\mathbf{1 7 7 7}$ to France where he lived as a woman, but came back to England in 1785, and ten years later, having lost everything in the French Revolution, dressed as a woman he gave an exhibition of fencing in London, where he died, May 21, 1810 . See Historical Mysteries. A. Lang, 1904.

Eos. In Greek mythology, goddess of the morning. She is iden tified with the Latin Aurora (q.v.).

Eosin. Scarlet-coloured aniline dye prepared by the action of bromine upon fluorescëine. It occurs as dark brown crystals with a green metallic lustre, dif. ferent strengths and shades of colour being distinguished com. mercially by the addition of letters, e.g. A, GGF, DH. The colour, although not fast, is much used for dyeing silk and other fibres. See Dyes.

Eōthen (Gr., from the East). Travel book by A. W. Kinglake, first published in 1844 with the full title of Eōthen : or Travels Brought Home from the East. A most engaging book, it describes the author's journeyings from Belgrade to Constantinople and Cairo, and through Palestine.

Eötvös, Jozsef, Baron (18137I). Hungarian novelist and states man. He was born Sept. 3, 1813, at Buda, and educated at the uni. versity there. After travelling extensively in Western Europe, he returned to Hungary, and in 1838 produced his novel The Carthusian, a sentimental study of a wealthy young French count who retires from the world and becomes a monk. His second novel, The Village Notary, 1846, is an attack upon serfdom and other evils. His Hungary in 1514, an historical romance describing the great peasant rising under Dozsa, and the terrible vengeance taken by the nobles, appeared in 1847 . The Influence of the Leading Ideas of the Nineteenth Century upon the State $(1850-54)$ is an attempt to show how tar it is possible fully to realize the doctrines of liberty, fraternity, and equality. Eötvös was twice minister of public instruction, in the first Hungarian ministry of 1848 and in the Andrassy ministry of 1867 .

died at Buda, Feb. 2, 1871.

Eozoon (Gr. eōs, dawn; zōon, animal). Name given to mineral structure consisting of thin wavy layers of white calcite and green silicate (serpentine), curiously intergrown, and resembling structures of certain lowly organisms (foraminifera). Found in the earliest formed rocks in Canada, it was formerly regarded as of organic origin, formed by Rhizopods.

Epacris (Gr.epi, on ; akris, top). Genus of shrubs of the natural order Epacrideae. Natives of Australasia, they have scattered leaves and abundant, cylindrical, bell-shaped flowers produced singly

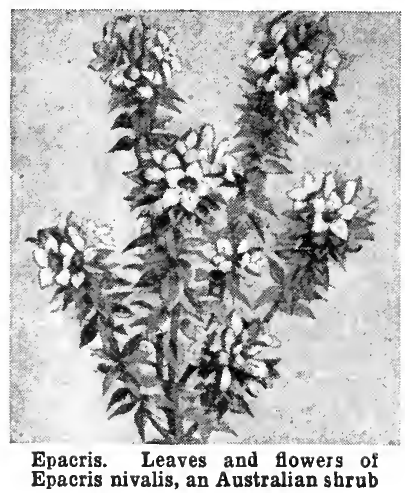

from the axil of a leaf. They are largely grown in European greenhouses, and many varieties and hybrids have been produced.

Epact (Gr. epaktos, brought on, added). Number of days by which the solar year exceeds the lunar year, or the excess of a calendar month over a lunar month. The excess of the solar year is about 11 days. Should a new moon fa!! on Jan. 1, the epact of the ensuing year would be zero or 0 . On Jan. 1 of the calendar year following the epact would be 11 . The number is increased accordingly until, at the end of the lunar cycle, 19 years, the moon's aspects begin to be repeated. As the moon's age cannot exceed 30 days, the epact 22 , e.g., would be followed by 3 , thus : $22+11=$ $33-30=3$. The epact for 1901 was 10 ; for 1920,10 . See Calendar ; Chronology: Golden Number : Lunar Cycle; Solar Cycle.

Epaminondas (Gr. Epamein ondas). A Theban general and statesman. Born about 418 B.c.,

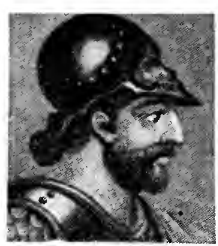

Epaminondas, Theban genera although of aristocratic f a mily, his early life was spent in pov. erty. He first came forward as a man of o utst a ding ability at the battle of Leuc. tra (371), when he was chiefly responsible for the great defeat inflicted on the Spartans which brought to an end the Spartan hegemony over Greece. Epaminondas determined to follow up his victory and to break the power of Sparta in Peloponnesus, her particular stronghold. With this object, he united the citie; of Arcadia in a league, with the new city of Megalopolis, founded by himself, as the capital. As part of the same policy, Messenia, which had been for three centuries under the heel of Sparta, was made into an independent state. Dissension, however, arose in the new Arcadian league, some of its members inclining towards Sparta. In 362 the Spartans sent an army into Arcadia, which was defeated at the battle of Mantinea, but Epamin. ondas fell in the battle. During his lifetime, Epaminondas had raised Thebes to be the leading power of Greece, but the hegemony did not last after his death.

Epaulette (Fr., little shou!der). Shoulder ornament worn by officers of the British Navy and bearing the marks that indicate their rank. Jieutenants and superior ranks wear fringed epaulettes The British Army abolished epaulettes in 1855 , but they are worn in many foreign armies, as well as in navies.

Énés Club. London club for the practice of fencing and swordsmanship. It was founded in 1900 , just after the holding in England of the first open épée tournament for amateurs. Before the Great War, international tournaments were held under its auspices, and these were revived in 1919. See Fencing.

Epéhy. Town of France, in the dept. of Somme. It lies $13 \mathrm{~m}$. S. by $\mathrm{E}$. of Cambrai. It was captured by the British April 1, 1917, and was one of the places where there was heavy fighting in the German counter-attack, Nov. 30, 1917, in the Cambrai (q.v.) sector. Retaken by the Germans, Mar. 22, 1918, it was captured by the British in Sept., 1918 , in the battle of that name. 
Epéhy, Battle of. Fought between the British and the Germans, Sept. 12-25, 1918. After the severe German defeats by the British armies in the battles of Bapaume and Arras, Ludendorff decided to fall back to the Hindenburg Line, confident that his troops would be able to hold this gigantic fortress system in the face of any attack through the winter of 1918-19. Sir Douglas Haig was equally confident that the line could be captured. But before delivering the

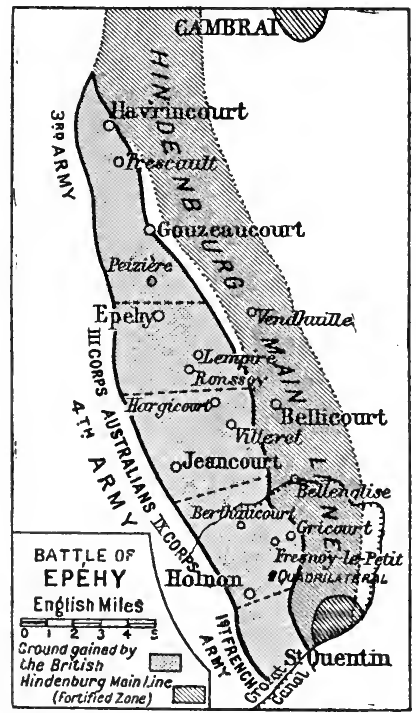

Epéhy. Plan of the battlefield showing the ground gained by the British in the battle of Sept. 12-25, 1918

decisive attack upon it, its ad. vanced positions and outworks had to be taken.

For this purpose the battle of Epéhy was fought, in very difficult country. A fortified belt three miles deep had to be traversed before the main Hindenburg Line could be reached, and several subsi. diary lines of defences had to be taken. The British forces operating were troops of the 3rd army under Sir Julian Byng on the left, and of the 4th army, including the Aus. tralian corps, under Sir Henry Rawlinson on the right, with the $36 \mathrm{th}$ French corps, forming part of Debeney's Ist French army on the extreme right, operating south of Holnon. The German forces engaged were troops of the 2nd and 18th German armies, forming part of von Boehn's army group, and they included several crack corps, among them the Alpine corps and the 2nd Guards division.

The first operation was the attack on the German positions at
Havrincourt and Trescault, which was begun by the 3rd British army on Sept. 12. Both villages were taken on that day, and a determined German counter-attack on Sept. 13 was beaten off at Havrincourt. Meantime the Australians captured Jeancourt, and on Sept. 17 the 9th corps on the extreme British right fought its way into Holnon, where a struggle continued for some days with doubtful result for the possession of the village.

The main battle was timed to open at 5.20 a.m. of Sept. 18 and, as in the first battle of Cambrai and the battle of Amiens, the infantry was to advance without any preliminary bombardment and to deliver a surprise attack, covered by a creeping barrage. The Germans expected attack, but were not certain of the exact date or time; as the British troops advanced to the assembly points, a heavy gas-barrage was put down by the German guns; and two hours before the moment for the advance rain began to fall and the weather became thick and unfavourable.

On the extreme British left the 3rd army beat off a determined German attack at Havrincourt. The 3rd corps cleared Peizière, Epéhy, and Ronssoy, but was held up at Lempire and could not reach its objectives. In the centre the Australian corps under Gen. Monash advanced with great dash and initiative, broke through the German front over an extent of 5,000 yards, and pershed rapidly forward to a depth of nearly four miles through the fortified zone, taking Hargicourt and Villeret, and foroing its way into the outer defences of the main Hindenburg Line, where it established itself firmly about $1 \mathrm{~m}$. W. of Bellicourt. To the south of them the 9 th corps was held up at Fresnoy-le-Petit and in the Quadrilateral; but the village of Berthaucourt was stormed.

On Sept. 19 the 3rd corps made an advance of about a thousand yards towards Vendhuille. The 36th French corps, south-east of Holnon, could not get forward, but Holnon village was captured at last by the British after a three days' struggle in which it had changed hands repeatedly. On Sept. 20-22 the 3rd corps reached the positions which had to be attained before a direct attack was delivered on the Hindenburg Line. On Sept. 24 the 9 th corps attacked once more at Fresnoy-le-Petit and in the Quadrilateral. The German gas-shelling was exceedingly violent, but Fresnoy and Gricourt were taken, and the French south-east of Holnon advanced some distance. On Sept. 25 the Quadrilateral was in British hands, and all the ground needed for the attack on the Hindenburg Line had been secured.

This battle was fought on the British side with very limited resources, but all the objectives were attained and 100 guns and 11,750 prisoners were taken from the Germans on the British section of the front. In all, 14 British divisions were engaged against 15 German. The British success was the more notable because it was won by troops that had been fighting almost continuously for seven weeks and in that time had suffered casualties totalling 72,000. See Cambrai, Battles of.

Bibliography. Earl Haig's Despatches, 1920; The Last Four Months, Maj.-Gen. Sir F. Maurice, 1919; My War Memories, 1914-18, Gen. Ludendorff, 1919; The Story of the Fourth Army in the Hundred Days, Maj.-Gen. A. Montgomery, 1920; Tanks in the Great War, 1914-18, Col. J. F. C. Fuller, 1920; Australian Victories in France,1918, Sir J. Monash, 1920.

Eperjes, Eperies or Pressow. Town of Czecho-Slovakia, formerly in Hungary, capital of the comitat of Sáros. It stands on the Tarcza, a tributary of the Theiss. $25 \mathrm{~m}$. W. of Leutschau. Encompassed by walls, the town is well planned, with fine streets, gardens, and buildings, including an 18th century cathedral. A thriving trade is carried on in pottery, beer, grain, wine, cattle, and linen goods. The seat of a Catholic bishop, it possesses an academy of law and theology. There are mineral springs and opal mines in the neighbourhood. Pop. 16,323.

Épernay. Town of France, in the dept. of Marne, about $19 \mathrm{~m}$. W.N.W. of Châlons-sur-Marne. It

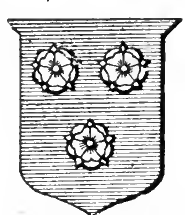

Epernay arms has important in. dustries, including spinning, tanning, cork and cask making, and brewing, but its chief importance is its connexion with the champagne industry, the wine being stored in cellars hollowed out of the chalk rock. In normal times about 5 million bottles are laid down annually. The town was occupied for a brief period by the Germans in the early stages of the Great War, and came into prominence later, being one of the German objectives in the second battle of the Marne, July, 1918. The assistance of the British divisions, composed of Yorkshiremen and Highlanders, in the defence of Epernay, was specially recognized by Gen. Berthelot. Pop. 21,800. See Marne, Battles of the. 
Ephah. In the O.T., name for the first in order of the sons of Midian (Gen. 25; 1 Chron. 1; Isaiah 60) ; concubine of Caleb in the line of Judah (1 Chron. 2); son of Jahdai (1 Chron. 2). The word, of Egyptian origin, was adopted as the name of a Hebrew dry measure which corresponded to the bath in liquid measure. See Weights and Measures.

Ephelis (Gr.). Pigmented spots appearing on the skin after exposure to the sun. See Freckles.

Ephemera or MAY FLy (Gr. ephemeros, living only for a day). Family of neuropterous insects, with a long, ten-jointed abdomen terminating generally in three long processes resembling bristles. The eyes are large and compound, the wings lace-like, and the mouth parts undeveloped, as the perfect insect does not eat. The larval stage is passed in the water, where the insect usually feeds on the vegetation, though some species are carnivorous, and prey on small aquatic animals. The perfect insects
Epistles of the Captivity, because they seem to have been written, probably, between A.D. 61 and 63, during S. Paul's first imprisonment in Rome. It was probably intended to be a circular letter, and was not addressed particularly to the Ephesians. It contains no personal greetings to the friends of the apostle, and in the two best Greek MSS. the words "in Ephesus" ("to the saints which are in Ephesus") are omitted. Moreover, Marcion speaks of it as the Epistle to the Laodiceans.

Its connexion with the Epistle to the Colossians is so close that the one is sometimes supposed to be an expansion of the other, but such a supposition is unnecessary. The external evidence for the authenticity of the epistle is sufficient, if not conclusive. As regards internal evidence, the fact that the language and thought differ somewhat from those of other Pauline epistles has caused difficulties, but these are by no means insuperable. The circum.

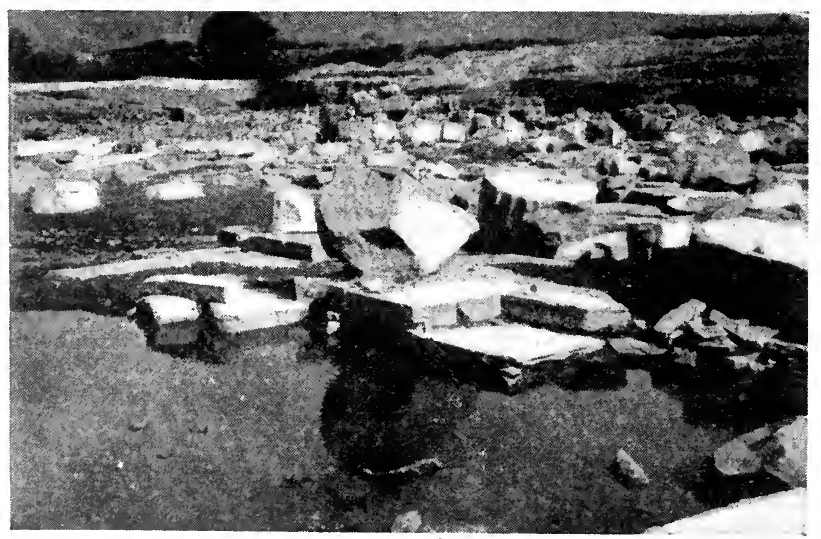

stances that impel a writer to take up the pen, the mood in which he writes, are not always the same, and, in the interval between the writing of one cpistle and another, the language and thought of $S$. Paul may have undergone considerable development as a result of his experiences.

Ephesus. Ancient city of Asia Minor, situated on the Caÿster (Gr. Kā-ystros), near its mouth. It was the chief of the twelve Ionian colonies of Asia, and was founded probably about 1000 B.c. In the 6th century it fell, with the other Greek cities of Asia Minor, under the dominion of Croesus, king of Lydia, and later under that of Cyrus the Great, king of Persia. During the Athenian hegemony it paid tribute to Athens, but about the beginning of the 4th century B.c. it again passed under Persian rule. When Persia was overthrown by Alexander the Great, it acknowledged the Macedonian supremacy, and eventually, after the Roman conquest of Greece, became the administrative capital of the Roman province of Asia.

Ephesus was noted for the worship of Artemis or Diana; its temple to the goddess was regarded as one of the seven wonders of the ancient world. The city was visited by $S$. Paul on his second and third journeys, and was an early seat of Christianity. Ephesus was the birthplace of the philosopher Heraclitus. There are ruins of a theatre (Acts xix, 27), a stadium or racecourse, an odeum or hall in which musical and poetical contests took place, and the temple of Artemis. See Discoveries at Ephesus, J. T. Wood, 1877 ; Excavations at Ephesus, D. G. Hogarth, 1908.

emerge about the end of May in most species, and their life is very short. 'The name suggests that the insect lives only for a day, but some examples live only for a few hours, while others survive several days if the weather is favourable. About fifty species of may fly are found in Great Britain, and are in great favour with anglers for bait. See Insects.

Ephemerides (Gr., journals). Table or tables showing the pre. dicted positions of a heavenly body for every day during a given period. These are right asccnsion. declination, horizontal, parallax, semi-diameter, in the case of the moon and planets: cquation of time, in the case of the sun, etc.

Ephesians, EPIStee to THe. 'The first of the group of Pauline epistles commonly known as the

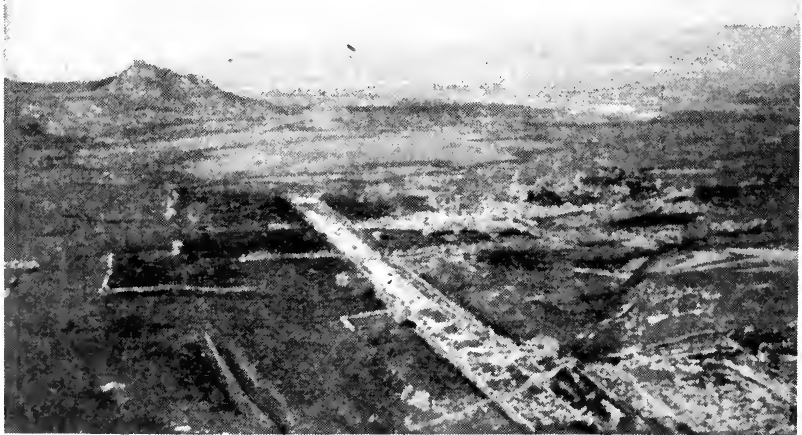

Ephesus. Ruins of the city viewed from above the theatre, looking towards the sea. In the foreground. ancient main street; in the distance the Prison of S. Paul, on the hill top. Above, remains of later temples in the Artemisium 
Ephesus, Councils of. Six im-i portant councils of the Church held between the 2nd and 5th centuries. The first took place A.D. 197, on the question of the date of the observance of Easter; and the second in 245, against the heresy of Noëtus,

The third council, 431, was the third ecumenical council of the Church, and dealt especially with the Nestorian controversy on the person of Christ (see Nestorians). Cyril, archbishop of Alexandria, had denounced Nestorius, and the emperors Theodosius and Valen. tinian convoked a general council to decide the matter. The council confirmed the Nicene Creed, condemned the heresy of Nestorius, and also settled certain points of discipline. The fourth council, 440 , and the fifth, 447, met to decide a question of episcopal succession. The sixth or robber council, convened by Theodosius in 449 , dealt with disputes about individual bishops and clergy, but its general findings were tainted by outside influences and were superseded by the council of Chalcedon in 451.

Ephialtes (d. 456 в.c.). Athenian statesman and democratic leader, who opposed Cimon (q.v.), the leader of the aristocratic party, and was associated with Pericles. Among the reforms of Ephialtes was the limitation of the power of the Areopagus. He is not to be confused with the traitor of the same name who, when Leonidas and his Spartans were defending the pass of Thermopylae in 480 B.c. against the Persians, showed the enemy a path whereby the defenders of the pass could be taken in the rear. In Greek mythology, Otus and Ephialtes were giants, who rebelled against the gods, and endeavoured to pile Ossa on Olympus and Pelion on Ossa. Pron. Effi-alteez.

Ephod. Symbolical waistcloth worn by the Jewish priests when officiating. That worn by the high

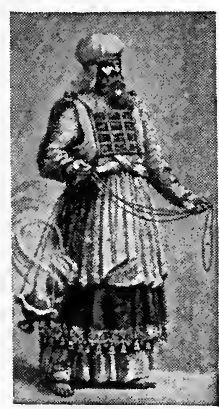
priest was of fine linen, col. o ured gold, blue, purple, and scarlet, worn over a blue robe, fas. tened round the body by a girdle, and supported by two shoulderstraps, each ornamented with an onyx stoneinscribed with thenames

Ephod. Jewish high priest wearing the ephod, shown knotted below the breastplate the breastplate $(q . v)$. References are made in Exodus 28, 29, 39 ; Lev. 8; Judges 17; 1 Sam. 2 and $22 ; 2$ Sam. 6.

Ephor (Gr. ephoros, overseer). Spartan official. Originally appointed by the kings to take over certain police and judicial duties, the ephors gradually became the most influential body in the state. After the second Messenian War (685-668 B.c.), they became an independent magistracy. Five in number, and elected by the Apella (the Spartan general assembly), they held office for a year. They possessed civil jurisdiction, looked after public morals, had the right of dismissing, fining, and imprisoning public servants, and even the kings were subject to their authority. Two of them accompanied the king in the field to keep a watch on his movements. They summoned and presided at the public assemblies, controlled the finances, and conducted negotiations with the representatives of foreign powers. When Ayis IV tried to limit their authority, he was imprisoned by their order, and murdered (240). The ephorate was abolished by Cleomenes III, but restored after he lost the throne in 221 , although it never recovered its former position. See Sparta.

Ephraem Syrus or EPHRAIM THE SyRIAN (c. 306-378). Theologian and sacred poet. A native of Nisibis, where he spent his youth in study, about the year 363 he removed to Edessa, where he lived the life of a hermit, and was ordained deacon. Hedevoted hislife to teaching and writing, and assisted the poor during a great famine.

Ephraim. Second son of Joseph. With his brother, Manasseh, he was adopted by their grandfather Jacob, and their descendants were reckoned among the tribes of Israel. Ephraim took precedence of his elder brother Manasseh, but nothing is known of his personal career. The tribe of Ephraim occupied part of the northern territory of Palestine. Joshua belonged to this tribe.

Ephrath or EPHRATHAH (fruitful). Old name for Bethlehem (q.v.), in Palestine.

Epiblast (Gr. epi, on ; blastos, shoot). Term used in embryology for the outer covering of the organism when it has reached the stage of a sac or gastrula. It is sometimes referred to as the ectoderm, the exterior germinal layer of a developing embryo in an early stage. See Embryology.

Epic (Gr. epos, tale, song). Name given to narrative poetry which deals in dignified and elevated style with some important action, usually heroic. The great examples are the Iliad and Odyssey of Homer, which are unmatched in any other language. Other peoples and later ages, however, produced poetry descriptive of great events to which the term epic has been generally and legitimately applied, such as the French Song of Roland and the English Beowulf. These all belong to the authentic, as distinguished from the literary, type, that is, they are "poems of growth," not the work of a single age or author, but stitched together by generations of bards from the myths and traditions of their race, embodied in older and more primitive lays and ballads. Such poems are important as historical documents. Though mingling fiction with fact, they preserve irreplaceable accounts of the manners and customs, and the political, social, and religious ideas of times otherwise unchronicled.

\section{English Epics}

Beowulf, for example, raises the curtain which hides the early life of our forefathers, and in its persons, scenes and episodes reveals many of the mental and moral characteristics of the race, as well as elements of the social order which still prevails in the British islands. Several other narratives which fall short, indeed, of the unity and completeness of the more famous heroic poems, still display many of their essential features, like the English Maldon, a splendid though comparatively late piece of the 11th or 12th century. Rhymed chronicles like Layamon's Brut partake of the epic character in that they contain fragments of actual history and are heroic in scope and intention, but deficient in plan and insufficiently elevated in style to bear comparison with the Iliad or Paradise Lost. Para. dise Lost belongs, like Virgil's Aeneid or Tasso's Gerusalemme Liberata, to the artificial, invented or literary type. These are imitative poems, written in the epic manner by learned authors in epochs of advanced civilization. They are the works of bookmen, who describe events of which they had no personal knowledge and their value and interest rest wholly upon the imagination and poetical skill at work in their construction.

Few such attempts were greatly successful ; nevertheless, since they followed the tradition and endeavoured to treat a noble subject worthily, they are properly to be styled epic. The Renaissance, on the other hand, produced many chivalric and romantic narratives, of epic dimensions certainly, like those of Ariosto and Spenser. Some are humorous, soms serious, but 
even when serious, and however charged with poetic quality-since they forsook the region of the heroic, of events that might have happened, for the region of the symbolic, marvellous or incredible -have little in common with the true and original types. In the mock-heroic, like the classical $\mathrm{Ba}$ trachomyomachia, or Battle of the Frogs and Mice, or Pope's Rape of the Lock, the manner and machinery of epic poetry are imitated, the great style applied to the trifling subject, with humorous intention or for the purposes of parody or burlesque. In modern times probably the nearest approach to the epic spirit is realized in The Dynasts of Thomas Hardy. See Poetry.

Epicharmus (c. 560-470 B.c.). Greek comic poet. Born at Megara in Sicily, he lived there until its destruction in 483 , when he removed to Syracuse, where he enjoyed the patronage of the "tyrants" Gelo and Hiero. The chief representative of the Dorian or Sicilian comedy, his 35 plays written in the Doric dialect, of which only scanty fragments remain, dealt chiefly with mythological subjects (Busiris, the shipwrecked Odysseus, the Sirens). They were distinguished by rapidity of action, in which, according to Horace, they served as a model for Plautus.

Epictetus. Stoic philosopher who lived about 100 A.D. Born at Hierapolis in Phrygia, he was taken as a slave to Rome. Having been given his freedom, he became an adherent and teacher of Stoicism, and when Domitian expelled the philosophers from Rome, Epictetus removed to Nicopolis in Epirus, where he lived until the reign of Hadrian. One of his pupils, Arrian the historian, published his Dis. courses and a Manual of his doctrines. The latter and four books of the Discourses are extant. Accord. ing to Epictetus, we are only concerned with things that are under our control; all other things are adiaphora (indifferent). The good is that which corresponds to reason and the general moral ideas im. planted in us; the bad is that which runs counter to them. The highest principles of life are pa. tience, abstemiousness, and selfcontrol. Epictetus assumed the existence of daimonia, spirits which, like that of Socrates, accom. panied man everywhere and acted as his guardians through life.

Epicureanism. The doctrines of the school founded by the Greek philosopher Epicurus (341-270 B.c.). He was of Athezian parentage, and born in Samos. Coming to Athens, he founded his school in his Garden, which became as famous as the Stoic Porch about 306. Epicurus divided philosophy into three parts : Canonics (logic, the theory of knowledge), Physics, and Ethics. The basis of all knowledge is the evidence of sensual perception; all perceptions are true and irrefutable. Opinions are true or false, according as they are confirmed or refuted by perception.

In physics Epicurus agrees in the main with Democritus, the founder of the atomic theory. Bodies are formed by the collision and com. bination of an infinite number of atoms in infinite space. The num. ber of worlds also is infinite. The gods, made of the finest atoms, do not trouble about the world or human affairs, but live happily in the empty spaces between the different worlds. The soul is material, made up of the finest atoms dis. persed throughout the body. There is no such thing as immortality; after death the soul-atoms are scattered. Sensation is due to effluxes and images, which issue from the surface of things and pass through the air to the sight or understanding.

In ethics Epicurus follows the Cyrenaics. Pleasure is the aim of life, the only happiness. No pleasure is bad in itself, but only pleasure in rest-freedom from pain-is a true good. The virtuous man, he who rightly pursues pleasure, is alone happy. In modern language, Epicureanism is used for addiction to sensual enjoyment, more particularly that of the table. See Ethics; Philosophy.

Epicycle (Gr. epi, upon; kyklos, circle). A circle, the centre of which moves along the circumference of a greater circle. In Ptolemy's system of the heavens each of the "seven planets" was supposed to revolve in an epicycle. This obsolete explanation describes with approximate truth the relative motion of a planet with regard to the earth, if the earth is assumed to be stationary.

Epidaurus. Town of Argolis, ancient Greece, situated on the Saronic Gulf. It was famous for its temple of Asclepios (Aesculapius), the god of healing, about $8 \mathrm{~m}$. distant, which was extensively visited by the sick from all parts of Greece. Miraculous cures similar to those at Lourdes are recorded. Excavations carried on since 1881 have revealed remains of the tem. ples of Asclepios and Artemis, of a tholos or rotunda, and inscrip. tions connected with the worship of Asclepios.

Epidemic (Gr. epi, in; dēmos, people). Occurrence of a disease among a number of persons about the same time. When a disease is continually present in a locality the term endemic is usually employed. A pandemic is an outbreak of a disease which extends over the whole or a large part of the world. In the Middle Ages, when sanitation was still in its infancy, epidemics were of frequent occurrence and were usually regarded as manifestations of divine wrath. Later the communicability of the disease from one person to another was recognized, and the cause of the outbreak was looked for in clima. tic occurrences or cosmic phenomena-for example, the influence of a comet.

\section{How Epidemics are Spread}

In the 18th and 19th centuries more scientific views were gradually established, and it was recog. nized that the disease was conveyed from one to another by some virus or poisonous agent, which was eventually found in most cases to be a bacillus or other microorganism. Epidemics are spread by various agencies. Pollution of drinking water by sewage has been the commonest cause of outbreaks of cholera and typhoid fever. Epidemics of diphtheria have frequently been spread by contaminated milk. In other cases insects or animals have been the transmitting agent. Typhus-fever, for example, is conveyed by the bite of the louse, and plague by the rat flea. Airborne infection is probably the method of transmission of influenza, and possibly of scarlet fever and small-pox. Epidemics may also be caused by the wholesale contamination of food with poisonous substances. In 1900 there was an epidemic of arsenic poisoning in the N. of England due to the contamination of beer with arsenic derived originally from arsenical iron pyrites from which sulphuric acid used in the manufacture of the beer had been made. Epidemics of lead poisoning have also followed the contamination of drinking water by lead derived from cisterns and conduit pipes.

\section{Measures of Prevention}

'Ihe prevention and arrest of epidemics necessitate active measures which vary with the particular circumstances controlling the disease. Often a system of notification of affected persons, followed by their isolation, is important. This is only possible in advanced communities and where the severity of the disease justifies the course and the numbers are not too great to cope with. It could be followed, for example, in this country during outbreaks of small-pox, but it could not be done 
for influenza. Search must be made for any causative factor, particular attention being paid to the purity of food and drinking water. Accumulations of filth or rubbish should be removed. In fact, cleanliness both of habitation and person is an important feature in the prevention of epidemics. See Plague; Public Health.

Epidendrum (Gr. epi, on ; dendron, tree). Large genus, mainly of epiphytes, of the natural order Orchidaceae. They are natives chiefly of S. and Central America

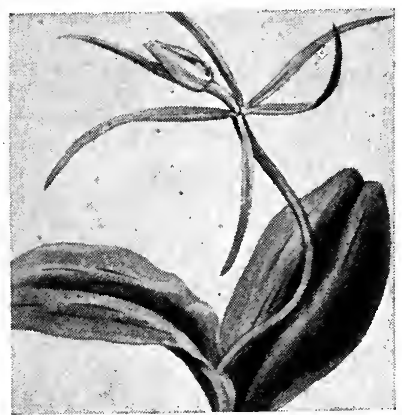

Epidendrum. Flower bud and leaves

and the W. Indies. They have leathery, strap-shaped leaves, and flowers solitary or disposed in spikes and sprays. The characteristic features of the genus are the union (more or less complete in different species) of the fleshy base of the lip to the column, a passage at the base of the lip, and the four compressed pollen-masses. Some of them have handsome flowers, but in many species these are of a dingy green hue.

Epidermis (Gr. epi, on ; derma, skin). Name for the superficial layer of the skin, lying above the cutis vera or true skin. It is formed by a number of layers of cells, the most superficial of which consist of stratified epithelium, and are horny in character. These form the thickest part of the epidermis. Beneath the horny layers are several layers of clear rounded cells forming the stratum lucidum; next is a layer of granular cells, the stratum granulosum. In these strata the change from protoplasm to horny material takes place. The deepest layers constitute the rete mucosum or Malpighian layer, and consist of soft protoplasmic cells. The epidermis grows from the deeper layers, the superficial horny cells being continually shed. It has no blood vessels, but fine nerves ramify in the deeper layers. See Anatomy ; Skin.

Epidiascope (Gr. epi, on ; dia, through; skopein, to look). Apparatus of the optical lantern type.
Originally intended for projecting on to a screen images of opaque bodies such as insects, coins, diagrams, etc., in their natural colours, it may also be used for projecting transparent objects, e.g. lantern slides and microscopic preparations may be shown with considerable magnification. The illumination is obtained from an arc lamp located at the focus of a parabolic mirror the light is thrown upon, or trans. mitted through, the object by a system of condensers and mirrors. Means are provided to effect the change over from transmitted to reflected light, or vice versa.

Epididymis (Gr. epi, on ; didymos, testicle). In anatomy, a convoluted tube which receives the ducts from the testicle, and is prolonged into a tube, the vas deferens, through which semen passes to the urethra.

Epidiorite (Gr. epi, on ; diorite). Crystalline rock much altered by metamorphism. It is composed of the minerals hornblende and felspar, and sometimes a little quartz. Hornblende is the result of alteration of augite in the original rock, the felspar is granular, and all constituents rearranged. It occurs as large intrusive sheets with schists in the Scottish highlands and N. Ireland. See Diorite.

Epidote (Gr. epi, on, besides ; dotos, given). Hydrous silicate of calcium and aluminium. It is found abundantly, but outside Austria and America is rarely of sufficient transparency and fine colour to be cut as a precious stone. The colour ranges from green to brown. Its specific gravity is from $3 \cdot 25$ to $3 \cdot 5$; it stands low in the scale of hardness. Piedmondite is a manganese epidote found in Pied. mont, some valued specimens being characterised by a magnificent cherry-red colour. Epidote is so called because the base of the primary crystals is enlarged in some of the secondary forms.

Epigastrium (Gr. epi, on ; gaster, belly). Upper central portion of the abdomen, or pit of the stomach.

Epigenesis (Gr. epi, on ; genesis, generation). Term used in biology to express the development of an organism as the result of the growth and subsequent differen. tiation of a single germ-cell into the complicated tissues of an individual. This takes place by the segmentation or division of the fertilised cell. See Biology; Cell ; Reproduction.

Epiglottis (Gr. epi, on ; glossa, glotta, tongue). Thin leaf-shaped structure, consisting of fibro-carti. lage, placed behind the root of the tongue and in front of the superior opening of the larynx. It was formerly supposed that it was bent back during the act of swallowing and served as a lid to close the larynx; but it is now recognized that the closing of the glottis is effected by the arytenoid and thyroarytenoid muscles.

Epigoni (Gr. descendants). In Greek legend, the sons of the seven heroes who fell in the war against Thebes. See Adrastus.

Epigram (Gr. epi, upon ; gram$m a$, a writing). Originally a simple inscription attached to religious offerings. It was afterwards written on the temple gate, and by easy transition passed to other public edifices and to statues of gods, heroes, and all who had distinguished themselves by patriotism, courage, and virtue. The term at first included inscriptions in verse or prose, and the form was employed by legislators and philosophers to convey any political or moral precept, its brevity impressing it readily upon the memory. Finally, among the Greeks, the epigram came to signify any short piece of poetry which conveyed a single idea with neatn€ss and grace. The Greek Anthology contains epigrams characterised by delicacy and truth of sentiment, and by elegance of expression, and entirely devoid of satire, play upon words, and even of conceit. Even in the lighter convivial epigrams the thought is generally of a melancholy cast, and the sepulchral inscriptions are remarkable for their simple delicacy and their perfect appropriateness.

In the hands of the Latin epigrammatists the epigram acquired a new character. The term was

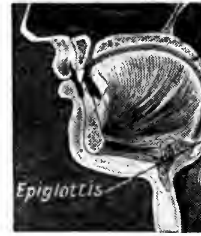

the point made by antithesis, surprise, or play Catullus and Martial are the acknowledged masters of the Latin verse epi. gram, Tacitus of its prose equiva. lent. Despite much concert and some obscenity Catul. lus excelled all other Roman upon words. now applied to any brief and concise composition in prose or verse, in which a single idea was expressed and

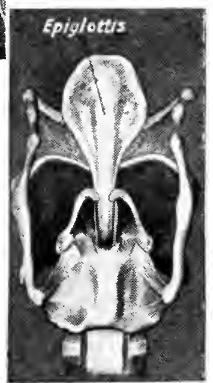

Epiglottis seen from the front. Above, sectional diagram showing position of this structure in the throat 
wits in elegance and beauty, while Martial stands supreme in wit and fecundity, in brevity, smartness, and variety. His greatest fault is his licentiousness. As used by Martial, and in the modern sense, the verse epigram has been defined as a short poem, generally of a personal character, meant to vex somebody, to pay off an old score, or to be smart at someone else's expense. In the best examples the point is made unexpectedly in the last word, wherefore the epigram has bcen compared to the scorpion because "as the sting of the scorpion lyeth in the tail, so the force and virtue of the epigram is in the conclusion."

Of modern literatures the Italian contains the nearest approximations to the Greek epigram in respect of feeling, though not of simplicity, in the softly melodious, elegant, and pathetic songs of Metastasio and the amatory verse of Guarini, Tasso, and others, while Pananti, in the early 19 th century, wrote many epigrams notable for their causticity, political allusion, and boldness. The French madrigal is sometimes written in the spirit of ancient Greece, and is often uncqualled in condensation of thought, happiness of epithet, and delicacy of turn. Voltaire, how ever, is the supreme French epigrammatist, the author of an im. mense number of epigrams on every conceivable subject and of every degree of merit.

English literature is deficient in the serious and tender style of epigram, but singularly rich in the witty and satirical. The 18 th century was the flowering time of the English verse epigram, which was admirably suited to the malicious wit of Pope, the whole of whose poetry, indeed, is a string of epigrams. As epigrammatist, he stands head and shoulders above all other English poets. While, owing to their vagueness and inappropriateness, his epitaphs are notoriously bad, his epigrams are of the highest polish and point. His epigram on epitaphs, addressed to Dr. Robert Freind, headmaster of Westminster School, may fitly be adduced:

Freind, for your epitaphs l'm grieved;

Where still so much is $\mathrm{s}$ ic

he $h$ if $w i l l$ never be believed, The other never read.

Epigraphy (Gr. epi, on; gra. phein, to write). Study of inseriptions. In practice it concentrates upon inscriptions on durable materials such as stone, metal, and wood, including coins, gems, ornaments, seals, vases, and weapons, whereas palaeography studies the forms of writing upon papyrus, parchment, and paper. When concerned with form it is a branch of palaeo. graphy, but in addition it deals with subject-matter. Important departments are Chinese, Greek, Hittite, Latin, Indian, Runic, and Semitic epigraphy. See Inscriptions; Palaeography.

Epilepsy or Faling Sickness (Gr. epilēpsis, seizure). Disease of the nervous system characterised by periods of unconsciousness. Two forms are recognized: petit mal, or minor epilepsy, in which convulsions do not occur; and grand mal, or major epilepsy, marked by the occurrence of convulsions or fits. Epilepsy most commonly begins in childhood, before the fifth year, and the first indication of the disease after thirty is very exceptional. The fundamental cause of the disease is unknown, though fright, injury, alcoholism, and an attack of illness sometimes appear to be exciting causes. Hereditary influences play a part, the offspring of those who suffer from insanity or neurasthenia being rather more prone to exhibit epilepsy than other children. In petit mal the attacks of unconsciousness often last no longer than a few seconds. The individual may suddenly stop talking and his eyes stare fixedly; after a few moments he resumes his conversation as if nothing had happened.

\section{Symptoms of Grand Mal}

Grand mal is characterised by the occurrence of convulsive fits. In many cases the subject has a preliminary sensation or aura, which warns him of what is going to happen. This may take the form of tingling or sensation of heat or cold in the limbs or face, flashes of light before the eyes, noises or voices in the ears, or uneasy sensations in the stomach. After an interval of varying duration the patient suddenly loses consciousness, and may fall to the ground without making any effort to save himself. Sometimes the beginning of the fit is marked by a loud cry. At first the muscles are rigid; the jaws are clenched, the limbs ex. tended, and suspension of respiration causes blueness of the face. After a few seconds, violent convulsions occur; the limbs are jerked about, the muscles of the face twitch, and the tongue may be severely bitten. After one or two minutes the patient passes into a state of somnolence which may be succeeded by prolonged sleep. In severe cases fits may rapidly follow each other, and consciousness may not be regained in the intervals.

Masked epilepsy is a form in which the fits are replaced by attacks of delirium or outbursts of maniacal fury, during which the sufferer may commit crimes of brutal violence or destroy himself. In another form there is loss of memory. A person may leave his home and wander about the country, behaving as a normal being, but having forgotten his previous life or even his name. After an interval his old self returns and he has no knowledge of what has happened in the interval.

Jacksonian epilepsy is a condition in which consciousness is not lost, and the spasms affect only part of the body. The condition is probably quite distinct from true epilepsy, and is the result of some irritation of the brain.

Treatment of Epilepsy. During an actual fit all that can be done is to prevent the patient from hurting himself. $\mathrm{He}$ should be allowed to remain in the recumbent posture, the clothes should be loosened round the neck, and a roll of cloth should be introduced between the teeth to prevent the tongue from being bitten. The most useful drugs in the treatment of epilepsy are the bromides of sodium and potassium. These should be given for a long period, possibly two years, the amount and frequency of the dose depending upon the severity of the condition, the age of the patient, and the manner in which he reacts to the treatment.

An epileptic should lead a quiet life. Alcohol should not be taken; meals should be light and moderate in quantity; and meat should not be eaten more than once a day. It is better for the patient to be at work or occupied, provided the occupation is not one which subjects him to danger if a fit occurs. When epilepsy develops in childhood, a thorough examination should be made of the child in order to eliminate any possible sources of reflex irritation such as adenoids, worms in the intestine, etc.

Epilogue (Gr. epilogos, conclusion, peroration). Short address in prose or verse frequently employed to round off a dramatic performance ; sometimes in the form of an appeal to public favour for the play it followed, sometimes explanatory or even apologetic. Many of the plays of Shakespeare and other great dramatists were provided with epilogues. In the 17th and 18th centuries the epilogue was frequently written by a friend or patron of the playwright. The use of the epilogue, as of the prologue, went out of fashion before the close of the 19th century, except on special occasions. See A Study of the Prologue and Epilogue in Eng. lish Literature from Shakespeare to Dryden, G. S. B., 1884. 
Epimenides. Greek legendary priest and miracle-worker. A native of Crete and associated with the worship of the Cretan Zeus and Apollo, he was summoned to Athens in 596 B.c. to purify the city from the curse of Cylon (see Alcmaeonidae). He was the author of oracular and purificatory poems, and is supposed to be the "prophet" of S. Paul's epistle to Titus (i, 12), according to whom the Cretans were "always liars." Some regard him as an entirely mythical character. Pron. Epimeni-deez.

Epinal. Town of France. The capital of the dept. of Vosges, it is situated on both sides of the Moselle, 190 m. E.S.E. of Paris. It has various manufactures, and has long been noted for the production of pictures for children. It has extensive quays and promenades. With Belfort, Verdun, and Toul it formed, during the Great War, the first line of the French permanent defences along the lines of the Moselle and the Meuse. The fortress of Epinal was built after the Franco-Prussian War, and was one of France's most important works of defence. There is a monument to the French who fell in the war of 1870-71. In the Great War it remained in French hands, though it was threatened by the Germans in the first three months. Pop. 30,042.

Épinay, Louise Florence PéTRONILLE D'ESCLA VELLES D' (172683). French author. Born at Val-

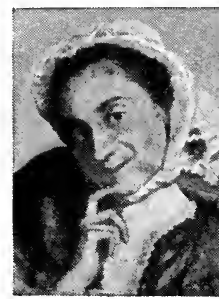

Louise d'Epinay,

French author

After Liolard nciennes

March 11 1726, she mar ried in 1745 her cousin Denis de La Live de Belle. garde, wh o soon after. wards de. serted her. Her charm and literary ability made her many friends among writers of her day, J. J. Rousseau, Voltaire, Diderot, and Grimm among others. For Rousseau she built in 1756 the Hermitage, in the valley of Montmorency; the story of their intimacy is told in his Confessions, but after little more than a year they quarrelled. She died April 17, 1783.

Her chief writings were her Mémoires, published in 1818, a lively picture of her literary circle and Parisian society, the names being fictitious, and her Conversations d'Emilie, 1774, crowned by the French Academy, 1783.

Epiphany (Gr. epiphainein, to manifest). Festival of the Christian Church, celebrated on Jan. 6. The

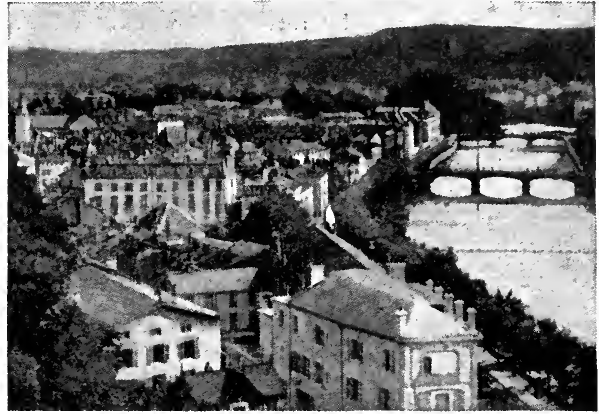

Epinal. The town, looking up the Moselle towards the wooded Vosges Mountains

tion and is at first attached to the main part of the bone by cartilage, which ultimately is replaced by bone. In the humerus, or upper arm bone, for instance, the upper end forms an epiphysis which is not united to the shaft by bony union until about the 20th year, and the lower end is another epiphysis which unites

English Prayer Book title is The Epiphany, or The Manifestation of Christ to the Gentiles. Formerly the Epiphany seems to have been part of the festival of Christmas, which lasted twelve days. It com. memorated the manifestation of Christ's birth to the magi (which in medieval times was associated with a mass of picturesque legends), the manifestation of the Trinity at Christ's baptism, and Christ's first miracle at Cana.

In the Greek Church the festival, a special day for baptism, is known as Epiphaneia, or showing forth.

In England on this day it was customary for the sovereign to offer gold, frankincense, and myrrh at the altar. Since the time of George III this offering has been made at the Chapel Royal, St. James's, by an officer of the royal household. See Calendar; Festival; Twelfth Day.

Epiphora (Gr., bringing upon, sudden attack). Persistent overflow of tears down the cheek, usually due to obstruction of the lachrymal duct. See Lachrymal Gland and Duct.

Epiphyllum (Gr. epi, on; phyllon, leaf). Small genus of climbing

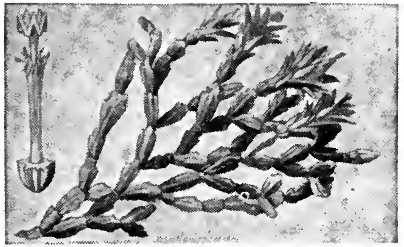

Epiphyllum. Fleshy branches and fowers of Epiphyllum truncatum, a Brazilian cactus

sub-shrubs of the natural order Cactaceae. They are natives of Brazil. They have thin cylindrical stems, $2 \mathrm{ft}$. or $3 \mathrm{ft}$. high, with short, fleshy, leaf-like branches, whose broad ends produce large, showy flowers of pink or crimson hue.

Epiphysis (Gr., on-growth). Part of a bone which develops from a separate centre of ossifica- about the 16th. See Arm; Elbow.

Epiphytes (Gr. epi, on ; phyton, plant). Plants which, instead of being rooted in the soil, grow upon the surface of other plants, chiefly trees. Large numbers of the tropical orchids are of this character, and are therefore known as epiphytal orchids. Some ferns and mosses have the same habit. True epiphytes do not derive any of their nutriment from their hosts, and are therefore often called air-plants.

Epirus (Gr. épeiros, mainland). Country in the N.W. of ancient Greece. It was bounded by Illyria, Macedonia, and Thessaly on the N. and E., and by the Ionian Sea on the W. The original inhabitants were so-called Pelasgians, like those in other parts of Greece, but the Epirots of historical times were a mixed race. The most famous king of later times was Pyrrhus (d. 272 B.c.), who seriously challenged the power of Rome. In Epirus was the celebrated oracle of Zeus at Dodona. The modern district includes part of southern Albania and northern Greece. In Nov., 1914, Greece occupied North Epirus, but in Nov., 1920, this occupation had not been recognized, nor the future of the country settled. Pop. about 250,000. See Albania; Greece.

Episcia. Genus of perennial herbs of the natural order Gesneraceae. Natives of Central America and the West Indies, they have opposite leaves and beautiful funnel-shaped flowers. In colour they are white, flesh-tinted, lilac, vermilion, or crimson.

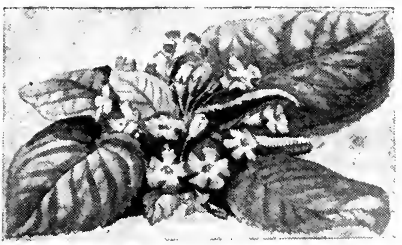

Episcia. Foliage and bloom of the American plant 
Episcopacy (Gr. episkopos, overseer). Government by bishops. It is thus a particular type of Church government, as are Presbyterianism, Congregationalism or Independency, and Papalism. Any organized society must have a seat and organ of its authority over its members, and these the Christian Church began from the first to develop. The New Testament, however, by its reticence and am. biguities on the subject, indicates that constitutional questions were not of primary importance in the Ist century. The system of authority was, naturally, first modelled on that of the Jewish synagogue, with its board of elders. Later it conformed increasingly to the lines of Greco-Roman institutions, political and social, in which responsibility tended to settle in the hands of one representative official.

Bishops and elders appear concurrently in the New Testament, and, though the former title begins to attach to the presiding elder only, the whole board is at least once (Phil. i, 1) referred to as bishops. The position of Timothy and Titus appears to be exceptional, corresponding to that of Paul himself; among the functions of each is the appointment of bishops over local churches.

Early in the 2nd century the growing need of a centre of unity and source of discipline in each church led Ignatius to emphasise the local bishop as such, and so the importance of the presbytery, over which he presided, lessened. From the middle of that century the bishop is the representative and spokesman of each local church, and the appeal of Irenaeus, in his arguments with heretical sects and groups, to episcopal consensus, and to the continuity of the Christian tradition from bishop to bishop in certain churches, shows the development towards the monarchical episcopate. It remains, however, on a thoroughly democratic basis.

\section{Consent of the Laity}

The bishop was chosen by the church, and his powers as ruler were limited by the concurrent rights of his presbyters, in the appointment of whom the laity also had a decisive influence. The nominee of the local church had then to be recognized and "consecrated" by the bishops of the surrounding churches or dioceses, which gradually formed themselves into provinces under metropolitan bishops ; and thus the system acquired that catholic, or world-wide, quality and range to which nc rival system has ever attained.

To this day no bishop of the Church of England can ordain a priest without the consent of the laity and cooperation of the other priests, i.e. presbyters, present, who all join in the laying on of hands; and the pope still addresses the bishops of his obedience as Venerable Brethren, though, since the Vatican Council of 1870 , all idea of joint authority is gone.

The naturalness and convenience of the episcopal system are emphasised by the way in which some of the non-episcopal churches are developing a virtual episcopate ; and the system prevailing in the Lutheran Churches of Germany and Scandinavia, the Moravian Church, and the Methodist Episcopal Church of America.

The historic episcopate may only imply that, in point of historical fact, the succession of bishops in a particular church goes back unbroken to the first bishops of all, or it may be pushed further to cover the claim that the whole value of episcopacy lies in this unbroken continuity, so that, where that is broken, even episcopal government does not produce real membership in the Catholic Church.

\section{Apostolic Succession}

The latter view rests on the assumption that the earliest bishops were the successors of the Apostles, and, like them, an order divinely appointed and apart, deriving their authority, not by delegation from the presbyters or the congregation, but from above, in the sense of from their predecessors. On this showing, valid consecration is crucial, and can only be performed by one who is himself in the Apostolic Succession, and therefore a recognition of non-episcopal bodies as churches endangers the chief powers and possessions, especially the valid sacraments, committed by Christ to the Apostles for the Church.

This view, however, is not that of the Church of England, nor yet is it that of modern scholarship. Iightfoot's assertion that "the Episcopate was formed, not out of the apostolic order by localisation, but out of the presbyteral by elevation," is endorsed by .J. Armitage Robinson, in an authoritative volume, in which also C. H. Turner shows that the supposed connexion between the Apostolic Succession and the validity of sacraments only emerges in the 3rd century. What the historic episcopate really stands for, and helps to secure, is the unity and cohesion of the Church throughout time and space-from the 1st century onward, and across all six continents. The exclusive claims associated with the phrase tend to counteract the inclusive and reconciling influence of the ideal.
But such a document as the Report of the Lambeth Conference of 1920 marked a great advance on the part of the Church of England towards the broader and more ancient view. See Anglicanism; Church of England; consult also Essays on the Early History of the Church, ed. H. B. Swete, 1918 .

E. A. Burroughs

Episcopius, SrmoN (1583-1643). Dutch theologian whose family name was Bischop. $\mathrm{He}$ was born at Amsterdam, Jan. 1, 1583, and educated at Leiden, where he came under the influence of $\mathrm{Ar}$ minius $\left(q . v_{0}\right)$. In 1612 he was appointed to a chair at Leiden University, and became recognized as the leader of the Arminians against the Calvinists. He took a prominent part in the synod of Dort in 1618, with the result that he was deprived of office and had to live for a time in France. About 1626 he returned to Holland, and became rector of the Remonstrant College at Amsterdam, where he died April 4, 1643 . His Confessio, Apologia pro Confessione and Institutiones Theologicae are the standard works on Arminianism.

Episode (Gr. epi, on, in addition ; eisodios, coming in). (1) In ancient Greek tragedy, that part of the dialogue which comes between the choric songs. (2) In music, part of a composition in which some departure is made from the main theme, or form, for the sake of variety. In the fugue form, the episodes allow the use of fragments of the subject matter, varied treatment of the subject, entries at irregularintervals of time and pitch, and free changes of key. In sonata and rondo forms, episodes are of the nature of second subjects, but of less importance than the true second subject which appears again fully in the recapitulation section. (See Rondo; Sonata.) (3) In literary composition, a minor event or incident introduced to give variety to a narrative, or to illustrate a character or event. A story, for instance, is said to be episodical when it consists of loosely knit incidents, or where the incidents do not merge together in a natural succession to the making of a harmonious whole.

Epistaxis (Gr. epi, on ; stazein, to drip). Bleeding from the nose. It may arise from injury, ulceration of the mucous membrane, tumour in the nose, rupture of a varicose vein, the presence of a foreign body, or cerebral congestion. Epistaxis may also be a symptom of enteric fever, influenza, and other disorders, or may occur in chronic Bright's disease. As a rule, the haemorrhage can readily be stopped 
by applying cold compresses to the root of the nose and nape of the neck. Holding the nose for a short time may allow the blood to clot and close the bleeding vessel. Frequently the bleeding point can be detected, and a touch with a cautery or with a piece of cotton wool soaked in a 5 p.c. solution of chromic acid, will usually suffice. In severe cases plugging of the nostril may be necessary.

Epistemology (Gr. epistēme $\bar{e}$ knowledge ; logos, theory). Theory or science of human knowledge. It investigates the origin and limits of knowledge; defines the part played in it by experience and thought respectively; and examines the formation, meaning, and employment of its fundamental notions.

Epistle (Gr. epistolē, message, letter). Term generally applied in English literature to verses written in the form of letters addressed to specific persons, or to readers generally, as in the epistle dedicatory. In the former sense it was a revival of the use of the epistle by Horace and other classical poets. Satiric or moral epistles, such as Pope's Essay on Man and Moral Essays, more or less on the Latin model, were a notable feature of English literature in the 18th century, at the close of which Burns gave the epistle an easier and freer form.

There are examples of epistles in the O.T. and in the O.T. apocryphal pseudepigraphic writings; but the famous letters or epistles of the Bible are confined to the N.T. The chief writer is the apostle Paul, to whom thirteen Epistles are ascribed. These are commonly divided into four groups (1) 1 and 2 Thessalonians, written from Corinth in A.D. 52 or 53. (2) Galatians, 1 and 2 Corinthians, and Romans, written in A.D. 57-58. (3) Ephesians, Philippians, Colossians, and the Epistles of the (first Roman) Captivity, written in A.D. 62 or 63 . (4) 1 and 2 Timothy, Titus, the Pastoral Epistles, so called because they are addressed to two pastors and deal with matters relating to the ministry, written in A.D. 65. The so-called Epistle to the Hebrews does not claim to have been written by Paul, though ascribed to him in the Eastern and later in the Western Church, and the description Epistle is hardly correct. Its author is unknown. It seems to have been written between A.D. 75 and 85 .

The rest of the N.T. Epistles are commonly known as General or Catholic Epistles, because they are apparently addressed to Christians in general. They are: James, Jude, 1 and 2 Peter, 1, 2 and 3 John. The author of the Epistle of
James may have been the brother of the Lord. Jude describes himself as "servant of Jesus Christ" and "brother of James." Peter is the famous apostle. The First Epistle of John is closely related to the Gospel of John. The Second and Third Epistles claim to be written by " the Elder."

Epistolae Obscurorum Virorum (Letters of Obscure Men). Series of satirical letters addressed to Ortwinus Gratius and called into existence by the Reuch. lin-Dominican controversy. They played an important part in the Reformation, and have been many times reprinted. The first part, consisting of 41 letters, was published in 1515, seven more letters being added in the 3rd edition, 1516. The second part, comprising 62 fresh letters, appeared in 1517 ; its 2nd edition, same year, contained eight more. The two series were not published in one volume until 1556. Their authorship, long in doubt, was established by W. Brecht, who proved the principal writers of Parts 1 and 2 respec. tively to have been Johann Jäger, called Crotus Rubianus, and Ulrich von Hutten. See text, ed. with Eng. trans. F. G. Stokes, 1909 : consult also Die Verfasser der Epis. tolae obscurorum Virorum, W. Brecht, 1904. See Reuchlin, Johann.

Epitaph (Gr. epi, on ; taphos, tomb or grave). Inscription on a tomb. The desire to record in lasting form the virtues or great deeds of the dead is universal, and has found expression in all ages. Some of the earliest extant epitaphs are found on Egyptian sarcophagi, and they were commonly used among the Jews. One of the most famous Greek epitaphs is that recorded by Herodotus as having been in scribed in honour of the Spartans who fell at Thermopylae: "Stranger, go tell the Lacedae. monians that we lie here obedient to their commands." Various an. thologies and the catacombs of Rome supply numerous Greek and Latin examples.

Epitaphs vary infinitely in style, and reflect the literary taste of their age. In England they range from the lengthy recital of the deceased's titles and dignities in Latin and the solemn and elaborate survey of his career in the English of the eighteenth century to the severely simple and the frankly humorous. An effective Latin epitaph is that on Sir Christopher Wren in S. Paul's Cathedral, London, Si monumentum requiris, circumspice (If you seek his monument, look around); while humorous epitaphs of the jesting sort frequently allude to differences between husband and wife. Much ingenuity has been devoted to the play of words in epitaphs, e.g. in S. Benet, Paul's Wharf. London, is the following :

Here lies one More, and no more than he; One More and no more,--how can that he? hy, one More and no more may lie But here lies

than one more, and that's more

Uncons carelessness or ignorance is occasionally found, as on a tombstone at Ventnor :

Here lies the hody of Samuel Young, who came here and died for the benefit of

Frequently, however, epitaphs of the humorous kind are not genuine, being composed as a form of literary amusement. Some of fine quality come almost under the head of epigrams. Such are most of the epitaphs in Ben Jonson's works; for instance, the lines Underneath this sable hearse, and the beautiful tribute to Elizabeth L. H. :

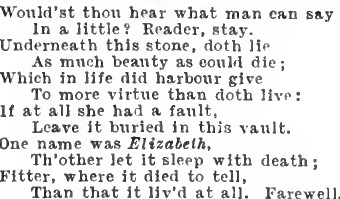

Epithalamium. Nuptial song in praise of a newly wedded pair and invoking blessings on them, sung before the bridal chamber (Gr. thalamos). Fragments of Greek epithalamia by Anacreon, Pindar, and others have been preserved. One of the most celebrated by Latin poets is the epithalamium on Peleus and Thet is by Catullus. In English literature Spenser's Prothalamium and Epithalamium are among the most beautiful poems of this kind.

Epithelioma. Form of cancer in which the growth is mainly eomposed of cells pertaining to the enithelial or surface laver of the skin or mucous membrane. See Cancer.

Epithelium (Gr. epi, on ; thēlé, nipple). Tissue composed almost entirely of cells with little cement ing material. It forms the superficial layer of the skin and lines the internal cavities of the body. Pave ment epithelium, consisting of one layer of cells fitted together like a mosaic, is found in the air-sacs of the lungs. Columnar epithelium lines the stomach and intestines. Stratified epithelium consisting of numerous layers of cells, covers the surface of the body. Ciliated epithe lium is a form in which the surface of the cell carries a bunch of fine filaments having a continuous movement which sets up a current over the surface of the tissue. Thi form occurs in the air passages where the ciliary movement helps to clear the tissues of fine particles of foreign material and other debris. 
Epoch (Gr. epochē, pause). In astronomy, a date arbitrarily fixed; and necessary for computing the place of a heavenly body. Jan. 1, 1901, might, for example, be the date for the definition of the positions of the planet Mercury, and all the changes in its positions would then be noted in succeeding periods of time. See Chronology.

Epode (Gr. epi, on ; òdē, ode). Third part of the triple system of the Greek ode, which consisted of strophē, antistrophē, and epode. The term subsequently came to be loosely used in a wider signification, being applied to certain of the lyrics of Archilochus and his imitator Horace. See Ode.

Eponym (Gr.epi, on ; onoma, name). Name of a real or fictitious person, the reputed founder of a country or people. Such are the mythical Brutus, from whom the name Britain is supposed to be derived, and Hellen, the traditional founder of the Hellenes or Greeks.

Eponym Canon. Assyrian chronological table. 'The Sumerian identification of years by significant local events was simplified in Assyrian records by naming years after official personages in an orderly sequence. The word eponym is used after the analogy of the Greek archon (q.v.). The king was eponym in his first year, followed by his commander-in-chief, court officials, city governors, and others. Inaugurated in 1500 B.c. if not earlier, the canon hitherto recovered comprises fragmentary name-lists from Ashurbanipal's Nineveh library dated continuously from 893 to 666 , and discontinuously from 911 to 640 . From a supplementary list mentioning important events as well, an eclipse record was dated by astronomical calculation June 15,763 , thus fixing the whole series.

Epping. Market town and urban district of Essex. It stands on the summit of a hilly ridge, $382 \mathrm{ft}$. above sea level, near Epping Forest, 17 m. N.E. of London by the G.E. Rly. The church of S. John Baptist (1832) was rebuilt in 1890 and superseded AllSaints at Epping Upland as the parish church in 1889. Its tower was added in 1908. The town hall was built in 1863 . Epping has an agricultural trade, while cattle fairs are held here. It gives its name to a division returning one member to Parliament. Market day, Fri. Pop. 4,253.

Epping Forest. Stretch of wild woodland in Essex, England. All that remains of the old Royal Forest of Essex, known after the 13th century as the Forest of Waltham, it consists of about 6,800 acres between Leytonstone, S., and

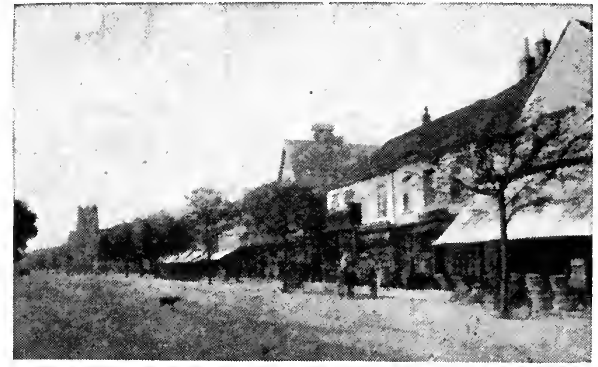

Epping, Essex. The High Street, looking towards the new parish church of S. John Baptist

In 1627 Curtenbach devised a small mortar, on the mouth of which rested a heavy conical shot which travelled vertically up a stretched wire passing $\mathrm{through}$ it. 'The power was measured by the height to which the charge raised this shot. In 1647 Nye, a master gunner, proposed

Epping, N., with Loughton, E., and Chingford, W., on high ground between the valleys of the Iea and Roding. The best of the wooded section includes Monkwood, N.W. of Loughton, and Epping Thicks, N.W. of Theydon Bois. Dark brown fallow deer run wild; a few small roe deer were introduced from Dorsetshire in $\mathbf{1 8 8 3}$. The last of the old red deer were removed to Windsor in 1827. Rabbits are numerous, and a certain number of badgers, foxes, squirrels, and weasels are also found.

While the pollarded hornbeam is a striking feature, there are a few aged oaks, and the beech, blackthorn, crab-apple, birch, willow, holly, and brushwood, together with gorse, broom, wild rose, and honey suckle, lend charm and variety to the landscape. Of two ancient camps, Ambresbury Banks, $2 \mathrm{~m}$. N. of Loughton, is popularly assigned to Queen Boadicea ; and Loughton Camp, about 11 acres, to early British or pre-Roman origin. After protracted legal proceedings Epping Forest was secured to the public by the City Corporation and the Commons Preservation Society, at a cost of $£ 250,000$, and was opened by Queen Victoria, May 6, 1882 . It is controlled by a committee of the City Corporation. There is an excellent Guide by E. N. Buxton, 1911 ; see also The Forest of Essex, R. Fisher, 1887 ; the Royal Forests of England, 1905 ; and Memorials of Old Essex. 1908, J. C. Cox. See Essex; Forests.

Éprouvette (Fr., testing apparatus). Instrument for measuring the strength of gunpowder. The first recorded specimen is that described by William Bourne in Inventions or Devises, 1578. It consisted of a small metal cylinder to which was hinged a heavy metal licl, which was prevented from falling by engaging with a ratchet. The strength of the powder was measured by firing a standard weight of explosive in the cylinder with the lid closed and noting the angle to which the latter was raised. to measure the strength of gunpowder by noting the depth to which bullets fired from a pistol penetrated into clay. He also suggested measuring the strength of powder by the distance which a heavy spherical shot travelled when fired from a mortar. This method was taken up by the French government and the mortar was called éprouvette. In 1742 a further advance was made, when Robins invented the ballistic pendulum, by means of which the be measured. About 1820 much use was made by sportsmen of the hinged lid éprouvette in the form of a flint lock pistol. For the testing of modern explosives much more complicated and accurate instruments have been designed to estimate the various characteristics of the explosives. See Gunpowder.

Epsom. Urban district and market town of Surrey, England. It is $14 \mathrm{~m}$. S.W. of London on both the L.B \& S.C. and L. \& S.W. Rlys. It was first known for its mineral springs accidentally discovered in 1618 by Henry Wicker when grazing his cattle. The town became a fashionable spa in the 17th century and was visited by royalty and London society, being especially popular about 1690 . S. Martin's, the parish church, has works by Flaxman and Chantrey. Epsom College is a public school, especially associated with the medical profession. Near the town is Lord Rosebery's seat, The Durdans.

Epsom is known for its race meetings, held on the downs, which stretch for some miles. Here the Derby, the Oaks, and other races are run and there are several large racing stables around. The town has some industries and is an outer suburb of London. It gives its name to a division sending one member to Parliament. Pop. 19,150. See Derby ; Horse-racing ; Oaks.

Epsom Salts. Magnesium sul phate $\left(\mathrm{MgSO}_{4} 7 \mathrm{H}_{2} \mathrm{O}\right)$. It crystallises in small rhombic prisms, and forms a useful saline purgative. actual velocity of a projectile could 
Epstein, ЈАСов (b. 1880). Britisl sculptor. Born in New York, of Russo-Polish parents, Nov. 10,

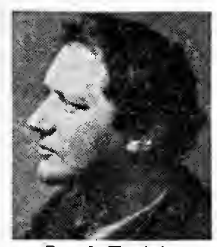

Jacob Epstein, British sculptor Beresford 1880 , he studied in Paris at the E c o le des Beaux Arts and a t J u l i en's Academy. $\mathrm{He}$ has a lways shown originality of thought and design and remarkable technical skill. His sympathies are both catholic and eclectic. Rodin's influence can be traced in the figures on the British Medical Association's quarters in the Strand, 1907-8, while the sculpture for Oscar Wilde's tomb, 1913, is interesting for its echoes of Abyssinian and Egyptian art. Among his most notable busts are those of Admiral Lord Fisher, the Duchess of Hamilton, Muirhead Bone, and Mrs. McEvoy, the last-named in the Johannesburg Art Gallery, and the Contemporary ArtSociety possesses excellent examples of his craftsmanship in a Seated Figure and the Head of Mrs. Lamb. Much discussion was aroused also by his large figures of Venus, 1917, and of Christ, 1920. See Monograph, B. van Dieren, 1920.

Epulis (Gr. epoulis, gumboil). Tumour of the jaw growing from the alveolar periosteum or fibrous membrane in contact with the bone.

Epworth. Market town of Lincolnshire, England. It is on the Isle of Axholme, 9 m. N.N.W. of Gainsborough and $24 \mathrm{~m}$. from Lincoln. It is famed as the birthplace of John Wesley, whose father was rector here, and here the Wesleyans have a church to his memory. Pop. 1,836 .

Equaliser. In engineering, a bar which serves to equalise a pull or

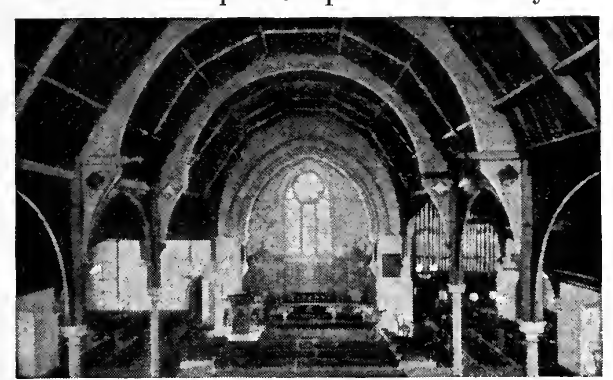

Epworth. Interior of the Wesley Memorial church built in 1889 to commemorate the birthplace of John Wesley

thrust, applied at an intermediate point equally between its two ends. See Compensating Beam.

Equal Temperament. Systém of tuning keyboard instruments with twelve equal semitones to the is an example.

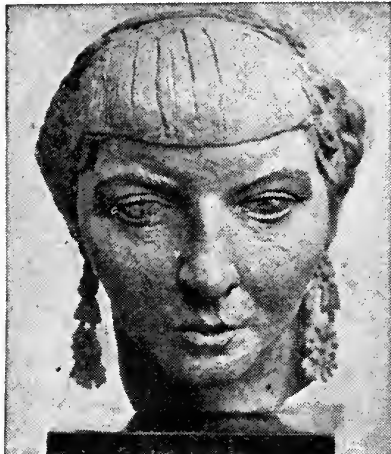

Epstein. Bronze mask of the sculptor's wife, a typical example of his work

octave instead of according to nature's scale. See Harmonic Series; Temperament.

Equation (Lat. aequare, to make equal). Statement of equality between two quantities. Thus 19 $+6=25$ is an arithmetical equation. In algebra an equation is usually a statement involving known and unknown quantities, the knowns being denoted by the earlier letters of the alphabet, $a, b$, $c$, and the unknowns by the later letters $x, y, z$. $a x=b$ is a simple algebraic equation, $x$ being the unknown quantity, $a$ and $b$ being supposed known. If $a=6$ and $b=42$ then $x=b / a=42 / 6=7$.

Equations involving a number of unknowns, $x, y, z$, may form a system, and are then called simultaneous equations.

$$
\begin{aligned}
a x+b y+c z & =d \\
e x+f y+g z & =h \\
k x+l y+m z & =n
\end{aligned}
$$

are simultaneous equations, and the problem is to find values of $x, y$, and $z$ which will satisfy all three equations. The degree of an equation is in-
dicated by the highest power of one of its unkmowns. Thus in the equation $a x^{2}+b y=c$ the highest power of the unknown $x$ is 2 , and the equation is said to be of the second degree. An equation which is true for any values whatever of the quantities conrermed is called an identity, and the connecting symbol is usually three parallel straight lines: $x^{2}-y^{2} \equiv(x-y)(x+y)$

There are as many solutions to an equation as the degree of the unknown. An equation of the second degree has two solutions, an equation of the third degree three, and so on. The methods of solving equations up to and including the fourth degree are well known, and it has been proved impossible to obtain the algebraic solutions of equations of a higher degree. The symbol= was first used by Recorde (1510-58). See Algebra; consult also W. S. Burnside and A. W. Panton, The Theory of Equations, 1899-1901.

Chemical Equations.

The change which occurs in a chemical reaction is represented by formulae and symbols which show the distribution of the molecules of the reacting bodies before and after the change. The elements are represented by symbols and atomic weights, and the sum of the weights of the original substances equals the sum of the weights of the products of the reaction: hence the representation is termed an equation. Chemical equations merely express symbolically the verified results of the action of different molecules upon each other. Berthollet formulated the conditions as regards solutions as follows:

1. When two or more substances are brought together in solution, a substance will form and separate as a precipitate, if by any rearrangement of the atoms a product can be formed which is insoluble in the liquid.

2. When two substances are brought together in solution, if a gaseous body or one that is volatile at the temperature of the experiment can form, it will escape as a gas or vapour.

For example: When silver nitrate solution and hydrochloric acid are mixed, the insoluble silver chloride is formed as a white precipitate (1); when vinegar is added to a solution of washing soda (sodium carbonate) a brisk effervescence results from the carbon dioxide given off (2).

The equation representing the formation of water $\left(\mathrm{H}_{2} \mathrm{O}\right)$ from its elements (hydrogen and oxygen) is written :

$$
\begin{gathered}
2 \mathrm{H}_{2}+\mathrm{O}_{2}=2 \mathrm{H}_{2} \mathrm{O} \\
2(1 \times 2)+(16 \times 2)=2(1 \times 2+16)
\end{gathered}
$$

This equation symbolises the formation of two molecules of water from two molecules of hydrogen and one molecule of oxygen. The numbers beneath the symbols are the parts by weight of the elements involved in the reactions. The equation, however, does not tell us the conditions of the experiment; in this case a mere mixing of the gases does not result in a reaction, it is necessary to cause them to combine by means of an electric current. 
As another example, the reaction between washing soda and vinegarmay be used. Washing soda is sodium carbonate $\left(\mathrm{Na}_{2} \mathrm{CO}_{3}\right)$, with ten molecules of water of crystallisation which need not be shown in the equation. The acidity of vinegar is due to the acetic acid it contains. The formula for acetic acid can be written in several ways, e.g. $\mathrm{HC}_{2} \mathrm{H}_{3} \mathrm{O}_{2} ; \mathrm{C}_{2} \mathrm{H}_{4} \mathrm{O}_{2} ; \mathrm{CH}_{3}$. $\mathrm{COOH}$; or $\mathrm{C}_{2} \mathrm{H}_{3}$. OH. Taking the first expression as most suitable, we obtain the following equation :

$$
\begin{aligned}
& \mathrm{Na}_{2} \mathrm{CO}_{3}+2 \mathrm{HC}_{2} \mathrm{H}_{3} \mathrm{O}_{2} \\
&= 2 \mathrm{NaC}_{2} \mathrm{H}_{2} \mathrm{O}_{2}+\mathrm{H}_{2} \mathrm{O}+\mathrm{CO}_{2} \\
& 118+120=176+18+44
\end{aligned}
$$

On the right hand side results are shown, sodium acetate (which remains in solution), water, and carbon dioxide. We have thus accounted for the products of the reaction in accordance with the doctrine of the indestructibility of matter. The sums of the molecular weights on both sides are equal (rounded figures have been used), showing that all the atoms are accounted for.

Equation of Tine. A solar day is the interval which elapses between two successive passages of the sun over the meridian of a given place (e.g. London).

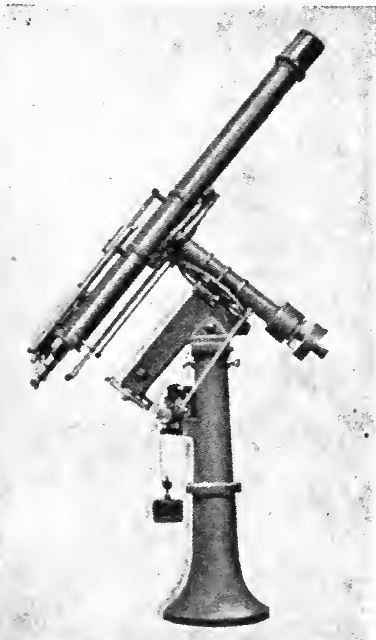

Equatorial telescope mounted to enable the observer to follow the heavenly bodies across the sky

By courlesy of $T$. Cooke \& Son

Owing to the obliquity of the ecliptic to the equator, and to the varying velocity of the earth in its orbit, this interval is not alwaye the same. Hence solar time differs from the mean solar time, registered by a perfectly even-going clock, constructed so as to record 24 hours to a mean solar lay. There will be a difference between noon as registered by the sun and as

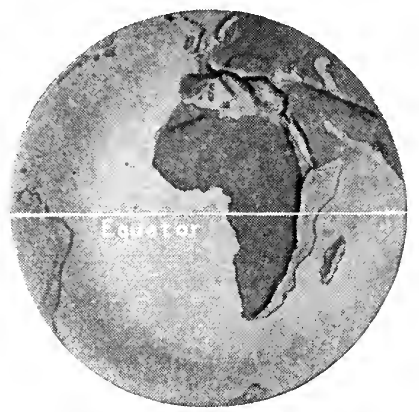

Equator. Perspective view of the earth, showing where the equator cuts Africa and $a$ portion of $S$. America

registered by the clock, and the difference will vary from day to day. This difference is called the equation of time, and is expressed in the minutes and seconds at which apparent noon takes place before or after mean noon. See Horology.

Equator (Lat. aequare, to equalise). Circle drawn round the globe midway between the N. and S. poles. At the equator the sun is seen directly overhead at noon at the equinoxes. Latitude is measured N. and S. of this circle. It is the longest line, in one plane, that can be drawn round the earth, measuring approximately $24,902 \mathrm{~m}$.

Strictly speaking, this line is the terrestrial equator. The great circle in which the plane of the terrestrial equator cuts the celestial sphere is called the celestial equator. The magnetic equator is that line drawn round the earth at any point on which the vertical components of the force of the earth's magnetism is zero. See Earth ; Equinox ; Latitude.

Equatorial. Instrument so mounted that it can follow a heavenly body from its rising to its setting. This continuous observation is regulated by clockwork machinery. In the best arrangement, a strong steel pillar supports a headpiece, in which is fixed the polar axis of the instrument, parallel to the axis of the earth. This polar axis is turned round once in twenty-four hours. A telescope fixed to such an axis will always move in a "cirele of declination," and thus a clock driving the tele. scope in one direction as fast as the earth is carrying it in the opposite direction will always keep the telescope fixed on the same point in the sky. It is not convenient to at. tach the telescope directly to the polar axis, because its range is thereby limited; it is therefore fixed to a declination axis placed above the polar axis and at right angles to it. Most of the great modern refractors are equatorials. See Observatory; Telescope.

Equatorville. Alternative name for the administrative and trading centre of the Belgian Congo, better known as Coquilhatville (q.v.).

Equerry. Originally an official of the royal stables. In the British royal household the equerries are army officers in the department of the master of the horse. The chief or crown equerry is a permanent official, who looks after the stables and stud. The sovereign always has an equerry in attendance. The form of the word, originally meaning stable (Fr. écurie, late Lat. scuria), has been influenced in English by a supposed connexion with Lat. equus (horse).

Equidae (Lat. equus, horse). Family of Ungulate mammals, including the horses, asses and zebras. In geological history, the horse family can be traced back to ancestors that had five toes instead of the single toe of modern horses. The Phenacodus, a five-toed animal about the size of a bull-dog, lived at the beginning of the tertiary period. The next stage is seen in Hyracotherium, with four equal toes on the fore limbs, found in lower eocene strata. Succeeding stages are represented by Anchitherium, with three toes and a diminutive fourth, in the Miocene age in Europe; Hipparion, with one large middle toe and two smaller side toes, in the Pliocene age ; and Equus, two diminutive toes on each side of the large toe, in the Pliocene age. See Horse.

Equilibrium (Lat. aequus, equal; libra, balance). In a system of forces a state of equilibrium exists when the forces under consideration are so arranged that they balance or have no resultant at any point. A body is in stable equilibrium when it returns to its original position after being disturbed; in unstable equilibrium, when it continues to move in the direction given to it by a disturbing force.

Chemical Equilibrium. A balanced action between chemicals similar to that indicated by equilibrium in mechanics. It most closely resembles the mechanical equili. brium established when friction is large or inertia small, because in a chemical system there is nothing corresponding to the oscillations in mechanics. See Dynamics; Motion.

Equinoctial Gales (Lat. aequus, equal; nox, night). Term indicating a belief that gales normally occur about the equinoxes. In N. America and Europe and over the N. Atlantic Ocean, from Nov. to Jan. is the period of most frequent and most intense gales. See Meteorology; Weather. 
Equinox. Dates on which the day and night are of equal length, and the length of day is the same for all parts of the world. Twice a year-at the vernal equinox, March 22, and at the autumnal equinox, Sept. 22-all places on the earth experience a day and a night each twelve hours long.

The plane of the path of the centre of the earth round the centre of the sun is called the plane of the ecliptic. The earth is tilted, and the axis of its rotation makes a constant angle with this plane. Consequently the plane of the earth's equator infinitely produced cuts the celestial sphere in a fixed great circle which is called the celestial equator. At the points where the plane of the ecliptic cuts the plane of the equator, or more precisely, when the earth in its annual path is at these points, it will be so placed with regard to the sun that all over the earth day and night will be equal in length.

Equipment. Term employed popularly to describe the complete outfit worn and carried by the soldier in the field, but officially restricted to weapons and accessories as distinct from clothing and necessaries. The equipment of the British infantryman com. prises ammunition ( 150 rounds 303 inchfor rifle), bayonct withscabbard and frog, belt with braces and cartridge carriers, haversack with rations, knife, fork, and spoon, entrenching implement and carrier, mess tin, pack containing great. coat, mending and cleaning materials, toilet necessaries such as razor, towel, and brushes, rifle, and water-bottle.

Cavalry carry similar equipment, but with leather belt and bandolier in place of the webbing belt, braces and cartridge carriers, and in addition a sword and scabbard (also in some cases a lance), and various articles of saddlery and harness. They do not carry a pack, the small articles which the infantryman places therein being accommodated in the haversack. The normal weight of the infantry equipment is about $60 \mathrm{lb}$., and a cavalry horse carries about $270 \mathrm{lb}$. including the rider. The present webbing belt and braces issued to the infantry weigh much less than the old leather gear, permit of exact adjustment to the most comfortable position for the individual wearer, and are so designed that no straps cross the chest or back, thus permitting of unrestricted breathing in spite of the heavy load. The cartridge carriers are arranged on the front of the braces which support the belt, their weight being balanced by that of the pack secured to the braces on the shoulders, the remaining items being slung on the belt so that the shoulders bear all the weight.

Equisetaceae(Lat. equus, horse; seta, bristle). Small natural order of Pteridophytes. It consists of the single genus Equisetum - the horsetails. They are mostly natives of the $\mathrm{N}$. temperate regions, but a few are sub-tropical. They have creeping rootstocks from which arise the erect, hollow, jointed stems, which are round, and finely grooved. They are solid at the joints, which have toothed sheaths into which the next joint fits and from which the branches are given off in whorls. 'The spores are produced on the undersides of scales of a terminal oval cone. E. martii, a native of Brazil, attains a height

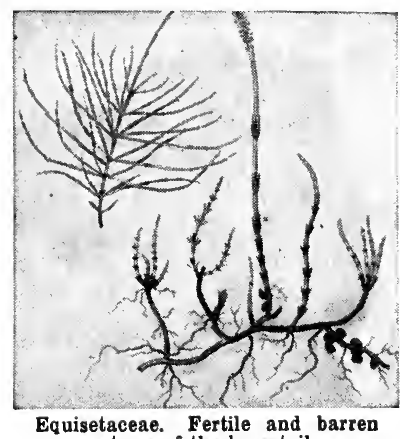

stems of the horsetail

of $30 \mathrm{ft}$., but the other species are only a few feet high. The stems are covered with silica, and those of $E$. hyemale constitute the Dutch rushes of commerce, used for scouring and polishing.

Equitable. British life assurance company, in full the Equitable Life Assurance Society. Founded in 1762 as the Society for Equit. able Assurance in Life and Survivorship, it is one of the oldest of the kind. In 1892 it was registered as a company. It is what is known as a mutual office, i.e. it has no shareholders merely as such. It has a controlling interest in the University Life Assurance Society and the Reversionary Interest Co. The head offices are 110, Mansion House Street, London, E.C.

Equitable Charge. In English law, a charge on property which formerly was not enforced by a court of common law, but only by the court of chancery. Wherever the chancery court found an intention in a document that a sum of money should be secured on property, or paid out of it, the court would enforce it as a charge. For instance, if A owes B money, and gives B a letter saying "I will pay you out of the money due to me by C," this is a charge on C's debt, and the court will restrain C from paying the debt to $\mathbf{A}$ without satisfying B's claim. To-day all courts recognize and enforce equitable charges.

Equitable Estate. In English law the legal ownership of property may be vested in one person, and the equitable ownership in another. Thus a trustee is the legal owner of the trust property, but the beneficiaries have the equitable estate.

Equites (pl. of eques, horseman). In ancient Rome, originally citizens wealthy enough to support the burden of serving as horse soldiers. With lapse of time, as the citizen militia gave way to a paid army, the equites, conventionally translated knights, became merely a class in the state possessed of a certain amount of wealth, ranking below the senatorial order, but above the common people. As senators were forbidden to engage in trade, this equestrian order tended to be composed largely of merchants and other capitalists.

The farming of taxes was an equestrian privilege, and at one time jurymen were exclusively drawn from the ranks of the knights. Under Augustus the order became more sharply defined; certain posts in the state service were reserved for them, the most important being the governorship of Egypt, the commissionership of corn supply, and the command of the fleet. The originally military associations of the equites survived only in state ceremonies. Pron. ek-wit-eez.

Equity (Lat. aequitas). Term used by English lawyers to describe that part of the law of England formerly enforced only by the court of chancery, and not by the common law courts. Equity was of two kinds: (1) where the court of chancery gave rights which the common law courts did not give ; and (2) where chancery gave remedies which the common law knew nothing about.

Equitable rights unknown to the common law were numerous. The common law knew nothing of trusts and trustees. If a man had property conveyed to him, he was the legal owner, but if the property had been conveyed to him to be applied for the benefit of another, the chancellor would enforce the trust. The chancellor's jurisdiction was said to be founded on conscience. Gradually, side by side with the common law and sometimes conflicting with it, a great system of equity or chancery law grew up. When rights at common law and rights in equity did so conflict, the chancery court would grant an injunction to restrain the defendant 
from exercising his legal rightsthat is, from bringing or going on with a common law action to enforce those rights. Since the Judicature Act, 1873, all courts administer common law and equity side by side, so that such injunctions are now unnecessary.

Equitable remedies unknown to the common law were invented by the chancellors. The chief were the injunction and specific performance. The latter compels a man to carry out the contract he has made, and does not allow him to break it and pay damages. This jurisdiction was founded on the inadequacy of the remedy at common law, whose one and only panacea for every wrong and every breach of contract was damages. On the same principle the chancellor would grant an injunction to restrain a breach of contract, or the continuance of a wrong, or the commission of a threatened wrong, where damages would be an inadequate remedy. Thus, if I had a right of way over a footpath across A's field, and A stopped up the path, at common law I would get damages; but in equity $I$ would have an injunction to restrain A from continuing to obstruct the path; and if $\mathrm{A}$ dis. obeyed, he would be attached. Equity, however, would not grant specific performance of every contract, or grant an injunction to prevent every wrong; but only when the remedy in damages was inadequate.

At common law there was no discovery, and, until comparativcly recently, neither plaintiff nor defendant, nor anyone privy to them in blood or estate, was allowed to give evidence. This did not apply in the chancery court. So a common law plaintiff or defendant used to "file a bill " for discovery. That is, he made the other side answer on oath as to what documents he had in his possession. Also he could ask a long string of questions about the common law action, and compel the other side to answer them in writing and on oath. This procedure is now obsolete, as all courts, even county courts, have power to order discovery and interrogatories.

The principal subjects of the equitable jurisdiction are the enforcement and administration of trusts, the winding-up of partnerships; the administration of deceased persons' estates; the guardianship and property of infants; injunctions; the specific performance of contracts; the taking of accounts; the rectifica- tion, setting aside, or cancellation of deeds or other written instruments, on the ground of mistake, misrepresentation, fraud, or undue influence; and the partition or sale of real estates.

At one time a court of equity could not award damages. They were reserved for the courts of common law. By the Judicature Act, 1873, however, all branches of the high court can now award damages in proper cases; though it is still unusual to bring an action for damages alone in the chancery division. See Juris. prudence: Law.

\section{R. Storry Deans}

Equuleus (Lat., young horse). One of the Ptolemaic constella. tions. It is a small group of stars close by the head of Pegasus, so placed as to suggest that another horse is galloping by Pegasus.

Era or AERA. In chronology, a fixed point of time from which years and historical events are reckoned. Generally the date of some decisive occurrence in the history of the world, or of a particular people or individual, it also denotes the series of years reckoned therefrom. Important eras are : the Greek Olympiads, from 776 B.c. ; the Roman, from 753 B.C., the traditional date of the foundation of Rome; the Babylonian, that of Nabcnassar, 747 B.c. ; the Spanish from 38 B.c., the conquest of Spain by Augustus; the Christian; the Mahomedan, 622. See Chronology.

Era, THE. Weekly organ of the theatrical and musical professions. It was founded, Sept. 30, 1838, and acquired by Frederick Ledger in 1856 , being afterwards edited by his son Edward. It was bought by Sir William Bass in 1904; and in 1916 was owned by Messrs. Bert Feldman and Alfred Barnard, the editor. The Era Almanack was first issued in 1868 .

Eradicated (Lat. ex, out; radix, root). In heraldry, a term applied to a tree shown torn up by the roots.

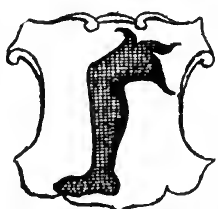

Erased in heraldry
Erased. In heraldry, a charge, such as a head, a limb, a branch of a tree, show n with a jagged end. But a branch shown as torn off is generally said to be slipped if small, or snagged if large.

Erasmus, Desiderids (14661536). Dutch humanist. He was probably born at Rotterdam, Oct. 28,1466 , the illegitimate son of Gerard de Praet of Gouda. For the name Gerard, meaning well-beloved, he afterwards substituted the incorrect Latin and Greek equivalents, Desiderius Erasmus. After four years' schooling at Deventer, he was sent by his guardians to a seminary of the Brothers of the Common Life at Hertogen. bosch (Bois-le-dur), and in 1486

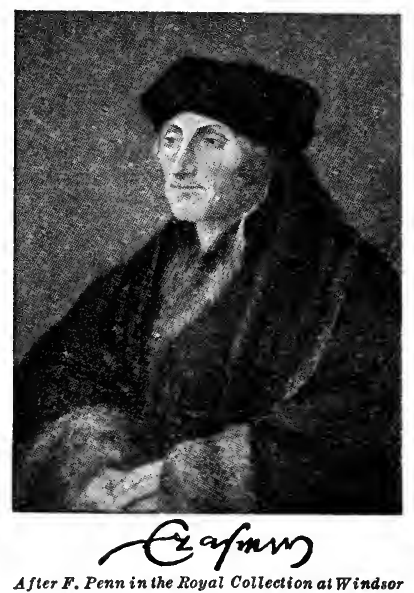

entered the cloister of Stein and took the vows of the Augustinian order. In 1491 he became secretary to the bishop of Cambrai and a priest in 1492. After spending some time at the Collège Montaigu in Paris, he returned to Cambrai, but resumed his studies in Paris in 1496. At the same time he took pupils, one of whom, Lord Mountjoy, invited him to England.

Residing chiefly at Oxford, he became the friend of Thomas More and Colet, and received instruction in Greek from Grocyn and Linacre. $\mathrm{He}$ re-visited England in 1506 and 1509 , the last time at the invitation of Fisher, bishop of Rochester and chancellor of Cambridge university. He taught Greek in Cam. bridge, and was appointed Lady Margaret professor of divinity. Between his visits to England and for some time afterwards he led a wandering life. From 1521-29 he was at Basel, where most of his works were published, and at Freiburg from 1529-35, whence he returned to Basel and died July 12, 1536.

Of his editions of classical works the most important is Terence, 1532. Adagia, 1500, and Apophthegmata, 1531, contain maxims and anecdotes from classical authors, accompanied by moral re. flections ; Ciceronianus, 1528, is an attack upon the Italian school of Latin prose writers, who refused to admit any words or phrases not found in Cicero. $\mathrm{He}$ edited many of the Fathers of the Church, but his greatest service to 
theology was his edition of the New Testament, 1516, the Greek text with a Latin translation, his treatment of which entitles him to be called the pioncer of Biblical criticism. The Enchiridion Militis Christiani (Dagger or Manual of the Christian soldier), 1502, is an attack on the inefficacy of formal religion. Other famous treatises are Encomium Moriae (Praise of Folly), 1509, a satire on clerical abuses and human follies, and Colloquia, 15l6, specially a castigation of the vices of priests and others. Much of his correspondence throws light on the manners and customs of the England of his day.

Erasmus has been much criticised for the part he played in the Reformation and his attitude towards Luther. "Erasmus laid the egg and Luther hatched it," it was said. The truth is that Erasmus was a scholar, not a theologian; he was not the stuff of which religious zealots or martyrs are made. To use his own words, "I am afraid if I were put to the trial, I should imitate S. Peter." While conscious of the faults of Roman Catholicism, he always remained a Catholic, and while acknowledging the need of religious reform, he clearly saw the dangers that would inevitably follow extremist efforts in that direction. See Humanists; Renaissance.

Bibliography. Collected Works, ed. J. Clerisus (Le Clerc), 10 vols., Leyden, 1703-6. Lives, by R. B. Drummond, 1873, R. C. Jebb, 1890 , E. F. H. Capey, 1902 (with bibliography). The Epistles of E. (to his 5lst year), Eng. trans. with commentary, F. M. Nichols, 1901-4 ; Opus Epistolarum Erasmi, ed. P. S. Allen, 1906; The Age of Erasmus, P. S. Allen, 1914.

Erastianism. Term specially applied to the view of Church policy which regarded the Church as mainly or solely a department of the state. Its upholders urged that while the choice and practice of religion was a matter for the individual conscience, the external organization of churches-including the appointment of ministerswas a function of the State. In a general sense, Erastianism means the doctrines of Thomas Erastus.

Erastus, Thомаs (1524-83). Swiss theologian. His family name was Lieber or Liebler, of which Erastus (beloved) is the Greek form. Born at Baden, Switzerland, of peasant origin, he studied theology at Basel, and medicine and philosophy at Padua. In 1558 he became professor of medicine at Heidelberg, and later of ethics at Basel. A strong opponent of Calvinism, he upheld the Zwinglian doctrine. In an important post.

humous work, he maintained that the offences of Christians should be punished rather by the civil power than the ecclesiastical (see The Theses of Erastus touching Excommunication, Eng. trans. R. Lee, 1844).

Erasure (Lat. e, out; radere, to scratch). Word meaning to obliterate, used mainly in connexion with written documents. In a legal document an erasure may be fatal to its validity, unless it can be proved that it was made before the document was executed. The parties concerned should initial the place where the erasure is made.

Eratosthenes (c. 284-204 B.c.). Greek geographer, mathematician, astronomer, critic, and poet. Born at Cyrēnē, he studied at Alexandria and then at Athens, whence he was summoned in 235 by Ptolemy Euergetēs to take charge of the library at Alexandria, a post which he held until his death. His chief work, Geographica, was a treatise on physical, mathematical (based on his method of measuring the earth), and political geography. His mathematical works included a treatise On Means; the Koskinon (sieve) was a mechanical device for finding prime numbers. He also wrote an astronomical poem, Hermes, a description of the heavens and the mythological legends associated with the stars; a Chronographia or Annals; a valuable list of the victors in the Olympic games and a history of old comedy.

Erbium. Metallic element of the rare earth erbia, which is its oxide. Its atomic weight has been determined as $167 \cdot 7$, and its specific gravity as 4.77 ; but while pure compounds have been prepared, the element has not yet been isolated. The oxide was first recognized in 1843 . With dysprosium, holmium, and thulium it forms the erbia sub-group of rare earths, all of which are included in the yttrium group. Erbia is found in almost all the rare earths, but is most conveniently extracted from zenotine, fergusonite, euxenite, polychrase, and blomstrandin.

Ercilla y Zuñiga, Alosso DE (1533-95). Spanish poet. He was a native of Madrid, and became

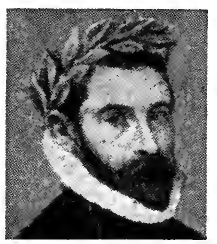

Alonso de Ercilla y Zuñiga Spanish poet attendant to $\mathrm{Philip} \mathrm{I} \mathrm{I}$ whom he ac. companied to England in 1554. Ercilla fought in Chile ag a inst the Araucanians. The closing years of his life were lived in poverty and

neglect. His poems are mainly heroic, notably Ia Araucana, which embodied his war expcriences.

Erckmann-Chatrian.

Com. pound signature of two successful literary partners and collaborators. They were Emile Erckmann, born May 20, 1822, at Phalsbourg, and Alexandre Chatrian, born Dec. 18, 1826, at Soldatenthal, both in Lorraine. They began to col. laborate in 1S48, but first won success in 1859 with L'illustre Doc.

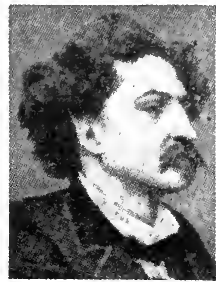

Alesandre Chatrian, French author teur Mathéus. In 1862 they began, with L'invasion : ou le fou Yégof, a series of novels which included Histoire d'un Conscrit and Water. loo, which remain among the best war stories ever written. Industrious playwrights, also in collaboration, they wrote Le Juif Polonais (Thćâtre Cluny, June, 1869), fami-

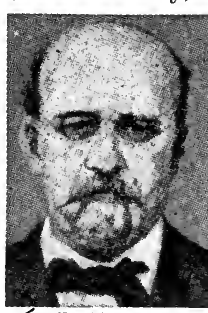

Emile Erckmann

French author liar in English to all plavgoers as The Bells. Another of their plays, L'ami Fritz, 1876 , retainsits popularity in various modified form s. The collaboration was terminated by a difference of opinion oll money matters. Chatrian died in Paris, Sept. 4, 1890. Erckmann died at Lunéville, March 13, 1899.

Ercole da Ferrara (c. 14621531). Italian painter. Born at Ferrara, little is known of him except that he was in the service of the Duke of Ferrara from 1492-99, and died in Ferrara in 1531 . Among his best works. distinguis hed by the warmth of their col-

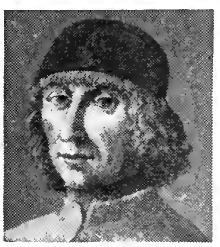

Ercole da Ferrara, Italian painter From an old engraving ouring, are The Madonna and Child, and Conversion of S. Paul in the National Gallery, London. $\mathrm{His}$ real name appears to have been Ercole di Giulio Grandi, and his pictures have often been confounded with those of his fellow. townsman and contemporary, Ercole di Roberti Grandi (c. 1455-96), probably his brother. The latter 
was obviously influenced by Mantegna in his earlier work at Bologna; his second style, adopted after he settled in Ferrara in $\mathbf{1 4 8 6 ,}$ was more suave and graceful.

Erdelli, Dimitri. Russian soldier. A corps commander early in the Great War, in 1917 he com. manded the 1lth army. The troops, however, were infected with insubordination following the revolution, and on his sector occurred the first great breach leading to the Russian retreat, although he made strong efforts to restore discipline. Appointed military governor of Petrograd by Kerensky. July, 1917, he was arrested with Denikin, Sept., 1917, but was released. Latcr, he was reported to have been shot.

Erdington. Suburb and ecclesiastical district of Birmingham. It lies $\mathbf{N}$. of the city proper, of which it is a residential suburb. It is now part of the municipality, and has a station on the L. \& N.W. Rly. Pop. 28,940. See Birmingham.

Erebus (Gr. erebos, darkness). In Greek mythology, son of Chaos and father of Hemera (Day) by union with his sister Nyx (Night). The word is sometimes used as equivalent to the lower world generally, sometimes for the region throngh which souls passed on their way to Hades proper.

Erebus. Volcano of Ross Island, off S. Victoria Land, Antarctica, in lat. $77^{\circ} 30^{\prime} \mathrm{S}$. It has an alt. of $12,370 \mathrm{ft}$. Another volcanic peak, Mt. Terror (alt. 10,900 ft.), lies 30 m. farther E. They were dis. covered by Captain James Ross in 1841, who named them after his

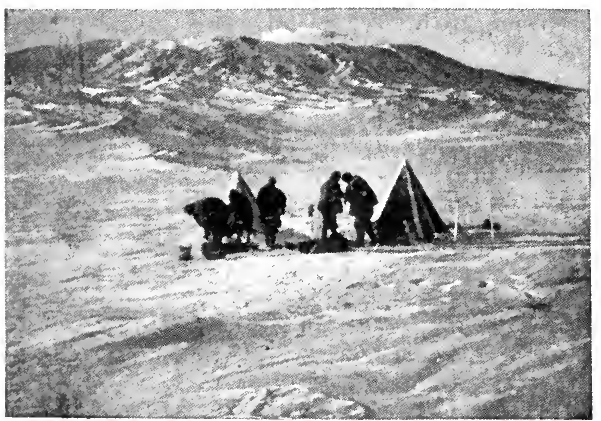

Erebus. Sir Ernest Shackleton's camp 7,000 fi. up Mt.

Erebus. The steam from the active crater is visible on the mountain top

By courlesy of Wm. Ueinemann

ships. Erebus has been recently active, but Terror is dormant or extinct. The former was reached in March, 1908, by the expedition under Shackleton.

Erech. Biblical rame of the Sumerian city Uruk. Its site is occupied by the modern village of
Warka on the left Euphrates bank between Samawa and Shatra. 138 m. S.S.E. of Bagdad, and its extensive ruins attest its former greatness. Mentioned in Gen. 10, the hegemony established by Lugalzaggisi (c. 2825 B.c.) was finally secured by Ur about 2450. Ashurbanipal deported to Samaria some of its inhabitants, the Archevites of Ezra 4. Loftus's excavations, 1854, revealed the temple and zig gurat (or tower) of its city-goddess Nana. Further excavations in 1913 brought to light relics of the Arsacid and Seleucid period.

Erechthẽum (Gr. Erechtheion). Ionic temple on the Acropolis, Athens (q.v.), just N.W. of the Parthenon. It was built partly in honour of the Greek hero, Erechtheus, and contained the shrine and a sacred wooden image of Athena Polias, guardian of the city, and the tomb of Cecrops, beside other treasures. A unique and beautiful structure, much of which is still standing, it is noted for its remarkable porch of the Caryatides (q.v.), six draped female figures supporting the roof. The original building was destroyed by the Persians in 480 B.c.; the new, begun about 437 or later, was much damaged by fire in 406, and was unfinished in 395. See Athens.

Erechtheus or ERICHTHONIUS. In Greek mythology, legendary king of Athens. He was said to have been the founder of the great Athenian festival of the Panathenaea, and to have introduced the worship of Athena.

Eregli. Name of three towns, two in Asia Minor and one in Thrace. (1) a port of Asia Minor on the Black Sea, between the Bosporus and Sinope. This was the ancient Heracleia, when ce Xen oph on's 10,000 Greeks set out on their reurn to Greece by sea. Sometimes c a ll e d Bander. egli, it is a busy place, with some shipbuilding and an export trade in silks, cattle, and coal. Pop. 5,000 . (2)Town of Asia Minor the ancient Cybistra. It stands on the Bagdad Rly., halfway between Konieh and Adana. 'There are remarkable Hittite re. mains in the neighbourhood. Pop. 10,000. (3) Town of Thrace. It stands on the European side of the Sea of Marmora, about 50 m. W.S.W. of Constantinople. It is also known as Eski Eregli and was the ancient Perinthus. Pop. 3,000.

Eremurus. Genus of perennial herbs of the natural order Liliaceae. Natives of Asia, from $S$. Russia to Hindustan, they have fascicled roots, long slender leaves, and leafless flower stems terminating in a long spray of yellow, rosy, or white flowers, much like those of the hyacinth.

Eretria. Ancient city of Greece, on the W. coast of Euboea It stood on the Euripus, $14 \mathrm{~m}$. S.E. of Chalcis. It sided with the Greeks of Asia Minor against the Persians in 498 B.C., who destroyed it eight years later. Rebuilt by the Athenians, it was the seat of a short-lived school of philosophy founded by Menedemus, whose tenets were akin to those of the Megarians. Eretria figured prominently in the war between Athens and Philip of Macedon. Recent excavations have revealed the remains of a theatre, an early temple, and other relics of the pre-Persian period. The site is now occupied by the unhealthy and swamp-bound town of Nea Prasá.

Erfurt. City of Germany, in Prussian Saxony. It stands on the Gera, $14 \mathrm{~m}$. from Weimar. The finest building is the cathedral,dedicated to the Virgin Mary, which was mainly built in the 13th century and restored in the 19th. Among its features are the beautiful chancel, the cloisters, and the lofty towers. It has decorations by Peter Vischer and others. Next to it. on the Friedrich Wilhelms Platz, is the church of S. Severus.

There are other old churches, including the Prediger, the mer. chants', and the Barfüsser. All date from the 12th and 13th cen. turies, when Erfurt was a great monastic centre. Two of its convents still remain, but the monas. tery to which Luther belonged is now an orphanage, being called in his honour the Martinsstift. Other buildings are the town hall, a picture gallery, a library and museums. Two citadels overlook the city, which was fortified until 1873 .

Apart from its historical interest, Erfurt is a busy industrial town, having become so in the 19th century. Rly. stock and various kinds of clothing are manufactured, also chemicals, machinery, furniture, etc. Brewing and dyeing are other industries. In and around much land is devoted to growing flowers and vegetables, for which the city is one of the chief markets in Germany. There are theatres, baths, and a service of electric tram. ways. In the suburb of Ilversgehofen is a noted salt mine. 


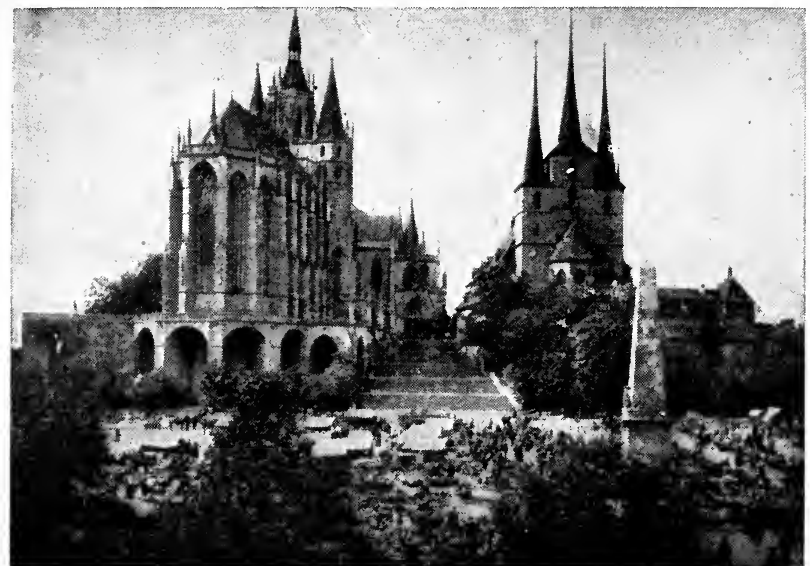

Erfurt. The Gothic cathedral church of Our Lady seen from the east. Below it is the Friedrich Wilhelms Platz and to the right the 15 th century church of S. Severus

Erfurt was a town in the 8th century or earlier, being then made a bishopric. The archbishop of Mainz took possession of it, maintaining it with difficulty. For a time it was part of Thuringia, but in 1255 it became a free city, as such joining the Hanseatic League, this being the time when its wealth and prosperity were most marked. The electors of Saxony secured it, but in 1648 it was again given to the elector of Mainz, who held it until 1802, when it became Prussian. From 1806 to 1814 the city was in the power of Napoleon. In 1850 the states of N. Germany held a parliament here. From 1378 to 1816 Erfurt had a university. Pop. 123,548.

Erg (Gr. ergon, work). Measure. ment of work done by the force of one dyne acting on a body through a distance of one centimetre. The unit of power is the erg per second. See Dyne.

Ergasteria (Gr., workshops). Port of Greece, better known as Laurium (q.v.).

Ergeri. Alternative name of the Albanian town of Argyrokas. tro (q.v.).

Ergot (Fr., spur). Fungoid pest (Claviceps purpurea) that attacks the flowers of cereals-especially rye-cultivated grasses, such as ryegrass and Timothy grass, and wild grasses. What should have been a grain is replaced by a hard spur. like outgrowth (ergot), which, if devoured by pregnant stock, may cause abortion. Ergots should not be sown with grain or grass seeds, and wild grasses infested by them should be destroyed.

The chief active principle of ergot is ergotoxin, a substance which causes powerful contractions of the uterus. For this reason ergot or its preparations are sometimes administered after labour to ensure efficient contraction of the uterus and diminish the risk of post-partum haemorrhage. 'This property of ergot formerly led to its use to induce labour where this was desir. able on medical grounds, but its action in this respect is very uncertain, and the drug is now hardly ever used for this purpose. It is sometimes resorted to with criminal intent, but it may cause severe symptoms of general poisoning without achieving the desired result.

Poisoning by ergot may be acute or chronic. Acute poisoning, which may result from taking a single large dose, gives rise to giddiness, vomiting, colicky pains in the abdomen, disturbance of vision, cramps, muscular weakness, coma or delirium, and convulsions. Fatal cases are rare, but if the poisoning is associated with premature expulsion of the uterine contents the risk is much greater. Chronic poisoning is generally the result of eating, for a considerable period, bread which has been made from rye or other cereals infected with the fungus. Ergotism, as the condition is called, is not often seen in this country, but it is common in certain parts of the Continent, particularly Russia. The early symptoms are those of irritant poisoning : vomiting, diarrhoea, and pain inthe abdomen. The latter symptoms present two types, the nervous and the gangrenous form. In the former there may be tingling sensations in the skin, spasms, and painful cramps in the muscles. Generalised convulsions resembling those of epilepsy may occur. Paralysis and affections of the mind, such as delirium, melancholia, or dementia, are other manifestations. The gan- grenous form may lead to mortification of the fingers and toes. Both sets of symptoms may be present in one individual.

Eric. Masculine Christian name. A Scandinavian word meaning ever king, it has been especially popular in the Scardinavian countrics. It was brought from there into Eng land. Thereis a feminine form, Erica

Eric XIV (1533-77). King of Sweden, 1560-68. Born Dec. I3. 1533 , he was the son and unworthy successor of Gu s t a v u s Vasa. His short reign was marked by the limiting of the power of the royal dukes and by the securing of Esthonia, which began

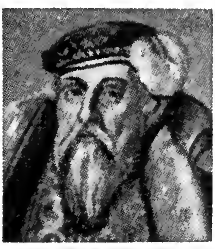

Eric XIV,

King of Sweden Sweden's policy of oversea expansion. His insanity and cruelty cut short his reign, for after the murder of the Stores in 1567 the nobles rose and deposed him (1568). At different times he contemplated marriage with Elizabeth of England, Mary of Scotland, Christina of Hesse, and Renée of Lorraine, but finally contented himself with marrying his mistress, Katrina Mánsdotter, a peasant. $\mathrm{He}$ is believed to have been poisoned Feb. 26, 1577, by his brother and successor, John, to put an end to conspiracies in his favour.

Ericaceae (Gr. ereikē, heath). Large natural order of evergreen shrubs, under-shrubs, and a few small trees. They are chiefly natives of temperate and cold climates.

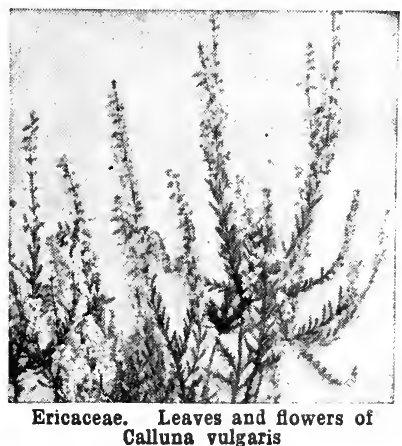

They have simple leaves, and regu. lar flowers, some, e.g. the heaths (Erica), bell-shaped or tubular, others expanded, e.g. the rhododendron.

Ericht. Loch on the borders of Perthshire and Inverness-shire, Scotland. Lying 1,152 ft. above sea level, it is $14 \frac{1}{2} \mathrm{~m}$. long and has a greatest depth of $513 \mathrm{ft}$. Overlooking the W. shore is Ben Alder 
$(3,757 \mathrm{ft}$.$) Here is a cavern in$ which Charles Edward sought refuge after the battle of Culloden.

Ericsson, JoIn (1803-89). Swedish-American engineer. Born July 31, 1803, in Vermland, Swe.

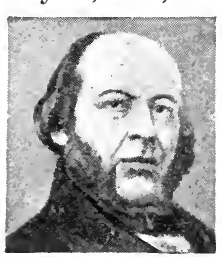

Jobn Ericsson. Engineer den, at an early age he d evelo ped great aptitude for mechanics, and in 1820 became an engineer in the Swedish army. See king a wider scope for his talents, he came to England in 1826 and occupied himself with improve. ments in steam machinery. Three years later he built, with John Braithwaite (g.v.), the Novelty locomotive engine to compete with Stephenson's Rocliet. Ericsson was occupied with various inventions, chiefly marine engines, up to 1836 , when he brought out a marine screw propeller.

Not obtaining the recognition he expected from the British Admiralty, in 1839 he went to America, where he lived for the remainder of his life. Turning his attention to defensive armour for warships and improvements in marine engines, he gained a wide reputation. In 1861 he designed the famous armoured turret ship the Monitor, and in 1862 built a number of similar vessels for the American navy. Ericsson's contributions to the science of mechanical engineering had a marked effect on the navigation of the world. He died in New York, March 8, 1889. See Life, W. C. Church, new ed. 1892.

Eridanus. In classical myth. ology, a river and river-god of Italy. It was identified with the Padus, the modern Po, which rises in the Alps and discharges into the Adriatic by several mouths.

Eridanus. One of the Ptolemaic constellations. The larger part of it is below the northern horizon. Alpha Eridani or Achernahr is known as the End of the River ; but the title was given by Ptolemy to Theta Eridani much farther N. Beta Eridani is known as Cursa, the footstool of Orion. The constellation is also called the River, which may have referred to the Euphrates. See Cursa.

Eridge Castle. Seat of the marquess of Abergavenny in Sussex. near the Kentish border, $3 \mathrm{~m}$. from Tunbridge Wells. The estate has belonged to the Nevilles since the 13 th century, but the present castle is modern, being built early in the 19 th century. 'The park covers 2,000 acres. At Eridge Green are the

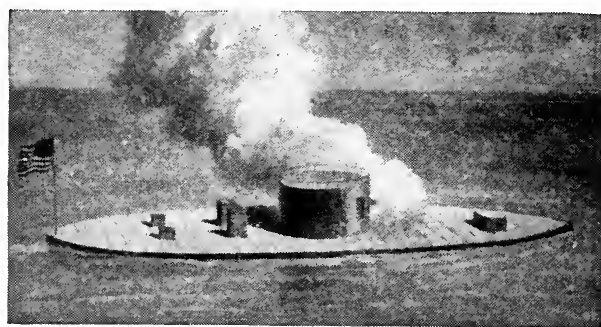

Ericsson. The Monitor, an ironclad turret ship, built from Ericsson's plans by the Federal Navy during the American Civil War

Eridge Rocks. 'The village has a station on the L.B. \& S.C. Rly., and the place gives its name to the Eridge Hunt. It is probable that there was a deer park here in 1086.

Eridu. Sumerian settlement at Abu Shahrain, S. of Muqayyar (Moghair or Ur), S. Babylonia. Originally an islet on a Persian Gulf estuary, sacred to the water-god $\mathrm{Ea}$, it was the traditional cradle. land of some aspects of Babylonian religion. Examined by J. E. Taylor, 1854, its sandstone wall, $20 \mathrm{ft}$. high, enclosed a platform with marble staircase, bearing a twostaged brick tower. Capt. R. C. Thompson's excavations in 1918 revealed a pre-Sumerian neolithic substratum, and copper-age culture, further explored by $H$. R. Hall during 1919.

Erie. Southernmost of the chain of great lakes of N. America. It forms part of the boundary between the U.S.A. and Canada. Area, $10,000 \mathrm{sq}$. m. It is $250 \mathrm{~m}$. long, and its greatest breadth is $60 \mathrm{~m}$., while its average depth is $90 \mathrm{ft}$. The lake is $565 \mathrm{ft}$. above the level of tide water in the Hudson river at Albany, and $330 \mathrm{ft}$. above the level of Lake Ontario, into which it discharges its waters by the Falls of Niagara. At its N.W. end it receives the surplus waters of lakes Superior, Michigan, and Huron, through the river Detroit. Contributory feeders are the rivers Thames and Grand. A large number of steam. ers and other ships traverse it, except in winter, when it is generally frozen over for a considerable period. In very hard winters it is possible to cross from the U.S.A. to Canada over the ice.

Iake Erie is the outlet of a large system of connecting canals, which render its navigation of great importance. The Welland Canal connects with Lake Ontario; the Erie Canal affords communication between Buffalo and Albany, thus linking up with the Hudson river ; the Ohio Canal begins at Cleveland and ends at Portsmouth, on the Ohio river; and the Miami and Erie Canal connects Toledo with Cincinnati. During the war of 1812-15 an American squadron, under Commodore Perry, captured here a British force of six vessels on Sept. 10, 1813.

Erie. City of Pennsylvania, U.S.A., the co. seat of Erie co. On Lake Erie, 88 m. S.W. of Buffalo, it is served by the New York, Chicago and St. Louis, and other rlys. Its fine natural harbour, with artificial improvements, is protected by Presque Isle, a strip of land $6 \mathrm{~m}$. long and $1 \mathrm{~m}$. in extreme breadth, and has a maximum depth of $25 \mathrm{ft}$. An important industrial and commercial centre with a valuable

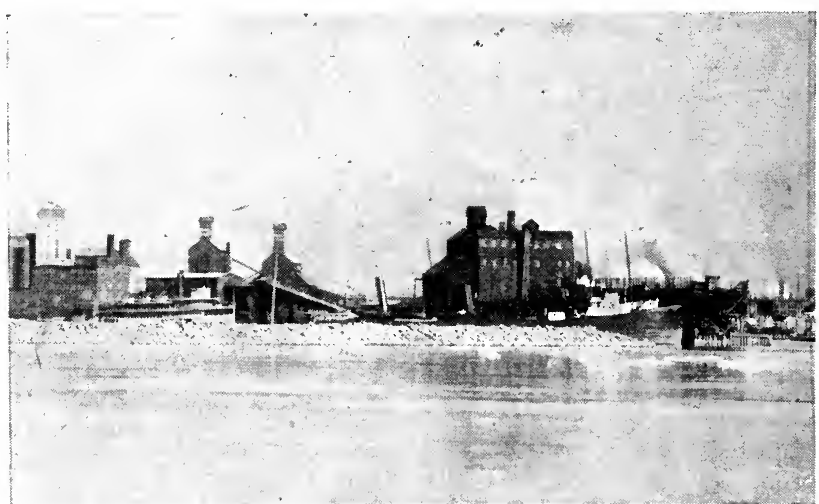

Erie. Engineering works on the shores of the lake at Buffalo, N.Y. By courtesy of Grand Trunk Railway of Canada 
trade by lake and rly. in coal, iron, grain, and agricultural produce, Erie has ironworks, machinery, paper, woollen, silk, motor-car, and tobacco factories, foundries, and chemical works. Its chief buildings include the court house, city hall, two cathe. drals, and a publie library, and it has several educational establish. ments and benevolent institu. tions. Founded on the site of the old French fort of Presque Isle,

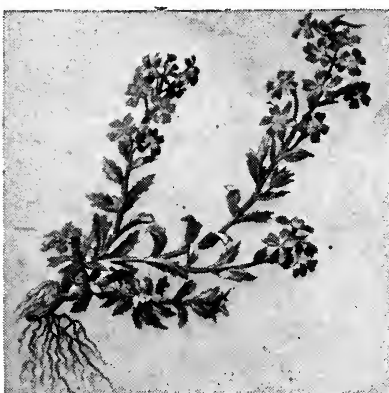

\section{Erinus. Roots, foliage, and flower} of Erinus alpinus

erected 1753, Erie's city eharter dates from 1851. In Aug., 1915, the city was inundated by a cloudburst, when many people perished and considerable damage was done to property. Pop. 76,590.

Erie Canal. Largest artificial waterway in the U.S.A. Extending across New York State from Buffalo to Albany, it communicates between the Hudson river and Lake Erie. Begun in 1816, and completed in 1825 , it has a length of $361 \mathrm{~m}$. Originally only accessible to boats of 70 tons, periodical alterations increased its breadth to $70 \mathrm{ft}$. and its depth to $91 \mathrm{ft}$., making it navigable for vessels of 250 tons. Vessels of 1,000 tons can make its passage. For five months in the yearnavigation is obstrueted by ice. It serves Rochester, Syracuse, Utica, and Troy.

Erigena, Johannes Scotus (c. 810-877). Scottish philosopher and theologian. He was a Scot born in Ireland, which at the time was called Greater Seotland, the name Erigena (Ierugena, Erugena, Eriugena) probably meaning Irishborn. About 840 he was summoned by Charles the Bald to Paris, where he became teacher at the court school. Erigena attempts to combine the neo-Platonist theory of emanation with the Christian idea of the Creation and the doctrine of the Trinity, the result being a kind of pantheism, the view that all things are contained in God.

Erin. Poetical name for Ireland. It was popularised by Thomas Moore's Irish Melodies, but is of much earlier origin. Philologists assume an old Celtic form, Iveriu or piveriu, probably meaning fertile (cf. Gr. pi-ōn, fat), in old Irish Eriu, in the declension of which Frin, Erinn, appear. The Grcek name Iernē $=$ Ivernē, the $\mathrm{v}$ being preserved in the Latin Juverna or Juberna, of which Hibernia (q.v.) is another form.

Erin go bragh. Irish phrase meaning Ireland for Ever. Through its association with Ireland's demand for a freer and more independent government it became a party instead of an entirely na. tional ery. It is widely used as an expression of national sentiment, equivalent to Scotland for Ever.

Erinus. Genus of alpine herbs of the natural order Scrophulariaceae. They are natives of $W$. Europe. The spoon-shaped leaves, which grow in a tuft, have their broad ends boldly cut into about five pointed teeth. The leafy stem ends in a cluster of pretty rosypurple or yellow flowers.

Erinyes. In Greek mythology, older name of the Eumenides $(q . v$.$) ,$ or tragic furies.

Eriocaulaceae (Gr. erion, wool; kaulos, stalk). Natural order of rush-like perennial marsh herbs. Chiefly natives of the tropics, they have slender, spongy leaves, and minute flowers gathered into a head. These flowers are either male or female, the former having two or three stamens and a rudimentary ovary, the latter with developed ovary and short style, but no stamens. Pipe-wort (Eriocaulon septangulare) of European lakes is typical of the order.

Eriphȳlē. In Greek legend, sister of Adrastus, king of Argos,

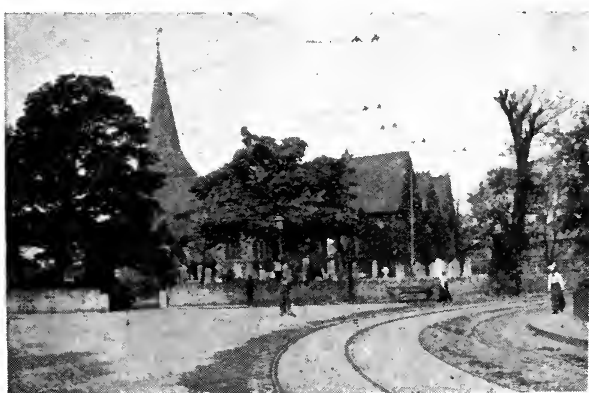

Erith. The parish church of S. John the Baptist, founded in the 12 th or 13 th century

and wife of Amphiaraus. Before he joined the expedition of the Seven against Thebes, Amphiaraus charged his son Alcmaeon to murder his mother as soon as he should hear of his father's death, and in due course Alemaeon obeyed his behest. See Alcmaeon ; Amphiaraus.
Eris. In Greek mythology, gorldess of discord. Annoyed at not being invited with the other gods to the wedding-feast of Peleus and Thetis, she threw a golden apple into the midst of the feast inscribed "For the fairest." It was claimed by Hera, Athena, and Aphrodite, and the shepherd Paris (q.v.) had to decide.

Erith. Market town and urban district of Kent. It stands on the S. side of the Thames, $14 \mathrm{~m}$. E. of

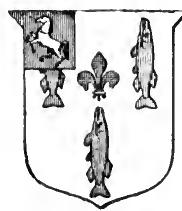

Erith arms London, being a station of the S.E. \& C. Rly. A bus $\mathrm{y}$ industrial place, there are large engineering works, while other industries are the making of gunpowder, glue, manure, etc. Pleasure grounds have bcen laid out along the river,

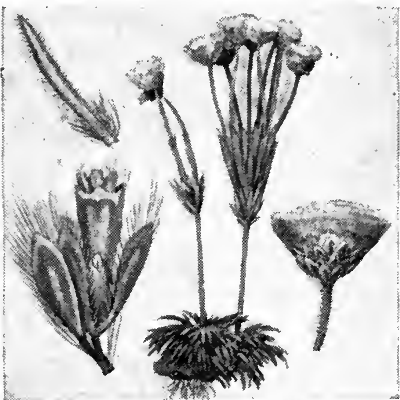

Eriocaulaceae. 1. Leaf. 2. Male flower. 3. Entire plant. 4. Head of flower

and the town is the headquarters of several yachting elubs. The chief ehurch is that of S. John the Baptist, which has some interesting brasses. Parts of it date from the 12 th or 13th century. Here is a home for disabled seamen. Erith bas an interesting his. tory, as it was made a borough in the Middle Ages and in the 17th century was used by the navy. Changes deprived it of both advan. tages, but it became an industrial centre in the 19th century. Pop. (1921) 31,568.

Eritrea. Italian colony situated on the Red Sea. Its coast is about $670 \mathrm{~m}$. long ; it is bounded N. and W. by the Anglo-Egyptian Sudan, S. and S.W. by Abyssinia, and on the extreme S. by the French Somali Coast Protectorate. Eritrea 
contains the following administra. tive divisions : Massowah, Hamas. sen, Assab, Accheli Guzzi, Serae, Cheren, Barca, Gasc and Setit. Generally arid and extremely hot, there is yet good pasture for cattle, sheep, and goats, and camels are

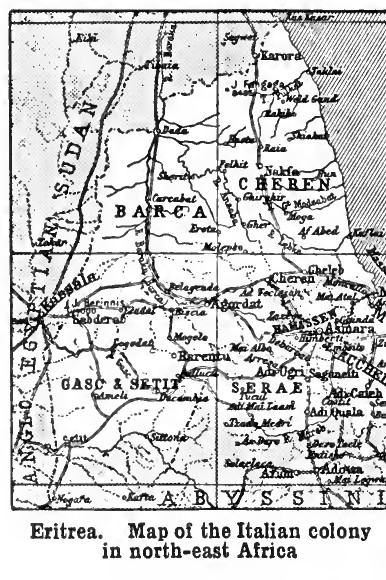

numerous. A rly. (74 m.) joins the capital, Asmara, to the chief port, Massowah. The chief products are hides, butter, palm-nuts, gold, ostrich feathers, and mother-ofpearl. Pearls are gathered at Massowah and in the Dahlak Archipelago, which is included in the colony. Massowah was occupied by Italy in 1885, and the surrounding territory was formed into the colony of Eritrea in 1889. Italian enterprise was checked by the disastrous defeat of the Italians by Abyssinian forces at Adowa, March 1, 1896. Area, 45,800 sq. m. Pop., mostly nomadic, 450,000 .

Erivan. Former govt. in Transcaucasia, since 1918 an Armenian republic. It is bounded by Turkish and Persian Armenia, the prov. of Kars, and the govts. of Tiflis and Elizabetpol. It is a mountainous country, the chief heights being Great and Little Ararat and Alagyuz, and is watered by the Aras, ancient Araxes. On an island in Lake Goktcha is the famous convent of Sevanga, founded in the 4th century A.D. Minerals abound, especially rock-salt. The inhabitants are chiefly engaged in agriculture and cattle-breeding. The area is $10,000 \mathrm{sq}$. m. Pop. 1,034,800.

Erivan. Town of Transcaucasia, capital of Erivan. It stands on the Sanga, $40 \mathrm{~m}$. N.E. of Ararat and $145 \mathrm{~m}$. S.S.E. of Tiflis. It is the seat of a bishopric and contains the remains of an old palace of the Persian viceroys. An active trade is carried on with Russia and other countries in leather, pottery, and cotton. After being alternately in the hands of Turks and Persians, it was taken by the Russians in 1827, and definitely ceded to Russia by the treaty of Turkmanshai, 1828. Pop. 34,000 .

Erlangen. Town of Bavaria, Germany. It is in Franconia, $15 \mathrm{~m}$. N.W. of Nuremberg, just where the Schwabach joins the Regnitz. Its chief buildings are the town hal and the university, and there are a number of churches; schools, etc.,

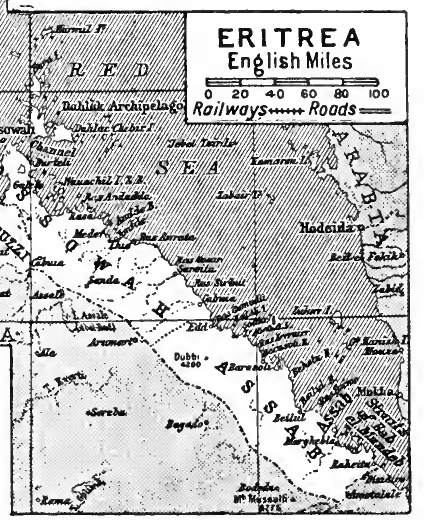

but none is notable architecturally. The principal industries are the making of beer, paper, and textile goods, the last, to which the town owes much of its prosperity, having been introduced by the Huguenots. The university was founded in 1742 by Frederick, margrave of Baireuth. It has a large library, a botanical garden, and hospital, in addition to laboratories, etc. Erlangen passed in the Middle Ages from one ruler to another. It was made a town in 1398 , and until 1791 was in the margraviate of Baireuth; the palace of the margraves is now used for the university. In 1791 it passed to Prussia and in 1810 to Bavaria. Pop. 24,900.

Erlanger, Emile Beaumont, BARON D' (b. 1866). British financier. Of German parentage, he was born in Paris and educated privately. Naturalised a British subject in 1891 , he became interested in many commercial undertakings, and was senior partner of the firm of Emile Erlanger \& Co. Baron d'Erlanger was chairman of many companies, was interested in S. Africa, and took a prominent part in the Channel tunnel scheme, being chairman of the Channel Tunnel Co., Ltd.

Erlau. Variantname of the city in Hungary better known as Eger. The red wine produced around here is frequentlycalled Erlauer. See Eger.
Erl-king on ErLkönig. Figure in German mythology. He personifies an evil spirit haunting forests and plotting mischief to passers-by, especially children. The word, meaning king of the alders (Ger. Erle), from the vapours that cling to these trees at night, is a mistranslation, and should properly be elf-king, its meaning in Scandinavian (Dan. Ellerkonge). The character was introduced to German folklore by Herder's translation of the Danish ballad, Sir Olaf and the Erl-king's Daughter, 1778-79. It is the subject of a famous ballad by Goethe, set to music by Schubert.

Ermeland or ErmLand. Dist. of E. Prussia, Germany. It is a level and sandy region, stretching inland from the Frisches Haff between Elbing and Königsberg. It covers about 1,700 sq. $m$. The name was borne by a district in Prussia before that country passed into the possession of the Teutonic Order. It was later the principality of a bishop, who was a member of the medieval empire. In 1466 it was added to Poland, but at the partition of the latter in 1772 it was seized by Prussia. There is no town named Ermeland, the chief places being Braunsberg, Allenstein, and Frauenburg, where the bishop had his cathedral. At Braunsberg is the Ermeland Museum.

Ermine. Name given to the winter phase of the stoat, when the fur is white with the exception of the black tip to the tail. In Great Britain this change from the brown of summer takes place regu-

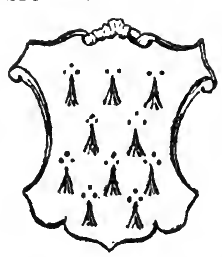
larly in Scotl a $\mathrm{nd}$, a n d often in the N. of England; but further S. it is very rare. The ermine fur of commerce comes from more northern

Ermine in heraldry 1 a t i t u d e s, chiefly from Alaska; but it is now in little favour, except for official robes. The name is either a corruption of Lat. Armenius (mus), i.e. Armenian (mouse), or of Ger. Hermelin, ermine, ermine-fur.

In heraldry, ermine is the principal fur. It is represented as silver or white powdered with sable spots, usually depicted like a small arrow head surmounted by three dots. There are four variants: ermines represented as black powdered with silver spots; erminetes or erminites, represented as black with silver spots between two red hairs; erminois, black with gold spots; and pean, gold with black spots. See Stoat. 
Ermine Street. Early English name for an ancient British high. way from London to Lincoln, and thence to York. Incorporated in part into the Romano-British road system, it passes through London along Kingsland and Stoke Newington to Royston, thence through Godmanchester, Castor, Ancaster to Lincoln. It appears in the laws of Edward the Confessor as one of four royal roads. See Britain.

Ernakulum. Town of India, the capital of Cochin state. It is the terminus of the Cochin State Rly., which connects the state with the main line of the Madras Rly. The Raja's College here accommodates 700 students. Pop. 21,195, 53 p.c. Hindus, 40 p.c. Christians.

Erne or Sea Eagle. Name given to the white-tailed sea eagle, the only member of its group still found in Great Britain. It is of brownish colour, has a white tail, and is about $3 \mathrm{ft}$. in length. It still breeds in the Hebrides, but is becoming very rare. See Eagle.

Erne. River of Ireland. It issues from Lough Gownagh, in co. Longford, and flows mainly $\mathrm{N}$. through Lough Oughter and both upper and lower Lough Erne until it falls into Donegal Bay near Bally. shannon. Its main feature is the Balleck Falls on the lower river. Its length is $70 \mathrm{~m}$. Enniskillen is the chief town on its banks, and after leaving Longford it passes through counties Cavan and Fermanagh.

Erne. Name of two loughs or lakes of Ireland. The upper lake is $13 \mathrm{~m}$. long, and in one place $4 \mathrm{~m}$. wide ; the lower lake is $18 \mathrm{~m}$. long, and from 2 to $5 \mathrm{~m}$. broad. The river Erne passes through them, the distance between the two being 10 $\mathrm{m}$. The lakes occupy hollows in the limestone, and have a very irregular shape ; the upper portion is merely a collection of narrow ponds abutting on the river. In both, but especially in the upper lake, are numerous islands.

Erne, EarL of. Irish title borne since 1789 by the family of Crichton. In 1788 Abraham Creighton, an Irish landowner, was made Baron Erne. His son John (d. 1828) was made a viscount and an earl, and John the 3rd earl (1802-85) changed the spelling of the name to Crichton. He was made a British peer as Baron Fermanagh in 1872, and from him the present earl is descended. The family es. tates are mainly in counties Fermanagh and Mayo, and the residence is Crom Castle, Fermanagh. The earl's eldest son is known as Viscount Crichton. Pron. Cryton.

Ernest. Masculine Christian name, probably derived from the German ernst, serious. The French form is Ernest; Ital. and Span. Ernesto. Its comparatively recent introduction into Britain is largely due to the fact that the fifth son of George III was Ernest Augustus, whilst the father and brother of the Prince Consort were named Ernest. The feminine form of the name is Ernestine.

Ernest Augustus (1771-1851). King of Hanover. The fifth son of George III of England, he was born at Kew, June 5, 1771. He entered the Hanoverian army and distinguished himself during the Napoleonic wars. In 1799 he was made duke of Cumberland and Teviotdale, and in the House of Lords he acted with the more extreme Tories in opposing all kinds of reform, especially Roman Catholic emancipation and the great measure of 1832. In 1810 some excitement was caused by a murderous attack made on the duke by his valet; the latter was afterwards found dead, and some went so far as to accuse Ernest of his murder.

At one time it seemed likely that Ernest would inherit the English throne, but by the operation of the Salic law he succeeded to Hanover in 1837. There he reigned for fourteen years. $\mathrm{He}$ would not hear of anything in the nature of constitutional reform, but in spite of troubles caused by this unyielding attitude he appears to have been popular with his subjects. $\mathrm{He}$ died Nov. 18, 1851, and was succeeded by his son George. His wife was Frederica, daughter of Charles, duke of Mecklenburg-Strelitz. See photo. p. 2399.

Ernle, Rowland Edmund ProTHERo, Baron (b. 1852). British politician and writer. Born Sept. 6, 1852 , a younger son of the Rev. G. Prothero, canon of Westminster, he was educated at Marlborough and Balliol Col. lege, $\mathrm{Ox}$ ford, b e c o $\mathrm{m}$ i $\mathrm{ng}$ fellow of All Souls in 1875. $\mathrm{He}$ was ad-

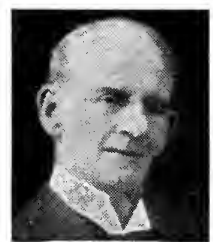

Baron Ernle, British politician Elliott \& Fry mitted to the bar, did literary work for some years, and in 1894 was made editor of The Quarterly Review. An authority on agricul. ture, he was appointed agent-inchief to the duke of Bedford in 1899.

In 1914 Oxford University chose Prothero as one of its members, and in 1916 he was included in the Coalition Government as president of the board of agriculture. $\mathrm{He}$ continued in office after the general election of 1918, but was made a peer as Baron Ernle, the name being that of a Wiltshire family with which his mother was connected. $\mathrm{He}$ wrote The Pioneers and Progress of English Farming, 1888; English Farming, Past and Present, 1912 ; but his most popular works are Life and Correspondence of Dean Stanley, 1893 (with G. G. Bradley); and The Psalms in Human Life, 1903. His only son was killed during the Great War.

Ermulf or ARNUlF (1040-1124). English ecclesiastic. He was born in France and educated at $\mathrm{Bec}$, under Lanfranc, on whose advice he came to England. Made prior of Canterbury by Anselm, he was abbot of Peterborough from 1107 14, when he became bishop of Rochester. He was a great authority on canon law, and the author of the Textus Roffensis, preserved in the library of Rochester Cathedral, which comprises records of the cathedral, and other historical, ecclesiastical, and legal documents. This collection contains the form of excommunication entitled The Pope's Dreadful Curse, quoted by Sterne in Tristram Shandy to show his veneration for the pious bishop who had ready for use "fit forms of swearing suitable to all cases."

Erode. Town of Madras, India. It is in the Coimbatore district, and was at one time a place of some importance. It suffered during successive invasions of the country in the 17th and 18th centuries. The town, which is the headquarters of the divisional officer, contains two old temples. Pop. 16,701, five-sixths Hindus.

Eros. In classical mythology, the Greek name for Cupid (q.v.).

Eros. Nearest of the minor planets, discovered in 1898. The importance of the discovery lay in the fact that it had then approached nearer to the earth than Mars. The asteroid's subsequent nearest approach to the earth was in 1901, when many of the great telescopes of the world, then engaged on the Great Star map, were turned on Eros with a view to deter. mining its nearness. Another near approach is due in 1931 .

The task of coordinating the observations of Eros was undertaken by A. R. Hinks, of Cam. bridge University observatory. By 1909 Hinks was able to announce a most satisfactory result for the distance of the planet, and by implication for that of the sun and of the other members of the solar system. The value of $92,830,000$ $\mathrm{m}$. was obtained for the sun's distance, and it was estimated that this result was probably within 30,000 miles of the actual distance. See Asteroids; Parallax. 
Erosion (Lat. erosio, eating away). The wearing down of the earth's surface through the action of the atmosphere, rain, rivers, ice, and the sea and its tides. Atmospheric erosion is either ehemical or mechanical. Wind transports particles and polishes surfaces over which they are carricd, e.g. in deserts. Sudden changes of temperature cause particles of rock to split off, subsequently to be removed by wind or water. Atmosphere acts chemically through rainfall, in causing decomposition of rocks. Disintegration of rocks being thus effected, the products are afterwards removed by running water, in most cases the water eroding the boundaries of its course by abrasive action of materials carried.

Erosion beneath the surface of the ground is chiefly chemical, and often results in formation of caves and caverns, especially in limestone districts. Glacial erosion takes place over large areas and on an extensive scale, ice being, under certain conditions, a powerful seouring agent. Marine erosion is in continuous progress along eoasts, the sea often using débris broken from cliffs by waves as batteringrams for further destruction. The burrowing of animals, e.g. worms, and penetration of roots of plants assist also in disintegration of land surfaces. The general result of all erosion is to lower the level of land. See Coast; Glacier ; River.

Erotic Literature (Gr. erōtikos, amatory). Literature inspired by the theme of love. The name is generally applied to poetry, and latterly more especially to poetry of a warmly impassioned character. The classical erotic poets include Anacreon, Callimachus, Sappho, and Theocritus among the Greeks and Catullus, Horace, Ovid, and Tibullus among the Latins. 'The troubadours of the Middle Ages carried on the erotic tradition in France, and at the Renaissance this form of literature had a revival on the eontinent of Europe. In English literature it reached a high level in the lyrical work of poets of the 17 th century, such as Donne, Cowley, Herrick, Waller, Lovelace, and Suekling. In the 19 th century, more especially in the latter half, it had a recrudescence in the poems of Rossetti and Swinburne, and in France in the writings of Baudelaire and others.

Er Ram. Village of Palestine. It is situated on a hill on the Jeru. salem-Nablus road. Identified as the ancient Ramah (q.v.) of Benjamin (1 Kings xv, 17), it formed a kind of frontier castle between the N. and S. kingdoms of Palestine, and was repeopled after the return

from captivity. The modern village was captured by Allenby, Dec. 28,1917 , in the advance following the capture of Jerusalem. ., See Palestine, Conquest of.

Erratics (Lat. errare, to wander). In geology, portions of rock of varying size which have been moved from their original home by natural agencies. They commonly consist of rock-fragments torn away by glaciers, and often bear scratches resulting from movement under great pressure. They occur in great profusion in glacial boulder-clays, and are often spread over high levels by glacial torrents. See Glacier; Rock.

Errigal or ARIGAL. Mountain of Donegal, Ireland, the highest point in Ulster. It is $5 \mathrm{~m}$. S.E. of Gweedore and is 2,460 ft. high.

Erroll, EarL of. Scottish title borne since 1452 by the family of Hay. William Hay, hereditary

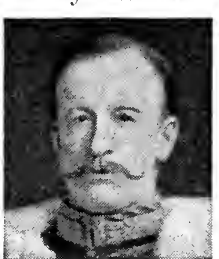

20th Earl of Erroll, British soldier Lafayette constantly in rebellion against James VI. He was then a Roman Catholic, and in league with Spain ; in 1594 he led a small rising, after which his residence, Slains Castle, was destroyed. Later he became a Protestant.

A dispute as to whether Erroll or the earl marischal was the rightful constable was decided in favour of the former, and so the earls take precedence in Scotland just after the royal family. When the 13 th carl died unmarried his sister succeeded to the title. The greatnephew who followed was a son of the earl of Kilmarnock who was executed for his share in the rising of 1745 , but this did not affect his earldom, and from him the later earls are descended. The 18 th earl, lord steward of the household, was made a peer of the United Kingdom as Baron Kilmarnock in 1831, and in 1891 his grandson, Charles Gore Hay (b. 1852), became the 20th earl. The earl's estates are in Aberdeenshire, where is his seat, Slains Castle. His eldest son is called Lord Kilmarnock.

Erromanga. One of the S. group of the New Hebrides. It measures $30 \mathrm{~m}$. long by 20 wide. The chief anchorage is Dillon's Bay; the chief product, eopra.
Here John Williams, the missionary, was killed and eaten in 1839 , since when most of the natives have been Christianised. Est. pop. 2,500.

Error. False idea which is regarded as true. Errors are due to an appearance of truth, which deceives the subject. When referring to the logical form of the judgement, they are formal, and contradict the laws of thought; when to its content they are material, and contradict the facts.

There are two important classes of error: those which are of so little consequence that they may be neglected, and those which are inevitable, but must be allowed for.

Error in Mechanics

Most munition workers were introduced to the necessity for extreme accuracy of measurement in dealing with delicate machinery, and brought to realize that errors of small magnitude but important consequences were unavoidable. They learnt something of the delicacy of modern scientific measurements, and, in many cases, found that the instruments which they used were subject to a constant error, for which allowance had to be made. No scientific investigator uses an instrument for precise measurement without first finding the constant error to which it is subject. Consequently a piece of metal reputed to be 31 ins. in length is almost certainly not precisely 31 ins. If the ruler used is accurately graduated to tenths of an inch the possible error may be $\frac{1}{20}$ in. too much or too little; this error is solely due to the fact that the ruler only shows tenths of an inch. It becomes a matter of importance to investigate the character of such errors, and statisticians have formulated the "law of error," from which the probable error in the measurement can be calculated.

It is found mathematically that the likelihood that the actual error will exceed the probable error is small, there is only one chance in six that the actual error will be double, and one in 1,388 that it will be five times the probable error. Scientists, eonsequently, express numerical results in the form 6.17 \pm 0.02 , which means that the mea. sured value is probably $6 \cdot 17$, and certainly not more than $6 \cdot 19$, nor less than $6 \cdot 15$, and, further, that there is a very great probability that the error is less than \pm 0.01 , although the porjible erroris \pm 0.02 .

Errors are sometimes conveniently expressed as percentages, e.g. \pm 1 p.c.; and when calculations are made with quantities, each of them subject to a possible error, the final result is subject to a much larger error, e.g. if $\mathrm{A}, \mathrm{B}$, 
and $\mathrm{C}$ are measured quantities with possible errors of $\pm 1, \pm 2$, and \pm 3 p.c. respectively, then the result of computations $\mathrm{A} \times \mathrm{B} \times \mathrm{C}$, or $\mathrm{A} \times \mathrm{B}$ $\div \mathrm{C}$, or $\mathrm{A} \div \mathrm{B} \div \mathrm{C}$, is subject to an error of $\pm(1+2+3)$, i.e. \pm 6 p.c.

The practical consequences of these considerations are numerous and important. Unless considerable time and skill be expended over the operation, measurements expressed by more than three significant figures are probably incorrect: it is almost certain, for instance, that a value of 16.34 feet is incorrect; the final 4 is almost certainly wrong, and the 3 may be doubtful. Consequently it is useless to try to measure $18 \cdot 69$ yards or $26 \cdot 75$ cwts. This fact justifies the grocer who weighs butter, etc., to the nearest half ounce.

Error, Writ of. Name of a writ of appeal to the king's bench in criminal cases, or to the court of exchequer chamber or the House of Lords in civil cases. It was for errors appearing on the record, but it is now abolished in all cases.

Ersch, JohanN Samuel (17661828). German bibliographer. $\mathrm{He}$ was born at Grossglogau, Silesia, June 23, 1766, and studied at Halle. $\mathrm{He}$ was successively librarian, 1800, and professor, 1803, at Jena, and principal librarian, 1808, at Halle. His Handbuch der deutschen Literatur seit der Mitte des 18ten Jahrhunderts, 1812-14, laid the foundation of modern German bibliography. In 1818 he began, with J. G. Gruber, the famous Allgemeine Encyklopädie der Wissenschaften und Künste, which was not completed a century later. $\mathrm{He}$ died at Halle, Jan. 16, 1828.

Erse. Early Scottish variant o: Irish. In the 14th-15th centuries the term was used of kings and

$21 \triangle B$ B Cc Do ee FF弓丂クh\| $(12 \eta m N n$ Oo $p p$ $\mathrm{R}_{\mathrm{S}} \mathrm{Sr} \tau \tau \mathrm{Uu}$

\section{Erse. Irish Gaelic alphabet of} eighteen letters

caterans. In the 18th century it denoted Gaelic speech; at first Scottish Gaelic, and subsequently Irish Gaelic. It is no longer in current usage in this sense. In modern philology it sometimes designates the language-group, embracing Gaelic and Manx, which is now usually called Goidelic. See Gaelic Language and Literature; Goidels; I reland: Language and Iiterature.

Ersekújvár. Town of CzechoSlovakia, formerly in Hungary, now known as No vé Zámky. It oc-

cupies an important situation on the Nyitra (Nitra) river, and is both a rly. and road junction, $57 \mathrm{~m}$. by rly. almost due E. of Bratislava (Pressburg). Pop. 16,2C0, ninetenths Roman Catholic Magyars.

Erskine, EBENEZER(1680-1754) Scottish divine and founder of the Secession Church. Born at Dry-

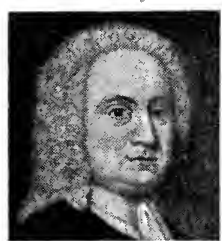

Ebenezer Erskine, Scottish divine

shire, whence he in Kinrosschurch at Stirling. There he came into collision with his ecclesiastical superiors, and the matter came to a head when, in 1732 , he declared that parishes should choose their own ministers. This led to his suspension, but with some associates he founded a separate presbytery, which developed into the Secession Church. In this Erskine remained until 1748, when the section opposed to him secured his removal from the ministry. $\mathrm{He}$ died at Stirling, June 2, 1754. See Presbyterianism; Secession Church; consult also The Erskines, A. R. MacEwen, 1900.

Erskine, JoHN, of DUN (1509$91)$. Scottish reformer. He was educated at King's College, Aberdeen, travelled on the Continent, and in 1534 returned with a French scholar, who introduced the study of Greek into Scotland. His enthusiasm was equally divided between the new learning and the new faith. He was an intimate friend of John Knox, and his influence was always exerted in the direction of moderation. He was several times moderator of the general assembly and in 1579 was appointed a member of the king's council.

Erskine, Thomas Erskine, lst Baron (1750-1823). British lawyer. A younger son of the 10th earl of

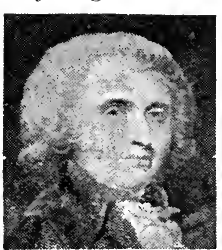

1st Baron Erskine, British lawyer After Hoppner ferred to the army. This career, too, he abandoned after a few years, and in 1778 he was called to the bar.
As a barrister Erskine's success was instantaneous. He made his name in his first case, and in 1781 he added to his reputation when junior counsel for Lord George Gordon. In 1783 he waselected M.P. for Portsmouth, and after six years' absence he was again returned for that borough in 1790 . He made no mark in Parliament, but, having been attorney-general and chancellor to the prince of Wales, he was lord chancellor in the Whig ministry of 1806-7. He was then raised to the peerage. He died Nov. 17, 1823. The barony still remains with his descendants. See Speeches, ed. J. Ridgway, with Memoir by Ld. Brougham, 4 vols., 1847 ; Lives of the Chancellors, Lord Campbell, 4th ed. 1856-57.

Erskine's eldest brother, Henry Erskine (1746-1817), was also a distinguished advocate. Trained at St. Andrews and Edinburgh for the Scottish bar, he was lord advocate in 1783, and again in 1806-7. He was for a short time M.P. and died Oct. 8, 1817. Like his brother, his reputation rests upon his stately and pleasing eloquence. See Life, A. Fergusson, 1882.

Erskineville. Industrial suburb of Sydney, New South Wales. Pop. 7,299. See Sydney.

Erubescite (Lat. erubescere, to grow red). Ore of copper also known as variegated copper pyrites and as horse-flesh ore. In colour it varies betwcen copper-red and pinkish brown; it is brittle and tarnishes rapidly on exposure ; its specific gravity is 5. Chemically it is a sulphide of the metal, its composition being copper $62 \cdot 8$, sulphur $25^{\circ}$, and iron 11 , and traces of impurities. It does not occur in large quantities, but is found frequently with other copper pyritous ores in granite and allied formations in Cornwall, Ireland, Norway, Silesia, Saxony, Siberia, the U.S.A., and Canada. See Copper.

Eruptive Rocks. Rocks which have been either extruded at the surface of the earth or have consolidated bencath the surface under pressure of overlying rock-masses. Those extruded (effusive rocks), as in volcanic eruptions, are of the type of lava and are found near volcanoes, active or extinct ; they frequently exhibit flow-structure, indicating rapid consolidation. Basalts and rhyolites are examples.

Rocks consolidated beneath the surface (intrusive rocks) are of two kinds : very deep-seated (plutonic) and less deep-seated (hypabyssal). Plutonic rocks are usually coarsely crystalline, never glassy or with vapour cavities; hypabyssal rocks are often coarsely crystalline, but show great variation in structure. 
Intrusive rocks occur as areas of great extent and irregular shape (batholiths), in spreading sheets forced up from below between other strata (laccoliths and sills), as filling the pipes of old volcanoes (necks), as occupying more or less vertical fissures (dykes), or as branching injections (veins). See Geology; Rock.

Ervillers. Village of France, in the dept. of Pas-de-Calais. It is on the Arras-Bapaume road, $6 \mathrm{~m}$. N. of Bapaume. Taken by the Allies in the spring of 1917 , it was recaptured by the Germans a year later, and stormed by the British on Aug. 23 1918. Sce Bapaume, Battle of ; Somme, Battles of the.

Ervine, St. John Greer (b. 1883). Irish dramatist and novelist. He was boin at Belfast, Dec.

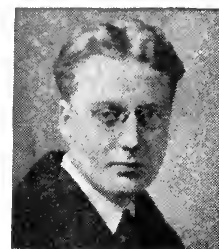

St. John Ervine, Irish dramatist Lena Connell
28,1883

Notable plays written by h i m a $\mathrm{re}$ : Mixed Marriage, Dublin, 1911 ; The Magnanimous Lover, D u b. lin, 1912; Jane Clegg, Manchester, 1913; and John Ferguson, Dublin, 1916. In 1915 Ervine was appointed manager of the Abbey Theatre, Dublin. In 1916 he joined the Household Cavalry, and being transferred to the Royal Dublin Fusiliers, went with them to the French front. $\mathrm{He}$ has also written novels and volumes of short stories, including Eight O'Clock and Other Studies, 1913 ; Mrs. Mar. tin's Man, 1914; Alice and a Family, 1915; Changing Winds, 1917 ; and The Foolish Lovers, 1920.

Erymanthus (mod. Olonos). Mountain of Arcadia, ancient Greece. The loftiest peak in the Kalliphonia range, it is associated with the story of Hercules and the Erymanthian boar which haunted this region and was slain by the hero. Alt. $7,296 \mathrm{ft}$.

Erysipelas (Gr. erythros, red; pella, skin). Acute contagious discase due to infection by the microorganism Streptococcus pyogenes. Infection occurs through some in. jury to the surface of the skin, which may be quite trivial, such as a cut while shaving. It was formcrly believed that the disease could arise without a wound, the so-called "idiopathic" form, but it is now recognized that in every case there is some lesion, however small. The skin rapidly bccomes swollen and red, the inflammation advancing with a more or less well-defined margin and dying away behind this. The face is most frequently involved, and the swelling may cause the eyes to close. The temperature rises to $103^{\circ} \mathrm{F}$. or more, and delirium may occur.

The duration of the disease is variable, but generally it lasts from one to three weeks. Death in healthy adults is rare, but in aged, debilitated persons and chronic alcoholics the outlook is not so good. Recently delivered women exhibit an increased liability to the disease. Treatment by drugs does not appear markedly to influence it, but some physicians strongly recommend perchloride of iron. Ichthyol has been found to be a useful local application, and belladonna or opium may be employed to relieve pain. Injections of antistreptococcic serum have been used with success. The patient must be strictly isolated.

Erythema (Gr. from erythainein, to make red). Redness of the skin owing to dilatation of the small blood-vessels. It is usually associated with swelling or infiltration. The condition may be localised, when it may be due to simple in. flammation, burning, or irritation by chemical substances; or it may be more or less present over the whole body, when it is usually a symptom of infectious fever, e.g. scarlet fever or measles; or of poisoning by unsounc food or certain drugs, particularly belladonna; or is a manifestation of disease of the skin.

Erythrite OR ERYTHROL (Gr. erythros, red). Sweet-tasting substance first prepared by Stenhouse in 1848 from several species of lichen such as orchella weed (Roccella tinctoria). The lichen is boiled with milk of lime, fil. tered, and precipitated by adding hydrochloric acid; the precipitate being afterwards purified by crystallisation from alcohol. The name erythrite is also applied to the mineral known as cobalt bloom, a hydrated arsenate of cobalt.

Erythromelalgia (Gr. erythros, red ; melos, limb ; algos, pain). Rare disease characterised by acute pain in the foot, or less frequently the hand, with purplish-red congestion of the skin and moderate swelling. The cause is unknown.

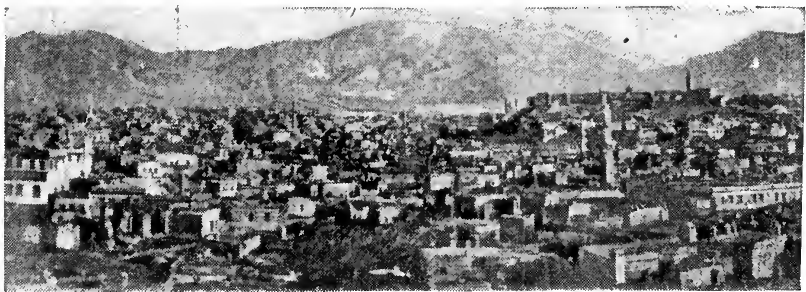

Erzerum. The mountain city of Armenia, once a frontier fortress of the Byzantine Empire. To the right is the medieval citadel
Eryx (mod. Monte San Giuliano). Mountain of Sicily near Drepanum (Trapani). It was crowned by a famous temple of Aphroditē, who was locally called Erycina. The temple derived its revenue from 17 Sicilian towns belonging to it. On the W. slope of the mountain is the decayed town of Eryx. Its old Roman walls still exist beside the ruins of the temple. The mountain is $2,465 \mathrm{ft}$. high.

Erzberger, MatThIas (18751921). German politician. B. at Buttenhausen, Sept., 1875, and educated at Freiburg, he deto the study of political e c o n o m y. Earlyinterest. ed in the Christian Soment, in 1897 he was a dele-

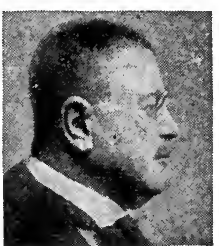
German politician ence at Zürich. $\mathrm{He}$ entered the Reichstag, and came into promincnce when, as a member of the Catholic or Centre Party, he made a speech on July 6, 1917, accusing ministers of misrepresenting the military situation, and at the same time demanding the reform of the Prussian franchise and a statement of the peace aims of Germany. In 1918 Erzberger was secretary of state when Prince Max of Baden was imperial chancellor, and in June, 1919, after holding office in Scheidemann's cabinet, he was min. ister of finance and vice-premier. He resigned in Feb., 1920, and was assassinated, Aug. 26, 1921.

Erzerum. Vilayet or province of Armenia. It consists of a high plateau traversed from $\mathrm{E}$. to $\mathrm{W}$. by several lofty chains of mountains, in which are the sources of the Euphrates, the Aras, the Chorok, and other rivers. The capital is Erzerum. Area. 19,180 sq. m. Pop. 645,700.

Erzerum or Erzrom. City of Armenia. Situated in a wide plain, surrounded by mountains, and lying $6,200 \mathrm{ft}$. above the sea, it is $120 \mathrm{~m}$. S.E. of Trebizond, its port, and about $150 \mathrm{~m}$. W. of Mt. Ararat, voted himself cialist move- 
and is an important commercial town and military position. It is walled, and its streets are narrow and crooked. It has few fine buildings, the chief being the Armenian and Greek churches. Erzerum is the seat of an Armenian bishop.

Its main importance came from its position strategically with respect to Russia. Under the Turks, who occupied it in the 16th century, it was made into a fortress and was the headquarters of an army corps. It was taken by the Russians in 1829 and again in 1878. During the Great War it was captured by the Russians in Feb., 1916 , but during the winter of 1917-18 it was abandoned by them by order of the Bolshevist Government, and was reoccupied by the Turks in March, 1918, in spite of strong resistance by the local Armenians. Before the Great War its pop. was approximately 80,000 , a large number of whom were Armenians. It was the scene of massacres of Armenians in 1895 and again in 1915 .

Erzerum, Capture of. Russian success against the Turks, Feb. 16 , 1916. After capturing Köpriköi, Jan. 19, 1916, the Russians under Yudenitch pressed on to Hassan Kale, 23 m. from Erzerum. The enemy retreated to Deve Boyun, a strongly fortified ridge on the east front of that city, and on Jan. 26 Yudenitch stood before it.

The Russian right wing pushed the Turks from Tortum to the Chorok, crossed the mountains, and reached Kara Gubek on the Kara $\mathrm{Su}$, or Western Euphrates, thus threatening Erzerum from the N. The left wing worked its way from the S.E. to Palandoken, capturing the enemy positions there, and menacing Erzerum from the S. On the N. Kara Gubek was taken on Feb. 12, and Tafta, 5 m. nearer Erzerum, on Feb. 13. Yudeuitch now attacked the Deve Boyun forts, nine of which fell into his hands on Feb. 15; the defence collapsed, and he entered Erzerum next day. As a military operation its capture was a great feat, considering that it was the depth of winter, that his wings had to advance through high and most difficult mountain coun. try, and that the city itself was protected by many forts. In and about Erzerum the Russians captured 13,000 prisoners, more than 300 guns, and immense quantities of munitions and supplies. The total loss of the Turks was put t 60,000 men. The town was reoccupied by the Turks, March 11, 1918. See Caucasus, Campaign in the.

Erzgebirge or ORE MOUn'taINs. Mountain range of Germany. It is partly in Saxony and partly in
Bohemia, stretching for about 90 m. from the Elbe to the Elstergebirge. The highest peaks are the centre, the Keilberg being over $4,000 \mathrm{ft}$. high. Only a little lower are the Fichtelberg and the Spitzberg. On the south the range has a precipitous face, but on the north, or Saxon side, it slopes more gradually to the plain. The range, as the name suggests, is rich in minerals, silver, lead, tin, copper, iron, and some gold being found here. There are a number of health resorts in the mountains which are visited both for health and pleasure, much of the scenery being very fine. The hills are densely wooded and the district is well served by railways.

Erzingan, Erzinjan, or ErzinGHIAN. Town of Asia Minor, the medieval A rsinga. This formerly im. portant military centre of the Turks lies on the W. Euphrates (Kara Su) about $75 \mathrm{~m}$. W. of Erzerum. During the Great War it was the headquarters of a Turkish army corps, and as a military base was second in importance only to Frzerum. It was taken by the Russians in July, 1916. The pop. was 25,000 in 1914 , but many of its Armenian inhabitants were massacred in 1915 .

Erzingan, FALL of. Russian success, July 26, 1916. After the capture of Erzerum on Feb. 16, 1916, Yudenitch advanced his main forces towards Erzingan, $75 \mathrm{~m}$ distant. In Mav, however, he was held up at Mamakhatun by the Turks, whose front reached from Baiburt on the N. to Oghnut on the S. At the beginning of July Yudenitch resumed the offensive, took Mamakhatun on the 12 th, drove the enemy out of Baiburt on the 15th, and on the 18th captured Kighi, N.W. of Oghnut. From Baiburt he struck IV. to Kelkid, almost due N. of Erzingan, marched to the N. and took Gumushkane and Ardasa by July 22, thus making easy his descent on Erzingan from the N. Meanwhile other of his forces had advanced from the $\mathrm{E}$. and S.E., and by July 25 had cap. tured Mertekeli, $8 \mathrm{~m}$. from Erzingan, which he occupied the next day. The fall of Erzingan completed the Russian conquest of Armenia. See Caucasus, Campaign in the.

Erzśebetfalva. Town of Hungary, in the cumitat of Pest Pilis. It is a summer resort, $7 . \mathrm{m}$. S.E. of Budapest, on the main line from the capital to Belgrade. Pop. 30,970 , including a number of Jews.

Esarhaddon. Assyrian king, who reigned $680-668$ B.c. His first three years were marked by the re. building of Babylon, destroyed by his father, Sennacherib (2 Kings 19). Besides conducting campaigns against Cilicia, Arabia, and Elam, he sacked Sidon, 676, and Memphis, 670. At Shamaal he set up a stela with his portrait in relief, and erected palaces at Nineveh and Calah. His son Ashurbanipal succeeded him. See Sinjerli.

Esashi. Town and seaport of Japan, on the island of Hokkaido. It is a port of call on the S. W. coast, 35 m. W.N.W. of Hakodate. Pop. 12,500 .

Esau. Son of Isaac and elder brother of Jacob, whose great rival he became after the younger brother had secured by a trick the privileges of primogeniture. $\mathrm{He}$ became a hunting man, married wives of Hittite nationality, and founded a tribe which occupied the mountains S. of the Dead Sea. In his later days he was on friendly terms with Jँacob, but his descend. ants were always hated and despised by the Jews. See Jacob.

Esbjerg. Seaport of Denmark, in Jutland. It stands on the Nor'h Sea, opposite the island of Fanö, $56 \mathrm{~m}$. by rly. W. of Fredericia, and is the principal port on the W. Jutland coast. 'The harbour was built in 1868-74, and is state subsidised. Its exports to Great Britain mainly consist of bacon, beef, cattle and dairy produce. The fishing and manufacturing industries

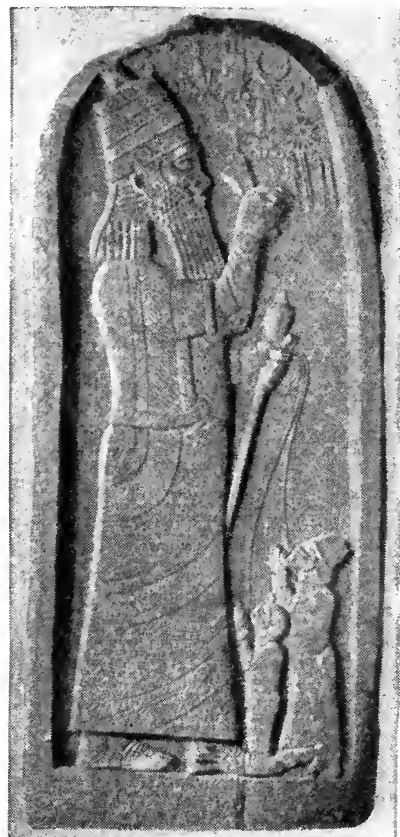

Esarhaddon. Monument excavated at Sinjerli, showing the Assyrian king with an inscription, $6 \% 0$ B.C., detailing his conquest of Egypt Berlin Museum 
are important and there is cable communication with Calais. Before the construction of the harbour it was a small fishing village. Pop. 18.208.

Escalade (Lat. scala, ladder). Method of attacking fortifications in the Middle Ages. The walls

\section{FCe
Escalator. Diagrammatic view of
an escalator as used on the London Electric Railways}

were reached by the use of scaling ladders or by a staircase or ramp of faggots or similar material placed against them.

Escalator. Moving stairway, consisting of an endless chain of steps running round sheaves at the top and bottom of the staircase. Every step is mounted on two twowheeled trucks, the forward wheel of a truck being out of line with the rear one, so that they may run on separate rails. On the sloping part of the staircase the rearwheel rails are set higher than the front-wheel, but gradually reach the same level as the horizontal portions are approached; the treads are always horizontal.

The "risers" of the steps are curved to keep close to the treads immediately above them while the steps are moving vertically relatively to one another. The stairchain is driven by an electric motor. An escalator transports more people than a lift in a given time, vertical travel and power consumption being equal in both cases, costs less in attendance, and is generally more convenient to use. At several stations on the London underground railways it has already displaced lifts ; and its use will probably be considerably extended where large numbers of people have to be moved from one level to another.

Escallonia. Genus of evergreen shrubs of the natural order Saxifragaceae, natives of $S$. America. The undivided, leathery leaves are covered with resinous glands which render them somewhat sticky. The tubu. lar white, pink, or red flowers are disposed in small clusters at the ends of branches. $E$. rubra and $E$. macrantha are much grown in the $\mathrm{S}$. of England near the sea as garden hedges. The shrub is named after Escallon, a Spanish traveller.

Escanaba. City of Michigan, U.S.A., the co. seat of Delta co. On an arm of Green Bay, Lake

Michigan, $72 \mathrm{~m}$. S. by E. of Marguette, it is served by the Minneapolis, St. Paul and Sault Ste. Marie, and other rlys. . A favourite summer resort with a fine harbour, it exports iron ore and trades in fish, coal, and other commodities. It has various manufactures, furniture and lum. niture and lum.
ber products

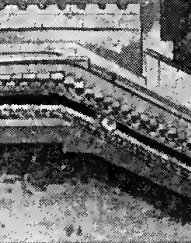

being the chief, and rly. workshops. Settled in 1863, it became a city twenty years later. Pop. 14,747.

Escapement. Part of the mechanism of a clock by which one tooth of a wheel is released or escapes from the pallet at each swing of the pendulum.

Escarpment (Fr. escarper, to cut vertically). Steep face or ridge along which a bed or formation of rock abruptly ends. Escarpments are often found where gent. ly tilted beds of liard and soft rocks occur in alternate layers. The diagram shows a simplified

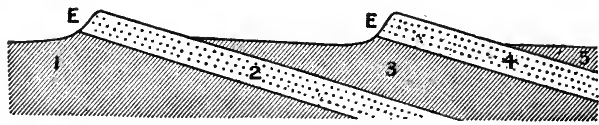

Escarpment. Sectional diagram illustrating formation of escarpments E E. 1. Soft layers of lower Severn Valley. 2. Oolitic limestone of Cotswold Hills. 3. Soft layers of middle Thames basin. 4. Chalk beds of Chiltern Hills.

5. Soft layers of London basin section from Gloucester to London. First therc are the soft layers of the Severn Valley. This is overlooked by the steep face, or escarpment, of the oolitic limestone of the Cots. wold Hills. These measures gently dip below plains of soft clay, which in turn are dominated by the escarpment of the chalk Chilterns. Formerly both the chalk and limestone measures extended farther $W$. The steep southern face of the $N$. Downs and the abrupt nortliern face of

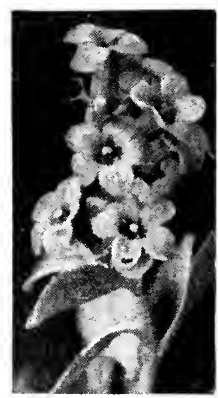

Escallonia. Foliage and flower of Es callonia macrantha man and Lazarus and the descrip. tions in the book of Revelation are couched in the language of Orien. tal imagery, and were not intended to be taken literally.

The general teaching of the Christian Church on the subject has been marked ky great reserve, with the exception of the Church of Rome in the Middle Ages, when the doctrine of purgatory was developed in detail. The present attitude of theologians is one of opposition to speculation on the subject. See Immortality ; Survival.

Escheat (Lat. excidere, to fall out). Term used in law for the reversion of land to its ultimate owner because there is no other heir. It is a relic of feudal times when land was granted by the king or other lord on the condition that in certain contingencies it escheated or came back to him. Land also escheated when the holder was attainted, the theory being that his blood being thus corrupt, his heirs could not inherit. This, however, was abolished in England in 1870. The majority of escheats fell to the erown. Escheat through failure of heirs was recognized by both 
English and Scottish law, until it was abolished in 1922 . It applied both to freehold and to copyhold land. See Feudalism.

Eschscholtz Bay. Inlet of Alas. ka. An arm of Kotzebue Sound, Bering Strait, near the Arctic Circle, its name commemorates Johann Friedrich Eschscholtz, the Russian naturalist.

Eschscholtzia. Botanical name for the perennial herb Californian poppy (q.v.).

Eschwege. Town of Germany. It stands on the Werra, 38 m. E.S.E. of Cassel, in the Prussian prov. of Hesse-Nassau. The old buildings include a 14th century castle, restored in 1581, and the tower of an 11 th century monastery. Theindus. tries include weaving and tanning. The town was part of Hesse until taken by Prussia after the war of 1866. Pop. 12,600.

Eschweiler. Town of Germany, in the Prussian Rhine prov. It is on the Inde, $8 \mathrm{~m}$. from Aix-laChapelle, and stands on a large coal. field. The chief industries are the manufacture of iron, steel, zinc, and copper goods; also brewing, tanning, etc. Pop. 24,718.

Escombe, HaRRY (1838-99). South African politician. Born July 25, 1838, and educated in Lon-

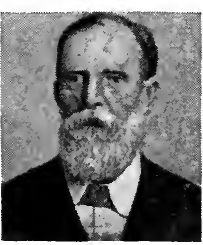

Harry Escombe, S. African politician Lafayette

Council of Natal. After a short visit to England he returned to Natal, fought through the Zulu (1879) and Transvaal (1881) wars, and defended Dinizulu successfully against the charge of rebellion. In 1893 he was made attorney-general and devoted himself to developing the commercial resources of the colony. Elected premier in 1897, at the same time being minister of education and of defence, he came to London for Queen Victoria's Diamond Jubilee, and on his return resigned office. He died Dec. 27, 1899.

Escott, Thomas Hay Sweet (1844-1924). British journalist and author. Born at Taunton, he was

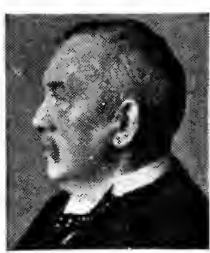

T. H. Sweet Escott, British journalist Russell

86 , was for many years leader writer on The Standard, and became a prolific writer on political and social affairs. His numerous books include England: its People, Polity, and Pursuits, 1870 : Social Transformations of the Victorian Age, 1897 ; King Edward VII and his Court, 1903 ; The Story of British Diplomacy, 1908; monographs on Lord Randolph Churchill, 1895, and Anthony Trollope, 1913; Masters of English Journalism 1911 He died June 14, 1924.

Escudo (Port., shield). Silver coin, monetary unit of Portuguese currency since May 22. 1911.
Divided into 100 centavos, and of nominal value 4 s. 5 d., it replaced the old milreis gold piece; 2, 5, and 10 escudo pieces are minted in gold, and 1,000 escudos form a conto. The shield with the national arms is on the obverse. In Spain, a silver escudo, equal to 10 reals, was used from 1864-68. In Chile, since 1895, a gold escudo worth 5 pesas has circulated.

Escurial (Span. Escorial). Palace and monastery of Spain, situ. ated $26 \mathrm{~m}$. N.W. of Madrid, on a spur of the Guadarrama moun. tains. It was designed for Philip II of Spain by Juan Bautista de 'Toledo, the first stone being laid April 23, 1563. His pupil, Juan de Herrera, carried on the work, which was completed about 1582 . Philip dedicated the building to S. Lorenzo, and intended it to be a retreat to which he could retire and meditate upon his own end. With this idea, he ordered that the structure should be of the plainest character.

It is built of grey granite, in the severest Doric style. The plan is that of an immense rectangle, with a comparatively small rectangular wing, embodying the Palace of the Infantas, projecting beyond the $\mathrm{E}$. side. The gloomy severity of the exterior is emphatic. The façades are pierced by rows of small square windows, each row marking a storey. At each of the four angles of the main structure is a tower $200 \mathrm{ft}$. in height; other towers rise above the roofs, and there are four flanking the great dome of the church. The main entrance, in the centre of the W. front, is sevcrely Doric, in keeping with the rest of the façade. The door itself is $20 \mathrm{ft}$. high by 12

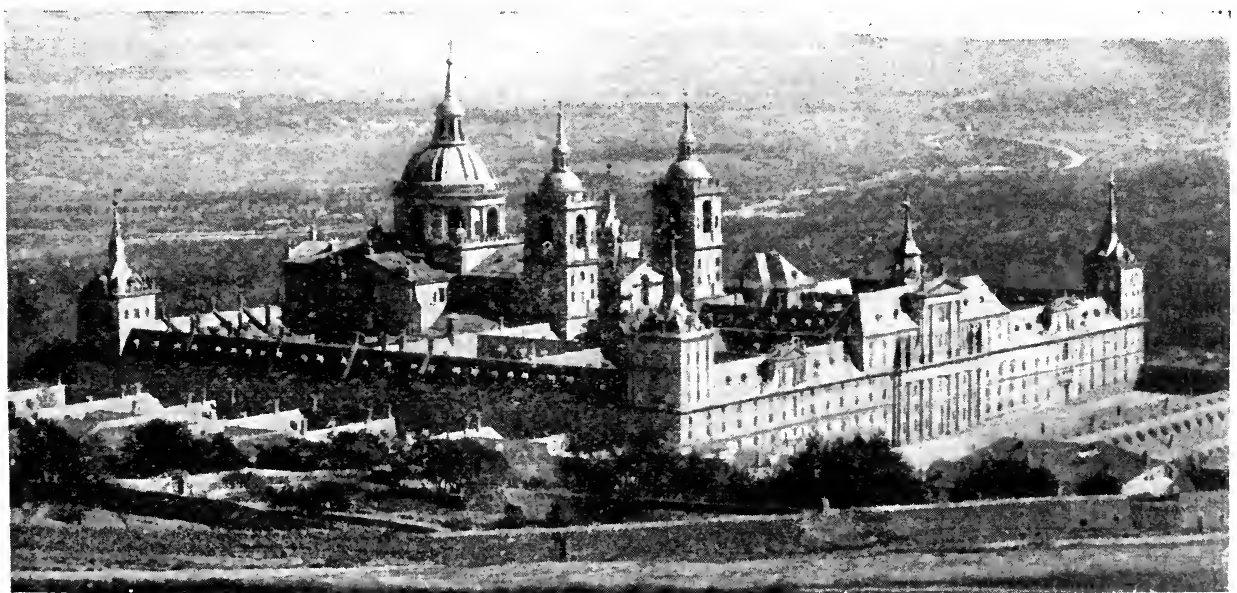

Escurial. The palace and monastery, covering neariy 400,000 sa. ft., seen from the north. In the centre is the greal church, and the palace, college, and convent occupy parts of the surrounding buildings 
ft. wide; above it is a colossal statue of S. Lorenzo, the work of the sculptor Monegro. The head, hands, and feet of this statue are wrought in white marble, but the rest of the figure is granite. This entrance leads into a vestibule 80 $\mathrm{ft}$. wide, flanked on the right hand by the convent, including library and refectory, and on the left by the college.

The central space is occupied by the church, the plan of which was based on the original one of $S$. Peter's, Rome. The dome and lantern are carried on four enormous piers, from which spring the arches of the three naves. There are 48 side chapels, and below the high altar is the famous Pantheon, containing the tombs of the kings and queens of Spain. The decoration of this octagonal chamber, consisting of precious marble linings, dates from 1654; more interesting art treasurcs are the paintings distributed over the church, particularly those by Tintoretto, El Greco, Zurbaran, and Ribera in the sacristy, and the masterpieces of Coello in the chapels.

On the $\mathrm{N}$. side is the palace, in the N.E. corner of which wcre the apartments of Philip himself. In the room in which he died was a panel, by opening which the king could look down upon the high altar of the church. Other apartments of the palace were added to and embellished by later monarchs, the bulk of the decoration belonging to the 18th century. Philip II was the founder of the Escurial Library. Don Diego de Mendoza, the Inquisition, and Augustin, archbishop of Tarragona, were other donors, the collection being further increased by confiscated libraries, and by the rule that a copy of every book published in Spain should be presented to it.

The Hermits of S. Jerome were the first tenants of the monastery, which was stormed in 1807 by French troops; only part of the looted treasure was restored at the peace of 1814. See Architecture.

Escutcheon (old Fr. escuchon, Lat. scutum, shield). In heraldry, term used to describe a shield blazoned with armorial bearings or other insignia. See Shield.

Esdraelon, Plain of. District of Palestine. It is sometimes called the plain of Jezreel, a term which applies more specifically to its eastern extension towards the Jordan. An historic tract of country, it has been the scene of many battles, from Gideon's victory over the Midianites to the actions fought by Allenby's cavalry in his conquest of the Holy Land. It lies
S.E. of Haifa, between Mt. Carme and the Mountains of Gilboa, in N. Palestine, and is the Armageddon of the Apocalypse. Watered by the Kishon, the plain is very fertile. During the Great War the British, after defeating the Turks at El Lejjun, a village on its $\mathrm{S}$. edge, marched across it to Nazareth in Sept., 1918.

Esdras, The Books of. Several works bear the title Esdras. One of these (O.T. Apocrypha) contains substantially the same ma. terials as the Biblical books known as Ezra, Nehemiah, and II Chronicles. In the Septuagint and in the Latin and Syriac versions this is called I Esdras; but in Latin bibles since the time of Jerome, III Esdras (the O.T. books of Ezra and Nehemiah being reckoned as I and II Esdras). Modern scholars prefer to call it "Greek Esdras." The other work in the O.T. Apocrypha is commonly called II Esdras, but sometimes IV Esdras. It contains seven visions, and is the only specimen of Apocalyptic Literature in the O.T. Apocrypha. I Esdras was used by Josephus, and may have been composed in the first cen. tury B.C. II Esdras was probably written in the reign of Domitian (A.D. 81-96). The author appears to have witnessed the destruction of Jerusalem in A.D. 70 (iii, 1); and in the Eagle Vision the eagle seems to represent Rome.

Esdud. Village of Palestine. On the Mediterranean, it occupies the site of ancient Ashdod (q.v.).

Eserine Sulphate. The sul. phate of an alkaloid extracted from Physostigma venenosum, the Calabar bean. It produces contraction of the pupils, and in minute doses is useful in various affections of the eye. In large doses it is very poisonous.

Esh. Village and parish of Dur. ham. It is $5 \mathrm{~m}$. W. of Durham, and is a mining centre. Near here, at Ushaw, is the Roman Catholic college of S. Cuthbert, the successor of the one at Douai. It has a collection of pictures and antiquities, while its chapel was designed by Pugin. S. Michael's is the chief church. Pop. 1,075 .

Esher. Parish of Surrey, England, a residential suburb of London. I stands on the Ports mouth Road neal the little river Mole. Pleasantly situated it is $15 \mathrm{~m}$. S.W. of
London by the L. \& S.W. Rly. Esher Place, beside the Mole, built by William of Waynflete in 1460 , and now represented by a ruined tower, was the residence of Wolsey after his fall in 1529. One mile $\mathrm{S}$. of the town is Claremont (q.v.). Pop. 2,609. The urb. dist. includes Esher, Thames Ditton, and Long Ditton. Pop. 12,518 .

Esher, William Baliol Brett, lst Viscount (1817-99). British judge. The son of a clergyman, he was born Aug. 13, 1817, and went from Westminster School to Caius College, Cambridge. In 1840 he became a barrister, and after some successful years at the bar entered the House of Commons as Conservative M.P. for Helston in 1866, a tie at this election ending in the House allowing both candidates to sit. In 1868 Brett was made solici. tor-general, but very soon he left political life to become a judge of the court of common pleas. In 1876 he was promoted to be a lord jus. tice, and in 1883 to be master of the rolls. He retired in 1897 , and died May 24, 1899. In 1885 Brett was made Baron Esher and in 1897 was raised to the rank of viscount.

Esher, Reginald Baliol Brett, 2ND Viscount (b. 1852). British publicist. Born in London, June 30,1852 , he was the son of Wil. liam Baliol Brett,the judge, created Viscount Esher in 1897. Educated at Eton and Trinity College, Cambridge, he was Liberal M.P. for Pen ryn and Falmouth 1880 85. $\mathrm{He}$ was secretary to the office of works 1895-1902, and enjoyed Beresford the confidence of both Queen Vic. toria and Edward VII, under whom he was deputy-governor of Windsor

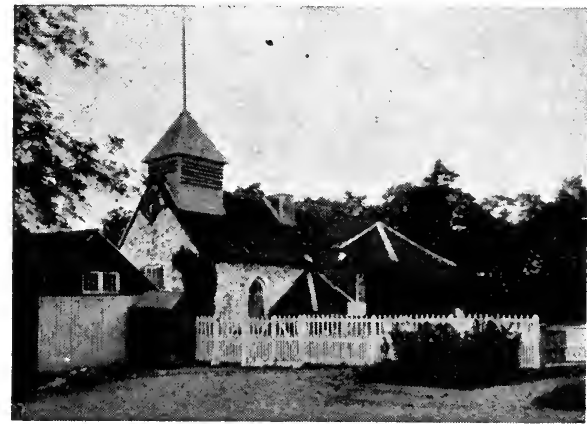

Esher. The old parish church of S. George, disused since 1853. One of the bells was brought from $S$. Domingo Island by Sir Francis Drake 
Castle. Esher took a great interest in the Territorial Force. $\mathrm{He}$ was on the committee of imperial defence, and in 1904 was chairman of the committee appointed to inquire into the constitution of the war office. He wrote To-day and 'Tomorrow and Other Essays, 1910 ; and, with A. C. Benson, edited the Letters of Queen Victoria, 1907.

Eshowe. Town of Zululand, Natal. It is 30 m. S.S.E. of Ulundi, and there are asbestos mines in the neighbourhood. It was besieged for a time by the Zulus during the Zulu War of 1879. Pop. 1,523.

Esk. River of Great Britain Formed by the confluence of the Black Esk and White Esk, which meet in Eskdalemuir, it flows for $35 \mathrm{~m}$. through Dumfriesshire and Cumberland to the Solway Firth, about $5 \mathrm{~m}$. below Longtown.

Esk. River of Midlothian, Scot land. It is formed by the junction of the N. Esk and S. Esk in Dal keith Park, flowing thence $3 \frac{1}{2} \mathrm{~m}$. N. to the Firth of Forth at Mussel burgh.

Esk, NoRTH. River of Kincardineshire and Forfarshire, Scotland. It is formed by the junction of the Lee and Mark, which unite at Invermark, and flows S.W. for $29 \mathrm{~m}$. to the North Sea, $4 \frac{1}{2} \mathrm{~m}$. N.N.E. of Montrose.

Esk, South. River of Forfar. shire, Scotland. It rises in the Gram. pian Mts. and flows $49 \mathrm{~m}$. S.E. and E. to the North Sea at Montrose.

Esker (Irish eskar). Long, winding ridge of coarse gravel and sand. Formed by torrents of water released from glaciers, eskers are situated in areas formerly occupied by ice-sheets.

Eski-Djumaia, -JUMA OR -JUMAYA. Town of Bulgaria. It is situated on the rly. from Sofia to Varna, about $16 \mathrm{~m}$. W. of Shumla. Pop. 10,000 .

Eskilstuna. 'Town of Sweden, in the prov. of Södermanland. It stands on the Hjelmar river, between the Mälar and Hjelmar lakes, $60 \mathrm{~m}$. W. of Stockholm. Known as the Sheffield of Sweden, it has ironfoundries, steel works, a royal arms factory, and a technical school. It is celebrated for its cutlery and damascened work. Named after S. Eskil (d. 1181), the English apostle in Södermanland, its 12th century monastery was destroyed by fire in 1680 . Pop. 28,485 .

Eskimo (Abenaki, raw flesheater). Primitive race inhabiting arctic America. Numbering (1911) about 12,500, Greenland; 14,000, Alaska; (1915) 1,099, Siberian coast and 3,447 , Canada, their geographi cal range of $5,000 \mathrm{~m}$. is the widest of any aboriginal race in the world. The Danish form Eskimo has dis. placed the French Esquimaux. The
Hudson Bay "husky," used of man and dog, is a colloquial variant. The

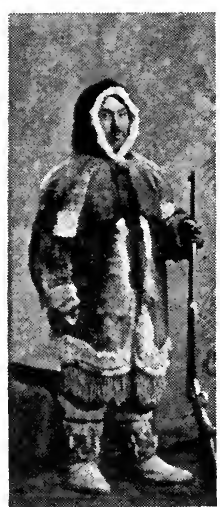

Eskimo man in

hunting dress native name is Innuit (men). Long - headed, broad - faced, lank - haired, and of a yel. lowish brown colour, an origin in prehis toric Europe is suggested. 'Thus, besides theirseal-food, they still hunt musk-ox and reindeer. Their bone arrowheads, har. poons, shaft. straighte ners, and orna. ments, their stone lamps and ivory engravings - almost reaching picture-writing-support this view, which, however, has recently been contested in favour of relationships more definitely mongoloid. That they crossed by the Bering Strait is undisputed, so that a pre-American habitat in $\mathrm{N}$. Siberia is a reasonable inference. The claim that they extended at one time to the Scandinavian, and even to the $N$. coasts of Britain, is less fully established. Their one-man skin canoes (kayak), transport boats (umiak), summer tents of skin, winter huts of turfed stone, migrant snow-houses (igloo), harpoon floats, dog sledges, cairnburials, all betoken an intelligent adaptation to adverse conditions.

The language-stock, with its many dialects, attests a long ancestry, anterior to their American advent. Their animism embraces a crude magic, governed by medicine-men (angakok), akin to African witch-doctors rather than Siberian shamans. Their communal life recognizes no national chiefs ; tribal warfare is unknown. Their ample folklore points to a belief of some tribes in a woman of the sea, perhaps Scandinavian, of others in a moon-god. The Aleuts of the Aleutian Islands are a self-contained branch of the race, exhibiting traces of Asiatic rather than American Indian contact. A tribe of blond Eskimo was discovered by Stefansson during his 1909-11 expedition on Coronation Bluff, far in the Arctic Zone. See Aborigines; Ethnology; also illus. p. 561.

Bibliography. The Central Eski. mo, F. Boas, 1888 (Smithsonian In. stitution : Bureau of Ethnology); The People of the Polar North, K. Rasmussen, compiled from the Danish by $G$. Herring, 1908; The Labrador Eskimo, E. W. Hawkes, 1916.
Eskimo Dog. Breed of dogs kept by the Eskimos of Arctic America. They are little more than domesticated wolves of the district. The practice of crossing the females with wild wolves tends to check those modifications which domestication produces.

The Eskimo dog has a sharp muzzle, upright ears, rough coat, and a bushy tail. Though usually of the colour of the wolf, blackand-white specimens are not uncommon. like the wolf, it does not bark, but howls. The dogs are fed on frozen fish, but in spring often find birds and eggs. Their usual drink is snow. They are employed for sledgo drawing, about eight being usually yoked

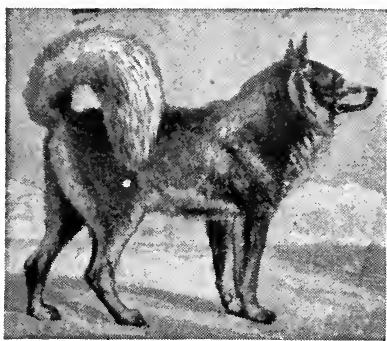

Eskimo Dog. Specimen of the

breed, closely akin to the wolf

together. When the going is good a dog will draw on an average over $300 \mathrm{lb}$. for $35 \mathrm{~m}$. in a day. See illus. facing p. 2624.

Eski-Sagra. Alternative name for the Bulgarian town better known as Stara-Zagora (q.v.).

Eski Shehr (Turk., old city). Town of Asia Minor, the ancient Dorylaeum. This important town, with its rich deposits of meers. chaum and considerable trade in pipes of that material, stands on the Pursak Su. It is the junction at which the main rly. from the Bosporus divides into two, one branch going E. to Angora and the other S.W. to connect on the W. with the Smyrna rly., and on the E. with the Bagdad rly. Pop. 20,000. See illus. p. 683.

Esla. River of Spain. It rises on the S. slopes of the mts. of Asturias, in the $\mathrm{N}$. part of the prov. of Leon, and flows a generally S.W. course to discharge its waters into the Douro, $16 \mathrm{~m}$. below Zamora. It has a length of $120 \mathrm{~m}$.

Eslava, Miguel Hilarion (1807. 78). Spanish music composer. Born near Pampeluna, Oct. 21, 1807, he became master of the choir in Ossuña cathedral in 1828. $\mathrm{He}$ moved to Seville in 1832, and was appointed maestro at the cathedral, and to a similar position at the court of Isabella in 1844. He died at Madrid, July 23, 
1878. He wrote three operas, El Solitario, 1841 ; Las Treguas de Tolemaida, 1842; Pedro el cruel, 1843; and about 150 masses and other pieces of ecclesiastical music.

Esmarch, JoHANNes FriedRICH AUgust von (1823-1908). German surgeon. Born Jan. 9, 1823, at Tönning, Slesvig-Holstein, he studied at Kiel and Göttingen, served in the wars of 1848 and 1864, and, in the FrancoPrussian war, 1870-71, was surgeon-general to the army. Afterwards he specialised in hospital management and military surgery. $\mathrm{He}$ invented an indiarubber bandage for field work and temporary dressing. Of his many works three have been translated into English.

Esmeraldas. Maritime dept. of N.W. Ecuador, S. of Columbia, S. America. The surface is broken and hilly, but there are the open pasture valleys of the Esmeraldas, Cayapas, and other rivers. The hills are heavily forested, yielding many kinds of timber. Although the mineral resources have not been largely exploited, gold and platinum are found. Area, 7,430 sq. m. Pop. 14,600. Esmeraldas, the capital, is a Pacific port at the mouth of the Esmeraldas, $96 \mathrm{~m}$. N.W. of Quito. It manufactures tobacco and exports rubber, cacao, sugar, fruit, and cattle. Pop. 3,020.

Esmond. Novel by Thackeray published in 1852, the full title being The History of Henry Es.

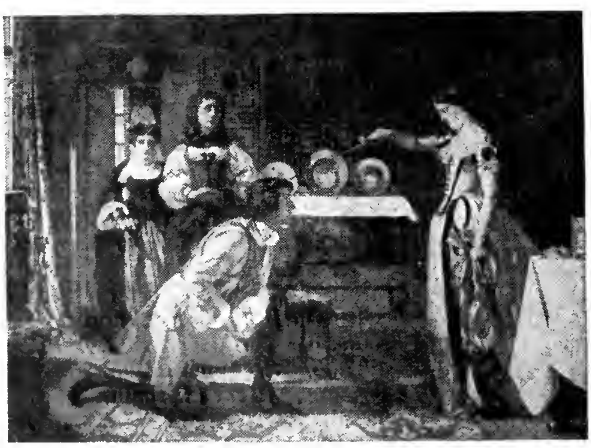

Esmond being knighted by Beatrix. From a painting of a scene in Thackeray's novel, by Augustus L. Egg

$$
\text { Tatc Gallery }
$$

mond, a colonel in the Service of Her Majesty Queen Anne, Written by Himself. The hero, true heir to the Viscount Castlewood, though he magnanimously destroys the evidence of his right, tells his own story from boyhood and as soldier through the campaigns of Marlborough, and so to the end when his adoration of the lofty Beatrix has changed into devoted affecit deals is complete.

tion for her mother. This vivid and fascinating story is a masterly presentation of early 18 th century life and manners; the illusion as to its having been written by a man of the very time with which

Esmond, Henry Vernon (18691922). Stage and pen name of Henry Vernon Jack, British dramatist and actor. $\mathrm{He}$ was born at Hampton Court, Nov. 3, 1869, was educated privately, and went on the stage in 1885. He was the author of many plays, some of which enjoyed considerable popu. larity. They include Bogey, 1895 ; The Divided Way, 1895; One Summer's Day, 1897 ; Grierson's Way, 1899; The Wilderness, 1901 ; The Sentimentalist, 1901 ; My Lady

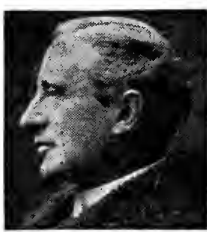

Henry V. Esmond, British dramatist
Virtue, 1902: Under the Greenwo od Tree, 1907 ; A Young Man's Fancy, 1912; Eliza Comes to Stay, 1913 (previously called Sandy and His Eliza); The Dangerous Age, Vaudeville, 1914 (previously called The Dear Fool). He died April 17, 1922.

Esneh or EsNa. Town of Egypt. It is on the W. bank of the Nile, $36 \mathrm{~m}$. by rly. from Luxor. It is identical with the Tesnet of ancient Egypt, but was called Latopolis by the Greeks, after the locally venerated latos fish. The chief object of interest is the temple of Khnum, which was embellished by Roman emperors from Titus to Decius (251). A subterranean Cop. tic church was identified here in 1895. The barrage at Esneh ensures adequate irrigation for a large tract of land.

Espagnols-surMer (Fr., Spaniards on the sea). Name given to a sea fight that took place off Winchelsea between the English and the Castilians, Aug. 29, 1350. The two peoples were not actually at war, but the Castilians had helped the French in the war then raging. Moreover, acts of piracy had been committed on both sides.

'The sequel was an attack on a Castilian fleet of armed merchantmen as it was returning from
theNetherlandstoSpain. Under the command of Edward III the Eng. lish fleet was assembled at Winchel. sea, and there the Castilians, nothing loth, joined battle with them. This was rather an encounter of soldiers than of sailors. Crossbowmen on the Castilian ships did much execution, and lying side by side, the crews of each fought hand to hand. In Cog Thomas, King Edward and his nobles took a gallant part, and this ship was sunk just as the royal party had boarded an enemy vessel. Forty or fifty ships were engaged on either side, the Castilians being the larger. Night, rather than a decision, put an end to the combat, which is described by Froissart.

Espalier (Fr.). Shape or form of fruit-tree which has been trained from its earliest or budded stage. An espalier consists of a main root stem, the original stock, from which fruit branches in tiers extend horizontally right and left, one above another. During the year after budding, when the sideshoots make their appearance, all should be removed except three, which should be grouped close together. One of these shoots is trained upwards to form a continuation of the main stem, and the remaining couple are coaxed by sticks and strings to grow right and left, parallel with the surface of the ground. When the main stem produces three more buds suitably situated, the process is repeated at a distance of about one foot above the original tier. The word seems to have originally denoted the trellis-work on which the trees were trained. See illus. p. 497.

Espartero, BALDOMERO (17921879). Spanish soldier and statesman. Born Feb. 27, 1792, at Gran-

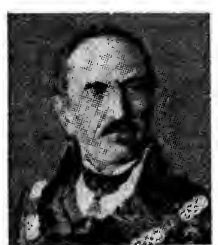

B. Espartero,

Spanish soldie successes against the Carlists, and in 1839 concluded the treaty of Vergara, which ended the war. Turning to politics, he became prime minister, and from 1841-43 was regent, but in the latter year he fell from power and passed the next few years as an exile in England. Pardoned, he returned to Spain in 1848, and from 1854-56 was again premier. In 1868 he was put forward as a candidate for the throne, and later was made prince of Vergara. He died Jan. 9, 1879. 
Esparto Grass (Stipa tenacissima). 'Tall perennial grass of the natural order Gramineae. It is a

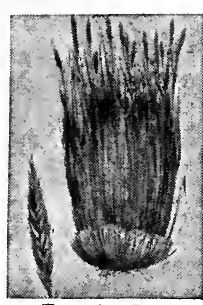

native of $S$. Europe and N. Africa, where it grows in rocky soil. Its leaves are rolled in from the edges, so that they appear thread. like. Being tough and wiry, it is used in the manufacture of ropes, mats, and a very durable kind of paper. For the latter purpose mally thousands of tons of the grass are imported into Britain annually. As a crop it yields about 10 tons per acre. See Paper.

Esperance. Harbour of W. Australia. It is situated on the $\mathrm{S}$. coast, $220 \mathrm{~m}$. N.E. of Albany. Gold from Coolgardie is shipped here. Pop. 239.

Esperanto. International language invented by Dr. Zamenhof, an oculist of Warsaw. Completed in 1878, and first published in 1887, it has since made great strides, the number of Esperanto societies rising from 26 in 1901 to 2,700 in 1913. The alphabet consists of 28 letters, none of which offers any difficulty to English-speaking people. The omission of $Y$, however, and its representation by $\boldsymbol{J}$ may at first cause slight confusion. The follow. ing are the terminations of words : $-o$, noun (nominative); $-a$, adjective ; $-j$, plural ; $-n$, objective (accusative); $-e$, adverb; (tenses) $-a s$, present, -is, past, -0s, future ; (active participles) -anta, present, -inta, past, -onta, future; (passive participles) -ata, -ita, -ota.

The passiveis formed by theaid of est $i$, to be, the tense required bcing indicated by the proper participle. About 30 prefixes and suffixes are employed to form derivatives; e.g. mal-, indicating the exact contrary: bona, good, malbona, bad; -il, instrument; haki, hew; hakilo, axe ; -ist, trade or occupation; boto, boot, botisto, bootmaker ; ig-, factitive (causing an action), bruli, burn, bruligi, cause to burn. Compounds are formed by combining the root or simple forms of words : fervojo, railway, iron way. The word gesamideanoj (people of the same idea) is a good illustration of word-formation; ge denotes males and females; sam, same ; ide, idea; $a n$, a partisan ; $o$, noun ending; $j$, plural. There is an in. geniously constructed table of cor. relative words-demonstrative, indefinite, inclusive, negative, and relative.
The language is easily learned, every rule being without exception, the spelling phonetic, and the vocabulary surprisingly small.

International congresses have been held annually since 1905 , except during the years 1914-18, at Boulogne, Geneva, Cambridge, Dresden, Barcelona, Washingtion, Antwerp, Cracow, Berne, Paris, San Francisco, and (Aug., 1920) The Hague. These have been attended by representatives of 30 or more countries, with an attendance varying from 1,000 to 4,000 . The language is controlled by an international academy and a language committee, and the organization of the movement by the central office at 51, Rue Clichy, Paris. Many eminent philologists have pronounced warmly in its favour. It is officially taught in a number of colleges and schools. Many firms now use it for business purposes, and there is a growing demand for competent teachers.

There is a flourishing literature, translated and original, and some 70 Esperanto periodicals are now published regularly. The language is recognized by the British Post Office, and has received much government support in other countries. It is claimed that the general adoption of Esperanto as an auxiliary language for international use would remove one of the chief obstacles in the way of world-peace, facilitate the working and effectiveness of international congresses, save money and effort now spent on transla. tions and interpreters, lighten the curricula, and increase the effi. ciency of schools, render literary masterpieces and scientific works accessible to the world, and facilitate the study of other tongues, besides its obvious utility in travel, science, commerce, and in all branches of human activity. The headquarters for the British Em. pire is The British Esperanto As sociation, Incd., 17, Hart Street, London, W.C. The Universala Esperanto-Asocio, 14, Museumstrasse, Berne, deals with the practical application of the language to business, travel, etc. See Language ; Phonetics ; consult also International Language, W. J. Clark, 1907.

Esperanza, LA. Town of Hon. duras, capital of the dept. of Intibuca. It stands on a plateau at an alt. of nearly $5,000 \mathrm{ft}$. above sea level, 45 m. W.N.W. of Tegucigalpa. The Indian city of Intibuca is adjacent. Pop. 11,453.

Espinal. Town of Colombia, in the dept. of Tolima. It stands at an alt. of $1,020 \mathrm{ft}$., $25 \mathrm{~m}$. N.E. of Purificación, and $75 \mathrm{~m}$. S.W. of
Bogotá. It is the centre of an agricultural district, producing coffee, cocoa, and tobacco, and manufactures pottery. Pop. 10,010.

Espionage (Fr. espion, spy). Aiding an enemy by supplying in. formation otherwise than as a belligerent engaged on reconnaissance duty, or as a citizen openly helping his own country. The soldier if captured must be treated as a prisoner of war ; a civilian may be guilty of a war crime, such as war treason, but in neither case, if no dissimulation has been practised, is the offence that of espionage.

Espionage as defined by the Hague Rules was extensively em. ployed during the American Civil War of 1861-65, and as the belligerents spoke a common language, the offence was hard to detect. A favourite plan of the "couriers" was to be captured by the enemy, and as prisoners of war, on the way to the enemy's base, to make a careful study of his camps and depots. When the hour approached for internment, an escape was effected, the outpost lines recrossed, and a report prepared. British officers on the retreat from Mons in Aug., 1914, testify to the execution of two German officers, who, dressed in the correct uniform of the British staff, made a tour of British positions in a British motorcar, and in faultless English questioned the troops at important points. In Westminster Abbey lie the remains of John André (q.v.), an English soldier, who was hanged as a spy in 1780, during the American War of Independence. Even in time of peace soldiers are employed as agents of the Intelligence Departments to visit other countries and obtain information by stealth. General Baden-Powell has described his own adventures as ons of these agents. He cannot be regarded as a spy, since his investigations had no reference to an actual enemy. On the other hand, he was knowingly breaking the laws of the country visited in pursuing illegitimate inquiries, and so risked a term of imprisonment.

The methods by which Germany obtained information of economic and military value in peace time are peculiar. An insurance office in Paris would afford a pretext for the employment of German reserve officers to tour the E. of France, ostensibly in search of clients. An offer was made to a French insurance office to relieve it of all risk in respect of important clients such as the Creusot Works, and thus the German agency was furnished with daily reports in regard to the staff and also the material of war manufactured by the French company. 
Such an act is not criminal ; and in time of peace no question of espionage in a military sense can arise. Yet to the popular mind the term spying would seem appropriate. Even in war time, it is difficult to define the offence committed by a Swiss concern which, in 1915, invited 10,000 French families to send the address of a French soldier to whom a present of tobacco would be acceptable. The addresses thus obtained were forwarded to Germany as an indication of the whereabouts of French units. Carl Lody, a German ex-officer, was discovered during hostilities to be collecting information about the British navy and sending it to Germany. He was tried by court-martial for war treason and shot. As he was avowedly serving his country outside the war zone, he became a war criminal under British law; similar action within the zone of operations would have involved espionage, according to the Hague Rules.

It may be concluded, then, that almost any act done in the interests of the enemy after war has been de. clared, by whomsoever committed, is a war crime, but whether it is to be classed as espionage or war treason depends upon the circumstances. See Secret Service; Spy.

Espirito Santo. Maritime state of S.E. Brazil. It is bounded N. by Bahia, W. by Minas Geraes, E. by the Atlantic, and S. by Rio de Janeiro. Hilly in the interior and on the W., where runs the Serra dos Aimores and the Serra do Mar, elsewhere it is level, and in parts marshy. Well watered by the Rio Doce and its tributaries, it pro. duces coffee, sugar, cocoa, tobacco, rice, and salt ; its forests yield valuable timber and drugs. The Parahyba do Sul flows along the S. boundary. The mining resources of this region are not yet tapped, but deposits of iron ore are known to exist. Three rlys. serve the state. Education is backward. The capital is Victoria, on the bay of Espirito Santo. Area, 17,308 sq. m. Pop. 434,512 .

Espiritu Santo. Largest and westernmost of the New Hebrides, Pacific Ocean, in lat. $15^{\circ} \mathrm{S}$., long. $167^{\circ} \mathrm{E}$. It is $65 \mathrm{~m}$. long by $20 \mathrm{~m}$. wide, and mountainous, attaining an altitude of over $5,000 \mathrm{ft}$. Maize, coconuts, millet, coffee, and bananas are grown. Trade is mostly with Sydney. Area, 1,850 sq. m. Pop. 20,000.

Esprit des Lois, DE L'. Title of a great work by Montesquieu. It is divided into 31 books, each of which contains a number of short chapters, some only a few lines in length, and made a big quarto volume. Published anonymously at Geneva in 1748 , it has been many times reprinted. It is a comprehensive survey of the nature of laws and government "almost unique in its entire freedom at once from doctrinairism, from visionary enthusiasm, from egotism, and from an undue spirit of system." Its con. tents may be expressed by its subtitle, "the relation which laws should have to the constitution of every govern. ment, to manners, climate, religion, commerce, etc."

\section{Espronceda,} José DE (181042). Spanish poet. Born near Almen d ralejo, Estremadura, he was educated at the college of $\mathrm{S}$. Matthew, Madrid, and before the age of 15 was im. prisoned as a nember of a revolutiosiary secret. society. On returning to the capital he found himself suspect, and after a further spell of incarceration escaped to England. In London he studied Shakespeare, Milton, and Byron (by whom he was most markedly influenced), and while there wrote his fine ode A la Patria (1829). In 1830 he was in Paris, fighting in the brief revolution there. On the amnesty after the death of Ferdinand, 1833, he returned to Spain and entered the queen's bodyguard, but was cashiered for writing a political song. Journalism, novel-writing, and various revolutionary movements occupied him for a few years, and in 1841 he became secretary of the embassy at the Hague. In 1842 he returned to take his seat in the Cortes as deputy for Almeria. He died May 23, 1842.

Showing early gifts as a poet, he gained a leading position among 19 th century Spanish writers, and his influence on his successors was marked. His best work was of a lyrical and self-revealing character, as is seen in the Don Juan-like narrative, The Student of Salamanca, and the Faust-like The Devil-World. See Spain: Literature; consult also Modern Poets and Poetry of Spain, J. Kennedy, 1852; Hist. of Spanish Literature, J. Fitzmaurice-Kelly, 1898.

Esquiline Hill (Mons Esquilinus). The highest of the "seven hills " on and around which ancient Rome was built. Iying between the Caelian and the Viminal, in the original city it was regarded as including the Oppian, Cispian, and Fagutal. On the Esquiline were the Colosseum (q.v.), erected on the site of the Golden House of Nero, and the thermae, or warm baths, of Titus and Trajan. See Rome.

Esquimalt. Port of British Columbia, Canada. It is on Vancouver Island, $3 \mathrm{~m}$. from Victoria. It has a magnificent harbour and is the Pacific coast headquarters of the Canadian navy, for which 
attempted an abortive coup d'état, was arrested but released, and after the mpret's departure made himself head of the provisional government, Oct. 5, 1914.

In Jan., 1916, he sided with the Allies. In Feb. the Austrians overran Albania, and Essad escaped to Salonica. His connexion with the Serbians, whom he had aided in their 1915 retreat, made him distasteful to the Italians who occupied Albania after the Austrian retreat, 1918, and he was not al. lowed to return there. He lived for some months in Paris, and was murdered by an Albanian student, June 13, 1920. See Albania.

Es Salt. Village of Palestine. Identified as the ancient Ramoth (Deut. iv, 43 ; Josh. $x x, 8$ ), it is $15 \mathrm{~m}$. N.E. of the crossing of the Jordan at El Ghoraniyeh, 20 N.E. of the N. end of the Dead Sea. Situated at an elevation of $2,740 \mathrm{ft}$. above the sea, it is the capital of the Kadâ (division) of El-Belkâ. Wine and raisins are produced in the district. The inhabitants are twothirds Moslems, the rest Greeks, Protestants, and Roman Catholics. During the Great War it was a large depot of the Turks, who when they retired from it, April 1, 1918, brought away some thousands of Jewish, Syrian, and Armenian refugees. On April 30 Allenby resumed operations E. of the Jordan, and Australian mounted troops en. tered Es Salt. It was evacuated May 3, when Allenby withdrew his whole force to the Jordan crossings. See Palestine, Conquest of.

Essay (Fr. essai, attempt; Lat. exigere, to examine). Literary composition, generally in prose, of a short and informal character. The origin of the word is the same as that of assay, for at first it was taken as indicating a testing or trying of a subject. The word has, however, at different times been applied to a great variety of compositions, embracing at once the sententious brevities of Bacon and the fullness of such a philosophical work as that of Locke, On the Human Understanding. It is also applied to certain of the didactic poems of Pope.

Montaigne (16th century) is generally regarded as the originator of the modern essay, as he was the first to employ the word as title for his pleasantly discursive and personal writings; yet, as Bacon, the earliest notable master of the English essay, wrote, "the word is late, but the thing is ancient." Bacon's Essays, 1597, are mainly a succession of pithy maxims, and differ greatly from the essay as it was evolved during the succeeding centuries; for it was rather from the Frenchman than from their countryman that the English essayists derived. Ignoring its use as something of an apologetic prefix to philosophical and historical studies, and its employment in poetry by Pope and some of his imitators, the history of the essay in English literature may be followed in a record of some of its exponents.

Abraham Cowley, the first Eng. lish author to write in the easy, familiar, personal style of Montaigne, though he frequently rounded off his essay with a poem on its theme, or wrote the essay as little more than introduction to a poem, may be called the father of the familiar essay in English. It was with Richard Steele and Joseph Addison that the essay established itself as a popular form of literary composition. Their personal studies in essay form in The Tatler and The Spectator are regarded as adumbrating the English novel; as two laughing philosophers, with their genial comment on men and affairs in periodical essays, they established a form of the composition which continued throughout the 18th century.

In the hands of Daniel Defoe early in that century, the periodical essay received that particular bent out of which developed the news. paper leader. Towards the middle of the century the periodical essay was revived in The True Patriot, The Rambler, The Covent Garden Journal, The Adventurer, The Idler, The Bee, The Citizen of the World and many more, and found its most notable writers in Henry Fielding, Samuel Johnson, and Oliver Goldsmith. These various works were brought together in British Essayists, with prefaces by A. Chalmers, 45 vols., 1817.

With the 19th century the essay branched more definitely into two main kinds, both already, but less distinctly, differentiated, the familiar and the critical essay. Of the writers of the former kind the greatest examplar is Charles Lamb, whose Essays of Elia, 1823, Last Essays of Elia, 1833, and uncollected essays may be said to have influenced many of his successors up to the present day. At the same period William Hazlitt was writer of essays of a more robust character, and Leigh Hunt was master of a dainty, graceful essay style, less charmingly individual than that of Lamb. The critical essay received a stimulus from the establishment of the quarterly reviews and the rapid growth of the magazines, Francis Jeffrey, Sydney Smith, and Thomas Babington Macaulay being among its most notable exponents.
Later essayists of note were William Makepeace Thackeray, whose Roundabout Papers (1863) takes high rank among familiar essays, James Anthony Froude, and Matthew Arnold; while more recently Robert Louis Stevenson, Austin Dobson, Augustine Birrell, Arthur Christopher Benson, and Edward Verrall Lucas have won applause by their diverse writings in this form. In America Ralph Waldo Emerson has been the most notable essayist, though Edgar Allen Poe, Oliver Wendell Holmes, James Russell Lowell, and more recently Paul Elmer More (Shelburne Essays) must be mentioned. See English Essays, ed. J. H. Lobban, 1896.

walter Jerrold

Essay on Man, AN. Moral poem by Alexander Pope. It takes the form of four epistles to Lord Bolingbroke, who is supposed to have suggested the theme, and was published anonymously in 1732-34. Though it has been objected that the author was hampered by the metaphysical nature of his subject, and gives no consistent scheme of beliefs, the Essay will always be remembered for the many terse sentences it has added to the great body of familiar quotations. Among these are: "The proper study of mankind is man," "Hope springs eternal in the human breast," "Die of a rose in aromatic pain," "Pleased with a rattle, tickled with a straw," and a large number of others.

Essays and Reviews. Volume by seven writers, six of them clergy men of the Church of England. On its publication in 1860 , its rationalistic tendencies aroused a storm of criticism. Two of the clergymen-Williams and Wilson -were suspended by the ecclesias. tical courts, but the suspension was revised on appeal to the Privy Council, when, as it was said, Lord Chancellor Westbury "dismissed eternal punishment with costs." The contents of the volume were : The Education of the World, Frederick Temple; Bunsen's Biblical Researches, Rowland Williams: On the Study of the Evidences of Christianity, Baden-Powell ; The National Church, H. B. Wilson; The Mosaic Cosmogony, C. W. Goodwin; Tendencies of Religious Thought in England, 1688-1750, Mark Pattison; and the Interpreta tion of Scripture, Benjamin Jowett.

Essays of Elia. Volume of familiar papers on various themes by Charles Lamb, published in volume form in 1823 after appear. ance in The London Magazine, and supplemented in 1833 by the Last Essays of Elia. These essays, vary. ing from grave to gay, pervaded 
with delightful fancy and rich in humour and tenderness, reveal much of the life and character of the author. They not only include the best of Lamb's work, but stand alone and unchallenged as the supreme collection of familiar essays in the English language. Pron. Ellia. See Lamb, Charles.

Esseg. Variant spelling for the name of the former Hungarian town better known as Eszék (q.v.).

Essen. Town of Germany. In the Prussian Rhine province, it is $20 \mathrm{~m}$. N.E. of Düsseldorf. Situated

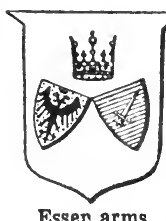
near the vast iron and coal deposits of Westphalia, it was here that the Krupp works were established, and to them the town owes its growth, the population having increased from 9,000 in 1850 to 295,000 in 1910. It is also an important rail. way centre, and has manufactures of machinery and other iron goods, tobacco, etc.

Although so modern in most respects, Essen is an old place. It grew up around a Benedictine nunnery, and has a notable church, the minster, dating in the main part from the 10 th century ; it was restored in the 19th. The town was ruled by the abbess, a princess of the empire, who retained her powers until 1803. In 1814 it became part of Prussia. In addition to the minster, which is noteworthy both on account of its design and its decorations, there are several modern churches. Other buildings include a fine town hall, rebuilt in the old style, 1899, the large railway station, theatre, etc. There are several technical schools and hospitals; also parks and other amenities. Essen, together with neighbouring towns, was occupied by the French in Jan., 1923, in their seizure of the Ruhr district, and the Krupp directors imprisoned. See Krupp Works; Ruhr.

Essen, Hans HenrtK, Count (1755-1824). Swedish soldier and statesman. Born in West Gothland, Sept. 26, 1755, and educated at Upsala, he entered the army. He became a favourite of Gustavus III, whom he accompanied in the war against Russia, 1788-90, and whose assassination he witnessed in 1792 . In 1795 he was appointed governor of Stockholm. From 1800 to 1807 he was governor-general of Pomerania and distinguished him. self by a stubborn defence of Stral. sund against the French. In 1810 he negotiated a peace with France by which Pomerania was restored to Sweden, and in 1811 was pro. moted field-marshal. In 1813 he commanded the successful expe. dition against Norway, and was governor there, 1814-16. He died at Uddewalla, June 28, 1824.

Essen, AdMiral VON (18601915). Russian sailor. He commanded the Vladivostock fleet in the Russo

Japanese War, and took a prominent part in the re organization of the Russian navy. Com mander of the Russian Baltic fleet in Aug.

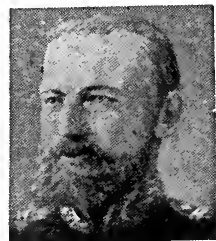

Admiral von Essen, 1914 , he Russian sailor

brought his fleet out from Libau by a daring manoeuvre. He disguised several of his ships as German, and, engaging the German fleet in the Gulf of Finland, Aug. 27, destroyed the German cruiser Magdeburg and damaged another. He died at Reval, May 20, 1915.

Essence (Lat. esse, to be). The sum of the permanent, constitutive qualities which make an existing thing what it is. The name quintessence (fifth essence) was given by Aristotle to ether, the other four being fire, water, earth, air. Es. sence is now used to denote the best and purest part of anything. As a theological term, essence or substance (ousia) is used of that which is common to the three Persons of the Trinity, in contrast with hypostasis (person), which refers to the special characteristics of each Person.

Essence. Strong flavouring used in puddings, cakes, and

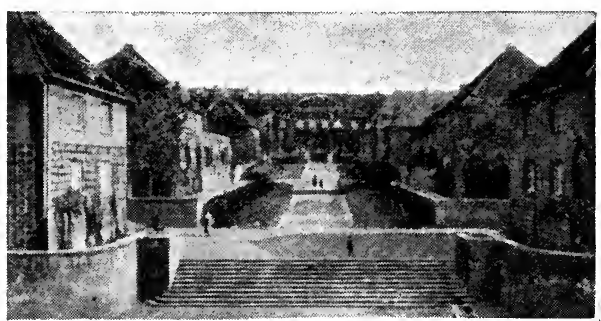

rennet is made from the stomach of the calf, which poured into milk produces curds. Beef essence or extract is used in the making of gravies, and also as a nourishing food for invalids

Essendon. Parish and village of Hertfordshire, England. It stands on the Lea, $3 \mathrm{~m}$. E. of Hatfield. During the Great War it was bombed by German aircraft. Pop. 601 .

Essendon. Town of Victoria, Australia, in Bourke co. It forms a suburb of Melbourne, from which it is $5 \mathrm{~m}$. distant. Pop. 23,749.

Essenes. Ancient Jewish sect. It sought to combine the ascetic practices of the Jewish religion with various Oriental tenets and rites. Probably an offshoot of the older sect of the Chasidim or Assideans, it would appear to have originated in the days of the Maccabees (2nd century B.c.). The Essenes believed in one God and in cternal predestination. While maintaining the immortality of the soul, they denied the resurrection of the body ; and they held a Greek view of future rewards and punishments. Strongly opposed to an official priesthood, they refused to take part in the Temple sacrifices, but held ceremonial feasts with prayer in their own houses. They led very austere lives, some living in community under a kind of monastic rule, while others lived apart in contemplative solitude. Community of goods was practised, and the time was divided between prayer, study of the sacred books, and agriculture.

Later, becoming tainted with the Gnostic tenets of the essential evil of matter and the dualistic origin of the universe, they abstained from flesh, wine, and marriage. They paid peculiar reverence to certain angels, and insome cases practised

sweets. It is mad. by extracting or distilling the volatile oil from plants, seeds, or kernels, such as vanilla, coriander, musk, anise, nutmeg, peppermint, and coffee. Ratafia is prepared from bitter al. monds and other kernels and orange peel. Essence of

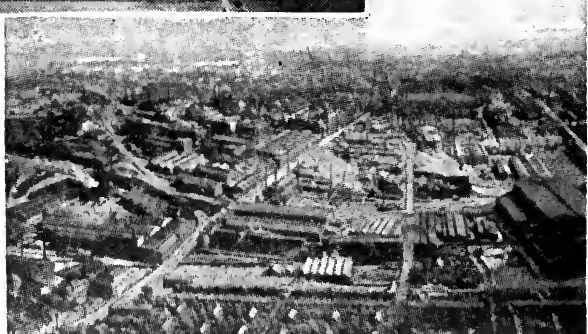

Essen. Krupp's steel works at the great German manutacturing town. Above, model village in whicb some of the workmen are housed 
a form of sun worship. Strongly opposed by orthodox Jews, though favoured by the Herods, they were. cruelly persecuted by the Romans. They had a settlement near the Dead Sea ; Josephus estimated the stricter Essenes of his day at about 4,000 . The sect died out before the 3rd century. Pron. Es-seenz. See Jews.

Essential oR Volatile OIIS. Oils representing in the majority of cases the characteristic properties of the plant from which they have been extracted. The term volatile oil refers to the fact that this class of oils can be entirely volatilised without change, whereas the fixed or fatty oils make a permanent greasy mark if placed on a piece of paper. The methods of preparation vary according to the nature of the plant from which the oils are extracted. Delicate perfume oils are produced by an absorption process known as enfleurage.

Essequibo. Settlement and river of British Guiana, S. America. The settlement extends to the Venezuelan frontier and borders on the Atlantic Ocean for $120 \mathrm{~m}$. It contains locust trees, iron wood, ebony, greenheart, and other hardwood trees. It was the subject of rival claims, settled by the Arbitration Treaty of Feb. 2,1897, between Great Britain and Venezuela.

The river rises near the equator, among the mountains on the Brazilian border, and flows N., entering the Atlantic near Georgetown through a long estuary, from $15 \mathrm{~m}$. to $20 \mathrm{~m}$. wide, containing several islands. Its length is about $600 \mathrm{~m}$., only $40 \mathrm{~m}$. being navigable to vessels of deep draught, owing to cataracts; its mouth is impeded by sand bars. The largest river of the colony, it receives important tributaries, e.g. the Rupununi, Masaruni, Cuyuni, and the Pólaro.

Essex. Agricultural and maritime county of S.E. Fngland. It is bounded S. by the Thames, E. and S.E. by the North Sea, N. by

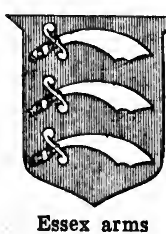
Suffolk and Cambridgeshire, and W. by Hertfordshire and Middlesex. Its area is 1,530 sq. m. Its $90 \mathrm{~m}$. or more of seaboard, indented by several river estuaries, is marked by low-lying islands: Canvey, Foulness, Wallasea, Mersea, etc. The chief rivers are the Thames, Lea, Stour, Colne, Chelmer, Blackwater, Crouch, and Rod. ing. While the coastal region is flat and marshy, there is comparatively high ground in the N.W. and centre, the highest points being reached at High Beech, in Epping Forest; Danbury, between Chelms. ford and Maldon, and in the Lang. don Hills. Harwich is the chief port. Southend-on-Sea, Waltonon-the Naze, Dovercourt, Clactonon-Sea, and Frinton-on-Sea are popular holiday resorts.

The county produces wheat, barley, and fruit, but apart from brewing (Romford) and engineering (Colchester), the manufacturing industries are to a large extent confined to the metropolitan area, in which is the bulk of the population, that of the agricultural centres having decreased of late years. The Crouch, Blackwater, and Colne have productive oyster beds, the Colchester Oyster Feast, an annual event of some importance, dating from early times. There is a gun.

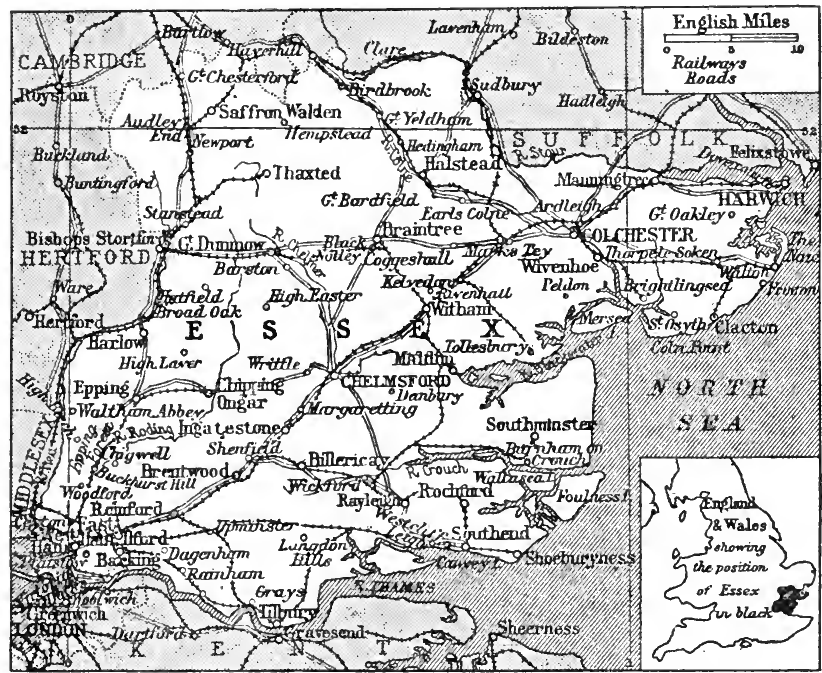

Essex. Map of the deeply indented county, showing its relation to the London area powder factory at Waltham Abbey, and the Tilbury Docks and Victoria Docks (Plaistow) are on the Thames. Yachts and pleasure boats are built at Burnham-on-Crouch, which is also a yachting centre.

The forest of Essex, known after the early part of the 14 th century as the forest of Waltham, has dwindled to what is known as Epping Forest $(q . v$.$) , a public pos-$ session since 1882 . There are eight municipal boroughs: Chelmsford, Colchester, Harwich, Maldon, Saffron Walden, Southend, West Ham, and East Ham. The county is served by the G.E., L.T. \& S., Mid., and Colne Valley Rlys. Eight members are returned to Parliament.

In the lst century B.c. Essex was the home of the British tribe of the Trinobantes. Later the kingdom of the East Saxons, it became the scene of many conflicts between Saxons and Danes. William of Normandy laid a heavy hand upon it. In the 12 th century it gave its name to an earldom created by Stephen in favour of Geoffrey de Mandeville. From the 7 th until the middle of the 19 th century it was ecclesiastically attached to the see of London. It was next linked first to Rochester and then to St. Albans. In 1914 the see of Chelmsford was founded. There are bishops suffragan of Colchester and Barking.

By the earthquake of April 23, 1884, affecting the area between Colchester and the Blackwater, 1,200 houses were damaged.

The county is rich in prehistoric, Roman, Anglo-Saxon, medieval, and monastic remains ; has many notable churches and some fine old

houses, Audley End among them, while the remains of Norman castles, e.g. Colchester and Hedingham, and the fragment at Hadleigh, bear witness to the Norman occupation. Pop. (1921) $1,468,341$.

Literary Associations. In Chigwell is the gabled King's Head Inn described as The Maypole in Dickens's novel, Barnaby Rudge. The Rose Inn at Peldon and the marshes figure in Baring-Gould's Mehalah. Miss Braddon laid the scene of her Lady Audley's Secret at Ingatestone. John Locke; the philosopher, spent the last ten years of his life, and was buried, at High Laver. John Ray, the botanist, was born and died at Black. Notley; Thomas Tusser, author of Five Hundred Points of Good Husbandry, 1573, was born at Rivenhall; Sydney Smith at 
Woodford; Isaac Taylor at Ongar, his father at Lavenham; and Francis Quarles, the poet, near Romford. Dr. William Harvey was buried at Hempstead, near Saffron Walden.

Bibliography. Handbook for Es sex, Miller Christy, 1887; High ways, Byways, and Waterways of Essex, C. R. B. Barrett, 1892-93 Memorials of Old Essex, A. C. Kelway, 1908 ; Romantic Essex, R A. Beckett, 2nd ed. 1907; Victoria History of the Counties of England, ed. H. A. Doubleday and W. Page, 2 vols., 1903-7; Essex, J. C. Cox, 3rd ed. rev. 1915.

Essex, Earl of. English title now held by the family of Capell. There were earls of Essex soon after

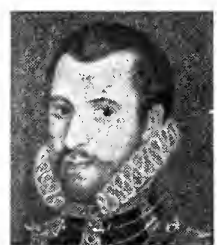

Walter Devereux. 1st Earl of Essex

From a portrait in the collection of Baron

title passed to Thomas of Woodstock, duke of Gloucester, who had married one of the heiresses of the Bohuns. Henry Bourchier, a grandson of Gloucester, was the next earl, but his family died out in 1540. Thomas Cromwell was made earl of Essex in 1540, and William Parr, marquess of Northampton, in 1543, but both lost the title when they lost their lives.

The family of Devereux, to which the most famous earls of Essex belonged, was related to the Bourchiers, and probably for this reason Walter Devereux (1541-76) was made earl of Essex in 1572. $\mathrm{He}$ married a daughter of Sir Francis Knollys, and spent three years in unsuccessful efforts to colonise Ulster, whither he went with a small army in 1573 . He was succeeded by his son, the favourite of Queen Elizabeth, and with the death of the latter's son Robert, in 1646, the title bccame extinct.

In 1661 Arthur Capell was made earl of Essex. He was succeeded in 1683 by his son Algernon, and the title is still held by his descen. dants. His seat is Cassiobury Park (q.v.). The earl's eldest son is known as Viscount Malden. In 1916 Algernon (b. 1884) became the 8th earl.

Essex, Robert Devereux, 2ND EARL OF (1566-1601). English soldier and courtier. Eldest son of the 1st earl, he was born at Nether wood, Herefordshire, Nov. 19 , 1566, educated at Trinity College,
Cambridge, introduced at court, 1577 , and was general of the horse under his stepfather in the Nether-

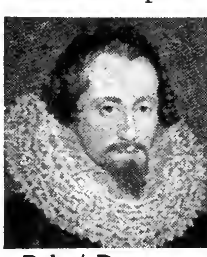

Robert Devereux, 2nd Earl of Esse

After Hilliard lands, 1585-86, being made a knight for gal. lantry at Zutphen. $\mathrm{He}$ in herited Leices ter's c our t feud with the party in which the Cecils and Raleigh were prominent, but became a fa. vourite of the queen, though his lack of self-control led to frequent quarrels, and his marriage with the widow of Sir Philip Sidney especially angered her.

Essex took part in Drake's ex. pedition to Portugal, 1589, com. manded an expedition to Normandy, 1591, secured the conviction of Roderigo Lopez for conspiracy against the queen's life, 1594, distinguished himself at the capture of Cadiz, 1596, lost favour by the failure of the Islands, or Cadiz Voyage, 1597, and was master of ordnance, earl marshal, informal foreign secretary to the queen, and chancellor of Cambridge. In 1599 he was appointed governor-general of Ireland, and, returning without leave, from his attempt to suppress the rebellion of O'Neil, earl of Tyrone, with whom he was accused of making a dishonourable treaty, he was dis. missed from office and imprisoned from Oct., 1599, to Aug., 1600.

Thwarted in his efforts to regain influence at court, and broken in health, he was implicated with Southampton and others in an attempt to secure the dismissal of the queen's advisers. He attempted a rising in London, was arraigned, and beheaded Feb. 25, 1601 . Bacon, whom he had befriended, appeared against him on his return from Ireland, and with Raleigh was largely responsible for carry. ing out the death sentence, to which Elizabeth reluctantly consented. The story that the queen gave Essex a ring, the return of which would have ensured his pardon, is generally discredited, though what was described as the identical ring was sold at Christie's, May 19, 1911, for $£ 3,412$. Essex was fearless but head strong, reckless but generous, and a popular favourite. He was a writer of sonnets and masques.

Bibliography. Lives and Letters of the Devereux, Earls of Essex, W. B. Devereux, 1853 ; Bacon and Essex, E. A. Abbott, 1877; With Essex in Ireland, E. Lawless, 1890 ; Hatfeld MSS.; correspondence in Manchester Guardian, Oct., 1907.
Essex, Robert Devereux, 3Rd EARL of (1591-1646). English soldier. Son of the favourite of Queen Elizabeth, he was restored in 1604 to the title his father had lost, James I being then on the throne. He began life in the king's circle, being chosen as one of the com. panions of Henry, prince of Wales. In 1620 Essex went with a force to recover the Palatinate for the elector Frederick, and in 1625 with the fleet that went to capture $\mathrm{Ca}$. diz In 1639 he held a command in the army sent by Charles I against the Scots in the first Bishops W ar, after which there w a s an es. trangement between him and the king. On the outbreak of the Civil War Essex took the side of the parliamentari-

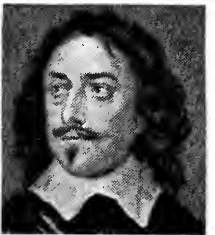

Robert Devereux, 3rd Earl of Essex A fter Walker ans, and was appointed general of their forces.

The earl led the army at Edyehill, relieved Gloucester and fought the first battle of Newbury. He proved his incapacity when, after leading his army into Cornwall, he left it to surrender at Lostwithiel, himself escaping by boat. He resigned his position when the self-denying ordinance was passed in 1645, and died Sept. 14, 1646.

Essex Regiment. Regiment of the British army. Formerly the 44th and 56th Foot, raised in 1741

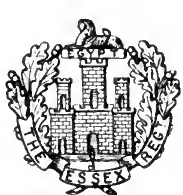
and 1745 respec. t i vely, the se troops took part in the siege of Gibraltar (177983 ), where their services are commemorated by the

Essex Regiment Castle and Key badge and the word Gibraltar on their colours. They fought in the West Indies and Egypt against France, before taking part in the Peninsular War; there the regiment won the nickname of the "little fighting fours." They were at Waterloo, and in the retreat from Kabul (1842), the Crimean War, the Indian Mutiny, the China War (1860), and the Nile Campaign (1884-85). During the S. African War they took part in the battle of Paardeberg and the relief of Kimberley. In the Great War the 2nd Essex were in the retreat from Mons. In the German counter-offensive at Cambrai, 1917, a company of the 13th Essex made a gallant stand at Moeuvres. The regimental depot is at Warley. 
Essexites. Crystalline granular rocks named after Essex co., Mass., where they were first found. They belong to the gabbro group and usually contain felspar (labradorite), olivine, augite, hornblende, and biotite.

Es Sinn, Atrack oN. British operations, Jan.-May, 1916. After his retreat from Ctesiphon, Mesopotamia, Townshend was closely invested by the Turks at Kut-elAmara, Dec. 3, 1915, and a relief force was organized under Aylmer. To reach Kut the Indo-British forces had to storm several posi. tions on the Tigris. The British base camp was Imam Ali Gherbi ; and the final objective was the strong entrenched position of Es Sinn, 7 m. E. of Kut.

On Jan. 7-8, 1916, Aylmer forced the Turks from Sheikh Saad, and on Jan. 13-15 they were driven from the Wadi positions, about 25 m. from Kut. Delayed by adverse weather conditions Aylmer was unable to make any considerable movement until March 8, when he attempted a flanking movement by attacking the Dujailar redoubt at the S. end of the Es Sinn position. On March 12, Gorringe, who had succeeded to the command of the relief force, planned an attack on the left bank of the Tigris. On April 4 the Hannah position was carried, by which time the Felahieh position had been won.

Townshend was in great need of food and supplies, and great efforts were made by the relief force. On April 17 the British achieved a small success at Beit Aiessa, but the Es Sinn positions could neither be turned nor carried. On April 24 a desperate effort was made to break the blockade of Kut, and get supplies to Townshend. The steamer Julnar was dispatched at night up the Tigris with 270 tons of supplies under Lt. H. O. B. Firman and Lt.-Com. C. H. Cowley. It reached Magasis, behind Es Sinn, where it was captured by the Turks. 'Townshend sui readered on April 25. The Turks failed to follow up their success. Instead of attacking the exhausted Indo-British army they retired from their advanced position by Es Sinn on May 19. The British followed up and cleared most of the right bank of the Tigris, but they were too exhausted to carry on a vigorous offensive, and the situation developed into a stalemate until autumn. See Aylmer; Kut; Mesopotamia, Conquest of ; consult also My Campaign in Mesopotamia, C. V. F. Townshend, 1920 .

Essipoff, ANNETTE

(1851-

1914). Russian pianist. Born at St. Petersburg, Feb. 1, 1851, she studied at the Conservatoire under Theodor Leschetitzky, whom she married in 1880 . For many years she was a teacher at the Conservatoire. She played with great success in most of the chief cities of Europe and America. She died in Dec., 1914.

Essling. Village of Lower Austria. It stands on the Danube, $7 \mathrm{~m}$. E. of Vienna. Between this village and the neighbouring one of Aspern a battle was fought between the French and Austrians, May 21-22, 1809. See Aspern, Battle of.

Esslingen. Town of Germany, in Württemberg. It stands on the Neckar, 7 m. E.S.E. of Stuttgart. Its chief interest is historical. The old town, around which are the modern suburbs, is still girt with its walls and towers, while above is the ruined castle. The public buildings include the church of $\mathrm{S}$. Dionysius, dating in part from the 11 th century; the 14th century church of Our Lady, a Gothic building restored in the 19 th century, and containing some beautiful stained glass and a fine tower;

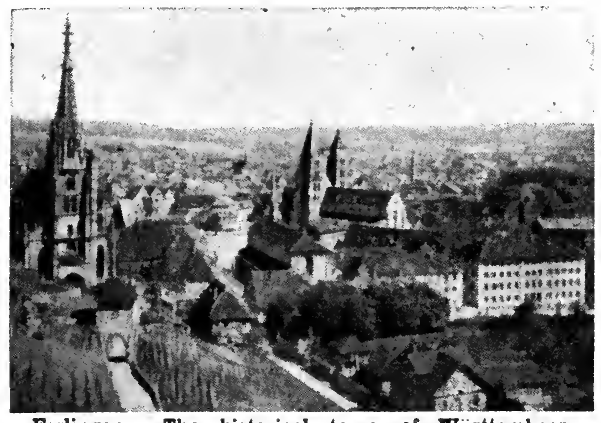

Esslingen. The historical town of Wuirttemberg,

showing, on the left, the Gothic church of Our Lady

the 13th century Gothic church of S. Paul; a hospital, and several schools. There are two town halls : the older one, dating from 1430 , is now a school, and has a wonderful clock ; the newer one was formerly a palace. The industries include large engineering works, railway shops, electrical and lithographic works, also the making of cloth and a trade in wine. Esslingen, a town since 886, was a free city from 1209 until 1802, when it was taken into Württemberg. Pop. 32,364.

Est, Canal de L'. Canal of N.E. France. It extends from the Meuse, near Givet in Ardennes, to Porte-sur-Saône in Haute-Saône, and has connexion with the Marne and Rhône Canal at Void. Portions of the Meuse and Moselle are included in the canal system, which has a length of $286 \mathrm{~m}$.
Estaing, Charles Hector ThóoDAT, CoMTE D' (1729-94). French sailor. Born in Auvergnc, he entered the army and attained the rank of brigadier. After serving in India, he returned to France and entered the navy, being promoted vice-admiral in 1777. The following year he fought against Britain, and in 1779 took St. Vincent and Grenada. After his return to France, he was colonel of the national guard at Versailles in 1789 , but his royalist tendencies aroused suspicion. He gave evidence at the trial of Marie Antoinette in 1793 , but was subsequently accused of being a royalist, and was guillotined April 28, 1794

Estaires. Town of France, in the dept. of Nord. It is on the river Lys, $13 \mathrm{~m}$. W. of Lille, and was prominent in the Great War The Allies occupied it early in Oct. 1914, and it continued in their possession until 1918. In the German offensive against the Channel Ports, April, 1918, it was the scene of spirited fighting. At the Estaires drawbridge the British held the enemy until the great steel and concrete structure was blown up. The town was held by the Brit is h throughout the day and night of April 9-10. On April 11 men of the 50 th division were engaged in street fighting here. Occupied by the Germans, April 11 it was recovered by the Allies early in Sept. See Ypres, Battles of.

Estate. Origin ally a condition, or rank, the idea expressed by the modern word state. It is chiefly used, however, for landed and other property, and all property is by English law classed as either real estate or personal estate. By the word alone is meant landed property, generally a considerable amount under a single ownership and all contiguous. An estate may be of various kinds, freehold, leasehold, or copyhold. See Land Laws : Real Property.

Estate Agent. One who acts for another in the management or sale of landed or house property. $\mathrm{He}$ lets and collects the rents of es tates, farms, houses, cottages, etc. and generally represents the landlord in dealing with tenants. $\mathrm{He}$ should have a knowledge of agriculture, bookkeeping, surveying, valuing, forestry, drainage, building 
construction and repair, and the laws concerning the relations of landlord and tenant. See Surveyor.

Estate Duties. Name given in the United Kingdom to the duties paid on the estates of deceased persons. They date from 1894, before which time there were death duties of various kinds, including legacy, probate, and succession duties. In 1894 two new principles were introduced. Real property, hitherto exempt from charges of this kind, was made to pay at the same rate as personal property, and the duties were levied on a graduated scale. The first scale was from 1 p.e. on small estates to 8 p.c. on those over $£ 1,000,000$ in value. The duties on the larger estates were increased several times, these rising to 10,15 , and then to 20 p.c., and in 1919 there was another increase on the latter, the scale rising to 40 p.c. on estates of $£ 2,000,000$ and over. In 1917-18 the receipts from the estate duty were $£ 25,742,554$.

Gifts made within three years of death, unless part of the deceased's normal expenditure, are charged with duty. Payment may be made in real or leasehold property ; also in war loan, which is taken at its nominal value. Estates under $£ 500$ may pay an inclusive fee of $30 \mathrm{~s}$. or 50 s., which covers all duties. Interest on the duty on personal property is charged at the rate of 4 p.c., reckoned from the day of death. On real estate this can be paid by instalments, on which interest is only charged after twelve months. See The Law and Practice of the Estate Duty, A. W. Soward, 5th ed. 1914.

Estates. Word used for "an organized collection, made by re. presentation or otherwise, of the several orders, states, or conditions of men who are recognized as possessing political power." Its interest is now solely historical, although we still speak of the estates of the realm. In France, Germany, and some other European countries, the same idea is translated by the word states, and so we have the states-general of France and the Dutch Republic.

The idea of estates began about the 13 th century with the growth of the representative system, and we soon find them in Spain and France, as well as in England and Scotland. In France the various provinees, e.g. Brittany and Languedoe, had their local estates, and in Spain the various kingdoms had theirs. The German eountries had also their estates who met in a land. tag or diet. It is usual to assume the number of estates as three, but this is purely accidental. In Sweden and Aragon there were four estates. In England the merchants and lawyers might easily have formed a separate estate, but they did not, and so we have the three estates of lords spiritua!, lords temporal, and commons, sitting, however, in two houses. In Scotland the lesser barons formed a separate estate, not sitting, as they did in England, with the representatives of the towns. The sovereign is sometimes referred to as an estate of the realm, and the press is known, a tribute to its power, as the fourth estate, a phrase said to be due to Burke. See Diet; Landtag ; Par. liament; Representation.

Estcourt. Town of Natal. It stands at an elevation of $3,830 \mathrm{ft}$., on the rly. from Pietermaritzburg to Ladysmith, $76 \mathrm{~m}$. N.W. of the former. It was the scene of important operations during the S. African War. At Weenen, 28 m. E., parties of Boers were massacred by the Zulus in 1838 . Pop. 1,295.

Este (anc. Ateste). City of Italy, in the prov. of Padua. It stands on the slopes of the Euganean Hills, $20 \mathrm{~m}$. by rly. S.W. of Padua. It is enclosed by medieval walls, has a ruined castle, a cathedral, and two other churches, one with a leaning bell-tower. The National Museum is rich in prehistoric, lacustrine, and sepulchral relics, besides Greco-Roman antiquities. The manufactures inelude pottery, ropes, and iron goods. A Roman

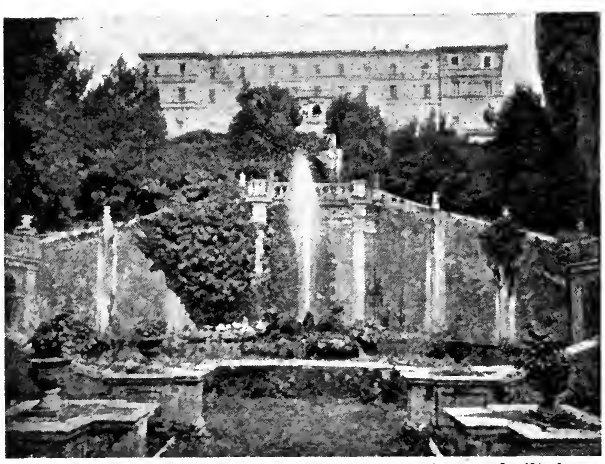

Este. The Villa d'Este at Tivoli, near Rome, built by Cardinal Ippolito d'Este in $\mathbf{1 5 4 9}$

Hanoverian sovereigns of Great Britain are descended.

From the latter came the Italian family which held the lordships of $\mathrm{Fer}$ rara, Modena, and Reggio, the e $m$ p e $r$ or Frederick III making Barco d' E s t e (d. 1471) duke of Modena and Reggio in

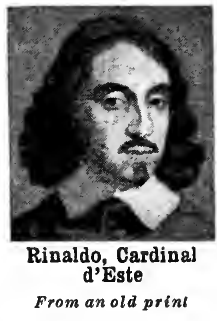
1452, while Pope Paul II created him duke' of Ferrara in 1471. His brother, Ercole I (1431-1505), was father of Beatrice (1475-97), duchess of Milan, one of the most beautiful and cultured women of the Italian renaissance.

Alfonso I (1486-1534), who married Lucrezia Borgia as his second wife, he being her third husband. was a statesman and a soldier. His son, Cardinal Ippolito (150972 ), built the magnificent Villa d'Este at Tivoli. Alfonso II (1533-97) kept a luxurious court, where he detained the poet Tasso, who was in love with his sister Eleanora. Alfonso IV (1634-62) was father of Maria Beatrice, queen of James II of England. The Italian branch of the family ended with Ercole III (1727-1803), who was dispossessed of the duchy of Modena by the treaty of Campo. formio in 1797, and whose only daughter, Maria Beatrice, married Archduke Ferdi. nand, third son of Francis I of Austria. His son Francis IV (1779 -1846) was made duke of Modena by the congress of Vienna in 1814 , but his son Francis V (181975) was dispossessed by the incorporation of the duchy in the kingdom of Italy in 1859. See Modena. Pron. Es-ty.

town, it became the seat of the Este family in the 10th eentury, and in 1405 it surrendered to Venice. Pop. 11,704.

Este. Name of a noble Italian family founded by Oberto II ( $c$. 1015), margrave of Casalmaggiore. His grandson, Azzo II, became duke of Milan, and his sons, Guelph and Fuleo, founded the German and Italian branches of the family respectively. From the former the
Ester. Substance formed by the union of alcohols and acids with the elimination of water. Gmelin first used the term ester to distin. simple and mixed "ethers." An ether is an oxide of the alcohol radical analogous to metallic oxides, whereas in esters both an alcohul radical and an acid radical are present. Esters are prepared (1) by the direct action of an acid upon guish this class of compounds from 
an alcohol, (2) by the action of an acid chloride or the anhydride of an acid upon an alcohol, or (3) by treating the salt of an acid with an alkyl halide, e.g. methyl acetate may be prepared by treating silver acetate with methyl iodide.

Esterhazy, Marie Charles FerDINAND WaLzin, Count (b. 1847). French soldier. $\mathrm{He}$ served in

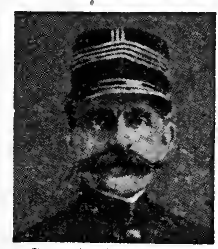

Count Esterhazy.

French soldier
Esthonia. Republic of N.W. Europe, formerly part of the Rus. sian Empire. It is bounded N. by the Gulf of Finland, E. by Russia, S. by Latvia and the Gulf of Riga, and $W$. by the Baltic. It comprises the N. part of Livonia, the former govts. of Estland and the N.W. part of Pskoff. Its area is about 23,160 sq. m., and in 1920 its estimated pop. was $1,800,000$. Except in the S.E., which is hilly, the mainland lies low, it is inter sected by numerous rivers and streams, and much of it is swampy. There are many lakes, and about half of Lake Peipus lies within it. About 30 p.c. is forest. The climate is rather hot in the summer and cold in the winter. Dago, Oesel (Ezel), and other islands belong to it

The chief occupation of the people is agriculture. This is conducted scientifically, with the result that good crops, particularly of flax, are raised from a naturally poor soil, and there is a flourishing livestock industry. Oil-shale in rich quality is plentiful. Manufactures include iron. steel. mach. were few class distinctions among the Esthonians proper.

The carly history of the country is obscure, but early in the 13th century it was conquered by Danes and Germans. The Danes founded Reval in 1219, and later divided the land between themselves and the Germans, finally selling their part of it in 1346 to the 'leutonic Knights who joined it up with Livonia. After the dissolution of the Teutonic Order in 1560, N Esthonia passed to Sweden. S. Esthonia remained under Poland till 1629,when the whole of Esthonia became a Swedish province with $\mathrm{Li}$ vonia, which was ceded to Russia in 1721. German influence was always strong owing to the presence of the Baltic Barons, the descendants of the Teutonic Knights, and of numerous German settlers (Balts), who called the country Estland or Esthland and its natives the Ests. Only after the Russian revolution and the Esthonian war of liberation was this German influence crushed.

In religion the Esthonians are Lutherans, except about 15 p.c. colled to Germany. He the truth became known, and later confessed the forgery. See Drey. fus Case.

Esterházy de Galantha. Family of Hungarian noblemen. Dating back to the early 13 th century, in the 17th they became princes of the German empire. They were great supporters of the house of Haps. burg and have included several notable men. Among these were Paul IV (1635-1713), a great gen. eral in the wars against the Turks ; Nikolaus Joseph (1714-90), gen. eral, diplomatist, and patron of art, literature, and musio; and Nikolaus IV (1765-1833), founder of a famous collection of pictures at Vienna, who declined Napoleon's offer of the crown of Hungary, and supported the national Hun. garian movement.

Esther, Book of. O.T. book so named after the chief character in the story. When Vashti, the con. sort of the Persian king Ahash. verôsh (Xerxes), was deposed, Esther, the adopted daughter of Mordecai, a Jewish exile, was chosen in her place. She was thus enabled to frustrate the plots of Haman (q.v.), a powerful enemy of her people. Haman had cast lots (purim) to destroy the Jews, and the real purpose of the book seems to be to explain the origin of the Jewish festival Purim (called in 2 Maccabees $x \nabla, 36$, the Day of Mordecai). The book of Esther would seem to have been written between 300 B.c. and the Christian era. See Commentary by 'T. Witton Davies in the Century Bible.

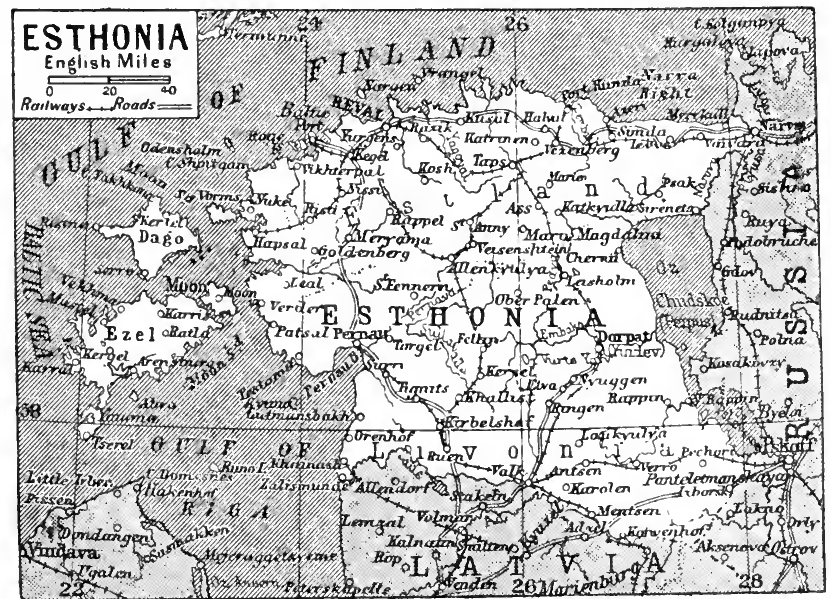

Esthonia. Map of the Baltic republic, which, before the Great War, was part of the Russian Empire

inery, cotton, paper, wood pulp, and spirits. Esthonia carries on a large transit trade, the seaport of which is Reval, the capital, con. nected by railway with Petrograd. Baltic Port and Pernau are other shipping centres. Other towns of note are Narva and Dorpat, or Yuriev. Arensburg and Hapsal are famed for their curative mud baths.

The Esthonians are of Finnish origin, but about 10 p.c. of the pop. are Russians, Germans, Swedes, etc. The pure Esthonians have a language and a culture of their own. Before the Great War the upper classes consisted chiefly of Russian officials and Germans, and there who belong to the Greek Orthodox Church, forming an independent apostolic church of Esthonia. The standard of education is very high, there being hardly any illiterates. Secondary education is provided by numerous grammar schools and lyceums. Dorpat University, established by Gustavus Adolphus in 1632, was reopened on Oct. 6, 1919, as an Esthonian university, with faculties of theology, mathematics, physics, history, law, agriculture, etc.

All instruction is given in Es. thonian; until recently Russian and German were compulsory. There is a polytechnic school in 
Reval and technical schools in various parts of the country. Esthonia is rich in folklore, the chief records of which are Monumenta Estoniae Antiquae, and the MS. collection of Jacob Hurt, containing songs, tales, proverbs, and other folklore items. After F. R. Kreutzwald published the national epic Kalevipoeg in 1861, a new Esthonian literature developed in the 19th century, among the best known writers being Otto Masing, Lydia Koldula, Mihkel Weski, and Johan Liiw.

Esthonia and the War. By decree of the Russian provisional government on April 12, 1917, the prov. of Esthonia was united with the N. part of the prov. of Livonia, which was inhabited by Esthonians, and formed into a new autonomous prov. called Esthonia, under a national council or diet. This council was elected by universal suffrage, May-June, 1917, and met at Reval, June 14, when a national government was set up.

\section{Declaration of Independence}

After the seizure of the supreme power in Russia by Lenin, Esthonia, like Finland, decided to become independent. She was about to hold a constituent assembly when the Bolshevists intervened, and summarily dissolved the national council. The Esthonian Government, under Paets, still remained in being, though precariously, and on Feb. 24, 1918, proclaimed Esthonia an independent republic. During the BrestLitovsk negotiations, the Germans, to compel Lenin to come to terms, took Reval on Feb. 25, and, march ing through Esthonia and Livonia, captured Dvinsk and Pskoff.

By the Brest-Litovsk treaty the Bolshevists undertook to evacuate those territories, which were to be policed by the Germans until the state organization of both provinces was restored. As this would have virtually meant the complete Germanisation of these regions, the people, 90 p.c. of whom were pure Esthonians, made emphatic protests to the Allies, and on May 3, 1918, Great Britain, and later France and Italy, recognized the national council as the de facto government of Esthonia.

But the Germans remained masters of the country, and it was not till Nov. 11 that the Esthonians recovered supreme power. On Nov. 19 they concluded an agreement with Germany, who undertook to evacute Esthonia at once, but did not do so, preferring to play into the hands of the Bolshevists, then beginning an invasion which carried them to within $15 \mathrm{~m}$. of Reval. Finland then came to the aid of Esthonia with 5,000 rifles, some guns, and 10,000,000 Finnish marks. On Dec. 12 a British fleet, under Admiral Sinclair, entered Reval with arms and munitions, and on Dec. 26 captured two Bolshevist destroyers, which were handed over to the Esthonians.

Meanwhile Esthonia had organized her army under General Laidoner, a former Russian staff officer, and by Feb. 24, 1919, her soil was free of the enemy.

A general election took place in Esthonia, April 5-7, the constituent assembly opened on April 23, and a democratic government was formed, with $\mathrm{O}$. Strandmann as prime minister; he remained in power until Nov., 1919, when a new coalition government, under J. Toenisson, was established. The chief work of the assembly lay in agrarian reform-the nationalisation of the estates of the Baltic barons, and the division of the land among the people, but also a constitution was elaborated, and several bills were passed.

After five years of almost con. tinuous fighting Esthonia longed for peace, and as Koltchak, Denikin, and Yudenitch were averse from recognizing its independence, the new state accepted the proposals for a peace conference made by the Soviet Government through'Tchit. cherin on Aug. 31. This took place at Pskoff, Sept. 19, but the Estho. nian delegates made it a condition that Bolshevist peace proposals were to be submitted to all the Baltic States together, to which the Soviet representatives agreed. Conclusion of Peace

Various conferences were held by Esthonia, Latvia, and Lithuania, and $j$ was decided to hold a conference with the Soviet Government in Oct. at Dorpat. But in that month Yudenitch, supported by the British and Esthonian fleets, advanced on Petrograd, and Bermondt, ostensibly in the anti. Bolshevist interest, began operations in Latvia; therefore the peace conference was not held. Yudenitch's attempt failed, and the Reds heavily attacked Narva in Nov.-Dec., but were checked by the Esthonians.

Peace negotiations were resumed, an armistice was signed on Dec. 31, and peace was finally made Feb. 2,1920 . By the peace treaty the full independence of Esthonia was recognized by the Soviet Government, which promised to pay to her $15,000,000$ roubles in gold, and also granted preferential rights for build. ing a rly. from Reval to Moscow.

Bibliography. L'Allemagne et la Baltikum, G. Gaillard, 1919; L'Esthonie, les Esthonians, et la question Esthonienue, M. Martna,
1920 .
Estimate (Lat. aestimare, to value). Generally, a statement of the probable cost of any contem. plated undertaking. More particularly, it is a statement furnished by builders, contractors and others, naming the sum for which they are prepared to execute a specified picce of work.

In the Imperial Parliament the consideration of the estimates of national expenditure is an important part of the financial work of the year. The various departments send to the treasury before Dec. 1 particulars of the amount they are likely to want for the year beginning April 1 following. These are examined and sometimes reduced by the treasury officials, and in their amended form are presented to the House of Commons in three groups: civil service, navy, army.

\section{Civil Service Estimates}

The civil service estimates proper are divided into eight classes: (1) public works and buildings; (2) salaries and expenses of civil departments ; (3) law and justice ; (4) education, science, and art; (5) foreign and colonial services; (6) non-effective and charitable services; (7) miscellaneous ; insurance and labour exchanges; and the estimates of the revenue departments into three : (1) customs and excise; (2) inland- revenue; (3) post office. The Commons consider the estimates early in the year, as they must be passed before March 31, or the money cannot be legally spent. This difficulty, however, is usually met by voting a sum on account.

The twenty days allowed for their discussion afford a recognized opportunity for criticising ministers and officials and the work of the various departments. The procedure is for a member to move that the vote in question, e.g. for the salaries of consuls or the provision of rifles, be reduced by a certain amount. In practice, however, a few, often trivial, points are picked out for debate, and the bulk of the estimates are passed en bloc and without a word on the last of the allotted days. If the amounts provided by the estimates are insufficient, which, apart from ordinary miscalculations or changes, may be due to a sudden emergency, e.g. an outbreak of disease, supplementary estimates are presented later. In 1912 a select committee was appointed to examine and report upon the estimates, and this course has since been followed each year. In 1918 another select committee made recommendations with a view to securing for the House more control over them. See National Finance. 
Estoile (old Fr., star). In heraldry, a star, usually represented as having wavy rays. If there are

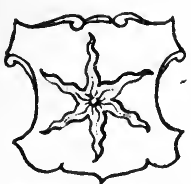
six rays or more, only the alternate rays are wavy. An estoile with a number of long rays springing from it at an angle, Estoile, in heraldry or with a long tail, is called a comet. See Mullet.

Eston. Urban dist. and town of N. Riding, Yorkshire, England. It is $5 \mathrm{~m}$. S.E. of Middlesbrough, on the N.E.R. There are important blast furnaces, iron-foundries, and saw-mills, and steel rails are largely made. Ironstone is quarried extensively in the Cleveland Hills. Pop. 12,026.

Estoppel (old Fr. estoper, late Lat. stuppare, to stuff with tow, stuppa). Doctrine of English law. Broadly, it means that in certain circumstances a party will not be allowed to show the truth in his own favour, when he has, by some act or deed or negligence, led the other party to believe that something else is the truth. Estoppel is (1) by deed; (2) in pais, or by act; (3) by negligence. (1) If A makes a deed of conveyance of Whiteacre to $B$ on March 1 , reciting in it that he (A) is the owner, and in fact he is not, but on some subsequent day he becomes the owner, the estate at once passes to $\mathrm{B}$, because $\mathrm{A}$ will not be allowed to come and say that on March 1 he had no right to convey. Generally speaking, every statement made by a man in a deed estops him from denying the truth of it. (2) If A does an act or makes a statement which causes $B$ to alter his position, $\mathbf{A}$ is not allowed afterwards to aver against $B$ anything to contradict the act or statement. Thus, if A takes lease of a house from $B$, he cannot afterwards say that $B$ is not the owner thereof and refuse to pay his rent. (3) If $\mathrm{A}$ by his negligence causes $B$ to alter his position, he is not allowed to dispute the correctness of B's action so as to take advantage of his own negligence.

Estournelles de Constant, Paul Henri Benjamin, Baron d' (b. 1852 ). French pub. licist. Entering the diplomatic service, he became c hargé d'affaires in Montenegro, and was attached to the embas. sy in London, 1890-95. In

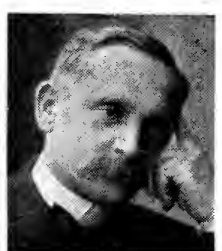

Baron d'Estournelles de Constant,
French publicist
1904 he was elected a senator, and as a member of the Hague Court exerted his influence for peace. $\mathrm{He}$ received the Nobel Peace prize in 1909. He wrote much for French, English, and American reviews.

Estovers or Botes. Certain furnishings of wood that a tenant is allowed to cut and use for the purpose of his holding. They in. clude firebote, or wood for firing ; ploughbote, to mend his plough; housebote, to repair his house ; and hedgebote, to maintain his fences. Estovers are usually, if not always, enforceable by the custom of a manor, and are rights indefeasibly attached to the freeholds and copyholds of that manor; that is to say, they are not personal rights, but must be claimed in the character of tenant of the manor. Estovers is old Fr., necessaries; bote is mid. Eng., advantage. See Lopping.

Estray (old Fr. estraier, to stray, wander from the street, Lat. strata). Term used in law for a strayed animal. A quaint old law of England says that if valu. able tame animals are found wan. dering at large they are to belong to the sovereign. But in most cases the sovereign long ago granted the right in them to the lord of the manor where they might be found. They must be "proclaimed" in the nearest church and two market towns, and, if not claimed in a year and a day, are irredeemably lost to the owner. See Pound.

Estreat (old Fr. estrait, extract). Term used in English law, meaning to forfeit something, generally a sum of money, by way of enforcing an obligation to the crown. It usually occurs in the case of recognizances, where a person has agreed to do or not to do something in face of a court under penalty of paying so much if he does not fulfil the obligation. Thus, A. B. will enter into a recognizance to keep the peace for six months under penalty of $£ 50$. If he breaks the peace within that time his recognizance may be estreated, and the like happens if $X$. Y. goes bail in $£ 50$ that A. B. should appear and stand his trial. The bail will be estreated if A. B. does not duly appear. Estreat is enforced by levying a distress upon the property of the person liable. The original meaning of the word is a copy or extract of an original record or document.

Estrées. Name of four villages of France: (1) in dept. of Nord, slightly S. of Douai ; (2) in dept. of Aisne, slightly E. of St. Quentin Canal, $\mathbf{N}$. of Bellenglise. On Oct. 1, 1918 , the British stormed the village and its defences in the great offensive N. of St. Quentin ; (3) in dept. of Somme, on the AmiensSt. Quentin road, prominent in the battles of the Somme, 1916-18; (4) in Oise dept., known as Estrées-St. Denis, W. of Compiègne. See Cambrai, Second Battle of; Hindenburg Line; Somme, Battles of the.

Estrées, Gabrielle d' (157399). " Mistress of Henry IV of France. Daughter of Marquis

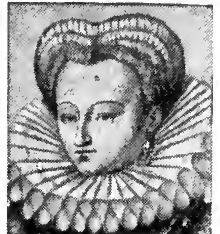

Gabrielle d'Estrées

From an old portrait Antoine d'Estrćes, she met Henry at Coeuvres in 1590 . Impressed by her beauty, the king caused her to be divorced from her hus band, Nicholas d'A m e rval, Sieur de Liancourt, and in

1592 he fetched her to Paris, where she bore him several children. He created her marquise de Monceaux and duchesse de Beaufort, and was so infatuated that hod she not died suddenly at Paris, April 4, 1599, he would have divorced Marguerite de Valois and made her his queen. See Life (in French), A. Desclozeaux, 1889. Pron. Estray.

Estrella, Serra DA. Range of mountains of Portugal, in the prov. of Beira. Lying midway between the Tagus and the Douro rivers, virtually forming the watershed between the Mondego and the Zézere, the highest point is Malhão, 6,540 ft. A beautiful verdure-clad range, it commands extensive views, and runs, from S.W. to N.E., a distance of $75 \mathrm{~m}$.

Estremadura. Province of W. Portugal, S. of Beira. It is divided into the districts of Leiria, Santarem, and Lisbon. Its otherwise regular coast-line is broken by the estuaries of the Tagus and the Sado rivers. N. of the Tagus it is hilly ; to the S. it is low-lying with marshy land. Some parts are fertile, others barren; barely half is under cultivation. In the Tagus valley wine, oil, and fruit are produced. The manufactures are of little importance, but cork, salt, soda, and fish are exported, and herbs are grown on the sandy plains. Area, 6,937 sq. m. Pop. 1,438,726.

Estremadura. Former territorial division of S.W. Spain, co-extensive with the present provinces of Cáceres and Badajoz. An arid plateau, denuded of its forests, lacking water, and depopulated by emigration to America, it is largely a barren, heath-covered waste or undulating pastureland, feeding huge droves of migratory sheep and pigs. Wine, oil, figs, and almonds are produced, but agriculture is hindered by drought 
and locusts. Minerals exist, but mining is neglected. Area, 16,000 sq. m. Pop. 1,034,799.

Estrup, J VENIUS (1825-1913). Danish statesman. In 1864 he became a member of the Landsthing, From 1865-69 he was minister of the interior, and took part in the revision of the constitution and improved the country's rly. system. In 1875 he became minister of finance and president of the council, and, supporting the king in his conflict with the democratic parties, made use of the royal prerogative in issuing acts, and even governed for 10 years by provisional budgets. He resigned in 1894, and his retirement indicated the change to more democratic rule in Denmark. In 1902 he opposed the sale of the Danish West Indies to the U.S.A. He died Dec. 26, 1913.

Estuarine Deposits. Accumulations of sediment transported by a river and laid down near its mouth. They depend on grade of sediment, strength of current, and depth of river. Frequently the dropping of sediment, caused by the checking of the stream by the sea, forms a barrier across the mouth, and lagoon conditions are established inside. In former geological periods such conditions have resulted in deposits marked by comparatively limited extent, usually sandy facies, and accompanied by characteristic vegeta. tion and animal remains (shellfish, etc.), e.g. inferior oolite beds of Yorkshire.

Estuary (Lat. aestus, tide). Arm of the sea into which a river flows. As a rule an estuary consists of the drowned lower portion of a valley. Where the land slopes gently down below sea level and the shores are wider apart nearer the open sea the estuary is a ria, or drowned river valley; the indentations of S.W. Ireland belong to this type. The indentations of the Norwegian coast, the fiords, are steep-sided, deep estuaries which are shallow near the entrance ; they are due in part to glacier action. On some coasts estuaries arise from the emergence above the water of sand banks, which transform a bay into a lagoon filled with river water. Such estuaries are the haffs of the S. shores of the Baltic. British estuaries are notably more extensive than the rivers which now flow into them, thus inconformity indicates submergence. Estuaries tend to be filled up with alluvium, the Dee estuary being thus almost uscless for navigation. See Coast; River.

Eszék, Osiek or Esseg. 'Town in Yugo-Slavia, formerly in Hungary. It is situated on the right bank of the Drave, $125 \mathrm{~m}$. by rly. N.W. of Belgrade, and is the first important town above the confluence with the Danube. Here one rly. crosses the Drave from the $\mathrm{N}$. and four lines radiate $S$. of the river to various centres in Slavonia. As the capital of Slavonia, it is a busy trading centre and is strongly fortified. Silk factories and flour mills derive their motive power from the river. Pop. 31,400, one-third Croats, nearly one-third Germans; threequarters Roman Catholics.

\section{Esztergom oR} GraN. City of Hungary, on the right bank of the Danube, $38 \mathrm{~m}$. by rly. N.W. of Budapest. It is the eccles. capital, and guards the river bridge for road traffic from Buda. pest to the Little Alföld. The cathedral is said to be the finest building of its kind in Hungary. Agriculture and the culture of the vine are carried on, and

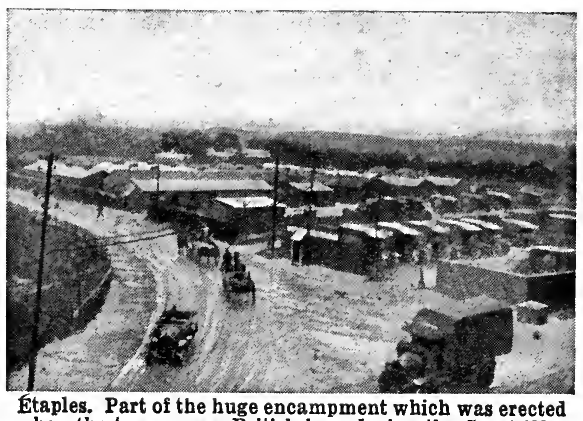
Etaples. Part of the huge encampment which was erected
when the town was a British base during the Great War the town is noted for its thermal springs. Below the town the Danube flows in a contracted valley and makes its great bend to the S. Pop. 17,900, nearly all Magyar Roman Catholics.

Etah. District and town in India, in the Agra Division of the United Provinces. The area of the district is $1,729 \mathrm{sq} . \mathrm{m}$. Sixty p.c. of the land is cultivated, among the chief crops being wheat, barley, maize, grain, cotton, sugar-cane, and indigo. The headquarters of the district are situated in the town of Etah, which dates from the 14th century.

Etah. Settlement on the coast of Greenland. In Prudhoe Land on Smith Sound, it is inhabited by Eskimos.

Etampes. Town of France, in the dept. of Seine-et-Oise. It stands on the Juine, $38 \mathrm{~m}$. by rly. S.S.W. of Paris, and has a number of small industries, including flour-milling, but is chiefly a market for agricultural produce. In the Middle Ages it was comparatively more important than it is to-day, and it retains some of its old buildings. These include the churches of Notre Dame, S. Basil, S. Gilles, and S. Mortin; and the 16th century hôtel de ville. Francis I made one of his mistresses duchess of Etampes. The house, once occupied by Diana of Poitiers, is now used for public purposes. Pop. 9,454.

Etang (Lat. stagnum). French word for a shallow sheet of water somewhat similar to a lagoon.
Such are frequent in the S.W. part of France, bordering the Bay of Biscay. One of the largest is the Etang de Berre, in the dept. of Bouches-du-Rhône. It has communication by the Passe de Martigues, a narrow channel, with the Gulf of $\mathrm{Foz}$ and the Mediterranean. Its area is about 81 sq. m., and its average depth is $20 \mathrm{ft}$. It is noted for its eel fisheries and salt works.

Étaples. Town of France, in the dept. of Pas-de-Calais. It stands on the estuary of the Canche, $17 \mathrm{~m}$.

S. of Boulogne, and near the coast. It is the railway terminus for Paris. Plage, and is a fishing centre. In early days it was a flourishing port, and here, in 1492, England and France made a treaty.

The Great War created a new Etaples of wider dimensions. It expanded $\mathrm{N}$. along the main road to Boulogne, a city of hospitals in that direction, with the British military cemetery on the Camiers road, containing 11,300 graves. It was a huge British encampment of huts, tents, canteens, barbedwire compounds, as well as a centre of the Y.M.C.A., Church Army, and other huts, Chinese coolie compounds, Red Cross centre, and motor traction yards. Here were extensive training grounds, including the well-known Bull Ring. It was noted as a British hospital and convalescent camp, and its Tipperary road leading to the latter on the hill-top was known to thousands of British soldiers. On May 19, 1918, the Germans made a night air raid on its hospitals, causing about 300 casualties among the nurses and patients. Pop. 6,000.

Etawah. District and town of India, in the Agra Division of the United Provinces. The district has an area of 1,691 sq. m. Fifty p.c. of it is under cultivation, the chief crops being wheat, gram, millet, and barley; cotton is also grown. Etawah town is situated on the Jumna and on the East Indian rly., 60 m. S.E. of Agra. It contains a mosque and a number of Hindu 


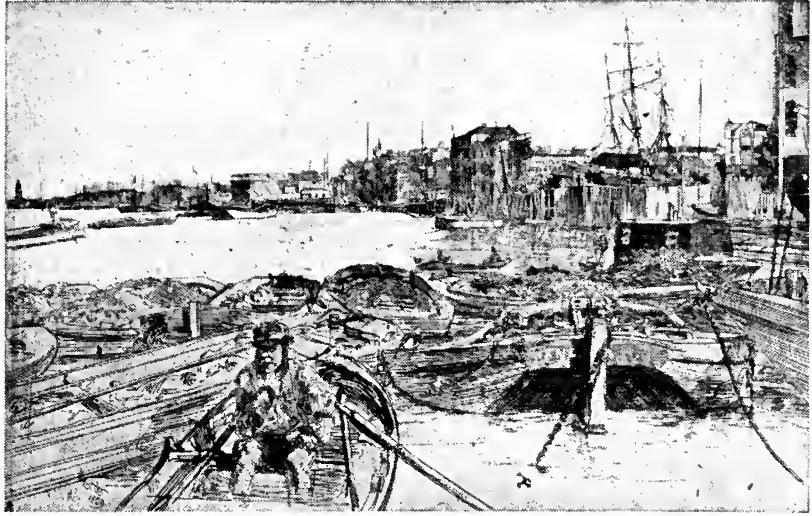

Etching. The Pool, London, a typical etching by J. M. Whistler, dated 1859

temples. Trade consists largely in ghi, gram, cotton, and oilseeds. Pop. of dist., 760,121, 90 p.c. Hindus; of town, $45,350,60$ p.c. Hindus, 30 p.c. Mahomedans.

Etching (Ger. ätzen, to corrode). Method of engraving on metal either by biting with an acid a design drawn through a ground specially laid on the metal, or by drawing with a needle directly on the metal. Though several metals, such as iron, zinc, and pewter, have been employed, copper is almost universally used.

In etching by acid, the plate is covered with a coating of wax or other resinous substance, and tothis ground are transferred the details of a drawing by laying upon it the paper upon which the design has already been made in black pencil or red chalk and passing it through a hand press. The drawing is then traced with a steel needle through the wax down and into the copper, and when it is finished the plate is submitted to the action of nitric or other acid. The parts that are to come light and sketchy are exposed for a certain time to the mordant and then "stopped out" with a suitable varnish to prevent further action of the acid in these passages; the parts which contain more work and are to be darker are exposed for a further period, and when sufficiently eaten are, in turn, stopped out; the parts which contain the heavy shadows and blacks are then exposed long enough to complete the erosion. The duration of the bath will depend upon the amount and elaborateness of the drawing.

In the dry-point method of etching, the artist draws his subject with a hard, sharp steel point upon a perfectly clean, unscratched, flawless copper plate. Dry point was also employed to some extent to define the general features of a

drawing that was to be finally treatcd by the method of line engraving, and, on the other hand, the graver was occasionally borrowed to open up work or strengthen an effect which the unaided needle could not satisfactorily accomplish. Etching dates from the time of Albert Dürer (1471-1528), who dry-pointed two or three plates in 1512 and etched a few more between 1515 and 1518, but no practitioner has ever equalled the wonderful productions of Rem.

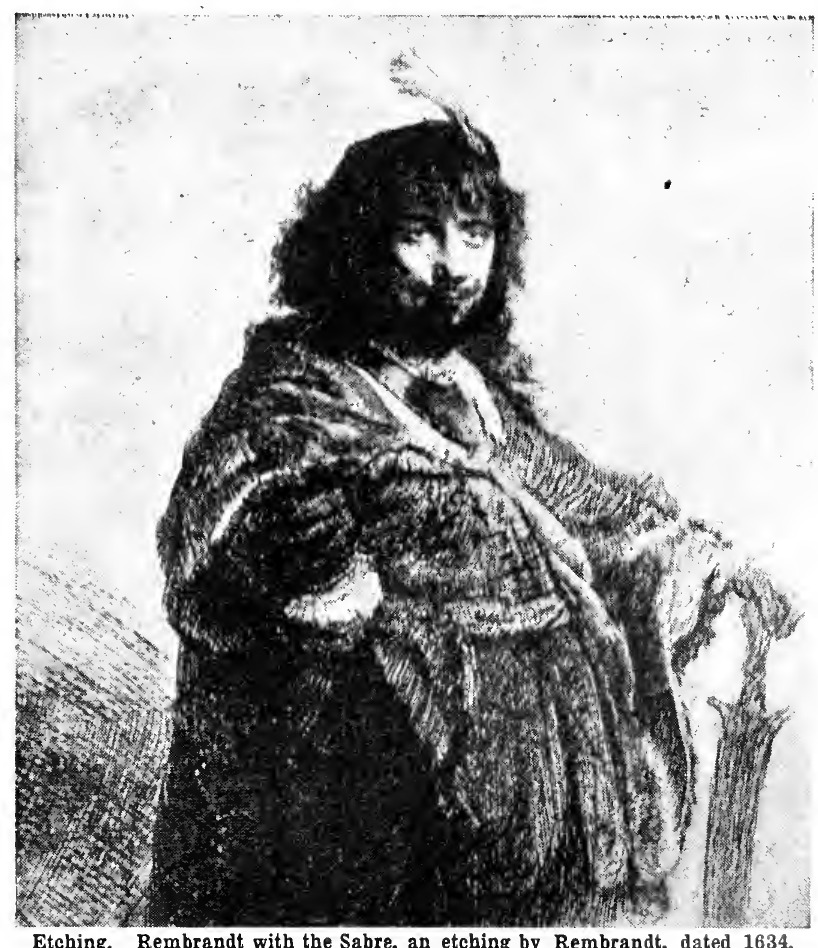

Etching. Rembrandt with the Sabre, an etching by Rembrandt, dated 1634 .

Only lour first impressions of this exist, one being sold in 1893 for $£ 2,000$

brandt (1606-69). Modern etchers like Sir Seymour Haden (18181911), James McNeill Whistler (1834-1903), David Young Cameron, William Strang, Joseph Pennell, Muirhead Bonc, and many Continental artists, carry on the best traditions of the art. See Short History of Engraving and Etching, A. M. Hind, 2nd ed. 1911 ; Modern Etchings and their Collectors, T. Simpson, 1919.

Eteoclēs (Gr., of true renown). In Greek legend, son of Oedipus, king of Thebes. See Oedipus; Polynices. Pron. Eti-o-kleez.

Etesian Winds (Gr. etēsios, yearly). Prevailing northerly winds blowing in summer in the Mediterranean region. They blow very strongly up the Nile valley, and are of great value to the dahabiyehs, as they help them to ascend the river against the current. See Wind.

Ethane or ETHYL HYdRIDE $\left(\mathrm{C}_{2} \mathrm{H}_{6}\right)$. Gas discovered in 1848 by Frankland and Kolbe. It occurs in the gases evolved from oil wells, but can be made artificially. Kolbe obtained it by the electro. lysis of potassium acetate and Frankland by allowing zinc ethyl to drop into iced water. Ethane is a colourless and odourless gas which burns with a faintly luminous flame. 
Ethel. Anglo-Saxon word meaning noble and formerly spelt aethel. It is found as a prefix to many Anglo-Saxon names for both sexes, c.g. Ethelfrith and Ethelflaeda. 'To-day its chief use is as a feminine Christian name.

Ethelbert (d. c. 616). King of Kent, son of Eormenric, and a descendant of Hengist. $\mathrm{He}$ became king about 560 and was defeated by the W. Saxons, 568. In 597 his over-lordship is said to have extended over all the English kings as far $\mathrm{N}$. as the Humber. His wife was a Christian-Bertha, daughter of the Frank king of Paris, Charibert-and in 597 Ethelbert was baptized by S. Augustine. He issued in 600 a code of laws known as dooms (q.v.), one of the earliest documents in English. See illus. p. 753.

Etheldreda, SaINT (c. 630-679). Abbess of Ely, often called S. Audrey. The third daughter of King Anna of E. Anglia, she was born at Exning in Suffolk. Married first to Tonbert, an E. Anglian prince, secondly to King Egfrid of Northumbria, she shunned the married state and became a nun at Col. dingham. About 672 she founded a monastery on her own estate at Ely and died June 23,679. Ely Cathedral marks the site of her grave.

Ethelfleda (d. 918). Eldest daughter of Alfred the Great,known as the Lady of the Mercians.

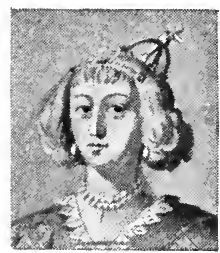

Ethelfleda, daughter of Alfred the Great From an old engraving

866. In his reign the northern kingdoms were in the hands of the Danes, against whom in 871 Ethel. red and Alfred fought six battles, the most notable being the English victory at Aescesdun, or Ashdown. The white horse at Uffington,Berks, is traditionally supposed to commemorate this success. Ethelred made a pilgrimage to Rome, possibly in the hope of averting the Danish peril, and died of wounds received in battle, April 23, 871 . $\mathrm{He}$ was buried at Wimborne.

Ethelred II (c. 968-1016). King of the English. Son of Edgar by his second wife Aelfthryth, he was known as the Unready or the Redeless from his inability to discern good rede or counsel. He succeeded hisstepbrother Edward the Martyr, 979 . In constant conflict with the Danes, he instituted the danegeld, for raising tribute to buy them off. In 1002 a general massacre of the Danes in England was carried out on S.Brice's day by Ethelred's com-

\section{ETHER: ITS FUNCTION IN THE UNIVERSE}

Sir Oliver I. Lodge, F.R.S.. Author of Man and the Universe This article deals with one of the most interesting and difficult of all problems. See also Atom; Matter; Relativity

Ether or Aether (Gr. aithēr) is the name given to a super-sensible elusive medium supposed to fill all space, not only the space between the worlds, but the space between the atoms of matter even in the most solid object. Most authorities consider it to be an all-permeating perfectly continuous substance, linking the otherwise detached particles of matter together and welding the whole into a coherent cosmos.

This view regards the ether as responsible for gravitation and cohesion as well as for electric and magnetic attraction; but all this must be regarded as still to some extent hypothetical, since the theory of these forces has not yet been finally worked out. Indeed, a recent school of mathematical physicists seeks to dispense with the ether, or at any rate to proceed on the explicit assumption that we shall never know anything about it, so that for all practical purposes we may concentrate our attention on matter alone. This doctrine, the principle of relativity, leads to remarkable consequences, some of which have apparently been vorified.

We shall assume, however, that the ether exists, and that it is proved to exist by facts ascertained concerning light. Light is known to be a tremor or exces. sively rapid vibration, too rapid to be associated with the properties of any ordinary matter. The ether mand, which merely led to further invasions, higher danegeld, and eventually to the recognition of Sweyn, king of Denmark, as king of England. Ethelred fled to Normandy, 1014, but reigned again after Sweyn's death. His wife was Emma, daughter of Richard, duke of Normandy. He died A pril 23, 1016.

Ethelwulf (d. 858). King of Wessex. Son of Egbert and father of Alfred the Great, he succeeded his father in 839, Athelstan being made king of Kent. The Danes wintered in England for the first time in his reign. In 851 he routed them at Aclea, perhaps Ockley. $\mathrm{He}$ went on pilgrimage to Rome in 855 with his son Alfred and brought back a second wife, Judith, daughter of Charles the Bald. On his return he is said to have made over Wessex to his son Ethelbald, who in his absence had seized Kent, which Ethelwulf retained for his own rule. He was buried at Winchester. ordinary matter, though it may be the fundamental substance out of which matter is made.

We do not know many of its properties. The most definite thing we know is that it transmits every vibration that can be imparted to it with the enormous speed of 300,000 kilometres, or roughly $187,000 \mathrm{~m}$. per sec., a rate which would enable a flash of light to travel from London to New York and back in the twink. ling of an eye.

Whether these vibrations or socalled waves are long or short, whether they are ultra-microscopic ones such as appeal to the eye, or are the immensely large ones employed in wireless telegraphy, makes no difference to the rate at which they travel. Hence the ether must be of simple constitution. When light enters matter, it is retarded; and if the matter is not quite transparent, some light is absorbed and converted into heat; but no such accident happens to it in the ether, which is perfectly transparent. The velocity of light is a definite physical constant in free or empty space, and as it proceeds on its way it is enfeebled only by gradual spreading out, not by conversion into some other form of energy. The term " empty space" means space empty of matter but full of ether; no space empty of ether can be imagined. The ether is a positive name for 
the negative idea of a perfect vacuum, and we know that it contains ether because light can travel across it.

Sound has no existence in a vacuum; nor heat either; both are affections of ordinary matter, and apart from matter are nonexistent. This cannot be said of either light or magnetism or electricity, though it is true that in order to detect and display thesc agencies a material medium or instrument is necessary.

The eye is a physiological organ adapted for the reception and detection of etherial tremors; so is a photographic camera with its sensitive plate. Without the eye we should be wholly ignorant of the ether, and it is the only organ of the body which responds to etherial influence. The information which it conveys to us, however, is not about the ether, but about the material bodies which have either emitted, scattered, or otherwise modified etherial tremors.

Light conveys to us certain information about the source emitting it, and hence, by what is called spectrum analysis, the constitution of sun and stars has been chemically examined, and their relative motions along the line of sight have been measured.

Even the constitution of atoms is yiclding to the scrutiny made possible by still finer kinds of etherial vibration, those known as ultra-violet light and X-rays. For these are ether-tremors emitted by electric particles vibrating or revolving with incredible rapidity, thousands of millions of million times a second.

\section{Density of Ether}

It used to be thought that the ether was an exceedingly tenuous rarefied substance, far more subtle than any ponderable matter, and this is the meaning which poets associate with the word ethereal. In fact, a series of chemical liquids have been rather inconveniently designated "ethers" by chemists because they are lighter and more mobile than water. But the modern view of the ether of space is that it must be at least as dense and substantial as any form of matter which exists in it. If atoms of matter are in any way composed of ether, and if the etlier as a continuous medium is incompressible, then no atom of matter can be denser than the medium of which it is made. And inasmuch as we now know that matter, even the most solid, is excessively porous, and consists of specks permeated by otherwise empty space, it has become probable that the ether is immensely more substantial than lead or gold or platinum ; in fact, as some think, more than a million times as dense.

But here we are getting out of our depth. The density of the ether is not yet known. But we should remember that the word etherial, when it signifies properties relating to the ether, need not mean ethereal at all, and had better not be so spelt; there is literary authority for both spell. ings, and the meanings associated with them are clearly different.

The modern view of matter is that matter, and not ether, is the rare and tenuous substance; a milky way or gossamer structure of detached particles, immersed in a substantial medium, and held together by the force which it exerts; that is how matter now appears to a physicist.

\section{Electric and Magnetic Properties}

A difficulty is sometimes felt as to how bodies can move through a dense or massive ether, and the question has not been finally answered, but it is clear that the ether possesses no viscosity, and so causes no frictional resistance to motion. It is certain that motion is the fundamental property of matter, and it is almost equally certain that the ether as a whole is at what we should call at rest. But it is susceptible of elastic strain, and therefore is responsible for the recoil and restoration of particles of matter when, as in a spring or raised weight, they have been displaced from their equilibrial position. One way of expressing that is to say that all potential or static energy is possessed by the ether, while kinetic energy is possessed by matter.

The properties of ether are perfect; it has no opacity, nor any kind of imperfect elasticity. In other words, it dissipates no energy, but stores without loss anything committed to it. It is in the interaction of matter and ether that loss or dissipation occurs. medium filling all space was originally needed for carrying light, whence it was called the luminiferous or light-carrying ether, but it is also required to explain most of the phenomena of electricity and magnetism, both of which agencies are at home in a vacuum, and are only modified by ordinary matter. The ether must have both electric and magnetic properties, and Clerk Maxwell discovered that these electric and magnetic pro. perties were both utilised in the propagation of light, so that for the first time it was perceived that light was an electro-magnetic phenomenon. Ether waves can be excited by any rapid electric or magnetic oscillation, just as sound is excited in air by a rapid mechanical oscillation. Electric oscillations are employed in wireless telegraphy, and if they are of sufficiently high frequency they appeal to our eyes as light.

\section{Matter and Ether}

At a time when the oscillations of ether were considered to be mechanical vibrations, the ether was thought to be analogous to an elastic solid and was likened to a jelly. Now that we know the oscillations to be electro-magnetic, these analogies become unserviceable. People sometimes think that contradictory properties have to be attributed to ether; but these belong to the exploded elastic solid theory, and are only appropriate to a mistaken view as to its con stitution.

Electric strain can exist just as well in a fluid as in a solid, for the strain is not really in the matter, but in the intervening and connecting medium. It is not to be supposed that the ether is structureless; it is continuous, and yet it may be in a constitutional state of vortex motion ; but if so its elements or units of in. trinsic motion must be excessively fine-grained, far finer than even the electrons which stand out in it as knots or singularities, related to the main bulk of the ether of space somewhat as an ordinary knot is related to the rest of a piece of string. We cannot press this analogy, or any other, at present, for we know too little about it. Nor do we know as yet whether human beings, or living things generally, make any use of ether, after the same fashion as they make use of ordinary matter. Much remains to be discovered about the interaction between matter and ether, and still more about the interaction of life and mind with both.

Ether (ETHYL ETHER) $\left(\mathrm{C}_{2} \mathrm{H}_{5}\right)_{2} \mathrm{O}$. In chemistry, a colourless, inflam. mable liquid, lighter than water, prepared by heating together a mixture of sulphuric acid and alcohol. First described by Valerius Cordus in 1540 , the product made by his method was employed as a stimulant, later popular as Hoffmann's drops. S. A. Frobenius in Great Britain communicated to the Royal Society a recipe for making ether, 1730-41.

The chemical name is ethyl sxide. Boullay's process is generally followed in its manufacture. This employs nine parts of concentrated sulphuric acid to five parts of 90 p.c. alcohol, and is continuous, i.e. by adding fresh alcohol the etherification is continued with 
the same sulphuric acid. Heckmann's apparatus is employed on a small, and Barbet's on a commercial, scale. The product is further purified by re-distillation over calcium chloride. Owing to its inflammable nature, special precautions have to be taken against fire and explosion. Large quantities of ether are used in the manufacture of cordite, aniline dyes, and artificial silk. As a solvent of gun-cotton it is employed in making collodion, used in the wet-plate process of photography.

In medicine, ether is employed in doses of 15 to 30 minims for repeated administration, and 45 to 60 minims for single administration. The following preparations of ether are also used : spiritus aetheris, ether 1 part and alcohol 2 parts, dose 20 to 40 minims repeated, 60 to 90 minims single administration ; and spiritus aetheris compositus, or Hoffmann's anodyne, in the same doses. Ether evaporates rapidly, producing great cold, and a spray directed against the skin eventually numbs sensation sufficiently to permit the performance of small operations. Small doses act as gastric stimulants, and are of service in various forms of dyspepsia. Ether also stimulates the heart and is an excellent restorative in cases of fainting. Its most frequent use is as a general anaesthetic, either alone or in combination with chloroform. Though less dangerous than chloroform, it is more apt to irritate the respiratory passages, and should not be administered to those suffering from bronchitis.

Etherege, Sir George (163491). English dramatist. Born of an Oxfordshire family, he studied law, but gave his time mainly to the life of a man of fashion. In 1664 his first comedy, The Comical Revenge, or Love in a Tub, was produced at the Duke's Theatre, and from that time its author's name and fame were assured. A second, She Would if She Could, and then a third, The Man of Mode, followed, each a distinct success. In 1685 Charles II, having knighted Etherege, sent him to represent England at Ratisbon. In 1688 he left that city, and passed most of his later life in Paris.

Etherege may be described as the orginator of the modern comedy of social life. His knowledge of the life of his time was complete, and his portraiture of its gallants, ladies, and their surroundings perfect See Works, ed. A. W. Verity, 1888.

Ethers. Oxides of the alcohol radicals formed by the elimination of water frcm two molecules of

alcohol. Ethers which contain the same radicalt wice are termed simple ethers, those which contain different slcohol radicals, mixed ethers. The chief method of preparation is by the action of sulphuric acid on the alcohols. Another method is to dissolve metallic sodium in ethyl alcohol and warm the sodium ethy. late, when ethyl oxide is obtained. Ethers are volatile bodies and are either gases, liquids, or solids. Cetyl ether is solid, methyl ether gaseous, and ethyl ether (ordinary ether) liquid.

Ethical Society. Society founded for the culture of morality apart from theology. Its members profess freedom from all religious

\section{ETHICS: THE PROBLEM OF CONDUCT}

A. D. Iindsay, M.A., Fellow of Balliol College, Oxford

Further information on philosophy, of which Ethics is a branch, wall be found in the articles Metaphysics; Philosophy; Psychology. See also biographies of Aristotle; Green; Hegel; Kant; Plato, and other philosophers

Ethics is the inquiry into human conduct in so far as conduct is right or wrong, or has moral value. The term good is used to denote that which possesses such value, and thus ethics is sometimes described as consisting of an inquiry into the meaning of good. It is to be distinguished from anthropology or sociology, sciences which do not exclusively refer to moral values, being mainly descrip. tive or scientific, while ethics is essentially reflective or philosophic. "How is human life organized and carried on ?" is the question of sociology and allied sciences. "What is the aim of human life, and what the chief end of man's activities?" is the question which ethics has to answer. Starting with men's moral judgements of right and wrong, of good and bad, it asks what they imply as to man's nature, in what relation they stand to scientific and aesthetic judgements, and how and in what sense they are objective.

\section{Economic Activity}

The fundamental conception of ethics is that of value. It assumes that man is not an animal with certain fixed wants, whose different actions are merely different ways of satisfying the same fundamen. tal needs, but that, over and above his simple physiological requirements, man has other wants, changeable and changing, between which he chooses. This act of choosing between different wants, or the preference of one satisfaction to another. is valuation.

From this valuation or appraisement of wants must be distinguished the actual steps which have to be taken to satisfy these wants, or the discovery of means towards the ends which man has approved. Generally speaking, this may be called the sphere of economic activity, whether technical, if occupied with the adaptation of the material world to man's peculiar wants, or economic in the strict sense, if occupied with men's relations so far as they will produce most efficiently what man wants. Economic activity, then, unlike ethics, takes for granted the end of man's efforts and deals solely with the means to attain that end. It is not immoral, but simply nonmoral.

\section{Naturalistic Ethics}

Some have denied that this distinction between these aspects of human conduct exists. Naturalistic ethics tries to show that man's conduct can in all respects be explained by the working of certain evolutionary laws and forces. Be. haviour, it is argued, has not changed owing to any change in the conception of the end to be attained, but, being directed always to the one end of the survival and continuance of the human species, has only altered with changes in human environment. Were this conception true, ethics would become only one part of biological science. Looking more closely, however, at the struggle for survival, it is plain that both degeneracy and progress have been produced. The survival of the fittest means strictly the struggle of the fittest to survive, and the judgement that the results of the process are some good and some bad, cannot be got from the process itself, but from ethical reflection upon it. Adaptation to environment must certainly be taken into account in a history of ethics, 
but no less must ethics make allowance for those variations in the ultimate standard of life for which men are prepared to struggle. The attempt to explain history by assuming that men's aims are al ways the same will not fit the facts

This distinction between technical activity and conduct was first elaborated in Greek moral philosophy. The ethics of Plato deal with the good of the in. dividual, the good of society, and the relations existing between them. Thus, in The Republic, he sought chiefly to determine the nature of justice as such, and the means of attaining justice in the relations of men, i.e. in society. He showed that life could be regarded as divided between a number of skilled processes or arts.

\section{Plato and Ethics}

Conduct, however, was not one of these, but was concerned rather with the relations between the ends of all these human processes and the relation of these ends to life itself. All the arts and activities of life he regarded as subordinate to the one purpose of life as a whole, which he called the good. This idea of the good is at once the eternal object of all human speculation, and a practical ideal capable of human attainment, such as justice or tem. perance. Ethics, then, was an inquiry into the good which all men sought, but the nature of which none properly understood. Greek thought sometimes regarded the good as attainable by the harmonious adjustment of human desires to one another, making pleasure, or the satisfaction of the greatest possible number of desires, the summum bonum, or highest good. But Plato showed that such a harmony was impossible without the recognition that certain activities or wants of the soul were higher than others. Thus, though Plato still regarded ethics as a matter of knowledge, he made clear that knowledge of the good was different from skill and involved certain emotional elements, was not in fact purely a matter of reason.

Aristotle elaborated the distinction between knowledge and moral insight, dwelling especially on the nature of the deliberate choice or will of man in his search after the good life. Here he insisted that both emotional and intellectual elements must be recognized, and pointed out that in an art the end existed outside the means, calling therefore for knowledge, while in conduct the end lay within the act itself, a recognition of moral insight.
Greek moral philosophy, however, preoccupied with the notion of the supreme good, remained intellectualistic, as may be seen in its difficulty in explaining that outstanding fact in human conduct, moral conflict and the weakness of the will. Characteristic also was the Greek identification of ethics with politics. The relations of men with each other were conceived as analogous to those of the different desires within the individual, a manifold to be reconciled within the harmony or unity of the good life, that is, according to Aristotle, the complete exercise of man's rational functions which differentiate him from the rest of creation. Other important schools of Greek ethical thought were those of the Cyrenaics and Epicureans, who interpreted morality in hedonistic terms, and those of the Cynics and Stoics, who held rational virtue to be an end in itself.

In modern times the greatest influence has been the growth of the natural sciences with their view of nature as one deterministic system. This assumption made a sharp contrast with the Christian, and especially the Protestant, in sistence on the absolute worth of the individual, and so has focussed ethical inquiry on the problem of the freedom of the will.

\section{Immanuel Kant}

The modern point of view is represented better by Immanuel Kant than by anyone else. He regarded the outstanding fact of conduct as the contrast between what is and what ought to be, and emphasised the impossibility of deriving the latter from the former. However much we may learn of the influence of heredity and environment upon human action, the statement that an action is wrong implies that it ought not to have been done, and therefore need not have been done. Here is the contrast with the deterministic conceptions of modern science. The possibility of alternatives of action is as fundamental for human conduct as determinism for the natural sciences.

How the two are to be reconciled is a matter for metaphysics. Ethics is content to show that con. duct implies a definite principle of action, not inconsistent with man's heredity or environment, but different and underivable from such influences. The judgement of value, then, so closely bound up with conduct, is seen to tell us something about the nature of man.

How its underivable and immediate character is consistent with the change and development of ethical judgements in history ; how ethical progress takes place in the developed moral insight of individuals ; how ethical progress finds expression in a system of social rights and obligations; how moral judgements imply something more than the mere results of human reasoning, and yet may have an objectivity different from, but as real as, that of scientific judgementsthese are the questions with which ethics is concerned.

Bibliography. Prolegomena to Ethics, T. H. Green, ed. A. C. Bradley, 1883; The Theory of Good and Evil, H. Rashdall, 1907; A Study of Ethical Principles, James Seth, 10th ed. 1908; The Classical Moralists, B. Rand, 1909 ; Ethics, John Dewey and J. H. Tufts, 1909; Manual of Ethics, J. S. Mackenzie, 5th ed.1915; The Method of Ethics, H. Sidgwick, 6th ed. 1901 .

Ethiopia or Aethiopla (Gr. Aithiopia). In ancient geography, name given by the Greeks to the whole of Africa from the Red Sea to the Atlantic, in a narrower sense to the territory comprised in the modern Nubia, Sennar, Kordofan, and part of Abyssinia. The name, derived according to Greek popular etymology from aithein, to burn, and $\overline{o p s}$, face, was originally applied to all countries inhabited by persons of dark-brown or black colour, the result of the heat of the sun. In the Homerio poems the Ethiopians are described as dwelling on the uttermost confines of the earth, a pious and blameless people, often visited by the gods. According to Herodotus, they were divided into the straight-haired Ethiopians of the E. and the curly. haired Ethiopians of the W.

From the earliest times the history of the country was intimately connected with that of Egypt, which was more than once under the rule of Ethiopian kings. The first Ethiopian kingdom was that of Napata (mod. Merawi), founded about the 11th century B.C. After the invasion of the country by Cambyses in 524 B.C. the capital was removed to Meroë (Assur, near Shendi) in the S., and a new kingdom arose which lasted until about the beginning of the Christian era, chiefly ruled by princesses called Candacē, probably not a name but a title like Abgar and Pharaoh. The Romans made expeditions into the country, in one of which (24 B.c.) the Etbiopians suffered a severe defeat; but the conquered territory was abandoned by order of Augustus. The name Ethiopia is also given to a Christian king. dom established in the Abyssinian highlands, with capital Axumis (mod. Axum). This was the origin of the empire of Abyssinia, the official title of which is still Ethiopia. 
The inhabitants of Ethiopia were of Semitic origin, and spoke a language called Geez, which showed greater affinities with the Arabic of the Sabaeans in S. Arabia than with classical Arabic. The alphabet was perhaps of Phoenician origin. There was an Ethiopic version of the Bible, including various apocryphal books added to was superseded by Amharic as the official language, but continued to be used in the churches and in literature. It is now represented by two dialects, Tigre and Tigrai. See Abyssinia; also illus. facing p. 129.

Ethmoid Bone (Gr. ëthmos, strainer, sieve ; eidos, form). Bone which projects downwards from the frontal bones of the head. It enters into the formation of the floor of the cranium, the orbits or both the O.T. and the N.T. Geez

eye-sockets, and the deeper parts of the nose. Roughly cuboid in shape, it is of a spongy, porous consistency, a very complicated structure, and contains a number of small cavities.

Ethnography (Gr. ethnos, nation; graphein, to write). Branch of anthropology, which comprises

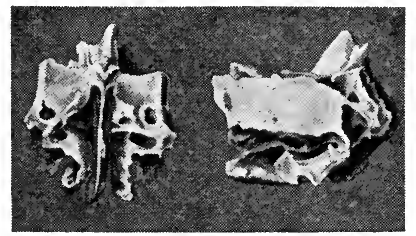

Ethmoid Bone. Left, front view of the bone; right, side view

the study and description of various nations, in reference to their distinctive material characteristics.

\section{ETHNOLOGY: THE SCIENCE OF RACE}

Sir H. H. Johnston, G.C.M.G., K.C.B., ete.

One aspect of a great question is here discussed. See also Anthro. pology; Family; Tribe; also articles on American Indians ; Celt; Slav; and other branches of the human race

This term is artificially derived from Greek words, meaning a discourse about human races or nations; but has gradually come to mean the science dealing with the results of man's mental development in contradistinction from Anthropology.

The classification of existing human races or sub-species belongs rather to anthropology proper than to ethnology, which deals with the history, distribution, and intellectual achievements of Homo sapiens. But for the better understanding of the ethnological disquisition which follows, we might briefly consider the present racial divisions of humanity and the criteria on which they are based. In this classification we can only take into consideration physical traits ; it is useless to go by mental developments and degrees of culture, since these vary according to circumstances, and not always according to the size or structure of the brain.

The comparative size and weight of the brain is of some im. portance. For instance, the Australoids and Melanesians are set apart from the other subspecies of man by their lower average in skull capacity and weight of brain, and by the reten. tion in the conformation of the brain of a few anthropoid features. The hair of the head and body is another criterion in race classification. The two extremes in hair are that of the Negro-flat in sec. tion and curly-and that of the
Mongol-Amerindian-round and straight. The hair of the white man varies between these two extremes and further tends in the N. European to be flaxen, brown, or redcharacters which also reappear among the Berber mountaineers in $\mathrm{N}$. Africa and the Aryan tribes of Afghanistan and the Hindu Kush. Stature is a variable factor. The Negro sub-species includes both the shortest and the tallest men. Skull form, round and broad, narrow and long, with or without strong brow ridges, prognathous, or vertical from brow to chin, and the conformation of the lower jaw are points of great importance in classification. Skin colour is ac. cepted as a general characteristic of each distinct sub-species; that is to say, the Australoid is usually brown, the Negro black, the MongolAmerindian yellow, and the European white.

\section{Primary Divisions of Mankind}

The generally accepted primary divisions of existing humanity are as follows:

Homo sapiens australis.-The Australoid.

Homo sapiens aethiops.-The Negro. Homo sapiens mongolicus.-The Mongol and Amerindian.

Homo sapiens europaeus.-The White Man.

The first of the four may be further sub-divided into the Vedda and Dravidian types of India and the Melanesians of Oceania; the second into the Bushman, the African Negro, the Asiatic Negro, the Oceanic Negro, the Papuan and the extinct Tasmanian; the third into the true Mongol or Kalmuk, the long-headed Eskimo, the Tibetan, Chinese, Indo-Chinese, and Malay; and into the main stocks of the Amerindian ; and the fourth into Nordic (Aryan), Mediterranean, and Armenian-Alpine Man. There are also indeterminate and composite human races obviously derived from comparatively recent intermixture, such as the Finns and Lapps of N. Europe, the Egyptians, the Hamitic and Sudanese Negroids of the Sahara, W. and E. Africa, the Gala-Somali (ancient hybrids between Mediterranean man and the Negro), many tribes in India composed of Negro, Med. iterranean, Nordic, Australoid, and Mongolian elements ; the Indonesians, and the Polynesians resulting from a fusion of Indo-Mediterranean man, and the Mongol-Malay, Melanesian, and Oceanic Negroid; the Ainus of North-east Asia, very primitive "white men," not without ancient Australoid affinities and Mongol-Amerindian intermixture ; the very composite Japanese and Formosans, the Malay-Negro hybrids of Madagascar, the Australoid-Negro Papuans of New Guinea and the E. islands of the Malay Archipelago.

\section{Origin of Man}

In what part of the globe did Homo sapiens originate? Almost certainly not in America, because in the New World no fossil remains have ever been discovered showing the existence there at any time of such Old World apes and anthropoids as are known to be the near. est relations of the human family. Moreover, up to the present time, no vestiges have been discovered in the New World of any human type approximating more than Homo sapiens in its skull formation or bones to any more ape-like stages in man's ancestry.

On the other hand, such remains have been found in the Old World : in Java, for example, and in the English county of Sussex, in Germany, France, Spain (Gibraltar), and Austria. And there abound in Asia and Africa at the present day living human types on the very borderland of the sapiens species, which still exhibit in teeth, limbs, face, viscera, and brain remarkable affinities with the ancestral and more anthropoidal forms of the human stock. Perhaps the most "Simian" type of humanity, Pithecanthrōpos erectus, may have only been a late survivor in Java of an early type of Man, and there exist reasons for thinking that he migrated thither from India, and represented the transitional form between the actual Ape and the actual Human which must 


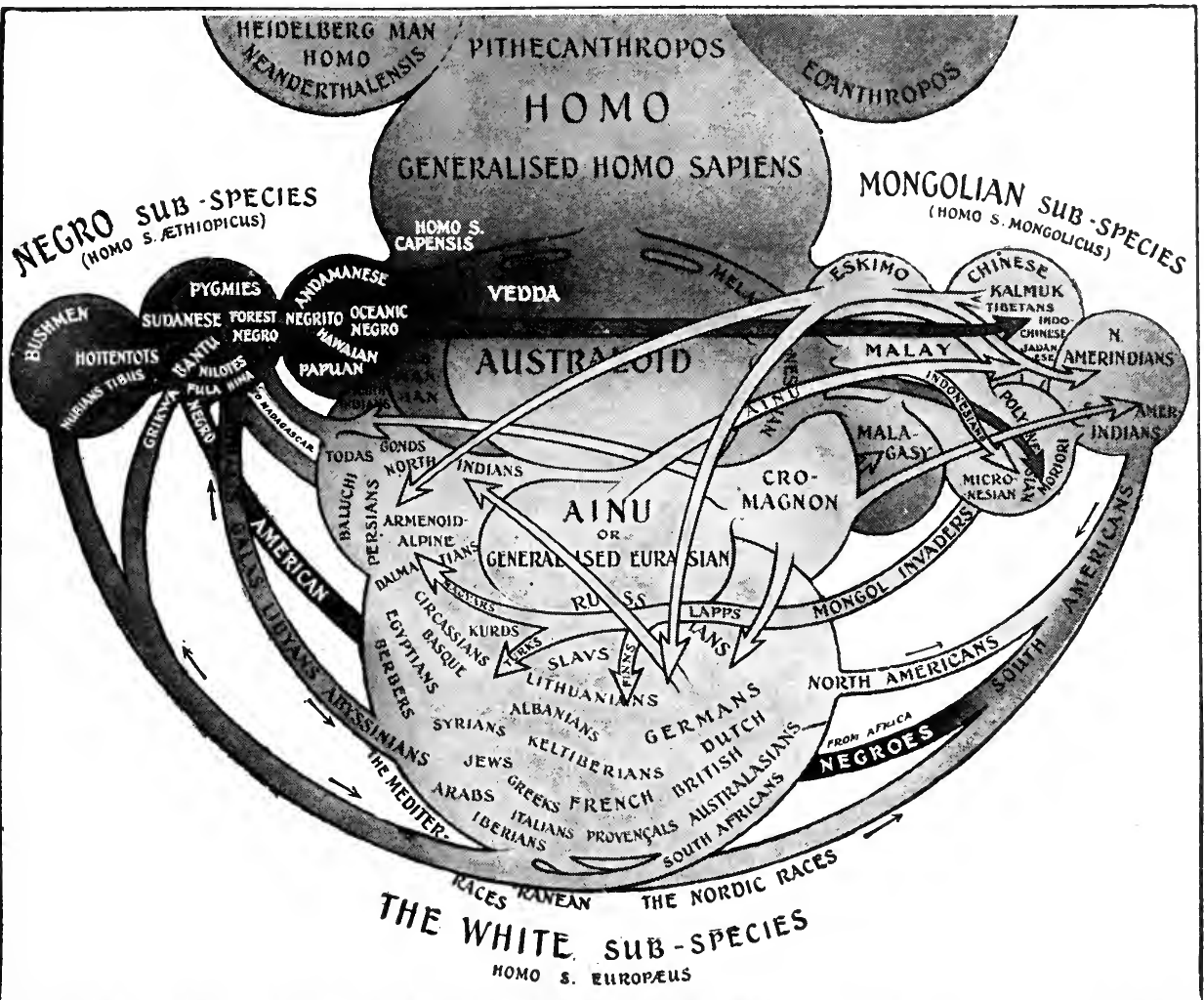

Ethnology. Diagram illustrating the main developments of the species of Man, and the inter-relationships of the existing and recent races of mankind. From the generalised HOMO, related to earlier species, emerge the Negro, Mongolian, and White sub-species, within which numerous racial specialisations appear. Tinting indicates the approximate skin colours or degrees of nigrescence : size indicates only evolutionary, not nnmerical or political, importance. The races of mankind have been, and still are, constantly modifying each other by their movements, penetrating and fusing with each other. Thus, the Ainu type infuenced Russian races and penetrated to Japan. Mongols influenced $\mathbf{N}$. America, $\mathbf{N}$. India, and became the dominant stock of the Oceanic Polynesians. The extinct Crô-magnon race, originating in Asia, penetrated Europe, crossed to Africa, left descendants in the Punjab, and crossed throngh N. Asia to mingle with Amerindians. Negroes have influenced $S$. and W. European peoples, and great parts of the New World. The ribands of communication show these various processes : where they have no arrow-heads, or where small arrows point both ways, there has been give-andtake in the process of penetration; where the ribands end in arrow-heads, there has been one definite hybridising impulse. with little or no reciprocity

have inhabited a considerable area of S. and W. Asia, N. Africa, and Europe. The Piltdown Man of Sussex (Eoanthrōpos), whose remains are more abundant and definite than those of Pithecanthrōpos in Java, was nearer to the modern human type, but it is probable that he was a fugitive to $S$. England before the pressure of more advanced types in France.

Europe was in comparatively early times a favourite region for the development of Man. From some human base of generalised characters like the existing Austra. loid, there seems to have developed on independent and specialised lines the remarkable Neanderthal species, which apparently got no nearer to Britain than the Channel Islands, but which certainly reached Gibraltar, and possibly N. Africa, and dwelt principally in France,
Germany, and Austria. There may also have arisen another divergent human species in S. Africa, Homo capensis, so named from a fossil skull found at Boskop, in Cape Colony, in 1915.

\section{The Colonisers of Europe}

The generalised Homo sapiens, in the form more or less of the Black Australian, seems to have colonised much of Europe south of N. Germany and Scandinavia, to have penetrated even to Ireland (as evidenced by the Sligo skull), to have passed over $\mathbf{N}$. and perhaps $\mathbf{E}$. Africa, over W. and S. Asia. In Asia at the present day he is represented by the Veddas of Ceylon, and by the black people of Australia, and some of the Melanesian islands. In N. and E. Asia this Australoid type specialised into the Mongolian; in Europe into the white man, with his two main branches of the fair-haired Nordic and the dark-haired Mediterranean type; in W. Asia into the Armenian-Alpine and the Dravidian; and in the same region possibly into the Negro.

The region in which the negroone of the most specialised forms of Homo sapiens at the present day-had his origin has been much discussed. Sometimes it has seemed as though India was the negro's original home and focus of distribution. There is undoubtedly a considerable negroid strain in the forest peoples of S. India, and absolute negroes exist now in the Andaman Islands. There is a negro tinge about Burma, and there are negritos or pygmy negroes living in the Malay Peninsula. Sumatra and neighbouring islands are negroid. Oceanic negroes are the dominant population of the large islands to 
the N.E. and E. of New Guinea, and a very generalised type of negro existed in Tasmania down to the close of the 19th century. Oceanic negroid influence extends even to Hawaii, Fiji, and New Zealand. But there are also traces ofconsiderable ancientryindicating a negroid race inhabiting $\mathrm{S}$. France and Italy, rather more related in head-form to the Asiatic than to the African negro. Skulls of a somewhat generalised negro type have been recently discovered in $\mathrm{E}$. Africa and at the Cape of Good Hope. In probably very ancient days, the negro sub-species somewhere in N. Africa, possibly in the Sahara Desert, gave birth to a remarkable variant, the Bushman, not necessarily a negro pygmy, because in some districts he attains to almost normal height, but very spccialised in regard to head-form, bodily conformation, and the peculiarities of certain organs. The Bushman seems to have been pushed by force of circumstances across the Sahara into Nigeria, and more particularly into equatorial E. Africa. South of the Victoria Nyanza he has left traces of his remarkable type of language, with its baboon-like clicks. But it was in the sterile region of $\mathrm{S}$. Africa that the "Bush" type attained its most marked development, and there alone it is now found.

\section{Migrations into America}

Human migrations into America seem to have begun in the interglacial episodes of warmer climates, when N. America was more or less broadly connected with N.E. Asia. Quite possibly the first human type to cross by this land bridge from Kamchatka to Alaska was more akin to the Australoid, and later to the primitive Ainu-like type of White man that developed out of the Australoid. This last-mentioned is the predominant type of the Russian population at the present day, and recurs again with a marked resemblance in $\mathrm{N}$. Japan and amongst the coast tribes of British Columbia. But the dominant human type to colonise the New World in early times was certainly Mongol-a generalised Mongol, mixed, it may be, with the Crô-magnon race of Europe and Asia, and resembling further the generalised Mongolians of the Malay Archipelago.

This mixed Mongolian followed closely on the heels of the early Australoids and Ainu, and rapidly penetrated America till it reached the S. extremity. Mongoloids, consequently, formed by far the bulk of the aboriginal population of all America. The peoples of east or forested S. America, especially Brazil, resemble very closely in appearance, and even in manners and customs, the Mongoloid peoples of Borneo. In prehistoric times there was a drift of human emigration across the $\mathrm{Pa}$ cific from islet to islet and archipelago to archipelago, until at last western S. America, and perhaps Central America, were invaded by Polynesian Mongoloids, akin in race to the Moriori type of prehistoric New Zealand and of the Chatham Islands.

Japanese and Amerindians

Probably in much later times, when the Mongol peoples of China and Japan acquired sufficient knowledge of shipbuilding and navigation, ships manned by these people were occasionally stranded on the Californian coast, giving an early Japanese civilization to the Amerindians of Central America. A recent interesting theory is that the Phoenicians of the Persian Gulf and S. Arabia first of all opened up trade with Peninsular India, and thus gave such a tremendous impulse to the adventurous semi-Caucasian element in N., Central and Further India, that not only was the shipping trade opened up with China a few centuries before the Christian era, but this Phoenician-inspired adventure in the Far East was followed by a crossing of the Pacific.

Probably, too, after the beginning of the Christian era there still occurred from time to time Asiatic immigrations into N. America by the short canoe journeys across Bering Straits. The Eskimo race seems to have originated in boreal Asia or Europe. Though closely allied to the typical Mongol, it is long-headed and not broadheaded. There is evidence of Eskimo culture and race having extended to the N. of Scotland. In the New World they only colonised the $\mathbf{N}$. of Alaska, the extreme north of the Canadian Dominion, and Greenland; but in course of time they extended S. almost to Nova Scotia. But in addition to the Eskimo in comparatively recent times it would also seem as though the Tartar and Ainu peoples of N.E. Asia found their way into S. Alaska and eventually influenced the Red Indian tribes of N. America.

After remaining for some 100,000 years but sparsely populated with humanity, the American continents attained an amazing develop. ment in human history, following on the discovery of Columbus. In the 17 th century began the great set of the huwuan iwce from the Old World towards the New-an outstanding event in human his- tory which culminated early in the 20th century. Central and S. America were first colonised on a large scale by Spaniards and Portuguese, who further introduced the negro from Africa. The more Nordic races of N.W. Europe colonised N. America-French and British, together with a certain number of Basques.

N. America has now a White population of $100,000,000$, chiefly representative of the physical types of Britain, W. and Central Europe, with, however, a large number of Jews and a not inconsiderable recruitment of Syrians. The European element in S. America is mainly Spanish, Portuguese, and Italian, but there still remain some 16,000,000 of Amerindian race, and these Amerindians in Brazil have mingled extensively with European immigrants or with negroes. Negroes constitute the main type of population in the Guianas, in portions of E. Brazil, as well as in the S.E. States of N. America. But a remarkable change is taking place in the distribution of the N. American negro. Owing to the discomforts and disabilities inflicted on him in the S.E. States, he is migrating to the N., the W., the centre, and to Canada.

Reviewing the prehistoric past of Europe we find, especially in W. and $S$. Europe, indications that after the anthropoid Piltdown man and the aberrant Neanderthalwho differed so much from Homo sapiens in the structure of his teeth, skull, and skeleton, that it is difficult to believe he was able to min. gle with Homo sapiens and leave hybrids behind him-had passed away, the next stage of human types was somewhat Australoid in physical characteristics, with even a negroid development on the Mediterranean shores.

\section{The Crô-magnon Race}

But as the recurrent glacial periods gave way to more normal conditions of climate, there appearedin France-possibly emigrating thither from $W$. Asia-the remarkable Crô-magnon race, of large brain development,tallstature, and great talent in the arts, altogether a superior form of Man. The Crômagnon had rather projecting cheek-bones and is thought to have resembled the handsome, darkskinned peoples of $\mathrm{N}$. India, or the better-looking types of Amerindian in N. America. He gave human culture a decided uplift, and was a conqueror and successful invader of many regions. Possibly he not only entered N. Africa, but penetrated southwards across the Sahara into southernmost Africa, and was the origin of the Strandlooper 


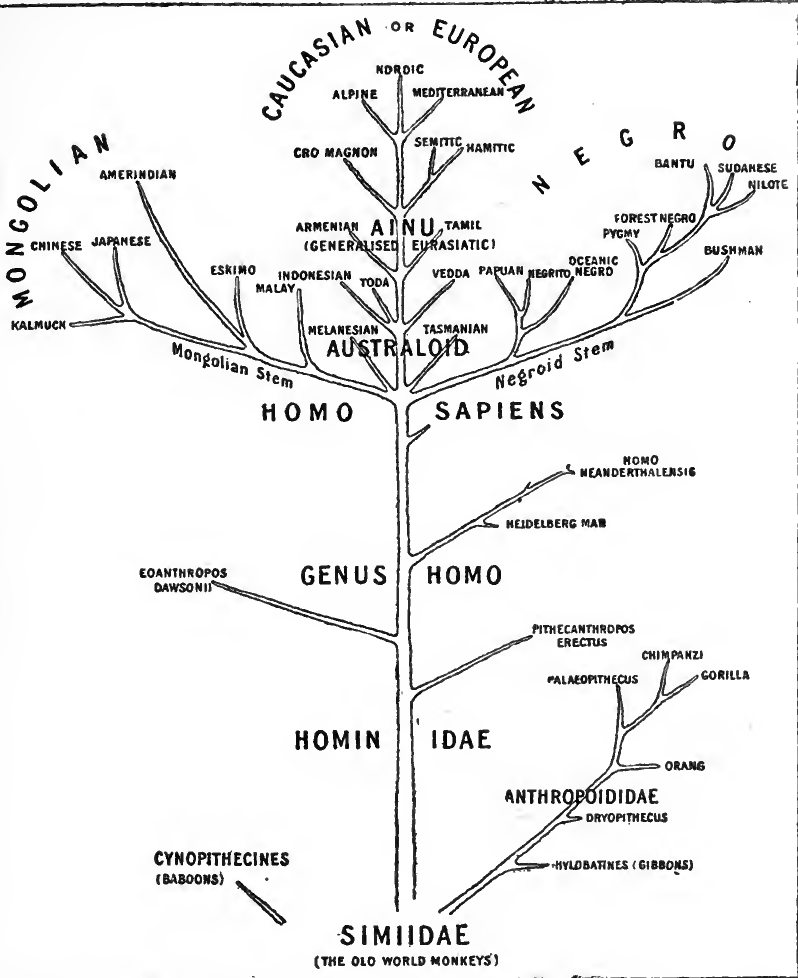

Ethnology. Man's family tree. A diagrammatic representation of the emergence of the human race from its early origins. From the Simiidae or manlike apes there is gradually developed, through stages not yet fully explored, the family Hominidae and finally, the genus HOMO, which culminates in the species Homo sapiens. This species, represented in its primitive form by Australoid types, branches along Mongolian, Eurasiatic, and Negroid stems into numerous specialised races, whose movements and inter-reactions are described in the article. Note the Ainu type of N.E. Asia, intermediate between the Australoid sub-species and the bighly developed European; it has probably influenced the development of the Russian, E. Asiatic, N.W. American, and other important peoples

art and civilization which existed thousands of years ago in Cape Colony. The Crô-magnon apparently also entered, if he did not come from, Central Asia. He may even have migrated across Bering Straits and influenced the Red Indian peoples of $\mathrm{N}$. America.

In course of time he gave way in Europe to shorter and less remarkable types of humanity. By that time the dominant human in S. and W. Europe was of the Iberian or Mediterranean race, a white man with dark hair and dark eyes, of medium stature and somewhat hairy face and body. This Iberian type certainly penetrated to the British Islands and subdued and absorbed the pre-existing Eskimo and Ainu breeds. The Mediterranean race spread over Asia Minor, mixing with the Armenoid or Alpine (which had also invaded Central Europe), the Arabian Pen. insula, and much of N. and N.E.
Africa, forming subsidiary races by mixing with the earlier Dravidians, Australoids, and Negroes. The Mediterranean race produced by intermixture the Dravidian that preceded the Nordic Aryan in the conquest of India. This ever more diluted Mediterranean race may even have started the Indonesians, that semi-white people which penetrated into Further India, and into the Malay Archipelago and parts of New Guinea, and ended up by colonising New Zealand and most Pacific archipelagoes between 2,000 and 600 years ago.

To a great extent the Mediterranean race stands for the typical Caucasian. In the early days of ethnological study the superior White was named Caucasian because it was erroneously thought to be represented by the people of the Caucasus, but these are compounded really of mixed elements. Perhaps the best example of the
Mediterranean race is the Berbers of N. Africa, where they are free from intermixture. The Semite stock from which the Arabs are descended has a Mediterranean basis, but contains also Armenian (Alpine) and Asiatic Negroid blood, besides here and there a Mongolian element derived from the early Mongolian colonisation of Mesopotamia.

In Old Wor'd dominance, the Mediterranean or brunet type of White man was succeeded by the Nordic peoples of N. Europe. No doubt there is Crô-magnon blood and influence in the Nordic stock. The early Nordics were certainly tall, but their most striking varia. tion from preceding types lay in their development of red hair, which further specialised into the yellow-brown, flaxen, golden, or even lint-white; while the brown iris of the eye changed into greygreen or blue-grey. This type at present is purest in Scandinavia and in N. Germany and N.W. Russia. The Goths of history were of pure Nordic stock. The Caledonians of N. Scotland represented a more primitive offshoot, with red hair and rough-hewn facial features of the Crô-magnon type.

This tall, fair-haired, grey-eyed or blue-eyed man first began to trouble Mediterranean Europe over 3,000 years ago. $\mathrm{He}$ originated the Aryan languages and carried them into W. Asia and India. But in culture he had been forestalled in W. Asia by the Al. pine or Armenoid stock, a squarer or rounder-headed variant of the Mediterranean race. The Armenoids had civilized the Mongols of Central Asia, thus starting the civilization of China 3,000 to 4,000 years ago, as earlier still they had started that of Mesopotamia.

\section{Aryan Influence}

The Aryan conquest of Europe and Asia was due in the main to the Aryan discovery of the uses of iron in Central or N. Europe, and the iron weapons with which they could overcome the $\mathrm{S}$. races using weapons of bronze or stone. These golden-haired, blue-eyed Aryans descended with their Aryan languages on the Balkan Peninsula, and, by fusion with the Mediterranean race and civilization of the Aegean, founded classical Greece They equally founded the empire of Rome by invading the Italian peninsula and subduing the Etruscans and Ligurians. More than $3,0 \mathrm{C} 0$ years ago they had Aryanised Sicily.

In Central Europe they originated the Celtic race, which mingled freely with the Armenoids of the Bronze period. The Aryan 
Celts crossed France and invaded N. Spain. They passed from France or Belgium into Britain, spread to N. Scotland and all over Ireland. In Ireland they remain mixed with the pre-existing Iberians, and therefore require to be known (as in N. Spain) as Celtiberians. This Celtiberian type in England and Scotland was overlaid by a much later Celtic invasion of the Belgae or Britons, surviving in language in Wales. The Celts overspread Holland and Belgium and probably Denmark, and most of S Germany, Austria - Hungary, and perhaps S. Russia. The Aryan invaders of N. Persia and Armenia were more related to the early Aryan peoples of Russia, whose language type survives in Lithuania. Allied with these invaders of Persia were those who colonised much of Turkistan, Afghanistan, and $\mathrm{N}$. India, and originated the Sanskrit language.

\section{Goths, Germans, Northmen}

The next great Aryan uprising was the Gothic, followed by the German, divided again into the High German or Allemanic and the Low German or Frank. One branch of Low German speech was Frisian, whence came Anglo-Saxon and modern English. Then came the Scandinavians or Northmen, who originated modern Scandinavia, and profoundly affected the history of the British Isles, Iceland, prehistoric N. America, Sicily, S. Italy, and the Byzantine empire. Originally, the Scandinavian people only occupied the extreme S. of Sweden, the Danish peninsula, and S. Norway, with the islands off Finland and patches of N.W. Russia.

Their predecessors in Scandinavia were Mongol types culminating far back in the European Eskimo. Russia was peopled in the N. by the same Mongol races, and over the rest of the area anciently by a primitive type of white man akin to the Ainu of Japan, noteworthy for their hairiness of face and body. From these dark-haired forms of white man arose the Lithuanians, who were early Aryanised by the Nordic peoples and still speak a primitive Aryan language. In time the Nordic races romped cver Russia on their way to invade W. Asia. The Goths became dominant in Russia in the first half of the Christian era, and Gothic was spoken in S. Russia down to a few centuries ago.

We cannot leave out of account the effects of the Arab outpouring in the 7 th century A.D. They reSemiticised Syria (fast becoming Hellenic), paved the way for the
Turkish invasions of Asia Minor and the Persian culture-conquests of India and Central Asia. The Arabs awoke the Berbers of $\mathrm{N}$. Africa and carried Hamitic N. Africa into Spain and France and across the deserts into W. Africa and the Niger Basin, the Egyptian Sudan and E. Africa, till at last their influence reached the confines of Zululand, and even permeated much of the N. and E. watershed of the Congo. They Arabicised India and Malaysia to the verge of New Guinea and the Philippines.

After the Aryan migrations, the next great event that affected Europe and Asia was the boiling over of the Mongol tribes of N.E. and Central Asia. These, as Huns, Avars, Turks, and Tartars, ravaged two-thirds of Russia and much of E. and Central Europe down to the conquest of the Byzantine empire. They also invaded Asia Minor, and as rulers or soldiers of fortune penetrated to $\mathrm{N}$. Africa, bringing with them first the Buddhist, and secondly the Mahomedan, religion. Mediterranean and Nordic Europe only began to make headway against this latest Mongol invasion about the 17 th century.

In the 19th century, however, after having laid the foundations of a white man's America, the Nordic and Mediterranean Europeans commenced their last tremendous expansion of power and colonisation. They discovered and colonised nearly all Australasia. They dominate all but E. Asia to-day. They conquered and took under control the whole of Africa, wherein also they planted prosperous colonies of white people. In the Old World and the New they are the ruling type. Whether they will remain so must depend on many factors: race fertility, conquest over disease and alcohol, education, reconcilement of ambitions, and international cooperation. Nature, however, is entirely without "pink and white" sympathies, and cares little for the skin colour of the coming super-man.

Bibliography. The Races of Europe, W. Z. Ripley, 1900 ; Ethnology, A. H. Keane, 2nd ed. 1901 ; The Wanderings of Peoples, A. C. Haddon, 1911 ; A Survey of the Ethnography of Africa, etc., vol. xliii, R. Anthr. Inst., H. H. Johnston, 1913 : The Antiquity of Man, A. Keith, 1915; The Peoples of India, H. H. Risley, 1915 ; Men of the Old Stone Age, H. F. Osborn, 1916 ; The American Indian, $C$. Wissler, 1917; British Museum, Guide to the Fossil Remains of Man, 1918; Comparative Study of the Bantu and semi-Bantu, etc. H. H. Johnston, 1919: Man, Past and Present, A. H. Keana, rev. ed. 1920.
Ethyl. Organic radical represented by the chemical formula $\mathrm{C}_{2} \mathrm{H}_{5}$. It has not been isolated, but its combinations, e.g. ethyl alcohol (ordinary alcohol) and many compounds, are well known. The name was introduced by Berzelius as Ethule. It is denoted by the contraction Et. Ethyl is a con. traction of ether and $y l$, an abbreviation of $\mathrm{Gr}$. hylē, material.

Ethyl Alcohol $\left(\mathrm{C}_{2} \mathrm{H}_{6} \mathrm{O}\right)$. Chemical name for alcohol, the active principle of intoxicating liquors. It is also known as vinous alcohol or aqua vitae. See Alcohol.

Ethylamine. Organic base with an ammoniacal odour, burning taste, and strong alkaline character. It is liquid, behaves in most respects like ammonia, and is used in the manufacture of some aniline dyes. First prepared by Wurtz, 1848, by distilling cyanic ether with caustic potash, ethylamine is now made by Hofmann's process, in which crude ethyl chloride, a by-product in the manufacture of chloral, is acted on by ammonia. This produces diethyloxamide, which, purified and distilled with caustic potash, yields ethylamine.

Ethyl Chloride or MoNochlorETHANE $\left(\mathrm{C}_{2} \mathrm{H}_{5} \mathrm{Cl}\right)$. Ethereal liquid known to the alchemists as sweet spirit of salt. It is made by passing hydrochloric acid gas into absolute alcohol containing zinc chloride, and distilling the product. Ethyl chloride is a volatile liquid, used as a solvent, and as a local and general anaesthetic.

Ethylene $\left(\mathrm{C}_{2} \mathrm{H}_{4}\right)$. Colourless gas prepared by the action of sulphuric acid on alcohol, and purified by passing through sulphuric acid and caustic soda. It was first investigated, 1781, by the Dutch chemists, Deimann, Paets van Troostwyk, Bondt, and Lauwerenburgh. It is also known as heavy carburetted hydrogen, elayl, and ethene. It is easily in. flammable, burns with a luminous flame, and forms an explosive mixture with air or oxygen.

Ethyl-hydrocupreine. A derivative of cupreine, an alkaloid occurring in cuprea bark (Remijia pedunculata). Known also as opto. chin, it has been used in treating pneumonia, but is a dangerous drug.

Ethyl Nitrite. A solution containing 3 p.c. of ethyl nitrite, by weight, with 95 parts of absolute alcohol and five parts of glycerine. It forms the Liquor Ethyl Nitritis of the British Pharmacopoeia. It causes the small blood-vessels of the skin to dilate, the face to flush, and the heart to beat rapidly and violently, and relieves the pain of heart affections. The dose is from 15 to 60 minims. 


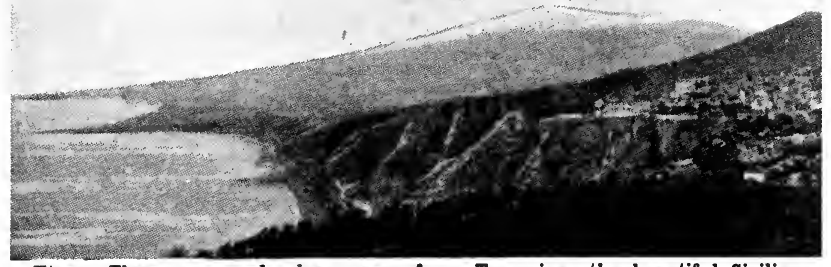

Etna. The snowcapped volcano seen from Taormina, the beautiful Sicilian coast town on the Straits of Messina

Etienne, Eugk̀ne (b. 1844). French politician. Born at Oran, Dec. 15,1844 , he was educated at

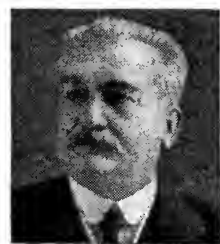

Eugène Etienne,

French politician Manuel
Algiers. He be.

came deputy

for Oran in

1881 ; under. secretary for the colonies, 1887,1889 , and 1892 ; minister of the interior, 1905, and of war, $1905-6$, a n d 1913. He was also elected vice-president of the chamber of deputies in 1913 and again in 1914 .

Etiology or Aetiology (Gr. aitia, cause ; logos, account). The doctrine of causes, of the origin of things, specially applied to the origin of diseases. By some it is classed with ontology and teleology, as a branch of metaphysics (q.v.).

Etiquette. French word introduced into English to denote a routine of behaviour established by. custom. It includes court ceremonial, formalities of diplomatic intercourse, procedure in parliament, in the army and navy, etc. ; rules of behaviour in social inter. course ; and the code observed by professional men, especially doctors and lawyers, for safeguarding the dignity and interests of their profession.

Of all peoples the Chinese attach the greatest importance to etiquette. From remote times they have codified their ceremonial, and the Book of Rites, though rela. tively modern, dates from the lst century B.c. See Manners.

Etive. River and sea-loch of Argyllshire, Scotland. The river issues from Loch Mathair Etive and flows $15 \mathrm{~m}$. S.W. to the head of Loch Etive. The loch extends $10 \frac{1}{2}$ m. S.W. and then $8 \frac{1}{2} \mathrm{~m}$. W. to the Firth of Lorne. There are interesting ruins on its shores. The river is noted for its salmon and trout. Pron. Et-iv. See illus. p. 2730.
Etna (Lat. Aetna; Sicil. Monte Gibello). Active volcano, situated near the E. coast of Sicily, and the loftiest in Europe. Its present alt., $10,755 \mathrm{ft}$., shows a decrease of 115 ft. since 1861. The base covers an area of about 460 sq. m., and has a circumference of $90 \mathrm{~m}$., while the floor of the crater, which constantly alters and has become wider in recent years, is $9,765 \mathrm{ft}$. above sea level. In the distance Etna presents the appearance of a huge symmetrical cone, but on closer observation discloses an irregular surface, studded with some 200 minor cones, attaining $3,000 \mathrm{ft}$. in height, and broken on the $\mathbf{E}$. side by the Valle del Bove, a gaping abyss from 2,000 to 4,000 $\mathrm{ft}$. deep. Its slope comprises three distinct zones of vegetation. The lower, or lava, region rises $3,000 \mathrm{ft}$. from the base, and is thickly populated and well cultivated; the middle, or wooded, region, between $3,000 \mathrm{ft}$. and $6,850 \mathrm{ft}$., is covered with forests of pines, birches, and other trees ; the upper, or desert, zone is a barren waste, under snow during most of the year.

The ascent is generally made from Catania or Nicolosi, and 1,100 ft. from the summit is an observatory, with accommodation for tourists. Pindar describes an outbreak in 476 B.c. Violent explo-

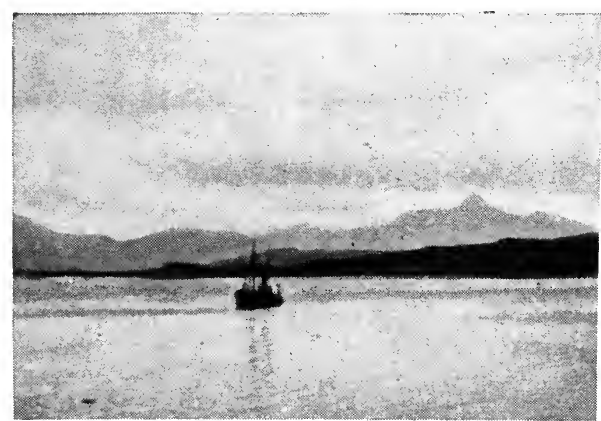

Etive. The Argyllshire loch, famous for its salmon and trout fishing sions occurred in $1169,1527,1669$, $1693,1792,1830,1852,1865,1879$, 1886,1892 (when a new crater was formed near Monte Gemellaro), 1899 , and 1910. The eruption of 1169 partly destroyed Catania, and that of 1693 caused enormous los of life. Of over 80 recorded activities, the most recent took place in May, 1914. Ancient legend connects the volcano with the giant Typhōn, who is said to have been buried beneath it by Zeus, and to have caused its eruptions by his heavy breathing; and with the workshops of Hephaestus (Vulcan), wherein the Cyclopes fabricated thunderbolts.

Eton. Town and parish of Buckinghamshire, England. On the left bank of the Thames, opposite Windsor, of the parl. bor. of which it forms part, it is $21 \mathrm{~m}$. W.S. W. from London. Dating from Anglo-Saxon times, it has a church in Early Decorated style dedicated to S. John the Evangelist, 1852-54, and a noted inn, the Christopher. Pop. 3,300. See Old Days of Eton Parish, J. Shephard, 1908.

Eton College. English public school. Founded by Henry VI as the College of the Blessed Marie of Eton beside $\mathrm{W}$ ind s or, and now known as the King's College of Our Lady beside Windsor, its first charter is dated Sept. 12, 1440. A supplementary charter was granted in

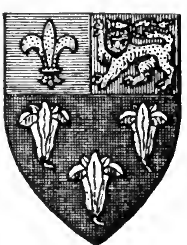

Eton College arms 1441, when the buildings, completed 1553, were begun. The constitution (based upon that of Winchester, 1382) provided for a provost, head master, 10 priests, 4 clerks, 6 choristers, 25 poor scholars and 25 bedesmen. Henry Sever was the first provost, succeeded by William of Waynflete,1443. Among the heads have been Nicholas Udall, 1504-66, John Keate, the famous flogger, 1773-1852, J. J. H or n b y, 1826-1909, a nd Edmond Warre (q.v.). Arms were granted to the College in 1448.

$\mathrm{T}$ h e founder's statutes were formally repealed in 1872. The foundationnow consists of the provost, appointed by the crown, 10 fellows, who form the nominal governing body, vice-provost, head and lower 


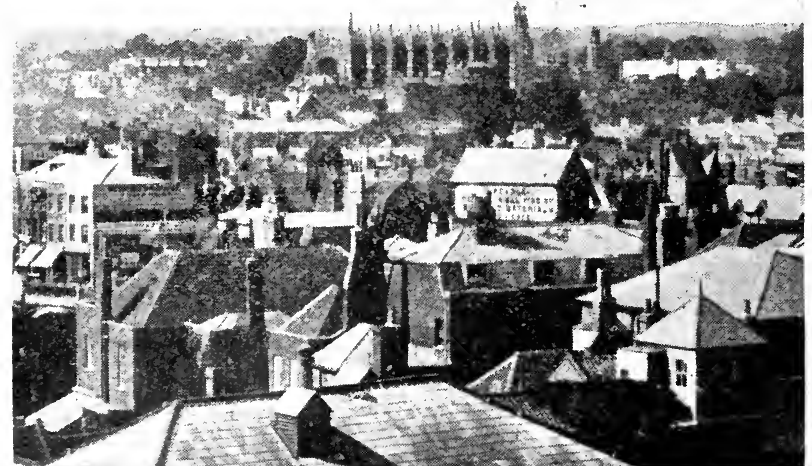

Eton. The town viewed from Windsor. In the centre is seen the college chapel, built by Henry VI

masters, one or more bursars, and two chaplains or conducts. The number of collegers (or Tugs) is 70 . In $19 \cdot 0$, in addition to the college

stored in 1848-60. The old buildings, of dark red brick, with stone dressings and clustered chimney shafts, form three sides of a quad-

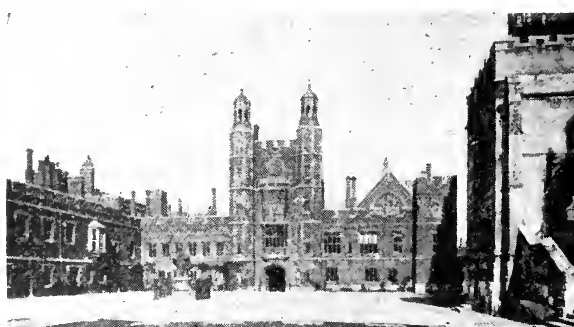
rangle which is completed by the chapel. The library was built in 1729 , and new buildings in 1844 -46 and 1885 87. In athletics the wall game is

1899 ; Hist. of Eton College, L. Cust, 1899; Eton, A. Clutton-Brock, 1900; Memories of Eton Sixty Years Ago, A. C. Ainger, 1917.

Étourdi, L'; or Les ContreTEMPs(The Thoughtless, or The Mishaps). Five-act comedy by Molière, adapted from Italian sources. The scene is laid in Messina. The title refers to the character Lélie, who is often doing the wrong thing from right motives. His rascally servant Mascarille, a character played by Molière, is the life and soul of the play, which was first produced at Lyons, 1653.

Etretat. Town and wateringplace of Normandy, France, in the dept. of Seine Inférieure. Facing the English Channel, 16 m. N.N.E. of Havre, it became a popular holiday resort in the latter part of the 19 th century. The chief build. ing is the Romanesque church of Notre Dame, dating in part from the 11 th century. There are public gardens, a casino, and ample bathing facilities. Pop. 1,973.

Etrich Taube. Type of aero. plane (q.v.) developed by Igo Etrich in Austria. It was one of the early types with a large degree of inherent stability, due chiefly to the form of its wing. Each wing was swept backward and upwards to. wards the outer extremity like a bird's wing. The type was copied by many German $1(1+2)$ and Austrian constructors, and from the wing form became known as Taube or dove.

Etruria (Gr. Tyrrhēnia). An. cient district of Italy nearly corresponding to the motern Tuscany. To what race i t $\mathrm{s}$ inhabitants, variously c alled

stone, Gray, Hallam, Kinglake, Milman, Peel, Porson, Pusey, Shel. ley, Swinburne, and Wellington, whose remark that Waterloo was won on the playing-fields of Eton has been explained as a reference to the fights that took place there.

In the Great War about 5,000 Etonians served and over 1,100 were killed. The restoration of the vestry chapel, a register in a Golden Book of the names of all who served, and a statuc in the playingfields constitute the proposed war memorial. In addition Etonians undertook to help to rebuild the French village of Eton, destroyed in the early days of the war.

Of the buildings, the hall, 1448 , restored 1858, is the only part built according to the founder's final plan. The Gothic chapel, 1442-80, originally parochial as well as collegiate, resembles that of King's College, Cambridge, and was re-

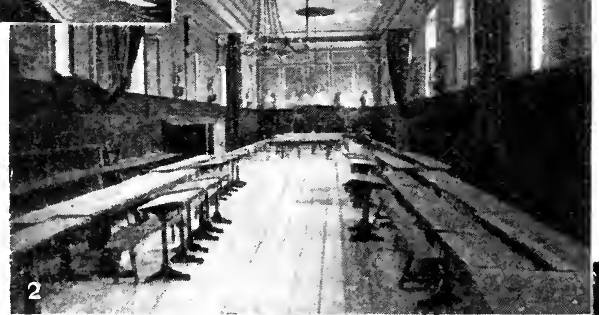

a special feature, and the rowing boys are known as "wet bobs," the cricketers as " dry bobs." The school gives its name to the familiar short jac ket worn by boys.

Bibliography. Histury of Eton College, H. C. Max well I,yte, 4 th ed. 1911. Annals of Eton, W. Sterry, 1898; An Eton Bibliography, L. V. Harcourt, new ed. 1902; Fasti Eton. enses, A. C. Benson,

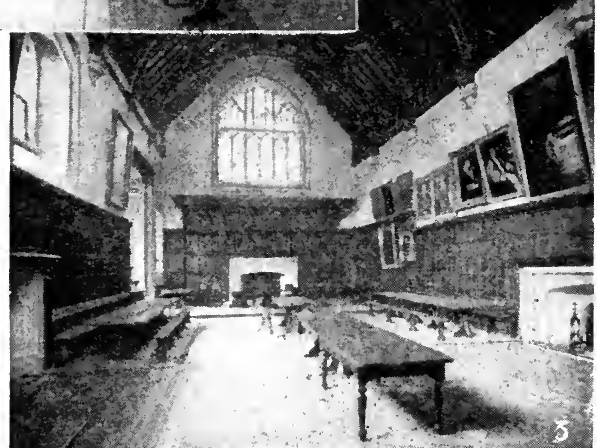

Eton College. 1. The School Yard and Lupton's Tower built in the 16th century. 2. The Upper School, built 1690-91.3. The Hall, one of the original buildings of Henry VI, restored in 1858 
Tusci, Etrusci, or Rasenae, and their language belonged are pro blems yet unsolved. They were a warlike and enterprising people, whose power, at its height during the 7 th century B.C., began to decline two centuries later. The chief authority was in the hands of an aristocratic caste called lucu mons; the 12 principal cities were confederated, with a generalcouncil controlling matters of peace and war. They early came into con tact with Rome, whose Tarquin kings were of Etruscan origin, and in 285 finally submitted to her yoke.

There is a bundant archaeological evidence that the Etruscans were a wealthy, highly civilized people. Although their architecture was mainly borrowed from Greece and the East, it exhibits a certain originality. Above all, they were the first to make practical use of the principle of the arch, as in the bridges at Chiusi (q.v.). Their walls, unattached by cement, consisted of large blocks of stone, sometimes rectangular, sometimes roughly hewn. The Servian wall at Rome was of Etruscan construction. The tombs, all subterranean, differ according to periods and the condition of the soil. In mountainous districts they were usually cham. bers hewn out of the rock. Where the soil was yielding and crumbly they took the form of a tumulus, a conical earth-mound erected on a walled substructure, frequently having a pear-shaped ornamental top, e.g. the so-called tomb of the Horatii and Curiatii at Rome. The walls of the grave chambers were often adorned with paintings.

In their plastic arts, three stages have been distinguishedEgyptian, Etruscan, and Hellenic. Special excellence was shown in the preparation of clay vessels adapted from Greek models, cinerary urns, and terra-cotta sarcophagi. $\mathrm{Nu}$ merous specimens are extant of statues, from tiny lares (household gods) to colossal figures, such as the she-wolf of the Capitol; and of all kinds of vessels, candelabra, silver goblets, ivory, gold, and silver thrones, and ornamented weapons. Most of the sculpture is sepulchral.

It is perhaps in painting that the Etruscans achieved the greatest success, whether on the walls of the sepulchral chambers or on pottery. The painted vases also passed through the three stages of Egyptian (or perhaps archaic Greek), Etruscan, and Hellenic. In the first the figures are of a blackish brown, in the second black, in both cases painted on the yellowish-red ground of the clay; in the third, the ground is black, the figures red.

The Etruscan mirrors are well
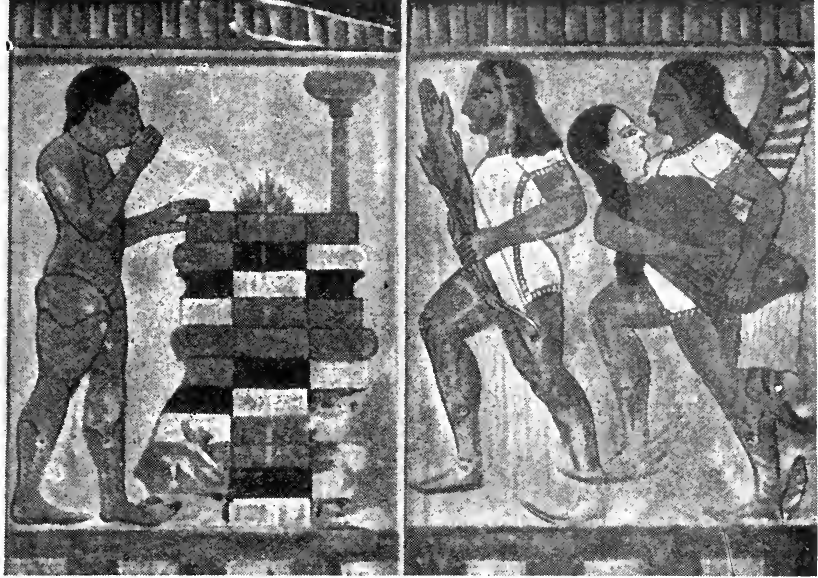

Etruria. Paintings discovered at Cervetri, the ancient Etruscan city of Caere, illustrating the ceremonial burning of the dead

$$
\text { By courtesy of } \mathrm{Wm} \text {. Heinemann }
$$

known - round or pear-shaped plates of bronze, the outer side polished and the inner adorned with figures. Some of them are very beautiful and more than anything else throw light on the national life. The Etruscans were skilled musicians, their national instrument being the flute. See Archaeology; consult also Manuel d'archéologie étrusque et romaine, Jules Martha, 1884; Cities and Cemeteries of Etruria, G. Dennis, ed. W. M. Lindsay, 1907.

Etruria. Eccl. dist. and village of $\mathrm{Staffordshire,}$ England. It is within the bor. of Stoke, with a sta. tion on the $\mathrm{N}$. Staffordshire Rly. Josiah Wedgwood established his potteryworks here in 1769. Etruria Hall, where Wedg. wood died in 1795 , has been convert. ed into the offices of a large iron, steel, and coal works. Pop. 8,056. See Burslem.

Etruria Marls. In geology, beds of red and purple marl and clay, occurring in the upper coal measure strata of the coal-basins of the Midlands and N. of England. They are used in pottery manufacture. See Pottery.

Ettlingen. Town of Baden, Germany. It stands on the Alb, $4 \mathrm{~m}$. S. of Karlsruhe. The chief buildings are a castle, standing in large grounds, the town hall, several churches, and a monastery, now put to secular uses. It is still surrounded by walls and a moat. Its industries include the manufac. ture of paper, dating from before 1500 , textiles of various kinds, and machinery. A Roman station, Ettlingen was made a town in 1227 and has since been part of Baden. It is famous for the battle fought here between the French and the Austrians, July 9-10, 1796, the French being the victors. Pop. 9,400 .

Ettmüller, ERNSt Moritz LUDWIG (1802-77). German philologist. Born at Gersdorf, Saxony, Oct. 5, 1802. he became professor of $\mathrm{Gel}^{-}$

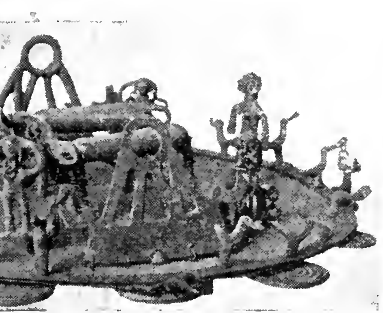

Etruria. Plate of primitive Etruscan work ornamented

$$
\text { British Museum }
$$

man literature at the Zürich Gym. nasium, 1833, and professor at the university there, 1863 . His writ. ings contributed largely to the knowledge of early German, AngloSaxon, and Scandinavian litera. tures. His best known works are a translation of Beowulf, 1840, and a Lexicon Anglo-Saxonicum, $185 \mathrm{I}$. He died April 15, 1877.

Ettrick Forest. District of Selkirkshire, Scotland. Formerly a part of the Caledonian Forest which comprised Selkirkshire and portions of Peeblesshire and Midlothian, it was at one time a hunting ground of the Scottish kings. It is now almost denuded of its trees. 
Ettrick Water. River of Selkirkshire, Scotland. It rises in Ettrick Pen and flows $32 \mathrm{~m}$. N.E. to the Tweed, about $2 \mathrm{~m}$. below Selkirk. In the churchyard of Ettrick parish are buried James Hogg, the " Ettrick shepherd," Thomas Boston (1677-1732), the Puritan divine and author, and Tibbie (Elizabeth) Shiel (17821878), who kept the famous inn at the head of St. Mary's Loch.

Etty, William (1787-1849). English painter. Born in York, March 12, 1787, he was apprenticed to a printer in Hull. Coming to London he began copying famous pict u res. In 1806 he ente red $t h e$ Royal Academy schools and was for a year a pupil of Sir Thomas Lawrence. Between 1816

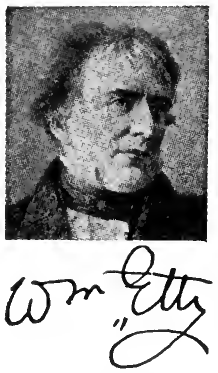
Prom a photo, 1849 Continent, he returned with a fine sense of colour and of graceful composition. In 1824 he was elected A.R.A., and R.A. in 1828. He died in York, Nov. 13, 1849. Not until late in life did he obtain good prices for his work, probably owing to his preference for vast canvases. Of his smaller pictures Youth on the Prow and Pleasure at the Helm at the National Gallery is the most popular. The nobility and dignity of his huge works, such as The Combat and the three Judith pictures atEdinburgh, and Ulysses and the Sirens in the Royal Institution, Manchester, compel admiration. See Life, A. Gilchrist, 1855.

Etymology (Gr. ctymon, true; logos, science). The investigation of the origin and meaning of words. The term dates back to the early schools of Greek philosophy, whose theories are ridiculed by Plato in the Cratylus, where he himself propounds some extraordinary derivations. The Stoics and Alexandrian grammarians also devoted much attention to the study of words and the parts of speech. Owing to complete ignorance of phonetic laws, the older etymologists laid down arbitrary and impossible sound changes, and even went so far as to derive words from others of opposite meaning, e.g. lucus (grove), a non lucendo (from not shining). In the Middle Ages the influence of theology led to the attempt to derive everything from Hebrew as the parent of all languages.
Etymology as a science is of comparatively recent origin, and became possible with the introduction of a knowledge of Sans. krit into Europe by Sir William Jones. This led to a thorough examination of the vocabulary of the Indo-European languages and the establishment of certain fixed principles of sound-change which governed the changes in the form of a word in different languages.

What is called popular etymology is really false analogy, and is an endeavour to adapt the form of a word not directly intelligible to that of one more familiar and apparently related; for example, crawfish (French écrevisse), wormwood (German Wermuth), bridegroom (A.S. brideguma, brideman), Charterhouse (Chartreux). See Language; Place Names.

Eu. Town of Normandy, France, in the dept. of Seine Inférieure. It stands on the Bresle, $64 \mathrm{~m}$. N.E. of Rouen. It has a few industries, flour mills, brickyards, and glass works among them, and a transit trade, but its main interest is his torical. The church of S. Lawrence is a fine Gothic building of the 12th and 13th centuries, and the château, partly burned down in 1902 , dates from the 16th century, when it replaced an older one. Louis Philippe, who restored it, often resided here. Pop. 4,900.

Eua or EoA. Island of the Tonga group in lat. $21^{\circ} 24^{\prime} \mathrm{S}$. and long. $174^{\circ}$ $50^{\prime} \mathrm{W}$. Densely populated, it is $10 \mathrm{~m}$. long, $3 \mathrm{~m}$. broad, and has an area of $67 \mathrm{sq} . \mathrm{m}$. It is mountainous, well watered, and fertile.

Euboea (Turk. Egripo; Ital. Negroponte). Large island of Greece, in the Asgean Sea. It lies off the E. coasts of Boeotia and Attica. has a length of $115 \mathrm{~m}$., a breadth varying from $4 \mathrm{~m}$. to $32 \mathrm{~m}$. and is separated from the main. land by a narrow channel called Euripus. The surface is mountainous with fertile valleys, pasturing large herds of cattle. Oil,

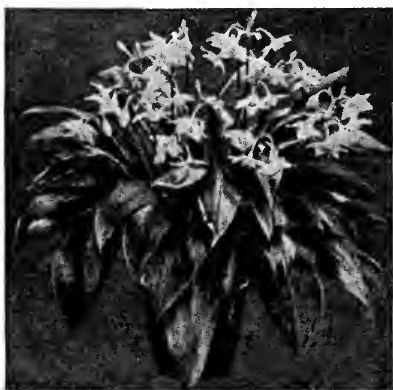

Eucharis. Foliage and flowers of Eucharis Amazonica, a S. American bulbous herb wine, corn, fruit, honey, and pitch are produced, but stock-breeding is the principal occupation. The highest point is Mt. Delphi, 5,720 ft. Its thermal springs have been esteemed since ancient times. The chief town is Chalcis. Its history is merged in that of Greece and Rome. In medieval times it belonged to Venice. It was taken by the Turks in 1470, and in 1830 was restored to Greece. Area 1,430 sq. m. Pop. 116,903. Pron. Ev-via.

Eubulus (d. 330 B.c.). Greek orator and demagogue. He was a friend of Aeschines, whose clerk he had been, and a violent opponent of Demosthenes. It was chiefly owing to him that Aeschines was acquitted when accused of treacherous dealings with Philip of Macedon. A decided pacifist, Eubulus carrjed a proposal that whoever suggested applying any portion of the theoric or festival fund to any other purpose, such as war, should be put to death. In 346 B.c., negotiating with Philip, he concluded a peace highly disadvantageous to Athens.

Eucaine (Gr. eu, well ; and cocaine). Artificially prepared alkaloid allied to cocaine. It is used as a local anaesthetic in small operations and extraction of teeth. It is safer than cocaine, but is not so powerful.

Eucalyptus (Gr.eu, well ; kalyptos, covered). Genus of trees of the natural order Myrtaceae. The name is given to it because the petals cover thoroughly the unexpanded flowers. See Gum Trees.

Eucalyptus Gum. Exudate of the red gum-tree of Australia. It contains tannic acid and is a powerful astringent, being used in lozenges or in gargles for relaxed throat, and occasionally prescribed in diarrhoea and dysentery. Eu. calyptus oil is distilled from the eucalyptus globulus, the blue gumtree. It is used as an antiseptic, and as an inhalation or spray in conditions accompanied by foetid expectoration.

Eucasin or CASEIN Ammonia (Lat. caseus, cheese). Soluble form of casein. It is prepared by passing ammonia gas over casein, or into a suspension of casein in alcohol or ether. It is used as a food.

Eucharis (Gr. eucharis, pleasing). Small genus of bulbous herbs of the natural order Amaryllidaceae. Natives of New Granada, they have egg-shaped bulbs, broad, elliptical leaves with long stalks, and white flowers, from 3 ins. to 5 ins. across. These are borne in clusters on top of a tall stem, and consist of a slender tube expanding into a cup, surrounded by six sepals and petals. 
Eucharist (Gr. eucharistia, thanksgiving). One of the names used from early times for the Sacrament of the Lord's Supper. The term occurs frequently in the N.T. in the general sense of thanksgiving, but for the most part without special reference to the Lord's Supper or Holy Communion. The special application of the word arose from the Gospel accounts of the Supper, in which Christ is recorded to have given thanks over both the bread and the cup. The Apostles followed His example, and thus the blessing or consecration of the elements became known as a eucharist or thanksgiving. Later the

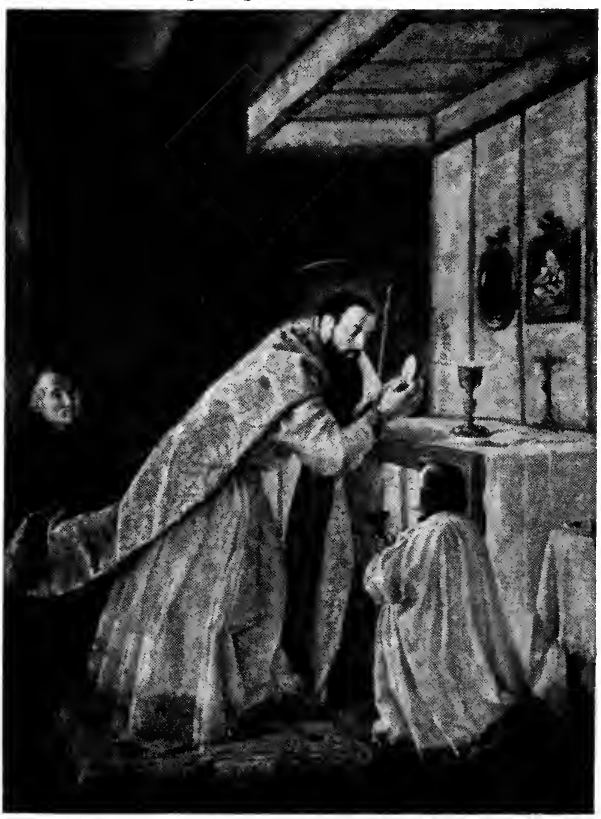

Eucharist. S. Benedict celebrating Mass, from the painting by Sebastiano Ricci (1662-1734) in the academy of $\mathrm{S}$. Fernando, Madrid

consecrated elements themselves became known as eucharistia, and the service itself was called the Eucharist, as being the Christian sacrifice or offering of thanks. giving and praise.

The Eucharist is the act of united worship directly commanded by Christ Himself in the words, "Do this in remembrance of Me." It has always been the central act of Christian worship in all the churches, save in a few bodies, such as the Quakers and the Salvation Army. In the early Church it was commonly called the Oblation or Liturgy, as it is still in the Eastern Churches. The Roman Church styles it the Mass, the Anglican Church Holy Communion, while most of the Protestant denomina- tions prefer the primitive name of the Lord's Supper.

As the central act of worship, the Eucharist has been the cause of much embittered controversy. The history of Eucharistic doctrine exhibits two main points at issue : (1) the nature and method of the presence of Christ in, or associated with, the consecrated elements ; (2) the sacrificial aspect of the service. From comparatively early times it was held that after the act of consecration, the Body and Blood of Christ are really and sub. stantially present, and "are verily and indeed taken and received by the faithful in the Lord's Supper.' But in defining the method of the mysterious Presence, wide differences of opinion arose.

Throughout the Western Church the doctrine of Transubstantiation became, in the course of time, a matter of faith. This taught that the substance of the elements was changed into or replaced by that of the Body and Blood of Christ, so that only the accidents or ap. pearance of the bread and wine remain. Consub$\mathrm{stan} t$ i a $\mathrm{t}$ io $\mathrm{n}$ taught that both substances a re present as a com. pound substance. At the Reforma. t ion, Transub. stantiation was generally aban. doned by Protestant bodies; but no one theory took its place. The Lutheran view was nearly identical with Consubstantiation; the Anglican Church maintained the Real Presence, but without defining its method; and most other reformed churches adopted the view of Calvin that there is no Real Presence in the elements themselves, but simply a spiritual presence of Christ in the souls of the faithful.

As regards the sacrificial aspect, the Roman Church teaches that in the Eucharist there is a " true and proper" sacrifice of Christ, Who is offered to the Father as a propitiation for both living and departed. The Eastern and Anglican Churches recognize a perpetual memorial or pleading before God of the sacrifice of Christ on Calvary, but not a repetition of it. The various Protestant churches altogether reject the sacrificial idea.

In primitive times the Eucharist was celebrated in the evening, but from the time of Trajan it began to be a morning service. This practice has prevailed ever since, except in the Free Churches, and is connected with the ancient custom of receiving the Communion fasting. At first the celebration of the Eucharist followed the Agape (q.v.) or common meal, and was probably held daily. Later on the two were separated, and as a rule the Com. munion service was held on Sundays and Festival days. There is evidence that in some of the larger churches daily celebrations took place, but this was not the general custom. Originally all the faithful communicated at each celebration, the catechumens, penitents, and strangers withdrawing before the consecration ; but as the sacrificial aspect became emphasised, the practice of non-communicating attendance became common, all the faithful attending each service, but only communicating occasionally or on obligatory feasts.

Except the Church of Rome, all Churches from Apostolic days have given Communion to the people in both kinds. In the Roman Church the cup has not been given to the laity through fear of accidents since the 14th century; while in the Greek Church the consecrated bread is dipped in the cup, and the elements are thus given together. Throughout the Western Church unleavened bread has been used; but this practice has not been adopted by the Eastern Churches. In the Anglican Church either kind of bread is permissible. The practice of adding water to the wine is general, except in Protestant churches, on the ground that the cup was thus mixed at the Passover.

The reception of Holy Commu. nion is a condition of membership throughout the Christian Church. The Roman Church requires at least one annual participation at Easter; the Anglican Church fixes three times a year, Easter to be one, as the minimum. See Communion; Consubstantiation; Mass ; Real Presence ; Sacrament; Transubstantiation; also illus. p. 1892

Euchlorine $\left(\mathrm{ClO}_{2}\right)$. Yellow gas formed when potassium chlorate is treated with hydrochloric acid. First prepared by Davy, in 1815, it was thought to be a new oxide of chlorine, but is merely a mixture of chlorine and chlorine peroxide. An efficient disinfectant, it is sometimes used instead of chlorine. 
Euchre. A card game. It is played with 32 cards, the $2,3,4$, 5 , and 6 of each suit being thrown out. There are two players, or four in partnership. The dealer gives five cards to each player, three at a time and then two, turning up the next face upwards on the pack for trumps. In the trump suit the knave, the "right Bower," is highest, the other knave of the same colour coming next, the "left Bower." The remaining cards of the trump suit, and those of the other three, rank from ace to seven.

In the two-handed game the non-dealer begins by deciding whether he shall play or pass. If satisfied that he can win the odd trick he says, "Order it up." His opponent then puts one card face downwards on the table and is entitled to the card turned up for trumps, but generally leaves this card until he wishes to play it. Should the non-dealer be dissatisfied, he passes; the dealer may then either take up the top card in exchange for one of his own, and play, or he may pass also. Both having passed in turn, either player has the chance of going on any other suit he chooses to make trumps. If both pass again, the hands are thrown up.

Two cards constitute a trick. A player must follow suit if he can, but need not take a trick unless a higher card is his only play in that suit. The game is five up. If the player ordering up succeeds in making five tricks he wins a march, and scores two points; if three tricks, he makes the point, and scores 1 (four tricks count for no more than three). If he fails to make three tricks he is euchred, and his opponent scores 2 .

There is a variant of the game, called cut-throat euchre, for three players. Pron. U-ker. See, The Standard Hoyle, 1887.

Eucken, Rudolf Christoph (b. 1846). German theologian and philosophical writer. Born Jan. 5,

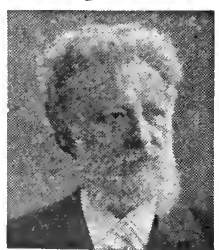

Rudolf Eucken, German theologian similar post at Jena. His views and writings show the influence of Plato and the elder Fichte. He upholds the Christian standpoint, and is the opponent of naturalism in all its forms, whether as empiricism, positivism, or utilitarianism.

His chief works translated into English are: The Fundamental Concepts of Modern Philosophic Thought, critically and historically considered, 1880 ; The Problem of Human Life as viewed by Great Thinkers, 1909; The Meaning and Value of Life, 1909 ; Christianity and the New Idealism, 1909.

Eucla. Township of W. Australia. It stands at the head of the Great Australian Bight near the S. Australian border, on the overland telegraph route through W. and S. Australia.

Euclase (Gr. eu, well; klasis, breaking). Rare mineral consisting of hydrated silicate of beryllium and alumina. Occurring in short prisms, with vertical striae on crystal faces, it is either colourless, yellowish, green, or blue. It is found in Minas Geraes, Brazil, in the Ural mts. and Austrian Alps.

Eucleides ( $f$. 300 B.c.). Greek mathematician, whose more familiar name is Euclid. Little is

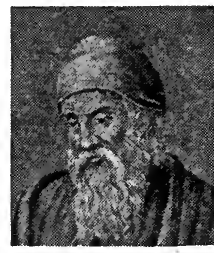

Eucleides, Greek mathematicia dieval writers attempted to prove that he never existed. Besides the Elements of Geometry, Euclid wrote De Divisionibus, a collection of 36 problems on the division of areas, possibly the only survivor of many such collections.

Eucleides (5th cent. B.c.). Greek philosopher. A native of Megara, he founded the Megarian school, one of the so-called imperfect Socratic philosophical schools. He held that there was only one good (Reason, Truth), and only one virtue (a knowledge of this good), all else being non-existent-a Socratic modification of the Eleatic doctrine of the Absolute One.

Euclid. Text-book on the elements of geometry, based upon the work of Eucleides (q.v.). The course in elementary mathe. matics in vogue during the latter portion of the last century unwittingly introduced the student to a set of brilliant exercises in deductive logic in the guise of Euclid as an introduction to geometry. Many pupils never surmounted the Pons Asinorum (Euclid I), others managed by a sheer exercise of memory to master Euclid Bk. I, but only the comparatively select few succeeded in enjoying Euclid Bks. I to IV. As a school text-book in the days of dull drill and lengthy routine, Euclid was admirable. The propositions supplied material for the dullard, and the hosts of exercises kept the keener intellects busy.

Euclid has been discarded by schools mainly for two important reasons: it is unsuitable to students of school age because it is entirely deductive; it is almost valueless as an introduction to geometry because it takes no note of modern ideas. Measurement and constructive movement are dominant in modern life, and Euclid ignores both. See Geometry; Mathematics.

Eucomis. Small genus of perennial bulbous herbs of the natural order Liliaceae. They are natives of the Cape of Good Hope. They have broad lance-shaped or oblong leaves, and a stout, leafless flower-stem, the upper half crowded with greenish brown flowers, and surmounted by a small tuft of leaflike bracts.

Eucrite. Crystalline granular rock, a variety of gabbro. It is characterised by the presence, among mineral constituents, of basic species of felspar. It is well developed in Tertiary eruptive rock in the Isle of Rum and near Carlingford, Ireland.

Eudaemonism (Gr. eudaimonismos). Greek term for the theory that happiness (eudaimonia) is the chief end of life. This happiness, according to Aristotle, must be striven after for its own sake, not as a means to an end, and is defined by him as a perfect activity in a perfect life. The most excellent and specially human activity is that of the reason; happiness therefore is to be sought in a contemplative, otherwise a virtuous, life. Eudaemonism is to be distinguished from Hedonism (q.v.).

Eudiometer (Gr. eudia, fine weather; metron, measure). Instrument used for measuring gases, Originally designed for determining the amount of oxygen contained in a sample of air, it is now commonly used for determining the constituents of a gaseous mixture. In some forms it comprises a graduated glass tube or cylinder, either straight or Ushaped, closed up at one end and open at the other, and having inverted near the closed end two platinum wires, which are near enough to allow the passage of an electric spark through the mixture.

A Cavendish eudiometer is a ressel closed at both ends, having a screwed connexion by which it can be pumped clear of air before being filled with a gaseous mixture 
for analysis. A mixture of two volumes of hydrogen and one of oxygen can be exploded in a eudiometer tube to form water.

Eudocia (c. 393-460). East Roman empress. Daughter of the Athenian philosopher Leontius, celebrated for her beauty and intellect, she was converted to Christianity by Pulcheria, sister of Theodosius II who married her in 421. Before conversion her name was Athenais. The two sisters-inlaw, however, quarrelled over the Eutychian heresy (see Eutyches), and Eudocia was banished, returning to a life of good works at Jerusalem. She wrote several poems, chiefly of a religious nature.

Euganean Hills. Isolated group of hills of N.E. Italy, in the prov. of Padua. Lying in the W. of the prov. they are of volcanic origin, have numerous thermal springs, and extensive trachyte quarries. The loftiest point is Monte Venda, $1,895 \mathrm{ft}$. On their slopes are sev. eral villas and a ruined convent.

Eugene. City of Oregon, U.S.A. the co. seat of Lane co. It stands on the Willamette river, $46 \mathrm{~m}$. S. of Albany, and is served by the $\mathrm{S}$. Pacific rly. It is the seat of the Oregon university (opened 1876). It has machine shops, ironfounding and tanning industries, and manufactures of furniture, cotton goods, window-sashes and doors. Eugene is at the head of navigation, and carries on a brisk trade in lumber, cereals, cattle and animal products and canned fruit. It is a rapidly growing city, settled in 1854, and incorporated 10 years later. Pop. 14,257.

Eugene (1663-1736). Italian prince and Austrian soldier. Born in Paris, Oct. 18, 1663, his father

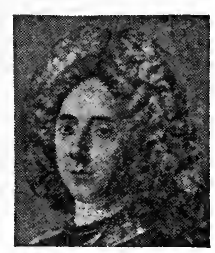

Prince Eugene, From a contemp. portrait Austrian soldier was Eugene Maurice, prince of Savoy, and his mother a Frenchwoman, a niece of $\mathrm{Maz}$ arin. $\mathrm{He}$ was baptized as Francois Eugene. Educated in France, at first for the church, he entered the Aus.

trian army, as Louis would not admit him to the French, a fact which some think gave a distinct anti-French impetus to his military career. His early experiences were gained fighting against the Turks, and his advance was rapid.

In 1691 Eugene held a com mand in Italy, where, between then and 1693, he won several successes over the French. In 1697, in command of the im.

perialists in Hungary, he crushed the Turks at Zenta. In 1701, when the war of the Spanish succession broke out, he was sent to Italy, where again he won considerable successes over the French. In 1704 began the association with Marlborough which has linked together the two names in history. The prince helped in the battle of Blenheim, but when Ramillies was fought (1706) he was again in Italy, where his outstanding feat was the capture of Turin. $\mathrm{He}$ fought at Oudenarde, but after the English had withdrawn from the struggle, he advised his master, the emperor, to do the same. This counsel being taken, he arranged in 1714 the peace of Rastatt.

Next began one of Eugene's greatest campaigns, the one that made him the idol of the Aus. trians. In the war against the Turks that opened in 1716, he won a victory at Peterwardein, and a greater one when he captured Belgrade. A period of peace fol.

\section{EUGENICS : THE SCIENCE OF BREEDING}

J. Arthur Thomson. Prof. of Natural History, Aberdeen

The attention given by modern scientific students to this subject justifies the following article, wi, which should be read those on Biology; Heredity; Life. See also Birth Rate; Death Rate; Population

Eugenics (Gr. eugenēs, well born) is defined by Sir Francis Galton as "the study of agencies under social control that may improve or impair the racial qualities of future generations, either physically or mentally." It is based on what is known of heredity and other factors affecting the organic welfare of the human stock. Its primary reference is to the inborn qualities of the race, considered as a breed. In plain words, eugenics is the art of breeding well. But it is artificial to consider a living creature apart from its surroundings and activities, so that eugenics must be supplemented by a study of environment and function.

For the combined influences of environment and function, Galton used the term nurture, opposing it, as Shakespeare did in The Tem. pest, to the inborn or inherited nature, and it has been much dis. cussed whether nature or nurture is the more important. But nature and nurture are complementary, not antithetic. If a good in. heritance is to develop fully it must have an appropriate nurture, which liberates the possibilities that might otherwise remain undeveloped. Good nurture develops the good, and inhibits the bad elements in an inheritance. Bad nurture stimulates evil predispositions and hinders the emergence of the good. Thus euge- nics cannot be separated from nurture, and this commonsense conclusion is the more important since nurture is more in man's control than the inheritance ean ever be.

The fundamental fact of eugenics is that the chief determining factor of human life is what the child is or has to start with, in virtue of its hereditary relation to parents and ancestry. The statistical inquiries of the workers in the Galton Eugenics Laboratory show the fundamental importance of natural in. heritance. Exception may perhaps be taken to the form of the statement that " nature is five to ten times as influential as nurture," for no matter how fine the seed, it will not yield a rich crop without good soil and plenty of sunshine and rain; but it must be allowed that the fun. damental determinant of racial welfare is heredity. This emphasis on the inherited nature has this further justification, that there is no secure warrant at present for believing that gains made by the individual as the direct results of beneficial nurture can be entailed on the offspring.

The peculiarities which are acquired by the individual's careful choice of surroundings do not seem to be transmitted as such to the next generation. This may sound discouraging, but three points must be noticed. (a) If the 
gains of good nurture are not handed on, neither are the losses due to deteriorative nurture. ( $b$, The bodily and mental health of mothers, whieh depends in part on individual nurture, influences the general development of the un born ehild, which lives in long antenatal partnership with her. Thus nurture indirectly affects the general vigour of the race. (c) The new departures in a race, known as variations or mutations (see Evolution), appear to be expressions of intrinsic changes in the constitu. tion of the germ. In course of de. velopment these find expression, and they have to stand the criti. cism of everyday life. It is plain that a promising new departure, whether idiosyncrasy, originality, or genius, may be nipped in the bud without congenial nurture.

The results of nurture may thus prove of great importance as part of that social system which decides whether new departures are to sur. vive or not. Promising novelties, which the eugenist regards as the raw materials of progress, the most precious things in life, may fail to persist, and the race is obviously the poorer if the clever artist or musician is starved into celibacy. Fortunately the same process may operate against the establishment of variations in vice or criminality.

The question arises how the intrinsic endowment can be practically controlled. To this it may be answered, that while men and women cannot select their parents, they can and do select their partners in life. This may operate, in the first place, negatively. There are unsound types of constitution who should not become parents, because by so doing they still further deteriorate the quality of the race. There are some types of constitutional disease, defect, or unsoundness which have peculiar staying power in inheritance, which sometimes behave as Mendelian characters. These should be allowed to die out.

\section{Eugenics and Legislation}

A character like colour-blindness, which usually passes from a father through an unaffected daughter to a grandson, is not of great moment, but no one can contemplate without grave regret the spoiling of a more or less sound stock by the introduction of predisposition to diabetes or S. Vitus's Dance, a well-defined mental instability, or a defect like deaf-mutism. How far eugenic legislation should go is a difficult question. It is certainly desirable to educate public opinion so as to form rational prejudices against the spoiling of approxi- mately good stock by bad, strong by weakly, fine by poor. Without adopting drastic measures a nation might do much in the way of negative eugenics.

In some races, e.g. Jews and Chinese, the strong eugenic tradition has expressed itself in a pride in sustaining a vigorous, alert, wholesome lineage. Preoccupation with the struggle for wealth, selfish love of ease, and immoral gratifications of the sex-impulse tend to destroy pride in having a vigorous family. That many celibates are the salt of the earth does not dispose of the fact that there are selfish, we may almost say non. mammalian, forms of celibacy. A few social arrangements, e.g. in connexion with taxation, seek to lessen the difficulty of bringing up a family, and Galton contemplated the direct pecuniary encourage. ment of the early marriages of highly desirable members of the community.

\section{Eugenic and Economic Ideals}

It may be doubted, however, whether indirect encouragement is not much safer. A community which realizes the racial value of types with, let us say, high artistic gifts associated with health, will in its criticised expenditure tend to secure their continuance. The applications of this economic idea of "the criticism of consumption " are endless and far-reaching. All expenditure which promotes unbealthy rather than healthy occupations, which helps to multiply undesirable types, which makes for sweated labour and slums rather than for well-paid work and gardens, is necessarily dysgenic, and not eugenic. In many ways it will probably be found possible to combine eugenic and economic ideals by ceasing to penalise maternity.

When primitive man's mastery of nature was only beginning, there must have been an intense struggle for existence The ranks were thinned by storm and flood, by famine and pestilence, by wild beasts and poisonous herbs. When the thinning was sifting, i.e. when those who survived did so in virtue of some quality, say of vigour or alertness, which those who perished lacked, then it was natural selection, and made for evolution. With the progress of civilization there has been a continual rebellion of men against the yoke of natural selection.

The growth of kin-sympathy and social solidarity has led to persistent endeavours to interfere with the crudity of natural selection, and to save the weak, the diseased, and the foolish. Here is a dilemma where biological and social ideals are opposed. It is biologically unsound that the unhealthy and unstable should be allowed to multiply their kind, it is socially unsound that altruistic sympathies should be outraged. This dilemma still remains.

\section{"Social Surgery"}

The problem is to substitute for nature's régime, which man has in great part abolished, a process of rational selection which will sift out the tares from the wheat. The seriousness of the dilemma has led to proposals implying some measure of "social surgery." It has been suggested that obviously undesirable types who have fallen back upon the community for support should be prevented from re. producing their kind.

Objections against this are (1) that in some measure society may be responsible for the making of those absolute failures, and that their production as much as their reproduction should be stopped ; (2) that measures of repression and segregation are repugnant to the social sentiments of freedom and solidarity. Some strong-minded counsellors, not lacking in humane feelings, have advised a return to " the purgation of the state" which Sparta to some extent practised and Plato approved. It has been suggested that weakly infants whose life must be more or less miserable should be allowed to pass away in their sleep. The gravest objections to this are : (1) that many weaklings have been makers and shakers of the world; (2) that the proposals outrun our present secure knowledge ; (3) that it would remove the results of evil without touching the causes; and (4) that it outrages social sentiment in its finest expressions.

Another line seems at present safer and more promising, namely a criticism of the processes which thin the ranks of mankind. Some of these are more or less indiscriminate elimination, as microbic diseases like cholera. As such diseases do not select the weaker as their victims, leaving the stronger to survive, their reduction, much marked in modern times, is in a eugenic direction. A wasteful thinning of the population is avoided, and many fine lives, which might have been gratuitously sacrificed, are saved.

The reduction of infantile mortality, which has still a long way to go, must be approved by all eugenists. Similarly, the reduction of infection by the tubercle bacillus operates against a profitless wast. age of fine types. The case of syphilis is more difficult, since its curability may remove a deterrent from vice; but a consideration of the 
poisoning of innocent mothers and the blinding of innocent children makes it clear that the curative treatment of the disease will operate eugenically.

In regard to war, it is generally agreed that a war may be socially and ethically inevitable and justifiable, though in itself a regrettable anachronism. But it is certain that a prolonged war in which a large proportion of the men of fighting age are engaged must have dysgenic consequences. On the whole, the best and the bravest will tend to be eliminated, and this means impoverishment of the stock. The costliness of war also operates dys. genically in diverting expenditure from the support of the more highly individualised and less readily replaceable members of the community.

This illustration of the dysgenie influence of war clearly points to two highly important considera. tions. First, that man's great problem is to substitute for dysgenic elimination eugenic selection, for indiscriminate thinning a discrim. inate sifting, for the cruder forms of natural selection the subtler forms of rational and social se. lection. Secondly, that it is absolutely vital for the student of hu. man eugenics to bear in mind, what is to the breeder of other organisms irrelevant, that man is a rational, social personality. Man's mind to him a kingdom is, and not less important than the natural inheritance mysteriously transmitted in the vehicle of the germ-plasm is that external systematisation or registration of institutions and traditions, of literature and art, which form his social heritage.

Bibliography. Eugenics: its definition, scope and aims, F. Galton, 1905, etc. ; National Life from the Standpoint of Science, K. Pearson, 2nd ed. 1905 : The Methods and Scope of Genetics, W. Bateson, 1908; Darwinism and Human Life, J. A. Thomson, 1909; Parenthood and Race-Culture: an outline of eu. genics, C. W. Saleeby, 1909; The Scope and Importance to the State of the Science of National Eugenics, K. Pearson, 2nd ed. 1909 ; Biological Fact and the Structure of Society, W. Bateson, 1912; Heredity in Re. lation to Eugenics, C. B. Davenport, 1912 ; An Introduction to Eugenics, W. C. D. and C. D. Whetham, 1912 ; Problems in Eugenics, Eugenics Education Soc., 1912; The Task of Social Hygiene, H. H. Ellis, 1912 ; Eugenics, E. Schuster, 1913 ; The Progress of Eugenics, C. W. Saleeby, 1914 ; Heredity and En. vironment in the Development of Men, E. G. Conklin, 2nd ed. 1916 ; Genetics and Eugenics, W. E. Castle, 1916 ; Towards Racial Health, N. H. March, 3rd ed. 1918; Heredity, J. A. Thomson, 3rd ed. 1919.

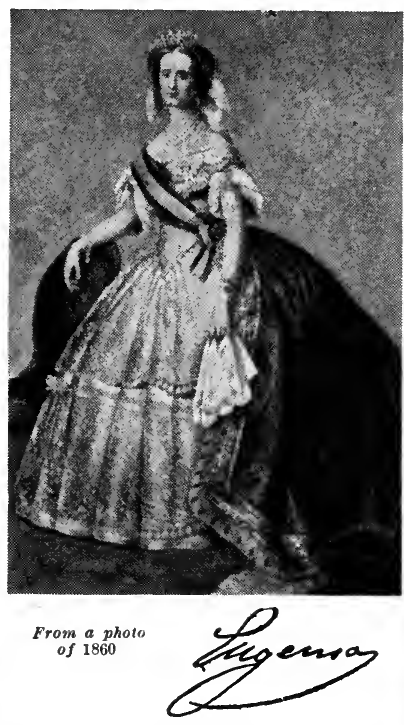

Eugénie (1826-1920). Empress of the French. Born at Granada, Spain, May 5, 1826, the daughter of count de Montijo and Maria Manuele Kirkpatrick, whose Scottish father was U.S.A. consul at Malaga, she made her début in Paris society in 1851, where her beauty attracted Napoleon III, who married her, Jan. 30, 1853. The marriage created a great sen. sation, and the comparatively humble origin of the new empress made for many jealousies. Under her influence the court became a centre of luxury and extravagance.

In political affairs the empress exercised a strong, not always beneficial, influence upon Napoleon. She favoured the disastrous Mexican expedition of 1863-66, and, anxious to show her devotion to the Church, hindered the emperor's Italian policy until all his influence with the liberals was lost. At the outbreak of the Franco-Prussian War, 1870, into which she urged Napoleon in order to strengthen the dynasty for her son, she became regent when the emperor went to the front, but after Sedan fled to England, where she was joined by the emperor, 1871, and they settled at Chislehurst. Napoleon died in 1873 ; their only son, the Prince Imperial, was killed with the British army in the Zulu campaign in June, 1879.

Henceforward the empress lived in seclusion, her chief friend being Queen Victoria. She moved to Farnborough in 1887 and usually spent the winters in the $\mathrm{S}$. of $\mathrm{Eu}$. rope, and died whilst on a visit to Spain, July 11, 1920. Her body was brought to England and buried in the mausoleum with Napoleon III and her son, at Farnborough. See The Empress Eugénie and her Son, E. Legge, 1916; Memoirs, Comte Fleury, 1920.

Eugenius. Name of foŭr popes, of whom two are notable. Eugenius III (d. 1153) was born at Pisa, where he was educated and ordained. He joined the Cistercian Order, came under the influence of Bernard of Clairvaux, and was made abbot of the monastery of Tre Fontane at Rome. His elevation to the papacy, 1145, coincided with a revolt against the temporal supremacy, and he was driven to Viterbo. The activities of Arnold of Brescia (q.v.) compelled him to leave Italy, 1146. During his two

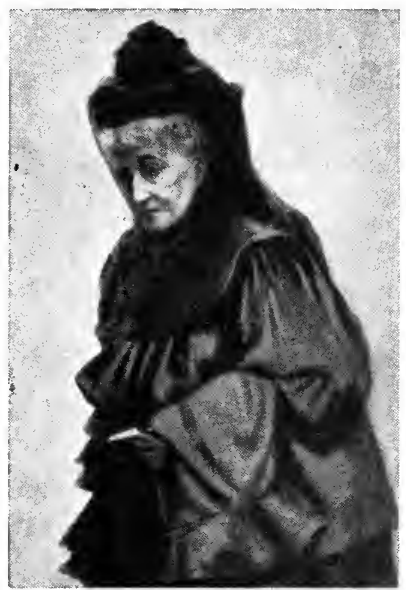

Eugénie. From a photo of the exempress taken in 1906

years in France he promoted the second crusade, and promulgated measures for the reform of the clergy. It was not until shortly before his death, July 8,1153 , that, thanks to the intervention of the emperor, Frederick Barbarossa, he was able to return to Rome.

Eugenius IV (d. 1447) was a Venetian and a monk of the Celestine order. He was bishop of Siena and became pope in 1431. He was first engaged in a struggle with the Colonna family, and then with the Council of Basel, which refused to dissolve on his order in 1431, the recalcitrants of the council declaring him suspended and deposed, and electing the anti-pope Amadeus of Savoy (Felix V), Outside a comparatively small party, however, Eugenius maintained his position as rightful pope. From 1433-53 he was driven to live at Florence by a revolt of the Romans. He effected a temporary union with the Greek and Armenian churches, 1439. 
Eugenol. Chief constituent of clove oil. Obtained by distilling cloves, and from pimento-leaf oil, the oil contains from 80 to 90 p.c. of eugenol. It has the same spicy odour as clove oil, from which it is separated by caustic potash. Eugenol is used medicinally as a carminative, and frequently as a palliative in toothache, a pledget of cotton-wool wetted with eugenol being inserted into the hollow tooth. Commercially euge$\mathrm{nol}$ is of importance in the manu. facture of vanillin.

Eugubine Tables. Seven large bronze tablets found in 1444 in a vault near Gubbio (ancient Igu. vium, middle-age Eugubium), in central Italy. They are covered with inscriptions in Umbrian and Latin, one in both languages, in excellent preservation. The oldest date from 200 B.c. They embody almost all that is known of the Umbrian dialect and throw valuable light upon the religious cus toms of ancient Italy. The text contains the proceedings of a priestly corporation named the Attidian brothers, a code of religious ceremonies with directions for auguries, sacrifices, and expiatory ceremonies. See Inscriptions

Euhemerus (4th century B.c.). Greek rationalist. A native of Messene in Sicily, and a follower of the Cyrenaic school, he lived at the court of Cassander, king of Macedonia. Euhemerus was the author of a Sacred Register, in which he tells how, having been sent by Cas. sander to the Indian Ocean, he landed in the mythical island of Panchaea. Here he discovered, inscribed on a golden pillar in a temple of Zeus, a history of the world, the study of which led him to the conclusion that the gods and heroes were nothing but supermen, on whom divine honours had been be. stowed after death. Other Greek writers had already expressed similar views. but they were first systematised by Euhemerus, whose name and ideas survive in the modern term Euhemerism. His writings were translated into Latin by Ennius, and fathers of the church, such as Lactantius, made use of them as a source of arguments against paganism.

Eulenburg, Philipp, Prince zU (1847-1921). German diplomatist. Born at Königsberg, he served in the Franco-Prussian War, 1870, studied law from $1872-75$, and then entered the diplomatic service. Prussian ambassador to Stuttgart, 1890, and Munich, 1891, he was imperial ambassador to Vienna from 1894-1902, when he retired owing to ill-health. In 1907 he was virulently attacked by Maximilian
Harden in his Zukunft. His reputation never recovered, and he died Sept. 16, 1921.

Eulenspiegel, TYLL. Name of a peasant to whom were ascribed the jests and practical jokes in a popular Low-German collection of the late 15th century (now lost). The High-German version, the basis of all subsequent editions, was printed in 1515. Eulenspiegel is supposed to have been an actual person, who died in 1350 , and his traditional grave is shown at Mölln. His story was widely popular in Europe and in England, and is the basis of the well-known symphonic poem by Richard Strauss, 1895. See Tyll Owlglass.

Euler, LEONARD (1707-83). Swiss mathematician. Born at Basel, April 15, 1707, he became professor of mathematics at St. Peters. burg, 1733, and at Berlin by Frederick II's invitation, 1741, returning to Russia in 1766 . He died there Sept. 18, 1783. He was an accomplished mathematician and a prolific writer on the subject, doing valuable work in mathematical analysis, in revising and coordinating the existing branches of pure mathematics, and in a study of planetary motions.

Eumaeus (Gr. Eumaios). In Greek legend, the faithful swineherd of Odysseus, to whom his master revealed himself when he arrived in disguise in his native Ithaca after 20 years' absence. Eumaeus afterwards helped Odys seus to slay the suitors of Penelope(q.v.). Pron. U-mē-us.

Eumenes of CARdia (c. 360 316 B.c.). Private secretary to Philip of Macedon and Alexander the Great. He accompanied the latter on his Persian campaigns, and on Alexander's death, in 323 B.c., became ruler of Paphlagonia, Cappadocia, and Pontus. After a four years' struggle with Antigonus (q.v.), he was taken prisoner by the latter and put to death. See Craterus. Pron. U-men-eez.

Eumenes. Name of two kings of Pergamum. Eumenes I reigned 263-241 B.c., but Eumenes II, who reigned 197-159 B.C., is the more important. Realizing that his interests lay in recognition of the power of the Romans, he entered into an alliance with them, assisted them in the war against Antiochus the Great, taking part in the battle of Magnesia, and was established by them as ruler of Mysia, Lydia, Phrygia, Lycaonia, and Pamphylia. His lukewarmness in the war against Perseus, king of Macedonia, caused him to be suspected of intriguing with the enemy, and he never completely regained Roman favour. Under his rule Pergamum became a city of great magnificence. Eumenes founded a library said to rival that of Alexandria. See Pergamum.

Eumenides or ErINYES. In Greek mythology, avenging deities who pursued those guilty of crime, especially crimes against the family and crimes of bloodshed They are represented as winged women with snakes sprouting from their heads instead of hair, and bearing torches and scourges. They were three in number-Tisiphone (avenger), Alecto (unceasing, relentless), and Megaera (jealous). Erinyes was the older name, Eumenides (the kindly) being a euphemistic title, bestowed upon them after they had aban. doned their persecution of Orestes. In Attica they were by preference called Semnai, the awful goddesses. They were propitiated by wineless libations of water, milk, and honey. Furiae and Dirae were the Roman equivalents. Pron. U-meny-deez.

Eumenides. Tragedy by Aeschylus, last of the trilogy Oresteia. The subject is the trial of Orestes before the Areopagus (q.v.) for the murder of his mother, Clytaemnes. tra. The Erinyes act as prosecutors, and Orestes, who is defended by Apollo, is acquitted by the cast. ing vote of Athena. The play ends with a panegyric of Athens and its venerable court of justice, and the Erinyes are propitiated by their name being changed to Eumenides. See Agamemnon; Choephori.

Eumolpus (Gr., sweetly singing). In Greek mythology, son of Poseidon, the sea-god, by a mortal mother, Chiōnē, who, in remorse, threw the infant Eumolpus into the sea. He was saved by Poseidon, and after many adventures reached Attica, where he perished in a war with Erechtheus, the Athenian king. He was credited with being the founder of the Eleusinian mysteries, and his descendants, the Eumolpidae, were priests at Eleusis throughout all Greek history.

Eunuch (Gr. eunē, bed ; ekhein, to keep). Word originally applied to a man in charge of the women's apartments in Oriental countries, but afterwards to a castrated attendant in the harem. The custom of entrusting women to eunuchs has prevailed in the East since Babylonian times, and was imitated by the later Roman em. perors. These eunuchs frequently acquired great power and high position. In modern times lads were castrated in order to preserve their clear boyish voices. Italian churches employed castrati in choirs, but Leo XIII abolished the practice in 1878. From time to 
time religious fanatics have undergone self-mutilation, the Skoptsi, of Russia, being notable examples. The only Christian self-castrate of note was Origen.

Euonymin. Extract of the bark of Euonymus atropurpureus, the spindle-tree of the U.S.A. It is useful for constipation associated with disturbance of the liver. See Spindle Tree.

Eupatoria. Seaport of $\mathrm{S}$. Russia. It stands on the W. coast of the Crimea at the N. end of Kalamita Bay, 40 m. N.W. of Simferopol. The chief industries are soap-boiling and tanning, and considerable trade is done in grain, wool, hides, and salt. Its Tartar name was Gyuzleve, Russian Kozlov. In 1783 it was taken from the Tartars by the Russians, who re-named it Eupatoria, after the ancient town founded by Mithradates VI the Great, King of Pontus. In 1855-56 Eupatoria was occupied by AngloFrench troops. Pop 30,432, mainly Tartars and Karaite Jews.

Eupatridae (Gr. eu, well ; paterr, father). Nobility of Athens and Attica, supposed to be descended from the ancient heroes. The rest of the inhabitants were roughly divided into Geomori or farmers, and Demiurgi or artisans and traders. As the kingship declined, the influ. ence of the Eupatridae increased until they virtually governed the state. Their influence was checked by Draco's Code of Laws, providing for the administration of justice equally among all classes, and ended by the constitution of Solon. See Draco ; Solon.

Eupen. District and town of Belgium. The territory known as the Kreis (circle) of Eupen lies S. of Aix-la-Chapelle, and covers an area of 400 sq. m., with a pop. of about 40,000 . It is fertile, with rich pastures and meadows, and its chief industry is dairy farming. It contains Eupen, Raeren, Kammersdorf, and Conzen. The town, the administrative centre of the Kreis, has a pop. of about 14,000 . It is situated on the Weser, $10 \mathrm{~m}$. $\mathrm{S}$. of Aix-la-Chapelle, and is a busy industrial centre, manufacturing woollen and cloth goods, paper, soap, and machinery. It has ironfoundries, breweries, and tanneries.

Formerly part of the duchy of Limburg, Eupen was under the government of Austria until 1801, when by the peace of Lunéville it passed to France. In 1814 it was given to Prussia, later forming part of the Rhine province until 1919. The town reverted to the old French name of Néaux (q.v.).

By the treaty of Versailles, Germany renounced in favour of Belgium all rights and title over the

territory comprising the whole of the circles of Eupen and Malmédy. The inhabitants were "entitled to record in writing a desire to see a whole or part of it remain under German sovereignty." This was not the same procedure as adopted in the plebiscite areas like $\mathrm{N}$. Slesvig. Belgian troops occupied Eupen on May 26, 1919, taking it over from the French. See Belgium.

Euphemism (Gr. eu, well ; phèmé, voice). Substitution of refined and delicate words for coarse and vulgar words conveying the same idea. The object is to suppress as far as possible painful or unpleasant subjects which yet must be referred to. While literature, like art, properly embraces the entire range of human activity, its function is to idealise and refine, and it therefore employs euphemism in dealing with such matters as strong animal passions, gross pleasure, excessively painful or repellent conditions. The shock of an ugly or revolting image is more violent when presented in words used only by the coarse-minded, but it is mitigated if presented in a less familiar euphemism. Thus by euphernism refined pleasure may be extracted from subjects which at first seem repugnant.

Euphonium (Gr. eu, well ; phōnê, sound). Brass wind instrument of the saxhorn family. Of

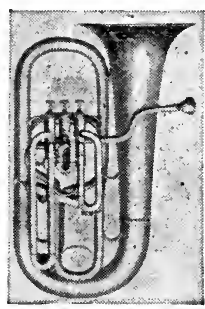

Euphonium.

4-valve instrument

By courtesy of
Hawkes \& Co.

cornets. It also plays bass parts with the heavier bass instruments, bombardon, bass tuba, etc. Euphoniums are made in $\mathrm{C}$ and $\mathrm{B}$ flat, both played as nontransposers. In brass bands the $B$ flateuphonium is sometimes written for on the treble stave, when it becomes a transposer, and the notes are placed a major ninth higher, i.e. :

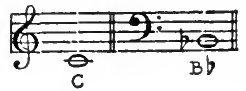

The open notes of the B flat instrument are :

$$
\Omega \cong \underline{\underline{E}}
$$

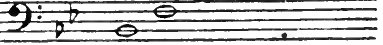

$\overline{0}$ and its three, four, or five pistons complete the scale, and give a chromatic compass of over three octaves.

Euphorbiaceae(Spurge Family). Large natural order, comprising trees, shrubs, and herbs. They are mostly with milky juice, found in all parts of the world except the Arctic zones. The leaves are all undivided, and either alternate or opposite. The sexes are always in

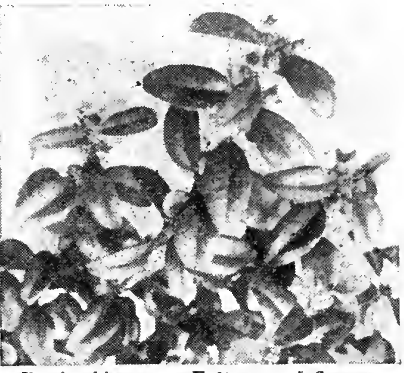

Euphorbiaceae. Foliage and flowers of the box, Buxus sempervirens

separate flowers without petals. About 3,500 species are known, including spurges, mercury, box, castor-oil plant, etc. Preparations of Euphorbia peplus and Euphorbia pilulifera are sometimes used in medicine, to relieve conditions associated with difficult breathing. The order is named after a Greek physician, Euphorbus (1st century B.c.).

Euphorbus. In Greek mytho$\operatorname{logy}$, a Trojan hero slain by Menelaus. Pythagoras, who taught the transmigration of souls, believed that he himself had once been Euphorbus, and in proof he unhesitatingly identified the shield of Euphorbus in the temple of Hera near Mycenae as his own.

Euphotide (Gr. eu, well ; stem, $p h o ̄ t$, light). Coarsely crystalline basic rock, belonging to the family of gabbros. It consists essentially of the mineral diallage and plagioclase felspar, with minor quantities of iron and carbonates as acces. sories. It occurs in the Alps, Corsica, and elsewhere.

Euphrates. The western river of Mesopotamia, flowing over the alluvial plain to join the Tigris and enter the Persian Gulf. One of the notable rivers of antiquity, the joint valley was the home of the earliest civilization. The river, called Frat by the Turks, rises in the Armenian highlands, about lat. $40^{\circ} \mathrm{N}$. The parent streams, the $\mathrm{Kara} \mathrm{Su}$ and the Murad Su, originate well over $1 \mathrm{~m}$. above sea level, in a land snow-covered and icebound for three months. Both flow at first W. between snow-clad 


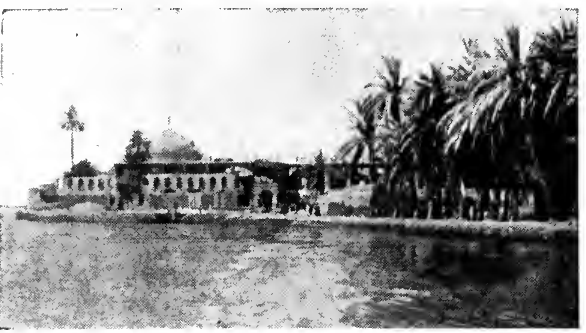

Euphrates. Tomb of Ezra near Kurna, at the junction of the Euphrates and the Shatt-el-Arab allusion, and the extravagant drafts upon natural his. tory for purposes of moral reflection. The high artificiality of euphuism carried the seeds of decay within it, and it died before the 16 th century was out. Scott claimed to have modelled Sir Piercie Shafton in The Monastery

ridges; the Kara $\mathrm{Su}$ crosses the plain of Erzerum, and is a big river, $200 \mathrm{ft}$. in width; it breaks through the southern ridge by a series of rapids, receives the Murad $\mathrm{Su}$ at Keban Maden, flows still to the $W$. and then breaks through a second ridge by a long, narrow gorge, to enter the Malatia plain at a level of about 2,600 ft. The Murad $\mathrm{Su}$, which rises near Mt. Ararat, has a wilder course than the Kara $\mathrm{Su}$, and receives greater quantities of melted snow

From the plain the Euphrates has a rocky course through the Tauric mts. to Samsat, falling $1,500 \mathrm{ft}$. in about $100 \mathrm{~m}$., to emerge on to the lowland and fall 1,000 ft. in $1,800 \mathrm{~m}$., a broad, majestic stream only crossed until quite recently by primitive ferries. In the neigh bourhood of Aleppo, the river is but 80 m. from the N.E. corner of the Mediterranean Sea, but it almost immediatelyturns definitely to the S.E. on its way to the Persian Gulf. The lowland course is in a sandy trough, comparable to that of the Nile in Egypt ; a narrow bordering strip is cultivable by the use of river water; it receives only one important tributary, the Khabur, and consequently decreases in volume by excessive evaporation.

During hot summers it becomes fordable ; nearer Kurna, where it joins the Tigris, it percolates into marshes, losing still more water. The combined stream is the Shatt. el-Arab. The Euphrates has no large modern town on its banks, yet the site of Babylon is due S. of Bagdad. The stream is navigable for small craft to Birejik on the caravan route to Syria. During the Great War important battles were fought at Ramadie and Khan Baghdad. See illus. facing p. 811 and p. 813 .

Euphuism(Gr. euphuēs, clever). Name given to the artificial style in which John Lyly (q.v.) couched his famous romance, Euphues, the Anatomy of Wit, 1579, followed in 1580 by Euphues and His England. The characteristics of this "new English" were the balanced antithetical sentences marked by elaborate alliteration, the excess of classical on the euphuistic fashion which prevailed for some years.

Eupolis (d. c. 410 B.c.). Athenian comic writer. He was a contemporary of Aristophanes and Cratinus, with whom he was as. sociated by Horace and others as one of the chief representatives of the old comedy. Among his comedies, of 12 of which fragments remain, were Kolakes (the Flat. terers), ridiculing the wealthy Callias, a patron of learning, who was always surrounded by a host of toadies; Marikas, an attack on the demagogue Hyperbolus (q.v.), represented as a slave; Dêmoi, lamenting the unhappy condition of the state under the encroach. ments of democracy ; and Baptae (the Dippers), an exposure of the licentious practices of Alcibiades and his companions in connexion with a Thracian ritual.

Eurasian. Term originally denoting the offspring, and their descendants, of a European father and a Hindu mother. It was formed out of the continental names, about 1820 ; the colloquial name in previous use was chee-chee. In India 100,451 were returned at the last census under the official designation Anglo-Indians. The term now denotes any mingling of European and Asiatic blood, and, in physiology and ethnology, natural or ethnic characters common to both con. tinents.

Eure, River of France. It rises in the dept. of Orne and flows through the dept. of Eure et Loir to the Seine, which it enters near Pont de l'Arche, not far from Rouen. Its length is about $70 \mathrm{~m}$. and Chartres is the chief place on its banks.

Eure. Department of France. In the N.W. of the country, it is a fairly level area, and the soil is fertile. Much of it is covered with forest, but elsewhere wheat is grown. Horses, sheep, and cattle are reared, a great deal of fruit is cultivated, and the peasants export butter and eggs. The Seine borders the dept., which is also drained by the Eure, Rille, and other tributaries of that river. Evreux, the capital, Elbeuf, Les Andelys, and Louviers are the chief towns of the dept., which has five arrondissements. Before the Revolution, Eure was mainly part of Normandy. Its area is 2,330 sq. m. Pop. 323,651.

Eure et Loir. Department of France. An inland dept. in the N.W. of the country, it is flat and fcrtile in the S. and E., but less so in the N. and W. The former is included in the plain of Beauce, while the latter is known as the Perche and the Thimerais. The chief rivers are the Eure, Loir, and their tributaries. The main products are wheat and oats. Apples are grown, while cattle, sheep, and horses are reared. Chartres is the capital, and the dept. is divided into four arrondissements. Dreux and Châteaudun are other towns. Before the Revolution it was partly in Normandy and partly in Orléanais. Its area is $2,293 \mathrm{sq}$. $\mathrm{m}$. Pop. 272,225.

Eureka (Gr. heurēka, I have found). Exclamation of Archimedes (q.v.), on finding that he had discovered a method of detecting the alloy in the gold of Hiero's crown. In modern language, the term is applied to an expression of delight on making some great discovery.

Eureka. City of California, U.S.A., the co. seat of Humboldt co. It stands on Humboldt Bay, $225 \mathrm{~m}$. N.W. of San Francisco, on the North-Western Pacific Rly. A port of entry, with a fairly good harbour, it is largely engaged in shipping lumber, obtained from the red wood forest region in which it is situated. Its industrial establishments include saw-mills, tanning and shingle works, and tobacco factories. The federal building, city hall, and a public library are among the chief buildings. Settled in 1850 , it was incorporated in 1856. Pop. 13,770 .

Eureka Springs. City and watering-place of Ârkansas, U.S.A. It stands near the White river and is chiefly noted for its medicinal springs, opened in 1879 and now public property; to them the town owes its growth and prosperity. Pop. 3,230.

Eurhythmics (Gr. eu, well ; rhythmos, measured motion). Art of expressing harmony by gestures, in which physical movement is made to reflect musical notation. It was invented by Emile Jaques. Dalcroze, professor of harmony at the Geneva Conservatoire, towards the end of the 19th century. Time is shown by movements of the arms and notes by movements of the legs. The unit is the crotchet, which is 


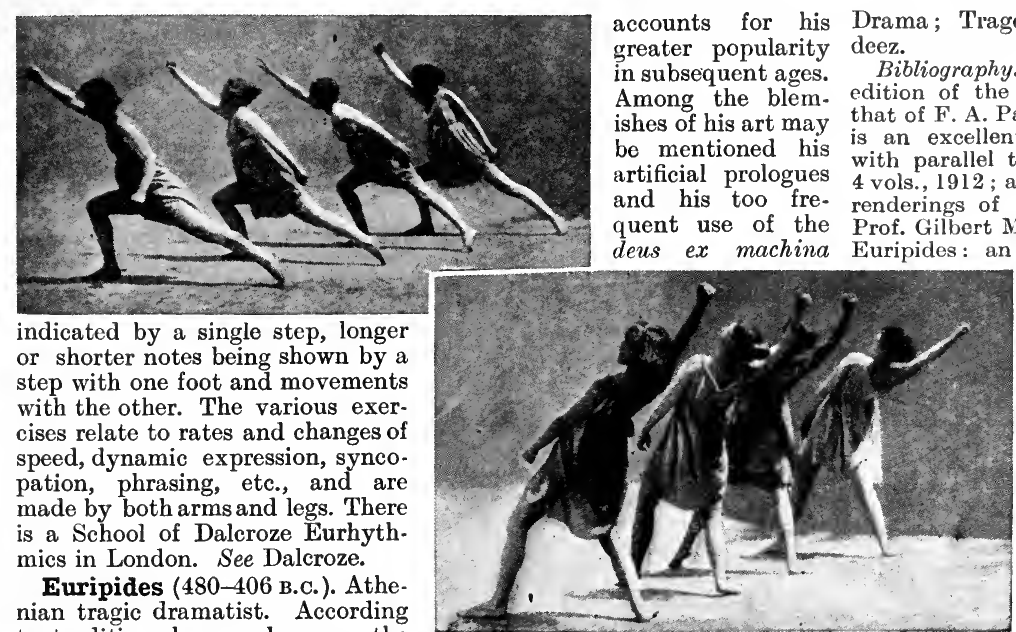

nian tragic dramatist. According to tradition, he was born on the

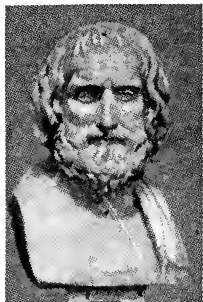

Euripides,

Greek dramatist

From a bust island of Sala-
mis on the day of the great naval victory over the Persians. A pupil of the famous sophist Prodicus, he seems to have been at first intended for a professional athlete, and secondly, for a painter, but soon took to writing for the stage. In 455 B.c. he exhibited his first tragedy, and in 441 gained the first prize for the first time. $\mathrm{He}$ was credited with over 90 plays in all, of which 18 survive. He gained the first prize only five times, his contemporaries apparently regarding him as inferior to both Aeschylus and Sophocles and other dramatists. His vogue increased, however, after his death, and though never the favourite of the critics, he has been the favourite dramatist of many of the world's poets, notably Virgil, Horace, and Milton.

Euripides is undoubtedly a master in the handling of the tender and the pathetic; Aristotle truly called him "the most tragic" of the poets. A reputed misogynist, he has yet portrayed women as fine as any to be found in all literature. As a playwright also Euripides stands high; there is an excitement about his plots and a vividness in his situations, although they sometimes verge on the ridiculous, which are lacking in the plays of Aeschylus and Sophocles. Euripides is, in fact, the most human of the three dramatists, and this quality of humanity
Eurhythmics, Two attitudes in a plastic exercise in the rhythmic method of training

(q.v.) or divine intervention in unravelling a plot.

The extant plays of Euripides are: Alcestis, Medea, Hippolytus, Hecuba, Andromache, Ion, The Suppliants, Heracleidae, The Mad Heracles, Iphigenia among the Tauri, The Trojan Women, Helen, The Phoenician Maidens, Electra, Orestes, Iphigenia at Aulis, Bacchae,Cyclops, the last being theonly extant specimen of a satyric drama. The Rhesus is certainly spurious. Of the plays perhaps the best are Alcestis, notable for its exquisite delineation of woman's devotion; Hippolytus, the tragic story of the illicit love of Phaedra, a plot used by Racine in his Phèdre; and Bacchae, a brilliant glorification of the worship of Dionysus or Bacchus. The plots of Euripides were all drawn from the old mythology, yet the characters are not cast in heroic mould, but act and talk like Athenian men and women of his time. Euripides was accused by his contemporaries of endeavouring to undermine $f$ it $h$ in the gods and in morality, and for tendency, as well as for his alleged bad art, he was bitterly attacked by Aristophanes. The last few years of his life were spent at the court of King Archelaus in Macedonia, where he died, 406 B.c. See Greek Literature; this supposed

Doge's Palace, Venice

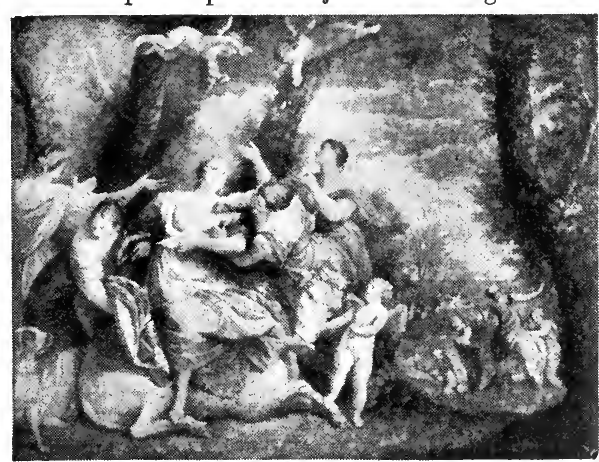

Europa. The story of Europa depicted by Paolo Veronese

klydon, wave). Name given in Acts xxvii. 14, A.V., to the gale which, blowing off Crete, seized the ship in which S. Paul was wrecked on the coast of Malta. The form adopted in the R.V. is Euraquilo, meaning a tempestuous N.E. or E.N.E. wind of the Mediterranean.

Europa. In Greek mythology, daughter of Agenor, king of Phoenicia. While she was playing one day with her maidens, Zeus ap. peared in the form of a white bull, and Europa was induced to mount on the animal's back. 'The bull thereupon carried her off over the sea to Crete, where by Zeus she became the mother of Minos, Rhadamanthus, and Sarpedon.

Europa Point. Headland at the extremity of the peninsula of Gibraltar, Spain, just S.E. of Europa Bay. To the N.W. is Little Europa Point and to the E. Great Europa Point. Europa Bay is a small circular inlet in the S.W. coast of the peninsula just S. of Shingle Point. 


\section{EUROPE: THE CONTINENT AND ITS HISTORY}

A. D. INNES. M.A., A uthor of A General sketch of Political History, and B. C. WALLIS, B.Sc.

This article, like those on Africa, Asia, North America, etc., is a general sketch of the physical and racial features, industries and history of the continent. In addition there are articles on each of its countries, whether old or new, on all cities and towns of importance, rivers, lakes, and mountain ranges. See also the biographies of Napoleon; Metternich and other great European figures; also articles on French Revolution: Reformation: Renaissance, and other movements

Europe is almost the smallest of the six continents, and covers about $3 \frac{3}{4}$ million sq. m. It is thus about the same size as Canada and slightly larger than Australia. Excluding Russia, where twofifths of the continent is in an indeterminate political condition, France has the greatest area in Europe. Spain, Germany, and Sweden are almost as large; Norway, Rumania, and Italy are about the same size as the British Isles, which has about three-fifths the area of France.

The total population of Europe lies between 350 and 400 millions of people, of whom about a quarter live in Soviet Russia. Germany is the next most populous state; then the United Kingdom, France, and Italy. Several countries have roughly about half the population of one or other of these fourSpain, Poland, Rumania, Czecho Slovakia. The remaining states have less than 10 million inhabitants each.

The chief factor regarding population is not so much its absolute number as its relative distribution over the land. The people of Europe live almost wholly S. of the latitude of Petrograd $\left(60^{\circ}\right.$ N.). Not numerous between the latitudes of Petrograd and Copen. hagen, they are most numerous in a belt of country, about 200 miles or less in width, roughly in the latitudes of London, Cologne, and Cracow $\left(50^{\circ}-52^{\circ}\right.$ N.).

\section{Belts of Population}

From Lancashire and the W. Riding of Yorkshire, through the midland counties to the London area, across the sea through Belgium and S. Holland, through the middle of Germany near Cologne, Leipzig, and Dresden, through Bohemia, Moravia, S. Poland (Galicia), and the Ukraine to the valley of the Don, the people are clustered together in a belt of dense population most numerous between Cologne, Lille, and Rotterdam, and gradually thinning out eastwards. From this belt two projections of dense population go southwards - one up the Rhine valley to Zürich and Bern, the other across the Danube at Vienna to Graz and Zagreb (Agram).

Apart from this great popalous area, the only other large densely peopled portions are the coastal strip of Portugal and N.W. Spain and part of Italy. In the latter peninsula, the plain of Lombardy, and a strip of land on each flank of the Apennines reaching some distance S. of Naples, have large numbers to the sq. m. Sicily is almost equally densely populated. 'These areas with many people do not merge suddenly into sparsely inhabited tracts except where they reach the mountains, the Alps, or the Carpathians. The peninsulas of Jutland, the Balkans, and Spain (except for a fringe along the N.E. coast) have few people ; the Rhône valley in France is densely peopled alongside the river.

These facts give an added im. portance to certain of the small states. Belgium, Holland, CzechoSlovakia, and Poland are thus intrinsically greater than Spain, Sweden, or the major portion of Russia, the and of the Great Russians, because-density of population implies closer community of interests and a fuller national life.

\section{Anthropological Classification}

A ithropologists classify people physically with reference to the shape of the skull. The two extremes are round heads where the width exceeds 85 p.c., and long heads where the width is less than 77 p.c. of the length. Except in Portugal, England, and the areas near the Rhine, the districts of dense population are inhabited by round heads: the Slavs, Italians, and South Germans in these areas are round-headed. In Portugal the people are long-headed. Elsewhere in the densely peopled areas they are mixed, approaching on the average the long-headed type

Physical Features. From the physical point of view the continent of Europe may be regarded as a peninsula of Asia, extending westwards about one-sixth of he distance round the world from the indefinite E. boundary which is only approximately marked by the Ural Mountains. This peninsular characteristic enters even into the details of the continent, for in addition to the great Scandinavian peninsula in the north and the smaller peninsula of Jutland, there are the three Mediterranean peninsulas, the Iberian, Italic, and Balkan peninsulas. 'The truly Asiatic character of Europe is revealed by the mountain back- bone and the great plain which lies between the backbone and the N. seas.

The Alps are merely the central European portion of a great Old World chain of folded mountains which extends from S. Spain by way of the Atlas Mountains in N.W. Africa, the Apennines. Alps, Balkans, and the Caucasus through the Himalayas almost to the shores of the S. China Sea. From the French shores of the Bay of Biscay the Great European plain stretches E. with ever-increasing width until it reaches from the Arctic to the Caspian, and forms a W. continuation of the great plains of N. Asia.

The only section of Europe which is not physically Asiatic is the N.W., where the Scandinavian mountains and the uplands of Scotland and Iceland belong to a continental land mass, older than the rest of Europe, which, it is conjectured, once joined Scandinavia to Greenland, and has become submerged. The E. boundary of Europe is a purely conventional line, the political frontier which separated Russia in Europe from Russia in Asia.

It follows the Ural Mountains across the uninhabitable tundra, but lies well to the $\mathrm{E}$. of the $\mathrm{S}$. two-thirds of this range; in the $\mathrm{S}$. it follows the Ural river almost to Orenburg, and then it lies W. of that river until it reaches the Caspian. Even were the boundary purely physical, i.e. the Ural mountains and river, it would not serve any better than the present administrative limit to separate the natural vegetation, the types of cultivation, or the peoples of W. Asia from E. Europe. The steppes, the forests, the nomad Kirghiz are continuous across the frontier.

\section{The Great Rivers}

Beginning with the Garonne, many rivers flow across the Great European Plain The chief of these are the Loire, Seine, Oder, Vistula, and the streams that cross $\mathrm{N}$. Russia to the Arctic. The Iberian streams, Douro, Tagus, Guadiana, Guadalquivir, and Ebro have carved valleys in the plateau. The $\mathrm{Po}$, the Vardar, Struma, and Ma. ritza flow to the Adriatic or the Aegean, their course guided by the great chain of mountains. The Dniester, Dnieper, Don, and Volga 


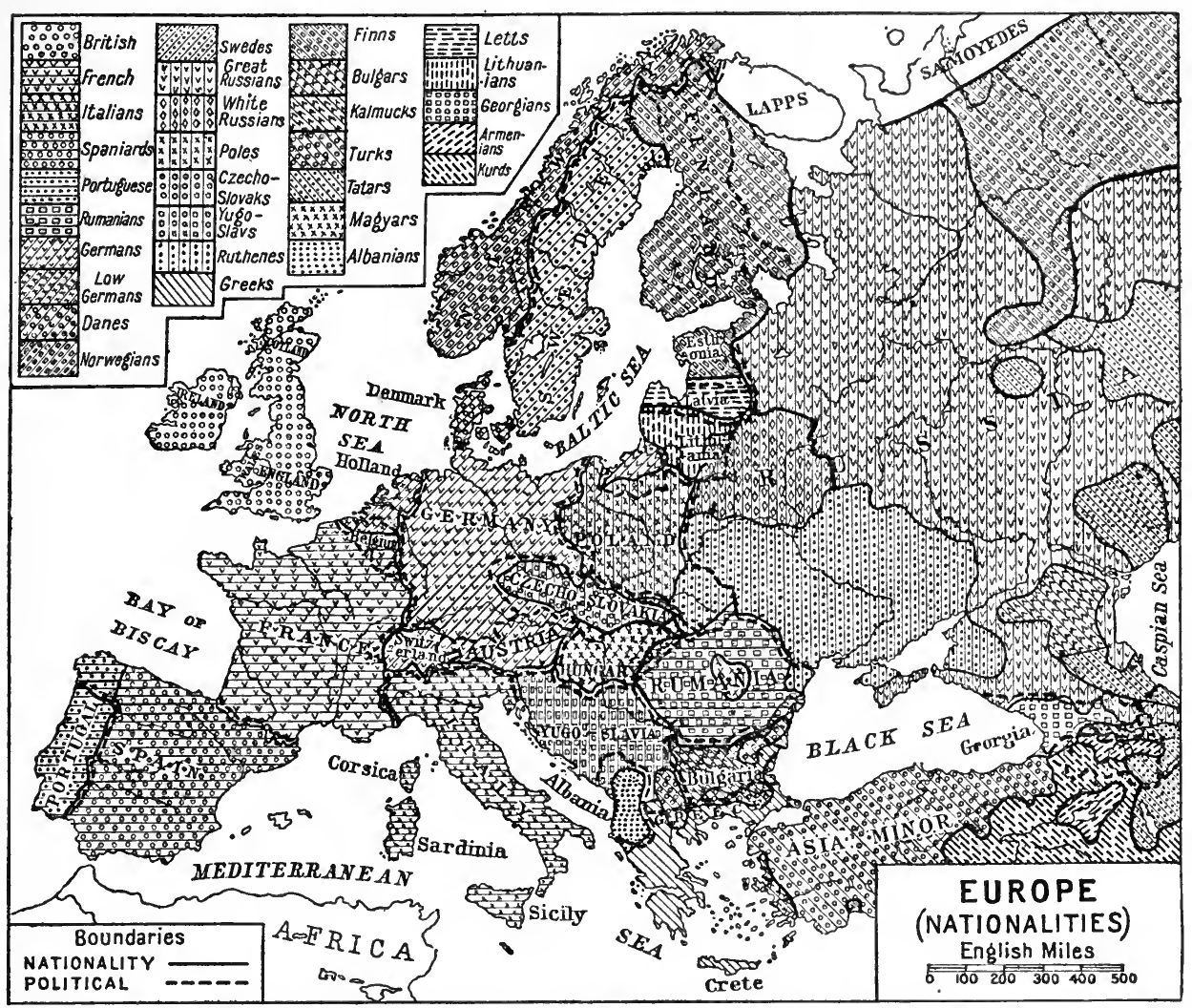

Europe. Map showing the main distribution of the nationalities of Europe. Scattered peoples such as the Jews and Gypsies are omitted. The Celts of Scotland, Ireland, and Wales are included under British, and those of Brittany under French

are lowland rivers which have Alpine origin. Next in importance found their way to the Black Sea or the Caspian across the plain.

But the most important rivers of Europe are the three great Alpine streams, the Rhône, Rhine, and Danube. Their sources lie near together, but their mouths are as far apart as they could well be. The Rhône leaves the Alps at Lake Geneva and flows to the Mediterranean in the trough between the central massif of France and the W. Alps, the trough occupied in the $\mathrm{N}$ by the Saône, the principal tributary of the Rhône.

The Rhine suddenly turns N. at Basel, and by a geological accident flows through the gorge between Bingen and Coblenz, ultimately to the North Sea. The Danube flows along the $\mathrm{N}$. edge and round the $\mathrm{E}$. end of the Alps, fed first by streams from the transverse valleys of the Central Alps and later by streams, such as the Drave, from the longitudinal valleys of the $\mathrm{E}$. Alps. Its lower course is along the $\mathrm{N}$. edge of the mountainous Balkan peninsula; here it receives only one great tributary, the Theiss, not of is the Eibe, which issues from the Bohemian plateau to cross the Ger. man plain to the North Sea.

The most useful rivers are those which cross the plain to the Chan. nel, the North and Baltic Seas; there is considerable river traffic on the Rhine and the Elbe, and a fair volume of traffic on the Seine, the Schelde, Oder, and Vistula. E. of the Rhine there is some trouble with winter ice and spring floods. Rivers and Canals

But the greatest value of these streams lies in their use in connexion with canal systems, which are being developed in order to join them all together; these canals have been made more or less parallel to the coast and some distance inland, so that eventually it will be possible to send goods by barge from Paris to Bromberg through a series of canal ports, Hanover Berlin, etc, which lie parallel to the seaports Havre, Antwerp, Rotterdam, Bremen, Hamburg, Stettin, and Danzig, with which they will have barge and steamer connexions.
The lakes of Europe are not so large or important as those of Africa or N. America. The largest, Wener, Ladoga, Onega, and the Finnish lakes are shallow expanses on the plains, due to dams across the lower ends of hollows scraped in the rock surface during the Great Ice Age. The most beautiful, those of the Alps, Como, Maggiore, Lucerne, etc., are long, narrow, deep lakes due to dams across the ends of glacier-moulded valleys.

The Arctic coast of Europe is flat. The Norwegian coast, like the W. coast of Scotland, has a welldeveloped system of fiords, submerged glacier-moulded valleys. For $100 \mathrm{~m}$. along the coast of the great European plain there is a belt of sand dunes, best known in Holland, Belgium, and S.W.France (the Landes). The rocky coast of the French peninsulas, the Cotentin and Brittany, is a break in this belt. The N. coast of Spain drops sheer from the mountains to the great depths of the Bay of Biscay. The W. Iberian coast, like that of S.W. Ireland, consists of drowned river valleys, known technically as 
rias. The Mediterranean coasts are rocky, and in the $W$. are the edge of a fractured area, the W. Mediterranean covering a foundered land mass. The E. Adriatic coast is the edge of a mountain ridge like that of the Aegean; the gulfs of Cattaro, Corinth, and Salonica are flanked by ridges and headlands.

Europe's Physical Boundary

The Baltic and North Seas, including the English Channel, are shallow, and are really watercovered portions of the great European plain. This implies that the physical boundary of Europe lies well W. of Ireland. It is customary to indicate the edge of the land, the limit of the deep ocean, by the 100 fathom (600 ft.) line. This line runs to the coast in the Bay of Biscay, sweeps round the British Isles, runs in a well-marked deep $\mathrm{S}$. of Norway, and continues $\mathbf{N}$. near the Norwegian coast. The British archipelago consists, therefore, of continental islands with shores which shelve gradually below the sea.

Geology. The dominant physical features of Europe mark its geological development. N.W. Ireland, N. Scotland, Scandinavia, and Finland are the oldest parts of Europe ; they consist of Archaean igneous rocks, which are the residue of an ancient continent once extending away to the N. and W. Within and adjacent to these areas arose a series of folded mountains, consisting of Silurian rocks with intrusions of granite, still to be seen in the heights of Wales, N.W. Ireland, Scotland, Scandinavia, and Esthonia. Among these peaks the old Red Sandstone of the Devonian horizon was laid down in the valleys. Carboniferous rocks, magnesian limestone, etc., were then deposited under a Carboniferous sea, or in the marshes along its edge.

At the next stage a new set of mountain folds arose ; their relics are the hills of S.W. Ireland, S. Wales, Cornwall, and Brittany, the Ardennes, the Black Forest, the Vosges, the plateau of Bohemia, the Auvergne plateau, and the Mcseta or major portion of the Iberian plateau. These folds belong to the Armorican period. The next great incident was the invasion of the Cretaceous Ocean, which washed the shores of the ancient continent and of the islands which were the exposed tops of Armorican Mts. No land had yet appeared to the $\mathrm{S}$.

In tertiary times, first the Pyrenees and later the Sierra Nevada, N. African Atlas, the Apennines, Alps, Carpathians, Balkans, Crimean and Caucasus
Mts. emerge as crumplings of the earth's crust. Their sinuous curves are due to the resistance of the stable relics of the Armorican Mts. During this epoch most of the old continent sank beneath the ocean, and as the new mountains rose they were denuded, and the products of erosion filled the seas between them and the more ancient land. The new mountains vary in the amount of material removed as they gradually uprose; in the Apennines and Carpathians the older underlying igneous rocks are not laid bare as they are in the Balkans and the Alps.

While these great changes were taking place the arrangement of land and water upon the earth was greatly modified beyond European limits. The N. Atlantic Ocean was formed, the ancient ocean between the beginnings of Europe and an older continent to the S., now represented by Africa and India, dwindled to form the Mediterranean; the relative level of sea to land was gradually altered, and the shallow seas then existing have been gradually filled in with alluvial deposits since tertiary times. These shallow seas were at least once disturbed by a great ice sheet which extended from the $\mathrm{N}$. as far $\mathrm{S}$. as the Thames, Bohemia, and the Carpathians.

\section{Erosion and Glaciation}

In its subsequent retreat the ice left behind it quantities of glacial débris, so that the whole of the great European plain from Ostend to Archangel is the product of erosion from the southern mountains and glaciation from the remains of the ancient northern continent. The plains of the Po, Hungary, the lower Danube, and N.W. of the Caspian are, however, solely erosion deposits.

Climate. Owing to its peninsular character the climate of Europe is modified by the oceanic conditions which affect it on the W. The prevalent surface air currents are the W. winds, which regularly traverse definite cyclone tracks from the Atlantic Ocean, and carry moisture far into Europe. The prevalent surface oceanic movements are the drifts of wind-driven warm water, which prevent the coasts of W. Europe $\mathrm{S}$. of the North Cape from being ice-bound in winter.

In relation to its latitude, winter conditions are abnormal. In Jan. the temperatures of Scotland are $35^{\circ} \mathrm{F}$. above the average for the latitude, so that Cape Wrath, which has a temperature of $40^{\circ} \mathrm{F}$., lies in a latitude where the average temperature is $5^{\circ}$ F., i.e. 27 degrees of frost. Only in the extreme
E. of Europe, on the Kirghiz steppe, is the January temperature colder than the normal for the latitude. From Brittany through Stettin to Petrograd the coast strip is $15^{\circ} \mathrm{F}$. above the normal The boundary line, $32^{\circ} \mathrm{F}$. isotherm, which limits the area frost bound in winter, starts at the North Cape, goes S. to Hamburg and the Alps, and crosses the Balkans and the Crimea to Baku. E. and N. of this line the winter frosts last from 1 to 7 months, the period lengthening towards the N.E. of Europe. These facts show the influence of oceanic conditions.

In summer, temperatures are normal; the Arctic circle has a temperature of $50^{\circ} \mathrm{F}$., lat. $55^{\circ} \mathrm{N}$., $70^{\circ} \mathrm{F}$., while the coast lands of the Mediterranean have three hot months, when the temperature exceeds $68^{\circ} \mathrm{F}$.

The rainfall exceeds 60 ins. annually on the highest areas and on parts of the W. coast. The Pyrenees, Alps, Balkans, and Caucasus include districts where the rains exceed 40 ins., but most of Europe has an annual precipitation of between 20 and 40 ins. Spain, E. and N. Russia receive less than 20 ins. In the Mediterranean area most rain falls during the cool season; the summers are hot and dry. On the Atlantic coast rains are usually heaviest during late autumn. In the E. most rain falls during hot weather.

The Mediterranean peninsulas are lands of clear skies with a maximum duration of sunshine in excess of 2,500 hours annually. Scandinavia is a cloudy area with less than half as much sunshine. In December Scandinavia does not average 1 hour of sunshine a day, while Spain averages at least 3 hours daily.

Vegetation. From N. to $S$. the natural growth occurs in belts merging each into the next. Along the Arctic shore the tundra has stunted willows and a few annual plants ; to the S. lies the forest, at first coniferous, then deciduous; farther S. the trees give place to the steppe or natural grass land; in the extreme $\mathrm{S}$. there is little grass, only evergreen shrubs, cypresses, and chestnut trees.

\section{Growth of Economic Plants}

The vegetation zones are best marked in the E. In the W., Germany and England, for example, have had their natural forest cover removed by man; there are no wide plains in France to be grass land like the Hungarian Alföld (q.v.). The mountains are forested on the lower slopes, and, if high enough, snow-capped; the plateaus tend to be forested, or bare if there is insufficient soil. 
-

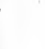

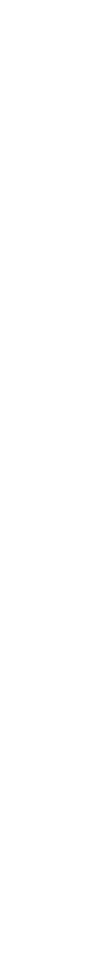




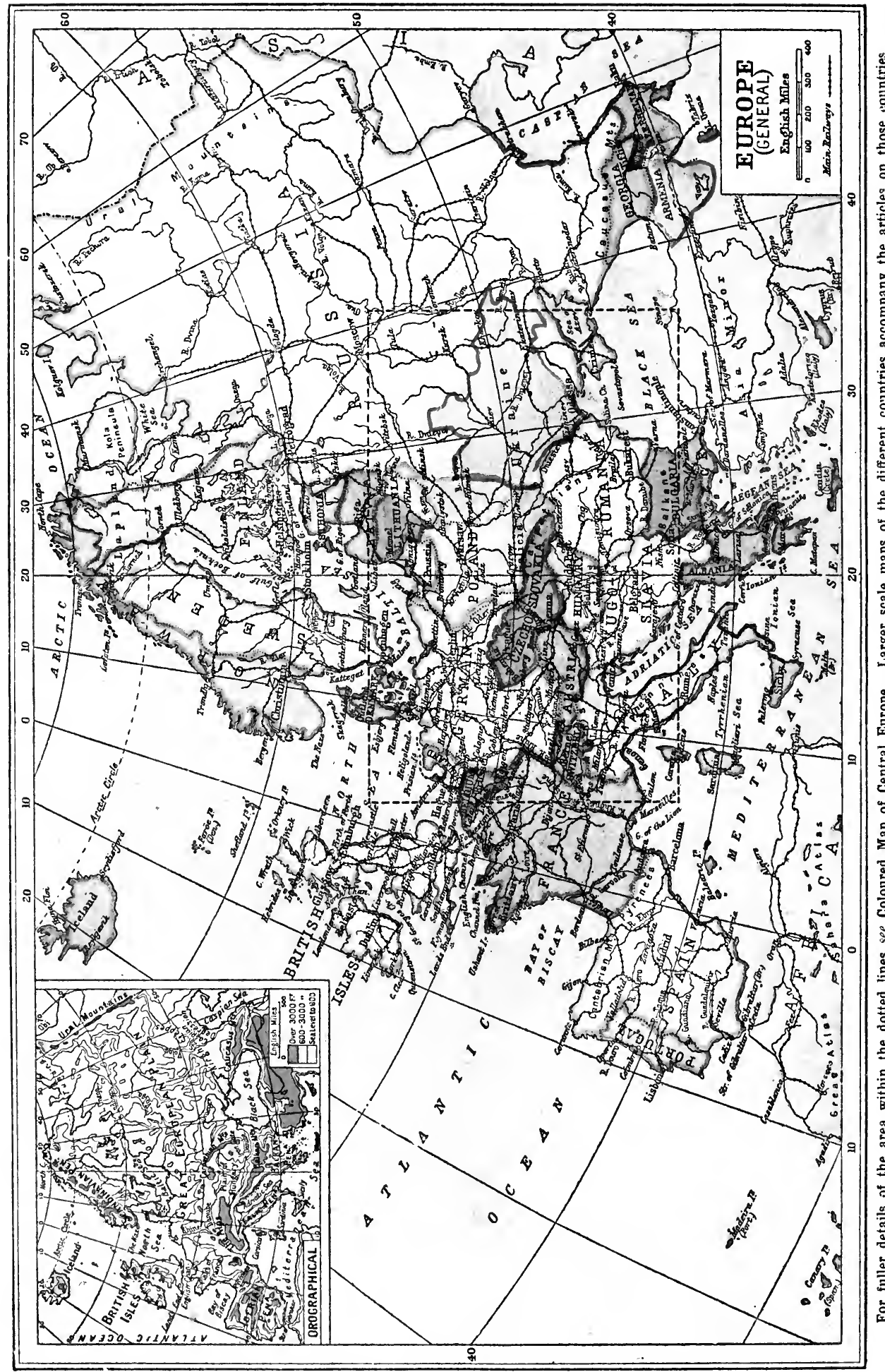


The $\mathrm{N}$. limit of the growth of economic plants illustrates the effects of climate. Greece, peninsular Italy and S. Spain are suitable for olive trees. The $\mathrm{N}$. limit of the vine is approximately $50^{\circ} \mathrm{N}$., of wheat $60^{\circ} \mathrm{N}$. Wheat grows best between $40^{\circ}$ and $50^{\circ} \mathrm{N}$., maize about $45^{\circ} \mathrm{N}$., rye about $55^{\circ} \mathrm{N}$. The most characteristic region of Europe is the Mediterranean area, the land of wheat, wine, and olive oil as the staple foodstuffs, of winter rains and summer droughts, of luscious fruits-oranges, lemons, etc. The W. margin is the land of wheat, meat, and milk, of autumn downpours and muggy warm winters; the N.E. lands are notable for rye and alcohol, hard frosty winters and hot, dusty summers.

Nationalities. Politically, Europe is the most important portion of the Old World. Along its S. and W. margins has developed a civilization which has been carried to the New World and to Australasia, while in modern times the civilization of W.Europe tends to dominate the world and to guide or control the younger states now achieving nationhood.

\section{Branches of the Slavs}

The boundaries of the new European states coincide fairly completely with the limits of the habitation of definite types of people. Finland, Esthonia, Latvia, and Lithuania are the homes of people, Finns, Esthonians (akin to the Finns), Letts, and Lithuanians, who are not Slavs and are mostly Protestants. By speech, history, and religion, they were antagonistic to the Russian Slavic autocracy. Poland is the land of the Poles, a Roman Catholic Slav people with a distinct Slav speech, who maintained for many centuries a king. dom ultimately divided between Russia, Prussia, and Austria.

Czecho-Slovakia includes within its boundaries Czechs, Moravians, and Slovaks, a Slav people akin to the Poles, Roman Catholics as a rule, but with a distinct Slav tongue and a separate history, mainly centred round the former kingdom of Bohemia. These two branches of the N. Slavs have adopted republicanism. The S. Slavs of Yugo (S.) Slavia include the Slovenes, Croatians, and Serbs.

The Slovenes and Croats are Roman Catholics with no definite separate history; the Serbs belong to the Greek Orthodox Communion, and their kingdom of Serbia was in existence before the Turks invaded Central Europe. The common speech of the three branches has been obscured by the use of different scripts, the Serbs use Cyrillic and the others Latin characters for the written language, but the unity of tongue and of nationality have given rise to the extension of the kingdom of Serbia into the SerbCroat-Slovene (S-C-S) kingdom.

The Bulgars are akin to the S. Slavs and their state was carved in 1878 out of the Turkish dominions. The Rumanians are not Slavs, although almost completely surrounded by Slav peoples.

Hungary is the land of the Magyars, an Asiatic people from the Siberian steppes. Their speech has no affinities among the main European languages ; its strangeness has tended to isolate the Magyar from the peoples of W. Europe. This isolation has been intensified by the strong national feeling which maintains a nice distinction between Magyars and foreigners, and possibly accounts for the unique government compromise which has been established. The new Austria is almost precisely the habitation of the Austrian Germans, all the non Germanic areas of the old Austria have been detached and the Germanic section of the old Hungary has been added to the Germanic nucleus of the once powerful Aus trian Empire ; the new Austrian republic is prohibited from joining the republican states of Germany. Greece, like Rumania, has exten ded its boundaries to include areas largely inhabited by co-nationals.

\section{Denmark and North Slesvig}

The Danes of N. Slesvig are now included in Denmark. Of the other states France has regained the lost provinces, Alsace and Lorraine, Italy has gained the Trentino and Istria, and Belgium has gained Malmédy,etc.,all acquisitions based upon nationality. The peoples of the remaining countries, Portugal, Spain,etc., are homogeneous except in Belgium and Switzerland. In both these small countries two peoples, one Teutonic and the other French in speech and origin, constitute the nation. The Jews are scattered in many lands in small numbers, chiefly in the large cities, but forming considerable proportions of the population in Poland, the Ukraine, Rumania, and in Hungary.

Agriculture and Fisheries. The largest portion of the people of Europe work on the land, or are dependants of farmers and peasants. Wherever it is at all possible the land is cultivated, even if only to grow some crops for home use. These domestic harvests must be ignored in this summary, and attention paid to the cultivation of the ground as a business. Of the great cereal crops Europe produces half the world's wheat, two-thirds of the oats, three-quarters of the barley, nearly all the rye, but only a seventh of the maize.

Of animals, Europe has nearly half the world's horses, a third of the shcep, more than half the pigs, and ncarly a third of the cattle.

\section{European Wheat Belt}

Within Europe the wheat belt is approximatcly the $N$. edge of the area of the densest population, and in the $\mathbf{E}$. the areas $\mathbf{E}$. and $\mathbf{S}$. of this belt. The rye belt lies farther N., where it is colder, the maize belt farther S. Oats are grown largely between rye and wheat; barley is grown with the wheat and to the S. of it. W. Europe-i.e. the U.K., France, Belgium, Holland, and Germanymay be compared with the rest of the continent. This area produces almost a third of the wheat of Europe, half the oats, a third of the barley and rye, and contains a third of the sheep, nearly half the horses, three-fifths of the pigs, and a third of the cattle. In the colder areas of poor soil in W. Europe, potatoes are produced in large quantities, and rootsswedes, mangolds, etc.-are an important crop in the W. where required as winter food for stock.

Europe produces roughly half the world's sugar from the sugar beet, extensively grown in Germany, N.E. France, Czecho-Slovakia, Poland, Austria and Hungary. Nearly all the rest of the world's sugar is obtained from tropical sugar canes.

Flax and hemp are grown on the cold wet soils of Russia, Germany, and Ireland. In the Mediterranean area the products are chiefly fruits-oranges, lemons, currants, figs, plums, prunes and olives. The cultivation of the vine extends from the Mediterranean to lat. $50^{\circ} \mathrm{N}$. Europe leads the rest of the world in the production of these fruits, which require dry, hot summers and cool, moist winters.

Europe produces no coffee or cocoa, only about one-eighth of the world's tobacco, and a small harvest of rice, chiefly in Italy. In addition to the flax mentioned, Europe produces a fifth of the world's wool from a third of the world's sheep, no cotton or jute, but obtains some raw silk in France and Italy.

Much of the fishing along the coasts is for local consumption. The main fisheries of world-wide importance are located in the North Sea, and off the Norwegian coast, where herring and cod constitute the main catch. The fishing grounds are in shallow waters, where the sea temperatures are never low enough for freezing nor 
too hot for the fish. In these waters large quantities of fish food accumulate, probably borne S. from the Arctic Ocean. Although much of the catch is sold fresh, being distributed by rail from the fishing ports, a great deal of it is salted or cured and sent overseas or to Mediterranean countries.

Mining. About half the world's coal and three-fifths of the world's iron ore are mined in Europe. The chief collieries of Europe lie within the belt of dense popula tion, but the iron mines are more widely scattered, Spain and Sweden gaining large quantities of iron ore, but little or no coal. Half of the world's bauxite, the source of aluminium, is mined in France. Greece, Yugo-Slavia, and Russia are sources of chrome ore. Over a tenth of the world's copper is obtained in Germany and Spain

Gold is mined in the Ural Mts., and in the Perm district in Russia, Europe producing an eighth of the world's total. Gra phite, used for pencils and as a lubricant, is obtained in Bavaria and Austria. France obtains a third of the world's gypsum, the source of plaster of Paris. Two-fifths of the world's lead is mined in Europe.

\section{Oil Fields and Mineral Products}

Europe produces about a quarter of the world's petroleum, of which about two-thirds is obtained in the Baku district. The other main oil fields are in Rumania and E. Galicia.

About 90 p.c. of the world's supply of platinum was, before 1914 , obtained from the Ural Mts. The Strassfurt deposits, Germany, are the world's chief source of potash salts, valuable fertilisers. Half the world's mercury is European in origin; the chief sources being Almaden (Spain) and Idria (Carniola); new sources are being tapped in Italy (Mts. Amiata and San Salvadore). Sicily is responsible for half the world's supply of sulphur. Portugal mines half the tungsten ore of Europe, the industry being state controlled. Zinc is mined in Germany, Belgium, Czecho-Slovakia. Poland, Sardinia, and Spain.

Manufactures and Trade. Parts of Europe are almost as primitive in their industrial outlook as England was before the indus. trial revolution; almost everything in use is of local or domestic manufacture. Nearer the big centres of population this primitive simplicity is gradually left, and the opposite extreme is met in the big cities, where everything is bought, and nothing! made at home. In every country domestic industries abound, and in some, domestic products enter slightly into general trade. The present outline of
European industrial activities must be limited to the great industries, and must assume reconstruction of industry on the same lines and scale as it existed in 1914 .

'The belt of dense population is due partly to the fertility of the soil, but especially to the presence of coal and iron, and the consequent development of ironworks and textile factories. On the mainland the industrial area begins in N.E. France with the textiles of Rouen, Lille, Roubaix, passes through Belgium with the factory towns centring on Liége, and on to the Rhine district near the ironworks at Essen, the textiles of Crefeld, Barmen, and Elberfeld.

\section{Hardware and Textile Industries}

'The central group of factories include those of Saxony (Chemnitz), Silesia (Breslau), CzechoSlovakia, near the mountainous rim in many small towns, and Poland, near Lodz. Farther E. in the Moscow district. near the Oka coalfield, hardware and textiles are made. The southward exten. sion of the crowded Rhine population is intimately related to the collieries, iron mines, steel works, and textile factories of Alsace and Lorraine. This extension continues even into $\mathrm{N}$ Switzerland, for the absence of coal is balanced by abundance of water power, and Zürich is noted for textiles. The southward extension past Vienna is dependent in part upon the development of textile industry in Moravia, and in part upon the iron and steel works of Austria.

The isolated areas of dense population resemble the main belt In Lombardy the soil is fertile, water power is used as well as imported coal and timber, and there is a textile industry round Milan. In N.E. Spain the textiles of the Barcelona district depend upon sea-borne coal. In the Rhône valley the factories of the Lyons neighbourhood obtain coal from a small local coalfield. It thus appears that W. Europe in particular is a great manufacturing district, and that the main factor in the localisation of the industrial towns was the circumstance that, in the dim geological past, carboniferous deposits were laid down in the swamps that fringed the island relics of the Armorican mountains.

On the continent there is no such distinct separation of cotton, woollen, and linen districts as exists in Britain ; all the cotton factories work under the climatic disadvantage of a drier atmosphere than prevails in S.E. Lancashire, and are unable to specialise in fine counts of cotton. Only the silk mills of S. France, Italy, and Swit- zerland are separate; this is due in part to the localisation of sericulture to the Mediterranean lands.

The elementary fact behind the trade of Europe is that she requires foodstuffs for the people and raw materials for the factories. Food and cotton must be paid for with factory products. But the factories cannot all produce the same type of goods equally cheaply; consequently some specialise, others produce only half manufactured articles, others become noted for articles of luxury. At the same time Europe is so large that the products of the E. and W., of N. and S., differ considerably; so Russian wheat is sent to England, Lyons silk is sold in Petrograd, and Manchester goods are bargained over at Nijni Novgorod. Russia, Hun. gary, and Rumania send wheat, oats, barley, and rye to Britain, Germany, Belgium, Denmark, and Holland ; France, when her harvest is poor, imports wheat. British coal goes to Italy, Spain, and the Baltic ports. German chemicals, Austrian glass, Danish butter, Dutch cheese, and Greek currants are sent away in considerable quantities. The products of the fisheries of the North Sea find their readiest market in Spain and Italy.

\section{Imports from 0verseas}

Raw silk, tea, and rice reach Europe from India, China, Japan, etc. Coffee from Brazil and cocoa from the Gulf of Guinea, meat, wool, and wheat from Argentina, reach W. Europe from the S. Atlantic: The U.S.A sends wheat, meat, tinned goods, iron and steel goods machinery, and motor-cars across the N. Atlantic. Australasia supplies wool and mutton, butter and fruits, chiefly through the Suez Canal. W. Europe sends away cottons, woollens, silks, hardware, and leather goods in exchange, usually to the respective colonies established by the European states.

Communications. The ordinary railway map fails to represent the railway system correctly, not differentiating between single and double track lines, frequently not indicating narrow gauge lines, rarely showing the lines used for slow or express traffic, or the frequency of the service. In general there are no double tracks $\mathbf{E}$. and S. of a line from Trieste to Moscow, or in S Italy or Spain. Narrow gauge lines are used for mountainous areas or in Balkan lands for branches which end "in the air." Express traffic lines are rare except for the connexions betwcen the great cities, and the frequency of the trains decreases away from the Great European Plain to the E., S.E., or S. 
Paris, Berlin, and Vienna are the great rly. junctions. Cologne, Dijon, Munich, Milan, Warsaw, Budapest, and Moscow are junctions of less importance. The Alps and Carpathians interfere with rly. traffic, as a glance on the rly. map shows, though each range is traversed by passes or bored by tunnels The Pyrenees are circum. vented by the $E$. and $W$. routes and the straits of the Danish archipelago are crossed by train ferries. The great rivers control rly. development as definitely as the mountains, for either the streams themselves or their flood plains are too wide to be crossed by many bridges, so that the Rhine, Danube, and Rhône have rlys. on either bank and connexion from one line to the other must be most often made by ferry.

The rivers of the plains are used for barge and steamer traffic. Most have been canalised, e g. the Rhine, Seine, Elbe, Oder, Danube. Where the river is unregulated traffic is interfered with by the spring floods. The E. rivers, Volga, Dnieper, Don, are frozen for months; the Central European streams are made dangerous by drifting ice, ice harbours being necessary on the Rhine. From Paris to the Vistula the Great European Plain has many canals connecting the fluvial waterways ; Antwerp is an outport for Germany, as much merchanise unloaded at the seaport is distributed by the canals radiating thence.

These waterways link up the canalised rivers, and facilitate the distribution of goods from the seaports at the river mouths It was a German dream to improve the canals so that large vessels could traverse Europe from the North Sea to the Black Sea, either by the Rhine-Danube or the ElbeDanube routes ; this ideal was connected with the use of the Kiel ship canal to help Hamburg to dominate the Baltic Sea commercially.

SEaports. Owing to the increasing size of modern ships, the tendency is to concentrate the ocean traffic of each country upon one or two great ports. In Britain, London and Liverpool far outstrip any other seaport; Marseilles and Havre, Antwerp, Rotterdam, and Hamburg are pre-eminent in their respective countries The chief Baltic ports are Petrograd, Stockholm, Riga, Königsberg, Danzig, Stettin, Kiel, and Copenhagen. The chief Black Sea ports are Odessa, Varna, Constantsa, and Galatz, on the Danube; Constantinople, the Piraeus, (Athens), and Salonica are the great ports of the S E. In the Adriatic Sea, Venice, Trieste, and Fiume are the main ports, while Brindisi is a packet station. In the W. Mediterranean Naples, Genoa, and Barcelona are the chief ports. Cadiz, Lisbon, and Bordeaux lie on the Atlantic; Dunkirk, Amsterdam, and Bremen on the North Sea.

B. C. Wallis

Bibliography. Prehistoric Europe, J. Geikie, 1881 ; Europe, G. G. Chisholm, 2 vols., 1899 and 1902 (in Stanford's Compendium of Geography and Travel); The Mediterranean Race : A Study of the Origin of European Peoples, G. Sergi, 1901 ; Regions of the World, ed. H. J. Mackinder, 1902-5 ; Historical Geography of Europe, E. A. Freeman, 3rd ed. 1903; The Face of the Earth, E. Suess, Eng. trans. H. B. C. Sollars, 1904, etc. ; The Anthropological History of Europe, J. Beddoe, 1912: The Expansion of Europe, R. Muir, 1917; Present-Day Europe : Its Natural State of Mind, T. L. Stoddard, 1917 ; The Statesman's Year Book, publ. annually.

HISTORY. The continent of Europe with its present contours emerged after the last ice age, probably not less than 20,000 years ago. For untold ages before, the greater part of ithad been subjected to Arctic or tropical conditions of varying intensity. so that geologists divide the whole period into a succession of ice ages with non-Arctic intervals between them. Man had existed before the last ice age, but the new Europe was repopulated, not by the descendants of the "drift" men, but by men who, moving from warmer regions, made their way across it as the ice receded In the course of some thousands of years tribes coming either from the East or out of Africa had spread thinly over the habitable area settling in communities, acquiring to a limited degree the arts of agriculture, and developing the use of tools and utensils.

\section{Aryan Immigrations}

Somewhere about 3000 B.C. began the migration of the Aryan races from a centre somewhere in Asia or in Russia. The presumption is that they were races hardened by life in northern and com. paratively unproductive regions, and wherever they moved they went as conquerors, but rarely as exterminators. The evidence of their kinship is to be found in the evidently common origin of their languages and the common characteristics in bone and skull struc. ture, as witnessed by their burying grounds. Those who spread over Europe are commonly divided into four main groups, Celtic, GrecoItalian, Teutonic, and Slavonic

The first made straight across Europe to the W., dominating, though not exterminating, the earlier inhabitants of modern France Spain, and the British
Isles. The second pushed $\mathrm{S}$. towards the Mediterranean, and by 1000 B.c. were masters of the Balkan and, less completely, of the Italian peninsulas. The Teutons, moving later than Celts and S. Aryans, gradually occupied Scandinavia and modern Germany, and first came into contact with the Roman Empire when it was almost supreme over the whole area W. of the Rhine and S. of the Danube at the close of the 2nd century B.c. The movement of the Slavonic group came still later A group of Aryans, less advanced than the Greeks and Italians, had long been in occupation of Austro-Hungary and Rumania and the mountain regions $\mathrm{E}$. of the Adriatic, but whether they were nearer akin to the Greeks and Italians or to the Slavs is uncertain.

\section{Aegean and Greek Civilization}

Recorded European history begins somewhere after 2000 B.c. with pre-Aryan races who dominated the islands and coasts of the Aegean Sea, and developed an advanced civilization to which the modern excavations principally in Crete and at Mycenae bear witness. Between 1500-1000 B.C. the Hellenic Aryans mastered all the S. portion of the Balkan peninsula, the islands of the Aegean, and the W coasts - though only the coasts -of Asia Minor Greek political organization developed rapidly in the form known as the city state. The system was fostered by geographical conditions. Hellas, the area under Greek occupation, did not form a political unity, but was broken up into a large number of small communities, often hostile to each other,though sharing a sense of common race and tradition.

Maritime and commercial development followed naturally, as there was easy communication by sea with earlier civilizations and state systems of W. Asia and Egypt. Between 1000-500 B.c. a high political organization was attained by many city states, together with a remarkable intellectual and artistic activity. The Greeks were so far in advance of the rest of the world that it has been said that "nothing moves in the world which is not Greek in origin." The statement is not strictly true. Moving forces, notably Christianity, have come out of the East; Celts, Romans, and Teutons have all made contributions; but the truth remains that the most active forces of progress had developed so far with the Greeks before the other westerns came in contact with them, that their more rapid advance was the direct outcome of the assimilation of Greek ideas 
Later than the Greeks in the Balkan peninsula, and developing more slowly, the Latin or Italian branch of the same or of a kindred stock found its way through the passes in N. Italy, crossed the Lombard plain, and pushed S., breaking across the Apennines into the W. plains. There they fought with the carlier inhabitants, notably the Etruscans, supposed by some authorities to have been of the same race as the makers of the Cretan civilization. On the W. of the Apennines they, like the Greeks, developed politically on the city state system, the Latin states warring with each other, but uniting against the Etruscans on the N., and the new tribes of their own kinsfolk, Sabellians or Samnites, who followed them. Greeks and Italians alike seem to have passed through a stage when each state had an hereditary monarch to a stage when the monarchy was absorbed by an aristocracy, displaced in its turn by a military despotism or tyranny.

\section{The Rise of Rome}

The primacy among the Latin states, whose league stretched $\mathrm{S}$. from the Tiber, was won towards the end of the 6th century B.c. by the Romans, whose city, Rome, founded according to tradition in 753 B.c., was the barrier fortress holding the Tiber between Etruscans and Latins.

The next 200 years formed the most brilliant period in Greek history, in which first the Hellenes stemmed the westward pressure of the Asiatic powers, then carried their own political, literary, and artistic development to its highest point, and finally, led by Alexander the Great, shattered the great empire of Persia. The passion of each state for individual independence and their mutual jealousies prevented the Greeks from building up a common national structure. Neither Athens nor Sparta succeeded in establishing her own supremacy over the rest of the states; Macedon at last won the leadership about 340 B.c., but failed to create a united empire.

Meanwhile Rome, after a severe struggle, broke up the Etruscan power, which received its coup de grâce at the hands of Celtic invaders from the $N$., who renetrated as far as Rome (394 B.c.), but then rolled back beyond the Apennines to the plain of the Po. It would appear that long after the first Celtic migration, which had passed Italy by, a second great Celtic flood poured across Europe till it collided with its own Celtic predecessors. The result was that the $\mathrm{S}$. wing, being beaten back, forced its way into Italy and occupied the N. plain.

The Romans blocked the Celtic invasion of Italy, and, freed from the severe Etruscan pressure on the N., gradually came to dominate the Latin states and the kindred tribes, first known as Sabines and then as Samnites, who were pushed down on the E. and S., after the Latin occupation of the lands W. of the Apennines. Rome, compelled by her position to maintain a political organization adapted to military needs, won in Italy an undisputed ascendancy over her rivals.

Meanwhile Hellas had attained the high-water mark of her progress with Alexander the Great, whose death in 323 B.c. left his uncompleted empire to a century of disintegration. That same century, 300-200 B.C., saw the great struggle between Rome and the Semitic power of Carthage, which had established itself in N. Africa, to some degree in Sicily, and in Spain. Carthage was not decisivelycrushed until 202 B.C. Italy had supported Rome in the momentous conflict; the result of which was that not only was her ascendancy overwhelmingly confirmed in Italy, but her sway was also established in the Spanish peninsula, with its mixed population of Celts and preCeltic Iberians.

\section{Roman Power Expands}

During the next 170 years (20030 B.C.) the dominion of the Roman republic expanded. The conquests of Julius Caesar in Gaul (58-50 B.C.) completed the subjection of all Europe W. of the Rhine and S. of the Danube, including the whole Celtic or partly Celtic area, except Britain, of which the part now called England was absorbed 100 years later. But all along the Rhine and the Upper Danube, the Teutons were now pressing upon the Roman frontier. The system which had built up the might of the Roman republic was not adapted to the administration of so heterogeneous an empire. Concentration of control was a necessity. Caesar gathered into his own hands the powers which enabled his genius to shape an imperial system under a single control.

For 400 years and more, the civilized world meant the Roman empire, which covered much of Eurore and parts of Asia and Africa. On its borders there was incessant war ; within it reigned the Roman Peace, save when the death of an emperor afforded a commander in some distant province the chance of snatching at the imperial purple.

W. of the Adriatic and the Rhine, the peoples of the continent became thoroughly Latinised in language and political ideas, though across the Channel Latinism was little more than a superficial veneer which touched not at all either Celtic Ireland or the Celtic north of the island of Britain. In the Balkan peninsula, Hellenism held its own against Latinism except in the one trans-Danubian province of the empire, Dacia, the modern Rumania, planted with military colonies from Italy.

Towards the end of the 3rd century A.D. Teutonic hordes were surging against the Roman barrier, pressing now southward as well as westward upon the middle and lower Danube. At the close of the 3rd century the imperial system was reorganized by Diocletian, and a few years later by Constantine, who transferred the headquarters of the empire in 324 from Rome to Byzantium, which he renamed Constantinople. At the same time, after three centuries of repression and persecution, Christianity became the popular religion under the imperial sanction, and the ecclesiastical organization of the Church was officially recognized. One result of this was that Rome acquired the religious primacy of Christendom when her political primacy was lost.

\section{Barbarian Irruptions}

With the beginning of the 5th century, when the empire was parted into $E$. and $W$. under the two sons of Theodosius, the flood. gates of the imperial frontiers burst, and the Teutons swept over the barrier. The Visigoths burst into Italy under Alaric, and moved W. into S. Gaul and Spain, whither they had been preceded by Vandals and Sueves. Behind the Goths came a more terrible conqueror, Attila and his Huns, not Teutons, but Tartar hordes who for two generations had been moving across S. Russia from Central Asia. The Goths in the W. had chosen to profess allegiance to the empire ; they helped the imperial armies to turn back the Huns at the battle of Châlons, 451.

The dispersal of the Huns made way for fresh Teutonic irruptions. The Ostrogoths, after overrunning much of the Balkan peninsula, turned W. and established a new Gothic dominion in Italy under Theodoric, who called himself a lieutenant of the single emperor now reigning at Constantinople. Then at the beginning of the $6 \mathrm{th}$ century the Teutonic Franks swept over the Rhine and made themselves masters of the land which still bears their name, though the Franks themselves never completely Teutonised the country, 


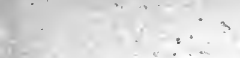




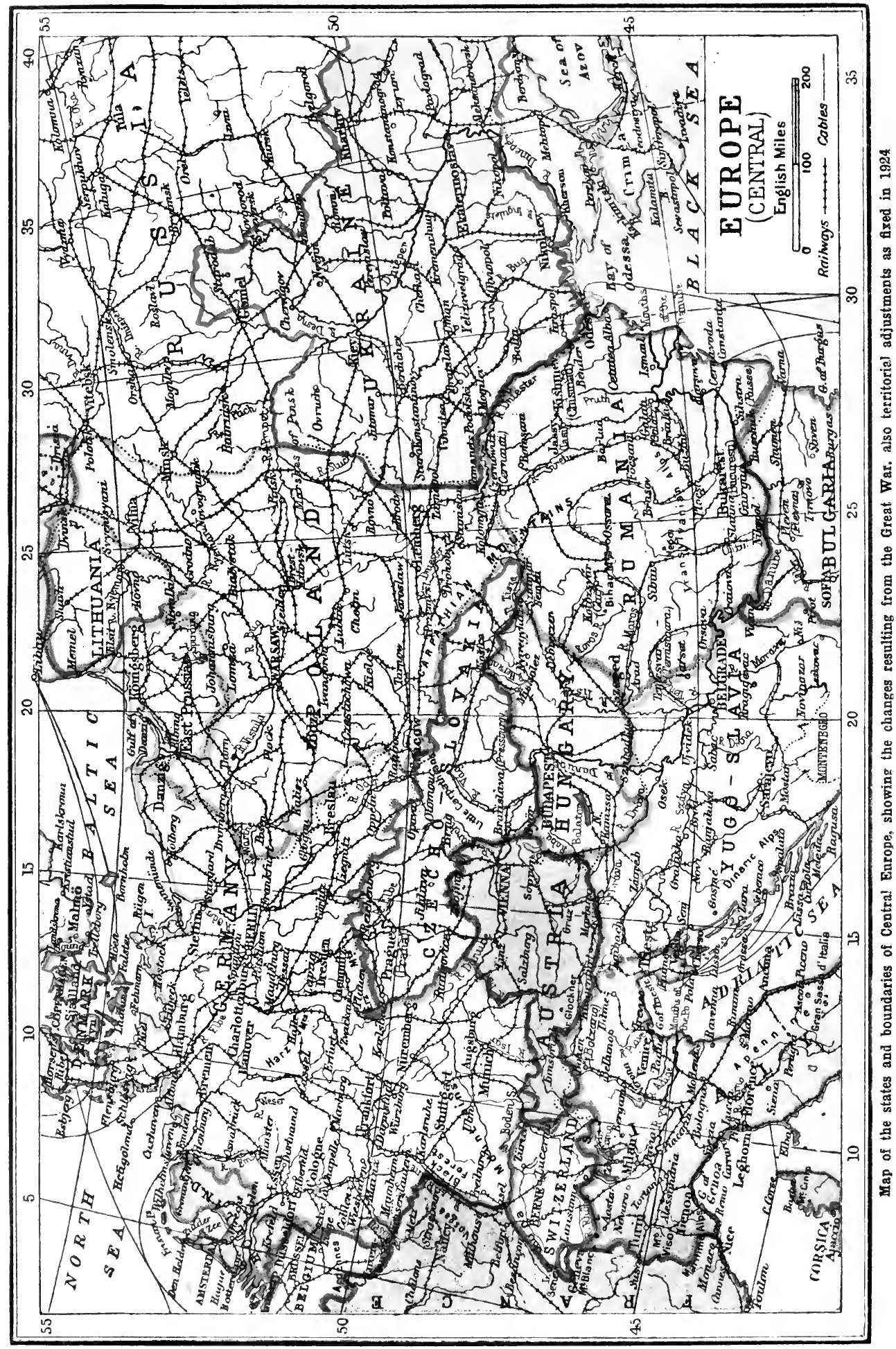


which remained persistently Latin. At the same time the native customs of the Franks in France, as of the Goths in Spain, fusing with the established Latin system, produced the social and political system known as feudalism. Other Teu. tonic tribes followed; Burgundians into the Rhône valley, and Langobards into the Lombard plain. The latter established their lordship over most of Italy, the Ostrogoths having been extirpated by the generals of Justinian, whose successors failed to retain the domination of the E. over the W. But nowhere did the Teutons effectually Teutonise populations already Latinised. Italy, France, and Spain remained essentially Latin, though Latinism hardly expanded E. of the Rhine or N. of the Danube.

With the rise of Mahomedanism in the 7th century, Europe was once more threatened with Orientalism. Early in the 8th century the Moors invaded Spain and drove the Christians into its $\mathrm{N}$. corners. But when they flooded over the Pyrenees, their armies were shat. tered by Charles Martel at the battle of Tours or Poitiers, 732, and the tide was rolled back for ever behind the Pyrenees, though Saracen sea-rovers established a footing in Sicily. In the E. the Mahomedan onslaught had been hurled back 14 years before by the emperor Leo the Isaurian under the walls of Constantinople. Except in the S. of Italy all sem. blance of control by the emperor at Constantinople vanished from W. Europe.

\section{The Empire of Charlemagne}

Charlemagne now revived the W. Empire. He crossed the Pyrenees and drove the Moors S. of the Ebro. He completed his father's work of crushing the Lombards in Italy. His armies smote the heathen Saxons in the N. and the Bavarians in the S., and compelled them to adopt Christianity ; still pushing E., they shattered the Mongolian kingdom of the Avars in Hungary. At the instance of the pope, Charles was crowned emperor in Rome on Christmas Day, 800 . When he died in 814 , the Elbe and the Adriatic were approximately the E. boundaries of the new Holy Roman Empire which he had created. The Danube still remained in effect the $N$. boundary of the Byzantine empire.

Under the grandsons of Charle. magne his êmpire parted into three domains, the W., which shaped it self into the kingdom of France, the E., which was German, and the intermediate, " middle," or Burgundian, which stretched from the North Sea to the Gulf of Lyons, and included most of Italy, the S. of which, however, still belonged to the E. Empire. The crown of the Holy Roman Empire generally went with the E. or German kingdom. Burgundy broke up, part going with France and part with Germany, but never with a definite bond, while Italy became a congeries of dukedoms and counties over which the emperor on the other side of the Alps could exercise little authority. When the house of Charlemagne died out in Germany, the crown of the German kingdom, of the Holy Roman Empire, passed by election to the dukes of Saxony. The first, Henry the Fowler, was never crowned emperor; but he and his son, Otto the Great, stemmed the onrush of the third Mongolian horde which occupied Hungary, the Magyars, who nevertheless retained permanent possession of that tract.

\section{The Middle Ages}

The close of the 10th century, then, is the era of transition from the chaos of the earlier Middle Ages to what is generally more distinctively meant by the medieval period. During the 9th and 10th centuries the sea-rovers from Scandinavia had planted their colonies of Danes or Northmen in theBritish Isles and in the N. of France, and had shaped their own kingdoms in Norway, Denmark, and Sweden. In the 5th and 6th centuries the Teutonic English had conquered more than half the island of Britain, and in the 10th century England had become a fairly consolidated state.

France was on the way to consolidation under the house of Capet, which had displaced that of Charlemagne, but as yet the king of France was little more than a premier baron amongst many, some of whom ruled wider domains than the king himself. Spain was still mostly under the Saracen sway, though the Christian princes were soon to emerge from their northern fastnesses to win it back, establishing the kingdoms of Castile and Leon, Portugal, Aragon, and Navarre.

In the Spanish kingdoms, as in France, the king was hardly more than a premier baron. Central Europe regarded the German king as its head, though scarcely as its ruler, while to W. Christendom, in his character of emperor, he represented the idea of Christen. dom as a unity. The popes, as spiritual heads of Christendom, now began gradually to claim an authority higher than that of any lay potentate. Outside the empire on the E. the Slavs were establishing the Polish and Bohemian king. doms, and had already given half the Balkan peninsula and the whole Danube basin a Slavonic character. though they owned the supremacy of the emperor at Byzantium. The latter, with his hardly held dominion in Asia, barred the door into E. Europe against the Mahomedans.

The new age was the age of feudalism, which before the end of the 11th century had established itself everywhere. Theoretically, the king owned every inch of soil in his kingdom. He had granted great tracts or small to his servants on condition of military service. They in turn had granted portions upon like conditions, while every one had settled husbandmen upon the soil, allowing them patches on con. dition of agricultural and other services to the lord.

But outside England, the tenant generally owed his services to his immediate lord and was bound to fight for him against anyone else, even the king. Hence if one of the king's men or barons accumulated enough territory, he had at his back an army of tenants with which he could levy war against the king. The royal authority depended upon the loyalty to the king of a proportion of the baronage. Thus the French dynasty and each German dynasty tried to expand the crown estates at the expense of the great barons. In France the counts of Anjou acquired by marriage the dukedoms of Normandy and Aquitaine as well as the independent kingdom of England. Essentially the Hundred Years' War between England and France in the 14th and 15 th centuries was a struggle between the crown and the duke of Aquitaine, who happened also to be king of England. The final victory of the French crown, and its absorption of the duke's dominions, cleared the way for the final establishment of an absolute monarchy in France.

\section{Pope and Emperor}

In Germany, on the other hand, the monarchy was elective; each time that the succession changed, the new dynasty had to start afresh the absorption of feudatory territory, and consequently the German kings failed to establish absolute monarchy. Germany remained an aggregation of estates great and small, over which the emperor exercised little control.

The papacy again established its own supreme authority over the whole ecclesiastical organization of W. Christendom, and sought to assert that authority over all lay potentates. Within the empire, in Germany and in Italy, the struggle between the pope as the spiritual head of Christendom, and the 


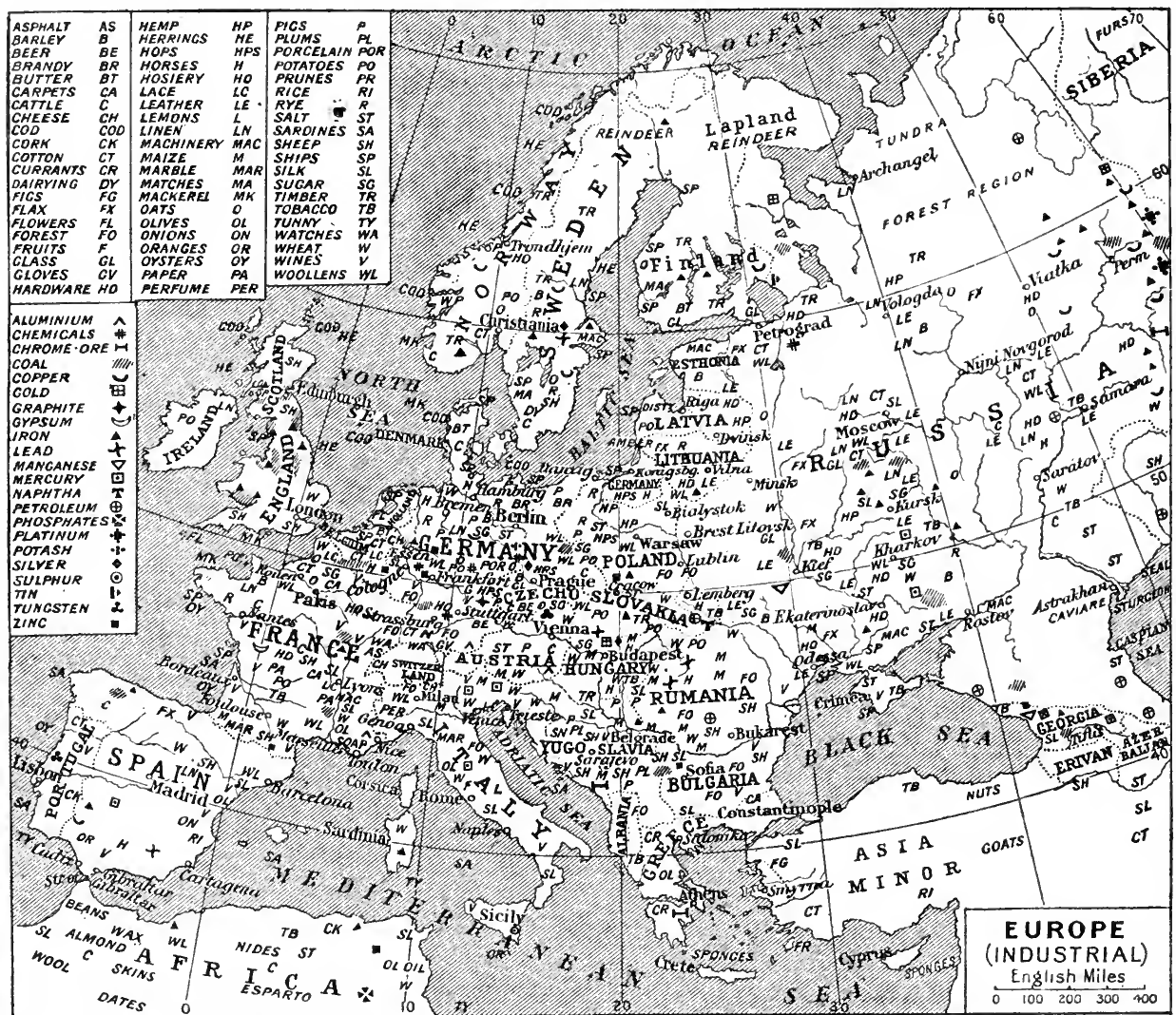

Europe. Map indicating the principal industries and occupations in the various countries of the Continent. The areas in which minerals are obtained and worked are also shown

emperor as its temporal head, helped the baronage to maintain their independence, since they could support emperor or pope as best suited themselves.

Europe, then, in the second as in the first half of the Middle Ages, shows nothing like the system of organized states to which we are accustomed. Through the Scots' War of Independence and the Hundred Years' War between England and France, the defined kingdoms of England, Scotland, and France were consolidating themselves during the four centuries which followed the Norman conquest of England in 1066. Spain shaped into a group of four separate kingdoms, the Moorish kingdom of Granada in the S., and the kingdoms of Portugal, Castile, and Aragon, to the last of which Sicily was attached in 1282. Central Europe-Germany-was only a loose confederation of states in a state of perpetual flux.

Italy became practically a collection of city states, in which there was developed an intellectual life far in advance of that of the rest of to revolutionise warfare. The voythe world, especially during the ages of Christopher Columbus and 14 th and 15th centuries. On the N. Vasco da Gama opened the ocean of the empire lay the Scandinavian pathway to a new world in the W. kingdoms; to the E. of it Poland, and to the E., hitherto cut off from Bohemia, which had a connexion Europe by the Moslem wall which with the empire, and Hungary. S. the crusaders had failed to break of Hungary chaos for the most through. The intellectual revival part reigned in the Balkan penin- in Italy received a new impulse sula, though Byzantium held back from the revived study of ancient the Asiatic invaders till its fall literatures following upon the fall in 1453, when a Turkish dominion of Constantinople and the disperwas established in the European sion of Greek scholars in the W., continent. E. of Poland, the de- and men were beginning to chalvelopment of a Russian empire lenge the doctrines of the Church was prevented by the great Tartar itself.

incursion in the 14th century; but by the end of the 15th the Muscovite kingdom was shaping itself.

The latter half of the 15th century marks the transition from medieval to modern Europe. The union of the crowns of Castile and Aragon by the marriage of Ferdinand and Isabella, 1469, unificd the Spanish monarchy. The imperial crown had passed to the Hapsburg, FrederickIII of Austria, in whose dynasty it became hereditary. The use of gunpowder was
With the 16th century the history of Europe becomes international, as it had never been before. The struggle of individual states for a general European ascendancy now begins, and against this effort the common interest in the preservation of a balance of power makes itself felt. Across this for 150 years cuts the religious struggle between Protestantism and Romanism, and this again is crossed by the struggle for dominion overseas. 
The accident of marriages conveyed to one man, Charles $V$, the entire Spanish inheritance, including Sicily, S. Italy or Naples, the Netherlands, and the whole Haps. burg territorial inheritance in Germany, while he also succeeded his grandfather as emperor in 1519 . A year later the floodgates of the Reformation were opened by Luther's defiance of the papacy. The German inheritance of the Hapsburgs was transferred to Charles's brother Ferdinand, who acquired for his own house the crowns of Hungary and Bohemia, and the Hapsburg monarchies became the barrier between Europe and the Turks. During Charles's reign Protestantism was established in Scandinavia, over the N. half of Germany, and in the $\mathrm{N}$. half of the Netherlands; while it was planted as yet insecurely in England, Scotland, and France.

\section{Religion and Politics}

When Charles died in 1558 his son Philip II was ruling over the Spanish dominions and the Netherlands, Ferdinand was emperor, and a truce had been confirmed between the Protestant and Catholic states of the empire. By the end of the century Philip had virtually lost the N. Netherlands, which became the United Provinces of the Dutch Republic, while the Catholic S. still remained the Spanish Netherlands. England and Scotland had both become definitely Protestant, soon to be united under one crown; while France remained Catholic, with freedom of worship secured to the Protestants, and her foreign policy directed by purely political considerations irrespective of religion. Maritime ascendancy, once enjoyed by Italian city states, had first passed from them to Portugal and Spain, but was now decisively transferred to England and the Dutch states.

The struggle of the religions was fought out in the Thirty Years' War (1618-48), the emperor himself championing the Catholics, while Gustavus Adolphus of Sweden intervened on behalf of Protestantism. Its outcome left the division between Catholic and Protestant states in Germany very much where it had been at the beginning. It also broke the last attempt to establish an effective central control of the empire in the hands of the emperor. And meanwhile Spain had become practically a secondary power while France, by Richelieu's policy, had developed a strong central government.

In the next phase, Louis XIV of France, a monarch whose abso- lutism in his own country was almost unqualified, sought through a long series of wars, 1667-1713, to enlarge the borders of France and to make her the dictator of Europe. For 40 years the main resistance came from Spain and Austria, and from the little Dutch state under William of Orange, whose accession to the thrones of England and Scotland brought Great Britain into the European struggle, of which the last phase at this stage was the War of the Spanish Succession (1702-13) That war gave Spain herself to a Bourbon, Philip, a grandson of Louis, who was himself succeeded on the throne of France by his great-grandson Louis XV. It also transferred the Spanish Netherlands to Austria, together with the Two Sicilies.

Meanwhile within Germany the electorate of Brandenburg had been erected into the kingdom of Prussia (1701); and outside, England and Scotland had been incorporated in the kingdom of Great Britain (1707), while in the E. Russia had at last been organized into a consolidated dominion by Peter the Great, and Sweden, under Charles XII, had made her last effort to retain among the European powers the position won for her by Gustavus Adolphus. Britain had now emerged as the supreme maritime power, and es tablished naval bases at Gibraltar and Minorca. The reign of Louis $\mathrm{XV}$ in France (1713-74) covers an era of protracted European strug gles. The last aggressive effort of Turkey was crushed in 1718 Russia established herself on the Baltic and the Black Sea, and ex tended her boundaries eastwards.

\section{Prussia and Silesia}

The War of the Polish Succes sion (1733-38) set up a Bourbon dynasty in the Sicilies. The War of the Austrian Succession (1740 48) saved the Austrian dominion from disintegration, except for the annexation of Silesia by Frederick II of Prussia-a robbery which led the way to a regrouping of the powers in the Seven Years' War (1756-63). Great Britain, the former ally of Austria, now supported Prussia, which had to defend itself against the French on the W., the Austrians on the S., and the Russians on the E. Great Britain's part in the war was mainly on the seas and beyond them, where she fought the French in America and in India, and in effect turned them out of both. In Europe, the war confirmed Prussia as a first-class power, still in possession of Silesia ; but no fighting was needed when, in 1772 , the tsarina
Catherine arranged with Frederick of Prussia and with Austria the first partition of Poland, a partition carried farther in 1793 and 1795 , when the whole of Poland was absorbed by one or other of the three.

The development of the last 300 years had established despotic governments in every state in the European continent, large or small, with the exception of Switzerland and Holland. The despots were generally well disposed towards their subjects. Many tried to im prove the conditions of their people, and some succeeded. But, broadly speaking, most of the populations lived actually or approximately in serfdom. Political liberty was nonexistent, and between the classes there was an almost impenetrable social barrier, while the burdens of taxation and service pressed most heavily upon those least capable of supporting them.

\section{The French Revolntion}

The summoning of a popular assembly in France-the statesgeneral of 1789 -in the hope of discovering a panacea for the imminent financial ruin of the country, proved to be the first step in a wide revolution. Successive assemblies passed from advocating the abolition of privileges to demanding the abolition of the privileged. The extremists captured the control of the government, first emasculated and then wiped out the monarchy, and went on to proclaim themselves the liberators of Europe from the tyranny of monarchs and aristocrats.

Great Britain, whose constitutionalism had been the model of the reformers before they were swept away by the revolutionary tide, was swung into the vortex when the new republic tore up treaties, and set about annexing the Austrian Netherlands in 1793. Long before the terrors of the revolution within France had exhausted themselves, the armies of the republic, reckless of established methods, were facing and routing the orthodox armies of the monarchies. Prussia and Spain soon retired from the struggle; Bonaparte's Italian campaigns broke Austria. Bonaparte betook himself to Egypt ; Britain, fighting on alone, won the mastery of the Mediterranean; Austria returned to the attack, supported by Russia. The return of Bonaparte and his establishment as First Consul of France was followed by the shattering of the new coalition, and even by the accession of Great Britain to the peace of Amiens, 1802 .

In 1803 the Franco-British duel was renewed; two years later a new coalition was formed. Nelsøn 
sealed the naval supremacy of Great Britain at 'Trafalgar, 1805, but Napoleon, now emperor of the French, shattered the new coalition at Austerlitz. Prussia, aroused at last, took up the challenge and was crushed at Jena, 1806, and Napoleon made his peace with Russia at Tilsit in 1807, and set about the reconstruction of Europe according to his own fancy. His attempt to appropriate the Spanish peninsula brought Great Britain into the war for the first time as a military power, 1808. For five years Napoleon's generals strove in vain to drive the British into the sea. But Napoleon quarrelled with the tsar, and his Moscow expedition in 1812 ended in irretrievable disaster. The uprising of the peoples rather than of the governments overwhelmed him, he was compelled to abdicate in 1814, and though he reappeared to make a last bid for victory, he was finally crushed at Waterloo, 1815.

The congress of Vienna restored the map of Europe so that the state boundaries were much as they had been in 1792, except that the Netherlands were formed into a new kingdom. The old dynasties were replaced and the old despotisms renewed, the former states of the empire forming the German Confederation. But the French Revolution had kindled new ideas of liberty, partly democratic, partly nationalist, and despite the efforts of Metternich, those movements could not be crushed. Greece broke free from her subjection to Turkey; France turned out the Bourbons and established the constitutional Orleans monarchy in 1830. The S. Netherlands separated from Holland in 1839 and became the Belgian kingdom. Liberals and reactionaries did battle in Spain and Portugal.

Austria and the German Confederation

Then in 1848 came the Year of Revolutions. In almost every country, nationalist, constitutionalist, or democratic movements came to a head. Generally, though not always, the Reaction was for the time victorious. France made herself into a republic, but in five years the nephew of Napoleon had turned the republic into the Second Empire. Limited constitutions were conceded in sundry German states. Austria kept her grip on the diverse portions of her empire, and though the title of the Holy Roman Empire had been dropped since 1806, she still retained her place as leader, or as joint leader with Prussia, of the German confederation. 'The mutual jealousies and distrust between Great Britain and Russia, the causes of which were more Asiatic than European, were a constant disturbing factor in European affairs.

The three great movements afoot were towards the liberation of the Balkan peninsula from Turkish rule, towards the unification of Italy, and towards the unification of Germany under the headship of Prussia. The rising of N. Italy under the leadership of Victor Emmanuel, king of Sardinia, sup. ported by Napoleon III, in 1859 , liberated most of $\mathrm{N}$. Italy from Austria and from the temporal control of the papacy and created the kingdom of $\mathrm{N}$. Italy. The revolt of Sicily and Naples against the Bourbon dynasty in 1860 was followed by the adhesion of S. Italy to the N. kingdom, and in 1861 the united kingdom of Italy was established, though Austria still held the N.E. corner and Rome still belonged to the pope. In 1871, however, it was united to the new kingdom of which it was made the capital.

\section{Policy of Bismarck}

Bismarck organized the Prussian military power, contrived the annexation of Slesvig and Holstein from Denmark, and procured the Seven Weeks' War with Austria in 1866, which in effect ejected Austria from the German confederation and gave Prussia decisive ascendancy therein. Incidentally, Italy was rewarded for her assistance to Bismarck by the acquisition of Venetia. Bismarck's policy achieved its triumph with the Franco-Prussian War of 1870 71. The recovery of the Rhine provinces from France was accompanied by the recognition of the king of Prussia as German em. peror and by the consolidation of the new German Empire under Prussian direction, with a machinery which, for the first time in Germany's history, brought her under a single control and made her the first military power in Europe. Another outcome of the war was the establishment of the third republic in France.

Turkish misrule was the excuse or justification of the wars with 'Turkey upon which Russia entered in 1853 and 1877. In both, British intervention was responsible for the preservation of Turkey, but those wars brought about the virtual independence, first of $\mathrm{Ru}$ maria and then of the Slav states of Bulgaria, Serbia, and Montenegro, while Bosnia and Herzegovina were placed under Austrian administration, paving the way for annexation after an interval of 30 years. 'The outstanding features, however, of the European situation in the latter years of the 19th century were the alliance of the three emperors, and the substitution for it of the alliance of the three powers, Germany, AustriaHungary, and Italy, which was answered by the alliance between France and Russia. The settlement of outstanding differences between Great Britain and France in 1905 prepared the way for the Triple Entente between Great Britain, France, and Russia, which became an accomplished fact in 1907, while its solidarity was proved to the great dissatisfaction of Germany in 1911 by the British support of the French in connexion with the Agadir incident. The Balkan Wars of 1912-13 liberated the Balkan States from the last relics of Turkish sovereignty, but failed to establish a concord among them, whereof the fruits were later to become apparent.

Two more events prior to 1914 have here to be noted. In the 15th century Denmark, Norway, and Sweden had been united under one crown; in the 16th Sweden had separated herself, but Norway had remained attached to Denmark. At the European reconstruction in 1815 Norway had been taken from Denmark and attached to Sweden. The union, however, had never been harmonious or satisfactory to Norway, and in 1905 she procured her establishment as a separate kingdom. In 1908 a revolution in Portugal expelled the reigning dynasty, and changed Portugal into a republic.

\section{The Great War, 1914-1918}

In 1914 Europe was again flung into the melting-pot, from which it had not fully emerged at the close of 1920 . The Kaiser, with the carefully educated public opinion of Germany at his back, planned to bring on at Germany's own time a world conflict which should result first in the subjection of France and the paralysis of Russia, and ultimately in the collapse of the British Empire. Reckoning that she would have only Russia and France to deal with immediately, Germany prepared for an Austro-Russian quarrel in the Balkans which should either at once establish AustroGerman supremacy in the Near East or precipitate the great conflict in which she anticipated prompt and overwhelming triumph.

But while Russia, necessarily joined by France, met the challenge, Germany's violation of Belgium brought Great Britain de cisively into the struggle. For four years Europe was the stage of the most terrific and devastating war in the annals of mankind. In the west the German rush just failed to reach Paris, and a long battle. 
line of entrenchments was estab. lished from the Swiss border to the North Sea. In the east the Russian invasion of German territory was swept back. Turkey threw in her lot with the Central Powers; then Italy, which at first stood neutral, broke from the Triple Alliance and joined the Entente Powers. Bulgaria joined the attack on Serbia; in 1916 Rumania came into the fray with disastrous results for herself. The tide of the Russian war surged backwards and forwards over Poland and Galicia.

In 1917 came the Russian revolu. tion, first wearing a constitutional aspect, then developing into the Bolshevism which freed the Central Powers from the Russian grip which they had hitherto failed to break. The German submarine campaign drew the U.S.A. into the struggle. Before the U.S. armies could come in, the Germans in the spring of 1918 launched the concentrated attack in the west. It failed by a hair's-breadth to attain its object, and then the decisive counterstroke was delivered which forced Germany to sue for the armistice, of which the terms were accepted on Nov. 11.

The German Empire went down. Therein every state, from Prussia downwards, ejected its hereditary dynasty. Austria-Hungary was dissolved into its component parts -Czecho-Slovakia, Yugo-Slavia, Hungary, Austria; Italy recovered what remained of Italia Irredenta, and France her lost provinces. Poland was reconstituted. In Russia the tsardom had been horribly swept away, but the whole empire was torn in fragments under the Bolshevist régime.

Rumania was greatly enlarged as the result of the addition of Bessarabia, Bukowina, and Transylvania; Turkey was practically confined to Constantinople, Greece receiving from her most of Thrace. In Nov., 1920, the Adriatic question was settled, Fiume being declared independent, and a new frontier being drawn between Italy and Yugo-Slavia. See N.V.

A. D. Innes

Bibliography. Periods of Euro. pean History, ed. A. Hassall, 8 vols., 1893 , etc.; History of Modern Europe, R. Lodge, 4th ed. 1897 General Sketch of European History E. A. Freeman, 1898; History of Modern Europe, T. H. Dyer, ed. A. Hassall, 1901 ; Medieval Europe, H. W. C. Davis, 1911 ; General Sketch of Political History, A. D. Innes, 1911; General History of the World, O. Browning, 1913; Euro. pean History chronologically ar. ranged, 476-1920, A. Hassall, new ed. 1920. For ancient history see bibliographies under Rome and Greece.
Europium. Rare element discovered by E. A.Demarçay in 1896. Found associated with samarium, it is separated by fractional crystallisation. It was first isolated in 1901. Its symbol is $\mathrm{Eu}$.

Eurotas. River of ancient Laconia, Greece, now known as Iri. It discharges into the Gulf of Laconia after a course of $60 \mathrm{~m}$. Sparta stood on its banks.

Euryale ferox. Aquatic perennial herb of the natural order Nymphaeaceae. It is a native of the E. Indies. Its circular floating leaves are $1 \mathrm{ft}$. to $4 \mathrm{ft}$. in diameter, the rich purple underside, like the sepals of the purple flower, being protected by numerous spines. The fruit is a round berry containing numerous farinaceous seeds, which are eaten after being baked in sand. The Chinese cultivate the plant for these seeds.

In Greek mythology Euryale is the name of one of the Gorgons (q.v.). Pron. U-rī-alee.

Eurydice. In Greek mythology, wife of the poet Orpheus. When she died Orpheus went down into Hades, and by the power of his

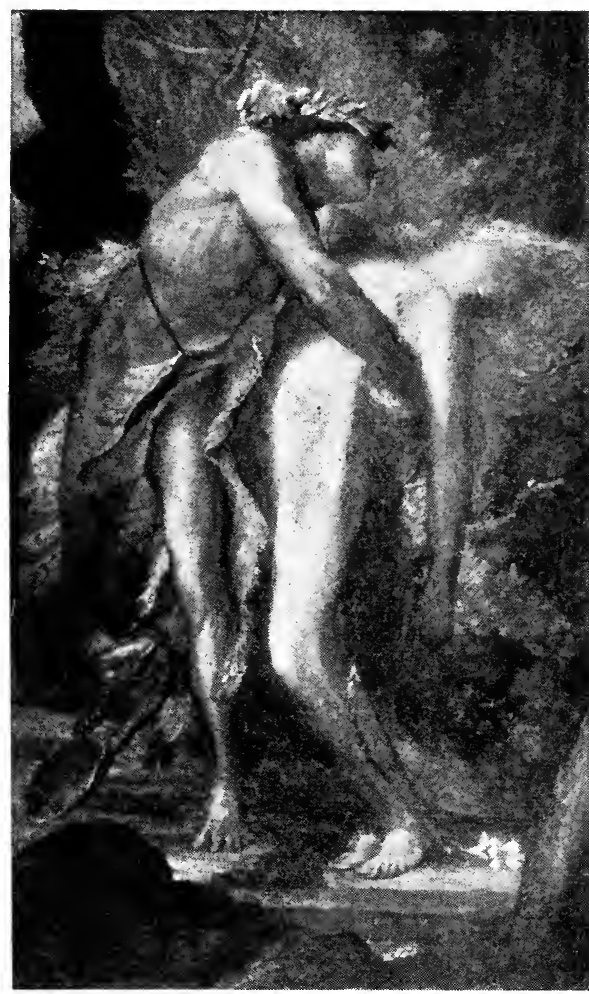

Eurydice. By disobeying the command of Pluto Orpheus loses the wife whom he had nearly rescued from Hades

From the painting. Orphewe and Eurydice, by G. F. Watte, $R, A$. lyre induced Pluto, ruler of the underworld, to restore his wife to him, on condition that he did not look behind until he reached the earth again. In his eagerness to see

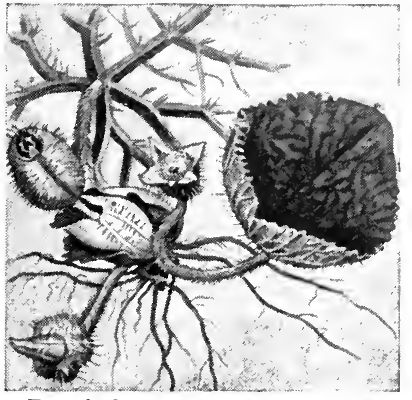

Euryale ferox. Leaves and flowers if his wife were following, he forgot the condition, and Eurydice was lost to him for ever. See Orpheus. Pron. U-riddy-see.

Eurymedon. Ancient name of the Köpru Su, a river of Pamphylia, Asia Minor. It flowed into the Mediterranean, W. of the Taurus Mts., and at its mouth the Athenians under Cimon (q.v.) defeated the Persians 466 B.C.

Eurypterida(Gr. eurys, broad: pteron, wing). Extinct scorpion-like animals of the class Arachnida (q.v.). The body is rather flat, sometimes as much as $6 \mathrm{ft}$. in length, covered by a thin horny covering (carapace) and ornamented by fine, scale-like markings. The head is semicircular, consisting of six segments. fused together, and six pairs of appendages are attached to the head-shield, the last pair being adapted as swimming paddles The abdominal portion is long, of 12 segments, the first six bearing plate-like appendages with leaf-like gills. The last segment is a tail - plate, sometimes produced into a long spine. The upper surface of the head-shield has two eye-spots 
near the centre, and a large pair of facetted eyes near the margin. Eury. pterids originally inhabited the sea, but became adapted to brackish and possibly to fresh-water conditions. Fossils are found in Silurian, Devonian, and carboniferous strata.

Eusebius (c. 264-340). Church historian., Often called Eusebius Pamphili, he was probably a native of Palestine and spent his youth at Caesarea. After the martyrdom of his teacher Pamphilus, he took refuge in Egypt for some years, and about 313 was appointed bishop of Caesarea by his patron, the emperor Constantine the Great. At the council of Nicaea, 325 , though himself orthodox, he showed leanings towards the Arian party. His historical writings. especially Praeparatio Evangelica (selections translated by $\mathrm{H}$. Street, 1842), Demonstratio Evangelica, and Historia Ecclesiastica, entitle him to be called the father of ecclesiastical history. The Historia has been translated into English by A. C. McGiffert, 1890.

Euskirchen. Town of Germany, in the Prussian Rhine prov. It stands on the Erft and is a rly. junction, $20 \mathrm{~m}$. S.W. from Cologne. Textiles are manufactured and beer is brewed, other industries being tanning and the making of chemicals. Pop. 11,350.

Eusol. Solution containing free hypochlorous acid. Introduced 1915 as an antiseptic in treating wounds, it is prepared by shaking 25 grams of a mixture of bleaching powder and boric acid (called eupad) with one litre of water and filtering the solution after some hours.

Eustachian Tube. Tube leading from the upper part of the pharynx to the tympanic cavity of the ear. Its function is to maintain equal atmospheric pressure on both sides of the ear-drum. It is ordinarily closed, but is opened by each act of swallowing. Blocking of the tube, as in catarrhal conditions or from the growth of adenoids, leads to bulging of the membrane and partial deafness. If the passage does not open when the catarrh disappears, the obstruction can usually be removed by blowing air into the tube or passing a fine catheter. When due to adenoids, the growth is usually removed. The tube is named after Bartolommeo Eustachio (d. 1574), an Italian anatomist. Pron. U-stā-kyan. See Ear.

Euston Road. London thoroughfare. With Marylebone Road on the W. and Pentonville Road on the E., it forms part of the New Road laid out in 1754-56 to connect Paddington and Islington, and extends from Great Portland Street rly. station to King's Cross.
In Euston Square is the entrance to the terminus of the L. \& N.W.R. An obelisk $45 \mathrm{ft}$. in height is to be erected between the terminus and Euston Road by the L. \& N.W.R. as a memorial to their employees who fell in the Great War.

St. Pancras is the terminus of the M.R., and King's Cross that of the G.N.R. The Metropolitan Rly. has a station (Euston Square) at the Gower Street corner, and the Hampstead and City and $S$. London Rlys. have stations at the back of Euston Square and at King's Cross. In Euston Road are the (new) church of St. Pancras, built 1819-22, a modified copy of the Erechtheum at Athens; and Unity House, headquarters of the National Union of Railwaymen.

Eutaw Springs. River of S. Carolina, U.S.A., a tributary of the Santee river. Near here on Sept. 8, 1781, was fought an indecisive battle in the War of Independence. The American force under General Greene gained an early success over the British under General Stuart, but the latter successfully withstood a second onslaught.

Eutectic (Gr eu, well; têkein, to melt). Term introduced to denote a condition of equilibrium which was found to exist in solution of common salt, and since extended to include similar conditions.

Between 1875-78 Guthrie investigated the freezing point of salt solution. He found that, no matter what the initial strength of the solution, there was a certain concentration ( 23.5 p.c. of salt) and temperature $\left(-22^{\circ}\right.$ C. $)$ when the solution completely solidified. This he called the eutectic, which has always for the same solute and solvent a constant composition, but is not a chemical composition. This helped to explain the state of metals in alloys. Those which are looked upon as "solid solutions" exhibit eutectic properties. Pig iron, for example, is eutectic when it has a proportion of $4: 3$ p.c. of carbon. Plumbers' solder, consist. ing of two parts lead and one part tin, is a eutectic alloy, solidify. ing at a lower temperature than any other alloy of these metals, which constitutes its utility in "wiping" a joint.

Euterpē (Gr., the well-pleasing). In Greek mythology, one of the nine muses. Her special province was tyric poetry. See Muses.

Euthanasia (Gr. eu, well ; thanatos, death). Easy or comfortable death; in medical language, the employment of means calculated to render the death of those suffering from painful and incurable diseases as painless as possible. Induced euthanasia was advocated by Plato, and was common under the Roman em. perors, many of Pliny's friends being recorded as submitting to it. In the island of Ceos (Zea), in the Cyclades, euthanasia was enjoined on citizens over 60 . In old Marseilles it is said that the authorities were memorialised in cases of serious illness, or even of dire misfortune, as to the advisability of euthanasia. In More's ideal state, Utopia, euthanasia was practised.

Eutheria (Gr. eu, well; thèrion, beast) OR Placentals. One of the three sub-classes of Mammalia, the other two being the prototheria or monotremes and the metatheria or marsupials. Of these the prototheria are oviparous; the metatheria bring forth their young prematurely and nurture them in a pouch; and the eutheria produce more or less perfectly developed young, which during gestation are vitally united to their mother by a placenta. See Mamma!.

Eutropius. Roman historian of the 4 th century A.D. He was the author of Breviarium ab urbe con. dita, a short history of Rome from its foundation to A.D. 364. The work has little historical value, but the simplicity of its style has made it a favourite text-book for beginners in Latin.

Eutyches (5th century A.D.). Founder of the Eutychian heresy. Superior of a monastery at Constantinople, he taught that the human nature of Christ was absorbed in the divine, and therefore non-existent, even His body not being truly human. For this he was condemned by a synod at Constantinople in 448 , restored by the "Robber" council of Ephesus in 449 , but finally condemned by the council of Chalcedon in 451 , and afterwards banished. Pron. U-ty.keez.

Eutychus. Name of a young man who, baving fallen into a deep sleep while Paul was preaching at Troas, fell from the third loft, and was healed or restored to life by the Apostle (Acts xx, 9-10).

Euxine. Ancient name of the Black Sea, the Pontus Euxinus, or hospitable sea. It was originally called Axenos, inhospitable, from the prevalentstorms, and the hatred of strangers shown by the dwellers on the coasts. The name was probably changed when increasing commerce and the establishment of Greek colonies made it better known. See Black Sea.

Evagoras (d. 374 B.c.)." King of Salamis in Cyprus. An able ruler, he greatly developed the naval power of his kingdom. He was on friendly terms with the 
Athenians, especially with the Athenian admiral Conon (q.v.), and it was due to him that Conon was helped by the Persian fleet at Cnidus (q.v.) in 394. Subsequently, in the war between Evagoras and the Persians, the Athenian fleet came to his aid. The war with Persia dragged on for several years, and was eventually ended by a settle. ment which guaranteed Evagoras his kingdom.

Evagrius (c. 536-600). Byzantine eccles. historian. Born at Epiphania, in Coele-Syria, he flourished during the reigns of the emperors Tiberius and Maurice. At first he studied law at Antioch, whence his surname Scholasticus (advocate). One of the continuators of Eusebius, his history covers the period from the council of Ephesus, 431, down to 593. It throws light chiefly on the religious controversies of the period, but also on secular affairs.

Evander. Legendary Italian hero. Some time before the Trojan war he was said to have conducted a band of colonists from Pallantium in Arcadia to Italy, where he founded a settlement on the Palatine hill. Writing and other arts and the institution of the Lupercalia in honour of the Arcadian god, Pan, were ascribed to him. Evander is really the Italian Faunus (the favourable one), to whom the Greek Pan also corresponds, and the story of the Arcadian colony, like much in Roman mythology and legend, is due to Greek influence.

Evangelical (Gr. evangelikos, of the Gospel). Term applied to the two religious revivals within and without the Anglican Church in the 18th century. The movement led by John Wesley (q.v.) became exterior to the Church. The other movement is attributed to the teaching of William Law. author of The Serious Call, and with it are prominently associated the names of Henry Venn, James Hervey, Joseph and Isaac Milner, John Newton, William Cowper, Richard Cecil, Thomas Scott, Henry Martyn the missionary, Charles Simeon, John Thornton, and his fellow members of "the Clapham sect," William Wilberforce, and Selina, Countess of Hunttingdon. The movement has left its mark on hymnology, notably in the compositions of Toplady and the hymnal of E. H. Bickersteth. With its views are associated such societies as the C.M.S., Church Association, Church Parochial Mission, Y.M.C.A., Y.W.C.A., and many organizations for bringing the Gospel message to the poor.

The Evangelicals emphasised original sin, the efficacy of the Atonement, the need of personal conversion, justification by faith and veneration for the letter of the Scriptures. What is known today as the Low Church party in the Church of England (to be dis. tinguished from the Low Church party of the period preceding the Evangelical revivals) is usually called evangelical; it holds many things in common with English Nonconformity, and its leaders meet annually at the Keswick Con. vention and the Islington Conference. 'The term evangelical is applied to the United Church in Germany and to the Jansenists of France. It forms part of the title of the world's Evangelical Alliance; the Evangelical Association of North America, founded early in the 19 th century by aLutheran named Jacob Albrecht; and the Evangelical Union, constituted in Scotland in 1843 by the Rev. James Morison, of Kilmarnock See The Evangelical Revival in the 18th Century, J. H. Overton, 2nd ed. 1900.

Evangelical Alliance, WorLD's. Protestant organization founded in Liverpool in 1845, and incorporated in 1912. Its objects include the maintenance of evangelical principles, the promotion of Christian unity, the holding annually of a universal week of prayer, the relief of persecuted Christians in all lands, and the defence of religious liberty. lts work is carried on by means of international conferences in different countries, by bringing influence to bear on governments, and by the formation of public opinion. Its organ is Evangelical Christendom, published bi-monthly in London, and its central office is 19, Russell Square, London, W.C.

Evangelical Union or MoRIsonIans. Scottish Presbyterian body. It was founded by the Rev. James Morison, 1816-93, of Kilmarnock, and other seceders from the United Secession Church in 1843. Soon afterwards they were joined by ministers expelled from the Congregationalist Union. They rejected the doctrine of predestination, and maintained universal redemption and the freedom of the will. Thechurcheswereindependent and free to adopt Presbyterian or Congregationalist forms of govern. ment. All ministers had to be total abstainers. The bulk of the congregations joined the Congregational Union (of Scotland) in 1896.

Evangeline. Narrative idyllic poem by $\mathrm{H}$. W. Longfellow. First published in 1847, the story is a romantic account of the deport. ations in 1755 of the French Acadians from Acadie (Nova Scotia), owing to their lack of sympathy

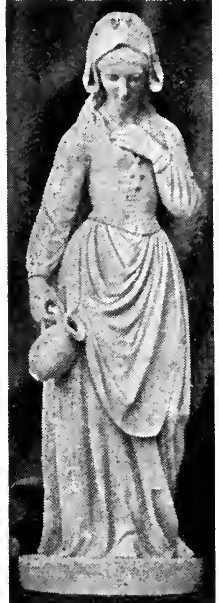

Evangeline, the Acadian heroine From a statue by Sarah
Terry with their British and Protestant rulers. It is a tender, tragic romance, beautifully told, and one of the most successful instances in English of the sustained use of hexameters. The poem is named from the heroine, who was first to have been $\mathrm{Ga}$. brielle, a name later adapted as Gabriel for the hero. A monument to her was unveiled atGrand Pré, Nova

Evangelist (Gr. evangelistēs, proclaimer of glad tidings). Originally one chosen by the apostles to preach the Gospel where it was unknown. Theodoret first restricted the name to travelling preachers; Oecumenius first applied it to the authors of the four Gospels; to-day it is also used for missionaries and revivalist preachers. (See Eph. 4 ; Acts 8 and 21 ; 2 Tim. 4.) The four living creatures referred to in Ezek. I and 10 , and Rev. 4, were regarded by Jerome as symbols of the four evangelists - the man, Matthew ; the lion, Mark ; the ox, Luke ; the eagle, John. Irenaeus assigned the lion to John and the eagle to Mark; Augustine and Bede, the lion to Matthew and the man to Mark. See Apostle ; Gospel ; Preaching.

Evan Harrington. Novel by George Meredith. After serial appearance in Once a Week, as Evan Harrington, or He Would be a Gentleman, it was published in volume form in 1861. It is one of the author's best stories, including in Evan's sister, the Countess de Saldar, one of his triumphs of portraiture. Evan is the son of a tailor, the great Mel, and the whole Har. rington family is founded on members of Meredith's paternal family.

Evans, Sir ARTHUr JoHN (b. 1851). British archaeologist and numismatist. Born at Hemel Hempstead, the eldest son of Sir John Evans (q.v.), he studied at Harrow, Oxford, and Göttingen. $\mathrm{He}$ travelled in Finland and Russian Lapland, 1873-74, and was engaged in researches in the Balkan peninsula between 1875-82. From 1884-1908 he was keeper of the 


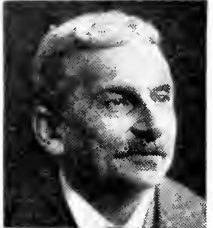

Ashmole a Museum at Oxford. $\mathrm{His}$ discovery in Crete in 1893 of a pre-Phoenician script was discussed in his Cretan Pictographs, Sir Arthur Evans, British archaeologist La fayelle reloped in his

Scripta Minoa, 1909. His excavati. 1 of the Minoan palace of Cnossus in 1900-8 elucidated the Aegean civilization first revealed by Schliemann at Mycenae. $\mathrm{He}$ became extraordinary professor of prehistoric archacology at Oxford in 1910, and was president of the British Association, 1916-17. In 1911 he was knighted.

Evans, EDWARD Radclifie Garth Russell (b. 1881). British sailor and explorer. The son of a barrister, h e was educated at the Merchant 'Taylors' School. Entering the navy in 1897, he became lieutenant in 1902 , and was navi. gating officer to the Ant. arctic relief

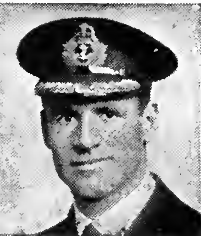

E. R. G. R. Evans, British explorer Russell

ship Morning, 1902-4, making two voyages to the $S$. Polar regions to the relief of the Discovery when she was frozen in MacMurdo Strait. $\mathrm{He}$ joined the British Antarctic Expedition as second in command in 1909, and after the death of Captain Scott in. 1912 he brought it back. A commander in the navy, on the outbreak of the Great War he took part in the bombardment of the Belgian coast in 1914. $\mathrm{He}$ was in command of the Broke when, in 1917, that vessel and the Swift defeated six German destroyers. He was promoted captain in 1917, and received the D.S.O. See Antarctic Exploration.

Evans, SIR Georae DE LACY (1787-1870). British soldier. Born at Moig, co. Limerick, Ireland, he

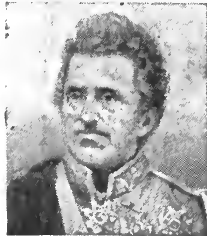

Sir G. de Lacy Evans, British soldier entered the Indian army in 1806 and in 1812 joined the 3rd Dragoons in the Penin. sula. He was present at Vittoria, Pampeluna, and Tou. louse. In the American War he took part in the seizure of Washington, and in the operations before New Orleans, and, returning

to Europe, was present at Waterloo. After a short time in Parliament as an advanced radical, he commanded the legion recruited in England to assist Queen Isabella of Spain against the Carlists. 'The legion, though ill-equipped and neglected by the Spanish government, fought well under Evans's command, 1835-37. Evans's last active service was in the Crimean War, from which, however, he was invalided home. He resumed his seat in the House, received the thanks of Parliament, and was made a G.C.B. He died Jan. 9, 1870.

Evans, Sir JoHN (1823-1908). British archaeologist and numis. matist. Born at Britwell Court, Buckinghamshire, Nov. 17, 1823 , in 1840 he entered his uncle's paper mills at Hemel Hem pstead. $\mathrm{He}$ was president of the Geological Society, 1874-76; the $\mathrm{Num}$ is. British archaeologis matic Society,

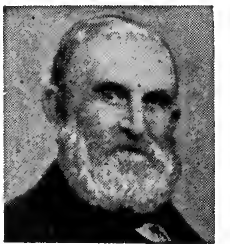

Sir John Evans,

Elliott \& Fry

1874-1908; the Society of Antiquaries, 1885-92: and the Anthropological Institute, 1877-79. Admitted a Fellow 1861, he was treasurer of the Royal Society, 1878-98. He wrote Coins of the Ancient Britons, 1864, with supple. ment, 1890 : Ancient Stone Implements of Great Britain, 1872, 2nd ed. 1897; Ancient Bronze Implements of Great Britain and Ireland, 1881. He died May 31, 1908. His collection of 1,700 coins was presented to the British Museum by his son in 1919 .

Evans, MarLaN or Mary ANN (1819-80). Maiden name of the British novelist better known as George Eliot (q.v.).

Evans, OLIVER (1755-1819). American inventor. Born at Newport, Delaware, he entered his brother's milling business, and invented and fitted up various appliances for economising time and labour. The machinery was worked by water power, and revolutionised the grinding of corn. Americans claim that Evans designed the first steam engine on the high-pressure principle, and it is agreed that his plans, sent to England, were seen by Trevethick. Although never so successful as Watt, he was one of the pioneers of steam locomotion, and ranks as one of the most ingenious mechanics that America has produced. He died at New York, April 25, 1819.

Evans, ROBLEY DUNGLISON (1846-1912). American sailor. Born in Virginia, Aug. 18, 1846, he received his naval training in the U.S. Naval Academy in 1863. He saw considerable service during the Civil War, being wounded in the land attack on Fort Fisher, 1865. In 1891 he was in command of the Yorktown off Valparaiso, where his attitude towards Chile, between whom and the U.S.A. relations were at the time strained, earned him the nickname of Fighting Bob. Promoted captain in 1893, in the Spanish-American War he commanded the Iowa under Admiral Sampson off Santiago, and fought Cervera's fleet, July 3, 1898. Promoted rearadmiral 1901, he was commanderin-chief of the Asiatic station in 1902. He died Jan. 3, 1912.

Evans, Sir Samuel Thomas (1859-1918). British lawyer and politician. Born at Neath, Glam. organshire, he graduated at London University, an d became a solicitor in $\mathbf{1 8 8 3 .}$ Practising in his native town, he was elected M.P. for mid-Glamorganshire in 1890, wh ic h

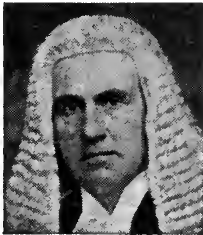

Sir Samuel Evans. Russell British lawyer

constituency he represented for twenty years. He became a barrister in 1891, a Q.C. in 1901, was recorder of Swansea from 1906-8, and in 1908 was appointed solicitorgeneral and knighted. In 1910 he left Parliament to become president of the probate, divorce, and admiralty division, which, after the outbreak of the Great War, included the business of the prize court. $\mathrm{He}$ died at Brighton, Sept. 13, 1918.

Evanston. City of Illinois, U.S.A., in Cook co. It stands on Lake Michigan, $13 \mathrm{~m}$. N. by W. of Chicago, and is served by the Chicago, Milwaukee and St. Paul, and the Chicago and N.W. Rlys. It is the seat of the Northwestern University, and contains various educational institutions. Settled in 1835, it was incorporated in 1863, and received a city charter in 1892. Pop. 29,305.

Evansville. City of Indiana, U.S.A., the co. seat of Vanderburg co. On the Ohio river, $150 \mathrm{~m}$. W. by $\mathrm{S}$. of Indianapolis, it is served by the Louisville and Nashville and other rlys. A port of entry, it carries on a thriving trade in coal, flour, and tobacco, and has cotton, woollen, and flour mills, in addition to foundries, machinery works, and cigar, glass, and leather factories. Evansville dates from 1816, and became a city in 1847. Pop. 77,531 . 
Evan-Thomas, SIR HugH (b. 1862). British sailor. Born Oct. 27, 1862, he entered the navy in

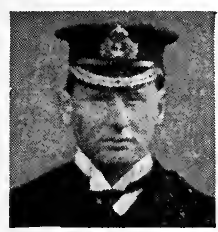

Sir H. Evan-Thomas, British sailor Russell 1875. He was flag-captain to the Channel Heet, 1903-4, and private secretary to the first lord of the admiralty, 1905-8. From 1910-12 hewas in command of the R.N.

College, Dartmouth, being A.D.C. to the king, 1911-12, when he was promoted rear-admiral. Rearadmiral of the first battle squadron, 1913-14, he commanded the fifth battle squadron in the battle of Jutland. Knighted for his services, he was commander-in-chief at the Nore, 1920-23.

Evaporation (Lat. $e$, from, out; vapor, vapour). Name commonly given to the process by which a liquid, and less commonly a solid such as carbonic acid snow, changes into a state of vapour. Evaporation may be said to be a function of heat and pressure. Liquids may evaporate at all tem. peratures; under the application of heat or the removal of pressure from their surfaces, they evaporate more quickly. At a given temperature evaporation in a closed vessel ceases when a certain pressure of vapour is attained, for condensation of the vapour balances the evaporation of the liquid.

The rate of evaporation of a liquid depends upon the area of the surface exposed, the freedom of the space surrounding it from vapour, and the difference between the vapour pressure and the ex. ternal pressure. Thus a given volume of a liquid evaporates more quickly in a shallow dish than a deep one, in a dry atmosphere than a damp one, and on a warm day than a cold one. The movement of the atmosphere over the surface of the liquid also increases the rate of evaporation, as the evaporated particles are carried away.

In converting a liquid into a vapour at the same temperature, heat has to be supplied. In other words, heat is absorbed in the process of evaporation. The quantity of heat that has to be supplied to one gram of liquid at the boiling point without changing its temperature is called the latent heat of vaporisation. This is the same thing as the quantity of heat given out by one gram of the vapour at boiling point, when condensing to a liquid at the same temperature.

Evaporation of water is of great importance in nature. In spring

and summer wind and rising temperature increase evaporation, while in autumn and winter falling temperature and cold spells decrease the capacity of the air for holding water particles, causing mists, fogs, and rain. See Boiling Point; Condenser : Heat.

Evaporation Value. Method by which the relative values of different fuels may be expressed. It consists in stating the amount of water which each is capable of converting into steam when burnt under specified conditions. Thus one pound of average coal is cap. able, theoretically, of converting 15 pounds of water at boiling temperature in the atmosphere into steam ; while under the same conditions petroleum would convert 21 pounds, and ordinary dry straw $8 \frac{1}{2}$ pounds. These figures represent the evaporation values of the fuels named. See Fuel.

Eve. Name of the first woman in the Biblical story of creation. In Hebrew the form of the name is Chawwah. It was given to the woman by Adam (Gen. iii, 20), and is explained as meaning "living" or "life." She was so called, it is stated, because she was the mother of all living. See Adam; Creation.

Evection (Lat. $e$, from, out ; vehere, to carry). Inequality of the moon's motion, which increases or diminishes the mean longitude of the moon to the extent of $1 \mathrm{deg}$. 20 mins. See Moon.

Evelina. Fanny Burney's first novel. The first avowed novel of society, it was published anonymously in 1778 under the title of Evelina ; or a Young Lady's Entrance into the World. Johnson declared that there were passages in it which might do honour to Richardson.

Evelyn, ЈонN (1620-1 706). Eng. lish author and diarist. He was born at Wotton House, Surrey,

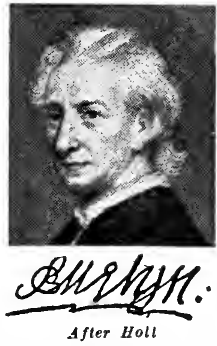

A sincereroyalistand chy his admiration for Charles II in exile did not blind him to his faults later, when, after the restoration, he enjoyed favour at Court. From 1653-94 Evelyn was settled at
Sayes Court, Deptford, where he transformed a rude orchard and ficld of 100 acres into a pleasaunce of notable charm. He befriended Jeremy Taylor and other divines, was on terms of intimacy with many notable men of his time, in. cluding Bentley, Boyle, John Wil. kins, Pepys, Grinling Gibbons, and Hollar. He helped to found the Royal Society, and was its secretary in 1672. He was a commissioner for the rebuilding of $\mathrm{S}$. Paul's Cathedral ; aided church establishment in the plantations; was a commissioner of the privy seal, 1685-87; and treasurer of Greenwich Hospital, 1695-1703.

In addition to gardening and forestry, he took an active interest in agriculture, architecture, art, engraving, music, and navigation. His Sylva, 1664, first drew attention to the importance of forestry in England; Terra, 1676, was a first attempt in English at a. scientific study of agriculture; Sculptura, 1662, a work on engraving, was suggested by Boyle. $\mathrm{He}$ wrote a Character of Eng. land, 1659, an admirable Life of Mrs. Godolphin, a discourse on Medals, and a History of the Dutch War, which is lost.

$\mathrm{He}$ is remembered for his Diary, 1620-1706 (more properly described as his memoirs), a work valuable for its reflection of the political, social, and religious life of his time. The MS. of this was in danger of destruction when, at the suggestion of William Upcott, it was edited by William Bray, and first published in 1818. After 1694 he lived at Wotton, where he died, Feb. 27, 1706, and was buried in the chapel. He is well described as a patriot who kept his loyalty in dangerous times, a Christian who preserved his integrity in the most immoral, and a philosopher who viewed every object with a desire to extract from it all the beauty and goodness it contained. See editions of the Diary, with Life by $\mathrm{H}$. B. Wheatley, 1906 ; and by Austin Dobson, with introduction and notes, 1908; The Early Life and Education of John Evelyn, 16204l, H. Maynard Smith, 1920.

Evening News, THE. London evening newspaper. Started in 1881 in the Conservative interest as a rival to The Echo, in 1889 it absorbed The Evening Post, founded 1887. In Aug., 1894, it was acquired for $£ 25,000$ by a new company of which Alfred Harmsworth (Viscount Northcliffe), Harold Harms worth (Viscount Rothermere), and Kennedy Jones were the proprietors. Under the new direction it emerged from an almost mori. bund concern into a property 
yielding in the first year a profit of $£ 14,000$ and in the second $£ 25,000$. Its ever-increasing success-it had in 1920 a net sale of 825,825 -led to the foundation of The Daily Mail. From 1894 until 1896 Kennedy Jones was editor; he was succeeded by W. J. Evans. Prominent regular contributors have included Claude Burton (C. E. B.), Oswald Barron (The Londoner), P. H. Fearon (Poy), and Arthur Machen. With The Daily Mail and The Weekly Dispatch it is issued by The Associated Newspapers, Limited, from Carmelite House. See Daily Mail ; Northcliffe, Viscount.

Evening Primrose (Oenothera biennis). Bicnnial herb of the natural order Onagraceae. It is a native of $\mathrm{N}$. America. The leaves are oblong-l a n c eshaped; the flowering stem (2nd year), $4 \mathrm{ft}$. or $5 \mathrm{ft}$. high, branched with n a r row e r. toothed leaves, terminates in a long spike of large, pale yellow flowers, opening in the

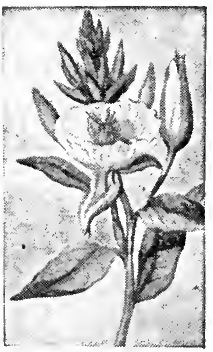

Evening Primrose, 8 biennial herb evening. The variety lamarckiana has much larger flowers than the type form, and has been much studied. See Mutation.

Evening Schools. Term specifically given to evening classes established in the Uniterl Kingdom, mainly during the first half of the 19 th century, for giving elementary instruction to illiterate adults. One of the earliest was started at Bala, $\mathrm{N}$. Wales, in 1811. The system was warmly supported by Bishop Hinds in 1839, and was adopted by the Ragged School Union, founded 1844, and known since 1898 as the Shaftesbury Society. The term is still officially used to cover schools in which pupils beyond the com. pulsory school age may continue their education. See Continuation School; Education.

Evening Standard, THE. London evening newspaper, started June 11, 1860, as a pendant to its morning namesake, itself originally an evening paper first published May 21, 1827. Acquired from the Johnstone family in 1905 by C. Arthur Pearson, who had in 1903 purchased the St. James's Gazette (founded in 1880), The Evening Standard was merged with the latter. In 1910 Davison Dalziel secured the controlling influence; in 1915-23 it was owned by Hulton \& Co., and from 1924 by Lord Beaverbrook.
Everest. Loftiest peak of the Himalayas. Its height is $29,002 \mathrm{ft}$. $\left(5 \frac{1}{2} \mathrm{~m}\right.$.), the highest on the globe. It stands on the border between $\mathrm{Ne}$ pal and Tibet, and its snow-covered peak is difficult of access, and has never been ascended or thoroughly explored. It was named after Sir George Everest (1790-1866), surveyor-general of India, and has often been confused with the neighbouring peak, Gaurisaukar. British expeditions, in 1921,1922 , but without success

Everett. City of Massachusetts, U.S.A., in Middlesex co. It stands on the Mystic river, $4 \mathrm{~m}$. N.E. of Boston, and is served by the Boston and Maine Rly. Its indus. trial activities include ironfounding and the manufacture of steel, boots and shoes, radiators, and leather goods. Settled in 1643, it became a city in 1892 . Pop. 40,150.

Everett. City of Washington, U.S.A., the co. seat of Snohomish co. A port of entry on Puget Sound, it is $34 \mathrm{~m}$. N. of Seattle, and is served by the Chicago, Milwau. kee and St. Paul, and other rlys. Situated in a mineral and lumbering region, it has an excellent harbour, and trades largely in the products of the locality. Settled in 1891 , it was incorporated in 1893. Pop. 32,050.

Everett, EDWARD (1794-1865). American statesman and writer. Born at Dorchester, Massachusetts, April 11, 1794, he was for two years a Unitarian minister. Leaving the ministry, he became professor of Greek at Harvard College, 1819-25, and president, 1846-49. He edited the North American Review, 182024, was member of Congress,1824and 1924 attempted to scale. it,

35, minister to Great Britain 1841-45, and senator 1853-54, when he abandoned public life. In politics

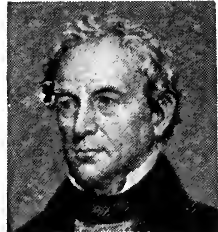

Edward Everett, Boston, Jan. 15, 1865. His literary output consists mainly of articles in The North American Review, and A Defence of Christianity, 1814. His reputation, however, chiefly rests upon his speeches, highly elaborate and most carefully prepared. See Orations and Speeches, 1850-59; Life and Services of Edward Everett, R. H. Dana, 1865.

Everglades. Swampy wilderness in S. Florida, U.S.A. The region is low-lying and its heavy rainfall and high temperature encourage the rank growth of vegetation, thus increasing the natural difficulty of drainage. Situated in the $S$ part of the state, it extends $\mathrm{N}$. to S. for about $120 \mathrm{~m}$. and is about $45 \mathrm{~m}$. broad. During the rainy season it has a depth of $1 \mathrm{ft}$. to $10 \mathrm{ft}$. It contains a number of islands bearing cypresses, pines, palms, and vines, but is mainly a huge, almost impenetrable, tract covered with saw-grass which reaches a height of $6 \mathrm{ft}$. Attempts at reclamation by cutting canals sugar-cane has been cultivated in the drained portions. See Florida. have met with some success, and

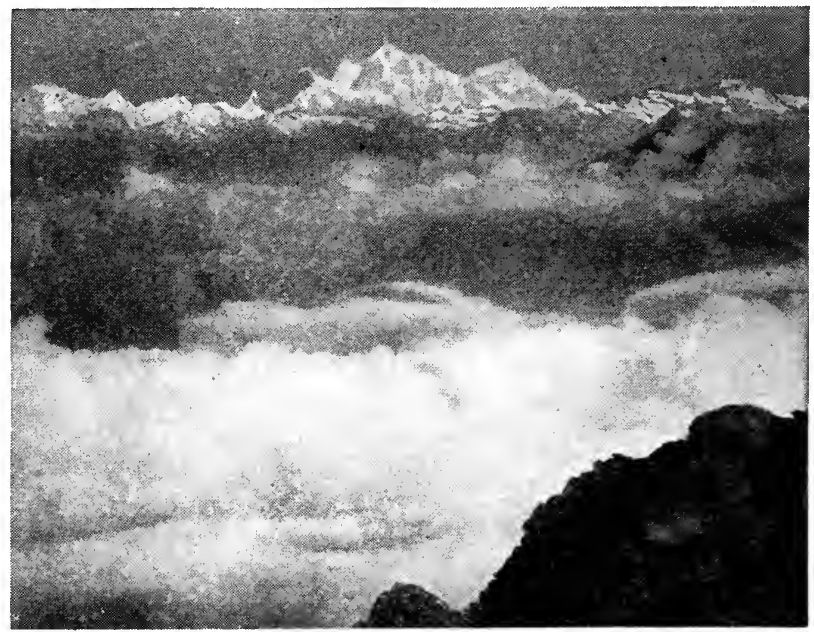

Everest. The highest peak in the world viewed from Mt. Phalnt, Darjeeling. Five miles high, its summit is almost inaccessible 


\section{Evergreens. Plants whose} leaves last several years and are not shed simultaneously. The plants are thus never leafless. The holly, for example, produces new leaves each season, but each of these lives for three or four years; therefore, although there is a leaffall every year, it only affects the oldest leaves and the foliage as a whole is always full and green. Evergreen leaves are of leathery consistence with glossy surface, and are thus protected against rapid loss of moisture in summer and the effects of frost in winter.

Everlastings oR IMMORTELLES. Term applied to the flower-heads of certain composite plants. Their bracts are of a hard, parchment-

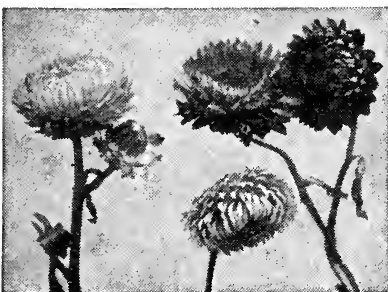

Everlastings. Flowers of Helichrysum bracteatum, which, when dried, retain their colour and form for years

like character and coloured, so that if gathered in their prime, i.e. just before they are fully expanded, they will retain their form and colour for several years. The most striking of these are species of Helichrysum, Acroclinium, Rhodanthe, Aphelexis, Waitzia, and Xeranthemum. When gathered they are hung heads downwards to ensure perfect drying.

Eversley. Village and parish of Hampshire, England. It is $14 \mathrm{~m}$. N.E. of Basingstoke, and almost on the borders of Surrey. The church of S. Mary, which dates from the early part of the 18th century, had Charles Kingsley for its rector from $1844-75 .^{\circ}-\mathrm{He}$ is buried in the churchyard and the place is chiefly known for its association with him. Near is Bramshill House, a fine building erected for Prince Henry, son of James I. Pop. 841.

Eversley, CharLes Shaw-LeFEVRE, 1ST VISCOUNT (1794-1888). British politician. Born Feb. 22,

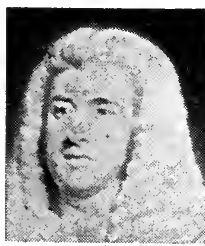

1st Viscount Eversiey, British politician scrving as chairman of various com. mittees, he was elected speaker in 1839 , and filled that office with distinction, reforming procedure and maintaining order in the difficult times of O'Connell and the free trade debates. In 1857 he retired and was created Viscount Eversley. $\mathrm{He}$ died at Heckfield, Hampshire, Dec. 28, 1888. The title became extinct, but was revived as a barony in 1906 in favour of his nephew, Rt. Hon. G. J. Shaw-Lefevre.

Eversley, George John ShawLEFEVRE, BARON (b. 1832). British politician. Born June 12, 1832, he was educated at Eton and Trinity Colle g e, C a mbridge. As a Liberal he was M.P. for Reading, 1863-85. and for Brad. ford, 1885-95. $\mathrm{He}$ was civil lord of the admiralty in

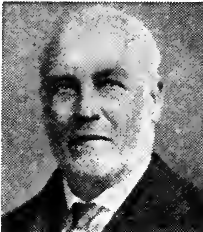

1st Baron Eversley, British politician Russell

1856, secretary to the board of trade, 1869-71; secretary to the admiralty, 1871-74 ; first commissioner of works, 1881-83 and 189293 ; postmaster-general, 1883-84; and president of the local govern ment board, 1894-95. He was raised to the peerage in 1906 . In 1919 he published his Reminiscences.

Evert, Alexis Ermolaevitch (b. 1857). Russian soldier. Born Feb. 20, 1857, he entered the army in 1874, saw active service in the Russo-Turkish War, 1877-78, and took part in the Russo-Japanese War, 1904-5. After the outbreak of the Great War he commanded one of the Russian armies in 'S.E.
Poland, which defeated the A ustrians under Dankl in Aug.-Sept., 1914. In 1915$16 \mathrm{he}$ was c o $\mathrm{m} \mathrm{m}$ a nder. in-chief of the Russian central armies,

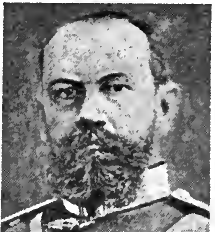

Alexis Evert. Russian soldier and skilfully conducted the retreat from the Niemen. He resigned his command in March, 1917.

Everton. Parish of Lancashire, England, forming a N.E. suburb of Liverpool, and within its borough limits. Here is S. Edward's Roman Catholic College, founded 1842 and enlarged in 1875. It stands in its own grounds of 11 acres. Everton is celebrated for its toffee. Pop. 120,865. See Liverpool.

Everton. Association Football Club. Founded in 1879 , it originated from a church school, the first ground being in Stanley Park, Liverpool. In 1885 it adopted professionalism, and in 1888 was one of the twelve clubs that formed the Football League on its foundation. The club has played in the premier division ever since. In the first year of the competition it occupied eighth place in the league table, and in 1890-91 secured the champion. ship, scoring 29 points out of a possible 44. In 1914-15 it again won chief honours, its record being 46 points out of a possible 76. On six occasions the club has been runnerup. Everton won the Football Association Cup in 1905-6, beating Newcastle United by one goal to nil in the final. Their ground is Goodison Park, Liverpool. See Football.

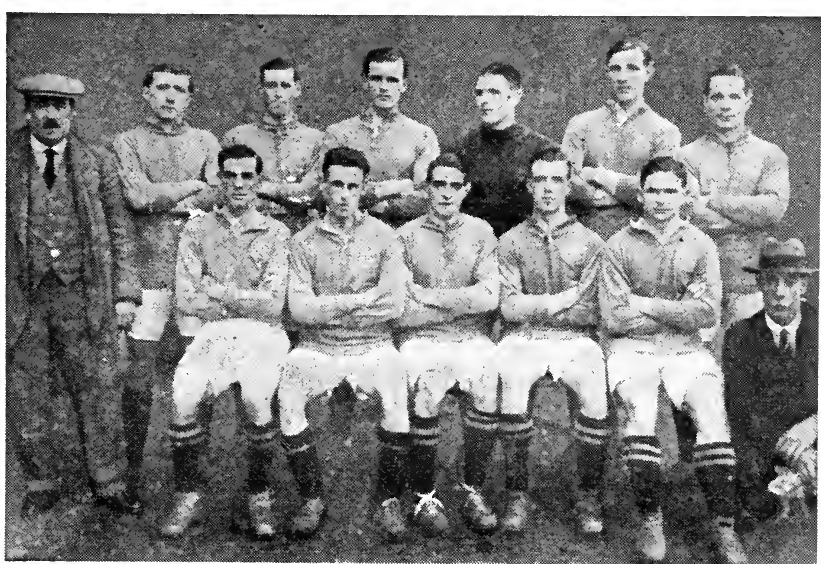

Everton. Association Football Club Team, 1920-21. Left to right, standing : J. Elliott (trainer), T. Fleetwood, J. McDonald, A. Grenyer, T. Fern, G. BrewG. Harrison, - Clarkson ster, R. Downs; sitting, S. Chedgzoy, W. Kirsopp, J. Peacock, D. Reid, 
Everyman. English morality play of the late 15 th century, pro. bably translated from its Dutch counterpart, Elckerlijk (printed $c$. 1495). The earliest known editions of Everyman were printed by Richard Pynson (undated, but apparently before 1531). The play, which "comprises the whole pitiful pathos of human life and death," is one of the finest examples of the moralities. The story of God's summoning of Everyman (all man. kind represented as an individual) by Death on that journey which none may escape, and of Everyman's attempts to find a willing companion, is based on an earlier parable told in the religious romance of Barlaam and Josaphat (q.v.).

Bibliography. Select Collection of Old Plays, R. Dodsley, ed. W. C. Hazlitt, vol. 1, 1874; Everyman, introd. by F. Sidgwick, 1902; The Summoning of Everyman, ed. J. S. Farmer, 1906.

Everyman Theatre. Theatre at Hampstead, London, N.W. A drill-hall close to the Tube station at Hampstead was acquired and fitted up as a small theatre with a seating capacity of about 300 . This was opened as a repertory theatre on Sept. 15, 1920, with Bonds of Interest, a Spanish com. edy by Jacinto Benevente, and other high-class plays followed in quick succession. Norman MacDermott was the first manager.

Evesham. Mun. bor. and market town of Worcestershire, Eng. land It stands on the Avon, $15 \mathrm{~m}$.

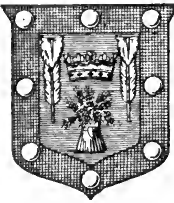

Evesham arms E.S.E. of Worcester, on the G.W. and Mid. Rlys. S. Egwin founded a Benedictine monas. tery here in the 8th century, of which a bell tower and gateway still remain. The town hall is an Elizabethan structure, and the grammar school was founded by Abbot Lichfield in 1536. The battle of Evesham was fought at Green Hill. The site is marked by an obelisk. Fruit growing and market gardening are actively engaged in. There is excellent boating on the Avon. Market day, Mon. The town lends its name to a co. div. returning one member to Parliament. Pop. 8,340.

Evesham, Battle of. Fought Aug. 4, 1265, between the royalists under Edward, afterwards Edward $I$, and the baronial party under Simon de Montfort. Defections had broken Montfort's power, and in the summer of 1265 he was retreat. ing before his foes. The force which his son Simon was bringing from the $S$. to join him was destroyed by Edward at Kenilworth, Aug. 1, and the elder Simon, falling back into Wales, halted at Evesham, Aug. 3. Prince Edward hastened up and cut off all chances of escape. His plans were so cleverly laid that Earl Simon exclaimed: "God have mercy on our souls, for our bodies are theirs." The royalists attacked in two divisions, and the battle was soon over. Numbers told, both Simon's horse and foot gave way, the former only after a stubborn resistance, and Montfort and his son Henry were killed.

Eviction (Lat. evincere, to overcome). Name given to the process of ejecting a tenant from a house or land. In the United Kingdom, as the law stood before 1914, an eviction order could be obtained from a magistrate by the landlord, provided he had given due notice to the tenant. The legislation occasioned by the Great War made evictions more difficult, and by the Courts (Emergency Powers) and other Acts, tenants could only be evicted if the landlord required the premises for his own use. The word is chiefly known in connexion with the evictions of Irish tenants for refusing to pay their rent, which was a marked feature of the land trouble between 1880 and 1900 . In 1907 an Act for the benefit of the evicted tenants was passed; it gives powers to commissioners to secure land for them. See Distraint; Ireland; History; Rent Restriction.

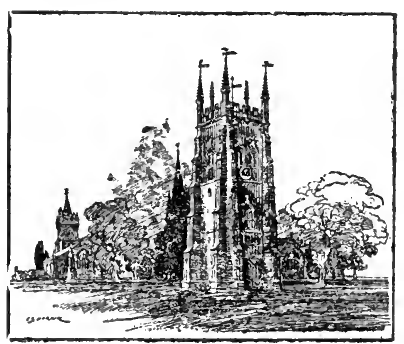

Evesham. Bell tower of the old Benedictine monastery

From a sketch by C. G. Harper

Evidence (Lat. evidentia). Word used for the legal method of proving facts in a court of law. The law of evidence is one of the chief points of difference in the administration of justice between Englishspeaking countries and others. English courts are very strict in their admission of evidence, or rather in their exclusion of certain matters of evidence and modes of proof. The chief rules of evidence are : (1) That all evidence must be relevant to the issue; (2) that such relevant matters must be proved by the "best" evidence.

Relevancy is really a matter of logic. How far any given fact offered to be proved tends to prove any matter in issue is for the judge to decide. One or two things may be borne in mind. A witness's opinion (e.g. "I think the driver of the car was to blame") is no evidence. It is never relevant, except where technical matters are in dispute, and then the opinion of skilled experts is admitted because there is no other way of arriving at the facts. The character of the parties is not relevant; and, therefore, if I sue a man for damages for fraud I arn not allowed to call 50 witnesses to show that he is a man who has committed other frauds. All I am allowed to do is to cross-examine him as to his character, and try to drive him to admit that his record is bad. But even this is not evidence that he defrauded me.

The only time a plaintiff, or prosecutor, can call evidence of the kind above described is where the evidence shows a system of wrong. doing, and the act in issue is a part of the system-long firm frauds for example. On the other hand, a man accused of crime may always bring evidence of his good character. A plaintiff's character can be attacked to reduce the damages in an action for slander or libel; because, obviously, a man of bad character does not suffer so much from an attack on his reputation as a man of good character does.

The rule of best evidence is a rule of exclusion. It excludes hearsay. If you wish to prove something seen or heard, you must put in the box the man who saw or heard it, and not a man who heard that another man saw or heard it. This is English law. The contents of a document must be proved by producing the document itself. If the document is, or has been, in the possession of the other side, who does not produce it after notice to do so, secondary evidence may be given. Again, if the judge is satisfied that it has been lost, stolen, or destroyed, secondary evidence is admissible. Bankers are allowed, instead of producing their books in court, to send a certified copy. And there are whole classes of public documents, such as entries in marriage, birth and death registers, wills, or bills of sale, which can be proved by officially certified copies.

A statement made by one of the parties (admission or confession) is always evidence against him, but not in his favour. 'Thus, a trades. man cannot put in his books to 
prove his claim; but the other side can call for them and put them in to disprove it.

There are a few exception's to the rule against hearsay, i.e. in pedigree cases, the statements made by a deceased member of the family before the litigation was mooted. For example, the question being whether Harry Smith is the son of John Smith of Chichester, a member of the family can say, "My mother was John Smith's sister. She is now dead. I often heard her say that her brother John married, and had a son he called Harry after my grandfather." On this principle, entries in family Bibles, and even inscriptions on tombstones can be called into play. Another class of hearsay admissible is "declaration against interest" by a deceased person. Thus, a deceased solicitor's bill, receipted, but not otherwise, is admissible in evidence to prove the facts set out in it. Yet another class of hearsay admissible is any entry made by a person, since deceased, which it was his duty to make when he made it.

At one time, the English com. mon law did not allow any person who was interested in an action to give evidence, whether his interest arose from blood or was pecuniary. This restriction has now been done away with. The only remnant of it remaining is that in a criminal case, except in a case of bigamy, a husband or wife cannot give evidence for the prosecution, unless it is on a charge brought by one spouse against the other. See Jurisprudence ; Law.

Evidences of Christianity, A VIEW OF THE. Theological work by William Paley first published in 1794, containing (1) the direct historical evidences of Christianity; (2) the auxiliary evidences; and (3) a consideration of some popular objections. Largely based on Butler's Analogy of Religion and $\mathrm{Na}$ thaniel Lardner's Credibility of the Gospel History, the work, in its time hailed as a crushing reply to scepticism, has come to be regarded as inadequate.

Evil. In the theological and ethical sense the absence of good, or unsatisfied desire. But neither definition is satisfactory. To say that evil is the absence or the opposite of good at once raises the question, "What is good?"; and the answer must depend largely upon the standpoint of the in. dividual. To define evil as unsatisfied desire pre-supposes that the desire itself is not evil. If it is, its frustration is good rather than evil. To find the supreme good in the satisfaction of desire, and evil in its frustration, ignores the possibility of a higher and external moral imperative taking precedence over mere personal desire.

From the theological point of view, the definition of evil is com. paratively simple. It is that which does not conform to the Will of God. But the Will of God is manifested by both direct command and by permission. Evil, like all other things, can only exist by divine permission; and in this sense its existence is not contrary to the Will of God. But the thing in itself and the fact of its existence are not the same thing. The Will of God may permit the existence of an evil which is itself directly opposed to that Will; and such permission in no sense makes God the author or the cause of evil.

\section{The Problem of Relativity}

Why evil is permitted to exist has always been a perplexing problem ; and it is not greatly helped by the counter question, "Does evil exist ?" If evil is a mere negation or absence of good, it has no real existence, and is nothing at all. What really happens is that the good exists in a less degree than is to be desired. The existence of so-called evil, therefore, resolves itself into this - that the universe is not perfect. Viewing evil as merely imperfection, the problem of its existence becomes less difficult. It is no reflection on the goodness of God that $\mathrm{He}$ is pleased to let the world progress through imperfection to perfection. Such a process of progression and growth is analogous to what is seen in the world of animal and vegetable life.

Another element in the problem of evil is that of relativity. In certain circumstances and in some relations a thing may be evil which is not necessarily evil in itself. But we are not in a position to judge the circumstances or to weigh the relations; for the simple reason that only a portion of the world of reality lies within our ken. We only see part of the machine; and those parts which appear inappropriate or superfluous may be essential or beneficial to the part of which we know nothing. See Ethics.

Evil Eye. Faculty of causing material harm by means of a glance. In Shakespeare, and in modern rural England, it is called overlooking. From its ancient Roman name fascinum comes the word fascination. Distinguishable from the subjective influence of the eyes of snakes, it denotes a form of witchcraft, owing its origin to the presumption that the eye is capable of operating at a distance.
It may be exerted, voluntarily or involuntarily, upon human beings and domestic animals, especially when young, besides crops, dwellings and other objects. Envy (Lat. invidia, on-looking) is a potent incentive of evil eye.

The belief is traceable to the beginnings of recorded history, and its widespread survival in primitive culture attests its primeval origin. Various curative and preventive measures are employed. Prevention is sought by spitting, muttering counter-charms, making offensive figures or gestures, giving to children opprobrious names, wearing knotted cords, or displaying amulets, many of which are specific for evil eye. They include representations of eyes-such as the ancient Egyptian $u z a-$ hands, horns, teeth, shells, nuts, lunar crescents-such as the camelornaments of Judges 8-red and blue objects, and magical or sacred texts. Evil eye is referred to by its technical name in the N.T. in Gal. 3, where it is translated " bewitched." The Greek belief is enshrined in the mythical gorgon Medusa, whose glance turned its victims to stone; the use of the gorgon's head as a preventive amulet persists in modern doorknockers. See Divination; Magic: consult also Evil Eye, F. T. Elworthy, 1895.

Evil-Merodach (d. 560 B.c.). King of Babylon. The name is the Biblical spelling of the cuneiform Amel-Marduk, servant of Marduk. $\mathrm{He}$ succeeded his father, Nebuchadrezzar II, and after a career of tyranny and unrestraint was, within two years, violently slain by his brother-in-law, the Nergalsharezer of Jer. 39, who seized the throne. In II Kings 25 he is said to have shown special clemency to Jehoiachin, king of Judah, after 37 years of rigorous imprisonment.

Evolute (Lat. e, from, out; volvere, to roll). In geometry a curve which is the path of all points that are the centres of curvature of a second curve called the involute. To measure the curvature of any involute we find a circle which coincides with the curve for a short distance. If the curvature to be measured is great this circle of curvature can only have a small radius because it will accompany the first curve only a small way. If the curvature is small the radius of the circle will be correspondingly larger. The centre of this circle at any point on the curve is the centre of curvature at that point. It is clear that there will be a number of these circles for any curve. When their centres are all joined up they form the evolute. See Circle: Geometry. 


\section{EVOLUTION : THE DEVELOPMENT OF LIFE}

\section{J. Arthur Thomson, II.D., Regiug Prof. of Natural History, Aberdeen}

This important article can well be supplemented by those on Biology;

Life; Sex. See also Cell; Heredity; and other articles bearing on the subject; also Darwin; Galton; biographies of other biologists

Evolution (Lat. evolvère, to unroll) is a process wherein one kind of living creature gives rise to another kind, which persists alongside of or in place of the original stock. Thus we believe that birds evolved from an ancient reptilian stock, and mankind from a primitive simian lineage, the origins in both cases being extinct. In the case of domestic pigeons derived from the wild rock-dove (Columba livia), or of poultry derived from the junglefowl (Gallus bankiva), the origins are still extant. Similarly, wild ancestors of such cultivated plants as cabbages and apple-trees stil exist. The evolutionary process is going on among wild plants and animals, e.g. in some evening primroses, or in many birds and butterflies, but it is not readily detected in a lifetime or in the relatively short time since precise biological registration began.

\section{What Evolution Means}

While evolution is strictly a slow racial change in living creatures, the term is often used much more widely. Evolution should not be confused with development, which is best restricted to a continuous change in one and the same unity, such as a germ, a seed, an organ, an institution, or a solar system. Development agrees with evolution in being a series of changes in a definite direction from one position of equilibrium to another, but differs from it in concerning one and the same individual system from beginning to end, whereas evolution is racial, im. plying a succession of generations and a sifting process. Briefly, development in biology is the individual's coming to be (Ontogeny); evolution, in biology, is the genetic history of a race (Phylogeny). Hence we should speak of the development, not of the evolution, of the earth.

Evolution may be in the direction of increased complexity and control (differentiation and integration), or in the opposite direction. A tapeworm is the result of a process of evolution just as surely as is the golden eagle within which it lives. Yet in spite of many instances of retrogressive evolution in animate nature, the general trend of the process has been progressive, i.e. towards increased differentiation and integration of fuller and freer life. This fact must never be lost sight of in contemplating the history of things as a whole.
As applied to living creatures, the evolution theory states the broad idea that the present is the child of the past and the parent of the future. The fauna and flora of to-day, both in themselves and in their myriad inter-relations, are the outcome of an antecedent state of affairs in which animals and plants were on the whole rather simpler. This again originated in organisms and relations simpler still, and so on back through hundreds of millions of years, until all clues are lost, and we find ourselves in the mist of life's beginnings. The evolution theory thus states the view that the manifold intricacy of animate nature has arisen by a natural process of slow organic change, similar to that seen in the history of domestic animals and cultivated plants.

One point remains to be emphasised. The statement that living creatures have come to be as they are by evolution, only means that their history has been a natural history, the moves in which have known, or at any rate knowable, causes. To think that any result whatsoever acquires dig. nity, permanency, worth, invulnerability, or sanctity, because it is the result of evolution, is a misunderstanding, for the value of survival, as judged by human standards, depends on the conditions under which survival is secured.

Evidences of Organic Evolution

This general evolution theory, or doctrine of descent, cannot be proved like the law of gravitation. It is the only scientific way of answering the question: How has the present-day system of animate nature come into being ? But while all the facts of zoology and botany serve as evidences of evolution, four main lines of argument have been followed by Darwin and others.

The first is mainly anatomical. Many facts in regard to structure corroborate the evolu. tionist interpretation, and seem to naturalists to admit of no other. Thus, the fore-limb of a frog, the paddle of a turtle, the wing of a bird, the fore-leg of a horse, the flipper of a whale, the wing of a bat, the arm of a man, exhibit in diverse guise the same essential parts, twisted into manifold forms for different uses, but always of the same fundamental type. There is essential similarity in the important bones, and considerable re. semblance in the musculature, innervation, and blood-supply. All these fore-limbs are homologous with one another, i.e. they agree in fundamental structure and development. It is difficult to understand this adherence to type except on the theory of the actual flesh-and-blood relationship of backboned animals. Many vestigial organs in animals, especially the higher animals, remain very slightly developed and are of no use; comparable, as Darwin said, to unpronounced letters in words, the $o$ in leopard, or the $b$ in doubt. Man has a minute useless third eyelid and a hint of muscles for moving the trumpet of the ear. The only rational interpretation of such structures is the evolutionist one, that they are dwindling relics of structures well developed and of some functional importance in ancestral forms.

\section{The Physiological Aigument}

The second line of argument may be called physiological. When the blood of a horse is transfused into an ass, or that of a hare into a rabbit, there is harmonious blending. But when human blood is transfused into a horse or rabbit there is great disturbance, marked, for instance, by destruction of red blood corpuscles. The harmonious mingling is evidence of near bloodrelationship, the destructive reac. tion proves the reverse. By modification of this experiment it is possible to gauge the degree of relationship between man and the various groups of apes and monkeys. Along with this physiological argument may be taken the abundant evidence of the variability of living creatures. In a short time man has established over 200 breeds of domestic pigeons, which seem all to have been derived from the blue rock-dove.

Another line of argument is historical or palaeontological. From the rock record we have accumulated a great mass of material in regard to the successive appearance of horse-types, elephanttypes, crocodile-types, and so forth, all reading like a lineage or pedigree. Moreover, there are many connecting links now extinct, such as Archaeopteryx (see Birds), which, though an indubitable bird, had several well-marked reptilian features, e.g. teeth in both jaws, a lizard-like tail, and claws on the three digits of the hand. Again, there is the big fact that in the rock record amphibians appear after fishes, reptiles after amphibians, birds and mammals after reptiles; as age succeeded age, nobler and nobler forms of life emerged. 


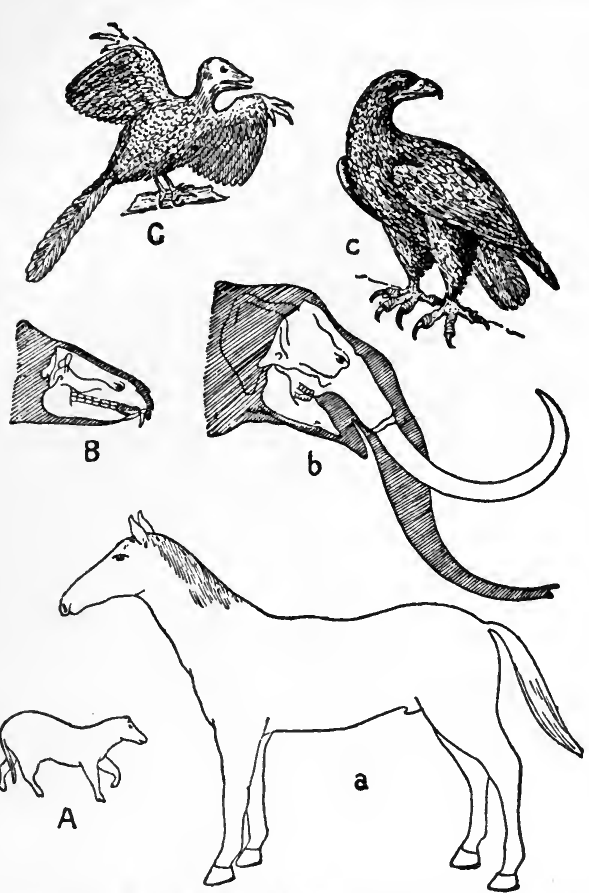

Evolution. Early and late stages in evolution. A. Early four-toed ancestor of the horse. Its proportionate size is shown by comparison with a. B. Head and skull of an early ancestor (Meritherium) of the elephant, whose head and skull are shown in b. C. The oldest known bird, Archaeopteryx. two specimens of which have been obtained from Jurassic strata, compared with, c, golden eagle

By courtesy of Andrew Melrose

the first organisms were much simpler in organization than any clearly visible living creatures of to-day. It has bee $n$ suggested that the earliest living beings were minute, pos sibly ultra-microscopic particles of the nature of chromatin, a protein material characteristic of all cell-n u clei. These hypothetical primitive organisms have been called biococci. Some of these may have given rise to the bacterial type of organism, consisting of a minute globule of chromatin surrounded bya firm envelope. Astime went on and size increased the chromatin-globules might increase in number and acquire some complexity of arrangement, and a non-chromatinic ground sub-

The embryological evidence is very striking. The embryos of the higher vertebrates, viz. reptiles, birds, and mammals, develop for a considerable distance along the same road, or along closely parallel roads, before they diverge. For instance, in the neck region of the embryo higher vertebrate, there are gill-clefts or visceral clefts which have no respiratory significance, and can hardly be said to be useful, except that the first becomes the Eustachian tube connecting the ear passage with the back of the mouth. These can only be recapitulations of the respiratory apparatus of remote aquatic,lower vertebrate, ancestors.

\section{Great Steps in Organic Evolution}

There was a time when the temperature of the earth was far too high to admit of the existence of any forms of life like those we know. Whether germs of living organisms reached the earth from elsewhere, or whether very simple living organisms evolved upon the earth out of non-living matter, is unknown, but it is certain that living organisms did have a beginning upon the earth, and probable that stance (cytoplasm) might accumulate around them and within the envelope.

On another line of evolution a less vegetative and more predatory organism may have arisen by the formation, around a number of biococci or chromatin-grains, of an enveloping matrix of active semi-fluid substance exhibiting streaming or amoeboid movements. This was a prototype of the animal, and it preyed upon other minute creatures. Later on, the chromatin-grains probably concen trated to form a definite cellnucleus in the midst of the active matrix, and a true cell was formed. These suggestions serve to indicate that probably a long journey had to be travelled before even the first true cells appeared.

The next great steps probably consisted in the establishment of numerous distinct types of cellular organization, besides the bacterial and the amoeboid. On the animal line of evolution, towards which the primeval amoeboid organisms pointed, there doubtless arose all sorts of specialisations of the creeping cell, many with support- ing skeletal framework. More active forms had lashes of protoplasm instead of outflowing threads and lobes. Others, with anenclosing cyst, were adapted for spending much of their life as passive parasites.

One of the primeval great events must have been the emergence of green plants. These perhaps originated among flagellate infusorians on the animal line which had been able to build up the green pigment chlorophyll, the most important substance in the world, next to living matter itself. The divergence between plants and animals was one of the greatest cleavages in evolution. While all typical animals require organic food which has been worked up for them by other living creatures, green plants are able to utilise the energy of the sunlight, shining through a screen of chorophyll, to break down the carbon dioxide of the air, the carbon being used in the rynthesis of complex organic compounds. Thus green plants feed at a low chemical level, on air, water, and salts, and build up nutritive materials which animals utilise.

Moreover, the plant cell is almost always surrounded by an envelope or cell-wall of cellulose, and this restriction, taken along with the poorly developed means of getting rid of nitrogenous wasteproducts, may explain the fixity and sluggishness of plant-life. We are unable here to follow the evolution of the plant world which went on simultaneously with that of the animal world. One of the striking general impressions is that of a succession of dominant groups, each reaching supremacy, and then yielding to another. Thus the gigantic club-mosses and horse-tails which made great forests yielded to Cycad-like forms and passed into relative insignificance; the Cycadophytes in turn yielded to the flowering plants.

\section{Multicellular Organisms}

It was a red-letter day in organic evolution when "bodies" began to be, i.e. when some living creatures passed from the unicellular to the multicellular grade of organization. Many flagellate infusorians form colonies or families of connected cells, the daughter-units, formed by division of the motherunit, remaining associated, instead of drifting apart to live isolated lives, and it was probably in some such way that multicellular organisms began. It must be clearly understood that the step was not primarily one of increase in size, for a rotifer or wheel-animalcule built up of a thousand cells is much smaller than a unicellular infusorian such as the Noctiluca (q.v.). 
Nor was the step primarily one of increasing complexity either of organization or activity, for many ciliated infusorians, though unicellular, are far more complex in plasmic architecture and in ways of life than the fresh-water polyps, built up of thousands of cells. The step was on to a new line of organization, the formation of a many-celled body in which scope was given to division of labour among the component units. The structural side of this is called differentiation. The at tainment of a multicellular body opened the way to unlimited specialisation of function, and also to an increase of size, which, other things being equal, counts for something in a rough and callous physical environment. The nemesis of this great step of gaining a body was apparently that organisms became liable to natural death in proportion to the complexity of the bodily framework. For natural death appears to result from the accumulation of wear and tear effects, and the failure of the ceaseless attempts to cope with these.

\section{Evolution of Sex}

Another big step was the evolu. tion of male and female multicellular individuals within the same species, the two sexes being complementary in the process of reproduction which secures the continuance of the race. The biological significance of the evolution of sex among multicellular animals was threefold. First, sexual reproduction implies that multiplication is effected by the liberation of germ-cells, which is more economical than separating off fragments or buds. There is also an increasing possibility of a large number of offspring. Secondly, to have special germcells in some measure apart from the body-cells tends to secure the hereditary persistence of a success. ful constitution, and lessens the risk of the offspring being prejudiced by disadvantageous dints made on the parent's body.

Thirdly, to have two different kinds of sex-cells, which have to unite at the beginning of each individual life, offers opportunities for new permutations and combinations of qualities, for those new departures technically called variations and mutations. The separation of sperm-producers or males and egg-producers or females, which differ deeply in constitu. tion, would also tend to increase the range of cross-fertilisation which is often advantageous, and would permit of a profitable division of labour between the parents in their relations to the offspring.
Differentiation includes a multitude of evolutionary steps. In the creature called Volvox, which consists of a thousand or ten thousand flagellate green cells united in a ball, all the component units, except those concerned with reproduction, are alike. There is no division of labour in the colony. In sponges, however, we see the beginnings of tissues, i.e. groups of similar cells performing the same functions. Thus contractile tissue, connective tissue, and flagellate lining tissue (or epithelium) appear among sponges. In the next great series of animals, the Coelentera or Stinging animals, other kinds of tissue, such as nervous and glandular, are differentiated, and we find the first occurrence of organs, such as sen. sory, digestive, and reproductive organs.

In most sponges and stinging animals the symmetry of the body is radial, i.e. there is no right or left side; the animal is the same all round. This is well suited to a sedentary or drifting existence, but for more strenuous life involving the pursuit of prey and mates, and the avoidance of enemies, bilateral symmetry, which virtually began among "worms," is incomparably more effective. It implies a right and a left side, a head end which leads the way, and a tail end.

With the acquisition of bilateral symmetry was associated the establishment of an anterior brain and the development of a head worthy of the name. This opened up another line of advance, technically called integration, in contrast to differentiation. Differentiation means increasing complexity of parts, integration means their more perfect unification and control, and one of the main functions of the nervous system is integrative.

\section{Differentiation and Integration}

The story of evolution, apart from retrogressive parasites and other degenerates, is one of progressive differentiation and integration, and the evolutionist has to record a long series of achievements. Among these are : an open food canal; a body cavity or coelom between the food canal and the body wall ; striped or swiftly contracting muscle; a circulatory system for distributing digested food and oxygen throughout the body and for collecting waste; oxygencapturing pigments such as haemoglobin; a segmented body as in earthworms; a renewable external armour as in crustaceans; muscular appendages first unjointed and then jointed; specialised sense organs such as eyes and balancers, improved respiratory arrangements reaching extraordinary perfec. tion among insects; delicate adjustments for filtering out the poison. ous nitrogenous waste of the body.

We can only allude to the establishment of the leading types of architecture represented by the various series of invertebrates or backboneless animals. Besides the sponges and coelenterates, we have to deal with the great variety of worm-types ; with the higher segmented worms or Annelids; with the starfishes, sea-urchins, and the like forming the Echinoderms; with the jointed-footed Arthropods, such as crustaceans, insects, and spiders; with the unsegmented molluses without appendages, such as bivalves, snails, and cuttles; and with many smaller groups.

\section{Origin of Vertebrates}

A step of great magnitude was the origin of the backboned animals or Vertebrates. It is not unlikely that these emerged from the stock of segmented worms. Their origin meant a fresh start on a new line of more masterful life. A dom. inant feature was the establishment of a relatively large brain protected by a skull, and of a long, spinal cord protected by the backbone. Of great importance also was the first appearance of bone and of an internal living skeleton (usually of bone) pervading the whole body, and contributing to integration. In the establishment of numerous glands of internal secretion, whose hormones or regulative substances are distributed by the blood throughout the body, a chemical integration began to operate, or to do so on a larger scale.

Skulls began with the hags and lampreys; jaws and paired fins, scales and typical gills with the true fishes ; digits, true lungs, vocal chords, and a mobile tongue with Amphibians; the antenatal robes (or foetal membranes) known as amnion and allantois with the reptiles ; a four-chambered heart with the crocodilians; warm-bloodedness, or keeping the temperature of the body approximately constant, with birds and mammals, which also show an enormous advance in brain development; the usually prolonged antenatal connexion between mother and offspring with the placental mammals. And just as amphibians mark the transition from water to dry land, so the extinct flying dragons (Pterodactyls) pointed towards that mastery of the air which birds and bats have attained.

Along with the great structural advances, there went a functional progressiveness. The smooth working that marks even the simplest creatures is not lost with intricate organization. But the scope of the 
life is widened and its agency becomes more free. In a sense, the behaviour of a ciliated infusorian is just as perfect as that of a bird, but the range is narrower, and the resources are fewer. The behaviour of ants and bees is extraordinarily effective on the instinctive line (see Instinct), and in its way unsurpassable. It cannot be profitably pitted against the behaviour of a horse or a dog, which is on the in: telligent line, but its range resources are narrower. The instinctive creature is apt to be sadly non. plussed by some slight alteration in the routine of its experience. What Sir Ray Lankester has called the "little-brain" type, rich in inborn or instinctive capacities but slow to learn, must be distinguished from the "big-brain " with little ready-made equipment, but with prodigious educability.

The "big-brain" type came to its own in birds and mammals, and there convincing evidence is found of an inner mental life of subjective experimenting, called perceptual inference, or intelligence. Interesting also is the fact that, as an organism attains to complex efficiency and to more or less intelligent mastery of its en. vironment, it is able to practise reproductive economy. There are fewer offspring, but there is less mortality.

\section{Emergence of Man}

In the Early Eocene age, perhaps three million years ago, there emerged an arboreal race, the Primates, differentiated from other mammals in digits, teeth, skull, and brain. From this stock there diverged in succession the New World monkeys, the small anthropoid Apes (gibbon and siamang), and the large anthropoid Apes (orang, chimpanzee, and gorilla). This left towards the end of the Oligocene (or perhaps in the Miocene) a generalised human stem, from which there diverged in succession Pithecanthropus the erect, the slouching man of Neanderthal, and the early Briton of the Sussex Weald-known by the famous Piltdown skull. None of the offshoots came to much, it seems, but the main stem continued as the stock of modern man, broken up in relatively recent times into African, Australian, Mongolian, and European races.

With the emergence of Man evolution passed on to another grade. For there are several reasons for avoiding the false sim. plicity of regarding social evolution as no more than a continuation of infra-human evolution. The first and chief reason is to be found in man's undeniable apartness and pre-eminence as a rational and social person. Man is differentiated by his language, by his capacity for forming and experimenting with general ideas, i.e. by his reason, by his vivid self-consciousness of his own evolution and by purposeful determination to control it ; and by his strong kin-instincts. The second reason is the fact that in social history we have to deal with integrates of social persons, operating as unities of a higher order. The third reason is the importance of what lies outside the individual, namely, in literature and art, the folk-ways of customs and tradition, the external registrations which we call institutions. In all this new notes are struck, and the evolution of man, though continuous with, is more than a mere continuation of, the evolution that goes on in infrahuman animate nature.

\section{Factors in Organic Evolution}

While the general idca of evolution is accepted by most naturalists, there is great un certainty in regard to the operative factors. The uncertainty is partly due to the difficulty of arguing from a meagre experience of the present to a past of many millions of years, and partly to the fact that the inquiry is still very young, for it virtually dates from Darwin's Origin of Species, 1859.

There are two main problems. The first asks how the continual emergence of new things, of changes or variations which make an organism appreciably different from its parents or its kin, is to be accounted for. The second asks what directive factors may operate on the variations which arise, determining their elimination or persist. ence and working towards the familiar but puzzling result-the existence of distinct and relatively well-adapted species.

Some of the peculiarities or observed differences distinguishing members of the same species can be shown to be individually acquired bodily modifications directly due to some peculiarity of nurture in the widest sense. But as there is no secure evidence that these characteristics are transmitted to the offspring, they can only be of indirect importance to the race. The raw material of evolution is furnished not by these modifications, but by variations which are inborn, not acquired or imposed from without.

Among these variations there may be distinguished minute pecu liarities, and larger abrupt sports of notable amount, such as a fantail pigeon or a copper beech. The former, Darwin's " individual variations," may be usefully termed fluctuations. The sports correspond to Galton's " transilient variations," Bateson's " discontinuous variations," De Vries's "mutations," and the last term should be kept for them. The transmissibility of inborn fluctuations has been proved in a few cases, and it was Darwin's conviction that "it is by the accumulation of such extremely slight variations that new species arise."

As to the origin of those minute novelties, a falling out of some feature, or a rearrangement of certain characters displayed by ancestors, it is possible to think of them as due to the intricate permutations and combinations that occur in the germinal material in the history of the germ-cells, especially during maturation and fertilisation (see Embryology)

But the baffling problem is the origin of the distinctively new, where the novelty is qualitative, not quantitative, where a new pattern, like a genius, appears. At present science cannot go beyond tentative suggestions. Some facts suggest that environmental influences may act as variational stimuli on the germ-cells and provoke mutation. It is also known that one species may differ from another in the number, shape, size, and structure of its nuclear bodies or chromosomes, and just as bacteria sometimes change suddenly in their physiological properties, so the chromosomes which last on from generation to generation may change in their stereochemic architecture or functional powers.

Germ-cells and Variations

This again might be due to environmental influence or to processes of ageing or rejuvenescence occurring in the germ-cells. Just as a remarkable regulatory process, called endomixis, takes place periodically in a "pure line" of slipper. animalcules (i.e. in a stock all descended from one individual), so in a lineage of germ-cells, within the organism that bears them, a similar process might occur.

It must be borne in mind that a germ-cell is no ordinary cell, but an organism telescoped down into a one-cell phase of its being. Just as a Protozoon may make experiments as well as a Mammal, so the germ-cells may conceivably make architectural experiments in self adjustment or self-expression, the outcome being seen in variations.

The most clearly discerned directive factor in organic evolution is natural selection, the process by which, in the struggle for existence, certain variants of a species, marked from their fellows by the presence or absence of some 
character, are on that account favoured with longer life or more successful families than their neighbours, who are therefore sooner or later eliminated. The full title of Darwin's great work should be remembered: The Origin of Species by Means of Natural Selection, or the Preserva. tion of Favoured Races in the Struggle for Existence. He stated the gist of the theory, which Alfred Russel Wallace had independently reached, in a couple of sentences : "As many more individuals of each species are born than can possibly survive, and as, consequently, there is frequently recurring struggle for existence, it follows that any being, if it vary however slightly in any manner profitable to itself, under the complex and sometimes varying conditions of life, will have a better chance of surviving, and thus be naturally selected. From the strong principle of inheritance any selected variety will tend to propagate its new and modified form."

\section{Natural Selection}

There are several different modes of natural selection; thus it is useful to distinguish between "lethal selection" which works by the discriminate elimination of the relatively less fit, and " reproductive selection," which works through the increased multiplication of the relatively more fit. The operation of natural selection has been satisfactorily demonstrated in a few cases, and it is certainly a potent directive factor. But it is still on trial as regards its scope. Thus, if reason be found for believing that great steps in evolution have been made by sudden mutations, we must reduce our estimate of the importance of natural selection except as a pruning agency. To turn to a less difficult point, it is important to avoid the popular fallacy that natural selection works out the survival of the fittest in any absolute sense; what ensues is the survival of the relatively more fit to the given conditions-which may not imply desirability.

On the other hand, we would reemphasise the idea that natura selection operates in part in reference to a system of inter-relations which is continually becoming more complex, which is made up of many stable and beautiful and intelligent components that have stood the test of time. Therefore,natural sclection does not work capriciously; we get at least a hint of the reason for its working on the whole progressively. Besides selection some have recognized isolation as a directive factor, that is to say all the barriers which restrict the range of intercrossing

within a species. " I do not doubt," Darwin said, "that isolation is of considerable importance in the formation of new species."

Retrospect aND Prospect. When we look back on the majestic process by which the present system of animate nature has come to be, certain general impressions arise in the mind. In the course of the ages there has been, in the animal world, a progressive evolution of the nervous system, an increasing elaboration of behaviour, a gradual increase of free agency, a growing emancipation of mentality. Since the beginning of life there has been on the part of living creatures an increasing appreciation and mastery of their world. To Man, who is part and parcel of the order of Nature, though also singularly apart from it, there is encouragement in the fact that we know of no reason for believing that the evolutionary process will stop. Another general impression of great interest is that while organisms are ever experimenting and tentative, proving all things, they are just as characteristically given to holding fast to that which is good. Species become extinct and races perish, but great organic inventions, such as amoeboid movement or haemo. globin or hormones, are carried on by some collateral lineage. There is a strong power of conservation in the midst of the evolutionary flux.

Complexity of the Process

As Lotze said, the process of evoIution has the unity of an onward advancing melody. Retrogressions and involutions there have been and are, but the big fact is progress to finer issues. With the growing differentiation and integration (i.e. complexity and control) in organisms, there was correlated some degree of external registration in the system of inter-relations gradually established. For one result of organic evolution has been the weaving of a web of life whose pattern has become more and more in. tricate, as in the inter-relations between flowers and their insect visitors. This complexifying of relations has probably been of great importance in evolution, for it is in reference to this externa' system that new organic experiments are tested and that selection works. Thus it seems that the intensification of life has been in part secured and in part prompted by the growing complexity of the external system of Nature.

Thus living creatures contribute to the evolution of their kind, not only directly by exhibiting variations and by personally testing these, but also indirectly by contributing to the complexifying of the external web of life. If this be so, there is for Man the hint that progressive evolution depends not merely on the improvement of the natural inheritance and intensification of the individual life, but also on the ennoblement of the external heritage-so much Man's own creation-the treasures of literature and art, the tradition of high ideals, and the multitudinous linkages - many in need of amelioration-in the framework of society itself.

\section{The Philosopbic Conclusion}

When we try to think of facts in their entirety, that is to say philosophically, we are probably wise if we hold firmly by the Aristotelian conviction that there can be nothing in the end which was not also present in kind in the beginning. So, if Man is altogether an outcome of the evolutionary process, as most naturalists believe ; and if experience of reality to the best of mankind includes a spiritual life, i.e. persistent activity towards the ideals of the true, the beautiful, and the good; then we may be sure that the primordium from which this was evolved could not be adequately or exhaustively formulated in terms of matter and motion. For by no jugglery is it possible to evolve mind out of matter and motion.

Bibliography. Origin of Species, C. Darwin, 1859: Darwinism, A. R. Wallace, 1889 ; Materials for the Study of Variation, W. Bateson, 1894; The Evolution Theory, A. Weismann, Eng. trans. J. A. and M. R. Thomson, 1904 ; Species and Varieties : their origin by mutation, H. de Vries, ed. D. T. MacDougal, 1905 ; Experimental Zoology, T. H. Morgan, 1907 ; Darwinism and $\mathrm{Hu}$ man Life, J. A. Thomson, 1909 ; Story of Creation, a plain account of evolution, E. Clodd, rev. ed. 1910 ; Creative Evolution, H. Bergson, Eng. trans. A. Mitchell, 1911 ; Evolution Old and New, Samuel Butler, 3rd ed. 1911 ; Evolution, P. Geddes and J. A. Thomson, 1911 ; Problems of Genetics, W. Bateson, 1913 ; Recent Progress in the Study of Varia. tion, Heredity and Evolution, R. H. Lock, rev. ed. L. Doncaster, 1916; The System of Animate Nature, J. A. 'Ihomson, 1920.

Evora. District of Portugal, in the prov. of Alemtejo. It is bounded on the $\mathrm{N}$. by the dist. of Portalegre and on the $\mathrm{S}$. by the dist. of Beja. 'The river Guadiana forms its E. boundary. Hilly on the N.W. and S. it slopes E. and S., furming the basin of the Degebe and smaller streams flowing into the Guadiana. A large portion of the district is barren, but there are cork-oak forests. Evora is the capital, and Redondo and Montenior are other important towns. Pop. 144,307 


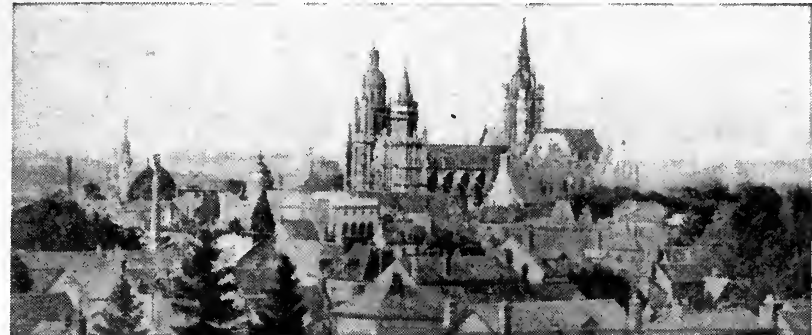

Evreuz. The city and cathedral seen from the south. To the left is the 15th century Tour d'Horloge or Belfry

Evora (anc. Ebora). City and archiepiscopal see of Portugal, capital of Evora dist. Beautifully situated on a low hill in a fertile plain, $72 \mathrm{~m}$. by rly. E. of Lisbon, it is enclosed by ancient walls and towers, has many Roman and Moorish remains, and is as interesting as it is ancient. It has a cathedral, founded in 1186 , a 16 th century church, an art gallery, a museum, many old convents, a library, a Roman temple, various palaces, and a famous aqueduct. It manufactures cloth, cotton and woollen goods, and hats, and trades in wine. In the vicinity are copper and iron mines, and marble and asbestos quarries. An important fair is held annually. A stronghold of Sertorius (q.v.) and a Roman colony, Evora was a bishop's see under the Visigoths, taken by the Moors in 715, and recaptured by the Christians in 1166. Pop. 17,901.

Evreux. City of Normandy, France. It is $67 \mathrm{~m}$. W.N.W. of Paris, and stands on the Iton, a branch of the Eure, in the dept. of Eure, of which it is the capital. The chief building is the cathedral of Notre Dame, the earliest part dating from the lith century and some part from the 16 th. It was completely restored at the end of the $19 \mathrm{th}$ Other old buildings are the church of S. Taurin, a Romanesque building of the 11 th century, to which an abbey was at one time attached, the episcopal palace, and the belfry. The hôtel de ville, museum, public library, and botanical gardens are notable. There are some small manufactures and a considerable agricultural trade.

Evreux was frequently besieged and taken in the wars between England and France. At Vieil Evreux, $4 \mathrm{~m}$. distant, extensive remains of a Roman theatre, baths, aqueduct, etc., have been unearthed. In the Middle Ages the counts of Evreux were powerful nobles; the dignity was given in 1427 to Sir John Stuart of Darnley, a Scot in the French service. The English family of Devereux takes its name from here. Pop. 18,950.

Evzones or Euzones. Greek troops. They bear a variant of the name given to troops in the times of ancient Greece, Euzonoi, mean. ing well-girdled, and so girt-up for fighting. They are light troops consisting normally of about six battalions, and from their dress are known as the Greek Highlanders. Their uniform consists of a white kilt or fustanella, widesleeved white shirt, embroidered vest, red-pointed shoes, and bluetasselled red cap. The Evzones fought in Macedonia and Serbia in the Great War.

Ewald, CARL (1856-1908). Danish novelist. Born in Slesvig, when a child he removed with his family to Copenhagen after the an. nexation of the duchy by Germany.Hestarted in active work as a for. e s ter, but turned to mis. cellaneous lit. erary work, and then to the

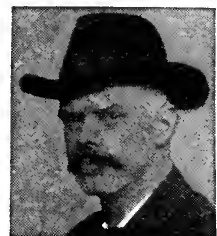

Carl Ewald, Danish novelist novel, in which he chiefly won dis. tinction. In The Old Room he depicted a rebel against orthodox life, and in Cordt's Son his opposite in a strict observer of the conventions. Several of his stories have been translated into English by Texeira de Mattos, notably Two-Legs and Other Stories, 1907 ; My Little Boy, 1908; and The Pond and Other Storios, 1909. Pron. Ayvahld.

Ewald, Georg HeInRICH August voN (1803-75). German Biblical critic and Orientalist. He was born at Göttingen, Nov. 16, 1803, where

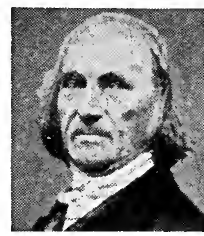

Heinrich Ewald, German scholar in 1827 he became professor of Oriental languages and philosophy. In 1838 he was appointed to the chair of theology at Tü. bingen, and in 1848 returned to Göttingen, where in 1867 his retirement came about through political complications. His numerous works includea Hebrew Grammar, 1827, and various works on the O.T., but the most important was his Geschichte des Volkes Israel, 1843-59. His criticism was cautious, and he exposed the extreme views of the Tübingen school. He died May 4, 1875. See Heinrich Ewald : a centenary appreciation, T. W. Davies, 1903. Pron. Ayvalt.

Ewald or Evald, JoHANNES (1743-81). A Danish poet. Born at Copenhagen, Nov. 18, 1743, a yearn. ing for change and adventure induced him, while still a student of sixteen at Copenhagen University, to join the army of Frederick the Great, then engaged in the Seven Years' War. In 1760 he returned to Denmark and resumed his studies. A cantata written in $\mathbf{1 7 6 6}$ on the death of Frederick $V$ of Denmark placed him in the front rank of lyric poets; but his drama, Balder's Death (1773), in which he introduced the old gods of Scandinavian mythology, first ensured his fame and gave an im. mense stimulus to the national pride in the legendary past of Denmark. George Borrow's English translation of this was published in 1889. Other well-known works are Adam and Eve, 1769 (rewritten from his rejected Adamiade, 1764), and The Fishermen, 1778. He died March 17, 1781. Collected Works, ed. H. Brix and V. Kuhr, 1914, etc.

Ewart, JAMes Cossar (b. 1851). Scottish naturalist. Born at Penicuik, Nov. 26, 1851, he was educated at Edin. burgh. In 1878 he became professor of $\mathrm{Na}$ tural History at Aberdeen, where he established a marine zoological station, and in 1882 at Edin. b u r g h. He did much to

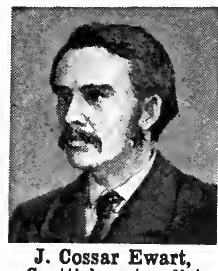
Scottish naturalist From an etching develop the Scottish fisheries, and is an authority on marine zoology.

Ewart, Sir JoHn SPENCER (b. 1861). British soldier. Born March 22,1861 , he was educated at Marl.

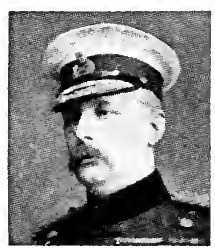

Sir John Ewart British soldier borough and Sandhurst, joining the Cameron Highlanders, 1881. He saw service in Egypt, 1882, $1884-85$, in the Sudan, 188586,1898 , and in S. Africa, 1899-1901. 
He was director of military operations at the War Office, 1906-10, adjutant-general and a member of the Army Council from 1910-14, when he was appointed G.O.C. Scottish Command, May, 1914, which post he held until May, 1918. He was created K.C.B. and lieut. -general in 1911.

Ewbank, Tномаs (1792-1870). British author. Born at Barnard Castle, March 11, 1792, at the age of 13 he was apprenticed to a plumber, and in 1812 obtained employment in London as a labourer. He emigrated to America about 1819, and started metal tube manufactory in New York, from which business he retired in 1836 . After travelling in Brazil, 1845-46, he published his Life in Brazil, 1856. Ewbank was commissioner of pa. tents from 1849-52. The remainder of his life was spent in writing on engineering subjects and contributing to scientific journals. He died in New York, Sept. 16, 1870.

Ewe (Lat. ovis, a sheep). Word used for thefemale of the sheep $(q . v$. and of certain other animals.

Ewé. W. African language. group. Mostly found in Dahomé, $\mathrm{S}$. Togoland, and the Gold Coast Colony, it forms part of a primitive W. Sudanic speech once widespread in the Guinea region before the advent of Bantu influences. Of the Ewé. speaking peoples the chief French tribes are the Dahomé and Mahi ; the British tribes include the Awuna, Agbosomi, and Krikor, E. of the Volta river. The racial type tends to be shorter, fairer, and rounder-headed than that of the true negro.

Ewell, Richard Stoddard (1817-72). American soldier. Born at Georgetown and educated at the military academy of Wust Point, on the outbreak of the Civil War he resigned his com. mission in 1861 to fight for the Confederacy, and took part in both battles of Bull Run, Antietam, Chancellorsville, Gettysburg, and others. In the closing days of the war, in 1865, Ewell and his force were captured by Sheridan at Sailor's Creek. He died at Spring. field, Tennessee, Jan. 25, 1872.

Ewer. Pitcher or jug with a wide mouth. It is particularly one for holding water for toilet pur. poses. The word is a corruption of Lat. aquarium, watering place: cf. Fr. eau. See illus. p. 2443.

Ewing, Sir JaMrS AlFred (b. 1855). British physicist and engineer. Born at Dundee, March 27, 1855, he was educated at the high school and at Edinburgh University. Until 1878 he assisted Lord Kelvin, and from 1878-83 was professor of mechanical engineer-

ing at the imperial university of Tokyo, Japan, where he studied earthquakes. From 1883-90 Ewing was professor of engineering at University College, Dundee, and of me chanis m and applied mechanics in Cam bridge University, 1890-1903. He

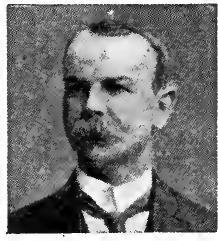
Sir Altred Ewing, British physicist at on the ex plosives committee, and became a member of the ordnance research board in 1906. In 1903 he was appointed director of naval educa. tion, and in 1916 became principal and vice-chancellor of Edinburgh University. Among his important inventions were: magnetic curvetracer, hysteresis tester, and a permeability bridge, all used in testing the iron employed in making dynamos and transformers. He has written much on engirieering and scientific subjects, and a Treatise on Earthquaize Measurements, 1883. He was knighted in 1911.

Ewing, Juliana Horatia (1841$85 \%$ W riter of stories for children. She was the daughter of Alfred

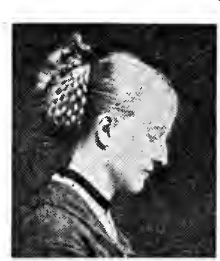

Gatty, vicar of Ecclesfield, Yorkshire, and the wife of Major Alexander Ewing. Among the pleasantest of her tales are The Land of Lost Toys, 1869; A Flat Juliana H. Ewing. British anthor Iron for a Irar-

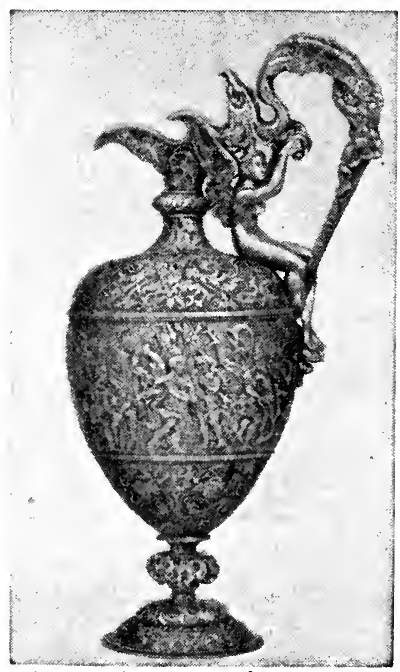

Ewer. Silver repousse ewer in the style of early German goldsmiths thing, 1873 ; Jackanapes, 1884 ; and The Story of a Short Life, 1885. She died May 13, 1885.

Examinations. The raison d'être of examinations is the desire to find some ready test of capacity. 'The system, so far as is known, started in China about 2200 B.c. 'The medieval universities sought to test intellectual capacity by dialectical discussions called disputations. The result was to reward mere "quickness in logical fence."

'The change from disputations to questions, the germ of the modern examination system, dates from the 18th century, when the Cambridge tripos list and senior wranglership began to acquire fame. Originally intended "to guide men so that they might learn what was thought best for them," the mathematical tripos soon degenerated into a test for allocating the college fellowships. The incorporation of the university of London in 1836 was important as first differentiating the teaching and examining functions of a university, and in 1848 Dr. Whewell, at Cambridge, sought by introducing compulsory examination in elementary subjects to prevent perfunctory reading of the higher subjects. Thereafter we observe two educational parties-one trying to train men to play a successful part in life; the other, to supply the scientific world with expert mathematicians for professorial chairs.

At first the whole examination was conducted viva voce. As the number of candidates increased, the viva voce method proved too slow and costly. The need for a close discrimination between large numbers of candidates, not greatly differing in ability, led to the introduction of an ever-increasing number of questions on paper, covering an expanding field of facts, and the allotment of marks, which, added up, established an order of merit by a comparison of totals differing sometimes by only a few figures. As the members still in. creased the screw was progressively tightened by enlarging the field of acquisition and deepening the obscurity of the tests until many of the examination questions of a body like the old university of London became, in Pope's satiric words,

tricks to show the stretch of human brain.

Mere curious pleasure, or Ingenious pain

Inevitably those candidates succeeded best who by nature could acquire the largest number of facts, retain them until the opening of the examination halls, and place them most rapidly on paper. On the other hand, examiners strove 
to discover questions which had not been set before and could be marked with precision and speed. The use of this "ready reckoner" of ability was both fostered and abused by the call of democracy for some means of distinguishing merit apart from birth and parentage. Thus arose the competitive examinations for the Civil Service, the Navy and the Army, the emoluments of a university career, and latterly even for the acquisition of a stool in bank and counting-house. When also degree examinations ceased to be used as tests of teaching capacity, professional examinations in music, pharmacy, surveying, and so forth were introduced. Schoolleaving examinations and the submission of theses for degrees have been imported from the Continent.

\section{Merits and Demerits}

Though examinations have failed to accomplish their original purpose, they nust not be regarded as an unmixed evil. They tell us little about moral qualities and tend to destroy spontaneity and originality. They overstrain the mind, particularly in "information subjects," to the serious detriment of physical development at a critical age. They foster false intellectual values by tempting both teacher and pupil to concentrate on one subject or a single group, in order to achieve some reward therein, a prize or scholarship, to the exclusion of general culture. They encourage memory far more than mind. Lastly, they have gathered round them a body of sterile scholarship which glories in a vast knowledge of dead tongues and a heap of learned antiquarian lumber valueless to the progress of true science and the growth and culture of the human heart.

Nevertheless, examinations must be credited with some good effects. They act as stimulants to the desire of excellence and development, both personal and intellectual, and force young minds to traverse intellectual paths which they would never have trodden for any other reason. A much examined man may remain a poor piece of humanity; but he will have come under valuable influences, have become acquainted with vast tracts of knowledge, and obtained a breadth of vision, if not a profundity of judgement, of which the untested man or woman is too often quite innocent. Lastly, they militate against loose thinking and inchoate knowledge.

With a view to improving secondary school examinations the board of education of England and Wales has (Circular 996) undertaken "the functions and responsibilities of a coordinating authority," with the assistance of a Secondary-School Examinations Council of 18 persons, representing the leading universities and examining boards, councils, and associations. This Council will, under the coordinating authority of the board of education, deal with the recommendations of examining bodies, the maintenance of adequate standards of examination, the investigation of complaints thereupon from school authorities, the promotion of examination conferences, the form and contents of examination certificates, inter-university negotiations for equivalence of rival examinations, and the effecting of general improvements in examination schemes by bringing teachers into touch with examiners, by examining schools on their own syllabuses, and by taking into account the teachers' estimates of the merit of the candidates from their own schools (Circular 1002).

\section{Remedies for the System}

In view of the establishment of such a Council it may be well to state succinctly some obvious remedies for the faults of the present system. If the pupil's mind is not to be narrowed by the withdrawal of his interest and at tention from all matters beyond the purview of the examination, its scope must be so limited that preparation for it occupies only part of his school time. Moreover, examination schemes must be frequently reviewed. If expository power is not to be paralysed, systematic training must be given in composition. The "chancy" nature of written examinations must be counteracted and the handicap of ill-health or nervousness removed by calling into council the teacher and learning the pupil's past record. Individual ability must be drawn out of the examination crowd by combining oral and practical tests with written answers. Multiplicity must give place to equivalence of school leaving and entrance examinations. The uni. versity rewards which are now the Dead Sea fruit of a sterile facility in passing examinations, must be given in future to men and women who have proved their ability to "teach" and to "discover" by actual performances.

In conclusion, examinations do not show men and women how to teach or write in the higher sense ; but they do train them how to set down, clearly, succinctly, and rapidly, the facts which they havo acquired and retained. If such persons are not born with creative power, this acquired knowledge becomes mere "learned lumber." But, if they are born to do and to make, the acquisitions of the examination course and the habits of the examination hall may enable them to lay the foundation of deeds and works which the world will inscribe upon its scroll of honour. See Education; School; University. w. K. Hill

Examiner of Plays. Official acting on behalf of the Lord Chamberlain, who has the theatres under his jurisdiction. A copy of every new piece, or alterations of old pieces intended to be revived, must be forwarded to him seven clear days before the intended production. No alteration of the text, when licensed, is permitted without express sanction. The selection of Charles Hallam Brookfield (q.v.) for the post in 1911 in succession to G. H. Redford amused many people and shocked others, for he had at one time been one of the chief adapters of frankly nonmoral French comedies for the English stage, his Dear Old Charley (Newcastle, 1906), in particular, enjoying a succès de scandale. He was succeeded by George S. Street, the critic and essayist, appointed Dec. 30, 1913 See Censorship.

Exarch (Gr. exarchos, leader). In Byzantine history, a title specially applied to the military governor of the district of Ravenna in Italy. The exarch has been compared to the viceroy of India. The direct representative of the emperor, he commanded the troops, controlled the civil administration and finance, and exercised great influence in ecclesiastical affairs. The exarchate of Ravenna lasted from 584-752.

There was also an exarch of Africa, the earliestmention of whom occurs in 591. The name exarch was also given to a dignitary of the church who held a position below that of the patriarch, but above that of the metropolitan, and to the head of certain monasteries, and survives as the title of the patriarch of Bulgaria.

Excalibur.

King Arthur's magic sword; called Caliburn and made in the isle of Avalon. In the Morte d'Arthur the King takes the sword from the hand of the Lady of the Lake, and learns that its name signifies Cut-Steel, and that while he has the scabbard he can never be sore wounded and cannot lose blood. When stricken down in the final battle, Arthur commanded that the sword be thrown into the lake, where it was caught by a hand and vanished. See Morte d'Arthur. 
Excambion.' Term used in Scots law for an exchange of lands. The law allows this to be done in the case of entailed property, as well as unentailed, several statutes to this effect having been passed. It is often done to make boundarics and the like more convenient.

Excavation. In engineering, term used for the removal of material for building and other purposes. In nearly every branch of engineering excavation work occurs, from the sinking of a well to the construction of huge reservoirs, ship canals, railway tunnels, etc., several tons each, and work on a face 12-16 ft. high. This machine, usually self-propelling, has in front a swivelling jib made up of two powerful girders, between which swings the back end of a beam.

To the forward end of the beam is attached a large steel scoop, holding up to five cubic yards of material, and provided with a flap bottom that can be tripped by pulling on a cord. The mechanism includes gear for revolving the jib; racking the beam inwards or outwards to vary the reach of the shovel : and lifting the

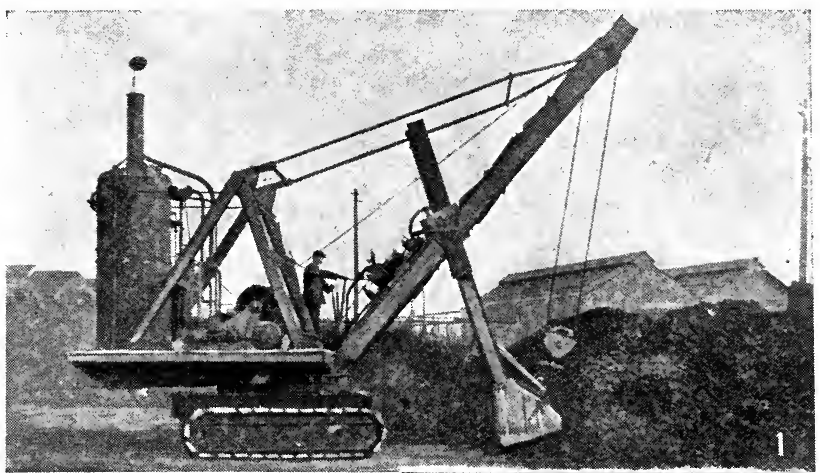

involving the use of tools from the simple pick and shovel to giant excavators (q.v.), dredges, etc.

Excavation problems are among the most difficult the engineer has to solve, the mere task of removing the material being a simple one compared with the difficulty of preventing the sides of the excavation from collapsing. The excavation of the Panama Canal (q.v.), in. volving the removal of $175,000,000$ cubic yards of material, was considerably delayed for this cause. The original plans were altered because the soft earth could not be prevented from spreading. Great masses of earth, constituting the adjoining banks in the deepest parts of the Culebra Cut, slid down into the canal, necessitating constant dredging to restore naviga. tion. Excavating is an important part of archaeological work. See Archaeology ; Canal ; Dredging ; Foundation ; Tunnel; also illus. pp. 811 and 813 .

Excavator (Lat. ex, from, out; cavare, to hollow). Mechanism for removing large masses of earth. Some of the digging machines used closely resemble the vamous kinds of dredgers. The spoon dredger has its counterpart in the steam-shovel or steam-navvy, which will deal with anything from soft earth to lumps of blasted rock weighing

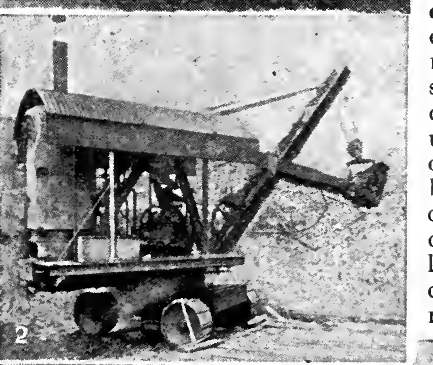

shovel by means of a chain or cable passing over the end of the jib. In operation the scoop is lowered to about rail level, and thrust forward while being lifted. At the end of the stroke, the jib is swung to bring the scoop over a dirt car, and the contents are dumped by releasing the bottom.

In the hands of skilful operators a shovel will pick up and deliver four loads per minute. A ninetyton machine, controlled by three men, can move 3,600 tons a day, performing the work of 2,000 hand labourers. An immense amount of excavation was done on the Panama Canal works by these giant diggers in combination with mechanical unloaders which enabled ten men to clear in a day as much as would have kept 500 men busy with shovels. The steam-navvy is found very valuable for purposes other than those of civil engineer ing, being widely used for stripping the useless " overburden " of surface deposits of coal and iron ore, digging ore and phosphates, and excavating dry gold-bearing gravel in "placer" mines.

Another excavator, used chiefly for earth and gravel, is the French navvy, which moves on rails along the top edge of the cut, drawing the spoil towards it in an endless chain of buckets running round a sheave at the end of $a \mathrm{jib}$ supported ladder. The buckets excavate while travelling upwards under the ladder, and the spoil is discharged into a shoot, or on to a belt-conveyer for delivery to cars, or directly on to a dump. As ex cavation proceeds, the ladder is lowered gradually till the full depth commanded by the machine is reached. The excavator then lifts

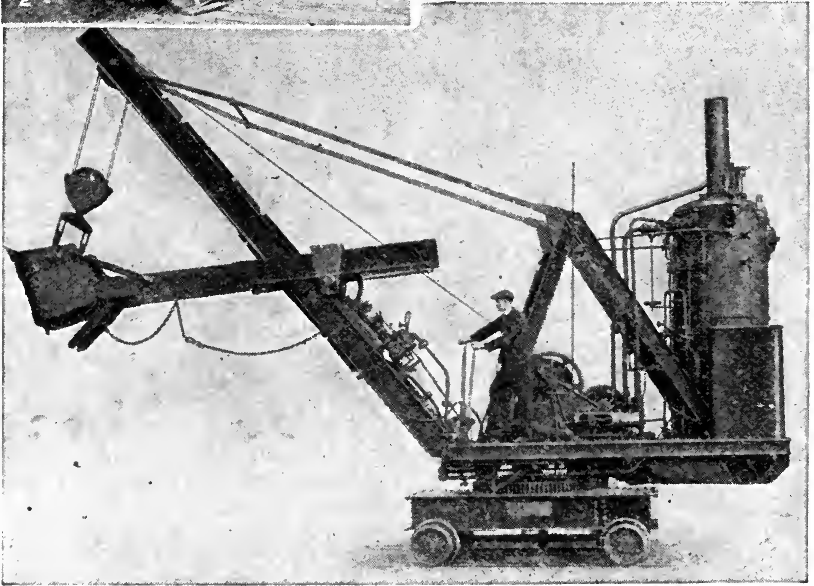

Excavator. Crane navvies on mountings suitable for various types of work. 1. With caterpillar travelling gear. 2 . On road wheels. 3 . Mounted on rail wheels By courtesy of Ruston \& Hornsby, Ltd. 
the ladder, moves forward a little. and takes a fresh cut. This type of digger is very effective for canal and dock work.

The latest form of mechanical excavator for surface work is a rotary machine. It travels on two main traction wheels at the rear, and on a forward steering wheel, the height of which can be adjusted. In the space between the traction and steering wheels the frame supports a spokeless excavating wheel of large diameter, with buckets mounted on its circumference. It revolves in a fore-and-aft plane, making a cut, as the machine moves forward, $6 \frac{1}{2} \mathrm{ft}$. wide and from $1 \mathrm{ft}$. to $5 \mathrm{ft}$. deep, according to the adjustment of the steering wheel, which is supported by the undisturbed ground. A belt-conveyer, running transversely through the wheel, receives the spoil and empties it at onc side into cars or on to a heap. 'The capacity of the machine is 325 cubic $\mathrm{ft}$., or about 16 tons, of material per minute.

An apparatus with a scoop wheel working in the manner just described, but mounted on a fourwheeled frame like that of a trac. tion engine, has proved very successful in excavating ditches or trenches for water and drain pipes. The scoop wheel revolves between the arms of a falling jib at the rear of the machine. The "ditcher," as it is called, will deal with any kind of ground that can be moved with a pick, even macadam road, and will cut through buried roots and logs. The largest machines excavate trenches $4 \frac{1}{2} \mathrm{ft}$. wide to a depth of $12 \mathrm{ft}$. A correct grade is maintained by means of the jib gear and a sighting-box on the wheel frame.

Some sections of the London " tube" tunnels were driven by an electrically operated rotary boring digger, a transverse wheel with six radial arms carrying chisels and scoops. Rotary motion is imparted to the wheel by pinions engaging a circumferential rack. The cutting chisels loosen the material, which falls into the invert and is picked up by the buckets and emptied on to a belt-conveyer. See Engineering.

Excellency. Title of honour, formerly applied to emperors, kings, princes, and other high personages. In modern British usage it is confined to the governor-general of India, the lord-lieutenant of Ireland, colonial governors, and ambassadors and envoys. In France and the S. American republics the president is styled Excellency, but not in the U.S.A. The Italian eccelenza is a common mode of addressing strangers.

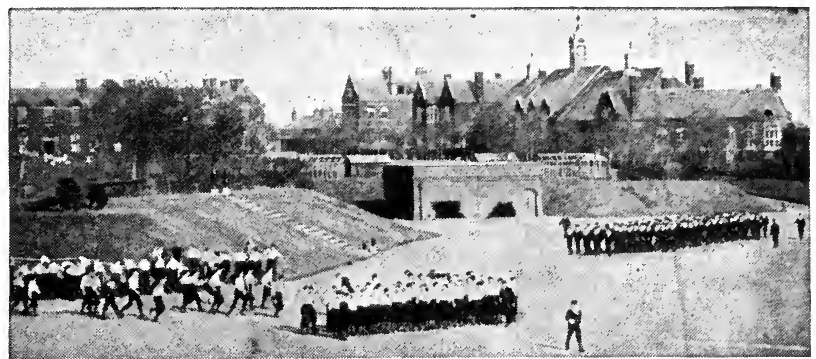

Excellent. Parade ground of the chief school of naval gunnery on Whale Island, Portsmouth Harbour Cribb, Southsea

Excellent. Name of a British warship, and of the chief school of naval gunnery, also known as Whale Island. It is situated in Portsmouth Harbour on a small island made up largely of earth excavated for the construction of new docks. In the Excellent gunnery school officers and men are trained as specialists.

The Excellent, a 3rd class gunboat, built in 1870 , displacing 508 tons, with one $7 \cdot 5$-in. and one 4 -in. gun, took part in the bombardment of the Belgian coast in the early months of the Great War.

Excelsior. Lyric poem by $\mathrm{H}$. W. Longfellow, published in Ballads and Other Poems, 1841. It is intended to show the life of a man of genius, resisting all temptations, laying aside fears, heedless of warnings, and pressing right on to accomplish his purpose. After every warning, in the face of every temptation, he repeats his motto, Excelsior, higher; and then perishes without having reached the perfection he longed for. The voice

\section{EXCHANGE : INTERNATIONAL FINANCE}

zllis T. Powell, D.Sc., Author of The Mechanism of the City

Banking; Credit; and Money are articles which deal with subjects of kindred interest. See also Bill of Exchange and the articles on the great banks, both British and foreign

The science of the foreign exchanges is concerned with the transformation of the currency of one country into that of another. The exchange is necessary in order to adjust the international obligations which arise from the worldwide operations of finance, industry, and trade.

Giving change for a sixpence is proverbially unprofitable; nobody here and now will give more than sixpence for sixpence. But sixpence here may be worth more or less than sixpence somewhere else, while sixpence now may be worth more than sixpence in three months' time. This principle is the key to the mysteries of the foreign exchanges, the machinery by which money in one country is trans- heard in the air at the close is the promise of immortality and proress ever upward.

Excess Profits Duty. Tax levied by the British Government to meet the expenses of the Great War. It was first imposed in Sept. 1915 , when all excess profits made in business were taxed at the rate of 50 p.c., the amount being raised to 60 p.c. in 1916 and to 80 p.c. in 1917. Excess profits were defined as those in excess of the average made in the two or three years before the outbreak of war, and the tax was not charged on the first $£ 200$. Farmers and professional men were not liable to the tax, which in the financial year 1919-20 produced $£ 290,045,000$. A similar tax was introduced in Canada and Australia, and in several foreign countries. The duty, reduced to 40 p.c. in 1919 , was raised to 60 p.c. in 1920. The duty was very unpopular and by Sept. 20, 1920, there was a drop of over twenty millions in the estimated total. It was abolished in Mar., 1921. formed into money of another. By money we mean coin, or else some bill, or note, for example-convertible as of right into coin.

I want to pay $15 \mathrm{~s}$. to McGinty in Glasgow. I could, if I liked, send him a 10s. currency note and two half-crowns in a registered letter; but this is cumbersome. The ideal method is to find somebody in Glasgow who owes me 15s. and tell him to pay it to McGinty. Unfortunately, I have no debtor in Glasgow ; but I know an individual who does possess large funds there, and it occurs to me that I might buy 15s. of his Glasgow money with my London cash. This individual with the large Glasgow bal. ances is the postmaster-general. 
At a post office I buy a Glasgow claim for $15 \mathrm{~s}$., paying the postmaster-general an extra $1 \frac{1}{2} \mathrm{~d}$. beyond the $15 \mathrm{~s}$. for the convenience he has afforded me. This claim on the postmaster-general's Glasgow balances, called a postal order, I send to my creditor. In due course he cashes it and is perfectly satisfied. This was an exchange transaction, a transformation of London money into money somewhere else. What I bought was, in fact, a bill of exchange drawn by the postmaster-general upon his balances in Glasgow.

In ordinary circumstances the postmaster-general's balances at Glasgow are sufficient to meet all demands. But suppose that circumstances create an abnormal number of remittances to Glasgow, so that the postmaster-general has to make special arrangements involving extra expense and labour for dealing with them. It is conceivable that he must then raise the price which he charges for the means of making remittances to the north. Instead of selling a 15s. bill or order for $15 \mathrm{~s} .1 \frac{1}{2} \mathrm{~d}$., he must demand $15 \mathrm{~s}$. $3 \mathrm{~d}$. or $15 \mathrm{~s}$. $6 \mathrm{~d}$. In the language of the foreign exchanges we should say that the London. Glasgow exchange was moving against London, because a given amount in the metropolis was exchangeable for a less in Glasgow.

\section{A Hypothetical Example}

In the supposed instance why should the London-Glasgow exchange move against London? Simply because so many London people were anxious to acquire claims to Glasgow money in order to meet their obligations there. Finding such a strong demand for Glasgow money, the postmastergeneral put up the price at which he was willing to sell his Glasgow balances. For some commercial reason everybody was desirous of providing funds in Glasgow to pay for goods bought there; consequently pcople like the postmastergeneral with money in Glasgow were besieged by London buyers of their Glasgow funds. Bills on Glasgow were eagerly snapped up people were bidding for them against one another. The result was that the price of Glasgow money went up; the LondonGlasgow exchange moved against London. Let us turn from this simple illustration of the principle, to its working throughout the business world.

If English exporters, at a given time, had sent so large a quantity of commodities to France as to create the nccessity for unusually extensive remittances to London in payment thereof there will arise an insistent French demand to exchange franes in Paris for sovereigns in London. The price of the sovereign, as expressed in francs, will advance. Now the Paris exchange, as quoted, expresses the price of the sovereign in francs; therefore the higher it goes the cheaper do the francs become, since the sovereign will buy more of them at the higher quotation than at the lower. This is what is meant when the Paris exchange is said to move in favour of London.

\section{Exchange Quotations}

At the same time it must be remembered that some of the exchanges-the Portuguese, for example-are quoted the other way round. While the Paris exchange is francs to the sovereign, the Portuguese exchange is pence to the milreis. This reversal turns the whole process upside down, with the result that the lower the quotation the better for the English buyer of Portuguese currency, since it increases the amount which he can purchase in Lisbon for a given sum in London. The varying methods of quoting the exchanges are at first sight perplexing. The inquirer will discover, however, that in the quotations of the foreign exchanges in the daily newspapers the exact significance of the figures is indicated. $\mathrm{He}$ is informed, for instance, that the Amsterdam exchange is quoted florins to the $£$; that of Hong Kong is the value of the dollar in shillings and pence. In theory, of course, these transactions are exchanges of money for money; but the buyer of London sovereigns in Paris will get a draft or bill of exchange on a London firm or bank. Hence the French exchange quotation is for Paris cheques. This represents the money, and is in due course transformable thereinto. The element of time, as well as of an alien currency, has to be taken into consideration. Some of the exchange quotations in the current lists are for so many days' sight. They represent the price asked on a given date for English pounds payable in London after the expiration of 90 days, plus the days of grace.

As the speed of modern business tends ever to accelerate, there has arisen a need for a quicker remittance from distant points, than is represented by a draft payable at 60 or 90 days. Hence the "T.T." quotations in the published lists of exchange rates, i.e. the prices of telegraphic transfers. They stand for the terms upon which the exchange dealer in Shanghai, for instance, will buy or sell sovereigns in London, the money to be pay- able as soon as the cable can carry instructions to the London agent.

This element of time is important. Obviously a Rome draft on London, payable eight days after sight, or really 11 when the days of grace are added, will not be worth so much in the Italian capital as a sight draft on the same place. In the one case the recipient of the draft can get his money at once across the London counter. But with the draft at eight days' sight he must wait 11 days before he handles the coin. Similar principles operate between countries employing the same currencies. The price of the English sovereign, as expressed in terms of its Australian brother, undergoes a constant fluctuation. So again, large remittances from New York to Chicago will send up the price of the Chicago dollar as expressed in the New York dollar.

\section{The Gold Point}

In our preliminary illustration the postmaster-general gradually raised his London price for Glas. gow money. But he could not go on doing this indefinitely. If he advanced his charges beyond a certain rate, it would pay better to send coin or notes to Glasgow by registered letter, or by train, than to buy his Glasgow bills. The cost of remitting coin is easily calculable. It is the value of the coin, plus freight, insurance, and the expense, in large remittances, of packing and unpacking. Unless the postmaster-general keeps his charges below the aggregate of these expenses, people will send coin and notes to Glasgow in preference to buying postal remittances. If $£ 150$ in notes or gold can be sent to Glasgow for $£ 1$ in freight, insurance, and expenses, nobody will pay a commission of fl 10 s. to the postmaster-general.

The same principle holds good in international exchange. If the Paris price of English money rises above a certain point, the exchange dealers will ship gold to London. They can then sell, in Paris, the English money obtained for their gold. With the rate at its supposed high figure, they would make a profit, since they would get more for their English coin than it had cost them in shipping, insurance, and expenses. The rate of exchange which tends to encourage the transit of bullion, in preference to the purchase of bills, is called the gold, or specie, point

Bullion, however, is not invariably remitted whenever this point is passed. Other factors in the international monetary situation may prevent this. Certain governments, e.g., place obstacles 
in the way of the export of gold. Consequently their subjects might be deterred or prevented from making remittances in specie, although the rate of exchange had passed the gold point.

We can now discern the modus operandi of the exchange market. There is a demand, constant in kind but variable in intensity, for the means of meeting claims in every centre of commercial activity. Bankers and brokers specialise in the practice of buying remittances. They know who is likely to have them for sale. Frequently they sell their own foreign balances and embark upon various delicate operations in order to restore them. For more than a century, however, there has been a tendency to settle all international indebtedness by means of bills on London, and it has been the policy of London to honour all international obligations in gold.

Until the outbreak of the Great War in 1914 this availability of gold was an unbroken tradition. Occasionally the workings of international finance led to the prospect of a shortage in London's gold resources, but that state of affairs was remedied by raising the Bank of England rate so as to attract gold from abroad by the offer of higher interest. The effect of this gold-paying policy was to render the draft on London negotiable throughout the world, and to create a preference for it as against drafts on any other monetary centre. The possessor of a sound draft on London knew that it was as good as gold; he lacked this assurance if he held only a draft on Berlin or Paris. The effect of this knowledge and preference was to stimulate the settling of all international obligations by drafts on London, rather than by drafts on the place where the business which created the obligation had actually been done.

A fine (i.e. absolutely first-class) bill of exchange, payable at a future date, is clearly an instrument whose usefulness is not con. fined to the original holder. If he requires the money forthwith, he can discount the bill with his banker. The banker will, however, pay more for it if it is accepted by some firm of the highest repute. From this fact has arisen the practice, on the part of banks and certain eminent mercantile firms and finance houses, of systematically accepting approved bills, in return for a commission. Firms who specialise in this class of business are known as accepting-houses.

Bibliography. The Theory of the Foreign Exchanges, G. J. G. Go- schen, new ed. 1896 ; A B C of the Foreign Exchanges, G. Clare, 4th ed. 1905; Money, Exchange and Banking, H. T. Easton, 2nd ed. 1907 ; Money Changing, H. Withers, new ed. 1915.

Exchange. Name given to a building wherein merchants meet for the transaction of business. It is frequently referred to as 'Change and is the equivalent of the French bourse. Prominent among such buildings is the Royal Exchange, London. In modern times many forms of business have their own exchange. There are stock exchanges in London, Montreal, Sydney, Johannesburg, and other large cities. London has a hop exchange and a coal exchange, while many towns have a corn exchange. See Stock Exchange.

Exchange (Lat. ex, out; late Lat. cambiare, to change; Fr. échange). As a legal term this has two principal meanings. Exchange of lands in England is effected by deed of exchange. A true deed of exchange demands that like shall be given for like, though not necessarily in value: a freehold for a freehold, leasehold for leasehold, copyhold for copyhold. The parties to the deed must actually enter upon the property to complete the transaction; so that the deed is void if one party to the deed dies before entry. Exchange of livings by incumbents is allowed by ecclesiastical law. Each in. cumbent resigns his living into the hands of the bishop, who then inducts them both into their new livings; but, as in exchange of lands, if one dies before both are inducted, the exchange becomes null and void.

Exchange, Military. Term designating the privilege extended to officers of the regular and Indian armies of exchanging with one another from one unit or corps to another. Officers desiring to exchange must forward their applications to the War Office, stating their reasons, and accompanied by the recommendations of the commanding officers concerned, who must certify that the exchange does not originate through any question affecting the honour, character, or professional efficiency of the applicants. Medical certificates are also required stating that the officer is in a fit state of health for duty in the locality where the unit to which he desires to transfer is stationed. Exchanges, when sanctioned, are notified in The London Gazette. Exchanges are usually made for private reasons, and are made between officers of similar rank. See Commission.
Exchange and Mart, THE. Name sometimes given to the London paper, the full title of which is The Bazaar, Exchange and Mart (q.v.).

Exchequer.

England to the Nepartmen in trusted with the duty of receiving the royal revenues. The word means a chess board bccause it was by means of a device of this kind that the early accounts were kept. The late Lat. equivalent is scaccarium, and the Dialogus de Scaccario, a treatise of the time of Henry II, gives most of our existing information about the early exchequer. The sittings were held at Winchester and then at Westminster.

The early kings had both a treasury and an exchequer, and the functions of the two have been somewhat intermingled even until the present day. The Dialogue tells how the exchequer met, the justiciar, treasurer, ehancellor, and other high officials with their clerks attending its meetings, how the receipts were entered on rolls, and how tallies were used in this connexion. It met twice a year, at Easter and Michaelmas, and its main dealings were with the sheriffs who attended to account for the royal revenues which they had collected or failed to collect. In addition to this court there was a lower exchequer, which was a permanent department and in practice a branch of the treasury.

Gradually certain changes were introduced. The treasurer took the place of the justiciar as its president, and then these high officials ceased to attend its sittings in person. The seal, hitherto held by the chancellor, was given to a new official, and the chancellor of the exchequer came into being. The chief members were known as barons, and as they began to hear cases affecting the revenue, they resolved themselves into one of the regular courts of law, the court of exchequer, with a court of appeal, the court of exchequer chamber, which existed from 1357 to 1830 .

As the country became richer, the duties of the exchequer became more varied and numerous. It dealt not only with the accounts of the counties, but with others which concerned the royal revenue. The exchequer continued in existence until the 19th century. It collected and paid out the royal income and expenditure, while its five barons, under a chief baron, heard cases as a court of law.

In 1834 great changes were made, the old exchequer being practically abolished, the paymaster-general taking over its 
duties. A new exchequer was set up, but this was an audit office, and in 1866 the present cxchequer and audit office was established. The name exchequer remains in several connexions, exchequer bonds, etc., but the main financial work of the country is done by the treasury, whose actual head, however, is the chancellor of the exchequer, and not the first lord of the treasury. The court of exchequer lasted until the legal reforms of 1876 .

Scotland and Ireland had each their exchequer and their court of exchequer on the English model. The union of both kingdoms with England made these separate institutions unnecessary, although the Irish exchequer lasted until 1817 , and the Scottish court of exchequer until 1856. See National Finance ; Treasury.

Exchequer and Audit Department. Government department under the comptroller and auditor-general. His business is to see that all public money is expended in accord with the wishes of Parliament. Without his authority no money is paid out of the exchequer. He is also the national auditor, bound to notify any irregularities in his annual report to the House of Commons. The office, established in 1866, took over the duties formerly discharged by the comptroller-general and the commissioners for auditing public accounts. He can only be dismissed at the request of both Houses of Parliament. His offices are on Vic. toria Embankment, London, E.C.

Exchequer Bill. Form of British Government security in vogue from 1696 to 1896 . First issued under William III, when metal money was scarce owing to the reform of the coinage, they were really promissory notes for money borrowed by the Government from capitalists. They usually ran for five years, but were sometimes repaid earlier, and taxes could be paid with them; the rate of interest varied, but they were free from any risk of depreciation. Their place was largely taken after 1877 by Exchequer Bonds; the last bills were paid off in 1896. See National Debt; National Finance.

Exchequer Bond. Form of British Government security first issued in 1853. They are promissory notes issued generally for three or five years, and redeemable at par. During the Great War much money was raised by the sale of these bonds; most of them bore 5 p.c. interest, but at one time 6 p.c. bonds were sold. An attempt was made to sell them through the Post Office to the small investor, as advised in 1916 by a committee on war savings for this class. To do this they were issued in bonds of $£ 5$ and multiples of $£ 5$; after the issue of the National War Bonds in Oct., 1917, the special need for them ceased. In 1920, however, an issue of five-year bonds, carrying $5 \frac{3}{4}$ p.c. interest, was made. See National Debt; National Finance.

Excise (Lat. ad, to; census, a $\operatorname{tax})$. Name given to taxes levied on goods produced within a country, as opposed to customs, which are taxes on goods coming into it from without. The early taxes of both kinds were known as customs, and for long there was a similar loose use of the word excise, but the distinction is now generally recognized. In the time of the Civil War the parliamentary party introduced the first excise duties, placing them on ale, beer, and other beverages and then on salt, starch, and certain victuals. Some were removed in 1649 .

During the 18th century the number of excise duties was in creased. In 1711 they were placed on soap and paper; in 1746 on glass ; then came bricks, candles, etc. In the 19th century the process of reducing and simplifying these began, and to-day the number of articles so taxed is very few. In 1917, to meet the cost of the Great War, excise duties were laid on table waters, entertainments, and matches. The following figures show the classes and net receipts from the excise duties in the U.K. for year ended Mar. 31, 1921.

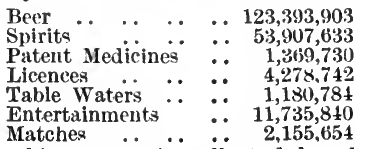

Matches $\quad . \quad \ldots \quad \ldots 2,155,654$

This money is collected by the board of customs and excise. See Customs; National Finance, Taxation.

Excise Bill. Measure introduced by Sir Robert Walpole in 1733 for the substitution of an excise instead of a customs duty on wine and tobacco. His object was to lessen smuggling and, by making the ports free, to stimulate a reexport trade. The billaroused much opposition and was withdrawn.

Exciter. Generator for producing electric current for exciting the field magnets of an alternator or a dynamo. In the case of alternators, the field magnetism of which it is difficult to excite by current generated by the alternator itself, the exciter may consist of a separate dynamo. Direct current dynamos are usually self-excited, i.e. their magnetic fields are produced by their own current. See Dynamo.
Exclusion Bill. Measure introduced into the English Parliament in 1679 for the purpose of exclud. ing James, duke of York, from the throne. The country was greatly excited by Titus Oates' story of a Roman Catholic plot, and the bill was introduced, Mary and William of Orange being named to succeed Charles II. To save his brother, Charles dissolved Parliament, but the bill was again brought forward in 1680 and passed by a large majority in the House of Commons. The Lords rejected it ; and a proposal to substitute the duke of Monmouth for James led to its abandonment in 1681. See James II; Monmouth.

Excommunication (Lat. $e x$, out of ; communis, common). Term used specifically for the temporary or permanent exclusion of an offending member from the fellow. ship of the Christian Church. Generally it means exclusion from any organized community. Ex. amples are to be found in the history of the Jews (Lev. 13; Num. 9 and 12 ; Ezra 10). It existed among Greeks, Romans, and Druids, and has affinity in the tabu of the Polynesian islanders.

The Christian Church claims Scriptural authority for excommunication (Matt. 16 and 18 ; John 12 and 16 ; 1 Cor. 5 ). Imposed first by the community and then by the bishops as a penalty for heresy, immorality, or disobedience, its primary objects were the bringing of the offender to repentance, and the protection of the Church from corrupting influences. In pagan and Christian usage it has been imposed in degrees of varying severity, ranging from admonition to temporary and partial suspension, and, finally, anathema (q.v.).

Gregory VII first claimed the right to depose kings by excommunication, and an ecclesiastical authority could place a whole country under an interdict. Papal claims of this nature led to much trouble in Elizabethan England.

In the Roman Catholic Church excommunication is now provided for by the constitution Apostolicae Sedis, 1869 , ratified Jan. 6, 1884. The Anglican view is represented in Hooker's Ecclesiastical Polity and Canons 65 and 68. At one time in England, after a person had been under excommunication for 40 days he might, on the issue of a certificate of the diocesan authority to the court of chancery, be imprisoned on a writ of excommunicato capiendo until he submitted and was absolved, and the sentence carried with it a number of civil disabilities. By an Act of George III, 53, c. 127, it was 
provided that no person excommunicated could be imprisoned for more than six months and that no civil inca pacity should be imposed.

By 54 George III, c. 68, a similar law was enacted for Ireland. Civil penalties were abolished in Scotland in 1690. In Great Britain, though disciplinary jurisdiction of the eccles. courts over the laity exists still, it is subject to statute and common law, and excommunication in the old sense is virtually obsolete. In recent times imprisonment has been imposed only in cases of ritualistic disobedience. In the Scottish Presbyterian churches, lesser excommunication is an affair of the kirk session; the greater excommunication is a prerogative of the presbytery.

Modern cases of excommunication were those of Bishop Colenso (q.v.), 1863, whose deposition was negatived as invalid by the Judicial Committee of the Privy Council in 1865 , and of Father George Tyrrel for his criticism of Pius X's encyclical against modernism (q.v.) in 1907. Notable excommunications in earlier times were those pronounced by Gregory VII against the emperor Henry IV, 1077 ; Innocent III against King John of England, 1208-14; Gregory IX against the emperor Frederick II, 1228-45 ; Julius II against Louis XII of France, 1570; Leo X against Luther, 1521 ; Paul III against Henry VIII, 1535; and Pius V against Elizabeth, 1570.

Excoriation (Lat. ex, from; corium, skin). Superficial destruction of the skin (q.v.).

Excursion (Lat. excursio, running out). Popular name for a brief holiday. In the United Kingdom and other countries previous to the Great War, the railways gave special facilities to those who desired to visit various seaside and other pleasure resorts for short periods. They issued excursion tickets, at low rates, the day excursion to Brighton and back from London being only $3 \mathrm{~s}$. The Great War put an end to these excursions, but in 1920 the running of day excursion trains on certain railways was resumed. Single fare was charged for the double journey. Thomas Cook was the pioneer of the cheap excursion traffic. See Railways.

Excursion, The. Blank verse poem by William Wordsworth. Published in 1814, it forms the second part of a projected work in three parts entitled The Recluse, conceived as a philosophical poem on Man, Nature and Society. Wordsworth never wrote the third part, but The Prelude, an introduction, and the first book of the first part of The Recluse were published posthumously in 1850 and 1888 respectively.

Exe. River of Devon, England. It rises in Somerset on Exmoor and flows right across Devon, mainly S., to the English Channel, which it enters by a navigable estuary 6 $m$. long. Exeter stands on it, as does Tiverton, while Exmouth is at the mouth of the estuary. Its length is $55 \mathrm{~m}$. Its chief tributaries are the Barle and other streams that rise on Exmoor. A ship canal, 5 m. long, connects Exeter with Topsham, from which point the river is navigable. There is some trout fishing in the Exe, which flows mainly through wild and beautiful scenery.

Execution (Lat. exsequi, to follow out, carry out). Act of performing anything. It is used in law (see below), and also in other senses, as in executing a commission, or the execution of a piece of music. In a special sense the word has come to mean the carrying out of a death sentence. In England the death penalty was carried out mainly in two ways, by hanging or by beheading. 'The former was the face of the ordinary offender. Beheading was reserved for political offenders and persons of rank.

When, in course of time, the death penalty was confined to serious crime, hanging became the only form. For long these executions were a public spectacle to which thousands flocked, but in 1866 a royal commission recommended that they should be carried ont in private, and this change was quickly made. Burning and drown. ing were also practised in former days. In France the guillotine is adopted for executions, while electrocution has been used in the U.S.A. See Capital Punishment; Electrocution; Guillotine.

Execution. In English law, term generally used to mean the carrying into effect of the judgement of a competent court. In civil cases this is done by the successful litigant applying to the court for a writ of execution, which as a rule can be had for the asking at an office attached to the court. Some kinds of execution, however, require an order from a judge or judicial officer. Execution is also used in the sense of perfecting a legal document by signing, sealing or delivering it with all proper formalities.

Executive. Name given to a body of men who carry out the orders of others. In most modern states there is a sharp distinction between the executive and the legislature; the latter making the laws which the former carry out. In the United Kingdom the executive consists of the Cabinet and the various state departments under its control. The local government bodies have also a legislature and an executive. See Cabinet; Government; Parliament.

Executor. In English law, the person or persons appointed by a will to carry into execution a will as the "legal personal representative" of the deceased. An executor becomes the legal owner of all the deceased's property. He must first prove the will. Armed with the probate copy thereof he collects the property, realizes enough to pay (1) funeral and testamentary expenses; (2) debts, crown debts coming first; (3) legacies in order; and then hands over the balance to the persons entitled under the will.

If the will does not completely dispose of it, the executor must share the balance or residue of personalty amongst the next of kin ; and hands the freeholds to the heirat-law. He must not dispose of realty to pay debts unless specially empowered by the will to do so ; or unless the personalty is not enough. When an executor has paid out all the assets to creditors he is not liable for any debts he may have left unpaid, unless he has paid one of a lower class of creditor, a simple contract debt, before paying a higher, a crown or specialty debt. That is, he is not bound, as between one creditor and others of the same class, to pay them rateably if there is not enough for all. $\mathrm{He}$ is allowed a year to wind up the estate before any legatee can sue him for his legacy. See Will.

Executory. Term used in English law in two senses. An execu. tory contract is one which consists of a promise on both sides, e.g., I will make you a chair if you will pay me $£ 10$ for it. An executory devise or bequest is a gift of land by will, without the intervention of a trust, where the estate of the devisee, or the legatee if a leasehold, is to arise upon a contingency.

Exegësis (Gr., explanation). Branch of study concerned with the interpretation of Holy Scripture. Properly including all that is connected with the full exposition and understanding of the Bible, it is more commonly restricted to literary interpretation, which determines the sense of the sacred text upon the same principles that would be applied to any other literary work. It differs from Biblical criticism in taking the text as it stands, and examining its meaning rather than its origin and authenticity. Being concerned not merely with the precise meaning of the 
text, but with the doctrines and practical inferences to be drawn from it, the study of exegetics is an extensive one.

Exegetes have from early days been divided into two classes: the Literalists took the statements of Holy Scripture in their literal and grammatical meaning; the Allegorists found an inner and spiritual signification underlying the obvious meaning of the text. The N.T. writers afford many examples of the influence of this school. For example, many O.T. passages are applied to Christ which obviously referred originally to contemporaries of the writers. The two schools were long in antagonism, believers in verbal inspiration naturally demanding a literal interpretation of the text of Scripture; while the medieval tendency to read sacramental doctrine into every text of Scripture led to the most far-fetched allegorisation.

The history of exegesis shows a great activity of commentators among both Jews and Christians in the days of the Early Church : but little was done during the Middle Ages. The allegorical interpretation of a few favourite texts was the subject of most of the books and sermons that could be called exegetical ; and collections of patristic comments replaced critical investigation. The Reformation saw a great revival of Bible study, and most of the commentators of this period belonged to the literal school. This may be largely attributed to the need for proving from Scripture the doctrines that were now emphasised, as opposed to accretions to primitive doctrine which owed their existence mainly to allegorical exegesis. See Bible ; Criticism.

Exelmans, REMy Joseph IsIDORE, COMTE D' (1775 - 1852). French soldier. Born at Bar-le-Duc, Nov. 13, 1775, he joined the Revolutionary armies in 1791, becoming a captain of cavalry in 1799 , after his courageous behaviour during the Italian campaigns. On Murat's staff from 1801, he was promoted general after Eylau, 1807, the climax of his active service during the campaigns in Prussia and Poland. Captured in Spain, he was held a prisoner in England from 1808-11. He took part in the Russian expedition, 1812, and in the fighting in France in 1814. At Waterloo he commanded a cavalry corps, and after the Bourbon restoration lived abroad in exile nntil 1823. His high reputation, however, led to his restoration as a peer of France, 1830 , and to his elevation to the rank of marshal. He died Nov. 11, 1852.
Exemption (Lat. eximere, to take out). Term used in Britain during the Great War for freedom from compulsory service. Under the various Military Service Acts, 1916-18, all men within prescribed age limits were liable to join the forces unless they had secured exemption. Married men, forexample, were not liable under the first Act, which came into force in Feb., 1916, nor were doctors and clergymen. Other grounds of exemption were medical and compassionate, as in the case of a man the sole support of dependents, and men in industries essential to the successful prosecution of the war. Tribunals set up under the Act granted either temporary or complete exemption, according to the circumstances of the applicant. A second Service Act, which came into force in May, 1916, did away with exemption for married men, as such, though they were protected in the same way as single men on compassionate and occupational grounds. Conscientious objectors, married and single, if they satisfied the tribunal, were exempted from combatant service only, as was the same class in Australia and S. Africa.

Meantime many men were being exempted on medical grounds in somewhat haphazard manner, and in 1917 a Military Service(Review of Exceptions) Act was passed. All men previously medically exempted were re-examined, the examination was more thorough, and only men definitely rejected by a qualified army doctor were exempt. As the need for men became more pressing many semi-skilled and unskilled men had their exemptions taken away. An Act of Jan., 1918, enabled the Government to take into their own bands the whole question of exemptions of men on an occupational basis, as hitherto the Trade Unions had partly undertaken this. A final man-power bill, introduced into Parliament April, 1918, raised the age limit to 50, and removed the exemption hitherto granted to duly qualified medical practitioners up to the age of 56 . In France and other countries exemption from service was granted on certain medical grounds and to only sons. See Certified Occupations ; Compulsory Service ; Manpower.

Exercise (Lat. exercitium). Movements of the muscles, either voluntary or passive. Voluntary exercise means deliberate movement ; passive exercises are movements effected by the manipulation of another person or by a machine. Muscular contraction, such as occurs during steady walking, stimulates the circulation of the

blood through the muscles. This, in turn, acts on the heart and the respiratory system, which both act more vigorously. The formation of more waste products in the tissues makes increased demands upon the excretory system.

Severe exercise is beneficial to the young and healthy, but should not be undertaken by persons beyond middle life or those suffering from cardiac or other serious affections. Heavy muscular effort, long continued, such as that of a blacksmith, tends to produce a thickening of the walls of the arteries, which may eventually lead to heart disease, apoplexy, and other diseases, especially if associated with alcoholism or syphilis. Regular daily exercise is an im. portant adjunct to medical treat. ment in obesity, gout, digestive disorders, insomnia, neurasthenia, and other nervous affections. Suitable exercises are of value to children and young persons, to strengthen the muscles and correct wrong methods of carrying the body, which may have resulted from weakness or curvature of the spine, and other affections which may follow rickets or malnutrition.

Passive exercises are mainly employed to prevent wasting of the muscles and stiffening of the joints following sprains of the bones or other injuries to limbs, and to increase the mobility of joints in those suffering from rheumatism or similar conditions. See Physical Training; also illus. p. 2718.

Exeter. City, county, parl. and mun. bor., county in itself since 1537 , river port, and county town of

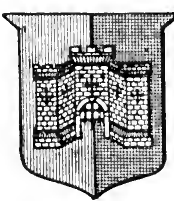
Devonshire, Eng. land. It stands on the Exe, $171 \frac{1}{2} \mathrm{~m}$. W.S.W. of Lon. don, on the L. \& S.W. and G.W. Rlys. Still partly surrounded by its old walls, it occupies an elevated position on a ridge of land overlooking the Exe.

The chief attraction of the city is its comparatively small but magnificent cathedral, with massive Norman transeptal towers (a unique feature except for a copy in the collegiate church at Ottery $\mathrm{S}$. Mary), dating from the 12 th century ; the remainder of the edifice was transformed between 1280 and 1370 from the Norman to the Decorated style, and a complete restoration was undertaken by Sir G. G. Scott towards the end of the 19 th century. Among other interesting buildings are the guildhall, rebuilt in 1330, the episcopal palace, the College of Priest Vicars, 


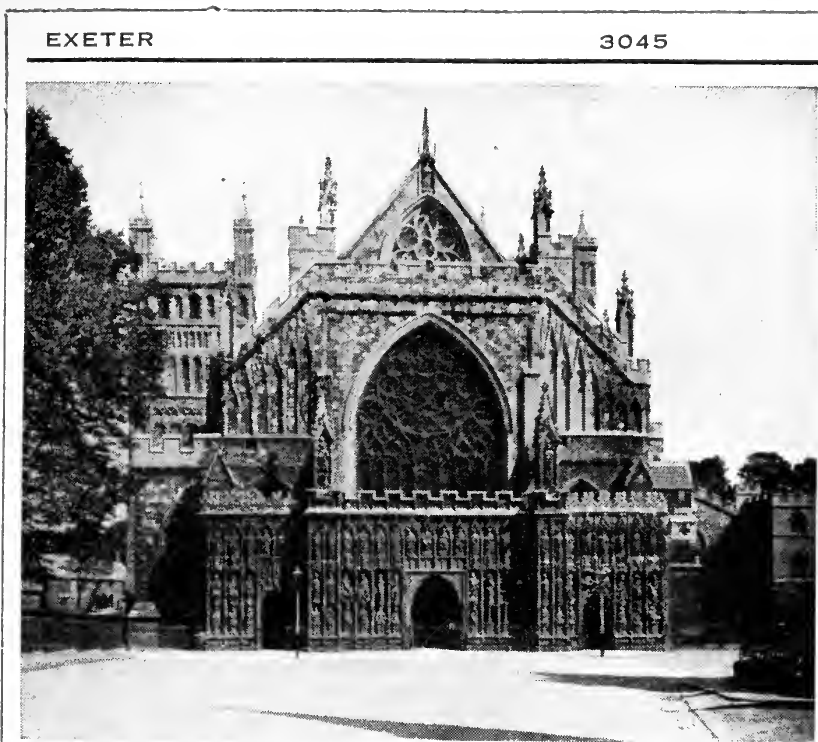

Exeter. West front of the cathedral and the 14th-15th century screen ornamented with sculptured figures of Biblical characters

S. Nicholas Priory, the remains of Rougemont Castle, and Royal Albert Memorial Museum, Library and Art Gallery.

The chief educational establishments in the city are the Royal Albert Memorial College and Exeter School. The former, which is affiliated to the universities of Oxford and Cambridge, was founded in 1865 as a technical college, and was given the rank of a university college in 1901. Exeter School, one of the most important public schools in the west of England, was founded in 1629. In 1876 it was reorganized and new buildings were erected for it; they include a chapel, gymnasium, laboratory, swimming baths, etc. The old buildings in the High Street were then abandoned, and the school is now outside the city proper. There are also training colleges for teachers.

An important rly. centre, Exeter has a floating basin and is connected with the sea by a ship canal (begun in 1564), which extends five miles and opens into the estuary near Topsham. Formerly the seat of an active woollen industry, it is now an important agricultural centre, while brewing, iron-founding, and Honiton lace and paper manufactures are carried on. Market day, Friday. One member is returned to Parliament. Pop. 59,608. The British Caer Isc, the Roman Isca Damnoniorum, and the AngloSaxon Exancestre, Exeter, as the principal fortified town of the W., was frequently besieged by the Danes and other invaders ; it capitulated on terms to the Conqueror in 1068, was surrendered in 1136 , successfully withstood attacks in 1467,1497 , and 1549. It surrendered to the royalists in 1643 ,

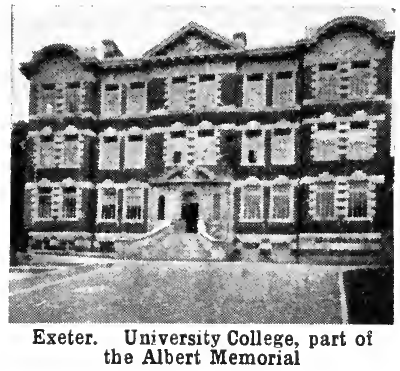

but the parliamentarians were re. admitted three years later. It is the Chatteris of Thackeray's Pendennis. Its motto is Semper Fidelis.

Exeter, MARQuess and DUke of. English titles borne by several distinguished families. The first duke was John Holand, a half-brother of Richard II and a descendant of Ed. ward I. The son of Thomas Holand, earl of Kent, and Joan, afterwards

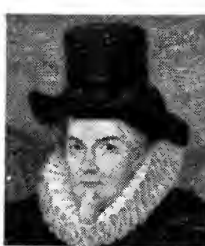

1st Earl of Exeter, English statesman After Jansen the wife of the Black Prince, he was made a duke in 1397. $\mathrm{He}$ had already married a daughter of John of Gaunt, made earl of Huntingdon. One of Rich. ard's chief and had been assistants, he was condemned and executed in Jan., 1400, for conspiring against Henry IV, his titles and estates being for feited. After Thomas Beaufort, earl of Dorset, had been duke of Exeter from 1416 to 1426 , the title returned to the Holands ; in 1443 John Holand, a son of the executed John, was made duke of Exeter. His son, Henry, lost his title during the Wars of the Roses.

The title of marquess of Exeter began with the Courtenays. In 1525 it was given to Henry Courtenay, earl of Devon. He was executed in Dec., 1538, his heirs being deprived of his titles. In 160.5 Thomas Cecil, Lord Burghley, $(q . v$.$) , a son of the great Lord$ Burghley, was made earl of Exeter, His descendants continued to hold the title, and in 1801 Henry, the 10th earl, was made a marquess. In 1898 William Thomas (b. 1876) became the 5 th marquess. The seat is Burghley House (q.v.), and the eldest son is known as Lord Burghley.

Exeter Book, THE. MS. collection of Anglo-Saxon poems in the library of Exeter cathedral, to which it was presented in the 11th

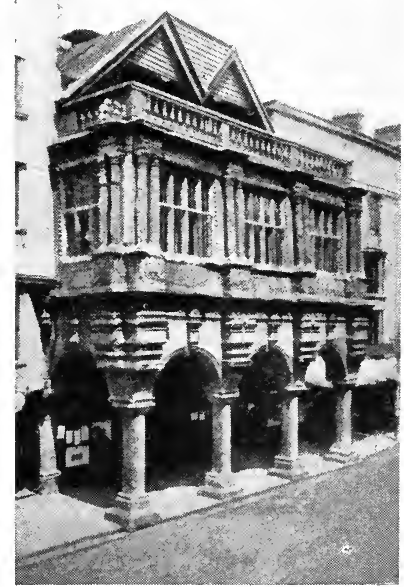

Exeter. The pillared facade of the Guildhall, added to the original building in 1593

century by Bishop Leofric. It is clearly written on vellum by one scribe, and forms the most important body of Anglo-Saxon literature that has come down to us. It includes Cynewulf's Christ, The Legend of S. Juliana, a metrical life of Guthlac, Widsith, and The Wonders of Creation. It was first printed as Codex Exoniensis in 1842 , with translations by Benjamin Thorpe. See English Writers, H. Morley, vol. ii, 1888 . 


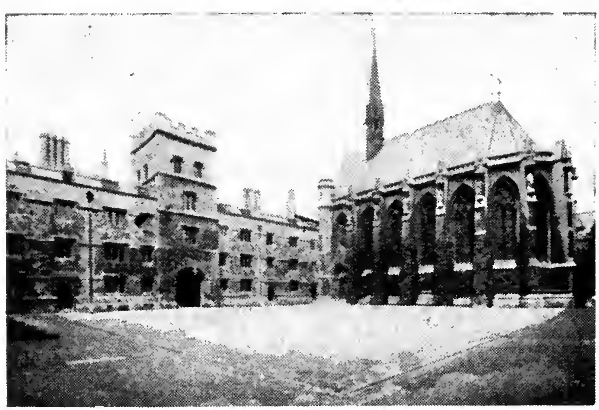

Exeter College, Oxford. The front quadrangle, shownng the fine Gothic chapel Hills \& Saunders

Exhaust (Lat. ex, from, out; haurire, to draw). Word meaning in general the stream of burnt gases ejected from the engine, or it may be ap. plied to the exhaust piping it. self. In the internal combus. tion engine the waste gases after combustion a re expelled through the exhaust valve, and the

Exeter College. One of the col. leges of the university of Oxford. Founded in 1314 by Walter de Stapeldon, bishop of Exeter, it was first called Stapeldon Hall, afterwards Exeter

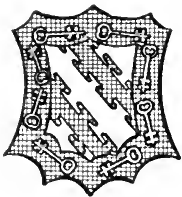

Exeter College arms Hall, and then Exeter College, being enlarged by Sir William Petre in 1565. It has always had a special con. nexion with Devon and Corn. wall, and certain scholarships are confined to schools in those counties. Among famous Devonians educated here were R. D. Blackmore and Archbishop Temple. The buildings face on Turl Street and Broad Street, and their chief feature is the 19th century chapel, with decorations by Burne-Jones and William Morris, both members of the college. The hall is notable and there is a small but beautiful garden. The head is called the rector.

Exeter Hall. Public building in London, the site of which is now occupied by the Strand Palace Hotel. Built in 1831 on land be. longing at one time to the mar. quess of Exeter, it was first the headquarters of the Sacred Harmonic Society, where most of the great singers of the time, including Jenny Lind, a p peared. It later became known as the place where the annual meetings of many religious bodies were held.

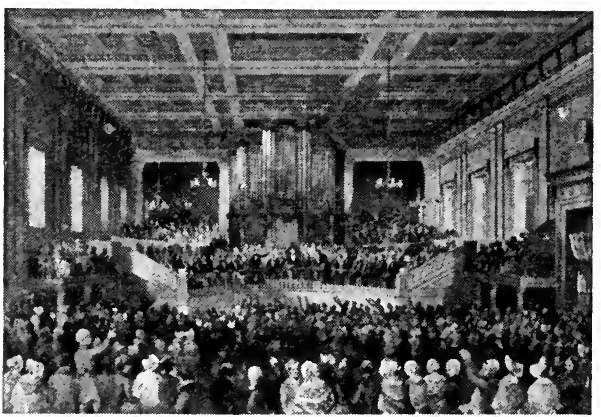

Exeter Hall. An anti-slavery meeting held in the hall in 1841 From a contem porary engraving

In 1880 it was acquired by the Y.M.C.A., which occupied it until 1907. The hall held 5,000 people.

exhaust port into the exhaust pipe at the exhaust stroke of the piston.

Exhibition. In education, a grant made to assist persons to pay for their education. It ranks as less important and is usually less valuable than a scholarship. There are exhibitions at most of the colleges of Oxford and Cambridge. This use of the word comes from an old meaning when exhibition meant maintenance. See Scholarship.

Exhibition (Lat. ex, out; habere, to have). Term used for a display or show of any kind. Thus there are exhibitions of pictures and other works of art. In a special sense, however, the word is used for displays of manufactured goods, and national and international exhibitions of this kind were organized on an enormous scale during the 19 th and 20 th centuries. These are known to the French as ex positions. In a sense they are the modern equivalent of the great medieval fairs, although the idea is not so much to sell goods directly as to make them known.

Several exhibitions were held during the 18th century. In 1797 one was held at St. Cloud, and 
1923 in London, is intended to foster imperial interests, both commercial and political. Exhibitions are held by particular trades, such being the motor trades, drapery trades, etc. Other exhibitions are promoted by newspapers, a notable instance being the Ideal Home Exhibition arranged by The Daily Mail, at Olympia, in 1920 , and the Efficiency Exhibition arranged for 1921 .

Exhumation (Lat. ex, out of ; humus, ground). Act of digging up and removing any object from the ground, but generally applied to the removal of a dead body from its burial place. It is a misdemeanour to do this for any purpose with. out legal authority. In England, such authority may be the coroner where foul play is suspected or a post-mortem examination ordered, and the ordinary (q.v.) of the diocese when reinterment is the reason. See Autopsy; Burial Acts.

Exile (Lat. exsilium). Removal from one's native land, either voluntarily or under compulsion. The word probably means "leaping forth," from the root sal-, which occurs in con-sul and Salii, the leaping priests of Mars.

In Greece, exile was chiefly a punishment in cases of homicide, but was also enforced for certain crimes and offences against the state and society. Homicides could anticipate their sentence by voluntary withdrawal, but were liable to be put to death if they returned. Exile was also a political measure employed in troublous times. It carried with it disfranchisement and confiscation of property. A peculiar method of banishment was ostracism (q.v.).

At Rome, exile did not become a recognized form of punishment until about the time of the Gracchi. Theoretically, a citizen's life and liberty were inviolable, so the fiction of aquae et ignis interdictio, exclusion from the use of fire and water, was invented, since anyone deprived of these necessaries in Rome would perforce have to seek a home elsewhere, it being an offence for anyone to supply them to a person under the ban. It is uncertain whether interdictioinvolved loss of civil rights and confiscation. The sentence was at first pronounced by the comitia centuriata (q.v.), later by the quaestiones perpetuae, the standing courts which dealt with serious offences, such as high treason, poisoning, and arson. Everyone had the right of voluntarily leaving the city, but was forbidden to return under pain of death.

In early imperial times, deportatio took the place of interdictio. The

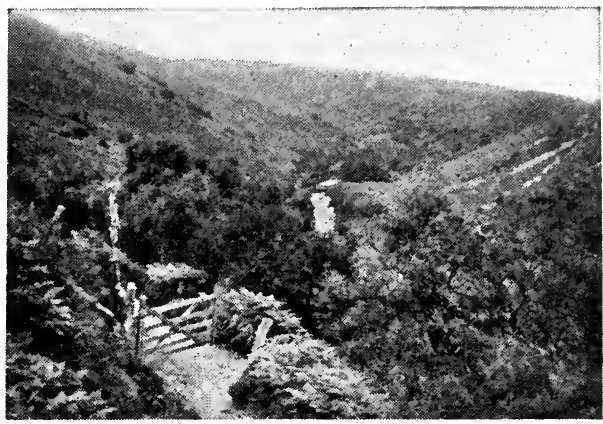

Exmoor. The Doone Valley, part of the romantic country in which Blackmore laid the scene of his Lorna Doone

study of bookplates. See Bookplate.

Exmoor. Pic. turesque and ele$v$ a ted moorland expanse in Somersetshire and Dev. onshire, England. Formerly a forest, its trees have largely dis ap peared, and three-fourths of its area is now covered with heather and a coarse grass, on which are pas.

condemned person was compelled to take up his abode for life in some place out of Italy, or on some island. He was sometimes allowed to choose the place of exile him. self, but generally it was assigned to him. Deportation entailed loss of civil rights and confiscation.

A milder form of banishment was relegatio, temporary or for life, pronounced by a higher magistrate or the emperor against any person whose presence in the city was considered undesirable. It entailed neither loss of civil rights nor confiscation, as is expressly stated by the poet Ovid, who was exiled by Augustus to Tomi on the Black Sea for some unknown offence. See Deportation; Outlawry ; Transportation.

Ex Libris (Lat.. from books). Label of ownership usually called in England a bookplate. Pasted inside the front cover of a book, it bears the name and device of the owner, preceded by the words Ex Libris. This Latin appellation is incorporated in the titles of societies devoted to the

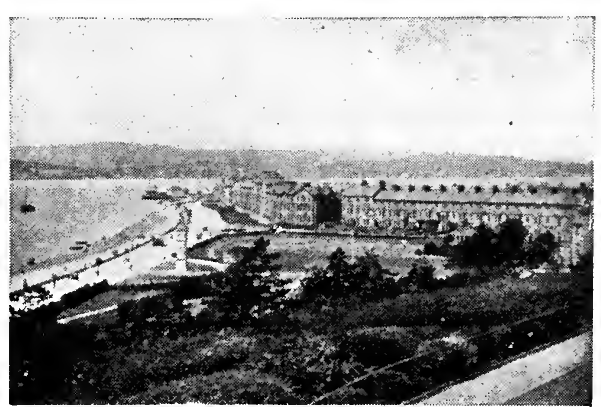

Exmouth from the east, looking along the promenade and sands towards the mouth of the Exe tured ponies, sheep, and red deer, the last preserved for stag-hunting. On Feb. 22, 1917, Sir Thomas Acland granted a lease of lands covering between 7,000 and 8,000 acres to the National Trust for 500 years under an arrangement whereby he relinquished the rights to develop the property as a building estate, and granted the Trust power to preserve the estate in its present condition, retaining for himself and his successors the rents and profits and rights of an owner The area thus placed in

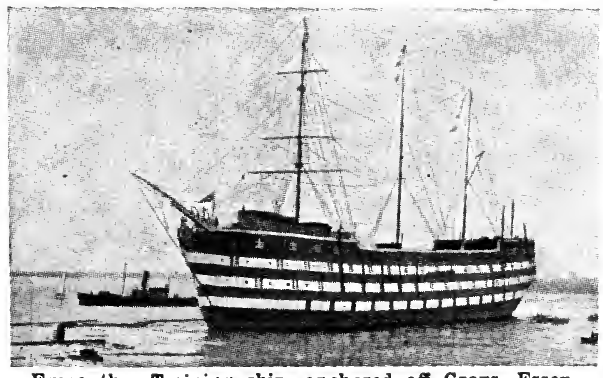

Exmouth. Training ship, anchored off Grays, Essex, service. See page 3048

trust for the nation includes some of the finest hill, valley, and woodland scenery of Exmoor. Lorna Doone, Blackmore's romance, has made Exmoor familiar. The river Exe takes its rise here. The highest point is Dunkery Beacon, $1,707 \mathrm{ft}$.

$\mathbf{E} \times \mathbf{m}$ o u t h. Urban dist., seaport, market town and wa tering. place of Devonshire. England. It stands at the mouth of the Exe, $10 \frac{1}{2}$ m. S.E. of Exeter on the L. \& S.W.R. Exmouth was the first seaside resort in the county, 
and is largely resorted to by sufferers from lung complaints. Once a flourishing seaport, Ex. mouth contributed ten ships for the attack on Calais in 1347. The chief industries are brick-making, fishing, and the manufacture of Honiton lace. Market day, Tues. Pop. 11,962.

Exmouth. Training ship for the British navy and mercantile marine. Moored off Grays, Essex. boys are trained on it for the above services, and also for em. ployment in naval and military bands. Attached to it is a seagoing tender, Exmouth II.

Exmouth, Edward Pellew, Ist Viscount (1757-1833). British sailor. He was born at Dover, April 19,1757 , and en tered the navy at the age of 13. In 1776 by $\mathrm{h}$ is gallantry at Lake Champlain (q.v.) he secured his promotion to lieutenant. In 1793 he was appointed to the frigate
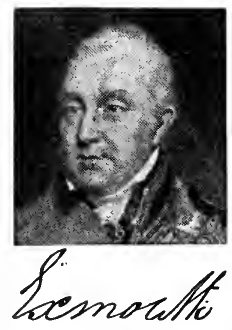

Nymphe. For his capture of the Cléopâtre he was knighted in 1793, and in 1794 commanded one of the western squadrons. Baronet in 1796, and M.P. for Dunstable, 1802 , in 1804 he was promoted rear-admiral and commander-inchief in India.

Returning to England in 1809, he became commander-in-chief of the North Sea, 1810, and of the Mediterranean station, 1811. In 1814 he was raised to the peerage as Baron Exmouth of Canonteign. In 1816, on the refusal of the dey of Algiers to cease his piracies, Exmouth was sent to bombard that city, with the result that over 2,000 slaves were liberated. Made viscount in that year, he died Jan. 23, 1833. The title is still held by his descendants, Edward (b. 1890) having become the 5th viscount in 1899 .

Exmouth Gulf. Inlet of the W. coast of Australia. It penetrates inland about $65 \mathrm{~m}$., and at its entrance is $30 \mathrm{~m}$. across. It is sheltered from the Indian Ocean by a peninsula $80 \mathrm{~m}$. in length, which terminates in the North West Cape.

Exodus. The second book of the Pentateuch, or rather Hexa. teuch. The title, taken from the septuagint (Ex. xix, 1), means the "Going-forth." The Hebrew titlo $\mathrm{s}$ "Names" or "And these are the Names." The book falls into two main divisions: (a) history of
Israel in Egypt, Ex. 1-18; (b) account of Moses' administration at Sinai, whither he had led the children of Israel, Ex. 19-40. The former section incorporates a much earlier composition, the Song of the Red Sea (Ex. 15). The latter includes one of the three chief Hebrew codes of law (Ex. xx, 22-xxiii, 19), described by scholars as the Book of the Covenant. See Hexateuch.

Exogamy (Gr. exō, outside gamos, marriage). Primitive in. stitution binding a man to marry outside his own social group. Its primal impulse was probably economic rather than eugenic. In those societies wherein the family is overshadowed by the kinship group, the exogamous clan is often associated with a totem, a mystical token of kinship. Highly developed with the Australian aborigines, it is usual among the N. Mongols, and widespread with the American Indians. Arising from it are such marriage customs as marriage by capture. A special form called hypergamy exists in some Hindu castes; it requires a woman to marry into a caste higher than her own. See Marriage; Society.

Exogens (Gr. exō, outside; stem, gen, to be born). Name for the great division of plants now generally known as dicotyledons. It indicates that the annual increase of girth is due to the addition of a ring of new wood between the old wood and the bark. See Botany.

Exophagy (Gr. exō, outside; phagein, to eat). The practice among some cannibal peoples of seeking their human food outside their own kin, totem or tribe. The contrary usage is endophagy. The words are loosely employed by different writers; endocannibalism and exocannibalism might usefully be reserved for the man-eating of totemic tribes, exophagy for extratribal cannibalism (q.v.)

Exophthalmic Goitre, Grave's or BASEDOW's Disease. Condition associated with increase in the size of the thyroid gland, the organ situ. ated in front of the lower part of the neck. It may be due to excessive secretion from that gland (hyperthyroidism), or may result primarily from an affection of the nervous system. Strong emotions, such as fright, grief, or worry, are antecedent factors in some cases. The disease is more common in women than men, and generally begins betwcen the age of 20 and 30. Usually the first symptom is severe palpitation of the heart and throbbing of the large blood. vessels in the neck. The enlargement of the thyroid may affect the whole gland or only one lobe.

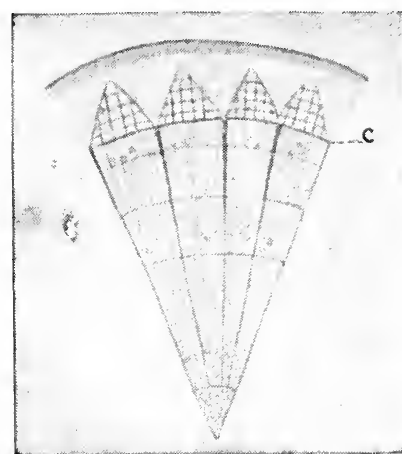

Exogens. Diagram in transverse section of an exogenous shoot. C shows the point where the growth takes place

Exophthalmos, or protrusion of the eyeballs, is a prominent feature. A fine tremor of the muscles of the lower and upper limbs is sometimes an early symptom.

Occasionally the disease runs an acute course, and death occurs in a few months. More frequently the condition becomes chronic, and extends over years with periods of improvement and exacerbation. A certain number of cases recover, but rarely completely when the symptoms are well marked. Death may result from disturbance of the heart, tuberculosis, or exhaustion. Treatment consists in giving absolute rest in bed, followed by a quiet country life. Iron and strychnine have proved useful, and application of the galvanic current may be tried. Serum therapy has given inconsistent results.

Exorcism (Gr. ex, out; horkiz. ein, to adjurc). The expulsion of malign spirits by ritual means. Belief in demon-possession and demon-obsession is revealed in early Sumerian inscriptions. The Semitic Babylonians regarded most mental and bodily ailments as due to intrusive demons, whose expulsion was sought by the incantation of charms containing a divine name, fortified by material aids. Exorcism passed into the GrecoRoman world, was rife in W. Asia in N.T. times, was taken over by early Christianity, and survives here and there in ecclesiastical ritual. Baptismal exorcism is retained by the Roman and Old Lutheran communions.

In primitive culture disease is commonly attributed to evil magic wrought by one person upon another. The intrusive evils, whether human hosts or nonhuman demons. miy haunt persons or places. Preventive exorcism is one chief purpose of the amulct. Expulsion may be attempted by sympathetic magic. 
such as the Babylonian wasting of a wax effigy of the sorcerer, or the Dakota shooting of a bark effigy of the demon.

Ills may be driven out by drums, as in Patagonia, or other musical means, as in the case of David and Saul; they may be transferred to scape-animals, such as fowls, as in W. Africa; to goats, as in Arabia; or to swine (Matt. 8). They may be enclosed in a receptacle left by the roadside, or thrown into the stream, as in Uganda; conjured into a proa, driven out to sea, as in the Malay archipelago ; or attached to a rag or wisp of hair suspended from a tree. An appeal or command addressed to the demon may be fortified by a promised sacrifice or a vow. See Demonology ; consult also The Devils and Evil Spirits of Babylonia, R. C. Thompson, 19034 ; The Golden Bough, pt. i, J. G. Frazer, 3rd ed. 1911.

Exostosis (Gr. ex, out; osteon, bone). Abnormal outgrowth of bone. See Bone.

Expansion (Lat. ex, from, out ; pandere, to spread). If the temperature of most bodies is raised the body expands. The amount by which solids expand when heated through any reasonable degree of temperature is very small. A bar of iron one metre in length only extends a little more than a thousandth of its length when heated from $0^{\circ} \mathrm{C}$. to $100^{\circ} \mathrm{C}$. The coefficients of expansion of a number of metals have been experimentally determined by very refined methods. For each degree Centigrade the following are the coefficients of expansion of some materials :

$\begin{array}{ll}\text { Platinum } & =0.00000899 \\ \text { Copper } & =0.00001678 \\ \text { Zine } & =0.00002918 \\ \text { Glass } & =0.0000083\end{array}$

The expansion, both apparent and absolute, of some liquids can also be determined. The mean value for the coefficient of cubical expansion of mercury between $0^{\circ}$ C. and $100^{\circ} \mathrm{C}$. is $0^{\circ} 0001819$. Water does not expand normally because, at ordinary pressures, water has a maximum density at a temperature of $4^{\circ} \mathrm{C}$., and if it is cooled below this it expands and decreases in density. Gases expand with heat at all temperatures, but pressure changes their coefficients of expansion. At ordinary atmospheric pressure, the coefficient of expansion of air is 0.003671 , of hydrogen, $0^{\circ} 00366$; in both cases practically $\frac{1}{27} \delta$. See Heat; Tem. perature.

Ex parte (Lat., from one side). Expression used in English law to signify something done or said by one person not in the presence of his opponent. Thus an ex parte ap- plication is one made in the absence of the other side. An ex parte statement is one made when no one is present to contradict it.

Expectant. Term used in Eng. lish law. An expectant estate is one that comes into possession and enjoyment when some date arrives or event happens. Reversions and remainders are the only expectant estates known to common law ; but when wills of land were allowed the law permitted executory interests. An expectant heir is one who is bound to come into property on the death of another.

Expectation. State of expecting something. In the plural it is used for the money which one should receive under a will. If this is a certainty, i.e. if the will is that of a person already dead, money can be borrowed on this antici. pation. The Sunday after Ascension Day is sometimes called Expectation Sunday, because the apostles were then expecting the Lord.

Expectation of Life. Term used by actuaries and others engaged in life insurance business for the number of years a person may be expected to live. By careful calculations from a large number of cases tables have been worked out which are used when annuities are bought and sold. The expectation differs for males and females, and for different ages, but a roughly accurate method is to value the expectation of life at two-thirds of the difference between the present age and 80 . Thus a man of 41 may count upon living to 67 , this being 26 more years, two-thirds of 39 which is the difference between 41 and 80 . Some writers have ob. jected to the term, and equation of life has been suggested as a substi. tute. See Annuity; Death-Rate; Insurance.

Expectorant (Lat.ex, out; stem, pector-, breast). Drug which assists the expulsion of mucus from the lungs and air passages. Those most frequently employed are am. monium carbonate, senega, squills, ipecacuanha, benzoin, and balsam of tolu.

Expectoration. Term applied to the act of spitting, and to the material ejected. By expectoration medical men usually mean material coughed up from the lungs, not merely saliva. In health there should be practically no expec. toration; in diseases of the lungs or air passages the secretion may contain blood, pus, and bacteria.

Expeditionary Force. Name given in the British army organization to the force of regulars trained and ready for operations abroad. As planned in the re organization of the army, 1907, and developed in the next few years, it was to consist of six divisions of infantry, each composed of 598 officers and 18,077 men, with 54 field guns, $184^{\circ} 5$-in. howitzers, and 4 heavy 60-pounder guns, and one division of cavalry, composed of 485 officers and 9,412 men with 24 horse-artillery guns. In addition, troops were provided for the line of communications. The total strength available for the firing line was thus about 130,000 officers and men, with 480 guns. Each infantry division included the usual divisional troops, engineers, medical unit, etc. The cavalry division had four brigades.

The actual British Expeditionary Force that reached France in Aug., 1914, had a combatant strength of about 60,000 men-four divisions, and one cavalry division. The other two divisions did not reach the front till the middle of Sept. The original force, divided into two corps under Haig and SmithDorrien, and the whole, commanded by French, took its place on the front in Belgium, Aug. 23. See Army, British ; Great War: Mons ; consult also 1914, Field-Marshal Viscount French, 1919.

Expenditure (Lat. ex, out; pendere, to weigh). Act of paying out money. In large firms expenditure passes through the counting. house and is checked by the audi. tors. National expenditure is voted by the House of Commons, and the expenditure of local authorities, which is under the control of finance committees and officials acting under their orders, is checked by auditors of the ministry of health. See Accountancy; National Finance.

Experience (Lat. experiri, to try). Generally speaking, any sense-perception; in a narrower sense, a systematic organization of perceptions. The knowledge derived from experience, which alone provides communication with the objective world outside, is closely connected with the mental activity which comprehends and shapes experiences. Kant, while admitting that all true knowledge is derived from experience, held experience itself to be the result of the application of a priori forms to phenomena. One defect of experience is that, owing to differentimpressions being produced upon different persons by the same things, it receives a personal, individual tone, and fails to be completely general. Again, it lacks absolute certainty and necessity; since it does not acquaint us with the foundation of our knowledge. See Psychology. 
Experiment: Testing a provisionally adopted theory by facts. The great progress of natural science in modern times has been chiefly due to the systematic employment of experiment. Ancient philosophers and inquirers had a contempt for this method, which first received due recognition by Francis Bacon in his Novum Organum, 1620. An experiment may be defined as an observation which can be repeated, varied, and explained.

Experimental Farm. Farm at which science is applied to the processes of agriculture, and the results tabulated for reference and publication. The best known and oldest of English experimental farms is that founded by Sir John Lawes at Rothamsted in 1843 . He succeeded to the estate in 1834 , and from the first carried out certain experiments ; but it was not until 1843 that he obtained the assistance of Dr. Gilbert, and began his famous systematic experiments. Since that pioneer work, the great agricultural societies started other stations such as that at Woburn, and of Pum. pherston in Scotland. The oldest French station was founded by Boussingault at Bechelbronn in Alsace. Most governments have established similar agricultural research institutions, among them being several in Canada. See Agriculture ; Crops ; Farm.

Expert (Lat. expertus, tried). Term used by English lawyers to describe one who has special skill in and knowledge of a trade or profession. A surgeon, an architect, a builder, a chemist, for example, are experts in surgery, building, and chemistry. Experts are often called to give their opinions in technical cases.

Exploder. Term designating (a) the priming employed in highexplosive shell, and $(b)$ the electric machine for firing blasting charges fitted with electric detonators.

(a) The high-explosive charge employed in a shell is always in a very dense condition in order to reduce its sensitivity, utilise the greatest possible weight in the limited space, and prevent movement owing to the shock of discharge when the projectile is fired. High explosives in a dense condition cannot readily be detonated by fulminate of mercury or other initiators, and in order to build up sufficient violence it is necessary to interpose a quantity of loose or lightly compressed high explosive between the detonator in the fuze and the bursting charge. This priming may be confined in a gaine $(q . v$.$) , or$ placed in a bag, or merely loosely stemmed into a cylindrical cavity in the bursting charge just below the fuze, and is termed the exploder. The high explosive employed in exploders is usually trinitrotoluene, tetryl, picric acid or picric powder. See Ammunition; Explosives; Shell.

(b) Exploders for firing blasting charges occasionally utilise current from a set of accumulators passed through an induction coil, but the more usual machines are of the magneto type, a sectional illustration of such a machine being shown. It consists essentially of a double-wound armature, A, which can be rotated between the poles of the horseshoe magnet, B, through the free wheel pinion, $\mathrm{C}$, which is actuated by the rack, having a hand grip, D, at its upper end. The free wheel ensures that the armature does not rotate as the handle is pulled $u p$, but only when it is pushed down and the current is normally short-circuited by the switch, E. When the rack reaches the bottom of its stroke, and the armature is revolving at maximum speed, the rack opens switch, E,

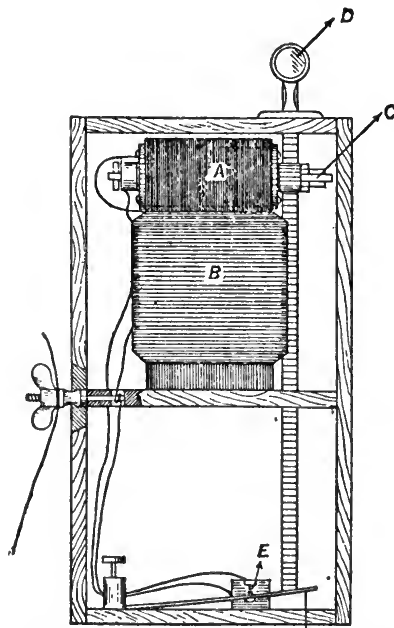

Exploder. Sectional diagram of magneto exploder. For explanation see text

and the whole of the current passes to the main leads secured by the wing-nuts shown on the left, and thus to the detonators. A machine of this type weighs som? $16 \mathrm{lb}$, and is capable of simultaneously firing up to 100 charges if desired.

Exploitation (old Fr. esploit, profit). Stage in the life of a mine when ore is extracted and sold. the previous stages being prospecting and development. During the earlier periods the money expended is regarded as capital invested in the business; during exploitation the revenue from sales is regarded partly as return of the capital expended and the interest thereon. See Mining ; Prospecting.

Exploits. River of Newfoundland. The longest river in the island, it rises in the hills of Long Range and flows right across in a N.E. direction. It passes through a well-wooded district which sup. plies timber for the pulp mills, and on it is the town of Grand Falls. It empties itself into the Bay of Exploits, having drained about $4,000 \mathrm{sq}$. m. Its length is about $160 \mathrm{~m}$. , and it is navigable by steamers for $12 \mathrm{~m}$.

Exploration (Lat. explorare, to search out). Literally, any kind of discovery, but the word is applied specially to discovering and making known the hitherto unknown parts of the world. There was little in the way of exploration from the time of the Greeks to almost the end of the Middle Ages.

In the 13th century something became known about China, and Marco Polo may fairly be ranked as a pioneer of exploration. It was, however, towards the end of the 15 th century that the great discoveries were made that gave a remarkable impetus to the work of the explorer. In 1492 Columbus reached the W. Indies; in 1497 Vasco da Gama rounded the Cape of Good Hope, and reached India ; while about those years notable voyages were undertaken by Bartholomew Diaz, the Cabots, and others. Newfoundland was discovered; Cabral reached Brazil; Balboa saw the Pacific. From these discoveries followed the exploration of America. In the N. the lead was taken by Frenchmen, La Salle being one of their greatest names, and in the S. by the Spaniards and Portuguese. Gradually the nature and extent of the two continents were made known; the Amazon and the Mississippi were discovered and then explored, while the secrets of the wonderful Aztec civilization were revealed.

In the 18th century Australia was discovered by Captain Cook. although the Dutch Tasman had some time before found Tasmania and New Zealand. Early in the 19 th century the continent was explored by Oxley, Sturt, Eyre, and a host of others. More and more was becoming known of Asia, although it was long before its central area was explored by Hedin and others, the final stage being the entry into Lhasa, 1904 . In the 19th century, too, came the exploration of Africa, the work of 
Livingstone, Stanley, Hanning, Speke, and others among Englishmen, and of a number of Frenchmen and Germans. The secrets of the Nile and the Congo were revealed, and soon there was little for the explorer to do.

From the time of the discovery of America, explorers had turned their attention to a north-west or north-east passage, and from this came the desire to reach the north pole. The south pole, too, was aimed at, and the exploration of the world's surface may be said to have ended when these goals were reached. See Africa; Antarctic Exploration; Arctic Exploration; Australia.

Explosion (Lat. ex, from, out; plaudere, to clap). Accidental ignition of gas. Explosions in coal mines are due to the fact that coal deposits are liable to give off certain gases which, when mixed with air in certain proportions, form explosive compounds which only require a spark or flash to fire them with possibly disastrous consequences to the workers, as at Courrières in France in 1906, when 1,100 lives were lost. Not all coal mines are equally liable to have explosions ; many, indeed, are so entirely free from fire-damp that naked lights are used by the miners in all parts of the workings, while electricity is freely employed both for lighting and for power purposes. In others the danger is always present, and the most exacting precautions are necessary to avoid a disaster.

It is, indeed, contended by many authorities that no coal mine can be absolutely safe, as dust alone without any admixture with methane or fire-damp may give rise to an explosion. The flame from a blown-out shot, that is from an explosive cartridge which has not expended its force upon the coal in which it has been embedded, but has blown out the tamping by which it was shut in, may be $20 \mathrm{ft}$. in length and even $35 \mathrm{ft}$. in narrow galleries, and may travel $80 \mathrm{ft}$. or more along the workings if dust be present in the air ; consequently a real danger may exist even in mines which are not "fiery."

Apart from blown-out shots, which are regular occurrences, an explosion may be caused by any kind of spark or flame or any ignited substance-a blown electric fuse, a broken electric lamp, for example, where electricity is employed; or an overheated safety lamp. It is a remarkable circumstance that mine explosions began to be more frequent as the ventilation of the workings was improved, a circumstance which led to an im. portant inquiry as to the relations

between explosive gas and the oxygen in the atmosphere of the workings. Legislation in this country requires that the oxygen in the air of the workings shall not be below 19 p.c. and that the carbonic acid gas shall not exceed a definite very low proportion, but inquiry has shown that an explosion would be almost impossible if the proportion of oxygen were reduced to 17 p.c.

Thus the measures taken on the one hand to improve the working conditions of the miners would appear only to increase his risk in another direction. Other precautions recommended to prevent an explosion comprise watering the dust of the floor at the working face before firing a shot; removing the dust from the intake haulage ways by reversing the air current from time to time; watering the floor, sides, and roof of the roadways, and rendering the coal-dust unignitable by mixing it or covering it with

\section{EXPLOSIVES: IN PEACE AND WAR}

Capt. E. de W. S. Colver, Author of High Explosives

In addition to the following introductory sketch this work contains shorter articles on all the lcading explosives, e.g. Dynamite; Gunpowder, etc. See also Ammunition; Artillery; Gas, etc.

Explosives (Lat. explosus, driven out) are solid or liquid substances or mixtures which are capable, when suitably initiated, of being converted in a very small interval of time into other more stable substances which are wholly or chiefly gaseous.

Contrary to popular belief, the energy content of explosives is comparatively low, as shown by the relative heat (energy) content of the following: petroleum, 15 ; coal, 10 ; wood, 5 ; nitroglycerine, 2. The tremendous explosive effect is solely due to their capability of releasing the whole of their energy in a minute interval of time.

The early history of explosives and their actual invention is a matter of much speculation. Gunpowder is certainly the oldest variety, and whilst many writers confer on it great antiquity and connect it with "Greek fire," it is doubtful whether saltpetre of sufficient purity was known at the time. Saltpetre was known to the Chinese and Arabic people about 1200 , and they used it in fireworks for military purposes. Roger Bacon's writings contain undoubted references to gunpowder, instructions for its manufacture being concealed by cyphers, and he was well acquainted with the fact that it explodes violently when ignited in confinement. No real development of gunpowder occurred until it was used for the propulsion of missiles from guns, and this invention appears to be due to a German stone-dust, which may be made by grinding waste shale. "The use of safety-lamps (q.v.) is made imperative and certain classes of explosives prohibited by legislation in all dangerous mines ; while arrangements now exist for giving all coal mining regions warnings of any approaching atmospheric changes which may be calculated to favour the escape of gas in the workings

Where risk of normal condition of a mine, special preparations are now made at the most modern works for the prompt release of miners who happen to be at the time of the explosion. These men may escape with their from the explosion itself only o fall victims to the after-damp or hoke-damp, unless they can be promptly got out, and as a rule their ways of escape will be blocked by destroyed or damaged workings. See Coal-dust; Fire-damp.

monk, Berthold Schwartz.

Old manuscripts record different dates for the discovery, but guns were certainly in use by 1320 .

For some six centuries gunpowder remained the only explosive known to man, and its composition remained almost unchanged, saltpetre, charcoal, and sulphur being the ingredients, in varied proportions. Its progress from an uncertain, irregular medium to a uniform and reliable explosive has been entirely due to improved manufacturing methods and greater purity of ingredients, this tending to more intimate contact of the components and consequently to faster and more regular burning. A mechanical mixture of oxidiser and combustible can never exceed a certain degree of intimacy of contact, so the rate of burning or violence of explosives was limited whilst gunpowder remained the only type.

Marked progress was made after 1846, when both nitrocellulose and nitroglycerine were discovered, the former simultaneously by two Germans, Schönbein and Böttcher, and the latter by an Italian, Sobrero. Both proved to be extremely violent explosives, incomparably more powerful than gunpowder. The reason for this is that both are chemical compounds, the oxidiser and combustible being combined in the same molecule, and hence in the closest possible contact. They are types of a 
distinct class of explosives, termed the nitric esters, in which the hydroxyl groups $(\mathrm{OH})$ of the raw material are more or less completely replaced by nitrate groups $\left(\mathrm{ONO}_{2}\right)$ during nitration.

The molecular arrangement of the product is such that the carbon atoms are linked to the $\mathrm{ONO}_{2}$ groups by hydrogen. The oxygen has the greatest affinity for carbon and hydrogen, but is bound to the nitrogen, resulting in the substances being in an unstable state, and when they are suitably initiated, re-grouping occurs in accordance with the chemical affinities and with the production of heat.

Attempts to utilise these new substances commercially showed a number of unexpected difficulties. Many disastrous explosions occurred during storage and handling, and, although a spark or flame had been the accepted method of firing gunpowder, these were quite inadequate for the new explosives, which were easily exploded by percussion. Credit for solving the ignition problem rests with a Swedish chemist, Alfred Nobel, who, in 1864, after years of patient research, evolved a tube containing mercury fulminate which, when exploded by a spark, initiated complete detonation in nitroglycerine.

\section{Invention of Dynamite}

Fulminate of mercury had previously only been used in percussion caps for firing guns, and Nobel's application of it to the initiation of explosives is one of the greatest advances in explosives science, and alone has rendered possible the use of most of our modern high explosives.

In commenting on the early difficulties with nitroglycerine and nitrocellulose, reference was made to two very important properties of explosives-stability and sensitivity. Stability is the ability of a substance to remain unchanged during prolonged storage, and early explosives were deficient in this respect. Nitric esters slowly decompose if minute traces of the nitrating acid remain in the product, sufficient heat being eventually generated to explode the mass, and some compounds which would be successful explosives are, inherently, so unstable that they cannot be used. In the case of explosives, sensitivity is always comparative, and is employed to express the ease with which the compound may be exploded by such agencies as heat, friction, percussion, etc. Many compounds are known which cannot be used as explosives owing to being excessively or insufficiently sensitive. It is a popular but fallacious belief that a successful explosive is sensitive and detonates as soon as disturbed, whereas the desideratum is one that is so insensitive as to be unaffected by rough usage, but which detonates with great power or violence when suitably initiated.

Many years of patient work were required to make nitroglycerine and nitrocellulose of commercial value. The former was so sensitive to percussion that soon Nobel was the only worker who persevered with it. He suffered grave family casualties, and accidents were so numerous that many countries prohibited the transport of the substance, but in 1867 he was rewarded by the discovery that kieselguhr would absorb about three times its weight of nitroglycerine, yielding a plastic mass of sufficient insensitivity. This was christened dynamite and its rapid adoption founded Nobel's fortune. Progress in the use of nitrocellulose was equally slow, and attended by numerous accidents, much work being done by von Lenk and later by Abel. Improvements in manufacture increased its stability, and in 1868 guncotton was made a successful military blasting explosive. Neither of the new explosives, however, was capable of use in guns, being too violent in their action, whilst they were too sensitive for employment as shell fillings.

In 1867 mixtures of ammonium nitrate with various combustibles were introduced as explosives, but were too insensitive for use until nitroglycerine was added, when they found a certain amount of favour. Another elass of explosive was invented by Sprengel in 1871, when he employed mixtures of nitric acid with organic combustibles, the essential feature being that the ingredients were non-explosive until mixed just before use. These have been extensively used for blasting.

\section{High Explosives for Shells}

Sprengel also experimented with picric acid or trinitrophenol in 1871 , but he was not encouraged by the British Government, and this explosive was not taken up until 1885, when Turpin proposed its use for shell filling, and France adopted it. This was the first high explosive which was sufficiently insensitive for this purpose, and belongs to a new class-the nitro derivatives of aromatic hydrocarbons. These also are chemical compounds, but, during nitration, hydrogen atoms are displaced by nitryl groups (ONO), which are consequently joined direct to the carbon atoms, and the products are more stable and less sensitive than the nitric esters. Aromatic hydrocarbons occur chiefly in coal tar and petroleum, which are the raw materials for this class of explosives.

Smokeless powder became a successful sporting propellant in 1865 , and a military one in 1884 . The successful use of nitrocellulose for this purpose became possible when its structure was destroyed by gelatinisation, its decomposition being then more of the nature of extremely rapid combustion than explosion.

Picric acid did not prove an ideal explosive for shell filling, as it was liable to form picrates which are sensitive, and in itself proved somewhat too sensitive for use in large guns. Nitration of other aromatic hydrocarbons was therefore essayed, but did not become a commercial success until the manufacture of cheap, highly concentrated sulphuric acid was a commercial possibility. Trinitrotoluene then sprang into prominence, and was shortly adopted by Germany for military purposes, most other powers following, with the exception of Great Britain and France.

\section{Explosion and Combustion}

Chlorates became cheap in 1889 , and as they contain much available oxygen, attempts were made to employ them in explosive mixtures. Early attempts to use them in gunpowder had proved disastrous owing to their sensitivity to percussion and friction, and to avoid such trouble some use was made of porous cartridges of potassium chlorate, which were dipped into a liquid combustible just before use.

The invention of cheddite $(q . v$. was, however, the first completely successful application of chlorates. Ammonium and potassium perchlorates have also been employed. They contain more available oxy gen, and are less sensitive than the chlorates, the ammonium salt being the more advantageous as all the products of explosion are gaseous, but for use underground it possesses the disadvantage that the products of explosion contain hydrochloric acid gas, which is poisonous, and if the explosive is to be so used it must contain some metallic or alkaline ingredient to fix this gas.

The power of an explosive can be increased by raising the temperature of the gases evolved, and this effect may be obtained by including a combustible having a high temperature of combustion, and metals are generally em. ployed for this purpose, such explosives being designated Thermit explosives. 
Dynamite, gelatine dynamite, and blasting gelatine are generally used where great shattering effect is required, and gunpowder is still employed for rending. Military requirements generally demand a most brisant effect from shell fillings, and here nitro-aromatic compounds alone are most used, trinitrotoluene being pre-eminent; but during the Great War shortage of supplies rendered it necessary to employ ammonium nitrate explosives for this purpose, and amatol and schneiderite are examples of successful practice. Smokeless powders all have nitrocellulose as a basis, and some contain nitroglycerine in addition-(see Cordite, Poudre B., Ballistite, E.C. Powder, Schultze Powder, etc.)-propellants for rifled weapons being required to burn much more slowly than for smooth bores.

Combustion, explosion, and detonation are terms designating the same chemical change, the sole variant being the speed with which reaction occurs, detonation being so rapid that an explosive wave apparently propagates the change instantaneously through the whole mass, whereas in combustion and explosion the reaction proceeds by layers through each particle.

\section{Use in Mining}

In mining, explosives are used to supplement the work of the miner's pick in breaking down the rock which it is desired to remove. The explosives in common use comprise: gunpowder; cheddites, which are chlorate preparations; dynamite, blasting gelatine, gelignite, Ardeer powder, britonite, cambrite, arkite, carbonite, kolax and duxite, which are preparations of nitroglycerine; ammonite, bellite, Faversham powder and roburite, which are preparations of ammonium nitrate, and fulminate of mercury, which is used for detonators. Gunpowder is still largely used, especially for the softer rocks, on account of its cheapness and general security. The dyna. mites, blasting gelatine, and gelig. nite are most used for hard rocks where an intense shattering effect is desired.

For use in coal mines, particu larly those where there is a risk of a gas or coal-dust explosion, safety explosives are employed, these usually having an ammonium nitrate base, sensitised with either nitroglycerine or an aromatic nitrocompound. Explosives of a similar type, but of a more brisant nature, including some of the cheddites, ammonals, etc., are used in mining and quarrying. For military demolitions guncotton or trinitro. toluene is usually employed, but dynamite or blasting gelatine may be used in an emergency. For land mines the British army used ammonal extensively during the Great War. See illus. p. 2346.

Bibliography. ExplosiveMaterials, M. P. E. Berthelot, Eng. trans. M Benjamin, 1883 ; Traité théorique et pratique des explosifs modernes, P. F. Chalon, 2nd ed. 1889 ; Manufacture of Explosives, O. Guttman, 1895 ; with supplement, 1909 ; Poudres et Explosifs : dictionnaire des matières explosives, J. Daniel, 1902 ; Explosives, H. Brunswig, Eng. trans. C. E. Monroe and A. L. Kibler, 1912 ; Les Poudres et Explosifs, L. Vennin and G. Chesneau, 1914; Explosives, A Marshall, 2nd ed. 1917; Notes on Military Explosives, E. M. Weaver, 4th ed. 1917; High Explosives, E. de W. S. Colver, 1918.

Explosives Law. A new Act concerning explosives was passed in England in 1860, and amended in 1861 and 1862 , repealing all previous Acts. In 1875 a new Explosives Act was passed dealing comprehensively with the whole question. This was based on the report of the House of Commons Committee appointed to enquire into the terrible explosion on the Regent's Canal in 1874, and still governs the whole question. Part I deals with gunpowder, which may only be manufactured in licensed factories and kept in licensed maga zines under specified conditions. Part II deals similarly with nitroglycerine, and other high explo. sives; Part III with inspection accidents, search, etc., and Part IV gives supplementary provisions. The Act is administered by the home office, which publishes annual reports of its inspectors, and is responsible for new regulations, etc. The term explosive may include any substance deemed to be specially dangerous, and the Act provides for the com. position, quality, character, and classification of any explosive to be defined by an Order in Council. Owing to many of the newer explosives being of a poisonous nature, regulations can also be made to safeguard the health of workers. Most other countries have introduced similar legislation. The Merchant Shipping Act of 1894 regulates the carrying of explosives in British vessels.

Exponent (Lat. ex, from, out; ponere, to place). Symbol of an algebraic expression denoting the number of times the expression is to be multiplied by itself. Thus in the expression $a^{3}$, the figure 3 is the exponent of $a$, and the expression is equivalent to $a$ times $a$ times $a$.

Exponential. A term used in mathematics. The exponential function is the inverse of the loga- rithm: thus if $y=\log x$, then $x$ is said to be the exponential of $y$. See Logarithms.

Exports (Lat. exportare, to carry out). Name given to goods sent out of a country. These are valued at the custom houses, or by other authorities, and all civilized countries issue periodical returns showing their value. In the United Kingdom this is done monthly by the board of trade. They are divid ed into four main classes: food, drink and tobacco ; raw materials manufactured articles; miscellaneous. The total value of a year's exports from the United Kingdom rose from $£ 354,400,000$ in 1900 to $£ 962,694,911$ in 1919 , but this great increase was largely due to an advance in prices, not to an advance in volume.

The difference between a country's exports and its imports is known as its balance of trade, but to strike an accurate balance certain considerations should be remembered. For instance, exports are valued at their price when put on board ship, whereas in the price of imports the cost of carriage is included. Invisible exports is the name given to charges for freights and the like. These are paid to the country owning the carrying ships and play a part in the balance of trade, but are not included in the monthly figures. See Balance of Trade; Trade.

Exposition (Lat. exponere, to set forth). In music, the placing out or setting forth of the themes and materials upon which a piece is constructed. In fugue the exposition includes the first entries of all the voices or parts. In sonata form it includes the first presentation of the chief themes, before their development or elaboration is entered upon. See Fugue; Sonata.

Express. Literally to press out, a word used in several senses, all, however, conveying the idea of speed. It is given to a fast train and to a newspaper. See Railways.

Expression, FactaI. Outward indication on the features of the inward character or emotions. Sir Charles Bell first put the matter on a scientific basis in his essay on the Anatomy of Expression in Painting, 1806. Continental writers fol. lowed, but the great classic work on the subject is Charles Darwin's Expression of the Emotions in Man and Animals, 1872, in which are set forth the physiological reasons for the variety of expression of which the human face, and in a lesser degree the faces of animals, are capable.

Darwin maintains that some human expressions, such as the bristling of the hair under the influence 
of extreme terror, or the uncovering of the teeth under that of furious rage, can only be understood on the assumption that man once existed in a much lower and animal-like condition. He thinks the movement of the same facial muscles during laughter by man and by various monkeys indicates descent from a common ancestor. See illus. p. 59.

Express Service. Organization for the rapid transit of small parcels. Companies for this purpose are especially numerous in the U.S.A. and Canada, where they undertake the carrying of money and valuables, as well as of ordinary goods. They insure these, and if required collect the money on delivery. Express companies are controlled by the government as to charges, etc., much as railway companies in Great Britain.

In the U.S.A. the first express company was organized in 1836 . Others followed, and soon the whole country had an efficient service, each company with its own coaches and riders. Among the largest were the Adams, the American, the United States and the Wells, Fargo. Soon they made agreements with the railway com. panies, by which most of their loads are now carried. In 1912 their prosperity was gravely affected by a law permitting the post office to carry heavier parcels than had hitherto been the case.

In Canada there are four large companies, in addition to those of the U.S.A., which work the country. The four have a capital of $£ 1,000,000$, and in 1916 the turnover of the whole, those of the U.S.A. included, amounted to $£ 11,000,000$. The four are Canadian, Canadian Northern, Dominion, and British America.

Extension. Term used in engineering for the stretching of materials under strain. All materials stretch under a pull, though the amount may be relatively very small. A bar of wrought iron, for example, one inch square will only stretch one twelve-thousandth of an inch with a pull of a ton on it. Heat is an important cause of extension of metals, and due allowance for that extension is made in all engineering construction. In railway engineering, for example, a space is left between each set of railway lines to allow of the expansion due to the heat of summer. If this were not allowed for, the rails would become twisted completely out of shape. See Engineering.

Extensometer. Instrument for measuring the stretch or small deformation of materials under various kinds of stresses. The use and design of extensometers have become of increasing importance in the modern engineering with the increasing refinements in the use of metals and other materials. The stretch and deformation of materials under certain conditions must be allowed for, as for example in railway construction, bridge building, etc. Modern extensometers will measure to less than the millionth part of an inch. See Materials, Strength of ; Testing.

Extent. English writ of execution to recover crown debts. Under writ called an extent in aid, a crown debtor can, on making an oath that otherwise the debt will be lost, obtain an order to seize the lands and goods of a debtor to him. self, so that he may be able to pay what he owes to the crown. See Crown Debts.

Extenuating Circumstances. Term used in English law. A jury may add a rider to a verdict of guilty that there were extenuating circumstances in favour of the prisoner. The judge may take this into account in the sentence, except in cases of murder and high treason, when he is bound to pass the capital sentence. In France, "Guilty with extenuating circumstances" is a different verdict from guilty; and the sentence is different.

Extortion (Lat. ex, out; and torquere, to twist). In English law, a demand by an official, or someone else penforming a public service, of money in excess of the amount due, or of money not yet due. It is applied by an extension to the act of obtaining money by means of threats, the offence known as blackmail. Extortion in the strict sense is punishable by fine and imprisonment, a number of statutes having forbidden it. Other forms may become robbery and be punished as such.

Extract (Lat. extractus, drawn out). Term applied, in chemistry and pharmaceutics, to products obtained by treating any substance with solvents and then evaporating the latter. In a more restricted sense, an extract is a concentrated form of a vegetable drug. It contains the active part of the drug, the inert portion, consisting of woody fibre, being exhausted of its active principles during the process of extraction.

The various operations involved in extraction have received special names. Infusion is the process of allowing a drug to remain in contact with hot or cold water for definite periods of time; if the solvent is boiled during the period the process is decoction. In another common method, known as percolation, the comminuted drug is placed in a conical vessel and the solvent slowly passed through it. To reduce the liquid to a more concentrated form it is evaporated by heat. The extracts prepared in pharmacy are either thick liquids or soft pastes. The pastes are used as ingredients in making pills and lozenges.

Extradition (Lat. ex, out ; traditio, handing over). Term used in law for the surrender, by one state to another, of fugitive criminals. As between the states, this depends on treaty; no state has an inherent right, apart from express agreement, to claim extraditory rights from another. Treaties for extradition now exist between most civilized states, but political criminals are invariably excepted from their operation. The manner in which extradition is applied for and granted depends upon the law of the country where the fugitive is. In England it is governed by the Extradition Acts, 1870, 1873, 1895, and 1906, and the Fugitive Offenders Act, 1881. The lastnamed statute applies to the Colonies.

By these Acts, a fugitive offender is not to be surrendered unless the foreign state concerned undertakes to try him only on the charge on which he is extradited. The fugitive is to be brought before a magistrate, who must be satisfied that the alleged offence is not political, and is one of the crimes for which extradition can be claimed. These offences range from murder to bribery. If the magistrate decides that the case is made out, he commits the offender to prison, and then a secretary of state makes an order for the gaoler to hand the offender over to the representative of the foreign state. See International Law.

Extraterritoriality. Term used in international law. It describes the status of a person who, when in foreign territory, is immune from the jurisdiction of local laws and courts. Sovereigns and diplomatic agents are considered such persons by ancient usage. If a sovereign is abroad, his house is extraterritorial; and the official residence of an ambassador is, by courtesy, part of the country which he represents. Hence no arrest can be made there under a local warrant; nor is the house assessable to rates and taxes. Sometimes by treaty all the subjects of one state residing in another are made extraterritorial for purposes of justice. A ship of war in a foreign harbour, behaving peacefully, remains $a$ part of the country whose flag she flies; and a military force in a foreign country is not subject to 
the laws of that country except by agreement, e.g. the British army in France during the Great War was subject to English, not to French. military law. See International Law

Extravasation (Lat. extra, out side, beyond; vas, vessel). Out. pouring of fluid into the tissues from an injured vessel. The most familiar example is the extravasation of blood which may follow a blow on the skin resulting in the formation of a bruise.

Extreme Unction or SACRA MENT OF THE DYING. Fifth of the seven sacraments of the Roman Catholic Church. It was instituted for the spiritual and bodily comfort of those in extremis. Recognized also in the Greek, Coptic, Armenian, and Nestorian Churches, with varying ceremonial, and dating from the 12th century, it is regarded as authorised by James $v, 14-15$, and is administered by the priest, who anoints the dying person.

Unction is usually applied to the seat of each of the five senses, with prayer, e.g. "Through this holy unction, and His most tender mercy, may the Lord pardon thee whatever sins thou hast committed by seeing. Amen." With the other senses the necessary word is used in place of "seeing." In Roman usage the oil is applied in the form of a cross, after reception of the Viaticum or Holy Communion. In the Church of England the rite was abolished in 1552, the Protestant claim being that the words of $\mathrm{S}$. James have reference to a miraculous cure, and that the anointing ceased to have efficacy with the withdrawal of miraculous powers from the Church. See Sacrament.

Exudation (Lat. ex, from, out ; sudare, to sweat). Emission of a liquid constituent or mixture of ingredients from a solid or gelatinous explosive. The material ejected is also occasionally termed the exudation. Dynamites which have become damp and blasting gelatines which have been subjected to pres. sure and high temperature are liable to exude nitroglycerine, when the material becomes highly dangerous owing to the sensitive nature of this explosive.

Exuma. Two of the Bahama Islands, known as Great and Little. They lie S.E. of Andros Island and W. of Long Island. Great Exuma is $30 \mathrm{~m}$. in length and contains the chief settlement, Georgetown. The area of the two islands, including the numerous cays (low islands), is about 250 sq. m., and the total pop. is 3,465 .

Eyam. Parish and village of Derbyshire, England. It stands in Eyam Dale, 5 m. N. of Bakewell.
In the churchyard is a Runic cross, and there are several barrows, one of which, on Eyam Edge, is more

and brilliant as it was 500 years ago, and they so improved the method of oil painting that they made

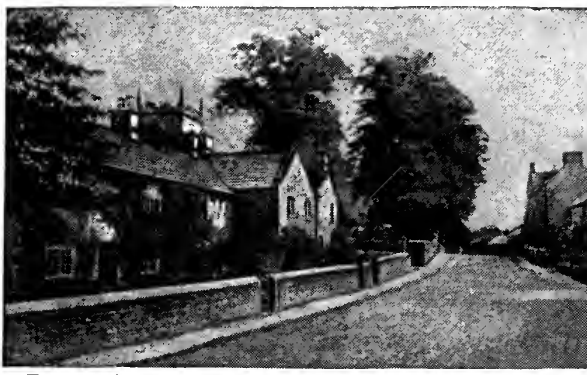

Eyam. Cottages dating from the plague of 1665-66, when three-fonrths of the inhabitants died it virtually a new medium. The y were not, however, as some times alleged, its discoverers.

A 10th century MS. by the monk Fraclius (De Coloribus et Arti. bus Romanorum) states that method of grinding colours with oil was then " in the air," and Rogierus, a monk of $\mathrm{the} \quad 12 \mathrm{th}$ than $100 \mathrm{ft}$. in diameter. During the plague in 1665-66 the greater part of the population perished. Pop. 1,224. Pron. Eem.

Eyck, HUBERT VAN (c. 13661426). Flemish painter. He was born at Maeseyck, in the province

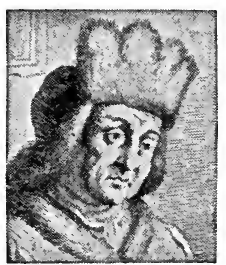

Hubert van Eyck. Flemish painter

From an old print of Limburg. Before set. tling at Ghent a court painter, early in the 15th century, he spent a con siderable time in N. Italy. He began, and his brother J a c c m . pleted, $\quad \mathrm{th} \theta$ famous altar-piece of The Adoration of the Lamb, executed for the cathedral of S. Bavon, Ghent, where he died, Sept. 18, 1426. Certain panels sold in 1816 and long in German possession were restored in Oct., 1920, under the treaty of Versailles. Both painters rank among the very greatest of the Flemish school. Their drawing and finish were meticulously exact, their colouring is almost as fresh

century, recommended that colours should be ground with oil and mixed. The nature of the im. provement introduced by the $\mathrm{Van}$ Eycks seems to have been regarded as a craft secret, but it is conjectured that it was some essential oil which yielded a clear, transparent, liquid vehicle, which retained its limpidity, dried without darkening, and, when mixed with colours, gave results so superior as to supersede the viscous varnishes formerly in vogue.

Eyck, JAN vaN (c. 1385-1440). Flemish painter, brother of Hubert. Born at Maeseyck, he appears to

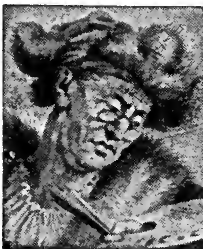

Jan van Eyck, Flemish painter

From an old print have resided in The Hague from 1422-24, at Bruges for a few months in 1425, in which year he went to Lille, where he re. mained for four years, a n d ater visited various foreign countries in an official capacity as painter to fulfil State commissions.

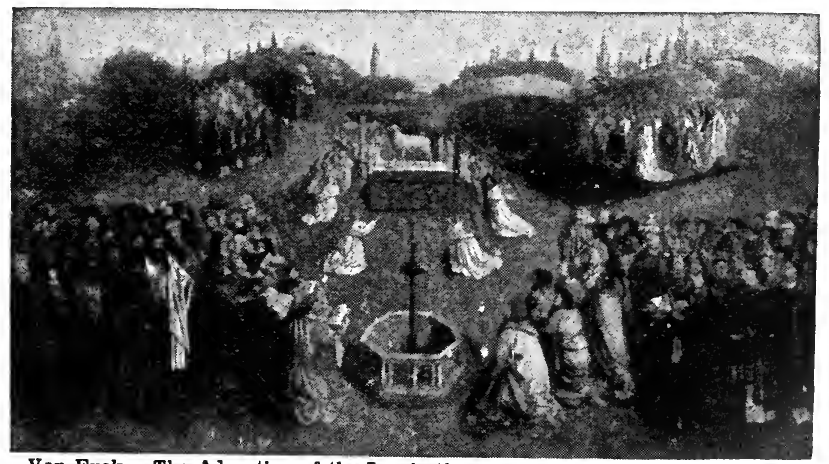

Van Eyck. The Adoration of the Lamb, the central nanel of the altar-piece at the cathedral of S. Bavon, Ghent, the masterpiece of the Van 
He died at Bruges on July 9, 1440. $\mathrm{He}$ is represented at his best in the National Gallery, London, by the magnificent picture of John Arnolfini and his Wife, and at the Louvre by the exquisite Chancellor Rollin Kneeling before the Virgin.

Of Margaret van Eyck (c. I3771430 ), his sister, nothing is known beyond the bare fact that she also was an excellent painter. Some writers have even questioned her existence. See Hubert and Jan van Eyck: their life and work, W. H. J. Weale, 1908.

Eye. The organ of vision. Well protected from injury by its situation in the bony orbit, it possesses an extensive range of vision, the movements of the globe being effected by three pairs of opposing muscles. The eyeball consists of segments of two hollow spheres, of which the smaller, representing about one-sixth of the whole, is anterior. This segment is convex anteriorly and projects in front of the remainder of the globe. It is covered by the cornea, which consists of five layers of transparent cells, the innermost layer known as Descemet's membrane.

The posterior and larger sphere, rather longer transversely than in other directions, is formed by three tunics or coats, the sclerotic externally, the choroid and iris medially, and the retina internally. The sclerotic is white in colour externally, tough and fibrous, and forms the chief means by which the shape of the globe is maintained. It is perforated posteriorly by the optic nerve and by blood-vessels, forming the lamina cribrosa, and is attached internally by a layer of delicate connective tissue (lamina fusca) to the choroid. The choroid consists mainly of pigment and blood-vessels. Chocolate-brown in colour, it extends forward to the ciliary ligament, where it is con-

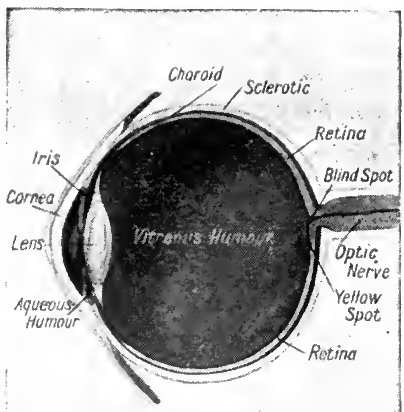

Eye. Sectional diagram showing formation and principal parts of the eye nected with the iris, and where its inner surface is thrown into folds known as ciliary processes.

The iris (rainbow) forms a thin contractile curtain, having a perforation, the pupil, which is slightly to the nasal side of the centre, for the transmission of light. The iris is of different coloursin different in. dividuals ; the colour varying from light blue to dark brown according to the amount and position of the pigment contained. In the albino this pigment is entirely absent. Composed of radiating and circular muscular fibres which are innervated by fibres of the sympathetic nerve and of the third cranial nerve respectively, it regulates the amount of light entering the eye.

The pupil con. tracts or dilates according as the eye is exposed to a bright or $\mathrm{dim}$ light. The iris is immediately i $n$ front of and in contact with the lens. The retina consists of three principal la yers, chiefly of nerve tissue. The external layer is formedby terminal cells of the optic

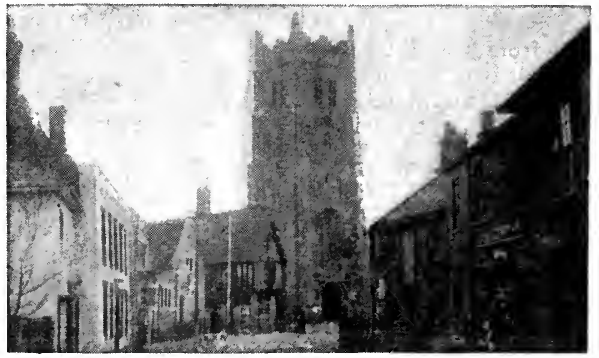

Eye, Suffolk. The parish church of SS. Peter and Paul, whose tower is a magnificent specimen of E. Anglian

nerve called from their shape rods and cones. Exactly in the centre of the posterior part of the retina. and in a line with the central axis of the globe, is the yellow-spot in which the sense of vision is most acute. At a distance of one-tenth of an inch to the nasal side of the yellow-spot is the point of entrance of the optic nerve. It possesses no vision and therefore is known as the blind-spot.

The refracting media of the eye constitute the contents of the globe and consist of the aqueous humour, the crystalline humour or lens, and the vitreous humour. The aqueous humour fills the space between the cornea and the lens. It is very small in quantity, weighing from 4 to 5 grs. The vitreous humour forms four-fifths of the entire globe. It is perfectly transparent, of the consistency of thin jelly, and is enclosed in a delicate transparent membrane. The crystalline humour is a double convex lens with the greater curvature posieriorly. It is situated immediately behind the pupil, and is held in place between the aqueous humour in front and the vitreous humour behind by an elastic capsule and a suspensory ligament. It measures about $\frac{1}{3}$ in. across and about $\frac{1}{4}$ in. antero-posteriorly. Its shape is modified by the action of ressed flint work

the ciliary muscle which surrounds the outer edge of the iris and is ing, that is to say when a near object is being viewed.

Rays of light entering the eye should be brought to a focus on the retina. If the globe is too long in its antero-posterior dimension, as in the short-sighted, it is necessary to place a concave lens before the eye to throw the focus farther back. With advancing years the cornea and the crystalline lens tend to become flattened, and the lens partly loses its ability to alter its shape when accommodating, a condition known as presbyopia. Therefore, it frequently is necessary, after middle life, to

use convex lenses when reading or occupied in near work. See Blindness.

H. E. Davison

Eye. Small hole, or loop, at the top of certain articles. Eyebolts are screw bolts with a ring in them. The eyes of a sail are holes which take the lashings when reefing. A Flemish eye is the end of a rope bent to form a loop.

Eye. Mun. bor. and market town of Suffolk, England. It stands on an affluent of the river Waveney $19 \mathrm{~m}$. N. of Ipswich, on the G.E.R. An ancient town, it has castle ruins, a grammar school founded in 1566 , a town hall and corn exchange. Brewing is an industry. Market day, Mon. It gives its name to a co. div. returning one member to Parliament. Pop. 2,001.

Eyebar. Metal bar with one or both ends enlarged. In the enlarged end a hole is drilled so that by means of a pin or bolt the end of the bar may be secured to another object. Eyebars vary in size, from a fraction of an inch in diameter up to the great eyebars used in the Quebec bridge, each sustaining a pull of 300 tons.

Eyebolt. Bolt with one end formed like an eye or rigid ring instead of an ordinary head. Eyebolts are used for many purposes, e.g. as door fastenings and attachments for stays and guys. more convex when accommodat- 


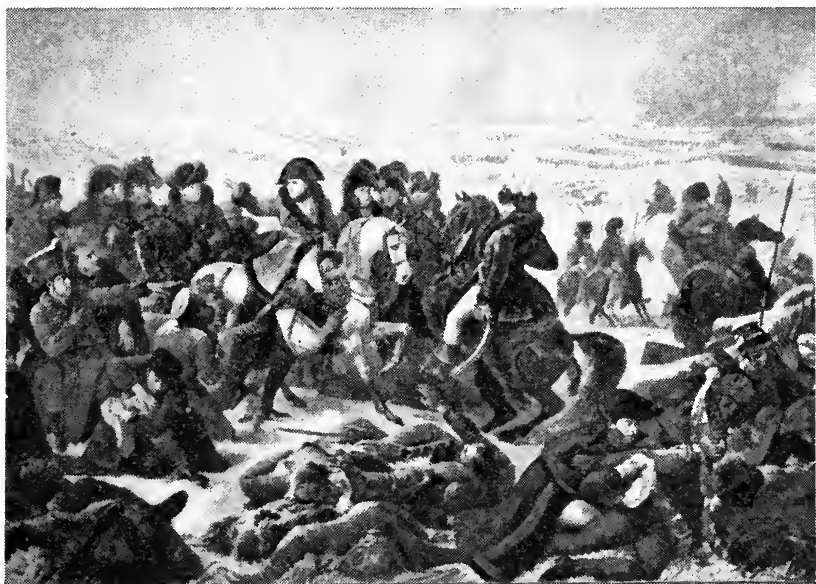

Eylau. Napoleon riding across the battlefield after his victory over the Russians, Fob. 8, 180\%. From a painting by Baron Gros

Louvre Museum, Paris

Eyebright (Euphrasia officinalis). Small annual herb of the natural order Scrophulariaceae. A native of N. Europe, N. and W. Asia, and N. America, it is a parasite upon the roots of grasses, sedges, etc. The leaves are oval or lance-shaped, with cut edges, the flowers small, white. veined with purple, and the middle lobe of the lip yellow. It grows in meadows and heaths.

Eyemouth. Burgh of Berwickshire. It stands at the mouth of the little river Eye, $8 \mathrm{~m}$. from Berwick, and has a station on the N.B. Rly. It is a fishing centre, for which industry there is a good harbour, protected on the N. by St. Abb's Head. The town hall is the chief public building. Pop. 2,450.

Eye-piece. Lens of a telescope nearest to the eye. In a telescope light falls in nearly parallel rays on the object lens, which throws an image of the field of vision. The eye-piece enables the eye to form an image of the image.

The eye-pieces used with astro. nomical telescopes vary in form. The first telescope made by Galileo had a bi-concave eye-piece such as opera glasses now have. This eye-piece is placed between the object glass and the focus at which the image is thrown. Convex eyepieces are placed outside the focus. But both these kinds of eye-pieces colour the light coming from the image owing to the refraction of the rays. Huygens discovered that this defect might be remedied in the eye-piece by employing two plano-convex lenses, both with the flat sides towards the eye, the larger placed nearer the image, and the smaller nearer the eye. This construction is in general use, except for micrometer eye-pieces, which have spider-webs for measuring the sizes of the different objects In these the flat sides are both turned away from the eye. See Telescope.

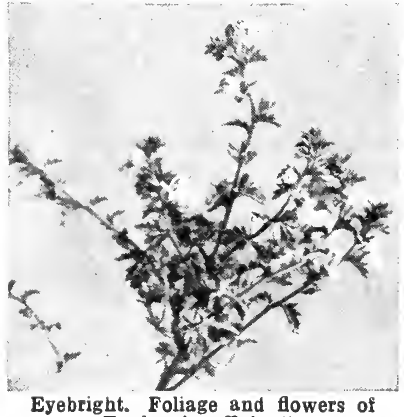

Eyebright. Foliage and flowers of Euphrasia officinalis

Eye-Witness. Pseudonym of Col. W. S. Swinton (q.v.) He was the first to write accounts of military operations in France and Flanders for the press, under official sanction, during the early part of the Great War (1914-15).

Eylau. Town of Prussia. It stands on the Pasmar, about 24 m. from Königsberg, and is noted for the battle fought here, Feb. 8 , 1807, between the French under Napoleon, and the combined Rus. sians and Prussians. After his de.

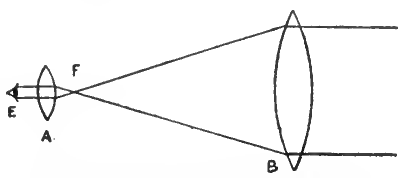

Eye-piece. Diagram showing principle of working. $\mathbf{E}$, eye ; $\mathbf{A}$, eyepiece ; $\mathbf{F}$, focus ; $\mathbf{B}$, object lens feat at Pultusk, Dec. 26, 1806 , Bennigsen, who, pursued by $\mathrm{Na}$ poleon, had begun to retreat upon Königsberg, decided to make a stand at Eylau. In an engagement on Feb. 7, 1807, Bagration and Barclay de Tolly, after several assaults by the French, were forced to abandon the village.

In a snowstorm on the morning of the 8 th the battle developed. The emperor could only bring into the field Augereau's and Soult's corps, together with six divisions of Murat's cavalry; his other troops were hurrying up over snow-bound roads. An advance by the French from Eylau was beaten back and the Russians attacked in force against Eylauwindmill. Augereau's 7 th corps was thereupon ordered by Napoleon to stem the Russian advance. The day was going against the French, and the battle reached a crisis when Augereau's troops, blinded with driving sleet and snow, enfiladed by artillery and attacked by infantry, suddenly had a mass of cavalry launched against them. Augereau was hit, and all his colonels and brigadiers were killed or wounded.

The French broke, and were in full flight when Napoleon hurled 18,000 of Murat's cavalry upon the Russians. The effect was decisive. The Russians were scattered, regiments were ridden down in the blinding snow, the squares were broken, 16 standards were taken, and the victorious French only stopped on encountering Bennig. sen's reserves. As the afternoon wore on, with the arrival of Napo. leon's reserves, the day was won, and Bennigsen retired on Königsberg, having lost 18,000 men and 24 guns. The French losses amounted to 15,000 men. Napoleon brought into action altogether 79,000 men; the Russians num. bered 75,000. Pron. Ile-ow.

Eyot (A.S. iget) or ArT. Islet in river or lake, especially one overgrown with willows. Pron. eight.

Eyra. S. American wild cat. Resembling a large weasel with a long tail, it is reddish brown in colour, without stripes. It ranges from Mexico to Brazil, and is a trouble to the poultry farmer.

Eyre. Lake in S. Australia. It is $4,000 \mathrm{sq} . \mathrm{m}$. in area, but in dry seasons merely a salt marsh. In wet seasons the Barcoo and Diamantine rivers flow into it. Edward John Eyre discovered it in 1840.

Eyre. Word derived from the Latin iter, a journey. It is used chiefly in connexion with the itinerant justices sent out by Henry II and known as justices in eyre. In Scotland the form aire came into use. See Henry II ; Judge. 
Eyre, EDwaRd JoHN (18151901). British explorer and colonial governor. Born at Hornsea,

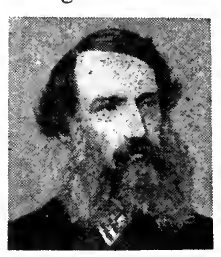

Edward J. Eyre, British explorer
Y orkshire, Aug. 5, 1815, he emigrated to Australia in 1833, and carried out valuable explora$t$ ions of unknown territory, especially of the coast between Adelaide and King George Sound, in 1841. He went to New Zealand as governor in 1846 , to St. Vincent, 1854, and to Jamaica, 1861. His stern handling of the negro rising there in 1865 caused his recall to England, where his action roused wide controversy. In 1872 the government repaid the legal expenses which he had in self-defence incurred, and awarded him a pension in 1874. He died Nov. 30 , 1901.

Eyre, Sir James (1734-99). English lawyer. Born at Wells, he was the son of a clergyman. From Winc:iester he went to S. John's College, Oxford, and became a barrister. He was counsel for the defence of John Wilkes in 1763. From his post as recorder of London he was promoted in 1772 to be a judge; in 1787 he became chief baron of the exchequer and in 1793 chief justice of the court of common pleas. He remained at the common pleas until his death, July 1, 1799, having been for a few months commissioner of the great seal when there was no lord chancellor, and having presided at the trial of Horne Tooke.

Eyre, Sir VINCENT (1811-81). British soldier. The son of a soldier, he was born Jan. 22, 1811, and educated at Norwich Grammar School. He joined the service of the E. India Co. in 1828 and, in the artillery, was with the force that entered Afghanistan in 1840 ; after the siege of Cabul by the Afghans he and his family were surrendered to them as hostages. In 1843 they were rescued by a relieving force, after which Eyre commanded the artillery at Gwalior. During the Mutiny he distinguished himself by his prompt action in marching against some rebels at Arrah and defeating them also at Jagdespur. He held a command in the force that relieved Lucknow, was recom. mended for the V.C., and retired as a major-general in 1863 . During the Franco-Prussian War he organized an ambulance service. $\mathrm{He}$ died at Aix-les-Bains, Sept. 22, 1881. Eyre wrote an account of his imprisonment in Afghanistan.
Eyre's Peninsula. Tract of land in S. Australia. It lies between the Great Australian Bight and Spencer Gulf, an area of sand, scrub, and salt marsh. Port Lincoln, near its apex, exports wheat.

Ezekiel, Book or. One of the prophetic books of the O.T. Ezekiel was both priest and prophet. He was one of the priests of Jerusalem, who, with King Jehoiachim and other members of the upper classes, were deported to Babylonia in 597 B.c. by Nebuchadnezzar (605-562 в.c.). The exiles were settled at different points, Ezekiel becoming a member of the community at Tel-abib, near the river Chebar, which has been identified with the grand canal in the neighbourhood of Nippur. We are told that the prophet received his call in the fifth year of the reign of Jehoiachim (592 B.c.).

The book falls int o five divisions: $(a)$ the prophet's call and consecration, Ezek. i, 1-iii, 15; (b) discourses on the imminent destruction of Jerusalem, Ezek. iii, 16xxiv, 27 ; (c) oracles against Ammon, Moab, Edom, Philistia, Tyre, Sidon, and Egypt, Ezek. xxvxxxii ; $(d)$ prophecies of the restoration of Israel and the overthrow of her foes, Ezek. xxxiiixxxix; $(e)$ vision of a restored theocracy of a united Israel, Ezek. xl.xlviii. The book itself assigns definite dates to many of the prophecies, the latest mentioned being about 570 B.c. On one occasion the prophet admits that a prediction had not been fulfilled. In Ezek. xxvi, 7-14, Nebuchadnezzar is expected to capture Tyre. Tyre, however, did not fall, and in Ezek. xxix, 17-21, Nebuchadnezzar is promised Egypt as a recompense.

The authorship and integrity of the book of Ezekiel present no difficulty. The difficulties are associated with the Hebrew text, often obscure and corrupt. As the author was a priest, it is not sur. prising to find that he lays more stress than the other great prophets on externalities, rites, and ceremonies. We find points of affinity with the priestly phraseology of the later legislation, which has been called the Code of Holiness (Lev. xvii-xxvi). But due emphasis is laid also upon personal responsibility and personal religion. He has been described even as "pastor rather than prophet."

Ezekiel's visions of the chariot and cherubim (Ezek. i, 1-iii, 15) had considerable influence on the later symbolical literature. They have been interpreted (e.g., by the Rabbis) as a synopsis of theosophy. The vision of the valley of dry bones in Ezekiel xxxvii has become famous. In Ezekiel xxxviii and xxxix occur the curious creations Gog and Magog. Gog, perhaps suggested by Gyges, king of Lydia, is a prince from the land of Magog, who leads a great host of nations against the restored Israel, and is defeated ignominiously. In the later Jewish eschatology Gog and Magog are represented as leading in vain the final attack of the powers of the world upon the Kingdom of God.

Biblicgraphy. Introd. to the Literature of the O.T., S. R. Driver, 8th ed. 1909; The Books of the O.T., O. C.Whitehouse, 1910 ; Critical Introd. to the O.T., G. B. Gray, 1913 ; Lit. of the O.T., G. F. Moore, 1914.

Ezra, Book OF. Book of the O.T. Ezra was a Jewish scribe living in exile in Babylon, under Artaxerxes Longimanus. $\mathrm{He}$ is said to have belonged to the priestly line, and to have been a descendant of Seraiah, the high priest when Jerusalem was captured by Nebuchadnezzar. About 458 B.c. he was allowed to return to Jerusalem with about 1,500 men, in addition to women and children. There he found that the remaining Jews had intermarried with heathen women, and great laxity prevailed, and he set out to restore worship and order. He started the rebuilding of the Temple, and restored the text of the Jewish law.

The O.T. Book of Ezra is closely related to the Book of Nehemiah, soclosely indeed that, asthe Talmud and early Christian writers indicate, they form really one work. Closely related to them are the Books of Chronicles, of which Ezra and Nehemiah are a continuation. The three-fold work, ChroniclesEzra-Nehemiah, covers the history of Israel from the period of Adam to the second visit of Nehemiah to Jerusalem in 432 B.c.; but the history is viewed from a different standpoint from that of the other O.T. books from Genesis to Kings, namely an ecclesiastical and priestly standpoint.

Ezra-Nehemiah(which together appear in the Septuagint as II Esdras) includes the history from 538 B.c., when Cyrus issued a decree permitting Jewish exiles to return, to 432 B.0., when Nehemiah made his second visit to Jerusalem. The Ezra portion records the return of the exiles, the rebuilding of the temple, and the mission of Ezra, who was sent as royal commissioner from Babylonia to Jerusalem by Artaxerxes. Part of the book is written in Aramaic (iv, 8-vi, 18, and vii, 12-26). Ezra-Nehemiah seems to have been compiled from various sources, including the Memoirs of Ezra and Nehemiah, between about 300 and 250 B.c. 


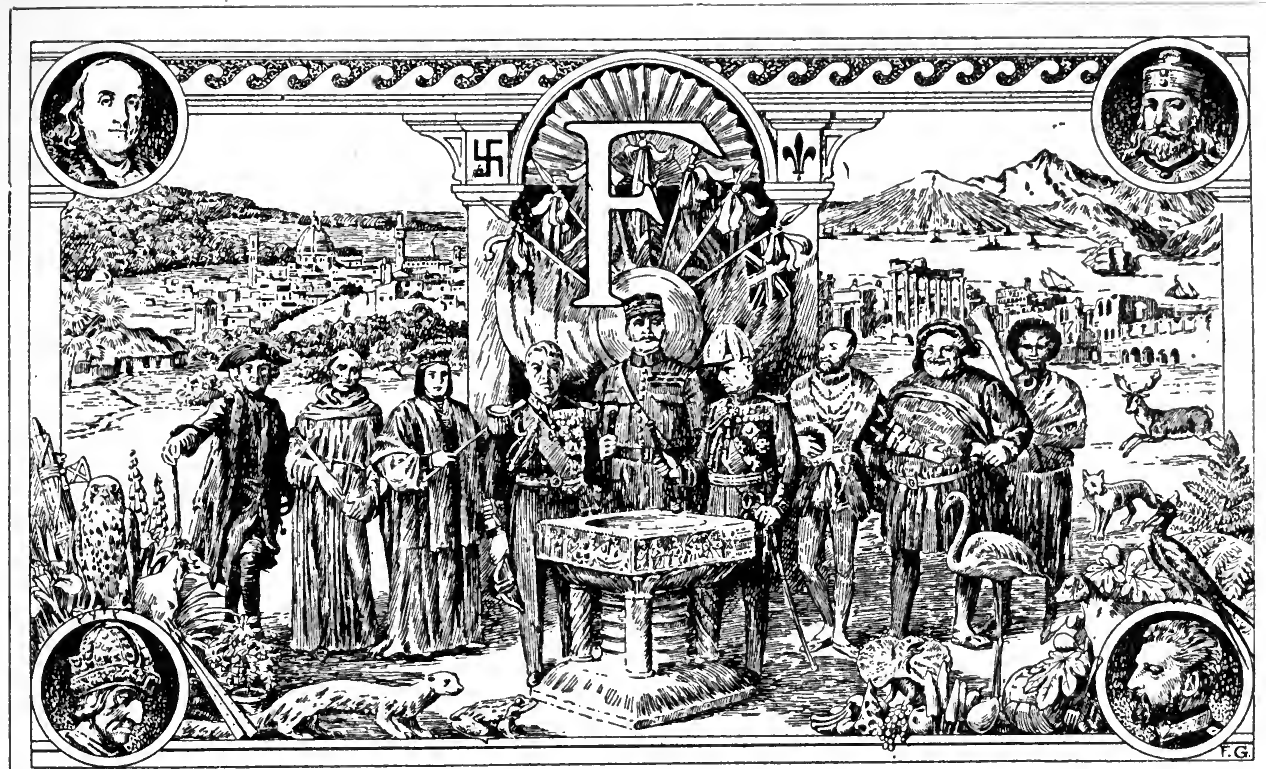

$\mathbf{F}$.

Sixth letter of the English and Latin alphabets. Its form is that of the old Greek digamma, the double Gam. ma, one $\Gamma$ being superposed on the other. It is a hard labial (lip-sound), the corresponding soft letter being $V$. Its ordinary sound is as in fat. In the single word of it is pronounced as $v$, but in its compounds as hereof, thereof, it commonly retains the hard sound. In halfpenny both $f$ and $l$ are mute (hā-peny). In the plural, $f$ is often softened, as in loaf, loaves. The sound of $f$ is also represented by $p h$ in words derived from the Greek, as in philosophy, phrase. See Alphabet; Phonetics.

F. In music, the fourth note of the natural scale of $\mathrm{C}$. $\mathrm{F}$ is only a semitone above $E$, instead of a whole tone. F sharp is the first sharp to appear in a key signature -key of G. See Key Signature ; Pitch.

F.A. Abbrev. for Football Association (q.v.).

Faber, Frederick William (1814-63). British divine. Born at Calverley, Yorks, June 28, 1814, he

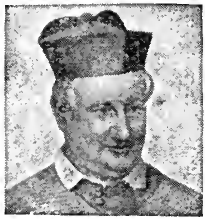

at lege, Oxford. and became rector of Elton, Huntingdonshire. In 1845 he seceded to the Roman Church, and F. S. Faben fouryearslater became su. perior of the Oratory of S. Philip Neri, now at Brompton. A popular preacher, he is best known by his hymns, which include Sweet Saviour, bless us ere we go, Hark, Hark, my soul, and Souls of Men, why will ye scatter? He died at Brompton, Sept. 26, 1863.

Fabia. One of the oldest Roman gentes or clans, probably of Sabine origin. They appear to have been originally priests, who took part in the supervision of the festival Lupercalia (q.v.). They were a patrician clan, whose chief families were those of Ambustus, Labeo, Maximus, and Pictor.

Fabian Society. English political organization. Founded in 1884 to promote the principles of socialism, it was so called because its promoters preferred the slow and sure methods of the Roman general, Fabius Maximus, to violence. It has attracted the most intellectual socialists, such as G. B. Shaw and Sidney Webb, and exercised an influence greater than its numbers alone would merit. It has sought to influence public opinion by lectures and writings, directed especially to the more thoughtful part of the population, and by taking an active part in elections, especially thosefor the government of London. The society, which is officially connected with the Labour Party, has offices at 25, Tothill Street, Westminster, S.W. Since 1912 it has had a labour research department, and the weekly New Statesman is closely connected with the society. See Socialism.

Fabius Maximus, Qunveus (d. 203 B.c.). Roman general. He was appointed, with dictatorial powers, to the command of the Roman forces after the defeat by the Carth. aginians at Lake Trasimenus, 217
B.c. By a series of delaying tactics -whence his surname, Cunctator (the delayer)-Fabius avoided pitched battles with Hannibal, wore down the offensive power of the Carthaginians, and gave the Romans time to reconsolidate their forces. He thus paved the way for Scipio's victories, which ended the Second Punic War. Fabian tactics have become proverbial for a waiting and cautious policy.

Fabius Pictor, Garus. Painter of a battle scene, the first recorded Roman painting, on the walls of the temple of Salus (Safety) in ancient Rome (c. 302 B.c.). In the reign of Claudius both temple and picture were destroyed by fire.

Fabius Pictor, QurNTus (c. 225 B.c.). Earliest Roman historian. His writings, which were in Greek, are lost, with the exception of some fragments, but he was one of the authorities used by Livy, Diodorus Siculus, and Polybius. A Latin version was also in existence, whether by himself or a later writer is doubtful.

Fable (Lat. fabula, story, narrative). Short allegorical story in which generally animals, trees, etc., are endowed with speech and human qualities, and by their words and deeds are made to convey moral lessons. Its invention is frequently ascribed to Aesop (q.v.), but many fables associated with his name probably originated at a much earlier date in India, where they are known sometimes as the fables of Bidpai or Pilpay, a tra ditional ancient Indian phitoso pher, and sometimes as the work of Buddha. Some of the fables 
traditionally ascribed to Aesop are but variants of those found on ancient Egyptian papyri. Many, too, are traced to the Arabs, by whom they may have been brought from India.

It is probable that tales of a fabulist character are common to most primitive peoples, mark, indeed, a definite stage in raceculture; the addition of a "moral" to any beast tale being a natural development, and not peculiar to one originating writer or people. Of later fabulists the French writer La Fontaine is perhaps the most celebrated. See editions of Bidpai, 1888, and Aesop, 1889, by Joseph Jacobs: The Big Book of Fables, ed. Waitter Jerrold, 1912.

Fabliaux. Short tales in verse, almost always octosyllabic couplets, dealing from the comic point of view with incidents of ordinary life. The fabliaux appeared in France in the 12th century, and remained popular for about 200 years. The tales are licentious both in subject and treatment, frequently satirising priests or women or both in language that is gener. ally coarse, but many of them have real humour and the best are free from objection. The fabliaux were first collected and published by Barbazan in the 18th century, and were re-collected and issued in six volumes by Anatole de Montaiglon and Gaston Raynaud in 1872-90. Averaging 200-300 lines in length, the fabliaux, with their smallness of range, delicacy of argument, wit, irony, and provocative treatment, are the direct ancestors of the French short story.

Fabre, Ferdinand (1830-98). French novelist. Born at Bédarieux, Hérault, he studied for the priesthood, medicine, and the law in turn before producing his first novel, Les Courbezon, 1862. He died in Paris, Feb. 11, $1898 . \quad$ A moderate realist, he depicted with minute fidelity the people and manners of the Cévennes, as in Le Chevrier, and excelled particularly in studies of clerical life, as in L'Abbé Tigrane, 1873, and Mon Oncle Célestin, 1881. See French Profiles, E. W. Gosse, 1905.

Fabre,Jean Henri(1823-1915). French entomologist. $\because$ Born at Sainte-Leone, Aveyron, his early years were passed in great poverty. At 18 he was in charge of a primary school, where he improved his knowledge of mathematics and physics in his spare time, and where he bought his first book on entomology. Becoming professor of philosophy in the college of Ajaccio and in the Lycée at Avignon, he turned his attention to the study of insects. His earliest ob- servations appeared in the Annales des Sciences Naturelles, 1855-58, subsequently enlarged in Souvenirs Entomologiques, 10 vols., 2 nd ed. 1914, etc. The earlier volumes are remarkable for their close and painstaking observations on living

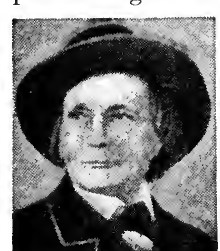

Jean H. Fabre, French entomologist insects, bringing to light many unsus pected habits and instincts of wasps and bees in par. ticular. $\mathrm{Hi}$ is work, though gaining the praise of Dar. win popular attention.

The insect's Homer, as he has been called, Fabre's reputation has been steadily increasing. A curious blend of White of Selborne and Darwin, he displays not only most amazing powers of minute and careful observation, but his writ. ings have an unusually high literary quality. He died Oct. 11, 1915. See Works, complete Eng. trans. A. Texeira de Mattos, 1912, etc.

Fabre d'Eglantine, PHLLIPPE François NazaIre (1750-94). A French revolutionary and drama. tist. Born at Carcassonne, July 28, 1750 , he became a member of the National Convention and for a time was secretary to Danton. His play Philinte attracted some attention in 1790 , but perhaps his most successful literary achievement was the renaming of the months for the revolutionary calendar, 1793. He was guillotined on a false charge of forgery, April 5, 1794.

Fabriano. City of Italy, in the prov. of Ancona. It stands on the E. slopes of the Apennines, at an alt. of over $1,000 \mathrm{ft}$., $45 \mathrm{~m}$. by rly. S.W. of Ancona. It has a cathe. dral, a town hall, and some of the churches contain pictures of the Fabriano school. The city is celebrated for its paper mills, estab. lished in the 13th century. Gunpowder, glue, parchment, and felt are also made, and there is trade in cattle and cereals. It is the rly. junction for Urbino. Pop. 23,752.

Fabric (Lat. fabrica, workshop, skilled production). Word used for any kind of manufactured cloth. $\mathrm{By}$ an extension it is also used for the outer body of a building, as the fabric of a church or, figuratively, the fabric of the constitution. See Textiles.

Fabricius Luscinus, GaIUS (c. 280 B.c.). Roman general. He won notable victories over the Lucanians, Bruttians, and Samnites, and in the war with Pyrrhus twice conducted negotiations with that monarch. After the Roman defeat at Heraclea in 280 B.c. Pyrrbus tried hard to buy Fab. ricius over, but the stern Roman was incorruptible. "Later, after Fabricius had delivered up a traitor who had offered to poison Pyrrhus, negotiations were resumed, with the result that in 278 satisfactory terms of peace were arranged. During his censorship in 275 he made great efforts to check the growing tendency to luxury and extravagance. He himself died so poor that his daughters had to be provided with dowries by the state. Fabricius was lauded by subsequent generations as the embodiment of the old republican virtues. Pron. Fab-rish-ius.

Fabricius, JoHANN AlberT (1668-1736). German classical scholar. Born at Leipzig, Nov. 11 1668, at the age of 25 he removed to Hamburg, where shortly after publishing his Bibliotheca Latina, 1697, he became a professor at the gymnasium. His later works on classical bibliography, storehouses of learning and still indispensable, included Bibliotheca Graeca, 170528 ; Bibliotheca Ecclesiastica, 1718; and Bibliotheca Latina Mediae et Infimae Aetatis, 1734. He died at Hamburg, April 30, 1736. Pron. Fab-reets-ioos.

Fabrizi, Nicola (1804-85). Italian patriot. Born at Modena, April 4, 1804, he was implicated in the Carbonari insurrection of 1831 . $\mathrm{He}$ fled to Marseilles and thence to Spain, where he fought against the Carlists, 1837. One of Mazzini's most trusted agents, he moved to Malta, whence he assisted the Sicilian insurrection of 1848 . When revolution broke out in Italy, he fought at Venice and Rome, retir. ing to Malta after the fall of Rome. He raised a revolt in Sicily in 1860 and joined forces at Palermo with Garibaldi, who made him governor of Messina and war minister. $\mathrm{He}$ opposed Garibaldi's Rome cam. paign of 1862 , but in 1867 fought at Mentana. He died March 31, 1885. Pron. Fab-reet-si.

Fabroni, ANGELO (1732-1803). Italian biographer, called "the Plutarch of modern Italy." Born at Marradi, Tuscany, Sept. 25, 1732, he became prior of San Lorenzo, Florence, in 1767, and was appointed tutor to the sons of Leopold, grand duke of Tuscany, in 1773. His chief work was Vitae Italorum Doctrina Excellentium qui Saeculis XVII et XVIII florue. runt, in 20 vols., 1778-1805, vol 19 containing his autobiography. $\mathrm{He}$ also wrote biographies of Lorenzo de' Medici, 1784; Cosimo de' Medici, 1788-89; and Petrarch, 1799. He died Sept. 22, 1803. 
Façade (Fr.). Architectural front of any building or part of a building. Not necessarily confined to the principal front, the term is mostly used in connexion with street architecture, where one face of the building is mainly important. A façade is, strictly, a front in one plane. Thus a front with one or more pavilions projecting from its surface could not be referred to as a single façade, the pavilion having its own façade. See Architecture ; also illus. p. 508.

Face. Front of the head. The face may be divided into the regions of the forehead, temples, ears, eyes, nose, mouth, cheek, and upper and lower jaws. The bones of the face are fourteen in number, twelve being in pairs, namely : the superior maxillary, malar, nasal, palate, lachrymal, and inferior turbinated bones. The mandible or lower jaw and the vomer, which forms part of the septum dividing the nose into two parts, are single bones.

The palate bone is situated deeply in the region of the mouth and nose. Besides these bones, some of the bones assigned by anatomists to the cranium also take part in the formation of the face, namely : the frontal, parietal, sphenoid, and temporal bones. The forehead is formed by the frontal bone. Underlying the scalp is the frontalis muscle, contraction of which causes the furrows which appear on the forehead when the brows are lifted to express surprise. Running up on each side of the forehead is the temporal artery which, in elderly persons, is often prominent and well marked, owing to thickening of the walls of the vessel, an indication of senility. The superciliary ridges are bony prominences above the eyes, best seen in adult males. These ridges were strongly developed in certain prehistoric forms of man, particularly the type known as Neanderthal man. The vertical furrows seen in the act of frowning are produced by a small muscle, the corrugator supercilii.

The eyeball is situated in a bony framework known as the orbit, which, together with the projection of the nose, serves to protect it from injury. The aperture between the eyelids is known as the palpebral fissure. The nose is divided into two parts by a septum formed partly of bone and partly of cartilage, the junction of the two being marked by the bridge of the nose. The outer angle of the orbit is prolonged towards the ear into a bridge of bone known as the zygoma. The temporal muscle occupies a fossa

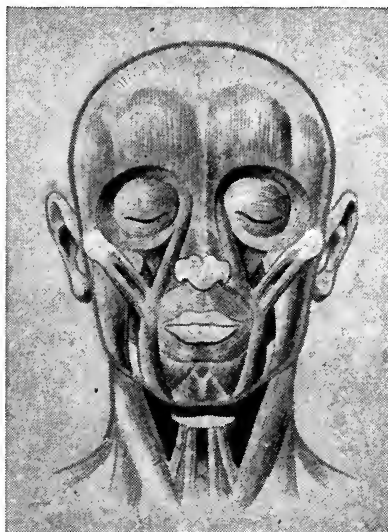

Face. Diagram showing the muscles of expression in the human race

forming the greater part of the temporal region, its tendon passing beneath the zygoma to be attached to the lower jaw. This muscle takes part in the act of mastication, and can be felt contracting when the mouth is firmly closed. The anatomical features of the ear, chin, and mouth are described under their respective headings.

The principal nerves of the face are the fifth or trigeminal nerve, which is the main sensory supply to the face, and the seventh or facial nerve, which supplies most of the muscles of the face. The face is well supplied with bloodvessels, which explains the profuseness of haemorrhage following injury to the tissues.

Face Conveyer. Machine used for the transport of coal. The transport of coal from the point where it is cut out of the working faee comprises three stages-from the face to the main haulage way; the main haulage to the foot of the shaft; the raising of the coal to the surface. The first stage is relatively costly, and often difficult on account of the very limited space usually available, and particularly the low roof. Although usually performed by manual labour, of recent years very ingenious mechanical appliances known as face conveyers have been introduced.

The jigging conveyer consists essentially of a long steel trough suspended on short arms in such a way that the trough may be "jigged" to and fro. The coal is shovelled on to the trough, and at each stroke or movement is thrown or jerked bodily forward a short distance until it is finally thrown off the end of the conveyer. The chain conveyer consists of a fixed trough or bed 'along which a chain is drawn. The chain is composed of bars of steel, forming links and crosspieces all of which have their faces vertical. The coal is thrown on to the chain, the large pieces being carried along on the tops of the links and cross-pieces, while the small drop through the chain to the bottom of the trough, and are scraped forward by the under edges of the chain. These machines admit of being moved forward as the working face is ex. tended, and are driven either by compressed air or electrically. A Blackett patent chain conveyer can remove 360 tons from a face of 100 yards in eight hours. See Coal; Conveyer; Mining; also illus. p. 2238.

Face Value. Nominal value of debentures, stocks, shares, and securities generally, as opposed to their real or market value. For instance, the face value of consols is in $£ 100$ and multiples of $£ 100$, and of a share in the Amalgamated Press $f 1$, although in each case the selling value is very different.

Fâcheux, LEs (The Bores). A three-act comedy-ballet or masque by Molière. Written and played within a fortnight, it was first produced in the garden of Fouquet's residence, Vaux-le-Vicomte, Aug. 17, 1661. It displays ten bores, satirical portraits from society, who prevent an ardent young lover from speaking with the object of his devotion. It was the first play written by Molière for Louis XIV, and the first play of its kind on the French stage.

Facial Angle. Method of measuring the facial profile, especially in man and the anthropoid apes. The earliest, Pieter Camper's (c. 1770), was subtended by two lines (1) drawn from the glabella to the upper jaw, (2) drawn in a plane passing through the

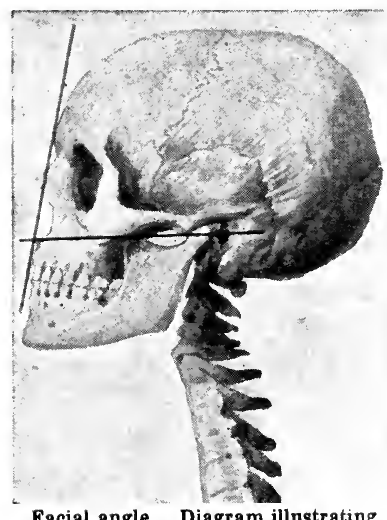

Facial angle. Diagram ilustratin method of messuring facial angle 
base of the nose and the centre of the aural orifice. This measures $40^{\circ}$ (orang-utan), $70^{\circ}$ (negro), $80^{\circ}$ (European). Camper's angle is now superseded. See Craniometry.

Facial Nerve. Seventh cranial nerve. It supplies most of the muscles of the face, and the sense of taste in the anterior part of the tongue. Paralysis of the facial nerve (Bell's Palsy) may be due to injury to the brain, blows near the lower part of the ear, and syphilis, but most commonly is caused by exposure to cold. Movements on the affected side are lost, the eye cannot be closed, the lower lip drops, the forehead cannot be wrinkled. The difference in the two sides is obvious when the patient smiles. When due to injury of the brain or nerve, recovery cannot be expected, but is possible where the paralysis has followed exposure to cold.

Facility (Lat. facilis, easy). Ability to perform anything easily. In Scots law it has a special mean. ing. By it is understood a condition of mental weakness that falls short of idiocy. The person suffering from it is one easily persuaded.

Facings. Cloth of contrasting colour worn on the collar and cuffs of the full dress military uniform. In general the facings are of white cloth, but regiments entitled to the prefix royal, King's Own or Queen's Own, wear blue facings, and in a few cases, for example the Buffs and the Sherwood Foresters, special coloured facings are authorised on account of historical or similar associations. See Uniform.

Facsimile (Lat. fac simile, make like). Term meaning an exact copy. It is used chiefly for the reproduction of ancient MSS. and the like, e.g. facsimiles of Domesday Book. See Process; also illus. pp. 424 and 447 . Pron. fac-simily.

Factor (Lat, maker). In mathematics, any of two or more numbers or expressions which when multiplied together produce a given number or expression. Thus 7,3 , 2 are factors of 42 and $(a+b)$, $(a-b)$ of $a^{2}-b^{2}$. A factor which can only be divided by itself and unity is called a prime factor. The factor of the greatest degree which is common to two algebraic expressions is called the highest common factor. In arithmetic the highest number which is a factor of two or more numbers is called the greatest common divisor. See Algebra; Mathematics.

Factor (Lat. facere, to make). Word meaning an agent, but in a special sense an agent who buys and sells for a principal. He carries on business in his own name, but differs from a broker in that he usually handles the goods in which he deals and transfers them to his principal; moreover, he has a greater latitude about buying and selling. In English law several statutes have regulated the relations between a factor and his employer, these having been consolidated by the Factors Act of 1889. Much, however, is left to custom, and this differs obviously very much between one trade and another. The main provision of the Act is to give the principal a valid title to the goods bought for him by the factor, as in transactions of this kind this was the main difficulty.

Factor is used in Scotland for a man who manages an estate, a land agent. A judicial factor is one appointed by a court of law to manage the estate of a minor or imbecile.

Factor of Safety. Ratio or figure which indicates the maximum strength of any part of an engineering structure in relation to the maximum stress which it is called upon to bear. The figure is obtained by dividing the stress under which the body collapses by the maximum stress which it is subjected to in ordinary usage. Thus a factor of safety of five to one indicates that the part so described is five times as strong as the maximum stress which will be placer upon it. The figure is not wholly accurate, since in actual use there may be set up stresses above those calculated for. In aeroplane structures the factor of safety is replaced by the factor of loading, based on the forces acting on the aeroplane in horizontal flight.

Factory. Building or assembly of buildings devoted to the manufacture of goods. Factories are defined by the Factory Act, 1901, as premises wherein "steam, water, or other mechanical power" is used in aid of the manufacturing process carried on. Most important are the textile group, where cotton, wool, silk, and other fabrics are made. The non-textile factories include engineering works, iron mills, foundries, and blast furnaces, paper mills, lace warehouses, dyeing and chemical works. The employment of mechanical motive force distinguishes all of these from workshops, where the power is supplied by human effort.

\section{Considerations as to Site}

In planning a modern factory, the first consideration is that of site. The buildings should be near the sources of the principal raw materials needed, and conveniently placed for the transport of goods into and out of the factory. Coal being a prime necessity for almost all machinery, coalfield areas at tract a large proportion of the factories. In alkaline works, however, where salt and lime are also first necessaries, it is cheaper to erect the building over brine supplies than to be within immediate reach of lime and coal at the cost of trans porting brine in large quantities.

The most usual type of modern factory consists of a group of light, well-ventilated, one-storey buildings, so constructed that they can be readily expanded or adapted at need. But the structures vary widely in character, according to the nature of the industry followed there. Proximity to railways, roads, and waterways is an obvious requirement. Other considerations are accessibility for workers, good supplies of water, and a dry, bracing air. The last-named condition has a marked influence upon out. put. The same individual workers, transferred from a low, humid site to an airy position, have been shown to respond by substantially increased production. In a welldesigned factory the buildings are so placed that the internal transport of goods is reduced to a minimum. Each stage of manufacture naturally involves transference to another workshop; but the journey should be the shortest practicable.

Example of Sound Planning

The Bayer Chemical Works afford an instance of sound planning. Placed between the river and the railway, the factory receives its raw material by water. The first processes of manufacture are carried on in buildings adjoining the wharves. Thence the products pass to neighbouring workshops, and from these to the next group, and the next, as they undergo the successive stages of manufacture - moving meantime in a direct line away from the river, until the finished goods reach the packing department beside the railway by which they are to be dispatched. A centrally placed power station distributes motive power radially to each department. Its central site ensures the utmost economy in transmission.

Labour-saving devices, especially those that avoid lifting and carrying goods by hand, such as continuous belt conveyers, are profitable. Light railways between the shops enable heavy products to be transmitted from point to point with the minimum of effort. At the Maypole Dairy Company's model factory in Southall, the force of gravity is utilised so that bulky materials are made to slide over frictionless bearings, from stage to stage, by their own weight. Modern engineering shops are provided 
with every type of hoist and pulley for the easy handling of heavy castings.

Electricity is increasingly employed to supply power to the shops; but the earlier system of large central dynamos with huge shafts and many driving belts is replaced more and more by small electric motors at various points, each being supplied with current, which can be converted into power at will.

\section{Expenditure and Economy}

Fearless expenditure and vigilant economy are required to ensure success. Large savings have been effected by the utilisation of waste and of by-products. In a steam. heated factory, the warm water arising from condensation of the vapour is usually "fed" to the boilers instead of cold water from the main. A substantial saving of fuel is thus effected. Coal tar, once thrown away in the process of preparing coal-gas, has proved to be of greater value than the gas itself. Otherwise useless rubbish is burnt in a destructor, the resultant heat being duly turned to account. The sheets of tinned iron "scrap" from tinware factories, formerly discarded as useless, are now chemically stripped, and the recovered tin is used again.

The work of a factory is technically divided into two classes : $(a)$ the actual process of manufacture, and $(b)$ the services which facilitate those processes. The latter and subsidiary branch comprises the supply of power, maintenance of buildings, repair of tools and machines, packing and labelling finished products, and the care of the workers.

A typical factory includes most or all of the following departments :-

(a) Manufacture: Receipt and storage of raw material; actual manufacture (in successive stages); finishing and assembling ; packing, labelling, and analysis; and dispatch. (b) Services : Transport by motor, rail, or water; power (including water services, light, heat, and motive force-hydraulic, steam, or electrical); engineers' shop and stores; social service (rest rooms, canteens, etc.) ; timekeeping; accountancy, and storekeeping.

Each manufacturing department is restricted to a single phase of the complex process of converting the raw material into the finished product. To coordinate the output of all these independent parts, so that none of them is kept idle by any other, is a task requiring the closest care, and it is upon such fine adjustments and economies that the margin of profit often depends. Under the general control of the departmental managers, a foreman in charge of each workshop is responsible for the work it turns out.

The modern tendency in favour of a shorter day for the factory hand appears to be justified even upon purely economic grounds. Experimental studies in the psychology of fatigue as exhibited in factories, have afforded surprising results. Ten minutes rest per hour was found to increase the hourly output, and an eight-hour day to be more productive than one of nine hours. But the enormous sums now sunk in machinery require a longer working day than before, so that the earning capacity of the machines may be increased.

\section{Psychology of Factory Life}

The problem is solved by em. ploying two shifts of labour daily, of 7 or 8 hours each. It is found that a weekly or fortnightly change of shift has a beneficial effect on the psychology of factory employees, and stimulates their powers of work. Strict cleanliness, order and quiet in the workrooms, and tools and equipment exactly adapted to their function, have similar results on output.

Increased care for the worker's well-being, thus justified by financial as well as moral considerations, is not restricted by providing him with better physical conditions at his work. Many factory owners maintain a "social service" department, supplying rest rooms, libraries, and recreation grounds, and promoting schemes for sport and study. They regard as proven the contention that the master key to successful factory control is health and content in the worker.

\section{Ernest A. Carr}

Factory Acts. In the United Kingdom, a series of over twenty statutes, aimed at regulating conditions in factories and workshops, especially on behalf of women and children. The first was passed in 1802, Addington's Act, "for the preservation of the health and morals " of apprentices, etc., employed in cotton and other factories; child employees were not allowed to work more than 12 hours a day nor later than 9 p.m., and had to be taught the three R's in working hours.

The Act of 1833 barred the em. ployment of children under nine years of age at factories and provided inter alia for an eight-hour day for children under 13 , for certain holidays, and for factory inspectors. The 1844 Act initiated the following interpretations, viz. "young person," between 13 and 18 years old ; child, under 13 years; it laid down that women were to be employed on the same conditions as to hours as young persons, who, together with children, were not to work on Saturdays after 4.30 ; and regulated the fencing of machinery. The 1847 Act set up an eleven-hour day maximum for factory workers and a ten-hour day for women and young persons, with a 58 hours' maximum for the week.

Lord Ashley (earl of Shaftesbury) was perhaps the most prominent of the reformers of abuses which for years disfigured the industrial system in the 19th century. Other Factory Acts were passed at intervals to safeguard the workers further from accident, disease, or oppression, and to provide for the education of children employed at factories before national education was adopted.

Important changes were made by the 1874, 1878, 1883, 1891, 1895 , and 1897 Acts, but the present law is contained in the consolidating Factory and Workshop Act, 1901, of 163 sections. By this Act a young person is between 14 and 18 years and a child under 14, unless such child, though over 13 and under 14 , has obtained an educational certificate of proficiency. A child is not allowed to clean machinery, and women and young persons may not clean machinery in motion. Minute provisions are laid down for ventilation, sanitary conveniences, means of escape from fire, as to inspection and accidents, and working hours.

\section{Working Hours for Women}

In textile factories the hours for women and young persons must not exceed 66 a week, which period includes at least 10 hours for meals, and they must not start before 6 a.m. or leave off after 7 p.m. There are detailed working-hour limitations for this type and other classes of factories. The Saturday half-day is stereotyped with fow exceptions. No female may be employed within four weeks after her confinement. Children who work half-time are not to be employed otherwise. For these classes of employees Sunday work is barred, with specific exceptions, and overtime and night work are the subject of restrictions.

In 1911 a further Factory Act was passed empowering the Home Secretary to make regulations for cotton cloth factories, and a statutory order was made for the regulation of "home-work." There are now many women as well as men inspectors, and during the Great War welfare committees were set up throughout the industrial system on behalf of the workers. See Children; Labour. 
Factory Inspector. Class of British civil servants attached to the Home Office. Stationed all over the country, they serve under a chief inspector, and supervise the observation of the laws regulating employment in factories and workshops; they are concerned with the hours of labour of women and young persons, sanitary conditions, etc. Some inspectors are women, and in 1920 women became eligible for all posts. See Factory Acts.

Faculae (Lat. facula, small torch). Bright spots on the sun's granular surface, most often found associated with the dark sun-spots. They appear after sun-spots, and reaches of them may stretch tens of thousands of miles. High in the sun's atmosphere, they escape some of its absorptive influence, and thus acquire their brilliancy of aspect. See Sun.

Faculties, Court of. Court held on behalf of the archbishop of Canterbury. It takes no litigation, but is merely for the purpose of grant. ing faculties to perform certain actions in connexion with church buildings, to be married otherwise than by the publication of banns, or at a place or time outside the ordinary places and hours, or to be made a public notary. The president is the judge of the court of arches and the court has a registrar and other officials. Its offices are at 23, Knightrider Street, Doctors' Commons, London, E.C. In the archdiocese of York similar work is performed by the archbishop's chancery court, while in the ordinary dioceses consistory courts are held in the names of the various bishops. See Ecclesiastical Law.

Faculty (Lat. facultas, facility, ability). Word having several meanings. One indicates any special mental power; e.g., the faculty of speech. This use has come down from the early philosophers. Derived obviously therefrom is the use of the word for a department of a university, and for its instructors, thus in modern universities we have the faculties of arts, medicine, law, theology, science, etc. Similar is its occasional application to the members in a collective sense of a learned profession, e.g., the faculty of advocates in Scotland.

In English ecclesiastical law and usage the term means a permission to do something which is not al lowed by the common law; e.g., to be married otherwise than after the publication of the banns, or to make an alteration in a church. For such matters as the altering of churches, putting up monuments, etc., therein, each bishop deputes his chancellor to hear the application. See Ecclesiastical law.

Faed, Thomas (1826-1900). Scottish painter. Born at Gatehouse of Fleet, Kirkeudbright.

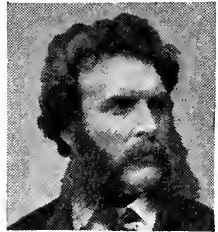

Thomas Faed,

Scottish painter

1852, and became A.R.A. 1861, and R.A. in 1864. He died. Aug. 17, 1900 , almost blind, at St. John's Wood. His Faults on Both Sides, Silken Gown, and the Young Highland Mother are in the Tate Gallery.

Faenza (anc. Faventia). City of Italy, in the prov. of Ravenna. It stands on the Lamone, $31 \mathrm{~m}$. by rly. S.E. of Bologna. Surrounded by medieval walls, it has for centuries been famed for its art pottery called "faïence" (q.v.). On the principal square are the cathedral (1474), the former palace of the Manfredi, now the city hall, and the church of S. Michele. There is an arcaded market-place, and the municipal art gallery has frescoes, sculptures and fine specimens of local majolica. Silk spinning, weaving, and sulphur refining are carried on. Founded as Faventia by the Romans, it was the scene in A.D. 542 of the defeat of the Byzantines by Totila, and was prominent in the medieval wars of the Guelphs and the Ghibellines. Captured in 1240 by Frederick II, it fell successively to the. Manfredi, the Borgias, Venetians, and the popes. Pop. 40,164.

Faery Queene, THe. Poem by Edmund Spenser published in 1590-96. The published poem consists of six books, divided into 12 cantos, between 50 and 60 stanzas in each canto, and is written in nine-line stanzas, each ending with a twelve-syllable line. The poem blends the Arthurian legend of knights errant with classical lore, Christian teaching, and allegory, both general (concerning the virtues and vices) and particular (concerning people of the poet's time). Devised as an allegory on a grand scale, and only half completed, it remains a wonderful medley of poetic romance, shot through with threads of allegory, full of descriptive beauty and rich verbal music.

Fafnir. Treasure-guarding worm or dragon of Scandinavian and Teutonic mythology. In both a smith's brother is supposed to have been transformed into this form. In the Scandinavian Volsung Saga, Sigurd slavs Fafnir, guardian of Ardvara's hoard, and is thereafter known as Sigurd Fafnirsbane : while in the Nibelungen Lied Siegfried kills Fafnir, who guards the great Nibelung hoard.

Fagaceae. Natural order of trees. The fruit is enclosed in a cup, and the order includes the sweet chestnut (Castanea), oak (Quercus), and beech (Fagus).

Fagan, JaMes Bernard (b. 1873). British dramatist. He was born May 10, 1873, and educated at Clongowes Wood College and Trinity College, $\mathrm{Ox}$ f o r d. He gained an in timate know ledge of stage craft during four years as an actor. His first play, The Rebel,was per-

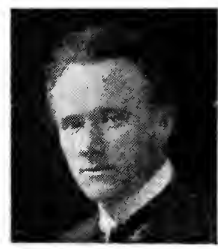

James B. Fagan, British dramatist Russell formed in 1899. It was followed by The Prayer of the Sword, 1904; Under Which King, 1905; Hawthorne, U.S.A., 1905; The Earth, 1909; A Merry Devil, 1909; The Dressing Room, 1910 ; and Bella Donna, adapted from Robert Hichens's novel, 1911.

Fagging. Old-established system at English public schools under which the older boys are empowered by the school authorities to exact certain duties from the younger boys. The duties, formerly heavy, now consist of running errands, tidying studies, etc., and games' fagging. The system, sometimes elaborately organized, varies at different schools. All boys are liable to fagging until they reach a certain form. As a rule the sixth form alone are entitled to fags, but some schools extend the privilege to the fifth and also to the cricket eleven and football fifteen.

Faggot Voter. Name given to a class of voters, now non-existent at elections in England. The main qualification for a vote in the counties was the ownership of land worth $40 \mathrm{~s}$. a year. When instituted in the 15th century this meant a considerable estate, but in the 18th century it meant little. Landowners therefore gave patches of ground to their servants and dependants on the implied condition that they voted as their masters wished, a practice not completely destroyed till the Reform Act of 1884 .

Fagin. Character in Dickens's novel Oliver Twist. A disreputable old Jew, he is a prominent member of the criminal gang to which Bill Sikes belongs, and is hanged for complicity in Sikes's murder of Nancy. His special province is the 
training of children to be thieves and pickpockets. In Comyns Carr's adaptation of Oliver Twist, produced at His Majesty's, July 10, 1905, Beerbohm Tree played Fagin to the Nancy of Constance Collier and the Sikes of Lyn Harding.

Fagotto. Italian name for the bassoon, the bass wood-wind instrument. See Bassoon.

Faguet, ÉmiLe (1847-1916). French critic and literary historian. Born at La Roche-sur-Yon, he

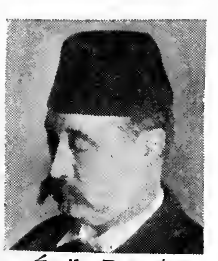

Émile Faguet,

French critic became professor of poetry at the university of Paris, 1897 . H is writings, which are characterised by a catholicity of taste and a flexi bility of judgement reminiscent of Sainte-Beuve, include La Tragédie au XVIe Siècle; a series of studies of great French authors of the 16th, i7th, 18th, and 19th centuries ; Politiques et Moralistes du XIXe Siècle; and monographs on Voltaire, Flaubert, and Zola. He died, June 6, 1916. See Emile Faguet, A. Seché, 1904.

Fa-Hien or FA-HSIEN (c. A.D. 400). Chinese traveller and antiquary. A Buddhist monk, he set out in 399 from the ancient capital Hsian-fu, Shensi, for a prolonged pilgrimage of the Buddha's cradleland. Traversing the Gobi desert, mostly afoot, to Khotan, he crossed the Hindu Kush into the Afghan valleys, and remained ten years, visiting Peshawar and the Ganges cities. He proceeded by sea in 412 to Ceylon, whence he returned home in 414, with numerous pictures, images, and books. The account of his pilgrimage was translated into French by J. P. Abel Rémusat, 1836 ; into English by S. Beal, 1869, and James Legge, 1886.

Fahl Ore (Ger). Steel-grey copper ore consisting of copper, sul. phur, antimony, arsenic, silver, iron, and zinc. The silver sometimes runs to 30 p.c., such an ore being known as argentiferous grey copper ore, or formerly silver fahlerz. Owing to the arsenic and antimony it is not easily worked as a copper ore; but a rich silver content makes it worth while to treat it for that metal primarily. It is found in Cornwall, Germany, Chile, and Mexico. See Copper.

Fahlum or Falum. Town of Sweden, cap. of the lën or govt. of Kopparberg. It stands near Lake Runn, $57 \mathrm{~m}$. by rly. W. of Gefle. The town was burnt down in 1761 . Its only notable feature is the 14 th century church, which escaped the fire. Minor buildings include the town hall, a mineralogical museum, and technical schools. Its copper mines, once the richest in Europe, now nearly exhausted, have been worked for six centuries, and the company owning them has existed since about 1345. Iron pyrites, gold, silver, and sulphur are still produced. Fahlum has railway wagon works, wood pulp factories, and textile industries. Pop. 12,213.

Fahrenheit, Gabriel DaNiEL (1686-1736). German physicist. Born at Danzig, May 14, 1686, his life was spent chiefly in England and Holland, where he studied physics and constructed meteorological instruments. His name is commemorated by a thermometric scale. $\mathrm{He}$ died in Holland, Sept. 16, 1736.

Fahrenheit Thermometer. Thermometer invented by G. D. Fahrenheit. He encountered tem. peratures $32^{\circ}$ below the freezing point of water, and fixed that degree of cold as the zero of his scale. The freezing point of water thus became $32^{\circ}$. The difference in temperature between this and the boiling point of water Fahrenheit divided into 180 degrees, so that the latter is $212^{\circ} \mathrm{F}$.

The centigrade scale of tem. perature has the melting point of ice for its zero degree, and the boiling point of water is fixed at 100 degrees. Réaumur's scale (used in Germany) divides the difference between the freezing and boiling points of water into 80 degrees. To convert these scales :

$$
\begin{aligned}
& \mathrm{F}=\frac{9}{5} \mathbf{C}^{\circ}+32=\frac{9}{4} \mathbf{R}^{\circ}+32 \\
& \mathrm{C}^{\circ}=\frac{5\left(\mathrm{~F}^{\circ}-32\right)}{9} \mathrm{R}^{\circ}=\frac{4\left(\mathrm{~F}^{\circ}-32\right)}{9}
\end{aligned}
$$

See Centigrade ; Thermometer.

Faidherbe, LoUIS LÉoN CÉSAR (1818-89). French soldier and scholar. Born at Lille, June 3, 1818, he entered the en. gineers, after a military education, in 1840. Almost at once he saw service in Algiers, and in $\mathbf{1 8 5 4}$ he was a $\mathrm{p}$ pointed governor of Senegal.

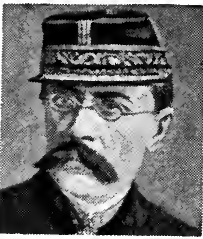

France was then just entering upon her policy of acquiring colonies in Africa, and of this Faidherbe was a pioneer. After holding a command in Algeria, he returned to France in 1870 to lead the army of the north after the disasters at Sedan and Metz. He showed great ability when fighting a number of battles against heavy odds, but at last he was beaten at St. Quentin. For a short time he sat in the National Assembly, and in 1879 he was elected to the Senate. He died in Paris, Sept. 28, 1889. Faidherbe was also an archaeologist, and wrote an account of his campaign of 1870-71.

Faidit, GaUcelm (c. 1159-1216). French troubadour. Born at Uzerche in Limousin, the son of an artisan, his singing gifts attracted the patronage of Richard Coeur de Lion. About 70 of his poems have been preserved, including a beautiful planh, or song of sorrow, in memory of Richard. His poems are included in Chrestomathie Provençale, C. Bartsch, 6th ed. 1904.

Fairence. Term loosely used to designate every description of glazed pottery and earthenware painted with decorative designs. The name comes from the Italian city of Faenza, which has made a speciality of this kind of ware from the close of the 13th century. It had a soft paste and thin transparent glaze, which heightened the colours. The very rare French Oiron ware is called Henry II faience. Some varieties from Josiah Wedgwood's work are styled Eng. lish faïence. See Pottery.

Failsworth. Urban dist. of Lan. cashire, England. It is $4 \mathrm{~m}$. N.E. of Manchester on the L. \& Y.R In the Manchester area, although just outside the city boundary, its main industries are connected with the manufacture of cotton. Gas and water are supplied by the Oldham corporation. Pop. 15,998.

Fainting or SynCOPE. Temporary unconsciousness due to in sufficient supply of blood to the brain. The condition may be caused by defective action of the heart, sudden violent emotion, over-exertion, loss of blood, blows on the head or abdomen, and other causes. A person about to faint feels giddy, and everything around him seems to be becoming dark. He turns pale, the pupils dilate, the skin becomes cold and often sweaty, and if standing he falls heavily. The pulse is weak and hurried.

Recovery is usually rapid. So long as he is unconscious, the person should be allowed to lie quietly on his back with his head as low as possible, and the clothing about the neck and chest should be loosent d. If in a room the window should be opened, and if outside, persons should be prevented from crowding round. Smelling salts may be held beneath the nose, but until consciousness returns nothing should be given by the mouth. When able to swallow, a little brandy or sal volatile in water 
may be given. When feelings of faintness first come on, complete loss of consciousness can often be prevented by the person bending forwards and placing his head between his knees at as low a level as possible.

Fair (Lat. feria, holiday). Periodical assembly of traders at a place and time fixed by charter, statute, or immemorial custom. In early times certain localities came to be used for the periodical exchange of commodities, either by reason of their situation or because they were resorted to at stated times for religious or other purposes. In Greece the Olympic games and such religious festivals as those of Delos and Delphi provided occasions for trading. Among the Incas of Peru fairs were held thrice a month in the most populous places and were visited by the outlying agricultural populations. In ancient Mexico, fairs took place every fifth day in the chief cities.

The earliest royal charter for a fair was granted in 642 by the Frank king Dagobert to the monks of S. Denis, Paris. The concourse of worshippers at a famous shrine afforded great opportunities for trade, and nearly all medieval fair charters were granted to ecclesiastics. The fairs were usually held on a saint's day and on its vigil and morrow, and often, until prohibited by statute, in the churchyard. The religious associations of medieval fairs are indicated by the German word for "fair," Messe (mass), and in the term kermesse or kirmess (church mass) used for the quasireligious carnivals of Brittany and the Low Countries. In every fair there was a court specially appointed for settling disputes, called in England pie-powder courts (q.v.). Fairs and Trade

To promote trade, fairs were encouraged by the sovereigns of Europe. During fair time in the 10th century Otto the Great pronounced the ban on breakers of the peace and suspended the right of private feud. In the 14th century the emperor Charles IV's charter for the great fair of Frankfort-onMain declared fair-goers free from arrest and imperial taxes during the fair as well as for 18 days before and after.

Though fairs were invaluable for international trading, loca] traders were usually compelled to close their shops in fair time. During the Westminster fair the city tradesmen were commanded to shut their shops, and during the fair on St. Giles's Hill, near Winchester, which lasted 16 rlays, the Winchester and the Southampton shopkeepers were only allowed to trade in the fair. The bishop of Winchester was the lord of the fair, and while it lasted the powers of the regular city officers were in abeyance. On the Eve of S. Giles the keys of the city gates were handed over to the bishop, who appointed a mayor, bailiff, and coroner of his own for the duration of the fair.

The influence of country fairs was far-reaching. In 1338 the statutes of St. Mary Ottery's College in Devonshire ordained that $200 \mathrm{lb}$. of wax for the choir should be bought annually at Winchester fair. In the 15 th century the monks of Maxstoke and Bicester laid in their yearly stores at Stourbridge fair, and in the 16th century it was still customary for stewards of country houses to purchase their year's supply of household stores at remote fairs. With the improvement in communications the im. portance of fairs diminished, and by 1855 all those in London were abolished.

\section{"Fun of the Fair"}

Amusements formed an important feature of fairs, many of which became mere disorderly revels and were suppressed as nuisances. This was the fate of Donnybrook fair in Dublin, of Charlton or Horn fair, of Greenwich fair, and of all the London fairs. The "fun of the fair" included jugglers, mountebanks, rope-dancers, acrobats, wrestling and other sports, wild beasts, learned animals, freaks and monstrosities, puppet-shows, miracle plays, mysteries, moralities, and stage plays of every description; ballad-singing, grinning through horse-collars, swings, roundabouts, and, in modern times, steam music. Ballad-singers were very popular at fairs ; Outroaring Dick and Wat Wimbers, two Elizabethan trebles, were paid as much as 20 shillings a day at Braintree fair. Of fairings, or gifts bought at fairs, the most familiar are the little gingerbread figures, usually gilt, possibly a survival of images of saints.

The most celebrated London fair was Bartholomew fair (q.v.), and among existing English livestock fairs may be mentioned those for horses at Horncastle (described in George Borrow's Romany Rye), Barnet, and Woodbridge: Weyhill, for shcep, and Ipswich, for lambs: Exeter, for cattle and horses; and Carlisle and Ormskirk, for cattle. Nottingham has a goose fair; Falkirk, a fair, or tryst, for cattle, sheep, and horses; and Ballinasloe, co. Galway, one for cattle. Gloucester cheese fair is well known. In parts of England and Wales, and in Scotland, servants are engaged at the hiring, or statute, fairs.
On the continent of Europe, the Lyons fair is supposed to have been founded by the Romans and long enjoyed a great reputation; bills of exchange from all parts of Europe were often made payable at Lyons fair. The fairs of Champagne and Brie were world renowned, and are referred to as early as the 5th century. Those of Frankfort-onMain and Frankfort-on-Oder and those of Leipzig, especially the great Easter book-fair, are the best known German fairs. The most important Russian fair is the Makaryerskaya fair at NijniNovgorod, which lasts from July 29 to Sept. 10. It has been held from remote times at various points on the river Volga, and was settled at Nijni in 1817, taking its name from a monastery near Makaryev, where it was formerly held. The fair comprises over 8,000 shops as well as circuses, theatres, banks, and other buildings. Trade is carried on in cotton, woollens, silk and linen goods, furs, iron, corn, salt, etc.

In the Nile delta Tanta is famous for its fairs, held thrice yearly at the tomb of Said el Bedawi, a 13th century saint. One of the largest fairs in Asia is that at Hardwar, or Hurdwar, in Upper India. The Meccan fairs existed long before the time of Mahomet. In America the term "fair" denotes an industrial exhibition. See Exhibitior.

Bibliography. Fairs, Past and Present, C. Walford, 1883: Memoirs of Bartholomew Fair, H. Morley, 1859; History of English Poetry, T. Warton, 1871, for an account of Winchester fair; Treatise on the Law of Markets and Fairs, J. G. Pease and $H$. Chitty, 1899 .

Fairbairn, ANDRew Martin (1838-1912). British theologian. Born near . Edinburgh, Nov. 4,

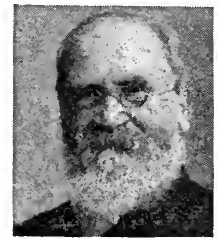

Andrew M. Fairbairn British theologian Elliott \& Fry 1838 , and educated at the u n iversity there and at Berlin, forsome years he was a Congregational minister at Bathgate and Aberdeen. $\mathrm{He}$ became principal of the Aire. dale Congrega-

tional College, Bradford, in 1877 , and in 1889-1909 was principal of Mansfield College, Oxford. He was Muir Lecturerat Edinburgh, Gifford Lecturer at Aberdeen, and Lyman Beecher Lecturer at Yale. $\mathrm{He}$ published numerous books chiefly on the philosophy of religion, among them The Place of Christ in Modern Theology, 1893, and Philosophy of the Christian Religion, 1902. He died Feb. 9, 1912. 
Fairbairn, SIR Wildiam (17891874). British engineer. Born at Kelso, Roxburghshire, Feb. 19,

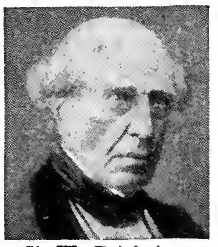

Sir W. Fairbairn, British engineer
1789 , the son of a farmer, in 1804 he was apprenticed to a millwright in Newcastle, and educated himself in his spare time. Coming to London in 1811, in 1817 he started, in partnership with James Lillie, an engineering business which proved successful. In 1830 he turned his attention to iron boat construction, and in 1835 opened shipbuilding works at Millwall. Moving thence to Manchester he invented a riveting machine, and superintended the construction of the Menai Bridge, 1848. He was made a baronet in 1869 , and died Aug. 18, 1874.

Fairbanks, Charles Warren (1852-1918). American politician. Born in Ohio, May 11, 18.52. he graduated a t the Wesleyan universit $y$ 1872 , a n worked for The Associated Press. Ad mitted to the $\mathrm{Oh}$ io bar in 1874, he was elected a Re. publican sena

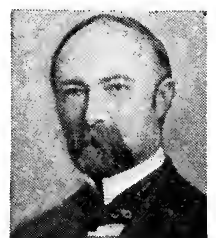

C. W. Fairbanks, American politician tor for Indiana, 1897-1909. He was elected vice-president in 1904. $\mathrm{He}$ stood unsuccessfully for the vice-presidency in 1916 . He died June 5, 1918.

Fairbanks, Douglas (b. 1883). American actor. Born at Denver, May 23, 1883, he was educated there and studied mining at the Colorado School of Mines. His first appearance on the New York stage was in 1901. Engagements at various New York theatres followed, and he toured the U.S. from 190810 in A Gentleman from Mississippi. About 1914 he took up cinema work, at which he made a great success. In 1920 he married Mary Pickford (q.v.), with whom he visited England in that year.

Fairey. Name given to British aircraft manufactured by the Fairey Aviation Co., Hayes, Middlesex. The firm's activities have been almost entirely confined to the design and construction of seaplanes, but in 1914 Fairey designed, and in 1916 completed and delivered to the R.N.A.S., one of the first examples of the large, twinengine type of machines used for bombing. See illus. p. 3068 .
Fairfax, Ferdinando Famfax, 2ND BARON (1584-1648). English soldier. The son of Thomas Fair. fax, a Yorkshire landowner, he was born March 29, 1584, and when young served against Spain in the Netherlands. In 1640 he succeeded his father as Baron Fairfax of Cameron, a Scottish title dating from 1627 , but this did not prevent him from becoming a member of the Long Parliament. Therein, taking the side of the parliament, he was chosen to command its forces in Yorkshire when war began in 1642. He served for about two years, but only met with one or two minor successes; on the other hand, he was routed at Adwalton Moor, and driven from the field at Marston Moor. $\mathrm{He}$ died March 14, 1648.

Fairfax, Thomas Fairfax, 3RD Baron (1612-71). English soldier. The son of the 2 nd baron, he was b o r $n$ a t $\mathrm{D}$ e $\mathrm{nton}$, Y orks hire, Jan. 17,1612. $\mathrm{He}$ went to S. Joh n's Co 11 e g e , Cam bridge, after which he saw military service i $\mathrm{n}$ t $\mathrm{h}$ e Netherlands. In 1640 he s e r v e d against the

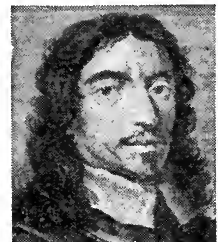
Scots, but when the civil war began in 1642, he and his father were prominent among the king's opponents.

In 1644, on the passing of the self-denying ordinance, Fairfax was made commander-in-chief of the parliamentary armies, and as such was responsible for the victory at Naseby. At the end of the first period of the war he was something of a national hero, but he had little sympathy with the policy of the more violent of the army leaders. He helped, however, to put down the royalist rising in 1648 , and was one of the judges appointed to try Charles. But when the trial began he refused to sit, and in $\mathbf{1 6 5 0}$ he resigned his position as head of the army, receiving a pension of $£ 5,000$ a year. In 1659 he came from retirement, and helped Monk to place Charles II on the throne, going as head of the deputation to The Hague. $\mathrm{He}$ was elected as M.P. for Yorkshire to the new parliament, and that was the end of his public career, although he lived until Nov. 12, 1671, dying at Nun Appleton. Fairfax was a man of culture, who wrote two accounts of his campaigns, verses, and made translations. His correspondence was published in four volumes, 1849-49. See also The Great Lord Fairfax. Sir C. R. Markham, 1870.

Fairfax was succeeded in the barony by his son. It passed to his descendants, coming in 1710 to Thomas Fairfax, who became the 6th baron. He sold Denton Hall, the Yorkshire seat of the family, and settled in Virginia, where he inherited some millions of acres, and lived in princely splendour. His brother, the 7 th baron, died without sons, when the title passed to a distant relative. For a time, the heirs being American citizens, it was not claimed, but in 1912 Albert Kirby Fairfax was permitted by the House of Lords to take it. He ranked as the 12 th baron.

Fairfax, SIR JAMES READING (1834-1919). Australian newspaper proprietor. Born at Leamington, Eng. land, Oct. 17 . 1834 , he joined the staff of his father'spaper, 'T' h e Sydney Morning $\mathrm{Her}$ ald, in 1851 .

Five years later he became a part$\mathrm{n}$ e r, a n d

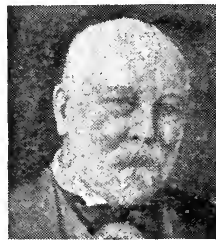
Sir James Farriax paper proprietor mainder of his life was actively engaged in the management of The Herald and The Sydney Mail, which he founded. Knighted in 1898, he was a director of the Bank of N.S.W., and president of the national art gallery of N.S.W. He died March 28, 1919.

Fairfield. Parish of Derbyshire, England, partly within the borough of Buxton. Pop. 4,114. There are a number of other Fair. fields in England, one being a suburb of Manchester and another of Liverpool. Fairfield is the name, too, of a mountain $(2,863$ ft. high), near Helvellyn, in Westmorland.

Fairford. Parish and village of Gloucestershire, England. It stands on the Coln, $25 \mathrm{~m}$. W.S.W. of Oxford, and has a station on the G.W.R. Its 15 th century church, dedicated to S. Mary, and built by John Tame, a London merchant, contains some of the most wonderful stained glass in the country. The 28 windows figure the whole story of the Creation and of the work of Jesus Christ. The village has a fair and was a centre of cloth manufacture. It is visited for trout fishing, and was the birthplace of John Keble. In the neighbourhood are Hatherop Castle and Fairford Park. Pop. 1,410. 
Fair Head or Benmore. Headland on the N. coast of Antrim, Ireland. It is $4 \frac{1}{2} \mathrm{~m}$. N.E. of Bally. castle, is $636 \mathrm{ft}$. high, and being a sheer precipice from a height of $320 \mathrm{ft}$. presents a superb basaltic columnar formation.

Fairing. In aeronautics, any streamline-shaped cover or casing, or any part so shaped that it provides a streamline form. In aircraft construction it is most essential to reduce the wind resistance set up by every part of the structure, and this is attained by giving as far as possible a streamline shape, or in other words fairing them off. The word is used also for a present, originally one brought from a fair. See Aeronautics.

Fair Isle or SHeEP Isle. One of the Shetland Is., Scotland, about equidistant from that group and the Orkney Is. It is $3 \mathrm{~m}$. long and $2 \mathrm{~m}$. broad, and rises to 480 ft. in Sheep Craig on the E. coast. Fishing, knitting, and sheep-rearing are engaged in. The island has two lighthouses, and is in telegraphic communication with the mainland. Pop. 139.

Fairlie. Parish, village, and watering-place of Ayrshire, Scotland. It stands on the Firth of Clyde, $2 \mathrm{~m}$. S. of Largs by the G. and S.W.R. It has a noted yacht. building yard, and there are ruins of a castle. Pop. 800 .

Fair Maid of Perth, The, OR St. Valentine's DAY. Romance of the last years of the 14th century when Robert III was king of Scotland. Published in May, 1828, it forms the second series of Scott's Chronicles of the Canongate. The scene is laid in and around Perth; the titular heroine is Catharine, the beautiful and devout daughter of

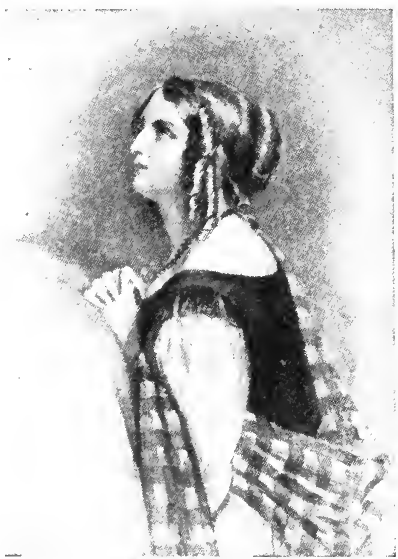

The Fair Maid of Perth. Catharine Glover, the heroine of Scott's novel, from a drawing by Charies Landseer, R.A.
Simon Glover, burgess of the city. In addition to the unique study of the Highland lad Conachar (Eachin MacIan), nominally Simon's apprentice, who is destined to be the last chief of the Clan Quhele, and whose inherent cowardice offers a striking contrast to the dauntless courage of Henry Smith (Hal of the Wynd), the armourer who is also Catharine's suitor, the story contains a vivid description of the Palm Sunday battle on the North Inch between the champions of the rival clans Chattan and Quhele.

Fair Oaks, Batrue of. Federal victory in the American Civil War,
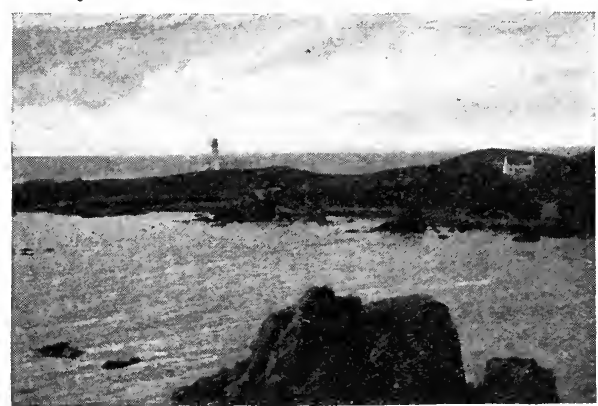

Fair Isle, Shetland Islands, from the east, with the lighthouse on the southern extremity Valentine

May 31-June 1, 1862, also known as the battle of Seven Pines. In command of the Federals, McClellan was forcing Johnston back upon Richmond when the Southern general made a stand as the Fed. erals were crossing the Chickahominy river. 'Two of McClellan's corps were already to the $\mathrm{S}$. of the river when they were attacked by Longstreet. Reinforcements were hurried up, and stubborn fighting took place, during which Johnston was severely wounded, being succeeded by G. W. Smith. The next day, June 1, Longstreet's attack was repulsed, and Lee only arrived in time to withdraw the Confederate army to Richmond. About 42,000 men were engaged on either side. The Federal losses were 5,000 , the Confederates losing more than 6,000 .

Fair Trade. Term much used in the United Kingdom during the latter part of the 19 th century for what was later called tariff re. form. It was used by the opponents of free trade, who demanded $\mathrm{th}$ a $\mathrm{t}$ the United King. dom should only admit the goods of other nations on the same terms as British goods are admitted there. After languishing for a time the cause revived early in the 20 th cen. tury in the shape of Tariff Reform. See Free Trade; 'Tariff Reform.

Fair Wages Clause. Agreement in public contracts to protect the wage earner. It is usual to insert in agreements with contractors, who undertake works paid for from public money, a clause to the following effect: "The contractor shall pay his workmen the wages usually deemed fair in the district in the trade to which they belong, i.e. the trade union rate of wages, under a penalty of $\mathfrak{E}$ - or under pain of forfeiting the contract at the option of the employer." F o rmerly a clause was often inserted f orbidding the contractor to pay his employees in kind or in any. thing but money.

Fairway. Navigable part of a river or other channel. It is continually under su. pervision in order to keep it free from obstructions.

Fairweather. Mountain of Alaska, U.S.A. It is a volcano in the $\mathrm{St}$. Elias Range, alt. $15,290 \mathrm{ft}$.

Fairy. Legendary or mythical being common to the folklore of most peoples. They are manifested in varied forms, from tiny creatures in human shape which haunt the flowers, to the ordinary size of human beings. Fairies are, however, generally regarded as relatively small, whence it has been surmised that the origin of the fairy myth is to be found in a dim antiquity when surviving races were in conflict with smaller races that have become extinct. The discovery of the African pygmies has lent colour to this ; Sir Harry Johnston pointing out that the actions of those dwarf people again and again suggested the traits attributed to the brownies and goblins of fairy lore. Fairies in their many manifestations are some-

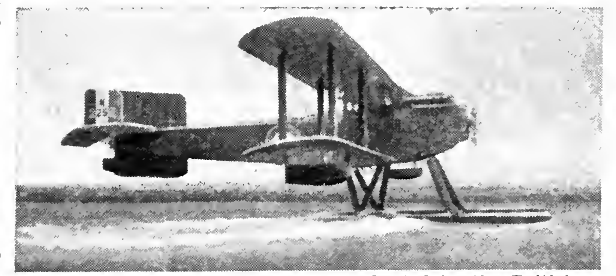

Fairey Seaplane, type III C, as adopted by the British Government. See p. 3067 
times friendly and beneficent, some times mischievous and malevolent.

The term is occasionally em. ployed as covering the whole field of terrestrial supernatural beings, hence Fairyland is a sort of fourth dimensional world that coexists with that in which we live, and the term Fairy stories is applied to all tales introducing earthly beings of an extra-natural character. In poetry and modern fairy stories the fairy is generally represented as a tiny dainty creature. Since fairy ori. ginally meant enchantment, and then fairy people collectively, a single fairy is better called fay, Fr. fée, Ital. fata, from late Lat. fata, a fate or fay, the neut. pl. of fatum being used as a singular. See Brownie; Changeling; Elf; Folklore; Gnome; Goblin; Puck; Sylph.

Bibliography. Observations on Popular Antiquities, J. Brand, rev. ed. 1893; Fairy Legends of the South of Ireland, T. Crofton Croker, new ed. 1862 : Teutonic Mythology, Jacob Grimm, 1835 (Eng. trans. J. S. Stallybrass, 1880-88): Fairy Mythology, T. Keightley, 1847 : Science of Fairy Tales, E.S. Hart land, 1889; The Childhood of Fiction, J. A. MacCulloch, 1905; Myths and Legends of the Celtic Race, T. W. Rolleston, 1911.

Fairy Ring. Ring of a more vivid green than the surrounding grass of fields, fancifully ascribed to fairies dancing in a circle at night. They are really caused by the growth of certain species of fungi-notably the fairy-ring champignon (Marasmius oreades) which, starting from the centre, extend their underground threads (mycelium) in all directions, form ing a circle increasing every year.

Faisans, Ille DES (Fr., Pheas. ants' Isle). Isiand in the river $\mathrm{Bi}$ dassoa, lying between France and Spain, about 15 m. S.E. of St. Sebastian. Its position between two frontiers made it on two notable oc casions the meeting-place of French and Spanish negotiators. Louis XI and Henry IV of Castile met here in 1463, and Mazarin and Don Luis de Haro here concluded the Treaty of the Pyrenees in Nov. 1659, by which Spain ceded Artois and other northern possessions, and gave up her claims to Alsace and Lorraine, while France gave up territory taken in Italy and N.E. Spain.

Faith (Lat. fides). In ordinary speech a term used to denote the leap of the mind from the known to the unknown. In the sphere of nature it signifies the acceptance of fundamental assumptions which in themselves are incapable of logical demonstration. The law of the Uniformity of Nature, for instance, is an act of scientific faith enunciating a universal principle on the basis of certain established data. The fact that the sun has in. variably risen at daybreak does not in itself afford a demonstrative proof that it will always rise, but it justifies our faith that such will be the case. In the sphere of human relations the term is also employed to denote the confidence which we feel in other men whose character and integrity are known to us.

From ordinary usage the term naturally passed into the religious sphere-to which it preeminently belongs, and it is commonly used to describe the faculty or organ of the soul by which a man grasps the realities of the unseen and divine universe. What the eye is to the body, faith is to the soul. It is the medium or instrument by means of which the soul enters into com. munion with God.

Philosophers and theologians have made many attempts at a psychological analysis of the faculty of faith. Somc have held that it is a divine endowment-a special religious sense, created in the soul for the purpose of the exercise of spiritual functions. Others have regarded it as an aspect of the emotions analogous to the aesthetic sense. A third school has made it a department of the intellectual side of human nature-while a fourth has located it in the activity of the will. All these theories are inadequate, for intellect, feeling, and will are all involved in the act of faith.

Corresponding to these different views as to the character of the organ of faith, there are similar divergences of opinion as to the scope of its activity. Even in the New Testament itself the term is used in three different senses. In the Epistle of James it is employed to signify the intellectual assent of the mind to the primary Christian beliefs, and from this use of the word has grown up the conception which identifies faith with the acceptance of a creed. In the Epistle to the Hebrews, on the other hand, faith is defined as " the assurance of things hoped for, the proving of things not seen," words which Dr. Moffatt has paraphrased, "Faith means we are confident of what we hope for, convinced of what we do not see." It is out of this interpretation of faith that Christian mys ticism developed. To the Apostle Paul faith has still a deeper signification. It implies nothing less than the complete surrender of the soul to Christ as its Redeemer and its living Lord. And it is to this great Pauline idea of faith that the Evangelical interpretation of Christianity owes its genesis and inspiration. See Faith and its Psy. chology, W. R. Inge, 1909.
Faithfull, Emily (1835-95). British publicist. Born at Headley Rectory, Surrey, daughter of Rev.

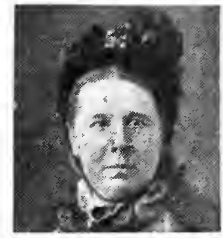

Emily Faithfull, British publicist Doroney
Ferdinand Faithfull, and educated at Kensington, she devoted the greater part of her life to advocating the claims of women to remunerative employment. In 1860 , in Great Coram Street, London, she founded a printing-office in which women were employed as compo. sitors, and for which she secured the approval of Queen Victoria. Later, in Farringdon Street, she formed the Victoria Press, and was appointed printer and publisher in ordinary to the queen. In 1863 she started a monthly entitled The Victoria Magazine. In 1868 she issued a novel, Change upon Change. Her lectures in the U.S.A., 1872-73, were described in her Three Visits to America, 1884. She received a civil list pension of $£ 50$ in 1889 and died May 31, 1895

Faith Healing. Cure of disease by faith in the healing power of God. In the early Church the practice of anointing the sick for the purpose of curing them was a normal function of the clergy, and still survives in an altered form and with different intention in Extreme Unction. In medieval days the touch of a saint or of his relics was resorted to for healing; and down to the time of Queen Anne the British sovereign used to touch persons to cure them of scrofula.

The practice of faith healing is common among certain Protestant bodies, such as the Peculiar People. Most of the miracles at Lourdes and elsewhere are probably examples of faith healing. Such cures are usually effected in functional and nervous complaints, not in cases of organic lesion; and medical science attributes them to the power of suggestion upon the minds of persons who are at the time in a state of strong religious emotion.

Faithorne, WILliam (1616-91). English engraver. Born in London, he studied painting and drawing under Robert Peake, and engraving with John Payne. Made prisoner by the Roundheads in the Civil War, he pursued his art in Aldersgate prison, and on his liberation proceeded to Paris, becoming a pupil of Robert Nanteuil. Returning to London in 1650 , he set up as a print-seller near Temple Bar, retiring in 1680 . He died in 


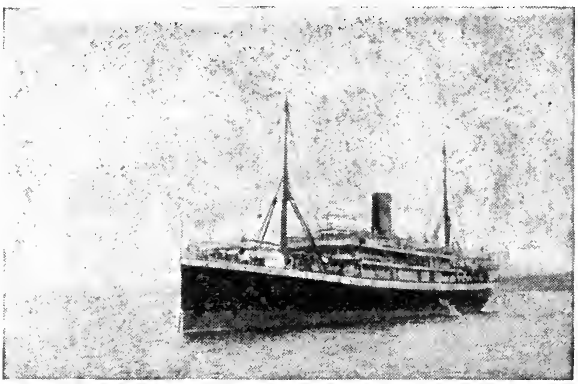

Salaba, The British liner torpedoed in St. George's Channel by a German submarine, March 28, 1915
English Channel at Falmouth, and is navigable for nearly $10 \mathrm{~m}$.

Falaba. British liner torpedoed by the German submarine U28 S. of St. George's Channel, March 28, 1915. At the inquiry it was stated that the $\mathrm{sub}$ marine was flying British colours, and its crew wore khaki. Herr Dernberg atBlackfriars, May 13, 1691. Faithorne engraved portraits of most of the conspicuous figures of the Commonwealth and Restoration after Van Dyck, Lely, Dobson, and others, among them the notorious Lady Castlemaine. His portraits of Charles I, Charles II, James II, the Duke of Monmouth, Milton, Thomas Killigrew and Thomas Hobbes may be specially men tioned.

Faiza bad or Frzabad. Division, district, and town of Oudh, United Provinces, India. Faizabad city, the administrative headquarters (with cantonment) of the district, is situated at the junction of three branches of the Oudh and Rohilkhand Rly., and forms with Ajodhya a single municipality. Its chief industry is sugar refining, and it has a large agricultural trade. It is the terminus of the river steamers on the Gogra. The main crops of the district are rice, grain, wheat, lentils, peas, barley, and sugar-cane. Pop., div., 6,646,362, 75 p.c. Hindus; dist., 1,154,109, 90 p.c. Hindus: town, $54,655,70$ p.c. Hindus.

Fakenham. Parish and market town of Norfolk, England. It stands on the Wensum, $24 \mathrm{~m}$. by rly. from King's Lynn. It has two stations, one on the G.E.R. and the other on the Mid. \& G.N. joint line. The chief building is the church. with a lofty tower. Pop. 3,181.

Fakir (Arab. faqir, beggar). Religious devotee, especially in In. dia. They numbered in $1911,787,124$ Mahomedan, 175,902 Hindu, 16,187 Sikh, and 80 Jain. The Mahome. dans are orthodox members of the marrying dervish orders or un orthodox celibate mendicants who dispense with abstinence, fasting, and prayer. The Hindus include members of the monastic yogi orders devoted to education and poor relief, besides mendicant vagabonds who practise jugglery and resort to mutilations and austerities. See illus. p. 740.

Fal. River of Cornwall, Eng. land. It rises near Roche, flows $\mathrm{S}$. and S.W. for $23 \mathrm{~m}$. to the

tempted to justify this crime by saving that it was a return for Britain's attempt to starve out Germany. The Falaba, 4,800 tons, belonged to the Elder Dempster Co.

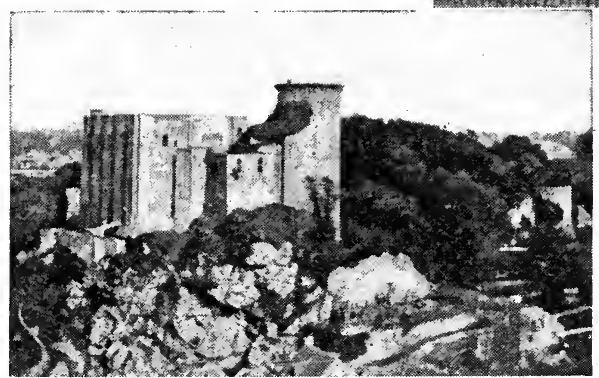

Falaise. The castle where William the Conqueror was born. Above, statue of William by Louis Rochet. erected in 1851

Falaba. Town of Sierra Leone, W. Africa. It is fortified, and lies near the frontier of French Guinea, $170 \mathrm{~m}$. N.E. of Freetown, at the junction of many trade routes. There is trade in palm kernels and kola nuts. Pop. 6.000

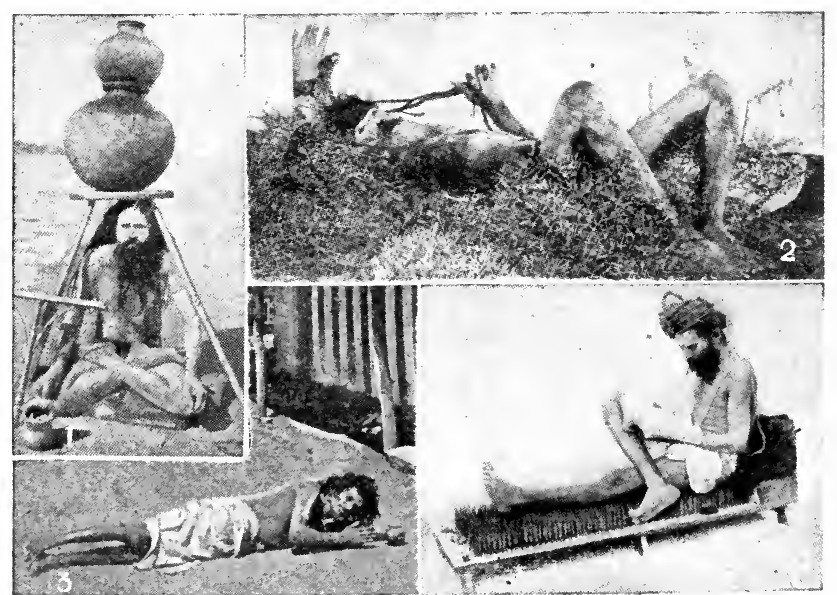

Fakar. 1. Undergoing thirst ordeal; with the river by his s1de and jars of water overhead, he abstains from drinking. 2. Lying on a bed of thorns. 3. Rolling his way from shrine to shrine. 4. Seated on a bec of nails
Falaise, Town of France, in the dept. of Calvados. It stands on the Ante, 20 m. S.S.E. of Caen. It is a $n$ agricultural centre, and Guibray, a suburb, is noted for its horse and cattle fairs. are tanning and the manufacture of hosiery, cottons, and dyestuffs. The chief churches are S. Gervais, with its fine Norman tower and some beautiful stonework, and the Trinity, but the most interesting building is the castle, famous as the birthplace of William the Conqueror and at one time the residence of the dukes of $\mathrm{O}$ ther industries 
Normandy. It stands on a hill above the town and is largely intact, the remains including the keep and Talbot's Tower, dating from the 15th century. Near the town hall is an equestrian statue of William the Conqueror, and there is a fine Norman church at Guibray. As part of Normandy, Falaise was long a possession of the English kings. In 1450 it was finally captured by the French. Pop. 6,847.

Falashas (Ethiop., strangers). Communities of Hamitic stock, mainly between Aksum and Gondar, in Abyssinia. Although allied racially to the Galla, and ignorant of Hebrew and the Talmuds, they profess Judaism, there being three distinct sects. They are farmers and artisans, speaking an Abyssinian (Agao) dialect, and they practise a rigid racial and ritual exclusiveness.

Falces. Town of Spain, in the prov. of Navarre. It stands in a plain between the rivers Ebro and Arga, 30 m. S.W. of Pamplona. It has ruins of a Roman castle, but is chiefly known for the mineral springs in the vicinity. Pop. 3,200 .

Falchion. Type of sword used in medieval times. It was usually slightly curved, rather heavy, and the blade was broader towards the point than at the hilt. The word is derived from Lat. falx, sickle. See Sword.

Falcon (Lat. falco). Name applied generally to the family of birds of prey which includes falcons, hawks, kites, and eagles ; but more especially to a sub-family which includes the true falcons, the peregrine falcon and the kestrels. All these have short, curved beaks with one notch in the upper man. dible, round nostrils, short pointed wings, and long toes.

Several species of falcon are found in Great Britain. Of these the peregrine falcon builds sparsely on cliffs in the S. of England. It preys mainly on birds, and its rav. ages among game are compensated by the fact that it only attacks the weaklings, and thus tends to maintain the strength of the breed. It was formerly trained to bring down birds in hawking.

Other species which occur in the British Isles are the Greenland falcon, the Iceland Jer-falcon, and the Scandinavian Jer-falcon, all of which are occasional winter visitants. The birds take their name from the hook-shaped claws (Lat. fals, sickle). See Hawking.

Falcon. Volcanic island of the Tongo or Friendly Islands. It is in lat. $20^{\circ} 20^{\prime} \mathrm{S}$. and long. $175^{\circ} 20^{\prime}$ W. It made its appearance above the ocean on Oct. 14, 1885, after a voleanic eruption. It disappeared for a time but was again uplifted.

Falcón. Mari. time state of N. Venezuela, facing the Gulf of Maracaibo and Caribbean Sea and bound. ed $S$. by the state of Lara. It has been a separate state since 1904 when it was separated from Zulia. Tho coastal region is low-lying and sterile, but inland there are several ranges of hills with fertile valleys. Agriculture and stock-r a i s in $g$ are the chief industries ; coffee, cocoa, sugar, cotton, tobacco, and maize are produced. Coal is worked in small quantities, but the mineral re. sources of the state are virtu.
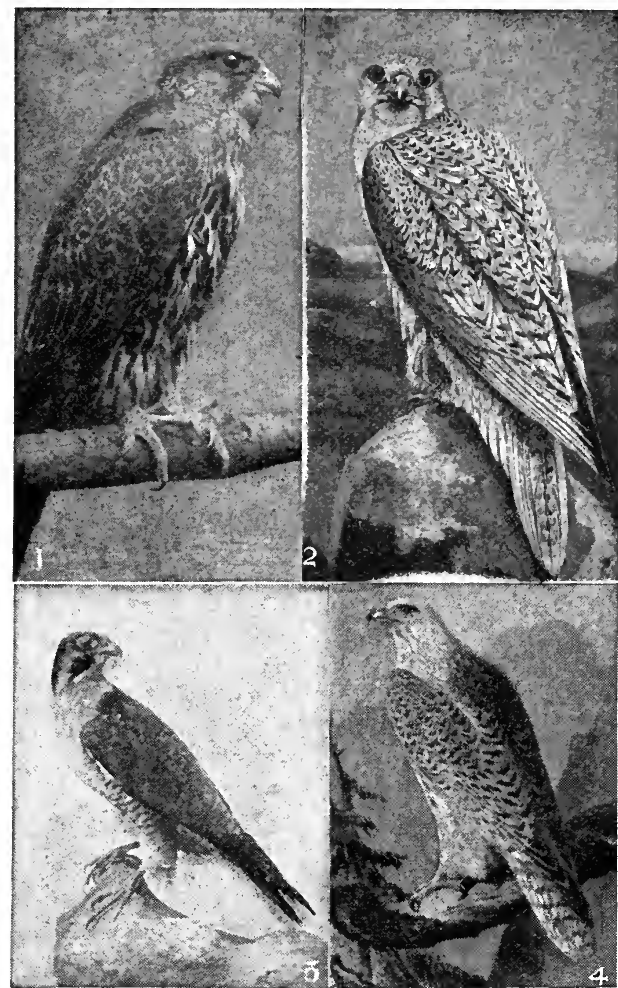

Falcon. Species found in the British Isles. 1. Iceland Jer-falcon. 2. Greenland falcon. 3. Peregrine falcon.

4. Scandinavian Jer-falcon

ally untapped. The capital is Coro. Pop. 170,154.

F'alcone, ANIELlo (1600-65). Italian painter. Born in Naples, he was a pupil of Ribera, and became famous as a spirited painter of battle-scenes. During the insurrection of Masaniello, 1647, Falcone gathered a band of his friends and pupils, among whom was Salvator Rosa (q.v.), and this "Company of Death " made many Spaniards pay with their lives for the murder of the leader's nephew and of one of his pupils. Pictures painted of these events are in the museum at Naples. Falcone worked in Paris from 1648-56, when he returned to Naples, where he died. His Fight between Turks and Cavalry is in the Louvre.

Falconer, HuGH(1808-65). Scottish botanist. Born at Forres, Feb. 29,1808 , Falconer was educated at Aberdeen and Edinburgh universities, and entered the service of the $\mathrm{E}$. India Company as a surgeon in 1830. His chief interests, however, were in palaeontology and botany, in which sciences he made many important investigations. He experimented in tea- planting in India, and also discovered the assafoetida plant, used in medicine. Returning to England for a time, he arranged the Indian fossils at the British Museum,184447 , and then returned to India as professor of botany and curator of the botanical gardens of Calcutta, where he worked from 1848-55. Retiring in 1855, he died in London, Jan. 31, 1865.

Falconer, Str Robert AlexANDER (b. 1867). Canadian scholar. Born Feb. 10, 1867, at Charlottetown, Prince Edward Island, he was the son of a Presbyterian minister. His education, begun in Trinidad, was continued at the university of Edinburgh and at German universities, after which, in 1892, he returned to Canada and was ordained in the Presbyterian ministry. He became lecturer at Pine Hill College, Halifax, his subject being N.T. Greek. In 1904 he was made principal of Pine Hill, and in 1907 was chosen president of Toronto University. $\mathrm{He}$ was knighted in 1917.

Falconer, William (1732-69). Scottish poet. Born at Edinburgh, Feb. 11, 1732, the son of a barber, 
he became a sailor, and wrote The Shipwreck, 1763, a realistic poem, and a Marine Dictionary, 1769. He joined the navy, and, Sept., 1769, sailed for India in the frigate Aurora, which was lost off Cape Town.

Falconry. Sport of hawking and the breeding and training of hawks, more usually known as hawking (q.v.).

Faldstool (late Lat. faldistorium; Ger. falten, to fold, Stuhl, stool seat, or throne). Portable crossed or folding stool so constructed that it can be used as a prie-dieu or kneeling desk or a seat. In Eng. land it was used by bishops when occupying a seat in the sanctuary other than their throne, or were visiting a church other than their

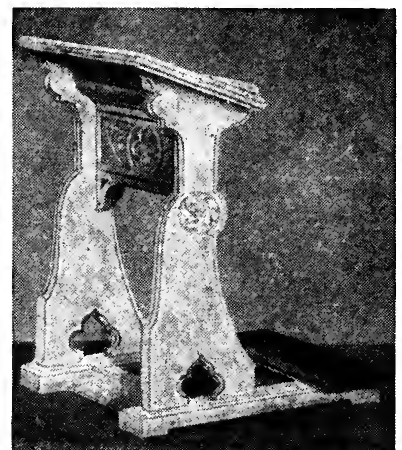

Faldstool or Litany desk of carved oak

cathedral; and it is still used in Roman Catholic churches. The term is applied to the small, low desk at which the Litany is enjoined to be sung or said, and to the stool at which a sovereign kneels at his coronation. The faldistorium on which Queen Mary sat at her marriage with Philip II of Spain is preserved in Langton's chapel, Winchester Cathedral.

Falemé. River of Senegal. It forms part of the boundary between the Senegal and Haut. Senegal and Niger colonies. It rises in French Guinea in the water. shed separating the Gambia and Bafing rivers, and runs N.N.W. to the Senegal river, which it enters near Bakel. It is partly navigable for small boats during the wet season. Its length is $200 \mathrm{~m}$.

Falerii. Ruined city of Etruria. Its site is near the modern town of Cività Castellana, $35 \mathrm{~m}$. N. of Rome. One of the league of 12 Etruscan cities, its origin is lost in antiquity. Destroyed by the Romans, 241 B.c., the inhabitants built a new town $3 \mathrm{~m}$. N.W. of the original site. Of the Roman Falerium Novum there are many remains, the walls, towers, and gateways being well preserved, and reputed to be among the most remarkable specimens extant of ancient military architecture. The town was deserted early in the 11th century.

Falernian Wine. Famous wine of the ancient Romans. It was light in colour and potent. A wine produced in the district, which is a fertile plain in Campania, near the Volturno river, is called Falerno.

Falguière, JEAN Alexandre JoSEPH (1831-1900). French sculptor and painter. Born at Toulouse, Sept. 7, 1831, he studied at the Beaux Arts under Jouffroy, and at Rome. His work was at first classical in manner, but afterwards became strongly realistic. A marble statue of Tarcisus, martyr, now in the Luxembourg, was his crowning success; one may cite also Cain and Abel, Les Lutteurs, and the statue of Lafayette. Falguière died at Paris, April 19, 1900.

Faliero, Marino (1279-1355). Doge of Venice. Member of an ancient Venetian family, he defeated the Hungarians at Zara in 1346, and captured the city. Elected doge in 1354, his troubles began with the defeat of the Venetian navy by the Genoese. The unrest caused by this disaster aroused Faliero's ambitions. He allied himself with the leaders of the populace, and a plot was hatched to murder the leaders of the nobility on April 15, 1355, and proclaim Marino prince of Venice. The Council of Ten, learning of the plot, seized Faliero, who confessed his share therein and was executed April 17, 1355.

Falk, Paul Ludwig Adalbert (1827-1900). German statesman. Born at Metschkau, Silesia, Aug. 10,1827 , after studying law he entered the Prussian diplomatic service in 1847. In 1867 he represented Silesia in the parliament of the N. German Confederation. Appointed Prussian minister for ecclesiastical and educational affairs in 1872, he successfully opposed Roman Catholic interven. tion in educational matters, and introduced a law declaring the right of the state to supervise all schools. Instigated by the pope, the bishops ignored this law and various penalties and fines were imposed on them. This brought such odium upon Falk that he resigned in 1879 . In 1882 he was given a judicial appointment and he died at Hamm, Westphalia, July 7, 1900.

Falkenhausen, FRIEDR I CH, BARON voN (b. 1869). German soldier. He was born at Potsdam, and entering the army in
1887 had a distinguished career. $\mathrm{He}$ commanded the 6th army corps, 1916-17, and in April, 1917. succeeded von

Bissing asgov. ernor - general of Belgium, where his rule was more oppressive than that of his pre. decessor. one year be had 170 Bel. gians shot, in. cluding women

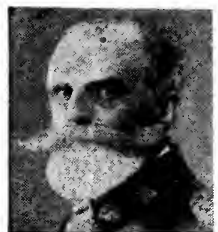

Friedrich von $\mathrm{Fal}$ kenhausen, German soldier and boys and girls, and he authorised severe penalties, deportations, and floggings. See Belgium.

Falkenhayn, ERICH vON (18611922). German soldier. He was born at Burg Belchau, Sept. 11, 1861, and entered the German army in 1880. After leaving the Academy of War in Berlin in 1890 he joined the general staff. $\mathrm{He}$ served on Count Waldersee's staff in the China Expedition in 1900. In 1911 he commanded the 4th regiment of Guards, and in 1912 was chief of the staff of the 4 th army corps. In 1913 he became minister of war, which post he held at the outbreak of the Great War ; but in Dec., 1914, he was definitely appointed chief of the general staff, and was its respon. sible head till removed in Aug., 1916, owing to the failure of the German offensive at Verdun.

In Sept., 1916, he was appointed commander-in-chief of the Ninth Army, composed of German and

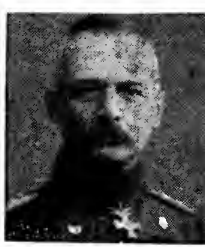

Erich von Falkenhayn, German soldier Austrian divisions, and after driving the Rumanians from the $\mathrm{N}$. side of the Transylvanian Alps, he forced the passes, and descendedinto the plains of Wallachia, the first step in the overthrow of Rumania. He returned to Germany in 1917 on Mackensen's taking entire control of the Austro-German forces in Rumania, and later went to the Middle East to direct the Turkish operations against the British in Palestine and Mesopotamia, but not being successful was recalled and replaced by Liman von Sanders in March, 1918. He died Apríl 8, 1922. By many, Falkenhayn was regarded as the ablest strategist produced by Germany during the Great War. In 1919 he published General Headquarters, 1914-16, and its Critical Decisions, Eng. trans. 1919. See illus. p. 249. 
Falkirk. Parl. and mun. burgh and market town of Stirlingshire, Scotland. It is $22 \mathrm{~m}$. N.E. of Glas-

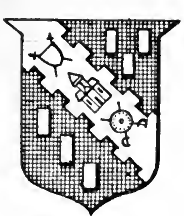

Falkirk arms gow on the N.B.R. Falkirk, which embraces the suburbs of L a a rieston, Grahamston Bainsford, and Camelon, is con. nected by rly. with Grangemouth (3 m. distant), its port on the Firth of Forth, and is and colliery district, the Carron, Falkirk, Camelon, and other large ironworks being situated in or near the town. Brewing, distilling, tanning, and the manufacture of bricks, tiles, chemicals, and explosives are flourishing industries. The famous cattle "trysts" or open sales, which were held thrice yearly, have been superseded by weekly markets. The Stirling and the centre of a busy ironworking

Scots, who were greatly outnumbered, were either dead or in flight.

The second battle was fought between the English, under General Hawley, and the Jacobites, Jan. 17, 1746. Charles Edward, the Young Pretender, returning from Derby, found his way N. barred by the English. His Highlanders, in an impetuous charge, swept away the English troops, and Hawley lost 700 prisoners.

Falkland. Royal burgh, mun. burgh, and village of Fifeshire, Scotland. It stands at the N. foot of East Lomond Hill, $36 \mathrm{~m}$. N. of Edinburgh, on the N.B.R. The chief attraction is its palace, formerly the residence of the dukes of Fife, in which David, the duke of Rothesay, heir to the Scottish throne, is said to have been starved to death at the instance of Albany, the regent, in 1402 . The palace was a favourite residence of the Scottish monarchs, and lere James $\mathrm{V}$ sought refuge and died in $\mathbf{1 5 4 2}$.

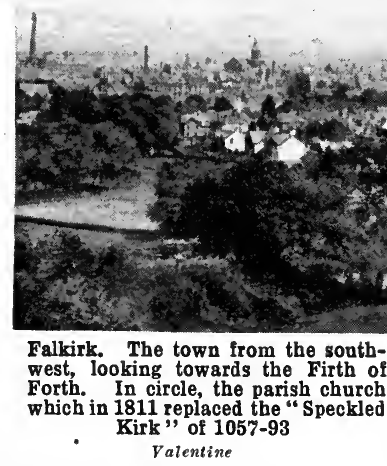

Falkirk burghs return one member to Parliament. Market day, Thurs. Pop. of mun. burgh, 33,574.

Falkirk, Battles of. The first battle of Falkirk was fought, July 22,1298 , between the English and the Scots. Under Edward I the English invaded Scotland to crush the rebellion of William Wallace. The two armies met near Falkirk. The Scots, mostly pikemen, were ranged in four circular groups, each ring surrounded by stakes. Between the groups were bowmen and behind a few horsemen. The English knights were in three columns, their traditional formation, flanked and backed by archers. The first line charged, only to flounder in a morass in front of the Scots ; the second drove away the bowmen, but made no impression upon the pikes. Edward, therefore, called upon his archers, whose deadly aim soon broke the Scottish rings. The knights seized their advantage, and soon the

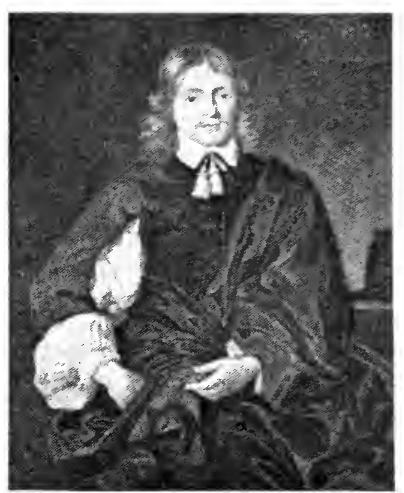

Lucius Cary, 2nd Viscount Falkiand After Van Dyck

Falkland, but by this time he had inherited from his grandfather, Sir Lawrence Tanfield, the estate of Great Tew in Oxfordshire, and had married Lettice Morrison. His political career began in 1640 with his election as M.P. for Newport. He opposed the worse illegalities of the king, but was never a bitter partisan, and gradually, as the opposition to Charles hardened, he became more definitely on his side. In 1642 he was made a secretary of state. He was at Edgehill with Charles, but soon he fell into the melancholy described by Clarendon, seeing nothing but misery before his country. Expressing a wish to be "out of it ere night," he found the death he desired at Newbury, Sept. 20. 1643 , when riding forward alone towards the foe.

Falkland is known mainly from the accounts given of him by his friend Clarendon, and these make him one of the most attractive men of his own or any age. He loved learning and the society of scholars, who gathered in delightful freedom at his hospitable house, Chillingworth and Hales, Suckling, and Waller among them. He wrote A Discourse of Infallibility. Of him Clarendon said, "Whosoever leads such a life need not care upon how short warning it be taken from him." The title passed to Fallkland's eldest son, but his direct line died out in 1694. It then passed to Lucius (d. 1730), a descendant of the 1st viscount, the ancestor of the present holder. See I, ife and Times of Lucius Cary, Viscount Falkland, J. A. R. Marriott, 1907.

Falkland Islands, British crown colony in the $\mathrm{S}$. Atlantic. The islands lie about $320 \mathrm{~m}$. E. of the Strait of Magellan, and 1,000 m. S. of Montevideo. The group contains two large islands and about 100 small ones, with an estimated land area of about 6,500 
sq. m., excluding S. Georgia, estimated at $1,000 \mathrm{sq}$. m. The chief are Falkland (area 3,000 sq. m.) and W. Falkland $(2,300$ sq. m. $)$. The highest point is Mt. Adam $(2,315$ ft.) on W. Falkland. E. Falkland is hilly in the $\mathbf{N}$., but low-lying, marshy, and boggy elsewhere. Trees are lacking, but grasses flourish ; vegetables and green crops are cultivated. The coasts are much indented, affording good anchorage.

The chief industries are sheepfarming and whale fishing; horses and cattle are reared. Apart from the important pastoral industry at the Falklands and the extensive whaling of the dependencies, there are few enterprises of commercial value. A mutton-canning factory has been established, and at $\mathbf{S}$. Georgia sealing is carried on. The climate in the Falklands, although very bleak, is healthy. In the S. Orkneys, S. Shetlands, and Graham Land, the land is covered with snow and glaciers, except in a few low-lying spots during the summer. The almost constant succession of strong winds, snowstorms and fogs makes it a most inhospitable region. The only indigenous mammals are the fox and mouse.

Stanley, the capital, is the only town. It is on E. Falkland, and possesses a good harbour. Regular communication is established, by steamer and wireless, with Great Britain. The Sandwich group (q.v.) is also a dependency. The chief exports are animal products. Pop. 950.

The Falklands were discovered by John Davis in 1592, and taken by the French in 1764. Recovered three years later by the British, who were ejected by the Spaniards, and it was not until 1832 that they finally became British. Off these islands Sturdee won a naval victory over a German squadron, under von Spee, in Dec., 1914. In 1917 a oommittee was appointed to study the development of the resources of the dependencies of the islands. Their report was issued as a blue-book (Cd. 657) in 1920 . Pop. of the colony, including $\mathrm{S}$ Georgia, 3,451.

Falkland Islands, Battle of THE. Naval engagement during the Great War, Dec. 8. 1914. Following his appointment as first sea lord at the end of Oct, 1914, Lord Fisher took immediate steps to concentrate overwhelming force against the German squadron, which had just,destroyed Cradock's two cruisers at Coronel (q.v.). He determined to dispatch the two battle oruisers Invincible and Inflexible secretly to the Falklands. The foroe of battle cruisers available for work in British waters was very small, and was reduced to three by

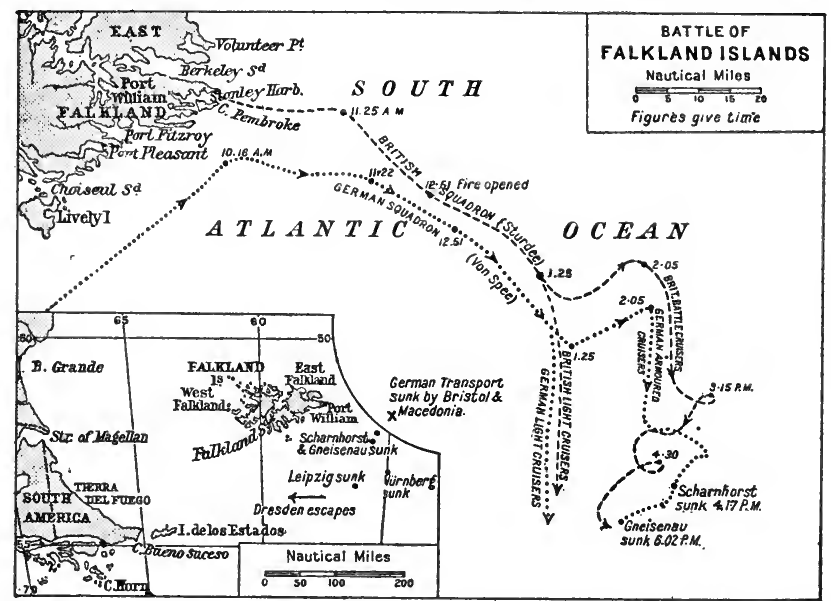

Falkland Islands. Chart illustrating the course of the naval battle of Dec. 8 ,

1914. Inset, map showing the relative position of the Falkland Islands to the main land

this detachment and by the dispatch of a battle cruiser to $\mathrm{N}$. American waters. On Nov. 11 the two ships left England under Vice-Adm. Sturdee. Off the Brazilian coast they were joined by the old armoured cruisers Car. narvon, Cornwall, and Kent, the light cruisers Glasgow and Bristol, and the armed ships Macedonia and Orama. They reached Port William in the Falklands on Dec.7, and immediately began to coal. In the harbour there was the old battleship Canopus, with 12-in. guns, so moored as to act as a floating battery.

Von Spee had heard nothing of the movements of the battle cruisers, and expected to find only a weak British force at the Falklands. His plan was to destroy any vessels there, and then to seize the British naval base. After that he intended to proceed to the Cape of Good Hope, where he expected to be joined by a large number of disaffected Boers. At 7.50 a.m. of Dec, 8 he was sighted off the Falklands. His flag was hoisted in the Scharnhorst, armoured cruiser, and with him was her sister ship, Gneisenau, the light cruisers Nürnberg, Leipzig, and Dresden, and three transports. As soon as the Germans were sighted Sturdee ordered his ships to raise steam for full speed and at 8.30 sounded for action.

At 9.20 Gneisenau approached the wireless station and was fired on by Canopus's 12-in. guns. Supposing that she was being attacked by coast defences of unexpected strength, she turned away; a little later her officers saw the tripod masts of the two British battle cruisers, whereupon all von
Spee's squadron increased speed and steered E. Von Spee ordered his crews to prayers, warning them of the ordeal before them. About 10 the British squadron put to sea, and as the Germans were in good view and reported to be going only 15 knots, the British cruisers steamed for some time at moderate speed $(20$ knots) to allow the older British vessels to close up. At 12.20 p.m. Sturdee quickened first to 22 and then to 25 knots; at 12.51 the first shots were fired, and a few minutes later the firing became general.

Soon after 1, the German light cruisers parted company with the armoured cruisers and fled S., followed by the British cruisers, while Sturdee with Invincible and Inflexible engaged Scharnhorst and Gneisenau, steaming generally S.E. Sturdee's two ships were now going "all out," and fast overhauled their opponents, who were repeatedly engaged at ranges of 16,000 to 13,000 yards. At 3.30 Scharnhorst was on fire; two funnels had been shot away and the red glow of flame could be seen in her. She struggled on gallantly and received a whole series of lits till at 4.4 p.m. she listed, turned over on her beam ends, and sank at 4.17 with every soul on board.

Fire was next concentrated on Gneisenau, at ranges of 10,000 12,000 yards. She had been much damaged in the earlier part of the action; now her second funnel was knocked over; and at 5.30 she was badly on fire with steam and smoke pouring from her. Just as the British ships were about to close, supposing that she had ceased resistance, she discharged 
several shots, and they resumed their fire At 5.45 her 8-in. ammunition was exhausted; ten minutes later she heeled over sud. denly as her sea-cocks had been opened, and she sank very quickly. Of her crew of over 800 only 94 officers and men could be rescued from the icy water.

Leipzig and Nürnberg were sunk in separate actions by the smaller British cruisers, and 25 of their crews were saved. Dresden was able to escape temporarily, but on March 14, 1915, she was caught by Glasgow and Kent off Juan Fernandez, in the Pacific, and was destroyed in Chilean waters, on the ground that she had been guilty of grave infractions of Chilean neutrality; most of her crew escaped. Thus von Spee's squadron was wiped out with a loss of 2,100 men.

The British loss in the battle cruisers was nil, though Invincible washit 22 times, twice below water, and Inflexible thrice. In Kent, four were killed and 12 wounded by a single hit; in Glasgow, one was killed and 4 were wounded. The strategy which brought overwhelm. ing force to bear was of extraordinary merit, and rendered the battle tactically a military execution. See The Navy in Battle, A. H. Pollen, 1918; Falklands, Jutland, and the Bight, B. Bingham, 1913; The Official History of the Great War, vol. i, Naval Operations, J. Corbett, 1920.

\section{H. w. Wilson}

Fall. Word used in several senses, all with the idea of dropping down. It is used in wrestling, also for the descent of a river, and the surrender of a fortress. In America it is used for autumn, the time of the fall of the leaf. In the plural it is a common abbreviation for waterfall, e.g. Niagara Falls. See River; Waterfall ; Wrestling.

Fall, THE. Defection of the first human beings from a state of innocence. This is represented in the Eden story as an act of wilful disobedience to a command of God at the instigation of the serpent. As a consequence, Adam and Eve became conscious of guilt, and were expelled from the Garden of Eden. Theology teaches that the disobedience of our first parents had a threefold consequence in (1) a change of man's relation to God; (2) the loss of certain privileges connected with that relation; and (3) the beginning of a degenerative process which tended to make human nature more and more corrupt and alienated from God.

From this results the doctrine of original sin-that all men are born in a state of sin and are prone to wickedness as a result of Adam's fall. This may be viewed in two ways. Adam was the representative man, and with Eve constituted the whole human family; so that the whole race fell in him. Or it may be viewed in connexion with theories of heredity, and sin be regarded as a mental and moral tendency transmitted by natural generation. In any case, all orthodox theologians hold that original sin infected the race in all its individuals, and could only be removed by the act of God in Redemption through Christ.

In recent theological development there is a tendency to question the foundation on which the doctrine of original sin depends. This criticism rests on the following grounds: (1) the assumption that the human race started in a state of perfection is in conflict with the findings of modern anthropology and is difficult to reconcile with the doctrine of evolution; (2) the account of the Fall in Genesis does not contain the doctrine; (3) there is no definite trace of the doctrine in the rest of the O.T.; (4) the doctrine of original sin was the creation of the intermediate period between the O.T. and N.T., and first appears in Ecclesiasticus ; (5) there is no hint of such a doctrine in the teaching of Jesus ; (6) it is doubtful whether Paul accepted the full implications of the theory, though it must be admitted that there is one statement in his epistles (Rom. $\nabla, 12$ ) which seems to contain it; (7) the theory is difficult to reconcile with a true conception of Divine justice on the one side and human responsibility on the other. See Sin ; consult also The Origin and Propagation of Sin, F. R. Tennant, 1902.

Fallacy (Lat. fallax, likely to deceive). Term meaning in general a false or mistaken belief or opinion ; in logic, a process of reasoning at variance with the recognized rules of the syllogism.

Fallacies may be verbal, real or material, formal (paralogisms). The commonest verbal fallacies arise from the use of ambiguous terms, words used in two different mean. ings ; thus, the word agreeable may be used of an occupation or of a pleasant-mannered person. Am. phibology is the use of an ambigu. ous phrase or proposition. Similarly, the meaning of a word may be altered by its position in a sen. tence and by the accent or stress laid on it.

Among material fallacies are petitio principii, begging the question or arguing in a circle, where the very thing which it is desired to prove is assumed at the outset; ignoratio elenchi, ignorance of the elenchus, in which an attempt is made to prove or disprove someshing irrelevant to the question at issue. Formal fallacies consist in violating the rules of the syllogism. Similarly, fallacies occur in the process of inductive reasoning. See Induction; Syllogism; consult also Logic, R. Whately, repr. 1851 ; Fallacies, H. Sidgwick,1883.

Fallières, Clf́ment Armand (b. 1841). French statesman. Born at Agen, Lot-et-Garonne, Nov. 6,

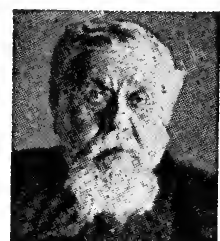

Armand Fallières,

French statesman
1841, he studied law in Paris, and became a barris. ter at Nérac, for which he was elected republican de. puty, 1876. $\mathrm{He}$ was under-secretary for the interior in

Ferry's ministry, 1880, minister of the interior in $1882,1887,1889$, of justice in 1887, of education from 1883-85, and president of the council in 1883. A senator in 1890 , he was president of the senate from 1899 1906. He was elected president of the republic on Jan. 17, 1906, defeating Paul Doumer. Among the chief events of his term of office, which ended Jan. 7, 1913, were his visit to England in May, 1908, and the cementing of the FrancoRussian alliance. Pron. Falli-yare.

Falling Sickness. Old name for the disease now generally known as epilepsy (q.v.).

Falling Stars. Name given of old to meteorites. There are many references in literature, for example, Shakespeare's Beatrice declared "A star danced, and I was born." See Meteors.

Fallopian Tubes. Two tubes, one on each side of the uterus or womb, which convey the ova or eggs from the ovary to the uterus. Each tube is about 4 ins. in length. The inner end opens into the uterus near its superior angle. The outer end opens into the peritoneal cavity, and terminates in an extremity in close relation to the ovary, and bearing a number of fimbriae or fringe-like processes.

Fallopius or FaLLOPIO, GabRIELLO (1523-62). Italian physician and anatomist, discoverer of the functions of the Fallopian tubes. Born at Modena, he studied medicine at Ferrara and other centres, becoming professor of anatomy at Ferrara. Afterwards he held the chairs of anatomy, surgery, and botany at Padua university, where he died Oet. 9, 1562. He published in 1561 his $\mathrm{Ob}$ servationes Anatomicae at Venice, where his works, Opera Genuina Omnia, were published in 1584. 
Fallow. Saxon word meaning reddish or buff-coloured, used to describe ploughed land without a crop. Before root-crops were known and artificial manures in use, land exhausted by the growth of crops was given a rest, and was then said to be in bare fallow. Proper tillage of a fallow cleans the soil thoroughly from weeds, while the air and water circulating in the soil gradually convert dormant plant-food into soluble and avail. able forms.

Land does not 'require a rest, as was formerly supposed, and the practice of allowing it to become overgrown with natural vegetation was a great mistake. On land which is very heavy, or full of weeds, bare fallowing is still practised; but in modern agriculture fallowing is replaced by the growth of rootcrops or kale or rape, which do not interfere with cleaning operations, and allow of replenishment of plant-food by suitable manuring. When the crop is fed off on the land, with an added ration of cake, the resulting manure keeps up the supply of plant-food in the soil. Half, bastard, or rag fallowing consists in letting a seed crop persist for two years, cultivation following when the hay has been carried, or the best of the keep eaten off by stock. See Agriculture.

Fallow Deer. Small group of deer, characterised by having antlers round at the base and palmated above. They have small heads, rather large ears, and comparatively long tails, and usually stand about $3 \mathrm{ft}$. high. The hair is generally fawn colour, more or less dappled with white, but some local races lack the white spots, and are of such dark brown as to approach black. This is the deer generally kept in parks in Great Britain, and it occurs in a wild state in Epping Forest. It was probably introduced into Great Britain from the Mediterranean district at some early period. The huge extinct deer of Ireland, often erroneously called the Irish elk, was a gigantic species of fallow deer, and stood $6 \mathrm{ft}$. high at the shoulder, with antlers spanning over $11 \mathrm{ft}$. Its remains are also found in England and Scotland. See Deer; also illus. p. 472.

Fallowfield. Suburb of Manchester. On the S. of the city, it is mainly a residential district. It has a station on the G.C. Rly., and is also connected with the city proper by tramways. Pop. of dist. 3,316. See Manchester.

Fall River. City of Massachu. setts, U.S.A., in Bristol co. On Mount Hope Bay, 50 m. S.S.W. of Boston, it is served by the New

York, New Haven, and Hartford Rly., and by an inter-urban electric system. It has a commodious harbour, is among the leading producers of cotton goods in the country, and manufactures calico, woollens, boots and shoes, hats, pianos, and machinery. There are also brass and iron foundries, and granite is largely worked in the neighbourhood. Abundant water-power is obtained from Fall River. Among the principal buildings are the custom-house and the state armoury. Forming part of Freetown down to 1803 , it was called Troy until 1834, and received a city charter in 1854. Pop. 129,630.

Falmouth. Mun. bor., seaport and market town of Cornwall, England. It stands at the mouth

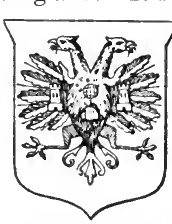

Falmouth arms of the Fal, $11 \frac{3}{4} \mathrm{~m}$. by rly. S. of Truro, on a branch of the G.W.R. It is an important port of call, and has an excellent harbour, accessible to the largest vessels. The two dry docks have been recently deepened by $4 \mathrm{ft}$., and pneumatic plant and electric welding apparatus in. stalled, and large vessels can now put in for repairs. A new dry dock to accommodate vessels of length $720 \mathrm{ft}$., beam $90 \mathrm{ft}$., and draught $28 \mathrm{ft}$., was under construction in 1920. Shipbuilding and engineering, brewing and rope-making are prominent industries, and there is a considerable pilchard fishery. Falmouth exports tin. Its mild and equable climate and the scenery of the Fal valley make it a favourite watering-place. Here are the headquarters of the Royal Cornwall Yacht Club. The corporation maintains the markets, library and pleasure grounds. Great improvements have been made along the sea front, a sub. tropical garden having been laid out and a concert pavilion erected. Market lay,Sat. Pop. (1921) 13,318.

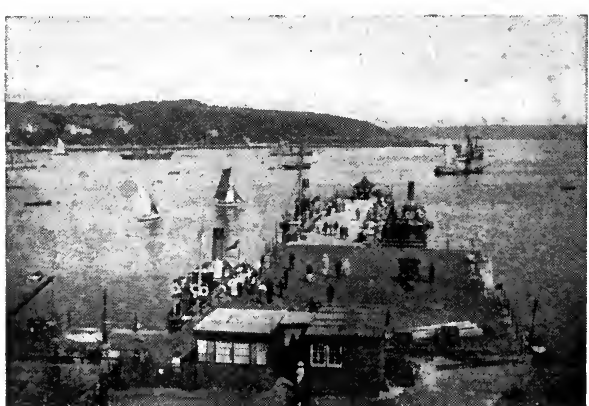

Falmouth. Prince of Wales pier, opened in 1905, from which all steamers start
Falmouth. British light cruiser. She was torpedoed in the North Sea, Aug. 19, 1916. Belonging to the Weymouth type, and completed in 1911 , she was $430 \mathrm{ft}$. long, $48 \frac{1}{2} \mathrm{ft}$. in beam, displaced 5,250 tons, and had engines of 23,500 h.p., giving a speed of $25 \mathrm{knots}$. She carried eight 6 -in. and nine smaller guns.

Falmouth, VIscount. British title borne by the family of Boscawen since 1720 . The family is an old Cornish one, members of it having possessed Boscawen-Rose in the time of King John. Several Boscawens were M.P.'s for Cornwall, and in 1720 one of these, Hugh, was made a viscount. The title passed to his son and grandson and came in 1808 to Edward Boscawen, who in 1821 was made earl of Falmouth. When his son, the 2nd earl, died in 1852 the earldom became extinct, but the viscounty passed to a cousin, Evelyn. The latter's son, Evelyn, the 7th viscount, succeeded in 1889 . He inherited from his mother in 1891 the ancient barony of Le Despencer and saw service in Egypt, 1880-85. In 1918 his son, Evelyn Hugh, became the 8 th viscount. The family seat is Tregothnan, 'Truro.

False Acacia (Robinia pseud. acacia) or Locust-TREE. Tree of the natural order Leguminosae,

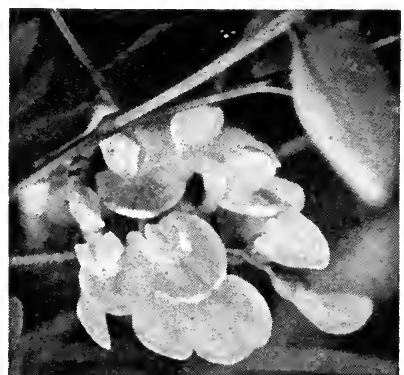

False Acacia. Flower of the Locusttree of N. America

native of $\mathrm{N}$. America. It attains a height of $60 \mathrm{ft}$. to $80 \mathrm{ft}$. Its long, narrow leaves are broken up into 5-12 pairs of oval leaflets, and at the base of the leafstalk are two stipules which, on the non-flowering branches, be. c o m e hardened into persistent spines. The fra. grant flowers are produced in long, pendant sprays, like those of the laburnum, but are white instead of yellow. 'The seed. pods, too, are like 
those of laburnum, but dark red in colour. The wood, though hard and durable, is liable to erack and is little used.

False Antiquities. Relics of the human past fraudulently forged, deliberately falsified, or erroneously attributed. The chief motives for their production are desire for gain and love of mystification.

The production of copies of genuine originals (coins, scarabs, paintings, porcelain) with a fraudulent intention is on a different plane. To a special category should be referred such literary deceptions as Bertram's fabrication (see Bertram, Charles Julius). Among famous modern forgeries are those of Shapira, a Pole, who sold a collection of spurious Moabite pottery to the Prussian government for $£ 3,000$, and afterwards offered the British Museum an alleged Mosaic MS. on leather, The Louvre Museum, Paris, acquired, in 1896, for $£ 8,000$, a gold tiara inscribed to a Scythian king, Saitarpharnes, which was found in 1903 to have been produced in Odessa by a Russian workman. In 1908 scarabs, purporting to record the circumnavigation of Africa under Pharaohnecho, led to a conviction for fraud.

Prehistoric remains have furnished the forger with a profitable field. Fifty years ago chipped flints were openly manufactured by Edward Simpson (Flint Jack). Meillet of Poitiers published grotesque palaeolithic engravings in 1864 .

Experts allow themselves sometimes by self-deception to attribute antiquity to modern relics, as when W. Bode acquired for Berlin in 1909 a wax bust made by an English sculptor, Lucas, and claimed it as the work of Leonardo da Vinci. See Literary Forgery ; consult also Archaeology and False Antiquities, R. Munro, 1905 ; Forged Egyptian Antiquities, T. G. Wakeling, 1912.

False Bay. Inlet of the Atlantic Ocean, on the E. side of the Cape of Good Hope. The Cape of Good Hope and Hangklip Cape form the W. and E. extremities. Its length is $22 \mathrm{~m}$. and its breadth $23 \mathrm{~m}$. It was much used as a rendezvous for the Cape Squadron.

False Point. Cape and port of India. In the Cuttack District of Bengal, the cape is on the Mahanadi estuary, and is situated in $20^{\circ} 20^{\prime} \mathrm{N}$. and $86^{\circ} 47^{\prime} \mathrm{E}$. It is so called from being mistaken by seamen for Point Palmyras, $1^{\circ}$ farther N. The port (opened 1860) has the best harbour between Bombay and Calcutta, and has canal communication with the interior of Orissa.

False Pretences. Term used in English law. It is a misdemeanour at common law to obtain or at- tempt to obtain money or property. by false pretences. The pretence must be false ; it must be a statement of fact and not merely of intention; the person making it must know it to be false; by it the other person must be induced to part with the money, etc., and it must be done with intent to defrand. The pretence may be made otherwise than by words-e.g. a man in an undergraduate's cap and gown enters a shop in Oxford and obtains goods on credit. He has represented himself to be an undergraduate of the university. A person enters a restaurant, and orders a meal value five shillings. He has represented that he has five shillings wherewith to pay. It must be distinguished from larceny by trick. See Larceny.

False Relation. In harmony, one note following a different note of the same letter in another part, e.g. C sharp in alto followed by $\mathrm{C}$ natural in tenor, in successive chords. It is not permitted in strict harmony, but is condoned if, using the above example, both parts have $\mathrm{C}$ sharp in the first chord.

Falsetto (Ital.). Term applied to a kind of high voice of men, who discard the natural pitch of speaking and singing in order to cultivate extreme high notes and sing an alto part. It is produced, according to some, by allowing only a short length and a portion of the breadth of the vocal cords to vibrate, in. stead of the whole. There are a few natural adult alto voices, but most choir singers who adopt this part are baritones or basses, using their falsetto range. See Voice.

Falsification. Term meaning making false. It is chiefly used in connexion with accounts. The falsification of accounts by a clerk or servant with intent to defraud is by English law a misdemeanour punishable by penal servitude. It is also an offence to falsify the service certificate of a seaman or soldier. Some forms of falsification come under the heading of forgery (q.v.).

Falstaff. Comic charaster in Shakespeare's King Henry IV and The Merry Wives of Windsor. In the former the fat knight is the boon companion of Prince $\mathrm{Hal}$; in the latter he is the dupe of Mistress Ford and Mistress Page, whom he courts with the intention of making money out of them. His boastfulness, cozening, drunkenness, and cowardice are balanced by his wit and gaiety. See illus. p. 58 .

Falster. Island of Denmark. It lies to the $\mathrm{S}$. of Yealand, between Laaland on the E. and Moen on the W., separated from them by narrow straits. It is $28 \mathrm{~m}$. from N. to S., with a maximum width of $15 \mathrm{~m}$. The surface is fairly level, but low and marshy near the coast, where malaria is endemic. The island is fertile and cultivated; stock-raising, dairy farming, and agriculture are the principal occupations: Sugar-beet and fruit are the chief crops. The largest towns are Nykjöbing and Stubbekjöbing, connected by rly. Area, $183 \mathrm{sq}$. m. Pop. 34,436.

Faluns (Fr.). Series of loose, sandy shell-beds, of Miocene age. They occur in the Touraine area of the S.W. part of France. Of marine, shallow-water origin, they often contain numerous fossils.

Fama Clamosa (Lat., crying report). Term used in Scottish Church law for any public seandal against a minister with which the authorities find it necessary to deal. The charge must be maintained by some responsible person who is prepared to prove it, or it must be a matter of such notoriety that no special complainant is necessary before it can claim official notice.

Famagusta (Lat. Fama $A u$ gusta). Seaport of Cyprus. It stands on the E. coast, $3 \mathrm{~m}$. S. of ancient Salamis. The cathedral of $\mathrm{S}$. Nicolas and a castle are notable features of the town. The harbour improvements were finished in 1906 , and a narrow gauge rly. connects the town with Nicosia and Evrykhou (76 m.). Agriculture is the chief occupation, and the town is noted for its pomegranates. The original Roman walls were strengthened by the Genoese and Venetians, and are still fairly well preserved. Here, in 1191, Guy de Lusignan (q.v.) was crowned king of Cyprus by Richard I. The town flourished under Venetian rule (1487-1571), but later was taken by the Turks, when its prosperity began to decline. An earthquake in 1735 destroyed it. Pop., including the village of Varashia, 5,327.

Famars. Village of France, in the dept. of Nord. It is $3 \mathrm{~m}$. S. of Valenciennes and was captured on Oct. 26, 1918, by troops of the 5lst Highland division in the fight for Valenciennes. See Sambre, Battle of the; Selle, Battle of the.

Famennian. Uppermost stage of the Devonian system of stratified rocks. It is well developed in Belgium and northern France, where it consists of fossiliferous shales and sandstones, and in Rhineland, where limestones also are developed. Beds of slate near Ashburton and the Petherwin beds near Dartmoor belong to this staga. The name is taken from the slates of Famenne (Belgium).

Familiar (Iat. familiaris). In the Roman Catholic Church, a person who belongs to the household of a pope or bisbop. He must at 
least reside in the same diocese. The office became at one time an easy ladder to ordination and prefer. ment. Consequently, the council of Trent decreed that a familiar could not be ordained by his bishop unless he belonged to the same diocese and had lived with him three years. Familiars of the Holy Office were officials of the Inquisition charged with the duty of arresting and imprisoning persons suspected of heresy or other offences against the spiritual authority. The name is explained by reference to their admission into the confidence of the Holy Office, as members of the family. (See Inquisition.)

Familiar was also the term ap. plied to the spirit supposed to be in the service of necromancers and witches, incarnate sometimes in the form of a black cat or other animal. In this instance the idea was derived from the universal belief in a daemon, tutelar genius, or guardian angel associated with an individual from the moment of birth. See Demonology.

Famille Jaune (Fr.). Much of the finest old Chinese pottery is classified into family coloured groups, according to the predomin. ating tints used. The most esteemed are the famille rose, noire, jaune, and verte (rose, black, yellow, green). See Pottery.

Family (Lat. familia). Group comprising father and mother, with their offspring. The unit of human society, its roots are traceable in the primeval life of mankind.

The first modern attempt to elucidate the origin of family life was Maine's patriarchal theory (1861). Based on Roman models, it assumed that the primitive father possessed uncontrolled power, the patria potestas, over his household. This view was impugned by MacLennan (1865), who postulated a primeval promiscuity, out of which emerged matriarchy, attributed to uncertain paternity; and exagamy, due to the theoretic kinship of the maternal clan; while communal marriage ultimately broke up into polyandry and polygyny. Working on similar material Lewis Morgan (1870) observed that in primitive communi. ties it was more customary to denote kinship by "classificatory" than by "descriptive" terms. The main classes were five in number, a man using the same words for all persons within the clan of the generations of his grandparents, parents, brothers, children, and grandchildren respectively. These systems were hailed as further evidence of a stage of communal marriage preceding the growth of family groups.
Westermarck (1891) reverted to Darwin's view (1871) that the family was from the beginning based upon the supremacy of the individual father. When the " matrimonial classes " of the Australian aborigines, based on the totem, were studied by Spencer and Gillen, Howitt, and others, they were held to point to a primitive form of group-marriage. Subsequently Atkinson and Lang (1903) suggested that the prohibition of marriage within an incest-groupwhence exogamy sprang-was due to the jealousy of the sire. The theory of promiscuity is inconsistent with the evidence ; the widespread variants of the normal family are explicable on other grounds.

In polygynous societies the family is composed of sub-families, which under the system of concubinage tend to become subordinate to that of the chief wife. The closer social relationship of the mother with her own children obscures the paternal status; one outcome of this is the toleration of union with the half-sister, e.g. Abraham and Sarah.

The matriarchal system, imposing rights and duties towards the child, first upon the kinship group, and afterwards, as their representative, upon the mother's brother, is a widespread social device for securing the observance of tribal law. It may be reasonably attributed to the beginnings of agriculture at the end of the neolithic age, having been found in Europe by the Aryan-speaking peoples who spread westward, bringing new conceptions of fatherright that lay at the base of patriarchal society. This view is confirmed by the matriarchy of early Egypt, and by the fact that patriarchy was well established at the dawn of Semitic history, which antedated the Aryan family.

In aboriginal America, where social organizations were developed on the neolithic foundationbrought from Eurasia, the family -in the sense of the homestead or "house. fire" - is traceable at every cultural level. See Kinship; Marriage; Society.

Family. In zoological classification, term used for a group of genera which resemble one another, but are not marked by such im. portant distinctive features as to justify making them into an order. For example, the domestic dog belongs to the genus Canis, which, with three other living genera and several extinct ones, is included in the family Canidae, or dog-like mammals; and this family forms one of the groups of the order Car. nivora, or flesh-eating mammals.
Family Compact. Arrange ments made in the 18th century between the kings of France and Spain for the maintenance of an alliance between them, the Bourbons being the family then ruling over both countries. There were three of these compacts. On Nov. 7, 1733, France and Spain signed a secret treaty directed against Austria, with whom war quickly followed. In Oct., 1743, this alliance was renewed in a new family compact, directed mainly against Britain, with whom Spain, but not France, was then at war. War with France quickly followed. A third was made in 1761, when the Seven Years' War was raging. By this Spain entered the war.

The term family compact was applied to the domination of Upper Canada or Ontario, by a narrow circle of men, attached to England and the English church, in the early 19 th century.

Family Herald, The. London weekly journal of useful information and amusement, "interesting to all ; offensive to none," founded in Dec., 1842, and the first periodical to be produced entirely by machinery. Until May, 1843, it was issued as a broadsheet, when the patent machinery was given up. The Rev. James E. Smith, M.A., the universalist, was its first editor. See "Shepherd" Smith the Universalist, W.Anderson Smith,1892.

Family of Love or FAMILISTS. Religious sect, founded by Henry Niclaes, or Nicholas (c. 1502-80). Influenced by the mystical teachings of David Joris (1501-56), he claimed to be a recipient of divine revelations. The sect made its way to England in the reign of Edward VI, and had a few scattered followers. They taught that no one outside their sect could have a true knowledge of God; gave all the chief doctrines of Christianity a purely allegorical interpretation; and were extreme antinomians in practice as well as in theory. They became extinct about the middle of the 17th century.

Famine (Lat. fames, hunger). Period of want or scarcity of food supplies, usually confined to a more or less restricted locality. Its chief primary cause is deficiency of rainfall, but floods, frosts, storms, visitations of insects or other pests, inadequate agricultural methods, illdirected labour, deficient transport, and the ravages of war are contributory causes. Neglect in the storage of food frequently brings about famine among primitive peoples, but it is sometimes to be accounted for by less obvious reasons, such as wholesale deforestation, which gives rise to local 

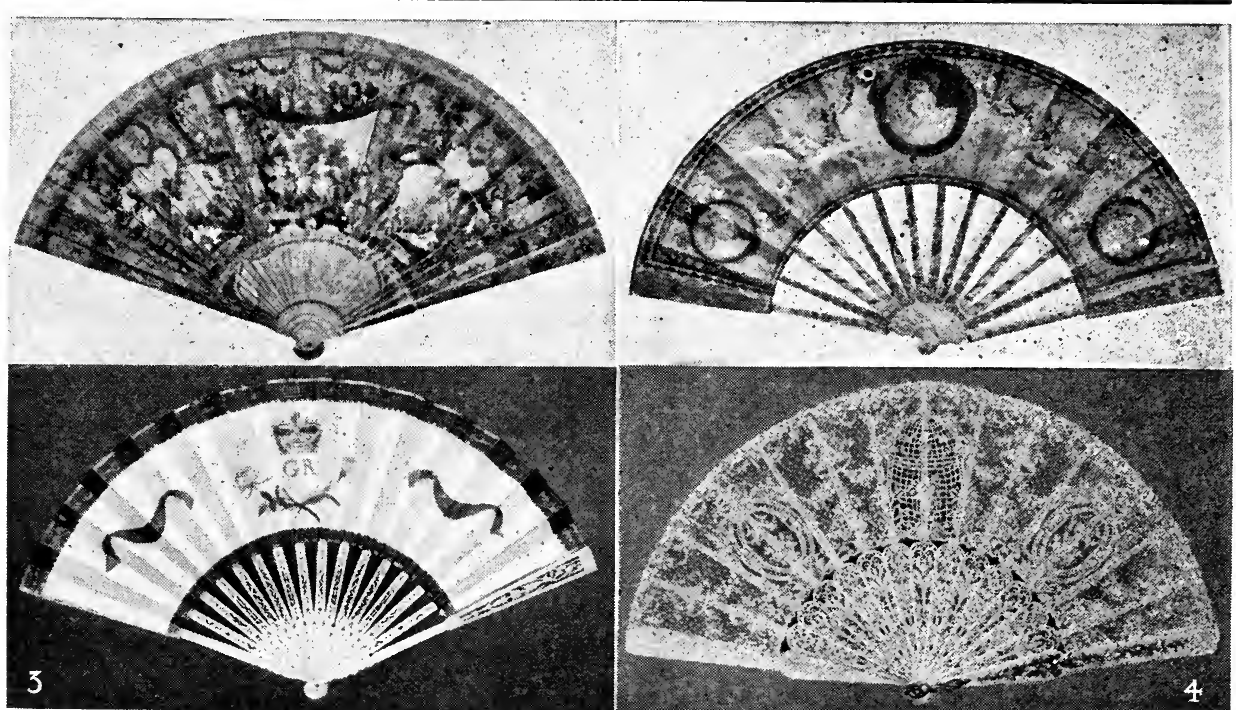

Fan. Examples of delicate and artistic work. 1. Richly painted gilt fan, decorated in Vernis Martin lacquer, period of Louis XIV, formerly belonging to Queen Victoria. 2. Silk fan with medallions painted by F. Boucher (1703-70). The ivory stick is carved and enriched with gold. 3. English fan made to commemorate the recovery from illness of George III in 1789, now in the British Museum. 4. White lace fan mounted on mother-of-pearl, formerly belonging to the Empress Eugénie

conditions of drought, and the dependence of a race upon one kind of food, as maize in S. America, rice in China, or the potato in Ireland.

Although scarcity is only partially preventable, the careful organization and governmental supervision of agricultural production in most parts of Europe and America has virtually freed civilization from the dread of starvation in normal circumstances. But all the foresight and accumulated experience of man is by no means equal to combating the conditions of serious dearth which follow prolonged hostilities. During and after the Great War of 1914-18 famine spread widely throughout Europe, especially in Russia, Germany, Austria, the Balkans, Czecho-Slovakia, and certain parts of France and Belgium.

The greatest recorded famines nccurred at an early period in history, when the world was entirely dependent upon local and circum. scribed supplies. In 439 B.c. Rome was visited by a famine so severe that thousands cast themselves into the Tiber. In Egypt famine lasted, 1.D. 1067-72, while in 1005 Saxon England, and eleven years later the whole of Europe, experienced a prolonged period of terrible dearth. Another great European famine occurred in 1162 , driving the population in many countries to cannib3lism and brigandage. Ireland has frequently suffered from periods of scarcity, especially severe visitations occurring in 1491,
1822, and from 1846-47, when the potato crop failed with conse. quences of the most disastrous kind, thousands perishing from the "famine fever" which followed. In the period of dearth which fol. lowed the 'Thirty Years' War in Germany multitudes perished from hunger.

Chiefly through its liability to conditions of drought, the East has been peculiarly susceptible to famine. In 1877, 1888, and again in 1920 , $\mathrm{N}$. China suffered from appalling famine. India has, perhaps, more than any other country experienced frequent dearth over widespread localities. Native records speak of disastrous famines in $450,941,1022,1033,1052-60$, 1344-45, 1396-1407, 1631, 1769-70, when $3,000,000$ people perished; 1782-84 and 1790-92. Later ones were in 1866 , when over a million natives perished; 1869 , when $1,500,000$ died ; 1877, 1897, and in 1899-1900, when the loss of life was estimated at 1,000,000.

Famine Fever. Popular name for rulapsing fever (q.v.).

Fampoux. Village of France, in the dept. of Pas-de-Calais. It lies slightly $\mathrm{N}$. of the river Scarpe, $5 \mathrm{~m}$. E. of Arras. It was stormed by the British, April 10, 1917. Severe fighting took place here in April, 1918, and at the end of Aug. in the same year the British in their great offensive advanced $\mathrm{E}$. of it See Arras, Battles of.

Fämund or Faemund. Lake of Norway, in Hedemarken, near the
Swedish border. It lies in a mountainous district, at an alt. of 2,199 ft., $85 \mathrm{~m}$. S.S.E. of Trondhjem. It is $37 \mathrm{~m}$. long from N. to S., with a maximum width of $5 \mathrm{~m}$.

Fan (Lat. vannus). Implement for agitating the air, especially used for cooling the face. Fans have been used from the earliest ages in hot countries, and in their primitive form they were made of feathers stuck into long handles. In Europe they came into general use in the 16 th century, and wero known as early as the 14th century, having probably been introduced from the East. They were usually made of feathers, straw, silk, etc., with handles of ivory, gold, silver, and wood, often richly carved and encrusted with precious stones.

The folding fan, an invention of the Japanese, was adopted in Europe towards the end of the 16th century. Fan painting became an art in the middle of the 17 th century, and printed fans, illustrating pastoral scenes, and reference to politics, etc., also became the vogue. Fans have always played a sym. bolic part in ceremonial, and even now are used in the East, and are carried on state occasions in papal processions in Rome. See Punkha; consult also Fans and Fan Leaves, collected and described by Lady Charlotte Schreiber (English), 1888 and (Foreign) 1890; History of the Fan, G. W. Rhead, 1910.

Fan Painting. Both folding and non-folding fans have been the object of elaborate decoration. 
Antoine Watteau, Nicolas Lancret, Jean Baptiste, Joseph Pater, François Boucher, and other 18th "eentury French artists produced fans of incomparable beauty. Among English artists who have practised the art the most notable was Charles Conder (1868-1909), who in this genre was no mean rival of Watteau himself.

Fan. In industry, a revolving wheel to move air or gas. To an axle, usually horizontal, is at. tached a series of vanes or blades, which may be flat or curved, the whole being enclosed in a casing of volute shape having a central open. ing for admission of the air or gas, and an opening in the circumference for the delivery of the air.

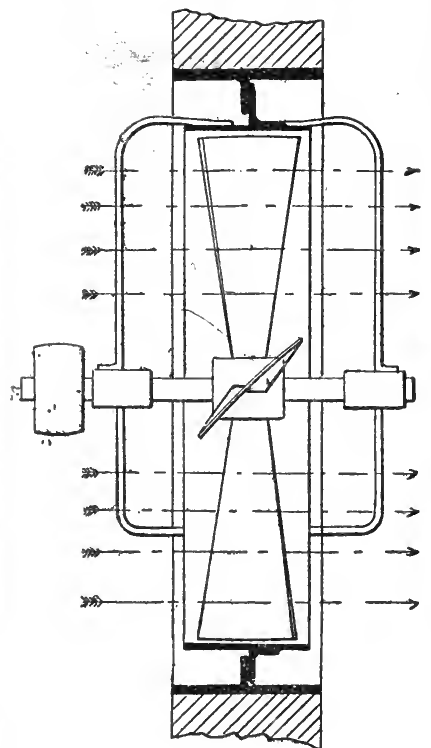

Fan. Propeller, wing, or tunnel type for moving large volumes of air at low pressure for ventilating, drying, or removing noxious fumes

When air enters it is caught by the vanes, whirled round with them, and thrown by centrifugal action to the circumference while it acquires the velocity of the revolving vanes. This combined action carries the air out through the discharge opening with a velo. city and at a pressurc determined by the size and speed of the vanes. The fan-wheel may be only a few inches in diameter, or it may be 20 or $30 \mathrm{ft}$., as in the case of mine and tunnel ventilating fans.

The volume of air moved by a large fan may amount to 700,000 cubic $\mathrm{ft}$. per minute. Fans are used largely for metallurgical furnaces where only a moderate pressure of air is required, as in the black. smith's fire. The type of fan shown below is known as the centrifugal ; another form, with'vanes set more or less spirally on the axle, the movement of the air being parallel to the axis, is the propeller or tunnel type. See Blowing Engine.

Fanariotes oR PhanaRiotes. Name given to the aristocratic

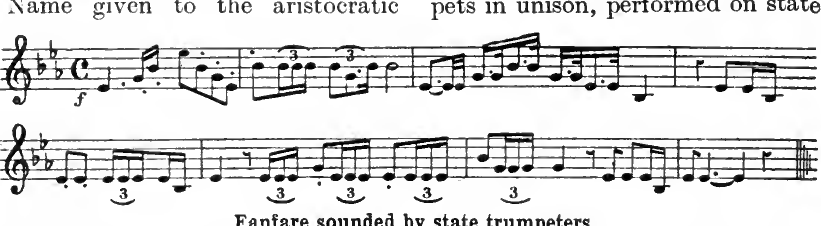

people to triple time. A characteristic rhythm of the music is :

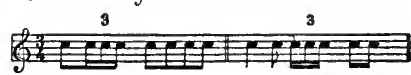

\section{See Castanets.}

Fanfare (Fr.) or Flourish. Properly, a short passage for trum. pets in unison, performed on state
Greek class in Constantinople prominent during the 18th century as governors of the E. European provinces of the Porte. The word is derived from Fanar, the Turkish name for that quarter of Constantinople which was inhabited by Greek residents. Members of this class, by means of a recognized

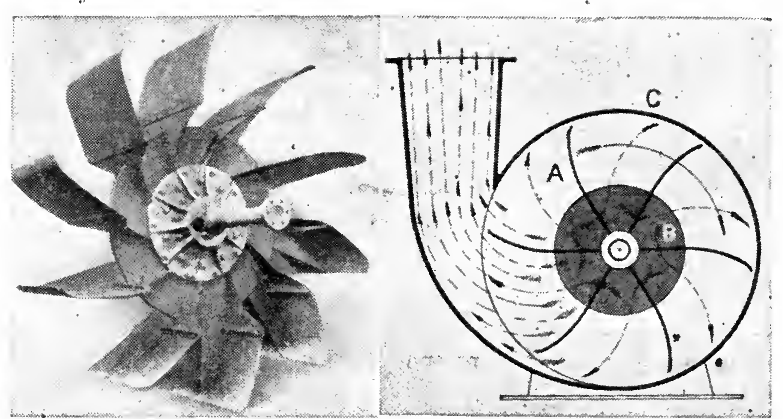

Fan. Standard centrifugal ventilating fan and, right, sectional diagram

$A$, fan-wheel ; B, air-inlet ; C, casing; course of air indicated by arrows system of bribery, obtained no. mination as rulers of principalities such as Wallachia, and set them. selves to recoup their expenses by unscrupulous taxation. The system of appointing fanariotes was dropped in 1821 .

Fancy. Shortened form of phantasy. It means primarily any crea. tion of the imagination. From this it came to be used for an inclination or liking, and thus we speak of fancying anything and have the phrase bird fancier. The fancy is sometimes applied to the adherents of pugilism, while De Quincey uses it for lovers of rare books. Fancy goods as a trade term refers to the lighter and supplementary forms of women's dress, such as ribbons, gloves, veilings, etc., also to handbags and articles used to ornament rooms, such as silver vases, picture frames, and the like.

Fandango. Name of a Spanish dance. It is usually accompanied by castanets to reinforce the strong rhythm, as well as by melodic instruments. It is danced by two occasions. That used at the opening of Parliament dates from the reign of Charles II. Some com. posers have used fanfares in opera, notably Beethoven, Spontini, Am. broise Thomas, and Wagner.

Fang. Specialised teeth in poisonous snakes by which the venom is conveyed into the wound

caused by the bite. In the viper tribe the fangs are channelled, so that the venom, exuding from the tip of the tooth, is conveyed to the deepest part of the wound. In cer. tain other snakes the fang is simply grooved, and most of the venom merely reaches the surface. The fangs may be either at the front of the jaw or at the back, and in the latter case the bite is seldom dangerous to man, though it may be fatal to small animals. The fangs usually fold back against the jaw when not in use. The venom is forced through the fang partly by constriction of the venom bag, partly by pressure on the base of the fang in the act of biting.

Fang or Pangwe. Negro tribe of the French Gabun colony and Spanish Guinea. Their debased Bantu speech, including the Maké dialect, is spoken within the coasthighland region bounded by the Ogowe, Ivindo, and Campos rivers. Well-built, slim, $5 \mathrm{ft} .7$ ins. in height, bronze-coloured, bearded, intelligent, they display Hamitic ele- 
ments, having migrated due $W$. from the valleys of the $\mathrm{N}$. Congo affluents about 1850, driving the weaker aboriginal negroes before them. They are hunters and fishers, using eross. bows and throwing-knives, and are adept potters and ironworkers. The men wear bark waistcloths, the women grass girdles.

Fanmakers' Company. I,ondon eity livery company, incor-

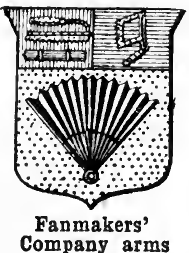

porated A p ril 19, 1709. Its offices are at 19, Great Winchester St., E.C.

Fannich. Loch or lake of Ross and Cromarty, Scotland. Near the centre of the county, it is drained by Fannich Water $\left(6 \frac{1}{2} \mathrm{~m}\right.$. long). The Fannich Mts. (Sgurr Mor, 3,637 ft.) and Fannich Forest $(20,000$ acres) lie to the $N$. of the lake, which is $6 \frac{1}{2} \mathrm{~m}$. long and about $1 \mathrm{~m}$. broad.

Fanning. Coral island in the Pacific Ocean, lying due S. of the Hawaiian Islands in lat. $3^{\circ} 50^{\prime} \mathrm{N}$. and long. $159^{\circ} 20^{\prime} \mathrm{W}$. Administratively it is annexed to the Gilbert and Ellice Islands Colony, and is a station of the submarine cable between Australia and Vancouver. It exports mother-of-pearl, and there are guano deposits. Area, $15 \mathrm{sq} \mathrm{m}$. Pop. 150. The name is also applied to a neighbouring group, viz. Christmas, Jarvis, Washington, and Palmyra, the last being claimed by the U.S.A. The total land area is about $260 \mathrm{sq}$. $\mathrm{m}$. They were discovered in 1798 by Edmund Fanning.

Fanning, EduUNd (1737-1818). American soldier. Born at Long Island, New York, he graduated at Yale in 1757. He became a lawyer in N. Carolina, and occupied various posts in the local government, where his malpractices and subservience to the home government earned for him unpopularity. In 1774 he was made surveyor-general, and in 1777 he raised a regiment to combat the revolution. Colonel in the British army in 1782 and governor of Prince Edward Island in 1787, he became major-general in 1794 and general in 1808. In those years he did some voyaging in the Paeific. He died in London, Feb. 28, 1818.

Fanning, Јонм Тномаs (18371911). American engineer. Born at Norwich, Conn., he was there educated. He became an engineer, but left his profession to serve the North in the Civil War. Returning to his work, he was for nearly fifty years one of the leading authorities on hydraulies, being concerned in the construction of numerous waterworks and similar undertakings in the U.S.A. He was consulting engineer to a large number of schemes for obtaining water and chief engineer of the water-power company at St. Anthony. His work, A Treatise on Hydraulic and Water Supply Engineering, 1877, was long the most authoritative American book on the subject.

Fannius, GaIUs. Roman annalist. He served in Africa, where he and Tiberius Gracchus were the first to mount the walls of Carthage 146 B.C., and in Spain 142. Through the influence of Gaius Gracchus he obtained the consulship 122, but when the former proposed to confer full citizenship upon the Latins, Fannius opposed him in a famous speech. Orator, advocate, and student of philosophy, Fannius was best known for his Annales, a history of Rome from the earliest days down to his own times. The work enjoyed a high reputation, and was used by Plutarch in his Lives of the Gracchi.

Fanny's First Play. Comedy by Bernard Shaw. It was first produced at The Little Theatre, April 19,1911 , where it ran for 624 performances, and afterwards at The Kingsway, Feb. 13, 1915.

Fanö. Island of Denmark. It lies off the S.W. coast of Jutland, and its N.E. point faces Esbjerg on the mainland. It is $11 \mathrm{~m}$. long and from $2 \mathrm{~m}$. to $3 \mathrm{~m}$. broad. There are three small towns on the island: Fanö, a health resort on the W. coast; Nordby, on the N.E. coast; and Sönderho, in the $S$. Fishing is the main industry. Area, 20 sq. m. Pop. 3,000.

Fano (anc. Fanum Fortunae) City and seaside resort of Italy, in the prov. of Pesaro e Urbino. It stands on the Adriatic, $8 \mathrm{~m}$. by rly. S.E. of Pesaro. It is enclosed by medieval walls, with bastions facing the sea. Its cathedral and churches contain many pictures by old mas. ters. The town possesses a fine theatre, formerly a palace, the remains of a triumphal arch of $\mathrm{Au}$. gustus, and a palace of the Malatesta. Fishing is the chief occupation of the inhabitants, and there is trade in corn, oil, and silk. The old harbour has silted up, and shipping is now conducted through a canal to the sea. Here, in 1514, the first printing press with Arabic type was set up. 'The Roman city owed its origin to a temple of Fortune com. memorating the defeat of Hasdrubal on the Metaurus. Pop. 26,928.

Fan-palm (Livistona). Genus of trees of the natural order Palmae. They have large, fan-shaped, plaited leaves, and are natives of Eastern Asia, Malaya, and Austral-

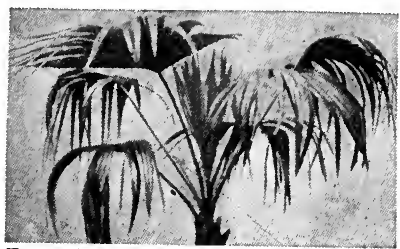

Fan-palm. Foliage of Livistona chinensis asia. 'The best-known species are L. australis, from Eastern Austra. lia, and L. chinensis, from S. China.

Fanshawe, Sir EDward Arthur (b. 1859). British soldier. Born April 4, 1859, and educated at

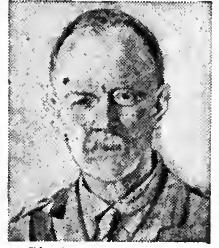

Sir E. Fanshawe,

British soldier

After Francis Dodd Winchester, in 1878 he entered the Royal Ar. tillery, serving in the Afghan War of 1878-80 and in Egypt in 1885 . In 1903 he became a li e u ten ant. colonel and in 1909 was put in charge of the artillery of the 6th division. When the Great War broke out he was commanding the artillery of a Territorial division, but in Sept., 1914, he went to France at the head of a regular brigade, the 6 th. In 1915 he took command of the cavalry corps. In 1918 be com. manded the 5th corps, and in 1917 was knighted.

Fanshawe, Sir Richard (160866). English diplomatist and writer. Born at Ware Park, Hertfordshire, after travelling in France and Spain, he was appointed in 1635 secretary to the embassy at $\mathrm{M} \mathrm{ad} \mathrm{rid}$. About 1644 he became secre. tary to the prince of Wales

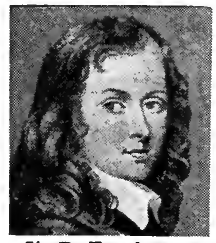

Sir R. Fanshawe, English diplomatist After Harding and in 1648 was made treasurer of the navy under Prince Rupert. He was created a baronet in 1650 . After the Restoration he sat in Parliament for Cambridge University from 1661 until bis death, and undertook various missions to Spain and Portugal. He translated the Lusiad of Camoens, 1655, and Guarini's Pastor Fido, 1647. He died at Madrid, June 26, 1666.

Fan Tan. Chinese gambling game. The implements for playing consist of a bowl full of beans or counters and an oblong card, placed on a table, the corners of which are numbered, or assumed to be numbered, from 1 to 4 : the lower right hand corner being 1 . 
the top right hand corner 2 , the top and bottom left hand corners 3 and 4 respectively. Or, in place of the card a corresponding oblong space is chalked upon the table. Bets are made upon these separate corners, which are decided by the banker taking a handful of beans or counters, and dividing them into fours; the number of odd pieces over deciding the winning number. If there is no remainder, No. 4 wins.

An American variety is played with an ordinary full pack of cards, by any number of players up to eight. One card is dealt to each player, the remainder forming the stock and being placed face downwards upon the table. Each player contributes a fixed stake. Unless an ace has been dealt to him, each player draws a card from the stock in rotation until he obtains an ace; each time he fails to do so, paying an ante or stake, which continues until all four are drawn by one or other of the players. The aces are laid side by side as they are turned up, and the different suits are built upon them, from ace to king. The player who first gets rid of all his cards takes the pool. See Gaming.

Fantasia (Ital.). Musical com. position in which strict form is not exacted, and everything is left to the "phantasy" of the composer. In different centuries and countries, this term and similar onesfancy, fantasie, rhapsody, phantasy, etc.-have denoted greatly varying types of music, but all possessing the idea of freedom from the more formal designs of their periods and surroundings. These terms have covered alike the naive old contrapuntal string trios of Or. lando Gibbons (early 17th cent.), the monumental organ fantasias of J. S. Bach (early 18th cent.), and much worthless pianoforte music of the 19th century.

Fanti (cabbage-eaters). Negro people in the Gold Coast colonv, W. Africa. They are allied to the Ashanti (q.v.), and their number is estimated at $1,000,000$. They are muscular, round-headed, chocolatehued, of medium stature, and live in small village-communities, and on the coast. Their tribal scars are three lines on each side of the jaw bone. Their Tshi dialect is the dominant speech round Cape Coast Castle. Ceremonial cannibalism formerly prevailed among them.

Fantin-Latour, IGNACE HENRI JEAN THÉODORE? (1836-1904). French painter. Born at Grenoble, Jan. 14, 1836, son of the painter 'Théodore Fantin-Latour, he studied under Boisbaudran and at the Beaux Arts. He began to exhibit at the Salon in 1861, and obtained his first award in 1876. Under the naturalistic influence of Manet and Bastien-Tepage, he achieved a

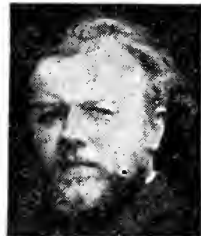

Fantin-Latour

French painter

Self-portrait in $U_{\text {flzi }}$

Gallery, Florence striking triumph with a portrait of the former; an even higher achievement is the portrait of Mr. and Mrs. Edwin Edwards, in the National Gal. lery, London. Simple and unaffected in arrangement, cool and reticent in colour, this picture shows an art refined and exquisitely delicate without departing from naturalistic principles. Fantin was known as an unsurpassed painter of flowers before his genius in portraiture was revealed; in the National Gallery is a study of roses by him. Among his other works may be cited L'hommage à Delacroix (Louvre), Portrait de Mme. Fantin-Labori (Luxembourg), Portrait de l'artiste à 23 ans (Grenoble), and Le Toast. He died at Buré, Orne, Aug. 28, 1904.

Fan-Tracery. In Perpendicular Gothic architecture, the rich tracery of a vault created by spring. ing the stone ribs from their various points of support in such fashion that the effect is that of a spreading fan. There are finely developed examples in Henry VII's Chapel, Westminster Abbey, and in St. Stephen's cloister at West. minster Hall. See Gothic Architecture.

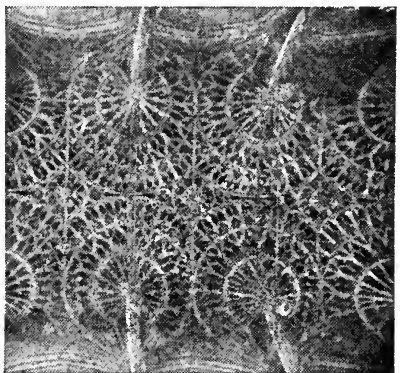

Fan-Tracery seen in the vaulting of Henry VII's Chapel, Westminster Abbey

Fao. Village of Mesopotamia. It lies on the right bank of the Shatt el Arab, about $3 \mathrm{~m}$. from the Persian Gulf, and before the Great War was of some importance as a cable and telegraph station of the Indo-European Telegraph Co. The mud fort erected by the Turks was captured by the British, Nov. 7, 1914 , at the beginning of the opera. tions in Mesopotamia. The forti- fications were afterwards strengthened by the British, who retained it as a sort of naval base through. out the war. Pop. 600 .

Farad. Unit of electrical capacity of an electrical conductor. A capacity of one farad is that which would be raised to a difference of pressure of one volt by a charge of one coulomb. For practical purposes the farad is too large, and a smaller unit-the microfarad, one millionth of a farad, is employed. See Capacity ; Unit, Electrical.

Faraday, Michael (1791-1867). British chemist and physicist. The son of a blacksmith, he was

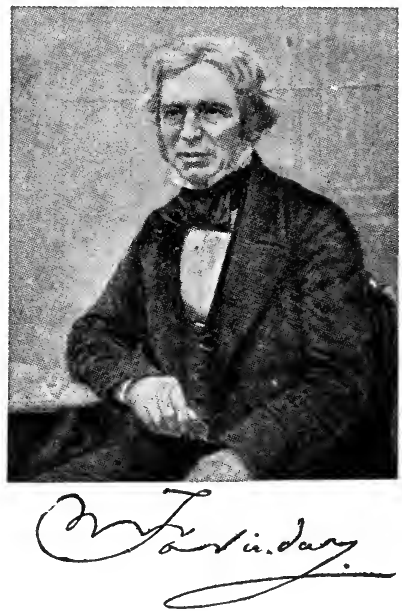

born at Newington Butts, London, Sept. 22, 1791. After a short apprenticeship with a bookbinder, he became assistant to Sir Hum. phry Davy at the Royal Institution. There he quickly showed remarkable ability as an acute observer and original experimenter. In 1813-15 he travelled with Sir Humphry Davy in Europe; ten vears later he became director of the laboratory; and in 1833 he was made Fullerian professor of the Institution for life.

Faraday stands at the head of scientific observers of the 19th century, and his discoveries have left their indelible mark on the progress of mankind. To-day his pointers to the paths of investigation in electricity are still being followed, and results are being obtained in accordance with his brilliant predictions. Faraday's earliest work under Davy was concerned with chlorine, two new combinations of which he discovered. $\mathrm{He}$ followed this up with the liquefaction of a number of gases, and the discovery of new kinds of optical glass. The later discovery was destined to lead to one of his 
most important investigations in electricity, that of magnetic rotatory polarisation in 1846 .

In 1831 he made the discovery of magneto-electrical induction, the forerunner of the modern dynamo, and each succeeding year brought fresh discoveries. In 1833 he proved the identity of electricity from different sources; in 1834 came the discovery of equivalents in electro-chemical decomposition ; in 1838 electro-static induction, followed the same year by the announcement of the relation between electric and magnetic forces; diamagnetism and the magnetic condition of all matter, 1849 ; atmospheric magnetism, 1851.

In 1835 Faraday was given a pension, and in 1858 a house at Hampton Court, where he died Aug. 25, 1867. Deeply religious, a member of the sect known as the Sandemanians, Faraday rigidly separated his religion from his science. In the latter, he was one of the most brilliant experimenters ever known, and to him must be given the credit for the solid foundation of electrical science as it is known to-day. See Lives by Tyndall, 5th ed. 1894; Bence Jones, 1870 ; J. H. Gladstone, 1872 ; S. P. Thompson, 1899.

Faraday's Law. Law discovered by Michael Faraday. In an electrolytic cell the amount of an ion liberated at an electrode is proportional to the strength of the current. An electrical current may thus be measured in terms of the quantity of an electrolyte which it decomposes. See Current; Electricity; Electrolysis.

Faraday Society. Society founded in 1903 in honour of Michael Faraday, to promote the study of electro-chemistry, electrometallurgy, and kindred subjects. Among its presidents have been Lord Kelvin, Sir Oliver Lodge, Sir Robert Hadfield, and Sir Richard Glazebrook. Offices, 10 Essex St., London, W.C.

Faradism or Faradisation. Term for the use of an interrupted current of electricity in medicine. Faradism is useful in cases of paralysis, gout, rheumatism, and neurasthenia. See Electricity.

Farce (Fr. from Lat. farcire, to stuff). Dramatic piece of an essentially ridiculous character to which extravagant language, caricature, and ludicrous situations may all contribute. The modern farce is more closely connected with the ludicrous element that came to be grafted on to early morality plays, and in time came to be given in separate performances. In its modern sense it is defined by A. W. Ward as the briefer sort of comic play in which a more unrestricted licence of fun is allowed, and a stronger demand made upon the sense of probability.

Modern farce may be said to have started with the plays of Samuel Foote, in the 18th century. In the 19th century the short farcical play as written by Poole, Maddison Morton, F. C. Burnand, and others was highly popular. The word originally meant an interpolation, like an actor's gag, hence a performance in which jests and humorous incidents predominated.

Farcy (Lat. farciminum). Disease affecting horses. It is a form of glanders (q.v.), and as such must be notified to the local authorities.

Fareham. Market town, seaport, and urb. dist. of Hampshire, England. It stands on a creek off Portsmouth Harbour, $8 \mathrm{~m}$. N.W. of Portsmouth and $76 \mathrm{~m}$. S.W. of London, and is a junction on the L. \& S.W. Rly. The chief building is S. Mary's Church, and near are the ruins of Porchester Castle. There is a trade in corn and coal. In medieval times Fareham was a prosperous port, but now it can only be reached by small vessels. It was also a borough, and at one time sent members to Parliament. Market day, Mon. Pop. 9,674.

Farewell. Cape of Greenland, at its southernmost point, in lat. $59^{\circ} 50^{\circ} \mathrm{N}$. It is on a small island off the coast, with an alt. of 1,000 ft. The ice drifting past it from the N.E. towards Davis Strait, in addition to the currents, makes it dangerous for navigators.

Far from the Madding Crowd. Novel by Thomas Hardy, first published in 1874. Ono of the earliest of his realistic novels of Wessex rustic life, it tells of the tragic relations of the woman farmer Bathsheba Everdene with three men, the mid. dle-aged farmer whom she inflames by means of a thoughtless valentine, the worthless Sergeant Troy, whom she first marries, and the fine loyal Gabriel Oak in whose love she eventually finds repose.

Fargo. City of N. Dakota, U.S.A., the co. seat of Cass co. The largest city in the state, it stands on the Red River of the North at the head of steamship navigation, $240 \mathrm{~m}$. N.W. of Minneapolis, and is served by the Chicago, Milwaukee \& St. Paul and other rlys. It contains the state agricultural college, Fargo College, other educational institutions, and several parks. An extensive trade in grain is carried on, and machinery and farming implements are largely dealt in. The manufacturing interests include flour and knitting mills, foundries, and leather goods factories. Settled in 1871, it was incorporated in 1875. A fire in 1893 caused damage estimated at

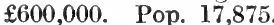

Faridkot. Sikh state of the Punjab, India. In the S. of Ferozepore district, its area is $642 \mathrm{sq}$. $\mathrm{m}$. The ruling family belongs to the Sidhu-Barar clan of the Jats. The E. of the state is irrigated from the Sirhind canal. Pop. 130,294; 42 p.c. Sikhs, 29 p.c. Hindus, 29 p.c. Mahomedans.

Faridpur. District and town of Bengal, India, in the Dacca division. The name is derived from a Mahomedan saint, Farid Shah, whose shrine has been set up in the town. Of the total area of the district, 2,576 sq. m., more than three-quarters is under cultivation. Other crops are jute, the chief export, and pulses. Hand weav. ing is the principal industry. Pop. dist., 2,121,914 ; town, 13,131.

Faridun. Hero of Persian mythology. His story is told in the Sháh-Námeh of Firdusi (Eng. trans. A. Rogers, 1907). Faridun overcomes the dragon tyrant Zuhak and occupies the throne. He is said to have reigned justly for 500 years, and to have gone about the world doing good and planting cypresses and roses.

Farina (Lat., meal). Starchy preparation used for food or in the industrial arts. The food-products of cereal grains and pulses, and starchy stems, roots, and tubers, are collectively called farinaceous. As a synonym for meal or flour the word denotes in N. America white, granular maize meal, finer than hominy, used for puddings, and in S. America starchy breadstuffs with fibrous admixture derived from cassava.

The farina used for sizing cotton textiles is principally potato starch, comprising normally starch $82 \cdot 70$ p.c., cellulose and ash 0.58 p.c., and water $16 \cdot 72$ p.c. It yields a thicker paste, and owing to its sparse nitrogenous matter is less liable to mil dew than any other starch. It is mixed with wheat flour and china clay for stiffening fabrics, and because of its purity is the chief source of British gum or dextrin. Fossil farina or rock-meal is a white crumbly form of calcium carbonate.

Farina; A LEGEND OF COLOGNE. One of George Meredith's shorter stories, first published in 1857. It is an extravagant medieval love romance, telling how it was that the famous scent, eau-de-Cologne, came to be associated with the name of Farina.

Farinelli (1705-82). Professional name of the Italian singer Carlo Broschi. Born at Naples, Jan. 24, 1705, Broschi was a pupil of Porpora, in whose opera, Eumene, he 
made his first appearance in $\mathbf{1 7 2 2}$. This made him famous, and procured him lucrative engagements

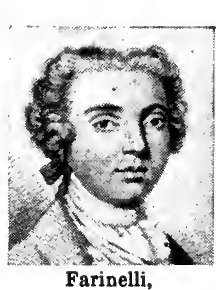

talian sing

From an engraving in Vienna and London. In 1736 he went to Madrid and became a favourite of Philip V. There he remained for 25 years, being loaded with honours and exercising almost regal powers. His last years were passed at Bologna, and he died July 15, 1782. The exceptional beauty and range of Farinelli's voice and his wonderful control over it made him one of the most remarkable singers who have ever lived, if not the greatest of all male soprano singers.

Faringdon. Market town of Berkshire, England, known also as Great Faringdon. A station on the G.W. Rly., it is $13 \mathrm{~m}$. W. of Abing. don and $17 \mathrm{~m}$. S.W. of Oxford. All Saints Church is a large build. ing with brasses and other memorials; among other buildings are the market hall and Faringdon House. The agricultural centre for a large district, Faringdon has a trade in corn, cattle, etc. Market day, Tues. Pop. 3,079.

Faringdon, Alexander HeNDERSON, lsT BARON (b. 1850). British business man and politician. A son of Ge orge Henderson of L a n g h ol m, Dumfries, he was born in London, Sept. 28,1850 . $\mathrm{He}$ bec a me a s t o c kbroker, head of the Ist Baron Faringdon firm of Greenwood \& Co. Having joined the board of the Great Central Rly. in August, 1894, he became chairman of the line, May, 1899. In 1898 he was returned to Parliament as Unionist M.P. for West Staffordshire, but lost his seat in 1906. From 191316 Henderson was M.P. for St. (ieorge's, Hanover Square. In 1902 he was made a baronet and in 1916 a baron, taking his title from Faringdon, near where is his seat, Buscot Park.

Farington, JosepH (1747-1821). British artist and diarist. A prominent P.A. in his day, he is now chiefly noted for his voluminous diaries, which were acquircd by The Morning Post early in 1922 and serialised in that journal. They

abound in anecdote and gossip, and most of the eminent men and women of his time figure in them. The diaries were published in book form in 1922 .

Farini, Luigr Carlo (1812-66). Italian statesman. Born at Russi, near Ravenna, Oet. 22, 1812, he

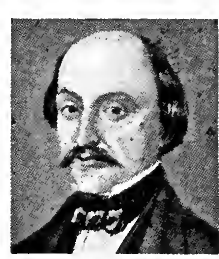

Luigi Farıni. talian statesman early became an ardent na. tionalist, and in 1843 was banished from the papal states. On the election of Pius IX in 1846 he returned to Rome as scereministry of the interior, and later was a p pointed to the department of publich health. On the declaration of the Roman Republic, 1849, he resigned, but, disappointed at the trend of Pius's policy, Farini went to Turin, and wrote his famous Lo Stato Romano dal 1815 al 1850 in 1851 . The same year he became minister of public instruction and an ardent supporter of Cavour, creating a deep impression by his letters to Gladstone on Italian problems. In 1859 Farini was sent as Piedmontese commis sioner to Modena, became dictator of the duchy, and negotiated the transfer of Modena, Parma and Tuscany to Piedmont. Appointed minister of the interior, 1860 , he became prime minister of the new kingdom of Italy, 1861-63, and died Aug. 1, 1866.

Farjeon, Benjamin Leopold (1833-1903). British novelist. Born in London, of Jewish descent, he early migrated to Australia. $\mathrm{He}$ edited a newspaper at Dunedin, New Zealand, before returning to

\section{THE FARM: TYPES AND ORGANIZATION}

J. C. Newsham, Principal, Monmouthshire Agricultural Inst.

This article describes the nature of the farm and its varieties, leaving the subject of its products to articles such as Agriculture; Cattle; Crops. See also Barley; Electro-Culture; Wheat

The word farm, when understood with etymological propriety, can designate only such land and buildings as are rented or held by a tenant, but in ordinary modern usage it may designate also the home farm of a large estate, or the small landed property of one who is himself both owner and farmer. The word itself originally comes from the late Lat. firma, a tribute or fixed payment.

The home farm on a large estate may be run on commercial lines to obtain the greatest profit, or merely to supply farm produce to the family and the immediate
London, where in 1870 he pubished Grif, A Story of Australian was immediately suc cessful. $\quad \mathrm{H}$ is tic and sentimental, frequently dealt with mysteries and the detecmore notable were London's Benjamin L. Farjeon, Heart, 1873; British novelist The Duchess of Rosemary Lane, 1876 ; The House of White Shadows, 1884 ; Toilers of Babylon, 1888 ; Aaron the Jew, 1894; and The Mesmerists, 1900. He died July 23, 1903.

Farley, ЈоHN MURPHy (b. 1842). Roman Catholic prelate. Born at Hamilton, co. Armagh

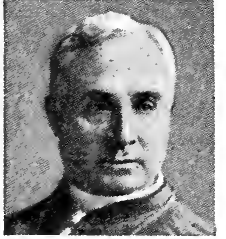

John M. Farley, Irish prelate reland, April 1842, he educated Tew York, and priest, 11, 1870, ant pastor of S.Peter's, New Brighton, StaArchishop private chamberlain to Leo XIII, 1884 ; vicar-general, New York diocese, 1891, and domestic prelate to Leo XIII, 1892. Consecrated 1895, he became archbishop of New , 1902, and was made ardinal, Nov. 27, 1911. He wrote Life of Cardinal M'Closkey, 1900 and a History of S. Patrick's Cathedral, N.Y., 1908.

dependents of the landowner, or as a model to exhibit all that is modern in the way of farmbuildings, and to demonstrate the best methods of husbandry suit. able for the district. The modern tendency is to conduct home farms on purely commercial lines, leaving agricultural colleges, farm institutes, and schools of agriculture to experiment and demonstrate in all matters pertaining to the advancement of agriculture.

The Great War resulted in many small patches of pasture land in the British Islands being brought under the plough. Thus farms are 


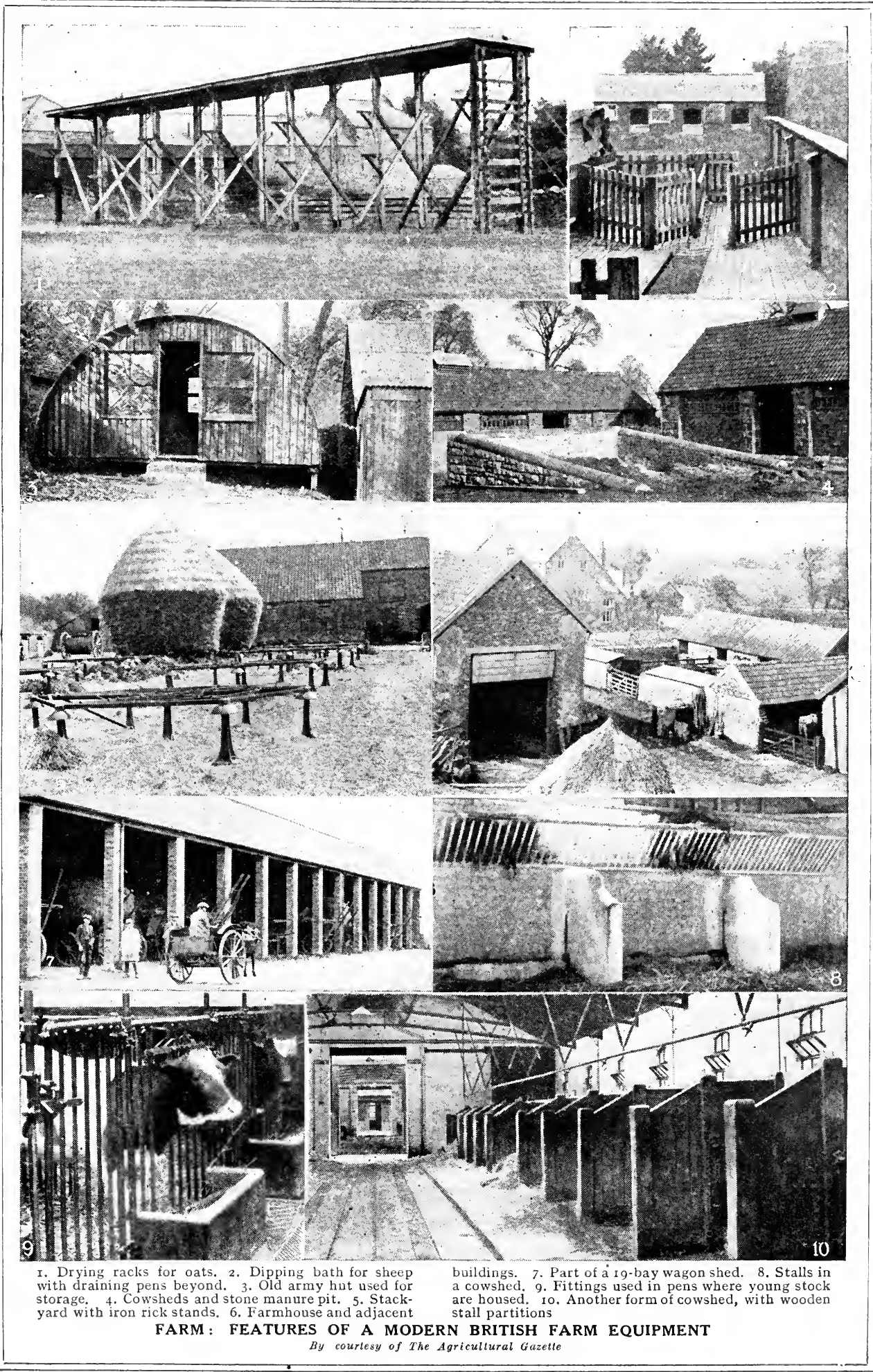


found varying in extent from a small arable holding little larger than a cottage allotment, with perhaps a barn to house the corn, to an estate of several thousands of acres of rich pasture and arable land, with a mansion, and houses for bailiffs, skilled workers, and farm labourers. In further contrast to the latter there are extensive areas of boggy land fit only for grazing cattle and sheep in summer ; there is also mountainous land, restricted entirely to the breeding and feeding of sheep.

\section{Types of Farm}

The wide variation in the soil and climatic conditions in Great Britain and Ireland has a distinct influence upon the systems of farm. ing adopted, and the farms are distributable into several widely different classes. Pastoral farms, such as those which exist throughout the west of England and in many parts of Ireland, are almost wholly utilised for the breeding of horses, cattle, and sheep. A pastoral farm may, of course, only comprise a sheep farm or "sheep walk" in the wild mountainous parts of Cumberland, or Scotland, or a cattle-rearing farm in rich pastoral counties like Devonshire. Or it may comprise a valley farm, where both dairy cattle and sheep of the heavier Down breeds flourish on the rich alluvial soils.

Distinct from these is the dairy farm for the production of milk and the manufacture of cheese and butter, where the by-products, including separated milk, buttermilk, and whey are utilised in calfrearing and pig-feeding. In close proximity to cities, large provincial towns, or industrial centres, typical mixed farms are encountered where almost every form of husbandry is practised, from horse-breeding and corn-growing to catch-cropping and the breeding and feeding of poultry and rabbits; special attention is also given to the cultivation of market garden crops.

In many of the southern counties of England, e.g. Hampshire, two classes of farms, known as upland and woodland farms, are met with. The former comprise large areas of arable land, overlying the chalk in many cases, and these farms are almost entirely restricted to the breeding and fattening of the heavy breeds of sheep, such as the Hampshire Downs, Oxford Downs, and Suffolks, and crosses of these breeds. The system of rotation cropping on these shallow upland farms is intricate, and requires considerable local knowledge.

Woodland farms usually com. prise one-third of their area as arable land, and as a rule the soil consists of a heavy retentive clay loam overlying clay, difficult and expensive to cultivate, and strictly limited as regards the variety of crops which can be grown. There are few farms in England where large areas of corn are grown without the assistance of sheep as a means of manuring and consolidating light and shallow soils, although here and there grain is grown by the use of chemical manures, while the ploughing in of green crops comprises the only means of returning organic matter to the soil.

Although there is a tendency to divide large into smaller farms, many do not readily admit of this, more especially where the proportion of light to heavy soil is well balanced. Where there is an excessive quantity of heavy soil the farmer stands to lose consider. ably, because both men and horses are often idle during the winter months. A typical mixed farm of not more than 400 acres would appear to be as much as one man can manage if he is to give the amount of personal attention to it necessary for the successful conduct of his business, especially in view of the amount of detail in modern intensive farming.

In order successfully to control large areas either privately or on cooperative lines, good organization is essential, including the employ. ment of skilled and experienced farm managers or bailiffs. The small mixed farm or holding is one of from 30 to 50 acres, on which the farmer, his wife and family may maintain themselves in reasonable comfort, simply through dint of hard work, economy, and thrift. In counties like Kent many families make quite comfortable livings by specialising in fruit-growing.

\section{Modern Farm Buildings}

The planning and erection of modern farm buildings requires as much expert advice as the erection of dwelling-houses or factories. The aspect most favoured is S. or S.E. ; to facilitate drainage the buildings should be erected on rising ground.

The production of milk under hygienic conditions calls for special attention in the erection of modern cowsheds, which are now usually equipped on American principles. Low mangers, tubular iron stanchions, stall division, and neck yokes have done much to ensure cleanliness, particularly in preventing the udders and hind-quarters of the cows from becoming soiled with manure. Ventilation, light, and drainage were far from satisfactory in the older types of cow houses, but these defects have been largely remedied of recent years. Surface drainage, the abolition of the old insanitary subsoil and indoor trap systems, the conservation of the liquid manure in suitable tanks apart from the buildings, and the removal of the solid excrements to some distance from the byres, all tend to more healthy, sanitary, and better economic conditions.

Although previous to the Great War something like $£ 10$ per acre was required to stock and equip a farm and leave something in hand for working expenses and current expenditure until stock and crops natured, under post-war conditions it requires at least an 80 p.c. increase on this estimate if the farm is to be reasonably well stocked and equipped. Farms are usually let on a lease for a term of years or on a yearly tenancy, but there can be no doubt that much of the land in the British Isles will be much more intensively farmed under some satisfactory system to ensure proper security of tenure. See A Pilgrimage of British Farming, A. D. Hall, 1913.

Farman. Name of aeroplanes built by the brothers Henry and Maurice Farman. The son of an English journalist, Henry (b. 1875) was born in France and began his career as a bicycle racer, then manufactured bicycles and motorcars. He took up aeronautics in 1907, and developed and perfected an aeroplane known by his name, making his first trials at Issy-les. Moulineaux, Nov., 1907-Jan., 1908. He was the first aviator to fly from town to town (Châlons-Reims, 1908 ), and to fly 100 miles (Reims, 1909). He established in 1908 a school of aviation and works at Buc, near Versailles.

Maurice Farman established aviation works a little later, and in 1912 the two combined their resources, erecting a factory at Billancourt. They supplied aeroplanes to the French army and other countries, including Britain. Various types of their machines did good work in the Great War. See Aeronautics; Aeroplane.

Farm Colony. Name given to a settlement of persons on the land for the purpose of cultivating it. The experiment has been tried in England, America, and elsewhere with varying degrees of success. General Booth established one in Essex to solve the unemployment problem. The first farm colony for ex-soldiers was established in 1916 at Holderness, in E. Yorkshire. It was intended to provide about sixty holdings, averaging thirty-five acres each. The Small Holdings (Colonies) Act, 1916, arranged for the settlement of discharged servioe men at Holbeach, Patrington, and elsewhere. 
An important farm colony was founded at Lasswade, near Edin. burgh, by Sir Robert Philip, in 1910. Known as the Royal Vic. toria Farm Colony, in four years it passed out 88 fit men to employments, who had entered it in various stages of disablement and disease. In 1920 it was proposed to establish a colony for sailors and soldiers suffering from tuberculosis, and 115 acres were acquired at Frimley, Surrey. See Land Settlement; Small Holdings.

Farmer. One who farms land, an agriculturist. Originally the word had a different meaning, referring to one who collected the taxes by contract. The farmer collected as much as he could, but paid over a fixed sum, called the firma, to the king. There was a system of this kind in Rome ; it was done by the sheriffs in medieval England. The word was used later for one who took over a piece of land, paying a fixed sum for the right to cultivate it, and this is the modern sense. See Agriculture; Farm.

Farmer, JoHN (1835-1901). British musician. Born at Not. tingham, Aug. 16, 1835, he studied

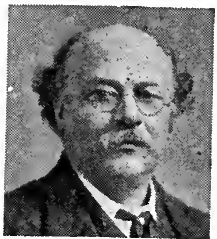

John Farmer.

British musician

Elliott \& Fry music at Leipzig andCoburg, and afterwards taught it at Zürich.In 1862 he settled at Harrow, and in 1864 was made music master at the school. From 1885 un. til his death he was organ. ist of Balliol College, Oxford, where he arranged Sunday evening concerts and founded the Musical Society. He died July 17, 1901. In addition to his song tunes, Farmer wrote oratorios and edited a volume of songs for soldiers and sailors, and another for children.

Farmer, JoHn Bretland (b. 1865). British botanist. Born at Atherstone, April 5, 1865, and educated at Magdalen College, $\mathrm{Ox}$ ford, he was demonstrator in botany to the university, 1887-92, when he became assistant professor of biology at the royal college of science, S. Kensington. In 1895 his chair was made independent, and he became professor of botany.

Farmer-General. Member of a financial organization in France under the monarchy, who, in consideration of payment of an agreed sum to the government, secured the privilege of collecting taxes. The system, based upon that of the Roman publicani (q.v.), seems to have been in existence in
France in the 14th century and was firmly established in the 16th. In the general reform of fiscal methods which followed the Revolution the farmers-general were abolished.

Farmer Labour Party. American political party. Organized in Chicago in July, 1920, it ran as its candidate for president at the election of that year Parley $P$. Christensen, of Salt Lake City, Utah. As its name implies, it was in the main composed of radical farmers from the West, dissatisfied with "Wall Street" and the general financial system, and Labour extremists, and it aroused special interest as representing for the first time in American politics a separate party of this kind.

Farmers' Alliance. Political party in the U.S.A. It began about 1873 when societies of the kind were established in 'Texas and other states, the movement being the successor of that known as the Grange. In 1882 some of these associations banded together in a national society, an in 1889 the name of National Farmers' Alliance and Industrial Union was taken. It consisted mainly of farmers of the South, and the adopted programme included many changes for the benefit of the farming interest. The alliance took an active part in politics, especially at the elections of 1890. In general it supported the Democrat candidates, but it secured seats for some of its own nominees, and controlling power in Kansas and Nebraska. In 1914 it represented about $3,000,000$ farm. ers, and had a programme which included the restriction of immigration and the free distribution of seed. See Grange Party ; Populist Party.

Farmers' Club. London club founded in 1842. Affording a con. venient social centre for those in. terested in agriculture, it is housed at 2, Whitehall Court, S.W. The term is also often applied to the co. operative trading societies formed under the auspices of the Agricul. tural Organization Societies of England, Scotland, and Ireland. See Agricultural Organization.

Farmer's Dynamite. Explosive of the gelatine dynamite type. It was specially manufactured to provide a mild, cheap ex- plosive which would be suitable for breaking up sub-soil, uprooting tree stumps, and similar agricultural purposes. It is a mixture of about 40 p.c. of nitroglycerine, gelatinised with nitrocellulose, 18 p.c. of dry wood meal, 40 p.c. of sodium nitrate, and a small proportion of magnesium carbonate.

Farnborough. Urban dist. and parish of Hampshire, England. It is $33 \mathrm{~m}$. S.W. of London, on the S.E. \& C., and L. \& S.W. Rlys. A mausoleum attached to S. Michael's Roman Catholic church, built by the Empress Eugénie, contains the remains of Napoleon III, the Prince Imperial, and the empress herself. 
May's long association with the House of Commons, together with his aptitude for research, made him the chief authority on its procedure, on which he wrote several books notably his Treatise on the Law. Privileges, Procecdings and Usage of Parliament, 1844. Taking a wider range, he devoted himself to the constitutional history of England, and his work dealing with the period, 1760-1860, published 186163 , remains the standard authority on the subject. He wrote also Democracy in Europe, 1877.

Farne, Fearne or Fern Islands, or the Staples. Group of seventeen rocky islets and rocks off the coast of Northumberland, England, separated from the mainland by the Fairway Channel. Farne or House, the largest ( 16 acres), was the retreat of $\mathrm{S}$. Cuthbert (q.v.) in the 7 th century, and Longstone with its lighthouse is famous for its association with Grace Darling (q.v.)

Farnese. Name of the Italian ducal family of Parma during the 16 th and 17 th centuries. First appearing in history as lords of Farnete, in Tuscany, in the 12th century they became prominent by the election as pope Paul III of Alessandro Farnese, 1534, brother of Giulia, favourite of pope Alexander VI. In 1545 pope Paul gave the duchy of Parma to his natural son Pierluigi (1503-47), a notorious libertine, murdered by partisans of Charles V. at Piacenza. Of Pierluigi's sons, Alessandro (1520-89) became a cardinal in 1534, and completed the Farnese Palace $(q . v$. in Rome, while Ottavio (1521-86), after a long struggle with his grandfather the pope, became 2nd duke of Parma in 1551, recovering Piacenza a few years later. His son Alessandro was the famous soldier

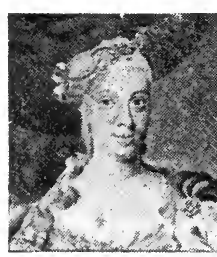

Elizabeth Farnese

Queen of Spain

From a print in Spanish service, better known as the 3rd duke of Parma (q.v.).

Elizabeth Farnese (1692 -1766 ) was the last notable member of the family. Daughter of Odoardo Far. nese, she married in 1714 Philip V of Spain, whose weakness, and in later years insanity, left her the virtual ruler of Spain during his nominal reign. With cardinal Alberoni she worked for the restoration of Spanish rule in the lost Italian provinces, a scheme only broken by the demands of the Quadruple Alliance in Jan. 1720. The direct Farnese succession ended with Antonio (1679-1731).

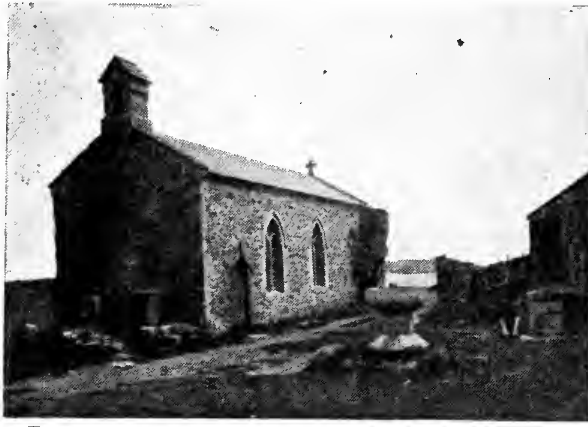

Farne. S. Cuthbert's chnrch, Inner Farne, on the site of the hermitage where the saint died in 687 Valegtine

Farnese Palace. Building in Rome, one of the finest examples of later Renaissance architecture. It was designed and begun in 1530 by Antonio da Sangallo, and the work was carried on and completed by Michelangelo, Vignola, and Giacomo della Porta. The length of the front façade is $190 \mathrm{ft}$., and the building is $260 \mathrm{ft}$. deep and 97 ft. high to the top of the cornice. The latter, the most striking feature, was added by Michelangelo, who was also responsible for the upper storey which it crowns. The courtyard on the S. side is surrounded by arcades, modelled on those of the Colosseum. The building was commissioned by Cardinal Alessandro

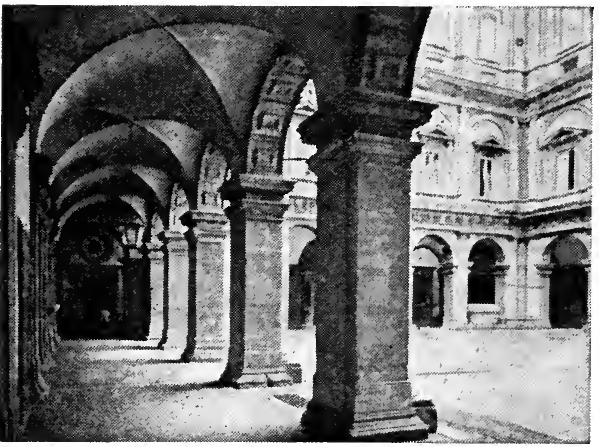

Farnese Palace, Rome. Arcade of the courtyard, a magnificent example of the architectural work of

Farnese, afterwards Pope Paul III, and it remained in the possession of the Farnese family until the latter became extinct in the 18th century. It then passed, with the Villa Farnesina, to the king of Naples.

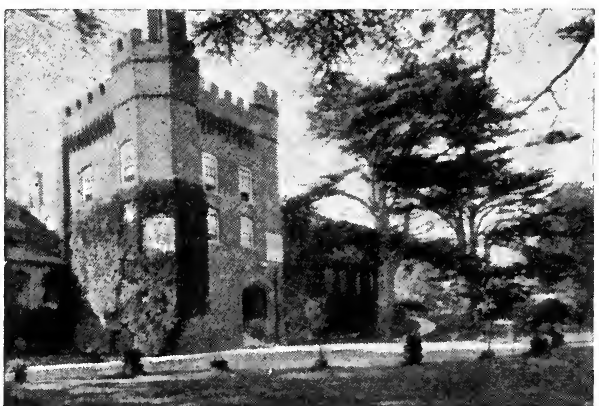

Farnham. Front view of Farnham Castle, the seat of the bishop of Winchester. The magnificent cedars on the lawn were brought direct from Lebanon Michelangelo

Farnham. Market town and urban district of Surrey, England. It stands on the Wey, $38 \mathrm{~m}$. S.W. of London, being served by the L. \& S.W.P. The centre of a district in which hops are grown, it has trade therein and in other agricultural produce, which it has developed partly owing to its proximityto Aldershot. S. Andrew's church is a noble Transition al grammar school.

Above the town stands the castle, the seat of the bishop of Winchester. The first castle was built in the 12th century, but this and also its successor were de.

stroyed. The present building dates mainly from the 17 th century, although there are slight remains of its predecessors. Near the town are Moor Park, the residence of Sir W. Temple, where for a time Swift lived, and the ruins of Waverley Abbey. Farnhambelonged to the bishop of Winchester before 1066 , and one of the bishops made it a chartered town. Having decayed, it ceased to be a borough in 1789 . Here Cobbett was born, his birth. place being now an inn, The Jolly Farmer. Market day, Mon. Pop. 7,365 . edifice, and the other buildings 
Farnol, John Jeffrey (b. 1878). British novelist. Born Feb. 10, 1878 , and educated at a private school, he began writing while in his teens. In 1902 he went to America, where he painted theatrical scenery, and contributed stories to various periodicals. In America he published his first volume, My Lady Caprice, 1907 (later reissued

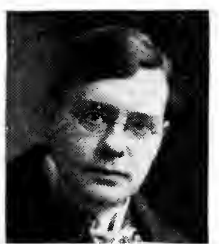

Jeffrey Farnol

British novelist

Elliott \& Fry as Chronicles of the Imp). In 1910 he re. turned to Eng. land, and by the publication of The Broad $\mathrm{H}$ ig h w a y achievedpopu. larity as a writer of healthy senti. mental adven.

turous romance. Later stories included The Money Moon, 1911 ; The Amateur Gentleman, 1913 ; The Honourable Mr. Tawnish, 1914; Beltane the Smith, 1915; Our Admirable Betty, 1918; and Black Bartlemy's Treasure, 1920. Farmol also wrote Some War Im. pressions, 1918.

Farnworth. Urban district and parish of Lancashire. It is $3 \mathrm{~m}$. S.E. of Bolton, of which it is practically a suburb, and has a station on the L. \& Y. Rly. Sharing in the industries of Bolton, it has spinning mills, engineering works, and machinery shops, while around are coal mines. Bricks and tiles are made here. S. John's is the chief church, and there are a number of Nonconformist places of worship. The council owns the electric lighting and tramway under. takings, markets, baths, cemetery, town hall, library, and refuse destructor. Water is supplied by Bolton Corporation. The gas supply is owned by a public company. Market days, Mon. and Sat. Pop. 28,131.

Faro. Gambling card game. It is one of the oldest of banking games, supposed to be of Italian origin, and under the name of Pharaon was very popular in the time of Louis XIV. It requires costly apparatus and a lay-out. A full pack of 52 cards is put into a dealing box with an open top, one card being released at a time. The first card in sight at the beginning of each deal is called soda and the last card left in the box is in hoc. The dealer or banker withdraws soda and places it some little distance away; the next card, termed the loser, he lays by the side of the box. The third card taken out is the winner, which he places on the soda; thus, each alternate card is a winner or loser, eventually forming two separate

piles, with soda and loser for foun. dation. The object of the players is to forecast correctly (indicated by the way in which they stake their money upon the lay-out) which particular card of any suit will win or lose.

Faro. Administrative dist. of S. Portugal, coextensive with the prov. of Algarve. The climate is genial and the soil fertile, producing olives, dates, almonds, figs, and cereals. Area, 1,937 sq. m. Pop. 274,122.

Faro. Seaport and city of Portugal, capital of Faro dist. It stands on the Atlantic, at the mouth of the Rio Fermoso, $20 \mathrm{~m}$. S.W. of Tavira, and is the terminus of the Lisbon-Faro Rly. Its har-

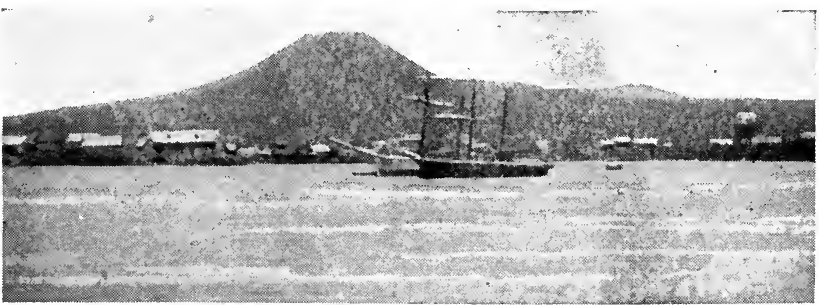

Faroe. Klaksvig, the principai town on Bördo Island, and Klaksvig Mountain

bour is large and sheltered, but shallow and tidal. The town possesses a cathedral, a military hospital, a museum, and a ruined Moorish castle. Its large public square is the centre of the life of the city. It exports fruit, vegetables, wine, cork, sumach, sardines, anchovies, tunnv, and baskets. Burned by the English in 1596, it was almost destroyed by an earthquake in 1755 . Pop. 11,789 .

Faroe (Dan. Färöerne, sheep island). Group of islands in the $\mathbf{N}$. Atlantic, belonging to Denmark. The group lies about $195 \mathrm{~m}$. N.W of the Shetlands, and $250 \mathrm{~m}$. S.E. of Iceland. There are 21 islands, 17 of them inhabited. Of volcanic and basaltic formation, they are mountainous, rising in Slatarretinde in the island of Osterö to $2,890 \mathrm{ft}$., with lofty and steep cliffs and deep fiords, and separated from each other by swift and dangerous cur. rents. The rainfall is heavy, and storms are frequent. Lying between lat. $61^{\circ} 20^{\prime}$ and $62^{\circ} 20^{\prime}$ N., not a great distance from the Arctic Circle, the climate is mild but moist, and the harbours are seldom frozen. There are no trees, and barley is the only cereal grown; turnips and potatoes thrive, and coal and peat are found.

The chief industries are sheepraising, cattle-breeding, wildfowling, whaling, and fishing.

Sheep, fish (wet and dried), wool, feathers, skins, tallow, butter, and fish-oil are exported. The largest island is Strömö, with the capital, Thorshavn; Suderö is the next largest. There are cathedral ruins in Kirkebö on Strömö. Colonised by the Norwegians in the 9 th century, they became Danish in 1380. The people still speak an old Norse dia. lect. 'They have a local parliament and are represented in the Danish parliament. The chief magistrates are an amtman, who is also a commandant, and a landvogt, who is chief of police. In religion they are mostly Lutheran. Area, 540 sq. m. Pop. 19,617. See Map, p. 2523 consult also The Faroes and Iceland. T N. Annandale. 1905

Farquhar, Horace Brand FarQUHAR, 1ST EARL (b. 1844-1923). British politician. Born May 19, 1844 , a younger son of Sir W. M. Townsend-Farquhar, he was edu. cated at Eton. He became a part. ner in the firm of Sir Samuel Scott \& Co., bankers, but, devoting much time to social life, became

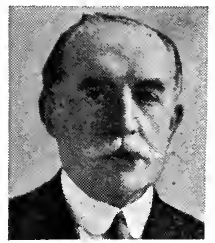

Earl Farquhar, British politician Russell bone, 1895-98, retiring on being made a baron. From 1889 to 1901 he was a member of the L.C.C. and he was actively connected with the central Unionist organizations. Extra lord-in-waiting both to King Edward and King George, he was lord steward, 1915-16, made an earl, 1922, and died Aug. 30, 1923.

Farquhar, Sir Arthur MURray (b. 1855). British sailor. Born Jan. 19, 1855, he entered the navy in 1868 and was lieutenant of the Bacchante 1879-82, on board which the duke of Clarence and George V (then prince George) were training. Promoted captain 
in 1896, he conveyed the duke and duchess of Connaught to the Delhi Durbar in 1902 on the Renown. $\mathrm{R}$ e a $\mathbf{r}$ - admiral 1906, he com. manded the fourth ; cruiser squadron, 1909 11 , and was pro. moted vice-ad. miral. In 1913 he was appoint. ed to command the coastguard and reserves, and in 1914 was

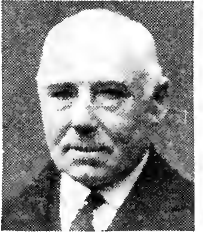

ir A. M. Farquhar. British sailor Russell

knighted and became admiral.

Farquhar, George (1678-1707). English dramatist. Born in Lon. donderry. and educated at Trinity

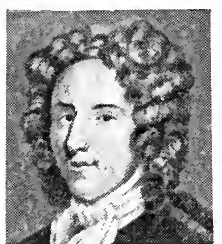

George Farquhar. English dramatist

From an old print

Author of many articles on statistics and actuarial matters, he wrote most of the papers on the causes of death in England in the annual reports of the registrar-general from 1839-80. He died April 14, 1883.

Farragut, David Glasgow (1801-70). American sailor. Born at Knoxville, 'Tennessee, July 5, 1801, of Spanish descent, he entered the navy, and in 1825 was promoted lieutenant. When the Civil War came in 1861, notwithstanding his southern birth, he offered his services to the Washington government, and in 1862 was given command of the Wes. tern Gulf blockading squadron. His great popularity was inten. sified by his brilliant forcing of the passage of the Mississippi

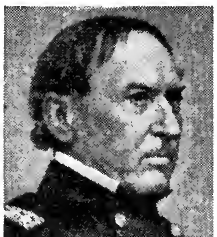
and capture of New Orleans. After an unsuccessful op. erationagainst $\mathrm{Vicksburg}$, with the aid of monitors he defeated Buchanan at

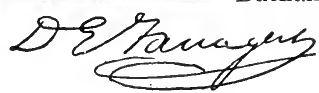

ple, 1700 and Sir Harry Wildair, 1701. Other notable productions were The Beaux' Stratagem, 1707, two characters in which, Lady Bountiful and Boniface, the innkeeper, have passed into the language as types. The Recruiting Officer, 1706, contains the song Over the Hills and Far Away. Far. quhar died in pecuniary difficulties. $\mathrm{He}$ had sold his commission to marry a professed heiress, who turned out penniless. Farquhar magnanimously forgave her. His large-heartedness is reflected in his comedies, which, though not perhaps so witty as those of Congreve, are pervaded by a human sympathy which gives reality to both plot and characters. Dramatic Works, ed. with Life, A. C. Ewald, 1892.

Farr, William (1807-83). British statistician. Born at Kenley, Shropshire, Nov. 30, 1807, he studied medi. cine in Paris, and practised in London. In 1838 he was a p p o in ted compiler of abstracts to the registrar general. For the two decen.

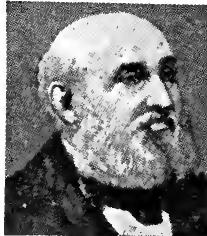

William Farr nial censuses, British statistician 1851 and 1861, he was assistant commissioner, and commissioner for that of 1871. Disappointed at not obtaining the registrar-general. ship in 1879, he resigned his post.
Mobile in 1864, but his health being undermined by the climate he re. turned to New York the same year, being made the first reat-admiral of the U.S. navy. In 1866 he was promoted admiral, and retired 1867. $\mathrm{He}$ died at Portsmouth, New Hampshire, Aug. 14, 1870.

Farrant, RichaRd (c. 1530-80). British organist and composer. A gentleman of the Chapel Royal, Farrant was for some time organist of S. George's Chapel, Windsor. Much of the music attributed to him has been proved to be by other composers, but it is probable that he composed the beautiful anthem Call to Remembrance. He died Nov. 30, 1580.

Farrar, Frederio William (1831-1903). British divine and writer. Born at Bombay, Aug. 7, 1831, he was educated at London University and Trinity College. Ca m bridge, and became in 1855 an as. sistant master at Harrow. He was head. master of Marlborough College from 1871-76, when he became canon of West. minster and rector of $\mathrm{S}$. Margaret's, being appointed archdeacon of Westminster in 1883. Farrar was made dean of Canterbury in 1895. His Life of Christ, 1874; Life of S. Paul, 1879; and Lives of the Fathers, 1889, enjoyed remarkable success. He died March 22, 1903.

Farren, ElizabETH (c. 17591829). British actress. The daughter of a Cork surgeon turned actor,

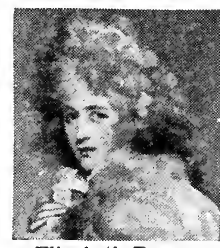

Elizabeth Farren,

British actress

After Sir T, Lawrence she made her first London appearance at The Haymar. ket, June 9 1777, as Miss Hardc a s t le. She made her début at Drury Lane, Sept. 8, 1788, as Charlotte Rusport in The West Indian, and acted at this theatre and The Haymarket till her retirement in 1797. At Drury Lane she succeeded Mrs. Abington as the impersonator of fine ladies and was received with favour as Lydia Languish, Milla. mant, Lady Betty Modish, Lady Teazle, Berinthia in Sheridan's Trip to Scarborough, and Angelica in Congreve's Love for Love. In 1797 she married the 12 th earl of Derby, and died on April 23, 1829.

Farren, ElleN or Nellie (1848-1904). British actress. Granddaughter of William Farren (q.v.),

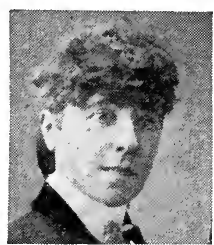

Nallie Farren,

British actress Downey and born at Liverpool, she played many parts in com. edy, farce, and burlesque at Sadler's We lls, The Olympic, and The Queen's. She joined John Hollings. head's co m.

pany in 1868 at the (old) Gaiety Theatre, where she remained under his management, and that of his successor George Edwardes, till her retirement in 1891, playing as principal boy in innumerable burlesques.

Farren, WILLIAM (1786-1861). British actor. He made his début on the London stage, Sept. 10, 1818, as Sir Pete!

'Teazle at Covent Gar den, where he remained till 1828. He ap peared as Sir Peter at Drury Lane, Oct. 16. 1828 , remain. ing a member of the com. pany for nine

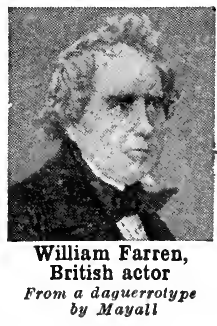


years. In 1837 he returned to Covent Garden, which he left a few years later to join Benjamin Webster as stage-manager at The Haymarket, where he stopped 10 years. Subsequently he managed The Strand and The Olympic, taking leave of the public at The Haymarket July 10, 1855, in his favour. ite part of Lord Ogleby in The Clandestine Marriage. He died in London, Sept. 24, 1861. As the old man of 18 th century comedy he was unrivalled.

Farrer, Thomas Henry FarRer, IsT BaRON (1819-99). British economist. The son of a London

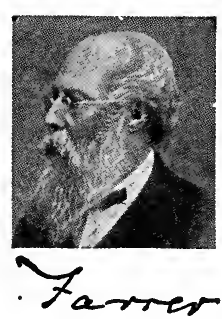

solicitor, he was born June 24, 1819. Edu. cated at Eton and Balliol Colle ge, Oxford, he became a barrister, but his career was influenced by his close friendship with Sir $S t$ a f $f$ or d Northcote, who secured for him in 1848 a position in the board of trade. He rose in the civil service and from 1865-88 was permanent secretary to the board. He was largely responsible for much valuable legislation, including some concerning merchant shipping and bankruptcy. In 1883 he was made a baronet, in 1893 a baron. As an economist Farrer made his reputation after his retirement. He was a strong free trader, at one time president of the Cobden Club, and was a critic of high national expenditure and bimetallism. From 1889-98 he was a member of the London County Council, and he died Oct. 12, 1899. of his writings the best known is Studies in Currency, 1898.

Farrier. Name given originally to a man who shod horses, the word being derived from the Latin ferrum, iron. After a time the farrier began to attend to the diseases of the horses, and farriery

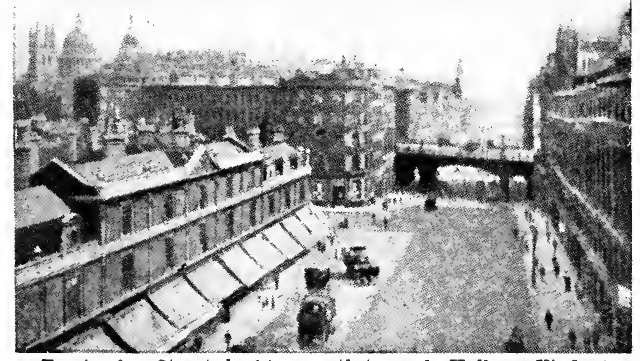

was the name for what is now more generally known as veterinary surgery (q.v.).

Farriers' Company, THe. London city livery company. Dating from 1356 as a fraternity, its first charter was granted in 1685 . Farriers, who were also called ferrers, ferriers, and fer. rones, are men. tioned in the 13th century. They owe their ordinances to a complaint that certain unskilled

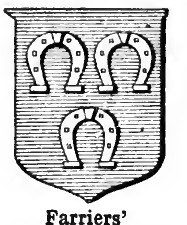

Company arms ferrones, having set up forges in the city, had caused the loss of many horses. In 1758 an act of common council imposed on all operative farriers the obligation of taking up the freedom of the com. pany. While this rule has been abandoned the company has taken in later years an active interest in the welfare of the craft by the offer of prizes for good workmanship, etc., and in 1890, in cooperation with the Royal Agricultural Society and the Royal College of Veterinary Surgeons, promoted a scheme for the national registration of farriers or shoeing-smiths. The archives of the company were almost entirely destroyed by fire in 1666. Its offices are at 140 , Leadenhall St., E.C.

Farringdon Street. London thoroughfare running $S$. from Charterhouse Street to Ludgate Circus, E.C. Named after the city ward in which it is situated, it was built over the Fleet Ditch, now a sewer, in 1826-30. Fleet Market, which once occupied the site, was opened Sept. 30, 1737, and for 92 years remained a centre for the sale of meat, fish, and vegetables. It was removed in 1829-30. The market for fruit and vegetables built between Farringdon Street and Shoe Lane, N. of Stonecutter Street, and known as Farringdon Market, was opened Nov. 20, 1829, but the site, which covered $1 \frac{1}{2}$ acres, was sold in 1892, and is now covered by a fine block of buildings $\mathrm{k}$ n 0 w $\mathrm{n}$ a Farringdon Avenue. The market is said to have cost the city corpora. tion $\mathfrak{£ 2 8 0 , 0 0 0}$

Farringdon St. is spanned by Holborn Viaduct, and contains the Memorial Hall (q.v.), built in 1874 to com. memorate the fidelity to conscience of 2,000 ministers ejected from the church in 1662 by the Act of Conformity; Fleetway House, headquarters of the Amalgamated Press; and is fronted on the E. side by part of the London Central (Smithfield) Markcts. Fleet Prison stood on ground partly occupied by the Memorial Hall. N. of Charterhouse Street is Farringdon Road, notable for its open market and old bookstalls, with a Metropolitan Rly. station and a goods station of the G.N.R. Farringdon Road was first called Victoria Road. It extends to King's Cross Road, and was made in 1856. See Fleet Prison.

Farrow's Bank. Former British bank. Founded in 1994 by Thomas Farrow, it was registered as a credit bank under the Industrial and Provident Societies Act. In 1907 it was registered as a joint stock company. With a capital of $f 1,000,000$, the bank had 75 branches, mainly in England. In 1921 Farrow and another official were sentenced to imprisonment for fraud in connection with it.

Farrukhabad. District and town of India. In the E. of the Agra division of the United Provinces, the area of the district is $1,744 \mathrm{sq}$. $\mathrm{m}$. 'The town was founded early in the 18th century. Farrukhabad city lies near the Ganges, on the rly. line from Cawnpore to Muttra, and at the end of a branch of the E. Indian Rly. from Shikohabad. It forms with Fatehgarh, lying $3 \mathrm{~m}$. to the $\mathrm{E}$., the headquarters of the district and the cantonment, a single municipality. Cloth printing is the chief industry. The principal crops are wheat, barley, millet, and gram ; the poppy, cotton, and sugar-cane are also grown; tobacco is exported. Pop. of dist., 900,022, five-sixths Hindus; of town, 56,573 , two-thirds Hindus, one-third Mahomedans.

Fars or Farsistan. Province of Persia. It lies on the E. side of the Persian Gulf, and is bounded on the N.W. by Khuzistan and Ispahan, E. by Yazd and Kerman. From the warm coastal plain the country rises into the mts., where the climate is cold. The highest mt. is the Kuh-i-Bul, 14,000 ft. The rivers are small and not numerous. There are several lakes, the principal being Niris. The capital is Shiraz, and the ports are Bushire, Linjah, and Bander Abbas. The province contains the ruins of Persepolis. Many parts of the province are fertile, and produce wheat, barley, rice, cotton, and an excellent tobacco. Area, 60,000 sq. m. Pop. 750,000. 
Farsetia. Genus of annual and perennial herbs, and sub-shrubs of the natural order Cruciferae. Na. tives of S. Europe, Asia, and Africa, they have opposite, undivided leaves, and white or yellow flowers.

Farther India oR INDO-CHINA. Term used to designate the S.E. peninsula of Asia, lying E. of India and S. of China. It includes Assam, Burma, the Malay and Federated States, the Straits Settlements, Annam, Laos, Cambodia, Tongking, and Cochin China. See Indo-China.

Farthing (A.S. feortha, fourth). Name of the smallest British bronze coin, value one quarter of a penny.

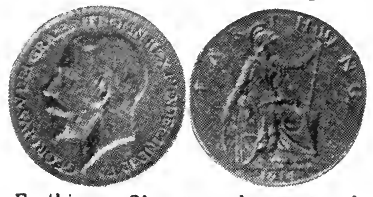

Farthing. Obverse and reverse of George V farthing, 1914

From its first appearance under Edward I, until about 1555 , it was a silver coin. A copper farthing was coined in 1613 , but did not form part of the true coinage till a reissue in 1672, under Charles II, who also struck a tin farthing, with a circle of copper inset, in 1684 . Copper half-farthings circulated between 1842-69. The farthing became a bronze coin in 1860, and has a standard weight of $43 \cdot 750$ grains. The coin is legal tender up to the number of four at one time. See Coinage; Numismatics.

Farthingale (Span. verdugado, hooped). Hooped framework supporting and extending a wide skirt. The fashion was introduced from Spain into England in the time of Elizabeth, and continued until about the middle of the 17 th century. It grew to a prodigious size, the big hoop at the level of the hips giving a flat, circular surface, and keeping the skirt well away from the figure. 'The fardingale, as it was then called, was revived in rather a different form in the time of Queen Annc, when the skirt became more bell-shaped. It was abolished by royal command in Gcorge IV's reign, but it later reappeared as the crinoline.

Fasa. Town of Persia. It is an important centre in the prov. of Fars, about $80 \mathrm{~m}$. S.E. of Shiraz. Pop. 15,000.

Fasano. Town of Italy, in the prov. of Bari. It is $35 \mathrm{~m}$. by rly. N. W. of Brindisi. The old palace of the Knights of $\mathrm{S}$. John is now the town hall. In the vicinity are the ruins of Egnatia, an ancient port on the Appian Way. Situated in an olive-growing district, Fasano has many oil mills. Pop. 20,077.

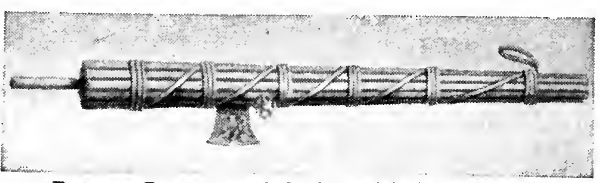

Fasces. Roman symbol of magisterial authority

ash often exhibit the abnormality in their upper branches.

Fascine (Lat. fascina, fagot). Name for a long fagot of thin

Fasces (Lat., bundles). Bundles of rods with an axe bound up in the middle. They were the symbols of the authority of certain of the higher magistrates in ancient Rome and were borne over the shoulders of attendants (lictores) who preceded them. See Imperium.

Fascia. In anatomy, layer of connective tissue interposed between the skin and the muscles, and prolonged inwards between the muscles so as to form sheaths around them. The strength and thickness of fascia vary in different parts of the body. On the outer side of the thigh, for instance, it forms a dense, strong structure, the ilio-tibial band, which helps to steady the body in the erect position.

Fascia or FACIA (Lat., bandage, fillet). Architectural term applied originally to the bands or divisions of an Ionic entablature (q.v.), now extended to include any flat band or facing in an entablature.

Fasciation. Abnormal growth of stems when they become flattencd. and the branches, instead of being separate, coalesce with the stem. This is the constant condition of the flowering parts of cock's comb (Celosia cristata) (q.v.) ; but is often found in other herbs and trees. The willow family and the

boughsorbrushwood, tightly packed and securely bound, used in military

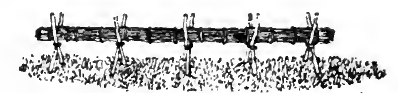

Fascine. A fagot of brushwood on

the trestles upon which it is made

engineering. For making fascines a cradle of trestles is arranged at a uniform height, the lengths of brushwood are placed thereon, and tightly packed by means of a choker, which consists of a length of chain, the two ends of which are secured to stakes, enabling considerable leverage to be brought "to bear on the bundle of wood. After bcing compressed, the fascine is secured by withes of flexible wood bound round it.

Fascisti, The (Lat. fascia, bun dle). Society recruited from Italian Nationalists to oppose extreme socialism. Started in 1919, at first it met opposition with force, but gradually under its leader, $B$. Mussolini, the movement became passive, and a fascist government. with Mussolini as premier, came into being in 1922. Under him Italy recovered from the dislocation following the Great War, abuses were put down, and trade was stimulated. See Italy; Mussolini, B.

\section{FASHION : IN ANCIENT \& MODERN TIMES} M. E. Brooke, Member of the editorial staff of Eve

The article Costume supplements the information given below. See also Dressmaking and articles on the various items of dress : Boot: Cap: Glove: Hat: Skirt, etc.

Derived from Iatin factio, making, old Fr. fachon, this word has come to mean the prevailing mode or custom, primarily in dress but also in social intercourse, sports, and the like.

So far as Europe is concerned, many authentic records of raiment are found on tombs and cathedral doors, and stained-glass windows. In 1321 a direct attempt was made to disseminate fashion, a fashion doll being sent to the queen of England. Later these dolls werc sent out at regular intervals at the beginning of the spring, summer, autumn, and winter seasons. They were dispatched from Paris to London, St. Petersburg, Rome, Lisbon, and Berlin. In the days of Catherine de' Medici, when Colbert declared that France should supply the wardrobes of the world, two dolls were dressed in accordance with the last word in the story of fashion, one en grande tenue and the other en deshabille. They were half life-size, and, having been exhibited at the Hotel Rambouillet, duplicates were sent to the leading cities. These dolls were the forerunners of the modern fashion papers.

Curiously enough, the first paper devoted to fashion was neither published in Paris nor written in French. It was brought out by Josse Amman, a painter who was born at Zürich, and died at Nuremberg in 1586 . It was published in Frankfort, was writ. ten in Latin, and was followed by Les Modes de la Cour de France, which treated of the costumes of the court of Louis XIV from 1675-89. 
June, 1798, saw the production of Le Journal des Dames et des Modes by Sellèque and Madame Clément. They were joined by Pierre Lamésangère, a professor of literature and philosophy who had fallen on evil times. Two years later, on the death of Sellèque, Lamésangère took entire control, frequenting the theatres and all fashionable rendezvous in order to study the dresses. The journal was published at intervals of five days, with one coloured plate of a woman in an attractive gown, and on the 15th of the month there were two plates. It lasted until the death of Lamésangère in 1829 .

\section{History Reflected in Fashions}

The vast fortune he amassed caused others to follow in his footsteps, and in a short time appeared Le Petit Courrier des Dames, Le Follet and La Psyche; also La Mode, which was under the patronage of the duchess of Berri.

Conquests have always influenced the modes. The Roman dominion of England was responsible for the abandonment of the braccae (breeches) and the adoption of the Roman tunic. To the Crusader is due the introduction of the taste for things Oriental. The conquests of Edward III were responsible for the French fashions in England. The "blistered" modes followed the defeat of the duke of Burgundy in 1497, for it was a compliment to the vanquished. The Wars of the Roses robbed fashion of all gaiety. The prosperity of the reign of Henry VIII was reflected in the richness of attire ; the persecutions of Mary's reign had the opposite effect, and the anti-Catholics showed their disapproval in their clothes. In Queen Elizabeth's reign the magnificence of raiment, for men as well as women, was unprecedented.

This was followed by the Puritan influence. The French Revolution sounded the knell of gaiety in masculine dress. Women adopted the Athenian costume, as best expressing the feelings of the day, and the harvest of this diaphanous attire in mid-winter was consump. tion. Shortly afterwards public feeling became favourable to common sense in clothes whereby health received due consideration. This resulted in the disappearance of the waspish waist and tight shoes, and the adoption of wool or wool mixture underwear. In 1887 began a new era of life in London. Before that date all entertaining had been done at home. Dining in public resulted in women giving moreconsideration to their toilettes.

Cycling was introduced in Paris and became the rage in England about 1896. Golf followed and caused an improvement in tailormade costumes. In 1896 the Locomotives on Highways Act became law and the motor arrived. The South African War in 1899 put a check on fashion, but it revived after the coronation of Edward VII in 1902, when daylight drawing-rooms were abolished. In 1906 came the revival of roller-skating. In 1919 the aeroplane began to be used as a general means of locomotion, and for this last-mentioned event the notable dressmakers on both sides of the Channel were already designing costumes in 1918 .

A good income may be made by fashion writers as well as artists. The former should have a thorough knowledge of the history of cos. tume. There is no better training for this work than a subordinate position in the office of a paper, where a knowledge of what is needed, as well as of the pitfalls to be avoided, is acquired.

The fashion artist must be a clever draughtswoman, and must possess a peculiar qualification that may be called the "dress sense." "There are many schools that teach fashion drawing. This they are able to do in a highly satisfactory manner provided that the student has talent and is able to draw. They are au fait regarding the work of reproduction for various kinds of papers, and the best methods of accentuating the essential points of the article to be sketched. See Costume; also illus. p. 1702.

Bibliography. Dresses and Decorations of the Middle Ages, 2 vols., H. Shaw, 1843; A Cyclopredia of Costume (53 B.C.-18th cent.), J. R. Planché, 1876-79; Costume in Eng. land, a History of Dress from the Earliest Period till the close of the 18th Cent., F. W. Fairholt, 3rd ed. 1885; Le Costume Historique, 6 vols., A. Racinet, 1888 ; Mesdames nos Aieules, A. Robida, 1891, Eng. trans. Yester-Year, Ten Centuries of Toilet, C. Hoey, 1892; A History of English Dress from the Saxon Period to the Present Day, 2 vols., G. Hill, 1893 .

Fashoda, Now Kodok. Town of the Anglo-Egyptian Sudan. It is situated on the W. bank of the Bahr-el-Abiad or White Nile, 470 $\mathrm{m}$. S. of Khartum. The climate is extremely hot and the place is in. fested with mosquitoes. On the caravan route from Kordofan, it has several government buildings.

Fashoda Affair. Name given to an episode which occurred just after the British reconquest of the Sudan in 1898. A small French expedition under Major (afterwards General) Marchand made itsway up the Niger to Fashoda, which was occupied on Sept. 7 , in spite of the fact that in 1895 the British Government had given formal notice that the Nile valley was within its sphere of influence. Sir Herbert Kitchener, who was then sirdar, went at once to Fashoda and asked Marchand to withdraw. 'The French officer refused, but on Nov. 5 after further negotiations, his government ordered him to give up the post. By an agreement signed March 21, 1899, France undertook to withdraw from the Nile valley, and a new boundary between the areas protected by the two countries was outlined. The affair caused a good deal of excitement in both countries.

Fassaite. Greenish variety of mineral augite. It is named after the Fassathal Tirol, where it was first found. See Augite.

Fast and Loose. Dishonest game formerly much played by gypsies and tricksters, known also as prick the garter. The victim was invited to push a pin or bodkin through a folded belt so as to fix it to the table, but the folds were so disposed by the owner that on the ends being pulled it came free, and the stake was forfeit. From this came the expression "to play fast and loose,"i.e. to repudiate expressed obligations when these seem no longer convenient to acknowledge.

Fast Castle. Ruined fortress of Berwickshire, Scotland. It stands on a steep cliff about $3 \frac{1}{2} \mathrm{~m}$. N.W. of St. Abb's Head, and was formerly a stronghold of some importance, though little now remains of the buildings. It was to Fast Castle that James VI of Scotland was to have been brought by the Gowrie conspirators, and it is described as Wolf's Crag by Scott in 'The Bride of Laminermoor.

Fast Colours. Broadly speak ing, colours which behave satis factorily in wear for a reasonable time-say, six months. Colours should be fast against sunlight and water, rubbing, the action of street mud, and of perspiration. Colours are frequently required to be fast against specific finishing or manufacturing processes, e.g. against milling and potting. Sce Dyes.

Fasti (Lat. fas, divine law). Latin word meaning lawful, applied to those days (dies fasti) in the year on which legal business could be done, as opposed to days on which it could not (dies nefasti). The word then came to mean a calendar. Such calendars were of two kinds: Fasti diurni, a calendar indicating religious festivals, market days, etc. ; Fasti annales, a calendar giving the names of the magistrates for the year and the chief events. 
Fasting(A.S. faestan, to hold fast, obscrve). Total or partial abstention from all or special kinds of food and drink: Such abstinence has been practised for religious or other reasone sy people of all nations from early times. It has formed part of both pagan and Christian asceticism (q.v.), in a religious sense being enjoined or commended together with prayer and almsgiving, and regarded as a method of self-discipline which, controlling the animal a ppetites, enables the mind more clearly to apprehend and appreciate spiritual truths.

The Mosaic law prescribed one great fast day in the year, the Day of Atonement or 10th day of the 7th month (Lev. 16); others were added in commemoration of events connected with the captivity (Zech. 8); and in the O.T. many instances are recorded of individual and communal fasting. The king of Nineveh, when Jonah prophesied its fall, proclaimed a general fast, and the city was spared (Jonah 3 ). In the N.T. Jesus Christ is represented not as enjoining His disciples to fast, but as teaching that, whenever fasting was undertaken, it was to be without ostentation and with purity of intention (Matt. 6). At the same time $\mathrm{He}$ indicated that it would be a duty after His departure (Matt. 9; homily On Fasting ii); and said of certain demons (Mark 9, A.V.): This kind can come forth by nothing but by prayer and fasting (R.V. omits " and fasting "). Fasting was recommended and practised by the apostles (Acts 13, 14; 2 Cor. 6, 11). In the early Church fasts were kept on Wednesdays and Fridays, and during Lent.

Unlike the Roman Catholic Church, the Church of England makes no distinction between fasting and abstinence (q.v.). In the homily On Fasting, the custom is said to be of itself a thing merely indifferent. It is regarded not as a means of grace but as a prepara. tion for the means of grace, and is voluntary, and the rule, obligatory among Roman Catholics, as to partaking of the Holy Communion fasting, is observed only among High Church Anglicans. The proclamation of 1548 for the abstain. ing from flesh in Lent time (2 and 3 Edward VI, c. 19) was issued for political and economic reasons. At the same time, the Book of Com. mon Prayer enumerates as days of fasting or abstinence the 40 days of Lent, Ember days, Rogation days, all Fridays except Christmas Day, and the evens or vigils of certain festivals where these festivals do not fall on a Monday, Sunday never being a fast day.
The manner of fasting or abstinence is left to the individual.

In the Roman Catholic Church all baptized persons who have com. pleted their 21 st year are bound to observe the days of fasting, on which they may not eat more than one full meal, this meal to be without flesh meat, and to be eaten after mid-day. The days of fasting are all Lent, except Sundays, the Ember days, vigils of the more solemn feasts, all Fridays except those falling within 12 days of Christmas, and between Easter and the Ascension. Fasting is exceptionally strict in the Eastern Church, in which 226 days are set apart for it in the year; it is an important religious duty among the Hindus; and among Mahome-

dans, who regard the practice as mitigating the penalties of sin, the month of Ramadan (q.v.) is a period in which fasting is obligatory. In ancient Greece rigid fasts preceded the solemnities of the Eleusinian mysteries; and in Rome every fifth year a general fast was held in honour of Ceres.

From a physiological or medical point of view, abstention from food leads to the tissues of the body being consumed in order to main. tain the output of heat and energy. Hence, progressive emaciation occurs, absorption of the fat in the tissues being well marked. The face becomes pale, the cheeks sunken, and the eyes hollow. The abdomen sinks in and the bones become prominent. The temperature is aften subnormal.

Towards the end, mental symptoms may appear and hallucinations may be followed by coma and death, the immediate cause of which appears to be reduction of the bodily temperature. The duration of life under such conditions varies within wide limits. Instances apparently well authenticated are recorded of survival for upwards of forty days. A notable case of fasting was that of the lord mayor of Cork, Terence MacSwiney, who in 1920 fasted in Brixton prison, dying, after abstaining from food for 73 days, on Oct. 25, 1920. After a fast the stomach is not in a condition to exercise its functions normally, and at first only very small quantities of liquid and easily digested food should be given. See Hunger Strike; Starvation.

Fastnet, Rock off the S.W. coast of co. Cork, Ireland. It has a lighthouse showing a flashing light visible for $18 \mathrm{~m}$.

Fat. Chief constituent of fatty or adipose tissue, which is present to a varying extent in nearly all
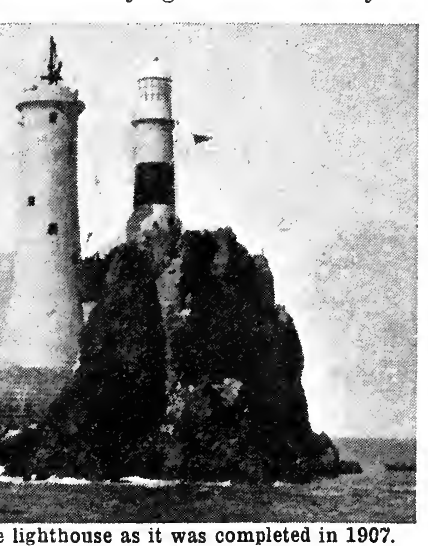

parts of the body. Adipose tissue consists of a foundation of connective tissue in the meshes of which are the fat-cells containing an oily material which is a mixture of palmitin, stearin, and olein formed by combination of fatty acids with glycerol. Chemically, fat consists of carbon, oxygen, and hydrogen, and its function in the animal economy is to provide a reserve of combustible material which is drawn upon to maintain the heat of the body. See Obesity.

Fatalism (Lat. fatum, fate). View that all the events of human life are ordained beforehand by an absolute necessity. Such was the view of Epicurus and the Stoics, and it is held by Mahomedans at the present day. Fatalism differs from determinism, according to which events stand in a relation of cause and effect to other events immediately preceding, in that it asserts that, no matter how much the antecedent causes may be varied, it will not affect the preordained result. See Free Will.

Fata Morgana. Form of mirage seen in the straits of Messina between Sicily and Calabria. The name is due to the fact that it was supposed to be the work of a fata or fairy named Morgana. In this type of mirage, which is seen across calm water, inverted images of ships, etc., are seen in the air above the real objects. The term is in general use to describe a mirage (q.v.). 
Fat Boy, The. Character in Dickens's Pickwick Papers. Pageboy to Mr. Wardle, Joe is enormously fat and given to somnolence in the intervals between meals. On his own confession he delights in making people's flesh creep by making himself the vehicle for unpleasant news.

Fatehganj. A village of the United Provinces, India. In the district of Bareilly, it is $23 \mathrm{~m}$. S.E. of Bareilly, and was founded to commemorate the British victory over the Rohillas in 1774. A few miles N.W. in the same district there is another village of this name, where the Rohillas were defeated by the British in 1796. Pop. 2,569, two-thirds Hindus.

Fatehgarh. Town of the United Provinces, India. The headquarters of Farrukhabad district, it forms with Farrukhabad city, $3 \mathrm{~m}$. to the W., a single municipality. The fort near the Ganges was built in 1714 by Nawab Mahommed Khan. A monument commemorates the European residents who lost their lives in the Mutiny. See Farrukhabad.

Fatehpur. Dist. and town of the United Provinces, India, in the Alla. habad division. The area of the district, which lies between the Ganges and the Jumna, is 1,642 sq. m. Slightly more than half the district is under cultivation, the chief crops being gram, barley, wheat, rice, and cotton. Fatehpur town is on the E. Indian Railway. Pop. dist., $676,939,90$ p.c. Hindus ; town, 16,939 , almost equally Hindus and Mahomedans.

A second town of the same name, which is situated in the Bara Banki district of the United Provinces, is "noted for its old buildings, some of which tradition assigns to the 14 th or 15 th century. Pop. 6,801, three-fifths Mahomedans, two-fifths Hindus. A third town belongs to the Sikar chiefship in Jaipur state, Rajputana. It is $146 \mathrm{~m}$. N.W. of Jaipur. Pop. 17,294 , two-thirds Hlndus, 30 p.c. Mahomedans.

Fatehpur Sikri. Town of the United Provinces, India. It is $23 \mathrm{~m}$. W. of Agra city, and was founded in 1569 by the Mogul emperor, Akbar, to whom the saint Salim Chishti foretold the birth of a son. A wall nearly $5 \mathrm{~m}$. long runs along three sides of Akbar's town. The modern town lies near the western end. Prominent among the buildings are the mosque with Salim Chishti's mausoleum in the quadrangle, the palace named after Akbar's Rajput wife, and his own palace and audience halls. Pop. 6,132, three-fifths Hindus, the rest Mahomedans.
Fates. In classical mythology, goddesses who presided over the destinies of men. By the Greeks they were called Moirai, by the Romans Parcae. They were three in number, and were daughters of Zeus and Themis, or daughters of Night and Erebus. Clotho, the youngest of the three sisters, held the distaff which spun the thread of life; Lachesis mixed good and evil fortune with it; Atropos cut the thread at the allotted moment. Theywere very powerful goddesses, with whose decrees even Zeus himself was unwilling to interfere. In art the Fates are generally represented as aged women, but sometimes as maidens of grave mien : Clotho with a distaff or book of fate; Lachesis pointing with a staff to a globe; Atropos with a pair of scissors or a pair of scales.

Father. Word common to most Indo-European languages, the forms of which differ slightly in accordance with phonetic laws. Originally denoting a male parent, then by extension a remoter rela. tionship such as ancestor or forefather, it came to be applied to the inventor or first person prominent in any art or pursuit. Thus, the Greek historian Herodotus is popularly called the father of history. Father is also a term of respect, as conscript fathers for the senators of ancient Rome ; father of his country for Cicero, Augustus, and other emperors; father Thames and father Tiber. Special applications are the Pilgrim fathers, the first settlers in North America; father of the House, the member of the House of Commons who has sat in it longest without a break. In theology, Father is used for the Supreme Being, the First Person of the Trinity; for a priest of the Roman Catholic Church; and for the earliest Christian writers. In Rome the father of the family had very wide powers over his children and household. See Family; Patria Potestas.

Fatherhood. Theological term for one aspect of the relationship of God to the universe generally, and to man particularly. In most ancient religious systems the idea of paternity, usually associated with that of maternity, is connected with the Deity or the chief of the deities worshipped. The deity is married, and is a father, but the goddess never ranks on an equality with him. In monotheistic systems the two ideas of paternity and maternity are combined in one God who is the cause and progenitor of all existence.

In Christian theology the term father is applied to the First Person of the Trinity, both as expressing a special relationship to the Son and an attitude as Creator, sustainer and chief benefactor of the human race. This aspect of God as the Father of His people was only gradually unfolded in the Hebrew Scriptures, and it was not until post-exilic days that the idea of a warrior king appears to have been superseded by that of a loving and merciful Father. The teaching of Christ developed the doctrine to a degree unknown before. He claimed to be in a spccial sense the Son of God, and in Him all Christians are the children of God by adoption and regeneration. This feature of Christ's teaching was unique, and is the key to the whole Christian system. It is becausc God is our Father that His love prevails over His wrath at man's disobedience, and $\mathrm{He}$ sends forth His only begotten Son to be an atonement and to make possible the repentance of the sinner and the pardon of his sin. See Trinity.

Father Lasher. Marine species of bullhead. Common around the British coasts, it has a large flattened head, and the spines can inflict an unpleasant wound if the fish is carelessly handled. The male acts as guardian of the spawn. See Bullhead.

Father of the Chapel. Name given to one who presides over the meetings of employees in a printing or newspaper office. See Chapel.

Fathers of the Church. Term specially applied to early Christian writers pre-eminent forlearning and sanctity, whose works are regarded as having authority next after that of the Bible. The name seems to have been generally accepted by the 4 th century. It has, however, always been used rather loosely. Even writers like Origen, whose orthodoxy was open to dispute, have been included among those who are known as fathers of the church.

The prominent writers of the lst century were known as the apostolic fathers from their personal association with the apostles, whose teachings they are held to reflect. The list of the church fathers has been held to include writers down to the 12th century; but in com. mon practice it is restricted to those antecedent to S. Gregory the Great (A.D. 604) in the Western Church and to John of Damascus (A.D. 756) in the Eastern. Some authorities, however, regard $\mathrm{S}$. Bernard of Clairvaux (d. 1153) as the last of the fathers.

The chief church fathers are usually divided as follows : Doctors of the church-Athanasius, Basil the Great, Gregory Nazianzus, Chrysostom, Ambrose, Augustine, Jerome, 
and Gregory the Great. AnteNicene Fathers-Justin Martyr, Clement of Alexandria, Origen, Tertullian, Irenaeus, Cyprian, Gregory Thaumaturgus; Post-Nicene Fathers-Eusebius, Cyril of Jerusalem, Gregory of Nyssa, Theodoret, Hilary of Poitiers, Hilary of Arles, Leo the Great, John of Damascus, and others. The Venerable Bede is sometimes included in the last category.

In the Roman Church, the fathers, in their testimony to the fundamental doctrines of the faith, are held to be without fault, and their teaching is to be accepted without question; but in details and method of teaching they are of varying authority and value. Among Protestants no such authority is assigned to them; but the general consensus of the fathers is regarded as of the highest importance as showing how the early Church understood the teaching of Christ and His Apostles. The writings of all the chief fathers of the Church are included in Migne's edition, in 387 large volumes, 1844 . 66 ; and most of them have been translated into English.

Fathom. Nautical measure $6 \mathrm{ft}$. in length. Cables, etc., are measured by the fathom, and lead lines are marked off in fathom spaces.

Fatigue. Condition produced by prolonged or excessive muscular activity, due partly to consumption of the available energy-producing materials, and partly to the accumulation in the tissues of the waste products formed during these efforts. The physiology of fatigue in a single muscle can be studied graphically with the aid of the muscle-nerve preparation, obtained by dissecting ont the gastrocnemius muscle from the leg of a frog with the nerve attached. In the living being, besides the changes in the muscles, the development of fatigue is increased by the exhaustion of the central nervous system which follows the accumulation of waste products in the blood.

The scientific study of fatigue in workers received a great impetus during the Great War owing to the importance of securing the maximum output from munition factories. Researches show that both the hourly and the absolute output may be materially influenced by fatigue, and that to secure the best results for each form of work there appears to be a definite period of labour. If this period is exceeded the worker never recovers fully from his fatigue, and the total decline in the average hourly output may be greater than the increase made by working overtime. Among women engaged in moderately heavy work, it was found that a diminution of the hours by 8.5 p.c. actually increased the weekly out. put by 8 p.c. Among men engaged in heavy labour a decrease of hours from 61.5 to 56.2 per week eventually increased the hourly output by 24 p.c. Similar observations have shown that in the great majority of cases Sunday labour is a mistake, the worker requiring at least one full day's rest a week.

Other investigations showed that fatigue is less severely felt by workers who are well and properly fed. A group of women, whose early morning period of work was suspended so that they had time to obtain a properly cooked meal, increased their average output in the remaining hours by $12 \cdot 4$ p.c., although the length of the working day was reduced by 20 p.c. The general application of these principles to industry should be of great benefit, for at present most managers of factories have a tendency towards establishing uniformity of hours for all types of labour and for workers of both sexes, and in consequence do not always get the best results. See Factory.

Fatigue. Term used in metal lurgy. It was at one time generally assumed that so long as a metal was not stressed beyond its limits of elasticity, it could never give way ; thus one might go on bending a bar of steel or iron backwards and forwards for ever, and, so long as the bar was not bent so far that it did not recover itself, it would never break. It has been shown, however, that a continued vibratory stress, even well within the limits of elasticity of a metal, will in time " fatigue " it and cause a rearrangement of the molecules, a crystallisation in fact, or a change in the original crystalline structure, which will result in fracture; or a microscopical flaw may by such stressing be developed into a plane of rupture. Formerly, before the manufacture of steel was so well understood as it is to-day, when the axles of railway carriages were made of malleable iron, breakages occurred and serious accidents resulted owing to the original fibrous structure of the axle having been changed into a crystallisation by repeated vibra. tory stresses. See Steel.

Fatigue. Duty performed by solcliers in connexion with the administration of the troops. It includes coal carrying, loading bag gage, cleansing surface drains and flushing latrines, sweeping yards and removing snow, but not personal service for officers. When employed on whitewashing build. ings or other technical work, which properly should be performed by a departmental corps, the troops are called "working parties," and receive " working pay."

Fatima (c. 606-632). Daughter of Mahomet by his first wife Kadijah. Born at Mecca, she was the prophet's favourite daughter, and was called by him one of the four perfect women in the world. She bore her husband Ali three sons, Al-Hassian, Al-Hussein, and AlMuhsin. From the first two are descended the Fatimate caliphs of N. Africa and Syria.

Another Fatima was the heroine of Perrault's story of Bluebeard, where, as his seventh and last wife, she discovered the bodies of her predecessors. (See Bluebeard.) The name also occurs as that of an en. chantress in the Arabian Nights story of Sindbad the sailor.

Fatshan. City of China, in the prov. of Kwang-tung. It lies in the Si-Kiang and Pe-Kiang delta, $7 \mathrm{~m}$. S.W. of Canton. It has iron and steel industries, and a trade in cereals, oil, timber, and cassia. At Fatshan Creek, a number of Chinese junks were destroyed by British naval forces during the war of 1857. Pop. est. 400,000 .

Fatty Acids. Series of acids with the general formula $\mathrm{C}_{\mathbf{n}} \mathrm{H}_{2 n} \mathrm{O}_{2}$, so-called because most of them occur in natural fats. The formula given above requires the number of hydrogen atoms to be double the carbon atoms in each acid. The following is a list of those at present known, arranged in order of their carbon atoms:

C $\mathrm{H}_{2} \mathrm{O}_{2}$ Formic.

$\mathrm{C}_{2} \mathrm{H} 、 \mathrm{O}_{2}$ Acetic.

$\begin{array}{llll}\mathrm{C}_{3} & \mathrm{H}_{6} & \mathrm{O}_{2} & \text { Propionic. }\end{array}$

$\mathrm{C}_{4} \mathrm{H}_{8} \mathrm{O}_{2}$ Butyric.

$\mathrm{C}_{5} \mathrm{H}_{10} \mathrm{O}_{2}$ Valeric or pentolc.

$\mathrm{C}_{8}{ }^{\circ} \mathrm{H}_{12} \mathrm{O}_{2}$ Caproic or hexoic.

$\mathrm{C}_{7} \mathrm{H}_{14} \mathrm{O}_{2}$ Oenanthylic or heptoic.

$\mathrm{C}_{8} \mathrm{H}_{16} \mathrm{O}_{3}$ Caprylic or octoic.

$\mathrm{C}_{9} \mathrm{H}_{18} \mathrm{O}_{3}$ Pelargonic or nonoic.

$\mathrm{C}_{10} \mathrm{H}_{20} \mathrm{O}_{2}$ Capric or decatoic.

$\mathrm{C}_{11} \mathrm{H}_{22} \mathrm{O}_{2}$ Undecylic or hendecatoic.

$\mathrm{C}_{12} \mathrm{H}_{24} \mathrm{O}_{3}$ Lauric or dodecatoic.

$\mathrm{C}_{13} \mathrm{H}_{26} \mathrm{O}_{2}$ Tridecylic or tridecatoic.

$\mathrm{C}_{2} \mathrm{H}_{38} \mathrm{O}_{2}$ Myristic or tetradecatoic.

$\mathrm{C}_{15} \mathrm{H}_{30} \mathrm{O}_{2}$ Pentadccatoic.

$\mathrm{C}_{26} \mathrm{H}_{32} \mathrm{O}_{2}$ Palmitic or hexadecatoic.

$\mathrm{C}_{17} \mathrm{H}_{34} \mathrm{O}_{2}$ Margaric or heptadecatoic.

$\mathrm{C}_{18} \mathrm{H}_{38} \mathrm{O}_{2}$ Stearic or octodecatoic.

$\mathrm{C}_{10} \mathrm{H}_{38} \mathrm{O}_{3}$ Nondecatoic.

$\mathrm{C}_{20} \mathrm{H}_{+0} \mathrm{O}_{2}$ Arachidic or enendecatoic. $\mathrm{C}_{21} \mathrm{H}_{42} \mathrm{O}_{2}$ Medullic.

$\mathrm{C}_{22} \mathrm{H}_{44} \mathrm{O}_{2}$ Behenic or icosoic.

$\mathrm{C}_{24} \mathrm{H}_{4} \mathrm{O}_{2}$ Lignoceric.

$\mathrm{C}_{25} \mathrm{H}_{50} \mathrm{O}_{2}$ Hyaenasic.

$\mathrm{C}_{27} \mathrm{H}_{54} \mathrm{O}_{2}$ Cerotic.

$\mathrm{C}_{30} \mathrm{H}_{80} \mathrm{O}_{2}$ Melissic.

$\mathrm{C}_{34} \mathrm{H}_{68} \mathrm{O}_{2}$ Dicetylic.

$\mathrm{C}_{84} \mathrm{H}_{1{ }_{2}} \mathrm{O}_{2}$ Theobromic.

The fatty acids may be roughly divided into two classes, liquid and solid. Those containing ten or more atoms of carbon are solids. All dissolve readily in alcohol and ether. The lower members of the series are soluble in water, but the solubility decreases as the number of carbon 
atoms increases. The acidity diminishes with the increase in the carbon atoms, this property being utilised in a process for separating the various acids. Another process of separation depends upon the progressive decrease in the solubi. lity of the barium, magnesium, and lead salts. All the fatty acids, except formic and acetic, are oily or greasy. The boiling-point rises about $19^{\circ}$ for each addition of $\mathrm{CH}_{2}$ in the formula, in the case of the acids from formic to capric. The melting-points of the solids show a similar rise. The volatility of the acids decreases as the carbon atoms increase, so that lauric acid and those higher in the series can only be distilled without decomposition under diminished pressure. The acids with an odd number of carbon atoms are comparatively rare.

Fatty Compounds. In organic chemistry, those in which the carbon atoms are connected together by a single linking. They are also known as saturated compounds because chemical changes are brought about by substituting one atom or group by other groups. Another series of organic compounds containing less hydrogen than the fatty compounds are known as unsaturated compounds, as they can combine directly with hydrogen or chlorine. The fatty acids belong to the group of fatty compounds.

Fatty Degeneration. Change in the cells of animal tissues in which the constituents of the cell become partly broken down into fat. It may be the result of various dis. eases, e.g. pernicious anaemia, or poisoning by certain substances, such as phosphorus or arsenic, or, more frequently, may follow lessen. ing of the blood supply to an organ owing to narrowing of the arteries. The last is the usual cause of fatty degeneration of the heart.

Fatwa. Town of Bihar and Orissa, India, in the Barh subdivision of the Patna district. It is situated on the E. Indian Rly.. $7 \mathrm{~m}$. S.E. of Patna, at the junction of the Punpun with the Ganges. It is a resort of pilgrims. Pop. 74,757, 90 p.c. Hindus.

Faubourg. French word for a suburb, e.g. the Faubourg St. Honoré in Paris. It comes from Latin words meaning outside the borough or burg, and in the days when cities had walls was given to suburbs outside them.

Faucher, LÉoN JosepH (180354). French economist and politician. Born at Limoges, Sept. 8, 1803 , he became prominent as a journalist, chiefly on Le Temps and Le Courrier Français, between 1830-42, making a close study of economic problems and exerting a

moderating influence on the liberal factions. Elected a deputy in 1847 , he was also returned to the constituent assembly of 1848 for the Marne dept. He was a strong advocate of free trade principles, influenced by a visit to England in 1843. Although minister of the interior in 1848-49, and again in 1851, his active political career was not successful, and he retired from public life in protest against the adoption of universal suffrage in 1851. He was largely responsible for the foundation of the Crédit Foncier $(q . v$.$) in 1852. He died$ Dec. 14, 1854.

Fauchet, Cladde (1744-93). French Revolutionist. Born Sept. 22. 1744, he became a priest in Paris and tutor in a noble family. His preaching won fame for him, and after being dismissed from his position as court preacher he joined the Revolutionary party. He helped in the attack on the Bastille, and was afterwards a member of the legislative assembly and the national convention. He was made bishop of Calvados, but ceasing to act with the advanced republicans, he was guillotined, Oct. 31, 1793 .

Faucille, CoL DE LA. Mt. and pass of France, in the dept. of Ain. 'They are in the Jura Mts., $16 \mathrm{~m}$. N.W. of Geneva. On the summit of the mountain $(4,355 \mathrm{ft}$.) are two hotels. The pass leads through the valley of the Dappes, which in 1862 was partitioned between France and Switzerland.

Faucit, Helena Saville (182098). A British actress. She made her first London appearance at

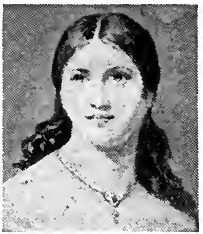

, Helena Faueit, British actress

mona, Imogen, and Hermione. Macready engaged her as leading lady from 1837 at Covent Garden, The Haymarket, and Drury Lane. Among other parts she acted Cordelia to his Lear, Virginia to his Virginius in Knowles's drama, and Pauline to his Claude, Julie to his Richelieu, and Clara to his Alfred Evelyn, in the original production of Lytton's plays, The Lady of Lyons, Richelieu, and Money. In 1851 she married Sir Theodore Martin, who wrote her life, 1900 . She died Oct. 31, 1898.

Fauconberg, Baron. English title dating from 1283 and now united with that of Conyers.
Walter de Fauconberg, who was summoned to Parliament as a baron in 1283 , was the first holder, and the title passed to his descendants until it came in 1362 to Thomas, the 5th baron. He left an only daughter, Joan, who married Sir William Neville, and he, following the custom of the time, became Lord Fauconberg. He was made earl of Kent, but died without sons, and from the time when his widow died (1491) to 1627 the barony was in abeyance. In that year Charles 1 gave Thomas Belayse the title of Baron Fauconberg, and in 1642 created him a viscount. To those titles his grandson Thomas succeeded in 1652 . He was a parliamentarian and married Mary, daughter of Oliver Cromwell. Afterwards he became a royalist and courtier under Charles II. He was made an earl in 1689 and died without sons in 1700 . In 1903 the barony was granted to the countess of Yarborough, a descendant of Joan Neville.

The barony of Conyers dates from 1509 and was held by the families of Conyers and Darcy until 1888. In 1892 an abeyance was ended in favour of the countess of Yarborough. See Holderness, Earl of.

Fauldhouse. Parish and town of Linlithgowshire, Scotland. It is $7 \mathrm{~m}$. S.W. of West Calder, on the Cal. and N.B. Rlys. Coal and ironstone are worked, and there is a paraffin industry. Pop. 3,923.

Faulhorn. Mt. of Switzerland, in the canton of Berne. It is in the Bernese Oberland, 32 m. S.E. of Berne, between the lake of Brienz and the Grindelwald valley. It is composed of calcareous, fri. able schist. Alt. 8,803 ft.

Fault. In geology, a dislocation of rock-beds due to movements of the earth's crust. Three main types are recognized: normal, reversed, and transcurrent. In normal faults the displacement is more or less inclined, rarely vertical. On one side of the line of fracture rock-beds are thrown to a lower level, the amount of vertical displacement being known as the throw, the inclination from vertical being termed the hade.

Normal faults may run in approximately the same direction as inclination of beds (dip faults), or at right-angles to it, that is, coinciding with the trend of the bed (strike. faults). They may be oblique, or occur in groups (step or troughfaults), and intersection of faults often takes place. When dislocation is inclined to the upthrow, the reversed type of fault is produced. Reversed faulting is usually associated with highly inclined or folded strata, and may lead to 


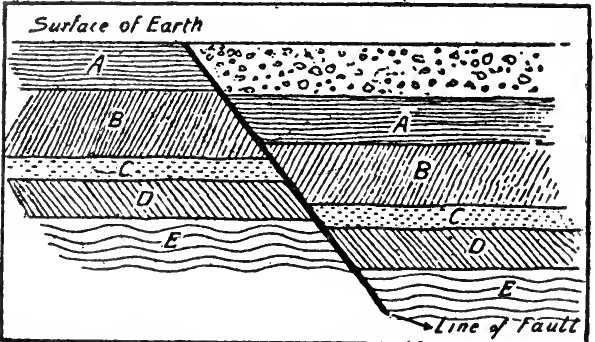

Fault. Diagram illustrating a fault in the earth's surface. The relative positions of the letters $\mathbf{A} \mathbf{A}, \mathbf{B} \mathbf{B}$. etc., show the extent of dislocation

development of overthrusts. With transcurrent faulting the move. ment has been in horizontal direction, and there are neither upthrows nor downthrows. Friction is set up along the planes of all faults, and results in the crushing and polishing of the opposing rock-surfaces, "slick ensides" and "crush - brec. cias" being produced. See Dip; Earth. movement; Tectonics.

Faun.

Roman myth. ology, a minor nature deity identified with the' Greek satyr. See Faunus.

$\mathbf{F}$ a $\mathbf{u}$ a. Term used by naturalists for the collective animal life of Fa un, a statuette any special locality or

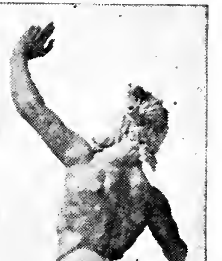
nation, Jan. 15, 1895, defeating Brisson by 69 votes. An unsuccess. ful attempt on $h$ is life was made, July 14, $1896 . \quad \mathrm{Th}$ e chief events marking his tenure of office were the visit of the tsar of Rus. sia and the conclusion of the Franco-Russian

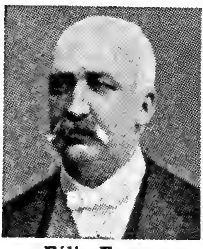

Félix Faure, French statesman alliance, 1896, and the opening stages of the Dreyfus affair, at a critical point in which Faure died suddenly, Feb. 16, 1899.

Fauré, Gabriel (1845-1924). French music composer. Born at Pamiers, Ariège, May 13, 1845, he studied in Paris and became or. ganist, first of S. Sulpice, and then of La Madeleine, 1896. Director of the Conservatoire Nationale, 1909-20, he was elected to the Academy of Fine Arts in 1913. Among his works are orchestral poems and suites, a symphony, and a berceuse for solo violin. He died Nov 4, 1924.

Faure, Jean Baptiste (18301914). French singer. Born at Moulins, Jan. 15, 1830, he excelled in singing as a boy. After studying at the Conservatoire in Paris, he appeared at the Opéra Comique in 1852, and achieved success in opera in Paris, London, Vienna, and Brussels. He died Nov. 10, 1914.

Faust. German scholar of the 16th century whose name has become the centre of a great body of legend and poetry in European literatures. There is good historical evidence for the existence of a real doctor of this name who, during the first half of the 15th century, practised magical arts, and gained wide notoriety as a clever charlatan in various parts of Germany, especially, it is believed, at Cracow. The numerous stories popularly attached to his name were collected anonymously and published by Johann Spiess at Frankfort in 1587 as 'The His. tory of Dr. Johann Faust, a book which went through many editions, translations, and adaptations. In this work the essentials of the story are given as follows:

Faust, weary of the pursuit of learning and worldly pleasures alike, has taken up the study of magic and necromancy. He conjures the devil, who engages to serve him in all he may desire for a period of 24 years, after which he passes into the devil's power. The devil accordingly procures for Faust all sorts of pleasures and supernatural aids to his study of sorcery, alchemy, and philosopliy. Faust has occasional fits of repentance, which pass as his servant provides fresh delights; among his lovers is Helen of Troy, a familiar medieval incarnation of pagan delights. When the appointed time expires, Faust dies in an agony of fear, and falls irrevocably into the devil's hands.

The Tragicall History of Dr. Faustus, the drama by Christopher Marlowe, published in 1604, is the first appearance of the story in serious literary form in England. It was derived from an English version of the Spiess pub. lication, published probably about 1590. Faust is depicted as a young man, enjoying to the full his illgotten pleasures; and the devil, Mephistopheles, is a genuinely tragic figure, fallen from heaven and tor. tured by regret for his lost state. Helen of Troy is conjured up near the end of the tragedy, symbolising, as some hold, the return of ancient beauty in the Renaissance to challenge medieval doctrines.

\section{Goethe's Faust}

The Faust of Goethe, the greatest version of all, is a long verse drama in two parts. First begun in 1773 , Goethe did not complete working on it until 1832, a few days before his death, but parts were published in 1790 and 1808 . The story is developed on widely different lines from the early Faust books. Faust, inspired by a fierce desire for knowledge and for pleasure, and convinced of the unreality and uselessness of his life, sells himself to Mephistopheles. He seduces and deserts the beautiful Marguerite, who in despair kills her child and is thrown into prison. Faust visits her, and tries in vain to persuade her to flee with him, but she dies in his arms. A voice from Heaven declares that peni. tence has saved the soul which he had imperilled. This is the central episode in the story, but the Prologue in Heaven describes how the temptation of Faust is undertaken by Meplistopheles as a wager with God, who believes that Faust can withstand his seductions. 
In Goethe's second part, the phil. osophic aspect forms the exclusive interest, although the symbolism is often very obscure. Faust comes to the conclusion that neither learning nor bodily pleasures can satisfy his soul, but only a life of useful activity, contributing to the beneficent works of God and Nature. By this decision his soul is saved from perdition. Goethe has thus transformed the old Faust story, with its stress on the punishment awaiting those who seek human and rational knowledge in preference to theological doctrine, into an ex. pression of the noblest humanism in thought and action.

Faust has also been the subject of a romance by Friedrich Klinger, 1791 , of a dramatic poem by Nikolas Lenau, 1836, and used as the basis for operas by Spohr, 1818, Berlioz, 1846, and Gounod, 1859. A tragedy, Faust, by W. G. Wills, based on Goethc's version, was produced successfully by Henry

$$
\text { prod uced successftlly by Henry }
$$

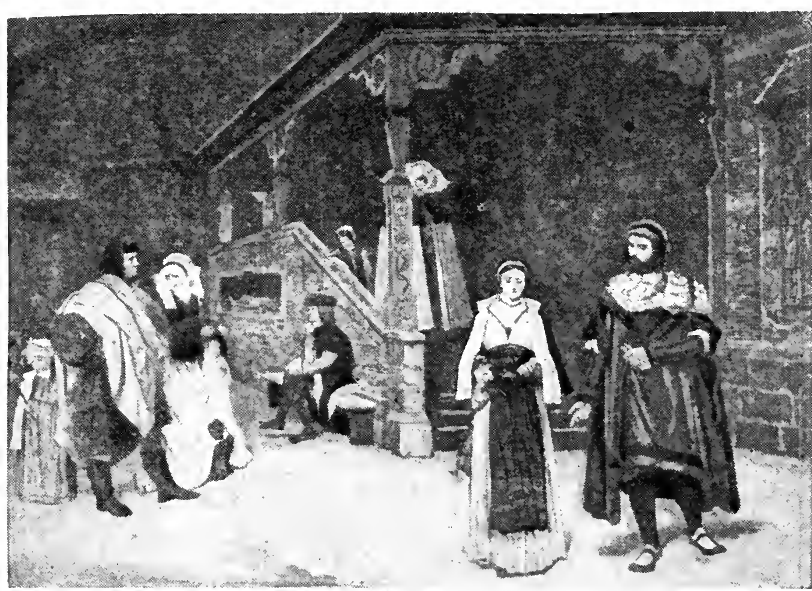

Faust. The meeting of Faust and Marguerite, from the painting by J. J. J. of Faust and Marguerite, from the
Tissot, in the Luxembourg, Paris

Irving at the Lyceum, London, Dec. 19,1885 , revived in 1888 , 1894, and 1902. In Oct., 1920, the original version of Goethe's Faust, found by Friedrich Schmidt of Berlin University in a contemporary manuscript copy, was produced in Berlin by Max Rein. hardt. Pron. Fowst. See Goethe; Mephistopheles.

Faustina (d. A.D. 14l). Wife of the Roman emperor Antoninus Pius. His daughter of the same name (d. A.D. 175) married Marcus Aurelius, successor of Antoninus. Mother and daughter were noted for their profligacy, yet their memory was held in honour after their death by their husbands, who founded institutions for the educating of orphan girls called after them Faustinianae.
Faust Up to Date. Burlesque written by George R. Sims and Henry Pettit, with music by Meyer Lutz, produced Oct. 30, 1888, at The Gaiety, London, where it ran for 180 performances.

Fauvette. British mercantile auxiliary. She was sunk by a mine off the E. coast of England, on March 9, 1916, when two officers and 12 men were lost.

Favara. Town of Sicily, in the prov. of Girgenti. It stands at an alt. of $1,100 \mathrm{ft}$., $5 \mathrm{~m}$. S.E. of Girgenti, and $9 \mathrm{~m}$. from the Mediterranean. It is the centre of a fruitproducing district, and is noted for its rich sulphur mines; other products are marble, alum, and tourmaline. There is a 14 th century castle of the Chiaramonti. Pop.21,599.

Favart, Charles SimoN (171092). French dramatist. Born in Paris, Nov. 13, 1710, he produced his first light opera, Les Deux $J$ umelles, in 1734 , with such success that he left his father's bakery

business and turned to playwriting. Under his direction the Opera Comique became the centre of this class of wor k for many years. A protégé of Madame de Pom. padour, he scored other notablesuccesses with La Chercheuse d'Esprit, 1741 ; Les Moissoneurs, 1747 ; Les Trois Sultanes, 1761 . His wife, Marie Justine du Roncerai (1727-72), was a colebrated actress, whose coldness to the enamoured Mar-

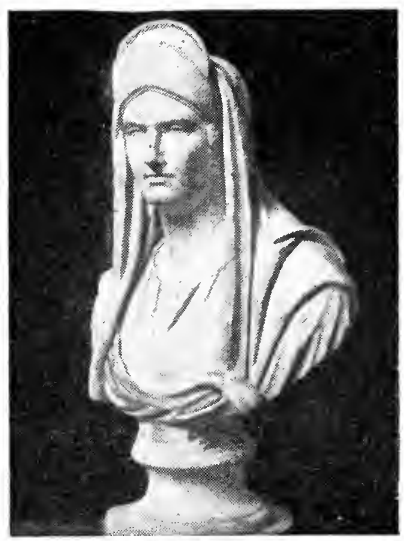

Faustina, wife of the emperor Antoninus Pius

From a bust in the Naples Museum

shal de Saxe, when the Favart company was performing in his camps in Flanders, 1747, brought his wrath on her, and a lettre de cachet on her husband, the execution of which he escaped. Favart died in Paris, May 12, 1792. See Favart, L'Opéra Comique, et la Comédie-Vaudeville aux 17e et $18 \mathrm{e}$ Siècles, A. Font, 1894.

Faversham. Mun. bor. and market town of Kent, England. It stands on a branch of the Swale, called Faver.

sham Creek, and is $9 \frac{1}{2} \mathrm{~m}$. N.W. of Canterbury, on the S.E. \& C.R An ancient town, in 1147 Stephen and $M$ a tild a founded here a Cluniac a b bey,

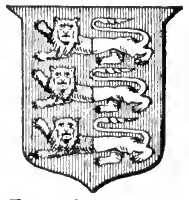

Faversham arms of which traces still exist. In it the royal pair and their son Eustace were buried. The cruciform church of S. Mary of Charity, in the Early English style, restored by Sir G. G. Scott in 1874, contains some superb brasses.

Faversham has a trade in fruit,

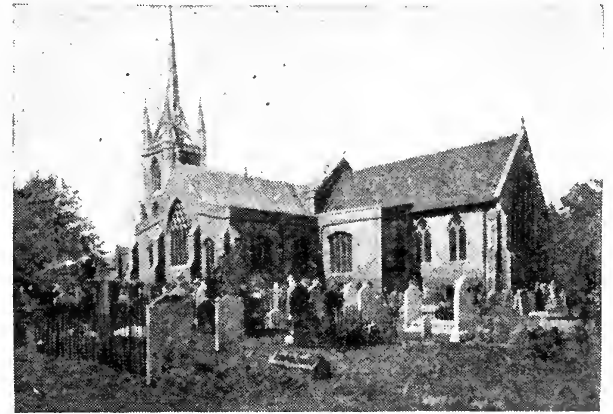

Faversham. The parish church of S. Mary of Charity, restored in 1874 
hops, and agricultural produce, also powder mills, brick and cement works, breweries, and an important oyster industry. The port has a trade in coal, timber, etc. The corporation owns the electric lighting plant, a recreation ground, and a cemetery. Owing to its position at the point where Watling Street touched the river, Faversham was an important place in Anglo-Saxon times, having probably been so in Roman ones. It was a member of the Cinque Port of Dover, had its own mayor and corporation, while its abbot was rich and powerful. It is still governed by a mayor and corporation. A serious explosion occurred at a powder factory here in April, 1916. Market days, Wed. and Sat. Pop. 10,619.

Favier Explosives. Original name of ammonium nitrate explosives, and a term by which the class is still generally known. Owing to a number of accidental explosions due to blasting in coal mines, attention was drawn to the suitability of ammonium nitrate explosives for this work, owing to their low explosion temperature, and Favier patented the type in 1884-85, the manufacture being taken up by the French govern. ment. The official French explosives generally consist of about 95 p.c. of ammonium nitrate and 5 p.c. of di- or tri-nitronaphthalene, for use in fiery mines, whilst the latter ingredient is increased to 12 p.c. for use in others. Ammonite is an Eng. lish representative of this class.

Favignana (anc.Aegusa). Island of the Mediterranean, belonging to Italy. It lies off the N.W. coast of Sicily, and is the largest of the Aegades Islands. Favignana, the chief town and fishing port, lies on the N. shore, and has a fortified harbour. Off the island the Carthaginian fleet was defeated by the Romans in 241 B.c. The island is 6 $\mathrm{m}$. long, and rises over $1,000 \mathrm{ft}$. It is honeycombed with caves. Area, 8 sq. m. Pop. 6,079.

Favonius. In Roman mytho$\log y$, the name of the W. or S.W. wind which blew in spring, identified with the Greek Zephyrus.

Favorinus. Greek sophist and rhetorician. A native of Arelātē (Arles) and a great traveller, he flourished during the reign of Hadrian. He wrote several miscellaneous works, but none survives.

Favre, Jules Claude Gabried (1809-80). French statesman. Born at Lyons, March 21, 1809, he entered the legal profession, and, an ardent republican from the first, was elected deputy for Lyons to the constituent assembly, 1848. A bitter enemy of Louis Napoleon,

he attempted an armed riot against his election to the presidency, 1851, defended his assailant Orsini,

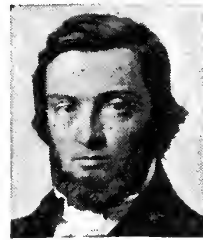

Jules Favre, French statesma fence, 1870 Favre was foreign minister and vice-president, but mismanaged the armistice negotiations, Jan. 28,1871 , and as foreign minister under Thiers, 1871, was easily out-manoeuvred by Bismarck. The treaty of Frankfort brought about his resignation, July 23, 1871. He was elected to the senate in 1876, and died Jan. 20, 1880. His writings include politica studies, and an account (1873-75 of The Government of National Defence, in which he describes his part in the events of 1870-71

Favus (Lat., honeycomb). Dis. ease caused by a parasite fungus, the Achorion Schoenleinii, which most frequently attacks the scalp, but may affect any part of the skin. Favus is common in Eastern Europe and Asia, but is rare in Great Britain. On the scalp it first a ppears as small, irregular cups of a sulphur-yellow colour. Large sæabs are gradually formed which eventually drop off, leaving a depressed scar destitute of hair. The condition is intractable, and may persist for years. The contagion may be derived from rabbits, dogs, fowls, and other animals. Exposure of the patch to $\mathrm{X}$-rays, followed by vigorous treatment with antiseptics, give the best results.

Fawcett, HeNRy (1833-84). British politician and economist. Born at Salisbury, Aug. 26, I833, he graduated at Cambridge in 1856, distin. guishing him. self in mathe. matics. He was a c ciden tally blinded at a shooting party in 1857 , but, taking up his fellowship at

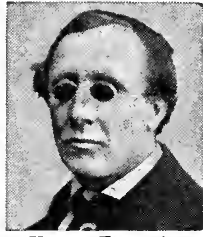

Henry Fawcett. British politician
Trinity Hall, devoted his time to the study of political economy, of which he became professor in 1863 . In 1867 he married Millicent Garrett, a distinguished advocate of women's rights. In 1865 he became Liberal M.P. for Brighton, and took up an independent line which brought him into opposition with every other party. .'Identifying himself with many schemes of reform and devoting himself especially to all questions concerning India, he became known as the member for India. In 1875 he was chosen M.P. for Hackney, and in 1880 became postmastergeneral under Gladstone, but with out a seat in the cabinet. $\mathrm{He}$ introduced several postal reforms. Hedied at Cambridge, Nov. 6, 1884. See Life, Leslie Stephen, 1885.

Fawcett, DAME MILLICEN T GarReTt (b. 1847). British writer and feminist. Born June 11. 1847 , she was the daughter of Newson Gar. rett, and sister of Mrs. Garrett Anderson. In 1867 she married Hen ry Fawcett. She be. came a leading
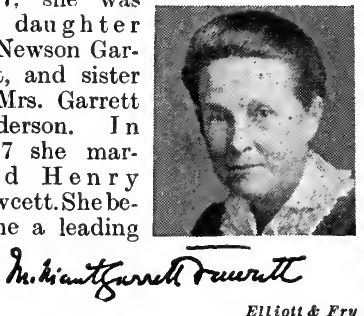

advocate of women's suffrage, being president of the national union of women's suffrage societies until 1919. Mrs. Fawcett was known also as a writer on educational and political subjects. Her two text-books, Political Economy for Beginners, 1870, and Tales in Political Economy, 1875, had great popularity. She wrote Essays and Lectures, jointly with Henry Fawcett, 1872: Life of Queen Victoria, 1895; Women's Suffrage, 1912. She received the G.B.E. in 1925 Her daughter, Philippa Garrett Fawcett, was senior wrangler in fact, though not in name, in 1890. Afterwards she was engaged in educational work.

Fawkes, Guy (1570-1606). English. conspirator, central figure in the Gunpowder Plot. Born at York, April 16, 1570, he served for some years in the Spanish armies in Flanders from 1593. The circum. stances of his implication in the conspiracy were as follows.

In 1604 a small group of Roman Catholic zealots, finding that they had nothing to hope from the accession of James I, formed a plot for the overthrow of the government by blowing up king, ministers, and parliament together ; in the resultant chaos, the Roman Catholics, headed by the conspirators, were themselves to seize the government. TThe secret, imparted to few-Catesby, Percy, Digby, Rookwood, and Tresham are the most familiar of the names of the plotters-was for a long time well kept. The design was to be carried out on the day of the assembling of parliament in Feb., 1605. 
But the meeting was adjourned till Oct., and finally till Nov. 5. The conspirators procured an adjoining house which gave them access to the chambers under the Parliament House, where gunpowder was stored, while the actual execution of the plot was entrusted to Fawkes.

But at the critical moment a hint was conveyed by one of the conspirators, Francis Tresham, to Lord Monteagle, warning him to absent himself from the ceremony, since "this Parliament shall receive a terrible blow, and shall not know who hurts them." The meaning of the hint was unexpectedly elucidated; on the night of Nov. 4 Fawkes was found at his post, and was seized after a desperate resistance. The rest of the conspirators fled, but were hunted down and captured or slain. A full confession was extorted under torture from Fawkes, who, with the surviving conspirators, was executed, Jan. 31, 1606.

The share taken in the affair by the Jesuits is a matter of dispute, but two of them, Gerard and Garnet, the head of the order in England, certainly knew of the plot, though the latter is said to have received his information only under the seal of confession. The effect of the plot was to establish in the minds of the English people an unreasoning and persistent fear and hatred of the Roman Catholics; though none but a few desperate fanatics had been in any way concerned. See Gunpowder Plot.

Fayal on FaIAL. Island of the Azores, belonging to Portugal. It lies W. of Pico. Almost wholly mountainous (highest point 3,300 ft.), it is fertile, cereals, fruit, and vegetables being cultivated. The fig tree flourishes, and from its pith carvings are made; lace is made from the agave. Basket-making is carried on, but the so-called Fayal wine was made in the neighbouring island of Pico. The capital and chief port is Horta, with a wireless station. Area, 65 sq. m. Pop. 22,385.

Faye, Hervé Auguste Étienne (1814-1902). French astronomer. Born at St. Benoit-du-Sault, Indre, Oct. 5,1814 , he was made professor of astronomy at Nancy in 1854. In 1873 he was appointed professor of astronomy and geodesy at the Ecole Polytechnique in Paris. He discovered the comet named after him, Nov. 22, 1843. It has a period of $7 \frac{1}{2}$ years, and pursues the most nearly circular path of any known object of the kind. His name was associated with the cyclonic theory of sunspots, with the nature of, and velocities in, prominences. He died in Paris, July 4, 1902.

Fayolle, Marie Emile (b. 1852). French soldier. Born at Le Puy, Loire, May 14, 1852, he entered the French army as a lieutenant of artillery in 1877, and saw active

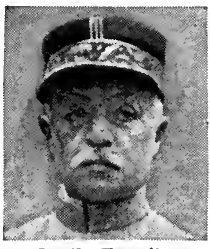

Emile Fayolle, French soldier

\begin{abstract}
service in Tu-
\end{abstract} nisia. He was later a professor in the École Supérie u re d e Guerre, became colonel 1907 , a n d general 1910 . At the out. break of the Great War he was in command of the 139th brigade, and then, after leading a division, commanded the 33rd army corps. Succeeding Castelnau, he led the French Sixth and First Armies in the battle of the Somme, 1916. In 1917 he commanded the Army of the Centre, which took part in the Aisne bat. tles. In Oct., 1917, he was in Italy as commander - in - chief of the French forces. In 1918 he returned to France and was placed at the head of the reserve army. For a time, in 1919, he commanded the French Army of Occupation in Germany. In 1920 he was a p ointed French military representative on the permanent armaments com. $\mathrm{mission}$ of the League of Nations.

Fayum (Coptic, lakeland). Prov. of Upper Egypt. It contains the districts of Etsa, Fayum, and Sen. nures. The district of Fayum consists of a nearly circu.

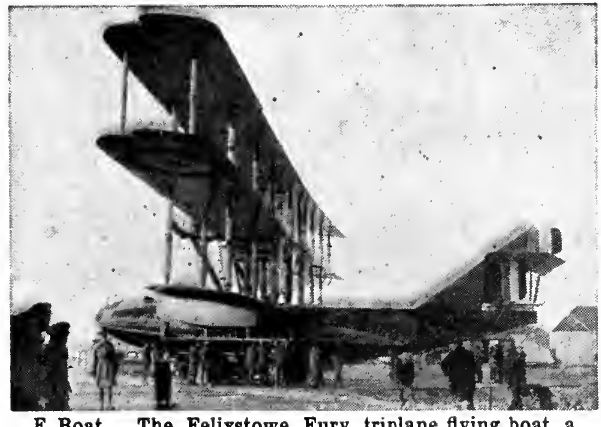

F Boat. The Felixstowe Fury triplane flying boat, a development of the earlier F boats. See page 3107 covered from mummy-wrappings ; other papyrus collections have come from Arsinoë and elsewhere.

Fazakerley. Suburb of Liverpool. It has a station on the L. \& Y. Rly. and is also connected with the centre of the city by tramways.

Fazogli or FAzOKL. Region of the Anglo-Egyptian Sudan. It is intersected by the Blue Nile and borders Abyssinia on the S. and E. The inhabitants are negroes, but there are Arab settlements. The chief town is Famaka. Gold, ivory, gum, and fruits are exported, and tobacco and lurra are produced. Pop. (est.) 500,000.

F.B.A. Abbrev. for Fellow of the British Academy (q.v.), an important learned society.

F.B.A. Name of a two-seater flying boat manufactured by the Franco-British Aircraft Co., fitted with a 100-h.p. Gnôme engine. It was $45 \mathrm{ft}$. in breadth and $28 \mathrm{ft}$. in length, and was used during the Great War for patrol work and submarine spotting.

F Boat. Name given to a class of flying boats developed by the Felixstowe experimental seaplane station of the R.N.A.S.-later lar basin, well irrigated and fertile, sunk below the level of the surrounding desert. In it are Lake Moeris and the town of Medinetel-Fayum. The chief products are rice, cotton, flax, hemp, figs, olives, and oranges. The prov., which is watered by the Bahr Yusuf, an old Nile branch, abounds in ancient remains, its sites having been dug by Flinders Petrie mainly between 1888-90. The area of the prov. is 669 sq. m. Pop. 507,617.

Its overflow was embanked by Amenemhat III, who built a funerary temple, known in ancient times as the Labyrinth, two colossal statues on limestone pedestals, and the Hawara pyramid. Adjacent Roman tombshave furnished many mummy-portraits. Senwosri II erected the Illahun pyramid. At Gurob precious papyri were re-
R.A.F. The types F 2, F 2A, F 3, and $\mathrm{F} 5$ were built in considerable numbers by various contractors, and were extensively employed in the Great War for anti-submarine patrols. These four types were all biplane flying boats of large size, fitted with two Rolls-Royce engines from 250 to 375 h.p., carrying generally a crew of five, a formidable machine-gun armament, and a large load of bombs. See Felixstowe Fury.

F.E. Name of a type of British aeroplane built at the Royal Aircraft Factory, Farnborough, later known as the Royal Aircraft Establishment. The letters originally indicated Farman Experimental. It was a pusher biplane, and was named after Henry Farman, who was credited with having originated the pusher type. 
Feale. River of Ireland. Rising in N.W. co. Cork, it passes N.W between cos. Limerick and Kerry and thence W. through co. Kerry to the Shannon, which it enters as the Cashen. Its length is $37 \mathrm{~m}$.

Fear. Feeling of mental uneasiness arising from the expectation of evil to come. Exercising a disturbing and lowering effect, it drives the blood to the heart, giving rise to paleness and accelerated heart. beat; perspiration exudes from the skin, the hair stands on end. The eye, on the other hand, is stimulated. The aggravated form of fear is terror; a modified form is known as shyness. See Emotion Psychology.

Fear. Cape or headland of North Carolina, U.S.A. It is the extreme S. point of Smith's Island and of the state. A lighthouse has been erected on the point.

Feast. Term applied to days on which notable events in Chureh history, giving occasion for solemn joy, are commemorated. From this has developed its use for occasions of rejoicing in public or private; for public dinners, e.g. mayoral or civie feasts, etc. See Festival.

Feather. Outgrowth from the skin in birds, forming an external protective covering. They do not oecur in any other phylum of the animal kingdom, their place being taken by hair in the mammals. Feathers are of a horny character, and are composed structurally of an axis and a large number of barbs. The hollow base of the axis is fixed in the skin, and is known as the quill. The small hole at its base is the opening through which nutrition is supplied during growth. The solid upper part of the axis is called the shaft, from which branches or barbs grow out on either side. These barbs have smaller branches or barbules, which interlock and so resist the pressure of the air in flight. In flightless birds, as the ostrich, the barbules do not interlock, and the feathers are soft an ${ }^{\mathrm{x}}$ loose.

Although the body of a bird appears to be pretty uniformly covered with feathers, it is not really so. The feathers grow in definite tracts, and certain portions of the body are without them. Feathers are of many types, the strongest being the flight feathers on the wings. Small soft feathers, known as down, form an underlayer for purposes of warmth, and are most developed in the water-fowl. In some species, as the birds of paradise, certain feathers are modified to produce plumes and crests of varied form.

Economically, feathers - were formerly much used for stuffing

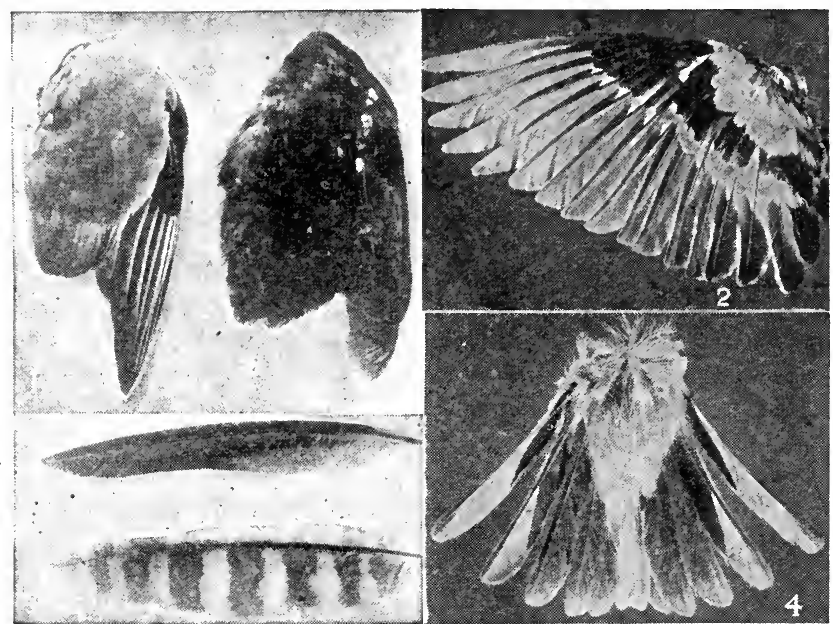

Feather. 1. Left, wing of wood pigeon; right, of tawny owl. 2. Wing of chaffinch. 3. Primary feather of tawny owl; above, of wood pigeon. 4. Tail of male chaffinch

beds, quilts, and cushions, especially the down of the eider duck, but have now largely given way to more sanitary materials. They are much employed for personal adornment, and the larger quills are still to some extent used as pens. For long an agitation has been carried on against the wearing of feathers obtained from birds

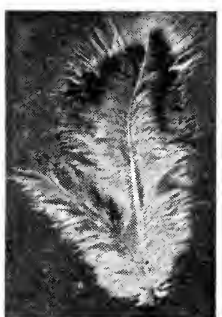

Feather of common fcwl of plumage. A Plumage(Prohibition) Bill to probibit the importation of the plumage of birds and the sale or pos. session of plumage illegally import. ed was intro. duced in to Parliament in 1920. (See Ostrich; Plumage.)

The preparation of feathers for the market includes eleaning, blanching, dyeing, and curling or bending to some required shape. The most important decorative feather is taken from the wings of the ostrich, being cut-close to the root-about three times in two years; the root either falling out or being extracted later. The feathers are sorted according to size, colour, and quality, are well washed, and sometimes dipped in strong starch, then shaken together in bundles in the hot sun until quite dry. Burning sulphur is sometimes used in purifying them. All but feathers which are to be dyed black need blanching, by which cape feathers from the male bird can be made perfectly white.
Stiff feathers have the quill scraped with glass to make them more pliable. Dyeing follows blanching, and the last process is curling the filaments according to the fashion in vogue with a blunt knife. Sometimes they are glycerined instead of curled, and under those conditions they present a lank, threadlike appearance.

Feather. River of California, U.S.A. Rising in many headstreams in the Sierra Nevada range, it flows S.W. and S. to the Sacramento river about $20 \mathrm{~m}$. above Saeramento city. Over $230 \mathrm{~m}$. long, it is navigable for only $30 \mathrm{~m}$. Its basin contains valuable gold deposits, which are extensively worked

Feather Grass (Stipa pennata). Perennial grass of the natural order Gramineae. A native of Europe, it was long cultivated in gardens as an ornamental plant. The glume containing the seed is covered with stiff hairs pointing upwards, whilst its base terminates in a sharp point. Above it is continued as a long, spirally twisted awn, ending in a long feather-like tail, the whole being about $1 \mathrm{ft}$. long. The wind acting on the glume detaches the seed, ete., from the plant, and when it reaches the earth the spiral, by expanding in dry and contracting in wet weather, forces the seed into the ground, the bristles on the glume allowing it to enter but preventing its return. If these seeds get into the fleece of sheep they are driven by the same mechanism into the flesh of the animal. Two allied speeies, S. capillata (Russia) and S. spartea (N. America), are known to kill sheep in this manner. 
Feather Star. Class of the Echi. noderma (q.v.), otherwise known as sea lilies. They resemble very

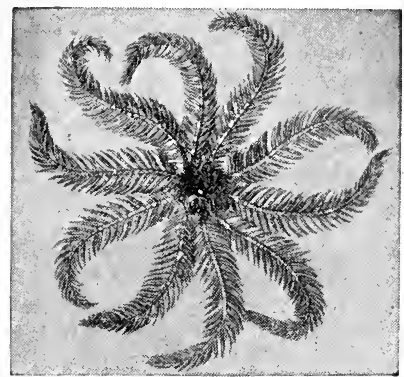

Feather Star. Specimen of rosy featber star, Comatula rosacea

slender starfish, with long rays bearing little branches or pinnules, somewhat like feathers. They live in deep water. Only one species, the rosy feather star, occurs around the British coasts. See Crinoidea.

Featherstone. Urban district and parish of Yorkshire (W.R.). It is $2 \mathrm{~m}$. S.W. of Pontefract, on the L. \& Y.R., and is a coal-mining centre. The place is specially known because, during a strike, there was a riot here, Sept. 7, 1893. Colliery works having been destroyed, the military arrived, and order was not restored without bloodshed. Pop. 14,374.

Feathertop. Mt. of Victoria, Australia. It lies N. of the Divid. ing Range and rises to $6,303 \mathrm{ft}$.

Featherweight. Literally a weight absolutely exact, so much so that the addition of a feather would make it wrong. The term is used in racing for the lightest weight that can be carried by a horse in a handicap race. In box. ing it refers to the lightest class but one of competitors in a recog. nized competition. Under English rules such must not exceed $126 \mathrm{lb}$. in weight; under American rules the figure is $115 \mathrm{lb}$. See Boxing; Handicap.

Febrifuge (Lat. febris, fever; fugare, to put to flight). Term used for any medicine that cures or attempts to cure fever. Antipyrin and phenacetin are febrifuges, while quinine is another in frequent use.

Febris. In Roman mythology, the personification of fever and also the goddess who was supposed to avert it. Three temples in Rome, one on the Palatine, were sacred to her.

Febronianism. Reform movement among the Roman Catholics of Germany. It was started in $\mathbf{1 7 6 3}$ by Johann von Hontheim, who wrote under the name of Justinius Febronius. Its object was to limit the autocratic power of the pope and to secure a larger measure of independence for national churches.

February. Second month of the Christian calendar, ordinarily consisting of 28 days, in leap year of 29. The name comes from Latin februare, to purify, in allusion to the Lupercalia $(q . v$.$) , the Roman$ expiatory festival, which, as well as the Feralia, or general festival of the dead, was celebrated at Rome during this month. The month is popularly known as February "filldyke." January and February were additions to the old Roman calendar. See Calendar.

Fécamp. Town and seaport of Normandy, France. It stands on the English Channel, at the mouth of the river Fécamp, 28 m. N.N.E. of Havre. The port, which has a harbour and docks, has a trade in coal, timber, etc. ; it is also a fishing centre. There are some industries, mainly shipbuilding, and here is made the liqueurcalled benedictine.

The most interesting building is the church of the Trinity, built in the 12th century, once the abbey church. A magnificent building, it has a spacious and noble interior, while it has some fine memorials and decorations, tombs, stained glass, etc. S. Etienne is a 16th century church, while the remaining monastic buildings are now used for the town hall, library,

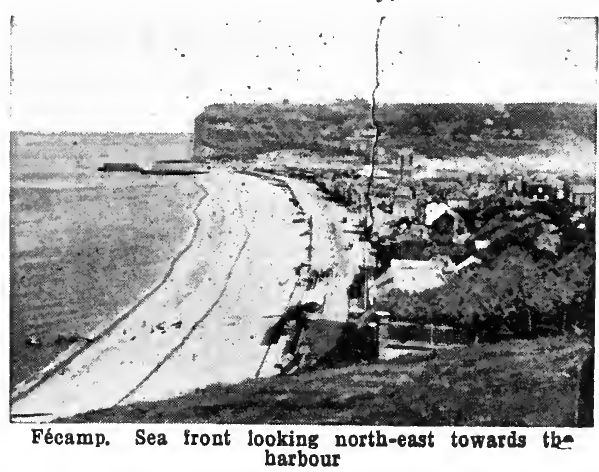

system. His chief scientific works are The Supreme Good, 1846, and Elements of Psychophysics, 1860. Fechner was also the author of a number of s a t i r i c a l writings o $\mathrm{n}$ various subjects, published under the name of Dr. Mises. He died Nov. 18, 1887. See Psychophysics.

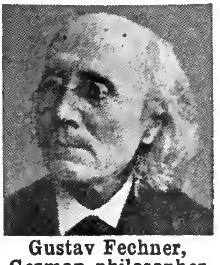

anilosopher ). British-French actor. Born in London, Oct. 23, 1824, he was a sculptor before he went on the French stage in 1844. He soon became recognized as the leading

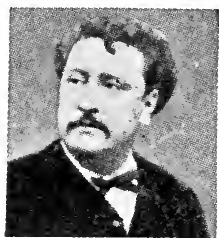
French jeune premier, not. ably by his Armand Du. val in Dumas fils's La Dame aux Camélias, $1852 . \quad \mathrm{H} \mathrm{e}$ appeared a $\mathrm{t}$ 'ThePrincess's, Onar.Pectian London, Oct. 27,1860 , as Ruy Blas in a version of Hugo's play, with great success. His Hamlet, March 20, 1861, was enthusiastically received; but his Othello, Oct. 23, 1861, proved disappoint. ing. From 186367 he was lessee of $\mathrm{T} h \mathrm{e} \mathrm{L}$ y ce u m, where he played in various melo. dramas, such as The Duke's Motto, The Roadside Inn, and 'The Corsican B rothers. In 1870 he appeared in New York. He finally left Eng. land in 1872, remaining in America until his de ath, Aug. 5, 1879.

and museum. The town grew up around a nunnery founded in the 7 th century to hold a relic of the True Blood, which was washed ashore in the trunk of a fig tree. Hence the name, a corruption of ficus campus. Pop. 15,380.

Fechner, Gustav Theodor (1801-87). German philosopher and physicist. Born near Muskau, Prussia, April 19, 1801, he was professor of physics and afterwards of philosophy in the university of Leipzig. The founder of psychophysicism, he held that all mental changes were accompanied by a parallel change in the nervous
Feckenham, JоHN (c. 1515-84). Last abbot of Westminster. Born about 1515 at Feckenham, near Droitwich, he became a Benedictine monk at Evesham. He was rector of Solihull, Warwickshire, and was confined in the Tower by Cranmer, 1549-53... When Mary restored the monastery of S. Peter at Westminster he was chosen abbot. At the accession of Elizabeth he refused to acquiesce in the reformation of the Church, oppos. ing the new liturgy and the Act of uniformity, 1559. The monastery was soon afterwards dissolved and Feckenham lived in retirement. 
Feddan. Modern Egyptian land measure. The feddan is 1.038 acres, but in certain localities it is equivalent to $1 \cdot 127$ acres, whilst formerly it equalled as much as 1.266 acres. The measure is divided into 24 kirats.

Federalism (Lat. foedus, a league). Form of government generally distinguished from the unitary organization of a state. The federal form of government involves limitations upon the power of the central government of a sovereign state, and fairly large units of subordinate government. Thus a federal state is distinguished from a confederation of states in having a powerful, though limited, central government; and federal units are distinguished from units of local government in being large and controlling elements in the governmental organism.

Federation means either the character of the government in a federal state, or the political movement towards decentralization; and thus it may be best explained by reference to the practice of federal governments. Such governments may be formed either by the unification of diverse units, as in Switzerland and the original United States of North America, or by decentralization of a single unit of government, as in the case of the Dominion of Canada. The federal states of South and Central America vaguely reflect both methods of formation.

The subordinate elements in a federation are sometimes called states, as in N. and S. America, and sometimes called by other names, as cantons in Switzerland. The idea of subordination, however, is not quite adequate, for the distinction between the functions of central and non-central government in a federal state is not one between a superior and an inferior. The distinction is based on a division between equally important functions.

The non-central governments generally deal with industrial issues of a localised character, with education, with taxation or a large part of it, with roads and summary justice; the central governments deal with peace and war, foreign or international affairs, basic administration of justice, and eommunication. Clearly the way in which the functions are divided must vary with the peculiar eircum. stances or the history of the people concerned, and where there is an increase of governmental functions there may be disputes as to the competence in particular issues of the central and the non-central governments. Thus the state of California in U.S.A. may make the foreign policy of the central government difficult by excluding some Japanese.

In the United Kingdom federalism would involve the partial separation of the old kingdoms and the principality of Wales, with a view to decentralizing some parts of the administration; and it is therefore connected with devolution. The tendency in the great states of modern times is towards federation because of the separation between a highly centralized machine of government in a large population from the necessary contact with local differences. Thus, while in the United Kingdom there is only one Parliament and executive for about fifty million persons, in the Scandinavian States there is a complete organism of government for about five million. The tendencies point to changes of the older form of federal government, e.g. in the U.S.A., and to experiment in new forms. See Devolution; Home Rule; Politics; Sovereignty; State.

Biblioyraphy. History of Federal Government, E. A. Freeman, 1863 ; The American Commonwealth, J. Bryce, 1888; The Federal Solution, J. A. Murray Macdonald, 1920.

Federalists. American political party formed in 1787. When the thirteen British colonies of $\mathrm{N}$. America were recognized as an independent nation in 1783 , the most urgent problem before them was the provision of a common central government which at the same time should not interfere with the autonomy. of the several states. The practical result was that politicians were grouped into two parties with an indefinite line of demarcation - the Federalists, who emphasised the necessity for strengthening the authority of the central government, and the antiFederalists, who emphasised the rights of the individual states. Since the individual interests of the northern states clashed with the individual interests of the southern states, while if representation rested upon population and wealth the north would dominate the central government, the northern politicians became roughly identified with the Federalists, the southern with the anti-Federalists.

Washington, as president, did not wish to identify himself with a party; Hamilton, the leading Federalisi, and Jefferson, a prominent anti-Federalist, served under him in the same government. But at bottom the real question was whether the interests of the $\mathrm{N}$. or those of the S. should predominate. The series of presidents from Jefferson onwards were anti. Federalists-mainly a consequence of want of solidarity among the Federalists and of the popular anti British policy of the anti-Federalist statesmen. The Federalist party broke up and disappeared after the " Hartford Convention," which was held by the Federalist states of New England in 1814, with the somewhat paradoxical aim of organizing defence against encroachments upon the rights of the northern states, while it was strongly suspected of really aiming at the separation of the New England states. See United States : History.

Federated Malay States. Name given to a federation of native states under British protection in the Malay Peninsula. There are four of them-Perak, Selangor, Nigri Sembilan, and Pahang, and the seat of government is at Kuala Lumpur. The states have an area of 27,500 sq. m. and a pop. of about 1,000,000. Each state has its own sultan and a British resident, while over them is the British high commissioner. Large quantities of tin and gold are mined in these states, and dense forests yield valuable timber. See Nigri Sembilan; Pahang; Perak; Selangor.

Federation of British Industries. British organization of manufacturers. Established in 1916 as a central organization of manufacturing interests, its main object is to decide upon and carry into effect a definite line of policy in regard to various matters affecting British industry. It seeks to expand and develop overseas trade by means of ambassadors of commerce. It has a large membership, representing millions of industrial capital. It was incorporated by royal charter in 1923 . The head. quarters are at 39 , St. James's Street, London, S.W.

Fee. Payment made for services, especially of a professional kind. The fees of doctors, lawyers, architects, and others are usually settled by custom, although as regards solicitors a maximum scale of fees is fixed by the Law Society. The fees of barristers, being originally honoraria, are not recoverable in a court of law. Fees vary very considerably, more especially those of medical men and lawyers. Those of architects, surveyors, and the like are generally arranged on a percentage basis. The charge made for entrance to societies, clubs, etc., also the right to sit at examinations, is called a fee.

Feeder. Main lead or conductor from an elcctric generating station which runs direct to a point or district to be served without supplying intermediate points. A positive feeder is that connected to the positive terminal of the generator or 
battery ; a negative feeder is connected to the negative terminal. A neutral feeder is a common conductor which completes two separate circuits from a pair of dynamos coupled in series. See Circuit ; Dynamo.

Feeding Stuffs. Food for cattle, which may be roughly divided into five classcs: (1) Oil seeds such as cotton cake, linseed cake, rape, palm-nut, coconut and earthnut cakes ; (2) leguminous crops, such as peas, beans, lentils, malt, dried grains, etc.; (3) cereals, including wheat, barley, oats, maize or Indian corn, rice ; (4) grass and hay ; (5) root crops, such as swedes and mangolds, potatoes, carrots, kohlrabi, etc.

The oil cakes so largely used as winter feed for cattle are valuable, not only for the oil which they contain, but also for their albuminous matter. Linseed cake contains from 9 p.c. to 13 p.c. of oil, and 26 p.c. to 30 p.c. of albuminoids. Decorticated cotton cake may contain 40 p.c. to 45 p.c. of albuminoids. Besides oil and albuminoids, a good sample of linseed cake holds valuable carbohydrates as well as a certain amount of mineral matter not without value. The value of oil cakes does not depend upon the amount of oil which they contain. Samples of linsecd cake and of rice meal may each contain 13 p.c. of oil, yet while the linseed oil is highly esteemed, that in the rice meal is considered of very slight value. Beans and peas are among the most valuable of feeding stuffs, the reason being that they contain from 50 p.c. to 55 p.c. of starchy bodies as well as from 20 p.c. to 24 p.c. of albuminoids.

Of the cereals, maize contains as much as 70 p.c. of starch; rice, at the other end of the scale, containing 50 p.c. Grass, clover, cabbage, tares, etc., are valuable principally for their succulent qualities. With these may be included brewers' grains, so largely given to cows in milk. The bulky dry foods, such as hay and straw, are valuable chiefly for their fibre, while the root crops are useful on account of their sugar and their easily digested carbohydrates. Sugar has a rapidly fattening effect upon stock, and of late years a large amount of molasses, from both cane and beet, has been used in the manufacture of artificial feeding stuffs.

The Fertilisers and Feeding Stuffs Act passed in 1906 was designed to protect the farmer against frauds in connexion with the sale of these articles. The seller of any artificially prepared article of food for cattle or poultry is bound to give the purchaser an invoice stating the substances or seeds from which it has been prepared, and the percentages (if any) of oil or albuminoids contained in it. See Agriculture ; Cattle ; Farm.

Feeler. Name given to the antennae or other similar organs of insects. The word is also used for a lever on a loom, and for the jaws of a measuring instrument. See Antennae.

Feeling. Act of perceiving by one of the five senses, more particularly the sense of touch and the sensations produced by it. Feelings again have been divided into skin sensations, which are referred to external things, and organic sensations, which are referred to ourselves, and are accompanied by an element of pleasure or pain. Among organic sensations are hunger, thirst, disgust, cheerfulness, depression. Psychologically, feeling is distinct from sensation. Sensation is always preceded by an organic impression; not so feeling, which only manifests itself in the body by virtue of the natural reac. tion of the mind on certain organs. Various classes of feelings are sug. gested: sensual and intellectual, material and formal. Some psychologists admit only two qualitative differences of feeling-pleasure and displeasure; others six-pleasure, displeasure, tension, relaxation, elevation, depression.

Fee Simple (Lat. feodum sim. plex). Highest estate known to English law. A tenant in fee simple is what is popularly styled a freeholder. Though in theory the sovereign is the lord paramount, the freeholder can grant his land away or devise it to whomsoever he likes by will. An estate in fee simple must be granted by deed and a peculiar form of words, except in a will where words are more widely construed than in deeds. See Land Laws.

Fee Tail (Lat. feodum talliatum, limited). Form of freehold estate set up originally by the Statute De Donis, 1285 , by which a grant to $\mathrm{X}$ and the heirs of his body gave $\mathrm{X}$ an estate tail. This estate would last only as long as X has heirs of his body, and would then revert to the grantor. This led to Fines and Recoveries, tortuous legal fictions by which the estate became fee simple. In 1833 a new Act was passed by which, by a deed enrolled, $\mathrm{X}$ could convert his holding into a fee simple. The holder of a fee tail cannot dispose of it by will.

Fehling's Solution. Alkaline solution of copper used for the detection of sugars. Solution No. 1 is prepared by dissolving $34 \cdot 65$ grams of pure copper sulphate in distilled water and diluting to 500 c.c. Solution No. 2 is made by dissolving 50 grams of sodium hydroxide containing not less than 97 p.c. of the salt, and 175 grams of recrystallised Rochelle salt in about 400 c.c. of water, and afterwards diluting to 500 c.c. When required for use equal volumes are mixed together.

Fehmarn or Femarn. Island in the Baltic Sea, belonging to Germany. Area, $70 \mathrm{sq}$. m. It lies off the E. coast of Holstein, from which it is separated by the narrow Sound of Fehmarn and from the island of Laaland on the N. by the Fehmarn Belt. The surface is level and the soil fairly fertile. Its few harbours can only accommodate vessels of shallow draught. Agriculture, fishing, and the rearing of cattle and sheep are the main occupations. The only manufacture of importance is hosiery. The capital is Burg. Prussia annexed the island in 1866 as a result of her victories over Denmark and Austria. Pop. 10,000.

Fehmarn Belt. Channel between the islands of Fehmarn and Laaland, Denmark. It has a width of about $12 \mathrm{~m}$., and leads from the Baltic to Kiel Bay. Fehmarn Sound is a narrow passage between the island of Fehmarn and the mainland.

Fehmgericht or VEMGERICHT (Ger. Fehm, a criminal court ; Ger icht, judgement). Medieval German tribunal. Known sometimes as the Holy Vehme, it exercised power, especially in Westphalia, in the 14th and 15th centuries, and is believed to have been a survival from the jurisdictions of the Saxons. The courts were open for trial of civil matters, but might be secret in special cases. It has been estimated that, in the 14th century, the members (Schoffen or Freischoffen), bound by an all-embracing oath of fidelity, numbered about 100,000 .

The government of the tribunal was vested in a chapter presided over by the emperor or his deputy, called theOberstuhlherr, before whom all members were liable to account for their acts. It had affinity with the process of summary jurisdiction in Anglo-Saxon England, those found guilty of capital offences being hanged, a dagger bearing the secret letters S.S.G.G. being placed on the corpse. As civilization progressed its power waned, to some extent through abuse. The Fehmgericht existed in attenuated form down to the middle of the 18th century, and was finally suppressed by Jerome Bonaparte in 1811. See Introduction, Anne of Geierstein, W. Scott, 1831 ; On the Rise and Progress of the English Common- 
wealth, F. Palgrave, 1832 ; Die Feme, T. Lindner, 1887 ; Das Femgericht Westphalens, P. Wigand, 1893.

Fehrbellin. Town of Germany, in Brandenburg, $40 \mathrm{~m}$. N.W. of Berlin. It is famous for the great victory gained by the Prussians, or, as they were then, the Brandenburgers, over the Swedes, June 18, 1675. A monument marks the site of the battle, which the Prussians regard as a memorable one. It was the beginning of Prussia's military power, as till then the Swedes had been considered all but invincible.

Feilding. Town of New Zealand, in North Island. It is $90 \mathrm{~m}$. by rly. N.N.E. of Wellington, and is the centre of an agricultural and pastoral district, carrying on butter and cheese making, saw and flour. milling. Pop. 3,483.

Feilding, Sir Geoffrey Percy THYNne (b. 1866). British soldier. Born Sept. 21, 1866, a son of Sir

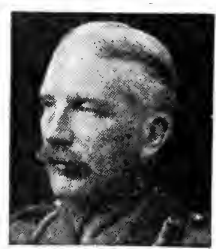

Sir Geofirey Feilding. British soldier Russell Percy Feilding, he belonged to the family of the earl of Denbigh. From Wellington College he entered the Coldstream Guards in 1888, and with them served through the S. African War, where he won the D.S.O. When the Great War broke out, Feilding, as lieutenant-colonel, led one of the battalions of Coldstreamers to the front and was wounded. He commanded the lst brigade of the Guards division at the battle of Loos, and later was promoted to the command of the division. $\mathrm{He}$ was in command of the London district, 1918-1920, and was knighted in 1919.

Feilding, ROBERT (c. 165l1712). English rake, called Beau Feilding. A member of the Denbigh family, he led a regiment in Ireland for James II. After squandering the fortune of his first wife, a daughter of the lst viscount Carlingford, he married a daughter of the lst marquis of Clanricarde. After her death he married, in 1705, Mary Wadsworth, represented to him as a wealthy widow, and in the same year also married the duchess of Cleveland, Charles II's former mistress. In 1706 he was convicted of bigamy. Feilding was satirised by Steele and Swift. He died May 12, 1712.

Feira de Santa Anna. Town of Brazil, in the state of Bahia. It is about $30 \mathrm{~m}$. N.W. of Cachoeira, on the Bahia-S. Francisco Rly. The centre of a region rich in minerals, it produces marble, gold, and diamonds. There is trade in cereals, tobacco, and cotton. Cattle fairs are held. Pop. 16,000.

Feis. Irish word for an assem. bly. Something like the folk moots of the Anglo-Saxons, these were mainly meetings for the promulgation of laws by the kings, but they had also a festive element. They were frequently held in Ireland, some being national and others local. The most noted was the feis held regularly at Tara for several centuries until 560. Over it the supreme king presided. The word is still in use; for instance, in 1897 a feis ceoil was founded to encourage Irish music.

Feisal or FeIsul (b. 1887). King of Irak. The third surviving son of Hussein, king of the

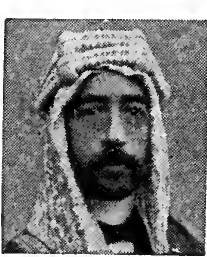

Feisa!

King of Irak Russell Hedjaz, he was born in Arabia, but left it when five years old. $\mathrm{He}$ spent the next 18 years in Constanti. nople, where he received a modern educa. tion and, later, appointments und e $r$ the Turkish government. Along with his brothers, Ali and Abdulla, he took a leading part in the move. ment which led to the deposition of Abdul Hamid. He commanded the Arab contingent in the Turkish campaigns in the district $S$. of Mecca, against a new religious sect which was threatening the stability of the emirate of the Hejaz which had been restored after the downfall of Abdul Hamid.

When, in June, 1916, his father sided with the Allies against Turkey, the Emir Feisal commanded the rebels in Medina, but was defeated by the Turks. He then presented to the British a scheme for the formation of an Arab regular army. This was accepted and Feisal's army eventually formed Allenby's right wing in Palestine. His services in the conquest of Palestine and Syria were rewarded with the privilege of setting up in eastern Syria (Amman, Damascus and Aleppo) a provisional military ad. ministration which was guaranteed to tne Arabs as an independent sphere by the Sykes-Picot Treaty. In March, 1920, he was made king of Syria, but owing to his failure to recognize the rights of France in Syria, he was deposed by Gen. Gouraud, the latter entering his capital, Damascus, on July 25. Feisal became king of Irak in Aug.,
1921. See Arabia; Damascus; Hejaz; Lawrence, T. E. ; Palestine, Conquest of.

Felahiyeh. Village of Mesopotamia. It stands on the N. bank of the Tigris, $5 \mathrm{~m}$. from Sanna-iYat, and about $25 \mathrm{~m}$. W. of Kut. It was prominent in the earlier stages of the campaign in Mesopotamia, and was captured by Gorringe, April 4, 1916. See Es-Sinn, Attack on ; Kut, Battles of ; Mesopotamia, Conquest of.

Felanitx or Felaniche. Town of Spain, in the island of Majorca. It stands in a mt. valley, $28 \mathrm{~m}$. S.E. of Palma, and $5 \mathrm{~m}$. from its port, Puerto Colon. On the mt. of Puig de San Salvador, in the vicinity, is a Moorish castle with underground vaults. The church of San Miguel is a fine building. Brandy is dis. tilled and soap manufactured. There is trade in cattle, wine, fruit, and earthenware, the water coolers of Felanitx having been noted from the 3 rd century B.c. Pop. 11,223.

Félegyháza or KISKunfélegY HÁzA. Town of Hungary, in Little Kumania. An important rly. junction, it is $70 \mathrm{~m}$. S.E. of Budapest. It has a handsome town hall, and a large church. The town is noted for its cattle markets, while there is considerable trade in cereals, wine, tobacco, and fruit. The town was sacked by the Turks in the 16th century. Pop. 34,924.

Felidae (Lat. felis, cat). Family of the carnivora, or flesh-eating mammals, which includes the catlike animals. They comprise only two genera, but a large number of species, and are generally regarded as the typical carnivores, being the best adapted for catching and preying upon living animals, and, with the exception of the weasels, the most lithe and active of the order.

They are provided with finely developed canine and carnassial teeth and their sharp claws are retractile. One marked feature of the family is the short and rounded muzzle, which is in conspicuous contrast with the long and sharp muzzle in the dogs. Their fur is soft and often handsomely marked, and their feet are provided with cushion-like pads which enable them to move about silently. All are of savage disposition, and only two species have been domesticated with any success. See Cat.

Felix (d. c. 647). English saint and bishop. A native of Burgundy, he came to England, and, helped by Sigebert, king of E. Anglia, preached Christianity. He became bishop of Dunwich, and is said to have founded the monastery at Soham. His name survives in Felixstowe, Suffolk. 
Felix. Name of four popes and five anti-popes, of whom the following are notable. Felix I (d. 274) is entered in the Roman martyrology probably in mistake for a Roman martyr of the same name buried on the Via Aurelia. A letter of the pope's in response to a report by the Synod of Antioch, which had deposed its heretical bishop, Paul of Samosata, was made use of at the council of Ephesus (431). To Felix I, who reigned 269-74, was attributed a decree for the celebration of masses over the tombs of the martyrs. His festival is kept May 30.

Felix II, pope from $355-58$, was a Roman archdeacon who was in. truded into the papal chair on the banishment of pope Liberius by the emperor Constantius. On the return of Liberius, Felix was exiled and lived in retirement until his death, Nov. 22, 365. Felix III, pope from 483-92, was chiefly engaged in conflicts with heretical bishops at Alexandria and Antioch. $\mathrm{He}$ finally excommunicated Acacius, patriarch of Constantinople, and this schism lasted until 518 . Felix IV, pope from 526-30, was the nominee of Theodoric the Goth. He obtained an edict from Theodoric's successor ordering all charges against the clergy to be taken to ecclesiastical courts

Felix V, anti-pope, was born at Chambéry, Dec. 4, $1383 . \quad \mathrm{He}$ reigned as duke Amadeus VIII of Savoy from 1416-34, when he retired in favour of his son. In 1439 the remnant of the council of Basel elected him as pope, although he was not in orders, in place of pope Eugenius IV, whom they declared deposed. As Felix $V$ he was crowned in July, 1440. He never obtained general recognition, but with some show of a following, especially in Switzerland and Savoy, he held his position till 1449, when he abdicated. He died at Geneva, Jan. 7, 1451, last of the anti-popes.

Felix Antonius. Brother of the freedman Pallas, minister of the Roman emperor Claudius. He was procurator of Judaea, but was recalled in A.D. 62 to answer charges of oppression made against him by the Jews. It was before Felix that S. Paul preached at Jerusalem (Acts 23, 24).

Felix Holt the RadicaL. Novel by George Eliot, first published in 1866. It presents in broad effect the life of a midland county during the 1832 Reform period, but there is something unreal about the central figure, who is too philosophical and cold-blooded to represent the enthusiastic reformer of that time.

Felixstowe. Seaside resort, urban dist. (Felixstowe and Wa!. ton), and parish of Suffolk, Eng-

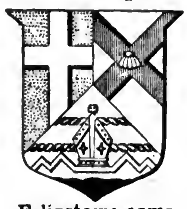

Felixstowe arms land. It stands on the estuary of the Orwoll, $10 \mathrm{~m}$. from I pswich Excellent bath. ing facilities and a fine pier, yacht. ing, a mode] yacht pond. and golf links are among its attractions. It has a small dock and a wireless telegraphic station. Phosphate of lime is produced for export. Nu. merous $R$ oman remains have been discovered. The corporation owns the electric light undertaking and pleasure grounds. During the Great War the Germans made an air raid upon the place, July 22, 1917, which was attended with loss of life. Pop. 11.65.5

Felixstowe Fury. Namegiven to a large flying.

boat designed by Col. J. C. Porte. A triplane with five Rolls-Royce engines, each of 375 horse-power, it had a span of $123 \mathrm{ft}$., an over-all length of $60 \mathrm{ft}$. and a height of $27 \mathrm{ft}$. 6 in. After many successful flights the machine was wrecked, Aug. 11, 1919, when starting on a test flight with a heavy load, preparatory to a journey to Egypt. Seeillus. p. 3101 .

Fell (Scand. fjeld, mountain or rock). Term occurring in the names of many British mountains, e.g., Cross Fell, Goat Fell, Hart Fell, Snaefell. See Mountain.

Fell, JoHN (1625-86). English pedagogue and divine. Born June 23,1625 , he was educated at Christ Church, Oxford, of which he be came dean in 1660 . Vice-chan cellor of the university from 1666 69 , he was appointed bishop of Oxford in 1675. He notably im proved the buildings as well as the discipline of his college, and is chiefly remembered by some lines "I do not love thee, Dr. Fell," etc., attributed to Thomas Brown (g.v.). He died July 10, 1686.

Fellah (plur. Fellahin). Arabic word for peasant or ploughman. especially in Egypt. Forming the bulk of the native population the fellahin descend in direct lineage from the ancient Egyp tians. They dwell in villages, mainly of mud hovels, under a village chief, the sheikh-el-beled. A wooden statuette, now at Cairo, of a IVth-dynasty official, found by Mariette at Sakkara, was given that title by the workmen from its likeness to their own headman. (See illus. p. 2825.) Some are Christian Copts, $9 .(4 N), 000$ are Moslems.

Of medium height, black-eyed, thick-lipped, and straight-nosed, the Semitic and Nubian elements they have absorbed have but slightly affected their racial make-up as a Caucasian people of the Mediterranean type. The progressive deepening of hue from $\mathrm{N}$. to $\mathrm{S}$. marks the influence both of climate 
of a dervish sect, whose ritual demonstration, zikr, is the occasion of much festivity, wherein quarterstaff, nabut, is a favourite game. The veneration of trees and stones, and the universal employment of amulets, mark the persistence of the predynastic animism of the Nile valley. The sedentary peasantry of Palestine, also called fellahin, are largely descended from the primitive Canaanite stock. Except for a few colonies introduced under Mehemet Ali, they have no ethnic identity with their Egyptian namesakes.

Felling. Urban dist. of Durham, England. It is $1 \frac{1}{2} \mathrm{~m}$. S.E. of Gateshead, of which it forms a suburb. It has a station on the N.E.R., also coal-mining, engineering, shipbuilding, and other industries. Pop. 25,026. See Gateshead.

Fellmonger. Dealer in the pelts of slaughtered sheep, one who separates the wool from the hides. The skins may be soaked in limewater until the roots of the fibre are loosened sufficiently to come away with ease, a method which gives the so-called sliped wool. Alternatively the skins may be hung in moist air until bacterial action has loosened the fleece, and this is the method adopted in Mazamet, France, the chief centre of fellmongering. Chemical means may be substituted, the flesh side of the hide being painted overnight with a solution of sodium sulphide. See Leather.

Fellow. Word meaning a male person. It is now used in two senses. In general speech, usually in a slighting sense, it means a man, and academically it refers to certain members of colleges at Oxford, Cambridge, or elsewhere, and to members of learned societies. The original meaning was that of a companion, hence the phrase fellow-countryman, and this survives in its use at the universities, where it is the equivalent of the Latin socius.

In the colleges of Oxford and Cambridge, a fellow is a member of the governing body and foundation, and a fellowship is a coveted distinction only bestowed on scholars of exceptional ability. Before the reforms of 1877-81 fellows were usually chosen for life, or until marriage. To-day the fellows are chosen by the existing fellows, usually for a definite term of years. They may be elected on a reputation or after examination, or because suitable for a particular vacancy on the teaching or managing staff. Many of them act as tutors, and form the group that with the head is responsible for the daily work of the college.
The fellows of Eton and Winches. ter form the governing body. The fellows of Trinity College, D u blin, who are divided into senior and junior fellows, are elected after exa mination, and hold the position for life. King's College, London, and some other col. leges, have fellows, but their duties are rather different from those at the older universities. Following this use, fellow is used for member of a learned society. See University.

Felo de se (late Lat. felo, evil doer, i.e. slayer; de se, of himself). English legal term, meaning a man who commits a "felony against himself "-in other words, a suicide. A suicide used to be buried, as Thomas Hood puts it, "at four cross roads, with a stake in his inside." This ended in 1824 , and the body of a suicide was ordered to be buried in the usual burial-ground without divine service, between 9 p.m. and midnight. In 1882 the night burial was abolished and a religious service permitted; but the Burial Service of the Church is not allowed by the rubrics to be used. See Suicide.

Felony. Class of crime in English law. By common law all crimes are either felonies or misdemeanours. Nobody knows for certain the original distinction between them; one theory is that a felony was originally a crime involving a breach of the king's peace. Certainly until 1870 the lands and goods of a felon were forfeited to the crown.

Jurymen are sworn separately in a trial for felony, but together for misdemeanour. The accused is called the prisoner at the bar in felony, but the defendant in misdemeanour. To be convicted of felony after a previous conviction for felony is itself a felony. To conceal a felony is a crime-misprision of felony. A prisoner convicted of felony must be "called upon" that is, asked if he has anything to. say before sentence is passed.

Felsite. Close-grained or compact rock of varying colour. It consists of altered lava which has lost its glassy structure. Small crystals of felspar and quartz are scattered through the ground. mass of the rock. See Rhyolite.

Felspar. Important group of rock-forming minerals, variable in chemical composition, crystalline form, and colour. Chemically they able proportions of potassium, sodium, or calcium : hence sometimes distinguished as potashfelspar, soda-felspar, lime-felspar. Widely distributed, they are usually opaque and dull of colour. A few varieties are handsome, and are cut as gem stones. Amazon stone is a potash felspar of a verdigris green colour with bluish tinge, found in N. America and the Urals. Sunstone is a semi-translucent, almost white material, showing by reflected light a brilliant red metallic glitter, and is obtained in Siberia, Norway, and N. America. Moonstone is a translucent white felspar emitting by reflected light a milky, bluish gleam. In crystalline form felspars are either monoclinic or triclinic.

Monoclinic species are orthoclase (potash-felspar) and its glass-clear variety sanidine. Other varieties are adularia (colourless), moonstone, sunstone (aventurine). Triclinic species include microcline (a potash-felspar), anorthoclase (soda-potash felspar), and the plagioclase felspars. See illus. p. 2389.

Felsted School. English public school. It was founded in 1564 by Richard, Lord Riche, and is now governed by a scheme dating from 1876. It consists of the school house, divided into four houses, another house, and a junior house, the accommodation being for about 300 boys. It stands in grounds of 42 acres, and there are scholarships to the school. The village of Felsted, sometimes called Felstead, is $3 \mathrm{~m}$. S.E. of Dunmow and has a station on the G.E.R. Pop. 1,969.

Felt (A.S.). Cloth made of wool, hair or fur, or mixtures, compacted by moistening, heating, rolling, and pressing. Some felts are woven, but the true felts are unwoven. Wool possesses the highest felting properties, and the fur or hair of the ox, goat, hare, rabbit, and beaver are readily felted.

The principal hat felts are made of rabbit ("coney" in the trade), hare, beaver, musquash, and 
nutria; cow hair is used largely for roofing felts. Felting is probably older than weaving, the cloth having been used for tents, clothing, and other purposes from the remotest times. The invention is sometimes ascribed to Oriental shepherds, and stories are extant of kings, monks, and others putting wool into their shoes or sandals and finding it turned by walking into a new fabric. Clement of Rome was commemorated by hatters as the inventor of felt. See Hat.

Feltham. Urb. dist. and village of Middlesex, England. It is $16 \mathrm{~m}$. W.S.W. of London, on the L. \& S.W.R. The London County Council has an industrial school for boys here, and there are large nurseries and market gardens in the neighbourhood. Extensive aeroplanebuilding works were established here by the Whitehead Aircraft Co. during the Great War. Pop. 5,135.

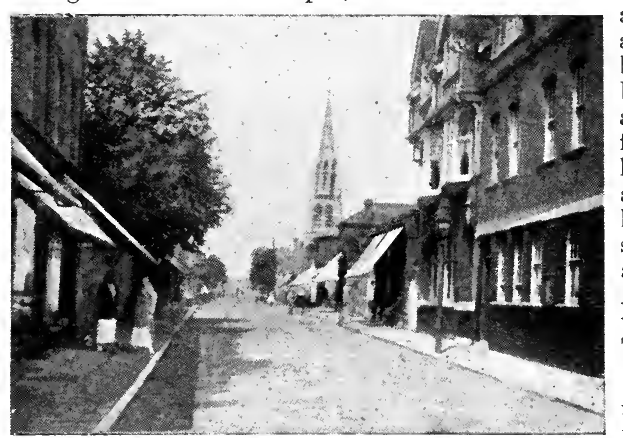

Feltham, Middlesex. The High Street looking tow ards the church of S. Catherine

Feltmakers' Company, THe. London city livery company. Incorporated 1604 and an offshoot of the

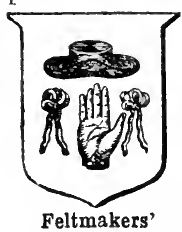
Haberdashers, it was founded to regulate the making and sale of felt hats. Feltmakers were formerly known as felt. mongers, and as such existed in the Company arms 12th century. The offices are at Arundel House, W.C.

Felton, JoHN (c. 1595-1628). English soldier. He came of a good Suffolk family, early entered the army, and served as lieutenant atCadiz in 1625 . Failing to obtain a captain's com$\mathrm{mission}$, he applied personally to the duke of Buck. ingham, who refused his request. Porerty
John Felton,

English soldier
From an old engraving

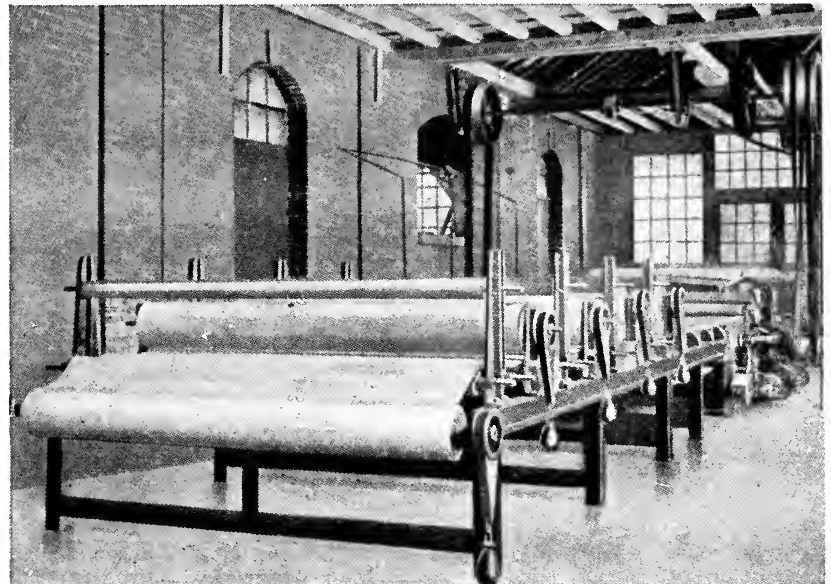

Felt. Table or plate machine for felting four pieces at one time By courtesy of W. Bywater Ltd., Leeds

and his animosity against Buckingham, increased by brooding over the attacks on the favourite, turned his thoughts to assassination, and he mortally stabbed the duke at Portsmouth, Aug. 23, 1628. He was hanged at Tyburn, Nov, 28.

Feltre (a n c. Feltria). City of Italy, in the prov. of Belluno. A picturesque place, standing on an eminence near the Piave river, it is $34 \mathrm{~m}$. by rly. N.W. of Treviso. It has a ruined castle, a cathedral, a modern palace, and a municipal pawnshop, said to be the oldest establishment of the kind in Europe. Minor buildings include a hospital, gymnasium, seminary, and an asylum for orphans. In 1819 the bishopric was incorporated with that of Belluno. There is trade in wine, oil, and silk. Pop. 15,465.

Felucca (Arab. falūka, Ital. feluca). Vessel used in the Levant and on the Nile. It is propelled by lateen sails and oars, and moves swiftly. Sometimes the helm can be used at either end of the hull.

Feluja. Town of Mesopotamia. Situated on the Lower Euphrates, it is about $40 \mathrm{~m}$. W. of Bagdad. with which it is connected by a rly. built by the British during the Great War after the capture of that city. It was occupied by the British on March 19, 1917.

Felup or Fulup. Collective name applied by Portuguese traders to numerous primitive negro tribes in the coast-lands of French
Senegal and Portugnese Guinea. Under the Mandingan name Jola they extend into British Gambia. Their allied semi-Bantu dialects prevail from the Gambia and Casamance to the Cacheo and Geba rivers. The typical Felup are muscular, flat-nosed, thick-lipped, darkbronze-coloured hunters, almost unclad, using bow and arrow and inhabiting roughly constructed $\log$ huts or earth-houses.

Feme or Femme. Anglo-Norman legal term for a woman. A woman who is married is called feme couvert, and a woman who is either a spinster, a widow, or divorced, is feme sole.

Feminism (Lat. femina, a woman). Term which may be taken to embrace the movement for the raising of the economic, legal, and political status of women. In the decade before the Great War the attention of feminists in most European countries was necessarily concentrated on the acquisition of the right to vote, and now that

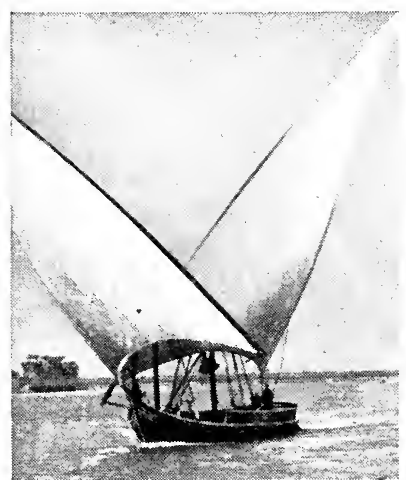

Felucca. Egyptian sailing boat on the Nile above Cairo 
political power has been won in the Anglo-Saxon, Teuton, and Slav nations, women are considering how that power shall be used to secure the necessary legal and social reforms. The status and the ambitions of women differ widely even in advanced and modern civilized countries, but the stages of the feminist movement in each racial group are fairly well defined.

Scondinavian women have long had equal educational advantages with men ; they early acquired political power, and are determined to securo absolute equality in professional and industrial life, and independence, as nearly as may be, in marriage and family life. There is no suggestion that a woman should abandon her profession when she marries, and so place herself in dependence on her husband.

In Great Britain feminist ideals tend more and more towards the Scandinavian, but with a difference due probably to temperament and education. The English feminist claims equal pay for equal work, an adjustment of the marriage laws, equal partnership and give and take between the sexes, but she clearly wishes to develop on her own lines, not on masculine lines. She is inclined to think that the Scandinavian development takes too little account of sex. Olive Schreiner's work, too little acknowledged, has had great influence on English women in this connexion.

The German feminist moves rather slowly in the direction of her Scandinavian sisters, but in Czecho-Slovakia women have leapt at one stride into full political activity. In the Latin countries the ideal of domestic and social life is, and always has been, very different, and this is no doubt the reason why the demand for suffrage has not been insistent. The Frenchwoman still, in the main, exercises her power indirectly. It is remarkable that in France, where the authority of the mother, and even of the grandmother, is very great in the family, and where women of the lower middle class are con. spicuous for successful and often equal share in their husband's business, women should so long have submitted to the injustice of the Code Napoléon, which leaves them legally in the position of minors, and with virtually no personal lib. erty before the law. But even in France, and more slowly in the two other great Catholic countries of Europe, Italy and Spain, women are beginning to demand greater in. dependence and a voice in public affairs.

The social and political unrest in the Middle and Far East is having its repercussion on women. In Islam, women are beginning to resent their immemorial position of servitude; they are demanding education and the right to come into the open. In non-Mahomedan India, women are demanding and receiving a better education and a better industrial position. They also look for a change in the marriage law. Similar movements are taking place all over the East.

American women, like their European sisters, have received the vote. Feminist propaganda has in some ways a less favourable soil to work on. There is to a great extent co-education, there is less pressure on women to earn their own living, and divorce is less difficult than in Europe. And because of these conditions there is less incentive to violent discontent. It remains to be seen on what characteristic lines American feminists will move.

Margaret Bryant

Femmes Savantes, LFs (The Learned Women). Five-act comedy by Molière, first acted at the Palais-Royal, Paris, March 11, 1672. In it Molière returns to the theme of feminine affectation less seriously treated in his Les Précieuses Ridicules. The easy-going bourgeois Chrysale is at the mercy of a wife and one of his two daugh. ters. The wife has more pretence to learning than knowledge or intelligence, and the elder daughter, Armande, is like her mother, who is abetted by an old maid, Chry. sale's sister. Clitandre, suitor to Armande, is rebuffed, and turns to her more simple-minded sister Henriette, whom the mother wishes to marry the parlour-poet Trissotin. The dénouement, in which Henriette and Clitandre are united, is brought about by Chrysale's brother Ariste, who exposes the mercenary character of Trissotin. Molière acted the part of Chrysale. Trissotin is usually accepted as a caricature of the Abbé Cotin, the feeble pettiness and pretentiousness of whose verses Molière regarded as fair game for satire.

Femoral Artery (Lat. femur, thigh). Main artery of the thigh running from the groin to a point rather above the knee, where it becomes the popliteal artery and is continued down the leg. It gives off numerous branches, which supply the muscles and skin with blood.

Femur on THGH-BONE. Longest bone in the human body. Above it articulates with the pelvis to form the hip-joint, and below with the patella (knee-cap) and tibia to form the knee-joint. The superior extremity consists of a rounded eminence, the head, which fits into the acetabulum or socket of the pelvis, the neck, which is set at about an angle of $125^{\circ}$ with the shaft of the bone, and two bony prominences known as the greater and lesser trochanters, which serve for the attachments of muscles. The shaft of the femur is somewhat convex forwards, and in the central third of the posterior surface bears a prominent ridge, the linea aspera, to which muscles are attached. The inferior extremity broadens out into two expansions, the internal and external tuberosities, which terminate in two smooth rounded articular eminences known as the condyles, separated from each other by a deep depression, the inter-condylar notch.

Fracture of the shaft of the femur is a common accident. If due to indirect violence the fracture is usually oblique, if due to direct violence more or less transverse. Unless complicated by serious damage to the soft parts, the fracture usually unites in from 6 to 8 weeks, though the leg should not be made to bear the full weight of the body for another two months. Fracture of the neck of the femur is most often met with in elderly persons, whose bones have become weakened by atrophy. The condition is always serious in aged persons, owing to the difficulty of getting the broken fragments to unite, and to the risk of pneumonia supervening, which is always present when it is necessary to keep an elderly patient in bed for any considerable length of time. See Hip-joint; Knee-joint.

Fen. Anglo-Saxon word for marshy or boggy land. The district of this nature in Cambridgeshire, Norfolk, Huntingdonshire, and Lincolnshire is known as the Fens. The will o' the wisp is sometimes called the fenfire, while fenberry is another name for the cranberry. See Fens.

Fence. Device used on farms for boundary purposes, to prevent stock from wandering and as a wind-screen. The proper establishment and maintenance of fences is costly; they often waste valuable ground, and neglected hedges in particular harbour vermin and weeds, the latter often serving to maintain insect and fungoid pests.

Turf fences, chiefly consisting of mud and stones, are cheap and fairly durable if properly drained and protected from the rain by coping-stones. Walls, usually of the dry sort, without cement or mortar, are much favoured where suitable flat stones are available. They last for many years if carefully built, but after 50 years or more they are liable to get out of plumb, and fall after winter frosts. 
Wood and wire fences include a large number of contrivances. These may consist entirely of wood (palings, stakes, and brushwood, post and rail), wood and wire, or wire with iron or concrete standards. Wood lasts much longer if treated with creosote or stop-rot composition, or simply tarred. That part of a post driven into the ground should previously be tarred. A farmer can only employ barbed wire lawfully if it falls entirely within the boundaries of his own holding ; if used in a fence adjoin. ing another farm, or adjacent to a public road, he will be liable for any injury it may cause to human beings or other people's stock. One useful kind of wire is rabbit-proof netting, for keeping out hares and rabbits. Hedges are particularly characteristic of many parts of England, and when well established present many advantages. They are costly, however, and require continual care.

Hedging is an expert rural art, and involves not merely lopping of superfluous twigs and branches, but also "laying" at least every 20 years. In this process the main stems are partly cut through not far from the bottom, bent into an oblique or horizontal position, and then secured. This promotes the growth of shoots at the base of the hedge, without which it will never form a thick continuous stockproof barrier. Equally important is the provision of a ditch adequately drained, and its maintenance in a clean condition free from weeds and rubbish. The best hedge-plant is the hawthorn (quick), while beech and hornbeam also give good results. Mixed hedges are not to be recommended. See Hedge.

Fenchurch Street. London thoroughfare. The name is believed to have been derived from the fenny ground in the vicinity when the Langbourne was a running brook. The street runs E. from Gracechurch Street, describing a northward curve until it meets Leadenhall Street at Aldgate Pump. At the London Tavern, rebuilt in 1877, Queen Elizabeth is supposed to have dined in 1554 . Iron. mongers' Hall is in this street. Mark Lane, a turning on the S. side, is known for its Old and New Corn Exchanges. Lloyd's Avenue was made in 1899 .

Fencible. Term applied to regiments of horse and foot raised for limited service within the kingdom and for a limited time. They ranked junior to the standing army. The new armies raised in 1915 would have been called fencibles in 18th century England. The word meant anything capable of defence.

\section{FENCING: ENGLISH AND CONTINENTAL}

Sir T. A. Cook, Captain, English Fencing Team, 1903 and 1906

The art of using various light weapons is here outlined. Allied in. formation will be found in the articles Rapier; Sabre; Sword, etc.
Fencing is the art of using as a recreation the épée, foil, sabre, or other light weapon. In England it may be said to have come in about periority of the rapier and the point over the edge and broadsword was realized. But the introduction of pistols in duelling, the disuse of the sword as a customary accompaniment to every gentleman's attire, and the national preference for boxing combined to drive the practical Englishman from fencing lessons, which retained a merely academic interest. It was only about 1905 that the badge of the English fencing team (a Tudor rose) recalled for the first time for nearly three centurics the official patronage extended to masters of arms by Henry VIII. Even this would not have been accomplished had the revival of English fencing depended solely on the scholastic graces of conventional foil-play. To the épée de combat, the modern French duelling sword, but with a the time of Elizabeth, when the su- button on its point, we owe the rapid development of fencing in the 20 th century.

Moreover, the conventions of foil-play had overgrown its beauty, and the extreme difficulty of scoring, if scoring be indeed advisable at all, added yet another reason against its general popularity. The average young Englishman at the dawn of the 20th century liked to know whether he was really better or worse than his opponent, and objected to being told he could score nothing when his weapon, had it been sharp, would obviously have slain or seriously disabled his adversary. When he was given a game which enabled him to hit his man anywhere from the top of his head to the sole of his feet, and necessitated the guarding of an combination of possibilities became interesting. When he realized that his old lessons with the foil were just as essential as before, by way of a correct foundation for sound equal area in his own person, the
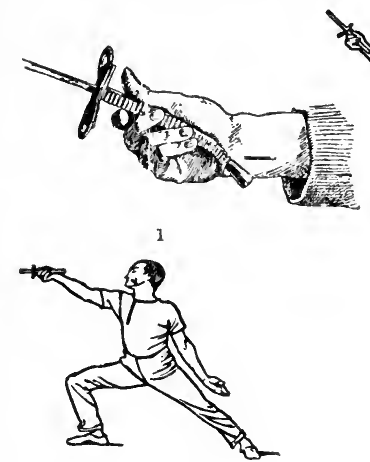

4

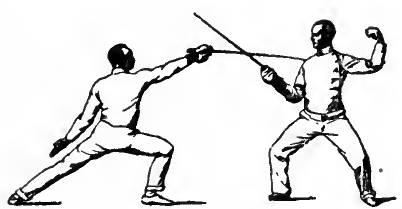

6

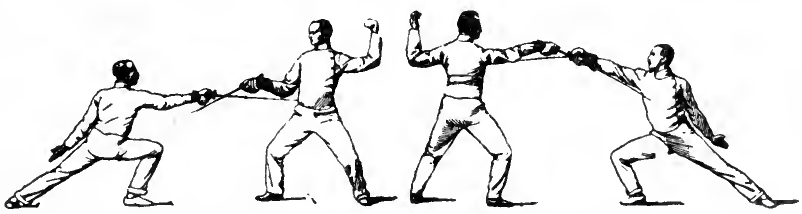

8

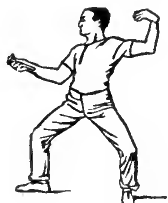

3
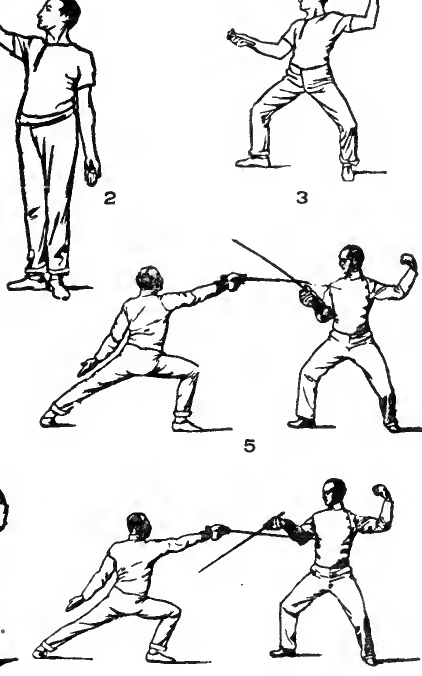

9
Fencing. 1. Position of hand on foil. 2. Preliminary position. 3. On guard. 4. Lunge. 5. Parry of quarte. 6. Parry of sixte. 7. Parry of septime. 8. Parry of octave. 9. Riposte from parry of quarte 
sword-play, but were now the introduction to far wider and more thrilling practical problems, he began to see that fencing was one of the best games in the world. By swift degrees he took up the science and art of the épée until he could at least make a fair fight with the best exponents of the sword in Europe.

In 1900 Sulzbacher fought in the first pool ever seen by an English audience. In 1903 the first fencing team to represent Great Britain was sent out to Paris by the amateur fencing association to compete in the grande semaine for the international medals. It was beaten by France; but it won the second place by conquering Belgium, who had her revenge in 1912 at Stockholm, where France was not represented. In 1906 at the Olympic Games at Athens a British team for the first time fought France to a dead heat in the final of an international tournament, and a Britisher hit four Frenchmen one after another. In the Olympic Games at Antwerp in 1920 the challenge cup, presented by British fencers for amateur épée teams, open to the world, was won by the Italians, chiefly owing to the fine fencing of the brothers Nadi, who also put their country ahead in foils and sabres. The English team, though well up to the average, did not do as well as usual in any of the three weapons at these games, one reason being a new rule which gave points in foil-play to hits on the swordarm from the shoulder to the elbow.

To obtain practice fencers often form a pool. The winner is he who is least hit. The score-sheet would be something of this kind:

\begin{tabular}{c|c|c|c|c|c|c|c}
\hline & A & B & C & D & E & F & $\begin{array}{c}\text { Hits } \\
\text { received }\end{array}$ \\
\hline A & & 0 & 1 & 0 & 1 & 1 & 3 \\
\hline B & 1 & & 0 & 0 & 1 & 0 & 2 \\
\hline C & 0 & 1 & & 1 & $1 \mathrm{~d}$ & 0 & 3 \\
\hline D & 1 & 1 & 0 & & 0 & $1 \mathrm{~d}$ & 3 \\
\hline $\mathrm{E}$ & 0 & 0 & $1 \mathrm{~d}$ & 1 & & 1 & 3 \\
\hline $\mathrm{F}$ & 0 & 1 & 1 & $1 \mathrm{~d}$ & 0 & & 3 \\
\hline
\end{tabular}

This would show that B wins because he received less hits than anyone else, having lost only to $\mathrm{A}$ and to $\mathrm{E}$. Turning to A's line, under the column marked B one finds a cipher showing that he won his fight against 3 , and another cipler apjears in E's line, also under the column marked $B$. It will be noticed also that $\mathrm{C}, \mathrm{D}, \mathrm{E}$, and $F$ have each one square with the mark ld; this means a coup double, to signify that a hit was scored against each man, probably because one of them, when attacked, defended himself by a counter-attack instead of a parry, and though he hit his man he was not quick enough to do so before being hit himself. Though this is sometimes a calculated stroke on the part of a fencer admittedly inferior to his opponent, it is not generally considered good fencing.

A pretty variation of the pool, when there are eight fencers or more, is the team fight. The number of fights in a pool can be easily calculated. Let $X$ be the total fencers ; the number of fights will be $\mathrm{X}(\mathrm{X}-1) / 2$. Therefore if the pool is composed of six fencers there will be $6(6-1) / 2=15$.

\section{Style in Fencing}

To turn to style. In fencing it is possible to analyse all the useful movements mathematically into conic sections, the point of the sword describing the base of the cone of which the apex is the pummel. Again, they may be described geometrically by assuming the position of the point in the final thrust to be within one or other of the quadrants of the circle on a compass, i.e. between the cardinal points $\mathrm{N}$. and $\mathbf{E}$. or $\mathrm{N}$. and $\mathrm{W}$. in the upper lines, and the cardinal points $\mathrm{S}$. and $\mathrm{E}$. or $\mathrm{S}$. and $\mathrm{W}$. in the lower lines. Practically this exhausts the possibilities of the fleuret. It also serves as a definition for any thrust or parry with the sword; for wherever an attacking blade threatens a thrust, thither should the defending sword immediately follow it, and though the central point of the circle on the compass may shift from breast to throat, or breast to knee, the relative movements of the subsequent final attack or defence will remain the same. To make any movement outside the imaginary circle, with a radius of about fifteen inches at most, would obviously be dangerous.

The easy way in which diagrams and mathematics can be applied to perfect swordsmanship was the pitfall in the progress of the art of fencing with the point. It resulted in vast and complicated encyclopedias which were of little practical use, if any, in a real fight. The riposte, perhaps the most deadly stroke of all, was only " invented " after duelling had been largely discontinued; and the basic principle of all first-rate exercise in the early days of fencing was entirely lost siglit of ; indeed, it has only emerged into general view in the last generation. The principle may be briefly stated as the employment, in any sudden action, which may in this case involve life or death, of the simplest, most direct, and most instinctive movement-instinctive in the special sense of the result of putting into unconscious practice a series of simple and perfectly executed movements originally learnt with more or less difficulty.

In the thrust the knuckles must be turned toward the ground if the point is to be straight, the head must be erect, the point of the toe in a direct line with the point of the sword, the shoulders at once loose and low, the left foot exactly at right angles to the right. Unless these things at least have become instinctive (in the sense defined), it is useless to try fencing either with foil or sword even in any friendly competition. But these things being granted, an illimitable field for activity, for delicate speed, for subtle character, for courage, for patience, opens up before the courteous swordsman. No game in the world enables you so quickly to take the measure of your man. The sword becomes a nerve stretching from your heart right down to the searching, pulsating point in front of you. It feels the opposing blade. At last it seems as if you might fence blindfold, so extraordinarily is that sixth sense developed which deals with " time, distance, and proportion," as you fight. The parry that fails to find your adversary's sword automatically repeats itself. The thrust that meets his guarding blade slips almost unconsciously the other side of it.

\section{French and Italian Schools}

It is held that the French school of foil and épée-play is invariably the best, in spite of occasional brilliant exceptions like the brothers Nadi at Antwerp in 1920, while the Italian school of sabre leads the world in that deadly and beautiful weapon, the sciabola. This is as light as an épée de combat and almost as deadly with its point, while the swift play of its edge adds great variety and excellence to any contest. It is the combination of edge with point which is the supreme beauty of this weapon, and those who know only either singlestick or heavy sabre could never appreciate the subtle, swift, and delicate play required of the firstrate swordsman in the Italian school of sabre.

Bibliography. \& Bibliography of Fencing and Dtrolling, C. A. T. Thimm, 1896 ; L'Escrime, J. Joseph Renaud, 1911; The Sword and the Centuries, Alfred Hutton, 1901 ; Sccrets of the Sword, Barancourt, Eng. trans. C. Felix Clay, 1900 ; The Works of George Silver, 1599, ed. Cyril Matthey, 1898; Schools and Masters of Fence, Egerton Castle, 1892 ; Cold Steel, Alfred Hutton, 1889 ; Fencing (with Boxing and Wrestling), W. H. Pollock, in The Badminton Library, 1889. 
Fender. Article of domestic furniture. It is used as a guard against the falling of hot cinders from the fire into the room. It is generally made of a flat oblong of japanned metal, with a raised edge of brass or steel along the outer side and the two ends. Its use followed upon the introduction of grates raised from the floor, and it superseded the old shallow kerb which enclosed the open stone hearth.

Fender. Nautical term for a bundle of sticks, rope or wood dropped over a vessel's side to prevent her from rubbing against another vessel or the wall of a quay. Hence the expression to fend off, i.e. to keep away, to protect. A "pudding fender" is a large ball of old rope used as a fender.

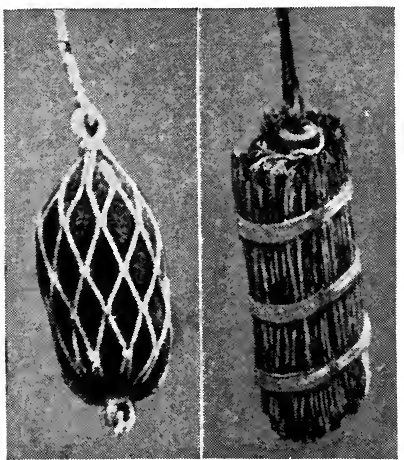

Fender. Left, rope fender in net right, fender of hazel wood bound with wire

Cribb, Southsea

Fénelon, Francois de Salignad DE LA Mothe (1651-1715). French ecclesiastic, author and academician. He was born near Sarlat, Aug. 6, 1651. Ordained priest in 1675 , he was director of the convent of the Nouvelles Catholiques, and missionary to the Protestants in the disturbed provinces of Poitou and Saintonges, the fascination of his personality being a great factor in his success. In 1689 ho was appointed preceptor to Louis XIV's grandson, the duke of Burgundy, and in 1695 was made arch. bishop of Cambrai. Soon after this his interest in Quietism and defence of its leader, Mme. Guyon, brought him into collision with his old friend Bossuet, who, after a bitter controversy, obtained the condemnation by Rome (1699) of his offending volume Explication des Maximes des Saints sur la Vie In. térieure. He died Jan. 7, 1715.

Fénelon was a man of great ver. satility and his writings cover a wide range. The best known is the didactic romance, Les Aventures de Télémaque, 1699, which, like his Fables and his Dialogues des Morts,
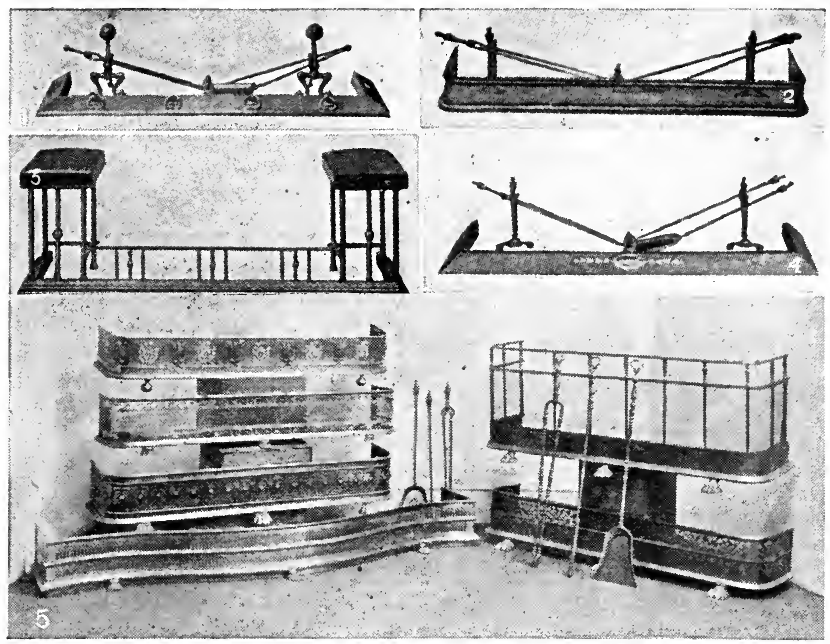

Fender. Examples in domestic use. 1 to 4 , the modern kerb form: 1, of cas steel; 2, of polished brass, pierced and beaded; 3, brass, fitted with seats : 4, copper, antique style. 5, Steel and brass fenders of the 18th century

1-4, by courtesy of Waring \& Gillow, Ltd.; 5, of Gill \& Reigate, Ltd.

was designed to instruct his royal pupil in the conduct of life and the responsibilities of absolute government. His Education des Filles, 1687 , has also a place in the pedagogical literature of the time. See Lives, Viscount Saint-Cyres, 1901 ; and P. E. R. Janet, Eng. trans. V. Leuliette, 19]4.

Feng-huang-cheng. Town of Manchuria, China, in the prov. of Fengtien, on the Mukden-Antung Rly. It was opened to international trade by agreement between China and Japan, 1905. Pop. 25,000.

Feng-siang. Town of China, in the prov. of Shensi. It is perched on a high loess terrace on the main road from Peking to Lanchow.

Fengtien or SHeng-KnNG. Dependency of the Chinese Republic.

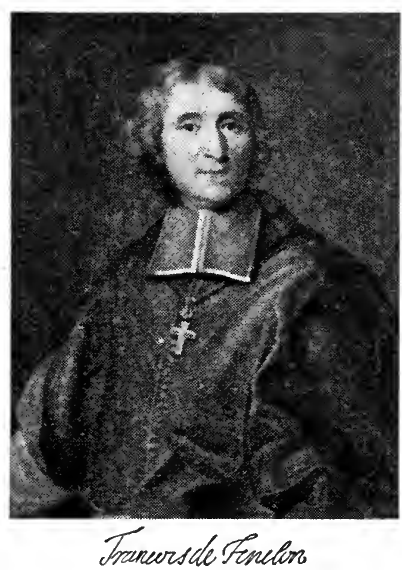

It is the most southerly of the three provs. of Manchuria, lying between Pe-chili on the W. and Korea on the E. In the S. the Liau-tung Peninsula projects between the Gulf of Liau-tung and Korea Bay. At its S. extremity is Port Arthur, leased to Japan for 99 years from 1915. The capital is Mukden, other towns of importance being Fu - chau, Kinchau, and Newchwang. Area, 56,000 sq. m. Pop. 10,312,241.

Feng-yang. City of China, in the prov. of Anhui (Nganhui). It was the birthplace of the Mings, but the first emperor transferred his capital to Nanking.

Fen-ho. River of China, in the prov. of Shansi. It is a tributary of the Yellow River.

Fenianism. Name given to the revolutionary movement springing from the Fenian brotherhood. Its real name was the Irish Revolu. tionary Brotherhood. One of the organizers, O'Mahoney, gave it the name of the Fenian Society, and by that name it became known.

The name was derived from the semi-legendary warrior bands (Fianna) of early Irish history. The society was really a political association of Irish and IrishAmericans whose object was to overthrow British government in Ireland and establish a republic there. There was an American branch and an Irish branch. It has been said that the movement began in America, but really the plans for both branches were drawn up in Paris by a small band of Irish revolutionaries in 1848 . 
The Irish famines in the 'forties caused a great emigration to America, and the emigrants laid the blame for their exile on the British Government, which had been pain. fully unsuccessful in its efforts to cope with distress. The sentiment of hatred towards England was fomented by James Stephens and others, who had escaped after the abortive Young Ireland insurrec. tion of 1848. The organizers knew that onen rebellion against the armed forces of the British Government could bring only disaster, but were persuaded that justice could not be won by peaceful method. Therefore they held it justifiabls to foster "secret warfare"-which those who did not sympathise with them called outrage and assascination. Their aim was purely political; being neither religious nor agrarian, it appealed neither to the priesthood nor to the peasantry.

James Stephens returned to Ire. land to organize the society in that country, while the real headquarters remained in America. In the American Civil War, which ended in 1865, large numbers of American Irish had learnt the business of fighting. The moment seemed ripe for the organization of risings, and an active secret propaganda was set to work in Ireland ; but the authorities were on the alert, seized the offices of the Fenian organ, "The Irish People," and arrested sundry ringleaders. For the time the vigilance of the government seemed to have para-

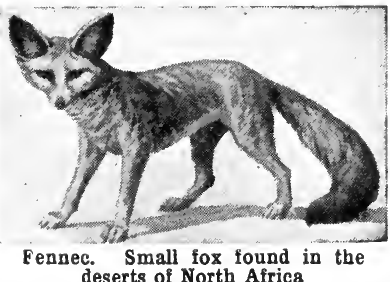

lysed the conspirators. In 1866 some hundreds of American Irish attempted to raise an insurrection in Canada, but failed completely, receiving none of the support expected from the U.S.A. government. Another effort, however, had been prepared in England and Ireland. In Feb. 1867 a plan to seize the arsenal in Chester Castle was forestalled by drafting troops to that city." is

In Sept, two Fenians were arrested in Manchester on charges of felony. A rescue was attempted, the prisoners cscaped, and a police officer was killed. but 29 Fenians were arrested and three were hanged for the murder of the serjeant, which had not been inten. ded, and of which the men convicted had been guilty only in a technical sense. These men became known as the Manchester Martyrs. A worse crime was the blowing up of a part of Clerkenwell prison on December 13. The brotherhood after this time became merged in other societies of a similar character, such as Clan-na-Gael (q.v.), and the Irish Republican Brotherhood. See Irejand : History; Parnell.

Fenn, George Manville (18311909). British novelist and storywriter for boys. He was born at W e s t $m$ inster and was edu. cated at private schools. Having early contributed to popular period. icals, he was in 1870 appointed editor of Cas. sell's Magazine, and in 1873 became pro.

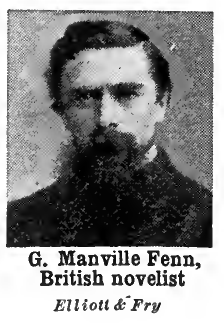
prietor of Once a Week. His published work totalled close upon 200 volumes and included numerous stories told in pleasant narrative style, among them being The Sapphire Cross, 1871 ; The Parson o' Dumford, 1879 ; Off to the Wilds, 1881 ; Nat the Naturalist, 1883 ; Bunyip Land, 1885; The Bag of Diamonds, 1887 ; A Crimson Crime, 1899.

Fennec (Canis zerda). Small foxlike member of the dog family, found in N. Africa. The ears are enormously long, sometimes a quarter the length of the whole body. The colour is a very pale buff, with white beneath and a black tip to the tail. It lives in burrows in the desert and feeds at night on birds, lizards and small mammals.

Fennel (Foeniculum vulgare). Tall perennial herb of the natural order Umbelliferae. It is a native of Europe, N. Africa, and W. Asia. The leaves are much divided into thread-like segments. The tubular, but almost solid stem is $3 \mathrm{ft} .-4 \mathrm{ft}$. in height, crowned with compound umbels of minute yellow flowers. The fruits are compressed from side to side. The leaves are used as a pot-herb, and for garnishing dishes, and the fruit supplies an aromatic oil which possesses carminative properties.

Fenny Stratford. Market town and urban district of Buckingham. shire, England. It stands on the Ouzel, $48 \mathrm{~m}$. N.W. of London and $17 \mathrm{~m} . \mathrm{S} . \mathrm{W}$. of Bedford, and has a station on the L. \& N.W. Rly. It has a trade in agricultural produce. The chief building is S. Martin's church, dating (from the 18th cen- tury. Market dav, Thurs. (alternate). Pop. 4,000.

Fens. Extensive flat and low. lying region of England, $70 \mathrm{~m}$. in length and $35 \mathrm{~m}$. in extreme breadth, occupying parts of several counties in the neighbourhood of the Wash. They represent the silted up portion of a bay of which only the Wash is left, and systematic drainage at various periods has rendered them extremely fertile. The Romans attempted to drain the Fens by constructing causeways and throwing up immense embankments along the rivers and the seashore, but the sluices were gradually choked and the district again became waterlogged, serious inundations by the sea occurring at intervals down to the second half of the 16th century.

In 1634, Francis, earl of Bedford, and thirteen co-adventurers undertook to drain the area now known as the Bedford Level (q.v.). It was not until 1807, however, that the effectual draining of the entire region was finally accom. plished, the Holland and neigh. bouring fens having been reclaimed in 1767 , the Witham Fens in 1807 , and the Welland Fens almost totally reclaimed by 1801 . Grain, flax, cole-seed and potatoes are extensively cultivated, and wild. fowl abound. The Fen country is the home of English skating.

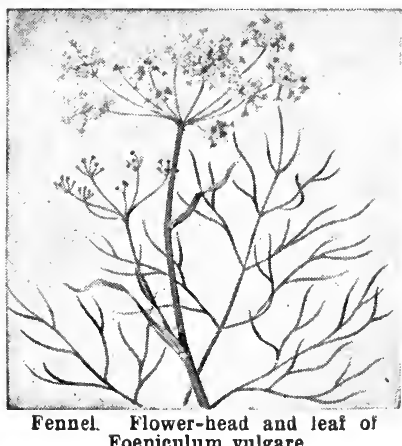

During the second half of the 7 th century, Peterborough, Ely, Ramsey, Thorney, Crowland and many other places were settled by mem. bers of various monastic orders. who erected churches, monasteries and abbeys.

Fenton or Great Fenton. Parish of Staffordshire, England, now part of the county borough of Stoke-on-Trent. It has a station on the N. Staffis Rly., and is largely engaged in earthenware manufacture. To the east of Stoke, it was a separate urban district until absorbed. Market day, Sat. Pop. 25,626. See Stoke-upon-Trent. 
Fenton, Lavinia (1708-60). English actress. She made her first appearance in 1726 as Monimia in Otway's 'The Orphan. Her beauty, voice, and charm soon made her a reigning toast, and her success as Polly Peachum in Gay's Beg. gar's Opera (Jan. 29, 1728) at Lincoln's Inn Fields was

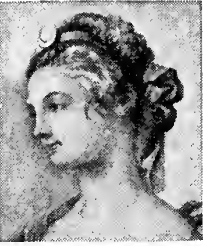

Lavinia Fenton, English actress

After Hogarth such that the opera was played 62 times during the season, and in it the actress made her last appearance on the boards. The 3rd duke of Bolton married her in 1751. She died on Jan. 24, 1760.

Fents (Fr. fente, slit). Rem. nants of cloth from one yard to a few yards in length. They are too short for sale in a regular way, and are generally sold by weight.

Fenugreek (Trigonella foenum Graecum). Annual herb of the natural order Leguminosae. It is a native of S. Europe. The leaves are divided into toothed oval leaflets, flowers pea-like, white, on unbranched stems $1 \mathrm{ft}$. to $2 \mathrm{ft}$. high. The plant, whose name means Greek hay, has the odour of new. mown hay, into which it was made by the ancients. The seeds are used in veterinary medicine.

Fenwick, Charles (1850-1918). British politician. Born at Cramlington, Northumberland, May 5, 1850 , he worked on the pit-bank

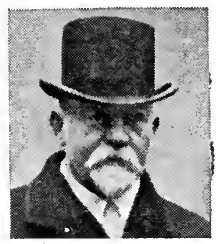

Charles Fenwick, British politician Barratt at the age of nine, and on his tenth birth. day became an underground labourer. $\mathrm{He}$ was employed as a miner until 1885 . Having edu. cated himself in his spare time, he held offices under the Northumberland miners' association. He was elected to Parliament as LiberalLabour candidate for the Wansbeck division in 1885. He was the first Labour M.P. to preside over the House of Commons in committee. He was secretary of the parliamentary committee of the Trade Union Congress, 189094 , and was made a privy coun. cillor in 1911. He represented the Wansbeck division until his death on April 22, 1918.

Fenwick, Sir JoHN (c. 1645-97). English conspirator. Of an old Northumberland family, he early entered the army. $\mathrm{Be}$. coming major general in 1688, he sat in Parliament for his native county,Northu m be rland, from 1677-85. Against William III Fen. wick is said to

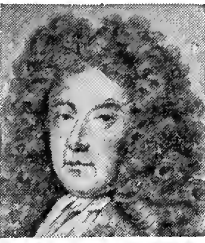

Sir John Fenwick, English conspirator

From an engraving have had an old personal grudge, perha ps reciprocated, and in 1696 he was arrested in connexion with an assassination plot. In his confes sion he cast aspersions on many prominent Whigs. $\mathrm{He}$ was at tainted and beheaded on Tower Hill, Jan. 28, 1697.

Feodor (1557-98). Tsar of Russia. The son of Ivan the Terrible, he was born May 11, 1557 and came to the throne in 1584 . Mentally deficient, he was never capable of ruling, and was under

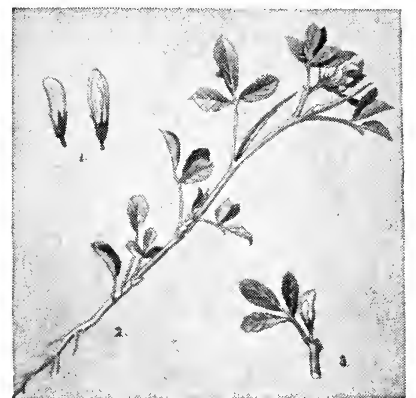

Fenugreek. 1. Flower. 2. The entire plant. 3. Flower and leaf

the direct influence of his brotherin-law, Boris Godunov, who, upon Feodor's death, Jan. 7, 1598, ascended the throne.

Feoffment. In England, the Common Law method of trans. ferring a fee, or freehold. It was a symbolical placing of the transferee in possession of the estate by delivering it to him. If it were a house, the transferor might hand him the key of the front door. If it were land he would hand him, on the land itself, a sod, or a twig, saying, "I liver this to thee in the name of seisin of Whitacre, which is bounded by" (here he would name the boundaries of the estate), "to have and to hold to thee and thy heirs," or for life, or as the case might be.

After a while it became custom. ary to set out the boundaries, etc. in a deed on parchment, sealed with the seal of the parties, and then the feoffment was somewhat in this form, "I liver this (sod, twig, etc.) to thee in the name of all the lands set out in this my deed," at the same time handing over the deed. The deed was called a charter of fcoffment. The Statute of Frauds (Charles II) made some writing necessary on the sale of land; but livery of seisin or feoffment was still necessary as well. To evade the necessity for feoffment the device was introduced of employing two deeds, (1) a lease to the transferee, and (2) a release to him of the reversion. Neither lease nor release required feoffment. By the Real Property Act, 1845 , conveyances of freeholds are made lawful by deed of grant, which is the method in force to-day.

Ferdinand. Masculine Christian name. It comes from Teutonic words meaning a life of daring. Popular in Germany, it never became so in England. It was carried, however, into Italy and Spain, where many kings and other rulers bore it. The Spanish form is Fernando or Hernando, and the Italian Ferdinando.

Ferdinand I (1503-64). Germall king and Roman emperor. Born March 10, 1503, he was the younger son of the archduke Philip and of Joanna of Cas tile. $\mathrm{He}$ was thus a Haps. burg, a grand. son of the emperor Maxi. milian and a brother of Charles V. His early years

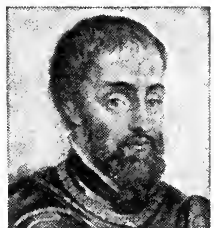

Ferdinand I, German king $\Delta$ fter Titian were passed in Spain, but after Charles was chosen emperor in 1519 he was given extensive territories in Germany and helped his brother in the work of government. In 1521 he married Anna, daughter of the king of Hungary and Bohemia, and when her childless brother Louis was killed in 1526 he put himself forward as his successor. In both lands he was chosen and crowned; in Bohemia he had some semblance of authority, but in Hungary he had for long little more than the name of king.

It is from Ferdinand, not from Charles, that the modern Hapsburgs are descended. The brothers agreed that on the elder's death Ferdinand should succeed him in Germany, leaving to Charles's son Philip only Spain and its colonies. Ferdinand, therefore, was chosen German king in 1531, and when Charles abdicated in 1559 the arrangement was carried out. In the intervening years Ferdinand was fighting for Hungary and dealing as best he could with the religious disorders in Germany and Bohemia. He was useful to Charles after the 
latter's humiliation at the hands of Maurice of Saxony, and arranged with the Protestants the peace of Augsburg. His own reign as em peror (1558-64) saw but a continu ance of his war with the Turks and of his efforts to settle the re ligious differences. He died in Vienna, July 25, 1564, his eldest son. Maximilian II, succeeding hinı.

Ferdinand II (1578-1637). Ger. man king and Roman emperor. Born at Gratz, July 9, 1579 , he

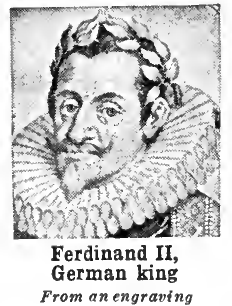

was a son of the archduke Charles and a nephew of the emperor Maximilian II. Educated by the Jesuits, he began his pub. lic life as ruler of Styria and Carinthia, the portion of the

Hapsburg domains that had been his father's share. His rule was chiefly distinguished for his persecution of the Protestants. In 1612 the emperor Rudolph, Ferdinand's cousin, died, and another cousin, Natthias, became emperor. He was old and childless, and the outcome of much political strategy was the dccision that Ferdinand, and not one of his own brothers, should succeed him. The family agreed to the arrangement, and as a beginning the archduke was chosen king of Bohemia and king of Hungary. Matthias died in 1619 and in Aug. his nephew was elected German king.

Meanwhile, in 1618, the Thirty Years' War had begun. A rival to Ferdinand, set up by the Protes. tants in Bohemia, kindled the flame, and the struggle lasted throughout the emperor's lifetime. Ferdinand acted vigorously, and until the appearance of the Swedes, aided by Maximilian of Bavaria, he was completely victorious. He recovered Bohemia, put an end as far as possible to Protestantism, and by the edict of 1629 gave back lands taken from the Church. The Swedish interven. tion followed, and in 1635 the em. peror made the treaty of Prague with some of his foes. He died Feb. 15,1637 , leaving by his wife, a Bavarian princess, two sons, his successor, Ferdinand III, and Leopold, a prelate. See Thirty Years' War.

Ferdinand III (16) $18-57)$. German king and Roman emperor. Son of the emperor Ferdinand Il, he was born at Gratz, July 13 , 1608. To secure his position his father had him crowned king of Hungary and king of Bohemia during his own lifetime, and in 1636 he w'as chosen German king. In 1637 his father died and Ferdinand

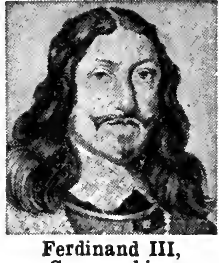

Ferdinand III, bec a me the real ruler of these king. doms and as. sumed the title of em. peror. The 'Thirty Years' War, in which he had taken part, was then $\mathrm{r}$ a $\mathrm{g}$ in $\mathrm{g}$, and his reign saw its end in 1648 . $\mathrm{He}$ died April 2, 1657. Ferdinand was succeeded by his eldest surviving son, Leopold I.

Ferdinand (b. 1861). Ex-tsar of Bulgaria. Born at Vienna, Feb. 26,1861 , he was the youngest son of Augus.

tus, prince of Saxe - Coburg Gotha, and Clementine, daughter of Louis Philippe. $\mathrm{He}$ was well educated, and with his brother Augustus published a

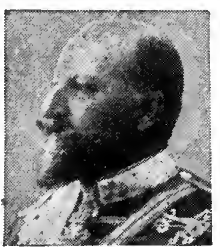

Ferdinand, Ex-tsar of Bulgaria book on his botanical observations in Brazil. He entered the Austrian army, but soon his ambition led him in another direction. In 1887 Alexander, prince of Bulgaria, abdicated, and after much intrigue Ferdinand was chosen as his suc. cessor. Russia was opposed to him, but he won through and by 1896 most of the objections to him had ceased. In 1908 he proclaimed the independence of Bulgaria, and called himself king or tsar, winning recognition from the powers shortly afterwards. He was an advocate of the Balkan League, and was one of the instigators of the war of 1912-13.

On the outbreak of the Great War, Ferdinand was cautious enough to await developments before committing himself to any definite policy. His strong German tendencies gradually became more apparent, however, and finally, having exhausted all the prevarications of diplomacy, he declared war, Oct. 13, 1915. He played no conspicuous part in the war itself, and, on the final breakdown of the Bulgarian effort, he abdicated, Oct. 4,1918 , in favour of his son Boris, and retired to Germany. Ferdinand married first, in 1893 , a Bourbon princess, daughter of the duke of Parma ; and secondly, in 1908, Eleanor, a princess of Reuss.

Ferdinand (b. 1865). King of Rumania. Born at Sigmaringen,
Aug. 24, 1865, he was a son of Leopold, a member of the non. reigning and Roman Catholic branch of the Hohenzollern family. ln 1866 his uncle Charles had been cho. sell king of Rumania, and as his heir Fer. dinand became king in Oct., I 914 . $\mathrm{T} \mathrm{h} \mathrm{e}$ Great War was then in pro. gress, but it

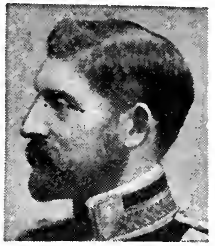

Ferdinand,

King of Rumania was not until 1916 that Rumanıa joined in on the side of the Allies. The land was soon overrun by Aus. tro-Germans, and during the difficult period that followed there were rumours of the king's abdication; but these did not materialise, and the end of the war saw him again in possession of his country. Ferdinand married in 1893 Marie, cousin of King George V.

Ferdinand. Name of several kings of Spain and Naples. Other than those who are given separate biographies, the principal are Ferdinand I (d. 1065), El Magno, or the Great, who became king of Castile in 1028; Ferdinand II (d. 1188), king of Leon; and Ferdinand IV (d. 1312), king of Castile. Of the Neapolitan kings, Ferdinand I (1423-84) was the natural son of Alphonso $\mathrm{V}$ of Aragon and $\mathrm{I}$ of Sicily. He succeeded to the throne by the will of his father. His reign was troubled by the jealousy of the other Italian states, wars with the Turks, and difficulties with France. His grandson, Ferdinand II (1469-96), was temporarily dispossessed by Charles VIII of France. The Bourbon Ferdinand III (1751-1825), king of Sicily, welded the titles of Naples into one and became Ferdinand I of the Two Sicilies.

Ferdinand III (1199-1252). King of Castile and Leon, called the Saint. Son of Alfonso IX of Leon and Berengaria of Castile, he succeeded his cousin Henry as king of Castile in 1217, and showed him. self a prudent and merciful ruler. In 1231 the death of his father brought him the throne of Leon, and as king of Castile and Leon he waged war vigorously against the Moors, eventually confining them to Granada, and securing Seville in 1.248. He was canonised by Clement $\mathrm{X}$ in 1671 on account of his un. flinching orthodoxy in repressing the Albigenses, and for his services towards the Crusades.

Ferdinand V (1452-1516). King of Spain. Known as Ferdinand of Aragon, he was the son of John II, king of Aragon and Sicily, and was 
born March 16, 1452. He was as. signed the Sicilian kingdom in 1468 , and succeeded his father as Ferdinand II of Aragon in 1479. In 1469 he had married Isabella, sister of Henry IV of Castile, the recognized heiress to the Castilian throne. Henry died in 1474, and Isabella was established as queen of Castile in 1479, the year in which Ferdinand succeeded to the crown of Aragon. There were now in the

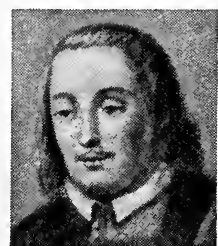

Ferdinand V,

King of Spain

From a contemp. portro rate governments. with Granada ended triumphantly with its annexation in 1492; and in 1512 Ferdinand acquired almost all of Navarre.

Thus during his reign the entire peninsula, except Portugal, was brought under a single dominion. Sicily was already attached to the kingdom of Aragon, to which S. Italy or Naples was added by the ousting of the French in 1504. Further, the discovery of America, 1492, by Columbus, under the aus. pices of Ferdinand and Isabella, secured what was almost the monopoly of the New World to Spain. which had thus been raised to the position at least of equality with France. Isabella was something more than the partner of Ferdinand in the expansion of their joint dominion and in bringing each of their separate kingdoms under the effective control of the crown. She rendered ill service to Spain, however, by introducing the Inquisi. tion (q.v.) in 1480. The expulsion of the Jews and the harsh restrictions imposed upon the Moors were also highly injurious. The course of future events was greatly influenced by the marriage of the elder daughter Joanna to Philip, duke of Burgundy, heir to the Austrian Hapsburgs, and of the younger, Catherine, first to Arthur, prince of Wales, and after his death to his brother Henry.

Ferdinand was noted as the craftiest sovereign of his day, his only rival in that quality being Henry VII of England, with whom he was usually joined in an alliance in which each sought the maximum advantage at the other's expense. After the death of Isabella, 1504, Ferdinand's craft degenerated into mere cunning. The crowns of Castile and Aragon were actually parted when Isabella died; but Joanna, duchess of Burgundy, was heiress of both, and her place was taken by her son, afterwards Charles V. Except during a brief interval, Ferdinand retained the government of Castile as regent until his death, Jan. 23, 1516 . The character of Ferdinand is summed up in the story of his reply when told that Louis XII complained that he had cheated him once. "He lies: I have cheated him thrice." See Hist. of the Reign of Ferdinand and Isabella, W. H. Prescott, ed. J. F. Kirk, repr. 1902. See illus. p. 2158.

Ferdinand VI (1712-59). King of Spain. The second son of Philip V, he was born Sept. 23, 1712, and ascended the throne in 1746 . $\mathrm{He}$ immediately set himself to carry out internal reforms, having first concluded the peace of Aix-laChapelle, 1748. At the outbreak of the Seven Years' War in 1756 he declared his neutrality. Three years later, broken-hearted at the loss of his wife, Maria of Portugal, his reason gave way, and he died Aug. 10, 1759. The crown of Spain passed to his half-brother, Charles III of Naples.

Ferdinand VII (1784-1833). King of Spain. Son of Charles IV, he was born Oct. 14, 1794, and five

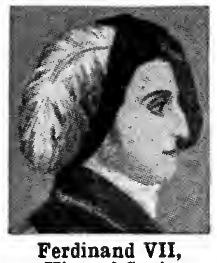

Ferdinand VII,
King of Spain years later be. came prince of Asturias. In opposition to his father, in 1806 he ap proached the court of France with the project of marrying on e of $\mathrm{Napoleon}$ 's nieces. He was imprisoned by his father, but the French invasion of Spain caused the latter to abdicate in Ferdinand's favour in 1808. Charles, however, appealed to Napoleon, and withdrew his abdication, and Ferdinand went into retirement. After the Peninsular War in 1814 Napoleon reinstated Ferdinand. A reign of terror fol lowed, and such chaos and rebellion prevailed that in 1823 a French army was sent to establish Fer dinand on his throne. To secure the succession for his daughter, Isabella, in 1830 he abolished the Salic law as applying to the Span ish throne, thus excluding his brother Carlos, an act which led to grave complications later. $\mathrm{He}$ died Sept. 29, 1833, and Isabella came to the throne under the regency of Maria Christina. See Carlists ; Spain : History.
Ferdinand I (1751-1825). Kins of the Two Sicilies. Born in Naples,

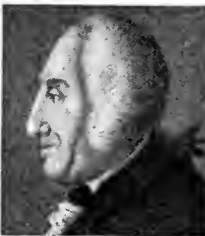

Ferdinand I, King of the $T w 0$ Sicilies Jan. 12, $175 \mathrm{l}$ when his father ascended the Spanish throne as Charles III in 1759 , he became his successor as king of Naples and of Sicily. In 1768 he married Maria Carolina of Austria, and was completely dominated by her violent and tyrannical nature.

After the short-lived Parthen. opean Republic (1799), in the bloody repression of which Nelson, deluded by Lady Hamilton and Maria Carolina, played a part, Ferdinand oppressed his subjects still more. He aided the Austrians against Napoleon, who sent troops to occupy Naples, whereupon Ferdinand fled to Sicily, and Joseph Bonaparte was proclaimed king in his place. In 1815 Murat, who had succeeded Joseph as king in 1808, was deposed, and Ferdinand returned to vent his spite on the populace by the indulgence of an inconceivable tyranny and cruelty. Uniting Naples and Sicily, he became the first king of the Two Sicilies. At the suggestion of the European powers he promised various reforms, but consistently with the whole tenor of his life he broke all his oaths and repudiated his own signature. $\mathrm{He}$ died on Jan. 4, 1825.

Ferdinand II (1810-59). King of the Two Sicilies. Born at Palermo, Jan. 12, 1810, he succeeded to the throne at the age of 20 , in augurating his reign with the promise of many reforms. $\mathrm{H}$ is despotic and c r u e l nature soon showed itself,

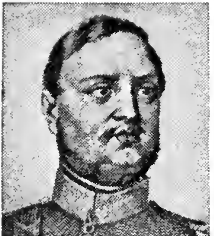

Ferdinand II, King of the Two Sicilies however, and ing under oppression and corruption. The insurrections of 1837,1843 , and 1844 culminated in a rising in Sicily and Naples, 1848, which terrified him into granting a constitution. The crushing of Italian hopes after Novara, 1849, encouraged him to annul this, and in order to quell the revolutionary spirit he caused Messina and Palermo to be bombarded, thus earning the nickname of King Bomba. Those who showed liberal tendencies were imprisoned to the number of about 30,000 under 
conditions which Gladstone, who visited the country in 1851 , exposed, describing Ferdinand's rule as the "negation of God." $\mathrm{He}$ died May 22, 1859

Ferdinand (1769-1824). Grand Duke of Tuscany Born May 6, 1769 , he was a younger son of the emperor Leopold II. In 1790, when his father became German emperor, he succeeded to the grand duchy of Tuscany. In 1799 he was deposed by the French, in 1802 was made elector of Salzburg. and in 1806 became grand duke of Wurzburg. Hc was restored to his Tuscan throne in 1814, and by his liberal government saved his people from the misfortunes which overtook their neighbours on the restoration of the old monarchies. He died June 18, 1824, succeeded by his son Leopold II

Fère-en-Tardenois. Town of France, in the dept. of Aisne. It is on the river Oureq, $12 \mathrm{~m}$. N.N.E of Château-Thierry, and was prominent in the Great War. It was the British G.H.Q. during the first battle of the Aisne. The Germans reached it on May 30, 1918 , in their thrust for Paris. It was recaptured by the Allies on July 28, 1918, with 2,000 prisoners. See Aisne, Third Battle of the Marne, Second Battle of the.

Ferentino (anc. Ferentinum) City of Italy, in the prov. of Rome. It stands on an eminence, at an alt. of $1,290 \mathrm{ft} ., 48 \mathrm{~m}$. by rly. E.S.E. of Rome. It has extensive remains of the fortifications of the ancient city, including two gateways. It has a fine cathedral with mosaic floors, and there are a few Gothic churches. The town carries on trade in oil and wine. Pop. 12,928.

Ferg, Franz De PaUla (16891740). Austrian painter. Born at Vienna, he studied under his father, Pancrazius Ferg, J. Orient, and Jean Graff, and painted land. scapes in the manner of Poelenberg and genre in the Flemish style. After some years at the court at Dresden, he visited Brunswick, and then London, where, after enjoying some years of affluence. he died in poverty.

Ferghana. Prov. in Russian Turkistan, W. Asia, between Syrdaria in the $N$. and Semiryechensk in the N.E. Its area is $55,483 \mathrm{sq}$. $\mathrm{m}$. Much of the land is barren and hardly fit for pasturage, but is rich in minerals-coal, lead, graphite, and petroleum. The silk industry has long been famous. The chief towns are Khokand, Marghilan, and Andijan. Ferghana, once part of the ancient Sogdiana, was formed from the old khanate of Khokand, and was annexed by Russia in 1876. Pop. 2,169,600.

Fergus. River of Ireland. rises in the N.W. of co. Clare and flows S.E. for $25 \mathrm{~m}$. to its estuary at Clare village. The estuary, about $10 \mathrm{~m}$. long and $4 \mathrm{~m}$. in extreme breadth, is dotted with green islands and contains salmon.

Ferguson, ADAM (1723-1816). Scottish philosopher. Born at Logierait, Perthshire, June 20, 1723 , he was educated at Perth and the university of St. Andrews. He became an army chaplain, and was present at Fontenoy and elsewhere with the Black Watch. He was then a private tutor until in 1759 he was chosen professor of natural philosophy at Edinburgh. He retained his post there until 1785, and lived until Feb. 22, 1816 Ferguson is known by his Essay on the History of Civil Society, and his philosophy elaborated in his Institutes of Moral Philosophy, 1772, and Principles of Moral and Political Science, 1792. He wrote also a History of the Progress and Termination of the Roman Republic, 1783.

Ferguson, JAMES" (1710-76). Scottish astronomer. Born Apri 25. 1710. near Rothiemay, Banff-

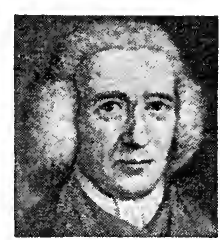

James Ferguson, Scottish astronomer From a print broken in health, but his ingenious construction of a clock attracted the attention of Sir James Dunbar. who took him into his own household. In 1734 hewent to Edinburgh. where he painted miniatures. In 1743 he removed to London, and was elected a F.R.S. in 1763 . $\mathrm{He}$ became a popular lecturer on experimental science, but was specially noted as an inventor of astronomical and other instruments. $\mathrm{He}$ died in London, Nov. 16, 1776.

Ferguson, RoBert (c. 16371714). Scottish conspirator and pamphleteer, known as "the Plotter." Born in Aberdeenshire, he came to England about 1655, and was appointed to the living of Godmersham, Kent, from which he was ejected in 1662 by the Act of Uniformity. He took part in the various plots against Charles II, James II, and William III, but always succeeded in escaping from justice. His writings include a History of the Revolution, 1706, and Qualifications requisite in a Minister of State, 1710.
Ferguson, Sir Samuel (1810$86)$. Irish poet and antiquary. Born at Belfast, March 10, 1810,

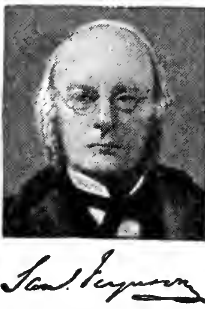
and educated at Trinity College, Dublin, he was called to the Irish bar in 1838. Deputy keeper of the public records of Ireland in 1867, he was knighted in 1878. He died Aug. 9, 1886.

His poems, for the most part metrical versions of Irish legends, comprise Lays of the Western Gael, 1865 ; Congal, an epic poem, 1872 ; and a second volume of lays, Poems, 1880. He helped to prepare the way for the Gaelic revival.

Fergusson, Sir Charles (b. 1865). British soldier. Born in Edinburgh, Jan. 17, ] 865 , he suc. ceeded to his father's baron. etcy in 1907. Educated at Eton and Sand. hurst, he joined the Grenadier Guards, 1883 , and in 1896 transferred to the Egyptian SirCharles Fergusson. army. He saw British soldier service in Barnett

Egypt, being wounded and winning the D.S.O. He returned to England to take command of the 3rd Grenadiers in 1904. From 1909-13 Fergusson was inspector of infantry, and in 1913 was appointed to the 5th di. vision, which he led in the retreat from Mons. He took over the com. mand of the 2nd corps in 1915, and in 1917 was at the head of the 17th which he led in the final offensive of 1918. He was military governor of Cologne from 1918 to Aug., 1919. He was appointed governor-genera! of New Zealand, 1924.

Fergusson, Robert (1750-74). Scottish poet. Born in Edinburgh. Sept. 5, 1750, he studied at St. An drews University, and entered the office of the commissary clerk at Edinburgh. In 1771 he began to contribute poems, mostly in the Scottish dialect, for Ruddiman's Weekly Magazine, and these appeared in collected form in 1773 . He died Oct. 16, 1774, largely as the result of convivial excesses. His work greatly influenced Robert Burns, who in 1789 composed the epitaph for the headstone of his grave in Canongate churchyard. See Life, A. B. Grosart, 1898.

Feriae. Sacred festivals or holidays of ancient Rome. The most important were the Feriae Latinae, 
the great Latin festival. During the holding of the feriae the city was in charge of special officials and no business was done. See Festival.

Ferial and Festal. Terms used in music. In the Christian Church ferial signifies any day not specially observed either as festal or penitential, and the music is of a simpler order on ferial than on festal days.

Feringhi (Pers. farangi). Corruption of Frank, the name given by Asiatics to a European. It is now generally used as a term of contempt.

Fermanagh. Inland county of Ireland, in the prov. of Ulster. The irregular surface is marked by numerous hills, the highest of which, wholly within the county, is Belmore (1,312 ft.). Lough Erne consists of two lakes, the Upper and Lower. Enniskillen is the co. town. Agriculture is engaged in, coal, iron. and building stones are found, and the lakes supply salmon. The G.N.I. and other rlys. serve the county. Two members are returned to Parliament. Tumuli, raths, castle ruins, and a round tower are among the antiquities. Area, 653 sq. m. Pop. 61,636.

Fermat, PIERRE DE (1601-65). French mathematician. Born at Beaumont-de-Lomagne, Aug. 17, 1601 , he early showed remarkable mathematical ability, especially with regard to the theory of numbers, upon which he has left his mark. Most of his work was not published till after his death, and some of his more important trea tises have been lost. He died at Toulouse, Jan. 12, 1665.

Fermentation (Lat. fervere, to boil). Result of the action of organic substances known as ferments. In 1680 the Dutch microscopist Leuwenhoeck showed that yeast consists of definite globules, but only in 1836 was it settled that yeast cells originated fermentation.

Latour first observed that the cells were living organisms, and his "vital hypothesis," violently opposed by Liebig, was supported by Pasteur, who in 1857 gave it as his opinion that "the chemical action of fermentation is essentially a correlative phenomenon of a vital act, beginning and ending with it. I think that there is never any alcoholic fermentation without there being at the same time organization, development, multiplication of globules, or the continued consecutive life of globules already formed." In fermentation the amount of matter consumed and changed into other compounds is much greater than the size and weight of the consuming organisms. Yeast globules decompose many

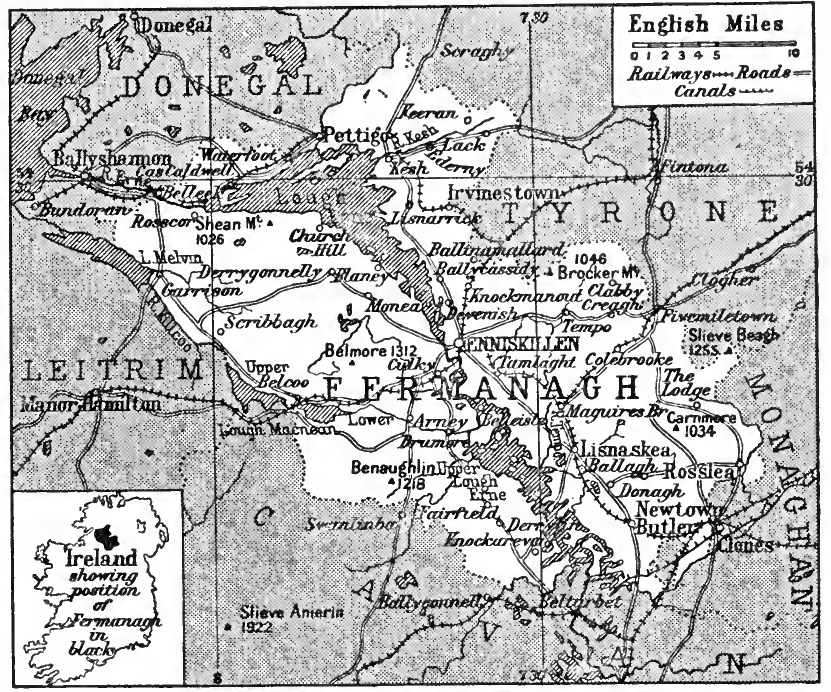

Fermanagh. Map of the Ulster province containing Lough Erne, famous for salmon and trout fishing

times their weight of sugar and produce a relatively large quantity of alcohol and carbon dioxide. Experimental work has thoroughly determined the action of ferments, and also that each particular organism has its special products of fermentation. All ferments are nitrogenous organic substances whose activity is destroyed by high temperatures.

They are organized and un. organized, the difference being that an organized ferment is one which does not leave the living cell during the progress of fermentation, whereas the unorganized ferment is shed out of cells and then exerts its activity. Unorganized ferments are known as enzymes or chemical ferments. Organized ferments, which will be considered first, are divided into moulds or fungi, yeasts or saccharomycetes, bacteria or schizomycetes.

\section{Moulds and Yeasts}

Moulds are the most highly organized of the ferments, in that cell-wall and protoplasmic contents are distinguishable in the microscopic cells. The best known moulds are Mycoderma cerevisiae, which causes mould in beer ; Peni . cillium glaucum, the green mould that forms on bread, jam, etc.; Aspergillus glaucus, a similar fungus; Micrococcus prodigiosus, which causes red bread; Puccinia graminis, the "rust" or mildew of wheat; Ustilago segetum, the "smut" of cereal crops; and Oidium abortifaciens, which causes ergot on rye.

Yeasts, also called saccharomy- cetes because they live mostly in saccharine solutions, converting sugar into alcohol, form a group of micro-organisms of the greatest importance in fermentation. Yeast cells are round or oval in shape, and multiply by the process known as gemmation or budding, which goes on indefinitely under proper conditions. In other cases they form spores or new cells liberated by the dissolution of the mother cell.

Although the cells can use oxygen, they appear to be independent of an environment of free oxygen. Time, strength of saccharine solution, and temperature also influence the process of fermentation. The alcohol formed retards the growth of the yeast cell, which ceases action when 14 p.c. of alcohol is formed.

Alcoholic or vinous fermentation is the characteristic function of yeasts. Ethylic alcohol (ordinary alcohol) is formed when sugar is fermented. The higher alcohols, propyl, butyl, amyl, and capryl alcohols, are also produced under suitable conditions. Fernbach has recently discovered means of increasing the proportion of amylic alcohol produced during fermentation. From this alcohol artificial rubber is made by the Matthews process. Various forms of starch are used as the source of sugar, which is formed by the action of diastase in the process of brewing. Only the glucoses are capable of direct fermentation.

The chief yeasts are: (1) Saccharomyces cerevisiae, the ordinary yeast of the brewer and distiller. 
Two kinds are recognized, "high" and "low" yeast, the former rising to the top of the liquid during fermentation and the latter forming a sediment in the vats. High yeast is the one used in English ale fermentation, low yeast producing the lighter lager beer.

(2) Saccharomyces ellipsoideus is the ordinary ferment of vinous fermentation by which " must" or grape juice is converted into wine. (3) Saccharomyces pastorianus also occurs in wine-making, and when present during brewing gives a bitter taste to the beer.

(4) Saccharomyces mycoderma is the cause of "mother" which ap. pears on the surface of wine or beer after exposure for some days to the air.

Hansen, the Danish brewing chemist, has isolated and cultivated two pure yeasts, species of Saccharomyces cerevisiae, by using which it is possible to obtain beers of distinctive properties.

Acetic Fermentation. It has long been lnown that when wine is exposed to the air it sours-turns into vinegar - and the manufacture of vinegar wort is an old-established art. It is essentially an oxidation process, and Pasteur first detected the organism, "flowers of vinegar," Bacillus aceli, which effects the change. Hansen has detected two distinct-species with the same properties. Both require oxygen for their growth, which is most favoured by a temperature of $33^{\circ} \mathrm{C}$.

Lactic fermentation produces sour milk. The milk sugar is first split up into lacto-glucose and then into lactic acid by the agency of Bacillus acidi lactici. A special bacillus, named Bacillus Caucasi. cum, was found by Mechnikoff to be present in the soured milk employed as a beverage under the name "yoghourt."

Viscous fermentation, due to Pediococcus cerevisiae, is the cause of "ropiness" in brewing, and a similar condition in bread-making.

\section{Nitrification in Agriculture}

Nitrification or the oxidation of ammonia into nitrous and nitric acids takes place through the agency of bacteria. Warington's investigations at Rothamsted have shown the importance of nitrification in agriculture. Recently special preparations of nitrification bacteria have been employed com. mercially in promoting the growth of leguminous plants.

Enzymes or soluble ferments may be defined as substances produced by living plants or animals, and capable of acting catalytically on contiguous compounds. They are thus classified:
Amylolytic, which convert starch paste into soluble starch and soluble starch into maltose and dextrose. To this class belong diastase, derived from malt ; ptyalin, from saliva; and amylopsin, from pancreatic juice. Cellulolytic, represented by cytase; this is derived from green malt, which dissolves the cellulose walls of grain. Coagulative, such as fibrin-ferment from blood, myosin-ferment from muscle, and rennet from gastric juice, which coagulate protein mat. ter. Emulsive, which convert glucosides into glucose and other compounds. Examples are emulsin, obtained from almonds, and myrosin, from mustard Inversive, such as invertase from yeast and invertin from intestinal juice, which convert sucrose in to glucose, and maltase from yeast, which changes maltose into glucose.

\section{Enzymes in Industry}

Proteolytic enzymes convert proteins into peptones. Examples are pepsin from gastric-juice, trypsin from pancreatic juice and papain from Carica papaya. Steato. lytic enzymes, of which steapsin of the pancreatic-juice is an example, separate fats into fatty acids and glycerin. Zymase ob. tained from yeast converts sugar into alcohol and carbon dioxide.

Enzymes play a considerable part in several important indus. tries, such as brewing and leather making. In the preparation of rubber, the drying of tea, and the curing of tobacco the proper treat. ment of the vegetable enzymes contained in these substances determines the quality of the products. In drying drugs the activity often depends upon the prompt killing by heat of the enzymes in the plants. Special proccsses have been evolved in which the vapour of boiling alcohol is employed for this purpose.

Putrefaction is the process of fermentation of nitrogenous organic matter, especially albuminoids, accompanied by the production of evil-smelling gases. The process is due to microorganisms, the decomposing substances yielding, among other organic bases, methylamine, trimethylamine, and the important bodics known as ptomaines. Many of the ptomaines are very poisonous. They are produced readily in decaying meat and fish, and when introduced into the human body give rise to very serious blood poisoning. See Brewing; Distilling : Liebig ; Pastcur; Sterilization.

Fermo (anc. Firmum Picenum). City of Italy, in the prov. of Ascoli Piceno. It stands on an eminence, rather more than 1,000 ft. high, $4 \mathrm{~m}$. from the Adriatic and $36 \mathrm{~m}$. by rly. S.E. of Ancona. Enclosed by battlemented walls, it contains a 13th century cathedral, a town hall and library, besides remains of Roman buildings. Porto San Giorgio, its port, exports grain, wool, and silk. Fermo was founded by the Romans in 264 B.c., and was a free city from 1199 to 1550 , when it fell to the papacy. Pop. 7,000.

Fermoy. Urban dist. and market town of co. Cork, Ireland. It stands on the Blackwater, $15 \mathrm{~m}$. E. of Mallow, on the G.S. \& W.R.

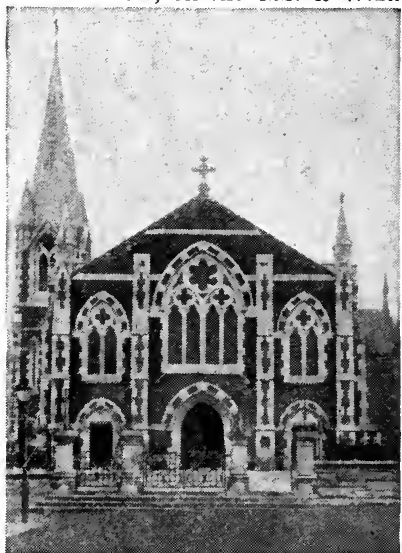

Fermoy, Ireland, the Roman Catholic church of S. Patrick

Its importance is chiefly due to the efforts of John Anderson, a Cork merchant, who began to build here in 1791, and later gave a site for the erection of military barracks and founded Fermoy college. The town contains a Roman Catholic cathedral and S. Colman's Roman Catholic college. Salmon and trout fishing is engaged in, and a trade in corn carried on. There is a racecourse in the vicinity. Fermoy was the scene of rioting on June 28-29, 1920 , when the military wrecked a number of buildings as reprisal for the capture of General Lucas. Market day, Sat. Pop. 6,863.

Fern (Pteridophyta). Most highly organized division of the flowerless plants (Cryptogamia), which are characterised in the main by being built solely of cells. Pteridophytes alone of the cryptogams possess vessels. They are mostly perennial herbs, only a few being annuals. A few others have shrubby roots or woody trunks, e.g. the tree-ferns. Besides the ferns proper, the pteridophytes include the horsetails and slub-mosses, all agreeing generally in their mode of reproduction. This is known as the Alternation of Generations. As it has been tersely put by a modern writer: "Of four successive generations of fern-life, 


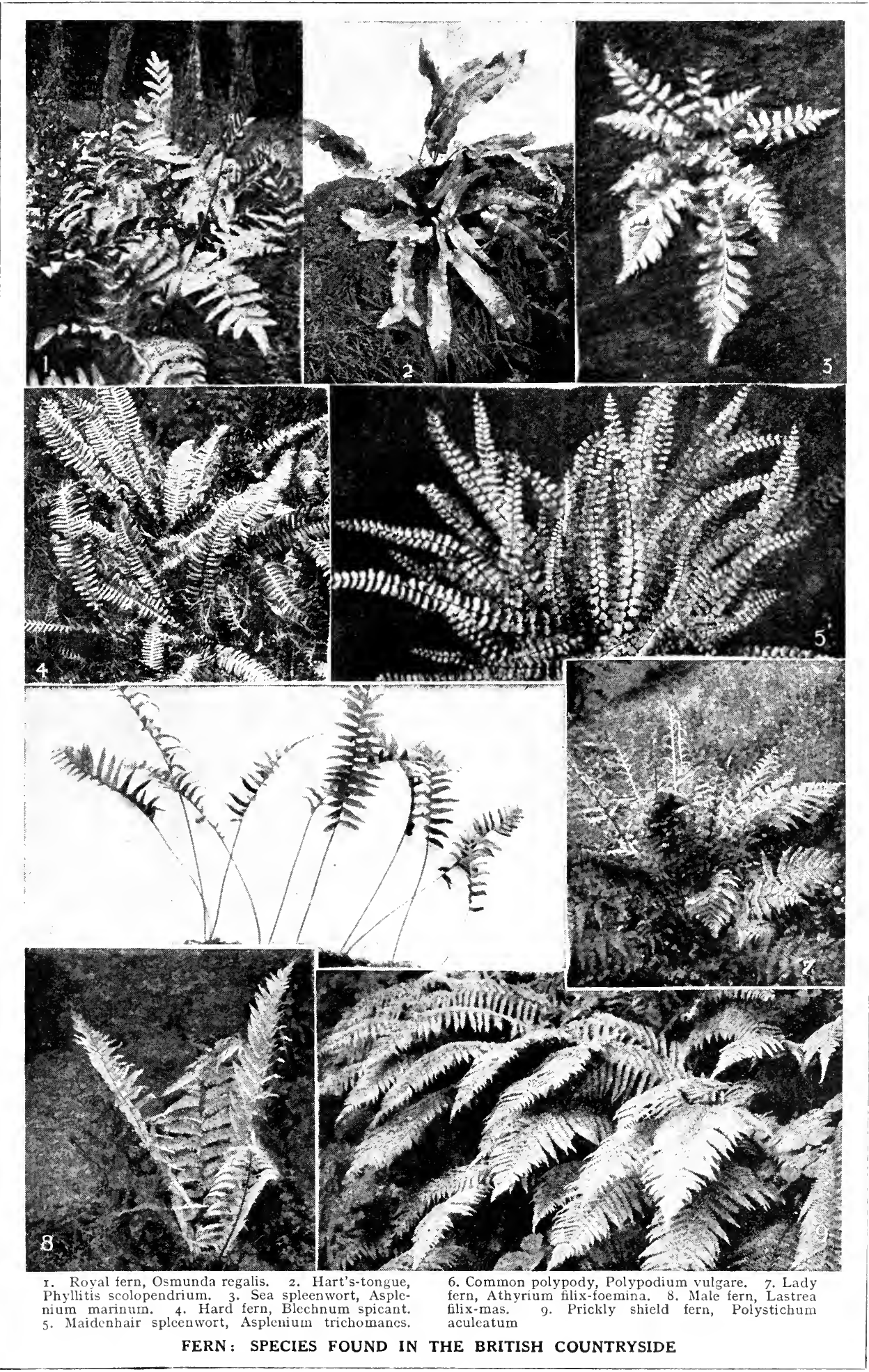


generations 1 and 3, though agreeing each with the other, will differ widely from generations 2 and 4, though they are all in the direct line of descent one from another."

The furry, red-brown patches on the back of the fern-leaves consist of thousands of minute eapsules (sporangia), each containing about 64 microseopic spores. Each spore under suitable conditions develops, not into a fern like that by which it was produced, but into a tiny heart-shaped grcen scalc (prothallium), which bears on its under surface two kinds of sexual organs-the counterpart of the anthers and ovaries of flowering plants. The male organs (antherids) contain motile bodies termed antherozoids, which find their way to the female organs (archegones) and fertilise them. The result is the production of an embryo from which in due course arises a leafy fern-plant like that which produced the spore. This leaf-bearing form is known as the sporophyte generation, and i. c prothallium as the oophyte generation.

From the gardener's point of view hardy ferns are valuable to fill moist, shady places for which the choice of flowering plants is limited, but the use of exotic ferns except as specimens, or in elaborate winter gardens, has fallon into disuse, since some consider that the space they occupy can be employed to greater advantage by flowering plants. This, however, is purely a matter of taste; the beauty of the fern is lasting, that of the flower ephemeral.

Hardy ferns are not particular as to soil, though to obtain the best results a mixture which contains a considerable percentage of welldecayed leaf-mould or peat is desirable, or, failing this, some old stable manure should be mixed with the loam when making up the bed. The situation is more important; the north side of a wall or hedge, where less hardy things are difficult to grow, will suit ferns admirably. It is well not to plant them too near ivy, however, as this climber is so greedy a feeder that it specdily takes all the nourishment away from the ferns, especially if they are of choice kinds. The ordinary brake fern, or bracken, will grow anywhere, but except for very smoky and shady town gardens, its employment in any quantity is not recommended as it is a greedy feeder.

Exotic ferns should be taken in hand in early spring, when the new growth starts. They will thrive in any ordinary potting mixture, one which contains a liberal admixture

of silver sand for preference, and they may be shifted into larger pots when necessary, at any time of the year except the winter. Ferns are most easily in. creased from spores, which are found upon the undersides of the leaves. When these are ripe the most fruitful leaf or leaves should be severed from the

parent fern, and stored away in a box or piece of paper for a few days, and kept dry until the spore cases burst. The spores should then be lightly sown upon the surface of a box of finely sifted potting soil, and kept moist. Tiny ferns will appear in the course of a few weeks, and these should be very carefully potted into thumb-pots when large enough to handle, and afterwards repotted as desired. When ferns such as the maidenhair, ribbon-fern, or any of the native species have been grown in the greenhouse, it will be found that the top-soil of the pots is already sown with their spores. If this is removed to a shallow pan and covered with glass, it will soon be covered with prothallia. Observation of the evolution of the adult fern from this beginning is a valuable lesson in botany.

Gold and silver ferns are popular names given to several species to denote their appearance. It is due to the under surface of the leaves being coated with fine particles of white or yellow wax, which looks silvery or golden. Cheilanthes argentea, an Asiatic species, is an example of a silver fern. Others of the same genus are $C$. clevelandi (N. America), C. eatoni (W. United States), and C. farinosa (Tropics). The genus Gymnogramma also affords examples of silver ferns in G. chrysophylla (Tropics), G. decomposita (S. America), and $G$. sulphurea (W. Indies).

Bibliography. Structure and De. velopment of Mosses and Ferns, D. H. Campbell, 1895 ; Book of British Ferns (with special reference to the raising of fancy varieties), C. T. Druery; Wayside and Woodland Ferns, with Figures of all the British Species, E. Step, 1908.

Fernandez, JuAN (c. 1536 1602). Spanish navigator. A native of Cartagena, Fernandez spent his life as a pilot on the Pacific coast. In 1571 he discovered the island now called by his name, on which he vainly tried to settle some Indians. His skill as a sailor won and also brought him under the notice of the Inquisition.

Fernando de Noronha. Island in the Atlantic, belonging to Brazil. It is about $200 \mathrm{~m}$. E.N.E. of Cape St. Roque, $8 \mathrm{~m}$. long by $1 \frac{1}{2} \mathrm{~m}$. wide, is of volcanic origin, reaching an elevation of $1,100 \mathrm{ft}$., and has several good harbours protected by forts. The surface is rugged, but fertile, producing cereals, cotton, and fruit. At Remedios (pop. 2,100) is a convict settlement, with a cable and wireless telegraph station. The island was discovered by a Portuguese navigator, whose name it bears.

Fernando Po. Island in the Bight of Biafra, belonging to Spain. The key to this portion of the African coast, it is mountainous, fertile, and beautiful. Of volcanic origin, it is $35 \mathrm{~m}$. long and $22 \mathrm{~m}$. broad. Densely forested in the N. and covered in most parts with luxuriant vegetation, it yields sugar-cane, bananas, and yams, while cotton, coffee, rice, tobacco, and cinchona are cultivated. The highest mt., Clarence Peak, 10,190 $\mathrm{ft}$. , is called by the Spaniards Pico Santa Isabel. The island is in. habited by a Bantu tribe, the Bubis, and a few negroes.

Santa Isabel, the chief town, is the administrative capital of the Spanish possessions in the Bight of Biafra. Rubber and palm oil are exported. The climate is considered unhealthy. The island is named after its Portuguese discoverer, Fernão do Po, who sighted the island in 1471, and it was ceded to Spain in 1778. Area, 1,185 sq. m. Pop. about 19,000 , of whom some 500 are Europeans. See From the Congo to the Niger and the Nile, Adolphus, duke of Mecklenburg-Schwerin, 1913.

Ferndale. Eccles. district and village of Glamorganshire, Wales, It is $6 \mathrm{~m}$. N.W. of Pontypridd, on the Taff Vale Rly. There are extensive collieries in the neighbourhood. Pop. 18,144. 
Ferney or Ferney-Voltarre. Village of France, in the dept. of Ain. It stands near the Swiss frontier, $4 \mathrm{~m}$. N.W. of Geneva. The château de Ferney was built by Voltaire, who lived in it from 1758 to 1778 ; it contains numerous me. morials and personal relics of the philosopher, who in 1768 founded a watch factory, which at one time employed 800 hands. In the townhall is a statue to Voltaire (q.v.), and his name was officially added to the town in 1878. Pop. 1,172.

Fern Palm (Cycas revoluta). Tree-like perennial of the natural order Cycadaceae. A native of China, it has a stout stem, in old individuals as much as $7 \mathrm{ft}$. high, crowned by the arching, palm-like leaves. These are cut into narrow segments in a feather-like manner, and vary in length from $2 \mathrm{ft}$. to 6 ft. The reproductive organs are found in the heart of the leaf-crown: the males in cones, whose scales bear anthers on their under surface; the females bearing ovules in the marginal notches of woolly, leaf-like organs.

Ferns. Town of Ireland, in co. Wexford. It stands on the Bann, $74 \mathrm{~m}$. S. of Dublin by the Dublin and S.E. Rly. Its interest is wholly historical. It was long the seat of a bishop, and has a modern church, formerly the cathedral. Other buildings of interest are the episcopal palace, the ruins of the castle, of a church, and a monastery. The town grew up around a monastery founded by $\mathrm{S}$. Edan about 600 . The kings of Leinster had a palace here, and here the Norman invaders built a castle. The diocese was united with Ossory in 1836. James I made it a chartered town, and until 1800 it sent two members to the Irish Parliament.

Ferozepore. District and town of the Punjab, India. The area of the district is $4,286 \mathrm{sq}$. $\mathrm{m}$. There are no important manufactures: the chicf crops are wheat, gram, barley, and millet. Half the cultivated area is irrigated. Ferozepore town is situated at the junction of the Rajputana and North-Western Rlys., some $4 \mathrm{~m}$. from the Sutlej. It is the site of a large cantonment, and has an arsenal; it is also the centre of a considerable grain trade. Pop. dist., 959,657, 25 p.c. Hindus, 25 p.c. Sikhs, 50 p.c. Mahomedans; town, 50,836, 42 p.c. Hindus, 47 p.c. Mahomedans. The Jats are the chief tribe.

Ferozeshah, Batrue of. British victory in the first Sikh war. On Dec. 21, 1845, Sir Hugh Gough, who had just won the victory of Moodka, advanced against the Sikhs, and after a violent cannon- ade attacked with his infantry. The first British attack was repulsed with heavy loss. In the second effort the Sikhs were routed, losing 73 guns. See Sikh Wars.

Ferragus, Ferracute, FerRAUTE, OR VERnagu. Giant of early Frencl romances. In the Charlemagne legends he overcomes all that monarch's paladins except Roland, by whom he is slain. In Ariosto's Orlando Furioso he is a Saracen who threw away his helmet, declaring that he would never wear another until he had won that of Orlando, by whom he was killed.

Ferranti Meter. Type of electrical meter invented by $\mathrm{S}$. Z . Ferranti, in 1883. It consists of an

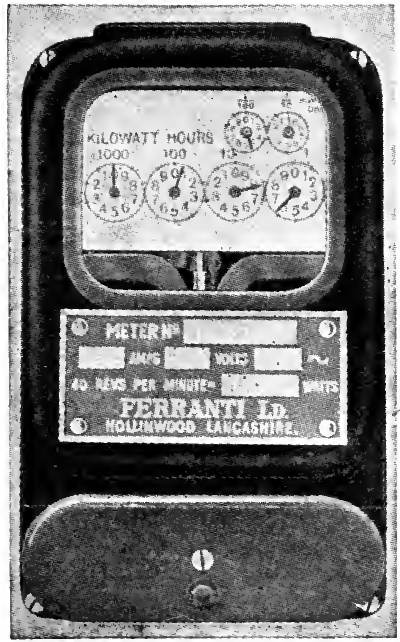

Ferranti Meter. Front of the instrument used for measuring electric currents

electro-magnet containing mer cury in the shape of a thin disk. The rotation of this disk serves as a measure of the strength of the current passing through the meter. See Meter, Electrical.

Ferrar, NichоLAS (1592-1637). English theologian and founder of the Little Gidding community. Son of a Lond on merchant, he was educated at $\mathrm{Clare}$ Hall, Cambridge, and worked for the Virginia Company, 1619-23. He was elected to Parlia. ment in 1624 , but in 1625 retired, with his mother and brother-in-law, Collet, and their f a milies, to the manor of Little Gidding, Huntingdonshire, to a sechuded life of devotion, study, and good works. In 1626 he was ordained deacon by Laud. He died Dec. 4, 1637.

The members of Little Giddling household were famed for their skill in embroidery, bookbinding, and "scrap book" making, and examples survive in the British Museum and elsewhere of cunningly constructed "harmonies," or "concordances" of the Bible. illustrated with prints collected by Ferrar on his travels. The "Arminian Nunnery," as it was called, was twice visited by Charles I, and was broken up by the Puritans in 1647 ; it figures in J. H. Shorthouse's philosophical romance John Inglesant, and in Izaak IValton's Life of George Herbert.

Ferrar, Robert (1500-55). English divine and martyr. $\mathrm{He}$ studied at Oxford, was ordained, and later was head of a religious house in Yorkshire, but only became prominent on the accession of Edward VI. Owing to the influence of Somerset he was made bishop of St. Davids. He was a zealous reformer, but charges were brought against him, and, Somerset having fallen from power, he was imprisoned in 1552. In 1554 his bishopric was taken from him, and he was put on his trial. Found guilty, he was burned at Carmarthen, March 30 , 1555. The chief charge against him was that he had violated his vow of chastity by marrying.

Ferrara. Prov. of N.E. Italy. It is bounded $\mathrm{N}$. by the river Po and E. by the Adriatic Sea. Area, $1,019 \mathrm{sq}$. m. Low-lying and marshy in parts, it lies mostly within the delta formed by the Po and its branches and by the Primaro and the Panaro, and embraces the lagoons of Comacchio (q.v.). Fairly fertile, it produces rice, grain, wine, hemp, silk, salt, and fish. The capital is Ferrara. Pop. 326,447.

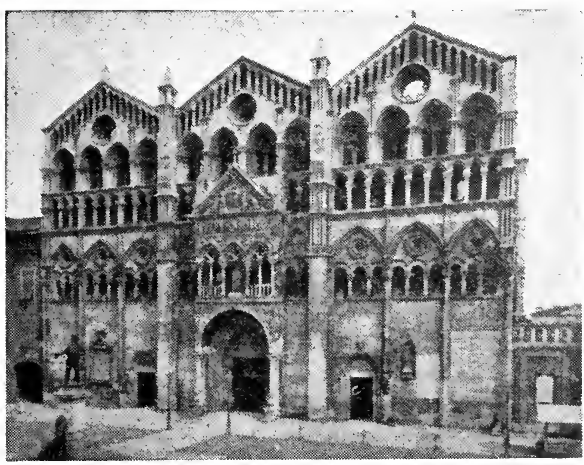

Ferrara. Facade of the cathedral oi S. George, in the city of Ferrara, the lower part dating frcm 1135 
Ferrara. City of Italy, capital of the prov. of Ferrara. It stands about $3 \mathrm{~m}$. S. of the river $P$ o $\mathrm{di}$ Volano, $30 \mathrm{~m}$. by rly. N.N.E. of Bologna. An archiepiscopal see, its cathedial dates from the early 12th century. The city is surrounded by crumbling walls, but its palaces and other structures attest its former splendour. It was the seat of the court of the family of Este (q.v.), and their castle (now utilised as public offices) was a moated fortress with four towers. The university was founded in 1264 , and its library is rich in MSS. of Tasso, etc. Among other buildings of interest are a picture gallery, and the houses of Ariosto and Guarini.

From the 14th to the 17 th cen tury Ferrara was a prosperous city, and in the 15th was noted for its school of painting. It has a trade in hemp, soap, wax, candles, glass, and silk. Guarini and Savonarola were natives. It came into the possession of the Este family in 1146, and was their capital until 1598 , when it passed to the papacy. Pop. 102,550.

Ferrara, ANDREA, Italian sword. maker of the 16 th century. He was working in Belluno in 1585, and swords bearing his name were used in Scotland in the 16 th and 17 th centuries. The steel had a temper which was claimed to be that invented by the swordsmiths of Damascus. The name Andrea Ferrara was afterwards employed rather as a trademark than as implying any connexion with the original maker.

Ferrara-Florence, CouncIL OF. Oecumenical council of the Church held at Ferrara, and later at Florence, between April, 1438, and July, 1439. It was called by Pope Eugenius IV as a continuation of the council of Basel, and had as its main object the healing of the breach between the Roman and Greek churches. The Latin emperor, John Palaeologus, representing the Greeks, brought a large delegation at the pope's invitation to Ferrara. The scene of the council was changed to Florence in Jan., 1439. The debates turned chiefly on the Filioque controversy, i.e. the question whether the Holy Ghost proceeus from the Father and Son (ex Patre Filioque), or from the Fathe $r$ alone. On July 6 a decree was published which declared that, "while the pope was the supreme head of all the Church, the rights of the Eastern patriarchs were to be unaffected.

The two churches were thus momentarily united in intention, but not in effect. Isidore of Kiev was sent as legate to Constanti-

nople by Pope Nicholas V in 1452 , in order to push the process of union forward, but before he had accomplished his mission the city was taken by the Saracens, 1453. This undid the work of the council, the last effort at Eastern and Western reunion.

Ferrel, William (1817-91). American meteorologist. Born in Bedford co., Pa., he early turned his attention to the study of meteorology, then a neglected science, and his researches soon won him world-wide fame. In 1867 he became a member of the United States coast and geodetic survey, and began to formulate the laws of meteorology on a scientific basis. His invention of a tide-predicting machine came into general use in the U.S. government coast surveys, He wrote much on his subject, including Tidal Researches, 1874; Meteorological Researches, 1877-82 ; and Popular Treatise on the Winds, 2nd ed. 1898.

Ferrel's Law. Law of the deflection of bodies moving in the air of the rotating globe. If a body moves in any direction except E. or W. on the earth's surface, the rotation of the earth will cause it to be deflected to the right in the northern hemisphere, and to the left in the southern hemisphere. The law is an example of the general case in mechanics when a body acted upon by two forces moves in a direction com. pounded of the original directions of the forces. In the northern hemisphere a body forced northwards receives an eastward im. pulse from the earth's rotation, and moves towards the north-east.

Ferrer, Francisco (1859-1909). Spanish revolutionist. Born ncar Barcelona, he was employed as a

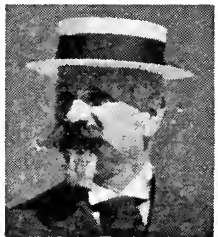

Francisco Ferrer, Spanish revolutionis Zorrilla, with whom he lived in Paris. $\mathrm{He}$ returned to Barcelona in 1901, and was prominent in founding lay schools and centres of advanced socialist and rationalist teaching. In June, 1907, he was acquitted of having taken part in the attempt to assassinate the king in 1906 . In July, 1909, he was active in the insurrections in Barcelona, aiming at the establishment of a new antiCatholic state in Catalonia. Con- demned as the prime instigator, he was shot on Oct. 13, 1909, his execution raising much indignation, directed mainly against Roman Catholic influence in Spanish politics, and leading to the fall of the Maura cabinet.

Ferrers, EARL. British title borne since 1711 by the family of Shirley. The family of Ferrers, ancestors of the Shirleys, first appeared in England with William the Conqueror, having previously been powerful in Normandy. Henry Ferrers was a great landholder under the Conqueror, especially in the North Midland counties, and his son Robert was made earl of Derby in 1138. His successors, who had Tutbury Castle for their main stronghold, were known as earls Ferrers or earls of Derby. William, the 4 th earl, was one of the richest and most powerful nobles of the time of Henry III, as was his son, the 5th earl. Robert, the 6 th earl, having rebelled against the king, lost his lands and title.

The family, however, survived in several branches. Rubert's son, John, was summoned to Parliament in 1299 as Baron Ferrers of Chastley, this being one of the family seats. This title passed to the family of Devereux in 1461 and remained therein until $\mathbf{1 6 4 6}$, when it fell into abeyance.

The Shirleys became connected with the title through the marriage of Sir Henry Shirley, Bart., with the daughter of Robert Devereux, 2nd earl of Essex. In 1677 Sir Robert Shirley, a descendant of Sir Henry, was allowed to assume the baronial title, and in 1711 he was made Viscount Tamworth and Earl Ferrers. On his death in 1717 the barony passed to a granddaughter, Elizabeth, wife of the 5 th earl of Northampton, while a son became the 2nd Earl Ferrers.

The barony passed to other families and fell into abeyance in 1855 . Laurence, the 4th earl (1720-60), was the last peer in England to be executed as a felon. In 1745 he succeeded to the title on the death of his uncle. In a moment of anger he shot his steward, a man named Johnson, and was tried for murder by his peers in Westminster Hall. Found guilty, he was hanged at Tyburn, May 5, 1760. The story that he was hanged with a silken rope is now disbelieved. The titles passed to his brother, Washington, who became the 5th earl. His descendants held them until the loth earl died in 1912, when an heir was found in a descendant of the lst earl, Walter Knight Shirley (b.1864). Tamworth Castle, long the family seat, no longer belongs to the Shirleys. 
Ferrers, Georae (c. 1500-79). English politician and poet.' $\mathrm{He}$ was page of the chamber to Henry VIII, who took him with him in the Scottish and French wars and bequeathed him 100 marks. He is mainly remarkable for having produced and probably written masques for Edward VI's Christmas entertainments in 1551-52 and for having contributed several tragical episodes to Baldwin's Mirror for Magistrates, 1559-78.

Ferret (Putorius). Domesticated variety of the polecat, kept for hunting rabbits. According to Roman writers the polecat came from Africa, and although it is now quite unknown there, it is probable that it was originally domesticated in $\mathrm{N}$. Africa or Spain, and after. wards introduced into Italy. As a result of domestication, the polecat became smaller and slimmer, and albinos became the rule instead of the exception. In this way the

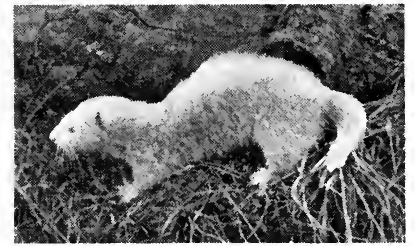

Ferret. The domesticated polecat used for rabbiting

ferret developed. It is a somewhat delicate aninial, and its in tolerance of cold suggests its Mediterranean origin. It breeds readily with the wild polecat, and the brownish variety known as the polecat-ferret is probably tho result of such crosses. The ferret is only semi-domesticated. It has no affection for its owner, is very ferocious, and is as likely to bite the hand that feeds it as any other. It therefore needs to be handled with caution, the best way being to grasp it close behind the shoulders.

The method of hunting a rabbit warren with ferrets is to net or stop all the holes except one, at which the ferret is inserted. The rabbits, finding an inveterate enemy on their track, bolt for the holes and are thus caught in the nets. It is a common practice to muzzle the ferret, otherwise, if it catches a rabbit in the burrow, it will remain there to make a meal of it.

Ferrets need great care to keep them in good health, warmth and scrupulous cleanliness being the chief essentials: Dlenty of warm litter must be proviaed, and the hutch should be thoroughly cleaned and disinfected at least once a week. The food should consist of fresh bread and milk, and a little raw meat may be given once a week. Ferrets breed freely in captivity and usually rear two families in the year. See Rabbit.

Ferrex and Porrex. One of the titles under which the earliest extant English tragedy is known. See Gorboduc.

Ferri, ENRICo (b. 1856). Italian socialist. Born near Mantua, Feb. 25,1856 , he was educated in that

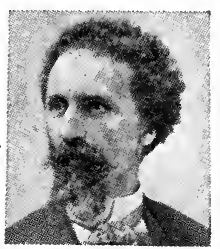

Enrico Ferri.

Italian socialist city and at Bo. logna, taking a legal d egree, 1877 , and studying under L o m broso, 1879. In 1880 he became professor of criminal law at Bo. logna university, andin 1891 succeeded the criminologist Carrara at Pisa university. Appointed to a chair in the new university at Brussels, 1895, he received a similar appointment at the Collège des Sciences Sociales at Paris, 1901. A radical deputy, 1886-93, in the Italian chamber, he afterwards joined the socialist party.

Ferric Salts. Iron forms with acids, two series of salts, ferrous and ferric. The ferric salts are generally yellowish or reddish brown in col. our, and are reduced to the ferrous state by means of zinc. Ferric chloride $\left(\mathrm{FeCl}_{3}\right)$ is prepared in the anhydrous state by heating iron wire in a current of dry chlorine gas, and in the form of solution by dissolving iron wire in hydrochloric acid and then passing chlorine into the liquid until it smells of the gas.

As a tincture ("steel drops") ferric chloride is employed in medieine as a tonic. With a soluble thiocyanate, ferric chloride gives an intense blood-red colour. Ferric sulphate, $\mathrm{Fe}_{2}\left(\mathrm{SO}_{4}\right)_{3}$, obtained by oxidising ferrous sulphate by means of nitric acid, is used in dyeing cotton black, in combination with logwood. Iron alum is a compound of ferric sulphate and potassium sul. phate. This and ferric nitrate are employed in dyeing. Ferric oxide, which occurs naturally and is also produced by distilling ferrous sulphate, is known as red ochre and colcothar, and used as colouring matter and polishing material.

Ferricyanides. Salts of ferrieyanhydric acid, $\mathrm{H}_{3} \mathrm{Fe}(\mathrm{CN})_{6}$, first made by Gmelin by decomposing lead ferricyanide with dilute sulphuric acid and evaporating the solution after filtration. Potassium ferricyanide or red prussiate of potash is prepared by passing chlorine through a solution of potassium ferrocyanide or over the dry salt until it no longer gives a blue colour with a ferric salt.
The salt is in deep red crystals and forms with water a dark yellow solution which darkens with age and becomes converted into ferrocyanide. On adding ferrous sul. phate (green vitriol) to potassium ferricyanide solution a blue precipitate known as Turnbull's blue is obtained. When chlorine is passed into a solution of potassium ferricyanide a green precipitate known as Prussian green is formed, the appearance of which is the indication that the end of the process has been reached. Potassium ferricyanide, a powerful oxidising agent, when employed with caustic potash, is used in the preparation of ferroprussiate paper upon which "blue prints" are made. See Colour Printing.

Ferrier, Sir David (b. 1843). British physician. Born at Aberdeen, he was educated at the

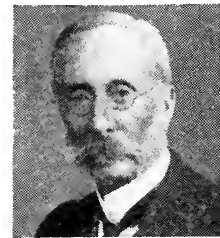

Sir David Ferrier, British physician Maull \& For un iversity there and at E d in bu rg h and $\mathrm{Heidel}$ berg. Having taken his med. ieal degree at Edinburgh, he began to practise as a specialist and soon won a reputation as an authority on the brain. In 1889 he was appointed professor of neuro-pathology at King's College, London, and he was also consulting physician at King's College Hospital. His many honours include an F.R.S. Ferrier, who was knighted in 1911, wrote The Functions of the Brain, etc., 1876.

Ferrier, JaMes Frederick (1808-64). Scottish metaphysician. Born at Edimburgh, June 16, 1808, he was professor of moral philosophy and political economy at St. Andrews from 1845 until his death, June 11, 1864. Like Berkeley, he is an idealist and im. materialist. There is no such thing as independent matter, all external things exist only subjectively ; the only material world which really exists is one with which intelligence also exists. The conscious subject is inseparably connected with the conceived object. At the same time, he does not deny the existence of the real material world per se, as distinct from that known to us through thesubjective medium of space and time, but declares it to be simply unknowable. His writings are distinguished by a clearness of style extremely rare in the discussion of abstruse subjects. His most important works are Institutes of Metaphysics, 1854, and Lectures on Greek Philosophy. 
Ferrier, PACL (1843-1920). Freneh dramatist. Born at Montpellier, he studied for the bar, but turned to playwriting after the produetion of his first piece, a verse play, Ia Revanche d'Iris, in 1868. $\mathrm{He}$ wrote and eollaborated in a large number of opera libretti, comic operas, and eomedies, well known in France for their gaiety and humour. Among the most successful were Les Mousquetaires au Couvent, 1880 ; 'Tabarin, 1884; L'Article 231, 1891; La Belle Mère, 1898. He died at Nouan-le-Fuzelier on Sept. 11, 1920.

Ferrier, Susan Edmonstone (1782-1854). Seottish novelist. Born at Edinburgh, Sept. 7, 1782

she published

her first novel,

Marriage, in

1818 , followed

by The Inherit -

ance, 1824 , and

Destiny, 1831.

Published an-

on y mously,

they gave

a shrewd.

lysatirical picture of contemporary Scottish soeiety, and won great popularity and the praise of critics as eminent as James Hogg and Scott. She was known familiarly as Scott's "sister-shadow," and died at Edinburgh, Nov. 5, 1854. Her Recollections of Visits to Ashestiel and Abbotsford were published in 1881. See Life, J. Ferrier, 1899.

Ferrite. Term used in mineralogy for the particles of iron hydroxide which constitute some of the binding elements in many rocks ; and also to a particular form of chrysolite. In chemistry it refers to compounds of iron oxide with other oxides more distinctly basie, as in barium ferrite, calcium ferrite, and others; and in metallurgy to the pure iron constituent of stecl. See Steel.

Ferro-Concrete. One of the several names for reinforced con. crete. Concrete is reinforced for use as a building material by placing within its substance mild-steel bars which resist the pulling forces that would destroy plain concrete. No other building material is equally fire-resistant, and its ability to withstand all kinds of stresses has rendered possible new methods of construction-balconies or galleries, for example, ean be projected without the propping-up from below that would be needed for any other system of construction; and the enormous strength of the material enables the construction of mueh thinner walls than would be allowable with brick or stone. See Building : Concrete.
Ferrocyanides. Salts of ferrocyanic aeid, $\mathrm{H}_{4} \mathrm{Fe}(\mathrm{CN})_{6}$. Most ferrocyanides are coloured, and those of the soluble alkalis are non-poisonous, although from them hydrocyanic or prussic acid can be readily prepared. The most important of these salts is potassium ferrocyanide or yellow prussiate of potash. The old process of manufacture consisted in fusing together potassium carbonate with iron borings and nitrogenous animal matter such as leather cuttings or woollen rags, and lixiviating the mass with water. Potassium ferrocyanide is made largely as a byproduct in the manufacture of coal-gas. It is used in producing Prussian blue (ferric ferrocyanide) and other cyanogen compounds in calico-printing, and for case-hardening iron.

Ferrol. Seaport of Spain, in the prov. of Corunna. It stands on the $\mathrm{N}$. arm of the Bay of Betanzos, and is the chief Spanish naval station on the Atlantic. The harbour is sheltered and commodious, with shipbuilding yards, docks, and quays, defended by both nature and art. It has a first-class arsenal, a naval academy, and many fine public buildings. It manufactures naval stores, leather, sailcloth, cotton and linen, and exports pitprops, vinegar, brandy, and sardines. The British besieged it in 1799, and took it in 1805, after defeating the French fleet off the bay. It was captured by the French after six weeks' blockade in 1823. Pop. 26,270.

Ferro-manganese. One of the most important of a series of iron, manganese, carbon alloys now largely used in the preparation of steel. The constitution of the alloy varies according to the character of the metal which it is desired to convert into steel, manganese ranging from 50 p.c. to 80 p.c. The alloy is prepared in blast-furnaces and cast into pigs, in all essentials precisely as ordinary pig-iron is made. See Bes. semer Process; Metallurgy; Steel.

Ferrous Salts. Group of iron salts. Ferrous sulphate, $\mathrm{FeSO}_{4}$, $7 \mathrm{H}_{2} \mathrm{O}$, or gree n vitriol is obtained in large quantities by exposing the pyrites occurring in coal-measure to the atmos phere. The soluble ferrous sulphate toge ther with the excess of sulphuric acid, runs into underground tanks where the excess of acid is removed by means of scrap iron. The liquid, on evaporation, yields crystals of ferrous sulphate.

Ferrous sulphate is used in the manufacture of ink, in dyeing and tanning: and in the preparation of Prussian blue. The pure salt is used in medicine. Ferrous oxide, $\mathrm{FeO}$, has the property, when freshly made, of oxidising with incandescence on exposure to the air. Ferrous iodide, $\mathrm{FeI}_{2}$, is used in medicine, as are also ferrous phosphate, $\mathrm{Fe}_{3}\left(\mathrm{PO}_{4}\right), 8 \mathrm{H}_{2} \mathrm{O}$, and ferrous carbonate, $\mathrm{FeCO}_{3}$. The last-named is contained in chalybeate waters, from which the ferrous carbonate is deposited, on exposure to air, as the hydrated oxide.

Ferrule. Short metal tube driven tightly into a hole in an iron or steel pipe and soldered or otherwise secured to another pipe so as to connect the two. It is also a short tapered tube driven into the end of a boiler-tube where it passes through the fire-box plate. The wedging action of the ferrule expands the boiler-tube end and ensures a tight connexion between the boiler-tube and the plate. There are also other types of boiler-tube ferrules. In common speech the word is used of a metal ring on the handle of a tool, and of the thimble-shaped ring fastened to the end of a walking-stick or umbrella to protect it from being worn down by use.

Ferry. Public passage-way across water, usually linking up roadways or tracks on both banks. The most usual means of transport is a floating vessel of some kind which, in the case of small loads and short distances, is frequently a flat-bottomed boat. guided by a taut wire cable and propelled by an endless rope. For heavy loads the ferry-boat may be moved to and fro by a windlass on board, which pieks up and pays

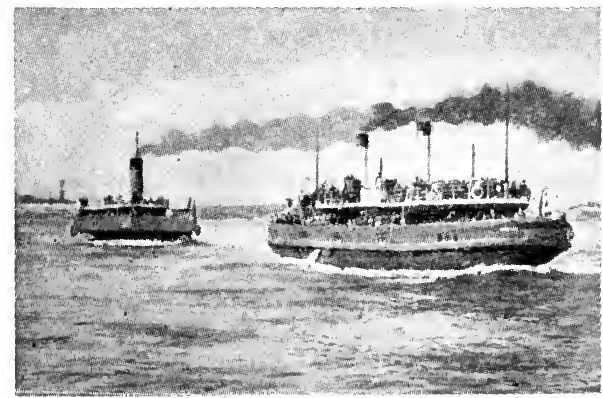

Ferry. 'Type ot steam ferry-boats tormerly in use on the Mersey between Liver 00 ! snd Birkenhea 
out a chain crossing the bed of the river. Where there is a strong current in one direction only, the ferry-boat may be attached to a chain the other end of which is moored in midstream some dis. tance higher up, the current being used to move the boat across by oblique pressure. See Channel Ferry ; Richborough ; Train Ferry ; also illus. p. 2207.

Ferry, Jules François Camille (1832-93). A French statesman. Born at St. Dié in the Vosges, April

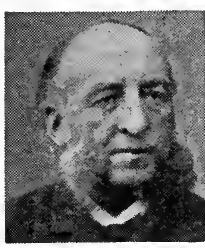

Jules Ferry, French statesman 15,1832 , he be. came a lawyer and a journalist. In 1869 he was chosen as deputy for Paris, being al. ready known as a vigorous opponent of the emperor. When Paris was besieged, as prefect of the Seine he was responsible for its government. After being minister at Athens, he returned to the Chamber of Deputies in 1873 and entered the ministry in 1879. In 1880 he became premier for a short term, and was again premier, $1883-85$, being in the meantime minister for education. In 1885 he retired, but was active in politics until his murder by a lunatic, March 17, 1893, just after he had been chosen president of the senate. Ferry did much to promote secular education, and establish French influence in Africa and Indo-China.

Ferrybridge. Hamlet of Yorkshire (W.R.), England. It stands on the Aire, $2 \mathrm{~m}$. N.E. of Pontefract, on the M. \& N.E.J.R. In 1461 it was the scene of an engagement during the Wars of the Roses.

Ferryhill. Parish and market village of Durham, England. It is $6 \mathrm{~m}$. S. of Durham, on the N.E.R., with ironworks and coal mines. Market day, Fri. (alternate). Pop. 10,133.

Ferryman's House. Fortified point on the E. bank of the Yser eanal, midway between Dixmude and Ypres, for which there was prolonged fighting in the winter of 1914. The troops engaged were French of the 9 th corps. The position was of importance because, if it remained in German hands, the Germans might cross the Yser canal and turn the defences of Ypres, moving by a short line upon Poperinghe, $6 \frac{1}{2} \mathrm{~m}$. to the rear of Ypres. By attacking at this point the French also took pressure off the Belgians, who were being subjected to artillery fire on the Yser. On Dec. 4, 1914, the French stormed the Ferryman's House, and established themselves there.
Fersen, Fredrik Axel, Count voN (1719-94). Swedish soldier and politician. Of Scottish descent, Fersen was born at Stockholm, and as a young man served with the French army with distinction. In 1748, he fought against Prussia in the Seven Years' War. Marshal of the Swedish diet in 1755, and again in 1769 , Fersen was prominent as leader of the aristocratic party (the "Hats"). From 1786 he was an open and powerful opponent of Gustavus III, and was put under arrest for a time in 1789 , after which he retired.

Fersen, Hans Axel, Count von (1755-1810). Swedish soldier. Borm at Stockholm, Sept. 4, 1755, he served in the Swedish army. Afterwards he resided at the court of Louis XVI of France, with whom he became a great favourite. During the American War of Indepen.

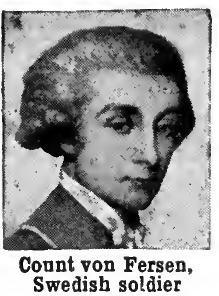
dence he fought under Lafayette. When the king and Marie Antoinette, to whom Fersen was devoted, fled to Varennes in 1791, Fersen was the driver of the coach. After his return to Sweden he was murdered by a mob, June 20, 1810, on suspicion of having been concerned in the death of the Crown Prince Christian.

Fertilisation. Biological term for the union of the male and female germ-cells which precedes reproduction in almost all multicellular organisms, and in all the higher animals. Plants and animals in which the sexual organs are distinct produce male germ-cells, or sperms, and female germ-cells, or ova, respectively, but unless there is a union at some period or other in the life cycle of the individual between a male and a female germcell, these cells perish, and reproduction does not occur. Some fow species consist only of female organisms, where fertilisation is absent, and reproduction takes place by parthenogenesis.

In some other species the organism has both male and female reproductive organs in the same individual, and when the respective germ-cells in such a case unite the process is termed self-fertilisation. This occurs in many plants, where the pollen grains (male) unite with the ovules (female), the result being a fertilised ovum. In the higher animals cross-fertilisation, how. ever, is the rule, and in this process the sperm and the ovum which unite come from two distinct indi- viduals of opposite sexes. Cross. fertilisation takes place in some plants frequently by the pollen grains and the ovules, which are carried on the same plant, ripening at different periods, so that they become fertilised from the corresponding elements of other plants of the same species. The single cell formed by the union of a male and a female germ-cell is termed a fertilised ovum, or a zygote.

Fertilisation is brought about by the activity of the male sperm-cell. Under the microscope this cell is seen to consist of a head and a tail, and the essential part of the process is the fusion of the head of the sperm with the nucleus of the female ovum. After this fusion the sperm loses its tail and becomes a rounded body, then termed the male pronucleus. Gradually it penetrates more and more deeply into the female germ-cell, until it unites with the female pronucleus to form a combined or segmentation nucleus. Fertilisation is then complete, and the eell thus formed is the first stage in the develop. ment of a new unicellular embryo, totally unlike the parents from which it springs, or the individual into which it will develop.

Cross-fertilisation is evidently one of the latest products of evolution, since it is the usual method of fertilising in the highest plants and animals. It must, therefore, have some very important function. It is thought that one of the objects of cross-fertilisation is to secure the production of vigorous offspring, and Darwin found in the case of some plants which usually reproduce by cross-fertilisation that if self -fertilisation was artificially produced the resulting offspring were feeble. Nevertheless, both plants and animals which normally reproduce by parthenogenesis produce healthy offspring. It would appear, therefore, that cross-fertilisation is essential for the continued vigour of a species in which that process is normal. See Biology ; Embryology; Eugenics; consult also The Flower and the Bee, John H. Lovell, 1919; Problems of Fertilization, F. Rattray Lillie, 1919.

Fertiliser. Chemical substītute for animal manures. It is used to restore to the soil various elements and ingredients abstracted from it by plants in the course of cultivation. Fertilisers are easily procured, cleanly to handle, and less likely to introduce insect pests than the old-fashioned stable manure. For flower gardens proprietary complete fertilisers, the bases of most of which consist of dried blood and ground bones, may 
be safely used according to directions, but for vegetables, in particular, three chief food ingredients have to be applied directly to crops in the form of manure. These are nitrogen, phosphates, and potash. The presence of lime, also, is necessary, not so much as a plant food as on account of its action on the soil. The best and most economical application of chemical tertilisers to vegetable crops is summarised below.

For potatoes use sulphate of ammonia, $\frac{1}{2}$ oz per sq. yd., just before the first earthing up. Superphosphate of lime, or superphosphate and steamed bone flour mixed in equal proportions, may be applied when planting, at the rate of $1 \frac{1}{2} \mathrm{oz}$. per sq. yd. For the cabbage for family use sulphate of ammonia, $\frac{1}{2} \mathrm{oz}$. to $\frac{3}{4} \mathrm{oz}$. per sq. yd. before the first earthing up or as soon as growth starts, and super. phosphates at the rate of $1 \mathrm{oz}$. per sq. yd. On very light soils, salt at the rate of $1 \mathrm{oz}$. per sq. yd. will help. The pea and bean family require a mixture of superphosphate and steamed bone flour in equal proportions applied to the ground before or after sowing the seed, at the rate of $1 \mathrm{oz}$. to $4 \mathrm{yds}$. of drill. The mixture must ot come into direct contact with the seed.

Onions, leeks, and celery require sulphate of ammonia, $\frac{1}{2}$ oz. per sq. yd., superphosphate and steamed bone flour, $1 \mathrm{oz}$. per sq. yd., and, on light soils, 1 oz. of salt per sq. yd., all in the early stages of growth. For carrots, parsnips, and beet, use sulphate of ammonia, $\frac{1}{2}$ oz. per sq. yd., after thinning out or singling, and superphosphate, salt, etc., as for onions. For lettuces, spinach, and radishes, use sulphate of ammonia and superphosphate as above. Where the soil is known to be overstocked with organic matter, containing nitrogen, producing a very rank growth of leaf, the sulphate of ammonia should be withheld.

Where potash salts are unob. tainable, wood ashes which contain potash should be collected and applied at the rate of $1 \mathrm{oz}$. per sq. yd. Ashes must be collected as soon as possible after burning, as rain quickly washes out the potash. On heavy soils, those rich in organic matter, basic slag may replace superphosphate, particularly in districts with a good rainfall. The quantity used should be from one and a half times to twice as much as is recommended in the case of superphosphate.

During the Great War the prob. lem of fertilisers became acute in all countries. In Great Britain the utilisation of by-products from munitions making and other manufacturing industries partially relieved the situation. A commission recommended the utilisation of the excess production of sulphuric acid in the manufacture of superphosphates. Both France and Italy suffered seriously, the latter country only securing 16 p.c. of the normal supply of phosphate. Germany took steps to increase her production of fertiliser nitrogen, phosphoric acid and potash, her total production rising from 220,000 tons in 1917-18, to 520,000 tons in 1918-19. She also developed the production of synthetic nitrogen compounds. See Crops; Manure.

Ferule (Lat. ferula, fennel, cane, ferire, to strike). Instrument of punishment. The stalk of the giant fennel, Ferula communis, was used as a rod or cane, to which it gave its name. The word is applied also to a sole-shaped strap, comparable to the Scotch tawse, with which boys are bcaten on the palms of the hands in some schools.

Fescennine Verses. Improvisations in dialogue form made at rustic gatherings in ancient Italy, the origin probably of the native Roman satura, or satire, in which the speakers made capital out of the faults and follies of their neighbours. As a feature of wedding celebrations they were commonly characterised by broad licentiousness. Hence the derivation of the name from the Lat. fascinum, a phallic emblem, by some etymologists who deprecate its other derivation from Fescennia on the ground that the custom was widespread throughout Italy, and not peculiar to that small Etruscan town. From the Fescennine verses the epithalamium, or nuptial song, was ultimately developed, a literary form of which Catullus, for one, made exquisite use, and which has been successfully reproduced in the literature of many countries, notably by Herrick in England.

Fesch, Jostri (1763-1839). French cardinal. Born at Ajaccio, Jan. 3, 1763, the step-brother of Letizia Bonaparte, he was archdeacon of Ajaccio until the French revolution, when he retired. $\mathrm{He}$ had always befriended the Bonaparte family, and in 1802 Napoleon made him archbishop of Lyons, and procured for him a cardinal's hat. Ambassador at Rome in 1804, he persuaded Pius VII to crown Napoleon in Paris, and was made grand almoner and senator of the Empire. His position as intermediary between Napoleon and Pius was extremely difficult during the years 1806-7, and Fesch's relations with both became strained, especially after the Gallican council of 1811 , from the presidency of which the emperor dis $m$ issed $h$ is uncle. Retiring to Rome on the fall of the Empire in 1814, he ret u r n ed to Lyons during the Hundred Days, but after Napoleon'sab. dication he once more went to Rome where he died, May 13, 1839.

Fes c u Grass Fes tuca). Exten. sive genus of grasses. Of the natural order Gram in eae, they are natives of cold and temperate regions. The

f lat t e n ed

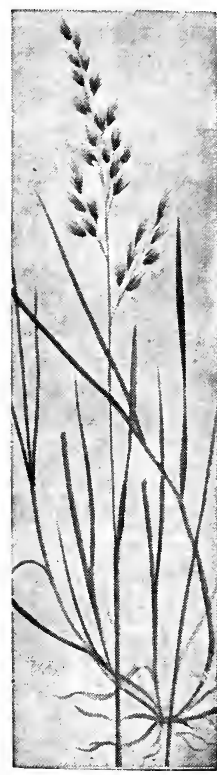

Fescue Grass, Festuca pratensis flower spikelets are grouped in panicles or racemes; there being three or more flowers in each spikelet. Many of the species are among the most valuable of meadow and pasture grasses, being rich in saccharine matter. Sheep's fescue ( $F$. ovina), with bristle-like leaves, meadow fescue ( $F$. pratensis), and hard fescue ( $F$. duriuscula) are most useful for this purpose.

Fess (Lat. fascia, band). In heraldry, a horizontal band carried across the middle of the shield

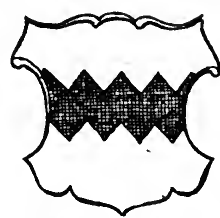

Fess, in heraldry and occupying one-third of the field. It is one of the ordinaries (q.v.). The middle of the field is known as the Fess Point. A shield or charge divided by a horizontal line in the middle is said to be "per fess"; but if it is divided into any number of horizontal bands above four, it is called "barry." If there are three divisions it is "tierced" or "tiercy per fess"; if four, "quartered per fess." Charges placed in horizontal rows are termed " in fess."

Festiniog or FFestiniog. Urban dist. and town of Merionethshire, Wales. It is $16 \mathrm{~m}$. N. of Dolgelly, and stands amid the hills, surrounded by beautiful scenery, one feature of which is the Cynfael Falls. A narrow gauge rly. runs to Portmadoc. The place is also 
served by the G.W. R. The main industry is the large slate quarries, which employ most of the male inhabitants. Pop. 9,674.

Festival (Lat. festivus, joyful). Days on which some deity or person was honoured or the memory of some important event kept with certain solemnities, ordinary work being as a rule suspended. Such festivals or feasts no doubt were originally nature festivals, connected with its changing phenomena, its decay in winter and renas ence in spring (see Adonis). They were partly merrymakings and thanksgivings for benefits received, partly prayers for benefits to come, and partly ceremonies to appease the anger of the gods for sins committed, though even from the latter the festive element was not absent.

The Greek festivals were held in honour of national heroes; of gods connected with the fruits of the field, such as the Dionysia, Lenaea, and Eleusinia; and of the tutelary deities of Athens, such as the Panathenaea. The four great games-Isthmian, Nemean, Olympian, and Pythian-set the seal on the national unity. At Rome each family kept the festival of its domestic gods, the Lares and Penates; the public festivals were under the control of the statefestivals in honour of the tutelary deities of Rome, Romulus, Mars, and Quirinus, and of the divinities who presided over the crops, the fields, and boundaries, such as the Cerealia, Lupercalia, Saturnalia, and Terminalia. The public games (ludi) were also national festivals. (See Feriae ; Ludi.)

\section{Religious Festivals}

Religious festivals are days set apart for rest, thanksgiving, and special observance. Some are fixed, as Christmas; others movable, as Easter. In the Christian calendar the greater festivals are called red letter days; while the lesser are known as black letter days.

Among the Jews such days are regarded as days appointed by God for meetings with His children. They include Passover, or Unleavened Bread, Nisan 15-22 ; Pentecost, Sivan 6 ; Trumpets, or New Year, Tishri 1 ; the Day of Atonement, or Great Sabbath, observed on Tishri 10 , by complete rest and fasting, the only fast not postponed by the occurrence of the Sabbath; the Tabernacles, or Ingathering of the Harvest, Tishri 15-22; Jubilee, at the end of every seven Sabbatical Years; Purim, etc.

In the Christian Church the earliest festivals were the love feasts or Agapae (q.v.). Confusion has been caused by disregard of the fact that both authorship and date of festival homilies are uncertain. Until the beginning of the 4 th century, record exists only of Easter and Pentecost, though as each Friday was a fast in remembrance of the Crucifixion, so each Sunday was a festival in remem. brance of the Resurrection. The feast of the Nativity was observed about 300 ; Christmas, Epiphany, and Ascension Day were added later.

\section{Saints and Martyrs}

Days in memory of the Apostles were next observed, and were followed by observance of days devoted to the memory of saints, of the Purification of the Virgin Mary, the Annunciation, the nativity of S. John the Baptist, the Circumcision, the death of martyrs, the transfer of their relics or the consecration of churches dedicated to them. Many Christian festivals are of local origin, some adapted from Jcwish and pagan practice, and they increased in number during the Middle Ages. In the Roman Catholic communion, feasts are divided into doubles, semi-doubles, simples, etc., according to the offices appointed for them.

Inclusive of Sundays, festivals in the Anglican calendar number 149 ; of these the principal have proper collects, epistles, Gospels, and lessons, and some have a proper preface at Holy Communion and proper Psalms. The movable festivals which depend upon Easter are Septuagesima, Rogation Sundav, Ascension Day, Whit Sunday, and Trinity Sunday. In Great Britain public observance of Church festivals, apart from Easter, Whitsun, and Christmas, has fallen into abeyance; formerly all were made the occasion of some difference in the ordinary daily life of the people.

\section{Bairam and Ramadan}

The chief festivals among Mahom medans, whose rest day is Friday, the day on which Mahomet was born, are the Feast of Bairam, that of Sacrifices, and that following the fast of Ramadan. The Hindus have their festivals, as that of Siva ; and among certain tribes of North Amcrica is observed a festival called the Day of the Dead. The French Revolutionary calendar included five festival days, dedicated respectively to Virtue, Genius, Labour, Opinion, and Rewards, all in September. See Calendar; Prayer Book; articles under the name of each festival or saint; consult also Church Festivals, A. J. Maclean, in the Prayer Book Dictionary, ed. G. Harford and M. Stevenson, 1912.
Festubert. Village of France in the dept. of Pas-de-Calais. It is $3 \mathrm{~m}$. W. by N. of La Bassée and was prominent in the Great War. There was an engagement here between the British and the Germans, Nov. 23-24, 1914. On the night of Nov. 23, 1914, the Germans had carried up a sap close to the Allied trenches, E. of Festubert, which were held by troops of the Indian corps. When day broke next morning the German infantry poured a storm of bombs

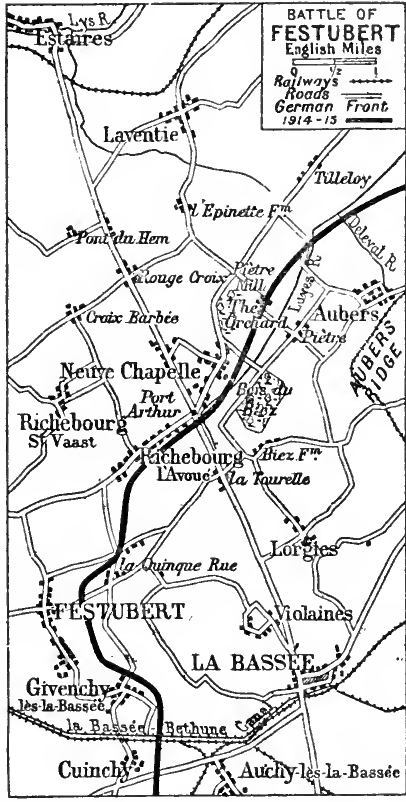

Festubert. Plan of the country over which were fought the battles of Nov., 1914, and May, 1915

and hand-grenades into the most advanced British trenches. They followed up this bombardment with an attack, and penetrated into the British trenches.

In the afternoon Sir J. Willcocks, commanding the Indian corps, ordered the original line to be recovered and held at all cost. All available British guns were directed to shell the trenches that the Germans had captured, as preparation for a British counterattack, which was to open at 4.30 . The infantry had to advance over snow-covered ground and they were received with violent machinegun fire. But after hard and continuous hand-to-hand fighting, the ground lost was recovered.

Festubert, BatTLE of. Fought during the Great War, May, 1015. In May, to assist the French operations in Artois and at Arras, where Foch was attacking, the British 
First Army (Haig) was ordered to take the offensive on a front N.W. of La Bassée, from Laventie to Richebourg l'Avoué, against the German works on the Aubers Ridge. On the N. portion of this front the 4th corps (Rawlinson) attacked on the S., the Indian corps (Will cocks) and the 1st corps. On May 9 the infantry advanced after a 40 . min. bombardment, but found that the Germans were perfectly prepared, and that their wire had not been cut or their defences demol. ished by the artillery. The attack failed with heavy British losses. The total of killed, wounded, and missing exceeded 12,000, without any result, except that the Germans were lield down in the section of attack. The failure was due to the weakness of the British artillery.

Nevertheless, French decided to resume the attack, extending it S. to Festubert. On May 15 the British once more assaulted, late in the night, after a pro. longed artillery preparation. The troops engaged were the Indian corps on the British left, with the 2nd division at Givenchy and the 7th at Festubert. The Canadian division was placed in support. The 2nd division broke into the German trench system, carrying it for about half a mile, and the 7 th division, attacking E. of Festubert, took another section of the German line, but between these two indentations the Germans could not be dislodged. They counter-attacked in the night of May 16, and forced back the 2nd division slightly, though most of the ground won was held. On May 17 the British, both from N. and S., assaulted the German wedge, 1,000 yds. long, between the two dents, and cleared it.

The trench battle continued on the following days; the British were much hampered by wetweather and insufficient ammunition, but ground was slowly gained, always at the price of heavy sacrifices. On May 20-21 the Canadians took up the work of the 7 th division before Festubert; on May 25 the 47 th London Territorial division was put in on the British right at Givenchy, and captured a section of the German line there, which was successfully held. The battle brought little result, as the capture of some thousands of yards of trenches was no compensation for the heavy sacrifices incurred. In killed, the British loss was 3,620 ; wounded, 17,$481 ; \operatorname{missin} \alpha, 4,321$.

H. W. Wilson

Festus. Poem by Philip James Bailey $(q . v$.$) . First published in$ 1839 , it was added to and otherwise altered during 50 years until in its final form, 1889, it consists of about 10,000 lines. A variant of the Faust legend, illustrating the ulti. mate triumph of good over evil, its scenes take place in Heaven and on the earth, and though it introduces "the three Persons of the Trinity as interlocutors in its wild plot" in a way which many readers resented, it has frequent terse and happy lines which have become familiar quotations.

Festus, Porcius (d. A.D. 62). Procurator of Judaea in succession to Felix, about A.D. 58. He heard, in the presence of Herod Agrippa II and Berenice, the case of S. Paul, whom he sent to Rome for trial (Acts 24-25 ; Josephus's Ant. of the Jews, xx, 8 ; Wars, ii, 14). He is said temporarily to have suppressed the Sicarii or Assassins, and was, if cynical, inclined to justice. $\mathrm{He}$ is introduced in a powerful short story, The Procurator of Judaea, by Anatole France.
Festus, Sextus Pompeids (3rd century A.D.). Latin grammarian. He was the author of an abstract of the important work by Marcus Verrius Flaccus, On the Meaning of Words, containing an alphabetical list of obsolete words, together with valuable information concerning old state institutions and ceremonial. Part of it (M-T) has been preserved in the abstract of Festus and a further epitome by Paulus Diaconus (8th century), which is complete.

Feth Ali Shah or Baba KHAN (1762-1834). Shah of Persia. Nephew of Aga Mohammed, he came to the throne in 1798, and threw himself into a contest with Russia to recover Persia's lost Caucasian territories. This brought him into conflict with Britain in 1812 , and by the treaty of Gulistan, 1813, Feth Ali was forced to cede Georgia and seven adjacent provinces to Russia. War with Turkey

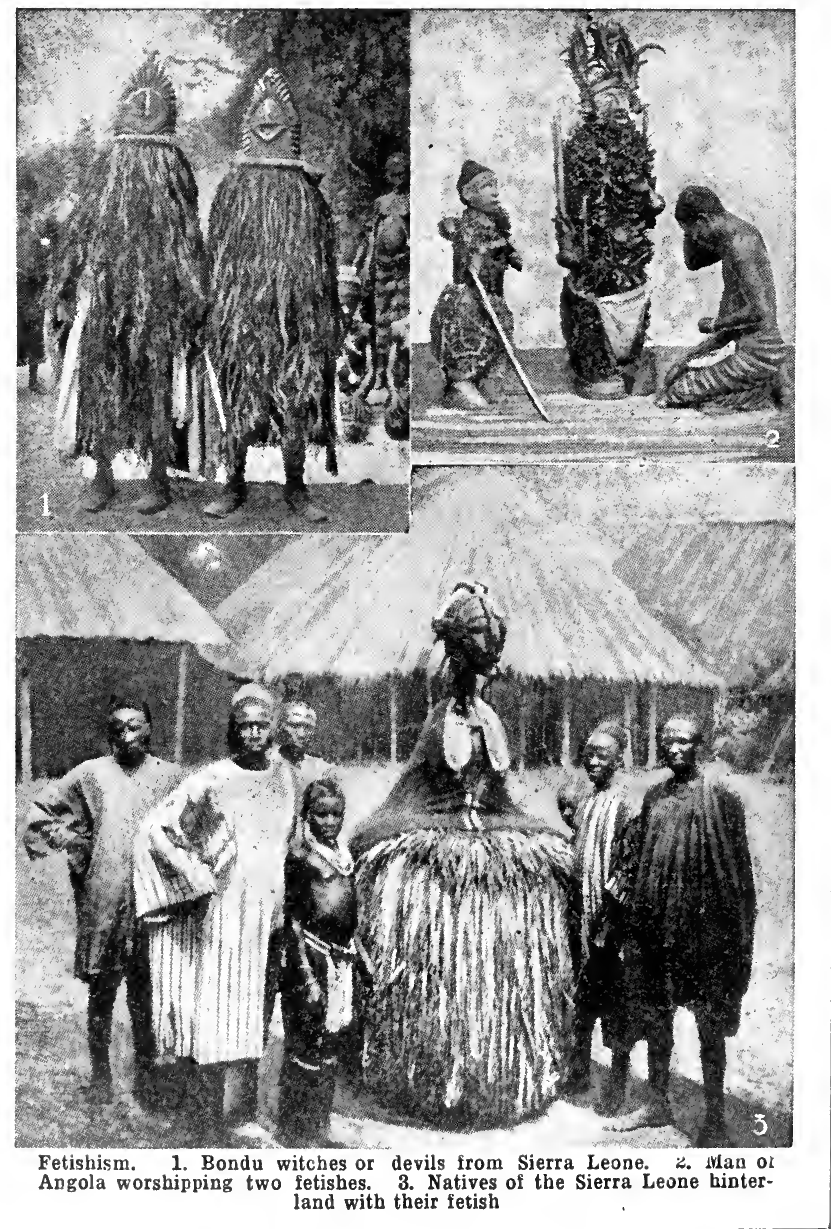


followed, 1821-23, but neither side gained material advantage. $\mathrm{He}$ died at Ispahan, Oct. 20, 1834.

Fetishism (Lat. factitius, artificial). Belief that the services of a spirit may be appropriated by the possession of its material em. bodiment. The 15th century Portuguese navigators applied to the sacred objects of the W. African negroes the term feitiço, a variant of the English "factitious," which they used of their own amulets. There is, however, a radical distinction between a fetish, which is a subservient spirit in its shrine, and an amulet, which -as in a modern mascot-is merely an instrument of spirit service. So also a fetish is not a god or even a divine image, and fetishism is not idolatry. The term has been used variously and confusingly, but as defined above it conveniently describes a phase of the magico-religious life of negro Africa, and an analogous though not identical one of that of aboriginal America.

The fetish spirit may be bodiless or a disembodied soul; it may reside in a shell or a tooth, a hoof or a horn, a bead or a rag. The choice of an object as a fetish is often determined by its unusualness; the Mendi people consecrate to the same use rude soapstone statuettes (British Museum) found in caves abandoned by an earlier race.

Stock-and-Stone Worship

In the heart of Africa there is a tendency to turn a shapeless stone or a post-by a dab of paint or by rough chiselling - into human semblance. This belongs to a widespread stock-and-stone worship that in some senses is transitional between fetishism and idolatry. But the fetish is treated as a genie or guardian spirit, rather than as a superior. It is consulted or implored, praised or reproached, treasured or discarded. Its special "medicine" is discovered by experiment; the strings of -wongs hung about the neck, over the hut door, at the village entry, have their several potencies, bestowing health or success, children or rain.

Among the American Indians, spirit-possessed objects are employed in an analogous way, and are called fetishes by American ethnologists. With the Zuni, objects bearing or made to bear an animal semblance are highly prized, especially when consecrated by long tribal tradition. Here, however, a totemic aspect is observ. able; both in N. America and elsewhere objects once classed as fetishes are now perceived to be totems. The Amerind fetish usually differs from the African in

possessing, instead of a spirit, an impersonal power which the Iroquois call orenda and the Algon. quins manito. See Totemism.

Fetter Lane. London thoroughfare linking Fleet Street with Holborn. First mentioned in 1612 and once a way leading to gardens, its name is variously derived from faitours, vagabonds; and feutriers, felt-makers. 'The town hostel of the bishops of Norwich was once here. On the W. side is an entrance to Clifford's Inn (q.v.), with the Record Office and Breams Buildings, containing Birkbeck College, beyond. On the E. is a Moravian chapel, rebuilt 1748, where Richard Baxter, Wesley, and Whitefield preached. Nevill's Court has old houses, and in Fleur-de-Lis Court, the scene of Mrs. Brownrigg's murder of her apprentice, Mary Clifford, in 1767, is Newton Hall, for long a Positivist meeting-place. The White Horse, an old coaching inn, stood at the Holborn end.

Fettes College. Scottish public school. Founded by money left by Sir William Fettes (1750-1836), lord provost of Edinburgh, it was opened in 1870 , on a site near

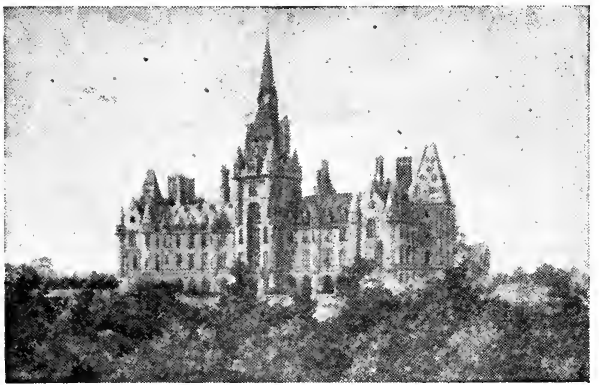

Fettes College, Edinburgh. Buildings seen from the soutb J. C. Inglis

Inverleith Park, Edinburgh. It is now governed under a scheme dating from 1886. It possesses a

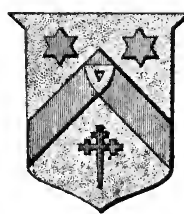

Fettes College arms fine range of buildings and all the accessories, laborat ories, g y m n a si u m, playing fields, etc., of a large public school. There are four There are four
houses and a c c ommodation

\section{for about 250 boys.}

Fettling. Engineering term used to describe the lining of the hearth of a puddling furnace. It is usually sand or cinders, or a mix. ture of ore. See Furnace.

Feud. Word meaning a state of animosity, generally between two parties. It carries the idea of continuous hostility. A notable in- stance is the feud between the Guelphs and Ghibellines, and there are instances among the Scottish clans, e.g. between the Campbells and the Macdonalds. See Vendetta.

Feudalism (late Lat. feudum, A.S. fesh, cattle, property). Name given to the social and political structure or organization which grew up on the ruins of the Imperial Roman system in Western Europe during the early Middle Ages. Universally established in its main features by the end of the 11th century, on its political side, it was by the 16 th century yielding to the effective concentration of the sovereign authority in the hands of supreme central governments.

It was based upon tenure of land. According to the lawyers, every foot of soil was actually the property of the king. Estates had been granted by him to his servants upon recog. nized conditions. On those conditions the king's "men," "barons," "tenants-in-chief," "vassals," held their lands from their overlord the king. They in their turn had granted portions of their estates upon like conditions to their own men or vas. sals. At the bottom of the scale came the actual occupants of the soil, who also held their plots of land u p on conditions, from their immediate overlord, whoever he might be. Except the king, every holder of land was the vassal of someone, whether his im mediate overlord was the king him. self, or a baron holding from the king, or a vassal holding from a baron, or a vassal of a vassal.

The primary condition of hold. ing land was the rendering of military service to the immediate overlord; at the bottom of the scale agricultural or other kinds of service took the place of military service. The vassal rendered hom. age to his overlord, taking the oath of allegiance and service to him as his man, the lord taking corresponding oath to be "true lord and protector" to his man, the whole system being based upon the recognition of mutual obligations. Further, since the small landholder was not strong enough to protect himself against a powerful neighbour, and could only with great difficulty appeal to a distant overlord for protection, it was customary for the small men to "commend" themselves to the 
powerful-that is, to surrender their land (since it was alienable) to a lord, from whom they received it back as his tenants or vassals. Custom established the right of hereditary succession in various forms, and the claims a lord was entitled to make upon his tenants.

Broadly speaking, on the continent of Europe, it was generally held that the vassal owed allegiance only to his immediate lord, the result being that the king's great vassals, dukes or counts, could, if they chose to resist him, call upon their own vassals to serve against the king; the royal power depended in effect on the loyalty of the great vassals who individually, or by combination, were strong enough to defy him. Thus when a duke of Aquitaine, a vassal of the French crown in respect of Aquitaine, happened also to be king of England in respect of which he was independent of the French crown, he was able singly to defy his overlord; so also when one person was at once duke of Aquitaine, duke of Normandy, and count of Anjou.

In England the feudal system was not accompanied by an equal danger, because until the 15th century no single feudatories held sufficiently extensive domains to be strong enough to defy the crown except by means of widespread combination. Also, in England, the doctrine prevailed from the first that allegiance to the overlord prevailed over allegiance to the immediate lord. 'The last remaining relies of feudalism were abolished by the Law of Property Act, 1922. See Manor; Villeinage ; consult also Constitutional History of England, W. Stublos, 1897.

Feu de Joie (Fr., joy-fire). Running fire of musketry used generally on occasions of rejoicing. Ranks of soldiers fire one after another, beginning on the right of the front rank and continuing from the left of the second rank, etc.

Feuerbach, Ludwig (1804-72). German philosopher. Born at Landshut, Bavaria, July 28, 1804 ,

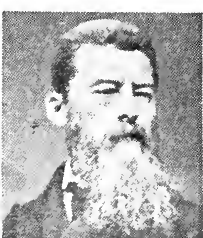

he attended Hegel's lectures at Berlin, and became a tutor at Erlangen. $\mathrm{He}$ abandoned teaching for a literary career in consequence of the excite. Ludwig Fenerbach, ment caused German philosopher by his Thoughts on '... Death and Inmortality (published anonymously 1830), in which he denied the im. mortality of man. Subsequently inclining towards atheism, he declared the reconciliation of faith and science to be impossible, and in the place of theology substituted anthropology. The body is the very essence of man; the idea of a superhuman power is a fiction of man's own imagination. Man is only what he eats. Sensuous enjoyment is the supreme good, but only attainable by man as a member of society. He died near Nuremberg, Sept. 13, 1872. His other works include The Essence of Christianity, 1841, Eng. trans. M. Evans, 1854; and The Philosophy of the Future, 1843.

Feuillants. Religious order that flourished in France from the 16 th century. It was an offshoot of the Cistercians, and the name originated in their monastery at Feuillant, near Toulouse. The abbot there, Jean de la Barrière, got into trouble with the authorities, so with a following he migrated to Paris in 1587, and founded the new order, one adopting a stricter form of life. A home was given to them in Paris by Henry III, and in 1589 they were recognized formally by the Pope. A later pope divided the order into two branches, French and Italian. The French kept the original name, and at the Revolution had in France 24 monastic houses, including one in the Rue St. Honoré, Paris.

Feuillants. Name of one of the parties that sprang up during the Prench Revolution. It was given to the members of a club because they met in the building in Paris formerly occupied by the religious order bearing this name. They originated with some Jacobins who, in 1791, refused to ask for the deposition of Louis XVI, and thereafter they formed the moderate wing of the revolutionary party.

They wished to maintain the constitution and to set up a stable government, and at the outset they called themselves the Society of Friends of theConstitution, but they never secured any great amount of support from the populace, although they were the largest party in the Constituent Assembly. Sieyès, Barère, and Lafayette were perhaps the most prominent mem. bers. Their wealth and their conservatism brought them under the suspicion of the extremists, and, after the rising of Aug. 10, 1792, their names were published as enemies of France. This put an end to their activities, although the name was still used to describe men holding moderate opinions.

Feuillet, Octave (1821-90). French novelist and dramatist. Born at St. Lô, in La Manche, Aug.
11,1821 , he became an assistant to Dumas the elder. When he started on independent work he soon

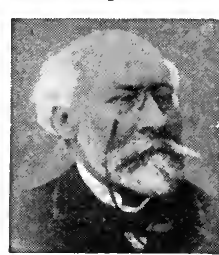
achieved con siderablepopu larity with plays and with the novel, Le Roman d'un Jeune Homme Pauvre, 1858 ; this was followed by the

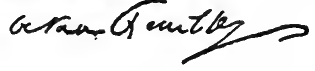

mystical romance Histoire de Sybille, 1863. In 1862 he was elected to the Academy, and was later made librarian at Fontainebleau. Monsieur de Camors, 1867 . and Le Journal d'une Femme, 1878, were the more notable of his later works. His stories are characterised by a blend of romanticism and realism. He dicd in Paris, Dec. 29, 1890.

Feuilleton (Fr., leaflet). French word for the part of a newspaper, usually the lower part of a page, devoted to gossip, literary, artistic or dramatic criticism, and especially serial fiction. The practice, though not the name, has been traced to the section in Defoe's Review headed Mercure Scandale, but the feuilleton, as at present understood, originated in the Journal des Débats in the early years of the 19th century.

Fever (Lat. febris). Condition of the body, the most characteristic feature of which is a rise of temperature. Accompanying symptoms are increase in the pulse-rate, headache, thirst, and, in the early stages, sensations of chilliness which in severe cases may amount to fits of acute shivering or rigors. The skin is usually dry at first, but later there is profuse sweating, and the skin is hot and flushed. The urine may be diminished in amount and is highly coloured. The tongue is often coated, and in children vomiting is frequent. The normal temperature of the body in health varies between $98^{\circ}$ and $99^{\circ}$ F. Up to $102^{\circ} \mathrm{F}$. the fever may be spoken of as "moderate." Temperatures of $105^{\circ}$ or $106^{\circ}$ are high, and above $106^{\circ}$ the term hyperpyrexia may be employed. A temperature of $107^{\circ} \mathrm{F}$. is very grave and recovery is improbable.

The cause of fever is most often the circulation of a poison in the blood, and in most cases the poison is a product of bacterial actiyity in an acute infectious disease. - It is now recognized that the rise of tcmperature indicates the reaction of the body against the poison in the blood, and, provided it does 
not reach a dangerous height, it is to be regarded as a beneficial process. The treatment of fever depends upon the disease with which it is associated. Dangerously high temperatures may be reduced by cold sponging, or the application of an ice-pack.

Certain clinical terms are used to describe various types of fever. Continued fever is the condition in which the fever remains persis. tently high; in remittent fever there are daily fluctuations of two degrees or more ; and in intermittent fever the increased tempera. ture is only present during part of the day. In malaria, when there is a daily rise of temperature, the condition is termed quotidian; when the rise occurs on alternate days it is said to be tertian; and when two days elapse between the paroxysms it is quartan. See Scarlet Fever.

Feverfew (Matricaria parthenium). Perennial herb of the nat. ural order Compositae. A native of Mid and South Europe, it has small, clustered, daisy.like, yellow-

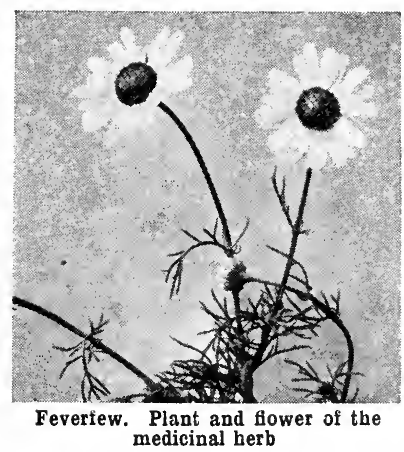

centred, white flower-heads. The leaves are deeply cut into toothed oblong segments. The whole plant has a bitter, tonic smell, and was used as a rustic medicine in slight fevers. The name, formerly spelt feverfuge, is derived from Lat. febrifugia (febris, fever ; fugare, to drive away).

Fever Hospital. Hospital for the reception of patients suffering from infectious diseases, e.g. scarlet fever and diphtheria. Such a hospital should be built on a site with a dry subsoil and good fall for drainage. It should be, where possible, outside the town which it serves but with good facilities for access, and there should be ample grounds around the hospital. There should be a detached administrative, block, separate wards for patients suffering from different diseases, and out-buildings, such as laundry, stores, mortuary, and disinfecting chamber.

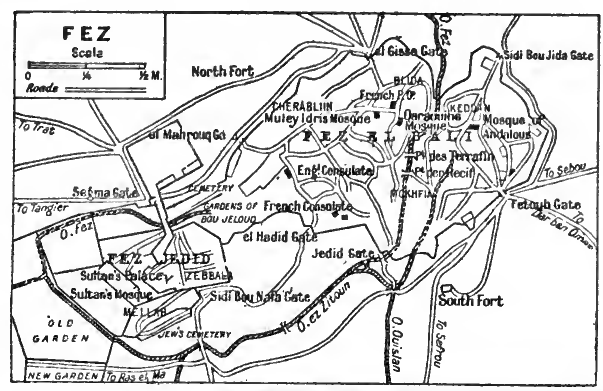

compatriots. $\mathrm{He}$ was a champion of woman, and advocated a higher position for her" in the community. $\mathrm{He}$ was attacked by several writers, and called before the Inquisition, which, bowever, he refused to attend. Pron. Fâ-ee-ho.

In the wards of hospitals the minimum floor space should not be less than 144 sq. ft., and the $\mathrm{minim} \mathrm{um}$ cubic space 2,000 cubic ft. per head, the system of ventilation providing that this is changed three or four times an hour. Where space permits the system of one. storeyed pavil. ions is the best. These should be connected with each other by corridors open to the air. Isolation hospitals for small-pox require a larger space around them than hospitals for other infectious diseases, and should not be situated close to any populated neighbour. hood. See Hospital.

Feversham, EARL OF. British title borne by the family of Duncombe since 1868. Charles Duncombe (1764-1841) was a descendant of Thomas and Ursula Browne, who, on inheriting the wealth of Ursula's brother, the London banker, Sir Charles Duncombe (d. 1711), took his name. In 1776 Charles Duncombe was made Baron Feversham. His grandson William, the 3rd baron (1829-1915), was made an earl in 1868. His grandson, who succeeded to the title, was, as Vis count Helmsley, Unionist M.P., 1906-15. In 1916, during the Great War, he was killed in action and his son Charles became the 3rd earl. The family seat is Duncombe Park, Helmsley, Yorks.

Feyjoó, Benito (1676-1764). Spanish poet and monk. Born Oct. 18,1676 , of good family, he entered the Church in his youth. Of a studious disposition, he devoted himself to scientific pursuits, and the art of healing. Most of his life was spent in a monastery at Oviedo, where he died, Sept. 26, 1764. In his Teatro Critico (Critical Theatre) 1751-59, Feyjoó indicts the metaphysical views of his
Fez or Tarbush. Close-fitting red with a black tassel. It is worn chiefly by the Turks with or instead of a turban (q.v.). The name comes from Fez, in Morocco, where these caps were originally made. See colour plate, Caps.

Fez or Faz. City of Morocco, and the northern capital. It is situated in a valley about $100 \mathrm{~m}$. E. of the port of Rabat (q.v.), and is one of the sacred cities of Islam. The city, surrounded by ancient walls, is picturesque, and contains the Mosque of the Cherubim or of Muley Edris, to which is attached a Mahomedan university, once the centre of learning in N.W. Africa, with a library containing some 30,000 MSS. Tlie city, which was founded in A.D. 808, is connected with Rabat by a light railway opened Feb. 8, 1915. Pop. 105,855 .

Fezzan. Country occupying the S. portion of the Italian 'colony of Libia (Tripolitania) and politically attached to it. It was occupied by Italian troops towards the end of 1913. Fezzan extends some $400 \mathrm{~m}$. N. and S., and $300 \mathrm{~m}$. E. and W., and belongs to the desert region of N. Africa. The inhabitants, who are Mahomedans belonging to the Sunnite sect, are estimated to number about 70,000. The chief oases are Ghat in the extreme S.W., and Murzuk.

F.F.A. Abbrev. for Fellow of the Faculty of Actuaries. cap of felt with a flat top, usually 
Ffestiniog Group. Series of grey flagstones belonging to the Cambrian system of sedimentary rocks, developed in Merioneth. It is characterised by abundant fossil remains of a small brachiopod ( $\mathrm{Lin}$ gulella davisi), and has persistent upper beds crowded with remains of Lingula. It was deposited under shallow water.

Fiacre (Fr.). Name of a saint and of a hackney carriage. The saint, also known as S. Fiachrach, a native of Ireland, died at Breuil, near Paris, about 670 , and is commemorated on Aug. 30. Outside the Hôtel de S. Fiacre, in Paris, in the 17th century, was the first stand for hackney carriages, and hence, it is supposed, is derived the application of the name fiacre to the vehicle. See Cab.

Fians or Fianna. In Celtic tradition, the band of warriors led at the height of their power by Finn (q.v.). Opinions differ widely as to their original nature, but they are generally believed to have flourished about the middle of the 3rd century. They existed in the time of Finn's father, Cumhal, and formed a militia force of specially chosen fighting men to expel foreign invaders from Ireland. The Gaelic legends of Ireland and Scotland have much to tell of their exploits in war and love and hunting, and in some, the Fians appear as a knightly order similar to that of the Round Table. Numerous cairns, standing-stones, etc., all over Ireland and in some parts of the Scottish highlands are associated with them.

Their strength, however, grew dangerous, and in their last great battle at Gabra (283) they were broken by Coirpre, son of Cormac. The anglicised form, Fenians, gave title to the Fenian Brotherhood. See Fenianism; consult also The Dean of Lismore's Book, ed. with trans. T. MacLauchlan, 1862; Leabhar na Feiune, J. F. Campbell, 1872; The Fians, ed. J. G. Campbell, 1891 ; Bards of the Gael and Gall, G. Sigerson, 1897 ; Ossian and the Ossianic Literature, A. Nutt, 1899; Myths and Legends of the Celtic Race, T. W. H. Rolleston, 1911 .

Fiar. In Scots law, name given to the ultimate owner of an estate, the one in whom the ownership is really vested. The fiar is, therefore, the opposite of the tenant for life.

Fiars Price. Price of grain in Scotland as fixed by the sheriff of the county, sometimes with the aid of a jury. It is done for each county each year, the object being to set up a standard in order that the cash value of certain payments, formerly made in kind, can be calculated. Among these are certain elcrical and other incomes derived from tenants, and in some cases rents. The practice, which is very old, was regularised by an Act of 1723 .

Fiat (Lat., let it be done). Term used in English law for an order that does not need to be drawn up formally. Fiats are issued by judges and other high officials under certain conditions and according to certain rules.

Fibre (Lat. fibra, filament). Term used for threadlike construction or appearance of many substances. Hair, wool, silk threads of the cocoons of silkworms, parts of leaves, bark of certain trees, grasses, etc., are all fibres. Though under certain conditions some metals exhibit a fibrous construction, it is difficult to separate the fibres, but occasionally metals spun into fine threads are spoken of as metal fibres, as also is spun glass. With the exception of asbestos, the fibres of which are woven into a kind of cloth, the fibres of commerce can be conveniently divided into two classes, animal and vegetable.

Animal fibres are the wool and hair of animals, and the silk of insect cocoons. Though comparatively few animals produce com mercial fibre, these few are of great importance. Sheep's wool, mohair from the Angora goat, the hair of the llama and alpaca, and those of the cow, camel, and rabbit - the latter for felts-and horsehair are the chief commercial animal fibres, and their uses are dealt with under their respective headings.

Vegetable fibres constitute a large and important class, and are put to a greater variety of uses than animal fibres. Flax, China grass or ramie, hemp, jute, cotton, raffia, sisal hemp, tampico, coconut, esparto grass, and Mexican whisk or broom root are among the chief vegetable fibres.

The grasses or fibres of $\mathrm{S}$. America and Africa are collected and sent over to importers in the British Isles, who sell them to the dressers, who in turn cut the fibre to different lengths for various uses and sell it to brush-makers. Brush-making is an important industry, and an enormous amount of fibre is used, so that some brushmakers dress and clean their own raw material. The fibre is clcaned of all dirt, cut, and hackled to make it clean and strong; then cut again, dyed if necessary, steamed and so made straight, and then it is left to dry hard.

Palmyra fibre, commonly known as bassin in the brush trade, is a strong, medium-sized fibre, and is very often dyed to look like Bahia piassava, which is the best fibre for street brushes, etc. Mexican fibre, of which there are two kinds-tula, which is short, and jumava, a longer variety-is a white fibre which, when dressed, is used for toilet hair brushes, nail brushes, etc. Coco fibre from the husk of the coconut is used for making mats, and also for the large brushes and brooms which are used for domestic purposes.

The principal use of coir yarn is for thatching, though it is sometimes used for large mats. Piassava, the most important fibre in the brush trade, is used for all kinds of brushes and brooms, and is found chiefly in Brazil and $W$. Africa. It is also largely used in S. America for rope-making. Kitool, from Ceylon, is the aristocrat of fibres, being polished and treated with oil, making it very expensive. It is used for making fine brushes and also for the manufacture of ropes of good quality in India.

Such brushes as dandy brushes for horses are generally made from Mexican fibre. Animal fibre, as horsehair, badger's hair, sable, and camel's hair, are also extensively used in brush-making. Fibres, chiefly of the cheap kinds, which pulp easily, are used for papermaking. Among them are esparto grass, the paper mulberry - the bark of which is converted into paper extensively used in Japancotton grass, and Deccan hemp. From the leaves of Carludovica palmata is obtained the fibre from which Panama hats are manufactured ; from Cibotium barometz, a fern growing in the Sandwich Islands, comes a variety of vegetable silk used for stuffing upholstery work, especially in the U.S. ; and from Eriodendron anfractuosum comes kapok, a soft, silky, elastic fibre used in upholstery, for the stuffing of cushions, seats, etc. See Asbestos; Cotton; Flax; Hemp : Jute; Paper; Rope ; Silk.

Fibrin (Lat. fibra, filament). Threads of solid proteid formed in the process of coagulation of blood. The fine threads entangle the corpuscles of the blood and, gradually shrinking, squeeze out the fluid part of the blood or plasma, the solid mass of fibrin and corpuscles forming the clot. See Blood.

Fibroid. Tumour composed mainly of fibrous tissue, more correctly called fibroma (q.v.). A common tumour of the uterus is spoken of as a fibroid, but is really developed from the muscular tissue. See Uterus.

Fibrolite. Variety of mineral sillimanite (q.v.), one of the andalusite group. Chemically a silicate 
of aluminium, it occurs in crystalline schists in form of lenticular lumps consisting of finely fibrous aggregates.

Fibroma. Tumour composed mainly of fibrous tissue. Soft fibromata most frequently develop from the connective tissue of the skin, and may form pedunculated outgrowths. Hard fibromata are found in connexion with the periosteum or tissue covering the surface bones, the ear, and other parts.

Fibrositis. Disease of an inflammatory nature affecting the fibrous tissue or fascia which surrounds muscles and extends between the muscular fibres. Pain is the most prominent symptom. The causes of the disorder are exposure to cold and wet, sudden chilling after heavy labour, and sometimes a blow. Persons of gouty tendency are most likely to be affected. See Lumbago; Pleurodynia; Stiff Neck.

Fibrous Tissue. Tissue composed chiefly of bundles of fine white fibres. It is found in tendons, ligaments, fascia, and the deeper layers of the skin.

Fibula (Lat., buckle). Outer of the two bones which form the skeleton of the lower leg. It is a long, slender bone, firmly attached to the tibia by ligaments at its upper and lower extremities. The lower extremity forms the external malleolus or bony protuberance on the outer side of the ankle, and helps to form the socket in which the foot articulates with the bones of the leg. See Leg.

Fibula (Lat.). Brcoch or clasp, especially of the early metallic ages. The neolithic bone pin, often made from the splint bone or fibula of a vertebrate animal, was imitated in bronze; when bent over until the looped head clasped the point the safety - pin resulted. Com. mon in Italian pile-dwellings, and the early Aegean, it developed at Hallstatt a bolder bow, often much decorated. Under

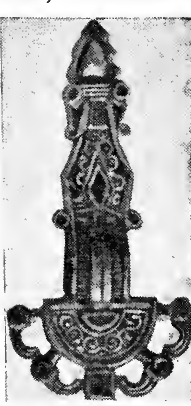
an these late-Celtic bronze - gilt brooch forms, the set with garnets, Roman fibula $\mathrm{Th}$ is sequence serves to date iron-age anti. quities wherever these types are fo und. Unlike La. Tène influther stages are traced, the catchplate beas to (i) ap proach, (ii) clasp, (iii) unite with the bow. was in two pieces. Anglo-Saxon types, sometimes betraying continental influence, mostly display native developments, especially in cloisonné. The choicest Gaelic examples came from Hunterston, Tara, and Aesica. They are now in Edinburgh, Dublin, and Newcastle respectively. See Brooch.

Fichte, Johann GotTlieb (17621814). German philosopher. Born at Rammenau, Lusatia, May 19, 1762, he left Germany owing to poverty, for Switzerland, where he became acquainted with Kant's philosophy. The attention at tracted by his A Critique of All Revelation, written while he was a tutor at Königsberg, helped him

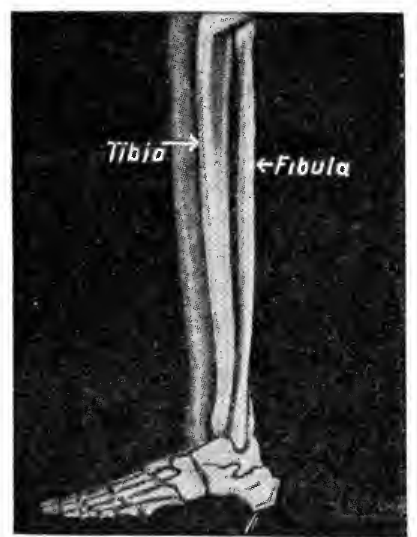

Fibula. Diagram illustrating relative positions of tibia and fibula in the human leg.

to obtain the professorship of phil osophy at Jena. In 1799, having been accused of atheism, he resigned his post and retired to Berlin, where he was allowed to lecture on philosophy. In 1807, when the French invaded Prussia, Fichte showed his ardent patriotism in his Addresses to the German Nation.

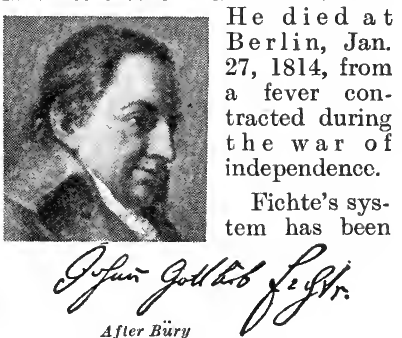

$$
\text { After Büry }
$$

ism, according to which the power of the will in the Ego is supreme. The Ego or self is a purely active being, which derives from itself the entirety of know. ledge. It is to the Ego that we have to look for the explanation of everything. The Ego, feeling itself limited, "posits itself" as determining the non-Ego. The counterpart of whatever belongs to the Ego belongs to the non-Ego. The Ego created the non-Ego; it creates nature and God. But God is not merely a creation of the Ego, but the absolute Ego, the infinite will of the universe, the "source of the finite Ego, to which we must ever strive to become united. Fichte's most important work is The Founda. tion of the Whole Doctrine of Knowledge, 1795.

Fichtelgebirge. Mountain system of Germany. Its central nucleus is situated in N.E. Bavaria between the basins of the Regnitz and the Naad. The name is derived from the pine trees (Fichte), with which it was formerly covered. It forms a watershed between the sources of the Elbe, Rhine, and Danube. The principal summits are Sckneeberg $(3,46 \mathrm{l} f t$.$) and$ Ochsenkopf $(3,334 \mathrm{ft}$. $)$. It has connections with or ramifications into the Erzgebirge and the Thuringian Forest, and stretches in a southwesterly direction to the banks of the Altmühl, near Eichstadt.

Fiction (Lat. fictio, feigning). Term now applied almost wholly to prose romances or novels, although strictly it means anything that is feigned, and is applicable to any literary productions of the imagination. See Literature; Novel : Romance.

Fiction, Legal. Legal phrase denoting an assumption of fact without question of its truth, for the purpose of evading technical difficulties. Fictions occur in every system of jurisprudence. They have been invented to enable changes to be effected in the substance of the law while deferring to the wholesome imaginative reverence for its old symbols and formalities. Fictions of law are not allowed to be denied, their proper operation, according to Blackstone, being "to prevent a mischief, or remedy an inconvenience, that might result from the general rule of law," while further the maxim is invariably observed that no fiction shall extend to work an injury.

In England it was through fictions that the courts of king's bench, exchequer, and common pleas encroached on the previously distinct jurisdiction of one another. By the common law no mere civil action could be prosecuted in the king's bench, but plea of any civil action could be held there, other than actions real, if the defendant was an officer of the court, or in the custody of the marshal of the court, for a breach of the peace or any other offence; hence the fiction was introduced into the 
pleadings that the defendant had been arrested for a supposed trespass, and so, being in the custody of the marshal, could be proceeded against for any other personal injury.

Similarly in the court of exchequer, personal actions were gradually admitted by the fiction that the plaintiff was the king's debtor, and was prevented from discharging his liability by the failure of the defendant to pay. By another fiction, actions for ejectment were made to serve the purpose of claimants to land, the names John Doe and Richard Roe (q.v.) being employed as those of an imaginary lessee and wrongful ejector.

Other fictions impose a conrentional rule where exact facts are difficult to be ascertained, e.g. the law takes no notice of fractions of a day, so that if a thing is to be done on a certain day, as payment of rent on quarter day, the whole day is allowed for its performance. Again, an infant becomes 21 the day before his 21 st birthday, because on that day he completes 21 years of existence; but because it would be highly inconvenient to ascertain the precise moment of his birth, he becomes 21 legally on the first moment of that day.

Fictions tend to disappear by legislation. Surviving examples that may be cited are found in the lord mayor's court, London, where the plaintiff always avers that the defendant promised him in the parish of S. Helen's, so as to bring the matter within the city juris. diction. See Jurisprudence: Law.

Fid. Def. Ablorev. for fidei de. fensor, defender of the faith (q.v.), a title of the British sovereign.

Fiddle. Old English name for the violin and its ancestors. Generically, it denoted sometimes any stringed instrument played with a bow, but latterly the word was applied chiefly to the smaller sizes of such instruments. The etymology is doubtful, but fiddle, with viol, is connected with the Latin vitulari, to celebrate a feast.

Fidei Commissum (Lat. commissum, entrusted: fidei, to good faith). Term of Roman law. By the civil law of Rome, a citizen could neither make a foreigner his heir nor leave him any legacy. As foreign settlers (peregrini) became more numerous in Rome, citizens often desired to leave their property, or part of it, to some foreign friend. The only way to do this was to leave the property to a citizen, asking him to carry out the testator's wishes, and hand the property over to the foreigner. At first it was entirely optional on the heir whether he carried out the request or not. It was left to his faith. But, in the end, fidei commissa became legally enforceable.

Fidelity Guarantee. Contract by which a person or persons undertake to make good losses due to fraud or negligence on the part of another person occupying a position of trust. Banks and business houses frequently require a guarantee of this kind on behalf of such of their employees as handle large sums of money, and many insurance offices, in return for an annual premium, enter into guarantees of this kind. Guarantee societies exist for the same purpose. See Guarantee ; Insurance.

Fidenae. Italian town of Latium. It was situated about $5 \mathrm{~m}$. N.E. of Rome, on a hill between the Anio and the Tiber. Frequently at war with Rome, it was finally conquered 438 B.c., and destroyed in the year following. Thereafter, though rebuilt, it never became a place of importance.

Fides. In Roman mythology, the goddess held as symbolical of faith and honour.

Fief. Name given to an estate held under the feudal system. It was, therefore, one which was held on condition of rendering certain services to an overlord, and which in certain eventualities re. verted to that lord. 'The word is sometimes rendered in English as feu or fee. From it come feoffee, the one who receives the estate, and feoffment $(q . v$.$) , the act of$ granting it to him. See Feudalism : Land Laws.

Field. Anglo-Saxon word, mean. ing the open country. It is now used for a piece of enclosed land, e.g. a wheatfield, and by analogy we speak of a coalfield or oilfield. It is employed also in a military and sporting sense. In the former, field is a synonym for battle or battleground, e.g. the field of Waterloo. 'This use has many com. pounds, such as field ambulance, relating to war. In sport the field has various meanings, e.g. the horses in a race or the riders at a hunt meeting are the field; field sports are hunting, racing, and the like. See Cricket: Horse-Racing.

Field. In heraldry, the surface of an armorial shield on which charges are placed. The same term is applied to the body of a flag, e.g. the British white ensign is a red cross on a white field, with the union jack in a canton (q.v.).

Field, THe. London weekly newspaper devoted to all forms of sport, natural history, and country life occupations. Founded Jan. 1, 1853, by Bradbury and Evans, its first editor was Mark Lemon. Its prosperity dates from its acquisition, in Nov., 1854, by Mr. Serjeant Cox, and the appoint. ment in 1857 of J. H. Walsh ("Stonehenge"), as editor. Fred. erick Toms succeeded to the editorship in 1888, being followed in 1900 by William Senior (Red Spinner), who resigned at the close of 1909, when Theodore A. Cook (who was knighted in 1916) took over the editorship. Early in 1913 George Binney Dibblce became general manager. In 1919, with The Queen and The Law Times, The Field was purchased by the proprietors of Land and Water (q.v.).

Field, Sir Arthur Mostyn (b. 1855). British sailor. Born June 27, 1855, he entered the navy in 1868 , becoming commander, 1889 , and admiral, 1913. His chief work was done in surveying, notably on the W. African coast, Strait of Magellan, S.E. American coast, Strait of Malacca, and the China Sea. He was hydrographer of the navy from 1904-9.

Field, Cyrus West (1819-92). American financier. 'Born at Stockbridge, Massachusetts, Nov. 30,1819 , he made a fortune and re tired from business at the age of 33 , when he became interested in the idea of the trans. Atlantic cable. In 1854 he organized the New York, Newfound.

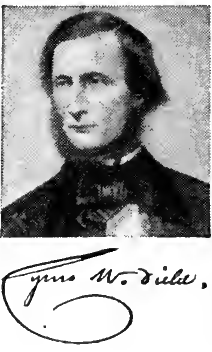
land,andLondon'l'elegraph Co., and 10 years later persuaded the U.S.A. and British governments to confirm by soundings the existence of Telegraph Plateau in the Atlantic. After various attempts the first cable was laid in 1859. Heavy financial losses necessitated Field's return to business, and he was an originator of the New York elevated rly. He died at New York, July 12, 1892. See Atlantic Cable.

Field, Eugene (1850 95). American poet and journalist. Born at St. Louis, Missouri, Sept. 2, 1850 ,

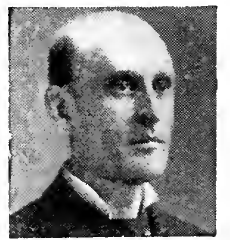

from 1883-95 he contributed to The Chicago Daily News a column entitled Sharps and Flats, in which most of his best work first appeared.

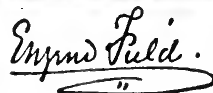
His poems in. clude A Little Book of Western Verse, 
1889, and With Trumpet and Drum, 1892, charming verses for children. His most attractive essays are collected in The Love Affairs of a Bibliomaniac, 1896. He died Nov. 4, 1895.

Field Allowance. Emolument granted to officers on going into camp or taking the field, in compensation for the extra expense of tent furniture, messing, etc.

Field Ambulance. Active unit of the Royal Army Medical Corps. Organized in companies for administrative purposes in peace time, the medical units are rearranged for active service, and the field ambulance is the unit which can deal with all cases of wounds and sickness in their early stages, and which is sufficiently mobile to accompany the troops in the field. The personnel of a field ambulance numbers 10 officers and 241 other ranks, with 10 ambulance wagons, 6 general service wagons, 3 water-carts, and 3 forage-carts. They are divisional troops under the command of the administrative medical officer, and three field ambulances are allotted to each division in the field.

The cavalry field ambulance is a similar but smaller and more mobile unit, the personnel num. bering 6 officers and 110 other ranks, with 6 light and 4 heavy ambulance wagons, 2 general service wagons, 2 water-carts, and 2 forage-carts. Four are allotted to a cavalry division and one to a detached cavalry or mounted brigade. The general principle on which the field ambulances work is to treat slight cases which can be returned to their units, to give temporary aid to the more serious, and transport them to the clearing hospitals, and only to retain for any length of time such cases as it is inadvisable to move. See Ambulance.

Field Dressing. In modern armies a packet, containing antiseptio materials, stitched to the clothing of every officer and man proceeding to the firing-line. Recent wars have shown that uncomplicated wounds caused by modern high velocity bullets require little treatment beyond the exclusion of dirt and air, and consequently all ranks are now provided with a dressing for immediate application which will effect this purpose. The dressing actually consists of a pad of sterilised gauze or lint, to which is fastened a length of bandage so that it can be securely held over the wound.

Fieldfare (A.S. feldefare, ficld traveller). Bird of the thrush family. Visiting Great Britain in vast flocks in winter, it spends the rest of the year in Scandinavia

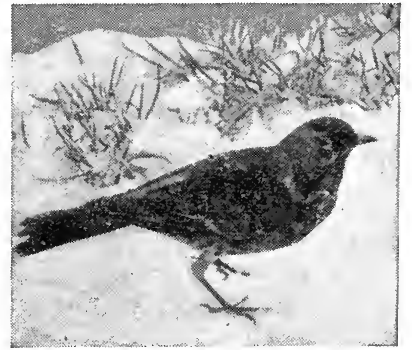

Fieldfare. Member of the thrush family, found in Great Britain

and Russia. In plumage and general appearance it closely re. sembles the common thrush, but it has not its vocal powers. It is seldom seen in parties of less than twenty, and often the flock will exceed a hundred. It feeds upon grubs, small snails, and berries. When feeding it continually advances in one direction, and a flock of the birds appears to move forward in open order with almost military pre. cision. It nests in great colonies, and returns year by year to the s a me site, the nests being usually built in pine woods.

Field-g la s s. Small binocular telescope for viewing distant objects. The earlier field-glasses consisted simply of two short telescopes mounted side by side in a frame and focussed by means of a screw. The telescopes were of the "Galilean" type, in which the object-glass is a convex lens which converts the parallel beam of light from a distant object into a convergent pencil of rays. The tube is a short one, and before the convergent rays can come to a focus they pass through the concave eye-piece which transmits them to the eye as a parallel beam. In order that the images may be free from coloured fringes, it is necessary to substitute achromatic combinations for the simple lenses.

The advantage of this type of telescope for field-glasses lies in the shortness of the tube, its disadvantage in the narrowness of the field of vision. Rays trom objects slightly off the direction in which the glass is pointed get lost inside the tube, and fail to reach the eyepiece. To avoid this defect, prisms were introduced into the tube to catch the aberrant rays and reflect them into the eye-piece. This was the origin of the modern form of field-glass, the prismatic binocular.
There may be one object-glass or two, but in either case the entering pencil of rays is reflected twice or more between parallel prisms, and finally directed into the eye-piece. This arrangement gives a wider field than in the simple type of field-glass, but as a certain amount of light is lost at each reflection the field is not so bright. In fact, the prismatic binocular was rendered possible only by the invention of a glass for the prisms which reflected a specially large percentage of the light falling on it. See Telescope.

Field Gun. Mobile piece of artillery. It is mounted on wheels, and capable of horse transport of sufficient mobility to keep in touch with advancing infantry. The field guns of all the great powers have become standardised at about three inches calibre, and are capable of throwing a shell weighing about $16 \mathrm{lb}$. to an extreme range of 9,000 yards, the effective range being about 5,000 
Field Hospital. Popular name for the clearing hospital, the nearest stationary, but mobile, medical institution to the actual battle line. A clearing hospital is established by the Royal Army Medical Corps attached to each division in the field, and is situ a ted in buildingsschools or similar structures for pre ference-in civilized country, or in tents and marquees when no better acconimodation is available. Technically, it forms a unit of the cracuating zone, and is preferably placed out of the enemy's range, and near rail-head, but should be as close to the firing line as is practicable, and must be in touch with the field ambulances. The normal accommodation is for 200 casualties, but the equipment and organization must be such that far larger numbers can be dealt with if occasion demands.

It is the central point on which a definite section of the collecting zone converges, and the station to which the field ambulances bring casualties, and from which thelatter are dispatched by ambulance train or water transport to the stationary hospitals. Transport for the hospital and lor the wounded it has received are arranged by the inspector-general of communications. A clearing hospital only acts as a hospital in the generally accepted sense of the term during such time as it is unable to pass its patients farther down the line, and for such casualties as are unfit to be moved. See Ambulance; Red Cross.

Fielding, HENRY (1707-54). English novelist. Born near Glastonbury, April 22, 1707, a scion of the Denbigh family, he was educated at Eton and at the university of Leiden, studying civil law. Coming to London about the age of 20 , he gave up his legal studies and began to work for the stage.
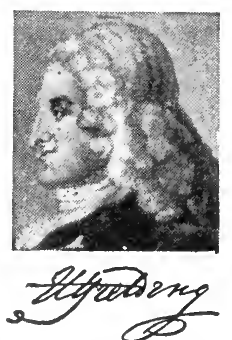

From a prin

He wrote a number of farces and other light pieces which have all passed int the limbo of literary curiosities. Called to the bar in 1740 , he was appointed justice of the peace for Westminster in 1749 and proved a conscientious and painstaking magistrate. His private life, how.

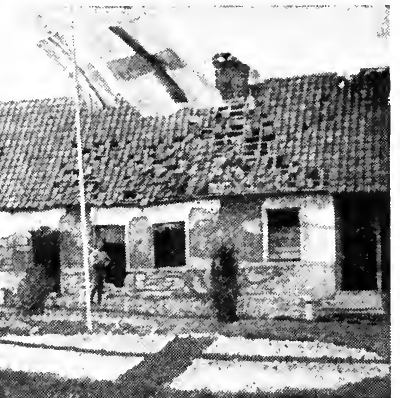

Entrance to a clearing hospital
Front during the Great War

ever, had not been beyond reproach and careless living had undermined his originally strong constitution. He died at Lisbon, whither he had gonefor his health, Oct. 8, 1754 .

Fielding's first novel, Jose ph A ndrews, ap. peared in 1742 . It began as a de. liberate caricature of Richardson's Pamela, then just published. As the narrative pro. gressed, Fielding became interested in his characters

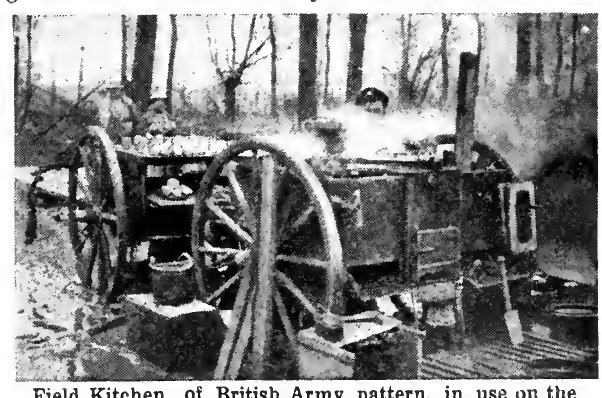

Field Kitchen, of British Army pattern, in use on the Western Front during the Great War

the caricature fadcs into the background, and the result is a human and lifelike story. Joseph Andrews was followed in 1743 by Jonathan Wild, a grim portrayal of the career of a consummate scoundrel. Then in 1749 came Tom Jones, which some critics regard as the greatest novel ever written. The plot is a masterpiece of construction, the narrative is Homeric in its power to sustain interest, while the intensely lifelike characters - the hard-drinking, hard-swearing Squire Western, his beautiful and lovable daughter Sophia, the hypocrite Blifil, the egregious humbugs Thwackem and Square, and the ingenuous Partridge-will live for ever.

Fielding's last novel, Amelia, 1751 , is subdued in tone as compared with the boisterous high spirits of Tom Jones. It is to a certain extent autobiographical, the original of the erring Captain Booth being Fielding himself. Amelia was the favourite novel of Thackeray, who gives a masterly appreciation of Fielding in his English Humour. ists. See English Literature; Novel ; consult also The History of Henry Fielding, W. L. Cross, 1919.
Fielding, William Stevexs (b. 1848). Canadian statesman. Born at Halifax, Nov. 24, 1848, he became a journal. ist. In 1882 he entered the legislature of Nova Scotia, and from 1884 96 was prime minister of that province. In 1896 he entered the Dominion par. liament, and

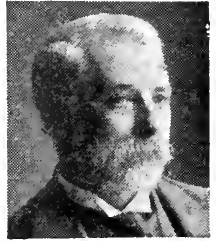

W. S. Fielding, Canadian statesman Russell from 1896-1911 was minister of finance in the Laurier cabinet, being responsible for tariff changes. In 1921 he again became minister of finance.

Field Kitchen. Boiler and selfcontained furnace mounted on wheels for horsed transport. It is sufficiently mobile to move with

marching infantry. Field kitchens enable soup and stews to be cooked while on the march. See Supply.

Field Madder (Sherardia arvensis). Annual bristly herb of the natural order Rubiaceae. It is a native of Europe, Asia, and the Canaries. Its trailing stems, a foot or more in length, spread from the root, and are clothed with whorls of sharp-pointed lance-shaped leaves. The lilac funnel-shaped flowers are about $\frac{1}{8}$ in. across. It grows in cornfields and pastures.

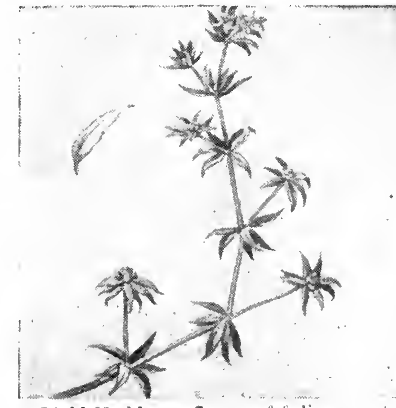

Fieid Madder. Spray of toliage and flower, and a detached leaf 
Field-Marshal. The highest title of rank in the British army, equivalent to admiral of the fleet

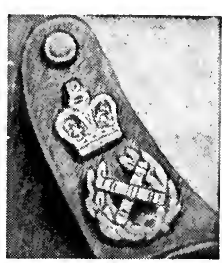

Field-Marshal. in the navy. It was instituted in $\mathbf{1 7 3 6}$ when George II conferred the rank on John, duke of Argyll. Any officer on either the active or retired Shoulder strap of the lists may be highest rank in the promoted to British Army field-marshal without reference to seniority, but it is laid down that there shall not be more than eight fieldmarshals on the active list. Colonels of the Royal Artillery, Royal Engineers, King's RoyalRifle Corps, and the Rifle Brigade are selected from the field-marshals, who are also eligible for appoint. ment as governors of the Tower and Chelsea Hospital. The pay of a field-marshal is dependent on the appointment he actually holds, his half-pay is $£ 1,300$ per annum, and his gratuity for a scrious wound, $£ 3,500$. Actually, the title is conferred on the most distin. guished soldiers of the day, and the holders carry a baton in addition to their swords when in full dress. See Marshal; also illus. pp. 968 and 2806.

Field Mouse. Name erroneously given to several small rodents, both mice and voles. It is correctly

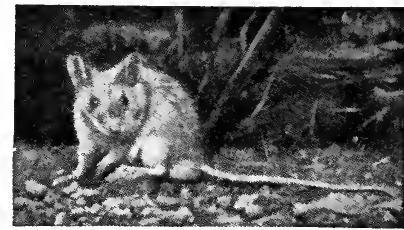

Field Mouse. Brown, long-tailed Mus sylvaticus

applied only to Mus sylvaticus, the wood mouse, otherwise called the long-tailed field mouse, a common pest in most parts of England, in gardens and hedgerows, and occasionally in corn-stacks.

Field Officer. Any officer below the rank of general and above the rank of captain. These officers were mounted in days when other infan. try officers marched on foot with their companies. Field officers not having the charge of companies, etc., were assigned special duties, such as presiding at courts-martial, inspection of guards. A brevet major, being a regimental captain, would perform either class of duty as required. Sentries pay compliments to field officers by presenting arms. See Colonel; Major.

Field of the Cloth of Gold. Term applied to the meeting-place of Henry VIII and Francis I of France, June 7-24, 1520. The meeting took place near Guines, and the name was given to it on account of the magnificence displayed.

Field Punishment. Punishment authorised by the Army Act

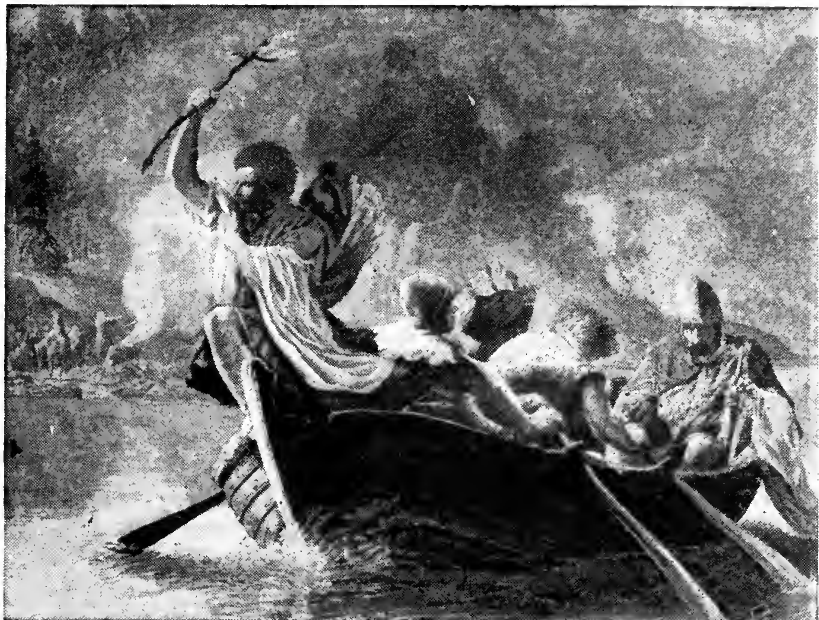

Fiery Cross, from a painting by J. Drummond, R.S.A., depicting the bearer of the fiery cross carrying his summons by boat from village to village

J. Caird Inglis

to be inflicted on private soldiers on active service in consequence of the lack of prisons or detention barracks. Field punishment No. 1, abolished in 1923, involved such restraint as is usua! in cases of imprisonment with hard labour, and in addition the prisoner could for three days out of four be " attached to a fixed object," such as a tree or a gunwhee!, with straps or ropes, for not more than two hours a day. This mode of restraint could not, however, be adopted for more than 21 davs in all. See Court Martial.

Field-train. Name given to the transport allotted to fighting units for the conveyance of the stores, supplies, and baggage necessary for their subsistence. The train is divided into two sections, baggage and supply, the latter being known as first line transport, since it is an integral part of the fighting unit, without which the necessary tactical functions cannot be performed. See Supply ; Transport.

Fieri facias (Lat., cause thou to be made). Term of English law. It refers to a writ of cxecution directed to the sheriff of a county, ordering him to cause to be made of the goods of A. B. a sum of money due by A. B. on a judgement.

Fiery Cross. Charred sticks dipped in goat's blood and usually joined in the form of a cross, which fleet-footed retainers of the chief carried round among the Scottish clansmen to call them together in time of emergency. Disobedience to the summons rendered any man between the age of 16 and 60 liable to the extreme penalties of fire and sword, emblematically denounced by the bloody and burnt marks upon the signal. During the "Fortyfive" the fiery cross made many circuits. A fine description of the custom is given in Scott's Lady of the Lake, Canto III.

Fiery Serpent. Name given to the serpents sent to the Israelites in the wilderness (Num. 21). They were probably sand snakes, called fiery because of the effect of their bite. See Snake.

Fiescherhorn. Mt. of Switzerland. In the Bernese Oberland (q.v.), near Grindelwald, its height is $13,286 \mathrm{ft}$. The ascent from the Bergli Hut by the Mönch-Joch should not be attempted without the help of a guide.

Fiesole (anc. Faesulae). City of Italy, in the prov. of Florence. It stands on an eminence overlooking the valley of the Arno, $3 \mathrm{~m}$. N.E. of Florence. It was one of the 12 Etruscan cities, and is enclosed by crumbling cyclopean walls. Its cathedral, founded early in the 11th century, contains many interesting paintings and sculptures. Straw-plaiting is carried on by the inhabitants. Here in 225 B.c. the Gauls defeated the Romans, and Sulla's veterans formed a colony, later the headquarters of Catiline. For long an opulent city, its prosperity waned as Florence grew in power. Pop. 10,434. Pron. Feeay-zoly. 
Fife (Fr. fifre, Ger. Pfeife, Lat. pipare, to chirp, pipe). Small flute used for military marching. It is associated with drums when a full band is not available. In a drum and fife band the chief melodic work is allotted to the B flat fifes, arranged to play in unison or in two or three parts; they are assisted in lower notes by larger flutes, in $\mathrm{F}$ and in $\mathrm{E}$ flat, and in the higher ranges by piccolos (q.v.) in $\mathrm{F}$ and in $\mathrm{E}$ flat. As the cpen key of all the flutes is called $\mathrm{D}$, transpositions are reckoned from $D$, instead of from $C$, as is the case with most other instruments. For example, the first two bars of "God Save the King," in key B flat, would be written as follows to secure a unison effect :

Piccolo in $\mathrm{F}$.

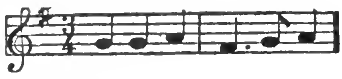

Piccolo in ED.

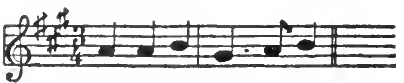

Fife in B 0 .

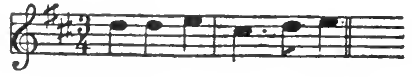

Fiute in $\mathrm{F}$.

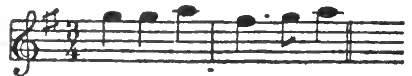

Flute in $\mathrm{E}$.

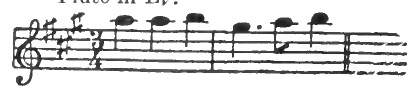

and the actual pitch would be :

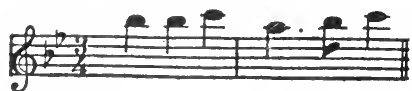

In fife bands the percussion instruments include side-drums, bass drum, cymbals, and triangle.

Fife or Fifeshire. Eastern maritime and peninsular county of Scotland. Lying between the Firth

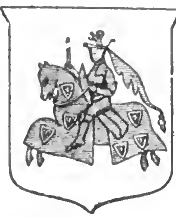

Fifeshire arms of Tay and the Firth of Forth,its area is $504 \mathrm{sq}$. m. The surface al. ternates between hill ridges and fertile and well. cultivated val. leys, the highest eminence being West Lomond, 1,713 ft. There are several small lakes; of the rivers, the Eden and Leven are the largest.

Nearly 75 p.c. of the soil is cultivated, a large area being permanent pasture ; wheat, barley, oats, and potatoes are raised. Tho mineral wealth of the county is largely represented by coal, but limestone,

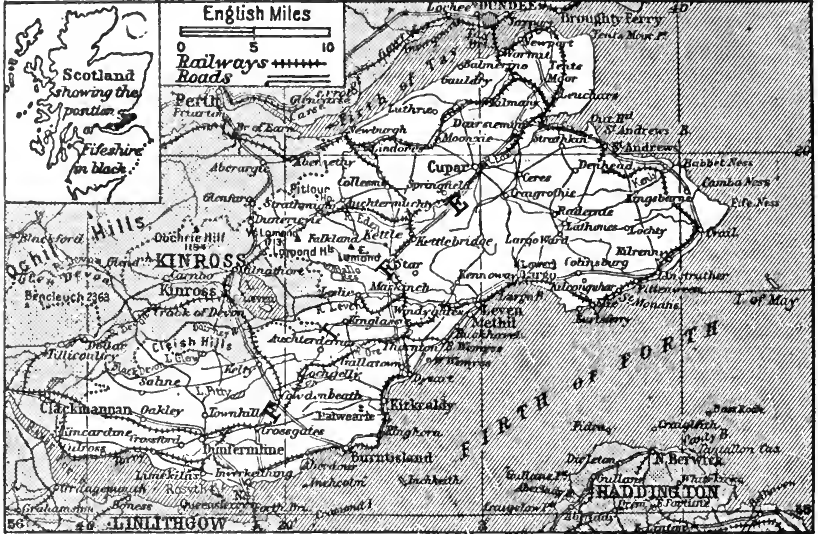

Fife. Map of the Scottish county north of the Forth

ironstone, freestone, and oil-shale are also worked. Most of the coast towns and villages engage in fishing, and the linen and floor-cloth manufactures are prominent. St. Andrews has a university, and is an important golf centre. The rly. is the N. B. R. Two members are returned to Parliament. Cupar or Cupar-Fife, the county town, Kirkcaldy, Dunfermline, St. Andrews, Cowdenbeath, and Buckhaven are the largest towns. Pop. 267,739. Evidences of Roman occupation exist, and other ancient objects of interest are the monastic ruins found in many parts of the " bingdom," as the county is still popularly called.

Lrterary Assoclations. To Cupar belonged Sir David Lindsay, the 16 th century satiric poet, and another of the Lindsays of Fife was Lady Anne Lindsay, who wrote Auld Robin Grey. Ádam Smith, the political economist, was born at Kirkcaldy, while Balwearie, near by, was the birthplace of Michael Scott the "wizard." At Kirkcaldy, too, Thomas Carlyle sojourned as the pupil of Edward Irving. To Pitlour belonged Miss Campbell, who wrote The March of the Cameron Men. At Lower Largo was born Alexander Selkirk, who is immortalised as Defoe's Robinson Crusoe, and is the subject of a poem by William Cowper; a niched statue of him as Crusoe was erected here in 1885 . St. Andrews, which is crowded with associations with notable students, has memories of George Buchanan and of John Knox, who began his work as reformer here.

Fife. Settlement in Nerthern Rhodesia, on the Stevense Road from Lake Nyasa to Lake Tanganyika.

Fife, Earl and Duke of. British titles born by the family of Duff. In 1735 a certain William Duff, who had been M.P. for Banffshire, where he owned large estates, was made an Irish peer, as Baron Breco. An earldom followed in 1759 . James, the 4th earl, was a majorgeneral in the Spanish army during the Peninsular War, and James, the 5th earl, was made a British peer as Baron Skene in 1857. He died in 1879 and his son and successor was the nobleman who married Princess Louise. $\mathrm{He}$ had been previously made a British peer (1885), and in 1889 he was created marquess and duke. $\mathrm{He}$ died in 1912, when his Irish title became extinct, but the newer ones passed by special remainder to the elder of his two daughters, who became duchess of Fife. The duke had enormous estates in Banffshire and Aberdeenshire, but much of his land has been sold. His chief seats were Mar Lodge, Braemar, and Duff House, Banff. The heir to the title is known as the earl of Macduff.

Fife, Alexander William George Duff, Duke of (18491912). British nobleman. Only son of the 5th earl of Fife, he was born Nov. 10,1849 , and at Eton. $\mathrm{He}$ sat in the $\mathrm{H}$ ouse of the counties of E lg in and $\mathrm{N}$ a i r n, from

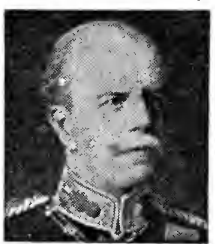

Duke of Fife

Downey
1874 until he succeeded to the peerage in 1879. In 1889 he married L.ouise, eldest daughter of the prince of Wales, and was created duke of Fife. He died at Assuan Jan. 29, 1912, from a chill contracted at the wreck of the steamer Delhi off Moroeco, and was buried Aug. 8, 1912, at Braemar. was educated Commons for 
Fife, Alexandra, Duchess of (b. 1891). British princess. The elder daughter of the duke of Fife

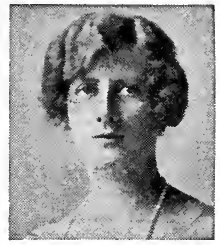
and $\mathrm{L}$ ou ise, daughter of Edward VII, she was born May 17, 1891. In 1912, on the death of her father, she succeeded by special remain. der to $h$ is

Princess Arthur of

Connaught Duchess of Fife Corbett dukedom and some of $h$ is other titles,

and on Oct. 15, 1913, she was married to her cousin, Prince Arthur of Connaught. A son, the earl of Macduff, was born Aug. 9, 1914.

Fifteenth. In English history, a tax usually associated with a tenth. Taxation of property other than land began in the time of Henry II, and in 1193 one-fourth of their incomes was demanded from laity and clergy alike. Succeeding taxes of this kind were levied, but the amount varied from a fourth to a fourteenth. Officials from the exchequer arranged for a fixed amount from each shire, leaving it to the sheriff to collect it from individuals. After 1290 it was a grant voted by Parliament, each estate voting its own share to the king. Tenths and fifteenths became the regular amount of the votes, townsfolk, i.e. the owners of personal property, paying one-tenth of their incomes and those in the country one-fifteenth.

The next charge was to make the amount voted a fixed sum, done by taking the assessment of 1332 , which produced $£ 39,000$. Henceforward $£ 39,000$ represented a tenth and fifteenth, and if more money was needed Parliament voted two tenths and fifteenths. In later votes certain towns were sometimes excepted, and the assessment became antiquated and unfair as conditions changed. The last vote of this kind was in 1624 ; its place being taken by the subsidy (q.v.). See Taxation; Tenth.

Fifth. Musical interval. A fifth includes five scale names in order, as C, D, E, F, G. Therefore C to G is a fifth, and as G occurs in the major scale of $\mathrm{C}$, this fifth is called perfect, or by some major. See Consecutive; Interval.

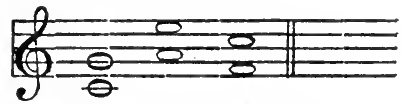

Fifth Mowarchy Men. Sect of the Puritan period in England who believed that a millennium or kingdom of Christ upon the earth was at hand. This was to be the fifth monarchy of the world, the earlier ones being the empires of the Assyrians, the Persians, the Greeks, and the Romans. The Fifth Monarchy men were to be found in considerable numbers in Cromwell's army. In 1661, shortly after the Restoration, they took part in a revolt in which many were killed.

Fig (Ficus carica). Tree of the natural order Urticaceae, native of the Mediterranean region. It at. tains a height of $20 \mathrm{ft}$. to $30 \mathrm{ft}$., and has large, lobed, alternate leaves, rough above and downy beneath. The sexes are in separate flowers, but on the same tree. The minute blossoms are contained inside a hollow, pear-shaped flowerstalk. Externally nothing indicates the presence of flowers, and but for the ministrations of a small wasp (Blastophaga grossorum), it would be impossible for the pollen of the males to reach the female flowers. In the same receptacle as the male flowers are some aborted females, and these are attacked by the female wasp, which lays its eggs in them.

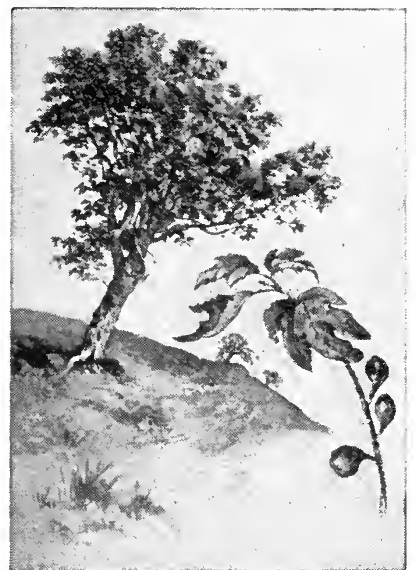

Fig. Tree of Ficus carica and, right, branch with leaves and fruit

The wasp-grubs feed upon their cradles, and in due time become wasps. In seeking the external air they have to pass among the male flowers, and get dusted with their pollen. Then they are attracted by the odours emanating from a cavernous stalk containing female flowers, and enter it, shaking off much of the pollen that covers their bodies; and thus the female flowers are pollinated and the flower-stalks become swollen and juicy. Numerous other species of the genus Ficus in other parts of the world bear edible fruit, such as $F$. roxburghii (India), which has them in clusters from the bare trunk, quite near the ground.

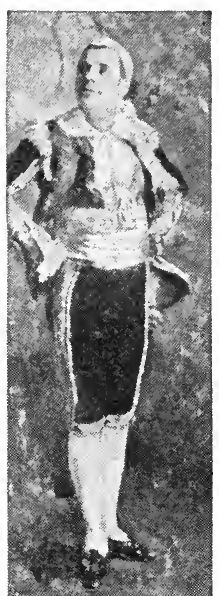

Figaro, as presented by Coquelin aîné
Figaro. Central character, the barber himself, in Beaumarchais' comedy, The Barber of Se. ville. $\mathrm{V}$ a let, poet, dramat. ist, etc., he is th $\theta$ personification of the easy gaiety which has come to be accepted as a type of the witty social philosopher. Encouraged by the success of The Barber of Seville, 1775 , Beaumarchais wrote TheMar. riage of Figaro. wh i c h, how ever, was not acted until 1784 , and he also introduced Figaro into La Mère Coupable, 1792. Mozart wrote an opera on The Marriage of Figaro, and Rossini one on The Barber of Seville. See Beaumarchais.

Figaro, Le. Satirical journal founded in Paris, 1826. It was named after the hero of two of Beaumarchais' comedies, and contributed to by Jules Janin, Alphonse Karr, and George Sand. It ran till 1833. The title was revived for a weekly started by J. H. de Villemes. sant, April 22, 1854. This became a morning daily devoted to politics and literature in 1866, its writers including Edmund About, Gabriel Hanotaux, Pierre Loti, Edmund Rostand, and Ernest Daudet. Under the control (1901-14) of Gaston Calmette, who was shot by Mme. Caillaux, wife of the French finance minister, March 16, 1914, it enjoyed a great vogue as a society as well as a literary organ. It publishes a literary supplement, and a monthly, Le Figaro Illustré.

Fighting Fish. Name given to a small fresh-water fish, Betta pugnax, found in Asia and Africa. The Siamese breed it for fighting contests, as it fights furiously when matched with an opponent. It assumes vivid colours under ex. citement.

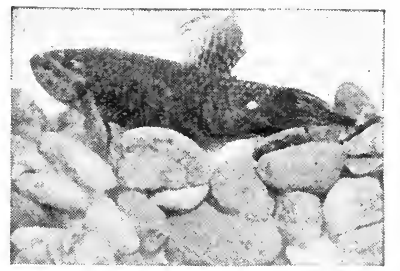

Fighting Fish, the Japanese Betta splendens 
Fighting Top. In ancient naval warfare, a platform or large barrel high up on the mast from which heavy weights could be thrown into any vessel lying alongside, either to disable men or to drive a hole through the bottom of the ship. Later on, fighting tops were occupied by archers and riflemen; in sailing ships they were represented by the "tops," or platforms built at the head of the lower masts, where picked marksmen were stationed during closefought actions. It was from the mizen-top, the platform on theaftermast, of the Redoutable that the shot was fired which killed Nelson.

In the later years of the preDreadnought era fighting tops were equipped with machine and light quick-firing guns for driving off hostile torpedo-craft, but as the size of the latter and the range of torpedoes increased, it became impossible to mount in these positions guns sufficiently heavy and far-reaching for the purpose. Modern ships still have large structures built high up on the masts, but these are occupied in action by the spotting officers and apparatus connected with firecontrol. See Battleship.

Figig. Walled oasis of Morocco, on the borders of Algeria. It lies three miles N.W. of Beni Unif, and 165 m. E.S.E. of Fez, and is a station on the rly. from Oran to Colomb Béchar. There are 250,000 date palms and a considerable trade is carried on with Morocco. The inhabitants, numbering about 15,000, belong to the Amour tribe. After a revolt in 1903, order was established by a French military mission. Alt. $2,700 \mathrm{ft}$.

Figline. Town of Italy, in the prov. of Florence. It stands on the river Arno, $15 \mathrm{~m}$. by rly. S.E. of Florence. It manufactures wine and cutlery, and straw-plaiting is carried on. In the vicinity is Monte Ferrato (alt. 1,385 ft.), noted for its quarries of serpentine. Pop. 12,035. Pron. Fil-yeeny.

Fig Marigolds (Mesembryanthemum). Large genus of fleshy herbs and sub-shrubs. Of thenaturalorder Ficoideae, they are natives of hot, dry climates, especially S. Africa. The leaves vary greatly in the different species; the flowers are large and conspicuous, white, yellow or red, with many long, slender petals. See Ice-plant.

Figueira, Gurllex (c. 11901250). One of the later Provençal troubadours. $\mathrm{He}$ was born at Toulouse, and is reported to have been a tailor. When the persecution of the Albigenses took place, he wrote vigorously in their de. fence, and on the persecutors'

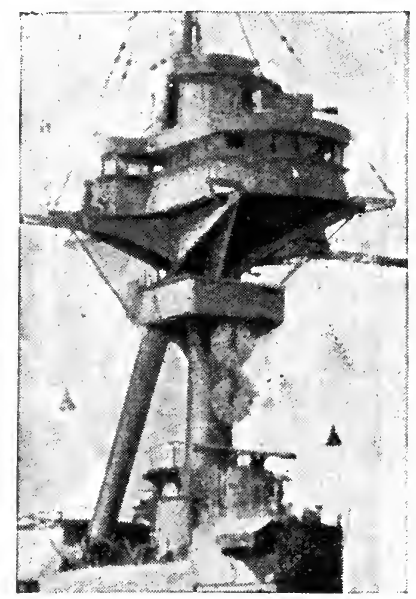

Fighting Top or Fire Control platform of the battle cruiser Renown Cribb, Southsea

capture of Toulouse took refuge in Italy. In the struggle between the Empire and Rome he sided with the former, and one of his sirventes is a denunciation of the latter. $\mathrm{He}$ also composed some notable love songs. Pron. Feegayeera.

Figueras. Town of Spain, in the prov. of Gerona. It stands in a fertile plain near the French frontier, $27 \mathrm{~m}$. N.E. of Gerona on the Barcelona-Perpignan Rly. The town is strongly fortified, with a citadel built by Ferdinand VI, which has been called the key of the frontier. There is some trade in soap, wine, leather, and textiles; gold and copper mines are in the district. The town fell three times to the French -in 1794, 1808, and 1823. Pop. 11,778. Pron. Feegayrahss.

Figueras y Moracas, EstanisLAO (1819-82). Spanish statesman. Born at Barcelona, Nov. 13, 1819, he studied law. As a republican he was elected to the Cortes in $\mathbf{1 8 5 1}$. Prominent in the revolution of 1868, he strongly opposed all attempts to restore the monarchy, and upon the establishment of the republic of 1873 became president of the provincial council of ministers. He occupied a prominent position in politics until 1874 , when the restoration drove him into retirement. He died at Madrid, Nov. 11, 1882.

Figurate Number. Term used in mathematics. In an arithmetical progression, if the first number is a unit and the successive numbers differ from it by whole numbers, as in such a series as $1,2,3,4,5$, then a new series may be formed by adding together the first two terms, then the first three terms, then the first four terms, etc. The new series would thus be $1,3,6$,
10, 15. These numbers are called figurate numbers. Similarly another series, 1, 4, 10, 20, 35, etc., might be formed from the second series.

Figured Bass. In music, a bass part provided with figures to indicate the chords which should be added to it. See Basso Continuo.

Figure-Head. Image painted or carved on the prow of a war vessel. It doubtless originated in the sentiment that a ship was a living thing and should be given in at least one respect the external appearance of one. Possibly, too, the ferocious aspect of a grotesquely shaped animal in the bows had some sort of moral effect upon ancient or uncivilized warriors.

In the days of the oared galley the figure-head was made to fill the purpose of an above-water ram. Projecting further in advance of the bow than the ram below water, it was driven with such force against an enemy's side as to cause the vessel to heel over, thus giving the submerged projection the opportunity of striking in a more vulnerable and vital part of the hull. When the sail superseded the oar as a means of propulsion, the figure-head ceased to have any practical value, but it was retained for ornament, and as an expression of sentiment. No British warship has had a figurehead, or even a bow scroll, for many years, excepting only the Triumph and Swiftsure, which were completed as they were designed for the Chilean navy. Many figureheads of old British warships are to be seen in naval museums in the royal dockyards and elsewhere.

Figwort (Scrophularia). Large genus of herbs, of the natural order Scrophulariaceae. They are natives of Europe, Asia, N. Africa, and America. They have tuberous or creeping rootstocks, oppositeleaves, and somewhat globular flowers of a greenish-purple or yellow hue, succeeded by a two-valved capsule. As a rule they have an unpleasant odour. S. nodosa,

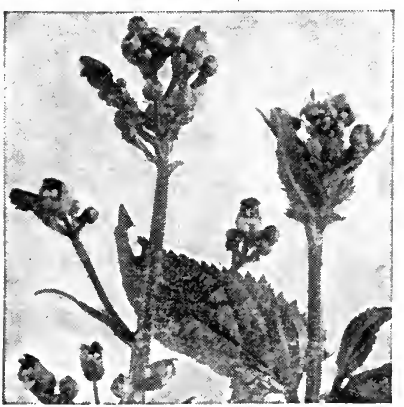

Figwort. Leaves and flowers of the knotted figwort 


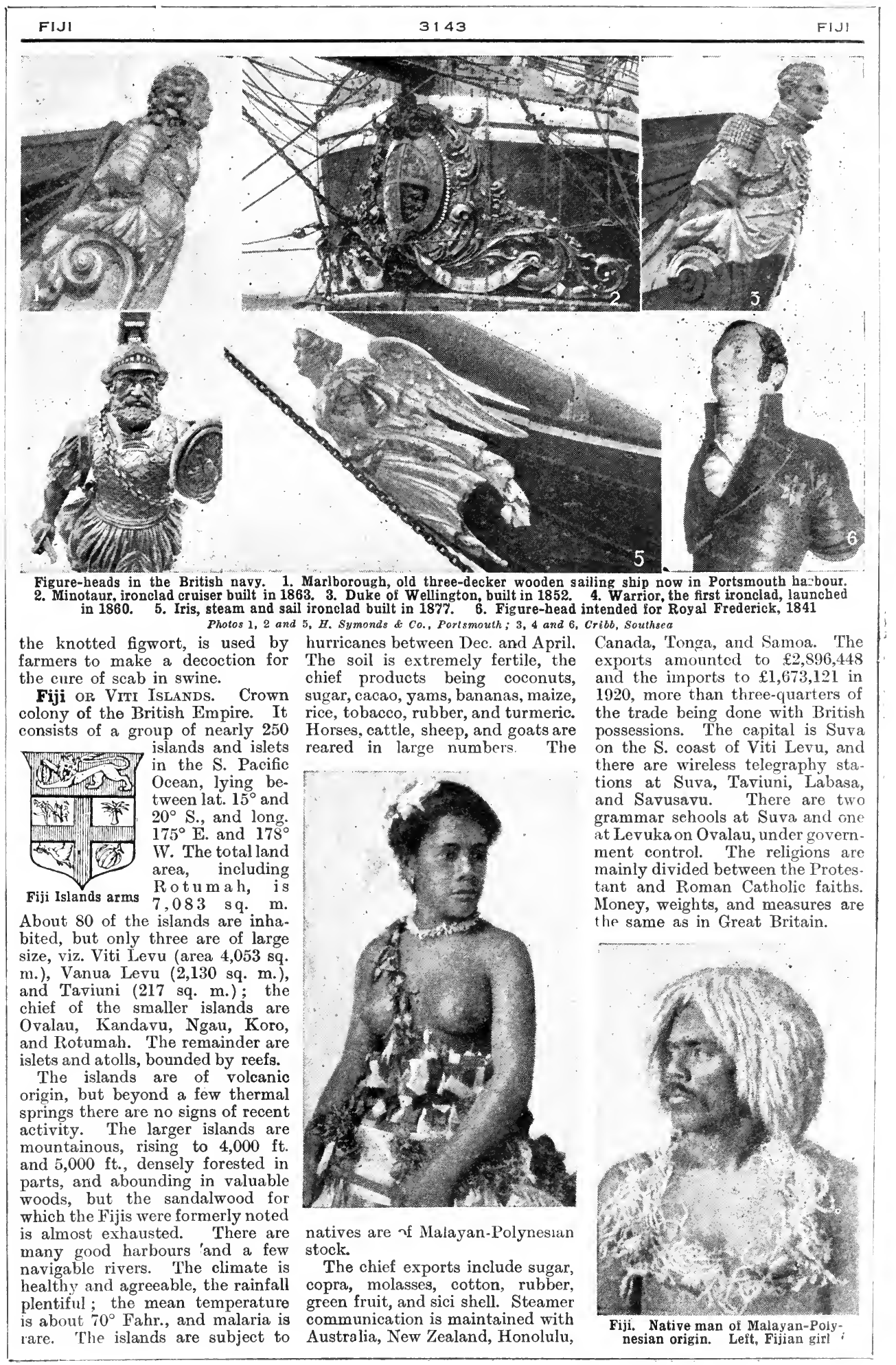




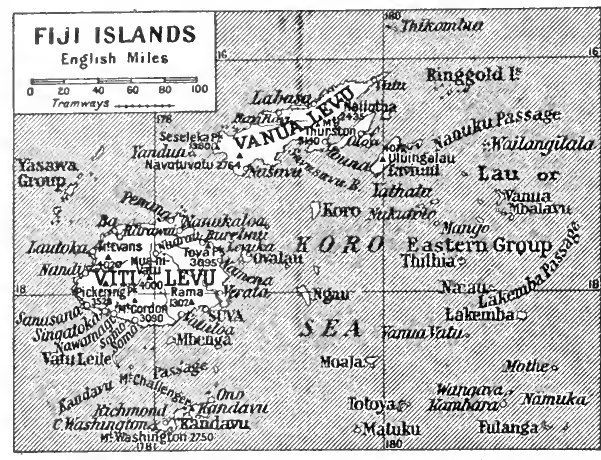

Fiji. Map of the South Pacific islands ceded to Great Britain in 1874

The Fiji Islands were ceded by the ruling chiefs to the British Empire on October 10, 1874, and are administered by a governor appointed by the crown, who is assisted by executive and legislative councils, but a fair amount of self-government is allowed. The governor is high commisioner and consul-general for the West Pacific. The islands were discovered by Tasman in 1643 and visited by Cook in 1769. Pop. 163,416 , of whom 87,761 are Frians, 61,745 Indians, 4,800 Europeans, the remainder being Chinese, Polynesians, and Rotumans.

Filangieri, GaETaNo (1752-88). Italian lawyer. The son of Caesar Filangieri, prince of Arianiello, he was born at Naples, Aug. 18, 1752 , and became a lawyer. He is chiefly known for his work, The Science of Legislation, which secured a European reputation. This is unfinished, only four out of its six books being completed; it deals with legislation, economics, and education, and shows its author as a thinker much in advance of his time. Filangieri passed much of his life in Spain, where he held appointments at court, and he was there when he died, July 21, 3788. The Science of Legislation has been translated into English by Sir R. Clayton, 1806.

Filangieri had a son, Carlo (17841867), famous as a soldier in the French service. $\mathrm{He}$ began his career under Napoleon and saw service at Ulm, Austerlitz, and elsewhere. He was afterwards in Spain, but his name is chiefly associated with Sicily. In 1848 he was sent there by Ferdinand II, king of Naples, to subdue the rebels, which he did. He remained in the island as governor until 1855. In 1859 he was made prime minister by Fran. cis II, king of Naples, but he soon resigned because his suggestions for a more liberal form of govern. ment were rejected. Made prince of Satriano, he died Oct. 9,1867

Filaria (Lat. filum, thread). Genus of Nema. tode or thread like worms, many of which are parasitic in the bodies of man and other animals. Certain of these minute worms are the cause of various diseases, most of $\mathrm{them}$ peculiar to tropical countries. Filaria bancrofti, which occurs in Southern Asia, Egypt, Australia, and Brazil, lives in its adult stage in the lymphatic glands, while its embryos, Microfilaria sanguinishominis, are found in the blood. It is conveyed by the bite of a mosquito, and is the cause of elephantiasis and haematuria. $F i$. laria medinensis is known as the guinea worm, and encysts under the skin of the back and legs, forming serious subcutaneous abscesses. The larval stage is passed in the cyclops, and the larvae probably conveyed to man by drinking impure water. See Tropical Diseases.

Filariasis. Disease caused by infection with a nematode worm belonging to the family Filariidae. Several genera and species are recognized, but by far the most important is the Filaria bancrofti. See Elephantiasis.

Filbert. Fruit of the cultivated hazel. In it the leathery husk is greatly extended so as to conceal the nut. Its proper name is Philibert nut, so called from S. Philibert, whose day is kept Aug. 22 during the height of the nutting season. See Hazel.

Fildes, Sir Luke (b. 1844 ). British artist. Born at Liverpool, he studied at Chester, Warrington, South Kensington and the Academy schools. He began his eareer with black and white work for The Graphic, contributing a sketeh of Casuals for the first number, 1869 ; this was, in 1874, the subject of a

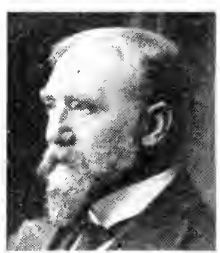
popular pic. tureat the R.A. He illustrated Dickens's Ed. win D rood. Casuals was followed by The Doctor, 1892 (Tate G a 11 e r y). which set the

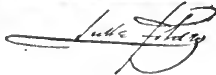
seal on his reputation as Russcll

pathetic subjects, $r_{3}$ In 1887 he turned to portraiture, and afterwards produced little else. In 1901 he painted the official portrait of King Edward VII, and in 1905 that of Queen Alexandra. He was elected A.R.A. in 1879 and R.A. in 1887. Knighted in 1906, he was created K.C.V.O. in 1918.

File. Important hand tool used largely in the metal industries. Its purpose is to smooth down, by means of sharp edges or points

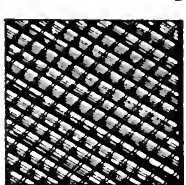
formed upon its surface, a rough or irregular surface or remove a fil $\mathrm{m}$ or excrescence of material. Files are also used to shar. pen saws. Many varieties are used : flat, taper, r o und, square, three-square or triangular, halfround, and rat-

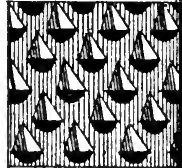

File. Top, doublecut rough file; centre, single-cut rough file; at foot, horse rasp, showing burrs made of the finest crucible cast steel; the eutting edges are formed by means of a short chisel, which is held at a particular angle on the "blank," as the uncut shape is called, and struck with a hammer. A rasp is a file in which a series of strong burrs are made by a pointed punch.

The cutting begins at the point of the file and advances by steps according to the intended fineness of the file. After the first cutting is finished, if the file is to be double cut, it is gone over again with the chisel held so as to cross the former cuts at an angle. Cutting surfaces of files are distinguished in a com. plete series as rough, middle cut, bastard, second eut, smooth and dead smooth. The sizes range from a watchmaker's tool, about three. quarters of an inch long, to files three feet in length. Most classes are provided with a "tang," a pointed end intended to be driven into a wooden handle. The best files are still cut by hand, thougl file-cutting machines are now largely in use. Files are cut while the blanks are in the soft or annealed state, and are afterwards hardened, great care being taken to avoid distortion of their shapes. Skill in filing, the ability to file a 
surface flat, is the hall-mark of a go od mechanic; but machine tools have diminished the importance of the art.

File (Lat. filum, thread). Military term for soldiers formed up behind one another. In the British army men fall in in two lines; those abreast form the ranks; each man in the front rank with the man immediately behind him forms a file. When numbered off, the front rank man numbers for his file, odd numbers being called right, even numbers left, files. When the total of the men in the squad is an odd number the last man but one in the front rank, who is known as a blank file, has no man to cover him.

Filey. Urban dist. and seaside resort of E. Riding of Yorkshire, England. It is $9 \mathrm{~m}$. S.E. of Scar-

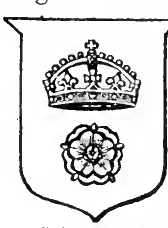

borough on the N.E.R., and is pleasantly situ. ated on the cliffs overlooking Filey Bay with a fine stretch of $\mathrm{firm}$ sand, a good promenade, and golf links. The urban

Filey arms council owns the gas and water-
works. Filey Brigg, on the N. part of the Bay, is a ridge of sandstone stretching $\frac{1}{5} \mathrm{~m}$. out to sea. $\mathrm{S}$.

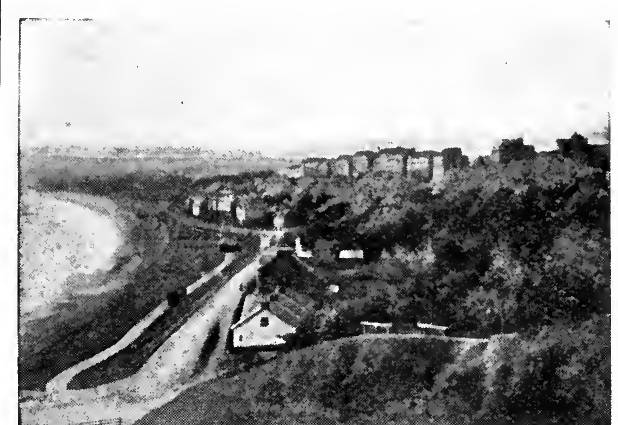

Filey. The town and sea front seen from the North Cliff Frith

Oswald's, a cruciform building, partly of Norman work, is the chief church. Until recently the bound. ary between the E. and $\mathrm{N}$. Ridings of Yorkshire separated this church from the town proper. Roman antiquities have been discovered here. ${ }^{\mathcal{D}}$ op. 3,228.

Filibuster. 'General term for a freebooter. It is now used of private individuals who wage unauthorised warfare against a foreign state. In the U.S.A. obstructive legislators are called filibusters. The word was originally applied to the buccancers or 17 th century pirates of the West Indies, and is used specifically for the adventurers who, after the Mexican war, organized expeditions in the U.S.A. to fight in Spanish-American revolutions, e.g. $\mathrm{Narciso}$ Lopez against $\mathrm{Cuba}$ (1850-51) and William Walker against Nicaragua (1855-60). Th e Spanish form of the word is filibus. tero, a corruption of Dutch vrijbuiter (vrij, free; buit, booty).

Filigree (Lat. filum, thread; granum, grain). Form of decorative work carried out with fine wire of gold, silver, or copper. It has been used for jewelry and orna. ment from prehistoric times, sometimes alone, sometimes in combination with solid metal, enamel, and precious stones. The Etruscans and later the Byzantines combined filigree work with granulation-a type of decoration c o n. sisting of small and large balls. In early work the dainty wire patterns were attached to metal plates, and when the space between was filled with enamel it was known as filigree enamel. Treatment differs a good deal. Indian work is mostly floral, very thin wire filling in the space between the outline of thicker flattened wire. Maltesefiligreeis likecobwebby lace, and soismuch of that from Portugal.

Apart from articles for personal adornment, filigree decoration was largely used in medieval times for embellishing reliquaries, and, from this, detached lacework in Gothic architecture is sometimes called filigree work.

There are two types of filigree glass: (1) interwoven or spirally twisted clouded or coloured threads embedded in the glass; (2) surface decorations or other ornaments carried out in glass threads. See illus. p. 1537.
Filing. Method by which cor $^{-}$ respondence or other records are kept in order to be available for quick and easy reference. In business circles flat filing, i.e. using a board with a metal holder attached to it, which can be opened and closed at will, took the place of a spiked wire, and in its turn gave way to the vertical filing system introduced into England between 1890 and 1900.

The primary idea of vertical filing is to bring together in one place all letters to and from a customer or client, and to arrange them in such a way as will give instant access to any particular one. Each correspondent has a separate folder, in which the letters are arranged in chronological order, and the folders are arranged in cabinets. See Card Index; Indexing.

Filipescu, Nicola (1857-1916). Rumanian statesman. After study. ing law in Paris and returning to

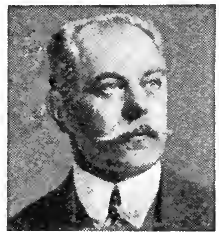

Nicola Filipescu, Rumania, he was elected a deputy, and in 1900 became $\mathrm{minister}$ of agriculture and domains. Minister of war, 1911-12, he was largely Rumanian statesman responsible for the reorganization of the army. On leaving the war office he was minister of agriculture until 1913. 
On the outbreak of the Great War he was a strong advocate of the participation of Rumania on the side of the Allies. He died on Oct. 13,1916

Filipinos. Name applied generally to the native inhabitants of the Philippine Islands (q.v.). They belong to tribes of Malayan stock. The Liga Filipina was founded about 1890 by Dr. José Rizal (q.v.) with the object of securing more freedom for the inhabitants than they then had under Spanish rule, and subsequently the term Filipino came into general use.

Filite. Italian propellant. Ballistite was adopted as the standard propellant by the Italian Government very soon after it was invented by Nobel, but whereas the original ballistite was in the form of flakes, the Italians drew it into fine threads by the addition of a solvent and named it filite. See Solenite.

Fillan (d. c. 777). Early Scottish saint. According to the Aberdeen breviary, he was the son of $\mathrm{S}$. Kentigerna, and early in life became a monk. He lived for some years in a cell near St. Andrews, where he was later elected abbot. Resigning this position, he retired to Glendochart in Perthshire, where he founded a church, which he served. He was buried at Strathfillan, Perthshire.

Filler. Word used in several senses, and specially applied to the contents of a cigar which are surrounded by the wrapper. In preparing ground for building, and in canal or rly. work, etc., a filler is the man who fills the barrows or trucks with excavated material.

Fillet (Old Fr. filet, little thread). Term in architecture, sig. nifying a narrow moulding or flat band in a moulding. It is also used to indicate the flat ridge between the flutes of a shaft. See Fluting; Moulding.

Fillmore, Millard (1800-74). President of the U.S.A. Born Feb. 7, 1800, in New York state, the son of a settler, he had a rough boyhood. Apprenticed to the cloth trade, he began to study law, and earned a livelihood by teaching at Buffalo until qualified to practise. This he did at Aurora, where he was soon the head of a prosperous firm. In 1829 he entered the legislature of New York. This led to Congress, wherein he sat as a Whig, 1833-35 and 1837-43, becoming a prominent speaker in the House of Representatives. In 1848 he was chosen vice-president, and in July, 1850, he succeeded to the presidency.

On the slavery question Fillmore was a moderate. On the one side he pressed forward in 1850 the

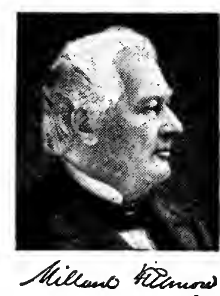

fugitive slave law and other measures of compromise ; on the other he had supported legislation for preventing the extension of slavery out. side the exist. ing slave

states. In 1850 the Whigs declined to put Fillmore forward, and when he stood for president in 1854 only one state supported him. He died at Buffalo, March 8, 1874.

Film. System of photography in which a flexible material is used in place of glass plates as the sup. port of the sensitive emulsion in the making of negatives. Its ad. vantages are reduction of weight and the facility of loading the camera and developing the negatives without a dark-room, and non-liability of the negatives to breakage when stored. Celluloid is almost exclusively used as the flexible support; paper is employed to a slight extent. The sensitive film is generally used as a long band wound on a spool or bobbin along with a longer band of black paper, the extra length of which at each end allows of the spool being inserted in one chamber of a film. camera, and then of the film being wound on to a second but empty spool after exposure.

Owing to the enveloping black paper both operations can be done in full daylight, and material for any number of photographic subjects thus carried and used without a dark-room. The modern use of films dates from 1891, when this so-called "daylight loading" was introduced commercially by the Eastman Kodak Co. for the East. man roll-film introduced in 1889 . In 1914 a new (autographic) pattern of Eastman film spool was introduced in which, by means of a special paper between the film and the black paper, the title or date of exposure may be impressed below the negative when taking the photograph.

Emulsion-coated film of stiffer substance is also used in cut pieces, and is handled very similarly to dry plates. Emulsion-coated paper for the making of negatives is also made in relatively small quantity in rut sheets. (See Photography.)

Film is also used as a general term for the cinematograph industry, in which the photographic film is a prime factor. Plays written for the film are examined in Great Britain by a board of film censors who in 1919-20 examined $6,233,155$ feet of film, embracing
2,311 subjects. A large number of persons earn a livelihood by working for the great companies that prepare films for the public, while the works of many novelists are adapted for this purpose. See Cinematography; Picture Theatre.

Filmer, SIR RoBERT (d. 1653). English political writer. Educated at Trinity College, Cambridge, he was a staunch royalist, and suffered much during the civil war. His political treatises, mostly published posthumously, are of an absolutist character, defending the patriarchal theory of the origin of government, and attacking the doctrines of Hobbes, Milton, and others. The most important is Patriarcha, published 1680 and to which Lock replied in his Treatise on Government. He died May 26, 1653.

Filmy Fern. Fern of delicate texture belonging to the genera Trichomanes, Hymenophyllum, and Todea. 'The leaves are so thin in

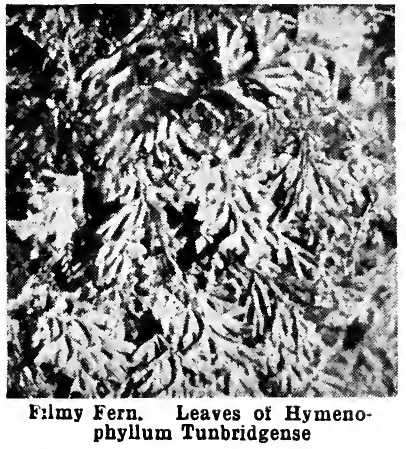

substance that they are more or less pellucid, and lose moisture so rapidly that they are found grow. ing only where the atmosphere is humid. Consequently in cultivation they require to be kept in a closed case. The Filmy ferns proper form the genus Hymenophyllum, of which $H$. tunbridgense is a well-known European form, with leaves only two or three inches long, growing in matted sheets on moist, shaded rock. The Killarney fern (Trichomanes radicans) is a much larger species, with leaves as much as a foot long.

Filon, Pierre Marie Augustin (1841-1916). French author. The second son of the historian, Charles Auguste Filon (1800-75), in 1867 he was appointed tutor to the Prince Imperial, only son of Napoleon III, and after the FrancoPrussian War he accompanied the prince to England. He died at Croydon, May 13, 1916.

Besides numerous studies of English life and literature contributed to French reviews, his 
voluminous works include Guy Patin, Sa Vie et Sa Correspondance, 1862 ; Histoire de la Littérature Anglaise, crowned by the Academy, 1883 ; Nos Grand-Pères, 1887 ; Profils Anglais, 1893 ; Mérimée et ses Amis, 1894; Le Théâtre Anglais, 1896, Eng. trans. F. Whyte, 1897 ; Prosper Mérimée, 1898 ; De Dumas à Rostand, 1898 ; and La Caricature en Angleterre, 1902.

His son, Louis Napoleon George Filon (b. 1875), a mathematician, was appointed professor of mathematics and mechanics in the university of London, 1912 . He served in the army and on the air board during the Great War.

Filter (late Lat. filtrum, felt). Mechanism designed to act as a very fine strainer and to arrest solid suspended matter, even down to germs and microbes where potable water is in question.

The filter bed ordinarily used by water companies is formed either of bricks or paving slabs laid in cement or, more generally now, of fine concrete finished with a layer of asphalt or bitumen, the aim being to secure a water-tight surface. The floor will not be laid level but will slope a little from the sides towards the middle or to one end, where the arrangements for withdrawing the water will be placed. On this floor will be laid either coarse gravel to a thickness of about 6 ins., or two layers of bricks or pipes, the lower one having the bricks spaced an inch or so apart, and the upper one having them placed close against one another. Upon the latter will be spread fine gravel to the depth of about 6 ins., and over this a mass of clean, sharp sand to a depth of from $2 \mathrm{ft}$. to $4 \mathrm{ft}$. This combination of bricks, gravel, and sand constitutes a filter bed. The term is peculiarly appropriate, as no part of this formation may be the real filtering medium, which will be formed usually by the fine deposit which the water itself gradually lays on the surface of the filter bed.

When the filter has been working for some time a film of mud, produced by the life-processes of innumerable bacteria, which destroy organic matter and are an essential feature of the filter, forms on the sand, and the filter is then in its most efficient condition. The rate of filtration should not exceed about one gallon per sq. ft. of bed per hour. In the U.S.A. the mechanical or pressure filter is much used. The water, dosed with a minute proportion of alum, which precipitates clay and organic matter almost instantaneously, is forced through large metal containers al- most filled with sand. The rate of filtration is up to 100 times higher than that of a gravity filter.

The best forms of household filter are $\mathrm{those}$ in which unglazed porcelain or biscuit china is the filtering medium. Microbes
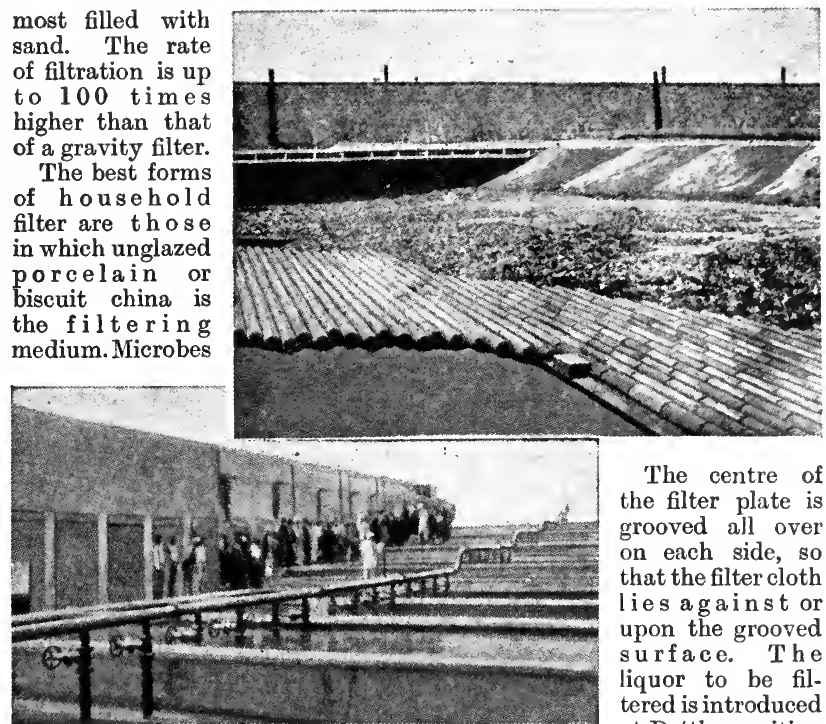

The centre of the filter plate is grooved all over on each side, so that the filter cloth lies against or upon the grooved surface. The liquor to be filtered is introduced at $\mathrm{D}$ (the position

Filter. Multiple filters and raw water reservoir at Accra, Gold Coast Colony. Above, filter bed as used in London waterworks, under construction. The three depths of loose pipes, gravel, and sand are visible

hown is conven. tional for simplici. ty of illustration) cannot pass through or into such and at once fills the whole of the material, and water itself perco. lates so slowly at low pressure that a filter of this kind should, if possible, be attached directly to a tap connected with the main.

To use a neglected filter may be more dangerous than not using one at all, as a foul filter provides an ideal breeding-place for injurious microbes. See Water Supply.

Filter Press. Appliance much used in a variety of industries, including the manufacture of chemicals, dyes, sugar, paints and colours, pottery, yeast, starch, and many pharmaceutical preparations. To some limited extent it is also used in the treatment of sewage.

Its construction and operation are best explained by the aid of a diagram as appended. $\mathbf{A}, \mathbf{A}^{\prime}$ are two frames, of cast iron usually, though sometimes they are made of wood and occasionally of special metals-lead, brass, and even gold. These are filter plates. $B$ is a frame corresponding generally to $\mathbf{A}, \mathbf{A}^{\prime}$, and prepared so that it may malke perfectly water-tight joints with them at $a, a, a, a$, but with the centre hollow. This is the "cake" plate. A series of these plates, alternating as shown, are placed in a frame which is provided with gear by which all the plates may be pressed tightly up against one another, a "press" being thus constituted. Over each of the filter plates is placed a filter cloth, C, C', or double cloths may be used, one being fine and the other coarse. hollow space of the oake plate; the liquid passes through the filter cloth into the grooves on the surface of the filter plate and is led by those grooves into the vent $\mathrm{E}$ (conven-

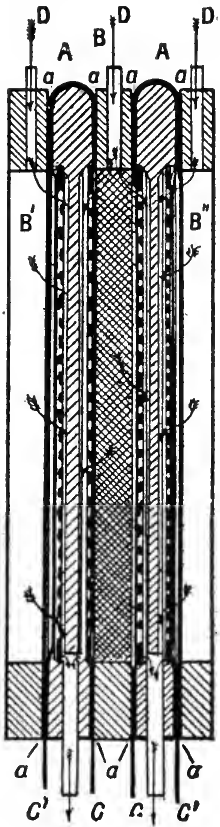

E

E.

Filter Press For explanation see tex tional position) a $t$ the bottom of the plate, whence it escapes. As the process goes on the hollow space of the cake plate gradually fills with solid ma. terial filtered out of the liquid which has passed through the cloth, until in time this space is closed with a f i r m, com. pacted mass through which it is difficult or impossible to force any more liquid. $\mathrm{The}$ press is then o pened, the plates drawn apart, the "oake" removed, the filter cloths cleaned or replace 
by others, and the press closed up again for a further operation. Not all substances, however, will form a firm cake in the press, and sometimes the solid material must be removed in the form of sludgc. A remarkable degree of purity may be obtained in the effluent by the use of this apparatus. In older types of filter press the separate cake plate was not used, and the space for the cake was provided by recessing the centre of the filter plate on each side. There were thus fewer joints, but the more modern arrangement has decided advantages, though it is rather more costly to construct.

It should be noted that sometimes it is the filtered liquor which is the chief object of the process, but in others it is the "cake." Thus in sugar manufacture and refining it is the liquor; in the manufacture of yeast and paints and colours it is the cake.

Filter Pump. Term given to the pump used to operate a filter press. The pump is of any good ordinary design, but must be constructed to work against a high pressure, as the filter press cakes formed in the appliance, when they become compacted, offer great resistance to the passage of a liquid through them. This resistance may represent as much as $100 \mathrm{lb}$. to the square inch or more.

Fin (Lat. penna, wing, fin). Expansion of the skin or body wall in aquatic animals, by means of which they swim. In the fishes they are of two distinct kinds, paired and unpaired. The former correspond to the limbs in the higher animals, and are connected with bones; the latter, which consist usually of dorsal, anal, and caudal fins, are simply folds of skin more or less supported by fin-rays.

Fin. In aeronautics, any fixed subsidiary plane or surface set vertically to the rear part of the fuselage of an aircraft. The fin is generally mounted in front of the rudder, and its purpose is to increase the stability of the machine. A cooling rib of metal formed on the cylinder of an engine is also termed a fin. Its purpose is to facilitate the radiation of heat from the engine and prevent overheating. A fin post is the strut or post to which the stabilising fin of an aeroplane is fixed. See Aeroplane.

Finale (Ital., end). Closing movement of a composition of extended character, such as a sonata, symphony, or concerto ; or the last portion of one of the acts of an opera, in which as a rule a large force of the performers assembles on the stage. The operatic finale often consists of sevcral distinct movements, but all leading up to the final ensemble. As the coda is the concluding section of a single movement, so the finale winds up a complete work consisting of several movements. During the past two centuries the coda and finale, from being mere perfunctory endings of little significance, have become an important summing up and climax.

Finance (late Lat. finare, to pay a fine). Word used for money matters in general, but especially for those of a country, town, or other corporate body. A financier is one who is concerned with money matters, but refers rather to bankers and business men than to the civil servants who manage a country's finances. The finances of each country are part of its system of government and are dealt with as such. See Consols ; National Debt; National Finance.

Finance Act. Name given to the annual Act of Parliament that legalises the proposals contained in the Budget. The taxes made for the coming year were embodied in a Customs and Inland Revenue Bill until 1894, in which year the scope of the bill was enlarged and its title changed to Finance Bill. In 1899 provisions relating to the National Debt were included therein. See Budget.

Financial News, THE. London daily newspaper. Started by H. H. Marks, Jan. 23, 1884, as The Financial and Mining News, it was at first issued only on five days of the week. It initiated the publication in London of daily cables from the New York stock market.

Financial Times, THE. London daily newspaper. It was founded in 1888 by G. D. Macrae and F. M. Bridgewater. From the same office are issued an Investor's Guide, Oil Handbook, and Mining Handbook.

Financier and Bullionist, ТнE. London daily newspaper. It was incorporated with The Financial Times in 1924. Its then title dated from 1900, when The Financier, begun in 1870, was amalgamated with The Daily Bullionist, a paper begun in 1866 as The Bullionist and renamed The Daily Bullionist in 1899

Finch (Lat. Fringilla). Name applied to a large family of small birds, distributed over most of the temperate zone, except Australasia. They are characterised by hard conical beaks with smooth edges, and have nine primary wing feathers and twelve feathers in the tail. The nostrils are close together, and there are a few short bristles around the mouth. In all the species the sexes are differently coloured or marked. Finches are in the main seed-eaters; they are apt to be found in small companies, and they frequent both woods and open country. Among the commoner finches in Great Britain are hawfinch, greenfinch, chaffinch, bram. bling, goldfinch, siskin, linnet, and house sparrow. See illus. p. 1334.

Finchley. Residential district and parish of Greater London. Lying E. of Hendon, N. of Golder's Green, Hampstead and Highgate, and S. of Whetstone and Barnet, it is approached from St. John's Wood by the Finchley Road, from Highgate by the Great North Road,

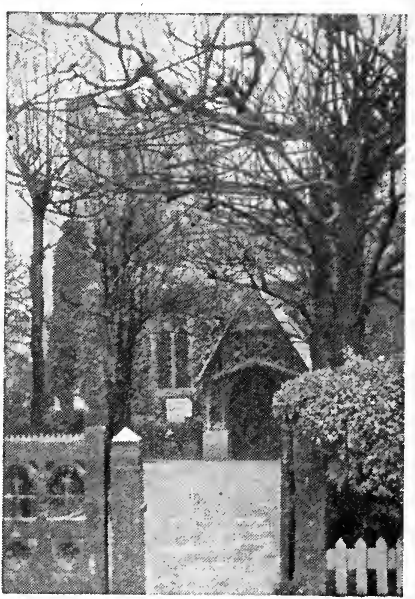

Finchley. The parish church of $\mathbf{S}$. Mary, restored in 1872

has stations on the G.N.R., and electric tram and motor-'bus services. It comprises $\mathbf{N}$. Finchley, E. Finchley, and Church End. Near the Perpendicular parish church of S. Mary, restored in 1872, is Christ College, founded 1857. About 90 acres of what was Finchley Com. mon, once a resort of highwaymen, and the scene of several military encampments, are occupied by the Islington and St. Pancras cemeteries; Marylebone cemetery is between East Finchley and Church End. General Monk mustered his forces here in 1660, and the Guards were assembled here in 1745 , an event commemorated in Hogarth's picture, The March to Finchley. An urban district, Finchley gives its name to a co. div. returning one member to Parliament. Pop. 39,419 .

Finck, Herman (b. 1872). British conductor and composer. Born in London, Nov. 4, 1872, he studied at the Guildhall School of Music. In 1900 he was appointed musical director of the Palace Theatre. He has written more than 50 light operas and some hundreds of songs. 


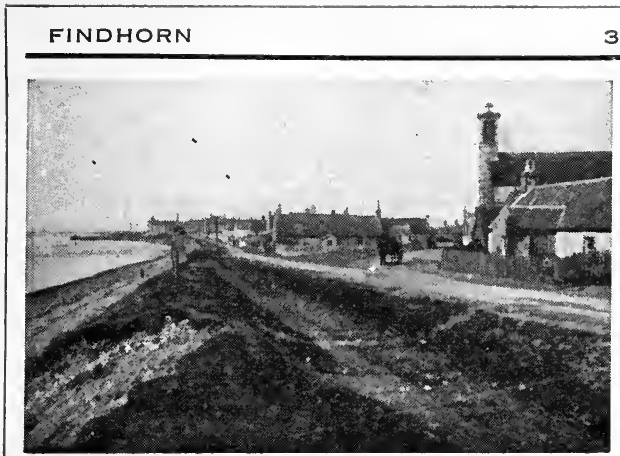

Findhorn, Elgin. The fishing village, looking along the sea front towards the west

Valentine

Findhorn. River of the counties of Elgin, Nairn, and Inverness, Scotland. It issues from the Monadhliath Mts., and flows N.E. for $62 \mathrm{~m}$. to Moray Firth, which it enters $2 \mathrm{~m}$. N. of Forres through Findhorn Bay. Findhorn, a fishing village and watering-place, is on the E. shore of the bay.

Findlater, JANE HeLEN. British novelist. Born at Edinburgh, she published her first novel, The Green

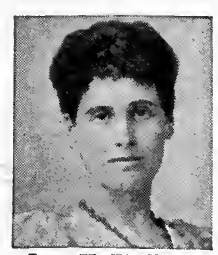

Graves of Balgowrie, in 1896. It was followed by A Daughter of Strife, 1897 ; Rachel, 1899 ; The Story of a Mother, 1902 ; Stones from a Glass House, Jane H. Findlater, 1904; and The British novelist Ladder to the Ellioll \& Fry Stars, 1904. She also wrote several stories in collaboration with her sister, Mary Findlater (q.v.), including Tales That Are Told, 1901 ; Crossriggs, 1908; Penny Moneypenny, 1911; Seven Scots Stories, 1913 ; Content With Flies, 1916; and Seen and Heard, 1916.

Findlater, MARY (b. 1865). British novelist. She was born at Lochearnhead, Perthshire, and educated at home. Besides the stories written with her sister, Jane $\mathrm{Helen}$ Find later, her worksof fiction included Over the Hills, 1897; Betty M u s g r a $\mathrm{re}$ 1899; A Nar- After Lady Jane Lindsay row Way, 1901; The Rose of Joy, 1903; A Blind Bird's Nest, 1903; and Tents of a Night, $19 \mathrm{I} 6$.

Findlay. City of Ohio, U.S.A., the co. seat of Hancock co. On the Blanchard river, $44 \mathrm{~m}$. by rly. S.S.W. of Toledo, it is served by the Ohio Central and other rlys. Its buildings include Findlay College, a public library, and several benevolent institutions, and there is a good park system. Findlay is situated in an agricul. tural, oil, and natural gas region, and has foundries, machinery works, oil refineries, lime kilns, and motorcar, carriage, boot and shoe, and glove factories. Settled in 1813, it was incorporated in 1837, and chartered as a city in 1890. Pop. 14,858 .

Findlay, Georat Grlanders (1849-1919). British scholar. Born Jan. 3, 1849, he was educated at Wesley College, Sheffield, Richmond theological college, and London University. Entering the Wesleyan ministry in 1870, he was assistant tutor at Headingley College, 1870-74, classical tutor at Richmond College, 1874-81, and tutor in exegesis and classics at Headingley, 1881-1917. His writ. ings include commentaries in the Expositor's Bible on S. Paul's Epistles, contributions to the Ex. positor's Greek Testament, and the Cambridge Greek Testament and the Bible for Schools. $\mathrm{He}$ died Nov. 2, 1919.

Findon. Village of Kincardineshire, Scotland. It is on the coast, $6 \mathrm{~m}$. S. of Aberdeen. Fishing is carried on, and the village gives its name to the Findon or Finnon had. docks, which were first cured here.

Fine (Lat. finis, the end). Term common in English law. Originally a sum of money imposed upon someone by way of compounding i.e. paying to make an end of the matter instead of going to prison or paying in several instalments. By feudal law a leaseholder often pays a fine for the renewal of his lease, and copyholders on change of ownership. But the word is best known in its connexion with criminal offences, being a sum of money imposed by way of penalty for a crime or breach of some law or regulation. As a rule, the amount of fine to be imposed is in the discretion of the judge, 'subject to the rule of Magna Carta that the fines must not be excessive, a maximum in most cases being fixed by statute.

Fine Arts. Term comprehensively embracing all the five greater arts which minister to the love of the beautiful, the intellectual, and the tasteful, viz.: music, poetry, painting, sculpture, and architecture. Custom, however, has confined the term to the last three par. ticularly, and these again include allied subjects, such as engraving, decoration and design. The French term Beaux Arts has a similar sig. nificance.

Sculpture.

Finedon. Urban dist. and village of Northamptonshire, England. It is $3 \mathrm{~m}$. N.E. of Wellingborough, on the Mid. Rly. Boot and shoe making is engaged in, and there are iron-ore mines close by. Pop. 3,782.

Fines and Recoveries. Legal fiction introduced in England to override an Act of Parliament which was against the public interest. By the statute De Donis Conditionalibus (on conditional gifts) in 1285 , it was enacted, in effect, that land which was entailed could never be disentailed; so that if an estate were given or left to $\mathrm{A}$ in tail, it must always keep in A's fam. ily and could never be sold. By this, among other things, the creditors of $\mathrm{A}$, or his heir in tail, could never touch the land for their debts. The judges were strongly opposed to the policy of the barons who had passed this Act, because they thought it against the public interest that land should be made inalienable.

Therefore, from about 1400 they connived at fines and recoveries, which were fictitious actions worked thus. A is the holder in tail of Whitacre. He wishes to disentail, so that he can sell or mortgage, or divide his land amongst his family. An action is brought by $\mathrm{X}$, claiming the land from $\mathrm{A}, \mathrm{X}$ alleging that the land was his in fee simple (q.v.). A, on getting into court, says that theland was granted to him by $Q$, who was, in fact, the usher of the court; $Q$ was then called upon to come into court and defend his title. Of course $Q$ put in no appearance. Judgement was thus given in favour of $\mathrm{X}$; and $\mathrm{X}$, having recovered the land as a fee simple, promptly re-conveyed it to $A$ as a fee simple, free from the entail. By an Act of 1833 fines and recoveries were abolished. See Fiction, Legal.

Fingall, EARL of. Irish title borne since 1628 by the family of Plunkett. In 1403 Sir Christopher Plunkett, a member of this old family, became by marriage the holder of the barony of Killeen in Meath. This made him an Irish peer, and his descendants sat in the Irish House of Lords until the union of 1800. Lucas, the 10th lord, was made earl of Fingall in 1628, and both he and his son were supporters of Charles I. Peter, the 4th earl, was outlawed after 1689 for adhering to the Stuart cause, 
and after his tine the title passed to another descendant of the 1st earl. Arthur James, the 8th earl. was made a peer of the United Kingdom in 1831, and in 1881 an other Arthur James became the 11 th earl. The earl's seat is Killeen Castle, co. Meath, and his eldest son is known as Lord Killeen.

Fingal's Cave. Cavern in the island of Staffa, the most notable of its kind. Hollowed out of the basalt, the grotto is $228 \mathrm{ft}$. long, 48 $\mathrm{ft}$. wide, and $60 \mathrm{ft}$. high. It is remarkable for its regular basaltic columns, for its wonderful and varying colours revealed as the light plays upon it, and for its stalactites. On the S. of the island, it was discovered by Sir Joseph Banks in 1772. Sea birds live in the cave, which is also noted for the sound made at times by the wind rushing out of it. In Gaelic speech it is called the cave of music.

Finger. Terminal member of the hand. The bones or phalanges of the fingers are three in number in each finger, except the thumb, which has only two. The fingers articulate with the metacarpal bones of the palm. Along the backs of the fingers pass the tendons of the extensor muscles, which straighten the fingers, and along the fronts the tendons of the flexor muscles, which close the hand. The blood supply of each finger is derived from two digital

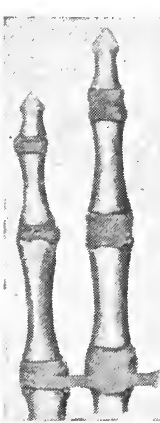
arteries which run along each side of the finger a $\mathrm{nd}$ unite at its ex. tremity. The nerves which supply the skin of the fingers are derived from the ulnar, radial, and median nerves.

Supernumerary fingers are not un. common. In a case on record there were twelve fingers on one hand and

Finger. Bones of thirteen on the buman finger

other, and twelve toes on each foot. Absence of one or more fingers, or part of a finger, may also be a congenital deformity, i.e. present at birth. In webbing of the fingers, or syndactylism, a thin web, usually consisting chiefly of skin, unites one or more fingers. Sometimes the bond of union is thick and fleshy. See Anatomy.

Finger and Toe. Disease causing malformation of the roots of turnips and other cruciferous crops (cabbage, rape, radishes, etc.). It is also known by the names of clis broot and anbury. In a typical speci. men the main root will not be fully

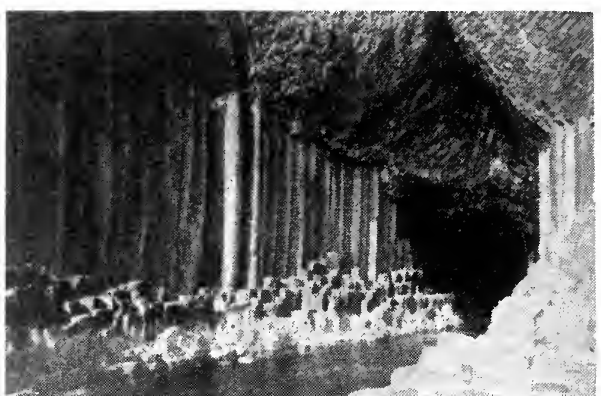

Fingal's Cave, Stafia. The pillared entrance to the grotto

developed, but the lateral roots will be much swollen. The cause of the disease is a microscopic fungus (Plasmodiophora brassicae), one of a group of organisms (Mycetozoa) regarded by many authorities as animals. The disease is highly infectious and difficult to stamp out. It is scarcely known on soils rich in lime, and the best plan of dealing with it is by application of a dressing -2 to 4 tons per acre-of slaked lime, preferably 18 months before the turnip or other crop is to be sown. The remains of diseased plants should be burnt. Judicious rotation is of much importance, and continuous cropping, especially in kitchen gardens, must be avoided.

Fingerboard. Portion of a stringed instrument against which the fingers press the strings in order to regulate the vibrating lengtils of the strings, and so control the pitch of the sounds. Bowed instruments of the violin family have smooth fingerboards on which the player must judge and remember the correct stopping-places; the plucked instruments such as the guitar, mandoline, and banjo usually have frets or cross ridges to assist the player.

Finger Print. Impression of the human finger. It is used to classify human beings; but chiefly for the identification of persons who have passed through the hands of the police.

The individuality of finger prints and their value in proving identity were known to the Chinese about 200 B.C., and an impression of the thumb was used in lieu of signa. ture; but it was not till the 19th century that the classification of the ridges on the finger tips was attempted. In 1823, Purkenje, professor of physiology at Breslau,

.

Herschel's, and Galton's work was only recognized when Sir Edward

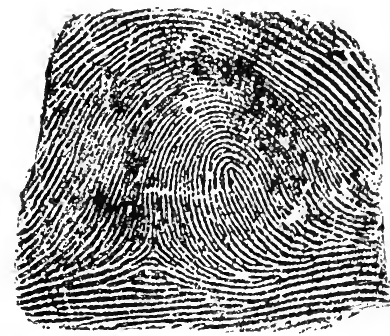
of classification, and in $1858 \mathrm{Sir}$ William Herschel laid the founda. tions of the present system in Bengal. In 1890 Sir Francis Galton pointed out that ridges on the fingers of a new. born infant were absolutely identical to the day of death.

'The full value of Purkenje's

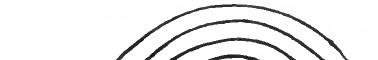


prints of every sailor in the American merchant marine were taken for classification of able seamen etc., and the prevention of fraud, while in the war department finger print records were kept of every soldier. It has been shown that the chance of identity of two finger prints is less than one in sixty-four thousand millions, and the prints of one finger, therefore, are enough to decide the question of identity. If, as is customary, the prints of three or more fingers are taken the possibilities of error are entirely eliminated.

All finger print impressions are divided into two groups of four types and eight distinct patterns, such as loops, arches, etc. The ten fingers in the Henry system are divided into five pairs, and by a special way of numbering these pairs the classification of a particular finger print is made simple. See Scotland Yard.

Bibliography. Classification and Uses of Finger Prints, Sir E. R. Henry ; Asquith Committee Report on Means of Identification of Habitual Criminals, 1894; Origin of Finger Printing, Sir W. J. Her. schel, 1916.

Fingo or AMafengu (Zulu, wanderers). Collective name for Bantu-speaking peoples of Kaffir stock whose tribal unity was destroyed by the Zulus under Chaka. In 1835 the Cape government gave them asylum near the Great Fish river; this Fingoland reserve became, in 1877, one of the Transkei districts. Always friendly to the

shop of the Pollaiuoli. He is stated by Vasari to have invented engrav. ing on metal, but he was only one of the pioneers in this craft, which he practised together with niello work, of which he was a master. Intarsias by him are to be seen in the sacristy and the cathedral museum, Florence; his prints and drawings are in the Uffizi gallery and the British Museum. There has been much controversy as to his alleged invention of engraving.

Fining (Lat. finis, end). Process by which liquids are freed of solid matter and impurities, and thus clarified. Though somewhat akin to filtering, it is used in a special sense in the brewing and distilling industries, various substances such as isinglass, sulphate of lime, etc., being employed to collect and carry off the matter in solution, leaving the liquid bright and clear. In fining syrups white of egg may be used, the albumen being dissolved by heat. Wines are similarly fined without the application of heat, the alcohol acting as the solvent. (See Brewing ; Distilling.) Fining is also a process in glass-making, and was used in the production of malleable iron before the introduction of puddling.

\section{FINLAND: THE LAND AND ITS PEOPLE}

R. N. Rudmose Brown, M.A., Professor of Geography, Sheffield

This article describes the country of the Finns and deals also with its language, literature, history, etc. See also Finns; Russia; Sweden; and articles on Abo; Helsingfors, and other places in the land British, they have become largely Europeanised and Christianised, with a high educational standard. They furnish labour contingents for the harbours and mines.

Finial (Iat. finis, end). In architecture, a foliated ornament capping a pinnacle, gable, or stairpost. Occasionally the finials of

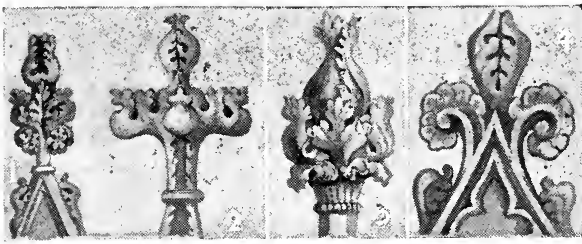

Finial. 1 and 2. From Canterbury Cathedral. 3. Norwich Cathedral. 4. Lady Chapel, Winchester Cathedral
This republic of N. Europe lies between Russia on the E., Sweden and the Gulf of Bothnia on the W., Norway on the N., and the Gulf of Finland on the S. The country has an area of 144,253 sq. m. Helsingfors is the capital.

Its coast-line, which is entirely on the Baltic, is $1,000 \mathrm{~m}$. long, low-lying, highly ind ented, and fringed with islands of which the Aaland Islands in the S.W. are the most import. ant. The country consists of a great plateau, at an elevation of 300 to $500 \mathrm{ft}$., with lowlands round the stair-posts themselves acted as supports for statuary, as those at Cromwell House, Highgate, where they are surmounted by Roundhead figures.

Finiguerra, Maso (c. 1426-64). Italian goldsmith and engraver. Born probably at Florence, details of his life are uncertain. He was trained as a goldsmith in the work.
Finistère. Dept. of France. In the extreme N.W. of the country and part of Brittany, it is bordered by the sea on three sides. The Aulne is the most important river. The coast is rocky and broken, but contains some good harbours. Off it are Ushant and other islands. It is a hilly, though not mountainous, region, and much of the land is covered by forest and heath, useless for growing crops. Elsewhere, however, especially in the south, there is fertile land which produces asparagus, onions, and other vege tables, as well as apples and fruit. Oats and wheat are grown; cattle and horses are reared, while the peasants also keep bees and make butter. Many of the inhabitants are employed in the fisheries. The dept. has five arrondissements. Quimper is the chief town, but Brest is the most important. Morlaix is also a flourishing port. Area, 2,713 sq. m. 809,711 .

Finisterre. Cape on the N.W. extremity of Spain, in the prov. of Corunna. Off the cape two naval actions were fought in 1747 bethe British and French, reAdmiral Anson commanded the British forces on May 3, and Admiral Hawke on Oct. 14.

ern part of the country is linown as Lapland and is inhabited by the nomad race of Lapps.

Of Finnish lakes the largest are Saima, 502 sq. m. ; Inari, 534 sq. m. ; Paijane, 429 ; and Uleatrask, 387 . Half of Lake Ladoga $(7,000$ sq. m. $)$ is Finnish and half Russian.Thereare numerous short rivers which are broken by rapids, and are navigable only in stretches,

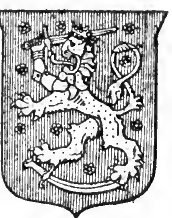

Finland arms but are useful for floating timber. Finland has a short, hot summer and a long, cold winter. Rainfall is not heavy, and there is comparatively little snow, but it lies on the ground from Oct. to March. Rivens and lakes are frozen from Dec. to May. A bo, Hango, and Helsingfors are the only ports open in winter. Coniferous forests cover 60 p.c. of the country. Wild animals include reindeer, bear, wolf, and lynx. Mosquitoes are a plague. The population numbers $3,329,401$, and is found mainly in the S. and along the W. coast. In the days of 


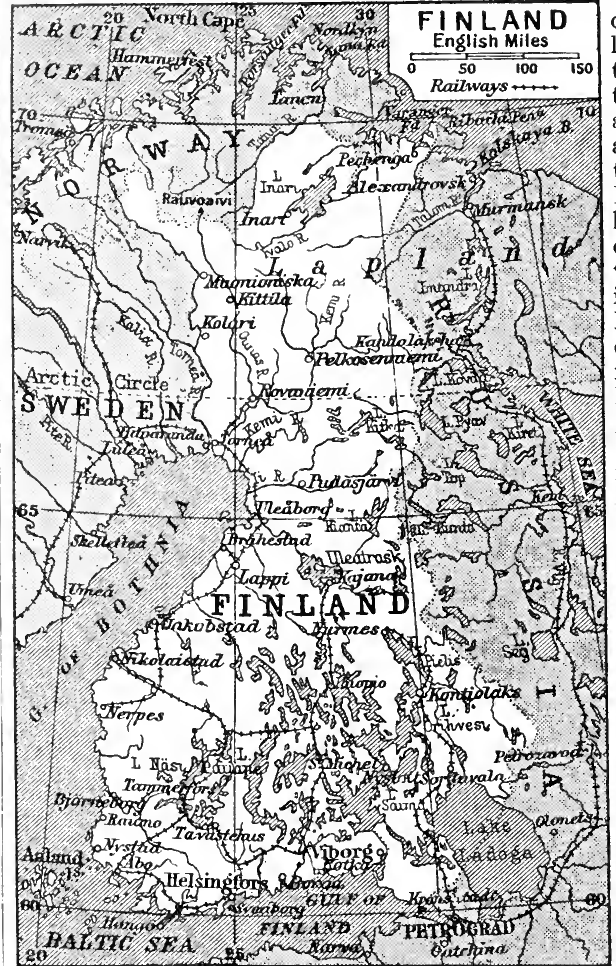

Finland. Map ot the North suropean repuolic, tormerly part of the Russian Empire

Russia's rule there was much emigration to America. Finns, either Tavastlanders or Karelians, form 90 p.c., and Swedes about 9.5 p.c. of the population. There are a few thousand Lapps in the North.

The language is Finnish, but Swedish is understood in the larger towns and is the language of the Aaland Islands. Swedish was for long the official as well as the literary language. Finnish literature may be said to have begun in 1835 , when Elias Lönnrot collected and published in Finnish the traditions and folklore of Finland as expressed in its national songs. This epic of Finland, the Kalevala, was later revised and extended, and in 1888 translated into English. The Finnish Literary Society has done much to revive Finnish as a literary language, although many Finnish books are mere translations from Swedish and other tongues.

Writers and Explorers

Amóng Finnish writers may be mentioned A. Stenvall, dramatist and poet; M. Canth, dramatist ; P. Päivärinta, noted for the work entitled His Life; and J. Aho. Finnish novels and playsare frequently grim and realistic, but often show much simplicity and tenderness of thought.- They largely reflect the hardships of the Finnish peasant's life. Literary and scientific societies are active in Finland, particularly in the study of the home country. Several Finns, including A. E. Nordenskjöld, the discoverer of the north-east passage, have been distinguished in Arctic exploration. Finnish painters include E. Järnefelt and A. Gallen.

History. The Finns reached Fin. land from their Asiatic home in the 7 th and 8 th cen. turies. In the 12th century $\mathrm{S} w$ eden began to get a hold on the country, and establis hed Christianity. Gradually Swedish influence spread round the coasts, and by the $16 \mathrm{th}$ century Finland was raised to a grand duchy which had a large mea. sure of self-government, but was an integral part of the Scandinavian kingdom. Early in the 18th century Russia began to pay attention to Finland, and by the treaty of $\mathrm{Ny}$ stad (1721) secured the province of Viborg. Sweden unsuccessfully tried to recover the lost province in 1741, and the Russian sphere was extended.

In 1809 , after years of fighting, Sweden finally withdrew from Finland, the whole of which, with the Aaland Islands, passed to the grand duchy under the tsar Alexander I, who guaranteed the Finn constitution and became grand duke. For many years the relations between Russia and Finland were cordial and Finland prospered. Successive tsars respected the Finnish constitution and the right of Finland to settle her own affairs. Gradually, how. ever, a Finnish national party arose whose first object was to put Finnish on the same standing as Swedish as the official language of the country. They succeeded in doing this in 1863, in face of the opposition of the Swedish element.

Meanwhile the reactionary party in Russia tried to exert its influence against the Finnish national party, and for the next 50 years succeeded in oppressing Finland. By the "February manifesto" of 1899, the tsar claimed the right to interfere in Finnish affairs, to overrule the diet, and to merge the Finnish in the Russian army. The Finns met these measures with opposition, but were overawed. The as. sassination of the Russian governor in 1904 and a general strike in Finland led to a temporary respite, and in the following year the constitution was restored. By 1908 the curtailment of Finnish rights began again, the aggressor being the Duma in place of the tsar.

\section{The Great War}

At the outbreak of the Great War coercive measures increased, with the result that the Finns, distrustful of Russia's allies, sympathised with the Germans. The Russian revolution of March, 1917, restored freedom to Finland, which declared itself a republic within Russia. After the Bolshevist revolution, Nov., 1917, Finland declared her independence and civil war spread to the country. The White, or constitutional, party, failing to get help in arms and food from Britain and Sweden, turned to Germany for help against the Reds and Bolshevists. A German force landed and subdued the Red forces. The Germans, after making a treaty with Finland, almost wholly to their advantage, tried to foist a German prince on the Fin. nish throne, but their collapse in Nov., 1918, put an end to the scheme. In Oct., 1920, a state of war continued between Finland and Soviet Russia, without actual hostilities. Finland demanded from the former the port of Petschenga, the province of Karelia, and certain islands in the gulf of Finland.

Finland then became an indepen. dent republic recognized by all the powers. Government is by two houses, senate and diet. The diet is elected by all men and women over 24. Women are eligible. After the declaration of independence'a conscript army was raised. There is no navy. Education is good except in remote parts where the population is too scattered for the children to attend school. About a third of the population is said to be unable to writc. There are several high schools, technical schools, and agricultural colleges. The University of Helsingfors has about 3,500 students, among whom are a large proportion of women.

About 90 p.c. of the population belong to the Lutheran Church. There are a few adherents of the Greek Church, and a small number of Roman Catholics. There is an archbishop of Abo, and bishops of Borga, Nyslott, and Kuopio. 


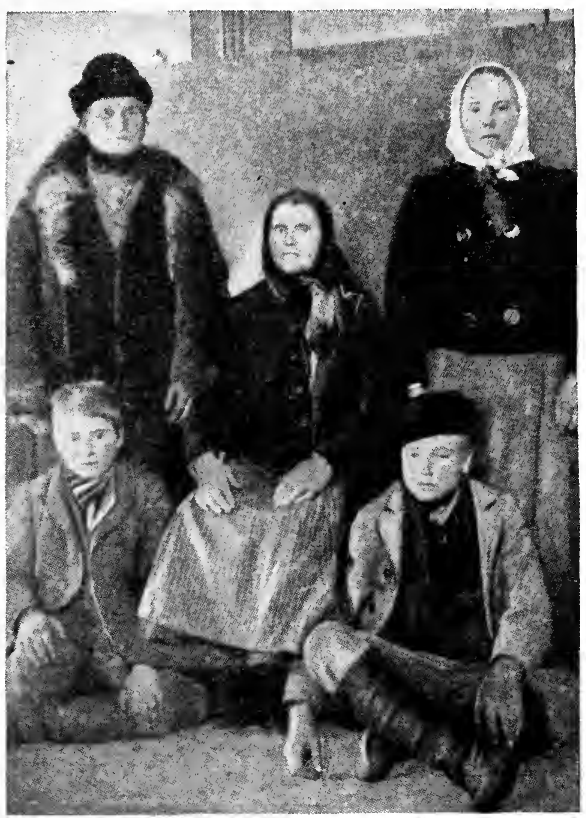

Finland. A typical Finnish family cereals and other foods, cotton, mach inery, and coal. Much inland traffic is by water, but roads, in the S., are numerous and well made. The southern half of the country is well served by rlys., which are linked with those of Russia and meet those of Sweden. 'The gauge is chiefly $5 \mathrm{ft}$; mileage in $19 \mathrm{I} 4$ was $2,500 \mathrm{~m}$. Most rlys. are state-owned. A rly. through Lap. land to the Arctic Ocean is being built. The telegraph and telephone systems are well developed.

Bibliography. Through Finland in Carts, A. Tweedie, new ed. 1900 Finland as it is, $\mathbf{H}$. de Windt, 1901

late the Church has lost influence with the advance of socialism, now to be reckoned as one of the great. est forces in the country, with a majority in the diet.

Finnish peasants live simply, and their food is poor, but, except in the N. and E., there is little real poverty. 'The bath house attached to every farm is characteristic of the country. The Swedish element of the population is found in the towns, where until recently they formed the weaithy commercial classes. The Finns now are well represented among the more prosperous classes in the towns. Local veto and strict regulations on the sale of alcohol have made the Finns a sober nation. The organization of public wealth and preventive measures, particularly against cholera, are well developed.

INDUSTRIEs. Oats, barley, and rye are the chief crops, and potatoes are important. A little flax is grown. Numbers of cattle are kept for dairy purposes. Minerals are few and of small importance. Manufactures are well developed, mainly by help of water power. They include engineering, machine and shipbuilding, pulp and papermaking, cotton goods and tanning. Saw-mills number about 1,000 . The chief ports are Helsingfors, Hango, Abo, Kotka, Viborg, and Uleaborg. The main exports are timber, butter, paper, pulp, and textiles, and the imports include

A Summer Tour in Finland, P. Waineman, 1908; Through Finland to St. Petersburg, A. M. Scott, 1908 ; Finland To-day, G. Renwick, 1911; Finland: the Land of a Thousand Lakes, $\mathbf{E}$. Young, 1912 ; Finland and the Finns, A. R. Reade, 1915; Peace Handbooks: No. 47, Finland; No. 48 , Aaland Islands, 1918; The Red Insurrection in Finland, 1918, H. Söderhjelm, Eng. trans. A.I. Fansholl, 1919.

Finland, Gulf or. Eastern arm of the Baltic Sea, between Finland and Esthonia. It is studded with islands. Several important towns are on the coast-Petrograd, Helsingfors, Viborg, and Reval. Its length is $250 \mathrm{~m}$. and its average breadth $60 \mathrm{~m}$.

Finlay, Robert Bannatyne FinLAY, IST VISCOUNT (b. 1842). British lawyer and politician. Born July 1$]$, 1842, he was educated at E d in bu r g h academy and university. $\mathrm{He}$ qualified as a doctor, but became a barrister in 1867 . Success quickly came to him, and, assured of a good prac.

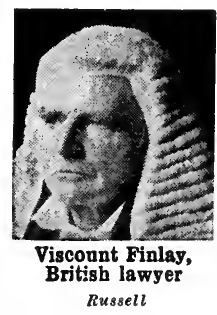

tice, he sat in Parliament as Liberal M.P. for Inverness Burghs from 1885-92, and from 18951906. From 1910-16 he represented the universities of Edin. burgh and St. Andrews, having been since 1886 a strong Unionist. From 1895-1900 Finlay served as solicitor-general, and from 1900-6 as attorney-general. $\mathrm{He}$ became lord chancellor in the Government formed by Lloyd George in Dec., 1916, retiring in Dec., 1918. On his appointment he was made a baron, and a viscount in 1919. He was ap. pointed British member of the permanent court of arbitration at the Hague, in 1920, and was lord rector of Edinburgh University, 1902-3.

Finlay, GEORGE (1799-1875). British historian. Born at Favers. ham, Dec. 2l, 1799, he was educated at the universities of Glasgow and Göttingen. $\mathrm{He}$ espoused the cause of Greek independence, saw much of Byron at Missolonghi, and finally made Greece his home, never visiting England after 1854 His great work, A History of Greece from the Conquest by the Romans to the Present Time, was published complete in 1877, its main parts having previously appeared in 1844,1856 , and 1861 . Among the other writings of Finlay, who had a clear if not pictur. esque style, were articles in Black. wood's Magazine, The Athenaeum and The Times, and studies of classical geography, published in German, 1844. He died at Athens, Jan. 26, 1875.

Finmark. Maritime fylker or county of N. Norway. It is bounded N. by the Arctic Ocean and S. by Lapland, and is the northern. most portion of the European land mass, culminating in the North Cape. Area, 18,535 sq. m. Its rugged coast is indented by bays and fiords fringed by numerous islands. The surface is elevated, rising to over $3,000 \mathrm{ft}$. in parts. Fishing and reindeer-breeding are the chief occupations. Hammerfest (q.v.) is the chief town. Pop. 44,777, mostly dwelling on or near the coast. Nomad Lapps occupy the interior.

Finn, Fionn, Find, or Fingal. Warrior hero of Celtic tradition. 'The legends which gather round his name have almost certainly a real historical figure behind them. Finn was the son of Cumhal (pron. cool) of Leinster and Morna of the White Hand, and was born after his father's death in battle at Cnucha; first called Demne, he came to be called Finn, the Fair One, from his appearance. He took over the leadership of the warrior band known as the Fians or Fianna from his life-long enemy Goll MacMurna. His sons Oisin and Feargus, his grandson Oscar, his herald Ullin, his fav. ourite hound Bran, were famous figures in his story. One of the chief episodes in his career was the 
pursuit of Diarmid, who eloped with Grania, Finn's betrothed.

In Scottish legends Finn is known as Fingal, and was king of Morven, in Argyll. He was slain in the great defeat of the Fians at Gabra, probably in 283. His memory has never faded among the Gaelic peoples of Ireland and Scotland. See Gaelic Language and Literature; consult also Finn and His Companions, S. J. O'Grady, 1892; Gods and Fighting Men, Lady Gregory, 1910.

Finnesburg, The Fiant at. Fragment of heroic Anglo-Saxon poetry, discovered in the binding of a MS. in Lambeth Palace library in the 16th century. It de. scribes incidents of the battle between the Frisian chieftain Finn and the Danes.

Finns. Name denoting in general a people inhabiting central and northern Russia before the Slavonic dispersion. At first a medium-headed race of hunters and fishers, akin to the tall, blond, blue-eyed Nordic type, they min. gled in the course of centuries with Alpine rather than Mongolian elements, and are now classifiable mainly by their dialects. These form, with the Ugrian, a branch of the Ural-Altaic family, out of which Aryan probably emerged. Numbering about $6,000,000$, they are grouped as Volga, Permian (Votyak), and Baltic Finns. Of the last group the true Finns (Suomi), in Finland and contiguous territories, number $2,600,000$. These, having absorbed Swedish influences of race, culture, and speech, display a progressive civilization, a high intellectual attainment, and a passionate love of country. See Finland; Mordvin.

- Finsbury. London parl. and met. borough. Bounded S. by the City, it has the boroughs of Isling. ton on the N., Shoreditch E., and Holborn and St. Pancras W. At one time a manor or lordship, form. ing one of the prebends of S. Paul's Cathedral, N. of Moorfields, and known as Fensbury, from the swampy nature of the ground, its old fields were practising grounds for military and archers, referred to by Shakespeare and Ben Jonson. Here, in 1548, the Protector Som. erset was met by the lord mayor on his return from Scotland. Finsbury was once a residential quarter for doctors and surgeons, and it includes Clerkenwell, a clock and watch making centre. Within its area are included the Charterhouse, the headquarters of the H.A.C., Bunhill Fields, Northampton Institute, and S. John's Gate. Finsbury returns one member to Parlia. ment. Pop. 87,923.

Finsbury Park. Recreation ground of $\mathrm{N}$. London, the name of which is applied to the district im. mediately surrounding it. Just outside the county boundary, it occupies 115 acres between the G.N.R. main line and the N. con. tinuation of Seven Sisters Road and the Green Lanes. On the site of old Hornsey Wood House, it was opened by the metropolitan board of works in Aug., 1869, the land costing $£ 56,869$ and the laying out about $£ 50,000$. It owes its name to the fact that it was planned to serve as a public park for the borough of Finsbury, which reached as far as its S. border. Part of it is intersected by the New River. Adjoining are stations of the G.N., G.N. \& City, and G.N., Piccadilly \& Brompton Rlys. In 1920 a pro. ject was mooted for a tube rly. from Finsbury Park to the Crys. tal Palace.

Fi n s b u r y Pavement. Lond on thorough. fare. It $\operatorname{ran} N$. from London Wall to Finsbury Square, with Finsbury Circus and South Place on its E. side. Finsbury Pavemenc and Moorgate Street were incorporated, 1922, as Moorgate. In Finsbury

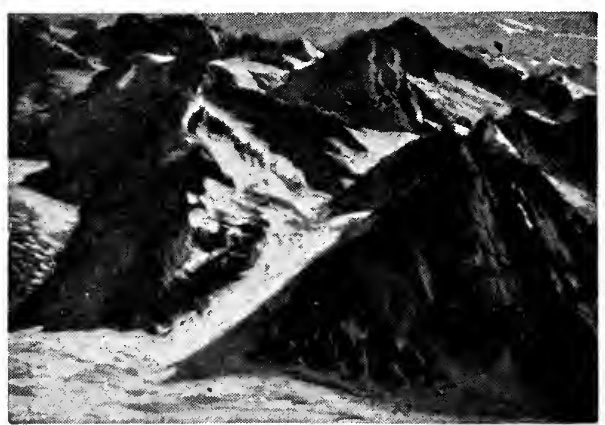

Finsteraarhorn, Switzerland, and the Aletsch glacier, Circus, in the old home of the Lon don Institution, is the School of Oriental Studies, opened in 1917. In South Place is South Place Institute, a well-known centre of the Ethical Society. See illus. p. 546.

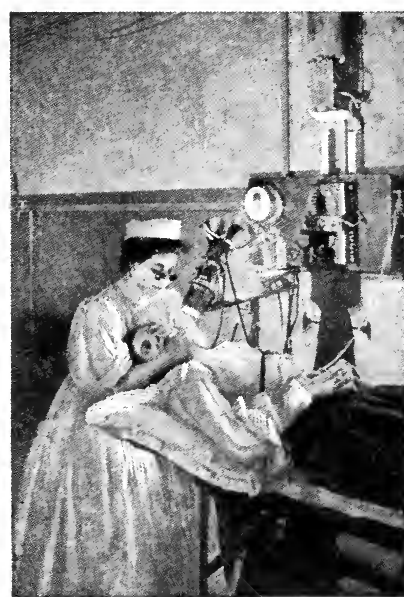

Finsen Light Patient under treat ment in the London Hospital seen from the air

Finsterwalde. 'Town of Brand.

Finsen Light. Form of treat ment for lupus, invented by the scientist Niels Ryberg Fin. powerful electric arc lamp are passed into an absorbent medium which allows only the actinic or chemically active rays to pass through it. These rays, having been concentrated by means of lenses of rock crystal and cooled by being passed through a continuous current of cold water, are directed on to the affected area. The application is usually continued for an hour.

Finsteraarhorn. Mt. of Switzer. land, between the cantons of Berne and Valais. It is the highest peak of the Bernese Oberland (alt. 14,025 $\mathrm{ft}$.,) and extremely difficult of ascent. The summit was first reached in 1812. 'The Schreckhorn lies to the $N$. and the Jungfrau to the W.

nburg, Prussia. It is $40 \mathrm{~m}$. N. of Dresden and $70 \mathrm{~m}$. by rly. S.E. of Berlin. It has several iron-foun. dries; agricultural and other machinery is manufactured here, and coal is procured in considerable quantities in the near neighbour. hood. Pop. 13,100.

Fin-whale or Fiv-Back (Balaenoptera). Name sometimes given to the rorqual, a common and widely distributed whale, of which four species are usually recognized. As their yield of blubber is small and their whalebone of inferior quality, they are not in great demand; this doubtless accounts for their being still found in great numbers in nearly every sea except near the Poles. They are of somewhat slender form, and have a short back fin, and narrow and pointed flippers. They have a large pouch in the throat for the reception of the fish on which they feed; and when this pouch is collapsed the skin of the throat lies in folds which are character. istic of the genus.

All four species are included in the British fauna. The common 


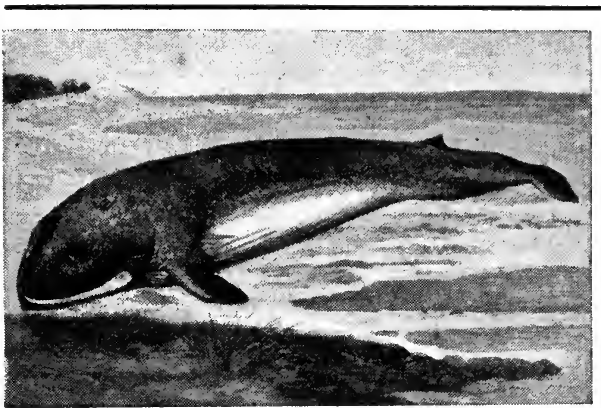

Fin-whale. Stranded specimen of rorqual, Balaenoptera musculus

rorqual (B. musculus) is often met with in the English and Irish Channels and is frequently cast up on the coasts. Sibbald's rorqual (B. Sibbald $i$ ) is the largest of all whales, often exceeding $80 \mathrm{ft}$. in length. It is abundant in the North Sea, and occurs occasionally around the Hebrides. Rudolphi's rorqual ( $B$. borealis) is much smaller, and during recent years has been found around the E. and S.E. coasts of England. The lesser rorqual (B. rostrata) is about $30 \mathrm{ft}$. in length, and is fairly common around all the British coasts. See Whale.

Fiord (Scand.). Type of inlet found on the coasts of regions which have been greatly glaciated. During the ice age great glaciers scooped out deep trough-like valleys with precipitous sides, and the disappearance of the glaciers admitted the sea. A fiord is usually very deep except near the entrance, and in some cases subsidence of the land has added to its size. Fiord coasts are found in British Columbia, Scotland, and Norway.

Fir. Cone-bearing tree of the natural order Coniferae, and genera Abies, Picea, and Pinus. A native of Britain, N. Europe, N. America. Japan, and the Himalayas, its height varies from $10 \mathrm{ft}$. to $200 \mathrm{ft}$. In gardens firs are best grown as specimen trees on lawns, where

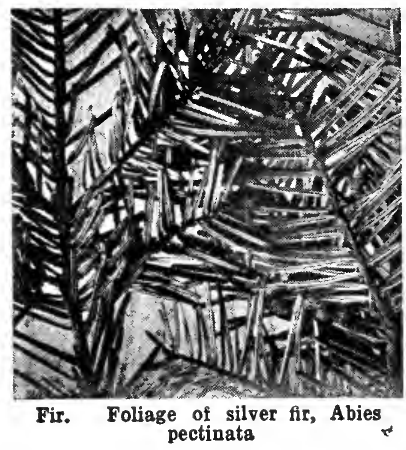

their beauty can be fully appreciated. They thrive in any deep, rich loam, may be planted in autumn or spring, and are propagated by seeds sown in a cold frame in spring. Much confusion in nomenclature exists among these conifers, but it is now generally accepted that the true fir means Abies, the silver fir. The genus Picea embraces the spruces, and Pinus the pines. Their cultivation in large quantities for timber is a branch of forestry $(q . v$.$) . See illus. p. 1287$.

Firbolg. Legendary name of an early Irish race, usually said to mean bag-men. Some ethnologists employ it to denote the aboriginal

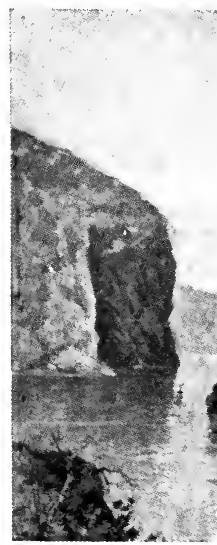

people, mainly composedof dark h a i red, longheaded non Aryan Iberians, whoweresubdued by the Milesians, a wave of Goidelic Celts that may have crossed from Great Brit. ain. See Milesian.

Firdausí or Ferdusí (c. 940 1020). Pen-name

of Abú-'l Kásim Mansúr, Persian poet, called the Homer of the East. He was born at Schadab, near Tús, Khorassan, son of a small land owner. Carefully educated and an apt scholar, he is famous as the author of the Sháh-Námeh, or Book of Kings, a metrical history of Persia from early times to A.D. 641 ; and $Y$ ûsuf u Zulîkhâ, a poem on Joseph and Potiphar's wife. The first-named work, in 60,000 couplets, was commissioned by Mahmúd, sultan of Ghazni, who promised 60,000 gold pieces as a reward. Firdausí, however, excited the enmity of Mahmúd's vizier, and when, at the end of his task, which occupied him for 30 years, the vizier sent him pieces of silver instead of gold, the indignant poet divided the money between the keeper of a bath, a sherbet seller, and the vizier's messenger, penned a flaming satire on Mahmúd, and, after spending the remainder of his life a proscribed man, died at Tús. According to legend, as his body was being borne to the grave, a messenger laden with 60,000 gold dinars from Mahmúd arrived, and, as Firdausí's daughter refused the money, it was spent on some muchneeded public buildings in Tús.

The Sháh-Námeh, which has been described as the Iliad of Persia, is characterised by its Persian vocabulary, the simplicity of its style, its high qualities of invention, its original transcripts from nature, its patriotism, its dramatic dialogues, and its reflection of the author's Zoroastrian faith. Battles, combats, feasts, scenes of riot, and carnage alternate with pictures of innocence and peace. Much is taken up with the wars of Persians and Tartars, and one of the central characters is Rustum, the Persian Hercules, who unwittingly kills his own son, an episode familiar to modern readers in Matthew Arnold's poem, Sohrab and Rustum.

Bibliography. Poems of F., Eng. trans. by J. Champion, 1785 ; SháhNámeh, trans. and abridged, J. Atkinson, 1832, new ed. 1892; Sooh.

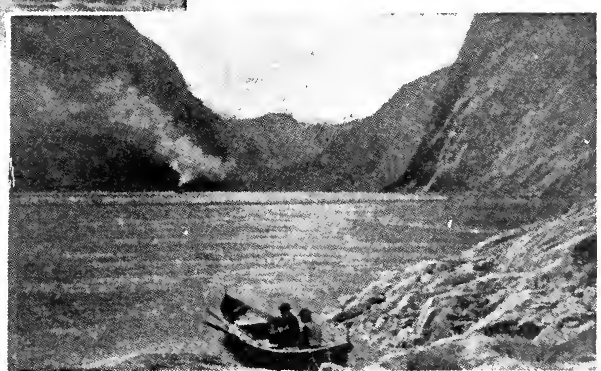

Fiord. View in the Naero Fiord, Norway; above, typical cliff-walls of a fiord

rab, a free trans., J. Atkinson, 2nd ed. 1828; Episodes from the Sháh Námeh, trans, into English verse, S. Weston, 1815 ; Biographical No. tioes of Persian Poets, Gore Ouseley, 1846 ; Sháh-Námeh, the orig. text with French trans. in prose, J. Mohl, 1876-78; The Epic of Kings, H. Zimnern, 1886 ; Literary History of Persia, E. G. Browne, 1902-6; Yûsuf and Zalîkhâ,ed. H. Et hé, 1908. 
Fire (A.S. fyr). Word embracing in its widest sense any manifestation of glowing heat. It commonly denotes the visible effect of the combustion of substances by means of the chemical combination of atmospheric oxygen with one or more of their constituents, the incombustible residue being called ash. Flame is formed when glow. ing gas is produced, either as a primary or as a secondary result of the burning. There may also be non-luminous vapours called smoke or fume.

The process of raising the temperature of combustible or inflammable substances to the point at which self-sustaining combustion procceds is calledignition. This may be brought about bysolar radiation, terrestrial heat, molecular action, electrical discharge, friction, pres. sure or percussion. Fire may be extinguished before combustion is completed by reducing the temperature of the burning mass below the ignition point, or by stopping the access of air. In the domestic and industrial arts heat and light are commonly obtained from sub. stances-solid, liquid, or gaseouswhich are called fuels, mostly derived from carbonaceous materials of vegetable origin.

Primeval man first encountered fire as a natural manifestation, which he came to regard as an all. devouring spirit to be feared and shunned. Ages may have elapsed before the recognition of fire as a physical fact was followed by any attempt to control it, and then to turn it to account, at first perhaps as a defence against wild beasts. The next advance consisted in devising means for its preservation, an achievement which furnished a potent incentive to a sedentary habit of life. Out of this arose the customs concerned with its perpetuation, sanctity, and worship. During this period of prehistory were laid the foundations of the use of fire for warming the person, cooking food, hardening implements and utensils, and producing artificial light. Fire-making, the artificial production of fire at will, which followed in due time, facilitated nomadism and migration, and was destined to become man's mightiest auxiliary in the conquest of the globe.

From the primitive notion of an all-devouring spirit ancient philosophy advanced to the conception of fire as a thing stolen from heaven, as in the Prometheus myth, and then to the view, attributed to Heraclitus (c. 500 B.c.), that the universe was evolved from an om. nipotent fire-god. Medieval alchemy pictured the world as com. posed of four elements : fire, water, earth, and air. When modern chemistry began, Boyle (1626-91), while still holding fire to be a material element, discovered that air is essential to combustion. A theory propounded by Stahl (16601734), that combustible bodies contain a substance called phlogiston, which is released by their decomposition, was not exploded until Lavoisier (1743-94), after discovering oxygen, explained burning as caused by this gas being extracted from air and joined to other substances.

Man is still confronted, as at the beginning, by fire in its destructive aspects. Sometimes they are released intentionally, as by the wasteful agricultural methods practised by jungle-burning tribes in India. Sometimes property is fired maliciously, a felony punishable in England as arson and in Scotland as fire-raising. More evil, however, is wrought by thoughtless or unintentional incendiarism, or by the operation of such causes as spontaneous combustion. Out of these perils have arisen the organized services concerned with fire precaution, proofing, prevention, extinction, and insurance. The Great Fire (q.v.) of London in 1666 was one of the greatest conflagrations on record. Since then still costlier conflagrations have occurred in Moscow, 1812 ; Paris, 1871 ; Chicago, 1871 ; Boston, 1872 ; Baltimore, 1904; San Francisco, 1906 ; and Salonica, 1917.

Fire Alarm. Mechanism for making known the fact that a fire has broken out. An electric fire alarm is a device which automatically closes an electric bell circuit when the air in its neighbourhood attains a high temperature such as would be due to an outbreak of fire. The expansion of matter by heat is the principle used in fire alarms of all kinds. The mercurial type consists of a thermometer with platinum wires entering the bulb and the top of the tube through fused joints. When the mercury rises to a certain height it completes the circuit of which the wires form part, and a bell rings. An adjustable form has the top of the tube open and a sliding upper wire.

Pneumatic alarms are operated by the expansion of air in a closed tube or vessel, and the pressing out ot a diaphragm which brings a moving contact against a fixed contact. One variety has a bowlshaped container with a concentrically corrugated top. The chamber is partly exhausted and then sealed. An alarm is given if the air inside be expanded by heat, or the chamber leaks and the vacuum is broken, as in either case the diaphragm bulges outwards. In another variety air at atmo. spheric pressure is contained in a small chamber and in very fine tubes running from it round the walls of the apartments it protects. The air in the tubes is heated quickly by a fire and communicates its pressure to the main chamber.

Metallic fire-alarm contacts employ two metals of unequal expansibility. A common form consists of a bar, compounded of a strip of steel and a strip of copper welded together, or otherwise rigidly joined, fixed at one end and free to move at the other. When the bar is heated the copper expands more than the steel, and the bar curves towards the steel side, bringing the free end against a contact.

The May-Otway alarm has a horizontal steel bar several feet long, to the ends of which the extremities of a piece of copper wire are fastened. A contact-piece hangs from the centre of the wire. The bar and the wire form together a very obtuse-angled triangle. If the temperature rises slowly-on a hot day, for example-the steel bar takes in heat as fast as the copper wire and their relative lengths are changed but slightly, whereas a sudden influx of hcat affects the wire much more quickly than the bar, and the wire droops sufficiently to let its contact-piece touch a contact below. This quality of discrimination is im. parted in various ways to several other kinds of automatic alarms.

Fire-arm. Generic designation of weapons which throw a missile by virtue of the propellant power generated by a charge of suitable explosive. While popular use is inclined to restrict the term to such weapons as can con. veniently be used by hand, such as rifles, sporting guns, and pistols, these are more correctly termed small-arms (q.v.), and fire-arms includes even the largest artillery.

The history of fire-arms is, naturally, closely associated with that of explosives," but there is no doubt that in early times progress was far more dependent on the smith than the powder-maker, as the latter was always in a position to supply a more powerfúl explosive than the contemporary guns could employ with safety. The invention of fire-arms is usually ascribed to a German monk, Berthold Schwarz, but the date is not definitely known. From illustrations and accounts in contemporary manuscripts, it is evident that guns were in use by 1320, and the English used them at Crécy, 1346. 
These were both bottle-shaped and tubular in form, and at first were employed to fire darts with either metal vanes or a leather pad in place of feathers, but spherical shot were early introduced, being usually made of stone, as the guns would not withstand the charge necessary to propel the heavier metal missiles.

\section{Early Developments}

The early guns were generally built up of wrought-iron strips welded together, but some consisted of wooden staves bound with iron, and all were valued far more for the moral effect occasioned by the noise of their discharge than for the material damage caused. "Hand guns," which appear to have come in use about 1400 , were merely smaller sizes of cannon mounted on a rough wooden stock, and all weapons were discharged by applying a piece of smouldering match to the touch hole.

The next improvement was the invention of the matchlock about 1460 , and it was not until the invention of the flint lock early in the 17th century that they were generally superseded. Flint locks remained supreme until early in the 19th century, when percussion caps were introduced. During this time the only improvement in cannon was better construction, and they were cast in bronze in the 15 th century and in iron by the 18th, enabling more powerful charges and heavier missiles to be fired, while larger weapons could be constructed. The advent of the wheel lock (q.v.) in 1515 had also made it possible to produce a practicable pistol, so that three distinct varieties of firearm, cannon, musket, and pistol, were in existence.

In order to increase the accuracy of weapons, rifled barrels were introduced about 1520, probably by August Kotter of Nuremberg, but the slowness of loading from the muzzle end with this type of weapon restricted its use to sporting weapons until the end of the 18th century, when a few regiments of marksmen were formed, but it was not until breechloaders were definitely established that the rifle superseded the musket.

Breechloading guns have been known for many years. Henry VIII had a sporting weapon of this type, but the Prussian needle gun of 1841 was the first weapon in which the principle was applied with any real success. With a view to increasing the rapidity of fire, double-barrel guns were introduced about the middle of the 17 th century, and magazine rifles about 200 years later, one of the earliest being the Winchester of
1867. Revolvers date from 1835, when Colt developed a successful type.

Since 1880 progress has been most rapid, improved construction and the advent of smokeless powder enabling weapons of great power and extreme accuracy to be constructed; improved breech blocks and the absorption of the recoil by hydraulic buffers have revolution. ised artillery practice; the employment of the force of the recoil to reload, cock, and fire the weapon enables machine guns to fire at the rate of 600 shots per minute.

Developments in firearms during the Great War were chiefly in the employment of larger guns and howitzers as mobile equipment; in the use of guns of immense power as instanced by anti-aircraft artillery and the German gun having a range of 80 miles, which threw $9 \cdot 1$-in. shell, weighing about $3 \mathrm{cwt}$. each, into Paris; the introduction of new types of ammunition; and the use of trench mortars, which were essentially extremely light cannon, generally smooth-bored and often muzzle-loading, which were capable of firing heavy projectiles to short and medium ranges.

\section{Firearms Act, 1920}

In Great Britain everyone who wishes to use or carry a firearm, except when the latter is solely employed for the destruction of vermin or is used in the course of military duty, is required to take out a licence, which costs $10 \mathrm{~s}$. In addition the Firearms Act of 1920 requires that everyone in possession of a pistol, revolver, or rifle after Nov. 1, 1920, shall obtain from the chief officer of police in the district in which he usually resides, a permit authorising him to keep such weapon or weapons and the ammunition for them. Particulars (such as maker and number) sufficient to identify the weapons have to be recorded. Permits are not required for military equipment if the owner is a member of the forces, or smooth-bore weapons such as sporting shot guns, nor for antiques, curiosities, trophies of war, etc., but in the latter cases no ammunition suitable for the weapons must be kept. See Ammunition; Arquebus ; Breech Block; Bullet; Cartridge; Explosives ; Ordnance; Pistol; Revolver; Rifle; Trench Mortar.

Fireback. Back wall of a fireplace, introduced about the middle of the 16th century as a protection for the walls. Firebacks were of cast iron, often elaborately decorated with designs of flowers, figures, etc., in high or low relief. The most interesting series were those with coats of arms and other heraldic devices, with inscriptions.
Fireball. Obsolete military term employed to designate certain early types of projectiles, thrown from mortars for incendiary and illuminating effects. They consisted of a hoop iron frame covered with canvas and filled with composition. The term is occasionally applied to the early fireworks used in warfare by the ancients. It is also used to describe an electrical phenomenon occurring during thunderstorms. . See Lightning.

Firebox.

copper, or boiler, in which fuel is burnt for generating steam in the boiler. A firebox is fitted internally with an arch of firebricks so arranged as to check an undue escape of heat through the boiler tubes and to prevent the passage of solid material through them. In a loco. motive boiler a water space is provided over the top of the firebox, and for the full depth on each side and in front so as to present as great a heating surface as possible.

Firebrick. Bricks intended for use in the building of structures which are to be exposed to high temperatures, particularly furnaces for the melting of metals. They are made of various materials all of a highly refractory character, according to the particular purpose for which they are intended. Common firebricks are made from special clays; while other materials used comprise ganister, a sandstone with just sufficient clay to permit the ground material to be moulded; Dinas rock, flints, and other siliceous sands and stone; lime; magnesia; graphite; chromite, an iron ore containing chrome ; " bull-dog," a mixture of iron oxide and silica used for lining puddling furnaces; and some other special compounds. See Brickmaking ; Furnace.

Fire Brigade. Organization for combating outbreaks of fire. There apparently existed fire brigades in Egypt 4,000 years ago ; while a very elaborate organization was already in operation in Rome by 40 B.c. Early in the Christian era hose pipes appear to have been in use. In England we owe the development of the fire brigade to the early fire insurance companies, though an Act of Parliament of 1774 obliged the churchwardens of all the London parishes to maintain a proper engine for putting out fires in their own boundaries. In their own interests the insurance com. panies organized very complete brigades and equipped them with the best appliances available. The members at first were composed of their own clerks and other officials. 
In 1833 the London insurance companies combined, and formed the London fire brigade under the command of James Braidwood, who built the first steam fire engine and was killed while at a fire near London Bridge in 1861. In 1866 the Metropolitan Board of Works took over the entire London organization, which in 1918 , under the L.C.C., comprised 79 land stations, 3 river stations, and 6 ambulance stations, with 75 motor fire engines, 81 motor fire escapes, 5 motor hose tenders, 8 horsed fire engines, 18 horsed fire escapes, 4 electrically driven turntable ladders, 19 long ladders, 9 motor ambulance vans, 16 motor cars, 4 fire floats on the river and 4 steam engines on rafts, 60 miles of fire hose, and 1,582 street fire alarms. The personnel comprised 1,297 firemen and drivers and 58 ambulance attendants, with three principal and one chiet officer. The horsed turn-out was abolished in $192 \mathrm{~L}$.

All important cities and towns now maintain more or less efficient fire brigades, though the number, character, organization, and equipment of the units of the brigades vary considerably. In the larger cities and towns they are composed of paid officials, while in the smaller ones voluntary workers usually man the brigade.

Fireclay. Material so called from the high refractoriness of the articles made from it, i.e. its quality (when manufactured) of resisting intense heat, and its freedom from splitting when exposed to rapid changes of temperature. The determining factor of the refractoriness is the chemical composition of the clay, which contains but small quantities of fluxing impurities (such as iron, lime, magnesia, alkalis), and very little free silica. A " proximate" analysis of a typical Scottish fire. clay shows the following percentages: Clay substance, $85 \cdot 42$; quartz, $13 \cdot 42$; felspar, 1·16. Fireclays should dry and fire without cracking and have an open texture to resist alternate heating and cooling. In the manufacture of some fireclays sawdust is mixed with the clay and is burnt on firing, leaving the open porous texture required. The minimum fusion point for a fireclay is usually taken at about $1,600^{\circ} \mathrm{C}$.

Fireclays abound in the British coalfields. Often the finest clay is found at the depth of many feet, and underlying or alternating with coal-seams. - The beds do not usually exceed two feet in thickness. Deposits are worked in Cornwall, Devon, Dorset, and else- where in the S. of England. Fireclay from Stourbridge, in Worcestershire, said to have been worked in the 16th century, is largely exported on account of its excellent qualities. See Brickmaking.

Fire Command. Unit in coast defence artillery. In every fortified area the efficiency and general readiness for action is entrusted to an officer, usually of field rank, who, as fire commander, is responsible for the fire control of all batteries and groups in the area. It is for him to organize and decide upon the measures to be adopted in the event of attack, and he orders the commencement and cessation of fire on the target, directing which forts or batteries shall engage individual enemy vessels, and what tactics shall be employed to prevent a bombard. ment or landing. See Artillery.

Fire Control. System under which a warship's guns are used in action. Fire is controlled from a station aloft, ranges, etc., being passed down to the gun crews. The gunnery officer from his post aloft controls a ship's armament at will, his orders going through a transmitting station to all parts of the vessel. Director firing is the most scientific phase of gunnery, and its methods are confidential. All turrets, i.e. the armoured positions wherein the big guns lie in pairs, are indicated by a letter for fire control purposes, and the gunnery officer can use the weapons singly or in groups at his discretion. See Gunnery.

Firedamp. Name given by miners to the most important of the gases which are found occluded in the crust of the earth. It is the carburetted hydrogen or marsh gas $\left(\mathrm{CH}_{4}\right)$, which appears in coal mines. When diluted with air in certain proportions it forms a mixture which will explode with great violence if lighted either by a flame or by contact with an incandescent surface. Such an explosion occurring in a coal mine may kill the workers either directly, by its mere mechanical violence, or indirectly, by destroying the workings or machinery of the mine.

Like marsh gas itself, firedamp has been formed by the decompo. sition of vegetable matter. All beds of coal are more or less porous, being traversed by numerous seams, while pockets may occur here and there. In many cases firedamp has accumulated in a bed or in adjacent strata until it has attained a considerable pressure. A stroke of a pick or a drill or the falling of a block of coal may suddenly release this gas, which may be distinctly heard escaping. If the barometer is low, that is if the nor. mal pressure of the air in the work. ings becomes reduced, the gas will the more readily tend to escape ; hence the importance to miners of weather forecasts or warnings.

The proportion of air needed to make an explosive mixture varies according to the composition of the gas itself, which may contain other gases, particularly oxygen and nitrogen, and still more according to the state of the atmosphere of the mine, e.g. the amount of coal dust in the air. The proportion may range from one part of the gas to from seven to fifteen of air. A dangerous accumulation of the gas may thus be recognized by a change in colour of the flame of a miner's safety lamp, the use of which, to the exclusion of naked lights, is imperative in all mines where any large quantity of firedamp may suddenly appear. See

Mining; Safety Lamp.

Fire Door. Steel or iron door of a furnace through which fuel is passed. In some cases the doors are arranged to hinge open, and in others to slide across the opening, and hand-levers are fitted for opening and closing them. See Furnace.

Fire-eating. Branch of the juggler's art. It includes exhaling or swallowing flame, holding redhot iron between the teeth, drinking molten substances, and similar pretensions. A writer of the 2nd century described breathing from the mouth of flame and smoke as arising from inflammable matter inside a nutshell wrapped in tow in 1672 Evelyn saw Richardson chew and swallow glowing coals and brimstone, besides pouring molten lead-perhaps cold quicksilver-on his tongue. In 1762 Strutt saw Powell broil a piece of beefsteak upon his tongue with glowing charcoal placed beneath it. In 1814 Josephine Girardelli claimed to put molten lead into her mouth and to spit it out marked with her teeth. These effects were produced partly by utilising unfamiliar physical and chemical principles, partly by sleight of hand.

Fire Engine. Particular kind of water-pumping machine used for the purpose of throwing a stream or streams of water on to a fire to extinguish it. Fire engines were among the earliest applications of mechanical science to useful purposes. Hero of Alexandria, the inventor of the first steam engine, about 150 B.c., describes what he calls a " siphon" used in his time to put out fires.

This apparatus, in its essential ideas, was identical with the common manual fire engine developed slowly during the centuries and 

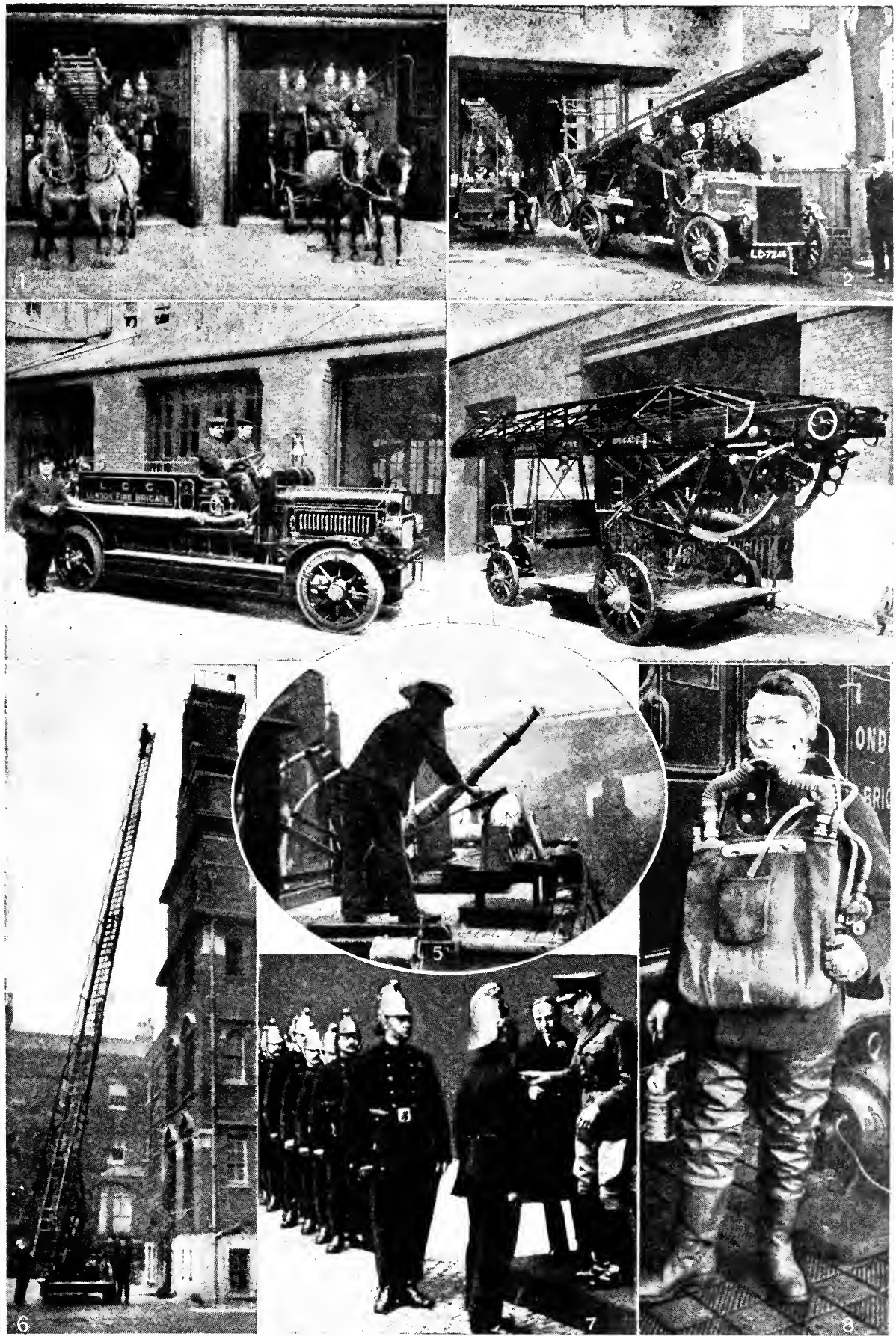

I. Old style turn-out with horse-drawn engines. 2. Turn-out of motor equipment. 3. I919-20 pattern of motor fire engine. 4. Turntable firetower, with reach of shown in No. 4 raising a man to a height of $90 \mathrm{ft}$. by at Southwark Bridge Road station, Feb. I2. I 220 FIRE BRIGADE: THE LONDON COUNTY COUNCIL FIRE BRIGADE AND ITS WORK 
still largely used to-day. It consisted of two cylinders with plungers working in them and connected with a common wooden beam by which the plungers were alternately moved up and down in their cylinders. In the former movement the plungers drew water into the cylinders, and in the latter they forced it out through a common jet, the double arrangement permitting a continuous discharge. It also appears that the apparatus, either by design or accident, included an air chamber which would give steadiness to the discharge.

The Romans made large leather bags which they filled with water and then forced the water out by pressing the bags, thus enabling them to throw the water some considerable distance through long spouts attached to the bags. Water syringes were used in Germany in the 16th century and in Great Britain till the end of the 17th. The latter took two or three men to work them, but were not very effective. In 1657 there existed in Nuremberg a fire engine which was drawn by horses and took 30 men to work it which from the description given by a contemporary writer was a practical adaptation of the apparatus described by Hero. The hose and suction pipe were introduced by the Dutch engineer Jan der Heide in 1670 , while in 1684 the French architect Claude Perrault suggested the use of the air chamber.

The immediate precursor of the modern fire engine was the machine made by Richard Newsham, a pearl button maker of London, who took out patents for his engine about 1730. Again in essential ideas this machine was on the lines of the form described by Hero, but it was a practical and efficient apparatus, and Newsham constructed a considerable number, one of which at least was sent to New York. At a demonstration in London, Newsham threw a jet of water over the grasshopper which crowned the top of the then Royal Exchange, a height of $160 \mathrm{ft}$. One of his engines, supplied to Dartmouth, is now in the museum at South Kensington, in good working condition. Newsham's engine was similar to the hand-power engines now found in many large country mansions.

A modern fire engine consists of a special type of tubular steam boiler, very compact, and capable of raising steam to a pressure of from 100 to $200 \mathrm{lb}$. per square inch in a few minutes, and one or more steam-driven pumps, all mounted on a light but strong wheeled carriage. Until recently the engine was drawn by horses, although it has frequently been proposed to draw it by its own steam; but of recent years the petrol motor tractor has displaced horses to a very large extent. Such an engine will throw from 500 to 1,400 gallons of water per minute to a height of 150 feet. Its total weight will be about $2 \frac{1}{4}$ tons. Specially powerful engines will weigh from four to five tons, inclusive of the water in their boilers. Engines with motor tractors and motor-operated pumps are also largely adopted. The whole engine is much lighter than a steam engine, thus reducing the weight that has to be transported through the streets, while the trouble of getting up steam is avoided. Nevertheless, many competent fire engineers consider that the steam-operated pumps still have the balance of advantages.

Fire Escape. Device of two general classes: those which are permanently attached to the building, and those which are brought to it when a fire has broken out. To the former belong many appliances, from the simple knotted rope attached at one end to a window frame, and by the aid of which a cool man may climb down to the ground in safety or lower a person from a considerable height, to the elaborate external staircases and balconies built of iron with which many modern buildings, such as factories and large hotels in this country, and still more in the United States, are now provided.

Of the portable appliances the chief is the familiar wheeled ladder, consisting of a principal ladder and a number of supplementary or extension ladders, which when joined together permit a height of 60 feet and over to be reached. The escape is also provided with a chute or shoot of copper wire netting which is attached to the under side of the ladders and rises with the extension. A person may slide down this shoot to the ground without risk of injury. For the same pur. pose shoots of stout canvas are adopted and kept permanently ready for use in many establishments where numerous workers are congregated on upper floors. They are in the form of a large pipe, with appliances at one end by which the shoot may be attached to a window or held from the inside of a room in the building. When in use the lower end is held by two or three persons on the ground, standing at a distance from the building, so that the shoot hangs at an angle. A child may be sent down such a shoot with perfect safety. The hook ladder may be used as a fire escape, although its primary object is to enable a fireman to gain access to the upper floors of a burning building. See Fire Prevention.

Firefly. Name applied generally to beetles which are luminous in the dark. In Europe they are represented by the family Lampyridae, of which the glow-worm is a familiar example. In America and the West Indies the genus Pyrophorus of the elater beetles are famed for the green and red lights which they display in flight. Fireflies are frequently used as hair ornaments in the W. Indies, and also in S. Italy.

Firelock. Musket in which the means of igniting gunpowder was by flint and steel. About 1690 it replaced the matchlock, a musket that required a burning match to discharge it. In the old drill books the command "Shoulder your firelock" was used before "Shoulder arms" came into use. See Flint Lock; Gun; Musket.

Fire-making. Artificial production of flame, spark, or glowing heat. Of primeval invention, it became one of the mightiest factors in human culture. Natural manifestations of fire were doubtless feared before man perceived its beneficent possibilities. Use gave rise to preservation, preservation to production at will.

Artificial fire may have originated in wood-friction. A Mous. terian beechwood fire twirl (Tylor's fire drill) was found in 1904, at Krapina, in Croatia. Fire twirls are rotated between the palms in Australia, as in ancient India and Mexico, are aided by a cord by the Maoris, and by a bow in early Egypt; they are gripped by the teeth by the Eskimo, and weighted with a spindle-whorl by the Chukchi. Other frictional appliances are stick-and-groove fire ploughs rubbed along the grain in Polynesia, and fire saws rubbed across the grain by the Malays. A pneumatic fire piston is peculiar to modern S.E. Asia. The primeval percussion implement-strike-alight-resulted from flint-knapping, and flint and pyrites developed into the early iron-age flint and steel.

Fireplace. Recess in the wall of a room, formerly consisting of an open space walled on three sides by stone or bricks, but now generally filled with a metal fitting, which contains a fire for heating purposes. The earlicst form of fireplace is commonly believed to have been the hearth in the centre of a room, but there is evidence that the wall fireplace has an equally long ancestry. In the Norman keep, for example, where the rooms were placed onc over the 


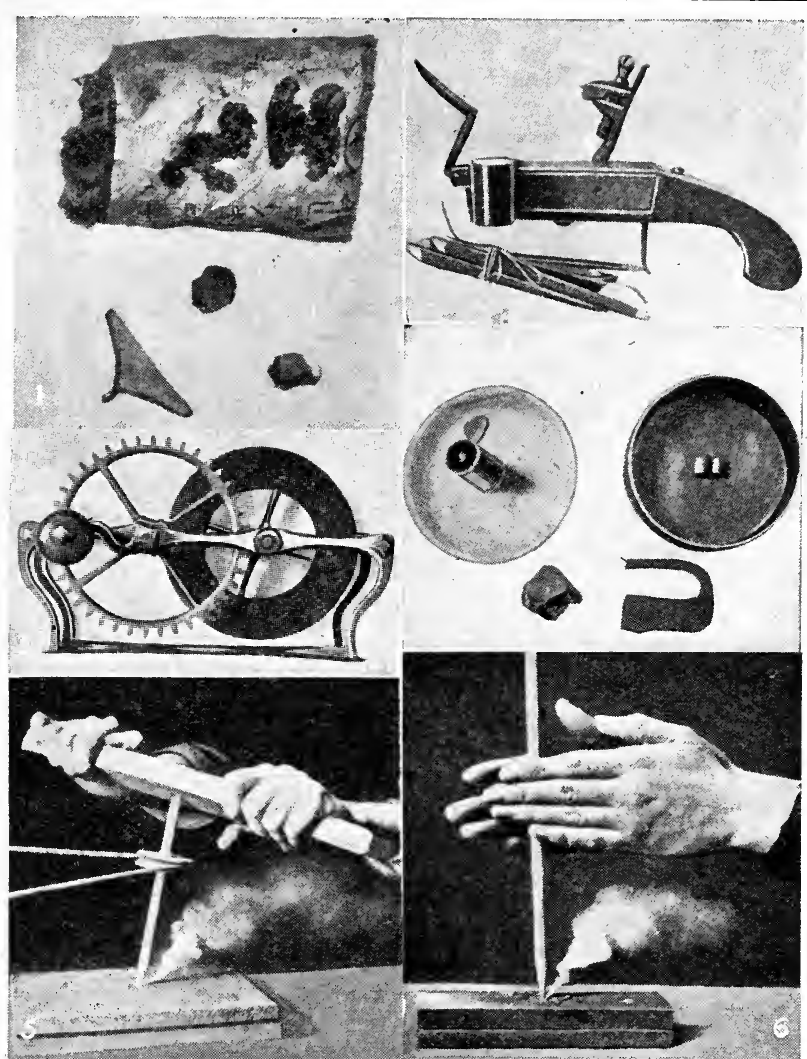

Fire-making. 1. Chinese flint, steel, and bag of tinder. 2. Early 19th century strike-a-light. 3. Steel mill, formerly used in coal mines for striking a light. 4 . Tinder box with flint and steel. 5 and 6 . Fire drills, making friction between hard and soft wood

other, wall fireplaces were the rule, since a central hearth in any but the topmost room would have been an impossibility.

Extant specimens show that these fireplaces were recesses in the wall surmounted by round arches. There was no chimney shaft; the smoke escaped by a short flue lead. ing almost directly to a small vertical opening in the outside wall, concealed in the angle of a buttress. In one-storeyed buildings the central hearth was often used, and this type of fireplace persisted until late in the 16th century. The great hall at Richmond Palace, and the hall at Penshurst Place, Kent, retain examples.

The opening in the roof, through which the smoke was carried, was protected by a small turret, or louvre, which kept out the rain while allowing the smoke to escape. Chimney shafts began to appear about the middle of the 13 th century, but were not carried above the level of the eaves until considerably later, and it was not until Elizabetlan times that the chimney stack was developed as an architectural feature. Then the number of fireplaces greatly in. creased, calling for a corresponding enlargement and beautification of stacks to contain the flues.

Gothic fireplaces are generally treated in the simplest manner. The hood, sometimes with corbels, is the chief and only decoration of most 13th century fireplaces, and the single square-framed arch which followed it was equally devoid of ornament. The Renaissance brought the architectural chimney-piece and elaborate overmantel, and though there was a return to greater simplicity in the Later Renaissance, the taste for a decorated fireplace had taken firm hold. See Building ; Chimney. piece: Chimney Shaft: House ; also illus. pp. 1948 and 1949 .

Fire Prevention. Fire prevention systems are of two classes: those directed to the prevention of an outbreak, and those designed to deal promptly with one when it has already occurred. The former are chiefly structural and are mostly represented by the use of non-inflammable materials in the erection of buildings. If the floor, the walls, and the roof or ceiling of a room can be made of materials which do not readily take fire, the contents of the room may be destroyed by fire without serious risk to other parts of the building.

Iron, notwithstanding its great strength and structural value in building, is not a good fire-resisting material. It will bend and twist and bring about the collapse of a whole building; and even where it retains its position and form in the course of a fire while merely exposed to the heat, it may be almost instantly destroyed by being drenched while hot with water from the fire hose. Hence, in the modern " fireproof" building, while iron or steel is very largely used, it is invariably enclosed in some form of protective covering-brickwork, concrete, or cement-which will shield it from the direct action of a fire. The extensive use in modern buildings of reinforced concrete is due not alone to the moderate cost of that system of construction, but also to the fact that it is so largely fire-resisting. The general and unavoidable use of wood in buildings still constitutes a serious fire risk nearly everywhere, and not least on board ship; but timber is much less extensively employed than formerly, and the risk of fire may be reduced by the use of wood fireproofing processes.

To the second class of fire pre. vention systems belongs a large number of appliances, comprising internal fire hydrants or stand. pipes connected permanently to a reliable source of water, which may be brought into operation instantly on any floor of a building and in large buildings at more than one point on any floor; the free provision of fire buckets always kept filled with water and always maintained in proper number and in order at definite stations; the adoption of sprinklers; the use of automatic pumps which are either arranged to be driven by a separate electrical connexion or by any independent steam service, so placed and arranged that they may be put into operation instantly; chemical fire extinguishers and the instalment of automatic fire alarms (q.v.). See Concrete; Sprinkler.

Fireproofing. The idea underlying this term is, of course, that of treating a material, normally inflammable paper, fabric, or wood, in such a way that it will not take fire. The idea is a very old one, and innumerable processes have been 
suggested in connexion with it. No method has yet succeeded in rendering any such materials incom bustible. The most that has been achieved is to render them less $i n$ flammable than they are in their natural conditions. That is to say, the materials may after treatment slowly burn away, if the surrounding temperature be raised sufficiently high, without bursting into flame. This may obviously be an important end attained, as if flame can be avoided the risk of a fire spreading is immensely reduced.

The substances proposed as fireproofing agents include common salt, alum, sulphate of zinc, sulphate of ammonia, sulphate of soda, sal ammoniac, borax, sulphate of lime and of baryta, lime water, ammonium phosphate, ferric sulphate, and silicate and tungstate of soda, the two latter probably being those most generally and successfully employed. Many of these substances are unsuitable for use on fabrics, for the reason that they rot them more or less. All such substances, which are applied by soaking the fabric in a solution of the salt in water, act by depositing minute crystals of the salt in the pores of the fabric. By thus closing up the pores of the material with a non-inflammable substance, access of air to the pores is prevented, and thus, while the fabric may char superficially by the exposure of its surface to a high temperature, it will not take fire.

To secure the best results it may be necessary to soak the material in the solution more than once, drying carefully after each immersion. Also it may be necessary to repeat the process from time to time if the proofed material is much used, as, for example, in the case of theatre fabrics, as the crystals are only held mechanically in the pores of the fabric and will gradually shake out. In fireproofing wood, for which purpose tungstate and silicate of soda and sulphate of zine are chiefly used, the penetration of the pores of the wood by the solution is usually assisted in the best processes by first exhausting the air from the wood as far as possible by keeping the material under a vacuum for some time before the solution is introduced.

In addition to substances which are intended to penetrate the material, eertain so-called fireproof paints are employed for coating wood superficia!ly. These paints are composed chiefly of sodium silicate, zinc chloride, and asbestos, frequently in combination. They undoubtedly assist to prevent wood from catching fire, but are liable to peel off more or less. Brushing timber with common limewash two or three times will render it to a great extent non-inflammable.

Fire Raising. Term used in Scots law for the act of wilfully setting on fire the property of another. The English equivalent is arson $(q . v$.$) .$

Fireship. Wooden vessel filled with combustibles that used to be set on fire and made to drift down upon an enemy fleet when it was at anchor or in harbour. The fireships were sent in thus to create panic or set on fire enemy vessels as they came in contact with them. The coming of steel and steam made the fireship obsolete.

A notable instance of the use of fireships was the attack made by means of them on the French fleet in the Basque Roads, on April 11, 1809. At Lord Cochrane's suggestion eight fireships and three explosion vessels, containing 1,400 barrels of powder with 400 shells and thousands of hand-grenades were sent against the French on a dark night. So great was the panic caused by the explosion of these vessels that most of the French crews cut the cables and allowed their ships to drift ashore. An earlier instance was their use against the Spanish Armada. See Armada.

Fire Step. In the military sense, the raised portion of the floor of a fire trench on which

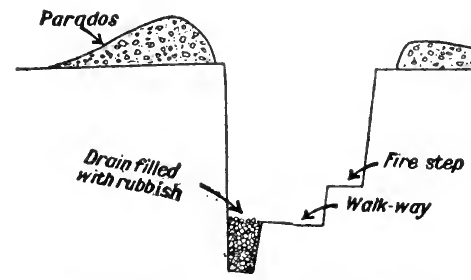

Fire Step. Sectional diagram illustrating method of trench construction

stand the men who are actually firing over the parapet or through the loopholes. In temporary trenches, which are made narrow, the lower portion of the floor has little width, and chiefly acts as a drain to remove any water which may find its way into the position. In trenches which are to be occupied for a considerable length of time, the whole excavation is made wider and the floor arranged at three different levels, the highest on the forward face being the fire-step, one at an intermediate level, furnished with duck boarding, providing a walk-way, along which people may pass without interfering with the men who are firing or acting as lookouts, and where the parapet affords them complete cover while in an erect position, the lowest portion of the floor serving as a drain.

Fire Tactics. Term employed to designate the arrangements made for bringing hostile troops under effective fire, whether from small arms or artillery. Fire tac. tics includes both the dispositions made of the troops who bring fire to bear and the fire control by which the fire is directed. It is always a great advantage if some troops can be located so as to be in a position to bring enfilade fire to bear on the enemy, while indirect fire, which is brought to bear from a position in which the enemy is not visible, is usually demoralising. Surprise effect is always of the greatest value, and may frequently be obtained in defence by some units withholding their fire until a definite stage has been reached by the attack, and in attack by working some units round to a position in which the enemy does not expect them.

The method was occasionally em. ployed by the Germans during the Great War of placing machine guns in the area over which an attack was expected in such a way that they remained concealed until the attacking troops had passed, and then fired into their rear. The extensive use of strong field entrenchments necessitated violent artillery bombardments in order to obliterate these defences as a preliminary to any infantry attack. Barrage fire was developed in order to screen any area from reinforcements and sup. plies, and the creeping barrage was a most successful method of protecting attacking troops.

Another rôle played by the artillery in fire tactics is counter battery work, certain units being detailed for the special duty of keeping the hostile artillery under such heavy fire that they will be unable effectively to support their infantry. Successful fire tactics are largely dependent on effective observation and communications in order that every advantage may be taken of the changing situations. See Artillery; Tactics.

Fire-Walking. Magicaì rite practised by several primitive peoples, mainly to ensure sunshine and bountiful crops. The celebrants walk barefoot over heated stones or embers, and are reputed to emerge unscathed. S. P. Langley, witnessing the ceremony at $\mathrm{Ta}$ hiti in 1901, found that the volcanic rock used was a bad conductor, the upper surface being 
only moderately warmed. W. L. Allardyce, watching it in Fiji in 1904, reported that a handkerchief was charred by the stones, and that a thermometer registered an air temperature over the pit of $280^{\circ}$ F. Other modern accounts come from Mauritius, New Zealand, Japan, China, India, and Bulgaria. The rite sometimes consists in passing through flame, especially as an act of devotion, a custom preserved among European rustics when leaping over bonfires "for luck."

Fire-walking as a chastity or sanctity ordeal was recorded in

\section{FIREWORKS: FOR WAR AND DISPLAY}

\begin{abstract}
This article, which traces the development of fireworks, is supplemented by shorter ones on the various fireworks themselves, e.g. Rockct; Roman Candle; Squib. See also Gunpowder
\end{abstract}

The science of pyrotechny is of great antiquity in the East, where, however, little progress has been mada The Indian pyrotechnists are con.iderably in advance of the Chinese in display work, but both depend on gunpowder, Chinese fire, and a few simple colour compositions, the remainder of the display being made up of such adventitious aids as transparencies, paintings, decorated framework, and, among the Chinese, paper patterns. Travellers in China give enthusiastic accounts of Chinese exhibitions which-without these accessories which have no claim to be called fireworkswould not produce a display equal to that given in their own country at a provincial flower show.

Although originally the art was introduced in Europe from the East, most of the set pieces and devices used in India to-day are primitive copies of European originals. The European method of outlining pictures with a series of small fireworks known as lances, connected by quickmatch, is imitated by the Hindu pyrotechnists with small wicks burning in oil.

\section{Early European Fireworks}

The Japanese alone of Eastern peoples have made progress in genuine firework effects, the aerial shells being particularly fine, depending for their effect on their wonderfully careful and exact construction.

In Europe there is very little early record of fireworks, but it seems most likely that pyrotechnic compositions were introduced by the Crusaders in the 13th century. Richard Coeur de Lion used Greek fire in his own galley. Jebb, in his preface to Bacon's Opus Majus, refers to two fireworks evidently early Vedic India (c. 1200 B.c.), passed into medieval Europe, and in the form of treading barefoot over nine glowing ploughshares was successfully accomplished by Queen Emma, mother of Fdward the Confessor. See Ordeal.

Fire-Water. Generic, popular name for any spirituous or distilled liquor, originally used by the natives of half-civilized lands for European cordials. It is akin to the Spanish name for brandy, aguardiente, or "burning water," to the Celtic usquebaugh, or "water of life," and the French eau-de-vie. See Brandy.

prototypes of the rocket and the cracker. Stowe mentions that two foreigners, Peter Band and Peter van Cullen, made for Henry VIII hollow shot of cast iron filled with " firework or wild fire." The first serious work on pyrotechny published in Great Britain is Pyrotechnia, by John Babington, Gunner, 1635 ; there is another work on fireworks pub. lished the same year by John Bate, who mentions in his pre. face that other authors were writing on the same subject. The contents of these works indicate that by this time the art had greatly developed, the form, methods of making, and nomenclature of the firework units approximating to those of the present day. The methods of displaying and the contained compositions, however, have greatly advanced since then.

\section{Display in St. James's Park, 1749}

Up to the beginning of the 19th century the display was expanded, as in the East, by the addition of pictures, transparencies, bonfires, etc. In the official programme of the display in St. James's Park to celebrate the peace of Aix-laChapelle, 1749, several pages are devoted to a description of the Machine for the Fireworks in the form of a Doric temple $114 \mathrm{ft}$. high and $410 \mathrm{ft}$. long, ornamented with "frets, gilding, lustres and artificial flowers, inscriptions, statues, "and allegorical pictures." It seems that these adjuncts were looked upon as the fireworks proper, the fireworks themselves as now ac. cepted being known as "artificial fireworks." During the 19th century, displays became gradually to consist of veritable fireworks; great advances were made. The weekly displays carried out by
Messrs. Brock at the Crystal Palace from 1865 to 1910 and after the Great War were perhaps the most important factor in the development of the art. Other historical displays in recent years are the display on the Tagus for the marriage of the king and queen of Portugal in 1886 ; that for the tercentenary celebration at Quebec in 1908; and the official Peace Day display in Hyde Park in July, 1919.

Broadly speaking, the same principle governs the compositions of all fireworks, that is to say, a suk. stance which readily takes up oxygen is put in intimate contact with one which readily supplies it. of the latter the most frequently used are nitrate of potash (saltpetre) and chlorate of potash, and of the former, sulphur and charcoal, or other carbon compounds, such as gums, resins, starch, etc.

Composition and Construction

Many of the metals are used either in the form of salts, as those of copper, lead, or mercury, or pure, in the form of powder or filings, as iron, steel, magnesium, and aluminium. The pure metals are generally added to produce glowing sparks or coruscations, or to add brilliance to the burning. Colours are produced by the addition of metal salts, strontium producing red, sodium yellow, copper blue, barium green. The salts most com. monly used are the nitrates, chlorates, carbonates, and perchlorates.

The usual method of construc. tion is to charge the composition into a case composed of strong paper rolled on a former; the end to be ignited is covered with an easily ignited and hotly burning composition or priming, the func. tion of which is to ignite the main filling. Priming compositions usually contain mealed gunpowder. In some fireworks the case burns down with the composition, as in the case of lances, and starlights and Catherine wheels. The latter consist of a long, charged case wound round a circular block of wood, the fire issuing with suffi. cient force to rotate the wheel round a pin inserted through a hole in the centre of the block. Generally the case does not burn, and by this means the fire is projected with more force from the mouth of the case. To this type belong Roman candles, which have at intervals down their length stars which are projected upwards from the mouth of the case to a considerable height. These stars of colour or other suitable compositions are compressed into small cylinders to fit the bore of the case, and primed. When still more force is required, 


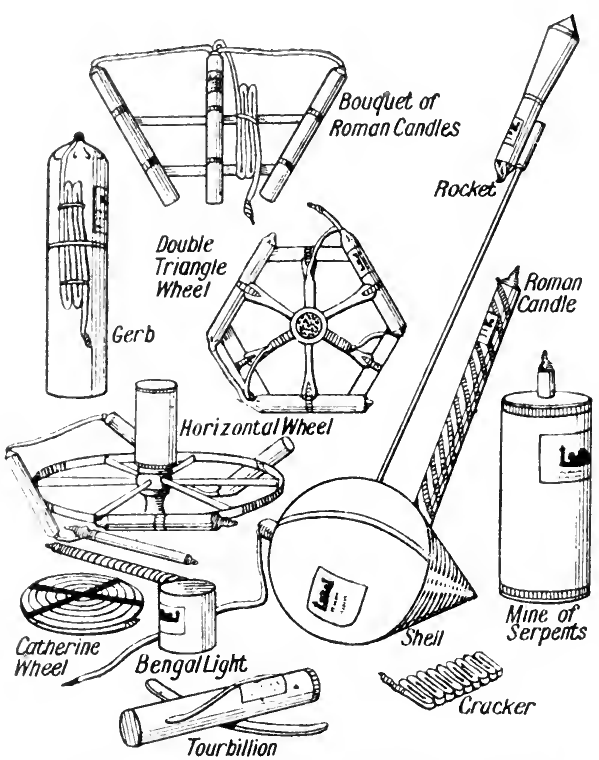

Fireworks. Various types of fireworks in popular use for displays and illuminations the mouth of the case is choked, either by a diaphragm of compressed clay with a central hole, as with gerbs and small rockets, or by constricting the case itself before drying, as with large rockets.

Tourbillions and Saxons are similar in action; both have the ends of the case closed with clay and a horizontal hole bored near either end, so that the fire issues at right angles to the axis. The holes in the Tourbillion rotate the case on a piece of curved wood secured to its centre, and secondary holes pointing downwards project it into the air. The Saxon revolves on a nail, fixed horizontally, driven through the centre of the case.

What may be called compound fireworks are composed of a number of the foregoing, fixed to wood frameworks in the form of wheels or geometrical patterns. In the revolving pieces the motive power is supplied by gerbs or turning cases which are in effect small rockets without heads. The best known pieces are rainbow, single and double triangle or caprice wheels, revolving fountains, Saxon cross, chromatrope, tree piece, and many others. The fireworks are connected on the framework with quickmatch, which is cotton wick soaked in a paste of starch and gun powder, dried, and threaded in a paper tube.

What are known as lancework set pieces are carried out with small coloured fireworks or lances spaced at short intervals following the lines of a design or picture and connected by quickmatch. The real development of lancework, which had hitherto been used merely to outline spokes and scrolls on wheels and for similar purposes, dates from 1879 , when portraits and other pictorial effects were introduced at the Crystal Palace.

Aerial fireworks are either rockets or shells, or modifications of them. Rockets consist of rolled paper cases choked at one end. In fill. ing, the case is placed on a metal nipple having a tapering spindle in the centre, the composition is

poured in in small quantities and solidified by blows of a mallet on a hollow wooden drift. 'The top of the case is fitted with a paper cap containing the "garniture" of the rocket, stars producing various colours and effects. The case has a short tube fixed to the side to receive the dowelled end of the stick, which directs the flight and, by passing through two rings on a post or frame, holds the rocket in position whilst firing.

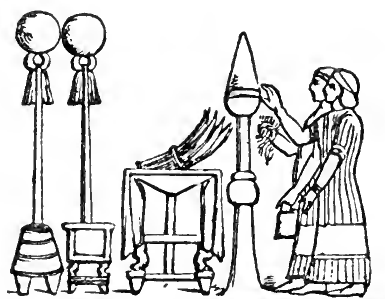

of the shell. The quickmatch which lights the lifting charge also ignites a time fuse at the top of the shell, which again ignites the bursting charge and contained effects upon reaching its maximum height.

Besides their spectacular value, fireworks have many utilitarian uses. The life-saving rocket used by the coast guard and National Lifeboat Institution carries a line from the shore to wrecked ships, and the later development, the Schernuly and Brock rockets, carry the line from the ship to shore, thus getting the advantage of the wind, as the vessel is generally on a lee-shore.

During the Great War pyrotechnics were of great value for signalling and other purposes, the Very light being practically a single star Roman candle fired by percussion from a specially constructed pistol. Parachutes fitted with lights for illumination or signalling purposes and coloured smoke-producing stars were used from aeroplanes, either fired from Very pistols or through a dropping tube which ignited them electrically. The Dover flares, giving over a million candle-power, used on the attack on Zeebrugge, and by the Dover anti-submarine patrol, aeroplane landing lights, star shells, and many others were the outcome of experience gained by pyrotechnists in the manufacture of recreative fireworks.

Fire-worship. The ritual expression of reverence for fire as a natural element affecting human welfare. It is traceable in Dahomé, among the Ainu, some Mongols and American Indian tribes. In ancient Mexico, Xiuhtecutli was reverenced with daily offerings and periodic rekindlings before his image. The cult prevailed in early Aryan India, whose fire-god Agni, personifying earth-kindled fire, lightning, and solar heat, was reborn daily of ten maidens, the fingers which twirled the sacred fire-drill. Honoured by 200 Vedic hymns, his ritual still survives here and there.

Shells are papier-maché hollow spheres filled with stars, or other pyrotechnic effects, and bursting charge. They are fired from a mortar of approximately the same diameter by means of a lifting charge of gunpowder in a conical bag fastened to the lower side

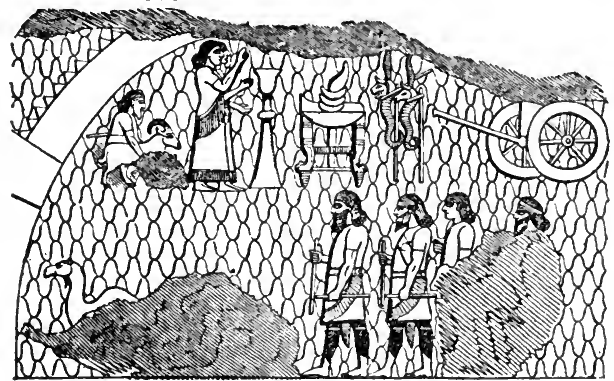

Fire-worship in ancient Nineveh. Fire-altar and sacrifice, from a bas-relief at Kouyunjik, Assyria. Above, fire-altar from Khorsabad, Assyria 
In early Persia a less developed fire-worship appears in the Avesta, wherein Atar, a son of Ahura. mazda, shares his conflict with darkness and impurity. In the Mazdean ritual, sacred fire, preserved in fire-temples, is not an object of worship but an emblem of divine power. This view is maintained by its modern exponents, the Persian Gabars and the Indian Parsees. At Baku, on the Caspian Sea, 18th century pilgrims gathered for expiation before stone temples near the burning oil wells. Many phases of culture exhibit fire-rituals loosely classed as fireworship. The perpetual fires of the Greek prytaneum and the Roman regia with its vestal virgins were forms of Aryan hearth-ritual. These rites survive, with much primitive superstition, among E. European peasantry, and in Damaraland. The Semitic use of perpetual firealtars for burnt offerings, incidental rather than essential, passed into the ceremonial lights of ritual Christianity. See Moloch; Sun-worship ; Zoroastrianism.

Firing Test. Experimental firing of pieces of ordnance to ensure their reliability. Before acceptance guns are required to fire one or more rounds with increased charges without showing undue expansion of the bore, and a number of rounds with normal charges to ascertain that the range and accuracy of the piece meets the requirements of the specification. The firing test is additional to careful measurement of the bore and all working parts, and mechanical and chemical tests of the materials used in construction. See Artillery.

Firkin. Old English ale measure, the fourth of a barrel, or 9 galls. Originally it varied from $7 \frac{1}{2}$ to 8 galls., and now it would equal $9 \frac{1}{7}$ imperial galls. As a small wooden cask to hold butter, a firkin contains $56 \mathrm{lb}$. The word is derived from Dutch vierde, fourth, and a diminutive suffix -kin.

Firlot (Four lot). Obsolete Scottish measure of dry capacity, being the fourth part of a boll. It varied for wheat and barley, and in different localities.

Firm (Span. firma, signature). Word used for an association of business men. In commercial circles of the 17th century and thereabouts it was used for a business signature, one that clinched a deal, and was then applied to the business house that signed. It is now the legal term for members of a partnership (q.v.).

Firmament (Lat. firmare, to make firm). Term used for the area of the heavens. It is used to trans-

late the Hebrew word rakia (Gen. $i, 6)$, and refers to the universe. See Stars; Universe.

Firman (Pers.). Passport issued to favoured travellers by the Turkish government. The term is also applied to a licence to carry out some enterprise or undertaking, or to engage in a particular trade. A firman bears the name of the sultan, and only a special minister, the nishanji (signer) effendi, has the right to affix the sultan's name.

Firminy. Town of France. It is in the dept. of Loire, $8 \mathrm{~m}$. S.W.

\section{FIRST AID: HOW TO HELP THE INJURED}

H. E. Davison, M.D., Examiner, St. John Ambulance Assuciation

This article is one of a group that includes Ambulance; Hospital; Red Cross. See also Dressing Station; Medicine; Surgery

First aid is a term for assistance which may be given in cases of accident or sudden illness before medical advice can be obtained. A knowledge of the principles of first aid has been promulgated widely in Great Britain by the operation of the St. John Ambulance Association, St. John's Gate, Clerken well, E.C. ; the British Red Cross Society; the St. Andrew's Ambulance Association, and various educational authorities. During the Great War, 1914-18, men pos sessing first aid certificates from one or other of these associations proved of great value in augmenting the established strength of the Royal Army Medical Corps, and, in civil life, in undertaking stretcherbearer and dressing-station duty during air-raids.

As regards the details of first aid, bleeding demands priority of attention in any accident. It may be stopped by firm and continuous pressure upon the bleeding point, or on the appropriate pressure point in the case of arterial haemorrhage. All dirt, etc., should be removed and the wound thoroughly cleansed with boiled water and dressed with clean lint, linen, or cotton. Out of doors, a wound should never be bathed with water unless one can be certain that the water is clean. A handkerchief, if clean, should be applied to the wound, or, if only a soiled hand. kerchief is available, the inside of an envelope may, in the emergency, be placed next to the wound, and the handkerchief used as a bandage.

\section{Treatment of Fractures}

All fractures should receive attention before any attempt is made to remove the patient from the place of accident. Treatment should be directed towards the immobilisation of the broken bone. Splints consisting of any rigid material, as wood from boxes, stout cardboard, walking sticks, umbrellas, broom-shanks, etc., should be applied and held in position by extemporised bandages. If practicable the splints should be of such length and so arranged that the joints above and below the seat of the fracture are kept at rest. In fractures of a bone of one of the limbs, the limb should be gently straightened before the splint is applied, and in the case of the upper limb support should be afforded by a sling.

\section{Dislocations and Sprains}

In dislocations the limb should be placed and supported in the most comfortable position, and cold dressings applied ; but otherwise not treated except by a doctor, as by unskilled manipulation grave damage may be done to bloodvessels and nerves in the neighbourhood of the injured joint.

In sprains a firm bandage should be applied and kept wet by the application of cold water. If the ankle is sprained when out of doors the boot should not be removed until the patient returns to his house, as a laced boot acts temporarily as a useful support. Whenever it is doubtful whether the injury sustained is one of sprain or fracture the case should be treated as if it were a fracture.

For burns and scalds treatment should be directed towards the exclusion of air from the injured part, and this may be effected most readily by the immersion of the part, if a limb, in warm water in which bicarbonate of soda has been dissolved. The burn or scald should then be dressed as soon as possible with strips of lint, linen, or cotton, covered with some antiseptic ointment, e.g. boracic ointment. Any clothing adherent to the burned flesh should be allowed to remain, the remainder of the garment being cut away.

If clothing is set on fire the patient should lie down at once on the floor with the flames uppermost. The flames should then be 
smothered by covering them with any rug, blanket, cushion, or tablecover which may be at hand. Apparent drowning or asphyxiation should be treated by the im. mediate and sustained application of artificial respiration.

In cases of poisoning a message should be sent immediately to the nearest doctor explaining the nature of the case, and, if possible, giving the name of the suspected poison. The bottle or other vessel containing the suspected poison, together with any vomited material, should be kept until it has been examined. 'Treatment should be directed to the elimination of the poison by the administration of an emetic, except in the case of poisoning by a corrosive fluid, such as oil of vitriol, etc., when the lips, etc., will be found $t_{1}$ ) be burned; towards antagonising the action of the poison by administering the appropriate antidote and by giving the patient demuicent drinks ; and by neutralising the tendency to shock by promoting the warmth of the patient. Emetics readily obtainable are mustard, one tablespoonful in a tumbler of warm water, and salt, one or two tablespoonfuls in a tumbler of warm water. For children a convenient cmetic is the wine of ipecacuanha, of which one teaspoonful should be given every twenty minutes until vomiting occurs. Demulcent drinks are milk, milk beaten up with eggs, cream, and any vegetable or animal oil.

\section{Loss of Consciousness}

When loss of consciousness occurs, all tight clothing should be loosened, and the patient put where he can obtain an ample supply of fresh air. If the face is pale, the head should be placed on the ground, and the lower limbs elevated. If the face is flushed, the body should be laid flat on the ground with the head slightly raised. In all cases the face should be inclined to one side lest vomiting oecurs, and the vomited matter be sucked into the air-passages. No alcohol, or indeed any other liquid, should be given to an unconscious patient. The patient should be kept warm.

Foreign bodies in the eye may readily be removed, if on the under surface of an eyelid, by a camel's hair brush, or the moistened corner of a handkerchief. If the foreign body, however, is on the ball of the eye, and not easily removed by gentle brushing, a drop of almond or castor oil should be dropped into the eye, and a pad of cotton wool bandaged over the eyelid in such a manner that the light pressure of the cotton wool prevents undue movements of the eyeball, until medical advice can be obtained.

Foreign bodies in the nose or ear should not be interfered with by the unskilled. They will do no harm during the time necessary to secure medical advice. No at. tempt should be made to remove a needle unless a part of it is projecting. The limb should be kept at rest, and medical advice sought. Stretchers are necessary in cases of serious illness or of accident out of doors, to convey the patient to his home or to a hospital. These may be improvised by removing a door or a field gate from its hinges, or by the use of a ladder.

Clothing should always be removed very carefully from an injured limb. In all cases, it should first be removed from the sound limb, and in some instances it is necessary also to cut away the garment on the injured side. If this is necessary, the trousers or coat. sleeve should always be cut up the outer, and not the inner, seam. A boot is best removed by cutting the lace and then the back seam; the boot will then fall away easily from the foot.

\section{Bites and Stings}

Bitesof animals should be cauterised by a liquid caustic, such as pure carbolic acid or caustic potash, but if no such fluid is at hand, a red-hot wire should be used. If there is any suspicion that the animal which has in. flicted the injury is mad, a doctor should be consulted, that treat. ment for rabies may be carried out without loss of time. In stings of plants and animals the sting should be removed, the part bathed with weak ammonia, and then dressed with a paste of bicarbonate of soda with water or sal volatile.

Firstborn. Technical term among the Jews. It signifies "that which openeth the womb," and does not necessarily imply the birth of other children. In commemoration of the deliverance from Egypt, all firstborn human males were con. secrated to God, but every child that lived more than one month could be redeemed. In lieu of the firstborn the tribe of Levi were chosen for service, thus becoming the priesthood.

in the case of animals the firstlings, if clean, were offered in sacri. fice; if unclean, redeemed. For an ass a lamb had to be substituted, otherwise the neck of the ass had to be broken. The Jews, who are referred to as the firstborn among the nations, still solemnise the redemption of the firstborn on the 30th day after birth. In the N.T. the term firstborn is used in relation to Christ, the dead, and the Church (Ex. 4, 13, 22, 34; Num. 3, 8, 18 ; Col. 1 ; Heb. 12 ; Rev. 1 ). See Birthright; Passover.

First Empire. Name given in France to the period between 1804 and 1814. In May, 1804, Bona. parte was made emperor, and the first republic eame to an end. The empire lasted until Napoleon's ab. dication in April, 1814. See French Revolution; Napoleon.

First Footing. New Year's Day folk custom, especially in Scotland and the N. of England. It was re. garded as unlucky for a woman or a fair-haired man to be the first visitor to any house on New Year's Day. As soon as midnight chimed people hurried to give their friends first footing, to offer them good wishes, and to partake of their hospitality. The custom may be traced back to Druid times, when the priests sent their young men from house to house bearing branches of mistletoe.

First Fruits. Ancient religious practice of offering to God a portion of the first fruits of a crop or of the first profits of any commer. cial undertaking. Prescribed by the law of Moses, among the Hebrews it was usuallyone-sixtieth, but might be as much as onefortieth. In the early Christian Church the practice was continued, though it was regarded as a work of devotion and not of obligation. Later, it was claimed by the clergy as their due, and formed part of their official income.

The Apostolic Constitutions (q.v.) direct that the first fruits of cattle and crops should go to the clergy, and that other first fruits should be devoted to the relief of widows and orphans. See Annates; Tithes.

First Offender. In England at common law there was always jurisdiction to bind over any offender to be of good behaviour. But since many magistrates seemed to ignore this, the First Offenders Act, 1887, was passed, giving all courts of criminal jurisdiction power to bind over first offenders instead of punishing them. The Probation of Offenders Act, 1907, extends this power to all cases, whether first offences or not; and gives the court power to order the first offender to be placed under the supervision of some person named (generally the probation officer) for a period. The order may also provide that the offender shall abstain from intoxicating liquor, refrain from assooiating with thieves, etc., and shall lead an industrious life. See Borstal System; Children. 

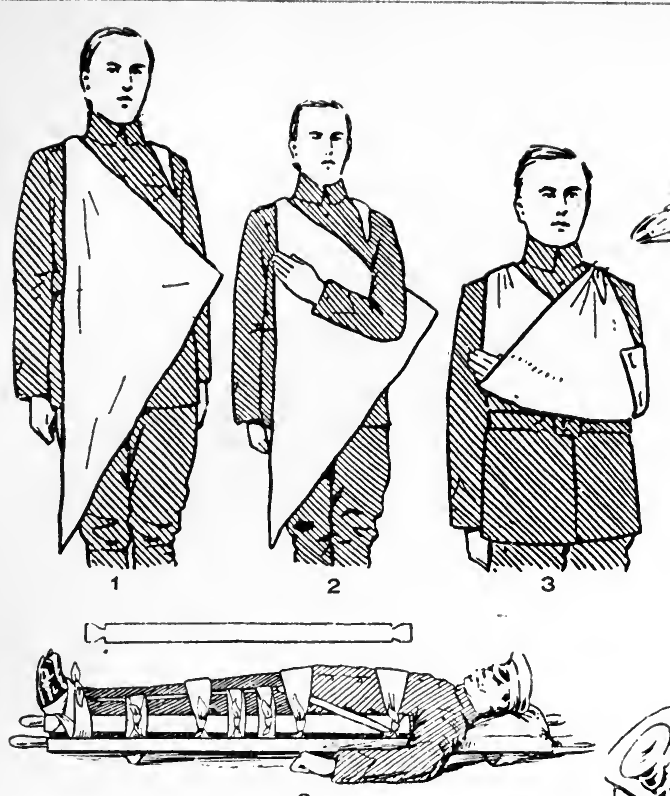

8
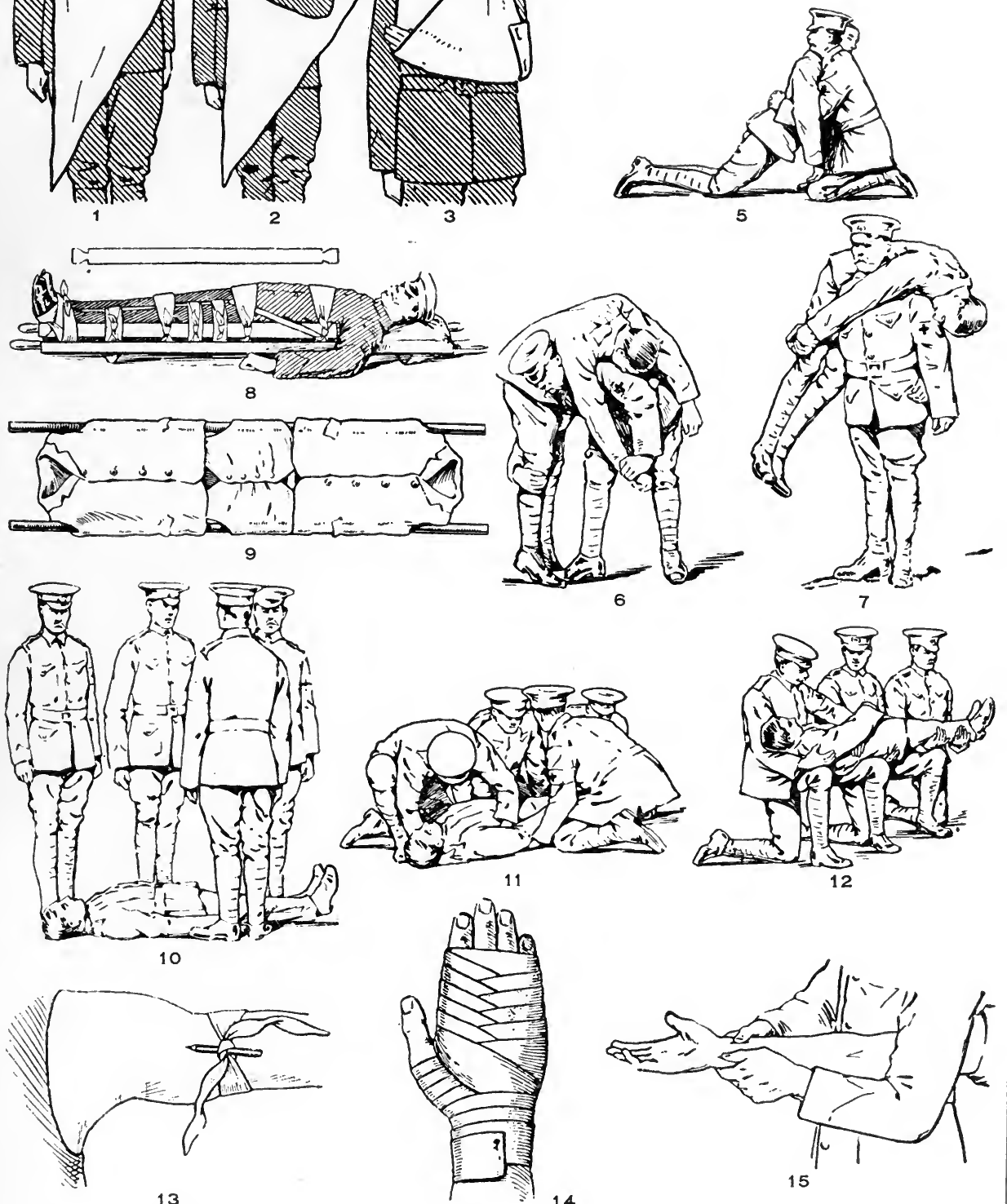

13

14

12 , and 3. Arrangement of large arm sling. 4, 5, 6, and 7. Stages of the fireman's lift. 8. Application of splint, A, to tractured thigh. 9. Stretcher made by passing noles through inverted sleeves. Io. Bearers in position for loading stretcher. II. Bearers kneeling to lift a

patient. I2. Patient on knees ut bearers Nos. I, 2, and 3. 13. Tourniquet for brachial arteries, backward view. I4. Figure-of-8 bandage for hand with simple spiral for wrist. 15. Digital compression of radial and ulnar arteries to stop bleeding

$$
\text { FIRST AID: ELEMENTARY MEASURES AND DEVICES IN FIRST AID TRAINING }
$$


First of June, Battle of. Fought on June 1, 1794, it was the first great naval action in the

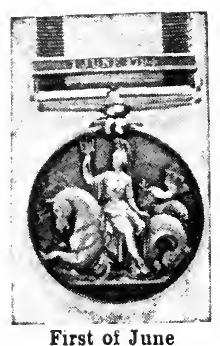

First of June War of the French Revolution. France, though victorious on land, was in a situation little short of desperate. It was the epoch of the Terror, the harvest of the previous year had been poor, and fam. ine was threatened. The British blockade was crippling the avenues of supply. The Committee of Public Safety had endeavoured to relieve the situation by purchasing large supplies of grain in the U.S.A., and a convoy of 116 vessels was dispatched, which approached the French coast towards the end of May. RearAdmiral Nielly was sent out to meet the convoy, which Lord Howe was instructed to intercept.

The main French fleet, under command of Admiral Villaret. Joyeuse, left Brest on May 16 to cover the arrival of the great grain convoy, and it was not unti! the 28th that Howe sighted his adversary. A good deal of fighting pre. ceded the great action, in which Howe's fleet was shown to be the superior fighting force. His plan was to attack the enemy in line, van to van, centre to centre, and rear to rear, to break through the opposing line, prevent retreat, and fight to a finish on the lee side. His ships were to pass through the intervals in the French line, but the approach was slow, and the order could not be completely executed.

The Bellerophon, Russell, Royal Sovereign, and other ships attacked to windward, and'several French ships thus slipped or were driven away. The Marlborough and Queen Charlotte, the latter Howe's flagship, broke through the line, and delivered their broadsides with shattering fire. Captain John Harvey, in the Brunswick, endeavoured to drive through the French line, but brave Captain Renaudin, in the Vengeur, stopped his way and the two ships were locked together in a furious struggle which has become famous, until the Vengeur, swept and broken by fire, went down with all her company.

At every point the action was fought with the utmost gallantry and resolution on both sides. Six prizes remained in English hands, and the success, if not decisive, was enough. For two years to follow there was no great action at sea.
The French, too, claimed a victory, for their fleet, damaged as it was, had not been destroyed, and their convoy reached Brest in safety. John Leyland

First Republic. Name given in France to the period from 1792 to 1804. On Sept. 21, 1792, the convention declared the monarchy at an end and the country a republic. This lasted until May, 1804, when Bonaparte was declared emperor. See French Revolution; Napoleon.

Firth. Name given to the narrow inlets or arms of the sea found on the coasts of Scotland. Most of them are estuaries or gulfs into which rivers discharge themselves, e.g. firths of Clyde, Tay, and Forth, but Pentland Firth is a broad strait or channel. Firths are, as a rule, valleys which have been flooded by the sea owing to the subsidence of the land.

Firth, Sir Algernon Freeman (b. 1856). British manufacturer. Born Sept. 15, 1856, the eldest son of Sir Thomas Freeman Firth, Bart., he entered his father's business, T. F. Firth \& Sons, of Heckmondwike. In 1909 he became its head, succeeding in the same year to the baronetcy. Sir Algernon became known as a spokesman of business interests, specially during $1912-13$, as president of the association of chambers of commerce.

Firth, Sir Charises Harding (b. 1857). British historian. Born in Sheffield. March 16, 1857, he was educated at Clifton and Balliol College; Oxford. He devoted himself to historical work, became fellow of All Souls College, 1901, and was chosen in 1904 to succeed York Powell as regius professor of modern history at Oxford. $\mathrm{He}$ edited Ludlow's Memoirs, 1894, The Clarke Papers and The Memoirs of Colonel Hutchinson; wrote monographs on Cromwell, 1900; and Cromwell's Army, 1902; and continued S. R. Gardiner's unfinished history of the Commonwealth and Protectorate. This work and his contributions to The Dictionary of National Biography have thrown much light on the middle decades of the 17 th century. His other works include Scotland and the Commonwealth, 1895. He was knighted, 1922.

Firth, MaRK (1819-80). Brit. ish manufacturer. Born at Shef. field, April 25, 1819, he was the son cf an artisan in the steel industry. In 1833 he began to follow the same calling, and in 1843 his father, brother, and himself together opened a steel furnace. Mark was the moving spirit of this enterprise, and soon made it one of the largest concerns in Sheffield. The Norfolk Works were built to cope with the increasing business, while others were erected outside the city. Firth died Nov: 28, 1880 . Known as a philanthropist, he built alms. houses at Ranmoor, and founded Firth College, the nucleus of the university of Sheffield.

Firuzkuh. Province of Persia. It lies in the Elburz Mts., and its chief town, of the same name, is situated about $90 \mathrm{~m}$. E. of Teheran. Pop. 5,000.

Fisc (Lat. fiscus, treasure chest). Term used in England in the Middle Ages for what is now the treasury, the account into which the public revenues are paid. From it comes the more familiar word fiscal. See Fiscus.

Fischart, JoHANn (c. 1545-90). German satirist. He was born in Alsace, and studied at Worms. He travelled in Holland, England, France, and Italy, and studied law in Strasbourg; he had already published some of his lampoons and satires against the Jesuits and others, and a free rendering of Gargantua into German, 1575, when he was appointed magistrate at Forbach, near Saarbrücken, 1583. Under various pen names, Fischart did good service to the Lutheran movement. The best known of his reprinted works is the simple verse narrative Das Glückhafft Schiff von Zürich (The Lucky Boat of Zürich), 1576.

Fischer, JoHANN GEoRG, voN (1816-97). German poet and dramatist. He was born, Oct. 25, 1816, at Gross-Süssen, Württemberg. Having studied botany and literature at Tübingen, he was in 1846 appointed professor at the Stuttgart Oberrealschule. In 1854 he published his first volume of poems, and in 1896 his last, Mit Achtzig Jahren (In my eightieth Year). He also published some dramas, notably Saul, 1862; and Kaiser Maximilian von Mexiko, 1868. His lyric poetry is characterised by natural beauty and exalted tone. He died at Stuttgart, May 4, 1897.

Fischer, Kuno (1824-1907). German philosophical writer. Born at Sandewalde, in Silesia, after studying at Leipzig and Halle, he became a tutor at Heidelberg, but owing to his advanced ideas was compelled to discontinue his lectures. For 16 years he was professor at Jena, and in 1872 succeeded Zeller as professor of philosophy at Heidelberg, where he died. A modified Hegelian in his views, he did much to popularise Kant. His greatest work, History of Modern Philosophy (latest ed. 1897-1904), is distinguished by lucidity and brilliancy of style and by wide knowledge. 
Parts of it have been translated into English : Commentary on Kant's Critick of Pure Reason, J. P. Mahaffy, 1866; Descartes and his School, J. P. Gordy, 1887; A Critique of Kant, W. S. Hough, 1888; Life and Character of Benedikt Spinoza, Frida Schmidt, 1882.

Fiscus. Latin word, meaning a purse, which came to be applied to the treasury of the emperor in ancient Rome, as opposed to the aerarium (q.v.), the treasury controlled by the senate. As the power of the latter declined, the fiscus gradually became the state treasury for the whole empire, the functions of the aerarium being ultimately limited to the municipal finances of Rome.

Fiset, Sir Joseph Eugene (b. 1874). Canadian surgeon and soldier. Born at Rimouski, March 15, 1874, he was the son of Hon. J. B. R. Fiset, a senator. Educated at Rimouski, and Laval University, he completed his medical training in London and Paris. Having joined the Canadian militia, Fiset served with the Canadian contingent in S. Africa. In 1903 he was given the D.S.O. and reached the rank of colonel. From 1903-6 he was director-general of medical services, and in 1906 he was made deputy-minister of militia and defence. As such, he had much to do with equipping the Canadian forces for service in the Great War. In 1917 he was knighted.

Fish. One of the phyla or subkingdoms of the animal world. Fishes may be defined as coldblooded vertebrate animals, living in water, and breathing by means of gills. In a few cases a primitive lung is present, and the fish can breathe air directly. The limbs, when present, are modified into paired fins ; there are also unpaired. fins which consist of folds or outgrowths of the skin. The body generally tapers towards the extremities, and is specially adapted for rapid passage through the water with the minimum of resistance. Sometimes the body is greatly flattened-either vertically, as in the rays, or laterally, as in the sole and turbot. In nearly all the genera the heart has two chambers and contains venous blood only. With few exceptions fishes reproduce their kind by eggs which are deposited in the water and fertilised by the male after they leave the body of the female, though a few species bring forth living young.

Fishes are found in all waters, both marine and fresh, and at almost all temperatures. Something like 2,300 species of fresh-
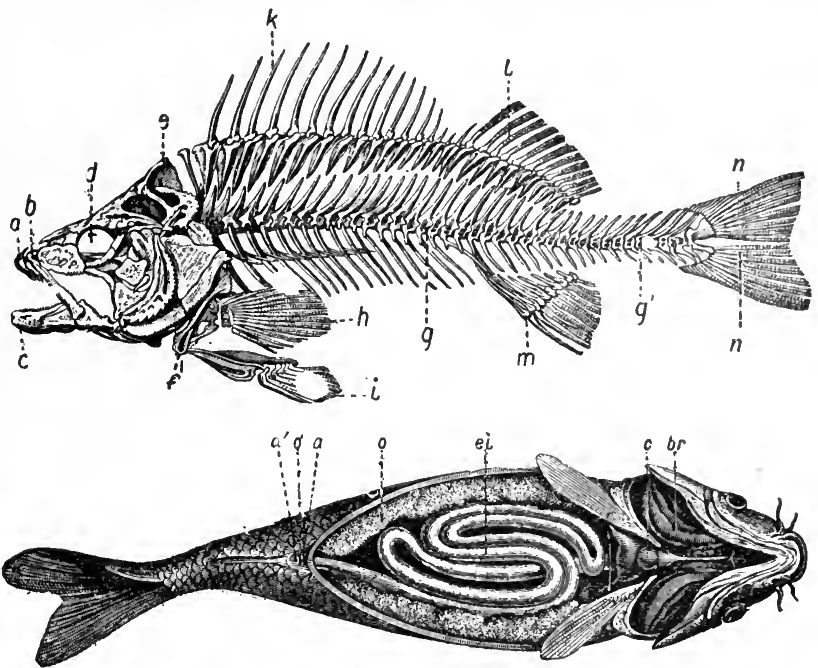

Fish. Diagrams illustrating the structure of fishes. Above, skeleton of common perch : a. pre-maxillary bone ; b, maxillary bone; c, under jaw ; $d$, palatine arch; e, cranium; $f$, inter-operculum; $g, g^{\prime}$, vertebral column; $h$, pectoral fin; $i$, ventral fin ; $\mathbf{k}$, 1 , dorsal fins ; $m$, anal fin ; $n$, $n^{\prime}$, caudal fin. Below, internal anatomy of carp : br, branchiae or gills; c. heart; ei, intestinal canal ; 0 , ovaries ; $a, a^{\prime}$, anus ; $o^{\prime}$, oviduct

water fishes are known to science ; about 3,500 species are littoral ; many others inhabit the seas far from land; and about 100 genera, including numerous species, have been met with in the lowest depths of the ocean.

The skeletons of fishes are in most cases bony; but in the Elas. mobranohs they are cartilaginous in character. In addition to the skeleton supporting the body outline and the limbs, there are often numerous bony rays supporting the unpaired fins also. The tail, with the caudal fin, is the principal propelling instrument, the paired fins being used as auxiliaries and for steering. The unpaired fins on the dorsal and ventral sides of the body serve mainly as balancers. The scales with which the body is more or less covered are in some cases horny in character and in others bony. In the latter case they are often nearly allied to teeth in structure and contain dentine or ivory.

\section{How Fishes Breathe}

Fishes breathe by extracting the air contained in water, which is taken in by the mouth and passed out through the gill-clefts on either side at the hinder part of the head. In its course it passes over a serie of arches or plates, abundantly supplied with blood-vessels, and the oxygen is thus brought into contact with the blood very much as in the lungs of terrestrial animals. Most fishes are well supplied with teeth, which in some families are very numerous. They may be confined to the edges of the jaws, but are often found on the palate and even on the gill arches and in the throat. There may be both cutting teeth and grinding ones, the latter often taking the form of plates. They usually grow from the surfaces of the bones of the mouth, but are sometimes found in sockets. They are usually replaced when worn down by fresh teeth developing from behind and not from beneath.

Fishes have in most species welldeveloped eyes, and their power of vision is good. A few genera, found in underground streams or in the greatest depths of the ocean, are without eyes. Experiment proves that most species can hear well; and their sense of touch is highly developed, the barbels which are found around the mouth in many species being used for this purpose. Whether the sense of taste is at all developed is uncer. tain. In colour fishes vary greatly, from the most sombre tones to the most brilliant hues. As a rule, the upper surface is darker than the lower, an arrangement which helps to make them inconspicuous. The silvery appearance is due to the presence of minute crystals in the scales, and causes the surface of the fish to act like a mirror and by re. flecting its surroundings render it almost invisible. Protective coloration is often present, notably in the flatfish, which often so exactly resemble the mud and sand that 
they are very difficult to see when lying on the bottom. Many species, especially in the tropics, are gorgeously coloured and variegated to match the seaweeds and corals.

In the matter of diet fishes vary greatly, and almost everything, both animal and vegetable, that lives in the water is preyed upon by one species or another. Small crustaceans and molluses form the most important item in the food of most fishes ; but many prey on smaller fish, and others browse on the aqua. tic vegetation. Some swallow mud and extract nutriment from it. As a rule, the appetite of fishes is large, and some species have such expansive powers that they will even swallow other fish larger than themselves. Nearly all fish are edible, though many are coarse and indigestible and a few appear to be actually poisonous. But the poor reputation of certain species is simply due to unskilful and unsuitable cooking. Fresh-water fishes, with the exception of salmon and trout, are as a rule of muddy or insipid flavour and contrast poorly with the marine fishes.

Fishes are usually divided into four sub-classes: Elasmobranchii or cartilaginous fishes, which are now all extinct with the exception of the sharks and the rays; Holocephali or chimaeroids, of which only three genera now exist and are of very eccentric appearance ; Dipnoi or lung fishes, which can breathe air and are now all extinct, with the exception of three species; and Teleostomi or end-mouthed fishes, which include all the other fishes. See Animal; Fisheries; Zoology.

W. J. Wintle, F.z.s.

Bibliography. Fishes, Living and Fossil, Bashford Dean, 1895; The Study of Fishes, A. Gunther, 1880 ; Marvels of Fish Life as revealed by the Camera, F. Ward, 1911.

Fish, Hamilton (1808-93). American statesman. Born Aug. 3, 1808, in New York, he became a barrister in 1830 . In 1842, as a Whig, he was returned to Congress, and in 1848 he became governor of New York State. In 1851 he was elected senator. After visiting Europe, he took a prominent part in the election of Lincoln. Organizing many schemes for the assistance of troops during the Civil War, Fish was also largely responsible for relief measures for the prisoners. From 1869-77 he was a secretary of state under Grant. One of the commissioners for the treaty of Washington, he was identified with many negotiations which im proved the relations between Great Britain and the U.S.A. He died Sept. 7, 1893. His son, Hamilton

Fish, was assistant treasurer of the U.S.A., 1903-8, and a member of Congress, 1909-11.

Fish, Sturvesant (b. 1851). American railroad official. Born at New York, June 24, 1851, the son

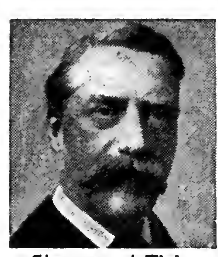

Stuyvesant Fish,

American railroad official From 1883-1906 he was trustee of the Montreal Life Insurance Co. of New York. He was vice-president and director of the National Park Bank, and from 1904-6 presi dent of the American Railway Association.

Fish Culture. Art or industry of artificially increasing stocks of food fish, both fresh-water and marine. Ponds or stews for freshwater fish have been common from time immemorial. The Chinese have cultivated fish for thousands of years and still lead the world in the amount of fresh-water fish bred for food. At the beginning of the Christian era every wealthy Roman had his piscinae or fish ponds.

So far back as the Saxon epoch large landowners had stews for carp, pike, perch, bream, eels, etc. In Domesday Book ponds are mentioned which were valued at five to twelve shillings yearly, representing at least twelve times the value of a similar area of agricultural land at that date. In 1275 Parliament passed a stringent Act punishing poaching and injury to ponds, and somewhat later the 52 Plowden Ponds of Ashton, Northamptonshire were said to be capable of producing a ton of fish weekly.

\section{French and German Methods}

On the Continent fish culture never fell into disuse as it did in Britain. France possesses fresh waters devoted to fish farming, of a total area of nearly 500,000 acres, while in Germany every town or village where running water is obtainable has its fish ponds or stews. In Germany, as a rule, three or more ponds are constructed in line along the course of a brook, and while two are filled with water holding fish, the remainder are drained and the beds cultivated. This method pays doubly in that the cultivated ponds, when refilled, supply a stock of insect food for the fish, while the drained ponds make rich soil for gardening purposes.
The culture of coarse fish is com. paratively simple. It is merely necessary to place the ova or young fish in the pond or lake and leave them to increase and multiply naturally. In a pond which is supplied with fresh water from springs or a brook, perch, tench, roach, bream, barbel, and pike will flourish. For a stagnant pond, carp, German carp, and eels are the only fish suitable. From the beginning of the food shortage caused by the Great War, the British government did all in its power to stimulate fresh-water culture in Britain, especially that of eels. The fisheries department supply elvers, that is young eels, at a moderate price to all individuals who desire to stock ponds.

The fish hatchery for salmon and trout was established in 1853 at Stormontfield, near Perth, on the Táy. It consisted of a series of open-air breeding boxes capable of containing half a million ova. A number of fish hatcheries were afterwards formed in different parts of the kingdom, in which are reared salmon, brown trout, Loch Leven and rainbow trout. These are sent to all parts of the world.

\section{Spawning and Hatching}

The spawning fish are netted when on the spawning beds. By gentle pressure the eggs are removed from the female and are then fertilised with the milt of the male. The fecund eggs are carefully conveyed to the hatchery, and placed in shallow trays or boxes through which flows a gentle current of pure water. When hatched, the small fish are kept in the boxes until the yelk sac is absorbed and are then turned out into ponds, or into the open river itself. In pure and scrupulously clean water the proportion of ova safely hatched is as high as 95 p.c. In the U.S.A. the government has established salmon hatcheries on a large scale on the Pacific Coast and at present something like $300,000,000$ young salmon are liberated every year.

The stock of salmon in a river can be largely increased by im. proving the means of access to the upper water by constructing salmon ladders at spots where there are falls, to enable the fish to reach their spawning grounds more easily. By an outlay of $₫ 2,000$ the duke of Sutherland doubled the fishing value of the Helmsdale river. The question of the close time for nets is also important as regards the increase of salmon. The stock of fish in a trout stream and the size of the trout can be largely increased by deepening the pools by means of ty rough stone dams. These dams, 


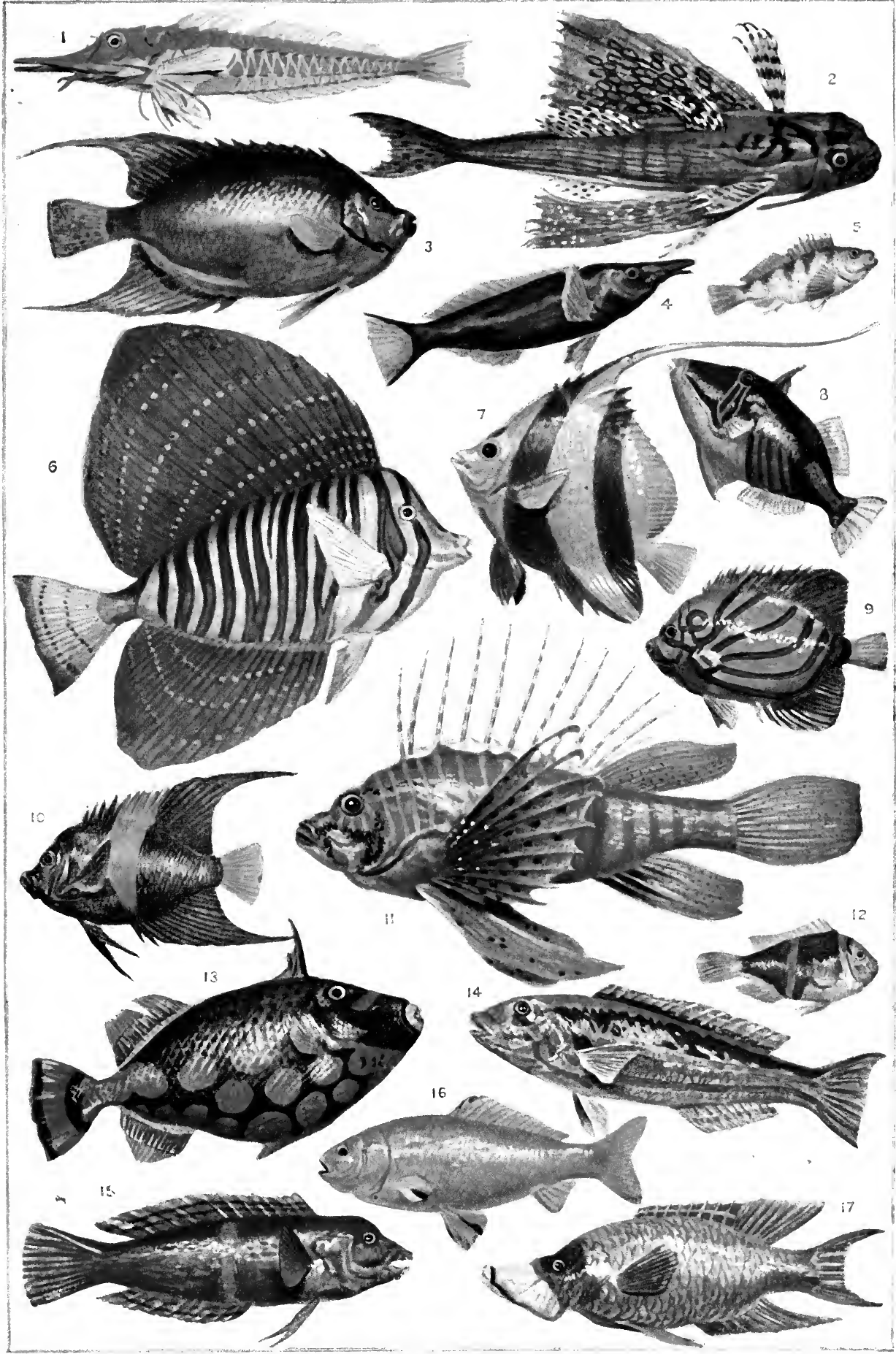

1. Peristedion cataphractum, European seas, 2. Dactylopterus larıs, Nalay Archpelago. 10. Holacanthins asfur. Red Sea.

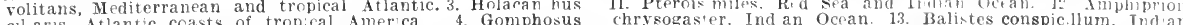
coeruleus, Indian Ocean. 5. Cirrhites cinetus. Indian ocean and Pacific Oceans. 14. Julis trilobata, and 15. Coris aycula auratus, China Sea. $1 \%$, Ep bulus insidiator, Indian Ocean and 8. Balistes aculeatus, tropcal seas. 9. Holacanthus annu- Malay Arch pelago.

FISH : VIVIDLY COLOURED SPECIES. HABITANTS OF MANY SEAS 

called "croys" in Scotland, are particularly valuable in swift rocky or moorland streams where there is not any great accumulation of silt or mud.

Flat fish, such as plaice, sole, and turbot, are being reared in large numbers by the Scottish Fishery Board at ponds on the shore of the bay of Nigg, near Aberdeen, and elsewhere. The Norwegian government liberates yearly hundreds of millions of young cod hatched in salt water ponds. On the W. coast of France there are a number of brackish ponds, where salt-water fish are not only hatched but raised to maturity for the market. It is there that the curious fact was first discovered that plaice, dabs, and several other species of flat fish will fatten as rapidly in water that is almost fresh as in tidal ponds. The Fish Commission of the U.S.A. practises the artificial rearing of marine fish on the greatest scale. Shad, in particular, are reared in millions, and the artificial propagation of lobster is pursued with great success. See Close Time.

T. C. Bridges

Fish Curing. Curing, drying, pickling, or otherwise preserving fish. The curing of cod, mackerel, and herring are the most important branches of the industry in Great Britain, and the methods employed in large Scottish curingyards are typical. Cod are gutted and bled as soon as they are caught, being carefully packed in boxes, or otherwise protected from the sun and air.

As soon as the fish have been brought ashore, the heads are cut off and the fish carefully cleaned by being brushed in fresh water, and then split. The backbone is cut about 20 joints from the tail. The fish are then washed in salt water, and the black lining membrane removed. They are then pickled in covered vessels, the proportion of salt allowed being about $50 \mathrm{lb}$. to $100 \mathrm{lb}$. of the dried, cured fish. In packing the fish into barrels a particular method is adopted, as a result of which the lighter side of the fish is uppermost, until the top layer is reached, when the dark side is placed upmost. Two fish make a layer in the barrel. In 1913 the amount of dried codfish in Scotland was 161,722 cwt., from which 3,279 barrels of pickled cod were obtained, and over 120,000 cwt. of smoked cod.

Mackerel should be split, cleaned, and salted as soon as possible, because this fish soon becomes soft and flabby. The fish are cut with a clean, sharp knife down the back from head to tail. The intestines are extracted, the gills removed, and the blood expressed. The fish is then washed in three stages, the first merely a quick swill, the second a short soaking, and in the third the fish are left in clean water for about an hour. Finally, the mackerel are reamed and salted, the reaming consisting of the making of a shallow cut from the bottom of the belly to the head. Salting is done as quickly as possible, sufficient salt being used to cover every part lightly, the fish then being transferred to a barrel in which enough salt is placed between the layers to prevent actual contact between fish and fish. The pickle, which consists of clean salt water or clean fresh water with salt added, is put in until the barrel is quite full, and in this the mackerel are left five or six days. After this the mackerel are re-packed into the final shipping-barrel.

Herring curing is carried on on a very large scale in normal times in Great Britain. As a rule only the large and medium fish are used. Curing commences directly the herrings are emptied into the farland, a large oblong box about $2 \mathrm{ft}$. high, with inward sloping sides and ends to allow the gutters to work more conveniently. As the fish are emptied into the farland, platefuls of salt are thrown on to them at once. A light sprinkling is sufficient if they are to be gutted immediately, a more heavy sprink. ling if they are to be left all night. The women gutters stand usually at one side of the farland and work with great rapidity. A sharp. bladed knife is inserted through the gills, with the edge towards the worker. By means of a sharp movement the gills and the stomach, etc., are completely removed. The gutted herrings are then salted until every fish has come into contact with the salt.

The herrings are packed tior by tier, the heads to the sides of the barrel, the tails meeting or overlapping, the middle herring being placed in front of the tails of the last two, then two more with their heads to the sides of the barrel, this being repeated until the tier is complete. Salt is sprinkled between the tiers. One barrel of salt is usually necessary to cure three barrels of herrings. The herrings are packed a little above the level of the barrel at first, as they sink a little in the salt. On the following day the barrels are filled up to the level, the ends put in, and the barrels laid on their sides. They are left in this way for eight or ten days. They are then bored in the bilge, set on their ends, and the pickle is run off through the bung- hole. In normal times the herringcuring business can be seen on a large scale in Shetland from the beginning of May until the middle or end of Sept., and on an average, in normal years, 100,000 barrels are sent annually from Shetland to Petrograd alone. See The Art of Fish-curing, R. J. Duthie, 1911. G. Leighton, M.D.

Fisher, ANDREW (b. 1862). Australian politician. Born Aug. 29, 1862, at Crosshouse, Kilmar. nock, Scot-

l a n d, h e worked as a boy in the coalmines. In 1885 he emigrated to Queensland, and in 1893 was elected in the labour interest to

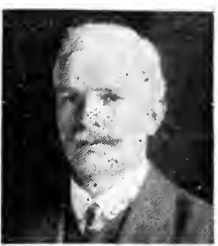

Andrew Fisher, Australian politician

the state legislature. In 1899 he was made minister of rlys. Fisher entered the Commonwealth parlia. ment as M.P. for Wide Bay in 1900. In 1904 he became minister of trade and customs, and in 1907 leader of the labour party. As such he was prime minister for a few months in 1908-9. In 1910 the labour party returned to power, and he was prime minister until 1913, when his party was defeated. Fisher returned to power in 1914, and he was premier when the Great War broke out. In Oct., 1915, he resigned the premiership to become high commissioner for the Commonwealth in England resigning in 1921 .

Fisher, Herbert Albert LaURENS (b. 1865). British historian and politician. Born in London,

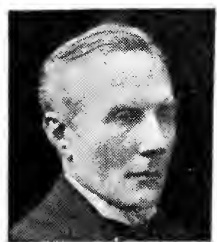

Herbert Fisher, British historian March 21, 1865 he had a brilliant career at Winchester and New Col. lege, Oxford, of which he became a fellow. As lecturer and tutor in history he remained in Oxford until 1912, when he was chosen vicechancellor of Sheffield university, holding that post until in 1916 he was made president of the board of education, resigning in Oct., 1922. As such he was responsible for the Education Act of 1918. $\mathrm{He}$ entered Parliament as M.P. for Sheffield in 1916, and in 1918 and 1923 was returned as a member for the newer English universities. In 1907 he kecame a fellow of the British Academy, and in 1909 delivered the Lowell lectures at Baston. Fisher's historical 
books include; Studies in Napoleonic Statesmanship, 1903; and Napoleon, 1913. He became warden of New College, Oxford, in 1925.

Fisher, JoHN (c. 1459-1535). English prelate. He was educated at Cambridge, becoming master of

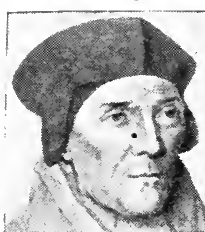

John Fisher,

English prelate After Holbein
Michail House in 1497 and chancellor of the university in 1504. In 1497 he had beenappointed confessor to Henry VII's mother, Mar. garet, countess of Richmond, and in 1503 became the first Lady Margaret professor of divinity. In 1504 he was made bishop of Rochester. He was a keen opponent of Henry VIII's divorce from Catherine of Aragon, was imprisoned in the Tower in 1534 for re. fusing to swear to the Act of Succession, and on June 22, 1535, was beheaded on Tower Hill for refusing to recognize Henry as supreme head of the Church. He had been created a cardinal on May $20 . \mathrm{He}$ was a zealous humanist, and was instrumental in bringing Erasmus to Cambridge. He was beatified on Dec. 9, 1886.

Fisher of Kilverstone, ЈоHN ARbuthnot Fisher, lst Baron (1841-1920). British sailor. Born Jan. 25, 1841, at Rambodde, in Ceylon, he entered the navy on June 12,1854 , on board the Victory at Portsmouth, "penniless, friendless, and forlorn," as he wrote himself. He saw active service in the Calcutta with the Baltic fleet during the Crimean War and later in China, when he was present atthe capture of Canton and the attack on the Peiho forts.

Promoted captain in 1874, he commanded the Inflexible at the bombardment of Alexandria, 1882. He landed there with the Naval Brigade, and was the adap. tor of the armoured train, which he commanded in several engagements, receiving the C.B. for his services. In Feb., 1892, he was appointed to the board of admiralty as controller of the navy, a post which he held until Aug., 1897, when he took command of the squadron on the $\mathrm{N}$. America station. Fisher returned to Europe in 1899 to represent British naval interests at the Hague peace con. ference. From July, 1899, until May, 1902, he was commander-inchief in the Mediterranean, and on his return was appoirted second sea lozd of the admiralty.

He was largely responsible for the scheme of entry and training for naval officers which abolished the Britannia, substituting the colleges at Osborne and Dart mouth, and trained executive officers, engineers, and marines together up to the rank of lieutenant, after which they specialised into the various branches. From Aug., 1903, to Oct., 1904, he was commander-in-chief atPortsmouth, and served as a member of Lord Esher's committee on national defence. He was appointed first sea lord on Oct. 21, 1904, and resigned this office in 1910 .

Remarkable changes in naval organization and material were carried out in this period, due mainly to the rapid rise in strength of the German navy and to the development of naval ordnance and the science of gunnery. The British fleets on foreign stations, particularly in the Mediterranean and the Far East, were drastically reduced, and in 1907 a Home Fleet

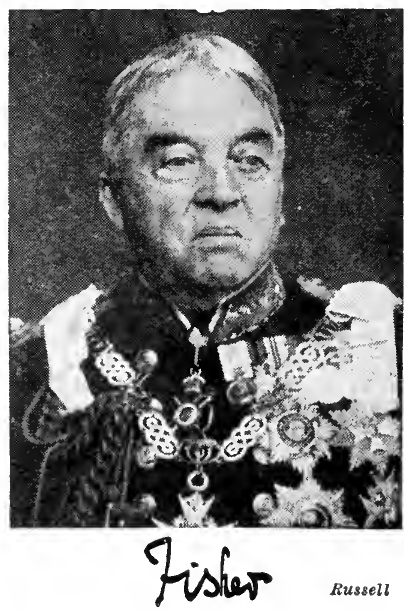

was formed which, two years later, absorbed all of the commis. sioned naval forces in home waters.

Lord Fisher, who was knighted in 1894 and created a baron in 1909 , was the creator of the Dread. nought and battle-cruiser type, and the introducer of oil fuel and submarines into the British navy. His work in improving the shooting of the navy was of the utmost importance. $\mathrm{He}$ was specially promoted to admiral of the fleet, and was appointed in 1912 chairman of a royal commission on oil fuel in relation to the navy. $\mathrm{He}$ was rccalled to be first sea lord on the resignation of the marquess of Milford Haven, Oct. 29, 1914.

He took steps to lay down 612 new ships of various types, many of which were designed for special work in the Baltic. $\mathrm{He}$ also ordered a large number of aircraft, including the small airships often known as "blimps," which proved of great value for reconnaissance in the early stages of the war at sea. He advocated the introduction of much heavier guns, and had a battle cruiser planned which would have mounted six or eight 20-in. weapons.

In one very important matter Fisher's naval leadership was defective-he attached insufficient importance to tactical training and to the spiritual side of his profession. $\mathrm{He}$ provided admirable weapons, but not the staff to use them to the best effect, and he never properly understood the necessity of a staff in modern war.

$\mathrm{He}$ strongly opposed the Dardanelles expedition, and was with difficulty prevented from resigning when it was ordered, early in $\mathbf{1 9 1 5}$, by the Cabinet. He finally resigned on May 15, 1915, on the ground that ships required by the Grand Fleet in the North Sea were being imperilled at the Dardanelles. Though publicly censured by the Dardanelles committee for his conduct, he refused to defend himself.

In the general conduct of the war he was successful ; the decisive result of the battle of the Falkland Islands, Dec. 8, 1914, was entirely due to his action in sending two battle cruisers secretly from the North Sea, despite the opposition of the Cabinet and the British com. manders in home waters. In July, 1915 , he was appointed president of the board of invention and research. He died July 10, 1920, retaining to the last his vigour of mind and speech. His letters to The Times in 1919-20 were memor. able for the refrain " sack the lot," and he always spoke of himself as "ruthless and relentless." Yet he had a warm heart and never bore malice to a fair critic. Beyond question he was one of the great figures of his age, and did much to achieve the British victory.

I. W. wilson

Bibliography. Lord Fisher on the Navy : A Series of Articles reprinted from The Times, Sept., 1919; Re. cords, 1919 ; Memories, 1919.

Fisher, Sir Norman Fenwack WARREN (b. 1879). British civil servant. Born Sept. 22, 1879, he was educated at Winchester and Hertford College, Oxford. He was private secretary to Sir Robert Chalmers, 1908-10, and a special commissioner of income tax, 1910 13. He was on the National Health Insurance Commission, 1912-13, and a commissioner of inland revenue in the latter year. Deputy chairman of the board of inland revenue, 1914-18, he was chairman 
from 1918 until Aug., 1919, when he succeeded Sir John Bradbury as permanent secretary of the treasury. His signature succeeded that of Bradbury on the currency notes. .

Fisher, Wrutram Mark. BritishAmerican artist. Born at Boston, U.S.A., of American and Irish parents, he studied art in Paris when 20 years of age, and after a brief sojourn in America, settled in England. He was elected A.R.A. in 1911, and R.A. in 1919. His subjects are rural scenes, mostly taken from the Essex country in which he lived.

\section{FISHERIES: THE INDUSTRY \& ITS GROWTH}

Gerald Ieighton, M.D., Inspector, Scottish Board of Health

Additional information on the subject of fisheries will be found in

the articles on the various fish, e.g. Cod; Herring; Mackerel, etc.

See also Trawling and the articles Fish Culture; Fish Curing, etc.

Dwellers upon coastal margins have always depended to a large extent upon their skill as fishermen for their sustenance. In modern times, however, the world's fisheries mean more than the catching of local fish for local needs. As knowledge of fishing areas has become greater, and methods of catching have developed, the industry has taken a prominent position in world commerce.

Methods of preservation and treatment have caused fish to be distributed all over the world, even to the interior of continents, where fish food, unknown previ. ously, is to-day common. In this advance the processes of drying, smoking, refrigerating, and canning have played an important part.

\section{Pelagic and Deep Sea Fish}

Marine fish may be divided into shore, pelagic, and deep sea fish. The shore fish live either on or just under the surface of the water close to the land. Some are confined to shallow coasts with sandy bottoms, others to rocky coasts. Pelagic fish live near the surface of the open ocean, and only come near the shore for spawning or food. Most of them spawn in the open sea. They roam over large areas, either in virtue of their strength as swimmers or by the aid of ocean currents.

Deep sea fish live in the depths, where light, temperature, and movement are but little felt. These groups cannot be separated by hard and fast lines. They merge gradually, and fish probably change from one to the other. These changes are occasioned by the search for food. Thus the surface of the sea near the shore sometimes contains numerous small crustaceans, or molluses, upon which fish in the open ocean feed.
The latter, therefore, come close into shore, pursued in their turn by other large fish which prey upon them. Edible fish all come within the groups of shore or pelagic fishes.

\section{European Fisheries}

Of the principal European fisheries, the shore fishing of France includes herring, mackerel, sardines, anchovies, sprats, tunny, salmon, sturgeon, and oysters. The deep sea fisheries, including those from Iceland, the North Sea, and Newfoundland, are mainly those of the cod, but include herring and mackerel. German fishing vessels land their fish on the coasts of the North and Baltic Seas, the most important being cod, haddock, coal-fish, whiting, plaice, lemon sole, ling, and herring. Holland's vessels land principally herring, plaice, flounders, anchovies, and smelts. The chief fishery of Belgium is of the inshore kind, and that of Denmark consists of flat fish, eels, herring, and cod. Of the produce of the Portuguese fisheries, more than half is sardines.

The Norwegian fisheries are by far the most important of the European fisheries, and have steadily increased in value during recent years, cod and herring being the first on the list. In 1915 the value of the fish landed rose to over $£ 10,000,000$.

Newfoundland's chief catches are cod, herring, and whale. The Canadian fisheries embrace cod, the largest quantity, followed by salmon, hake, pollack, halibut, haddock, white fish, sardines.

The main fisheries of the U.S.A. are: (1) on the Atlantic-herring, cod, alewives, haddock, hake, pollack, shad, flounders, halibut, mackerel, menhaden, and mullet; (2) in the Gulf of Mexico-mullet and snapper; (3) on the Pacific coast-salmon, halibut, flounders, and cod. In the Mississippi River, carp, and in the Great Lal ies, lake herring are caught.

Britisir Fisheries. The cdible fish included in the statistical returns of Great Britain are c btained from such widely scparated spots as N. Scotland and the Bay of Biscay, the Porcupine and Reckall Banks of the Atlantic Ocean, and the coasts of Denmark, Holland, Norway, and Shetland. During the past 30 years the industry has seen the disappearance of the old fishing smack in favour of the power. ful and fast steam trawler, together with improvements in the gear and machinery employed, and the introduction on a large scale of ice for preserving the fish. Thus fish can now be brought from far greater distances than was formerly the case, and trawlers can remain at sea for one or two weeks before landing their catch.

The position of Great Britain as an island has given her an unique advantage in the industry; and the enormous figures given in the official returns suggest either that the quantity of fish must seriously diminish as time goes on, or else that the supply is inexhaustible. The latter is probably the truth, provided that the fish get fair treatment. The reason is biological, the extraordinary power of reproduction possessed by fish. A herring produces from 20,000 to 30,000 annually - a small figure compared to turbot and cod, and some others, which produce millions. This fertility explains why, for example, it is possible for the Scottish herring fishery alone to handle about $1,000,000,000$ fish annually.

\section{Experimental Conservation}

Fishermen do little or nothing towards the conservation of their catch. The few efforts made to restock the sea are experimental, and negligible from the point of view of the total result. In the period preceding the Great War, there were some 80,000 men and boys engaged in the fishing fleets of Great Britain, excluding Ireland, entirely engaged in eatching and landing fish, and not in any way producing them in the sense that the farmer produces meat.

Edible Fish. From a theoretical point of view any fish which is wholesome food would be considered edible; but a number of the smaller fishes found along the sea-shore are commercially to be ignored Different countries have different tastes. For example, the bass is highly esteemed in Constantinople, and grows in Turkish waters to a much larger size than 
in British waters. In Great Britain it is much neglected, possibly beeause.it requires to be caught with hook and line, and then only in restricted districts. Pollack, again, is caught in large quantities on the line off Cornwall and other places, but it does not pack well, or keep well, and is thus neglected. Skate and ray, until recent years, were not seen in the fishmongers' shops nearly so much as they are now, but are highly esteemed in French restaurants. Other fish are consumed almost entirely in or near the locality of their capture, among t'em the coal-fish and cat-fish of Seottish waters, the pollack and pilchard of Cornwall, the conger, the dog-fish, and weever of Sussex.

Landings in England and Wales

In 1913, the last completed year before the Great War, the total landings of fish in England and Wales reached a maximum, while in Scotland the quantity was less than that of the previous year, though of greater value. For the 11 years, 1903-13, the quantities and value of fish landed in England and Wales were as follow:

\begin{tabular}{|c|c|c|c|c|}
\hline \multirow[t]{2}{*}{ Years } & \multicolumn{2}{|c|}{$\begin{array}{l}\text { Fish (exclusive of } \\
\text { shell Fish) }\end{array}$} & Shell Fish & Total Value \\
\hline & Cwts. & & $f$ & $\mathfrak{f}$ \\
\hline 4 & $11,365,000$ & $\begin{array}{l}930,0 \\
490,\end{array}$ & $\begin{array}{l}9,000 \\
0,000\end{array}$ & $6,780,000$ \\
\hline 1905 & $11,310,000$ & $1, \mathrm{C}$ & 2,000 & $7,503,000$ \\
\hline 1906 & $12,195,0$ & $7,641,0$ & 324,000 & $7,965,000$ \\
\hline 190 & 13,994 & 7,8 & 000 & $8,155,000$ \\
\hline 19 & 13 & & 00 & 42,000 \\
\hline 1909 & $13,055,000$ & 7 & 00 & 0,000 \\
\hline 1910 & 8000 & 7 & 228,000 & $8,194,000$ \\
\hline 1911 & 9.000 & 1,000 & 273,000 & $8,324,000$ \\
\hline 1912 & 12,000 & $8,884,000$ & 327,000 & $9,211,000$ \\
\hline 1913 & $16,152,000$ & $10,009,000$ & 328,000 & $10,337,000$ \\
\hline
\end{tabular}

The total landed showed an increase, largely attributable to the record eatch of herring in 1913 , of 44 p.c. on that of 1903 , and of 10.5 p.e. on that of 1912. The E. coast contributed about 92 p.c. of the pelagic fish.

Marketing. The placing of fish upon the market involves first the production and eatching of the fish, and, secondly, the means of distribution. The catching is done either by nets, baited hand-lines, or traps, the latter used especially for shell-fish. The nets are the trawl, the drift-net, and the trammel. Commercial distribution bears little relation to the natural distribution of the fish in the sea. Thanks to improved methods of transport, and ice-packing, thousands of tons of fish are brought a thousand miles to be sold at Billings. gate. Much of this is collected in the fishing grounds themselves by fast steamer's. This is known as the "fleeting system." About 40,000 tons per annum is brought to the Thames every year in this manner.
Fish caught in trawl-nets are dead when brought on board, and must be packed in ice. The same thing applies to fish caught on lines, only hauled up at long intervals.

Other fish, such as cod and halibut, which are hauled up by handline as soon as hooked, can be kept alive in salt water until reaching their destination, a process which is somewhat cruel, and, moreover, does not conduce to keep the fish in good condition. Marine fish really keep better if they are killed as soon as they are caught, gutted at once, then washed and salted. The great bulk of the fish in Great Britain, probably about $1,000,000$ tons per annum, is distributed by rly., and the various rly. companies have special departments for dealing with the fish traffic alone. How complicated the whole question of distribution and cost is, may be realized from the fact that (as F. G. Aflalo says) "a slice of turbot eaten in a London club may have been caught in the Bay of Biscay, then brought on ice to Plymouth Barbican, sent by S.W. Rly. to Waterloo, thence by van to Billing s g a t $\mathrm{e}$, and finally by cart to the Bond Street shop from which the club buys it."

INSPECTION. $\mathrm{Fish}$ com e under the notice of the food inspector, whose duty it is to see that

should not be eaten. The same remark applies to fish whose flesh comes readily off the back bone. The gills in a fresh fish are red, but the exact colour differs in different species. Thus, the gills of the whiting and the haddock are not as dark in colour as those of the salmon. After 24 hours the gills lose their fresh red colour, though frequent washing tends to retain it. If the fish be held out by the hand and remains horizontal with. out drooping, it is a sure sign of freshness. As staleness comes on, the body becomes more and more limp, before there is any really unpleasant smell. This stiffness, or rigor mortis, sets in about twelve hours after death, and may last for another 24 hours, or even longer in fresh fish placed on ice at once. These tests are used by experienced inspectors.

Finally, one may just note that eod should be very firm to the touch; skate should be thick, firm, and the flesh pure white; eels should be bought alive; whiting deteriorate quickly; the flesh of turbot is not pure white ; herrings show redness about the head when fresh, but in mackerel this redness indicates decay. It should be noted that certain frauds are perpetrated by un. scrupulous salesmen on ignorant purehasers. The street-hawker often sells slices of halibut as turbot, not showing the whole fish. The skinned weever is also sometimes sold for sole, and lemon soles frequently as soles. It is a good rule never to buy a portion of fish unless the skin is on it.

they are of sufficient freshness to be good for food. Absolute freshness is desirable in fatty fish, such as mackerel, herrings, and eels, but the firmer cod and turbot eat better the day after they are caught. Purchasers should avoid fish which are bruised, as often happens to those caught in a trawl.

It is by no means easy to tell a perfectly fresh fish. The sense of smell is an unsatisfactory test, being more acute in some people than in others, and, moreover, a fish may be fresher or staler than its smell suggests. Frequent washing of the fish, as is carried out on the slabs of many fishmongers, keeps away the smell. Well-marked dullness in the eyes of the fish is a re. liable test for freshness, but sets up a somewhat high standard, because the eyes become dull in $\mathbf{2 4}$ hours, and decomposition may not set in for much longer.

Another test is that of the rubbing off of the scales. If this can be done with oase the fish
Fish in Season
Cookery books and calendars usually contain tabulated lists of edible fish in season, but many of these lists are misleading. Strictly speaking, there is no season in which any fish should not be sold for food, except from a legal point of view. Speaking generally, it may be said that a fish is at its best at the half-spawn period, i.e. when the roe is about half ready for depositing. Some fish, however, are at their best in full roe. Immature fish, on the other hand, i.e. fish too young to spawn, are never out of condition, but should be avoided for the sake of conserving the supply.

Fish are brought to the markets from such great distances that it becomes more and more difficult to define their seasons. Thus it used to be considered that the winter was the proper season for cod, but excellent cod may now be got during the summer. Soles may be had in good condition all the year round, but plaice are inferior 


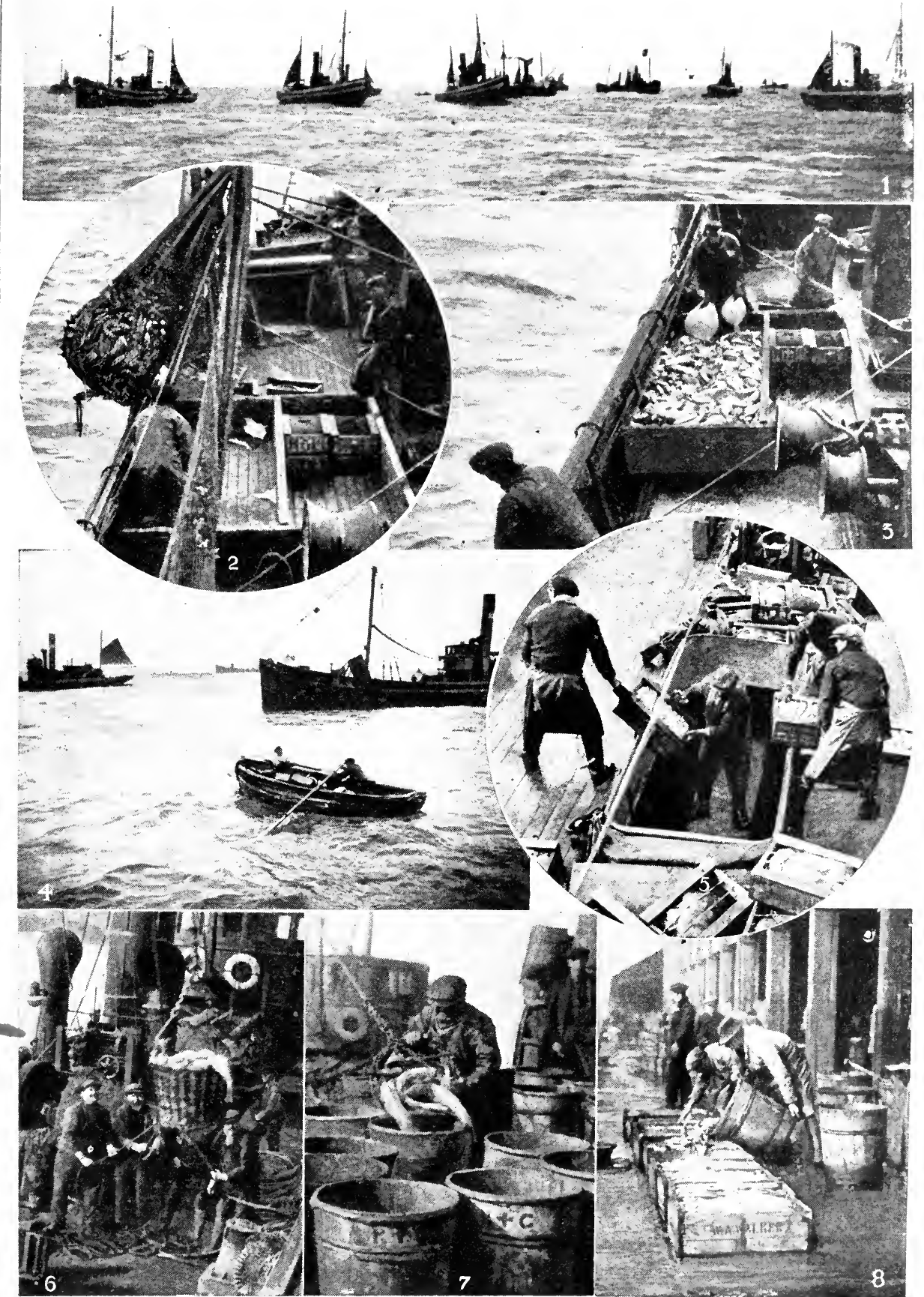

1. The fleet at work off the Dogger Bank. 2. A netful of cod being hauled aboard. 3. A normal catch. 4. Taking a load in a small boat to the carrier. 5. Passing fish into the hold of the carrier. 6. Unloading the carrier at FISHERIES: SCENES AND INCIDENTS IN THE WORK OF THE NORTH SEA FISHING FLEET 
during the first three months of the year. The season for herring and other migratory fish is determined by the time of year at which they come within reach of the trawlers. Salmon are protected by special laws. (See Close Time.)

Speaking generally, it is illegal to buy or sell British salmon from Sept. 3 to Feb. 1, but the law ap. plies to fresh salmon only, not to cured fish. Mackerel and whiting are at their best in the cold months, because they do not keep well in warm weather. If perfectly fresh they are also in season in the summer. Oysters are usually avoided from May to August, and are not very good even in Sept. Lobsters are always in season, as far as fitness for food goes, but the females are protected in most places while carrying the eggs. The legal seasons for fish are usually posted up in all fish markets.

Fisherman. The term usually applied to one who earns his living by fishing in the sea. From the earliest times off-shore fishing has been the principal occupation of dwellers on the sea coast, while trawling and deep-sea fishing have largely developed with the introduction of steam and of wire haw. sers. Fishing in streams and rivers is usually called angling (q.v.), and is subject to various restrictions. See Angling; Close Time.

Fisher's. Island of the U.S.A. Situated at the E. end of Long Island Sound, it forms a part of Suffolk co., New York. It is about $8 \mathrm{~m}$. long by $1 \mathrm{~m}$. broad. It is frequented as a summer resort, and the chief occupation is agriculture. Fort Wright, one of the defences of Long Island Sound, stands at the E. end. Pop. about 200.

Fishery Board. In Gt. Britain a body of men whose work it is to foster and protect the fishing industry. Scotland has a separate board, consisting of paid and unpaid members. Its offices are in George St., Edinburgh. In England and Wales the fisheries are looked after by the board of agriculture and fisheries, and in Ireland by the department of agriculture and technical instruction. In Nov., 1919 , the fisheries department of the board of agriculture was placed under the direct control of the parliamentary secretary, who would act as deputy-minister of fisheries. The officer in charge of the department is known as fisheries secretary to the board.

Fishguard or ABErgwaen. Ur ban dist., seaport, and market town of Pembrokeshire, Wales. It stands on the Gwaen near its en trance into Fishguard Bay, $12 \frac{1}{2} \mathrm{~m}$.
N. of Haverfordwest. The terminus of the G.W.R. on its route to Ireland, Fishguard has an excellent harbour and a fine breakwater $(2,500 \mathrm{ft}$. $)$ a coastguard and lifeboat station, and a pier constructed by the rly. co. in 1906 . Slate is worked in the neighbour. hood and fishing is an industry. There is regular steamer communication with Rosslare in co. Wexford, Ireland. In 1797 Fishguard was invaded by some ],200 French soldiers, who were forced to surrender to the local yeomanry. Market day, Thurs. Pop. 2,892.

Fish Hatchery. Place for hatching the eggs of fish. Various fish hatcheries have been established, especially by the United States Fish Commission. This body, in 1902 , hatched and set free nearly $1,500,000,000$ young fish, the principal species dealt with being cod, flounders, and lobsters. In Canada the hatcheries established devote their attention mainly to cod and lobsters. In Europe hatcheries have been started in Norway, England, and Scotland, and the methods for obtaining the eggs vary in different places. See Fish Culture.

Fish Hook. Apparatus for catching fish. At first a flake of flint sharpened at both ends, with a thong attached to the centre, was employed for this purpose. But the antiquity of the metal book is great, bronze fish hooks of modern shape having been found in lake-dwellings in Switzerland and elsewhere.

The modern fish hook is made of soft cast steel wire. The wire is cut into lengths and the barb formed and sharpened before the wire is

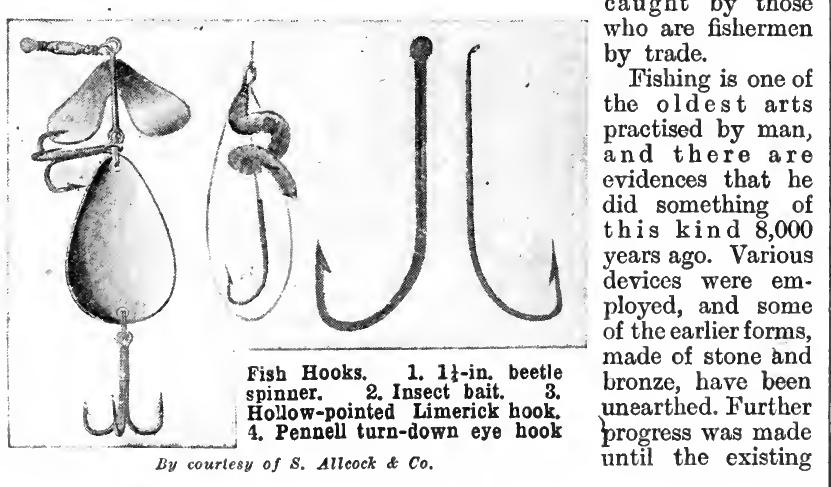

bent into shape. The shanks are then ringed or flattened, and the hooks are hardened, tempered, and scoured. Machinery performs the 
varieties of rod, bait, and all the accessories were evolved. Close times are enforced by law, while a long series of Acts, which may be said to date from Magna Carta, lay down the law on the matter as far as the United Kingdom is concerned. Dealing with fisheries of every kind, deep sea, inshore, and inland water, they forbid the use of poison or explosives for the purpose of catching fish, make regulations about the registration and management of fishing boats, and lay down other conditions for the purpose of conserving the supplies and using them in the interest of the whole nation.

For England and Wales the law is administered by the board of agriculture, which has a special branch to deal with fisheries, while Scotland and Ireland have cach their own department for the purpose. The United States, Canada, and other countries are equally vigilant in this matter. Inter national agreements deal with areas, such as the Newfoundland banks and Bering Sea, where men of different nations come into contact. See Angling; Close Time; Fisheries; Fly-fishing; Trawling.

Fishing Rod. Rod employed by anglers. Used for casting the line and keeping it clear of the bank or shore upon which the fisherman is standing, the rod varies largely with the nature of the sport. Sal. mon fly rods, which are liable to great strain, are usually of cane with a steel rod in the centre, and measure from $16 \mathrm{ft}$. to $17 \mathrm{ft}$. $6 \mathrm{ins}$. For trout and other fresh-water fishing a lighter rod from $12 \mathrm{ft}$. to $13 \mathrm{ft}$. in length has been found the most suitable. Fishing rods are usually jointed for greater convenience, and are fitted with a reel to wind in the line. See Angling.

Fishkill. Town of New York state, U.S.A., now part of the city of Beacon. It stands on a creek of the Hudson, $59 \mathrm{~m}$. from New York city, and its full name of Fishkill Landing throws light on its origin. One of the oldest places in the state, it has two churches dating from the 18th century, one being the building in which the congress of New York met in 1776. It was a base for the Amcricans during the War of Independence. It is connected by rail and ferry with New. burgh on the other side of the Hudson.

Fish Lice. Small crustaceans of the order Copepoda (q.v.), which are parasitic on fishes. They de. part widely from the typical forms of the order, and are degenerate in both structure and function. The usual head appendages are modified into sucking or adhesive organs.

Fish Measure. Special mea. sures of capacity used in the sale of fish. These can be summarised thus: 4 fish make 1 warp; 33 warps, a long hundred; 10 long hundreds, a long thousand; 10 long thousand $(13,200 \mathrm{fish})$, a last. In addition to this 500 herrings make a code, 600 herrings a mease, and 615 herrings a maze; $37 \frac{1}{2}$ gallons of fresh herrings equal a cran, and $26 \frac{2}{3}$ gallons of cured herrings a barrel. A barrel of anchovies is $30 \mathrm{lb}$.

Fishmongers' Company. Lon. don city livery company. Founded

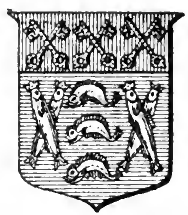

Fishmongers' Company arms fraternity of $S$ Peter existed in the 12th century. Sir William Walworth, the lord

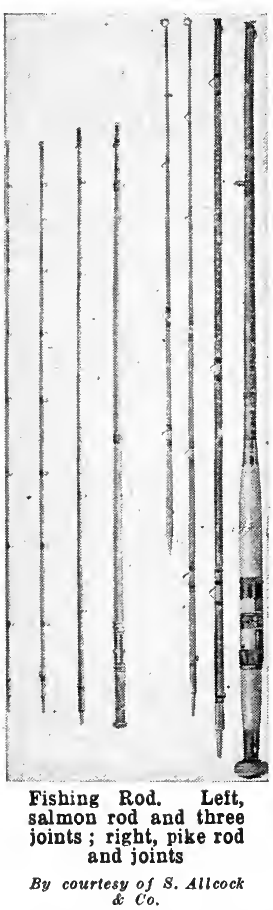
$m$ a $y$ o $r$ who slew Wat the Tyler, and Dogget $t$ (q.v.), who bequeath. ed money for the annual race for Doggett's coat and badge o $n$th e Thames, were mem. bers; the king and the prince of Wales are free. men. The co mpany, w h i c h e $x$ a mines all $f$ is $h$ brought into Billingsgate, has a corpor a t e and trust i n $0 \mathrm{me}$ of $0 \mathrm{ver}$ $£ 50,000$. The hall. in Upper

'I'hames Street, E.C., was built in 1831-33, near the site of its two predecessors, the first of which was burnt in 1666 and rebuilt 1671. In it are shown Sir W. Walworth's dagger, an embroidered Tudor pall, and a chair made from one of the original piles of old London Bridge.
During the Great War the hall was used for the purposes of a military hospital.

Fishponds. Ecclesiastical district within the county borough of Bristol. In the N.E. of the city, it has a station on the M.R. It is divided into three ecclesiastical districts, All Saints, S. John's, and S. Mary's. See Bristol.

Fish Residues. Fish offal suit. able for manufacture into various by-products. The main products are fish meal, oils from the livers of fish, and oil and manure from the intestines. Fish meal is made chiefly from the head and bones. It is a valuable food for cattle and pigs. Medicinal oil is principally the product of the livers of the cod. Other oil used in com merce and industry, especially in the process of tinning and in the manufacture of soap, is extracted from the livers and intestines of various fish. Fish manure is a valuable fertiliser, used particularly in the growing of beet.

The fish from which most of the waste material is obtained con sist of herring, codfish, whiting, and haddocks. A large amount of herring waste is obtained from the herrings prepared for curing, in which usually the head, the gills, and the viscera are rejected. In making kippers from herrings the gills and viscera are rejected. From the codfish the liver is always separated for the manufacture of cod-liver oil, the head, gills, viscera, and the backbone being used for by-products.

The industry is extensive in the U.S.A. and in Norway, but is still in its infancy in Great Britain, where in many fishing ports there is no provision for utilising the waste, which is emptied into the sea. Factories already exist, however, at Grimsby, Hull, Milford Haven, Falkirk, Montrose, Fraserburgh, Wick, and Aberdeen. The industry has received considerable stimulus from the shortage of the supplies of natural guano from Peru. Two kinds of fish guano are made, one from herring, the other from white fish. The former contains a large percentage of oil which has to be extracted in the manufacture of guano, the pro. duct from the oily residues being a dark-coloured, soft fish guano. The product from the white fish is a dry, friable, - light-coloured, more valuable guano. The value of fish guano depends upon its ascertained chemical analysis, the two most valuable constituents being phosphate of lime and nitrogen.

Cod-liver oil comes from the liver of that fish, the oil in white fish being accumulated in the liver 
instead of being scattered throughout the flesh, as it is in the herring. Hence the livers of the cod when caught are immediately separated, kept fresh, then broken up and allowed to ferment, after which they are cooked until the oil is free, and can be run off. A certain amount of stearine is present in this cod-liver oil, and has to be separated out before the oil can be used medicinally. This is done by means of extreme cold.

Fiske, Bradlex Allen (b. 1854). American sailor. Born at Lyons, New York, June 13, 1854, and trained at U.S. naval academy, he was promoted lieutenant in 1887. He was on the Yorktown during the affray at Valparaiso in 1891, was mentioned for services at Manila, 1898, and took part in the bombardment of San Fernando, 1899. He became commander in 1903, captain in 1907, and rearadmiral in 1911. Fiske invented many electrical naval appliances, notably a naval telescope sight, and wrote much on naval matters. See From Midshipman to RearAdmiral, B. A. Fiske, 1919.

Fiske, JoHN (1842-1901). American historian and philosopher. Born March 30, 1842, he was

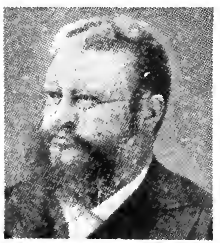

educated at $\mathrm{H}$ a $\mathrm{r}$ v a $\mathrm{rd}$, where he became lecturer on philosophy and assistant librarian. In philosophy, especially in Outlines of Cosmic Philo-

\section{Solue Fiske: sophy, 1874, Solue Fiske: sophy, 1874,} popularise the evolutionist theory, combined with a belief in immor. tality, which he supported. His historical works cover most of the development of the U.S.A. from the earliest times. He died July 4, 1901.

Fisk University. American educational institution. Founded in 1866 at Nashville, Tennessee, it is for the education of coloured persons and is named after Clinton B. Fisk (1828-90), American soldier and philanthropist, to whom its establishment was largely due. The teaching given at Fisk is some. what off the ordinary university lines. Money for its endowment was raised in Great Britain by the Jubilee Singers $\left(q . v_{.}\right)$, as they were called; coloured men also gave. concerts, etc., for this purpose.

Fismes, Capture of. American exploit in the Great War, Aug., 1918. After the Franco-American capture of Château-Thlerry,July 21, 1918 , the 3 rd and 26th U.S. divisions swept forward towards the
Ourcq and the Vesle in pursuit of the Germans. On July 28 severe fighting took place at Sergy, which changed hands several times, the New York Irish regiment holding it through the night, and the Germans recapturing it next day only to be again driven out when the Americans resumed their advance.

On Aug. 1-2 the 42nd division, with the 28 th division and a brigade of the 3rd division, was close to the Vesle; it was relieved by the 4 th division, which, with the 32 nd division, tried to get across the river and take Fismes, but was repeatedly beaten back. The 77th New York national army division and the 28th division next made the effort, and on Aug. 4-5, by outflanking movements which threat. ened the complete envelopment and capture of the German forces in Fismes, compelled the enemy to withdraw from the town. Thereafter the Americans gained ground on the N. side of the Vesle. See Marne, Second Battle of the; United States: History.

Fissirostres (Lat. fissus, split ; rostrum, beak). Obsolete term for birds which have gaping mouths, as the swallow and the goat-sucker. As a means of classification this feature is useless, for widely separated families of birds possess it.

Fissurellidae (late Lat., little fissure). Family of small limpets which have a hole at the apex or margin of the shell, whence their popular names, keyhole and slit limpets. Five species are found around the British coasts.

Fistula (Lat., pipe). Abnormal opening between a cavity in the body and the skin, or between two cavities in the body. For instance, a communication between the rectum and bladder is termed a recto-vesical fistula.

Fit (A.S. fitt, struggle). Popular term for a sudden seizure, accompanied by loss of consciousness with or witlinut convulsions. See Convulsions ; Epilepsy; Hysteria.

Fitch, Sir Joshua Girling (1824-1903). British educationist. Son of Thomas Fitch of Colchester, he was educated there and at University College, London. $\mathrm{He}$ became a teacher, and in 1856 was made principal of a training college for teachers in elementary schools. In 1863 he was appointed an in. spector of schools, and the rest of his working life was passed in the public service, from which he retired in 1894. When chief inspector of training colleges he was entrusted with various special duties, and from 1870-77 was an assistant commissioner of endowed schools. He died July 14, 1903. Fitch, who was knighted in 1896 , was one of the foremost educationists of his day, and wrote a great deal on the subject of education.

Fitch, William Clyde (18651909). American playwright. Born and educated in New York, he

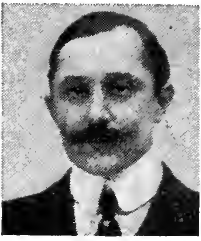
scored a success with his first p la $y, B$ e a Brummell,1890. In 1899 he produced Nathan Hale, an his. t orical play dealing with the American William Clyde Fitch, War of IndeAmerican playwright pendence, and, in London, The Cowboy and The Lady. The Last of the Dandies, 1901, and The Woman in the Case, 1909 , were also produced at London theatres. He died Sept. 4, 1909.

Fitchburg. City of Massachusetts, U.S.A., one of the co. seats of Worcester co. On a branch of Nashua river, $49 \mathrm{~m}$. W. by $\mathrm{N}$. of Boston, it is served by the New York, New Haven and Hartford, and the Boston and Maine Rlys. It contains a state normal school, several benevolent institutions, a public library, and a number of fine parks. Settled 1719, it was incorporated, 1764, and received a city charter, 1872 . Pop. 42,420 .

Fitchée (Fr. fiché, fixed). In heraldry a cross with a spike at its lower extremity is said to be fitchée or fitchy. It represents the proper cross of the old pilgrims and crusaders, which was stuck in the earth to improvise an altar. See Cross.

Fitchett, William Henry. Australian author and journalist. Educated at Melbourne Univer. sity, he entered $t h e$ Methodist ministry. A practical journalist, he edited The Melbourne Daily Telegraph and Souther in Cross, and, being greatly

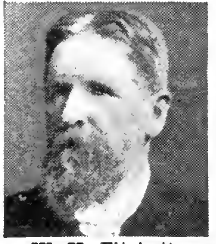

W. H. Fitchett, Australian author Elliott \& Fry interested in education, became principal of the Methodist Ladies' College. In 1897 his Deeds that Won the Empire attained immediate success. His other works include How England Saved Europe, 1899; Fights for the Flag, 1900; Wellington's Men, 1900; Nelson and his Captains, 1902; Wesley and his Century, 1906: Ithuriel's Spear, 1906; The Tale of the Great Mutiny, 1907; Beliefs of Unbelief, 1908; The New World of the South, Australia in the Making, 1913. 
Fitter. Term used in engineering to designate the workman who assembles parts of machinery, and makes them fit. The work is highly skilled. The term is also applied in tailoring to one who takes measurements, tries on and adjusts gar. ments. See Engineering.

Fittings, ELECTRIC. Accessory to a principal electrical apparatus. Thus, an electrical glow lamp is not a fitting; but the holder into which the lamp fits, the wall plug or the ceiling rose with which it is connected, and the switch by means of which the light is turned on or off, are all fittings. The number of classes in which electrical fittings may be ranged isnotvery large; they are chiefly switches, wall plugs, ceiling roses, adapters or connectors such as are used to connect a lampholder to a fan or to a flat iron, cut-outs, junction boxes, lampholders, and shade carriers: all in an almost infinite varietv
Thus, under switches we have distribution boards or panels which are simply collections of switches, suspension, bracket, bolt, plate, and rotary switches; while the scale on which switches are used extends from the simple button which puts on or off a single glow lamp to the elaborate switchboard structure, which may occupy some hundreds of square feet, by which the current supplies from a great power station are controlled. Again, the ordinary glow lamp holder, which is essentially a socket provided with a bayonet joint in which the end of the lamp engages, may also be provided with a switch to put the light on or off, and this switch may be a push-bar, rotary, or chain-pull ; or it may have a locking device which ensures that once the lamp is in place and locked it cannot be removed, or it cannot be turned off or on, withont the authority of the person who holds the key. Other forms as used in mines and on board ship are specially adapted to resist vibration. See Lighting, Electric.

Fitz (Lat. filius; Fr. fils). Old Anglo-Norman word formerly spelt fiz and meaning son. Like Scots Mac, Irish O', and Welsh ab, ap, it is prefixed to proper names to show parentage. Familiar examples are Fitzalan, Fitzgerald, and Fitzwilliam. It is specially used to indicate natural sons of royal blood, e.g. Fitzjames, duke of Berwick, son of James II.

Fitzclarence, CHARLES (18651914). British soldier. Born May 8 , 1865 , a son of the earl of Munster, he was educated at Eton and Wel. lington. He joined the Royal Fusiliers in 1886, and the Irish Guards in 1900 . He served in S. Africa 1899-1900, in which campaign he won the V.C. He went to France in Aug., 1914, and commanded the 1st Guards brigade at the first

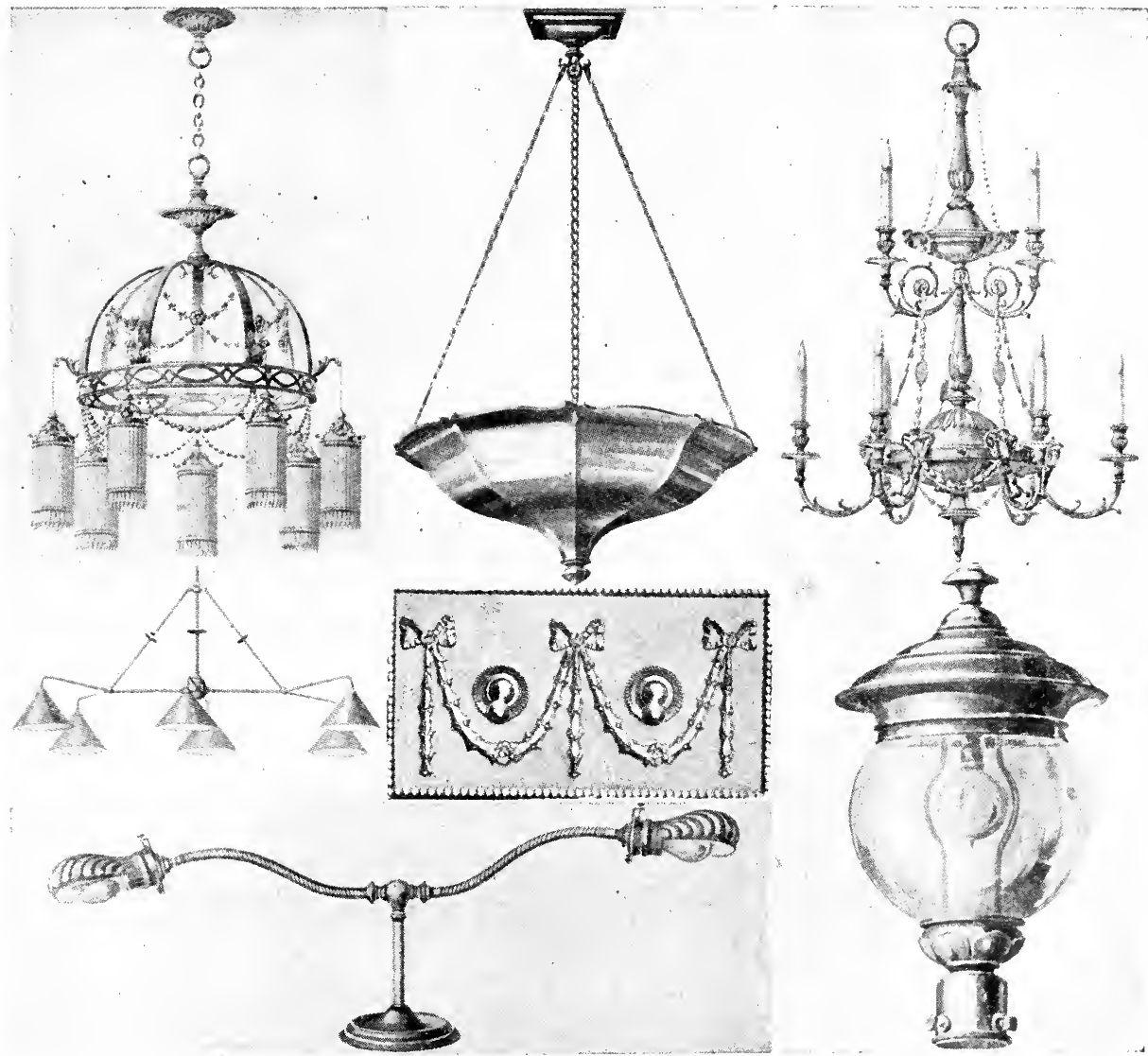

Fittings. Examples of fittings for electric lights. 1. 7-lamp electrolier. 2. Inverted pendant for reflected light. Fittings. Exam electrolier. 4.6-lamp electrolier for billiard table. 5. Switch designed in Adam style. 6. Standard desk lamps. 7. Electric lantern for public streets

By courtesy of General Electric Company 
battle of Ypres, in which his leadership helped to stem the German onrush towards the Channel ports. On Oct. 31, the most critical day, he was killed in action. See Ypres, First Battle of.

Fitzgeorge. Name taken by the three sons of the duke of Cambridge and his morganatic wife, Miss Louisa Fairbrother, the actress, whom he married in 1840. One of them, Sir Adolphus Augustus Frederick Fitzgeorge (b. 1846), entered the navy and retired with the rank of rear-admiral. In 1904 he was knighted. Another, Sir Augustus Charles Frederick Fitzgeorge (b. 1847), entered the Rifle Brigade in 1865 and later served in the 11th Hussars. He retired as a colonel and was knighted in 1904.

Fitzgerald, LoRd EDwARD (1763 $-98)$. Irish rebel. Son of the lst duke of Leinster, he joined the English army, served in Ireland, and in 1781 was wounded at the battle of Eutaw Springs in America. He was elected to the Irish parliament as member for wards tra. velled in America, and in 1792 was cashiered for attending a revolutionary banquet in Paris. $\mathrm{He}$ joined the United Irishmen in 1796 and took an active part in the plans for the French invasion. The plot was discovered, and Fitzgerald died in prison, June 4, 1798, from wounds inflicted by one of his captors. His wife Pamela was generally, but wrongly, believed to be a daughter of Madame de Genlis by Philippe Egalité, duke of Orleans. She, who was probably born in Newfoundland, married Fitzgerald in 1792 and lived until Nov., 1831.

Fitzgerald, EDwaRd (180983). English poet and translator. $\mathrm{He}$ was born March 31, 1809, at Bredfield House, near Woodbridge,

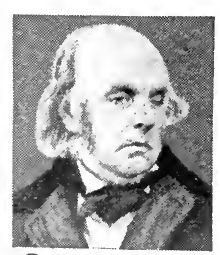
Suffolk, the son of John Pur. cell, who as. sumed his father-in -law's name, Fitzgerald, nine years after the poet's birth. Spending his boy. Eluand Ithgerali abroad, he was sent, in 1821, to a school in Bury St. Edmunds, entering Trinity College, Cambridge, five years later. $\mathrm{He}$ became intimate with Thackeray and Spedding; later with Mennyson and Carlyle. On leaving the university, he spent a short time in France, but, returning to Suffolk in 1831, never left it again, for more than a week or two, till his death, June 14, 1883.

His life was that of a recluse spent among books, flowers, and music; he began the study of Spanish in 1850 , that of Persian in 1853. The world-famous translation of The Rubáiyát of Omar Khayyam, preceded in 1856 by an anonymous version of the Sála. mán and Absál of Jami in Miltonic verse, was first published in Jan., 1859 ; but lay for months neglected, even by the translator's own friends, until Rossetti discovered it in the fourpenny box of a second - hand bookseller, and Swinburne proclaimed its genius to the world. A second, greatly revised, edition appeared in 1868 , and its subsequent popularity has been phenomenal. Fitzgerald also published Euphranor, a Platonic Dialogue, 1851; Six Dramas of Calderon, 1853; a version of the Agamemnon, 1876 ; two Oedipus Tragedies, 1880-81; and Readings in Crabbe, 1882. The dedication of Tennyson's Tiresius to "Old Fitz" advanced Fitzgerald's personal reputation, but it was not till W.Aldis Wright brought out, in 1889 , his Letters and Literary Remains, and, in 1895, his Letters to Fanny Kemble, that the world knew much of the man whose work it had long since taken to its heart.

He married, in middle life, Lucy, daughter of Bernard Barton, the Quaker poet, and the interest of his later years was centred in the sea, "knocking about somewhere outside of Lowestoft," as he puts it himself. He was a witty, picturesque, and sympathetic letter. writer, on terms of intimacy with the most interesting men and women of the day. His verse is tranquil and exquisite: the cultured expression of most attractive speculations.

R. B. Johnson

Bibliography. Letters and Liter. ary Remains, ed. W. A. Wright, new ed. 1902; Letters to Fanny Kemble, 1895; Two Suffolk Friends, F. H. Groome, 1895 ; Lives, J. Glyde, $1900 ; \mathrm{T}$. Wright, 1904.

Fitzgerald, PERCY HeTHERINGTON (b. 1834). Irish writer. Born in co. Louth, he was educated at Stony hurst, and Trinity College, Dublin.

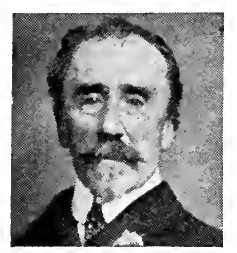

Percy Fitzgerald, Irish writer Russell
Called to the Irish bar, he became crown prosecutor, but aban. doned law for literature and removed to London: $\mathrm{He}$ contributed stories to Dickens's All the Year Round, and produced many literary studies, historical and theatrical works, and novels. In 1895 he published Memoirs of an Author. He engaged in sculpture as a hobby, and his statue of Dr. Johnson stands in London in the churchyard of S. Clement Danes.

Fitzherbert, MARIA ANNE(17561837). Wife of George IV. A daughter of Walter Smythe, of Brambridge, Hampshire, she married in 1775 Edward Weld, of Lul-

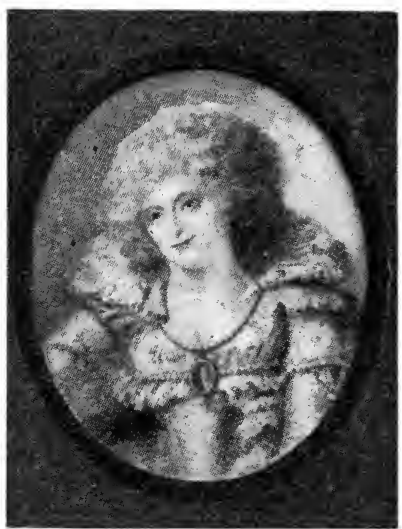

Maria Anne Fitzherbert, wife of George IV

Afler R. Cosway

worth Castle, Dorset. Her second husband was Thomas Fitzherbert, and after his death in 1781 she lived at Richmond. In 1785 she met the prince of Wales, who fell in love with her, but to avoid his attentions she went abroad. $\mathrm{He}$ pressed bis suit, however, and the pair were married privately on Dec. 21, 1785.

According to the Royal Marriages Act, 1772, the union was illegal, and some, but not the prince, held that it was invalid; the lady being a Roman Catholic, it was sanctioned by the pope. In 1795 George married Caroline of Brunswick and Mrs. Fitzherbert left him for a time. They lived together again until 1803, when the prince began to tire of her. They finally parted, but George seemed to retain some affection for her to the end. Mrs. Fitzherbert, who had an allowance of $£ 6,000$ a year, died at Brighton, March 29, 1837. A box of papers was left by her to her executors for use at their discretion, but its contents have never been really examined. See Mrs. Fitzherbert and George IV, IV. H. Wilkins, 1905. 
Fitzmaurice, Edmond George Fitzmaurice, 1st Baron (b. 1846). British politician. Born June 19,

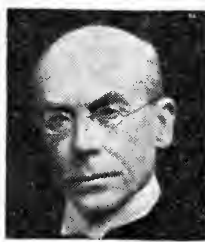

1846, second son of the 4 th marquess of Lansdowne, he was educated at Eton and Trinity College, Cam. bridge. En. tering political

Baron Fitzmaurice, British politician Elliott \& Fry life, from 1869 85 he was M.P. for Calne. In

1880 he was commissioner for the reorganization of the European provinces of Turkey and Crete under the treaty of Berlin, and second plenipotentiary at the Danube Conference, London, 1882-83. In 1882 he became under-secretary for foreign affairs in the Liberal ministry, but in 1885 he lost his seat, and until 1898 he remained out of Parliament. He was then returned for the Cricklade division of Wiltshire, retiring in 1905 . Again under-secretary for foreign affairs, he was made a peer in 1906, and in 1908-9 was chancellor of the duchy of Lancaster. Lord Fitzmaurice wrote a number of books, the best known being Life of William, Earl of Shelburne, 1875-77 ; and Life of Earl Gran. ville, 1905.

Fitzmaurice-Kelly, JAMES (1857-1923). British man of letters. Born June 20, 1857, he devoted himself to the study of the language and literature of Spain. He held the posts of Taylorian lecturer at $\mathrm{Ox}$. ford University,1902;Nor-

man MacColl J. Fitzmaurice-Kelly, lecturer at British man of letters Cambridge, 1908 and 1912; and pro. fessor (Cervantes chair of Spanish) at King's College, London, resigning in 1920. His works include Life of Cervantes, 1892 ; A History of Spanish Literature, 1898 ; Lope de Vega and the Spanish Drama, 1902 ; Chapters on Spanish Litera. ture, 1908; Miguel de Cervantes Saavedra: a Memoir, 1913; and an edition of Cervantes' works in English, 1901-3. He died Jan. 11, 1023.

Fitzpatrick, SIR Charles (b. 1853). Canadian lawyer. Born in Quebec, Dec. 19, 1853, he was educated at St. Anne's College and Laval University there. In 1876 he became a barrister, and in 1879 crown prosecutor for Quebec. From 1890 to 1896 he was a member of the legislative assembly of Quebec,

being one of the representatives of the capital therein. At the general election of 1896 Fitzpatrick entered Dominion politics as member for the same city in the House of Commons at Ottawa. In the same year he was made solicitor-general in the Laurier administration, and in 1902 he became minister of justice. In 1906 he was chosen chief justice of Can. ada, retaining this post until made lieutenant-governor of the province of Quebec in 1918. In 1907 he was knighted. From

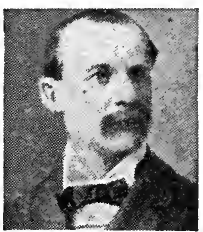

Sir C. Fitzpatrick, Canadian lawyer

1908-10 Sir Charles was a member of the Hague tribunal.

Fitzroy. River of Queensland, Australia. It is formed by the union of the Dawson with the Mackenzie, and flows an easterly course to discharge into Keppel Bay. It is navigable for steamers up to 1,000 tons to Rockhampton, a distance of $35 \mathrm{~m}$. One of the most important rivers in Queensland, its fertile valley contains many stock farms which supply the refrigerating works on the coast; this industry will develop. There is another river of this name in W. Australia. It rises in King Leopold range, and pursuing a generally westerly course it empties into King Sound on the Indian Ocean. It is navigable for $100 \mathrm{~m}$. Length, $300 \mathrm{~m}$.

Fitzroy. North-eastern suburb of Melbourne, Victoria, Australia. It is a manufacturing centre, with a rly. station and several large recreation grounds, including the Edinburgh Gardens to the N.E., the Carlton Gardens to the S.W., and the Fitzroy Gardens to the S. The last are laid out with fine avenues of trees and adorned with statues and fountains. Pop. 34,283. See Melbourne.

Fitzroy, Robert (1805-65). British sailor. Son of Lord Charles Fitzroy, and grandson of the 3rd duke of Grafton, he was born in Suffolk, July 5, 1805. He entered the R.N. College in 1819, and became lieutenant in 1824. In 1831 he sailed in command of the Beagle, a brig engaged in surveying the $\mathrm{S}$. coast of S. America, with Charles Darwin as naturalist. During this voyage, 1831-36, Fitzroy surveyed most of the $\mathrm{S}$. American coasts and ran a chronometric line round the world. In 1839 he published his Narrative of the Survey. ing Ships H.M.S. Adventure and Beagle, in three volumes, the last written by Darwin. In 1841 he was
M.P. for Durham, and in 1843 was appointed governor of New Zealand, but his attitude towards the settlers incurred their anger and he was recalled in 1845. He became vice-admiral in 1863 and died April 30,1865 . He is remembered by his invention of the Fitzroy barometer.

Fitzroy's Cypress (Fitzroya patagonica). Evergreen tree of the natural order Coniferae. A native of Patagonia, it has slender, spreading branches and flat, over. lapping, oval-oblong leaves. The cones are small and star-shaped, consisting of nine scales. The height of the trunk is $100 \mathrm{ft}$.

Fitzsimmons, ROBERT (18621917). British pugilist. Born at Helston, Cornwall, June 4, 1862 , he went to New Zealand with his parents at the age of nine, and was trained as a blacksmith. After several local successes he entered the ring as a professional, and moved to Sydney, where he beat Bill Slam, West, and Professor Hall, but was himself beaten by Jem Hall in the contest for middleweight championship.

Proceeding to the United States in 1890 , he defeated Jack Dempsey - to be distinguished from the later pugilist of the same name -in 13 rounds in the fight for the middleweight championship of the world; nine months later he beat Peter Maher in 12 rounds, and in 1897 obtained the heavyweight championship at Carson City. In June, 1899, he was defeated by Jeffries, and in 1902 , although forty years of age, he challenged Jeffries again, but was beaten in the eighth round, after putting up a splendid fight. In 1905 he was beaten in 13 rounds by Jack O'Brien, and after meeting Jack Johnson in 1907, and Bill Lang in 1912, he retired from the ring after an exceptionally long career. He died Oct. 22, 1917.

Fitzwilliam, EARL. British title held by the family of Fitzwilliam since 1746. The family is an old one, tracing back its descent to Sir William Fitzwilliam of Elmley, Yorkshire. It became specially prominent in the time of Elizabeth. Sir William Fitzwilliam (15261599) was the grandson of another Sir William, a London merchant who was also one of the scrvants of Cardinal Wolsey. The younger Sir William passed much of his time in Ireland as lord deputy, 1571-75 and 1588-94. Having acquired lands in Ireland, his grandson was made an Irish baron in 1620.

William, the 3rd baron (16431719), was created a viscount and an earl in 1716, and from him the present peer is descended. 
William, the 3rd earl, was made baron (1742) and earl (1746) in the peerage of the United Kingdom. He married Anne, daughter of the marquess of Rockingham, a union that brought Wentworth Woodhouse and large estates to the family. In 1902 William (b. 1872), who as Viscount Milton had been M.P. for Wakefield since 1895 , became the 7 th earl. The earls own large estates in Yorkshire and Wicklow, also Milton Hall, Peterborough, which has been in the family since about 1500 . His eldest son is called Viscount Milton and his chief seat is Wentworth Woodhouse, near Rotherham.

Fitzwilliam, Winlian Went. worth FitzwilliaM, 2ND EARL (1748-1833). British statesman.

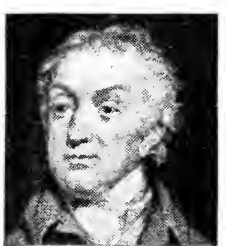
Born May 30, 1748 , he was the eldest son of the first earl, whom he succeeded in 1756. In 1782 on the death of his uncle, Lord Rocking.

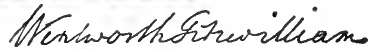

After $W$. Owen

ham, he suc-

ceeded to the Yorkshire estates of the Wentworths and took the additional name of Wentworth. $\mathrm{He}$ was president of the council in 1794, and later in 1806, and was lord-lieutenant of Ireland for a few months in 1795 . In 1798 he was appointed lord-lieutenant of the W. Riding of Yorkshire, but was dismissed in 1819 for censuring the Peterloo massacre. Fitzwilliam died Feb. 8, 1833.

Fitzwilliam Iuseum. Art and archaeological museum in Cambridge. It was founded by Richard Fitzwilliam (1745-1816), 7th Viscount Fitzwilliam, an Irish peer, who must be distinguished from Earl Fitzwilliam. $\mathrm{He}$ bequeathed to the university his collection of books, illuminated MSS., pictures, drawings, engravings, etc., together with certain dividends, for the erection of a gallery to accommodate them. The money was allowed to accumulate, and when $£ 40,000$ had been amassed the Fitzwilliam Museum in Trumpington Street, Cambridge, was begun in 1837 from the designs by George Basevi, continued (1845) by Charles Robert Cockerell, and completed (1874) by Edward Middleton Barry. The schools of art are well represented by over 700 pictures, the original bequest has been increased by other donors, and the museum now possesses in addition a fine collection of antiquities and a valuable library.

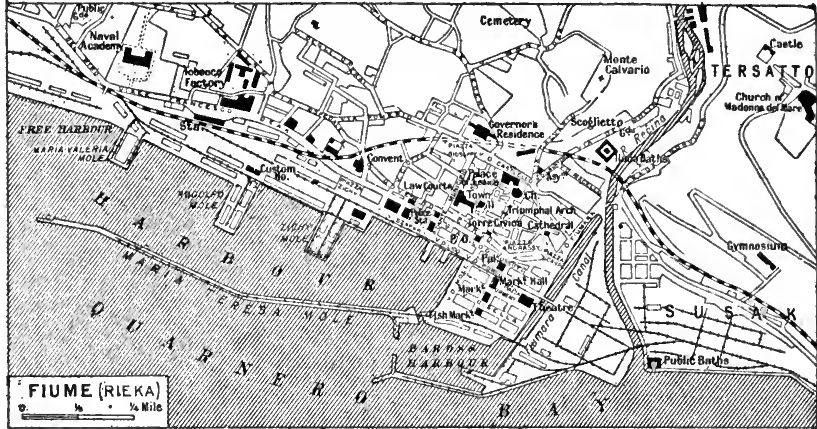

Fiume. Plan of the Adriatic port, formerly belonging to Austria-Hungary, and one of the most important seaports of the Adriatic
Fiume. Seaport and, since the Treaty of Rapallo (1920), an independent State. It stands on the river Rečina, at its outfall into the Bay of Quarnero, at the N.E. extremity of the Adriatic. It has several harbours-the Fiumara canal, used by coasting vessels; the Baross harbour; the main harbour, which is protected by a mole; and the free and petroleum harbours to the W. Practically all the shipping trade of Hungary passed through its port, and the fisheries are of great importance. Among the features of architectural interest, the cathedral, the Roman triumphal arch, and the governor's residence may be mentioned.

The town possesses distilleries, petroleum refineries, and mills, while there is trade in fruit, barrels, staves, furniture, tobacco, paper, chemicals, fertilisers, and soap. Fiume constituted under the old régime a crown-land of Hungary, with an area of $8 \mathrm{sq} . \mathrm{m}$. The pop. is largely Italian, but the suburb of Sushak across the river, and the surrounding area, is inhabited by Yugo-Slavs, chiefly Croats. Pop. 49,806 .

Fiume's mixed population of Italians, Croats, Magyars, and various other nationalities made it a point of racial dispute. Long a small centre of coastwise trade, it came into prominence only when the Budapest-Zagrab-Fiume Rly. Vitus in Flumine, in 1465 it became a Hapsburg possession. Charles VI declared it a free port in 1717 , and in 1776, by a decree of Maria Theresa, it was handed over to ated in Hungary. Two years later, under the rule of Napoleon, it became part of Illyria. In 1822 Fiume was restored to Hungary, but as a result of the Croatian national movement of 1848 was reunited to Croatia. In 1861 it was made autonomous. The Magyars of Fiume under this arrangement favoured the Italian section of its inhabitants, and for nearly fifty years this union strove to prevent Slav predominance. It became in was built. Originally known as S. Croatia. In 1807 it was incorpor-

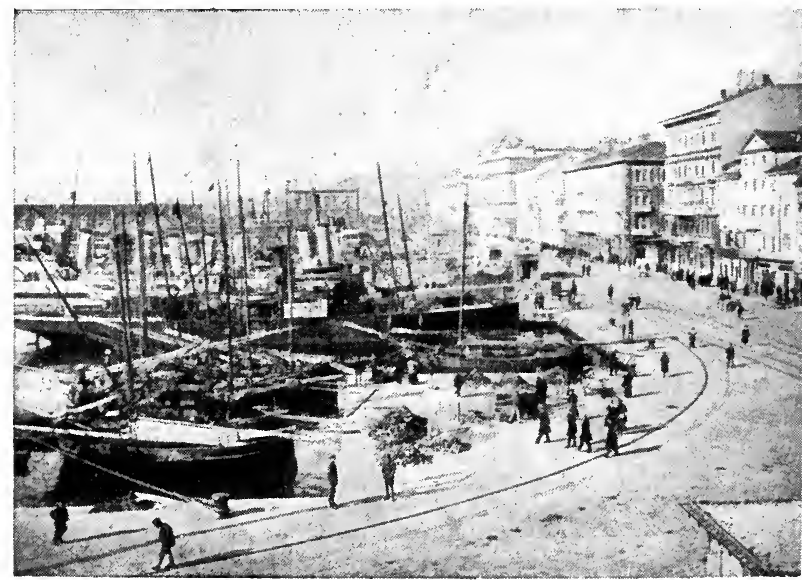

Fiume. The quays looking north-west from Zichy Mole 
appearance a Magyar-Italian city, though the bulk of the shipping was owned and manned by Croats.

Since the Great War its posses. sion has become a burning question. Though not assigned to Italy by the Treaty of London (April, 1915) it was claimed as Italian because it contained a majority of Italian. speaking inhabitants. The Croats, and on their behalf the new SerbCroat-Slovene government, claimed it as a Southern Slav port as being historically Croatian, further claiming that with the suburb of Sushak it was inhabited by a majority of Southern Slavs.

The feeling between Yugo-Slavia and Italy as to its possession became more strained. The latter maintained it was the most vital port on the Adriatic and was neces. sary for her. Matters came to a head when on Sept. 11, 1919, Gabriele d'Annunzio, at the head of the Italian volunteers, seized Fiume and set up a national council or provisional government. On Nov. 12, 1920, the Treaty of Rapallo, signed by the representatives of Italy and Yugo-Slavia, established an independent state of Fiume which was to be slightly larger than the independent administrative district formerly incorporated in Hungary; and provided that the new territory should be delimited by a commission. The insurgents in Fiume denounced the treaty, and d'Annunzio declared that Fiume was in a state of war with Italy. The government of the lat$t \in \mathrm{r}$ expelled the insurgents in Dec., 1920, and in 1923 Fiume was annexed by Italy with the consent of Yugo-Slavia. See Annunzio, Gabriele d'; Italy; Yugo-Slavia ; N.V. Consult also Abridged Political History of Rieka (Fiume), F. Šisic, 1919.

Five Knights' Case, THE. Trial in the court of king's bench, Nov. 22, 1627. Sir Thomas Darnell, with four other knights, Corbet, Earl, Hampden, and Heveningham, had been committed to the Fleet prison the previous March by warrant signed only by the attorney-general for refusing payment of the forced loan raised by King Charles I. They applied for a writ of Habeas Corpus, demanding that the warden of the fleet should bring them before the court of king's bench and specify the cause of their com. mittal.

The case came on for argument Nov. 22, 1627, when the gaoler returned that they were imprisoned by the king's special command, i.e. for no stated offence, and the court, presided over by Chief Justice Hyde, decided, Nov. 28, that this was sufficient ground for commit. tal. The prisoners did not deny the right of the erown to imprison in certain circumstances without showing eause, but pleaded that they were imprisoned for refusing to subscribe to the forced loan, of which they denied the legality. See Forced Loan.

Five Members. Specially, the five members of Parliament whom Charles I tried to arrest, Jan. 4, 1642. The relations between the two parties were very strained when the king ordered the attorney-general to prepare articles of impeachment against the five : John Hampden, John Pym, Denzil Holles, Sir Arthur Hazlerigg, and William Strode. This was done, one of the charges being that of levying war against the king, and the House of Lords was asked to order their arrest, a necessary prelim. inary to their trial before that body. This the peers refused to do, so the king went with the serjeant-atarms to do it himself; with him were about 300 attendants.

He entered the house just as the warned members had escaped by river to the city, and asked the Speaker for them. The latter, Lenthall, replied that he could only do as the house directed him, to which the king answered, "I see all the birds are flown." Next day Charles went to the city, but again he failed to secure the five. The impeachment was declared illegal.
On the 11th the members returned to Westminster, a great concourse of people, both on the river and on the banks, cheering their arrival.

Five Mile Act. Act passed in 1665 which forbade those ministers who had been expelled from their livings in 1662 from residing within five miles of any corporate town or teaching in any sehool. They could only obtain relief by subscribing to the Act of Uniformity and taking an oath that resistance to the king was unlawful. The Act was part of the Clarendon Code, and became inoperative by lapse of time.

Five Nations. Name given to the Indian nation of the Iroquois, because it consisted of five tribes. These were Mohawks, Oneidas, Cayugas, Onondayas, and Senecas. Early in the 18th century they were joined by the Tuscaroras and were known as the Six Nations. (See Iroquois). It is also the name of a volume of poems by Rudyard Kipling, the five nations being the five chief members of the British Empire.

Fives. Game of handball. It is played either with the bare hand or with gloves, though at the present time almost invariably with the latter. The derivation of the word fives is doubtful, although various suggestions have been made that it is so called from the five fingers of the hand, or that it was played by five people on each side.

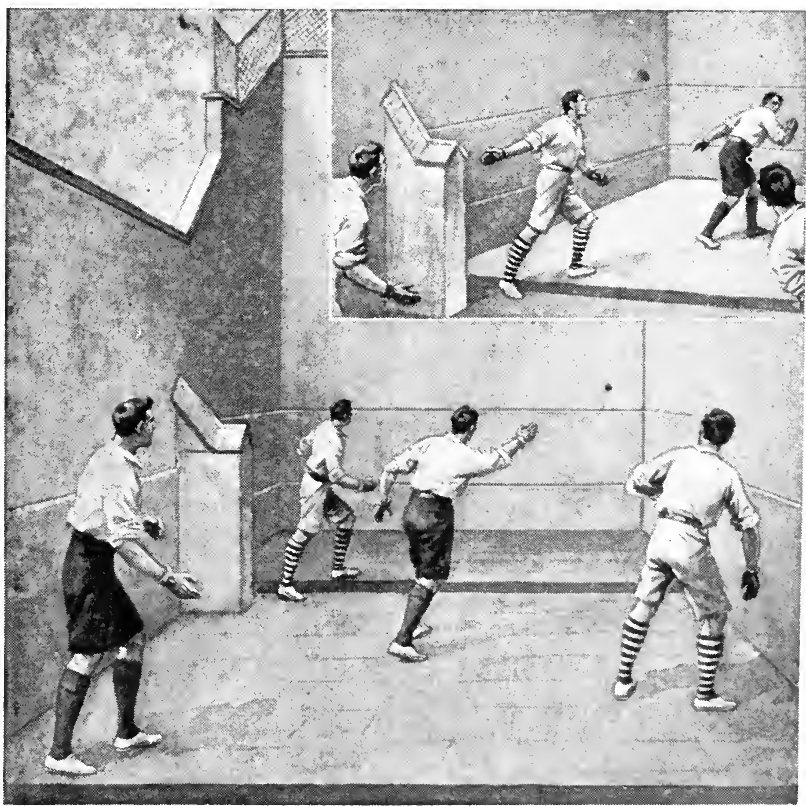

Fives. An Eton game in progress, illustrating the construction of the court. Above, about to volley for the pepper-box 
Fives was very popular in the early part of the 19th century, when it was played in closed spaces, especially built for the purpose, and also in tennis courts. One of the most famous of fives courts was in St. Martin's-in-the-Fields, and there is an old print representing Fives in the tennis court in Leicester Fields, which gives some idea of the game as then played. A feature of the game was that the ball was bounced on the ground, and then struck with the hand for the service. This has now entirely disappeared. The ball in the modern games is invariably thrown up by one player and hit by one of the adversaries. William Hazlitt's obituary of John Cavanagh, the Fives Player, which appeared in The Examiner, is the best known piece in the literature of the game.

In modern days fives is played chiefly in three forms of court, and is mainly confined to the public schools and universities. One form is Eton Fives. The court, unique in several features, which is now very carefully constructed for this game, originated from part of the chapel at Eton against which the game used to be played. A buttress and some of the chapel steps gave rise to the present hazards in the court which afford so much interest and variety to the game. The court has three walls, and up to a few years ago all courts were uncovered. Now there are a few courts which are covered by a pent-house roof. The game is played by four players, and demands the highest skill and quickness of movement. It is also possible, but not usual, to play a single. The rules of the game for many years existed in oral tradition only, but were eventually codified.

A Rugby fives court, called after the school of that name, is a fourwalled building covered with a roof. The walls are all plain, except that on the front wall there is a ledge or board, above which the ball must be struck to be in play. The game is played at the majority of the public schools. The rules were revised and brought up to date in 1913, and are printed in the Tennis Rackets and Fives Association's Handbook.

Winchester fives is practically similar to the Rugby game, except that in the left-hand side wall of the court there is a projecting buttress which forms a hazard. Courts of this kind exist only in one or two places outside Winchester. Both the Rugby and Winchester games can be played either by one or two players a side. The service is given by one player throwing the ball on to the wall. $\mathrm{His}$ adversary can refuse any service, but if he does not refuse it, he must hit the ball on to the right-hand side wall, and then on to the front wall above the ledge or line. The rally then proceeds in the ordinary way, i.e. the ball is returned on the volley or the first round above the line. The player who first fails to do this loses the rally, and either yields the service to another player or loses a point. A game consists of 15 points.

The ball used in fives is made like a racket ball. The foundation is of cloth, bound tightly round with twine and covered with white kid. The weight of the ball in Eton fives is $1 \frac{1}{4} \mathrm{oz}$., and in Rugby $1 \frac{1}{8} \mathrm{oz}$.

E. B. Noel

Bibliography. Tenn is, Lawn Tennis, Rackets and Fives, J. M. Heathcote and others, 4th ed. 1897; Tennis, Rackets and Fives, J. A. A. Tait, 1890.

Fivizzano. Town of Italy, in the prov. of Massa e Carrara. It stands among the Apuan Alps, at an elevation of $1,045 \mathrm{ft}$., $20 \mathrm{~m}$. N.N.E. of Spezia. It is surrounded by medieval walls, and has castle ruins and other antiquities. In the vicinity are noted quarries of Carrara marble. An earthquake in Sept., 1920, caused widespread havoc. Pop. 17,250.

Fixture (Lat. figere, to fix). Term used in English law for a thing of a chattel nature which is affixed to the freehold, so as to become part of it, and, therefore, to become realty and not personalty. Sometimes these things can be removed again by the people who put them there, so that they become personal property again, and sometimes not. Practically, questions about fixtures become important as between landlord and tenant, between the heir and the personal representative of a deceased, and between the representative of the owner of a particular estate, e.g. a tenant for life, and the ultimate owner. In the last two cases, the personal representative is entitled to claim only such articles as were put up for domestic use, ornament, or trade use, provided that they are easily removable.

As between landlord and tenant the right of removal is stronger. A tenant is entitled to remove all fixtures put up by him for orna. ment or convenience which can be removed without much damage to the premises, e.g. marble mantelpieces, pier-glasses, tapestry, grates, etc., or cupboards fixed in the holdfasts. In the case of trade fixtures, the tenant may remove them, unless in so doing he causes serious damage to the property. Similarly agricultural fixtures can always be removed, but the tenant must make good any damage he does.

A tenant must remove his fixtures before his tenancy expires-he cannot go back afterwards and take them away. If he leaves them behind he has no claim to them, or to compensation for them, as many people suppose ; nor can he demand that a succeeding tenant shall pay for them. They are the landlord's property See Landlord; Tenant.

Fizeau's Experiment. Wellknown experiment first used by A.H.L.Fizeau for the determination of the velocity of light. The apparatus used consisted of a toothed wheel, which was made to revolve at a definite speed. The teeth of the wheel cut off the view from a distant light when a certain speed was reached, and enabled calcula. tions to be made of the time taken for the light to travel from its source to a mirror and back again. See Light.

Flaccus. Name of a well-known Roman family, the following members of which deserve mention: (1) Quintus Fulvius Flaccus, Roman general in the second Punic War. Together with his colleague, Appius Claudius Pulcher, he captured Capua in 212.

Marcus Fulvius, one of the commissioners appointed to carry out the agrarian measures of Tiberius Gracchus, who met his death, with Gaius Gracchus, in 121. (3) Marcus Verrius, a grammarian in the reign of Augustus, the author of a work on the Meaning of Words, abridged by Festus (q.v.). The poets Horace and Valerius also belonged to the family. See Horace; Valerius.

Flacius or Vlacich, Matthias (1520-75). Lutheran divine. Born at Albona, Illyria, March 3, 1520,

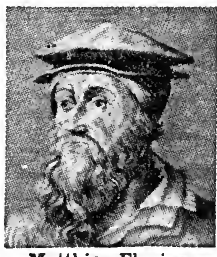

Matthias Flacius, Lutheran divine Hebrew in 1554. series of controversies, siding with Luther against Melanchthon. $\mathrm{He}$ settled in turn at Magdeburg, Jena, where he was professor of theology, Ratisbon, Antwerp, Strasbourg, and Frankfort-on-the-Main, where he died in poverty, March 11, 1575.

One of the charges against Flacius was that of Manichaeism, based on his statement that sin was inherent in human nature from the Fall. The work in which this appeared, Clavis Scripturae Sacrae 


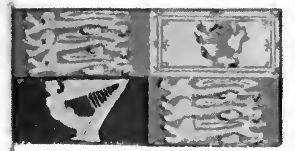

ROYAL STANOARD (UNITED KINGOOM)

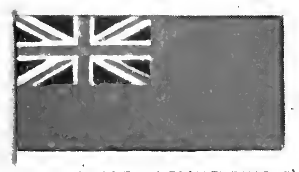

REO ENSIGN(RRITISH MERCANTILE MARINE)

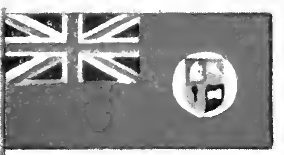

UNION OF SOUTH AFRICA (ENSIGN)

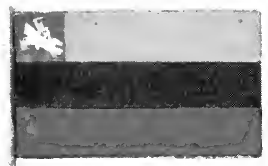

LITHUANIA

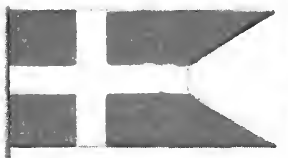

DENMARK (ENSIGN)

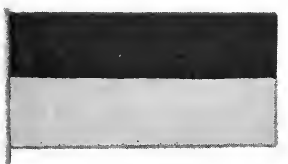

UKRAINE
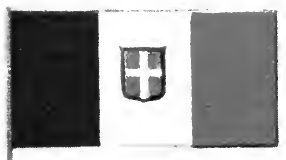

ITALY

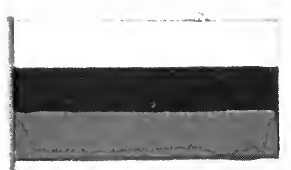

RUSSIA

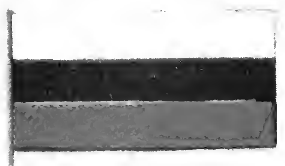

BULGARIA

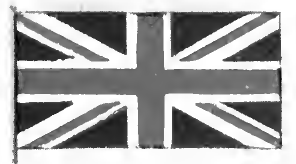

UNION JACK
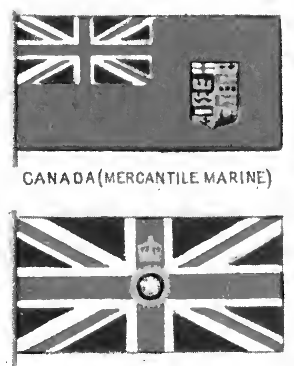

INDIA (GOVERNOR GENERAL)

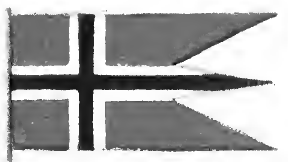

NORWAY

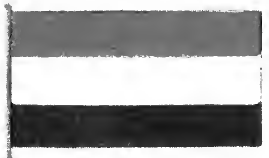

HOLLAND
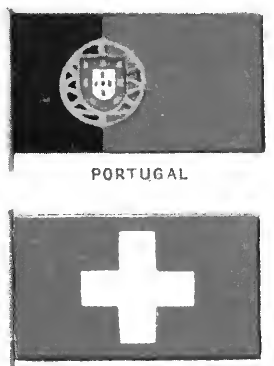

SWITZERLAND

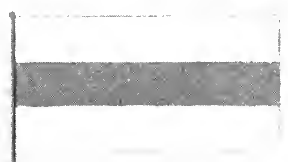

ALLIES (SHIPPING)

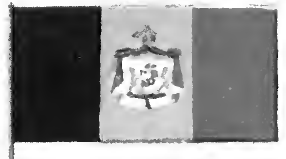

RUMANIA

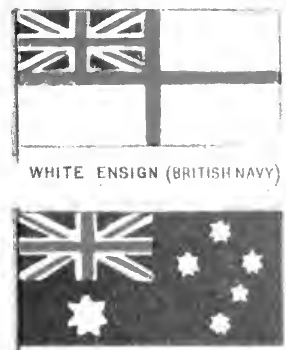

AUSTRALIA (ENSIGN)

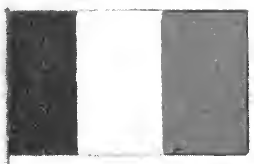

FRANCE

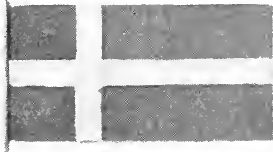

SWEOEN

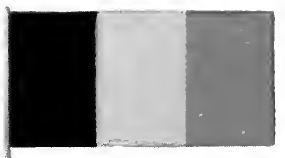

BELGIUM

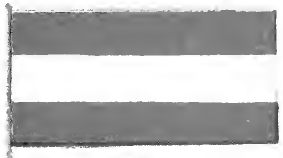

AUSTRHA

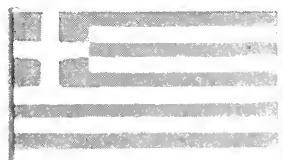

GREFCE

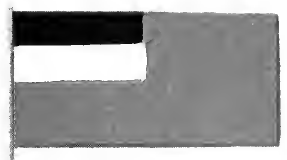

GEOP.GIA

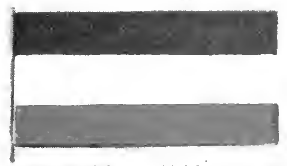

$Y U G O=S L A V I A$

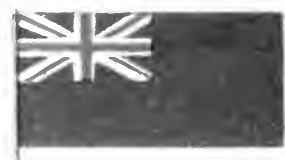

BLUE ENSIGN (NAVAL RESERVE)

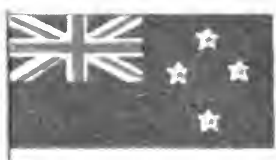

NEW ZEALAND (ENSIGN)

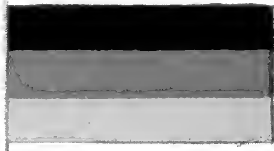

GERMANY

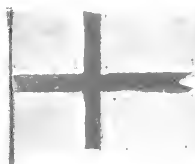

ICELAND (OFFICIAL)

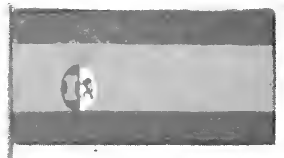

SPAIN

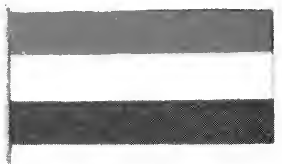

HUNGARY

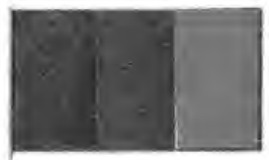

ARMENIA

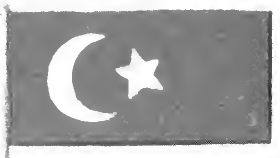

TURKEY

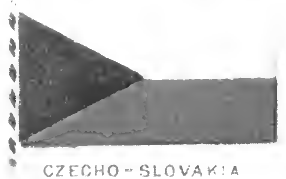

FLAGS OF THE NATION;, INCLUDING THOSE ADOPIED AFTER THE GREAT WAR Specially drawn for Harmsworth's I'niversal Encyclopedia lin I. F'. Cumphell 


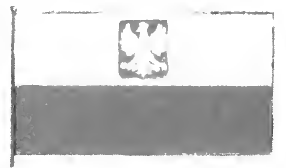

POLAND

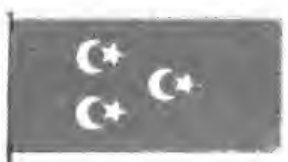

EGYPT

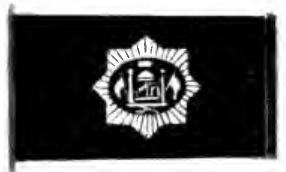

AFGHANISTAN
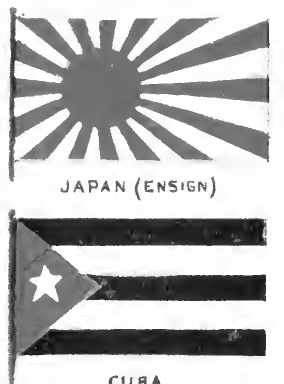

CUBA

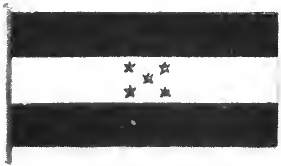

HONDURAS

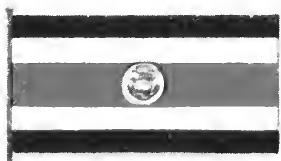

COSTARICA

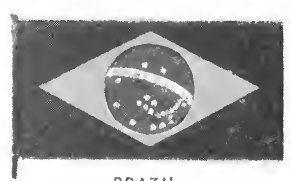

BRAZIL

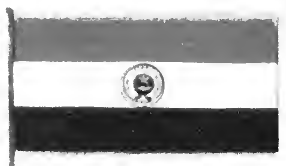

PARAGUAY

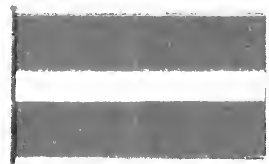

LAT VIA

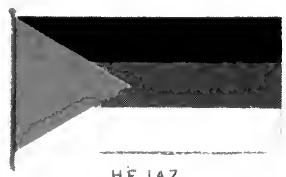

HEJAZ

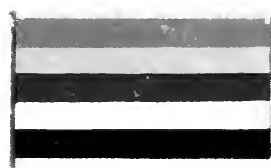

CHINA (NATIONAL)

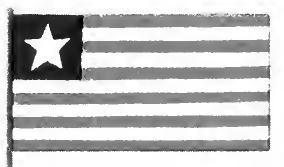

LIBERIA

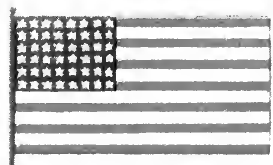

UNITEC STATES

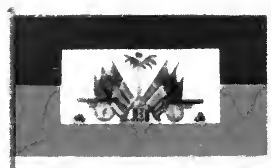

HAIT I

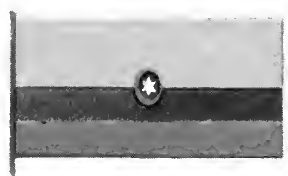

COLOMBIA
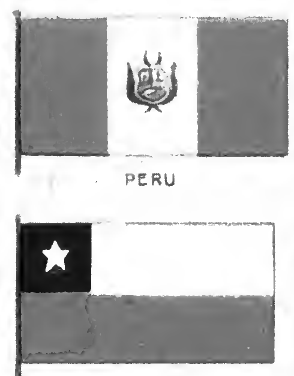

CHILE

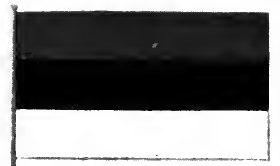

ESTHONIA

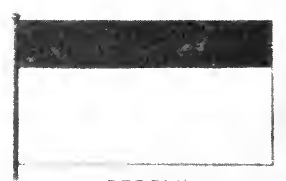

PERSIA

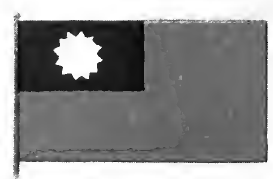

CHINA (NAYAL)

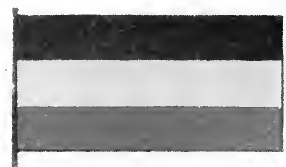

ABYSSINIA

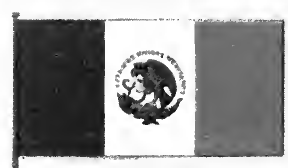

MEXICO

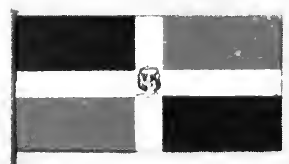

SAN DOMINGO

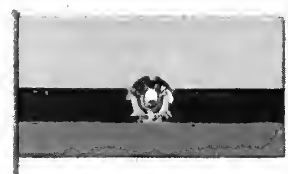

ECUADOR

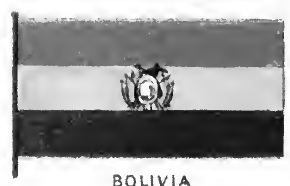

BOLIVIA

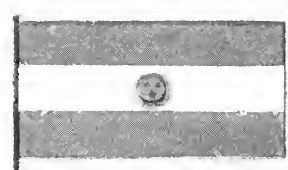

ARGENTINA
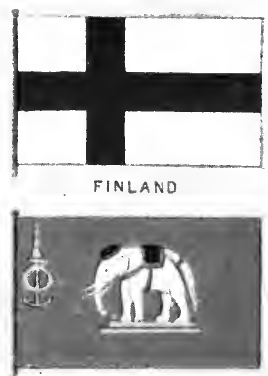

SIAM

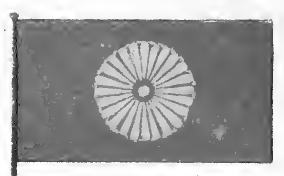

JAPAN (STANDARD)

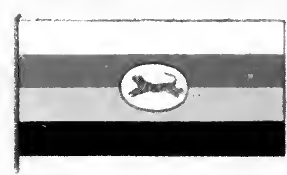

FEDERATED MALAY STATES

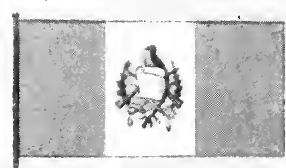

GUATEMALA

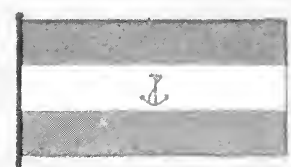

NICARAGUA
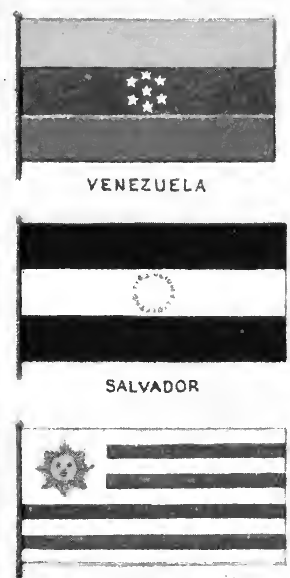

URUGUAY

FLAGS OF THE NATIONS, INCLUDING THOSE ADOPTED AFTER THE GREAT WAR 
(Key to Holy Scripture), 1567, formed the basis of biblical hermeneutics, a term defining the principles of biblical interpretation as distinguished from exegesis or interpretation. Other works of Flacius replied to the Roman objection to the Reformation as a mere innovation, and traced Church history from an evangelical standpoint.

Flag (Iris). Large genus of perennial herbs. Of the natural order Iridaceae, they are natives of the N. temperate regions. The species form two groups: one in which the rush-like foliage dies down each autumn, and the life of the plant is continued by a long bulb-like tuber ; the other in which the thick, sword-shaped leaves arise from stout, slightly creeping rhizomes. The term flag is generally applied to members of the second group, the others being spoken of by the name Iris. The leaves enfold each other at the base, and from their midst rises the flower stem, bearing the large brightly coloured flowers. There are three sepals and three petals, the sepals much larger than the petals, and the stigmas expanded to look like petals. The yellow flag (I. pseudacorus) is common in ditches and marshes. The blue flag (I. germanica), so common in gardens, is wild in $\mathrm{S}$. and Central Europe. The seed vessel is a large, leathery capsule, splitting when ripc into three pod-like divisions, packed with large flattened seeds. See Iris.

Flag. Pieces of suuff, particoloured, or of a single colour, plain or bearing symbols, and flown from a staff or halyard. They may be national or personal. Flags were known to the ancients, though the standard or symbol placed on the top of a staff, like the Roman eagles, were more common. This was followed by the gonfalon type, and then by the guidon, a small piece of stuff attached to a lance. In medieval days the shapes and sizes of flags were diverse, but were soon strictly regulated. The standard was a large and long flag, often with one, two, or more points, parti-coloured and decorated with crests, badges, and devices. The banner was large and square, or rectangular, em. blazoned with armorial ensigns, and denoted that the bearer was entitled to levy and lead troops.

The standard with one point was known as the guidehomme (abbreviated into guidon); the ancient was a small guidon; the pennon (bearing badges and motto only) was half the size of the guidon, and had one tail; the pendant was

the ship's guidon; the pennoncelle, or pencil, a small pennon, attached to a lance and usually bearing a single heraldic symbol; the pavon was a triangle, with horizontal base; the banderolle a long narrow flag or streamer, such as the modern pennant.

National flags only evolved slowly. The English white flag with the red cross of S. George appears to have been introduced by Richard I on his return from the East, but it long appeared side by side with many others, in. cluding the Royal armorial banner. The British national flag is the Union Jack (q.v.). The white ensign, with the red cross of $S$. George and the Union Jack in the upper quarter, is a naval flag, reserved for the Royal Navy and certain privileged yacht clubs.

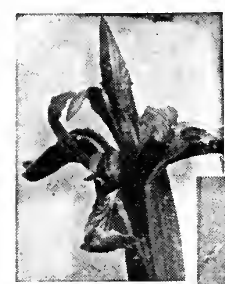

Naval Reserve, certain national service ships and privileged yacht clubs. The red ensign, similar to the above in design, is the merchant flag. Regimental flags are similar to the above, the field being of the colour of the regimental fac. ings (see Col. o u r s). Th e British colonial flags are the blue and red ensigns, with

Union Jack supplemented by na. tional emblems or armorial shields placed in the fly.

As the result of the Great War, several new national flags came into existence. The flag of Latvia (Lettland or Ietonia), one of the new Baltic States, is red, white, red, horizontally, the two red stripes being each double the width of the central white. Esthonia has blue, black, and white in horizontal stripes. The present emblem of Austria is similar to that of Latvia, the colours being red, white, red, hori- zontal, but in this case of equal width. This design only differs from the old flag of Austria-Hungary in not having the lowest stripe half red, half green, the latter colour representative of Hungary. The new flag of YugoSlavia has included the colours of blue, white, red, horizontally. These are the old colours of Serbia and Montenegro rearranged. The kingdom of Hejaz has black, green, and white in horizontal stripes. See Colour Plate.

Flag Day. Day set apart for the raising of money for charitable purposes by selling small emblems, usually flags, in the streets. The origin of the scheme was due to the success attending the sale of the artificial roses on Alexandra Day. During the Great War millions of pounds were raised for various war funds by means of flag days. The method was to make millions of little flags, each showing in colour scheme or device the nature of the particular fund. These were sold in the strects by ladies, and were provided with pins so that they could be worn.

In London it was necessary to obtain permission for flag days. Applications were submitted to the commissioner of police. A check on abuses was the stipulation that after the collection, accounts showing the total money received and spent had to be submitted. Statistics compiled from accounts in the metropolitan area between May 13, 1916, and April 9, 1918, howed that a total sum of $£ 286,830$ was collected at a cost of $£ 51,432$, leaving a net amount of $£ 235,398$.

Flagellants (Lat. flagellum, little whip). Name given to various ascetic bodies in the Roman Catholic Church, that practised flogging themselves or one another as a means of disciplining the flesh and promoting spiritual growth. They arose in Italy in the 13th century, and continued to break out sporadically for about 150 years. One of their chief leaders was Cardinal Peter Damiani, who taught that a vigorous scourging was worth many years of ordinary self-denial and mortification. In 1260 there was a great outbreak of this form of fanaticism at Perugia, and in the following century it caused trouble in Germany and Hungary.

When the Black Death swept over Europe in 1348, the Flagellants had a great revival, and held processions through the streets stripped to the waist and singing penitential psalms. A halt was called at intervals, and all scourged one another in turn. About 120 of these enthusiasts reached London, 
but they won no followers in England. They were denounced by Pope Clement VI, and finally suppressed by the Inquisition. Sce Asceticism.

Flagellata. Sub-division of the Infusorians, or minute protozoa. Found in stagnant water, they have "whiplike" threads of protoplasm which by their lashing movements propel the animal through the water. The minute Noctiluca, which causes the phosphorescence of the sea, belongs to this order.

Flageolet (Fr.). Wind instrument of flute tone, played vertically through a mouth-tube. 'The modern instrument has a separate mouthpiece but those of the 17th cen tury had the blowing bole on a sloped end of the main tube, like the present. day penny whistle. The true 17 th cen. tury flageolet had two of its six fin. ger-holes at $\mathrm{t} h \mathrm{e}$ back, governed by the player's thumbs. See Elûte - à - Bec ; Recorder.

Flag Lieutenant. In the British navy, the personal aide. de-camp of an admiral. Flag Jack, as the navycalls him,

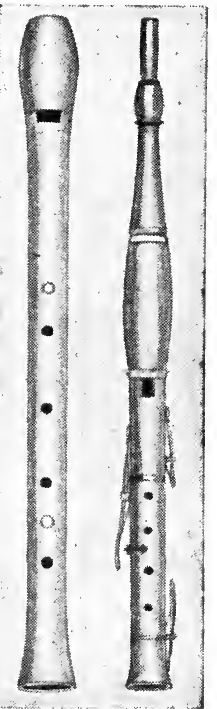

Flageolet. Left, $17 \mathrm{th}$ century instrument the open circles show thumb positions at back of tube. Right, modern flageolet with four keys is usually a specialist in signalling. $\mathrm{He}$ is distinguished from the other lieutenants by the aiguillette or golden cord on his left breast.

Flag Officer. Naval term meaning an officer of admiral's or flag rank. Only admirals hoist flags ; other officers, when in command, fly pennants. In the British navy there are four grades of flag officer, viz. rear-admiral, vice-admiral, admiral, and admiral of the fleet, the last being the equivalent of field-marshal in the army. 'The admiral's flag is derived from the banners which in the old days used to be hoisted aboard ship by generals who held a command at sea. Admirals' flags are: Rearadmiral, S. George's "Cross with two red balls; vice-admiral, S. George's Cross with one red ball; admiral, S. George's Cross ; admiral of the fleet, Union Jack. See Admiral.

Flagship. Vessel in which a flag officer is accommodated, and in which he flies a distinctive flag to indicate the ship to which others must look for signals. A single fleet may have many flagships, according to the number of its tactical units. The tactical unit is a division of four ships, usually with a rear-admiral in command: and two divisions make a squadron, over which is a vice-admira], who also has charge of one of the two divisions. A number of battle squadrons, with their attendant craft, make up a fleet, the commander-in-chief, as a rule, flying his flag in a vessel which is outside the divisional formation, and at liberty to place herself where she chooses.

At the principal home naval stations the flag of the loca] commander-in-chief is flown in an old warship, i.e. the Victory at Portsmouth, the Impregnable at Devonport, the Pembroke at Chatham, and the Crescent at Rosyth, but the officer lives in an official residence ashore. Most of the senior departmental officers in flagships, i.e. those chosen for staff, gunnery, torpedo, navigation, or engineering duties, receive a special flag allowance in addition to their pay. Vessels that are not flagships are sometimes called private ships. See Battleship; Navy.

Flagstone. Fine-grained argill. aceous sandstone, which splits easily in slabby fashion along the bedding plane. Fine sandstones which do not show this so-called lamination are sometimes included under the same name. Flagstones are composed mainly of minute grains of quartz, but generally contain also some felspathic and micaceous material 'The colour of flags varies from almost white to grey or yellow, while the mica flakes, if present, give the stone a sparkling appearance in the sunlight. 'I'h eir fine, even texture, their strength, and the readiness with w'lich they break into blocks of convenient size make them suitable for use as building stones.

Flagstones are mainly used, how. ever, for paving-stones, kerbstones, hearths, sills, and steps, and those varieties which split into very thin layers are used for roofing.
Flail (Lat. flagellum, little whip). Hand implement for threshing. It is now little used, except on a small

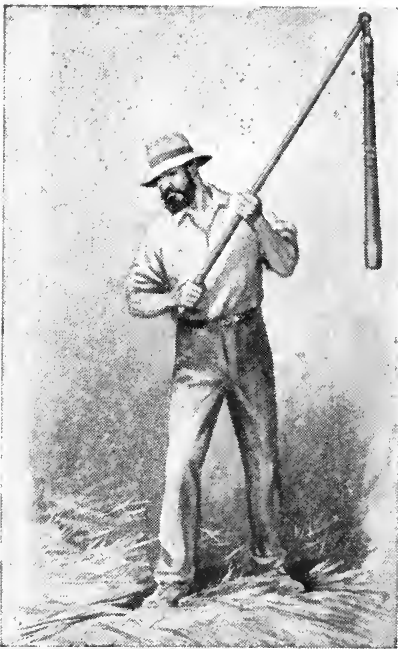

Flail. The old-fashioned tbreshing implement in use

scale for flax or when securing peas and beans for seed purposes. It consists of a shaft or handle, commonly made of ash, and a swingle (swiple) of some hard, nonsplitting wood. The two are fixed together so that the swingle can move freely, this being effected either by leather thongs or by interlocking an ash swivel on the shaft with a leather loop on the swingle. See Agricultural Implements.

Flambard, RaNulf or Ralph (d. 1128). Chief minister of William Rufus. Son of a Norman priest, he was made chaplain to the bishop of London, and after William II's accession became his

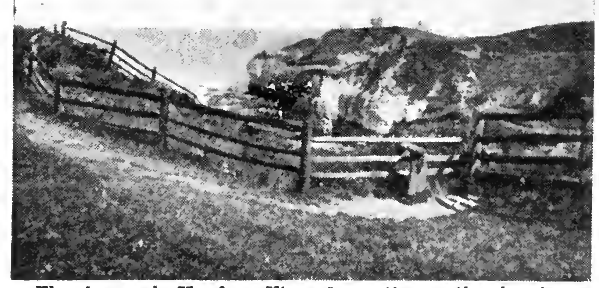

Flamborough Head. View from the north, showing part of the lighthouse Photochrom

principal adviser, especially in financial matters. In 1099 he was made bishop of Durham. $\mathrm{He}$ incurred unpopularity by his extortionate fiscal methods, and after the death of Rufus was imprisoned, but escaped to Normandy, where 
he became bishop of Lisieux. $\mathrm{He}$ returned to England in 1106, after the battle of Tinchebrai.

Flamborough Head. Promontory on the E. coast of Yorkshire, England. It lies to the $\mathrm{N}$. of Bridlington Bay. The limestone rocks, which rise to a height of $450 \mathrm{ft}$., are pierced by a number of caverns, and the action of the sea has fashioned the rocks into fantastic shapes. The lighthouse is $214 \mathrm{ft}$. above sea level, and its flashing light is visible for $21 \mathrm{~m}$.

Flamboyant (Fr., flaming). In architecture, a development of late French Gothic. It owes its name to the flame-shaped openings in tracery which were its chief characteristic. The period of Flamboyant was the late 15th and early 16 th centuries. The style hardly penetrated to Great Britain, though some of the flowing tracery in Chester Cathedral approximates to it. Among French examples are the church of S. Maclou at Rouen, and part of Tours Cathedral. See Architecture.

Flame, Gaseous matter raised to a temperature at which it becomes self-luminous, as a result of

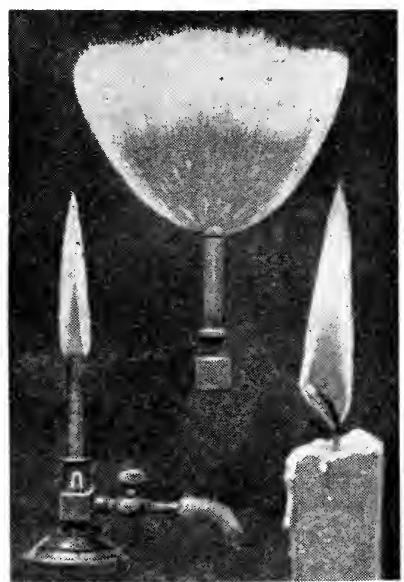

Flame. Types of flame. Left to right. Bunsen burner; ordinary burner for lighting purposes; wax candle

combustion. Some gases inflame spontaneously because the ignition temperature is as low as the ordinary temperature of the air. Ex. amples are cacodyl, phosphorus dihydride, and zinc ethyl. As a rule, however, the temperature of the gas must be raised before the chemical reaction with the oxygen of the atmosphere takes place. An agency which lowers the temperature below ignition point puts out the flame; a copper helix placed in a candle flame extracts heat so rapidly that the flame is extinguished.

This cooling action is employed in the Davy miners' safety lamp, where the wire gauze prevents the flame being communicated to the inflammable fire-damp in the mine. It has long been known that ordi. nary flames are hollow and that there are "solid" flames in cases where the complex molecule of a gas is by combustion broken up into simpler forms, e.g. in burning nitrogen trichloride. Berzelius pointed out that a candle or hy. drocarbon flame shows four distinct regions : (1) the dark central region, (2) the yellow region, (3) the blue region, and (4) the faintly luminous portion. The dark portion consists of unburnt gases, whilst the yellow portion occupy. ing the greatest part of the flame is the luminous portion.

The temperature of a flame depends upon the heats of combina. tion of the constituents and the specific heats of the products of the combination. The temperature of sulphur burning in air is comparatively low, whereas an oxy-acetylene flame reaches $2,500^{\circ} \mathrm{C}$. The colour of a flame is not as a rule in. dicative of the calorific power. The yellow gas flame is converted into a hotter non-luminous flame by the admixture of air, such burners, knuwn as Bunsen burners, being used for heating operations in the laboratory and the kitchen.

A sensitive flame is a gas flame produced by a pin-hole burner in which the pressure of the gas has been increased till it is on the point of flaring. This long, thin flame is a very sensitive detector of sound waves, particularly of those of high pitch and tiny amplitude. When a train of these sound waves im. pinges on the sensitive flame it flares and suddenly shortens. See Fire ; Heat.

Flame-flower oR REDHOT POkER (Kniphofia aloides). Perennial herb of the natural order Liliaceae. It is a native of $\mathrm{S}$. Africa. The leaves, which grow in a compact tuft from the root, are long, narrow, and of tough consistence; they are channelled above and keeled below, the keel and the edges finely toothed. The brilliant red, tubular Howers are disposed in a close oval

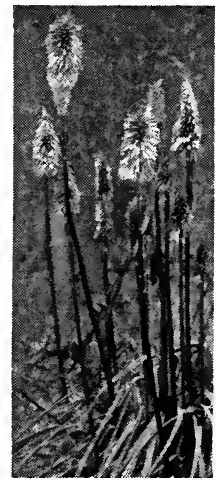

Flame-flower. Specimens in bloom spike, at the summit of a stem $3 \mathrm{ft}$. or $4 \mathrm{ft}$. high. The aspect of the flowers gives the herb its descriptive name.

Flamen. In ancient Rome, a priest devoted to the service of a particular god. The chief of thesc priests, who had to belong to the patrician order, was the flamen Dialis or priest of Jupiter. Not only the flamen Dialis himself, but his wife, who was called Flaminica, and the whole household were regarded as consecrated to the god.

Flamingo (Phoenicopterus). Order of large birds, nearly related to the ducks. They have extremely

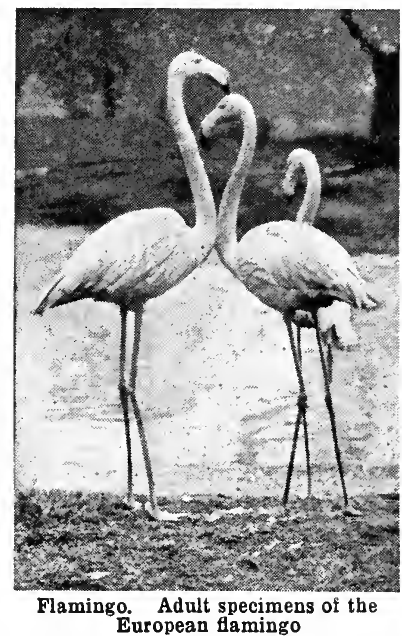

long legs and necks, rosy or scarlet plumage with black on the wings, and beaks sharply bent down at an angle. Adult specimens sometimes exceed $6 \mathrm{ft}$. in height. One European species, four or five American, and one African are known.

Flamingoes are wading birds, as their long legs and necks suggest, and are found in great flocks by the margin of lakes and rivers, feeding on molluscs and aquatic vegeta. tion. When feeding, the flamingo's head is turned upside down and the curved beak acts as a scoop for picking up food. The birds are fairly strong in flight, and can swim well. The nests are made of mud, and when built on land rather resemble large soup plates. When constructed in the water, they are tall and conical. The European flamingo is common in the S. of France and in Spain during the nesting season, and it ranges through many parts of Africa. It is very rarely met with in Great Britain. 'The French name is flamant, Span. flamenco, ultimately from Lat. flamma, flame, in reference to the bird's colour. 
Flaminian Way (Via Flaminia). Ancient Roman road. It took its name from C. Flaminius, censor in 220 B.C., who extended it to Ariminum, making it the first Roman road to cross Italy. Previous to this time it had existed only as far as Spoletium. It issued from Rome at the Porta Flaminia, being a continuation of the Via Latina, and, crossing the Tiber by the Milvian bridge, reached Spoletium by way of Narnia.

Flamininus, Titus Quinctios (d. c. 175 B.c.). Roman general. Before he was 30 , he attained the consulship, and in 197 defeated the Macedonians at Cynoscephalae (q.v.). A clever diplomatist and an admirer of the Greeks and their culture, he was appointed to settle the affairs of that country. At the Isthmian games in 196 he proclaimed amidst great enthusiasm the independence of Greece, really the exchange of a Roman for a Macedonian master. After crushing the Spartan tyrant Nabis, he was honoured by a splendid triumph on his return to Rome in 194 . In 192 he was again in Greece and prevented the pro-Syrian party from assisting Antiochus in his struggle against Rome. In 183 Flamininus was sent to demand the surrender of Hannibal from Prusias, king of Bithynia.

Flaminius, GaIUs. Roman statesman. $\mathrm{He}$ introduced an agrarian law in 232 B.c., providing for the distribution of recently conquered territory in Picenum and Senonian Gaul among the plebeians. During his censorship in 220 he built the great Circus Flaminius, and constructed the Via Flaminia. He was one of the generals in command of the Roman army at the battle of the 'Trasimene lake in 217 , in which he himself was slain.

Flammarion, CAMrLLE (1842 1925). French astronomer. B. Feb. 26,1842 , at Montigny-le-Roi, he stud-

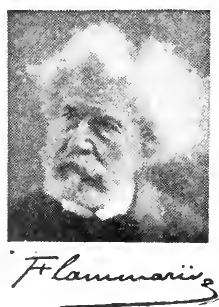
ied theology at Langres and Paris. In 1858 he entered the Paris observatory, and was a member of the Bureau des Longitudes in 1862 . From 1863 onwards he edited Cosmos and L'Astronomie. We carried out numerous observations, especially on Mars, at his private observatory? at Juvisy. He won wide fame as a popular writer on astronomy, and founded the astronomical society of France in 1887. In Oct., 1920, he married Gabrielle Renaudot, his collaborator in some of his chief works. Among his books translated into English are: Popular Astronomy; Astronomy for Ama. teurs. He died June 4, 1925.

Flammenwerfer (Ger., flamethrower). Special type of blow. lamp for military use. German equipment of this type was designed as a method of cutting barbed-wire entanglements by melting the strands, but during their attack at Hooge in 1916 was employed by them against the defenders, and was subsequently used on many occasions as a short range weapon in trench fighting. Similar devices were later adopted by the Allies.

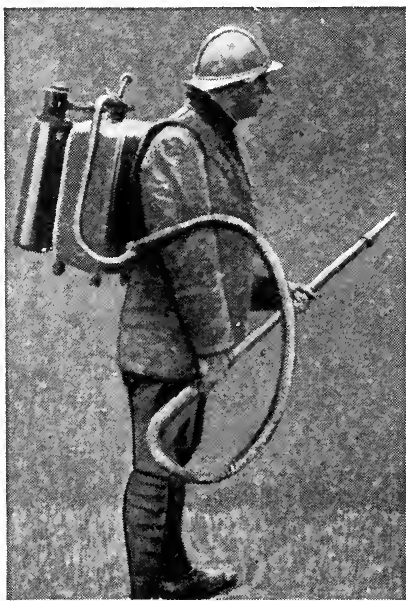

Flammenwerfer. French soldier testing a cantured German flame-thrower of the portable type

The Flammenwerfer consists essentially of a reservoir of inflammable oil, usually petroleum or benzene, which can be thrown to a considerable distance in the form of a spray, by means of a suitable nozzle, the oil being forced through the nozzle by the pressure of gas contained in a separate reservoir. The end of the nozzle is fitted with mechanism for igniting the spray. The grosser (large) Flammenwerfer held nearly $\mathbf{3 5 0}$ pints of oil.

The kleiner (small) Flammen. werfer was portable, and held about 16 pints of oil in a reservoir with attached gas reservoir, so designed as to carry from the operator's shoulders a short length of hose carrying a nozzle. See Trench Warfare.

Flamsteed, JoHs (1646-1719). English astronomer. Born at Denby, Derbyshire, Aug. 19, 1646, he was educated at Cambridge, and devoted himself early to the study of astronomy, $\mathrm{He}$ was appointed King's Astronomer in 1675 , with an annual salary of $£ 100$,

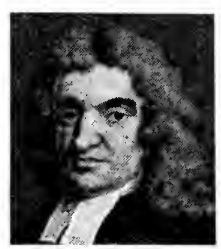
and installed eventuall at the New Greenwich Observatory, begun in that year. His observations there gave Newton much help in the perfohn flasensted tecting of his though there was much ill-feeling between the two men. Flamsteed's chief work was the great catalogue of the fixed stars, the origin of all later catalogues, which was incomplete at his death on Dec. 31, 1719 , but was published with his other observations in 1725. See An Account of the Rev. John Flamsteed, the first Astronomer Royal. To which is added his British Catalogue of Stars, F. Baily, 1835.

Flanches or FlaÃues. In heraldry, the dexter and sinister sides of a shield cut off by curved lines, giving the middle an hourglass form. They are usually borne in pairs. Classed among the SubOrdinaries (q.v.)

\section{Flanders.} Name given to that part of the Netherlands

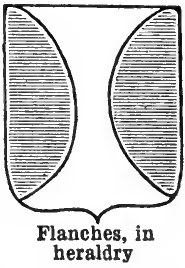
which is bounded roughly by the lower reaches of the river Schelde, the Lys valley, and the coast from Calais to the Schelde estuary. The political frontiers of Flanders have varied considerably, but most of this territory now lies in Belgium, and the old name is retained in the two provinces of W. Flanders (Flandre Occidentale), and E. Flanders(Flandre Orientale). These provs. are markedly different in character from the Walloon provs. of Belgium, being mainly peopled by peasant Flemish stock, almost entirely speaking their own Flemish tongue, a Teutonic language closely akin to Dutch. Ethnologically, a large part of the French dept. of Nord is Flemish, and is often referred to as French Flan. ders. The chief towns of W. Flanders are Bruges, Courtrai, Ostend, Roulers, Thielt, Furnes, Ypres, Dixmude ; of E. Flanders, Ghent, Alost, Audenarde, Eecloo, St. Nicolas Termonde. - W. Flanders, area 1,249 sq. m., pop. 884,777 ; E. Flanders, area 1,158 sq. m., pop. $1,134,079$.

The original inhabitants of Flanders were known to the 
Romans as the Menapii and the Morini, whom they conquered about 51 B.c. During the 7 th century Christianity was introduced, chiefly by S. Bertinus, S. Omer, and S. Bavon. The treaty of Verdun, 843 , by which the empire of Charlemagne was partitioned among his sons, gave the greater part of Flanders to Charles the Bald of the W. Franks. Finding this part of his dominion constantly harassed by the Northmen or Normans, he entrusted its defence to Baldwin Bras-de-Fer (Iron-Arm), who founded the historic line of the counts of Flanders. The last of the direct line, Baldwin VII, died in 1119, and Flanders passed to his cousin Charles, called the Good.

\section{Flanders and Hainault}

In 1157 Count Thierry resigned in favour of his son Philip, who ruled with marked success, being largely responsible for the early economic prosperity of the great Flemish market towns of Bruges, Ypres, Ghent, etc., and who died crusading at Acre, 1191. He left his Flemish dominions to his sister Margaret of Hainault, who thus united the crowns of Flanders and Hainault, though ceding Artois to Philip Augustus of France. Her son, Baldwin IX (1171-1205), emperor of Byzantium, succeeded her in 1194. His daughter, Joanna, was married to Ferdinand of Portugal, who resisted the suzerainty of France, but was disastrously defeated at Bouvines, 1214.

After Joanna's death, 1244, the kingdoms of Flanders and Hainault were torn by a war of succes. sion, and were eventually separated by the arbitration of S. Louis, who awarded Flanders to William of Dampierre, and Hainault to his stepson, John of Avesnes, 1246. Guy of Dampierre, who succeeded in 1280, waged war, in alliance with Edward I of England, against Philip the Fair of France. Supported by popular feeling, directed by the Flemish patriots, Deconninck and Breydel, he routed the strong force of French knights near Courtrai, 1302 , and for a time Flanders was definitely free from France. But under Louis of Nevers, $1322-46$, it was again virtually a French fief.

The following period of internal dissensions was marked chiefly by the resistance of the Flemish com. munes to the arbitrary and extortionate rule of Louis II of Mâle, who succeeded in 1346. The names of John and Philip van Artevelde (q.v.) hold a great place in Flemish history as spokesmen and leaders of the popular party, or White Hoods. By the autumn of 1382 Philip had become very powerful in W. Flanders, established in

Bruges, and assured of the people's support. But at Roosebeke, Nov. 27,1382 , he was utterly defeated by Louis with the aid of Charles VI of France. Thenceforth Louis ruled with a firm hand until his death, 1385, when Flanders fell to his daughter Margaret, wife of Philip the Bold of Burgundy.

From this date Flanders was for historical purposes part of Burgundy, until, in 1477, Mary of Burgundy married the emperor Maximilian and brought it into the empire. It was in this period that the extraordinary economic prosperity of the great Flemish towns reached its highest point. The abdication of Charles $\mathrm{V}$ brought Flanders into the Spanish dominions under Philip II in 1555, intro. ducing the long wars for the independence of the Netherlands, and the old-time prosperity suffered sadly. In 1648 the treaty of Westphalia made Flanders part of the United Netherlands, and in 1659 and 1713 Louis XIV absorbed large parts of Flemish territory as well as Artois. In 1714 the treaty of Rastatt put Flanders again into Austrian possession, and in 1794 it fell into French hands once more. But when the new kingdom of Belgium was formed in 1830 ,

\section{FLANDERS: THE BATTLE OF 1918} H. W. Wilson, Military Critic of The Daily Mail

This engagement was one of those that finally broke the German resistance. For the other battles of these closing months of the Great War see Cambrai; Le Cateau; Sambre; Selle. See also Foch; Haig; Great War

This battle was fought in Sept.Nov., 1918. The heavy fighting in Flanders in 1914, sometimes known as the 1st battle of Flanders, is more usually described under the titles Ypres and the Yser.

In accordance with Foch's general plan, which was, after recovering the initiative from the Germans in the 3rd battle of the Marne (July 18-Aug. 3, 1918), to press them continually by attacks which should gradually develop along the whole Allied front in the W., preparations were made in Sept., 1918, for a great Allied offensive extending from Dixmude to the S. of the Ypres salient. For that purpose a group of armies was formed and placed under the king of the Belgians. It consisted of the Belgian army, with three divisions on the Allied left, the 6th French army (Boissoudy), with three divisions in line and one in reserve, which were to engage in the centre, and the 2nd British army (Plumer), with the 2nd and 19 th British corps, on the right. Gen. Degoutte, one of the French officers who had particularly distinguished himself in the 2nd and
Flanders entered into her present position therein.

m these many changes of sovereignty, nor the unfortunate position of Flanders as a battlefield of the nations, has destroyed the individual character of the Flemings or their country. Within Belgium itself racial consciousness is sharply marked. 'The possession of a tongue and literature of their own has given the Flemish national movement considerable strength. It has won recognition of Flemish rights, linguistic and educational, and is to-day an important factor in Belgian politics. A strong body of feeling has long favoured Flemish autonomy, and during the Great War the Germans tried unsuccessfully to exploit this against Belgian unity by establishing the so-called Council of Flanders at Ghent, 1917. But despite the discredit done to the cause by a few extremists, the movement is growing in strength, and may well modify still further the Belgian See Belgium; conalso Histoire de Belgique, $H$. ne, 1900, etc. ; Belgium, R. C. K. Ensor, 1915 ; The Language Question in Belgium, A. van de Perre, 1919.

J. E. Miles

3rd battles of the Marne, acted ss King Albert's chief of staff. The German force on the front selected for attack was only 5 divisions strong, and formed part of the 4 th army under Sixt von Armin. The date fixed was Sept. 28, coincident with the tremendous assaults which were being delivered by the British armies on the Hindenburg line, and by the French and American armies.

At 5.30 a.m. of the $28 \mathrm{th}$, without any preliminary bombardment, the Allied infantry suddenly advanced, covered by a creeping barrage, and employing all the latest tactical methods, including the "leapfrogging" of fresh divisions through the assaulting troops as these tired. The hideous terrain S.E. of Ypres was crossed at a single bound. Wytschaete, lost in April, 1918, Zandvoorde, Gheluvelt, and Becelaere were stormed by the British. The French and Belgians took Zonnebeke, Poelcappelle, and Houthulst Forest. The country was almost impassable; rain fell heavily and hampered the assailants, but the Germans at the outset offered only a feeble resistance. 


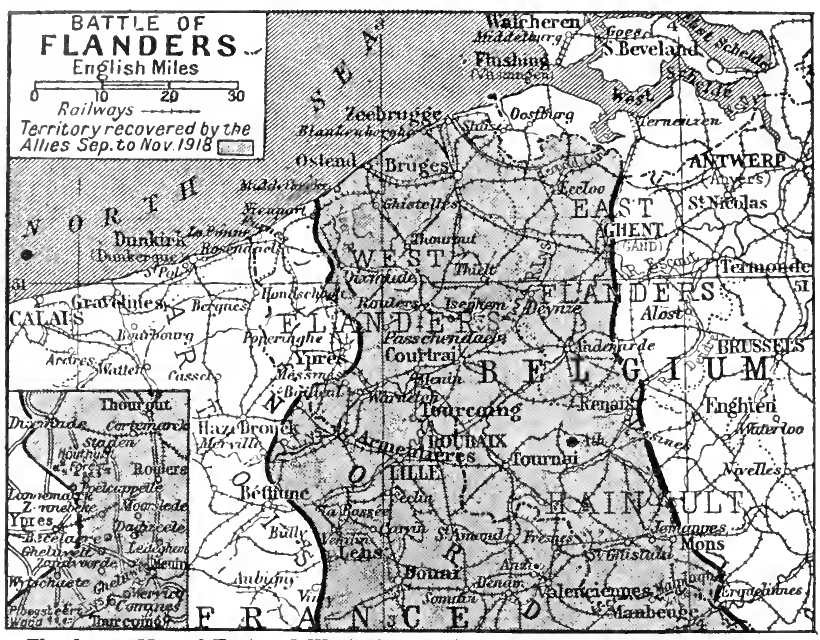

Flanders. Map of East and West Flanders indicating the area recovered from the Germans during the great battles of Sept.-Nov., 1918

On Sept. 29 the attack was continued with the utmost de. termination. That day the Belgians took Dixmude and Passchendaele, and reached the high road from Roulers to Menin, while the British cleared Ploegsteert Wood, recovered Messines, and reached Warneton and Dadizeele. On Oct. 1 the British were elose up to Wervicq, and had crossed the Menin-Roulers road near Le. deghem, while the Belgians and French had cleared Moorslede and Staden. It was then necessary to suspend the advance in order to bring up the heavy artillery and repair the roads. The German front had been penetrated to a depth of over $8 \mathrm{~m}$., and all the German main defensive lines on the Flanders front had fallen. The capture of 10,000 prisoners and 200 guns, half of them taken by the British 2nd army, afforded practical proof of the importance of the victory. The Germans at once began preparations for the evacua. tion of the Flanders coast, which had so long been a menace to London as the base of their cruel air attacks, and which they had at one time decided to annex permanently.

Between Oct. 1 and 14 another British corps, the 10th, was brought up and the Allied com. munications were reorganized. The Germans had utilised the respite to lay wire, construct machine-gun positions, and bring up what reserves they possessed. At $\mathbf{5 . 3 5}$ a.m. of Oct. 14 the second phase of the battle opened along the whole front from Comines to Dixmude. The Belgians reached the outskirts of Iseghem, and the French enveloped Roulers. The British carried Gheluwe, and fought their way into the outskirts of Menin. On the next two days further important gains were made. Thourout and Cortemarck were captured, and the British at several points secured bridge-heads over the Lys. The sound of heary explosions in the German lines and along the Flanders coast told that von Armin was destroying his dumps and blowing up his heavy guns.

The Belgians directed their advance northwards to clear the Germans out of the coast, and, if possible, to get on the line of their retreat; but von Armin was too quick. On Oct. 17 the last Germans quitted Ostend, almost exactly four years from the date on which they had entered it, and that same day the British entered Courtrai. On Oct. 18 the Belgian advance compelled the Germans to abandon Zeebrugge, and this naval base, with the city of Bruges, was occupied by the Allies on Oct. 19. To the S. the Germans were also compelled to retreat to avoid envelopment, and on Oct. 18 they had abandoned the industrial centres of Tourcoing and Roubaix. On the 20th the Belgians reached the Dutch frontier.

The Germans were now in slow retrcat along this whole section of the front; they were steadily pressed, and, by the date of the armistice (Nov. 11), the Allies had reached a line which ran from the Dutch frontier south of Temeuzen to Ghent, and thence along the Schelde past Ath, to a point near St. Ghislain where they linked up with Haig's main group of British armies. In the second battle of Flanders the British captured 6,000 prisoners and 210 guns, and the French and Belgian captures were about as large. The trials of the Allied troops were severe; they had to march and fight in most difficult country with deplorable communications which rendered the supply of food and ammunition exceedingly difficult. Mines with delay-action fuses were left by the Germans at all cross-roads, and at many points on the railways, as they retreated, and these exploded, sometimes weeks after their retirement. Foch, who visited the 5th British army (Birdwood), which took part in the Allied advance on the front south of the 2nd army, gave the British troops just praise for the magnificent character of their work. "Your soldiers," he said, "marched when they were exhausted, and they fought, and fought admirably, when they were worn out. It is with such indomitable will that the war has been won."

Flandin, Eugkèe Napoléon (1809-76). French painter. Born in Naples, Aug. 15, 1809, he studied in Italy, and under Horace Vernet in Paris, and travelled widely in the East. He painted many land. scapes, notably of Venice, Athens, Algiers, and Constantinople, and wrote valuable accounts of his travels and archaeological discoveries. He was awarded the Legion of Honour in 1842, and died Feb. 15, 1876.

Flandrin, JEAN Hippolyte (1809-64). French painter. Born at Lyons, March 23, 1809, son of a miniature painter, he studied there, and at Paris under Ingres (q.v.). Obtaining the Grand Prix in 1832, he went to Rome, whence he returned in 1838 to Paris, and was employed in the mural decoration of S. Séverin, 1841, S. Vincent-dePaul, 1850, and other ehurches at Paris and elsewhere. Later he took to portrait-painting, among his best works in this genre being the full-length portrait of Napoleon III, at Versailles. He died of smallpox at Rome, March 21, 1864.

Flandrin, JEAx PAUL (18111902). French painter. A brother of J. H. Flandrin, he was born at Lyons, May 8, 1811, and studied under Ingres. $\mathrm{He}$ was a prolific artist, his best work being of landscapes. Among the most noteworthy are his Solitude in the Sabine Mountains, 1852, in the Luxembourg, Paris : 'The Rhône, 1857: Meadow near Mantua, 1874; and Diggers at Work, 1884. He was awarded the Legion of Honour in 1856, and died in 1902. His eldest brother Auguste (1804-43) worked under Ingres, and was a teacher of painting at Lyons. 
Flange (Fr. flanc, flank, side). Projection which guides, strengthens, or affords a means of attachment. Circumferential flanges are used on wheels which run on rails or over which rails, belts or ropes run, to prevent displacement. In metal beams or girders the central part, or web, has a flange at one edge or, more usually, at both edges, to give lateral stiffness and take the bending stresses of tension and compression. Annular or oval flanges are used on the ends of steam and other pipes which are subject to heavy pressures, so that the pipes may be drawn and held together by bolts. The hubs of wire-spoked wheels have flanges to which the heads of the spokes are secured. See Girder.

Flank. Military term used for the side of a unit, whether in column, line, mass or any other formation. On the march troops are protected by flank guards, and, when taking up a position, by outposts, unless the nature of the ground makes an attack impossible. See Tactics.

Flank Guard. Patrols or bodies of troops detailed to protect the main body from flank attacks while on the move or at rest. The strength of the flank guard and its distance from the main body depends on the size of the latter and the nature of the country. It should always be strong enough to hold up any attack until the main body has had time to deploy into fighting formation, if the attack is too strong to be defeated by the flank guard. A large flank guard must protect itself by advanced and flank guards so that it can move in close formation.

Flannan Isles. Cluster of seven small islands in the Outer Hebrides, Ross and Cromarty, Scotland. Called also the Seven Hunters, they lie $16 \mathrm{~m}$. N.W. of Gallon Head, Lewis Island, and contain many Caledonian remains. They are the Insulae Sacrae of Buchanan. Large numbers of sea-fowl frequent them.

Flannel. Soft woollen cloth used for clothing, blankets, etc. Highly absorbent, it is eminently adapted for wearing next the skin. The word is probably of Celtic origin ( $c f$. Welsh gwlan, wool). Wales is the original home of the flannel industry, and has long held flannel fairs. Falstaff calls Sir Hugh Evans the "Welsh flannel." Welshpool, in Montgomeryshire, formerly the chief seat of the manufacture, has been superseded by Newtown. Lancashire and Yorkshire are noted for flannels, particularly the town of Rochdale. See Blanket.
Flannelette. Cotton imitation of flannel, used for pyjamas, underwear, etc. The term was first used towards the end of the 19th century. Flannelette is now made extensively in Europe and the U.S.A., and is a popular clothing material, though it lacks the absorbent properties of flannel, and is liable to catch fire. A "non-flam" flannelette has been patented.

Flare. Fireworks of the nature of coloured fires. They are used in warfare to illuminate portions of the front at night, and in some cases are arranged so that they are automatically ignited if anyone moving about stumbles over a trip wire placed in front of the position. Screens should be arranged behind the flares so that the enemy troops are illuminated, while their opponents remain in the shadow and are not inconvenienced by the light. Small hand flares are used for both illumination and signal purposes, and generally burn for about three minutes. Larger ones may be thrown from trench howitzers. Flares intended to illuminate the ground usually contain a mixture of powdered magnesium and a chlorate or nitrate of one of the alkali metals. They give an in tense white light, throwing strong shadows. Similar flares were also employed on board ship to illumi nate particular operations, as at Zeebrugge and Ostend. Signal flares are frequently required to give a coloured light, and for this purpose the following compositions are typical:

\begin{tabular}{|c|c|c|c|c|}
\hline & lied & Green & Blue & Yellor \\
\hline $\begin{array}{c}\text { Potassium } \\
\text { chlorate }\end{array}$ & 78 & - & 45 & - \\
\hline Strontium & & & & \\
\hline carbonate. . & 15 & - & - & - \\
\hline Shellac.. .. & 7 & 1 & 5 & - \\
\hline $\begin{array}{l}\text { Barium } \\
\text { chlorate }\end{array}$ & - & 66 & - & 一 \\
\hline Milk sugar & - & 33 & - & - \\
\hline Sodium nitrate & 一 & - & - & 70 \\
\hline $\begin{array}{l}\text { Sulphur } \\
\text { Antimony sul- }\end{array}$ & - & - & - & 20 \\
\hline phide & - & - & - & 7 \\
\hline lampblack .. & - & - & 5 & 3 \\
\hline $\begin{array}{c}\text { Basic copper } \\
\text { carbonate. }\end{array}$ & - & - & 10 & - \\
\hline Calomel & - & - & 35 & - \\
\hline
\end{tabular}

\section{See Fireworks.}

Flash. Bow of broad black silk ribbon with long ends, which is attached to the back of the tunic collar of the Royal Welch Fusiliers. No authentic explanation of this custom is forth. coming, but in an inspection report of 1786 it was noted that "the officers of this regiment wear the hair turned up behind." Evidently the flash is a survival from the days of queues and hair powder; it is issued officially as an item of "personal clothing." See Uniform.

Flashlight Photography. Photography by the brilliant light obtained by burning the metal magnesium. It is used chiefly for portraits, groups, and interiors of moderate size. In one apparatus fine magnesium is blown through the flame of a spirit lamp, but the magnesium is usually combined with chlorate or perchlorate of potash, and fires readily on the application of a tapcr or electric spark. The chief drawback to these "flash-powders" is the smoke which is produced by them. See Photography.

Flash Point. Temperature at which an inflammable liquid gives off vapour which takes fire when a flame is passed over the surface. It is also used for that at which the vapour that collects forms an inflammable mixture with the air in the closed vessel of the test apparatus. The former is called the open and the latter the closed test. The test is specially applied to petroleum products. The open test was employed in accordance with Petroleum Acts, 1868 and 1871.

In consequence of the unsatisfactory results, Sir Frederick Abel investigated the matter, with the result that the Petroleum Act, 1879 , was passed, legalising the closed or Abel test. The new standard was fixed at $73^{\circ} \mathrm{F}$. $\left(22 \cdot 8^{\circ} \mathrm{C}\right)$. The Abel apparatus, which is standardised by the board of trade before use, is employed in this country for low-flash oils, and by order in Council, 1907, the Abel-Pensky apparatus for high-flash oils. For determining the flashing point of the heavier mineral oils modifications of the above apparatus are used. These are the Pensky-Martens and Gray apparatus. See Oil ; Paraffin; Petroleum.

Flask. Word used in various senses. (1) In founding, a wooden or iron box or frame-like structure for holding the sand or material forming a mould into which molten metal is poured for making a casting in a foundry. The flask comprises a cope, or top member; a drag, or bottom member; and, when used, intermediate members termed cheeks. If the mould is contained in two or more members, the structure is known as a twopart flask, a three-part flask, etc. (2) A vessel of glass, metal, etc., usually having a neck, and provided with a body portion which 
may assume a variety of shapes, for use in storing and heating liquids, and, formerly, as a receptacle for gunpowder. (3) As applied to ordnance, a flask is a metal reservoir for storing compressed air which forms the actuating medium of a motor $f c_{\downarrow}$ ar, automobile torpedo.

Flat. Self-contained residence. It is on one floor, with a private entrance door, and opening on to a common staircase. Many buildings are composed of such separate dwellings. The upper stories of business premises are frequently used as flats, and sometimes ordinary dwelling-houses are so adapted. In Scotland a block of flats is known as a flatted house, and in the U.S.A. as an apartment house. See Housing.

Flat. In music, a sign (b). It indicates that the note to which it refers is to be a semitone lower in pitch than the ordinary note of the same alphabetical name or in the same position on the stave. It was first applied to the note $B$, and the sign was actually a little $b$, to distinguish this note from $B$ which in Germany was and is still called $\mathrm{H}(=h)$. See Double Flat; Natural ; Semitone; Sharp.

Flatbush. Suburb of Brooklyn, U.S.A. Formerly a township in King's co., Long Island, it was acquired by Brooklyn in 1894, and became a part of that borough four years later. The battle of Long Island, Aug. 27, 1776, is sometimes cailed the battle of Flatbush.

Flateyjarbok. Icelandic manuscript dating from the 14th century. Among other things it contains some account of the voyages of the Norsemen of the 10th and 11 th centuries to the American continent. Flateyjarbok (the Book of Flatey) is preserved at Copenhagen. See Anecdotes of Olave the Black, J. Johnstone, 1780 : Flateyjarbok, ed. G. Vigfusson and C. R. Unger, 1860-68.

Flatfish (Pleuronectidae). Large group of fishes of flattened shape, in which the two sides are unlike in colour and the two eyes are on one side. The plaice and sole are examples. In these fish the body is greatly compressed later. ally. In early life the flatfish are symmetrical, and swim like round fishes. Then they become flattened, the body tilts over, and the fish takes to swimming on its side and to lying on the bottom of the sea. The upper side then becomes darkened, and assumes a hue which approximates to the nature of the ocean bed on which it lies, while the markings closely resemble the gravel and motlings of the sand or mud. At the same time, the eye on the under ide gradually works round to the apper surface and the mouth becomes more or less twisted.

Flatfish are marine in habit, though flounders frequently ascend rivers, and a few species have a lapted themselves to a life in fresh water. Most are good table fish.

Flat Foot. In mankind, a condition in which the arch of the foot is reduced, or in bad cases nearly abolished, so that almost the whole extent of the sole comes in contact with the ground. Flat foot is most common in young persons of poor physique, whose occupation has necessitated their

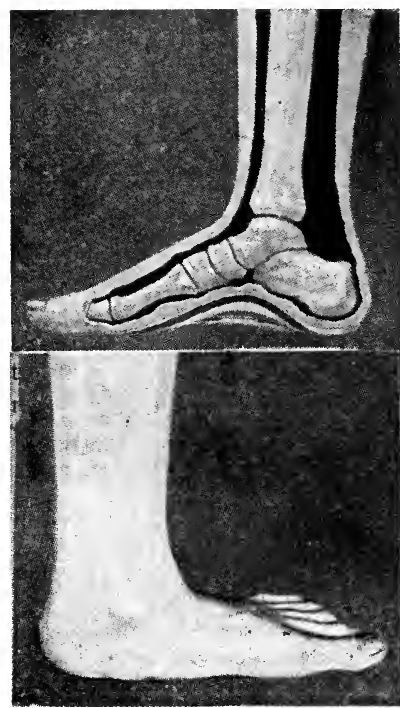

Flat Foot. Illustration of a severe case. Above, diagram of the foot with corrective apparatus supporting the arch

standing for long periods, or frequently carrying heavy weights. Occasionally it may result from injuries to the foot which have torn or weakened some of the ligaments.

Flat foot produces feelings of fatigue and weakness after a comparatively small amount of exercise. Severe pain may be felt in the sole, and the gait becomes shuffling and awkward. Eventually, the whole posture of the body may be altered, particularly when the condition is more marked in one foot than in the other. Compensatory changes may result in a tilting of the pelvis, curvature of the spine, and even changes in the position of the shoulders.

In early cases, where weakness rather than actual deformity of the arch is present, rest should be enjoined; at the same time, the patient should undergo a course of instruction in exercises specially designed to strengthen the weak parts. When the condition is more marked, it is necessary to afford artificial support to the arch of the foot by means of insteppads worn inside the boots. These, however, merely relieve the symptoms, and exercise no curative functions. In long-standing cases, remedial measures may prove useless, and a surgical operation alone will relieve the condition. See Foot.

Flatman, Tномаs (1637-88). English miniaturist. $\mathrm{He}$ was born in London, and educated at Winchester and New College, Oxford, of which he was scholar and fellow. He became a barrister and practised poetry and miniature painting as an amateur, the latter with conspicuous success. Walpole cites a portrait of Dr. 'Tooke's father by him which was highly praised by contemporary connoisseurs. He died Dec. 8, 1688 .

Flattening Out. In aeronautics, a manoeuvre whereby an aeroplane in making a descent decreases its gliding angle until its flight path becomes almost horizontal. It also means to raise the nose of a flying-machine after a steep dive, and thus bring it back to its normal line of flight.

Flattery. Cape or promontory of Washington, U.S.A. At the S. side of the entrance to the strait of Juan de Fuca, it is the extreme N.W. point of the state. There is another cape of this name in Queensland, Australia, in Banks co., about lat. $14^{\circ} 52^{\prime} \mathrm{S}$.

Flatulence (late Lat. flatulentus, full of wind). Gas in the stomach or intestines. It is due partly to air which is swallowed with food, and partly to the fermentation of food in the alimentary canal. The con. dition is often associated with disorders of digestion, and results from too hasty swallowing of food or imperfect mastication. Hysterical persons are more prone to develop the condition. Intestinal flatulence is often associated with constipation.

The treatment consists in attention to the teeth, thorough mastication and avoidance of starchy food and sugar. Intestinal flatulence necessitates proper attention to the bowels. Dyspeptic conditions should receive appropriate treatment. See Dyspepsia.

Flaubert, Gustave (1821-80). French novelist. Born at Rouen, Dec. 12,1821 , the son of a surgeon, he went to Paris to study law in 1840 , but spent a number of years in travel, visiting the East in 
1849-50. Returning to Paris in 1850, he began his first novel, Madame Bovary. It took six years

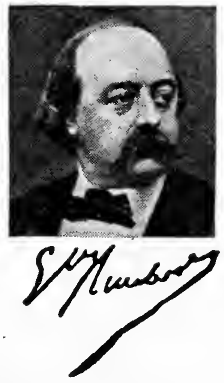
of constant labour tocomplete, and was $\mathrm{published}$ serially in 1857. An action against a u th or and publisher for its alleged immorality was $\mathrm{d}$ i s $\mathrm{m}$ is sed, and the book, his undoubted master. piece, made

his name famous. There followed Salammbô (Eng. trans. M. F. Sheldon), 1862; L'Éducation Sentimentale, 1869; La Tentation de S. Antoine (Eng. trans. R. Francis), 1874 ; Trois Contes, 1877 ; and the posthumous Bouvard et Pécuchet, 1881. Flaubert died at Croisset, near Rouen, May 8, 1880.

$\mathrm{He}$ was the dominant figure among French novelists of the last epoch of Romanticism. A literary descendant of Balzac, he was by turns a sheer realist and a sheer romanticist, in both aspects brilliant and infinitely laborious. $\mathrm{He}$ took his art very seriously, tormenting himself for days in the search for a word, polishing his work with untiring zeal. His technical skill, especially as a realist, greatly influenced later French writers, in particular the De Goncourts and Zola. See Flaubert's Correspondence with George Sand, preface by Guy de Maupassant, 1884; Life, E. Faguet, 1899.

Flauto traverso (Ital., cross flute). Ordinary present-day flute. It is played crosswise, with a side blowing-hole; formerly it was called the German flute. See Flute.

Flaveria contrayerba. Biennial herb of the natural order Compositae. A native of Peru, it has opposite, saw-toothed, lanceshaped leaves, and yellow flower heads. In Chile a yellow dye is obtained from the plant.

Flavine (Lat. flavus, yellow). Antiseptic, the value of which was discovered in 1916 by the BlandSutton Institute for Clinical Patho. logy of the Middlesex Hospital, London. The discovery of the drug itself was due to Prof. Ehrlich, who treated cases of sleeping sickness with it. Flavine is a yellow dye belonging to the acridine series, hence its official name acriflavine. Unlike most germicides, it is absolutely harmless to the tissues. The discovery of its efficacy as an antiseptic was hastened by the need for such a drug occasioned by the Great War. See Antiseptics; Surgery.

Flavouring. Condiment put into food to give it a distinctive taste. Spices, herbs, and essences are flavourings, also lemons, juice of various fruits, onion and garlic.

Flax (Linum usitatissimum). Annual herb of the natural order Linaceae. Its native country is unknown; but it is found in a wild state, as an escape from cultivation, in every temperate country where it is grown for the production of linen or oil. Linen fabrics, thread, and stores of linseed have been found in excavations of the Stone Age. It is a slender plant, with erect stems, about a foot and a half high, and narrow, lance-shaped alternate leaves. The numerous flowers are comparatively large (1 inch diam.), and purplish-blue in colour. The flax fibres of which linen is woven are obtained by macerating the skin of the stems. Flax seed, from which linseed oil

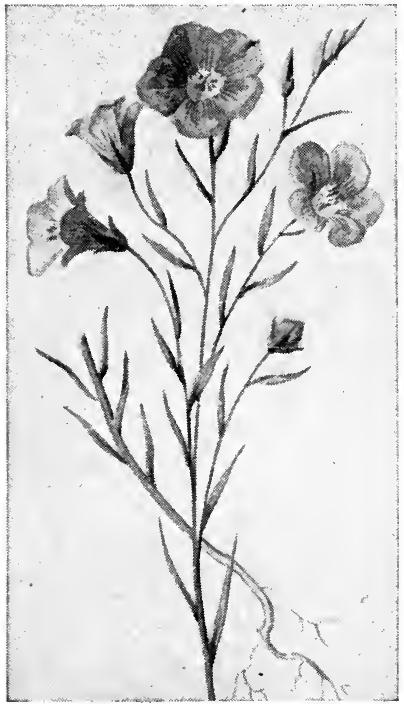

Flax. Stem, leaves, and flowers of Linum usitatissimum

comes under pressure, leaving oilcake as a valuable residue, is obtained from this species.

Flax is little grown in the United Kingdom, except in Ulster and some parts of Yorkshire. The seed is broadcasted or drilled, at the rate of $70 \mathrm{lb}$. to $80 \mathrm{lb}$. per acre in the former case, $40 \mathrm{lb}$. to $60 \mathrm{lb}$. in the latter, and the seed time varies from April to mid-May. Well-drained, deep loam is the most favourable soil. Rotation is necessary, and an average of seven years should elapse between two crops on the same land. It is not usual to apply farmyard manure directly, for highly fertile soil is apt to cause "lodging"; but the preceding crop should be well dunged. Artificials, however, can be used with advantage : for flax production, 5 cwt. kainit or $1 \frac{1}{4}$ cwt. muriate of potash per acre; for seed production, a mixture of $\frac{1}{2}$ to $\frac{3}{4}$ cwt. sulphate of ammonia, $3 \mathrm{cwt}$. superphosphate, and $\frac{1}{2}$ to $\frac{3}{4}$ cwt. muriate of potash per acre.

Flax should be cultivated on clean land, and when drilled, weeds must be kept down. Harvesting takes place in August, and the best fibre is obtained by hand. pulling, though the reaping hook and reaping machine are also used. The crop should be cut before the seed is quite ripe, for it matures in the stook (shock). The sheaves should be small. When grown on a large scale, it may be necessary to use the threshing machine, and this should be set close and run at a high speed. The best results, however, are obtained by the flail, afterwards crushing the seed-heads (bolls) with a roller; by passing the plants through a mangle; or by drawing them through a rippling comb, and afterwards using the roller. The average yield per acre is 36 to $40 \mathrm{cwt}$. dried straw (giving about $4 \frac{1}{2} \mathrm{cwt}$. fibre), and 8 to $10 \mathrm{cwt}$. seed.

The board of trade appointed a committee to investigate the question of increasing the supply of flax in the British Empire. In its report, issued June, 1920, reference was made to substitutes for flax, such as ramie, the main difficulty in preparing which for spinning was the elimination of the gum which holds the fibre together. Germany before the Great War had succeeded in discovering a process of degumming. This process was successfully transferred to England, and ramie yarns of very good quality are now produced in Yorkshire. The report showed that, while for a number of the purposes for which flax is employed substitutes exist, none of these can satisfactorily replace flax in the manufacture of fine linens, damasks, and similar articles. During the latter part of the Great War flax was controlled by a board set up for that purpose.

New Zealand flax (Phormium tenax) is a perennial herb of the natural order Liliaceae, native of New Zealand. The tough, leathery leaves are sword-shaped, springing from the root in two ranks, and from $3 \mathrm{ft}$. to $6 \mathrm{ft}$. in length. The dull, yellowish-red, tubular flowers, about 2 ins. long, are produced on short, alternato branches of a tall, flowering stem, $6 \mathrm{ft}$. or more in 
height. See Linen; consult also Flax and its Prodiscts, H. R. Carter, 1920.

Flaxman, JонN (!755-1826). English sculptor. Bor at York, July 6,1755 , he was $t$ e son of a

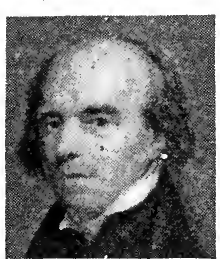

After Jackson

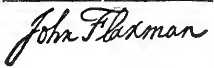
ine. ier of plasto c a s t s. Os.ing to physical defornity, his cif thood in Lot don was pas sed mainly in lis father's shop, where he drew, modelled, and studied the classics. In 1770 he entered the Academy schools, having previously exhibited and gained awards at the Society of Arts, the Free Society of Artists, etc.; and in $\mathbf{1 7 7 5}$ began to be regularly employed by the Wedgwoods in designing classical friezes and medallions for their ware. Married in 1782, Flaxman and his wife went to Rome in 1787. Returning in 1794, they settled in London. In 1797 he was elected A.R.A., and R.A. in 1800, and in 1810 was appointed professor of sculpture. He died Dec. 7, 1826.

Flaxman's most notable monumental works are in Westminster Abbey and S. Paul's, his classical figures and groups at Petworth, Woburn, and other country seats, and his characteristic memorial reliefs are numerous in the British cathedrals and churches. Collections of his drawings are in the British and South Kensington museums, and the Fitzwilliam Museum, Cambridge. University College, in Gower Street, London, contains in the Flaxman gallery a large number of his original draw. ings and sketches in pen and pencil, and also plaster casts from his clay models. See Sculpture.

Flea. Family of small wingless insects, more or less parasitic on other animals. The body is laterally compressed, and strongly encased in a coating of chitin; the last pair of legs is very long, enabling the insect to jump about 200 times its own length. The jaws are modified into a picreing instrument and a sucking tube, and the
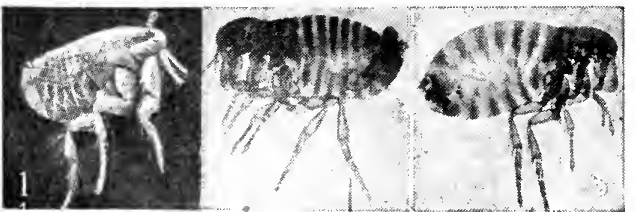

Flea, Much enlarged specimens 1. Rat flea, 2. Common flea, Pulex irritans, male and, 3 , female I Photograpict at Nat. Hist: Museum, S. Kensington

insect in the adult stage lives by sucking blood.

Most of the numerous species confine their attention to some one genus of the animal world. While a rat flea or chicken flea will on occasion attack man, it will not stay with him. The rat flea is known to be the con. veyer of plague, and it is probable that otherfleasalso carry disease. The human flea (Pulex irritans) deposits its eggs in the dust of floors, where the white, worm-like la rva feeds on

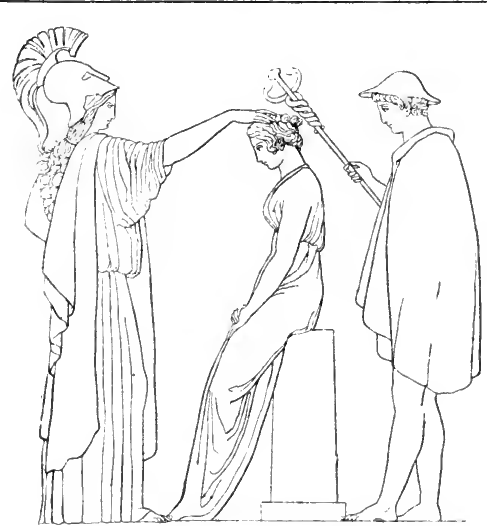

Flè che, $L_{L}$. Town of France. It stands on the Loir, $24 \mathrm{~m}$. from Le Mans, in the dept. of Sarthe. It is an agricultural centre, trading in corn, wine, etc. and has also some small manufac. tures; its build. ings include a town hall, mu. seum, and the. atre. More famous is the military school here known as the Prytanée, from which students decaying organic matter, taking about a month to attain maturity. See Insects ; Parasite.

Fleabane (Pulicaria and Erigeron). Herbs of the natural order Compositae. P. dysenterica, a native of Europe, N. Africa, and the Himalaya, is a perennial, with creeping rootstock, erect stems, and heart-shaped,oblong, woolly leaves. The daisy-like flower-heads are bright yellow. It was formerly used as a medicine in dysentery. Canadian fleabane (Erigeron canadense), generally distributed in warm and gions, is an annual, with stem 1 or $2 \mathrm{ft}$. high, and narrow, lance-s $h$ a p ed leaves. The small, yellowcentred, white flower-heads are clustered.

pass to St. Cyr. Founded in $\mathbf{1 7 7 4}$ this occupies the buildings of a Jesuit college, and has a large library. The earlier college, at which Descartes was educated, was founded in 1604 by Henry IV, to whom there is a statue in the market place. Pop. 10,700 .

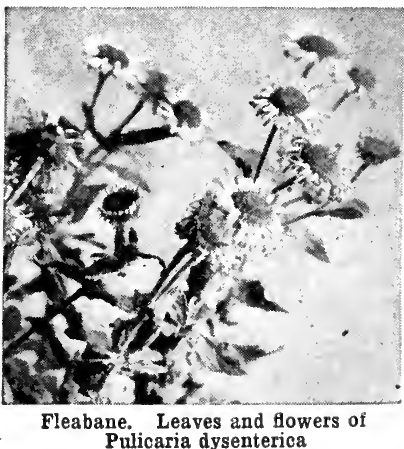


Fleece. Coat of the live sheep removed by shearing and forming a fairly coherent mass by the interlocking of adjacent fibres. Fleeces deprived of some of their inferior portions are rolled into bundles, secured by a twist of their own fibre, and packed into bales or into bags known by the trade name of sheets. Locks and pieces are portions of the coat separated by accident or design from the main bulk or fleece. In the course of wool-sorting the fleece is opened out and examined. Fleeces of like quality placed together are described as cased.

Wool of different strengths grows upon different parts of the body, and in sorting wool fully the fleeces are broken up. When the respective sorts of wool from many fleeces have been collected together the lots are given the name of matchings. The term fleece wool in some parts of the country implies wool not of the first clip. Certain manufactured goods, e.g. warm linings, are called fleece from their warmth and fleecy appearance. See Woollen; also illus. p. 1181.

Fleet. In the naval sense, a number of ships under a single command. The word simply means to float or flow, hence its use in this connexion. At one time fleet was almost synonymous with squadron, but it is now used for a much larger unit. The whole of a navy is often called the fleet, e.g. the French fleet, and during the Great War there was the Grand Fleet (q.v.). See Navy ; Squadron.

Fleet. Urban district of Hamp. shire, England. It is $6 \mathrm{~m}$. N.E. of Odiham and $36 \mathrm{~m}$. S.W. of London, having a station on the L. \& S.W.R. Near the village is Fleet Pond, a sheet of water 130 acres in extent. Pop. 3,280 . There is also a village of this name in Lincolnshire, 2 m. S.E. of Holbeach. Pop. 1,155.

Fleet, THE. Name of the navigable part of an old London river which, rising in Hampstead, entered the city S. of Chick Lane (now Charterhouse Street) and joined the Thames at Blackfriars. First mentioned in 12th century MS., it was known as the Flcet Ditch, owing to the frequency with which it became choked with refuse. The N. part was known as the Holbourne, hence Holborn. After the Great Fire of 1666 it was cleansed, deepened, and called the New Canal. Wharves were erected as well as bridges at Holborn, Fleet Lane, Fleet Street, and Bridewell. The part between Holborn and Fleet Street was arched over in 1737, and later the stream was converted into a sewer, its course being covered by Farringdon Street $(q . v$.$) and New Bridge Street.$

Fleet Prison, THE. Former prison of old London. Its history has been traced back to the 12th century. Named after the Fleet river, it stood on the E. bank of that stream, S. of Fleet Lane, was burnt in the Great Fire, re.

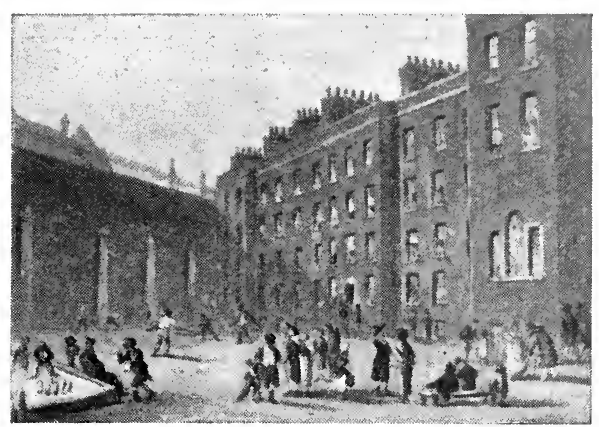

Fleet Prison. The inner court with prisoners engaged in a game of racquets

From a draving by Rowlandson \& Pugin, 1807
They were called out on the outbreak of the Great War, and on Aug. 15, 1914, numbered 27,395. Their strength on Nov. 15, 1918, was 19,189. See Navy, British.

Fleet Street. London thoroughfare, in Farringdon Ward Without. Running W. from Ludgate Circus to Temple Bar,its precincts are closely associated with the ecclesiastical, legal, theatrical, banking, publishing and printing activities of the metropolis. It contains two churches of note, S. Bride's and S. Dunstan's in the West, the remains of Clifford's Inn and the second Serjeants' Inn, part of the Law Courts, entrances to

built, desiroyed in the Gordon riots of 1780 , rebuilt again in 1781-82, purchased by the City Corporation in 1844, used as a stone-yard, and sold in 1864 to the L.C. \& D.R. On part of the site was erected the Memorial Hall. The prison was used for prisoners of the Star Chamber, and later for debtors and bankrupts. The register books are preserved at Somerset House.

The poet Surrey, Bishop Hooper, Thomas Nash, Dr. Donne, Falk. land, Prynne, James Howell, Wycherley, and Richard Savage were among notable prisoners here; as, among literary creations, were Falstaff, Mr. Pickwick, and Shandon, the shiftless journalist of Thackeray's Pendennis. Here, and in the liberties, clergymen imprisoned for debt celebrated clandestine marriages, known as Fleet marriages, between 1614 and 1754 , when they becameillegal. Favoured debtors were allowed to live in what was known as the rules or liberty of the Fleet, which included the N. side of Ludgate Hill and the Old Bailey to Fleet Lane and Market, and along the E. bank of the Fleet to what is now Ludgate Circus. See Farringdon Street; consult also The Fleet: Its River, Prison and Marriages, J. Ashton, 1888 ; The Chaplain of the Fleet, W. Besant and J. Rice, 1881.

Fleet Reserve, The Royal. British naval unit. It was constituted in 1901 as a scheme to secure the services in war of men who had retired from the navy. With the Royal Naval Reserve it was designed to form a reserve of personnel from which to draw in the event of war. Men composing it undergo a period of training. the Temple $(q . v \cdot)$, and, near to the last-named, a restored timber house of 1610 , the projecting upper storey of which, called Prince Henry's Room, is described as the council chamber of the duchy of Cornwall in the time of James I.

On each side of Fleet Street are lanes and courts and squares, e.g. Chancery Lane, Fetter Lane, Shoe Lane; Bolt Court, Crane Court, Wine Office Court, Mitre Court; Gough Square and Salisbury Square-all with some interesting story to tell. Whitefriars Street still serves to remind the passer-by of the Carmelite monastery which once stood near ; and Anderton's, the Cheshire Cheese, the Cock, Peele's, and the Rainbow represent the taverns and coffee houses of an earlier day. The site of the old Mitre tavern of Johnson's time is covered by Hoare's Bank, and that of the Devil tavern by Child's Bank.

Notable modern buildings are those of Child's Bank, the Jaw Courts branch of the Bank of Eng. land, the Norwich Union Insurance Co., and, in Bride Lane, the S. Bride Foundation Institute. Most of the buildings in Fleet Street are wholly or in part newspaper offices. Here are the chief offices of The Daily Telegraph and The Daily Chronicle, branch offices of The Daily Mail and The Daily News, and London offices of provincial, Indian, Australian, and American journals. The Great Fire of 1666 extended to Clifford's Inn on the $\mathrm{N}$. side and to the Temple on the S. side, and after it the street was virtually rebuilt.

Wynkyn de Worde, the printer, worked at No. 32, near Temple Bar; Richard Tothill had his 


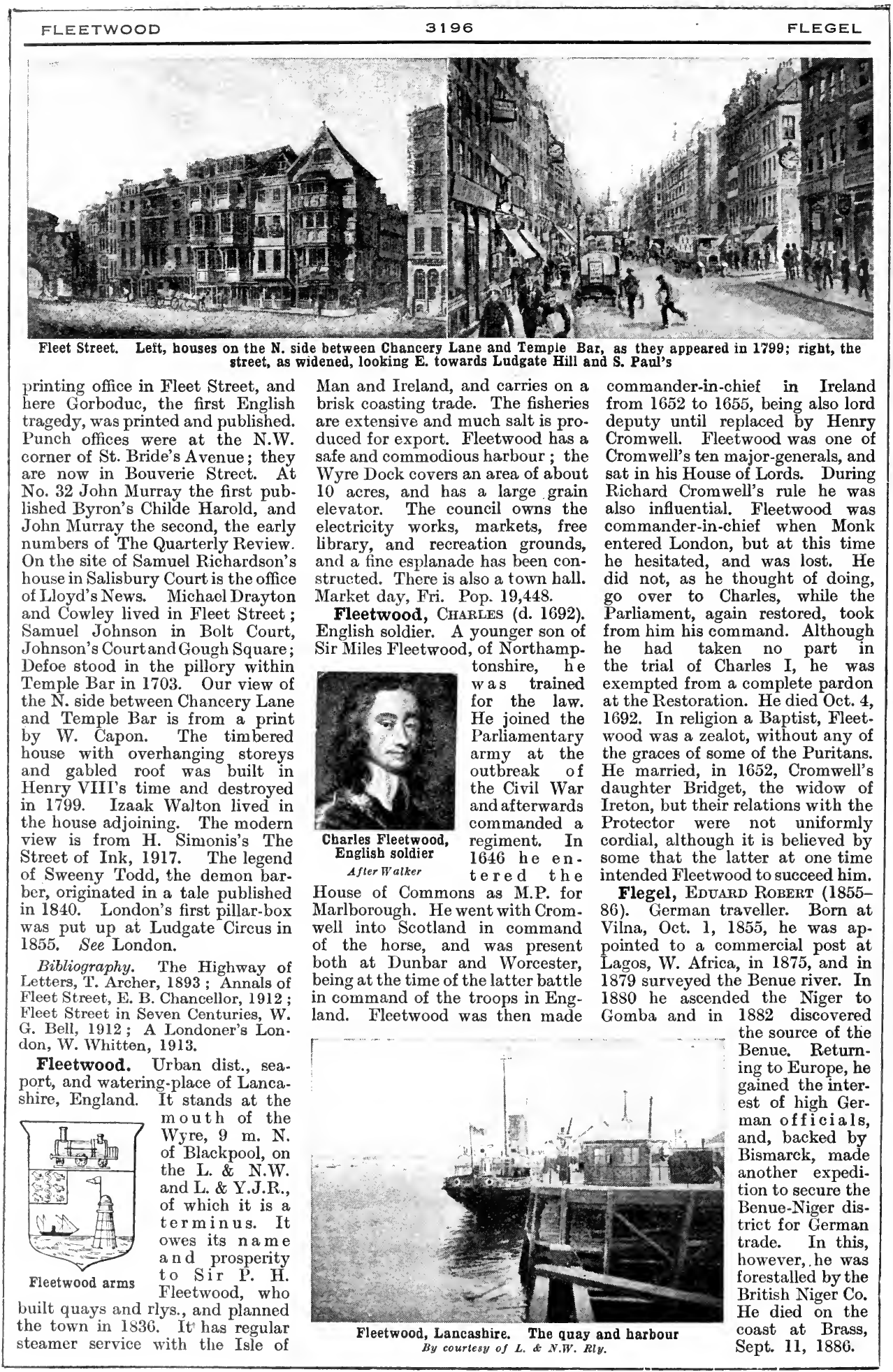


Fleming, John A мвRоse(b. 1849). British engineer and physicist. Born at Lancaster, Nov. 29, 1849, he was educated at University College, London, and S. John's College, Cambridge, where he gained a fellowship, and became lecturer on applied mechanics at Cambridge. In 1881 he took up the position of electrical engineer to the Edison Electrical Lighting Co. While professor at University College, London, and since 1910 of electrical engineering in the university, he remained in business as a consult. ing engineer and devoted much attention to radio-telegraphy.

Fleming, Margaret OR MAR. JORIE (1803-11). Infant prodigy and favourite of Sir Walter Scott.

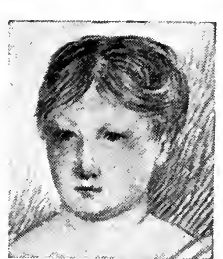

Margaret Fleming After a water-colour by I. Keith A niece of Mrs. Keith of Ra. velston, at whose house Scott fre. quently saw her, she read history at the age of six and wrote diaries and poems which were preserved by her family. Her story is told in Pet Margarie : A Story of Child Life Fifty Years Ago, H. B. Farnie, 1858; and Dr. John Brown includes an essay on her life and character in Horae Subsecivae.

Fleming, Sir SANDFORd (18271915). Canadian engineer. Born at Kirkcaldy, Jan. 7, 1827, he went to Canada and became connected with rly. construction about 1846. After 1871 the Dominion Government employed him to survey and construct the Intercolonial line, and afterwards he surveyed a route through the Rockies for the C.P.R. $\mathrm{He}$ advocated an imperial cable system and standard time. In 1897 he was made a K.C.M.G. He died at Halifax, July 22, 1915.

Flemings. Name given to the inhabitants of Flanders. A small sect of early Protestants, in. fluenced by the Mennonites, were called Flemings or Flandrians about the middle of the 16th century.

Flemish immigrants to England have frequently played a part in English and Welsh history. Early chroniclers speak of Tostig having Flemish auxiliaries under his flag at Stamford Bridge, 1066. Henry I settled a number of Flemings at Dyfed, in S. Wales, about 1108 , who were long the objects of Welsh hostility. In the battle with the S. Wales marchers at Teifi Ford, near Cardigan, in 1136, large numbers of these Flemish settlers were slain. Other attacks on them in 1144 and 1164 were avenged by their harrying of Iscold or Lower Gwent in 1165. Strongly attacked by the Welsh leader Maelgwyn Gwynedd in 1188, they made submission to Llewellyn $I$ in 1217.

Flemings were important in the growth of the woollen and weaving industries in England, especially in E. Anglia. See Flanders.

Flemington. Suburb of $\mathrm{Mel}$ bourne, Victoria. It is $3 \mathrm{~m}$. from the city and has a fine racecourse, founded 1861, on which is run the race for the Melbourne cup. Pop. 6,109. See Melbourne.

Flemish Art. Art of Flanders. As it is difficult to distinguish between Dutch and Flemish painters, the word Netherlands is sometimes used for the school which suddenly attained power in the 15 th century. There were distinct schools at Bruges, Ghent, and Antwerp. The earliest phases of the two first are still obscure; the first great masters of the Netherlands were the Limburg brothers, illuminators of Maaseyck. Next come the two Van Eycks, masters of the school. The so-called Maître de Flemalle (possibly Robert Campin), Jacques Daret, Roger van der Weyden, Dierick Bouts, and Petrus Christus are the great names of the next

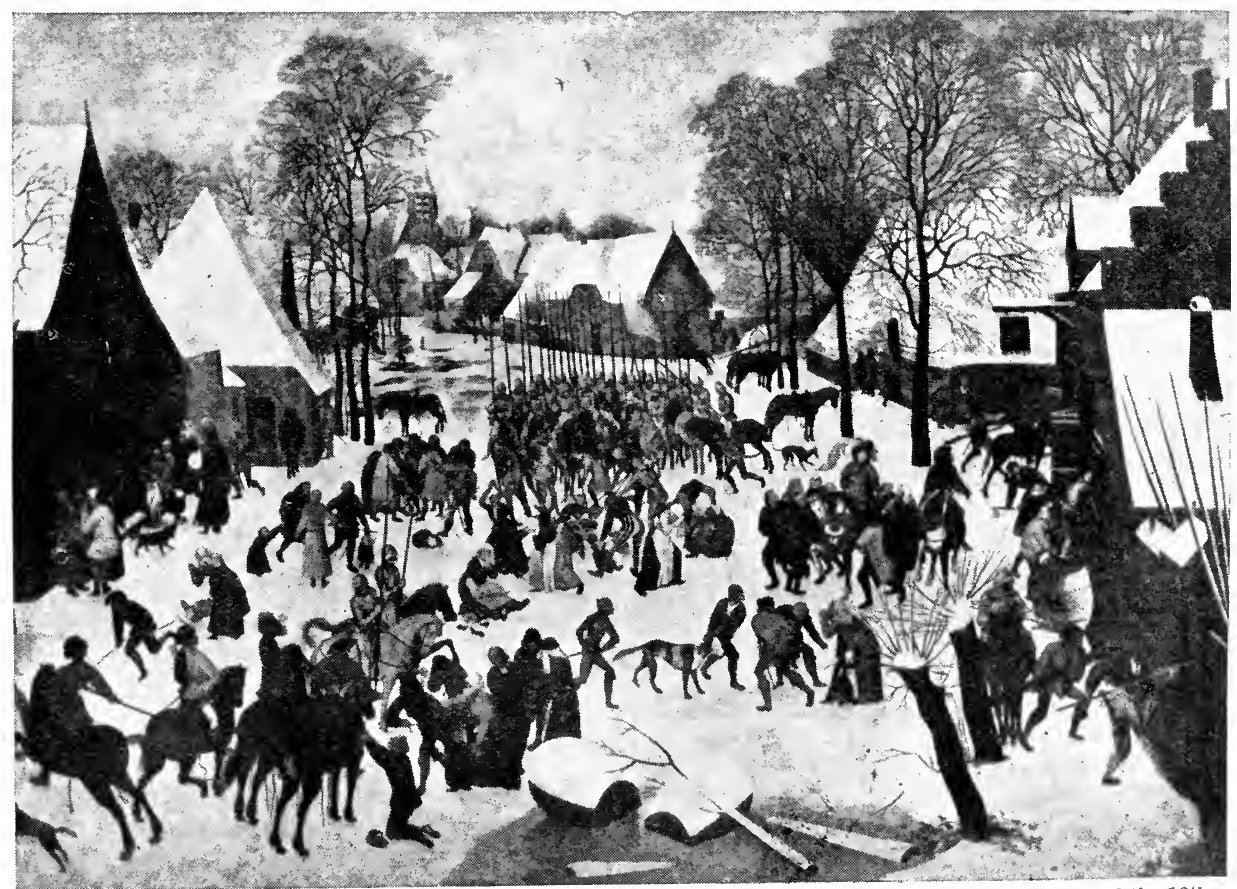

Flemish Art. Massacre of the Innocents, by Pieter Brueghel the Younger, typical of the detailed composition of the 16th Flemish Art. Massacre of the Innocents, by Pieter Brueghel the Younger, typical of the by $P$. Brueghel the Elder in Vienna century Flemish painters. This picture, in the museum at Brussels, is an exact copy of one by P. Brueghel the Elder in Vienna 
generation. A little later comes Hans Memlinc and Hugo van der Goes, followed by Gerard of Haarlem (Geertgen of S. John), Gerard David, and Quinten Massys. This closes the list of the first-rank Netherlandish religious painters.

Their contemporaries were Jerome Bosch, the earliest satirist, and Patinir, the landscape painter.

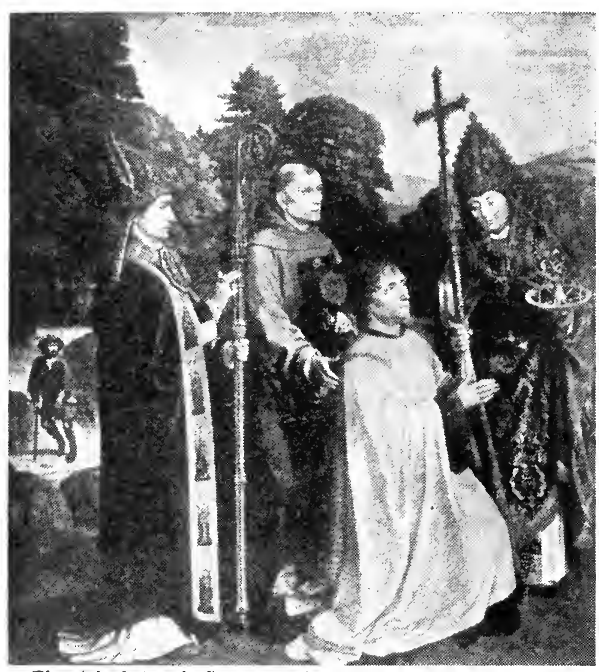

Flenish Art. A Canon with Patron Saints, by Gerard David (c. 1450-1523), a pupil of Hans Memlinc

$$
\text { National Gallery, Londone }
$$

Mabuse represents the next phase of Flemish art, when it was invaded by Italian influence; the rococo period of excessive elaboration, compensated by no serious interpretation, is seen in B. van Orley, Mostaert, Jacob Cornelisz, and Cornelis Engelbrechtsen. Better masters were Lucas van Leiden and Scoreel. In this period was popularised the satirical genre picture best known in Marinus von Reymerswael, whose Moneylenders and Misers are still famous. P. Aertsen of Amsterdam is a precursor on a large scale of Dutch genre. The great genre and land. scape painter of the school, the last Flemish Primitive master, and one of the greatest, is Fieter Brueghel, the most original painter of his school. The influence of the Flemish masters of the 15th century in Germany and to a small extent in Florence was important. In Spain, too, and Portugal, the northern school left a deep impression, and in England, chiefly in East Anglia, Flemish painters for a short while had considerable business.

In the great Flemish Primitives, before Italian influence came north, the true Gothic spirit found some expression. If nothing comparable Art; Painting. with the mystic emotion of the French 13th century sculptors is found in the van Eycks, Roger van der Weyden, Dierick Bouts, and Hugo van der Goes, yet they echoed the intensity of the Gothic conception of the Christian drama. Withal they reflected the desire for richness and elaboration of detail inseparable from the Gothic ideal. No Italian master rivalled the northern artists in this respect; nor, even when the technique of the Netherlands was practised in Italy, could any southern painters attain the brilliance and delicacy native to the trans. alpine schools. In. deed, the almost enamel-like perfection and durability of a van Eyck is unique.

At the same time it should be noted that, apparently derived from missal illumination, the technique and style of the Flemish were unsuited to the large issues of wall decoration which engrossed

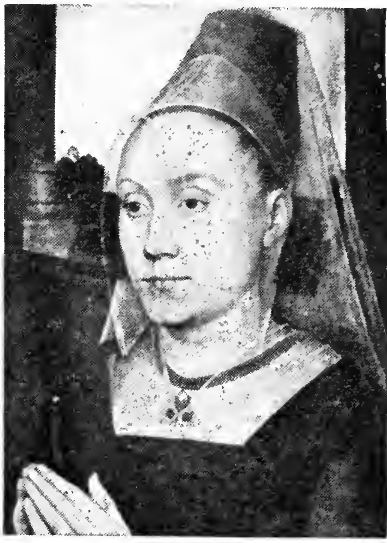

Flemish Art. Barbara van Vlanderberghe, by Hans Memlinc (c. 1430-94) Musee Royal, Brussels

Bibliography. The Flemish School of Painting, A. J. Wauters, Eng. trans. H. Rossell, 1885; Anciens Arts de Flandre, E. Durrand. Gréville, 1905; La Peinture en Belgique, H. Fierens-Gevaert, 1909 ; Art in Flanders, MI. Rooses, 1914.

Flensburg. Seaport of Slesvig, Germany. It lies at the S. extremity of the Flensburg Fiord, about $23 \mathrm{~m}$. N. of Slesvig town. Beautifully situated on the steep shores of the land-locked fiord, it has a good harbour, with shipyards, foundries, and breweries as the chief industries. Whaling the Italian painters. Only Brue. ghel attained a mural largeness of style. Even in recent times the influence of the Flemish Primitives has reasserted itself. For instance, the English school of PreRaphaelites owed much of its technique and vision to the masters of whom Rosset $\mathrm{i}$ and Holman Hunt became aware in Belgium in 1849 . Commercially s peaking, the Primitives are giltedged securities. Only within a com. peratively short time have these masters met with this desirability in collectors' eyes. See Art; Dutch C. H. Collins Bajer

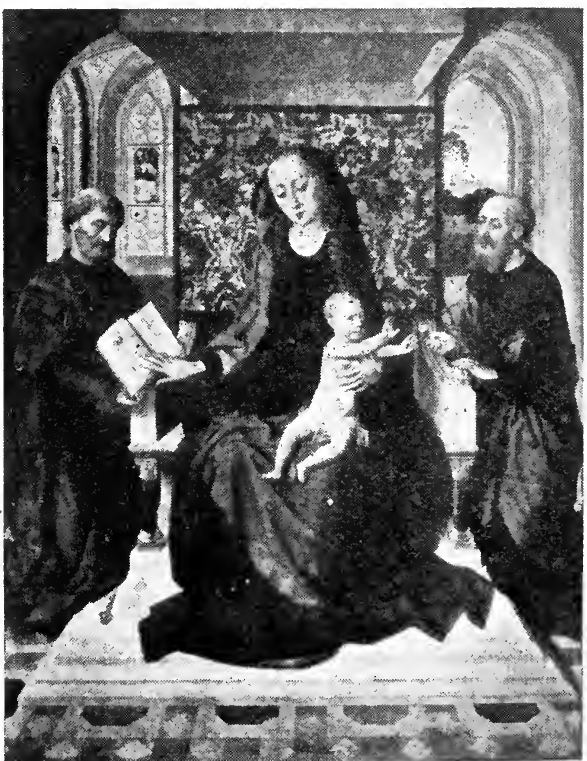

Flemish Art. Madonna and Child Enthroned, by Dierick Bouts (c. 1410-75)

Nalional Gallery, London 
vessels leave annually for the Greenland fisheries. Originally founded during the 12th century, Flensburg has several fine old buildings, notably the churches of S. Nioholas (14th century) and S. Mary (15th century). Formerly a Danish town, it was entered by German troops Feb. 7, 1864, and annexed with Slesvig. During the Slesvig-Holstein plebiscite after the Great War, there were serious disturbances in the town in Sept., 1919. The subsequent voting results showed a large majority for German rule. Pop. 60,922.

Flers. Town of France, in the dept. of Orne. It stands on the Vère, $40 \mathrm{~m}$. from Caen. It has a 16th century château, and cotton spinning, bleaching, and dyeing works. Pop. 13,600. Pron. Flare.

Flers. Village of France, in the dept. of Somme. It is $3 \mathrm{~m}$. N. of Guillemont and $5 \mathrm{~m}$. E. of the Albert-Bapaume road. It was prominent in the battle of the Somme, being captured by the 4lst and New Zealand divisions on Sept. 15, 1916, on which day the tanks were first used. Retaken by the Germans in their spring offensive, 1918 , it was regained by the Allies at the end of Aug.,1918. See Somme, Battles of the.

Flers, RoBerT DE (b. 1872). French dramatist and writer. Born at Pont-l' Evêque, Nov. 22, 1872,

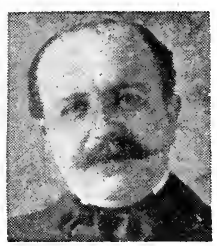

Robert de Flers, French dramatist Manuel and educated at Paris, he made his reputation as collaborator with G. A. de Caillavet in a series of light and witty come. dies. Among them are Les 'Travaux d'Her. cule, 1901 ; Primerose, 1911 ; L'Habit Vert, 1912 ; La Belle Aventure, 1913. Also a well-known journalist, he became assistant editor of Le Figaro under Gaston Calmette, in April, 1914, succeeding him as editor, with Alfred Capus, in June. He resigned this post in 1920 , rejoining the paper in 1922 .

Fleshly School of Poetry. THe. Derisive name given to certain 19 th century poets, chiefly D. G. Rossetti and A. C. Swinburne. It originated in an article in The Contemporary Review, entitled The Fleshly School of Poetry and Other Phenomena of the Day, by Thomas Maitland (Robert Buchanan), which was afterwards published as a pamphlet, 1872 . Swinburne replied in Under the Microscope, 1872. Buchanan later made a full amende honorable in regard to Rossetti's work.
Flesquières. Village of France in the dept. of Nord. It is S. of Bourlon Wood, $1 \frac{1}{2} \mathrm{~m}$. S. of the Bapaume-Cambrai road, and $2 \mathrm{~m}$. W. of Marcoing. Here on Nov. 20 1917 , in the first battle of Cambrai the British encountered stubborn German resistance. Taken by the British, Nov. 21, it was evacuated in March, 1918, and regained at the end of Sept., 1918. See Cam. brai, Battles of.

Fletcher, ANDREw, of Saltoun (1655-1716). Scottish politician Born at Saltoun (now Salton),

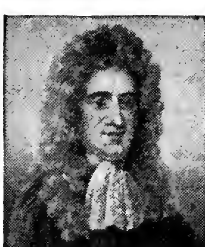

Andrew Fletcher, Scottish politician After Aikman East Lothian, he was educat. ed by the pari s h minister, Gilbert Burnet, a f t erwards bishop of Salis. bury. He sat as a commis. sioner in the Scots conven tion of estates in 1678 , and

vigorously opposed the government. In 1685 he joined Monmouth's expedition to England, but, having killed a man in a private quarrel, fled to Spain. $\mathrm{He}$ returned in 1688 with William of Orange, and became a determined opponent of the Union. $\mathrm{He}$ is remembered by the remark from his Account of a Conversation, "I knew a very wise man, so much of Sir Christopher's (Sir Christopher Mus. grave's) sentiment, that he believed if a man were permitted to make all the ballads, he would not care who should make the laws of a nation."

Fletcher, AlFred EweN (18411915). British journalist. Born at Long Sutton, Lincolnshire, and educated a $t$

Owens College and Edinburgh University, he was for a few years engaged in the teaching profession. In 1872 he en. tered journal. ism, and in 1878 became

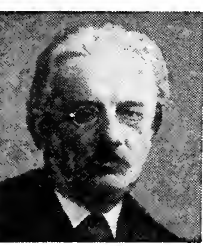

Alfred E. Fletcher, British journalist Elliout \& Fry leader writer edited from 1890 until he resigned in 1895. He contested Greenock as an independent radical in 1895, and the Camlachie division of Glasgow as a radical and labour candidate in 1900. He edited Sonnenschein's Cyclopedia of Education, 1889, contributed a monograph on Gainsborough to the Makers of British Art series, and published The Sermon on the Mount and Practical Politics, 1911. He died Nov. 14, 1915.
Fletcher, Banister Flight (b. 1866). British architect and author. Born in London, Feb. 15, 1866, he studied at the R.A., and elsewhere. A barrister and a trav. eller, he practised also as an architect, and lectured on architecture. His books include A History of Architecture on the Comparative Method, 5th ed. 1905, A Life of Palladio, 1902, and other works.

Fletcher, Giles (c. 1588-1623). English poet. Brother of Phineas and cousin of John Fletcher, the dramatist, he was educated at Westminster and Cambridge, and died rector of Alderton, Suffolk. His principal work, an allegorical poem entitled Christ's Victory and Triumph, 1610, was modelled on Spenser's Faerie Queene, and influenced Milton.

Fletcher, ЈонN (1579-1625). English poet and dramatist. Son of Dr. Richard Fletcher, he was born at Rye, Sussex and educated at Bene't (Corpus $\mathrm{Christi)}$ College, Cam. bridge. On his father's death, being left without means, he took to writing for the stage, collaborating with Francis

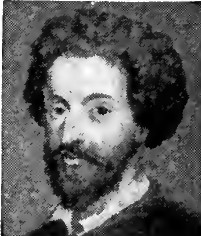

John Fletcher, English dramatist From an old engraving
Beaumont and others in plays which introduced tragi-comedy to the English theatre. Independently he wrote fifteen plays, including The Faithful Shepherdess (a beautiful pastoral play), Valentinian, The Wild-Goose Chase, Monsieur Thomas, Woman's Prize (a sequel to The Taming of the Shrew), A Wife for a Month, and The Chances. He also collaborated with Mas. singer, Middleton, Rowley, Field, and Daborne.

To what extent Fletcher was responsible for The Two Noble Kinsmen and Henry VIII remains a vexed question. He wrote beautiful lyrics and some of the raciest dialngue in English dramatic literature, and the free movement of his blank verse is a clue to his contribu. tions to plays partly written by others. He died of the plague and was buried in S. Saviour's, Southwark. See Beaumont; consult also John Fletcher, O. L. Hatcher, 1905 ; Works of Beaumont and Fletcher, ed. A. Dyce, 1843-46; A. Glover and A. R. Waller, 1905-12.

Fletcher, JosepH Sмiтн (b. 1863). British author. Born at Halifax, and educated at Silcoates School, he wrote much for Yorkshire and other papers, signing many of his contributions, Son of the Soil. His many books include 
works of topography, novels, etc. ; among them A Picturesque History of Yorkshire, 1899-1903 ; A Hisstory of the St. Leger Stakes, 1902 ; The Threshing Floor, 1905; Mothërs in Israel, 1908; Recollections of a Yorkshire Village, 1910; Memories of a Spectator, 1912 ; Perris of the Cherry Trees, 1913; The Annexa. tion Society, 1916; Scarhaven Keep, 1920; Exterior to the Evidence, 1920.

Fletcher, SIR Iazartos (18541921). British scientist. Born at Salford, Mar. 3, 1854, he was educated at Manchester Grammar School and Balliol College, Oxford. Having taken a very good degree in science and mathematics, he was appointed a demonstrator in the Clarendon Laboratory at Oxford, and chosen fellow of University College. He remained lecturing in Oxford until 1890, when he was ap pointed keeper of minerals in the natural history department of the British Museum. He was promoted to be director of the department in 1909 , and he resigned in 1919 . In 1916 Fletcher was knighted, and his many honours include an F.R.S. From 1888 to 1909 he was secretary of the Mineralogical Society. His published works include Introduction to the Study of Minerals, 1884 ; Introduction to the Study of Rocks. 1895. He died Jan. 6, 1921

Fletcher, PhIneas (1582-1650). English poet. Phineas was brother of Giles Fletcher, and, like him, an imitator of Spenser. He died rector of Hilgay, Norfolk. His works have been edited by Grosart, 1868, the most important being a poem of 4,800 lines entitled The Purple Island, an "extraordinary allegory of the human body.

Fletchers' Company, THE. City of London livery company. Of ancient origin and associated with

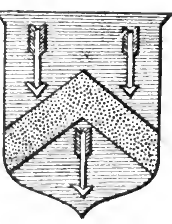

Fletchers'

Company arm the Bowyers, the Fle $t \mathrm{ch}$ e $\mathrm{r}$ (Fr. flèche, an arrow) is a com. pany by prescription, not charter, was granted arms in 1467 , and pos. sessed a hall in St. Mary Axe. The old records have been lost, the earliest extant being dated 1775. The offices are at 4, Broad Street Place, E.C.

Fleur-de-Lis (Fr., lily-flower). In heraldry, an extrcmely ancient symbol. Found among Egyptian hieroglyphics and used by the Anglo-Saxon kings, it was probably a conventional representation of some such flower as the lotus, river side flags, or the iris. It consists of a central bulbous petal and two side curving petals, a fillet and a

stalk, usually triparted. The fleurde-lis was early assumed as a cognizance by the Carlovingian kings

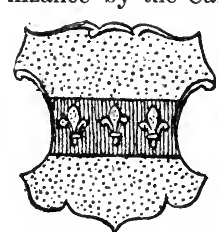

Fleur-de-Lis, in beraldry and so became identified with the roy a $h$ ou ses of France, who bore the golden flowers on a blue shield.

At first the shield was strewn with the lis, but occasionally only three appeared, some say in allusion to the Holy Trinity, a fashion which became permanent under Charles VI. The French arms (azure, semée de lis d'or) was quartered with the arms of England by Edward III ; Henry IV reduced the number of lis to three, and after the treaty of Amiens and the Union with Ireland in 1801, the French quartering was omitted from the arms of the English royal family. Pron.Fler-de-leess. Seeillus.p.1549.

Fleurus. Town of Belgium, in the prov. of Hainault. It stands in a plain, $8 \mathrm{~m}$. N.E. of Charleroi, and is a junction for the rly. to Gembloux, Landen, and Nivelles. There is a steam tramway to $\mathrm{Na}$ mur. Four important battles have been fought near this small Belgian town. In the first the duke of Brunswick defeated the Spaniards under Cordova, Aug. 29, 1622. Under Marshal Luxembourg the French gained a victory over the allied Spanish, Dutch, and Germans, July 1, 1690. On June 26, 1794, the French inflicted a crushing defeat upon the Austrians and forced them to evacuate Flanders. Finally, Napoleon here defeated the Prussians, June 16, 1815, in the battle usually known as the battle of Ligny (q.v.). Pop. 6,100.

Fleury, Flory, or Flowery. In heraldry, any charge decorated with fleurs-de-lis. Examples are

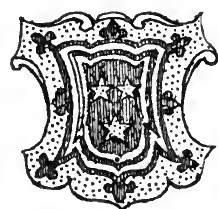
crosses at the ends of the limbs or in the angles, on the tress ure, and on sceptres, etc. See illus. p. 2375 .

Fleury, ANFleury, in heraldry DRé HERCULE DE (1653-1743). French statesman. Born at Lodève, Hérault, June 22, 1553, he was educated at Paris, took holy orders, and became chaplain to Louis XIV, who made him bishop of Fréjus in 1698, and tutor to the future king Louis XV in 1715 .

In 1726 he became chief minister and was appointed cardinal. His administration was upright and

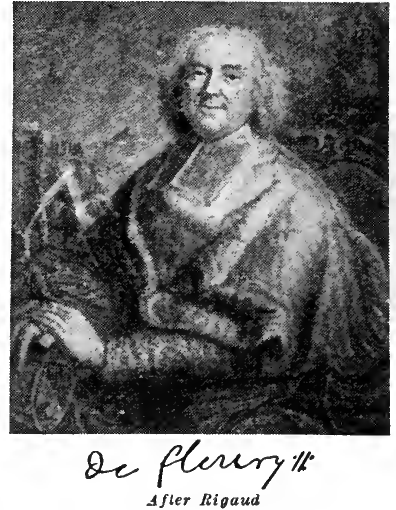

strictly economical, but he did nothing to check the early dissipations of the king or the abuses of the farmers-general. His foreign policy was directed chiefly towards ensuring peace, and to this end he worked closely with the English minister Walpole. The French intervention in Polish affairs in 1733 was undertaken against his better judgement, but he failed to prevent France from being involved in the war of the Austrian Succession, 1740 , and died discouraged and in ill-favour, Jan. 29, 1743.

Fleury, Cladde (1640-1723). French church historian. Born Dec. 6,1640 , at Paris and educated there, he practised for nine years as an advocate, and then devoted himself to theology. In 1672 Louis XIV entrusted him with the education of the young princes, and he became nominally the abbot of Loc-Dieu and later prior of Argenteuil. From 1691 onwards he was writing his Ecclesiastical History in 20 volumes. He died July 14, 1723.

Flexner, Srmon (b.1863). American pathologist. Born March 25, 1863, at Louisville, Kentucky, he took his medical degree in 1889 and studied in Germany. Professor of pathological anatomy at Johns Hopkins University, 1891-99, he was from 1899-1904 professor of pathology at Pennsylvania University. In 1903 he was given charge of the laboratories of the Rockefeller Institute for Medical Research, where his researches added largely to our knowledge of the causes of infantile paralysis.

Flibbertigibbet oR DICKIE SLUdGE. In Scott's novel Kenilworth (q.v.), a mischievous but ambitious dwarf, in league with Wayland Smith in deceiving the Berkshire villagers.

Fliegende Blätter, Drw (Fly. ing Leaves). German weekly illustrated comic paper. Established in 1844, it is published in Munich. 


\section{FLIGHT: IN THEORY AND PRACTICE}

J. Laurence Pritchard, Editor, The Aeronautical Journal

In this article are described the main underlying principles that have made possible the conquest of the air. For the history of flight and aviation consult Aeronautics. Sec also Aeroplane; Airship; and the articles on the various types of machine

Though for many centuries attempts have been made to discover the principles of flight, it was not till Langley in America made his experiments on a scientific basis in 1890-1900 that any real ad. vance was made. Langley showed that a flat plate of material could be made to support itself if forced through the air at a certain angle, and at a certain speed. $\mathrm{He}$ announced that a weight of $750 \mathrm{lb}$. could be lifted by an engine of 25 h.p. The experiments of Lilienthal

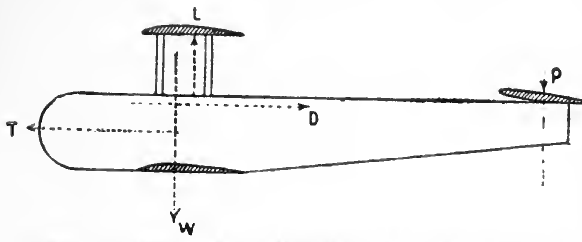

Flight. Diagram of the forces acting on an aeroplane in horizontal flight. $T$, the thrust of the propeller; $L$, the lift on the wings ; $\mathbf{W}$, the weight of the aeroplane $D$, the resistance or drag; and $\mathbf{P}$, the force on the tail plane to maintain equilibrium

and others added that curved surfaces were better than flat ones for flying purposes.

Air resists the rapid passage of any body through it, and this resistance is proportionately less, compared with lifting-power, in certain curved surfaces than in flat surfaces. But though the surface was discovered, the next step forward, that of the discovery of the engine which could force it through the air at the necessary speed, remained in abeyance till the invention of the petrol engine, though Sir Hiram Maxim actually lifted $10,000 \mathrm{lb}$. off the ground, using a steam engine. With the advent of the internal combustion engine and the experiments resulting in the present-day curved or cambered wing, flying became possible.

The study of the flight of birds has had a marked result on the ultimate methods of flight adopted by man, with certain differences largely due to mechanical difficulties. The aeroplane has its wings and balancing tail, and a certain
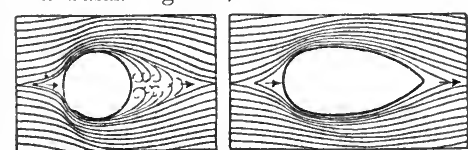

Flight. Diagram representing the difference of air flow past a round body and a streamline bods freedom to alter the shape of its wings as the bird has. In place of flapping wings we find the airscrew, and a vertical fin and rudder for steerage and control purposes, not observable in the bird. But the principles of bird flight and human flight remain identical.

An aeroplane flies as a result of the support given to it by its driven through the air. As the aeroplane moves forward, the wings, owing to their curved shape, drive downwards the air through which they pass. Called by Lord Rayleigh the "sacrificial" principle, this prin. ciple of flight is an expression of the fact that if you do not want to fall yourself you must make something else fall. It is the constant falling of the air, as it were, which gives that support necessary for flight to the aeroplane. Exactly how the air is made to move downwards by the curved wings of an aeroplane is a matter of experiment, the theoretical solution of the problem being beyond the power of present-day mathematics.

It was early discovered that the air is forced downwards in a way depending upon the angle at which the wings are set to the air, and also the speed at which they are forced through the air. With the wings set at any particular angle it was found that the lifting power increases as the square of the speed. But with the increase of speed there natur. ally comes in. crease of resist. ance to forward wings when the latter are being particular angle at which the wings are set. If the speed of the aeroplane is increased, then the angle of the wings must be altered to satisfy this principle. The curved wing has the great advantage over the flat wing that its resistance is relatively much smaller at the usual flying speeds.

There is one important aspect of mechanical flight which is relatively unimportant in bird flight, and that is flying at great heights. An aeroplane has flown to a height of $5 \mathrm{~m}$., and the conditions of flight at such a height, where the mercury stands at 10 ins. instead of 30 ins., are very different from those on the ground. Here another principle is enunciated, namely at the same altitude and speed of flight of the aeroplane the air force is proportional to the air density. The problem is further complicated by the fact that the power of an engine decreases more rapidly thau the density of the atmosphere.

The general laws of flight are simple, but their detailed applica cations often present insuperable theoretical difficulties which can only be solved by experiment on model or full-sized aeroplanes. In steady horizontal flight the lifting force on the wings is equal to the total weight of the aeroplane, in climbing flight it is greater, and in diving flight it is less. These are simple laws, but to calculate exactly how much greater the lifting force is under certain conditions, in order to find out how fast an aeroplane will climb, is not nearly so simple. The calculations are complicated by the varying density of the atmosphere and consequent varying efficiency of the engine. The solution of these com.
Flight. Diagram showing how the stream of air is deflected by the curved wing, shown in section in black, of an aeroplane. The air is forced downwards at the rear or trailing edge of the wing, and a partial vacuum is created above the wing with increased pressure below it, so making it lift

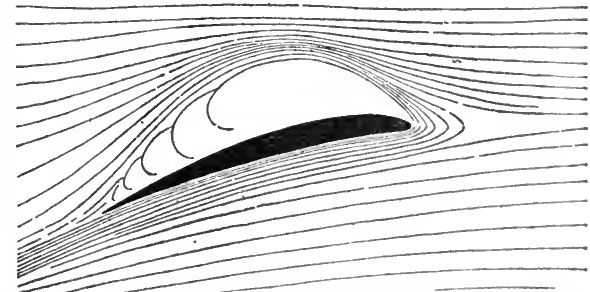
motion, requiring increased plications depends upon a very engine power to overcome it, large number of experiments carand, therefore, increased ried out in the wind tunnels at the weight, so complicating the National Physical Laboratory, and problem. The principle which practical flying experiments at the may be stated here is that in Royal Aircraft Establishment and any given aeroplane there is at Martlesham, as well as correonly one speed of flying for a sponding experiments in America, 


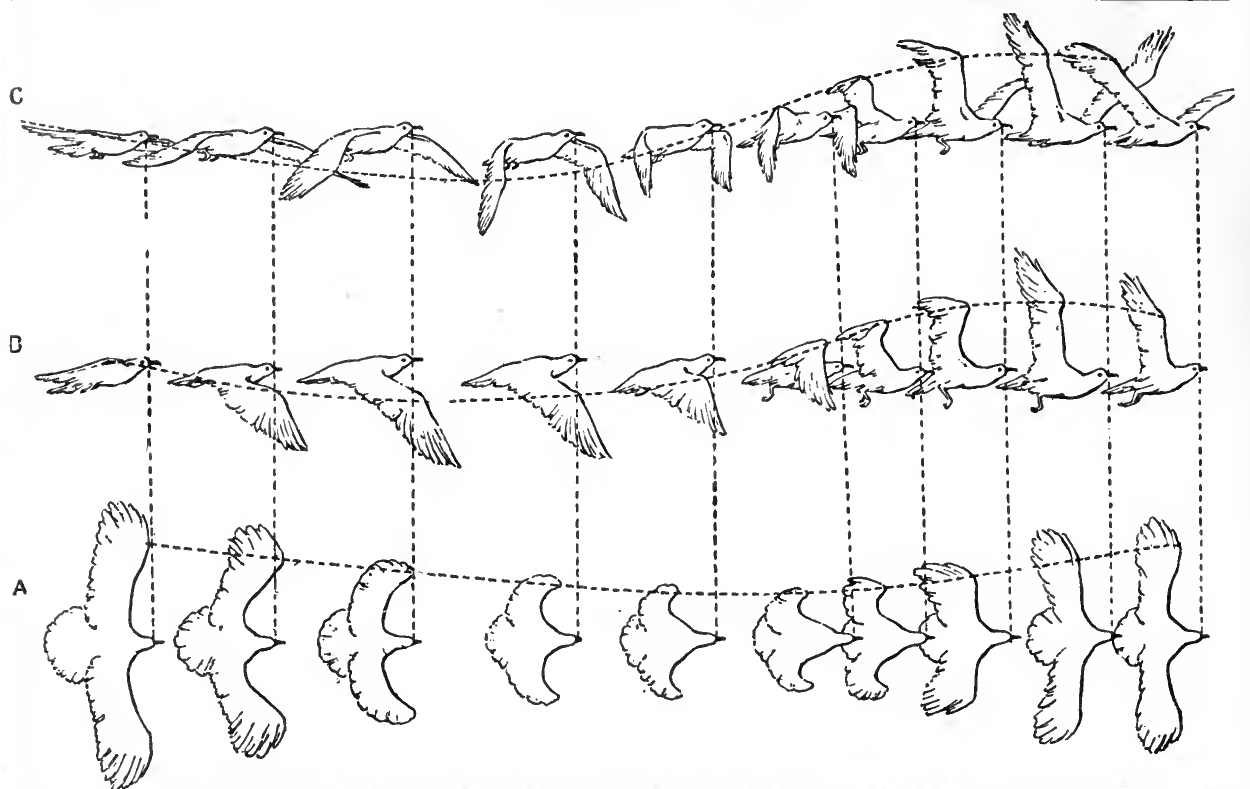

Flight. Diagrams illustrating the flight of a pigeon viewed from three standpoints; A, from above; B, from the side; C, obliquely from side and front

$\Delta$ fier the diagram by $E$. J. Marey in "Movement," by permission of Wm. Heinemann

France, Italy, Germany, and Russia. Many problems await an answer, but in the main it may be stated that the great problem of safe flight has been solved.

The problem of stability in flight is one which has been for all practical purposes solved, though the actual mechanical contrivances for maintaining that stability have not yet reached the state of perfect automatic response found in birds.

The problem is complicated in that, though the surfaces, both main and control, may be sufficient to maintain equilibrium for a particular speed of flight, they are not sufficient at some other speed. Many of the aeroplanes used during the Great War, for example, were stable at some flying speeds, but not at others. The rudder of an aeroplane is used to give directional control, i.e. for turning; the ailerons or wing-flaps to bank the aeroplane when turning in order to prevent it side-slipping; the elevators for altering the incidence of the main planes and so altering the speed of flight. If all or any of these control surfaces are insufficient, the aeroplane will be unstable or uncontrollable at some particular speed.

The control system of the modern aeroplane is so arranged that the natural movements made by the pilot are those which make the aeroplane manoeuvre as he would expect from those movements. He leans forward and pushes the joy stick forward, and in contradistinction to the forcing the aeroplane tends to dive; he of the air past a curved surface and moves back, pulling the joy stick so downwards by means of an airback, and the aeroplane puts its screw as in the aeroplane. nose up. Moving the joy stick to the right makes the aeroplane roll to the right, and conversely for a left-hand movement. The rudder bar is worked by the feet, and pressure on it with the right foot causes the aeroplane to move to the right, and conversely. The joy stick is connected by wiring to the ailerons and elevators, and the rudder bar similarly to the rudder.

Flight IN NATURE. In nature the power of flight is possessed by most birds, most insects, and all the bats. The flying fish springs out of the water and skims along for some distance by the aid of its winglike fins, but it is very doubtful if any true propulsive movement is made by them. The socalled flying squirrels, lemurs, and lizards do not really fly. They are merely able to stretch out the loose skin of their sides to form a kind of parachute by the help of which they are able to take long flying leaps through the air from one tree to another. The principles of flight in birds, bats, and ingects are iden. tical with those of the aeroplane, though manifested in different ways. In all there is the cardinal principle that air is forced downwards in order that the bird or insect may sustain itself in flight. This forcing down of air is accomplished by the beating of the wings,
Soaring flight calls for some attention here. It is well known that certain birds, as the albatross, are able to keep in the air for long periods without any appreciable flapping of their wings. This soaring flight is not peculiar to birds or insects, aeroplanes soaring in an exactly similar way. Soaring flight is possible where there are currents of air moving upwards, as Lord Rayleigh and Prof. Langley have shown. These currents act as the necessary source of energy to support the bird or the aeroplane, though naturally they must be much stronger for the latter. Such upward currents, usually very local, exist round coasts, mountainous country, hot ground, etc., and an upward wind of $5 \mathrm{~m}$. an hour is not uncommon. Soaring flight is, however, only possible for short distances in aeroplanes. The speed of an upward current for soaring flight is proportional to the speed of flight of the aeroplane or bird, so that the latter with their slower flying speeds are able to soar where an aeroplane cannot.

Bibliography. Military Aeroplanes, tures, A. J. S. Pippard and J. I. Pritchard, 1919; Applied Aerodynamics, L. Bairstow, 1920 , Aero. nautics in Theory and Experiment, W. L. Cowley and J. H. Levey, 2nd ed. 1920. G. L. Loening, 1918; Aeroplane Struc- 
Flight Lieutenant. In the R.N.A.S., the rank equivalent to that of lieutenant in the R.N. and of captain in the army, and origin. ally confined to pilot officers. In the Royal Air Force the title has been revived for the equivalent rank, but it has been extended to all officers of that rank in that force. See Air Force, Royal ; Naval Air Service, Royal.

Flight Path. The line which represents the course of an air craft in flight. See Aeronautics.

Flinck, GovaERT (1615-60). Dutch painter. Born at Cleves, Jan. 25,1615 , he was one of Rembrandt's most successful pupils. His earlier work, painted under the influence of the master, is of greater value than his later Italianate style of court painting. Not. able works are The Annunciation to the Shepherd, Louvre; The Grey Bearded Man, Vienna; The Expulsion of Hagar, Berlin, painted for the elector of Brandenburg, and The Civic Guard Fête, Amsterdam. He died at Amsterdam, Feb. 2, 1660.

Flinders. River of Queens. land, Australia. It issues from the N. extremity of Lake Neelia in Rupert co., and flows a generally N.W. course of about $220 \mathrm{~m}$. to discharge into the Gulf of Carpentaria, $10 \mathrm{~m}$. S.W. of Kimberley. It was named after Matthew Flinders (1760-1814), the navigator and hydrographer, who surveyed the coast of Australia.

Flinders, MatTHEW (17741814). British sailor. Born March 16,1774 , the son of a surgeon, in 1790 he went to transplant bread-fruit trees from the South Sea Islands to the W. Indies. Returning in 1793 , he was posted to the Bellero. phon, s a w action on the Glorious First

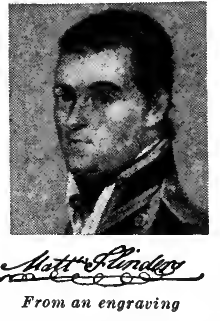
of June (1794), and sailed in the Reliance to New South Wales, where he began a series of explorations lasting until 1799, circumnavigating Tasmania, which was hitherto supposed to be part of the mainland.

In 1800 Flinders was appointed to the Investigator, and again sailed (1801) for Australia, where he charted the Gulf of Carpentaria, and surveyed the coast of New Holland. On his voyage home, unaware that Britain and France were at war, he was detained by the French at Mauritius, and imprisoned, 1803. In June, 1810, he was released and made his way to
England, where he wrote an account of his discoveries. He died July $19,1814$.

Flindersia. Small genus of evergreen trees of the natural order Meliaceae. Natives of Australasia and the Moluccas, they have hard, close-grained wood of a yellow tint, useful for many purposes. $F$. australis (Crow's Ash), found in Queensland and New South Wales, grows to a height of $60 \mathrm{ft}$, with smooth, flaking bark, and alternate leaves broken into three to six oblong leaflets. The numerous small white flowers are in dense clusters. The wood is very durable. The trees are named after Matthew Flinders (q.v.).

Flint. Crystalline mineral composed mainly of silica; a variety of chalcedony. It is compact, almost opaque, usually dark grey or brown, somewhat harder than steel, and breaks with a shell-like fracture, forming sharp-cutting edges. When first unearthed it is brittle, becoming toughened by exposure. Chert and hornstone are coarser forms.

In Great Britain

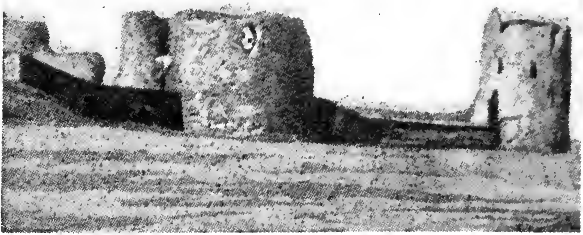

Flint, Wales. Ruins of the castle built by Edward I

times in beautiful colour zones. As road metal it is unsatisfactory because of its readiness to pulverise. This quality is utilised for pottery and optical or flint-glass. A snowwhite quartz powder is obtained by heating flints and throwing them into cold water. In France

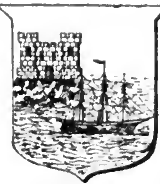

Elint arms they are crushed between chert blocks and ex. ported to Great Britain and America. In Es. sex and the home counties S. of the Thames there is a normal annual output of 30,000 tons, and a similar output in Belgium. SeeChalk; FlintImplements.

Flint. Mun. bor., formerly the county town of Flintshire, Wales. It stands on the S. shore of the Dee estuary, $12 \mathrm{~m}$. N.W. of Chester and W. Europe flint occurs mainly in the middle and upper chalk formations, where it forms irregular nodules, tabular masses, and veins. It is also scattered through tertiary gravels and alluvial soils, sometimes in great numbers, derived from disintegrated chalk rock. The nodules, sometimes several feet across, are often the silicified remains of sponges, or are hollow shells formed by the concretion of gelatinous silica around urchins, sponges, and other marine organisms. When this dense, non-crystalline constituent, the cause of black flint, is removed, white flint results. The veins were deposited in joints and fissures in chalk rock, carbonate of lime being displaced by dissolved silica of organic origin.

The cutting edge produced by flaking enabled palaeolithic man to invent edged tools, prior to the introduction of metallurgy. Utilising at first water-worn pebbles or cliff-exposed nodules, this industry led to flint-mining. The discovery that sparks are produced when flint is struck with iron pyrites brought about the percussive method of fire-making. In medieval E. Anglia flint was largely used in church-building, walls being made of undressed or split flints, and porches and battlements panelled with squared flints, someon the L. \& N.W.R. In earlier times an important harbour, the accumulation of sand in the estuary now keeps the tidal waters away from the town. Hundreds of acres of marshland in the estuary could be profitably reclaimed. Artificial silk is made here. There are alkali and copper works, and lead and coal mines in the neighbourhood. The castle, built by Edward I, was the scene of the meeting between Richard II and Bolingbroke, described by Shakespeare, and was twice captured by the Parliamentarians and dismantled in 1647. It was taken over by the office of works in 1920. Market day, Sat. Pop. (1921) 6,302.

Flint. City of Michigan, U.S.A.. the co. seat of Genesee co. It stands on Flint river, $70 \mathrm{~m}$. by rly. N. by $\mathbf{W}$. of Detroit, and is served by the Grand Trunk Western and the Père Marquette rlys. It contains a Federal building, a state asylum for the deaf and dumb, a city hall, a high school, and a public library. It is a centre for the manufacture of motor-vehicles, wagons, and carriages, and has woollen, flour, cigar, and lumber indus. tries. Settled in 1820 , it received a city charter in 1855. Pop. 70,100.

Flint. River of Georgia, U.S.A Rising in the N. part of the state it flows $350 \mathrm{~m}$. generally S.W. to unite with the Chattahoochee in 
forming the Apalachicola. Large vessels ascend to Bainbridge, $50 \mathrm{~m}$. up, and for smaller craft it is riavigable for a further $100 \mathrm{~m}$.

Flint Implements. Primitive tools and weapons made of flint. The term popularly includes quartzite, chalcedony, felsite, chert, hornstone, and other siliceous stones. Perhaps originating in N. Africa, and traceable in a rudimentary form in the dawn of prehistoric Europe, they reached a high level of development during the Stone Age. When flint is broken up by percussion or pressure a conchoidal or shell-like fracture results, with a bulb of percussion where the blow falls. The products are classed as nodules, cores, flakes, chips, and splinters. Prolonged exposurecauses a characteristic tinting or patina.

Palaoolithic workshops - with anvil-stones, discarded cores, and spoiled implements-are plentiful, as at Crayford, Kent, and Caddington, Beds. The early neolithic industry is revealed at Campigny and Grand Pressigny, France; later British factories are Grovehurst, Kent; Skelmuir, Aberdeenshire. Early flint mines have been localised at Spiennes, Belgium, Cissbury Hill, and Grime's Graves. The last flintknapping for gun-flints and strikea-lights survived at Brandon, Suffolk, until 1917. English flints are sometimes 9 ins. long; the finest, sometimes 14 ins. long, come from predynastic Egypt and from Denmark, with exquisite ripple-markings.

Implements of remote date are found in S. and W. Africa, Somaliland, Palestine, India, Burma, and America ; their production survives in various parts of the world, e.g. in Australia. Pygmy flints, $\frac{8}{16}$ in. to $\frac{5}{8}$ in. long, traceable in the upper palaeolithic age, became commoner in the mesolithic Tardenoisian: they range from Britain (E. Lan. cashire; Scunthorpe, Lincs.) across Europe to Egypt (Helwan), and thence to India in the Vindhya hills. See Celt; Eolith; Neolith; Palaeolith; Tomahawk; also Anthropology and Aztec, illus.

Bibliography. Ancient Stone Im. plements, J. Evans, 2nd ed. 1897 Stone Implements of S. Africa, J.P. Johnson, 1910: Stone Age Guide, British Museum, 1911; Handbook of American Aboriginal Antiquities :

The Lithic Industries, W. H. Holmes, 1919.

Flint Lock. Musket in which ignition of the powder is obtained by a mechanical device causing a piece of flint to be struck on a steel hammer when the trigger is pulled. Chicfly owing to the fact that this type of lock is also known as a Snaphaunce, from the Dutch word for poultry thief, the inven.

tion has been ascribed to a Dutch source. A Spanish origin has also been suggested, but it is not im. probable that the idea was first ob. tained by Portuguese traders from Japanese tinder boxes.

A piece of flint is held in the jaws of the cock, whilst the ham. mer is so arranged that it also serves as a cover for the flash-pan, preventing the priming falling out or getting wet, being held in position by an external spring. In the illustration the lock is at half. cock, and is unaffected by pressure on the trigger. When the cock is pulled farther back the piece is ready to fire, and on pressing the trigger the cock flies forward, the flint knocking the hammer back and allowing the shower of sparks

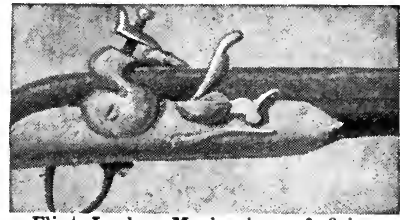

Flint Lock. Mechanism of firing device of a 17th century musket

to fall in the flash-pan and ignite the priming.

The early flint locks were not very reliable, and a match-lock was frequently fitted in addition. Flint lock weapons became common about 1630 , and were introduced to Eng. land in the reign of William III, and gradually became the favourite weapon, until the use of percussion caps displaced them. Flint lock weapons were the standard equip. ment of the British army until 1840. See Gun; also Brown Bess, illus.

Flintshire. Northern maritime and the smallest co. of Wales. It lies to the $W$. of the Dee estuary,

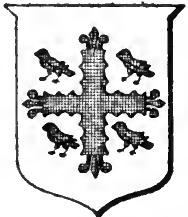

Flintshire arms with a detached portion situated E. of Denbigh. shire; area, 255 sq. m. A hill range partly crosses the co. parallel to the Dee estuary, which at low contains the lower courses of the Dee and Clwyd; there are several valleys of considerable beauty, and in these the soil is fertile and under cultivation. Butter and cheese are produced in fair quantities. Coal, lead, iron, and other minerals are worked. There are ironworks along the Dee estuary; artificial silk, flannel, and cement are manufactured. The L. \& N.W. is the chief rly. Mold, the county town, Rhyl, Flint, Buckley, Connah's Quay, and Holywell are the largest towns. One member is returned to Parliament for the county. Pop. (1921) 106,466.

Biblioyraphy. Historical Notices, etc. of the Borough of Flint, H. Taylor, 1883 ; History of the Diocese of St. Asaph, D. R. Thomas, 1908-13 ; Ancient Monuments in Wales and Monmouth, vol. 2, The County of Flint, publ. Royal Commission, 1912 ; and publications of the Flintshire Historical Society.

Flintshire Lead Process. Air reduction process which has been used from very remote times in $\mathrm{N}$. Wales. Pure ores obtained from limestone formations are used. The furnace is of the reverberatory type, having the hearth sloping to a central well, from the bottom of which a tap hole leads to a pot outside. A preliminary roasting of the charge on the hearth is followed by a raising of the tem. perature till the lead begins to run freely, then by a further rise to melt the charge down, the introduction of lime, stirring and mix. ing, a further roasting, draining, the introduction of a little coal slack to finish, and the tapping out of the metal. See Lead.

Flite, Mrss. Character in Dickens's Bleak House. One of the victims of the law's delays, she is a little mad old woman who is always in court, and who, though she has lost her reason, still retains her tenderness of heart. 
Float. Raft or a quantity of timber secured together for float ing or towing through water. It also means a float board of a paddle steamer or water wheel; a piece of wood or a closed, watertight, metal case which floats, used for various purposes such as actuating cistern valves, indicating depth of water in tanks and reservoirs, and gauging the velocity of streams; an angler's accessory; and a plasterer's tool for floating or rendering smooth a surface of cement, mortar, or plaster. The word is also used for the light hollow vessel or cork body used in the engine carburetter.

Floating Battery. Obsolete method of carrying big guns for use afloat. Floating batteries as such were used in the Crimean War.

Floating Debt. Name given in the United Kingdom to that part of the national debt which is not funded. It consists mainly of treasury bills, but also of advances made by the Bank of England and by government departments. On June 12, 1920, the floating debt amounted to $f 1,301,020,000$.

In 1919 and 1920 the enormous amount of the floating debt was considered to be one of the chief reasons of the rise in prices. The idea behind this theory was that the creation of treasury bills gives their holders borrowing powers and so increases the demand for money, thus leading to higher prices. If this debt were not floating but funded, it would be held in the main by genuine investors who would not raise money on their securities. See Credit; National Debt; National Finance.

Floating Island. Floating mass of peaty vegetable materials. Such materials collect in the shallower parts of the floor of a lake, and are probably made temporarily buoy. ant by the formation of gases produced by their decomposition.

Floating Kidney. Condition in which the kidney is abnormally mobile and can be freely moved within the abdomen by manipulation. Lesser degrees of the condition are known as palpable kidney and movable kidney. The causes of floating kidney are repeated pregnancies, tight lacing, displacement of the organ by tumours, and a general sagging down of the viscera known as enteroptosis. Mild cases can be treated by suitable padding and bandaging of the abdomen.

Float Seaplane. Type of aircraft capable of rising from and alighting on water by means of floats. Except for the floats, which replace the ordinary wheeled type of undercarriage of the land aeroplane, the construction of the float seaplane follows that of other heavier-than-air craft. Float seaplanes, as the Short, Fairey, etc., were extensively used during the Great War. See Fairey; Flying Boat; Short.

Flocculi (Lat. floccus, a lock of wool). Bands of bright woolly matter parallel to the sun's equator which appear upon certain types of solar photographs. See Sun.

Flock (Lat. floccus, a lock of wool). Stuffing for beds and upholstery, a by-product in woollen manufacture. Short and more or less curled fibre is brought away from woollen piece goods in the course of finishing, notably in scouring, milling, and shearing the face of cloth. Again flocks are generated in pulling well-worn woollen rags to their constituent fibre. In Great Britain, under the Rag Flock Act of 1911, a test standard of cleanliness has been set up which applies both to flocks produced from new cloth and to rag flock. See Wool.

Flock Book. Register of sheep. Special societies, dealing with almost every variety of sheep, publish a flock book in which al! pure-bred animals belonging to members are regiştered and the points of the breed laid down officially. See Sheep.

Flodden, Batrle of. Fought between the English and the Scots, Sept. 9, 1513. Flodden is a ridge of the Cheviots on the English side of the border. It is $3 \mathrm{~m}$. S.E. of Coldstream, and nearer is the village of

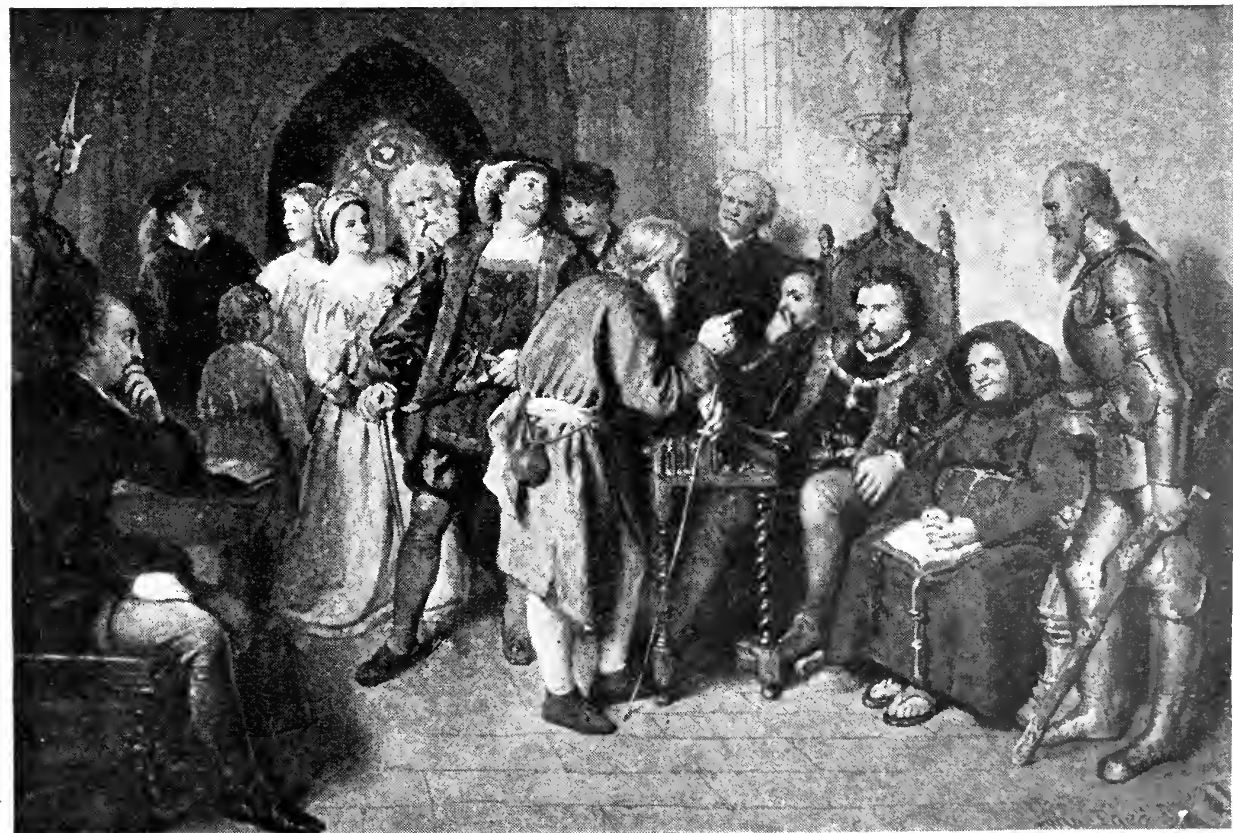

Flodden. The Morning of Flodden. James IV of Scotland receives news of the strength of the English forces under the earl of Surrey. From the picture by John Faed, R.S.A. 
Branston. Along it runs the road to Scotland, and near is the Till, flowing to join the Tweed.

Suddenly renewing the war with England, James IV crossed the border on Aug. 22 with a large army and besieged Norham Castle. Surrey collected an army and marched N., for Henry VIII was fighting in France, learning on the way that Norham and other castles had fallen to the invader. On Sept. 7 the two forces were only a few miles from each other. Surrey, by a circuitous march, placed his vanguard between the enemy and their line of retreat. The rest of the army moved on an interior line, and on the afternoon of the 9 th were ascending the ridge whereon the Scots stood-but from the N., not from the S.

Seeing the enemy, James led his men down the ridge to meet them, and the battle was joined at once. Gradually the English gained the upper hand, and the Scots on the wings were soon in flight. On both sides the centre, picked soldiers under James and Surrey respectively, stood to fight it out. It was an unequal duel, for other bodies of English closed round the Scots, who were charged by horsemen from the rear, and when their king was killed they had definitely lost the battle.

The losses of the Scots have been placed at 11,000 out of 40,000 engaged, but both figures are too high. Certain it is that they lost heavily, especially among the nobles, who fought to the last around the king, and it is this that made the day so sad to Scottish memories. The English losses were perhaps 1,000. The best known reference in song is the description in Marmion. A monument marks the spot where James is supposed to have been killed.

Flogging. A punishment for crime. It is only applicable in English law (a) to young male offenders, by birching; (b) to persons convicted of stealing from the person with violence; and $(c)$ to certain male offenders under the Criminal Law Amendment Act, 1912 , i.e. men who live on the immoral earnings of women or who procure girls for immoral purposes.

Flong. Technical name for the matrices of prepared paper used in stereotyping. See Autoplate; Multiplate ; Printing ; Stereotyping.

Flood. Submersion of land by overflow of water. After extra heavy or prolonged rainfall, or in spring and summer, when snow and ice fields melt, great quantities of surface water drain directly into rivers. The banks cannot contain all the water, which, overflowing, submerges the low-lying parts of the valley. Many parts of the world have clearly marked wet and dry seasons. In such places heavy rains during the wet season cause floods, while the same rivers during the dry season are merely dry courses containing small lakes in the deepest parts of the bed.

Egypt is aptly called " the Gift of the Nile," for in that land occurs the phenomenon of extensive floods in a land of little or no rainfall. The Nile rises in great lakes, situated in a region where rain falls at all seasons, thus ensuring a steady current of water. But tributaries like the Sobat, Blue Nile, and Atbara have their sources in regions of heavy sum. mer rainfall, and the summer water they bring down causes floods along the lower course of the main stream. But for these flood waters Egypt would be a desert.

The character of the soil may also aid floods. Large areas of $\mathrm{N}$. England and Scotland are com. posed of hard or impervious rocks, from which the water is rapidly drained into the rivers, so that the latter are quickly in flood during heavy rains and very low during dry weather. Where limestone or other pervious rocks are found. rain sinks into the ground and the rivers maintain a steady flow even in dry weather.

The most disastrous floods of recent years were experienced in the basin of the Mississippi river, but especially in the basin of the Ohio, in March, 1913. See Deluge.

Flood, Henry (1732-91). Irish statesman and orator. Educated at Trinity College, Dublin, and Christ Church, Oxford, he entered the Irish House of Commons in 1759 as member for Kilkenny. His closely reasoned oratory and his mastery of parliamentary tactics made him leader of the national party, and in 1775 he was made a privy councillor and vice-treasurer of Ireland. His opposition to Henry Grattan (q.v.) on the "simple

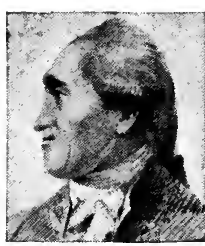

Henry Flood, Irish statesman After Comerford repeal " question led to their famous quarrel, Flood urging the renunciation by England of all claims to in. fluence Irish legislation. In 1783 Flood was returned to the British House of Commons as one of the members for Winchester. He died Dec. 2, 1791.

Floor. The lower horizontal surface in the interior of a building or part of a building. A floor is constructed either in a solid mass of some material such as concrete, or of assembled pieces such as boards or blocks of wood called parquet, or by the combination of both. A double floor is one in which large principal joists, called binders, carry the actual floor joists above them, and the joists of the ceiling below. Fireproof floors are composed of slabs of concrete, reinforced with metal rods or wires. Floors of tiles, stone, etc., used in the ground storey of a building, are generally called pavements. See Building; House.

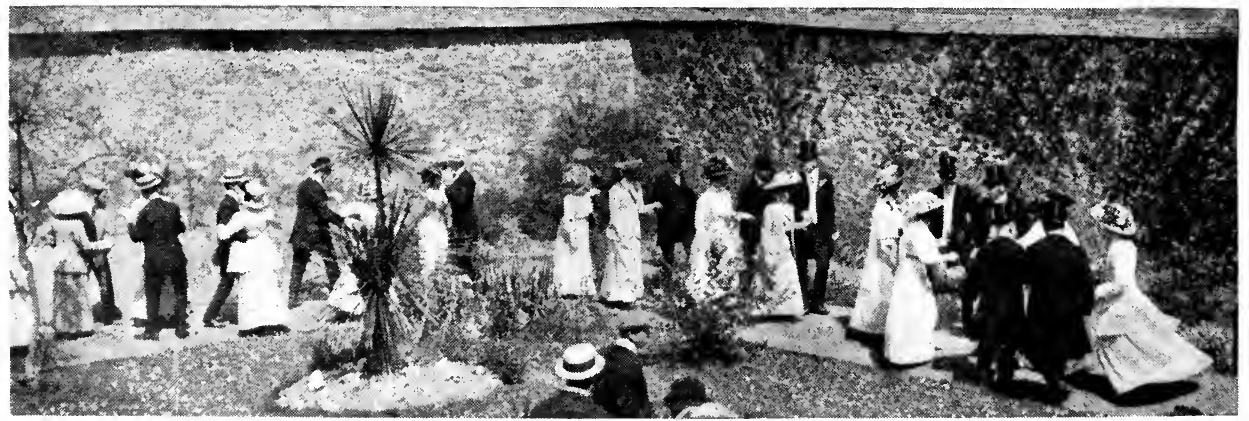

Flora Day. Dancing, or faddying, on Furry Day through the streets and gardens of Helston, Cornwall. An ancient ceremony performed every year in the month of May 
Floorcloth. Material used as a substitute for carpets. A preparation of indiarubber and ground cork was patented in 1844 under the name of kamptulicon, but was too dear to become popular. The principal floorcloth in use is oilcloth composed of coarse-textured canvas to which coats of oil-paint have been thickly applied. Linoleum is a preparation of ground cork and oxidised linseed oil. It was in. vented by $F$. Walton in 1860 , and has had many imitations. See Linoleum ; Oilcloth.

Floors or Fleurs Castle. Seat of the duke of Roxburgh. It stands on the Tweed just outside Kelso. The Kers had long had a residence here when in $1718 \mathrm{Sir}$ John Vanbrugh planned a new house for the duke of Roxburgh. In the middle of the 19th century it was largely rebuilt, being made into a magnificent building in the Tudor style. It has large gardens, and commands extensive views.

Floquet, Charles Thomas (1828-96). French statesman. Born at St. Jean-Pied-de-Port,

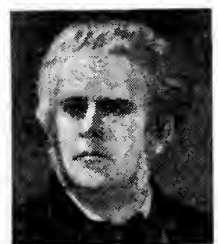

Charles T. Floquet,

French statesman Basses Pyré. nées, Oct. 2, 1828, he became an advo cate at Paris, and early joined the Republican party. He was active in the overthrowing of Napoleon III, and sat as deputy for the Seine dept. in the national assembly, Feb. 8, 1871. Suspected of deal. ings with the communists, he was imprisoned by Thiers's government, but returned to the chamber as one of the deputies for Paris, 1876.

President of the chamber 188588 , he became president of the council, and formed a radical ministry, April 3, 1888. On July 12 General Boulanger demanded a dissolution, and his accusations of falsehood against Floquet led to their fighting a duel next day, in which both were wounded. His ministry began to lose favour after his introduction of a constitutional reform bill, Oct.,1888, and he resigned Feb. 14, 1889. Re-elected president of the chamber in Nov., 1889, he held this post until his implication in the Panama scandal, when it was shown that he had received about $£ 11,500$ from the company for the use of his party. This forced his resignation, Nov., 1892, though he made a full statement of defence at the trial of those more culpably involved, March 10, 1893. He died Jan. 18, 1896 .

Flora. List of the species of plants growing naturally in any district or country, e.g. the flora of Wales. They are arranged according to the laws of botanical classification.

Flora. In Roman mythology, the goddess of flowers. She had a temple near the Circus Maximus, and a festival called Floralia was held in her honour every year from April 28 to May 1.

Flora Day or FurRY DAY. Holiday observed at Helston, Corn wall, on May 8. The custom, lately revived, may be a survival of the Roman Floralia, or may be of Celtic origin. The day is given over to revelry, any person found work ing being made to leap the river. Boughs of flowering hawthorn are gathered, the ancient Furry Day Song is sung, and long lines of revellers, with hands joined, "faddy"

\section{FLORENCE: ITS HISTORY \& TREASURES}

Cecil Headlam, Author of Venetia and Northern Italy

The city and its buildings are here described, and the history of the state that grew up around it is outlined. See Tuscany; Medici; and biographies of Savonarola, Macchiavelli, and other great Florentines; also Italy: History, Literature, Art; Guelphs and Ghibellines

Florence, called by the Italians Firenze, lies on both banks of the Arno. The river is spanned by six

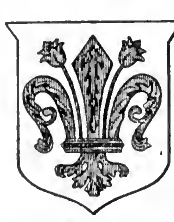
bridges, and lined by modern quays (L u n g'arno ). Broad boulevards mark the line of the old walls on the right bank. Across the river (Oltr'arno), th e walls and gate1285 , in succession to the smaller circuit of 1173, and still earlier Roman square, remain intact. Set in a valley among the foothills of the Apennines and the Monti di Chianti, Florence owes to the proximity of mountains and sea a variable and trying climate, to which, however, may be ascribed in part the intellectual pre-eminence of her citizens.

The site and development of the city were determined by a natural crossing point in the Arno, where, narrowed by the hill of San Giorgio and deepened by the tributary Mugnone, its navigable course begins soon after it turns $W$. towards Pisa and the Tyrrhenian Sea. Here, at a point indicated by the recently destroyed Mercato Vecchio, or old forum, now the Piazza Vittorio Emanuele, and the picturesque Ponte Vecchio, designed by 'Taddeo Gaddi in 1365, successor to a Roman bridge, the Roman road to the N. probably crossed an older Etruscan road running $E$. and $W$. Etruscan walls at Fiesole and
Etruscan antiquities in the Museo Archeologico recall the original settlers.

Roman remains include a theatre at Fiesole, and in Florence, baths (Via delle Terme), and an amphitheatre (Piazza Peruzzi). A great temple of Mars is represented in its Christianised form by the baptistery of San Giovanni (Battistero), with its superb bronze gates by Pisano and Ghiberti. The Tuscan-Romanesque churches of S. Apostoli and San Miniato mark the rise of Florence in the 11th century. They inspired the Re. naissance churches of Brunelleschi, San Spirito, and San Lorenzo. The latter, near the palace of the Medici, has always been closely connected with that family. Here, besides the domed mausoleum added by Cosimo $I$, is the new sacristy built by Michelangelo for Pope Clement VII (1524), where that artist's wonderful statues of Day and Night, Evening and Dawn, guard the monuments of Lorenzo and Giuliano de' Medici. Here, too, is the Biblioteca Laurenziana, the priceless library of books and manu. scripts collected by Cosimo and Lorenzo il Magnifico, and housed by Michelangelo.

In the 13th century Florence became a veritable forest of towers, built by turbulent nobles, as in the Borgo Santissimi Apostoli. She was now to be adorned with vast Gothic churches and splendid public buildings, such as the palace of the Podestà, the Bargollo, 
which enshrines the National Nuseum, and the Palazzo Vecchio, with its soaring tower and projecting battlements, designed (1298) by Arnolfo di Cambio, for the safe housing of the Priori. The adjoining open-vaulted Loggia dei Priori (or Lanzi) was begun in 1376 . The captain of the people resided at the Badia, a Benedictine Abbey founded by the mother of Count Hugo of Tuscany, whose graceful campanile dates from 1300 .

The first great period of Florentine art coincided with the establishment of democratic government. Niccolò and Giovanni Pisano in sculpture, and in painting, Cimabue, his pupil Giotto, and Andrea Oreagna led the way in the great era of artistic freedom and grace, inspired by that same passionate interest in life as Dante and Boccaccio exhibit in verse and prose. In architecture, Arnolfo di Cambio, besides the eity walls and the Palazzo Vecchio, built Santa Croce for the Franciscans (1297). Here, as in the building of the Duomo, he was succeeded by Giotto and Francesco Talenti. In 1420 the great dome of this, the fourth largest church in Europe, was begun by Filippo Brunelleschi. Giotto's lovely campanile, with its four storeys of marble, was begun, 1334, and completed by Andrea Pisano and Francesco Talenti, 1387.

Church Architecture

S. of the Piazza del 1)uomo is the graceful little Loggia del Bigallo (1352), resembling in style Andrea Orcagna's more gorgeous tabernacle in that splendid sanctuary of the guilds, Or San Michele, begun in 1337. The Dominican church of Santa Maria Novella was begun in 1278. The façade is by Leo Battista Alberti, the lovely arcade by Brunelleschi, and the exquisite Spanish chapel by Fra Jacopo Talenti. The much modernised church and convent of San Marco fascinates both by the art of Fra Angelico and Fra Bartolommeo, and its memories of Savonarola. The great 14th century church of the Santissima Annunziata has also been much altered, but contains some of the finest work of Andrea del Sarto.

The story of Florentine art, as it developed through Masolino and Masaceio, Fra Angelico, Lippi, Andrea del Castagno, to Andrea Verrocchio, Sandro Botticelli, Dom enico Ghirlandaio and Leonardo da Vinci, Michelangelo Buonarroti and Raphael, and a host of other great artists, including Luca and Andrea della Robbia, Vasari, Ben. venuto Cellini, and Gian dí Bologna, can be followed in these and other churches, as well as in the great galleries, the Academy of Fine Art, the Uffizi Palace, government offices constructed by Vasari for the grand duke Cosimo I, and the Pitti Palace. The latter, like the Palazzo Strozzi and Palazzo Rucellai (Alberti), is a typieal Renaissance palace, and was begun by Luca Pitti, the opponent of Lorenzo the Magnificent, and afterwards occupied by his successors.

History. Florence was founded by the Etruscans. They had first settled at Fiesole, about 700 B.C., upon a rocky height to the N., commanding the way across the neighbouring Apennines to the Adriatic coast. Tempted down to the banks of the Arno by the com. mercial advantages of plain and river, they were presently supplanted by the Romans, whose quadrangular castrum is described as municipium splendidissimum in the time of Sulla.

Saved from the Goths by the legions of Stilicho and the prayers of Zenobius, a saintly bishop whose miracles often figure in Florentine art, the inhabitants fled later for refuge to Fiesole before the Lombards, but prosperity returned to their city under Charlemagne. The great power of the margraves of Tuscany delayed the rise of the Tuscan towns; but under the protection of Matilda, countess of Tuscany, and after her death in 1115 , while Papacy and Empire were fighting for her heritage, Florence developed into a powerful, independent burgher city. Members of the chief families who had administered Florence in Matilda's name, now became consuls of the commune, annually elected, two for each sestiere, and were advised by a senate of 100 drawn mainly from the trade guilds. They led the burgher forces in their struggle against imperial vicars and feudal nobles. For the surrounding country, called the contado, bristled with castles, whence barons, of Teuton origin and adherents of the Empire, harried the pack-trains of the eitizens.

\section{Growth of the Commune}

As the commune made herself mistress first of Fiesole (1125), and then of the contado, she compelled these barons to take up their residence within the city. There they joined with other citizen-nobles of aristocratic tendencies and fortified themselves in lofty towers. Against these societies of the towers, and the domination of an alien power, the burghers of the commune, a com mercial democracy of Latin descent, grouped into trade guilds, strove unceasingly. This is the form which the feud betwixt
Guelph and Ghibelline took in Florence.

Her interest as a growing banking and carrying community on the trade-route from Rome naturally inclined Florence to the side of the Church, while involving her in commercial rivalry with Pisa, which barred her free communication with the sea; with Siena, the leading city between her and Rome; Pistoia, and other Ghibelline cities. For centuries she waged deadly trade wars with these rivals until she finally reduced them to subjection. The murder of one of the Buondelmonti, leaders of the democratic party, accentuated the bitterness of party faction.

Beneath the mask of family feuds, the Florentine commune was always striving, through successive changes in the constitution, and in spite of frequent reactions, towards the completest form of democratic liberty known to the Middle Ages. The lower class of artisans and the populace had as yet no share in the government (Signoria), except as a parliament (Arengo), assembled in the city square to shout a decision upon momentous matters. But the struggle between people and patrician magnates by this time had already begun.

\section{Democratic Developments}

The Guelph magnates remained in power, leading the Carroccio and red and white banner (gonfalone) of the commune to victory against their neighbours until, in 1249, the Uberti, aided by the Emperor's German troops, thrust them into exile. On the death of Frederick II in 1250, however, the people rose and established the first democratic constitution. Twelve elders (anziani) and thirty-six corporals (caporali) were appointed as a central government. A popular militia was formed, and a foreign Guelph noble, assisted by a special and a general council, was annually elected as "captain of the people" to champion their cause against the Podestà (1250).

This officer, also an annually elected foreign noble, had replaced the consuls about 1200 , and became the representative of the Ghibelline aristocrats and of imperial claims. $\mathrm{He}$, too, presided over two councils; so that there were now two political organizations, that of the nobles and that of the people, within the Republic. Ten years later the exiled Ghibellines, rallying at Siena, and reinforced by the German mercenaries of Manfred of Sicily, defeated the Guelphs at Montaperti.

The coming of Charles of Anjou, after the battle of Benevento, put an end to the domination of Ghibelline and German (1266). The 


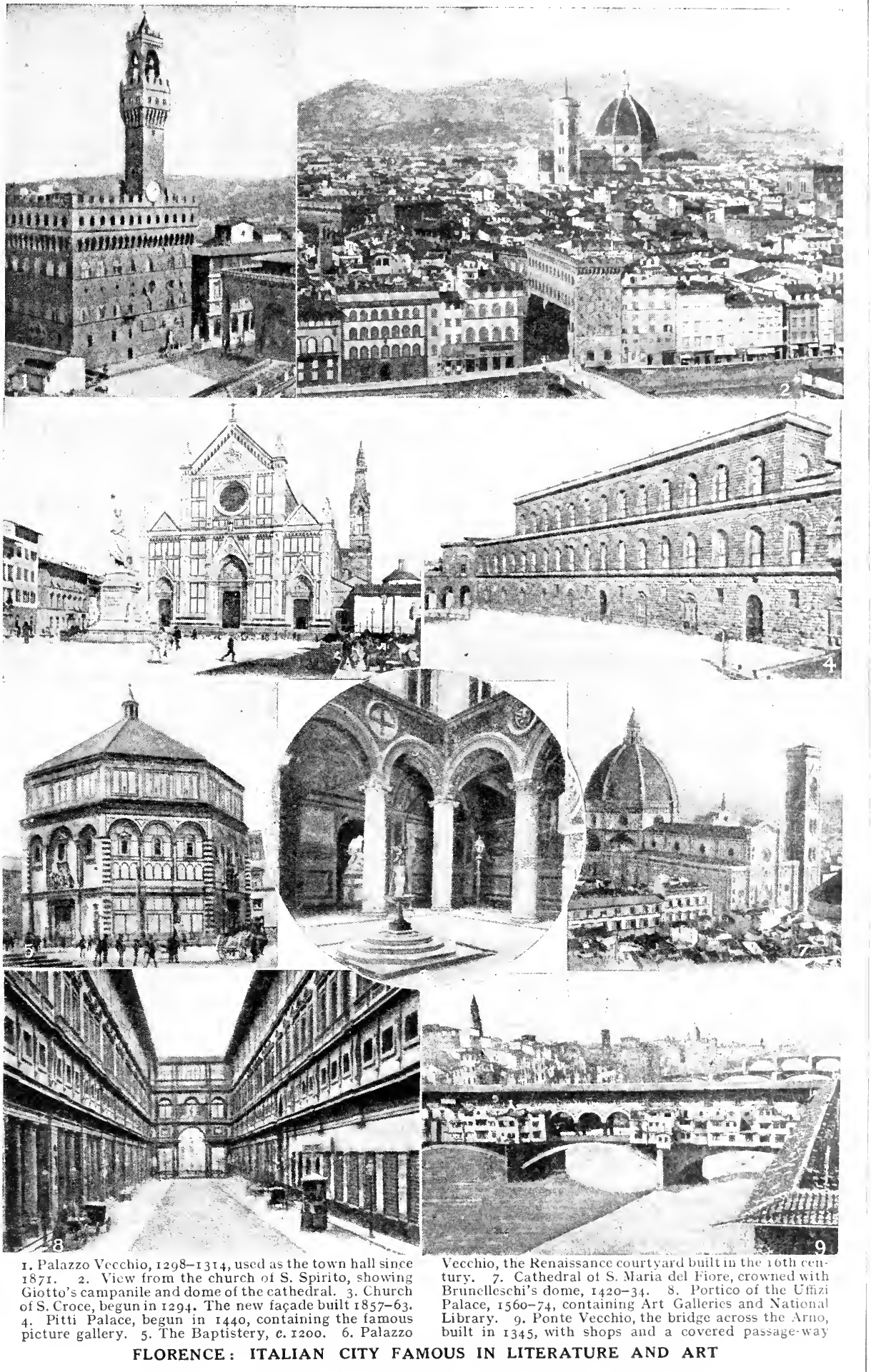




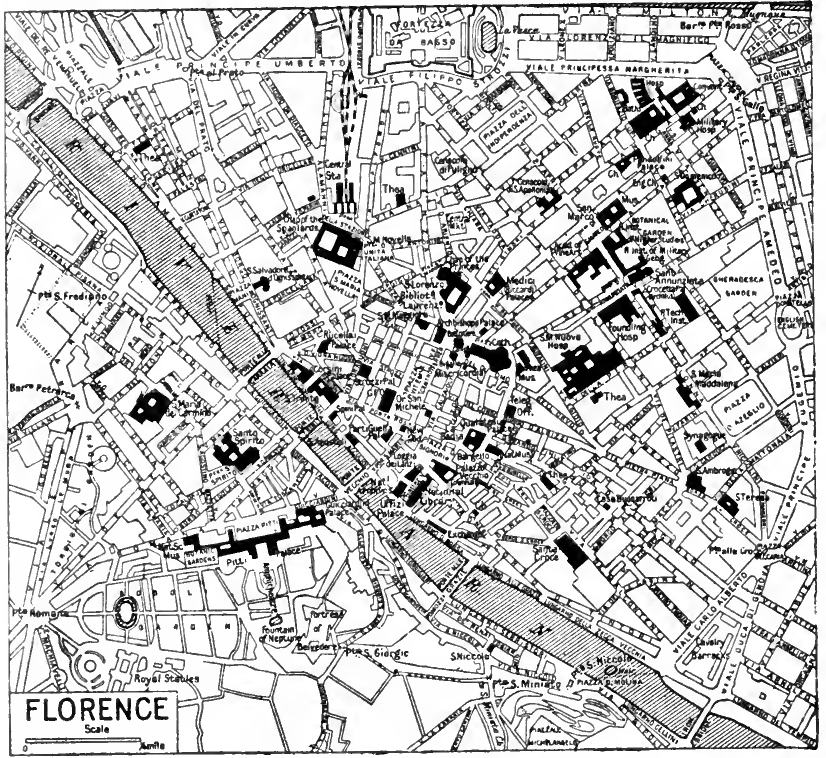

Florence. Plan of the centre of the city, showing the principal buildings and bridges

Florentine Guelphs acknowledged Charles's suzerainty as king of Naples and Sicily. An organization (Parte Guelfa) was formed to persecute Ghibellines, and a new constitution (Secondo Popolo) similar to the first, but of a more democratic character, was set up.

In 1293 the famous ordinances of justice were enacted, intended to restrain the reviving power of the nobles, and barring them alto. gether from the Signoria. In 1300 a new officer of justice, the Gonfaloniere, or standard-bearer of the people, was added. Under this republic of merchants (Villari) the great "Trecento" era of art and literature blossomed forth.

Commercial Prosperity

The commercial prosperity of Florence was now great. Her merchants dealt in the wool of Latium and Lombardy, the oil and wine of Tuscany, the spices, silks, and dyes of the East; the craftsmen of the Calimala guild dressed and dyed foreign cloth into artistic fabrics, which were prized throughout Europe; while her bankers with their standard golden "florin," first coined 1252, provided the necessary medium of exchange, and extended her financial influence far and wide.

Head of the Guelphic League, Florence was now the chief power in Tuscany. At Campaldino (1289) she had shattered the remaining forces of the Tuscan Ghibellines. The Guelphs, however, soon split into factions, Neri and Bianchi, headed by the Donati and Cerchi families. Dante, an adherent of the Bianchi, was banished when Charles of Valois, in alliance with the Neri, sacked the city, 1301. Nevertheless, the merchant republic succeeded in forming what was practically a confederation of all Italy.

The victorious Neri soon split into factions. Florence then fell a prey to the exactions of the Angevin sovereigns of Naples, and the tyranny of a French soldier of fortune, Walter de Brienne, duke of Athens. After his fall the people rose and annihilated the magnates, 1343.

\section{Dawn of the Renaissance}

The struggle for political power was henceforth between the rich burgher aristocracy (Ottimati) of the greater guilds and popolo minuto, the rest of the unenfranchised guilds and people, typified by a rising of the latter (Ciompi), led by Michele di Lando, a patriotic wool-comber. The dawn of the Renaissance found Florence full of artists and scholars patronised by the Ottimati. Fierce wars were waged with Milan and other cities by mercenaries, such as those led by the English captain Hawkwood, and the dominion of Florence was extended over Pisa (1406), Arezzo, Cortona, and Leghorn. But the divisions of the Re. public finally placed it at the mercy of Cosimo, son of Giovanni de' Medici, the richest banker in Italy. Returning from exile, he took his place as Despot of Florence (1443). The outward forms of the old constitution were retained, while Cosimo controlled the elections and broke the power of the Ottimati. At home he patronised artists (Brunelleschi, Michelozzo, Dona. tello, Fra Lippo Lippi, Fra Angelico), and encouraged the NeoPlatonism of the Renaissance by his Platonic Academy. He was succeeded by his son Piero (1464) and his grandson Lorenzo il Magnifico.

\section{Lorenzo and Savonarols}

Lorenzo maintained the balance of power among the five Italian states, and was treated as an equal by foreign potentates. At home, Florence, beautified by artists sprung from the people, became the brilliant world-centre of the revival of Greek culture. But before Lorenzo's death Fra Girolamo Savonarola, denouncing the tyranny and corruption of state and church, had prepared the way for Repub. lican reaction. Roused by Piero II's surrender to the French invaders, the people expelled the three sons of Lorenzo. Charles VIII entered the city, Nov. 17, 1494, and took the Republic under his protection. A brief period of political and spiritual reform, inspired by the prophetic fervour of Savonarola, was followed by the excommunication and burning of the monk (May 23, 1498).

The Gonfaloniere, Piero Soderini (1502), with Niccolò Macchiavelli for secretary of state, maintained the Republic until the Medici were restored by the Spanish invaders (1512). Republicanism made one last glorious effort under Niccolò Capponi (1527). But the emperor Charles V, in alliance with Pope Clement VII, who had ruled Florence as Cardinal Giulio de' Medici, reduced the town after a siege of eleven months.

Charles appointed Alessandro, illegitimate son of Lorenzo, son of Piero II, duke of Florence. Alessandro suppressed the ancient Signoria for ever. He was murdered in the Palazzo Medici by his kinsman, Lorenzino, and was succeeded by Cosimo I de' Medici, "the Great"(1537). Allying himself with Spain and the Papacy, and making himself master of the surrounding country, while he patronised the artists of the late Renaissance, Cosimo founded a long line of grand dukes of Tuscany (1569).

Florence remained the capital of Tuscany when, in 1737, the Medici line having become extinct, the duchy was annexed by the emperor and became an appanage of the House of Austria. After the Napoleonic interludes of the republic and kingdom of 
Etruria, 1801-7, Tuscany joined the growing Kingdom of Italy by a plebiscite of March, 1860, and Florence became the first capital of the United Kingdom of Italy (1865-71). See Door illus.

Bibliography. Storia della Re. pubblica di Firenze, 1875; Histoire de Florence, F. T. Perrens, Eng. trans. H. Iynch, 1892; The Two First Centuries of Florentine His. tory, P. Villari, Eng. trans. L. Villari, 1901 ; The Story of Florence, E. G. Gardner, 4th ed. 1902; Florence, A. J. C. Hare, 1904 ; Florentine History, N. Macchiavelli, Eng. trans. N. H. Thomson, 1906; Florence, G. Allen, 1906 .

Florence of Worcester (d. 1118). English chronicler. A monk at Worcester, he lived in the time of William II and Henry I and died in July, 1118. His chronicle of English history begins with the Creation, is filled with stories and legends from earlier writings, and is only valuable for the period covered by the author's life. The work was continued to 1141 by John of Worcester. See Eng. trans., ed. B. Thorpe, 1848.

Florence Station. Hamlet of Tennessee, U.S.A., in Rutherford co. It is situated $26 \mathrm{~m}$. S.E. of Nashville, and has a small export trade in grain and cotton. Near here, Dec. 31, 1862, to Jan. 2 , 1863, was fought the battle of Stone River.

Flores. Island of the Azores, in the Atlantic Ocean. It is the most westerly of the group. The surface is mountainous, and sheep are reared on the grassy slopes. The soil is fertile, and fruit and vegetables are cultivated. The chief town is Santa Cruz. Off Flores, in 1591, took place the naval action between Sir Richard Grenville in the Revenge and several Spanish vessels. Pop. 8,250.

Flores. Island of the Dutch East Indies, in the Sunda group of the Malay Archipelago. A de. pendency of Timor, it lies S. of Celebes, from which it is separated by the Flores Sea, midway between Java and Timor. Oblong in shape, it is $230 \mathrm{~m}$. from W. to E., with an average breadth from $\mathrm{N}$. to $\mathrm{S}$. of $28 \mathrm{~m}$., and an area of 5,860 sq. m. The chief products include sandalwood, cotton, edible birds'. nests, dyewoods, tortoiseshell, and beeswax, while rubber culture is making progress. Pop. 250,000.

Flores. Department of S.W. Uruguay. It is bounded on the N. by Durazno and on the S. by San José. It is hilly, with good pastur. age ; agriculture and stock-raising are the principalindustries. It is traversed by the rly. running $\mathrm{N}$. from Montevideo. The capital is Trinidad. Area 1,744 sq. m. Pop. 22,079.

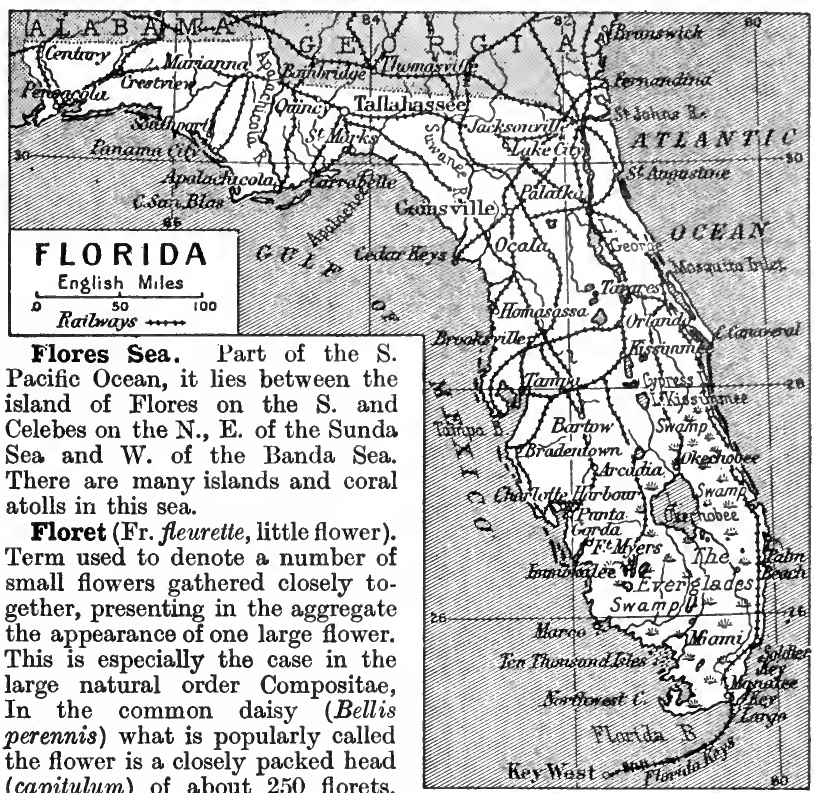
(capitulum) of about 250 florets, of which four-fifths are short, yellow-coloured tubes, constituting the disk. Around the disk is an outer series in which the tube has been split into a much larger white strap. These ray-florets, as they are called, contain no stamens; their principal purpose is to make the flower-head conspicuous and attract insects to effect cross-pollination. Groundsel (Senecio vulgaris) has all its florets without rays, while in dandelion (Taraxacum officinale) they are all rayed.

Florian, Jean Pierre Claris DE (1755-94). French author and academician. Born March 6,1755 , he obtained an appointment in the household of the duke of Penthièvre, and afterwards held a commission in a cavalry regiment. He was imprisoned when the Revolution broke out, and died Sept. 13, 1794, soon after his release. Author of several comedies, romances, and pastorals, he was elected to the French Academy in 1788. He is remembered chiefly for his Fables, 1792

Florianopolis. New name for the capital of the state of Santa Catharina, Brazil, more commonly known as Desterro (q.v.).

Florida. State in the extreme S.E. of the U.S.A. Its area is 54,861 sq. m., excluding the water area, slightly larger than that of England and Wales. It is designated the "Peninsular State" from its shape, and the "Everglade State" on account of the large swamp or lake in the $\mathrm{S}$. containing hundreds of thickly wooded islets. Of many

\section{Florida. Map of the Everglade State} of N. America

navigable rivers the Apalachicola and Suwanee are the chief, and the largest lake is the Okeechobee ; around the coast are several good harbours. Pineapples, oranges, various cereals, cotton and tobacco are cultivated; phosphate rock is the chief mineral. bacco, lumber, turpentine, tar, and resin. There are a state university at Gainsville, and a state college for women at Tallahassee. More than $4,900 \mathrm{~m}$. of railroad are worked. Two senators and four representatives are returned to Congress. Tallahassee is the capital. Pop. 920,181, of whom one-third are negroes. Florida derived its name from the day in 1513 on which it was discovered by Ponce de Léon-Easter Day (Spanish, Pascua Florida or Feast of Flowers) - and was by turns in the possession of Spain, France, and Great Britain till 1819. The state was admitted to the union in 1845 .

Florida. Central dept. of Uruguay. The surface consists of undulating grassy tracts, watered by the $\mathrm{Yi}$ river, upon which are reared vast herds of cattle. Arca, 4,673 sq. m. Pop. 62,666. The capital is Florida, $70 \mathrm{~m}$. by rly. N. of Montevideo.

Florida Bay. Arm of the Gulf of Mexico. It separates Florida state, U.S.A., from Florida Keys.

Florida Keys. Curved chain of reefs off the S. coast of Florida, U.S.A. They extend from Soldier Key, near Miami, in a S.W.
Manufactured products are to- 
direction to Key West, a distance of about $140 \mathrm{~m}$. These low-lying islands, principally coralline, arc traversed by the Florida Coast rly. from Key West to Key Largo, where it joins with the mainland.

Florida Straits oR Channel. Coastal waters off Florida, U.S.A., alternately known as the New Bahama Channel. They separate the S.E. extremity of Florida and the Florida Keys from Cuba and the Bahama Islands. 'The channel is some $300 \mathrm{~m}$. long, has a mean breadth of $80 \mathrm{~m}$., and a greatest depth of $6,000 \mathrm{ft}$. It is traversed by the Gulf Stream.

Florideae or RhoDophyceat. Class of Algae or seaweeds. In them the chlorophyll, or green colouring matter, is masked by a red pigment (phyco-erythrin). They have no true roots, but are attached to their supports by suckers, the absorbent function of roots being carried on by the sur face cells of the entire plant.

Floridia. Town of Sicily, in the prov. of Syracuse. It stands on the river Ciani, $7 \frac{1}{2} \mathrm{~m}$. W. of Syracuse, in a fertile district producing cereals, vines, and olives, and trades in grain, wine, and oil. Pop. 12,522.

Florin. Name of several gold and silver coins of various European currencies. A gold coin struck

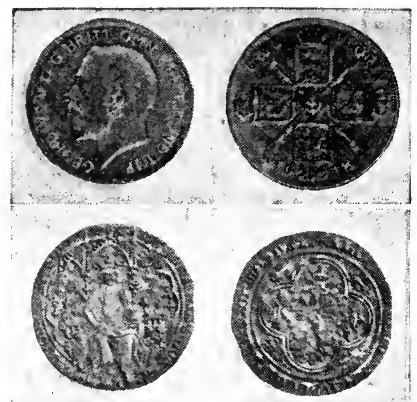

Florin. Gold coin of Edward III above, silver florin minted in 1918 Actual diameter of Edward 111 florin, $1 \frac{3}{16}$ ins. of George $V$ florin, $1 \frac{1}{8}$ ins.

at Florence in 1252 bore. obverse, the figure of S. John Baptist, re. verse, the Florentine lily, whence came the name florin (Ital. fiorino, little flower). Similar pieces appeared in various parts of Italy as a result of its wide circulation. Gold florins were also minted by Charles I of Anjou, $c$. 1335, and by John of Luxembourg c. 1340. The English gold florin, of approximate value six shillings, issued by Edward III in 1343, was with. drawn in 1344.

The British silver florin, value two shillings, weighs 174.55 grains. It was issued in 1849, and is still minted. It was at first dubbed the "graceless florin," as the customary D.G. (Dei Gratia) did not appear on the issues between 1849-52. The life of a florin in circulation is estimated at about $45 \frac{1}{3}$ years. A double florin, or four-shilling piece, was minted from 1887-90, but proved inconvenient. The Australian florin has the same value as the British. but a different design. Among modern continental florins, the Austrian florin issued in 1857 , and the silver florin struck by Louis Napoleon, king of Holland, 1807, are notable, the latter be coming the Dutch gulden.

Florina. Town of Greece, in Macedonia, formerly in Turkey-in - Europe. It is about $15 \mathrm{~m}$. S.S.E. of Monastir, and was one of the towns in the tract of territory acquired by Greece as a result of the Balkan wars, 1912-13. Pop. 10,155. It came into prominence during the Great War. Captured by the French in April, 1916, it was retaken by the Bulgarians, Aug. 20, 1916, and retaken by Franco-Russian troops, Sept. 18, 1916. See Salonica, Expedition to ; Serbia, Conquest of.

Florio, JoHN (c. 1553-1625). Author and translator. Born in London, his father was an Italian, who, being a Protestant, had left his own country for England, where he became minister to a congregation of Italians who shared his religious opinions. The son waseducated at Magdalen College, Oxford, became a teacher of French and Italian in the university, and held various offices at court, including that of tutor to Prince John Florio, transHenry, son of lator of Montaigne James I. In 1598 appeared his Italian-English dictionary, A World of Words, and in 1603 his famous translation of Montaigne's Essays, on which his reputation rests. He compiled two collections of proverbs, sayings, etc. Florio died of the plague at Fulham. Ben Jonson was one of his friends.

Florist. Cultivator or vendor of plants and flowers. The florist in large towns deals largely in exotic flowers raised under glass, and also imports flowers from milder cli- mates. The Scilly Islands and the S. of Europe furnish many of the flowers sold by London florists. Floral Hall, in Covent Garden market, is devoted to the sale of flowers. See Flower Farming.

Florizel. Character in Shakespeare's A Winter's Tale. He is the son of Polixenes, king of Bohemia, and falls in love with Per- 
serve to entangle the minute particles on which the animal feeds. It is just visible to the naked eye.

Flotation. When a body is placed in a fluid, an upward force acts on it, equal to the weight of fluid displaced and due to the pressure of the fluid. If the quantity of fluid displaced weighs less than the body, the latter sinks; otherwise the body floats. Thus when a solid floats, the weight of the volume of liquid displaced is exactly equal to the weight of the whole body. A balloon in the air will continue to rise till the density of the air in which it floats is such that the amount of it displaced by the balloon is equal in weight to that of the balloon and its contents. See Hydrostatics; Metacentre.

Flotilla (Span., small fleet). In the tactical organization of a fleet, usually a number of destroyers grouped under a commodore or a captain and intended to be worked as a whole. The senior officer is accommodated in a fast light cruiser or flotilla leader, and the flotilla itself generally consists of 20 boats representing four or five tactical units. Submarines are normally organized in flotillas, though they usually work as independent units. A number of mine-sweeping trawlers or anti-submarine drifters working together is sometimes referred to as a flotilla. See Navy.

Flotilla Leader. Ship between a light cruiser and a destroyer in size and intended for service as senior vessel of a destroyer flotilla. Dimensions vary, but the leaders all displace about 2,000 tons, have a speed of approximately 35 knots, and are armed with 4-in. guns and 18-in. torpedo tubes.

Flotsam and Jetsam (low Lat. flottare, to float; Lat. jactare, to cast). English law term. Goods found floating up on the sea are flotsam. Jetsam means goods jettisoned, cast overboard in a storm, or washed upon shore after a wreck. They become the property of the crown unless claimed by the rightful owners; hence people finding them must hand them over to the receiver of wrecks.

Flounder (Pleuronectes flesus). Small species of flatfish, common in the sea and the lower reaches of rivers. It belongs to the same

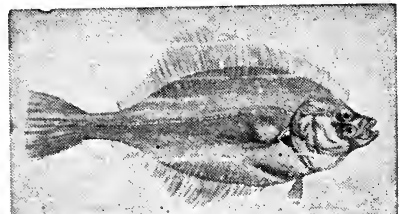

Flounder a small flatfish found round the coasts of the British Isles genus as the plaice, but is smaller, being seldom 12 ins. long. It has dark mottlings, and lacks the orange-coloured spots of the larger fish. The flounder is very prolific and produces from one to two million eggs. Its flesh is delicate, but its small size makes it unimportant as a food fish.

Flour. Term denoting especially the ground contents of the wheat berry freed from its dermal envelopes. The corresponding product of some other grains, particularly maize and rice, is called cornflour. Similar starchy meals are yielded by other cereal grasses, buckwheat, pulses, and banana; sago-palm pith, and tapioca, arrowroot, potato, and other roots and tubers.

The stone pounders used in neolithic times gave rise to handmills or querns, wherein wheat-meal was ground between two stone disks. In the early metal age the upper millstones were rotated by slave or cattle power, in classical Greece and republican Rome by geared water - wheels, later by windmills, and since 1784 by steam. As the 19th century advanced flour manufacture was revolutionised by the invention of roller-mills.

The wheat berry comprises four dermal coats, weighing 5 p.c., the germ and the embryo membrane, 5 p.c., and the kernel or endosperm, 90 p.c. It is composed of carbohydrates, $71 \cdot 2$ p.c., cellulose, $2 \cdot 2$ p.c., proteins, 11 p.c., fats, 1.7 p.c., mineral salts, 1.9 p.c., and water, 12 p.c. Of the four proteins, gliadin and glutenin, forming fourfifths of the whole, are collectively called gluten. Besides their flesh. forming value, their sticky nature confines the carbonic acid gas which yeast generates in dough within tiny cavities whose expansion causes the spongy lightness of bread.

The innermost core of the endosperm yields fine, white, weak, starch flour; that from the outer kernel is strong, granular, and glu. tinous. Outside this come the middlings, comprising fine sharps or seconds, and coarse sharps or thirds. The outer envelopes yield fine, coarse, and long brans. Flour is graded into patents, $50-70$ p.c. ; supers, $20-30$ p.c. ; bakers, from the lower grades, sometimes bleached; and households, the lowest of all. When all grades are mixed together straight-run flour results. Roller-milling produces about 70 p.c. of stock flour; when 10 p.c. of sharps is added the product is 80 p.c. or standard flour. Besides its use in bread-making, wheat flour is also made into semolina, macaroni, and vermicelli. It is a thickening agent in textile printing, and the base of some violet powders.

The imports of meal and flour into the United Kingdom in the year ended August 31, 1915, amounted to $3,529,573$ qrs., besides $22,483,587$ qrs. of wheat. Out of its 1917-18 crop Canada exported to the Allies, besides unmilled wheat, $10,000,000$ barrels of flour. Sce Bread; Wheat; consult also Processes of Flour Manufacture, P. A. Amos, 1912.

Flourens, Gustave (1838-7l). French politician. The son of the physiologist, Marie J. P. Flourens (1794-1867), known as the associate of Cuvier, he was born in Paris, Aug. 4, 1838. He began life as a lecturer and writer, but was soon associating with revolutionaries in Italy and elsewhere. In Feb., 1870, he headed a futile rising against Napoleon III, and after the abdication of the emperor he was one of the leaders of the commune. He was killed during the fighting, April 3, 1871.

Flour Mill. Building equipped for grinding grain, especially wheat, into flour. The application of steam-power to millstone grinding in 1784 led, not only to improved methods of direct reduction, but also to the invention of systems for gradual reduction by means of rolls. Millstones are still used for whole wheatmeal, oatmeal, and other grains and pulses. The stonesFrench burrs, Derbyshire peaks, or composition disks-are usually $1 \mathrm{ft}$. thick and $4 \mathrm{ft}$. or $4 \frac{1}{2} \mathrm{ft}$. in diam., scored with straight furrows tapering to $\frac{1}{4}$ in. in depth. The upper stones rotate at a maximum of 150 r.p.m.

Although small hand-turned roller-mills were produced casually from the 16th century onwards, it was not until 1837 that Sulzberger a Swiss engineer, founded the modern iron-roller system. Porcelain rolls, introduced in 1870 , and popular for a time, are still preferred here and there. Roller mills were erected in Glasgow in 1872 , and in Dublin in 1878. For some years stones and rolls were em. ployed in the same mills. But after 1881, when an exhibition was held in Islington, British millers rapidly adopted the roller system, which to-day deals with all but a minute fraction of the merchant flourmilling of the world. During the Great War a large Chinese rollermill was crected at Wusih, near Snochow.

Poller-mills are equipped with silos or granaries, containing capa. cious storage bins. These originated in N. America, where they are 
called elevators. They are fed in bulk through wall hoppers direct from truck or ship's hold by conveyer bands or pneumatic suction. At this stage or afterwards, dry cleaning is effected by means of warehouse separators. These are systems of sieves utilising differences of size, and of air currents operating upon differences of weight, some screen surfaces being magnetised for extracting nails and the like. Cockle and barley cylinders are furnished with depressions and apertures for catching smaller and rejecting longer seeds respectively. Scourers fitted with rotating beaters and polishing brushes were formerly used before storage, but this purification is now often deferred until reduction is actually in progress. Wet cleaning is nceded by some descriptions; some require conditioning by heat.

Breaking is effected in four or five 4-roller mills, rotating at differential speeds. The chilled iron rolls, preferably set diagonally, are furnished with saw-tooth groov. ing, ranging from 10 to 26 per inch. The rolls may be 8 ins. to 10 ins. in diam., and 15 ins. to $60 \mathrm{ins}$. long, the speed of the longest fast or cutting rolls being 350 r.p.m. The berry being sheared open, the kernel is broken up into angular particles graded into semolina, middlings, and dunst. Various appliances blend different kinds of grain, and extract light offal or bran and dust; smooth rolls crack the granules and flatten the germ; and the floury stock is then dressed and sacked. Plansifters are horizontal sieves which replace or eliminate some of the older methods. The whole process, from the crude berry to the sack of finished flour, is automatic throughout. See Milling; consult also Processes of Flour Manufacture, P. A. Amos, 1912 ; Wheat and its Products, A. Millar, 1916 ; Flour Milling, P. A. Kosmin, trans. M. Falkner and T. Fjelstrup, 1917.

Flow. Term used in metallurgy. Metals are usually considered as typical of rigidity and hardness; nevertheless they can all be made to flow while in the solid state. Thus a block of malleable iron or copper may be hammered out into a thin sheet. Other examples of the "flowing" of a metal are provided by the drawing and rolling of a billet into a bar or plate, and by the drawing of a tube or wire.

These operations are usually made on metals while at temperatures raised more or less above the normal, but the terhperature is always much below that of fusion. Every instance of the forging of a metal object is one of flow, but metals may be made to flow while solid and cold in a still more strik. ing fashion. All that is necessary is to provide sufficient pressure and to give time. Solid lead may be readily made to flow through a hole as a solid pencil; while harder metals will behave in a similar fashion under suitable conditions. See Metallurgy.

Flower (Lat. flos ; stem, flor-, flower). Part of a plant containing the organs of reproduction. In the complete flower it consists of four distinct whorls of organs, which differ in form and number in differ. ent species; in some cases one or more of the sets of organs being absent. The lower or outer set are the calyx-leaves, which form the bud of the unopened flower; separately they are known as sepals, and are usually green. The second series are corolla-leaves, mostly brightly coloured, separately known as petals. The third series are stamens, consisting of a stalk or filament and the anther, the latter containing pollen-the male element. The fourth series is the pistil, which consists of the ovary, containing ovules or seedeggs, surmounted by a stigma or stigmas which may be supported by stalks or styles. Grains of pollen caught by the sticky or rough surface of the stigma send out shoots which penetrate the style and fertilise the ovules, which then develop into fertile seeds.

Sometimes the sepals are all joined together and can only be spoken of as the calyx. Similarly, the petals may be united to form a tube, and be funnel-shaped, bellshaped, urn-shaped, etc. Where there is no distinction between sepals and petals (as in the Crocus and Daffodil) the floral envelope is termed the perianth. In the Gymnosperms (Conifers) there are neither sepals nor petals; and in other forest trees these organs are often very small and inconspicuous, because the pollen is carried by the wind. As a general rule, where the petals are brightly coloured the pollinating agents are insectsmainly bees, butterflies, and moths. All flowers of special shapes have been thus adapted to fit particular insects or groups of insects.

In the majority of such specialised flowers nectar-producing glands are su placed as to make certain the transfer of pollen from one flower to the stigma of another by insect agency. So also the streaks, or lines of dots, of a second colour on the petals point to the position of the nectar. The long tubes of certain flowers (tobacco, convolvulus, etc.) are related to the long probosces of the larger moths and butterflies; broad, open flowers like buttercups to beetles, etc. The perfume emanating from flowers attracts insects-bees, butterflies, and moths. On the other hand, some flowers, such as those of the stapelias, arum family, etc., emit fetid odours attractive only to flies, which are their pollinating agents.

Edward step

Flower Farming. Branch of market gardening. It includes growing flowering plants for the sake of marketing their cut blooms, and raising annual and perennial plants in vast quantities for bed. ding out purposes, or in pots for decorative uses. The daffodil fields of the Scilly Isles, and the gardens under glass of Worthing, Swanley, Mitcham, and various districts in the North of London, are variations.

Flower farming is carried on by the mixed system, where the flowers are grown indiscriminately between standard and bush trees; the distinct method, where separate plots are allotted to vegetables, fruit, and flowers; or the alternate system, where all crops are grown in rotation. The last is found to have the fewest defects, and the ordinary methods of culti. vation are applicable.

\section{Markets and Prices}

The most profitable and popular subjects for market are forced daffoails, hyacinths, and tulips in pots ; cut violets, roses, lilies, white flowers of all sorts for wedding and funeral purposes ; chrysanthemums, and all fine foliage plants. Blossoms of good bright simple colours find a readier market than those of fancy or bizarre hue. Flowers for marketing should be cut when only half expanded, put in water, and kept in a cool, dark place until they can be packed. They should be gathered for preference early in the morning of the day upon which they are to travel, and with stems as long as possible, although cutting into the hard wood of the parent plant should be carefully avoided. Flowers are consigned to market salesmen for disposal on commission. The rate varies from 5 to 10 p.c., $7 \frac{1}{2}$ p.c. being a fair and usual basis of remuneration.

The board of agriculture issues a weekly return of prices prevailing in the nine big markets in the British Isles: Birmingham, Bristol, Evesham, Glasgow, Leeds, Liverpool, London, Manchester, Wolverhampton.

The contents of all boxes of flowers should face towards the top, as the flowers are usually sold direct in the box as they arrive at the market, or at the place of retail sale. 


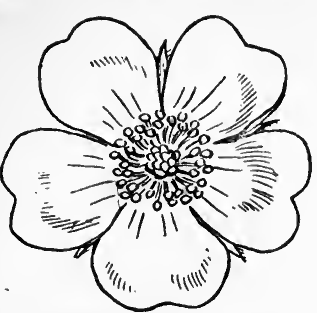

Regular : wild rose

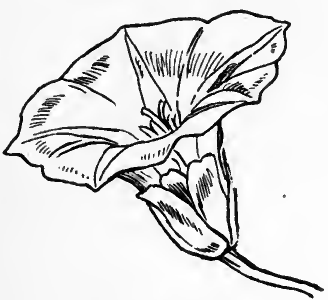

Funnel-shaped: bindwęed

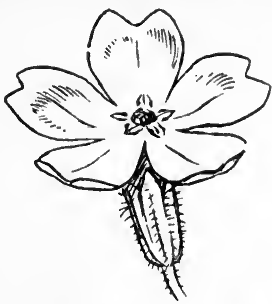

Salver-shaped : primrose

$\curvearrowright$

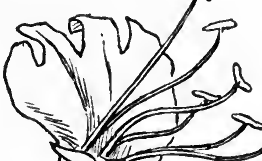

Rotate or wheel-shaped: periwinkle

Labiate or twolipped: dead-nettle

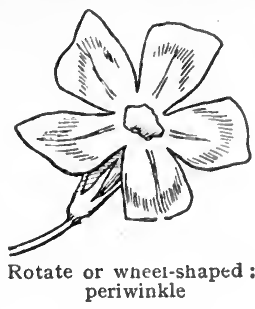

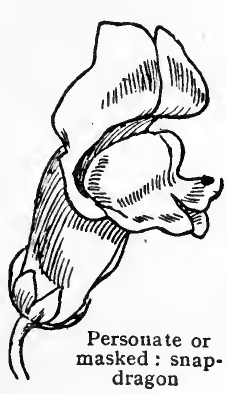

dragon

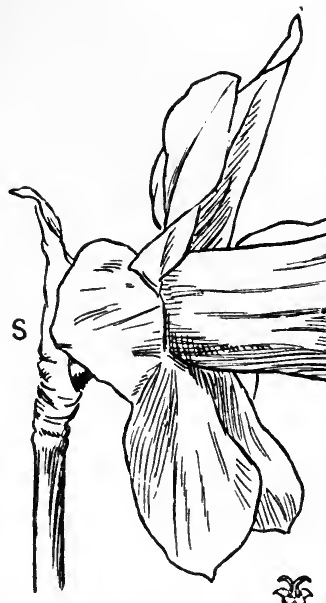

Trumpet-shaped : honeysuckle

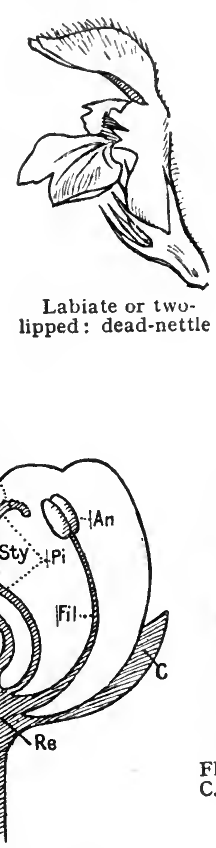

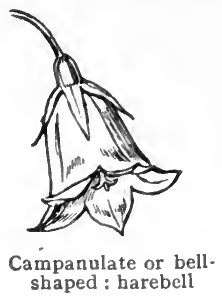

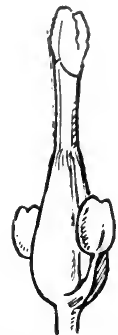

Apetalous or without petals: ash

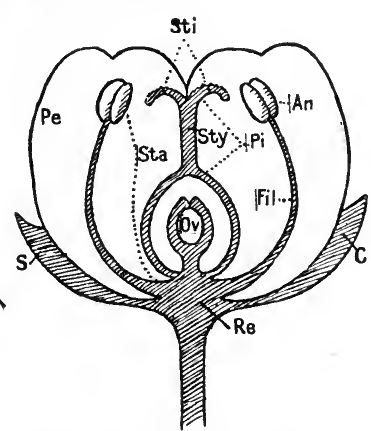

Diagrammatic section of flower. An., anther; Fil., filament ; Ov., Re., receptacle ; S. and C. sepals (calyx); Sta., stamen
Sti., stigma; Sty., style
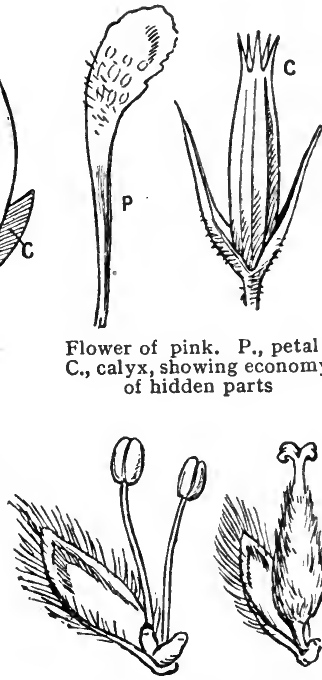

Flower of pink, $P$, petal ; C., calyx showing economy of hidden parts

(a)

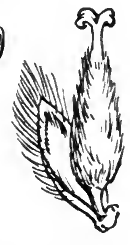

Dioecious or unisexual:

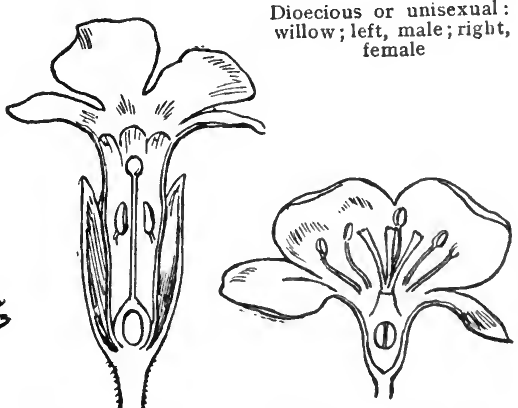

Inferior ovary : apple Trumpet-shaped : daffodil.
C., corona; S., spathe 
Flower, Sir WILIIAM HENRY (1831-99). British zoologist. Born at Stratford-on-Avon, Nov. 30,

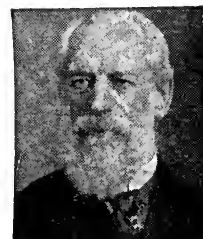

Sir W. H. Flower, British zoologist

Elliout Fry 1831 , and educated for the medical profes. sion, he served as a surgeon in the Crimean War, and became curator of the museum of the Royal College of Surgeons in 1861. $\mathrm{He}$ was appointed director of the natural history department of the British Museum at South Kensington, in 1884, which position he held till retirement at the age limit. He was the author of various books on anatomy, zoology, and other natural history subjects. He died in London, July 1, 1899

Flowering Rush (Butomus umbellatus). Perennial marsh herb of the natural order Alismaceae. A native of Europe and Asia, it has a stout, creeping rootstock, from which the slender leaves rise erectly to a height of $3 \mathrm{ft}$. or $4 \mathrm{ft}$. The tall flower-scape is leafless, and bears at its summit an umbel of many rose-red flowers, each 1 in. across, of which only a few open at one time.

Flower of Jove (Lychnis flos. jovis). Perennial herb of the natural order Caryophyllaceae. A native of Europe, it is covered with white, silky hairs, and has lanceshaped, stem-clasping leaves in pairs. Each branch of the stems ends in a small cluster of purple or scarlet flowers of the campion type. See Campion.

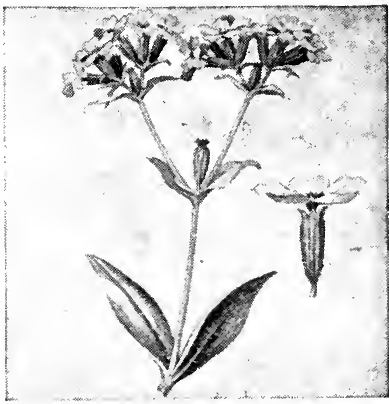

Flower of Jove. Leaves and flower spray with, right, detached flower

Flower-Pot. Common garden utensil of potter's clay, usually manufactured unglazed for porosity. The top surface of the accompanying saucer should, however, always be glazed in order to retain the water which reaches it through the medium of the soil in the pot and conserve moisture. The outsides of pots should be scrubbed at intervals, and thoroughly washed out when the contents are knocked out and the utensils are to be used for other purposes. See Gardening.

Flowers, Language of. Custom said to derive from the East, by which a particular sentiment is attributed to every flower, so that a bloom or posy may convey a message. Little volumes in which the language of flowers was set out were popular in England in the midpart of the 19th century. Gorse, for example, indicates enduring affection; jonquil, reciprocated affection; eglantine, I wound to heal, etc.

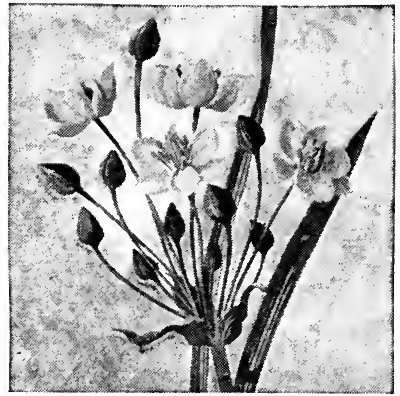

Flowering Rush. Foliage, buds, and flowers of Butomus umbellatus

Flower Show. Horticultural exhibition, held for the purpose of encouraging the cultivation of flowers, fruit, and vegetables. Local shows to stimulate interest in cottage gardens and allotments are hold in many parts of the United Kingdom. The judges should be three in number, a local amateur, a professional gardener, both non-competitive, and a stranger. The Royal Horticultural Society will often send down a competent, impartial judge.

Rules governing shows vary much under differing local conditions, but it is necessary to insist upon a written guarantee that all exhibits are the absolute property of the competitor, and have been grown by him for a period of not less than six consecutive months immediately preceding the date of the show. This stipulation should be embodied in a printed list of simple rules as to date of entry, number of classes, etc., which every entrant is requested to sign.

Good judges of flowers. will look out for a combination of good colour, size, form, and, where it exists, perfume.

Fruit is judged by size, colour, flavour, and shape. Vegetables must necessarily be judged entirely by appearance, and must be smooth, straight, well coloured, and of even size. Good judges will ignore root crops that are crooked or tap-rooted, no matter how large they are. Crooked cucumbers will not win prizes, neither will stringy beans, even if of great length, soft or loose-hearted cabbages and lettuces, deep-dyed potatoes, or spongy radishes. Root crops and celery are often injured for the show table by being scrubbed and scratched by a hard brush to get the dirt off, instead of being washed with a cloth.

All flower show schedules should state whether flowers are to be staged with foliage, or bare. The same remark applies to dressing vegetables with parsley. The most important flower show in the kingdom is the annual exhibi. tion in May by the Royal Horticultural Society, in the grounds of the Royal Hospital at Chelsea. It was formerly known as the Temple show, because it was held in the Temple Gardens, London.

F.I.S. Abbrev. for Fellow of the Linnaean Society.

Fludd or Flud, Robert (15741637). English physician and mystic. Born at Milgate House, Bearsted, Kent, son of Sir Thomas Fludd, he was educated at $S$. John's College, Oxford, and took his degree of M.D. at Christ Church. $\mathrm{He}$ studied chemistry abroad, where he became acquainted with the writings, and adopted many of the views, of Paracelsus (q.v.). Returning to England in 1605, he became a fellow of the College of Physicians.

Known as "the Searcher," under the name of Robertus de Fluctibus he wrote many works in Latin, engaged in controversy with Gassendi, Kepler, and Mersenne, and is believed by some to be the inventor of the barometer. As the supposed author of the Summum Bonum, 1629, and an apology for Rosicrucianism, 1617 , he is credited by De Quincey with being " the immediate father of Freemasonry." He founded a philosophy on the Hebrew scriptures. He died in London, Sept. 8, 1637. See Freemasonry; Rosicrucians ; consult also Athen. Oxon., A. Wood, 1691-92 ; Works, De Quincey, vol. xiii, p. 421, 1890 ; Robert Fludd, Life and Writings, J. B. Craven, 1902.

Flüela." Mt. pass of Switzerland, in the canton of Grisons. It extends between the Schwarzhorn and the Weisshorn, on the carriage road from Davos to Sus. On the latter mt., at an alt. of $7,835 \mathrm{ft}$., is the Fluëla hospice. The road has refuge galleries, used for shelter in winter. 
Fiuelen. Village of Switzerland, in the canton of Uri. It stands at the head of Lake Uri, a S.E. extension of Lake Lucerne, 2 m. N.N.W. of Altdorf on the St. Gothard Rly. The port for Altdorf, it is the terminus for lake steamers. The Axenstrasse carriage road, constructed in 1863-65, leads from here to Brunnen. The village has a château and several hotels. Pop. 1,010 .

Fluellen. Character in Shakespeare's Henry V, a Welsh officer in the king's army. Of hasty temper and verbose speech, he is ever ready to compare the fighting of his day with that of the ancients.

Flitgel Horn. Brass instrument. It is similar to the cornet, but of wider bore, like the bugle, and of mellow, horn-like tone. It is a modern improvement of the key bugle. The soprano instrument is the most usual. The term means wing horn. See Cornet.

Fluid. That form of matter which is unable to resist permanently any shear stress, however small. Matter is solid, liquid or gaseous. Fluids are liquids or gases and they are distinguished from solids in that they owe their shape at any particular time to a containing vessel or restraining forces. The line of demarcation between a solid and a liquid is one which cannot easily be drawn. Many solids flow like liquids, e.g. a glacier down a mountain side, though at a con. siderably slower rate, while even solids like lead can be made to flow under the action of suitable forces. See Flow ; Hydrodynamics; Hydrostatics; Gas; Liquid.

Fluid IMeasures. Nearly all fluid measures have been derived from corresponding measures of length or weight and suffer all the variations of the latter which were taken from parts of the human body. It is only within comparatively recent times that fluid measures have become standardised by law in different countries. In the United Kingdom the gallon is the unit measure for fluids, and in countries where the metric system is standardised the litre is the unit. A gallon contains a little over four and a half litres. See Weights and Measures.

Fluke. Group of trematode worms of parasitic nature, usually leaf-shaped. One, the liver fluke (Fasciola hepatica), in its adult condition lives in and devours the liver of the sheep, causing the much-dreaded "rot." The eggs pass out of the body of the sheep with the dung, and if they fall in a wet place hatch out into tiny ciliated embryos that swim about in search of a small water snail
(Limnaea truncatula), perishing in about eight hours if unsuccessful. Within the body of such a snail other stages of life are passed, until finally one shaped like a minute tadpole is attained (cercaria). This leaves the snail and swims to a stem or leaf of grass, to which it attaches itself, and passes into an encysted or dormant stage. Its tail has gone, it is covered by a limy coat, and resembles the adult fluke except in size.

Should a sheep swallow one of these capsules or cysts, the limy covering is dissolved by the gastric juice, and when it passes into the small intestine the tiny fluke makes its way up the bile-duct into the liver of its victim, there to increase in size and become sexually mature. The disease may be entirely prevented by keeping sheep

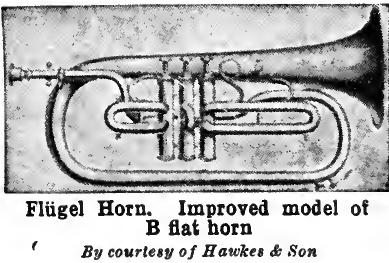

away from damp, ill-drained land. As there is no cure for the disease, sheep showing signs of rot should be slaughtered as soon as possible. See Sheep.

Fluorantheneor $\operatorname{IDRYL}\left(\mathrm{C}_{15} \mathrm{H}_{10}\right)$. Substance found in coal-tar and in the residue known as "stupplett" obtained after the distillation of mercury ores. Crude pyrene from coal-tar is converted into the picric acid compound, whence the fluoranthene is obtained in the free state and recrystallised.

Fluorescence. Absorption of light of certain colour or wavelength, and radiation or emission of light of other wave-lengths by certain bodies. A solution of the green colouring matter of plants, chlorophyll, placed in a dark room where a beam of white light reaches it, becomes luminous and emits a red light from the portions of the liquid on which the white light falls. Paraffin oil, solutions of quinine, of some of the coal-tar dyes such as the red-ink eosine, and of salts, such as barium or potassium platino-cyanide, act similarly. Beams of coloured light do not always excite fluorescence.

For example, although red, yellow or green fail, blue or violet light will at once provoke in a solution of quinine the characteristic pale blue fluorescence. The solution of chlorophyll, on the other hand, retains its red fluorescent light when exposed to most kinds of light, though in viodet light the glow becomes brownish. The light emitted by a fluorescent body is found spectroscopically not to be light of one colour or of one wave-length only, but to comprise light of various colours, with a wave-length always greater than the wave-length of the light which causes the fluorescence. Thus when a beam of sunlight passes through a solution of quinine, it is deprived of its invisible ultra-violet rays, which the quinine converts into blue and violet rays of longer wave length, visible to the eye.

The emission of the fluorescence stops as soon as the light which causes it is cut off. But some substances, particularly the sulphides of barium, calcium and strontium, continue to emit light after the exciting cause has been cut off. 'Thus, after exposure, they glow in the dark. This glow is called phosphorescence, although the glow of phosphorus itself is not due to these causes, but to slow chemical action. See Phosphorescence.

Fluorescein. An aniline dye formed by heating five parts of phthalic anhydride with seven parts of resorcin at a temperature of $200^{\circ} \mathrm{C}$. in an enamelled cast-iron pot. When the reaction has taken place the mass becomes solid and forms a dark-brown cake. The solution in alcohol or alkalies exhibits a brilliant yellow-green fluorescence from which the substance takes its name. It is used for dyeing silk and also for preparing the liquid in druggists' show bottles.

Fluorine. Gaseous element of greenish-yellow colour, first isolated by Moissan in 1886. Its chemical symbol is F. Derbyshire-spar or "blue-john" is calcium fluoride. Cryolite, a double fluoride of aluminium and sodium, is found in Greenland, and the element occurs widely throughout the mineral kingdom, but only in small amounts. Scheele in 1771 first recognized that fluorspar is a fluoride of calcium and prepared hydrofluoric acid, but all attempts to preparefluorine were unsuccessful before 1886. It was liquefied in 1897 and solidified in 1903.

The difficulties in preparing fluorine are very great on account of the extremely active chemical affinity it has for glass and most metals. 'Traces of the gas are very irritating to the mucous membrane, and if brought into contact with the skin the gas causes a bad burn. Alcohol, ether, benzene and turpentine take fire on contact with fluorine. Moissan isolated the element by the electrolysis of anhydrous hydrofluoric acid to which acid potassium fluoride had 
been added in order to make the liquid conduct the electric current. One compound of fluorine and hydrogen is known, but no oxide has been prepared. Although fluorine is akin to chlorine in many properties, there are no fluorine compounds corresponding to hypochlorites and chlorates.

Fluorides. Salts of hydrofluoric acid. They are prepared by acting on a metal, or its oxide hydroxide or carbonate, with hydrofluoric acid. Calcium fluoride $\left(\mathrm{CaF}_{2}\right)$ oceurs native as fluorspar or "blue-john," and from it most of the preparations of fluorine are made. The fluorides of the alkalis are soluble in water and are employed with mineral acids or acetic acid in the processes of etching glass. Some of the fluorides are gaseous at ordinary temperatures, but most of them are stable bodies, and are not decomposed by heat. A series of double fluorides is known. Fluorides are recognized by the evolution of hydrofluoric acid on heating with sulphuric acid.

Fluorspar. Common mineral widely distributed in rock crevices. It is a compound of calcium and fluorine and is used as a source of hydrofluoric acid and as a metallurgical flux. When colourless and transparent it is used for lenses; amethyst, purple, green, or yellow specimens yield "false" amethysts, sapphires, etc., for cheap jewelry. Derbyshire "bluejohn" is made into ornamental vases. The mineral is

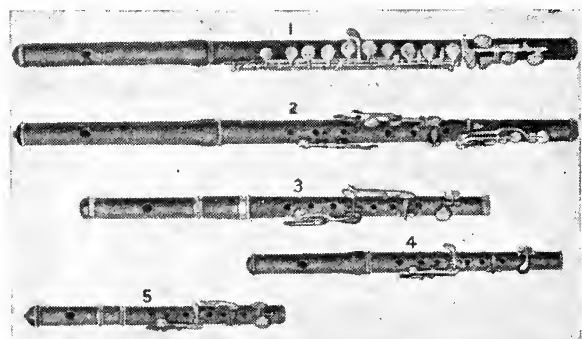

Flute. 1. Boehm concert flute, 26 ins. 2. 8-keyed concert flute, 26 ins., 17th-19th centuries. 3. Military tute in F, $19 \frac{1}{2}$ ins. 4. Military fife in $B$ flat, 15 ins. 5 . Piccolo or octave flute, 12 ins.

also found in Cornwall and Cum berland. In 1920 a new field for the supply of fluorspar was found near Wirksworth, Derbyshire.

Flushing (Dutch, Vlissingen). Seaport of Holland. On the S. coast

porated with the borough in 1908 . It contains schools and a public library, and manufactures chemicals and cinematograph films. Settled in 1643 , it later became the residence of many Quaker families.

Flustra. Group of polyzoa. Usually known as seamats, they resem. ble small brown seaweeds. They are common around the British coasts, and con. sist of a horny, leaf-like skeleton, containing vast numbers of tiny cells. Each of these is occupied by a tiny flowerlike polyp with a row of tentacles which can be protruded from the cell in search of food.

Flute (Lat. flatus, blast). Family name of many wind instruments of the whistle type, whether blown vertically through a mouthpiece or transversely through a side hole.

Down to the end of the 18th century the number of flutes employed in the orchestra was uncertain, and on account of their weak tone several of them were often used in unison; but the modern instruments are so much improved that it is now customary to employ them singly, and the two (or occasionally three) flutes of the modern orchestra play independent parts. Flutes have been made at various pitches, but the scale of the open finger-holes is always called $D$. The transposing of flutes, other than the concert flute of ordinary pitch, has been usually reckoned from $\mathrm{D}$ in. stead of from C. Originally, the six finger-holes were the only means of obtaining a scale, and chromatic notes had to be made by crossfingerings, half stops, and other unsatisfactory means; but key after key has been added until now all the semitones are producible, in good tune and with even tone. The conve. nient compass of the concert flute is as shown, and three semitones higher are possible. The flute is the most agile of the wind instruments, modern mech.

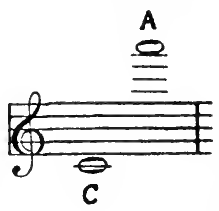
anism having reduced finger difficulties to a minimum. Flute is also the name of an organ stop imitating the tone of the orchestral instrument of the same name. See Fife ; Flageolet; Organ; Recorder ; consult also History of the Boehm Flute, '1896; Six Lectures on the Recorder, C. Welch, 1911.

Flûte-à-bec. Beaked flute, or flute with a mouthpiece, played vertically. See Flageolet; Flauto Traverso; Recorder.

Fluting. In architecture, the grooves in a column, separated by fillets. $\mathrm{Th}$ e elliptical channels in Doric columns a re, however, not called flutes. Fluting is generally verti c a l, but spiral fluting occurs in Norman architecture. See Fluting of column in Architecture. Canterbury Cathedral 
Flux. Term used in metallurgy. Comparatively few metals present themselves in nature in the metallic form, or native, to use the metal. lurgical term; most are combined with other elements, the combina. tion forming an ore. These ores are often difficult to melt, and are smelted by the aid of fluxes.

The chief fluxes are lime or limestone, common salt, sodium carbonate, clay, silica, borax litharge, nitre, carbon, argol or bitartrate of potash, flour, starch, and potassium cyanide, while argol and nitre are used in combination toform "black" and "white" fluxes. See Metallurgy; Smelting.

Fluxion. Term used by Sir Isaac Newton to signify the rate or proportion at which a variable (or flowing) quantity increased its magnitude The fluxion is now usually regarded as the differential. See Differential Calculus; Newton.

Fly. Insect of the order known as Diptera from being charac. terised by the possession of only

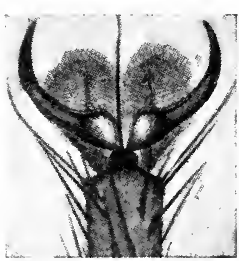

Fly. Foot of housefly bighly magnified tw o wings. 'The fore wings alone remain as flying or. gans, the hind ones having beco $\mathrm{me} \mathrm{re}$ duced to two small balan. c e rs resem. bling drumsticks and known as hallēres, upon which depends the insect's power of balancing itself in the air; if they are removed, the flight at once becomes unsteady.

The wings are without scales and usually hairless, but strongly veined. 'The buzzing sound is produced by the rapid vibration of the wings in flight, which often amounts to 600 beats in a second. The jaws have been modified to form piercing or sucking instruments or both, and the insect feeds entirely on fluids. In the biting species, as gnats and horse-flies, the mouth is provided with a pair of sharp lancets contained in the pro. boscis. The feet of many flies have pads covered with minute suckerlike hairs, with which they can walk upside down or ascend the glass of window-panes.

Flies pass through a complete series of metamorphoses. The eggs are usually deposited in situations where the young may find a supply of food ready to hand, and the larvae are in many cases small white maggots without apparent head, as those of the house-fly and the blue-bottle. In other species, as the gnats, they are aquatic and are
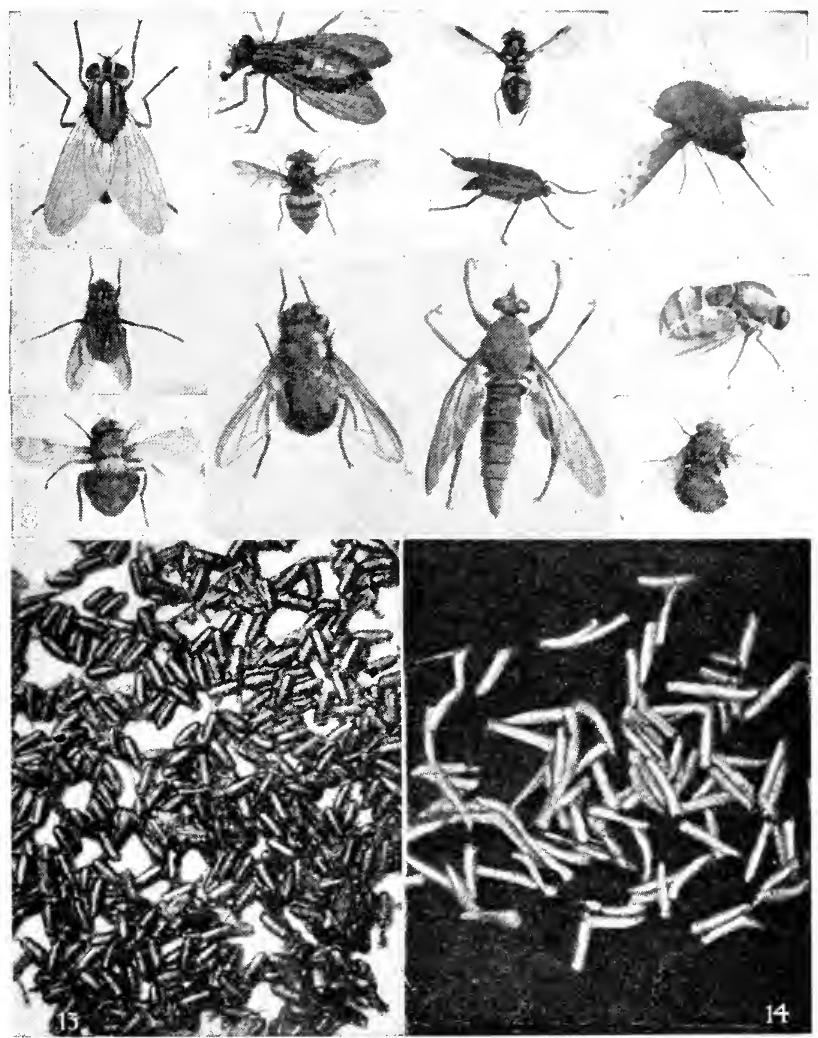

Fly. 1 and 2. House Hy. Musca domestica. 3. Girdled drone tiy, Volucella inanis. 4. Gold-girdled fly, Chrysotoxum bicinctum. 5. Dung fly, Scatophaga stercoraria 6. Humble-bee fly, Bombylius major. \%. Bacon fly, Polictes lardarius. 8. Humble-bee's drone fly, Volucella bombylans. 9. Noontide fly, Mesembrina meridiana. 10. Hornet fly, Asilus crabroniformis. 11. Humpbacked fy, Ogcodes gibbosus. 12. Great Bristly fy, Tachina grossa. 13. Pupae and, 14, maggots of house-fly

1, Nat. Hist. Mus., S. Kensington; 13 and 14, Pub. Health Dept., Liverpool

variously modified to suit their mode of life. In a few species the larvae are parasitic and live in the bodies of their hosts. See Insect; also Bot-fly, illus.

Fly. Word used for a hackney cab, presumably on account of the fact that its speed, when intro-

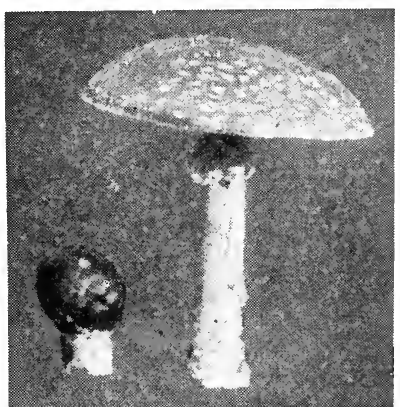

Fly-agaric, the large toadstool. Amanita inuscaria duced, was, comparatively speak. ing, considerable. The space above the proscenium in a theatre, from which the scenes, etc., are controlled, is called the flies. See C'ab; Theatre.

Fly. Largest known river of New Guinea or Papua. It rises among the Victor Emmanuel Mits. in the E. part of the island, and flows S.W. and then S.E. to discharge its waters into the Gulf of Papua by a long, wide estuary. For part of its course it forms the frontier between Dutch and British New Guinea. It bas a length of about $620 \mathrm{~m}$., and is navigable for small craft for nearly the whole of its course. The principal affluents are the Alice and Strickland rivers.

Fly-agaric (Amanita muscaria). Large toadstool of the family Agaricinae. It has a creamy-white stem and gills, the former with a broad soft frill around its upper 
part. The upper side of the cap is orange-scarlet, flecked with irregular particles of white-the remains of an outer envelope. Well known as a poisonous species, it was formerly employed for poisoning fly-papers. It has also intoxicating properties, and is used in Kamchatka in preparing vodka.

Fly Catcher (Muscicapa). Small bird of a family including nearly 300 species. All feed upon insects, which they usually catch on the wing. The tail is in most species considerably shorter than the wing, and while the European species are plainly clad in sombre hues, some of the tropical ones are extremely gorgeous. The pied fly catcher $(M$. atricapilla) comes to Great Britain in the spring, the spotted fly catcher (M. grisola) late in summer, and the red-breasted fly catcher ( $M$. parva) is occasionally seen in autumn. See Egg, colour plate.

Fly Fishing. Fishing with an artificial fly. The flies are made of feathers, silk, tinsel, fur, and other materials. Trout-flies, especially those used in the dry-fly method, are made to resemble as closely as possible some form of fly or other aquatic insect.

The fly, which is attached to the line by a cast of gut of a thickness varying with the shyness of the fish, the colour of the water, and other conditions, may be either sunk deeply in the water, or fished wet near the surface, or floating. The opinions of experts differ about the value of colour in artificial flies, as compared with thcir size and form, but all agree that the principal factor in success is the way in which the fly is pre. sented to the view of the fish. Recent experiments in underwater photography have done much to confirm the view that, when fished "dry" or floating, the important factor in an attractive fly is its silhouette as seen against the light.

It is esiontial in fly fishing for the angler to keep himself and his rod out of sight of the fish, and this condition is usually ensured by keeping low when fishing up or across a stream, and by using a long line when fishing down stream or casting over a loch. Correct casting requires skill which can be attained only by practice. Where the surroundings permit, the rod can be kept up and the cast made overhead; it can also be made underhand, or the line can be got out by the Spey throw or other such methods, such as the downward cut employed against the wind. The best sport to fishermen with the fly in the United Kingdom is given by salmon, sea-trout, and

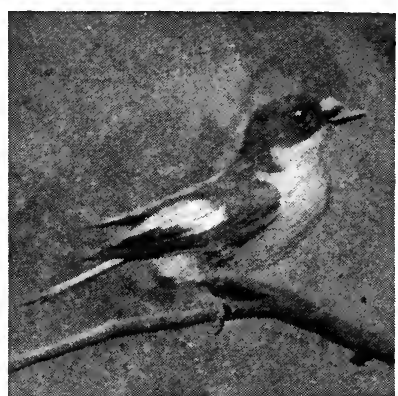

Fly Catcher. The pied fly catcher, a spring visitor to Great Britain

brown trout of different species, and grayling.

Fly fishing with natural flies is another method, but, owing to the difficulty of keeping them on the hook when casting, the method of dapping is employed. The fly is dropped on the water and raised again with a short line, or a long rod is used with a light blow-line, taken out by the wind. See Angling.

Flygare-Carlén, Emirie SмiтH (1807-92). Swedish novelist. Born at Stroemstad, Aug. 8, 1807, in 1827 she married Axel Flygare, and was left a widow in 1833 . She published her first novel, Vladimir Klein, in 1838, under the pseudonym "Fru F." In 1841 she married John Gabriel Carlén, lawyer and man of letters, and continued to write many stories, largely concerned with the life of the Norwegian coast. She died at Stockholm, Feb. 5, 1892. Many of her novels have been translated into English, including The Rose of Tistelon, 1844; The Birthright, 1851 ; The Guardian, 1865. Her collected novels were published in 31 vols., 1869-75. See her Remin. iscences, 1878.

Flying Boat. Aeroplane the body of which is of boat formation. The flying boat is exactly what its name implies. In the hull of the boat space is provided for passengers, pilot, petrol supply, and cargo. The engine is usually placed between the wings, which are attached directly to the boat. The boat itself is capable of being anchored out in harbour in exactly the same way as the ordinary boat, and it can, if necessary, move underits own power on the water without rising. Flying boats are among the heaviest types of aircraft. The N.C. 4 type, for example, which flew the Atlantic in 1919, weighed over 11 tons in flight.

During the Great War flying boats, especially the A.D. flying boat and the large Felixstowe boats built by Commander J. C. Porte, were employed extensively on patrol work and submarine spot- ting. Flying boats are invaluable for all coastal work, while for cross ocean transport, types have been constructed to alight with equal facility on either land or water. See Seaplane.

Flying Buttress. In architecture, a half arch used to transmit the thrust or pressure of a structure, usually a vault, to a main buttress or solid foundation. Flying buttresses were first used in France in the 12th century, and formed a principal decoration of the exterior of French cathedrals. There are fine examples at West. minster Abbey. See Buttress.

Flying Column. Body of lightly equipped, self-supporting troops which operates for short periods at a distance from its base. Such bodies are necessary when regular armies are engaged in putting down guerrillas. The term has also been applied to large forces like those of Sir Donald Stewart and Sir Frederick (later Earl) Roberts, which during the Afghan War of 1878 abandoned their communications in order to march to the relief of a beleaguered garrison.

Flying Corps, Royal. Former branch of the British army. Early military aviation in the British

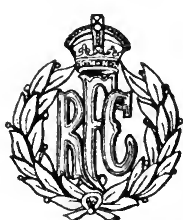
army was in the hands of the bal. loon section of the Royal Engin. eers, a branch formed when the value of observa. tion balloons was first recognized. Flying Corps badge It subsequenly controlled the

service airships and, later, aeroplanes, but little encouragement was offered officially. In 1912 the Royal Flying Corps was formed, being mainly constituted of officers convinced of the value of the new arm who had become pilots privately at their own expense. It incorporated a Naval Wing, though this was controlled from the air department at the admiralty and became independent in 1914 as the R.N.A.S.

The R.F.C. was much handicapped by inefficient equipment and lack of official foresight, and at the outbreak of the Great War had a total personnel of approximately 2,000 and only 82 aeroplanes in fit condition to send overseas. Indomitable courage and individuality enabled many difficulties to be overcome, and the services rendered in the early stages of the war were invaluable, but the equipment was never superior to that of the enemy until the De Haviland and F.E. machines ẁere introduced to counteract the 
German Fokkers. The corps was greatly expanded until April, 1918 , when it was merged into the Royal Air Force, the officers being granted the option of remaining in the army. The badge of the corps was R.F.C. as a monogram within a wreath surmounted by a crown. See Air Force, Royal.

Flying Dutchman, The. Spec. tral ship traditionally haunting various seas. It is generally associated with the latitude of the Cape of Good Hope, about which it was said to be ever moving under crowded canvas, unable to reach port. The vessel was supposed to be thus doomed owing to the abominable acts of her crew headed by their captain, Vanderdecken. Her appearance is deemed a por. tent of disaster. The legend was dramatised in The Flying Dutchman by Douglas Jerrold, 1829, and later by Edward Fitzball ; Captain Marryat founded his story, The Phantom Ship, on it, 1839; and it inspired Richard Wagner's opera, The Flying Dutchman, 1844.

Flying Fish (Exocoetus). One of a yroup of tropical fishes. It includes over forty species which have the pectoral fins so lengthened as to resemble wings. 'They are in the habit of leaping out of the water to escape their enemies, and taking long skimming flights above the surface, supported by their dis. tended fins, which are not used as propelling instruments.

Flying Fox. Erroneous name for the fruit bat, of the genus Pteropus. It is due to the fact that

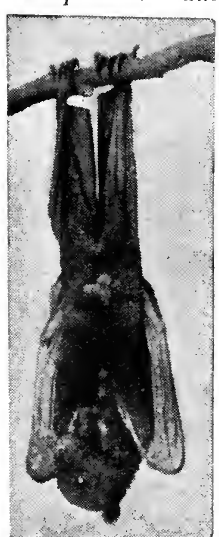
its head slight. ly resembles that of a fox. Unlike other bats, which it greatly sur. passes in size, it feeds entirely on flowers and fruit. It is found in $S$. Asia, the E. Indies, Mada. gascar, Aus. tralia, and some of the Pacific islands. 'The largest species, that of Malaya, Pleropus edulis,

Flying Fox. The measures over Malayan flying fox, $5 \mathrm{ft}$. between the largest bat the tips of the wings, and is considered a great delicacy. The fruit growers of Australia suffer much from its depredations, and in 1920 the Queensland dept. of agriculture made the experiment of employing flame projectors against it. Sce Bat.
Flying Lemur (Galeopithecus). Popular name for the colugo of Malaya. The loose skin along the

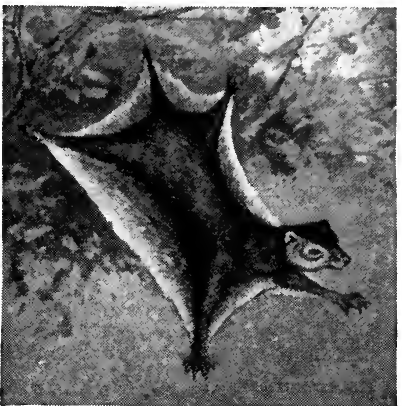

Flying Lemur, Galeopithecus, with skin distended for gliding

sides of the body and neck spreads into a kind of parachute when the animal launches itself into the air, enabling it to cover at one bound as much as $70 \mathrm{yds}$. from tree to tree. It feeds chiefly on leaves.

Flying Machine. Any heavierthan-air machine designed for mechanical flight. The term is now usually applied to an aeroplane in contradistinction to an airship. See Aeroplane.

Flying Officer. Royal Air Force title for officers, other than those who have specialised as observers. Officers of equal rank who are employed as observers, having specialised in this branch, are known as observer officers.

Flying Phalanger (Petaurus). Small squirrel-like opossum, of which there are three species, found

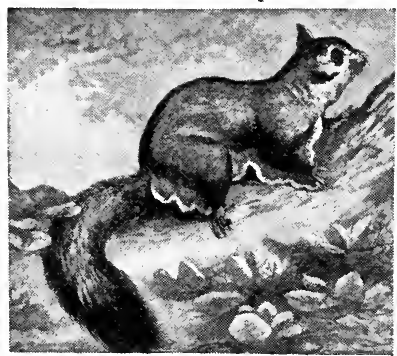

Flying Phalanger, a squrrel-like marsupial

only in Australia and New Guinea. It is able to take long gliding leaps through the trees, partly supported by a membranous extension of skin. It feeds upon insects, fruit, and blossoms.

Flying Speed. Normal speed which an aeroplane must maintain in order to remain in the air, or the actual air speed of a machine neces. sary for its support in the air. This must not be confused with the apparent or ground speed of the machine. See Air Speed.
Flying Squid (Ommastrephes sagittatus). Species of squid or cuttle fish. Long and nar. row in shape, it is common in the open seas, and forms an im. portant part of the food of the sperm whale. It is of ten called the sea arrow, from its habit of darting backwards out of the water for a considerable height.

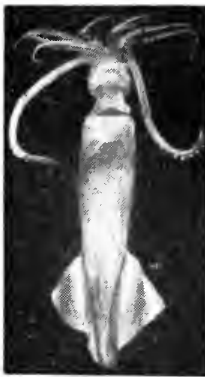

Flying Squid, a cuttle fish which springs out of the water

Flying Squirrel (Pteromys). Squirrel found in N. America, Asia, and E. Europe. Members of this group are able to simulate flying

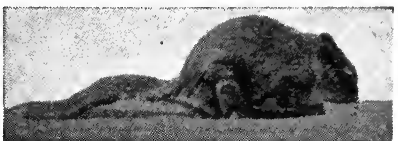

Flying Squirrel of North America

by the extension of the loose, lateral folds of their skin. There are a large number of species, varying considerably in size and colour, and all are nocturnal in habit. See Squirrel.

Flysch. Geological formation. It consists of enormously thick series of sandstones and shales, occurring in the Alps, Apennines, Carpathians, Istria, Dalmatia, Bosnia, Greece, Asia Minor, Caucasus, stretching through S. Asia and still further East. Their exact age is uncertain, but varies from lower Cretaceous to middle Tertiary. They represent a phase of deposition of sediments of long duration and great geographical extent.

Fly-wheel. Large, heavy-rimmed wheel mounted on a shaft which is subjected to, or has to exert, a turning effort more or less intermittently. By virtue of its inertia it acts as a reservoir of energy and has a powerful steady. ing effect. A fly-wheel is essential on any crankshaft driven by reciprocating engines which by themselves would not keep the shaft in continuous motion, to help the crank or cranks over their dead centres (q.v.), and, even where there is continuous motion, to prevent it being spasmodic through sudden fluctuations of load, or, in the case of the internal-combustion engine especially, of turning force. See Steam Engine.

Foal. Young of the horse and of the ass, of either sex. The term colt has come to be appropriated to the young male animal; filly, a 
diminutive of foal, to the young female, but formerly the distinction was less rigid. The word is connected ultimately witlı Gr. pōlos, foal, and Lat. puilus, young animal.

F.O.B. Abbrev. for free on board. When goods are sold f.o.b. it means that the price quoted covers all charges until they are placed on board ship.

Focal-plane Shutter. Appliance for very rapidly uncovering and re-covering the photographic

\section{FERDINAND FOCH : FRENCH SOLDIER}

Sir W. Beach Thomas, K.B.E., Special Correspondent of The Daily Mail

This biographical sketch should be supplemented by the articles on the various battles of the Great War, especially those of I9I 8 when Foch broke down the German resistance. See Clemenceau; French: Haig ; Pétain

Ferdinand Foch bears a surname probably derived from fioch, a local word meaning fire. The Foch family belonged to Valentine, a town in the Haute Garonne, and Foch, like Joffre, is of southern stock, both on his mother's and father's side. His father, Bertrand Jules Napoléon, left his ancestor's woollen trade to become a civil servant. Ferdinand Foch was born at Tarbes on Oct. 2. 1851. A younger brother, Germain, became a Jesuit, a fact of cardinal im. portance in Foch's career.

Ferdinand was a studious boy. At 12 years old his favourite reading was Thiers' History of the Consulate and Empire, and he always earned high commendation from his instructors. He was educated wherever his father's movements dictated: first in Valentine, then in St. Etienne, at the Collège $\mathrm{S}$. Michel, which was under the direc. tion of the Jesuits. After taking his degree there he was sent to the Collège de $\mathrm{S}$. Clément at Metz. In 1870 the Franco-Prussian War broke out, and Foch enlisted.

After the war he at once returned to Metz, but at the end of a year entered by request the engineering and artillery establishment at Fontainebleau, which he left as 2nd lieutenant in 1874 . $\mathrm{He}$ was first attached to the 42nd regiment of artillery stationed at Tarbes. Two years later he took a course at the cavalry school at Saumur, and in 1878 was made captain of the loth regiment of artillery. He was one of the officers picked for the school of war in 1885 , and on leaving it was put on the staff of a division. $\mathrm{He}$ was appointed to the general staff in 1894, a year later appointed associate professor, and later full professor, of military history, strategy, and applied tactics at the Ecole Supérieure de Guerre, or staff college. plate in photographing quickly moving objects. It is an opaque flexible blind mounted on spring rollers close in front of the plate, having in it either severa lits of different widths or ne width of which can be altered. The plate can thus be exposed for a time ranging from $\frac{1}{10}$ th to $\frac{1}{1000}$ th of a second, axcord$\mathrm{ng}$ to the width of the slit and the tension at which the spring is set. see Photography.

Foch's lectures there made his name, first in France, then outside. The bulk of them were collected in two books, The Conduct of War and The Principles of War, the latter translated by $\mathrm{H}$. Belloc, 1918; both have become classics. They are not narrow military treatises. Much space is

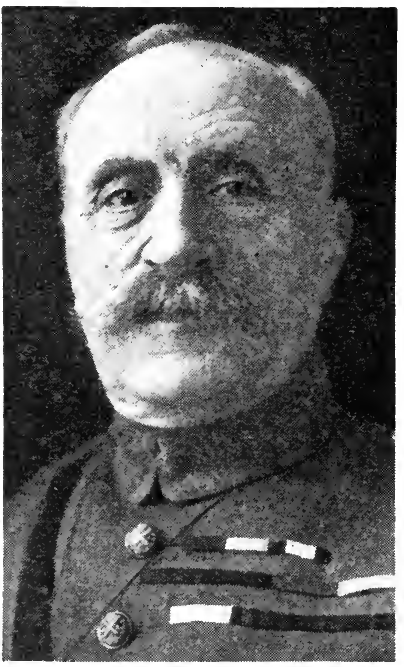

devoted to win power and moral f orce. The

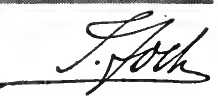
general argument is that though the art of war is simple, few can acquire it, for its execution is complicated and it demands the highest will, purpose, and strength in a commander who can impart them to his soldiers.

In 1901 Foch was sent to com mand a regiment. It was generally held that his religious belief, and the fact that a brother of his was a Jesuit, were the causes of this transference, which seemed to in. volve a great setback in his career In 1903 he was appointed full colonel, in 1905 chief of staff to the 5th Army Corps, in 1907 brigadiergeneral with a position on the general staff. Clemenceau had just become prime minister, and offered General Foch the command of the Ecole de Guerre. His $4 \frac{1}{2}$ years in that position were invaluable to France. He made good officers, and was intensely admired by his pupils. His work was done when in 1911 he became general of division, in 1912 of the 8th Army Corps, and in 1913 took command of the 20th Army Corps at Nancy.

On four critical occasions during the Great War, before he was appointed generalissimo, Foch proved his principles in action, first in the defeated French offensive, and the subsequent defence of Nancy in Aug., 1914; secondly, at the battle of the Marne in Sept. ; thirdly, with the British at Ypres in Oct. of the same year; and fourthly, on the British right flank in the battle of the Somme, which began on July 1, 1916. As soon as Nancy was saved, largely through the 20th corps under Foch, Joffre called on him to form and command a new army, the 9 th.

This was Aug. 24. The work was done with amazing speed and thoroughness, and on Sept. 5 the battle of the Marne began, Foch having his headquarters at La Fère. 'The turn of the tide was marked by a dispatch from Foch that will always be famous: "I am heavily pressed on my right; my centre is giving way; I cannot redistribute my forces. The situation is excellent, and I shall attack." $\mathrm{He}$ attacked and won.

Again on July 1, 1916, Foch shared in one attack, taking the right wing on both sides of the river Somme. His artillery work was so perfect that the first ad. vance of the infantry were singularly bloodless, and the success overwhelming at every point. On Sept. 30, 1916, Foch reached the age limit. He was given the military medal, kept on the active list, but taken from any particular command. On Dec. 13 he became director of a new bureau for the study of inter-Allied questions.

He soon began to press for the creation of a strong Allied reserve, and it was decided early in 1918 to give the command of it when formed to Foch. But other counsels began to prevail, and against his earnest protest the inter-Allied reserve was whittled down. Then came the very critical German offensive on March 21, 1918. The way to Paris lay open, a wedge was driven between 
French and British, and the imminence of the danger brought every. one round to the principle of unity of command.

A momentous inter-Allied conference took place at Doullens on March 26, as the result of which Foch became "Generalissimo of the French, British, American, and Belgian forces fighting upon the western front." After checking the final German offensive opened between Reims and Soissons on July 15, Foch on July 18 launched his decisive counter-offensive on the Marne, the result of which was seen when on Oct. 28 the German message agreeing to an armistice on the basis of President Wilson's Peace note came, and on Nov. 11 the armistice was signed. General Foch, who was elected marshal of France on Aug. 6, showed his great qualities in the peace as in the war. He was the chief cause of the acceptance of the German offer, and largely framed the preliminary terms of peace. He had indeed "deserved well of his country," as the deputies unanimously voted on Nov. 11, 1918.

But he had yet much to do: the organization of the advance to the Rhine and the bridgeheads, repeated conferences at Spa and Trèves with the Germans and Allied leaders. In every act of a continuously strained situation his opinion was the master opinion.

Throughout all this strain Marshal Foch, in spite of illness, and even when his son was killed, lost none of his calm, and at every juncture gave those who met him the sense of a man who possessed in himself an inexhaustible reserve of quiet confidence, founded on force of will and clearness of intellect in effective combination. See Marshal Ferdinand Foch, A. H. Atteridge, 1919; Foch, His Character and his Leadership, Raymond Recouly, 1920.

Fochabers. Village and tourist resort of Elginshire, Scotland. It stands on the Spey, $8 \mathrm{~m}$. S.E. of Elgin, and is the trading centre for the surrounding district. Near is the duke of Richmond's seat, Gordon Castle. Pop. 972.

Focsani, Focshani or FokshanI. Town of Moldavia, Rumania. It is $90 \mathrm{~m}$. N.E. of Bukarest, about $4 \mathrm{~m}$. from the river Sereth, and was in normal times a prosperous agricultural centre, with a considerable grain trade. Fortified, it formed a bridgehead on the Sereth line during the Great War; it was the scene of very bitter fighting in the first week of Jan., 1917, falling on Jan. 8 to the Germans. Pop. 25,000. See Rumania, Conquest of ; Sereth, Battles of the.
Focus (lat., hearth). Primarily the point at which converging lines or rays meet, but usually any point through which rays of light, heat, etc., or lines pass.

In mathematics a focus is a point from which, if lines are drawn to any points on a curve, the lengths of these lines are connected by some law, e.g. in a parabola any point on the curve is equidistant from the focus and a fixed straight line.

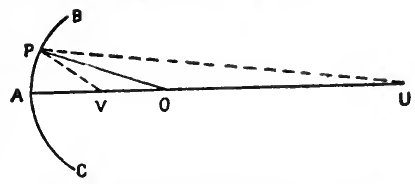

Focus. In the diagram C A B is part of a spherical mirror whose centre is 0 . A ray of light from $U$ strikes the mirror at $P$, and is reflected along $\mathbf{P}$. The angle U P $\mathbf{O}$ is equal to $\mathbf{0} \mathbf{P}$ V

In optics, sound, heat, etc., where rays or waves are considered, the focus is the point to which the rays are brought after reflection from a curved surface or after refraction through a lens. See Conic Sections; Concave Mirror and Lens ; Convex Mirror and Lens; Lens.

Fodder. Name applied to the bulky part of the food of stock. It may be either green and succulent, or dry, like hay or straw. The first of the four chambers of the stomach of cud-chewing animals, such as the ox, sheep, and goat, is very large, and digestion cannot go on properly unless it is well filled. Fodder is, of course, more or less nutritious, but it is rendered bulky by the presence of a large amount of fibre, only a small part of which can be digested. Fodder thus contrasts strongly with grain and artificials, such as the different kinds of cake, which contain nutriment in a highly concentrated form.

Foetus (Lat., offspring). Biological term meaning the young of an animal, usually with reference to a visible embryo either in an egg or within the womb. The term is applied to that stage of the development of the embryo after its various parts can be distinctly distinguished up to the period of birth. See Embryology.

Fog. Clouds either close to or in contact with the ground. The conditions for the formation of clouds are the presence of dust and water vapour in the atmosphere, and the falling of the temperature of the air below dew point, i.e. that temperature at which the atmosphere is incapable of holding its invisible water vapour without condensation. If these conditions are fulfilled, each particle of dust receives a thin coating of water. In the country, fog is usually white, but in large towns and cities it is sometimes dense and black.

Extensive fogs are also produced where currents of air of different temperatures come in contact with each other. Thus, off Newfoundland, the warm air from over the Gulf Stream Drift meets the air chilled by the cold Labrador current, and the region is probably the foggiest in the world. Valley bottoms and low-lying meadows frequently experience light fogs or mists due to the chilling of the lower atmosphere during the night, but such fogs are usually dispersed by the morning sunshine, except in winter, when the sun's rays may be of insufficient strength. Extensive fogs are prevalent over lowlands during spells of cold but quiet weather. See Cloud.

Fog Signals. Warning or information given by various contrivances, usually for producing sound, when visual signals are obscured by atmospheric conditions.

On the roads horsed vehicles sometimes use bells, motor vehicles their normal horn equipment. On railways detonators clamped to the rails and exploded by the approaching engine warn its driver of danger. Fogmen exhibit red flags or lamps, subsequently notifying the all-right position by changing to green. Various mechanical and electrical devices for com. municating these signals from signalbox to driver have been proposed.

On the sea, in fog, mist, snow, or heavy rainstorm, board of trade regulations require vessels at anchor to ring bells, steamships under way to sound whistles or sirens, sailing vessels foghorns, fishing craft bells and horns alternately, all according to a prescribed code.

The prototype of modern coastsignals was the medieval bell, as on the Inchcape Rock (q.v.). Bellbuoys are numerous in Great Britain, whistling buoys in the U.S.A. In pierhead and breakwater bells the clappers are operated by clockwork, sometimes motor-driven. Two-ton bells, with a 14-m. range, have been used. Some ports and harbours have rced-horns, some lighthouses Mait. land bell-mouth guns. Guncotton rockets, introduced in 1878, are now superseded, especially on rock stations such as Eddystone, by explosive signals, usually tonite cartridges on iron jibs, detonated electrically at fixed intervals. Unattended acetylene fog-guns in the Clyde are switched on by wireless energy transmitted from aerials on Gourock pier. Steam or air whistles, general in N. America, are sometimes fitted with megaphones. 


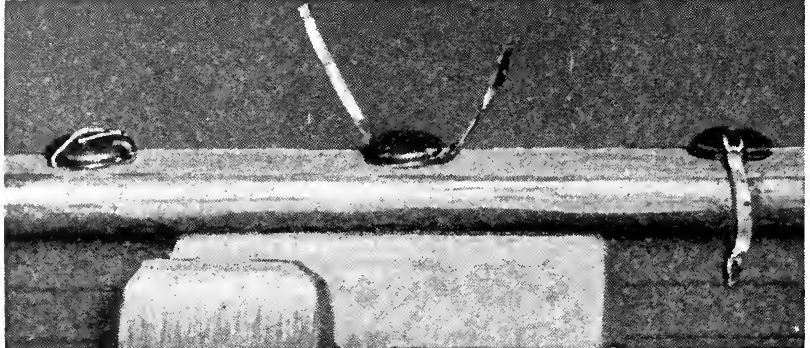

Fog Signal. Left to right: explosive cap with flanges folded, as kept in store; flanges opened for adjustment to rail ; cap attached to rail

The most powerful contrivances are trumpets-22 ft. long at $\mathrm{St}$. Catherine's Point-attached to compressed-air sirens. - These usually comprise two slotted disks or cylinders. In Canada singlecylinder diaphones have slots alternately covered and uncovered by piston-strokes. Mushroom trumpets, as on the Caskets, distribute sound all round the horizon. The siren at Platt Fougère, Guemsey, has been heard $33 \mathrm{~m}$. away. Sounddirection is attempted in America by megaphones rotating singly, or by eight megaphones fixed radially, short and long blasts of Morsesignal type being sounded according to the compass direction. Topophones are double-trumpet receivers with ear-pieces, for direction-finding.

Under certain atmospheric conditions soundless zones are interposed between near and distant audible zones. Hence the ntility of submarine bells, placed on seafloors, buoys, and light-vessels, and audible to ships fitted with ears having a $10 \mathrm{~m}$. range, and connected with telephone receivers on the bridge. In Oct., 1920, it was decided to lay down in French ports submarine cables emitting during fog musical sounds audible through similar telephone receivers. In 1910 the United Kingdom had 308 coast-signals; Canada, 215 ; France, 48 ; U.S.A., 407.

As to aircraft, aviation soundsignalling is in its infancy. Owing to the dominating noise of the propellers, bells, horns, and whistles are practically ineffective. Airships at rest, when hearing the propellers of an invisible neighbour, sometimes fire pistol-shots. Under suitable conditions aircraft and aerodromes use Very lights and directional wireless to facilitate landing in fog. 'The erashing of an American dirigible against a Califormian mountain-peak in fog on Sept. 30, 1920, shows that complete immunity from fog perils is unattainable by external signalling alone. See Foghorn; Siren.
Fogaras. Former county of Austria-Hungary, in Transylvania, now belonging to Rumania. It is traversed by the Fogaras Mts. which constitute part of the 'Transylvanian Alps, the loftiest peak being Szkára, which reaches an alt. of $7,570 \mathrm{ft}$. The capital is Fogaras.

Fogaras. Town of Rumania, in Transylvania, formerly in AustriaHungary. It is on the river Aluta, $55 \mathrm{~m}$. E. of Hermannstadt, and N.W. of Kronstadt (Brasso), and is the capital of the county of Fogaras. Taken by the Rumanians in their campaign against Austria, Sept., 1916, it was evacuated by them Oct. 4-5, when the Rumanian second army retreated towards Kronstadt, yielding up the Fogaras. Vladeni sector. See Rumania, Conquest of.

Fogazzaro, Antonio (18421911). Italian poet and novelist. He was born at Vicenza, March 25 ,

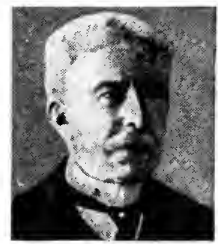

1842. His first poems, 1863 , were followed by a poetic romance, Mirand a, 1874 , and a volume of lyrics, Vals o ld a, 1876 , which established his repu.

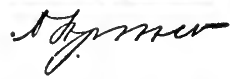

tation as a poet. These were succeeded by the stories, Malombra, 1882, and Daniele Cortis, 1885. In 1888 came his first considerable success, the idyllic Mistero del Poeta; then the notable trilogy, Piccolo Mondo Antico, 1895 ; Piccolo Mondo Moderno, 1901; and Il Santo (The Saint), 1906 ; the last of which, his most famous work, was translated int: most European languages. A staunch Roman Catholic, Fogazzaro sought to reconcile the theory of evolution with the teaching of his church; he has been described as Italy's modern poet of hope and faith. He died March 7, 1911. See Study (in French) by L. Gonnari, 2nd ed. Paris, 1918.
Fog-bow. White-coloured rainbow sometimes seen in a thick fog. It is due to the extreme smallness of the floating drops of water which constitute the fog.

Fog Crystal. Phenomenon observable during fog and frost. Fog crystals are usually formed by particles of ice on surfaces in a fog, in frosty weather, as the fog is driven over those surfaces. 'These crystals, most common in hilly districts, are feathery in appearance, often reach several feet in thickness, and form with great rapidity in favourable conditions. See Frost; Snow Crystal.

Foggia. Prov, of S.E. Italy, formerly known as Capitanata. Bounded N. and E. by the Adriatic Sea, it has an area of $2,683 \mathrm{sq}$. m. Mountainous in the N.E. and W., the central part is occupied by the fertile plain of Apulia. The coast is low and flat, and the climate hot and dry. There are numerous rivers, the chief of which is the Candelaro, with many tributaries. The lakes of Lesina and Varano lie in the N. of the prov., and the Lake di Salpi in the S.E. The highest point is Monte Calvo, which has an elevation of $3,460 \mathrm{ft}$. Vast flocks of sheep are pastured on the plain. Pop. 484,557. Pron. Foj-ja.

Foggia. City of Italy, capital of the prov. of Foggia. It stands in the centre of the Apulian plain, 78 m. E.N.E. of Naples, and $20 \mathrm{~m}$. W. of Manfredonia, a junction of the coast rly. and the lines to Benevento and Potenza. The 12 th century Gothic cathedral was partly destroyed by an earthquake in 1731, and rebuilt. An important fair is held every May for the sale of sheep, wool, corn, capers, and cheese.

An ancient city, Foggia was a favourite residence of the emperor Frederick II, whose English wife, the daughter of King John, died here. Three miles $\mathrm{N}$. of the eity are traces of the ancient town of Arpi, or Argyripa, reputed to have been founded by the great hero, Diomedes. Pop. 79,213.

Foghorn. Instrument carried by ships to indicate their presence to other vessels during a fog at sea. Foghorns differ in shape. A com. mon type looks like a chimney cowl. Board of Trade regulations require sailing vessels under way, and vessels towed, to sound foghorns at one-minute intervals. They may be operated by mouth, hand, or mechanical power, and make a raucous sound in monotone, of uniform or varying intensity.

The types designed for shore use are especially employed for port and harbour signals. The note is 


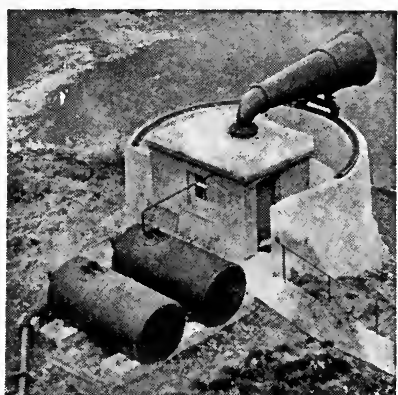

Foghorn installed on the Bass Rock

usually produced in reeds with metal tongues like organ-pipes, which may be manual or engine. driven. The more powerful horn installations used on steam vessels, and some coast stations, are technically called sirens.

Fogo (Port., fire). Volcanic island of the Cape Verde archipel. ago. Circular in shape, and mountainous in character, it has an area of about $190 \mathrm{sq}$. m. The loftiest point, the Pico do Lano, nearly $10,000 \mathrm{ft}$., has often been in erup. tion, notably in 1847, when it caused immense damage. Fertile in the $N$., where coffee, sugar, maize, and fruit are produced, it is almost barren in the $\mathrm{S}$. The chief town and port is São Filippe, or Nostra Senhora da Luz-our Lady of Light. Pop. 16,500.

There is another island of this name off the N.E. coast of Newfoundland in lat. $49^{\circ} 40^{\prime} \mathrm{N}$. and long. $54^{\circ} 10^{\prime} \mathrm{W}$.

Föhn (Ger.). Warm, dry wind experienced in Alpine valleys. In the circulation of the atmosphere air is caused to descend mountain slopes. During its descent it is heated by compression, and being thus enabled to hold more moisture, it descends as a warm, drying wind, which in a few hours clears away more snow than many days of bright sunshine, and uncovers the upland pastures.

In some valleys the early sowings are entirely dependent upon this wind, whilst in others it is relied upon to ripen the grapes in autumn. Strictly the term should not be used of a wind, but mercly of the effect of descent upon a wind. The föhn effect may be recognized in most mountainous areas in temperate latitudes.

Föhr. Island in the North Sea, one of the N. Frisian group, belonging to Germany. It lies off the $W$. coast of Slesvig, opposite Dagebuill on the mainland, and has an area of $32 \mathrm{sq} . \mathrm{m}$. Largely marshland, protected in the $\mathbf{N}$. by dykes, it is elsewhere elevated and timbered, with fertile soil. The inhabitants live by wild-fowling, fishing, and sea-faring. The chief town is Wyk, which is a resort on the E. coast. Pop. 4,500.

Foie-gras (Fr.,fat liver). Livers of geese enlarged abnormally by keeping the birds in a heated com. partment, and made into the paste known as pâté de foie-gras. The Strasbourg variety is well known. See Goose.

Foil. Weapon used in fencing. It is a very slender, four-sided steel blade, with a handguard to the hilt, and a button on the tip, the object of the fencer being to tou ch some part of his op. ponent's body with that button. See Fencing.

Foil. metallurgy, a thin form of metal, which may be said to occupy a position intermediate between a leaf, as gold leaf, and sheet metal. A very thin tinfoil is $\mathrm{made}$ for ehemical and electrical uses,

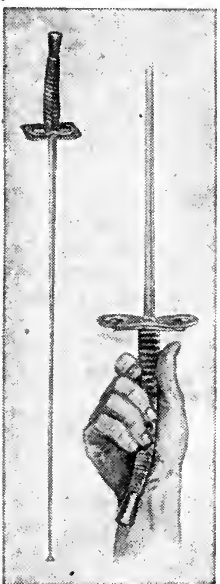
showing method of and for backing mingording a rather thicker foil much used for theatrical purposes; Dutch foil is specially prepared for the backing of artificial gems, being made very thin, and coloured by means of Prussian blue and other pigments. Gold foil is used by dentists for stopping teeth.

Ordinary commercial tinfoil, largely used for wrapping tobacco, chocolates and other sweets, and toilet articles, is made of lead coated on one or both sides with tin, the two metals being rolled together so that they become quite inseparable. The tin surface may have merely an infinitesimal thick. ness, yet it is sufficient to prevent contact with lead. The latter metal contributes the substance and the flexibility to the foil; the tin, which is much the more ex. pensive metal, provides the nonpoisonous surface.

Attempts have been made to substitute aluminium in the manufacture of foil, on account of its light weight, but so far without much success. A beautiful variegated foil, which we owe to the Japanese, is made by soldering together by their edges 30 or 40 thin sheets of gold, silver, copper, and various alloys ; punching or cutting a pattern through these sheets, the holes going to varying depths, then rolling down the "book" of sheet. to the desired thinness. The holes entirely disappcar in the finished product.

Foix. Town of France, capital of the dept. of Ariège. It stand. between the rivers Ariège and Arget, $46 \mathrm{~m}$. S. of Toulouse. It interest is mainly historical. The capital of the county of Foix, the powerful counts of Foix lived in it castle, of which there are some remains on the rock, round which the older part of the town clusters. The church of S. Volusien dates from the 14th century. There are some small industries, and the town is the commercial and ad. ministrative centre for a large district. The county of Foix varied in extent from time to time. It was ruled by its counts, vassals of the king of France, and was one of the provs. into which France was di. vided before the depts. were created. Pop. 6,806. Pron. Fwah.

Foix. French family, rulers of the county of Foix, between about 1000 and 1500. A Roger, a descendant of the count of Carcas. sonne, first assumed this title when he inherited the lordship of the town and the surrounding lands. A succession of counts followed, who, like other nobles of the time, went on crusades; fought with neighbouring rulers; at times defied the king; frequently quarrelled with the Church; and had their own special feud with the family of Armagnac.

About 1300 one count married the daughter of Gaston, viscount of Béarn, and this union brought to the family the name of Gaston, and also the district of Béarn. The counts were now much more powerful than formerly, and this culminated in the career of Gaston Phoebus, whose splendid court is so vividly described by his guest, Froissart. For forty years he was almost constantly at war, but he found time for the things of the mind. He died in 1391, leaving to Charles VI his possessions of Foix and Béarn.

Charles gave these to a descendant of one of the earlier counts, and a second ruling family arose, to play the part of great French nobles for another century. They married into the royal families of France and Navarre, and in 1479 one of them, Francis Phoebus, became king of Navarre. He left no sons, so the county passed to his sister, the wife of Jean d'Albret, and thence to the family of Bourbon (q.v.). Henry IV, on becoming king of France in 1589 , added Foix to 
the royal domain. A member of a younger branch of the family was the famous soldier Gaston de Foix (1489-1512). An earlier member was Peter, a cardinal and archbishop of Ailes.

Fokchany.Alternative spelling of the Rumanian town Focsani (q.v.).

Fo-Kien or FU-KIEN. Coast prov. of China, lying almost entirely between lat. $24^{\circ}$ and $28^{\circ} \mathrm{N}$. Area, 46,332 sq. m. The prov. is mountainous, comprising a series of ranges running parallel with the coast. The chief waterway is the river Min, $260 \mathrm{~m}$., which flows into the sea below Foochow, the capital. Fo-Kien is noted for its tea and timber, but the value of the tea trade has steadily diminished. Minerals abound, but have not been worked. Fishing is an active industry. Amoy is an important town. Pop. 8,560,000.

Fokker. German type of aeroplane $(q . v$.$) . It sccured much notori-$ ety during a stage of the Great War. A. H. S. Fokker was a Dutch aviator who just before the outbreak of war was building monoplanes in Germany. For war purposes he evolved a very fast biplane with which the Germans gained a considerable amount of success until they were met by better pilots and machines. Fokker also produced a triplane which in many respects was a copy of the Sopwith triplane.

Fold. In geology, the curvature of strata induced subsequent to their deposition in more or less horizontal layers. The result of lateral compression due to movements of the earth's crust, it varies in com. plexity. The simplest form of flexure is in one direction, monocline; folding round a dome is termed quaquaversal ; that forming a basin centroclinal. Symmetrical folding about an axis may result in production of troughs (synclines) or of arches (anticlines). Doubling over of beds forms overfolds, which are termed recumbent when the axial plane is nearly horizontal. Irregular complex folding results in contortion. See Earthmovement; Geology ; Rocks.

Folding Machine. Machine primarily in use in printing to convert into sections the flat sheet of printed paper as it comes from the press. Before its adoption these flat shects were folded by hand.

Each class of machine varies in its action, but generally the folded sheets are automatically fed up to a side-gauge on the machine bed, and then brought to the correct position by an automatic device to en sure accurate folding. A descending blade then presses the sheet between two revolving rollers through which the sheet passes, thus mak. ing the first fold. The sheet $t h$ e $n$ travels to the second pair of rollers, set at right angles to the first pair, where a simi. lar action is per. formed, and so on for each succeed. ing fold.

Some machines a re made for parallel fo $1 \mathrm{~d}$ in $\mathrm{g}$, i.e. folding the $\mathrm{sheet}$ over and over in the same direction by blades and rollers parallel with each other operating consecutively. Imagine the first fold down the centre of one way of the sheet and the second fold parallel with the first; we then have the sheet the original length one way, and one-fourth the original length the other way; a third parallel fold is then made, and as this enters the delivery it is slit into sections by slitting disks. Thus a

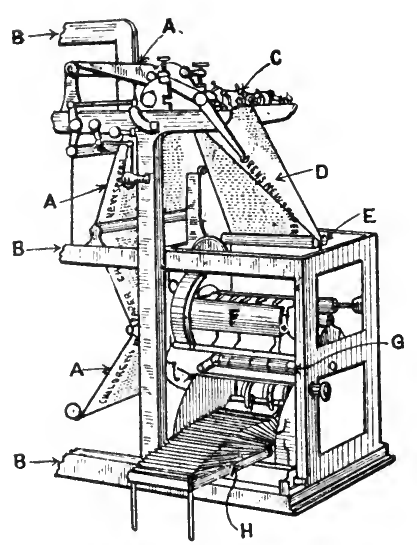

Folding Machine. Diagram illustrating mechanism of folder section of newspaper press. A. Endless of newspaper press. A. Endless
paper web. machine. C. Rotary knife to slit paper. D. Paper over $V$ plate. E. Rollers to bend paper. F. Folding cylinder. G. Folding roller. H. Copies ready folded

work, 128 pages, of the same size as the Universal Encyclopedia would consist of 8 sections of 16 pages folded in the manner last described, 2 sheets each 40 ins. by 54 ins. being converted into 4 sections 10 ins. by $6 \frac{3}{1}$ ins. This principle of parallel folding is adapted to printing machines producing magazines. For example, The London Magazine is printed and folded in 96 pages at one operation and delivered in six sections of 16 pages.

In all the latest styles of folding machines the sheets are fed in auto- matically, and in some instances sheets are supplied from piles, folded, gathered, stabbed, and the covers glued on before delivery.

The uninitiated have probably been puzzled as to the reason of letters in the bottom margin of a book; these are identification marks, and indicate the sections in which the book is folded, thus, the first page of the first section of 16 pp. or $32 \mathrm{pp}$. will be marked A and the first page of the second section $B$ and so on. These letters enable the sections to be collected in their right sequence instead of by pagination.

Newspapers are folded by means of an auxiliary part of the printing press. The endless web of paper travels over a V-shaped plate, forming the first fold or spine of the newspaper; the web continues its course (now in page size) until it reaches another section of the machine, the next fold being then accomplished by means of a turning blade which is attached to and rotates in a cylinder. There are many types of folding machines for boxmaking, notepaper folding, etc.

A. B. Blayney

Foleshill. Parish and village of Warwickshire, England. It is $3 \mathrm{~m}$. N.E. of Coventry and is really an industrial suburb of that city, having manufactures of the same kind, while around are collieries. The church of S. Lawrence was restored in 1889. Foleshill has a station on L. \& N.W.R. Pop. 7,780.

Foliation. In gcology, a structure characteristic of metamorphic rocks, particularly of schists. It consists of the arrangement of the rock-material in more or less parallel, sometimes lenticular, and frequently undulating layers. Splitting usually takes place readily along these layers. See Rock.

Foligno (anc. Fulginium). City of Italy, in the prov. of Perugia. It stands in a beautiful valley, on the river Topino, $23 \mathrm{~m}$. by rly. S.E. of Perugia, and is enclosed by medicval walls. It has a 12 th century 
cathedral, which has been modern ised, several old palaces, and a pic ture gallery. There is trade in paper, leather, parchment, silk, and soap. An ancient city, it became a place of considerable im portance, but was razed to the ground in the wars of the 13th century. Rebuilt, it was greatly damaged by earthquakes in 1831 and 1832. Pop. 28,373.

Folio (Lat. folium, leaf). In bibliography, a book of the largest size, the sheets of which are folded once into two leaves, making four pages. For convenience in binding, two or more sheets are inserted into each other. In all but modern books the watermark of the paper is seen in the centre of the page if the work is a folio; if in the middle of the inner margin, divided by the fold at the back of the book, with the chain lines horizontal, the book is a quarto (q.v.).

The word folio is applied to the numerical mark on each page of a printed work or each leaf of MS. It is used to indicate the number of words in a page of law writing, or report of parliamentary proceedings, to a case for holding music and, in book-keeping, to the two facing pages of a ledger or account book containing respectively the creditor and debtor accounts. In 16 th century English the word was used to mean "on a large scale." See Book ; Paper. Sizes of.

Folkestone. Mun. bor., watering-place, and market town of Kent. It stands on the English Channel

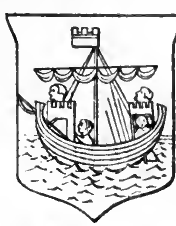
$71 \mathrm{~m}$. S.E. of London by the S.E. \& C.R. For visitors the attractions include the Leas-a fine promenade on the top of the W. cliff, command. Folkestone arms ing a splendid view of the sea-pleasure gardens, a theatre, and a pier. Radnor Park is a public pleasure ground, and

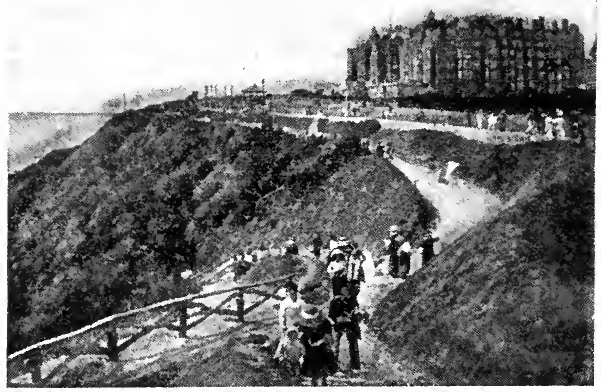

Folkestone. The Leas, looking westward important. there are tennis courts, golf links and a racecourse. The bathing is good. Between Folkestone and Dover is a large open space called the Warren, an extensive landslide, in which numerous fossils are found. In 1920 this, with the east cliff, was given to the town by the earl of Radnor.

Folkestone consists of an old town in a valley, now the fishing and shipping quarter, and a newer town on the hills around, where are spacious roads and buildings. The chief church is dedicated to S. Mary and S. Eanswith; it is an Early English building, with a fine tower, much restored. There are also modern churches and several fine hotels. The town has a 17th cen tury grammar school, a technica. school, a public library and mu. seum, hospitals, etc. Many schools are located here. As a seaport Folkestone has been much improved during the 20th century, both harbour and pier having been enlarged. It is one of the chief ports for the service to France and Holland, there being a regular connexion with Boulogne and Flushing. The herring and mackerel fisheries are

During the Great War it was a port of embarcation for the troops. It suffered from air raids, the most serious being one by 17 aeroplanes

\section{FOLKLORE : ITS ORIGINS AND STUDY}

E. S. Hartland, Author of The Science of Fairy Tales

There are in this work articles on the various characters in folklore, among them Cinderella; Fairy; Genie; Roc; Valkyrie; Witch. See also Legend: Mythology

The term folklore was suggested by W. J. Thoms, the antiquary, in 1846 , to replace the more cumbrous title of popular antiquities, hitherto employed for the traditional tales, songs and sayings, customs and superstitions of the peasantry. On the foundation in 1878 of The Folk-Lore Society, it was adopted and incorporated into the name of the society. But researches and inquiries have since compelled a broader view. All the evidence went to show that the traditional customs and institutions, songs, tales, and amusements, beliefs, leechcraft, and so forth of the peasantryin civilized countries are survivals of an indefinite past, and for the most part bear the inpress of a far ruder age; they present innumerable analogies to those of modern savages; resemble them in particular in the one essentialfeature that they are traditional; and may reasonably be supposed to be ultimately derived from a social condition represented by many tribes who are still living in a low state of culture.

Accordingly in the second edition of The Handbook of Folk Lore,issued by the society in 1914, the definition adopted for the term folklore was "the generic term under which the traditional beliefs, customs, stories, songs and sayings current among backward peoples, or retained by the uncultured classes of more advanced peoples, are comprehended and included." The same term is used for the scientific study of these objects; and folklore as a science may be more succinctly and exactly defined as the study of tradition.

To quote the handbook again: "Folklore is the expression of the psychology of early man, whether in the fields of philosophy, religion, science and medicine, in social organization and ceremonial, or in the more strictly intellectual regions of history, poetry and other 
literature." It thus embraces the whole outlook of uncultured man upon the world, his beliefs concern. ing his own nature and destiny, his relation to other beings, whether objective or imaginary, whether human or non-human, the rites and customs which are the outcome of his beliefs and the expression of these varied relations, and, finally, the amusements of his vacant hours.

The English use of the word folklore does not include, as the corresponding German word Volks. kunde does, the technology of the arts and industries practised either by the unlearned classes of civilized peoples or by the uncivilized or semi-civilized peoples of distant regions. The English student of folklore is concerned rather with the non-technical rules which govern the employment of implements, and with the ceremonies and taboos observed in relation to them, for these reveal the deeper thoughts of the community and the direction of its mental and spiritual life.

\section{Old Devonshire Customs}

Folklore may be said to be the deposit left by successive waves of culture on the minds of the com. munity. The record is usually far too fragmentary to present anything like a history. What is preserved is that which-whether tale, institution, rite, or custom-has most deeply entered into the popu. lar mentality. At the village of Holne, on Daitmoor, on May-morn. ing before daybreak a ram-lamb used to be hunted down by the young men, fastened to a monolith, killed, and roasted whole. At midday a struggle took place for a slice of the animal, which was supposed to confer luck for the ensuing year on the fortunate person who ate it.

At King's 'Teignton, on WhitMonday, a lamb is drawn about the parish in a cart covered with garlands. On the following day it is killed and roasted whole in the middle of the village; and slices are sold to the poor at a cheap rate. The custom is said to date back to heathen days, and to owe its origin to a drought, in which the inhabitants prayed for water. Their wants were supplied in answer to the prayer by the bursting forth of a spring, which even now is adequate in a dry summer to work three mills. The sacrifice of the lamb is said to be a votive thankoffering (Sir Laurence Gomme, Ethnology in Folklore, 1892).

In these two Devonshire customs it is impossible to avoid recognizing a survival from very ancient times of a sacrificial ceremony. It is a striking and picturesque rite; but from our point of view this is by no means essen- tial to its preservation. Thousands of traditional observances are of a common-place character, some even disgusting ; and it is difficult to say what quality in them caused them to survive. The prohibition, for luck, to put both shoe and stocking on one foot before the stocking is put on the other, has no striking or picturesque features, but the importance it attaches to a trifling detail in the order of dressing indicates that it descends from so remote a past that the original reason seems undiscoverable.

The belief that it is a bad omen if a child do not cry at its baptism, the prohibition in Scotland to give fire out of the house on New Year's Day, and many other precepts and beliefs obviously derive their origin from a much lower stage of culture. Of such survivals it may very often be said, in Sir Arthur Mitchell's words, that "they show the continuance among a people long Christianised of ceremonies and practices emphatically pagan." Where they cannot be said to be "emphatically pagan" they are alien in spirit from modern thought.

From time to time it has been sought to disentangle and classify such survivals, so as to show the ethnic elements of which they are composed. Thus, Sir Laurence Gomme argued that the sacrifice of the lamb in Devonshire was an inheritance from a pre-Aryan society and a pre-Aryan culture. W. H. R. Rivers instituted an elaborate inquiry into the different strata of the institutions and cus. toms obtaining in the Melanesian islands of the South Pacific (History of Melanesian Society, 2 vols., 1914). He arrived at some very interesting results, but the questions raised are so complex, the influences are so numerous and varied, and many of them so hypothetical, that it cannot be said that the possibility of assigning the different elements of folklore to their original ethnic source has anywhere yet been demonstrated.

\section{Folklore and the Historian}

The value of folklore as a record of facts and of the succession of events is much more limited. Ancient historians-for instance, Herodotus-necessarily relied to a great extent on tradition. All through the Middle Ages, and even more recently, it was treated as authoritative. Modern historians have become more sceptical: and the untrustworthiness of oral tradition, in comparison with the more certain evidence of written documents or the statements of eye-witnesses, has been generally regarded as axiomatic.
In the lower zones of culture. howcver, documentary evidence of events long past is, of course, unprocurable. The evidence of tradition is the only direct evidence possible. In these circumstances some anthropologists have been disposed to rely on it for such matters as the origin and migrations of a people, the pedigree of its chiefs and rulers, the beginnings of its institutions, and the vicissitudes of its history.

\section{Subjects of Tradition}

Careful examination shows that this reliance is hardly justified. Illiterate persons certainly develop a greater strength of memory than those who habitually depend on books and written memoranda. But both individuals and com. munities differ widely in this respect: all are not gifted alike. Much depends, also, on the subject. Pedigrees may be remembered because they appeal to the vanity of a family, or because they are important in relation to the descent of property, or the hearlship of a clan. The interest thus aroused tends to preserve tradition. On the other hand it almost inevitably deforms it. Whether it be material prosperity, or only pride in the doings of ancestors, or the position of a family, what is sure to be insisted on is the glory and advantage of the carriers of the tradition, and the depreciation or the misdoings of their opponents ; and where there is no precise record, there is no conclusive answer to their claims. These are, in a sense, private traditions.

Where a tradition is not so closely related to the interest of the individual, or of a close corporation, it is liable to become less definite, the details will be speedily forgotten, and though outstanding facts will continue to be longer remembered, they will remain isolated and unexplained. Ultimately they will pass out of memory, unless an effort to explain and account for them be made. For this explanation the imagination must be drawn on. Without any real historical sense, the story can only be reconstituted as the carriers of the tradition think it ought to have been, in accordance with their ignorance, their mental condition, and their consequent sense of the fitness of things. The result is a mere travesty of the facts, and oftentimes, indeed, is a complete reversal of them.

It might be thought that bare lists of kings or genealogies would be easily remembered by the aid of a fair memory, and would lend themselves but little to freaks of 
imagination. In practice this is not so. Apart from the constant occurrence at the head of such lists of eponymous heroes whose former existence is a mere postulate to account for the name of a tribe or clan, a single example of the untrustworthiness of genealogies may be taken from the pedigrees of the chiefs of various sections of the great Thonga tribe in South Africa. It by no means follows that the names given in these pedigrees represent successive steps in the genealogy.

A step may be omitted because in the native mind for this purpose the distinction between a son and a grandson is immaterial. Steps may be duplicated, because a brother may have succeeded a brothe- in the chieftainship. Or a longer gap may intervene between two names reprcsented as those of father and son. All these errors and others occur in the pedigrees in question, and the native depositories of tradition do not agree among themselves on the subject. The lists do not affect to contain the names of more than eight or ten generations, going back at the most from 200 to 250 years. Yet a Portuguese document dated in 1554: already mentions several of the names, some of which were then probably the names of clans rather than of persons, and two of them are in the document $e x$ pressly stated to be the names of rivers (Junod, Life of a South African Tribe, i, 24-26).

\section{A Typical Legend}

A legend very widespread in Eng. land and other parts of the W. of Europe concerns the position of a church. It asserts that the church, generally a parish church, was intended to be built elsewhere than on its actual site, but that the materials and the building so far as erected were nightly removed by invisible powers, and that the builders were ultimately compelled to accept the site thus supernaturally chosen.

Two examples, both taken from Gloucestershire, will show how tradition may disguise, and in one case entirely reverse, the facts. The story of Bisley church is that it was to have been built in a certain spot definitely pointed out, but the stones were removed at night by the devil to its present site. Actually, the place pointed out as the intended site was the site of a Roman villa, from the ruins of which the materials for the church, or some of them, were obtained. When the church was restored in the 19th century, portions of the villa, including an altar of the Pcnates, were found embedded in the walls (Gloucestershire N. \& Q., i, 390). Of Churehdown church, a few miles away, on the top of an isolated hill, the tradition recorded is that it was begun " on a more convenient and accessible spot of ground, but that the materials used in the day were constantly taken away at night and carried to the top of the hill, which was considered as a supernatural intimation that the church should be built there."

The fact is that the hill-top was fortified probably from prehistoric times (the rampart is still to be seen), and the original village was there with its church, but that some time before 1170 , doubtless in consequence of the greater security of the country, the village- -but not the church-was removed down to the side of the hill, and the top subsequently became deserted. The tradition, now comparatively old, could not have originated until the history of the village had been forgotten.

\section{Vagueness of Tradition}

It may be said in general terms that the exact facts eannot be recovered from tradition after a century, or at most two. Subsequent to that they become vague, confused, and at length fade out of recollection. In France memory hardly goes beyond the Revolution. It is " a sort of chronological landmark, the only one, beside the reigns of some modern sovereigns and the war of 1870 , which the people really knows" (Sébillot, Folklore de France, 1904-7, iv. 379 ). All beyond is vague or forgotten. "Before the Revolution" conveys the utmost antiquity.

Some American Indian traditions go back to the events of the 17th century. They are generally pre. sented under more or less romantic guise, and they eannot be depended on. The Wyandots suffered a very great disaster about the years 1648-50: they were massacred, and the tribe was almost totally extinguished by the Iroquois. It might be supposed that so terrible an experience would have been deeply impressed on the minds of the people. So far, however, is this from being the case that "practically nothing seems to have been remembered" (Barbeau, Huron and Wyandot Mythology, 1915).

Instances like those cited might be multiplied indefinitely. They render it impossible to rely upon folklore to transmit a know. ledge of events. What it does transmit is a record of the mentality of past generations and of earlier stages of civilization. Such a record is transmitted not merely by tale and song and saying, but also-and perhaps still better-by game, institution, periodical observances, and the more intimate doings and cautions of daily and family life, as well as by the shapes taken by the beliefs in the supernatural and the uncanny. The problem for students of folklore is to unravel them, to compare them with familiar phenomena elsewhere, and to assign to each of them its place and meaning in human evolution. See The Handbook of Folklore, new ed., by Miss C. S. Burne, 1914, and the works there enumerated in Appendix D.

Folk-Lore Society.

British society formed with the object of collecting and preserving the relics of folklore. It was founded in 1878, and publishes a quarterly journal, Folk-Lore, and also occasional volumes and periodical Transactions. It meets at University College, Gower Street, W.C., and the address of the secretary is 4, New Square, Lincoln's Inn, W.C.

Folkmoot. Name given to a moot or meeting of the folk or people. There were moots of various kindsin medieval times, e.g. the shiremoot. Theoretically all freemen could attend, but practically nothing is known of the matter except that among the Teutonio tribes there were meetings of this kind. In England, according to one theory, there was a folkmoot in each of the little kingdoms until these were united and the witan became the dominant assembly. See Moot; Witenagemot; consult Primitive Folkmoots, G. L. Gomme, 1880.

Folk-Song. Song created by the common people, those whose cultural development has been effected, not by any formal system of training or education, but through the unconseious and intuitive exercise of natural and inborn faculties. Albeit folk-music is the creation of unlettered and technically unskilled musicians, it is not on that account embryonic, i.e. undeveloped or inferior music. The difference between the music of the people and that of cultivated musicians is one of kind, not of degree, akin rather to the difference between the wild and the garden flower-neither of which can be said to be incomplete or imperfect.

Folk-music ordinarily consists of melody only ; it is very seldome.g. among the peasants of Great Russia - that it has been carried as far as the harmonic stage. Tech. nically, the folk-tune is essentially non-harmonic in construction and implication, being devised by those in whom the harmonic sense is dormant. It is frequently cast in one or other of the diatonic modes. more rarely of the chromatic, 
and occasionally in the major, but never in the minor mode; and it is free in its rhythm, metrically irregular, often in five-time and other compound measures. Aesthetically, the characteristic of the folk-tune is its transparent sincerity, freshness, spontaneity, naïveté, and directness of statement.

These considerations, coupled with the fact that folk-tunes are invariably anonymous, have led to speculative theories concerning their derivation. Some experts maintain that folk-songs, like other songs, were composed in the past by individuals, and have been handed down more or less incorrectly by oral tradition, i.e. that the folk-song is not a genuine wild flower, but merely a garden escape. Others contend that folk-songs are the creation, not of individuals, but of homogeneous groups or communities; that the process of oral tradition has been responsible, not only for their preservation, but for the course of their development, and, in a sense, for their actual creation; that the alterations unconsciously made by individual singers have at every stage of the evolution of the folk-song been weighed and tested by the community and accepted or rejected by their verdict; and that the lifehistory of the folk-song has, therefore, been one of continuous growth ever approximating to a form congenial to the taste of the community and expressive of its feelings, aspirations, and ideals.

The weakness of the individualistic theory is that it fails to account not only for the anonymity of the folk-song, but also for its distinctive national flavour, which is, perhaps, the most characteristic and most valuable of its many peculiar qualities. It is because folk-song is pre-eminently a national utterance that its preservation is essential to the musical well-being of the nation of which it is the natural musical expression. No nation has suffered more than England through the failure to realize the nccessity of maintaining a close connexion between its folk and its art music, as may be seen by contrasting the foremost position which the country held in musical Europe prior to Purcell, with the humble place to which it has since been relegated.

Fortunately for the futuro history of English music, the efforts that have been made since the beginning of the century to collect and record its popular music have been attended with a success far greater than, in "the circumstances, could have been expected. In this all-important work the
English Folk Song Society, founded in 1898 , has played a leading part, having already recorded in its Journal several thousand authentic folk-songs. In addition, several seleotions of harmonised folk-songs have been published by musicians and collectors, e.g. Lucy Broad. wood, Ralph Vaughan Williams, George Butterworth, and Cecil Sharp. Cecil J. Sharp

Follen, KaRL (1795-1840). German poet. Born at Ramrod, Hesse, Sept. 5, 1795, his father was a lawyer. He was educated at the university of Giessen and became a teacher of law, but his revolutionary ideas made it necessary for him to betake himself to Switzerland and then to the U.S.A. He became a professor of German at Harvard and later a Unitarian minister at Lexington. In Jan., 1840 , he lost his life when on a burning steamer. $\mathrm{He}$ is known by his patriotic songs. His brother, August Iudwig Follen (1794-1855), was also a poet.

Follicle (Lat. folliculus, little bag). In anatomy, a minute gland or sac such as the hair-follicles of the skin. In botany, a dry dehiscent seed case, consisting of one carpel, which opens along the ventral suture.

Follies, The. Pierrot troupe which achieved popularity in London between 1907 and 1912 The Follies owed their success largely to the personality of H. G. Pélissier, "an admirable parodist, not only of words and of actions, but above all of music." Potted Plays, a series of burlesques of contemporary productions, were a popular feature.

Following-up System. Name given in business to the method by which possible buyers have the merits of goods brought before them more than once, by means of the post. It was developed in the United States, where the selling of goods through the post is on a very large scale, and was soon taken up in Great Britain. The system is worked from a card index containing the names of possible customers; these receive a first letter; after a time another follows, and then possibly others, until business results or the name is crossed off as hopeless. See Advertising.

Folly. Name given generally to a building for which there appears to be no particular use or reason. The term is of twofold origin and dcrives from both the French word folie-meaning a pleasance, a delight, or a whimsical phantasy, and as a rule applied to gardenpavilions, belvederes, or look-out towers-and from a castle built in the Welsh marches by Hubert de
Burgh. He had scarce completed it when, under the terms of a treaty with the Welsh, he was obliged to demolish the fortress. This futility was styled "Hubert's Folly."

A typical instance of what the rustic calls a folly is the Folly Gate of Brookmans Park, near Hatfield, an embattled red-brick structure of imposing design, thought to have been erected by Sir Jeremy Sambrooke in the 18th century.

"Roebuck's Folly" in the grounds of Midford Park, near Bath, is said to have been built in 1700 to commemorate the winning of a fortune by the ace of clubs. The Farmers' Folly, a pillar erected at Alnwick in 1816 by the tenants of the duke of Northumberland, to testify to their appreciation of him, was completed by the duke at his own expense. Sham Castle, or "Allen's Folly," overlooking Bath, was built in 1760 by Ralph Allen. The palatial building erected at Fonthill, Wiltshire, by the author of Vathek, is sometimes referred to as Beckford's Folly.

Folquet of Marseilles (c. 1150 1231). Provençal troubadour. He was the son of a merchant from Genoa settled at Marseilles. His few surviving poems show his amorous and passionate. disposition; his verses won him the admiring friendship of distinguished men and gained him a place in Dante's Paradiso (Book ix). $\mathrm{He}$ became abbot of $\mathrm{Le}$ Toronet, Provence, in 1198, and seven years later was made bishop of Toulouse. With Simon de Montfort he fanatically persecuted the Albigenses.

Fomalhaut (Arab. fum al hüt, mouth of the fish). Star Alpha in the constellation of Piscis Australis, the southern fish. It is a star of the first magnitude, and one of the four ancient royal stars. It can be seen low down the southern horizon in Great Britain in Sept. Pron. Fō-ma-lō.

Fomentation (Lat. fovere, to warm). Fold of boracic lint or similar material, wrung out in boiling water and applied to relieve pain or inflammation, or to assist the discharge of pus. It should be covered with jaconette, or oil silk, and cotton wool, in order to retain the heat as long as possible, and renewcd every three or four hours .

Fomorian (Goidelic, sea-people, or giants). Legendary name of an early Irish race. They are claimed by some as Gaelic spirits of darkness and the sea, by others as an echo of the Viking age. Archaeology, however, points to early arrivals of Nordic "giants" from the Hebrides, and of early voyagers from the Mediterranean. 
Fonck, Lreutenant (b. 1896). French airman. During the Great War he became known by his exploits in bringing down German aeroplanes. He took up flying in 1912, began his career as a military airman in the observation service, and, having transferred to the battleplane service, brought down his first Gierman aeroplane on Aug. 6,1916 . On May 9, 1918, in the region of Montdidier, he brought down six German biplanes. This success carried him to the head of the fighting arm of the French flying service, displacing Nungesser. He fought with the British airmen in Flanders and was awarded the D.C.M. and M.C. Just before the armistice he had brought down in all 75 German aeroplanes.

Fond du Lac. City of Wisconsin, U.S.A., the co. seat of Fond du Lac co. At the head of Lake Winnebago, $59 \mathrm{~m}$. N.N.W. of Milwaukee, it is served by the Chicago, Milwaukee \& St. Paul and other rlys. It contains the Grafton Hall girls' school, a state women's reformatory, a public library, and two parks. The industries include tanning, and the manufacture of machinery, lumber products. motor-cars, carriages, and flour. Settled about 1836, it received a city charter in 1852 . Pop. 21,485 .

Fondi (anc. Fundi). City of Italy, in the prov. of Caserta. On the Appian Way, 11 m. N.E. of Terracina, it is enclosed by crumbling walls. Among its buildings are a cathedral, and a Dominican convent in which Thomas Aquinas dwelt. Fundi was a Volscian town of some importance. It came under the sway of the popes in the 8th century, and suffered at the hands of Barbarossa in 1534. Fondi lies in a fertile district, and in ancient times was celebrated for its wine. Pop. 11,378.

Fonsagrada (Sp., sacred foun. tain). Town of Spain, in the prov of Lugo. It stands on the slopes of the Cantabrian Mts., at an alt. of $3,166 \mathrm{ft}$., $26 \mathrm{~m}$. N.E. of Lugo. It is a mart for local agricultural produce, and carries on flour-milling and the mariufacture of frieze and linen. Pop. 19,219.

Fonseca. Gulf or arm of the Pacific Ocean. It penetrates inland to a depth of $40 \mathrm{~m}$. between Hon duras, Salvador, and Nicaragua. Two volcanoes-Conchagua and Coseguina-stand on either side of its entrance, which is $21 \mathrm{~m}$. wide. On the small island of Tigre in the gulf is the port of Amapali, a name by which the gulf is sometimes called.

Fonseca, Manoel Deodoro DA (1827-92). First president of Brazil. Born at Alagoas, Brazil,

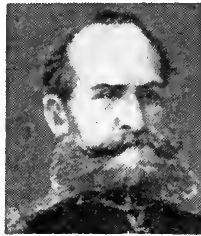

Manoel da Fonseca. Brazilian president
Aug. 5, 1827, he joined the army in 1849. He was engaged, 186470 , in the fighting against Montevideo and Paraguay, and rose to the rank of gen eral. Though sympathetic with the republican party he was a personal friend of the emperor, Dom Pedro, and was, 1886, appointed governor of the province of Rio Grande do Sul. Becoming more closely identified with the republican movement, he was recalled; he headed the insurrection which was followed by the establishment of the republic of Brazil. He was appointed its first president in Feb. 1891, but resigned in Nov. He died on Aug. 23, 1892.

Font (Lat. fons, stem font-, fountain). In eccles. architecture, the basin for the rite of baptism. Con. structed of either marble, stone, or lead, it was placed in a part of the church reserved for the pur-
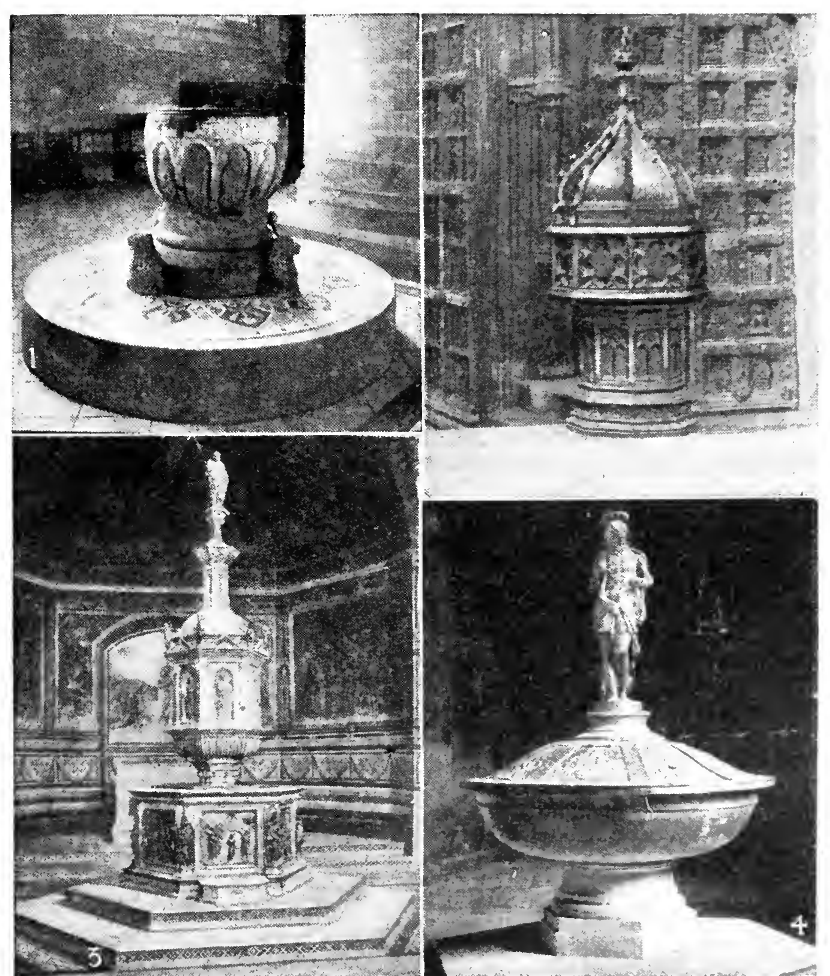

Font. 1. Carved Norman example in Hereford Cathedral. 2. Font in Henry VII's Chapel, Westminster Abbey. 3. Marble font, 1425-32, with bronze figures by Jacopo della Quercia, baptistery of S. Giovanni, Siena. 4. Marble font. 1546, and bronze cover with statue of S. John Baptist by F. Segala, 1585, S. Mark's, Venice

pose, or in a separate baptistery. Since total immersion was customary in the early Christian baptism, fonts were of considerable size. Gothic fonts were often by a lid of elaborate con The church of Notre at $\mathrm{Hal}$, Belgium, retains a font with a heavy brass cover of ane attached to the wall. are often ornamented with sculp tured figures or other decoration: there were few sculptured fonts before this period, the Saxon examples being mostly plain tub. haped structures made, in the early stages, of wood. A few preNorman fonts, however, are rudely culptured. During the Gothic period fonts followed the line of general architectural development. Thus the pedestals in the 13th century are often made up of clustered shafts. Most of the ex ant font covers in Great Britain to the 17th century, but a added to existing fonts during the

font, 1546, and bronze cover with 


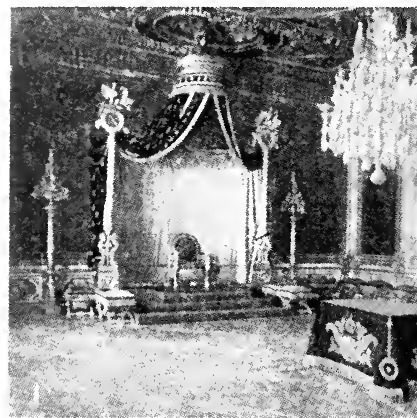

Georgian era. Such is the canopy to the 13th century font at Beverley Minster, which is fashioned in the Renaissance manner with cherub heads and other ornament.

Fontainebleau. Town and commune of France, in the dept. of Seine-et-Marne. Lying $37 \mathrm{~m}$. S.E. of Paris on the Paris-Lyons rly., and about $1 \frac{3}{4} \mathrm{~m}$. from the left bank of the Seine, it is famed chiefly for its palace and for the forest of Fontainebleau which surrounds it. The town has manufactures of porcelain and gloves, paving-stone quarries, and grows a fine type of dessert grapes. A favourite Parisian resort during the summer season, it has an important school of military engineering and artillery. Pop. 14,700.

The palace of Fontaineblean was founded probably by Robert II of France about 998, and rebuilt by Lonis VII. His building was demolished by Francis I, who built a new palace on the same site, which was in turn expanded and ornamented by almost each successive monarch, and became the favourite dwelling-place of Napoleon I. It was also much altered and decorated by Louis I'hilippe between 1837-40. It re. mains one of the finest buildings in France, no less for its internal than its external and garden beauty. There are four principal courts forming the main structure the Cour du Cheval Blanc, Cour de la Fontaine, Cour Ovale, Cour d'Henri IV. 'The staircase of Louis XIII, the gallery of Francis $I$, the banqueting hall, and many paintings and tapestries are notable. The palace has seen many historic events, including the signature of the revocation of the erlict of Nantes, 1685, and the abdication of Napoleon I, 1814.

The forest, which is a state property, has an area of some 42,500 acres, and a cireumference of nearly $57 \mathrm{~m}$. Its beautiful mixed woods, covering broken and of ten rugged ground, have attracted many artists to the smaller vil.

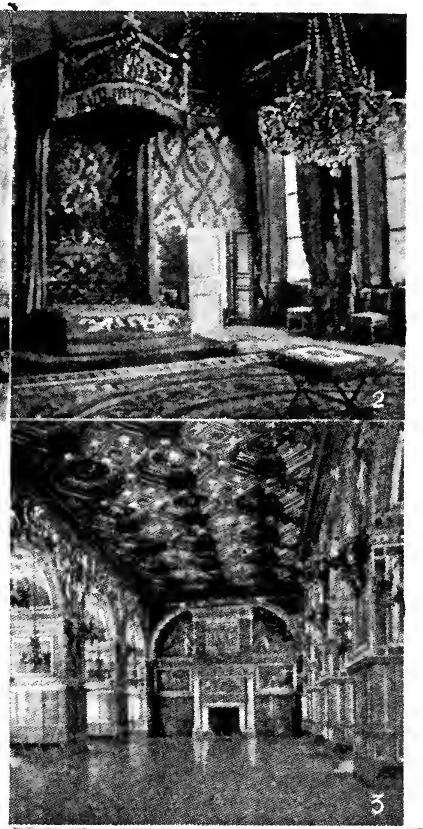

Fontana, Domenico (15431607). Italian architect. Born at Mili, Iake Como, he studied at Rome, where he obtained the patronage of Cardinal Montalto (Pope Sixtus V), becoming pontilical architect under him in 1585 . His works included the Lateran Palace, the N. transept of S. John Lateran, Rome, and the lantern of the main dome of S. Yeter's (ac. cording to Michelangelo's design). After Sixtus's death, 1590, he became royal architect at Naples, where he built the Palazzo Reale. and where he died.

Fontane, 'Th German novelist and poet. He was born at Neu Ruppin, Brandenburg, Dec. 30, 1819. He first attracted notice by his romantic ballads: later, as novelist, he was known as an uncompromising realist. Some of Fontane's more notable stories were Vor dem Sturm, 1878 ; Stine, 1890 ; Der Stechlin, 1899 ; and Cécile, 1900. Having visited Britain three times, he wrote Ein Sommer in London, 1854, and in 1860 two vols. of letters and sketches concerning England and Scotland. He acted as war corre-

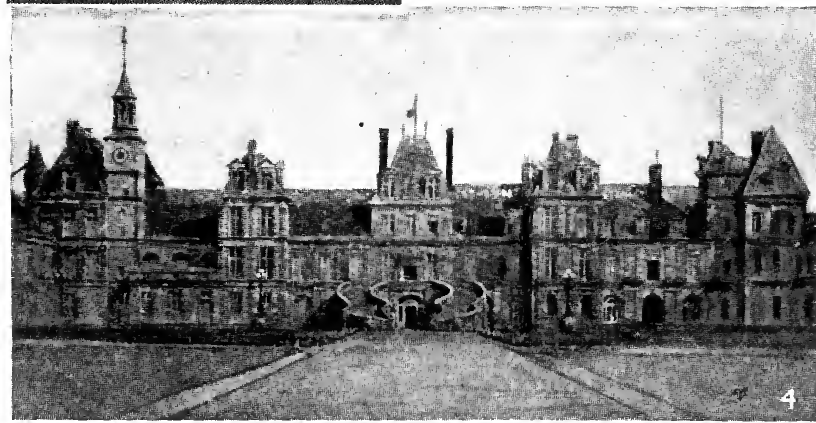

Fontainebleau. 1. Napoleon's throne. 2. Bedroom of the Empress Josephine. 3. Gallery of Henry II, or ballroom, $16 \mathrm{th}$ century. 4. Cour du Chevai Elade, where Napoleon bade farewell to men of the Old Guard, April 20,1814

lages in and near them, notably to Barbizon (q.v.). It suffered severely trom fires in 1895 and 1911

\section{Fontainebleau Sandstone.} Division of the Oligocene system of rocks developed near Paris. It is notable on account of the remarkable purity of the sands, which are composed almost entirely of water-clear quartz, with high silica-content (over $99 \cdot 65$ p.c.), and of great value in glass-naking.

Fontaine Notre Dame. Village of France, in the dept. of Nord. It is on the Bapaume-Cambrai road, $2 \frac{1}{2} \mathrm{~m}$. W. of Cambrai. Captured on Nov. 21, 1917, by the British in the first battle of Cambrai, it was recaptured by the Germans in their counter-attack, and finally regained by the British in Sept., 1918. See Cambrai, Battles of. spondent in the Slesvig-Holstein campaign and in the Franco-Prussian War. He published his autobiography in 1898, and died at Berlin, Sept. 20, 1898. See Theodor Fontane: A Critical Study, Kenneth Hayens, 1920.

Fontanelles (Fr., little foun. tains). Soft spaces present in the skull of the infant. 'The anterior fontanelle, the largest, is a quadrilateral area occupying the place where later the angles of the two frontal and the two parietal, or side, bones of the head will unite. 'The posterior fontanelle lies between the posterior angles of the parietals and the occipital bone which forms the back part of the skull. The lateral fontanelles, two on each side, are small and irregular' in shape. The anterior fontanelle 
does not completely ossify until a year or more after birth ; the others close shortly before or after birth.

Fontanes, Louis, MarQdis DE (1757-1821). French politician and poet. Born at Niort, March 6, 1757 , he was prominent as a journalist during the Revolution. Later he beeame an ardent supporter of Napoleon, but ultimately went over to the Bourbons. His poetry belongs to the classic school, but is not lacking in premonitions of romanticism. He died in Paris, March 17, 1821.

Font de Gaume. Palaeolithic eave, $165 \mathrm{yds}$. long, in Dordogne, France. It contains many mural paintings, monoehrome and poly. chrome, of the Magdalenian period. some of them masterpieces of pre. historic art. The bison, horse, reindeer, mammoth, and rhinoceros are depicted, besides a human face and hands, and designs of huts.

Fontenay le Comte. Town of France, in the dept. of Vendée. It stands on the river Vendée, $30 \mathrm{~m}$. from La Rochelle. The chief build. ings are the churches of Notre Dame and S. Jean, and there are also some fine old houses. There are some manufactures, and also a trade in horses, cattle, and agrieultural produce, the fairs being important. An old town, Fontenay was in Poitou during the Middle Ages. A fortified town, it was several times taken and retaken, and there was also fighting here during the Revolution. Pop. 9,750.

Fontenay-sous-Bois. Town of France, really a suburb of Paris. In the department of the Seine, it is $5 \mathrm{~m}$. from the capital, with which it is connected by tramways. It lies to the N.E. of the Bois de Vincennes. Market grordening em- ploys many of the inhabitants, but the town is chiefly residential. Pop. 15,200.

Fontenelle, Bernard LE Bovier DE (1657-1757). French author and academician. He was born at Rouen, Feb. 11, 1657, living there till 1687, when he went to Paris, where he remained till his death, Jan. 9, 1757. His best work is to be found in his books of popularised science, Entretiens sur la Pluralité des Mondes, 1686, and Histoire des Oracles, 1687, and in his eulogies on deceased members of the Academy. His plays were failures, and his Poésies Pastorales, 1688 , have little merit.

Fontenoy, BatTle of. Fought May 11, 1745 , between the British, Dutch, and some Germans on the one side and the French on the other. The Allies' object was to relieve Fontenoy, a fortified village about $5 \mathrm{~m}$. S. $\dot{\mathrm{E}}$. of Tournai, Belgium, then besieged by the French.

The French under Marshal Saxe were drawn up across the road from Mons along which, coming from the S., the Allies had to advance. Obstacles had been placed in front, while on their right was the $S r^{\prime}$ nelde and the fortified village of Antoing; on their left was the wood of Barri. The Allies under the duke of Cumberland arrived before this strong position on the 10 th, and early on the 11th were ready for battle. Allied attacks were repulsed, the Dutch in the centre failing to take Fontenoy.

After some delay the British and Hanoverian infantry made their advance. Lord Charles Hay of the Guards greeted the enemy with lively taunts, and the two lines opened fire. At closer quarters the fight was continued, and the cavalry were drawn into it. The British and Hanoverians had elosed into a square, but after repelling the first attacks they were at length overwhelmed in the general mêlee. More French infantry were brought up; the artillery fire became more intense, and, most vital of all, a brigade of Irish bore down upon the Allies. The square was broken, but they withdrew from the field in good order, although they left behind some of their guns. The losses were about equal, something like 7,000 on each side. The British and their allies had about 45,000 men engaged; the French somewhat more. A monument at the village commemorates the Irish brigade.

Fontesvilla. 'Township of Portuguese E. Africa, in the territory of the Mozambique Company. Now known as the Ponte do Pungue, it stands near the mouth of the Pungue river, $36 \mathrm{~m}$. N.W. of Beira, and is served by the Beira. Mashonaland Rly. The Pungue river is here crossed by a rly. bridge about $420 \mathrm{ft}$. long.

Fontevrault or Fontevraud (Well of S. Evrault). Town of France, in Maine-et-Loire dept. It is on the Vienne, $10 \mathrm{~m}$. S.E. of Saumur. Here, in 1099, Robert d'Arbrissel (1047-1117) founded a great Benedictine abbey and an order after which it was named. The abbey, which at one time housed 300 nuns and 200 monks under the rule of an abbess, existed down to the time of the Revolution. The church, conseerated by Calixtus II in 1119 , contains re. cumbent statues of Henry II of England and his queen Eleanor of Aquitaine, Richard Coeur de Lion, and Isabella of Angoulême, widow of King John. In 1804 the

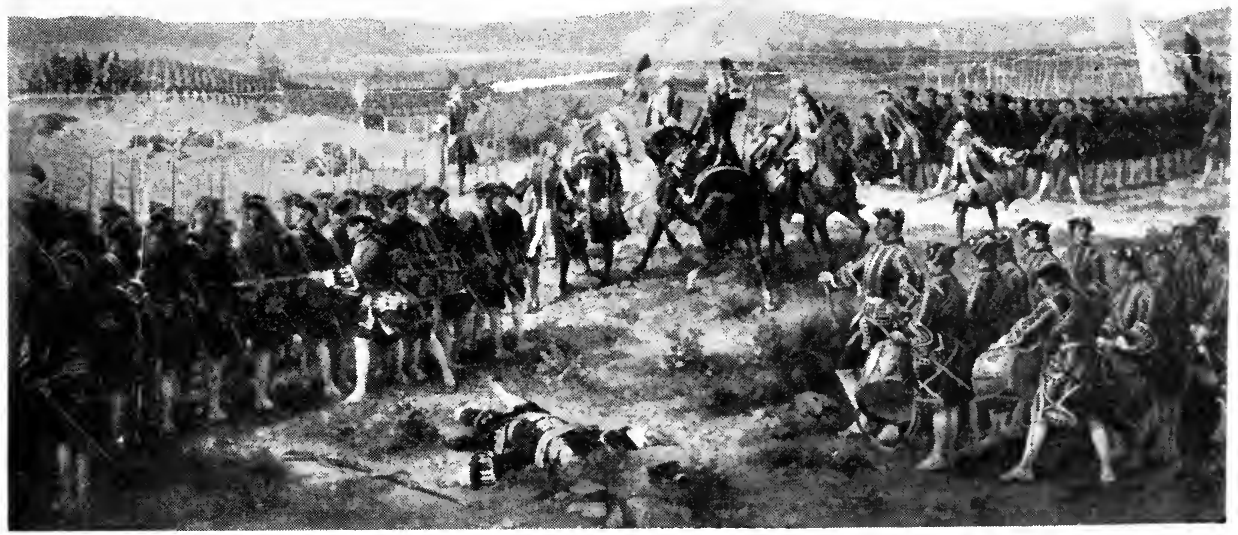

Fontenoy. The French and the Allies confronting each other before the battle. From a rainting by F. Philippoteaux South Kensington Museum 
abbey buildings were converted into a prison. In 1910, when the abbey church was restored, the tombs of Henry II of England, his wife Matilda, and his son Richard I were discovered. See Fontevrault, son Histoire et ses Monuments. L. A. Bosseboeuf, 1890 .

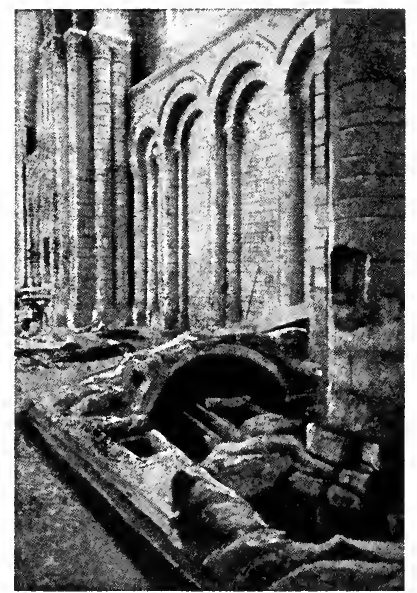

Fontevrault. Opened vaults in which the remains of two English kings were discovered in 1910

Fonthill or Fonthill Giffard. Parish and village near Hindon, Wiltshire, England, $1 \mathrm{~m}$. N.E. of Hindon. William Beckford (q.v.), who settled here in 1796 , built Fonthill Abbey at a cost of over $£ 250,000$, and disposed of it and the greater part of its contents in 1822 for $£ 330,000$. A second Fonthill Abbey was built on the same site by the 2nd marquess of Westminster. The church of Holy Trinity, built 1866, replaced that erected by Beckford in 1748.

Fonvielle, WILFRID dE (18241914). French aeronaut and author. Born in Paris, July 24, 1824, he early showed a genius for mathematics, and became a teacher. His opposition to Louis Napoleon during the revolution of 1848 caused his banishment to Algeria after the coup d'état of 1851 , but he returned at the amnesty (1859), engaged in politics, and studied aeronautics. His two days' balloon ascent of 1868 inaugurated a series of ascents, in many of which he was associated with Tissandier. During the siege of Paris, 1870, he made his escape in a balloon, and went to London, where he gave political lectures. He died April 29, 1914

Foochow on Fuchow. Treaty port of China, capital of the prov. of Fo-Kien. It stands in a plain surrounded by hills on the river Min, $36 \mathrm{~m}$. from its mouth. The

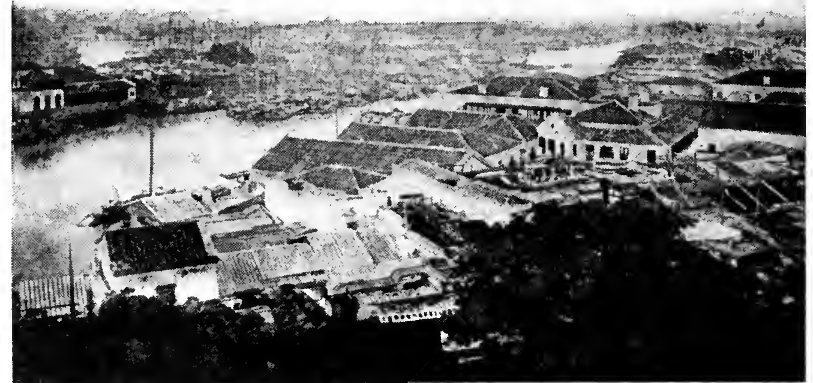

Focchow. General view of the town and river Min, from above the European quarter on the island of Nan-tai

town is enclosed by old and crumbling walls, pierced by seven gate. ways crowned by towers. The suburbs lie outside the walls, and are almost as extensive as the town itself. The river is spanned by the bridge of Ten Thousand Ages, which is supported by stone pillars, and is a marvellous example of Chinese engineering; it connects with the island of Nan-tai, the European quarter. The bridge is

supposed to be over 800 years old. 'There are shipbuilding yards, an arsenal, a dry dock, numerous wharves, and a school of navigation. The leading industries are connected with cotton goods, tim. ber, tea, paper, matches, spices, cereals, and ores, while there is a large trade with Japan and the maritime provinces of China. Foo. chow was opened to foreign trade in 1842. Pop. 624,000.

\section{FOOD: ITS VARIETIES AND VALUES}

W. A. Brend, M.D., Author of Health and the state

The article Diet deals with another aspect of this question. See also

Butter; Cheese; Mutton; Pork, and the articles that follow on Food Inspection and Food Control; Digestion

Food is the term applied to the nutritive matter taken by animals of all kinds to sustain life. The various classes of food vary very much in their constituents and in their value as nourishment. The principal nutritive constituent of meat is protein, the percentage varying in different kinds of meat, and also with the amount of fat. The percentage composition of lean beef, according to Bischoff and Voit, is as follows :

$$
\begin{array}{lllllr}
\text { Protein } & \ldots & \ldots & \ldots & \ldots & \mathbf{1 8 . 4} \\
\text { Gelatin } & \ldots & \ldots & \ldots & \ldots & 1.6 \\
\text { Fat } & \ldots & \ldots & \ldots & \ldots & 0.9 \\
\text { Extractives } & \ldots & \ldots & \ldots & 1.9 \\
\text { Ash } \ldots & \ldots & \ldots & \ldots & \ldots & 1.3 \\
\text { Water } & \ldots & \ldots & \ldots & \ldots & \mathbf{7 5 . 9}
\end{array}
$$

In bacon, on the other hand, there is 65 p.c. of fat, and only about 8 p.c. of protein. The digestibility of meat on the whole is lessened by cooking, hence underdone meat is often the most appropriate form for dyspeptics. The treast of chicken is the most digestible form of meat. Veal is not so digestible as beef or mutton, and pork is still less digestible. Tripe is a valuable, readily digested food. Gelatin is not capable of forming new tissues, but is a source of heat and energy.

In fish the chief nutrient con- stituents are protein and fat, which vary largely in amount and proportion in different fish. Boiled herring contains about 26 p.c. of protein and 10 p.c. of fat, eels contain 17 p.c. of protein and 17 p.c. of fat, mackerel about 17 p.c. of protein and 7 p.c. of fat, cod 22 p.c. of protein and 0.3 of fat.

Thin soups, beef-tea, meat extracts, and similar preparations contain chiefly the flavouring constituents of meat, and very little nutritive material. They possess dietetic value, inasmuch as they stimulate the flow of the gastric juices, and experience has shown that a warm drink containing a meat extract possesses a certain amount of stimulating power when a person is fatigued and cold. The average percentage of com. position of milk is as follows :

$\begin{array}{llllr}\text { Water } & \ldots & \ldots & \ldots & 87 \text { to } 88 \\ \text { Proteln } & \ldots & \ldots & \ldots & 3 \text { to } 3 \cdot 5 \\ \text { Sugar } & \ldots & \cdots & \ldots & 4 \text { to } 5 \\ \text { Fat } & 0 & \ldots & \ldots & 3.5 \text { to } 4.5\end{array}$

Mineral matters 0.0 .7

We see from this table that milk contains a certain amount of all the essential constituents. It is easily digested, and is therefore appropriate for invalids, for whom it may often with advantage be diluted with lime or barley-water. 
Milk straight from a healthy cow is a sterile fluid, but during the process of transit and distribution from the country to the town consumer, there is considerable risk of it becoming contaminated with dirt and, in unsanitary surroundings, infected with mieroorganisms. Milk may thus spread epidemics of diphtheria, typhoid, and other diseases. It can be sterilised by boiling, but this tends to diminish its nutritive value. Pasteurisation, by which the milk is kept at a temperature of about $70^{\circ} \mathrm{C}$. for 20 to 30 mins., destroys most forms of bacteria, but is not so certain a method of sterilisa. tion as boiling.

Cream and butter constitute easily digested forms of fat. Margarine is prepared from animal fat, and from vegetable fats derived from nuts and seeds. It contains 82 p.c. of fat, and is an excellent digestible nutrient substitute for butter. It is considerably cheaper than butter, and there are no scientific grounds for popular prejudice against its use. Cheese consists chiefly of the casein and fat of milk. It is highly nutritive but somewhat indigestible, and not suited therofore to persons with dyspeptic tendencies.

The constituents of eggs are as follow :

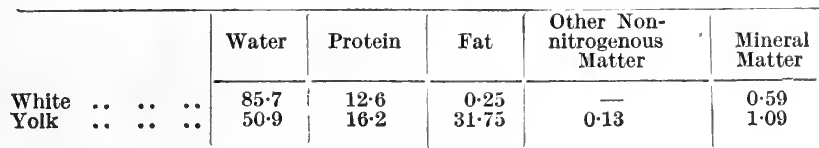

Eggs are highly nutritive, and are most digestible when lightly boiled.

Vegetable foods contain a large proportion of carbohydrates, usually present in the form of starch or sugar. They contain a little protein and fat.

A grain of wheat consists of a minute germ or embryo, which would eventually grow into a new plant; a kernel or endosperm, which makes up 85 p.c. of the grain, and consists of nutritive material for the growth of the young plant; and bran, the outer protective covering of the grain, which consists mainly of cellulose. The process of grinding or milling is to reduce the grain to flour before it can be made up into bread. The germ, which is tough, does not become broken up, but is flattened out by rolling, and is subsequently removed as "offal," and the outer coat is removed as "bran," "sharps," and "middlings," the "flour " being derived only' from the endosperm. Different forms of flour are obtained from different layers of the en- dosperm, some being richest in starch ("whites"), while others ("seconds") contain a higher percentage of gluten, a protein found within the endosperm. In some flours, special processes are employed by which the germ is retained and the nutritive value of the bread increased; in others, certain nutritive elements in the bran are also extracted. Flour, mixed with water and baked, forms ship's biscuit. This, however, is hard, difficult to masticate, and not very digestible. By fermenting dough with yeast, gas is developed in the mass, and thus the bread when baked is light and spongy in texture, and much more readily digested. The percentage composition of wholemeal and whitemeal bread, given by Robert Hutchison, is as follows :

$\begin{array}{lrrrr} & & & \text { White } & \text { Wholemea } \\ \text { Water .. } & \ldots & \ldots & 40.0 & 45.0 \\ \text { Protein.. } & \ldots & \ldots & 6.5 & 6.3 \\ \text { Fat } & . & 1.0 & 1.2 \\ \text { Starch, sugar, } & \text { and } & 1.0 & \\ \text { dextrin } & \ldots & \ldots & 51.2 & 44.8 \\ \text { Cellulose } & . & 0.3 & 1.5 \\ \text { Mineral matter } & \ldots & 1.0 & 1.2\end{array}$

The digestibility of bread depends to a considerable extent upon the completeness with which it is chewed and ground up, so as to be easily acted upon by the saliva and other digestive juices in the alimentary canal. Bread is not

so easily chewed when moist; hence new bread is less digestible than stale bread, and toast is more easily digested than ordinary bread. Bread is a highly nutritious but by no means perfect food, since it oontains so small a proportion of protein.

Of other cereals, oats are rich in nitrogenous matter, and particularly rich relatively in fat. The husk of oats, however, is not easily removed completely from the kernel; hence, oatmeal is apt to contain a good deal of cellulose, which may act as a stimulant to the intestine where the movements of the bowel are sluggish, but is apt to be irritating to some persons. Gatcake eaten with butter, and porridge with milk, make valuable and nutritious foods. Maize also is as nutritious as wheat, and richer in fat. Meal made from maize is highly nutritive and economical. Barley is rich in mineral matter, but comparatively gluten, and hence does not make good bread, but, when mixed with poor in protein. It contains little half its weight of wheat flour, can be made into good loaves. Rice is poor in protein, fat, and mineral matter. It contains little cellulose, and for this reason is very com. pletely absorbed in the intestine, which renders it a valuable form of food in some diseases.

Peas, beans and lentils are rich in nitrogenous material, 95 p.c. of which is in the form of protein. They contain a large amount of carbohydrate, but are poor in fat. The nutritive value of these foods is high, but they are not readily digested. Potatoes are very rich in starch, and are most digestible when eaten in the form of a purée. Green vegetables, such as cabbage, spinach, etc., contain only a small proportion of nutritive material, but play an important part in digestion, in stimulating the intestinal movements, and also are valuable as a source of mineral salts.

Some fruits, such as bananas, dried dates, prunes, currants, and raisins, contain a considerable amount of carbohydrate, mostly in the form of fruit sugar. They are of value owing to the presence of mineral constituents. Nuts are of very considerable nutritive value, but are not readily digested.

Besides the essential foodstuffs described above, certain other bodies, which occur only in small amounts, aro necessary in order to maintain health. These substances, known as vitamines, have not yet been fully investigated. There are, however, several different forms of vitamine, and it is the absence of these bodies which gives rise to scurvy, beriberi, and possibly rickets. The vitamine which prevents scurvy is particularly abundant in fruit juices and green vegetables. The vitamine which prevents beriberi occurs in the pericarp of rice. Wheat, eggs, and other food contain varying amounts of vitamines. These substances are destroyed or rendered less active by boiling or preserving food; hence the importance of a certain amount of uncooked food, in the form of fruit or vegetables, in the diet. See Food and the principles of Dietetics, Robert Hutchison, 4th ed. 1916.

Food, Inspection of. Purity of the food supply is of manifest in. portance to the well-being of a community, and the duty of looking after this aspect of the public health plays a great part in the activities of various government departments. In the United Kingdom there is a regular system of administration in food inspection duties which begins with Parliament and ends with a local 
inspector in a town or county. The duties and powers of those appointed to look after food inspection are laid down in various Acts of Parliament, and administered in the first place by the ministry of health and the Scottish board of health.

The ministry of health for England and Wales may be taken as the typical department responsible for this phase of public health work. It has a chief inspector of foods, who is responsible for administration. Under him are a number of other inspectors, medical men, largely travelling inspectors, whose duty is to keep in touch with the different parts of England. They also supervise the inspection of foreign foodstuffs arriving at different parts. All these officials report to the chief inspector of foods, who in his turn reports to the head of the department. Then, outside the Government share of the work, there is the whole army of public health and sanitary officials employed by counties, towns, or other administrative areas.

In a large town the official responsible to the corporation for the inspection of food is the medical officer of health, or, by arrangement, the chief sanitary inspector. With him will be possibly a qualified veterinary surgeon, who inspects particularly the abattoirs, dairies, cowsheds, meat, and milk. In addition there will be a staff of expert food inspectors, who visit the various food shops periodically, take samples for analysis, and report on the general conditions of their area. In a smaller town, all these multifarious duties are supposed to be carried out by the medical officer of health. Large cities have a specially appointed analyst for checking adulteration of foodstuffs, and, in smaller towns or scattered areas, a number of local anthorities may combine in order to secure the services of one analyst between them. In this way there is a fairly thorough inspection of all the different kinds of foods throughout the whole country.

\section{Imported Foodstuffs}

Special attention is paid to imported foodstuffs. Food inspection at the ports is under the supervision of the medical officer of health of the port in question, who is assisted by other expert technical inspectors. It is their business to see, not mercly that all foods arriving in this country are in a condition fit for human consumption, but also that only such foodstuffs come in as are permitted by the foreign meat regula- tions and other laws affecting im. ports. In this latter part of their work the food inspectors are assisted by H.M. Customs.

A food inspector, apart from the heads of departments, who are usually qualified medical men or veterinary surgeons, requires a special training. The royal commission on tuberculosis recommended in 1898 that no person be permitted to act as a meat inspector until he had passed a qualifying examination before such authority as may be prescribed by the local government board or the board of agriculture. As a matter of fact, in recent years all inspectors in important districts have been required to pass the examinations of one or other of the institutions which teach for this purpose.

A part altogether, however, from his technical training, the food inspector must have certain qualities, without which he is useless. Outstanding amongst these is that of transparent honesty. Acting in the interests of the public as he does, he must be fair to the consumer, producer, and vendor, and for this reason it is extremely important that the food inspector should be a wholetime official.

\section{Statutory Powers}

Before the Great War the inspection of food in the United Kingdom was carried out under certain statutory powers comprised chiefly in the Public Health Act, 1875 ; the Public Health Acts Amendment Act, 1890 ; the Public Health (London) Act, 1891 ; the Sale of Horseflesh Regulation Act, 1899 ; the Markets and Fairs Clauses Act, 1847; the Towns Improvement Clauses Act, 1847 ; and the Foreign Meat regulations. These various Acts or sections of Acts set forth the statutory powers of local authorities, medical officers, and inspectors, as well as dealing with definitions and the procedure in courts.

In addition, a considerable number of Acts have been passed with reference to the adulteration of food. They are especially the Bread Act, 1836 ; the Sale of Food and Drugs Act, 1875, amended in 1879 and 1899 ; the Margarine Act, 1887 ; the Butter and Margarine Act, 1907; the Public Health (Regulations as to Food) Act, 1907; and the regulations as to unsound food and foreign meat. It should be mentioned that it is no part of the duty of a medical officer of health to make analyses of food or of drugs in order to detect any adulteration that may be present. He may be appointed by a local authority for this purpose, or they may appoint the inspector of nuisances as an inspector under the Sale of Food and Drugs Acts, and this is not infrequently done. As a rule, however, all the analyses for local authorities are carried out by borough or county analysts appointed for the puryose.

During the Great War a large number of orders were issued by the ministry of food, all of which superseded, as long as they were in existence, the operation of the various Acts mentioned above, so far as the special foodstuffs dealt with were concerned. These orders, however, mainly dealt with questions of prices, or methods of distribution, and not as a rule with quality, so that they did not materially affect the duties of food inspectors as before defined.

Foreign Systems of Inspection

In most civilized countries food inspection proceeds very much along the lines indicated above. The U.S.A. have a very thorough system of meat inspection, termed the federal meat-inspection service. The inspectors must complete a three years' course at a veterinary college, and the meat inspector is required, in addition, to be an expert in pickling, salting, smoking, and otherwise curing meat. Experienced inspectors travel through country districts and submit their reports to Washington. In addition, the various States issue their own regulations under their health departments.

In the British colonies and dominions a similar system is in force to that of the mother country, but in addition special veterinary inspectors are appointed to examine all the carcasses in the great freezing works, such as those of New Zealand and Australia, and every carcass coming into Great Britain bears a ticket upon which is the name of the inspector who examined it. In France veterinary supervision of abattoirs dates from 1882 , and is now under the general supervision of the ministry of agriculture. In Germany, where tuberculosis in cattle is extremely common, the meat-inspection law obtains throughout the empire, and covers even the smaller slaughterhouses. In Scandinavia, Denmark, and Holland meat inspection is very carefully carried out by well-trained officials.

\section{G. Leighton, M.D}

Bibliography. The Meat Industry and Meat Inspection, Leighton and Douglas, 1910; The Food Inspector's Handbook, F. Vacher, 1913 ; Bell's Sale of Food and Drugs, C. F. Lloyd, 1914; Practical Meat and Food Inspection, W. Robertson, 1908. 
Food Control. Organization and husbanding of supply and an equitable distribution of essential foods. The outbreak of the Great War involved all the Powers en. gaged in serious difficulties with regard to food supplies. As the Allied blockade proved more effective, it became clear that Germany and Austria must depend on their internal resources, and that these, insufficient even to meet a normal demand, must inevitably diminish as time went on. As early as 1916 central offices existed for their effective control.

As soon as scarcity developed, it became extremely difficult to induce the peasants to part with the food they produced, and in spite of the most drastic administrative measures the German country districts fared better than the towns. Milk was throughout the war an urgent problem, the farmers being reluctant to submit to strict rationing of that commodity and to regulations that laid down the proportion that might be converted into butter and cheese.

In Britain the problem was different, because that country depends more on imported foods. Increase in the area of arable land and close supervision of agriculture with a view to increased production were an essential part of policy, but the real danger was that the submarine campaign might cut the country off from oversea supplies. The first crisis arose in connexion with sugar. The production of beet sugar in Germany, Austria, Russia, and other countries to a large extent ccased, thus making Britain and the importing countries almost entirely dependent upon cane sugar. A sugar commission was therefore formed for its collective purchase. National security de. pended on bread, and the responsibility for the purchase of wheat, flour, and other essential cereals was placed upon the royal commission on wheat supplies, which bought in the country of origin.

\section{The Submarine Campaign}

As the submarine campaign developed, the situation became more grave. Ships had to be used as economically as possible, and it gradually became a question of limiting the import of foodstuffs to essentials, and of buying food from the nearest sources. Thus, on account of the shortness of the journey many foods had to be purchased from America which could have been more economically purchased in Australia and New Zealand, and Australian wheat, purchased by the Government, remained on the quays at Sydney. This position only developed slowly, and it was not until the end of 1917 that drastic steps for the control of food were taken.

A food controller, with extensive powers under the Defenec of the Realm Act, was appointed at Christmas, 1916, but the main energies of his department were at first devoted to exhortations to economy. By the following summer it was evident that more was required, and Lord Rhondda took office with instructions to tackle the question at the root.

The fundamental principles on which he worked formed the basis not only of his own policy but of that of his successors. They were : (1) to secure essential bulk supplies, if necessary by Government purchase ; $(2)$ to secure priority of tonnage for essential foods; (3) to prevent an undue rise in prices by fixing maximum prices at each stage between the producer or im. porter and the consumer of all essential foodstuffs, allowing a reasonable profit based on pre-war figures to producers and distributors ; (4) the elimination of speculators and unnecessary middlemen, and the supervision of local distribution by local authorities.

\section{Securing Supplies}

The first and most urgent question was the securing of sufficient supplies, leaving a margin for accidents, such as the sinking of a food cargo or the destruction of a food store by aircraft or by fire. Then the price paid overseas for these supplies had to be kept down in spite of feverish bidding from other countries. Happily the American food administration was very efficient, and by its efforts American production was enormously increased. The British Government themselves purchased Australian and New Zealand meat, the greater part of which was used for the army and navy, and at one time took the whole output of New Zealand butter and Canarlian cheese, handing over the quantities not required for the forces for distribution to recognized traders. The purchase of wheat and sugar by the wheat and the sugar comnissions steadied markets and ensured supplies. The board of trade bought meat and cheese for the army and navy. The oilseeds trade was organized so that, although a large proportion of the small amount of nuargarine consumed had previously been imported, it was possible to provide a full ration of home-produced margarine.

All this necessitated some restrictions on traders, most of whom were licensed by the ministry of food and had to act under orders. There were two possible methods : (1) to set up a bureau cratic control regulating every detail of import or purchase and distribution; (2) to constitute trade organizations representing various sections of the trade, and to entrust the carrying out of the necessary regulations to trade committees. The latter method, or a compromise between the two, was adopted as the exigencies of each case dictated. Generally speaking, it was found that the price to the consumer could not be regulated without having some form of control reaching back to the original sources of supply.

\section{Government Purchase}

This was the reason for the Government purchase of some foods, and the unified furchase of others by trade committees acting under Government instructions. For the very extensive purchases made in the U.S.A. it was found necessary to set up Allied commissions for buying to prevent the forcing up of prices by Allied bid. ding, and to meet the difficulty of financing purchases in America.

But the world shortage of sugar made the continuance of sugar control essential, and the world supplies and price of wheat made it necessary to continue this control also. In the case of wheat, the im. ported price had risen from $36 \mathrm{~s} .4 \mathrm{~d}$. in 1912 to $55 \mathrm{~s}$. or $60 \mathrm{~s}$. in 1920 ; while home-produced wheat, ordinarily sold at about $2 \mathrm{~s}$. below imported whcat, stood at over $70 \mathrm{~s}$. In 1917 the loaf was artificially retained at $9 \mathrm{~d}$. for political reasons at the cost of a subsidy varying from 30 to 50 millions sterling. It was therefore impossible to relinquish the control of wheat and of wheat sup. plies unless the Government were prepared to see the loaf rise in proportion to the price of wheat. In April, 1920, this subsidy was reduced, not abolished, and after that date bread was not subject to a controlled maximum price. The result was the $4 \mathrm{lb}$. loaf costing 1s. In October, 1920, the subsidy was further reduced, thus raising the cost of the loaf to ls. 4d. In Dec. the price was reduced by $\frac{1}{2} \mathrm{~d}$.

In Germany and Austria ex. treme scarcity had brought into being an army of people who made it their business to evade the food regulations. In the United Kingdom the numerous rules and regulations were, on the whole, faithfully observed, and food remained accessible to the poor. In France there was not the same willingness on the part of merchants, shopkeepers, and the general public to submit to regulations, so control was less effective. See Rationing.

Margaret Bryant 
Food Controller. Name given in Great Britain to the official responsible for carrying out the Government's scheme to exercise control over the food supplies. The post was created by the exigencies of the Great War, and something of the kind existed in Germany and other countries besides Great Britain. From Dec., 1916, to June, 1917, Viscount Devonport was the controller. He was succeeded by Lord Rhondda, who occupied the position until his death in July, 1918, when J. R. Clynes (q.v.) was appointed. He held it until Nov., 1918, and was succeeded by G. H. Roberts, who was, in turn, succeeded by C. A. McCurdy, March, 1920. His depart ment was known as the ministry of food, which was wound up in March, 1921.

Food Preservation. Food that is preserved in some manner or another enters very largely into the dietary of modern civilized communities. Doubtless for ages past there have been methods on a small scale of preserving food, used chiefly by those who produced it in order to tide them over the winter seasons.

Modern bacteriological know. ledge has revealed the meaning of putrefaction and decomposition, and the secrets of the life histories of the organisms upon which these processes depend. By taking steps to prevent those conditions being present, the organisms themselves cannot live. For example, if a fresh potato be sliced and the slices left open in an ordinary atmosphere, in a day or two the surface of these slices will become mouldy from the growth of an organism, and the potato as a foodstuff will be rapidly spoiled. This mouldiness is the growth of a living organism, which for its success in life depends upon the presence of moisture and a favourable temperature. If, then, the sliced potato is treated in such a way that all the moisture or water is driven out of it, and it is then packed in a tin hermetically sealed so that no moisture or organism can gain access to it, there is no apparent reason why that potato should not keep indefinitely.

As a matter of fact that actual process is carried out, and sliced dried potatoes prepared in Great Britain have been sent to British troops all over the world, to be eaten, after having been resoaked, as still fresh potatoes. In the same way a very large quantity of fish is preserved by drying. The fish are cleaned, the heads removed, they are exposed either to the sun or to artificial heat, packed so that they are kept dry, and sent thousands of miles, perhaps, before they are consumed. Organisms of decay cannot flourish in low tem. peratures. If a sheep, therefore, be killed in New Zealand and subjected to a process of freezing while still fresh, it can be sent all over the world in that fresh condition so long as it is kept cold enough.

\section{Borax and Boracic Acid}

There are various substances which can be added to foodstuffs without injuring their nutritive properties, to preserve them from decay. Salt or saltpetre enter into many forms of pickling solutions. But by far the most important of the chemicals used in this way is boracic acid, or borax, which fulfils the requirements of a food preservative, in that while it possesses distinct antiseptic properties it can be consumed by human beings in small quantities without harm. A half p.c. solution of boracic acid is as effective from a preserving point of view as a 4 p.c. solution of common salt. Furthermore, it does not unpleasantly affect the taste of the food to which it is added, nor has it any smell or other objectionable character. Precisely how much per cent. of borax should be used in this way is a question for experts; but of its general value as a food preservative there can be no question. It has been used for preserving fresh milk which has to be transported a long distance before delivery, but this application is largely being superseded by the process of cooling. Fresh unsalted butter can likewise be treated with borax.

The whole question of food preservatives was carefully investigated by a parliamentary com. mittee, whose report was issued in 1901. This committee recommended that formalin should be absolutely prohibited as a preservative of food or drinks, and that the only preservative which should be lawful for use in cream, butter, or margarine should be boracic acid or mixtures of that with borax. They recommended that the use of copper salts should be prohibited, and that no chemicals should be added to any dietetic preparation intended for infants or invalids. See Canning; Refrigeration.

Fool (Lat. follis, wind-bag). Retainer kept in the medieval period, and up to the 17th century, by kings and nobles for their entertainment. He was licensed in the exercise of his antic buffoonery, his fooling and the shrewdness of his tongue, and is scarcely to be differentiated from the jester. Shakespeare's Touchstone (q.v.) is the typical fool. The fool wore a special parti-coloured dress, and a cap shaped like a cock's comb with ass's

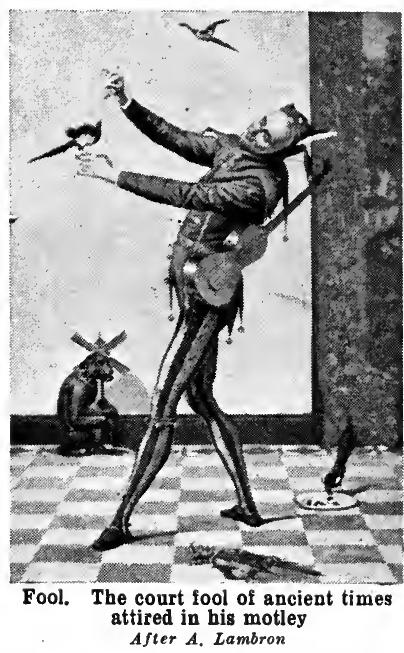

ears, and carried a mock sceptre with a fool's head carved on it, and a bladder at the end of a string.

Fools, Feast of. Medieval bur. lesque religious festival. A survival of the Roman Saturnalia (q.v.), it was originally celebrated on the first day of the year. The Church, although originally opposed to it, eventually allotted special days for its observance. The chief characteristic was at first the inversion of rank. A boy or young man, known by such names as the boy bishop (q.v.) or the abbot of unreason $(q . v$.$) , was chosen to$ conduct the ritual; but the ceremonies quickly degenerated into buffoonery.

The ass, representing Balaam's ass, the ass which stood by the manger, that on which the Virgin and Child fled to Egypt, or that on which Christ rode into Jerusalem, often played a part. In some places there was a special Feast of the Ass, e.g. at Beauvais, where the flight into Egypt was represented by a girl carrying a baby or doll and mounted on an ass, and the priest dismissed the congregation by braying three times, the people responding in the same fashion. The Feast of Fools survived until the Reformation, and as late as 1644 at Antibes in France.

- Foolscap. Properly, the cap worn by fools and jesters, usually conical in shape with bells fastened to it. It is also the common name for a sheet of paper, strictly 17 ins. by $13 \frac{1}{2}$ ins., but frequently smaller. This is so called because it had formerly a fool's cap and bells for its watermark. 


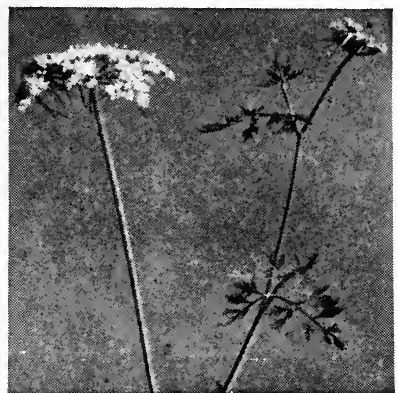

Fool's Parsley. Leaves and flowers of Aethusa cynapium

Fool's Parsley (Aethusa cynapium). Annual herb of the natural order Umbelliferae. It is a native of Europe and Siberia, growing chiefly in cultivated ground. It has a spindle-shaped root and a smooth stem about $2 \mathrm{ft}$. high. The large, wedge-shaped leaves are much divided into small, thin segments. The minute white flowers are massed in compound umbels. Though somewhat like parsley, it is considered that its nauseous odour would prevent any but " a fool" from being imposed upon by the resemblance.

Foot. Lower extremity of the leg on which man stands or walks. The bones fall into three groups: (1) seven forming the tarsus or posterior part of the foot, which correspond to the bones of the wrist; (2) the five metatarsal bones; and (3) the fourteen phalanges, forming the toes. The tarsus consists of the os calcis, which is the largest bone of the foot and forms the heel; the astragalus, which articulates with the tibia and fibula, the two smaller bones of the leg, to form the ankle joint; and five smaller bones-the scaphoid, three cuneiform bones, and the cuboid bone. The metatarsal bones are elongated, and articulate behind with the tarsus and in front with the phalanges.

The phalanges are fourteen in number, three in each of the four outer toes and two in the big toe. The foot is arched in the centre, the posterior pier of the arch being formed by the heel and the anterior by the heads of the metatarsal bones. The dropping of the arch of the foot produces the condition known as flat foot (q.v.). Club foot or talipes is a deformity which may be present at birth or acquired during later life. In talipes equinus the heel is drawn up and the patient walks on his toes. In talipes calcaneus the toes are raised from the ground. In talipes varus the foot is inverted, the inner side of the foot being raised, and

the patient walking mainly on the outer side. In talipes valgus the foot is everted, and the patient walks on the inner side. These deformities may be more or less corrected by massage, manipula. tion, the use of suitable splints or other apparatus, forcible wrenching, and in some cases operation. In claw foot, or pes cavus, there is an increased concavity in the arch of the foot. See illus. Anklet.

Foot. One of the oldest and commonest measures of length, based upon that of a man's foot,

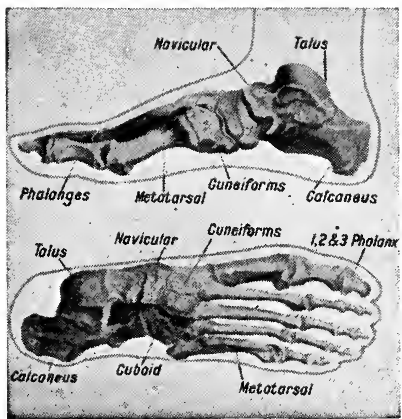

Foot. Diagrams showing the bones of the human foot, seen from above and from the side

traditionally the king's. The English statute foot is divided into

\section{FOOTBALL: ASSOCIATION AND RUGBY}

F. B. Wilson, of The Times Sporting Department

This article describes the growth of this popular game and the way its two main forms are played. See also Cricket; Hockey: Rackets; Tennis, and articles on other sports

A form of football was known and practised in Derby and Chester as far back as A.D. 217, but in all probability it was then, and for long afterwards, merely an unorganized amusement, indulged in on occasions of public rejoicing by factions, irrespective of numbers, the only object aimed at being the driving of the ball by one faction into a district defended by another.

In the 12th century the game appears to have been an after-dinner diversion of London school-boys. Many proclamations forbidding football were issued in the 14th, 15th, and 16th centuries. In Scot. land James III decreed that "foot. ball should be utterly cryed down." Various municipal authorities continued to legislate against the game, which in those days appears to have been a riot rather than a sport, up to, and possibly later than, 1700 . Not until 1800 was any attempt made to limit the number of players, or to secure numerical equality of sides.

For many years football was almost exclusively confined to the public schools, where the first recorded game took place in 1710 . The Rugby game, with its tackling, throwing, and charging, takes its name from the school where it originated, which had a grass field; and the flagged courts of the Charterhouse no doubt brought into existence what afterwards became known as the Association game.

Westminster was probably the first to develop football in an orderly manner. Other schools gradually followed the example, although certain schools still use their own rules. The wall game at Eton would hardly be called football by an outsider. Eton also plays the field game, a hard and very fast game of football which furnishes excellent training for dribbling. Harrow has a game of its own played with a big, clumsy ball like a footstool. Winchester has yet another puzzling variation, in which ropes and netting or "canvas" form a part. Both Eton and Winchester, however, have turned out many brilliant ex. ponents of the Association game. 


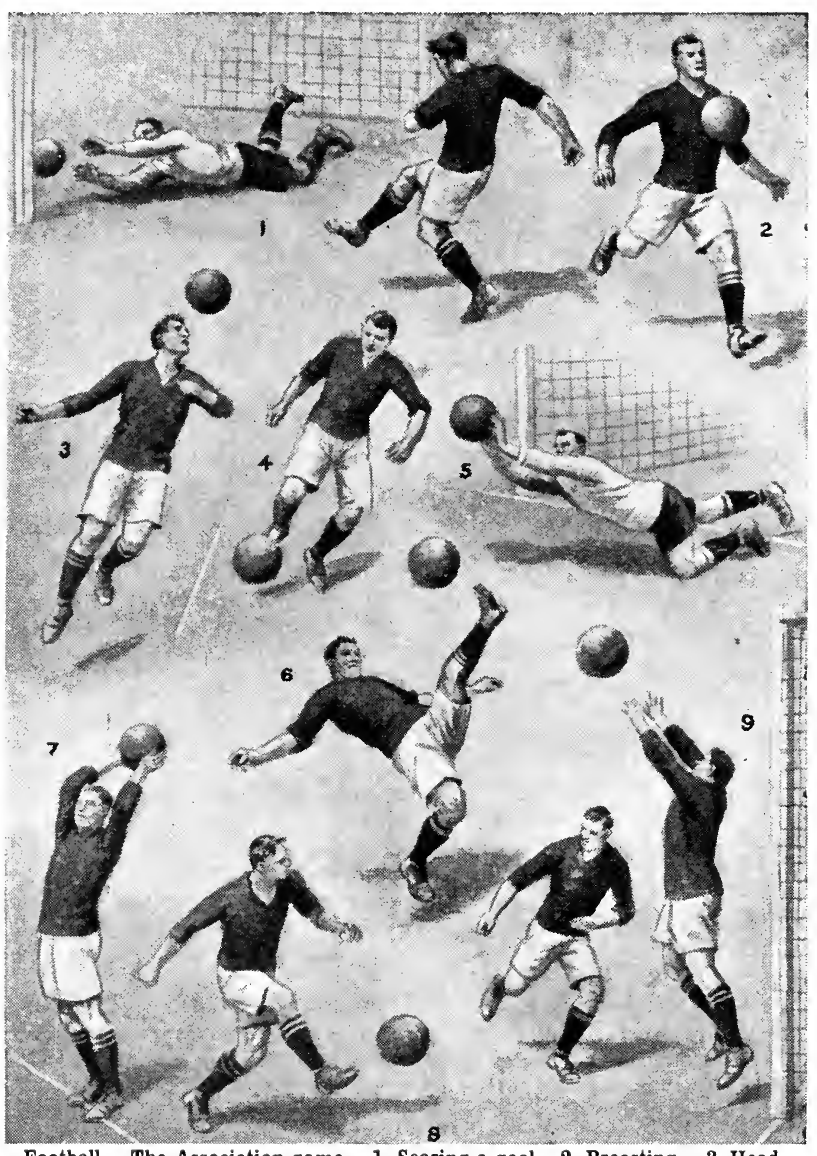

Football. The Association game. 1. Scoring a goal. 2. Breasting. 3. Heading. 4. Dribbling down the wing. 5. Goal-keeper saving a good shot. 6. Overhead clearance. \%. A throw in. 8. Combination. 9. Punching clear

The Association Game. The es- 1871-72, 1872-73, 1875-76, 1876tablishment of something like a 77, and 1877-78. They thus made regular set of rules for the Asso- the cup their absolute property, ciation game dates from 1863, but returned it to be retained as a when a committee, consisting of perpetual trophy. Later, in 1882representatives of Eton, Harrow, 83, and the two succeeding years, Marlborough, Rugby, Shrewsbury, Blackburn Rovers won the cup, Westminster, Charterhouse, and and they were presented with a other clubs, drew up rules, and special shield by the Association. from this moment Association and The Wanderers and Blackburn Rugby football were two different Rovers have each won the cup five games. The rules of the Football times in all. When Aston Villa Association, which thus came into won it in 1919-20, however, their existence, were brief and simple in number of victories was brought up character. In 1867 the off-side rule to six. No southern team won the was changed; up to that time it had cup after 1882 until 1900-1, when been virtually the same as it is in Tottenham Hotspur beat Sheffield Rugby football to-day.

In 1871 a resolution was passeu by the Football Association "That it is desirable that a challenge cup should be established in connexion with the Association, for which all clubs should be invited to compete." The Wanderers, composed chiefly of old public school boys, won the cup in
The Welsh Football Association cup, first played for in 1877-78, has been won twelve times by Wrexham and seven times by Druids : and the Irish cup, first competed for in 1880-81, has fallen to Linfield eleven times, while Distillery and Cliftonville have secured it eight and seven times respectively. The Football Association amateur cup, open to all English amateur clubs, dates from 1893-94, in which season the Old Carthusians defeated the Casuals in the final at Richmond by two goals to one.

In 1872 the first official Association international was played between England and Scotland, and ended in a draw. Since then the match has been an annual one, played alternately in Scotland and England, with the exception of one year when it was played at Bir. mingham instead of in Scotland. During the war the match was discontinued, but it was revived in 1920 .

Prior to 1883-84 the England and Scotland match decided the international championship, but in that season Jreland and Wales entered the lists, and the championship is now determined on points, each country meeting the others once, two points being allotted for a win and one for a draw. Scotland have been successful 24 times, England 22, and Ireland and IVales twice each, these figures including ties. International teams are selected from both amateur and profes. sional players, but in recent years they liave been almost entirely composed of paid players. Inter. national matches restricted to amateurs were instituted in 1906. English amateurs met, in addition to teams chosen to represent Ireland and Wales, several Continental elevens, and almost invariably proved successful. Great improvement has, however, been made by foreign countries since the outbreak of the Great War, as was

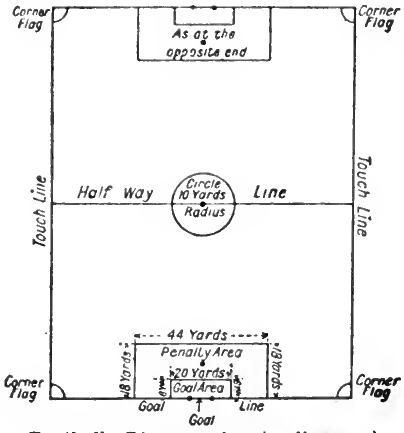

Football. Diagram showing lines and dimensions of Association football ground 
evidenced in 1920, when Belgium defeated England at Brussels, and again in the Olympic Games the same year, when Norway gained a surprise victory over England.

After the inauguration of the Cup and the first international, the popu. larity of the game increased enormously, and in 1882, to check the increase of professionalism, a new rule was added making it illegal for any player to receive remuneration or consideration of any sort above his actual expenses and any wages lost. In 1885, in spite of much opposition, professionalism was legalised. In 1888 the Football League $(q . v$.$) was founded. This was fol-$ lowed by the formation of the Scottish League and the Irish League in 1890 , and the Southern League in 1834 .

In 1891-92 the first of the inter. league games between the Football League and the Scottish League was played at Bolton, and two years later the Irish League joined in these games. From 191011 to 1914-15 all four leagues met in opposition, the Football Ieague and Scottish League each winning two of the contests, and the Southern League the other. The latter took no part in the 1919-20 matches when the Football League headed the table. Among the principal minor leagues deroted to the Association game are the Midland League, Birmingham League, Central League, London Combination, London League, Isthmian League, and Athenian League, the two last named being for amateur clubs only.

In 1900 the Footbali Association passed a resolution to the effect that wages paid to a player should be limited to $£ 4$ a week, or $£ 208$ a year. This rule, in spite of great opposition, held good to the season of 1909-10, when it was removed. In 1907 came the unfortunate split which resulted in the formation of the Amateur Football Association as distinet from the Football Association, but in 1914 the dispute was settled and the Amateur Football Association affiliated to the governing body.

As regards the laws of the game, the chief, somewhat abridged, are as follows: The game shall be played by 11 players on each side. These are one goal-keeper, two fullbacks, three half-backs, and five forwards, known as outside-right, inside-right, centre, inside-left, outside-left.

The dimensions of the field of play shall be: maximum length 130 yds., minimum length 100 yds., maximum breadth 100 yds., minimum breadth $50 \mathrm{vds}$. The field of play shall be marked by boundary

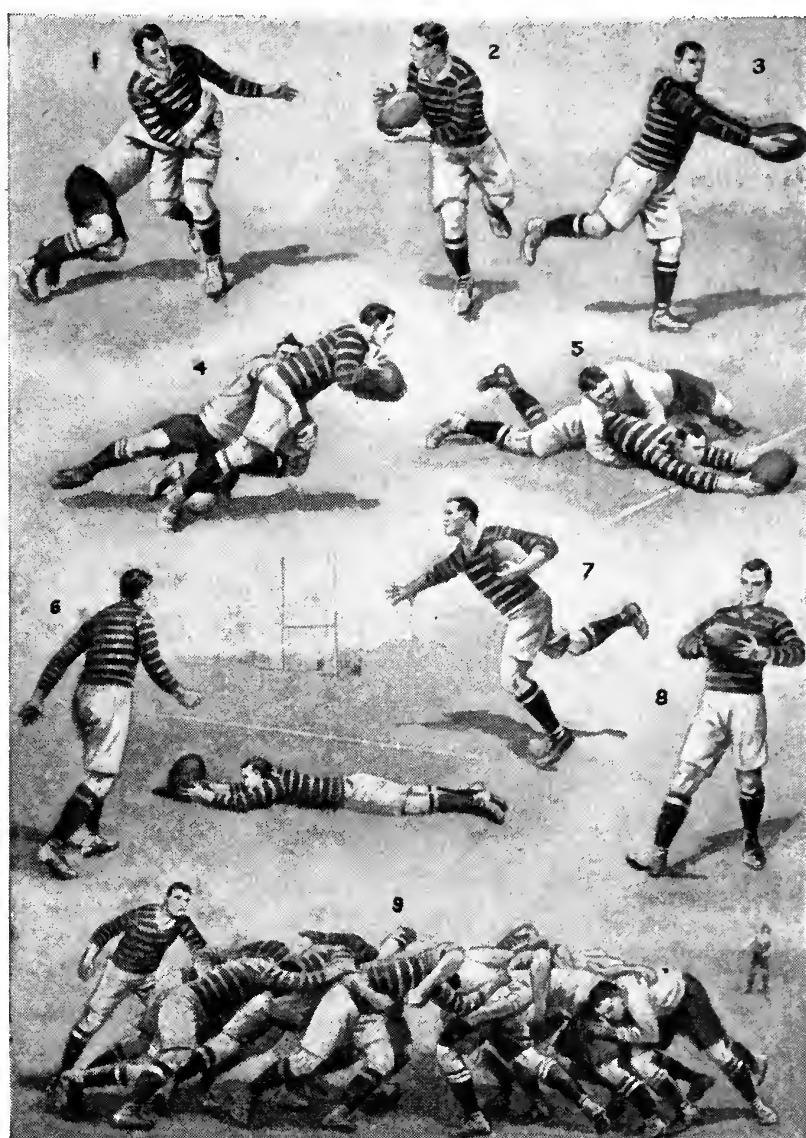

Football. The Rugby game. 1. Passing on being tackled. 2. Taking a pass. 3. A drop kick. 4. A tackle. 5. Scoring a try. 6. Place kicking. 7 . A dash for a try. 8. Making a mark. 9. A scrum

lines. The goals shall be upright goal-keeper may not be charged, posts fixed on the goal-lines, equidistant from the corner-flag staffs, 8 yds. apart, with a bar across them $8 \mathrm{ft}$. from the ground. The circumference of the ball shall not be less than 27 or more than 28 ins. The casing of the ball must be of leather and no material shall be used in its construction which would constitute a danger to the players.

At the beginning of the game the weight of the ball shall be from 13 to $15 \mathrm{oz}$. The duration of the game shall be 90 mins. unless otherwise mutually agreed upon. The wirners of the toss shall have the option of kick-off, or choice of goals. Ends shall only be changed at half-time. The interval at halftime shall not exceed 5 mins. except by the consent of the referee. The goal-keeper may, within his own penalty area, use his hands, but may not take more than two steps while holding the ball. The except when holding the ball or obstructing an opponent, or when he is outside the penalty area. Tripping, kicking, striking, or jumping at an opponent are not allowed, or the intentional handling of the ball. Holding or pushing with the hands is not allowed. Charging is permissible, as long as it is not dangerous.

A referee is sole judge of fair and unfair play, and can award a free kick or a penalty kick for infringement of the rules, and may even order a player or players off the field. In the case of a penalty kick, the ball is placed on a mark $12 \mathrm{yds}$. from and opposite the centre of goal. All players, with the exception of the player taking the penalty kick and the opponents' goalkeeper, must be outside the penalty come out beyond his yoal-line. A free kick is a kick at the ball in any direction a player pleases when area, and the goal-keeper must not 
it is lying on the ground. A free kick or a penalty kick must not be taken until the referee has given a signal for the same.

Touch is that part of the ground on either side of the field of play. When the ball is kicked or headed into touch the opposing team is awarded a throw-in. The thrower must keep part of both feet on the touch-line and throw the ball from above his head with both hands from the point on the touch-line at which the ball left the field of play. If the ball be thrown in any other manner it is a foul throw, and the opposing team is awarded a free kick, to be taken from the same point on the touch-line. A goal can be scored directly from a free kick only when it has been awarded for an infringement of law 9 , which relates to tripping, kicking, handling, etc. When 'a free kick has been awarded opponents may not approach within ten yards of the ball before the kick is taken, unless they be on their own goal-line.

The Law of Offside

The law dealing with offside is the one most frequently infringed and least understood. A player is onside at all times when there are three or more opponents between him and the opponents' goal-line. A player cannot be offside from a cornerkick, a throw-in (amendment made to law in 1920), a goal-kick from either goal, a backward pass, or when the ball is last played by an opponent. It is important to realize that a player is adjudged on or off side according to his position at the time the ball was last played. Providing he is not attempting to play the ball, or is not in any way interfering with an opponent, a player can be in any position on the playing field and not be ruled offside.

RUGBY Football. Running with the ball, the distinctive feature of Rugby football, was once unknown at Rugby. It came into vogue as the result of the spirit of enterprise and audacity shown by one William Webb Ellis. In the school play it was customary for a boy, having caught the ball from an opponent's kick, to step back and punt, or drop-kick, or place it for another of his side to kick. In 1823 Ellis astonished his fellow players, after having caught the ball, by running with it in the direction of his opponents' goal. This innovation was not recognized in the school rules until 1841, and then only with certain limitations.

Rugby school boys took their game to Oxford and Cambridge, and also founded clubs. The oldest of these, the Blackheath Club, was founded in 1860 . Those were the days of hacking and tripping. The
Blackheath rules stated, "No player may be hacked and held at the same time; hacking above or on the knee, or from behind, is unfair. No player can be held or hacked unless he has the ball in his hands. Although it is lawful to hold a player in the scrummage, this does not include attempts to throttle or strangle, whioh are totally opposed to the principles of the game. A goal must be a kick through, or over, and between the poles, and, if touched by the hands of one of the opposite side before or whilst going through, it is no goal."

Rugby football found its way to Edinburgh and Glasgow, and in 1873 the Scottish Football Union was founded to encourage football in Scotland, to cooperate with the Finglish Rugby Union, and to select international teams. The Irish Union came into existence in 1874, the Welsh Union in 1880.

Originally there were 20 players a side, and a set of 59 rules was compiled. Hacking and tripping were abolished. A player, being offside, was placed onside when one of his own side had run in front of him with the ball, or kicked it when the offside player was behind him. A try having been gained, the ball was brought straight out from a mark made on the goal-line opposite to the spot where it was touched down. It was also provided that captains should arbitrate on all disputes.

\section{Point Scoring in Rugby}

In the course of time these rules came to be considerably altered, a system of penalties exacted, and scoring was revolutionised. In the early days a goal beat any number of tries. Subsequently it was resolved that if no goal was kicked a match could be decided by a majority of tries. A system of points was instituted later. The goal kicked from a try (the try not counting) is now valued at 5 points, the dropped goal 4 points, the penalty goal 3 points, the goal from a mark 3 points, and a try 3 points.

In a few years, however, forward play became faster and more open. The arrangement of the backs in the field was altered, the greater part of the offensive work falling upon the half-backs, and of the defensive upon the full backs alone. The original notion was to have only two classes of players behind the scrummage, half-backs and backs, there being two halfbacks, three backs, and ten forwards. The earliest development of the game was to put the centre back in front of the two backs at the sides to enable him occasionally to get away on a run after a drop kick from the back ranks of the other side.

Forwards continued to shove vigorously, while the backs had the more showy part, the running and tackling. Half-backs of fine individual powers came on the scene, and meanwhile captains had begun to realize that more was required from forwards than mere shoving. In $1882 \mathrm{H}$. Vassall introduced running and passing among the Oxford forwards. From that time the game became more and more open. A further alteration was made in the composition of the side, and the new plasing consisted of one full back, three threequarters, two half-backs, and nine forwards. Wales, pursuing the principle of running and passing, tried the experiment of only eight forwards, putting the extra man in the three-quarter line, and this innovation became general.

\section{International Matches}

The first international match was played between England and Scotland at Edinburgh in the season of 1870-71, and was won by Scotland by a goal and a try to a try. The first match between England and Ireland was played at the Oval in 1874-75, and won by England by 2 goals and a try to nil. The first international between England and Wales took place at Blackheath 1880-81, and won by England by 8 goals (one dropped) and 6 tries to nil. The first international between England and France was played in Paris, in 1905-6, and England won all the ten matches played to 1919 .

The series of matches between Fngland and Scotland was interrupted in the season 1884-85, owing to a dispute over a try scored by

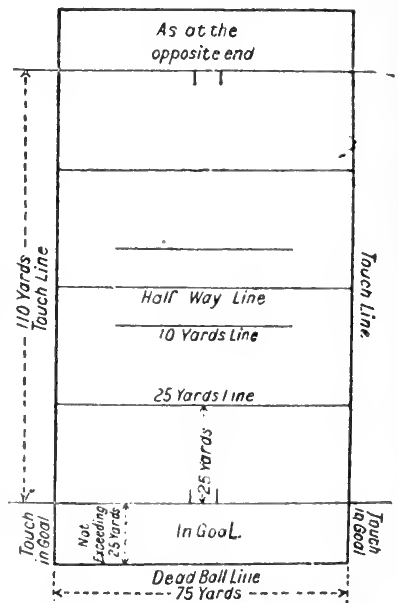

Footbal!. Plan of Rugby football ground 
R. S. Kindersley in the match of the previous year. Again, owing to a controversy, no matches were played between England and Scotland in the seasons 1887-88, 188889. The controversy occurred with regard to the constitution of the international board. After considerable negotiation in 1890 an international board of twelve representatives, since reduced to 10 , four from the English Rugby Union, and two each from the Scottish, Irish, and Welsh Unions, was set up :-(i) To frame the laws for international matches. (ii) To settle all questions connected with, or arising out of, an international match, but without jurisdiction over the game as played in the separate countries.

After this the question of money began to oreep in. In Yorkshire and Lancashire the game had become a popular spectacle; feeling ran high, aided, as it was, by cupties. While old public school boys were content to play for the love of the game, clubs and committees began to hold out certain inducements to promising young players of other classes.

Eventually those who favoured the idea of payment seceded and founded, in 1895, the Northerm Union, with a separate code of laws, and a system of scoring different from that of the Rugby Union. For some years Northern Union Rugby was played by 15 a side, but subsequently the sides were reduced to 13 . While the new game gained few converts in the south of England, some Australians saw that the Northern Union game, with its spectacular openness, its quickness, and its scope for the individuals, held propositions not to be neglected, and in New South Wales a league plays this game.

\section{New Zealand Rugby}

Rugby football was degenerating throughout Great Britain, in England especially, when the New Zealand team of 1905-6 came over. They came ostensibly to learn, but from their first match overran even the best club sides. They brought an innovation in the shape of a wing-forward, whose play was merely that of an obstructionist, and against the spirit of the game. The New Zealanders beat. Scotland, Ireland, and England, but were beaten by a try to nothing in Wales. A South Áfrican team came over in the following year. The South Africans were beaten by Scotland, drew with England, just beat Ireland and beat Wales decisively. These two sides had a great effect on British football.

It was largely in consequence of the lessons learned from the New
Zealanders and South Africans that A. D. Stoop brought a new spirit of football into play, first to the Harlequins, and secondly to England. $\mathrm{He}$ brought together enterprise, individuality, and combination, himself setting the example of all three. In the season 1909-10, England beat Wales at Twickenham for the first time in 11 years. Wales kicked off and Stoop caught the ball. Instead of kicking into touch, as had been the custom from time immemorial, Stoop ran with the ball and started a passing movement which resulted in a try for England in the first half-minute.

In 1912-13 the South Africans sent over another team, which won all its internationals. The South Africans were tremendously heavy and fast forward, and wore down every pack they played against.

\section{Rugby Rules}

The Rugby game should be played by 15 players on each side. The field of play shall not exceed $110 \mathrm{yds}$. in length nor 75 in breadth, and should be as near these dimensions as practicable. The lines defining the boundary of the field of play shall be suitably marked, and shall be called the goal-lines at the ends, and the touch-lines at the sides. On each goal-line and equidistant from the touch-lines shall be two upright posts, called goal-posts, exceeding $11 \mathrm{ft}$. in height, placed $18 \mathrm{ft}$. $6 \mathrm{in}$. apart and joined by a crossbar $10 \mathrm{ft}$. from the ground. The object of the game shall be to kick the ball over thiscrossbar and between the posts. The game shall be played with an oval ball, as nearly as possible 11 ins. to $11 \frac{1}{4}$ ins. in length ; circum ference, 30 ins. to 31 ins. : width (circumference), $25_{2}^{1}$ ins. to 26 ins. weight, $13 \mathrm{oz}$. to $141 \mathrm{oz}$.

The following are the chief terms employed in the game. A drop. kick is made by letting the ball fall from the hands, and kicking it as it rises; a place-kick by kicking the ball after it has been placed on the ground for the purpose ; a punt by letting the ball fall from the hands and kicking it before it touches the ground; a tackle is when the holder of the ball is held by one or more players of the opposite side so that he cannot at any moment, while he is so held, pass or play it.

A scrummage is formed by the forwards from each side closing round the ball when it is on the ground, or by closing up in readiness to allow the ball to be put on the ground between them. A try is gained by the player who first puts his band on the ball in his opponents' in-goal. A goal is obtained by kicking the ball from the field of play by any place-kick except a kick-off, or by any dropkick except a drop-out, without touching the ground or any player of either side, over the opponents' crossbar, whether it touches such crossbar or either goal-post or not. A kicker and a placer must be distinct persons, and the kicker must not under any circumstances touch the ball when on the ground, even though the charge has been disallowed. A fair catch is a catch made direct from a kick or knock-on, or throw forward by one of the opposite side; the catcher must at once claim the same by making a mark with his heel at the spot where he made the catch.

Free kicks by way of penalties shall be awarded if any player: intentionally either handles the ball or falls down in a scrummage, or picks the ball out of a scrum. mage, either by hands or legs; does not immediately put it down in front of him on being tackled; being on the ground, does not immediately get up; prevents an opponent getting up or putting the ball down; illegally obstructs an opponent ; or wilfully puts the ball unfairly into a scrummage, or, the ball having come out, wilfully returns it by hand or foot into the scrummage. The referee shall be sole judge in all matters of fact, but in matters of law there can be an appeal to the union.

\section{New Rules Added}

At the beginning of the season 1920-21, several new rules were passed by the governing body. The two most important were : that after a try has been scored, and the kick at goal has failed, the game shall be restarted from mid-field instead of being dropped from the 25-yard line ; that any player who has made a fair catch must take the resulting kick himself. The first rule neutralises, to an extent, a too heavy wind; the second encourages every individual, and is directed against undue specialising.

See Corinthian Football Club, illus.

Bibliography. Football : its history for 5 centuries, J. E. Vincent, 1885 ; Football : the Rugby Union Game, F. Marshall, 1892; Football : the Badminton Library, 1904; Foot. ball: Montague Shearman, 1904; Football: the Rugby Game, H. Vassall and A. Budd, 1909; The En. cyclopaedia of Sport, 1911 edition The Complete Association Footballer, B. S. Evors and C. E. H. Davies, 1912; The Science of Soccer, F. Davison Currie, 1919 : Association Football, K. R. G. Hunt, 1920 ; The "Green Book" Association Football Annual (edited by Alfred Davis and H. R. McDonald); The Rugby Football Annual. 
Football Association. Governing body of English amateur and professional association football. It was founded in 1863 to establish a definite set of rules to govern both Rugby and Association foot. ball, but at a preliminary meeting the representatives of the Rugby elubs objected to the proposal to make hacking illegal, and with. drew. The F.A. is responsible for all legislation under the dribbling eode, and all clubs on its register must abide by its rulings. In 1871 the F.A. promoted a cup competi. tion open to all clubs, and in 1872 sanctioned the playing of international matches. The F.A. was formed into a limited liability company in 1903. Its council consists of the president, six vicepresidents, the hon. treasurer, ten divisional representatives, and one representative of each affiliated association with membership of at least 50 elubs. See Association Cup.

Football League. Union of Association football clubs for the purpose of playing matches against each other. The main principle is that every club in a league shall play every other club twice during the football season, once at home and once away.

The idea was borrowed from the U.S.A., where it was practised by baseball clubs, and was suggested to certain football clubs by W. McGregor of Birmingham in 1888. The first league, the Foot. ball League, was then formed, and eonsisted of twelve of the leading English professional clubs. Each was to play every other twice during the season; a win was to count two points and a draw one, so a club could make a maximum of 44 points. The club totalling the greatest number of points was declared champion of the League. The number of clubs in the League was raised to $14,16,18,20$, and then to 22 .

To maintain the high standard of the Lcague clubs a system was adopted by which the four lowest on the list were liable to be dropped in favour of other clubs from outside. the matter being decided by the governing body of the League. In 1892 a second division of 12 clubs, later increased to 22, was added. and, down to 1895 , when the num. ber was altered to two, the practice prevailed of the three lowest clubs in the first division playing the three highest in the second for entrance into the former during the follow. ing season. These test matches were, however, abandoned in 1898 , since when the two lowest clubs in the first division and the two highest in the sccond division have automatically changed places. At various times proposals were made for the formation of a third division, and in $1920 \mathrm{it}$ was arranged that the Southern League should become the third division of the League.

Footboard. Continuous step running along the side of a rly. carriage a few inches below the floor level. It is also the longitudinal step on either side of a motor-car.

Foote, Sir Enward JaMEs(17671833). British sailor. Born at Bishopsbourne, Kent, April 20, 1767, he entered the navy at the age of 12 , was in the aetion on the Dogger Bank, 1781 and at Domin. ica, 1782. Lieutenant in $\mathbf{1 7 8 5}$, he went to the East Ind i es,

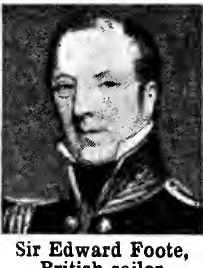
was made comBritish sailor mander in 1791, and post-captain in 1794. In 1797 he was in the Mediterranean under Sir John Jervis, and the following year served under Nelson, who, in 1799, appointed him senior officer in Naples. Rear-admiral in 1812 , he became second in command at Portsmouth in 1814, and vice-admiral in 1821 . He was knighted in 1831, and died at Southampton, May 23, 1833.

Foote, SAMUEL (1720-77). Eng. lish aetor and dramatist. Born at Truro, 1720, he was educated at

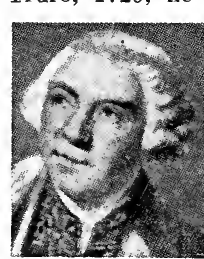

Samuel Foote English dramatist

1 fler Sir J. Reynolds
'The Diversions of the Morning, in which he burlesqued well-known living persons. The magistrates having prohibited its performance, he defied them by issuing a general invitation to his friends to "take a dish of tea with him," tickets for which could be obtained at George's Coffee Housc, Temple Bar.

With The Haymarket, rebuilt by him in 1767 , he remained connected till 1777, playing many parts and producing there several of his caricature comedies, the best of wlich are Taste, The Minor, The Orators, The Mayor of Garratt, The Devil upon 'Two Sticks, and The Capuchin. He died suddenly at Dover, Oct. 21, 1777, and was buried in Westminster Abbey.

Footpath. Narrow path, used by pedestrians only. In the United Kingdom the preservation of public right of way over footpaths is a matter of general interest. Such a right is in the nature of an easement. It may be acquired by grant made by some person, such as the freeholder, who had power to grant; or by user. In the latter case, after 20 years' uninterrupted enjoyment, the law presumes a grant made before the user commenced; after 40 years the right is deemed absolute, unless enjoyed by some con. sent expressed by deed or other evidence in writing.

Obstructions placed in $\varepsilon_{0}$ footpath may be removed by anyone enjoying the right to use it. The safeguarding of the public right to use footpaths is now entrusted to the parish and district councils, without whose consent no public right of way may be diverted or stopped. The right is also made the object of solicitous attention by the Commons and Footpaths Preservation Society, 25, Victoria Street, London, S.W. See Commons; Right of Way.

Footplate. Metal plate on a locomotive which covers the floor where the driver stands and extends along both sides of the engine and in front of the boiler. It is also a metal floor-plate secured to the end of a railway corridor carriage, which rests and is free to slide upon the end of the next carriage, so as to form a floor to the gangway between the carriages. See Steam Engine.

Foot Pound. Work done in raising one pound through a dis. tance of one foot in lat. $45^{\circ}$ and at sea level. See Horse-power.

Footprint. Fossil record of the impressions of the feet of extinct reptiles or amphibians. Alluvial deposits must at all periods retain footmarks for a short time; some of these have been accidentally preserved by later solidification of the silt.

Foot Rot. 'Term usually applied to a disease affecting the feet of sheep. The animal suffers great pain from an acute inflammation of certain structures of the foot, caused by a microscopic organism which infects low and damp pastures. The disease is readily noticed, for infected animals adopt a kneeling position when grazing.

Affected animals must be removed at once to a dry yard or shed. Drymess is absolutely essential, and if the animals are allowed to stand for a short time daily on a floor covered with slaked lime, the healing process is considerably hastened. Foot rot is highly contagious, and since it takes three weeks to develop, newly purchased sheep should be kept apart from the rest for twenty to thirty days. 
Foot's Cray. Urban dist. and parish of Kent, England. One of the four contiguous parishes on the riverCray-St. Mary Cray, St.Paul's Cray, Foot's Cray, and North Cray -it is $2 \mathrm{~m}$. S. of Sidcup station on the S.E. \& C.R. Its name is derived from that of its owner in the time of Edward the Confessor, Godwin Foot; but is sometimes found written Votes' and Foet's Cray. N. of the village is the Early English church of All Saints. In the time of Henry VIII Foot's Cray belonged to the Walsingham family. In 1920 the official name was changed to Sidcup. Pop. 8,493.

Footscray. Suburb of Melbourne, Victoria, Australia. It is intersected by the Saltwater river, and is $4 \mathrm{~m}$. by rly. S.W. of the capital. There is a dry dock here. Pop. 23,643.

Foppa, V I N. CENZO (c. 1425

1516 ). Italian painter. Born at Brescia, he stud. ied, probably with Squarcione, at Padua. About 1450 he returned to Brescia, but a few years later settled at Pavia. He exercised an enormous influ. ence on the Milanese school, and the best collec. tion of his paintings is at Milan. The National Gallery possesses

an Adoration of the Magi by him.

Forage OR FODDER CROPS. Plants grown for the use of their stems and leaves as provender. Grasses, etc., cultivated for hay or grazing, and such things as kohlrabi and cabbage, are classified as root crops. Forage crops are often taken as catch crops in $\mathrm{S}$. Britain, and may either be eut green or fed on the land. On the whole, they increase fertility and help to keep down weeds, but are only available for a short time. The chief forage crops are cereals and grasses : barley, winter oats, and rye, as cateh crops; Italian ryegrass (cut green); cruciferous forms : rape and mustard; leguminous forms: gorse, lucerne, lupins, sainfoin, trifolium, and trefoil. See Agriculture; Crops.

Forain, Jean LouIs (b. 1852). French artist. Born at Reims, he studied under Gérôme at the Beaux Arts. After contributing to the Monde Parisien and other illus. trated journals, he expressed his satirical talent at its best in the Courrier Français and Le Rire, and later in the Psst!, an anti-Dreyfusard slicet founded by himself and Caran d'Ache. He is, above all, the interpreter and castigator, in exquisite draughtsmanship, of the seamy side of Paris life, but his im. pressionist paintings are interesting.

Foraminifera (Lat. foramen, small hole). Minute creatures of low organization, belonging to the sub-kingdom Protozoa. Many of them are scarcely visible to the naked eye. Most of them are marine. They secrete a limy or membranous shell, usually perforated with minute holes through which thread-like processes of the body protoplasm can be extruded.
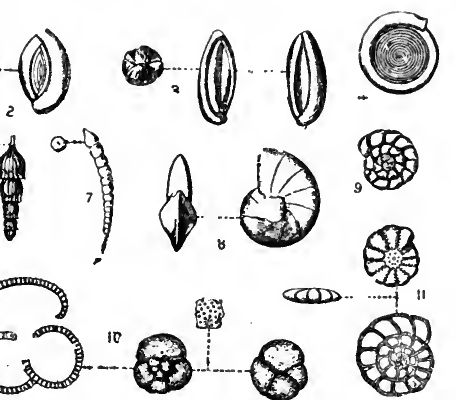

1. Frondicularia Goldfnssi, Cretaceous, Bohemia. 2. Spiroloculina badensis, Miocene, Baden,
Vienna. 3. Quinqueloculina saxornm, Eocene, Paris. Miocene, Vienna 8. Cristelaria rotulata Creta ceous, Bohemia. 9 and 11. Rotalia Beccarii, Pliocene, obigerina conglomerata, Pliocene, CarNicobar, Bay of Bengal

With the aid of these pseudopodia (false feet) the animal is able to creep about and to secure the particles of organic matter on which it feeds. The ooze of the ocean beds, and the vast deposits of limestone which form so large a portion of the earth's crust, are largely composed of the dead shells of foraminifera.

Forbach. Town of France, in Lorraine. It is $5 \frac{1}{2} \mathrm{~m}$. S.W. of Saarbrück, and $33 \mathrm{~m}$. E. by N. of Metz. The French were defeated at the battle of Spicheren on the hills near by (Aug. 6, 1870), and the Germans occupied the town. It was returned to France with AlsaceLorraine in 1919. Pop. 10,100.

Forbes. Town of New South Wales, Australia. It stands on the Lachlan river, $290 \mathrm{~m}$. W. of Sydney. It is an important centre of sheep and horse breeding. Pop. 4,654.

Forbes, Alexander Penrose $(1817-75)$. Scottish divine. Born at Edinburgh, June 6, 1817, and educated there and at Glasgow, in 1836 he entered the Indian civil service. His health failing, he returned to England and won a Sanskrit scholarship at Brasenose College, Oxford. Ordained in 1844 , he became in turn incumbent of Stonehaven and vicar of $S$. Saviour's, Leeds. He was ap pointed bishop of Brechin in 1848 .

A prominent high churchman, he was tried in the ecclesiastica courts on a charge of heresy, arising out of the statement of his views on the Eucharist contained in his primary charge, and was censured. He was the author of numerous commentaries and liturgical works. He died in Dundee, Oct. 8, 1875 .

Forbes, ArchibaLd (1838-1900). British war correspondent. Born in Elginshire, April 17. 1838, and educated at

King's College, Aberdeen, he broke off his universit $\mathbf{y}$ course to enlist in the Royal Dragoons, and, while still a trooper, contri. buted articles to the papers. In the Franco. Prussian War

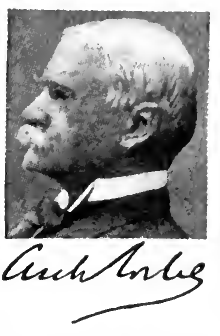
of $1870-71$ he made his reputation as correspondent, first of The Morning Advertiser and then of The Daily News. He saw much subsequent service as a war correspondent. notably in the Russo-Turkish and Zulu Wars, being able in the latter to give Britain the first news of the battle of Ulundi. Between campaigns Forbes lectured. $\mathrm{He}$ wrote Memories and Studies of War and Peace, 1895, and died in London, March 30, 1900.

Forbes, Duncas (1685-1747). Scottish lawyer. Born near Inverness, Nov. 10, 1685, he studied law

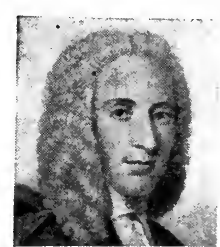

Duncan Forbes Scottish lawyer

From an engravirg at Leiden, was admitted ad. vocate and ap. pointed sheriff of Midlothian in 1709, and, for his services in suppressing the rebellion of 1715 , was made deputyadvocate. Re. turned to Par-

liament for the Inverness burghs in 172:, he was appointed lord advocate in 1725 and lord president of the court of session in 1737. In the rebcllion of 1745 he strove hard to keep the rebels in check, but his services were coldly received by the Government. He originated the idea of raising High. land regiments, later adopted by Pitt. He died Dec. 10, 17t7. 
Forbes, EDward (1815-54). British naturalist. Born at Douglas. Isle of Man, Feb. 12, 1815, he was appointed in 1843 to the chair of botany at King's College, London, and became curator of the Geological Society. In 1853 he became professor of natural history at Edinburgh. He is chiefly known by his work on the starfishes, 1841, and British mollusca (with Hanley), 1853. He died near Edinburgh, Nov. 18, 1854.

Forbes-Robertson, SIR JoHN. stoN (b. 1853). British actor. Born in London, Jan. 16, 1853, eldest son of John Forbes-Robertson, art critic and journalist, of Aberdeen, and educated at the Charterhouse

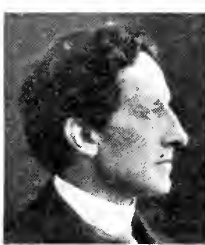
and Rouen, he studied art at the R.A. $\mathrm{school}$, and elocution un. der Samuel Phelps. He made his stage début, March 5 , 1874, at The

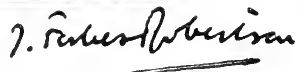

\section{Dourecy}

Princess's, London, as Chastelard, in Mary Queen of Scots. In the same year he appeared with Ellen Terry at Astley's. Associated in turns with Charles Calvert, the Bancrofts, Henry Irving, Wilson Barrett, and John Hare, he achieved his first notable success as Geoffrey Wynyard in Dan'l Druce, at The Haymarket, Sept. 11, 1876. His first venture as an actor-manager was at The Lyceum, Sept. 21, 1895, when be appeared as Romeo to the Juliet of Mrs. Patrick Campbell. His farewell season in London was opened at Drury Lane, March 22, 1913, and closed on June 6 following. In this year he was knighted.

Gifted with a magnetic personality and exceptional elocutionary ability, he was one of the most popular actors of his time. Of the many parts he played, his Hamlet, the title-rôle in The Passing of the Third Floor Back, and Dick Heldar in The Light That Failed, were memorable.

$\mathrm{He}$ toured in the U.S.A. in $1885,1891,1903-4,1906,1909-10$, 1911, 1914, and 1915; and in Germany in 1898. His brother, whose stage name is Norman Forbes (b. 1859), also won distinction as an actor; and his sister, Frances Forbes-Robertson, was the author of several novels.

In 1900 Sir Johnston married May Gertrude, sister of Maxine Elliott (q.v.) and daughter of Thomas Dermot, of Oakland, Califormia, who, as Gertrude Elliott, made her

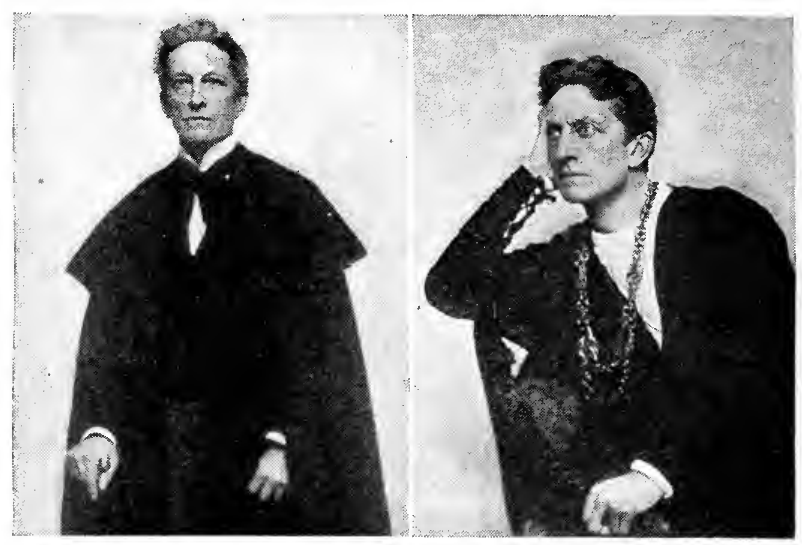

Sir J. Forbes-Robertson in character as, left, The Stranger, in The Passing of the Third Floor Back ; right, Hamlet

Lizzie Caswall Smith

first appearance on the American stage in 1894, and later won much public favour as Peggy, in Mice and Men; Ophelia; Desdemona; Portia; Cleopatra, in Caesar and Cleopatra; Maisie, in The Light That Failed; Stasia, in The Passing of the Third Floor Back ; and other parts.

Forcados. River and town of Nigeria, W. Africa. The river forms the most important deltaic arm of the Niger, discharging into the Bight of Benin. Vessels proceeding to Burutu, the headquarters of the Niger Company, and all ships proceeding to the ports of Warri, Kokotown, and Sapele enter here. The town is on the left bank of the Forcados river, near the coast, with a commodious harbour. It is 60 m. S.S.W. of Benin. Pop. 3,189, including 33 Europeans.

Force (Lat. fortis, strong). Fundamental conception defined by Newton as that which changes or tends to produce change of motion in a body on which it acts. Originally a muscular conception, it now incorporates electrical and magnetic manifestations, e.g. the power of a magnet to attract iron, etc. the attraction of the earth, sun, etc., i.e. gravitational force, etc. Force has been defined also as the rate per unit of length at which energy is transferred or trans. formed, so avoiding the conception that force is a thing of itself, or that it can exist without the presence of matter. Certainly the existence of force without matter is unknown.

In dynamics force is measured by the rate of change of momentum (q.v.), and is usually represented by lines of definite length and direction, and the resultant of two forces can be represented as the diagonal of a parallelogram, the sides of which represent the forces. (See Composition of Forces.)
The British unit of force, called a poundal, is a force which produces in one second a speed of one foot per second to a mass of one pound. In the centimetre, gramme, second system of measurement, the unit of force, called a dyne (q.v.), is the force which produces in one second a speed of one centimetre per second in a mass of one gramme.

The word force is also used of a body of men, e.g. police force; in card playing for the forced production of certain cards ; in horti. culture for the forcing of plant growth; and for the power exerted by an explosion.

Forced Landing. Aeronautical term for the coming to earth of an aircraft through some cause over which the pilot has no control.

Forced Loan. Money taken by kings and other rulers from their subjects by compulsion, but with the promise of repayment, thus differentiating it from taxation proper. Something of this kind has been done almost as long as society has existed, but in England it first became prominent in the time of Charles I. In 1626 Charles resorted to the device of a forced loan. He dismissed Coke from the chief justiceship for denying its legality, and he punished those who refused to pay by billeting soldiers upon them and in other ways. The question was tested in the courts of law by the Five Knights' Case ; in this the judges' decision implied that the king alone could decide whether or not a loan was illegal. To this the parliament replied by the Petition of Right, which declared the exaction of "any gift, loan, benevolency or tax without common consent by Act of Parliament to be illegal." During the Great War suggestions were made from time to time that 
money should be raised by a com pulsory loan, but nothing was done in this direction.

Forceps. Instrument consisting of two blades for grasping or compressing tissues or objects. The midwifery forceps, used for assisting delivery with difficult labour, is one of the most beneficial instruments ever invented. There is some evidence that forceps of a kind were used in childbirth at Pompeii, and in the 10th century by Arabian physicians. The know ledge was, however, entirely lost, and was rediscovered about the beginning of the 17th century by Peter Chamberlen, a Huguenot refugee, who fled to England. Chamberlen and his sons and grand sons kept the secret in their family for nearly one hundred years, and it was not until 1733 that Chapman published a full description of the midwifery forceps. The word forceps meant an instrument for holding hot iron (Lat. formus, hot; capere, to grasp). A form of forceps is employed in nearly all surgical operations, and by dentists, watchmakers, etc. See Dentistry, illus.

Forcible Entry. Term used in English law. By a statute of Richard II, it is forbidden for any. one claiming land to make a forcible entry on it. However good his title may be, he must not assert it by force, or he will be guilty of a breach of the peace, and be liable to a fine.

Forcible Feeding. Adminis. tration by force of food to a person who refuses to take it. Liquid food is introduced into the stomach through a tube passed down the throat, or sometimes through the nostril. The procedure is occasion. ally necessary in the case of lunatics, and was resorted to in order to keep alive imprisoned women suffragists during the agitation for women's suffrage in Great Britain, about 1910-13.

Forcing. Art of bringing flowers, fruit, and vegetables to a state of maturity at an earlier date than in ordinary circumstances. Any heated greenhouse can be used as a forcing house, but where this is not available, fresh stable manure may be spread at the bottom of a pit, about $3 \mathrm{ft}$. in depth, and, when the rank steam has escaped, covered with a thick layer of good, rich loam, a cold frame or a series of portable hand-lights being placed over it. The decaying manure will create a high temperature, and the frames can be used for starting all half-hardy plants, and when the temperature of the decaying manure falls, the frames will serve to grow rhubarb, seakale, and sometimes mushrooms. If the tempera-

ture falls too rapidly, it must be renewed by the addition of fresh manure and litter. See Gardening.

Forcite. Term used for certain explosives in the U.S.A. and in Belgium. In the U.S.A. it is frequently used to designate blasting explosives, prepared by mix. ing gelatinised nitroglycerine with sodium nitrate (76), wood tar (20), sulphur (3), and wood pulp (1). The best known explosives under this name, however, are those which are manufactured at Baelen. sur-Nèthe, in Belgium, in which 40 to 67 p.c. of gelatinised nitroglycer. ine is mixed with wood meal and sodium, potassium, or ammonium nitrate.

Ford (Anglo-Saxon). Point in a river or lake at which man or beast can cross on foot. Fords and bridging facilities have fixed the site of all important riverine towns. Modern London includes the old city, built at the then best bridging point nearest the sea, and Westminster, founded where the Thames could be forded before London Bridge was built.

Ford, Edward Onslow (1852 1901). British sculptor. Born at Islington, he studied at Antwerp

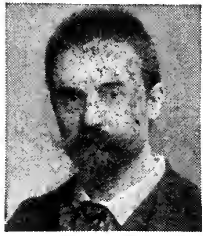

E. Onslow Ford, British sculptor Elliott \& Fry and Munich. I. $\mathrm{n} 1875$ h e first exhibited at the R.A., became A.R.A. in 1888, and R.A. in 1895 . Among his works are the Gordon group, 1890 , of which replicas are at Chatham and Khartum; the Queen Victoria Memorial, Manchester, 1901 ; Folly (Tate Gallery). His many portrait busts are marked by delicate modelling and truth of likeness. $\mathrm{He}$ died at St. John's Wood, London, Dec. 23, 1901.

Ford, Henry (b. 1863). American manufacturer. Born at Green field, Michigan, July 30,1863 , he began to work when a boy in an engineering shop at Detroit. He rose to be chief engineer at the Edis on Illu. minating Co., and in 1903 founded a busi-

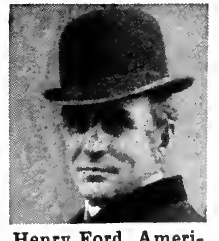

Henry Ford, American manufacturer ness of his own at Detroit. This became the Ford Notor Co., and under his presidency the largest maker of automobiles in the world, turning out 3,000 a day, and employing 50,000 hands. Ford also turned his attention to farm tractors, and these, known as Fordsons, were produced in great numbers.

In 1914 he instituted a scheme of profit-sharing for his employees, and as regards wages and hours of labour his firm was always most liberal. In Dec., 1918, he announced his intention of retiring in favour of his son, one of his new interests being a weekly periodical, The Dearborn Independent. In 191:) Ford brought a party of Americans to Europe in the hope of ending the Great War. But later he was con vinced of the futility of this policy, and when his country became a belligerent he placed his resources at its disposal, produced war material on a vast soale, and subscribed $£ 1,000,000$ to the U.S.A. Liberty Loan.

Ford, JohN (1586-c.1639). Eng. lish dramatist. Born at Ilsington, Devon, April 17, 1586, he spent a year at Exeter College, Oxford, and then entered the MiddleTemple. His reputation rests on his tragedies, 'Tis Pity She's a Whore, 1626; The Broken Heart, 1629; and the historical drama of Perkin Warbeck, 1634. $\mathrm{He}$ collaborated with Dekker, Rowley, and Webster, with the two first in The Witeh of Edmonton, $c .1621$; with the last in a lost play, called A Late Murder of the Son upon the Mother. Charles Lamb placed Ford in "the first order of poets," though his genius was peculiarly sombre. W. Gifford's edition of his works, 1827, was revised by $\mathrm{A}$. Dyce, 1869, and by Hartley Coleridge, 1840.

Fordun, JoHN of (d. c. 1384). Scottish chronicler. He wrote the Chronica Gentis Scotorum, which make up the first five books of Walter Bower's Scotichronicon. and the Gesta Annalia, which carry this work from 1153 to 1383 , and. as completed by Bower, to 1437 . He was probably a chantry priest in Aberdeen Cathedral.

Fordwich. Parish and village of Kent, England. It is $2 \mathrm{~m}$. N.E. of Canterbury, and was once a place of importance. In the Middle Ages and later, the Stour, which flows by here, was navigable, and Fordwich was a port, serving as the port of Canterbury, and a corporate member of the Cinque port of Sandwich. It has an old chureh, S. Mary's, with a Norman shrine and other features of interest. The old sessions liouse still stands, and there are remains of the port. It was a borough until 1884, when it lost its mayor and corporation under the Act of 1883. Pop. 254.

Fore and Aft Rig. Sails set towards bow and stern of a vessel, as in a cutter's rig. A vessel is square-rigged when her sails are 
set athwart the beam or across the decks. In the Royal Navy fore and aft rig is colloquially used for the uniform worn by chief petty officers, or any other uniform of which peaked cap and monkeyjacket form a part.

Forecastle oR Fo'c'sle. For ward part of a ship where the crew live. The term is reputedly derived from the forecastle which used to stand here in the fighting ships of medieval days. A monkey forecastle is a small deck below the level of the forecastle proper.

Foreclosure (old Fr. forclos, shut out). Term used in English law. When a mortgagor has failed to pay the debt in accordance with his covenant, the mortgagee may take possession of the land or other security; but the mortgagor has, at any time, the right to come and say, "Here is your money and interest, give me back my security." This right is ealled an equity of redemption. If the mortgagee desires to exclude the mortgagor from this equity, he must bring an action to foreclose, when the court orders that if the mortgagor does not redeem within a certain time, generally six months, the equity shall expire, and the mortgagee shall become the owner of the sccurity. See Mortgage.

Foreign Bondholders, CorPORATION OF. British association to protect the interests of those who have lent money to foreign countries. Founded in 1868 and incorporated in 1898, it consist of a president, vice-president, and council. The corporation is especially concerned with bringing pressure upon states, e.g. Honduras, which have failed to pay interest on their bonds, and negotiates with such in order to get something for the bondholders. It has been successful in many nego. tiations of this kind. Its offices are 17, Moorgate Street, London, E.C.

Foreign Enlistment Act. British Act of Parliament. 'There are two such Acts, the first passed in 1819 and the second in 1870 . The substance is that British subjects must not take military service under a foreign state without the royal licence, nor equip ships to be used against any foreign state with which the country is at peace. In 1835 the Act was suspended in order to allow a legion to be raised to serve against the Carlists in Spain, and it was evaded during the struggle for Italian freedom. This, but more especially the event of the American Civil War, made necessary the stronger Act of 1870 , which inflicts heavy penal. ties on those who fit out ships for raiding purposes on neutral ports and shipping." It was under this Act that Dr. Jameson was tricd in 1896. See Jameson Raid.

Foreign Jurisdiction " Act, 1890. Statute providing for the exercise of jurisdiction over British subjects in certain countries. These are where the British crown has acquired such rights by conquest or cession, e.g. certain parts of China, and where there is no settled government. It also empowers the crown to make laws for the ordering of British subjects in ships in eastern waters within 100 miles of the Chinese and Japanese coasts. See International Law.

Foreign Law. English law treats foreign law solely as a matter of fact. If an English court has before it a case that turns on a question of foreign law, it will not refuse to decide the dispute. For its satisfaction, therefore, quali. fied lawyers of the country in question must prove in evidence what the law is, and on that the ease will be decided.

Foreign Legion (Fr. légion étrangère). French corps in which, previous to 1919, Alsatians and Lorrainers who were born under German rule could enlist voluntarily. It also included men of other nationalities who had French sympathies, or desired a life of adventure. In peace time it gar. risons a French colony, and in recruiting for the Legion the authorities are not particular as to age or character. The Legion has a great reputation as a fighting force.

The Legion consists of two regiments of four battalions, whose headquarters are in Algiers, and is officered chiefly by Frenchmen. Connected with the Legion are certain battalions known as the Zephyrs, which are in fact disciplinary units, the conscripts drafted into them as a punishment serving in the unhealthiest French colonies. 'The Legion greatly distin. guished itself in France in the Great War. In Aug., 1920, it was announced that the Legion was to

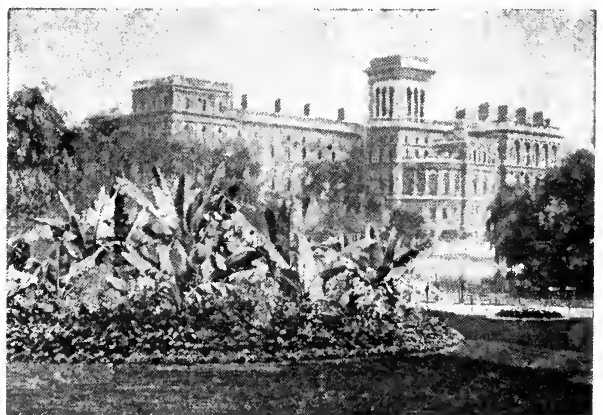

Foreign Office, London, seen from St. James's Park

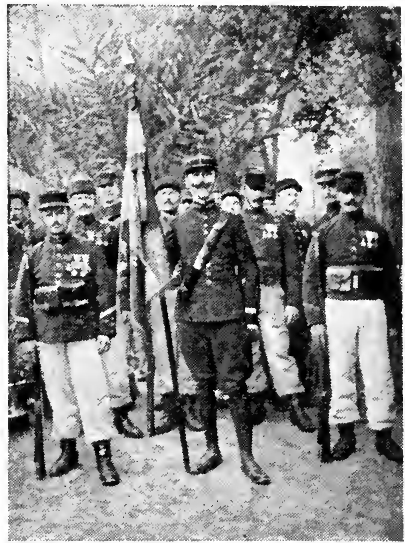

Foreign Legion. Officer and men of the First Foreign Legion with their colours

be reinforced and its scope considerably widened. A regiment of cavalry and of artillery and an engineers' battalion were to be added.

Foreign Office. British government department. Its head, the secretary of state for foreign affairs, has charge of all business affecting the relations of Great Britain with foreign powers. $\mathrm{He}$ appoints, sends out, and supervises ambassadors, consuls, and other diplomatic agents, and by various means, not excluding the use of secret agents, keeps himself acquainted with the course of affairs abroad. Much of the work is of a confidential character, and the staff is recruited by a different system from the rest of the civil service.

Until Sir Edward Grey became foreign secretary in 1905 the position was almost invariably filled by a peer, among the holders being Lords Palmerston, Claren. don, Salisbury, 'Rosebery, and Lansdowne. Before 1782, when the foreign secretary first came into existence, the control of foreign affairs was divided between the two principal secre. taries of state. The secretary is assisted by a par. liamentary and a permanent undersecretary, and his office, entered f r o m Downing Street, overlooks St. James's Park.

Foreign Press Association. London society for the promotion of the interests of editors and correspondents of 
foreign newspapers, periodicals, and news agencies, living in the United Kingdom.

Foreland, North aND South. 'Two chalk headlands on the coast of Kent, England. The North Foreland, about $2 \frac{1}{2}$ m. S.E. of Margate, is theCantium of Ptolemy, and has a lighthouse $188 \mathrm{ft}$. above sea level, with a light visible at $20 \mathrm{~m}$. 'The South Foreland, $3 \mathrm{~m}$. N.E. of Dover, has two lighthouses respectively $375 \mathrm{ft}$. and $275 \mathrm{ft}$. above sea level, and visible at $26 \mathrm{~m}$. and $23 \mathrm{~m}$.

Foreman. First or chief man. The word has two main senses. It means the one who speaks for his colleagues, the foreman of a jury. It is also used in industrial life for ore who supervises constantly and in person the work of others. In factories, works, and building operations the workers are controlled by foremen.

Foreshore. Part of a beach or seashore which lies between the extreme limits of high and low water marks, i.e. is covered at high tide and uncovered at low tide. The extent of the foreshore depends partly upon the slope of the ground and partly upon the height of the tides. The boundary has been fixed, by a decision of English law, as the mean between the high and the low water mark. Foreshore is vested in the crown. See Coast.

Foreshortening. Technical term in perspective drawing. An object is represented as diminish. ing in extent according to the angle from which it is viewed, while at the same time its real length must be adequately sug. gested. Thus, in a portrait, an arm represented as pointing at full length directly towards the onlooker occupies less space than it would fill were it shown as point ing to one side; yet the perspective must be so managed as clearly to indicate that the length of the arm is the same. Faulty drawing might suggest an outstretched hand without proper support, or there might be some other defect. See Drawing.

Forest. Term originally applied to a royal demesne set apart for the preservation of beasts of the chase and to afford the sovereign facilities for hunting. Not necessarily wooded or uncultivated, it was frequently so called only because forest law was applied to it. The word forest (late Lat. foresta), ultimately derived from Lat. for is (out-of-doors), in modern times came to be more particularly associated with such uncultivated tracts as were thickly wooded. Even yet in Scotland the term deer-forest is used to describe an

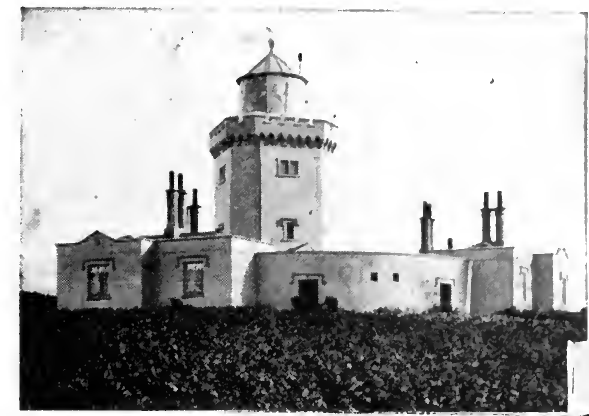

cial value, are now used for the manufacture of wood.pulp for paper-making. In Nova Scotia and British Columbia especially, the lumber industry constitutes $t \mathrm{~h}$ e staple of wealth, although in the

extensive region quite devoid of timber. A forest consisted of vert and venison. 'The former comprised the high wood, underwood, an d turf; the latter the beasts of the forest, chase, and warren.

The most extensive forest areas in the British Empire, and, indeed, in the world, are those of Canada, which cover between 500 and 600 million acres, about one-half of which are planted with commercial timber. Extensive reserves for the permanent supply of timber have been created by the Dominion Parliament since 1887, and those provincial governments which have forestry jurisdiction have adopted a similar policy, with the result that the total forestry reserves of Canada have increased from $7,413,760$ in 1901 to $152,833,955$ acres in 1918. Certain depleted areas have also been re-afforested. In Ontario spruce and other trees, which had previously no commer-

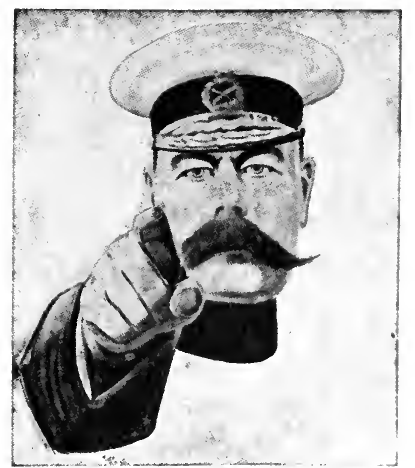

Foreshortening. Example of foreshortening of an arm, from a recruiting poster issued during the Great War

Courtesy of London Opinion former colony a rather rigorous protective policy has been in vogue for some years. Still, spruce deals are exported and the manu facture of wood-pulp is carried on. British Columbia, on the other hand, with its 15,000,000 acres of marketable timber, possesses an almost inexhaustible quantity of paper-making woods, especially Douglas fir, yellow cedar, white pine, and arbor vitae.

British Guiana, perhaps, pos sesses the rarest and most exten sive variety of timbers. Its forests are estimated to cover 78,500 sq.m. of country, but at present the workable area is confined to 11,000 sq. m. situated in the more access ible parts extending from the sea. coast to where the large rivers are broken by rapids and falls which do not permit of the water-carriage of timber. 'The woods chiefly' grown are mangrove, courida. kakaralli, wallaba, bullet tree, crabwood and hard-wood such as purple-heart, locust and suradanni, most of which are used in the manufacture of furniture.

Forests occupy a very small portion of the Union of South Africa. The largest are those in the Knysna and Hunanselorp districts of the Cape, on the southern slopes of the Outeniqua, Longkloof, and Zitzikamma nountains.

In N. America the northern forests of Maine are remarkable for densits and volume of growth, maple, birch, beech, and pine predominating. The forests of the 
Southern states are by no mean so thick, and produce oaks, pines, cypresses, gums, and cedars. The central states are rich in hardwood forests, growing chestnuts, hickories, and ashes. W. of the Rocky Mountains the forests of the Pacific coast produce trees of immense size, chiefly redwood, hemlock, spruce, and fir, and what is known as the "big " tree. The Rocky Mountains are in places covered with pine and spruce. Valuable stretches of timber exist in Alaska, especially along the river courses and on the lower slopes of the hills.

In S. America dense tropical forests prevail in the regions of the Amazon and Marañon, but because of the thick undergrowth and the numerous wild animals and reptiles which dwell therein, they are wellnigh impenetrable.

Thickly wooded areas still occupy a considerable proportion of the European continent. In France, where one-sixth of the afforested areas of $2,500,000$ acres is state property, the forests of Ardennes, Orleans, Fontainebleau, Compiègne, and Rambouillet are administered by official agency. In Germany the Black Forest and those in Franconia and Thuringia are similarly managed. Russia has about $500,000,000$ acres under timber, most of which is of small commercial value.

Forestalling. Commercial term denoting interference with public trade by buying up merchandise on its way to a market, or keeping other people's goods off the market, or making a ring in a mar ket, all agreeing to charge the same high price. It was similar to the modern profiteering. Originally an offence, it was taken away from this category by an Act of 1844 . See Engrossing.

Forest Bed. Series of deposits formed above the Pliocene Weyboume Crag and occurring beneath the glacial boulder-clay cliffs on the Norfolk coast. It comprises a lower fresh-water bed of clayey silt, an estuarine forest-bed ( $20 \mathrm{ft}$.) above, with stumps of trees and bones of mammals, and an upper bed of sand and blue clay (2-7 ft.), containing fresh-water shells. See Pliocene.

Forest Cantons. Four cantons of Switzerland, enclosing the Lake of Lucerne (Ger. Vierwaldstätter See). They are Unterwalden, Uri, Schwyz, and Lucerne.

Forest Court. Special courts of restricted jurisdiction formerly held in Ergland. "According to Blackstone, they were instituted "for the government of the royal forests in different parts of the kingdom, and for the punishment of all injuries done to the king's deer or venison, to the vert or greensward, and to the covert in which such deer are lodged."

There were the court of attachments, held before the verderers every forty days to inquire into offences against vert and venison; the court of regard, or survey of dogs, held every third year, for the lawing or expeditation, by cutting off the claws and ball, or pelote, of the forefeet of mastiffs, the only dogs permitted within the forest precincts, to prevent them chasing the deer; the court of sweinmote, held thrice a year before the verderers as judges, with the sweins or freeholders within the forest as jurors, to inquire into oppressions committed by the officers of the forest, and also to try cases presented by the court of attachments ; and the court of justice-seat, a court of record, held every third year before the chief itinerant judge to hear and determine all pleas and causes whatsoever arising within the forest. The last court of justice-seat was held pro forma only, shortly after the Restoration, and since the Revolution of 1688 the forest laws, and with them the forest courts, have fallen into desuetude.

Forester, BARON. British title borne since 1821 by the family of Forester. A Shropshire gentleman, Cecil Weld Forester, 1767-1828, was first holder, and the title passed to his sons, the second being M.P. for Wenlock 1828-74, and comptroller of the royal household. A third brother succeeded, and from him the present baron is descended. His estates are in Shropshire, where he has a seat, Willey Park, Broseley.

Foresters, ANCIENT ORDER OF. British friendly society. Founded in 1834 to provide its members and

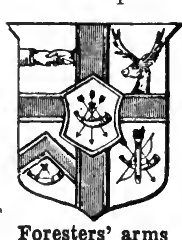
their dependents with weekly allowances during sickness, old age, or widowhood, it has always been one of the most progressive in in. troducing $\mathrm{new}$ benefits in the way of endowment insurance, etc. The society, to which an initiation ceremony must be undergone, though the mystic ritual has been largely abandoned, is organized in courts and districts which owe allegiance to a central headquarters. Contributions vary according to the benefits desired. The order has spread to America and the British Dominions overseas. See Friendly Societies.
Forest Gate. District of Essex, England, and an E. suburb of London. It is $5 \frac{1}{4} \mathrm{~m}$. N.E. of Liver. pool Street station on the G.E.R. There are chemical and other industries. It is mostly included in W. Ham and E. Ham.

Forest Hill. Residential dist. and ward in the metropolitan borough of Lewisham, London, England. It is $5 \frac{1}{2} \mathrm{~m}$. S.E. of London Bridge station, on the L.B. \& S.C.R. The Horniman Museum, standing in a public park, and built at a cost of $£ 40,000$, was opened to the public in 1901. Pop. 20,804.

Forest Marble. Name of a geological formation comprising shelly and flaggy limestones. Alternating with layers of clay or marl, it is one of the Great Oolite group of Jurassic stratified rocks, and occurs in Dorset, Somerset ( $135 \mathrm{ft}$. in thickness), Wiltshire, through Oxfordshire into Buckinghamshire, where limestone thins out and is thence represented by clays. The formation is named after Wychwood Forest, Oxfordshire, where it was formerly quarried for building stone.

Forest Pig. Genus of huge black wild swine discovered in 1904 in the Ituri and Nandi forests of Central Africa. They have enormous heads, with conspicuous curved tusks; and there are large warty growths on the face. The animal has rarely been seen alive by Europeans.

Forest Reserves." Name given in the United States to areas reserved for purposes of conserving the trees, and now known also as National forests. In 1896 the National Academy of Sciences was asked to outline a rational forest policy, and in 1897 a further $21,000,000$ acres were added to the existing reserves of $18,000,000$. On June 30, 1917, there were 152 national forests with an acreage of $155,000,000$.

Canada also has large forest reserves, something over $150,000,000$ acres having been set apart. Of these, $107,000,000$ acres are in the province of Quebec. In Alberta, on the E. slope of the Rockies, there is a reserve nearly $14,000,000$ acres in extent. There are also extensive forest reserves in India. Under the state forest department these comprised 101,000 sq. m. in 1917-18.

Forest Row. Parish and village of Sussex, England. It is $3 \mathrm{~m}$. S.E. of East Grinstead, on the L.B. \& S.C.R., and a convenient startingpoint for a visit to Ashdown Forest. Between Forest Row and East Grinstead are the ruins of Brambletye House, once the home of the Lewknor family, and the theme of a romance by Horace Smith. Pop. 3,035. 


\section{FORESTRY : PRINCIPLES AND PRACTICE}

J. R. Ainsworth-Davis, Iate Principal, Royal Agrio. Coll., Cirencester

The article Afforestation deals with another branch of this subject. See also Timber and the articles on the various forest trees, e.g. Beech; Birch; Oak; Pine, etc.

Forestry is the science of cultivating trees, especially for providing timber.

Apart from the chemical composition of the soil, the amount of moisture it contains is a question of vital importance in the proper maintenance of a wood or forest. Climate is altered by the establish. ment of woods and forests. Within a wood the air is cooler in the summer time than it is in the open air, but the opposite is the case in winter time. This is due to evaporation, which, in the active growing season, is more abundant than in the winter time, when growth is at a standstill and sap is stagnant.

Problems of Soil and Climate

It is mainly on the selection of the suitable trees for the proper soil that successful forestry depends. No hard and fast rules can be laid down, but it is certain no trees will really thrive in a soil that is waterlogged, that is to say, where stagnant moisture is present in large quantities. On moist soils, such as are found at the sides of natural water-courses, but where the water is in circulation and percolating through the soil, the wil low, alder, spruce fir, and poplar may be planted with reasonable hopes of success. On chalky soils larch, Scots pine, beech, oak, ash, and sycamore are the best. On the ordinary rich loam any British timber tree will flourish. On sandy soil, only the coniferous trees, such as the pines, firs, and spruces, may be expected to produce profitable results; wl:ile on the heavy clay lands the British oak is the only tree, with perhaps the solitary exception of the horn. beam, which is likely to repay the trouble of planting and upkeep.

The most generally practised system of forestry is that of utilising old pasture or waste lands, and planting one- or two-year-old trees upon it. These young trees are roughly but simply planted by the process of cutting a triangular or tongue-shaped piece of turf up with a spade, splitting the tongue in the middle, loosening the soil underneath, placing the young tree in position, and then pressing down hard upon it the two half tongues of turf. Such young trees are usually planted about $5 \mathrm{ft}$. apart every way. In bleak and exposed situations it is sometimes the practice to harrow the surface of the ground before planting, and to sow seed of the common gorse or furze, which, being a quick-growing subject, will act as a "mother" for three or four years to the young trees, until they have fully established themselves. Sometimes, however, when the soil hap. pens to be rather more fertile than was originally imagined, the gorse will obtain such a hold upon the place that it will probably strangle all the trees it is intended to " mother," and render replanting necessary.

Owing to the vagaries of the British climate, the establishment of a forest or wood from seed rarely proves successful. But where prime cost is a matter of consideration, even if only one in four of the trees sown turns out to be fertile, the results will be found eminently satisfactory financially. In establishing a forest from seed the surface of the ground must first of all be broken up. This can be done by a harrow or, in the case of stiff clay lands, by the plough. It is well to sow seed with a liberal hand, as losses from dead seed, the ravages of vermin, and bad weather are enormous. The following quantities of seed are ample for sowing one acre of ground: Beech, 8 bushels ; elm, 15 lb. ; larch, 15 lb.; oak, 9 bushels ; silver fir, 30 lb. ;

Acorns and beech-mast are, of course, much more bulky than the seed of other native British forest trees. A pound of Scots pine seed consists roughly of 60,000 seeds, and larch bulks about the same. Ten thousand acorns fill a bushel measure, which would hold 50,000 beech nuts.

\section{Depredations by Rabbits}

Rabbits constitute a grave danger in all newly made plantations, and the only effectual method of guarding against their depredations is wire netting well pegged down and sunk into the surface of the ground. Several instances are recorded in which, during a hard winter, rabbits have disturbed and destroyed a whole plantation of young firs by gnawing away the bark of the trees, and leaving the stems exposed to the frost. Where sufficient labour is available, it is well to cut a niche some 6 ins. or a foot below the level of the ground and bury or plant the wire netting to that depth.

It is only to be expected that young trees raised from seed sown Scots pine, $8 \mathrm{lb}$. thickly and indiscriminately will die down right and left, especially in dry and exposed situations. In the S.W. of England, the sandy heaths of Surrey and Hampshire, and the moist districts of Ireland, plantations, especially of conifers, will quickly establish themselves. At the end of three years a fir plantation may be considered to be a commercial proposition, and the young trees will have attained sufficiont strength to carry on until thinning is requisite. It should be borne in mind that conifers and beeches prefer shady situations, while the ash and the oak are better in broad sunlight.

Guarding against Decay

One of the chicf difficulties in forming a new wood, or clearing up and rejuvenating an old one, is usually the presence of old and unhealthy timber. All dead and dying trees, ragged and tangled undergrowth, and other unprofitable stuff must be promptly cleared away in order to afford room for new seedlings, which require light, air, and sun. A competent forester will watch keenly for signs of decay among the trees under his care.

Decay begins to take place as soon as a tree has attained full maturity, and ceases to put forth fresh branches and vigorous leaves. It has reached the zenith of its power and should be at once cut down and sold. If, for sentimental reasons, the tree is allowed to stand and continue to decay, it will spread that decay to other trees, and thus bring a plague upon the whole plantation. The grand old oaks, yews, and other trees which are supposed to have existed at the time of the Norman conquest, and still continue to exist, are examples of splendid sentiment but bad forestry, and it is well that they are chiefly found in isolated specimens, and not in groves or forests, where they would cause an incredible amount of damage.

The question of thinning timber is a vexed one. In the case of larch, ash, and other close-growing woods, thinning may be carried out almost with impunity, for the young poles find a ready and remunerative market. This does not apply to the oak, becch, or other trees where girth is a greater consideration than height. The ideal wood or plantation is the one where the troes exhibit long and straight trunks, with the minimum number of side branches. Where planting has been carried out sufficiently closely, these side branches die off naturally for want of light and air, and this process or operation is called natural pruning. Pines and firs lend themselves 
most readily to close planting, and such plantations are naturally the most easy of management.

Dealing with the timber trees in the degrees of. importance, pride of place must be given to the oak, which for timber purposes may bc planted, in the case of young trees, within $3 \mathrm{ft}$ of each other, so as to destroy the chance of lateral branches asserting themselves and destroying the strength of the main trunk. Even when thinned the trees in an oak plantation should never be more than $12 \mathrm{ft}$. from each other.

The beech, the best tree for a calcareous or challky soil, is not of great value as a tiniber tree. The wood is best if cut in the middle of winter, when the vitality of the tree is at its lowest ebb, and is useful for brush handles, dairy utensils, chairs, and other purposes not of the first importance.

\section{Spruce, Pine and Fir Planting}

If planting for the present generation, and not for posterity, is the object to be considered, the most remunerative plantations to lav down are those of spruce, pine, and fir. These will thrive in comparatively poor soils, cost less to establish than woods of any other kind, show a cash return from thinnings at an earlier date, and attain maturity sooner. British forests have been denuded of coniferous timber to an unparalleled extent by the demands of the Great War, and both in Britain and on the Continent the prices which obtain on the market will be unprecedented for many years. Larch is always a good marketable timber, and there is a level demand for asl in the furniturs trade, but it is doubtful if ash, sycamore or chestnut will command the prices they have done in the past.

For the first few years after planting, young trees, except conifers, need very little in the way of attention. Plantations of spruce, pine, and fir should be gone over carefully to look for the defect generally known as pronging. Pronging is the presence and growth of a superfluous side shoot near the top of the main stem, dividing the stem at the apex into two false heads, like the prongs of a catapult. The continued exist. ence of this secondary stem will prove fatal to the tree both from an ornamental and useful point of view, and therefore it is necessary to cut it ruthlessly and promptly away, otherwise the symmetry of the tree will be destrnyed. Sonie foresters merely break the second. ary stem away from the main trunk and leave it hanging on the tree to die.
The common-sense object of practical forestry is to obtain the heaviest yield of timber possible per acre, consistent with profitable marketable quality ; hence it is a golden rule in sowing or planting to err rather on the generous side as regards the quantity of seeds or young trees established per acre. It is always possible, and, indeed, beneficial, to thin plantations which are overloaded with young timber. It is not so easy to make up a plantation which, for reasons of false economy, has been thinly planted, and in which for want of mutual support the young trees are weedy and leggy. Naturally, the closer trees are planted together, the longer, straighter, and more valuable will be the timber.

Thinning of woods should be in exact proportion to the amount of exposure to which they are subjected. For instance, a plantation upon a bleak hillside in Scotland needs less attention than one in the Lowlands. Thinning should also be carried out with a lighter hand on, and towards the edge of, the wood which faces the direction of the prevailing winds, since the outer belt of trees will afford some protection from the violence of tempests.

In old and neglected woods, where thinning has not been carried out for some time, the operation should be spread over a number of years, otherwise the sudden exposure of the whole plantation to wind and weather may cause serious and permanent injury. The tops of growing trees should not be opened too freely with the idea of admitting light and air. This only checks their growth, and is better deferred until the trees have nearly attained their full height. In addition, when young trees are very thin in the trunk in proportion to their height, to tamper with their heads will tend to cause the trees to grow crooked.

\section{Thinning Mixed Plantations}

When thinning an old wood in which there is no undergrowth or coppicing, it is necessary to preserve a canopy overhead, that is to say, a complete covering of foliage, in order to protect the roots and conserve moisture. Where, however, the wood is liberally planted with underwood this is not necessary, as the coppice will form a screen. Indeed, in dealing with these mixed plantations it is often better to thin the older timber with a free hand in order to admit plenty of light and air to the coppice, which may prove to be the most profitable part of the plantation. During the first seventy years of its existence an oak plantation needs to be thinned approximately once every ten years, according to soil and situation. At the end of that period, once in every twenty years is sufficient. Pines and other tim. bers, being, generally speaking, of more rapid growth, require thinning at more frequent intervals.

The quality of timber depends upon its weight, toughness, and durability or hardness. Where the tissues are closely compressed and the structure is dense, the wood will be heavy, but timber which contains much watery sap shrinks rapidly, and decays quickly when exposed, owing to excessive evaporation. Oak and pine shrink very little, and slowly; elm, poplar, and willow very rapidly. As a general rule those trees which take the longest time to attain maturity yield the hardest tim. ber, e.g. box, yew, and ebony, although the last is not a British timber tree. Oak is hardest when grown in loam upon a subsoil of blue clay, which renders the ground ferruginous, i.e. impregnated with oxide of iron. Soil of this nature improves the quality of the timber, but at the same time retards the full development of the tree.

\section{Use of Axe and Saw}

The axe is by no means the best implement to employ where economy of timber is desirable. The simplest form of felling, as practised in Britain, is "grubbing." This consists of clearing away the soil from around the roots of the trees, so that they are exposed, and then attacking them with axe and pick. As its supports are loosened the tree readily falls by its own weight, and though the remaining attached roots must be severed afterwards, this method has the advantage of leaving no stump in the ground, which saves considerable time and trouble where it is intended to follow with the plough, or to replant with timber. The use of the double-handed saw is, perhaps, the most general method of tree felling, though this as a rule necessitates the employment of the time of three men, two to saw and a third to wedge the cut with an iron wedge and sledge hammer, in order to prevent the weight of the trunk gripping the sawblade in the cut.

The simplest, quickest, and cleanest method of tree-felling, where a considerable quantity of timber has to be dealt with, is to use a patent steam tree feller, a machine invented in the 19 th century. With the huge demand for timber in Britain, it was freely employed, notably at the felling of the Ercall Woods, near Newport, in Shropshire. It consists of a simple 

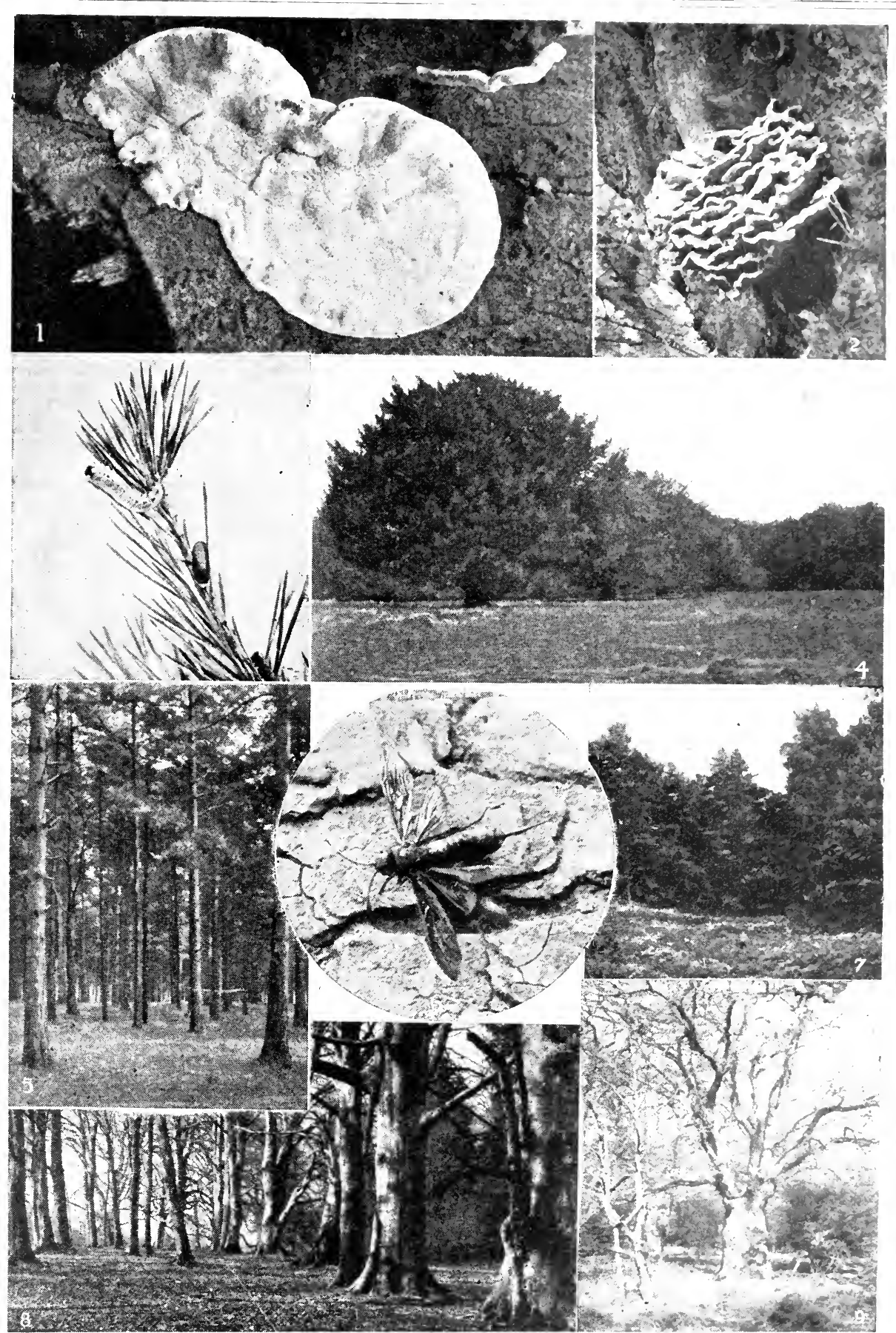

I. An outward symptou of iuternal disease: red-rot fungus, Fomes annosus, on Scots pine. Sulphur-tuft fungus, Polyporus sulphureus, on oak. 3. Larva of saw-
tly, Lophyrus pini, attacking young pine shoots. 4. Yew forest on Surrey chalk hills. 5. Wood of Scots pine grow 
form of horizontal engine, the piston-rod of which projects from the cylinder in the form of a saw blade. The machine is clamped at the foot of a tree, and steam at $80 \mathrm{lb}$. pressure is admitted direct to the cylinder through a hose pipe connected with a stationary vertical boiler.

The saw works to and fro as a piston-rod would do, and will cut through the trunk of an average fir, level with the ground, in one minute, or through a large tree in three minutes. The boiler is fod with waste wood, and the machine can be carried from tree to tree by two men. The area that can be cleared without the necessity for moving the boiler is only limited, within reason, by the length of the connecting hose pipe. The machine, run by a couple of men, will account for fifty trees a day.

The detection of decay in grow. ing timber is impossible to anyone but a trained expert, and, unless it has reached nearly to the bark, and is outwardly visible, its existence is usually unsuspected unless, as occasionally happens, it manifests itself in poverty of foliage. In a felled and stripped log or trunk, however, soundness may be ascertained in a simple manner. The ear should be placed close to one end of a log, and a person at the opposite end of the $\log$ should deliver a series of sharp blows with a hammer or mallet upon the wood. If only a number of dull thuds results it may safely be assumed that the wood is bad and decayed, but if the blows ring loud, clear, and continually resonant, it is sound.

Bibliography. Elementary Forestry, C. E. Curtis, 1905: Manual of Forestry, W. Schlich, 1911; Forestry Work, W. H. Whellens, 1919 ; Commercial Forestry in Britain, E. P. Stebbing, 1919.

Forestry Corps. Unit of the British army during the Great War. To secure an adequate supply of timber for the various purposes of the Great War, Britain decided to request help from Canada. Men were at once snrolled there, and the first draft reached England in
April, 1916, and proceeded to the extensive woods around Virginia Water, near Windsor. Two other drafts soon followed, bringing the strength up to 1,609 of all ranks.

The corps did not wait for the delivery of their own machinery, but adapted whatever they could get, both in England and Scotland.

The development of these lum. ber battalions from Canada into a distinct Forestry Corps took place in Oct., 1916, Colonel MacDougal being made its brigadier-general. By Jan., 1917, it was found neces. sary to provide a base, training and mobilisation camp in England, and by June of that year the corps in England and France totalled 15,000, and by Jan., 1918, it had grown to 18,000 . In Britain there were 38 camps or establishments and in France about 70.

Forez, Monts DU. Wooded range of mts. in the dept. of Loire, France. They lie in the W. of the dept., and divide the basins of the Allier and the Loire. The loftiest summit is Pierre-sur-Haute, 5,380 $\mathrm{ft}$. The range is also known as the Monts de la Madeleine and the Bois Noirs. The old division of Forez, in the prov. of Lyonnais, is now included in the dept. of Loire.

Forfar. Parl., royal and mun. burgh, and the county town of Forfarshire, Scotland. It stands in

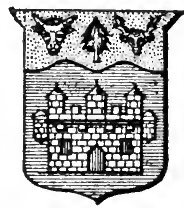

Forfar arms the Howe of Angus, $21 \mathrm{~m}$. N.E. of Dun. dee, on the Cal. Rly. The chief buildings are the county hall, town hall, court house, and Meffan Institute. A public hall and a park weregiven by Peter Reid, a merchant here. The chief industries are the manufacture of linen and jute; others are tanning, bleaching, and rope-making. It is also a rly. junction. The burgh is governed by a provost and council, and the corporation owns the gas and water supplies.

Forfar was a royal residence of Malcolm Canmore, whose castle on a hill to the $N$. of the town was taken and destroyed by Bruce in 1308 ; its site is marked by a cross erected in 1648. It was made a burgh in the 13 th century. Forfar is one of the five Montrose burghs which jointly return a member to Parliament. Market day, Sat. Pop. (1921), 9,585.

Forfarshire or ANGus. Eastern maritime county of Scotland. $\mathrm{F}_{\mathrm{t}}$ is bounded $\mathrm{S}$. by the Firth of Tay, and has an area of 873 sq. $m$. It has a grandly varied surface, falling into four natural divisions - the Braes of Angus, belonging to the Grampians and scored by several picturesque glens, in the N.W. ; the Howe of Angus, a part of Strathmore, in the centre; the Sidlaw Hills in the S.W., and the fertile plain in the S.E. Glas Meal (3,502 ft.), in the N.W., is the lof tiest summit. The $\mathrm{N}$. and S. Esks and the Isla are the main streams, and of several small lakes Loch Lee is the largest. Agriculture and cattle-rearing are prominent, and jute and flax manufactures occupy many people, but the minerals are of little economic value. Montrose and Dundee are fishing centres; Dundee, Montrose, and Arbroath are the chief ports.

The Cal. and N.B. rlys. serve the county. Forfar, the county town, Dundee, Arbroath, Brechin, and Montrose are the principal towns. One member is returned to Parliament. Pop. 270,950. Evidences of Roman occupation include camps; among other antiquities are the castle ruins of Edzell and Melgund, and the round tower at Brechin.

Literary Associations. AtDun. dee in 1465 was born Hector Boece (q.v.), and nearly two centuries later, at Baldovie, the classical scholar and educational reformer, Andrew Melville. Among the Forfar poets are Alexander Ross, the Lochlee schoolmaster who wrote Woo'd an' Married an' A'; William Thom, the weaver, who lived for some years in Dundee, and is buried there; and James

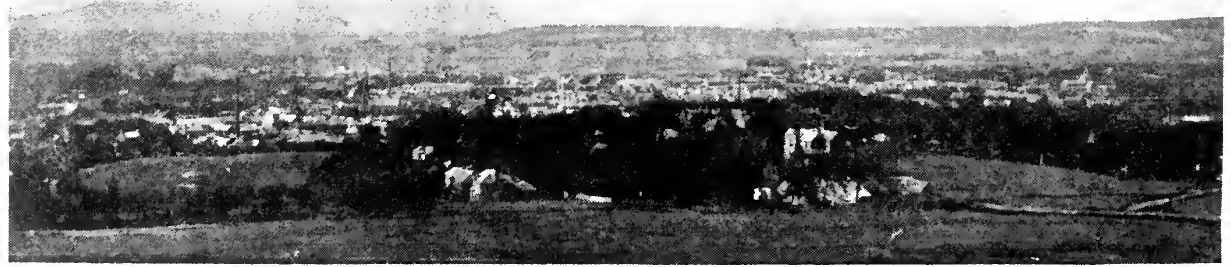

rortar. The county town of Forfarshire seen from Balmashanner Hill, looking towards the north 


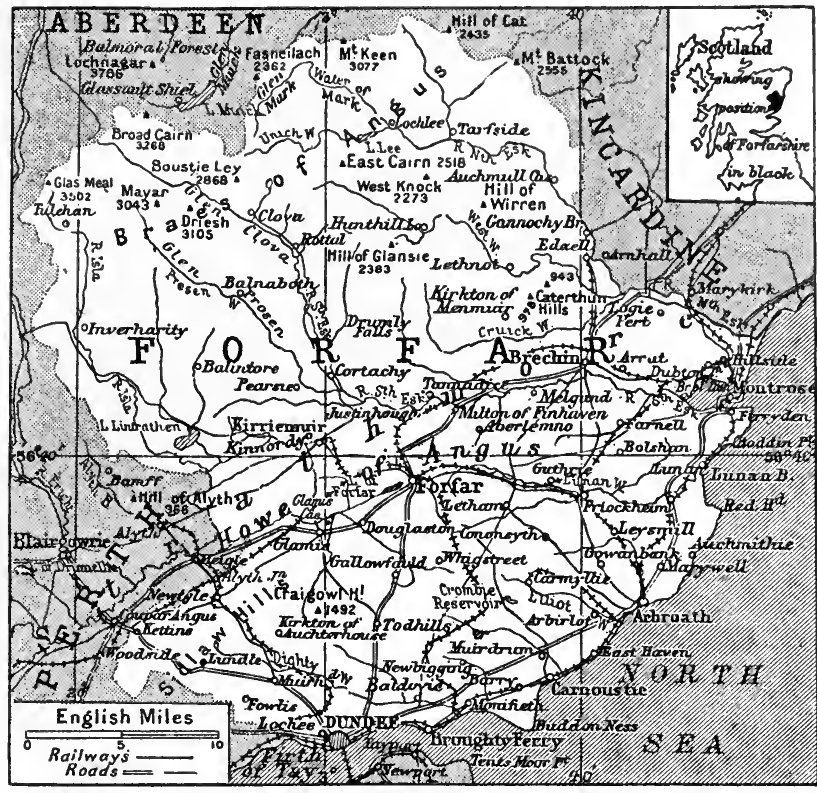

Forfarshire, Scotland. Map of the east coast county which includes the old district of Angus

Tytler, the dialect poet, who edited the second and third editions of The Encyclopaedia Britan. nica, and who was born at Brechin. Thomas Dick, writer and lecturer on popular science, was born at Dundee and died at Broughty Ferry. James Mill, the utilitarian philosopher, was born at Northwater Bridge, Logie Pert, and Sir Charles Lyell at Kinnordy, near Kirriemuir. At Kirriemuir itself was born Sir James M. Barrie, who has made his birthplace famous as Thrums.

Forfeiture (late Lat. foris fac. tum, something done outside). Deprivation of lands, goods, or other property, usually in consequence of a sentence passed by a court of law, or some breach of the law. In English law a person convicted of felony, treason, felo de $s e$, and certain other offences, including striking a judge, forfeited all his lands and goods to the crown. This was_abolished by the Forfeiture Act, 1870. At common law, also, an illegal conveyance of land, e.g. to an alien, before the Naturalisation Act, 1870 , or to a corporation in mortmain, was similarly punished.

The most common instance of forfeiture is in the case of lease. holds. Leases very generally contain conditions that if the tenant shall not pay his rent, or perform the convenant of the lease, e.g. to keep the premises in repair, the landlord may re-enter the premises to defraud. The common notion that forgery always consists in signing a false name, or imitating somebody's signature, is wrong. Thus, to alter the date or amount on a cheque, account, or receipt, though the signature is genuine, is forgery, if the alteration be made with intent to defraud. On the other hand, merely to subscribe a false name on a note or cheque may not be forgery at all if there is no fraudulent intent. The law on the subject is dealt with by the Forgery Act, 1913.

Forget-Me-Not. Hardy peren. nial plant of the natural order Boraginaceae, genus Myosotis. Na-

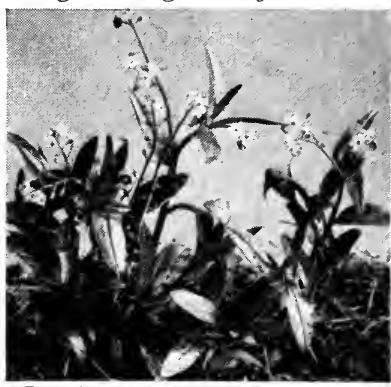

Forget-Me-Not. Leaves and flowers of the perennial plant equity, however, would always and still do relieve against the forfeiture, and allow the tenant to keep his lease if he comes and offers to make good his default and repay the landlord any expense he has been put to. On breach of any covenant, except a covenant for payment of rent or a covenant not to assign or underlet, a landlord cannot begin proceed. ings to enforce a forfeiture without giving the tenant notice to make good the breach. No notice is re quired or relief given where there is condition for forfeiture on the tenant's bankruptcy.

Forge (Lat. fabrica, workshop). In metallurgy, term with a wide meaning. It covers the simple hearth of the blacksmith, early fur. naces such as the Catalan forge (q.v.), in which malleable iron was produced in Europe for a long period, and the modern extensive plant comprising furnaces, cranes, ham mers, rolling mills, presses, engines, or motors and boilers, which make up a modern iron-manufacturing works. It always relates, however, to the working of iron from a crude or semi-manufactured form, to a higher order, as distingu shed from melting and casting. See Iron; Metallurgy; Steel.

Forgery (Lat. fabricari, to frame). English law term for making or altering a written instrument which purports to be valid on the face of it, with intent tives of Britain, their height is from 7 ins. to 18 ins.; the flowers are blue and yellow. Several cultivated varieties are raised from seed planted out of doors in spring, and transplanted to their permanent positions in the autumn, when they will flower in the spring and summer of the following and successive years. The best position is a moist corner of the rock garden. The well-known blue variety is $M$. palustris, which, though found naturally by the sides of brooks and streams, will thrive equally well in the garden as an edging, or in small beds or borders in moist peaty soil. A rarer natural spe. cies is $M$. palustris alba, which has white flowers.

Forget-Me-Not. Drama by Herman Merivale and F. C. Grove. It was produced at The Lyceum, Aug. 21, 1879, by Genevieve Ward, who acted in the piece all over the world.

Forging. Production of articles of iron or steel or other metal by hammering, pressing, rolling, or otherwise shaping the metal while heated but not in a molten condition. It is distinguished from casting by the fact that the metal is never raised to a temperature sufficiently high to melt it.

It is almost certainly the most ancient branch of the whole art of metallurgy, and was first practised by primitive man in shaping 
pieces of native copper into rough weapons or implements. It depends upon the property which metals possess, some more eminent ly than others, according to which they "flow" under pressure while in the solid state. In its broad sense it embraces all the operations of shingling, cogging, and rolling by which "merchant" bars and plates are produced; the works in which such operations are carried out, while frequently styled rolling mills to-day, were originally termed forges, and the term is still largely retained.

These processes involve, first, the proper hcating of the crude mass of metal to the requisite tempera. ture; and, secondly, the use of tools specially adapted to impart the desired shape to the heated mass of metal. They are modified more or less according to the metal which is to be operated uponiron, steel, copper, aluminium, IIuntz metal, Delta metal, phosphor bronze, gold or silver. The forging proper will nearly always begin with a reducing operation, "draw ing down" a piece of metal to a smaller size.

Thus, in the production of an ordinary stonecutter's chisel, a round or a six-sided bar of steel of the desired thickness will be taken. The end of this bar will be heated in the smith's fire, and as soon as the right temperature has been reached the bar will be withdrawn, the heated end laid on the smith's anvil and hammered out-drawn down-until it has assumed the required chisel shape. If the chise is a small one the whole operation so far may be done by the smith himself with his hand hammer.

Principal Operations of Forging

Otherwise the chisel will be finished by the use of a "swage,"which in this case will be a flat-faced tool held in a handle made of twisted iron rod. The smith will lay the face of this swage on the end of the chisel and his helper or striker wil strike it with his sledge-hammer, thus producing a finished surface of the desired shape, free from hammer marks. The end of the bar will then be notched by means of a smith's chisel at a distance up the bar corresponding to the length of the chisel desired, and the piece broken off. It is not yet finished, however; it will be desired to flatten out and round off the blunt end of the chisel. That end is therefore heated again, the chisel is then withdrawn, and the end hammered or knocked upon the anvil, when it will be broadened out more or less, as required. This operation iscalled "upsetting." The production of this simple article thus illustrates four principal operations of forging-heating, draw. ing down, cutting off, and upsetting.

Other principal operations are bending, holing, and welding. In the production of a great propeller or engine shaft which may weigh 100 tons, or of a 100-ton gun, the operations are essentially the same.

\section{Drop or Die Forging}

In the modern system of drop or die forging, the heated piece of metal is pressed into a die, a hardened steel form, by a hammer falling or dropping repeatedly upon the die. The hammer is worked mechanically, its weight amounting in large machines to $3,000 \mathrm{lb}$. Many of the parts of motor-cars, motor-cycles, bicycles, and innumerable other articles in iron or steel are now made by drop forging. Bolts and nuts, screw blanks and rivets are now made chiefly by machine forging, in which the machine takes a heated bar of iron or steel, cuts off a definite length, shapes the latter to the form required, and ejects it automatically. See Casting; Metallurgy ; Welding.

Forging Press. Instrument used in metallurgy. The increasing sizes and complexity of articles in malleable iron and stecl required in

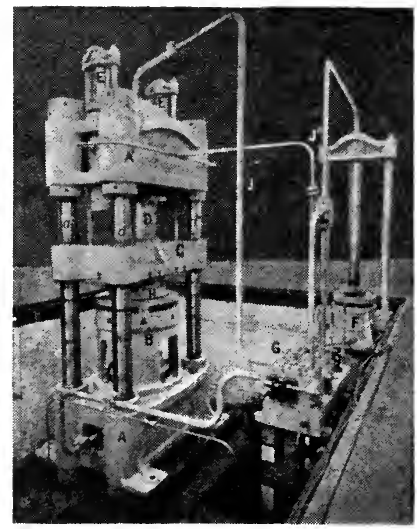

Forging Press. A, A'. Base and head connected by columns, a, $\mathbf{a}^{\prime}, \mathbf{a}^{\prime \prime}$. B. Stand attached to base and to upper part of which tables and dies are attached. C. Inverted platen attached tached. C. Inverted platen attached
to ram, D, which works up and down under hydraulic pressure. Platen slides up and down columns. $E, E^{\prime}$. Betractor rams which pull up the platen after each downward stroke. F. Intensifier which puts final extra F. Intensifier which puts final extra
pressure on ram, $D$, and articles being made. G. Hydraulic pumps workin rams. $\dot{H}$. Flanged tire of small railway truck wheel receiving finishing press. Ram, D, may make from 30 to 80 strokes per minute, each 30 to 80 strokes per minute, each
pressing article a little nearer final shape. J, J', J'. Hydraulic connexions conveying pressure to the various rams engineering particularly, such as heavy flanged plates, cranks, and crank shafts, began to make their production by means of the steam. hammer difficult. Attention was therefore directed to the hydraulic press as likely to prove a more effective appliance, and such objects are now largely produced by its aid. Very powerful presses, capable of exerting a total pressure of 10,000 tons, have been built for forging purposes. The illustration shows a press of this character with its pumps and control valves, adapted as it stands for the production of flanged wheels and other heavy flanged plates by direct pressure.

Forisfamiliation (Lat. foris, outside; familia, family). In Scots law, the alienation of a child from his father and exclusion from further inheritance, by mar. riage, by provision made for him by his parents in ante-nuptial settlement or other portioning, or by his own renunciation of his legal right to legitim $(q \cdot v \cdot)$. The custom is derived from the Roman law of emancipation of a son from his father's power by fictitious sale and manumission, by imperial rescript, or by formal declaration, after which the son became independent (sui juris), quitted the family to which he formerly belonged, and, as a general rule, lost the rights of agnation.

Fork (Lat. furca). Instrument for holding or lifting. It consists of a handle, terminating in two or more prongs. An example is the table-fork of silver or other metal. A tuning fork (q.v.) is a two-pronged steel instrument which when struck gives a fixed and definite note, used to determine musical pitch. By analogy the word is used for something (e.g. a road) which divides into two.

The farm implement of this name has a wooden handle and two or more steel tines. The two-tined kind, when large, is known as a pitchfork, used for loading hay or grain. Short, stout, emptying forks, of similar pattern, serve for unloading, while turning and collecting forks are still smaller, but with the same number of tines. Digging forks possess three to five tines, which may be round, square, or flat. Additional leverage is given by a sharply bent neck, and a short handle is preferred. Dung forks, for dealing with farmyard manure and litter, usually have three or four curved tines of circular section. Caving, cocking, or pooking forks, for collecting and loading short material, are somewhat similar, but the tines are long and wide apart, while they are continued backwards above the neck 
and connected by a cross-bar, so as to prevent the forked-up stuff from falling off again.

Forli. Prov. of N.E. Italy. Bounded E. by the Adriatic Sea and $\mathrm{N}$. by the prov. of Ravenna, its area is 730 sq. $\mathrm{m}$. The surface is flat and low-lying, and the soil fertile. The chief products are wine, grain, silk, and sulphur. Pop. 316,420. Pron. For-lee.

Forli. City of Italy, the ancient Forum Livii. The capital of the prov. of Forli, it stands in a fertile plain, intersected by the rivers Montone and Ronco, $40 \mathrm{~m}$. by rly. S.E. of Bologna by the main line from Bologna to Brindisi. A walled town, it contains a cathedral (rebuilt), a citadel, 1361, utilised as a jail, a lyceum, technical institute, a municipal art gallery, a town hall, a good library, and a hospital. The churches contain pictures and frescoes by local mas. ters. A thriving trade is carried on in cattle, cereals, wine, silk, and hemp, while the manufactures include furniture, earthenware, machinery, head gear, shoes, and silk goods. Founded about 200 B.c., in the Middle Ages it was part of the exarchate of Ravenna. It experienced many vicissitudes during the quarrels of the Guelphs and the Ghibellines, and fell to the papacy in 1504. Pop. 48,943.

Forlorn Hope (A.S. fore-lioran, to send forward, hauife, a troop). Military expression once signifying troops sent forward. The implication that they are to carry out a specially dangerous enterprise is a comparatively modern use of the expression. The French, Dutch, and German equivalents are enfants perdus, lost children, ver. loren hoop, lost troop, and verlorner Posten, lost post. In hunting phraseology, a hound that follows the chase in front of the rest of the pack is referred to as a forlorn or forloyne hound. In ordinary language forlorn hope is used of any hopeless undertaking, hope being erroneously identified with hope meaning expectation, a word of an entirely different etymology.

Form (Lat. forma). Word literally meaning shape. It denotes the manner in which the matter or parts of a whole are combined. Thus, a table or a chair may be made of pieces of wood, but the form of a table differs from that of a chair in the arrangement of the materials. 'Aristotle lays down four causes or principles of being the material, the formal, the efficiont, and the final. The three last-named on examination will be found to run into one another, leaving only the opposition of Form and Matter. Matter is possibility or potentiality (dynamis) which becomes actuality (energeia) by its conversion from indeterminateness into something definite. As an adaptation of the Platonic idea, form is the realization of the ideal e.g. of a perfect table, that the carpenter has in mind. See Matter.

Form. In music, the plan of construction, or the arrangement of phrases, sections, and movements. There is no limit to the possible varieties of musical form, but a few outstanding classes may be named. Binary form has two main divisions, as exemplified in the old air Barbara Allen; ternary form has three divisions, or in Charlie is My Darling. From these two germs most of the larger specific forms have bcen evolved, such as the rondo, the sonata, and all their derivatives. The fuigue is essentially a contrapuntal movement of continuity, but it has an underlying basis of sectional form.

Many compositions bearing other generic names are also referable to these forms ; e.g. many songs and short instrumental pieces are in simple ternary form, called also primary, song, or lied form ; many marches are in rondo form ; the minuet and trio, in a suite, or sonata symphony, are each in either binary or ternary forms, while together, with the recapitulation of the minuet, they constitute a larger ternary form. See Minuet; Suite; Symphony; Trio.

Formalin or FoRMALDEHYDE (HCOH). Pungent gaseous compound first prepared in 1867 by Hofmann by passing methyl alcohol vapour and air over a heated platinum spiral. A 40 p.c. solution of formaldehyde is known as formalin, and is the form in which the gas is obtainable in commerce. A current of air drawn by an aspirator is passed over methyl alcohol and in contact with copper gauze, formaldehyde being formed. The gas is made to pass through a series of receivers containing water, until the water is saturated with the gas. Formalin is employed as a preservative and antiseptic. Combined with ammonia, formaldehyde yields hexa-methylene-tetramine, which, under the name of urotropine, is extensively used in medicine as an internal antiseptic.

Formalin is a powerful caustic ; when mixed with ten times its volume of water it may be used for removing corns. A 30 p.c. solution may be employed for the treatment of ringworm of the scalp, and a solution of 1 in 500 may be used as a mouth-wash. Formalin is not much used in surgery as an antiseptic, as it tends to retard healing. It is a powerful disinfectant and has the advantage that it does not injure coloured fabrics.

Formalism. In philosophy, the tendency to consider mere form or externalities as the only valuable part of anything. Thus, the adherence to cut-and-dried rules, like those of formal logic, is formalism. The same applies to the rules of composition in sculpture or paint. ing. The term is specially used of strict adherence to religious forms and dogmas characterised by the absence of a genuine religious feeling. Formulism is rather the reduction of such forms and dogmas to a written system.

Forman, HaRRY BuxtoN (18421917). British author. Born in Łondon, he was from 1860 to 1907 in the Civil Service, rising to be second secretary to the general post office and controller of packet services. In addition to his Letters of John Keats to Fanny Brawne, 1878, his Elizabeth Barrett Browning and Her Scarcer Books, 1896, and his Bôoks of William Morris, 1897, Forman edited the standard edition, 1876-80, of Shelley's works. He collected Trelawny's Letters, 1910, deciphered Shelley's Note Books, 1911, and enlarged Medwin's Life. His industry and discrimination were of great value to students of Shelley and his work. He died June 15, 1917.

Forman, SimoN (1552-1611). English astrologer and quack doctor. Born at Quidhampton, Ham $\mathrm{pshire}$, Dec. 30, 1552, and left destitute as a boy, he entered Magdalen Col. lege, Oxford, a $\mathrm{s}$ a o o r scholar, 1573 . After some years' expcrience as an usher

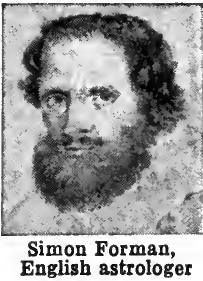

in small country schools he claimed miraculous powers, and in 1580 professed to be able to curediseases. He studied medicine and astrology in Holland, and in 1583 started practice in London, wrote treatises on mathematics and medicine, and began to seek the philosopher's stone. Though frequently arrested at the instance of the College of Physicians and other authorities, he worked among the poor in plague-stricken areas and obtained a large and far less honourable practice among court ladies: $e . g$. his aid was sought by Lady Essex to alienate the love of her husband and influence the affection in her favour of Somerset.

Cambridge granted him a licence to practise medicine in 1603. 


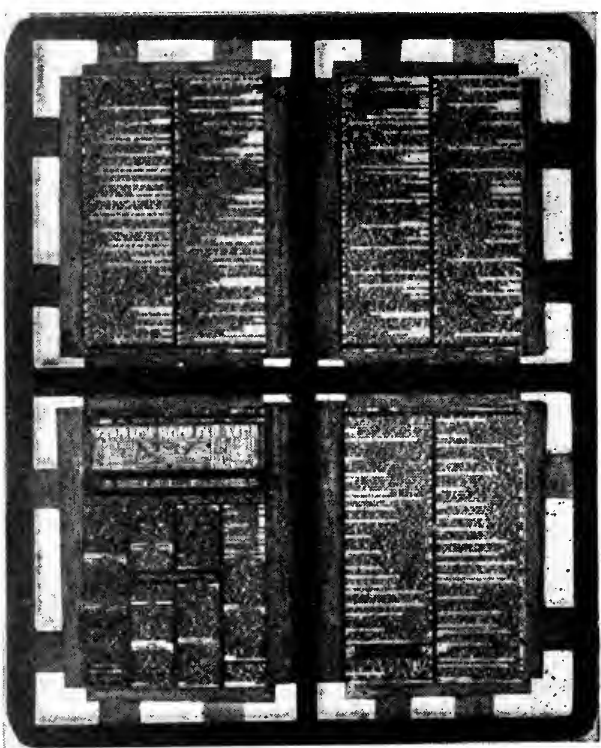

Forme. Four pages of type locked up in a chase making a forme ready for printing up" in a metal frame called a chase. See Printing. One of the Balearic Islands, in the W. Mediterranean Sea, belonging to Spain. I $t$ is the smallest and most south. erly of the group, and lies $7 \mathrm{~m}$. S. of Iviza. Area 37 sq. m. Fishing and salt-working are engaged in. l'op. 2,600.

Formia. Town 'ff Italy, in the prov. of Caserta, until recently called Mola di Gaeta. Situated in the N. side of the Gulf of Gaeta, $\$ 8 \mathrm{~m}$. by riy. W.N.W. of Caserta, it is a seaside resort. A Volscian

Richard Nicolas, in Overbury's Vision, 1616, thus refers to him : Forman was that fiend in human shape That by his art dld act the devil's ape.

His philtres are alluded to in Jonson's Epicoene (iv, 1), and his career suggested much in Jonson's play, The Alchemist. He died Sept. 11, 1611, and was buried in S. Mary's Church, Lambeth. His IISS., which came into the possession of Elias Ashmole, included a diary, 1564-1602, publ. 1849 ; Notes on Chemistry, Astrology, Alchemy, and Geomancy; and a Booke of Plaies.

Formation. In geology, an old term used to denote a group of strata or rock-beds. They are distinguished by common lithological characters, such as the Upper Greensand formation (sandstone) and Gault (clay). Modern divisions of stratified rocks are based on fossils enclosed, which often prove strata of different lithological as. pect to be of same age. For these divisions "stage" names are applicd, e.g. Selbornian stage, which includes both Upper Greensand and Gault formations.

Formby. Urban district, market town, and watering-place of Lancashire. It is $7 \mathrm{~m}$. S.W. of Southport, and has a station on the L. \& Y.R. It is really a residential suburb of Liverpool. Near are the Altcar Flats, on which the Water. loo Cup is decided. Pop. 5,950.

Forme. In printing, a page or number of pages of type, or stereoplates, arranged or "imposed" for printing and secured or "lockec" town, known as Formiae, it stood residential district for wealthy Romans, remains of whose villas stud the coast. Here Cicero lived, and met his death, near his villa, Dec. 7,43 B.c. The town has a little trade in olive oil and earthenware, and the surrounding districts yield an abundance of fruit. Pop. 8,734.

Formic Acid (Lat. formica, ant). The lowest in the important series of fatty acids. Its chemical formula is $\mathrm{CH}_{2} \mathrm{O}_{\%}$. It was first obtained by John Ray in 1670 by distilling red ants with water, his observations being printed in the Philosophical 'Transactions of that year. Formic acid occurs in other animal and vegetable substances, but is now made by: (1) heating to $60^{\circ} \mathrm{C}$. in a retort a mixture of sugar, water, manoanese peroxide, and sul. phuric acid; (2) by heating equal parts of anhydrous glycerine with oxalic acid and distilling the product. The liquid acid is colourless, and has a pungent, sour taste and odour. (Lat. formica, ant; vorare, to devour). Genus of passeriform family Formion the Appian Way and was a

Formicivora birds of the
Formentera.

cariidae - Ant-birds - natives of South and Central America. They have long, compressed and hooked beaks; the foot (metatarsus) is short and thick, and the outer and middle toes are joined towards their base.

Formidable. British battleship, the first of her class sunk by a submarine in the Great War. She was launched at Portsmouth in 1898 and completed in 1901, her principal characteristics being : length $400 \mathrm{ft}$., beam $75 \mathrm{ft}$., displacement 15,000 tons, specd 18 knots, with an armament of four 12-in., twelve 6-in., and 1812 . pounder guns. She was torpedoed in the English Channel on Jan. 1, 1915. About 600 lives were lost, and 71 officers and men were saved.

Formigny, Battle of. Fought between the English and the French, Apl.15,1450. To strengthen the English eause in France a force under Sir Thomas Kyriel was sent to Cherbourg. About 2,500 strong, it was joined in Normandy by another $1,000 \mathrm{men}$, and this army, having taken Valognes, moved to Formigny, not far from Bayeux. There it was met by a French force, and the English were routed.

Form Letter. Letter of which many copies are made, generally used for advertising purposes. Frequently they are printed so as to resemble a typewritten letter, the name and address being inserted afterwards, as far as possible in the same type and ink as the form letter. See Advertising; Mail Order.

Formocyanine. Name given to a British dye discovered in 1916 . Researches were carried out by the university of Leeds, and two dyes, formocyanine and tolucyanine, were prepared, both of which are used in colour printing. See Colour Printing ; Dyes.

Formosa. Island in the W. Pacific Ocean. It is "the beautiful island" of the Portuguese fareastern navigators of the 16th

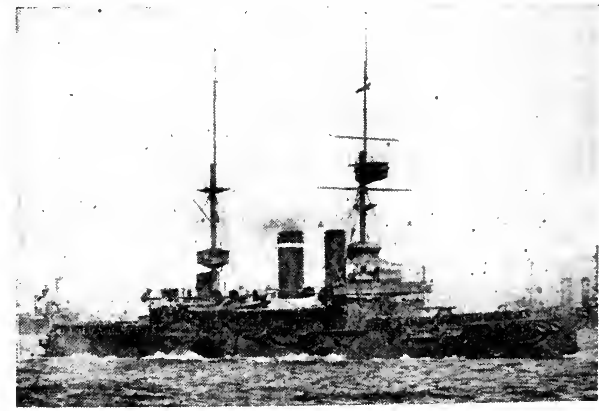

H.M.S. Formidable. The last photograph of the vessel. taken during the naval review, July 20, 1914 


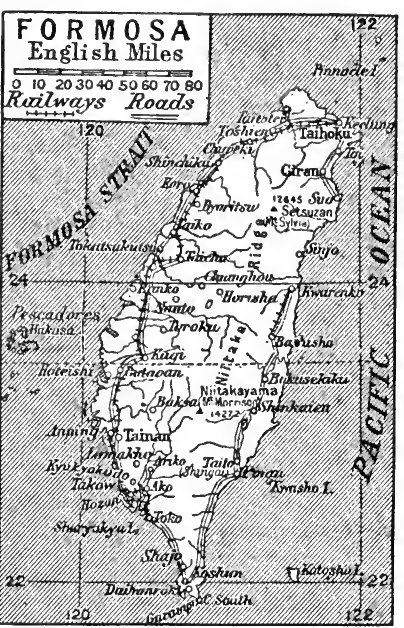

Formosa. Map of the island sur. rendered by China to Japan in 1895

century, called by the Japanese Taiwan or Terrace Bay. It is $244 \mathrm{~m}$. in length with a maximum width of $76 \mathrm{~m}$. Separated from the mainland of China by the storm-swept Strait of Formosa, it is crossed by the tropic of Cancer.

An island of wonderful fertility and great natural beauty, it is sharply divided into two nearly equal portions. The western side, facing China, consists of highly cultivated plains; the eastern, of lofty forest-clad mountain ranges, which extend to the E. coast, where the island faces the open Pacific, with steep, perpendicular cliffs, rising to a height in some places of $6,000 \mathrm{ft}$. The mountains are inhabited by tribes of fierce savages of Malay or Negrito origin, who, since the island was surrendered by China to the Japanese after the war of 1894-95, are being gradually brought into subjection. The western half is inhabited by Chinese agricultural and industrial settlers, and their descendants, and by Japanese, the total population of the island being $3,698,918$.

The chief products are rice, tea, sugar, salt, rattans, sweet potatoes, hemp, jute, indigo, and camphor. Its minerals are gold (alluvial), silver, coal, copper, petroleum, and sulphur. Eoonomie timber, as yet almost untouched, may be said to be inexhaustible. It is the principal source of the camphor supply of the world. The climate is hot, damp, and malarious. In the $\mathrm{N}$. there is a very heavy rainfall, and violent typhoons are frequent. The trunk rly. starts at Keelung, the chief harbour, passes Taihoku, the capital, Taichu, Tainan, the oldest city, and Takow to reach Hozan.
Formosa. Territory of Argentina, in the N.E. of the republic. It lies between the rivers Pilcomayo and Bermejo, with Paraguay on the E., the Gran Chaco on the S., and the prov. of Salta on the W. It includes part of the Gran Chaco. The interior contains forests and swamps, abounding in game. Area, $41,402 \mathrm{sq}$. m. The capital is Formosa, on the river Paraguay, a centre for agricultural produce, as well as for cattle, tobacco, and sugar. It has a port and a wireless station. Indians inhabit the interior. Pop. 20,458.

Formosa. Strait or channel separating the island of Formosa from China. It is about $150 \mathrm{~m}$. broad and contains the 12 Pesca. dores Islands, the largest of which is Hokoto.

Formula (Lat. forma, little form). Prescribed form of any. thing. In mathematics formulae are the general expressions used in solving problems; thus $a^{2}-$ $b^{2}=(a-b)(a+b)$ is a formula The word is most commonly used perhaps in chemistry. A collection of formulae in a book is called a formulary.

Chemical formulae are symbolical representations of the arrangement of the atoms within the molecule, the modes of the formation and de. composition of a compound, or the relation which the allied com. pounds bear to one another. Dalton, in 1808, devised a system of circles to represent atoms, grouping them together to show how compounds are made up. Later Berzelius employed a system based on the atomic theory from which the modern usage has developed, owing to the need of devising means oî expressing such facts as the rela. tion of the atoms which enter into the composition of the molecules.

The various kinds of chemical formulae are best illustrated by reference to acetic acid. The molecular formula is $\mathrm{C}_{2} \mathrm{H}_{4} \mathrm{O}_{2}$, indicating the atoms of which the molecule is com. posed. The em. pirical or rational formula is $\mathrm{HC}_{2} \mathrm{H}_{3} \mathrm{O}_{2}$, which emphasises the replaceable hydrogen of the acid. The following examples are constitutional or structural formulae
(1) $\mathrm{OC}<\mathrm{OH}$.
(2) $\mathrm{CH}_{3} \cdot \mathrm{CO} \cdot \mathrm{OH}$

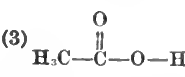
(4) $\mathrm{H}-\stackrel{\stackrel{\mathrm{C}}{\mathrm{C}}-\mathrm{I}}{\mathrm{H}}-\mathrm{C}=\mathrm{O}$

These are intended mainly to express the relations or linkage between the bonds which determine the behaviour of the sub. stance. No. 2 indicates that acetic acid is composed of the two compound radicals, methyl and carr boxyl. Constitutional formulae are determined by experiment and indicate properties which a com. pound may be expected to possess. See Chemical Signs.

Fornax. One of Lacaille's southern circumpolar constella. tions. Its name means the chemical furnace. See Constellation.

Forres. Royal burgh and ma-. ket town of Moray or Elginshire, Scotland. It stands on the river

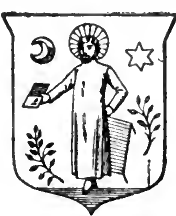

Forres arms Findhorn, near the Moray Firth, $12 \mathrm{~m}$. S.W. of Elgin. The prin. cipal buildings are the town hall, Falconer Museum, Anderson's Institution, and Mechanics'

Institute. An ancient monolith, named Sueno's stone, is said to have been placed here early in the 10th century. On Castle Hill was

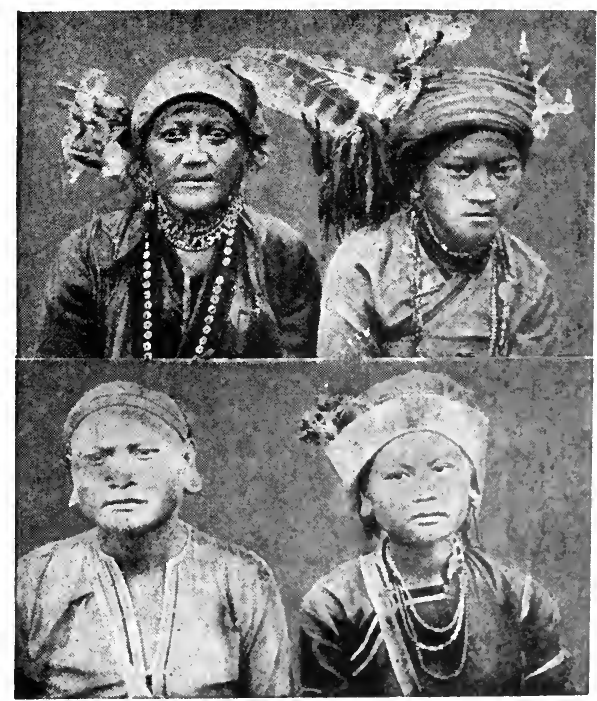

Formosa. Natives of the Paiwan group. Above, man and woman of the Tsuo group in elaborate head-dresses 


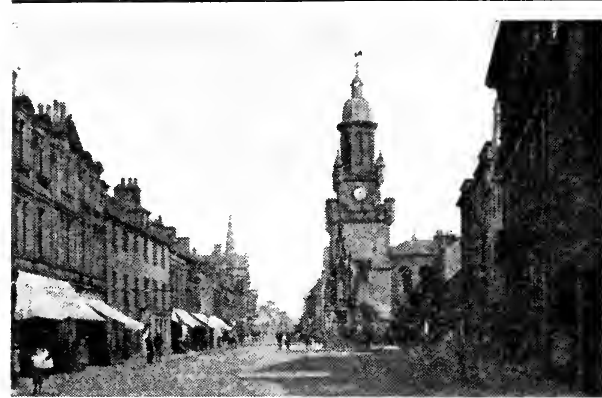

Forres, Scotland. The High Street, with the Court House, built 1839, and, in front of it, the Market Cross, 1844

$$
\text { Talentine }
$$

a royal residence in the 12 th century. Footwear, woollen goods, and chemical manures are manufac. tured. Forres is in a sheltered posi. tion at the foot of the Cluny Hills, and near by is the Cluny Hill hydropathic. Pop. 4,932.

Forrest, John Forrest, Baron (1847-1918). Australian states man and explorer. Born near Bun-

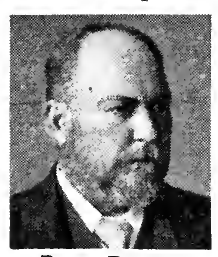

Baron Forrest, Australian statesman Elliolt \& Fry bury, W. Australia, Aug. 22 1847 , and edu. cated at Perth, he became a state surveyor, 1865, and explored the interior of $\mathrm{thc}$ continent. Survey or -general of W. Australia in 1883, he became its first premier in 1890 , a post which he held until 1901 . He was knighted in 1891 . He took part in the negotiations leading to the formation of the Commonwealth, and in 1901 became its first postmaster-general. He was minister of defence, 1901-3, of home affairs, 1903-4, and treasurer for four periods. He resigned in 1918 , and was created a peer, the first Australian so honoured. His title lapsed on his death, Sept. 3, 1918.

Forst. Town of Prussia, in Brandenburg. It stands on the Neisse, $44 \mathrm{~m}$. S. of Frankfort-onOder. The main industry is the weaving of cloth. Pop. 33,875.

Forster, Henry William Fors TER, IST BARON (b. 1866). British politician. Born Jan. 31, 1866, he was educated at Eton and Ne w College, Oxford, a nd represented both school and university at cricket. In 1892 he was elected M.P. for Sevenoaks division of

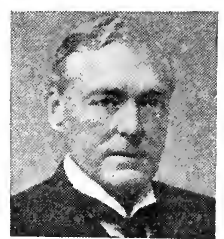

1st Baron Forster British politician Russell 1918. In June, 920 , he was appointed governorgeneral of Australia.

Forster, JoHN (1812-76). British historian and biographer. Born at Newcastle, April 2, 1812,

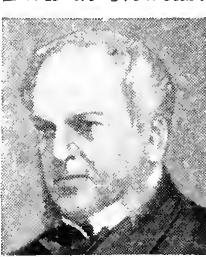

John Forster, British historian After C, E. Perugini

Kent, and was a lord commis. sioner for the treasury, 1902-5. In 1915 he became fin ancial secretary to the war office in the Coalition government, in 1917 a privy councillor, and in Dec., 1919, when he resigned, was created a baron. He had sat for Bromley since 1846. From Daily News edited The Examiner, resigning this post on his appointment as secretary to the commissioners of lunacy. From Nov., 1861, to 1872, he was commissioner of lunacy.

In addition to the two works by which he is best known, The Life and Times of Oliver Goldsmith, 1848, and The Life of Dickens (with whom he was most intimate), 1872-74, he wrote Lives of the Statesmen of the Commonwealth, 1836-39, Arrest of the Five Members, 1860, a Life of Sir John Eliot, 1864, and vol. i of a Life of. Swift, 1875. His collection of MSS., books, and pictures forms the Forster bequest at the $\mathrm{S}$. Kensington Museum. He died Feb. 1, 1876.

Forster, William Edward (1818-86). British politician. Born at Bradpole, Dorset. July 11, I818. his parents were Quakers, and he was educated at a Quaker school at, Tottenham. $\mathrm{He}$ entered business in Bradford and soon became a

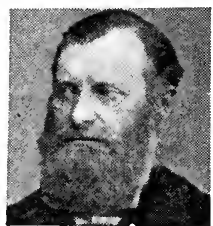

W. E. Forster, British politicia woollen manufacturer there. $\mathrm{He}$ found time also for public work; writing and lecturing made him known, and in 1859 he was par. liamentary candidate for Leeds. He was unsuccessful, but in 1861 he was returned as Liberal M.P. for Bradford. $\mathrm{He}$ retained the seat throughout his life.

In 1865 Forster joined the Liberal ministry as under-secretary for the colonies, but he was soon in opposition. In 1868 he became vice-president of the council in Gladstone's first ministry. He had already shown a lively interest in popular education, and it fell to him to frame and introduce the important Education Act of 1870 . $\mathrm{He}$ showed great perseverance in getting it through the Commons, for the religious question aroused acute controversies and both sides criticised him for steering a middle course. He remained in office until 1874 , and in 1880 returned thereto this time to the difficult position of chief secretary for Ireland. He introduced a Coercion Act, and though his life was constantly in danger carried on his duties with absolute fearlessness.

In 1882 he resigned, as Gladstone released the political prisoners from Kilmainham. Henceforward his attitude towards Irish policy was critical, and it was not surprising when he declared against Home Rule. On April 6, 1886, he died at his London residence.

Forster was a convinced but in. dependent radical, early urging reforms afterwards adopted, but he was never very.docile in following others. He was something of an imperialist, and was never afraid of expressing his views. He married, in 1850, Jane Martha, eldest daughter of Dr. Arnold, and he adopted four children, his wife's nephews and nieces, who were known as Arnold-Forster. See Life, Sir T. Wemyss Reid, 1888.

Forsterite. Light - coloured variety of mineral olivine. It contains a small proportion of silicate of lime, and occurs in limestones altered by intrusion of igneous rock.

\section{See Olivine.}

Forsythia. Genus of shrubs of the natural order Oleaceae. Natives of Japan and China, they have smooth, simple, or trefoil leaves, and scattered yellow flowers, abundantly produced in early spring, which makes the two species, $F$. suspensa and $F$. viridissima, favourites in European gardens. The genus is named after William Forsyth, an 18th century gardener.

Fort (Lat. fortis, strong). Dim. inutive of fortress. It was commonly used for fortified trading stations, and there were hundreds of these in N. America.and in India. Some of these, e.g. Fort Duquesne, still retain the prefix, but others, 
e.g. Ticonderoga, have lost it. Some rough shelter and protection was thrown up, and the fort served as a storehouse and rendezvous for the traders, being also in cases of attack a refuge for them. During the war between England and France the existing forts were strengthened and new ones erected, and many attacks made on them. The modern sense of fort is rather that of a part of a fortress. Thus Verdun and Liége were defended by rings of forts, each one having a distinctive name. See Fortification; Fortress.

Fort, PAUL (b. 1872). French poet. Born at Reims, he early migrated to Paris, where he founded the Théâtre des Arts, producing modern plays, and becoming a centre of the Symbolist poets. Issuing his early ballads as pamphlets, he published his first volume of Ballades francaises in 1897, and thenceforth produced one or more volumes annually, maintaining a remarkably high level. Pron. For.

Though master of varied lyric metres, he printed each verse as though it was a prose passage. His later volumes include Chansons pour me consoler d'être heureux, 1913 ; Poèmes de France, 1915 ; Que j'ai de Plaisir d'être français, 1917; Chansons à la Gauloise, 1919 ; Les Enchanteurs, 1919 ; Barbe Bleu, Jeanne d'Arc et Mes Amours, 1919. See Six French Poets, A. Lowell, 1915.

Fortaleza. Seaport of Brazil, capital of the state of Ceará. It stands on an open bay, near the mouth of the river Ceará, $350 \mathrm{~m}$. N.W. of Pernambuco, with an anchorage two miles out. Although the harbour has been much improved in recent years, cargo has to be taken off the vessels in the roadstead and landed on the beach in surf boats. There is a trade in rubber, cotton, coffee, animal products, sugar, and drugs. Previous to 1823 it was called Ceará. Pop. 70,000.

Fort Augustus. Parish and village of Inverness-shire, Scotland. It is finely situated at the head of Loch Ness, on the Calcdonian Canal, and is connected with Spean Bridge, $24 \mathrm{~m}$. S., by a branch of the Highland Rly. The fort, built originally in 1716 and enlarged in 1730 , was taken by the Jacobites in 1745, and recaptured a year later by William Augustus, duke of Cumberland, in whose honour it was named. Purchased by Lord Lovat in 1857, it was presented by him, in 1876, to the Benedictines, who transformed it into a monastery with college, hospital, and scriptorium, which in 1882 was raised to the rank of an abbey.
Fort Beaufort. Town of Cape Province, S. Africa. It is on the Kat river, 63 m. by rly. W.N.W. of King William's Town, and is an important ostrich-farming centre. Pop. 4,312.

Fort Chabrol. Name given to a house in the Rue de Chabrol, Paris, which was the scene of a remarkable siege in 1899. During the trial of Alfred Dreyfus $(q . v$.$) ,$ Nationalists, Royalists, and AntiSemites sought the opportunity for a rising, and Jules Guérin, an Anti-Semite leader, with 20 armed compatriots barricaded the AntiSemite club in the Rue de Chabrol, and defied the authorities to capture them. Each man had a magazine rifle, revolver, and 300 rounds, and the house was provided with bullet-proof doors and shutters. The siege became a farce. The French government decided to reduce the garrison by starvation, and "Fort Chabrol" was surrounded by a battalion of the Republican Guard. No one but doctors, who attended the garrison, were allowed to pass down the street; the water supply was cut off, and sewermen blocked up the drains to prevent the garrison digging their way out. After 38 days the "fort" capitulated without anyone being killed or injured.

Fort-de-France. Town of Martinique, French W. Indies, formerly known as Fort Royal. On the W. coast, 15 m. S.E. of St. Pierre, it is the capital and chief commercial centre of the colony. Its commodious harbour is fortified, and it has an arsenal, a college, a library, and several hospitals. It is the seat of the governor-general of the French West Indies. In the chief square there is a statue of the Empress Josephine. In Aug., 1891, the town was laid in ruins by a cyclone. Pop. 26,399.

Fort Dodge. A city of Iowa, U.S.A., the co. seat of Webster co. On the Des Moines river, $86 \mathrm{~m}$. by

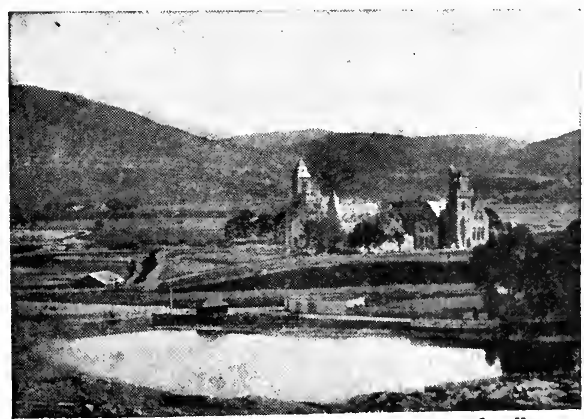

Fort Augustus, Inverness-shire. The abbey and college of $\mathrm{S}$. Benedict on the shore of Loch Ness Valentine rly. N.N.W. of the city of Des Moines, it is served by the Chicago Great Western and other rlys. It contains Tobin College and other educational institutions, a public library, and several parks. In the neighbourhood gypsum, glass sand, limestone, and coal are worked. The city's charter dates from 1869. Pop. 21,040.

Fort Donelson, Battle of. Federal victory in the American Civil War, Feb., 1862. Fort Donelson and Fort Henry, situated $12 \mathrm{~m}$. apart on the Kentucky-Tennessee border, were the two most important defences of the West. Occupied by the Confederates in 1861, Grant immediately recognized the necessity of capturing them, and in Feb., 1862, succeeded in seizing Fort Henry, although most of its defenders had escaped to Fort Donelson.

Moving against the latter with a combined naval and military force, Grant received a serious check, and on Feb. 15 the Confederates made an attempt to retreat to Nashville, but were stopped by Grant. The following day Buckner, in command of the fortress, asked for an armistice in which to settle terms of capitulation. Grant demanded unconditional and immediate surrender, to which Buckner agreed. This reply of the Federal general and the play upon the initials of his Christian names, U. S., gave him the sobriquet of Unconditional Surrender Grant.

Fort Duquesne. Eighteenth century stronghold at the junction of the Monongahela and Allegheny rivers. During the French and English disputes about the sovereignty of the land W. of the Alleghenies, George Washington recommended the spot as a suitable site for a fort, and in 1754 the English began to construct one. The French drove them away and themselves completed the work, calling it Fort Duquesne, after the French governor of that name. Attempts by Washington, and in 1755 by General Braddock, failed to recover it; but in 1758 General John Miles succeeded. $\mathrm{He}$ arrived there to find that it had been abandoned and destroyed by the French. The English then began to build a new fort, and this, named Fort Pitt, grew into Pittsburg, the great steel-working cen. tre of Pennsylvania. 
Forte. Italian term used in music, meaning strong or loud. It is sometimes represented by the abbreviations for., or $f$ Its superlative, meaning very loud, is fortissimo, shortened to $f f$ or $f f f$, or very rarely $f f f f$. See Musical Terms.

Fortescue. River of W. Aus tralia. It rises in the Hammersley Range, flows in a N.W. course of $250 \mathrm{~m}$., and discharges into the Indian Ocean in lat. $21^{\circ} 10^{\prime} \mathrm{S} .$, a few iniles below Cape Preston.

Fortescue, EARL. British title borne since 1789 by the family of Fortescue. In 1721, Sir Hugh Fortescue, a member of an old Devon family, obtained the barony of Clinton, and was made Baron Fortescue and earl of Clinton When he died, in 1751, his brother Matthew became Baron Fortescue, and Matthew's son, Hugh, the 3rd baron, was made Viscount Ebrington and Earl Fortescue in 1789 The 2nd earl was lord-lieutenant of Ireland from 1839-41, and the 3 rd earl held minor offices in the Liberal ministry between 1846 and 1851. The earl's estates are in Devonshire, and his eldest son is called Viscount Ebrington.

Fortescue, Granville Roland (b. 1875). American soldier and journalist. Born in New York, Oct. 12, 1875, and educated at the university of Pennsylvania, he served with the Rough Riders in Cuba, 1898; as lieutenant of volunteer infantry in the Philippines, 1899-1901 ; in the cavalry, 1902 , and graduated at the U.S. Staff College in 1904. Retiring from the U.S. army in 1906, he acted as The Standard's special correspondent with the Spanish army in the Riff War, 1909; and in the Great War as correspondent of The Daily Telegraph on the western front. He is the author of At the Front with Three Armies, 1915; Russia, The Balkans, and The Dardanelles, 1915 ; and What of The Dardanelles?, 1915.

Fortescue, Sir JoHN (c. 1394 1476). English judge and writer. The son of another Sir John For tescue, he belonged to the Devon family of that name. Born at Norris in Somerset, he was educated at Exeter College, Oxford, and became a lawyer in London. In 1442 he was made chief justice of the king's bench, and he held the post until Henry VI lost his throne in 1461. He went abroad with Queen Margaret of Anjou in 1463, and was with her and her son Edward for some time, but in 1471 he was pardoned by Edward IV. Fortescue is best known by his writings. His treatise on the laws of England (De Laudibus Legum Angliae) was published

after his death, and several times since. He also wrote a book, the earliest of its kind, now known as The Govern. ance of Eng. land. $\mathrm{Th}$ is was first pub. lished in 1714 as The Differ. ence Between an Absolute and a Limited Monarch y. and under its other title, with an intro-

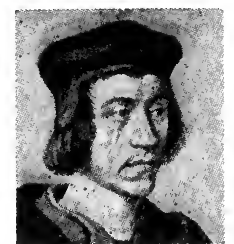

Sir John Fortescue. English judge After W. Faithorne

duction by C. Plummer, in 1885 .

Fortescue, JoHn William (b. 1859). British military historian. Born Dec. 28, 1859, a younger son of the 3rd Earl Fortescue, he was educated at Harrow and Trinity College, Cambridge. He was private secretary to the governor of New Zealand, and a captain in the Devon Yeomanry, but devoted much time to military history. In 1899 appeared the first volume of his History of the British Army, and eight other volumes appeared at intervals until 1920 , the story being then taken down to 1815 .

This is the most complete his. tory of its kind, a careful survey of the subject from the earliest times, and particularly valuable for the 18th century. In 1905 Fortescue was made librarian at Windsor Castle. He also wrote a History of the 17th Lancers, 1895, some novels, an animal study, The Story of a Red Deer, 1897, and wrote the article on The British Army in this work. He was lecturer on military subjects at the univer. sities of Oxford, Cambridge, and London. See port., p. xxi, vol. i.

Fortescue, Miss Stage name of May Finney, British actress. She made her stage début as Lady Ella, in Patience, at The Opéra Comique, London, April 23, 1881. A notable Celia in Iolanthe, at 'The Savoy, 1882, she appeared as Dorothy in Dan'l Druce, at The

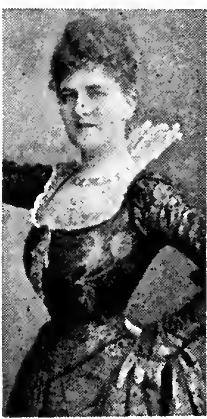

Miss Fortescue as Julia in the Hunch. back
Court, 1884. Among other parts in which she played were those of Mary Melrose in Our Boys, at The Strand, 1884 (after which date she organ. ized a touring company of her own, which she ran for some years): Julia in The Hun oh back; Pauline in The Lady of
Lyons; Galatea in Pygmalion and Galatea; Juliet; Rosalind; Lady Teazle in The School for Scandal; Fédora; Hypatia; the duchess of Strood in The Gay Lord Quex; Lady Faringford in 'The Return of the Prodigal; the duchess of Braceborough in $\mathrm{Mr}$. Hopkinson; Mrs. J. K. Rotterford in Billy's Bargain ; Lady Bagley in Our Mr. Hepplewhite, Lady Emily in Humpty Dumpty; Mrs. Devlin in Betty at Bay; appearing also at Drury Lane in the Best of Luck. She visited the U.S.A in 1886, and Germany in 1909.

Fort Garry. Former post of the Hudson Bay Co., erected 1835, on the site of which Winnipeg grew up. In 1873 the city was incorporated under the latter name. Old Fort Garry Gate, a castellated gate at the end of Broadway, is all that remains of the fort. A mounted unit of the Canadian army known as the Fort Garry Horse distinguished itself at Cambrai, Nov. 20, 1917. See Winnipeg.

Fort George. Fortress of Inverness-shire, Scotland. It stands on Moray Firth, 12 m. N.E. of Inverness, and was erected after the rebellion of 1745 to accommodate 2,000 men. There is ferry com. munication with Fortrose on the opposite shore of the Firth.

Forth. River of Scotland, which, flowing into the N. Sea, forms as its estuary the Firth of Forth. The meeting of the hill streams Duchray Water and Avondhu, near Aberfoyle, in Perthshire, forms the Forth, which flows through Perthshire, Stirlingshire, and Clackmannanshire, mainly in an easterly direction. The total length as far as Alloa is about 53 $\mathrm{m}$. Tidal to a point about four $\mathrm{m}$. above Stirling, the river is navigable for 300 -ton vessels as far as Alloa, for 100 tons to Stirling. Its chief tributaries are the rivers Teith and Devon and Allan Water. In the Carse of Stirling its course is extraordinarily sinuous, forming the so-called Links of Forth.

Forth, Firth of. Name given to the estuary of the river Forth, on the E. coast of Scotland. The Firth begins at Alloa, and stretching to a line drawn S. from Fife Ness, being thus about $51 \mathrm{~m}$. long and varying in width from one to 17 m. The chief islands are Inchkeith, Inchcolm, Cramond Island, and the Bass Rock, and Leith, Granton, Grangemouth, Alloa, Burntisland, and Methel are the chief harbours and fishing ports along both coasts. The Firth is spanned at Queensferry by the Forth Bridge, but a ferry service is maintained there and between Granton and Burntisland. 
The Firth has great strategic im portance. During the Great War it was a base of the Grand Fleet; many defences, forts, protective booms, etc., were constructed, and in the Firth off Inchkeith the German fleet surrendered, Nov., 1918. See Rosyth.

Fort Hall. Settlement in Kenya Colony, E. Afriea. It is situated between Nairobi and Mount Kenya, and is $4,500 \mathrm{ft}$. above sea level. A branch line from the Uganda Rly. has reached the Thika river $(32 \mathrm{~m}$. and is to be continued to Fort Hall.

Forth and Clyde Canal. Waterway extending from Grangemouth, on the Forth, to Bowling, on the Clyde. It was constructed between 1768-90 at a cost of $£ 330,000$, and has a length of $39 \mathrm{~m}$. Since 1867 it has been the property of the Cal. Rly, but no great volume of traffic uses the canal regularly.

Forth Bridge. Railway bridge in Scotland, begun in 1882 and opened for traffic in 1890 . By its construction across the Firth of Forth a long detour of the rly. westward was obviated and direct connexion between Edinburgh and the N. side of the Firth established, while its clear height of $150 \mathrm{ft}$. and long spans enable vessels of any size or type to pass below it.

From the engineer's point of view, it marked an epoch in the history of bridge building. Its enormous clear spans of $1,710 \mathrm{ft}$. between supports were rendered possible by the use of steel and by the cantilever design of the superstructure. The bridge, which carries two railway tracks, is slightly over $1 \frac{1}{3}$ miles in length. There are three main piers from which the six cantilever arms rise and project, the ends of which, in the main spans, support and are connected by long girder spans. The height of the cantilevers, over the piers, above water level is $361 \mathrm{ft}$. The main compression members of the cantilevers consist of steel tubes in some cases $12 \mathrm{ft}$. in diameter.

The extremities of the end cantilevers rest upon masonry piers whence the rly. is carried to the shore on approach viaducts comprising a number of comparatively small steel bridge spans and masonry arches. Each main river pier consists of four circular masonry supports resting upon caissons $70 \mathrm{ft}$. diameter, and sunk to a depth of from $70 \mathrm{ft}$. to $90 \mathrm{ft}$. below water level. The structure, designed by John Fowler and Benjamin Baker, comprises 51,000 tons of steelwork and 142,000 cubic yds. of masonry, cost nearly $₫ 3,000,000$, and occupied seven years to construct. See Bridge, illus. and plate.
FORTIFICATION :

PAST AND PRESENT

Sir George G. Aston, K.C.B., Author of War Lessons, New and old The principles of fortification are here outlined. The article Fortress should also be read, as well as those on Strategy, Tactics, and War. See also Artillery and articles on Antwerp: Mctz; Verdun, and the great fortresses of the past
From the siege of Troy the history of the world's wars is filled with heroic tales of human ingenuity displayed in the attack and defence of fortified places. Fortifications confer the power of prolonged resistance upon forces which are inferior in numbers, mobility, equipment, or moral to their enemies. Thus Wellington in the Peninsula took shelter behind the celebrated lines of Torres Vedras when his army required a safe refuge for recuperation, and in the Great War of 1914-18 both sides made use of the art of the engineer to enable their armies to hold their own on the defensive while collecting men and munitions for a serious offensive.

The advantages conferred upon armies by fortifications are temporary. Francis Bacon wrote truly that "walled towns, stored arartillery, and the like, all this is but a sheep in a lion's skin, except the breed of the people be stout and warlike." It is not fortifications but men that decide the fate of nations. Fortifications which afford all-round defence to their garrisons are called fortresses. While these can be of great value if skilfully applied, they sometimes have a harmful effect upon the commanders of field armies. Bazaine's army, sheltering behind the defences of Metz, took no further active part in the Franco-Prussian War, and Sir John French was sorely tempted to seek the protection of the fortress of Maubeuge after the battle of Mons.

Fortifications may take the form of "permanent" works, erected in time of peace, or of temporary " field " defences, constructed when and where they may be required in time of war. At certain periods in European history, when senals, and armouries ... ordnance, provisions were scarce and means of communication bad, the issue of a war was often determined by the attack and defence of fortified places, and the history of war be came a history of sieges. Large quantities of foodstuffs were collected in great fortresses where the people took refuge while the attackers tried to pass the fortified lines in order to reach them. If surprise, assault or bombardment failed, the attacking forces were obliged to resort to regular siege, approaching by cunningly devised forms of entrenchment called "parallels" and "saps," and by mining galleries, at the same time "investing" the place to starve out the garrison.

When the mobility of armies was increased by improvements in roads and wheeled transport, a complete change came over the nature of land warfare, and the value of fortresses now lies in the influence they can exert upon the operations of field armies. If placed where important roads and rlys., needed by an invading army, converge towards the crossings of obstacles such as rivers or marshy country, a well-placed fortress can delay an invader's advance. The delay imposed upon von Kluck's was one of the factors enabling Manoury's army to assemble N. of Paris in time to play an important part in the victory of the Marne.

Again, the need to detach forces to guard the communications of an invading army against the garrisons of fortresses may seriously reduce its strength in decisive battle. Von Kluck and von Bülow, having detached forces to watch the Belgian army in Antwerp and the garrison of Maubeuge, were too weak to perform their task in France. army by the forts of Liége in 1914

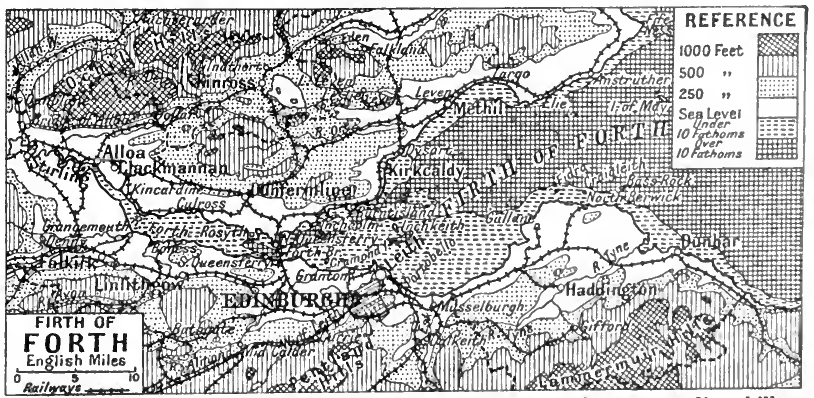

Firth of Forth. Layered map showing the heights of the surrounding hills and depths of the estuary 


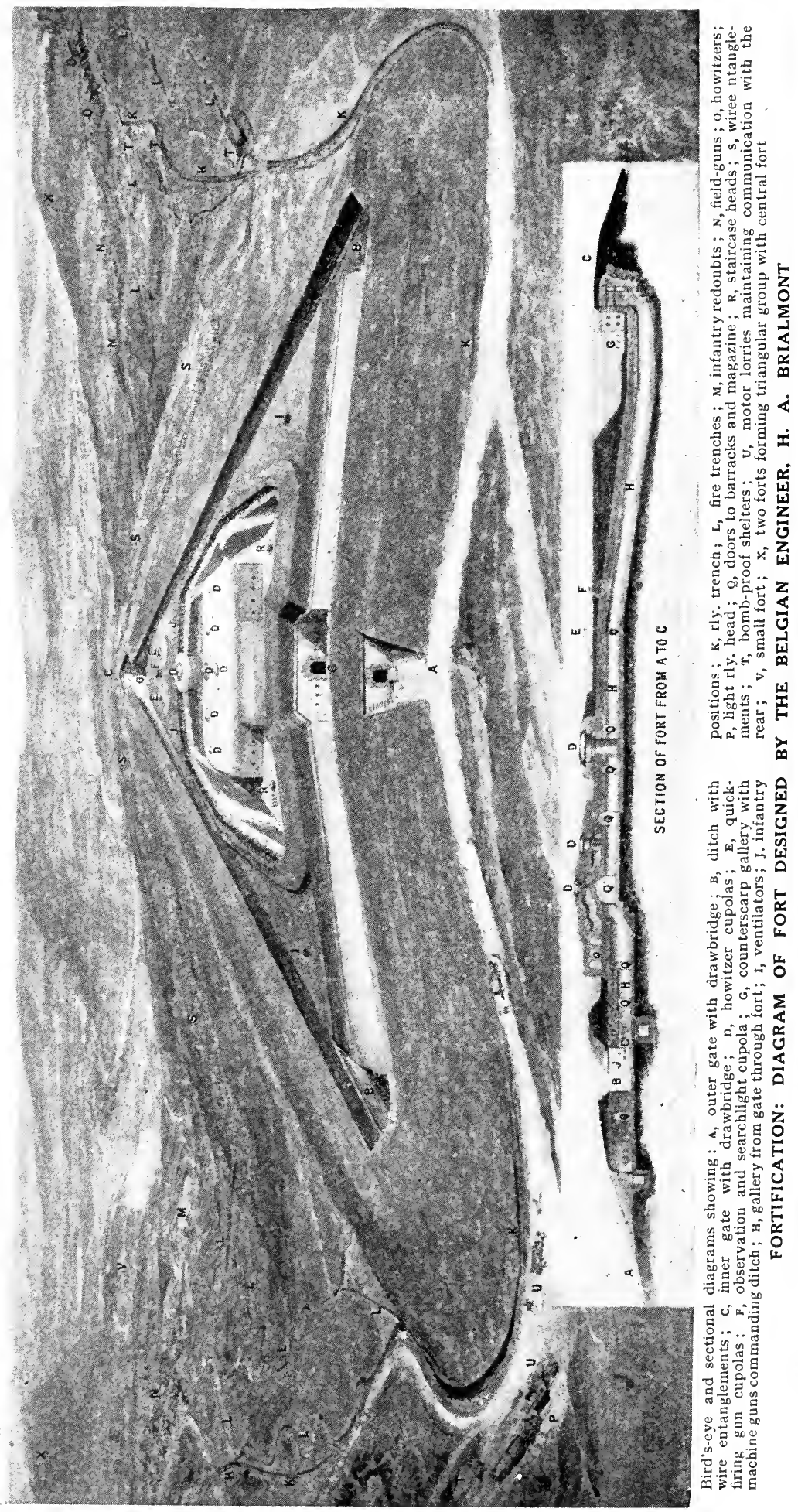


While the functions performed by fortifications in land war re main fairly constant, their nature has changed with the increased mobility of heavy ordnance used in the attack. In the days of bows and arrows a high wall was a formidable obstacle. With the introduction of ordnance the steepsided revetted diteh replaced the exposed wall, and various devices"bastions," "eaponiers," and the like-were introduced to bring a flanking fire to bear upon assailants who might effect a lodgment in the ditch. The garrisons were protected by large mounds of earth called "ramparts" and "traverses," under which they found shelter in "casemates" when not holding the lines of "parapet" surmounting the ramparts.

With the increased range and rapidity of fire of weapons of defence, barbed wire entanglements, which give full play to sueh weapons, replaced deep ditehes as obstacles. Then came the tank for crossing barbed wire, and so the competition proceeds, and will proceed, between inventions for defence and attack. Invisibility, from the ground surface or from the air, affords better protection to garrisons than earthworks or armour, and underground "dugouts" have replaced conspicuous ramparts of earth piled up above the surface. Heavy ordnance is no longer considered secure if mounted in visible fixed positions, and the tendency in modern fortification is to meet the mobility of siege ordnance bv similar mobility in the ordnance of the defence.

The functions performed by fortification in sea warfare differ materially from its functions in war on land. Only in exceptional cases, such as in narrow straits like the Dardanelles or in sea eanals like that of Panama, can ordnance mounted in forts exercise any direct effeet upon the movements of the war vessels which decide the issue of a naval war. War vessels, especially those of a weaker naval power or of a stronger power compelled to maintain detached forces in distant seas, require defended har'oours as bases from which to work, and fortification, so applied, may exercise a strong, though indirect, influe nce upon the issue of a sea-war.

War vessels being built to fight each ot'ser, not to fight forts, and ships being conspicuous targets, guns mounted on fixed platforms on shore have so many advantages over those mounted on moving platforms at sea that no fortress on the sea coast has fallen to sea attack in modern times. Port
Arthur in 1894, Wei-Hai-Wei in 1895, Santiago de Cuba in 1898 , Port Arthur again in 1905, and Kiao-Chau in 1914 were all taken by armies.

Commercial harbours are sometimes fortified as places of refuge for merchant shipping, but safety at sea, rather than in harbour, is the condition needed for the se. curity of the vessels carrying the trade of a community depending upon sea commerce for existence. See Text Book of Fortification, Royal Military Academy, 1893 ; Fortification, Sir G. S. Clarke, 1907. See also Bangalore and Cupola, illus.

Fortin (Fr., little fort). Small detached fort. It may be either one of a group or part of a general fortification.

Fort Jameson. Settlement in N.E. Rhodesia. On the Tanganyika plateau, it is about $300 \mathrm{~m}$ N. of Tete by road and $125 \mathrm{~m}$. W. of Lake Nyasa. It was until 1910 the headquarters of the administration of N.E. Rhodesia.

Fort Johnston. Settlement of Nyasaland, Central Africa. It stands $6 \mathrm{~m}$. south of Lake Nyasa, and about the same distance from Lake Malombe or Pamalombe.

Fort Mruli. Town of Uganda, Central Africa, the former capital of the distriet of Unyoro. It stands on the Nile, $200 \mathrm{~m}$. N.N.E. of Entebbe, at an alt. of $3,500 \mathrm{ft}$.

Fortnightly Review, THE. London monthly review first published as a fortnightly, May, 1865 under the editorship of George Henry Lewes. John Morley became editor in 1867, and made it a monthly. He was succeeded by T. H. S. Escott (1882-88), Frank Harris (1888-93), and W. L. Courtney. Its contributors have included Tyndall, Herbert Spencer, Huxley, Leslie Stephen, Walter Pater, F. Brunetière, Tolstoy, Edmund Gosse, Swinburne, Frederic Harrison, Prof. Dowden, J. L. Garvin, and H. G. Wells.

Fort Pearson. Fort erected at the mouth of the Tugela river, Natal, during the Zulu War of 1879.

Fort Portal. Chief centre of the Toro district, Uganda. It is an important missionary station and native town situated about $25 \mathrm{~m}$. N.W. of Mt. Ruwenzori. Pop. 25,000, of whom about 50 are Europeans.

Fortress (Lat. fortis, strong). Military position, sited and equipped so as to provide a point of resistance in case of attack, and act as a rallying point for troops who may be eompelled to fall back from more exposed positions. Fortresses have been a feature of all warlike operations from the earliest times, the simplest being merely enclosed by a palisade or zareba such as are still found among aboriginal peoples. The baileys of the Saxons were usually of this nature, generally situated on a hill or artificially constructed mound and enclosing the huts in which the inhabitants lived. Dwellers in the surrounding country repaired to these strong points in time of war. The Romans usually employed concentric mounds and ditches to protect their eamps, and in many instances the Saxon baileys utilised these older defences as outposts to the palisaded camp.

With the coming of the Normans the fortress was elaborated, but wood remained the chief material employed in the construction for something like a century, when stone became the general material. The Norman eastle usually consisted of a large walled spaceprotected by a moat in suitable localities-whieh could only be entered through a strongly defended gate. Its general plan was main. tained for many centuries, improvements in detail being made as military science progressed, as in the provision of corner towers to bring flanking fire to bear along the walls, machicolation of the latter and generally strengthened construction.

With the advent of artillery as an effective weapon, the use of fortresses of this nature became practically obsolete, although they played a part in the Wars of the Roses and even in the English Civil War. During this period it had become the practice to fortify important towns by walling them in, the walls being similarly constructed to those of the courts of castles. To enable such fortresses to withstand artillery fire, the walls were faced and backed up with mounds of earth, but the progress in gun construction and the use of explosives in mining and sapping rendered them only capable of temporary resistance. The general principle of construction, that is, a line of ram. parts elosely encircling the position to be defended, persisted until towards the close of the 18th century, when, in addition, an outlying circle of forts was constructed in such a way that the intervening country could be kept under fire from their guns.

In modern practice it is usual to equip as fortresses the centres of national, industrial, and military resources if liable to attack, strate gic centres, lines of communication where they cross frontiers, important river crossings and railway junctions. The girdle of forts 


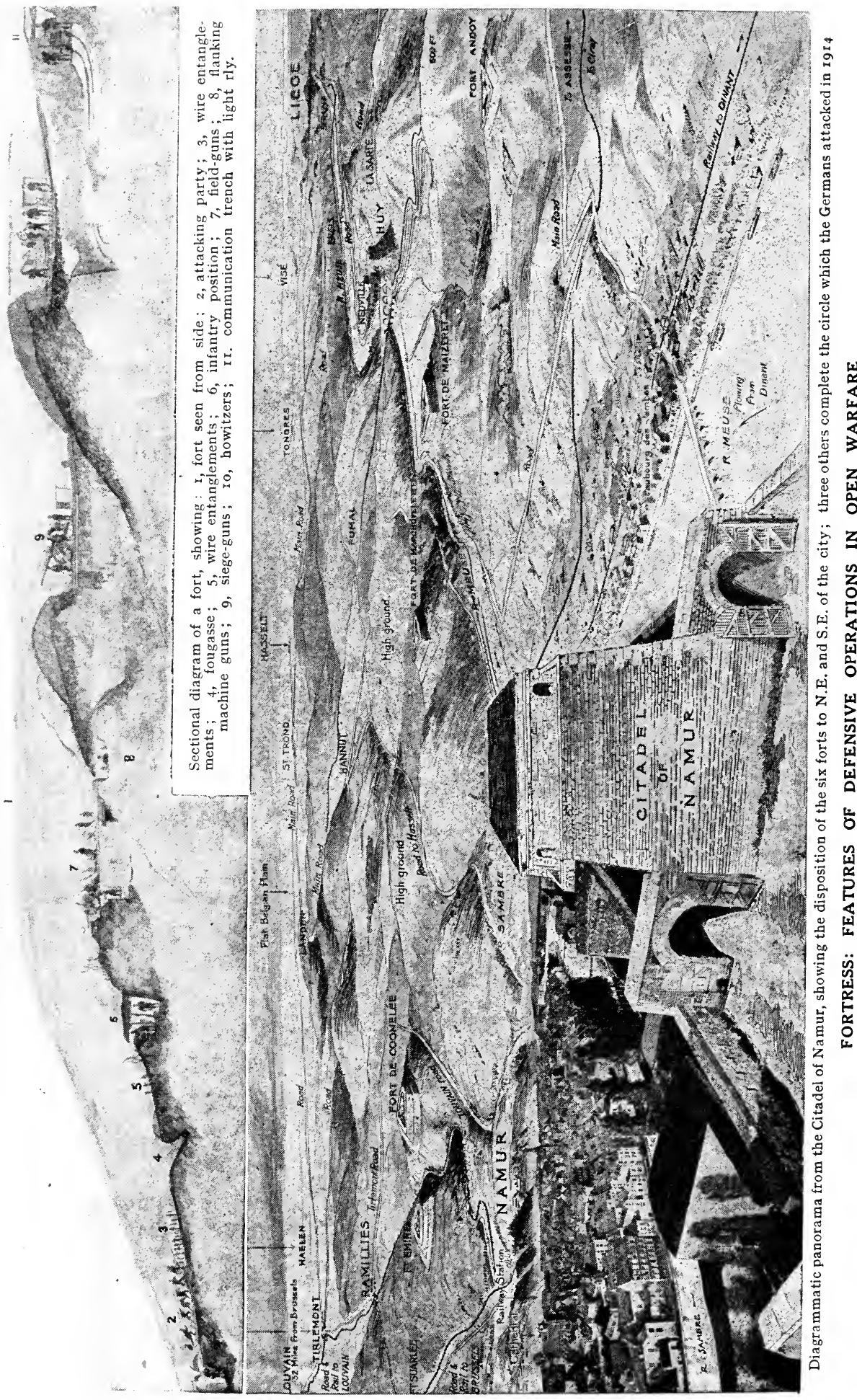


should be sufficiently distant to prevent the enemy from bom. barding the defensive point, which becomes essentially a military camp. The forts themselves should be constructed of reinforced concrete not less than $12 \mathrm{ft}$. thick, and the surrounding ground constructed as glacis so that an infantry attack will find no cover in the immediate vicinity. Search. lights form an essential part of the equipment, and only light guns are mounted in the forts, the heavier armament being in masked batteries some distance away. The general arrangement should be such that if one fort in the girdle is taken the neighbouring ones can sweep the intervening ground, and prepared infantry positions should be arranged between the forts. An enceinte nearer the central position is desirable, but it cannot be regarded as a line of resistance, but in the event of a break through may delay the enemy whilst the centre is evacu. ated. See Castle.

Fortrose. Royal, mun. and sea. port town of Ross and Cromarty, Scotland. It stands on the Moray Firth, 9 m. N.E. of Inverness, on a branch of the Highland Rly. There is a good harbour, and the fine scenery, bathing facilities, and golf links attract many visitors. Fortrosewasformerly the seat of the bishops of Ross, but the episcopal palace and cathedral were destroyed by Cromwell, who built his fort at Inverness with the stones. There is ferry communication across the firth with Fort George. Market day, Friday. Pop. 976.

Fort Rosebery. Settlement of N. Rhodesia. It is situated about $45 \mathrm{~m}$. W. of Lake Bangweulu. A former settlement of this name was on the Luapula river, about $60 \mathrm{~m}$. N.W. of the new township and $50 \mathrm{~m}$. N. of the Johnston Falls, in the S.E. of the Belgian Congo.

Fort Royal. Former name of the town of Martinique, French W. Indies, now known as Fort-deFrance $(q . v$.$) .$

Fort St. David. Ruined fort of Madras, India, in the S. Arcot district. It is on the Coromandel coast, less than $2 \mathrm{~m}$. E. of Cuddalore New Town. At one time the site of Dutch and French settlements, the fort was bought by the English in 1690, together with the land within the radius of a "randome shott of a great gun." The gun was actually fired, the shot indicating the extent of the boundaries. The name is supposed to have been given to the fort by a Welsh governor. The fort was captured by the French in 1758, who demolished the fortifications,

but, after changing hands again twice, it was finally restored to the English in 1785.

Fort Smith. City of Arkansas, U.S.A., one of the co. seats of Sebastian co. It stands on a great bend of the Arkansas river where it forms the $W$. frontier of the state, and is served by the St. Louis and San Francisco and other rlys. It contains a fine court house, a public school and other educa. tional establishments, and a public library. Standing in an agricultural, coal, and natural gas region, it is a trading centre for coal, cotton, livestock, and corn, and manufactures furniture, cotton goods, bricks, refrigerators, and lumber products. Settled in 1838, it was incorporated in 1842 and became a city in 1886. Pop. 29,390.

Fort Sumter. Fort in S. Caro lina. U.S.A It stands on an island

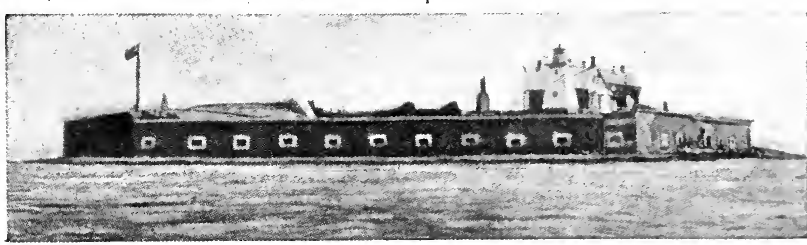

Fort Sumter. The island fortress at the entrance to Charleston Harbour, the scene of fighting in the American Civil War

at the entrance to Charleston harbour, $3 \mathrm{~m}$. S.E. of Charleston. It was bombarded by the Confederates, April 12, 1861, and sur. rendered the following day, the action immediately leading to the opening of the Civil War. In April, 1863 , it was violently bombarded by the Federal fleet and rendered practically untenable.

Fortuna. In Roman mythology, the goddess of chance or good luck. There were several temples in Rome erected in her honour, but the most famous seats of her worship were Antium and Praeneste. She is sometimes called Fors Fortuna. In art she is represented with a rudder as symbol of her guid. ance of things, also with a cornucopia as a symbol of the prosperity she brought to mankind.

Fortunate Isles. Alternative name for the Islands of the Blessed, or the Elysian Fields, of early Greek mythology. They were supposed to be at the edge of the earth, and were vaguely spoken of as beyond the Pillars of Hercules, i.e. the Straits of Gibraltar. It has been generally accepted that the Canary Isles are the Fortunate Isles of the ancients. Ben Jonson produced a masque entitled The Fortunate Isles in 1626. See Elysium.

Fortunatus. Character of a folk-tale found among many different races. It first appeared in print in a German form in 1509. Fortunatus is possessor of an inexhaustible purse, a wishing cap, and other marvels in different variants of the tale. The moral goes to show the little value to be put upon material treasures. The story was dramatised in Germany by Hans Sachs, 1553, and in England by T. Dekker, 1600. One named For tunatus succoured the A postle Paul.

Fortunes of Nigel, The. Fifteenth of the Waverley novels, published in May, 1822. In it Sir Walter Scott followed his masterly portraits of Mary Stuart and Elizabeth Tudor with an equally bril liant character-study of James I, and supplied vivid pictures of early 17th century London, from Alsatia to the Court. Nigel Olifaunt, Lord Glenvarloch, the young Scottish nobleman who comes south to petition the king; his devoted ser

vitor, Richie Moniplies; the pro fligate Lord Delgarno ; the crabbed old courtier Sir Mungo Malagrowther ; "Jingling Geordie" Heriot, the wealthy goldsmith; Margaret Ramsay, the modest but courageous heroine, and the unhappy ship-chandler, John Christie, are memorable characters in the work.

Fortune-telling. Revelation by non-rational processes of what is to befall a person in the future. As one of the principal aims of divina tion it is traceable from its first recorded manifestations in ancien Babylonia into early China and India. Thence it was brought across medieval Europe by the gypsies, who are recorded by Pepy to have practised the art at Lam. beth under society patronage in 1688. As a modern superstitious survival it is associated with palmistry, astrology, crystal-gazing, lot-casting by cards or otherwise, and subjective processes.

The alien origin of fortunetelling in Britain is confirmed by the fact that it is not a common. law offence. Its punishment as a form of witchcraft by death, under a statute of 1563 , was reduced by the Witcheraft Act, 1735, to imprisonment for one year and the pillory. Under the Vagrancy Act, 1824, any person who undertakes to tell fortunes, or uses any subtle craft, means or device, by palmistry 


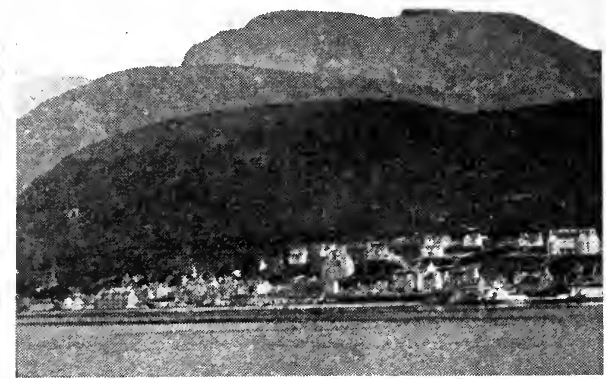

Fort William, Scotland. The town, with Ben Nevis in the background, viewed from Loch Eil Hardie

or otherwise, to deceive and im. pose upon any person, is liable to imprisonment as a rogue and vagabond. This Act was extended to Scotland in 1870, and the first conviction there, in 1877, was quashed on the ground that the plaint did not set forth that the pretence was with intent to deceive. In the United States fortune-tellers are usually classed by statute as dis. orderly persons, liable to arrest and summary examination. See Divination; Palmistry.

Fortuny y Carbo, Mariano Joś́ Maria (1838-74). Spanish painter. Born at Reus, Catalonia,

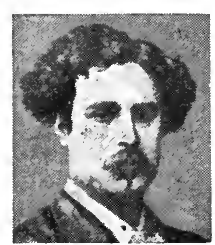

Fortuny y Carbo. Spanish painter
June 11, 1838, he studied at Barcelona Academy and at Rome. In 1859 he accompanied General Prim in his Moroccan expedition, and painted a large picture of The B a t t le of Tetuan; but most of his life was passed at Rome or Paris. Through the firm of Goupil Bros., he ob tained a large clientèle for his pictures of Spanish and Moorish genre. He died Nov. 21, 1874.

Fort Wayne. City of Indiana, U.S.A., the co. seat of Allen co. At the confluence of the St. Joseph and St. Mary rivers, which here merge into the Maumee river, it is $105 \mathrm{~m}$. N.E. of Indianapolis and is served by the Lake Shore and Michigan Southern and other rlys. It contains a fine court house, a U.S.A. government building, Concordia College, a state school for weak-minded youths, \& public library, and several hospitals and parks. An important rly. and trading centre, it has rly. workshops, flour mills, foundries, and ma. chinery, chemical, piano, and soap factories. On the site of a fort built in 1794, Fort Wayne received a city charter in 1839 . Pop. 75,220 .
Fort William. Town, police burgh, and tourist resort of Inverness-shire, S c ot. land. It stands on the E. shore of Lower Loch Eil, at the foot of Ben Nevis, 65 m. S.W. of Inverness, on a branch of the N.B. Rly. The fort, erected by General Monk in 1655 and rebuilt by General Mackay in 1690 , successfully with. stood a siege by the Jacobites in 1715 and 1746 ; it was dismantled in 1860 . Fort Wil. liam is a starting point for the ascent of Ben Nevis (q.v.). The chief industry is distilling. Pop. 2,002 .

Fort William. Port and city o Ontario, Canada, in Algoma dist. It stands at the head of Lake Superior, on the left side of the Kaministiquia river, its importance being due to its position between E. and W. Canada. It is $420 \mathrm{~m}$. E.S.E. of Winnipeg, and is served by three transcontinental lines of rly.-C.P.R., G.T.P.R., and C.N.R. It has a street rly. which goes to Port Arthur, $4 \mathrm{~m}$. away. Steamers ply from here to the ports on the Great Lakes and the St. Lawrence, and there are immense elevators to handle grain brought from the W.

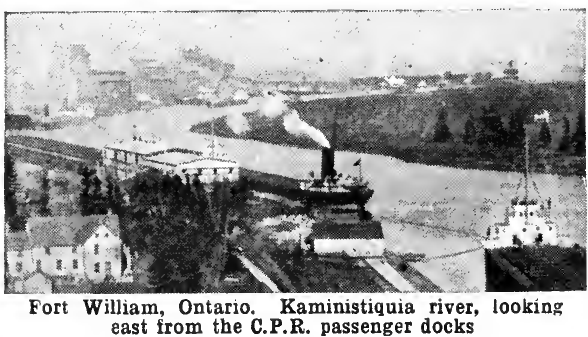
east from the C.P.R. passenger docks

In addition to its shipping, for which there is $28 \mathrm{~m}$. of deep-water frontage, the city has flour mills, iron foundries, and other industries. Fort William has electric light, and water power in abun. dance, churches, schools, hospitals, several hotels and public parks, a city hall and a court house. It was founded in 1801 as a Hudson Bay trading port. Pop. 16,499.

Fort Worth. City of Texas, U.S.A., the co. seat of Tarrant co. On Trinity river, $173 \mathrm{~m}$. N.E. of Austin, it is served by the Missouri, Kansas and Texas and other rlys. It contains a number of educational and other institutions, including Texas Women's College, formerly
Forum, The. New York quar-

the Polytechnic College, the Fort Worth medical college, and Texas Christian university. There are besides a public and other libraries, a large number of churches, and a fine system of parks.

The centre of an agricultural and stock-rearing district, the city has large packing establishments and stockyards, and manufactures clothing, cotton, chemicals, furniture, and carriages. The city occupies the site of a fort erected in 1849 , and was incorporated in 1873 . Pop. 109,595.

Forum. Among the ancient Romans, any open space used for public business. More particularly the term was applied to the open space in Rome, an irregular oblong in shape, lying between the Palatine and Capitoline hills, known as the Forum Romanum. Here the assembly of the people met; here magistrates and others addressed them from the tribunal or rostra. Adjoining were the Curia or senate house, the Basilica Julia and Basilica Aemilia, the temples of Julius and Vesta. Along one side the Sacra Via led to the Capitol (q.v.).

With the growth of the city other fora were added; the Forum Julium by Julius Caesar, the Forum Augustum, and the Forum Pacis, where Vespasian erected a temple of Peace, containing spoils from the temple of Jerusalem. The Forum Trajanum, erected $b_{r}$ the emperor Trajan, surpassed all others in size and splendour, and remains the greatest monument of Roman architecture. Its most conspicuous feature was the column of Trajan, erected by the em. peror in commemoration of his vic. tories. See Rome; consult also The Roman Forum, C. Hülsen,Eng. trans. J. B. Carter.

terly review of politics, finance, science, literature, and education. Founded as a monthly in 1886 , to afford publicity to rival opinions, it became a quarterly in 1902 . Under the editorship (1897-1907) of J. M. Rice, founder of the American Society of Educational Research, it promoted reforms in the American educational system

Forum Appii (mod. Foro Appio). Ancient town of Latium, on the Appian Way (q.v.). It stood amid the Pontine Marshes, $42 \mathrm{~m}$. S.E. of Rome, and near a canal which extended $S$. to near Terracina. The apostle Paul passed through the town on his way to Rome. 


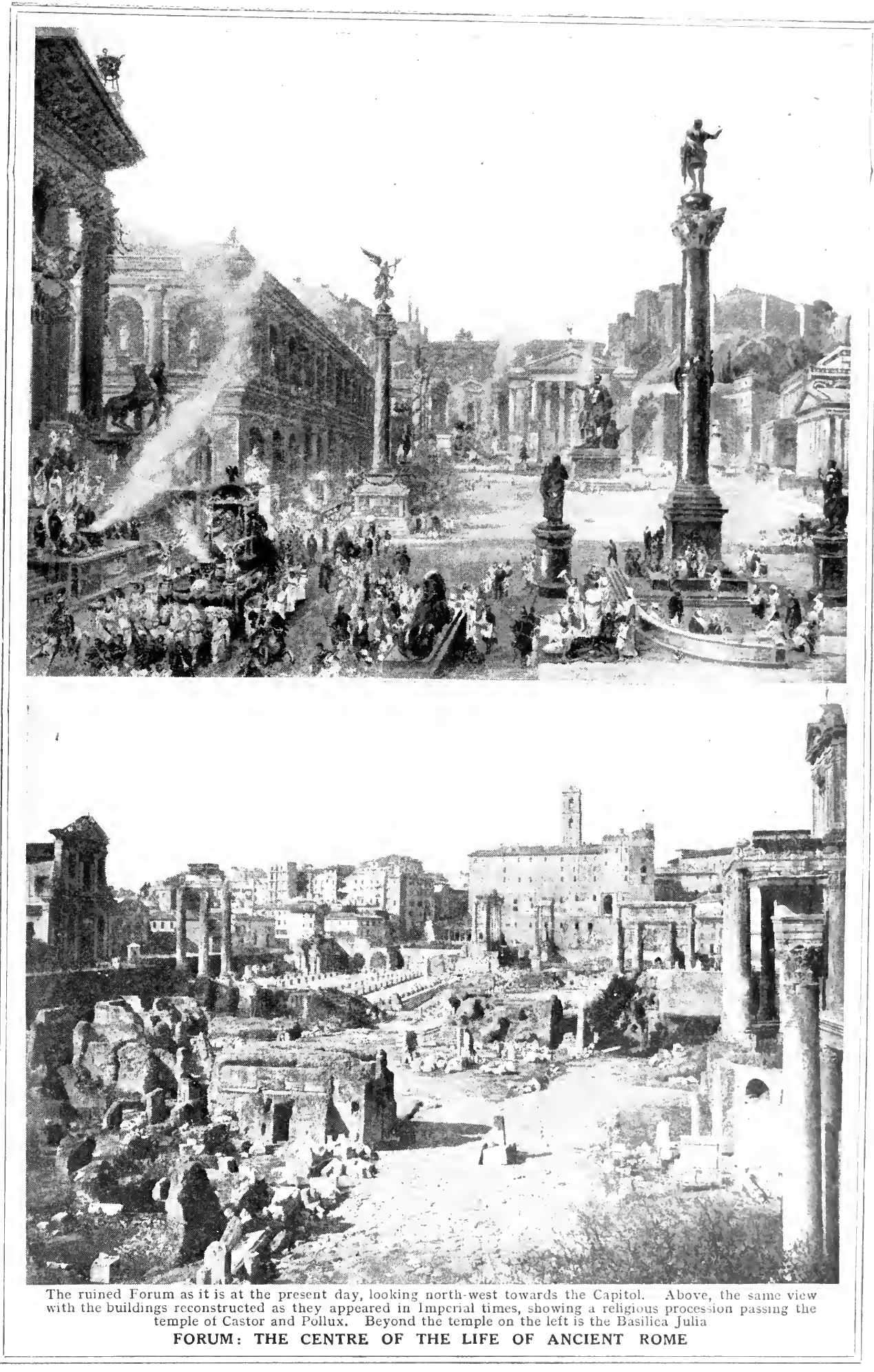


Foscari, Francesco (13731457). Doge of Venice. After holding various offices in the republic

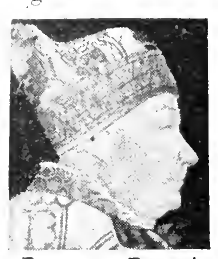

Francesco Foscari, Doge of Venice

fiter Gentile Bellin he was elected doge in 1423. Ambitious to extendVenetian power, he took an active part in the politics of the mainland, enteringaleague against the Visconti of Milan in 1426 , thereby acquiring Ber. gamo, Brescia, and Cremona. In 1441 Velaggio, Peschiera, and Lonato were added to the Venetian territories. The misdeeds of his son, Giacopo, brought about the doge's deposition, Oct. 24, 1457, and he died Nov. 1, 1457. Byron's tragedy, The Two Foscari, is founded on the lives of Francesco and his son.

Foscolo, Uao (1778-1827). Italian poet, romancer, and patriot. Born at Zante, Jan. 26, 1778, of Venetian and Greek descent, and christened $\mathrm{Niccolo}$ h e changed his first name to Ugo. His story, Let. tere di Jacopo Ortis, 1798, reflects the melancholy of the romantic period,

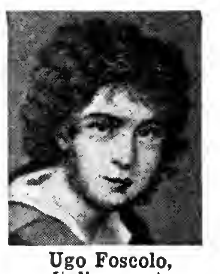

Italian poet and his best known poem, I Sepol. cri, 1807, was inspired by the reverence due to the tomb and the immortality of the memories of the great. Foscolo served for a time in the French army, but, disillusioned as to Napoleon's intentions, sought refuge in England when the Austrians took Milan. He died at Turnham Green, Oct. 10, 1827. Buried at Chiswick, his remains were renoved to Florence in 1871.

Fossa or Foussa (Cryptoprocta ferox). A carnivorous mammal, found only in Madagascar, and placed by most zoologists between the cat and the civet. It is about $5 \mathrm{ft}$. long, including the tail, which is nearly as long as the body. The fur is pale brown in colour, and the claws retractile like those of a cat.

Fossano. City of Italy, in the prov. of Cunco. It stands on a hill, overlooking the river Stura, $40 \mathrm{~m}$. by rly. S. of Turin, and possesses a 14 th century castle. Paper, silk, hemp, and leather are manufactured. The French and Austrians fought here in 1796 and 1799 . Pop. 18,731.

Fosse (Lat. fossa, ditch). Excavation outside the ramparts or outer walls of a fort. Its purpose was to hinder the advance of an enemy, and make it impossible for him to find ground upon which to erect scaling ladders. Frequently filled with water, its effectiveness was also occasionally increased by its being planted with pointed stakes and palisades. Barbed-wire entanglements may also be placed in it. See Castle ; Fortification.

Fosse Way. Early English name for an ancient British highway from Axminster to Lincoln. Incorporated in the Romano-British road system, no part of its $182 \mathrm{~m}$. deviates more than $6 \mathrm{~m}$. from a straight line between these places. It runs through Bath, Cirencester, High Cross, and Leicester. Mentioned in an Anglo-Saxon charter, 744 , it ranked as one of Edward the Confessor's four royal roads. See Britain.

Fossils (Lat. fossilis, dug up). Term applied to traces of plants or animals found in the earth's crust.

Early Greek philosophers recognized that the sea had at times encroached upon the land, and the discovery of marine shells among the mountains seemed on this ground natural enough. In the 16 th and 17 th centuries a controversy arose as to whether such objects were due to the entombment of animals in muds, which afterwards consolidated round them as firm rocks, or whether they were mere imitations of organic structures naturally produced.

Field observation, notably in Italy, showed that marine beds had been raised above the sea, that large areas had been at one time submerged, and that "organized fossils" could in consequence be utilised in reading the past history of the earth. For a time there was a tendency to refer all the remains of marine animals entombed in rocks to the Noachian deluge, or to a succession of such deluges sweeping round the globe; but the great variety of these remains, and the orderly succession of the beds in which they occur, gradually led to the acceptance of more rational views.

According to the influences to which they have been subject, and to a large extent according to their age, fossil plants, shells, and bones become altered in constitution, losing some of their chemical constituents and perhaps gaining others by substitution. The passage from wood-fibre into coaly matter by the giving off of gases and the retention of a large part of the carbon is a familiar example. Fossils may suffer complete solution, but at the same time some other substance may be deposited from the solvent which preserves the origi- nal form and structure. Corals or shells of molluscs may be replaced in this way by iron carbonate or by silica.

Frequently, however, the fossil is dissolved away, lcaving only a mould, an external cast, in the encasing rock. Shells or sea-urchins, with their central cavities, which were originally occupied by the organism, become filled with mud or some deposited mineral, and are represented after solution by internal casts, on which any perforations or patternings, or the impressions of muscular attach. ments, can be identified in reversed relief. The original colour is rarely preserved in a fossil state, and the sheen and iridescence of many specimens is due to the deposit of some chemical substance as a thin film, sometimes on the surface of a mere internal cast.

The accumulation of calcium phosphate in and around the fossils in certain beds has led to their being utilised as chemical manures.

It was not until the close of the 18 th century that it was realized that strata could be "identified by organized fossils." This phrase is due to the English land surveyor, William Smith, the great pioneer of stratigraphical geology, who showed conclusively that successive deposits contained successive types of animal remains. Hence, when a sequence has been established by observation, it is possible to determine from the fossil contents the relative age of a deposit. Fossils thus become the great clue to prehistoric times.

\section{A New Meaning}

At first it was taken for granted that the various associations of life-forms represented independent creations, one group of plants and animals being swept away and another substituted. The nobler view that is provided by the theories of organic evolution has given a new meaning to fossils and a new zest to palaeontology, the study concerned with their description. Indeed, the discovery of numerous links between one type and another; of animals like the early reptiles, which unite in themselves the characters of groups now far apart; and of a general specialisation of life-forms, sometimes by simplification, towards those now prevalent on the earth has raised the study of past forms of life, as revealed in fossils, into one of the highest branches of natural philosophy. See Geology; Consult also An Introduction to Palaeontology, A. Morley Davies, 1920; Invertebrate Palaeontology, H. L. Hawkins, 1920.

Grenville A. J. Cole 


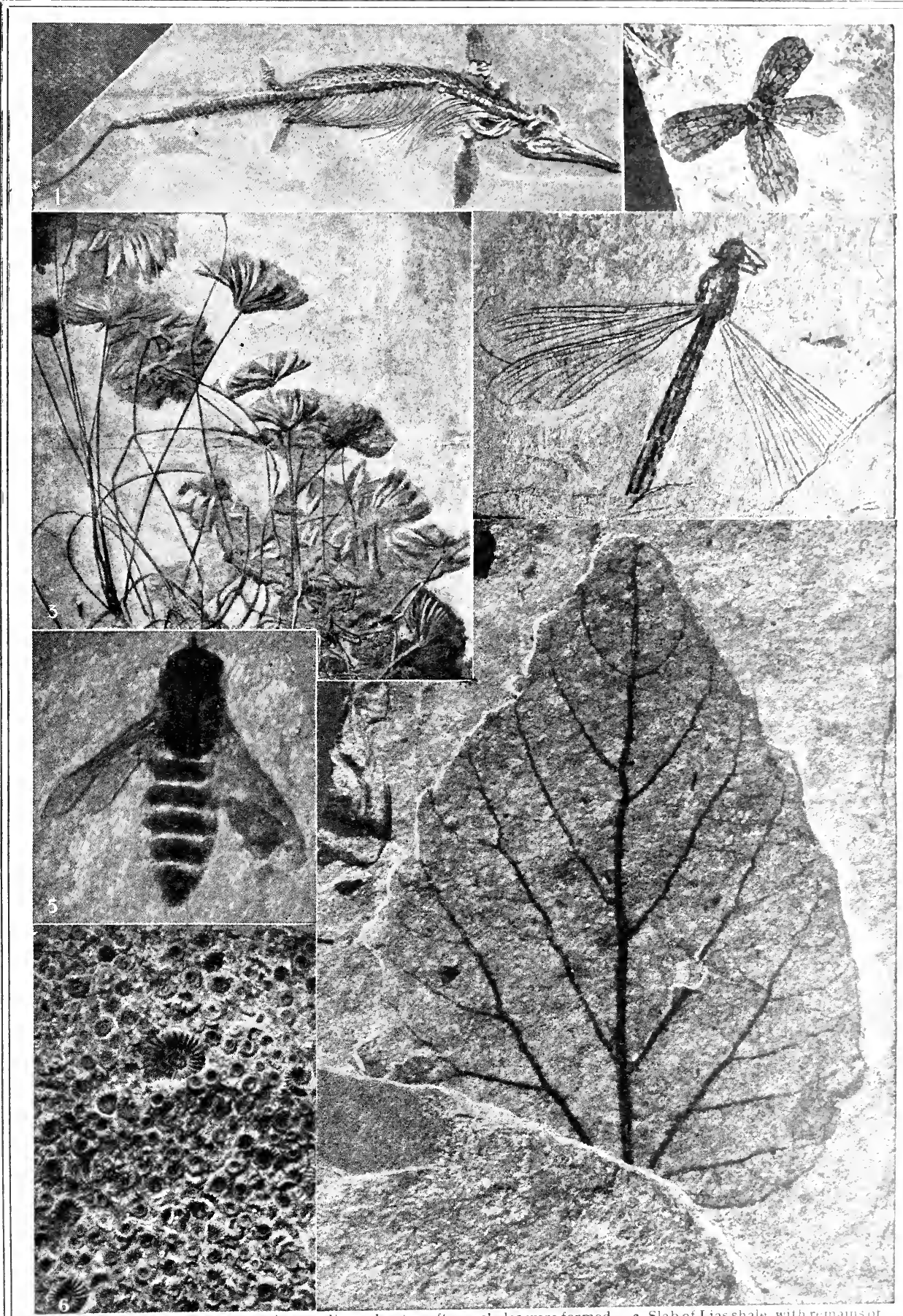

long, Lower Lias, Somerset. 2. Fossil tower of Porana

appearance in the Florissant shales, Colorado, suggests

of mulberry, Morus symmetrica, Florissant

FOSSIL: RECORDS OF NATURE BEFORE THE APPEARANCE OF MAN 
Fossombrone. City of Italy, in the prov. of Pesaro e Urbino. The ancient Forum Sempronii, it stands on the Metauro, here spanned by a handsome modern bridge, $10 \mathrm{~m}$. E.N.E. of Urbino. It has a castle and a cathedral rebuilt in the 18 th century. There are silk factories and mineral springs. Ruins of the Roman city, destroyed by the Goths and Lombards, lie about $2 \mathrm{~m}$. N.E. of the town, which had a bishop in the 6th century. Pop. 9,701.

Foster. Famous family of English cricketers. The sons of the Rev. Henry Foster, a master at Malvern College until his retire ment in 1915 they were there educated. Their names are as follow: $H . K$. Foster, Capt. W. L. Foster D.S.O., who won this honour in Somaliland, R. E. Foster,

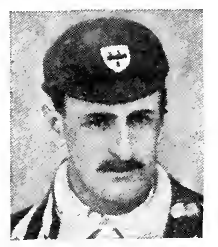

R. E. Foster,

English cricketer

B. S. Foster, G. N. Foster, and M. J. A. Foster. All played for Mal. vern and Worcestershire, which was sometimes called on this account Fostershire. H. K., R. E., and G. N. Foster gained their blues at Oxford. R. E. Foster, who died in 1914, was the finest batsman and fielder of the brothers. At Lord's in 1900 he scored a century in each innings for the gentlemen against the players, and at Sydney in Dec., 1903, he scored 287 against Australia, a record for a test match. He was a great fielder at slip.

Foster, Sir Georae Eulas (b. 1847). Canadian statesman. Born in New Brunswick, Sept. 3, 1847,

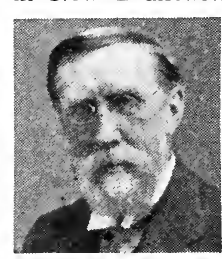

Sir George E. Foster, Canadian statesman Rus sell

Kings, New Brunswick. In 1885 he was minister of marine and fisheries under Sir John Macdonald. He became minister of finance in 1888, and remained in the cabinet until 1896.

In 1911 he took office as minister of trade and commerce under Sir Robert Borden, and acted as premier during his chief's absence from Canada on imperial business. He was made a G.C.M.G. in 1918 , was one of Canada's representa. tives at the Peace Conference in Paris, 1919, and was head of the Canadian delegation to the Assembly of the League of Nations at Geneva in 1920.

Foster, JoHn (1770-1843). Bri tish essayist. Born near Halifax, Yorkshire, Sept. 17, 1770, the son of a yeoman weaver, he spent some of his early years at the loom. At the age of 17 he joined the Bap. tists, and, after study at Brierly Ifall and the BaptistCollege

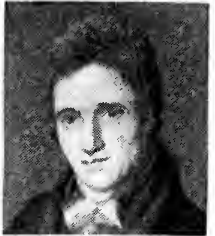
John Foster, British essayist at Bristol, he was inducted into his first charge at Newcastle-on-Tyne, 1792. After filling pastorates in Dublin, Cork, Chichester, Downend, and Frome, he resigned in 1806 owing to throat trouble.

In 1805 appeared his Essays, by which he is chiefly remembered, and in the same year he became one of the principal contributors to The Eclectic Review. He died at Stapleton, near Bristol, Oct. 15, 1843. A friend of Robert Hall, and a man of remarkable force of mind, Foster achieved success neither as preacher nor lecturer, but as a writer he was one of the masters of modern English prose. His Essays, particularly that On Decision of Character, are distinguished by imagination, depth, eloquence, and sincerity. See Life and Correspondence, J. E. Ryland, 1852 ; Historical and Biographical Essays, 1859.

Foster, Myles Birket (182599). British artist. Born at N. Shields, Feb. 4, 1825, of Quaker

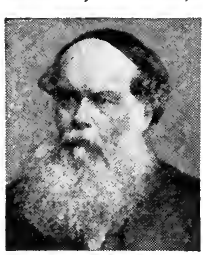

M. Birket Foster, British artist parentage, he studied under Ebenezer Landells, wood eng r a ver, for whom he drew m an y illustra. tions on the blocks. Starting on his own account in 1846 , h e illustrated in black and white many poetical publications, and in 1859 turned to water-colour, painting especially idyllic landscapes in Surrey and other home counties. He became associate of the Royal Water Colour Society in 1860 and member in 1861. He died at Weybridge, March 27, 1899.

Fosterage. Term used for the nursing and bringing-up of children by others than their parents. The custom prevailed in ancient Ireland, where the ties of fosterage were almost as close as those of blood relationship. Fosterage was undertaken either for payment or from affection, and lasted until the age of 13 for girls and 17 for boys. Apparently the mother paid for the fosterage of the boys and the father for that of the girls. A child was obliged to provide for the foster-parent in old age. See Family ; Kinship.

Fotheringhay. Parish and village of Northamptonshire, England. It stands on the Nene, $4 \mathrm{~m}$. N.E. of Oundle. Few traces remain of its llth century castle, famous as the scene of the im. prisonment, trial, and execution of Mary Queen of Scots in 1587, and as the birthplace of Richard III in 1452. Pop. 200.

Foucault, LÉoN (1819-68). French physicist. Born Sept. 18, 1819, and educated privately, he became physicist to the Paris Observatory, where he constructed various instruments, of which the gyroscope and the polariser which bear his name were the most notable. He determined the relative velocities of light in air, in water, and in a vacuum; but is best remembered by "Foucault's pendulum." From the roof of the Panthéon in Paris he hung a pendulum $200 \mathrm{ft}$. long, free to oscillate in any direction. The pendulum never retraced its path, but always deviated to the right, showing that the floor was moving and the earth rotating. Foucault died at Paris, Feb. 11, 1868.

Foucault Currents. Currents induced in solid iron cores by alternating current passing through coils wound thereon, and by rotation in a magnetic field. See Electricity; Magnetism.

Fouché, JosePH (1759-1820). French politician. Born near Nantes, May 21, 1759, he was educated by the Oratorians in Paris. Ordained priest, he became a teacher, and rose to be principal of Nantes College in 1790 . Throwing in his lot with the Revolution, he sat in the National

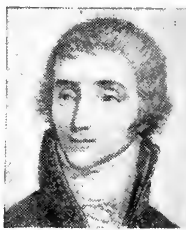

Joseph Fouché, French politician
Convention (1792), became a Jacobin, and vehemently advocated the execution of Louis XVI. Having renounced his orders, he was the moving spirit in the nummeries of the worship of reason and the spoliation of the churches.

Instrumental in the fall of Robespierre, Fouché occupied various positions in the succeeding government, becoming minister of 
police in 1799. Under Napoleon he retained this position, was raised to the senate, and, under the empire, was also minister of the interior. He was made duke of Otranto in 1808 and governor of Illyria in 1813. After Leipzig, seeing that Napoleon's power was on the wane, he prepared the way for deserting to the Bourbons, under whom, after 1815 , he again became minister of police. He was, however, exiled as a regicide in 1816, and died in Trieste, Dec. 25, 1820 It was Fouché who said of the murder of the duc d'Enghien, "It was worse than a crime; it was a blunder."

Fougasse (Fr.). Military mine originally placed under the glacis or ditch of a fortress. It is sometimes used to defend a defile or other approach by throwing a shower of stones upon the enemy. An excavation is made, the axis of which is inclined at an angle of about $40^{\circ}$ to the horizon; it is about $4 \mathrm{ft}$. deep, in the form of a frustum of a cone, $5 \frac{1}{2 t}$. at the surface. In a recess at the bottom is placed a square box of gunpowder, inclined to the horizon at $40^{\circ}$, and on the box a wooden shield about 6 ins. thick. The exeavation is filled up with stones, the excavated earth being placed in a mound in a line with the powder box to inerease the resistance upwards, and so ensure the effect of the explosion upon the stones at the required angle; the fuse is led up from the box over the mound. With a charge of $30 \mathrm{lb}$. of gunpowder the explosion will hurl three-quarters of a ton of stones a distance of 200 yds., spreading them over a surface 90 yds. wide.

Fougères. Town of Brittany, France. It stands on the Nançon, in the dept. of Ille et Vilaine, $30 \mathrm{~m}$. from Rennes and $23 \mathrm{~m}$. from $\mathrm{S}$. Malo. The chief buildings are the churehes of S. Sulpice and S. Leonard, both of the 15th century, while there are remains of the eastle and other fortifications built to protect the town in the Middle Ages. The eastle, standing on a rock, was partially restored in the 20 th century. Its eleven battlemented towers give an idea of its original size and strength. The hôtel de ville dates from the 15th century, and there are some old houses. The town is now a market for agrieultural produce and a centre of tanning and other industries connected with the manufacture of boots and shoes. Granite is found in the vicinity. Fougères was long one of the strong places of Brittany, and was more than once taken by the English. Pop. 23,500 .

Foula. One of the Shetland Islands, Seotland. It lies $16 \mathrm{~m}$. to the S.W. of the mainland, and is frequented by numerous sea. fowl. It is a thriving fishing centre. Its length is $3 \mathrm{~m}$., breadth $1 \frac{1}{2} \mathrm{~m}$., and highest point 1,370 ft. Pop. 184.

Foulard (Fr.). Soft, thin, flexible fabric made of silk or silk and cotton, usually printed in colours on a light or dark ground. The name was formerly applied to a gauze ribbon material manu. factured in France.

Fould, AchILle (1800-67). French statesman. Born in Paris of a wealthy Jewish family, Nov. 17,1800 , he succeeded $h$ is father in the direction of his bank, and was elected to the ehamber as deputy for Hautes Pyréné es, 1842. Throughout Napoleon III's

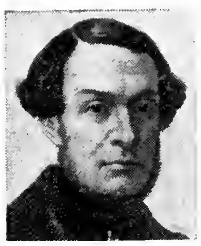

Achille Fould, French statesman After Philip poteaux dent and emperor, his financial abilities made him a prominent administrator. He was finance minister almost continuously between 1849-52, minister of state and of the imperial household, 1852-60, and minister of finance, Nov. 14, 1861, to Jan. 19, 1867. He extricated the national finanees from a difficult position by his reduction of the $4 \frac{1}{2}$ p.c. stock to 3 p.c., by additional taxes and stamp duties, 1862 , and by floating a suecessful loan, 1863. He resigned office on Napolcon's concessions to liberal reform sehemes, being succeeded by Rouher, and died Oct. 5, 1867.

Foulis, RoBERT (1707-76). Founder of the Foulis Press at Glasgow. Born at Glasgow, April

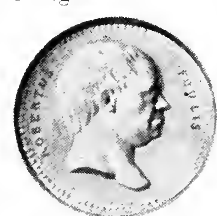

Robert Foulis, Scottish publisher From a medallion by J. Tassie

years later he was appointed printer to Glasgow University, and in 1744 took his brother Andrew (1712-76) into partnership. After the death of the two brothers the business was continued by Robert's son, Andrew (d. 1829).

The Foulis Press issued more than 550 vols., reprints of Greek, Latin, and British elassics, remarkable for beauty of type, format, and textual accuracy. They in. eluded the "immaculate" Horace, 1744 ; the fine Homer, in four folio vols., $1756-58$; a folio edition of Paradise Lost, and the poems of Gray and Pope. A collection of Foulis books is in the Mitchell Library, Glasgow. Pron. Fowls.

Foundation (Lat. fundare, to lay the bottom of, found). Literally, the base of a building, or that upon which a structure rests. It is freely used, however, for a society, such as a college or school, hospital or monastery, which is endowed, and so founded or set up on a permanent basis. The money given for this purpose and the conditions for which the society exists are the foundation, the work of the founder.

Those on the foundation of a college at Oxford or Cambridge, or of a school such as Winchester and Eton, are those scholars and others who receive money from the college funds, under the conditions laid down by the statutes. Permanent eharities, sueh as an almshouse or a hospital, are also known as foundations, as are eathedrals. The chapters of the English eathedrals are divided into old foundations and new foundations. The former are those which were unchanged at the Reformation; the latter those which being then com. posed of monks, were provided with new chapters. See

\section{Cathedral.}

Foundation. In building operations solid rock of a tough character is an ideal foundation. Gravel also is excellent, and the same may be said of dry sand, provided there be a fair depth of the material. Wet sand, elay, and alluvial deposits give a less trustworthy, uncertain support. When soft ground has to be dealt with, several alternatives are open to the engineer. He may prefer to distribute the weight orer a large area by means of a wide platform of eonerete or ferro-concrete: or to make the foundations comparatively narrow, but deep, and utilise the friction between them and the ground. If water be present, it may be necessary to drive piles down close together till the surface friction offers a sufficiently high resistance: or until they strike roek or other firm ma. terial. Wooden piles will stand loading up to 100 tons per square foot of head area, and make an excellent substitute for rock, when they aetually rest upon it or gravel. The heads of the piles are conneeted by erossbeams, which in turn support a platform of conerete or wood which eonstitutes the bearing surface.

Where the foundation site is 
large and covered by water, and excavation will not be deep, the area is enclosed by an artificial watertight wall, or cofferdam, and dried by pumping, after which work proceeds as on dry land.' In soft ground a cofferdam is usually formed by driving down two parallel rings of sheet piling, a few feet apart, and filling in the space between them with water-tight clay puddle. On rock, steel plates, cut to fit the contour of the surface, are used instead of piles, and the joint is made tight by concrete and clay packed outside. A cofferdam is, as a rule, removed when the work inside has been completed.

\section{Use of Caissons}

Deep foundations in waterlogged and water-covered ground are put in by means of cylindrical or box caissons (q.v.), which are sunk by excavating the ground inside and remain in their final position as part of the structure.

If a water-tight joint between caisson and ground be obtained. the interior is pumped dry and hand labour is used to excavate the space inside the caisson, the sides of which are raised as sinking proceeds. When a sufficient depth has been reached, the caisson is filled with masonry or concrete to above high-water level. Should water find its way in, grabs and dredges do the excavating and concrete is lowered through the water to displace it. Open caisson foundations have been carried to depths exceeding 150 feet.

For deep bridge foundations the closed or pneumatic caisson is generally preferred to the open. Such a caisson has a horizontal air-tight floor seven or eight feet above the cutting edge; and the working space below the floor is filled with air at a pressure sufficient to exclude the water outside. Air-locks and shafts are provided for the pas. sage of men and material.

Remarkable Feat at St. Louis

In 1854 the younger Brunel used a pneumatic cylinder for the central pier of the Saltash Bridge, which is founded on rock 88 feet below high water. ' Twenty years Iater Eads sank two piers of the St. Louis Bridge to 117 and 119 feet beneath the surface of the Mississippi on box caissons, building up the masonry as the caissons sank. This was a remarkable feat, since the air pressure required to keep the water out rose to nearly $50 \mathrm{lb}$. per square inch, and the working conditions were extremely exhausting. More recently, the foundations of the Forth Bridge and of the three great suspension bridges of New York were constructed in this way.

When a pneumatic caisson reaches its final level the chamber under the floor is filled with concrete, the men backing out through the shaft left in the masonry above, and the shaft itself is then closed.

Cast-iron cylinders, sunk either as open or pneumatic caissons, are commonly used to support the piers of railway bridges. Charing Cross Bridge is an example in point. The cylinders are 14 feet in diameter, and penetrate the bed of the river 20-50 feet. Some of the steel "skyscrapers" in New York are built upon cylinders sunk to rock. The Singer building rests on 34 caissons carried down 200 feet. In such cases the piers may be regarded as gigantic piles. See Building; Caisson ; Shaft-sinking ; consult also Practical Treatise on Foundations, W. M. Patton, 1900.

Foundation Sacrifices. Ritual immolation at the foundation of a building or settlement. Human skeletons are found beneath corner stones in early Palestine, as at Gezer and Megiddo. When Man dalay was built, 1860, 52 human victims were buried alive. Legends of living burial are recorded of $\mathrm{S}$. Columba's Cathedral, Iona; $\mathrm{S}$ Patrick's monastery, Clonmac noise. Animal bones were un earthed beneath old S. Paul's and Blackfriars Bridge, London. The Scandinavian kirk-grim was the spirit of the foundation victim. Animal slaughter as a foundation rite survives from W. Africa through Coptic Egypt and Moslem Syria to Borneo. The interment of statues in ancient Rome and effigies in medie val Europe points to an anterior custom of actual blood-shedding.

Founder. Disease affecting horses, cattle, sheep, and pigs. Known in veterinary science as Iaminitis, it is a painful inflammation of the laminae, or tissues con necting the hoof with the bones of the foot. It is caused by bad management and careless feeding, horses that have much corn and little exercise being very apt to develop it suddenly. Certain foods, such as Indian corn, beans, peas, and barley, undoubtedly predis pose to this form of fever. 'Treat ment consists in strong purgative medicines and blood-letting, and frequent warm bran poultices. The animal may be slung, in order to take its weight off its feet, and if the pain is very severe cocaine may be administered.

Founders' Company, THE. London city livery company. It was sometimes called Coppersmiths. Established as a fraternity in the 14th century, and incorporated in 1614, it had power of scarch over all brass weights and brass and copper wares in the city. The hall

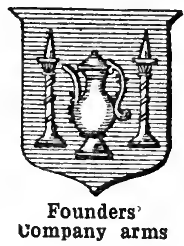

in Loth bury, E.C., built 1531, burnt 1666, and for a time let as a chapel, is now occupied by the G.P.O. The present hall, 13, St. Swithin's Lane, E.C., dates from 1877. See Annals of the Com. pany of Founders, W. M. Williams, 1867.

Founder's Share. Class of share granted to the originators of a joint stock company, or to others who have rendered services to it. They are usually few in number, and for very small amounts, 1s. perhaps ; but sometimes they become very valuable because they participate in the profits after a certain fixed amount has been reached. The fact that their total amount is small enables a successful business to pay an enormous percentage on such shares. This class of share is rarely issued now, and in some cases those issued earlier have been bought out and cancelled. See Company Law.

Foundling Hospital. Institution originally founded to prevent the murder or exposure of newly born children. Such institutions appear to have been coincident with the development of civilized society, and they undertake the education and training of children until the latter reach maturity. The first step towards avoiding the crime of child murder was the exposure or abandonment of an infant in a public place in the hope that it would be cared for by someone other than the parents. The earliest recorded case of exposure seems to be that of Moses (Exodus 2 ). Foundlings thus exposed were assigned as property to those who took them under their protection, and provision was made in ancient Greece and Rome for the upbring. ing of unadopted infants at the expense of the State, an example fol. lowed by the French in $\mathbf{1 7 9 0 .}$

At Trèves Cathedral, in the 6th century, foundlings were received and arrangements made for their care under the supervision of the archbishop. The first foundling hospital of which there is authentic record was that at Milan towards the end of the 8th century. The Order of the Holy Ghost, founded at Montpellier in the 12th century, made the care of foundlings a special duty. The Spedale degli Innocenti, or Foundling Hospital,-at Florence, dates from 1419-51. The Ospedale di S. Spirito, in Rome, founded by Innocent III. included a foundling institution. In 1536 


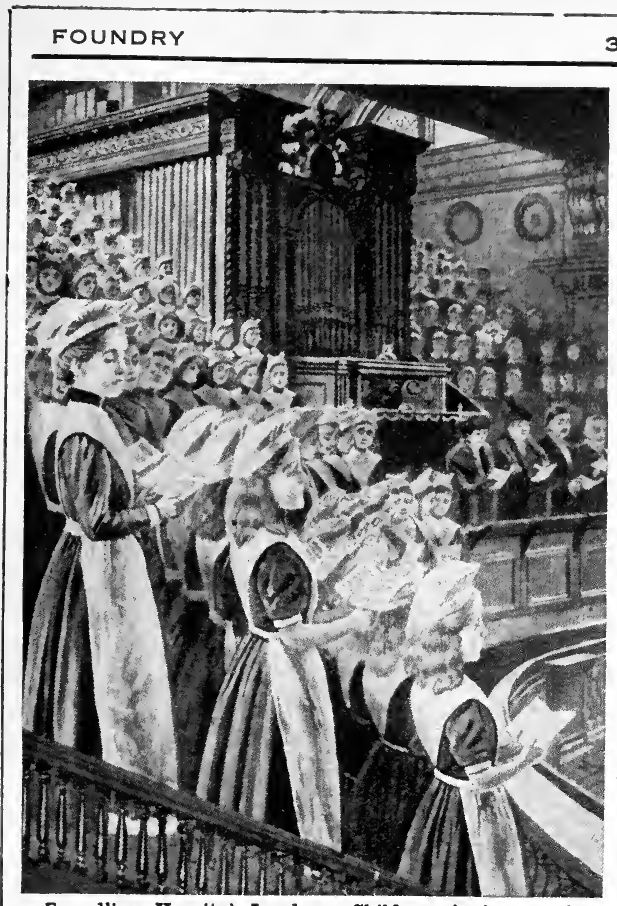

Foundling Hospital, London. Children singing carols in the chapel at Christmas

Marguerite of Valois instituted a foundling hospital which was incor. porated with the great Foundling Hospital in Paris, started in 1670 . Foundling hospitals now exist in all the great capitals of the world, though the word foundling does not correctly describe them all.

One of the most interesting of these institutions is that in London. Its founder, Thomas Coram ( $c$. 1668-1751), a captain in the mer. chant service, and a man of com. paratively humble means, advo. cated his project for nearly 20 years before, in 1739, it was realized. A house was taken in Hatton Gar. den, and opened March 25, 1741, for the admission of 20 infants. The existing building in Guilford Street, Bloomsbury, dates from 1754, when it had 600 inmates, supported at an expenditure of five times the income. Parliament voted a grant of $£ 10,000$, but stipu. lated for indiscriminate admission, which had to be abandoned. Since 1760 admission has been limited to illegitimate children who have been deserted by the father, but whose mothers can prove previous good character: In 1920 there were about 700 inmates. Hogarth, one of the earliest governors, began an art exhibition in its rooms which led to the foundation of the annual exhibitions of the Royal Academy. Handel was another tireless bene. factor, and since his day the hospi- tal has had a high musical reputa. tion. Its removal to the country and rebuilding was announced in Nov 1924.

The boarding out of infants in suitable homes before they become regular inmates of foundling hospitals has proved bene. ficial. The mortal. ity in these insti. tutions has, how. ever, taxed the best energies of philanthropy and medicine, but in London and Paris in recent years much im prove. ment has been effected. See Baby Farming; Child Welfare; Infanti. cide; Orphanage; consult also His. toire des Enfants abandonnés, Sennichon, 1880.

Foundry (Lat. fundere, to pour). Word used for (1) the art of founding or casting in metals, and (2) an establishment wherein metal is cast. See Casting ; Iron; Steel.

Fount. In printing, a term for a supply of type of one size and face, with a distinctive nick. The quantity is ordered according to the number of compositors em. ployed and the class of work for which it is required. For news. papers, an extra quantity of capitals and figures is necessary. With this proviso, a fount will contain a standard number of all the letters of the alphabet, graded in bulk according to the occurrence of the letters in the language in which the type is cast. In the U.S.A. the word is spelt font. See Printing; Typefounding.

Fountain (late Lat. fontana). Term applied to any construction for the supply of water, from a sim. ple spring to an elaborate artificial basin with ornamental jets. The need of fountains was experienced in Oriental countries at a very early date. Traces of their employment have been found among the relics of the Chaldaean civilization; $\mathrm{Pau}$ sanias mentions Hellenistic exam. ples; and in ancient Rome they were fully developed as a means of distributing the water brought to the city by the aqueducts. Pliny the Elder notes the construction or repairing of more than 1,200 foun. tains in Rome alone.
The treatment of fountains was at first purely utilitarian. During the Renaissance, however, the ornate fountain was rapidly devel. oped. 'The fountains of Berne, each dignified with a name of its ownThe Bear, The Ogre, Justice-and the Fountain of the Innocents in Paris (dated 1550) are imposing architectural structures. The com. mon type of Renaissance fountain was a shallow basin, with a pillar of marble often surmounted by a statue of stone or bronze in the centre, from which projected jets that supplied the running water. The more primitive type was re. presented by the drinking fountains at street corners. In France, the zenith of fountain-construction was reached under Louis XIV; one may cite the elaborate fountains at Versailles, with their thousands of jets. When the practice of installing a water supply in individual houses was introduced towards the end of the 18th century, utilitarian fountains became rare. But bodies like the Metropolitan Drinking Fountain Association, formed in London in 1859 , proved that the demand for this type still exists. Notable ornamental fountains of modern times are the Fontana di Trevi at Rome, and the fountains in the Place de laConcorde, Paris. Seeillus.

Fountain Pen. Pen in which ink from a reservoir in the holder is fed automatically to the nib. One or more fceders, fitted above or below the nib, regulate the supply of ink, which flows by capil. larity. The nibs are made of gold to prevent corrosion, and have iridium-osmium points.

Self-filling fountain pens are supplied with ink other than by pour. ing. One type has in the holder a long flexible reservoir from which the air is expelled, before filling, by a plate, actuated by a small outside lever pressing the reservoir tightly against the inner wall of the holder. When the air has been expelled, the nib is immersed in ink; the lever is turned back into its original position flush with the holder and the ink rises into the reservoir. Another type is fitted with a small plunger, the pumping action of which charges the reservoir. In a third type, the filling is effected by the pumping action of a rubber dome fitted to a bottle containing ink, the nib-end of the pen being inserted in a neck on the dome.

Fountains Abbey. Ruined abbey in Yorkshire, England. It stands near the little river Skell, $3 \mathrm{~m}$. S.W. of Ripon; it is in the grounds of the mansion of stud. ley Royal, while near it is a man. sion dating from Stuart times, Fountains Hall. The ruins are 
extensive, including those of the church with its tower, the former being $380 \mathrm{ft}$. long, the chapter house, the magnificent cloisters, and other parts. They are perhaps the most complete in England and, with the possible exception of 'Tintern, the most beantifully situated. The abbey, a Cistercian house, was a long time in building. Begun about 1140 , it was only completed 200 years later. The. monks came from S. Mary's Abbey, York. The house was dissolved by Henry VIII and the ruins and lands were sold. See Abbey; Cloister, illus.

Fouqué, Friedrich Heinrich Karl, Baron DE la MotTe (17771843). German author. Born at

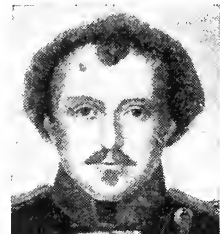

Baron de la Motte Fouqué, German author
Brandenburg. Feb. 12, 1777 . of Huguenot origin, he took part as a cavalry officer in the Prus. $\mathrm{si} \mathrm{n}$ c a $\mathrm{m}$. paigns of 1794 and 1813, but literature occupied most of his time. For

a while he was the most popular of German story-tellers, but his dependence upon the supernatural militated against a permanent popularity. He is chicfly remembered for his tale of Undine, 1811 . while Aslauga's Knight, and Sintram and his Companions, which have been translated into English, still find readers. He died in Berlin, Jan. 28, 1843.

Fouquet or Foucquet, NicoLAs, Marquis de Belle Isle, Vicomte de Melun et de Vaux (161580). French st at esman. Born of a noble family, he held various posts in the parlia. ment of Paris while still a youth, becom. ing procura tor-general in 1650. In 1653

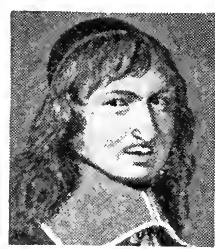

Nicolas Fouquet, French statesman
Mazarin made him superintendent of finances, and Fouquet used his position to make himself one of the wealthiest men in France. He worked to succeed Mazarin, 1661, as the king's chief minister, but Louis XIV, on Colbert's advice, passed him over.

Fouquet built himself a luxuri. ous palace at Vaux, entertaining lavishly and patronising the arts and letters. But Louis, exas. perated by his long mismanagement of the finances and his overweening ambition, had him arrested at Nantes, Sept., 1661. His trial, 1661-64, ended in his im. prisonment for life at Pignerol, Piedmont, where he died, March 23,1680 . The theory that Fouquet was the Man in the Iron Mask (q.v.) has been proved untenable.

Fouquier-Tinville, ANToINE Quentin (1747-95). French Revolutionist. Born at Hérouel, Aisne,

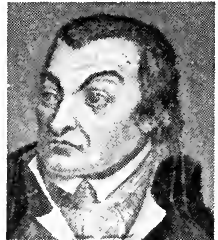

A. Q. Fouquier

Tinville, French Revolutionist

From a sketch and trained for the law, he came to Paris and entered the secret police in 1783 . A violent democrat, he joined the extremist party in the Revolution, and was appointed by Robespierre public prosecutor of the Revolutionary Tribunal, 1793. Utterly inhuman, he sent men and women of all ages and parties to the guillotine, Bailly, Danton, Robespierre, and St. Just amongst them, but in the reaction from the Reign of Terror he himself was convicted and guillotined on May 7, 1795 .

Fourberies de Scapin, LeS (The Tricks of Scapin). Three-act comedy by Molière. Derived partly from classical and partly from Italian sources, its scene is laid in Naples. Scapin, a servant, a character acted by the author, plays a series of tricks on two fathers, so that their sons may marry the two girls with whom they have fallen in love. The girls prove to be the brides whom the duped fathers had originally had in view.

The play, which has been described by Brander Matthews as a Punch-and-Judy piece for grownups, was first produced at the Palais-Royal, Paris, May 24, 1671. Otway wrote an English version, The Cheats of Scapin, 1677.

Fourcroy, Antoine François (1755-1809). French chemist. Born in Paris, June 15, 1755, he was appointed in 1784 to the chair of chemistry at the Jardin du Roi. At the Revolution he became a member of the committee of public safety, and to his indifference is attributed the execution of Lavoisier. Among his discoveries are adipocere, cholesterin, the double salts of magnesium and ammonium, and pure baryta. He died Dec. 16, 1809 .

Four Hundred, Tyranny of THE. Oligarchy of nobles established in Athens for four months in 411 B.C. The prime author of the change of government was the exiled Alcibiades (q.v.), who knew he could not return to Athens so long as a democratic government was in power; the chief conspirator was
Pisander. A reign of terror ensued and the Four Hundred made peace overtures to Sparta. The main Athenian army at Samos was furious, and the people at home, disgusted with the oppressive measures and pro-Spartan sympathies of the Four Hundred, took matters into their own hands, and with a surprisingly small amount of bloodshed restored the democracy. See Greece : History.

Fourier, FrançoIs Charles MARIE (1772-1837). French Socialist. Born at Besançon, April 7, 1772, the son of a well-to-do tradesman, having lost his inheritance in business, he served two years in the Revolutionary a rmy, and then became a commercial

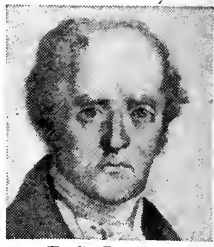

F. C. Fourier, French Socialist traveller. He set himself to evolve a new social system in a series of works, the chief of which are Theory of the Four Movements, 1808, and The New Industrial World, 1829.

Fourier's ideas attracted little attention during his lifetime, but were much discussed in the U.S.A. from 1840-50. Several communities, notably those of Brook Farm (g.v.) and Red Bank, were established to put them into practice, but met with little success.

Fourier's theory was that, man being essentially a gregarious animal, the population should be redistributed in a number of new social units, to which he gave the name of phalanges. Each phalange was to consist of 1,500 to 1,800 people, housed in a common building or phalanstère, with a square league of land attached, was to be industrially complete in itself and self-governing. Each worker was to receive a minimum wage, and the surplus was to be distributed thus: five-twelfths to labour, three-twelfths to talent, fourtwelfths to capital. Fourier died at Paris, Oct. 8, 1837.

Fourier, Jean Baptiste Joseph (1768-1830). French mathematician and physicist. Born at Aux-

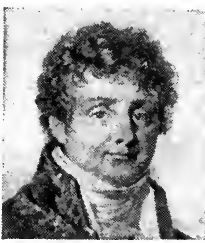

J. Baptiste Fourier, French mathematician erre, March 21, 1768. he took an active part in the Revolu. tion in that dis. trict. Later he accompanied Napoleon on his Egyptian expedition, and was made governor 


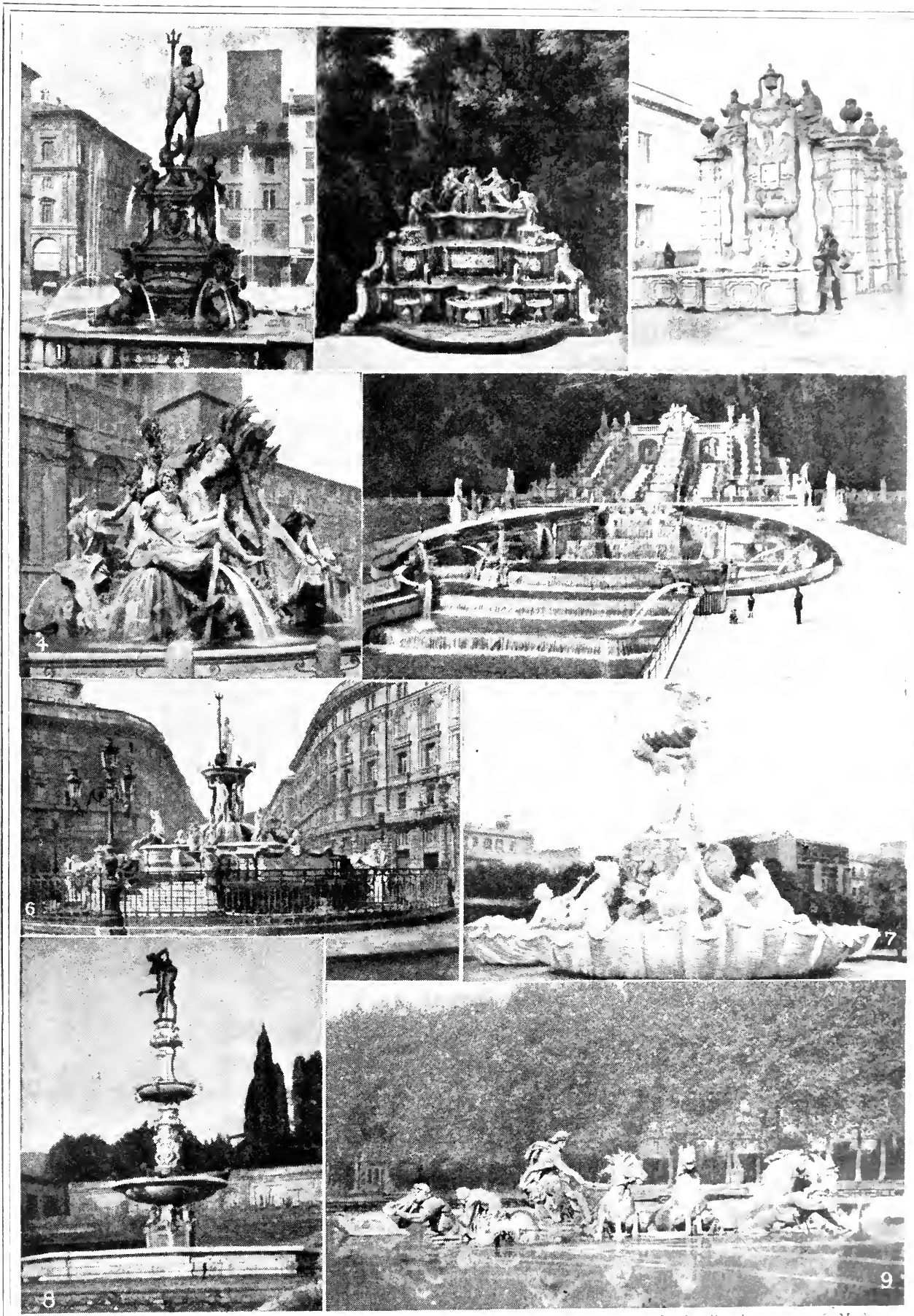

Neptune fountain at Bologna, by Giovanui da Bologna,

1563-67. 2. Buffet cascade, Grand Trianon Gardens,

painting. 3. Fountain of Falling Waters, Mexico City,

I755. 4. Fountain in Piazza Navona, Rome, by Bernini, I550).

FOUNTAIN : ARTISTIC EXAMPLES FROM GREAT CITIES OF EUROPE AND AMERICA 
Lower Egypt. On his return to France he carried out experiments on the propagation of heat. His Théorie analytique de la Chaleur, 1822, was based on Newton's Law of Cooling, and contains an account of the mathematical series by which he is chiefly remembered. He died at Paris, May 16, 1830.

Fourier Series. A trigonometrical series, involving sines and cosines of simple multiples of a variable which is restricted in pos. sible value between definite limits. Such a series, named after J. B. J. Fourier, is of value in the solution of many problems in physics.

Four-in-Hand Club. English club founded in 1856 to preserve the sport of driving four-horsed coaches. It succeeded the Bensing. ton Driving Club (1807-52), and is as exclusive. The Coaching Club, founded in 1870 , received as mem. bers gentlemen for whom no vacancy offered in the older club. The annual meet of the Four-inHand Club at the Magazine in Hyde Park is one of the social events of the London season. See Driving; also Coaching, illus.

Four Lakes. Name given to a series of four lakes in Wisconsin, U.S.A. They are the Mendota, Monona, Waubesa, and Kegonsa, and are situated in the S. part of the state. Occupying an area of 225 sq. m., they are drained to the Rock river, by the Yahara river, and are navigable by steamers. Madison, the state capital, stands between Monona and Mendota.

Fourmies. Town of France. In the dept. of Nord, it is $38 \frac{1}{2} \mathrm{~m}$. S.E. of Valenciennes. An industrial town, it had before the Great War manufactures of woollen, cloth, glass, and iron goods. The glass works date from about 1600 . The town is a rly. junction, and during the Great War it was in the occupation of the Germans. Pop. 13,800.

Fournet, D'Artige DU (b. 1856). French sailor. He saw service in the East, taking part in the Tong-

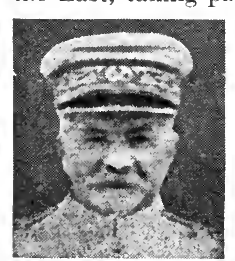

D'Artige du Fournet, French sailor king $W$ a $r$, 1883 , and the Chinese campaign, 1885, when he was awarded $\mathrm{th}$ e cross of the Legion of Honour. In 1893 he com manded $t \mathrm{~h} e$ Comète in the Siam War, forcing the passage of the Menam and reaching Bangkok. Becoming rear-admiral in 1900 , he commanded the French squadron in the international naval demonstra. tion during the Balkan War.

At the outbreak of the Great
War, as vice-admiral he com. manded the Flotte du Lévant off Syria, and later the Dardànelles fleet. In Oct., 1915, he was appointed commander-in-chief of the French navy with supreme command over the Allied fleets in the Mediterranean, obtaining the surrender of the Greek navy in Oct., 1916. He retired in Dec., 1916.

Fourth. Musical interval which includes four consecutive scale names, as C, D, E, F. The interval between $\mathrm{C}$ and $\mathrm{F}$ is called a fourth, and as $F$ is the fourth degree of the scale of $\mathrm{C}$ this

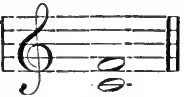
is called a perfect fourth, and by some a major fourth. See Interval.

Fourth Dimension. Term used for hyper space next to the three-dimensional space in which we live. A line has only one dimension, length ; a surface two, length and breadth ; a solid three, length, breadth, and thickness. A fourth dimensional body would have the last three and one other which may be argued about from a mathematical point of view and provides a plausible answer to many of the problems of physics, as for example the explanation of gravity and the fact that there are only a finite number of kinds of matter.

The idea of a fourth dimensional space springs logically from the algebraic expression of geometrical forms. If a quadratic equation can be made to express any geometrical figure on a plane surface, a cubic equation, $\mathrm{th} \mathrm{e}$ geometric rela tions of a solid. then an equation of higher powers might be held to represent the relations of points, lines, surfaces, and solids, or supersolids in space of more than threedimensions.

The Italian geometer Veronese wrote a work on geometry of $n$ dimensions, and the theorem was considered by mathematicians such as Cayley, Riemann, and Clifford in the middle of the nineteenth century. See Mathematics; consult also Scientific Romances, 1884-88; T'he Fourth Dimension, 1904, both by C. $\mathrm{H}$. Hinton.

Fourth Estate. Term sometimes applied to the press to emphasise its importance in the state, the three estates of the realm according to the constitution being the lords spiritual, lords temporal, and commons. The term was first used by Edmund Burke. See Estates; Journalism.

Fourth Party. Name given about 1880 to a small independent and irresponsible body of Conserva. tive politicians. They were Lord Randolph Churchill, Sir H. Drum. mond Wolff, Sir John E. Gorst, and at times A. J. Balfour. Throughout the Parliament of 1880-85 they frequently opposed and annoyed their leader, Sir Stafford Northcote.

Foveaux. Strait or channel separating Stewart Island from South Island, New Zealand. It is about $25 \mathrm{~m}$. across.

Foweira. Village of Uganda. It stands on the Victoria Nile, $62 \mathrm{~m}$. below Lake Kioga and $160 \mathrm{~m}$. from Namasagli. The Nile is navigable from Lake Kioga to Foweira, but here occur some $50 \mathrm{~m}$. of rapids.

Fowey. Seaport, market town, and watering-place of Cornwall, England. It stands on the W. shore of the Fowey estuary, $10 \mathrm{~m}$. S. by E. of Bodmin, on the G.W.R. It has a fine harbour, formerly protected by three forts now in ruins, is a favourite yachting station, and is largely occupied in the pilchard. fishing industry. An important port in the Middle Ages, it supplied nearly 50 vessels for the blockade of Calais in 1346. There is a trade in china clay. Market day, Sat. Pop. 2,276. Pron. Foy. 


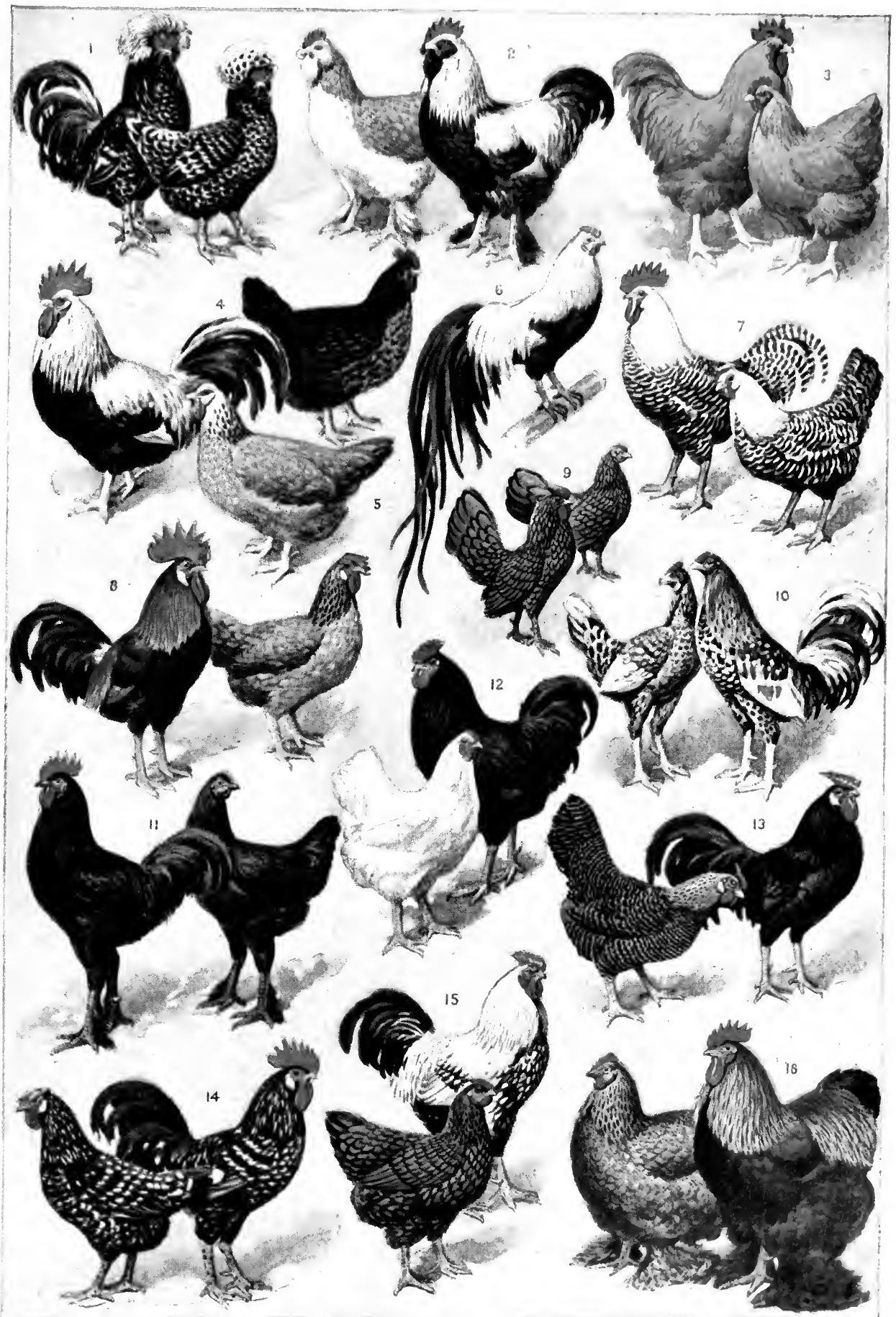




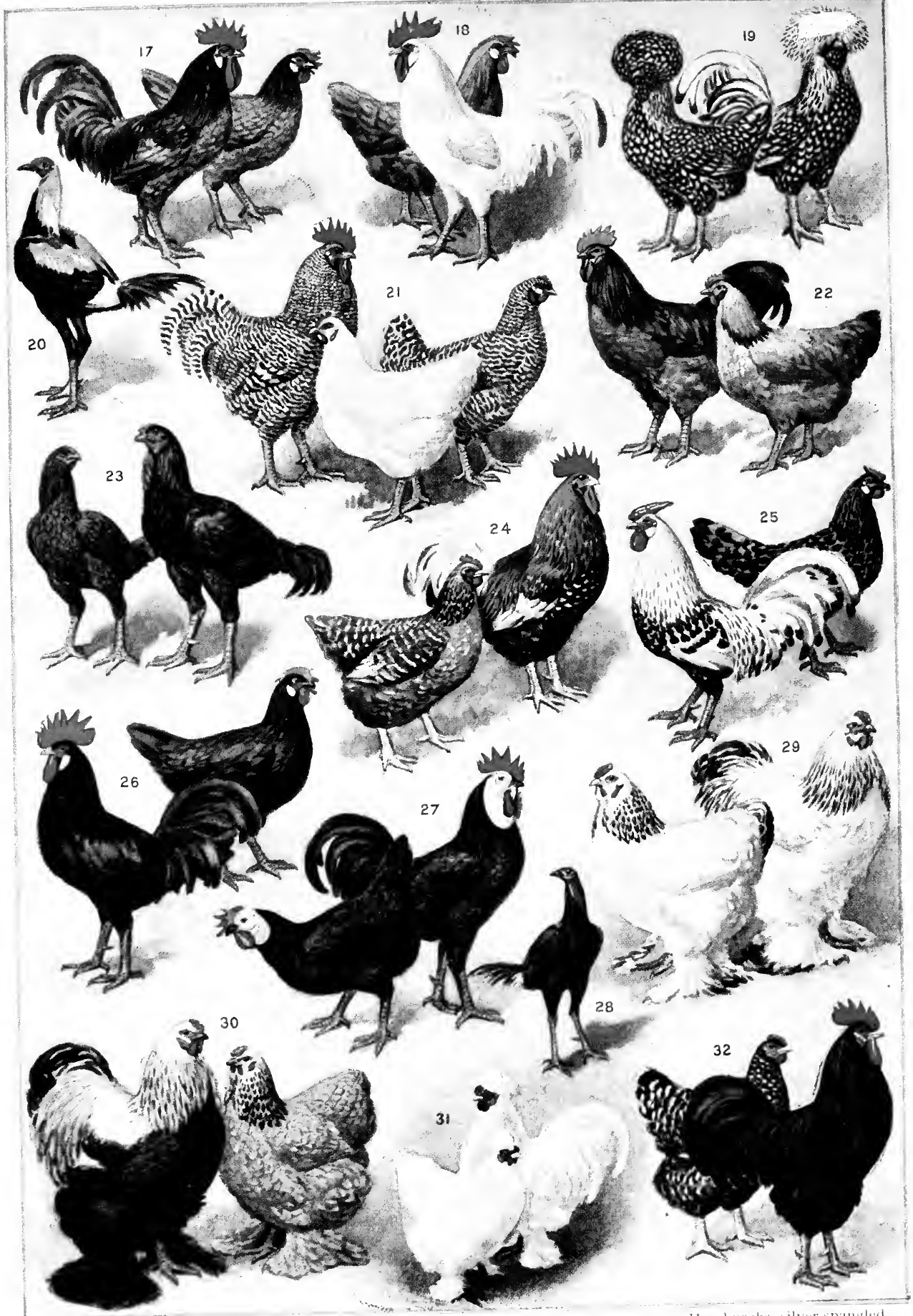


held until the outbreak of the Cornwall to obtain tin being pure Great War, when he was appointed engineer-in-chief of the expeditionary force, beeoming adjutantgeneral in Franee in 1916. He be eame lieutenant-general in Jan., 1919, and was created K.C.B. in 1916 and K.C.M.G. in 1918.

Fowl (A.S. fugol, bird). Name loosely applied to the various species of the genus Gallus of the pheasant family of the zoologieal order Gallinae, to which the game birds generally belong. Most of them have handsome plumage, and are provided with strong legs, being better adapted for running than for flight. They range in size from the quail to the turkey, are mixed feeders, and are all valued for purposes of the table.

Undoubtedly all the many varieties of the domestic fowl are descended from the wild jungle fowl of India. The jungle fowl, which flourishes well in captivity, breeds freely with the domestic varieties, and the hybrids are always fertile. There is no record of the original domestication of the jungle fowl. It is very improbable that it was at first used by the aneient inhabitants of India for cock-fighting (q.v.). It is far more likely that the bird was caught in greater numbers than were required for food at the moment, and that it was then found possible to keep it for a time in captivity, where it bred and thus suggested a means of multiplying and maintaining a supply of food always at hand.

\section{Early Domestication}

The bird is entirely absent from the remains of birds and animals found in the kitchen middens of the neolithic period, and it does not appear to have been known to the Greeks of the Homeric age. But it is mentioned in a Chinese eneyclopedia compiled about 1400 B.C., though it is not clear if the wild or domesticated bird is meant. There are, however, records in the Code of Manu of cock-fighting in India about 1000 B.C., and this makes it probable-though not certainthat domestication had taken place at an earlier date. It is curious that the spread of the domesticated fowl westwards was due to the love of coek-fighting rather than to any appreciation of the value of the bird as an article of food. Aristotle in his History of Animals mentions the domestic fowl and gives various details of its habits and laying powers; but there is no mention of domestic fowls in the Bible until New Testament days.

When the bird first reached Great Britain is unknown, the statement that it was brought by the Phoenicians when they visited speculation. It is thought that the breed now known as Dorkings was introduced by the Romans, but here again decisive evidence is lacking. But it is known that cockfighting was popular in Britain many centuries back. The earliest definite record dates from the reign of Henry II, when William Fitz. Stephen wrote an account of the coek-fights that took place in sehools on Shrove Tuesday.

\section{Size and Laying}

By selection in erossing, the little jungle fowl, which only weighs $3 \mathrm{lb}$., has developed into heavy breeds sueh as the Brahma, the Cochin, and the Houdan. The attention of breeders has been variously direeted in the interests of egg pro duction, table qualities, or merely ornamental character; it is seldom practieable to combine the three qualities in any high degree of excellence in the same bird. $\mathrm{Ob}$ viously, a hen which lays freely eannot put on much flesh at the same time, as the food consumed goes in the production of eggs. Thus it will be noticed that the most prolifie laying strains all tend in the direction of smallness. Even in the same breed it will usually be found that the small hen is the best layer, though it does not follow that she will make a good sitter. A good layer seldom reaches a weight of $7 \mathrm{lb}$.

Of the domestic laying breeds, the best one of British origin is the Hamburg, an exeeptionally handsome bird, with either black or gold or silver spangled plumage. Its egg-laying proelivities are extraordinary, but the eggs are rather small. The Redeap resembles the Hamburg in plumage, but is larger. It has the advantage of produeing larger eggs and does best in hilly districts. The Scottish Grey from north of the Tweed is long in the leg, with barred grey feathers, and is a capital layer. Other excellent laying strains are the Leghorn, which eame from Italy; the Minorca, a fairly large Spanish bird whieh lays eggs of unusually large size ; the Houdan, of French origin, both a table bird and a good layer: and the Polish, of doubtful nationality, which lays well but is difficult to rear.

Among British table birds, the Dorking, which is one of the oldest breeds known, stands pre-eminent, but will not do well on a damp soil. The various game fowl, which are modifications of the old fighting breed, make excellent table birds; the Sussex birds are famous everywhere under the misleading name of Surrey fowls.

In addition to these distinctively egg-laying and table birds, there are several breeds which may be described as of the general utility order. Most of them are eompara. tively new varieties, and have been bred as all-round birds. They lay freely and sit well ; their eggs are of good size and colour ; and their table qualities are excellent. They are favourites with poultry keepers who do not specialise in breeds, and are the birds for the small man.

The Orpington breed is a comparatively late one, but is already one of the most popular. The birds are large and deep in body, and the plumage may be white, buff, or spangled. They lay well in winter, their eggs are of the popular tint, and they mature very rapidly.

The Wyandotte is one of the handsomest breeds, yielding well for the table and laying well through the winter months. The Plymouth Rock is exceptionally hardy and flourishes under adverse conditions. The Brahmas and the Cochins are both Asiatic birds, of large size and heavily feathered down the legs. Formerly popular for their great size, they do not pay to keep and are seldom bred, exeept for show purposes.

\section{Ornamental Breeds}

Of the purely ornamental breeds little need be said. They are of handsome appearance, but since bone and feather ean only be produeed at the cost of flesh, their small size, slowness of growth, or poor egg-laying powers make them unprofitable for market purposes, and breeders prefer to produce a few prize birds which will command fancy prices at poultry shows. These include the bantams, the Malayan fowl, the Silkies, and a few other varieties. They are nearly all of Asiatie origin. See Poultry; also Ancona; Andalusian; Bantam; Dorking, illus.

Bibliography. Our Poultry and All about Them, Harrison Weir, new edition, 1904; The Races of Domestie Poultry, E. Brown, 1906 . Poultry for Prizes and Profit, James Long, 1909; The Book of Poultry, L. Wright, 1910; Commercial Poultry Farming, T. WV. Toovey, 1919.

Fowler, Ellen Thorneycroft (b. 1860). British novelist. Daughter of the lstViscountWolverhampton,
Ellen Thorneycroft Fowler,

British novelist Russell

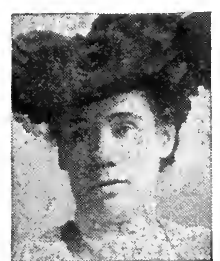
she married $\mathrm{A}$. L. Felkin in 1903 . $\mathrm{Her}$ novels, distin. guished by skill in eharacter drawing and a turn for epigram, include Concerning Isabel Carıaby, 1898 ; A DoubleThread, 1899 ; Fuel of 
Fire, 1902; Place and Power, 1903 ; In Subjection, 1906; and The Wisdom of Folly, 1910. They reHect mainly life in and around a midland town of England, and among Methodist surroundings.

Fowler, Sir JoHN (1817-98). British engineer. Born July 15 , 1s17. he became a eivil engineer

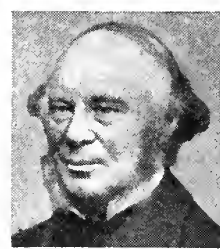

Sir John Fowler, British engineer and was largely employed in the many rail way schemes which accom panied the boom of 1846 . The Pimlico Bridge was built accord ing to his designs in 1860 .

The same year he was engaged in the construetion of the Metropolitan Rly., which was opened Jan. 9, 1863. In 1869 he was eonsulted by Ismail Pasha with regard to engineering schemes in Egypt. In 1883 , in partnership with Benjamin Baker, he designed the Forth Bridge, which was opened in 1890. For this Fowler, who had been knighted in 1881 , was made a baronet. He died at Bournemouth, Nov. 20, 1898.

Fowler-Dixon, Joun EDwin (b. 1850). Athlete and writer on athleties. Born Sent. 3, 1850, he de-

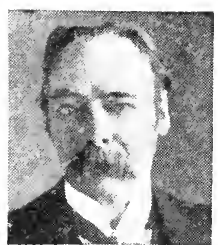

J. E. Fowler-Dixon, British athlete voted himself to athleties, and in 1877 won the 50 miles and the 100 miles ama teur walking re cords. In 1884 and 1885 he created 50 ini iles running records of $\hat{t}$ hrs. 20 mins. 47 secs. and 6 hrs. 18 mins. 26 secs. respectively. In the former year he also made the 40 miles running record of 4 hrs. 46 mins. 54 secs., which in 1920 had not been beaten. $\mathrm{He}$ was principal proprietor of The Athletic News. He belped to found the Amateur Athletic Association, and wrote Athletes and the War.

Fowler's Solution. Popular name for liquor arsenicalis. It is a 1 p.c. solution of arsenious acid in water with small amounts of potassium carbonate and com. pound tincture of lavender. It is used occasionally in medicine, chiefly in morbid conditions of the blood.

Fox. Animal belonging to the genus Vulpes, probably consisting of only one species including several local races. It differs from other dogs in the shape of its skull, and in the fact that the pupil of the eye is elliptical instead of circular. It is of slim build, with long bushy tail and rather long ears.

Foxes feed upon small mammals and birds, but also eat insects and fruit, feeding by night and spending the day in burrows, hollow trees, and clefts in rocks. They are found nearly everywhere throughout the northern hemisphere; and the common fox (Vulpes canis) is a well-known inhabitant of Great Britain. It is reddish-brown in colour, witl white beneath; but the hue varies considerably in local races, as in the so-called greyhound fox of the Lake District. It

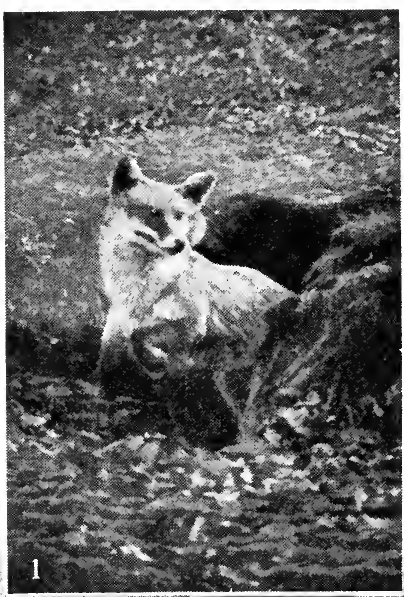

sometimes makes its own burrow, though it usually adapts that of the badger or rabbit. In the summer it often sleeps in a dry ditch, and has been known to make its abode in a straw rick. The young, usually four or five in number, are born about April.

The fox is valued for its fur, especially that of the black and silver varieties. It is a favourite animal for hunting, while on the other hand it often works havoc in the game preserve and the poultry yard. It would have become extinct in Britain long ago but for its preservation by the "hunts." See Fur.

Fox or Nement. River of Wisconsin, U.S.A. Rising in the S. part of the state, it flows S.W., N., and N.E. to Lake Winnibago. Emerging from the $\mathbf{N}$. end of that lake, it follows a N.W. course to Green Bay, a branch of Lake Michigan. In its upper reaches, near Portage, it is connected by a canal with Wisconsin river. It is $250 \mathrm{~m}$. long, and navigable for the greater part of its course.

Fox or Pishtaka. River of the U.S.A. Rising in Wisconsin, it flows $225 \mathrm{~m}$. generally S. and S.W., and passes through Illinois to unite with the Illinois river at Ottawa.

Fox. Channel of N. America. It lies to the $\mathrm{N}$. of Hudson Bay, separating Baffin Island on the E. from Melville Peninsula and Southampton Island on the W. It communicates by Hudson Strait with the Atlantic, and by Fury and Hecla Strait with the Arctic. Luke Fox, English navigator, explored it in 1631 .

Fox Islands. Variant name given to the Aleutian Islands (q.v.). It is more specifically confined to the extreme $\mathrm{E}$. group, consisting of Unalaska, Unimak, Umnak, and a number of smaller islands.

Fox Land. Desolate region in the S.W. of Baffin Island, British N. America. It lies between Fox Channel on the N.W. and Hudson Strait on the S.E.

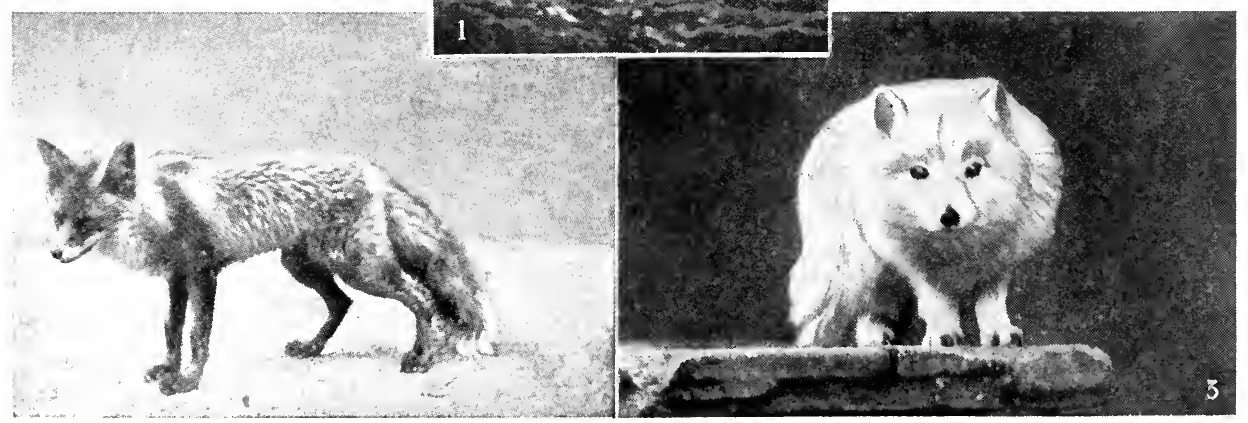

Fox. 1. Fox emerging from its earth. 2. Common fox, Vulpes canis. 3. Arctic fox in winter coat 

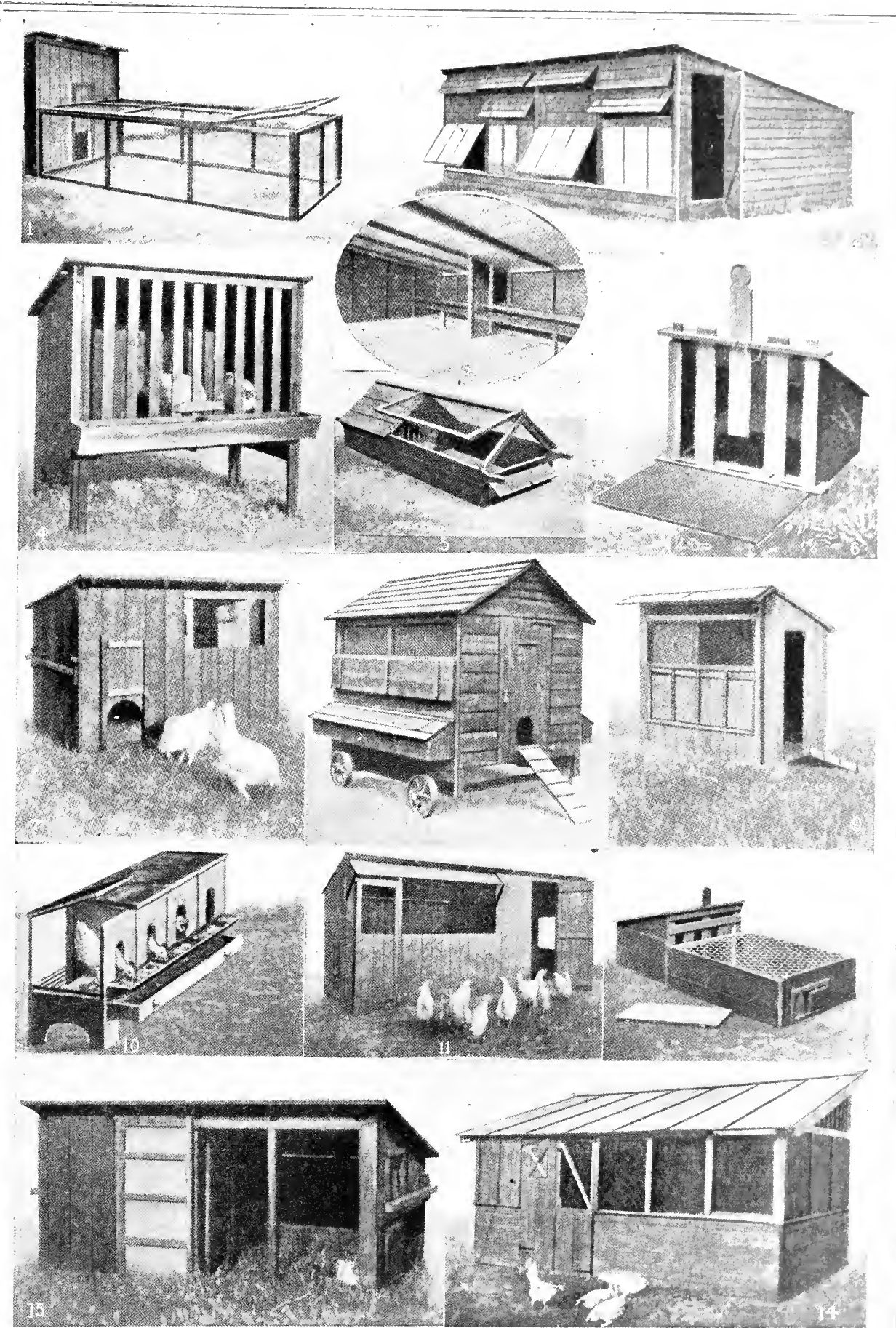

I. Simple run made with wood frame and wire netting. 2. House $20 \mathrm{ft}$. by $15 \mathrm{ft}$. to accommodate roo birds, and 3 , interior. 4. Broody coop. 5 and 6 . Coops tor chicken rearing. 7. House for birds of 12 weeks.

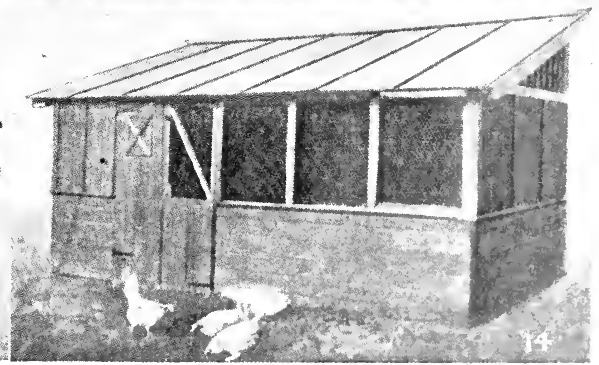

8. Movable poultry house. 9. House tor small pens. 10. Fattening pen. Is House suitable for it to ple and Io hens. I2. Another form ot coop. I 3. Cold brooder FOWL: COOPS AND RUNS USED IN MODERN POULTRY KEEPING By courtesy of Boulton \& Paul, Norwich 
Fox, Sir Charles (1810-74). British engineer. The son of Francis Fox, M.D., he was born at Derby, March 11, 1810. Having shown a distinet gift for mechanies, he was articled to an engineer, and was soon associated witl Robert Stephenson and other pioneers of the steam engine. He did engineering work on various rlys., especially the London and Birmingham, and the firm of which he became a partner began to make rly. stock, introducing therein various improvements suggested by him. Fox built the Crysta] Palace in Hyde Park and afterwards at Sydenham, and was very successful with his bridges. An enormous length of rly. line, almost in every part of the world, was undertaken by his firm, as well as tunnels, stations, among them Waterloo, Paddington, etc. In 1851 he was knighted. $\mathrm{He}$ died June 14, 1874, leaving his two elder sons to carry on the business of Sir Charles Fox \& Sons.

Fox. Sir Charles Douglas (1840-1921). British engineer. Born May14,1840, educated at Cholmondeley School and King's College, London, he joined his father, Sir Charles Fox, in business in 1861. Associated with him in railway and otherengineering work, he soon came to

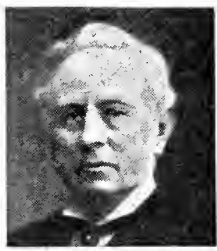

Sir C. Douglas Fox British engineer Russell the front. $\mathrm{He}$ was president of the Institute of Civil Engineers, and in 1886 was knighted. His brother, Sir Francis Fox (b. 1844), followed a like career. $\mathrm{He}$, too, joined the firm of Sir Charles Fox \& Sons in 1861, and was knighted in 1912. Sir Francis was called in to advise on the restoration of Winchester Cathedral, and was one of the experts consulted about the construction of the Simplon Tunnel. His published books include The Mersey Tunnel and The Simplon Tunnel. He died Nov. 13, 1921.

Fox, Charles James (17491806). British statesman. Borm in London, Jan. 4, 1749, he was a younger son of Henry Fox, Lord Holland ; his mother was a daugh. ter of the duke of Richmond. He was educated at a school at Wandsworth, at Eton, and at Hertford College, Oxford. He read widely, and his industry, coupled with his great natural abilities, made him a scholar. In addition to a knowledge of the classics, he was a good French scholar and read Italian well. He was only a boy when,

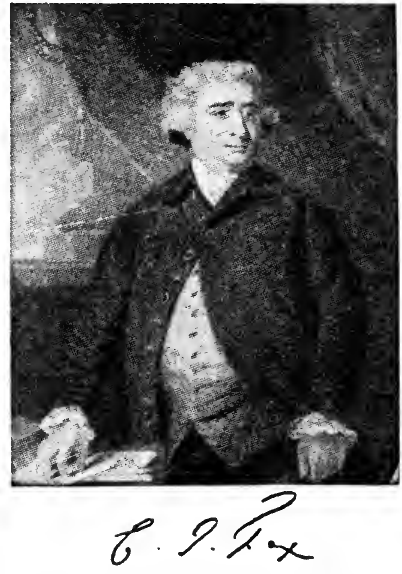

After Reynolds

encouraged by his father, he began his career as a gambler and shared the other pleasures of his dissolute elders. In 1769 he entered Parlia. ment as M.P. for Midhurst, his father's pocket borough, and in 1770 he was made a junior lord of the admiralty under Lord North. In 1772 he resigned owing to his opposition to the court, but in $1773-74$ he was again in office as a junior lord of the treasury.

Fox's career as a Whig leader may be dated from 1775. By then he had won the friendship of Burke, and had shown, in the case of the American colonies, for instance, that attachment to the cause of popular liberty which is the outstanding feature of his political career. He acted with the Whigs, then led by Lord Rockingham, but in many matters he was more advanced than they. His creed included parliamentary reform and purity in financial affairs, while, like many others, he saw a danger to the state in the undue influence of the crown. Soon came his advocacy of the repeal of Roman Catholic disabilities and of the causes of Ireland and the slave.

In 1782 Fox entered the cabinet of Lord Rockingham as secretary of state, but in a few months the premier died, and, refusing to serve under Lord Shelburne, he joined Burke and Sheridan in a Whig secession which in 1783 resulted in the extraordinary coalition be. tween Fox and Lord North. In this the former was again a secretary of state, but this ministry had but a brief life. It was dismissed by the king as soon as the House of Lords had rejected Fox's India Bill.

Fox, who in 1784 had fought at Westminster-for which constitu. ency he had been first returned in 1780 - one of the most fiercely con- tested battles in electoral history, now appeared as a leading opponent of Pitt's ministry, although on some matters-the impeachment of Hastings, for instance-he was in agreement with the premier. In 1789 came his famous declaration of welcome to the French Revolution, an encomium on the fall of the Bastille, and in 1791 his long friendship with Burke came to an end on this issue. By 1792 the majority of the Whigs had ceased to hail the Revolution with rapture, regarding it rather as a tyranny; but Fox, almost alone, continued to support it. $\mathrm{He}$ declared against the war with France, but by now he had few followers, and after 1797 he ceased for a time to attend parliament. In 1798 , for declaring publicly for the sovereignty of the people, his name was removed from the list of privy councillors.

About 1802 Fox returned to public life. He remained in opposition until the death of Pitt in 1806, when he again became a seeretary of state, this time in the ministry of all the talents. He then endeavoured to negotiate a peace with France, but he soon realized that he had misread Napoleon's character. His health was already failing, and on Sept. 13, 1806, he died at Chiswick. He is buried in Westminster Abbey.

The vices and the virtues of Fox were both on the large scale. A leading member of the dissolute circle that surrounded the Prince Regent, he lost an ample fortune at cards, and was more than once bankrupt, dependent upon the charity of his friends. He showed, as did others, a lack of consistency between words and deeds, while he was capable of carrying his private animosities into public life. For constructive statesmanship he showed no ability whatever. On the other hand, he was a great orator and a greater debater. To the last his mind maintained its freshness by contact with the masterpieces of literature. $\mathrm{He}$ possessed a really generous nature, while his sympathy with the oppressed was the outcome of genuine feeling. He was long the idol of the Whigs, among whom his is undoubtedly the greatest name. In $\mathbf{1 7 8 5}$ he married his mistress, Mrs. Armistead, and his later life was passed at St. Anne's Hill, near Chertsey. He began a life of James II, was something of a sportsman, and had fought a duel. See Pitt.

A. W. Holland

Bibliography. Memoirs and Correspondence of C. J. Fox, 1853-57; Life and Times of C. J. Fox, Lord J. Russell, 1859-66 ; Early History of 
C. J. Fox, Sir G. Trevelyan, 1880 ; Charles James Fox, J. le B. Ham. mond, 1903 ; and The Holland House Circle, Lloyd Sanders, 1908.

Fox, Georae (1624-91). Founder of the Society of Friends (q.v.). He was born at Drayton-in-the-Clay (now Fen ny Drayton), Leicestershire, in July, 1624, son of Christopher Fox, a weaver, called by $\mathrm{h}$ is neigh bours "righteous Christer." His early bent towards religious

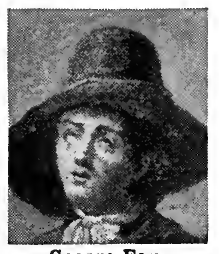

George Fox, English Quaker

study suggested to his relatives that he should be made a priest. He was, however, apprenticed to a shoemaker and grazier in Notting. ham. At the age of 19 he began a series of solitary wanderings in which he sought peace of mind from both churchmen and non. conformists, finally to decide that the one great qualification for the ministry was the presence of God in the heart-the inspiration of the Inward Light.

In 1648 he began to preach in public, adopting the terms "thee" and " thou," opposing many social conventions as well as ecclesiastical formalism, refusing to take oaths, condemning war, and advocating a rigid simplicity of dress. By 1658 communities of his fol. lowers were established in all parts of England. Founder and followers were, however, bitterly persccuted.

In 1669 he married Margaret Fell, of Swarthmore Hall, one of his early converts. He visited Scotland, 1657; Ireland, 1669; North America and the West Indies, 1671-72; and Holland, with Penn and Barclay, 1677 and 1684 . Shortly after a meeting at the Friends' Meeting House, Gracechurch Street, London, he died close by at the house of Henry Gouldney, in White Hart Court, Jan. 13, 1691, and was interred in the Friends' Burial Ground, Whitecross Street, Bunhill Row.

A man of sterling character whose practical gifts were displayed in the organization he gave to the society he founded, his voluminous writings are now seldom read, with the exception of his Journal, which, revised by a committee under the superintendence of Penn, first appeared in 1694. The MS. was sold at Sotheby's, July 26, 1920, for $£ 1,750$, and is now in the possession of the Society of Friends. See Life, T. Hodgkin, 1896; The Fells of Swarthmore Hall and their Friends, M. Webb, 1865; Fox and the Early Quakers, A. C. Bickley, 1884.
Fox, Sir Stephen (1627-1716). English courtier and founder of the family of Fox. Born at Farley, Wiltshire, March 27, 1627, he came into touch with Charles II through the Percy family, in whose service he was. He was very useful to the king in managing his personal affairs during his exile, and after the restoration many offices were given to him. In 1661 he entered Parliament as M.P. for Salisbury, and he remained therein during the greater part of his life, holding offices also under James II, William III, and Anne. For long Fox was paymaster-general, and the profits of this office made him very rich. Some of his wealth was spent in building churches and almshouses, but the bulk of it passed to his sons. He died at Chiswick, Oct. 28, 1716. Fox was the father of the 1st Lord Holland and of Stephen, who was created earl of Ilchester, and the grandfather of Charles James Fox. See IIolland, Baron ; Ilchester, Earl of.

Fox or Foxe, Richard (c. 14481528). English statesman and prelate. Born at Ropesley, Lincs, the son of a yeoman, he was for a time at both Oxford and Cambridge. In 1485 , in France, he entered the service of Henry VII. He began as the king's secretary, but was soon lord privy seal. Already ordained, and vicar of Stepney, he was made bishop of Exeter in 1487 ; in 1492 he was translated to Bath and Wells, and in 1494 to Durham. From 1501 until his death he was bishop of Winchester.

Fox was Henry's chief adviser, and most of the diplomatic work passed through his hands, includ. ing the momentous marriage and commercial treaties of this reign. Soon after the accession of Henry VIII, however, he lost his power. He was too steeped in the peaceful traditions of Henry VII to ap. prove of the spirited foreign policy of the new era. Wolsey was too strong for him, and he resigned the privy seal in 1516. He died at Winchester, Oct. 5, 1528, being buried in the cathedral. Fox's great work was the foundation of Corpus Christi College, Oxford. At Cam. bridge he was chancellor and master of Pembroke Hall.

Foxe, JoHN (1516-87). English martyrologist. Born at Boston, Lincs, and educated at Oxford, he was a fellow of Magdalen, 1539-45. He was a tutor in the Lucy family at Charlecote, and in the Howard family at Reigate. During Mary's reign he lived on the Continent, where he met Knox and other re. formers, publishing in Latin at Strasbourg the first draft of his Acts and Monuments, familiarly known as Foxe's Book of Martyrs. On Elizabeth's accession Foxe returned to England, was ordained priest by Grindal, lived in GrubStreet, where he worked on his A c t s a n d Monuments, published in folio by John Daye, 156263. He became prebend of Salisbury

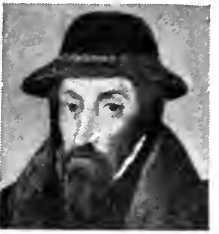

John Foxe,

English martyrologist and vicar of Skipton, 1563; and preached at Paul's Cross. He died April 18, 1587, and was buried at S. Giles's, Cripplegate. His principal work was a great favourite with Bunyan, greatly influenced the progress of Protestantism in England, and, although bitterly prejudiced, is an example of vivid prose.

There have been a large number of editions of the Book of Martyrs, and copies of the early ones are very valuable.

Foxglove. Hardy biennial and perennial plants of the natural order Scrophulariaceae and genus

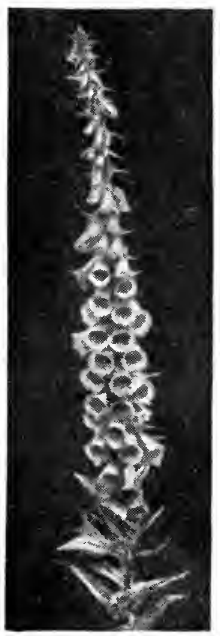

Foxglove. Flower of Digitalis purpurea Digitalis. Only of Great Britain, although there are a $\mathrm{number}$ of other species, the majority being of botanical valu e only, which were intro. duced from Western Asia and Southern Europe. Their height is from 2 $\mathrm{ft}$. to $5 \mathrm{ft}$., and their flowers are $p u r p l e$, pink, white,yellow, or brown. Foxgloves are raised from seed sown in gentle heat in May, the plants being moved to the open air as soon as they are large enough to be shifted with safety. In sheltered shrubberies and copses a little seed may be sown annually in the open air at the spot where it is desired to cultivate the plants. . In mixed borders fox. gloves should be placed at the back, in association with delphiniums, hollyhocks, sunflowers, and other tall-growing subjects. The wild purple foxglove of our lanes and woods is D. purpurea. See Digitalis. 
Foxhound. Breed of hound specially maintained for hunting the fox. Of mixed origin, it is generally believed to be descended from the old type of bloodhound

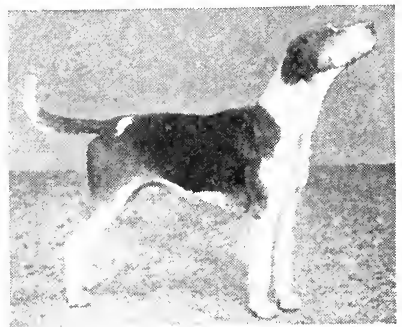

Foxhound. Hound from the kennels of the Oakley foxhounds

and the pointer, with perhaps a dash of the bulldog strain.

Fox hunting dates from the days of Edward I, but the dogs then used were entirely different from the present breed of hounds, which is probably not more than 300 years old. The breed has received much attention, and such packs as the Belvoir and the Quorn are of world-wide fame.

The foxhound is notable for its speed and for its endurance, having been known to follow the fox for ten hours. A good foxhound should stand about 24 ins. high at the shoulder, but the females are usually 3 ins. shorter. The head should be large and full, the nostrils wide open. Theshort, rounded shape of the ear is the result of cropping when a puppy, and is intended to prevent the ears from being torn when going through thick cover. The back and shoulders should be strong and muscular, the hind quarters well formed, and the legs straight. The coat, which is always parti-coloured, should be short, thick, and smooth. See Dog.

Fox Hunting. Popular English sport. Fox hunting, as carried on in the 20th century, is a compara tively modern sport. The old time sportsmen went out early in the morning, they hit on the drag of the fox, and the pack hunted steadily up to his kennel, where the fox had laid up for the day. Then began a chase which might often last for an hour or more. The hounds worked out the fox's line and wore him to death. But about 1750 , the modern system of hunting was introduced in the Quorn country by Meynell and by Lord Spencer in the Pytchley Hunt. Hounds and horses were bred for speed, and the foxchase became, in the words of Beckford, "short, sharp, and decisive." The "stud records of the Earls Spencer show that in breeding their hunters they tried for speed, using the very best racing blood of their time. A number of hard-riding men of all classes were attracted to the sport.

The ideal hunt was one lasting about 15 or 20 minutes. The fox was raced, not hunted to death. It required a good horse to live with the pack even for this short time. but it was not only the horses and hounds that were the faster; the huntsman was quicker in his methods. The older school would wait when the fox broke until all the pack were collected; the huntsmen of the new school went away with three couples, leaving the rest to come as they could, or trusting to the whippers-in to bring them on. In the same way the new school of huntsmen would not persevere after a fox if he was lost. They went on to find another. This rapid style of hunting, and the taste for short, sharp bursts remains, but it flourishes chiefly in those hunting countries which consist of wide, spreading grass fields, of from 50 to 100 acres, and where the coverts are rarely above 40 acres in extent, and in many cases are little spinneys or gorses, like Norton Gorse, or Sheepthorns, in the South Quorn country, of about three or four acres.

It is clear that where there are large woodlands, wide heather-clad moorland, or where the enclosures are small, these methods of hunting must be modified, and while in the most fashionable countries, or in parts of them, the ideal of a short and fast gallop remains, there are many hours of steady, slow hunting. One of the charms of hunting is its infinite variety, and riding to hounds is not its only, not indeed, for many men, its chief charm.
This is shown by the fact that hunting flourishes, not only in the Midlands and in grass countries, but also in the rougher, colder scenting districts, where woodland and ploughland abound.

Many men find their chief pleasure in the working of the pack, and there is also great interest in the woodcraft required to find and kill a fox. For example, a good woodland huntsman, in countries where the woods extend from 1,500 to 3,000 acres or more, knows that it is useless to look for a fox in all parts of the wood, but leads his hounds to those spots which his experience or observation tells him are likely haunts. In the same way a good huntsman learns the run of his foxes, i.e. the course usually taken by individual foxes, and is thus able to help his pack at critical moments.

The great popularity of hunting may be gathered from the fact that there are about 240 fox-hunting establishments in Great Britain. The cost of hunting is met by those, who hunt. In most cases the master finds from half to two-thinds of the money required, which is roughly estimated somewhere near $£ 1,000$ per annum for each day in the week hounds are out. Thus a pack going out two days in a week would cost $£ 2,000$ a year, four days $£ 4,000$, and so on. Sorne country packs might cost less, but the Quorn and Pytchley, Badminton or Belvoir, for example, would require $£ 8,000$ or $£ 9,000$ a year at least.

This money is spent on wages for the huntsman, two whippers-in, two second horsemen, a stud groom, a feeder, and two or more kennel men or boys, according to the number of hounds kept in kennel,

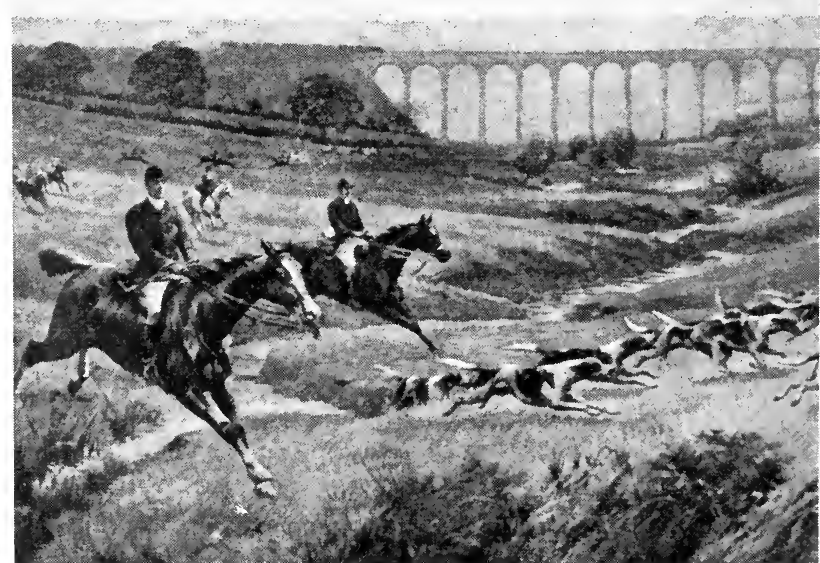

Fox Hunting. Scene with the Quorn hunt at Twyford Brook; the pack in full cry After A. C. Havell, by courlesy of Fores 
ranging say from 20 to 75 couples, or even more. Then there is oatmeal and horseflesh for the hounds, and oats and hay for the horses. Another portion of the money goes into the pockets of local artificers and tradesmen, while large sums are distributed to farmers and others, as compensation for damage to fences or the loss of poultry.

One of the benefieial results of hunting is that the sums of money spent in recreation are distributed in distriets which would otherwise receive none. If to the actual expenses of the hunt are added the sums paid by those whom hunting attracts to the neighbourhood, it will be seen that hunting causes the distribution of a very large sum. But this is not all.

\section{Hunting and Horse Breeding}

Great Britain is largely dependent for its horses on hunting people, who support the market for breeders of the best sort of riding horses, and thus keep a large horse reserve at no expense to the nation. English hunters are the best riding horses in the world, and are eagerly sought for by foreign and eolonial buyers. The needs of the hunting man or woman practically regulate the type of the hunter which breeders strive to raise, and thus there is a large export trade in riding horses which rests on hunting. But hunting requires hounds, and the English foxhound is the greatest triumph of the breeders. There are many different breeds of hounds hunting by scent in Europe and America, but the English foxhound in make, shape, nose, and pace beats them all. In England fox. hounds hunt all the three kinds of deer, the fox, the hare, and the otter. In France many packs are wholly pure foxhound, or the native breeds are largely crossed with foxhound blood.

The fox is a small animai, which in England, except in the Fell countries where 19 or $20 \mathrm{lb}$. is not unusual, averages about $10 \mathrm{lb}$. to $12 \mathrm{lb}$. weight, which can crawl down a 9-in. drain. The fox's great quality as a beast of chase is its wildness. Wild foxes are neeessary, and for these the goodwill of covert owners and farmers has to be depended on. In spite of some grumbling, people recognize the value of hunting in encouraging the breeding of horses and the training of men. Fox hunting is not only or c'liefly a rich man's sport, but gives pleasure and profit in England and Ireland to people of all elasses. See Life of a Fox, Thos. Smith, 1920 ; Hunting the Fox, Lord Willough by de Broke, 1920.

T. F. Dale

Foxtail. Means of preventing a bar of wood or metal bolt from being withdrawn from a hole. The entering end is split, the point of a wedge is inserted, and the bar is driven home, the wedge expanding the material against the sides of the hole.

Foxtail Grass (Alopecurus pratensis). Perennial grass of the natural order Gramineae. It is a

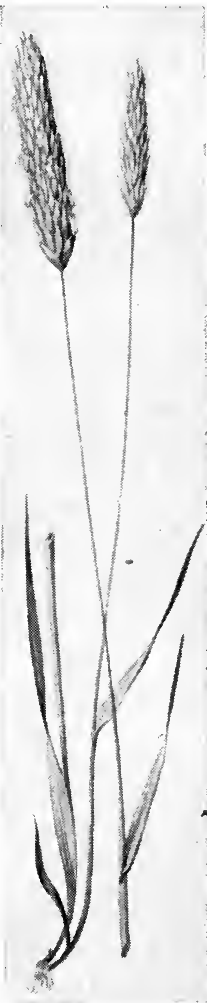

Foxtail Grass, Aopecurus pratensis and friendly disposition. No breed looks quite as smart and alert as a good fox terrier, and no other dog seems to be in such complete sym. pathy with its master. It is affeetionate to the degree of being sometimes troublesome; readily learns

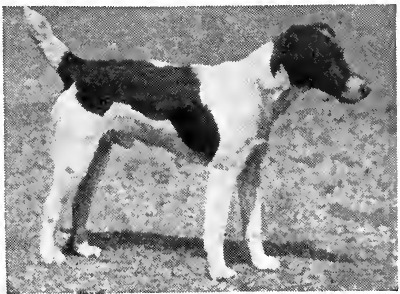

Fox Terrier. A prize winner in the London Fox Terrier Clubs' Champion. ship show to obey orders, and often displays an intelligenee almost human.

'There are two breeds, the smooth and the rough eoated. 'The former is perhaps the favourite as a eompanion, but the latter possesses the better hunting instincts. 'To judge by the show reeords, the smooth variety came into favour with breeders earlier than the other. In colour the fox terrier should be blaek, white and $\tan$; specimens that show liver-eoloured markings should be avoided. Of recent years there has been a tendency to introduce a bulldog strain into the breed with a view to develop a stronger jaw, but the wisdom of this is still a matter of eontroversy. In everything except coat, the two varieties are identical. See Dog and illus. on colour plate; Nammal.

Fox-trot. American dance. It originated in a dance, eonsisting of alternate slow and rapid movements, performed by a musie-hall artist. To this he gave the name Fox-trot. It seized upon the imagination of the audienee, was adopted as a social danee for two : and was brought to France and England early in the 20th century, with many variations.

Foy, Maximilien SÉbastien (1775-1825). French soldier. Entering the army in 1791, he first saw service un-

der Dumouriez.

Distinguishing himself in Italy, 1801 , and in the Austrian cam. paign, 1805, he was sent by $\mathrm{Napoleon}$ in 1807 with a small foree to Turkey to assist

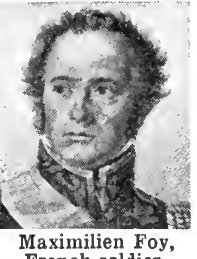
Maximilien Foy,
French soldier the sultan against the Russians and British. Ir 1808 he was in Spain, and fought in the Peninsular War, being made a divisional gen. eral in 1810. He held a command at Waterloo. After 1815 he made his peace with the new régime and sat in the French Chamber. He died at Paris, Nov. 28, 1825. His History of the Peninsular War was published in 1827.

Foyers. 'Two caseades (40 ft. and $165 \mathrm{ft}$.) near the mouth of the Foyers river, on the E. side of Loch Ness, Inverness-shire, Scotland. Sinee 1895 they have been used by the British Aluminium Company for generating eleetricity.

Foyle. Lough or inlet between eos. Donegal and Londonderry, Ire. land, into which drains the river Foyle, $16 \mathrm{~m}$. long. It is $18 \mathrm{~m}$. long and has a width of $1 \mathrm{~m}$. at the entrance, and an extreme width of $10 \mathrm{~m}$. Dangerous shoals obstruet navigation on the $\mathrm{W}$. side. 
F.P. Abbreviation for fire plug. Fraction (Lat. fractio, from fran. gere, to break). Arithmetical expression of the relation of a part to the whole. The simplest fractions express this relationship in the case where the whole contains the part an exact number of times; e.g. if there are seven equal parts each part is a seventh of the whole. The next step is the adding together of several such simple parts, to form a fraction like three-sevenths. Simple as this step may seem to the modern reader, it was beyond the mental grasp of the ancient Egyptians, who could realize this type of fraction only in the easy cases of two-thirds and three-quarters.

The handling of such fractions is greatly facilitated by their expres. sion, in the Arabic notation, by two numbers separated by a bar thus, three-sevenths is written $\frac{3}{7}$; 3 is technically called the numerator and 7 the denominator. Such a fraction as $\frac{3}{7}$ is called a vulgar frac. tion, in contrast with a decimal fraction, the denominator of which is either ten or a power of ten. This denominator, being understood, may be suppressed; thus 39 is interpreted to mean $\frac{39}{100}$. The decimal system affords great advantage in the comparison of fractions with different denominators (e.g. it is not immediately obvious that 7 is greater than $\frac{5}{8}$, but when expressed decimally as $\cdot \ddot{6} \dot{3}$ and $\cdot 625$ respectively, the fact is at once evident), and in computations where exact accuracy is not required, but it has the disadvantage of being cumbrous for the exact expression of some of the commonest fractions, such as one-third, which is expressed as $\dot{3}$, one-eleventh $\dot{0} \dot{9}$, or one-seventh 142857. Thus it is impossible to divide a dollar or a franc into three equal parts. See Arithmetic ; Decimal System.

Fracture (Lat. fractura). Word meaning breakage, but specially applied to breakages of the bones. These are usually caused by external violence, which may be direct or indirect. A fracture caused by direrst violence occurs at that part of the bone lying beneath the tissues which are actually struck. Indirect violence breaks the bone at some other part. For instance. a blow on the side of the chest will break the ribs at the spot actually struck and drive the fractured ends inwards ; but if a cartwheel passes over the chest of a person lying on his back on the ground, the ribs break by indirect violence at the point of maximum curvature, and the fractured ends tend to turn outwards. "Powerful muscular effort will sometimes fracture a bone. Thus the effort made by a person who stumbles to save himself from falling, sometimes fractures the patella or knee-cap; and the upper arm bone has been broken by the vigorous throwing of a cricket ball.

Conditions predisposing to frac ture are diseases which cause atrophy or weakness of the bones, such as rickets. In certain forms of lunacy the bones may be so weakened as to fracture from a slight effort or accident, a condition which has several times given rise to groundless accusations of ill-treatment. In a simple fracture there is no communication between the seat of fracture and the external air; in a compound fracture the skin or mucous mem brane is so torn or injured as to bring about this communication. In a comminuted fracture the bone is broken into more than two pieces, and in an impacted fracture the ends of the bones are driven into each other. A fracture which does not completely break the bone, but bends and splits it, is termed a green-stick fracture, and is most often seen in young children whose bones are relatively soft. A frac. ture of the skull which has resulted in the driving in of a piece of bone is a depressed fracture.

The general treatment of a frac. ture consists in first setting the broken bone, i.e. bringing the broken ends into opposition with each other in the normal position. This is done by manipulation, and as the process may be very painful, and muscular spas m may hinder the replacement, it is often desirable to place the patient under an anaes. thetic. The broken bone is next secured in normal position by means of bandages, splints, and, in appropriate cases, plaster of Paris. The limb must be kept at rest while re-union is occurring, but as disuse leads to considerable weakening and atrophy of the muscles, the limb should be mas saged daily, usually within a period no longer than a fort night after the in. jury. Gentle passive movements of the limb are also begun early in order to prevent contraction of the liga. ments and stiffness in the joints.

With single fractures in which the bones are readily maintained in good position these methods are usually sufficient, but for more complicated fractures, and when there is much displacement, operative measures are often desirable, the fragments of bone being bound together by silver wire or, in appropriate cases, united by metal plates. Compound fractures demand thorough cleaning of the injured tissues and removal of all loose fragments of bone, which are apt to undergo necrosis if left in the wound. If suppuration has occurred, the insertion of drainage tubes is generally necessary. Plat. ing or wiring is not as a rule desirable in these cases. See First Aid; Surgery.

Fra Diavolo (1771-1806). Nickname of Michele Pezza, an Italian brigand. Originally a monk, he became an outlaw chieftain in the mountains of Calabria, where his atrocities earned him his nick. name (Brother Devil). Ferdinand of Naples made him a colonel, and with Cardinal Ruffo he raised a revolt against the French in 1799. In 1806 he made a similar attempt, but was caught and hanged in Naples as a bandit, Nov. $10,1806$.

Fra Diavolo. Opera by D. F. Auber, nominally founded on the misdeeds of the brigand of that name. The full title of the opera is Fra Diavolo, ou l'Hôtellerie de Terracine; the libretto was br

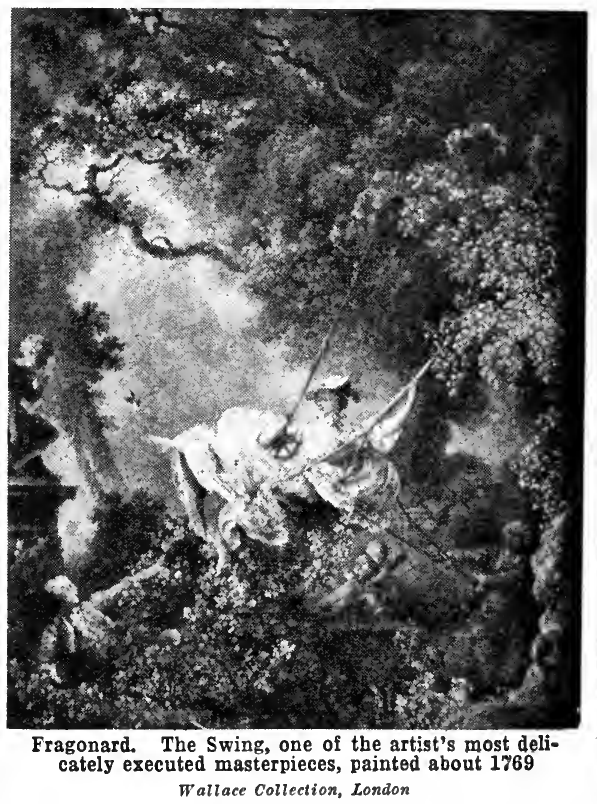


Scribe, and it was first produced at the Opéra Comique, Paris, on Jan. 28, 1830.

Fragonard, JeAN HoNoré (1732-1806). French painter and engraver. Born at Grasse, in Pro-

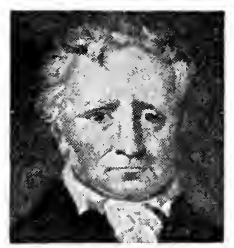

J. H. Fragonard,

French painter

After Gerard vence, A pril J, 1732 , he studied under Boucher and Chardin, and, having wo $\mathrm{n}$ the Grand Prix in 1752 at Rome, in 1763 he re turned to Paris, was re. ceived into the Academy in 1765, and shortly afterwards abandoned classical painting for the freer style appre ciated by the Court. During the Revolution he retired to Grasse where he completed the five paintings of The Lover's Progress, now in the Pierpoint Morgan collection and exhibited at the Guildhall in 1902. He returned to a changed Paris, and died there poor and neglected, Aug. 2, 1806. Apart from the Grasse pictures, his most famous works are in the Louvre and the Wallace Collection: Coresus and Callirrhoe, The Music Lesson, and The Storm, in the Louvre, and The Swing, in the Wallace Collection. His cravons and water-colours are charmingly facile.

Fragson, Harry. Stage name of the British comedian, Leon Pott, (1870-1914). Born at Brixton,

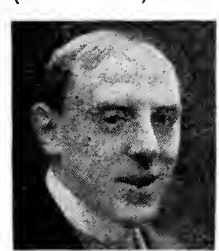

Harry Fragson, British comedian after a f e w years in business at Rich. mond he went on the stage and gave imitations of Paulus, then a w e 11 -k n o w n star of the Paris music halls. Meeting with little success in London, he moved to Paris, and after living in poverty made a success with his Ronde des Petits Cochons. By this time he had learned French perfectly. $\mathrm{He}$ soon gained popularity in France, and in 1904 appeared in pantomime at Drury Lane, where he made a success with his Love, love, whispers of love. Equally versatile in English and French, he was at the height of his popularity in both countries when he was murdered by his father, Jan. 1, 1914.

Fraizer, Alexander (c. 161081). Englisl physician. Of Scottish ancestry, he received his medical education at Montpelier. Having settled in London, he be-

came known at court, and when Charles II went abroad, after the execution of his father in 1649 , Fraizer went witl him in a profcssional capacity. He mixed also in the politics and intrignes that surrounded the exiled king. He returned to England at the Restoration, and remained in attendance on the royal family until his death, May 3, 1681. An incident in his career was his arrest for debt at the instance of Sir E. B. Godfrey, this being resented by the king to the extent of putting Godfrey in prison and punishing the bailiffs who carried out the order.

F.R.A.IM. Abbrev. for Fellow of the Royal Academy of Music.

Fram (Norweg., forward). Threemasted schooner of 402 tons built in 1892 for Nansen's Aretic

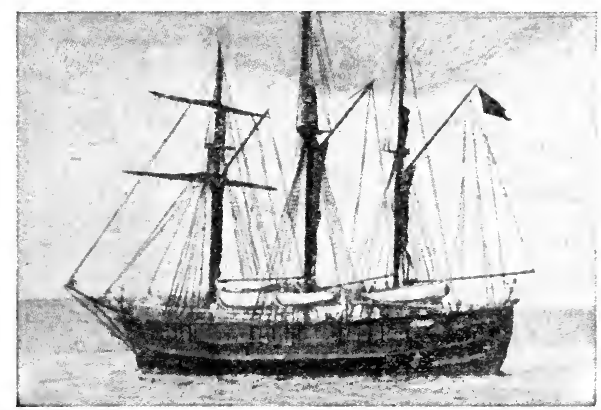

Fram. The polar exploration ship after she had been converted from steam to oil for Amundsen's expedition in 1910

expedition. She was $117 \mathrm{ft}$. in length, with triple external planking ranging from 24 ins. to 28 ins. in thickness, and auxiliary engines driving a screw propeller. Nansen sailed in her in Aug., 1893, and entering the ice at the new Siberia Islands, drifted northward. In June, 1895, he left the ship and marched north as far as $86^{\circ} 13.6^{\prime}$ In May, 1897, he fell in with the Jackson-Harmsworth expedition, with whom he returned in the Windward to Norway, whither the Fram also returned safely. In 1899 the ship was used by Sverdrup in his exploration of Jones Sound, in the N. of Baffin Bay.

In Aug., 1910, Captain Roald Amundsen (q.v.) left Norway in the Fram, intending, like Nansen, to drift across the North Polar basin, but, changing his programme, made his way from Madeira to the Antarctic regions. The ship was next heard of in the Bay of Whales, where Captain Scott discovered her while cruising along the Ice Barrier. Amundsen wintered near King Edward VII Land, and having accomplished his march to the South Pole, rejoined the Fram, aboard which he arrived at Hobart,
Tasmania, March 7, 1912, and later returned to Norway. See Nansen.

Framboesia or Yaws (Fr. framboise, raspberry). Infectious and contagious disease caused by infection with a minute spiral shaped organism, Treponema per. tenue, discovered by Castellani in 1905. The disease is almost con. fined to tropical and sub-tropical regions, being most prevalent on the W. coast of Africa, in Tripoli, the Malay Peninsula, Assam, Java, Ceylon, the West Indies, Samoa, and Fiji.

Three stages are recognized. The primary stage usually begins with symptoms of general ill health, headache, rheumatic pains, and a rise of temperature. In from two to four weeks after inoculation a papule appears on the skin at the point where the organism has entered the body, which may be an old ulceration, a serateh, or even an insect - bite. The papule may develop into a large nodule, or become ulcerated and sub. sequently heal. The second stage usually begins between one and three months after the primary lesion has appeared, and is characterised by the eruption of papules more or less all over the body, some of which develop into large granu. lomatous nodules, which may later become hard and wart-like.

In most cases these disappear within a year, and the patient recovers. In some instances, however, the third stage develops. Nodules may appear in any of the tissues, and deep ulcers may be formed. Contractions of groups of muscles are frequent, and painful nodes may develop on the bones. The disease is rarely fatal, but it is a cause of much sickness. Treatment by injection of salvarsan has been found very effective, and is now widely adopted. The disease is quite distinct from syphilis, with which it was at one time confused.

Frame. Border or case in which a picture is set for exhibition on a wall. It may be made of various materials, and should have some regard for the character of the pieture. An oil painting, being in a strong medium, will tolerate a heavy gilt frame which would " kill" a slighter medium, such as a water-colour. Engravings are framed in oak, walnut, maple, 
rosewood, and gold; but etchings and all prints in which the work is light, sketchy, or delicate should be framed in a plain and simple strip of black or dark wood. Fine prints are better unframed and kept in special portfolios.

Frame. Term used in engineering for a structure built up of members which are joined together. The theory of frames, which deals with the least number of members necessary to keep them rigid, and with the strengths of the individual members, is one of great importance in engineering. In a printing office the wooden structure on which are placed the cases at which a hand compositor works is called a frame. See Mechanics.

Framework Knitters' Company. London city livery company. It came into existence with the invention of silk stockings, and was granted its first charter by Cromwell in 1657 . A second charter was granted by Charles II in 1663 to "the wardens, Framework Knitassistants and so- ters' Company ciety of the art and

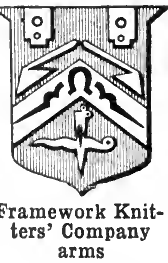
mystery of Framework Knitters in the citics of London and Westminster, the kingdom of England, and the dominion of Wales." The powers were limited by Parliament in 1753, the hall in Red Cross Street, E.C., was sold in 1821 , and the plate in 1861 , the proceeds being devoted to the Bourne almshouses in Kingsland Road. Corporate income, $£ 310$; trust income, £352; offices, 18, Essex Street, W.C. See The Framework Knitters, H. C. Overall, 1879.

Framlingham. Market town of Suffolk, England. It is a station on the G.E. Rly., $22 \mathrm{~m}$. N.E. of Ipswich and $90 \mathrm{~m}$. N.E. of London. S. Michael's Church, with a tower $95 \mathrm{ft}$. high, contains tombs of some

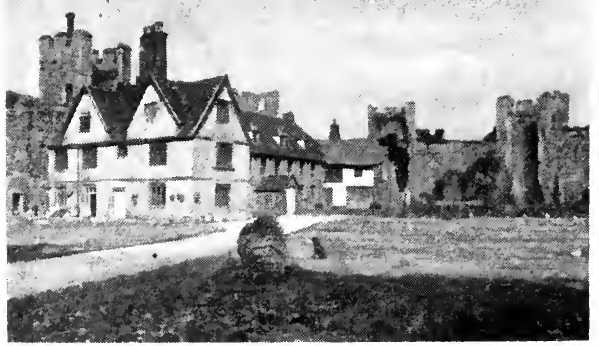

Framlingham, Suffolk, Walls of the ruined castle, with the workhouse built when the castle was dismantled in the 17 th century include a g a tew a y, the outer w a $11 \mathrm{~s}, 13$ towers, and a moat; it was the strongh old of the $\mathrm{Bi}$. gods, a nd later of the at the R.A. schools ; later, under P. Mercié and Dag. nan - Bouveret in Paris. $\mathrm{He}$ first exhibited at the R.A. in 1884 , was elected A.R.A. 1894, and R.A. 1902 , and of the Howards, including that of the earl of Surrey, the poet. The castle is a fine ruin. The remains

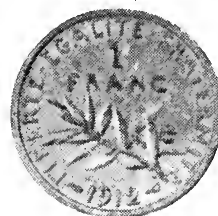

Franc. Left to right, reverse sides of French, Belgian, and Swiss

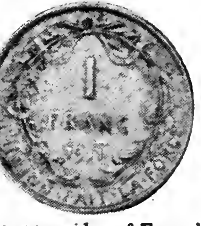

Howards, both families holding the earldom of Norfolk, in the lands of which the place lay.

Framlingham College is a public school in large grounds. Built to commemorate the Prince Consort, it was opened in 1865 as the Albert Memorial College. Framlingham is an old place, having existed before Roger Bigod built a castle here about 1100 . Its history is really that of the castle, which was more than once forfeited by the Howards, but restored to them. They lost it finally in the 17th century. Market day, Sat. Pop. 2,400.

Frampton, Sir George James (b. 1866). British sculptor. He studied under W. P. Frith, and

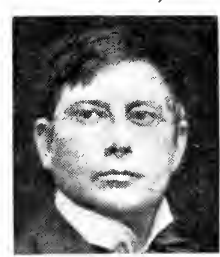

Sir George Frampton British sculptor knighted in 1908. As a decorative sculptor he is in the front rank, excelling in polychromatic figure work and architectural skill. Among his works are the bronze memoria to Charles Mitchell, 1898; S. George, 1899 ; statue of Queen Victoria, Calcutta, and the Edith Cavell $(q \cdot v$. memorial in London, 1919.

Franc. French silver coin, the unit of the French decimal monetary system. The name comes from the in scription Franco. rum Rex, king of the Franks, on the obverse of the gold coin issued by John II in 1360 . It was then the equivalent of the livre, and consisted of 20 sols. Gold francs were also coined by Charles V of France, and in 1575 Henry
III issued silver francs. In 1641 Louis XIII substituted the silver louis, but the name of the franc

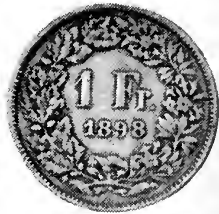

francs, actual size

survived the actual coin and was long synonymous with the livre. In 1795 the franc was again estabisshed, superseding the livre, and, consisting of 100 centimes, remains the unit of French currency, the standard being the gold piece of 20 francs.

An integral part of the metric system of weights and currency, its weight is exactly 5 grammes (78 grains), and it is the standard of the Latin Monetary Union (q.v.), which adopted it in 1865 . The coin has the same name in Belgium and Switzerland. 20- and 10-franc pieces are of gold, 5-, 2-, 1-, and 1 -franc pieces are of silver. French francs are nominally reckoned at 25 to the $£$ sterling, but the Great War caused great fluctuations of value. See Coinage.

Français, Antorve (1756-1836). French politician. He was born at Beaurenaire and sat in the legis. lative assembiy of 1791 , noted as a bitter anti-clerical. Under the consulate he was prefect of CharenteInférieure, and held high fiscal positions; he was made count by Napoleon, and died March 7, 1836.

Français, François Lou is (1814 -97). French painter. Born at Plombières, Vosges, Nov, 17, 1814, he studied art under Corot and Jean Gigoux. Among his works are A Song under the Willows, with figures by Baron, In the Park of St. Cloud, with figures by Meissonier, An Italian Sunset, in the Luxembourg, and decorations in the Church of the Trinity. He died at Paris, May 28, 1897.

Francatelli, Charles Eumé $(1805-76)$. British cook. Born in London of Italian parentage, Francatelli became, in turn, cook to several noblemen, to Crockford's Club, and to Queen Victoria. His fame as a cook of the highest skil was widespread, and he published The Modern Cook, 1845; The Plain Cookery Book for the Work. ing Classes, 1861; and other works. He died Aug. 10, 1876.

Francavilla Fontana. Town of Italy, in the prov, of Lecce. It is 22 m. by rly. E.N.E. of Taranto and trades in oil, wine, and leather goods. Pop. 21,527. 


\section{FRANCE: ITS HISTORY AND CULTURE}

HAMILTON FYFE, W. H. HUDSON and F. J, MACLEAN

The various sections of this article are each supplemented by shorter entries, e.g. those on the cities, tonens, and rivers of France, those on the kings and statesmen, and those on its artists and men of letters. See also Franks; French Revolution; Hundred Years' War; Architecture; Furniture

France is a country of vast plains, for the most part of great fertility; of high, inhospitable plateaux; of

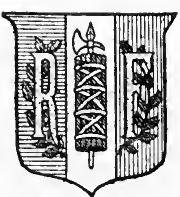

France. Arms of the Republic noble rivers; and of mountain ranges which serve as land frontiers. Its area is 212,659 sq. m., including the territories re. stored as a result of the Great War.

The districts of Lower Alsace, Upper Alsace, and Lorraine are now the depts. of Bas-Rhin (area 1,848 sq. m.), Haut-Rhin $(1,354$ sq. m.), and Moselle (2,403 sq. m.). With the English Channel on the $N$., the Atlantic on the $W$., and the Mediterranean washing the $\mathrm{E}$. half of its southern side, the country is well provided with harbours. The ports of greatest commercial importance are Havre, at the mouth of the Seine, Brest, St. Nazaire, at the mouth of the Loire, La Rochelle, Bordeaux, on the Gar. onne above the estuary of the Gironde, Marseilles, at the mouth of the Rhône, and Toulon.

The mountain ranges which divide France from Switzerland, Italy and Spain are the Jura, the Alps, and the Pyrenees. The Vosges, which, until the restoration of Alsace and Lorraine, served as frontier between France and the German Empire, are not high. At the $\mathrm{S}$. end of the Vosges is the Trouée de Belfort, through which invaders have passed many times. It is literally a "hole" between the Vosges and the Jura; through it runs a canal connecting the Saône with the Rhine, also the rly. into Germany and Switzerland.

\section{The Jura and Alps}

The Jura forms an extensive limestone plateau, well populated and productive. The hills, of no great height, are wooded, and the sheltered valleys between them are both cultivated and valuable for cattle-raising.

S. of the Jura begin the Alps, with Mont Blanc as the first of the giants: its northern approaches have been on French territory since Savoy was taken by France from Italy in 1860. Extending S. from Savoy, the Alps run almost to the sea behind Cannes and Nice, while in $\mathrm{a} \mathrm{W}$. direction they become the Alps of Provence, and stretch nearly to the Rhône. Around the
Gulf of the Lion, often incorrectly called the Gulf of Lyons, which takes its name from the-likeness of its shape to a lion asleep, there is flat land for some distance inland; but at the extreme S.W. point of the gulf the Pyrenees begin.

On French soil the Pyrenees run eastward for $230 \mathrm{~m}$., several of the peaks reaching heights of nearly $10,000 \mathrm{ft}$. Without the grandeur of the Alps, lacking vast glaciers and fields of eternal snow, they are preferred by most French people, and holiday resorts, such as Luchon and Cauterets, are full all summer and autumn. Pau, whence the best view of the chain of the Pyrenees is obtained, is more frequented by English visitors. No rly. cuts the Pyrenees, owing to the height of the passes. The lines run by the Gulf of the Lion at one end and along the Atlantic coast at the other. In many parts of the Pyrenees the inhabitants a re almost as much Spanish as French.

Thus, if France be regarded as a rough square, it is seen to have

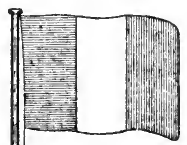
France. Flag of the Republic mountains on its E. and S. sides, while on the W. and N. its frontier is the sea. There is, however, another French mountain system independent of the others, and separated from them by later geo graphical formations. This in cludes the high central plateaux, somewhat to the $\mathrm{S}$. of the exact centre of the country; it consists of the Cevennes mountains, those of Auvergne (the Margeride), the Monts Dore, the Puy-de-Dôme, and the Causses, which, although barren and monotonous, reveal the most picturesque valleys of the entire region. In general, it is hard to cultivate successfully. The winters are long and cold, pasturage is poor, and most of the forests have disappeared. There are ranges of hills in Brittany and Normandy, there are the French Ardennes to wards the Belgian frontier, but nothing in the $\mathrm{N}$. or W. can be called a mountain.

of the rivers the Loire is the longest $(650 \mathrm{~m}$.$) . Rising on Mont$ Gerbier-de-Jonc, in the dept. of Ardèche, for a long distance it flows through the rocky defiles of the central plateau. Then, joined by the Allier, it sweeps onwards through the provinces which more than any other contributed to the formation and development of the French nation, the country of Touraine. Its course continues amid fertile fields and orchards as far as Nantes, where the estuary begins and carries it out to the ocean. Next in length comes the Rhône (507 m.), which flows from St. Gotthard range in Switzerland down into the Lake of Geneva. At Lyons it receives the Saône and then flows due $S$. in a delightful valley through vineyards, until it becomes sandy and shallow, and with a number of smaller streams makes the wide delta which gives its name to the dept. of Bouchesdu-Rhône.

Seine, Garonne, and Somme

The Seine rises in the $\mathrm{E}$. of France and takes its course of $485 \mathrm{~m}$. almost entirely through plains. It is, therefore, sinuous, but otherwise excellent for navigation. From Havre, where it runs into the sea, up to Paris, there is a large traffic. Rouen owes its importance to the Seine. Fourth among the great rivers comes the Garonne (378 m.), which is joined by the Dordogne near the ocean, the two forming the estuary of the Gironde. Here are the vineyards which produce the famous Bordeaux wines, most of them in the Médoc region. The Somme and the Marne are both in the Seine basin, though the former has its own outlet to the sea not far from Abbeville.

Except for the lakes of Geneva, Bourget, and Annécy, France has no large inland bodies of water. Her sea coasts, on the other hand, are of great length and value. Along the Mediterranean she has made of the Côte d'Azur a winter holiday ground for the people of all nations. On the Channel coast, in Brittany, and that part of Normandy which fronts the Atlantic, there are numerous plages (beaches), which in summer are thronged by visitors.

Various parts of the eoast of France support fishing industries of considerable importance. The chief fishing ports are S. Malo, Boulogne, Fécamp, Groix, and Ia Rochelle; among the lesser, Paimpol, Dicppe, Donamenez, Lorient, Yeu, Dunkirk, and Arcachon. From the ports of the Nord, Pasde-Calais, Somme, and SeineInférieure, mackerel are sought; from those of the Atlantic sea- 


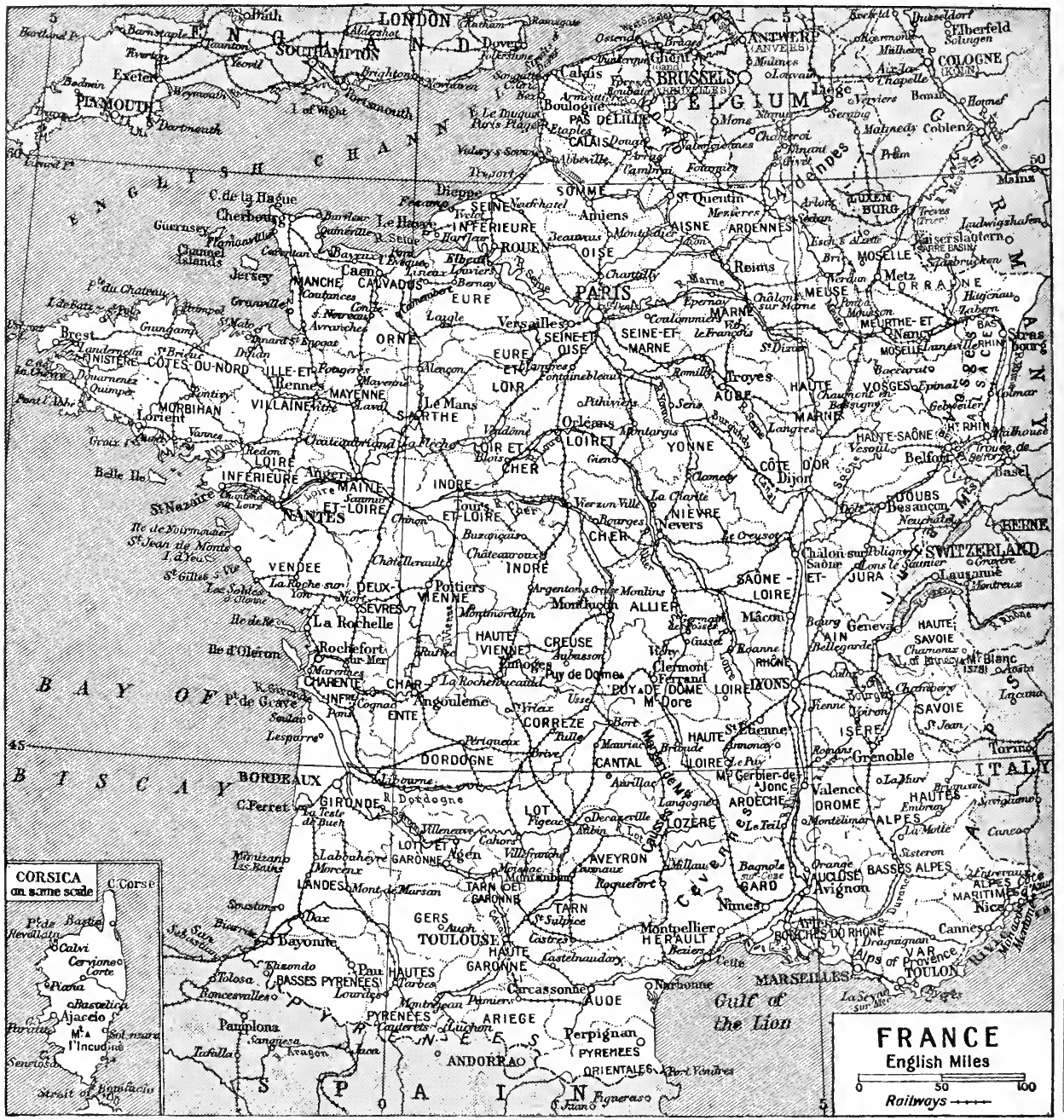

France. Map showing the departments, principal railway lines, and the frontier as determined by the Treaty of Versailles, 1919. Inset, the island of Corsica

board, tunny-fish and sardines; Boulogne and Fécamp have heavy herring-catches; cod fleets go out to the N. Sea and Atlantic from several Channel ports.

The N. and N.E. are the most fertile parts of the country. Most of the cultivation is done by peasant proprietors. The average size of the holdings is well under 25 acres, and only 2 ? p.c. of the total number of farms are over 100 aeres. At the same time it must be noticed that nearly half the total amount of land is owned by large holders. Since about 1870 the number of small farms which could support an owner and his family has shrunk; the number of peasants with holdings of an acre or two, who are obliged to hire themselves out as labourers, has been increasing. Eighty p.c. of those engaged in agriculture own their land; of the remainder more than two-thirds pay rent, while the others work on the métayer system, which divides the produce between the cultivator and the owner of the land.

More wheat is grown than any other cereal ; oats come next, then rye, which used to be the staple food of the people until wheat took its place. French farmers do not raise enough cattle and sheep to supply the national demand for meat, nor are their breeds of these animals exceptional. Hoise-breeding is a national industry, and for heavy breeds of horses France is famous. The Percheron and some
Flemish stocks are unrivalled. In the S., however, there are few horses on farms. Hay is scarce, owing to the climate and the nature of the soil. Oxen are, therefore, used as draught animals, as in Italy and Spain. They are bred specially for this purpose, but generally end by being eaten. In many mountainous regions the goat supplies most of the milk and a large proportion of the meat.

France still enjoys its reputation as the land of good wine. Vine. growing is a form of cultivation employing large numbers and adding much to the country's prosperity, though the amount of land devoted to it has diminished, owing chiefly to the harm done by fungus and phylloxera. This insect did so much damage that it was 
found necessary to import American vines and graft the farous French varieties on to them.

Vast quantities of fruit are produced in all parts-cherries, pears, apples, plums, and peaches, and in the $\mathrm{S}$. oranges and lemons as well. Chestnuts and walnuts also yicld large and profitable crops. Market-gardening is widely carried on, aided by the fertile soil and the high pitch to which intensive methods of culture have been brought; many families in the smaller towns and in country districts make a useful addition to their incomes out of small patches of garden-land.

Forests are well kept up, some by individuals, some by public authorities. Beeches and horse chestnuts are the trees most common, though in some parts oaks grow well. On the sandy soil of Landes, in the S.W., the fir flourishes.

These marshy districts are the poorest in the republic, excepting the mountains. The people form a race apart, the Basques, of Spanish origin, with language and customs differing from those of the rest of the population. They are quite unlike the other people of the S., who have more in common with Italians, being dark-haired, dark-skinned, dark-eyed, and of medium height. The northern French are much lighter in complexion. Pure Celts are still to be found in the Cevennes and in the central plateau as well as in Brittany.

\section{Climate and Character}

But although they are often classed with the Latins, the French have not, as a nation, the characteristics of a Latin race. To a certain degree they are affected by the climate. There is a great deal of difference between the hard winters of the $\mathrm{E}$. provinces and the genial sunshine of the $\mathrm{S}$. The $\mathrm{N}$. is affected by the Atlantic; it has changeable, often damp, weather; in the centre, the winters are long and liard, in the W. they are short and mild. Thus the S. and S.W. people are more expansive than the rest; they are great talkers, quicktempered, small eaters and sober.

One feature of the French character is much the same in all parts-they are all hard workers and their love of independence makes them thrifty. The small peasant farmers an the closestfisted; they grudge any expenditure even on their own comfort. French housewives are good managers and can make a little go a long way. And the French woman is her husband's adviser and partner, often she understands his business, often she carries on a business herself. In all domestic economy hers is the de- ciding voice. The manual labourer's wife does not have to ask him for money; she takes his wages and allows him so much out of them. One result of this is that women have more influence on the national life than in any other country, and as they are usually more cautious and provident than men, the habit of looking after the pennies has become engrained in the national character.

Trade and INDUSTRY. In industry and commerce, the French are averse from taking large risks. Their inventors are clever, and often take the lead when some fresh development of manufacture begins, as in the motor-car business and later with aeronautics. But they do not keep their pre-eminence; they let others who are more enterprising get ahead of them. French work is notable for its high finish and artistic quality. The articles produced for export are mostly luxuries. First among their in. dustries is the fine textile, and the French have a reputation all over the world for fine silks, fine linen, and fine cloths. In metalwork they are famous for things of daily use, for much of their machinery they are dependent upon other countries. This is partly because France had not, until after the Great War, coal and iron near together in large quantities. Around Le Creusot they are found together, and that became one of the principal homes of the iron and steel industry. The normal output of coal is about $40,000,000$ metric tons a year; of iron about $20,000,000$. No other metals are found in any great bulk. Their technical skill has given the French their reputation. Their jewelry is unrivalled. In china and porcelain they keep up their old reputation; also in perfumes and women's dress.

\section{Production of Luxury Wares}

By far their largest export is manufactured silk. Raw silk also figures high up in the list. Wine is, of course, prominent, but it is surprising to find that much more is imported than exported. This is mostly Spanish and Italian wine which, being mixed with French, becomes Burgundy or Médoc. The bulk of coal imported is large. The French coal mines, of which the most productive are in the N., do not yield nearly enough for the manufacturer's needs. In their houses the French burn mostly wood, so the domestic demand is not heavy.

Soap is manufactured in vast quantities, in all degrees of refinement. Cheese-making is practised where there is good pasture ; it is enough to mention Camembert, Pont L'Evêque, Brie, and Roquefort. Sugar-making from beets is carried on extensively in the $\mathrm{N}$. In and around Paris are the principal producers of luxury wares, but outside that region there are found many trades attached for some reason to certain localities, such as clock-making at Besançon,women's hat-making and hosiery at Troyes, porcelain at Limoges, tulle at Calais, table-glass at Baccarat, lace at Puy, Valenciennes, and elsewhere. As in most countries of Europe, the $\mathbf{N}$. is more occupied with manufacture than the S., though Marseilles is an industrial centre as well as a large port, and Lyons has grouped round it probably the largest produce of silk, and has made itself the chief market for that important product.

\section{State Monopolies}

The State enjoys several manufacturing and industrial monopolies. That of tobacco, established by decree of 1810 and reorganized in 1916, is controlled by the ad. ministration of manufactures, which buys all French-grown tobacco and imports, when possible, the remainder called for. The match monopoly dates from 1889 , there being six national factories. Certain explosives, but not dyna. mite or nitro-glycerine, are state products, and the artistic manu. factures of Sèvres porcelain, and Gobelin and Beauvais tapestries are famed for a higher quality than are the first-named monopolics.

The chambers of commerce perform useful functions in the commercial and industrial life of the country. Numbering about 150 , they are regulated by the law of 1898, advising the central government on commercial matters through the ministry of commerce, and organizing various commercial services of transport, etc. Since 1918 they have been associated in regional groupings, and during the Great War were responsible for the issue of local monetary notes. Another commercial centre of organization is found in the great fairs held at Lyons and Bordeaux, the former one of the most representative markets of all Europe.

Population. Notwithstanding its fertile soil and many productive industries, France has a small population $(41,475,523)$. No state in Europe has increased so little the number of its inhabitants during the past century. For half a century the population has been about the same. Economists, political thinkers, and religious teachers have all preached the dangers of this, but without effect. The mass of the French people are too 


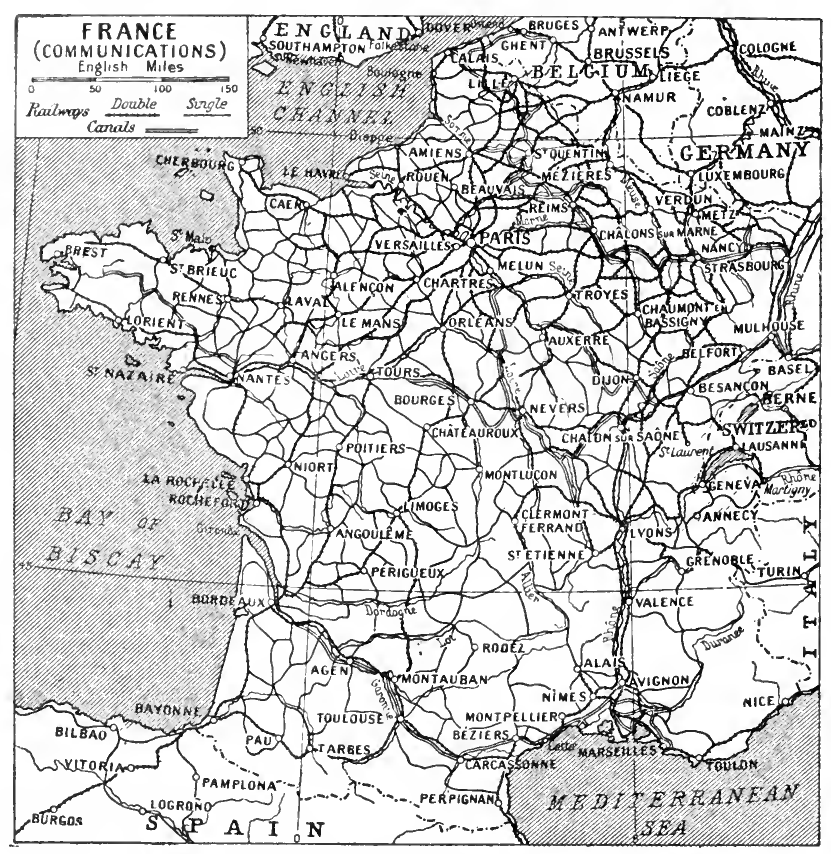

France. Map showing the main railway lines and the principal canals of the country

cautious and too comfortable to have large families. The proportion of marriages which yield only one child is very high. Even the peasant farmers, who use the labour of sons and daughters, are affected by the system which divides up landed property among all the children upon the father's death.

As a consequence of the smallness of the population in relation to the size of the country, French rlys. are imperfectly developed. The republic is well provided with trunk lines, but in most parts of the country local communications leave much to be desired. The total length of rlys. is between 25,000 and $26,000 \mathrm{~m}$., not much greater than the length of the rlys. in the U.K., although the area of France is nearly double that of Great Britain and Ireland. They are mostly in the hands of private owners. One has been worked for a long time by the state (the fit line), and more recently the west. ern system was bought by the government. But this only gives the state between $5,000 \mathrm{~m}$. and $6,000 \mathrm{~m}$., whereas the companies, Paris-Lyons-Mediterranée, Nord, Est, Orléans, and Midi, have nearly $20,000 \mathrm{~m}$. between them. There has been some agitation for nationalisation of all the systems, and in 1920 a strike was declared which had nationalisation, not for its elect a municipal council, whose decisions are subject to approval by the prefect, and sometimes by higher authorities. The head of the municipal council, the mayor, has control of the police, except in Paris and in Lyons, where they are under prefects. The largest communes are divided into cantons, which serve to link the commune and the arrondissement. Although in French local affairs, therefore, the people do not directly rule, yet the system works well on the whole.

The prefect is a figure of considerable importance in French affairs. Appointed by the president of the republic on the recommendation of the minister of the interior, he is held generally responsible for the government of his department, controls the administrative departments therein and their financial requirements, and acts as its legal representative. $\mathrm{He}$ is advised by the council of the prefecture. The general council of the department meets twice a year, with a depart. mental commission of certain members meeting at least once a month, and votes the annual budget and deals with questions of local taxation and departmental properties. The council of the arrondissements also deal with assessments of taxation and related subjects.

\section{The National Legislature}

The national government is carried on by a president, a senate, and a chamber of deputies. There are 314 senators, mostly representing departments, who cannot be elected before the age of 40 . Their term of office is nine years; every third year one-third of their number retires, and elections are made by a body composed of the deputies, the departmental councillors, the arrondissement councillors, and representatives of the municipal councils. The interest taken in the senate is not verry great; it is the chamber of deputies which attracts and holds popular attention, which makes and overthrows ministries, and which decides home and foreign policy. In 1914 there were 602 members; there have since been added 22 representatives of the recovered territories, Alsace and Lorraine.

All French subjects over 21 can vote at parlianientary elcctions, after six months' residence in an electoral district. No une can be elected under the age of 25 . The elections are made by a form of proportional representation, which was adopted in 1919, but has not proved altogether satisfactory. Both deputies and senators are paid 15,000 francs a year and can travel almost free on the rlys., making a small payment for their passes. 
The term for which each Cham. ber of Deputies is elected is four years. Instead of there being two parties, corresponding to Conservatives and Liberals, there are a number of groups. From the form of the hall in which the deputies originally sat the main divisions of the Chamber are known as right, right centre, left centre, left, extreme left, and so on, those who hold advanced opinions having their places on the left of the president and those whose views are moderate or reactionary on his right. Combinations of groups are continually forming and dissolving for the purpose of passing certain measures or driving ministers out of office. Ministries are seldom, therefore, long-lived. Nor are they, as a rule, composed of politicians agreed as to principles or strengthened by party discipline. The aim of a prime minister in forming a cabinet is to include the spokesmen of as many groups as possible and thus to secure the support of their members. There is now no group opposed to the republican form of government. A few supporters of the monarchy or the empire may be elected, but have little immediate influence.

\section{Powers of the President}

With the idea of preventing their presidents from exercising real power and so being tempted to make themselves tyrants, the French have made the office of first citizen almost entirely ornamental. The president of the republic is elected for seven years. The electors are the senators and deputies. They meet for the elections at Versailles. The president can do nothing on his own authority. Every decision he takes must be countersigned by a minister before it is put into opera. tion. War cannot be declared without the consent of both Senate and Chamber, which bodies must also approve of treaties with foreign powers. The president has theoretically the choice of ministers, but in practice the Chamber dictates to him as to who shall be asked to form cabinets, and whoever is asked to do so selects his colleagues. The president receives $£ 40,000$ a year, half of which is allowed for the expenses of keeping up the office. Another institution is the Conseil d'Etat (council of state), a body of high officials and experts who assist in the details of administration.

\section{Legal System}

The legal sy'stem separates civil from criminal jurisdiction. Crimes are dealt with by juges de paix (justices of the peace) and policecourts; by correctional tribunals

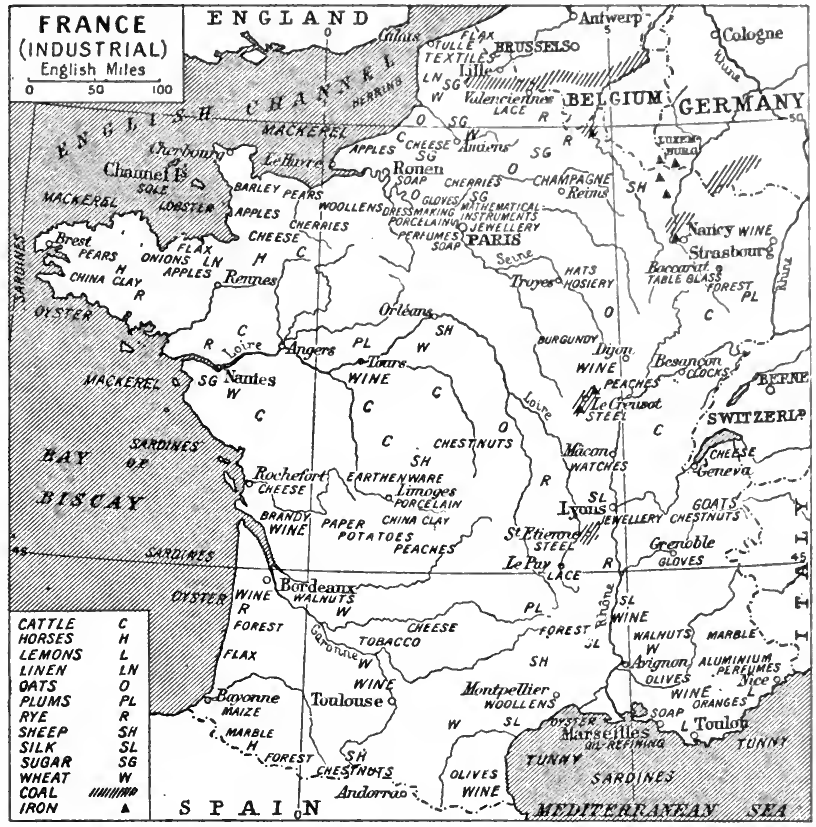

France. Map indicating the areas devoted to the principal industries and occupations which try persons charged with more serious offences; by the court of assizes, and by the courts of appeal and cassation. Before an accused person is brought before the three judges who comprise a correctional tribunal, the case is inquired into by a juge d'instruc. tion (examining magistrate). This official does all he can to induce the prisoner to admit guilt.

\section{Presumption of Guilt}

The juge d'instruction has power to order the release of a prisoner if there does not seem to him to be evidence enough to support a charge. In the court of assizes prisoners are tried before juries of 12 , which convict or acquit by a majority. The court of cassation revises cases which have been tried by juries and deals only with points of law. 'The courts of appeal rehear cases in which juries have not pronounced upon the evidence, and in which appeal may belodged, on the ground that the decision of judges were not in accordance with the facts.

Civil cases, if the sums involved are small, come before arrondisse. ment courts; tribunals of commerce, or courts of prud'hommes (experts) also deal with commercial disputes. The courts of cassation and appeal are also open to civil suitors. Speeches designed to affect the emotions of jurors, and even judges, are not uncommon. It is usual for the judges to side against accused persons and do their best to obtain convictions, for French law presumes the guilt of anyone in the dock until he can prove his innocence. Women are allowed to plead. All courts and prisons are in charge of the minister of justice. Those who are serving one year and less occupy departmental prisons. Those sentenced to hard labour, and habitual offenders are sent to the penal settlements-New Caledonia and Guiana, or sometimes to the Devil's Island.

Religion and Education. There is in France no established religion. It is a Roman Catholic country, and by far the greater number of its inhabitants profess that faith. Since 1905 church and state have been separated. Actually the changes made by the law of separa. tion were not very great. Churches were allowed to be taken over by the ecclesiastical authorities, pensions were granted to priests with a certain length of service. Mass continued to be performed as usual, congregations were as large as before. The separation had a visible effect, however, upon the religious orders and communities (friars, monks and nuns). It was required of all these that they should apply for legal authority to exist. Some would not apply, others applied and were refused. Of the 30,000 men and 130,000 women who were under vows a large number left France; many had their establishments broken up. 


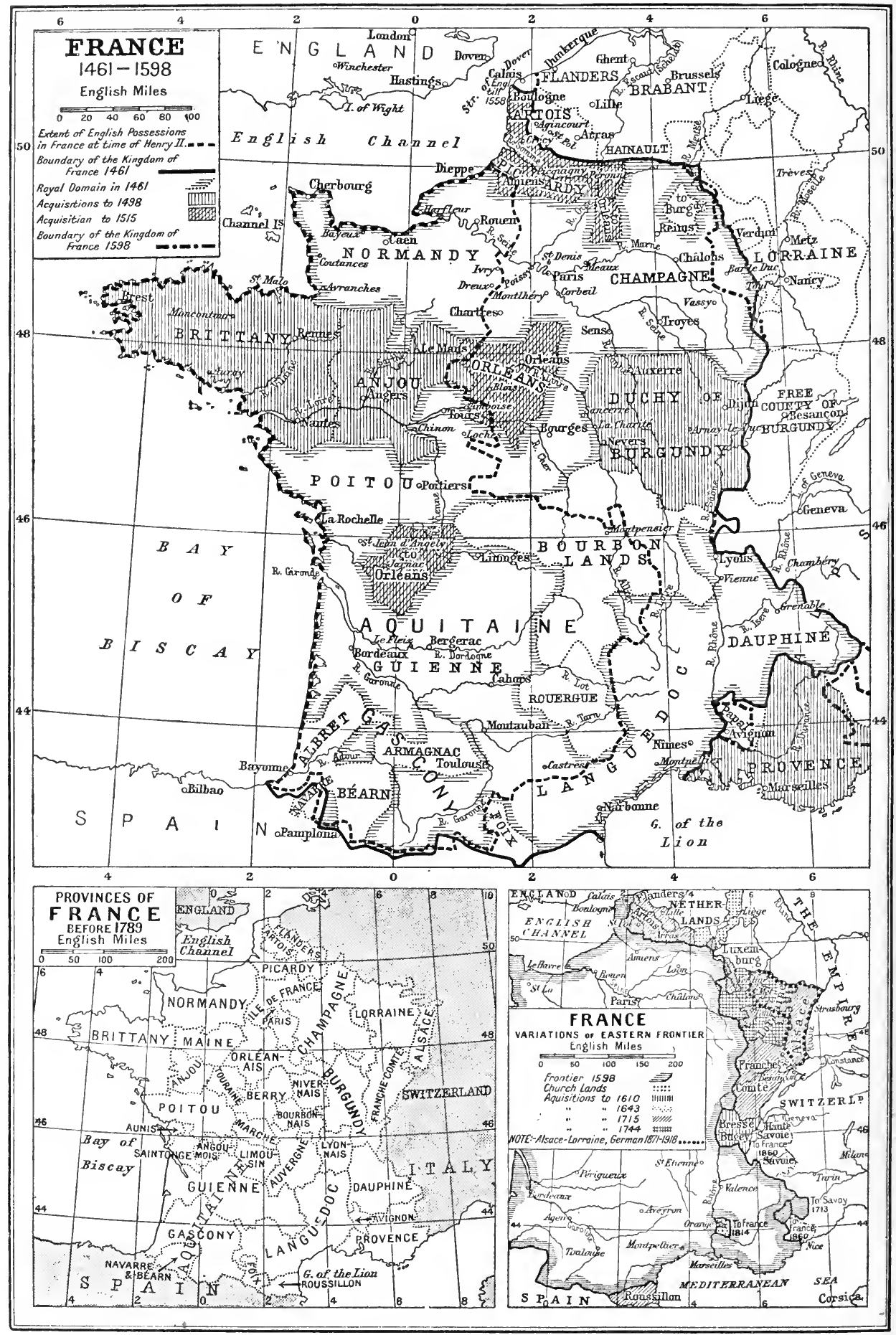

FRANCE : MAPS ILLUSTRATIVE OF THE HISTORICAL DEVELOPMENT OF THE COUNTRY 
In the state elementary schools, the teachers must not be priests, monks, or nuns. These schools are free, and children between 6 and 13 are compelled to attend them or others. For boys and girls over 13 there are state lycées and high schools provided by communes, as well as private establishments. Then there are a number of state universities, a number of technical colleges, schools of fine arts, and conservatoires of music and drama, all state institutions. The numerous technical schools do much to keep up the high standards of French workmanship. There is a good system of training teachers.

\section{Training of School Teachers}

Free instruction with board and lodging are provided in what are called normal schools; no post can be obtained without a certificate from one of these, and all who obtain posts undertake to remain teachers for 10 years. If they devote all their lives to teaching, they retire on pensions. Salaries are paid to them according to proficiency in their profession, not according to whether they are in populous or small places. Their proficiency is decided by the inspectors of schools. These inspectors are also trained so that they may understand thoroughly the responsibilities of their position. French education, as far as it goos, is good. It helps to keep up the standard of intelligence among what has been called the most in. telligent population in the world. Much is done also in the home. French children are encouraged to ask questions, to raise objections, to use their intellects. They are treated as reasoning creatures.

The state does much for the sick and poor, though it does not acknowledge any obligation to provide relief. There is an old-age pension system upon contributory lines. Special care is taken of children who are abandoned or illtreated. These are mostly placed with peasant foster-parents, and when they are of an age to begin work are given the opportunity, by apprenticeship or technical training, to enter a trade. Lunatics are well looked after at the expense of public funds. There is also widespread organization of charity through the bureaux de bienfaisance (alms-giving committees). which exist in all large communes under the presidency of the mayors. The funds at their disposal come partly from private sources, partly from taxes upon entertainments and special grants. Outdoor relief is given, hospitals are kept up, and medical attendance is provided for the sick in their homes. The idea has grown in the French mind that it is right and proper for the state and other authorities to look after those who need the community's help. The idea of dependence upon the au. thorities, and of liability to serve the general interest, is noticeable in many directions.

Thus there has never been any objection raised to military service as an obligation upon all men. Liability to this service begins at 20 and does not end until 48 . Before 1913 the term spent with the active army was two years, then it was raised to three. In Dec., 1920 , it was reduced to eighteen months. From 23-34 the Erenchman belongs to the reserve, then for seven years he is in the territorial army; his last seven years of service he passes in the territorial reserve. Twice during his reserve period he may be called upon for a month's training in camp or barracks; once while he is a territorial he is liable to a fort. night's resumption of soldiering.

\section{Military Traditions}

Since the period of Napoleon the French have prided themselves upon being a military race, and have been easily moved by the prospect of la gloire. They have never had in their army, however, anything approaching either the caste system or the brutal Prussian methods of training. French officers are drawn from the middle as well as from the upper class. There is no gulf fixed between them and their men; indeed, it often happens that a private is a very rich man, a scholar, or a man of famous lineage, while his officer is none of these things. The system of universal service gave the country a force in the field of $3,781,000$ men with 92,000 officers, a fortnight after the declaration of war in 1914. In the last year of war it had risen to $5,000,000$ men and 128,000 officers.

Universal service applies also to the navy, but there is also voluntary enlistment. Those who are obliged to serve are the men of the seafaring class between 18 and 50. The French navy has suffered much from the faulty management of politicians, but it showed in the war that it had overcome this handicap, and its work in the Mediterranean was excellent.

The finance of France, like that of most other nations, was metamorphosed by the war. Even before 1914 the public debt was considered very large, amounting to between 13 and 14 hundred millions of pounds. In 1920 it had swollen to the immense figure of 9,500 millions, and the payment of interest abroad was made all the more burdensome by the fall in the exchange value of the franc. The system of raising revenue has always made the indirect taxes large in proportion to the direct. The ratio was usually about four to one. Sugar, wines and other liquors, salt, candles, vinegar were all subject to duty by the excise; railway tickets were taxed before the war, and the high cost of tobacco and matches, due to the state monopoly of these articles, was really a tax. The proposal to establish an income-tax has always been opposed, and oven in the urgent need of revenue which followed the war no really severe demand was made for direct contributions. For a time it was hoped that enough would be extracted by way of indemnity from the Germans. As that hope faded the prospect of an unavoidable recourse to income-tax or capital levy faced each minister of finance in turn, but each in turn refused to look at it.

France was a very rich country before the war, and still has vast reserves of wealth, both existing and possible of development. Owing to the saving instincts of the mass of the population it was able to lend money on a vast scale abroad. For many years France stood next to Britain as a holder of foreign investments, and these two countries were easily ahead of all the rest. The difference between them was that, while the British investments were the property of a small number of well-todo people, the French holdings were spread over a large part of the nation. Special opportunities were offered to the small investor.

The Small Investor

He could buy small quantities of loan scrip at shops which sold it for cash across the counter. Investment thus became a regular weekly or monthly habit with large numbers of people earning small incomes. As a consequence of the support given by the French capital to all kinds of foreign and home enterprises, Paris became an important centre of finance. The big French banks, the Crédit Foncier, the Crédit Lyonnais, the Société Générale, and others, trans. acted enormous business.

Speculative finance, however, became at one period a positive canker on the moral health of the nation. The Panama scandals which were brought to light in 1892 showed an ugly phase of the process by which many were becoming rich. Even when the offensive growth had been probed and a number of persons tried, there remained an uneasy feeling that all 
had not been revealed, and a distrust of politicians who had come badly out of the investigation.

History. Little is known of the Gallic tribes who inhabited the greater part of France before the Romans conquered it in the lst century A.D. 'They were Celts who came, it is conjectured, from the Danubian plains in the 6 th century B.c. Tall, red-haired, with blue eyes and fair complexions, they drove the earlier, darker inhabitants before them and dwelt in loosely organized communities, mostly under chieftains.

\section{The Influence of Rome}

Caesar, who gives an account of them in his Gallic War, managed to bring them under the authority of the Roman empire. For several centuries the French were proud to belong to that empire, and Rome showed that they interested her by planting among them the elements of her civilization. In those centuries the character of the race was fixed. Although not Latin by descent, it became Latin by adoption. The Roman love of military prowess, the hard Roman tone of authority used by officials, the preference for the concrete and for prose over abstractions and poetry, were all absorbed by the French mind.

During the decline and fall of the Roman empire France suffered in common with all its provinces. It was almost a relief when something like stable government was established by the chiefs of a tribe from Germany known as the Franks. This marks the introduction of the name which replaced Gaul. These Franks founded the Merovingian dynasty, called after a certain Merovech (Merwig), which lasted until half-way through the 8 th century. Almost from the first the Merovingians fought among themselves, considered the country as their private estate, and fell into subjection to the powerful officials known as mayors of the palace.

In course of time the kings became mere figures of ceremony, and eventually a mayor of the palace became himself king. His name was Pepin, and his family was called Carolingian because it was founded by his father, Charles Martel or Charles the Hammer. a man of vigorous personality who ruled for years in the name of shadowy monarchs seldom even seen. The grandson of Charles Martel inherited his genius and surpassed his exploits. His name was Charlemagne, and he succeeded in bringing almost the whole of Europe under his rule. He strove to fit himself for the exercise of his vast responsibilities by submitting himself to teachers long after he had reached man's estate. He kept on good terms with the Church, and when he determined to declare himself emperor was solemnly crowned by the pope in S. Peter's at Rome. Thus he revived the empire of the West, which had been crushed by the barbarian invaders after the setting up at Constantinople of an empire of the East, and this empire survived nominally in a truncated and decrepit form until the Great War swept away the Hapsburgs and the last remains of Charlemagne's dominion.

After his death there followed the same family feuds which had ruined the Merovingians. For nearly 200 years what passes for the history of France is a monotonous record of struggles between men greedy for power. Then the descendants of Charles Martel disappeared, and the Capet family came upon the scene. By this time France had fallen under the feudal system, which soon took root in England also. The conquest of England by William, duke of Normandy, a rival prince to the kings of France, brought England and France into a conflict which continued on and off for 700 years. The kings of England, being foreigners, and having interests in France no less dear to them than their English possessions, were frequently moved to defend those interests, or to encroach upon those of French rulers. The throne had little territory or power. The country was parcelled out among small feudal chieftains, despotic, and actively jealous of each other.

\section{S. Louis and the Crusades}

With these independent rivals the kings of France struggled, until at the beginning of the 13 th century Philip Augustus managed, partly by force, partly by skilful negotiation, to bring the whole country under his sovereignty. His son, Louis IX (S. Louis), tried to do for Europe what his father had done for France. He was an idealist whose mind was set upon a crusade to free the Holy Sepulchre from the infidels; he dreamed of seeing all the monarchs and their peoples unite for this sacred end. Under his successor many circum. stances were brought to light which helped to explain the Crusades, and the real object with which they were undertaken. The Order of Knights Templars had taken a prominent part in the Crusades. It had grown immensely rich. It lent money to the crusaders and profited by the opening up of trade routes, and by pillage from the Saracens. Philip the Fair set covetous eyes upon the Templars' riches, and induced the Holy Inquisition to enquiry into their conduct. The inquiry revealed many startling facts not known by King Louis and the enthusiastic be. lievers in the Crusades.

Early in the 14th century the last of the direct male Capets died, and a younger branch of the family, the Valois, took up the burden of rule. War broke out in 1337 between Edward III of England and Philip VI of France. Edward thought he was being cheated of his right to the French throne, and used this as a pretext for the war, which was really caused by the rival trade interests of France and England in Flanders. For a long time the tide of success ran strongly in Edward's favour. He marched far into France and gained the day at Crécy. Calais remained in English hands. France lost heavily again at Poitiers, and the king had to surrender to save his life. Power then passed nominally into the hands of the young heir, Charles, the king remaining in captivity until his death. An attempt was being made to put the government upon a more popular basis by limiting the royal authority. The reformers, led by a merchant named Etienne Marcel, frightened the young prince from Paris. But they had no constructive programme, and, lacking the support of the nobles, they failed, and the chance of reforms, which might have made unnecessary the Revolution of four centuries later, slipped away.

In the years of peace which followed, no attempts were made to restore prosperity and order; the same struggle for power went on, for the opportunity to rule in the name of another young and feeble boy-king. The country was divided; civil war raged. At the height of the misery and disruption Henry V of England saw his opportunity and renewed the war. At Agincourt he won an easy victory.

\section{S. Jeanne d'Arc}

The French nobility could offer no serious resistance. From one success the English armies went on to others, and by 1428 they had subdued the greater part of France. At this time the French king was a wretched creature who had no stomach for fighting, no head for affairs. The country seemed destined to remain a dependency of England, and for some time it must have done so had not Jeanne d'Arc appeared and put fresh heart into the French people.

Jeanne, deeply religious by tempcrament, believed that she 
heard voices telling her how to save her country from the English, and restore her king to his throne. She gained access to the authorities, and informed them that she would lead the army, raise tho siege of Orleans, and have the king crowned in Reims. What she promised to do she accomplished.

The king was crowned, but when she would have pressed on to Paris the king's counsellors said that compromise was now the best hope for France. The generals were jealous of Jeanne's influence over the soldiers. Time was wasted and intrigues became more complicated, until certain French troops, acting in collusion with the English, captured Jeanne and shamefully sold her to be put to death. The English had counted upon this as likely to benefit them, but from that moment they fared worse and worse. Even the king played a man's part under the guidance of more honourable counsellors. Burgundy, which had been divided from royal France for many years, and had sided with England became reconciled. The French, united at last, drove their enemies off all their territory, except Calais, which remained English for two centuries longer.

After the Hundred Years' War

The condition of France at the end of the Hundred Years' War was pitiful. The land had been ravaged by successive invasions and by civil war. The nation, worn out by suffering, had no energy left to resist the increase of the powers of the monarchy, and so another step was taken towards the Revolution. For, while the monarchy under Louis XI did much to unite the French people, yet it set obstacles in the way of their governing themselves, and made the government autocratic.

Under Louis XI the claim of Burgundy to be a separate state was finally defeated. Nicknamed the "universal spider," he stands out in history as a type of cunning, cruel despotism. But he left his country well on the way to become the great power which it was under Louis XIV. More was done to build up royal authority by Francis I. Francis involved the country in wars provoked largely by his ambition and intrigues. Soon there was to be another cause for war, this time civil war, accompanied by assassination and massacre.

The Reformation began in Germany, and its echoes were heard in all lands. At first the demand for the purging of the Church from scandals was made in France, purely in the interest of religion. As time went on, social and eco- nomic grievances were added to those against the Church, and so the Reformers or Protestants became in France, as in England, a political party. Known as the Huguenots, their leaders were men of high position, such as the prince of Condé and Admiral Coligny. On the other side were the Guises, unprincipled and self-seeking, and Catherine de' Medici, an Italian princess with a passion for power and a genius forunscrupulous diplomacy, who was now queen-mother, ruling in the name of her son. The struggle was really one for the control of the government. Religious toleration had little to do with it. At one moment liberty of conscience and worship was conceded, but soon after that came the appalling crime of the massacre of S. Bartholomew's Day, 1572.

\section{Henry of Navarre}

At last an end was put to the savage religious wars by Henry IV, king of Navarre, a Bourbon. He was a good soldier and an honest man, who sincerely desired his country's advantage. A Protestant, he saw that the feeling of the people favoured the old Church, so he decided to become a Catholic for the sake of peace. "Paris," he said, with jovial cynicism, "is well worth a Mass." So he went to Mass, but, at the same time, he made an agreement called the Edict of Nantes, which gave the Protestants full freedom to follow and teach their faith, to have their ministers paid out of state funds, and to be admitted to all employments equally with Catholics. Henry and his minister, Sully, tried to restore prosperity to a land terribly damaged by discord and dishonest governors. But all that they did was on the old unsatisfactory lines. All power was kept in the king's hands. Such representative bodies as did exist were weakened and confused. The iniquity of throwing the burden of taxation upon working folk, and letting off the nobility and the official class, was not altered.

After Henry IV died another Italian princess became ruler of the unhappy kingdom. This was Marie de' Medici, the king's second wife, who became regent during the youth of her son. Her chief adviser was the cardinal de Richelieu, who continued to be the minister of Louis XIII until his death in 1642. His methods were disastrous for the people of France. His aim was to make the king's authority supreme, and he believed he could best accomplish this by safeguarding the privileges of the noble and wealthy. $\mathrm{He}$ was a man of narrow vision, but he perfected the autocratic system which Louis XIV inherited and used according to the motto L'Etat, c'est moi. It was Richelieu who made the Revolution inevit. able. He was followed by another cardinal, Mazarin the Sicilian. The widow of Louis XIII, appointed regent for her son, Louis XIV, was the mistress of the cardinal, and made him the ruling power. So hardly did he drive the people that he provoked rebellion.

The Glory of Louis XIV

For four years the wars of the Fronde devastated the country, and sowed bitter seeds of hatred among the population. Their only result was that when Louis XIV took upon himself the ruling power he inherited a method of government which was fated to bring about its own downfall. This king, whose reign, beginning no. minally in 1643 (actually about 16 years later), lasted until 1715 , has been made to stand out as a com. manding figure in history, and, much as historians have exag. gerated his force of intellect and personality, it is impossible not to recognize in him a man who would have made a name for him. self, no matter what his birth.

Brought up to believe that he was different from all other children, flattered as he grew by those who persuaded him that he was the representative of God upon earth, he lost all sense of reality. He held it to be indisputable that he was infinitely wiser than his subjects, that it was his right to give them laws and their duty to obey. $\mathrm{He}$ spent incredible sums upon the palace of Versailles, where he kept up a state never dreamed of by earlier kings. A whole literature of gossip and fiction has grown up round the court of the Grand Monarch. It was an age of splendour on the surface and of misery and corruption beneath. While the formalities of Racine and the satirical comedies of Molière were delighting the well-to-do, while preachers like Bossuet were drawing crowded congregations, while architecture was raising monuments which are still marvelled at, and triumphs of engineering, both civil and military, were being won, the mass of the French people were struggling under the burden of taxation, were being swept off by epidemics due to unhealthy conditions, were the prey of tyranny in its most odious forms.

The aims of Louis were to make himself greater both at home and abroad. For these ends he waged war, maintained spies, and put the royal intendants in a position to dragoon the nation. He renewed 
the persecution of the Huguenots, good and useful citizens, and revoked the Edict of Nantes. This reduced Protestantism in France to negligible dimensions and shut her out from the current of in. vigorating mental atmosphere which was then passing through other lands. In the Cevennes, professors of the reformed faith were exterminated. Even those within the boundaries of the Church who ventured to embrace new doctrines were severely repressed. Thus the Jansenists were made victims of royal vanity and impatience.

\section{France and the Netherlands}

The wars of Louis were equally due to his defects of character. His most dangerous opponent was the prince of Orange, later William III of England. Louis attempted to crush the government of the United Provinces of the Netherlands which had freed themselves from the dominion of Spain. He hoped to annex them, but he was beaten by the obstinate spirit of the Dutch. The prince of Orange stiffened their resistance at a moment when all seemed lost, and from that time onward he spared no efforts to make Louis regret his attempt to subdue a libertyloving race. 'Turenne was a general of ability, Vauban a master of fortification, but the obstinacy of William and the genius of Marlborough brought disaster on the French armies, and, after William's death, the pride of Louis was humbled by defeats at Ramillies, Oudenarde, and Malplaquet.

The end of this "magnificent" reign was pitiful, yet such as might have been foreseen. The best minds in France saw that the king had brought ruin upon the country. The national finances were worse than ever before. The minister Colbert had done his best to bring them into some kind of order. $\mathrm{He}$ tried to give an impetus to industry and to colonial expansion, and he built a navy to defend the new possessions. For a time France seemed to be on the way to become a greater colonial Power than England. In India, Canada, the W. Indies, Louisiana, and W. Africa the French established themselves. But the settlers and the generals commanding the French forces never received full support from home. One by one their greater colonial possessions fell into British hands.

Colbert might possibly have rescued France from her desperate financial sickness if he had been allowed a free hand, but he had to provide continually liuge funds for the carrying on of unsuccessful wars, and he failed completely to improve conditions for the mass of the people. They felt resentment which they were afraid to utter, until the death of the king gave their tongues freedom. Then they openly rejoiced.

The new sovereign, Louis XV, began with everything in his favour so far as popular feeling was concerned. He was no more than a child, and the kingdom was placed under a regent, the duke of Orleans. But from the first all went awry. Cardinal Fleury, who became chief minister, brought France low through unsuccessful wars. The finances showed no improvement. At one time it was hoped to restore them by adopting the scheme of a Scottish banker named John Law, who blew the Mississippi Bubble. After an orgy of wild speculation, he failed ignominiously, and left things more disordered than he found them. Louis XV was weak both in character and in intellect. He caused scandals by his love affairs, which smirched royalty in the eyes of the nation. His most notorious mistress was Madame de Pompadour, who governed him in everything.

\section{Decadence of the Court}

The result was catastrophic. Abroad France became more and more contemptible. At home there was distress and even famine. Yet the court and the fashionable world kept up a round of pleasure, poured out the money wrung from tenants and taxpayers, and danced to the tune of "After us the Deluge." Under the sway of Madame du Barry the king fell into even worse ways. The consequence was that when he died the same feeling of relief was experienced as on the death of Louis XIV.

There was hope that the new king would do better. Hopefulness was the keynote to the philosophy of the age, and in that age philosophy was the common read. ing of all educated men and women. The philosophers, Rousseau, Voltaire, Diderot, and the contributors to the great Encyclopédie, which was put together during the 18th century with the object of making knowledge supreme over superstition, wrote in a popular style. They saw that France was in a sad plight, but they held out the hope that all could soon be improved upon by "a return to Nature." There was little writing which could be called revolutionary in the political sense, yet all that was written of a serious kind prepared the way for revolution. A new spirit of human brotherhood, a fresh desire for simplicity and fair dealing, a readiness to consider great changes as inevitable and desirable, were found in the most unlikely quarters.

The young Louis XVI and his queen, Marie Antoinette, began their reign under favourable omens, at any rate on the surface. The king was an ignorant, well-mean ing, self-indulgent young fellow, who preferred his hobby of lockmaking to looking into state business. The queen was an attractive, high-spirited young woman, devoting herself, body and soul; to the pleasures of an extravagant and licentious society; she was inexperienced, injudicious, ill-advised. But no one told them that they were in the utmost danger. Unfortunately, the queen took to advising her weak husband as to his choice of ministers. Her advice was mostly bad, partly be. cause others made her the tool of their private interests. Thus, she was persuaded to take part in overthrowing the one statesman who might have saved the monarchy.

This was Turgot, who saw that more was required than tinkering with finance. $\mathrm{He}$ set to work to cut down expenses and introduce social reforms. He proposed to let the people have some sliare in governing themselves. After he had been dismissed at the bidding of the queen, came Necker, a Swiss banker, who pleased nobody, and after him the queen secured the appointment of Calonne, whose imbecile methods made it impossible for the king to carry on any longer. He was compelled, now, to ask for guidance from a body known as the Assembly of Notables, the socalled parliament, which for a short time exercised more power than the monarch. But its place was quickly taken by the StatesGeneral, a representative body of ancient institution, elected by the nation, which met after a long period of inaction on May 5, 1789 .

The States-General, 1789

The three estates of the realm were the king, the privileged classes, and the people. Very soon the Third Estate claimed to act as the nation, and demanded that henceforth no taxes should be imposed without their consent. This brought them into conflict with the monarchy, and on July 14 the Revolution began by the taking of the Bastille by an enthusiastic, mostly unarmed crowd.

At once there followed outbreaks of violence all over the country. The peasants, infuriated by heavy taxation and by their liability to be forced to work for the benefit of the indolent and luxurious rich, attacked the houses of the aristocracy, refused to pay 
further taxes, and seized the land. There was still, however, no attempt to upset the monarchy. So long as the king agreed to the decisions of the States-General he was acclaimed as a "patriot." The power was exercised by the middle class, which had been captivated by the doctrines of the philosophers, but did not consider that any violent change of system was necessary. The people were not so patient. As they learned more about the state of the kingdom, and as they felt their power, they became resolved that they would not be deceived again. The king, they said, must be in Paris. At Versailles there were military plotters against the Revolution. So they brouglit the royal family by force to Paris, and the StatesGeneral went to the capital also, and the first act closed.

In the next act the chief of the new performers was Mirabcau, an aristocrat who threw in his lot with the people, yet aimed at saving the monarchy. If Mirabeau had lived he might have saved France. After his death the voices which controlled the new Legislative Assembly were those of Danton, Robespierre, and Marat. All three belonged to the middle class, and were men of ability, but failed because they could not dominate the passions of the Paris mob. At last the mob broke into the Tuileries palace, carried off the king and his family, and put them in prison.

\section{The National Convention}

In the third phase the National Convention comes into being and, more important, the National Army, which was to sweep away the Revolution altogether for a time and make Napoleon supreme. This army was raised as a reply to the threat that the other lkings and emperors of Europe would avenge their brother, Louis XVI, who had been executed in January, 1793. Another consequence of this interference was the Reign of Terror. Everyone suspected everyone else of plotting against the Revolution. Upon flimsy pretexts men and women were arrested and guillotined. The Terror affected those who carried on the butchery not less than those who were its victims. The leaders were ambitious, and, jealous of each other, struck wildly at any who stood in their way. Yet amid all the horrors and uproar there went on the work of creating a new machine of government. Officials sat in their rooms day after day disregarding the turmoil and the bloodshed. The life of the country went on. The new army went on from triumph to triumph.
Gradually from these victories arose the star of Bonaparte. $\mathrm{He}$ had impressed the order-loving ele. ments by his " whiff of grape-shot" which ended a rising in 1795 . Then followed his Italian victories. In 1799 Bonaparte overthrew the Directorate, proclaimed himself First Consul (there were three, but the other two were shadows), and began his vigorous and in many ways admirable rule. It-was so productive of results that in 1804 he became emperor. From now on he governed not less despotically than Louis XIV, and by much the same methods, such as a widespread spy system and the crushing of all ideas which did not suit him.

\section{The Genius of Napoleon}

Yet there was one immense difference between Napoleon and Louis XIV : he was a man of exceptional ability. His mind was capable of vast and beneficent conceptions, and he could think out his plans with accuracy and harmony down to small details. He had the knack of enforcing men to enjoy obeying him, to sacrifice themselves for him willingly. All this increased his vanity, took away his sense of proportion, shook the balance of his reason, brought him to ruin in the end. He was not great as a man, for his human qualities were conditioned by his colossal selfishness; but he possessed a great capacity, an intellect of the rarest temper and usefulness, a person. ality which has never been surpassed in its power to influence the world's imagination and create that legend which alone can secure popular support. Partly because he was an ambitious soldier, partly because the other sovereigns resented his appearance among them, he was perpetually occupied in making war.

Combinations were formed against him time after time, yet his power still increased. His invasion of Russia in 1812, however, led to disaster, and encouraged all the Great Powers to combine against him. His armies retreated further and further; one after another the territories he had con. quered had to be given up. In March, 1814, Paris was taken by the Allies, and the emperor resigned the throne. Sent to Elba, he refused to accept defeat. The old monarchy had been restored, Louis XVIII was king, but as soon as Napoleon returned to France there was a hurried flight of royalty and the emperor was once more at the head of affairs. But at Waterloo his strength was broken. The restored monarchy lasted 15 years. Then it was swept away by a Republican rising, which did not, how- ever, result in a restored Republic. The opportunity was seized to put on the throne Louis Philippe, a prince of the Orlcans branch of the reigning family, who kept his uneasy seat for 18 years and was driven out to make room for the Second Republic in the year of revolutions, 1848. The first president of the new republic was the holder of the great name of Napo. leon, a nephew of the emperor, a man of small capacity, but of un. bounded faith in himself. He had lived in England as an exile. $\mathrm{He}$ had been imprisoned in France for a theatrical violation of the law excluding him from the country. Now ho was elected president by an immense majority, which was repeated in 1851, when he scized supreme power and prepared the way for his " acceptance" of the title of emperor at the end of 1852 . Once again the French people were under the domination of a tyranny. All institutions which aimed at keeping alive the spirit of freedom were suppressed. No criticism upon the doings of the government was permitted. Yet on the whole the nation was not dissatisfied. There was material prosperity to console it for the loss of liberty, if indeed liberty had ever really been either its possession or its desire. The second of the "great exhibitions" held in Paris in 1855 seemed to most observers to be evidence that the country was contented as well as prosperous, and that the revival of the Empire was likely to endure.

The Wars of Napoleon IIr

It has been said of Louis Napoleon that he spoke of its endurance as contingent upon " a war every four years." Whether he used the words or not, he skilfully carried out the policy they suggest. He drew England into the Crimean War for the defence of the Turkish Empire; he fought Austria for the supposed purpose of liberating Italy ; he sent an expedition to Mexico to bolster up an empire there. Finally, he was foolish enough to try to humiliate Prussia, and so gave Bismarck the opportunity he wanted for war with France and for consolidating the German Empire.

Bismarck was only too glad to take up the challenge rashly thrown down, and France alone had to face the armies of Prussia, Bavaria, Saxony, and Württem. burg. Europe looked in amazement while the Germans gained victory after victory, and in the early autumn, with the emperor a prisoner in their hands, encamped round Paris. The siege was gallantly endured, but at the close of 
Jan., 1871, the city capitulated, and peace was made. France surrendered Alsace and part of Lorraine, and paid an indemnity of $£ 200,000,000$.

France, however, recovered quickly, after the bloody episode of the Paris Commune. The republican form of government was tried for the third time, and to that form the country has remained constant ever since. Yet it was not for many years that the Third Republic could be considered stable. The monarchist party kept up unceasing efforts to upset it. Fortunately the royal pretenders to the throne which had been abolished were such poor creatures that they were never able to gain a serious following.

In France the Republic was accepted not so much because it was liked as because it scemed to offer the best hope of internal quiet. Under it the nation worked hard, paid off the indemnity much sooner than was expected, and reached a higher degree of general well-being than it had ever reached before. Political strife was unceasing and fierce, but the mass of people paid small attention to it. So long as they could go about their business with confidence, and so long as there was no danger of France being embroiled in foolish foreign adventures, they let the politicians talk.

\section{Boulanger and Dreyfus}

The moment of greatest danger through which the Republic has passed occurred in 1889 , when General Boulanger reached the pinnacle of his curious, meteoric career. If Boulanger had been anything more than a popularity-hunter, he might have caused a revolution. But when it was rumoured that the government intended to order his arrest, he fled.

A decade later France was again divided into two camps by the case of Alfred Dreyfus (q.v.). In the end Dreyfus was pardoned and Esterhazy, the wretched creature who was proved to be the forger of the evidence against Dreyfus, became the object of popular detestation in his place.

For all these years the affair had coloured politics, and its result was to weaken once more the parties of intolerance and reaction. That there was still life left in them, however, was the belief of those who resolved early in the century upon the separation of Church and State, and the suppression of the religious orders. All who held anti-clcrical opinions maintained that Clericalism had been strongly against the innocent Dreyfus. The politicians who were taking turns at holding office saw that a favour. able opportunity had come for weakening the influence of the Church. There was much agitation against the new laws, and some dis. turbances. There was, however, no general protest, which was taken to show that the Church had no great hold upon the Frenchman of the twentieth century. At the same time there were many young men of sincere religious conviction in the forefront of the forward movement which began to be noticeable within politics and literature about 1911. This had for one of its objects the freeing of France from the pin-pricks of Germany. When Germany set about putting itself into a state of greater readiness for war, the reply of France was to increase the term of military service from two years to three.

For a long time there had been an alliance between republican France and the Russian autocracy. The tsar had borrowed enormously from the thrifty French peasants, and had undertaken in return that France should not again be isolated as in 1870 .

For some years also Britain had encouraged the Dual Alliance to look to her for support if it should be attacked. Yet when the attack came in 1914 the French people showed no enthusiasm for war ; they did not trust their politicians ; they did not feel at all sure how things would go. Until the first battle of the Marne their un. easiness grew. After this they stif fened into that solidity of resist. ance which carried them through the long ordeal of Verdun. During the later stages they were less troubled by misgivings because they had put into power a man who ruled energetically and made them feel that all was going well. This man was Clemenceau. Amid the throng of doubters and dissem blers which filled the political stage the figure of the aged "Tiger" caught the popular imagination. He came into power as leader, not of a party, but of the nation.

\section{Influence of Clemenceau}

Clemenceau was a world celebrity during 1918-19. His influence was stronger than that of any other statesman in moulding the conditions of peace. So secure did his position seem that it was con. sidered almost certain he would be elected president of the Republic in January, 1920, but the choice fell on a man of much less vigorous personality, and Clemenceau retired. The arrangement made by Clemenceau for an alliance between France, Britain, and the U.S.A. (in spite of the clause forbidding such alliances in the League of Nations Covenant) broke down when the U.S.A. washed its hands of European re. sponsibility. This completed the circle of change in French feelings towards the American people.

When in 1917 the Americans declared war, the French recovered suddenly from a fit of severe depression, and for a while extolled them to the skies. By degrees this admira. tion altered to coldness, and at last to positive dislike. Indeed, the period which followed the end of the war saw France in a dissatisfied, uncomfortable frame of mind. The terms of peace had been made as severe almost as her leaders wished, yet the result was not what had been anticipated. The French are by nature more sceptical than the English; they had not, therefore, expected quite so much in the way of "a new heaven and a new earth." Yet there had been signs of a new idealism, of new spiritual horizons. Disillusion was felt there as elsewhere. When President Wilson declared that the government was controlled by " militarists" there was a loud outcry, but under their breath a good many French people were saying the same thing.

\section{After the Great War}

The mass of Frenchmen approved the effort of their government to crush Germany. When the president, Deschanel, was forced by bad heaith to resign, the premier, Millerand,was elected in Sept.,1920. The Leygues government resigned, Jan. 12, 1921, and A. Briand became premier, but was forced to resign in Jan., 1922, owing to the unpopularity of his foreign policy. A new ministry was formed by $\mathrm{R}$. Poincaré, under whom an intensive policy of pressure on Germany was undertaken, culminating in the French occupation of the Ruhr. The question of German repara tions was the chief pre-occupation of French politics from 1922-24 See Germany ; Reparations ; Ruhr. Hamilton ryfe

Bibliography. France, J. E. C. Bodley, 2nd ed. 1902; The French People, A. Hassall, 1902; France and the French, C. Dawbairn, 191 I Tho New France, W. S. Lilley, 1913; France (Making of the Na. tions series), C. Headlam, 1913 ; How France is Governed, R. Poincaré, 1915 ; France To-day, L. Jerrold, 1916 ; The Story of France, J. L. Beaumont.-James, 1916 ; Political History of France, 1789-1910, M. O. Davis, 1916; Twentieth Century France, M. Betham-Edwards, 1917; Short History of France, V. Duruy, 1917 ; Short History of France, from Caesar's Invasion to the Battle of Waterloo, A. M. F. Duclaux, 1918 ; Facts about France, E. Saillens, 1918; France, Mediacval and Modern, A. Hassall, 1918; History of Modern France, E. Bourgeois, 1919; My Second Country, France, R. Dell, 1920 . 
Language and Literature. One of the Romance family of languages, French had its origin in the popular Latin (sermo plebeius or rusticus) spoken by the Roman soldiers, merchants, and colonists in Gaul. Scarcely affected by Celtic influences, this popular Latin tongue, one distinguishing feature of which was the substitution of analytical forms for the elaborate case and verbal inflections of literary Latin, had already established itself by the end of the first century of the Christian era.

As they amalgamated with the Gallo-Roman people, the Frankish conquerors adopted it in their turn, adding to its vocabulary a small infusion of words chiefly of political or military significance, e.g. vassal, fief, haubert (halsberc), heaume (helm), guerre (werra), but contributing little to its phonetic or syntactical development. By the 7 th century this lingua romana rustica, spoken by all classes and accepted by the Church, though not yet committed to writing, had passed into a form which can be recognized as embryonic French.

The character of this transitional tongue may be judged from the first important monument of it, the Strasbourg Oath, by which, in 842 , Louis the German entered into alliance with his brother Charles the Bald: Pro Deo amur et pro christian poblo et nostro commun salvament, d'ist di en avant, in quant Deus savir et podir me dunat, et salvarai eo cist meon fradre Karlo, et in adjudha et in cadhuna cosa, si cum on per dreit son fradra salvar dift, in o quid il mi altresi fazet. In modern French this is: Pour l'amour de Dieu et pour le salut du peuple chrétien et notre commun salut, de ce jour en avant, autant que Dieu me donne savoir et pouvoir, je soutiendrai mon frère Charles et en aide et en chaque chose, ainsi qu'on doit, selon la justice, soutenir son frère, à condition qu'il m'en fasse autant.

\section{Langue d'Oc and Langue d'Oil}

But though now the common language of the country, the prevailing feudal confusion was fatal to its uniform development, and for a time it was broken up into a number of independent dialects. The principal division was into the langue d'oc of the south, which approximated to the Italian and Spanish modifications of the Romance stock, and the langue d'o:l of the north, the parent of modern French; but in the langue d'oil itself there were four wellmarked varieties-those of Normandy, Picardy, Burgundy, and the Ile de France. But the election to the monarchy of Hugh Capet, duke of France, in 987, made Paris the capital of the kingdom and gave the dialect of the Ile de France, or French as it was specifically called, an enormous advan. tage over its rivals, and with the steady political unification of the country from the 12th century onward this gradually became the official language of the entire people. The other dialects of the north, and later the langue d'oc or provençal, sank into the condition of mere patois. It was not, however, till the 15th century that the triumph of the French tongue was complete and its stability and uniformity definitely assured. By this time the case-endings and other synthetic features of the lingua romana, which had lingered in Old and Middle French, had entirely disappeared.

\section{Evolution from Latin}

Philology has established the fact that the evolution of French out of Latin was governed by certain fundamental laws, of which the most important are: (1) the persistence of the Latin tonic accent; thus amáre became aimér, pórticus, pórche; (2) the contraction or loss of the Latin termination, as in the examples just given; (3) the disappearance of the short vowel immediately preceding the stressed syllable; e.g. bonitatem = bonté, claritátem = clarté, septimana $=$ semaine; (4) the suppression of the medial consonant : e.g. maturus $=$ maurus $=$ mûr, confidentia $=$ confiance. These morphological rules, however, apply only to the natural and spontaneous evolution of the language and lapse entirely in respect of that large portion of the modern vocabulary which consists of words afterward imported from the Latin by scholars and writers (mots savants). Hence we can at once decide in the case of the many existing doublets, or words slightly differing in form though ultimately derived from the same sources, e.g. hôtel and hôpital, confiance and confidence, lier and liguer, which belong to the primitive and popular foundations of the language and which are of later and artificial origin.

Literature. Though a few religious poems of earlier date have come down to us, French literature really begins with the epic poetry of the 11th, 12th, and 13th centuries. This poetry, which is full of the chivalrous spirit and is essentially aristocratic in character, falls roughly into two divisions: the chansons de geste and the
romans épiques. Of the former, largely concerned with the fabu. lous exploits of Charlemagne and his paladins, the most famous example is the Chanson de Roland, dating from the second half of the 11 th century. Such chansons are supposed to rest upon slight historical bases; the romans épiques were legend or fiction.

\section{The Arthurian Cycle}

Most of these belong to the Celtic legend-cycle of Arthur and the Round Table, e.g. the poems of Chrétien de Troyes, of the second half of the 12th century. Others deal, albeit in a most cxtravagant way, with classical antiquity (romans antiques): e.g. the Roman d'Alexandre of the 12th century, which is specially interesting because it introduced the twelvesyllable verse, later the standard measure of French poetry and hence called the alexandrine.

After this epic poetry the most important branch of medieval French literature is the allegoricaldidactic poetry which reached its culmination in the Roman de la Rose, the first part of which, written c. 1237 by Guillaume de Lorris, contains a courtly " art of love" ; while the second, written by Jean de Meung, some forty years later, with its bold satire upon contemporary society, illustrates the rising reaction of the practical bourgeois spirit against the fantastic idealism of the aristocratic classes. This reaction further appears in the fabliaux, or short humorous stories in verse, of the 13th and 14th centuries, but its fullest expression is to be found in the Roman du Renard (12-14th centuries), which is indeed a kind of anti-romance or burlesque of the fashionable chansons de geste.

Although in the $\mathrm{N}$. narrative and didactic poetry flourished most, lyrical verse was cultivated in the S., notably by the Provençal troubadours, who sang of courtly love in elaborate and intricate stanza-forms; but as the old chivalrous sentiments wancd the poetry of the latter became increasingly vapid and unreal. The note of sincerity was however, struck by Rutebeul (d. c. 1280) and 200 years later by the great François Villon. Concurrently the drama, which in origin was the offspring of the liturgy of the Church, crolved through miracle, mystère and moralité into two popular forms of secular play-the sottie, a short satiric piece resembling the moralité in its allegorical machinery and didactic intention, and the farce, which may be broadly defined as dramatised fabliau. Meanwhile prose developed slowly, and it was not until the 13 th century 
that with Villehardouin's Conquête de Constantinople it began to displace Latin in the writing of history. Of the many other ehroniclers of the Middle Ages three are particularly noteworthy: Joinville with his Histoire de St. Louis, written 1305-9; Froissart with his Chroniques, written $c$. 1373-1400; and Commines witl his Memoires, written c. 14881500. Prose was also employed for fiction, as by Antoine de la Salie. The exquisite chantefable, Aucassin et Nicolette, of the later 12 th century, is an interesting connecting link between the verse and the prose roman.

\section{Renaissance Influence}

In the 16th century French lit. erature, thus far thoroughly medieval in character, was transformed by all the liberalising influences of the Renaissance and especially by the revived study of the literatures of Greco-Roman antiquity, to which the new writers turned for their inspiration and models. In poetry the transition is marked by Marot, and soon after his death the revolution was completed by a group of writers, collectively called La Pléiade, whose leading spirit was Ronsard. The manifesto of this brotherhood is contained in La Deffense et Illustration de la Langue Françoyse (1549), the author of which, Du Bellay, advocates the enrichment of French by the free importation of words and idioms from various sources and particularly from the classic tongues. In regard to literature, he insists that the poet should abandon entirely all the older native forms of verse and devote himself to the production of eclogues, epics, elegies, dramas, etc., in the classic style.

Ronsard himself attempted to naturalise some of the "great types" of ancient poetry in his Odes, 1550-53, and his unfinished epic, La Franciade; and Pléiade principles were also adopted by an outsider, the protestant Du Bartas, in his Biblical epics, Judith (1573) and La Semaine (1578). The dra. matic part of the Pléiade programme was earried out by Pon. sard's young disciple, Etienne Jodelle. His comedy, Eugène, 1552, has little historical importance; but in his two tragedies, Cléopâtre captive and Didon se sacrifiant, he laid the foundations of that Senecan or elassic type of tragedy which was to flourish in France for nearly 300 years. His lead was followed by other writers, notably Garnier, while Larivey, influenced by his Italian models, made a significant innovation by the substitution of prose for verse.
Meanwhile prose literature, hitherto little more than experimental, developed rapidly in many directions. Calvin's Institution de la Religion Chrétienne (1st French ed. 1541), though in subjectmatter interesting only to the theological student, and Amyot's version of Plutarch (1559), though a mere translation, deserve mention among the monuments of the new prose. This was now freely used for biography and history (e.g. Blaise de Montlue's Commentaires, written 1570-77), and for political purposes (e.g. ILa Boétie's Discours de la Servitude Volontaire, first printed 1576, and the Ménippée satire, 1594, by Pithou, Passerat, and others). But in general literature the two outstanding names are those of Rabelais and Montaigne, both of whom, despite their fundamental differences, are representative exponents of the emancipated spirit of the Renaissance.

With the 17 th eentury we pass into what French historians call le grand siècle, during which the consolidation of the power of the crown, begun by Richelieu, was completed by Mazarin and absolute monarchy finally established by Louis XIV. In literature the triumph of classicism was the concomitant and in large measure the result of this culmination in polities of the principles of centralization and autocracy.

\section{The Classic Period}

Under the influence first of the salons and then of the Academy, founded in 1635, and the court, literature, too, was reduced to law and order; the individualistic ten. dencies of the 16th eentury were checked, and general standards of judgement and taste were prescribed; with the result that, while an artificial unity and great brilliancy and polish were at. tained, they were attained only at the cost of originality and independence. In poetry the classical movement was initiated by Malherbe, who set out to elear the language of the archaisms of the Pléiade and the conceits which had more recently been introduced from Italy, and to regulate versifieation by the severest rules of technique.

But while Malherbe thus laid down the lines which poetry was to follow for the next 200 years, the rcal master of the elassic school was Boileau, whose L'Art Poétique (1674) was long accepted as its authoritative text-book. Only a few writers, one the satirist Régnier, were bold enough to resist the new tendencies. But one great poet of the century, the inimitable fabulist La Fontaine. though claimed by the classicists, occupies a place apart. While under the dictatorship of Malherbe and Boileau pure poetry declined, the drama, on the other hand, flourished in great splendour. After Jodelle and Garnier little progress had been made in tragedy, though the prolific Alexandre Hardy had done something to popularise it; but the classic type now reached perfection in Corneille and Racine, with whom we may also mention the minor writers, Rotrou, Thomas Corneille, and Quinault. At the same time the comedy of manners and social satire, which had slowly been emerging out of the popular farce, assumed its most brilliant form in the work of the greatest comic playwright of the modern world, Molière, among whose numerous followers two-Regnard and Dancourt-have substantial claims to distinction.

In the general prose of the century the foremost names are those of the moralists, La Rochefoucauld, Paseal, and La Bruyère; and of the preachers and religious writers, Bossuet, Bourdaloue, Mas. sillon, and Fénelon. But letterwriting and memoir-writing were also cultivated with great success ; the former in partieular by the incomparable épistolaire, Mme. de Sévigné : the latter, e.g., by the two famous chroniclers, De Retz and Saint-Simon.

To the 17th century also belong the beginnings of the novel. For its first 75 years indeed prose fiction was mainly represented by the prolix and hopelessly unreal pastoral romance, typified in L'Astrée, 1610 , of Honoré d'Urfé, and by such romans précieux as Gomberville's Polexandre, 1638-41 : La Calprenède's Cléopâtre, 1647, and Mlle. de Scudéry's Grand Cyrus, 1649-53. But a bourgeois reaction against these fantastic products of the aristocratic salons soon appeared in Charles Sorel's burlesque, Le Berger Extravagant, 1627; and in the same writer's earlier Franeion, 1622 ; in Scarron's Roman Comique, 1651-57 ; in Furetière's Roman Bourgeois, 1666 ; and in a different way in Mme. de la Fayette's Princesse de Clèves, 1678 , we mark the emergence of the novel in its modern form

\section{The Eighteenth Century}

While not altogether unchallenged, the classic ideal held sway until the death of Louis XIV in 1715. In the period of growing political and intellectual unrest which followed, though the established theories were maintained, the fundamental character of French literature underwent an 
entire transformation, to which the popularity of English literature, especially among the bourgeoisie, greatly contributed. In particular, under the influence of the critical and utilitarian tendencies of the age, literature came to be valued less for its aesthetic qualities than as a means for diffusing ideas, and for this reason the representative masterpieces of the century belong rather to the literature of polemical and propagandist purpose than to that of creative imagination. In prose the transition is marked by Bayle, Fontenelle, and Montesquieu. But as early as 1718 the most brilliant exponent of the 18th century spirit, Voltaire, had already opened his long career of prodigious activity and striking success in almost every field. Vast as was his influence, however, it was less profound than that exerted by Rousseau, who passionately attacked all the dominant ideals of his age, and who, in his subjectivity, sentimentalism, and love of nature, may be regarded as the first great precursor of romanticism. After these two the foremost prose writer of the century is Diderot.

Meanwhile, in this uncongenial atmosphere, poetry languished; Voltaire's epic La Henriade, 1728 ; the didactic verse of Louis Racine : the descriptive poems of SaintLambert, Roucher, and Delille; and the odes of Jean-Baptiste Rousseau adding little of interest to the possessions of French literature. Some excellent light verse is indeed to be found in the minor noems of Voltaire; in J. B. L. Gresset; and in the Fables of Nlorian; but in its higher forms 18th century poetry had only one acknowledged master, André Chénier, the last great product of the classic school. Tragedy, represented at its best by Crébillon and Voltaire, suffered from a similar dry rot; but comedy, on the other hand, maintained its vitality in the plays of Destouches, Piron, Marivaux, and Beaumarchais.

\section{Innovations in Drama}

The most significant feature in the history of the 18th century drama is the appearance of a new type of serious play, the tragédie bourgeoise or drame, in which the conventions of classic tragedy were repudiated and the truth of nature was sought. The way for this had been prepared by Marivaux and by the comédie larmoyante of La Chaussée, but its founders were Diderot and Sedaine. This innovation was closely connected with the progress of the democratic movement, the influence of which is also conspicuous in the further development of the novel in the hands of Le Sage, Marivaux, Prévost, Jean Jacques Rousseau, and Bernardin de Saint-Piorre.

While the Revolution overthrew the old social order, it did not at once destroy its art, and the literature of the revolutionary period represents in the main the final exhaustion of classicism. Two great writers, however-Mme. de Staèl and Chateaubriand-herald the romantic movement of the second quarter of the 19 th century. Romanticism, defined by Hugo as "liberalism in literature," was at bottom the result of the extension to art of the revolutionary principles of freedom and individuality ; whence its rejection of classic convention and all external authority, its assertion of the right of genius to be a law unto itself, its extreme subjectivity, and its frequent extravagances; while the medievalism, picturesqueness, and emotionalism by which it was also characterised arose from a sweeping reaction against the scepticism and aridity of the 18th century.

The new note in poetry was first clearly struck by Lamartine, but most powerfully by Hugo, the paramount personality of the entire movement. Vigny, Musset, and Gautier were also pre-eminent.

The Rise of Romanticism

Moribund classic tragedy was now displaced by a drama of the free romantic or Shakespearean type. Here the real pioneer was Dumas, but its principles were formulated by Victor Hugo in his preface to Cromwell (1827), the first great trumpet-call of romanticism, and it was his Hernani (1830) which assured its triumph on the stage. While, howerer, the glorified melodrama of Dumas had all the qualities which make for popularity, the finest art of the romantic drama must be sought in the plays of Vigny and Musset.

In fiction the historical romance, inaugurated by Vigny and Mérimée, attained enormous success with Hugo, Dumas, and a host of others, and side by side with this appeared the idealistic novei of George Sand in direct line from Rousseau's Nouvelle Héloïse, and the realistic novel founded by Balzac and Stendhal. Among the critics, Nisard held tenaciously to classical standards and methods, but the quickening and broadening influences of the time are clearly seen in Villemain and the greatest of all French critics, Sainte-Beuve. The period was also rich in religious and philosophical literature, e.g. Joseph de Maistre, Lamennais, Cousin, and Comte; and in history, e.g. Thierry, Guizot, and Thiers.
By the middle of the 19 th century romanticism had spent its force; the pendulum of taste swung in the opposite direction, and in response to new social and intellectual tendencies and the rapid spread of the scientific spirit, literature became for a time predominantly anti-romantic and realistic. The change is shown in the drama by the comedie de moeurs (a descendant of the later 18th century drama) of Augier and the younger Dumas; and the drame naturaliste of Bccque; in fiction by the roman réaliste of Flaubert and the brothers Edmond and Jules de Goncourt; and by the roman naturaliste of Zola, Fabre, Maupassant, and Daudet.

A few novelists, like Octave Feuillet, opposed the prevailing realism, while others, like C. A. A. Theuriet, were only in part affected by it. Outside fiction, much of the prose of this period belongs to the literature of the particular subjects dealt with rather than to general literature, and need not, therefore, be considered here; but in somo cases, as in those of Renan and Taine, even specialised history was by the technical qualities of form and style raised to the highest level of art. Another noteworthy feature of the time was the immense development of criticism by many writers of striking merit, as e.g. Taine, Brunetière, Scherer, Faguet, and Lemaître.

\section{Parnassians and Symbolists}

Poetry meanwhile passed through several well-defined phases largely associated, in consonance with the systematising habit of the French mind, with recognized schools. Two of Gautier's disciples, Banville and Baudelaire, mark the transition from the ideas of the romanties to those of the ParnassiensLeconte de Lisle, Hérédia, SullyPrudhomme, and others, who were broadly neo-classio in principle; and these in turn were succeeded by the Symbolistes-Mallarmé, Verlaine, and others, in whom may be detected the reawakening of the romantic spirit under fresh forms. Other poets of the time, however, notably Richepin. Moréas, Régnier, and Francis Jammes, cannot strictly be connected with either of these special groups. Jammes is one of the younger generation of writers who, carrying forward the movement initiated by Verlaine, have undertaken a fundamental revolution in the prosodial characteristics of French poetry. In the evolution of poetry may be noted the renaissance of the idealistic spirit, and after 1870, though the realists still held their ground, this 
became increasingly apparent in other fields of literature; as in the revival of the poetic drama with Bornier, Coppée, and Rostand. Liberated from the eramping theories of pseudo-scientific realism, all French literature indeed has since developed with healthy freedom along many independent lines. In two departments in par. ticular France still keeps her high place: in the drama, as in the plays of Lemaître, Hervieu, Brieux, Domnay, Bataille, and Bernstein: in fiction, as in the novels of Anatole France, Loti, Bourget, Bazin, Prévost, Barrès, Boylesve, and Bordeaux.

W. H. Hudson

Bibliography. Histoire de la Littérature Française du Moyen Age aux Temps Modernes, E. Géruzez, 1857; Histoire de la Littérature Francaise Depuis ses Origines Jusqu'à la Révolution, E. Géruzez, 1861 ; Histoire de la Langue Française, M. P. E. Littré, 1863 : History of French Literature, H. Van Laun, 1876-77; Historical Grammar of the French Tongue, A. Brachet, Eng. ed. P. Toynbee, 1896 ;

A History of French Literature, E. Dowden, 1897 ; Histoire de la Langue et de la Littérature Française, ed. I. Petit de Julleville, 1896-99 ; Manual of the History of French Literature, F. Brunetière, Fng. trans. R. Derechet, 1898 ; Histoire de la Littérature Française, G. Lanson, 11th ed. 1910; A Short History of French Literature, G. E. B. Saintsbury, 7 th ed. 1917.

Aкт. It is generally conceded that French art, more than that of any other country, reflects the national aesthetic judgement and feeling. Just as a Frenchman can be identified as such before he begins to speak, so is a French painting or piece of sculpture unmistakable by its particular quali. ties. For a long time, indeed, in the fine arts at any rate, the national quality overshadowed the personal; and though of late years the cosmopolitan spirit has affected French art like everything else, it is still true that the idiosyncrasies of individual French artists are much less remarkable than their mutual affinities.

\section{The Classic Tradition}

The outstanding characteristic of French art is its high standard of competence. Nowhere in the world is so high a level of accomplishment reached. On the other hand, the predominant element in that competence is an intellectual one; and this leaves little room for spirituality such as is found in the best Italian work, or for the poetry inherent in a good deal of British art. The intellect of the Frenchman is clear cut, extremely logical, almost untouched byisensuousness, and his art is endowed with precisely parallel qualities.
Hence comes his devotion for classicism. The main stream of French art has always been classie, whatever sporadic manifestations there may have been of other tendencies, romantic, impressionist, expressionist, and so forth. In no phase is the strength of the classic ideal more clearly shown than in architecture. French Gothic certainly had its own character and beauty, but it was a style imposed on France by the religious orders, and fostered by a temporary religious exaltation, rather than the product of the national genius. The great French cathedrals began to be built in the second quarter of the 12th century; but though these still remain as monuments to the period, Gothic as a building style in France, had exhausted its strength before the end of the 15th century, and was virtually extinct by the middle of the 16 th-never to be revived.

\section{The French Renaissance}

The classic revival, spreading out of Italy, appealed at once to French national aspirations, and, first introduced into the country by Italian workmen, was quickly assimilated by the French builderarchitects. This "French Renaissance" was the foundation of the classic style of building that has held the field in France, virtually without interruption, up to the present day, and, lasting from about the reign of Charles VIII (d. 1498) to the end of the 18th century, was an era of splendid accomplishment. The 16th century saw De L'Orme and Jean Bullant at work on the Tuileries, the 17th the building of the Royal Palace at Versailles, and the completion of the Louvre by Lemercier, as well as the career of François Mansart, one of the most individuãl geniuses of French and world classicism.

If the neo-Renaissance buildings of modern Paris seem paltry com pared with the older masterpieces, it is not the less true that French architecture continues to exercise an immense influence on the building of other countries. The tradition of classicism, balance, perfection of form, justness of proportion, persists very palpably in this phase of French artistic expression, and no survey of other phases would be complete without reference to the general principles it, so clearly embodies. The same principles reappear in the more permanent examples of French painting and sculpture.

French painting owed its beginnings to Flemish and Italian artists, in the same way as French architecture was indebted to the Italian craftsmen. An attempt has been made by patriotic French critics to establish the existence of an important national school at Moulins towards the end of the 15th century, and the identity of the "Maître de Moulins," the painter of a well-known triptych at that town, with Jean Perréac, a contemporary artist of French nationality. But apart from the uncertainty surrounding the personality of this Primitive and others, it is difficult to trace any material difference between their work and that of the Flemings of the same time.

Even Jean Fouquet, the illuminator of the Chantilly Book of Hours, is identified with several paintings that are Flemish or German in character, and the School of Tours, in which he was the outstanding figure, seems to have been almost entirely directed bynorthern masters. In the art of Nicholas Froment, of the School of Avignon, who flourished in the third quarter of the 15th century, Italianate influences manifest themselves as well as those of the Low Countries. Jean Clouet (d. c. 1540) and his son François (d. c. 1572) were Netherlanders domiciled at Tours. Both became court painters and helped to carry on the Flemish manner as opposed to the Italian manner which was then being fostered by Rosso and Primaticcio in the decoration of the royal buildings at Fontainebleau. The most notable "French" artist of the Fontainebleau group was Jean Cousin (d. c. 1584), called "The French Michaelangelo." Modern criticism, however, has dubbed him a mediocre follower of Primaticcio.

\section{Poussin and Lorrain}

The Fontainebleau decorative school died rapidly, and shortly after the dawn of the 17th century French painting had passed out of the stage of apprenticeship and was evolving on vigorous and eharacteristic lines of its own. The principal foreign impulse came from Rome. It was there that Nicholas Poussin (d. 1665), the real founder of the Classical school of French painting, found his inspiration. Poussin's art, nevertheless, represents the most typical expression of the purely intellectual side of French genius. Based on a definite theory of design and composition, it is coldly classical, wholly unemotional. Even his landscapes testify his devotion to the severely classical ideal, though they also show a genuine, if austere, love of nature. In landscape, however, he was easily surpassed by his great contemporary Claude Lorrain, who, adopting the same classical model in his combinations 
of both architectural and land. scape elements, clothed his work in light and atmosphere. Ruskin said of him that he effected a revolu. tion in art, which revolution "consisted mainly in setting the sun in the heavens" ; and in this respect he was the founder of modern French, and, indeed, of all modern landscape art.

A variant on the severe classic. ism of Poussin and Lorrain was introduced by Simon Vouet (d. 1649) in the form of a naturalism based on that of Caravaggio; and his pupil Charles Le Brun (d. 1690) succeeded in imposing on French painting a pompous character that checked for a time the growth of independent genius. This was the fruit of the minister Colbert's avowed policy, of which Le Brun was the instrument, of directing French art into industrial and decorative channels; and it was followed, in the 18th century, by a not unwholesome reaction.

\section{Chardin, Fragonard. Watteau}

Meanwhile, the genre painting of the brothers Le Nain, who flourished in Paris during the first half of the 17th century, had kept alive an older and simpler tradition than the Italian one. They painted the daily life of the people, very much in the manner of contemporary Dutch and Flemish schools, but with a certain southern grace in their realism. In much the same way Jean Siméon Chardin (d. 1779), an isolated figure among his flamboyant and sentimental contemporaries, concerned himself only with the aesthetic aspect and significance of the humble life he painted, and relied on delicacy of treatment and beautiful pigment to achieve beauty. French 18th century painting, however, as shown by Fragonard, Lancret, $\mathrm{Pa}$ ter, Boucher, and others, is essentially the mirror of the artificial mode of life and thought that had followed the heaviness of Louis XIV's reign. J. B. Greuze painted genre with a certain naturalness that did not enter into the sham shepherd and shepherdess compositions of the rest; but even he is not free from the charge of sentimental affectation. Watteau's temperament gave a seriousness to his Fêtes Galantes, which renders them unique of their kind.

The basis of this irresponsible and momentarily charming art was Classicism. But it was covered with a pseudo-romantic veneer. The sculpture of the time partook of the same character; that is to say, its aim, first and last, was to please. French sculpture in the Gothic period was entirely subordinate to architecture. The Renais. sance emancipated it, only to confine it once more within the rigid classicism of the 17th century. Then came the Bernini influence, and a host of rococo imitations of that Italian master. Seemingly the Revolution was needed to bring about a further emancipation both in painting and sculpture. For the first, this event produced Jacques Louis David; for the second, Houdon. David's classical formula was cold and repellent, and his historical compositions are bombastic; but the famous unfinished Mme. Récamier reveals the artist unchained from his conventions. Houdon was the first of a long line of French sculptors who, while working at first on the Greek and later the Renaissance models, designed with personal freedom and feeling. David d'Angers, Rude, Carpeaux, and Barye are names that most readily occur in this distinguished sequence, which, lasting throughout the 19th century, was only interrupted-roughly, perhaps-by the advent of Rodin.

In painting, the dull and lifeless classicism of David and his school waned in the early years of the 19th century. The Romantic movement of 1830 virtually demolished it. Romanticism, of course, was not confined to France, and was as much a literary movement as an artistic one; but it exercised an enormous influence on the future development of French painting. Headed by Eugène Delacroix and Théodore Gericault, it took the form of a revolt against the abstract and impersonal character of Classicism.

\section{The Barbizon Group}

It was an awakening to the objects of the external world, to the relations of those objects to each other and to their environment. In pure landscape it made possible the emergence of the Barbizon group, of Corot, Rousseau, Daubigny, Millet, and the rest, who in their turn became the forerunners of the Impres. sionists, Romanticism, in short, was the beginning of the sharp cleavage between academic and independent art which still persists. J. A. D. Ingres and, in a different way, Puvis de Chavannes, were the principal stalwarts of the Classical reaction that made itself felt from time to time during the century ; on the other side, Manet, Degas, and their Impressionist followers bore the brunt of an official persecution bitter enough to act as a tonic to men with new ideas.

As the century drew to a close, the development of French independent painting accelerated its pace. Claude IIonet, once ac- claimed as the last word in modern art doctrine, lost his supremacy, through the rise of a now groupthe Post-Impressionists. Thi movement, commonly attributed to Paul Cézanne, Vineent van Gogh, and Paul Gauguin, is described under a separate headin ; here it need only be said that its importance lay in the fact of its being the source of a series of revolts that still continue to agitate art circles. These also, viz. Cubism, Futurism, Vorticism, will be found described elsewherc. No one of them is an exclusively French movement ; but all have attracted their French enthusiasts. An attempt has been made to group a number of these ultra-modernists under the common title of expres sionists. One recent result of their rise, and of the cold-shouldering which the official salons continue to administer to the more extreme exponents of these cults, has been the vast accumulation in Paris of small "independent" galleries.

\section{The Modern Movement}

Expressionism has invaded French sculpture of to-day, though to a necessarily limited extent; but in painting it provides, for a nation of critics, the sensation of the hour. Maurice Denis, famous as one of the earlier Post-Impressionists, is among the most inventive and capable of the moderns : the idols of les Jeunes, however, are Henri Matisse and Derain. Side by side with these recent ebullitions the stream of traditional French art, informed by the classic spirit, continues to run its course; and if this outside movement appears to be even stronger in France than elsewhere, it derives a good deal of its strength from the very tradition of high accomplishment from which it seeks to break away.

French art has reached a stage at which an astonishingly high standard of technical proficiency no longer suffices, and there is a psychological reaction against the cool intellectualism of the older school. I ut even this is unlikely to disturb seriously the main tradition which is so firmly embedded in the roots of French character.

$$
\text { F.J. Maclean }
$$

Bibliography. Claude Lorrain painter and etcher, G. Grahame, 1895 ; French Painters of the 18th Century, Lady Dilke, 1899; French Engravers and Draughtsmen of the 18th contury, Lady Dilke, 1902 The Great French Painters and the Evolution of French Painting from 1830 to the Present Day, C. Hauelair, Fng. trans. P. G. Konody, 1903; French Painting in the 16th Century, I. Dimier, Eng. trans. H. Child, 1907; Watteau and His School, J. Edgcumbe Staley, 1907; 
Boucher: the man, his times, his art, and his significances, Haldane Macfall, 1908; The French Pas. tellists of the 18th Century, Haldane Macfall, ed. T. Leman Hare, 1909 ; Manet and The French Impressionists, T. Duret, Eng. trans. J. E. Crawford Flitch, 1910; The History of Painting, Haldane Macfall, vols. vi and viii, 1911 .

France, Bank of. Chief banking institution of France. Founded Feb. 13, 1800, by Napoleon I, it was granted the privilege of issuing bank notes in 1803. This privilege

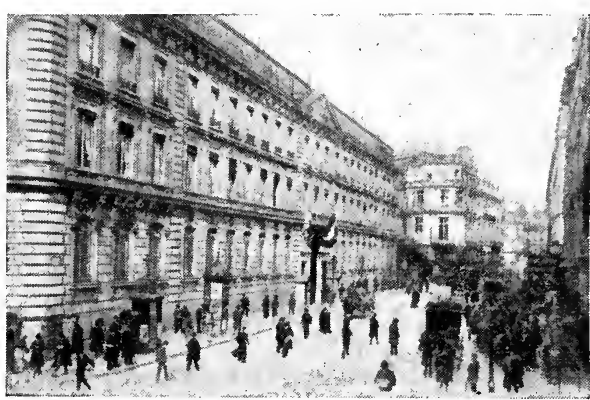

Bank of France. The head offices in Paris works of fiction, satire, and criticism which France has since produced, the following are the most noteworthy: Le Crime de Sylvestre Bonnard, 1881; Le Livre de mon Ami, 1885; Balthasar, 1889 ; Thaïs, 1890; La Vie Littéraire, a series of reprinted essays, 1888-92; La Rôtisserie de la Reine Pédauque, 1893 ; Les Opinions de M. Jérôme Coignard, 1893, and M. Bergeret à Paris, 1901, two satiric studies of contemporary French afrairs; Pierre Nozière, 1899; Crainque bille, 1902; His toire Comique, 1903; the sceptical but bril liantly written his. tory of Jeanne d'Arc, 1908; the satirical survey of modern French history, L'île des Pingouins, 1908; Les Dieux ont Soif, a story of the Revolution, 1912 ; and another great satire, La Révolte des Anges, 1914. Many of his books

became its monopoly in 1848 . Although a private joint stock bank, it is subject to state control, holding its peculiar privileges for definite periods. They were last renewed on Dec. 11, 1917, for a period ending Dec. 31, 1945. With branches all over France, it performs important clearing-house functions as well as ordinary banking business. Its capital is fixed at 172 million francs. 'The maximum note issue at the outbreak of the Great War was 6,800 million francs ; by Sept., 1917, it had risen to 24,000 million, and in July, 1919, stood at 40,000 million. Its head offices are in the Rue de la Vrillière, Paris.

France, Anatole (1844-1924). Pen-name of Jacques Anatole Thibault, French author. Born in

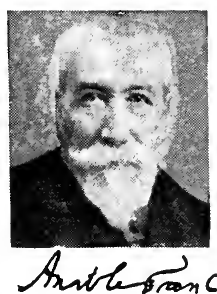

Paris, April 16, 1844, he was the son of a bo okseller, whose shop was much frequent. ed by literary men. Edueated at the Collège Stanislas, Par. is, he early de. Elliott \& Fry $\}_{\text {to }}^{\text {voted himself }}$ publishing his first book, a study of Alfred de Vigny, in 1868. After producing two volumes of poems in 1873 and 1876, he turned to prose work with the tales, Jocaste et le Chat Maigre, 1879.

Out of the long suecession of affair, and a prominent supporter of socialist, radical, and anti-militarist causes. He legendary tales inside out and showing us the modernity inherent in all humanity. In a sense he resembles Bernard Shaw, or even Wells; but he is less ruthless and restless than. either, perhaps because he does not indulge either in destruction or in reformation.

On the whole his work leaves us, not the somewhat acid taste of exposure or disillusion, but the pleasant conviction that we now know the humorous as well as the conventional side of whatever subject or personality he puts before us. He is a master of the old as well as of modern French tongue, and uses it freely. He died Oct. 13, 1924. See Anatole France. [) P Shanks. 1919.

Francesca, Piero della ( $c$. 1416-92). Italian painter. He was born at Borgo san Sepolcro, where he died. In 1439 he was employed by Domenico Veneziano on the frescoes of Sant' Egidio, Florence. Later he collaborated with Bra. mantino at the Vatican, and in 1469 entered the service of duke Federigo at Urbino. The master of Perugino and Luca Signorelli, he was learned in the laws of perspective and introduced some im. provements in oil-colours.

Francesca DA Rimini. Heroine of a famous Italian love-story. Giovanni Malatesta of Rimini was elected a mem. ber of the French Acadeniy in $\mathbf{1 8 9 6}$, and is an officer of the Legion of Honour. He visited England in 1913. He strongly supported his coun. try's entry into the Great War, even offering himself as a volunteer in 1914 , and strove always to uphold theideal ism of the French eause, publishing a striking appeal

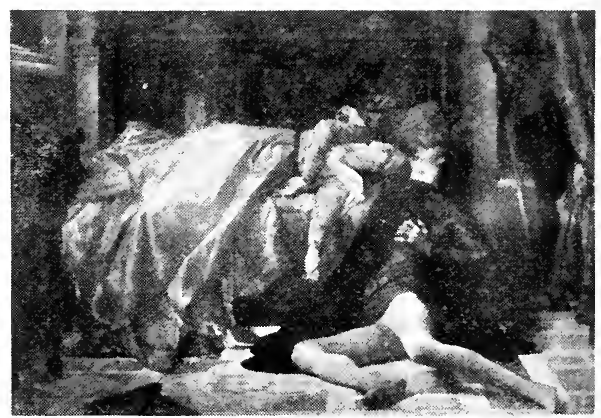

Francesca da Rimini. The fatal end of the love-story of Paolo and Francesca, as depicted by A. Cabanel Luxembourg, Paris

his old vigour, in August, 1920 .

At once erudite and keenly in. terested in actuality, he is perhaps the leading figure in contemporary French letters. It is hardly fair to call Anatole France a novelist; rather is he a kindly satirist, using the novel-the récit, as he would style it-as his medium for dissertation and analysis. A master of the impersonal and almost wholly impartial method which only a few of the greatest French writers have successfully compassed, he takes history ancient and modern as his theme; but his delight is in turning ancient or (nicknamed Scianciato, the lame) obtained her in marriage from her father, Guido da Polenta, lord of Ravenna, and sent his brother Paolo to fetch her. Francesca and Paolo fell in love and were caught together and slain by Giovanni, 1285. The story was told by Dante in the Inferno; it has also been used by Leigh Hunt, 1816, Silvio Pellico, 1818, Stephen Phillips, 1899, and D'Annunzio, 1901. Ingres, 1819, Cabanel, 1870, and G. F. Watts, 1879, have shown the story in paintings, and several operas have been founded on it. See Dante ; Rimini. 
Franceville. 'Military station in the Gabun colony of French Equatorial Africa. It is situated on the Passa, an affluent of the Ogowai (Ogoué) river.

Franche Comté. District of Europe; in full, the free county of Burgundy. It was first an independent state, then part of the duchy of Burgundy, and finally part of France. Its early capital was Dôle, but after 1678 Besançon; it lay between Lorraine and Switzer. land, while through it ran the Saône. After the dissolution of the Frankish Empire the free county was one of the many little states which arose on its ruins. It had its own counts, who retained a practical independence, in spite of occasional interference from the kings of France and Germany, until the 14th century, when it was in. cluded in the duchy of Burgundy.

In 1477 , on the death of Charles the Bold of Burgundy, it was seized by Louis XI of France, but a few years later it was regained by the emperor Maximilian, the son-in-law of Charles. From Maximilian it passed to Charles $V$ and Philip II of Spain, and then in 1668 it was conquered by Louis XIV of France, who formally secured it by the Treaty of Nimwegen in 1678. The last remains of its independence were then extinguished, and since then it has been part of France. Since the Revolution it has been divided, and now forms the depts. of Haute Saône, Jura and Doubs, and part of the dept. of Ain. See Burgundy.

Franchet d'Esperey, Lovis (b. 1856). French soldier. Born at Mostaganem, Algeria, and educated privately and at St. Cyr, he entered the army in Oct., 1876. He took part in the Tunis operations, $1881-82$, in the Tongking expedition, 1885-87, and served in Franchet d'Esperey, China, 1900-1.

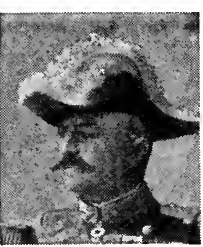

ranchet d'Espere
French soldier
He next saw active service in Morocco, 1912-13, and in 1914 was in command of the ] st Army Corps at Lille.

During the Great War he was placed at the head of the French Fifth Army, succeeding Lanrezac after the battle of Charleroi, Aug., 1914. He fought on the right of the British in the lst battle of the Marne, and gained a victory at Montmirail, Sept., 1914. Later he succeeded in holding the Aisne bridgeheads. In April, 1916, he was placed in command of a group of the armies of the East in France, and in Jan., 1917, of the group of the armies of the North, which he held till June, 1918, when he was given supreme command of the Allied armies of the Orient, rcceiving the surrender of Bulgaria, Sept., 1918. He was in comniand in Turkey-in-Europe until Nov., 19:0. and was ereated marshal, 1921.

Franchise (late Lat. francus, free). Originally something to which the idea of freedom was attached, i.e. the free grant of a privilege. It is now used in two narrower senses, one in law and the other in politics. In law, a franchise is a privilege granted by the crown to an individual, or more usually to a corporation, such as the right to hold a market or fair, or rights of fishing. This use of the term persists in the United States, where franchises are public rights handed over to private or semi-private bodies.

In politics, the franchise is the right to vote, especially the right to vote at elections of members of parliament. It varies in different countries, but the tendency at present is to bestow it upon all adults, men and women alike. In Australia, New Zealand, and the greater part of Canada the fran. chise is on these lines, as it is in the states of the U.S.A., in Ger. many, and in several other countries. Acts of Parliament bestowing the vote on fresh classes of the population are frequently known as Franchise Acts.

In England the franchise was at first the privilege of all freeholders, who voted in the county court; but by an Act of 1430 it was re. stricted, as far as the counties were concerned, to those whose freeholds were worth $40 \mathrm{~s}$. or more. In the towns the franchise varied very much, each borough having its own custom, usually conveyed to it by royal charter. There were variations, too, in the franchise in Scotland and Ireland. Uniformity was first introduced by the Reform Act of 1832. In England, in the counties, it was given, in addition to the existing freeholders, to copyholders and those renting land worth $£ 50$ a year. In the boroughs a uniform franchise was introduced, the vote being given to all householders whose premises were worth $£ 10$ a year and upwards. In 1867 a second Reform Act reduced the qualifications in the counties to the holders of land worth $£ 12$ a year, and in the boroughs gave it to all householders. In addition a lodger franchise was introduced. For Scotland and Ireland there were also Reform Acts, the main principles being the same as in England.

In 1884 a Reform Act introduced uniformity, not only between county and borough, but between England, Scotland, and Ircland. All householders were given the franchise, as were lodgers in counties as in boroughs. Certain classes were disqualified as before, e.g. aliens and criminals, and women were still excluded. In addition there was still a university franchise, based on the possession of a degree. In 1867 proposals for what were called fancy franchises were made, but were not passed into law.

The important Act of 1918 con. ferred the franchise on women, giving the vote to all adult males and to women over 30 years of age, six months' residence or occupation of business premises of the value of $£ 10$ a year or over being necessary in the case of men.

In addition to the parliamentary franchise there has been in the United Kingdom a uniform municipal franchise since 1835 , in which women have been included. Other franchises are the right to vote at elections for county councillors, introduced in 1888, and the right to vote at elections for urban and rural district councillors, dat. ing from 1894. From this use of the word comes enfranchise, to bestow the vote, or, as frequently used, to give a place the right of representation in Parliament; and disfranchise, to take it away. See Election ; England; Local Government; Parliament; Reform Acts ; Representation; Vote.

Francia, Francesco (c. 1450 1517). Italian painter. $\mathrm{He}$ was born at Bologna, his real name being Francesco Raibolini, and was apprenticed to a goldsmith. $\mathrm{He}$ achieved distinction as a worker in metal, in niello, and in type-found. ing, but shortly after the coming of Lorenzo Costa to Bologna, 1483, he became a painter. Costa and

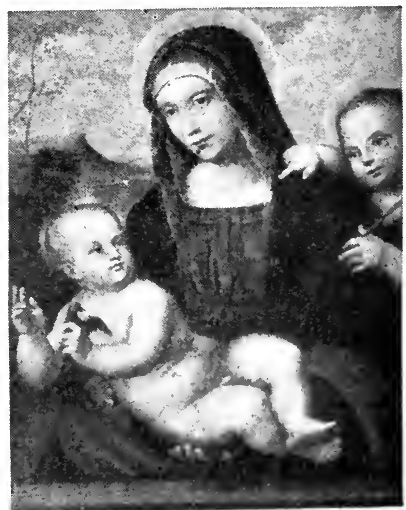

Francia. Madonna, Infant Jesus, and S. John, an example of the artist's work in the Dresden Gallery 
Francia were associated in an altarpiece for the Church of the Misericordia, Bologna, Francia's earliest dated work. Though at first he followed Costa's style he quickly surpassed that master in power of conception and colour. The Madonna and Saints, with S. Anne enthroned, in the National Gallery, London, is one of his masterpieces, but he is best studied at Bologna.

His famous Baptism of Christ is at Dresden. Among his portraits are those of Bartolommeo Bianehini (Salting collection), The Marchese Bovio (Lichtenstein Gallery, Vienna), Prince Federigo Gonzaga (Leatham collection).

fresco two episodes from the life of $\mathrm{S}$. Cecilia survive in the chapel of that saint at Bologna. $\mathrm{He}$ died at Bologna, Jan. 6, 1517. See Life, G. C. Williamson, 1901 .

Francia, José GaSPAR RoDRIGuE7. (1757-1840). Dictator of Paraguay. Born at Asunción, of Portuguese origin, and educated at the university of Córdoba de Tucumán, he first studied theology, but after taking his degree practised law. In 1811 Paraguay declared itself independent of Spain, and Francia, the ablest of its revolu-

\section{FRANCIS: THE SAINT OF ASSISI}

G. G. Coulton, Author of From St. Francis to Dante

The life and work of this saint is a necessary introduction to the articles on Monasticism; Franciscans; and on the other religious orders

Francis of Assisi was born in or about the year 1182. His father, Pietro di Bernardone, was a cloth merchant, and belonged to the eommercial aristocracy of Assisi. Pietro was travelling in France when the son was born to whom on his return he gave the then unusual name of Francesco. The saint's youth was marked by a love of pleasure, society, and song; all his life he retained a strong affection for the French language

-then the literary language of Europe-though he could never speak it well. As he grew up he began to repent of his irregularities, which had always been those of a generous and refined nature.

In 1202 Francis was taken prisoner in battle against the Perugians, and remained in captivity for a year, during which he was noted for his gaiety and his forbearance towards his fellow-prisoners. Returning to his former dissipations, he fell seriously ill, and, in a moment of convalescence, gazing out upon the landscape beneath the walls of Assisi, he found that "neither the beauty of the fields, the pleasantness of the vineyards, nor anything that is fair tc see could in any, wise delight him.... And from that day he began to despise himself, and in some tionary leaders, became secretary of the national junta, joint dictator, 1813, joint dictator for three years, 1814, and sole dictator for life, 1816. In 1816 he dissolved congress, and for the rest of his life ruled tyranically but beneficially. His vigorous opposition to intercourse with other countries resulted in the devielopment of Paraguay's re sources. He died Sept. 20, 1840.

Franciade. Name given to each period of four years in the new calendar set up by the authors of the French Revolution in 1793. The idea and form of the word were derived from the Greek Olympiad. See Calendar.

rancis. Christian name, used by both males and females. It is drom the word frank, free, form Francois. It passed over to England about the time of Henry VIII, in the form of Francis. In the 18th century the form Frances began to be used for girls. Frank is a variant. The German equivalent is Franz, a popular name in that country, and the Italian is Francesco. Francesca is the Italian feminine, and Franziska the German.

sort to hold in contempt what he had admired and loved before; yet not altogether, for he had not yet been loosed from the bonds of vanity." He dreamed of military fame, and had actually started on an expedition to Apulia when a vision recalled him. His gaiety now became more fitful; he was penetrated with a deeper pity for the poor, and especially for lepers ; the self-conquest which first enabled him to kiss a leper marked a fresh step in his spiritual life.

\section{A Religious Knight-errant}

Francis now spent much time in solitary prayer, and at one of these moments, in the little halfruined church of $\mathrm{S}$. Damiano, the crueifix seemed to speak to him with an articulate voice: "Francis, go repair My House, which as thou seest is wholly falling into ruin." Taking these words too literally, he sought to assist the reparation of $S$. Damiano by selling one of his father's horses with a load of valuable cloth. The result was a complete rupture between him and his father, and the saint went forth naked into the world. "Henceforth I may say freely "Our Father which art in heaven,' and no longer 'father Pietro di Bernardone."

This was in 1207. Francis then began a life of religious vagabondage - or rather, knight-errantry. We find him repairing $S$. Damiano with his own hands, tending the lepers and living among them, preaching in the streets and public squares, and often treated as a madman. At last, apparently on Feb. 24, 1209, the gospel for the day suggested a more definite rule of life (Matt. x, 7-10). Thenceforward he took as his ideal the literal imitation of Christ, and became perhaps the most Christlike of all the figures in Church history.

\section{Foundation of His Order}

At the end of 1209 , or more prob. ably in 1210, having already a small group of disciples, he went to Rome and begged Innocent III to confirm a brief rule which he had drawn up, and thus to authorise a new religious order. The monks were individually poor, but held corporate endowments. The friar was to be moneyless, not only individually but also in the mass; he was to live by the labour of his hands if possible, and, where that failed, by begging. The pope, after some natural hesitation, consented. The new order multiplied rapidly, thanks to the personal influence of Francis and to the crying need of the times.

Many reformers, in the latter half of the 12th century, had aimed at a return to apostolic life; but, sooner or later, all of these came into conflict with the Church. S. Francis combined the most extraordinary religious zeal and charity with a spirit of complete devotion to the hierarchy, and was thus able to renew religious life in Europe without breaking with the Church. There can be little doubt that he and his fol. lowers postponed the religious revolution of the 16th century by several generations. Yet this reconciliation was not effected with. out considerable sacrifices of ideal.

\section{Suffering and Self-Sacrifice}

As time went on S. Francis rose to even greater heights of suffering and self-sacrifice, but he lacked the more ordinary qualities required in the general of a religious order. Here his zeal for conversions actually stood in his way. Apart from his frequent mission. ary journeys in Italy, he planned others abroad. In 1212 he started for Palestine, but was driven by storms to the N.E. coast of the Adriatic. In 1214 he went to preach in Spain; in 1217 he was with difficulty restrained from a similar journey to France. In 1219 he at last found his way to Syria and Palestine, and was away more than a year. 
During his absence in Palestine, his vicars joined with other notables in a policy which tended to bring the Franciscans into line with the older orders. At this news he suddenly returned (summer of 1220 ), but was unable entirely to check the movement, which had considerable support from the papal court. Recognizing his own want of strictly business qualities. he resigned the direction of the Order to Pietro dei Cattani as vicargeneral, and from this time forward could only protest against the formalism which was creeping steadily into his Order. The rest of his life was spent in missionary journeys about Italy, and in remote her. mitages where he gave himself up increasingly to the contemplation of Christ's passion. At one of these (La Vernia, Sept., 1224) he is said to have miraculously received the Stigmata, or five wounds of Christ. He died Oct. 3, 1226. See Assisi. illus.

Bibliography. The Mirror of Perfection, ascribed to Ieo of Assisi, Eng. trans. S. Evans, 1898; The Little Flowers of St. Francis, Eng. trans. T. W. Arnold, 1908; Lives, Paul Sabatier, Eng. trans. L. S. Houghton, 1894; Thomas of Celano, Eng. trans. A. G. Ferrers Howell, 1908; J. Jörgensen, Eng. trans. T. O'Conor Sloane, 1912 ; Father Cuthbert, 1912; A Guide to Franciscan Studies, A.G. Iittle, 1920.

Francis of PaOLA (c. 14161507). Saint and founder of the Order of Friars Minims. Born at Paolo, of poor parents, when 15 years old he became a hermit. Being soon joined by others, he founded an order in 1436 . Their first monastery was built in 1454 , and the new order was authorised by Pope Sixtus IV in 1474. Other monasteries were founded in Italy, Sicily, France, and Germany, before Francis's death at Plessis-les. Tours, Aprii 2, 1507.

Francis DE SALES (1567-1622). Saint and writer. Born of a noble family at Annecy, Savoy, Aug. 21,

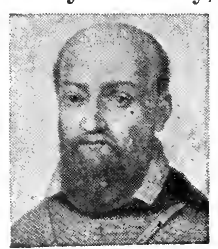

Francis de Sales. French saint

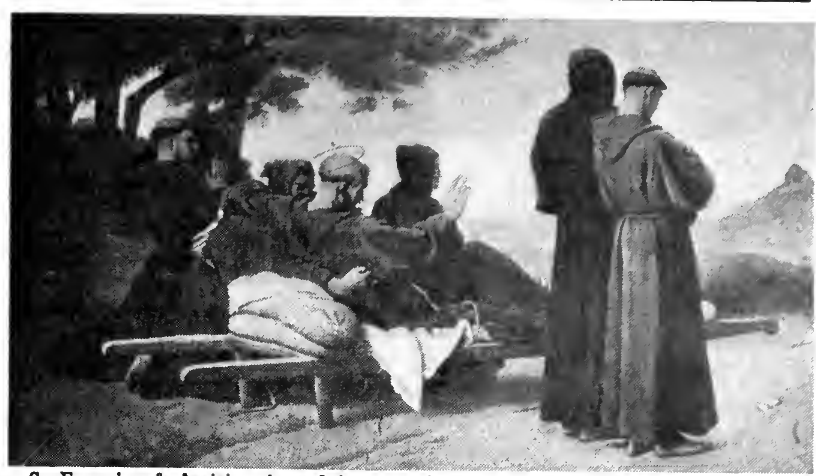

S. Francis of Assisi, when dying, carried upon a litter to bless the town of Assisi. From a painting by $\mathrm{L}_{0}$. Benonville

Visitation. He was a man of saintly life. His Introduction to the Devout Life, 1609 , is translated into many languages, and highly esteemed by Christian people generally. He died at Lyons, Dec. 28, 1622. was canonised in 1665 , and adopted as the patron saint of writers and journalists in 1923. See works, ed. H. B. Mackey (An. necy), 1892, etc.; Lives, H. L. Lear, 1871 , M. M. M. Scott, 1913 ; The Spirit of St. Francis de Sales, J. P. Camus, ed. Archbp. of Westminster, 1910.

Francis I (1708-65). Germar king and Roman emperor. The son of Leopold, duke of Lorraine, and,

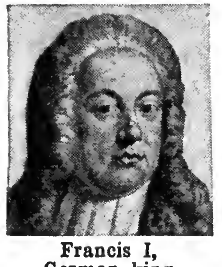

German king through $h$ is mother, a grandson of Philip, d u ke of Orleans, he w a s born Dec. 8, 1708. Related to the Hapsburgs, he was educated in the court cir. cle at Vienna, and a marriage $w^{a_{s}}$ arranged between him and the future empress, Maria Theresa. In 1729 he became duke of Lorraine, but in 1735 he exchanged that duchy for Tuscany, of which he became grand duke when the last Medici ruler died in 1737 , having in the meantime (1736) been married to Maria Theresa. In 1740 his father-in-law, the emperor Charles VI, died, and the war of the Austrian succession began. In the struggle against Frederick the Great, Maria, not her husband, was the dominant figure, and her efforts resulted in 1745 in the election of Francis as emperor. $\mathrm{He}$ died at Innsbruck, Aug. 18, 1765, having been merely the assistant of his wife. From the pair the existing Hapsburgs are descended, hence the family is known as HapsburgLorraine. See Maria Theresa.
Francis II (1768-1835). Em. peror of Austria and last ruler of the Holy Roman Empire. Born in

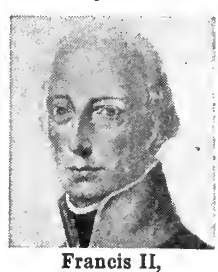
12,1768 , he was educated there and in Vienna. His father, hither. to grand duke of'Tuscany, be. came Roman emperor as Leopold II in years later (March 1, 1792) Francis succeeded him. A little earlier the French Revolution had begun. Francis's aunt was Marie Antoinette, and on both public and private grounds he was soon com. mitted to the war against France. One disaster followed another. $\mathrm{He}$ was forced to make the treaty of Campo Formio, and later that of Pressburg. The Netherlands were in revolt; Russia and Turkey were willing to take advantage of his difficulties. The states of Germany lost their last vestiges of unity, and in 1804 Francis took the title of emperor of Austria, thus seeking to unite more closely the various lands, Hungary and Bohemia among them, over which he really ruled. In 1806 the Holy Roman Empire, of which he was the nominal head, ceased to exist.

Although be had Metternich for his minister, Francis took a leading part in controlling the policy of Austria, both domestic and foreign. He came to terms with Napoleon, giving him his daughter in mar. riage; but in 1813 he joined the Allies, and his armies assisted in Napoleon's defeat. He died March 2 , 1835. He was four times married, and left his successor, Ferdinand I, and other children, one being the father of the em. peror Francis Joseph. See Europe: History; Vienna, Congress of. Florence, Feb. Emperor of Austria 1790 , and two
1602. In Sept., 1602, he becam bishop of Geneva. In 1610 he founded the order of Nuns of the 
Francis I (1494-1547). King of France. Son of Charles of Valois, he was born at Cognac, Sept. 12,

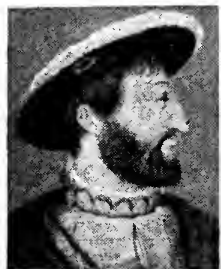

1494 , and in 1515 succeed. ed his cousin $\mathrm{L}$ o u is XII, whose daughter he had married in 1512. $\mathrm{He}$ in vaded Italy and defeated the duke of II i l a $n$ at (1) $)\left(\int\right) \int \begin{aligned} & \text { Marignano in } \\ & 1515 . \text { In } 1519\end{aligned}$ d) V $\int$ he made an u n successful bid for the i $m$ per i a l crown, which

Charles V ob-

From a portrail tained, and the famous rivalry of the two monarchs began. Francis's attempted alliance with Henry VIII of England, at the Field of the Cloth of Gold, 1520, came to nothing, but he again invaded Italy, 1525, and was captured at Pavia, Feb. 25. Kept prisoner at Madrid, he was set free in 1526 on surrendering Burgundy and abandoning various claims in favour of Charles. Once free, however, he renewed hostilities, and won certain modifications from Charles in 1529 , whose sister Margaret he married, 1530 .

The struggle was resumed in 1536, Francis making useful alliances with the German Protestant princes, and with the sultan Solyman I (1542), but had reached no definite conclusion on his death at Rambouillet, March 31, 1547. Despite the jealousies and vacillations of his foreign policy, Francis greatly strengthened the royal power. He secured for himself the nomination of bishops, reduced the judiciary powers of the nobility, strengthened provincial administration, reformed the national exchequer, and reconstituted the permanent army. A patron of many notable artists and writers of the Renaissance, he founded the Collège de France, 1530.

Francis II (1544-60). King of France. Born at Fontainebleau, Jan. 19, 1544, he was the eldest son of Henry II.

He was married to Mary Stuart, Queen of Scots, 1558 , and became king on $h$ is father's $m$ u rde $r$ in April, 1559. His reig n o n 1 y lasted for a year and a half.

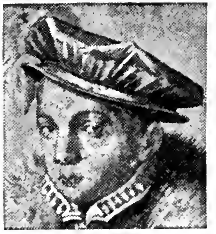

Francis II, King of France and during that time the government was conducted by his mother, Catherine de' Medici, and his kinsmen, the Guises. He died suddenly at Paris, Dec. 5, 1560. See Chenonceaux; illus.

Francis I (1777-1830). King of the Two Sicilies. Son of Ferdinand I, he was born in Naples, Aug. 19, 1777. In 1812 his father made him reyent of Sicily and in 1820 regent of Naples. He came to the throne in 1824 and placed himself under the tutelage of Austria, inaugurating an era of oppression and corruption which reduced his subjects to despair. An insurrection in 1828 was put down with unexampled cruelty, the commune of Bosco being razed to the ground. His alarm at the French revolution of 1830 , and the fear of the vengeance of his own people, caused his death, Nov. 8, 1830.

Francis II (1836-94). King o! the Two Sicilies. Son of Ferdinand II (Bomba), he was born Jan. 16, 1836, and ascended the throne in 1859. Characterless and weak, he rejected all proposals of reform until Garibaldi's invasion of Sicily, 1860, when his tardy offer of a constitution was rejected by his people. Hefled to Capua and thence to Gaeta, which, after a brief siege, surrendered, Feb. 12, 1861. The kingdom was incorporated with Italy and Francis took refuge in Rome. After 1870, Francis lived in Germany and Austria, dying at Arco, Dec. 27, 1994

Francis, JoHn (1811-82). Pub. lisher of The Athenaeum. Born in Bcrmondsey, July 18, 1811, and apprenticed to a London news. paper agent, he entered The Athe. naeum office as a clerk, Sept., 1831, and became business manager and publisher of that paper in Oct., 1832. He retained this post for nearly 50 years, also supervising the commercial side of Notes and Queries from 1872. He took an active part in the campaign for the repeal of the advertisement, stamp, and paper duties, 1853-61. He died April 6, 1882 , and was succeeded by his eldest son, John Collins Francis (d. 1916), who wrote a memoir of his father, 1888.

Francis, Mary E. Pen-name of Mary E. Blundell, British novelist. Born at Killiney Park, Dublin, a daughter of $\mathrm{Mich}$ a el James Sweetman, she married Francis Nicholas Blundell in 1879 Having early achieved success with her

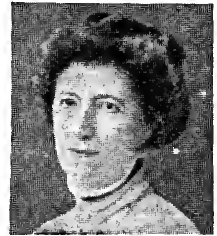

Mary E. Francis, British novelist stories of North Lancashire life and character, she enhanced her reputation by studies of Dorset life. Her books included Whither ?, 1892 ; In a North Country Village, 1893; A Daughter of the Soil, 1895; Pastorals of Dorset, 1901 ; The Manor Farm, 1902 ; Dorset Dear, 1905 ; The Story of Mary Dunne, 1913 ; A Maid o' Dorset, 1917; and Beck of Beckford, 1920. She also wrote some plays, The Widow Woos, 1904 (intro. Sydney Valentine); The Third Time of Asking, 1906 ; and Fiander's Widow (in collaboration with Sydney Valentine), 1907.

Francis, SIR PHILIP (17401818). Supposed author of The Letters of Junius (q.v.). The only son of Philip

$\mathrm{Fran} \mathrm{cis}$ ( $c$. 1708-73), the translator of $\mathrm{Horace}$, he was born in Dublin, Oct. $22, \quad 1740$ Educated in Dublin and at S. P a u l's School, London, where H. S. Wood-

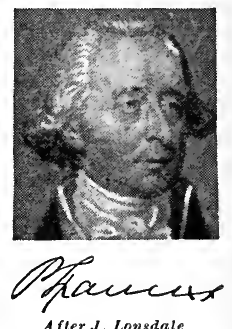
fall and $P$. Rosenhagen were his friends, he filled several minor government appointments and was first clerk at the war office, 1762 72. He married in 1762 a Miss Macrabie (d. 1806).

A member of the council of Bengal, 1774-81, he quarrelled with Warren Hastings, who wounded him in a pistol duel, 1779 . $\mathrm{He}$ paid 50,000 rupees as defendant in a marital action brought by G. F. Grand, an officer in the East India Company's service, whose young wife, after living for a time under the protection of Francis, became in 1801 the wife of Talleyrand, and returned to England with a large fortune. He was M.P. for Yarmouth, I.W., 1784 ; Bletchingley, 1790: and Appleby, 1802; assisted Burke in impeaching Warren Hastings; incurred the enmity of William Pitt ; became all intimate of the Prince Regent; and supported Wilberforce against the slave trade. In 1793 he founded the Society of Friends of the People; received in 1806 a K.C.B. instead of the coveted office of governor-general of India, and in 1814 married Emma Watkins, whom he encouraged in her belief that he was the author of the Junius Letters. , $\mathrm{He}$ died in London, Dec. 22, 1818. See Memoirs, J. Parkes and H. Merivale, 1867 ; Echoes from Old Calcutta, H. E. Busteed, 3rd ed. 1897. 
Francis Ferdinand (1863 1914). Austrian archduke. Son of the archduke Charles Louis and

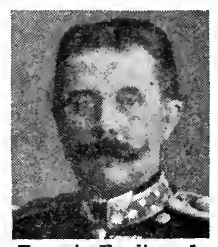
nephew of the emperor Fran. cis Joseph, he was born at Graz, Dec. 18 , $1863 . \quad$ f t e r inheriting, in 1875 , the wealth and titles of the house of Haps. Francis Ferdinand, burg-Este, forAustrian archduke merly dukes of Modena, he became, by the suicide of the crown prince Rudolf in 1889 , heir-apparent to the crown of Austria-Hungary. On his morganatic marriage in 1900 to the Countess Sophia Chotek, who was created Princess Hohenberg, he renounced for the children the right of succession, but his own position remained, and for the next fourteen years he was one of the directors of the policy of Austria-Hungary. He was making a tour in Bosnia when he was assassinated at Sarajevo, June 28, 1914, a crime which precipitated the Great War.

Francis Joseph I (1830-1916). Emperor of Austria. The eldest son of the archduke Francis and a grandson of the emperor Francis II, he was born at Vienna, Aug. 18, 1830. He was educated carefully but narrowly, as all the Hapsburgs, and owed much to the strong character of his mother, Sophia, daughter of Maximilian $I$ of Bavaria. In 1848 the shaking throne was occupied by Ferdinand, a childless imbecile. The hopes of the Hapsburgs were therefore centred on Francis Joseph, his nephew, and it was decided that he, who came of age Aug. 18, 1848 , should be placed upon the throne.

Francis Joseph reigned from Dec. 2, 1848, until Nov. 21, 1916, one of the longest reigns in the world's history. But its interest is not so much in its length as in its vicissitudes. He saw Austria lose her possessions in Italy, 1859, and, defeated by Prussia, 1866, driven from the German confederation. He saw the results of a hated rule in continuous discontent in Hun. gary and Bohemia. The acquisition of Bosnia and Herzegovina, 1908, hardly compensated for endless difficulties with the Balkan states, for the growing suspicions of Russia, or for disorder in the national finances, while Austria's adhesion to the Triple Alliance made her more than ever sub. ordinate to Prussia.

His private life was even more tragic. His wife Elizabeth, daughter of Maximilian Joseph, duke of Bavaria, was assassinated at Geneva in 1897 ; his only son, Rudolph, committed suicide, or was killed, in 1889 ; his nephew and heir, the archduke Francis Ferdinand, was murdered at Sara. jevo, June 28, 1914, with the most momentous consequences.

The emperor took a real part in ruling his empire with its warring races and inherited difficulties, and but for him it is probable that it would have fallen to pieces before it did. He was diligent and up to a point capable, but his outlook was narrow, and he could hardly be expected to understand, still less
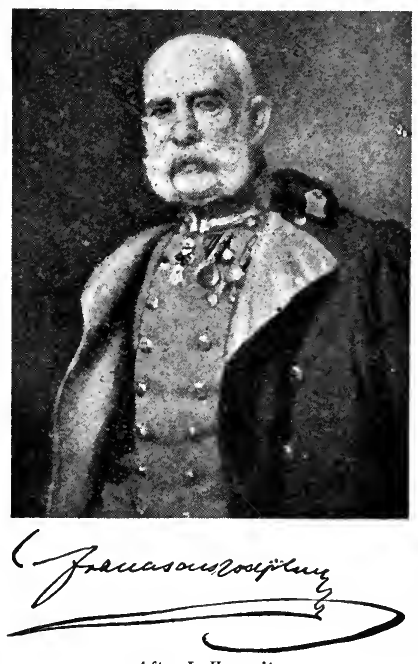

After L. Horowitz

to sympathise with, the liberal movement that shook Europe during his earlier years. His policy and actions, which have been described as opportunist, show little trace of consistency.

His carliest troubles were with Hungary ; it was not until 1867 that he was there recognized as king. His life story is that of Austria-Hungary, and to a large extent that of Europe, including Germany, which before the war of 1866 he tried hard to unite under his own overlordship. He died Nov. 21, 1916, and was succeeded by his grand nephew, the arch. duke Charles, who abdicated, Nov. 1918. His surviving family consisted of two daughters. See Austria - Hungary; Hapsburg ; consult also Lives, R. P. Mahaffy, 1908 ; F. H. Gribble, 1914; The Real Francis Joseph, H. de Weindel, Eng. trans. P. W. Sergeant, 1909.

Franciscans. Order of friars, also known as Friars Minor or Minorites, or Grey Friars, founded in 1209 by S. Francis of Assisi(q.r.).
The first general chapter, in 1219 , was attended by npwards of $\mathbf{5 , 0 0 0}$ members. The rule was solemnly $r$ a tif ied by Honorius III in 1223. A year later the order was established in England, at Canterbury. Following a relaxation of the strict rule of poverty, th e order was divided in to Conventuals, who lived in large convents under modified con. ditions; and Observantines, who adhered to the original rule. Known

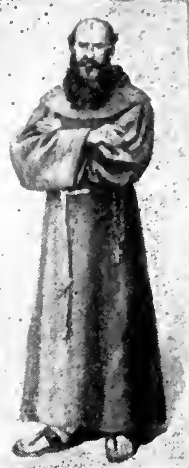
of the order
Franciscan. Dress

in France as Cordeliers, the Observantines subsequently divided into Observants, Reformed, Discalced, Recollects, and Capuchins.

In 1897 , as a result of the efforts of Leo XIII, while the Conventuals and Capuchins remained distinct, the other branches or families of the order were united under the name of Ordo Fratrum Minorum, or Friars Minor. The original dress of the order consisted of a coarse grey cloth habit, with pointed hood, under-tunic, drawers, and waistcord. Five popes and more than 50 cardinals have belonged to the order, which numbered among its members Cardinal Ximenes, S. Bonaventure, Duns Scotus, Alexander of Hales, Roger Bacon, and William of Ockham. Allied to it, as a second order, were the Poor Clares, and, as a third order, the Tertiaries. In the second half of the 14 th century its monasteries were computed at 1,500 with 90,000 friars. At the dis. solution the houses in England num. bered 64. See Monasticism; Poor Clares; Tertiaries; consult also Annales Minorum, L. Wadding, 1625-54; republ. with additions, Rome, 1731-1887. See Cowl, illus.

Francistown. 'l'own of the Bechuanaland Protectorate, S. Africa. In the Tati Concession, it stands near the Shashi river, $50 \mathrm{~m}$. N.W. of Tati, and near the border of S. Rhodesia.

Franck, César Acgoste (182290). French music composer. Born at Liége, Dec. 10,1822 , he studied at the Conservatoire there, and at Paris. After teaching for two years in Belgium, he settled in Paris in 1844, and devoted himself to teaching and composition. In 1858 he became organist at the church of S. Clotilde, and in 1872 
professor of the organ at the Conservatoire. He composed a large amount of music of varying merit, chiefly the oratorio Les Béatitudes, orchestral works, including Ruth, Redemption, and Rebecca, and chamber music, notably a quintet for piano and strings, and a string quartet. He died Nov. 8, 1890. Franck's influence upon his pupils was great, and he has beendescribed as the greatest of modern French teachers, and probably the greatest of church organists and composers sinco Bach. See Life, V. d'Indy, Eng. trans. R. Newmarch, 1910.

Franck, Sebastian (c. 14991542). German writer. Born at Donauworth, he was trained for the priesthood at Ingolstadt and Heidelberg. He had already taken orders when, about 1525 , he became a Protestant. He was ban. ished from Strasbourg on account of his opinions in 1531, and settled at Ulm; but the publication of his Guldin Arch, 1538, led to his expulsion therefrom in 1539 . $\mathrm{He}$ then went to Basel, and died there. His collection of German Proverbs, 1541, enjoyed a long popularity. His other writings are all remarkable for their freedom of thought, in which Franck was a pioneer.

Francke, AUgust HERMANN (1663-1727). German educationist. Born at Lübeck, March 23, 1663, he was trained at Erfurt and Kiel, and studied Hebrew at Hamburg. Settling at Leipzig, he established a kind of literary club, under the name of Collegium Philobiblicum. He taught Greek and Oriental languages at Halle University, where he established a paedogogium and orphans' house (1698), the success of which attracted much attention among philanthropists in England. Francke became famous through his lectures on the Bible. He wrote much on Biblical and educational subjects. See Faith's Work Perfected (Eng. trans. of Francke's Pietas Hallensis), ed. W. L. Gage, 1867.

Francolin oR SPUR-LEGGeD PARTRIDGE (Francolinus). Group of game birds, of which over forty species are recognized. Most of them are mottled with black, brown, and white ; they are found in Africa and S. Asia. and one species formerly occurred in Sicily, but appears to be extinct there now. They live among the high grass in the valleys.

Franconia (LAND of THE Frinks). Name given in the 9 th and 10 th centuries to one of the great duchies into which Germany was divided. It was the one founded and inhabited, as the people believed, by the Franks. The west-

central part of Germany, it was the district through which the Main runs, although a portion of it, in cluding the cities of Mainz, Worms, and Spires, was on the WV. side of the Rhine. Its capital was Frankfort.

The duchy had only a short life, as a few years after 1024, when its duke, Conrad II, became German king, it was broken up among various princes, especially the arch bishop of Mainz, and the bishops of Worms, Spires, and Würzburg.

\section{FRANCO-PRUSSIAN WAR, 1870-71}

J. Markham Rose, D.S.o., late Instructor, R. Mil. Academy, Woolwich

In addition to this general sketch there are articles on Metz, Sedan, and the other great battles of the war. See also Bazaine; Bismarck; Moltke; Napoleon III; William I; and the articles France; Germany

Prussia, desiring to lead the movement towards German unity, had an ambitious king in William I; a clever and not too scrupulous statesman in Bismarck; a great strategist in Moltke; and a sound military organizer in Roon. The short campaign of 1864 , in which Austria and Prussia overwhelmed Denmark and robbed her of Slesvig-Holstein, served Prussia as a practical lesson in her scheme of mobilisation, which she now laboured to improve. Two years later she showed Austria how much she had benefited by the experience, and taught the rest of Germany to look to Prussia as their head. The four great leaders of Prussia again used this war of 1866 as a training ground for perfecting their military organization, and prevailed upon the other German states, secretly, to place their troops under Prussian control.

France was ruled by Napoleon III, who had gained a small military reputation through the Crimean War, and his campaign in Italy in 1859 ; but the world generally, and Bismarck in particular, had discovered that he was not a great general. In pursuit of his ambition, he wished to push the French fron. tier to the Rhine, and hoped by mili. tary glory to remove his subjects' growing dissatisfaction with his inefficiency as a ruler. He further thought that Austria would join him to revenge 1866, and that Italy might also help him.

\section{Declaration of War}

Thus there were the makings of war if anything occurred to start it. On July 3, 1870, Prince Leopold of Hohenzollern-Sigmaringen was selected for the vacant throne of Spain. Napoleon feared a Prussian ised state on his Spanish frontier, and demanded that the idea should be abandoned. Bismarck knew that Germany was ready for war, and that France was not as ready as Napoleon believed, and by a tele. gram, which did not truly repre. sent King William's words, sent French feeling to fever point. Rulers on both sides desired war, and war was declared on July 19 . Both Austria and Italy declined to intervene. Napoleon believed his ministers' assurance that his army was " ready to the last gaiterbutton," whereas in reality it was badly trained and badly found, and the mobilisation plans were most imperfect; he showed his inability as a strategist in that his initial plan was to cross the Rhine and endeavour to separate the South German states from the Prussians, whom he could not believe they really loved. This was true in part, and, could he have been ready first, it was a possibility that a separated South Germany would not have proved such loyal allies to Prussia as they afterwards turned out to be.

Organization of Prussian Army

The Germans were organized in three armies. The first or northern one, under Steinmetz; the second, under Prince Frederick Charles, the "Red Prince" ; the third or southern army, under the Crown Prince. The first actual conflict of forces larger than reeonnoitring parties took place at Sarrebruck on Aug. 2, when the French drove back a few battalions and crossed the frontier. This fight was given undue prominence as a French victory, because it was the baptême de feu of the little Prince Imperial.

The positions of the opposing forces on Aug. 4 were as follows : The French were strung out along the frontier in Alsace-Lorraine, from Strasbourg in the S. to Sarrebruck in the N.; perhaps 150,000 E. of Metz; but the mobilisation was so incomplete and so confused that not even the French High Command knew where battalions were, or the precise number of troops in any division. Strasbourg 
and Metz were important fort resses, which should have been well supplied for a siege.

The crown prince's army was S. of Landau, assembled for the march which carried it over the frontier. The second army was marching through the Haardt Wald by Kaiserslautern. The first army, held back ky von Moltke, was cantoned between Neunkirchen, Tholey, and Lebach, making altogether a total of some 450,000 men.

On Aug. 6 came the first real clash of arms. To the S. the crown prince's army, which had driven in MacMahon's outposts from Wis sembourg on Aug. 4, defeated him severely on this day at Wörth, and drove his force headlong from the field. On the same day there was an important battle near Spicheren, where the advanced guards of the first and second armies forced back Frossard. So severe were these blows that nothing remained for Napoleon but to form "the army of the Rhine" round Metz, under Bazaine, while MacMahon gathered together fragments into another army at Châlons ; thus abandoning the whole of Alsace-Lorraine, except the fortresses, to the enemy.

\section{Disaster of Sedan}

The Germans, not entirely untouched by the two battles, for the French soldiers had fought well, and confronted by the new situation, paused for a moment before they pressed forward in overwhelm. ing strength. By Aug. 14 the German advanced guards interrupted a commencing retreat of Bazaine's troops from the $\mathbf{E}$. of Metz, and brought about the battle of Colombey-Nouilly, which seriously interfered with French plans. Two days later the second army, which had crossed the Meuse S. of Metz, again interfered with the proposed retreat on Verdun, by the battle of Vionville-Mars-la-Tour, and compelled Bazaine, on Aug. 18, to fight the battle of Gravelotte. Unsuccessful in this, he was driven inside the Metz fortifications.

With these reverses the second empire was tottering to its fall. The moral of the French troops was infected by the cry of "We are betrayed," and this feeling had its reflection, or its origin, in Paris. The emperor was with the army, doing little to save the situation; while the empress Eugénie in Paris was doing her best in a falling cause. MacMahon was now directed to effect the relief of Metz, and com. menced the desperate march $\mathrm{N}$. and E. which ended at Sedan.

The Germans, well informed of French movements, had left a suffieient investing force to hold Bazaine, and so liberated a for- midable army to deal with MacMahon. Caught up at Beaumont on Aug. 28, and forced back on Sedan with the Belgian frontier behind him, MacMahon fought a desperate losing action on Aug. 31 and Sept. 1. MacMahon was wounded, and on Sept. 2 de Wimpffen signed the surrender of the last imperial army in the field. Napoleon was present and became a prisoner of war. On Aug. 31 Bazaine made a desperate attemyt to break out of Metz, but was driven back under the guns of the place, where he remained until the surrender of his whole army on Oct. 27. Strasbourg, after a ferocious bombardment, had undergone a regular siege. Its commander, General Uhrich, held out until the inhabitants were in a state of star. vation and his defences were pierced. He surrendered to General Werder on Sept. 27.

On Sunday, Sept. 4, the empress fled from the Tuileries, and on the 5 th a republic was proclaimed, with General Trochu as president and governor of Paris, with full military powers for national defence; Jules Farre became minister of foreign affairs and Gam. betta minister of the interior. Energetic measures were taken for the defence of the capital and for the formation of a national army, but there were enormous difficulties to contend with. The German forces were moving forward practically unresisted to invest Paris, and probably at this time an opportunity was lost which would have saved both nations a vast amount of suffering and expense. On. Sept. 19 negotiations for an armistice were almost concluded by Bismarck and Jules Favre, but the chancellor demanded the surrender of Strasbourg, Toul, and Verdun; and these conditions the provisional government would not accept.

\section{The Siege of Paris}

The French position was practically hopeless. On Sept. 20 Paris was closed in. In the fortnight pos. sible for preparation, Trochu had swept into the place all available food, guns, and troops; raised volunteer corps from the inhabitants, and had done all that a man might to hold out for a long siege. The fortifications were formidable, but so were the German forces. 'The defence of a large town is no easy problem, since starvation is such an invaluable ally to the besiegers, yet Paris had a great spirit, and hoped greatly for relief from newly formed armies.

Gambetta escaped from Paris in a balloon, and from Tours roused the country to arms; but it is no easv task hastily to impro vise armies, however many highspirited men may be available. There were no great generals, no trained officer corps; arms and stores were lacking. An army of the north was formed about Soissons and Amiens under Faid. herbe, and a numerieally stronger Loire army about Orleans. By the beginning of December the Germans had the northern half of France in their grasp. They had taken the large and important fortified towns of Nancy, Stras. bourg, Metz, Reims, Dijon, Laon, Soissons, Orleans, and Rouen, and were operating under the able direction of von Moltke with wellfound armies in every direction. The army of the Loire was driven from Orleans on Dec. 3, and from that time became a negligible factor for the relief of Paris.

An army had been formed in the Vosges under the leadership of Garibaldi, and fighting in the neighbourhood of Dijon afforded a little distraction, but no real effect. The army of the north was severely defeated early in Jan., 1871. In the S.E. General Bourbaki had collected a considerable force to raise the siege of Belfort, but equal failure attended its efforts; and early in Feb. his army was com. pelled to retreat over the Swiss frontier and give up its arms.

\section{Germany's Peace Terms}

It was a terribly severe winter and the sufferings of the ill-found French soldiers were appalling, while the Germans were able to fight in comparative comfort. Paris during January was being regularly bombarded, and in addition was enduring the pangs of hunger. Disease and death were rampant, and the necessity for capitulation had become evident. General Trochu resigned, and Jules Favre was sent to arrange terms of surrender at Versailles, where William, now crowned as German emperor, had taken up his headquarters. Negotiations were opened on Jan. 24 ; a general armistice was proclaimed and the terms of surrender were definitely settled on the 28th. By the peace treaty, France lost her provinces of Alsace and Lorraine, and paid Germany a war indemnity of $£ 200,000,000$.

Bibliography. German Official Ac count, Eng. trans. F. C. M. Clarke, 1874-84; French Official Account, 1901, etc.; The Campaign of Sedan, G. Hooper (1887), repr. 1914; La Guerre, 1870-71, A. Chuquet, 1895 Bibliographie Générale de la Guerre de $1870-71$, B. E. Palat, 1896 Saarbruck to Paris, 1870 , a strate gical sketch, S. C. Pratt, 1904, The Franco-German War, 1870-71, F. B. Maurice, 1909 (in Camb. Modern History, vol. 11). 
Franc-tireur (Fr., free shooter). Term employed to designate the bands of men who, though uneonnected in any way with the regular troops, greatly harassed the Germans during the Franco-Prussian War. These bands wore no uniform, and, if detected, posed as civilians. Despite the fact that if caught they were immediately hanged, many alien French sympathisers served the country in this way, and it is estimated that not less than 35,000 men were so employed. The term francs-tireurs was also applied to organized bodies of volunteers, notably the Gardes Mobiles and an Italian contingent who cooperated with the French troops round $\mathrm{Or}$ leans in 1870 . At the best, francs tireurs are therefore organized corps of irregular troops, acting under a permanent leader, who wear some kind of uniform, if only a brassard, and who conform to the usages of war; while at their worst they are merely bands of tolerater assassins, whose conduct exasperates trained troops and results in innocent civilians suffering for their deeds. During the Great War the Germans made many accusations, more especially against the Belgians, of the employment of francs-tireurs against their invading armies.

Eraneker. 'Town of Holland. In the province of Friesland, it is $10 \mathrm{~m}$. W. of Lecuwarden, and is served by both rly. and canal. It has a celebrated school, the successor of the university that flourished here from 1585 to 1811 . S. Martin's, a 15th century building, is the chief church. There is a 16 th century town hall and an observatory. The town has small manufactures and a trade in agricultural produce. Pop. 7,642.

Frangip?ni. Name of a powerful Roman family. It arose in the 11 th century, and was conspicuous in the struggles of Guelph and Ghibelline in the two following centuries. Members of it still exist in Italy. Frangipani is also the name of a powerful scent, and of a kind of sweetmeat.

Frank Almoign. Term of French origin, meaning free alms. It is used for the kind of land tenure by which religious houses and corporations held thcir lands, and to some extent do so still. The idea behind it is that the land is held on the condition that, instead of military service, religious offices shall be performed. This form of tenure is very old, and was not confined to Fngland. There it was largely stopped by the famous Act of 1290 , which forbade any such tenures to be created save by the king. See Land Laws; Quia

Emptores; Tenure; consult also History of English Law, Pollock and Maitland, 2nd ed. 1898.

Frankau,Gilbert(b.1884). British author. Born April 21, 1884, the son of Arthur and Julia Frankau, he

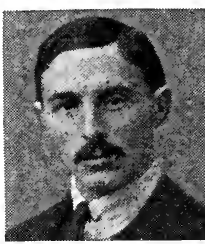

Gilbert Frankau, British author Russell

9 th E. Surrey regiment. In 1915 he transferred to the R.F.A. fighting at Loos, Ypres, and on the Somme. He was promoted staff captain for special duty in Italy, Oct., 1916, and in Feb., 1918, was invalided from the army. His pub. lications include One of Us, 1912 ; The Guns, 1916 ; The City of Fear, 1917; One of Them, and Peter Jackson, Cigar Merchant, 1919; Life-and Erica, 1925.

Frankau, Julia. British novelist, whowrote under the pseudonym of Frank Danby (q.v.).

Frankenau, BattLe OF. Fought between the Germans and the Rus sians, Aug. 23-24, 1914. While the Russian army of the Niemen, under Rennenkampf, was advaucing in Aug., 1914, into East Prussia from the N., the army of the Narev, led by Samsonoff, invaded that prov. from the $\mathrm{S}$. by three routes. One was along the rly. from Warsaw to Mlava and Soldau, on the opposite sides of the frontier; the second was by way of the rly. from Ossoveitz to Lyck; and the third lay across country to Lyck, whence Samsonoff struck S. of the Masu rian Lakes to Johannisberg.

His advance was rapid. Soldau and Niedenburg were quickly in his hands, and he then captured Allenstein, the headquarters of the 20th German Army Corps, which had taken up a strong position between Frankenau and Orlau, N.W of the Masurian Lakes. Samsonoff attacked it on Aug 23, 1914, and heavy fighting continued all day without a decision. The frontal attacks of the Russians failed, but next day the German line was outflanked on its right, and this threat, coupled with a determined renewal of the frontal attacks, forced the enemy to retire hurriedly on Osterode. Samsonoff's cavalry advanced N., and came within a few miles of Königsberg and also of Rennenkampf's troops, seeming to promise an early occupation of $\mathbf{E}$ Prussia. See Tannenberg, Battle of.
Frankenberg. Town of Germany, in Saxony. It stands on the Zschopau, an affluent of the Mulde, $32 \mathrm{~m}$. S.W. of Dresden. It is a manufacturing centre, and among its products are cotton, woollens, and silk-stuffs. Its dyeworks, of more than local renown, languished somewhat in the 20 th century. Pop. 13,576.

Frankenhausen. Town of Germany, in Schwarzburg-Rudolstadt ('Thuringia). It stands on a branch of the Wipper at the foot of the Schlachtberg, $27 \mathrm{~m}$. N. of Erfurt. It has extensive natural deposits and salt springs celebrated for the cure of rheumatic complaints, which are employed locally for thermal baths and exported for use as the basis of laxative salts. The buildings include a palace and a large secondary school. There is a local market for undressed wool, and several dye and glue works. Near here the rebellious peasants under Münzer were de. feated in one of the last battles of the Peasants' War (1525). A cave in which Barbarossa, surrounded by his warriors, is said to sleep, is in the neighbourhood. Pop. 6,600.

Frankeniaceae. Small natural order of herbs and small shrubs. Natives of temperate and warm regions, they are chiefly seashore plants. They bave jointed branches, small, opposite leaves, and small, solitary, regular flowers. The familiar sea heath (Frankenia laevis) of salt-marshes is a type of the order.

Frankenstein. Novel by Mary Wollstonecraft Shelley, first published anonymously in 1818, with the title Frankenstein, or the Modern Prometheus. It is the story of a man who succeeds in making a monster, and giving it life, and of the awful consequences. Frankenstein is the name of the man, not of the monster he creates.

Frankenthal. Town of Germany, in Bavaria. It stands on the Isenach, $7 \mathrm{~m}$. S.W. of Worms. It received a charter of township in 1577. It has a communication by canal with the Rhine, $3 \frac{1}{2} \mathrm{~m}$. distant. The place is distinguished by the width and regularity of its streets and its imposing public buildings, which include a handsome town hall. It has a considerable trade in wine and paper, linen and iron are manufactured, and its light beer is famous. Ironfounding and the manufacture of machinery, boilers, and toys are carried on. Pop. 18,779.

Frankenwald. North-western group of the Fichtelgebirge Mts. in Bavaria, situated between the rivers Saale and Main. The highest peak is the Döbraberg $(2,605 \mathrm{ft}$.). See Fichtelgebirge. 
Frankfort. City of Kentucky, U.S.A. It is capital of the state and the co. seat of Franklin co. On the Kentucky river, here spanned by a fine suspension bridge, $55 \mathrm{~m}$. E. of Louisville, it is served by the Chesapeake and Ohio and other rlys. In addition to the capitol, there are several state buildings, including an arsenal, penitentiary, library, a home for feeble-minded children, and a coloured normal school. A busy trade centre, Frankfort manufactures lumber products, carriages, glass, tobacco, flour, and shoes. 'The city dates from 1786, and became the state capital in 1792. Pop. 11,180.

Frankfort-on-Main. City of Germany, called by the Germans Frankfurt. It stands on the Main,

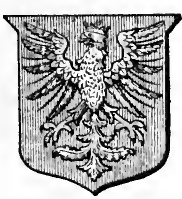
the city proper being on the right or N. bank, $24 \mathrm{~m}$. from its junction with the Rhine and in $t h e$ Prussian province of Hesse-

Frankfort arms Nassau. On the left bank is Sachsenhausen, a suburb with a history, while the city also includes Bockenheim, until 1895 a separate municipality, and populous modern suburbs all around. The city's population is 350,000 , about 32,000 being Jews, who have always been numerous.

The interest of Frankfort is in its buildings and historical associations on the one hand and in its banking and commercial interests on the other. It was, moreover, the birthplace of Goethe, while from it came the Rothschilds. In the centre of the old town, with its narrow streets, is the Römerberg or market place. The Zeil is the chief business street; the Markt contains the Goldene Wage, a 15th century house, and other historic buildings. Beyond the old town is the comparatively new town, begun in the 14th century. Beyond that are the Anlagen. or promenades, laid

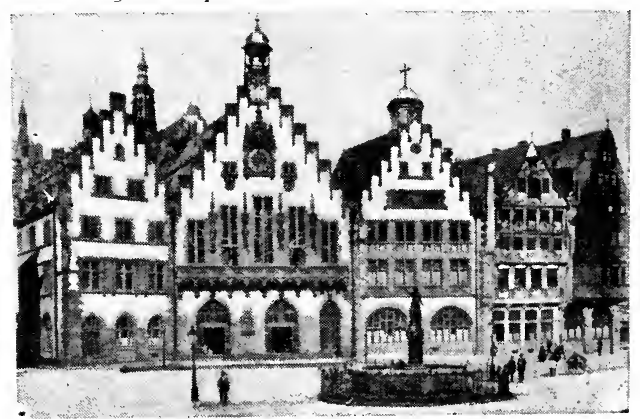

Frankfort-on-Main. The Romer or town hall, containing the famous Kaisersaal

out early in the 19 th century when the city walls were pulled down.

of the many churches, the cathedral was founded in the 9 th century. Much of the present edifice dates from the 14th century, but it was thoroughly restored in the 19 th century after a fire. In it the German kings were crowned after the pope ceased to perform that ceremony in Rome. Other churches are $\mathrm{S}$. Leonard's, with two 13th century Rom anesque towe r s;

$\mathrm{Nicholas;}$ the church of Our Lady; S. Peter's, with a fine interior; S. Paul's, and several synagogues. The town hall, called the Römer, which stands on the Römerberg, consists of a number of old houses linked together

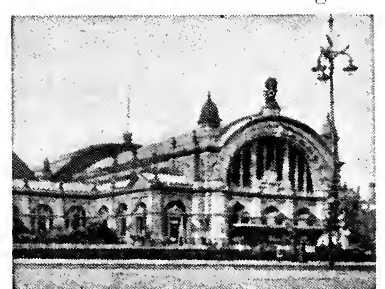

Erankfort-on-Main. The Central railway station

into one large building, to which modern additions have been made In it are two historically interesting apartments, the election cham ber, where the electors met to choose the German king, and the Kaisersaal, where the coronation feast, described by Schiller, was held. Th latter, now thoroughly restored, contains paintings of the emperors and kings.

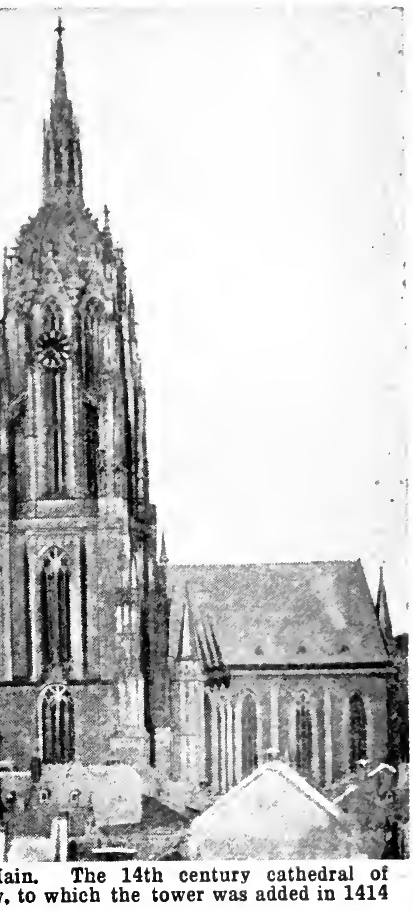

Other buildings inelude the Saalhof, which has a Romanesque chapel, the oldest edifice in Frankfort. The hall of the linen drapers still stands. The palace of the prince of Thurn and Taxis, where the federal parliament sat from 1816 to 1866 , is now part of the post-office pile. The opera house is a magnificent building of the 19 th century, while there are several theatres and many other places of amusement. The law courts is a fine modern building, and there is a new exchange or bourse and a fine central station.

of the museums the chief is the Städel Institution in Sachsen. hausen. This has some rare treasures, as well as a fine collection of paintings and antiquities. The linen drapers' hall houses the munieipal museum of paintings and antiquities. Other museums are the Bethmann Misseum and the museum of ethnology. The house of the Goethe family now contains relics of the poet and a large library of Goethe literature. The Roth. schild house still stands, this being the only existing remains of the Jews' quarter. Another museum is named after .J. C. Senckenberg, one of Frankfort's benefactors, who also founded a bospital and an almshouse.

Several bridges cross the Main. The most notable is the old bridge 
dating from the 14th century. On it are the mill, a statue of Charlemagne, and a crucifix crowned with a cock. The memorials include a fine one to Gutenberg and the early printers on the Rossmarkt, one to the Hessians who fell round the city in Dec., 1792, and one to Goethe on the Goethe Platz. The city has a zoological garden, and of its public grounds the finest is the palm garden. On the Römerberg is the Justitia Fountain dating from 1543 and restored in 1887. The Eschenheimer Tor, a gateway with a tower, is one of the few remains of the fortifications.

For centuries Frankfort has been a great commercial centre. It is now served by a network of railway lines, while the river adds to its facilities for transport. It has always been noted as a banking centre, while some of the earliest printing was done here. Two great fairs are held every year. Clothing, soap, chemicals, glass, leather, machinery, fancy goods, and other articles are manufactured in large quantities. There is a large trade in leather and other articles. Newspapers include the influential Frankfurter Zeitung.

Frankfort, the ford of the Franks, was a Roman and afterwards a Frankish settlement. Charlemagne and his successors, notably Louis the German, resided here and called here many of their diets. From the 12th century the German kings were elected here, and the Golden Bull of 1356 declared it to be the regular place for such elections. By this time it had taken a place among the free cities, and in the Reformation period the wealth and independence of the citizens were abundantly manifest.

The free city accepted the reformed teaching, joined the league of Schmalkalden, and was besieged by the forces of the emperor Charles V. The Swedes held it for a time during the Civil War. In 1806 Napoleon put an end to the privileges of the free city, but at the settlement of 1815 these were restored. It was the capital of a grand duchy (1810-14), the meeting place of the national parliament of 1848 , and the seat of the diet of the German Confederation. In 1866 Frankfort fought on the side of Austria, and as the penalty of defeat was incorporated in the king. dom of Prussia. A university was founded here in 1914. Frankfort was several times bombed during the Great War and after its con. clusion was occupied by the French April-May, 1920, during the tem. porary invasion of the Ruhr area by the German military party. They evacuated it, however, on
May 17 , as soon as the number of German troops in the district had been reduced to that laid down by the treaty of Versailles.

Frankfort-on-Oder. Town of Germany, in the Prussian prov. of Brandenburg. It stands on the left bank of the Oder, with the suburb of Damm on the right. It is about $50 \mathrm{~m}$. E. of Berlin. Of its old buildings the chief are the 13 th century church dedicated to S. Mary, and the town hall. Its numerous more recent buildings give $i t$ the appearance of a modern city. Frankforthas manufactures of machinery, chemicals, etc., but its prosperity is chiefly due to its trade. It is a port on the Oder, and also a big rly.junction; Frankfort was settled by merchants from Franconia in the 13 th century. It was then part of the electorate of Brandenburg, and for a time was a member of the Hanseatic League. Its situation has brought many sieges and sufferings upon it, and made it an important military centre before the Great War. From 1506 to 1811 there was a university here. Pop. 68,230.

Frankfort Parliament. Meet. ing of representatives of the German people at Frankfort-on-Main in 1848. In that year there was general unrest in Europe, and the idea of a closer union of the various German-speaking peoples was gain. ing strength. Certain prominent Germans met at Heidelberg and in. vited past and present members of the various diets and other important personages to meet at Frankfort. About 500 responded and made arrangements for calling an assembly that should be truly national and representative. It was agreed that each 50,000 persolls should send one member chosen by universal suffrage. The diet of the German Confederation gave its assent, and, although the various governments were more or less hostile, the elections went through.

The parliament met on May 18 , and after much discussion decided that for the present united Ger. many should be ruled by a regent who should choose his own ministers. The archduke John of Austria was elected to this office, and then the assembly began to discuss the fundamental laws of the proposed empire. Meanwhile Trussia and Denmark had come to blows ; the parliament ordered the Prussians to withdraw from Slesvig, but had no power to enforce this decree. The quarrel became so acute that civil war broke out in the streets and further meetings were only possible owing to the protection given by Prussian soldiers.
Discredited but not yet de. stroyed, the parliament decided on the fundamental laws and then turned to constitutional matters. Here trouble arose over the position of Austria, with its large nonGerman population. The majority were against admitting them to the new union, but Austria protested, and an alternative proposal was accepted-that the whole of the Austrian empire should be excluded and its relations to the rest of Germany specially regulated. Austria again protested, but this time in vain, for the idea found strong support in Prussia. Eventually it was decided to offer the crown to a German prince, who should be called German emperor. Austria and Bavaria objected, but the counter plan of an imperial vicar, an Austrian and a Prussian to fill the place alternatively, was rejected, and the majority chose Frederick William IV of Prussia as head of united Germany, the honour to be hereditary in his house. Realizing the strong op. position, he refused it.

The parliament, however, strug. gled on and tried to work the new constitution, although Prussia, following the example of Austria, soon withdrew her representatives. Many others resigned in May, 1849, and the few that remained went to sit at Stuttgart until they were ejected, June 18, 1849. The idea of a united Germany failed owing to the impossibility of ad. justing the rival claims of Austria and Prussia, a knot cut by the war of 1866. See Germany: History.

Frankfurter Zeitung (Frankfort Gazette). Founded in 1856 as the Frankfurter Handelszeitung (Trade Gazette) by Leopold Sonnemann, it became the first paper in the Gorman empire in authority and influence, the leading financial organ, and on foreign affairs a mouthpiece of the foreign office in Berlin.

Frankincense (old Fr. francencens, true incense). Fragrant gum exuded from several trees of the genus Boswellia. It is abundant on the Somali coast and in South Arabia. A cut is made in the tree trunk, and the weeping resin coagulates in breast-shaped globules which are scraped off and shipped to Bombay. Here the commodity is graded and re-exported to the various markets.

The ceremonial religious use of frankincense is of great antiquity, having been practised by the Egyptians, Persians, Babylonians, and Assyrians; by the Jews as a constituent of the incense of the sanctuary (Ex. xxx, 34), and by the Greeks and Romans. It was 
long employed in the East as an external application for tumours and sores, and, in China, as an internal remedy for leprosy and other diseases. See Incense.

Franking (Fr. franc, free). Free use of the postal service. To the extent of sending ten letters a day and receiving fifteen, it was a privilege granted to both the House of Lords and the House of Commons in 1764. With the introduction of penny postage in 1840 it was abolished, but letters are still franked by the public departments, and, if so franked, can be sent thereto free of charge. See Post Office.

Frankland, Sir Edward (182599). British chemist. He was born at Churchtown, Lancashire, Jan. 18,

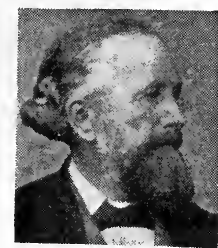

Sir E. Frankland,

British chemist
1825, and edu. cated at Lancaster gram. mar school, Royal School of Mines, Lon. don, and the universities of Marburg and Giessen. In 1850 he discovered the zinc compounds of methyl and ethyl, and next year was appointed professor of chemistry at Owens College, Manchester.

He was professor of chemistry at S. Bartholomew's hospital, London, 1857-63, and at the Royal Institution, 1863-67. His chief work was done as a member of the royal commission on the Pollution of Rivers, in a laboratory provided by the government. He died in Norway, Aug. 9, 1899.

Franklin (late Lat. francus, free). A freeman. The word was used in medieval England as a mark of distinction, though without any exact meaning. It seems to have referred primarily to a class of landholders between the noble and the more or less unfree; the coun. try squires of a later day. Such doubtless was the franklin in The Canterbury Tales.

Franklin, Battle of. Fought in the American Civil War (q.v.), Nov. 30, 1864. General Schofield, with 25,000 Federal troops, was ratreating to Nashville, Tennessee, when, as he was crossing the Harpeth river at Franklin, he was attacked by a Confederate army of 40,000 men under Hood. At first thrown into confusion, the Federals rallied, and, after a furious resistance, Schofield succeeded in withdrawing his men across the river. In no battle of the Civil War was greater determination or resistanee, shown on either side. The losses were very heavy ; those of the Federals being 2,326 killed, wounded, and missing, those of the Confederates more than 6,000 .

Franklin, BenJaMin (1706-90). American statesman and scientist. The son of an English immigrant, a tallow chandler, Benjamin Frank. lin was born at Boston, Mass., Jan. 17, 1706, and was apprenticed in 1719 to his eldest brother, a printer. $\mathrm{He}$ moved to Phila. delphia in 1723, and while working there as a compositor attracted the attention of the governor of Pennsylvania, Sir William Keith (1680-1749), who encouraged him to go to Fngland to buy printing materials wherewith to set up in business. Franklin accordingly made his way to London in 1725 , but Keith's promises proved illusory and he had to take em. ployment as a compositor. After a troubled eighteen months in London, he returned to Philadelphia, again as a printer's assistant.

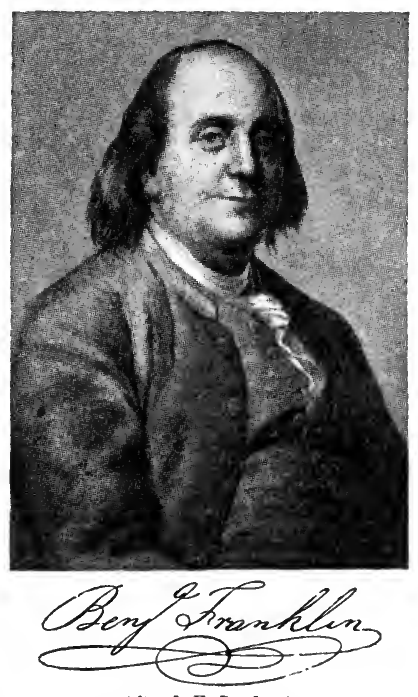

After J.H. Duplessis

In 1729 he purchased a weekly journal, The Pennsylvania Gazette. Three years later he issued his Poor Richard's Almanack, which continued to appear for 25 years, and was widely popular for its wealth of prudent maxims on industry and thrift. He became postmaster of the city in 1737 , clerk to the General Assembly from 1736-51, and a member from 1751-64, attracting notice by his scheme for intercolonial union at the Albany Convention, 1754.

Meanwhile Franklin had added scientific research to his many activities. About 1746 he began to investigate problems connected with electricity, his work leading to the invention of the lightning conductor in 1749. Earthquakes, meteorology, stoves and chimneys, ocean currents and navigation were all among the many subjects of his inquiries during these years : his experiments with the pouring of oil on stormy water and with agricultural fertilisers showed the versatility of his mind.

In 1757 he onee again crossed to England; this time as the agent of Pennsylvania in the colo. nial dispute with the Pennsylvanian proprietors. Franklin was widely welcomed, became known to many distinguished figures in political and literary life, and received degrees from the universities of Oxford, Edinburgh, and St. Andrews. In 1762 he went back to America, but 1764 found him again in London in his former capacity. In 1766 he gave evidence before the House of Commons which was largely instrumental in the repeal of the notorious Stamp Act. The unfortunate publication of certain letters entrusted to him for private circulation led to difficulties in London, and he returned to Phila. delphia in the spring of $\mathbf{1 7 7 5}$.

His old affection for the English oonnexion, weakened perhaps by this rebuff, turned into an active sympathy with the separationist policy. He was one of the five members commissioned to draft the Declaration of Independence in 1776, and in that year he went to Paris as commissioner for the colonies. He negotiated the alliance between America and France, and was then appointed plenipotentiary in Paris, where he remained throughout the war, negotiating the treaty of peace finally signed in 1783 . He returned to America in 1785 and took some part in framing the new constitution of the United States, retiring from public life in 1788 . He died at Philadelphia, April 17, 1790. J. E. Miles

Bibliography. Complete Works, including his Correspondence and unmutilated Autobiography, ed. J. Bigelow, 10 vols., 1887-88; Writings, ed. with Life and Introd., A. H. Smyth, 10 vols., 1905-7; Lives, J. T. Morse, 1890 ; J. Parton, 1892 ; Benjamin Franklin as an Economist, W. A. Wetzel, 1895; Franklin and his Press at Passy, L. S. Livingston, 1914 ; Benjamin Franklin, Printer, J. C. Oswald, 1917; Benjamin Franklin Self-revealed, W. C. Bruce, 1917.

Franklin, SiR JонN (1786-1847). British explorer. Born at Spilsby, Lincolnshire, April 16, 1786, and educated at Louth grammar school, he entered the navy as a midshipman in 1801, being present at the battle of Copenhagen. $\mathrm{He}$ distinguished himself in the service 
and took part, between 1818 and 1827, in three Arctic expeditions, during which he surveyed many

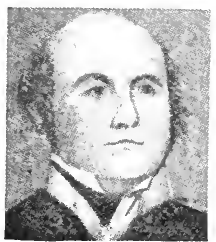
thousand miles of Aretic. A m e r i c a $n$ coast-line and the Saskatchewan, Coppermine and Mackenzie river basins. For these services he was pro. - Fother fercta moted cap. tain, knighted, 1829 , and awarded various scientific distinctions at home and abroad. From 1836-43 he was governor of Van Dieman's Land (Tasmania).

A new British expedition, consisting of the ships Ercbus and Terror, with Franklin in command, intended to explore the N.W. Passage, sailed from the Thames on May 19, 1845. The vessels were last sighted in Baffin Bay. Franklin had proposed to return in 1817 , and, no tidings being received from him, no fewer than 39 expeditions, four at Lady Franklin's expense, were sent forth from Great Britain and America between 1847 and 1857, in hope of rescuing the explorers. Some traces of them were found by Captains Ommanney and Penny, and Dr. Rae. In 1857 Lady Franklin equipped the yacht Fox and dispatched it to N.E. America under Captain, afterwards Sir, Leopold MeClintock. Two years were spent in search, and in June, 1859, a cairn was found at Point Victory in which was a record of Franklin's expedition down to April 25, 1848, with definite proof that he had discovered the N.W. Passage, and that he had died on June 11, 1847. Parliament voted $£ 2,000$ for the statue in Waterloo Place, London, and Lady Franklin erected the monument in Westminster Abbey. See Arctic Exploration.

Bibliography. Franklin's Narrative of a Journey to the Shores of the Polar sea in the years 1819 , 20,21 and 22, 1823; his Narrative of a 2nd Expedition, 1825, 26 and 27, 18:8 ; The Career, Last Voyage, and Fate of Sir John Franklin, S. Osborn, 1860 ; The Polar Regions, John Richardson, 1861 ; The Voyage of tho Fox in Arctic Seas in Search of Franklin and his Companions, Sir F. J. McClintock, pop. ed. 1908; Lives, A. H. Beesly, 1881 ; A. H. Markham, 1891 ; H. D. Traill, 1896.

Franklinite. Sometimes eonsidered an ore of zinc, but more properly an ore of iron. Its normal composition is peroxide of iron, 67 p.c. ; sesquioxide of manganese, 16 p.e.: oxide of zine, 17 p.e. It occurs in coarse, granular, massive form and in brilliant crystals fre'quently of large size. It is brittle and slightly magnetic, but blacker than magnetic iron ore, which it resembles. First recognized in deposits near the Franklin furnace at Hamburg, New Jersey, it is used in the manufacture of Bessemer steel.

Frank-marriage. In English law, a form of entailing land, now obsolete. It referred to land granted by a man to his daughter and her husband. This was free or franked from the usual feuda dues, except that of fealty, and so remained until the holder was removed more than four degrees of relationship from the overlord. See Land Laws.

Frankpledge. System by which a group of men were held re sponsible by the state for each other's misdeeds. The AngloSaxons called these associations frithborhs, and membership was imposed by law upon all freemen. William the Conqueror ordered every freeman to be in a frankpledge, which appears to have con. sisted of ten or twelve men, and later kings made like regulations. Sheriffs held periodical "views" of frankpledge, i.e. courts to see that the law was being obeyed. After a time the unfree were admitted to membership, and the frec dropped gradually out. The system was by then, say the 14th century, showing signs of decay, and it did not survive the advent of the Tudors, although courts for the view of frankpledge remained for some time longer, and in manorial court leets have one or two survivals to-day. See Jury.

Franks (late Lat. francus, free). Group of tribes dwelling in Europe in the 3rd century, who founded the kingdom of France, to which they gave their name. They are first mentioned in writing in reference to a victory obtained by Aurelian over some of them near Mogontiacum (Mainz) in 241.

The Frankish tribes were of Teutonic origin and were first found in what is now N.W. Germany and the Netherlands. They bore various names until by one of the accidents of history that of Franks began to prevail over the others and gradually supplanted them.

In the 4 th century or a little later the Franks were divided into two main branches : the Salian Franks around the mouth of the Rhine and the Ripuarian Franks higher up the river. They were first enemies and then tributaries of the Romans, and the decay of the Roman empire was their hour. The man to use it was Clovis, descendant of one Chlodio, who had led the Salian Franks into what is now France and had made Tournai his capital. Thirty years before he became king in 481 his tribe had sent warriors to that vast host that defeated the Huns in 451.

Clovis united many of the Salian Franks under his rule, and conquered much of Gaul. He made the Ripuarians, who had spread up the Rhine as far as Alsace, own his authority, and when their own king was murdered they took the Salian in his stead. Clovis was baptized as a Christian, and nominally at least the Franks were no longer pagans. His sons continued his career of conquest, and soon Frankland was a great district lying on both sides of the Rhine, the name being perpetuated in the German district of Franconia. Like Anglo-Saxon England, it was divided into more or less independent kingdoms, such as Austrasia and Neustria, but, in spite of civil wars, there was a certain brotherhood between them which facilitated the combination of several into one.

This union of Frankish tribes under Clovis and his descendants formed that Frankish realm which has so greatly influenced European history. It existed in one form or another from about 500 to about 900 , reached its height in the great but transient empire of Charlemagne, and from its ruins both France and Germany arose. It included parts of both, but soon a cleavage showed itself between $\mathbf{E}$. and W. Franks, and early in the 9 th century the one folk could not understand the speech of the other.

A definite division was made in 817 and soon afterwards the $\mathbf{E}$. Franks became Germans and the W. Franks became French. The boundary between them was not easily drawn; indeed, it may be said to have been a prime cause of a thousand years of intermittent European warfare. France added Celtic elements from the S. and W. to her Franks; Germany added Slavonic ones from the E. to hers, and for this and other reasons the two developed into distinct nations.

Gregory of Tours, the chief authority for the early history of the Franks, and other writers, describe the customs and habits of these people in peace and war, which do not seem to have differed very much from those of other Teutonic tribes. See France.

Franks, Sir Augustus WollasTON (1826-97). British antiquary. Born at Geneva, March 20, 1826, he was educated at Eton and Trinity College, Cambridge. After being assistant in the department 
of antiquities in the British Museum, he became keeper of medieval antiquities and ethnography, 1866. He was fellow, 1853, director, 1858-67, 1873-80, and president, 1891-97, of the Society of Antiquaries, was made F.R.S., 1874, and K.C.B., 1894. He applied large private means to purchasing porcelain and other objects of Oriental and medieval art, and en. larging the Henry Christy ethnographical collection. His own acquisitions were mostly presented or bequeathed to the British Museum. He died in London, May 21, 1897.

Frantz, Konstantin (1817-91). German publicist. From 1852-56 he was in the Prussian diplomatic service, but he retired in the latter year and turned his attention to the study of sociology and political economy. He advocated a union of the Central European powers against the rest of the world, and considered the future of the world to rest largely with Germany. His principal works are Der Foederalismus als das leitende Princip für die soziale, staatliche und internationale Organisation, 1879 ; Die Weltpolitik, 1882-83; and a contribution to Schuchardt's Die Deutsche Politik der Zukunft, 1899.

Franzen, Frans Mrkate (17721847). Swedish poet. Born at Uleâborg, Finland, Feb. 9, 1772, and educated at Åbo University, where he was later a professor of history, he left Finland in 1811, after the country had passed into the hands of Russia. He was for many years rector of a parish in Stockholm, and in 1834 was made bishop of Hernösand. He was one of the most widely appreciated of Swedish hymn-writers, and his ode to Count C. P. Creutz, the Finnish poet, was crowned by the Swedish Academy. He died Aug. 14, 1847.

Franzensfeste. An old fortress, one of a line of fortifications constructed to defend the Austrian frontier in Tirol. It commanded the railway line which passes between Innsbruck and the Brenner Pass and through the valley of the Puster to Klagenfurt.

Franz Josef. Glacier in the Southern Alps of New Zealand. It flows to within $600 \mathrm{ft}$. of sea level and discharges into the Waiho river only $15 \mathrm{~m}$. from the sea. It is $8 \frac{1}{2} \mathrm{~m}$. long.

Franz Josef Land. Archipelago in the Arctic Ocean, lying $\mathbf{N}$. of Novaia Zemlia and N.E. of Spitsbergen in lat. $80^{\circ}$ to $82^{\circ} \mathrm{N}$. and long. $42^{\circ}$ to $64^{\circ} \mathrm{E}$. The archipelago eonsists of about 100 small islands, the ehief of which are Graham Bell Land, Wilezek Land, MeClintockIsland, Alexandra Land and Crown Prince Rudolf Land.
They are mountainous, of voleanic origin, and largely glacier-covered; but on the shores and other fav. oured spots, mosses, poppies, saxifrages and other Arctic plants grow. The loftiest point rises to $2,800 \mathrm{ft}$. Bears, walruses, seals, foxes, and a large variety of birds inhabit the islands.

Diseovered by the Austrian explorers, Payer and Weyprecht, in 1872-73, the islands were further explored by Leigh Smith in 188182, the Jackson-Harmsworth expedition in $1895-96$, and by the duke of Abruzzi's expedition in 1899-1900. The sea on the $N$. is called Queen Victoria Sea; the wide opening $\mathrm{S}$. of it is known as the British Channel, and its westernmost point is Cape Mary Harmsworth. The islands are unin habited.

Franzos, Karl EMIL (18481904). German novelist. He was borm, the son of a Jewish doctor, in Podolia, Oct. 25, 1848 . Having educated himself, he entered the legal profession, but left it for journalism. After living for some years in Vienna, he settled in Berlin, where he founded, in 1886 , the fortnightly review, Deutsche Dichtung. His many works of fiction deal largely with the Jewish life of the country of his upbringing, and abound with pathetic incidents. Notable among his novels are The Jews of Barnow, 1877, Eng. trans. 1882; For the Right, 1882, Eng. trans. 1887; and Der Präsident, 1884, Eng. trans., The Chief Justice, 1890. In his Aus Halb-Asien, 1876, are many sketches of life in S. Russia and Rumania. He died Jan. 28, 1904.

Frascati. City and summer resort of Italy. In the prov. of Rome, it stands on the slopes of a wooded hill, at an elevation of about $1,000 \mathrm{ft} ., 15 \mathrm{~m}$. by rly. S.E. of Rome. The cathedral, founded in 1700 , contains a tablet to the Young Pretender, interred here in 1788. Among the many magnificent residences are the villas Aldobrandin i, Ruffinella, Torlonia, LancelottiandBorghese. In the neighbourhood are the remainsof numerous ancient villas, an amphitheatre, a theatre, and a re servoir belonging to the town of Tusculum, which was destroyed in 1191. Between the ruins of the ancient eity and Frascati, the villa of Cicero once stood, and on its site some monks in the 1lth century built a convent. Frascati is famous for its wine. Pop. 10,577.

Fraser. River of Canada, in the prov. of British Columbia. Rising in the Yellowhead l'ass in two branches, it flows N.W. for the first $160 \mathrm{~m}$. of its $800 \mathrm{~m}$. course ; it then takes a hairpin bend round the head of the Cariboo Mts., receiving the waters of the Nechaco at Fort George, and flows almost due $\mathbf{S}$. until it reaches Hope, after which it flows W. to its outlet in the Strait of Georgia at New Westminster. Important tributaries are the Thompson, Stuart, Nechaco, Chilcotin, Bridge, and Blackwater; among the lakes drained are the Stuart, Fraser, François, and Quesnel. It is notable for the salmon fisheries and hatcheries. It is navigable for only $80 \mathrm{~m}$. from its mouth. The area of the basin is 138,000 sq.m.

Fraser. Name of a famous Scottish family. It is supposed to be a corruption of Frisel and to be of Norman origin. Early Frasers settled in the south of Scotland in the 12th century, but soon they moved northwards and established themselves in the shires of Inverness and Aberdeen. 'They became very numerous, being one of the most powerful of the Seottish clans. Among the places owned by the Frasers was Lovat, and one of them, Hugh Fraser, was made Lord Lovat about 1430 . He was a grandson of Sir Simon Fraser, sheriff of Tweeddale, and from hin are descended the later lords L.ovat and a number of other branches of Fra. sers. Another branch of Frasers is now represented by Lord Saltoun, whose family name is commemorated in Fraserburgh. See Lovat, Lord ; Saltoun, Lord.

Fraser, JAMES (1818-85). British prelate. Born at Prestbury, Gloueestershire, Aug. 18, 1818, the

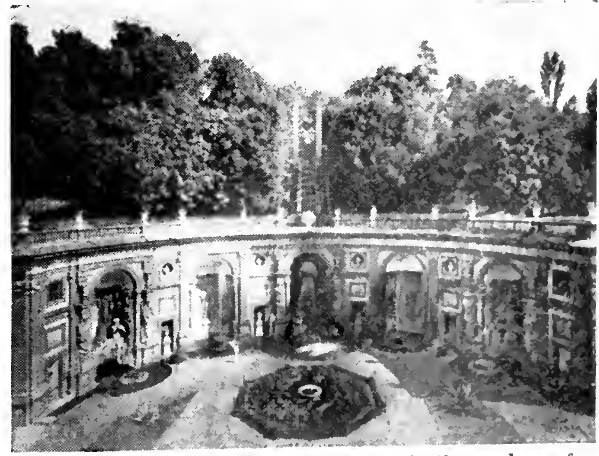

Frascati, Italy. Colonnade and cascade in the gardens of the Villa Aldobrandini 
son of a merchant, he was edu. cated at Shrewsbury School and Lincoln College, Oxford. His

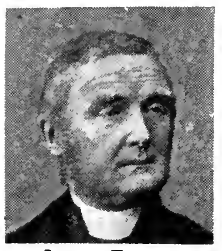

James Fraser British divine sc hol a rs hip won for him a fallowship at Orie l, a $\mathrm{n} \mathrm{d}$ having served for a time as tutor there, he was ordained in 1846. He held livings in Wiltshire and Berkshire, and was chancellor of Salisbury. In 1870 he was chosen bishop of Manchester, and he worked in that diocese until his death thero on Oct. 22,1885 .

He was the real founder of the diocesan organization, was chosen as arbitrator in several industrial disputes, and was unwillingly the defendant in a case arising out of ritualistic practice. Specially interested in education, Fraser had studied this subject thoroughly as an assistant commissioner in the diocese of Salisbury, and in 1868 he liad reported in an official ca pacity on education in Canada and the U.S.A. See Memoir, T. Hughes, 1887 ; Lancashire Life of Bishop Fraser, J. W. Diggle, 4th ed. 1890.

Fraserburg. Village of the Cape Province. It is $84 \mathrm{~m}$. N.W. of Fraserburg Road, a station on the rly. from Cape 'Town to De Aar, and is a sheep-farming centre. Pop. 800

Fraserburgh. Police burgh, seaport and fishing town of Aberdeenshire, Scotland. It stands on the W. shore of Fraserburgh Bay, and on the S. side of Kinnaird's Head, $47 \mathrm{~m}$. N. of Aberdeen, on the G.N.S.R. It is the chief centre of the Scottish herring fishery, and exports agricultural produce and imports coal. It has a large and good harbour, with piers and a breakwater. There are remains of the castle of the Frasers, while the town cross is worthy of notice. The town was named from Sir Alexander Fraser, who, in 1613 made it into a burgh. He also obtained permission to found a university here, and the buildings were begun, a tower erected for this purpose still standing. The Council owns the gas and water works, an isolation hospital, public abattoir and a free library. Market day, Tues. Pop. 10,574.

Fraserville. Town and watering place of Quebec, Canada, known also as Rivière $d u$ Loup. In Temiscouata co., it stands on the Rivière du Loup, near the junction of that river "with the $S$. Lawrence, $110 \mathrm{~m}$. N.F. of Quebec.
Here are the Fraser Institute, churches, schools, etc. The town is on the Inter-colonial Rly. and is the terminus of the Temiscouata Rly. Its industries include pulp mills, and the making of furniture, bricks, etc. The town is also a pleasure resort, trout fishing and caribou hunting being attractions for sportsmen, while steamers call bere. Pop. 6,774.

Fraticelli (dim. of Ital. frate, brother). Group of religious orders in medieval Italy. Originating in the Franciscan order in the 13th century, when the more zealous members of that order discountenanced the possession of money or property, it took a powerful hold on the popular imagination and gained many recruits. Carried away by their zeal, they regarded themselves as the true representa. tives of the Catholic church and elected popes, thereby bringing upon themselves the heavy hand of the Inquisition. Persecutions increased until 1449, when the constant imprisonments and executions deprived them gradually of their leaders, and the Fraticelli died out. See Hist. of the Inquisition of the Middle Ages, H. C. Lea, vols. ii and iii, repr. 1906 .

Fratricide (Lat. frater, brother ; caedere, to kill). Killing a brother or sister. In English law it is on the same footing as any other homicide, but in some ancient systems was a special species of crime, punishable more severely than killing a stranger in blood. See Murder.

Fratta Maggiore. Town of Italy, in the prov. of Naples. It is $8 \frac{1}{2} \mathrm{~m}$. N. of Naples, and is a favourite residential district of wealthy Neapolitans. The vineyards in the neighbourhood produce an excel. lent wine, silkworms are reared, and rope made. Pop. 13,720.

Fratton. District within the borough of Portsmouth. It has a station of the L.B. \& S.C. and L. \& S.W. Rlys., known as Fratton and Southsea. See Portsmouth.

Fraud (Lat. fraus, deceit). English law term, for which no comprehensive definition exists. The essence of the matter is deceit - some statement or suppression of fact in word or deed with intent to deceive. When a man sues on the ground of fraud, or claims property fraudently withheld from him, his right of action begins to accrue from the time he discovers the fraud, and not from the time it was perpetrated upon him. Some frauds are criminal, but not all. But a conspiracy to defraud is always criminal. If a person has been induced to enter into a contract, or to transfer property by fraud, he can always, on discovering it, have the contract or transfer set aside : but he must be careful to take steps immediately. And he cannot recover his property as against some innocent purchaser who has bought it without notice of the fraud.

Frauds, Statute of. English law passed in 1676. Its design was to substitute written for verbal evidence in large classes of transactions, and so diminish liability to fraud and perjury. Conveyances, wills and leases of land, except tenancies of less than three years, were required to be in writing and signed by the party or his agent. It was also enacted that no action should be brought upon certain agreements unless the plaintiff could prove the agreement by writing duly signed by the defendant or his agent.

These agreements were: (1) A promise by an executor or administrator to pay the deceased's debt or damages out of his own pocket ; (2) a guarantee ; (3) an agreement in consideration of marriage ; (4) a contract, sale of lands, or tene. ments or hereditaments, or any interest in or concerning them ; (5) an agreement not to be performed within a year from the making thereof. As to (3) it was soon held not to include a promise to marry; the consideration for which is not marriage, but a promise to marry by the other party. The section dealing with contracts for the sale of goods of the value of $£ 10$ and upwards has been repealed and almost re-enacted by the Sale of Goods Act, 1893; and other sections, which made writing necessary for a will of lands, have also been repealed, and the subject of wills generally dealt with by the Wills Act, 1837.

The statute and its policy have led to much litigation and difference of opinion. No doubt it was advisable to make written instruments and evidence compulsory, at any rate for wills, guarantees, leases and conveyances of land. It is questionable whether it was politic, having regard to mercantile usages, to include sales of goods within the purview of such a statute. Yet, as we have seen, this very section has been reenacted in modern times. It may be said, however, that in the Commercial Court the defence is very rarely set up that the contract is not evidenced by writing.

Frauenburg. City and port of E. Prussia, Germany. It stands where the Bande falls into the Frisches Haff, in the district of Königs berg, by rly. $42 \mathrm{~m}$. S.W. of Königsberg. Its interest is in its Gothic cathedral and its associa. tions. This, the cathedral of the 
bishops of Ermeland, was built in the 14 th century, and has a fine $W$. front. Copernicus was a canon here when he died in 1543. Pop. 2,522.

Frauenfeld. Town of Switzerland, capital of the canton of Thurgau. It stands on an eminence over,ooking the river Murg, near its confluence with the Thur, $26 \mathrm{~m}$. by rly. N.E. of Zürich. Its old castle has a 10th century keep, and its parish church dates from the 13th century. A prosperous town, it has iron industries, manufactures of machinery, firearms, leather, cotton fabrics, and gloves, besides a thriving trade in farm products, wine, and fruit. From 1712-98 it was the capital of Swit. zerland, and its abbot retained manorial rights until 1803 . The town was in the hands of the French and Austrians in 1799. The inhabi tants are German-speaking and largely Protestants. Pop. 8,105.

Frauenlob. Nickname by which Heinrich von Meissen (c. 1250 1318), German poet, came to be known. He is sometimes described as a minnesinger, and also as the founder of the Meistersingers at Mainz. He died at Mainz, and was carried to the grave by women of that city. He is supposed to have been called Frauenlob (praise of women) from his using the word Frau for woman rather than Weib.

Fraunhofer, JosePH voN (1787. 1826). German optician and physi. eist. Born at Straubing in Bavaria, the son of a glazier, he was apprenticed to a glass polisher, and eventually set up for himself as a maker and polisher of achromatic lenses. While working at this craft, at which he attained great skill, he taught himself mathematics and optics. In 1806 Fraunhofer was appointed optician in the mathematical institute at Munich, and later became the manager of another such institute, which he had helped to found. He died there, June 7, 1826.

Fraunhofer was responsible for great advances in the manufacture of lenses for telescopes and micro. scopes, while at the same time by his invention of the diffraction grating he opened up a new and fertile field of development for theoretical optics. But the discovery that has immortalised the name of Fraunhofer was that of the Fraunhofer lines. These lines had previously been noted by the English physicist Wollaston, but Fraunhofer not only discovered them independently, but studied them deeply, mapping several hundreds of them, and assigning to the seven most prominent lines the letters $A$ to $G$, by which they are still known. He also mapped the lines which he found in the spectra of several of the fixed stars, and from the fact that in no two cases were the lines exactly the same, he concluded that they must corre. spond to some definite property of the sun or star, and that they were not due merely to the effect of the earth's atmosphere. Fraunhofer thus became the founder of the science of spectroscopy (q.v.).

Fra unhofer Lines. Lines discovered by Fraunhofer. When a beam of sunlight that has been admitted through a thin slit is passed through a prism, so as to be drawn out into a spectrum, and this spectrum is examined through a telescope, it is found to be crossed by a multitude of dark lines. Careful investigation has revealed the existence of some 10,000 lines in place of the 600 originally counted. The position of each line corresponds to a definite angle of refrac. tion of the light, and thus to a definite wave-length, and the presence of any given dark line implies that light of that wave-length has failed to reach us. The reason for this failure in many cases is the absorption of a particular wave. length by some element in the sun's atmosphere.

It was established by the physicist Kirchhoff that the characteristic wave-lengths of light which an element gives out when heated to incandescence are just those which it absorbs when cooler. For example, the flame of burning sodium examined through a spectroscope shows a bright double line, which corresponds in position to the dark double line in the solar spectrum known as the "D" line. The presence of the " D" line in the solar spectrum thus indicates the existence of sodium vapour in the sun's atmosphere. See Spectroscopy.

Fraustadt (Polish, Wszowa) Town of Poland. It is $14 \mathrm{~m}$. N.E. of Glogau, formerly in Prussian Poland. It is an important com. mercial centre where, sugar refining, tanning, dyeing, and milling are carried on, and the nucleus of a mining district. A feature of the landscape is the number of wind. mills. Fraustadt is divided into a new and an old town. In the vicin. ity King Augustus of Poland was defcated by Charles XII of Swe. den (Feb. 13, 1706).

Fray Bentos. River port of Uruguay and capital of the dept. of Ris Negro. It stands on the Uruguay river, $172 \mathrm{~m}$. direct N.W. of Montevideo. It is a pleasant modern town, laid out in 1859 , with wide thoroughfares and fine public builclings and abattoirs. In the centre of a stock-raising dis- trict, it has a large export trade in extract of meat and animal products, and contains the chief factory of the Liebig Extract of Meat Co. Pop. 10,000. Its official name is Independencia.

Frazer or GREAT SANDY. Island off the E. coast of Queensland, Australia. It lies between Hervey and Wide bays, is barren, but has excellent fishing.

Frazer, Sir James George (b. 1854). British anthropologist. Born in Glasgow, he was educated privately and early devoted him. self to researches into the social institutions, mythology and folklore of mankind in all ages. His main work is embodied in The Golden Bough, first published in 1890, of which revised and ex. panded editions have since appeared. It forms the most com. plete work on comparative religion yet written. His other books in clude Studies in the History of Oriental Religion, 1906; The Scope of Social Anthropology, 1908 ; Totemism and Exogamy, 1910 ; and Folk-lore in the old Testament, 1918. He translated Pausanias's Description of Greece, 1898 : and edited Addison's Es. says, 1915. Long a fellow of Trinity College, Cambridge, he was made professor of social anthro. pology, Liverpool, 1907, in 1914 was knighted, and made O.M., 1925.

F.R.C.O. Abbrev, for Fellow of the Royal College of Organists.

F.R.C.P. Abbrev. for Fellow of the Royal College of Physicians.

F.R.C.P.E. Abbrev, for Fellow of the Royal College of Physicians, Edinburgh.

F.R.C.P.I. Abbrev, for Fellow of the Royal College of Physicians, Ireland.

F.R.C.S. Abbrev, for Fellow of the Royal College of Surgeons.

F.R.C.S.E. Abbrev, for Fellow of the Royal College of Surgeons, Edinburgh.

Fréchette, Louis HoxorÉ (18391908). French-Canadian poet. He was borm at Levis, Quebec, Nov. 16 , 1839, studied for the law and became a member of the Dominion Parliament in 1874. He was a busy journalist, and wrote several prose works, including Christmas in French Canada, 1899; but his reputation rests chiefly on his poems, Mes Loisirs, 1863 : La Voix d'un Exilé, 1869 ; Pêle-Mêle, 1877 ; Les Oiseaux de Neige, 1879; Les Oubliés, 1886 ; Poésies Canadiennes: and Feuilles Volantes, 1891. He died June 1, 1908.

Freckles. Rounded or irregular spots of yellowish or brownish pigment in the deeper layers of the epidermis, most common in fair and red-haired persons. Freckles 
are permanent in some people, but in many they appear in the summer months, following ex posure to sun, and disappear in the winter. Persons desirous of avoiding the eondition should wear veils in strong sunshine. Freckles may be removed or lessened by appli. cation of a dilute solution of perehloride of mereury, but only under medieal advice.

Fredegond or Fredegunde (d.597). Frankish queen. Of humble lirth, she attracted the attention of Chilperic 1 of Neustria, who murlered his wife, probably at her instigation, in order to marry her. A forceful eharacter, she dominated her lusband, had his sons murdered in orler to make a future for her own boy, and carried on a relentless feud with Brunhild, queen of Austrasia. In 584 Chilperie died, murdered probably by his faithless wife, who beeame the ruler of Neustria in the name of her younger son, Clothaire II. By wars she had added something to its area when she died in 597 .

Frederic, HAROLD (1856-98). Ameriean novelist and journalist. Born Aug. 19, 1856, he beeame a

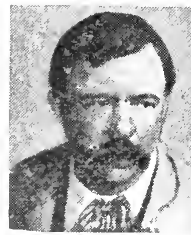

Harold Frederic, American novelist and the Baltimore and Ohio Rlys. It eontains a state sehool for deaf mutes, a women's college, and its in dustrialestablishments include canneries, brush, leather, and tobaceo factories, foundries and planing mills. It was settled in 1745 , and ineorporated in 1817. Pop. 11,225.

Frederick. Christian name of Teutonic origin. It means rich in peaee, and Friedrich, the German form, has been long a favuurite name in Germany, borne by many rulers. From Germany it passed into England in the time of the Georges, although similar names, formed from the Anglo-Saxon frith, peace, had been in use in early times, e.g. Frideswide. The Italian form is Federigo.

Frederick I (c. 1124-90). German king and Roman emperor, known from the redness of his beard as Barbarossa. Son of the duke of Swabia, nephew of the German king Conrad III, and a mem. ber of the family of Hohenstaufen, Frederiek beeame duke of Swabia in 1147 and was ehosen lking on his unele's death in 1152 . Three years later he was erowned emperor by the pope at Rome. His empire ineluded Germany and parts of Italy; the kings of Poland. Bohe. mia, and Hungary at one time or another reeognized him as their superior; and by his marriage he added Franche Comté to the lands inherited from his father and uncle. In Germany Frederick showed himself a strong and able ruler. $\mathrm{He}$

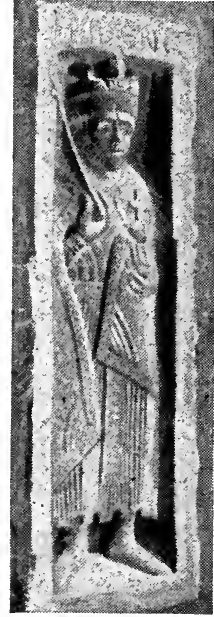

Frederick I, German king, from a relief at Reichenhall, Bavaria would tolerate no rival to his own power, and easily erushed $\mathrm{t} \mathrm{h}$ e rebellions engineered by t u r b u le n t princes.i ' $\mathrm{T} \mathrm{h}$ e duke of Bavaria washumiliated, and so, in 1181, was the power. ful duke of Saxony, Henry the Lion, his duehy being broken up and he him. self sent into exile. A little later the pope instigated some of the German prelates to rebel, but again the emperor was too strong for them.

The eventful years of Fred. eriek's life, however, were spent in Italy, where he earue into conflict with the rich eities of Lombardy. In 1158 began his long quarrel with Pope Alexander III. In 1160 the emperor was exeommunieated, Theron Ware), a keenly analytieal study of American religious life as seen by an agnostic and a Roman Catholie priest. Other works are The Copperhead, 1894; and March Hares, 1896.

Fredericia. Seaport of Denmark, in the S.E. of Jutland. It stands on the Little Belt, at its N.W. entrance, $14 \mathrm{~m}$. N.E. of Kolding, and is eonnected with that town and Esbjerg by rly., and with Middelfart in Funen by steam ferry. It manufactures eotton goods, hats, tobaceo, and ehicory, and exports eggs, meat, and fish.

Founded in 1652 by Frederick III, Fredericia was destroyed by the Swedes in 1657; re-fortified in 1709 , it was besieged in 1848-49 and 1864 , when it was again partly destroyed. A statue eommen. orates the Danish vietory over the silesvig.Holstein army in 1849 . Pop. $14.22 \mathrm{~s}$

Frederick. City of Maryland, U.S.A., the eo. seat of Frederick co. ft is $46 \mathrm{~m}$. N.W. of Washington, and is served by the Pennsylvania

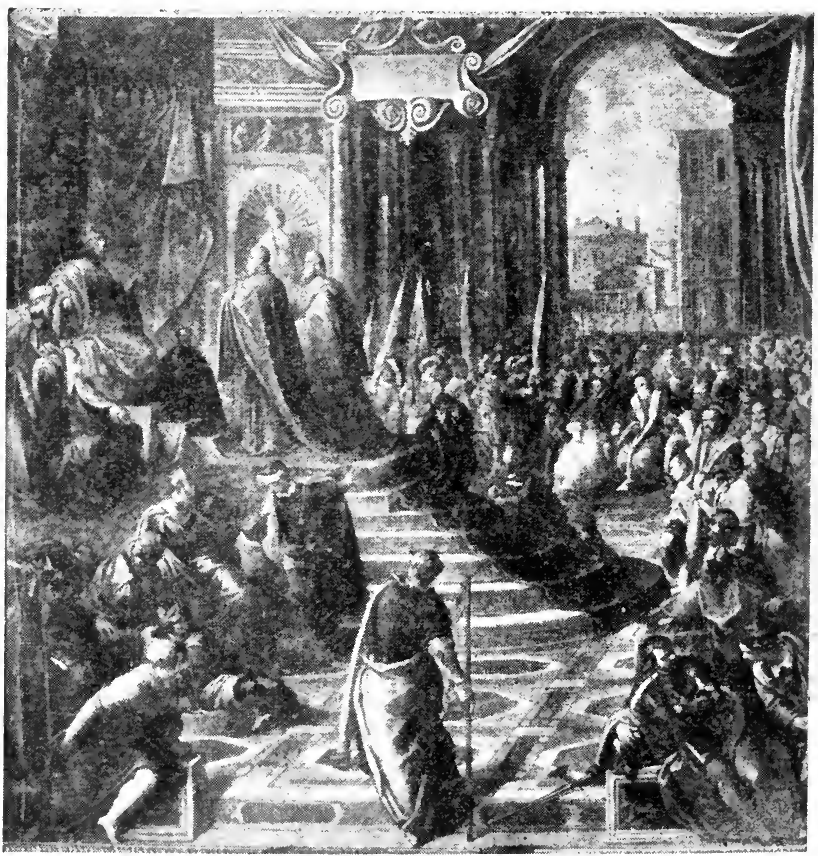

Frederick I. The delegates of the Doge and Pope Alexander III appearing before Frederick Barbarossa to resist his claims. From the picture in the ducal palace, Venice 
but he set up one anti-pope after another, and once entered Rome with an army and secured the coronation of his nominee. This success, however, was transitory, and soon his army was destroyed and he himself became a fugitive. To cow the cities he placed his own officials therein, and in 1162 stormed and humiliated Milan, but a few years later came the central disaster of his reign. The cities formed against him the Lombard League, an association blessed by the pope, and on May 29,1176 , the rival armies met at Legnano.

Frederick was totally defeated and fled from the field, after which no alternative was left to him but to sue for peace. A truce with the league became permanent a few years later, and in 1177 he signed the treaty of Venice with Alex. ander III. He had various dis. putes with Alexander's successors, but his power in Italy was never the same again. In 1189 he set out on a crusade, and on June 10 , 1190 , was accidentally drowned in a river in Cilicia.

Frederick was a commanding personality with marked ability and generous instincts, fearless, just, and devout, and his memory was long cherished by the Germans. But his reign was unfortunate for the Empire, and his costly cam. paigns in Italy didmuch to reduce it to impotence. See Empire; Papacy.

A. W. Holland

Frederick II (1194-1250). Ger. man king and Roman emperor. Son of the emperor Henry VI and grandson of Frederick I, Frederick was born in Italy, Dec. 26, 1194 , heir to the splendid Hohenstaufen inheritance and to that of his mother, Constance, the heiress of Sicily. Educated with more than usual care, his varied abilities earned for him the designation of stupor mundi, the wonder of the world. In 1196 he was chosen German king, and when his father died two years later he beeame king of Sicily and a ward of Pope Innocent III.

In 1212 , following an invitation from some of the princes, Frederick left Italy to supplant Otto IV in Germany, and was there crowned king by his partisans. After six years the old struggle between Welf and Hohenstaufen ended in his favour with Otto's death in 1218. In 1220 he was crowned emperor at Rome, and after spending some years in governing Sicily and fighting in Italy he tardily fulfilled his promise to go on crusade. In 1228 he reached the Holy Land, and, having already taken the title of king of Jerusalem, was crowned there as soon as he had obtained possession of the city and its neighbourhood. Returning to Europe, Frederick

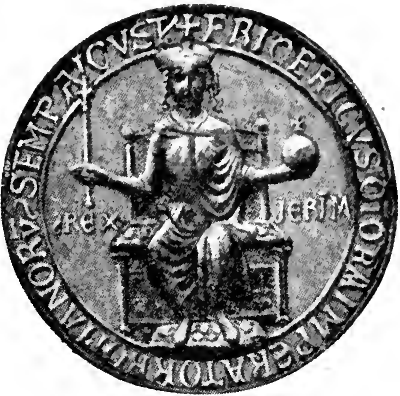

Frederick II. The emperor's seal as king of Jerusalem

was faced again with the hostility of the pope. Beginning soon after 1214, this was due chiefly to the emperor's evident intention of uniting Sicily and Gernıany, a course strongly resented by the papal court. Frederick was strong enough to force the peace of San Germano on Gregory IX in 1230 , after which he brought Sicily completely under his personal rule. In Germany he pursued a contrary policy, for there, by the privilege of Worms, 1231, he gave the princes a charter of independence.

The concluding years of Fred erick's reign were sad and unfortunate, not unlike those of Henry II of England. In 1231, and again somewhat later, his eldest son Henry had revolted; these risings were easily suppressed, and his second son, Conrad, was named as his successor. About 1239, how ever, began his last and greatest quarrel with the papacy. Excommunication he faced with a smile of contempt, but it was more serious when the pope allied him. self with the Lombards and worked upon the turbulent princes of Germany. War broke out both in Germany and Italy. In the former anti-kings were found and crowned; in the latter the emperor's troops were utterly routed at Parma in 1248. Struggling to the last against a ring of foes, Frederick died at Fiorentino, Dec. 13,1250 . His splendid tomb is in the cathedral at Palermo.

Frederick was thrice married. His second wife was Yolande, the heiress of Jerusalem, and his third was Isabella, a daughter of John of England. Besides his lawful children, he had several illegitimate ones, notably Enzio, king of Sardinia, and Manfred. The emperor, who wore six crowns, made a great impression on his age ; his court in Sicily was an intcllectual centre; in religious affairs he was tolerant, and in most other matters also in advance of his age. See Hist. of Frederick II, Emperor of the Romans, T. I. KingtonOliphant, 1862 ; Stupor Mundi, Life and 'limes of Frederick II, i. Allshorn, 1912. A. W. Holland

Frederick III (141;-93). (icrman king and Roman emperor. A prince of the house of Hajsburs. Frederick was chosen (ierman king in 1440 , and was nominal ruler of the country for over 50 years. He was lethargic and indifferent, and under him the Empire lost what power and prestige it had retained. His feeble attempts to secure the kingdom of Hungary and Bohemia failed, and he was for a time deprived of Austria, and was un. able to check the Turkish inroads. For some time before his death, on Aug. 19, 1493, he had ceased to take any part in the government of the country, which he left to his son Maximilian I, he himself being im. mersed in study and contemplation of the future greatness of his family. Frederick was the last emperor to be crowned in Rome, 1452.

Another and earlier German king is sometimes called Frederick III. A son of King Albert I, he was a Hapsburg. In 1314 a minority of the electors chose him as German king, and at once he was involved in war with the other king, Louis of Bavaris. He was defeated and taken prisoner, being released on acknowledging his rival. On this account he is not usualiy reckoned in the succession of German kings. He died Jan. 13, 1330. See Louis IV.

Frederick (1831-88). German emperor. Son of the emperor William I, he was born at Potsdam, Oct. 18, 1831 . After studying at Bonn he tra velled, and in 1855 w a s betrothed to Victoria, princess royal of England, whom he married in 1858. In politics he strongly

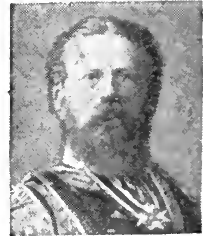

Frederick German emperor opposed Bismarck. In the Austrian war, 1866, he commanded an army at Sadowa. In command of an army in the war of 1870 , he fought at Wörth and Sedan, and took part in the siege of Paris.

Frederick was a strong advocate for the establishment of the Ger. man Empire, though his ideals differed eonsiderably from those of Bismarck. The Liberal party hoped great things when he eame to the throne, but he was attacked by cancer of the throat, and was obliged to go to Nice in 1857. On 
the death of his father in March, 1888, he succeeded to the throne, which he had only occupied for ninety-nine days when he died at Potsdam, June 15, 1888. He was succeeded by his son William II. His family consisted of two sons and four daughters. The former were William II and Prince Henry of Prussia; the latter were Charlotte, the wife of Albert, duke of Saxe-Meiningen; Victoria, the wife of Adolf, prince of Schaumburg-Lippe; Sophia, wife of Constantine, king of Greece ; and Margaret, wife of Prince Frederick Charles of Hesse. He is sometimes known as Frederick III because he is the third Frederick among the Prussian kings. See Frederick, Crown Prince and Emperor, $\mathbf{R}$. Rodd, 1888, and Life of Emperor Frederick, S. Whitman, 1901.

Frederick. Name of eight kings of Denmark. Several of them were comparatively unimportant personages, but the more important are noticed separately below.

Frederick III (1609-70). King of Denmark and Norway. Second son of Christian IV, he succeeded his father in 1648, having previously been bishop of Bremen and Verden. In war with Sweden, 1657 -60 , Denmark lost many islands and her territory on the Swedish part of the peninsula. In 1660 the people granted him absolute powers and made the monarchy hereditary instead of elective. $\mathrm{He}$ died in Copenhagen, Feb. 6, 1670.

Frederick IV(1671-1730). King of Denmark. Son of Christian V, he succeeded his father in 1699 . His reign was marked by successive wars against Sweden, but he was forced to sign peace when Charles XII besieged Copenhagen, 1700. In 1709 he again went to war, cap. turing Stralsund and Tönningen. By the Peace of Copenhagen, 1720, he had to surrender his gains for a money payment, and his last years were spent in the work of carrying out many much needed internal reforms.

Frederick VI(1768-1839). King of Denmark and Norway. Son of the insane Christian VII, he acted as regent from 1784 , and became king in 1808. His part in the maritime confederation of Den mark, Russia, and Sweden led to the destruction of his fleet by Nelson at the battle of the Baltic, 1801 . His unsatisfactory attitude to. wards Napoleon caused the bom. bardment of Copenhagen and capture of the Danish fleet in 1807 . His alliance with Napoleon brought about the loss of Norway in 1814 . Denmark became bankrupt and did not recover for some years. Himself not free from the taint

of insanity, Frederick had capable ministers, and his reign was marked by political and legal reforms.

Frederick VII (1808-63). King of Denmark. Son of Christian VIII, he succeeded his father in 1848 .

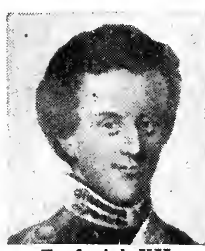

Frederick VII, King of Denmark stcin led to the revolt of that duchy in 1848 . Frederick was the last king of the Oldenburg dynasty. He died Nov. $15,1863$.

Frederick VIII (1843-1912). King of Denmark. Son of Christian IX, he was educated at a Danish $\mathrm{g} \mathrm{r}$ a $\mathrm{m} \mathrm{m}$ a $\mathrm{r}$ school, and at $\mathrm{O} x$ ford. $\mathrm{He}$ took part in the war against Prussia and Austria over Slesvig-Hol. stein, 1864. In 1869 he married Louisa, daughter of Charles

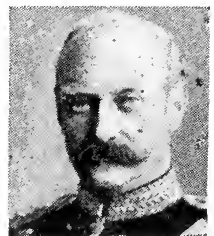

Frederick VIII King of Denmark $\mathrm{XV}$ of Sweden. He succeeded his father in 1906 and died suddenly at Hamburg, May 14, 1912. In 1905 his second son became king of Norway as Haakon VII.

\section{FREDERICK THE GREAT OF PRUSSIA}

The central incident of the reign was the elector's elevation to the rank of king. Taking advantage of the emperor's military needs, he won from him this grant, and on Jan. 18, 1701, he crowned himself king of Prussia at Königsberg. His troops fought for several years against France, and this and other reasons threw the finances of the country into disorder. $\mathrm{He}$ died Feb. 25, 1713, leaving an only son, Frederick William J, who was the father of Frederick the Great. The second of his three wives was Sophia Charlotte, sister of George I.

Frederick I (1657-1713). King of Prussia. The son of Frederick William, elector of Brandenburg and through his mother related to the Orange family, he was born at Königsberg, July 11,1657 . $\mathrm{H}$ is father married again, and there was some jealousy between Fred. erick and his

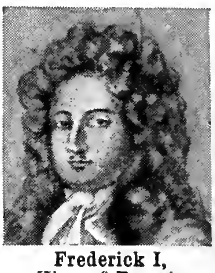

King of Prussia

stepmother and her offspring; the affair led to the voluntary exile of the young prince, while his father bequeathed parts of his lands to his younger sons. In 1688 Frederick became elector, and by a judicious use of money he persuaded his halfbrothers to give up their shares, thus securing the whole of the electorate.

\section{Major G. W. Redway, Author of The War of Secession}

With this article may be read those on Prussia: France; Germany, those on Frederick's battles, e.g. Leuthen, Prague, Rossbach, and those on his contemporaries, e.g. Catherine of Russia, the Emperor Joseph II, and Voltaire. See also Europe: Seven Years'War

Born at Berlin, Jan. 24, 1712, Frederick II of Prussia, known as Frederick the Great, was the son of Frederick William I. As a boy he did not share his father's military proclivities, and broke away from the parades of a cadet company of young noblemen which had been established for him to drill, in order to study music and philosophy.

$\mathrm{He}$ was to have married in his teens the Princess Amelia of England, but the influence of Austria prevailed with his father, who mated him in 1733 with the princess of Brunswick-Bevern. Meanwhile, Frederick, harassed at home by his royal father, who at table would spit in the dish to prevent his children eating their fill, and once attempted to strangle Frederick for refusing to resign his rights to the succession, ran away from court. He hoped to escape to Paris, but was caught, tried by court-martial, and sentenced to death. His companion Katte was actually beheaded, Frederick faint. ing at the sight.

The year after his marriage Frederick joined Prince Eugene in his last campaign on the Rhine. Then he entered into correspondence with Voltaire, and wrote the Anti-Machiavel, in which he set forth the duties of a sovereign as "the first servant of his people." $\mathrm{He}$ had become reconciled to his father, after whose death-May 31, 1740 - he ascended the throne. In the same year the emperor Charles VI was succeeded by his daughter Maria Theresa, who declined to recognize Frederick's claim to Silesia, arising out of political bargains made by his great-grandfather, Frederick William, called the "Great Elector." 
The new king of Prussia at once went to war. Marching up the Oder, he took Breslau in December, placed his army in winter quarters, and in the spring of 1741 met the Austrians near Brieg. At the battle of Mollwitz (April 10, 1741) the Austrian cavalry drove the Prussian horse off the field, and the king took flight with them; but Marshal Schwerin had 60 guns and solid infantry with a superior musket, and at sundown the Austrian general, Neipperg, ordered a retreat southwards to Niesse. Frederick was thus left in posses. sion of Silesia. Meanwhile, France, Bavaria, and Saxony had sided with Frederick, and their armies joined him in Moravia. The Austrian army, however, had not been disposed of, and on May 17, 1742, Prince Charles of Lorraine brought the Prussians to action at Chotusitz, S.W. of Königgrätz. Frederick won the battle by a resolute advance with his right wing after his left had been defeated, and so initiated those enveloping movements that have characterised Prussian tactics.

Frederick now hoped to settle down to enjoy his possessions, his flute-playing and literary correspondence, and to improve his army. He rose at 4 a.m. and put on uniform and the high boots which he only discarded once a year-at his wife's court on her birthday. By 9 a.m. he had finished work with his secretaries, and then gave audience to aidesde-camp and private individuals. He dined at twelve, keeping cooks of different nations to prepare special dishes, and drinking champagne. Then he walked rapidly till 4, when he dealt with state and education matters, and at 6 held a concert. By 11 the king was abed.

Meanwhile, Austria, having drawn to her side England and Hanover, was making headway against France, but the Austrian successes were inimical to Prussia, and Frederick, in support of his ally, moved an army into Bohemia. Marching up the Elbe through Saxony, he captured Prague (Sept. 8,1742 ), but was outmanoeuvred by Prince Charles and Marshal Traun, and compelled to retreat into Silesia. But on June 4, 1745 , at Hohenfriedberg, he attacked the Austrians under Prince Charles, and threw them back into the Riesengebirge. On Sept. .. 30 Frederick met Prince Charles again at Soor on the Elbe, and again drove the Austrians westward. In Dec. he concerted the measures by which Prince Leopold beat the Austro-Saxons at Kesselsdorf, and then Frederick entered the Saxon capital, where a treaty was signed on Christmas Day, 1745 , by which Austria resigned all claim on Silesia. But in the autumn of 1756 Frederick was compelled to draw the sword against a coalition of all the continental powers, and begin the contest known as the Seven Years' War.

The state of Prussia at the close of the struggle in 1763 has been painted by Macaulay in his well.

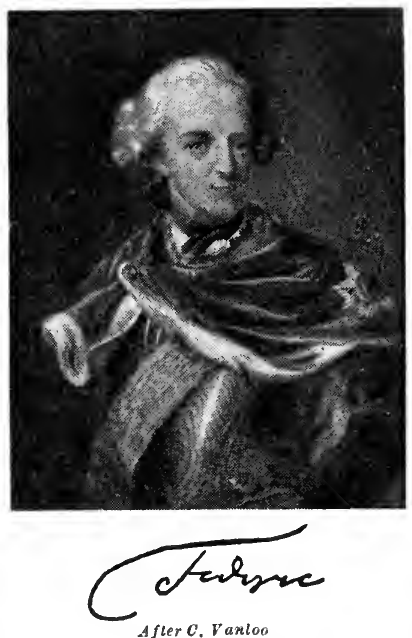

known essay on Frederick the Great. The king set about the work of reconstruction with his accustomed vigour. He was now fifty, but was to reign for another 23 years as a benevolent despot. No department of church or state was immune from his interference. He would clap a judge into jail, or appoint a cardinal for his Roman Catholic subjects, or keep a general in arrest for weeks. He set up loan offices, built an opera-house, and put his artillery horses to the plough, in the intervals of instructing ambassadors and publishing poetry. History has condemned him for his share in the partition of Poland in 1772, but in fact all but one-seventeenth part of that deso. lated country went to his two neighbours, and for years Poland had been virtually a province of Russia.

In 1779 Frederick took the field for the last time, for Austria was now ruled by Joseph I, who was bent on reviving the old claim to Silesia. Frederick and his brother Henry attempted an invasion of Bohemia, but the Austrians under Loudon and Lacy had entrenched $50 \mathrm{~m}$. of country so that the two Prussian armies could not unite. The campaign came thus to an inglorious end through the mediation of Catherine of Russia.
Frederick attended manoeurres in 1785 , and caught a chill from which he never recovered. $\mathrm{He}$ died childless at his palace of Sanssouci, Aug. 12, 1786, and was succeeded by his nephew, Frederick William II.

Bibliography. History of Frederick II of Prussia, Thomas Carlyle, 6 vols., 1858-65; abridged ed. A. MI. D. Hughes, 1916 ; Life, F. 'T. Kugler, Eng. trans. E. A. Mloriarty, repr. 1877; Hist. of Prussia (11341757), H. Tut tle, 1884-96; Frederick the Great on Kingeraft (i.e. Les Matinées du roi de Prusse : French original with Eng. trans.), ed. J. W. Whittall, 1901: Frederick the Great and the Rise of Prussia, W. F. Reddaway, 1904; Life of Frederick the Great, N. Young, 1919.

Frederick. Name of five electors palatine of the Rhine. They belonged to the family of Wittels. bach (q.v.). Frederick I ruled from 1451 to 1476 ; Frederick II, called the Wise, ruled from 1544 to 1556 , having before his accession been prominent in German affairs; Frederick III, elector from 1559 to 1576, made Calvinism the dominant faith in his electorate; Frederick IV ruled from 1583 to 1610 .

Frederick V (1596-1632). Elec. tor palatine of the Rhine and nom. inal king of Bohemia. A son of the elector Frederick IV, and grandson of William the Silent, Frede. rick became elector in 1610 and married, $1613, \mathrm{~F} l \mathrm{iza}$. beth, daughter of James I of Great Britain palatine of the Rhine By descent and training Frederick was a leader among the Protestants, and as their nominee was chosen king of Bohemia, Nov. 4, 1619. His rival, the emperor Ferdinand II, was, however, too strong, and the first stage of the Thirty Years' War was marked by Frederick's defeat near Prague, Nov. 8, 1619.

He was driven from Bohemia, the Palatinate was taken from him. and he was deprived of his position as an elector. From 1623 until his death, Nov. 29, 1632, Frederick remained an exile. He was the father of Sophia, electress of Hanover, and of the cavalier, Prince Rupert. On account of his short stay in Bohemia he is often called the Winter King.

Frederick I (1369-1428). Elector of Saxony. About 1388, when he succeeded to some part of the family lands in central Germany, Frederick began to take a leading part in the affairs of the country, 
and assisted the Emperor Sigismund against the Hussites. For those services he received, in 1423 , the duchy of Saxe-Wittenberg, the modern Saxony, and the attached dignity of an elector, a connexion of great importance both for Saxony and for Frederick's descendants. He died Jan. 4, 1428, his successor being his son, Frederick II, a comparatively unimportant person, who reigned from 1428 until his death, Sept. 7, 1464.

Frederick III (1463-1525)

Elector of Saxony, known as the Wise. Beginning his reign in 1486 , Frederick soon became prominent in German polities, and might have succeeded Maximilian I as emperor in 1519 had he so desired. He was anxious to improve the methods of governing Germany, but is best known for his friendship with $\mathrm{Lu}$. ther, whom he appointed to a chair in his own university at Wittenberg. After Iuther's memorable defiance of the Cburch, the elector protected him from his enemies. Frederick died May 5, 1525.

Frederick (1707-51). Prince of Wales. The eldest son of George II, he was born Jan. 6,1707 , his

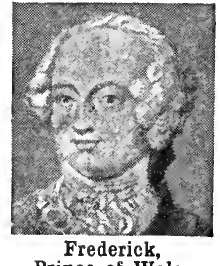

Prince of Wales father being then crown prince of Hanover. From 1714 , when his grandfather became king as George I, until in 1729 he was made prince of Wales, he was called duke of Gloucester. Frederick is important only as the centre of the opposition to George II, and as the father of George III. $\mathrm{He}$ and his father were constantly at variance on financial and other matters, and in 1737 the prince was banished from court. He replied by setting up a court of his own at Norfolk House, St. James's Square, and this became the resort of all who were opposed to George II and Sir Robert Walpole. He died March 20, 1751. In addition to George III he left four sons and two daughters by his wife, Augusta, daughter of Frederick, duke of Saxe-Gotha, who lived until $\mathbf{1 7 7 2}$. The sons were Edward, duke of York (1739-67), William, duke of Gloucester (1743-1805), Henry, duke of Cumberland (1745-90), and Frederick (1750-65). See Memoirs of the Reign of George II, Horace Walpole, 1847; A Forgotten i'rince of Wales, H. Curteis, 1912.

Frederick Augustus I (17501827). First king of Saxony. Son of the elector Frederick Christian, he was born at Dresden, Dec. 23,

1750. In 1763 he became elector, and in 1769 began personally to rule. His early years were marked

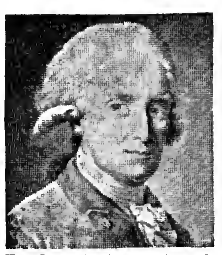

Frederick Augustus I, King of Saxony by a wise and jus t conduct of affairs, leading to a pros. perity whieh was in ter. rupted by the French Revolution. He had gained something by a short war against Austria in 1778, but he kept neutral on other occasions until in 1793, as a German prince, he joined in the war on France. He was out of it from 1796 to 1806 , when, after Prussia's defeat at Jena, he made peace with Napoleon, and in 1806 he took the title of king.

As an ally of Napoleon, his Saxons were in arms from then unti the end, for which action a high price was paid. 'The king was present at the battle of Dresden, and after Leipzig his capital and king dom were in the power of the allies and he himself their prisoner. The congress of Vienna took from him a large part of Saxony, about 7,800 sq. m., but he kept the title of king. Until his death, May 5, 1827, he did his best to help his people to recover from the ravages of war.

Frederick Charles (1828-85). German soldier, known as the Red Prince. A son of Prince Charles of Prussia and a grandson of Frederick William III, he was therefore a nephew of the emperor William I. Born March 20, 1828, he was trained from a child for the

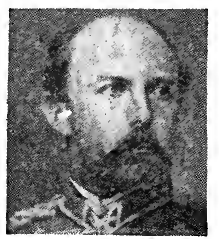

Frederick Charles, German soldier army, both at Bonn and with his regiment. Heserved Prussia against the Danes in 1848, and was with the Prussian force that invaded Baden in 1849 , being there wounded. In 1864 he led a corps into Denmark and was in supreme command during the later stage of the struggle against the Danes.

A scientific soldier and keen on his profession, the prince was closely associated with Moltke and his work. He rose from one com. mand to another, and from 1860 to 1870 he was at the head of the iron corps of Brandenburg, which attained under him its later reputation. In 1866 he was chosen to command an army in the war against Austria, and was largely responsible for the Prussian victory at Sadowa. In 1870 he was put in charge of one of the three armies that marched into France. He had a considerable share in bringing about the surrender of Bazaine and the fall of Metz, after which he conducted the operations against the French on the Loire, his great success here being at Le Mans. Made field-marshal in 1870 , his last post was that of inspector of cavalry. He died June 15, 1885.

The prince was a soldier of great energy, sparing neither himself nor his men in his efforts to improve the condition of the Prussian army. He appears to have been somewhat difficult to work with and his relations with his royal kinsfolk were not always harmonious. He married a princess of Anhalt, and one of his daughters became the duchess of Connaught. $\mathrm{He}$ owed his nickname to the colour of the uniform be habitually wore.

Frederick William (16201688). Elector of Brandenburg, known as the Great Elector. Born in Berlin, Feb. 16,1620 , the son of the elector George William, he passed $\mathrm{much}$ of his youth in the Netherlands, a stay that was re sponsible for $\mathrm{h}$ is marriage with Louise, a

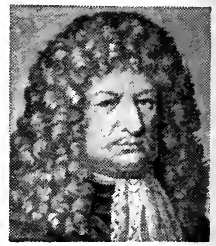

Frederick William, burg princess of Orange, 1646. In 1640 he became elector, and his first duty was to free Brandenburg from the horrors of the 'Thirty Years' War. He did this, and from the peace of 1648 to his death he saw his land growing in prosperity.

He organized the army, founded the navy, welcomed industrious immigrants, started colonies in Africa, and encouraged trade. $\mathrm{He}$ had great influence in European affairs, and helped William of Orange's invasion of England in 168s. He added to his land both east and west. The peace of 1648 gave him part of Pomerania, Prussia was firmly joined to Brandenburg and Cleves, and Jülich was secured. He died at Potsdam, May 9, 1688, and was succeeded by his son Frederick, lst king of Prussia.

Frederick William was the real founder of Prussia, for which his reign, autocratic though it was, was wholly beneficial. He was a Protestant and a supporter of the Em. pire, but neither sympathy was allowed to stand in the way of his main ambitions. See The Origins of the Kingdom of Prussia, A. W. Ward, 1908 (in Camb. Modern Hist., vol. v). 
Frederick William I (16881740). King of Prussia. Born Aug. 15,1688 , he was a son of Frederick

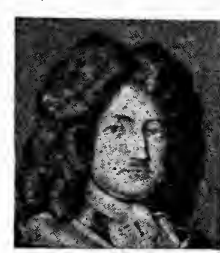

$I$, and related through his mother to George I of Great Britain. In Feb., 1713, after a some. what strict upbringing, he became king of Frederick William I, Prussia. In King of Prussia

the name of economy, he was continually cut. ting down expenses, although he spent much on the celebrated col. lection of giants for his army, which he raised to a high state of efficiency.

Frederick was a successful ruler, and greatly improved the condition of Prussia. He provided a more efficient administration; and with an increased revenue old debts were paid off. Trade was en couraged by restricting manufactured imports, and by other methods in harmony with current theories, while E. Prussia was peopled with industrious settlers. He secured Pomerania from Sweden, and was concerned in the various European alliances of the period. He founded a number of schools and, in a somewhat orthodox way, was a friend of learning. He died May 31, 1740. His wife was a princess of Hanover, and his son was Frederick the Great, and, although the king was by no means a wise parent, the wealth and the army that he left laid the foundations of his son's successes. See History of Prussia, H. Tuttle, 1884.

Frederick William II (1744 97). King of Prussia. Born in Berlin, Sept. 25, 1744, he was a grandson of Frederick William I, and a nephew of Frederick the Great. In 1757 his father, Prince Augustus William, died, and for the next 29 years he was the heir to the Prussian throne. Well educated, he passed this period occupied with his pleasures, chiefly music, troubling little about affairs of state. In Aug., 1786, he became king. In external affairs, Prussia was engaged in watching the progress of the revolution in France, and from 1792-95 in fighting against that country, not, however, with any great determination. A share of Poland was acquired, and there was a campaign against Holland. But in these matters the king was not the leading spirit, nor even the head of the army.

Before his accession he had become a Rosicrucian, and it was a member of this curious fraternity, Johann Christof Wöllner, who really ruled Prussia, his chief as. sistant being another Rosicrucian, Johann Rudolf Bischoffswerder. These men spared no efforts to crush liberty of thought, ostensibly in the interest of the Christian faitl, and in so doing they counter. acted the popularity gained when the king ordered the abandonment of some of the French ideas intro. duced by Frederick the Great. Frederick William, who died Nov. 16, 1797, was twice married, and had several mistresses. See A Mystic on the Prussian Throne, G. Stanhope, 1912.

Frederick William III (17701840). King of Prussia. Born Aug. 3,1770 , he was the eldest son of Frederick William II by his second wife, a princess of Hesse-Darm.

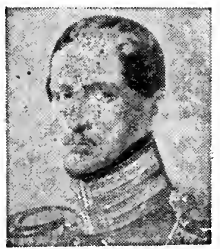

Frederick William III,

King of Prussia stadt. He was well educated and had served in the field when he became king in 1797. He suffered the hu. miliation of Jena and of the surrender of $\mathrm{much}$ of Prussia to Napoleon. But in 1812 he called upon his people to rise, and saw the victories and enthusiasms of the war of liberation. He took part in the European conferences of 1815 and after, but, as a rule, merely as an echo of the tsar Alexander I.

At home he showed a dislike for the current liberal movements, but died before Prussia had been seriously disturbed by them. $\mathrm{He}$ did something, however, to im. prove the administration of his lands, especially those acquired in 1815. He died June 7, 1840. His wife was Louise, a princess of Mecklenburg-Strelitz, and it was she who, more than the king himself, helped the ministers to free the country from the misfortunes of 1807. She died in June, 1810.

Frederick William IV (17951861). King of Prussia. The eldest son of Frederick William III, he was born Oct. 15,1795 . He saw a little military ser. vice in 1814, but his main interest was in arts and culture generally. He had been well and carefully educated,

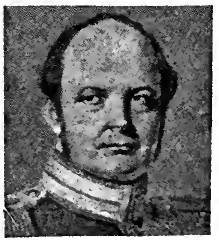

Frederick William IV, King of Prussia After J, C.Otto and showed a After J, C.Otto In 1840 Frederick came to the throne. Although he had some 'sympathy with the liberal movements of the age, he was a strong believer in maintaining the old order, including the divine right of his own position. He showed sense in acting with much more tolera. tion than his father.

In 1848 , during the rising in Berlin, Frederick William appeared, with some loss of dignity, as an enthusiast in the popular cause, but this was a passing phase. He refused, probably wisely, the new crown offered to him by the Ger. man princes, and the union was delayed until 1871. Next followed a return to the policy of hostility to Austria, but when this meant war he drew back, preferring ratler to give way in the convention of Olmütz. Later he carried forward a little the plan of constitutional reform in Prussia and was concerned in the international matters of his time. In 1857 the king's mind became deranged, and until his death, Jan. 2, 1861, his brother acted as regent.

Frederick William (b. 1882). German prince. The eidest son of the ex-Kaiser VVilliam II, he was

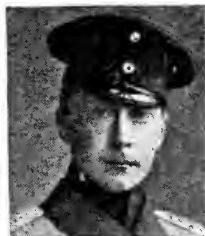

Frederick William, x-Crown Prince of Germany born Hay 6,
1882 , and in
1888 , on his
f a the r's ac-
cession, became
crown prince.
He was edu-
cated for the
throne, served
in the army,
and was loaded
with honours.
When the Great

War broke out he was given a high command and was nominally the head of a group of armies on the west front. He did not in any way distinguish himself, although from time to time his name was mentioned in official accounts of rictories. On the collapse of Germany in 1918 the crown prince associated himself with his father's abdication and took refuge in Holland. In 1903 he was married to Cecile, duchess of Mecklenburg. He published his Memoirs in 1922, and in Nov., 1923, returned to his estate in Silesia

Fredericksburg. City of Virginia, U.S.A., in Spottsylvania co. On the Rappahannock river, $60 \mathrm{~m}$. $\mathrm{N}$. of Richmond, it is served by the Potomac, Fredericksburg, and Piedmont, and other rlys. It con. tains Fredericksburg College, a state Normal school, two public libraries, and a monument to the mother of Washington. Waterpower is obtained for industrial purposes from a dam 300 yards long just above the city. Flour, woollen and silk goods, carriages, leather, 


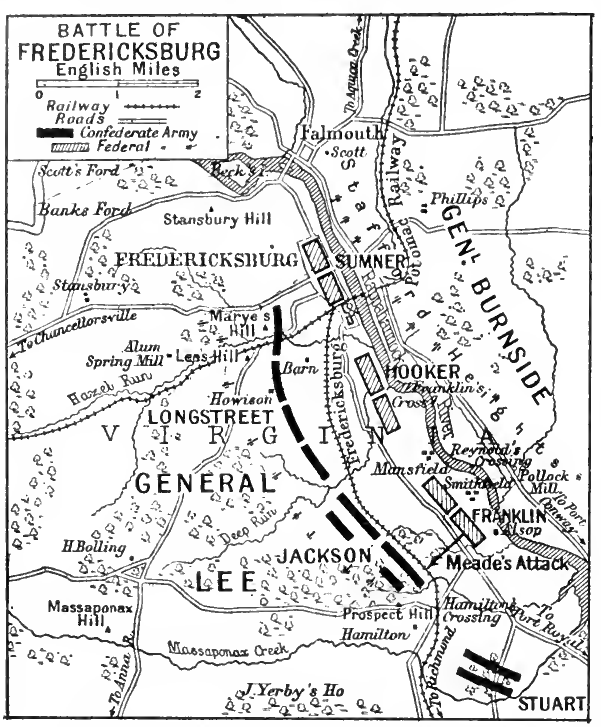

Fredericksburg. Map showing the disposition of forces in the American battle of Dec. 11-15, 1862
Lee's artillery consisted of rifled guns, Napoleons, and smooth bores. The Federal grand divisions were composed of six army corps, those under Couch (2nd) and Willcox (9th) constituting Sumner's command; those of Stoneman (3rd) and Butterfield (5th) were under Hooker: those of Reynolds (Ist) and Smith ( $6 \mathrm{th})$ under Franklin.

The Federal generalissimo might have reinforced these six corps by postponing his attack, for Siegel's (11th) and Slocum's (12th) corps were on their way to join shoes, and cigars are among the hin. For nearly a month the two manufactures. The town, incor- armies had been face to face, and porated in 1782, was the scene of most careful preparations had been an important battle during the made on both sides, but since Lee American Civil War. Pop. 5,874.

Fredericksburg, BatTle of. Fought in the American Civil War, Dec. 11-15, 1862, between the Federals under Burnside and the Confederates under Lee. It took place on the S. bank of the Rappahannock, near Fredericksburg. The object of the Federals, who were on the $\mathrm{N}$. bank of the river, was to cross and gain the road to Rich. mond, the Confederate eapital, but the Confederates barred the way. The Ferlerals numbered 125,596 against the Confederates 85,175 , an insufficient majority for attack moreover, the Confederates had a better supply of officers.

General Lee's army was organized in two corps under Longstreet (1st) and Jackson (2nd) respectively, and a cavalry division under Stuart. Burnside had formed his army in three grand divisions under Sumner (right), Hooker (centre), and Franklin (left). A bend of the river enabled the Federals to bring under the fire of their heavy guns on Stafford Heights a considerable part of the opposite bank, including the town of Fredericksburg, which eaused the Confederates to withdraw to a range of low hills about $2 \mathrm{~m}$. from the river, where Lee, on a front of $7 \mathrm{~m}$. or $8 \mathrm{~m}$., constructed defence works and emplaced his guns to sweep all the approaches. On the extreme right was Stuart's cavalry, in the centre Jackson's corps, and on the left Longstreet's. ing a salient where the ground in rear had been deemed impenetrable through a deep ravine and thick undergrowth. This obstacle, however, was overcome by Meade's division, which got in rear of Lane's and Archer's brigades, and captured part of the supporting brigades under Gregg and Thomas.

In military history this battle is remarkable as exhibiting the power of passive defence when time has been allowed for entrenching. It shows the natural results of a succession of vague orders and the lack of resolution, and the danger of frontal attacks was once again exemplified. It has been said that the defending general missed his opportunity for a decisive counter-attack, but according to Jackson, the Federal artillery completely dominated the plain over which the Confederates would have to advance towards the river. The Federals, therefore, were suffered to remain on the south bank for two days, under the fire of skirmishers.

After the battle Lee's defences were strengthened and his troops redistributed to meet any further attack. But Burnside withdrew his forces (113,000 men) just when the arrangements had been made by the naval authorities to support him by a feint attack with gumboats at Port Royal; he recrossed the river on the night of Dec. 15. Thus Lee's army was left in peace for the winter, for the attempt known as the Mud March, a month later, to move round his left tlank and cross the river above the town, collapsed. Violent quarrels ensued between Burnside and his subordinates, some of whom he dismissed; but in the end Burnside himself was relieved of his command. See American Civil War; Lee.

Fredericton. City and capital of New Brunswick, Canada. It stands on the river St. John, $84 \mathrm{~m}$. from its mouth, and $68 \mathrm{~m}$. N.N.W. of the city of St. John. It is a station on the C.P.R. and Intercolonial Rly., while steamers ply the river to St. John. The chief buildings are those of the provincial legislature and the government offices, Government House, the eity hall, the barraeks, an Anglican cathedral, and several churches; also the university of New Brunswick, colleges, and schools.

Fredericton is the centre of a lumbering district and its ehief industries are boat-building, canning, tanning, and the making of boots and shoes. The city was founded about 1740 , and, although not the largest town, was macle the capital in 1788 because it was less exposed to attack than St. John. Its first name was St. Ann's. Pop. 7,208. 


\section{Frederiksberg.}

Residential suburb in the S.W. of Copenlagen. The royal palace, erected by Frederick IV, on a commanding emin. ence, is now utilised as a military college. There are a fine park, zoological gardens, museum, and picture gallery. It is the seat of the royal porcelain factory, and there are also extensive breweries. Pop. 97,237. See Copenhagen.

Frederiksborg. Royal palace of Denmark. It is built on a group of small islands in a lake near Hilleröd, in the district of Frederiksborg, in Zealand, $21 \mathrm{~m}$. by rly. N.N.W. of Copenhagen. Erected in the 17th century by Christian IV on the site of an older castle, it was restored and embellished after a fire in 1859 , and now houses a national historical museum. Several Danish monarchs have been crowned in the chapel.

Frederikshald (formerly $\mathrm{Hal}$. den). Seaport of Norway, in the fylke or co. of Olstfold. It stands at the mouth of the Tistedal river, at its junction with the Ide Fiord, $58 \mathrm{~m}$. direct and $85 \mathrm{~m}$. by rly. S.S.E. of Christiania. Twice burnt down, it has been rebuilt in modern style. A great timber depot, it also exports wood pulp, marble, granite, and fish. It has sugar refineries and to. bacco and boot factories. The har. bour is safe and commodious.

The town, which was besieged by the Swedes for two years (1658-60), is defended by two fortresses, the famous Frederiksten, founded by Frederick III in 1661, and the Gyl. denlöve, near which Charles XII of Sweden was killed by a musket ball while besieging the town in 1718 . It was surrendered to Bernadotte in 1814. Pop. 12,000.

Frederikshavn. Seaport of Denmark, on the N.E. coast of Jut. land. It stands on the Cattegat, 23 m. by rly. E. of Hjorring, and its fine ice-free port, the second best port in Jutland, is a harbour of refuge. Its exports include butter, bacon, eggs, cattle, pigs, meat, and fish. It is connected by regular sailings with Sweden and England. A mere fishing hamlet in 1818, its population in 1920 was 7,916 . The former name was Fladstrand.

Frederiksstad. Seaport of Norway. It stands at the mouth of the Glommen river, $58 \mathrm{~m}$. by rly. S.E. of Christiania. A centre of the timber trade, it exports pit-props, planks, bricks, tiles, nails, and granite. There are shipbuilding yards and rly. and chemical works. The old town was built by Frederick II in 1570 and strongly fortified. Pop. 15,626.

Freebench. Term used in English law. It is the dower to which a widow is entitled, by the custom of the manor, out of her deceased hus. band's copyholds. The amount varies according to the custom of the manor. Sometimes the widow takes the whole of the copyholds for her life, occasionally half. The general rule is one-third; but it may be less. In most manors the

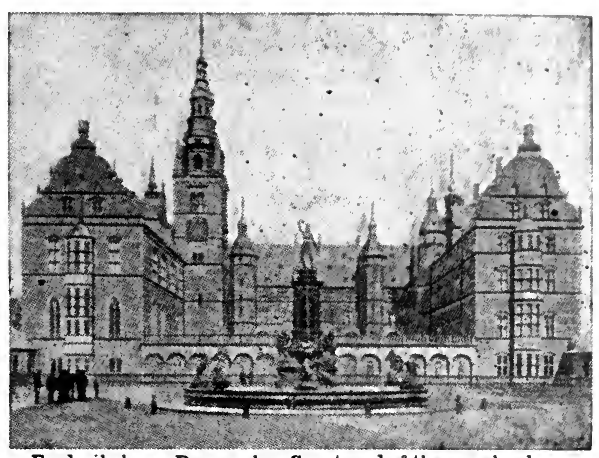

Frederiksborg, Denmark. Courtyard of the royal palace, rebuilt after the firc of 1859
Free Church of England. Title assumed at various times by oon. gregations which have separated from the Church of England on doctrinal or other grounds. It is more especially applied to a small scet which originated about 1844 in Devonshire as a protest against the Oxford Hovement. It has bishops, who derive their succession from Bishop Greig, who seceded from the American Church. Its doctrines are ultra-Low Church, and it uses a slightly modified version of the Book of Common Prayer It is now almost extinct in Great Britain.

Free Church of Scotland. Name adopted originally by those widow forfeits her freebench upon members of the Established Church re-marriage, and, in some, by un- of Scotland who severed them. chastity.

Freeboard. The part of a vessel's side above her water-line or line of flotation.

Free Church. Term adopted for the various denominations formerly known as dissenters. They claim to possess entire freedom in ehoice of doctrine, church government, and the appointment of ministers; but most of them are more or less controlled by the terms of the title deeds to their property.

Free Church Council. Central organization in England and Wales the object of whioh is to federate the various Free Churches. Officially styled the National Council of Evangelical Free Churches, it pro. motes united efforts in the evange. lisation of the people, and strives to prevent overlapping. It originated shortly before 1892 in a Free Church Congress held in Manchester, and numerous congresses and annual gatherings have been held since. The Free Church Council has been conspicuous in connexion with many religious and social movements. It has organized district councils or federa. tions all over England and Wales and has employed evangelists to conduct missions throughout the country, the most notable being Gipsy Smith (q.v.). Delegates to its annual conference are chosen locally by the Free Churches. A body known as the federal council of free churches was proposed in 1919. The headquarters are at the Memorial Hall, London, E.C. See Nonconformity. selves from that body in 1843. It is now that of a church dating from 1900 , and claiming to be the original Free Church.

In the third decade of the 19 th century a controversy arose in the Established Church of Scotland. The outstanding points at issue were patronage and liberty of individual congregations to reject ministers presented to livings. A Veto Act was passed in 1834 by the General Assembly, satisfying the objectors on these two questions. The famous Auchtcrarder case, decided in the Court of Session, 1838, and confirmed by the House of Lords, 1839, deprived congregations of their right to reject a presentee. The controversy then became acute. Petitions and appeals were made without any result.

The dissatisfied group, known as the non-intrusion party, meeting at the annual assembly in Edinburgh, May, 1843, decided to withdraw from the gathering and marched to Tanfield Hall at Canonmills. There they formed the first Free Church Assembly, electing Rev. Thomas Chalmers as moderator. This constituted what is termed the disrup. tion. In the same month 396 ministers and professors signed an act of separation, renouncing all claims to the benefices held under the Estab. lished Church. The signatures ultimately numbered 474 . This act of demission represented a voluntary surrender of an aggregate annual income of something like $£ 100,000$.

The new Free Church started a sustentation fund, erected new churches, and before long became a 
strong body, numerically, financially, and in foreign mission work. In 1900 it was amalgamated with the United Presbyterian Church in Scotland, and was thenceforward known as the United Free Church of Scotland. The present Free Church of Scotland consists of those members of the original Free Church who refused to unite with the U.P. Church in 1900. They are popularly known as the "Wee Frees."

After the union of 1900 the Free Church made legal claim to the entire property of the original Free Church. This claim led to the famous ecclesiastical law case of Bannatyne v. Overtoun. It was argued in the court of session, when judgement was given in favour of the United Free Church. The small Free Church party then appealed to the House of Lords, and judgement was given in their favour in 1904. An amazing situation was thus created, for a handful of mem. bers were given all the property, churches, manses, colleges, and funds of the original Free Church. In 1905 an Act of Parliament was passed to alter this. A royal commission allocated the property between the two bodics, and generally regularised the position. The Free Church of Scotland is strong. est in the Highlands, and at one time had about 180 congregations, but is on the decline. See Presbyterianism; Scotland, Church of : United Froo Church; United Presbyterian Church ; Chalmers, Thomas: Rainy, Robert.

Free City. City that is independent of any save the highest authority. The free cities of the Middle Ages were under the rule of none save the emperor himself, being in practice little republics, each with its own form of government. The modern free city, Danzig $(q . v$.$) , is under that of the$ League of Nations only.

The first free cities were towns standing on land ruled by the em. peror, but their numbers were augmented when the privilege was found to be a valuable one. Some bought it, to others it was given ; while on the other hand some were deprived of it-an instance of this being Donauwörth in 1607 . The free cities were represented in the imperial diet from about 1490 , and, as constituted later, one of its colleges was composed of their representatives. They were divided into two groups, Rhenish and Swabian, and played a considerable part in the affairs of Germany. Some of them had considerable forces, many had a good deal of wealth, so their help was frequently sought by emperors and other rulers, especially in times of war. The hostility of the free cities was feared by the most powerful; their support kept kings on their thrones. Their number varied; in 1521 a list gave 84 of them, after which there was a decrease.

With the changes caused by the French Revolution many of the cities lost their freedom, and in 1803 six only were recognized. They were Hamburg, Lübeck, Bremen, Augsburg, Frankfort, and Nüremberg. In 1806 Bavaria secured Augsburg and Nüremberg, but the other four lasted until 1866, when Frankfort, having fought against Prussia, lost its independence. As free cities the other three entered the German empire in 1871, and remained therein after the changes of 1918. See Germany : History; Town.

Freedmen's Bureau. Public department in the U.S.A. charged with the duty of looking after the freed slaves. It was established in 1865 and continued in existence until 1872, although only intended to last one year. The work was chiefly in the southern states, and took the form of providing for the maintenance and education of the freed slaves, regulating the conditions under which they were employed and administering justice to them. It also controlled the confiscated lands. Many of the officials acted very unwisely, and the bureau was used for political purposes. It fell into disrepute, doing, it was argued, more harm than good, and was ended in 1872 .

Freedom of the Press. Liberty to print and publish without official licence. By the Press is usually meant the newspapers, but the term includes printing generally. Before the introduction of the military censorship in 1914 the British press had enjoyed this liberty since 1694 , save for restrictions imposed by the paper duty, 1694-1861; stamp duty, 1711-1855; advertisement tax, 1712-1853; and libel laws which unfairly shackled expression of opinion until the middle of the 19th century, even to the restriction of references to foreign rulers.

Partial reports of parliamentary proceedings began to appear in print in 1729, but were regarded as a breach of privilege for which summary punishment was in. flicted. While this parliamentary privilege is still nominally preserved, reporters have been admitted to parliament since 1835 .

From the 15th century in Roman Catholic countries the Inquisition or the bishops acted as censors of the press. At the Reformation Henry VIII assumed this control, and it was exercised by the Star Chamber till 1640. In 1640-43 the press was virtually free. In June, 1643, parliament revived the censorship ; Milton's Areopagitica, or Speech for the Liberty of Unlicensed Printing, was published in 1644. The office of Licenser of the Press was operative in 1655-79 and 1685-94. The later struggles for a free press in Great Britain were carried on largely on political grounds, and the struggle has followed similar lines in all constitutional countries. See Censorship ; Defoe ; Journalism ; Libel ; Marprelate; Newspaper; Press Bureau ; Wilkes, John.

Freedom of the Seas. Term used in international law. Grotius, in his work Mare Liberum (the free sea), in 1609, advanced the theory that the waters of the ocean are free and open to all traffic, in peace, though he admitted that in war the goods of an enemy in a neutral ship could be seized and confiscated. His doctrine of the freedom of the seas was gradually extended to mean the com. plete immunity of neutral and even hostile shipping in war from all action by a belligerent navy, thus depriving a combatant fleet of the right to blockade and to seize hostile goods and contraband. In this form it became the second of President Wilson's 14 points of peace, laid down in his speech of Jan. 8, 1918, which required :

Absolute freedom of navigation upon the seas outside territorial waters alike in peace and in war, except as the seas may be closed in whole or in part by international action for the enforcement of international covenants."

Had this doctrine formed part of international law-it was always rejected by British authoritiesthen, in the American Civil War of 1861-65, the S. states could never have been defeated by the ruthless blockade imposed by the United States. In the Napoleonic wars Napoleon would have triumphed. In the Great War Germany would have been free to import arms, munitions, and food, and British sea-power, which eventually brought about her defeat, would have bcen paralysed.

The Allied governments, in a note to the U.S.A. in Oct., 1918, pointed out "that clause 2 (of the 14 points), relating to what is usually described as the freedom of the seas, is open to various interpretations, some of which they could not accept. They must therefore reserve to themselves complete freedom on this subject when they enter the peace conference." There is no reference to 
the freedom of the seas in the treaty of Versailles or the covenant of the League of Nations.

Such a doctrine, if generally accepted, would deprive sea powers of a right which they have almost without exception asserted in past wars, and would confer an enormous advantage on land powers. Armies on land can seize hostile property and interfere in any way they like with neutral trade. Fleets at sea would be forbidden to exercise similar authority. Germany, during the war, declared her acceptance of the new doctrine - precisely as she had accepted and guaranteed before the war the neutrality of Belgium; but what the German government meant by it was thus stated by Count Reventlow in March, 1917: "that Germany should possess such maritime territories and such naval bases that, on the outbreak of war, she would be able with her navy reasonably to guarantee herself the command of the seas." By indiscriminately sowing mines, without any warning, outside territorial waters on Aug. 25-26, 1914, in the North Sea, and on the main N. Atlantic trade route in Oct., 1914, at the very outset of the war the German navy showed its complete disregard of the doctrine which the German government professed to uphold. See Sea Power.

H. W. Wilson

Freehold. Term used in English law for land which is free from all charges save those to the state. The essence of it is that it cannot be held for a definite term of years, however long; it must be indefinite. It is the best kind of tenure known to English law, being superior to both copyhold and leasehold. It began as land held by a freeman on a free tenure, and is now the most common form of landholding. What is called a oustomary freehold is a kind of copyhold. See Land Laws.

Freelance (Ger. freier Lands. knecht, free land trooper). Term originally applied in Germany, and afterwards in other countries, to one who sold his military service to whom he pleased. This usually meant to the highest bidder, with. out regard to more than inclina. tion or pay. In the later Middle Ages, and for some time afterwards, freelances were very numerous in Italy and France, and spread over the rest of Europe. Sometimes called a soldier of fortune, sometimes a merconary, he wandered from place to place, if a noble, with a following of men-atarms, or in company with a number of others like himself. Captain Dugald D̂algetty, in Scott's

Legend of Montrose, was a soldier of this type. The English form freelance comes from confusion with Lanzknecht (lance trooper). See Condottieri ; Frano-tireur; Mercenary. In a modern sense the term is applied to anyone who in politics, or any form of contest, preserves his independence of party or association. In journalism a freelance is a writer who earns a livelihood by contributing to newspapers and periodicals without being attached to the regular staff of any one of them. The Free-Lance was a London weekly paper started by Clement Scott (q.v.) in 1900.

Freeman. One who is free, i.e. one who is not a slave. The distinction between the two classes, bond and free, is an old one. It was found among the Greeks and earlier. In Rome there were two classes of freemen, those who were born free and those who were freed. Among the Teutonic tribes of Europe, including the AngloSaxons, the freeman was the one who enjoyed political power and other privileges, who fought, held land, and, in general, formed the dominant class.

The freeman of to-day is one who possesses the freedom of a city or borough, e.g. London, this being in former days the right to share in its government and to enjoy certain material privileges. In Eng. land this freedom is now regulated under the Acts of 1835 and 1882. By these acts freemen by purchase or gift were abolished, the right being confined to birth, servitude, and marriage. Honorary freedom of a city or borough is a privilege granted to persons of distinction. Freemen of the City of London play an important part in the election of the sheriffs. See City Companies ; Slavery.

Freeman, Edward Augustus (1823-92). British historian. Born at Harborne, Aug. 2, 1823, he was

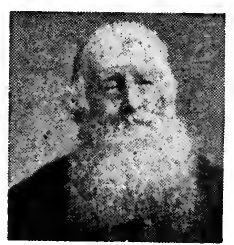

Edward A. Freeman, British historian Elliott \& Fry fellow of Trinity. Having married, he settled down in the country to the career of a writer, making his home from 1860 at Somerleaze, near Wells. His first book was A $\mathrm{His}$ tory of Architecture, 1849. He also wrote a great deal for the reviews, especially 'The Saturday
Review, and travelled much abroad. Freeman's historical works place him in the front rank of British historians, and are based upon an exhaustive study of original authorities. The first was an unfinished History of Federal Government, 1863 , followed by the History of the Norman Conquest, 6 vols., 1867 99 , which remains the chief authority for the period, although later scholarship has declared against some of its theories.

In 1884 Freeman was appointed regius professor of modern history at Oxford, a post he had desired in 1858 , but his best work was already done. He delivered the statutory lectures, but his health was bad, and he died at Alicante, Spain, March 16, 1892. A man of strong and outspoken views, he attained some eminence as a Liberal politician, but failed to enter Parliament. He denounced the iniquities of the Turks, and showed warm sym. pathy for the Greeks. His minor works include Historical Essays, 1871-92 ; The Reign of Rufus and Accession of Henry I, 1882 ; History of Sicily, 1891-4 (completed by A. J. Evans). See Life and Letters, W. R. W. Stephens, 1895.

Freeman, Mary Eleanor WiL. KINS (b. 1862). American novelist. Born at Randolph, Mass., and edu. cated at Mount Holyoke seminary, she contributed short stories to the leading periodicals, and published her book, The Adventures of Ann, in 1886 . In 1887 she won wide popularity with A Humble Romance. She gained valuable literary experience by her long work as secretary to Oliver Wendell Holmes. Her work shows sympathy and quiet humour in presenting country types of the New England villages. Later works included A New England Nun, 1891 ; Jane Field, 1892; Madelon, 1896 Silence, 1898; Jamesons, 1899 ; The Shoulders of Atlas, 1908; The Copy-Cat, 1914.

Freeman's Journal, The. Dublin daily newspaper. Started as The Public Register, or Freeman's Journal, a bi-weekly sheet, Sept. 10,1763 , it dropped its first title in July, 1807. In the opening part of the 19th century it became the organ of the I rish Nationalists. From 1879 to 1902 it was the official organ of Dublin Castle. Henry Grattan is said to have written first for The Freeman's Journal his character of Lord Chathanı. The paper was temporarily suspended in Dec., 1918, by the military authority because of alleged publications calculated to create disaffection; and, on a similar charge, was the subjeot of two courts-martial in 1920 . N.V. 


\section{FREEMASONRY : ITS ORIGIN \& HISTORY}

\section{Dudiey Wright, Assistant Editor of The Freemason}

This article gives some idea of the extent to which freemasonry has spread throughout the United Kingdom and over the civilized world. See also Guild

The origin of freemasonry cannot be traced with certainty. Many of its ceremonies and practices have a striking affinity with the ceremonies and ritual of the Eleusinian. Samothracian, Dionysian, and other ancient mysteries, as well as with the most ancient religious ceremonies known, particularly the initiatory rites and ceremonial proved to have prevailed among Indian races, the Druids, etc. Even the origin of the word freemason cannot be stated with precision. Legend ascribes it to an incident connected with the erection of Solomon's Temple, but O'Brien, in his Round Towers of Ireland, says that the word must be traced to Goban-Saer, the supposed architect of those towers, that the word Saer means Freemason, and that those towers were masonic edifices, exclusively ap. propriated to the worship of the Great Architect of the universe. The existing masonic constitution is also akin to that prevailing in the ancient trade guilds of England and other countries.

\section{Early British Lodges}

The oldest masonic records in the Britısh Isles are in Scotland. Edinburgh Lodge, No. 1, the oldest Scottish lodge, possesses record books from 1599 , but these do not record the beginnings of that ancient organization. The famous Kilwinning Lodge is also claimed to have been in existence at that date as a governing body, but its minute books date only from 1642 . There is a traditional list of grand masters in England, dating from A.D. 290 , beginning with Albanus, and ending, before the historical period, with the names of Charles Lennox, the first duke of Richmond, and Sir Christopher Wren. But the historical foundation even for these names, it must be admitted, is slender.

The first freemason to be initi. ated on English soil, so far as the lecords show, was Sir Robert Moray, who was also one of the founders and first president of the Royal Society. He was initiated at Newcastle-on-Tyne, May 20, 1641 , the entry being ratified by the signatures and masonic marks of four brethren, including General Hamilton. Flias Ashmole, also one of the original members of the Royal Society, was initiated at Warrington five years later. Some founders of the Royal Society and its principal officers and members for several years were leading members of the masonic order.

The organization of the grand lodge of England was effected June 24, 1717, by the union of four lodges then meeting in London three of which are still in existence, and since that date 140 other grand jurisdictions in various parts of the world have been formed, all of which owe their parentage, directly or indirectly, to the grand lodge of England. Of these 49 are in the U.S.A. ; 34 in Europe; 21 in Central America; 15 in South America; nine in Canada ; eight in Australasia; three in Africa; and one in Oceania. The grand lodge of Ireland was formed in 1729 and the grand lodge of Scotland in 1736.

\section{Grand Lodge of England}

In the grand lodge of England two offices only are elective, viz. grand master and grand treasurer, the remaining offices being in the appointment of the grand master a similar custom pertaining to the grand lodges of Ireland and Scotland. The practice varies in the U.S.A. and other countries, but most, and in some jurisdictions all, officers are elected by the members of the grand lodges.

In England when a prince of the blood royal is elected grand master, a pro grand master may be a ppointed. The head of the craft in Scotland is known as the grand master mason. In private or sub. ordinate lodges, the master, treas. urer, and tyler are elected by the members, but it is essential that the master should first have served one complete year as warden.

In 1813 the designation united grand lodge of England was adopted as the official title, on the occasion of the union with some rivals of the original body, who. in 1751, had formed an independent grand lodge, known as the "Ancients," and who eventually secured as grand master the duke of Kent, father of Queen Victoria. $\mathrm{He}$, however, reigned over that body for one month only with the object of bringing about the union. The duke of Sussex then became grend master of the united body, holding the office until 1843, since which date there have been but four grand masters, viz. the 2nd earl of Zetland, the marquess of Ripon, the prince of Wales (King Edward VII), and the duke of Connaught. In 1908 Lord Ampthill became pro grand master, and in
1903 Sir Frederick Halsey, Bart., was appointed deputy - grand master.

The grand lodge of England has within its jurisdiction. 46 provincial grand lodges in England and Wales and 35 district grand lodges overseas. There is not, however, inter-visitation between all the major grand jurisdictions, owing to the fact that a few have ceased to regard it as obligatory on the part of candi. dates for initiation to declare a belief in the existence of a Supreme Being and the doctrine of immortality, two of the most ancient landmarks of the craft, set forth in the earliest Book of Constitu. tions, published in England in Jan., 1723. This, by the way, speaks of Inigo Jones, one of the names mentioned in the traditional list, as " our great master mason." The discussion of religious and political subjects also is strictly forbidden in British, American, and Asiatic lodges, although it enters largely into Continental masonry.

The growth of freemasonry in all countries, with one solitary exception-that of Germany, which has nine grand lodges - has been extraordinary, particularly since 1914 . To-day the grand lodge of England has at least 3,600 lodges within its control, while the lodges through. out the world number between 27,000 and 28,000 , with an aggregate membership of approximately four millions.

\section{Benevolent Activities}

Freemasonry the world over is noted for its benevolent activities. In England there are three wellknown institutions, viz. the Royal Masonic Institution for Girls, founded in 1788, which has a senior school at Clapham Junction, with a junior school and convalescent home at Weybridge, opened in Aug., 1918, with nearly 800 girls receiving benefits; the Royal Masonic Institution for Boys at Bushey, Herts, founded in 1798, with nearly 900 boys receiving benefits; and the Royal Masonic Benevolent Institution for Aged Freemasons and the Widows of Freemasons at Croydon, founded in 1836 , which has nearly 15,500 annuitants on its register.

The war brought into existence the Freemasons' War Hospital in Fulham Road, the outcome of the original scheme for the establish. ment of a masonic nursing home and hospital, to which it has reverted, the institution being founded on an endowment fund provided by subscription. The income of the three first-named institutions, collected at the annual festivals, amounts approximately 

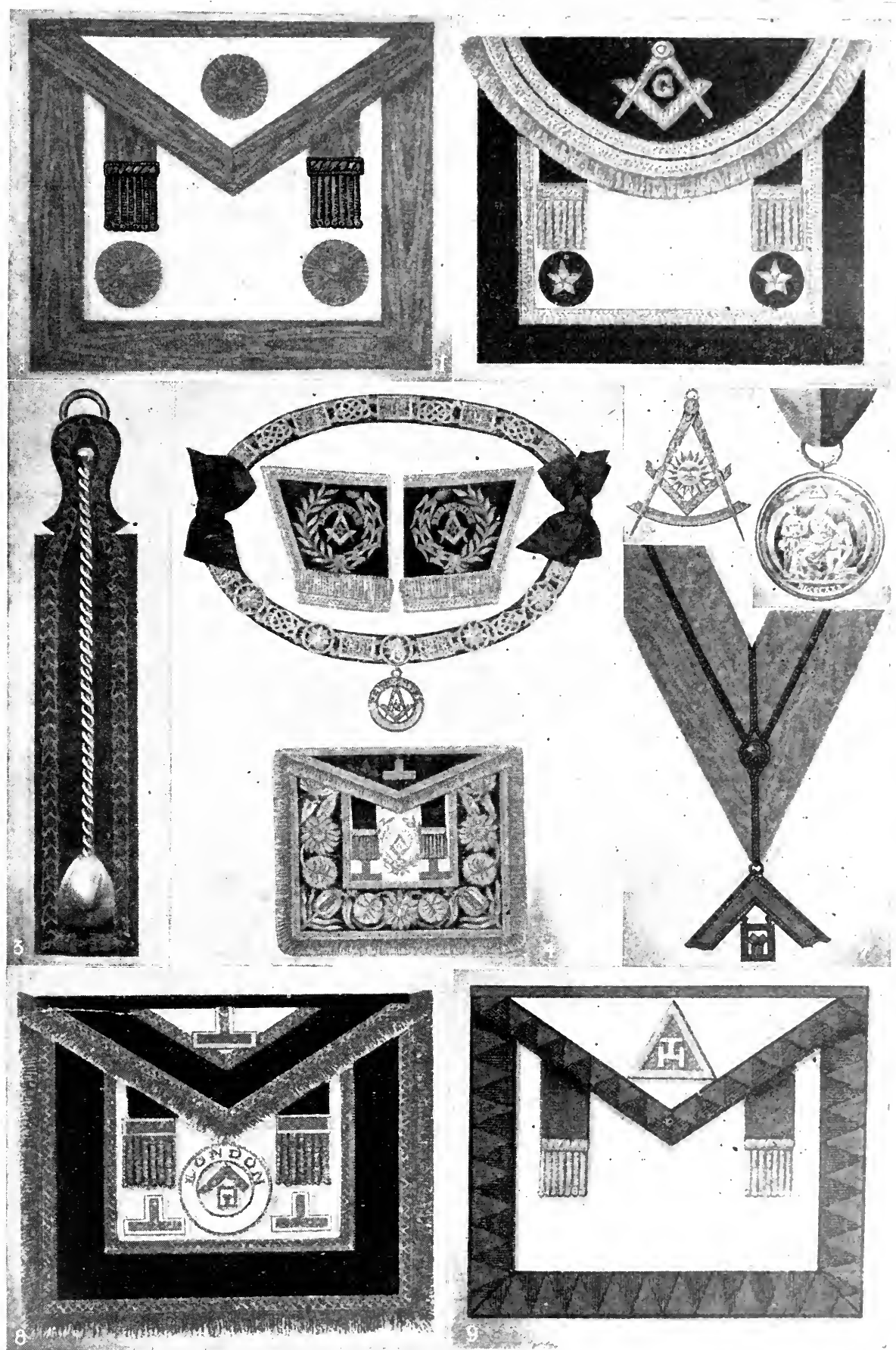

1 and 2. Master Masons' aprons: I, linglish

2. Scottish. 3. Plumb rule, warden's badge of office. 4. Apron, collar, and gauntlets of Provincial and District Grand Master. 5. Scottish Past Master's jewel. 
to $£^{2} 50,000$ per annum. In ad. dition to these central institutions every English province and nearly every district has one or more funds for local relief. Ireland and Scotland also have their institutions and benevolent funds, whilst all the American jurisdictions have established various hospitals, crèches, and other institutions.

The term freemasonry is applied strictly only to what is known as Craft Masonry. Outside this parent stock there are several branches. Royal Areh Masonry is governed in England by the Supreme Grand Chapter, Marl Masonry (including the Royal Ark Mariner degree) by the Grand Mark Lodge, both of which bodies, as well as the Craft, have the duke of Connaught as Grand Master. The next largest masonic body is that of the Antient and Accepted Scottish Rite, followed by the Knights Templar, of which bodies the duke of Connaught is respectively Grand Patron and Grand Master. Other branches are the Allied Masonic Degrees, the Royal and Select Masters, the Order of Malta, the Knights of the Red Cross of Constantine, the Royal Order of Scot. land, the Order of the Secret Monitor, and the Societas Rosicruciana. Initiation into Craft Masonry is indispensable for admission into any of these subsidiary degrees.

Bibliography.

Hist. of Freemasonry, G. J. G. Findel, 2nd Eng. ed. 1869; Hist. of Freemasonry, R. F. Gould, 6 vols., 1884-87; Lexicon of Freemasonry, A. G. Mackey, 7 th ed. 1884; Ars Quatuor Coronatorum, being the Transactions of the Lodge Quatuor Coronati, W. J. Songhurst, 1887, etc.; Encyclopedia of Freemasonry, A. G. Mackey, 7 vols., 1898-1900 ; A Conciso Cyclopaedia of Freemasonry, E. L. Hawkins, 1908; The Grand Lodge of England, 1717-1917, A. F. Calvert, 1917 ; The Builders, J. Fort Newton, 1918; The Origin and Evolution of Freemasonry, A. Churchward, 1920; Masonic Legends and Traditions, D. Wright, 1921.

Free Port. Port at which no customs or other duties are charged on goods. In the Middle Ages there were a number of these ports, some being in Italy, others in Germany and elsewhere. Their existence made it much easier for merchants to exchange their wares than would have been the case if duties had to be paid before this could be done.

A modern substitute for the free port is the bonded warehouse system, although some free ports still exist, e.g. Hong Kong and Singapore. In other cases a free port and an unfree one are side by side in the same seaport. Thus Hamburg and

Copenhagen have each a free port, as well as the ordinary one for the import of goods. The former is used for the receipt of merchandise that is not for sale in the country itself, but is being transhipped for sale elsewhere. The free ports of modern China are such in a different sense; they are ports open to foreign trade. See Bonded Warehouse.

Freeport. City of Illinois, U.S.A., the co. seat of Stephensor. co. On the Pecatonica river, 112 m. W.N.W. of Chicago, it is served by the Chicago and North-Western and other rlys. Here in 1858 occurred the celebrated debate between Douglas and Lincoln, in which the former proclaimed the Freeport doctrine. Settled in $\mathbf{1 8 3 5}$ it was incorporated in 1850 , and became a city in 1855. Pop. 19,845 .

Free Reed. In musical instru. ments in which the sound is due to the vibrations of a reed or tongue the reed is termed free when it is just small enough to pass through the frame on which it is fitted. When it is a little larger and beats against the sides of the opening, as in organ trumpet pipes, it is called a Beating Reed or Striking Reed. Most of the tongues used in the harmonium and American organ are free reeds. See Organ.

Freesia. Small genus (two species only) of bulbous herbs of the natural order Iridaceae. They are natives of the Cape of Good Hope. They have long, narrow, grass-like leaves and large funnelshaped white or yellow flowers. $F$. leichtlinii has yellow or cream

\section{FREETHOUGHT AND FREETHINKERS}

Right Hon. J. M. Robertson, Author of History of Free Thought

The point of view of the freethinker, as that of believers in the various religions, is the subject of an article in this Encyclopedia. See also Apologetics; Christianity; Dogma ; Rationalism; Renaissance

Though the appellation "freethinker" has not entirely lost the aspersive sense which generally attached to it among Christians from the time of its coming into common use (c. 1700), the term "free thought" may now be regarded as a scientific label for the attitude of mind which challenges all demands for belief on grounds of traditional "or documentary authority. Broadly considered, this attitude reacts in the same way against historical and other propositions as against religious dogmas and narratives; but inasmuch as the latter have always made the most menacing claim to un. critical acceptance, it is to the critical refusal of acceptance in their case that the term has always been commonly applied.

On a wide survey it becomes certain that while the normal coloured flowers, and $F$. refracta pure white blossoms, marked with

and sweetly scented.

Soil. Name given in the , before the total abolition Avery there, to soil on which it not permitted. Early in the th century the Union consisted of an equal number of slave and ree states, each entry of a new slave state being balanced by the y of a new free soil state.

In 1847, the anti-slavery cause having strengthened, it was proto make slavery illegal in all trict recently secured from Mexico, and so confine slavery to the existing slave states. To support this the Free Soil party was formed. It consisted of both Democrats and Whigs, seceders from their own parties, and was strong enough to secure the nomination of its own candidate, Martin van Buren, for the presidency. He failed, however, and they were equally unsuccessful in 1852, but they sent members to 1856, when they gave up their separate organization and became merged in the Republican party. The party motto was free soil, free seech, free labour, and free men. See Republican; Slavery; United History

Freestone. Sedimentary rock usually sandstone, but sometimes limestone, which can be easily worked with the chisel and lacks the usual tendency to split along certain planes. It is extensively used in architecture for mouldings.

attitude of the untrained mind towards all serious or minatory assertion concerning the unknown is one of credulity, there has occurred at all stages of human development some amount of variation towards rational doubt. Alike among savages, among barbarians, and among the more civilized peoples of all times and countries, there has always been a varying minority of minds who spontaneously doubted more or less the truth of current myths, legends, and dogmas. The "sceptical " attitude is thus a natural variation, like another, and it depends for its spread upon the totality of the circumstances which check or make for free discussion. These may be simply economic, or largely cultural or political.

Inasmuch as religious systems are readily able to employ all three 
factors, the assailing doubt generally suffers from that disadvan tage; but even in a primitive com. munity the economic factor may at times be negatively on the side of freedom, as when a series of famines may lead to the extinction, as impostors, of all the "rainmakers" of an African people. The primary bias to doubt, however, being by far less common than the contrary, freethought in progressive conditions is always a matter of resort to methods of rational appeal (whether well or ill conducted) as against the common bias to belief reinforced by "authority" on social, political, and economic lines.

That both attitudes are in some degree primarily temperamental is indicated by the significant fact that many adherents of a modern orthodoxy are found to show a spontaneous animus against ancient "freethinkers" as such, though the beliefs which those doubters rejected as false are also rejected as false by their modern assailants, and often described by them as pernicious.

Historically speaking, it is broadly certain that freethought spreads in the ratio of the culture contacts of peoples, whether by way of simple intercourse or of literary communication. The mere differences of early religious beliefs, being so marked and so innumerable, constitute a propulsion to doubt when they are simply noted. Where the doubt has most intel. lectual elbow-room it will be most developed.

\section{Ancient Times}

Thus, while doubt concerning the gods can be seen among the priestly circles of ancient India, Babylonia, and Egypt, to lead to a compromise on the lines of a pantheism which conserved the old cults upon economic motives, in the freer world of republican Greece, which enjoyed the maximum of culture contact and free discussion, and had the smallest development of priestly organization, the critical process was both more general and more searching. Josephus, in his diatribe Against Apion, expressly reproaches the Greeks with the multiplicity and divergence of their historical reconstructions as contrasted with the unquestioned uniformity of tradition among his own race.

The very fact that that tradition had undergone much priestly manipulation in the historic past had passed out of orthodox Jewish knowledge ; the Jewish community having come to represent a selection or survival of conformists and devout believers from among a race which had parted with multitudes of its doubters.

In that case the retaining power had been the successfully estab. lished cult of the Sacred Book. In Greece there was neither Sacred Book nor centralized priesthood. And the subsequent history of freethought turns mainly on the faith-commanding power of Sacred Books, whether in subordination to or in alliance with other factors. Roughly speaking, the history of the Catholic Church down to the Reformation consisted in the subordination of the authoritarian claims of the Sacred Book to those of the hierarchy, the former having been found to involve constant risks of destructive schism.

\section{Protestantism and Schism}

This was freshly illustrated in the schisms which rapidly overtook Protestantism, when that movement erected the claims of the Sacred Book to belief above all others; and to such schism the Catholic hierarchy were able to point as discrediting Protestantism from the point of view of the general bias of faith.

Since the Reformation, the history of western freethought has been one of more or less con. tinuous gain in intellectual prestige as against the authority of the Sacred Book in Protestant countries and that of the hierarchy in others, the lines of advance being those of science, historical criticism, ethics, and democratic politics. The bias of faith may often be found still subsisting in promoters of all of those movements; but the collective result is a growing proclivity to the critical method, broadly known as that of rationalism.

Perhaps the most generally disintegrating process is that which systematically develops the early factor of culture-contacts by the scientific comparative study of all the primitive forms of religion, from which the later are now generally recognized to derive. Religious beliefs are thus themselves in a state of increasingly rapid change, even among biased believers; and the critical process, grounded on the sciences and rationalistic ethics, becomes increasingly confident, even while growing less polemical.

The historic process has been, as regards the more educated classes or sections, one of action and reaction. In post-medieval and Renaissance Italy, clerical abuses promoted freethought; and in France and England after the Reformation it advanced considerably after periods of religious strife, being active in the later years of Elizabeth, and again after the Restoration. Yet again, as a result of both scientific and scholarly progress, it spread greatly, under the form of Deism, in the England of the first half of the 18th century.

Commercial and imperial ex pansion and the Methodist Revival later weakened the intellectual activity, which, however, was taken up in France, then ripening for the Revolution; whereafter political reaction in both countries produced a reign of conformity in the middle and upper classes, leav. ing the new democratic freethought partly at work among the lower, in so far as they were accessible to propaganda.

An organized freethought propaganda, mainly democratic, is a notable feature of the second half of the 19th century, alike in Britain, the U.S.A., France, Germany, and other European countries. Proceeding as it did on the subversive criticism alike of science and scholarship as against the Sacred Book, it was most active in the period of active religious resistance to such criticism, flagging as a specific activity when the Churches in general began to accept that criticism, thereby weakening their own foundations and turning belief into a passive rather than an active force.

\section{Influence of Freethought}

The relative subsidence of specific freethought propaganda is thus a mark of its success, the educative process being thenceforth carried on by the specific activities of science and ethics and general truth-seeking research. Churches which a few centuries ago were shedding blood for supernaturalist doctrines of sacraments, and later were battling against Deism for the divinity of Christ, are now concerned to prove His mere historicity.

Throughout civilized Europe, while a measure of social ostracism still falls in some countries upon those who openly reject the whole body of traditional religion, the shifting of the religious ground has greatly weakened the power of the Churches to resort to forcible suppression of criticism, and the economic and cultural obstacles to freethought are really the more powerful. In Great Britain it has been gradually recognized that persecution merely multiplies the assault, giving it new economic resources through popular interest and sympathy. Alike in the time of Thomas Paine and in that of Charles Bradlaugh, persecution greatly strengthened the popular movement. At the same time, grow ing knowledge of all kinds weakens 


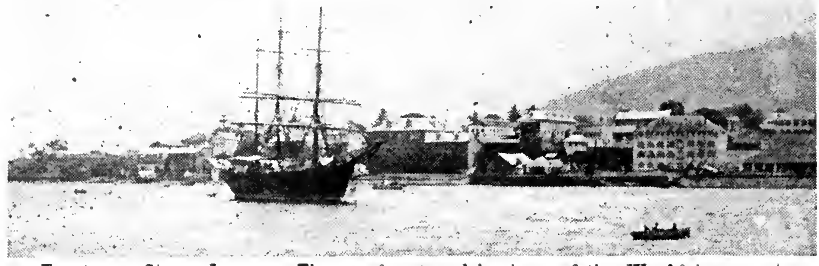

Freetown, Sierra Leone. The sea front and barbour of the W. African port

both the temper and the social basis of persecution; and Churches whose elergy are in most cases pronounced heretics from the point of view of their own official creeds are largely incapacitated for suppressive measures. Many cminent literary men of the last generation having committed technical " blasphemy " in a supreme degree, that offence is now never prosecuted in this country save when accompanied by contravention of ordinary police regulations.

Bibliography. Hist. of the Warfare of Science with Theology in Christendom, A. D. White, 1896 ; The History of English Rationalism in the Nineteenth Century, A. W. Benn, 1906; The Censorship of the Church of Rome, G. H. Putnam, 1906-7 ; Hist. of the Rise and Influence of the Spirit of Rationalism in Europe, W. E. H. Lecky, 1865, repr. 1910 ; A History of Freedom of Thought, J. B. Bury, 1914; A Short Hist. of Freethought, J. M. Robertson, 3rd ed. 1915.

Freetown. Port, coaling station and capital of Sierra Leone, British W. Africa. The city is situated on the Sierra Leone river, with wooded mountains to the $\mathrm{S}$. and E., at the N.W. extremity of the
Sierra Ifeone peninsula. The cl1mate was unhealthy for Europeans, but now that the malarial marshes are drained and the principal European residences built on the highlands, reached by the mountain rly., the conditions have been much improved. Freetown was founded as Granvilletown in 1788 as a residence for freed African slaves.

The barbour is the best on the W. coast of Africa, and is con. nected with the interior by a narrow-gauge rly., running in one direction towards the N.E. of the Protectorate, and in the other towards the S.E., near the frontiers of Liberia and French Guinea. Should the proposed western branch of the Trans-Sahara Rly. be built, Freetown, as one of the nearest points to $\mathrm{S}$. America, would, if joined to this Rly., become of great importance as a through route. The town possesses a cathedral and several educational establishments. The chief exports through the port are palm. kernels and oil, kola nuts, rubber, gums, and ginger. There is a wireless station. Pop. 34,090, including 558 Europeans.

\section{FREE TRADE : THE THEORY \& ITS GROWTH}

\section{Harold Cox, Editor of The Edinburgh Review}

With this article should be read those on Protection and Tariff Reform. the two sides of the question being thus brought together. See Smith, Adam; Wealthof Nations; also Political Economy, Wages, and articles on othereconomic questions: Industrial Revolution; Mercantile System

Free trade is a term meaning, in general, the absence of restrictions of any kind on trade. In modern speech it refers particularly to the system by which goods are allowed to enter one country from another without paying customs duty for the protection of home producers.

The intellectual revolt against protection began with the publication of Adam Smith's Wealth of Nations in 1776. Pitt was con. verted by Smith's arguments, and England was beginning to move in the direction of treer trade with France when the outbreak of war in 1793 put a stop to all legitimate trade betwcen the two countries. It was not until after Waterloo that the agitation against protec- controversy on tariff questions died down.

Fifty years went by before any renewed attempt was made to disturb free imports. During these years the population of the United Kingdom increased from $28,000,000$ in 1851 to $42,000,000$ in 1901 ; its total overseas trade per head of the population increased from $£ 610 \mathrm{~s}$. in 1850 to $£ 216 \mathrm{~s}$. $5 \mathrm{~d}$. in 1900 ; the yield of a penny in the income tax increased from $£ 1,200,000$ in 1861 to $£ 2,500,000$ in 1901 ; merchant shipping registered in the United Kingdom increased from $3,600,000$ tons in 1850 to $9,600,000$ tons in 1901. During the same period immense additions were made to the Empire and its unity was demonstrated.

During the twelve years that elapsed between 1902 and the outbreak of the Great War the com. mercial progress of the kingdom was in many respects relatively even more rapid than in the previous half century, and in 1914 the spontaneous action of the Do. minions finally disposed of the suggestion that their loyalty was dependent on tariff favours.

These broad historical facts show that since the free trade theory has been put into practice England has had little reason to be dissatisfied with the results.

\section{British Free Trade}

Concisely stated, the free trade theory is that the prosperity of Great Britain and Ireland and the unity of the British Empire are best advanced by leaving the ports of the United Kingdom open to the goods and the shipping of all the world, subject only to such charges as may be imposed for revenue purposes, and to such measures as may be necessary to guard the country against injury at the hands of an actual or a potential enemy. That a similar proposition is true for other countries most other countries have denied.

It was no mere accident that brought England to adopt the policy of free imports while most other nations remained protectionist. There are both mental and material causes for the difference. The principal mental cause is the long English tradition of individual liberty. That tradition makes government interference less tolerable to Englishmen than to other peoples. Americans share this Eng! ish mentality, but their material circumstances are different.

The U.S.A. is a vast area containing within its confines most of the requisites for civilized human life ; it is, therefore, possible for its citizens to live and flourish with an external trade which is very small 
in comparison with the internal trade of their continent. Conse. quently, if that external trade is subject to protective duties, the effect on the yeneral body of the people is relatively unimportant.

\section{Britain and Free Trade}

In the case of Great Britain the situation is entirely different. The country is not very large; its natural resources, except in the matter of coal and good pasturage, are extremely limited. If the people of Great Britain attempted to "keep themselves to themselves" they would have a very poor life indeed.

England's success in the world had its origin in the sea-going instinct of the English race which a long, indented coast-line further developed. To-day the industrial energies of Great Britain are devoted largely to the production of goods for export. But if a country is to carry on successfully a very large export trade against the competition of other countries, and often against the handicap of hostile tariffs, it must produce cheaply. One of the most important elements in cheap production is the cheapness of the materials and of the instruments employed in the processes of manufacture. Any tariff that is imposed to give protection to producers for home consumption almost inevitably injures producers for export. If, for example, a duty be imposed on imported steel bars in order to give protection to the producers of steel, it will injure the shipbuilding industry, the locomotive industry, and almost every branch of engineering.

These illustrations show that in a country with a highly developed and complicated export trade it does not suffice to exempt from taxation what are sometimes called raw materials, for that term cer. tainly could not be applied to such highly manufactured articles as steel bars or cotton yarn. Almost every important manufactured article is indeed itself the material for some further manufacturing or industrial process. If a tariff were confined to those imported articles, say French motor-cars or Austrian gloves, which were ready for inme. diate use by the ultimate consumer, it would protect very few industries and would indeed more appropriately be described as a luxury tax than a protective tariff In fact, in the United Kingdom protection cannot be given by means of a tariff to any of the great staple industries without injuring others which may be of equal or even greater importance.

It is, of course, arguable that an all-wise government, by picking out the more important industrics for encouragement and the less important for discouragement, might add to the economic strength of the nation. But even if it were quite easy to discover an all-wise government, it still would be difficult to see on what principle such a government would proceed. Among the most important industries of the United Kingdom are cotton manufacture, coal mining, and ship-building. They account together for a very large amount of well-paid em. ployment and for the production of a great volume of wealth. They cannot be benefited by any kind of tariff; they would be injured by al most any duties imposed to benefit other industries. Would an all-wise government select these great in dustries for discouragement and some other industries for encouragement? and if so, what other inclus tries and for what reasons?

\section{Agriculture and Protection}

There is indeed one industry which on national grounds can put forward a plausible case for protection, namely agriculture. The practical difficulty is that, if the tariff on imported agricultural produce were low, it would make very little difference to our home agriculture; while if the proposed tariff were high, the urban population would resist its imposition, and as against the urban vote the friends of agriculture are politically powerless. It is important, too, to remember that agriculture itself is not one industry, but many. The interests of the dairy-farmer and of the pig-breeder are by no means identical with those of the wheat grower.

These are examples of the considerations which lead the free trader to argue that it is better for the Government not to interfere in matters of trade between man and man, between one industry and another. Doubtless private enterprise may sometimes go astray. The search for individual profit does not necessarily lead to the highest national advantage. But in the main private enterprise can only succeed by developing those industries which are best suited to the character of the people and to the natural resources of the island. Where blundersare made by private enterprise they are quickly corrected, for to persist in an economic blunder means bankruptcy. On the other hand, the State in interfering with the course of trade is not necessarily guided at all by any sound economic motive ; it may be compelled to action solely by political corruption. Moreover, even if the intentions of a government are honest, there is no means by which it can constantly test the wisdom of its policy. It may blunder along, hampering where it intended to help, pulling down instead of build. ing up, continuing the mischicf un checked for decades, until new political forces have grown strong enough to sweep away the whole policy. That is why the free trader asks that, in matters of trade, politi. cians should leave the individual free to do his own blundering at his own expense, and free also to achieve success for himself and in cidentally for the nation by his own unhampered methods.

Bibliography. The Commeres of Nations, (. F. Bastable, 1892 Wealth of Nations, Adam Smith Free Trade Movement and its Results, G. Armitage-Smith, 1903 ; The Lifo of Riehard Cobden, John Mor ley, 1903. The Return to Protection, William Smart, 2nd ed., 1906 A Project of Empire, J. Shield Nicholson, 1909.

Free Wheel. Term given to a gear or pulley wheel which is provided with a clutch or detent in such a manner that the wheel may either turn with the axle on which it is placed or rest idle on the axle, while the latter turns. In the former case the wheel is working, in the latter idle. A now familiar example is provided by the com. mon bicycle and another by certain forms of lawn-mowers in which the wheel "works" when the mower is moved forward, but is idle while the machine is moved backwards. Many other varieties are found in mechanics. See Cycling.

Free Will. Psychologically, the theory that men's actions are not dependent on any external force, but are the result of conscious mo. tives operating from within. Metaphysically, free will is the power of acting independently of any eause whatever, external or internal-the capacity of willing or not willing the same thing at the same time. The question of its existence caunot be settled metaphysically byself-examination. 'The consciousness that we might have acted differently, had we so willed it, is beside the point, which is, could we have so willed? "It is certain that I can act as I will, but to say that I can will as I will is senseless ; (Hobbes). The existence of free will (metaphysically) is denied by determinism (q.v.), affirmed by indeterminism. See Calvinism.

Free Will Baptists. Arminian section of the Baptist denomination in America, corresponding to the General Baptists in Great Britain. Originating about 1780 through the preaching of Benjamin Randall, one of Whiteficld's con verts who joined the Baptists, they 
separated from the Baptist body, which at that time was strongly Calvinistic, and taught Arminian doctrines. See Baptists ; Calvinism.

Freezing Machine. Double pail for making ice-cream. Ice and salt, broken very small, are packed into the outer pail in layers of three inches of ice and one of salt nearly to the top. The cream mixture is poured into the central pail, which is provided with a dasher, its handle passing through a hole in the top; this is turned until the mixture is set. See Ice Cream.

Freezing Mixture. Mixture of two substances, usually ice or snow and some kind of salt, which pro. duces great cold. When common salt is added to snow which is on the point of freezing, its first effect is to lower the freezing point of that part of the snow with which it is brought into immediate contact ; some of the snow is accordingly melted and forms a strong solution of salt. In this solution the molecules of water and of salt enjoy much greater freedom of motion than in the solid form, and require extra energy, which is provided in the form of great heat from the surroundings. Thus the temperature of the snow is reduced below its normal freezing-point, and at the same time the saline solution melts more snow, this process continuing until a limiting low tem. perature is reached at which the whole mixture freezes. A tem. perature of $-20^{\circ} \mathrm{C}$. can be reached in this way with a mixture of snow and common salt, but by the use of other salts which dissolve with greater absorption of heat much lower temperatures can be obtained. For example, calcium chloride in its crystalline form, mixed with snow in the proportion of 10 parts to 7 , will produce a temperature of $-55^{\circ} \mathrm{C}$.

Freezing Point. Temperature at which a liquid assumes the solid form. The freezing point of water, that is, the temperature at which it ehanges into ice, is one of the fixed points on the thermometric scale $\left(0^{\circ}\right.$ Centigrade, $32^{\circ}$ Fahrenheit). Liquids may be roughly divided into two classes as regards the properties they exhibit in the process of freezing; water is an example of the liquids which undergo erystalline solidification, in which there is a change of volume, and the liquid gives out a definite quantity of heat, called the "latent heat," in its abrupt change to the solid form. On the other hand, molten glass is a liquid which undergoes "amorphous" solidification; as the temperature falls the glass ceases to run freely, and becomes viscous, then gradu- ally hardens into a solid. The second class of liquids can hardly be said to have a definite freez. ing point, although the corresponding solids have a melting point, namely, the temperature at which they begin to run.

To return to the first type, in which freezing is an abrupt change, it is a fact of great importance that the freczing point is not absolutely constant, but varies under pressure. Water expands when it freezes, and the effect of pressure is to lower the freezing point. Paraffin wax, on the other hand, contracts in freezing, and here the effect of pressure is to raise the freezing point. In other words, thoseliquids which can solidify only by expanding, are hindered from freezing by external pressure, while those which have to contract in order to freeze are helped by external pressure.

The freezing point of a liquid is lowered by the presence of a salt dissolved in it. Thus a solution of common salt in water will not freeze until its temperature has been lowered considerably below the freezing point of pure water. The reason for this appears plainly from the molecular theory. According to this theory the molecules of water, which in the liquid form have considerable freedom of movement, have to occupy definite relative positions when the water assumes the form of ice. Whien pure water is cooled to $0^{\circ} \mathrm{C}$., the energy of the molecules is sufficiently dim. inished to allow attractive forces to come into play, under which the molecules assume the positions required for freez. ing, but the pre. sence of particles of salt in the solution hinders this process, and the energy of the molecules of water $\mathrm{must}$ be diminished by a further reduction of temperature before solidification can take place See Heat; Tem. perature; Ther inometer.

Freiberg.'Town of Germany, in Saxony. It stands on the river Munz- bach, a tributary of the Mulde, $20 \mathrm{~m}$. S.W. of Dresden, and is the mining centre of the Erzgebirge. Around are extensive silver and lead mines, while the town itself has an old and celebrated school of mines. Other industries are the manufacture of textiles, iron and brass goods, cigars, thread, chemicals, beer, and gunpowder. The chief building is the 12 th century Gothic cathedral, restored in 1893 , and containing a famous doorway, called the Golden Door, which has some magnificent sculptures.

S. Peter's church is noteworthy, and there are remains of the town walls, parts of which have been turned into promenades, a museum, a park, and several public monuments. The town grew up around the castle of Freudenstein, which became a residence of the dukes of Saxony. One of them rebuilt it in the 16th century, and this building remains. The silver mines, to which the town owes its existence, were opened about 1250. Pop. 36,237.

Freiburg. Small country town in Silesia. It is built upon a hillside, $36 \mathrm{~m}$. S.W. of Breslau. There are manufactures of linen and watchcases. Pop. 9,800.

Freiburg-im-Breisgau. Town of Germany, in Baden. It stands on the Dreisam, near the western borders of the Black Forest, $40 \mathrm{~m}$.

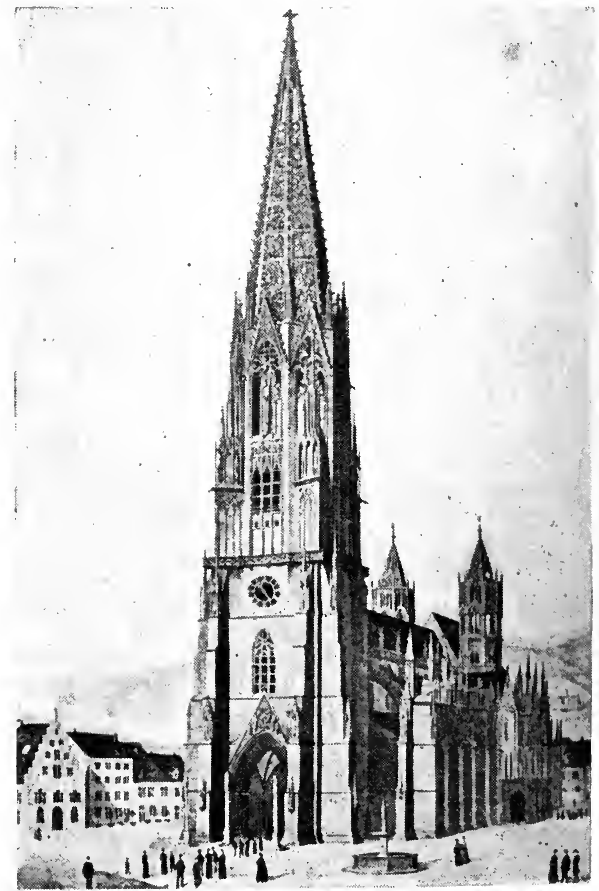

Freiburg-im-Breisgan. The early Gothic cathedral with famous 13 th century tower, $386 \mathrm{ft}$. high 
S. of Strasbourg. Its older streets are narrow and almost ruinous, but there are numerous handsome modern thoroughfares, and some fine public buildings. The Gothic cathedral, known locally as the minster, is one of the most complete specimens of its kind, and its tower is celebrated for its delicate beauty of outline.

The university, founded in 1455, has an excellent library; there are a fine archbishop's palace, ducal palace, and merchants' house, and spacious botanical gardens. The principal manufactures are cottonthread, sewing silk, paper, and chicory, and there is a fairly extensive trade in wine and timber. Long a possession of the house of Hapsburg, the town was on several occasions ceded to France, notably in the 17th and 18th centuries, finally becoming a part of Baden in 1806. Pop. 83,324.

Freight. Word derived from the Dutch, and meaning originally the burden or cargo of a ship. Hence it came to mean the rate paid for the carriage of goods by sea, and in this sense it is now chiefly employed. It is used in the U.S.A. for the carrying of goods by land, and railway freights is a common term, while a freight train is the equivalent of the goods train of Great Britain.

Freiherr. German title. It means free man or free lord, its origin being like that of baron. At first it was given to a man who held land, until in the 16 th century the emperors began to bestow it as a mark of favour. All German sovereigns until 1918 retained the right to create Freiherren, who rank after the counts or Grafen. The title is hereditary. See Baron.

Freiligrath, Ferdinand (181076). German poet. Born at Detmold, Lippe, June 17, 1810, his first volume of poems appeared in 1838 . Beginning with Ein Glaubensbekentniss (A Confession of Faith), 1844, he wrote some of the finest of Germany's revolutionary songs. After the failure of the revolution, he was an exile in London, until the amnesty of 1866 . He died March 18, 1876.

Freising. Town of Germany, in Bavaria. It stands on the left bank of the Isar, $18 \mathrm{~m}$. N.N.E. of Munich, and its chief industries are the making of agricultural machinery, brewing, and printing. Its main interest is historic, as it was an important ecclesiastical centre in the Middle Ages. The cathedral, parts of which date from the 12 th century, was restored and altered in the 17 th century. There are several churches, including $\mathrm{S}$. Benedict's, a Rathaus, and the

palace of the bishops, now a college. Near the town was a Benedictine abbey. Otto of Freising, the chronicler, was bishop here in the 12th century. Pop. 14,946.

Fréjus (anc. Forum Julii): Town of France in the dept. of Var. It stands on the Gulf of Fréjus, $22 \mathrm{~m}$. S.W. of Cannes, and is an old Roman station containing many Roman remains. It has been an episcopal see since the 4 th century, and parts of the cathedral date from the 12th century. A seaport of some importance in ancient times, the silting of the river Argens has now filled the harbour, and the town is a mile from the coast. Pop. 4,200.

Fremantle. Seaport of W. Aus tralia. It stands at the mouth of the Swan river, $12 \mathrm{~m}$. S.W. of Perth, with which it has rly. and river communication. It has a deep and well-equipped harbour, and is a port of call for European mail boats. Among the chief build-

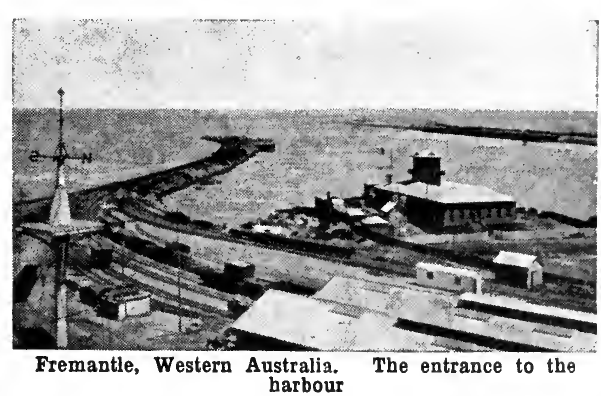

From 1888-91 he was commanderin-chicf in the $\mathrm{E}$. Indies; from 1892-95 in China, and from 1896 99 at Plymouth. In 1889 he was knighted, and he retired with the rank of admiral.

Fremantle, Sir Sydney Pobert (b. 1867). British sailor. The eldest son of Admiral Sir E. R. Fremantle, he was born, Nov. 16,1867 . In 1881 he entererl the navy and in 1903 becams a captain. In 1915 he served in the Darda. nelles, being in command of the Russell when she was sunk. After.

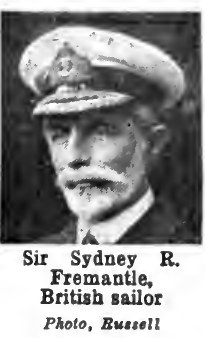

wards he was made deputy chief of the naval staff, from which he was transferred in 1919 to commiand a battle squadron of the Atlantic Fleet. $\mathrm{He}$ was then a rear-admi. ral. In 1919 he was knighted, and he has written on the science of his profession.

Fremitus (Lat. roaring noise). $\mathrm{Vi}$. brations produced in the chest when $\mathrm{t}$ he $\mathrm{p}$ atien $\mathrm{t}$ speaks, and in certain abnormal conditions, such as some forms of ings are a fine town hall, institute, public library, and an asylum. Its industries comprise smelting, iron founding, sawmilling, and boat building, and there are flour mills, breweries, tanneries, and leather manufactures. Wheat is largely exported. The town is divided into three districts. Pop. 21,670.

Fremantle, Sir EDMund RoBERT (b. 1836). British sailor. Born in London, June 15, 1836, he

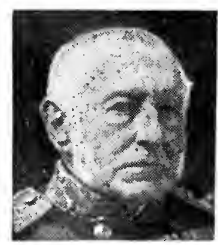

Sir Edmund Fremantle,

British sailor

Photo, Russell 66 , and in Ashanti, where he was severely wounded, in 1873-74. In 1885 he became a rear-admiral; in 1886 he was made second in com. mand of the Channel Squadron. in 1819 saw a good deal of service. He was in Burma in pleurisy or catarrh, simply by breathing. They are detected by placing the palm of the hand flat upon the chest, and their presence or absence may form useful diag. nostic signs of discase.

Frémont, John Charles (181390). American explorer. Of French extraction, he was born at Savannah, Georgia, Jan. 21, 1813 Graduating at Charlestown College. 1836. he accom panied a rly. survey party through Geor gia, N. Caro lina and Ten nessee in 1837 .

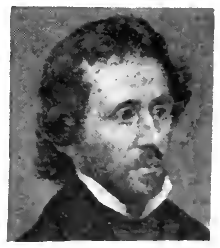
and surveyed Nebraska, Dakota, Minnesota, and Iowa, 1835-40. From 1842-54 he explored Oregon, California, and New Mexico, in which states he made rly. surveys and did much to open up the far west to settlers.

A senator in 1850 , he was nominated Republican candidate for the presidency in 1856, but his anti- 
slavery sentiments angered the Southern states and he was defeated by Buchanan. In the Civil War, 1861, he was major-general in command of the $W$. division at St. Louis. The rly. crisis of 1873 ruined him financially, but he was governor of the territory of Arizona, 1878-82. He died in New York, July 13, 1890.

Fremont's Peak. Mountain of the Rocky Mts., U.S.A. In Wyoming, it is the highest point in the
Wind River Mts., being 13,790 ft. high. It was ascended in 1842 by John C. Frémont, hence its name. Fremont's Pass is in Colorado in the Rocky Mts. It is $11,300 \mathrm{ft}$.high.

French. River of Ontario, Canada. It has its source in Lake Nipissing, and flows nearly due W. to Georgian Bay, Huron Lake. Its length is $60 \mathrm{~m}$., and it forms part of a projected scheme to connect this lake with the St. Lawrence river. See Georgian Bay Canal.

\section{J. D. P. FRENCH : EARL OF YPRES}

Sir W. Beach Thomas, K.B.E., Special Correspondent of The Daily Mail This is one of the biographies of the military leaders in the Grcat War. See also Foch; Haig; Joffre; Pétain; Rawlinson; Mons; Ypres, and others of French's battles; also War, Great

Sohn Denton Pinkstone French was born at Ripple, Kent, Sept. 28, 1852, the only son of Captain French, R.N., member of a wellknown Irish family, and of Mar. garet, daughter of William Eccles. At the age of 14 he entered the Britannia, but the navy did not appeal to him, and after four years as cadet and midshipman he left to join the militia; and in 1874 obtained a commission in the 8th Hussars, but soon transferred to the $19 \mathrm{th}$. He became captain in 1880, in which year he married Eleanora Anna Selby-Lowndes. He received his majority in 1883 .

In 1884 French saw active service for the first time. Proceeding to Egypt, he was attached to the force that was to relieve Gordon, started with the desert column in Dec., 1884, fought at Abu Klea, pushed through the Dervish army at Metemma; and after the death of Gordon endured the painful retreat across the Bayuda desert, Feb.-Mar., 1885. Promotion came steadily. He was lieutenant-colonel in 1885, and in 1889 obtained command of the 19th Hussars, which he left after four years to take up duties as assistant adjutant-general of cavalry. In 1897 he was given command of the 2 nd cavalry brigade at Aldershot and was transferred in 1899 as tem. porary major-general to the conımand of the first cavalry brigade.

In the South African War French was given the command of the cavalry division in Natal with the full rank of major-general, and was one of the few officers who made a name in the war. In one of the earliest actions he drove the Boers from the station at Elandslaagte and fought the successful battle of that name. After several cavalry actions he saw that Ladysmith would be surrounded, and escaped by the last train. Thróng a great part of the war he kept the Orange Free State troops at bay in their attempt to invade Cape Colony, and did wonders with a handful of troops and a few guns. As soon as

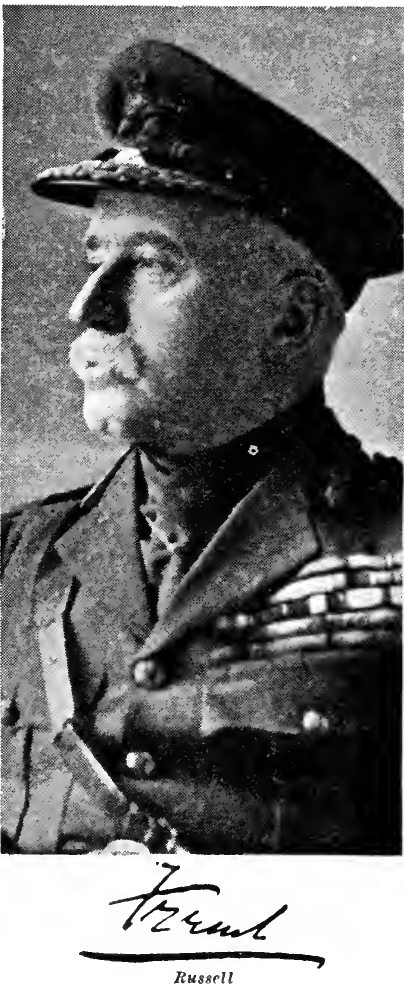

Lord Roberts came out he gave French 5,000 men for the relief of Kimberley, which the force entered, after perhaps the most romantic gallop of the war. From Kimberley he galloped again with a tired remnant to cut off Cronje as he escaped from Paardeberg. He commanded the cavalry in the operations that ended in the capture of Bloemfontein and Pretoria, and the left wing in the battles east of Pretoria, June 10-12, 1900, and was in charge of the operations in the eastern Transvaal until the war ended in 1902.

French received a K.C.B. and K.C.M.G., and in Sept., 1902, was promoted to the rank of lieutenant. general with the Aldershot command, which he retained till 1907. He became known as a worker who spared neither himself nor his men. At the age of $\mathbf{5 5}$ he became full general, and in Dec., 1907, succeeded the duke of Connaught as inspector-general. $\mathrm{He}$ became A.D.C. to the king in 1911, and in March, 1912, succeeded Sir William Nicholson as chief of the imperial general staff, an appointment that caused some comment on the ground that General French, like his predecesscr, had not been through the staff college. In 1913 he was made ficld-marshal. His reputation had grown even on the Continent, where he had repeatedly studied military operations.

\section{The Expeditionary Force}

French's carcer seemed to end in 1914, when he resigned, in consequence of the Government's action over the resignation of British officers at the Curragh Camp in connexion with the trouble in Ulster. On the first hint of the German threat, however, he was selected to lead the expeditionary force. Embarking with his staff on Aug. 14, he reached his own H.Q. at Le Cateau on Aug. 17. On Aug. 23 he was in contact with the enemy, the battle of Mons was fought, and the famous retreat began. It ceased on Sept. 5, and on Sept. 7 French ordered the advance across the Grand Morin river. The pursuit to the Aisne began and the armies there became static.

On Sept. 16 French deliberately came to the decision that frontal attack was hopeless, and began to urge the march to Belgium. as he wanted to prevent the Germans from capturing the Channel ports. His views slowly prevailed, though not in their entirety, and the terrible battle of Ypres opened on Oct. 19, ending successfully on Nov. 21, when the British troops defeated the German attempt to capture the salient. All this time and up to the close of the battle of Festubert in May, 1915, French had urged the supply of more and more ammunition, especially high explosive shells. He recorded the facts in his rather controversial autobiographical book entitled "1914." He saw the battle from a ruined tower, and was so overwhelmed by the contrast of ammu. nition supply of the contending 
armies that he told the whole story to Colonel Repington, military correspondent of The Times, whose dispatch caused in the sequel the fall ot Asquith's government, and, in French's words, " the organization of the nation's industrial resources upon a stupendous scale."

French's military career had now reached its climax. He surrendered his command to Haig on Dec. 15, and in 1916 a viscounty was conferred on him. He became Viscount French of Ypres and High Lake, Roscommon, the residence of his ancestors since the opening of the 17th century. He took command of the forces in Britain until, in 1918, he was appointed viceroy of Ireland. $\mathrm{He}$ remained there through thetroubled years following 1918 , though rumours of his resignation were frequent, retiring in 1921. He was created an earl and took the title of Earl of Ypres. His heir is his elder son, Hon. John R. I. French (b. 1881). His younger son was wounded in 1917 . French's many honours include the O.M. and the K.P.

\section{French Equatorial Africa.} Term including the three provs. of Gabun, Middle Congo, and Ubangi-Shari-Chad. The colony is bounded by the Cameroons on the W., the Anglo-Egyptian Sudan on the $\mathrm{E}$., the Belgian Congo on the S., and the Atlantic Ocean on the S.W. French Equatorial Africa is administered by a governorgeneral, with headquarters at Brazzaville, and the three provinces are administered by lieutenant. governors residing at Libreville, Bangui, and Fort Lamy respectively. Each province has adminis. trative autonomy and a separate budget, but there is also a general budget for the whole colony.

The resources of the colony are almost undeveloped, but it is ex. tremely rich in forestal and tropical products, and in the far $\mathrm{N}$. there are great cattle-grazing grounds. Communications are mainly along the waterways, the chief of which are the Congo, Ubangi, and Shari rivers, but native porterage is necessary on the connecting tracks. The area, exclusive of those portions allotted to the Germans in 1911 and now again French territory, is about $900,000 \mathrm{sq}$. m. Pop. about $6,000,000$, of whom about $2,000,000$ are in the Chad military territory and about $1,500,000$ in the rest of the Ubangi-Shari-Chad province. See Gabun; Middle Congo; Ubangi-Shari-Chad.

French Horn. Most important brass instrument used in the or. chestra. It is of tenor compass, and of mellow, vocal tone. See Horn; Orchestra.

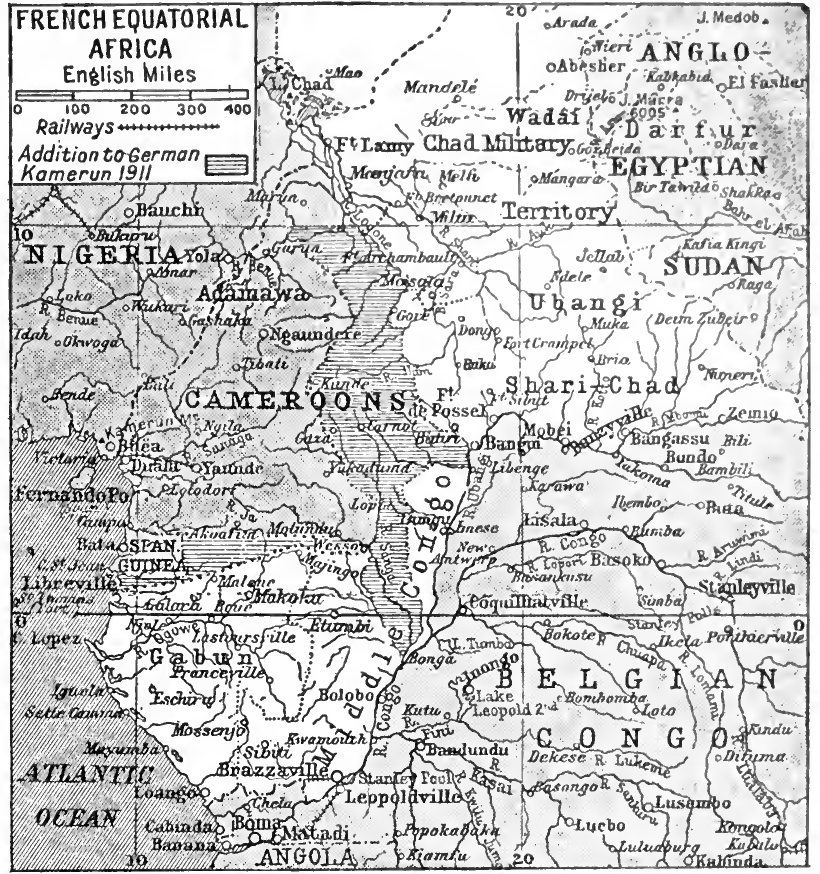

French Equatorial Africa. Map of the French Colony between the Congo and Lake Chad, with the territory ceded to Germany in 1911, and since regained as part of Cameroons

French Polish. Solution of gums or gum-resins employed to give a polish to wood. The process of producing the polish on the wood is known as french polishing. The composition of french polish varies according to the preference of the worker. Shellac is always the main ingredient, and the solvent is alcohol (spirits of wine, methylated spirit or finish). Finish is spirit denaturised by the addition of shellac ( 3 ozs. to a pint), so that it can be sold duty free and without the seller being licensed.

The simplest form of polish consists of a solution of 6 ozs. of shellac in a pint of spirit, but when other ingredients, such as mastic, sandarac, elemi, thus or benzoin are included in the formula, the quantity of shellac is correspondingly reduced. The gums and gum-resins mentioned are soluble in spirit if time be allowed, and if the bottle that contains the ingredients be kept in a warm place.

\section{Polishing Process}

The process of french polishing is really a series of operations consisting of (1) the preparation of the wood; (2) the polishing; and (3) the finishing. The surface of the wood is made as smooth as possible by glass-paper and sand-paper, and is then subjected to a process of filling in the pores of the wood with a creamy paste of plaster of Paris or whiting and linseed oil. The filler is coloured according to the nature of the wood, using rosepink for mahogany, brown umber for walnut, and yellow ochre for oak and other light woods. The colour of the wood is also darkened at this stage if desired by applying suitable colouring matters. The surface of the wood is again smoothed with sand-paper and the french polish applied. A pledget of woollen rag or cotton wool is saturated with the polish and enclosed in a piece of close-texturcd cotton fabric, so as to make a smooth, hard surface. A few drops of linseed oil and of polish are applied to the pad and rubbed on to the wood with a free, continuous and circular movement, taking care not to treat too large a surface at one operation.

The spirit evaporating during the polishing leaves a hard surface of shellac on the wood. The first polish is generally rubbed down with sand-paper, and the polishing repeated until a uniform surface is obtained. This is allowed to remain for a few days when the finishing process is carried out, i.e. wiping the surface with a small quantity of spirit. 


\section{FRENCH REVOLUTION, 1789-1795}

A. D. Innes, Author of A General sketch of Political History

This article deals with a special movement in French and European history. See the articles on Mirabeau: Robespierre, and the great figures of the Revolution; those on Directory; Feuillants ; Girondists ; Jacobins, etc. See also Europe; France; Louis XVI; Napoleon

The French Revolution is the name given to that period of volcanic upheaval in France, usually reckoned as beginning with the meeting of the States-General in May, 1789, and closing with the establishment of the Directory in Oct., 1795. Its ideal was set forth in the three wordsLiberty, Equality Fraternity. In form it was a terrific convulsion; its methods trampled its principles in the mire ; it issued, not in democracy, but in Caesarism. Nevertheless it undermined the foundations of the old order of privilege, and inaugurated the long struggle for the political, social, and economic emancipation of the masses of the European population.

France in 1788 had reached the stage at which drastic reforms had become a sheer necessity; failing reforms, the only possible alternatives were a stormy revolution or the establishment of an irresistible tyranny. Her political system, consummated under Louis XIV, was an uncompromising absolutism which allowed the pcople no share whatever in the government. The king ruled through ministers whom he appointed or dismissed at his own pleasure-ministers nearly always chosen from the aristocracy. and responsible to no one save to the king himself. Socially, the population was divided into rigid castes, forming primarily three groups, the noblesse or aristocracy of birth, the clergy, and the commons. In France all the members of a noble family remained of the noblesse, not commoners at all, from generation to generation. The clergy were separated from the rest not by birth, but by the rule of celibacy and by their sacred functions.

In the towns there was a middle class - the bourgeoisie, professional men and traders-and a working class; in the country districts the peasantry were virtually the serfs of the seigneurs, the landed proprietors who owned the soil, to whom they were legally bound to render payments and unpaid services, and who exercised a broad jurisdiction over them. Economically, noblesse and clergy were almost exempt from taxation. The whole burden of providing the national revenue, the cost of the court, of war, of administration, was on the shoulders of the commons. and pressed most heavily upon the peasantry who were least able to bear it. There was no liberty of the individual.
But the seeds of change had been sown by the "intellectuals." The mockery of Voltaire had shattered the sense of reverence for conven. tions. The writers in the Grande Encyclopédie, D'Alembert, Diderot, and others, had challenged all the principles upon which the social and political structure was based. Jean Jacques Rousseau had propounded palpably revolutionary doctrines, notably in his Contrat Social, teaching that the organization of society rested upon an original contract imposed by the strong, for their own interest, upon the weak, claiming that the ultimate authority is the Will of the People, and insisting upon "natural rights," the Rights of Man.

With a light heart France, in order to injure England, had taken the part of the Americans, and French aristocrats, unconscious that they were sporting on the crater of a volcano, played gaily at advocating those same revolution. ary ideas. Meanwhile, France was rushing towards bankruptcy, the result of accumulated expenditure upon wars of aggression from which there had been but very brief respites during the last century and a half.

The immediate cause of the cataclysm was this financial chaos. The crushing burden of taxation and forced labour imposed upon the unprivileged classes, the obvious need for reorganization, the opposition persistently offered to any

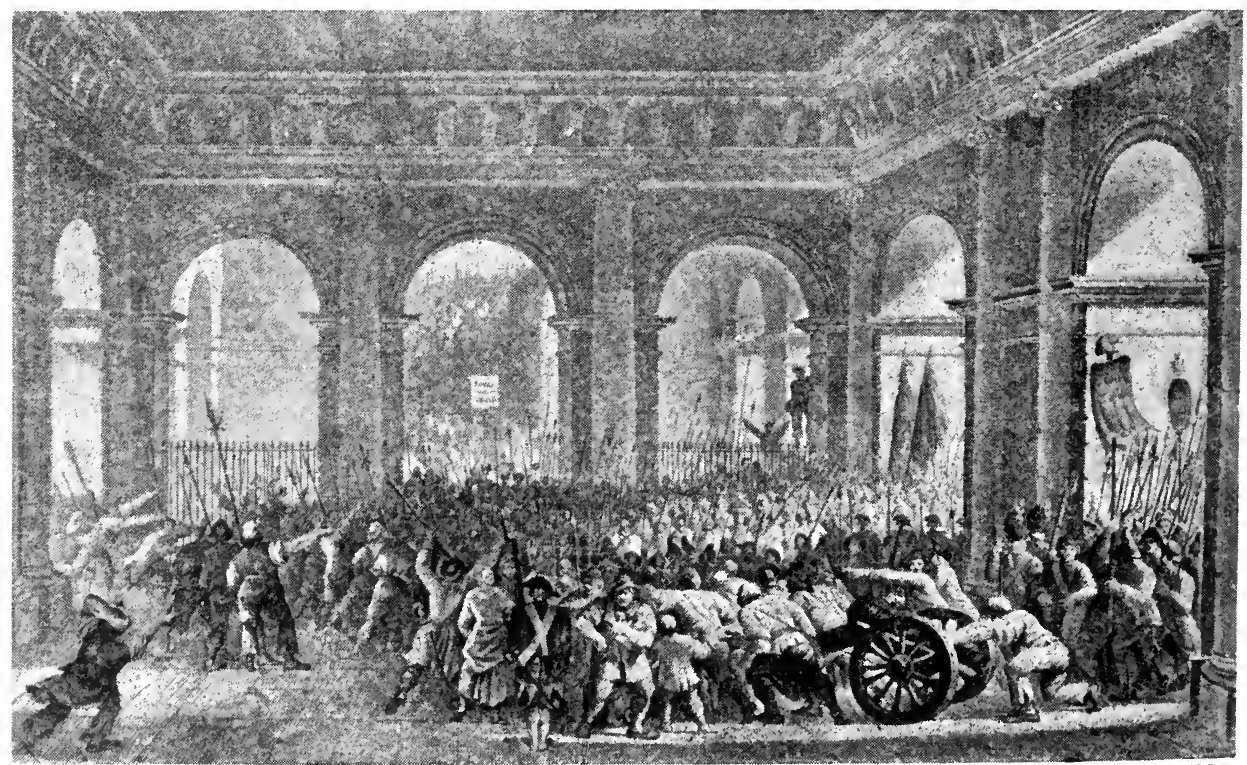

French Revolution. The mob invading the Tuileries palace in an attempt to intimidate the king and queer, June 20, 1792

From a drawing in the Louve, Paris 
reorganization by the privileged classes, the disastrous failure of a succession of incompetent ministers to discover any remedy for the chaos, led to the suggestion that the Government should consult the nation by summoning an Assembly of the three estates, noblesse, clergy and commons, an obsolete form of a National Assembly which had not been called together for the best part of two centuries.

In Jan., 1789, the States-General was summoned. At the beginning of May it assembled, the Third Estate, or commons, appearing by its elected representatives, among whom were included a sprinkling of aristocratic sympathisers. It was apparent that, if the three estates voted as separate chambers, as the government intended, the two privileged chambers would be in permanent agreement, resolved to

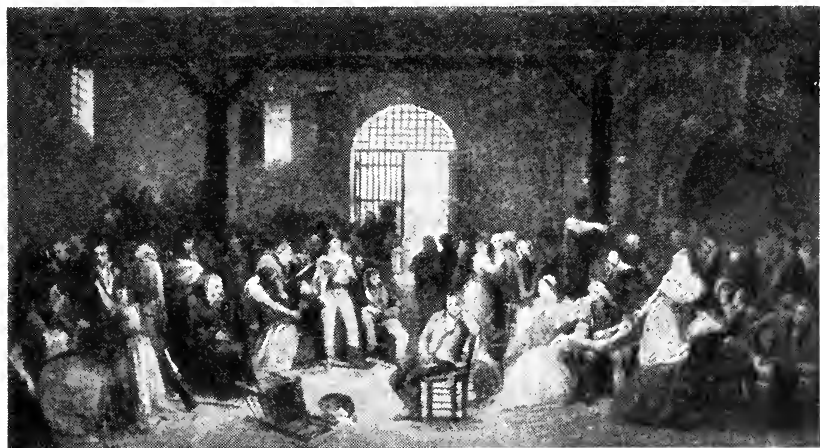

French Revolution. Roll call of the last victims of the Reign of Terror, 1794. The seated figure in the centre is André de Chénier, who wrote his most famous poems in the pr ison of Saint-Lazare

From a pieture by $C$. L Muller, al Versailles

surrender no fraction of the privileges which in their view constituted the safeguards of society. The voice of the Third Estate would count for nothing unless all the chambers voted together, giving the preponderant voting power to the preponderant numbers of the Third Estate.

This was the first battle-ground, and the fight was won by the Third Estate, led by the aristocrat Mirabeau. Its delegates assumed the title of the National Assembly, and were joined by many of the representatives of the lower clergy. The sympathies of the whole population of Paris and the whole rank and file of the soldiery were with them. An appeal to force was too dangerous to be attempted; the government gave way and the Estates were constituted as a single chamber.

The court sought to save itselt and to overawe Paris by means of mercenary regiments, Germans and Swiss. Paris armed itself ; on July

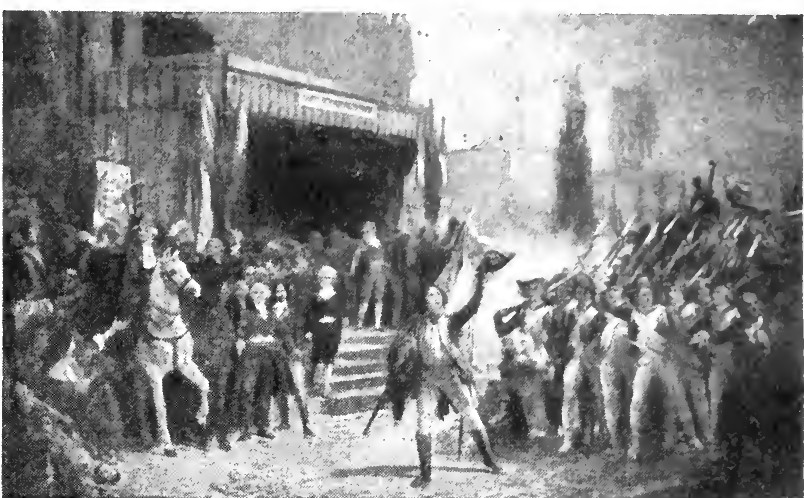

French Revolution. Enrolling volunteers to serve in the Revolutionary armies From a picture by Vinchon, at Versailles

14 the mob marched upon the Armed Paris organized itself as the Bastille, the fortress-prison which National Guard. The fall of the Bastille was hailed as typifying the fall of the old order. The National Guard was placed under the com. mand of the popular nobleman Lafayette; it adopted the tricolour for its colours. All over the country mobs rose, and the down-trodden peasantry turncd their fury upon the châteaux of the seigneurs, while payment of taxes was refused. The whole machinery of government had broken down, though some semblance of order was preserved by the efforts of the middle classes and by the organization in the provinces of National Guards after the Paris model.

On the other hand the king, Louis XVI, a man hopelessly lacking in insight, but with the best of intentions and abundant personal courage, won a moment's popularity by boldly preserting himself of the old system, and stormed it. in Paris, obviously at the risk of

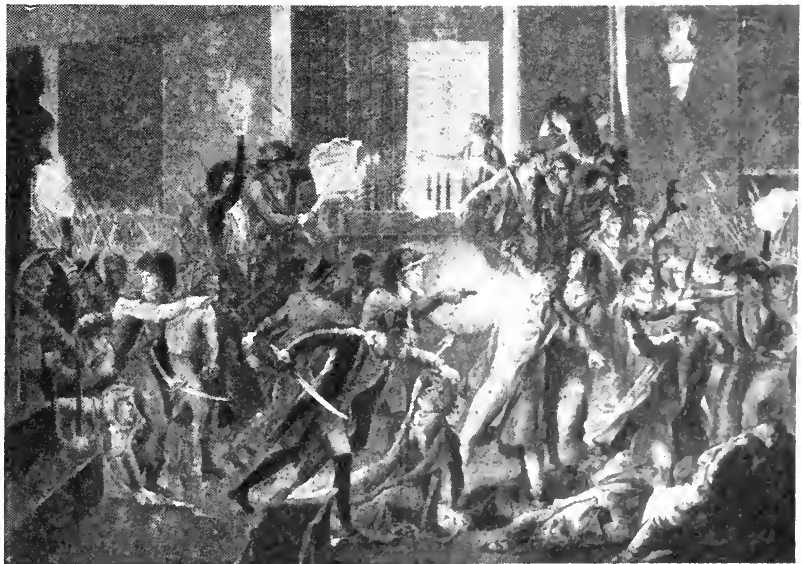

French Revolution. The arrest of Robespierre amidst the turmoil and strife of the night of $9-10$ Thermidor, 1794 From a contemporary print 
his life, and mounting the tricolour cockade. Popular hostility, however, was directed not against him but against the arrogance and the privileges of the noblesse. These, the enthusiasts declared, were at the root of the woes of France; and on Aug. 4 the National Assembly decreed the abolition of the whole mass of the obnoxious privileges; after which it set about formulating a constitution, taking to itself the title of the Constituent Assembly.

While the Assembly continued its work of wholesale abolition and wholesale reconstruction, the king was kept virtually a prisoner in Paris; numbers of the nobility were fleeing or had already fled into a voluntary exile in the hope of eventually recovering their lost privileges by force; and outside the Assembly was organized the political association of reformers known as the Jacobin Club, which derived its name from its meeting place, the Dominican or Jacobin convent of the Rue S. Jacques. The club, affiliating to itself similar clubs all over the country, became a great political power.

\section{Death of Mirabeau}

It is conceivable that Mirabeau, if the court party had placed itself unreservedly in his hands, might have succeeded in effecting a reconstruction combining a monarchical executive with a democratic legislature, capable of providing a strong government with popular sympathies; but the court party had few ideas apart from striving to paralyse the activities of the Assembly, in which they were aided by the extremists of the other wing. The last chance, such as it was, perished with the death of Mirabeau on April 2, 1791. The king, finding himself helpless, resolved upon flight. He attempted to execute the design (June), but was detected and stopped at Varennes as he was nearing the frontier, and was brought back.

The flight to Varennes and the documents which Louis had left behind made it clear that the king was antagonistic to the constitution which had been designed, also that it was probable he would seek to evade it or overturn it. There was more than excuse for the suspicion that he and his wife, Marie Antoinette, if they had crossed the border, intended to appeal to the crowned heads of Europe and more particularly to the queen's brother, the emperor Leopold II. The émigrés, the fugitive noblesse, notable among whom was the king's brother, the count of Artois (afterwards Charles X), were already clamouring for armed intervention from abroad.
Leopold, in conjunction with the king of Prussia, issued the declaration of Pilnitz - a warning that the Powers could not recognize the existing French government until the reinstatement of the king, and threatening intervention should the Powers be unanimous-a perfectly safe threat, since Leopold knew that the Powers would not be unanimous. On the other hand, the declaration was calculated to silence the émigrés.

The Legislative Assembly

Meanwhile in France the more advanced democrats were calling for the deposition of the king, even for the declaration of a republic. Moderates like Lafayette, men who two years before had been regarded as the leaders of the advance guard, rallied to the monarchy and urged on the king the adoption of the constitution promulgated by the Assembly. His acceptance reinstated him as king, with limited powers. The constitution provided for the appointment of a new Legislative Assembly in which all members of the National Assembly were prohibited from sitting.

The members of the National Assembly had at least attained some experience of administrative functions; the members of the new Legislative Assembly were without experience at all, and were for the most part doctrinaire republicans. On the reinstatement of the monarchy the declaration of Pilnitz was withdrawn. But it had had a fatal effect upon which Leonold had not calculated. Its subtle intention was mis. understood in France, and it was regarded simply as an insolent attempt on the part of foreign Powers to dictate to France on a domestic question with which they had no concern.

In the Assembly there were three main groups besides the infinitesimal sprinkling of thorough-going royalists : the Feuillants or Constitutionalists, the Girondins, who came from the department of the Gironde and may be described as literary republicans; and the ultrademocrats, now identified with the Jacobins. The Feuillants and the Girondins were both disposed to adopt a highly aggressive attitude towards the foreign Powers and the émigrés. Louis found himself forced to discard his royalist ministers and put Girondins in their places. Though the Jacobins held aloof, for which the leaders outside, Danton and Robespierre and Marat, had their own reasons, Louis was compelled to declare war upon Austria at the moment when the emperor Leopold died and was succeeded by Francis II (March, 1792).

Dumouriez, the new war minister, had again developed Louis XIV's conception that the borders of France should be extended to her "natural boundaries," the Rhine, the Alps, and the Pyrenees. Patriots hastened to join the as yet ill-organized armies on the frontiers. Ill-success was attributed to the aristocratic officers. Riots broke out in Paris, the mob invaded the Tuileries and insulted the king and the royal family. Prussia declared war in alliance with Austria-it must be remembered that at this time the Netherlands belonged to Austria, and the modern Belgian frontier was then the AustroFrench frontier. The duke of Brunswick, on behalf of Prussia, issued a threatening manifesto which filled Paris with wrath. The Jacobins had captured the Commune (the government of Paris), and virtually dominated the Legislative Assembly.

\section{The Victory of Valmy}

The prisons were crowded with suspects, persons supposed to be under suspicion of collusion with the émigrés. The advance of the Prussians created a panic; there was a widespread belief that there was a royalist plot for a royalist insurrection in Paris. The Com. mune organized a visitation of the prisons, and in the September Massacres hundreds of captives were slaughtered. Simultaneously came the news that the Prussians had been checked in an engagement at Valmy. From that time the armies of the Republic habitually proved themselves more than a match for their enemies.

With the close of Sept. the Legislative Assembly gave way to a new National Convention, part Girondist, part Jacobin, and altogether Republican. It proceeded at once to declare that the monarchy was abolished and a Republic established, and all populations in districts occupied by French troops were proclaimed freed from the monarchies under which they were supposed to have groaned. The French Republic had assumed the character of an aggressive champion of the Liberty which it was determined to impose upon the peoples of Europe in a general war against monarchy. It clinched its position by repudiating treaties, finally challenging England by declaring the opening of the navigation of the Schelde and by throwing down the head of a king as its gage of battle to the kings of Europe. Louis was brought to a sort of trial, and was beheaded Jan. 21, 1793. 
Then, while French armies were achieving successes against their enemies beyond the frontier, the parties in Paris fell to devouring each other. The Girondins had now become the party of moderation; the Jacobins won the supremacy, drove them from office, and sent many of them to the guillotine. A Committee of Public Safety was organized which wielded despotic power ; its emissaries accompanied the armies, and were scattered all over the country, none daring to dispute their behests. While one of the members, Carnot, was sufficiently occupied as the war minister organizing victories, the Reign of Terror was instituted, and the guillotine devoured its victims in numbers that increased week by week from scores to hundreds. On July 13 Marat was slain by Charlotte Corday, but his death made no difference. The mere accusation of being well affected to the aristocrats was the almost unfailing precursor of imprisonment and death.

On Oct. 16, 1793, Marie Antoinette, the widow of Louis, who had died with kingly calm and dignity, followed her husband to the scaffold. A month later the guillo. tine claimed among its victims Marie Roland, the heroine of the Girondists. Day by day the tumbrils rolled through the streets of Paris; in the provinces like scenes, and scenes even more repulsive, were enacted.

\section{The Fall of Danton}

Danton the inexorable, who shrank from nothing when he deemed that the cause of Liberty would be furthered by frightfulness, sickened of the purposeless slaughter ; even Robespierre was nauseated by the vulture flock that was headed by the detestable Hébert. Suddenly he turned on them, and on March 24, 1794, Hébert's own head fell. But Robespierre was minded for no more concessions to the Indulgents, the group of whom Danton, weary of bloodshed, was the leader; his own ascendancy was at stake; on April 5 the great Tribune was struck down. But the carnival of blood was no longer to be endured. A conspiracy was organized. Suddenly, on July 27, Robespierre himself was seized, and on the following morning he was beheaded. With his death and the execution of his partisans which immediately followed, the Reign of Terror was ended.

It remained to evolve one more constitution, a constitution which was to place the administration in the hands of a Directory of five, while legislation was to be entrusted to two Assemblies. This soheme, arrived at a year after the fall of Robespierre, did not command universal assent, especi. ally in Paris. But the government were prepared for an insurrection, and when it came they had entrusted the arrangements for its suppression to a young officer of artillery, Napoleon Bonaparte. His success was complete. The Directory was established by the coup d'état of Vendémiaire (Oct. 5, 1795), and Bonaparte was re. warded with the command of the armies of the Republic in $N$. Italy. Four years were to pass before another coup d'état made the young general First Consul, and in effect transformed the French Republic into a military monarchy. Not till 1871 was a republic to be permanently estab. lished in France.

\section{Results of the Revolution}

But the meaning of the French Revolution is not to be tested by its success or its failure in es. tablishing republican institutions. Republicanism was only one of its accidents; the basic principles on which it rested are no less com patible with a constitutional monarchy than with a republic. Essentially, its political demand was for the "government of the people for the people by the people"; the movement assumed its terrific character because it arose when nearly all the peoples of Europe were governed mainly in the interests of particular classes by absolute rulers. It did not succeed in establishing any. where the practice of "government by the people"; in Europe generally the force wielded by governments, not by the people, was too strong for them to be readily overthrown, and the actual excesses perpetrated in France checked for the time the moral forces which would naturally have been thrown into the scale on the side of Liberty. But a spirit had been aroused which, though it might be sternly repressed, could never again be completely allayed.

If the French people were still willing to submit themselves com. pletely to a master who could be idealised as a hero, it had yet become impossible after the Revolu. tion to lay upon them the old yoke, to subject them to the absolutism of an hereditary prince or the domination of an hereditary caste. Everywhere the Revolution forced upon privileged and unprivileged classes alike the consciousness that the unprivileged have rights which cannot altogether be ignored, that revolution will always lurk under the throne of tyranny; the peoples of Europe owe it to the French Revolution that, however slowly and gradually, they have yet won in a greater or less degree a hearing for them. selves in their own governments.

The French Revolution was the direct cause of the great movement which has turned South America into a group of self-governing states instead of a congeries of provinces administered as the estates of an absolute monarch. Politically, the feudal system of the Middle Ages had perished long before; as a social system it had remained rampantly dominant. As a social system the Revolution shattered it-utterly among the Latin peoples, though not so completely elsewhere. However we may shudder at the methods which the Revolution employed, at a time when elemental forces broke loose which no man could control, its fundamental principles have become part and parcel of the creed of civilized humanity. See Bastille, illus.

Bibliography. The French Revolution, Thomas Carlyle, 1837, and since frequently re-edited; The French Revolution, B. M. Gardiner, 1883 ; Hist of the French Revolu. tion. H. Morse Stephens, 1886, etc. ; The Revolutionary and Napoleonic Era, J. H. Rose, 6th ed, 1907 ; The French Revolution, H. Belloc, 1911 : The Relations of French and English Society, 1763-1793, C. H. Lockitt, 1920.

French Sixth. In music, chromatic chord consisting of a bass note with a major third, augmented fourth, and augmented sixth above it :

It belongs

to the key of its major third -in this case C-but it ean

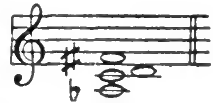

be used also in other keys. The origin of the name is uncertain. See Chromatic; Interval.

Frensham. Village and parish of Surrey, England. It is $3 \frac{1}{2} \mathrm{~m}$. S. of Farnham, and is noted for its two lakes or ponds. 'The larger of them covers 90 acres and is visited for boating and fishing. The church of S. Mary, restored in 1866, has some interesting features, parts of it being Early English. Frensham Common is a large open space, used by the military for manoeuvres and the like. Pop. 3,272.

Frenssen, Gustav (b. 1863). German novelist. Entering the Church as a young man, he became a country pastor. His first work, Die Sandgräfin, appeared in 1896 , and was followed two years later by Die drei Getreuen. Jörn Uhl, 1901 , was a great success and was followed by a series of novels. After 1902 he gave up his cure and devoted himself to literature. 
Frequency or Periodicity. The number of complete double reversals per second of an alternat ing electric current. It ranges from 10 to 100,000 or more in different kinds of apparatus. See Generator; Induction Coil; Wireless Telegraphy.

Frere, ЈонN Ноокнам (17691846). British diplomatist and translator Bornin London, May 2l,

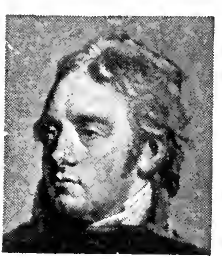

John Hookham Frere British diplomatist After J. Hoppner
1769 , eldes son of John Frere (1740 1807), the an tiquary, he was educated at Eton, where he began his friendship and literary colla. boration with George Can . ning, and at his father's college (Caius) at Cam. bridge, of which he was fellow 1793 1816. He entered the foreign office, and in 1796-1802 represented West Looe in the House of Commons. He was foreign under-secretary, 1799 ; envoy to Lisbon, $1800-2$; minister at Madrid, 1802-4; privy coun cillor, 1805 ; and minister to Spain again, 1808-9, being recalled after the retreat of Moore to Corunna. He settled in 1818 at Malta, where he died,Jan. 7,1846 , being buried in the English cemetery beside his wife.

Frere, who twice refused a peerage, as a writer sought more the critical approval of the few than the applause of the public for his work. While at Eton he joined Canning and others in promoting The Microcosm, 1786-87 ; and displayed a remarkable power of writing in the style of the ancient ballads. He was one of the found. ers of The Quarterly Review. His pungent wit and metrical facility show to advantage in his render. ings of The Acharnians, Knights, Birds, and Frogs, of Aristophanes, 1840. Byron was indebted to him for the ottava rima of Beppo. See Works, with memoir by W. E. and Sir Bartle Frere, 1872; the Translations of Aristophanes, with intro. by W. W. Merry, 1907.

Frere, Sir Henry Bartle EDWARD (1815-84). British ad. ministrator. Born at Clydach,

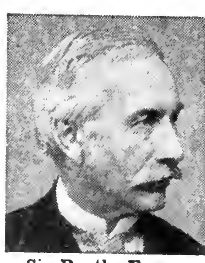

Sir Bartle Frere, British administrato B recknock. shire, March 29,1815 , and educated at Bath Gram. mar School and Hailey. bury, he en tered the Bombay civil service in 1834. For his

services during the Mutiny he re. ceived the thanks of both Houses of Parliament, and was created K.C.B. $\mathrm{He}$ was governor of Bom. bay from 1862-67, and after accom. panying the Prince of Wales to India, received a baronetcy in 1876 .

In 1877 , he was appointed gover-

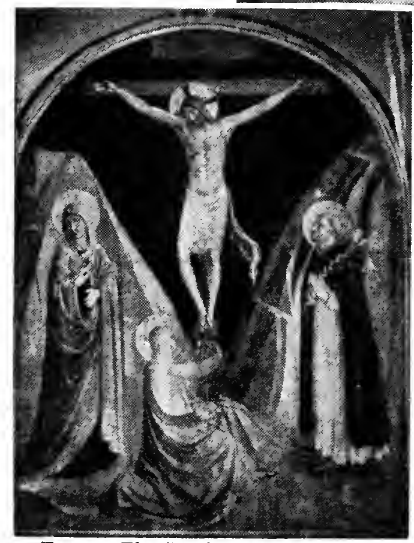

Fresco. The Crucifixion, and, above, Christ received by two Dominican monks, painted in fresco by Fra Angelico in S. Mark's, Florence

nor of the Cape, and high com. missioner for the settlement of native affairs in $\mathrm{S}$. Africa, with a view to the confederation of the S. Africa colonies. His action in relation to the Zulu War was censured by the Government, his conduct of affairs in India and Africa was violently assailed by Gladstone in the Midlothian campaign, and he was recalled in 1880 . The justi fication of his action is contained in his Correspondence relating to the Recall of Sir Bartle Frere, 1880 and in Afghanistan and South Africa : a Letter to the Right Hon. W. E. Gladstone, 1881. He died, May 29, 1884, and was buried in S. Paul's. A monument to him, on the Thames Embankment, was unveiled by the Prince of Wales in 1888, and a "house" at Hailey. bury College was named "Bartle Trere" in his honour. See Life and Correspondence, John Martineau, 1895 .

Frère-Orban, Hubert Joseph WALTtr (1812-96). Belgian states. man. Born at Liége, April 24, 1812 , he adopted the legal profession, and in 1847 was elected deputy for his native city. Minister of finance, 1848-52, he introduced various reforms, reduced postal rates and advocated free trade. $\mathrm{He}$ was prime minister, 1868-70, and was again in power from 1878-84, carrying through many educational reforms. Leader of the opposition until 1894, he died, Jan. 2, 1896.

Frere Town. Settlement of Kenya Colony. It stands on the mainland, opposite Mombasa, and was named after Sir Bartle Frere. Here is a station of the Church Missionary Society, founded in 1874, with schools and hospital.

Fresco (Ital., fresh). Method of painting in water colour upon fresh mortar. It was the favourite process of mural decoration before the introduction of oil painting. The plaster must be fresh in order to absorb the colour, and since it dries rapidly, the artist must work with great dexterity, decision, and speed. The wall must be free of saltpetre, and only such colours can be em. ployed as are not affected by lime - a limitation which excludes certain of the most brilliant greens, reds, and yellows.

The artist first of all drew a cartoon (q.v.), and then transferred it piecemeal to as much fresh plaster as he could cover "at a sitting." The palette was dispensed with because it could not hold enough colours, and pots of different colours were used instead. Though regarded as a process of water-colour painting without agglutinants, size, or white or yolk of egg was required to fix certain colours. Theoretically, frescoshould last as long as the wall which it adorns, but meteorological con. ditions are vital, a damp climate being fatal. See Painting.

Freshfield. Cape or promontory on the coast of King George $V$ Land (q.v.), Antarctica. It is in lat. $68^{\circ}-69^{\circ}$ S., and long. $151^{\circ}$ E., and separates Cook Bay from Deakin Bay. Discovered by the Mawson Expedition of 1911-14, it was named after the English explorer and mountaineer, D. W. Freshfield. 
Freshfield, Dovglas William (b. 1845). British traveller. Born April 27, 1845, and educated at

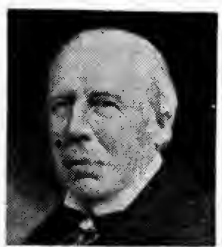

D. W. Freshfield,

British traveller

Elliotl \& Fry Eton and Uni-
versit y Col. lege, Oxford, lic was called to the Bar in 1870. An ar. dent moun. taineer,in 1869 he was the first to $\operatorname{climb} \mathrm{Mt}$. $\mathrm{K}$ a $\mathrm{s}$ b e k $(16,545 \mathrm{ft}$.$) , in$ the Caucasus.

In 1899 he made an expedition to Sikkim, and journeyed round Kangcbenjunga. He travelled in Uganda, Syria, Algiers, Caucasus, Armenia, etc. Member of the Council of the Royal Geographical Society in 1878, he was vice-president 1906-13, and president 1914-16. He was president of the Alpine Club, 1893-95, and chairman of the Society of Authors, 1908-9. He has published several books of travel, notably Travels in the Central Caucasus and Bashan, 1869 ; The Italian Alps, 1875 ; Round Kangchenjunga, 1903.

Freshwater. Parish and water. ing-place of the Isle of Wight, England. It stands on the river Yar, $1 \frac{1}{2} \mathrm{~m}$. S.W. of Yarmouth. It is the terminus of the I.W. Central Rly. Its parish church, built on the site of an older edifice, retains a Norman doorway, a 12th century arcade, and a memorial brass of 1390. Lady Tennyson was buried here. Freshwater cliffs attain a height of nearly $500 \mathrm{ft}$. Lord Tennyson resided for some time at Farringford House, in the neighbourhood, and a monument is erected in his memory on High Down. Pop. 3,192.

Fresh-water Deposits. Rocks containing fossil remains of fresh. water organisms, chiefly molluscs and plants. They occur most frequently in secondary and tertiary formations. In secondary rocks the fossil molluscs belong to types still living in fresh waters (e.g. Limneaea, Planorbis, Unio). Remains of land-mammals, reptiles, and land-plants are also found in these beds. The Old Red Sandstone with fossil mussel-like shells, and fish of ancient type, showing similarities to the Polypterus at present in habiting the Nile, is a notable example of fresh-water deposits of the primary period.

The Purbeck beds, including as fossils remains of fresh-water shells, ostracods, and mammalian bones and teeth, are a secondary deposit of this type. In the Tertiary (Oligocene) rocks of Isle of Wight occur fossils of similar affinities. Many fresh-water limestones, as in Isle of Wight, have been formed by action of lowly plants (Chara), which secrete lime contained in the water. Fresh-water deposits are often of great thickness, but having been laid down in lakes and estu. aries, are of limited extent in comparison with the vast areas of marine deposition. See Geology ; Rocks.

Fresnel, Augustin Jean (17881827). French physicist. Born at Broglie on May 10, 1788, he worked first as an engineer, and later made researches in optics, doing valuable work in connexion with the un. dulatory theory of light. He deduced the mathematical results of Thomas Young's experiments, and explained the interference of polarised as well as ordinary light. $\mathrm{He}$ died July 14, 1827.

Fresnes. Name of several villages of France prominent in the Great War: (1) in dept. of Pas. de-Calais, $4 \mathrm{~m}$. S. of Drocourt, notable in the third battle of Arras, April-May, 1917, and captured by the British, Oct. 8th, 1918. (2) in dept. of Meuse, known also as Fresnes-en-Woevre. It is near Les Eparges and N. of S. Mihiel. It was conspicuous in the French operations in the S. Mihiel salient, A pril, 1915 , and was captured by the 4 th U.S. div., Sept., 1918; (3) in dept. of Nord, $5 \frac{1}{2} \mathrm{~m}$. N. of Valenciennes, captured by the British, Nov., 1918; (4) in dept. of Somme, $3 \mathrm{~m}$. N. of Chaulnes, and $7 \mathrm{~m}$. S.W. of Péronne. Captured by the French in the spring of 1917, it was re-taken by the Germans in the spring of 1918 , and was re-captured by the Allies in the autumn of 1918. See Arras, Third battle of ; Sambre, Battle of the.

Eresnillo. Town of Mexico, in the state of Zacatecas. It stands on the slopes of the Cerro del Proaño, about 7,000 ft. above sea-level, and is $36 \mathrm{~m}$. N.W. of Zacatecas by the Mexican Central Rly. The chief industry is the working of the silver and copper mines, discovered in the middle of the 16 th cent. ; agricultural pursuits and stockrearing are engaged in. Pop. 6,750.

Fresno. City of California, U.S.A., the co. seat of Fresno co. It lies in the valley of the San Joaquin, 200 m. S.E. of San Francisco, and is served by the Atchison, Topeka, and Santa Fé and the Southern Pacific rlys. Irrigation is largely resorted to in the neighbourhood, which produces grain and grapes in considerable quantities. Petroleum is obtained, and mining and stock-rearing are carried on. The chief industrial establishments include preserved fruit, wagon, and macaroni factories, flour mills, and an oil refinery. The federal building, a city hall, and a public library are notable buildings. Founded in 1872, Fresno received a city charter in 1885 . Pop. 28,810.

Fresnoy. Village of France in the dept. of Pas-de-Calais. It is 4 m. S.E. of Lens, and slightly $\mathbf{N}$. of Oppy. Cantured by the Ist Canadian div., May 3, 1917, it was retaken by the Germans on May 8 , and finally regained by the British, Oct. 6, 1918. Fresnoy-le-Grand is $5 \mathrm{~m}$. N.E. of St. Quentin in the dept. of Aisne. It was captured by the Allies in the great offensive of the autumn of 1918. Fresnoylès-Roye, near Roye, was the scene of heavy fighting Aug.13-20, 1918. See Arras, Third Battle of ; Ie Cateau, Second Battle of.

Fret. In heraldry, mascle inter. laced by a cotice and a baton. A shield fretty is covered with a trellis or interlaced diagonal bands. The trellis may be nailed or cloué. See Ordinary.

Fret. Little ridge upon the fingerboard of some stringed instruments to mark the point at which the player's finger must shorten the vibrating length of string to produce a certain note. On the violin and its larger relatives the fingerboards are plain, and the player's sense of position and pitch is his sole guide; but the older viols had fretted fingerboards, as have also the popular plucked instruments such as the lute, man. dolin, guitar, and banjo. See Fingerboard.

Fretwork (O.F. frete, trellis work). Carved woodwork in perforated patterns. The wood used should be of fine grain, such as satinwood, walnut, lacewood, sycamore, lime or maple. The strongest is three-ply, being made of three sheets of thin veneer rolled and cemented together, the grain of the middle sheet crossing that of the others. The usual thickness is a quarter inch, though inch thick wood is used sometimes.

The chief tools are a saw, drill, and bradawl; a fret-saw board and carving board being also necessary. The former is a piece of ordinary wood with a V-shaped opening at the front which allows the saw to be moved freely. The buhl saw, chiefly used, is a three. sided frame of steel or wood, of which the fourth side is formed by the saw, often no thicker than a thread. The wood to be carved being placed on the sawing-board, a hole having been drilled through it, the saw, detached at one end, is passed through the hole, then refastened in its frame to work from that centre. A fret-machine is an elaboration of the saw and allows both hands to be free for the necessary 


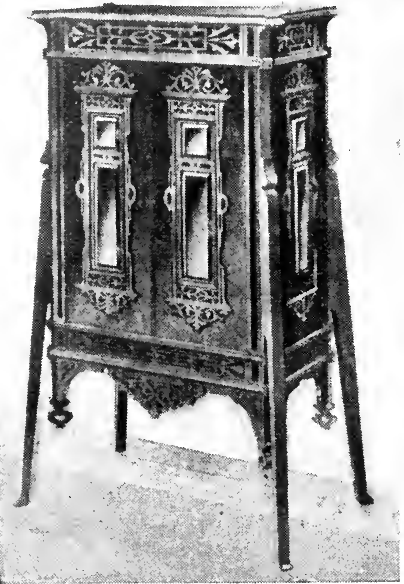

guidance. Fretwork in wood became popular for amateurs between 1870 80 ; but metal cutting, a branch of fretwork, for which the same method and tools are used, is of earlier origin. In architecture fretwork is the carved ornament, consisting of intersecting lines in relief, used as ceiling decoration. See Buhl.

Freud, Sigmund (b. 1856). Austrian scientist. Born at Freiberg, Moravia, May 6, 1856, he was edu-

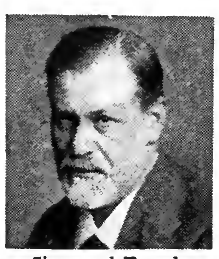

Sigmund Freud, Austrian scientist cated in Vien. na, and after studying in Paris and elsewhere, was appointed professor of the therapeutics of neurotic diseases at Vienna.

Freud made the discovery that many neurotic affections such as bysteria were due to a conflict between the conscious and the unconscious parts of the mind, the conscious endeavouring to act in conformity with social training and the restraints of civilization, while the unconscious was endeavouring to find an outlet for primitive tendencies which had been suppressed or partially sup. pressed by the patient. By gradually bringing the suppressed material into consciousness so that the patient understood his mental conflict, the symptoms were found to disappear. For this purpose Freud devised the method known as psycho-analysis, a process which may be employed in investigation of any form of fantasy, but is most often appled to dreams, which Freud considers represent in a disguised and symbolic manner the gratification of suppressed wishes. Freud's chief works which have been translated into English are: Selected Papers on Hysteria, 1895, 2nd ed. 1912 ; Interpretation of Dreams, 3rd ed. 1913; Delusion and Dream, 1917 ; Psychopathology of Everyday Life, 1901, new ed. 1914; Three Contributions to the Theory of Sex, 1905, 3rd ed. 1918 ; Totem and Taboo, 1913, new ed. 1919. See Dream; Psycho-analysis.

Freudenstadt (Ger., town of joy). Town of Württemberg, Germany. It stands on the river Murg, $40 \mathrm{~m}$. S.W. of Stuttgart. It has

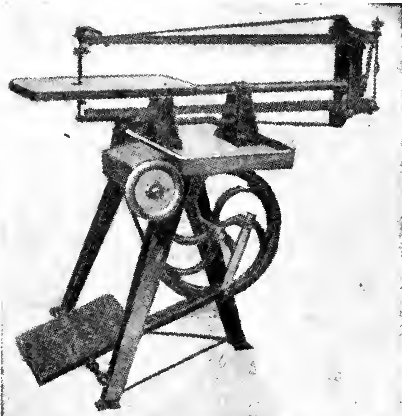

Fretwork. Treadle fret-saw. Above, cabinet made entirely of fretwork By courtesy of Hobbies, Ltd,

some small manufactures and a trade in timber; owing to its mild climate it is a health resort. There is a Rathaus and a remarkable old church consisting of two naves at right angles to each other, restored in the 19th century. The town has a theatre, baths, and other attractions for visitors. It was founded in 1599 by the duke of Württemberg for Protestants driven from Salzburg. Pop. 8,000.

Freyberg, BERNARD CYRIL (b. 1890). British soldier. Born in London, he was educated at Wel-

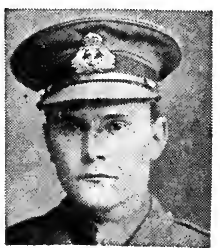

Bernard C. Freyberg, British soldier ling to n College, New Zealand, and became a lieuten. ant in the N.Z. territorial army. On the outbreak of the Great War he came to London, and joined the $R$.

Naval Division, serving at Antwerp, the Dardanelles, and in France (1914-18). He won the D.S.O. in April, 1915, in the Gulf of Xeros, and the V.C. for brilliant leading on the Ancre, Nov., 1916, where he organized the attack on Beaucourt. He was brigadier-general with the 29th division, 1917-18. See Beaumont-Hamel

Freycinet, Charles Lotis DE SAUloes dE (1828-1923). French statesman and engineer. Born at
Foix, Nov. 14, 1828, he be. came chief en. gineer for the Midi Rly. in 1856. Prefect of the dept. of $T$ a $r$ n-etGaronne, and assistant to Gambetta at the ministry of war, 1870 , he retired after the armistice, but was elected senator for the Seine dept. in 1876. He was minister of public works in two ministries between 1877-79, president of the council and foreign minister, 187980 and in 1882 and 1886, foreign minister under Brisson, 1885-86 (when his life was attempted, Oct. 29,1885 ), and minister of war in six different cabinets between 1888-99. In 1882 he was appointed inspector-general of mines.

No statesman held office more often under the third republic, and Freycinet's record included extensive reorganization of the rly. and canal systems of France, and reforms in the administration of French protectorates, and in the war office. The author of many books on scientific and political matters, he was elected to the French Academy in 1890. He died on May 15, 1923. Pron. Fraysineh.

Freyja. Goddess of love and healing in Norse mythology. Two white cats drew her chariot and she could fly in a magic feather skin. Her house in Asgard was Folkvang, where she received the souls of half the slain from Odin. She wept tears of gold for her absent husband, Odr.

Freyr or Frey. Norse god of rain, sunshine, and fruitfulness, especially worshipped in Sweden. Brother of Freyja, his house in Asgard was Alfheim. He possessed the Sword of Victory and also Skidbladna, a ship which could carry all the gods and yet be folded into his bag. He gave away the sword to win Gerda, a giant maiden, and thus was conquered in the last great fight.

Freytag, Gustav (1816-95). German novelist and dramatist. Born at Kreuzberg, Silesia, July 13,1816 , he studied philos. ophy at Breslau and Berlin, and taught for a time in Breslau University. Removing to Ber. lin, be edited Die Grenzboten, $1847-61$. $\mathrm{His}$ comedy

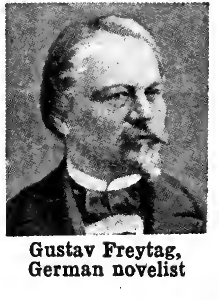


Die Journalisten (The Journalists), 1853, and Soll und Haben, 1855 (Eng. trans. Debit and Credit, 1857), dealing with middle-class life, established his fame.

In 1864 came Die Verlorne Handschrift (The Lost Manuscript), a successful deseription of the university life of the day. In the six parts of Die Ahnen (The Ancestors), 1872-80, he traced in a cycle of tales the evolution of the German social character. The first part was translated into English as Our Forefathers, 1873. He died at Wiesbaden, April 30, 1895.

Freytag-Loringhoven, AlexANDER, BARON VON (b. 1849). German soldier and writer. Born at

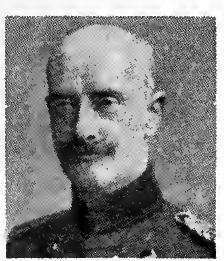

Baron von Freytag Loringhoven.

German soldier Rio de Janeiro, May 5, 1849 , he belonged to an old Prussian family; his father was a diplomatist. He was edu. cated at the universities of Dorpat and Berlin, entered the army in 1868, and served in the Franco-Prussian War. He became quartermaster-general in the field when Falkenhayn was chief of staff (1915-16). Later he was appointed deputy-chief of the general staff in Berlin. In 1917 he published Deductions from the World War. It was a candid explanation of the German failure and mentioned the methods by which Germany proposed to win " the next war."

Frezenberg. Village of Belgium, in the prov. of W. Flanders, $3 \mathrm{~m}$. E. by N. of Ypres. Conspicuous in the fighting in the Ypres salient in the Great War, it was the scene of a big German attack, May 8-9, 1915. A few days before, the Allied line had been withdrawn to the Frezenberg ridge, which commanded all the roads from $\mathrm{Y}$ pres by which men and stores were brought to that part of the salient. Yielded up to the Germans in April, 1918, it was finally retaken in the battle for the Belgian coast in the autumn of 1918. See Ypres, Battles of.

F.R.G.S. Abbrev. for Fellow of the Royal Geographical Society.

F.R.H.S. Abbrev. for Fellow of the Royal Historical Society and Royal Horticultural Society, which are sometimes written F.R.Hist.S. and F.R.Hort.S.

Friar (Fr. frère, brother). Term applied to members of the mendicant orders of the Roman Catholic Church. These have included Franciscans, 1209 ; Dominicans, 1215 ; Carmelites, 1245 ; Augustinians, 1256 ; Servites, 1233 ; Trinitarians,

1198; and Crutched or Crossed Friars, 1169. See Monasticism; consult also The Coming of the Friars, A. Jessopp, 1889.

Friars Crag. Hill overlooking Derwentwater, famous for its view. It is on the $\mathrm{E}$. side of the lake, about $1 \mathrm{~m}$. from Keswick. On it is a memorial to Ruskin.

Friar Tuck. Character in the stories associated with Robin Hood. $\mathrm{He}$ is described as chaplain to the outlaw. In the old time morris dance of the May games he attended upon Robin and Marian, the King and Queen of the May

F.R.I.B.A. Abbrev, for Fellow of the Royal Institute of British Architects.

Fribourg or Freiburg. Canton of W. Switzerland. It is S.E. of and in parts touching Lake Neuchâtel.

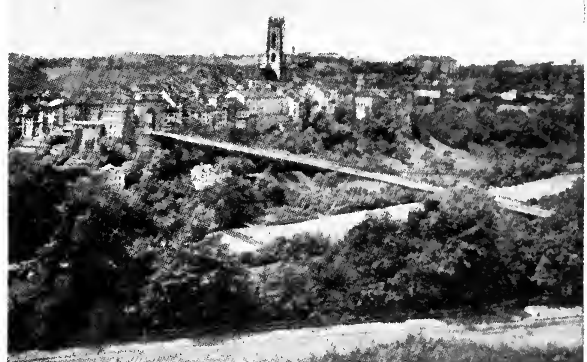

Fribourg, Switzerland. The town and suspension bridge across the Saane river

Area, 644 sq. m. Chiefly in the basin of the Aar, it is watered by the Saane with its tributaries, and the Broye. Undulating in parts, it is hilly in the S.E., where it impinges on spurs of the Bernese Alps, which rise to $8,000 \mathrm{ft}$. Mainly pastoral, it is noted for its cattle and cheese. French is generally spoken; German in the N.E. section of the Canton. There are hot springs at Bonn and Montbarry. Timber and tobacco are produced, watch and paper-making are carried on, and there is a chocolate factory at Broc. A Roman Catholic strong. hold, it has many convents; its cantonal constitution is not so democratic as that of the other cantons. Fribourg, the capital, is the only town of importance. Pop. 144,000.

Fribourg. Town of Switzerland, capital of the canton of Fribourg. It stands on the river Saane, $20 \mathrm{~m}$. by rly. S.W. of Berne. A lofty suspension bridge spans the river at the conflucnce with the Gotteron stream. The Saane cuts the town into two parts, that on the W. side standing on level ground, and the other among rocks and hills. The 13th century church of S. Nicholas is famed for its fine organ and its 15 th century belfry. Fribourg possesses a town hall, university, college, lycée, several libraries, and a museum of fine arts. Tobacco, pasteboard, leather, and art objects are manufactured. The town was founded in the $12 \mathrm{th}$ century. After passing to Savoy, it joined the Confederation in 1481 . It was taken by the French in 1798 . Pop. 20,394.

Fricassée (Fr.). Dish of boiled chicken or other meat, cut up and served in a white sauce. See Cookery.

Fricourt. Village of France, in the dept. of Somme. It stands on the stream of that name, $5 \mathrm{~m}$. E. of Albert. Captured by the British July 2, 1916, it was recaptured by the Germans, March, 1918, and retaken by the Allies in the follow. ing Aug. See Sonme, Battles of the.

Friction(Lat., a rubbing). Resist ance offered by one body to motion over another. As an example, con. sider a body resting on a table. It requires a certain force to move it along the surface of the table, and also to keep it moving. The magnitude of this force depends upon two things: (1) the material of which the substances are made, and (2) the normal pressure between the touching surfaces. In 1781 C. A. Coulomb pointed out that the friction was independent of the velocity with which the surfaces moved over one another. Though his statement is now known to be inaccurate, it. is, nevertheless, true for all ordinary velocities, though friction increases when bodies are moving very slowly over one another, and de creases when they are moving very rapidly. Friction between two bodies is greatly decreased by the use of lubricants.

It is easier to keep a body moving on a surface than it is to start it moving, and it follows that what is known as statical frietion, i.e. friction at rest, is greater than kinetic friction, or friction of motion. 'There is a third type of friction usually re. cognized. When a wheel or cylinder rolls on a surface, there is resistance to motion at the point of contact, and this is called rolling friction.

Frietion is of great importance in everyday affairs. Without it it 
would be impossible to walk, drive a tram along ordinary rails, etc., and all movement would have to be by the use of $\operatorname{cog}$ wheels or some similar arrangement. The friction of fluids and gases is properly called viscosity $(q \cdot v$.$) . See Force.$

Friction Tube. Device em. ployed for firing the charges in guns. It was adopted by the British service in 1853 to replace various adaptations of the flint lock, and mechanisms utilising percussion caps, for firing cannon. With the introduction of smokeless powders it was found necessary to provide some means of preventing the escape of propellant gases from the vent, as otherwise serious erosion occurred, and vent-sealing tubes were introduced. The fitting is T-shaped, and is clamped in the vent by the breech mechanism. The cross piece contains a rough. ened rod, embedded in a pellet of friction composition, provided with a looped end for the attach. ment of a lanyard, and secured by a safety-pin

The stem of the tube has a magazine filled with gunpowder, above which is a diaphragm bored with three fire holes, c o $\mathrm{mm}$ unicating with a tapered channel which ex. tends to the friction pellet, a soft copper ball being loose in the channel. The safety-pin is removed when the tube is fitted, and when the rod is withdrawn by pulling the lanyard, the friction composition ignites, and fires the magazine, the bottom plug being blown out and the charge fired. while the pressure wedges the copper ball against the sides of the

Friction Tube. $T$ tube used in the British army

taper channel and the body of the magazine against the walls of the vent, so preventing any escape of gas. In the British service the friction tube has largely been superseded by electric and percussion tubes, but is still largely used by other powers for all guns except quick-firing ones which use fixed ammunition. See Ammunition Artillery; Ordnance.

Friday. Sixth day of the week. The name comes from Frigg, the old northern goddess of love, and corresponds to the Latin Dies Veneris, day of Venus ( $c f$. French vendredi). The day is regarded as unlucky from its connexion with Christ's crucifixion, which is specially celebrated on Good Friday (q.v.). In the Roman Catholic Church it is a day of abstinence, except when Christmas falls on that day. 1881 .
Friday is the Mahomedan sabbath. The epithet Black is given to various disastrous Fridays, e.g. May 11, 1866 , when the failure of the banking house of Overend, Gurney \& Co. caused a financial panic. The Fridays in the ember weeks are called Golden Fridays.

Friday. Savage rescued by Crusoe from the cannibals about to sacrifice him, and named from the day on which he was so rescued. See Robinson Crusoe.

Frideswide. Fnglish abbess and patron saint of Oxford. Ac. cording to tradition, she was the daughter of Didan, viceroy of Oxford under Ethelbald, and Saxfrida his wife. At an early age she made a vow of chastity, and her father built and made over to her a church at Oxford, in connexion with which she founded a nunnery, and became herself its first abbess. Persecuted by a Mercian noble named Algar, she took refuge for a time at Binsey, where she built an oratory. After her death, in the latter half of the 8th century, her shrine became a centre of devotion, as did the well at Binsey, which is said to have originated in answer to her prayers. $\mathrm{Her}$ lieved to rest in Christ Church Cathedral, one of the four chapels in which is called after her.

S. Frideswide's nunnery was taken over by Austin Canons in 1004, and suppressed in 1525 by Wolsey,who replaced it by Cardinal College. Frideswide was canonised in 1481, has been regarded as Oxford's patron saint since 1180 , and her festival is still kept at Oxford o n O c t. 19 , though it dis. appeared from the English Church calendar at the Reformation. In addition to the church at Oxford, 1870-72,churches at Frilsham (Berks), Poplar, and at Borny, near Boulogne, are dedicated to her. See Christ Church; Oxford ; consult also Early History of Oxford, J. Parker, 1885; The Story of S. Frideswide, F. Goldie,

Friedland, BATtLE of. Victory of Napoleon over the allied Russians and Prussians, June 14, 1807. The failure of Murat's attack on the Russian entrenchments at Heilsberg, June 10, determined Napoleon to march on Königsberg. Bennigsen resolved to thwart this plan, and early on June 14 met Lannes' corps at Friedland, on the river Alle, $26 \mathrm{~m}$. S.E. of Königsberg. Owing to Lannes' stubborn resistance, Bennigsen could do no more than cross the Alle and hold him in check until the arrival of Napoleon. The Allies were now in a serious position. Behind them, in an irregular arc, lay the Alle, across which their only line of retreat lay over the bridges of Friedland.

The battle began at 6 p.m. Ney was ordered to attack Friedland, but his advance was checked by a furious charge of the Russian cavalry. Victor was hurried to his assistance, and an artillery concentration turned on the Russians, which, seconded by an irresistible dragoon charge, turned the tide of battle. A rout ensued, and the Russians, pursued by Ney, fled through Friedland and across the river. The numbers engaged were : French, 70,000, and Allies, 55,000. The Allies lost 20,000 killed and wounded, the French little over 9,000 . Ten days later Napoleon met the tsar Alexander on a raft in the middle of the Niemen, and the treaty of Tilsit was concluded.

Friedländer, LUDWIG (18241909). German scholar. Born at Königsberg, Dec. 16, 1824, after studying there and at Leipzig, in 1858 he became professor of clas. sical philology and archaeology in his native place. The work which established his reputation is Darstellungen aus der Sittengeschichte Roms (1862-71, 9th ed. 1919, etc. ; Eng. trans. Roman Life and Manners under the Early Empire, 1908-13), a perfect mine of information, but written in an unattractive style. His editions of Martial, Juvenal, and Petronius Cena Trimalchionis are also of considerable value. He died at Strasbourg, Dec. 24,1909 .

Friedrich, JoHaNn (1836-1917). German theologian. Born at Poxdorf, May 5, 1836, he was ap. pointed to the chair of theology at Munich in 1865. Refusing to accept the decree of papal infalli. bility, 1869, he was deposed and excommunicated, 1871 , and supported for a time the Old Catholic movement. In 1882 he became professor of history at Munich. He was the author of many controversial works. He died Aug. 11, 1917.

Friedrichshafen. Town of Württemberg, Germany. It stands on the lake of Constance, and consists of the two parts, Hofen and Buchhorn. It has a harbour on the lake, built by Frederick I, king of Württemberg, who united the two places and gave the town its present name. The ehief building is the palace, at one time used by the ex-kaiser William II. It stands in wooded grounds to the W. of the town, and has an interesting ehapel. 


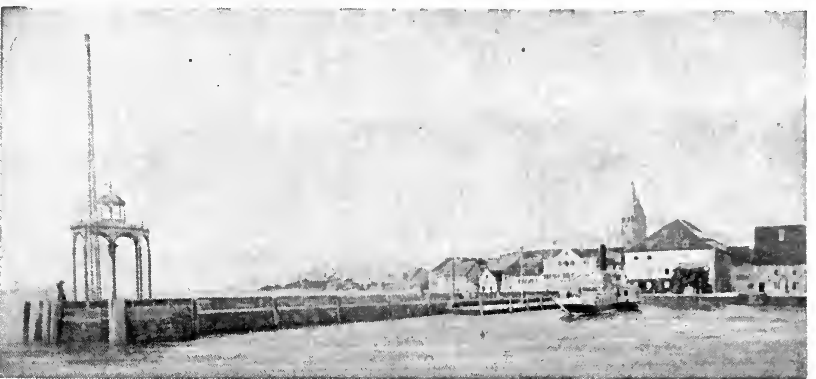

Friedrichshafen. The town, an important Zeppelin depot during the Great War, seen from the harbour entrance on the Lake of Constance

There is a Rathaus, a 20th century edifice, while the town has a meteorological station. Friedrichshafen is a tourist resort, and steamers go from here to various places on the lake, but in the 20th century, and especially during the Great War, its main interest was as a Zeppelin depot. In the workshops here the machines were put together and over the lake they made their trials, while for their reception were numerous hangars, bombed by Allied airmen in 1914-15. The building of boats is another industry. Hofen had a Benedictine mon astery, and Buchhorn was a free city. Pop. 5,500.

Friedrichshafen. German aero plane. It is a big two-engined biplane of the Gotha model, used for bombing purposes. Generally known as the F.F., this machine had the peculiarity of a single landing wheel under the forepart of its fuselage, a fact which ren. dered the type easy to recognize.

Friedrichsruh. Village of Holstein, Germany. It is $16 \mathrm{~m}$. S.E. of Hamburg, and is interest. ing because the castle here was Bismarck's residence. He died here in July, 1898, and is buried in the mausoleum. Pop. 279.

Friedrichsthal. Town of Germany, in the Rhine prov. It is 11 m. N.E. of Saarbrück, with which it is connected by electric rly. Pop. 10,500. A village of this name in Mecklenburg-Schwerin stands near the lake of Neumühlen. There is another Friedrichsthal, this being in the Black Forest.

Friedrich-Wilhelmshafen. Former name of a seaport of Kaiser Wilhelm's Land, in the former Ger. man colony of New Guinea. It was occupied by an Australian force, Sept. 12, 1914, and is now adminis tered by Australia and called Madang. White pop. 243.

Friendly or TONGA IsLands. Group of islands in the S. Pacific Ocean, a British possession. The kingdom, consisting of three groups of islands-Tongatabu,

Haabai, and Vavau - and the outlying islands of Niuatobutabu, Taofahi, and Niuafoo, lies between lat. $15^{\circ}$ and $23^{\circ} 30^{\prime} \mathrm{S}$. and long. $173^{\circ}$ and $177^{\circ} \mathrm{W}$. It is administered by a British high commissioner, with the assent of the king and native chiefs. The islands are

partly of volcanic and partly of coral formation, and only onefifth of the 150 are inhabited. The people are fair Polynesians. Area, 390 sq. m. The capital is Nukualofa. The native produce consists of copra, mats, green fruit, and fungus.

The Friendly Islands were so named by Cook in 1773, on account of the courteous behaviour of the inhabitants. Tasman first touched here in 1643 . There are numerous reefs and shoals around the islands, which abound in cocoapalms and a kind of fig tree with narrow, pointed leaves. There is steamer connexion with Sydney and Auckland via Fiji. British coin is the only legal tender. Salote, the queen, succeeded on April 29, 1918 , on the death of her father, George II. There is a pop. of 23,121 natives and 835 other nationalities.

\section{FRIENDLY SOCIETIES AND THEIR WORK}

John Freeman, Liverpool Victoria Legal Friendly Society

The various types of these societies are here described. See also the article Guilds, and those on the various friendly societies, e.g. Odd. fellows, and insurance companies, e.g. Prudential

Friendly societies are voluntary associations for the mutual relief and maintenance of members in sickness, old age, distress, etc. Roman origins have been claimed, and it is certain that in various forms they have existed for cen. turies. In Great Britain certain societies were founded about the end of the 17th and the beginning of the 18th centuries, but it was not until 1793 that the movement became sufficiently prominent to call for legislation. The first Friendly Societies Act was then passed, permitting an unlimited number of persons to raise funds for mutual advantage, make rules, impose fines, etc. Early societies secured the privileges of the Act by obtaining confirmation of their rules from a justice of the peace.

Various legislation followed. There were Acts in 1793, 1819, and 1829 , which required an examination of the rules by a barrister, followed by those of 1834 and 1846 , when the office of registrar was created. In 1896 the existing enactments were consolidated into two, affecting the main types into which the movement had developed, viz. friendly societies proper and collecting societies. The registry of friendly societies is responsible for the application of both Acts. The Friendly Societies Act, 1908, and the Assurance Com. panies Act, 1909, are the chief legislation of the 20th century.

Registration is voluntary. Societies may operate without regis. tration, but the advantages of the Acts are not available to unregistered societies. A registered society can legally hold land, own property in the names of trustees, carry on legal proceedings in such names, and take summary proceedings against persons commit. ting an offence in regard to its property. It enjoys freedom from income tax under schedules A, C, and D of the Income Tax Act, 1918. Its members may legally insure for funeral expenses on the deaths of wives and children, and may dispose of sums payable at death up to $£ 100$ by written nomination without a will.

To be registered, a society must have at least seven members, and its work is limited to its specified objects. The total amount insured on any one life may not exceed $£ 300$, whether issued by one or more than one society. Societies must make certain annual returns to the chief registrar, and must make a valuation of their assets and liabilities at least once every five years.

\section{Classification of Societies}

Societies generally may be classi. fied according to their purpose and the objects of their benefits. They can be established for the relief or maintenance of members during sickness or infirmity, in old age (i.e. any age after 50), widowhood, or distressed circumstances, when travelling in search of employment, or in such circumstances as shipwreck, or damage to 
boats or fishing-nets, or of the dependents of members in sickness, old age, or widowhood, or, if orphan children, during minority.

Others assure money to be paid on the birth of a member's child, or the death of a member; for the funeral expenses of a nember's husband, wife, or child, or of the widow of a deceased member; or, among persons of the Jewish religion, as allowance during the period of confined mourning.

Others insure against fire, up to a value of $£ 15$, the tools used by a member in his calling, or endow members or their nominees at any age, or guarantee societies or branches that their officers and servants perform their duties properly. Collecting societies may also insure money to be paid for the funeral expenses of a member's parent, grandparent, grandchild, brother, or sister.

A society with branches commonly gives sickness and maternity, medical, funeral, and in some cases unemployment benefits. Some of these benefits are for nembers only, some for wife or other dependents. Control is by means of delegates to an annual movable conference. It operates through local units, and organization is largely voluntary. In many instances a board of arbitrators of high standing exists to settle disputes. An example of this type of society is the Manchester Unity of Oddfellows, with over 4,000 branches in the United Kingdom, and about 14,000 in the rest of the British Empire. A centralised society gives benefits similar to the above, but it is without branches or local organizations.

Another type of society is represented by the National Deposit Friendly Society. Deposit societies combine friendly society features with savings bank features. The Friendly Societies Act provides that the rules of a society may permit the accumulation at interest, for the use of any mem. ber, of any surplus which may remain to his credit in the funds after providing for liabilities. Such societies are exempt from valuation requirements. Dividing societies which provide by rule for the periodical division of the whole or part of the funds without regard to actuarial solvency, are likewise exempted from the valuation provisions of the Act.

Collecting Socintres. There are in Great Britain about 50 of these, a few very large and the rest relatively small. They are in the main occupied with industrial in. surance, i.e. insurance for industrial classes at weekly or other periodical premiums, collected by paid agents from insurers. The sums insured are usually payable on death. Each of these has a very large approved section for national health insurance. Collecting societies are a special development. They are extraordinarily popular, and of late have regarded themselves not exclusively as offices insuring funeral expenses; endowments for adults and juveniles and life policies up to $£ 300$ have grown in favour. Other types of society coming under the same official supervision and included in the statement below, are cooperative and building societies, annuity socicties, cattle insurance societies, etc. The following are the figures of the different types of society:

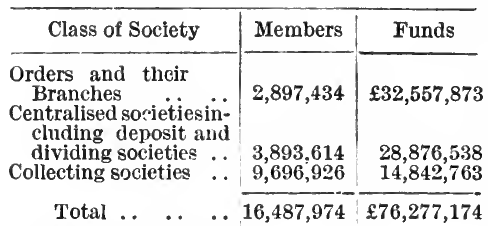

All other types includ-

ing trading and

Total of registered provident societies

\begin{tabular}{|l|l|}
$10,401,466$ & $148,105,646$ \\
\hline
\end{tabular} $\overline{26,889,440} £ 224,382,820$

bill led to friendly societies being empowered to form associations under the new Act. Collecting societies are specifically excluded.

Over 28,000 societies, including branches, under the Friendly Societies Act, and about 8,000 societies under other Acts, are supervised by the registry. It has limited powers, but it is able to take proceedings against defaulters, refuse improper rules, etc. Thus the registrar may appoint an inspector to investigate a society's affairs, and may call a special meeting of members ; he may also, in certain circumstances, order the dissolution of a society and the distribution of its funds. Various official inquiries have been made, particularly into the section transacting industrial life assur. ance. From 1870-74 a royal commission sat, and legisla. tion resulted. Adequate legis. lation, however, to prevent the establishment of insubstantial societies, to which the chief registrar has re. peatedly called attention, is even now still wanting. The last such inquiry was held in 1919, under the chairmanship of Lord Parmoor, its scope including industrial in. surance companies.

Political Developments. The rapid progress of social reform in Great Britain brought important changes in friendly societies. The National Health Insurance Act, 1911 , involved the cooperation of societies of all types. Originally the exclusion of collecting societies was intended, but the chancellor of the exchequer (D. Lloyd George) found it necessary to seek their assistance, fearing that in the absence of their extensive organization great difficulty would be experienced in bringing the Act into universal operation. Hence collecting and other societies were alike specially empowered to transact national health insurance, usually by means of separate sections. 44 p.c. of the total insured population of the United Kingdom is comprised in the organizations created by the collecting societies and their kindred institutions, the industrial insurance companies; while 45 p.c. are included in other types of friendly society.

A similar position was reached in the Unemployment Insurance Act, 1920 . The original bill excluded societies of all types from operating this Act, the intention being that the whole insured population should resort to a labour exchange or trade union. Parliament did not support the government's intention, and modifications of the
The friendly society movement received its strongest impetus in the earlier part of the 19 th century, while the opening years of the 20th century brought singular difficulties. Legislation appeared to threaten their existence, but they have survived. Generally their special characteristics have been scrupulously observed, alike by Parliament and the courts. For instance, legal provision has been made for the conversion of a society to a proprietary company, but the courts in interpreting this decision have made restrictions

Friendly Societies abroad. In some parts of the British Em. pire, the friendly society movement has taken some root. In Australasia affiliated orders are active ; and in Canada, also, various societies are opcrating. Generally speaking, the state supervision of societies is strict, and the result of this may well bethe establishment of unregistered societies. In the U.S.A. they are mainly of more recent origin than in Britain, and they have been stimulated by extensive immigration, including many members of British friendly societies, and by severe economic distress. A typical illustration is the Widows and Orphans Benefit Society, originally founded when distress had been most severely felt, and the traditional horror of pauper treatment 
was strongest, to provide friendly society benefits, and then converted into the Prudential Assurance Company of America, purely for insuring sums payable at death. Hence the development of other industrial insurance companies upon British lines.

In France, voluntary organizations have long existed, and those friendly societies which have been officially approved as distinct from authorised societies receive state assistance towards the payment of old-age pensions as one of their benefits. Germany presents a much more complete example of state domination, the voluntary organizations having being overshadowed, although not necessarily extinguished, by the schemes set up under different imperial statutes from 1876 onwards, for compulsory insurance upon lines which are largely followed by the British scheme of National Health Insurance, 1911. Belgium and Holland have each a considerable number of friendly societies.

Bibliography. Friendly Societies and Industrial and Provident Societies, F. Baden-Fuller, 1910 ; Official Guide Book of the Registry of Friendly Societies, 1920 ; Provident Societies and Industrial Welfare, E. Brabrook, 1898; Memorandum of Sickness and Invalidity Insurance in Germany, H.M. Stationery Office, 1911 ; Addresses and Papers on Life Insurance (America), John F. Dryden, 1909.

Friendly Societies Registry. Office created in $\mathbf{1 8 4 6}$ to look after the accounts of friendly, building, and similar societies which do not come under the operation of the Acts regulating public companies. These make periodical returns to the registrar, which are tabulated in blue-books. The chief registrar is a member of the four insurance commissions and also of the joint committee. His headquarters are at Dean Stanley Street, Westminster, London, S.W., and there are branches of the registry in Edinburgh and Dublin.

Friends of the People. Society formed in England in 1792 by some of the more advanced Whigs to bring about parliamentary reform. Sir Philip Francis was one of its founders and helped to draw up its original programme. The members were influenced by the French Revolution, but proposed to pro. ceed by constitutional means. The society had a short life, although its supporters included Sheridan, James Mackintosh, and Erskine.

Friesland (Dutch, Vriesland). Province of the Netherlands. The Zuider Zee and North Sea form its $W$. and $N$. boundaries, and it is contiguous on the E., S.E., and S. with
Groningen, Drente, and Overyssel ; it includes the three islands of Terschelling, Ameland, and Schier. monnikoog. The flat and in parts marshy country is mainly agricultural, fertile and well watered, but unsatisfactorily managed. Con. siderable tracts are under sea level. Dairy farming, stock rearing, horse breeding, and peat cutting are im. portant. At Sneek there is busy trade in cheese and butter, and at Franeker there was a university until 1811. There are several large, marshy lakes, with good fishing, notably the Fleussen, Tjeuke, Sneeker, Sloter, and Bergumer lakes. There are good communications by rly., steam tramways, and canals. The chief town is Leeuwarden $(q . v$.$) ; other centres$ are Bolsward, Sneek, Dokkum, Harlingen, Franeker, Stavoren, and Hindelopen. The prov. sends four members to the lower chamber, and is marked by the prevalence of the old Frisian dialect. In parts the country is pleasant and pictur. esque. Area, 1,243 sq. m. Pop. 384,779 .

East Friesland is the name of a district in Hanover, Germany. Lying between Groningen in the Netherlands and Oldenburg, it is also flat and marshy, and has agri. cultural and fishery interests. Its chief town is Aurich, others being Emden, Norden, and Leer. A canal runs from Emden eastwards to Wilhelmshafen. Area, 1,211 sq. m. Pop. 241,024. See Frisians.

Frieze. In architecture, the middle member of the entablature, between the cornice and architrave.

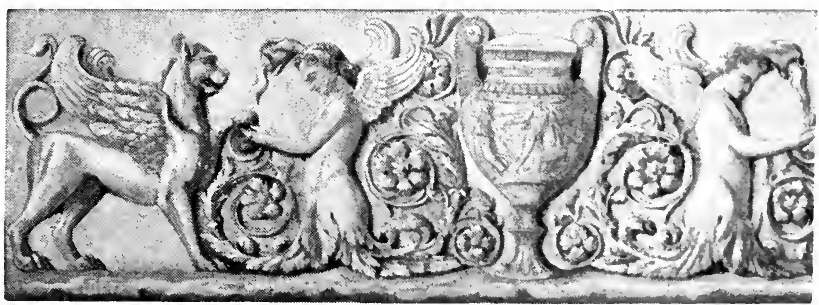

Frieze. Example of ancient frieze from Trajan's Forum, Rome

The Greek frieze in its simple form was divided into panels or metopes by triglyphs or channelled blocks, the metopes being sometimes sculptured with a floral design, and sometimes, as in the Parthenon, with figures. In the earliest temples the metopes and triglyphs were composed of separate blocks of stone, artificially bonded; but the Ionic and later styles aimed at making the frieze a continuous band encircling the building, with the joints concealed as much as possible.

Different varieties of frieze de- veloped in Roman and Renais. sance times, and when domestic architecture assumed importance the feature was applied both to exterior and interior decoration. 'The friezes in Inigo Jones's designs are sometimes divided up by attic windows. Tudor doors, windows, and walls often have classic entablatures with frimzes.' Exterior friezes are now mainly confined to public buildings, but modern rooms are frequently decorated with a wall-paper frieze, and occasionally with a frieze pattern in low relief. The word, Fr. frise, Ital. fregio, probably comes ultimately from Lat. Phrygium (opus), Phrygian (work). See Parthenon.

Frigate (Ital. fregata). Forerunner of the modern light cruiser. A fast vessel of from 25 to

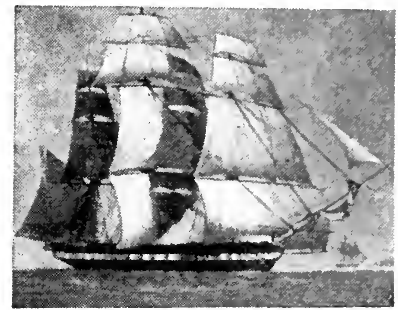

Frigate of war under full sail

50 guns, she was useful for either the attack or defence of commerce on the high seas, and for scouting duties with the line-of-battle fleets. The term was originally applied to craft in the Mediterranean using both oars and sails. The first English frigate was the Constant

Warwick, designed by Peter Pett for the earl of Warwick for use as a privateer, built at Ratcliff, on the Thames, in 1646, and purchased into the navy in 1649 . The desig. nation was retained in the Britis fleet for many years after the introduction of steam, and it was not until 1883 that it was replaced by cruiser. In sailing days any warship other than a stationary vessel. storeship, or troopship was classed as a cruiser; but this term is never applied now to any vessel built to lie "in the line." See Cruiser. 
Frigate Bird (Fregata aquila). Sea-fowl related to the gannet and the pelican. It has a long, slender

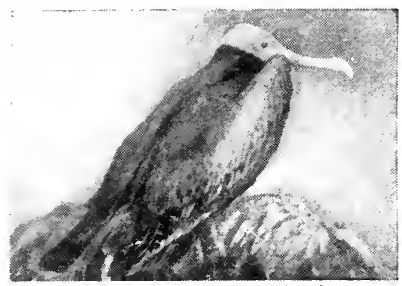

Frigate Bird. Specimen of the larger species found in tropical regions

body, ending in a forked tail resembling that of the swallow, and the beak is long and hooked. Found only in the warmer seas, usually far from land, it lives upon the fish that it catches or robs from other sea-fowl.

Frightfulness. Anything leading to fright or terror. The word came to have a special meaning during the Great War as translating the German Schrecklichkeit. The German theory of war taught that the ends could be most quickly secured by deliberate terrorism, and this policy of frightfulness inspired many of their actions in Belgium and France. See Atrocities.

Frilled Lizard (Chlamydosaurus). Australian lizard. Measuring nearly a yard in length, it is distinguished by a large membranous frill on either side of the neck. This is usually folded back, but can be erected when the animal is alarmed, apparently for the purpose of frightening its enemies. It is a harmless creature, found only in sandy districts.

Frilling (old Fr. friller, to tremble). Pleated edging for dresses or undergarments. In the 18th century, to frill meant to shiver, and frilling was at first an edging of lace or some material so light that it shook with movement. Later it meant a narrow edging of lace pleated into a band and sewn into the neck and sleeves of dresses.

Frimaire (Fr., the month of frost). 'Third month in the year as rearranged during the French Revolution. It began on Nov. 21 or $22 . \quad$ See Calendar.

Frimley. Urban dist. and vil. lage of Surrey, England. It stands on the Blackwater, 2 m. S. of Camberley, on the L. \& S.W.R. In the Aldershot area, it is mainly a residential district. A farm colony of 15 acres for sailors and soldiers suffering from tuberculosis was organized here in 1920. Pop. 13,673.

Fringe. Strictly, loose threads forming an ornamental border to anything, e.g. the fringe of a garment. The word is also used for hair cut straight across the fore- head. It is used by analogy for anything on the border, e.g. the fringe of empire. See Frilling.

Fringe Tree (Chionanthus). Genus of shrubs or small trees of the natural order Oleaceae. Natives

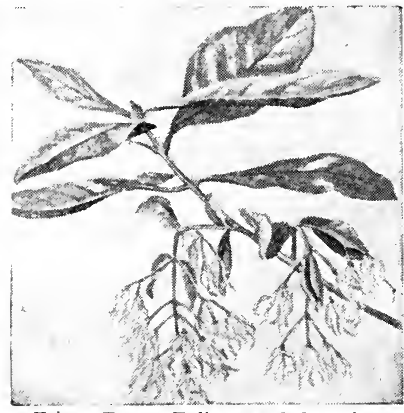

Fringe Tree. Foliage and drooping flower of the Chinese shrub

of China and N. America, they have large, smooth, magnolia-like leaves, and white, sweet-scented flowers which hang in graceful clusters; the corolla is cut into narrow segments, which give it a fringed appearance. C. virginica, the American species, is also known as snowdrop-tree.

Frinton-on-Sea. Urban dist. and seaside resort of Essex, England. It is $2 \mathrm{~m}$. S. of Walton-on-the-

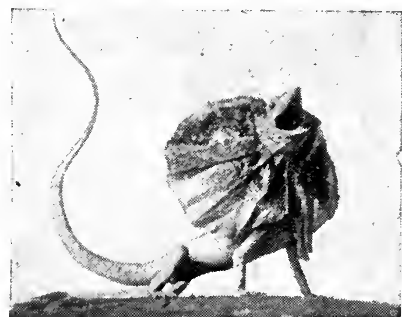

Frilled Lizard. Chlamydosaurus Kingi from Australia

Naze, on the G.E.R., and has good bathing facilities and golf links. A model garden town, its avenues are wide and are planted with trees. Sea walls and promenades have been constructed, and a pleasure ground of 50 acres. Pop. 1,510.

Fripp, Sir Alered Downing (b. 1865). British surgeon. Born Sept. 12, 1865, he was educated at Merchant Tay. lors' School, and took his degrees in medicine at Lc ndon Uni. versity. H e served in the South African War, where he was chief civilian medical officer a t $t \mathrm{~h} e$ Imperial Yeo.

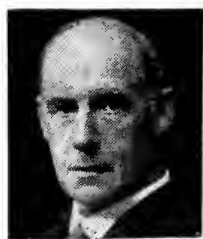

Sir Alfred D. Fripp, British surgeon Russell manry hospital. Surgeon to Guy's and other London hospitals, he was also surgeon to the king. In 1903 he was knighted.

Frisches Haff. Lagoon off the N. coast of Prussia. It is separated from the Gulf of Danzig by a strip of land $40 \mathrm{~m}$. long and about one mile wide, called the Frische Nehrung. The lagoon or haff is about $50 \mathrm{~m}$. long and of varying breadth; it covers 330 sq. m. The opening to the outer sea is at the N.E. end, where a channel has been dredged for traffic. Before 1510 the lagoon was entirely land. locked, but in that year a storm destroyed a little of the sand barrier. The Elbing, Passarge, Pregel, and Nagot flow into the Haff, while the port of Elbing is $5 \mathrm{~m}$. from it.

Frise. Village of France, in the dept. of Somme, $9 \mathrm{~m}$.W. of Péronne. Heavy fighting took place between the French and the Germans here, Jan.-Feb., 1916. It was captured by the former under Foch, July 2 , 1916 , retaken by the Germans in March, 1918, and finally recovered by the Allies the following Aug. See Somme, Battles of the.

Frisian Islands. Chain of islands extending from the coast of Slesvig-Holstein, Denmark, to the southern mouth of the Zuider Zee in Holland. 'They are the remains of a former coast-border of Jutland and Holland, and their sandy character and lack of vegetation attest the process of erosion they must have undergone in the course of centuries; local legends tell of old villages now submerged. Most are popular German sea-bathing resorts.

The chain may be divided into three groups, North Frisian, East Frisian, and Dutch. The North Frisian Islands lie off the W. coast of Slesvig-Holstein, from which they are separated by the Watten, an arm of the sea. Interspersed among them are the Halligen, low sandbanks covered with marine grass.

The principal member of the group and the largest German island in the North Sea is Sylt, which has an area of 39 sq. $\mathrm{m}$. and a population of 4,800 . Its capital is Westerland (pop. 2,400), situated on its W. side, consisting of two portions, Alt-Westerland, and the more modern Neu.Westerland, separated from the sea by a chain of sand-dunes and a stone embankment. Next in importance is the island of Föhr, on the E. coast of which lies the village of Wyk (pop. 1,800), which possesses an interesting museum of Frisian antiquities and handsome public gardens. Amrum, $6 \mathrm{~m}$. long by 
$3 \mathrm{~m}$. broad, lies S. of Sylt and has 1,000 inhabitants.

The East Frisian Islands form an almost continuous line masking the German coast between the mouths of the Ems and the Weser. Norderney (pop. 3,400) is $8 \mathrm{~m}$. long by $1 \frac{1}{2} \mathrm{~m}$. broad. Its mild climate and magnificent stretch of sandy beach make it a favourite summer resort. Borkum (pop. 3,300), situated at the mouth of the Ems, $9 \mathrm{~m}$. N. of the Dutch coast, is $5 \mathrm{~m}$. long by $2 \frac{1}{2}$ $\mathrm{m}$. broad, and is perhaps the most popular holiday resort, and its breed of milch-cattle is much esteemed. Wangeroog, $5 \mathrm{~m}$. long by $1 \mathrm{~m}$. broad, formerly belonged to Oldenburg. About $2 \mathrm{~m}$. W. of the present village are the ruins of an older inhabited site overwhelmed by a violent storm. Spiekeroog, regarded as part of Prussia, is $5 \mathrm{~m}$. long by $1 \frac{1}{4} \mathrm{~m}$. broad and attracts connected with the other Low German peoples along the coast, notably the Angles and Saxons, and the old Frisian dialect survives in the Dutch and German Fries. lands and in parts of W. Slesvig, especially in the coastal country near Tondern.

The Frisians were partially con. quered by the Roman general Drusus, c. 12 B.c., but their early history is obscure. Numbers of them were probably associated with the Angles and Saxons in their incursions into Britain during the 4th and 5th centuries. Friesland generally was made tributary to the Frankish empire of Pepin II in 689 , and after a revolt was reconquered by Charles Martel in 736 . It fell to Charlemagne in 784. It retained a fair degree of independence during the Middle Ages. For a short time in Saxon posses. more particularly barley, of north. ern Europe. It is not found in Britain, though there its allied species, C. taeniopus, frequently attacks barley.

Frith, JoHN (1503-33). English martyr. The son of a Kentish innkeeper, he was educated at King's College, Cambridge, afterwards becoming a member of Chriat Church, Oxford He helped Tyndal to translate the Bible, and his abilities and scholarship soon made him prominent among the advocates of the reformed faith. 'This led to his enforced departure from England, and for about six vears he lived in Germany and Holland. Having returned to England, he was arrested. In prison and on ex. amination, he defended by pen and word his beliefs ; consequently he was burned to death at Smithfield, July 4, 1533.

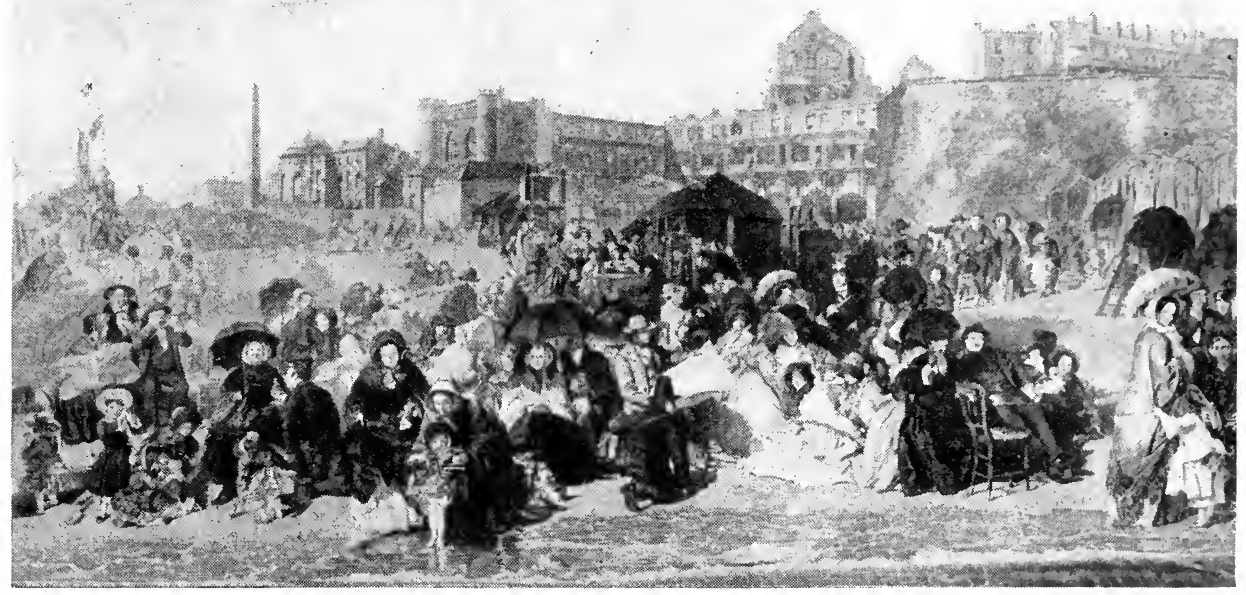

William Powell Frith. Ramsgate Sands, an example of one of the artist's larger compositions, exhibited at the Royal Academy in 1854 and purchased by Queen Victoria

comparatively few summer visitors. Langeoog is $8 \frac{1}{2} \mathrm{~m}$. long by $1 \mathrm{~m}$. broad, and has five thousand in. habitants.

The Dutch Frisian group, of which the most important islands are Terschelling, Vlieland, and Texel, screens the mouths of the Zuider Zee. The inhabitants are chiefly concerned with agriculture and dairy-farming, and though honest and good-natured, are back. ward. Frisian, the original speech of these islands, bears a remarkable resemblance to the older forms of English.

Frisians. People of Teutonic race originally inhabiting the country now covered by the Dutch provinces of Friesland and Gro. ningen and the German district of East Friesland. They were closely sion, Friesland was ceded to the emperor Charles V in 1523, but joined the United Provinces in 1579, remaining one of these until 1795 , when it was merged into the Dutch territories.

East Friesland became distinct from the rest of the Frisian lands in 1430 , when it became a fief of the powerful Cirkensa family, by whom it was ruled until 1744 , when it was incorporated in Prussia. Transferred to Holland in 1808 , and in French possession 1810-13, it was recovered by Prussia and ceded by her to Hanover in 1815 .

Frit. Name popularly applied to certain small dipterous insects destructive to corn crops. The one generally so named is Chlorops frit, a small black fly which sometimes causes havoc among the crops,
Frith, Willia m Powell (1819 1909). British painter. Born at Aldfield, Yorks, Jan. 9, 1819, son of

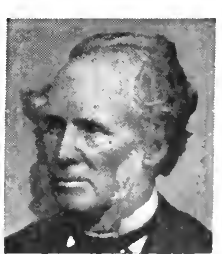
an innkeeper, he studied a $t$ Sass's A c a d e m y, Bloomsb u ry, and at the R.A. schools. Founding his style on that of Daniel Maclise, he Po began to paint historical sub. jects, his Mal. volio being llung at the R.A., 1840. He was elected A.R.A. in 1844, and R.A. in 1852. He scored popular successes with Ramsgate Sands, 1854 ; 
Derby Day, 1858; The Railway Station, 1862; Private View at the R.A., 1881. Dickens was among Frith's early friends. He died in London, Nov. 2, 1909. See Ashton, Lucy; Dickens, illus.

Fritillaria. In zoology, the name applied generically to certain Ascidians, commonly called sea squirts, of the free swimming class. In botany it is given to a large genus of Liliaceae. (See Snakeshead.) Fritillary is the name given to several species of butterfly of the Argynnis and allied genera. Several of these are native in Great Britain. See Butterfly, colour plate.

Friuli. District of Italy, at one time an independent duchy. It lies around the head of the Adriatic and was, before 1918, partly in Austria and partly in Italy. It is about $3,300 \mathrm{sq} . \mathrm{m}$. in area, and has a pop. of about 700,000 . The Isonzo and the Tagliamento flow through it, and there was much fighting here during the Great War. The adjective for Friuli is Furlanian.

The district takes its name from the Roman settlement of Forum Julii, the later Cividale (q.v.). The Lombards ruled it for some centuries, after which it passed from one ruler to another. Venice secured part of it, while eastern Friuli was added about 1500 to the lands of the house of Austria. In 1797 Austria obtained theVenetian portion, which she retained in 1815 . In 1866 the new kingdom of Italy was given the part that had previously belonged to Venice, and so matters remained until the Great War. After then Austrian Friuli was claimed by both Italy and Yugo-Slavia, but by the treaty of Rapallo (1920) the whole became Italian. The capital of the district is Udine $(q . v$.$) .$

Froben or Frobenius, Johannes (c. 1460-1527). German scholarprinter. Born at Hammelburg, Franconia, and educated at Basel University, he opened at Basel, 1491 , a printing office, where he printed many of the works of Eras. mus, a close friend, a Latin Bible, a Greek Testament, edited by Erasmus and illustrated by Holbein, and editions of the Latin Fathers.

Frobisher, SIR MARTIN (c.153594). English sailor. Born in Yorkshire, he made a voyage to Guinea in 1564 , and spent some years in voyages to the Levant and $N$. Africa. In 1575 he was commissioned by the Muscovy Company to search for the North-West Passage, and set out on June 7, 1576 , with two ships of 25 and 20 tons respectively, sighted Greenland, where he lost the smaller vessel, and reached Frobisher Bay in N. America.

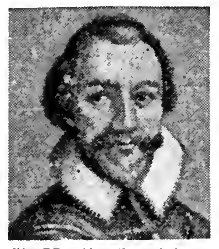

Sir Martin Frobisher,

From a print
English sailor

Returning to England, Frobisher repeated the voyage in 1577 as admiral of the company of Cathay, and brought back 200 tons of pyritic ore, which he in. correctly believed con. tained gold. In 1579 he made a third voyage, and discovered a new strait, but did not make any survey. In 1586 he was viceadmiral to Drake's expedition to the W. Indies, and, in command of the Triumph, helped to defeat the Armada (1588). He was knighted for his gallantry. He was vice-admiral to Sir John Hawkins in 1590 , being sent by Raleigh to harry the Spanish coast in 1591 . Mortally wounded in the sea attack against Brest, then held by the Spaniards, he died at Plymouth, Nov. 22, 1594 .

Frobisher Bay. Inlet off the coast of British N. America. Long and comparatively narrow, it cuts into the eastern end of Baffin Land from the Atlantic. Its length is about $250 \mathrm{~m}$., and its breadth about 20 . It is about $200 \mathrm{~m}$. S. of the Arctic circle.

Frock (late Lat. froccus). Word used as both noun and verb. In the former sense it is applied to a monastic robe, with loose sleeves, reaching to the feet; to a dress worn by women and girls; to a rough worsted garment (strictly, Guernsey frock) worn by sailors over or in place of a shirt; and to a double-breasted, skirted coat worn by men and properly called a frock coat. As a verb the word to frock means, figuratively, to make a man a monk or priest. To un. frock means to deprive monk or ecclesiastic of his privileges as such. See Costume; Gown; Smock.

Fröding, GustaF (1860-1911). Swedish poet. Born in Vaerm. land, Aug. 22, 1860, and educated at Karlstad and Upsala, he afterwards joined the staff of the Karlstad paper, and wrote occasional verse. Spending some time in Germany, he studied English and German lyrical poetry, from which he made various translations. His first book, Guitar and Concertina, 1891, was an immediate success. New Poems, 1894, and other books were issued, 1894-98, and in 1901-2 his collected works were published. Much of his verse was written in dialect.

Fröding's original humour and spontaneity, vivid portrayal of Swedish life, lyrical perfection, and pithy language, which has already influenced the Swedish tongue, have placed him first among modern Swedish poets. His last years were spent mostly in hospital, but in 1910 he published a volume of poems, Second Harvest. A selection of Fröding's poems was translated by C. N. Stork, 1916.

Frodsham. Parish and market town of Cheshire, England. It is $10 \mathrm{~m}$. N.E. of Chester, and has a station on the Chester-Manchester rly. It has a Norman church, dedi. cated to S. Lawrence, and restored in the 19th century, a town hall, and, formerly, a castle. The chief industries are the manufacture of chemicals, salt, and cotton. Frods. ham Marshes is a low-lying area between the Weaver and the Mersey, which rivers meet near here. Pop. 3,000 .

Froebel, Friedrich Wilhelm August (1782-1852). German educational reformer. Born at Oberwe is s b a ch, April 21,1782, he spent his youth in the heart of the Thuringian Forest, where his long observation of nature gave

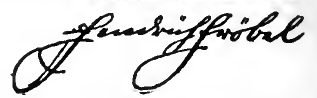

him many of the ideas which later marked his teachings. He studied at Jena, 1801, and at Göttingen, 1811 , teaching in the interval. In 1813 he served in the War of Liberation in Lützow's corps. In 1816 he opened a small school at Griesheim, Thuringia, transferred later to Keilhau.

His book,'The Education of Man, appeared in 1826 , and he did important work in training teachers at Burgdorf, Switzerland, between 1833-37. He opened his first kindergarten (children's gar. den) in Blankenburg, near Keilhau, in 1837, by which date his principles were making headway. Lecturing, writing, and teaching, Froebel spent his remaining years busily, and died June 21, 1852. See Froebel System.

Froebel Society. Society founded to assist in the dissemina. tion of the Froebel system of child education. It organizes lectures for teachers, students, and all persons interested in early education, maintains a library, and publishes periodical proceedings. Its headquarters are at 4 , Bloomsbury Square, London, W.C. The society is represented on the examination board of the National 
Froebel Union, which issues certificates to teachers of children under 14. To obtain these certificates, which are recognized by the board of education, about two years' training is required, colleges for which are found in most large educational centres in the United Kingdom.

Froebel System. Name given to the theory or plan of children's education enunciated by Friedrich Froebel (q.x.). Convinced of the essential unity of all things human, natural, and divine, Froebel held up as the ideal of educa. tion the leading of man to a full consciousness of this unity and the teaching of the ways to attaining it. Iike Heinrich Pestalozzi (q.v.), he believed that children should be allowed to develop naturally, in happy and harmonious surroundings, and with trained guides and helpers to safeguard the natural process. His system lays great stress on the value of play, which is regarded as a spiritual activity, and on the educational value of giving a free hand to the instinctive sense of rhythm and the natural creativeness of the child mind.

The main part of Froebel's theories was put into practice in the kindergarten schools, but the underlying doctrines are meant for all stages of education. In the kindergartens the child's senses are developed by such means as clay. modelling, paper-folding, work with colour brushes, mat-plaiting, beadthreading, ete., and the observation and care of natural objects, animals, flowers, etc., help to encourage his finer instincts. See Education ; Kindergarten; Montessori Method.

Frog. Smooth-skinned mem. ber of the order Ecaudata (tailless), of the class Batrachia. This order includes all the frogs and toads, numbering more than 1,000 species, which are distinguished from newts and salamanders by the absence of a tail in the adult stage. The name frog is restricted to the family Ranidae, of which nearly 200 species are known. The bony structure of all the frogs is peculiar in having the hinder half of the vertebral column modified into a simple jointless bone; while the two bones usually found in the fore arm and lower leg of verte. brates are fused together. They possess tongues whose base is in the front of the mouth; and have teeth in the upper jaw and palate only. 'The fore feet are not webbed; the hind ones partially webbed.

Frogs are found in all parts of the world, exeept in New Zealand, Papua, the extreme $S$. of South America, and the frozen regions. As

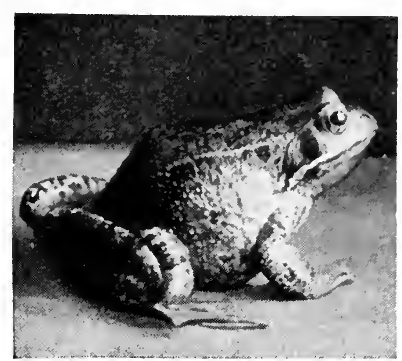

ally on the thighs. 'There is a dis. tinct fold along each side of the body, and the males have a conspicuous round sac on either side of the head, which is distended when eroaking. On the Continent and in $\mathrm{N}$. America the edible frog is often used for the table, the flesh of the thighs resembling that of a very young chicken: but it is rarely eaten in Great Britain. See Animal; Embryology, illus.

Frog. In engineering, two short I 'ngths of rail spliced together and

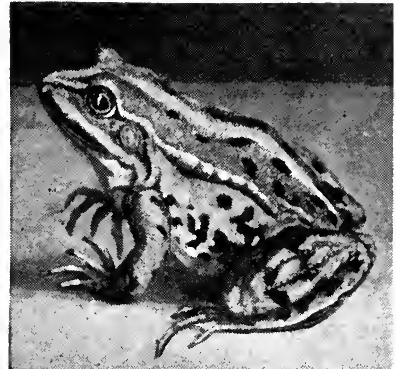

Frog. Bottom, the edible variety, Rana esculenta. Top, common frog, R. temporaria

they ean only live in damp places, theyare absent from deserts and the higher ranges of the mountains.

Like all batrachians, frogs pass through a series of metamorphoses. The eggs are deposited in a jellylike mass in fresh water, and hatch out as tadpoles, consisting of an oval body and a long tail. During this stage they breathe by means of gills. The tail and gills are gradually absorbed, and at the same time the four limbs make their appearance. At the completion of this stage they leave the water and take to a terrestrial life, breathing air by means of lungs. The air is taken in by a kind of swallowing action, and if the mouth is kept open for any length of time the animal will die by suffocation, as it cannot inhale apart from the action of the mouth, owing to the absence of ribs. The food consists of insects and slugs, which are seizcd by thrusting out the long. sticky tongue. Frogs are therefore valuable to the gardener and should never be destroyed. The winter months are passed in a state of hibernation, usually in the mud of ponds, but occasionally in holes and crevices.

Great Britain possesses two spe cies of frogs, of which the common frog (Rana temporaria) is found almost everywhere. The edible frog $(R$. esculenta) is found mainly in the eastern counties, and is distinguished from the commoner spe. cies by its usually larger size and more mottled appearance, especi- forming part of a railway erossing.

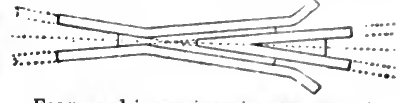

Frog used in engineering as part of a railway crossing

A wrecking frog is a device with one end raised to form an inclined plane by which derailed rolling stock can be replaeed on the track. 'The frog is laid alongside the rail with the lower end towards a wheel of the derailed vehicle; by pulling the latter the wheel mounts the frog, which guides it on to the rail. It is also known as a railway ramp. (See Railways.) The term is also npplied to part of a horse's hoof, and to that part of a soldier's equipment which carries the sword or bayonet.

Frogbit (Hydrocharis morsus. ranae). Floating aquatic herb, of the natural order Hydrocharideae. A native of Europe and N. Asia, it has long-stalked, kidney-shaped leaves, reddish beneath ; and threepetalled white flowers. It sends out runners which produce new plants, and in autumn bulbs which sink to the bottom of the ponds and ditches in which it lives, where they pass the winter in the mud. In spring they rise to the surface, and put out leaves. 'The male flowers are in clusters of two or three; the females solitary.
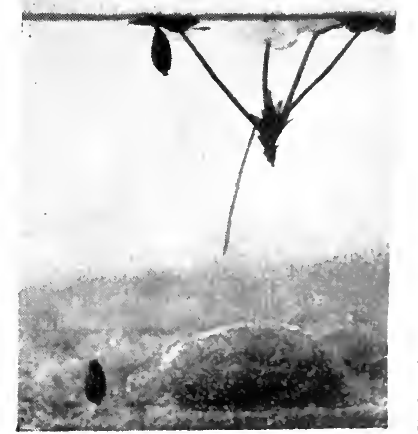

Frogbit. Bulbs rising to the surface. One has developed into a plant witb four leaves 
Frog Hopper. Name popularly given to a large family (Cercopidae) of hemipterous insects. 'Their

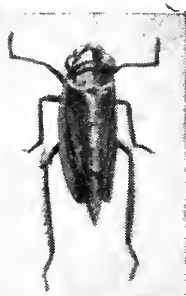
larvae may be noticed on plants, where the y a r s covered with froth and are often known as "cuckoo spit." The a d u l t insects

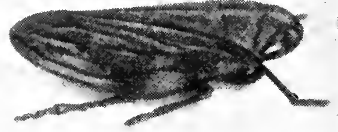

Frog Hopper of the Alder, Aphrophora alni. Above, spiny-legged frog-hopper, Evacanthus interruptus

are grey or greeny, and leap vigorously if clisturbed.

Frogmore. Royal residence of Berkshire, Fngland. It is within the Home Park, Windsor, 1 m. S.E.

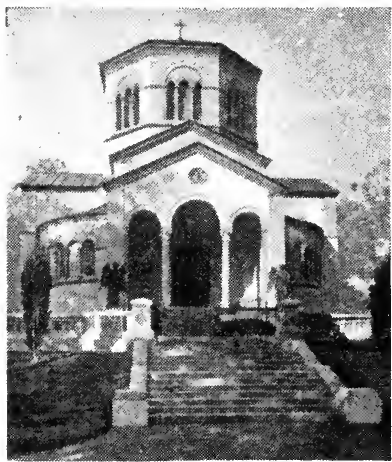

Frogmore, Windsor Royal Mausoleum built by Queen Victoria, 186270 F. W. Hardie

of the castle; and was purchascd by Queen Charlotte in 1800 . The duchess of Kent died here in 1861. Since then it has been used by other members of the royal family. A cruciform structure surmounted by an octagonal lantern was erected by Queen Victoria over the tomb of the Prince Consort. The re. mains of the queen were buried here in 1901 .

Frogmouth. Family of nightflying, insectivorous birds. Resembling the nightjar, they are notalle for their very wide mouths. There are numerous species, dis tributed over Australia, Malaya, and the eastern districts of India.

Frogs, The. Comedy by Aristophanes, produced 405 B.C. "The god Dionysos goes down to Hades to fetch up Euripides from the dead.

A contest for supremacy takes place between the rival tragedians Aeschylus and Euripides, in which each humorously criticises the specimens of style given by his opponent. The palm is awarded to Aeschylus, who returns to earth with Dionysos to offer the benefit of his advice to the Athenians. The play takes its name from the chorus of frogs who accompany the god in his passage over the lake of the underworld.

Frohman, Charles (1860-1915). American theatrical manager. Born at Sandusky, Ohio, June 12, 1860 ,

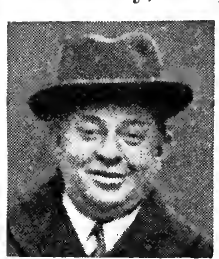

Charles Frohman

American theatrical manager tre, New York, and later had five other theatres under his con. trol in that city. In 1897 he became lessee of the Duke of York's, London, where he brought out Sir James Barrie's plays, The Admirable Crichton, 1903; Peter Pan, 1904 ; What Every Woman Knows, 1908 ; and experimented with a repertory system in 1910 , producing plays by Barrie, Bernard Shaw, John Galsworthy, and Granville Barker. He was drowned in the Lusitania, May 7, 1915. See Charles Frohman: Manager and Man, I. F. Marcosson and D. Frohman, 1916.

Froissart, JEAN (c.1338-c.1404). Freneh ehronicler. The son of all heraldie painter, Froissart was born at Valenciennes, and probably started to write the first part of his history about 1358. He became secretary to Philippa of Hainault, queen of Edward III of England, in 1361, and while in her service visited the court of David II of Scotland. For a short time he returned to his native Flanders, but in 1366 followed Edward the Black Prince to Gas.

cony, and paid visits to several courts of N. Italy. Philippa died in 1369 , and he found other patrons in Count Fobert of Namur, Duke Wenceslas of Brabant, and Guy de Blois, the overlord of Chimay. From the last he ob. tained the bene. fice of Iestines.
au-Mont. In 1388 Froissart visited Béarn, and travelled with the knight Espaing de Lyon, whose. stories gave him much picturesque mat. ter for his Chronicles, to the brilliant court of Gaston Phoebus of Foix at Orthez. In 1395 he paid another visit to England, a nd died at Chimay.

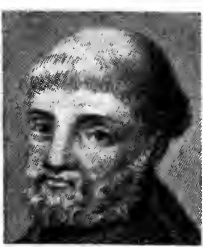

Jean Froissart, French chronicle
The Chronicles, in four books, trace the history of the main events in England, Scotland, Ireland, France, Flanders, and Spain, as well as happenings at the papal courts at Rome and Avignon, between 1325 and 1400, and form one of the greatest of medieval historical works. The first book, much of its material borrowed from the earlier chronicler Jean le Bel, views the course of events largely from the English point of view, written as it was under English patronage. But on the whole Froissart gives a fair version of events as he saw them, or as the witnesses available described them to him. He spared no effort in the search for reliable testimony.

Modern research has corrected errors of chronology, statistics, and topography, but Froissart shows a great advance on most of his predecessors. He definitely presents his picture as a whole, relating cause and event in due sequence, not content merely to enumerate bald facts. But his work is chiefly prized for its vivacious narrative of the best side of the chivalric age. Froissart, who also wrote some in. ferior verse, was the friend of several notakle poets, especially Eustache Deschamps, and probably Chaucer. The first dated edition of the Chron. icles appeared in 1504; the first Eng. trans. by Lord Berners, 1525.

Frome or Frome Selwood. Urban dist. and market town of Somerset, England. It stands on

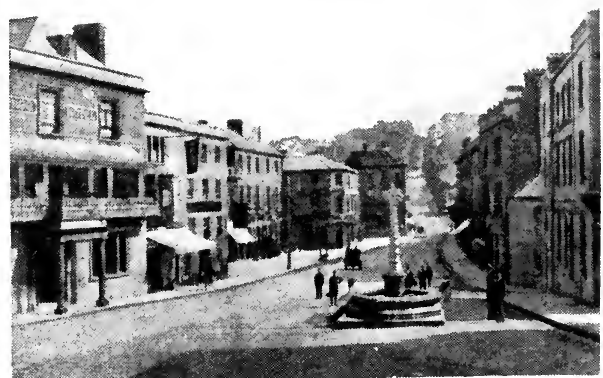

Frome, Somerset. The market place and cross 
the Frome, $24 \mathrm{~m}$. by rly. S.E. of Bristol on the G.W.R. Brewing, printing, and the manufacture of cloth are the chief occupations, the woollen industry having greatly declined. The parish church, a Decorated building dating from the 14th century, was restored on a magnificent scale in the 19 th. There are also a museum, market hall, and grammar school. Market days, Wed. and Sat. Pop. 10,901. Pron. Froom.

Frome. Lake of S. Australia. It lies in the Eastern Plains, $50 \mathrm{~m}$. E. of the Flinders Range. About $50 \mathrm{~m}$. long from N. to $\mathrm{S}$., it is $25 \mathrm{~m}$. wide from E. to W. The Wilpena river issues from its S. extremity.

Fromelles. Village of France, in the dept. of Nord. It is $6 \mathrm{~m}$. N.E. of Festubert, and came into prominence during the Great War, especially in the Allied offensive of the spring of 1915. The British attacked the Germans here on May 9. See Aubers Ridge, Attack on the; Festubert, Battle of.

Fromentin, EUGEेNe (1820-76). French painter and writer. Born near La Rochelle, he studied under Cabat and painted Algerian life and landscape. $\mathrm{He}$ is better known, however, as the writer of A Sum. mer in the Sahara, A Year in the Sahel, both models of the art of word-painting, and of The Masters of Past Time in the Low Countries, a book of descriptive art-criticism. He died Aug. 27, 1876.

Fronde, THE. Name given to the insurrection and civil war in France under the regency of Anne of Austria and Cardinal Mazarin, 164853. Its two phases are known respectively as the parliamentary Fronde and the Fronde of the princes. The name comes from that of a small sling used during the disorders in Paris.

In 1648 Mazarin sought the sanction of the parliament of Paris to fresh and burdensome taxes by offering that body certain fiscal exemptions. This the parliament refused, and drew up forthwith a series of 27 articles of constitutional reform, forbidding the imposition of unauthorised taxes, reducing certain imposts, etc. After momentarily yielding, the queen-regent suddenly arrested the parliamentary leaders, Broussel, Blancmesnil and Charton. 'The Parisians raised street barricades and the court party was alarmed into releasing the prisoners and granting the required reforms. Mazarin, however, strengthened by the adherence of Condé, obliged the parliament to sign the peace of Rueil, March 11, 1649, with which the first phase closed.

Jealous of Mazarin's power, however, Condé turned against him, but was orrested and imprisoned with other maleontent nobles. Conti and Longueville. Another foe of the cardinal, Paul de Gondi, a powerful ecclesiastic, stirred up, revolt in Paris, forcing the minister to release Condé and to quit France early in 1651 . He returned in Jan., 1652, whereupon Condé, with Spanish aid, headed a powerful movement against the court party. Raising an army in the south, he defeated the royal forces at Bléneau, and, despite Turenne's able defence at the Faubourg $S$. Antoine, occupied Paris. His un. popularity forced him to leave in July, when the court and the cardinal returned. By the summer of 1653 the Fronde, in spite of a deter. mined struggle in Guyenne, was crushed, and this singularly un. necessary civil war had ended in the powers of the parliament of Paris being severely curtailed and the monarchical power correspondingly consolidated. See France: History; Mazarin.

Front. Military term. In drill it has been differently applied at various periods, but at present it indicates the direction in which the troops face when in line, irrespective of whether the original front rank is in front or in rear. In war, the term front is employed to indicate that part of the war area in which the troops are in actual fighting contact and so far behind as is occupied by the immediate ad. ministrative services of the fighting troops and the reserves.

In modern warfare, the depth of the front has greatly increased owing to the much higher power and longer range of present-day artillery, the heavy guns often being situated several miles in rear of the infantry units which are in contact with the enemy's troops. Consequently auxiliary services which previously were entirely employed on the lines of communication are now required to operate actually " at the front." To facilitate organization a definite sector of the front is allocated to each unit. See Flank; Tactics.

Frontal Bone. In human beings the bone which forms the forehead, the upper margins of the orbits, and the forepart of the skull. See Anatomy; Man.

Frontenac, Lours dE BUAdE, Comte dE (1620-98). French gov. ernor of Canada. He belonged to a noble family of Béarn, and served in the French army with distinc. tion. In 1672 he was sent out to New France as governor, and held that position until 1682 , and again from 1689-98. As a ruler he was successful, but his autocratic temper caused constant quarrels

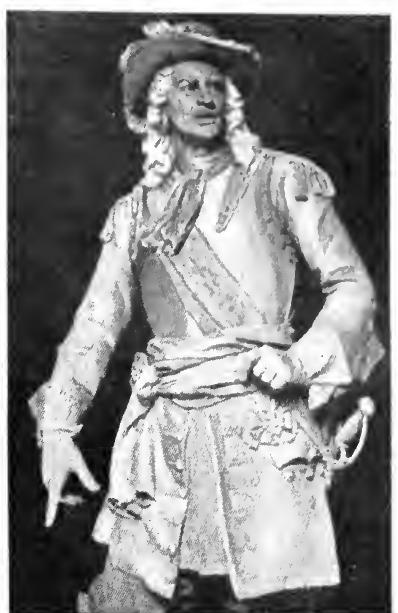

Louis de Frontenac, from the statue by $\mathbf{P}$. Hébert, Provincial Parliament Buildings, Quebec

with other high officials, especially Laval-Montmorency, bishop of Quebec. Frontenac died at Quebec, Nov. 28, 1698.

Frontinus, Sextus Julius ( $c$. A.D. 40-105). Roman soldier. While governor of Britain from 75-78 he gained a great victory over the Silures of S. Wales. He was the author of Strategematica, a collection of anecdotes of famous mili. tary leaders, and of The Aqueducts of Rome, an account of their construction, arrangement, and main. tenance, written after his appointment as curator aquarum or superintendent of the water-supply in 97

Fronico, Marcus Cornelius. Romar rhetorician. Born at Cirta in Africa, he flourished in the reigns of Hadrian and Marcus Aurelius, with the latter of whom he was on very friendly terms. As an advocate and teacher of rhetoric he amassed a large fortune, and was raised to the consulship A.D. 143.

A number of Fronto's letters, including eorrespondence with $\mathrm{Nar}$ cus Aurelius, discovered by Cardi nal Mai at the beginning of the 19th century, do not justify his great reputation among his fellow. countrymen, although they exhibit him as a man of honourable and upright character.

His importance in the history of Latin literature lies in the fact that he was the father of what was called the elocutio novella, "partly a return upon the style of the older (pre-Ciceronian) Latin authors, partly a new growth based, as theirs had been, on the actual language of common life" (Mackail). This elocutio novella was destined to be the parent of the Romance languages. Fronto died about 170. 
Front Range. Name given to a section of the Rocky Mts. It is the most eastern part of the range, hence its name. In the state of Colorado, its chief peaks are Pike's Peak and Long's Peak; both are over 14,000 ft. high. See Rocky Mts.

Frosinone. Town of Italy, in the prov. of Rome; the ancient Frusino. Built on a hill overlooking the Cosa, an affluent of the Sacco, $54 \mathrm{~m}$. by rly. S.E. of Rome, the town has many churches, holds an annual fair, and is noted for its wine. In former times its outskirts were infested by brigands. Near are remains of the Volscian city of Frusino, conquered by the Romans in 304 B.c. Pop. 11,646.

Frost. Term used for the formation of ice on ground, plants, etc., sometimes called hoar frost or rime. The formation of hoar frost is due to the condensation of water vapour on surfaces which are them. selves at a temperature of less than $32^{\circ} \mathrm{F}$. 'The frost consists of small particles of ice, crystalline in struc. ture, which often form the most variegated patterns. Hoar frost is in reality frozen dew. Frost coming in late spring and early autumn is often most injurious to crops, and many methods of frost protection are in use. A screen or light covering of any material helps to prevent hoar frost on plants by lessening the radiation of the plants' natural heat; fires, with plenty of warm smoke, are effective, especially in still air, when the smoke spreads evenly ; and the ground itself may be warmed by fires or flowing water.

Black frosts are long-continued severe frosts, generally with absence of hoar or white frost, and are so called because they kill or blacken vegetation. Among the great frosts of recent years in Great Britain are those of $1890-91$, lasting for eight weeks, most severe in England ; of Jan. and Feb., 1895, the coldest Feb. known in Great Britain, when ice 25 ins. in thickness was measured on many waters; and that of Feb., 1902. See Ice; Meteorology.

Frost, JoHN (d. 1877). English Chartist. Son of a Monmouthshire publican, and a tailor and draper by trade, he was appointed mayor of Newport in 1836, represented Monmouthshire at the Chartist convention of 1839 , and was re: moved from the commission of the peace for seditious speeches. Hailed as a popular champion, on Nov. 4, 1839 , he led an armed mob into New port. The rising was easily suppressed, and Frost was sen. tenced to be hanged, drawn, and quartered, but the sentence was commuted to transportation for life to Van Diemen's Land. In 1856 he received a free pardon and returned to England. He died at Stapleton, near Bristol, July 29, 1877.

Frost-bite. Localised gangrene of the tissues produced by exposure to severe cold. The parts of the body most likely to be involved are the fingers and toes, owing to the more sluggish circulation of the blood in the extrenities, and exposed parts such as the nose and ears. The first sign of frost-bite is a patch of redness with slight swelling and sometimes severe pain. If the exposure continues the part becomes white, hard, shrunken, and waxy-looking, but without pain, so that the individual may be quite unaware of what is taking place. Ultimately the affected part becomes black and ulcerated.

Treatment consists in very gradual restoration of circulation in the affected area. 'The patient should be kept in a cold room, the temperature of which is slowly raised, and the frozen part rubbed with snow or bathed with cold water. If actual gangrene occurs the part must be kept carefully protected and aseptic until a line of separation forms, and the subsequent ulceration heals.

Frostburg. Town of Maryland, U.S.A., in Allegheny co. A favourite summer resort, it occupies an elevated position about $2,150 \mathrm{ft}$. above sea level, and is $12 \mathrm{~m}$. W. of Cumberland, on the Cumberland and Pennsylvania and the West Maryland rlys. It contains a state normal school, and among its industries are founding and the manufacture of hosiery, bricks, and tiles, but coal-mining is the leading occupation. Settled in 1812, it became a municipality in 1870 . Pop. 6,028.

Frost Figure. Ice crystal formations which appear under certain conditions of cold weather. Figures, resembling ferns and often over two feet in length, are fre. quently formed by frost following rain. See Snow Crystals.

Froude, James Anthony (181894). British historian. Son of the Rev. Robert Hurrell Froude, he

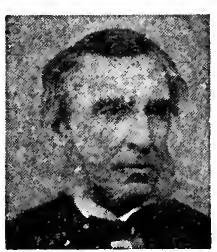

James A. Froude. British bistorian was born at Dartington, Devon, April 23, 1818. Educ a te d a t Westminster School, in 1835 he entered Uriel College, Oxford, afterwards becom. of Exeter. At Oxford Froude was associated with the Tractarians, but he never joined them, although he took Holy Orders in 1844. In. fluenced by Carlyle's books, he broke with orthodox religion. $\mathrm{He}$ expressed his changed views in The Nemesis of Faith, 1848, gave up his fellowship, and, as soon as the law permitted, became a layman once more.

In 1849 Froude married. $\mathrm{He}$ made the acquaintance of Charles Kingsley, and, more important, of Carlvle, and set to work upon his History of England from the Fall of Wolsey to the Spanish Armada, 1856-70. It was completed in twelve volumes and is the monu. ment to Froude's life. No historical work was ever more deservedly or more sharply criticised, and yet its merits are as conspicuous as its faults. The style is powerful, graceful, and restrained, for Froude, like Burke, is " one of the great masters of the high and diffi. cult art of elaborate composition." But against this are blemishes of partiality and worse, for critics have asserted that, in pursuance of his aim, the author did not hesitate to misquote his authorities. As pendants to this work Froude wrote The Divorce of Catherine of Ara. gon, 1891 ; The Spanish Story of the Armada, 1892; and Lectures on the Council of Trent, 1896.

In other directions Froude's writings led to acrimonious criticism. His book, The English in Ireland in the 18th century, 187174, was resented by the Irish and their friends. As the sequel to an intimate friendship, Froude was named as Carlyle's executor, and he published some Reminiscences, 1881, Mrs. Carlyle's Letters, 1882 , and Life, 1882-84, which gave a markedly unfavourable picture of the relations between Carlyle and his wife. For this Froude was attacked on the ground of mis. representations, and he replied with two books : Carlyle's Life in London; and My Relations with Carlyle. Another controversy arose out of Froude's book, Oceana, or England and her Colonies, 1886.

Froude took an interest in politics, and was twice sent on missions to S. Africa by Lord Beaconsfield's government. In 1892 he succeeded Edward A. Freeman as professor of modern history at Oxford. $\mathrm{He}$ died at Salcombe, Devon, Oct. 20, 1894. Froude's most delightful work is in the four volumes of Short Studies on Great Subjects, 186782. He also wrote The Life and Ietters of Erasmus, 1894; an historical romance, The Two Chiefs of Dunbov, 1889; and for many years edited Fraser's Magazine. See Carlyle; consult also Life of Froude, Herbert Paul, 1905. Pron. Frood. 


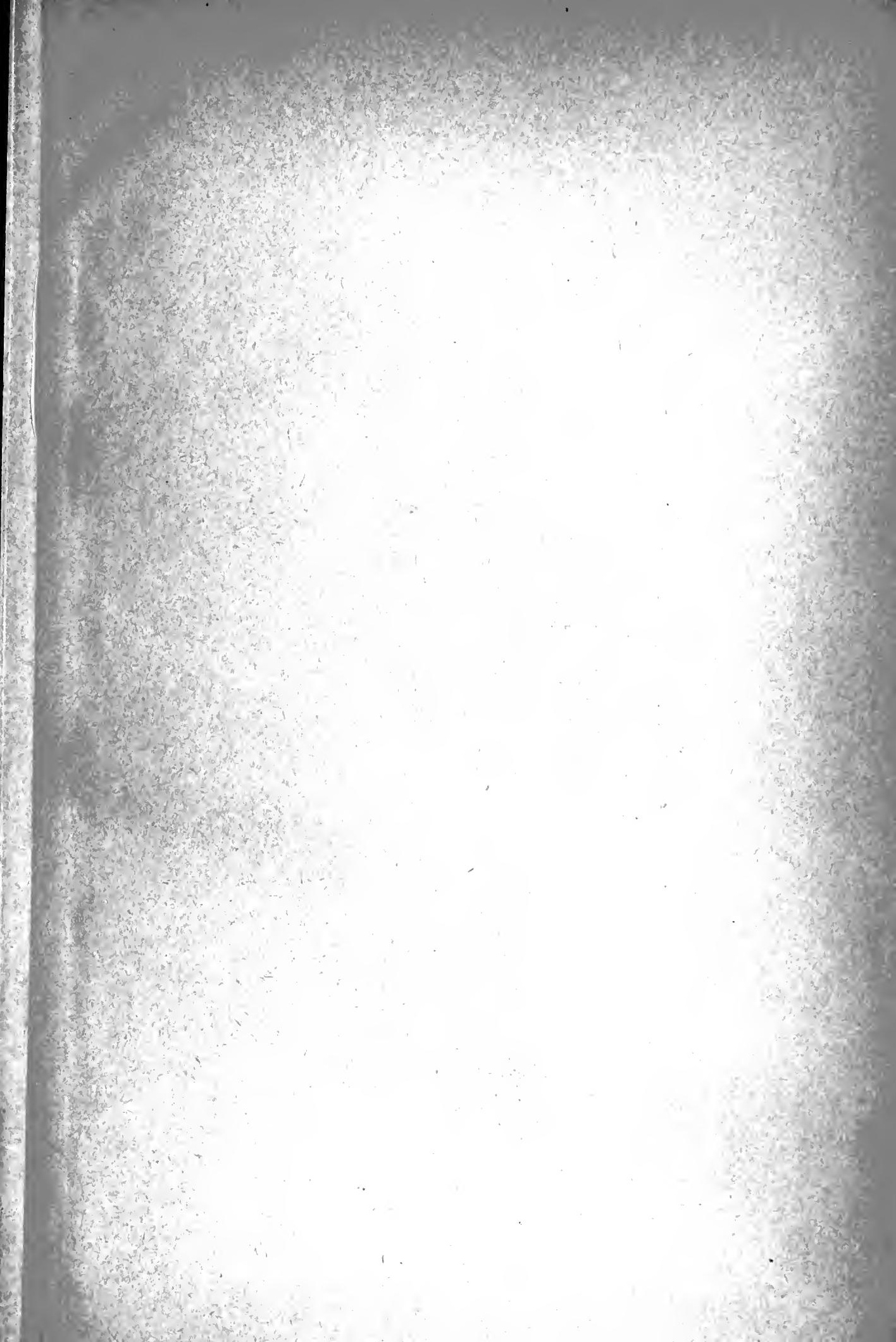



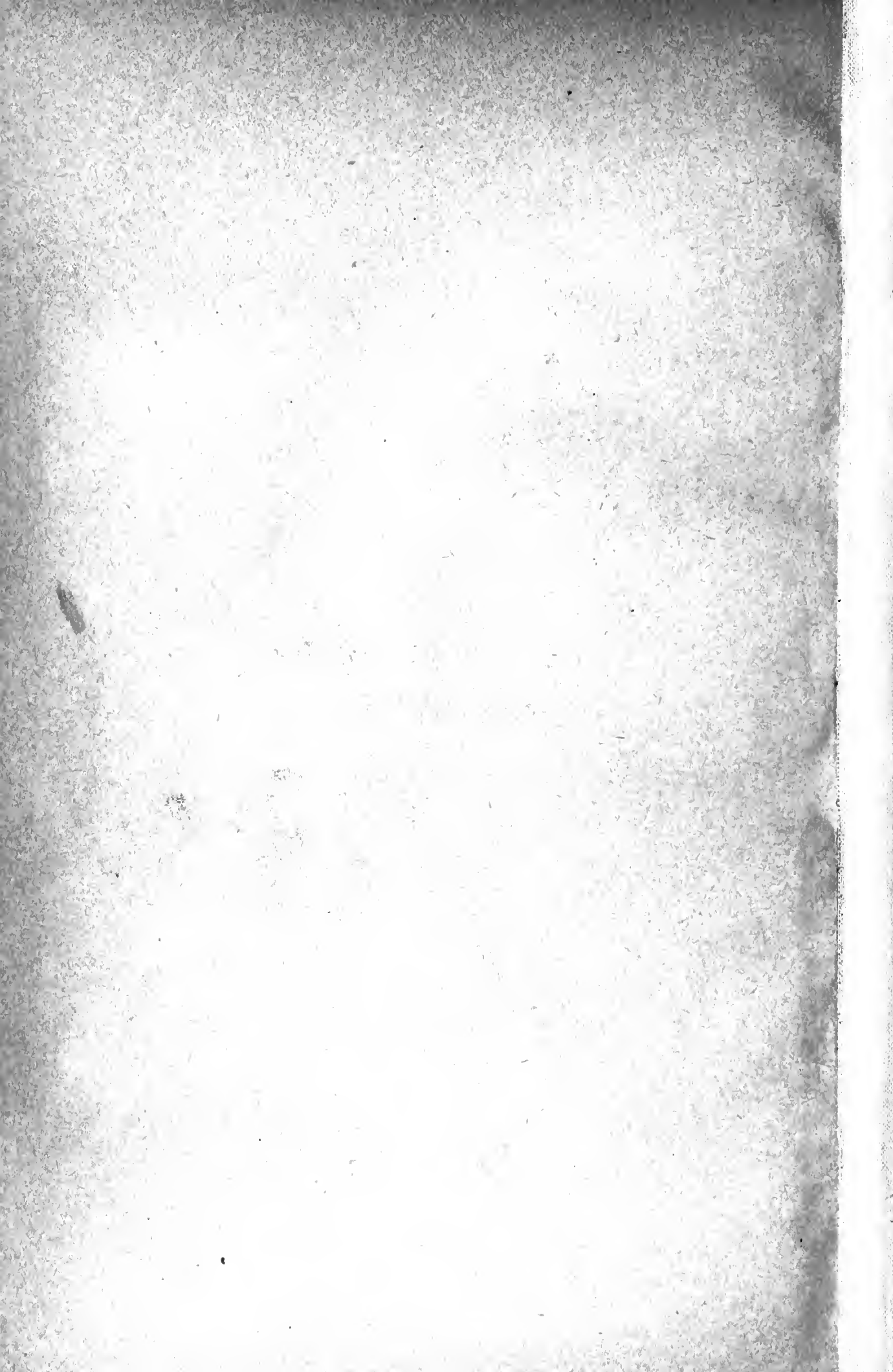

.




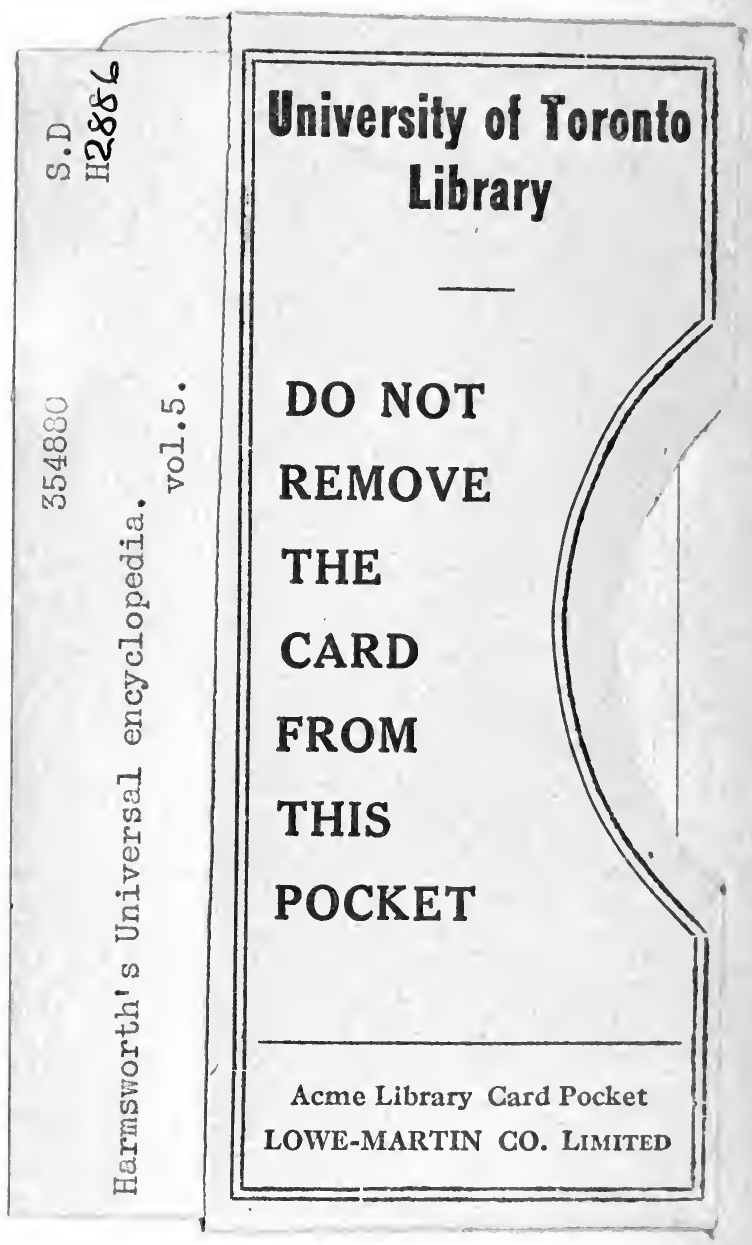


,

W.

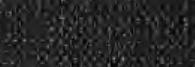

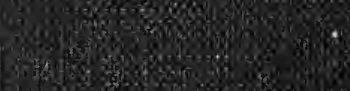

(4)

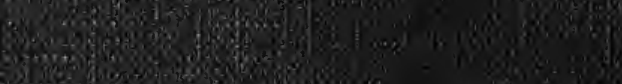

S.

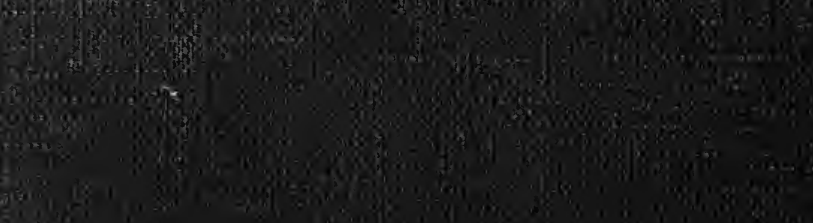

